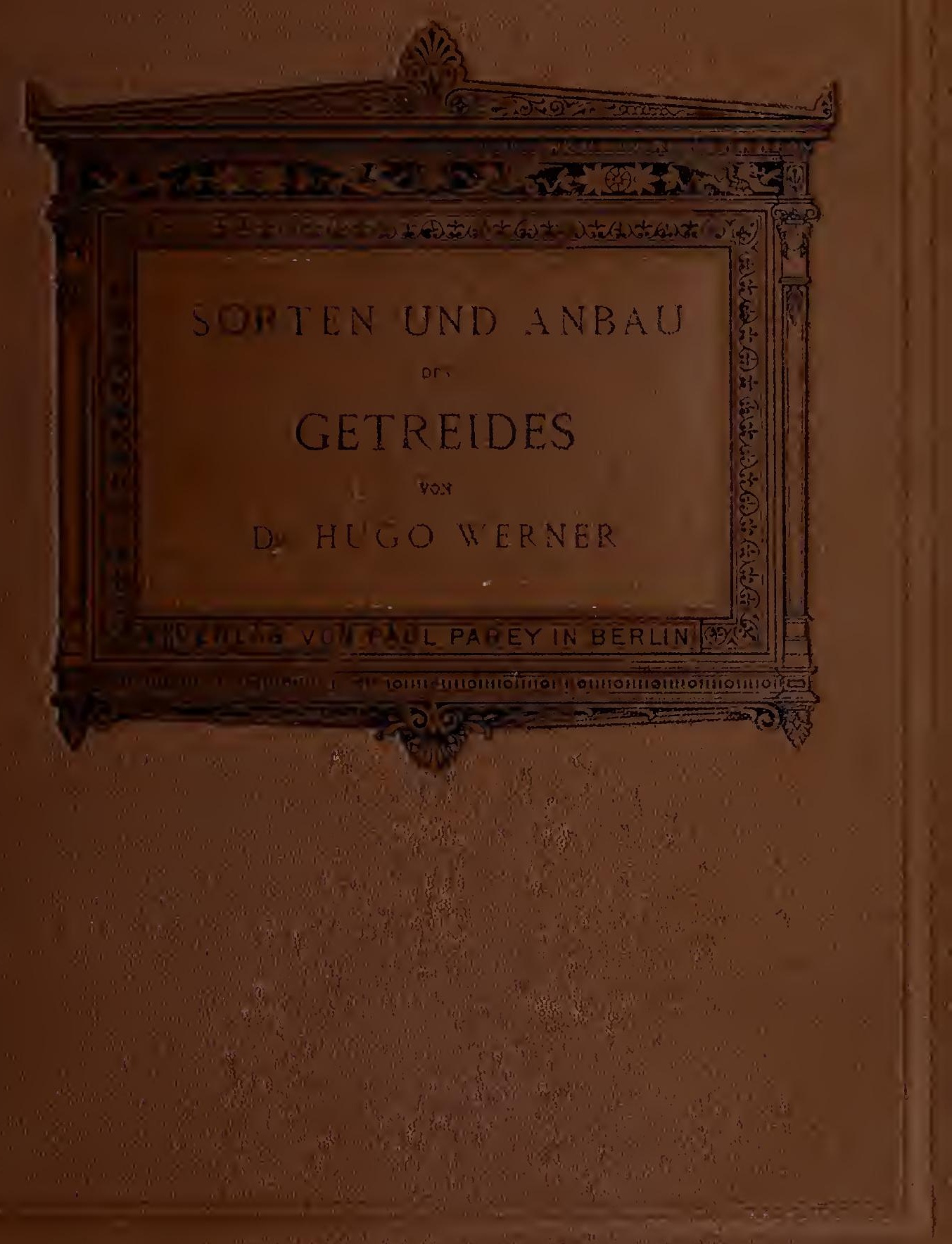




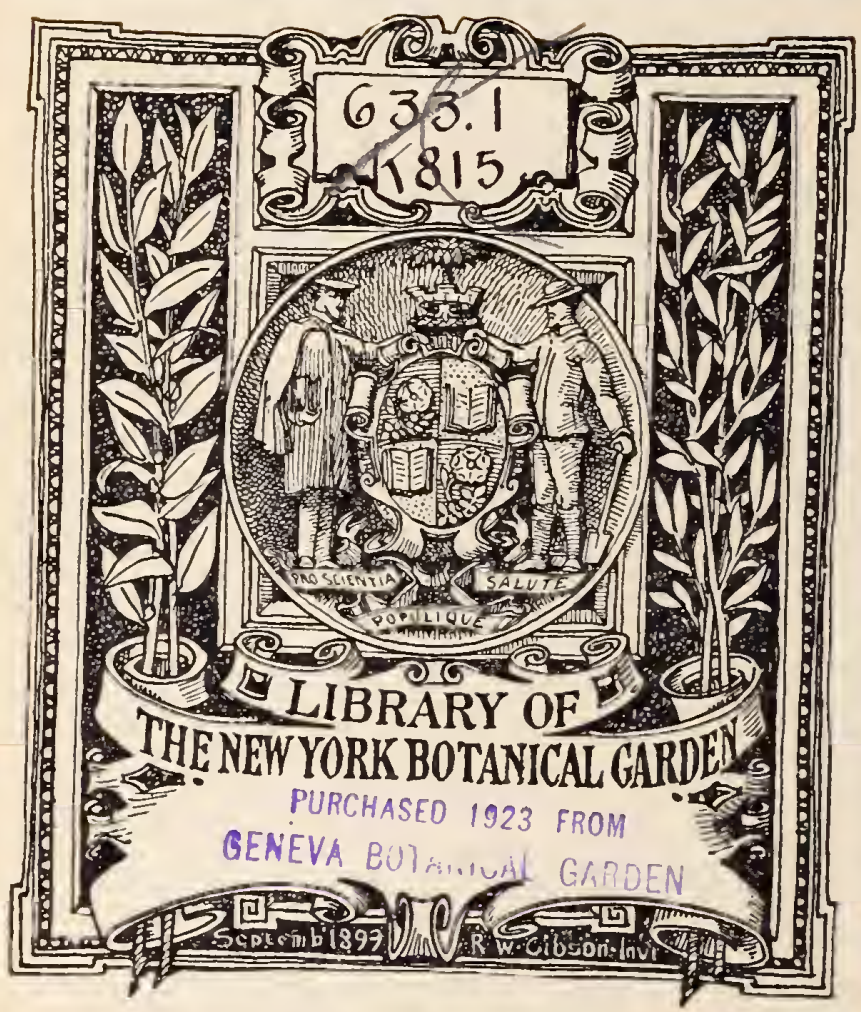




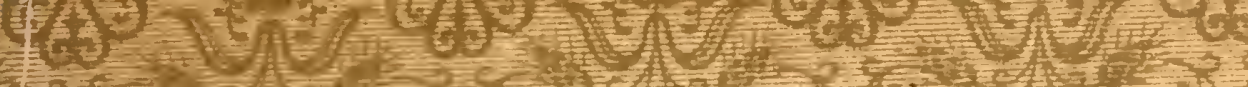

x) $x$.

$x$

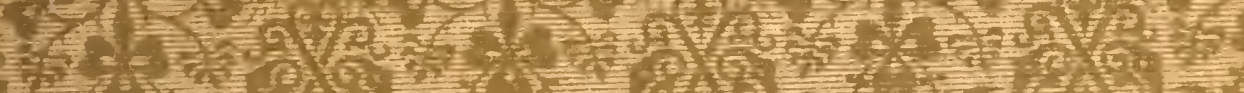

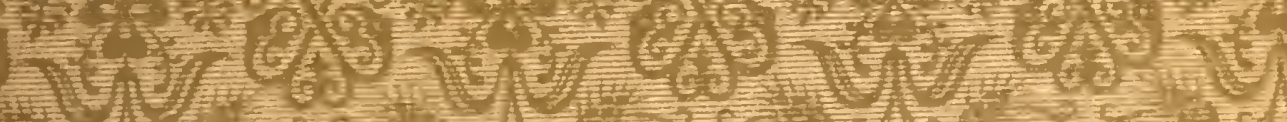

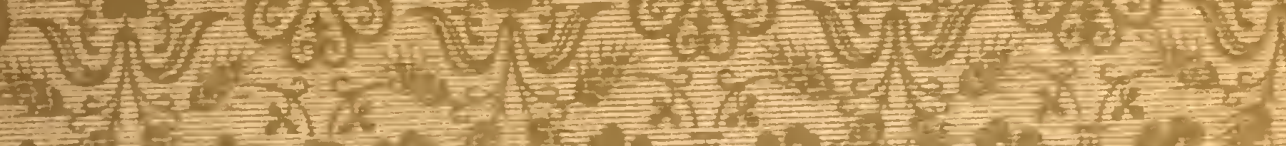

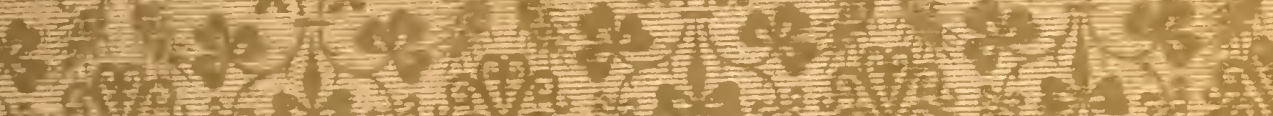

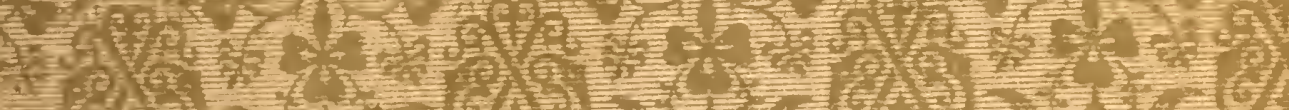

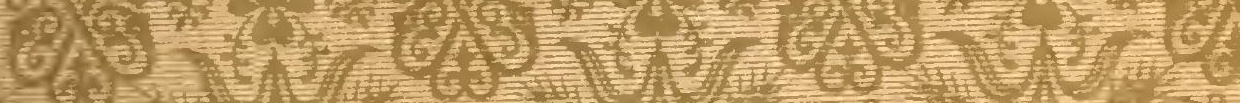

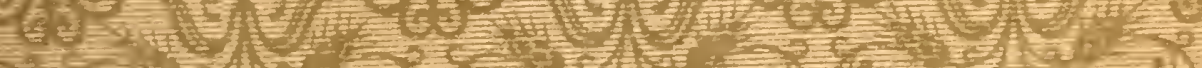

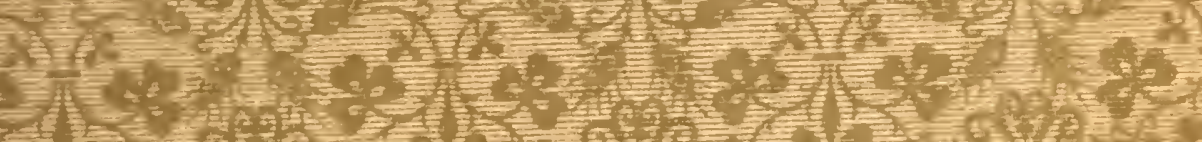
1 (1)

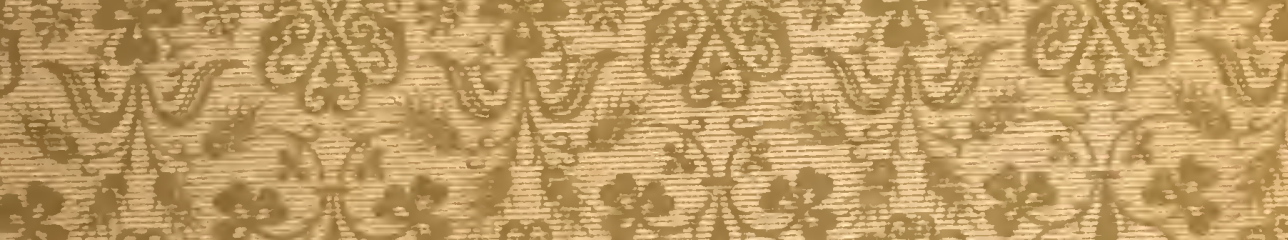

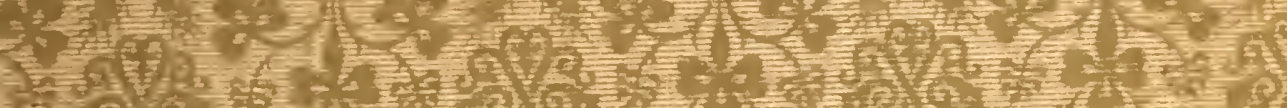

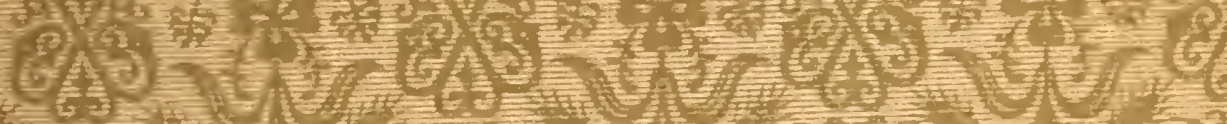

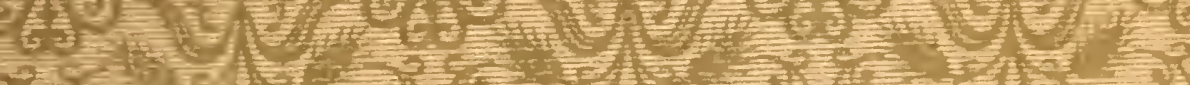

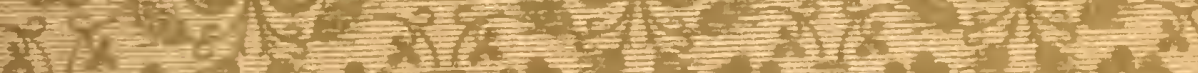

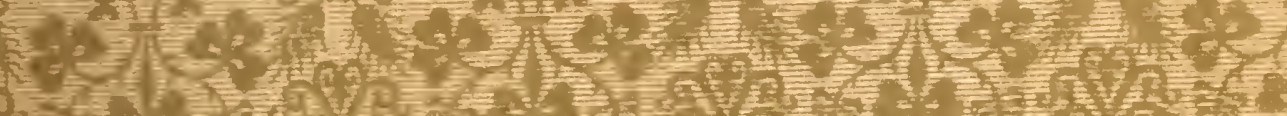

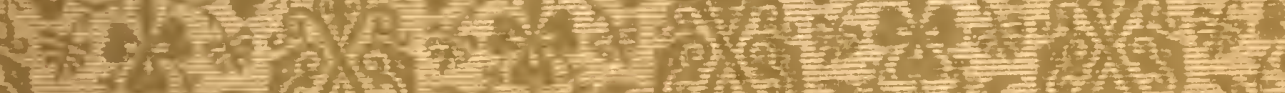

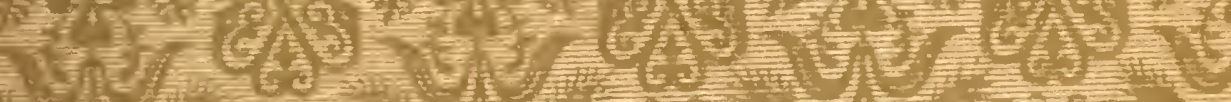

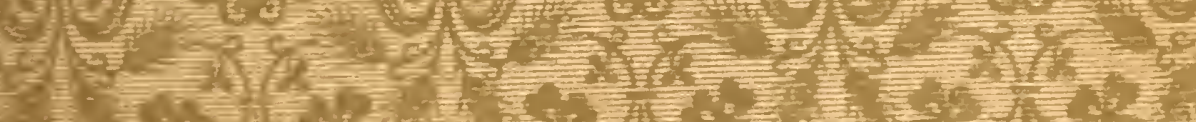
$x^{2}$
ent

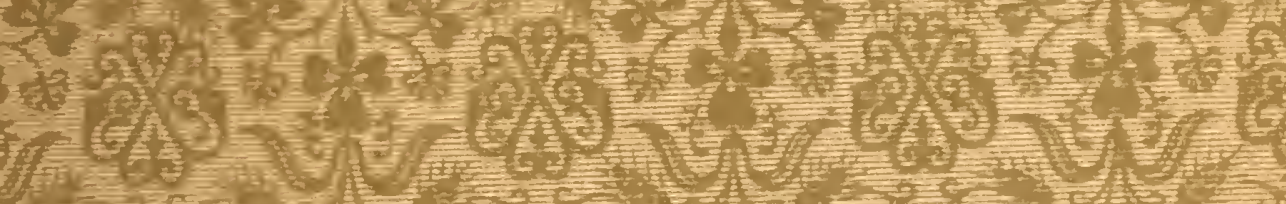

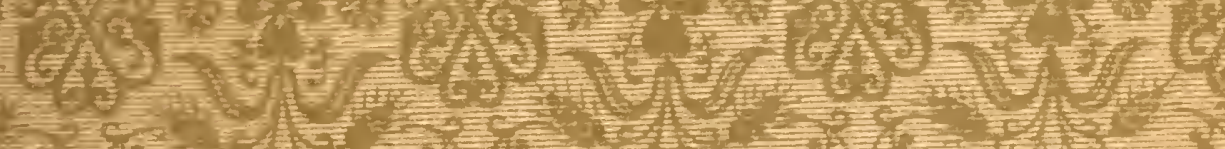
atist

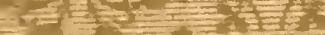
$5 \sum^{2}=1$

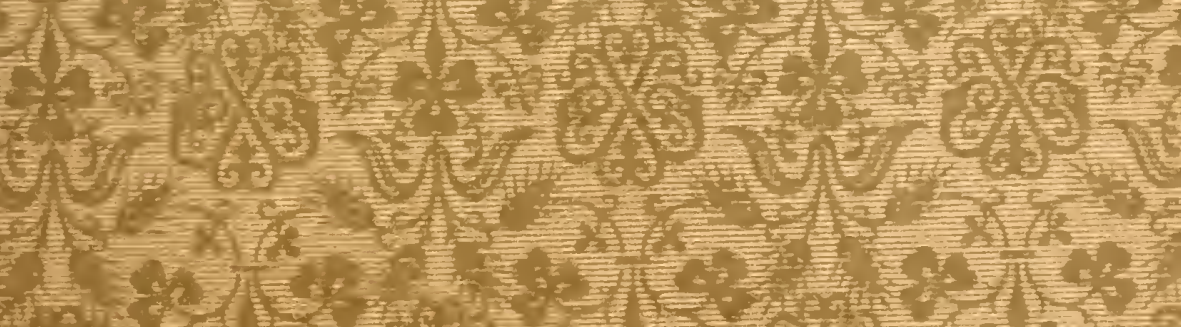


Digitized by the Internet Archive in 2016 


\section{-}




\section{Handbuch}

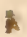

des

Getreidebaues

von

Prof. Dr. Friedr. Körnicke und

Docent iter Botanik

an der hönigljchen Landwirtschaftlichen Akademie zn Poppelsctorf.

Zweiter Band:

Die Sorten und der Anbau.

BERLIN.

VERLAG VON PAUL PAREY.

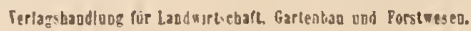

1885. 


\section{Die Sorten IT Sorten und der Anbau}

des

\section{Getreides.}

Bearbeitet von

\section{Dr. Hugo Werner,}

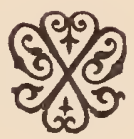

LIBRARY NEW YORK BOTANICAL (IARI)EN

BERLIN.

VERLAG VON PAUL PAREY. Ferlagshandlogg für Landgirtschath Gartenbau nad Porstresen. 
$S B 189$

. Wh

Universitäts-Buclıdruckerei von Carl Georgi in Buuu. 


\section{Inhalt.}

\section{Allgemeiner Teil.}

Der Einfluss des Klimas auf die Getreideproduktion . . . .

Die Verschiedenheit der Getreidearten bezüglich ihrer Bodenansprüche . . . . . . . . . . . . . . . . . . 14

Die Düngung des Getreides . . . . . . . . . . . . . 22

Die Stellung der Getreidearten in der Fruchtfolge . . . . . 32

Die Bodenbearbeitung zum Getreidebau . . . . . . . . . 39

Die Saat des Getreides . . . . . . . . . . . . . . 45

Die Pflege des Getreides . . . . . . . . . . . . . . 75

Erntemethoden, Ausdrusch und Auf bewahrung des Getreides . . 83

Die Erträge und Nahrungsbestandteile des Getreides . . . . . 119

Getreideproduktion, Getreidekonsumtion und Getreidehandel . . . 127

\section{Besonderer Teil.}

Sorten und Anbau des Weizens . . . . . . . . . . . . 209

, Roggens . . . . . . . . . . . . 530

der Gerste . . . . . . . . . . 600

des Hafers . . . . . . . . . . . . 681

"Maises . . . . . . . . . . . . 772

der Rispenhirse . . . . . . . . . . . 871

" Kolbenhirse . . . . . . . . . . . 890

"Bluthirse . . . . . . . . . . . 908

" Mohrhirse . . . . . . . . . . . 909

des Reises . . . . . . . . . . . . 938 
Universitäts-Buchdruckerei von Carl Georgi in Bonn.

$\longrightarrow$ 


\section{LIBRART \\ NEW YORK \\ BOTANICAL \\ (iARUEN \\ Allgemeiner Teil.}

\section{Der Einfluss des Klimas auf die Getreideproduktion.}

Die physiologischen Vorgänge in den Pflanzen, wie Keimung, Assimilation, Wachstum, Reife, sind von einem gewissen Wärmegrade abhängig, denn die genannten Processe können erst bei einem gewissen Temperaturminimum beginnen, werden energischer mit Zunahme der Wärme, um schliesslich bei einem Temperatur-Optimum den Höhepunkt zu erreichen. Von nun ab deprimirt jedoch eine weiter steigende Temperatur diese physiologischen Vorgänge, bis sie bei Erreichung eines Temperaturmaximunts aufhören.

Aus diesen Gründen ist es vorzugsweise die Verteilung der Wärme, worauf dic Verbreitıng der Getreidearten auf der Erde beruht.

Bekanntlich nehmen die Linien gleicher mittlerer Jahreswärme (Isothermen) nach den Polen zu an Wärme ab, fallen aber nicht überall mit den Parallelkreisen zusammen, sondern senken sich beträchtlich auf der östlichen Seite der Weltteile, daher diese unter gleichem Breitengrade in der Regel kälter als die westliche ist.

Eine noch grössere Beachtung für die Getreidekultur verdienen jedoch die Linien der mittleren Sommerwärme (Isotheren), sowie die der mittleren Winterkälte (Isochimenen), da von ihrem Verlauf bäufig. die Möglichkeit der Kultur einer gewissen Getreideart oder Sorte abhängt.

Im wesentlichen steigen die Isotheren von den Küsten nach dem Innern der Kontinente an und erst tiefer im Festlandc besitzen die Sommer bei einerlei Breitc auch gleiche Temperatur. In Gegensatz hicrzu sinken die Isochimenen im Festlande herab und steigen an den Küsten; dieses Auseinandertreten der beiderlei Linien zeigt also an, dass im Innern der Kontinente, bei gleicher Mitteltemperatur, die Sommer heisser und die Winter kälter als an den Kiisten sind. Diese Verschicdenheit des Klimas bei gleichel Polhöhe wird als Kontinental- und Sceklima bezeichnet.

Die Sỉdwestwinde bringen in Winter an die Westkïste Europas und Amerikas warme und feuchte Luft, deren Wasserdämpfe sich 
hier zu einem grossen Teil niederschlagen, wodurch nicht nur latente Wärme frei, sondern auch die Bodenstrahlungr geringer wird, woraus sich die hohe Temperatur dieser Jahreszeit in den rom Seeklima beeinflussten Ländern erklärt. Im Sommer dagegen wird durch die Nähe der See die Temperatur erniedrigt.

Ansserdem ist Europa in der glïcklichen Lage, dass seine nordwestlichen Küsten durch den Golfstroin beträchtlich erwärmt wcrden.

In dem Masse als der feuchtwarme Seewind in das Innere der Kontinente vordringt, verliert er, namentlich sobald Kondensatoren der Feuchtigkeit, wie grosse Waldungen und Gebirgsziige auf seinem Wege liegen, an Feuchtigkeit und Wärme, und trifft er hiernach auf baumlose und an grossen Wasserflächen arme Ebenen, z. B. auf die Steppen des siidöstlichen Europas, dann nimmt der nun trockene Wind noch die etwa Forhandene Feuchtigkeit begierig auf, ohne dieselbe der Ebene aus Mangel an Kondensatoren wieder zurïckzugeben.

Dieses extreme Kontinentalklima characterisirt sich durch jähe Temperaturspriinge, austrocknende Winde, heisse, meist trockene Sommer mit kühlen Nächten und starken Thauniederschlägen und kurze aber kalte Winter.

Selbstrerständlich ist in dem Steppenklima, z. B. in Ungam, die Laudwirtschaft weniger vom Jahresmittel als ron den Extravaganzen des Klimas ubberhaupt abhängig, da Frost oder Dürre zur Unzeit die Ernte in anssergewöhnlichem Masse benachtheiligen können.

Gemeinhin ist die Witterung im zeitigen Friihjahr dem Wachstum der Gewächse sehr giinstig, da weder Feuchtigkeit noch Wärme fehlen; doch gerade dieses ausserordentlich friihe und kräftige Austreiben wird ihnen hänfig zum Nachtheil, indem mit Bestimmtheit bis Ende April, gewöhnlich aber bis Ende Mai und selbst noch im Juni Nachtfröste rorkommen, welche sie schädigen und die Hoffnungen des Landwirtes wicderum zerstören.

Leberdaucrn nun auch die Saaten dic Frühjahrsfröste und leiden sie nicht durch die häufig abnorme Bodennässe im Früljjahr, so steht ihnen noch der harte Kampf mit der Dürre in den Sommermonaten beror.

Den Wintersaten schadet die Diirc am weniosten, da ilure Entwickelnng im Herbst und zeitigen Frühjahr durch Mangel an Feuchtigkeit selten gestört wird, auch reifen sie zeitiger als die Sommersaaten, können sich also lcichter der Diirre entziehen; werden dagegen die Sommersaten so zeitig gesäet, dass sie zur Zeit der eintretenden Diirre schon reif sind, so leiden sie leicht durch Nachtfröste und anderenfalls bei später Aussaat durch Dürre, mithin dieselben weit unsichere krichte sind.

Znr Keunzeichung der Unterschicde zwischen dem Sec-, Kontinental- und Steppen-Klima geben wir in der nachfolgenden Tabelle 
die Höhe des Regenfalls, sowie die Temperaturen in den Niederlanden (Seeklima), in Norddeutschland (Kontinentalklima), und Ungarn (Steppenklima).

\begin{tabular}{|c|c|c|c|c|c|c|}
\hline & \multicolumn{2}{|c|}{ Niederlande } & \multicolumn{2}{|c|}{ Ungarn } & \multicolumn{2}{|c|}{$\begin{array}{l}\text { Norddeutschland } \\
\text { (alte Provinzen) }\end{array}$} \\
\hline & $\begin{array}{c}\text { Regenfall } \\
\mathrm{mm} .\end{array}$ & $\begin{array}{c}\text { Tem- } \\
\text { peratur } \\
0 \mathrm{C} \text {. }\end{array}$ & $\begin{array}{c}\text { Regenfall } \\
\text { mm. }\end{array}$ & $\begin{array}{c}\text { Tem- } \\
\text { peratur } \\
0 \mathrm{C} .\end{array}$ & $\underset{\text { Regenfall }}{\mathrm{mm} .}$ & $\begin{array}{c}\text { Tem- } \\
\text { peratur } \\
0 \mathrm{C} .\end{array}$ \\
\hline $\boldsymbol{n}$ & 19 & +9.1 & 12 & +11 & 13 & +5.95 \\
\hline $\mathrm{im} \mathrm{S}$ & 21 & +17.7 & $14:$ & +20.97 & 233 & +16.31 \\
\hline im Herbst & 193 & +10.1 & 126.9 & +10.70 & 141.21 & $\begin{array}{l}1.23 \\
+\quad 7 .\end{array}$ \\
\hline im Winter & 154 & +2.4 & 94 & $+\quad 0.85$ & 111.51 & $-\quad 1.45$ \\
\hline Jährl. Durchschnitt & 692 & +9.8 & 485.5 & +10.92 & 620.73 & +7.01 \\
\hline
\end{tabular}

Nach Alexander von Humboldt lassen sich in Betreff der Uebereinstimmung der Temperaturverhältnisse und der Hauptcharaktere der Vegetation acht pflanzengeographische Zonen aufstellen:

1. Die Aequatorialzone $15^{0}$ beiderseits vom Aequator mit 28-36 ${ }^{\circ}$ C. mittlerer Jahrestemperatur. (Palmen, Bananen.)

2. Die tropische Zone vom $15-23 .^{0}$ nördlicher und südlicher Breite mit $26-23{ }^{0}$ mittlerer Jahrestemperatur. (Baumfarren, Zuckerrohr, Reis, Mais, Sorghum, Tabak, Indigo, Pfeffer.)

3. Die subtropische Zone vom $23-34{ }^{0}$ nördlicher und suidlicher Breite mit $23-17^{\circ}$ mittlerer Jahrestemperatur (Kaffee, Thee, Baumwolle, Reis, Mais, Sorghum).

4. Die wärmere gemässigte Zone vom $34-45 .{ }^{0}$ nördlicher und siidlicher Breite mit $17-12^{0}$ mittlerer Jahrestemperatur. (Weinstock, Feigenbaum, Oelbaum, Citronen, Reis, Mais, Sorghum und anderes Getreide).

5. Die kältere gemässigte Zone vom $45-58 .{ }^{\circ}$ nördlicher und siudlicher Breite mit $12-6^{0}$ mittlerer Jahrestemperatur (Region des Laub- und Tannenwaldes. Sie umfasst hauptsächlich die Ackerbautreibenden Districte mit ihrem Reichtum an Cerealien, namentlich an Wintergetreide.)

6. Die subarktische Zone vom 58-66. ${ }^{0}$ nördlicher und siidlicher Breite mit $5-4^{0}$ mittlerer Jahrestemperatur. (Zone der Nadelhölzer, Weidereviere. Bis auf weniges Sommergetreide verschwinden die Culturpflanzen.)

7. Die arktische Zone vom $66-72 .{ }^{\circ}$ mit $2-0^{0}$ mittlerer Jahrestemperatur. (Strauch- und Knieholz, Renntiere. Ackerbau hört auf.)

8. Die Polarzone rom $72 .{ }^{\circ}$ bis zu den Polen, die Jahrestemperatur steht unter dem Gefrierpunkt. (Moose, Flechten.) 
Von dem Getreide ${ }^{1}$ ) reicht die Gerste am höchsten nach Norden und werden als nördlichste Punkte unter dem $70 .{ }^{\circ}$ n. Br. Alten und Elvbaken im norwegischen Lappland angegeben, im schwedischen Lappland wird nach Wahlenberg noch bis Kyro $\left(69^{\circ} 40^{\prime}\right)$ Gerste gebaut, in Finnland sinkt die Anbaugrenze schon auf $67^{\circ}$, bei Archangel auf $65-66^{\circ}$, am Ural auf $60^{\circ}$, in der Mitte Sibiriens anf $58-59^{\circ}$, in Kamschatka auf $54^{\circ}$ und in Nord-Anerika auf $55^{\circ}$ herab. Auf den Far-Öer-Inseln gedeiht Gerste noch unter dem $62^{\circ}$ n. Br., doch reift sie jetzt nicht nehr auf Island, was in friiherer Zeit der Fall gewesen sein soll.

Die äusserste Grenze des Sommerroggens liegt nach Schubeler auf der Westseite Scandinaviens unter dem $69^{\circ} \mathrm{n}$. Br., auf der Ostseite unter dem $65-66 .{ }^{\circ}$ und sinkt in Innerrussland auf $62,5{ }^{0}$ herab.

Die Polargrenze des Hafers findet sich in Norwegen unter dem $65 .{ }^{\circ} \mathrm{n}$. Br., in Schweden (oberhalb Umea) unter dem 63,5. ${ }^{\circ}$, und fälit in Russland mit der Roggengrenze zusammen. In Schottland wird Hafer noch unter dem 58,5. ${ }^{\circ} \mathrm{n}$. Br. gebaut.

Nach Berghaus liegt die Polargrenze des Weizens an der Westkiiste Norwegens unter dem $64 .{ }^{0} \mathrm{n}$. Br. (nach Schübeler ist wahrscheinlich Skibotten in Norwegen unter $69^{\circ} 28^{\prime}$ der nördlichste Punkt, wo Weizen reif geworden, denn er erhielt 1870 aus dem Kirchspiel Lyngen eine dort gereifte Weizenprobe). Im mittleren Schweden reicht der Weizenbau bis zum $62 .{ }^{\circ}$ und sinkt in Russland auf $60-59^{\circ}$, im Innern Nordamerikas auf $58^{\circ}$ und an der Ostkuiste sogar auf $50^{\circ}$ herab. In Schottland reicht die Grenze des Weizenbaues bis zum $58 .{ }^{\circ} \mathrm{n}$. Br.

Die siddiche Polargrenze dieser vier Getreidearten erstreckt sich ungefähr bis zum $50{ }^{\circ} \mathrm{s}$. Br., denn wir erhielten durch den deutschen Ministerresidenten, Herrn von Gülich, zu Valparaiso, dureh Vermittelung des landwirtschaftlichen Museums zu Berlin 1880 diese vier Getreidearten aus der chilenischen Kolonie Punta Arenas de Magellanes.

Der Mais reicht als Getreidepflanze in Amerika sehr weit nach Norden, so wird als nördlichster Punkt Cumberland-House ${ }^{2}$ ) in Canada unter dem $54 .{ }^{\circ} \mathrm{n}$. Br. und dem 105 . Längengrade angegeben. während er in Europa seine Anbaugrenze schon unter dem 50-52. n. Br. findet. Nach Osten zu senkt sich dieselbe in der Bukowina bis zum $49.0^{\circ}$ und in Suid-Russland (Charkow) bis zum 50. ${ }^{\circ}$, in Asien soll sie noch weiter heruntergehen, so fand Bunge bei Peking Mais nicht mehr angebaut.

1) Vergl, De Candolle. Géogr. bot. rais. 1855. II. 334.

2) De Candolle. A. a. 0. 1858. Ir. 337. 
Die Südgrenze liegt in Amerika ${ }^{1}$ ) unter dem $40^{\circ}$ s. Br.

Annähernd den gleichen Verbreitungsbezirk mit dem Mais besitzen in Europa die Mohrhirse, sowie auch die Kolben- und Rispenhirse, wenngleich letztere noch am weitesten nach Norden geht, nämlich in Hinterpommern bis zum $53 .^{\circ} \mathrm{n}$. Br., während die Zuckermohrhirse in Europa nur bis zum $45 .{ }^{\circ}$, in Asien bis zum $30 .{ }^{\circ}$ und in Amerika bis zum $40 .{ }^{\circ} \mathrm{n}$. Br. reift.

Der Reis erreicht in Ober-Italien unter dem $400^{\circ} \mathrm{n}$. Br. seine Anbaugrenze.

Für den Pflanzenbau ist aber auch die vertikale Wärmeverteilung von allergrösster Wichtigkeit, denn von der meeresgleichen Ebene in das Gebirge hinaufsteigend, finden wir im Allgemeinen dieselbe Abstufung der Temperaturverhältnisse wieder, wie dies der Fall ist vom Aequator nach den Polen hin. Durchschnittlich darf für Deutschland angenommen werden, dass die Temperatur mit einer Erhebung von $160 \mathrm{~m} \mathrm{um} 1^{\circ} \mathrm{C}$. sinkt.

Diese sich mit der Zunahme der Höhe verringernde Temperatur bedingt jedoch nicht allein, dass sich mit der Erhebung iuber der Erdoberfläche der Anbau der Kulturgewächse ändert, sondern es iibt hierin auch die Lage, ob Süd- oder Nord-Abhang, einen bedeutenden Einfluss aus, ebenso der Eintritt der Nachtfröste, die Dauer des Winters, die Höhe des Schncefalles etc.

Wie wir gesehen, übersteigt die Kultur der Gerste nach Norden ein wenig die des Roggens, bedeutender dagegen die des Hafers, doch nähern sie sich in ihren Höhengrenzen derart, dass es sich kaum feststellen lässt, welche Getreideart höher hinaufgeht. Hier entseheidet die Lage der Dörfer, der Abhang, die Natur des Terrains, sowie das Bedürfniss der Bevölkerung.

Auf den Far-Öer-Inseln erhebt sich nach Forchham auf der Nordseite die Gerste bis zu $60 \mathrm{~m}$, dagegen auf der Stidseite bis zu 102 m Höhe. In Schottland ${ }^{2}$ ) liegt die Höhengrenze der Gerste bei $487 \mathrm{nl}$, in Nord-England bei $609 \mathrm{~m}$, im südlichen Norwegen bei $650 \mathrm{~m}$, in Deutschland bei $800 \mathrm{~m}$, in den Karpathen bei $1000 \mathrm{~m}$. In den Alpen stellt sich die Maximalgrenze in der Mittelschweiz auf $1300 \mathrm{~m}$, in Bern auf $1510 \mathrm{~m}$, im östlichen Teil der Centralalpen der Schweiz auf $1689 \mathrm{~m}$, in Graubündten auf $1754 \mathrm{~m}$ und im Wallis auf $1984 \mathrm{~m}$. In den Pyrenäen beträgt die durchschnittliche Höhengrenze $1640 \mathrm{~m}$, in den Cordilleren unter der Breite von Valparaiso $1689 \mathrm{~m}$, unter der von Peru $3248 \mathrm{~m}$, doch wird sie noch bis zu Höhen von $4482 \mathrm{~m}$ als Grünfutter cultivirt, in Armenien $2700 \mathrm{~m}$ und im Himalaya $4600 \mathrm{~m}$.

1) Meyer, Grundriss d. Pfl.-Geogr. 354.

2) Vergl. De Candolle, a. a. O. I, 376. 
Der Roggen erreicht im suidlichen Norwegen unter dem 66. ${ }^{0} \mathrm{n}$. Br. eine Höhe von $627 \mathrm{~m}$, in Nord-England $609 \mathrm{~m}$, in Mitteldeutschland $920 \mathrm{~m}$, in der europäischen Türkei $1050 \mathrm{~m}$, in der Schweiz bei Toggenburg 1104 m, ,im Wallis 1617 (Max. : $1984 \mathrm{~m}$ ), in den mittleren Pyrenäen Nord-Abhang $1592 \mathrm{~m}$, Süd-Abhang $1689 \mathrm{~m}$; in den Apenninen $1535 \mathrm{~m}$ (Max. : $2046 \mathrm{~m}$ ), in Siid-Italien $1575 \mathrm{~m}$, Siidseite der Alpen $1624 \mathrm{~m}$, St. Remi $1754 \mathrm{~m}$, Aetna $1782 \mathrm{~m}$, in der Krim 2000 m, zu Allos in der Provence $2200 \mathrm{~m}$, Siidseite der Sierra Nevada $2469 \mathrm{~m}$.

Die Höhengrenze des Hafers stellt sich in Schottland auf $487 \mathrm{~m}$, in der Auvergne und den Pyrenäen auf $1000-1300 \mathrm{~m}$, in den Alpen auf $1800 \mathrm{~m}$.

Der Weizen steigt in Norwegen unter dem $64 .{ }^{\circ}$ n. Br. noch $300 \mathrm{~m}$ an, erreicht im Suidabhang der Alpen Höhen bis zu $1264 \mathrm{~m}$, und nach Humboldt ${ }^{1}$ ) in Asien auf den Plateaux von Doompo und Daba in Tibet Höhen ron $4549 \mathrm{~m}$.

Der Mais erreicht seine Höhengrenze in den Pyrenäen ${ }^{2}$ ) bei $1566 \mathrm{~m}$, während er in der kälteren, gemässigten Zone Europas nicht höher als $600-700 \mathrm{~m}$ ansteigt.

Der Reis geht an Siidabhang des Himalaya bis zu Höhen rou $1600 \mathrm{~m}$ empor.

Es ist nun hicrnach die Annahme berechtigt, dass eine Hauptbedingung der Kulturfähigkeit der Pflanzen in der für den Lebensprocess genügend vorhandenen Wärme zu snchen ist, welche sich jedoch nicht gleichmässig iiber die ganzc Vegetationszeit zu verteilen braucht, viclmchr scheinen gewisse Temperatur-Differenzen während der cinzelnen Vegetationsphasen für das Gedeihen der Pflanzen sehr güustig zu sein. Gemeinhin bedürfen sie zum Keimen den geringsten Temperaturgrad, einen höheren für das Wachstum der vegetativen Organe und den höchsten zur Zeit der Stoffumbildung und Ablagerung der Reservestoffe.

Landwirtschaftlich ist es nun wichtig, feststellen $\mathrm{zu}$ können, ob im koncreten Fall die Temperatur einer Gegend zur lohnenden Produktion einer Pflanze ausreicht, wobei allerdings die Widerstandsfähigkeit des Wintergetreides gegen Frost oder starke, längere Zeit andauernde Schneebedeckung, und des Sommergetreides gegen Spätfröste $\mathrm{zu}$ berïcksichtigen wäre.

Unter der Annahme, dass sich bis zu eincm gewissen Grade die Dauer der Vegetation nach der vorhandenen Wärmemenge richten wird, wäre es notwendig, die mittlere Temperatur derjenigen Periode kennen zu lemen, in welcher sich die Vegetation vollendet.

1) Fragm. as. II. 371 .

2) Massot, Compte rendu de l'Acad. des sc. 1843. II. 751. 
Zuerst war es Boussingault ${ }^{1}$ ), der diese Frage zu lösen suchte und zu dem Resultat gelangte, dass die Daner der Vegetation zu der mittleren Temperatur im umgekehrten Verlı̈ltnis zu stehen scheine, so dass, wenn man die mittlere Temperatur mit der Anzahl der Tage, wälrend welcher eine und dieselbe Pflanze in den verschiedenen Klimaten vegetirt, multiplicirt, man fast gleiche Zahlen erhält.

Boussingault und nach ihm Andere, z. B. Meister, haben nun für die Getreidearten Berechnungen aufgestellt, aus denen sich aber nach unserer Ueberzengung nur schliessen lisst, dass der Vegetationsprocess um so schneller verläuft, je höher, innerhalb gewisser Grenzen die Temperatur steigt, aber nicht, dass eine Pflanze unter allen Umständen zu ilurer Entwickelung glcicher Wärmemengen bedarf.

Zum Beweisc, dass der Boussingaultsche Satz auf das Wintergetreide nicht einfach iibertragen werden kann, führen wir nachstchende durch Körnicke in Poppelsdorf ausgeführte Versuche an.

Um den Einfluss der Saatzeit auf die Reifezeit zn prüfen, wurden zwei Kontrollversuche gemacht, einmal mit Johannis-Roggen, sodann mit Probsteier Roggen.

1. Entwickelung des Johannis-Roggens bei verschiedener Aussatzeit.

\begin{tabular}{|c|c|c|c|c|c|c|c|c|c|}
\hline $\begin{array}{l}\text { Nr. } \\
\text { der } \\
\text { Aus- } \\
\text { saat. }\end{array}$ & $\begin{array}{l}\text { Aus- } \\
\text { saat- } \\
\text { zeit. }\end{array}$ & $\begin{array}{c}\text { Alles } \\
\text { ge- } \\
\text { keimt. }\end{array}$ & $\begin{array}{c}\text { Be- } \\
\text { ginn } \\
\text { Scho }\end{array}$ & $\begin{array}{l}\text { Ende } \\
\text { es } \\
\text { sens. }\end{array}$ & $\begin{array}{c}\text { Be- } \\
\text { ginn } \\
\text { der }\end{array}$ & $\begin{array}{l}\text { Ende } \\
\text { Blüte. }\end{array}$ & $\begin{array}{c}\text { Ernte- } \\
\text { zeit. }\end{array}$ & $\begin{array}{c}\begin{array}{c}\text { Länge } \\
\text { der } \\
\text { Aehren. } \\
\mathrm{cm} .\end{array}\end{array}$ & $\begin{array}{c}100 \text { Körner im } \\
\text { Durchschnitt } \\
\text { 3er Wägungen. } \\
\text { gr. }\end{array}$ \\
\hline $\begin{array}{l}1 * \\
1 \mathrm{a} \\
1 \mathrm{~b} \\
1 \mathrm{c} \\
1 \mathrm{~d} \\
1 \mathrm{e} \\
1 \mathrm{f} \\
1 \mathrm{~g}\end{array}$ & $\begin{array}{c}24 / 8 \\
8 / 9 \\
2 / 10 \\
30 / 10 \\
27 / 11 \\
23 / 12 \\
20 / 1 \\
5 / 2\end{array}$ & $\begin{array}{c}8 / 9 \\
15 \% 9 \\
30 \% 10 \\
26 / 11 \\
16 / 12 \\
20 / 1 \\
16 / 2 \\
1 / 3\end{array}$ & $\begin{array}{l}19 / 5 \\
21 / 5 \\
21 / 5 \\
24 / 5 \\
27 / 5 \\
3 / 5 \\
3 / 6 \\
7 / 6\end{array}$ & $\begin{array}{l}25 / 5 \\
26 / 5 \\
26 / 5 \\
31 / 5 \\
2 / 6 \\
5 / 6 \\
5 / 6 \\
8 / 6\end{array}$ & $\begin{array}{r}5 / 6 \\
5 / 6 \\
7 / 6 \\
8 / 6 \\
8 / 6 \\
11 / 6 \\
11 / 6 \\
11 / 6\end{array}$ & $\begin{array}{l}14 / 6 \\
14 / 6 \\
17 / 6 \\
17 / 6 \\
17 / 6 \\
22 / 6 \\
22 / 6 \\
24 / 6\end{array}$ & $\begin{array}{l}18 / 7 \\
18 / 7 \\
17 / 7 \\
21 / 7 \\
23 / 7 \\
27 / 7 \\
31 / 7 \\
4 / 8\end{array}$ & $\begin{array}{r}12-15 \\
11-18 \\
13-15 \\
13-17 \\
12-16 \\
12-24 \\
11-13 \\
9-13\end{array}$ & $\begin{array}{l}2.14 \\
2.30 \\
2.06 \\
2.29 \\
2.32 \\
2.55 \\
2.38 \\
2.29\end{array}$ \\
\hline
\end{tabular}

1) Die Landw. in ihren Bezieh. z. Chemie etc. I1. 435. 
2. Entwickelung des Probsteier Roggens bei verschiedener A ussatzeit.

\begin{tabular}{|c|c|c|c|c|c|c|c|c|c|}
\hline $\begin{array}{l}\text { Nr. } \\
\text { der } \\
\text { Aus- } \\
\text { saat. }\end{array}$ & $\begin{array}{l}\text { Aus- } \\
\text { saat- } \\
\text { zeit. }\end{array}$ & $\begin{array}{c}\text { Alles } \\
\text { ge- } \\
\text { keimt. }\end{array}$ & $\begin{array}{c}\text { Be- } \\
\text { ginn } \\
- \text { Scho }\end{array}$ & $\begin{array}{l}\text { Ende } \\
\text { es } \\
\text { sens. }\end{array}$ & $\begin{array}{l}\text { Be- } \\
\text { ginn } \\
\text { der }\end{array}$ & $\begin{array}{l}\text { Ende } \\
\text { Blüte. }\end{array}$ & $\begin{array}{c}\text { Ernte- } \\
\text { zeit. }\end{array}$ & $\begin{array}{c}\text { Länge } \\
\text { der } \\
\text { Aehren. } \\
\text { cm. }\end{array}$ & $\begin{array}{c}100^{\circ} \text { Körner } \\
\text { im Durchschnitt } \\
\text { 3er Wägungen. } \\
\text { gr. }\end{array}$ \\
\hline $\begin{array}{l}2 \mathrm{a} \\
2 \mathrm{~b} \\
2 \mathrm{c} \\
2 \mathrm{~d} \\
2 \mathrm{e} \\
2 \mathrm{f} \\
2 \mathrm{~g}\end{array}$ & $\begin{array}{c}8 / 9 \\
2 / 10 \\
30 / 10 \\
23 / 11 \\
23 / 12 \\
20 \% 1 \\
5 / 2\end{array}$ & $\begin{array}{l}19 / 9 \\
30 / 10 \\
26 / 11 \\
16 / 12 \\
20 / 1 \\
16 / 2 \\
4 / 3\end{array}$ & $\begin{array}{l}10 / 5 \\
12 / 5 \\
16 / 5 \\
19 / 5 \\
23 / 5 \\
28 / 5 \\
31 / 5\end{array}$ & $\begin{array}{r}16 / 5 \\
17 / 5 \\
21 / 5 \\
26 / 5 \\
28 / 5 \\
2 / 5 \\
5 / 6\end{array}$ & $\begin{array}{r}2 / 6 \\
2 / 6 \\
4 / 6 \\
5 / 6 \\
8 / 6 \\
11 / 6 \\
11 / 6\end{array}$ & $\begin{array}{l}11 / 6 \\
11 / 6 \\
11 / 6 \\
11 / 6 \\
17 / 6 \\
18 / 6 \\
19 / 6\end{array}$ & $\begin{array}{l}14 / 7 \\
16 / 7 \\
21 / 7 \\
23 / 7 \\
27 / 7 \\
31 / 7 \\
4 / 8\end{array}$ & $\mid \begin{array}{r}13-16 \\
12-16 \\
13-17 \\
13-15 \\
10-16 \\
8-14 \\
9-13\end{array}$ & $\begin{array}{l}2.53 \\
2.69 \\
2.91 \\
2.84 \\
3.03 \\
2.72 \\
2.88\end{array}$ \\
\hline
\end{tabular}

Die obigen Versuche zeigen, nach Hinzufügung der während der Vegetationsperiode verbrauchten Wärmesummen, dass bei rerschiedener Aussaatzeit derselben Sorte Wintergetreide an demselben Orte sehr verschiedene Wärmequanta zu ihrer Ausbildung verbraucht worden sind. Setzt man z. B. bei 1a das Ende des Keimens auf den 15. September und bei $1 \mathrm{~g}$ auf den 1. März, so erhält man an konsumirter Wärme für

$\begin{array}{cccc} & \text { Minimum } & \text { Maximum } & \text { Mittel } \\ 1 \mathrm{a} & 1833.4^{\circ} \mathrm{C} . & 3785.9^{\circ} \mathrm{C} . & 2809.6^{\circ} \mathrm{C} . \\ 1 \mathrm{~g} & 1204.3^{\circ}, & 2531.5^{\circ}, ; & 1867.0^{\circ},\end{array}$

Die Wärmesumme, wclche $1 \mathrm{~g}$ gebrauchte, ist also um ein Drittel geringer, als die ron 1 a.

Demnach ist es, zunächst für Wintergetreide misslich, auf die in einer Vegetation an verschiedenen Orten gebrauchten Wärmequanta besonderes Gewicht legen zu wollen, da zu günstiger Saatzeit ausgesäetes Wintergetreide gleichzeitig reift, wenn auch die Saatzeiten vier Wochen auseinanderliegen, so erntete $H$. Thiel ${ }^{1}$ ) Roggen, der vom 14. October bis zum 25. November, und Weizen, der vom 9. October bis zum 27. November in achttägigen Zwischenräumen gesäet war, gleichzeitig.

Was die übrigen Resultate dieses Versuches betrifft, so ist es auffallend, wie wenig Unterschied die verschiedene Aussaatzeit in der Grösse der Achren und der Körner hervorrief und ebenso zeigte auch die Höhe der Halme keine auffallenden Verschiedenheiten. Indessen traten auf den spät besäeten Becten zwischen den normalen vielc niedrigere

1) Zeitschr. f. d. landw. Ver. d. Grossh. Hessen. $1872 \mathrm{Nr} .38$. 
Halme mit kurzer spät blïhender Aehre auf, weshalb der Bestand wesentlich diinner und demzufolge der Ertrag geringer wurde.

Ausscrdem entspricht die Höhe einer Tempcratur durchaus noch nicht dem Empfangen ciner gewissen Wärmesumme, denn die Temperatur wird im Schatten bestimmt, während sich doch im direkten Sonnenlicht die Erwärmung wesentlich steigert.

Von diesen Gesiehtspunkten aus sind dic nachfolgenden Angahen über die notwendige Wärmesumme der Getreidearten zu betrachten, und dieselben nur für sehr allgemeine Vergleichungen in Betracht zu ziehen, zumal der Sortencharacter des Getreides in Bezug auf die Vegetationszeit ein schr verschicdener ist.

Nach unscren Ermittelungen scheinen die Getreidearten nachfolgende Temperatursummen zil beanspruchen:

Minima - Maxima.
$1960-2534^{0} \mathrm{C}$.
$1545-2120^{\circ} "$
$1700-2400^{\circ} "$
$1400-1800^{\circ} "$
$1700-2100^{\circ} "$
$1160-1800^{\circ} "$
$1200-2500^{\circ} "$
$1700-3500^{\circ} "$
$1500-2500^{\circ} "$
$1800-3000^{\circ} "$
$2500-4000^{\circ} "$
$3500-4500^{\circ} "$

Dic zweitc Wachstumsbedingung ist das Licht, das derselben Quclle wie die Waime entstammend, sich auch ebenso mngleichmässig ïber dic Erdoberfläche verteilt, indem es vom Aequator nach den Polen zu an Intensität abnimmt, doch reift noch in der arktischen Zone Getreide mit kurzer Vegetationsperiode, was sich daraus erklärt, dass, entsprechend der Polnähe die Sonne in jenen Breiten im Sommer weit längere Zeit lenchtet als in der Aequatornähc, daher die Pflanzen durch die fast ununterbrochene Erwärmung und Beleuchtung zur Frnchtansbildung gelangen, und wenn auch weniger, doch eine gewisse Nenge organischer Substanz crzengen.

In der Nïhe der Kiisten wird die Besonnung häufiger durch Nebel oder Wolken während der Vegetationsperiode der Pflanzen behindert, als im Innern der Kontinente, mithin sich auch in dieser Beziehung ein See- und ein Kontinental-Klima nnterscheiden lässt.

Die dritte Wachstumsbedingung ist das Wasser; welches den Pflanzen nur durch atmosphärische Niederschläge und hauptsächlich durch den Regen geboten wird.

Dem Landwirt muss nun daran liegen, zu wissen, ob die Nieder- 
schläge während der Vegetationszeit seiner Kulturgewäichse, unter Berücksichtigung der wasserfassenden und wasserhaltenden Kraft seines Bodens, denn dieser sammelt, erhält und verteilt den Regen je nach seiner physikalischen Beschaffenheit in sehr verschiedenem Grade, zur Produktion einer Míttelernte ansreichen. Helliegel ${ }^{1}$ ) fand nun, dass zur Befriedignng des Wasscrbediirfnisses der Pflanzen der Fenchtigkeitsgehalt des Bodens 40-60 Proc. (nach Fittbogen bei Hafer 60 - 80 Proc.) sciner wasserhaltenden Kraft danernd entsprechen soll.

Bei normaler Wasserzufuhr während der Vegetationszeit wird sich auch, unter sonst giinstigen Verhältnissen, die Pflanze normal entwickeln können, doch wechseln häufig trockne und feuchte Perioden mit einander $a b$, welche Wachstnmsstörnugen zur Folge haben.

Bei knapper Wasserversorgung in der Jugend und bei normaler Wassergabe zur Blütezeit bildet die Pflanze vortreffliche Körner, aber ihr Stroh nur mangelhaft ans, während besonders die Körnerbildung leidet, wenn den jiingeren Pflanzen eine normale und in der Blïtezeit eine mangelhafte Wasserzufuhr zu teil wird.

Es sind nun vielfach Untersuchnngen iiber das Wasserquantum, welches eine unit Getreide bestellte Fläche beansprucht, angestellt worden, doch dic Resultate derselben zur Zeit noch mit grösster Vorsicht aufzunehmen, denn bevor nicht die Pflanzenphysiologie durch exakte Untersuchungen die minimalen und maximalen Wassermengen bestimmt hat, welche durch cine bestimmte Fiäche verschiedener Pflanzen verdunstet werden, also die sich geltend machenden Einflüsse auf die Verdunstung hinreichend erkannt sind, darf ein allzugrosser Wert auf dicse Untersuchungen nicht gelegt werden, zumal nicht einmal die Wassermenge genan bekannt ist, welche den Pflanzen zur Verfügung steht, da nur der Regenfall und nicht Nebel und Thau in die Berechnung mit eintreten, auch die nach einem Regen abfliessenden und verdunstenden Wassermengen sich wohl kaum genau fixiren lassen.

Aus diesen Grïnden können die Versuche zur Ermittelung der Verdunstungsgrössen der Pflanzen nur cinen bedingten Wert beanspruchen, namentlich wenn, wie Habcrlandt gethan, dabei von vollkommen anormalen Verbältnissen ausgegangen wird. Haberlandt hob nämlich die zu untersuchenden Getreidepflanzen aus dem Boden heraus und versenkte ihre Wurzeln in Wasser, wodurch sich offenbar eine normale Verdunstung nicht crzielen lässt; ferner nahm er ganz willkiirlich an, dass nur 1 Million Pflanzen der echten Getreidearten

1) Landw. Centralbl. II. 1871, pg. 194. 
pro ha wachse, eine Zahl die um das Doppelte bis Vierfache zu gering gegriffen ist, und kommt hierdurch bei Bestimmung der Verdunstungsgrösse pro ha, trotz der iiberaus günstigen Verdunstungsverhältnisse, auf relativ kleine Zahlen, indem er pro ha eine Wasserverdunstung: fand auf 1 Million

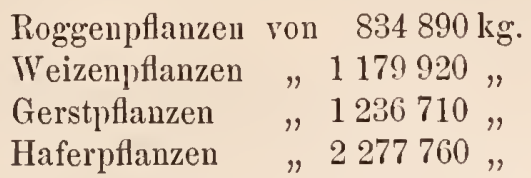

während sich nach der Berechnung von $\mathrm{R}$ issler das verdunstende Wasserquantum pro ha stellt:

$$
\begin{gathered}
\text { beim Weizen auf } 2471500 \mathrm{~kg} \text {. } \\
, \text { Roggen " } 2210000, \\
\text { " Hafer "4 } 180000,
\end{gathered}
$$

Hellriegel ${ }^{1}$ ) fand bei seinen 6 jährigen Verstchen, dass sich unter den klimatischen Verhältnissen ron Dahme der durchschnittliche Wasserverbrauch pro Gramm producierte oberirdische Trockensubstanz fïr Sommergerste auf' $310 \mathrm{gr}$, für Sommerweizen auf $338 \mathrm{gr}$, für Sommerroggen auf $353 \mathrm{gr}$ und für Hafer auf $376 \mathrm{gr}$ Wasser stellt.

Beträgt demnach die producierte oberirdische Trockensubstanz der Sommergerste in einer Mittelernte pro ha rund $3300 \mathrm{~kg}$, so werden $1.023 .000 \mathrm{~kg}$ Wasser, welche einer Regenhöhe von $102.3 \mathrm{~mm}$ entsprechen, während der Vegetationszeit verbraucht.

Letztere betrug von Mittc Mai bis Ende Juli $2 \frac{1}{2}$ Monate und fielen in dieser Zeit im Durchschnitte der Jahre 1859 bis $1873 \ldots$ $152.8 \mathrm{~mm}$ Regen.

Bei dieser Berechnung konnte der Verlust an Bodenfeuchtigkeit, weil hierfür die experimentellen Unterlagen fehlen, nicht mit in Betracht gezogen werden, doch dürfte wohl anzunehmen sein, dass in normalen Jahren die Wasserzufuhr während der Vegetationszeit der Gewächse unter den obwaltenden Verhältnissen geniigen wird.

Im Allgemeinen spricht die Erfahrung dafür, dass in der kälteren, gemässigten Zone die atmosphärischen Niederschläge zur Deckung des Wasserbedürfnisses der Getreidearten genïgen, obschon die während ihrer Vegetationszeit verdunstete Wassermenge häufig grösser ist, als die in dieser Periode gefallene Regenmenge, also das in der vegetationslosen Zcit auf den Boden gefallene und vou diesem festgehaltene Wasser den fehlenden Regen in der Vegetationszeit zu decken hat, und dies auch meistenteils vermag. Die dem Boden durch Regen zugeführten Wassermengen betragen in Nord-Deutsch-

1) Grundlagen des Ackerbaues, 1883. 
land nach Dore $6200000 \mathrm{~kg}$ p. ha und erhöhen sich im Seeklima auf iuber $7000000 \mathrm{~kg}$ p. ha.

Trotz dieser anscheinend ausreichenden Niederschlagsmenge können sich doch in manchen Jahren durch sehr ungleiche Verteilung derselben während der Vegetationszeit nachteilige Einflüsse auf das Ernteresultat geltend machen.

Aus dem Gesagten erhellt, dass sich die kältere, gemässigte Zone nicht nur in Betreff der Sommer- und Wintertemperatur, sondern auch der Befriedigung des Wasserbediirfnisses rorzugsweise zur Kultur der echten Getreide eignet.

Selten wird in dieser Zone zur Erzielung des Maximalertrages die Berieselung, dagegen weit häufiger in feuchten Lagen und auf bindigen Bodenarten die Entwässerung, namentlich durch Drainage, am Platze sein.

Für einige unechte Getreide, die an das Wärmequantum grössere Ansprüche stellen. wird die Auswahl einer günstigen örtlichen Lage, z. B. beim Mais, über die Möglichkeit ihres Anbaues entscheiden. Hierzu eignen sich Lagen, welche bei mässigem, den Wasserabzug fördernden Abhang nach Siiden ron $1-5^{0}$ und bei Schutz gegen rauhe Winde einen sich leicht erwärmenden, nahrungsreichen Boden besitzen.

Mit dem Fortschreiten nach den Polen zu verringert sich die Wärme und rermehrt sich die Feuchtigkeit, so dass hier immer mehr die Entwässerung über die Erzielung des Maximalertrages entscheidet; auch stellen die langen und kalten Winter die Kultur des Wintergetreides immer mehr in Frage, bis schliesslich an den Grenzen des Getreidebaues überhaupt nur noch Sommergetreide kultiviert wird.

Nach dem Aequator zu treten gerade entgegengesetzte Verhältnisse auf, indem schon in der wärmeren, gemässigten Zone das Getreide bei der hier herrschenden grösseren Wärme entweder bewässert, oder als Wintergetreide angebaut, die höchsten Erträge bringt. Dies Wasserbedürfnis steigert sich in dem Verhältniss als man sich dem Aequator nähert, doch hört gewöhnlich mit der Erreichnng der Aequatorialzone nicht nur der Anban der echten, sondern auch der unechten Cerealien in der meeresgleichen Ebene auf, indem die Pflanzen ihre Maximaltemperatur crreichen und wohl sehr schnell emporwachsen, doch kaum Friichte ansetzen, so dass sich nur noch in beträchtlicher Höhenlage Getreide anbauen lässt.

Auf dieses Verhalten übt auch das Bodenklima einen sehr wesentlichen Einfluss aus, indem sich die Bodenwärme nach den Untersuchungen ron Bialoblocki ${ }^{1}$ ) beim Getreide in der Abkürzung

1) Landw. Versuchsst. XIII, 424. 
oder Verlängerung der Vegetationsperiode und in dem äusseren Bau der Pflanzen geltend maeht.

Bezüglieh dieser beiden Punkte ergeben seine Versuche Folgendes:

a) Der Einfluss der Bodenwärme auf die Besehleunigung des Verlaufs der Vegetation findet hauptsäehlich in der ersten Periode der Entwiekelung statt;

b) mit steigender Bodenwärme wird bis $z \mathfrak{u}$ einem gewissen Punkte die Vegetation gefördert. Von dem Augenblicke an, wo dieser Punkt überschritten, hat die weitersteigende Bodentemperatur eine Verlangsanung des Wachstums zur Folge.

e) der Maximalpunkt günstig wirkender Bodenwärme ist für verschiedene Pflanzenarten versehieden;

d) eine konstant erhaltene Bodentemperatur von $10^{\circ} \mathrm{C}$. maeht sieh durch einen besonders kräftigen Bau der Versuchspflanzen bemerklieh;

e) als oberste Grenze einer konstanten Bodentemperatur, bei weleher noch Wurzelwachstum stattfinden kann, ist eine unterhalb, aber sehr nahe an $40^{\circ} \mathrm{C}$. liegende Temperatur zu betrachten;

f) die Bodentemperatur an $10^{\circ} \mathrm{C}$. gestattet der Gerstenpflanze, alle ibre Lebensfunktionen und Entwiekelungsstadien normal zu vollziehen;

g) die.erlı̈̈hte Bodentemperatur hat keinen bedeutenden Einfluss auf die Nährstoffaufnahıne durch die Wurzel;

h) mit dem durch die erhöhte Bodenwärme bcsehleunigten Waehstum ist ein höherer Wassergehalt der Pflanzen verbunden.

Im Allgemeinen reigten die im kältesten Boden waehsenden Pflanzen den kräiftigsten Bau, nämlieh nicdrige, dieke Halme mit auffallend kurzen, breiten, diekfleisehigen Blättern; mit steigender Bodenwärme wurden die Blätter lïnger, sehmäler und die Halme diinner.

Zwisehen 30 und $40^{\circ} \mathrm{C}$. Bodenwärme wird die Entwiekelung ganz abnorm, die Stengel werden dünn, zahlreich und ïbermässig lang, aueh welken die Pflanzen oft, und ibre wenigen Seitentriebe sterben bei $40^{\circ} \mathrm{C}$. ab.

Normal erwuehsen die Pflanzen bei Bodentemperaturen zwisehen 15 und $25^{\circ} \mathrm{C}$.

Für den Roggen liegt das Maximum der günstigsten Bodenwärme bei $20^{\circ}$, fiur die Gerste bei $25^{\circ}$ und für den Weizen bei $30^{\circ} \mathrm{C}$.

Eine Pflanze, die niedrigere Bodenwärme verlangt, wird sieh vermutlich auch mit niedrigerer Luftwärme begnïgen, also in nördliehen Gegenden gedeihen, doeh ist hierbei ausser der Temperatur auf das mehr nördliche oder südliehe Vorkommen die Vegetationsdauer in Betraeht zu ziehen.

So verlangt Weizen bei langer Vegetationsdauer noeh höhere Bodenwärme, während der Roggen bei anmähernd gleieher Vegetations- 
dauer weniger Wärme bedarf, also anch noch nördlicher als Weizen gedeihen wird. Die Gerste endlich beansprucht eine böbere Bodenwärme als Roggen, aber in weit kürzerer Vegetationsdaner, weshalb sie in nördlichen Gegenden mit kurzen, aber heissen Sommern gedeilht und am weitesten nördlich kultiviert wird.

Für den Getreidebau lassen sich nnn folgende allgemeine Sätze anfstellen:

Die Bewässerungskultur erstreckt sich bis znm $35 .{ }^{0}$ beiderseitig rom Aequator, und die Landwirtschaft, welche Dïngnng und Bewässerung teilweis anwendet rom $35^{0}-45.0^{\circ}$ n. n. sindl. Br., die Landwirtschaft mit Entwässerung und Düngung rom $45^{0}-67 .^{\circ}$ n. n. sỉdl. Br., und darüber hinans herrscht Jagd und Fischerei ror und Getreide wird nur rereinzelt in sehr giinstigen Lagen bis ungefähr noch zum $70^{0} \mathrm{n}$. Br. angebaut.

\section{Die Verschiedenheit der Getreidearten bezïglich ihrer Bodenanşprïiche.}

Die Feststellnng der Bodenansprïche des Getreides bernht zu einem grossen Teil auf der Kenntnis der Bewnrzelung.

Die Keimwurzeh des Getreides sterben bekanntlich sehr bald ab, um dnrch Adrentiv- oder Kronenwnrzeln ersetzt zu werden, die sich ans einem der dicht $(1 / 2-2 \mathrm{~cm})$ unter der Oberfläche liegenden Knoten, dem sog. Bestockungsknoten, welcher auch ans mehreren dicht unter einander liegenden Knoten, deren Axen nur nicht gestreckt sind, gebildet werden kann, entwickeln, nnd zwar zugleich mit den Bestocknngsknospen, mithin an der Basis der Schösslinge die Adrentirwurzeln erscheinen.

Diese Adrentirwurzeln bilden nnn ein mehr oder weniger büscheliges Wnrzelwerk, anf das sich vorzugsweise die Wurzelthätigkeit beschränkt, denn die bei grosser Tieflage des Saatkornes eintretende Bewurzelnng an einem oder mehreren unteren Knoten bleibt immer sehr unbeträichtlich, so dass sic znr Ernährnng der ganzen Pflanze nur verhältnissmässig wenig beiträgt.

Die grösste Beachtung znr Feststellung der Bodenanspriiche verdienen aber der Wurzeltiefgang und das Wnrzelrermögen.

Die ersten Anfklärungen iiber den Wurzeltiefgang brachten die Untersuchungen ronSchubar.t ${ }^{1}$ ) in Gallentin beiSchwerin. Sic zeigten dass sclbst Flachwurzler, wie die Getreidearten, teilweis ihre Wurzeln

1) Chem. Ackersm. 1855 pag. 193. 
und selbstschon in sebr friben Entwickelungsstadien in Tiefen zu senden vermöchten, deren Erreichung man bis dahin für ınmöglich gehalten hatte.

Seine 1855 eingeleiteten Untersuchungen ergaben folgendes Resultat:

\begin{tabular}{|c|c|c|c|}
\hline $\begin{array}{l}\text { Winterweizen } \\
\text { do. } \\
\text { do. } \\
\text { do. } \\
\text { Winterroggen } \\
\text { do. } \\
\text { Winterrübsen } \\
\text { do. nassgründig } \\
\text { Winterraps } \\
\text { do. } \\
\text { Gartenerbsen } \\
\text { do. } \\
\text { do. } \\
\text { Iilee } \\
\text { " }\end{array}$ & $\begin{array}{l}26 / 9 \text { gesät } \\
\text { do. } \\
\text { Ende Octbr. } \\
\text { do. } \\
16 / 9 \\
16 / 9 \\
20 / 8 \\
\text { do. } \\
\text { Anf. August } \\
5 / 4 \text { do. } \\
\text { do. } \\
\text { do. } \\
\text { do. } \\
\text { do. }\end{array}$ & 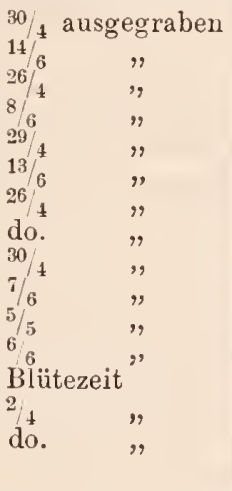 & 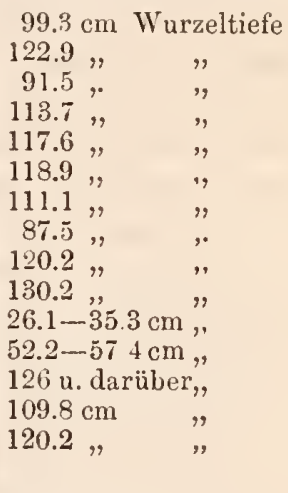 \\
\hline
\end{tabular}

Hieraus ist deutlich die relativ bedcutende Tiefe ersichtlich, bis zu welcher die Wurzcln der Getreidearten in den Boden einzudringen vermögen, welche Resultate durch weitere Untersuchungen voll bestätigt worden sind.

Stöckhard t untersuchte nun das von Sehubart ihm zugesandte Wurzelmaterial und bestimmte darnach, in welchem Verlültnisse sich die Wurzeln der Pflanzen and ilı Stickstoff (massgebend für die jüngsten aufnahmefähigen Wurzelgrebilde) auf die Ackerkrume von $23.5-26 \mathrm{~cm}$ Tiefe und den Untergrund verteilen, wobei er zu folgenden Resultaten gelangte:

\begin{tabular}{|c|c|c|c|c|c|c|}
\hline & \multicolumn{4}{|c|}{$\begin{array}{l}\text { Von } 100 \text { Wur- } 100 \text { Stick- } \\
\text { zeln kommen auf } \\
\text { soffder Wurzeln } \\
\text { kommen auf }\end{array}$} & \multicolumn{2}{|c|}{$\begin{array}{l}\text { Stickstoffgehalt } \\
\text { in } 100 \text { Teilen. }\end{array}$} \\
\hline en $v .3$ & 62 & 38 & - & - & - & - \\
\hline Winterweizen v. 8. Juni & 63 & 37 & 55 & 45 & 1.39 & 1.94 \\
\hline Winterroggen v. 29. April & 73 & 27 & 66 & 3 & 1.46 & 2.12 \\
\hline Winterrrübsen v. 26. April & 76 & 24 & 75 & 2 & 2.50 & 2.61 \\
\hline Klee (2) & 82 & 15 & 74 & 26 & 1.91 & 3.26 \\
\hline
\end{tabular}

Hicrmit ergibt sich evident, dass allerdings cin kleiner Teil der Wurzeln bei den Getreidearten in grössere Tiefen zu dringen 
vermag, jedoch die Iehrzahl dersclben mit aufnahmefähigen Endigungen sich in der Ackerkrume bis zur Tiefe von $26 \mathrm{~cm}$ vorfindet.

Auch Hellriegel ${ }^{1}$ )spricht sich dagegen aus, dass in gewöhnlichem Boden die Wurzeln der Getreidearten mit ihrer Hauptmasse tiefer als die Ackerkrume reichen.

Auffallen nulss es jedoch, dass einzelne Wurzeln in den mahrungsärmercn und härteren Untergrund bis zu sehr beträchtlichen Tiefen eindringen und lässt sich dies nur durch den Wachstumsreiz erklären, welchen der grössere Feuchtigkcitsgehalt der tieferen Bodenschichten auf die Wurzelenden ausiibt.

Auch Funke ${ }^{2}$ ) und Henrici ${ }^{3}$ ) sprechen unzweideutig die Ansicht aus, dass diese tiefgehenden Wurzeln die Bestimmung haben, Wasser zum Verbrauch der Pflanzen aus dem Untergrunde zn entnehmen.

Demnach gehören die Getreidearten zu den von Fraas ${ }^{4}$ ) so benannten Flachwurzlern oder Krumepflanzen, welche jedoch zur Erzielung einer maximalen Ernte einen reichen Vorrat an leicht assimilirbaren Pflanzennährstoffen in einer möglichst tiefen Ackerkrume, also in einem grossen Bodenvolumen vorfinden miissen.

Zum Beweise hierfür diene ein Versuch von Hellriegel ${ }^{5}$ ), der Gerste in Töpfen mit verschichenen Nengen Gartenerde zog und zu folgenden Resultaten gelangte: 8 Pflanzen prodncirten Tìockensubstanz in Töpfen mit

\begin{tabular}{crrr} 
& & Körner. & Stroh. \\
& & \multicolumn{1}{c}{ g. } & \multicolumn{1}{c}{ g. } \\
I. $12.50 \mathrm{~kg}$ Erde & 20.26. & 21.59 . \\
II. $5.00 \mathrm{~kg}$ Erde & 12.21. & 9.90. \\
III. $1.67 \mathrm{~kg}$ Erde & 5.20. & 4.65.
\end{tabular}

Hiernach hat also das grösste Bodenvolumen auch die grösste Masse an Trockensubstanz geliefert.

Wir können nun wohl den berechtigten Schluss ziehen, dass fuir die Getreidearten vorzugsweise die obere Bodenschicht, soweit sie der Bearbeitung unterliegt und welche wir Ackerkrume nennen, in Frage kommt und in zweiter Linie erst der Untergrund, welcher aber kcinesfalls bei der Beurteilung eines Getreidebodens iibersehen werden darf, da ja auch in ihn noch recht beträchtliche Wurzelmassen hineinragen, den entsprechend seine Beschaffenheit das Gedeihen des Getreides mit beeinflnsst, und aus diesem Gesichtspunkte

1) Monatsschrift d. 1. Prov.-Ver. d. Mark Brandenburg etc. 1864. No. 2 pag. 37.

2) Ueber Untergrundsdüngung. 1872. pag. 17.

3) Henneberg's Journ. f. Landw. 1863. pag. 280.

4) Das Wurzelleben d. Culturpfl. etc. 1870 pag. 54.

5) Landw. Centralbl. 1868 Bd. I. pag. 2. 
wollen wir uns jetzt der Betrachtung der sich zum Getreidebau eignenden Bodenarten zuwenden.

Nach den im Ackerboden vorwiegenden Hauptgemengteilen unterscheidet der Landwirt: Thon-, Lehm-, Sand-, Kalk-, Kreide-, Mergel- und Humusbödèn.

Der Thonboden enthält als Hauptbestandteil Thon, und ausserdem als Ncbenbestandteile, die aber sehr wichtige Pflanzennährstoffe sind, Kali, etwas Phosphorsäure, Kalkerde, Magnesia etc., und gilt er gerade wegen dieser Nchenbestandteile als ein von Natur rcicher Boden.

Seine physikalischen Eigenschaften beruhen vorzugsweise auf bedeutender Kapillarität, da er 75 Proc. Wasser aufzunclımen vermag; auch zeichnet er sich durch Porosität und in Folge dessen durch starke Absorption von Kohlensäure und Ammoniak aus.

Die ihm eigentümliche starke wasserhaltende Kraft trägt in nassen Jahren häufig die Schuld, dass die durch die Verdunstung des Wassers erzengte Kälte, sowie der mangelnde Luftzutritt das Pflanzenwachstum ernstlich gefährden, wic auch andererseits bei grosser Dürre der Thonboden durch Austrocknen schwindet und schliesslich berstet, wodurch die Wurzeln zerrissen und blossgelegt, also die Pflanzen krankhaft gestimmt werden.

Humus und Dung zersetzen sich im Thonboden relativ langsam, und gleich langsam gestaltet sich auch die Entwickelung der jungen Pflanze, doch schreitet diese später, da schroffe Temperaturwechsel nicht leicht auf die Pflanze wirken können, um so sicherer vorwärts.

Aus seiner Plasticität (50-70 Proc. Thon) erklären sich auch die hohen Bearbeitungskosten, welche er beansprucht, denn er lässt sich weder in feuchtem, noch in trockenem Zustande leicht bebauen.

Der Lelimboden setzt sich zu fast gleichen Gemengteilen Thon und Sand zusanımen und enthält noch eine Menge wichtiger Pflanzennährstoffe als Nebenbestandtcile.

Die physikalische Beschaffenheit des Lehmbodeus hängt vorzugsweise von der Menge des beigeniengten gröberen Sandes und Eisenoxydes ab, welches letztere ihm liäufig eine mehr odcr weniger rote Farbe verleiht. Nach Maassgabe der Menge dieser Bestandteile wird er lockerer und milder und folglich auch seinc Bearbcitung wesentlich erleichtert.

Bei guten Untergrunde und Kulturzustande liefert er hohe Erträge.

Beträgt sein Thongehalt 25-30 Proc., so bezeichnet nian ihn als sandigen Lehm, bei iiber 4 Proc. Humus oder 4 Proc. Kalk als humosen resp. mergeligen Lehmboden.

Der Sandboden entsteht entweder durch Verwitterung des Sand- 
steins oder durch Auswaschung der abschlämmbaren Bestandteile der Lehmböden, in Folge dessen die Quarzkörnchen zurückbleiben. Ein soleher Sandboden kann naturgemäss nur äusserst wenig Pflanzennährstoffe enthalten, ist also arm. Etwas besser wird der Sand dann, wenn er noch Partikelchen anderer Gesteine cnthält, welche verwitternd, Pflanzennährstoffe liefern.

Das Wasser filtrirt sich durch den Sandboden schr leicht hindureh und liält Quarzsand nur 20 Proc. Wasser zuriick; ferner zeichnet er sich durch starke Verdunstungsfähigkeit ans.

Enthält der Sand unter 10 Proc. Thon, so wird er als reiner Sandboden, bei ïber $10-25$ Proc. als lehmiger Sand und bei einem Humusgehalt von iiber 5-6 Proe. als humoser Sandboden angesprochen.

Da nun auf diese lockeren Bodenarten Sonne, Luft und Wasser sehr energisch einwirken können, so findet eine ausnehmend schnelle Zersetzung des Düngers statt, in Folge dessen der Boden bei starker Düngung die sich entwickelnden Gase selten vollständig zu absorbieren vermag.

Die Bodenbearbeitung ist seln leicht, nur kann der Sandboden in feuchtem Klima bei guter Kultur und Düngung und nicht zu durehlassendem Untergrunde noch recht befriedigende Ernten liefern.

Der Kalk- und Mergelboden weist nicht selten unbeträehtliche Mengen Thon oder Humus auf, welche ihm grössere Bindung verleihen.

Ein reiner Kalkboden ist höchst selten und ein Boden mit 20 Proc. Kalk wird schon als Kalkboden bezeichnet, mithin hängt seine Beschaffenheit vorzugsweise von den iibrigen Gemengteilen ab. Im Allgemeinen gilt der Kalkboden als mager und hitzig:

Der Mergelboden besitzt einen Kalkgechalt von 5-20 Proc. und werden thonige, lehmige, sandige und humose Mergelböden unterschieden.

Nach den vorherrschenden Bestandteilen richtet sich die Auswahl der auf Hergelboden anzubaucnden Getreidefriichtc.

Der Humusboden enthält in Verwesung befindliche organische Stoffe, von denen schon 5-8 Proc. geniigen, um ilım den Stempel des Humusbodens anfzudriicken.

Der Humus liefert Kohlensäure, Ammoniak und Salpetersäure welche nicht nur als directe Pflanzennahrung, sondern auch zur Lösung der Mineralstoffe höchst wichtig sind.

Je nach dem Zersetzungsgrade des Humus, näınlich ob noch Struktur vorhanden oder nicht, riclitet sich auch sein physikalisches Verhalten, denn die zellige Struktur macht ihn poröser als den erdartigen Humus, wodurch z. B. seine wasserhaltende Kraft eine nicht uncrhebliche Steigerung erfährt. Derselbe nimmt bisweilen 100 Proc. Wasser auf, und damit erfuillt, dehnt $\mathrm{er}^{*}$ sich beim Gefrieren 
sehrbedeutend aus, um beim Aufthauen wiederum gleich stark zusammenzusinken, wodurch die Pflanzenwurzeln leicht zerrissen und von Erde entblösst werden.

Die dunkle Farbe des Bodens lässt denselben sich leicht erwärmen, was aber dem Pflanzenwuchs zuweilen nachteilig werden kann, sobald auf dem feuchten Boden die Nachtkälte in einen zu grellen Gegensatz zur Tageswärme tritt, was Erkältung der Pflanzen zur Folge hat.

Ferner besitzt der Humus eine sehr bedeutende Absorptionskraft gegen Gase, welche dic Atmosphärc zu grösserer Teilnahme in Bezug auf das Pflanzenwachstum als auf humusarmen Böden zwingt.

Humussubstanzen finden sich in jeder Ackerkrume vor, doch betragen sie selten über 2 Proc. und in diesem Falle verbessert der Humus durch seine Eigenschaften wohl jeden Boden, während sich bei 5-8 Proc. schon zurveilen durch Erkälten und Aufziehen, bei 10 Proc. dagegen meist schon eine Beeinträchtigung der Tragfähigkeit des Feldes einstellt.

Landwirtschaftlich werden nach dem System der Acker-Klassification von Thaer und Koppe mit Vervollständigungen von Settegast ${ }^{1}$ ) folgende Bodenarten unterschieden:

Klasse I. Reicher, tiefer, milder Thon und Aucboden.

Warm, thätig, mild und miirbe, überhaupt in jeder Beziehung fehlerfrei. Ackerkrume mindestens $21-26 \mathrm{~cm}$ tief. Untergrund in erwiinschtem Grade durchlassend und bis zu einer Tiefe von $0,8 \mathrm{~m}$ wenig abweichend von der Ackerkrume.

Dieser Boden ist Weizenboden I. Klasse und zeichnet sich durch vorzügliches Gedeihen aller Kulturpflanzen, die einen grossen Sandoder Kalkgehalt im Boden nicht beanspruchen, aus. Gebaut werden: Weizen, Gerste, Hafer, Raps, Leguminosen, Rüben, Handelsgewächse aller Art. Zur Tiefkultur vorzilglich geeignet.

Klasse II. Humoser, reicher, milder Lehmboden.

Die physikalische Beschaffenheit der Ackerkrume und des Untergrundes ist gleich der von Klasse I, die Ackerkrume nicht flacher als $21 \mathrm{~cm}$.

Gerstenboden erster Klasse. Für Gerste auf's Vorzüglichste geeignet, sonst, mit Ausnahme des Weizens, der in Klasse I sicherer ist, dieselben Früchte.

Dieser Boden beguinstigt mehr die Blattbildung als die Entwickelung der Körner, welehe weniger schwer ausfallen als auf Klasse I.

Ferner gehört als Unterklasse hierhin der milde, thonige, lehmige Humus- und Aueboden.

1) Die Landw. u. ihr Betrieb. 1875 I. 229. 
Die Krume besitzt aufziehende Beschaffenheit, daher für Winterung unsicher.

Grosse Stroh-, qualitativ ungenügende Körnererträge. Gebaut werden: Roggen, Gerste, Rüben etc.

Klasse III. Schwerer, kräftiger Thonboden. Streng, stark gebunden, schwierig zu pulvern, leicht erhärtend. Ackerkrume nicht flacher als $21 \mathrm{~cm}$. Untergrund mässig durchlassend.

Weizenboden zweiter Klasse. Für Weizen und Hafer besser als für Roggen und Gerste geeignet. Liefert schwere Körner. Leguminosen, Klee, Runkelruiben. Die Bewirtschaftung erfordert starkes Angespann, mannigfaltige und stark gebaute Ackerinstrumente. Die Drainage äussert sehr günstige Wirkung.

Klasse IV. Milder, tiefer, frischer Lehm- und sandiger Lehmboden. Sein Thongehalt ist ausreichend, um einen giinstigen Feuchtigkeitsgrad selbst in trocknen Jahren zu sichern. Locker, porös, warm. Ackerkrume nnindestens $16 \mathrm{~cm}$ tief. Der Ackergrund ist der Ackerkrume ziemlich ähnlich; in den tieferen Schichten vermehrt sich del Sandgehalt. In erwïnschtem Grade durchlassend.

Gerstenboden zweiter Klasse. Für Roggen besser als fiir Weizen, für Gerste so gut wie für Hafer geeignet. Leguminosen, Hackfrüchte, Raps, Lein.

Ferner gehört als Unterklasse hierhin der milde Humusboden mit schwacher Lehm- und Sandbeimischung. Die aufziehende Beschaffenheit der Krume in dern Grade auftretend, dass die Winterfrucht gefährdet ist. Untergrund mässig durchlassend, in tieferen Schichten zuweilen zäher Thon.

Klasse Y. Leichter sandiger Lehm und lehmiger Sandboden. Trocken, thätiger als wiinschenswert; zu locker. Ackerkrume mindestens $13 \mathrm{~cm}$ tief. Der Untergrund hält wegen des mit der Tiefe zunehmenden Sandgehalts die Feuchtigkeit nicht genug an.

Roggenboden erster Klasse. Gebaut wird Roggen, bei hoher Kultur Gerste und Hafer. Kleegrasgemische, Kartoffeln, Kohlriben, Erbsen.

Eine Düngung mit passendem Mergel erhöht die Ertragsfähigkeit dieser Böden ausserordentlich.

Klasse VI. Kalter, zäher Thon- und Lehmboden.

Aehnlich der Klasse III, aber kälter, unthätiger und in nassen Jahren durch Uebermaass an Wasser das Pflanzenwachstum gefährdend. Ackerkrume mindestens $13 \mathrm{~cm}$ tief. Untergrund strenger, undurchlassender, steifer Thon (Lette); wassergallige, zälıe Lehmschichten; mit Lette verkitteter Kies.

Weizenboden dritter Klasse. Früchte wie bei Klasse III. Die Ertragsfrihigkeit des Bodens und die Sicherheit der Ernten sind durch Drainage wesentlich zu heben. 
Klasse VII. Leichter, magerer Sandboden; dürftiger, lehmiger Sandboden. $\mathrm{Zu}$ trocken. Feines Korn. In der Krume oft zu lose bis staubig. Ackerkrune mindestens $11 \mathrm{~cm}$ tief. Untergrund feinkörniger Quarzsand. Trocken.

Roggenboden zweiter Klasse. Winterroggen, Sommerroggen, Hafer. Lupinen, Weissklee etc. mit bescheidenen Gräsern, Kartoffeln. Dieser Boden ist von Natur diirftig, weil er mit den wichtigsten mineralischen Pflanzennährstoffen sehr stiefmütterlich bedacht ist.

Als Unterklasse zu VIl kann der saure, sandige Humusboden gelten. Der faserige Humus mit fcinem Sande innig gemischt. Die in trockener Zeit lose und staubige Krume fliesst bei Regen breiartig zusammen. Im Untergrunde Schluff, Lette, Quellsand. Roggen, Hafer, Buchweizen, Kartoffeln, Weidegräser. Durch Mergeln und Drainage wesentlich zu verbessern.

Klasse VIII. Strenger, zäher, nasskalter Thonboden von lettenartiger Beschaffenheit.

Kalt, unthätig, widerspenstig, bei Trockenheit steinartig erhärtend. Der beigemischte Sand meist von sehr feinem Korn. Das Wasser standhaft zurickhaltend. Die Ackerkrume ist häufig nicht mächtiger als $8 \mathrm{~cm}$. Der Untergrund ist ähnlich wie bei Klasse VI, nur noch steifer und undurchlassender.

Haferboden erster Klasse. Weizen, Hafer, Leguminosen. Grosse Unsicherheit in den Erträgen. Bearbcitung schwierig. Drainage wirkt vortrefflich.

Klasse IX. Armer Sand- und Kiesboden. Dürr, ohne genügende wasserhaltende Kraft. Krume oft mit Steinen erfüllt, $8-10 \mathrm{~cm}$ tief. Der Untergrund besteht aus grobem Sand und Grand oft mit Steinen gemischt.

Roggenboden dritter Klasse, auf dem sich dieselben Früchte wie auf Kl. VII bauen lassen.

Die Pflanzen brennen in Folge der dürren Krume und des trokenen Untergrundes leicht aus.

Hierzu gehört als Unterklasse der saure Haidehumus mit geringer Quarzsand-Beimischung. Hauptfrichte wie bei Unterklasse zu VII.

Klasse $\boldsymbol{X}$. 'Töpferthon, loser Sand, Grand-, Kies- und ähnliche Böden geringster Ertragsfähigkeit.

Krume über 5-6 $\mathrm{cm}$ nicht hinausreichend. Im Untergrund finden sich Kies, Steingerölle oder Schluff und Raseneisenstein. Haferboden zweiter und dritter Klasse. Auf trocknen Stellen Roggen, auf thonigen Hafer.

Hierhin gehört als Unterklasse der moorige, saure Torfboden, im Untergrunde Moor und Torf. Winterung zu unsicher. Hafer, Buchweizen, Gräser.

Einen vorzüglichen Getreideboden liefern die sog. Schwarz- 
erden ${ }^{1}$ ), welche Lehm- oder Thonmergelböden von grosser Mächtigkeit sind, in denen sich beträchtliche Humusmengen sehr fein verteilt finden. Demnach sind es von Natur ansserordentlich reiche Böden, denen gleichzeitig sehr giinstige physikalische Verbältnisse zukommen.

Herrmann fand in russischen Proben 10.4-8.6 und 8 Proc., Il genkow 10.4-2.6 und 2.3 Proc. Humus.

\section{Die Dïngung des Getreides.}

Das flachwurzelnde Getreide kann zur Erzielung holer Erträge eines bedentenden Vorrates fertiger Pflanzennahrung in der Ackerkrume nicht entbehren, demnach ist für Sommergetreide mit relativ kurzer Vegetationsperiode eine Düngung mit langsam sich zersetzendem Stallmist unvorteilhaft, dagegen schon giinstiger für solches mit langer Vegetationsperiode oder für Wintergetreide. Aus diesen Gründen bringt inan das Sommergetreide gern nach gediingten Vorfriichten orler in einen Boden mit alter Kraft. Dagegen lässt sich schnell wirkender Kuustdiinger zu allen Getreidearten mit Aussicht auf Erfolg verwenden.

In Betreff der Wirkung des Düngers ist, namentlich zur schnellen Ueberführung der Stickstoffkörper in Salpetersäure, die Beschaffenheit des Bodens zu berücksichtigen; so wird der gut durchliuftete, mässig feuchte, hohe Erwärmungsfähigkeit und Absorptionskraft besitzende Boden, und die Anwesenheit von Kalk sehr wesentlich die Zersetzung und günstige Wirkıng der Dünger beeinflussen.

Es werden von den hauptsächlichsten Pflanzennährstofien rom Boden absorbiert an Basen: Ammoniak, Kali. Natron, Kalkerde und Magnesia; von den Säuren: Phosphorsäure und Kieselsäure, wälırend Salzsäure, Schwefelsäure und Salpetersäure nicht absorbierbar sind.

Die absorbierten Stoffe werden durch die lösenden Kräfte der Wurzeln in die Pflanzen übergefiihrt; köunen sich aber anch wiederum lösen, sobald im Boden eine weniger koncentrirte Lösung auftritt, weshalb diese Absorptionserscheinungen für die Regulierung der Nährstoffvertheilung im Boden höchst wichtig sind.

1) Vergl. Dokoutchaéw, Tschernozéme de la Russe d'Europe. 1879. 
Für die wenig absorptionsfähigen Sandböden empfehlen sich schwache, doch in verhältnissmässig kurzen Zeiträumen sich folgende Düngungen, wodurch bei dem Mangel dieser Böden an zur Nährstoffverteilung notwendigen Stoffen (wasserhaltige Silikate) ein zu hoher Koncentrationsgrad der Bodenlösung vermieden wird, weil sonst das Pflanzenwachstum in trocknen Perioden unter dem sog. „Verbrennen" leidet und in nassen ein Teil der Nährstoffe in den Untergrund ausgewaschen wird.

Schwere Böden mit grosser Absorptionskraft verhalten sich den Sandböden entgegengesetzt.

Der gute Düngungszustand eines Feldes kennzeichnet sich durch sehr kräftige Entwickelung der oberirdischen Pflanzenteile, während im Verhältnis hierzı die Wurzeln eine schwächere Entwickelung zeigen, wie dies die Versuche von Hosäus ${ }^{1}$ ) beweiscn, in welchen sich die Wurzeln zu den oberirdischen Organen verhielten:

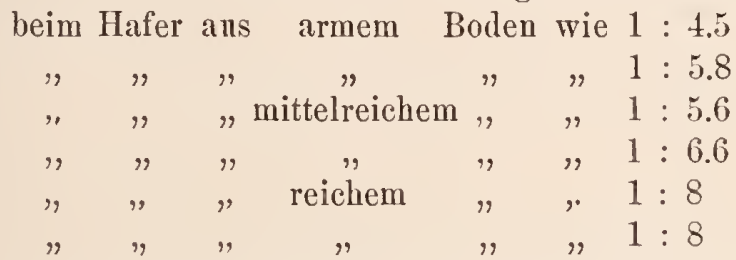

Dies Verhalten ist in dem Umstande zu suchen, dass die Wurzel zur Sammlung der Nährstoffe im nahrungsarmen Boden einer grösseren aufsangenden Oberflïche bedarf. Diese stärkere Wurzelentwickelnng wird aber notgedrungen auf Kosten der oberirdischen Organe zu geschehen haben, welche der grösseren Wurzel auch ein grösseres Quantum Bildungsmaterial überlassen miissen, was naturgemäss eine entsprechend schwächere Entwickelung derselben bedingt.

Es unterliegt keinem Zweifel, dass durch den jüihrlich bei der Ernte stattfindenden Entzug von Pflanzennährstoffen der Boden um die Bestandteile der Erntemassen daran ärmer werden muss.

Wie gross diese Verluste p. ha sein können, ergibt sich aus der nachfolgenden Tabelle:

1) Neve landw. Zeit. VI 1873 pg. 427. 


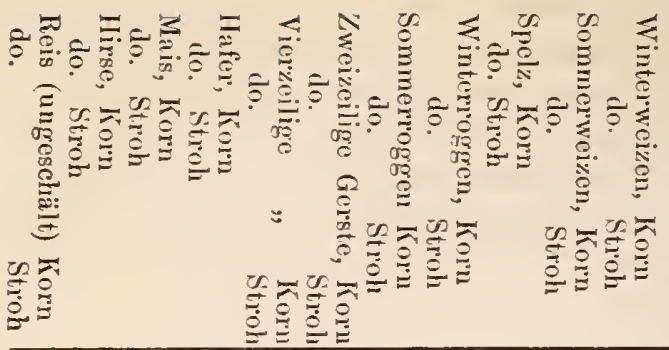

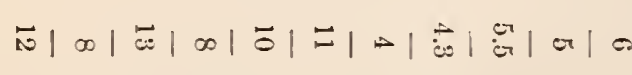

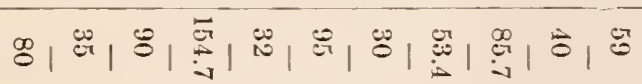

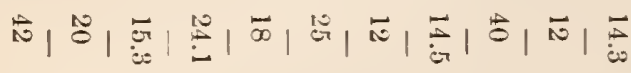

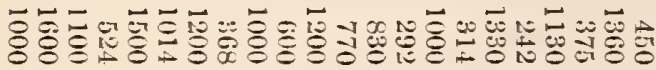

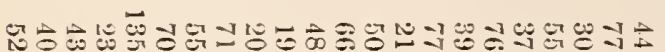

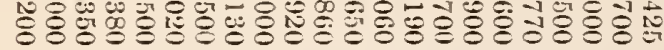

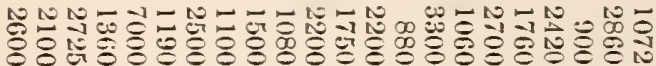

| N

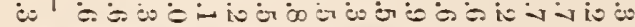

|

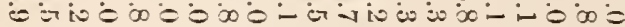

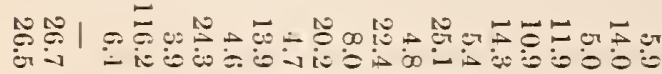

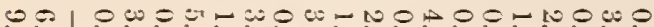

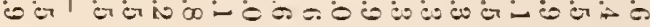

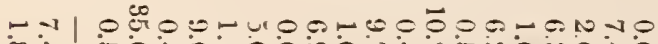

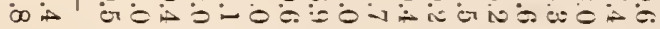

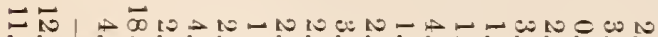

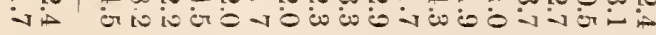

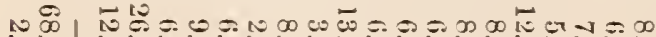

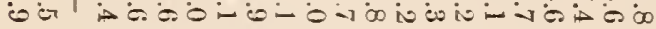

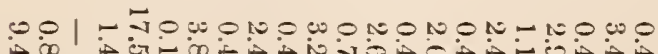

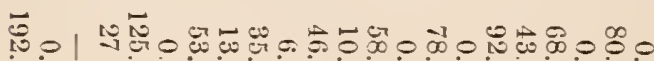

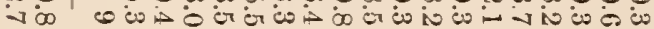

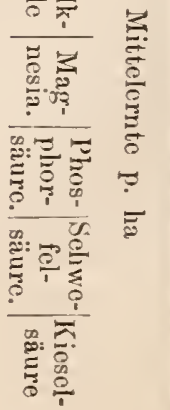


Der Nährstoffentzug ist biernach sehr beträchtlich, daher denn auch, soll der Boden seine Fruchtbarkeit nicht verlieren, für den Wiederersatz gewisser Pflanzennährstoffe zu sorgen ist, wobei man zwischen den vorzugsweise aus der Atmosphäre und den aus dem Boden stammenden einen beachtenswerten Unterschied zu machen hat.

So erbält der Boden aus der Atmosphäre einen jährlichen Zufluss von Kohlensäure, Ammoniak und Salpetersäure, demnach auch bei jährlichem Ernteentzug nur ein teilweiser Ersatz derselben notwendig ist.

Anders verhält es sich mit den Aschenbestandteilen, weil bei diesen durch die Ernte eine absolute Verminderung erfolgt und es für sie keine andere natürliche Quelle als den Boden gibt; doch ergeben sich für die einzelnen Aschenbestandteile hierbei sehr wesentliche Unterschiede, indem diesclben in selır verschiedenen Mengen im Boden, und davon unabhängig, auch in sehr verschiedenen Mengen in den Pflanzen erscheinen; hierin liegt mit der Grund, dass sich für einzelne Aschenbestandteilc der Entzug ans dem Boden durch die Ernte viel bemerkbarer macht, als bei anderen, die sich ebenfalls nur in geringen Mengen im Boden finden.

$\mathrm{Zu}$ den im Boden weniger häufigen, doch von den Pflanzen stark begehrten Aschenbestandteilen gehört zweifellos die Phosphorsäure, und ist auf deren Wiederersatz das grösste Gewicht zu legen, zumal eine vollkommene Entwickelung der Körner ohne Phosphorsäure nicht denkbar ist; weniger ist auf reichem Boden der volle Wiederersatz des Kalis zu beachten, wohl aber auf armen Sand-oder Humusböden. Die Notwendigkeit der Zufuhr der Magnesia, oder des Kalkes als Pflanzennährstoff liegt nur selten vor.

Der Stallmist ist allein im Stande, Ersatz für alle dem Boden entnommenen Pflanzennährstoffe zu bieten, und gleichzeitig einen günstigen physikalischen Zustand zu erhalten oder herbeizufiuhren.

Zur Diingung des Getreides stehen Pferde- und Schafmist in ihrer Verwendbarkeit dem Rindviehmist nach, weil ihr Stickstoffreichtum leicht zu übermässiger Entwickelung der vegetativen Organe, und damit zu mangelhaftem Kornansatz und zum Lagern führt.

Der wasserreichere und stickstoffämere Rindviehmist zersetzt sich dagegen langsamer, iiberladet daher den Boden nicht leicht mit Stickstoff.

Der Rindvichmist wird gern auf die lockeren, sandigen Bodenarten, bei denen es weniger auf Lockerung; wohl aber auf Humusbildung ankommt, und der Schaf- und Pferdemist auf die kalten, zähen, oder sauren, sehr humosen Böden gebracht, erstere werden durch sie thätiger und lockerer, letztere schneller entsäuert und zersetzt als durch Rindviehmist.

Die Jauchedüngung empfiehlt sich nur für sehr schwächliche 
Saaten, da sie die Entwickelung der regetativen Organe auf Kosten der Fruchtbildung zu sehr fördert, doch soll sie zmr Verwendung als Kopfdung rollkommen vergohren, d. h. das den Pflanzen schädliche Aetzammoniak in kohleusanres Ammoniak umgesetzt sein.

Die Stärke der Stallmistdüngung ist ron sehr verschiedenartigen Einfliissen ablängig, doch sieht man eine Düngung von 24000$30000 \mathrm{~kg}$ p. ha als eine nittlere, ron $40000-50000 \mathrm{~kg}$ als eine starke an, und schïtzt die Ausnutzung des frischen Stallmistes auf Mittelboden im 1. Jahr auf 35 Proc., im 2. auf 40 Proc., im 3. auf 25 Proc., des verrotteten im 1. Jahr auf 50 Proc., im 2. auf 35 Proc., im 3 . auf 15 Proc.

Begreiflicherweise sind diese Angaben nur als sehr unbestimmte anfzunehmen.

Die Verwendung von Kunstdiingern, und namentlich der leicht in Wasser löslichen, also zur schnellen Wirkung gelangenden, wird für das flachwurzelnde und in relatir kurzer Vegetationsperiode reifende Getreide von grosser Wichtigkeit sein.

Zunäehst sind die Stickstoffdünger zu erwähnen, welche auch als Kopfdung sehr giinstig wirken, und eine kräftigere Blattentwickelung, also iippigere Pflanzen ron dunkelgrüner Färbung erzeugen.

Rittha usen untersuchte bei mehreren Halmfrïchten sehr üppig (fett) und weniger ïppig (mager) erwachsene Pflanzen, und fand in 100 Teilen:

Trocken-

substanz

1) a. fetteGerstenpflanzen 16.5\& Proc.

b. magere

2) a. fette Haferpflanzen

b. magere

22.41 n

17.78 ,

21.33

3) a. fette Veizenpflanzen 24.90

b. magere

25.50

Wasser
83.49 Proc
$77.59 "$
$82.24 "$
$78.67 "$
$75.10 "$
$74.50 "$

Töllig trockner Stickstoff

2.52 Proc.

$1.43 "$

$1.94 "$

1.03

1.63

0.97

Hiernach rermehrte sich mit dem Proteïngehalt zugleich auch der Wassergehalt.

Die Ueppigkeit der Saaten kann aber unter Unständen einen den Pflanzen nachteiligen Grad crreichen, weshalb die Stickstoffdüngung nicht ganz ungefährlich ist, denn gar zu leicht wird bei warmer, fruchtbarer Witterung Lagerkorn erzengt, während sich sonst vielleicht dasselbe Feld bei kalter, nasser Witterung nicht als zu reich an Stickstoff darstellen wïrde.

Die einscitige und zu starke Anwendung der Stickstoffdüngung fuihrt aber zuweilen ancl zur Bodenverarmung, indem die Pflanzen gezwungen werden, gleichzeitig grössere Massen an Mineralstoffen aufzunehmen und darau den Boden bei foreirtem Getreidebau ersehöpfen können.

Ihre Wirkung dauert selten lïnger als ein Jahr.

An stickstoffreichen Kunstdiingern kommen zur Verwendung: 


\section{1) Schwefelsaures Amnoniak.}

Es enthält 20-21 Proc. Stickstoff und wird in der Stärke von $100-120 \mathrm{~kg}$ p. ha zur gleichmässigeren Verteilung mit der drei- bis vierfachen Menge Erde gemischt, ausgestreut, und zwar vor der Saat oder nach dem Auflaufen als Kopfdung.

Obwohl man dem schwefelsauren Ammoniak eine Wirkung als Kopfdünger nicht absprechen wird, so kann dasselbe für Chilisalpeter, der ihm in seiner Wirkung in dieser Richtung entschieden iiberlegen ist, doch nur einen Notbehelf abgeben. Nicht nur, dass seiner Wirkung erst die Umbildung des Ammoniaks in Salpetersäure vorausgehen muss, sondern auch die Absorptionsfähigkeit des Bodens für Ammoniak ist Ursache, dass der Stickstoff desselben, indem er an der Oberfläche des Bodens hängen bleibt und nur allmählich in den Bereich der Wurzeln gelangt, nur langsam zur Wirkung kommt.

\section{2) Salpetersaures Natron (Chilisalpeter).}

Der Chilisalpeter enthält 14-16\% Stickstoff und zwar in der günstigsten Form als fertig gebildete Pflanzennahrung und bietet den Vorteil, den Pflanzen, sobald sich Stickstoffmangel zeigt, in den hauptsächlichsten Vegetationsperioden zur Hïlfe kommen zu können, und häufig ist bei passender Witterung seine Wirkung so rapid, dass schon in Zeit von wenigen Tagen die Blätter ein dunkles Griin zeigen. Bekanntlich werden aber die salpetersauren Salze vom Boden nicht absorbiert und verbreiten sich sehr bald in der wässerigen Bodenlösung, weshalb sie sich bei feuchter Witterung und auf vegetationsleerem Boden in für die Pflanzen fernerhin unerreichbare Tiefen auswaschen lassen. In der Form als Kopfdünger hat man jedoch am wenigsten solche Verluste zu befürchten, denn der obenanf gestrente Dung wird begierig von den Wurzeln der in lebhafter Vegetation befindlichen Pflanzen aufgenommen. Die Kopfdüngung mit Chilisalpeter scheint bei Winterweizen und Winterroggen kurz vor dem Schossen, bei Gerste und Hafer nach Ausbildung des dritten Blattes am wirksamsten zn sein.

In der Regel wendet man auf stickstoffarmem Boden oder zu solchen Pflanzen, welche viel Stickstoff verlangen, eine Kopfdüngung: von Chilisalpeter in der Stärke von $100-160 \mathrm{~kg}$ p. ha an. Das Ausstreuen des Chilisalpeters erfolgt nach seiner sorgfältigen Zerkleinerung ohne Beimengung von Sand oder Erde am besten bei mässig feuchter Witterung.

3) Stickstoffreiche organisclie Substanzen.

Sie enthalten ausser Stickstoff noch Kohlenstoff utd anorganische Substanzen, z. B. phosphorsaure Kalkerde. 
Meist sind sie noch wenig zersetzt und kann daher ihre Wirkung durch Kompostirung rerstärkt werden.

Je grösser ihr Stickstoffgehalt und ihre Zerkleinerung ist, um so wertroller sind sie.

Sie finden namentlich zu Wintermng im Herbst in Quantitäten von $500-600 \mathrm{~kg}$ p. ha die beste Verwertung. abfälle.

Vorzugsweise gehören hierhin Hornmehl, Hornspäne und Woll-

\section{4) Peruguano.}

Derselbe wird jetzt meist im aufgeschlossenen Zustande benutzt und enthält dann ca. 9-10 Proc. Stickstoff, 10 Proc. Iösliche Phosphorsäure und 2 Proc. Kali.

Demnach sind in ihm die wichtigsten Pflanzennälırstoffe rertreten, aber nicht in den Mengen, wie sie die Pflanzen benötigen, weshalb er nur als Hülfsdünger anzusehen ist.

Zur Verhütung ron Geilstellen empfiehlt sich zur gleichmässigeren Verteilung die Beimischung einer $5-10$ fachen Erdmenge.

Das Ausstreuen geschieht kurz vor der Saat und ist zur Vermeidung eines Verlustes an Ammoniak ein flaches Unterbringen anzuraten.

Die aufzubringenden Quantitäten schwanken zwischen 300-400 $\mathrm{kg}$ p. ha doch eignet sich seine Anwendung nicht auf ron Natur armen Böden.

Eine zweite sehr wichtige Kategorie bilden ferner die phosphorsäurereichen Kunstdünger.

Ihre Wirkung zeigt sich rorzugsweise in der rollkommneren Ausbildung der Früchte, deren Gehalt an Phosphorsäure meistens in einem gewissen Zusammenhange mit dem Stickstoffgehalt steht, denn das Verhältnis der Phosphorsäure zum Stickstoff ist ziemlich konstant wie $1: 2$, nur bei aussergewöhnlich hohem Stickstoffgehalt stellt sich das Verhältnis wie $1: 2,65$, so ergaben W. Mayer ${ }^{*}{ }^{1}$ ) Untersuchungen

im Roggen ein Verhältnis wie $1: 2,2$,

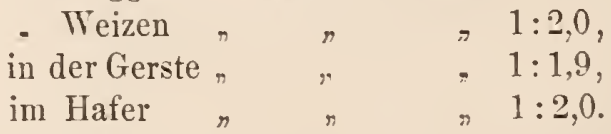

Häufig wird behauptet, dass nach einer starken Superphosphatdüngung und nach Eintritt trockener Witterung die Saat leicht , verbrenne" und man glaubte dies den ätzenden Eigenschaften des Superphosphats zuschreiben zu müssen, doch ist letzteres keineswegs der

1) Anualen der Chemie und Pharmacie, Bd. 101, pg. 129. 
Fall, demn schon nach Verlauf weniger Stunden verbindet sich die lösliche Phosphorsäure mit dem kohlensauren Kalk des Bodens zu einem neutralen Kalksalz, und sagt iiber das „Verbrennen“ Dr. Wagne ${ }^{1}$ ), dass diese Erscheinung nur im Zusammenhang stehe mit dem Mangel an Stickstoff im Boden. Wenn nämlich eine mit Superphosphat kräftig gedüngte Saat in Folge trockener Witterung an Wasser und zugleich auch an Stickstoff Mangel leidet, so wird die durch solchen Mangel und durch die hohe Lufttemperatur hervorgerufene Tendenz zu einer Abkiirzıng der Vegetationszeit durch die vorwiegende Phosphorsäure-Ernährung, die zur Samenbildung drängt, noch erheblich gesteigert werden. Die Pflanze wird unter zu grosser Beschleunigung des Reifeprocesses ihre Vegetation beschliessen und dann als ,verbrannt" bezeichnet werden.

Hieraus folgt, wie wichtig es ist, neben der Phosphorsäuredüngung auf stickstoffarmen Böden auch eine genïgende Stickstoffdiingung zu geben.

Wir unterscheiden leicht lösliche Superphosphate und weniger leicht lösliche und in Wasser unlösliche Phosphate.

Auf den biindigen, nit giinstigen Absorptionseigenscliaften versehenen Böden empfiehlt es sich, die fehleude Phosphorsäure als Superphosphat, dagegen auf ganz leichten Sand-, Kalk- oder Moorböden in Form weniger leicht löslicher Phosphate zu geben, da Superphosphat auf solchen Böden entweder nicht genügend absorbiert, oder in eine unlösliche Form iibergeführt wird.

Um mit dem geringen Sandboden anzufangen, so hat derselbe vermöge seiner grossen Armut an Kalk, Eisen und Thonerde iiberhaupt nicht oder nur in geringem Grade die Fähigkeit, die Phosphorsäure zu absorbieren. Die in den Superphosphaten gelöste Phosphorsäure wird daher der Gefahr ausgesetzt sein, durch Grundwasserbewegungen oder Regengüsse ausgespiilt und weggewaschen zu werden. In solchen Bodenarten ist daher ein unlösliches Phosphat, welches dieser Gefahr weniger ausgesetzt ist, weit besser am Platze.

Erklärt man im Sandboden die Wirkungslosigkeit der löslichen Phosphorsäure durch die Kalkarmut, so scheint es auf den ersten Blick schwer verständlich, dass auch in sehr kalkreichem Boden die Superphosphate ihre Wirkung versagen sollen, und doch hat die Theorie diese Verhältnisse vollkommen einleuchtend zı erklären gewusst. Der enorme Kalkiiberschuss in den in Frage stehenden Böden verwandelt nämlich die lösliche Phosphorsäure nicht nur in zweibasischen phosphorsauren Kalk, sondern direct in vollkommen unlöslichen, von der Bodenflüssigkeit schwer zersetzbaren und durch die Pflanzenwurzel

1) Fühling's landw. Zeit. 1878 pg. 274. 
sehwer assimilirbaren dreibasiseh phosphorsauren Kalk; anders verhält es sieh bei der zurüekgegangenen Phospborsäure in Form von zweibasiseh phosphorsauren Salzen; dieselben sind infolge ihrer festen Form ehemisehen Einflïssen im Boden weniger zugänglieh und verbleiben daher als solehe $d$. L. in einer von der Pflanze relativ leiehter assimilirbaren Form im Boden.

Was nun den Moorboden betrifft, so liegen hier teilweise dieselben Verhältnisse vor, wie bei dem leiehten Sandboden. Die interessanten Versnehe ron Fle iseher auf versehiedenen Moorböden Deutsehlands haben die Unfähigkeit derselben, Phosphorsäure zu absorbieren, zur Evidenz naehgewiesen. Jedenfalls ist hier der Grund dieser Erseheinung in einer Bildung löslieher Doppelverbindungen der Phosphate mit der organisehen Substanz der Moorböden zu suehen; in den Moorböden ist aber ansserdem noeh bei dem hohen Wassergehalt und der starken Bewegung der Bodenflüssigkeit in demselben die Gefahr einer Wegspülung und Auswasehung noelı viel grösser als bei den Sandböden.

Von den an Phosphorsäure reiehen Diingemitteln empfiehlt sich das Superphosphat.

Seine lösliebe Phosphorsäure, die leieht mit den kalihaltigen Silikaten des Bodens Verbindungen eingeht und sieh fein verteilt, gelangt zu sehr sehneller Wirkung. Sehr hänfig konmen aueh Miselıungen des Superphosphates mit schwefelsaurem Ammoniak (5-6 Proc. Stiekstoff'), oder mit salpetersaurem Natron vor. Doeh ist ersteres Gemiseh, weil absorptionsfähig, mit Ausnahme bei Verwendung zur Kopflüngung letzterem rorzuziehen. Eine reeht kräftige Wirkung üben $200-300 \mathrm{~kg}$ Superphosphat p. ha aus.

Unter den stiekstoffhaltigen Phosphaten sind zu nemnen der Baker-Guano und das Knoehenmehl.

Der Baker-Guano enthält ausser etwas Stiekstoff 70-80 Proc. phosphorsaure Kalkerde. In der Sehnelligkeit der Wirkung steht er hinter dem Superphosphat zurück, da er sieh weit langsamer zersetzt.

Das Knoehenmehl wird entweder ans rohen oder gedämpften Knnoehen bereitet und ist letzteres vorzuziehen, weil ein besseres Pulvern der gedämpften Knoehen möglieh und das Fett extrahiert ist, was beides die Einwirkung der lösenden Agentien erleiehtert und eine etwas sehnellere Wirkung erzielen lässt.

Diese Phosphate sind mögliehst im Herbst auszustrenen und flaeh unterzubringen, um eine bessere Wirkung herbeizufiuhren; am vorteilhaftesten erseheint aber ihre Verwendung mit Stallmist. weil die Kohlensïure und das Ammoniak des Mistes lösend einwirken, und die in dem stiekstoffreiehen Stallmist meist in relativ geringer Menge rorkommende Phosphorsäure ergänzen. 
Eine kräftige Beidüngung beträgt $200-400 \mathrm{~kg}$ p. ha und hält die Wirkung derselben zwei bis drei Jahre an.

Die Düngung mit Kalisalzen fördert unter Umständen ebenfalls das Gedeihen des Getreides, da es Böden gibt, deren Kaligehalt nicht grösser als ihr Phosphorsäuregehalt ist. Hier wiirde sich in Verbindung mit einer reichlichen Phosphorsäuredüngung die Kalidüngung wohl bewähren, denu ohne erstere ist dic Wirkung nur gering; da die Pflanzen dem Boden viel leichter das Kali als die Phosphorsäure $\mathrm{zu}$ entziehen vermögen, und ïben sie dann in Quantitäten von $200 \mathrm{~kg}$ Chlorkalium, sehwefelsaures Kali oder sehwefelsaure Kali-Magnesia eine reeht günstige Wirkung auf dic Quantität und Qualität vornämlieh des auf sehr humosem oder sehr sandigem Boden wachsenden Getreides aus.

Am meisten empfichlt sieh das Ausstreuen der Kalisalze zeitig im Herbst, oder auf Kompost und Stalldung mit denen zum Getreide gedüngt werden soll, weil sonst schädliehe Wirkungen, namentlieh bei Verwendung des Chlorkaliums nicht ganz ausgesehlossen sind.

Von den indirekt wirkenden Düngemitteln findet der gebrannte Kalk eine umfangreiche Verwendung. Derselbe bringt dic Humussubstanzen zu sehnellerer Zersetzung, führt den in organischer Form vorhandenen Stiekstoff leicht in Salpetersäure ïber, bindet die Humussäuren, zerlegt etwa vorhandenes schwefelsaures Eisenoxydul, das dem Pflanzenwachstum sehr nachteilig ist, in sehwefelsamre Kalkerde und leicht oxydirbares Eisenoxydulhydrat, beschlennigt die Verwitterung der Silikate in den thonhaltigen Bodenarten und wirkt günstig auf den physikalisehen Zustand der schweren Böden ein.

Demnach wird die Auwendung des gebrannten Kalkes auf den humusreiehen und den sehweren, thonhaltigen Böden von dem grössten Erfolge begleitet sein, während humnsarme und leichte Böden zu iibergrosser Thätigkeit angeregt werden, was leicht eine Bodenerschöpfung zur Folge liaben kann.

Gemeinhin diungt man auf regetationsleerem Boden alle $7-8$ Jahre mit $1000-2000 \mathrm{~kg}$ p. ha.

Ein zweites indirektes Düngemittel ist der Mergel, und enthält derselbe als wirksamen Bestandteil kohlensaure Kalkerde in fein verteiltem Znstande und ausserdem sehr versehiedenartige Nebenbestandteile, wie Sand, Thon, Lehm, Humus, aueh inmer etwas Phosplorsäure und Stickstoff, so dass eine direkte Wirkung auf das Pflanzenwaehstum nicht geleugnet werden kann. Seine clemische Wirkung ist analog der des Aetzkalkes, seine physikalisehe dagegen weit grösser, denn durelı genügende Mengen eines fiir den Boden passenden Mergels lassen sich häufig dessen Misehnngsverhältnisse vollständiğ ändern. Wird z. B. auf Thonboden Kalk- oder Sandmergel aufgebracht, so vermindert sich die zu grosse Bindigkeit und wasser- 
haltende Kraft desselben; auch rermag die Luft besser einzudringen, wodurch die Thätigkeit des Bodens erhöbt wird. Bringt man dagregen auf Sandboden Thonmergel, so erhöht sich seine wasserbaltende und wasserfassende Kraft und sein Absorptionsvermögen.

Demnach richtet sich die Menge des anzumendenden Mergels nach dem zu erreichenden Zweck und der Beschaffenheit des Mergels, weshalb die aufzubringenden Quantitäten ron $50-650 \mathrm{cbm}$ p. ha schwanken können.

\section{Die Stellung der Getreidearten in der Fruchtfolge.}

Zur Sicherung der möglichst zweckmässigen Stellung der Getreidearten in der Fruchtfolge ist die Wertigkeit der landwirtschaftlichen Kulturgewächse für dieselbe einer Betrachtung zu unterziehen.

Zunächst hat man dieBerurzelungsfähigkeit, d.h. die rertikale und horizontale Ausbreitung der Wurzel, sowie das Wurzelrermögen der hauptsächlichsten Kulturgewächse zu prüfen.

Im Allgemeinen soll die Bewurzelıngstähigkeit zur Erzielıng einer normalen Pflanzenproduktion mit dem Nährstoffreichtum des Bodens im Verhältnis stehen. Letzterer ändert sich jedoch fortwährend in der Fruchtfolge, sowohl in Folge der Duingung; wie der Entnahme ron Pflanzennährstoffen durch die Ernten, weshalb die Pflanzen nach Maassgabe ihrer Bewurzelungsfähigkeit den ihnen zusagendsten Platz in der Fruchtfolge erhalten müssen, d. h. Pfanzen mit hervorragender Berrurzclungsfähigkeit, wie die Tief- und Kraftwurzler, welchen beispielsweise die Leguminosen angehören, bedürfen im Allgemeinen eines geringeren Vorrates fertiger Pflanzennahrung in der Ackerkiume, als die zu' den Flach- und Schwachwurzlern gehörenden Getreidearten und Hackfriichte.

Somit rerhalten sich die Ansprüche der Kulturgewächse dem Reichtum an fertiger Pflanzennahrung in der Ackerkrume gegenüber sehr rerschieden, was fuir ihre Stellung in der Fruchtfolge ron allergrösster Bedeutung ist.

Einen Beweis für die sehr verschiedene Aufschliessungsfähigkeit der Gewächse hat Dietrich erbracht, indem er unrerwitterte Gesteinsarten pulrerisirte und das gewonnene Pulrer als künstlichen Boden benutzte. In solchem betrug das Mehr an löslich gewordenen Mineralstoffen, welche durch den Einfluss der Pflanzen, im Vergleich zur Aufschliessing durch die Verwitterung disponibel geworden war: 
bei Buntsandstein, Basalt.

100 Lupinenpflanzen
" Erbsenpflanzen
" Spörgelpflanzen
" Buchweizenpflanzen
" Wickenpflanzen
" Weizenpflanzen
" Roggenpflanzen

\begin{tabular}{|c|c|c|}
\hline 20.27 & pCt. & 24.97 \\
\hline 16.02 & $n$ & 23.77 \\
\hline 1.01 & $"$ & 1.84 \\
\hline 2.32 & $"$ & 3.27 \\
\hline 5.53 & $"$ & 6.30 \\
\hline .34 & " & 2.45 \\
\hline 0.1 &, & 1.64 \\
\hline
\end{tabular}

Demzufolge eignen sich die Getreidearten am wenigsten und die Leguminosen am meisten zur Aufschliessung der Pflanzennährstoffe.

Ein zweiter bei der Prüfung der Gewächse in Bezug ihrer Wertig. keit für die Fruchtfolge in Betracht konmender Faktor ist das Verhalten der Blätter, und zwar wird hierbei die Grösse der Blattoberfläche und das Vermögen der Blätter, sich mehr oder weniger energisch der Kohlensäure und vielleicht auch des Ammoniaks der Atmosphäre zu bemächtigen und Wasserdunst abzugeben, zu unterscheiden scin.

Die Tiefwurzler sind num zugleich mit einem sehr starken Blattvermögen ausgerüstet, daher sie auch vorzugsweise als Sammler dieser Nährstoffe der Atmosphäre anzusehen sind, und demnach die Nährstoffe der Ackerkrume weniger als die mit geringerem Blattvermögen ausgestatteten Getreidearten in Anspruch nelımen.

Aus diesem Grunde wird ein Wechsel zwisehen den Getreidearten und Leguminosen dem Gedeihen ersterer sehr förderlich sein.

Die Grösse der Blattoberfläche der Gewächse darf ebenfalls nicht unterschätzt werden, denn der günstige chemisch-physikalische Zustand des Bodens, welcher für das Gedeihen der Nachfrucht so überaus wichtig ist, bängt zu einem grossen Teil von der Intensität der durch die Vorfrucht erzeugten Beschattung ab.

Bei dichter Beschattung wird der Gälırungsprocess in der Ackerkrume fast ununterbrochen und energisch vor sich gehen können, da ihn unausgesetzt eine mässigg warme Temperatur und genügende Feuchtigkeit unterstiitzen, demn unter einer dichten Blattdecke ist die oberste Bodenschicht weniger der Verdunstung ausgesetzt und durch die zwischen den Pflanzen erfolgenden Thauniedersehläge stets feuchter als bei schwacher Blattdecke; ausserdem schïtzt sie die Ackerkrume vor dem schnellen Durchdringen der Tageshitze, iiberträgt somit die niedrige Nachttemperatur auf die Tageszeit, wodurch sehr günstige Bedingungeu für dic Umsetzungsprocesse im Boden geschaffen wcrden. Ferner erhält sich eine physikalisch günstig wirkende Bodenstruktur. Das Verhalten der landwirtschaftlichen Kultnrpflanzen bezüglich der Grösse ihrer Blattoberflächen ergiebt sich aus der nachstehenden Tabelle über Blattflächenausmessungen etc., welche voll mir in Poppelsdorf an einer Anzahl 
von Pflanzenarten, auf gutem, fruchtbaren Lehmboden kultiviert, vorgenommen wurden.

Bemerkt sei, dass hier unter "Blattoberfläche" nur die Blattoberfläche einer Blattseite, weil diese bei der Beschattung altein in Betracht kommt, zu verstehen ist.

Ausser den Blattoberflächen ist in der Tabelle auch auf die Produktion der Pflanzen an organischer Substanz und darin an Stickstoff und auf die wichtigsten Mineralbestandteile Rücksicht genommen, weil die Menge der producierten humusbildenden Substanz und des Stickstoffs, sowie die Entnalume von Mineralstoffen aus dem Boden für die Fruchtfolge nicht gleichgültig sein kann.

Die Mittelernte ist nach den Durchsehnittsertrïgen in Poppelsdorf berechnet, wcicht daher von der Mittelernte Deutschlands insofern $a b$, als sie höhere Zahlen ergiebt, die aber doch das verschiedene Verhalten der Pflanzen zu einander charakterisieren.

Tabelle ïber die Blattoberflächenausmessungen und die Einte an organischer Substanz, und darin Stickstoff, sowie über die wichtigen Mineralbestandteile.

\begin{tabular}{|c|c|c|c|c|c|c|c|c|}
\hline $\begin{array}{l}\text { Bezeichnung } \\
\text { der Pflanzen }\end{array}$ & 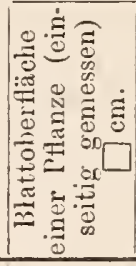 & 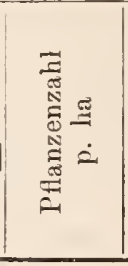 & 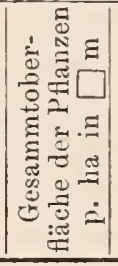 & $\begin{array}{c}\text { Mittelerntc } \\
\text { p. ha in } \\
\text { kg }\end{array}$ & 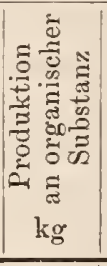 & 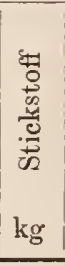 & $\begin{array}{c}0 \\
\vdots \\
: 0 \\
0 \\
0 \\
0 \\
0 \\
0 \\
0 \\
0 \\
0 \\
0 \\
\mathrm{ag}\end{array}$ & 浔 \\
\hline Luze & 2.312 & 370370 & 856333 & 320.0 & 6560 & 230 & 48 & 144 \\
\hline tklee & 713 & 3703703 & 264000 & 24000 & 4872 & 127 & 31 & 110 \\
\hline Bastardklee & 504 & $+545+54$ & 227000 & 22000 & 3520 & 117 & 22 & 77 \\
\hline Winterweizen & 878 & 2000000 & 175600 & $\left\{\begin{array}{l}2000 \text { Korn } \\
4700 \text { Stroh }\end{array}\right.$ & 55.17 & 57 & 27 & 33 \\
\hline Sommerweizen & 343 & 4120000 & 137700 & $\begin{array}{l}18100 \text { Kiorn } \\
3800 \text { Stroh }\end{array}$ & 4640 & 50 & 24 & 29 \\
\hline Winterroggen & 780 & 2000000 & 156000 & $\begin{array}{l}200() \text { Korn } \\
4200 \text { Stroh }\end{array}$ & 5050 & 45 & 24 & 43 \\
\hline Zweizeilige Gerste & 429 & 3390000 & 145400 & $\begin{array}{l}1800 \text { Koln } \\
2000 \text { Stroh }\end{array}$ & 3182 & 41 & 16 & 28 \\
\hline Vierzeilige Gerste & 351 & 4110000 & 144260 & $\begin{array}{l}1400 \text { Korn } \\
1800 \text { Stroh }\end{array}$ & 2635 & 34 & 14 & 23 \\
\hline Hafer & 578 & 3600000 & 211320 & $\begin{array}{l}3100 \text { Korn } \\
5000 \text { Stroh }\end{array}$ & 6659 & 67 & 26 & 60 \\
\hline Kornmais & 3.400 & 80000 & 27200 & $\begin{array}{l}1600 \text { Korn } \\
4000 \text { Stroh }\end{array}$ & 4612 & 45 & 24 & 70 \\
\hline Futtermais (Grün) & 5.870 & 200000 & 117400 & 60000 & 7800 & 192 & 42 & 174 \\
\hline Brachrübe & 3.312 & 66666 & 22800 & $\left\{\begin{aligned} 30000 & \text { Rüben } \\
6000 & \text { Laub }\end{aligned}\right.$ & 2880 & 76 & 38 & 109 \\
\hline Kohlıübe & 3.420 & $5000^{\prime}$ & 17100 & $\left\{\begin{array}{r}40000 \text { Rüben } \\
8000 \text { Laub }\end{array}\right.$ & 5760 & 138 & 77 & 221 \\
\hline Runkelrübe & 3.283 & 50000 & 16415 & 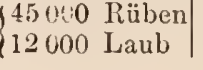 & 5616 & 116 & 46 & 245 \\
\hline
\end{tabular}


Vorstehende Tabelle zeigt deutlich, dass die Leguminosen die verhältnissmässig grösste Menge wichtiger Pflanzennährstoffe der Wirtschaft zuführen, ohne die Ackerkrume zu erschöpfen, denn die humusbildende Substanz und vielleicht auch der Stickstoff entstammen der Hanptsache nach der Atmosphäre, und die wertvollen Mineralstoffe den tieferen Bodenpartien, welche durch Flach- und Schwachwurzler nicht mehr auszunutzen sind. Ausserdem bewirkt ihre intensive Beschattung die Erhaltung der Bodenstruktur und des Humus im Boden. Ferner wird durch die kräftige Wurzelentwickelung der Leguminosen der Boden bis zu grösserer Tiefe nicht unwesentlich physikalisch verbessert, denn ihre starken Wurzeln durchsetzen die festeren Bodenpartieen und durchlochen siebartig die durch den Pflug festgeschleifte Grenzschicht zwischen Ackerkrume und Untergrund, wodurch nicht nur der Luft, sondern auch den Wurzeln der Nachfrucht das Eindringen ungemein erleichtert wird. Die in der tieferen Bodenschicht faulenden und hierbei Kohlensäure und Ammoniak entwickelnden Wurzeln beförderen aber auch die Zersetzung dieser Bodenschichten.

Die Getreidearten liefern der Wirtschaft eine nicht zu unterschätzende Menge humusbildender Substanz und Stickstoff, aber zu einem beträchtlichen 'Teil nicht auf Kosten der Atmosphäre, sondern der Ackerkrume, die daher einen gewissen Vorrat leicht assimilierbarer Pflanzennährstoffe zur vorteilbaften Entwickelung des Getreides besitzen muss. Auch in der Bodenbeschattung bleibt das Getreide weit hinter den Leguminosen zuriick, nur der Hafer zeichnet sich durch eine beträchtliche Blattoberfläche, sowie auch durch kräftige Bewurzelung und hervorragendes Wurzelvermögen aus, so dass er gewissermassen das Bindeglied zwischen den Blatt- und Getreidefrüchten bildet.

Was nun die Hackfriichte angeht, so bedürfen dieselben zur üppigen Entwickelung eines Ueberflusses leicht assimilierbarer Nährstoffe in der Ackerkrume, und zeichnen sich ihre Wurzeln durch die Energie aus, mit welcher sie diese Nährstoffe aufnehmen.

Die durch sie erzeugte Bodenbeschattung bleibt noch bedeutend hinter der der Cerealien zuruick, mithin sie ill dieser Beziehung für die Fruchtfolge keinen hohen Werth beauspruchen können, vielmehr ist ibr Nutzen darin zu suchen, dass durch die ihnen zu Teil werdende vorzugliche Kultur der Boden physikalisch verbessert und die Brache ersetzt wird. Auch trägt auf sehr reichem Boden ihr Anbau dazu bei, dem zu üppigen Gedeihen und Lagern des Getreides vorzubeugen.

Die der Wirtschaft durch sie gelieferten humusbildenden Substanzen, und der darin enthaltene Stickstoff, sowie ibre Mineralstoffe entstammen weit überwiegend dem leicht assimilierbaren Nährstoffvorrat der Ackerkrume. 
Weiter ist es die Menge der Stoppel- und Wurzelrückstände, welche der Ackerkrume verbleiben, die den Wert eines Gewächses für die Fruchtfolge mit bestimmen.

Um über die Zusammensetzung und Menge der dem Acker nach der Ernte verbleibenden Stoppel- und Wurzelrückstände Aufschluss zu erhalten, unternahm ich es in Herbst 1869, die Rückstände einer grossen Zahl landwirtschaftlicher Kulturgewäche, die unter ihnen zusagenden Verhältnissen auf dem Versuchsfelde zu Proskau angebaut worden waren nnd einen normalen Stand zeigten, zu gewinnen.

Dr. We iske hatte die Güte, auf der Versuchs-Station zu Proskau, unter Mitwirkung der Assistenten E. Sehmidt und E. Wildt, die gewonnenen Stoppel- und Wurzelrückstände sowohl in Bezug auf Quantität als Qualität einer eingehenden Untersuchung zu unterwerfen.

Zur Gewinnung des erforderlichen Materials wurden auf den betreffenden Feldern nach der Ernte an 2 resp. 4 verschiedenen Stellen genau $0,39 \square \mathrm{m}$ Boden $26 \mathrm{~cm}$ tief, als durchschnittliche Tiefe der Ackerkrume, unter jedesmaliger Anwendung "eines für diesen Zweck gefertigten Schemas, ansgegraben, gesammelt und die in jeder dieser Flächen enthaltenen Stoppeln und Wurzeln mittelst vorsichtigen Abschlämmens der Erde durch ein feines Sieb und Auslesens der Steine von anhängenden Unreinigkciten befreit. Nachdem auf diese Weise die gewïnschte Reinheit erlangt war, wurden die Stoppeln und Wurzeln jeder einzelnen Pfianzengattung an der Luft getrocknet, zerschnitten, gleichmässig gemengt und die Quantität von je 4 resp. $2 \times 0,39 \square \mathrm{m}$ Boden gewogen und zur Analyse verwandt, deren Endresultate hier folgen.

Tabelle über die der Ackerkrume verbleibenden Stoppelund Wurzelriickstände.

\begin{tabular}{|c|c|c|c|c|c|}
\hline \multicolumn{2}{|c|}{$\begin{array}{l}\text { Gesammtmenge der } \\
\text { wasserfreien Stoppel- und } \\
\text { Wurzelrückstände } \\
\text { pro ha in } \mathrm{kg}\end{array}$} & \multicolumn{2}{|c|}{$\begin{array}{l}\text { Menge des Stickstoffs } \\
\text { pro ha in kg }\end{array}$} & \multicolumn{2}{|c|}{$\begin{array}{l}\text { Menge der kohle- und } \\
\text { kohlensäurefreien Asche } \\
\text { pro ha in } \mathrm{kg}\end{array}$} \\
\hline Luzerne (4jährig) & 10810.8 & Rotklee & 214.6 & Rotklee & 2146.9 \\
\hline Rothklee (1jährig) & 9976.2 & Luzcrne & 152.6 & Roggen & 1842.7 \\
\hline DreischürigeEspar- & 6632.0 & Esparsette & 138.0 & Hafer & 1614.6 \\
\hline $\begin{array}{l}\text { sette (3jährig) } \\
\text { Roggen }\end{array}$ & 5887.0 & $\begin{array}{l}\text { Wundklee } \\
\text { Roggen }\end{array}$ & $\begin{array}{r}114.4 \\
73.2\end{array}$ & $\begin{array}{l}\text { Luzerne } \\
\text { Weizen }\end{array}$ & $\begin{array}{l}1341.6 \\
1218.7\end{array}$ \\
\hline Wundklee & 5596.5 & Serradella & 72.5 & Esparsctte & 1144.6 \\
\hline Raps & 4986.1 & Lupine & 69.7 & Wundklee & 1090.0 \\
\hline Hafer & 3725.7 & Raps & 63.1 & Erbsen & 750.1 \\
\hline Lupine & 3942.6 & Erbsen & 63.4 & Raps & 696.1 \\
\hline Weizen & 3888.3 & Buchweizen & 536 & Lupine & 616.0 \\
\hline Erbsen & 3603.6 & Hafer & 30.0 & Serradella & 610.3 \\
\hline Serradella & 3500.2 & Weizen & 26.4 & Buchweizen & 520.6 \\
\hline Buchweizen & 2455.0 & Gerste & 25.7 & Gerste & 425.1 \\
\hline Gerste & 2226.9 & & & & \\
\hline
\end{tabular}


In der Asche bleiben pro Hektar in Kilogrammen:

\begin{tabular}{|c|c|c|c|c|c|c|c|c|c|c|c|c|c|}
\hline & 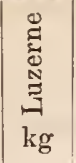 & 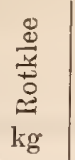 & 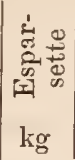 & 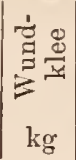 & 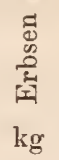 & 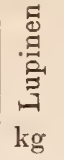 & 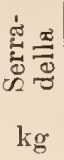 & 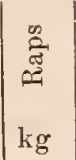 & 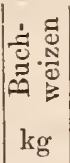 & $\begin{array}{l}\text { d] } \\
\stackrel{N}{0} \\
\mathrm{~kg}\end{array}$ & $\begin{array}{c}5 \\
80 \\
80 \\
80 \\
0 \\
\mathrm{~kg}\end{array}$ & 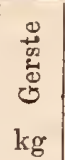 & \\
\hline Kal & 220.0 & 2929 & 148.6 & 152.3 & 80.5 & 90.1 & 89.5 & 138.3 & 89.7 & 86.0 & 82.1 & 47.4 & 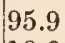 \\
\hline Magnes & 27.3 & 55.2 & 35.5 & 20.1 & 12.5 & 13.6 & 15.2 & 14.6 & 8.2 & 11.5 & 16.2 & 6.2 & 13 \\
\hline Kali & 41.1 & 90.0 & 47.8 & 29.1 & 12.7 & 19.1 & 10.0 & 41.1 & 10.3 & 20.7 & 35.1 & 10.9 & 27 \\
\hline Natro & 30.2 & 22.4 & 15.6 & 6.6 & 8.0 & 4.1 & 5.5 & 23.6 & 4.9 & 12.7 & 47.4 & 3.9 & 20 \\
\hline Schw & 20.9 & 29.1 & 232 & 15.2 & 10.7 & 8.0 & 10.3 & 34.9 & 7.6 & 8.4 & 13.4 & 6.2 & 9 \\
\hline Phospl & 44.0 & 83.9 & 33.3 & 27.1 & 16.8 & 15.6 & 20.7 & 35.9 & 12.3 & 13.3 & 28.5 & 13.5 & \\
\hline
\end{tabular}

Aus dieser Tabelle geht evident hervor, dass betreffs Bereicherung der Ackerkrume durch Stoppel- und Wurzclrückstände und in diesen vorzugsweise an Stickstoff, Phospliorsäure und Kali wiederum die Leguminosen die crste Stelle einnehnen, wogegen die Getreidearten mit Ansnahme des Roggens erheblich zurïcktreten. Letzterer itberragt nun in höchst auffallender Weise nicht nur die Getreidearten, sondern selbst die Serradella, Lupine und Erbse in seinen Stoppelund Wurzclrïckständen an den wichtigsten Pflanzennährstoffen. Allerdings entstammen diese grösstenteils dem Dungeapital der Ackerkrume, sind aber doch so bedeutend, dass sich hieraus die bevorzingte Stcllung hauptsächlich erklïrt, welche der Roggen, den anderen Getreidearten gegeniiber, als Vorfrucht geniesst.

Von den Wirtschaftssystemen benutzt die Dreifclderwirtschaft (Brache*, Wintergetreide, Sommergetreide) am wenigsten die Vorteile des Fruchtwechsels, daher führt auch dieser einseitige Getreideban leicht zur Verarmung des Bodens an sehr wichtigen Pflanzennährstoffen, wälırend andererseits die Nährstoffe der Atmosphäre und der tieferen Bodenschichten nicht genügend ausgenutzt wcrden, und zur Verschlechterung der physikalischen Beschaffenheit des Bodens, sowie zur Vermelıung der pflanzlichen ınd tierischen Feinde führen.

In den Koppcl- oder Schlagwirtschaften licgen die Verhältnisse schon günstiger, denn obwohl auch hier mehrere Halmfrïchte nach einander folgen, tritt doch eine Unterbrcchung durch mehrjähriges Kleegras und in den verbesserten Koppelwirtschaften auch dureh andere Blattfrüchte ein, wie dies naclistehende Beispiele zeigen:

Holstein'sche

Mecklenburg'sche

Koppelwirtschaft.

1) Drecschhafer,

1) Brache *,

2) Brache *,

2) Weizen,

3) Weizen,

3) Gerste,

4) Roggen,

4) Blattfrucht,

5) Gerste,

5) Roggen,

6-10) Kleegras,

6) Hafer, 7-9) Kleegras. 
Hiernach wird auch in diesem Wirtschaftssystem den Principien des rationellen Wechsels der Früchte noch zu wenig Rechnung getragen.

Anders liegen aber die Verhältnisse in der Fruchtwechselwirtschaft, denn diese sucht die Vorteile des Wechsels der Früchte möglichst vollkommen auszubenten.

Der einfachste Fruchtwechsel ist der Norfolker (Hackfrucht * Sommerung, Klee, Winternng), der dem Princip, nie Früchte derselben botanischen Klasse auf einander folgen zu lassen, streng Rechnung trägt. Auch befinden sich in demselben sämmtliche Friichte in der ihnen zusagendsten Stellung; so kommen im NorfolkFruchtwechsel die Hackfrüchte in ein tief kultiviertes, reich gedüngtes Feld, daher sie auch der nachfolgenden Halmfrucht noch genügende Mengen fertiger Pflanzennahrung, und ein gelockertes, von Unkraut gereinigtes Land hinterlassen, das auch noch dem Rotklee so günstige Wachstumsverhältnisse bietet, dass er sich kräftig entwickelt, und im nächsten Jahre die Ackerkrume dicht beschattet und durch seine wertvollen Stoppel- und Wurzelrückstände bereichert, mithin das Feld der Winterung in vorzüglichem Znstande übergeben wird.

Da sich in Dentschland die vierjährige Wiederkehr des Rotklees als unthunlich erwies, empfahl A. Thaer den nachfolgenden sechsfeldrigen Fruchtwechsel:
1) Hackfrïichte *,
2) Sommerung,
3) Rotklee,
4) Winterung, 5) Blattfrüchte *, 6) Winterung.

Dieses Fruchtwechsclsystem sucht nun nicht allein durch zweckmïssige Benutzung der Vorteile des Fruchtwechsels den Reinertrag; sondern anch die Sicherheit der Durchschnittserträge durch die Mannigfaltigkeit der ang'ebauten Gewächse zn erböhen, sowie einc möglichst gleichmässige Verteilung der Arbeitskräfte herbeizuführen. Ferner schmiegt sich dieses System, da es den Markt mit mannigfaltigeren Erzeugnissen zn versorgen im Stande ist, leichter den volkswirtschaftlichen Bedürfnissen an, und ist auch von natiirlichen Futterfeldern unabhängig.

$\mathrm{Da}$ es aber ein intensives Wirtschaftssystem ist, so beansprucht es einen ausgebildeten Handelsverkehr, lohnende Preise, namentlich der tierischen Produkte, zuverlässige Arbeiter, und vervollkommnete Maschinen, mithin ein grösseres Betriebskapital als die Dreifelderoder Koppelwirtschaft.

Zuerst glaubte man, die Frnchtwechselwirtschaft miisse mit Stallfuitterung verbunden, die schwarze Brache unter allen Umständen zu verwerfen und der Klee nur einjährig sein. Diese Anschauung ist nun nach und nacl binfällig geworden und in den hentigen modificierten Fruchtwechselwirtschaften begegnet man Weidegang anf mehrjährigen Kleegrasfeldern, auf schwerem Thonboden der Schwarz- 
brache und nicht selten folgen zu Ende der Rotation zwei Halmfrüchte nach einander, wie dies die folgenden Beispiele zeigen:

Milder Lehmboden.

1) Hackfiüchte *,

2) Gerste,

3) 4) Klecgras,

5) Winterung *,

6) Hafer,
Schwerer Thonboden.

1) Hackfriichte *,

2) Hafer,

3) 4) Klee,

5) Winterung,

6) Brache *,

7) Oclfucht,

8) Winterung,

9) Bohnen *,

10) Hafer.

In den meisten Fruchtfolgen lässt sich noch der Norfolk-Fruchtwechsel erkennen, der gewissermassen das Gerüst für den Aufbau der Fruchtfolgen abgibt.

\section{Die Bodenhearbeitung zum Getreidebau.}

Die Bodenbearbeitung erstrebt die Regulierung der Bodenfruchtbarkeit, welche letztere, abgesehen vom Klima, die Höhe der Erträge bestimmt.

Die Bodenfruchtbarkeit ergiebt sich nun nicht allein aus dem Vorhandensein cines genügenden Vorrates fertiger Pflanzennahrung im Boden, woriiber schou der Abschnitt über die Düngung Aufschluss gegeben hat, sonderu auch aus der Fähigkeit des Bodens der Pflanze als Wohnstätte $\mathrm{zu}$ dienen, und diese ist an seine giinstige physikalische Beschaffenheit geknüpft, welche ihrerscits bauptsächlich aus der zweckmässigen Bodenbearbeitung resultiert.

Dieser giinstige physikalische Znstand des Kulturbodens wird gemeinhin als "Ackergahre" bezeichnet und darunter verstanden: 1) ein gewisser Grad von Lockerheit und Feuchtigkeit; 2) ein gewisser Wärmegrad; 3) die gleichmässige Vertcilung aller Pflanzennährstoffe in Boden.

In Bctreff der Lockerheit ist zu bemerken, dass diese nicht nur durch Aufpfligen, Eggen und Walzen eines crhärteten Bodens erreicht wird; denn den einzelnen Erdklïmpehen würde inmer noch die alte Festigkeit und nicht jene Mürbigkeit hicr gleichbedeutend mit Porosität innewohnen, welche nur durch längere Zeit andauernde Einwirkung von Luft und Feuchtigkeit auf den mechanisch ge- 
brochenen Boden, wodurch in demselben physikalische und chemische Processe hervorgerufen werden, erzeugt wird. Demnach hat die Bodenbearbeitung den ungehinderten Zutritt von Luft und Feuchtigkeit zu erwirken; zu dieser indirekten Wirkung tritt auch eine direkte, denn ohne Umspülung der Wurzeln mit Luft und ohne möglichste Erhaltung der Bodenfeuchtigkeit und Wärme ist eine ausgiebige Produktion nicht möglich. Die Griunde für den notwendigen Luftzutritt zu den Wurzeln sind darin zu suchen, dass die Wurzeln zu ihrem Gedeihen athmen müssen, d. h. Sauerstoff aus der Luft aufnehmen und dafür Kohlensäure abscheiden, wie dies zuerst Saussure (1805) nachwies. Traube ${ }^{1}$ ) war es sodann, welcher 1859 den experimentellen Beweis lieferte, dass die Wurzeln bei Sauerstoffabschluss ihr Wachstum nicht uur einstellen, sondern sogar nach einiger Zeit $\mathrm{zu}$ faulen beginnen, also ohne Athmung nicht zu leben vermögen.

Aus dieser Thatsache erklärt sich auch die in der Praxis bekannte Erscheinung, dass Wurzeln, sobald sie auf einen feuchten undurchlassenden Untergrund stossen, absterben, weil ihnen die Athmung crschwert ist, daher Getreide auf feuchtem bindigem Boden kein gutes Gedeihen zeigt.

Demnach ist die Regulierung der Wasserrerhältnisse des Kulturbodens von allergrösster Wichtigkeit, denn nur auf einem nicht mit stagnierendem Wasser erfiillten, durehlüfteten Boden lässt sich von den Getreidearten eine ausgiebige Prodnktion erhoffen.

Das Verhalten des Bodens gegen Wasser wird aber durch seine Struktur bedingt und da sich nun die Feuchtigkeit, wie sie als Regen auf die Erdoberfläche gelaugt, quantitativ innerhalb gewisser Grenzen bewegt, und nicht selten in unseren Breiten Wassermangel besteht, ist der Bodeu in einen solchen Zustand zu versetzen, dass er möglichst viel Wasser aufnimmt, olne die Durchliftung zu gefährden, und möglichst wenig von dicsem Wasser durch Verdunstung verliert.

Der lockere, poröse Boden ist es aber gerade, der mehr Wasser als der feste aufnimmt und weniger verdunstet.

Dic Bildung einer grossen Zahl von Wurzeln ist beim Gretreide, weil es zu seinem Gedeihen einen relativ trocknen Boden verlangt, notwendig. um der stark transpirierenden Blattoberfläche, selbst bei extremer Trockenheit, die nötigen Wassermengen zufïhren zu können. Wasser- und Sumpfpflanzen besitzen liergegen eine auffallend geringere Bewurzelung.

Je grösscl aber das Wurzelsystem eincr Pflanze ist, um so leichter wird ihr die Aufnahme der erforderlichen Wassermengen aus trockenem Boden sein, während eine Pflanze derselben Art mit kleinem Wurzelsystem schon unter der Trockenheit leidet.

1) Kgl. Akad. d. Wissensch. zu Berlin 1859, pag, $89 \mathrm{ff}$. 
Das Waehstum der Wurzel und somit auch die Vergrösserung ihrer Oberfläehe wird aber dureh Lockerung des Bodens, also durch Verminderung der meehanisehen Widerstände, welehe der Wurzeleindringung entgegenstehen, sehr wesentlich gefördert und werden im Allgemeinen die Wurzeln um so länger und zarter, je lockerer der Boden ist.

Wir wissen jetzt, welehe Anforderungen die Getreidearten an den Boden stellen und hiernaeh hat sich die Bodenbearbeitung zu riehten.

Für die flachwurzelnden Getreidearten genügt zur Erzielung eines normalen Standes die tiichtige Loekerung der Aekerkrume bis zu ihrer vollen Tiefe, voransgesetzt, dass der Untergrund nicht zu fest und mit stagnierendem Wasser erfüllt ist, in wẹlchem Falle derselbe durch Drainage und Tiefkultur zu verbessern wäre.

Die Tiefkultur hat jedoeh bei sehr ungünstigem Untergrund nur dessen Lockerung, ohne ihn in die Ackerkrume zu bringen, oder bei sonst zusagendem Untergrund eine allnı̈llliche Vertiefung der Ackerkrume ins Auge zu fassen, weil das Getreide als Flachwurzler grössere Massen eines rohen Untergrundes in der Ackerkrume nieht gut verträgt; aus welchem Grunde aueh diese Tiefkulturen gern zu stark geduingten Haekfrichten und nicht direkt zu Halmfriiehten vorgenommen werden, zumal die Hackfrüchte den grössten Teil der Unkosten dureh böhere Produktion deeken.

Es sind vorzugsweise zwei Bodenbestellungsmethoden, der Ebenban and Beetbau, welehe bei der Getreidekultur zur Anwendung gelangen.

Der Ehenbau fordert gleieh ticfe Pflugfurchen, welche gleichmässig derart neben einander gelegt werden, dass die Oberfläche des gepflügten Ackers der Terrainoberfläche entspricht.

Seine Ausfiuhrung ist jedoeh von den zur Anwendung kommenden Pflugwerkzeugen abhängig, demgemäss er siel verschieden gestaltet, je naehdem mit Haken, Kehrpfligen oder Beetpfliigen, den sog. Umgängern geaekert wird. Haken und Kehrpflige gehen in derselben Furcle auf ind nicder, mithin der gepfliugte Aeker eben zı liegen kommt, während Beetpflige nur naeh einer Seite wenden, wodurch höhere Anfurchen, da sie dureh Zusammenstiirzen zweier Furehen gebildet werden, und dementsprechend auch tiefe Furehen zwischen den Ackerstreifen entstehen. Diese Uncbenheiten lassen sich später mit Hülfe anderer Ackerinstrumente nur schwer ausgleiehen, so dass bei einem nachfolgenden Querpflïgen das Land noch uncbener wird, und ist dies als ein beträchtlieher Nachteil der Beetpflüge anzusehen.

Dies sind die Gründe, welehe für Gegenden mit hoher Kultur oder kleinen Parzellen die Kehrpfliige zum Ebenbau vorteilhafter er- 
scheinen lassen, zumal in neuerer Zeit ihre Konstruktion so wesentliche Verbesserungen erfabren hat, dass sie in Betreff der Giite der Pflugarbeit nicht mehr hinter den Beetpfliigen zurückstehen. Die Hakenarbeit befriedigt dagegen weit weniger, weshalb in Gegenden, wo dieses Ackerinstrument gebräuchlich, wenigstens nicht sämmtliche Ackerfurchen damit gegeben werden sollten. Der Zeitrerlust beim Pfligen ist bei beiden Konstruktionen nahezn gleich gross, denn die Beetplüge erfordern beim Uebergang ron der einen Ackerseite zur anderen eine gewisse Zeit, aber ungefähr der nämliche Zeitverlust tritt auch durch Umstellen beim Kehrpfluge ein, mithin sich ein grosser Unterschied kaum nachweisen lässt.

Dem Ebenbau steht der Beetbau gegeniiber, da durch diesen der Acker in breiteren oder schmälerẻn Streifen flacher oder höher gewölbt, mithin die Oberfäche mehr oder weniger wellenförmig gestaltet wird. Die Nachteile einer solchen Bestellungsmethode liegen klar zu Tage, denn schon eine oberflächliche Betrachtung lehrt, dass das wirksame Querpflïgen des Ackers unmöglich ist, und die übrigen Arbeiten, wie Eggen, Walzen, Säen, Mähen etc. sehr erschwert werden; auch erfordert die Anlage solcher Beete grosse Uebung und Anfmerksamkeit.

Hierzu treten noch insofern andere sehr schwer wiegende Nachteile, als die Tiefe der Ackerkrume vom Riicken des Beetes nach den Furchen zu beträchtlich abnimmt, die Insolation, wenn die Beete nicht ron Nord nach Siid streichen, ungleichnässig ist, und ebenso das Abtrocknen des Beetes der Gleichmässigkeit entbehrt, da dies in der Mitte des Beetes friiher als an den Beetfurchen geschehen wird. Diese genaunten Uebelstände können naturgemäss schon allein einen sehr ungleichen Stand des Getreides und häufig auch Zweiwuchs erzcugen, denn die Bedingungen des Pflanzenwuchses sind unverkenubar anf dem Rücken des Beetes, zumal bei anhaltend nassem Wetter, beträchtlich giinstiger als auf den Seiten.

Ferner verteilt sich anch der Schnee ungleich anf dem Beet, indem der Wind den Riicken entblösst und den Schnee in die Furchen treibt, in Folge dessen die Riickenpflanzen leicht durch Frost leiden können, wälırend sich andererseits beim Abgehen des Schnees das Thauwasser in den Furchen sammelt und häufig zum grossen Nachteil der Saaten längere Zeit in ihnen stehen bleibt.

Trotz dieser Nacliteilc sind Fälle denkbar, in denen die Anwendung des Beetbaues voll berechtigt ist; ruht z. B. eine sehr flache Ackerkrume auf einer festen Unterlage ron Fels und Kies, oder steht der Untergrundwasserspiegel sehr hoch, so lisst sich durch Anlage sclumaler Beete die Ackerkrume niclit unbeträichtlich vertiefen.

Dic Enträssermug, sobald Drainage nicht ausfuhrbar, geschieht am zweckmässigsten durch Herstellung möglichst tiefer Beetfurchen, 
die mit dem Spaten ausgestochen werden, wodurch ein solches Beet bei anhaltendem Regen leichter entwässert wird und die Seiten des Beetes nicht längere Zeit unter zu viel Nässe leiden.

Eine eigentümliche Art des Beetbaues ist die Moor-DammKultur, welche Rimpau, Cunrau, in der Weise herstellt, dass er in Entfernungen von 22,5 m parallel laufende Gräben, deren obere Breite $5 \mathrm{~m}$ und deren Sohle $3,5 \mathrm{~m}$ beträgt, zieht; diese werden tief genug ausgegraben, dass eine $60 \mathrm{~cm}$ dicke Schicht des unter dem Moor lagernden Sandes als Deckmaterial heraufbefördert und der Grundwasserstand auf mindestens $1-1,3 \mathrm{~m}$ dadurch gesenkt wird, dass man die Gräben mit Vorflutgräben in Verbindung bringt. Der aus den Gräben gewonnene Sand wird $11 \mathrm{~cm}$ hoch auf das Moor gebracht, und trotz seiner fast absoluten Unfruchtbarkeit als alleinige Ackerkrume bearbeitet. Hierdurch gelang es Rimpau ein Substrat zu schaffen, auf dem viele Kulturpflanzen, namentlich aber die Getreidearten vortrefflich gediehen.

Von hervorragendem Erfolg, namentlich im ausgesprochenen Kontinentalklima, ist die Anwendung der Dampf'kulturapparate begleitet, denn die Bestellungsarbeiten lassen sich trotz Nässe im Frühjahr und Dürre im Sommer oder Herbst rechtzeitig, besser und auf entsprechend grossen Flächen auch meist billiger als durch Zugvieh ausführen. Vor allen Dingen ist die durch die Dampfkultur bewirkte tiefe und energische Lockerung des Bodens für die kräftige Entwickelung auch bei ungïnstiger Witterung von hohenı Wert.

Bei der Bodenbearbeitung kommt ausser der Pflugarbeit auch die der übrigen Ackergeräte in Betracht, weil mit ihrer Hülfe fuir den ungehinderten Zutritt von Luft gesorgt und der Wassergehalt des Bodens reguliert werden kann. Zu diesen Geräten gehören Egge, Grubber, Extirpator und Walze.

Durch die Zertrïmmerung grosser harter Erdschollen wirkt letztere lockernd und durch das Brechen der harten Kruste erschliesst sie den Boden wiederum dem Luftzutritt. Der lockernden Wirkung steht aber auch eine festdrïckende gegenuiber, die häufig, z. B. für frisch bestellte Acker, sehr erwiinscht ist, indem die Oberfläche dadurch feuchter wird, dass aus den tieferen Bodenpartien der stärker im zusammengedriickten als im lockeren Zustande verdunstenden Oberfläche das Wasser' mit den darin gelösten Pflanzennährstoffen mit grösserer Energie zufliesst. In dicser obersten Schicht erfolgt aber die Keimung der Samen, mithin bei trocknem Wetter das Walzen einen sehr guinstigen Einfluss anf das Antkeimen und Pflanzenwachstum ausiuben wird.

$\mathrm{Zu}$ beachten ist, möglichst kannelirte oder Ringelwalzen zu verwenden, die der Oberfläche Riefen eindrïcken, wodurch bei starkem Regen das Zusammenschlämmen und nachherige Verkrusten bis zu 
gewissem Grade rermieden wird, da die schweren Regentropfen an den Erhabenheiten der Oberfläche zerschellen. Auf leichtem Sandboden wird auch das Treiben des Sandes bei windigem und trockenem Wetter weniger stark eintreten, und schliesslich wirken sie zum Brechen der Kruste weit energischer als glatte Walzen.

Betreffs der Vorbereitung des Ackers zur Frühjahrsbestellung empfiehlt es sich, sofort nach der Aberntung die Stoppcln flach umzubrechen und später, wenn die Samenunkräuter aufgelaufen, zur Zerstörung dieser und der Wurzelunkräuter den Acker tüchtig durchzueggen; nachdem sich dieser geeggte Acker von Neuem begrünt hat, erfolgt vor Eintritt des Winters ein möglichst sorgfältiges Pflügen bis zur vollen Tiefe der Ackerkiume. Im Frihjahr wird nach dem Abtrocknen des Ackers geeggt, darauf durch Grubbern iiber Kreuz gelockert, glatt geeggt und eventuell gewalzt.

Die Vortcile dicser Methode bestehen darin, dass durch das zтeimalige Pflügen und Egggen im Herbst das Unkıaut zerstört und durch die erste flache Furche das Austrocknon und Erhärten der Ackerkrume mehr rermieden wird, mithin sich die chemischen Processe ununterbrochen und energischer in der Ackerkrume vollziehen und eine Ackergahre hcrrorrufen können, derzufolge bei der zweiten ticferen Furche keine grossen Stücke brechen, sondern der Acker rorzüglich krümelt.

Bleibt nun dieser tiefgepflügte Acker, mit Wasserfurchen woll versehen, übcr Winter den Einwirkungen der Luft, des Regens und Frostes mit seiner rauhen Oberfläche, die diesen Agentien die kräftigste Einwirkung gestattct, ausgesetzt, dam befindct er sich im Frühjahr in jenem porösen Zustand, der als Ackergahre bekannt ist, und ein solcher Acker wird sich leicht durch oberflächliche Lockerung und Ebıung durch Grubber und Egge sehr frühzeitig zur Saat herrichten lassen. Je friiher die Aussaat des Sommergetreides aber erfolgen kann, um so mehr ist auf ein gutcs Gedeihen zu hoffen.

Ausnahmen ron dieser Methode sollten nur dann stattfinden, wenu der Boden in Folge eines frostlosen, regenreichen Winters selur rerschlänmı ist, in welchem Falle nach dem Abtrockuen im Frühjahr noch eine Pflugfurche gegeben werden kann.

Bei der Herbstbestellung kommt wesentlich die Zeit der Aberntung der Vorfrucht und die Aussaat des Wintergetreides furr eine bestimmte Gegend in Betracht. Es können z. B. die Vorfrüichte im Juli, August, September, und sind es Rüben, sogar erst im Oktober oder Norember das Feld räumen. Aus diesen Gründen umfasst die Herbstbestellungsperiode entreder mehrere Monate oder nur einige Tage.

Gemeinhin, wenn nicht die Brache roransgeht, genügt zur Herbstbestellung ein zweimaliges und nach Hackftichten sogar ein einmaliges Pfliigen. 
Durch die erste flache Furche werden die Stoppeln gestürzt, und nachdem die Unkrautsamen aufgelaufen, wird geegrgt und auf scholligem Acker auch noch gewalzt; hieraut gibt man, meist kurz vor der Saat, die ziveite tiefere Furche, mit welcher event. auch der Dung untergebracht wird. Da diese Furche die Saatfurche ist, hat man mit besonderer Sorgfalt zu pflügen.

In der Regel empfiehlt es sich, anf bindigeren Böden die Oberfläche des Saatackers nicht fein zu präparieren, weil sich hinter den kleinen Schollen und in den Vertiefungen der rauhen Oberflaiche selbst wenig Schnee längere Zeit hält und die Pflanzen auf gefrorenem Boden, wenn sie Wasser nicht mehr aufnehmen können, gegen stark austrocknende Winde, welche sie zum Absterben bringen können, schïtzt.

\section{Die Saat des Getreides.}

\section{Beschaffenheit des Satgutes.}

Zur Erzielung einer quantitativ und qualitativ befriedigenden Ernte gehören keimfähige, reife vollkommen ausgebildete Samenkörner von gleichem und möglichst hohem absoluten Gewicht, welche frei von mulstrigem Geruch sind, leicht durch die Hand gleiten, sowie die der Sorte eigentïmlichen charakteristischen Eigenschaften besitzen; Bedingungen, welche sich bei dem in der Gelbreife gemähten, trocken geernteten, gut aufbewahrten, vorsichtig ausgedroschenen Getreide und bei Aussortierung der schwersten und vollkommensten Samenkörner finden.

Aus solchem Saatgut werden sich die kräftigsten Pflanzen und gleichmässigsten Bestände erzielen lassen, während unreife Samenkörner, denn bekanntlich eilt die Keimfähigkeit der Reife voran, oder unvollkommene, leichte Samenkörner eine geringere Keimungsenergie besitzen und gemeinhin schwächliche Pflanzen erzeugen, weil sie sehr viel ärmer an Reservestoffen als schwerere Samenkörner sind, mithin die Menge an Mutternahrung; welche jedes Keimpflinzchen empfängt, erhcblich geringer ist. Die hieraus den Pflanzen crwachsenden Nachteile können nur durch einen reichlich mit fertiger Pflanzennahrung erfïllten Boden und sehr günstige Witterungsverhältnisse aufgewogen werden, weshalb vorzugsweise auf armen Böden für ein möglichst vollkommenes Saatgut ${ }^{1}$ ) Sorge zu tragen ist.

1) Vergl. Hellriegel, Beiträge zu den naturw. Grundlagen des Ackerb. 1883, pag. 54 . 
Die nachfolgenden Untersuchungen ron A. M üller ${ }^{1}$ ) bezeugen, dass die Samenkörner mit grösstem absoluten Gewicht auch am reichsten an Reservestoffen sind:

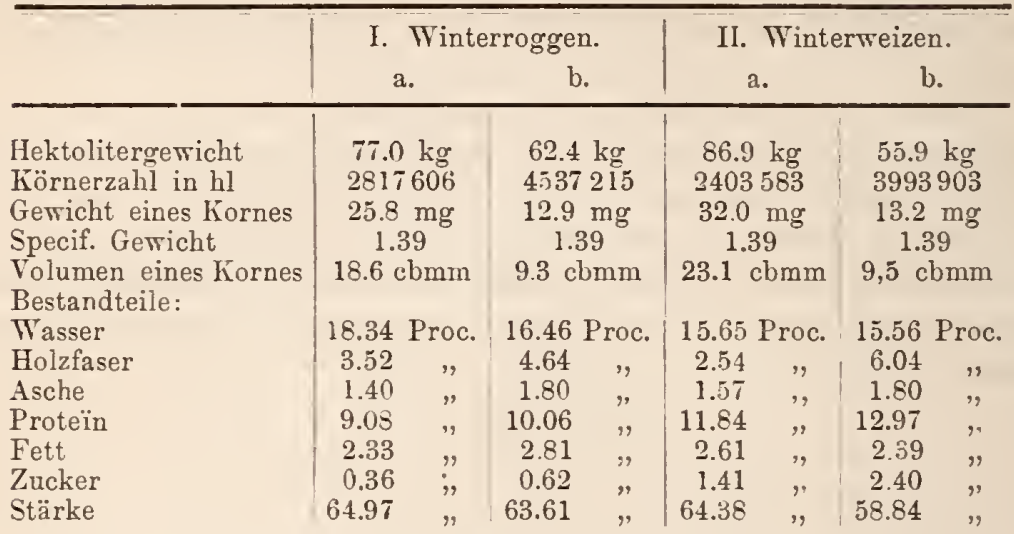

Nach den Untersuchungen ron Nobbe ${ }^{2}$ ) sind die Körner bei Gerste und Weizen ron der Längenmitte der Aehrenachse nicht nur die schwersten, sondern auch von mächtigster Triebkraft.

Zum Beweise der Wichtigkeit eines gleichmässig schweren Saatgutes will ich hier die Worte Liebig's ${ }^{3}$ ) anführen:

„Ton der ersten Bewurzelung einer Pflanze hängt ihre Entwickelung $a b$. und ist darum die Wahl der geeigneten Samen fiur die kiinftige Pflanze ron der grössten Wichtigkeit.

Ein Gemenge ron Samen, welche ungleich in ihrer Ausbildung sind, oder welche ungleiche Mengen von Stärkemehl, Kleber und unorganischen Stoffen enthalten, geben gesäet eine Vegetation, welche ebenso ungleich wie die frühere, ron der sie stammten, in ihrer Entwickelung ist."

$\mathrm{Zu}$ beachten ist ferner die Keimfähigkeit der Samenkörner, sowie die Menge der rorkommenden Vcrunrcinigungen, worüber rorzugsweise $\mathrm{Nobbe}^{4}$ ) sehr schätzenswerte procentische Angaben gemacht hat. Nach diesen enthalten:

1) Amtsbl. f. d. landw. Verein. 1855 pag. 38.

2) Handb. d. Samenk. 1876 pag. 302.

3) Die Chemie in ihrer Anw, auf Agric. u. Phys. I pag. 8.

4) A. a. O. pag. 431 u. 517 . 


\begin{tabular}{|c|c|c|c|c|c|c|}
\hline \multirow[t]{2}{*}{ Samenart: } & \multicolumn{3}{|c|}{$\begin{array}{c}\text { Keimkraft von } 100 \text { reinen } \\
\text { Samen. }\end{array}$} & \multicolumn{3}{|c|}{$\begin{array}{c}\text { Fremde Bestandteile in } \\
\text { Procenten. }\end{array}$} \\
\hline & Mittel & höchstens & mindestens & Mittel & höchstens & mindestens \\
\hline Hafer & 74 & 100 & 45 & 1.02 & 4.80 & 0.06 \\
\hline Gerste & 88 & 100 & 32 & 0.84 & 2.20 & 0.30 \\
\hline Roggen & 89 & 100 & 17 & 1.67 & 6.37 & 0 \\
\hline Weizen & 95 & 100 & 79 & 1.58 & 4.10 & 0 \\
\hline Mais & 70 & 97 & 23 & 1.53 & 7.51 & 0 \\
\hline Zuckerbirse & 73 & 73 & 73 & 0.26 & 0.43 & 0.09 \\
\hline Reis & $2 \pi$ & - & 一 & 1.18 & - & 一 \\
\hline
\end{tabular}

Die Keimfähigkeit der Samenkörner wird, je reicher ihre Zellen mit Wasser erfüllt sind, um so leichter durch hohe Wärme- oder Kältegrade zerstört, während lufttrockne beträchtlich widerstandsfähiger sind, wie Versuche von Göppert darthun, der Samen aller Art einer Kälte von $50^{\circ} \mathrm{C}$. ohne Nachteil aussetzte, während sie im imbibierten Zustande ihre Keimkraft bei weit niedrigeren Kältegraden einbüssten.

Auch Haberlandt ${ }^{1}$ ) fand, dass nach 24stiundigem Einquellen und durch Gefrieren bei 10 and $24^{\circ} \mathrm{C}$. die Getreidesamen, und zwar zuerst der Roggen, dann nackte Gerste, hierauf Hafer, Weizen, bespelzte Gerste, Mais, Moorhirse und schliesslich Rispenhirse ihre Keimkraft verloren.

Nach Sachs ${ }^{2}$ ) bewahren lufttrocknc Samen, selbst eine Stunde lang ciner Wärme von $60^{\circ} \mathrm{C}$. ausgesetzt, ihre Keimkraft, während mit Wasser imbibiert, bei Roggen und Weizen $50^{\circ} \mathrm{C}$. bedenklich sind und Gerste oder Mais ihre Keimkraft einbuissen.

Demnach sollten gedörrte Samenkörner möglichst als Saatgut vermieden werden.

Bei zweckmässiger Anfbewahıung erhält sich die Keimkraft 3-5 Jahre und zwar am längsten bei Hafer und Mais, doch verlieren nicht geniigend lufttrocken aufgespeicherte Körner, namentlich, sobald der Aufbewahrungsort schlecht ventiliert, dabei feucht und dumpfig ist, sehr bald ihre Keimkraft, weil dic Fenchtigkeit den Eintritt cliemischer Zersetzungen und die Pilzentwickelung begünstigt, in Folge dessen die Keimkraft geschädigt werden kann.

Jedenfalls empfichlt es sich für dic Praxis am meisten, Saatgut der letzten Erntc zu verwenden.

Bei ungünstigem Erntcwetter lässt sich häufig die Aussaat bereits ausgekeimter und wieder getrockneter Samenkörner nicht vermeiden, von denen diejenigen, bei welchen sich nur die Wurzelkeime entwickelt hatten, grösstentcils erneut keimcn, wäbrend die Zahl der keimfähigen

1) Der allg. landw. Pflanzenb. 1879, pag. 70.

2) Handb. d. Exp.-Phys. d. Pfl. 1865, 66. 
bei denen ungleich geringer ist, welche das Federchen schon bis über $15 \mathrm{~mm}$ hervorgetrieben hatten.

Aus Versuchen, welche Göppert mit Erbsen uud Weizen anstellte, erhellt, was auch für keimende Samen in trocknem Boden von höchster Bedeutung ist, dass durch Austrocknen des keimenden Samenkorns dasselbe auf der Stufe seiner Entwickelung verbleibt und nach erneuter Anfenchtung wiederum keimt.

Ebenso fand Nowoczeck, dass sich selbst bei wiederholter Unterbrechung der Keimung die im Anfang entwickelten, später vertrockneten Wurzeln immer wieder von neuem bildeten. Selbstverständlich büssten hierdurch die Samenkörner stets an Reservestoffen ein, in Folge dessen die sich entwickelnden Pflänzchen auch entsprechend weniger krä̈tig aufwuchsen.

Verletzte Samenkörner können ebenfalls recht wohl auskeimen, selbst noch bei gänzlicher Entfernung des Eiweisskörpers oder erheblicher Verletzungen des Keimlings ${ }^{1}$ ). Selbstverständlich werden Pflänzchen, die nur aus dem Keimling erwachsen sind, und dies ist möglich, da das Stengelchen eine wenngleich nur kleine Menge, jedoch sehr koncentrierter Reservestoffe enthält, bald eingehen, indem zum weiteren Fortkommen die Unterstützung durch Mutteruahrung fehlt. Gemeinhin wird eine Verletzung der Plumula oder der Wurzelspitze leichter ertragen, als die des Vegetationspunktes.

Hiernach ist es begreiflich, wie häufig, selbst bei starker Beschädigung des Keimlings durch Inseliten, das Getreidekorn noch keimfähig sein kann. Allerdings ist eine Verletzung des Keimlings immer bedenklicher als die des Eiweisskörpers.

Auch beim Ausdrusch entstehen vielfach Verletzungen und Risse in der Fruchtschale, wodurch einesteils der Transport der Reservestoffe verhindert und anderenteils durch Eintritt von Luft oder Beizmittel die Keimfähigkeit geschädigt werden kann, wie dies beim Maschinendrusch und unter Anwendung des schwefelsauren Kupferoxydes als Beizmittel vorkommit, was zahllreiche Versuche, z. B. von Nobbe ${ }^{2}$ ) darthun.

Beweisend ist auch ein Versuch, welchen die Meckl. landw. Annal. $1867 \mathrm{Nr} .24$ mitteilen und der zu folgenden Resultaten fiihrte:

1) Die zur Zeit iiblichen Dreschmethoden beeinträchtigen auch bei der heftigsten Einwirkung auf das Weizenkorn die Keimkraft desselben ohne Beizen nicht wesentlich; von 100 Körnern keimten 97.

2) Das Beizen mit frisch gelöschtem Kalk schadet venig Handdrusch gab 1-4 Proc. Maschinendrusch 8-9 Proc. nicht keimfähige Körner.

1) Vergl. die Untersuchungen von Heiden, Sachs, Bonnet, Boczisz ewski, Nowoczek u. A.

2) Vergl. A. a. O. p. $274 \mathrm{ff}$. 
3) Beizen mit Kupfervitriol $(0,5 \mathrm{~kg}$ auf $100 \mathrm{~kg}$ Samen) gaben beim Handdrusch 2-4 Proc. nicht keimfähige Körner, beim Maschinendrusch :

Gang rasch und mit Patentelevator mit Paternoster

Gang langsam, mit Patentelevator. dto.

* Putzmilihle

.$\quad 62$ Proc.
.$\quad 39$
$.24-34 "$

Gang rasch, Korn mit Wurfschaufel gereinigt 25 ,

Aus diesen Gründen empfiehlt es sich, bei zu beizendem Saatgut den Handdrusch anzuwenden, oder wenigstens den Maschinengang beim Ausdrusch zu verlangsamen und diejenigen Maschinentcile ausser Arbeit zul setzen, welche die Verletzungen hauptsächlich veranlassen.

Hierzu tritt noch, dass auch die der direkten Tötung entgehenden Samenkörner ein auffallend geschwächtes Wurzelsystem zeigen, was wiederum nachteilig auf die Entwickelung der gesammten Pflanze wirkt.

Glücklicherweise hebt nun die Ackerkrume die Wirkung einer nicht zu starken Einbeizung durch ihr grosses Absorptionsvermögen für Kupfer bis zu einem gewissen Grade wieder auf, wie dies die Versuche von J. Kühn, Dreis ch, Nobbe u. A. gezeigt haben, so dass der Procentsatz des Aufgehenden liier in der Regel grösser, und der Zustand des Wurzelsystems ein besscrer, als bei der Keimung in Fliesspapier ist. Auch scheint es, dass dic Bestockung der Pflänzchen aus gebeiztem Saatgut unter Umständen kräftiger als aus ungebeiztem sein kann, wie folgender von mir durchgeführter Versuch mit CleverHochland-Weizen und Frankensteiner-Weizen zu beweisen scheint.

Die Körner durch Ausdrusch auf einer Handstiftenmaschine gewonnen, wurden ausgesucht, so dass nur möglichst vollkommene und gleichschwere zur Aussaat gelangten. Die Körner des Clever-Hochland waren rot, glasig, länglich, die des Frankensteiner gelblichweiss, mehlig, rundlich; sie wurden nach der J. Kühn'schen Vorschrift (auf 2751 Körner $500 \mathrm{gr}$ Kupfervitriol mit 12 stündiger Einwirkung) gebeizt und am 10. Oktober 1878 auf Parzellen von $1 \mathrm{qm}$ Grösse ausgedibbelt.

Das Aufgehen vollzog sich auf allen Parzellen, und zwar wechselten Parzellen der gebeizten und ungebeizten Saat nit einander ab, gleichzeitig und war am 27. Oktober beendigt, doch keimten auf den gebeizten Parzellen bei beiden Weizensorten 4 Proc. Samenkörner weniger.

In der Frühjahrsentwickelung verhielten sich jedoch beide Sorten sehr verschieden zu einander, denn während beim Clever-HochlandWeizen die gebeizten und ungebeizten Parzellen, soweit sich dies feststellen liess, gleichmässig aufwuchsen, zeigten sich beim Frankensteiner-Weizen deutlich hervortretende Verschiedenheiten, indem sämmt- 
liche Parzellen der ungebeizten Saat ein weit energischeres Wachstum als die der gebeizten Saat erkennen liessen.

Am 20. April, nach Beendigung der Bestockung, wurden die Pflanzen aller Parzellen auf die Zahl der gebildeten Schösslinge untersucht, und ergab sich das höchst bemerkenswerte Resultat, dass die Bestockung bei den Pflanzen aller gebeizten Parzellen grösser als der ungebeizten war, wobei jedoch zu beachten, dass sich die Bestockung des gebeizten Frankensteiner-Weizens erheblich kräftigcr dem ungebeizten gegeniiber herausstellte, als dies beim Clerer-HochlandWeizen der Fall war.

Die Versuchsresultate sind folgende:

\begin{tabular}{|c|c|c|c|c|c|c|}
\hline \multirow[b]{2}{*}{$\begin{array}{l}\text { Parzellen- und Wachs- } \\
\text { raum p. Pflanze }\end{array}$} & \multicolumn{2}{|c|}{ Clever-Hochland } & \multicolumn{4}{|c|}{ Frankensteiner } \\
\hline & $\begin{array}{l}\text { Ungebeizt } \\
\text { Zahl der }\end{array}$ & $\begin{array}{l}\text { Gebeizt } \\
\text { össslinge }\end{array}$ & 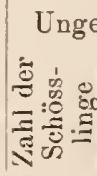 & 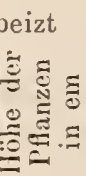 & 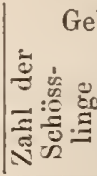 & 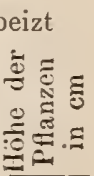 \\
\hline $\begin{array}{l}\text { I. }(8 \mathrm{zu} 8 \mathrm{~cm}) 64 \mathrm{qcm} \\
\text { II. }(7 \mathrm{zu} 7 \mathrm{~cm}) 49 \quad ", \\
\text { III. }(6 \mathrm{zu} 6 \mathrm{~cm}) 36 \quad ", \\
\text { IV. }(5 \mathrm{zu} 5 \mathrm{~cm}) 25 \quad ", \\
\text { Mittel: }\end{array}$ & $\begin{array}{l}11 \\
11.6 \\
8.8 \\
9.5 \\
10.23\end{array}$ & $\begin{array}{r}13,2 \\
11.4 \\
10.7 \\
9.9 \\
11.3\end{array}$ & $\begin{array}{c}13.5 \\
11.2 \\
9.7 \\
8.6 \\
10.75\end{array}$ & $\begin{array}{l}34 \\
40 \\
30 \\
40 \\
36\end{array}$ & $\begin{array}{l}18.6 \\
12.6 \\
12.9 \\
\cdot 9.7 \\
13.45\end{array}$ & $\begin{array}{l}24 \\
30 \\
24 \\
29 \\
26.75\end{array}$ \\
\hline
\end{tabular}

Demnach ist der sehr empfindliche Frankensteiner-Weizen durch die Beizung in seiner Entwickelung mehr als der Clever-HochlandWeizen zurückgehalten worden. Bekanntlich besitzen spätc Weizensorten im Allgemeienen eine kräftigere Bestockung als frühe und scheint es, dass der in der Entwickelung seiner Haupthalme durch die Beizung crheblich zurückgehaltene Frankensteiner-Weizen sich ähnlich einer späten Sorte verhält und daher stärker bestockt. Mithin ersetzt event. die stärkere Bestockung den Ausfall an zerstörtem Saatgut.

\section{Der Kcimungrprocess.}

Die zum Keimen notwendigen Bedingungen sind: Feuchtigkeit, Wärme und ungehinderter Luftzutritt.

Die erste Veränderung des keimenden Samenkorns dokumentiert sich in der durch Wasseraufnahme bewirkten Vergrösserung seines Volumens.

Das Aufquellen erfolgt olne Platzeu der Samenhaut, obgleich das quellende Samenkorn sein Volumen häufig mehr als um das Doppelte des lufttrocknen Zustandes vermebrt, und nur wirkliche Zellenneubildung reranlasst erst das Zerreissen der Samenhaut. 
Dieses Expansionsvermögen der Samenhaut ist für den im Boden ruhenden Samen höchst wichtig, denn wie Nobb e ${ }^{1}$ ) ausgeführt, würden die oft in geringer Bodentiefe im aufgequollenen Zustande uiberwinternden Samen, da der Quell ungsakt fast unabhängig von der Temperatur, so lange sich dieselbe iiber dem Gefrierpunkt hält, vor sich geht und ohne höhere Wärmegrade der Keimungsprocess nicht beginnen kann, durch das Aufplatzen der Samenhant den Embryo blosslegen, wodurch der in der "Milch“ ruhende Same auswintern würde, wie dies nicht selten dem unzeitig hervorgelockten Embryo mancher Kulturpflanzen geschieht.

An Quellungswasser werden nach den hier folgenden Angaben von $\mathrm{Hoffmann}{ }^{2}$ ) und Haberlandt ${ }^{3}$ ) in Procenten aufgenommen:

\begin{tabular}{|c|c|c|}
\hline Getreideart & $\begin{array}{c}\text { nach } \\
\text { Hoffma } n n\end{array}$ & $\begin{array}{c}\text { nach } \\
\text { Haberlandt }\end{array}$ \\
\hline Weizen & 45.5 & 68.8 Proc. \\
\hline Roggen & 57.7 & 85.0 \\
\hline Gerste & 48.2 & $68.0 \quad$, \\
\hline Hafer & 59.8 & $76.0 \quad$, \\
\hline Mais & 44.0 & 49.7 \\
\hline Reis & - & 35.8 \\
\hline Mohrhirse & $\overline{2}$ & 40.3 \\
\hline Rispenhirse & 25.0 & 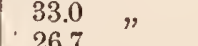 \\
\hline & & \\
\hline
\end{tabular}

Diese zum Keimen notwendige Menge an Quellungswasser nehmen die Samenkörner in kürzerer oder längerer Frist auf; so genügen im Wasser schon 24-48 Stunden, während sie in der Erde, je nach dem Feuchtigkeitszustande derselben, die doppelte und selbst vielfache Zeit gebranchen, und sogar in sehr trockner Erde unaufgequollen bis zum Eintritt eines ausgiebigen Regens verharren können.

Das Quellungswasser löst die im Samenkorn aufgespeicherten Reservestoffe auf, machtsie umbildungsfähig und transportiert sie, sobald bei Gegenwart von Sauerstoff nnd Wärme der Keimungsprocess beginnt, an den Ort der Neubildung.

Zur Einleitung des Keimungsprocesses muss der Sauerstoff in einer gewissen Verdiinnung mit Stickstoff Zutritt zu dem aufgequollenen Samenkorn erhalten und sind die notwendigen Sauerstoffmengen keineswegs geringe, z. B. bedürfen nach de Sa us sure keimende Weizen- und Gerstenkörner 10 Proc. ihres Gewichtes an Sauerstoff.

Ebenso wichtig für die Keimung ist auch eine in gewissen

1) Handb. d. Samenkunde 1876, pg. 70.

2) Jahresber. d. agrik.-chemisch. Untersuchungsstat. in Böhmen. 1864, p. 6.

3) A. a. 0. p. 28. 
Grenzen sich bewegende Wärmemenge, deren Höhe zu kennen sehr notwendig ist, weil durch sie vielfach die Aussaatzeit beeinflusst wird.

Die Keimung kann erfolgen zwischen $1-44^{\circ} \mathrm{C}$, doch wird dieselbe um so mehr verzögert, je mehr sich die Temperatur der unteren oder oberen Grenze nähert.

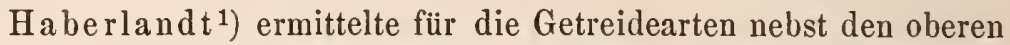
Grenzen auch noch die Minima und Optima der Keimungstemperaturen, und sind dieselben in nachstehender Tabelle angeführt:

\begin{tabular}{|c|c|c|c|c|c|}
\hline & & & Minimum & $\begin{array}{l}\text { Maximum } \\
\text { Grad Celsius }\end{array}$ & Optimum \\
\hline Weizen & . & . & . $3-4,5$ & $30-32$ & 25 \\
\hline Roggen & . & . & . $1-2$ & 30 & 25 \\
\hline Gerste & . & . & $3-4,5$ & $28-30$ & 20 \\
\hline Hafer & . & . & . $4-5$ & 30 & 25 \\
\hline Mais & . & . & . $8-10$ & $40-44$ & $32-35$ \\
\hline Mohrhirse & . & . & . $8-10$ & 40 & $32-35$ \\
\hline Reis . . & . & . & . $10-12$ & $36-38$ & $30-32$ \\
\hline
\end{tabular}

Bemerkenswert in dieser Tabelle ist, dass die Optima, also die guinstigsten Keimtemperaturen, den Maximis weit näher liegen, als den Temperatur-Minimis, bei welchen tiberhaupt noch das Auskeimen erfolgt.

Nach Aufnahme des Quellungswassers stellen sich, noch bevor die Zellenteilung beginnt, Bewegungen ein, und bald zeigt sich die Wurzelscheide. Zunächst werden zum weiteren Wachstum die in den Zellen des Keimlings in koncentrierter Form abgelagerten stickstoffhaltigen Reservestoffe verwendet, und hiernach die Reservestoffe des Endosperms dadurch löslich, dass sich aus einem Teil der Eiweissstoffe die die Stärke lösende Diastase bildet, jedoch beginnt die Auflösung der Stärke erst, nachdem das Würzelchen hervorgetreten und beim Weizen (nach Sachs) schon eine Länge von $1 \mathrm{~cm}$ erreicht hat.

Durch die Zellenumbildung nimmt der Keimling an Volumen zu, in Folge dessen die Samen- und Fruchthaut zerreisst, hierauf trennen sich die Zellen der Wurzelscheide und das erste Würzelchen erscheint. Ebenso durchbricht der Blattkeim am oberen Wulste die Samen- und Fruchthaut bis zum Epicarpium der letzteren und schiebt sich zwischen Epi- und Mesorcarpium gegen die Spitze des Samenkorns empor.

Was nun die Dauer der Keimzeit anbetrifft, so hat Haberlandt ${ }^{2}$ ) liber den Einfluss der Mitteltemperaturen der Monate März, April, Mai und Juni in Ungr. - Altenburg auf die Keimzeit der wichtigsten 
Kulturpflanzen Versuche angestellt, und bringen wir in nachstehender Tabelle die Keimungstemperaturen der Cerealien, nach 24 stïndigem Einquellen in Wasser:

\begin{tabular}{|c|c|c|c|c|c|c|c|c|}
\hline \multirow{2}{*}{ Getreideart } & \multicolumn{4}{|c|}{$\begin{array}{l}\text { Die Keimung erfolgte mit dem } \\
\text { Sichtbarwerden des } \\
\text { Würzelchens in Tagen }\end{array}$} & \multicolumn{4}{|c|}{$\begin{array}{l}\text { Durchschnittliches Längen- } \\
\text { wachstum des Stengelchens } \\
\text { für einen Tag in mm }\end{array}$} \\
\hline & $4.38^{\circ} \mathrm{C}$ & $10.25^{\circ} \mathrm{C}$ & $15.75^{\circ} \mathrm{C}$ & $19^{\circ} \mathrm{C}$. & $4.38^{\circ} \mathrm{C}$ & $10.25^{\circ} \mathrm{C}$ & $15.75^{\circ} \mathrm{C}$ & $19^{\circ} \mathrm{C}$. \\
\hline Winter-Weizen & 6 & 3 & 2 & 1.75 & 1.40 & 3.07 & 6.54 & 8.72 \\
\hline Sommer- , & 6 & 4 & 2 & 1.75 & 1.35 & 3.14 & 6.28 & 7.85 \\
\hline Winter-Roggen & 4 & 2.5 & 1 & 1 & 1.64 & 3.82 & 6.54 & 7.48 \\
\hline Sommer- , & $4 . \check{5}$ & 2 & 1,5 & 1 & 1.68 & 3.84 & 7.85 & 8.26 \\
\hline Winter-Gerste & 6 & 3 & 2 & 1.75 & 1.35 & 3.20 & 7.48 & 7.85 \\
\hline Sommer- , & 6 & 3 & 2 & 1.75 & 1.40 & 3.07 & 5.84 & 7.48 \\
\hline Hafer & 7 & 3.75 & 2.75 & 2 & 122 & 2.75 & 5.41 & 6.54 \\
\hline Mais & - & 11.25 & 3.25 & 3 & - & 0.22 & 2.66 & 6.54 \\
\hline Mohrhirse & - & 25 & 7.25 & 6 & - & 1.46 & 2.66 & 4.12 \\
\hline Rispenhirse & - & 1325 & 3.25 & 3 & - & 0.15 & 2.33 & 6.37 \\
\hline Mohar & 2.4 & 7.5 & 2.75 & 2 & - & 0.81 & 3.92 & 5.82 \\
\hline
\end{tabular}

Aus dieser Tabelle ist ersichtlich, dass niedrige Temperaturen, kombiniert mit einer grösseren Anzahl von Tagen, nicht die gleiche Wirkung hervorzubringen vermögen, wie höhere Wärme, wenn sie gleich eine verhältnissmässig kürzere Zeit eingewirkt hat.

Das Keimvermögen soll sich durch chemische Agcntien fördern oder verlangsamen und selbst vollständig aufheben lassen.

$\mathrm{Zu}$ den die Keimung fördernden Agentien gehört nach A. von Humboldt das Chlor, doch lieferte Nobbe ${ }^{1}$ ) den Nachweis, dass die Chlorbeize einen fördernden Einfluss nicht besitzt, wohl aber tritt schon bei $1 / 10-1 / 4$ der Sättigung der Chlorlösung ein nachteiliger Einfluss hervor, der sich bei halber und voller Sättigung bis zur gänzlichen Tötung der Keime steigert.

Durch einen hohen Procentsatz löslicher Salze im Boden kann die Keimfähigkeit stark benachteiligt werden. Die Grenze bis zu welcher diese Salze ohne Schädigung des Keimvermögens vorhanden sein können, liegt nach den von Wolff mit Gerste und Wickenkörnern angestellten Keimversuchen in Procenten des Erdreichs ausgedrückt,

1) A. a. 0. p. 259 


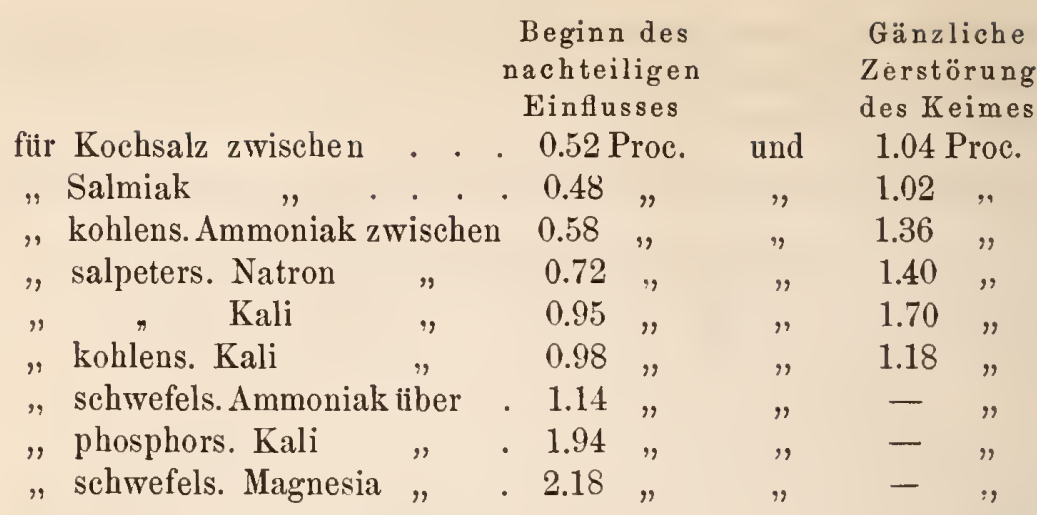

Aus diesen Betrachtnngen tiber den Keimungsprocess ersehen wir, dass ein zu nasser Boden, dessen Poren vollkommen mit Wasser erfüllt sind, zu rermeiden ist, weil nicht nur die znm Keimen des Samenkorns so notwendige Sanerstoffzufuhr mehr oder weniger behindert wird, sondern es sind anch diese nassen Böden zugleich kalt, daher sich die Keimung verzögert und sogar das Samenkorn in Fäulnis ibergehen kann. Mithin sollte die Aussaat nicht eher erfolgen, als bis der Boden geniigend ahgetrocknet und elwärmt ist.

Dem leichten, durchlässigen Boden fehlt es hinwiederum häufig an der zum Keimen erforderlichen Feuchtigkeit, weshalb, um unter solchen Umständen noch von der Winterfeuchtigkeit profitiren zn können, entweder die Herbst- oder sehr zeitige Frühjahrssaat am Platze ist.

Die grösste Garantie des sicheren Keimens und der kräftigen Entwickelnng des jungen Pflänzchens bietet unter allen Umstånden der poröse, geniigend durchlassende und zweckmässig bearbeitete Boden von hinreichend wasserfassender und wasserhaltender Kraft.

Eine Vorbereitung der Samenkörner des Getreides durch Einquellen darf meist als unzweckmässig angesehen werden, da sie bei genügend vorhandener Bodenfeuchtigkeit, ob eingeweicht oder nicht, doch zn gleicher Zeit anflaufen, demnach sich die Wasserversorgung in relativ kurzer Zeit bei dem Infttrocknen Samenkorn vollzieht.

Anf sehr trocknem Boden keimt allerdings das eingeweichte Samenkorn bald aus, hält aber die Diirre an, dann geht das junge Pflänzchen sehr leicht durch Mangel an Feuchtigkeit ein, während das lufttrockene Samenkorn überhaupt erst bei geniigend vorhandener Feuchtigkeit auskeimt, mithin die Möglichkeit der Schädigung des jungen Pflänzchens durch Mangel an Feuchtigkeit in geringerem Masse vorliegt.

Dagegen faulen eingeweichte Samenkörner auf bindigem, feuchtem Boden bei kalter Witterung sehr leicht.

Auch verlieren die Samenkörner, im Wasser liegend, durch Exosmose einen nicht nnerheblichen Teil ihrer organischen nnd anorgani- 
schen Bestandteile, und stellte sich der Gewichtsverlust nach 24 stündiger Einquellung ${ }^{1}$ )

\begin{tabular}{|c|c|c|c|c|c|c|}
\hline $\mathrm{im}$ & Weizen & & & & uf & 1.14 Pro \\
\hline & Roggen & & & & & 1.35 \\
\hline & Gerste. & & • & & $"$ & 1.33 \\
\hline & Hafer . & . & & & $"$ & 2.06 \\
\hline & Mais . & & • & & & 1.05 \\
\hline & Mohar . & & & & & \\
\hline
\end{tabular}

Von grosser praktischer Bedeutung ist auch die Tiefe der Saatunterbringung, die sich nach der Beschaffenheit der Samenkörner und des Bodens richtet.

Verhältnissmässig grosse Samenkörner ertragen ohne Schaden, weil reicher an Reservenahrung, eine stärkere Erddecke als kleine, denn bei ersteren reicht die Mutternahrung eher aus, bei grösserer Tieflage den Keimling bis an die Oberfläche zu bringen.

Für den leichten trocknen Boden ist dies Verhalten von Wichtigkeit, indem hier grössere Samen in Tiefen gebracht werden können, wo sie sicherer die nötige Feuchtigkeit zum Keimen finden, zumal diese Böden für die Sauerstoffzufuhr hinreichend porös sind. Entgegengesetzte Verhältnisse walten dagegen bei den schweren Böden $o b$, weshalb auf solchen eine verhältnismässig flache Unterbringung geraten erscheint. Gleiches gilt auch für die sehr humusreichen Böden, mit lebhafter Kohlensüureentwickelung, welche in grösserer Tiefe durch Mangel an Sauerstoff dic Keimung leicht stören kann.

Wie wichtig die Bestimmung der Saatticfe ist, geht aus dem nachfolgenden Versuch von Moreau ${ }^{2}$ ), Dept. du Nord, hervor, der $13 \mathrm{Ab}$ teilungen mit verschiedener Saattiefe einrichtete und in jede 150 Körner Weizen säete:

\begin{tabular}{r|c|c|c|c|c}
\hline Abtheilung & $\begin{array}{c}\text { Tiefe bis zu } \\
\text { welcher das } \\
\text { Korn gelegt } \\
\text { wurde in } \\
\text { mm }\end{array}$ & $\begin{array}{c}\text { Von 150 } \\
\text { Körnern } \\
\text { waren auf- } \\
\text { gegangen }\end{array}$ & $\begin{array}{c}\text { Zahl der } \\
\text { Aehren } \\
\text { jeder } \\
\text { Abtheilung }\end{array}$ & $\begin{array}{c}\text { Zahl der } \\
\text { auf jeder } \\
\text { Abtheilung } \\
\text { geernteten } \\
\text { Körner }\end{array}$ & $\begin{array}{c}\text { Ernte von } \\
\text { einem } \\
\text { gesäeten } \\
\text { Korne }\end{array}$ \\
\hline 1 & 160 & 5 & 53 & 682 & 4 \\
2 & 150 & 14 & 140 & 2520 & 17 \\
3 & 135 & 20 & 174 & 3818 & 25 \\
4 & 120 & 40 & 400 & 8000 & 53 \\
5 & 110 & 72 & 700 & 16560 & 114 \\
6 & 95 & 93 & 992 & 18534 & 124 \\
7 & 80 & 125 & 1417 & 35434 & 236 \\
8 & 65 & 130 & 1560 & 34339 & 229 \\
9 & 50 & 140 & 1590 & 36480 & 243 \\
10 & 40 & 142 & 1660 & 35825 & 239 \\
11 & 25 & 137 & 1461 & 35072 & 234 \\
12 & 10 & 64 & 529 & 10587 & 71 \\
13 & 0 & 20 & 107 & 1600 & 11
\end{tabular}

1) Haberlandt a. a. 0. p. 30

2) Boussingault, III p. 30, Deutsch von Gräger. 
Hiernach stellte sich die günstigste Saattiefe auf $2.5-5 \mathrm{~cm}$.

Uebrigens beweisen auch andere Versuche, z. B. von Ekkert ${ }^{1}$ ), dass die Saattiefe auf die Höhe des Ernteertrages nicht ohne Einfluss ist, insofern die geringere Saattiefe eine stärkere Bestockung und eine nicht unbeträchtliche Ertragsvermehrung nach sich zieht; dagegen scheint sie auf die Qualität der Ernte keinen Einfluss auszuiiben.

Nach Hoffmann keimte auf lehmigem Sandboden Mais noch in einer Tiefe ron $26 \mathrm{~cm}$, Weizen, Gerste, Hafer, Hirse von $21 \mathrm{~cm}$.

Ueber die zweckmässigste Saattiefe lassen sich nun keine allgemein giltigen Regeln aufstellen, vielnnehr richtet sich dieselbe in jedem einzelnen Falle nach den obwaltenden Verhältnissen.

Im Allgemeinen scheinen die nachfolgenden Zahlen in Bezug auf Saattiefe am meisten der Praxis zu entsprechen:

\begin{tabular}{|c|c|c|c|c|}
\hline & $\begin{array}{c}\text { In schwerem } \\
\text { Boden }\end{array}$ & $\begin{array}{l}\text { in mittl } \\
\text { feuchter } \\
\mathrm{Wi}\end{array}$ & $\begin{array}{l}\text { Boden } \\
\text { trockener } \\
\text { ang }\end{array}$ & $\begin{array}{l}\text { in leichtem } \\
\text { Boden }\end{array}$ \\
\hline $\begin{array}{l}\text { Weizen } \\
\text { Roggen } \\
\text { Gerste } \\
\text { Hafer } \\
\text { Mais } \\
\text { Hirse }\end{array}$ & $\begin{array}{ll}2 & \mathrm{~cm} \\
2 & \\
2 & " \\
2 & " \\
2 & " . \\
0.5 & \end{array}$ & $\begin{array}{l}2.5 \mathrm{~cm} \\
2.5 " \\
3 \quad " \\
3 \quad " \\
3 \quad " \\
1 "\end{array}$ & $\begin{array}{ll}4 & \mathrm{~cm} \\
4 & ., \\
5 & " \\
5 & " \\
5 & " \\
1.5 & \end{array}$ & $\begin{array}{l}-7 \\
7 \\
7 \\
8 \\
2.5\end{array}$ \\
\hline
\end{tabular}

Je flacher die Unterbringung der Saat erfolgt, um so kräftiger und zahlreicher werden die Schösslinge und die Kronenwurzeln sich entwickeln, weil weniger Reservestoffe zur Zurücklegung der Strecke bis zur Oberfläche des Ackers verbraucht werden, als bei tieferer Saat. Nan soll daher nur so tief säen, dass das Korn, je nach Boden und Witterung, den nötigen Schutz vor äusseren Feinden und die nötige Feuchtigkeit findet; jedes tiefere Säen schwächt die Pflanze, weil sie viel Material aufwenden muss, ehe ihre Blätter das Licht erreichen und die Assimilation beginnt.

\section{Die Bestimmung des Saatquantums.}

Die Dichtigkeit des Pflanzenstandes iibt auf die Höhe der Produktion einen sehr bedeutenden Einfluss aus, weshalb die Ermittelung des zweckmässigen Saatquantums von grösster Wichtigkeit ist.

1) Ueber Keimung, Bestockung und Bewurzelung der Getreidearten. Inaug.Dissert. Leipzig, 1873. 
Bekanntlich bedarf die Pflanze zur genügenden Entfaltung ihrer Blattorgane eines gewissen Raumes, damit letztere zur Atmosphäre gehörig in Wechselwirkung treten können und das Sonnenlicht zur Organisirung der aufgenommenen organischen Nährstoffe einzuwirken vermag.

Der Begriff „Dichtigkeit des Pflanzenstandes“ ist nun ein relativer und müssen wir uns deshalb zunächst darüber klar sein, was unter einem zu dichten Pflanzenstand zu verstehen ist.

$\mathrm{Zu}$ dicht ist bei dem Getreide der Pflanzenstand, wenn bei einer der Bestockung günstigen Witterung die meisten Pflanzen nur einen Halm entwickeln, dieser schmächtig ist, und eine nur wenig entwickelte Aehre trägt. Dieser Zustand wird durch eine sehr starke gegenseitige Beschattung bedingt, weil diese auf Kosten der Bestockung und Körnerbildung immer ein übermässiges Längenwachstum der Halme und Blätter, bei verminderter Bildung von Cellulose zur Folge hat.

Betreffs Erzielung normaler, leistungsfähiger Pflanzen, die unter den gegebenen Verhältnissen eine maximale Produktion in Aussicht stellen, darf der Pflanzenstand gerade so dicht sein, dass, einc entsprechend kräftige Bestockung vorausgesetzt, die Halme noch an ihrem Fuss durch Sonnenstrahlen getroffen werden, und auch der Boden genügend erwärmt wird; doch dürfen die Zwischenräume auch wiederum nicht so gross sein, dass zu viel Sonnenstrahlen für die Pflanzen ungeniitzt verloren gehen, und der Boden durch zu starke Besonnung erhärtet und sich schliesst, also eine ungünstige physikalische Veränderung erfährt.

Ueber die Beziehungen der Dichtigkeit des Pflanzenstandes zur Produktion lassen sich nun für das Getreide folgende allgemeine Gesichtspunkte aufstellen:

Mit der Dichtigkeit des Pflanzenstandes nimmt die Produktion von Körnern weniger zu als die des Strohes, und bei einer gewissen Dichtigkeit erreicht die Körnerproduktion ihren höchsten Grad in Bezug auf Quantität und Qualität, während bei zu grosser Dichtigkeit der Kornertrag bedeutend unter das Maximum heruntergehen kann.

Bei Feststellung der zweckmässigsten Saatquanta sind nụn folgende Momente zu berücksichtigen:

\section{a. Die Eigentümlichkeit der Pflanzen.}

Das Aussaatquantum kann um so schwächer gegriffen werden, je kleiner die Samen im Verhältnis zur Grösse der sich aus ihnen entwickelnden Pflanzen sind und je kräftiger das Bestockungsververmögen ist. 


\section{b. Die Beschaffenheit des Samens.}

Alte Samenkörner erfordern eine stärkere Aussaat als frische, weil sie an Keimfähigkeit verloren haben.

\section{c. Die Beschaffenheit des Klimas.}

Das warme, feuchte Klima erfordert eine weniger starke Einsaat als das kalte, trockne, denn das Erstere unterstiitzt das Pflanzenwachstum so kräftig, dass sich die Pflanzen weit üppiger entfalten, als in dem kalten, trocknen Klima, welches das Pflanzenwachstum wesentlich zurüickhält.

\section{d. Die Beschaffenheit des Bodens.}

Der schwere, bindige, dabei zicnlich kulturlose Boden beansprucht eine stärkere Aussaat, als der poröse, lockere, mit natürlicher Fruchtbarkeit versehene und kulturvolle Lehmboden, weil sein Uebermaass an Fenchtigkeit, sowie seine Neigung zur Krusten- und Schollenbildung manches Samenkorn nicht zur Keimung gelangen lässt; überdem gedeihen auf einem solchen Boden meist nur verhältnismässig schwächliche Pflanzen mit wenigen Schösslingen, mithin sich die wirtschaftlich wünschenswerte Dichtigkeit nur durch stärkere Einsaat erreichen lässt.

Auf leichtem Sandboden wird ebenfalls stärker gesäet, weil dieser Boden kleine Pflanzen mit wenigen Schösslingen erzeugt, auch manches Samenkorn bei trockner Witterung durch Mangel an Bodenfeuchtigkeit nicht zur Entwickelung gelangt.

Je grösser die natürliche Fruchtbarkeit und Kultur eines Bodens ist, um so normaler vollzieht sich auch die Keimung und das Pflanzenwachstum, mithin schädliche Einflüsse leichter iberwunden werden, die Pflanzen kräftig anwachsen und sich auch den Verbältnissen entsprechend kräftiger bestocken.

Im Allgemeinen lässt sich also auf nährstoffreichem Boden der höchste Ertrag durch eine geringere Saatmenge als auf nährstoffarmen erreichen.

\section{e. Der Zeitpunkt der Aussaat.}

Weizen, Roggen, Gerste, seltener Hafer, werden in den gemässigten Zonen auch als Wintergetreide kultiviert, dementsprechend man Herbstoder Wintersaaten und Frühahrs- oder Sommersaaten unterscheidet.

Die Herbstsaaten haben vor den Frühjahrssaaten einen Vorsprung voraus und können aus der Winterfeuchtigkeit namentlich auf leichtem Boden und im Kontinentalklima Vorteil ziehen.

Wintergetrcide, wenn es aus Gegenden mit strengem, langandauerndem Winter stammt, lässt sich nicht als Sommergetreide kul- 
tivieren, da es meist nicht iiber die Bestockung hinaus kommt, obgleich die Sommerwärme zur Ausreifung genügend wäre. Je kürzer und je weniger streng aber die Winter eines Landes, dem es entstammt, sind, um so mehr entwickelt es sich, im Sommer angebaut und gelangt nicht selten bis zum Schossen, sogar, wenigstens in einzelnen Halmen, bis zur Fruchtreife, und säen wir schliesslich Getreide aus Gegenden mit sehr milden Wintern, z. B. aus Italien, SüdFrankreich, Spanien etc. im Frühjahr aus, so erreicht dasselbe, wenigstens in vielen Fällen, denn auch hicr kommt echtes Wintergetreide vor, eine vollkommene Reife und lässt sich als sog. Wechselgetreide anbauen.

Dieses eigentïmliche Verhalten findet nur darin seine Erklärung, dass die Vegetation des Wintergetreides durch die Strenge des Winters längere Zeit unterbrochen wird und sich so vollständig diesen Verhältnissen angepasst hat, dass es, im Friihjahr angebaut, die Eigenschaft, eine längere Ruhepause in seincr Vegetation eintreten zu lassen, beibehält.

Ebenso gedeiht in Gegenden mit strengem Winter auch kein im Herbst ausgesïetes Sommergetreide, da dasselbe, weil zn weichlich, vollkommen erfriert.

Weicht nun in einer Gegend die Aussaatzeit von der für Wintergetreide als normal befundenen sehr wesentlich $a b$, geschieht also die Aussaat zu zeitig oder zu spät, so hat nıan zur Verhiitung von Nachteilen das Aussaatquantam den Verhältnissen entsprechend zu bemessen.

Durch zeitige Einsaat entwickeln und bestocken sich die Pflanzen im Herbst zu stark, gehen daher leicht, namentlich bei grosser Nässe oder starker Schneedecke durch Ausfaulen zu Grunde, oder es wohnt ihnen die Disposition zum Lagern inne, demnach das Aussaatquantum $\mathrm{zu}$ verringern ist.

Spätere Saaten zeigen dagegen cine geringe Bestockung und wenn die Pflanzen bei Eintritt des Frostwetters gerade die in den Samen enthaltenen Reservestoffe aufgezchrt und noch nicht wesentlich neue Stoffe durch Assimilation gebildet haben, so geht zu dieser kritischen Zeit auch manches junge Pflänzchen verloren. Durch den im Korn noch vorhandenen Vorrat an disponiblem Bildungsstoff erklärt es sich dagegen nach $H$. Thiel genügend, wenn sehr späte, oftmals vor Winter noch gar nicht aufgegangene Saaten besser gedeihen, als Saaten, die nicht so friih gesäet warell, dass sie sich vor Winter noch ordentlich bestocken und Reservestoffe ansammeln konnten.

Gemeinhin zeigen diese späten Saaten aus den erörterten Gründen einen zu dïnnen Stand, wenn nicht durch eine entsprechend 
stärkere Aussaat der Verlust, sowie auch die mangelnde Bestockung gedeckt wird.

Leider sind es vielfache besondere Umstände, die bäufig eine zu späte Aussaat erfordern, z. B. zu späte Aberntung der Vorfrucht, zu trocknes oder zu nasses Wetter, wirtschaftliche Verhältnisse etc.

Da nun die Bestockung ein höchst beachtenswerter Faktor bei Bemessung der Saatquanta ist, so sollen die nachfolgenden Untersuchungen zeigen, dass nicht nur die Aussaatzeit, sondern auch der jeder Pflanze zugewiesene Raum für dieselbe mitentscheidend ist.

Ueber den Einfluss der Aussaatzeit auf die Bestockung sind von uns Vcrsuche mit Johannis-Roggen bei gleichen Wachsräumen gemacht worden, die nachfolgende Resultate ergaben:

\begin{tabular}{|c|c|c|}
\hline Zeit der Aussaat & Tag der Untersuchung & $\begin{array}{c}\text { Zahl der } \\
\text { Schösslinge }\end{array}$ \\
\hline $\begin{array}{l}\text { Anfang Juli } 1876 \\
\text { 27. "November " } \\
\text { 23. Januar } \\
\text { 5. Februar } \\
\text { " ", }\end{array}$ & $\begin{array}{ll}\text { 10. April } & 1877 \\
\text { 10. " } & " \\
\text { 10. Ma } ", \\
\text { 25. Mai } ", \\
\text { 10. April " } \\
\text { 25. Mai " ", } \\
\text { 10. April ", } \\
\text { 25. Mai ", }\end{array}$ & $\begin{array}{c}12 \\
10 \\
4 \\
5 \\
2.8 \\
5.2 \\
1 \\
3.4\end{array}$ \\
\hline
\end{tabular}

Aus diesen Versuchsresultaten lassen sich folgende allgemeine Gesichtspunkte aufstellen: bei früher Herbstsaat bestockt sich das Wintergetreide teilweise schon vor Winter und die früheste Aussaat liefert unter sonst gleichen Verbältnissen auch die meisten Schösslinge, dagegen findet bei sehr später Herbstsaat die Bestockung grösstenteils erst im Frühjahr statt, sobald derselben die Frühjahrswitterung, die Bodenbeschaffenheit etc. günstig sind. Gesetzt nun, dass das Klima einer Gegend rauh und trocken, überhaupt das Frühjahr kurz ist, so werden bei dem hier gewöhnlichen plötzlichen Eintritt des Sommers die Hauptschösslinge der späten Saat zu schossen beginnen, worunter die Bestockungsfähigkeit und also auch die Dichtheit des Bestandes leidet, sobald dieser Nachteil nicht durch eine relativ starke Einsaat ausgeglichen wird. Unter solchen Umständen wird immer die zeitige Herbstsaat die richtige sein, während im Seeklima mit seinen längeren und feuchteren Frühjahren die nachteiligen Folgen einer späten Herbstsaat durch die noch im Fribjahr stattfindende stärkere Bestockung leichter überwunden werden.

Eine kräftigere Bestockung lässt sich ferner auch durch die Vergrösserung des Wachsraumes für die einzelne Pflanze erreichen, 


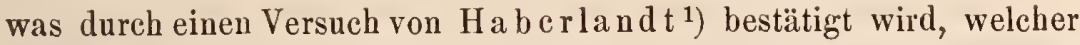
Wintergetreide am 29. September aussäete und die Zahl der Schösslinge bei verschieden grossen Wachsräumen ermittelte, danach gestaltete sich die Bestockung wie folgt:

Zahl der Schösslinge pro Pflanze:

Winterweizen Winterroggen Wintergerste

$\begin{array}{lrrc}\text { bei } 25 \text { qcm } & 1.9 & 3.2 & 1.7 \\ \text { bei } 100 " & 8.4 & 6.4 & 5.07 \\ \text { bei } 225 " & 14.8 & 12.1 & 13.3 \\ \text { bei } 400, & 14.2 & 8.8 & -\end{array}$

Auch scheint die Qualität der Samenkörner die Bestockung wenigsteus im Anfange zu beeinflussen, indem das schwerere Samenkorn der Pflanze eine grössere Menge an Reservestoffen als das leichtere zur Verfügung stellt, wodurch die Disposition zu kräftiger Bestockung verstärkt wird.

In der Regel säet man im Herbst zuerst Gerste resp. Hafer, darnach Roggen und am spätesten Weizen, da letzterer, im Gegensatz zu anderem Wintergetreide, seine Bestockung grösstenteils erst im Fruihjahr vollendet.

In der kälteren gemässigten Zone werden Wintergerste und Winterhafer im September bei 10.5-16.50 C., Roggen in der zweiten Hälfte des September und Weizen bis Mitte October bei $8-15^{\circ} \mathrm{C}$. gesäet.

Für die Frühjahrssaaten ist die Innehaltung des richtigen Zeitpunktes zur Aussaat noch wichtiger als bei den Herbstsaaten und richtet sich derselbe zunächst nach der zum Keimen notwendigen Wärmemenge, nach der Empfindlichkeit der jungen Pflanzen gegen Spätfröste, sowie nach der Bodenbeschaffenheit.

Unter Beachtung aller dieser Momente wird die möglichst frïhe Saat auch den besten Erfolg aufweisen und das geringste Saatquantum beanspruchen.

Gemeinhin werden in der kälteren gemässigten Zone Roggen und Weizen im März, Hafer und Gerste im April bei Temperaturen von 3.5-9 ${ }^{0} \mathrm{C}$. und Mais, Ripsenhirse, Kolbenhirse, Mohrhirse im Mai und Anfang Juni bei Temperaturen von $12-18^{\circ} \mathrm{C}$. ausgesäet.

f. Die Säemethode und die Tiefe der Samenunterbringung.

Die Samenverteilung hat möglichst gleichmässig zu erfolgen, damit jede Pflanze einen annähernd gleich grossen Wachsraum erhält, da sonst entweder Raumverschwendung oder bei zu dichtem Stande der Pflanzen ein Kampf um das Dasein stattfindet, der nur zur Schwächung der Saaten führt.

1) A. a. 0. pag. 717 . 
Aus diesen Gründen ist diejenige Säemethode als die beste anzuerkennen, welche den Samen ohne Verlust und möglichst gleichmässig verteilt, und dies ist nur möglich mit Hülfe der Drillmaschine, die demzufolge auch ein geringeres Saatquantum als die Breitsäemaschine und namentlich die Handsaat erforderlich macht, denn bei letzteren Säemethoden werden weit mehr Samenkörner verworfen. Zudem erfordert die breitwürfige Saat die Unterbringung des Samens mittelst Geräten und werden hierbei Verluste durch zu tiefes oder zu flaches Unterbringen unvermeidlich sein, während die Drillmaschine die Samenkörner in gleicher Tiefe in den Boden bringt.

Wie sehr die Aussaatmenge, je nach Anwendung der verschiedenen Säemethoden, schwanken kann, ergiebt sich aus der tabellarischen Uebersicht uiber die Bestimmung des Samenbedarfs, welche von mir in Anlehnung an Untersuchungen von $U_{g a z y^{1}}$ ) aufgestellt worden ist.

\begin{tabular}{|c|c|c|c|c|}
\hline $\begin{array}{l}\text { Bestimmung des Ver- } \\
\text { lustes an Saatgut. }\end{array}$ & $\begin{array}{l}\text { Drillsaat: } \\
\text { mit Drill- } \\
\text { maschine } \\
\text { Proc. }\end{array}$ & \begin{tabular}{|c|} 
Bre \\
Unterbrin- \\
gung mit der \\
Egge aufgeeb- \\
netem Felde \\
Proc.
\end{tabular} & $\begin{array}{l}\text { eitwürfige Saat } \\
\text { Unterbrin- } \\
\text { gung mitmehr- } \\
\text { schaarigen } \\
\text { Saatpflügen } \\
\text { Proc. }\end{array}$ & $\begin{array}{c}\text { Unter- } \\
\text { bringung mit } \\
\text { dem gewöhn- } \\
\text { lichen Pfluge } \\
\text { Proc. }\end{array}$ \\
\hline $\begin{array}{l}\text { Verlust an nicht keim- } \\
\text { fähigen Samcn } \\
\text { Verlust für verworfene } \\
\text { und zu tiefoder zu flach } \\
\text { untergebrachte Samen } \\
\text { VerlustfürBeschädigung } \\
\text { mittelst der Huftritte } \\
\text { Verlust für die Beschä- } \\
\text { digung durch Insekten } \\
\text { undElementar-Unfälle }\end{array}$ & - & $\begin{array}{r}36 \\
4 \\
25\end{array}$ & $\begin{array}{r}46 \\
4 \\
25\end{array}$ & $\begin{array}{r}61 \\
4\end{array}$ \\
\hline Notwendige Mehraussaat & 35 & 75 & 85 & 100 \\
\hline
\end{tabular}

g. Die Pflege der Pflanzen.

Werden die Pflanzen während ihrer Vegetationszeit behackt oder erhalten sie eine das Wachstum stark fördernde Kopfdüngung, so ist das Saatquantum ebenfalls zu verringern.

1) Vollständige auf Versuche u. Erfahr. gegründete Abhandl. ü. d. Anbau d. Getreidesamen. Wien, 1822. 
Die oben besprochenen Punkte zeigen, dass sich allgemein zutreffende Saatmengen fül die einzeln en Getreidearten nicht aufstellen lassen und die unter gewissen Verhältnissen gefundenen Saatmengen im konkreten Falle nur einen sehr bedingten Wert beanspruchen können.

In der hiernach folgenden Saattabelle ist nun voll mir der Versuch gemacht, auf theoretischem Wege den Saatbedarf pro Hektar für den reichen, kulturvollen, im richtigen Grade durchlässigen und kalkreichen Lehmboden des Poppelsdorfer Feldes zu bestimmen.

Dieser Boden, sowie auch das Klima eignen sich für die Kultur der Cerealien sehr gut und bei der Bestellung wurde zu allen Getreidearten dic Drillkultur angewandt und eine Entfernung der Drillreihen von $20 \mathrm{~cm}$ als die passendste zur Erreichung eines normalen Standes erkanut.

Der für eine jede Getreidesorte notwendige Wachsraum wurde gefunden, indem durch mehrere Jahre dic Grösse der Bestockung, also die Zahl der fruchttragenden Schösslinge pro Pflanze bestimmt wurde, gleichzeitig stellte ich die Anzahl der Halme pro qm dureh Auszählung fest, so dass sich die Pflanzenzahl durch Division der Anzahl der Schösslinge pro Pflanze in die Zahl der Halme pro qm ergab, da nun 1 qm 10000 qcm enthält, so liess sich sehr leicht der Wachsraum pro Pflanze in qem und die Pflanzenzahl pro ha berechnen.

Der absolute Bedarf an Saatgut pro ha wïrde hierauf naeh Auszählung eines bestimmten Gewichtes der Samenkörner, wodurch die Anzahl derselben pro $\mathrm{kg}$ und durch Ermittelung des Volumengewichtes auch die einesHektoliters gefunden wurde, durch einfache Rechnung bestimmt.

Zur Entscheidung der Frage über die Dichtheit des Pflanzenstandes erschien mir auch dic Ermittelung der Oberflächen in der Blüte befindlicher Getreidehalme sehr wichtig, in Folge dessen von jeder der angebauten Getrcidesorten alljährlich 5 Halme pro qm, welche den mittleren Habitns der Sorte an meisten darstellten, ausgesucht und in der Weise gemessen wurden, dass die Halmhöhe und an vier gleich weit entfernten Stellen der Halmdurchmesser (incl. Blattscheide) bestimmt und daraus die Halmobertäche berechnet wurde. Die Obcrfläche beider Seiten der Blattspreiten wurde durch Ermittelung der Blattbreite mit Hülfe von vier Ordinaten und Messung der Blattlänge gefunden und durch Multiplikation mit der Blattzahl die Grösse der Blattoberfläiche eines Halmes bestimmt. Da uun ferner die Anzahl der Halme ciner Pflanze festgestellt worden war; so liess sich auch die Gesammtoberfläche derselben sehr leicht bercelnen.

Da diese Untersuchungen durch mehrere Jahre an jeder Getreidesorte vorgenommen wurden, so glaube ich in der nachstehenden Saattabelle ein ziemlich richtiges liild der mittleren Oberflächenentwickelung der zu Poppclsdorf angebauten Getreidevarietaiten zur Darstellung zu bringen. 


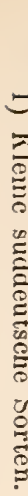

$\operatorname{NON}=$ $\circ 0$

$=5 N=$

吃新

$\begin{array}{lll}1= & 10 \\ \infty & 0 \\ 0 & 0\end{array}$

\begin{tabular}{ll|l|}
\hline a s & 0 & 0 \\
i & $=$ & \\
\hline 0 & 0 & 0
\end{tabular}

œ

\section{बू}

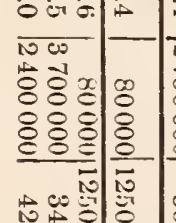

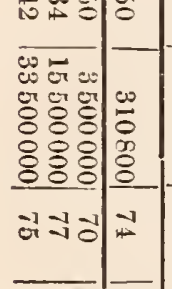

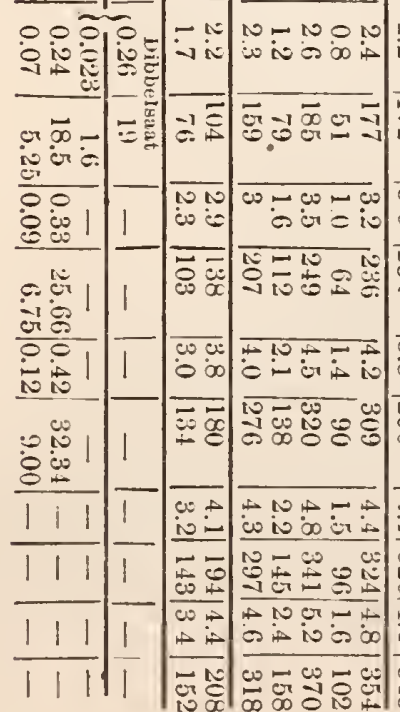

Non et no

7

$\overrightarrow{0}-\overrightarrow{10}$

w w

N

- $\infty \infty_{\infty} \infty \infty_{\infty}^{\infty}$

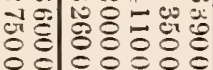

ᄋ్ㅇㅇㅛ

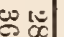

$\infty^{\infty}$

$\underbrace{\infty}_{0} \mathrm{~g}$

ज氙

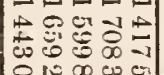

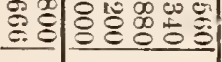

$\stackrel{4}{*}$

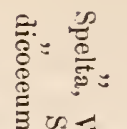

ข2

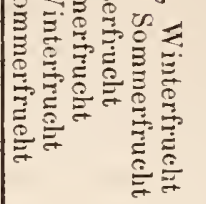

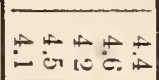

8 is 00 w ol

ब

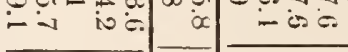

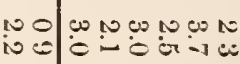

두요

\section{$\omega$}

o is $\rightarrow-\infty i c$ er

Ne

कo

Non

$\triangle$ er

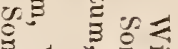

Z

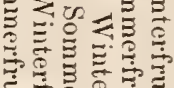

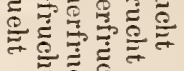

$\approx$ 它$$
7
$$

年ง
必泫二

- estenco

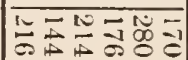

ONANCNA

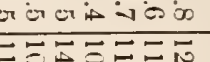

Anzahl der Schōss-
linge pro Pfianze

Halmlänge

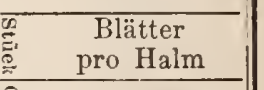

Gesammtoberflāche eines Halmes

- Auf 1 qm Boden-

- $1000 \mathrm{~A}$

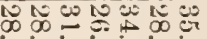

is iv it it i is i-

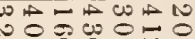

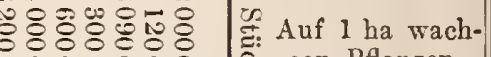
Sen Pflanzen

Wachsraum

pro Pflanze

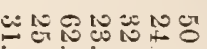

$\cong$

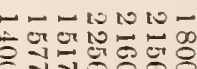

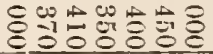

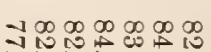

vit it is is os

N N:-

cutocos o:

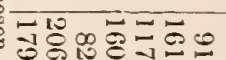

w w

Er if or ex er

DNDNG心

$\rightarrow+$ is

$\Xi$ Unterbringung mit der Egge auf geebnetem

Felde. Verlust:

75 Proc.

E Unterbringung ơ rigen

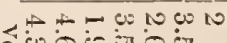

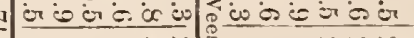

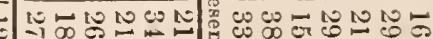

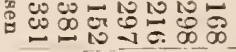

$\rightarrow$ or is con $n$ con

of or an

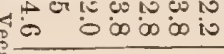

$\widetilde{T}$ plügen. Ver-

lust: 85 Proc. है

- Vuterbriogung

= mit dem gewöhnlichen : 100 Proc.
Pfluge. Verl 
Selbstverständlich sollen die Zahlen dieser Tabelle nur als Anhalt dienen, und sind nur für die Poppelsdorfer Anbauverhältnisse massgebend. Für andere Fälle würde die absolute Saatmenge vermindert oder auch vermehrt werden müssen, so influiert schon allein die Bodenbeschaffenheit sehr wesentlich, setzen wir z. B. das Saatquantum für sehr reichen Boden $=1$, dann kann es auf Mittelboden $=1,5$ und auf sehr leichtem Boden $=2$ sein.

Zum Beweise dafuir, dass die von uns gefnudenen Saatmengen der Wirklichkeit recht gut entsprechen, bringen wir hier eine Saattabelle, welclie Stöckhardt nach Hlubeck's Ermittelungen aufgestellt hat:

\begin{tabular}{l|c|c|c|c}
\hline & $\begin{array}{c}\text { Absoluter } \\
\text { Raum }\end{array}$ & $\begin{array}{c}\text { Bedarf an } \\
\text { Pflanzen }\end{array}$ & $\begin{array}{c}\text { Absoluter } \\
\text { Salnenbedarf }\end{array}$ & $\begin{array}{c}\text { Durch- } \\
\text { schnittliche } \\
\text { Stärke der } \\
\text { Breitsaat } \\
\text { kg }\end{array}$ \\
\hline Weizen & $\square \mathrm{cm}$ & pro ha & $\mathrm{kg}$ & \\
Roggen & 58 & 1463132 & 63.08 & 174.08 \\
Gerste & 48 & 1828915 & 39.07 & 183.25 \\
Hafer & 62 & 1630057 & 87.85 & 192.41 \\
Hirse & 68 & 1463123 & 5.13 & 201.57 \\
Mais & 1970 & 50803 & 14.65 & 27.48 \\
& & & & 36.65
\end{tabular}

4. Die Aussaatmethoden.

Die Aussaat geschieht entweder breitwurfig mit der Hand oder mittelst Säemaschinen und die Unterbringung durch verschiedene Ackerwerkzeuge, oder in Reihen (Drillsaat), sowie in Horsten (Dibbelsaat), mit der Maschine oder Hand unter gleichzeitiger Bedeckung der Samenkörner mit Erde.

Die breitwurfige Saat geschah früher ganz allgemein mit der Hand, doch tritt in neuester Zeit immer mehr und mit Recht die Säemaschine in den Vordergrund, da sie eine weit regelmässigere Verteilnng bewirkt, denı bei der Handsaat hängt dieVerteilung nicht nur von der Geschicklichkeit und Aufmerksamkeit des Säemannes, sondern auch von der Witterung, namentlich vom Winde, und von der Vorbereitung des Saatiandes ab, da bekanntlich auf scholligem Lande bei der Handsaat weit mehr Samen von den Unebenheiten abspringen, verfallen und sich in den Bodenvertiefungen anbäufen als bei der Maschinensaat.

Dagegen verteilt die Säemaschine eine bestimmte Saatmenge sehr gleiclımässig auf eine Ackerfläche von bestimmter Grösse, während schon eine kleine Differenz in der Saatmenge, welche der Säemann mit einem Wurf auszustreuen hat, einen merklichen Unterschied 
in Gesanmtquantum ausmacht, was häıfigg geschieht, wenn das Saatquantum einmal von der gewöhnlichen Norm abwcicht. Meistenteils greift der Säemann zu viel, so dass in diesem Sinne durch Anwendung der Säemaschine eine Saatersparnis von ea. 10 Proc. erzielt werden kann.

Betreffs der Zeitersparnis durch Maschinensaat lässt sich nun allerdings einwenden, dass nur 7-10 ha durch eine Maschine besäet werden können, und zu ihrer Bedienung, ausser dem Pferde, zwei Leute erforderlich sind, und dieselbe Fiäche sich recht gut auch durch zwei Säeleute besäen lässt; doch ist hierbei zu bemerken, dass geschickte sïeleute in grösserer Zahl selbst in einer unfangreichen Wirtschaft selten angetroffen werden, weshalb sich vielfach aus Mangel an Säeleuten die Bestellungsarbeiten verzögern, wozu noch tritt, dass zwei gute Säeleute, neben einander säend, niemals eine gleichmässige Aussiat bewirken.

Durch eine rechtzeitige Aussaat mit IHälfe der Säemaschine werden aber sämmtliche Bestellunysarbeiten gefördert, weshalb in diesem Sinue auch von einer Zeitersparnis gesprochen werden kann.

Die Unterbringung der breitwurfigen Getreidesaat erfolgt nach Massgabe der Umstände durch Pflügre, Haken, Saatpflüge, Exstirpatoren und Eggen.

Die Wahl des Verfahrens richtet sich zunächst unter Beriicksichtigung der Bodenbeschaffenheit nach der für das Samenkorn passendsten Tiefe.

Pfiige und Haken finden in Allgemeinen nur bei der Frülijahrsbesteliung und trocknem Wetter Anwendung, und kommt durch sie ein Teil der Samenkörner beim Wenden des Bodens bis auf die Furchensohle, während sich der Rest über dic ganze Furchentiefe von der Sohie bis zur Oberflaclie verteilt. Eine solche ungleichmässige Verteilung muss aber jedenfalls mit Saatversehwendung und ungleichem Erwachsen der jungen Pfanzen verbunden sein.

Mehrscharige Saatpflige sind dagegen den vorerwähnten Pflugwerkzeugen weit vorzuzichen, weil ihr Tiefgang sich leichter reguliert und gleichmässiger ist; f'erner schneiden sie Erdbalken von geringerer Breite ab, in Folge dessen auch die Samenverteilnng gleichmässiger geschicht und die Erde feiner zerkrümelt über das Samenkorn gedeckt wird.

Exstirpatoren, Krimmer ete. leisten zu einer mässig tiefen und gleichmässigen Unterbringung der Saat sehr gute Dienste, auch fördern sie die Arbeit ungleich melır als Pflüge oder Haken.

Die gewöhulichste Unterbringung der Saaten auf schwerem Boden und vorzugsweise der Herbstsaten ist die mit der Egge, doch sollte ilure Anwendung auf rauher Furche vermieden werden, weil auch iı diesen Falle der Same sehr ungleichmässig untergebracht wird; wiinseht man aber cine ticfere Unterbringungr, als durch die 
Egge auf vorher geebnetem Felde erreichbar, dann sind Saatdecker zu rerwenden.

Zur Saatunterbringung sehr taugliche Eggen sind: die Zickzackegge von Howard, die schottische sog. Rhomboïdal- und die Brabanter Egge.

Was nun die Drillkultur anbetrifft, so lässt sich dieselbe auf allen Bodenarten anwenden, welche frei von Wurzelunkräutern und Steiven, sowie nicht zu steil sind. Der Fortschritt des Getreidebaues hängt zu einem grossen Teil von der rationell durchgefuihrten Drillkultur ab, denn ausser der Samenersparnis und Verminderung des Lagergetreides gewährt sie durch dic gleichmässige Unterbringung der Samenkörner in entsprechend zweckmässiger Tiefe und ihre gleichmässige Verteilıng gegenüber der Breitsaat sehr wesentliche Vorteilc.

Mit ihrer Hülfe werden bei richtiger Bemessung der Saatmenge und Reihenweite seh॰ kräftige, produktive Pflanzen, welche unter dem Kampf un das Dasein nur wenig leiden, erwachsen, und wird folgerichtig eine nach Quantität und Qualität besserc Ernte als bei der Breitsaat aufzubringen sein, zumal, wenn auch eine Bearbeitung der Zwischenräume während der Vegetationsperiode stattfindet.

Die Reihenentfernungen (Drillweiten) bemessen sich nach dem notwendigen Wachsraum, welchen die Pflanzen im konkreten Fall bealspruchen und hängt hiervon hauptsächlich der Erfolg der Drillkultur ab.

Von ganz besonderer Wiclitigkeit bei Bemessung der Reihenentiernung ist aber auch der Unistand, ob eine Bearbeitung der Zwischenräume stattinden soll oder nicht, denn erst bei $20 \mathrm{~cm}$ Reihenentfernung lässt sich ein erfolgreiches Behacken mit Pferdehacken vornehmen.

Dic geringste Reihenentfernung unserer besten Drillmaschinen geht nun nicht unter $8 \mathrm{~cm}$ herunter, dic wir demnach als die unterste Grenze anzusehen haben, während die uns bekannte oberste Grenze bei den echten Getreidearten 50 en erreicht.

Dicse letztere Reihenentfernung fanden wir, namentlich zum Schutz gegen das Lagern in der berihmten Wirtschaft des Herrn Amersfoort zu Badhoeve, im Haarlemermeer, Niederlande, wo auf stark gediingtem lehmigen Humusboden diese Entfernungen gewählt worden waren und zwar betrug das Aussaatquantum p. ha bei

Ende Oktober ausgesäetem Roggen $0.40 \mathrm{hl}$

Ende März ausgesäetem Hafer $1.50 \mathrm{hl}$

Bei unserer Anwesenheit, Ende Mai, deckte der Roggen schon rollständig das Feld.

Gemeinhin schwanken die Drillweiten und Saatquanta wie folgt: 


\begin{tabular}{|c|c|c|}
\hline & henweite & Saatquantum \\
\hline Weize & $10-30 \mathrm{~cm}$ & $2.00 \mathrm{hl}-1.00 \mathrm{hl}$ \\
\hline Rogge & $10-26 \mathrm{~cm}$ & $2.70 \mathrm{hl}-1.00 \mathrm{hl}$ \\
\hline Gerste & $10-26 \mathrm{~cm}$ & $2.50 \mathrm{hl}-1.10 \mathrm{hl}$ \\
\hline Hafer & $10-26 \mathrm{~cm}$ & $4.00 \mathrm{hl}-2.00 \mathrm{hl}$ \\
\hline Hirse & $10-26 \mathrm{~cm}$ & $0.22 \mathrm{hl}-0.10 \mathrm{hl}$ \\
\hline
\end{tabular}

Nach Feststellung der Rcihenentfernung wird je nach dem Pflanzraum, welchen eine Pflanze einnehmen soll, die Saatmenge berechnet, und nach derselben die Drillmaschine entsprechend eingestellt.

Bei Anwendung der Drillmaschine zur Aussaat ist der Acker vorher zur Saat vollständig fertig zil stellen und kann dies ebenfalls, namentlich auf schwcrem Boden, als ein Vorteil der Drillkultur angesehen werden, indem das nach der Einsaat so schädlich wirkende Festtreten des Saatlandes rermieden wird.

Zeigen sich die Drillreihen nach der Einsaat nicht genügend geschlossen, was auf schwerem, noch etwas feuchtem Boden wohl vorkommen kann, so gibt man mit einer leichten Egge quer iber dieselben einen Eggenstrich.

Die Qualität der Arbeit hängt aber ausser von der Vorbereitung des Bodens von der Drillmaschine selbst ab und wird von dieser verlangt, dass sie die Samenkörner unter allen Verhältnissen mit der wiinschenswerten Bedeckung in gleiche Tiefen bringt. Hierzu ist eine zweckmässige Form und eine gewisse Beweglichkeit der Drillschare erforderlich, damit sich bei momentanen Widerständen die Tiefe leicht reguliert; auch ist zur Herstellung paralleler Reihen ein steter Gang und eine leichte Lenkbarkeit der Maschine sehr erwünscht; ferner sollen sich Drillweite und Saatmenge leicht verändern lassen.

Die Drillmaschine soll zu ihrer Fortbewegung nur zwei mittelschwere Pferde beanspruchen, und bei günstiger Lage, sowie gehöriger Vorbereitung des Feldes durchschnittlich täglich $4.5-5$ ha besäen können.

Allen diesen Anforderungen entsprechen am meisten die nach dem Löffelsystem konstruierten Drillmaschinen, ron denen wir die Maschinen ron Zimmermann, Sack, Garret, Hornsby etc. anführen wollen.

Schliesslich haben wir noch, wenn auch streng genommen nicht hierhin gehörig, den Samenwechsel zu erwähnen.

Bekanntlich sind die Ansichten der Landwirte über die Vorteile 
des Samenwechsels sebr geteilt, indem sich einige cntschieden für unbedingten Samenwechsel aussprechen, sobald nur das Getreide aus Gegenden bezogen wird, in denen es vorzüglich gedeiht und zwar selbst auf die Gefahr hin, dass Klima und Bodenbeschaffenheit des Ursprungsortes sehr erheblich von denen des neuen Kulturortes abweichen. Andere halten dagegen das selbstgczogene Getreide für das beste, weil es sich dem Boden und Klima angepasst labe und bei sorgsamer Kultur seine guten Eigenschaften auch bewahre; wieder Andere nehnen einen vermittelnden Standpunkt ein, indem sie nur dann den Samenwechsel empfehlen, wenn das angebaute Getreide den an dasselbe gestellten Anforderungen nicht mehr entspricht.

Dieser letztere Standpunkt schcint uns nun der allein richtige zu sein, denn unzweifelhaft stiitzt sich der Samenwechsel darauf, dass Getreide mit besonderen hervorragenden Eigenschaften in einzelnen sehr begünstigten Gegenden konstant erzengt wird und diese ihm innewohnenden niitzlichen Eigenschaften in andercn weniger begüustigten Gegenden durch einige Generationen hindurch fortzupflanzen vermag; wollen wir daher die Vorteile, welche ein solches Getreide bictet, geniessen, dann haben wir cinen rationellen Samenwechsel einzuführen; wird aber der Samenwechsel zur Mode, d. h. principicnlos durchgefiihrt, so ist derselbc rom Uebel, denu in vielen Fällen lässt sich das einheimische Getreide durch Gewälırung eines besseren Standortes, guter Kultur und Pflege, sowie bei vorsichtiger Samenauswahl sehr erheblich verbessern.

Der Samenwechsel setzt nun eine genaue Sortenkenutnis des Getreides voraus, und wird nicht allein durch die Verbesserung der Kommunikationsmittel und den genossenschaftlichen Bezug, soudern auch durch strenge Samenkontrolc erleichtert.

Die Grïnde, welche zum Samenwechsel führen, können folgende sein:

1) Hebung der Produktion nach Quantitit und Qualitiit.

Durch die Kultur sehr ertragreicher Sorten lässt sich die Produktion erfolgreich erhöhen, wobei jednch nach Haberlandt ${ }^{1}$ ) das aus feuchten Klimaten bezogene Saatgut verhältnismässig mehr Stroh und wcniger Körner licfert, als das aus trocknen Wacbstumsgebieten mit kurzem Fruihjahr und heissem Sommer, auch widerstehen die aus letzterem Saatgut bcrvorgegangenen Pflanzen besser der Trockenheit.

Die Richtigkeit dieses Satzes bezeugen unsere siebenjährigen in Poppelsdorf' gemachten Untersuchungen mit Original-Getreide aller Zonen und legen wir hier nur die auf Winterweizen bezuiglichen des Seeklimas von Grossbritannien, des Klimas Deutschlands, und des

1) Oestr. landw. Wchbl. No. 1. 1875. 
ausgesprochenen Kontinentalklimas (Steppenklima) des südöstlichen Europas vor :

\begin{tabular}{|c|c|c|c|c|c|c|}
\hline \multirow[b]{2}{*}{ Land } & \multirow{2}{*}{$\begin{array}{c}\text { Anzahl der } \\
\text { unter- } \\
\text { suchten } \\
\text { Winter- } \\
\text { weizen }\end{array}$} & \multirow{2}{*}{$\begin{array}{c}\text { Gesanımtfläche } \\
\text { eines Halmes } \\
\text { im Durchschnitt } \\
\text { qcm }\end{array}$} & \multicolumn{2}{|c|}{ Gewicht } & \multicolumn{2}{|c|}{ Procente an } \\
\hline & & & $\begin{array}{c}\text { von } 100 \\
\text { Halmen } \\
\text { gr }\end{array}$ & $\begin{array}{c}\text { der } \\
\text { Körner } \\
\text { gr }\end{array}$ & Korn & Stroh \\
\hline \multirow{3}{*}{$\begin{array}{l}\text { Grossbritannien } \\
\text { Deutschland } \\
\text { Ungarn, Rumänien, } \\
\text { Süd-Russland }\end{array}$} & 37 & 38 & 600 & 227 & 37.8 & 62.2 \\
\hline & 18 & 373 & 500 & 204 & 40.8 & 59.2 \\
\hline & 19 & 236 & 365 & 160 & 44 & 56 \\
\hline
\end{tabular}

Hiernach liefert allerdings das Getreide des feuchteren Klimas verhältnismässig mehr Stroh und weniger Körner, als das des trockneren, wärmeren Klimas, doch ist im Allgemeinen die Differenz nicht sehr bedeutend, während sich ein sehr erheblicher Unterschied betreffs der Gesammtoberfläche und des absoluten Gewichtes der Halme bemerkbar macht, woraus sich wohl folgern lässt, dass im feuchten Ḱlima und auf kulturvollem Boden die Erträge sich höher als im trocknen Kilima stellen werden.

Die bessere Qualität der Körner beruht nun hauptsächlich auf Kleberreichtum und Armut an Holzfaser und macht hiervon nur die Braugerste eine Ausnahme, deren Qualität sich vorzugsweise nach der Menge an Kohlehydraten, welche sie im Korn aufgespeichert enthält, bei relativ geringster Menge an Holzfasersubstanz richtet.

Hierzu bemerkt Habe rland t : „kontinentales Klima reift kleine hornige Getreidefriichte, mit kleberreichem Inhalte und specifisch schwereren Körnern; kühle feuchte Sommer hingegen oder künstliche Bewässerung und vermehrter Reichtum des Bodens an Pflanzennährstoffen vergrössern das Korn, lockern den Inhalt, derstatt glasig, mehlig erscheint und verringern das specifische Gewicht zugleich mit der Menge stickstoffhaltiger Bestandteile."

Dass nun in der That die Körner im trocknen Klima kleiner werden, aber ihr Volumengewicht steigt, zeigen unsere Untersuchungen, nach denen beim englisehen Winterweizen 1740000 Körner auf $1 \mathrm{hl}=83 \mathrm{~kg}$, beim deutschen 1746000 Körner auf $1 \mathrm{hl}=83 \mathrm{~kg}$, und bei Weizen aus dem Steppenklima 1942000 Körner auf $1 \mathrm{hl}$ von $84,8 \mathrm{~kg}$ Volumengewicht durchschnittlich entfielen.

Ferner kann auch ein grösserer Kleberreichtum in den Eigenschaften einer Sorte begründet sein und bringen wir zum Beweise hierfür aus dem Werk von Ritthausen, die Eiweisskörper etc. Bonn 1882 nachfolgende Analysen: 


\begin{tabular}{|c|c|c|c|c|c|c|c|}
\hline \multirow[t]{2}{*}{$\begin{array}{l}\text { Bezeichnung der } \\
\text { Weizensortcn }\end{array}$} & $\begin{array}{c}\text { Die } \\
\text { entha } \\
\\
\text { o. } \\
\infty\end{array}$ & 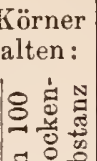 & $\mathrm{Da}$ & s Meh & $\begin{array}{l}\text { In } 10 \\
\text { ckensu }\end{array}$ & lben ent & hält: \\
\hline & $\geqslant$ & 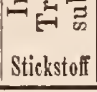 & $\geqslant$ & $\begin{array}{l}\text { Stick- } \\
\text { stoff }\end{array}$ & $\begin{array}{l}\text { Pro- } \\
\text { teïn }\end{array}$ & $\begin{array}{l}\text { Kleber, } \\
\text { trocken }\end{array}$ & frisch \\
\hline $\begin{array}{l}\text { Sommerweizen aus Jekateri- } \\
\text { noslaw }\end{array}$ & 11.81 & 3.41 & 12.54 & 3.27 & 19.62 & 19.70 & 55.00 \\
\hline Sommerweizen aus Cherson & 13.11 & 307 & 13.10 & 2.84 & 17.04 & 16.00 & 42.70 \\
\hline Winterweizen aus dem Banat & 12.62 & 3.08 & 13.81 & 3.07 & 18.42 & 16.87 & 42.80 \\
\hline , Cherson & 12.90 & 2.51 & 13.41 & 2.53 & 15.18 & 14.14 & 38.96 \\
\hline $\begin{array}{l}\text { Ungarischer Sommerweizen } \\
\text { (1 Jahr in Poppelsdorf ge- } \\
\text { baut) }\end{array}$ & 14.81 & 2.50 & 15.28 & 2.43 & 14.58 & 14.80 & 37.67 \\
\hline Winterweizen von Keszthely & 13.78 & 2.57 & 14.35 & 2.64 & 15.84 & 13.85 & 35.84 \\
\hline $\mathrm{K}$ ujavischer-Weizen, Posen & 16.61 & 2.36 & 15.94 & 2.04 & 12.24 & 12.33 & 29.88 \\
\hline Aarweizen, Nassau & 15.46 & 1.93 & 15.52 & 1.94 & 11.64 & 11.16 & 26.71 \\
\hline Kaiser-Weizen, Proskau & 15.42 & 2.01 & 15.39 & 1.65 & 9.90 & 10.65 & 26.36 \\
\hline Frankensteiner-Weizen & 14.49 & 2.01 & 15.07 & 1.75 & 10.50 & 11.27 & 25.50 \\
\hline Hallet's genealogischer & 15.53 & 1.92 & 15.83 & 1.78 & 10.68 & 10.41 & 24.11 \\
\hline Kessingland & 17.14 & 203 & 16.91 & 1.71 & 10.26 & 8.36 & 18.99 \\
\hline
\end{tabular}

Demnach scheint die Ansicht berechtigt $z u$ sein, dass das Steppenklima mit seinem von Natur reichen Boden aber mangelnder Kultur die kleberreichsten, also der Qualität wach besten Weizen erzeugt, während mit der Zumahme der Feuchtigkeit und Kultur der Klebergehalt immer mehr abnimmt. Soll daher der Klebergebalt vermebrt werden, so empfiehlt sich der Bezug kleberreicher Sorten, die je nach den im konkreten Falle vorlicgenden Verhältnissen längere oder kiirzere Zeit ihren höheren Klebergehalt bewahren werden.

2) Der Samenwechsel ist häufig nötig, wem sich das angebaute Getreide gegen Auswintern, Lagern, Trockenheit und Rost zu wenig widerstandsfähig zeigt.

In Bezug auf die Widerstandsfähigkeit der Wintersaaten gegen ungünstige Winterwittering bemerkt Haberlandt ${ }^{1}$ ), dass beim Bezug voll Saatgut der Westen Europas besser daran sei, wie der Osten, denn die westlichen und nordwestlichen Länder Europas können Wintergetreide zum Samenwechsel bezichen und sicher sein, dass solche dem Ausfricren weniger ausgesetzt sein werden, als ihre eignen einheimischen Sorten. Wollte aber der Osten oder Suid-Osten Europas mit seinen kontinentalen strengen Wintern Saatgetreide aus dem Westen Europas beziehen, so würde die vollständige Auswinterung solcher Saaten wohl die Regel sein.

Dieser Satz ist jedoch nach unseren Beobachtungen nicht im

1) Der allg. landw. Pflanzenb. 1879, p. 747 . 
vollen Umfange zu aeeeptieren, da in den Ländern des Ostens Weizensorten des Westens durch die ihnen lier zu Gute kommende sehützende Sehneedecke hänfig besser durehwintern als in den Ländern des Westens, in denen trockenc und kalte Witterung mit feuehter und milder hänfig ganz nnvermittelt abwechselt, so dass z. B. 1870 in Poppelsdorf der grösste Teil der Wintersaaten aus versehiedenen Ländern vollständig zu Grunde ging; während anf dem Versuehsfelde in Proskau, Ober-Schlesien, die Wintersaaten, von denen sehr viele dem Westen entstammten, gut dnrehwinterten, und bestätigt sich hier die bckannte, aber noeh unerklärte Thatsache, dass Pflanzen ohne Schaden zu nelımen gefrieren können, während ein mehrmaliges Aufthanen nnd Einfrieren sic tötet.

In Poppelsdorf erwiesen sieh in ciner Beobaehtungszeit von 1870-1881 von 40 englisehen Winterweizen nieht weniger als 52,5 Proe. als nicht winterfest.

Uebrigens ist es eine bekannte Thatsache, dass in Nord-Frankreieh und Siid-England einheimisehe Wcizen ebenfalls erfrieren.

Ans diesen Griunden ist beim Samenwechsel die Widerstandsfähigkeit gegen Frost für jede Sorte im konkreten Fall zu prüfen.

In Betreff des Lagerns führt nun II aberlandt ${ }^{1}$ ) aus, dass das Getreide regenreicher Länder leiehter als das regenarmer lagere, eine Anschauung, der wir nieht beipflichten können, sobald es sich darum handelt, behufs des Samenwechscls Getreide ans regenarmen in regenreiche Länder zu versetzen, denn naeh unseren Erfahrungen ist solches Getreide leichter als das einheimisehe dem Lagern ausgesetzt, wie anel naehfolgende in Poppelsdorf angestellte Untersuehungen an Winterweizen zeigen:

\begin{tabular}{|c|c|c|c|c|}
\hline $\begin{array}{l}\text { Bezeichnung der } \\
\text { Herkunft }\end{array}$ & $\begin{array}{l}\text { Anzahl } \\
\text { der } \\
\text { Sorten }\end{array}$ & $\begin{array}{l}\text { sehr } \\
\text { leicht } \\
\text { lagcrnd } \\
\text { Proc. }\end{array}$ & $\begin{array}{l}\text { ziemlich } \\
\text { leicht } \\
\text { lagernd } \\
\text { Proc. }\end{array}$ & $\begin{array}{l}\text { nicht } \\
\text { leicht } \\
\text { lagernd } \\
\text { Proc. }\end{array}$ \\
\hline $\begin{array}{l}\text { Englische Sorten } \\
\text { Deutsche ", } \\
\text { Sorten aus Ungarn, } \\
\text { Rumänicn, Süd-Russ- } \\
\quad \text { land }\end{array}$ & $\begin{array}{l}41 \\
22\end{array}$ & $\begin{array}{l}5 \\
3\end{array}$ & $\begin{array}{l}20 \\
37\end{array}$ & $\begin{array}{l}75 \\
60\end{array}$ \\
\hline
\end{tabular}

Hiernaeh sind die regenarmen Ländern entstammenden feinhalmigen Sorten, sobald sie in regenreichere und auf stark gedüngten Boden kommen, in weitans höherem Grade dem Lagern nnterworfen, als die starkhalmigen Sorten des feuehten Klimas.

1) Oestr. landw. Wchbl. No. 1. 1878. 
Demnach lässt sich auch in diescm Falle nur durch den An* bauversuch entscheiden, ob eine Sorte mehr oder weniger leicht lagert.

Selbstverständlich ist ferner, dass die feinhalmigen Getreidesorten regenarmer Länder leichter der Dürre widerstehen, als die sehr kräiftigen Pflanzen des feuchten Ḱlimas.

Die Widerstandsfithigkeit des Getreides gegen Rost ist nach unseren Beobachtungen hauptsächlich abhängig vom Charakter der Sorte, denn es befallen die Getreidesorten aller Länder mit Rost, jedoch zeigen sich sehr merkliche Verschiedenleiten in der Intensität des Auftretens bei den einzelnen Sorten, so dass neben einer sehr stark durch Rost befallenen Sorte eine sehr wenig erkrankte stehen kann. Haberlandt ${ }^{1}$ ) meint, dass frühreifende Sorten den Pilzen weniger als spätreifende ausgesetzt seien; doch ist dies keinesfalls richtig, vielmehl ergaben unsere beobachtungen, wie sich dies anch aus den weiter unten folgenden Beschreibungen der Getreidesorten leicht erkennen lässt, dass gerade frühreife Sorten dem Rost sehr leicht erliegen, und geneinhin spätreife weit widerstandsfähiger sind.

3) Häufig ist auch an Stelle einer spütreifen eine frühreife Getreidesorte erwïnscht, und hat diese Frühreife namentlich dann einen hohen Wert, sobald Getreidearten an der äussersten Grenze ihrer Verbreitungszone angebaut werden sollen, welcher Fall z. B. in Deutschland bei dem Mais, der Mohr-, Kolben- und Rispenhirse eintreten kann, auch würde für Gegenden mit kurzen oder in solchen mit trocknen Sommern der Auban frïhreifer Sorten wohl zu beachten sein.

Hierzu ist zu bemerken, dass Pflanzen mit frïh- oder spätreifer Entwickelung in Verhältnisse gebracht, welche z. B. der Fribreife nicht günstig sind, doch ihren Charakter für lange Perioden bewahren können, obwohl unter dem Einfluss sehr verschiedenartiger Beschaffenheit des Klimas und der Bodenverhältnisse sich sowohl die Beschaffenheit der Früchte, als auch der Habitus der Pflanze sehr wesentlich zu ändern vermag. So haben die Versuche von Körnicke ${ }^{2}$ ) mit nordischem Getreide, welche von 1873 bis 1881 durchgeführt würden, zur Genüge dargethan, dass diese Getreidesorten ihre eigentümliche und frühzeitige Entwickelung trotz neunjähriger Kultur in Poppelsdorf nicht eingebüsst hatten.

Ferner stellte Haberlandt den Satz auf, dass der Gegensatz zwischen Winter- und Sommerfrucht um so mehr schwindet, in je südlichere Gegenden man gelangt; und Wintergetreirle aus Gegenden

1) Allg. landw. Pflanzenbau 747.

2) Berichte u. vergl. Kult. mit nord. Getr. Landw. Jhrb. 1874. 75, 76, 77. 
nördlich vom $45 .{ }^{0}$ im Friihjahr ausgesäet, in demselben Jahre nicht mehr zum Schossen gelangt, dagegen aus südlicheren Breiten bezogen, sich im kälteren, gemässigten Klima ebenso wie Sonımergetreide verhält.

Diese Annahme erscheint uns insofern nicht ganz richtig, als auch echte Wintergetreide, welche sich nicht als Sommergetreide anbauen lassen, in wärmeren Zonen vorkommen; allerdings können wir bestätigen, dass sich das Wintergetreide wärmerer Zonen häufig anch als Wechselgetreide benutzen lässt.

So fanden sich in Poppelsdorf unter den Winterweizensorten (Triticum vulgare) aus Ländern sehr verschiedener Zonen nachfolgende Procentsätze an Wechselweizen und echtem Winterweizen:

\begin{tabular}{l|r|c|c}
\hline $\begin{array}{c}\text { Vaterland der Original- } \\
\text { Weizensorten }\end{array}$ & $\begin{array}{c}\text { Anzahl der } \\
\text { untersuchten } \\
\text { Sorten }\end{array}$ & $\begin{array}{c}\text { Procente an } \\
\text { Wechsel- } \\
\text { weizen }\end{array}$ & $\begin{array}{c}\text { Procente an } \\
\text { echtem } \\
\text { Winter- } \\
\text { weizen }\end{array}$ \\
\hline Nord- u. Mittel-Russland & 3 & - & 100 \\
Holland & 6 & - & 100 \\
Skandinavien & 2 & - & 100 \\
Grossbritannien & 79 & 4 & 96 \\
Nord-Drutschland & 39 & 5 & 95 \\
Nord-Amerika & 50 & 6 & 94 \\
Süd-Russland, Rumänien, & 12 & 9 & 91 \\
$\quad$ Ungarn, Serbien. & 9 & 20 & 80 \\
Italien & 35 & 28 & 72 \\
Flankreich & 4 & 50 & 50 \\
Spanien & 7 & 60 & 40 \\
Ostindien & 13 & 70 & 30 \\
Griechenland,Klein-Asien & & & \\
\cline { 2 - 4 }$\quad$ Summa: & 259 & 10 & 90 \\
& & &
\end{tabular}

Ueberdenken wir das iilser den Samenwechsel Gesagte noch einmal, so kommen wir zu den Schluss, dass cin Samenwechsel unter Umständen sehr verteilhaft sein kann, wenn die Wahl der neuen Sorte nach genauer Prüfung aller Verhältnisse geschieht.

$\mathrm{Zn}$ bemerken ist jedoch, dass jedesmal erst im Kleinen ein Anbauversuch mit dem nenen Saatgut zu machen ist, um zu prüfen, ob dasselbe auch wirklich allen Anfordcrungen entspricht.

Einige Getreide, wie Roggen und Mais, sind möglichst fern von anderen Sorten ihrer Art anzubanen, da sonst zu leicht Kreuzungen entstehen. 


\section{Die Pflege des Getreides.}

Die Pflege hat sich zunäehst auf eine dem Getreidebau giunstige Regulierung der Bodenfeuchtigkeit zu riehten, wobei hervorzuheben ist, dass das Getreide mit seiner relativ geringen verdunstenden Oberfläche besser Troekenheit, wenn sie ein gewisses Mass nicht iibersehrcitet, als zu viel Nässe verträgt, weshalb in der subarktisehen Zonc die Entwässerung platzzugreifen hat.

In der kälteren gemässigten Zone sind gemeinhin die Feuchtigkeitsverhältnisse derart, dass die Regenmenge für die Getreidekultur ausreicht und auf bindigen Bodenarten sogar die Entwässerung von grossem Vorteil sein kann, während vom $45^{\circ}$ nach dem Aequator zu häufig Wassermangel eintritt, weshalb hier beim Sommergetreide und nicht selten aueh beim Wintergetreide erst dnrch periodisclse Bewässerung dic Sicherstellung und Ertragserhöhung der Ernten erzielt werden kann.

Die Ackerbestellung zum Zweck der Bewässerung gesehicht in der Weise, dass entweder $1-1,5 \mathrm{~m}$ breite, gewölbte, oder $3-4 \mathrm{~m}$ breite flache Beete in der Richtung des grössten Gefälles $(1-1,50 \mathrm{~m}$ und mehr Gefälle auf $1000 \mathrm{~m}$ Länge) aufgepflïgt werden. In die Beetfurchen strömt das Wasser von einem Verteilgräbchen aus, das dem Bewässerungsgraben parallel läuft, langsam ein und sobald es am entgegengesetzten Ende angekommen und sich daselhst anf $3-4 \mathrm{~cm}$ erhöht hat, sieht man die Bewässerung meist als genügend an.

Während der Bliitezeit und der Ausbildnug der Aehren darf jedoch nicht gewässert werden.

In Italien stellt sich der Wasserkonsum für die Getreidekultur auf $0.377 \mathrm{l}$ Wasser $p$. ha und Seknnde, während der Vegetationsdauer.

In Spanien wässert man den Mais eimmal in 15 Tagen, das uibrige Getreide einmal in 30 Tagen, mit $500-700 \mathrm{clsm}$ p. ha.

Sind in suidliehen Frankreich die Regen des Mai und Juni nieht ausgiebig genug, so wässert man zwciural zu 0,12 m Stauhöhe, oder 1200 ebm p. ha, welehe einem beständigen Zufluss von 0,31 entsprechen.

Naturgemäss stellen sieh in den heissen Ländern die notwendigen Wasserquanta weit höher als in Süd-Europa, so erlü̈lt in Indien der Winterweizen (Aussaat Ende Oktober, Erute Anfang April) 5 Bewässerungen und zwar die erste mit $750 \mathrm{ebm}$ vor der Bestellung zur Erweiehung des Landes, die 4 folgenden $560 \mathrm{ebm}$ in der Vegetationsperiode, also im Ganzen $2990 \mathrm{cbm}$ Wasser p. ha. 
Im Nildelta werden alle 10-12 Tage sämmtliehe Wasserfurehen einmal vollständig gefüllt und konsumiren die Sommerfrüehte dureh sehnittlich pro Tag und ha $50 \mathrm{cbm}$ Wasser.

In Algier wässert man das Wintergetreide dreimal, das Sommergetreide viermal und werden für ersteres $1000 \mathrm{cbm}$, für letzteres 1600 ebm Wasser p. ha rerbraueht.

Hiergegen kann in der kälteren gemässigten und subarktischen Zone auf den bindigen Bodenarten erst vermöge genügender Entwässerung durch Drainage oder offene Grïben an eine lohnende intensive Kultur gedacht werden, und tritt die Notwendigkeit der Entwässerung um so schärfer hervor. je kälter und regenreicher das Klima sich gestaltet.

Unter solchen Umständen ist es geboten, den Ueberfluss an Wasser, beror durch dasselbe den Pflanzen Schaden zugefügt wird, möglichst sehnell abzuleiten, weshalb nach der Aussaat sofort Wasserfurchen anzulegen sind, welche eine längere Zeit andauernde Ueberflutung tief gelegener Partieen des Feldes rerhiiten sollen. Aueh sueht man auf stark abhängigen Feldern das Ausreissen und Wegspiilen der Krume bei lieftigen Regengïssen dureh Wasserfurchen, welehe in Halbbogen gezogen werden und sich unter einander kreuzen, mögliehst zu vermeiden.

Die Pflege hat sich ferner auf diejenigen Wintersaaten zu erstrecken, welehe auf sehr humosem Boden dem Auffrieren ausgesetzt waren, welehes bekanntlich dadureh entsteht, dass das die zahlieiehen Poren des humosen Bodens erfuillende Wasser gefriert, in Folge desseu sich die obere Bodensehieht ausdehnt und ron dem nicht gefrorenen Boden abhebt. Ist diese obere gefrorene Bodenschicht nur wenig mäehtig, so dass sieh die grösste Wurzelmasse noch in der nieht gefrorenen Schicht findet, dann werden die Pflanzen, namentlieh wenn sieh das Anfthauen und Gefrieren melırmals wiederholt, obne sehr starkes Zerreissen der Wurzeln förmlieh aus den Boden herausgehoben. Ungünstiger gestalten sieh jedoch diese Verhältnisse bei tiefer eindringendem Frost, weil dann auch ein starkes Zerreissen der Wurzeln unausbleiblich ist und die ron Erde entblössten zerrissenen Wurzeln sehr viel leichter absterben.

Durch das mögliehst zeitige Zusammendrüeken der gelockerten Bodensehicht, nach dem Abtroeknen derselben im Frühjahr, mit Hülfe einer schweren Walze oder dureh Uebertreiben einer Sehafherde sueht man die Pflanzen wieder zu befestigen und das Anwaehsen zu unterstiitzen.

Fiir die Wintersaaten auf bindigen Böden, welehe leieht erhärten und rerkrusten, hat sieh die Pflege im Frühjahr naeh dem Abtroeknen des Bodens zunäehst auf das Brechen der Kruste zu riehten, damit der Luft der Zutritt zum Boden wiederum ersehlossen, sowie dureh 
die erzeugte lockere Erde einer zu starken Verdunstung des Bodens entgegen getreten wird. Für diese Zwecke eignet sich kein Gerät besser als die Wiesenegge, indem sie die Kruste griindlich zerstört und lockere Erde schafft, auch sehr zeitig, da sie die Pflanzen nicht mit Erde zu stark überdeckt, zur Anwendung koumen kann. Später eggt man dic Saat mit schwereren, eisernen Eggen noch einmal tiichtig durch, um eine tiefere Lockerung und die Zerstörung einer Anzahl Unkräuter zu bewirken. Leider werden durch sie Kornblumen, Kornraden, Disteln etc. nicht vernichtet, welche daker durch $A$ usstechen $\mathrm{zu}$ entfernen sind.

Dic Sommersaat eggt man gern nach der Einsaat, doch bevor sie aufgegangen, un das zeitig hervorgelockte Samenunkraut z. B. den Hederich wiederum zu zerstören, oder um nach Schlagregen die Kruste zu brechen.

Die Keimung der Samenkörner wird auch auf trockenem Boden und bei trockener Witterung durch Walzen gefördert, indem in der obersten festgedruickten Erdschicht nicht allein die Samenkörner dichter durch Erde umlagert werden, sondern es wird ihnen auch das nötige Quellungswasser schneller zugeführt, denn es strömt ihr, da eine festgedriickte Erdschicht stärker als eine lockere verdunstet, aus den tieferen Schichten neues Wasscr zu, das sie feucht erhält.

Im Allgemeinen empfiehlt sich aber nicht die Verwendung von glatten Walzen, sondern von kannelirten oder Ringelwalzen, weil der geriefte Boden weniger leicht durch Schlagregen verkrustet, da die Regentropfen an den Hervorragungen zerschellen, auch sehr sandiger Boden weniger leicht durch starken Wind verweht wird.

Das Walzen wiederholt man, zur Förderung der Bestockung und Vermeidung des Zweiwuchses, sobald die Pflanzen die Länge eines Fingers crreicht haben.

Das Eggen und Walzen vertreibt auch manchen tierischen Getreidefeind, weshalb es nicht unterbleiben sollte.

Hat ferncr das Wintergetreide durch ungiinstige Winterwitterung und das Sonmergetreide durch kaltes, wenig fruchtbares Friihjahrswetter namentlich auf armem Boden gelitten, so sucht man durch zeitige Anwendung stickstofireichen Kopfdunges das Wachstum zu unterstiitzen.

Eine sehr ausgiebige Pflege kann den Drilisaaten und zwar hauptsächlich auf bindigen Böden durch die Hackkultur zu teil werden, welche den Boden den Einwirkungen der Luft, des Regens und Thaues zugänglicher macht, seine Vcrdunstung vermindert und das Unkraut zerstört. Ferner soll sich das Hacken auch als Mittel gegen Frostschaden bewährt liaben; so berichtet Mär cker, dass nach dem heftigen Nachtfroste vom 19. auf den 20. Mai 1880 mchrere in der Nähe von Halle befindliche Gerstenfelder sich gegen den Einfluss des Frostes sehr verschieden verhalten hätten. Es zeigte sich die 
Wirknng des Frostes auf unbehackten Gerstenfeldern in sehr starkem Masse, namentlich wenn dic Felder zugleich sehr tief lagen. Felder, welehe kurz vor Eintritt des Frostes, also am 18. und 19. Mai behackt waren, zeigten die Wirkungen des Frostes fast noch stärker als die unbehackten; dagegen blieben solche Felder, welche melsrere Tage vor dem Froste behackt worden waren, von der Wirkung des Frostes so gut wie ganz verschont; Felder, welche zwar behackt, aber nach dem Behacken wieder gewalzt worden waren, zeigten sich durch den Frost ebenso beschädigt wie die unbehackten und unmittclbar vor dem Frost behackten.

Das Hacken nimmt seinen Anfang, sobald das Getreidc cine solche Höhe erreicht hat, dass es nicht mehr mit Erde bedeckt werden kann, welche Gefahr sich auf sehr losem oder scholligem Boden durch vorhergehendes Walzen vermindern lässt.

Das Hacken lässt sich erst bei einer Drillweite von $20 \mathrm{~cm}$ mit der Pferdehacke gut ausführen.

Die Pflege hat sich auch auf die Verhiutung des Lagerns auszudehnen.

Dassclbe stellt sich sehr leicht auf stickstoffreichen Böden ein, namentlich wenı einem milden Herbst und Winter ein feuchtwarmes Friihjalırswetter folgt, mithin sich die jungen Pflanzen ïberaus kräftig entwickchn und bestocken. In dicsem Falle genügt aber der für normale Jahre angenommene Wachsraum pro Pflanze nicht mehr, d. h. die Pflanzen stehen zı dicht und treffen num zur Bliitezeit, oder kurz vor- oder nachher fortgesetzte schwere Nicderschlïge das Getreide, so findet das Umknicken des Halmes in zweiten Internodium statt.

Das Lagern schricb man friiher dem Mangel an aufnehmbarcr Kieselsäure im Boden zu, wodureh die Pflanzen verhindert werden sollten, ihrer Epidermis die zur Festigkeit des Halmes notwendige inkrnstierende Kieselsäure zuznfiilıren. Diese Ansicht wurde zuerst durch dic Thatsache erschüttert, dass die Blätter des Getreides reicher an Kieselsäure als dic Knoten und Internodicn sind, uud dass gerade die untersten Internodien, die doch dem Halm die Stcifigkeit verleihen, die geringste Menge an Kicsclsänre enthalten. Ferner wies Sachs nach, dass Halnufriichte in wässerigen Lösungen sich auch ohne Kieselsäure mit straffen Halmen und vollkommen entwickeln.

Hicrnach war es Schnmacher ${ }^{1}$ ), welcher zucrst erkannte, dass zum Lagern geneigte Getreidepflanzen sich dureh mangelhafte Verbolzung und Inkristation der Zellen und namentlich der Gefässe des Halmes auszeichneten und ist auch auf diesen Umstand der Hauptsache nach das Lagern zuriickzufiihren.

1) Physik in ihrer Anw. auf Agric. 1867. 
Ferner fand C. Gronemey e ${ }^{1}$ ), weleher das Lagern des Getreides näher untersuehte, dass das zum Lagern geneigte Getreide sieh dureh sehnelles Waehstum und Entwickelung zahlreicher, breiter, massiger dunkelgrüner Blätter auszcichnet, die eine ziemliche Turgeseenz besitzen, beim Reifeu aber eine bedeutende Sehlaffheit und Weichheit zeigen.

Die Sehwäche des Halmes, die sein Umknicken bedingt, liegt ganz besonders im zweiten Internodium und ist dasselbe von allen am meisten in die Länge gestreekt und am wenigsten verdiekt. Dieser Uebelstand tritt am sehärfsten dort hervor, wo dic Blattsehcide am unteren Ende des zweiten Internodiums dasselbe am festesten umschliesst, und gelingt es daher an dieser Stelle den Liehtzutritt zu gestatten, so verholzen die Prosenehymzellen und werden widerstandsfähiger.

Die Versuehe von L. Koch ${ }^{2}$ ) haben ebenfalls gezeigt, dass (ler Liehtmangel die Ursache des Lagerns ist. Fr fand, dass die Besehattung die Ueberverlängerung der waehsenden Stengelorgane und deren Zellen hewirkt und nur die Beliehtung im Stande sei, eine Verdickung der Zellen herbeizufülıren.

Als Vorbeugungsmittel des Lagerns gelten: Vermeidung sehr stiekstoffhaltiger Düngung, namentlich des Hordensehlages und iiberhaupt des Schafmistes; Verminderung des Saatquantums, Aussaat sehr starkhalmiger Sorten, und Drillkultur.

Steht nun aber trotz dieser Vorbeugungsmittcl das Lagern unmittelbar hevor, dann werden in der Praxis zur Bekämpfung desselben empfohlen: Abweiden, Sehröpfen, Eggen, Walzen und Kochsalzduingung.

Der Hauptzweek des Abweidens kann doch nur darin bestehen, bei zu dichtem Stande dic Zahl der Halme zu vermindern, und fragt es sich ob dies durch Beweidung mit Schafen, welehe sowohl im Herbst wie auch im Winter und Frihjahr stattinden kann, erreicht wird.

Jedenfalls ist die Beweidung nicht ohne Vorsichtsmassregeln auszuiblen. weun nicht das Saatland und aueh das Weidevich dureh dasselbe schwer geschädigt werden sollen.

Blcibende Nachtcile für das Saatland lassen sieh nur dann vermeiden, wenn eine mässige Beweidung auf trockner oder gefrorener aber sehneeloser Oberiäche stattfindet, damit die seharfen Klauen der Schafe den Boden nicht allzusehr zusammentreten. Ernstliehe Gefahren für die Saat stehen aber in Aussicht, sobald die Beweidnng längere Zeit selır energiseh betrieben wird, namentlich wenn die

1) Agron. Ztg. 1866, p. 721 .

2) Landw. Centralbl. 1872, Oktoberheft. 
Oberfläche gefroren ist, denn schliesslich wird dieselbe mürbe und staubig. in Folge dessen die Pflanzen ron Erde entblösst werden, somit der Haltung entbelıren, umfallen und eingehen. Diese Nachteile werden sich aber rorzugsweise an denjenigen Stellen der Saat, wo diese am dünsten steht, am deutlichsten bemerkbar machen, da gerade an diesen Stellen. anf denen dic Pflanzen am wenigsten iippig erwachsen sind, die Schafe am liebsten fressen, auch liegt es nicht im Interesse der Schäfer, die Schafe auf den ippigsten Stellen weiden zu lassen, da bekanntlich leicht Krankheiten mit tötlichem Verlauf die Folge zn wässerigen Futters sein können; daher kommt es denn. dass meist der Zweck der Berreidung rerfehlt, das Saatland geschädigt und die Gesundheit der Weidetiere gefährdet wird, wozu noch tritt, dass die Schafe das Trockenfutter im Stalle weniger gern anfnehmen und durch das reiche Weidefntter an Körpergewicht und Wollqualität einbiissen.

Durch die Bewcidung im Herbst und Winter werden demnach Pflanzen zerstört nnd geschieht die Beweidung zeitig im Herbst, so werden auch die Pflanzen weniger Reservestoffe ablagern, was eine schwåchcre Halmbildung im Friihjahr zu Folge hat, und ist dies nicht unbedenklich, denn man weiss nie roraus, wie das Getreide durch den Winter kommt.

Eine Beweidung im Frïhjahr ror vollendeter Bestockung wird aber gerade das Gegenteil, nämlich eine zu dichte. Saat durch rermehrte Bestockung erzielen lassen, denn sobald die primären Halme der in kräftiger Vegetation stehonden Pflanzen abgeweidet wcrden, wird sich die Bestockungsthätigkeit lebhafter gestalten nnd sich die Zahl der herrorspriessenden Halme rermehren miissen.

Aus diesen Grinden ist die Beweidung sebr iippiger Saaten nur dann entschuldbar, wenn der Stand im Herbst ein so üppiger ist, dass die Gefahr des Ausfaulens der Saaten nabe liegt, docb wirde in diesem Falle das Abmähen oder Absicheln (Schröpfen) noch rorzuziehen sein.

Das Schröpfen der Saaten im Herbst ist ebcnfalls, weun auch nicht in gleichem Masse wie das Abweiden nachteilig, kann jedoch im Frihjahr dann erfolgreich sein, wenn die Bestockung rollendet ist. indem ein Teil der Blätter fortgenommen, mithin der Fuss der Pflanzen ciner kräftigeren Beliclıtung ausgesetzt wird, jedoch ist das Schröpfen sofort zu unterlassen, sobald sich die Aehre im Halm soweit heraufgeschoben hat, dass sie verletzt werden kann.

Die Dünnerstellung der Saat lïsst sich wohl am besten im Friihjahr durch scharfe, schrere Eggen und auf bindigem Boden durch die Krümmercgre bewirken, woduch eine gremisse Anzahl Pflanzen entfernt, mitlin dic nötige Lichtung obne die Tachteile der Beweidung bewirkt werden kann. 
Ein einfaches Mittel zur Verhütung des Lagerkorns ist das von W. Schumacher empfohlene Walzen des noch nicht die Aehre zeigenden Getreides.

Durch diese Operation werden bei Anwendung leichter Walzen die schwächlichen, weichen Schösslinge in ihrer Entwicklung gestört oder sterben $a b$, während das Wachstum der älteren, kräftigeren, nur in ihren unteren Partiecn gequetschten, momentan gehemmt wird. Diese verletzten Stellen verholzen sodann sehr stark, wodurch sie fester und gegen das Lagern widerstandsfähiger werden, zumal gleichzeitig wegen des Absterbens der schwächercn Halme auch die Belichtung intensiver und somit das Wachstum normaler wird.

Da nun die Getreidehalme selbst in ihren älteren unteren Teilen die Fähigkeit besitzen, sich wieder aufzurichten, wenn sie heruntergewalzt sind, so erheben sich die Pflanzen wiederum nach einiger Zeit und zwar vermitteln die Aufwärtskrümmung die Knotengelenke ${ }^{1}$ ).

In welcher Weise die Schwerkraft die Pflanzenteile veranlasst, sich gerade in entgegengesetzter Richtung $210 \mathrm{kriimmen}$, als ein toter biegsamer Körper derselben Form, kann nur darin zu suchen sein, dass diese Kräfte von den Pflanzen selbst geliefert werden müssen und die Sehwere nur als Reiz wirkt.

In den Gelenken sind die Zellhäute weich und biegsam, Bastfasern fehlen ihnen und sind nur dureh das sehr dehnbare Collenchym mit seinen scheinbar gequollenen wasserreichen Zellwïnden vertreten. Die Ursache der Steifheit liegt in der Spannung der Zellinhalte, zumal denen des Parenchyms.

In jeder Parenchymzelle ist die Wand auf der Innenseite ron der dünnen Schicht des Protoplasmas bekleidet und der innere Raum von dem Zellsafte ausgefüllt, in dem Substanzen gelöst sind, für welche das Protoplasma undurchgängig ist; diese Stoffe haben aber das Vermögen, Wasser nit bedeutender Kraft an sich zı ziehen und dadurch das Volumen der Zelle zu vergrössern. Diese Spannung zwischen Wand und Inhalt, der sog. Turgor, bedingt nun die Steifheit des Gewebes der Knotengelenke.

Nach Sachs verhält sich nun die Oberseite des Knotens bei der geotropischen Krümmung völlig passiv, dagegen verlängert sich die Unterseite und ist diese demnach der Sitz der Kraft, welche durch die Schwere ausgelöst wird.

Die Zunahme des Gehalts an osmotisch wirkenden Stoffen wird in den Parenchymzellen der Unterseite durch die Wirkung der Schwere bald zu einer ansehnlichen Höhe aufgeführt, in Folge dessen

1) Vergl. de Vries, Ueber d. Aufrichtung des gelagerten Getreides; Landw. Jahrb. IX. 1880, Heft 3, 473. 
die betreffenden Zellen kräftiger Wasser anziehen, also den benachbarten Zellen entuehmen, und ihr Volumen vergrössern. Ihre nun grössere Turgorkraft ist aber im Stande, die entgegenstehenden Widerstände zu ïberwinden, d. b. es erfolgt eine Verlängerung der Unterseite, die selbstverständlich eine Krümmung des Knotens und ein Heben des Halmes herbeifiihren muss.

Eine andere, seltenere Art des Lagerns beim Wintergetreide beschreibt Sorauer ${ }^{1}$ ) wie folgt:

Die gelagerten Halmc hatten einen äusserst geringen Körneransatz; nicht selten waren die Aehren vollständig taub. Die Spelzen derselben waren russartig bestänbt; das unterste und vorletzte Stengelglied braun mit schwarzen Pünktchen oder Streifen besetzt und im Innern bisweilen weissflaumig. Die Blattscheiden der untersten Blätter waren in Zerfaserung begriffen, die noch festeren Teile ebenfalls schwar'z punktiert.

Die oberen Stcngelpartien waren gesund, wenn man ron einer durchaus nicht bedentenden Erkrankung dnrch Rost absieht, ebenso zeigten die Wurzeln nichts Krankhaftes.

Was die kranken Halme aber von den gesunden auf den ersten Blick unterschied, waren die mannigfachen Biegungen, welche die Stengel ansgeführt hatten. Die stärkste Biegung liess sich in dem zweiten Knoten von oben wahrnehinen; geringer war dieselbe am höchsten, am wenigsten merklich und oft fehlend zeigte sie sich am dritten Knoten von der Aehre abwärts. Diese Halnknoten wiesen die bekannte Erscheinnng auf, dass ihre nach dem Boden zugekehrte Seite merklich länger als die entgegengesetzte war. Durch diese ungleichmässigc Verlängerung war es dem Halme möglich geworden, bei seiner allmählichen Senkung durch Einknicken am zweituntersten Stengelgliede die Aehre wieder in eine annähernd anfrechte Stellung zu bringen.

Sorauer gelangt nun zu der Hypothese, dass die wahrscheinliche Ursache dieses Lagerns eine Beschädigung der Saat durch Spätfröste sei, die die Pflanzen zwar nicht töteten, wohl aber die bereits entrickelten untersten Stengelglieder angriffen. Die Folge daron war ein allmähliches Absterben einzelner Zellenpartien, auf denen sich als sekundäre Erscheinung ein Pilz, Pleospora culmifraga Fuck., ansiedelte. Der Halm hat sich dabei noch entwickelt, wälrend die Fruchtknoten meist nicht mehr zur Ausbildung gelangten.

Sehr häufig tritt das Lagern auch vor der Blüte nach starken Regenguissen ein, obne dass das Getreide eine Disposition zum Lagern besitzt. In diesem Falle hebt sich dasselbe nach dem Ab-

1) Der Landwirt Nr. 66. 1873. 
troeknen sehr bald wieder empor und bringt vollkommen normale Früehte, so dass hier nur ein einfaeher meehaniseher Einfluss vorlag.

Auf sehr reichen, stickstoffhaltigen Böden empfiehlt E. Wolff ') zur Vermeidung des Lagergetreides eine Düngung von $200-400 \mathrm{~kg}$ Kochsalz p. ha, indem er annimmt, dass durch die Koehsalzdüngung die Zersetzung der organischen Stickstoffverbindungen im Boden gemässigt und geregelt wird. Die Halme, namentlich der Gerste, bleiben unter dem Einfluss des Koclisalzes in der Regel kürzer, aber sie erhalten eine grössere Festigkeit und sind im Stande, sehr vollkommene Aehren zu tragen.

\section{Erntemethoden. Ausdrusch und Aufbewahrung des Getreides.}

Bekanntlieh wird in den Blättern der rohe Nahrungssaft organisiert und erzeugt die Pflanze bis zum Abblithen eine weit grössere Menge organisierter Substanz als sie zur Ausbildung ihrer Organe bedarf, und diesen Ueberfluss speichert sie in ihren Geweben auf. Nach dem Abblïhen fliesst nun nicht allein diese aufgespeieherte, sondern aneh die sieh noeh fernerweit bildende organisehe Substanz zur Ausbildung der Friiehte dem Fruehtstande zu.

Mit dem Eintritt der Entfärbung, der Blätter gelangt aueh die Bildungsthätigkeit derselben zum Abschluss und findet nur noeh Translokation der in den Geweben vorhandenen Bildungsstoffe, also der Eiweisskörper, Kohlehydrate und Salze, soweit dieselben noeh wanderungsfähig geblieben sind, statt.

Vor Eintritt der vollen Fruchtreife unterseheidet die Praxis versehiedene Reifestadien, so ist die Frueht "nilchreif", wenn ihr Saft von milehiger Beschaffenheit, "gelbre if* wenn waehsweich, und sieh die Frucht uiber den Nagel biegen lïsst, „vollreif oder überreif“, sobald sie vollständig erhärtet ist und lose in den Spelzen sitzt.

Der Zeitraum ron der Blite bis zur Vollreife umfasst beim Getreide in der Regel 3-4 Woehen, es sind dann Embryo und Spelzen vollkommen entwickelt und die Reservestoffe in der Frucht angesammelt, auch hat durch Wasserabgabe eine bedeutende Sehrumpfung stattgefunden, wodureh sich der organisehe Verband zwisehen

1) Prakt. Düngerlehre, 1869. 121. 
den Spclzen und der Frucht löst, so dass letztere nur noch rein mechanisch eine Zeit lang festgehalten wird, und schliesslich oin schwacher Anstoss geniigt, sie ausfallen zu lassen; selbstrerständlich tritt dieses Ausfallen zuerst bei den schwersten, bestausgereiften Früchten ein.

Würde sich die Ausreife sehr gleichmässig luber sänmtliche Früchte derselben Sorte eines Feldes erstrecken, dann liesse sich relativ leicht auch der richtige Erntezeitpunkt ermitteln, da dies aber nicht der Fall ist, kommt es darauf an, einen mittleren Zustand von Vorreife festzustellen, welcher bei der Ernte dem Ausfallen der bestentwickelten Frücbte vorbeugt, zumal die weniger ausgereiften ihre Quantität und Qualität durch eine Nachreife am Halme aufzubessern rermögen.

Dieser zweckmässigste Erntezeitpunkt ist gekommen, sobald die bestentwickelten Früchte der kräftigeren Fruchtstände "gelbreif “ geworden sind und gilt dies ebensowohl für das zur Saat als auch für andere Zwecke bestimmte Getreide, denn mit dem Eintritt der Gelbreife verändert sich die Masse und chemische Zusammensetzung der Trockensubstanz nicht mehr, sondern es findet nur noch Abgabe des iiberflüssig gewordenen Wassers, also Volumenveränderung und eine Erhöbung des specifischen Gewichts bis zur Vollreife statt.

Hierzı tritt, dass sich auch die Qualität der vollreifen Früchte, zumal bei trocknem, beissem Wetter verschlechtert, indem die Frncht und zwar vorzugsweise dic des Weizens, Veränderungen erleidet, welche die Mehlausbeute nicht unerheblich beeinträchtigen. Bei feuchtem Wetter lässt sich der Schnitt schon eber über die Gelbreife hinaus verzögern, da in diesem Fall die Verluste dırch Kornausfall und Verschlechterung der Qualität geringer sind.

Die Richtigkeit obiger Sätze ist durch vielfache Versuche ausser Zweifel gestellt und wollen wir zum Beweise hierfur die Resultate der hauptsächlichsten Versuche anführen.

Die ersten Versuche iiber den richtigen Erntezeitpunkt wurden 1840/41 ron Mr. Hannam ${ }^{1}$ ), North-Deighton, Yorkshire, angestellt, welcher fand, dass Weizen schnittreif sei, sobald der Korninhalt die Konsistenz frischen Brotes angenommen habe, indem dann das Korn feiner ausfalle und das Mehl besser sei.

In nenerer Zeit fand auch Nowacki2), dass mit Eintritt der charakteristischen Gelbreife beim Weizen die Ernährung der Körner bereits aufgebört hat. Als direkten Beweis führt er das Gewicht der Trockensubstanz ron 100 Körnern an, welche enthielten in der

1) Farmer's Mag. XXIV, p. 254. 1863.

2) Untersuch. ü. d. Reifen d. Getreides etc. 1870. 
Erntemethoden, Ausdrusch und Aufbewahrung des Getreides.

\section{Milchreife Gelbreife Vollreife \\ a. b. \\ $2.856 \mathrm{gr} \quad 3.581 \mathrm{gr} \quad 4.186 \mathrm{gr} \quad 4.218 \mathrm{gr}$.}

Allerdings zeigt sich zwischen der Gelb- und Vollreife bei diesem Versuch noch eine kleine Zunahine an Trockensubstanz, doch legt Nowacki auf diesc kein Gewicht, weil sie von ciner geringen Ungleichnässigkeit des Materials herriihren könne. Von der Milchbis zur Gelbreife hat aber eine beträchtliche Zunahme stattgefunden.

Isidore Pierre ${ }^{1}$ ) bestimmte die Trockensulstanzmenge eines Hektars Weizen 14 Tage nach der Blüte und zur Reifezeit und gelangte zu folgenden Resultaten:

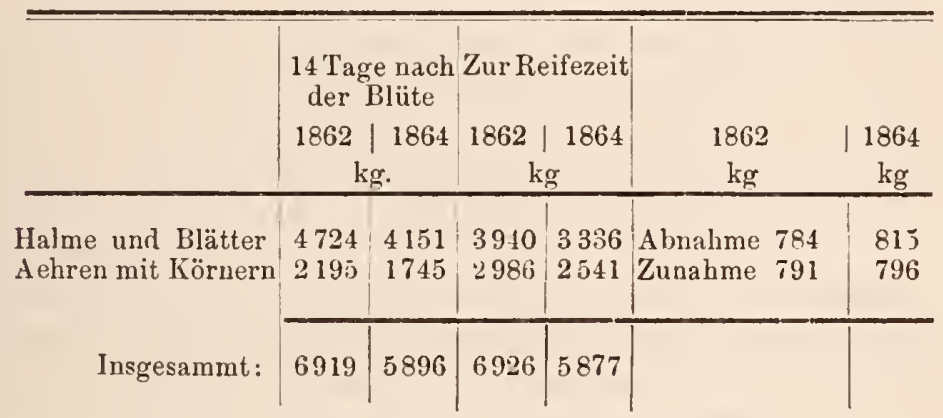

Wie man sieht, hatte seit der ersten Untersuchung bis zur Reife bei diesem Versuche keine Neubildung mehr stattgefunden. denn was die Halme und Blätter an Trockensubstanz verloren, gewannen nahezu die Körner.

Was nun die Nảhreife des geschnittenen Getreides anbetrifft, so liegen auch hieruber Untersuchungen vor.

Die Untersuchungen von Si e ge r $\mathrm{t}^{2}$ ) ergaben bezüglich der Nachreife beim Sommerweizen folgendes Resultat:

1) Recherches expérim. sur le Développement du blé. Paris 1866.

2) Landw. Versuchsstat. VI, p. 134. 
Trockengewicht von

100 Körnern

Zeit der Ernte

sofort später

enthülst

gr

$\operatorname{gr}$

I. Ernte am 19. August. Halm und Aehre noch völlig grün; Körner ziemlich ausgewachsen, grün, weich und milchig

II. Ernte am 22. August. Halm oben gelblich; Aehre gelblich-grün; Körner völlig ausgewachsen, geblichgrün, Inhalt weich und milchig.

III. Ernte am 25. August.

IV. Ernte am 28. August. Halm noch schwach-grünlich; Aehren völlig gelb; Körner hart werdend, jedoch noch nicht leicht ausfallend.

V. Ernte am 31. August.

VI. Ernte am 4. September. Halm zum Teil noch etwas grünlich; Aehre weiss; Körner hart, leicht ausfallend.

VII. Ernte am 7. September. Die ganze Pflanze weissgelb.

VII. Ernte am 11. September. Pflanze völlig überreif, weiss, spröde; Körner sehr leicht ausfallend.

18.2

22.4

26.9

28.8

27.0

29.2

28.0

29.7

30.0

30.6

30.1

30.5

30.0

29.6

28.7

29.1

Hiernach trat bei den später enthülsten, also in der Aehre nachgereiften Körnern, welche zwischen der Milch- und Gelbreife geschnitten waren, eine Zunahme ron 6 Proc. ein; während das Nachreifen bei dem vollreif geernteten 1 Proc. Zunahme zeigte; ob aber in diesen beiden letzten Fällen die Zunahme dem Nachreifen zuzuschreiben ist, bleibt sehr zweifelhaft, jedenfalls ist sie aber sehr unbedeutend.

In Bezug auf das Nachreifen des Weizens im Zimmer, im Schwad, in Puppen und in Stiegen gelangte Nowacki zu folgenden Resultaten:

100 Körner enthalten Gramm Trockensubstanz:

\begin{tabular}{|c|c|c|}
\hline $\begin{array}{c}\text { Reife- } \\
\text { stadium: }\end{array}$ & $\begin{array}{l}\text { Körner } \\
\text { gleich } \\
\text { getrennt: }\end{array}$ & Nachgereift: \\
\hline Milchreif & 3.581 & im Zimmer 3.707 \\
\hline Gelbreif & 4.186 & $" \quad, \quad 4.168$ \\
\hline ", & 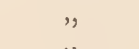 & $\begin{array}{ll}\text { in Puppen } 4.197 \\
\text { im Schwad } 4.295\end{array}$ \\
\hline Vollreif & 4.218 & , Zimmer 4.167 \\
\hline , & " & in Stiegen 4200 \\
\hline
\end{tabular}

Während die Körner von der Milchreife bis zur Gelbreife auf dem Halme noch um 14 Proc. an Trockensubstanz zunahmen, betrug die Zunahme bei den milchreif geernteten Körnerı durcb Nachreifen 
nur $3 \frac{1}{2}$ Proc. Bei den gelb- und volleeif geernteten Körnern ist durch das Nachreifen keine Zunahme eingetreten.

Vielfach herrscht die Ansicht, dass sich mit längerem Reifen und namentlich in der Vollreife die Fruchtschale wesentlich verdicke und hat Now acki zur Entscheidung dieser Frage eine grössere Anzahl von Messungen an demselben Material angestellt. Hiernach betrug die minimale Dicke der Schale in nachgerciften lufttrocknen Körnern:

$\begin{array}{lccc} & \text { in der Milchreife } & \text { Gelbreife } & \text { Vollreife } \\ \text { im Minimum } & 0.024 \mathrm{~mm} & 0.024 \mathrm{~mm} & 0.021 \mathrm{~mm} \\ \text { im Maximum } & 0.053 \mathrm{~mm} & 0.042 \mathrm{~mm} & 0.038 \mathrm{~mm} \\ \text { im Mittel } & 0.037 \mathrm{~mm} & 0.029 \mathrm{~mm} & 0.027 \mathrm{~mm} .\end{array}$

Es nimmt also die Dicke der Schale von der Milchreife wie übcrhaupt von der Befruchtung an fortwälırend ab und hört in der Gelbreife auf, dagegen nimmt dic Dicke der Zellwände durch Einlagerung von Substanz zu, doch hört dieselbe auf, sobald in der Gelbreife die Safteirkulation nicht mehr stattfindet.

Aus diesen Griinden lässt sich die Vermehrung der Kleie des in der Vollveife gemähten Getreides nur dadurch erklären, dass in Folge des starken und schncllen Austrockneus die der Schale angrenzende Kleberschicht, sowie die dieser zunächst liegenden Stärkezellen sich so fest mit der Schale verbinden, dass beim Vermahlen eine Trennung nicht erfolgt, also die Kleie verınehrt wird, während das in der Gelbreife gemähte und langsam getrocknete Getreide weniger Kleie aufweist. Hicrauf mag es auch beruhen, dass in der Gelbreife gemähter Weizen bei heissem Wetter, sobald er schnell im Schwad trocknet, weit mehr Kleie ausgiebt, als wenn das Trocknen in Puppen allmählich verläuft.

Wird ferner durch Eintritt sehr heissen und trocknen Wetters vor der Gelbreife, wie dies im Steppenklima sehr häufig der Fall ist, ganz plötzlich durch starke Wasserabgabe die Safteirkulation unterbrochen, dann schrumpfen die Früchte zu stärkearnem Schmachtkorn, das sehr viel Kleie liefert, zusammen.

Die Erntezeit des Getreides fällt, je nach den Anbauzonen und der durch diese wieder bedingten verschiedenen Jahreszeiten auf unserer Erde, in sehr verschicdene Zeiten, so dass in Laufe eines Jahres fast unausgesetzt geerntet wird. In Australien, Neu-Seeland, dem grössten Teile von Chile und einigen Strichen der argentinischen Republik findet die Ernte in den Monaten December und Januar statt; im darauffolgenden Februar beginnt sic in Ostindien und wird, je weiter gegen Norden fortschreitend, im März beendet. Mexiko, Aegypten, Persien, Syrien ernten im April, während dies im nördlichen Kleinasien, in China, Japan, Tunis, Algicr und Marokko, sowie in Texas im Mai geschieht. Des Weiteren erntet man 'in 
Californien, Spanien, Portugal, Italien, Griechenland, auf Sicilien und in einigen der siddlichsten Departements ron Frankreich im Monat Juni. Im iibrigen Frankreich, in Oesterreich-Ungarn, Südrussland und in einem grossen Teile der Vereinigten Staaten von Nordamerika wird im Juli geerntet und im August folgen Deutschland, England, Belgien, die Niederlande, Dänemark und die nördlichsten Staaten der nordamerikanischen Union. Im September endlich kommen Schottland, Schweden, Norwegen, der grösste Teil von Canada und Russ. land an die Reihe, und in den nördlichsten Gegenden des letztgenannten Reiches, sowie in Finnmarken, geschieht das letzte Einbringen gar erst im Oktober. Es ist also allein der Monat November, in welchem faktisch echte Getreidearten nicht gcerntet werden.

\section{a. Erntemethoden.}

Das Abbringen des Getreides geschieht entweder mit der Sense, dem Sichet (Hausicht), der Sichel oder der Mähemaschine.

Die Getreidesense kann eine Bügel-, Gestell- oder Reffsense sein. Die erstere wird vorzugsweise bei kräftigem Wintergetreide angewendet, denn hier wiirde die Gestellsense sehr schwer durchzuziehen sein, auch das lange Strolı über das Gestell hinwegfallen und sich verwirren, wcshalb man die Gestellsense nur ausnahmsweise in kurzem, sehr schuitterem Wintergetreide und sonst nur für kurzes Sonmergetreide, z. B. fïir Gerste anwendet.

Mit der Sense wird entweder auf das Schwad gehauen, wobei das abzumähende Getreide zur rechten Hand bleibt, oder es wird links gegen das steliende Getreide angehauen, in welchem Falle danı jedem Mäher eine Abrafferin folgt, welche das angelaanene Getreide entweder in Gelegen sammelt oder gleich einbindet.

Das Anhanen des Wintergetreides, wenn letzteres sofort eingrebunden werden soll, kann bei sehr grosser Länge des Strolıes rätlicher als das Mähen in's Schwad sein, weil dem Ueberfallen iiber den Bügel und dem Verwirren der Halme vorgebeugt wird.

Beim Sommergetreide, welches man selten sofort einbindet, liegt dem Anhauen nur Arbeitsverschwendung zu Grunde, da bei dem Mähen in's Schwad, welches eine gleichwertige Arbeit liefert, das Abraffen fortfällt.

Fernerhin fördert das Schwadenhauen mehr als das Anhauen.

Nach von Kirchbach mäht ein Manu pro Tag:

Wintergetreide beim Anhalen

$0.5-0.6$ ha

Schwadenhanen

$0.63-0.75$ ha

Sommergetreide beim Anhauen

$0.63-0.75$ ha

Schwadenhauen

$0.7-0.95$ ha

Gelagertes Getreide

$0.38-0.50$ ha. 
Das Mähen mit dem Sichet oder Hansieht erfordert eine besondere Gesehieklichkeit und viel Uebung. Mit Hiilfe eines Hakens, welchen der Hauer mit der linken Hand flihrt, wird das Getreide beim Mähen sofort in Gelage (Frösche) gebracht.

Im Allgemeinen ist anzuerkennen, dass das Sichet im Lagergetreide besser als die Sense arbeitet, doeh wird vollreifes Korn leicht zum Ausfallen gebracht, da die Bildung der Gelege nieht ohne beträchtliche Ersehiitterungen abgeht, und dieselben viel bedeutender sind als beim Mähen mit der Sense und nachheriger Garbenbildung. Anch leistet ein Haner mit dem Sichet beträehtlich weniger als mit der Sense, denn er mäht durehsehnittlich bei Winter- oder Sonmergetreide nur 0,25 ha ab.

Bei dem Mähen mit der Sichel fasst der Arbeitende eine Anzahl Halme mit der linken Hand zusammen und sehneidet dieselben mit der rechten Hand in sehräger Richtung von unten nach oben ab und legt sie hinter sich in Reilsen.

Das Sicheln hat den Vorzing, dass das Werkzeug und seine Fuihrung leieht ist, so dass auch Weiber damit arbeiten können, auch wird Lagerkorn ohne Ausfall und hesser als mit der Sense abgeerntet. Fehlerhaft dagegen sind die verbleibenden langen Stoppeln, wodureh viel Stroh verloren geht und die Langsamkeit der Arbeit, denn die gleiche Arbeiterzahl bringt im dritten Teil der Zeit mit der Sense die gleiehe Fläche ab, also sicheln Männer $0,15-0,2$ ha, und Frauen sogar nur 0,1 ha ab.

Die Mähemaschinen sollen das Mähen mit der Hand ersetzen, denn diese Arbeit ist nicht allein sehr anstrengend, sondern auch zeitraubend, daher es, namentlich bei mangelnden Arbeitskräften, wichtig ist, das Mähen mit der Maschine $\mathrm{zu}$ besorgen, denn mit ihrer Hülfe lässt sich das Getreide im richtigen Zeitpunkt der Reife schneiden, wodurch der Körnerausfall mögliehst vermieden und die Frucht in guter Qualität gewonnen wird, anch werden zahlreiche Arbeitskräfte zur schnellen Einbringung der Ernte verfügbar.

Eine Mähemaschine kann ungefähr zehnmal mehr mähen als ein Mann und bedarf zu ihrer Bedienung einen bis zwei Mann; in Folge dessen wird es häufig möglich, ohne Hinzuziehung bedeutender fremder und theurer Arbeitskräfte die Ernte abzubringen.

Die Mähemaschine hilft demnach dem grössten Uebel in der Ernte, dem Arbeitermangel ab, und erspart an Erntekosten.

$\mathrm{Zu}$ den besten Mähemasehinen, die sich auch dnreh sehr starke Konstruktion anszeichnet, gehört dic Mähemaschine mit Regulierrechen von Walther A. Wood, und, wenn anch leichter gebaut und daher in starkem Getreide mehr dem Bruch ausgesetzt, Johnston's Getreidemähemaschine mit gusseisernem Rahmen, die aber sonst eine vortreffliche Arbeit liefert. 
Nach der Erfindung der Getreidemähemaschinen musste sich namentlich in Ländern, in denen die Arbeitskiäfte zur Erntezeit fehlen, wie z. B. in Amerika, das Beduirfnis nach Bindemaschinen geltend machen, da zum Aufbinden des durch die Maschinen geschnittenen Getreides sechs bis acht und selbst noch mehr Arbeiter notwendig sind. Es gibt nun Konstruktionen solcher Mähe- und Bindemaschinen, welche entweder mit Draht, Schnur oder Stroh binden.

Zur Zeit sind die amerikanischen Maschinen von Mc. Cormick in Chicago und ron Walther A. Wood wohl als die besten anzusehen.

Wenn das Getreide gleichmässig steht, bindet nach Wü st ${ }^{1}$ ) der Apparat selbstthätig und macht etwa für $3 \mathrm{~m} \mathrm{Weg}$ eine Garbe, steht aber das Getreide sehr dünn, dann kaun der Kutscher mit dem Fusse die Bindevorrichtung ausriicken, damit alle Garben ziemlich gleich gross werden.

Die Leistung wird bei genügend leichtem Gange bei Vorspannung von 3 Pferden gerade so gross sein wie bei einer gewöhnlichen Mähemaschine.

Im Allgemeinen stellten sich bei in Deutschland vorgenommenen Priifungen die Kosten des Maschinenbinders ca. 50 Proc. theurer als das Handbinden. Wenn man sich daher durch längere Arbeit erst überzengt hat, dass nicht allzuviel Zeit durch Betriebsstörungen rerloren geht, wird man die Bindemaschinen, bis sich die Verhältnisse nicht günstiger für dieselben gestalten, nur da mit Vorteil anwenden, wo man bei nicht lagerndem, genügend trockenem Getreide entweder keine Handarbeiter haben kann, oder wo die Beschleunigung der Arbeit von besonderem Werte ist.

Das abgemähte Wintergetreide wird gemeinhin, wenn es nicht zu stark mit saftigem Unkraut oder Kleegras durchwachsen ist, sofort aufgebunden, während man das saftreichere Sommergetreide gern einige Tage anf dem Schwad trocknen lässt und dann erst aufbindet; doch ist hierbei nicht zu uibersehen, dass bei sehr ungiinstigem Wetter das Stroh leicht verwittert und die Früchte auswachsen, wenn die Schwade nicht genügend umgelegt werden, wodurch allerdings auch ein mehr oder weniger starker Körncrausfall unvermeidbar ist.

Das Aufbinden des Getrcides ist notwendig, damit es den Fährlichkeiten einer ungünstigen Erntewitterung nehr entrïckt wird, gut nachreift, sowie ohne Verlust trausportiert und leichter ausgedroschen werden kann. Das Binden geschieht bei grossen Garben entweder mit Weidenruthen oder Strohseilen und bei kleinen nit dem eignen

1) Jahresber. ü. d. Fortschritte im landw. Maschinenwesen, 1879 p. 69 u. Landw. Maschinenkunde, 1882 p. 295. 
Stroh, wenn dasselbe hierzu die nötige Längc und Zähigkeit besitzt. Letzteres Verfahren verdient wohl seincr Einfachbeit wegen den Vorzug, wenn dabei eine Methode angewandt wird, die nicht ein Ausreiben der Friichte in Scile beim Binden zur Folge hat.

Grosse Garben liaben ein Gewicht von $12-20 \mathrm{~kg}$, mittlere ron $8-10 \mathrm{~kg}$, kleine von $4-8 \mathrm{~kg}$.

Sehr starke Garben sind niemals anzuraten, weil sie zn langsam austrocknen, und bein Aufladen und Einbansen schwächeren Albeitern, z. B. Weibern, zu schwer werden; dahingegen gewähren mittelschwere Garben den Vorteil, dass sic bei relativ leichtem Austrocknen geniigend handlich sind, sowie anch das Auf- und Abladen und das Dreschen mehr fördern als kleine Garben; doch anch kleine Garben köunen unter Umständen vorteilhaft sein, da sie es häufig gestatten, selbst Sommergetreide, wenn cs ctwas spät gemäht worden ist, gleich nach dem Abbringen zu binden und anfzustellen, denn die weitere Anstrocknung vollzieht sich in ihnen schnell, und beregnet, trocknen sie leicht.

Bevor das Getreide eingefahren werden kann, hat es in den Garben, die nach verschiedenartigen Methoden zum Trocknen aufgestellt werden, erst einen vollkommen lufttrocknen Zustand zur Verhiitung des Verderbens im Lagerraum zı erreichen.

Die klimatischen und wirtschaftlichen Verhältnisse, sowie die Gewohnheiten der landwirtschaftlichen Bevölkernng bedingen die sehr abweichenden Erntemethoden der verschiedenen Länder nnd kann jede dieser Methoden auch ihre volle Berichtigung haben, wenn sie bei möglichst schnellem Trocknen des Getreides anch eine genügende Nachreife der noch milchigen Körner sichert.

Die nordischen Länder sowohl, als auch diejenigen der höheren Gebirgslagen, in denen sich dic Erntearbeiten in kurzen nud dazu feuchten und kiihlen Herbsten häufen, beanspruchen Methoden, die ein schnclles Anstrockncn gestatten und nöglichst wenig Arbeit erfordern, da bei ihnen weniger Rïcksicbt anf die Nachreife zu legen ist, inden das Klima schon an und für sich auf ein ganz allmähliches Versiegen der Saftcirkulation hinwirkt. Dagegen wird für Länder mit langen, warmen nnd trocknen Sommern cine Methode zu wählen sein, die allerdings Sclutz gegen eine etwaige ungünstige Erntewitterung gewährt, doch aber das Getreide zur Nachreife recht allmählich austrocknen lässt.

In Länderı dagegen, welche eine Erntewitterung besitzen, die zwischen diesen beiden Extremen sich bewcgt, werden Methoden zu wählen sein, welche die Mitte halten, oder sich der cinen oder anderen extremen Methode nähern.

Was nun die Erntemethoden der norlisehen Länder anbetrifft, 
so sind sie darauf eingerichtet, dass das Getreide nur sehr selten im Freien vollständig trocken wird und erst nach dem Einfahren ein Nachtrocknen erfahren muss, doch sucht man einen möglichst bohen Grad der Austrocknung im Freien zu erreichen.

In Norwegen nud in den mittleren und nördlichen Provinzen Schwedens werden die kleinen (ictreidegarben auf $3-4 \mathrm{~m}$ hohen spitzen Pfähleı, die in die Erde gestossen sind, kreuzweis iibereinander aufgebaut, so dass der Pfahl durch ihre Mitte geht; auf diese Weise sind sie dem Winde stark ausgesetzt, trocknen also leichter und die sofort nach dem Mähen gebundenen Garben werden dem feuchten lBoden und somit dem leichten Auswachsen entrïckt.

Für sehr feuchtes Wetter ist auch diese Methode nicht vollkommen ansreichend, weshalb die Scheunen eine Einrichtung erhalten, die das Nachtrocknen gestattet, nämlich ans beweglichen Latten hergestellte Seitenwände, welche sich jalousieartig öffnen und auf diese Weise einen kräftigen Luftzug ermöglichen lassen. Die Einfahrt in die Scheune befindet sich auf der Giebclseite und zwar unmittelbar unter dem Dach, zu welcher man, wenn die Scheune nicht dicht an einen entsprechend hohen Fclsen angebaut ist, auf einen aufgeschiitteten Wege oder einer Brücke gelangt.

Trotz dieser Vorrichtungen sind jedoch die ausgedroschenen Körner nicht selten noch anf besonderen Trockenapparaten durch Erwärmung genügend lufttrocken herzustellen.

Im nördlichen und mittleren Russland wird das Wintergetreide anf den grösseren Höfen meist mit der Gestellsense gehauen und in den Bauernwirtschaften, soweit die Arbeitskräfte reichen, mit der Sichel geschnitten, möglichst akkurat gelegt und wenn die Witterung es ellaubt, in kleinen Garben von $15 \mathrm{~cm}$ Durclımesser mit dem eignen Stroh $15 \mathrm{~cm}$ oberhalb der Schnittseite gebunden; hierauf werden die Garben zum möglichst schnellen Trocknen zu 10-12 zu einem Kreis derart zusammengestellt, dass sie in den Aehrenenden oben zusammenstossen, also die Garben einen Konus bilden, der unten einen grossen Kreis beschreibt, so dass von allen Sciten die Luft leichten Zutritt hat; das Aehrenende des Konus wird zur Befestigung mit einem Strohband umschlungen und darauf eine Sturzgarbe, mit den Aehren nach unten, befestigt.

Das Sommergetreide wird fast iiberall mit der Gestellsense gemäht und nur ausnalımsweise bei Ueberreife, zur Vermeidung des Körnerausfalles, abgesichelt. Zun Trocknen legt man das Sommergetreide ungebunden auf lange, zusammenhängende prismatische Holzgestelle dachförmig auf. Da diese Reuter in der Mitte cinell hohlen Raum aufweisen und auch das Getreide den feuchten Boden nicht berührt, trocknet es verhältnismässig gut.

Häufig bleibt das Getreide bei ungünstiger Witterung Wochen 
lang auf dem Felde und nur sehr selten erreicht es eine vollkonimene Lufttrockne, so dass noch ein kiinstliches Dörren notwendig, das auch seit undenklichen Zeiten angewandt wird.

Behufs des Dörrens richtete man friher, und bisweilen in Bauernwirtschaften auch noch jetzt, ein Zelt auf, höhlte darunter eine Grube aus, stellte über diese Stangen, worauf die Getreidegarben gelegt wurden, machte danu in der Grube Feuer an und dörtte. Nach Massgabe des landwirtschaftlichen Fortschrittes und in Betracht der Ersparung des immer seltener werdenden Holzes wurden die Getreidedarren verbessert und zweckmässige Vorrichtungen gegen Fenersgefahr getroffen, auch konstruierte man dieselben in der Weise, dass als Heizmaterial auch Torf und Stroh dienen konnte.

Da wun ferner in grösseren Wirtschaften kleine Darren zum Trocknen des ungedroschenen Getreides unbequem waren, legte man grosse Darren an. In neuester Zeit, mit der allgemeineren Benutzung der Dreschmaschinen, wurde vielfach auch ungedarrtes Getreide ausgedroschen und das Korn allein auf besonders hierzu eingerichteten Darren getrocknet.

Diese Getreidedarren sollen $11 u$ derart konstruiert sein, dass die Körner darauf nicht geröstet und hornartig werden, sonderu gleichmässig bis zur Lufttrockne austrocknen, möglichst wenig Heizmaterial verbrauchen, wenig Arbeit erfordern, auclı nicht feuergefährlich und möglichst billig sind.

Beide Darrmethoden ${ }^{1}$ ) haben nun ihre Vol- und Nachteile.

Beim Darren in Stroh, in dell sog. Riegen, wird das Korn weder hornig noch geröstet, behält seine Keimfähigkeit und drischt sich rein aus, doch erfordert diese Nethode 50-70 Proc. mehr Heizmaterial als beim Dörren der Körncr, und wenn letzteres aus Stroh besteht, ein Dritteil der gesammten Strohernte.

Ferner wird in Rauch gedörrtes Stroh nicht geru gefressen, und nehmen die Molkereiprodukte, sowie auch die Körner den Rauchgeschmack an. Die Darren muissen auch grösser und daher theurer sein und die Handarbeit und die Fenersgefahr vermehrt sich.

Beim Dörren der Körner erlıält das Korn keinen Rauchgeschmack, dasselbe geht rasch von statten und hält das Dreschen nicht auf und alle Unkosten verringern sich, doch wird das Getreide leicht geröstet, wodurch es teilweis seine Keimfähigkeit verliert, auch schlechteres Brot und geringere Spiritusansbeute liefert.

Eine verbesserte Getreidetrocknungsmaschine ${ }^{2}$ ), welche keinerlei Nachteile beim Trocknen im Gefolge hat, ist neuerdings in Eng-

1) Vergl. Mitteil. d. kais. r. ök. Ges. zu St. Petersburg. 1857, p. 173.

2) Vergl. Landw. Presse VII. 1880, No. 96. 
land konstruiert worden und zu beziehen dureh Petzold \& Co., Berlin N, Sehönhanser-Allee 41.

Der Apparat besteht ans ricr Cylindern von $4 \mathrm{~m}$ Länge. Der mittlere Cylinder, welcher drehbar ist, liat $30 \mathrm{em}$ im Durehmesser und dient zur Dampfkammer, die rom Kessel der Dampfmaschine durch eine kleine rulkanisierte Kautschukröhre mit Dampf versehen wird. Der Cylinder ist auf seiner äusseren Peripherie mit vier Schraubenblättern rersehen, durch welche das Getreide nicht allein fortgesehoben wird, sondern auch. da die Blätter durchlöehert sind, häufig ron oben nach unten in den Cylinder fällt und dadurch so viel als möglich der Wirkung der in Folgenden besehriebenen Trocknungsnittel ansgesetzt wird. Der Dampf wird mittelst ciner Röhre vom Ende des inneren Cylinders nach dem dritten Cylinder oder Dampfmantel geleitet. Auf dicse Weisc befindet sieh das Getreide zwischell zwei Dampfkammern, welche ron einem je naeh der Beschaffenheit des Korns regulierten Rumpf gespeist werden. Das Ganze ist ron einem Cylinder umgeben, welcher durch eine Anzahl ron Löchern an dem Ende, wo der Dampf einströmt, mit der Luft in Verbindung steht. Dieser Cylinder wird durch einen Fächer entlecrt und die einströmende Luft wird in ihrem Laufe geheizt und durch die Kornkammer getrieben, wo sie mit dem Getreide in Berïhrung kommt und es stark trocknet. Das Getreide ist auf diese Weise während seines Lanfes dureh eine $4 \mathrm{~m}$ lange Röhre der Wirkung ron zwei dampfgeheizten Flächen und einer heissen Luftströmung ausgesetzt. Der innere Cylinder wirl durch ein Kammradgetriebe ron 14 bis 104 Umdrehungen getrieben. Die Spinclel macht 34 Umdrchungen per Minute. Dic Temperatur an der Mündung der Ausströmung'söffuung beträgt $140-170^{\circ} \mathrm{C}$. Der kondensierte Dampf wird mittelst einer biegsamen Röhre in den Wasserkasten zuriickgeleitet, crheizt denselben und erspart dadurch Brennmaterial.

Das zu trocknende Material wird in seiner Passage durch die Kornkammer mittelst einer einfachen Einriehtung so scpariert, dass jedes Korn einem durch Rotieren um dic mit Dampfmantel bekleideten Cylinder erhitzten Windzug ausgesetzt wird, und da cs nur mit dicsen dampfgehcizten Cylindern und reiner heisser Luft in Beribrung. kommt, so kanı es weder in Qualitiit, woch Farbe verlieren oder beschädigt werden. Die Keinkraft des Getıeides wird niclıt zerstört. Die Vaschine ist einfach in der Konstruktion, hat nur wenige sich abnutzcnde Teile, kommt nicht leieht in Unordnung und erfordert bei der Arbeit nur wenig Aufsicht. Auf Räder gestellt, kann sie ron einem Pferde gezogen werden. Eine Maschinc, welehe $57.10 \&$ kostet, trocknet 24 Bushel feuchten Getreides pro Stunde bei einer Auslage ron $6 \mathrm{~d}$. Die Masehine kam an allen Lokomobilen angebracht, und da sic 
auf Rädern steht, leicht von einer Stelle zur anderen geschoben werden.

In feuchten Gelirgslagen sind cbenfalls besondere Vorriclitungen zur Erreichung der Lufttrockne notwendig, so wird das mit der Scnse oder Sichel abgebrachte Getreide in Garben aufgebunden, in Steiermark, Krain und zum Teil in Kärnten zum Trocknen auf sog. Harfen gebracht, von denen man zwei Formen, die einfache und die doppeltc Harfe, unterscheidet.

Die Doppelharfe ${ }^{1}$ ) besteht aus zwei parallel laufenden, $10-15 \mathrm{~m}$ von einander entfernten massiven Pfeilern ron $5-6 \mathrm{~m}$ Höhe und ist überdacht. Durch diese Pfeiler werden 12-15 horizontal liegende Latten oder Staffeln dergestalt gezogen, dass die unterste $60-80 \mathrm{~cm}$ vom Erdboden abstelıt, wälırend die iibrigen $30 \mathrm{~cm}$ von cinander entfernt angebracht werden. Auf diese Staffeln wird das Getreide zum Austrocknen gebracht und lässt sich diese Doppelharfe auch ganz gut als Scheune benutzen. Die einfache Harfe dagegen besteht nur aus einer einfachen aber bedachten Geristwand.

Eine höchst eigentümliche Erntemethode, die sog. „Ernte über die hohe Stoppel" hat sich in dem fenchten Klima des Salzkammergutes herausgebildet und soll auch in der Umgegend von liegensburg, wenn anch etwas modificicrt, bestehen. Es wird nümlich das Wintergetreide beinahe in der Mitte mit der Sichel abgeschnitten, in kleine Garben gebunden, und auf 3 bis $4 \mathrm{~m}$ hohen Fichtenstangen schranbenförmig, so dass der Wind von allen Seiten Zutritt hat, aufgesteckt, also ein Verfahren, das mit dem in Schweden gebräuchlichen sebr viel gemein hat; um Regensburg werden die kleinen Garben zum Trocknen einfach auf die hohe Stoppel gelegt, dadurch von der Erde entfernt und dem Luftzuge ausgesetzt.

Nach der Hinwegnahme des Getreides wird die Stoppel tief am Boden abgemäht, auf grosse Haufen gebracht und meist auf dem Felde in Feimen gesetzt.

Es leuchtet ein, dass bei unbeständiger Witterung das Getreide nicht leicht auswächst und schnell trocknet und der Maschinendrusch leichter von statten gelit, dagegen erfordert diese Methode vicl Arbeit.

In Tirol wird das Getreide ebenfalis auf Holzgeristen getrocknet, die aus einer in den Boden gestossenen Stange, an welcher Querstangen iiber Kreuz angebracht sind, bestehen und uber welche das Getreide zum leichten Abtrocknen iubergehangen wird.

Im Gegensatz zu diesen Erutemethoden stehen diejenigen der Länder mit trocknen, warmen Herbsten, in denen die Erntemethode

1) Vergl. Oek. Neuigk. u. Verhandl. 1847, pg. 945. 
weniger Schutz gegen ungiinstige Witterung, als vielmehr eine gute. Nachreife zu gewähren hat.

Zu diesen Ländern zählen namentlich die Steppenregionen des südöstlichen Europas. In Ungarn mäht mall mit der Sense oder Mähemaschine das Getreide in gewöhnlicher Stoppelhöhe ab, bindet dasselbe zu nittelstarken Garben mit eigenem Stroh nnd legt sie zu einem Kreuz in der Weise iibereinander, dass die untere Lage aus vier Garben gebildet wird, deren Stoppelenden nach aussen gerichtet sind, auf diese Garben werden andere in derselben Weise gelegt, und zwar richtet sich deren Zahl nach der Stärke des Getreides nnd der Dicke der Garben. dementsprechend die Haufen 11, 13, 15 und 18 Garben enthalten können. Unverkennbar widerstehen diese Haufen den Herbststïrmen der Ebene vortrefflich, und da die Witterung meist sehr trocken ist, steht cin Auswachsen kaum zu befürchten.

Das Einbansen des Getreides, da Schennen selten rorkommen, geschieht iiberwiegend in langen, dachförmigen nnd rortrefflich gesetzten Tristen.

Aehnlich ist auch die Erntemethnde in siidlichen Russland, nur wird hier das Getreide in Getreidehöfen, dic zur möglichsten Verhütung der Feucrsgefahr mit einem Erdwall umgeben sind, in Mieten eingebanst, um im Winter gedroschen zu werden.

Im mittleren nnd stidlichen Frankrcich ist diese Methode der Aufstellung im Kreuze ähnlich der in Ungarn verbreitet, und ist das Verfahren hierbei nach Henzé (Fig. 1) foigendes: man legt vorerst zwei Garben gegen einander, wobei man zu achten hat, dass die Aebren der einen anf die Aehren der anderen zu liegen kommen, dann werden zwei Garben senkrecht auf diese ersten niederlegt, womit die Basis des Kreuzes gebildet ist. Nun fährt man in dieser Weise

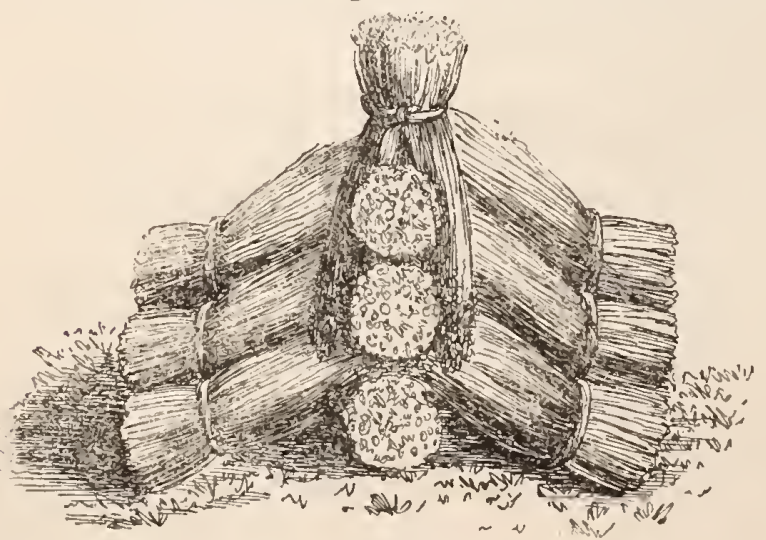

Fig. 1. fort, indem man jedesmal mit zwei Garben die Arme des Kreuzes erhöht. Nachdem zwölf Garben in dieser Weise verwendet worden sind, nimmt man eine etwas stärkere Garbe, stellt sie gerade auf, teilt ihre Aehren in rier nahezu gleiche 
Partieen und setzt sie den vier Armen des Kreuzes als Schlussgarbe anf. Ihre Halme mit den nach abwärts gekehrten Aehren schïtzen dergestalt die Aehren der iibrigen Garben gegen den Regen.

Auch sind in den trocknen kontinentalen Gegenden die prismatischen Mandeln (Dachlaufen), welche aus acht oder zwölf Garben gebildet werden, weit verbreitet. Bei nur acht Garben liegen die Aehren der drei Garben der untersten Reihe unmittelbar auf dem Boden, im zweiten Fall beriuhrt nur eine einzige Garbe die Oberfläche des Ackers. Man verfertigt diese letzteren Mandeln (Fig. 2) in folgender Weise: man legt dergestalt zwei Garben gegen einander, dass dic Aehren der einen auf den Aehren der anderen ruhen, dann legt man senkrecht auf ihre Längsrichtung und übereinander, zuerst eine Reihe von vier Garben, dann von drei und endlich von zwei Garben. Die zwölfte Garbe, auf die beiden letzteren gelegt, beschliesst die Figur.

Diese Aufstellungsart ist ganz entsprechend, wenn die Witterung schön ist.

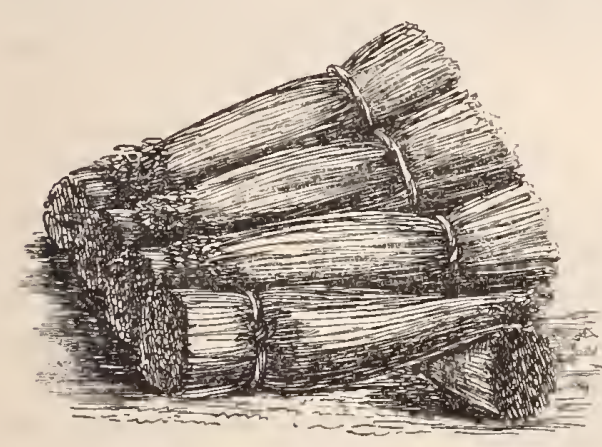

Fig. 2.

In Spanien wird das Getreide mit einer schmalblättrigen, wenig gekriimmten Sichel in halber Höhe geschnitten und sofort auf wenig iiber den Boden erhabenen, runden Tennen, welche entweder nur aus gestampftem Erdreich verfertigt oder mit Steinplatten belegt sind, im

Freien durch Maultiere, Esel oder Pferde ausgetreten.

In Nordspanien nimmt man den Ausdrusch meist in bedeckten Räumen vor, doclı Scheunen in unserem Sinne gibt es auch hicr nicht.

Zwischen diesen Ländern mit extremer Erntewitterung liegen nun andere mit mehr feuchten oder mehr trocknen Herbsten. In den ersteren, wie in Grossbritannien, Nord-Frankreich, Holland, Dänemark, Süd-Schweden und Nord-Deutsehland iiberwiegt die Methode, das Getreide in Stiegen aufuusetzen, während in den letzteren, also im östlichen Frankreich, Belgien, Mittel-, West- und Suid-Deutschland, sowie in Oesterreich die Methode des Puppens das Uebergewicht hat.

Natïrlich sind diese beiden Methoden nicht in allen Ländern gleichartig, sondern weisen gewisse Verschiedenheiten auf.

Das Trocknen des Getreides in Stiegen oder Hocken geschieht in Nord-Deutschland wie folgt: Nachdem mit der Mähemaschine oder 
Bügelsense das Getreide gemäht, wird das Wintergetreide sofort, das Sommergetreide einige Tage später, mcist mit dem eigenen Stroh, gebunden. Beim Binden folgt jedem Mäher eine Binderin und auf 3-4 Binderinnen gehört ein Aufhocker, der die Garben möglichst senkrecht, wenngleich zur Erhöhung der Widerstandsfähigkeit gegen Wind, die Fussenden der Garben etwas von einander entfernt, in zwei sich gegeniuber stchenden Reihen derart aufsetzt, dass die A ehrenenden in einander greifen: zur Versichcrung der beiden Garbenrei hen werden bisweilen an den Enden der Hocke Strebegarben anfgerichtet, oder die seitlichen Garhen mit einem Bande umschlın-

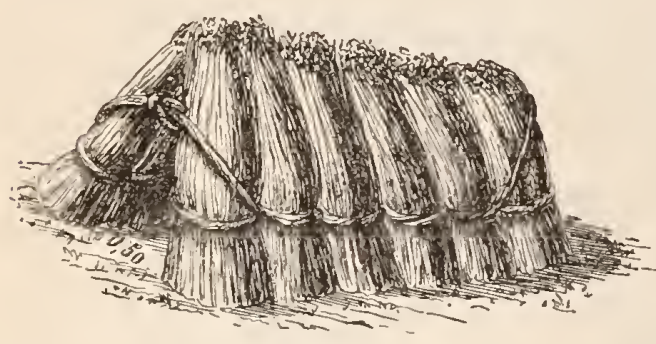

Fig. 3.

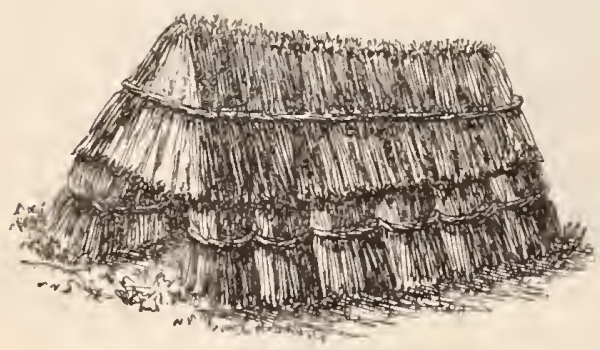

Fig. 4.

gen. Fig. 3. Hauptsächlich in Schottland, aber auch in England und NordFrankreich werden bäufig mit einer dritten Reihe geöffneter Garben die beiden aufgestellten Reihen in der Weise bedeckt, dass das Aehrenende nach unten sieht. Die Bedachung wird durch ein Strohband zusammengehalten. Fig. 4.

In den Stiegen fliesst der Regen an den Garben leicht $a b$, auch ist auf der Ebene der Luftzug meist stark genug, binnen verhältnismässig kurzer Zeit A ehren und Halıne zu trocknen. Nur dann liegt die Gefahr des Auswachsens nahe, wenn nach Regen und bei sebr warmer Witterung Windstille cintritt. Es vollzieht sich in ihnen in dem an und für sich temperierten Klima und bei dem Schutz, welchen sich die Aehreu einigermassen selbst gewähren, die Nachreife recht vortrefflich, und da diese Methode wenig Arbeit und Geschicklichkeit fordert, scheint sie in den regenreichen, aber dafür auch dcn Winden sehr ausgesetzten Ebenen des nördlichen Europas und bei dem hier vorwaltenden Mangel an Arbeitskräftel wohl am Platze zu sein.

In Gegenden, in welchen das Puppen des Getrcides vorherrscht, ist der Herbst gemeinhin trocken und warm und die Bevölkerung dicht, daher denn auch zur Abbringung des Getreides die Sichel, z. B. in Franken, Schwaben und den Rheingegenden, sowie in Belgien und in den Regierungshezirken Aachen und Köln das Sichet 
beim Wintergetreide bäufiger als die Sense oder Mähemaschine zur Aurvendung kommen. Sehr langes Wintergetreide wird nicht selten mit rwei Strohbändern sehr sorgfältig gebunden.

Die Puppen Fig. 5 stellt man in der Weise her, dass um eine Mittelgarbe herum erst vier und dann noch einmal vier weitere Garben recht fest dazwischen gesetzt werden.

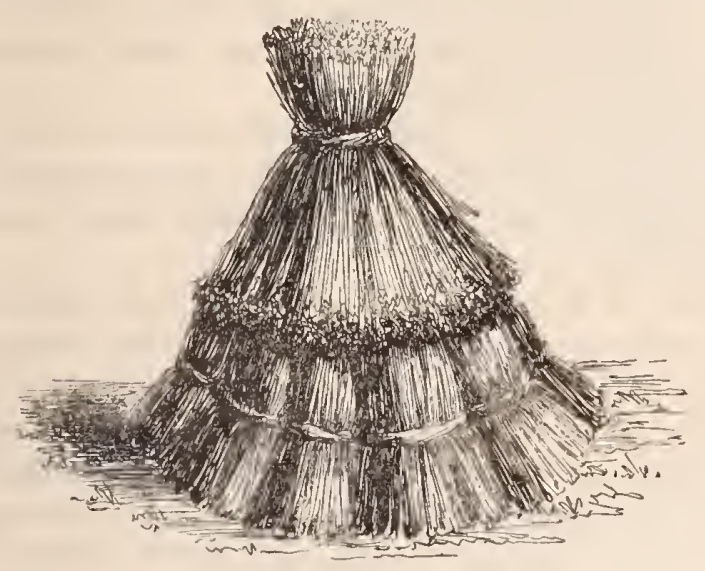

Fig. 5.

Ueber diese neun kegelförmig aufgestellten Garben wird hierauf eine zehnte so gestiilpt, dass die Schnittenden nach oben steben, und die Aebren rings herum trichterförmig nach unten gerichtet sind. Zuweilen wird auch die Spitze der neun Garben mit einem Seil umgïrtet, um das Umfallen bei Sturm zu verhindern.

Diese Puppen werden auch häufig nach Heuzé in der Picardie, in Artois und Flandern aufgestellt, aber mit einer Strohhaube rersehen, die schr zweckmüssig sein soll, und in neuerer Zeit auch am Niederrhein Eingang gefunden hat. Diese Strohhanben oder "Chaperons" sind aus gutem Langstroh und nach Art der Strohdecken auf den 'Treibhäusern gefertigt; sie bilden aufgerollt einen Halbkreis, der $1.30 \mathrm{~m}$ vom Mittelpunkt bis zur Peripherie misst. Der Chaperon wird mit geteertem Bindfaden in einer Entfernung von 25-30 und dann zum zweiten Male in einem Abstand von $60-70 \mathrm{~cm}$ vom Mittelpunkte zusammengeflochten. An der einen Seite endigen die Bindfäden in Oesen, an der anderen Seite sind Haken von Draht angebracht; auf diese Art wird der Chaperon, wenn er um den Getreidehaufen gelegt ist, befestigt. Die Chaperons sind während des Winters in Strohseilen zusammengebunden und werden in Mieten aufbewahrt; dieselben sollen bei vorsichtigem Gebrauch 15 Jahre halten. Bei der Ernte werden die Chaperons mit einem Wagen angefahren und zwischen den Reihen der Getreidehaufen nach beiden Seiten abgeworfen. Zwei Mann heben den Chaperon auf die Puppe und schliessen ihn.

Herr Schmitz, Winnenthal bei Xanten, hat diese Chaperons am Niederrhein eingefiihrt und berichtet dariiber wie folgt:

Das Getreide wird gleich aufgebunden und zu Haufen von 15-25 
Garben zusammengestellt. Bei Wintergetreide werden die ersten Garben senkrecht aufgestellt und die folgenden seitwärts anschliessend, so dass ein spitzer Kegel gebildet wird. Bei Sommergetreide mit kurzem Stroh bildet man kegelförmige Haufen. Abends werden die Kappen darauf gedeckt. Mit der untersten Schnur der Kappe wird der Haufen fest umzogen, und derselbe widersteht dann dem Sturme. Das Getreide trocknet in den starken gedeckten Haufen langsamer, aber sicher, Strob und Korn behält schöne Qualität und man braucht sich beim Einscheuern nicht zu übercilen.

In Sïd-Deutschland werden auch häıfig 10-12 Garben zu einer Puppe vereinigt und mit einer der Quere nach darïber gelegten Garbe bedeckt; in anderen Gegenden, wie vielfach am Rbein, lässt man die Sturzgarbe gänzlich fehlen.

In der Puppe sollen die Körner sowohl möglichst gegen Regen wie auch gegen die Sonnenstrahlen geschützt werden und gewährt sie auch diese Vorteile; dagegen passt sie nicht für das feuchtere Klima, denn in diesem bietet die Sturzgarbe doch nicht g'enügenden Schutz gegen das Einregnen, auch trocknet das Stroh weniger leicht als in der Hocke und die Arbeit ist zeitraubender; dass Letzteres der Fall, ergiebt sich aus der folgenden Anleitung zur Herstellung: der Puppen.

Ein Arbeiter nimmt die erste Garbe und setzt sie durch wiederholtes Aufstossen fest und senkrecht auf den Boden anf, umschlingt mit einigen Halmen, damit die Aehren nicht bunt durcheinander hängen, ihren Kopf und lässt nun, indem er die erste Garbe festhält, auf den beiden sich gegeniiberliegenden Seiten je cine Garbe etwas schräg ansetzen. Hierauf wird je eine Garbe an den beiden anderen gegentiberstehenden Seiten eingesetzt und schliessliclı geschieht dies auch in den vier Ecken. Es folgen nun zwei Arbeiter, denen das Eindecken der Puppe mittels der Sturzgarbe und das Umguirten derselben mit einem Strohseile obliegt.

In einzelnen Gegenden des nordöstlichen Frankreichs und Belgiens schlägt man ein modificiertes Verfahren ein, indem man das Getreide nach dem Mähen ungebunden in Puppenform zusammenstellt und mit einem gemeinschaftlichen Strohband und eincr Sturzgarbe oder Strohhaube bedeckt und ist dies die sog. flandrische Moyette auch bäufig villote, madame oder cavalière genannt.

Nach Heuzé wurde sie zuerst im Jahre 1760 durch Louis Rose, Schöffen in Béthune (Pas-de-Calais) vorgeschlagen. Heute wird sie in den Departements Seine-Inférieure, Eure u. s. w., und selbst dann angewendet, wenn der Zustand der Atmosphäre geeignet wäre, den Landwirten volle Sicherheit einzuflössen. 


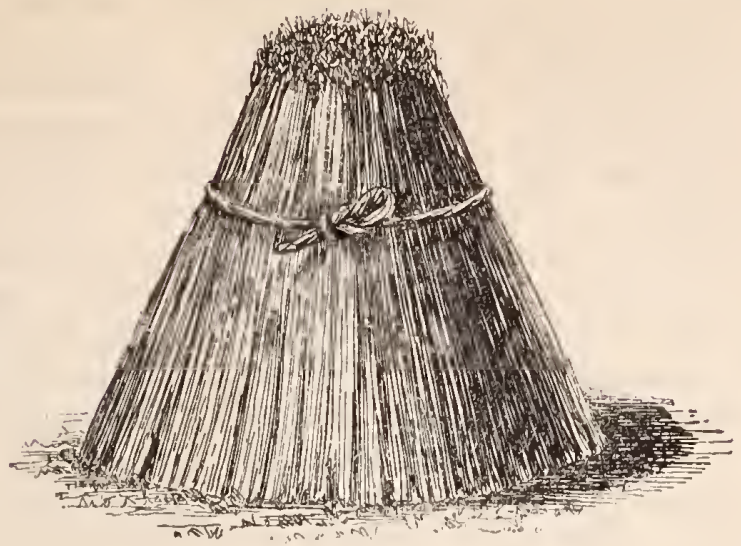

Fig. 6.

In dem Masse, als das Getreide unter der Sense oder der Sichel fällt, und wobei beachtet wird, dass es nicht durchfeuchtet sei, nimmt man die, fünf oder sechs Garben im durchschnittlichen Gewicht von 10 bis $12 \mathrm{~kg}$ entsprechende Quantität Halme, vereinigt sie mittelst eines 25 bis $33 \mathrm{~cm}$ unterhalb der Aehren angelegten Strohseiles zu einem starken Gebund, welches man dann unten öffnet, um ihm die nötige Basis zu geben und die Cirkulation der Luft im Inneren, so wie das Vertrocknen der Unkräuter zu erleichtern.

Nachdem man dieses Gebund, häufig poupée oder bonhommeFig. 6

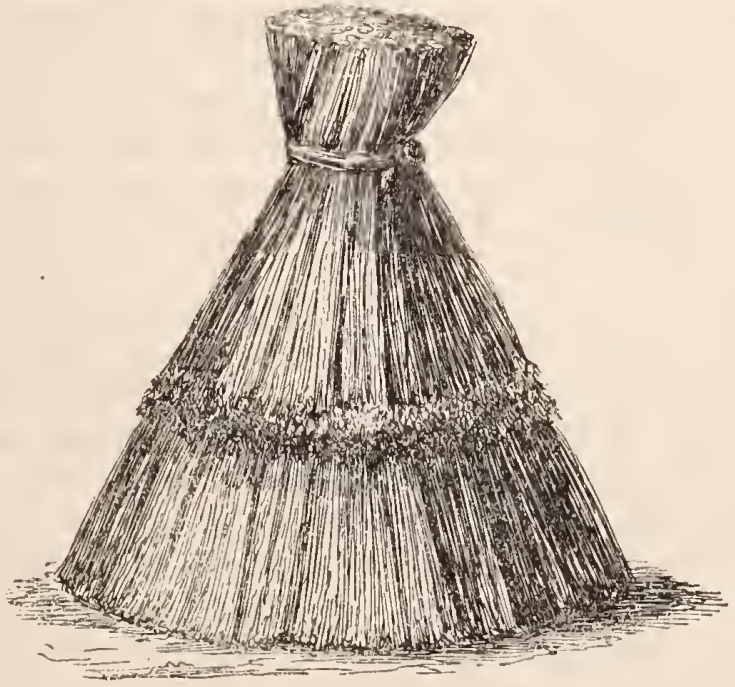

Fig. 7 .

genannt, aufgestellt hat, wird eine etwas schwächere Garbe Fig. 7, 
in umgekehrter Weise gebunden und geöffnet, als Hut aufgesetzt, womit die Puppe fertig ist.

Das Nachlassen ron Regenwetter und Sonnenbrand wird, besonders wenn die Halme und Aehren nicht rollkommen trocken waren, beniitzt, um den Hut zeitweilig wegzunehmen und das Gebund zu liiften.

Eine zweite Methode ist die im vorigen Jahrhundert von Ducarne de Blangy erfundene Picarder Moyette, unter der Bezeichnung huttes moyes u. s. w. in Flandern, Artois und der Picardie bekannt. Das hierbei einzuschlagende Verfahren ist folgendes:

Auf einer höheren Stelle des Feldes wird ein Bund Halme oder eine kleine unterbalb der Aehren gebundene Garbe niedergedrückt, mit der Vorsicht, dass keine Aehren auf den Boden zu liegen kommen. Nachdem dies geschehen, beginnt man die Errichtung des Schobers. Ein Arbeiter, durch vier oder fünf Weiber unterstützt, legt die erste Partie Schwaden mit den Aehren auf die niedergedrïckte kleine Garbe, wobei er darauf zu achten hat, dass die Halme kreisförmig ausgebreitet und sämmtliche Aehren gegen den Mittelpunkt gerichtet werden. Auf diese erste Schichte legt er eine zweite, dann eine dritte und so fort bis die Aussenseite des Schobers die Höhe von $1-1,3 \mathrm{~m}$ erreicht hat. Nachdem alle Aehren in der Mitte vereinigt sind, ist es naturlich, dass dieser Punkt im Vergleiche zum Unifang bedeutend erhöht ist, und dass dieser Anorduung gemäss alle Halme von innen gegen die Aussenseite geneigt sind, wodurch das bei starkem Regen in die fertige Moyette allenfalls eingedrungene Wasser, der Neigung der Halme folgend, zum Abfluss gebracht wird. Beendet wird die Moyette, indem man sie mit einer Garbe, die man in Form cines Trichters öffnet, nachdem man sie zuvor an ihrem unteren Ende gebunden hat, bedeckt; um das Abdecken durch heftigen Wind zu rerhindern, wird ein Band um den oberen Teil des Schobers geschlungen und mittelst Holzstifte an der aufgesetzten Garbe befestigt.

Der wesentliche Punkt für das Gelingen bei der Verfertigung der Moyette besteht darin, dass man dieselbe nur mit trockenem Getreide ausführt. Bei günstiger Witterung kann man auch den ganzen Tag hindurch die Moyette unbedeckt lassen und sie erst gegen Abend bedecken, wodurch Luft und Sonne ungehindert auf ihren Scheitel wirken und sie besser durchdringen können.

Alle diese Moyetten werden nach ihrer Aufstellung nicht weiter bcrührt; sind sie gut verfertigt, so widerstehen sie dem Regen.

Nachdem alles Getreide geschnitten worden ist und die Witterung geeignet erscheint, um sich mit dem Einbringen der Ernte zu befassen, wird der Hut entfernt und werden die Halme aus dem Gebund oder Schober in entsprechende Garben gelegt. 
Jede schlecht verfertigte oder mit feuchtem Getreide aufgestellte Moyette verhindert das vollständige Ausreifen der Körner; ist aber mit Sorgfalt bei ihrer Aufstellung vorgegangen worden, so bietet sie volle Gewähr für die nötige Nachreife, das Korn wird schön gefärbt, schwer und glatt. Diese Aufstellung ist daher als bestes Mittel anzusehen, um gelagertes, ungleich gereiftes oder frihreifes Getreide durch längere Zeit gegen Regengüsse gewahrt auf dem Felde stehen $\mathrm{zu}$ lassen.

Eine dieser Picarder Moyette sehr ähnliche Metlode findet sich auch im westfälischen sauerlande ${ }^{1}$ ), das ein sehr feuchtes und rauhes Klima besitzt.

Die unzweifelhaft einfachste Erntemethode gelangt in NordAmerika zur Anwendnng.

Hier wird alles Getreide entweder mit der Mähemaschine geschnitten und sofort aufgebunden, oder es komint eine Mähemaschine mit Bindevorrichtung zur Anwendung. Die Garben werden hierauf in Pyramiden zu je sechs oder acht Stiick anfgestellt, in welchen sie einige Tage trocknen, un dann auf dem Felde ausgedrosehen oder in Feimen zusammengefahren zu werden. In letzterem Falle wird mit dem Ausdrusch bis zu gelegener Zeit gewartet, doch wird derselbe immer in der kürzesten Frist und mit der grössten Energie in Angriff genommen.

$\mathrm{Zu}$ diesem Behufe vereinigen sich sechs oder acht Farmer zu gemeinschaftlicher Arbeit. Das ausgedroschene Getreide wird auf der Farm dann in einem aus Brettern zusammengeschlagenen und mit einem Dach versehenen Schuppen untergebracht und ist zum Verkauf fertig. Scheunen und Tennen gibt es nicht.

Ist das Getreide gebunden und aufgesetzt, dann verbleibt selbst bei sorgsamster Arbeit immer noch eine beträch tliche Menge von Halmen iiber die Fläche verstreut liegen, und dasselbe ist beim Einfahren der Fall, weshalb dieselben sofort nach dem Anfsetzen nnd hinter dem Erntewagen zu sammeln sind; denn wollte man nit dieser Arbeit bis nach Abräumung des Feldes warten, so würden sehr erhebliche Verluste durch Vertreten der Halme, Körnerausfall ete. eintreten.

Diese Nachlese geschieht entweder mit Handrechen oder auf grösseren Flächen mit einem Pferderechen, der sog. Hungerharke.

Am besten verrichtet diese Arbeit der englische Pferde- oder Heurechen, denn er arbeitet besser, billiger und schneller als Handgeräte oder der gewöhnliche und selbst der amerikanische Pferderechen ; denn der Körnerverlust ist bei ihm am geringsten und sein Gebrauch ein vielseitigerer.

Das Einbringen des Getreides in Scheunen oder Feimen erfolgt,

1) Vergl. Annal. d. Landw. III, 7. Heft, 1846, pg. 291. 
sobald dasselbe die vollkommene Lnfttrockne erreicht hat, also die Körner hart sind, leicht ansfallen und das Stroh durchaus trocken ist.

Halbtrockenes Getreide darf niemals eingebanst werden, weil es, fest zusammengepackt, sich sehr stark erhitzt nnd leicht verdirbt; wogegen man bein Verbleiben des Getreides im Freien, selbst bei der traurigsten Erntewitternng, imner noeh die Aussicht hat, wenigstens etwas zu retten.

Das Geschäft des Einbringens wird wesentlich gefördert, sobald Erntewagen in solcher Zahl vorhanden sind, dass nach dem Einfahren des beladenen Wagens die Pferde vor einen leeren gelegt werden können, also dieselben während des Abladens nicht mïssig vor dem Wagen stehen.

Die nötige Zahl der Anflader richtet sich nicht nur nach der Zahl der in einer Reihe fahrenden Gespanne, sonderı auch nach der Entfernung des Feldes von der Abladestelle. Ist dieselbe unter einer Viertelstunde entfernt, so wird von zwei Wagren inmer eincr auf dem Felde und einer unterwegs sein, während bei einer Entfernung über eine Viertelstunde von drei Wagen immer eincr in Laden begriffen ist.

Für jeden zu gleicher Zeit ladenden Wagen bedarf man, ausser dem Knechte, noch eines Anfgablers und zweier Lader.

Die Zahl und Einteilung der Ablader richtet sich wach der Be. schaffenheit der Abladestelle und der Zahl der abzuladenden Wagen. Geschieht das Abladen in zwei Reihen, so miissen sich auf jedem abznladenden Wagen zwei Ablader befinden und wenn es schnell gehen soll, emptiehlt es sich, einen Reservemann zu haben, demnach bei jedem dritten Wagen ein Ablader eine. Ruhepause erhält. Auf je $3 \mathrm{~m}$ Entfernung sind danu zum Einbansen zwei Abnehmer erforderlich.

Eine besondere Sorgfalt erfordert beim Einbansen in die Scheune das Aufstellen der untersten und der an der Wand befindlichen Garben, damit die Aehren nicht anf den Boden oder gegell die Wand zu liegen kommen; ferner ist beim Setzen der Feimen ganz besonders das Legen der Aussenschicht zu iiberwachen und sind hierzu sehr geschickte Arbeiter ausznsuchen. damit die Feime sich nicht nach der einen oder andern Seite hinneigt, oder gar umfältt. Im ersteren Falle würde das Einregnen unausbleiblich sein.

Was nun die Aufbewahrung der Getreideernte angeht, so geschieht dieselbe iiberwiegend in Schennen in Ländern, welche eine sehr ungünstige Winterwitterung und verhältnismässig billiges Baumaterial besitzen, und in denen der Ansdrusch anf dem Felde mit Hülfe der Dampfureschmaschine erst geringe Dimeusionen angenommen hat, wie dies zur Zeit noch in Skandinavien, Russland und in einem grossen Teil von Dänemark und Dentschland der Fall ist. Allerdings werden anch in diesen Ländern, wenn der Ertrag eine Mittelemte übersteigt 
und es daher an Scheunenraum gebrieht, und zwar in Nord-Deutsehland Feimen von runder Form und in Süd-Deutsehland und am Rhein Feimen von langer, dachförmiger Form gesetzt, die jedoeh meist noeh im Laufe des Winters in die Seheunen gefahren, um hier mit Hand- und Göpeldresehmasehinen, oder mit dem Flegel ausgedrosehen zu werden.

Anders liegen dagegen die Verhältnisse in Grossbritannien, Frankreich, Holland, Belgien und Süd-Europa, wo sämmtliehes Getreide, oder der grösste Teil desselben in sog. Feimen, Mieten, Diemen, Sehobern oder Tristen, wclehe mit Ausnahme der langelı, dachförmigen Tristen in Ungarn eine runde Form aufweisen, untergebraeht wird. In diesen Ländern ist nun das Klima zur Aufbewahrung des Getreides in Feimen weit besser geeignet, als in den nordisehen Ländern und leidet die Quantität und Qualität, namentlieh wenn der Ausdrusch mit Hülfe der Damptdresehmasehine bald erfolgen kann, in keiner Weise.

In feuehten Ländern, wie in England, werden die Feimen entweder sehr sorgfältig abgedeckt, oder wie in Holland, unter einem beweglichen Dach aufgebaut.

Im Allgemeinen seheint das Verfahren, das Getreide in Feimen zu setzen und aus diesen mit der Dampfmaschine zu dresehen, das riehtigste zu sein, während dagegen das Einfahren der Feime in die Seheune das Verfabren sehre erheblieh verteuert, und sueht L. Conradi ${ }^{1}$ ) dies dureh eine Berechnung klar zu legen. Er nimmt an, dass 200 Fuder à 8 Seheffel Körner und $15 \mathrm{Ctr}$. Stroh in Feimen untergebraeht werden und berechnet die Unkosten wie folgt:

Der Ausdrusch ist schwieriger und bleiben 2 Proc. der Kör-

ner $\mathrm{im}$ Stroh $=30$ Seheffel. $\dot{\mathbf{a}} 4 \mathrm{M}$. . . . . . . . $=120 \mathrm{M}$. Minderwert des Strohes p. Ctr 20 Pfg. . . . . . . . $=600$, Minderwert des Strohes zu Unterlagen und zum Bedecken $=1$ M. p. Ctr., zu je 30 Fuder sind ca. 60 Ctr. Stroh erforderlieh . . . . . . . . . . . . . . . $=396$ ” Minderwert der Körner p. Seheffel 25 Pfg. . . . . . $=410$, Mehrarbeit während der Erntezeit und Einfahren der Mieten in Winter

Summa Mehrkosten und Verlust: 1714 M.

Eine Scheune, welche bequem 200 Fuder fasst, liisst sich für ca. 10000 M. herstellen. Das Baukapital würde sich also, da nach Abzug der Zinsen à 5 Proe. ca. 1200 M. jährlich zur Amortisation bleiben, in spätesteıs 8 Jahren nach vorsteh ender Berechnung anortisiert haben, bevor noch an Unterhaltungskosten zu denken ist, die ja ohnehin bei Scheunen viel geringer sind, als bei anderen Gebäuden.

Die hier angeführten Mehrkosten und Verluste wïrden aber bei

1) Landw. Presse IV, No. 68. 
rechtzeitigem Ausdrusch mit Hülfe der Dampfdreschmaschine fortgefallen sein.

Wie wir gesehen, werden die Feinen entweder in runder Form (und als Muster diene hier die bekannte Mecklenburg'sehe Miete), oder in länglicher, dachförmiger Fornı angelegt, und besitzt jede derselben ihre Vor- und Nachteile.

Die runden Feimen lassen sich am diehtesten packen, und bieten im Verhältnis zu ihrem Inhalt die geringste Oberfäche dar; sollen sie jedoch eine grosse Menge Getreide bergen, so erreiehen sie eine sehr beträehtliehe Höhe, wodureh das Abladen, das mit zunehmender Höhe immer langsamer und nur mit Hülfe vieler Menschen vor sich geht, sehr erschwert und vertenert wird, auch kommt die Feime durch die vielen Aufreicheplätze leieht aus der runden Form heraus, zumal bei starkem Winde, weleher das lose Getreide auf die entgegengesetzte Seite treibt, in Folge dessen auf der einen Seite die Feime viel lockerer wird und sich beim Setzen nach dieser Seite hinneigt, event. umstïrzt, mindestens regnet es in solehen sehräg gestellten Feimen sehr leicht ein, was Verluste nach sich zicht.

Die langen dachförnilgen Feimen besitzen eine verhältnismässig grosse Oberfliiehe und, wenn nicht sehr gut gesetzt und eingedeckt, so sind im regenreiehen Klima durch Einregnen Verluste unausbleiblich.

In neuerer Zeit werden viclfach kiinstliche Werbungsmethoden empfohlen, unter denen die des Engländers Neilson zu Halewood, Derby, die Möglichkeit bieten soll, anf eine sehr einfache Weise bei nassem Erntewetter die Heu- und Getreideernten vollständig sieher zu stellen, und zwar noeh in dem Falle, wenn Grünfutter oder nasses Getreide in Feimen zusammengefahren werden musste. Der Erfinder behauptet, seit zehn Jahren die vortreffliehsten Erfolge erzielt zu haben. Nach seiner Vorschrift werden auf dem runden Feimenplatz von $6 \mathrm{~m}$ Durchmesser bis zur Mitte thönerne Muffenröhren, mit Cement gediehtet, so eingelegt, dass deren eines Ende von aussen zugänglich ist, und hierauf wird mit dem Aufbau der Feime anf einer Strohunterlage begonnen; doch ist bis zur halben Höhe der Feime, die $6 \mathrm{~m}$ hoch werden soll, in der Mitte derselben ein Luftschacht dadureh auszusparen, dass ein gefüllter Sack oder ein cylindrischer Korb eingesetzt und in dem Masse, als die Feinıe wächst, immer höher gezogen wird, bis das Dach der Feime die obere Oeffnung schliesst. Will man längliche, $6 \mathrm{~m}$ breite Feimen anlegen, so miissen in einer Entfernung von je $3 \mathrm{~m}$ Luftsehachte ausgespart und die Röhrentouren auf dem Ende bis zum letzten Luftsehaeht verlängert werdeı. Unterhalb eines jeden Schachtes muss in der Röhrentour eine Oeffnung angebracht sein, welehe ron aussen mittelst eines Sehiebers beliebig geöffnet und gesehlossen werden kann. An das änssere Ende der Röhrentour befestigt man einen Saugventilator, der 
die heisse mit Wasserdampf gesättigte Luft aus dem Innern der Feime absaugt, doch darf bei länglichen Feimen die Luft nur immer aus einem Schacht entfernt werdell, weshalb die andern Schächte durch Schieber zu verschliessen sind; denn wollte man in der ganzen Länge der Feime gleichzeitig liiften, so wiirden die dem Ventilator am näclisten liegenden Abteilıngen am stärksten, die entfernten aber zu wenig gelüftet werden, wodurch lcicht das Verderben der letztern herbeigeführt werden könnte.

Die Trocknung dieses feucht zusammengesetzten Materials beruht darauf, dass durch die Selbsterhitzung der Wasscrdampf cntbunden und mittels der Absaugung dureh den Sangventilator dic gesättigte warme Luft entfernt wird und dafür kältere Aussenluft an ihre Stelle tritt.

Nach Neilsons Vorschrift soll die Ventilation in Heufeimen beginnen, wenn die Temperatur im Inuern derselben $27^{\circ} \mathrm{C}$. und bei Getreidefeimen $21^{\circ} \mathrm{C}$. erreicht hat. Zur Feststellung der Temperatur dient ein Thermometer, welches in cine Eisenblechröhre mit Hülfe eines langen Drahtes eingefülırt wird. Am andern Ende der Röhre ist dieselbe geschlossen und zugespitzt, damit sie nach Belieben in die Feimen eingestossen werden kann.

Diese Selbsterbitzung des Materials geschieht aber keineswegs kostenlos, denn die erzeugte Wärme ist jedenfalls das Ergebnis einer Gärung, welche durch die Eiweissstoffe eingeleitet wird und mit der Zersetzung von Kohlehydraten, und zwar zunächst der leicht verdaulichen, endet, wodurcl der Futterwert des llaterials in sehr erheblichem Masse vermindert werden kann; dies zeigt die nachfolgende Berechnung, welche allerdings einen sehr ungünstigen Fall in Betracht zicht, nämlich die Trocknung frischen Grases bei feuchter Witterung. Da aber Neilson Grinfutter mit Hülfe seiner Methode trocknen will und dies doch nur bei feucliter iVitterung geboten crscheint, so sind wir wohl berechtigt, diesen Fall in den Kreis unserer Berechnung zu ziehen, wobei jedoch nur der Verlust an Kohlehydraten und nicht an Eiweissstoffen beriicksichtigt werden soll. Nehmen wir an, dass mit Wasserdampf gesättigte Aussenluft mit einer Temperatur von $10^{\circ} \mathrm{C}$. eintritt und den Saugventilator mit $20^{\circ} \mathrm{C}$. verlässt, denn wenn die Absaugung bei $27^{\circ} \mathrm{C}$. begann, kann sich die Luft bis zum Austritt aus der Röhrentour immerhin bis anf $20^{\circ} \mathrm{C}$. abgekiihlt baben, so enthält die eintretende Luft von $10^{\circ} \mathrm{C}$. ungefähr $9 \mathrm{~g}$ Wasserdampf pro Kubikmeter und die austretende von $20^{\circ} \mathrm{C}$. bei vollständiger Sättigung $17 \mathrm{~g}$ pro Kubikmeter; also beträgt die Differenz $8 \mathrm{~g}$ Wasser, welche dem Gras pro Kubikmeter eintretender Luft entzogen wird. Um nun aber 1 cbm Luft von $10^{\circ}$ auf $20^{\circ} \mathrm{C}$. erwärmen zu können, gehörcn etwa $3 \mathrm{Wärme-Einheiten} \mathrm{und} \mathrm{zur} \mathrm{Ver-}$ dunstung von $0.008 \mathrm{~kg}$ Wasser 4.8 Wärme-Einheiten; demnach sind 
zur Entfernung von $8 \mathrm{~g}$ Wasser aus dem Gras $3+4.8=7.8$ WärmeEinheiten erforderlich. Aus $100 \mathrm{~kg}$ Gras müssen jedoch bis zur Lufttrockne (Heu) etwa $60 \mathrm{~kg}$ Wasser verdampfen, wozu nach vorstehender Rechnuıg 58500 Wärme-Einheiten gehören. Diese Wärmesunme ist durch Verbrennung der Kohlehydrate zu erzcugen, und wenn wir die Wärme-Einheiten des Zuckers bei der Verbrennung annehmen, so entwickelt $1 \mathrm{~kg}$ Zucker $3300 \mathrm{Wärme-Einheiten;} \mathrm{un} \mathrm{dem-}$ nach die notwendige Wärmemenge zur 'Trocknıng von $100 \mathrm{~kg}$ Grtinfutter hervorzubringen, miïssten $18 \mathrm{~kg}$ Zucker verbrannt werden, und da der Futterwert von $1 \mathrm{~kg}$ Kohlelydrate sich auf $0.08 \mathscr{M}$ stellt, würde die Wärme-Erzeugung pro $100 \mathrm{~kg} 1.44$ M betragen. Erheblich giunstiger dürfte sich die Rechnung gestalten, wenn die Aussenluft nicht vollständig gesättigt und das Material schon beträchtlich an Wasser durch Abwelken verloren hat; deun nehmen wir an, dass anstatt $60 \mathrm{~kg}$ nur $30 \mathrm{~kg}$ Wasser zu verdampfen sind, so würden sich dic Wärme-Erzellgungskosten auf $0.72 \mathscr{M}$. ermässigen. Immerhin sind aber diese Kosten noch so hoch, dass sie gerechte Bedenken einflössen, wenngleich andererseits nicht $\mathrm{zu}$ verkennen ist, dass namentlich bei der Getrcidetrocknung bei sehr fenchter Erntewitterung Vorteile erwachsen können.

$\mathrm{Zu}$ dicsen Wärme-Erzengungskosten treten ferner noch die $\mathrm{An}$ lage- und Arbeitskosten hinzu. Für die Anlagekosten fehlt uns jeglicher Massstab, während sich die Kosten für die Arbeit des Lüftens annäherud feststellen lassen. Zum Trocknen von $100 \mathrm{~kg}$ Gras miissen $7500 \mathrm{cbm}$ Luft durchgesngen werden, wofür man, bei Anwendung von Mensehenkraft und ähnliche Verhältnisse wie bei der Zimmerventilation vorausgesetzt, mindestens 20 \& an Arbeitskosten in Anschlag zu bringen hat, die sich bei abgewelktem Material entsprechend verringern.

Nebmen wir nun an, dass sich die Rechnung im konkreten Falle vielleicht im 50 Proc. günstiger als nach unserer Berechnung stellen soll, so bleibt der Verlnst an Quantität und Qualität, der jährlich dem Futter durch diese Werbungsmethode zufällt, doch sehr erheblich und wiirden diese Verluste sich ohne Zweifel bei Anwendıng verbesserter Heuwerbungsmethoden, z. B. die Werbung auf Klecpyramiden, durchschnittlich weit geringer stellen. Leider zeigen sich dic Verluste bei der Neilsonschen Methode nicht offen und bleiben daher den meisten Landwirten verborgell, weshalb wir uns bemiissigt fanden, daranf hinzuweisen. Dass diese Methode aber wirklich zu tener ist, ergiebt sich schon darans, dass die Heuwerbungsmethode des Engländers Gibbs, der die Wärme durch Brennmaterial crzeugte, wegen ihrer zu hohen Kosten nur geringe Anwendung findet; man sollte doch annehmen, dass das Brennmaterial z. B. in Form von Coaks billiger sei als in Form von Kohlehydraten. 
Die Methode ron Gibbs gipfelt in folgendem: Ein mit Coaks geheizter Ofen gibt seine warme, relativ trockene Luft an einen Ventilator ab, der vermittelst eines Göpels durch Pferdckraft oder Dampfkraft in Rotation versetzt wird und die warme Luft $\left(150-200^{\circ} \mathrm{C}\right.$.) schnell austreibt, und dieselbe gelangt durch einen etwa $6 \mathrm{~m}$ breiten Spalt in einen mit Blech gedeckten Holzkasten. Hinter dem Spalt wird das Gras, frisch oder abgewelkt, etwa $1000 \mathrm{~kg}$ zur Zcit aufgeschichtet und mit Gabeln, die durch zwei Hebel vom Ventilator aus bewegt und durch zwei Arbeiter dirigiert werden, gehörig ungearbeitct, bis es lufttrocken geworden ist. Die Zeit, in welcher dies geschieht, ist nach dem Feuchtigkeitsgrade des Materials sehr verschieden, doch gentigen meist 5-10 Minuten. Das auf diese Weise kiinstlich getrocknete Heu riecht nach frisch gebackenem Brot, behält seine sämmtlichen Nährstoffe und fast vollständig seine grïne Farbe.

\section{b. Der Ausdrusch.}

Die ältestc Art des Ausdrusches ${ }^{1}$ ) war unstrcitig das Ausschlagen der Körner mit der Hand auf Hölzern, eine Methode, welche jetzt noch in Japan tiblich sein soll; aber auch in Tirol schlagen die kleinen Bauern noch heute die Körner auf Steinen aus, und cin Mädchen drischt dann von Hand mit einem sog. Pleuel nach.

Einen Fortschritt bekundet dagegen schon das Ausschlagen mittelst Stecken, ein Verfahren, dass bei vielen auf niedriger Kulturstufe stebenden Völkern und auch selbst noch bei den Chinesen angetroffen wird, welche sich vielfach eines Banbusrohres bedienen, obgleich auch Dreschflegel bekannt sind. Nach Plinius (Hist. nat. B. XVIII C. 72) droschen auch die Römer vielfach mit Stangen, wie es heute noch auf Malta und im ganzen Innern von Mittelafrika, in Ost-Sudan, Nubicn und Ober-Aegypten auf festgestampften Tennen der Fall ist. Bei einem Tcile der afrikanischen Völker wurde der Stccken zu sehr langen, am Ende mit Geflechten verbreiterten Dreschruten, wie z. B. nahe den grossen Seen, Albert Nyanza etc. Offenbar entwickelten sich aus den Stecken die Dreschflegel und sind solche nicht nur in Europa, sondern auch in Hochasien längst bekannt, doch weichen sie bei den verschiedenen Völkern in Gestalt und Gewicht stark von einander ab. Während z. B. der deutsche Dreschflegel so schwer ist, dass seine eigne Wucht zum Ausschlagen der Körner gentigt, muss bei dem leichteren englischen Flegel der Arbciter demselben erst durch Aufwand von Muskelkraft die nötige Wucht erteilen. Beim Flegeldrusch hat man auf gute Flegel und reines Aus-

1) Vergl. Fritz, Handb. d. landw. Maschinen. 1880, pg. 432 u. flgde. 
dresehen zu sehen, weshalb die Getreideanlage nur $16 \mathrm{em}$ hoeh geschehen sollte. In der Regel wird zur Erzielung des Reindrusches das Getreide dreimal gewendet und hierbei gut aufgesehüttelt. Zur Zeit wird der Flegeldruseh wegen seines hohen Kostenaufwandes, da gemeinhin der Dresehlohn $1 / 16$ bis $1 / 10$ rom Werte des ausgedroschenen Getreides beträgt, immer mehr dureh die Dresehmasehine verdrängt.

Das Austreten des Getreides durch unbesehlagene Tiere, namentlich dureh Pferde, Maultiere und Ochsen, kann wohl als der älteste Versueh, die Dreseharbeit dem Mensehen abzunehmen, angesehen werden.

Naturgemäss findet sieh diese Art des Dreschens nur in solchen Gegenden, in welchen das Klima die Vollfülnung dieser Arbeit im Freien erlaubt.

Die Tiere werden mehr oder weniger rasch in grösseren oder kleineren kreisförmigen Bahnen iiber das Getreide getrieben, wobei ilnen mitunter Wagen, Dreschwalzen oder Dreschsehlitten angehängt werden.

Das Anlegen und Wenden des Getreides geschieht hier in etwas anderer Weise als beim Flegeldruseh, indem die Frueht mehr aufreeht gestellt wird. Dass bei dieser Methode die Körnerverluste sehr bedeutende sein mïssen, aueh das Stroh mehr gekniekt und grössere Massen an Spren erzeugt werden, liegt anf der Hand, wozu noeh eine nieht geringe Verunreinigung durch Exkremente und Erde tritt.

Das Austreten namentlieh mit Pferden findet man noch heute vielfach in Russland, der Türkei, Ungarn, Sieilien, Italien, SüdFrankreich und Spanien. Ebenso bei den Hottentotten, in Maroeco, Aegypten, wie iberhaupt in Ost-Afrika. In Nord-Amerika war das Ausreiten vor der Einführung der Dresehmasehinen noeh sehr häufig und ist dasselbe in Süd-Amerika noch jetzt in vollem Gange.

Sehon seit den ältesten Zeiten ist man bemüht gewesen, die sehwere und langwierige Arbeit des Dresehens dnrch meehanisehe Dreschvorriehtungen zu erleichtern, und diese Bestrebungen führten schliesslieh zur Erfindung brauehbarer Dreschmasehinen, wie wir sie zur Zeit besitzen.

Von diesen unterscheidet man dem Systeme nach: Sehlagleistenmasehinen nach sehottiseher und Zapfendresehniasehinen nach amerikaniseher Erfindung.

Die Sehlagleistenmaschine wirkt dureh Erseliittern und Ausklopfen, die Zapfendreschmasehine aueh auf gleiehe Weise, wesentlieh aber dureh Ausstreifen.

Der Triebkraft naeh werden ferner untersehieden: Hand-, Göpel- 
und Dampf- oder Wasserdreschmaschinen. Entsprechend diesen Triebkräften vollzieht die Maschine nur eine oder mchrere Arbeiten.

Die Handdreschmaschine drischt nnr die Körner aus und schüttelt böchstens das Stroh aus; die Göpeldreschmaschine vollzieht meist beide Arbeiten nnd reinigt anch zuweilen das Getreide, während die Dreschmaschinen mit grösscrer Triebkraft nicht allein das Getreide dreschen, marktfähig reinigen und sortieren, sondern auch das Stroh bis auf eine gewisse Höhe mit Hülfe des Stroh-Stakers zum Anfsetzen auf Haufen liefern.

Diese letzteren, meist nach englischen Mustern gebauten Maschinen, sind vorzugsweise in Europa verbreitet, während in Amerika weniger grosse Anfordernngen binsichtlich des Reinigens und Sortierens gestellt werden, da diese Arbciten mit besonderen Maschinen ausgeführt werden, weshalb ein einfaches Gebläse und einige Siebe gentigen, wodurch sich die Dreschmaschinen weit cinfacher gestalten.

Ferner unterscheidet man, je nachdem die Halme mit den Aehren voraus oder parallel der Achse iiber die Dreschtronmel hinweggeben, Lang- und Qnerdreschmaschinen; sellstrerständlich können dic Zapfendreschmaschinen nur Langdreschmaschinen sein.

Die Vorteile der Dreschmaschine liegen in dem billigen. schnellen und reinen Ausdrusch dem Flegeldrusch gegenüber, und in der Möglichkeit, entweder in oder kurz nach der Ernte mit dem Ausdrusch beginnen zu können, wodurch cvent. das Feimensctzen ermöglicht nnd dic Scheune iiberfliissig wird.

Diesen Vorteilen stchen nuı auch allerdings Naehteilc gegenüber, doch sind dieselben nicht so gross, dass sic die Verbreitung der Dreschmaschinen wesentlich hindern kömnten.

Diese Nachteile bestchen vornämlich in der Beschädigung der Körner, in der'Zerknitterung und Zerreissung des Strohes, in dem nach Massgabe der aufgewendeten Triebkraft geringen Nutzeffekt, und in dem bedeutenden Reparaturbedlirfnis. Diese Nachteile können untcr Unständen sehr scharf hervortreten und den Handdrnseh rätlich erscheinen lassen, z. B. bei zur Saat oder für Gaihrungsgewerbe bcstimmtem Getreide, denn in beiden Fällen ruft gequetschtes oder gespitztes Getreide sehr beträchtliche Verluste hervor.

Dasselbe gilt, wenn es sich darum handelt, ftir irgend einen Zweck Glattstroh zu erzielen, denn selbst bei sorgsamem Einlegen in Breitdreschmaschinen lässt es sich nicht in gleich gutem Zustande wie durch Flegeldrusch erhalten.

Nach ciner Berechnung von Fritz ${ }^{1}$ ) ergoben sich als Dreschkosten pro 100 Garben: 
Extreme. Mittel.

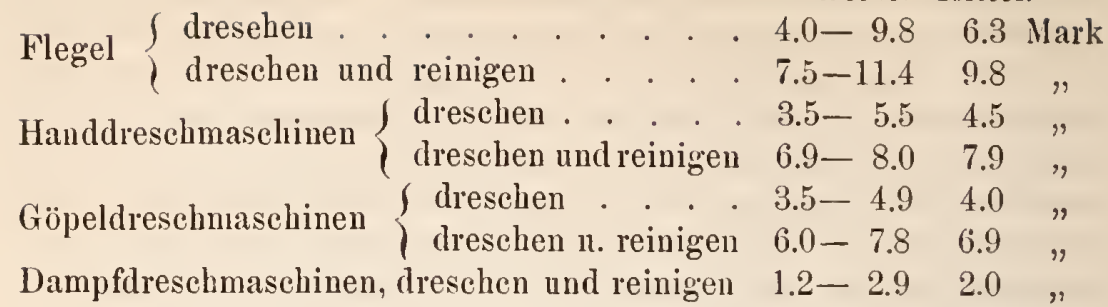

Zur bequemeren Reduktion der Dreschkosten und Leistungen bei den versehiedenen Getreidearten mögen folgende Mittelwerte dienen, welche angeben, dass sich gleich gut ausdreschen lassen:

Getreide: Weizen Dinkel Roggen Gerste Hafer

$\begin{array}{llllll}\text { Garben: } \quad & 100 & 110 & 107 & 126 & 134\end{array}$

Hektohiter: $100 \quad-\quad 115 \quad 174 \quad 215$,

sofern nicht örtliche Verhältnisse wesentliche Aenderungen dieser Zahlen bedingen.

Die Reinigung des Getreides von Staub, Sand, Spreu, Unkrautsamen etc. erfordert je nach dem Grade der zu erreichenden Reinigung einfachere oder zusammengesetztere Einrichtungen.

Bei den älteren Kulturvölkern geschah dies durch Worfeln und Sieben. Die Römer bedienten sich hierzu eigner Schwingen Vanni - die auch jetzt noch in urspriinglicher Form vielfach am Rhein benutzt werden, und Wurfsehanfeln -- Ventilabra.

Auch heute noch ist das Worfeln, z. B. in Nord-Deutschland, vielfach gebräuchlich.

Es bestebt dasselbe in dem einfachen Wurf der Körner gegen den Wind niittels einer Kornschaufel. Bei gleichmässigem Wurf und günstigem Winde fliegen Spreu, Staub etc. in der Richtung des Werfers zuriick, während sich vor demselben Korn und Unkraut, entsprechend ihrer specifischen Schwere, in der Weise ordnen, dass die schwersten Körner am weitesten naeh vorn fliegen. Gröbere Stroh- und Aehrenteile, die mit in das Korn vorfliegen, werden durch Kehren mit einem Binsenbesen nach hinten in das leiehte Korn und Unkraut zuriuckgekelırt; hiernach werden mit Hülfe von Sieben oder einfach konstruierten Getreidereinigungsapparaten die versehiedenen ihrer Qualität nach znsammengehörigen Partieen noch vollständig nachgereinigt.

Die jetzt zum Reinigen und Sortieren benutzten Maschinen beruhen wesentlich auf den gleichen Principien, denn an die Stelle des schwachen, natürlichen Luftzuges werden durch Ventilatoren erzeugte stärkere Luftströme und zur weiteren Reinigung und Sortierung Siebe benutzt.

In der Regel werden gleich nach dem Ausdrusch die Körner auf einer Windfege einfacher Konstruktion von den beigemengten 
Stroh- und Aehrenteilen, Kaff und gröberen Steinen befreit, und laufen dann zur vollkommneren Reinigung und Sortierung tiber kompliciertere Apparate, die sich zur Zeit einer sehr hohen Vollkommenheit erfreuen.

Die Vorteile der Reinigungsmaschinen liegen darin, dass an Zeit und Arbeitskraft erspart wird, die Arbeit zu jederZeit und in jedem Raum vorgenommen werden kann, während das Werfen von einem passenden Luftzug im hohen Grade abhängig ist; ferncr lässt sich durch sie ein höherer Grad der Reinigung erzielen, und ist derselbe nicht von der Geschicklichkeit des Arbeiters, wie beim Werfen abhängig; die Körner lassen sich ihrer Grösse nach genau sortieren und, was namentlich schwer in's Gewicht fällt, von jeglichem Unkraut, je nach der Leistungsfähigkeit der Maschine, reinigen; schliesslich sind die Konstructionen nicht compliciert und die Anschaffungskosten relativ gering.

Ueber die Wertigkeit der zur Zeit hauptsächlich benutzten Getreidereinigungsmaschinen geben Untersuchungen Anfschluss, welche von Seiten des Professors Dr. Gi cscler und des Verfassers in Poppelsdorf angestellt und in den landwirtschaftlichen Jahrbuichern 1880 veröffentlicht worden sind.

\section{c. Die Aufbewahrung des ausgedroschenen Getreides.}

Sanerstoff, gentigende Feuchtigkeit und Wärme sind die Faktoren, welche die Zersetzung der Bestandteile des Getreides und als sekundäre Erscheinung die Entwickelung von Pilzen herbeifiihren. Da nun, sobald einer dieser Faktoren fehlt, das Verderben des Getreides unmöglich ist, so sind die Aufbewahrungsmethoden anf die Fernhaltung des einen oder andern Faktors der Zersetzung zurïckzufiibren.

Aus diesen Grïnden wird daher entweder die Fernhaltung des Sauerstoffs durch möglichsten Abschluss der atmosphärischen Luft, oder die Fernhaltung der Feuchtigkeit durch ausreichende Lüftung des Getreides zu erreichen gesucht; wobei zu beachten, dass diejenigen Körner, welche im Stande sind, die grössten Massen an hygroskopischem Wasser aufzunehmen, auch am leichtesten verderben, also am kräftigsten zu lüften sind.

Nach R. Hoffmann verhalten sich die Frichte hierzu wie folgt:

Wassergehalt
der lufttrockenen
Körner
Proc.

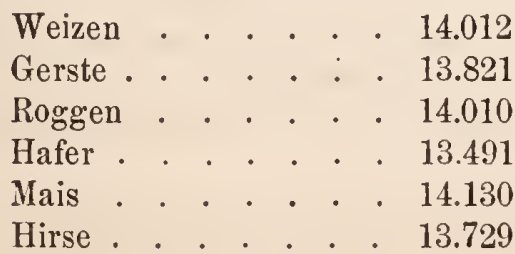

das Korn vermag an hygroskopischem Wasser aufzunehmen

Proc.

5.714

8.231

5.110

5.490

6.802

8.625 . 
Bei der Methode der Aufberahrung durch Abschluss der atmosphärischen Luft werden die Friichte meist in unterirdischen Fruchtbehältern den sog. Silos (nach dem baskischen siloa, das Loch) untergebracht, während bei Fernhaltung der Feuchtigkeit die Anfbewahrung anf möglichst luftigen Speichern geschieht, und ist im konkreten Fall, je nach den klimatischen Verhältnissen, die eine oder andere Methode berechtigt.

Die Kulturstaaten des Altertums, die im Gebiete des Steppenklimas oder in Gegenden, welche ohne Bewässerung kein Getreide erzielen konnten, lagen, haben auch, begünstigt durch die Trockenheit des Bodens und Klimas zuerst die Methode der Aufbewahrung in unterirdischen Erdgruben oder in grossen irdenen Geschirren etc. besessen und anch heute noch finden wir dieselbe rielfach in Nord-Afrika, KleinAsien und Inner-Asien, in Ungarn, Italien und Spanien in Gebrauch.

Die Hauptbedingung einer gnten Aufbewahrung des Getreides in Silos liegt in dem hermetischen Verschluss derselben, in der Einfiillung eines möglichst trocknen Getreides, in der Undurchdringlichkeit der Wandungen gegen Wasser und in der Erhaltung einer möglichst gleichmässigen Temperatur innerhalb des Silos.

Sind diese Bedingungen nicht gewährleistet, sondern ist $z$. B. das Getreide nicht ganz lufttrocken eingefuillt worden, so wird dasselbe sehr leicht in seiner Qualität geschädigt, oder fällt sogar vollständig dem Verderben ankeim. Ans diesem Grunde eignet sich auch der Hartweizen, der lufttrocken sehr wenig Wasser enthält und relativ wenig absorbiert, am besten zur Aufbewahrung in den Silos.

Vorzüglische Silos, in denen sich das Getreide ausgezeichnet hält, finden sich in Algier und Spanien, und legten die Mauren dieselben in in den Felsen gehatenen Räumen an, die häufig $3000-3500 \mathrm{hl}$ fassen konnten.

In Toskana wird das Getreide in oberirdischen Behältern, welche aus Backsteinen gemanert, $4 \mathrm{~m}$ hoch und 2 à $2 \mathrm{~m}$ breit, oben gewölbt und mit Cement luftdicht itberzogen sind, aufbewahrt. Diese Behälter befinden sich entweder in einem Oekonomie-Gebände oder im Hause des Kolonen selbst, und sind so angelegt, dass sie ron dem im zweiten Stockwerke belegenen Schüttboden aus gefiillt werden können. Nach der Einfüllung werden sie mit einem gut hermetisch schliessenden Deckel rersehen.

Weniger gut ist die Aufbewahrung des Getreides in Erdgruben, wie sie sich noch rielfach beim ungarischen Baucr findet ${ }^{1}$ ). Diese Silos werden an einem leicht $\mathrm{zu}$ bewachenden und nicht durch Untergrundwasser leidenden Ort angelegt. Die frisch gegrabenen Höhlun-

1) Werner, Bericht über eine landw. Studienreise durch Ungarn. Landw. Jahrb. 1880 pg. 576 . 
gen, welche meist die Form einer Flasche besitzen, brennt man mehrere Tage lang mit Stroh aus, damit die Kruste fest und undurchlassend, sowie der Höhlung der Erdgeruch genommen werde. Nach ihrer Ausfütterung mit Stroh und Fiillnng mit Getreide wird die Ocffnung mit Asche, Sand und Thon sorgfältig verschlossen. Selbstverständlich wird ein solches in Erdböhlungen aufbewahrtes Getreide niemals Exportware sein können.

Die Uebertragung dieses Systems der Silos in Länder mit feuchtem Klima ist ein vergebliches Bemühen, wenn das Getreide nicht vorher kiinstlich gedörrt wird, auch könnte der Vorteil für Länder wie Frankreich, England. Deutschland etc., welche ihren eignen Getreidebedarf nicht decken, sondern noch importieren, nur gering sein. da bei dem sebr entwickelten Getreidehandel die Notwendigkeit einer längeren Auf bewahrung des Getreides gar nicht vorliegt, vielmehr das Bestreben siclı geltend macht, mögliclıst sofort nach dem Ausdrusch dasselbe zu rerkaufen.

Der Kaufmann hat vielleicht mehr Interesse an einer längeren und dabei billigeren Aufberahrung und machen wir daher auf das Silo der „Patent Silos Company's Granaries" anfmerksam, welches von John Barker erfunden, und in Frankreich, wo der Erfinder auf der Weltausstellung ron 1867 die grosse goldene Medaille erhielt, patentiert wurde.

In diesen Silos wird der Sauerstoff durch Einpumpen von Stickstoff verdrängt, mithin die Zersetzung vermieden und das Ungeziefer getötct.

In den feuchten Klimaten bewahrt der Landwirt sein Getreide in der Regel auf luftigen Speichern auf, wobei jedoch nicht übcrsehen werden darf, dass das Getreide allen Schwankungen in dem Feucltigkeitsgelaalt der Luft ausgesetzt ist, deren schädliche Folge nur durch tiichtiges Umschaufeln, Bearbeiten mit Windfegen etc. ausgeglichen werden kann. Zudem lïsst sich ron diesen Speichern das Ungeziefer kaum abhalten, die Kosten des Auf- und Abtragens des Getreides sind hoch, ebenso ist die Herstellung dieser Speicher gegenüber der in ihnen aufgespeicherten Getreidemenge zu tener und die Feuersgefahr gross.

Auf den Getreidespeichern ist (nach Perels ${ }^{1}$ ) für 1 hl Getreide ein Flächenraum von $0,25-0,36$ qm erforderlich und kann die Etagenböhe $2,5-3 \mathrm{~m}$ betragen.

Die Höhe der Aufschüttung des frisch gedroschenen, also noch nicht völlig lufttrocknen Getreides, beträgt nur $15 \mathrm{~cm}$ und vermelırt sich in dem Masse, als die Trocknung fortschreitet, auf $50-80 \mathrm{~cm}$.

1) Handb. d. 1. Transportwesens 1882 , p. 397 . 
Das frische Getreide ist wöchentlich ein- bis zweimal, lufttrocknes im Winter alle 6 Wochen und im Frühjahr häufiger umzuschaufeln.

Diesen Getreidespeichern haften sehr bedeutende Mängel an, welchen man durch sinnreiche Konstruktionen abzuhelfen gesucht, wenngleich es bis jetzt noch nicht gelungen, sie sänmtlich zu beseitigen.

$\mathrm{Zu}$ den verbesserten Getreidespeichern gehört namentlich Vallery's grenier mobile; Sinclair's Getreideturm, ein parallelepipedischer, iiberwölbter Bau, dessen innerer Raum, von zahlreichen Luftrinnen quer durchsetzt, den Abfluss des Getreides durch einen unterseits befindlichen grossen Trichter gestattet. P a ry's "Conservateurs" bestehen aus hohen Cylindern, die bei kleinen Dimensionen aus Blech gefertigt, bei grossen aus Ziegeln aufgemauert sind. Oberseits befindet sich ein konisclier Deckel mit einem Rohr in der Mitte, durch welches die Füllung erfolgt, unterseits befinden sich genaue Messgefässe, um bestimmte Fruchtmengen aus dem Behälter ablassen zu können und seitlich sind Oeffnungen zur Durchliiftung angebracht.

Eines der besten Systeme scheint das von Devaux zu sein, welches in dem grossen Kornspeicher zu Triest zur Anwendung gelangt ist. Bei demselben ist der Platz sehr ökonomisch ausgenutzt und Maschinen mit Ventilator besorgen den Luftzutritt und den grössten Teil der übrigen notwendigen Arbeiten.

Von hervorragender Wichtigkeit für Länder mit ausgedelnntem Getreidehandel sind die amerikanischen Getreidedepôts (Grain elevator), von denen Thallmeyer ${ }^{1}$ ) nachfolgende Beschreibung gibt.

Die Beschreibung betrifft einen Getreideelevator New-Yorks, der zwar nicht zll den grössten zählt, aber seiner Einrichtung nach von den grossen nicht abweicht.

Das Gebäude ist zum grössten Teil aus Holz anfgeführt und bedeckt eine Grundfläche von $110 \times 33 \mathrm{~m}$ und erreicht eine Höhe von $47 \mathrm{~m}$. In dem Gebäude befinden sich in 7 Reihen 231 Getreideschächte (bins), 182 Stïck von diesen haben eine Grundfläche von $2,74 \times 3,95 \mathrm{~m}$ und eine Höhe von $22 \mathrm{~m}$, die anderen sind für geringere Füllungen durch Scheidewände abgeteilt.

Die Wände der einzelnen Schachte werden ron $5 \mathrm{~cm}$ dicken Planken gebildet, die flach aufeinander gelegt und fest zusammen gespikert sind, so dass also die Breite der Planke gleichzeitig die Dicke der Schachtwände ist. Die Behälter haben zusammen einen Fassungsraum von $1 \frac{1}{2}$ Millionen Bushels.

Den Weg verfolgend, den das Getreide in den Speichern durchmacht, finden wir zunächst, dass es von den Eisenbahnwaggons, die 
in das Gebäude einfahren, direkt in prismatische, in Mauerwerk versenkte und mit Holzplanken ausgekleidete eiserne Behälter (receiving pits) abgelassen wird.

Das längs den geneigten Wänden dieser Behälter abfallende Getreide wird von einem Elevator, dessen Gehäuse am Boden des Behälters aufsteht, in dic Höhe befördert. Die Grösse der zum Elevator führenden Zuflussöffnung richtet sich nach der unter Manipulation befindlichen Getreidegattung und kann mittelst eines von einem Handrade aus beweglichen Schiebers reguliert werden.

Der untere Teil der elf Elevatorgehäuse ist aus Eisenblech, der obere Teil von der Stelle an, wo das Gehäuse den Schachtboden durehdringt, aus Planken hergestellt. Den Elevator bildet ein $55 \mathrm{~cm}$ breiter Riemen aus Kautschuk, auf dem in Entfernungen von $30 \mathrm{~cm}$ Schöpfgefässe befestigt sind.

Die Elevatoren heben das Getreide bis in den Dachraum.

Der Elevatorricmen läuft oben über eine $183 \mathrm{~cm}$ im Durchmesser haltende Scheibe, deren Nabe in beweglichen Lagern aufgehängt ist, so dass sie in oder ausser Kontakt mit auf der Hauptwelle befestigten Friktionsscheiben gebraclit werden kanu, zu dem Zweck, die Bewegung des Elevatorriemens entweder einzuleiten oder abzustellen. Das Heben und Senken der Schciben geschieht mittelst an Scilen zu handhabenden Hebeln.

Das Getreide wird von den Elevatoren in die Wagebehälter (weighing hopper), entleert, die auf einer 18 Tonnen- (360 Centner-) Wage stehen. Sobald das Getreide gewogen worden, fällt es in ein Auslaufrohr (swinging spout), welches beweglich aufgehängt ist. Erwähntes Auslaufrohr kann mit der Hand in eine der am Boden in einem Kreise befindlichen Aufnahmeöffnungen cingestellt werden, um durch Leitungskanäle das Getreide in die Behälter oder Schachte gelangen zu lassen. Die Aufnahmeöffnungen sind den Schachten entsprechend, mit welchen sie korrespondieren, mit Nummern bezeichnet. Gleichzeitig wird dort auch der Stand des Füllungsgrades der einzelnen Behälter auf einem schwarzen Brette in Evidenz gehalten, so dass der Aufseher gleich weiss, wo er das Getreide hinzudirigieren habe.

Das auf solche Art in den Schachten anfoespeicherte Getreide verbleibt dann bis zu seiner Verschiffung oder sonstigen Verfrachtung in Ruhe. Wenn Kähne oder Sehiffe es aufnehmen sollen, so wird es aus den Schachten wicder in die untersten Behälter abgelassen, dann wieder bis in den Dachraum gehoben, von dort auf die Wagebehälter und von diesen in Leitungsröhren in den Schiffsraum geführt.

Soll das Getreide eingesackt werden, so wird es unmittelbar unterhalb des Bodens der Schachte in die Säcke laufen gelassen.

Die gefüllten Säcke übernimmt ein Arbeiter behufs Bindens und legt die gebundenen Säcke auf einen Transporteur, der, aus einem star- 
ken Kautschukriemeu bestehend, in einem Ausschnitte des Fussbodens in gleicher Höhe mit demselben läuft, und der die Säcke am Ende des Gebäudes einel schiefen Ebene iibergiebt, auf der sie, mittelst eines bereitstehenden Vehikels, hinabgleiten.

Als Betriebsmaschinen fungieren zwei verticale Dampfmaschinen von $85 \mathrm{~cm}$ Cylinderdurehmesser, $85 \mathrm{~cm}$ Cylinderhöh e und 60 Pfund Dampfdruck. Der Haupttreibriemen hat eine Breite von $1.2 \mathrm{~m}$ und eine Länge von $100 \mathrm{~m}$ bei einem Gewiehte von 100 Centnern.

In dem Elevator befinden sich ausserdem Naschin erien zum Putzen des Getreides, so wie auch sog. ,shipping bins" d. i. Schächte, die in einer gewissen Höhe über dem Wasser geneigte Böden haben, von denen aus das Getreide in die Leitungen und von dort in den Schiffsraum gelangt.

Es findet nun selbst bei sorgsamster Aufbewahrung immer eine nicht unerhebliche Schwindung der Körnerfriichte statt, und wie gross dieser Verlust selbst ınter sehr günstigen Verhältnissen sein kann, ergiebt sich aus den auf Grund jahrelanger, sorgfältigster statistischer Aufzeichnungen gewonnenen Zahlen der Königl. preussischen Proviantämter ${ }^{1}$ ).

Diese Verluste stellen sich, wenn das Getreide mögliehst staubfrei, frei von fremden Sämereien und von guter Qualität ist, wie dies die magazinmässige Besehaffenheit bei den Proviant-Aemtern bedingt, wie folgt:

Der Abgrang bei Weizen, Roggen, Gerste und Hülsenfrüehten heträgt:

$$
\begin{aligned}
& \text { Im 1. Vierteljahr . . . . . . } 1.3 \text { Procent }
\end{aligned}
$$

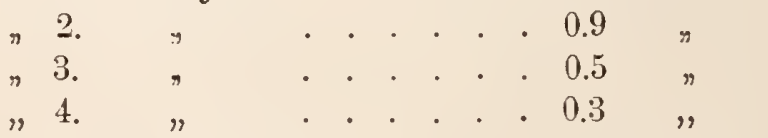

Mithin im ersten Jahre . . . 3.0 Procent und in jedem folgenden Jahre vierteljährlich $1 /{ }_{4}$ Pro cent oder jährlich 1 Procent.

Bei Hafer:

Im 1. Vierteljahr . . . . . . 1.7 Proeent

$\Rightarrow 2 . \quad$. . . . . . . $0.9 \%$

"3. " . . . . . . . . 0.6 "

"4. " . . . . . . . . 0.3 .,

Mithin im ersten Jahre . . . . 3.5 Procent und in jedem folgenden Jahre vierteljährlich 0.3 Procent oder jährlich 1.2 Procent.

1) Vergl. Deutsche landw. Presse. 1879. 
Selbstverständlich würde bei weniger gut gereinigtem Getreide das Manko ein viel grösseres sein.

Diese Verluste, sowie Lagerkosten und Risiko machen eine etwaige Preissteigerung im Frïhjahr meist illusorisch.

\section{Die Erträge und Nahrungsbestandteile des Getreides.}

Zuvörderst sind hier die Nomente der Wertbestimmung des Getreides und der Ertragsbestimmung von der Flächeneinheit zu erörtern.

Ein sehr wichtiges Moment der Wertbestimmung bildet zunächst das absolute Gewicht, also die Grösse und Schwere der Körner, doch ändert sich dasselbe nach der angebauten Getreidesorte, der Beschaffenheit des Bodens, der Witterung, der mehr oder weniger kräftigen Entwickelung der Pflanze, sowie schliesslich nach dem Ort, welchen das Korn in der Aehre inne hat. Die absolut schwersten Körner sinả im Allgemeinen reicher an Stärke, Zucker und Gummi als die leichteren, während letztere eine relativ grössere Menge an Eiweissstoffen und Holzfaser aufweisen.

Demnach hängen die Gewichtsunterschiede bei den nackten Friichten wesentlich von der Ausbildung des Samenkorns, also des Embryo und der Reservestoffe ab.

Nach den Untersuchungen von Blocziszewski beträgt der Embryo vom Gewicht des ganzen Kornes:

\begin{tabular}{|c|c|c|}
\hline eim Weizen & $2-3$ & Proc \\
\hline Roggen & $2.5-4$ & \\
\hline ste & $2-3.5$ & \\
\hline n Hafe & $\begin{array}{ll}3 & -4\end{array}$ & \\
\hline er Mohrhirse & $5-6$ & \\
\hline m Mais & $10-14$ & \\
\hline
\end{tabular}

Anders verhalten sich aber die bespelzten Früchte, da bei diesen die Fruchthille einen erheblichen Bruchteil des Gewichtes ausmacht, mithin der Wert anch von dem Gewichtsverhältnis zwischen den Spelzen und der nackten Frucht abhängt. So betragen die Schwankungen für den Gewichtsanteil der Spelzen beim Hafer nach unseren Ermittelungen 21 Proc. (Avena sativa mutica) bis 49 Proc. (Avena 
sativa praegravis), nach Haberlandt für Hafer überhaupt 17-50 Proc. Bei den Spelzweizen ergaben sich nach unseren Ermittelungen für Triticum monococeum 21-35 Proc., für Tr. dicoccum 19-26.5 Proc., für Tr. Spelta 20-36.5 Proc., und nach $\mathrm{Haberlandt}$ fiil die Spelzweizen überhaupt 22.5-27.8 Proc.

Beträchtlich geringer ist der Gewichtsanteil der Spelzen bei der Gerste, denn derselbe betrug nach Haberlandt nur 7-15 Proc. und zwar erwiesen sich im Allgemeinen die Spelzen der Wintergerste und der bläulichen Gerste (Hordeum tetrastichum coerulescens) am schwersten.

Haberlandt gibt ferner das Gewicht der Fruchthüllen für Mohrhirse auf 5-14 Proc., für Rispenhirse im Mittel auf 16.8 Proc. und für Reis im Mittel auf 21.26 Proc. an.

Das specifische Gewicht der Körner lässt über die in ihnen enthaltenen organischen Reserrestoffe keinen Schluss ziehen, weil dasselbe bei letzteren annähernd gleich hoch ist, z. B. beträgt das specifische Gewicht:

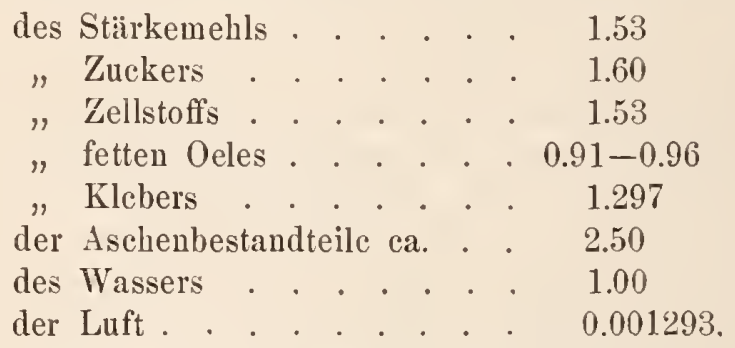

Diese Zahlen zeigen deutlich, dass die Dichte weit fühlbarer durch die Aschenbestandteile, da deren specifisches Gewicht sehr hoch ist, beeinflnsst werden kann, als durch die organischen Stoffe, und dass sich namentlich nicht die Dicke der Schale, also die Menge des im Korn rorhandenen Zellstoffs feststellen lässt, da sein specifisches Gewicht nicht von dem des Stärkemehls, das die Hauptmasse des Kornes bildet, abweicht.

Nichts destoweniger könnte nach Nobbe ${ }^{1}$ ) anf indirektem Wege ein Rückschluss ron specifischen Gewichte möglich sein z. B. bei im Zustande der Umreife eingeschrumpftem Korn, bei dem die Trockensubstanz einen geringeren Gehalt an Stärke und einen höheren an Zellstoff und Proteïn aufiveisen wïrde.

Von wesentlichem Einfluss ist aber der Gehalt von Luft und Wasser im Korn, so z. B. ist die eingeschlossene Gasmenge in den mehligen Weizen grösser als in den hornigen, und daher auch das specifische Gewicht letzterer etwas höher, und der Einfluss des

1) Handb. d. Samenkunde p. 314. 
wechselnden Wassergehaltes kann gross genug werden, um ihn praktisch beachten zu müssen, wie folgende Differenzen zeigen:

$\begin{array}{clc}\text { Weizen lufttrocken (Wassergehalt } 9.42 \text { Proc.) } & 1.3800 \\ & & 1.4085 \\ " \quad \text { wasserfrei } & \text { feucht (Wassergehalt } 27.03 \text { Proc.) } & 1.2820 .\end{array}$

Das specifische Gewicht der Getreidekörner stcht nun zum Volumengewicht, wie vielfache Untersuchungen ${ }^{\text {) }}$ beweisen, in gar keiner Beziehung, denn die Ziffer, welche sich durch Abwägung eines bestimmten Raummasses crgiebt, wird durch die Lufträume zwischen den Körncrn beeinflusst, und diese sind durch die Form und Grösse, sowie durch die Oberfläche und zufällige Lagerung der Körner bedingt. Trotzdem lat jedoch das Volumengewicht als Qualitätsmass zu gelten, denn das schwerste Getreide zeigt auch stets die grösste Homogenität in der Form, vermöge welcher sich die Körner glcichmässiger und dichter zusammenlegen.

Im Allgemeinen ist anzunehmen, dass der Wert des schwereren Getreides in höherem Verhältnis als das Volumengewicht steigt, soweit wenigstens Stärke und deren Produkte in Frage kommen, während zwischen dem Volumengewicht und dem Gelıalt an Eiweisskörpern gar keine Beziehung existiert.

Da nun mit dem Volumengewicht auch ausnahmslos das absolute Gewicht des einzelnen Korns steigt, so muss das Getreide, welches das höhere Volumengewicht aufweist, auclı die beste Qualität besitzen.

Die Differenzen im Gewichte gleicher Volumina derselben Getreideart können nach den Untersuchungen von A. Müller und G. Wunder sehr beträchtlich sein und sich verhalten

$\begin{array}{lll}\text { beim Weizen } & \text {, wie } 100: 155 \\ \text { " Hafer } & \text { " } 100: 137 \\ \text { bei der Gerste } & \text { " } 100: 131 \\ \text { beim Roggen } & , \quad 100: 123 .\end{array}$

Aus allen diesen Griinden ist das Volumengewicht zugleich als Qualitätsmass anzusehen. Allerdings hat die Füllung des Hohlmasses sehr sorgsam zu geschehen, weil sich leicht Messungsfehler einschleichen; geschieht z. B. die Füllung nicht durch gleichmässigen Einwurf mit zwei Schaufeln oder erfolgt das Abstreichen ungleich und dabei entweder zu schnell oder zu langsam, so resultieren daraus Gewichtsdifferenzen, die unter Unständen $2-6 \mathrm{~kg}$ p. hl und mehr betragen können. Mit Hülfe automatischer Vorrichtungen zum An-

1) 0 . Wolffenstein, Zeitschr. f. d. ges. Naturwissensch. v. Giebel u. Heintz XXXII, 15l; u. A. Müller, Centralbl. f. d. l. Ver. 1855 p. 38 u. 68; u. G. Wunder, ibid. 1857 p. 33. 
fiillen und Abstreichen lassen sich jedoch diese Fehler, wenn auch nicht gänzlich, doch der Hauptsache nach vermeiden.

Ertragsangaben nach dem Volumen allein z. B. in Hektolitern vorzunehmen, wiirde nach dem Gesagten noch fehlerhafter sein als nach dem Gewicht. Im ersteren Falle fehlt nicht nur die Qualitätsangabe, sondern auch die Quantität unterliegt Messungsfehlern, denn es ist dabei zu beachten, dass sich mit zunehnendem Wassergehalt der Körner anch ihı Volumen unverhältnissmässig vergrössert.

Diese Thatsachen sprechen dafiir, die Ertragsangaben entweder nach dem Volumen oder dem Gewichte unter steter Beifügung des Volumengewichtes zu machen. Als Mass soll nun das Hektoliter und als Gewicht das Kilogramm gelten.

Zur Orientierung folgt eine Zusammenstellung, aus welcher sich die Durchschnittszahl der Friichte in $1 \mathrm{hl}$, das specifische Gewicht und die Grenzen, in denen das Volumengewicht in Kilogrammen pro hl schwanken kann, ergeben:

\begin{tabular}{|c|c|c|c|}
\hline $\begin{array}{l}\text { Bezeichnung } \\
\text { des Getreides. }\end{array}$ & $\begin{array}{c}\text { Durchschnittszahl } \\
\text { der Früchte } \\
\text { pro hl }\end{array}$ & $\begin{array}{c}\text { Specifisches } \\
\text { Gewicht }\end{array}$ & $\begin{array}{l}\text { Volumenge- } \\
\text { wicht pro } \\
\text { Hektoliter in } \\
\text { kg }\end{array}$ \\
\hline 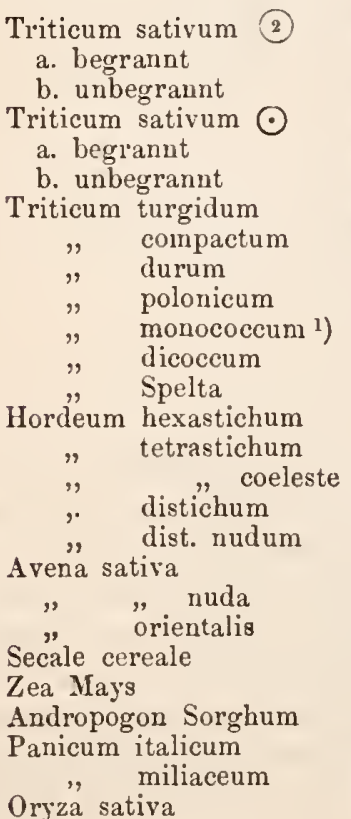 & \begin{tabular}{|c|}
1801000 \\
1860000 \\
1800000 \\
2150000 \\
2000000 \\
2200000 \\
1500000 \\
2200000 \\
1580000 \\
1400000 \\
1000000 \\
950000 \\
740000 \\
1660000 \\
1600000 \\
2100000 \\
1415000 \\
1200000 \\
1658000 \\
$3.4-7.7$ Millionen \\
1615000 \\
2275000 \\
$187500-1$ Million \\
3500000 \\
33500000 \\
15500000 \\
-
\end{tabular} & $\begin{array}{l}1.369 \\
1.403 \\
1.333 \\
1.355 \\
1.374 \\
1.337 \\
1.290 \\
1.332 \\
1.384 \\
1.371 \\
1.232 \\
1.072 \\
1.081 \\
1.350 \\
1.305 \\
1.371 \\
1.317 \\
1.401 \\
1 .(150 \\
1.314 \\
1.021 \\
1.340 \\
1.147 \\
1.270 \\
1.184 \\
1.179 \\
-\end{array}$ & $\begin{array}{c}73-90 \\
80 \\
77 \\
75-90 \\
80 \\
78 \\
72-84.5 \\
80-89 \\
75-86.5 \\
74.5-82 \\
40-50 \\
40-49 \\
40-48 \\
60-70 \\
50-64 \\
70-83 \\
62-78 \\
70-84 \\
36-57 \\
63-77 \\
43-48 \\
68-80 \\
68-87 \\
65-80 \\
66-76 \\
62-80 \\
40-66\end{array}$ \\
\hline
\end{tabular}

1) Sämmtliche Spelzweizen, Hirse und Reis unenthülst. 
Wie schon in den vorhergehenden Kapiteln zur Genüge dargethan, sind die Ernteerträge des Getreides in ihrer Quantität und Qualität von der Jahreswitterung, der Bodenbeschaffenheit, der-Düugung, den angebauten Getreidesorten, der Saatzeit, der Pflege, dem Erntezeitpunkt, der Erntewitterung und schlicsslich von der Aufbewahrmug abhängig.

Von diesen Faktoren liegen die Jahres- und Erntewitterung nicht in der Machtsphäre des Landwirtes, während er die iibrigen mehr oder weniger beherrscht.

Zur Gewinnung eines Ueberblicks iiber die Durchschnittserträge der hauptsächlich am Getreidebau beteiligten Länder soll die nachstehende Tabelle dienen, in welcher zur besseren Vergleichung: sämmtliche Angaben nach metrischem System gemacht worden sind, das wir iberhaupt auch allen iibrigen Berechnnngen zn Grunde legen wollen, und das Volumengewicht eines Hektoliters ist beim Weizen auf $75 \mathrm{~kg}$, beim Roggen auf $73 \mathrm{~kg}$, bei der Gerste auf $64 \mathrm{~kg}$, beim Hafer auf $46 \mathrm{~kg}$ und beim Mais auf $78 \mathrm{~kg}$ angenommen.

Tabelle über die Durchschnittserträge verschiedener Länder:

\begin{tabular}{|c|c|c|c|c|c|c|}
\hline \multirow{2}{*}{ Land } & \multicolumn{6}{|c|}{ Ertrag pro ha in hl } \\
\hline & $\left|\begin{array}{c}\text { Weizen } \\
\text { und Spelz }\end{array}\right|$ & Roggen & Gerste & Ilafer & Mais & $\begin{array}{c}\text { ImDurch } \\
\text { schnitt }\end{array}$ \\
\hline $\begin{array}{l}\text { Grossbritannien und } \\
\text { Irland }\end{array}$ & 24.4 & 22.0 & 33.0 & 38.0 & - & 31.3 \\
\hline Deutsches Reich & 18.4 & 14.4 & 21.7 & 28.2 & - & 20.0 \\
\hline Frankreich & 14.5 & 13.7 & 17.1 & 22.6 & 16.4 & 16.5 \\
\hline Oesterreich-Ungarn & 8.5 & 11.2 & 13.6 & 14.8 & 12.7 & 11.8 \\
\hline Italien & 11.1 & \multicolumn{2}{|c|}{14.40} & 16.7 & 18.3 & 13.4 \\
\hline Portugal & 10.8 & 9.0 & - & - & 13.6 & 11.8 \\
\hline Belgien & 22.0 & 22.0 & 30.0 & 30.5 & - & 25.0 \\
\hline Niederlande & 20.0 & 16.4 & 33.6 & 37.8 & - & 23.8 \\
\hline Russland & 9.5 & 8.8 & 8.1 & 14.3 & - & 10.2 \\
\hline Rumänien & 7.2 & 7.9 & 12.4 & 128 & 16.5 & 12.2 \\
\hline Dänemark & 24.0 & 22.0 & 25.0 & 28.0 & - & 25.3 \\
\hline Vereinigte Staaten & 10.9 & 12.1 & 21.4 & 23.4 & 20.0 & 17.6 \\
\hline Algier & 6.9 & - & 11.5 & 25.0 & 7.2 & 9.5 \\
\hline Australien & 12.0 & - & 13.0 & 20.0 & 180 & 14.0 \\
\hline Durchschnitt: & 14.3 & 14.5 & 20 & 24.1 & 15.3 & 17.3 \\
\hline
\end{tabular}

$\mathrm{Da}$ es nun jedenfalls von Interesse ist, auch die Minimal-, Maximal- und Mittel-Erträge an Körnern, Stroh und Spreu von den einzelnen Getreidearten kennen zu lernen, so haben wir uns bestrebt, eine solche Tabelle zusammenzustellen, bemerken jedoch dazu, dass die Maximalerträge meist sog. Wettkulturen, wie sie speciell im Königreich Sachsen durchgefuhrt wurden, oder Anbauversuchen auf 
Versuchsfeldern entnommen worden sind. Diese Maximalerträge lassen erkennen, bis zu welcher Höhe eine Ertragssteigerung möglich ist.

\section{Tabelle über Minimal-, Maximal- und Mittelerträge der Getreidearten.}

\begin{tabular}{|c|c|c|c|c|c|c|c|c|c|}
\hline \multirow[t]{2}{*}{ Getreideart } & \multicolumn{8}{|c|}{ Ertrag pro ha an: } & \\
\hline & Min. & $\underset{\mathrm{hl}}{\mathrm{Max}}$ & $\left|\begin{array}{c}\text { Mittel } \\
\mathrm{hl}\end{array}\right|$ & $\begin{array}{l}\text { Min. } \\
\mathrm{kg}\end{array}$ & $\underset{\mathrm{kg}}{\operatorname{Max}}$ & $\left|\begin{array}{c}\text { Mittel } \\
\mathrm{kg}\end{array}\right|$ & $\begin{array}{c}\text { Min. } \\
\mathrm{kg}\end{array}$ & $\underset{\mathrm{kg}}{\operatorname{Max}}$ & $\begin{array}{c}\text { Mittel } \\
\mathrm{kg}\end{array}$ \\
\hline Winter-Weizen & 6 & 84 & 14.3 & 1200 & 7000 & 2600 & 160 & 700 & 260 \\
\hline Sommer- ," & 5 & 40 & 12 & 1000 & 5000 & 2200 & 130 & 500 & 220 \\
\hline Spelz & 5.5 & 85.7 & 40 & 1200 & 7000 & 2500 & - & - & - \\
\hline Emmer & 13 & 83.8 & 40 & 1500 & 7000 & 2500 & - & - & - \\
\hline Einkorn & 8 & 84 & 40 & 1000 & 5600 & 2000 & - & - & - \\
\hline Winter-Roggen & 4.3 & 53.4 & 14.5 & 900 & 7000 & 3000 & 100 & 700 & 300 \\
\hline Sommer- " & 4 & 30 & 12 & 750 & 4600 & 2000 & 78 & 460 & 200 \\
\hline Winter-Gerste & 28 & 83 & 37 & 1340 & 5000 & 2500 & - & - & - \\
\hline Sommer- ,, 2-zeilig & 11 & 95 & 25 & 1200 & 4860 & 2200 & - & - & - \\
\hline , , 4-zeilig & 10 & 32 & 18 & 1000 & 2000 & 1500 & - & - & - \\
\hline Hafer & 8 & 154.7 & 24.1 & 1100 & 5000 & 2250 & 110 & 500 & 225 \\
\hline Mais & 7 & 225 & 15.3 & 730 & 20000 & 2500 & - & - & - \\
\hline Mohrhirse & 4.3 & 80 & 40 & 900 & 12000 & 6000 & - & - & - \\
\hline Rispenhirse & 8 & 35 & 20 & 1000 & 4000 & 2500 & 90 & 350 & 225 \\
\hline Kolbenhirse & 15 & 35 & 20 & 1200 & 4000 & 2500 & 50 & 140 & 100 \\
\hline Reis & 12 & 100 & 46 & 1000 & 6000 & 2600 & - & - & - \\
\hline
\end{tabular}

Die Qualität der Früchte richtet sich nach der Menge und Beschaffenheit der wichtigsten Nahrungsbestandteile und zwar der Kollehydrate, Proteïnstoffe und Salze.

Die Kohlehydrate sind entweder in Wasser unlöslich wie Stärke, Fett und Cellulose, oder löslich wie Dextrin, Gummi und Zucker. Diese Kohlehydrate machen durchsehnittlich 65 Proc. der lufttrocknen Früchte aus; doch haben sie für die Ernälırung, da sie nicht Organbildner sind, einen geringeren Wert als die Proteïnstoffe.

Letztere bestehen aus dem in Wasser löslichen Eiweiss (1-2 Proc.) und dem unlöslichen Kleber (10 Proc.). Dieser letztere Körper ist nun der wichtigste Bestandteil, weil er nicht allein die Hauptmasse der Proteïnstoffe bildet, sondern auch die Backfähigkeit der Mehle in hohem Grade beeinflusst. Seine Beschaffenheit kann jedoch eine sehr wechselnde sein, da er kein einfacher, sondern ein zusammengesetzter Körper ist, der sich nach Ritthausen aus den folgenden 4 stickstoffhaltigen Körpern zusammensetzt: 


\begin{tabular}{|c|c|c|c|c|}
\hline Bestandteile & 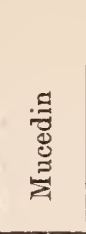 & 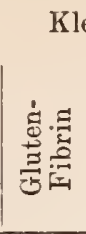 & 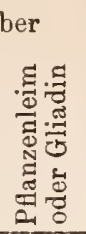 & 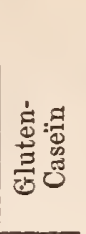 \\
\hline Kohlenstoff & 54.11 & 54.31 & 52.67 & 52.94 \\
\hline Wasserstoff & 6.90 & 7.18 & 7.10 & 7.04 \\
\hline Stickstoff & 16.63 & 16.89 & 18.01 & 17.14 \\
\hline SchwefeI & 0.88 & 101 & 0.85 & 0.96 \\
\hline Sanerstoff & 21.48 & 20.61 & 21.37 & 21.92 \\
\hline
\end{tabular}

Frischer Kleber enthält 25-27 Proc. trockne Substanz und 16-20 Proc. Gluten-Caseïn; die anderen Körper sind demnach in weit geringerer Menge vorhanden, doch beeinflussen sie die Qualität des Kleber's sehr bedeutend, und kann schon ein geringes Mehr oder Weniger eines dieser Körper darin ausschlaggebend sein; so macht das Mucedin den Kleber zerfliessend, das Gluten-Fibrin denselben brüchig und nicht zusammenhaltend, während der Pflanzenleim und das Gluten-Caseïn, diese beiden zähen, schleimigen Körper, den Kleber zusammenhaltend, zähe, stark elastisch und zugleich dehnbar machen. Letztere Eigenschaften sind nun aber für den Teig, aus dem das Brot gebacken werden soll, höchst erwünscht.

Für die Ernährung sind ferner die Salze der Körner, welche zwischen 0,5-3 Proc. des lufttrocknen Kornes ausmachen, von Wichtigkeit, da die Asche reich an Kali und Phosphorsäure ist.

Schliesslich wird der Wert der Körner auch durch ihren Wassergehalt, der zwischen 10-15 Proc. schwanken kann, bedingt.

Die hier folgende Tabelle bringt eine Uebersicht der einzelnen Bestandteile nicht nur der Körner, sondern auch des Strohes und der Spreu und haben wir uns hierbei an die Zusammenstellungen von Analysen durch Dietrich und König ${ }^{1}$ ), sowie durch J. Kühn in der Hauptsache gehalten.

1) Zusammensetzung u. Yerdaulichk. d. Futterst. Berlin, 1874. 


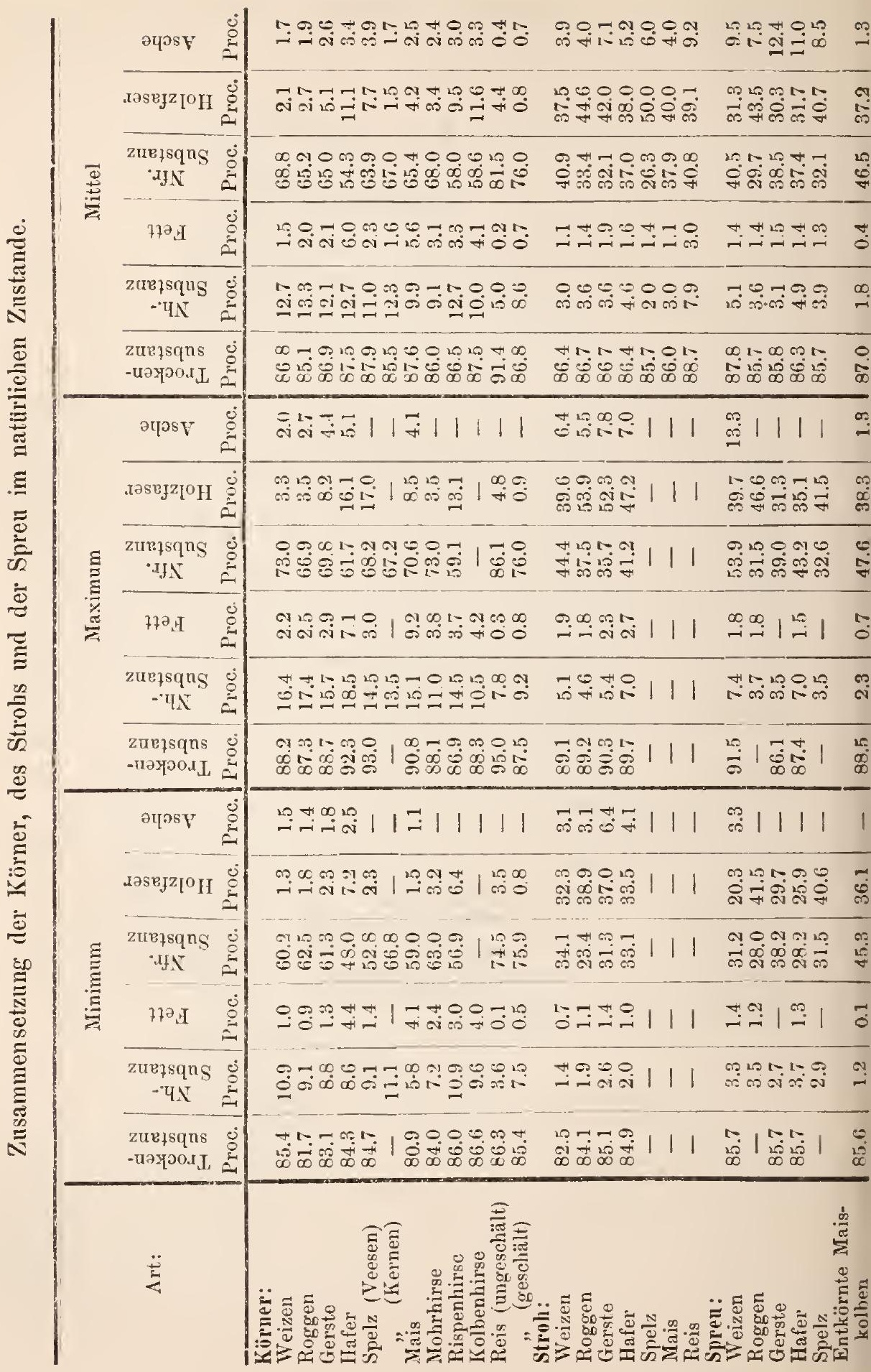




\section{Getreideproduktion, Getreidekonsumtion und Getreidehandel.}

Zunächst sollen Produktion und Konsumtion des Getreides einer Betrachtung unterzogen werden und beginne ich mit denjenigen Ländern, wclche ilıren Getrcidebedarf durch eigne Produktion nicht zı decken vermögen, denen diejenigen folgen, welche einen Mehrexport aufweisen.

Ich bemerkc jedoch ausdrücklich, dass die aufgestellten Berechnungen auf absolute Genauigkeit kcinen Anspruch crheben können, da bekanntlich die Zalılen der Produktions- nutd Konsumtions-Statistik zur Zcit noch sehr zweifelvoll sind.

Um vergleichbare Zahlen zu erhalten, sind die Anbauflächen in Hektare, die Erträge in Hektoliter und die Geldwerte in Mark umgerechnet worden. Das Durelischnittsgewicht pro $1 \mathrm{hl}$ ist beim Weizen anf $75 \mathrm{~kg}$, beim Roggen auf $73 \mathrm{~kg}$, bei der Gerste auf $64 \mathrm{~kg}$, beim Hafer auf $46 \mathrm{~kg}$, beim Mais auf $78 \mathrm{~kg}$ angenommen.

\section{Grossbritannien und Irland.}

Es betrig 1878 das Ackerland 94.138 qklm oder 29.8 Proc. der Gesammtfäche, wovon 14.5 Proc. mit Weizen, 0.3 Proc. mit Roggen, 11.1 Proc. mit Gerstc und 18.5 Proc. mit Hafer bestellt waren.

Der Weizen ist die Hauptbrotfrucht und wird am stärksten in den östliehen Grafschaften gebaut, von denen Lincoln, York und Essex $3600000 \mathrm{hl}$, ungefähr ein Vicrtel der Weizenproduktion iiberhaupt, liefern. Das beste Weizenland besitzen die Grafschaften York, Lincoln, Lancaster, Huntingdon, Northampton, Cambridge, Kent, welche einen Mittelertrag von $29 \mathrm{bl}$ p. ha aufbringen. sich fiür

Der 16jälırige (1852-1867) Weizcndurcbschnittsertrag stellt

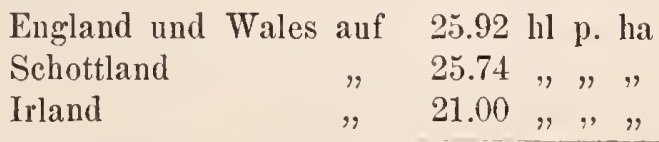

das Königreich auf: $24.40 \mathrm{hl} \mathrm{p.} \mathrm{La.}$

Die Minimalerträge betragen $12.5 \mathrm{hl}$, die Maximalerträge ${ }^{1}$ ) 59 hl p. ha.

1) Mc. Culloch. A descript. and statist. Acc. of the Brit. Empire. I. 1847. 
Auf den reichen Lehmböden werden überwiegend anspruchsvolle weisse und rote Winterkolbenweizen, mit starkem Halm und kräftiger Belaubung, welche nicht leicht lagern, und auf den schweren Clayböden vorwiegend bauchige (englische) Weizen (Trit. turgidum) gebaut, welche hohe Erträge bringen und nicht lagern, jedoch ein sehr kleberarmes Korn producieren.

Ueberhaupt lässt die Qualität der in England gebauten Weizen za wünschen, denn bekanntlich ist das Korn in dem feuchten Klima weich und reich an Stärkenehl, aber rerhältnissmässig arnı an Kleber und letzterer von geringer Qualität, weshalb das daraus gewonnene Mehl erst durch Zusatz von Mehl der kleinkörnigen, harten, kleberreichen Weizen des Kontinentalklimas gut verbackbar wird.

In günstigen Jahren beträgt das Volumengewicht des Weizens $78 \mathrm{~kg}$, in ungiinstigen $75 \mathrm{~kg}$ und in Mitteljahren $76 \mathrm{~kg} \mathrm{p}$. ha.

Der Roggen wird in sehr geringem Umfange und zwar hauptsächlich in Northumberland und Durbam, und meist im Gemenge mit Weizen, der darin von $1 / 8-7 / 8$ schwankt, als sog. "maslin" oder Mischel kultiviert.

Früher wurde dagegen der Roggen als Brotfrucht sehr ausgedehnt gebaut, so gibt Mr. Charles Smith ${ }^{1}$ ) an, dass 1765 in England und Wales noch ein Siebentel der Bevölkerung von Roggenbrot lebte. Dieses auffallende Nachlassen des Roggenbaues hat seinen Grund darin, dass sich die arbeitende Bevölkerung vom Roggenbrot abwendete, und auch bei der verbesserten Kultur in dem Seeklima Englands Weizen und Gerste selbst auf leichteren Böden höhere Erträge abwarfen. Dagegen benutzt man jetzt noch den Roggen sehr häufig als zeitiges Grünfutter.

Die Gerste nimmt einen sehr herrorragenden Platz in der Getreideproduktion ein und gedeiht in dem Seeklima und auf den hochkultivierten Feldern eine Braugerste vorzliglicher Qualität. Zur Zeit wird meist die zweizeilige Chevalier-Gerste gebaut. Früher diente die Gerste in hervorragender Weise, z. B. in Wales, Westmoreland und Cumberland ebenfalls als Brotfrucht und gibt Charles Smith (1765) an, dass sich 739000 Menschen von derselben nährten.

Jetzt wird in den östlichen Grafschaften und hauptsächlich in Norfolk die Gerstenkultur sehr umfangreich betrieben. Die Erträge schwanken zwischen $21.55-57.47 \mathrm{hl}$ und der Durchschnitt beträgt 33 hl p. ha.

Die höchste jährliche Produktion ergiebt sich beim Hafer, welcher sehr stark in Schottland, England und Wales gebaut wird. In Schottland berorzugt man den dickkörnigen Hafer (Avena

1) Mc. Culloch, a. a. O. Vol. I. 1847, pg. 477. 
praegravis), sowic die schwarzen Hafersorten, welche letzteren sich auch als sehr geschätztes Pferdefutter iber England verbreitet haben, doch werden ausserdem sehr wertvolle, ungegrannte weisse Hafersorten angebaut.

In den Hochlanden Schottlands wird noch heute, wie auch friiher in England und Wales, viel Haferbrot verzehrt; nach Smith sollen noch 1765 in England und Wales 623.000 Menschen Haferbrot gegessen Laben.

Der englische Hafer zeichnet sich durch eine auffallend kräftige Vegetation und rorziigliche Qualität des Kornes ans.

Die Erträge scbwanken zwischen $17.96 \mathrm{hl}$ und $71.84 \mathrm{hl}$ und als Durchsehnitt sind $38 \mathrm{hl} \mathrm{p}$. ha anzunehmen.

Dic Getreideproduktion und Konsumtion Grossbritanniens und Irlands ${ }^{1}$ ) stellte sich für den Zeitraum 1866-1876 durchschnittlich pro Jahr folgendermassen:

\begin{tabular}{|c|c|c|c|c|c|}
\hline Getreideart & $\begin{array}{l}\text { Durch- } \\
\text { schnittl. An- } \\
\text { baufläche } \\
\text { in ha }\end{array}$ & $\begin{array}{l}\text { Jährliche } \\
\text { Produktion } \\
\text { in hl }\end{array}$ & $\begin{array}{c}\text { Ertrag } \\
\text { p. ha in } \\
\text { hl }\end{array}$ & $\begin{array}{l}\text { Preis p. } \\
1 \text { hl in } \\
\text { Mark }\end{array}$ & $\begin{array}{c}\text { Geldwert der } \\
\text { Gesammtpro- } \\
\text { duktion in } \\
\text { Mark }\end{array}$ \\
\hline $\begin{array}{l}\text { Weizen } \\
\text { Roggen } \\
\text { Gerste } \\
\text { Hafer }\end{array}$ & $\begin{array}{r}1503360 \\
23787 \\
1009200 \\
1331155\end{array}$ & $\begin{array}{r}36414720 \\
523000 \\
33603840 \\
50500000\end{array}$ & $\begin{array}{l}24.4 \\
22.0 \\
33.0 \\
38.0\end{array}$ & $\begin{array}{r}18.5 \\
12.0 \\
13.4 \\
9.0\end{array}$ & $\begin{array}{r}675493056 \\
6276000 \\
450290456 \\
45450000_{0}\end{array}$ \\
\hline Im Ganzen & 3867502 & 121041560 & 31.3 & 13.1 & 1586559512 \\
\hline
\end{tabular}

Nach dem Census von 1876 betrug die Bevölkerung 33500000 Köpfe, mithin sich pro Kopf der Bevölkerung eine Produktion von 3.6 hl Getreide ergiebt.

Der Konsum der hauptsächlichsten Brotfrucht, des Weizens, wird pro Kopf und Jahr jetzt an Stelle der alten Achtbushelnorm, welche auf im vorigen Jahrhunderte gesammelten Daten begründet war, als weniger Fleisch und Gemiise verzehrt wurden, auf $5.5^{2}$ ) Bushel oder ca. 2 hl angenommell.

Die Produktion an Weizen beläuft sich nach Abzug eines Saatquantums von $1.9 \mathrm{hl}$ pro ha auf $33860160 \mathrm{hl}$; der Getreidebedarf im Ganzen anf $67000000 \mathrm{hl}$, demgemäss ein Mehrimport von rund 1877.

1) Farmers Magazine 1866-1877. Monthly Rep. of the Departm. of Agric.

2) 6,3 Bush. in England und Wales, 4,2 Bush. in Schottland, 3,3 Bush. in Irland, 5,5 Bush. im Vereinigten Königreich, 6 Bush. in Gross-Britannien. Farmer's Magazine pg. 316. Vol. LXV. 1869. 
33140000 hl Weizen zu erfolgen hat, soll die Bevölkerung genïgend mit Brotkorn versehen werden.

Der durchschnittliche Mehrimport stellt sich wie folgt:

\begin{tabular}{l|r|r}
\hline & hl & $\begin{array}{c}\text { Wert in } \\
\text { Mk. }\end{array}$ \\
\hline Weizen & $\begin{array}{r}33140000 \\
\text { Gerste }\end{array}$ & $\begin{array}{r}614747000 \\
\text { Hafer }\end{array}$ \\
Mais & 100000000 & 107200000 \\
90000000 & 17000000 & 170000000 \\
\hline & 68140000 & 981947000
\end{tabular}

demnach betragen Gesammtprodnktion und Mehrimport $189181560 \mathrm{hl}$ oder 5.65 hl pro Kopf der Bevölkerung.

\section{Deutsches Reich.}

Das Ackerland umfasst 257672 qkim oder 47.8 Proc. der Gesammtfläche und werden davon mit Weizen 8.5 Proc., Roggen 23.0 Proc., Gerste 6.3 Proc., Hafer 14.1 Proc. bestellt.

Das grösste Areal wird demmach der Hauptbrotfrucht, dem Roggen, eingeräumt, wohl deshalb, weil sich die leichteren Böden besser für ihn als für Weizen eignen. Verhältnissmässig am wenigsten ist der Roggenbau im suidwestlichen Deutschland, z. B. in Württemberg, Baden und Elsass-Lothringen ansgedehnt.

Der Winterroggen nimmt 96.53 Proc. und der Sommerroggen nur 3.47 Proc. des Roggenlandes ein, letzterer bleibt auch 25 Proc. im Korn und 20 Proc. im Stroh in seinen Erträgen gegen Winterroggen zurück.

Auf sehr geringem Roggenlande liefert der Winterroggen $4.3-8.6 \mathrm{hl}$, anf besserem 10.7-12.9 hl und auf sehr gutem 17--39 hl, doch sind bei Wettkulturen in Königreich Sachsen schon $53.4 \mathrm{hl}$ p. ha erziclt worden.

Der Gesammtdurchschnitt stcllt sich aber $111 \mathrm{r}$ anf $14.4 \mathrm{hl}$ p. ha, und sind bei diesem geringen Durchschnittsertrage die sehr armen Ländereien, welche noch zu seiner Kultur herangezogen werden, in Rechnung zil bringen.

Auf den besseren Böden werden die sog. Staudenroggen, auf den geringeren die gewöhnlichen Landroggen gebaut.

Ein vorzüglicher Roggen gedeiht $1 \mathrm{~m}$ Wirsitz in Posen, Stargard in Pommern, Glogan in Schlesien, sowie in mehreren Teilen der Oberlausitz und des Flämings, wo die an und für sich guten 
Böden doeh immer noeh mehr für Roggen als für Weizen geeignet sind. Sehr sehweren und als vorzügliehes Saatgut bekannten Roggen liefert die Probstei in Holstein.

Das Volumengewicht beträgt $72-75 \mathrm{~kg}$ und im Mittel $73 \mathrm{~kg}$ p. hl, wäbrend der Sommerroggen meist $74-76 \mathrm{~kg}$ wiegt.

Der Weizenbau stelıt hinter dem Roggenban bcträehtlieh zurüek, da nur ein Dritteil des Areals, welehes der Roggen einnimmt, Weizen trägt. Die liöehsten Proeentsätze der Aekerfläehe werden im südwestliehen Dentsehland mit Weizen bestellt, und zwar in den Bezirken am oberen und unteren Lauf des Rheins, dann in Niederbaiern und Oberlsessen. Aber aueh in Nord-Deutsehland, namentlieh um Leobschiitz, Frankenstein. Wirsitz, auf Wittow, sowie in den Kreisen Inowrazlaw, Kulm, Graudenz und Pyritz, ferner auf dem Hellweg und Haarstrange in Westfalen wird vorzüglicher Weizen erzeugt. Dagegen nü̈ssen die Höhen des prenssischen und pommersehen Landriickens und das reehte Oderufer in Sehlesien wegen des allzuhäufigen Auswinterns fast ganz auf den Weizenbau verzichten.

Die dentsehen Landweizen sind kleinkörnige, kleberreiehe Sorten, die ein gutes Mehl lieferm, doeh werden in Nord-Dentsehland auf den grösseren Giitern und anelı am Niedcrrbein läufig englisehe Weizensorten kultiviert, die allerdings wohl höhere Ertrïge aufbringen, doeh meist leicht auswintern und kleberarm sind, daher sie sieh wenig zum Export nach England, das kleberreiche Sorten verlangt, eignen und bei der obwaltenden Konkurrenz der kleberreiehen überseeischen Sorten immer melı an Exportfähigkeit verlieren.

Von dem mit Weizen bebauten Areal kommen in Deutsehland 94.09 Proe. auf Winterweizen und nur 5.91 Proe. auf Sommerweizen. Im Allgemeinen wird in Siid-Deutsehland ein verhältnismässig grösseres Areal mit Sommerweizen als in Nord-Dentsehland besäet, z. B. in Sehwaben 22.6 Proe., in der Oberpfalz 34.7 und in Wiirttemberg. 35.8 Proe. der Weizenfläche.

Die Weizenerträge anf geringeren Böden schwanken zwiseheı 12.3-14.3 hl, auf den besseren zwischen 16.5 und 21 lil und auf den guten zwischen 25 nnd $39 \mathrm{hl}$, und der Durehschnitt beträgt 18.4 hl. Der Sommerweizen bringt durehsehnittlieh 20 Proc. weniger Korn.

Die lıöchsten Erträge, welche im Königreieh Sachsen bei Winterweizen erzengt wurden, stellen sich anf 52 hl p. ha.

Das Volumengewicht der Verkaufsware beträgt $73-78 \mathrm{~kg}$ und im Mittel $76 \mathrm{~kg} \mathrm{p.} \mathrm{hl}$. Der Sommerweizen wiegt meist $2 \mathrm{~kg}$ sehwerer.

Die Spelzweizen sind vorzugsweise in Wiirttemberg, dem nördlichen Baden, Hohenzollern und in Sehwaben verbreitet, aueh wird etwas Spelz in den gebirgigen Teil der Rheinprovinz, namentlieh in der Eifel und zwar häufig im Gemenge mit Roggen (Misehel), sowie 
auch in Thüringen und in Hintelpommern bei Pyritz gebaut, dagegen kommt der Emmer nur sehr selten am Rhein vor und in Thiiringen wird zuweilen auch Einkorn kultiviert.

Vom Spelz nimmt das grösste Areal der Winterspelz ein, nämlich 99.24 Proc., so dass nur 0.76 Proc. für Sommerspelz verbleiben; das Wintereinkorn macht 88.19 Proc. und das Sommereinkorn nur 11.81 Proc. aus.

Die Erträge der Spelzweizen stellen sich sehr verschicden, z. B. kann beim Spelz der Ertrag an Veesen von 39-78 hl schwanken und wurden in Proskan auf vorziiglichem Boden selbst $85.74 \mathrm{hl}$ p. ha 1871 geerntet; rom Emmer berechnet sich der Ertrag auf armem Gebirgsboden häufig nur auf $13-18 \mathrm{hl}$, während sich 1871 in Proskau 83.82 hl ergaben; noch mehr überraschte die Ernte des Einkorns, die sich in der Regel auf armem Gebirgsboden auf 8-16 hl beläuft, dagegen in Proskan 84.09 hl p. ha betrug.

Die Veesen des Spelzes wiegen $40-47.6$ and im Mittel $45 \mathrm{~kg}$ p. hl, die des Emmers $40-49 \mathrm{~kg}$ und im Mittel $46 \mathrm{~kg}$; die des Einkorns 40-50 und im Mittel $45 \mathrm{~kg}$ p. hl.

Die Spelzweizen sind wegen ihrer nur lokalen Verwendbarkeit, denn ihr Volumen ist sehr gross und die entkernten Friichte verderben sehr leicht, nicht als Exportware anzusehen.

Die Gerste wird im stärksten Procentsatz von der Fläche in Hessen, Baiern, Wïrttemberg, Baden, in Teilen von Braunschweig, in Sachsen und Anhalt kultiviert und zwar auf den besseren Böden überwiegend die zweizeilige Gerste und namentlich die als vorzügliche Brangerste bekannte Chevalier-Gerste, auf den leichteren Böden dagegen die gewöhnliche vierzeilige Gerste. Der Anbau der Wintergerste ist sehr geringfiigig, denn sie nimmt nur 4.40 Proc. der Gerstenfläche ein und wird vorzugsweise in Elsass-Lothringen und den rom Seeklima beeinflussten Gegenden Nord-Deutschlands auf frischen humosen Böden gebaut.

Die Qualität der zweizeiligen Gerste ist vorzüglich, weshalb sie als Braugerste vielfach exportiert wird.

Die Erträge der Gerste stellen sich wie folgt:

\begin{tabular}{|c|c|c|c|c|c|c|c|c|}
\hline \multirow{3}{*}{ Sorte } & \multicolumn{3}{|c|}{$\begin{array}{l}\text { Qualität des } \\
\text { Gerstenbodens }\end{array}$} & \multirow{2}{*}{ 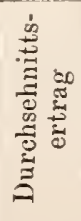 } & \multirow{2}{*}{ 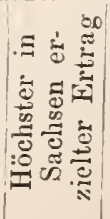 } & \multicolumn{3}{|c|}{$\begin{array}{l}\text { Hektolitergewicht } \\
\text { für Verkaufsware }\end{array}$} \\
\hline & gering & 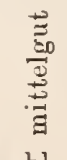 & gut & & & 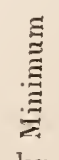 & 茯 & 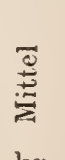 \\
\hline & $\mathrm{hl}$ & $\mathrm{hl}$ & hl & $\mathrm{hl}$ & $\mathrm{hl}$ & $\mathrm{kg}$ & $\mathrm{kg}$ & $\mathrm{kg}$ \\
\hline $\begin{array}{l}\text { Zweizeilige Gerste } \\
\text { Viezzeilige " } \\
\text { Wintergerste }\end{array}$ & $\begin{array}{c}15-17 \\
10-13 \\
-\end{array}$ & $\begin{array}{l}21-2 \\
15-2 \\
28-3\end{array}$ & $\begin{array}{l}0-40 \\
5-32 \\
7-50\end{array}$ & $\begin{array}{l}25 \\
18 \\
32\end{array}$ & $\begin{array}{l}95 \\
- \\
-\end{array}$ & $\begin{array}{l}62 \\
54 \\
54\end{array}$ & $\begin{array}{l}70 \\
62 \\
64\end{array}$ & $\begin{array}{l}64 \\
58 \\
58\end{array}$ \\
\hline
\end{tabular}


Der Haferbau wird sehr stark in Lothringen und Oberbaiern. sowie in einem zienlich grossen Distrikt zwischen Rhein und Weser, zu welchem Köln, Arnsberg, Wiesbaden, Kassel und Hildesheim gehören, ferner im Königreich Sachsen und in Oldenburg, nebst dem Bezirk Aurich betrieben.

Es werden jetzt meist sehr schöne ungegrannte wcisse Rispenhafer kultiviert, so nanentlich in der Weichselniederung, im Oderund Warthebruch, in der Probstei, auf der Insel Rügen, hier besonders auf der Halbinsel Wittow, und den höheren Gebirgen Schlesiens, sowie den Muschelkalkplateaus in Sachsen. Dic Kultur besserer Hafersorten ist cine Folge der Bodenverbesserung und der guinstigeren Steliung in der Fruchtfolge, welche der Hafer jetzt hăufiger als friher erhält. Zu Anfang dicses Jahrhunderts waren weniger diese schweren, ungegrannten Sorten, sondern überwiegend Grannenhafer in Kultur, wie Krause anführt, während letztere jetzt nur noch in armen Gebirgslagen angetroffen werden. Wahrscheinlich wurden die ungegrannten Rispenhafer zucrst aus England bezogen.

Die Erträge deś Hafers sind weit beträchtlicheren Schwankungen als die der anderen Fruchtarten unterworfen, weil er auf allen Bodenarten gedeiht und mit jeder Stellung in der Fruchtfolge vorlieb nimmt.

Demnach ergeben die geringsten Erträge $13-15 \mathrm{hl}$, die mittleren $21-38 \mathrm{hl}$, die höchsten $38-55 \mathrm{hl} \mathrm{p}$. ha und ist ein Durchschnittsertrag il Deutschland von $28.2 \mathrm{hl}$ anzunehmen. In Sachsen wurden Erträge bis zu 154.7 hl crzielt. pro hl.

Sein Volumengewicht beträgt 36-50 kg und im Mittel $46 \mathrm{~kg}$

Ausser diesen Hauptgetreidearten wird noch etwas Mengekorn gesäet, doclı zu einem grossen Teil als Grïnfutter verwandt.

Die S. 134 folgende Tabelle gibt eine Uebersicht der Anbauverhältnisse der Hauptgetrcidearten in den verschiedenen deutschen Gauen.

Den Umfang des Hirscbaus zeigt nachfolgende Uebersicht von 1878. Hiernach wurden besäet in:

\begin{tabular}{|c|c|c|c|c|c|c|}
\hline Preussen & 12205.8 & ha & $=0.07$ & Proc. & der & Ackerfläche \\
\hline Baiern & 2057.8 & , & $=0.07$ & $n$ & " & " \\
\hline Sachsen & 163.6 & 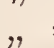 & $=0.02$ & 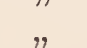 & , & , \\
\hline Württemberg & 135.0 & $"$ & $=0.02$ & ., &. & 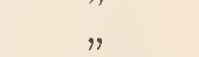 \\
\hline Baden & 28.6 & $\mu$ & $=-$ & , & $"$ & $"$ \\
\hline Hessen & 255.4 & , & $=0.06$ & ," & " & $"$ \\
\hline Elsass-Lothringen & 10.0 & , & $=-$ & , & ", & , \\
\hline Rest & 20.7 & & $=-$ & 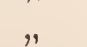 & , & , \\
\hline
\end{tabular}

In Preussen sind es die Provinzen Schlesien, Posen und Brandenburg, welche den stärksten Hirsebau besitzen, und ausserdem 


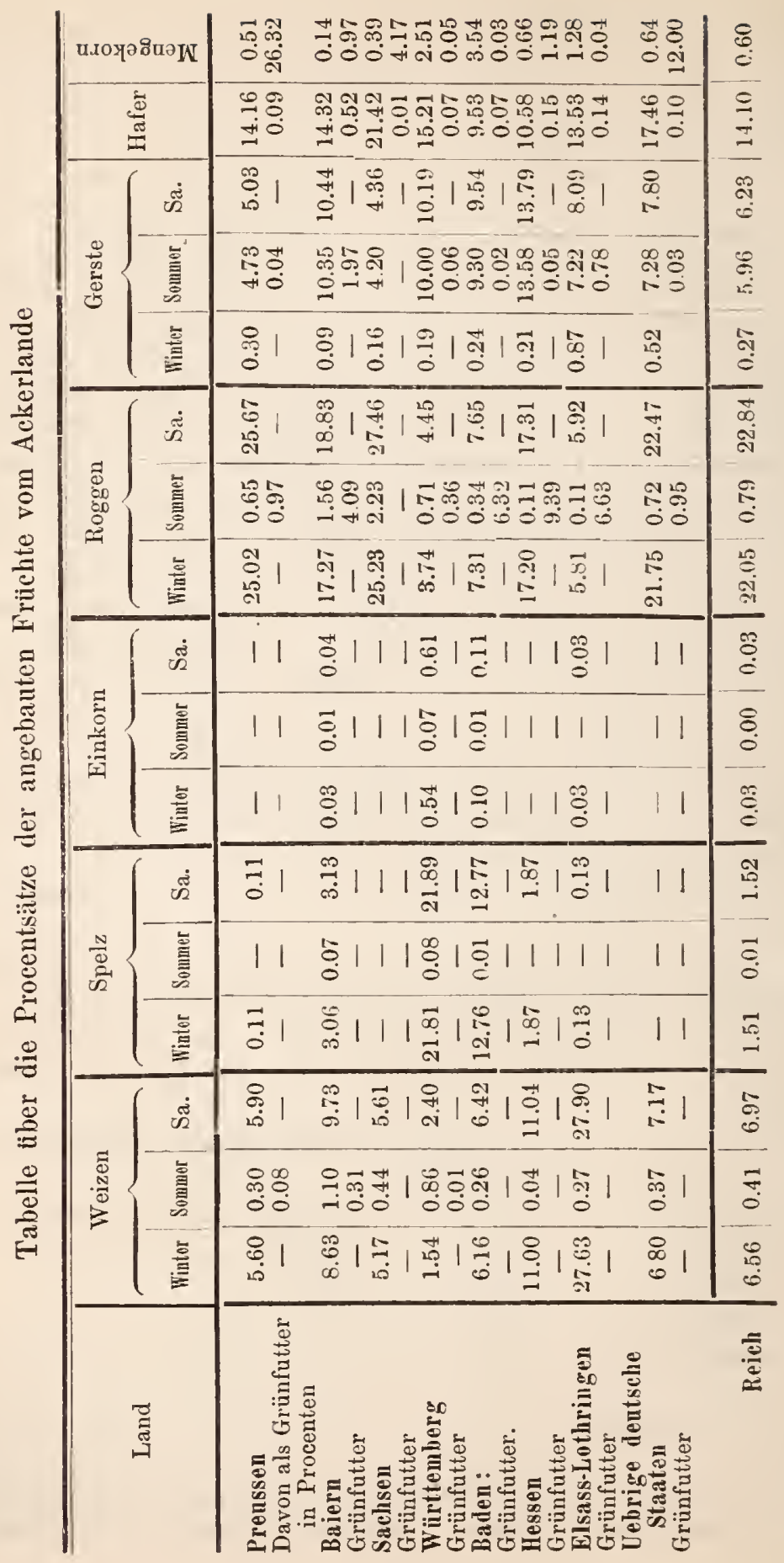


die Dörfer Malitzschkendorf und Jagsal im Kreise Schweinitz, am Südabhang des Fläming, die Kolonisten an der Netze und die Bauern in Masuren.

Ferner wird in Niederbaiern, in Sachsen, in der Lausitz, in Württemberg, im Neckar- und Jagstkreis und in Hessen in der Provinz Starkenburg Hirse gebaut. Ueberwiegend gelangt die Rispenhirse zur Kultur und nur ausnahmsweise im südwestlichen Deutschland die Kolbenhirse, denn da letztere eine sehr lange Vegetationsperiode besitzt, empfindlich gegen Frühjahrsfröste ist und nur in den wärmsten Lagen gedeiht, kanu sie nur unter besonders giinstigen Bedingungen kultiviert werden.

Die Erträge stellen sich in Minimo auf $8-12 \mathrm{hl}$, in Maximo auf $30-35$ hl und im Mittel auf $15-20$ hl p. ha.

Das Volumengewicht der Rispenhirse beträigt bei Verkaufsware $62-70 \mathrm{~kg}$ und im Mittel $65 \mathrm{~kg} \mathrm{l}$. hl.

Weit ausgedehnter als der Hirsebau ist dagegen der Maisbau. Bestellt werden in:

\begin{tabular}{|c|c|c|c|c|}
\hline & & & $\begin{array}{l}\text { Procent der } \\
\text { Ackerfläche. }\end{array}$ & $\begin{array}{l}\text { Davon zur Grün- } \\
\text { futternutzung. }\end{array}$ \\
\hline Preussen & 18722 & ba & 0.11 Proc. & $18264.5 \mathrm{ha}$ \\
\hline Baiern & 1216.6 &, & 0.04 & 378.6 \\
\hline Sachsen & 519.6 &, & 0.06 & 371.6 \\
\hline Württemberg & 2128.1 & $"$ & 0.24 & 149.8 \\
\hline Baden & 5417.6 & , & 0.88 & 2634.5 \\
\hline Hessen & 264.4 & $"$ & 0.07 & - \\
\hline Elsass-Lothringen & 4636.7 & , & 0.67 & 1076.8 \\
\hline Rest & 611.8 & $"$ & 0.03 & 428.1 \\
\hline
\end{tabular}

Hiernach wird Körnermaisbau eigentlich nur in Baden und hier hauptsächlich in den Kreisen Freiburg und Offenburg, im Elsass, in Wiirttemberg und zwar hauptsächlich im Neckarkreise und schliesslich noch in der Pfalz, in Unterfranken, in der hessischen Provinz Starkenburg und um Hanau betrieben.

Sehr beliebte Sorten sind in Baden der weisse Oberländer und gelbe Badenser-Mais; in Württemberg der gelbe Ellwanger und Cannstatter und im iibrigen Deutschland der Quarantino. Zur Grünfuttergewinnung werden meist die amerikanischen Pferdezahnsorten benutzt.

Was die Erträge angeht, so wurden nach der badischen Statistik von 1875 p. ha produciert im Kreise 


\begin{tabular}{|c|c|c|}
\hline Constanz & $1475 \mathrm{k}$ & $g=$ \\
\hline Freiburg & 1475, & $=$ \\
\hline Lörrach & 1610 & \\
\hline Offenburg & 1740 & \\
\hline Baden & 1710 & , \\
\hline Karlsioule & 1545 & , \\
\hline Mannheim & 2570 & $=$ \\
\hline Heidelberg & 1920 & \\
\hline Durchschnit & 375 & \\
\hline
\end{tabular}

Die Erträge schwanken zwischen 15 und $35 \mathrm{hl}$ und bringen im Mittel $22.5 \mathrm{hl} \mathrm{p}$. ha. Das Volumengewicht beträgt $72-80 \mathrm{~kg}$ und im Mittel $78 \mathrm{~kg}$ p. hl.

Die Produktion ${ }^{1}$ ) und Konsumtion der Hauptgetreidearten gestaltet sich wie folgt:

\begin{tabular}{|c|c|c|c|c|c|}
\hline Getreideart & $\begin{array}{c}\text { Anbaufläche } \\
\text { in ha }\end{array}$ & $\begin{array}{l}\text { Jahrespro- } \\
\text { duktion } \\
\text { in } 111\end{array}$ & 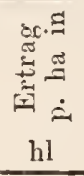 & 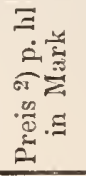 & $\begin{array}{l}\text { Geldwert der } \\
\text { Gesammt- } \\
\text { produktion } \\
\text { in Mark }\end{array}$ \\
\hline $\begin{array}{l}\text { Weizen und Spelz } \\
\text { Roggen } \\
\text { Gerste } \\
\text { Hafer }\end{array}$ & $\begin{array}{l}2200227 \\
5925675 \\
1617818 \\
3736168\end{array}$ & $\begin{array}{r}36512306 \\
85500000 \\
35100176 \\
105500000\end{array}$ & $\begin{array}{l}18.4 \\
14.4 \\
21.7 \\
28.2\end{array}$ & $\begin{array}{r}15.75 \\
11.68 \\
10.88 \\
6.90\end{array}$ & $\begin{array}{l}575068820 \\
998640000 \\
381889915 \\
727950000\end{array}$ \\
\hline Im Ga & $134^{\prime}$ & 262612482 & 20.0 & 10.2 & 5 \\
\hline
\end{tabular}

Die Bevölkerung des Deutschen Reiches beträgt 42727360 Seelen, mithin pro Kopf eine Produktion von 6.1 hl Getreide entfällt.

Nach Gaus ${ }^{3}$ ) wird der Gesanmtkonsum an Brotgetreide pro Kopf' der Bevölkerung geschätzt (excl. Hiilsenfriichte 0.11 hl);

in den Städten auf dem Lande

\begin{tabular}{|c|c|c|}
\hline Weizen & $0.54 \mathrm{hl}$ & $0.18 \mathrm{hl}$ \\
\hline Roggen & 1.64, & 1.87, \\
\hline Gerste & 0.05 & 0.27 \\
\hline Hafer & 0.02 & 0.18, \\
\hline
\end{tabular}

1) Die Produktion ist aus den Angaben der Monatshefte zur Statistik des Deutschen Reichs für die Jahre 1878 und 1879 berechnet.

2) Die Preise sind aus den Durchschnittspreisen der Jahre 1878 und 1879 berechnet. Monatsh. z. Statist. d. Deutsch. Reichs. Februarheft 1880.

3) Meitzen, Boden u. d. landw. Verhält. d. preuss. Staats. Bd. III, pg. 388 u. folgde. 
Obige Schätzung erfolgte für den Zeitraum 1831-1853 und lässt sich für die heutige Zeit bei gestiegenem Wohlstande und verminderter Kartoffelnabrung ein Konsum an Brotgetreide von $2.5 \mathrm{hl}$ pro Kopf annelimen.

Das Getrcidequantum, welches zu andercn Zwecken als zu Brotgetreide in Deutschland verwandt wird, beziffert sich selr hoch, denn trotz einer Produktion von $6.1 \mathrm{hl}$ pro Kopf findet noch eine bedeutende Mehreinfuhr an Gctreide statt.

Nach "Monatshefte zur Statistik des Deutsehen Reichs" ergicbt sich für die Jahrgäinge 1877 und 1878 nachfolgende durchschnittliche Ein- und Ausfuhr:

\begin{tabular}{|c|c|c|c|}
\hline Getreideart & $\begin{array}{c}\text { Einfuhr } \\
\text { in hl }\end{array}$ & $\begin{array}{c}\text { Ausfuhr } \\
\text { in } h l\end{array}$ & $\begin{array}{l}\text { Mehrein- } \\
\text { fuhr } \\
\text { in hl }\end{array}$ \\
\hline $\begin{array}{l}\text { Weizen } \\
\text { Roggen } \\
\text { Gerste } \\
\text { Hafer }\end{array}$ & $\left\{\begin{array}{r}13467600 \\
14739000 \\
7357840 \\
7145640\end{array}\right.$ & $\begin{array}{r}10250913 \\
2574440 \\
3478450 \\
3109420\end{array}$ & $\begin{array}{r}3216687 \\
12164560 \\
3879390 \\
4036220\end{array}$ \\
\hline Im Ganzen & 42710080 & $|19+13223|$ & $2329685 i$ \\
\hline
\end{tabular}

Nach Wilhelmi ${ }^{1}$ ) betring die jährliche Durchschnitts-Mehreinund Mehrausfuhr für den Zeitraum 1871/75

$\begin{array}{lr}\text { beim Roggen rund Mehreínfulr } & 7400000 \mathrm{hl} \\ \text { bei der Gerste " } & 1800000 ", \\ \text { beim Hafer " } & 2140000 ", \\ \text { beim Weizen rund Mehreinfuhr } & 650000 \% \\ \text { Durchschnittsmehreinfuhr } & 10690000 \mathrm{hl}\end{array}$

welche Mehreinfuhr sich also 1877/78 auf 23296857 hl Getreide gesteigert hat.

Auf absolute Richtigkeit können diese Zahlen keinen Anspruch erheben, da bekamntlich die Warcn-Einfuhr mit grösserer Zuverlässigkeit als die Waren-Ausfuhr nachgewiesen wird, so dass die Ausfuhrzahlen in den Kommerzial-Uebersichten bis zu 20 und 25 Proc. hinter der Wirklichkeit zurïckbleiben können.

Die Gesammtmenge des Konsumgetreides beträgt einschliesslich der Mehreinfubr 285909339 hl.

1) Landw. Kalender v. Mentzel \& Lengerke. 1878 pg. 7 u. flgde. 
Verbraucht werden:

an Saatgetreide ( $1 / 6$ der Produktion). 49932700 bl Brotgetreide (2.5 hil pro Kopf) . 106818400 " Malz 17700000

., Getreide zur Spiritusfabrikation 5200000 Hafer zur Pferdefütterung (3352582 Pfercle à $30 \mathrm{hl}$ pro Jahr) .

100577460

Nachweisbarer Verbrauch: $280228560 \overline{\mathrm{hl}}$

Nicht nachweisbarer Verbrauch:

Futter und diverse Fabrikate $5.680 .779 \mathrm{hl}$ der Konsum pro Kopf der Berölkerıng beträgt 5.5 bl (excl. Saatgetreide.)

\section{Frankreich.}

Das Ackerland umfasst in Frankreich 263008 qklm odel 49,7 Proc. der Gesammtfäche; ron der Ackerfläche werden 26 Proc. mit Weizen, 1,8 Proc. mit Mengekorn, 7 Proc. mit Roggen, 4 Proc. mit Gerste, 2,5 Proc. mit Mais und 12,4 Proc. mit Hafer besäet.

Das Hauptbrotgetreide ist der Weizen und werden die anspruchsvolleren Kolbenweizen, und zwar iiberwiegend Weissweizen, von denen viele Sorten urspriinglich aus England stammen, im Norden Frankreichs angebaut, und gilt der Weizen der Normandie, der Bretagne und ron Anjou als gute halbmellige Exportware. Im mittleren und siidlichen Frankreich treten häufiger Bartweizen, sowie auch Igelund Binkelweizen auf und ist namentlich der Weizen der Ebenen ron Toulouse, Castelnaudary und Arles sehr geschätzt.

Im siidlichen Frankreich beherrschen die bauchigen oder englischen Weizen (Trit. turgidum), sowie auch die Hartweizen (Trit. durum) und selbst die polnischen Weizen (Trit. polonicum), sehr ausgedehnte Anbaugebiete. Der bauchige oder englische Weizen wird im Sïden in den Thälern der Auvergne, im Tieflande des Languedoc, in der Gascogne, Provence, Dauphiné und in Saroyen, anderseits aber auch in Anjou, in der Normandie und in Flandern auf den schwersten Böden kultiviert.

Die Hartweizen sind vorzugsweise in der Gascogne, Aurergne, Prorence, in Saroyen, in der Beauce und Touraine verbreitet.

Die Spelzweizen werdea in den Gebirgen Siid-Frankreichs ziemlich umfangreich kultiviert.

Die Qualität der französischen Weizen (Trit. vulgare) ist eine vorzügliche und kommen namentlich sebr duinnschalige kleberreiche weisse und rote Sorten ror. 
Der Weizenertrag stellt sich in Frankreich im Allgemeinell sehr niedrig, so werden nach Heuzè auf armen Böden nur $6-8 \mathrm{hl}$, auf guten $16-20 \mathrm{hl}$ und auf sehr fruchtbaren Böden $30-40 \mathrm{hl}$ geerntet, und nach nnseren Berechnungen ergiebt sich eine Mittelernte von $14,5 \mathrm{hl} \mathrm{p}$. ha.

Es wiegt $1 \mathrm{hl}$ Weizen erster Qualitït $80-82 \mathrm{~kg}$, schlechtester Qualität 73-75 kg und im Mittel $78 \mathrm{~kg}$.

Ferner ist der Anbau von Roggen und Weizen als Mengekorn oder Mischling (Froment seigleux oder Méteil) auf Böden mittlerer Fruchtbarkeit, die sich also für eine Reinsaat von Weizen weniger als für Mischling eignen, sehr beliebt. Dieser Mischling ist als ,metellum" schon seit 1638 bekannt und heisst jetzt in dem Langnedoc „Mescle", in der Provence "Cossegail“, in der Bretagne „Méleard", in Burgund "Conceau," in der Picardie „Muison".

Herrscht in dem Mischling der Weizen vor, so wird er auch "gros ou passe-méteil" genannt, und ist dies mit dem Roggen der Fall „petit méteil".

Es scheint jedoch nit der steigenden Kultur der Mischelbau abzunehmen, wie folgender Nachweis erkennen lïsst:

$\begin{array}{cccc}\text { Jahrgang. } & \text { Areal } & \begin{array}{c}\text { Eltrag } \\ \text { p. ha }\end{array} \\ 1840 & = & 910.933 \mathrm{ha}= & 12.90 \mathrm{hl} \\ 1852 & = & 572.985 " & =14.26 " \\ 1862 & = & 514.412 " & =15.49 " \\ 1871 / 78 & = & 471.593 " & =14.30 "\end{array}$

Das Mehl liefert ein gutes, bei den Landbewohnern sehr geschätztes Brot.

Der Roggen hat dagegen als Brotgetreide fur Frankreich nur eine sehr geringe Wichtigkeit, obwohl derselhe früher ebenfalls die Hauptbrotfrucht bildete, und noch im 16. Jahrhundert ein grosser Teil der Bevölkerung Roggenbrot ass.

Jetzt ist der Roggen auf die leichtesten Böden zurïckgedrängt. Beachtenswert sind: Seigle des Alpes ou de Montagne, der in der Provence und Champagner-Hybrid, der in der Champagne gezogen wird.

Der Roggen bringt in Frankreich folgende Erträge:

$\begin{array}{lc}\text { armer Boden } & 8-10 \text { hl p. ha } \\ \text { mittlerer " } & 15-18, " \text { " " } \\ \text { guter " } & 22-25 " \text { " " } \\ \text { sehr fruchtbarer } & 30-35 " \text { " " } \\ \text { und im Mittel } & 13.7 " \text { " " }\end{array}$

Das Volumengewicht beträgt $68-75 \mathrm{~kg}$, im Mittel $72 \mathrm{~kg}$.

Die Gerstenproduktion steht in Frankreich noch hinter der des Roggens zuriick. 
Wintergerste wird rorzugsweise in Nord-Frankreich, namentlich in Flandern, in der Normandie und Artois kultiviert; hier und in allen Departements mit frischen Böden baut man ferner die zweizeilige Gerste und zwar iiberwiegend die Chevalier-Gerste für Brauzwecke an, wällirend auf den ärmeren Böden und im Süden die vierund sechszeilige Gerste, zuweilen auch nackte Gerste und zu Paillerols, Basses-Alpes etc. auch die schwarze zweizeilige Gerste vorkonmt.

Auf den ärmeren Böden schwankt der Ertrag der Sommergerste zwischen 11-14 hl, auf den reicheren zwischen $24-41 \mathrm{hl}$ und das Mittel beträgt 17.06 hl p. ha. Die Wintergerste bringt dagegen $50-70 \mathrm{hl}$ und im Mittel $60 \mathrm{hl}$ p. ha.

Es wiegt durchschnittlich in Frankreich die Kaufgerste $61 \mathrm{~kg}$ und

$\begin{array}{lll}\text { vierzeilige Gerste } & 58-62 \mathrm{~kg} \\ \text { zweizeilige } & 65-68, \\ \text { nackte } & , & 70-75,\end{array}$

Der Maisban, obgleich die Produktion zur Zeit nur ein Zehntel der des Weizens beträgt, scheint jedoch nicht unerhebliche Fortschritte im Süden Frankreichs zu machen; so wurden 1862 nur 8648116 hl, dagegen im Durchschnitt der Jahre 1871/78 10607591 hl produciert und bildet sogar der Mais in einigen Gegenden, z. B. in den Pyrenäen, die Hauptnahrung der Bevölkerung.

Sein Hauptverbreitungsbezirk liegt in Béarn, Navarra, Guyenne, Languedoc, Burgund und Franche-Comté; doch findet er sich auch in den Ebenen von Poitou, im südlichen Teil der Champagne und reicht bis Nancy.

Auf den leichten und armen Böden werden 16 bis $20 \mathrm{hl}$, dagegen auf reichen und zumal bewässerten Böden 35-40 und selbst 50 hl geerntet, doch stellt sich der Durchschnittsertrag nur auf $16.4 \mathrm{hl} \mathrm{p.} \mathrm{ha.}$

Das Gewicht der Handelswaare beträgt $72-75 \mathrm{~kg}$ p. hl, doch schwankt das Gewicht bei weniger gut ausgetrocknetem Mais zwischen 68 und $70 \mathrm{~kg} \mathrm{p}$. hl, und als Durehschnitt lassen sich $72 \mathrm{~kg}$ p. hl annehmen.

Im Allgemeinen sind die gelben Maissorten ertragreicher als die weissen.

Vom Hafer wird nur höchst selten exportiert, da er als Hauptfutter der Pferde namentlich in grossen Mengen in Paris verbraucht wird.

Die reichen Lehmböden Nord-Frankreichs werden meist mit sehr wertvollen englischen Hafersorten bestellt, doch besitzt Frankreich auch sehr gute einheimische Sorten, so gedeihen in Flandern und Artois geschätzte Goldhafer, in del Brie, Champagne, Beauce, Picardie und Houdan rorziigliche feinschalige und ertragreiche 
schwarze und braune Hafersorten, sowie im Westen und Südwesten sehr ertragreichc Winterhafer.

Ausserdem wird anf den Bergen der Auvergne der kurze oder Fliegenfusshafer (Avoine courte, on pied dle mouche) angebaut.

Geerntet werden an Hafer:

auf armem Boden

, mittlerem ,

"gutem ,

" sehr fruchtbarem Boden
$8-10$ hl p. ha

$20-25, ", "$

$35-40, ", "$,

$50-70, ", "$

Die mittlere Produktion zeigt eine entschiedene Steigerung, denn der Durchschnittsertrag stellte sich 1840 anf $16.30 \mathrm{hl}$ und ist 1871/78 anf $22.6 \mathrm{hl} \mathrm{p.} \mathrm{ha} \mathrm{gestiegen.} \mathrm{Geringer} \mathrm{Hafer} \mathrm{wiegt} 35-45 \mathrm{~kg}$, schwerer $48-54 \mathrm{~kg}$, Winterhafer $50-56 \mathrm{~kg}$, kleiner nackter Hafer $63-65 \mathrm{~kg}$, grosser nackter Hafer $66-68 \mathrm{~kg}$, und der Durchschnitt fiir gewöhnlichen Hafer beträgt $46 \mathrm{~kg}$ p. hl

Ausser diesen Hauptgetreidearten wird in Frankreicl auch noch Mohrhirse, sowie Kolben- nnd Rispenhirse, wenu anch nur in geringem Umfange angebaut.

Im südlichen Frankreich und zwar hauptsächlich auf dem reichen Alluvialboden des Rhonethales gedeiht auch die Besenmohrhirse und bringt Erträige von $40-50$ hl (à $65-70 \mathrm{~kg}$ ) Korn, und $4200-4300 \mathrm{~kg}$ Rispen zu Besen p. ha, und kann der Gesammtwert der Ernte 1360-1440 M. p. ha betragen.

Die Kolbenhirse gibt einen etwas höheren Ertrag als die Rispenhirse, ist aber weniger geschätzt.

In Frankreich wurden 1878 mit Hirse 50193 ha bebaut, welehe $744368 \mathrm{hl}$, also $14.8 \mathrm{hl}$ pro ha lieferten.

Die Erträge der Rispenhirse schwanken zwischen 10 und $20 \mathrm{hl}$, die der Kolbenhirse zwischen $15-30 \mathrm{hl}$ p. ha.

Das Volumengewicht der Rispenhirse beträgt $62-65 \mathrm{~kg}$, das der Kolbenhirse $66-70 \mathrm{~kg} \mathrm{p}$. hl.

Die Produktion und Konsumtion der Hauptgetreidcarten Frankreichs ergiebt sich nun aus folgender Zusammenstellung:

In Frankreich ${ }^{1}$ ) stellte sich die Getreideproduktion für einen Zeitraum von 8 Jahren (1871/78) wie folgt:

1) Barral, Journ. de l'Agric. 1874-79. 


\begin{tabular}{|c|c|c|c|c|c|}
\hline Getreicieart & $\begin{array}{c}\text { Durch- } \\
\text { schnittliche } \\
\text { Anbaufläche } \\
\text { in ha }\end{array}$ & $\begin{array}{l}\text { Jährliche } \\
\text { Produktion } \\
\text { in hl }\end{array}$ & $\begin{array}{c}\text { Er- } \\
\text { trag } \\
\text { p. ha } \\
\text { hl }\end{array}$ & $\begin{array}{l}\text { Preis } \\
\text { p. hl } \\
\text { in } \\
\text { Mark }\end{array}$ & $\begin{array}{l}\text { Geldwert der } \\
\text { Gesanmmt- } \\
\text { produktion } \\
\text { in Mark }\end{array}$ \\
\hline $\begin{array}{l}\text { Weizen } \\
\text { Mengkorn (Rogger }\end{array}$ & 6822335 & 98854621 & 14.5 & 17.60 & 1739841330 \\
\hline Weizen) & 471593 & 6751290 & 14.3 & 13.60 & 91817544 \\
\hline Roggell & 1849641 & 25191115 & 13.7 & 11.50 & 289697822 \\
\hline Gerste & 1064157 & 18 & 17.06 & 10.30 & 186986241 \\
\hline Mais & 644976 & 10607591 & 16.4 & 1000 & 106075910 \\
\hline Hafer & 3281372 & 74204648 & 22.6 & 8.00 & 593637104 \\
\hline Im Ganzen: & 14135074 & 233763269 & 16.5 & 13.3 & 3008056031 \\
\hline
\end{tabular}

Was den Import angeht, so wurden von 1820-1867 also in 47 Jahren 84 Millionen hl Weizen im Ganzen importiert, je naeh dem Einteausfall trat jedoch im Laufe dieser Jahre sehr häufig ein bedeutender Export ein. Unter den 47 Jahren waren 28 Jahre mit einer Mehreinfuhr von 129 Millionen hl und 19 Jahre mit einer Mehrausfuhr von 45 Millionen hl Weizen. Seit $1866 \mathrm{kam}$ nun eine Mehrausfuhr ron Weizen nicht mehr vor und wurden im achtjährigen Durchschnitte (1867/74) jährlich $6645733 \mathrm{hl}$ Weizen eingeführt.

Der mittlere Brotkonsum belïuft sich pro Tag und Kopf auf $582 \mathrm{gr}$ oder $450 \mathrm{gr}$ Getreide und das Quantum des Getreidekonsums überhaupt auf $5.8 \mathrm{hl}$ pro Kopf, mithin berechnet sich der Gesanmtkonsum bei einer Berölkerung ron 36100000

Seelen zu

Hierzu tritt das Saatgut $(1 / 6$ der Produktion)

Gesanmtkonsum:

Die Prociuktion incl. Weizeneinfuhr beträgt:

mithin durch Einfuhr anderer Getreidearten zu decken sind: Die Mehreinfuhr beträgt demnach bein Weizen:

bei anderem Getreide:

Im Ganzen :

Hierzu die Jahresproduktion:

Gesammtkonsum :
$209380000 \mathrm{hl}$

39000000 ,

$248380000 \mathrm{hl}$

240409002

7970998 hl.

$6645733 \mathrm{hl}=116964901 \mathscr{M}$ $7970998, \quad=\quad 79709980$

$14616731 \mathrm{hl}=196674881 \mu$ $233763269,=3008056031$,

$248380000 \mathrm{hl}=3204730912 \mathscr{M}$ 


\section{Oesterreich-Ungarn.}

Das Ackerland umfasst in Oesterreicl-Ungarn 101563 qklm oder 33.8 Proc. der Gesammtfläche, und werden von der Ackerfläche 9.6 Proc. mit Weizen, 19.2 Proc. mit Roggen, 11 Proc. mit Gerste, 17.6 Proc. mit Hafer und 3 Proc. mit Mais bestellt.

Die Anbanflächen der Getreidearten verhalten sich zu der Gesammtfläche in den verschiedenen Ländern Oesterreichs ${ }^{1}$ ) wie folgt:

\begin{tabular}{|c|c|c|c|c|c|c|c|c|c|}
\hline Land & $\begin{array}{c}\frac{\Xi}{\tilde{\Sigma}} \\
\frac{0}{2} \\
\text { Proc. }\end{array}$ & $\begin{array}{c}\approx \\
0 \\
\infty 0 \\
0 \\
0 \\
\simeq \\
\text { Proc. } \\
\end{array}$ & 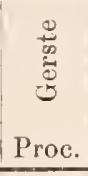 & 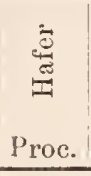 & $\begin{array}{l}\stackrel{\infty}{\pi}_{\vec{\pi}} \\
\text { Proc. } \\
\end{array}$ & 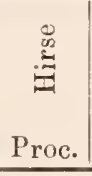 & 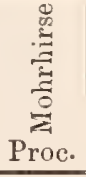 & $\begin{array}{c}\frac{N}{0} \\
\infty \\
\text { की } \\
\text { Proc. }\end{array}$ & $\begin{array}{l}\stackrel{\infty}{\infty} \\
\text { Proc. } \\
\end{array}$ \\
\hline Niederösterreich & 10.09 & 22.63 & 8.01 & 20.42 & 1.19 & 一 & 一 & 一 & - \\
\hline ster & 12.23 & 22.30 & 10.16 & 18.23 & - & - & - & 一 & - \\
\hline Salzburg & 15.75 & 20.31 & 3.29 & 15.63 & 一 & - & - & - & - \\
\hline Steiermark & 14.44 & 18.33 & 3.53 & 17.83 & 9.85 & 195 & - & - & 一 \\
\hline Kärnten & 11.95 & $29.5^{\prime 2}$ & 6.86 & 17.65 & 5.73 & 2.08 & - & - & - \\
\hline Krain & 12.98 & 11.35 & 9.60 & 13.47 & 11.02 & 7.85 & - & - & - \\
\hline Tirol & 8.52 & 17.66 & 8.07 & 5.99 & 407 & 一 & 一 & - & - \\
\hline Süd-' & 17.03 & 23.40 & 5.86 & 2.47 & 33.88 & 0.03 & - & - & - \\
\hline Vor: & 17.11 & 4.85 & 6.28 & 8.01 & 19.41 & - & - & 一 & 一 \\
\hline Böhr & 9.82 & 23.20 & 11.26 & 16.97 & - & - & 一 & - & - \\
\hline en & 4.93 & 21.02 & 9.58 & 23.44 & - & - & 一 & 一 & - \\
\hline Iäb & 5 & 22.85 & 11.14 & 19.42 & 0.73 & 0.81 & - & 一 & - \\
\hline $\mathrm{Bul}$ & 6.27 & 11.42 & 13.76 & 13.98 & 29.94 & 0.50 & - & - & - \\
\hline izie & 6.79 & 16.14 & 8.85 & 20.51 & - & 0.23 & - & - & - \\
\hline Ostgalizien & 9.17 & 16.02 & 13.51 & 17.59 & 1.99 & 0.77 & - & - & - \\
\hline Görz und Gra & 26.85 & 5.11 & 5.43 & 4.14 & 37.13 & 0.18 & 1.53 & 0.95 & 0.70 \\
\hline Triest & 13.05 & 16.39 & 11.07 & 1.05 & 38.22 & - & & 2.97 & - \\
\hline & 20.90 & 4.05 & 11.90 & 5.53 & 27.64 & - & 3.14 & 6.76 & 一 \\
\hline Dalmatien & 12.37 & 3.12 & 27.53 & 3.14 & 26.63 & 5.82 & 3.17 & 6.04 & 一 \\
\hline
\end{tabular}

In Ungarn umfasst das Ackerland 115983 qklm oder 41.4 Proc. der Gesammtfläche und werden 20.8 Proc. mit Weizen, 10.8 Proc. mit Roggen, 7 Proc. mit Gerste, 8 Proc. mit Hafer, 12.5 Proc. mit Mais und 3 Proc. mit Mischfrucht besäet.

Die österreichischen Länder besitzen mit Ausnahme der Gebirgslandschaften ein Kontinentalklima und Ungarn sogar ein ausgesprochenes Steppenklima, daher demn auch die angebauten Weizensorten kleinkörnig und kleberreich sind. Dic besten Weizen producieren Ungarn, Galizien und Böhmen.

1) Statistisches Jahrb. d. k. k. Ackerbauminist. f. 1874 . Wien 1875. 
In Ungarn trägt vorzugsweise der erst seit ku'zer Zeit in Kultur befindliche Steppenboden harte und halbharte vorzügliche Weizen, während dasselbe Land bei reichlicherer Dïngung und längerer Kultur weichere und grössere Körner erzeugt.

In Ungarn werden fast ausschliesslich rotkörnige, gelbährige Bartweizen angebaut, die urspriirglich, nach dem gemeinsamen Typus zu urteilen, aus dem Banater Weizen hervorgegangen sind, und bildet dieser rote Bartweizen den Landweizen Ungarns und nur versuchsweise gelangen andere Sorten zum Anbau, ohne dass es ihnen bis jetzt geglïckt wäre, an Verbreitung zu gewinnen.

Dem Kleberreichtum verdankt dieser Weizen scinen Wert als Exportware, doch werden die Gebirgsweizen etwas weniger gut bezahlt, da sie in dem feuchteren Gebirgsklima an Qualität verlieren.

So wurden nach den antlichen Notirungen der Budapester Waren- und Effektenbörse folgende Preise in österr. Gulden am 18. August 1879 fuir diverse Sorten gezahlt:

\begin{tabular}{|c|c|c|c|c|c|c|}
\hline Weizen & 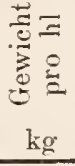 & $\begin{array}{c}\text { Preis } \\
100 \\
\text { von }\end{array}$ & $\begin{array}{l}\text { pro } \\
\mathrm{kg} \\
\text { bis }\end{array}$ & 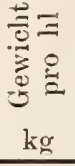 & \multicolumn{2}{|c|}{$\begin{array}{c}\text { Preis pro } \\
100 \mathrm{~kg}\end{array}$} \\
\hline Banater alt & 76 & 11.20 & 11.30 & 75 & 10.95 & 11.10 \\
\hline Theiss & 78 & 11.65 & 11.75 & 77 & 11.40 & 11.50 \\
\hline Theiss, & 76 & 11.25 & 11.35 & 77 & 1145 & 11.55 \\
\hline$" \quad "$ & 78 & 11.70 & 11.85 & 79 & 11.95 & 12.05 \\
\hline Pester Boden, alt & $\begin{array}{l}80 \\
76\end{array}$ & 12.15 & 12.25 & 81 & 12.30 & 12.35 \\
\hline$" \quad " \quad$ & 78 & 11.60 & 11.75 & 79 & 11.85 & 11.95 \\
\hline "urger, "alt & 80 & 12,20 & 1225 & $\overline{\pi 7}$ & - & - \\
\hline ger, alt & $\begin{array}{l}16 \\
78\end{array}$ & $\begin{array}{l}11.25 \\
11.70\end{array}$ & $\begin{array}{l}11.35 \\
1285\end{array}$ & $\begin{array}{l}77 \\
79\end{array}$ & $\begin{array}{l}11.45 \\
11.95\end{array}$ & $\begin{array}{l}11.55 \\
12.05\end{array}$ \\
\hline " $"$ & 80 & 12.12 & 12.25 & 81 & 12.20 & 12.35 \\
\hline Nord ungarischer, alt & 76 & 10.15 & 10.90 & 77 & 11.0 & 11.10 \\
\hline , & 78 & 11.20 & 11.30 & 79 & 11.45 & 11.55 \\
\hline$"$ & 80 & 11.65 & 11.75 & - & - & - \\
\hline
\end{tabular}

Aus dieser Zusammenstellung geht hervor, dass das Volumen gewicht, demnach auch die Qualität, hervorragend ist und zwischeu 75 und $81 \mathrm{~kg}$ schwankt, also im Mittel $78 \mathrm{~kg}$ beträgt.

Wertvolle rote Weizen erzengt auch Galizien und hat namentlich der Galizische Sommerweizen eine. weite Verbreitung gefunden.

Auch Böhmen zeichnet sich durch schöne rote Kolbenweizen aus, und sind der böbmische sammetige Kolbenweizen und der rote Wechselweizen a uch in anderen Ländern geschätzt.

Der Roggen wird ebenfalls in vorziiglicher Qualität in Ungarn geerntet, er ist klein, bellfarben, feinschalig, sehr schwer und 
die besten Sorten, wie Pester-Boden-, Nyirer-, Debrecziner-, Kecsiccmeter-Roggen besassen 1879 ein Volumengewicht von $81-82 \mathrm{~kg}$ p. hl, und ist dies für Verkaufsware ein aussergewölnnlich sehweres Gewicht.

Aneh Oesterreich und Böhnıen liefern vorziigliehe Roggen und haben sich von den angebauten sorten hauptsächlich der Klafterbrunner-, der böhmische Winterroggen-, sowie der böhmische Gebirgsstaudenroggen einer weiteren Verbreitung zu erfreuen.

Weniger befriedigt dagegen in Ungarn der Gerstenbau, weil die Braugersten unter dem cxeessiven Steppenklima leiden, denn sobald gegen die Reife hin, wie dies ziemlieh regelmässig in Steppenklima der Fall, die Witterung sehr heiss und trocken wird, verschrumpfen die Körner, werden dicksehalig und glasig, Qualitäten, welche für Braugerste nieht erwiinscht sind.

Damit ist num nicht ausgeschlossen, dass einige sehr begünstigte Lagen nicht doch gute Braugersten hervorbringen.

Das Gewieht der zweizeiligen Gerste, dic vorzugsweise in Ungarn angebaut wird, ist aber auffallend hoch und sebwankte nach unseren Untersuchungen mit Originalgersten zwischen 68 und $78 \mathrm{~kg}$ p. hl.

Sehr sehöne Braugersten werden in Böbmen, Mähren (Hannakisehe Gerste) und in Oesterreieh erzengt.

In Bezug auf den Hafer ist zn bemerken, dass in Ungarn vorzugswcise weisse Rispentafer und weniger Fahneu- oder Goldhafer kultiviert werden.

Einige von uns untersuchte Originalsorten aus den besten Gegenden ergaben nachfolgende Resultate:

\begin{tabular}{|c|c|c|}
\hline Name der Sorten & Beschaffenheit & $\begin{array}{l}100 \text { cbcm } \\
\text { wiegen g }\end{array}$ \\
\hline $\begin{array}{l}\text { Kaschauer Hafer } \\
\text { Graner ", } \\
\text { Bacskaer ", } \\
\text { Kanal " " } \\
\text { Viskolczer ", } \\
\text { Donau " } \\
\text { Slavonischer ", } \\
\text { Theiss }\end{array}$ & $\begin{array}{l}\text { sattgelb, kurz, dick, sehr schön } \\
\text { schön hellgelb, voll } \\
\text { hellgelb, voll } \\
\text { sattgelb, kurz, ziemlich voll } \\
\text { hellgelb, spitz, etwas lang } \\
\text { röthlicl, gelb, etwas spitz } \\
\text { hellgelb, lang, spitz }\end{array}$ & $\begin{array}{l}54.5 \\
53.0 \\
53.0 \\
53.0 \\
52.0 \\
51.0 \\
51.0 \\
50.0\end{array}$ \\
\hline
\end{tabular}

Auch Böhmen, Galizien und Mähren erzeugen guten Hafer und namentlieh hat der Mihrisehe Hafer für flachgrindige Gebirgsböden eine gewisse Bedeutung.

Was uun den Mais anbetrifft, so ist in Ungarn dic Zabl der angebauten Sorten eine relativ besehrïnkte, obwohl naeh dem 
Weizen der Mais die grösste räumliche Ausdehnung besitzt. Gemeinhin wird der gelbe ungarische Mais, und meist nur auf grösseren Gütern Cinquantino und Pignoletto kultiviert.

Obgleich nun Ungarn und namentlich Süd-Ungarn ein stark Mais bauendes Land ist, so dient der Mais doch weniger als in anderen Maisländern direkt zur menschlichen Nahrung, sondern er wird der Hauptsache nach als Viehfutter verwandt und sehr gern in Schweinefleisch umgesetzt, weil das speck bei Maisfiitterung rortreffliche Konsistenz erhält, wie Versuche in den Szallasen bei Budapest gezeigt haben, ausserdem wird er sehr gern ron den Schwcinen gefressen und bewirkt eine hohe Ausmästung.

Galizien und Steicrmark zeichnen sich ebenfalls durch umfangreichen Kornmaisbau aus und in letzterem Lande gelangt rorzugsweise der frühe gelbe steirische und der weisse und gelbe MureckerMais zum Anbau; hicran schliesst sich Krain mit der Kultur einer gelben einheimischen Sorte, und das Erzherzogtum Oesterreich, wenngleich derselbe hier schon in den Hintergrund tritt.

In allen diesen Lündern, aber vorzugsweise in Ungarn und Böhmen dient er auch als Hauptgriinfuttergewächs.

In Ungarn, ferner in Galizien, Istrien, Dalmatien, Käruten, Steiermark etc. wird auch die Kultur der Rispenhirse sehr stark und vorzugsweise auf den humosen Sandbödlen betrieben, deren Anbauresultate aus dem Jahre 1874 die nachfolgende Zusammenstellung zeigt:

\begin{tabular}{|c|c|c|c|}
\hline Land & $\begin{array}{l}\text { Acker- } \\
\text { fläche in } \\
\text { ha }\end{array}$ & $\begin{array}{c}\text { p. ha } \\
\text { in } \\
\text { hl }\end{array}$ & $\begin{array}{l}\text { Ernte } \\
\begin{array}{c}\text { in (ranzen } \\
\text { hl }\end{array}\end{array}$ \\
\hline $\begin{array}{l}\text { Steiermark } \\
\text { Kärnten und Krain } \\
\text { Tirol } \\
\text { Mähren und Schlesien } \\
\text { Galizien und Bukowina } \\
\text { Görz, Triest, Istrien, } \\
\text { Dalmatien }\end{array}$ & $\begin{array}{r}7959 \\
13502 \\
15 \\
9121 \\
23126 \\
13349\end{array}$ & $\begin{array}{l}16.5 \\
19.0 \\
10.0 \\
16.3 \\
14.8 \\
11.9\end{array}$ & $\begin{array}{r}131131 \\
259483 \\
153 \\
148784 \\
342069 \\
157966\end{array}$ \\
\hline Im Ganzer & 67072 & 15.5 & 1039586 \\
\hline
\end{tabular}

Ausser der Rispenhirse wird in Ungarn auch eine Kolbenhirse, und zwar Mohar, als Futterpflanze angebant.

In Ungarn, Görz, Triest, Istrien und Dalmatien baut man die Mohrhirse und zwar hauptsächlich die Besenhirse an, wenngleich auch vielfach die nickende MIohrhirse (Andropogon Sorghum ceruuus) rorkommt. 
In Görz, Triest, Istrien und Dalmatien werdeu nieht weniger als 7256 ha nit Mohrhirse bebaut und bringen dieselben $105187 \mathrm{hl}$ oder 14.5 hl Friiehte p. ha anf, die grösstenteils als Geflügel- und Sehweinefutter Verwendung finden.

In einem kleinen Teile des österreichisehen Kï̈stenlandes zwisehen Monfaleone und Marano kommen noch einige kleine Reisfelder, die zusammen ca. 1150 ha gross sind, vor, und liefern $40-50$ hl Reis p. ha.

Im Banat erzengt die Familie Timary auf dem Dentaer Prådium Topoly ${ }^{1}$ ) bei Partos jährlieh durehsehnittlieh $100000 \mathrm{~kg}$ Reis. Friiher soll auch im Temesvarer ${ }^{2}$ ) Banat auf den Königl. Kammergüteru $\%$ Gattai. Detta, Omor und Ujpets Reis gebant worden sein.

Die gesammte Getreideernte Oesterreiehs hat in den letzten Jahren ron 1868-1878 naehfolgende Durchsehnitte ${ }^{3}$ ) ergeben.

In Oesterreieh:

\begin{tabular}{|c|c|c|c|c|c|}
\hline Getreideart. & 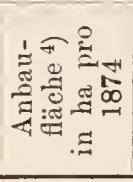 & 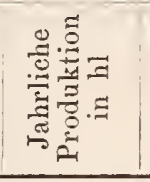 & 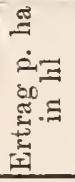 & 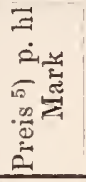 & $\begin{array}{l}\text { Geldwert der } \\
\text { Gesammt- } \\
\text { produktion } \\
\text { in Mark }\end{array}$ \\
\hline $\begin{array}{l}\text { Weizen } \\
\text { Roggen } \\
\text { Gerste } \\
\text { Hafer } \\
\text { Mais }\end{array}$ & $\begin{array}{r}977018 \\
1948272 \\
1117089 \\
1790020 \\
312710\end{array}$ & $\begin{array}{r}12090000 \\
24550000 \\
15610000 \\
28830000 \\
4950000\end{array}$ & $\begin{array}{l}12.4 \\
12.6 \\
14.0 \\
16.1 \\
15.8\end{array}$ & $\begin{array}{r}14.01 \\
10.67 \\
9.93 \\
6.15 \\
10.00\end{array}$ & $\begin{array}{r}169380900 \\
261948500 \\
155007300 \\
177304500 \\
49500000\end{array}$ \\
\hline $\operatorname{Im} C$ & 6145 & 000 & 14.0 & 9.45 & 813141200 \\
\hline
\end{tabular}

Ungarn produeierte durehsehnittlieh von $1868-1875$ von deu Hauptgetreidearten:

1) Land- u. forstw. Zeit 1858, pg. 318.

2) Lübeck, Ungar. Wchbl. 1804, Märzheft.

3) Vergl. F. X. v. Neumann-Spallart, Augustheft der Statistischen Monatsschrift 1877.

4) Statistisches Jahrbuch d. k. k. Ackerbauministeriums f. 1874. Wien 1875 .

5) Preise nach den wöchentl. Zusammenstellungen im Journal de l'Agriculture $1875-1878$. 


\begin{tabular}{|c|c|c|c|c|c|}
\hline Getreideart & 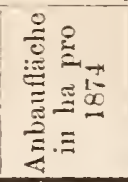 & 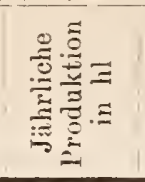 & 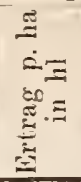 & $\begin{array}{l}\text { Preis } \\
\text { p. ha } \\
\text { Mark }\end{array}$ & $\begin{array}{l}\text { Geldwert der } \\
\text { Gesammt- } \\
\text { produktion } \\
\text { in Mark }\end{array}$ \\
\hline Weizen & 2416594 & 20720000 & 85 & 13.39 & $2 \pi+1+0800$ \\
\hline Roggen & 1251161 & 14030000 & 11.2 & 9.17 & 128655100 \\
\hline Gerste & 798536 & 10890000 & 13.6 & 8.65 & 94198500 \\
\hline Hafer & 915005 & 13520000 & 14.8 & 5.60 & 75712000 \\
\hline Mais & 1445879 & 18360000 & 127 & 9.00 & 165240000 \\
\hline Mischfrucht & 348987 & 3480000 & $: 0.0$ & 10.00 & 31800000 \\
\hline Im Ganzen: & 7176222 & 81000000 & 11.3 & 9.60 & 776016400 \\
\hline
\end{tabular}

Die Gesammtmonarchie produciert . . 167030000 hl Getreide davon ab an Saatgut $(1 / 7)$. . . . 24000000

Zum Konsum rerbleiben: 143030000 hl Getreide. Es entfallen nun in Oesterreich pro Kopf der Bevölkerung an

\begin{tabular}{|c|c|}
\hline Weizen & $0.58 \mathrm{hl}$ \\
\hline Roggen & 1.17 \\
\hline Gerste & 0.80 \\
\hline Hafer & 1.42 \\
\hline Mais & 0.20 \\
\hline
\end{tabular}

also auf 20700000 Seclen 86319000 hl Konsumgetreide. Nimmt man für Ungarn einen Konsum ron $4 \mathrm{hl}$ pro Kopf an, so brauchen seine 15200000 Einwohner $60800000 \mathrm{hl}$ und der Gesammtkonsum der Monarchie beträgt $147119000 \mathrm{hl}$ Getreide, mithin eine Mehreinfuhr von $40890000 \mathrm{hl}$ stattzufinden hat.

Ungarn ist in der Lage, nach Oesterreich Getreide abgeben zu können. abel vermag in Nitteljahren nicht das Deficit zu decken. Der mittlere Export erreicht nach Abzug ron 11500000 hl Saatgetreide ein Quantum ron $8700000 \mathrm{hl}$, von denen, da die Berölkerung sich vorzugsweise mit Roggren und Mais ernährt, ungefähr 5000000 hl aus Weizen bestehen.

\section{Italien.}

Die als Ackerland benutzte Fläche Italicns beträgt $109505 \mathrm{qklm}$ oder 37 Proc. der Gesammtfläche und entfallen hierron 20.8 Proc. anf den Weizenban, 15,5 Proc. auf den Maisban, 4.2 Proc. anf den Roggen- und Gerstenban und 3.7 Proc. anf den Haferbau.

Das Klima Italicns bildet gewissermassen den Uebergang zum 
tropischen Klima, indem im Herbst und Winter ein gewisses Regenquantum fällt, wälırend gerade in der iippigsten Vegetationsperiode des Getreides, in welcher viel Wasser verbraucht wird, nur relativ geringe Niedersehlagsmengen zu rerzeiehnen sind, daher denn auch ohne kuinstliehe Bewäisserung, die in der Poebene, sowie in den Flussthälern Mittel- und Unter-Italiens zur Anwendung gelangt, eine hohe und intensive Getreidekultur nicht zu erzielen ist.

Die Ackerböden Italiens weisen, je naeh ihrer Entstehung, eine sehr versehiedene Zusanmensetzung auf, so ist z. B. der Boden der Poebene auf dem linken Poufer aus dem Detritus der Alpenfluisse gebildet und befindet sieh in einer Tiefe von $3-5 \mathrm{~m}$ eine undurehlassende Lettenselicht, auf der eine Sand-oder Sehottersehieht lagert. Wo dieser Boden der kiinstliehen Bewässerung nnterlag, ist dureh die im Wasser suspendierten Stoffe ein hurnoser lehmiger Sandboden entstanden, während bei fehlender Bewässerung nur sandige, kiesige und selbst steinige Böden auftreten.

Das reehte Poufer lingegen, den Detritus des Apenin bergend, weist sehr fruehtbare, kalkreiehe Thonböden auf, denu dieses Gebirge, das der Jura- und Kreideformation angehört, ist vielfaeh von tertiären, plioeänen und mioeänen Sehiehten iuberlagert, deren Thone und Mergel einen besonderen Anteil an der Fruehtbarkeit des Kulturbodens tragen und mit Ausnahme der Böden vulkanisehen Ursprungs prägen sie auch dem Kulturboden Mittel- und Unter-Italiens ihren Charakter auf.

Was die Ausdehnung des Getreidebanes in Ober-, Mittel- und Unter-Italien anbetrifft, so gibt hieriiber die naehstehende Tabelle Aufsehluss :

Tabelle iiber die Ausdehnung des Getreidebaues.

\begin{tabular}{|c|c|c|c|c|c|c|c|c|}
\hline Kegion & $\left.\right|_{\text {ha }} ^{\text {Angebaut }}$ & $\begin{array}{l}\text { Er- } \\
\text { trag } \\
\text { p. ha } \\
\text { in } \\
\text { hl }\end{array}$ & $\begin{array}{c}\text { Angebaut } \\
\text { ha }\end{array}$ & $\begin{array}{l}\text { Er- } \\
\text { trag } \\
\text { p. ha } \\
\text { in } \\
\text { hl }\end{array}$ & $\begin{array}{c}\text { Angebaut } \\
\text { ha }\end{array}$ & $\begin{array}{l}\text { und } \\
\text { te } \\
\text { Er- } \\
\text { trag } \\
\text { p. ha } \\
\text { in } \\
\text { hl }\end{array}$ & $\begin{array}{c}\text { Angebaut } \\
\text { ha }\end{array}$ & $\begin{array}{l}\text { Er- } \\
\text { trag } \\
\text { p. ha } \\
\text { in } \\
\text { hl }\end{array}$ \\
\hline $\begin{array}{l}\text { Ober-Italien } \\
\text { Mittel-Italien } \\
\text { Unter-Italien } \\
\text { Sardinien }\end{array}$ & $\mid \begin{array}{rr}1 & 180969 \\
996584 \\
2 & 373443 \\
125489\end{array}$ & $\begin{array}{r}11.5 \\
10.7 \\
11.2 \\
8.3\end{array}$ & $\begin{array}{r}870378 \\
364852 \\
450003 \\
2290\end{array}$ & $\begin{array}{l}19.0 \\
18.7 \\
16.8 \\
12.3\end{array}$ & $\begin{array}{r}139012 \\
26648 \\
277542 \\
21578\end{array}$ & $\begin{array}{l}13.1 \\
12.7 \\
15.2 \\
15.2\end{array}$ & $\begin{array}{r}74913 \\
66489 \\
253229 \\
-\end{array}$ & $\begin{array}{l}17.3 \\
17.9 \\
19.6 \\
-\end{array}$ \\
\hline Staat: & 4676485 & 11.1 & 1696513 & 18.3 & 464780 & 14.4 & 398631 & 18.7 \\
\hline
\end{tabular}

Hiernach überwiegen in Ober-Italien Weizen und Mais, während Roggen, Gerste und Hafer nur ein Zehntel des Areals dieser beiden 
Hanptfriichte in Anspruch nehmen. Die hohe Kultur der Poebene und die Möglichkeit der Bewässerung garantieren aber auch vom Weizen nnd Mais die höchsten Durchschnittserträge, doch ist dies bei den anderen Getreidefrüchten nicht zutreffend, da sie auf die leichteren: nicht bewässerbaren und anf die Gebirgsböden angewiesen sind.

Noch stärker iiberwiegen Weizen und Mais in Mittel-Italien, denn Roggen, Gerste und Hafer nehmen nur den fünfzehnten Teil der Fläche ein; aber es stellen sich die Durchschnittsertrïge des Weizens weit niedriger als in Ober-Italien, da die Bewässerung meist fehlt, während die Maiserträge annähernd gleich loch bleiben, weil er grösstenteils das noch inundierbare Terrain in Anspruch nimmt.

Unter-Italien produciert die absolut grösste Getreidemenge und namentlich an Weizen, doch ist anch der Anbau von Roggen, Gerste und Hafer sehr ausgedehnt, denn diese Früchte nehmen ungefähr den fünften Teil der Weizenfläche ein.

Ausser vorgenannten Getreidearten wird ant den inundierbaren oder an sich sehr fenchten Terrains anch Reis gebaut, und da sich die Bedingungen zur Reiskultur hauptsächlich in der Poebene finden, so sehen wir sie anch hier im grössten Umfange betrieben, wie die nachfolgende Tabelle zeigt.

\begin{tabular}{|c|c|c|c|c|}
\hline Pegion & $\begin{array}{c}\text { Bebaute } \\
\text { Fläche } \\
\text { ha }\end{array}$ & $\begin{array}{c}\text { Ertrag } \\
\text { p. ha in } \\
\text { hl }\end{array}$ & $\begin{array}{c}\text { Total- } \\
\text { Ertrag } \\
\text { hl }\end{array}$ & 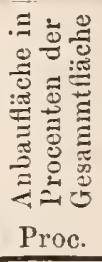 \\
\hline $\begin{array}{l}\text { Piemont } \\
\text { Lombardei } \\
\text { Venetien } \\
\text { Emilia } \\
\text { Provinz: Lucca } \\
\quad \text { " Campobasso } \\
\quad \text { " Napoli } \\
\quad \text { Catania,Sira- } \\
\quad \text { cusa,Girgenti }\end{array}$ & $\begin{array}{r}73733 \\
100835 \\
32460 \\
24462 \\
480 \\
70 \\
30\end{array}$ & $\begin{array}{l}44.46 \\
43.51 \\
38.89 \\
34.89 \\
31.00 \\
28.00 \\
25.00 \\
30.74\end{array}$ & $\begin{array}{r}3278569 \\
4387 \$ 87 \\
1262435 \\
853454 \\
14880 \\
1960 \\
750 \\
18416\end{array}$ & $\begin{array}{l}2.52 \\
4.29 \\
1.38 \\
1.19 \\
0.32 \\
0.02 \\
0.03 \\
0.02\end{array}$ \\
\hline Staat: & 232669 & 42.20 & 9818151 & 2.10 \\
\hline
\end{tabular}

Das vornehmste Getreide Italiens ist unzweifelhaft der Weizen und baut man in Ober-Italien iiberwiegend Weichweizen, Triticum vulgare (Grano gentile o tenero), doch von diesen die Kolbenweizen relativ selten, sondern und zwar vorzugsweise in der fenchten und 
den Stiirmen ausgesetzten Poebene, die Bartweizen, weil diese weniger durch Stiirme, Rost und Mehltau leiden.

Zuweilen wird anch anf den fenchten und reichen Böden der Ebene und Thäler der englische (banchigc) Weizen, Triticum turgidum L. (Grano grosso) seines hohen Lrtrages wegen gebaut, wenngleich das grauc, wenig backfähige Mehl, weit hinter dem weissen Luxusmehl der zu Trit. vulgare gehörigen Sorten zuriicksteht.

Die trockneren, weniger hoch kultivicrten Felder der Hölıclandschaften nehmen dagegen die halbharten, begrannten Sommelweizen, Trit. vulgare (Grano scmiduro) ein, die sich durch Kleinheit der Körner und Kleberreichtum auszeichnen, und deren Mehl, obgleich weniger weiss als das der Winterweizen, doch ein sehr vortreffliches Brot liefert.

In geringem Umfange kommen neben diesen anch die Hartweizen, Triticum durum. Desf. (Grano duro, o da paste, o da semolino, o Saragolla) vor, deren Mehl wegen seines hohen Klebergehaltes meist zur Nudelfabrikation dient.

In neuerer 'Zeit gewinnt anch die Kultur des polnischen Weizcns, Triticum polonicum (Grano di Polonia), der in seinen Vegetationsbedingungen und Kornqualitïteu dem Hartweizeu sehr nahe steht, in Obcr-Italien an Ausdchnumg.

In Mittel-Italien iibcrtrifft die Kultur der halblarten und Hartweizen die der Weichweizen, da sowohl der trockne, meist schwere Boden, wic auch die höhere Temperatur mehr auf ihre Kultur hinweisen und in noch erhöhterem Masse ist dies in Unter-Italien der Fall, wo die Weichwcizen mur ausnahmsweisc, dagegen die halbharten Sommerweizen, sowie die Hart- und polnischen Weizen und auf Sicilien anch die Binkel- und Igelweizen (Triticun compactum Al.) hauptsäichlich zur Kultur gelangen.

Im Allgemeinen werden die Winterweizen im Oktober und November, die Sommerweizen im Februar oder Mälı gesäict und die Ernte tritt Ende Juni oder Aufang Juli ein.

Das zweite Hauptgetreide ist der Mais und dient derselbe, zumal in Ober-Italien, als "Polenta" zur fast ausschliesslichen Ernährung der Arbeiterbevölkcrung, und wird angenommen, wenngleich auch viele Griunde dagegen sprechen, dass durch diesc Kost jeue abstossende und schreckliche Hautkrankheit, die „Pellagra“, crzeugt werde, die ihren höchsten Krankenstand in Ober-Italien mit 11.76 auf 1000 Einwolner und ilnren niedrigsten mit 0.09 in Latium zeigt.

Haluptsäichlich werden gelbe Maissorten, doch anch geschätzte weisse, aber nur sehr selten rote Sorten kultiviert.

Der Maisbau erreicht Höhen von 700-800 in und in den Siidabhängen der Alpen sogar von $1200 \mathrm{~m}$.

Die Hauptaussaatzeit dauert von Mitte $\Lambda$ pril bis Mitte Mai, 
doch werden friihreifende Maissorten nach einer Vorfrucht selbst noch Ende Juni oder Anfang Juli ausgesäet.

Der Rogggen hat für Italien eine untergeordnete Bedeutung, da seine Gesammternte nur 3348000 hl ausmacht. Seine Kultur erstreckt sich der Hauptsache nach auf die sandigen, trocknen, sorrie auf die gebirgigen Distrikte, dementsprechend findet er sich am ausgedehntesten in den Provinzen Udine und Torino, ferner auf Sicilien und dem Apennin, sowie in den Alpen bis zu Höhen von $1600 \mathrm{~m}$.

Im Gebirge wird meist Winterroggen (Segola di autunno) und auf Sicilien häufig Sommerroggen (Segola marzuola) gebaut.

Zuwcilen findet er sich auch als zeitiges Grünfutter.

Die Aussaat beträgt $1.50-2 \mathrm{hl}$ p. ha und die Ernte $15-20$ und in Naximo 38 hl p. ha und tritt dieselbe in der Ebene im Juni und im Gebirge je nach der Höhenlage später ein.

In einzelnen Gegenden wird auch Mischelfrucht, in Piemont "Barbariato" und in Toskana "Segolato" genannt, gesäet.

Von der Gerste werden in den Prorinzen Paria, Piemont, in den hochgelegenen Teilen ron Toskana und in den Südprovinzen vorzugsweisc vierzeilige, dagegen in den bergigen, feuchteren Distrikten der Alpen und des Apennin zweizeilige Gerstensorten angebaut. Im Allgemeinen ist jedoch die Gerstenkultur ebenso untergeordnet als die des Roggens, da nur $3400000 \mathrm{hl}$ und $22.50 \mathrm{hl} \mathrm{p}$. ha geerntet werden.

Der Haferbau Italiens ist ron rerhältnissmässig geringer Ausdehnung, und gehören ansserdem die meisten Sorten solchen Varietäten an, welche noch, wie Arena sativa rubida, trisperma, aristata, auf kulturlosem, trocknem Boden und bei hoher Sommertemperatur gedeihen, jedoch geringwertige Körner erzeugen, daher denn auch das Hektolitergewicht häufig nur $43 \mathrm{~kg}$ beträgt.

Am stärksten wird der Haferbau in den Prorinzen Foggia, Lecee, Bari, Cosenza, Caserta, Grosseto und hiernach in Sondrio, Ferrara, Pesaro, Lirorno, Caltanisetta und Siracusa betrieben.

Ausser Sommerhafer, dessen Aussaatzeit in den März und April fällt, wird auch ron Anfang September bis Mitte December Winterhafer gesäet. Häufig benutzt man den Hafer, namentlich in OberItalien, als Grïnfutter.

Die Mohrhirse wird in allen Provinzen zur Gewimnung von Naterial für Besen und Bürsten, zur Grinfutter- und Kornproduktion, oder auch rersuchsweise zur Syruperzeugung in rerhältnissmässig geringem Umfange angebaut.

Der Hirsebau besteht rornehmlich in Venetien, der Lombardei und Piemont, und benutzt man das Korn entweder als Geflügelfutter oder zur Mehlbereitung Sehr viel wichtiger ist jedoch die Verwendung der Hirse als Grünfutter auf trocknem Boden. 
Hauptsächlich gelangen von der Rispenlirse (Panicum miliaceum), welche bei einer Aussaat von $25-30 \mathrm{~kg}, 30-35 \mathrm{hl}$ à $70 \mathrm{~kg}$ p. ha aufbringt, gelbe, weisse nnd schwarze Sorten zur Kultur.

Weniger als die Rispenhirse wird die italienische Kolbenhirse (Panicmm italicum) zur Kornprodnktion, sondern weit häufiger zur Grünfutterproduktion verwandt. Zur Korngewinnung werden bei einer Aussaat von $15-20 \mathrm{~kg}$ p. ha rorziightich die gelbsamige grosse langborstige, die orangefarbige grosse borstenlose und die kleine gelbe Kolbenhirse, und zur Griinfuttergewinnung ganz besonders Sorten des ungarischen Mohars benutzt.

Die nittlere Getreideproduktion Italiens ${ }^{1}$ ) in der fünfjährigen Periode von 1870/74 ist folgende:

\begin{tabular}{|c|c|c|c|c|c|}
\hline Getreideart & $\begin{array}{l}\text { Anbau- } \\
\text { fläche } \\
\text { in ha }\end{array}$ & $\begin{array}{l}\text { Pro- } \\
\text { duktion } \\
\text { in hl }\end{array}$ & $\begin{array}{l}\text { Er- } \\
\text { trag } \\
\text { p. ha } \\
\text { in } h l\end{array}$ & $\begin{array}{c}\text { Preis } \\
\text { p. ha } \\
\text { in } \\
\text { Mark }\end{array}$ & $\begin{array}{l}\text { Geldwert } \\
\text { in Mark }\end{array}$ \\
\hline $\begin{array}{l}\text { Weizen } \\
\text { Mais } \\
\text { Gerste und Roggen } \\
\text { Hafer }\end{array}$ & $\begin{array}{r}4676485 \\
1696513 \\
464780 \\
398631\end{array}$ & \begin{tabular}{|r|}
51790005 \\
31098331 \\
6697288 \\
7443567
\end{tabular} & $\left\{\begin{array}{l}11.07 \\
18.33 \\
14.40 \\
18.67\end{array}\right.$ & \begin{tabular}{|}
18.76 \\
10.00 \\
11.77 \\
8.07
\end{tabular} & $\begin{array}{r}971580494 \\
310983310 \\
78827080 \\
60069586\end{array}$ \\
\hline Im Ganze & 7236409 & 97029191 & 13.40 & $14.70^{\prime}$ & 142146047() \\
\hline
\end{tabular}

Die Mehreinfuhr beläuft sich durchschnittlich auf $3135000 \mathrm{hl}$ Weizen, so dass nach Abzug von ca. 14000000 hl Saatgut znm Konsum für 26801144 Seelen 86164191 hl Getreide, also 3.2 hl pro Kopf verbleiben, während sich die Produktion pro Kopf der Bevölkerung anf 3.6 hl belïuft.

\section{Spanien.}

Die Gesammtfläche Spaniens beträgt,507716 qklm und macht davon die Fläche des Ackerlandes 26.1 Proc. ans.

Entsprechend der je nach der Lage sehr versehiedenen klimatischen und Bodenverhältnisse Spaniens gestaltet sich auch der Getreideban höchst mannigfaltig.

Was den Weizen ${ }^{2}$ ) anbetrifft, so werden die weichen Kolbenund Bartweizen am wenigsten kultiviert nnd beschränken sich wesent-

1) Ministero di Agric., Indust. e Commrc. Relazione intorno alle condizioni dell' Agricoltura in Italia. Bd. I. 1876.

2) Vergl. Wolffenstein, Jahrb. d. Laudw. VI. 1877. 4 u. 5. Heft. 
lich auf die Regionen mit geringer Regenhöhe und welche bei relativ geringerer Wärme das Maximum des Regenfalls im Herbst oder Winter haben. Die weissen Weizen machen procentisch den grössten 'Teil aller angebauten Weichweizen aus. Wintersaaten dieser Weizen finden sich hauptsäehlich in den baskischen Provinzen, in den beiden Castilien lind steigen bis zur Mancha hinab.

Von den Hartweizen werden iberaus zahlreiche Sorten. namentlich in Süd-Spanien, in den wärmeren und wärmsten Distrikten mit geringer Regenhöhe angebaut.

Die vorziiglichsten Hartweizen finden sich anf den schweren, fruchtbaren Böden siidlich der Sierra Jorena, also vorzugstreise in Andalusien, wenngleich auch der Anbau in Estremadura, sowie in Teilen von Valencia, Mureia, Aragonien und Castilien erfolgt. Diese Hartweizen werden wegen ihrer Ertragsfäligkeit und rorziiglichen Qualität des Kornes hoch geschätzt, auch zeigen sie sich gegen das Lagern sehr widerstandsfähig und lassen die Körner nicht leicht ausfallen, was bei der grossen Hitze und der in Folge dessen leicht eintretenden Totreife sehr ins Gewicht fällt.

Die sogenannten englischen oder bauchigen Weizen (Triticum turgidum) zeigen nach sortenzahl und Fläche die grösste Verbreitung in den regenteicheren Distrikten, in welehen sich die Regenmenge auf einen grösseren Zeitraum, nämlich auf zwei bis drei Jahreszeiten gleichmässig verteilt; daher beschrïnken sie sich fast ganz auf Catalonien und Navarra.

Der polnische Weizen hat den gleichen Verbreitungsbezirk mit dem Hartweizen gemein, verlangt guten Boden und ist gegen rauhe Witterung empfindlich; daher sein Anbau von allen Weizenvarietäten am besclirinktesten ist.

Die Spelzweizen finden sich rorzugsweise in den Gebirgsgegenden der nördlichen Provinzen, so die Spelze meist in Asturien, die Emmer in Navarra und Catalonien, während das Einkorn fast durch ganz Spanien auf geringen Böden vorkommt und anstatt der Gerste zu Viehfutter, zun Bierbranen und zur Graupeubereitung benutzt wird.

Der Mais gedeilt am besten in den weiten Thälern mit fruchtbarem Boden, vorausgesetzt, lass ihm in den regenarmen Distrikten von Central- und Siid-Spanien Bewässerung zu teil wird, und zwar bewässert man ihn in der Regel monatlich zwei Mal.

Er erreicht in Siicl.Spanien Höhen bis zu $1330 \mathrm{~m}$, in CentralSpanien $1000 \mathrm{~m}$, in Nord-Spanien $500 \mathrm{~m}$.

Das Korn dient zur Mehl- und Brodbereitung, sowie als Vieh-, besonders Schweinefitter. Die halbreifen Kolben werden, iiber Fener geröstet, allgemein gegessen.

Auf den besseren Böden wird in allen Provinzen die zweizeilige und bläuliche Gerste, anf leichten Böden die gewöhnliche 
vierzeilige und sechszeilige Gerste, letztere allerdings nur in geringer Ansclehnung; kultiviert.

Die Gerste liefert das Futter fiil dic Pferde, Maultiere und Esel, denn die Haferfütterung ist nur in den höchsten Gebirgslagen, wo Gerste nicht mehr gedeiht, gebrïuehlieh. In manchen Gebirgsgegenden Spaniens wird aueh Gerstenmehl, mit Roggen und Weizenmehl gemengt, $\mathrm{zu}$ Brot verbacken.

Der Roggen wird nur dort gesiiet, wo Mais und Weizen nicht mehr gut gedeihen wollen, d. h. in den kälteren Landstriehen des Nordens, in den Pyrenäen, anf den hohen kalten Plateaus der eentralen Kette und in den höchsten Gebirgen des Siidens, z. B. in der sierra Nevada 1800-2200 m, in Central-Spanien $1800 \mathrm{~m}$ und in den Pyrenäen-Thälern 1000-1300 no hoeh. In der Sierra Nevada baut man viel Sommerroggen.

Das spanisehe Roggenbrot, da es nicit gesänert wird, ist in der Regel sehr sehlecht.

Der Hafer findet sieh nur in den höchsten Gebirgsgegenden Nord-Spaniens.

Was die Kultur der Rispenhirse anlangt, so findet sie sich hier und da, doch nirgends in grosser Ausdehnung, nnd noch seltener die Kolbenhirse.

Die Mohrhirse, als Bewässerungspflanze, wird nicht selten in Castilien und besonders in den Mittelmeerprovinzen, wie in den wärmeren Gegenden von Andalusien, Granada, Mureia, Valencia und Catalonien kultiviert.

Die Reisproduktion Spaniens ${ }^{1}$ ) ist sehr betrïchtlich, nnd werden anf 20894 ha $1211993 \mathrm{hl}$ oder 58 lil pro ha erzeugt. Es findeu sich sehöne Reisfelder namentlich in den Morastniederungen längst beider Ufer des Júcar, in der sog. Ribera (Ufergegend), dann am See Albufera und im Ebro-Delta.

Die Getreideproduktion Spaniens stellt sieh in runden Zahlen anf 90 Millionen hl, also bei einer Bevölkerung von 16794963 Seelen auf $5.3 \mathrm{hl}$ pro Kopf, nnd entfallen von dieser Produktion 43 Millionen hl auf Weizen und Spelze, 20 Millionen hl auf Mais, 20 Millionen hl auf Gerste, 3 Millionen hl auf Rogonen und 4 Millionen hl anf Hafer. Ein Mehrexport ist kanm anzunehmen, so beklagt sich z. B. ein Mitglied der Cortes, Don Perruelas ${ }^{2}$ ), dass in Spanien nur $10.30 \mathrm{hl}$ Getreide p. ha, dagegen in Norwegen 11.4 hl p. ha erzeugt würden und sieh seit 1851 die Einfuhr immer gesteigert habe, dieselbe betrug $18601500000 \mathrm{hl}$ und 1870 nale an $7200000 \mathrm{hl}$ und zur Zeit sei auf einen Mehrexport nicht za hoffen.

1) Deutsch. Handelsarchiv 1881. pg. 419.

2) Monthly Rep. of the Departm. of Agric. 1876 Washington. 
Diese ungünstige Sachlage könute sich bei sorgfältiger Kultur und Anlage besserer Wege sofort indern und Spanien ein bedeutendes Weizenexportland werden.

\section{Portugal.}

In Portugal werden meist halbharte rote Bartweizen (Trit. vulgare) und im Siden Hartweizen, welche dort $5 / 6$ der Weizenproduktion ausmaehen, sowic in den höheren Gebirgslagen Spelzweizen und Roggen und in geringerem Umfange anch Gerste und Hafer gezogell.

In Allgemeinen ist die Hauptfrucht des Landes der Mais. ron dem nieht weniger als 23 Sorten existieren sollen, die sich der Hauptsache nach über die Provinzen Minho, Beira und Estremadura rerbreiten.

Das Maismehl dient, mit Roggenmehl vernischt, zur Bereitung eines groben Brotes und der Mais als Tiehfutter.

Nieht selten ist der Anbau der Hirse, namentlich der Rispenhirse, auf leichteren Böden, aueh wcrden in den Provinzen Estreinadura und Algarve, sowie bei Coimbra 4000 ha mit Reis bestellt, die einen Ertrag von $150000 \mathrm{hl}$, also durchschnittlieh $37.5 \mathrm{hl}$ p. ha abwerfen.

Trotz einer Berölkerung von nur 4745124 Einwohnern ist Portugal durch Vernaehlissigung seines Aekerbanes nicht im Stande, den Getreidebedarf zu decken und sollen noch 6-7 Millionen Hektoliter Getreide jährlich eingefülırt werden.

Die Getreideproduktion ${ }^{1}$ ) stellt sich wie folgt:

\begin{tabular}{|c|c|c|c|}
\hline Getreideart & $\begin{array}{c}\text { Anbau- } \\
\text { fläche } \\
\text { in } \\
\text { ha }\end{array}$ & $\begin{array}{c}\text { Pro- } \\
\text { duktion } \\
\text { in } \\
\text { hl }\end{array}$ & $\begin{array}{c}\text { Er- } \\
\text { trag } \\
\text { p. ha } \\
\text { in } \\
\text { hl }\end{array}$ \\
\hline $\begin{array}{l}\text { Weizen } \\
\text { Roggen } \\
\text { Gerste } \\
\text { Hafer } \\
\text { Mais }\end{array}$ & $\begin{array}{r}260000 \\
270000 \\
80000 \\
520000\end{array}$ & $\begin{array}{r}2800000 \\
2400000 \\
870000 \\
200000 \\
7100000\end{array}$ & $\begin{array}{c}10.8 \\
9.0 \\
- \\
- \\
13.6\end{array}$ \\
\hline Im Ganzen: & 1136000 & 13370000 & 11.8 \\
\hline
\end{tabular}

Wird ron der Getrcideproduktion das Saatgetreide mit 2000000

1) Thiel, Landw, Conversations-Lex. V, p. 404. 
hl abgezogen, dann bleiben zum Konsum noch 11370000 hl oder $2.4 \mathrm{hl} \mathrm{p.} \mathrm{Kopf;} \mathrm{tritt} \mathrm{aber} \mathrm{noch} \mathrm{ein} \mathrm{Mehrimport} \mathrm{von} 6000000 \mathrm{hl}$ hinzu, so stellt sich der Gesammtkonsum anf 3.66 lil p. Kopf. Die Produktion beträgt pro Kopf $2.8 \mathrm{hl}$.

\section{Griechenland.}

Die Hauptfrucht Griechenlands ist der Weizen, und treten vorweise die halbharten Bartweizen, welche meist Wechselweizen sind, hervor. Spelz, Roggen und Hafer nchmen die ranheren Gebirgslagen ein, und in den Flnssniedernngen wird etwas Reis knltiviert.

Die Produktion belänft sich

\begin{tabular}{|c|c|c|}
\hline n Weizen & auf & $1800000 \mathrm{hl}$ \\
\hline Mais & , & 1100000 \\
\hline Gerste & " & 800000 \\
\hline Roggen & . & 600000, \\
\hline Hafer & , & 100000 \\
\hline
\end{tabular}

Die Durchschnittsprodnktion beträgt pro Kopf $3.3 \mathrm{hl}$ nnd der Konsum excl. Saatgetreide ; hl, und ist zur Deckung des Bedarfs eine Mehreinfuhr von rund $200000 \mathrm{hl}$ Getreide notwendig.

\section{Die Schweiz.}

Vom Weizen sind rote und weisse Kolbenweizen, sowie auch rote Bartweizen, und in den höheren Gebirgslagen (bis $1264 \mathrm{~m}$ ) Igelund Binkelweizen, sowie Spelzweizen verbreitet, auch findet sich zuweilen auf reichem Thalboden der bauchige Weizen (Trit. turgidum), z. B. Blé Nonette de Lausanne.

Von der Gerste werden zwei- und vierzeilige Sorten auf den Bergen (1300 m, Nord·Abhang sogar $1984 \mathrm{~m}$ hoch), zweizeilige und Wintergerstensorten in den Thälern gebaut.

Der Roggen erreicht auf der Siidseite Anbanhöhen bis $1754 \mathrm{~m}$, und wird, wie auch Rispenhafer, in beträchtlicher Ausdehnung kultiviert.

Fiir die Schweiz wird eine Prodnktion angenommen von

1500000 hl Weizen und Spelz

1500000, Roggen
$2000000 "$ Hafer
1500000, Gerste

im Ganzen: 6500000 hl Getreide.

Die durchschnittliche Produktion beträgt $2.4 \mathrm{hl}$ p. Kopf, der 
Konsum $3 \mathrm{hl}$ excl. Saatgetreide, und soll ein Mehrimport ron 3000000 hl Getreide zur Deckung des Bedarfes notwendig sein.

\section{Belgien.}

Belgien enthält 2945516 ha, von denen 1589341 oder 54 Proc. als Ackerland beuutzt werden. Es besitzt eiu temperirtes, feuchtes Klima, das weniger heiss im Sommer, dagegen im Winter wärmer als dasjenige Dentschlands ist. und gerade dieses Klima eignet sich fuir den Getreidebau, der hier meist auf sehr leichten Böden betrieben werden muss, ausgezeichnet.

Landwirtschaftlich lassen sich drei Zonen unterscheideu, im Stideu die Kalkbcrge der Ardennen, in Norden das Diluvium der norddeutschen Ebene mit seinen leichten Böden und dazwischeu an den Flussläufen und am Meere das Alluvium, aus reichen, humosen Thonböden bestehend.

Der Weizen bildet die Hauptfrucht in Allurium, wird aber auch bei der hohen Kultur Belgiens auf den kalk- und lehmhaltigen Böden des Hennegau und rou Brabant gebaut.

Vielfach werden in den Niederungen englische uud nordfranzösische Weizeu kultiviert, doch gibt es anch einheimische Weizen, z. B. „Blé blane de Flandres". Auf dem Höhenlande sind hauptsächlich rote Kolbeu- und Bartweizen rerbreitet.

Mischel (,.Méteil"), cin Gemenge ron Roggen und Weizen in nicht fest bestimmten Verhältnissen, wird auf solchen Böden gebaut, die für Weizen allein zu uusicher sind, und stellt sich durchschnittlich der Ertrag hölier als ron der Reinsaat. Vorzugsweise fiudet sich dieses Gemenge in den Bezirken rou Arlou und Virton, sowie in der Umgegend ron Alost und Audeuaerde.

Der Spelz wird in den rauheren Gebirgslagen der Ardenueu und namentlich auf dem $350 \mathrm{~m}$ hohen Platean ron Condroz angebaut.

Etwas ausgedehnter als der Weizenbau ist der des Roggens und bildet derselbe dieHauptfrucht Flanderns und der Campine, auch ist er die Brotfrucht der Flamländer, welche rier Fünfteile der gesammten Produktion rer\%ehreu. In der Campine gedeiht auf den dortigen Sandböden der vortreffliche. schwere, dünnschalige Campiner-Roggen, während auf den humoseren, feuchteren Böden der Zeeländer-Staudenroggen vorherrscht. Beriihmt ist der Roggenbau im Waeslande; wo der Roggen eine erstaunliche Höhe, so z. B. massen wir schon im Juni (1881) $235 \mathrm{~cm}$, erreicht.

Die Gerste und hauptsächlich die Wintergerste bildet die Hauptfrucht der Polder und wird meist zur Bierbrauerei verwandt. Von der zweizeiligen Gerste ist die Cheralier-Gerste am beliebtesten. 
Der Hafer ist die Hauptfrucht des Gebirges und wird meist ein frühreifer Rispenhafer kultiviert.

Produktion und Konsuntion in Belgien ${ }^{1}$ ) sind folgende:

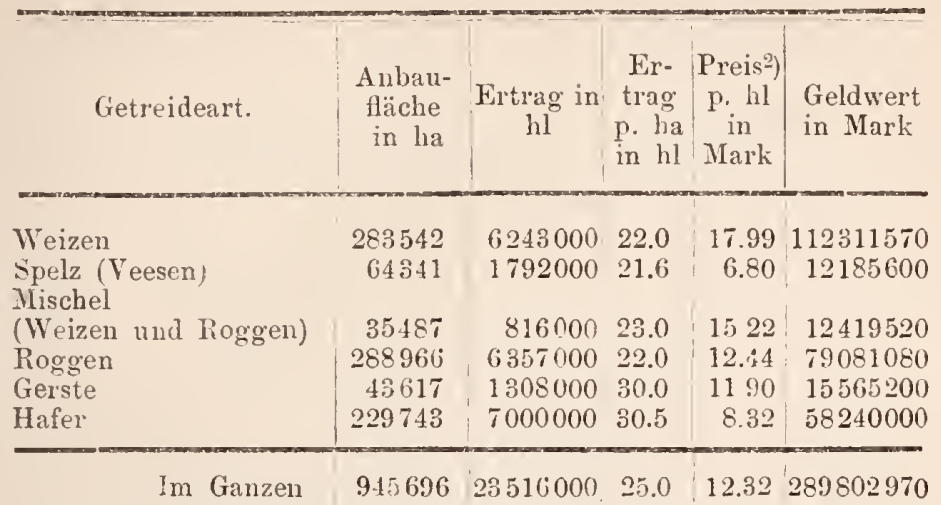

Wird ron dem Gesammtertrag das Saatgetreide mit $3900000 \mathrm{hl}$ abgezogen, so bleiben zum Konsum noch $19616000 \mathrm{hl}$, dic jedoch fiil eine Bevölkerung von 5087105 Einwohnerm nicht ausreichen und findet durchschnittlich ein Mehrimport von 2650000 hl Weizen und 455000 hl Roggen, also im Ganzen von 3105000 hl Getreide statt, mithin kommen zum Konsuul. . . . . . 22721000 hl Getreide und zwar als Konsum pro Kopf $3,5 \mathrm{hl}=.17805000 \mathrm{hl}$ Getreide für Branerei und Brenncrei . . . . . 2600000 , " .. diverse Zwecke . . . . . . . . . 2316000 ",

Die Produktion pro Kopf der Berölkcrung beträat $4.6 \mathrm{hl}$.

\section{Die Niederlande.}

Die Niederlandc besitzen:

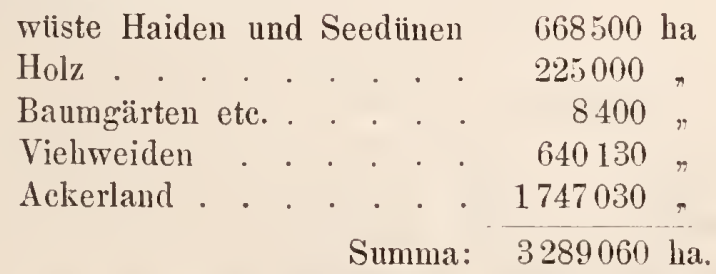

Demnach beträgt das Ackerland 53.1 Proc. der Gesammtfläche. Die klimatischen und Bodenverhältnisse sind im Allgemeinen

1) Vergl. Emil de Laveleye, L'Agric. belge. Paris 1878.

2) Durchschnitt 1874/78 nach Journ. de l'Agric. 
denen Belgiens gleich zu setzen, und haben wir es entweder mit Alluvialböden oder Sandböden zu thun.

Die Durchschnittserträge dieser beiden Böden sind folgende:

\begin{tabular}{|c|c|c|c|c|}
\hline & Alluvialboden & & Sandboden & $\begin{array}{l}\text { Durch- } \\
\text { schnit- } \\
\text { liches } \\
\text { Gewicht } \\
\text { pro hl }\end{array}$ \\
\hline $\begin{array}{ll}\text { Weizen } & 22 \\
\text { Roggen } & 25 \\
\text { Gerste } & 38 \\
\text { Hafer } & 42\end{array}$ & 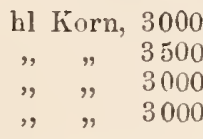 & $\begin{array}{ll}\mathrm{kg} & \text { Stroh } \\
, " & , \\
", & , \\
, & ,\end{array}$ & 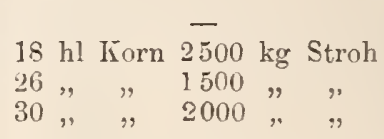 & $\begin{array}{l}75 \mathrm{~kg} \\
72 " \\
60 " \\
46 "\end{array}$ \\
\hline
\end{tabular}

Vom Weizen werden annähernd dieselben Sorten wie in Belgien gezogen, so findet sich in len Niederungen auf Thonboden der einheimische weisse Zeeländer Kolbenweizen (identisch: Blé blane de Flandres), doch kommen anch rielfacb englische Weizensorten auf diesen Böden vor, während auf clem Höhenlande rote Kolbenund Bartweizen vou befriedigender Korn-Qualität verbreitet sind.

In den Niederungen wächst ferner ein vorzüglicher Staudenroggen, der Zeeländer, während auf der Höhe meist Campiner-Roggen kultiviert wird.

Mit Ausnahme der Wintergerste, welche vorzugsweise gut in den Poldern gedeiht, ist der Gerstenban wenig ausgedehnt und wird rom Hafer ijberfügelt, der auf den feuchten, lnmosen Böden sehr lole Erträge bringt.

Die Produktion in den Niederlanden ${ }^{1}$ ) stellte sich in den Jahren $1860,66,67,69$ und 73 wie folgt:

\begin{tabular}{|c|c|c|c|c|c|}
\hline Getreideart & $\begin{array}{l}\text { Anbau- } \\
\text { fläche } \\
\text { in ha }\end{array}$ & $\begin{array}{c}\text { Durch- } \\
\text { schnitts- } \\
\text { pro- } \\
\text { duktion } \\
\text { in hl }\end{array}$ & $\begin{array}{l}\text { Er- } \\
\text { trag } \\
\text { p. ha } \\
\text { in hl }\end{array}$ & $\begin{array}{l}\text { Preis } \\
\text { p. hl } \\
\text { in } \\
\text { Mark }\end{array}$ & $\begin{array}{c}\text { Geldwert in } \\
\text { Mlark }\end{array}$ \\
\hline $\begin{array}{l}\text { Weizen } \\
\text { Roggen } \\
\text { Gerste } \\
\text { Hafer }\end{array}$ & $\begin{array}{r}82074 \\
198890 \\
44371 \\
96210\end{array}$ & $\begin{array}{l}1641000 \\
3249000 \\
1490000 \\
3641000\end{array}$ & $\begin{array}{l}20.0 \\
16.4 \\
33.6 \\
37.8\end{array}$ & $\begin{array}{r}17.56 \\
12.95 \\
11.24 \\
8.79\end{array}$ & $\begin{array}{l}28815960 \\
42074550 \\
16747600 \\
32004390\end{array}$ \\
\hline Ganze & 421545 & 10021000 & 23.8 & 12.00 & 119642500 \\
\hline
\end{tabular}

1) Vergl. Monthly Rep. of Agric. Washington 1869 und NeumannSpallart Behm's geograph. Jahrb. VI. Wien, 1876. p. 604. 
Getreideproduktion, Getreidekonsumtion und Getreidehandel.

Nachfolgende Tabelle bringt die Ein- und Ausfuhr:

\begin{tabular}{|c|c|c|c|c|c|c|}
\hline \multirow{2}{*}{ Getreideart } & \multicolumn{2}{|c|}{ Einfuhr } & \multicolumn{2}{|c|}{ Ausfuhr } & \multicolumn{2}{|c|}{ Mehreinfuhr } \\
\hline & $\mathrm{hl}$ & Mark & hl & Mark & $\mathrm{h}]$ & Mark \\
\hline $\begin{array}{l}\text { Weizen } \\
\text { Roggen } \\
\text { Gerste }\end{array}$ & $\begin{array}{l}1029565 \\
2576572 \\
1117002\end{array}$ & $\begin{array}{l}18079361 \\
33366607 \\
13454302\end{array}$ & $\begin{array}{l}394102 \\
748594 \\
553292\end{array}$ & \begin{tabular}{|l|}
6920431 \\
9694292 \\
6219001
\end{tabular} & $\begin{array}{r}635463 \\
1827978 \\
643710\end{array}$ & $\begin{array}{r}11158930 \\
23672315 \\
7235301\end{array}$ \\
\hline
\end{tabular}

310715142066546

Mehrausfuhr

Hafer $130450|1146655| 662148 \quad 5820281|531698| 4673626$

Im Ganzen Mehreinfuhr: 257545337392920

Wird von der Gesammtproduktion das Saatgut mit $17000000 \mathrm{hl}$ abgezogen und die Mehreinfuhr mit 2575453 hl wieder hinzuaddiert, so verbleiben dem Konsum 10896453 hl oder bei 3552695 Einwohnern 3 hl pro Kopf.

Diesen Getreide importierenden Ländern Europas stehen die folgenden Exportländer gegenüber.

\section{Russland.}

Das europäische Russland umfasst 1037400 qklm, wovon 21.6 Proc. der Gesammtfläche Ackerland sind.

Hinsichtlich der landwirtschaftlichen Produktion ${ }^{1}$ ) lassen sich die russischen Provinzen in 3 Hauptgruppen einteilen. Die erste Gruppe produciert weniger Getreide als für den lokalen Konsum erforderlich ist und gebören hierhin 3 nördliche, 6 nordwestlicbc und 6 centrale Gouvernements mit einer Bevölkerung von 14882664 Seelen und einer Ernte von ca. 81 Millionen Hektoliter Getreide.

In der 2. Gruppe, den Gouvernenents Perm, Wjatka, 3 Ostseeprovinzen, Kowno, Wilna, Grodno und Minsk mit einer Bevölkerung von 10631229 Seelen und einer Produktion von 88 Millionen Hektoliter wird der lokale Bedarf gedeckt. Dic 3. Gruppe allein erzeugt über den Bedarf hinaus Getreide und zwar vorzugsweise Weizen, sie umfasst 17 ecntrale, 4 südöstliche und 5 südliche Gouvernements, sowie das Gebiet der donischen Kosaken. In diesem weiten Gebiet mit einer Bevölkerung von 38644969 Seelen werden ca. 440 Millionen Hektoliter Getreide produciert.

1) Vergl. Schwanebach und Basenius, Statist. Skizze des russ. Reiches und von Finnland. 
Was die klimatischen Verhältnisse des europäischen Russland angeht, so sind die Sommer kurz und heiss, dagegen die Winter streng und lang, und nur in der Steppenregion des Südens, obgleich auch hier die Winter streng sind, folgen ihnen doch sehr milde Frühlinge und längere, heisse Sommer.

Da nun der Boden dieser letzteren Region zu einem grossen Teil aus bis $3 \mathrm{~m}$ tiefer, fruchtbarer Schwarzerde besteht, welche ihre Ernten meist ohne Dïngung liefert, während im mittleren und nördlichen Russland auf den hier durchschnittlich lehmigen Sandböden nur mit Hülfe der Düngung sich dem Boden einigermassen befriedigende Getreidearten abringen lassen, so erhellt hieraus, dass diese siidlichen Regionen die eigentliche Korukammer Russlands bilden.

In der Regel wird der Winterroggen Ende August gesäet und ror Mitte Juli geerntet; dell Winterweizen säet man einige Tage später als den Rogggen, und fällt die Ernte auch ein wenig später. Im Sommergetreide richten die Frühjahıssföste hänfig grossen Schaden an.

Die Aussaat des Hafers und der Gerste erfolgt gegen Mitte Mai, die Ernte im Juli, Mais und Hirse können erst gegen Mitte Mai, der Fröste wegen, ausgesäet werden.

Die Hauptfrucht Russlands ist der Rog geen und nimmt derselbe 27.5 Proc. der Ackerfläche ein. und zwar vorzugsweise in der nördlichen und nittleren Region. In den baltischen Provinzen stellt sich sein Durchschnittsertrag auf $11.3 \mathrm{hl}$, im Gebiet der Schwarzerde auf 9.5 hl und in den tibrigen Teilen Russlands auf $7 \mathrm{hl}$ und durchschnittlich auf $8.8 \mathrm{hl} \mathrm{p}$. ha.

Eine der beliebtesten Roggensorten des nordwestlichen Russlands auf gut kultiviertem Boden ist der Probsteier-Roggen, ferner wird in den nördlichen Provinzen das russische Schneekorn und JohannisRoggen, sowie auch der fiunländische Nyland- und Wasa-Roggen vielfach angetroffen, doch scheint die Kultur des Johannis-Roggens wegen der Kleinheit der Körner und ihres geringeren Nahrungswertes in der Abnahme begriffen zu sein.

Beriilumte Roggensorten sind ferner ,Saksonka" und die Roggen der Ukraine und Podoliens.

Der Roggenexport, namentlich nach Deutschland und den nordischen Ländern, ist in fortwäbrender Zunahme begriffen, denn es wurden durchschnittlich pro Jahr exportiert:

$\begin{array}{rr}1852-1855 & 2137000 \mathrm{hl} \\ 56-60 & 3423000 " \\ 61-65 & 3024000 \% \\ 66-70 & 4620000 \% \\ 71-75 & 12302000 \%\end{array}$

In zweiter Linie, wenngleich das Hauptexportgetreide, steht der 
Weizen, weleher 10.7 Proe. der Ackerfläche ausmacht, wovon ein Drittcil mit Winterwcizen und zwci Dritteile, und zwar hauptsächlich in der Steppenregion, mit Sommerwcizen bcsäet werden; doeh findet er sich noch hoch im Norden bis zum $61^{\circ} \mathrm{n}$. Br.

Am ausgedelintesten wird der Weizenbau in den südliehen und teilweise in den centralen und westlichen Gouremements betrieben.

In der Steppenregion werden hamptsächlich die beliebten Hartweizen, wie Beloturka oder Kubanka und Arnantka oder Garnowka, sowic halbharte rote Bartweizen z. B. der hochgeschätzte Ghirka gebaut; Weicliweizen mud zwar meist Winterweizen, finden sich in der mittleren und nördliclien Region, von denen der weisse Kolbenweizen von Kostroma, sowie der in Polen heimische SandomirskaWeizen sehr geschätzt sind. In den baltischen Provinzen wird dag'egen gern der rote Probsteier-Weizen angebaut. In den nordwestlichen Gourcrnements kommen zuwcilen aueh banehige oder englisehe Weizen (Triticum turgidum) vor.

Die Hartweizen werden rorzugsweise ihres Kleberreichtums wegen zur Nudelfabrikation exportiert; während der Ghirka eine sehr heliebte Exportware für Konstantinopel, Smyrna, Gricebenland, Spanien, Süd-Frankreich und England ist und cin sehr wertrolles, gut rerbaekbares Mehl licfert.

Der Umfang des Weizenexportes ergicbt sich aus nachfolgenden Zahlen. Es wurden durchschnittlich jährlich exportiert.

$$
\begin{aligned}
1836-1840 & =4345000 \mathrm{hl} \\
41-45 & =4479000 \mathrm{n} \\
46-50 & =7319000 " \\
51-55 & =6671000 " \\
56-60 & =8003000 " \\
61-65 & =10522000 " \\
66-70 & =16072000 " \\
71-75 & =19334000 "
\end{aligned}
$$

Der Anbau der Gerste ist von nur gcringer Bedeutung und nimmt dieselbe 6 Proc. der Ackerfläche ein.

Die Gerste der Steppenregion eignet sich wegen ibres Kleberreichtums und der Dicke der Schale nicht als Brangerste, obschon vielfach, so in Jekatcrinoslaw, zweizeilige Gerste gebaut wird; auch kommt in dicsen Distrikten dic nackte zwcizcilige Gerste zum Anbau. Im centralen Russland werden iiberwiegend vier- und seehszeilige Gerstensorten ausgesäet und auf den kulturvolleren Böden Polens und der baltischen Provinzen finden sich als Braugersten häufig die Chevalier- und Jerusalemer oder Imperial-Gerste, neben selı wertvollen vierzciligen Gerstensorten wie der Mandsehurei- und Kurlindisehen Gerstc. Wintergerste wird fast gar nicht gebaut.

Auf wenig kulturvollen Böden stellt sich der Durehschnitts- 
ertrag auf nur $7 \mathrm{hl}$, kaun aber unter sehr günstigen Verbältnissen auf $15-20 \mathrm{hl}$ p. ha steigen, der Durchschnittsertrag beträgt in Ganzen nur 8.1 hl p. ha.

Der Export belief sich:

$$
\begin{aligned}
& 1852-1855 \text { auf } 462000 \mathrm{hl} \\
& 56-60,1552000 \text {, } \\
& 61-65,1155000 \text {, } \\
& 66-70 " 1911000 . \\
& 71-75,3209000 \text {, }
\end{aligned}
$$

Der Hafer nimmt 12.8 Proc. der Ackerfläche ein, und riihmt man in der Steppenregion vorzugsweisse den schwarzen und weissen ungarischen Fahnenhafer, den Podolischen Goldhafer und die Rispenhafer aus Jekaterinoslaw und Charkow; im centralen Teil ist namentlich der schöne Rispenhafer von Tula, anch Schatilowskiy genannt, beliebt, während im Norden der Ossetinische Goldhafer, sowie der Irbit- und Finnländische Rispenhafer und in den baltischen Provinzen mit Vorliebe der Probsteier Hafer gebaut wird.

Der Export belief sich:

$$
\begin{array}{r}
1852-1875 \text { auf } 722000 \mathrm{hl} \\
56-60, \quad 3623000 " \\
61-65,, \quad 1755000 " \\
66-70, \quad 5184000 " \\
71-75, \quad 8331000 "
\end{array}
$$

Der Maisban wird in Russland sehr unbedentend und nur in den südwestlichen Gouvernements, z. B. in der Ukraine anf kulturrollem Boden betrieben und gelangen $1207500 \mathrm{hl}$ zum Export.

Der Hirsebau ist für die Steppenregion ron Wichtigkeit, wo er gern nach dem Umbruch auf Neuland betrieben wird, und dann nicht selten einen Ertrag von $50-60$ hl p. ha aufbringt. Vorzugsweise findet sich die Hirse im Lande der donischen Kosaken, dann in den Gouvernements Woronesch, Tambow, Saratow, Simbirsk, Cherson, Jekaterinoslaw und Taurien. Hauptsächlich gelangen weisse, graue, dunkelgelbe oder rote Rispenhirsen zur Kultur, von denen $21000 \mathrm{hl}$ exportiert werden.

Zuweilen wird auch Besenmohrhirse in der Steppenregion gebaut, auch sind, wenngleich mit geringem Erfolge, Versuche mit dem Anban der Zuckermohrhirse gemacht worden.

Der Anbau des Maises und der Hirse iibersteigt nicht 1 Proc. der Ackerfläche.

Die Getreideproduktion stellt sich in Russland ${ }^{1}$ ) (incl. Polen und Finnland aber excl. Asien) wie folgt:

1) Wilson, Erläuterung zur 4. Auflage der statist. Atlas d. europ. Russl. Schwanebach u. Basenius, Statistische Skizze d. russ. Reiches u. von Finn. 


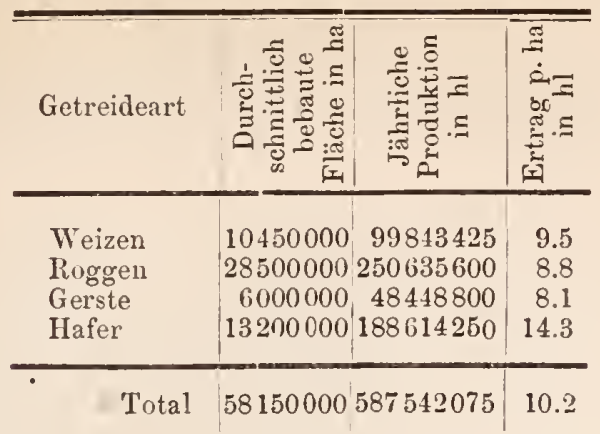

Nach dem Census von 1870 beträgt die Einwohnerzahl

$$
\begin{array}{clr}
\text { von Russland (exel. Asien) } & 71730980 \\
& 1857035 \\
, \quad \text { Fiumland } & 5500000
\end{array}
$$

Total: 79088015 Einwohner, mithin entfallen pro Kopf der Bevölkerung 7.4 hl Getreide.

Berechnet man den Geldwert von $1 \mathrm{hl}$ Getreide zu 10 Mark, so stellt sich der Wert der jährlichen Produktion auf 5875420750 Mark. Ausser den obeu angefülirten 4 Hauptgetreidearten wird an sonstigen Körnerfriehten, wie Leguminosen, Buchweizen, Hirse, Mais noch ein Quantum von 72871900 hl oder 0.9 pro Kopf der Bevölkerung produciert.

Von den 4 Hauptgetreidearten gelangten seit dem Jahre 1870 ca. $7 \frac{1}{2}$ Proc. zur Mehrausfuhr. Nach dem Wert des in den Jahren 1871-74 ausgefuihrten Getreides, meist Weizen und Roggen, ergiebt sich ein Durchschnittspreis von 12.5 Mark pro hl.

\begin{tabular}{|c|c|c|}
\hline & Weizen & $19334000 \mathrm{~h}$ \\
\hline & Roggen & 12302000 \\
\hline & Gerste & 3209000 \\
\hline n & Hafer & 8331000 \\
\hline & Mehl & 644000 \\
\hline
\end{tabular}

Die Mehrausfuhr Russlands betrug durehschnittlich in den Jahren $1871-75$ in $\mathrm{hl}$

dazu an Mais

1207000

Gesammtsumme :

$45027000 \mathrm{hl}$ à $12.5 \mathrm{M} .=562837500 \mathrm{M}$.

Wird diese Mehrausfuhr von der jäbrlichen Produktion abgezogen, so beläuft sich der Getreideverbrauch pro Kopf der Bevölkerung in Russland auf ea. $6.5 \mathrm{hl}$, und teilen sich darin del Weizen mit $1.03 \mathrm{hl}$, der Roggen mit $3 \mathrm{hl}$, die Gerste mit 0.57 hl und der Hafer mit $2.2 \mathrm{bl}$.

land. 1876. v. Lindheim, Russland d. neuesten Zeit, statist.•ethnograph. Mitteilungen. Wien. 1876. 


\section{Rumänien.}

Rumänien besitzt ein Areal von $120000 \mathrm{qklm}$ und ist ein durchaus Ackerball treibender Staat, denn vier Fiinfteile der Bevölkerung leben davon.

Es besitzt ein Steppenklima und der grösste Teil des Bodens gehört in das Gebiet der fruchtbaren Schwarzerde. Leider steht die Landwirtschaft dieses von der Natur reich gesegneten Landes auf geringer Stufe der Entwickelung, mit Leichtigkeit liesse sich der Ertrag bei Aufwendung einiger Intelligenz, etwas Kapital und Arbeit verdoppeln, dem die Produktionsbedingungen sind ausserordentlich giinstige, so z. B. bedarf ein grosser Teil des reichen Bodens bis jetzt nicht der Diingung. Kaum ein Dritteil des Landes ist bebaut, Maschinen und ein rationeller Wirtschaftsbetrieh fehlen, so dass in dieser Beziehung Rumänien von Ungarn und Russland iiberfliigelt ist.

Die angebauten Weizen gehören meist zu den roten halbharten Bartweizen, wie sie der von Natur reiche Boden und das Steppenklima erzeugen.

In den gebirgigen Teilen des Landes wird auch viel Spelz gebaut.

Die grösste Anbaufläche nimmt dagegen der Mais ein, welcher als Mamaliga auch vorzugsweise zur Nahrung dient.

Der Anbau der Gerste, von welcher ein bedeutender Teil zum Export gelangt, ist sehr ausgedehnt, während Roggen und zwar häufig im Gemenge mit Weizen, sowie Hafer (Fahnenhafer) gerade fuir den Bedarf ausreichen.

In recht bedeutendem Umfange kultiviert man die Kolben- und Rispenhirse und zur Erzeugung ron Besen, die Besenhirse.

Jahresproduktion ${ }^{1}$ ) und Export berechnen sich anf :

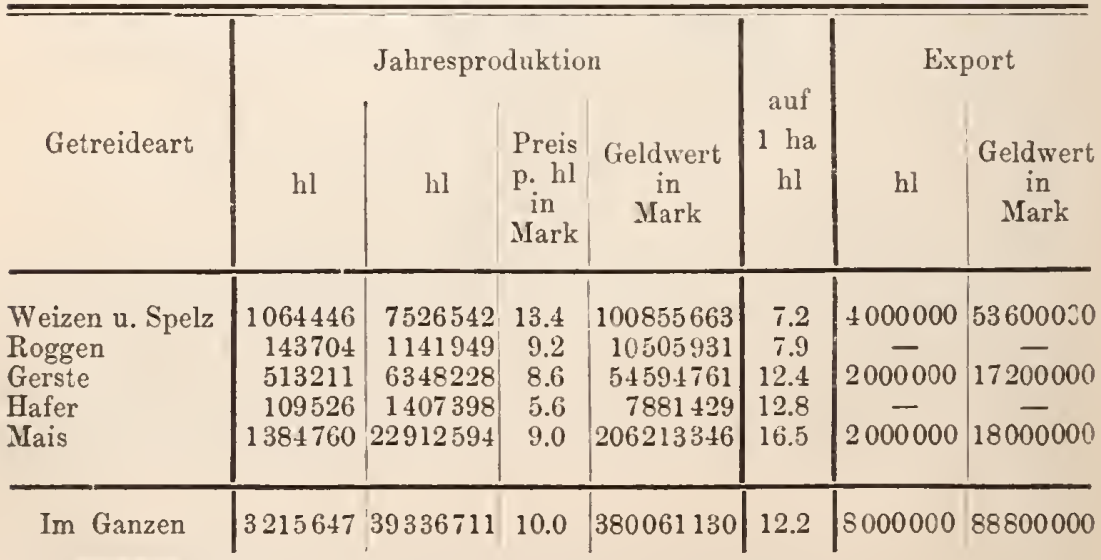

1) Fühling's landw. Zeit. Aprilheft 1879, p. 294. 
Wird von der Gesammtproduktion das Saatgut mit $7000000 \mathrm{hl}$ und der Export abgerechnet, so verbleiben zum Konsum 24336711 hl oder bei einer Bevölkerung von 5 Millionen Seelen 4.86 hl pro Kopf, während die Produktion 7.87 hl pro Kopf ausmacht.

\section{Die Türkei.}

Eine landwirtschaftliche Statistik dieses Landes ist so gut wie nicht vorhanden. Die Weizenernte des Jahres 1881 wird auf 34800000 hl Weizen geschätzt und liefern namentlich Thracien und Macedonien eine sehr gute Qualität, und werden durchsehnittlich 1500000 hl meist nach Frankreich und England exportiert.

Ausserdem wird viel Mais, in der Ebene anch Gerste, Hirse und Sorghum, im Gebirge Spelz, Roggen und Hafer, sowie an der Maritza bei Philippopel etwas Reis gebaut.

\section{Schweden und Norwegen.}

Schweden und Norwegen, sich iibcr 15 Breitengrade erstreckend, weisen ein sehr verschiedenartiges Klinı auf. In Norden ist es rauh und feucht, im Siiden dem des nördlichen Deutschland ähnlich und vielleicht der fast insularen Lage wegen noch etwas nilder.

Im Allgemeinen sind die Winter kälter, länger und schneereicher, die Sommer aber wärmer, wenn auclı kürzer als in NordDeutschland.

Das Jahresmittel beträgt in Christiania $5.16^{\circ} \mathrm{C}$, in Göteborg $7.97^{\circ} \mathrm{C}$., in Lund $7.25^{\circ} \mathrm{C}$., in Stockholm $6.96^{\circ} \mathrm{C}$., in Umea unter dem 64. Breitengrade nur noch $1.80^{\circ} \mathrm{C}$, weshalb auch in diesen Gegendeı nicht selten im August die Ernte durch Nachtfröste zu Grunde geht.

Im sïdlichen Schweden finden sich weite Ebenen aufgeschwemmten Landes, aus Lehm- oder sandigen Lehmböden bestehend, während im nördlichen Schweden sehr schwere Thonböden autitreten. Auf den Feldern Siid-Schwedens finden sich häufig grosse Massen Rollgesteine, während im Norden vielfach das Urgebirge hervorragt.

In Norwegen wird nur in den Tliälern mit angeschwemmtem Boden Getreide gesäet.

In den nördlichen Gegenden gedeilen vorzugsweise Sommergetreide, dagegen in Sid-Schweden die gleichen Getreidearten wie in Nord-Deutschland.

In Schweden unterliegen nur $25477 \mathrm{qklm}$ oder 6.4 Proc., und in Norwegen sogar nur 2297-2552 qklm, oder 0.7-0.8 Proc. der Gesammtfläche dem Ackerbau. 
Das Maximum an Ackerfläche, nämlich 51.6 Proc., besitzt die fruchtbarste und südlichste schwedische Provinz Skåne.

In Schweden erstreckt sich der Weizen eigentlich nur bis zum $62^{\circ} \mathrm{n}$. Br., und kann daher in Norrland nur unter sehr günstigen Verbältnissen gedeihen. In Norwegen reicht dagegen der Weizenbau bis zum $65^{\circ} \mathrm{n}$. Br., und reift der Sommerweizen in 110-120 Tagen, Vinterweizen wird noch bei Christiania kultiviert.

Der Roggen ist in Schweden rorzugsweise in den Mälarprovinzen, Östergötland und in Skåne verbreitet, und erstreckt sich in Norwegen bis zum $66^{\circ} \mathrm{n}$. Br., doch wird in den nördlichen Gegenden nur Sommerroggen (Vegetationszeit $90-100$ Tage) gebaut, weil Winterroggen unter der starken Schneedecke zu leicht fault.

Die Haferkultur findet sich ansgedehnt in Westergötland, Skåne und Wermland.

Das Hauptgetreide des hohen Nordens ist jedoch die vierzeilige Gerste, welche noch in Alten $\left(70^{\circ} \mathrm{n}\right.$. Br.) und unter dem $62^{\circ} \mathrm{n}$. Br. noch in Höhen ron $628 \mathrm{~m}$ reift. Ende Mai gesäet, wird sie Ende August, also nach 90 Tagen geerntet, und um in diesen hohen Breiten zeitig säen zu können, wird Russ auf den Schnee gestreut, damit die Sonne ihn schneller zu schmelzen rermag.

An der Westküste Norwegens wird von allem Getreide der Rispenhafer am meisten gebaut, und zum Schutze gegen das Erfrieren in den sog. "Jernnätters" oder Eisennächten (20.-24. August) bedient man sich seit grauer Vorzeit des Rauches.

Der Roggen ist die hauptsächlichste Brotfrucht des Landes, mit Ausnahme einiger Provinzen, in denen auch anderes Getreide zur Brotbereitung dient, so in Norrland die Gerste, in Dalarne, Wermland, Dalsland und Småland der Hafer.

Das schwedische Brot wird gerwöhnlich in harten und diinnen Kuchen gebacken, die häufig bei Hafer- und Gerstenbrot so dünn wie Papier sind, uud sich beliebig lange Zeit aufbewahren lassen.

Schweden und Norwegen producierten 1870.

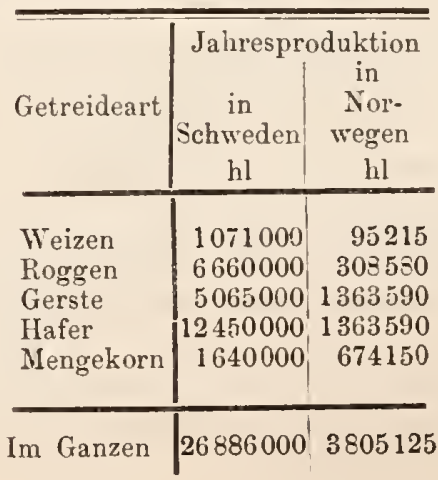


Die Ernteangaben für Schweden werden vielfach als zu niedrig angesehen, indem man die Durchschnittsernte auf ca. 15 Proc., also 31 Millionen hl schätzt.

Schweden ${ }^{1}$ ) produciert mehr Getreide als es konsumiert und umfasst die Ausfuhr besonders Hafer und Gerste, wohingegen aber nicht unbedeutende Quantitäten von Roggen und Roggenmehl aus Russland und von Weizenmehl aus Dänemark cingeführt werden, wie nachfolgende Tabelle zeigt.

\begin{tabular}{|c|c|c|c|c|}
\hline Getreideart & $\begin{array}{c}\text { Einfuhr } \\
\text { hl }\end{array}$ & $\begin{array}{c}\text { Ausfuhr } \\
\text { hl }\end{array}$ & $\begin{array}{l}\text { Mehr- } \\
\text { einfuhr } \\
\text { hl }\end{array}$ & $\begin{array}{l}\text { Mehr- } \\
\text { ausfulir } \\
\text { hl }\end{array}$ \\
\hline $\begin{array}{l}\text { Weizen } \\
\text { Roggen } \\
\text { Gerste } \\
\text { Hafer } \\
\text { Weizenmehl } \\
\text { Roggenmehl }\end{array}$ & $\begin{array}{r}5750 \\
51250 \\
28000 \\
- \\
86600 \\
141600\end{array}$ & $\begin{array}{r}77250 \\
26000 \\
554500 \\
4294500 \\
17800 \\
28000\end{array}$ & $\begin{array}{c}-\overline{25250} \\
- \\
- \\
68800 \\
113600\end{array}$ & $\begin{array}{c}71500 \\
- \\
526500 \\
4294500 \\
- \\
-\end{array}$ \\
\hline Im Ganzen & 313200 & 4998050 & 207650 & 4892500 \\
\hline
\end{tabular}

Demnach iiberwiegt die Ausfuhr dic Einfuhr um 4684.850 hl und kommen, wenn man auch noch das Saatgetreide mit $3700000 \mathrm{hl}$ abzieht, zur Konsumtion 18501150 hl Getreide, oder bei einer Bevölkerung von 4204177 Seelen 4.4 hl pro Kopf.

Hiervon werden als Brotgetreide verbraucht:

\begin{tabular}{ll} 
Weizen & $0.28 \mathrm{hl}$ \\
Roggen & 1.82, \\
Gerste & 1.11, \\
Hafer & 0.66, \\
\cline { 2 - 2 } & $3.87 \mathrm{hl}$
\end{tabular}

oder ein Gesammtquantum von . . . . . . 16270165 hl Ferner tritt hierzu der Konsum für die Branntweinbrennerei mit . . . . . . . . . . . 217000 Bleiben für diverse Fabrikate und Vichfutter . . . 2013985 hl

1) Statist. Mittheil. von Dr. E. Sidenbladh, Sekretair d. Kgl. schwedischen stat. Central-Büreau. Catalog zur Weltausst. Wien, 1873. 
In Norwegen betrug die Produktion $3805125 \mathrm{hl}$ davon ab das Saatgetreide mit 634200 bleiben

$3170925 \mathrm{hl}$

dazn ein Import von

1345300

bleiben zum Konsum $4516225 \mathrm{hl}$

oder bei einer Bcrölkerung von 1733000 Seelen 2.6 hl pro Kopf.

Es belief sich:

die Ausfuhr Schwedens auf . . . . . . . $4684850 \mathrm{hl}$ die Einfuhr Norwegens auf . . . . . . . 1345300

mithin Mehrausfuhr der Monarchie: $3339550 \mathrm{hl}$.

\section{Dänemark.}

Die klimatischen Verhältnisse sind denen Süd-Schwedens ana$\log$, und auf den Inseln, sowie auf der östlichen Hälfte Jütlands finden sich meist fruchtbare Lehmmergelböden, welche dem Getreidebau ausserordentlich günstig sind, während die westliche Hälfte Jiitlands arme Sandböden aufweist.

Von einem Areal von $40000 \mathrm{qklm}$ werden nicht weniger als 2550000 ha oder 63.8 Proc. der Gesammtfläche als Ackerland benutzt.

Der Roggen ist als die Hauptfrucht anzusehen und säet man auf' den besseren Böden Probsteier und Campiner, anf den weniger guten den gewöhnlichen dänischen braunen Roggen. Die Mittelernte ergiebt einen Ertrag von $22 \mathrm{hl}$, doch steigt derselbe bis zu 35 und 40 hl p. ha.

Der Weizen ninımt ungefähr nur den vierten Teil der Roggenfläche ein, und bringen englische Weizensorten, wie Hallet's red pedigree, Shiriff's square head und andere rote und weisse Kolbenweizen sehr hohe Erträge. Im Durchschnitt werden 24 hl, unter sehr günstigen Verhältnissen selbst $40-50$ hl p. ha erzielt. Vorziiglich gedeiht auch auf den mergelhaltigen Lehmböden die Chevalier-Gerste, welche als Braugerste stark in England gesucht ist; auf den leichten Böden wächst die vierzeilige Gerste und soll Erträge von $25-26 \mathrm{hl}$ und sogar $40 \mathrm{bl}$ p. ha liefern.

Der Hafer wird ebenfalls durch Klima und Boden in seinem Gedeihen sehr gefördert, so dass Erträge von 60 und 75 hl vorkommen. 
In Dänemark ${ }^{1}$ ) stellen sich Produktion und Konsumtion folgendermassen:

\begin{tabular}{l|r|r|r|r|r}
\hline Getreideart & $\begin{array}{c}\text { Grössc } \\
\text { der } \\
\text { Anbau- } \\
\text { fäche } \\
\text { in ha }\end{array}$ & $\begin{array}{c}\text { Er- } \\
\text { trag } \\
\text { p. ha } \\
\text { in hl }\end{array}$ & $\begin{array}{c}\text { Preis } \\
\text { p. hl } \\
\text { in }\end{array}$ & $\begin{array}{c}\text { Pro- } \\
\text { duktion } \\
\text { in hl }\end{array}$ & $\begin{array}{c}\text { Geldwert } \\
\text { in Mark }\end{array}$ \\
\hline Weizen & 61930 & 24 & 17.0 & 1486320 & 25267440 \\
Roggen & 253650 & 22 & 12.5 & 5580300 & 69753750 \\
Gerste & 308415 & 25 & 10.0 & 7710375 & 77103750 \\
Hafer & 381350 & 28 & 7.0 & 10677800 & 7474600 \\
\hline Im Ganzen & 1005345 & 25.3 & 9.7 & 25454795246869540
\end{tabular}

Nach Abzug des Saatgetreides mit 4250000 hl und der Mehrausfuhr von $4000000 \mathrm{hl}$ bleiben noch $17204795 \mathrm{hl}$ zum Konsum, der bei einer Bevölkerung von 1785000 Seelen 9.6 hl pro Kopf beträgt. Dieser ansserordentlich starke Getreidekonsum erklärt sich nur daraus, dass mit Ausnahme Amerikas, in keinem Lande so viel Getreide mit dem Vieh verfiittert wird als in Dïnemark.

\section{Die Vereinigten Staaten von Nord-Amerika.}

Das Ackerland der Vereinigten Staaten umfasst 576592 qklm oder nur 6.2 Proc. der Gesammtfläche, und werden davon bestellt mit Weizen 14.9 Proc., Roggen 1 Proc., Gerste 0.9 Proc., Hafer 7.7 Proc. und Mais 32.1 Proc.

In landwirtschaftlicher Beziehung lassen sie sich in folgende Regionen einteilen:

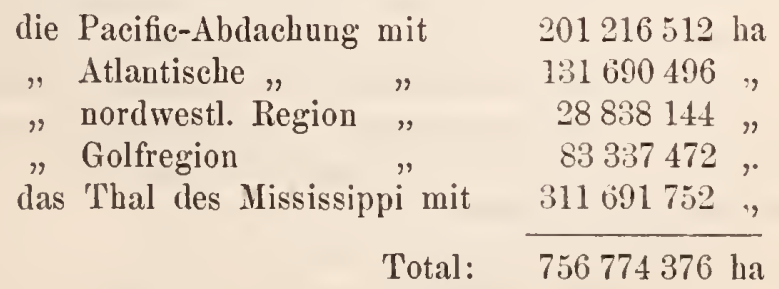

Die Region der Atlantischen Abdachung umfasst die alten Staaten (Neu-England-Staaten) New-Hampshire, Maine, Massachusetts,

1) Godefroy, Écom. rurale du Danemark. 1878. 
Vermont, Connecticut, Rhode-Island; (New-York-Staaten) New-York, New-Jersey; Kentucky, Virginia, Pennsylrania, Tennessee und den Süden ron Columbia.

Die New-England-Staaten sind nicht mehr exportfähig und beziehen einen grossen Teil ibres Brotbedarfs aus den westlichen Staaten, weil ihre Berölkerung zn stark angewachsen und das Land in früherer Zeit $z u$ sehr ausgeranbt worden ist. Gleiches lässt sich von Virginia, Kentuky, Pennsylranien und Tennessee sagen, doch können diese noch Mais exportieren.

Die Pacific- und nordwestliche Region umfassen die hauptsächlich Getreide exportierenden Staaten. Von diesen tritt die erstere Region, weil am Stillen Ocean gelegen, momentan weniger als die nordwestliche Region in Betreff des Exportes in den Vordergrund, doch bat sie eine bedeutende Znkunft als Exportland.

Von besonderer Bedeutung für Europa als Exportland sind zur Zeit die Staaten der nordwestlichen Region nnd zwar: Ohio, Indiaua, Illinois, mit dem Hauptgetreidehafen Chicago, Michigan, Missouri, Jowa, Wisconsin und mehrere neue Staaten. Die fruchtbarsten ron diesen sind Indiana nnd Illinois. Diese Staaten haben meist Weizenboden erster Qualität, der sich. Teil Prairie-Land und desshalb stein- und wurzclfrei, sehr leicht bearbeiten lässt. Sie producieren ca. 7.5 Proc. der ganzen Weizenernte der Vereinigten Staaten. Die Golfregion erzeugt bis jetzt wenig Weizen und importiert sogar aus den Nord-West-Staaten. Die fünfte Region, das . Mississippi-Thal, besitzt einen sehr reichen, fruchtharen Boden, und wiirde, rollständig kultiviert, eine Berölkerung ron 100 Millionen Menschen erü̈hren können, doch ist bis jetzt nur ein sehr kleiner Teil in Anbau genommen.

Der Weizen ist vor Allem das Getreide der Prairie und des erst urbar gemachten Landes der westlichen Staaten, denn sein Gedeihen ist weniger von der Bodenpflege als ron dem Klima und dem natiirlichen Bodenreichtum abhängig und erzielt bei in Vergleich zu seinem Werte relatir geringen Transportkosten einen höheren Preis als irgend cine andere Getreideart, daher er denn auch als Hauptgetreide in den Gebieten des Missouri, Mississippi und Ohio mit deren Nebenfliissen nördlich rom $35^{\circ}$ gebaut wird.

Ausserdem liegt noch eine andere Weizenfläche im Westen an der Küste des Stillen Oceans.

Das erstere Gebiet lässt sich durch eine Linie in eine Sommerweizen- nnd Winterweizen-Region teilen. Sie beginnt bei Boston, zieht sich durch Massachusetts und den südöstlichen Teil rou Connecticut an Saratoga vorbei in westnordwestlicher Richtung gegen den Ontario-See hin, geht dann den Eric-See entlang, berührt den Norden ron Indiana und Missouri, erreicht bei der Stadt St. Joseph den Staat Kansas und erstreckt sich bis an das Felsengebirge. 
Das Klima nördlich dieser Linie charakterisiert sich durch lange strenge Winter und heisse Sommer, und macht hiervon nur Michigan eine Ausnahme, welches, durch seine Lage zwischen den Seeen, ein gemässigteres Klima besitzt.

Diese klimatischen Verhältnisse bedingen hauptsächlich die Kultur weisser und roter kleberreicher Sommerweizen mit stahligem Bruch.

Der südlich dieser Linie gelegene mittlere Teil der Union besitzt dagegen ein gemässigteres, gleichartigeres Klima und werden hier zumeist mehlige rote Bart- und Kolbenweizen im Herbst angebaut.

In dem kleineren Weizenproduktionsgebiet im Westen des Felsengebirges, namentlich in den Straten Oregon und California, kultiviert man vorwiegend halbharte weisse Bart- und Igelweizen.

Von den in Poppelsdorf angebanten amerikanischen Weizensorten betrugen die weissen Kolbenweizen 34 Proc., die roten 26 Proc., die weissen Bartweizen 14 Proc., die roten 22 Proc. und die Igelweizen 4 Proc.

Im Allgemeinen machen die Sommerweizen 40 Proc. und die Winterweizen 60 Proc. der Produktion ans.

Der Durchschnittsertrag des Winterweizens stellt sich auf 10.9 hl p. ha und der Maximalertrag bei Preiskulturen ohne Dung in Ohio anf $33.67 \mathrm{hl}$, in Oregon angeblich auf $60 \mathrm{hl} \mathrm{p}$. ha.

Welchen Umfang zur Zeit der Export des Weizens angenommen hat, zeigt untenstehende Uebersicht, nach welcher der Export durchschnittlich pro Jahr betrug:

$\begin{array}{ll}1825-1830 & 1698000 \mathrm{hl} \\ 1830-1835 & 1947000 ", \\ 1835-1840 & 1620000 " \\ 1840-1845 & 2492000 " \\ 1845-1850 & 5199000 " \\ 1850-1855 & 5967000 " \\ 1855-1860 & 8545000 " \\ 1860-1865 & 17213000 " \\ 1765-1870 & 10097000 " \\ 1870-1871 & 19084000 " \\ 1871-1872 & 27808000 " \\ 1872-1873 & 18551000 " \\ 1873-1874 & 33004000 \\ 1874-1875 & 26367000 " \\ 1875-1876 & 27181000 " \\ 1876-1877 & 20744000 " \\ 1877-1878 & 33506000 " \\ 1878-1879 & 42825960 " \\ 1879-1880 & 53638550 "\end{array}$


Diese Zahlen legen beredtes Zeugniss ron der Exportkraft der Vereinigten Staaten ab, doch ist die Steigerung des Exportes in den letzten Jahren nicht nur durch die Erweiterung der Produktion, sondern auch durch sehr günstige Vegetationsrerhältnisse, welche zu reichen Ernten führten, erzielt worden.

Die zweite Hauptfrucht, wenn nicht die erste, bildet der Mais, welcher langsam aber sicher'den Weizenbau immer weiter nach Norden drängt und jetzt schon in einem grossen Teil der mittleren und östlichen Staaten das Uebergewicht erlangt hat.

Man findet ihn als Hauptsaat rom Golf von Mexico bis an die Küsten der grossen Seeen und ron Texas und Kansas in Westen bis New-Jersey, Carolina und Florida im Osten.

Die hauptsächlich Mais bauenden Staaten sind: Ohio, Kentucky, Indiana, Jowa, Illinois, Tennessee und Missouri, welche annähernd die Hälfte der gesanmten Maisernte liefern. Er findet in diesen Staaten nicht nur Böden mit natiirlichem Reichtum und geniigende Wärme, sondein auch ausgiebige Sommerregen, welche weiter im Westen fehlen, so dass der Maisbau dort nur noch bei Irrigation ermöglicht wird. Auch sind in den Siidstaaten, z. B. Georgia, Louisiana etc., auf den reichen Alluvialböden die Erträge häufig um die Hälfte geringer, als in den nördlicher gelegenen Staaten, was daher kommt, dass unter der Einwirkung der feuchteren Atmosphäre und höheren Temperatur sich massenhaft Halme und Blätter entwickeln, doch die Körnerproduktion leidet.

Zur menschlichen Nahrung rerdienen ihres besseren Mehles wegen die weissen, harten (Flint-) Maissorten den Vorzug, denn das Mehl der gelben Sorten hat einen strengeren Gcschmack, doch eignet sich ihr ölreiches Korn als Viehfutter. Im Allgemeinen gilt die Regel, dass je geringer die Reilienzahl am Kolben ist, um so härter sind anch die Kömer.

Welchen Unfang die Maiskultur nach und nach gewonnen, lässt sich aus den Erträgeu seit 1840 folgern, denn es wurden geerntet :

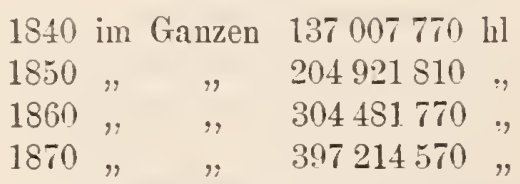

Ausserdem liefert der Mais das Hauptnahrungsmittel der Berölkerung, denn es entfallen pro Kopf $720 \mathrm{~kg}$ Mais, aber nur $150 \mathrm{~kg}$ Weizen und $94 \mathrm{~kg}$ Kartoffeln.

Auch gewinnt, wie nachstehende Zusammenstellung zeigt, der Maisexport inmer grössere Bedeutung. Es murden an Mais ausgeführt: 
1870

hl.

nach Grossbritannien und Irland 14412

$\begin{array}{ll}\text { " } & \text { Frankreich } \\ \text { ", } & \text { Delgien } \\ \text { " } & \text { Portugal }\end{array}$

83

15000
1880

hl.

19604338

3021182

872097

2674453

718024 .

Bei extensiver Kultur schwanken die Erträge zwischen 13.5 und $27 \mathrm{lll}$, und steigern sich bei intensivel bis auf $63 \mathrm{hl} \mathrm{p}$. ha, doch soll die Grenze der Produktion nach Enfield bei 225 hl erst erreicht sein. Der Durchschnittsertrag stellt sich auf $20 \mathrm{hl}$ p. ha.

Die Kultur des Roggens ist sehr unbedeutend; Pennsylvanien bant den meisten Roggen, hicrnach New-York, New-Jersey, Kentucky, Vermont, New-Hampshire, Maine, Ohio und Michigan, in welchen Staaten er auf die leichtesten Böden znrückgedräingt ist.

Das Mehl wird vielfach in den grossen Städten entweder fiir die Europäer zll Brot verbacken, oder mit Maismehl gemischt, daraus ein Brot, welches man als „Rye-and Indian or brownbread" bezeichnct, hergestellt. Auch bereitet man aus dem Korn den bekanntell „,RyeWhisky".

Der höchste Ertrag stellt sich auf 34 hl p. ha und gelangen ca. 400000 hl zum Export.

Noch weniger umfangreich ist der Anball der Gerste, deren Qualität in den meisten Distrikten verhältnissmässig dïrftig ansfällt, denn das Korn ist mager, unregelmässig gestaltet, und arm an Stärkemchl. Eine Ausnahme hiervon macht nur die in den feuchteren Lagen am Fnsse der Felsengebirge, und die bei besserer Kultur in Californien, Minnesota, Wisconsin, Jowa und in einigen Distrikten des Staates New-York gezogene Gerste, wclche mit den europäischen Braugersten konkurrieren kann. In dem letzteren Staat wird sehr viel Gerste fill die zahlreichen Branereien verbraucht und daher, trotz des hohen Zolles, viel canadische Gerste eingeführt.

Californien liefert ungefähr eiı Dritteil der gesammten Produktion der Vereinigten Staaten.

Ueberhaupt steigert sich die Gerstenproduktion mit der intensiveren Kultur ausserordentlich.

Es wurden erzeugt:

$\begin{array}{rrr}1840 & 1465910 \text { hl } \\ 1850 & 1854587 & \\ 1860 & 5602287 & \\ 1870 & 9545230 & " \\ 1880 & 16394895 & \end{array}$


Der höchste Ertrag stellt sich auf 29 hl p. ha.

Der Haferbau scheint an Ausdehnung zu gewinnen, und zwar hauptsächlich im Gebiete des Mississippi, westlich rom Michigan-See, südlich rom Oberen See, sowie in Pennsylvanien und im Staate New-York.

Die Qualität des Kornes und namentlich der in den NordwestStaaten sehr beliebten dickkörnigen oder Schwerhafer (Avena s. praegravis) lässt sehr zu wünschen.

Die Produktion betrug:

$\begin{array}{lr}180^{\circ} 0 \text { ungefähr } & 62637352 \mathrm{bl} \\ 1870 \quad " & 89761696, " \\ 1880 \quad " & 100000000 ",\end{array}$

und kommt daron nur 1 Million Hektoliter zum Export.

Der Maximal-Ertrag ergab 32.33 bl p. ha.

Eine für Amerika sehr wichtige Kultur ist die der Zucker- und Besen-Mohrhirse.

Erstere überschreitet kaum den $40 .{ }^{\circ} \mathrm{n}$. Br. und wird darüber hinaus nicht mehr auf Zucker, sondern nur noch zur Korn-, oder Grünfuttergewinnung angebaut.

Vor Allem sind es die Staaten Illinois, Indiana und Ohio, welche eine sehr ausgedehnte Kultur des Zuckersorghum besitzen, wie dies z. B. die Anbaustatistik des Staates Ohio ${ }^{1}$ ) zeigt. Es wurden mit Zuckersorghum angebaut:

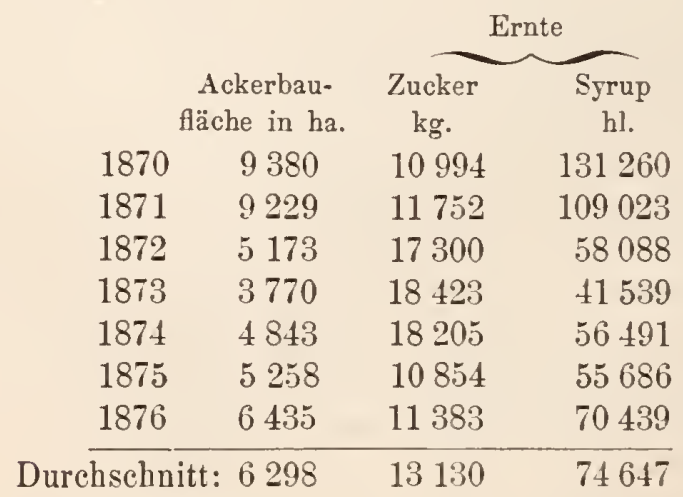

Demnach wurden auf 1 ha durchschnittlich erzeugt $2.2 \mathrm{~kg}$ Zucker und 12 hl Syrup, doch kommen auch Erträge bis zu 30 hl Syrup ror.

1) Report of the Commiss. of Agric. 1876. Washington. 
Eine sehr wichtige Industrie, die Besen- und Bürstenfabrikation, ist mit dem Anbau der Besenhirse entstanden.

Den Mittelpunkt ihrer Kultur bildet gegenwärtig lllinois und es befinden sich in Chicago, Cleveland und Philadelphia grosse Fabriken.

Als guter Ertrag werden auf reichem Boden $1100-1200 \mathrm{~kg}$, auf leichterem Boden $600-900 \mathrm{~kg}$ Rispen $\mathrm{p}$. ha angeseben, hierbei beträgt die Körnerernte noch $35-70 \mathrm{hl} \mathrm{p}$. ha.

Eine bcsondere Beachtnng verdient ferner die Reiskultur, welche hauptsächlich in South-Carolina, Georgia, Florida, Alabama, Mississippi, Louisiana und Texas betrieben wird.

Die Erträge sind ausserordentlichen Schwankungen unterworfen, je nach dem Reichtum des Bodens und seiner Kultur; geringe Erträge sind: $18 \mathrm{hl}$, mittlere $35 \mathrm{hl}$, hohe $54 \mathrm{hl} \mathrm{p}$. ha ( lassen sich unter sehr günstigen Umständen bis zu $80 \mathrm{hl}$ p. ha erzielen.

Durchschnittlich ergiebt die Reisproduktion der VereinigtenStaaten $700000 \mathrm{hl}$ à $60 \mathrm{~kg}$, welche auf einer Fläche von 20000 ha geerntet werden, von denen allein auf South-Carolina 6800 ha entfallen. Wegen seiner vorzüglichen Qualität ist dieser Reis eine gesuchte Exportware und werden ca. 400000 b1 à 14 M. jährlich exportiert.

Die Anbaustatistik ${ }^{1}$ ) der Vereinigten Staaten von Nord-Amerika macht folgende Angaben für die Zeit von 1868-1876.

\begin{tabular}{|c|c|c|c|c|c|}
\hline Getreideart & 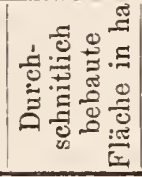 & 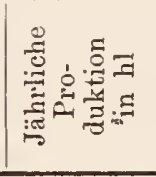 & $\begin{array}{l}\text { Er- } \\
\text { trag } \\
\text { p. ha } \\
\text { in hl }\end{array}$ & $\begin{array}{c}\text { Preis } \\
\text { p. } 1 \mathrm{hl} \\
\text { in } \\
\text { Mark }\end{array}$ & $\begin{array}{l}\text { Geldwelt der } \\
\text { Gesammt- } \\
\text { produktion } \\
\text { in Mark }\end{array}$ \\
\hline $\begin{array}{l}\text { Weizen } \\
\text { Roggen } \\
\text { Gerste } \\
\text { Mais } \\
\text { Hafer }\end{array}$ & \begin{tabular}{|r|}
8599740 \\
573985 \\
503047 \\
18492532 \\
4284839
\end{tabular} & $\begin{array}{r}93703324 \\
6971277 \\
10788265 \\
369621374 \\
100318404\end{array}$ & $\begin{array}{l}10.9 \\
12.1 \\
21.4 \\
20.0 \\
23.4\end{array}$ & $\begin{array}{r}12.8 \\
10.6 \\
10.6 \\
6.3 \\
5.0\end{array}$ & $\begin{array}{r}1204424390 \\
74220325 \\
113829295 \\
2312149073 \\
504849299\end{array}$ \\
\hline Total & 32454143 & 581402644 & 17.6 & 7.2 & 4209472382 \\
\hline
\end{tabular}

Bei 50 Millionen Einwohnern stellt sich die Produktion pro Kopf der Bevölkerung anf 11.6 hl Getreide (excl. Hülsenfrüchte, Reis, Hirse, Buchweizen).

Die Verteilung der Getreideproduktion gestaltet sich wie folgt:

1) Obige Zahlen sind entnommen aus "Rep. of the Commissioner of Agric." u. "Monthly Rep. of the Departm. of Agric." Washington. 


\begin{tabular}{|c|c|c|c|c|c|c|c|c|}
\hline $\begin{array}{l}\text { Ge- } \\
\text { treide- } \\
\text { art }\end{array}$ & 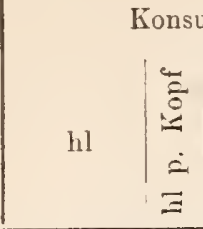 & $\begin{array}{l}\text { Geldwert } \\
\text { in Mark }\end{array}$ & $\mathrm{hl}$ & $\begin{array}{l}\text { atbec } \\
\left|\begin{array}{c}\omega \\
0 \\
= \\
\dot{\Xi} \\
\Xi\end{array}\right|\end{array}$ & $\begin{array}{l}\text { Geldwert } \\
\text { in Mark }\end{array}$ & hl & $\begin{array}{l}\text { Expo } \\
\left|\begin{array}{l|}\mid \\
0 \\
0 \\
\vdots \\
\vdots \\
\vdots\end{array}\right|\end{array}$ & $\begin{array}{l}\text { Geldwert } \\
\text { in Mark }\end{array}$ \\
\hline $\begin{array}{l}\text { Weizen } \\
\text { Mais } \\
\text { Roggen } \\
\text { Gerste } \\
\text { Hafer }\end{array}$ & $\begin{array}{r}60759>081.2 \\
3445517866.9 \\
52203070.1 \\
90382650.2 \\
773184041.5\end{array}$ & $\begin{array}{r}782747385 \\
2154210668 \\
57780043 \\
95279295 \\
389849290\end{array}$ & $\begin{array}{r}11635607 \\
4561676 \\
1150070 \\
1250000 \\
13000000\end{array}$ & $\begin{array}{l}0.2 \\
0.1 \\
0.02 \\
0.03 \\
0.3\end{array}$ & $\begin{array}{r}148935770 \\
28738559 \\
12200282 \\
13250000 \\
65000000\end{array}$ & $\left|\begin{array}{r}21307609 \\
20507912 \\
400000 \\
500000 \\
1000000\end{array}\right|$ & $\mid \begin{array}{l}0.43 \\
0.41 \\
0.01 \\
0.01 \\
0.20\end{array}$ & $\begin{array}{r}27274123 \\
12919984 \\
424000 \\
530000 \\
500000\end{array}$ \\
\hline Im & 09.9 & $3479866690 \mid$ & 315982 & 0.65 & 268124611 & 527158 & 1.5 & 然 \\
\hline
\end{tabular}

Hiernach steht der Maisbedarf in Amerika oben an, und treten in dieser Beziehnng alle iibrigen Getreidearten weit zurück, denn von $9.9 \mathrm{hl}$ Gesarnmtkonsum entfallen nicht weniger als $6.9 \mathrm{hl}$ auf den Mais.

\section{Canada.}

Das relatir feuchte Klima und die guten Lehmböden des siidlichen zwischen den Seeen und dem atlantischen Ocean gelegenen Canada begiinstigen die Produktion rortrefflicher weicher Kolben. weizen und Brangersten, während das kontinentale Canada sich dırch schneereiche Winter und heisse, trockne Sommer auszeichnet, so dass friihreifer Mais noch zeitigt und geschätzte Sommerweizen mit hohem Klebergehalt gedeihen.

Ausserdem produciert Canada Wintergerste, ausgezeichneten Roggen, sowie Schwerhafer und braunen Hafer.

Die Produktion beträgt:

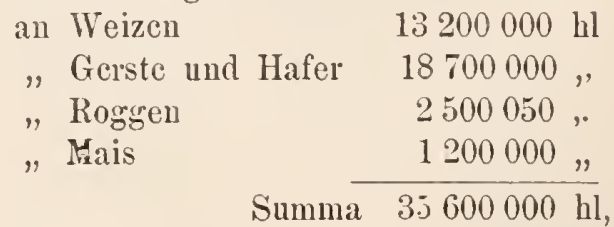

mithin werden bei einer Bevölkerung von 4350933 Seelen pro Kopf produciert: $8.2 \mathrm{hl}$; da sich der Konsum auf $6.8 \mathrm{hl}$ stellt, so können noch 6000000 hl zum Export gelangen. 


\section{Britisch-Indien.}

Die Hauptfruclit des Landes ist der in den Thälern während der Regenzeit, Mitte Juni bis Mitte September gebaute Wasserreis, welcher in beträchtlichen Quantitäten exporticrt wird, und der Bergreis, welcher noch anf Höhen von $1700 \mathrm{~m}$ fortkommt und im Lande verbleibt.

Im Frïhjahr (Maiı und April) erntet man Weizen und Gerste, welche im Herbst (Oktober) ausgesäet werden, während die Herbsternte aus Hirse, Reis und Mais besteht.

Der Boden, sowie die klimatischen Verlüilnisse sind, zumal bei kiinstlicher Wasserzufuhr, dem Getreideban sehr giinstig und ist das Land bei verbesserter Kultur eines hoch gesteigerten Exportes, namentlich ron Weizen fähig, wie sich aus folgenden Angaben erkennen lïsst.

Ein Feld, welches lange Zeit hinter einander Weizen auf Weizen getragen hattc, lieferte noch $3-4$ bushel Weizen p. acre; ein Feld eines Eingeborenen mit besserer Fruchtfolge 17 bushel Korn und $14 \mathrm{Ctr}$. Stroh, ein armes Feld von einem Engländer mit englischem Pflug bestellt. 19 bushel Korn, 17 Ctr. Stroh; ein Feld mit Bohnensprell gerlüngt $281 / 2$ bushel Korn, 30 Ctr. Stroh; ein Feld mit etwas Stalldung gedüngt, 36 bushel Korn, 48 Ctr. Stroh.

Nach Dr. J. Watson produciert Indien jälırlich 105 Millionen hl Weizen, welche Produktion sich wesentlich steigern lässt, weshalb Indien als Weizenlieferant immer wiclitiger wird, zumal sich del Weizen durch cine vortreffliche Qualität auszeichnet.

Es kommen vor: weiche, weisse und rote mehlige Weizen ${ }^{1}$ ), welche gerade in der englischen Flachuilillerei geschätzt sind, ferner harte und stahlige rote und braune Sorten mit bedeutendem Klebergehalt, welche sich für die Griesmüllerei cignen, und schliesslich ansser diesen zu Triticum vulgare zählenden Sorten auch Hartweizen.

Die Weichweizen gedeihen vorzugsweise auf denSïd-Ablängen des Himalaya und zwar nach Royle in Höhen von $2700 \mathrm{~m}$, nach Ge ra rd von $3300 \mathrm{~m}$ und Capt. Webb will noch bei $4000 \mathrm{~m}$ Weizen angetroffen liaben. Die Weichweizen reichen ungefährb is zum $22^{\circ} \mathrm{n}$. Br.. wenngleich rote Weichweizen auch noch etwas südlicher vorkommen. Die Hartweizen dehnen sich dagegen bis zur Spitze der Halbinsel aus.

Die Zunahme des Weizenexportes ist eine auffallend rapide und jetzt schon sehr erheblich, dem es wurden im Ganzen exportiert:

1) Vergl. Pekár, Weizen und Mehl p. 149. 


$\begin{array}{rr}1872-1873 & 252570 \mathrm{hl}=3353800 \mathrm{M} . \\ 1873-1874 & 1125600 "=16552128 \% \\ 1874-1875 & 685300 "=9808704 " \\ 1875-1876 & 1601400 "=18020510 " \\ 1876-1877 & 3579100 "=39126650 " \\ 1877-1878 & 40644_{i} 00 "=57139598 \%\end{array}$

6jähriger Durchschnitt: $1884695 \mathrm{hl}=24000232$ M.

Hiervon gingen allein nach England:

$$
\begin{aligned}
& 1872-1873=116600 \mathrm{hl} \\
& 1873-1874=870000 ", \\
& 1874-1875=500000 ", \\
& 1875-1876=1230000 ", \\
& 1876-1877=2289000 ", \\
& 1877-1878=3674000 "
\end{aligned}
$$

Die Gerste gedeiht nach Royle noch in Höhen bis zu $1700 \mathrm{~m}$, und zwar geht ".Siberian-barley" am höchsten. Auch ist die Kultur der Ziegenhorn- und nackten Gerste weit verbreitet.

Sehr ausgedehnt findet sich anch der Anbau der Rispen- und Kolbenhirse, sowie des Sorghums. Von letzterem werden bauptsächlich kultiviert: Andropogon Sorghum bicolor Willd., A. S. niger R. et Sch., und im Distrikt Manipur A. S. cernuus Roxb. Seine Saatzeit fällt in den Oktober, die Ernte in den Januar. Dagegen wird A. S. saccharatus zur Regenzeit in solchen Gegenden gebaut, welche für Reis schon zu hoch liegen.

\section{Aegypten.}

Man unterscheidet in Aegypten zwei Klassen von Ländereien, and zwar zunächst diejenigen, welche von der jährlichen Ueberschwemmung des Nil erreicht werden und während der Vegetationszeit die Bodennässe bewahren. Auf diese wird Wintersaat gebracht, deren Aussaat unmittelbar nach dem Zuriicktreten des Wassers, d. i. je nach der mehr südlichen oder nördlichen Lage von Oktober bis gegen Ende December geschieht.

In der hauptsächlichsten Vegetationsperiode werden 50 Proc. des Landes in Ober-Aegypten, 30 Proc. im Delta mit Weizen und 10 resp. 14 Proc. mit Gerste bestellt. Die Vegetationszeit umfasst 4 Monate, mithin dic Erntezeit ron Mitte Februar bis Ende April währt.

Die zweite Klasse bildet den künstlich bewässerten Boden, der drei Ernten zu bringen vermag, indem auf die Winterung von April 
bis August (Sommerperiode oder Sêfi) Reis oder Hirse folgt, doch erstreekt sieh die Ernte für einzelne Sorten mit langer Entwiekelung über den August hinaus und bis in die Winterzeit hincin z. B. für Reis.

Die dritte Periode fällt mit dem Steigen des Nil zusammen, und umfasst die Herbstsaat, welche im fetten Deltaboden aus Mais und Durrah besteht, deren Ernte meist naeh 70 Tagen eintritt.

Die Aussaat erfolgt oftmals ohne alles vorhergeheude Pflügen in den durehweiehten Boden und der ausgestreute Same wird ron einer dureh Ochsen gezogenen hölzernen Walze eingedrüekt, oder bloss dureh dariber getriebenes Vich eingetreten.

Zum Schneiden des Getreides bedient man sich der Siehel oder reisst die Halme einfaeh aus. Gedrosehen wird mit einem hölzeruen Schlitten.

Die Reinigung der Körner geschieht dureh Worfeln.

Meist gehören die ägyptisehen einheimischen Weizen zu Tritieum turgidum, welche wenig eoagulierenden Kleber besitzen. Ausserden konmen, namentlich in Unterägypten weisse und rote stahlige und kleberreiche Weizen (Trit. vulgare) und Hartweizen (Trit. durum) ror.

Die im Delta-Gebiete heimisehen Béhéra- und die oberägyptisehen Saîdi-Weizen sind naeh P ekár die schleehtesten der Welt.

Die meisten ägyptisehen Weizen haben dureh die Art der Ernte, des Erdrusehes und der Aufbewahrung einen höehst penetranten Erdgerueh, weleher ihren Wert vermindert.

Die bauchigen Weizen (Trit. turgidum) werden im Lande verbraucht, doeh ist das Hauptnahrungsmittel für Ober-Aegypten die Durrah ${ }^{1}$ ) (Andropogon Sorghim niger, eernuus, bieolor und saccharatus), deren Anban dort immer mehr die Weizenkultur verdrängt.

Bei Bewässerung gedeiht auch der Mais, der im Delta zwei Ernten in einem Jahre erzielen lässt. Derselbe wird im Lande als „Polenta" verzehrt.

Reis wird hauptsäcllich nur im Delta und zwar bei Rosette (Sultani-Reis) und bei Damiette (Mezelui-Reis) gebaut und werden von ihm 177300 hl geerntet.

In reeht beträehtlieher Ausdehnung findet sich der Hirsebau und wird das Produkt im Lande verzehrt.

Nach den offieiellen Angaben stellte sieh $1875^{2}$ ) die Getreideproduktion wie folgt:

1) Figari Bey, Studii scientifici sull' Egitto p. 104, 1864.

2) Buchta, Ausland, 1882. No. 41, pg. 803. 


\begin{tabular}{lr} 
Weizen & $12060000 \mathrm{hl}$ \\
Gerste & $5580000 "$ \\
Mais & $4800000 "$ \\
Durrah & $14100000 "$ \\
\hline Total: & $26540000 \mathrm{hl}$.
\end{tabular}

Die Mehrausfuhr beträgt an Weizen $2000000 \mathrm{hl}$.

\section{Algier.}

Wenige Kilometer von der Kiiste entfernt, beginnt ein excessives kontinentales Klima mit einer Sommertemperatur von $30^{\circ}$ C. (Max. $40-45^{\circ} \mathrm{C}$.) und einer Wintertemperatur von $+4^{0} \mathrm{C}$. Hierzu tritt, dass die Wasserverteilung sehr ungünstig ist, da der Regenfall im Winter $429 \mathrm{~mm}$, im Friihjahr $191.4 \mathrm{~mm}$, im Sommer $19.8 \mathrm{~mm}$ und im Herbst $205.8 \mathrm{~mm}$ beträgt, mithin im Winter die Niederschläge unverbältnismässig hoch, im Sommer bei grosser Hitze sehr niedrig sind und Dürre herrscht.

Das Wintergetreide, welches im Mai geerntet wird, profitiert noch durch die Feuchtigkeit des Winters, doch ist die Produktion einer zweiten Ernte wegen der Erhärtung des Bodens unmöglich, wenn nicht eine ausgiebige Bewässerung stattfindet. Die französische Regierung hat sich nun bemüht, Thalsperren anzulegen, um das Wasser der Gebirgsfiüsse aufstauen und im Sommer zur Bewässerung benutzen zu können, auf diese Weise wird z. B. die fruchtbare Ebene des "Tell" bewässert.

Die Feldbestellung zur Bewässerung geschieht nach Art des Furchenbaues und wird das Wintergetreide in der Regel dreimal gewässert; nur Mais, welcher im April gesäet und Mitte Juli geerntet wird, erhält vier Mal Wasser.

Vor der Eroberung Algiers wurden lediglich Hartweizen von seltener Schönheit und einem Gewicht von $75-80 \mathrm{~kg}$ p. hl kultiviert; die Franzosen importierten Weichweizen, so namentlich Touzelle blanche de Provence, richelle blanche; Blé de Ronsillon ou Seissette mit einem Gewicht von $73-79 \mathrm{~kg}$ p. hl. Diese Weichweizen sind sehr schön, rein, gleichförmig und von grossem Klebergehalt.

Die Hartweizen sind glasig, fast durchsichtig und liefern ein Mehl mit gelblichem Schein, das namentlich zur Nudelfabrikation geschätzt wird. Sehr beliebte Sorten sind: Blé d'Ismaël und Blé de Taganrog.

Der beste Weizen wird in Oran gebaut, doch stelıt ihm der von Titteri, Alger und Saint-Denis wenig nach.

Die gebauten Gerstensorten gehören meist der vierzeiligen und 
Getreideproduktion, Getreidekonsumtion und Getreidehandel.

hauptsächlich der bläulichen Gerste an, und dient dieselbe grösstenteils als Pferdefutter.

Sorghum und Hirse werden in beträchtlicher Ausdehnungkultiviert.

Nach dem Katalog der Pariser Ausstellung von 1878 berechnen sich die Erträge in Algier für die Jahre 1875 und 1876 wie folgt :

\begin{tabular}{|c|c|c|c|c|c|c|}
\hline \multirow[t]{2}{*}{ Getreideart } & \multicolumn{2}{|c|}{$\begin{array}{l}\text { Durch Europäer } \\
\text { angebaut: }\end{array}$} & \multicolumn{2}{|c|}{$\begin{array}{c}\text { Durch Eingeborene } \\
\text { angebaut }\end{array}$} & \multicolumn{2}{|c|}{$\begin{array}{l}\text { Euro- Einge- } \\
\text { päer, borene } \\
\text { Durchschnitt } \\
\text { von } 1862 / 76 \\
\text { Ertrag p. ha }\end{array}$} \\
\hline & ha & $\begin{array}{l}\text { Ertrag } \\
\text { in } \mathrm{kg}\end{array}$ & ha & $\begin{array}{l}\text { Ertrag } \\
\text { in } \mathrm{kg}\end{array}$ & $\begin{array}{c}\text { Ertra } \\
\mathrm{kg}\end{array}$ & $\begin{array}{c}\text { p. ha } \\
\text { kg }\end{array}$ \\
\hline Hartweizen & 309309 & 214267300 & 2080885 & 981126200 & 727 & 473 \\
\hline Weichweizen & 180893 & 161441300 & 82014 & 51666400 & 845 & 556 \\
\hline Gerste & 317400 & 275411000 & 2644205 & 1886774300 & 861 & 592 \\
\hline Hafer & 45916 & 53199400 & 4312 & 3235300 & 1199 & $68 t$ \\
\hline Mais & 12287 & 9592700 & 32207 & 15449800 & 842 & 583 \\
\hline
\end{tabular}

Nach diesen Angaben stellt sich die Produktion auf Hektoliter berechnet, wie folgt:

\begin{tabular}{|c|c|c|c|}
\hline Getreideart & $\begin{array}{l}\text { Anbau- } \\
\text { fläche } \\
\text { in ha }\end{array}$ & $\begin{array}{l}\text { Ertrag } \\
\text { in hl }\end{array}$ & $\begin{array}{l}\text { Er- } \\
\text { trag } \\
\text { p. ha } \\
\text { in hl }\end{array}$ \\
\hline $\begin{array}{llllll}\text { Weizen } & 1 & \text { hl } & \text { à } & 77 & \mathrm{~kg} \\
\text { Gerste } & 1 & & \text { à } & 64 & \\
\text { Hafer } & 1 & & \text { à } & 45 & \\
\text { Mais } & 1 & \text { à } & 78 & \end{array}$ & $\begin{array}{r}2653101 \\
2961605 \\
50228 \\
44495\end{array}$ & $\begin{array}{r}18300000 \\
33800000 \\
1254000 \\
321000\end{array}$ & $\begin{array}{r}6.9 \\
11.5 \\
25.0 \\
7.2\end{array}$ \\
\hline Total: & 5709428 & 53675000 & 9.9 \\
\hline
\end{tabular}

Im Jahre 1876 belief sich die Bevölkerung anf 2462936 Eingeborene und 353639 Europäer, also im Ganzen auf 2816575 Einwohner, mithin berechnet sich pro Kopf der Bevölkerung die enorme Produktion von $19 \mathrm{hl}$.

Der Export diirfte sich nahezu auf 3 Millionen Hektoliter Getreide stellen.

\section{Australien.}

Das Klima Australiens ist seiner heissen und trocknen Sommer wegen dem Getreidebau nicht ganz günstig, am besten gedeiht, da sie noch von der Winterfeuchtigkeit Nutzen ziehen kann, die 
Winterung. Der Mais lässt sich der Dürre wegen in Süd-Australien kaum anbauen, doch gedeibt er an der feuchteren Nord- und Ostküste besser und Hafer wird vorzugsweise auf dem feuchteren NeıSeeland kultiviert.

Die Getreidekultur stützt sich der Hauptsache nach auf Raubbau, so wird der Weizen breitwurfig in das ungedüngte, $7-10 \mathrm{~cm}$ tief gepfliigte Land im April eingesäet und im December geerntet und das Feld, je nach seinem natürlichen Reichtum, 10-30 Jahre lang ansgeranbt. Entsprechend diesem extensiren Getreidebau treten auch zahlreiche Feinde auf, so die Heuschrecken und eine specifische Weizenkrankheit ,take all" (Nimm Alles) genannt, wodurch häufig ausgedehnte Reriere zerstört werden.

Hauptsächlich baut man weisse Weichweizen von rorzüglicher Qualität, denn nirgends auf der Welt als in Australien wird ein gleich kleberreicher und guten Kleber enthaltender Weissweizen angetroffen, daher auch diese Weizen in London die höchsten Preise erzielen.

Leider geht diese forziigliche Qualität leicht rerloren, sobald diese Sorten in dem feuchteren West- und Mittel-Europa angebaut werden, wie andererseits die grosskörnigen, undurchsichtigen Weizen Englands in Australien glasig und kleinkörnig werden, wie wir uns an Sendıngen des Direktors des botanischen Gartens zu Adelaide, Herrn Schönburgh, überzeugen konnten, z. B. waren die rundlichoralen Fruichte des Square-head Wheat riel kleiner und schlanker geworden, und die nämliche Erscheinung zeigte sich anch bei "Golden-drop " and Kaiserweizen.

Vorzugsweise finden sich ron den weissen Weizen White Tuskan, sowie die durch Frame rerbesserte Form desselben, und Callaby's Purple Shaw Wheat, und ron den roten Weizen Biddle's Imperial- Wheat in Kultur.

Was die Gerste anbetrifft, so wird als Braugerste die ChevalierGerste, welche rollkörnig und feinschalig ist, und ausserdem Capeund Scotch-Barley angebaut. Vom Hafer sind Cape- und White-Tartarian-oat $\mathrm{zu}$ beachten.

Zur Besenfahrikation wird „,Dwarf and American Broom-Corn" (Besenmohrhirse) kultiviert.

Die Getreideproduktion Australiens ${ }^{1}$ ) wird wie folgt geschätzt:

1) Vergl. J. Joubert. LAustralie. Paris 1878. Monthly Rep. of the Depart. of Agric. 1872 Washington. Farmers Magazin 264. Vol. LXIV und Neumann-Spallart. 


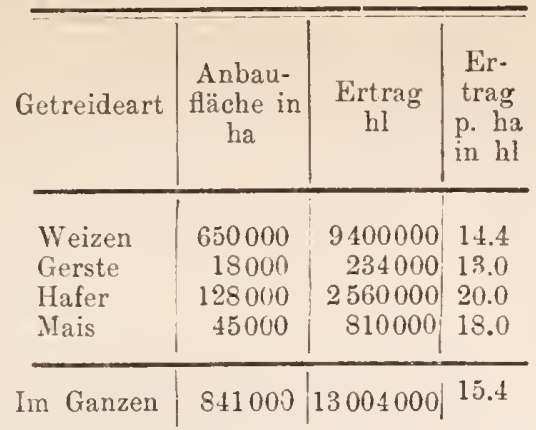

Da die Berölkerung aus 2230000 Seelen besteht, so ergiebt sich eine Produktion von annähernd 5.5 hl pro Kopf.

Der Export nach England ist fortwährend im Steigen, derselbe betrug

$$
\begin{aligned}
& 1870=62774 \mathrm{hl} \\
& 1871=250527 . \\
& 1872=376868 . \\
& 1876=917160 " \\
& 1877=159636 "
\end{aligned}
$$

demnach lässt sich der Export zur Zeit auf ca. 350000 hl Weizen berechnen.

Tebersicht der Getreideproduktion und Konsumtion. Siehe Tabelle Seite 186.

$\mathrm{Zu}$ dieser Tabclle ist zu bemerken, dass, sobald die noch fehlẹnden Länder in ihrer Getreideproduktion mit in Betracht gezogen werden, die durchsehnittliche Jahresernte der Erde an Getreide (excl. Reis und Hirsearten) auf rund 2500 Millionen Hektoliter im Werte von 25 Milliarden Mark, woron ungefähr für 5 Milliarden Mark in den Aussenhandel gelangt, anzunehmen ist.

Die bedeutende Verschiedenheit des Konsums pro Kopf ron $3 \mathrm{hl}$ (Niederlande) bis $9.9 \mathrm{hl}$ (Vereinigte Staaten) hat seinen Grund darin, dass bei geringem Konsum das Getreide fast nur als Brotgetreide, bei hohem hingegen auch noch als Viehfutter und zur Herstellung rerschiedener Fabrikate Verwendung findet, so z. B. werden in den Vereinigten Staaten nicht selten auf reifen Maisfeldern, die tausende von Acres Land umfassen, Ochsen fett geweidet, denen, damit Nichts verloren gehe, Schweine und diesen Truthibner folgen.

Je nachdem die einzelnen Länder vorzugsweise schweres oder leichtes Getreide bauen, zeigen sich für die Durchschnittspreise pro hl der Produktion grosse Untersehiede und ebenso ist auch davon zum Teil die grössere oder geringere Produktion pro ha abhängig, da eine grössere Zahl Hektoliter von dem leichteren als voll dem schwereren Getreide auf der Flächeneinheit erzeugt wird.

Ferner gelangt das schwere Getreide vorzugsweise in den 


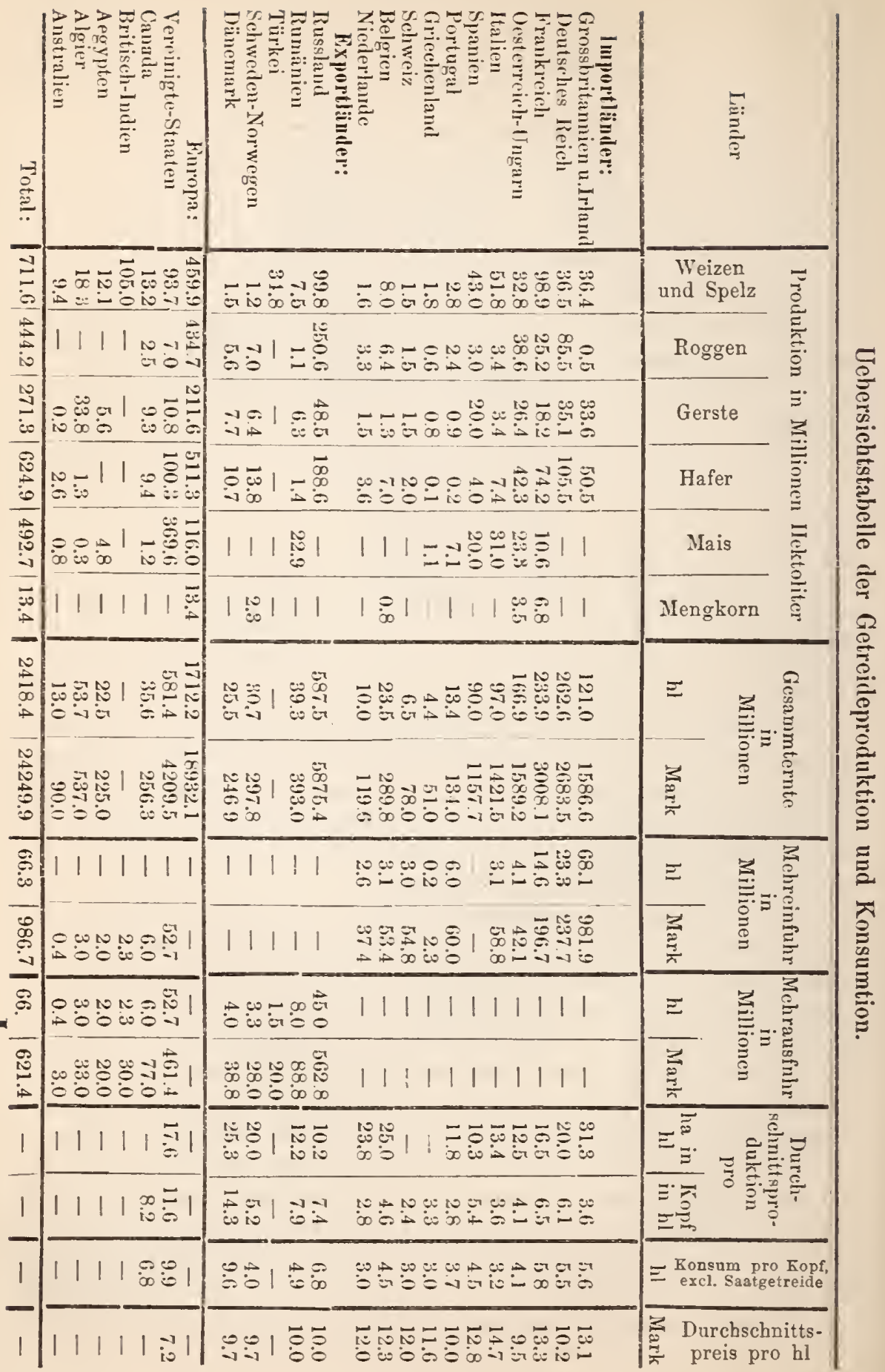


Aussenhandel, da es, bei geringerem Volumen höher in Preise stehend als leichtes Getreide, besser die Transportkosten trägt.

Die Höhe der Getreidepreise ist niclıt sowohl fiir die gesammte Getreideproduktion, sondern anch fuir den Umfang des Getreidehandels von der grössten Wichtigkeit, weshalb wir in dem Folgenden die den Getreidepreis bedingenden Ursachen einer Betrachtung unterziehen wollen.

Unzweifelhaft bestimmt sieh der Preis des Getreides $\left.{ }^{1}\right)$ durch das Verhältniss der Produktion zum Bedarfe, also dureh Angebot und Nachfrage, obgleich dieser Satz beim Getreide erst unter so günstigen Verkehrsverhältnissen volle Geltung erhält, wenn weit von einander entfernte Produktionsländer in Konkurrenz zu treten vermögen. Zur Zeit ist dies nun bei der Mehrzahl der Länder der Welt der Fall, daher sich ein "Weltmarkt" berausgebildet hat, der die Getreidepreise der participierenden Länder reguliert und mehr oder weniger zum Ausgleich bringt.

Sind die Verkehrsverhältnisse aber weniger giinstig, so tritt leicht ein Missverhältnis zwischen Produktion und Bedarf ein, in Folge dessen die Preise in unnatiirlicher Weise becinflusst werden und innerhalb kurzer Perioden sehr bedentenden Schwankungen unterliegen, denn in diesem Falle ist der Landwirt anf dic Benntying einer begrenzten zum Getreidebau fähigen Fläche angewicsen, da dieselbe der Hauptsache nach durch Boden, Klima und Wirtschaftsverhältnissc bestimmt wirl, und ein Betriebswechsel, wenn derseibe möglich wäre, mehrere Jahre in Ansprnch nehmen wiirde. Dies sind die Grïnde, welche unter solchen Verhältnissen dagegen sprechen, nach dem zeitweise mehr oder weniger lebendigen Absatze den Getreidebau erheblich einzuschränken oder anszudehnen. Hierzu kommt, dass das zll erntende Getreidequantum nit Zuverlässiggeit im Voraus keineswegs bestimmbar ist, mithin sich Vorsorge für cinen Ausgleich nicht treffen lässt, denn je nach Witterung und anderen Einfliissen kann die Produktion bis auf das Doppelte der gewöhnlichen Berechnung steigen, oder tief darunter sinken.

Dem gegenüber wechselt aber der tägliche Konsum nur wenig, so dass die Preise fuir gleichen Wert in der Regel in stetem Schwanken bleiben, und bei befiurchtetem Mangel oder wirklicher Not bis zu einer Höhe steigen können, welche alle anderen Werte gegenüber dem der Nahrungsmittel verschwinden lässt. Dass dies richtig ist beweisen die häufigen Hungersnöte friiherer Jahrhunderte, die nicht selten mit schr nicdrigen Preisen unvermittelt abwechselten; so stieg

1) Vergl. Meitzen. Der Boden u. die landw. Verh. des preuss. Staats. Bd. III. p. 352. Roscher, System der Volkswirtsch. 1875. 12. Aufl. p. 282. 
der Weizen zur Zeit Sulla's (82 v. Chr.) von 5 auf 1000 Drachmen, in Frankreich kostete $1 \mathrm{hl}$ Weizen im Durchschnitt 10.15 M. während der Periode $1350-56$, und fiel $1359-1365$ auf $4.26 \mathrm{M}$., 1438-46 stieg er auf 13.68 M. und fiel 1447-59 auf 1.98 M.; ähnlich schwankten im 17, und 18. Jahrhundert in Frankreich, England und Preussen die Getreidepreise, bis die durch die Dampfkraft bewirkten erleichterten Verkehrsverhältnisse in ihr Recht traten und eine immer grössere Ausgleichung der Getreidepreise in den alten Kulturländern herbeiführten.

Die Erkenntnis dass die Ausgeglichenheit der Getreidẻpreise in den Kulturländern nur in der Freiheit des Handels und in der möglichsten Beförderung der Transportmittel zu suchen, ist eine keineswegs alte Errungenschaft, denn erst du Quesnay (1768) und Adam Smith (1776) haben ihr Bahn gebrochen. sDie Vergangenheit huldigte durchats anderen Grundsätzen, indem eine Regulierung der Verkaufspreise durch kiinstliche Preisbestimmungen oder Taxen stattfand.

$\mathrm{Zu}$ der Zeit als sich die Verkehrswege nur anf mehr oder weniger schlechte Strassen beschränkten, galt das Getreide für eine sehwer transportable Nasse, die einen Transport iiber geringe Entfernungen hinaus nicht zu ertragen vermochte, daher denn auch nach dem Ernteausfall einer Grgend sich der Getreidepreis in derselben richtete, so dass gute Ernten billige Preise und umgekehrt zur Folge hatten, wie sich ans nachfolgenden Verhältnisszahlen von King ${ }^{1}$ ) für die Weizenernte und den Weizenpreis ergiebt:

Fehlen an einer Hittelernte so erhöht sich der Weizenpreis um

\begin{tabular}{|c|c|}
\hline 10 Proe. & 30 \\
\hline $20 \quad$, & 80 \\
\hline $30 \quad$, & 100 \\
\hline $40 \quad$.. & 280 \\
\hline $50 \quad .$. & 450 \\
\hline
\end{tabular}

Nach der Ansicht ron F. G. Schulze ${ }^{2}$ ) soll der Landwirt durch Preisaufschlag die Unkosten derProduktion zu decken suchen; wenn dies unter den heutigen Verhältnissen noch möglich wäre, wïrde der deutsche Landwirt zur Zeit nicht unter einer Krisis zu leiden haben, aber zu jenen Zeiten kostete der'Transport des Getreides auf Landwegen selbst auf geringe Entfernungen mehr als das Objekt an Werth besass.

Aus den untenstehenden Ermittelungen von Settegast ${ }^{3}$ ) uiber

1) Citiert in Du Commerce des Grains, par Roscher. Uebersetzt ron I a urice Block 1854, p. 5 .

2) Citiert durch Roscher, Du Commerce des Grains 1854, p. 4.

3) Settegast, Die Landwirtschaft und ihr Betrieb. II. Bd. 1877. 
die Transportkosten land- und forstwirtschaftlicher Erzengnisse lässt sich die Transportfähigkeit des Getreides, je nach den benutzten Verkehrswegen sehr leicht ersehen und liefern diese Ermittelungen gleichzeitig den Beweis, dass das friiher schwer transportable Getrcide in der Jetztzeit weite Transporte bei Benutzung geeigneter Transportmittel zu ertragen vermag.

\begin{tabular}{|c|c|c|c|c|c|c|c|c|c|c|}
\hline & 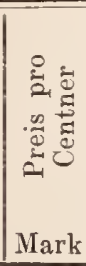 & \begin{tabular}{|c} 
Auf \\
entfa \\
des I \\
Tra \\
Land- \\
strasse \\
à 15 \\
pro
\end{tabular} & $\begin{array}{l}1 \text { Ctr. u. } \\
\text { allen Pr } \\
\text { Wertes b } \\
\text { nsport a } \\
\text { e Kunst- } \\
\text { e strasse } \\
\text { Ctà } 10 \\
\text { Ctr. u. }\end{array}$ & $\begin{array}{l}1 \text { Meile } \\
\text { ocente } \\
\text { oei dem } \\
\text { uf der } \\
\text { Eisen- } \\
\text { balın } \\
0.25 \text { - } \\
\text { Meile }\end{array}$ & $\begin{array}{r}50 \% \\
\text { durc } \\
\text { port } \\
\text { Land- } \\
\text { strasse }\end{array}$ & $\begin{array}{l}\text { Die } \\
\text { ihres W } \\
\text { den T } \\
\text { von M } \\
\text { Kunst- } \\
\text { strasse }\end{array}$ & $\begin{array}{l}\text { Ware } \\
\text { tertes } \\
\text { rans- } \\
\text { eilen } \\
\text { Eisen- } \\
\text { bahn }\end{array}$ & $\begin{array}{l}\text { verli } \\
\text { Whre } \\
\text { Tran } \\
\text { Land } \\
\text { strass }\end{array}$ & $\begin{array}{l}\text { durch } \\
\text { portv. I } \\
\text { Kunst- }\end{array}$ & $\begin{array}{l}\text { mten } \\
\text { den } \\
\text { Weilen } \\
\text { Eisen- } \\
\text { bahn } \\
\end{array}$ \\
\hline $\begin{array}{l}\text { Roggen } \\
\text { Gerste } \\
\text { Hafer } \\
\text { Weizen }\end{array}$ & $\begin{array}{r}7.50 \\
10.00\end{array}$ & $\begin{array}{l}2.00 \\
1.50\end{array}$ & $\begin{array}{l}1.30 \\
1.00\end{array}$ & $\begin{array}{l}0.33 \\
0.25\end{array}$ & $\begin{array}{l}25.00 \\
33.33\end{array}$ & $\begin{array}{l}37.5 \\
50\end{array}$ & $\begin{array}{l}150 \\
200\end{array}$ & $\left\{\begin{array}{l}50.00 \\
66.67\end{array}\right.$ & $\begin{array}{r}75 \\
300\end{array}$ & $\begin{array}{l}300 \\
400\end{array}$ \\
\hline
\end{tabular}

Es ist leicht einzusehen, dass die Handelsfreiheit der Jetztzeit und die hoch entwickelten Kommunikationsmittel die ehenaligen $\mathrm{Zu}$ stände vollkommen umgewandelt haben, und dass für die Bildung der Preise in den Kulturländern der örtliche Markt nur zu ausnahmsweiser Geltung gelangt, wenn der Grosshandel nicht bis in dicselben hineinzureichen vermag, wie sich dies in sehr charakteristiseher Weise in den Getreidepreisen einzelner Staaten Nord-Amerikas erkennen lässt, die durch Wasserstrassen oder Eiscnbahuen noch ungeniigend erschlossen sind und demnach ein Bild gewähren, wie sich in früherer Zeit auch in den alten Kulturländern Europas die Preise von dem örtlichen Markte abhängig machten. Eincn Beweis davon liefern die Durchschnittspreise per bushel in den Staaten der nordamerikanischen Union ${ }^{1}$ ). [Siehe Tabelle S. 190.]

Aus den Zahlen dieser Tabclle ist klar ersichtlich, in welcher Weise die Getreidepreise je nach den vorhandenen Kommunikationsmitteln in den einzelnen Staaten schwanken und der Preis dort am höchsten ist, wo das Mecr, Wasserstrassen oder Eisenbahnen die Staaten dem Welthandel erschlossen baben, so dass Schwankungen der Preise iiber 100 Proc. nicht ungewöhnlich sind.

Es entsteht also für die Getreidepreise eine mehr oder weniger deutliche, aber stetig fortwirkende Abhängigkeit von dem Bedarfe des Grosshandels, der seinerseits durch den allgemeinen Stand der

1) Bureau of Statist. Report of Immigration 1872. Washington. 


\begin{tabular}{|c|c|c|c|c|c|}
\hline Staaten. & $\begin{array}{l}\text { Weizen } \\
\text { Dollars }\end{array}$ & $\begin{array}{c}\text { Mais } \\
\text { Dollars }\end{array}$ & $\begin{array}{c}\text { Hafer } \\
\text { Dollars }\end{array}$ & $\begin{array}{l}\text { Roggen } \\
\text { Dollars }\end{array}$ & $\begin{array}{l}\text { Gerste } \\
\text { Dollars }\end{array}$ \\
\hline Pennsylvanien & 1.18 & 0.86 & 0.52 & 1.00 & - \\
\hline Maryland & 1.40 & 0.87 & 0.50 & - & - \\
\hline West-Virginia & 121 & 0.80 & 0.42 & 0.82 & - \\
\hline Ohio & 1.10 & 0.68 & 0.45 & 0.82 & 119 \\
\hline Kentucky & 1.19 & 0.64 & 0.50 & 0.82 & - \\
\hline Indiana & 0.98 & 0.60 & 0.46 & - & - \\
\hline Illinois & 0.95 & 0.55 & 0.37 & 0.65 & 975 \\
\hline Michigan & 1.07 & 0.62 & 0.60 & - & - \\
\hline Wisconsin & 0.85 & 0.61 & 0.49 & 0.70 & 0.82 \\
\hline Minnesota & 0.68 & 0.50 & 0.34 & - & 078 \\
\hline Jowa & 0.69 & 0.50 & 0.33 & 0.72 & 070 \\
\hline Missouri & 1.00 & 0.73 & 0.55 & - & - \\
\hline Kansas & 1.01 & 0.63 & 0.38 & 一 & - \\
\hline Nebraska & 0.60 & 0.40 & 0.30 & - & - \\
\hline Colorado & 1.25 & 1.00 & 0.73 & - & - \\
\hline Virginia & 1.35 & 0.83 & 0.50 & $0.8 s$ & - \\
\hline North.Carolina & 1.56 & 0.94 & 0.70 & 1.12 & - \\
\hline South- $\quad$, & 2.03 & 1.35 & 0.78 & - & - \\
\hline Alabama & 2.00 & 1.41 & 1.00 & - & - \\
\hline Mississippi & 1.50 & 0.92 & - & - & - \\
\hline Tennessee & 1.09 & 0.77 & 0.50 & - & - \\
\hline Arkansas & 1.25 & 0.92 & 0.75 & - & - \\
\hline Louisiana & - & 1.21 & - & - & - \\
\hline Texas & 1.50 & 0.80 & - & - & - \\
\hline California & 1.52 & 1.25 & 1.50 & - & 1.20 \\
\hline Oregon & 1.00 & - & 0.40 & - & - \\
\hline Washington Territory & 1.00 & - & 0.75 & - & - \\
\hline
\end{tabular}

Ernten und Vorräte aller am Welthandel teilnehmenden Länder bedingt ist, doeh stuft sieh der Einfluss dieser Abhängigkeit für den einzelneu Produktionsort, je nach der Leistungsfähigkeit und Kostspieligkeit der vorhandenen 'Transportmittel ab.

Fiur die Landwirtsehaft der einzelnen Gegend kanı aber daraus der Naelıteil erwaehsen, dass trotz spärlieher Ernte die Preise in Erwartung answärtiger Befriedig'ung des Bedarfes nielıt im Verhältnis zu den Produktionskosten steigen, wie aueh andererseits der Bedarf fremder Länder die Preise hoeh halten kann.

Die Staaten haben jetrt davon Abstand genommen. die Getreidepreise selbst zu beeinflussen und beschränkt sieh die Sorge auf mögliehst billige Eisenbahnfraehten, Erlass der Kommunikations-Abgaben und ähuliehe Verkelırserleichterungen.

Hiermit wollen wir die Betraehtung der die Getreidepreise in der Jetztzeit vorzugsweise beeinflussenden Faktoren besehliessen und fiige ielı hieran zur Erläuterung des Gesagten, wie zur Gewinnung eines Ueberblickes iiber die Getreidepreise friherer Jahrlunderte, die nachfolgende Tabelle über das wiehtigste Brotgetreide Europas, des Weizens, sowie die Preisuotierungen des Roggens, der Gerste und des Hafers aus neuerer Zeit. 


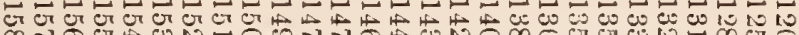
o

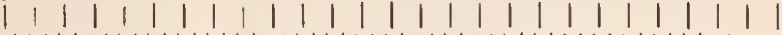

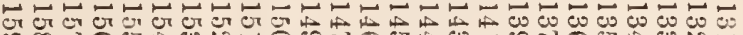

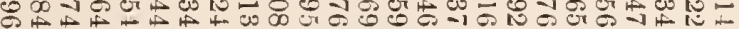

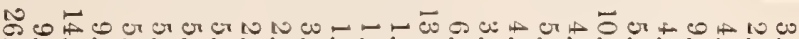
का

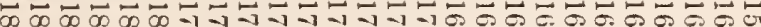

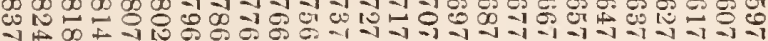

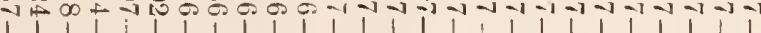

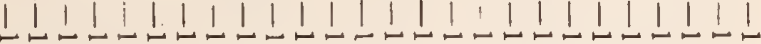

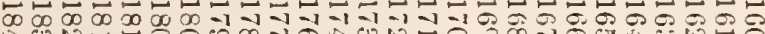

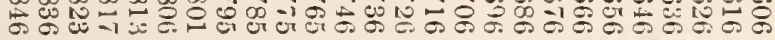

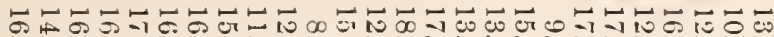

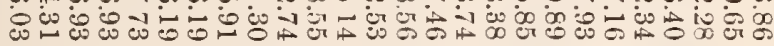

مै

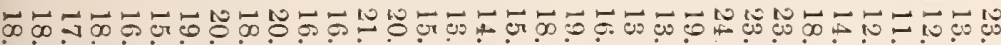
co o

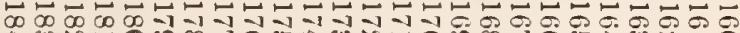

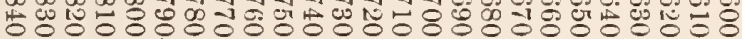

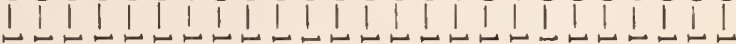

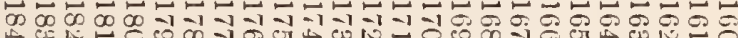

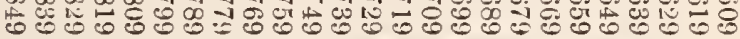

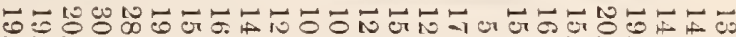

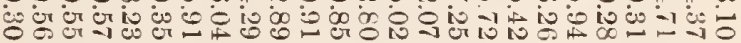

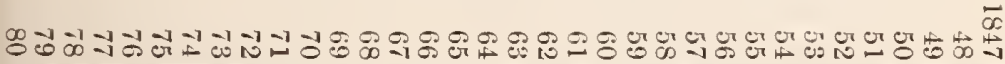

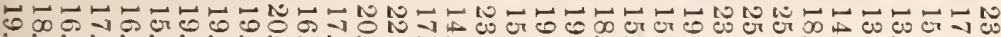

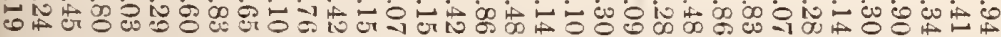
চ H心1 111111

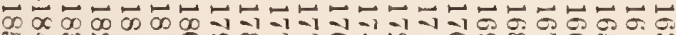

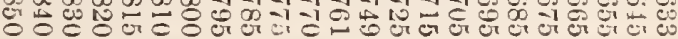

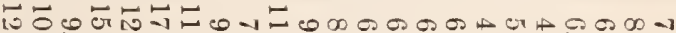

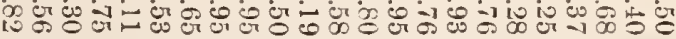
車

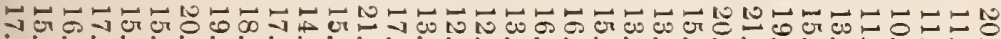
- ن 
Preise ${ }^{1}$ ) des ubrigen Getreides in Preussen und England pro 1 Hektoliter.

\begin{tabular}{|c|c|c|c|c|c|}
\hline \multirow[b]{2}{*}{ Zeitraum } & \multicolumn{3}{|c|}{ Preussen } & \multicolumn{2}{|c|}{ England } \\
\hline & $\begin{array}{c}\text { Roggen } \\
\text { Mark }\end{array}$ & $\begin{array}{l}\text { Gerste } \\
\text { Mark }\end{array}$ & $\begin{array}{l}\text { Hafer } \\
\text { Mark }\end{array}$ & $\begin{array}{l}\text { Gerste } \\
\text { Mark }\end{array}$ & $\begin{array}{l}\text { Hafer } \\
\text { Mark }\end{array}$ \\
\hline $1816-20$ & 11.55 & 8.11 & 5.67 & - & - \\
\hline $1821-30$ & 6.35 & 4.75 & 3.50 & - & - \\
\hline $1831-40$ & 7.42 & 5.47 & 4.00 & - & - \\
\hline $1841-50$ & 9,00 & 6.75 & 4.67 & - & - \\
\hline $1851-60$ & 12.00 & 9.10 & 631 & 12.33 & 8.38 \\
\hline-61 & 10.96 & 8.84 & 5.45 & 12.41 & 8.20 \\
\hline-62 & 11.40 & 8.20 & 5.47 & 12.10 & 7.79 \\
\hline-63 & 9.70 & 7.58 & 5.20 & 11.44 & 7.65 \\
\hline-64 & 8.05 & 7.04 & 5.26 & 10.31 & 6.95 \\
\hline-65 & 9.07 & 7.25 & 5.41 & 10.50 & 7.53 \\
\hline-66 & 10.05 & 7.71 & 5.91 & 12.90 & 8.28 \\
\hline-67 & 12.82 & 9.80 & 5.65 & 1380 & 8.66 \\
\hline-68 & 15.56 & 11.33 & 7.73 & 14.31 & 10.11 \\
\hline-69 & 12.24 & 10.18 & 7.29 & 13.53 & 9,13 \\
\hline-70 & 11.06 & 8.91 & 6.36 & 12.10 & 8.00 \\
\hline-71 & 1224 & 9.55 & 6.75 & 12.80 & 9.13 \\
\hline-72 & 12.24 & 9.68 & 6.18 & 12.80 & 8.13 \\
\hline-73 & 12.80 & 10.70 & 6.64 & 13.60 & 8.62 \\
\hline-74 & 15.41 & 13.00 & 8.36 & 15.34 & 10.00 \\
\hline-75 & 12.36 & 11.07 & 8.45 & 12.80 & 10.00 \\
\hline-76 & 12.30 & 10.75 & 8.10 & 13.00 & 10.00 \\
\hline-77 & 12.92 & 10.81 & 7.36 & 15.17 & 8.41 \\
\hline-78 & 11.83 & 1071 & 6.90 & - & - \\
\hline-79 & 10.60 & $\mathrm{I} 0.51$ & 622 & - & - \\
\hline-80 & 14.25 & 11.40 & 6.93 & - & - \\
\hline
\end{tabular}

Was nun den Getreidehandel anbetrifft, so gehorcht dem Einflusse des internationalen Verkehrs und Marktes am meisten in der Jetztzeit der Preis des Weizens, wie sich dies deutlich in den Tabellen zeigt, denn seine Preise sind rollständig ron der gesammten

1) Literatur: Tables of prices in Sir F. MI. Eden, State of the poor III. Append. 1. Rogers History of Agric. and prices (1866). F armers Magazine 1865. Vol. XXVII p. 477. The price of Wheat. H. Evershed, L'Agriculture de l'Angleterre. Paris 1878. Série de traités préparés sous la direction du conseil de la société royale d'agriculture d'Angleterre pour le congrés international. Dictionnaire du Commerce. Paris, 1850. Barral, Journ. de l'Agric. 1870-81. Économie rurale de la France. M. I de Lavergne 4 Éd. Paris, 1877. Jahrb. für die amtl. Statistik des preuss. Staates. II Jahrg. pg. 93 f. Beiträge zur landw. Statistik für Preussen 1876. 
Lage aller am Weizenlandel beteiligten Länder und nicht von dem Ernteausfall eines einzelnen Landes abhängig. Mehr scheint der Ernteausfall den Preis des Roggens zu beeinflussen, da sein liarkt weit beschränkter als der des Weizens ist. Das hauptsächlich Roggen exportierende Land ist Russland, mithin dic Importlïnder zum Teil von dem Ernteausfall Russlands abhängig sind. Können z. B. nur geringe Mengen zum Export gelangen, wic dies wibrend des russischtiirkischen Kriegs 1877 der Fall war, so steigt der Preis, 1878 gingen dafuir die Vorräte in den Export iiber, in Folge dessen die Preise in Deutschland und den nordischen Importländern wesentlich heruntergingen.

Weit hervorragender noch als der Roggen folgt aber die Gerste dem heimischen Ernteausfall, denn sie ist weniger Gegenstand des internationalen Handels, und tritt dies noch schärfer beim Hafer hervor, weil sein Volumen im Verhältnis zum Gewicht sebr gross ist, demzufolge er weite Transporte nicht leicht erträgt.

Der internationale Getreidehandel ${ }^{1}$ ) benutzt zi den Quantitiatsbestimmungen das Hohlmass und zwar hauptsächlich Hektoliter, Imperial-Quarters (England) $=2.9078 \mathrm{hl}$, amerikanische Bushels $=35.238$ hl, und Tschetwerts $=2.0991 \mathrm{hl}$, während die Getreidequalitait dureh Angabe der Gewichtseinheiten, welche eine gewisse Massquantitit wiegt, bestimmt wird, und nennt man dies kurzweg die Getreideprobe.

Als Normalmass zur Vergleichung wählen wir das metrische, also das Hektoliter.

Wie wir aus der Uebersicht der Getreideproduktion und Konsumtion der Erde ersehen, stellt sich der Mehrbedarf des europäischen Westens an Getreide auf 128.2 Millionen Hektoliter, welche der internationale Getreidehandel herbeischafien muss und welche ungeahnte Ausdehunng derselbe erreicht hat, geht daraus hervor, dass man denselben nach Neumann-Spallart im vorigen Jabrhundert auf 10-11 Millionen angab und jetzt anf 200 Millionen Hektoliter schätzt.

In Europa ist hauptsäichlich der Westen importbeduirftig und fliesst dorthin, sowohl von den aussereuropäischen Ländern (66.4 Millionen Hektoliter), als auch vom östlichen Europa (61.8 Millionen Hektoliter), der Ucberfluss an Getreide al.

In erster Linie stehen als Exportland die Vereinigten Staaten Nord-Amerikas, welche sich am Export mit 52.7 Millionen Hektoliter im Werte von 461.4 Millionen Mark beteiligen.

Die Quantität wird in anerikanischen Bushels und das Qualitäts-

1) Vergl. Sonndorfer, Usancen und Paritäten des Getreidehandels im Weltverkehre. 1880. 
gewicht in englischen Pfunden angegeben. Man rechnet im Durchschnitt Weizen zu 60, Roggen und Mais zu 56, Gerste zu 48 und Hafer zu 32 englischen Pfunden p. bushel.

Die bedeutendsten Getreidehandelsplätze und Exporthäfen sind: New-York, Chicago, Philadelphia, Baltimore, New-Orleans und S. Francisco.

Die vorzugsweise exportierenden Nordwest-Staaten besitzen bis zur See sechs Ausfuhrwege, 1) den Mississippi, 2) die Seeen und den Law rence-Strom, 3) Die Seeen bis Buffalo und die Eisenhahn bis New-York, oder 4) von Buffalo und Kanal und 5) oder Eisenbahn allein nach New-York, 6) oder Obio und Eisenbahn.

Die hauptsächlichste Exportroute geht von den grossen amerikanischen Seeen aus, auf denen alljälırlich übcr 50 Millionen Hektoliter Getreide verfrachtet werden, und ron diesen über die Hälfte allein von Chicago aus, und zwar bis Buffalo, von wo aus per Kanal die Weiterbeförderung erfolgt.

Die Frachtsätze von Chicago bis Lirerpool sind nach den Angaben ron $\mathrm{Clare}$ Lewell und $\mathrm{A}$. Pell pro Hektoliter folgende:

$\begin{array}{ll}\text { Fracht ron Chicago nach New-York } & 1.92 \text { M } \\ \text { B" New-York " Liverpool } & 1.84 \text {.. } \\ \text { Behandlung des Weizens in Amerika } & 0.40 \text { " } \\ \text { Spesen in Liverpool . . . . . . } & 0.80 "\end{array}$

$$
\text { Summa: } \overline{4.96} \bar{M}
$$

Von S. Francisco nach Liverpool stellen sich die Frachtsätze um 3.20 Al höher.

Russland ist das demnächst bedeutendste Exportland, denn es fiibrt 45 Millionen Hektoliter Getreide im Werte ron 562.8 Millionen Mark aus.

In südlichen Russland wird das Qualitätsgewicht in Pud und russischen Pfunden pro Tschetwert, in den Ostseeprovinzen dagegen in holländischen 'Troypfunden pro Zak bestimmt. Gewöbnlich rechnet man den Tsehetwert Weizen zu 10, Roggen zu 9, Gerste zu 7-8 und Hafer zu 6 Pud.

Die Exportfähigkeit Russlands lïsst sich ebenso günstig als dic der Vereinigten Staaten Nord-Amerikas beurteilen, denn nicht nur, dass ein bedeutender Landstrich sich eines fast unerschöpflichen Bodens (Schwarzerde) erfreut, sondern es werden auch grosse Strecken kulturfähigen Landes, ganz abgesehen von Sibirien, noch nicht bebaut. Die Produktion pro ha lässt sich ferner in gleicher Weise wie in Amerika durch intensive Wirtschaft recht gut um das doppelte Erträgnis stcigern, denn zur Zeit produciert Russland nur 10.20 hl, dagegen Deutschland 20 hl Getreide pro ha.

Demnach scheint sich in beiden Ländern die Konkurrenzfähigkeit der Hauptsache nach um die Transportkosten zu drehen, und 
das Land, welches die geringsten Transportkosten hat, wird als Sieger aus diesem Konkurrenzkampfe hervorgehen. Russland ist, was die Seefracht von den Häfen des schwarzen Meeres nnd der Donau nach Liverpool anbetrifft, gegen Amerika im Vorteil, da ein Hektoliter nur 2.41-2.76 . M Seefiacht kostet, und die Amerikaner von New-York nach Liverpool $3.76 \mathscr{M}$. pro hl zahlen müssen; dafür sind aber auch die Seeen, Fliisse und Kanäle Nord-Amerikas für den Getreidetransport weit geeigneter, denn obgleich Russland als grossartiger Agrikulturstaat ein Fluss- und Kanalsystem besitzt, man denke nur an die Wasscrstrassen des Dnjestr, Dnjepr, Don, wie kaum ein anderer Staat, so tritt wunderbarer Weise die Beförderung durch Wassertransport gegen Bahntransport zuriick, weil sich gegeniiber den langen Transporten, die häufig 4 Monate dauern, die Effektivkosten per Bahn billiger stellen und das Getreide weniger leidet; auch gefrieren die Wasserstrassen gerade während der Haupttransportzeit und bleiben dann nicht selten 7 Monate lang für den Verkehr geschlossen. Russland hat nun durch Eisenbahnen die Kommunikationsmöglichkeit und Exportfähigkeit in ausserordentlicher Weise in den letzten Deccunien erhöht, so hat sich seit 10 Jahren (1865-1875) die Bahnlänge um 300 Proc. vermehrt, während sie in OesterreichUngarn nur um 190 Proc. und in Dentschland um 110 Proc. zugenommen hat, und Frankreich und England unter 100 Proc. bleiben.

Wie Russland eifrigst an dem Ausbau seiner Verkehrswege arbeitet, geht aus folgender Uebersicht hervor:

1868

Eisenbahnstrassen

Chausseeen und Fahrwege

Wasserstrassen
$4228 \mathrm{klm}$

$88802 "$

9214 ,
1875

$19546 \mathrm{klm}$

87664,

10893,

Das Zurückbleiben des russischen Exportes hinter dem amerikanischen in den letzten Jahren gab vielfach zu dem Glauben an eine dauernde Konkurrenzmnfähigkeit Rnsslands Veranlassung, doch ist dies einfach auf das rapide Weichen der Schiffsfrachten zurückzuführen, wodurch der Bezug aus Amerika billiger wurde; steigen die Frachten, so werden Russland und zugleich anch die Donauländer, die unter der amerikanischen Konkurrenz ebenfalls in hohem Grade leiden, wieder exportfähiger werden, zumal, wemn diese Länder ihr Eisenbahnnetz weiter ausbauen, um die hohen Transportkosten auf den Landwegen zu verringern. Hätte Russland ein Eisenbahnnetz wie Amerika, so könnte Letzteres an eine ausgiebige Konkurrenz nicht denken, während zur Zeit, obgleich Russland billigere Seefracht hat, schon eine kleine Erniedrigung derselben himreicht, die Donauländer und Russland konkurrenzunfähig zu machen.

Der Hauptexporthafen Sild-Rnsslands ist Odessa, wohin durch Wassertransport auf dem Dnjestr, und Dnjepr sowie durch Land- 
transport ca. 15 Millionen Hektoliter Getreide gelangen, ferner Nikolaieff an der Bugmündung, während die kleinen Häfen des Asow'schen Meeres, wie Taganrog, Berdjansk, Mariupol und Kertsch, das Getreide aus der kleinen Tatarei und den Steppen, welche zwischen dem kaspischen und schwarzen Meere liegen, empfangen.

Die von hier aus verschifften Weizen sind von vorzüglicher Qualität (Ghirka-Weizen) und namentlich nach England begehrt.

Für das weisse $\mathrm{Hecr}$ enıfängt Archangelsk vermittelst der Fliisse Dwina, Mesen und Onega während des kurzen Sommers das Getreide aus dem nordöstlichen Russland und Sibirien (50000100000 hl). Die hauptsächlichsten Exporthäifen der Ostsee sind Riga, Reval und Libau. St. Petersburg wird im Sommer hauptsächlich durch die Newaschifffaht, im Winter durch Eisenbahn und Landtransport mit Getreide versorgt.

Sehr wichtig für den Getreideexport sind auch die unteren Donauländer und die europäische Tïrkei.

Rumäuien führt sein Getreide hauptsäcblich in die Donauhäfen von Galatz und Braïla, doch sind ferner noch wichtige Donauplätze: Oltenitza, Giurgevo, Zimnitza, Turn-Mogurello, Corabia, Piquet, Calafat und Turn-Severin.

In Bulgarien geht der Hauptexport von Rustschuk über Varna nach Koustantinopel. Bedeutende Plätze sind auch: Sistow, Nikopoli, Rahowa und Lom-Palanka, letzterer Ort exportiert viel Mais.

Serbien fiihit nur Weizen aus nnd sind die wichtigsten Verladeplätze Dubrovitza, Semendria, Milanovatz, Kladova und Radujevatz.

Das Getreide aus Rumelien geht iiber Adrianopel anf der Naritza in den Archipel oder per Eisenbahn nach Konstantinopel. Letzteres ist auch das Magazin für die Schiffsladungen, welche aus Odessa oder anderen Häfen des schwarzen Meeres, wie auch aus Klein-Asien anlangen. Die westliche Tïrkei exportiert über Salonichi.

In Ungarn sind Budapest, Wieselburg, Raab, Szegedin und Nagy-Kanizsa Hauptplätze des Getreidehandels, welcher vorzugsweise Weizen bester Qualität umfasst, und da die Ernte relativ zeitig eintritt, auch als erstes Enteprodukt per Eisenbahn nach Frankreich, Belgien, der Schweiz, Deutschland und Grossbritannien ansgeführt wird. Auch werden vorziggliche Mehle namentlich nach aussereuropäischen Ländern, z. B. Brasilien verschifft.

Seit dem in Jahre 1876 abgeschlossenen Kartell zahlt Ungarm nit geringen Abänderungen p. $100 \mathrm{~kg}$ Weizen

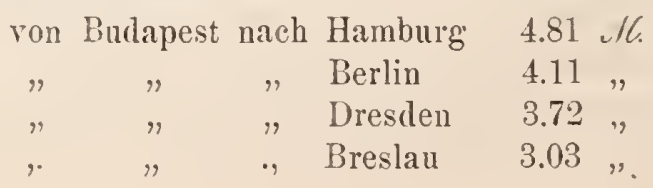


Für Ocsterreich sind wichtige Getreideplätze: Wien, Triest, Prag und Czernowitz.

Nach den Bestinumungen der Wiener-Warenbörse vom 1. Januar 1882 sind bei Verkäufen ohne Gewichtsgarantie nicht licferbar:

Weizen welcher weniger als $751 / 2$

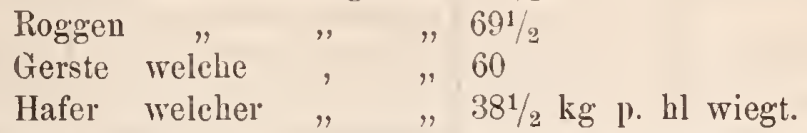

In Dänemark sind die wichtigsten Plätze anf Sceland: Kopenhagen, Korsïr; auf Fiinen: Odense, Nyborg, Assens, Svendborg; in Jiitland: Aalborg, Aarhuus, Randers und Horsens.

Das Hauptgeschäft wird in Weizen und Gerste gemacht, denn Roggen wird kaum exportiert und Hafer teilweise selbst und zwar aus Schwederı zum Konsum bezogen.

Was den Getreidehandel Schwedens und Norwegens anbetrifft, so führt ersteres Land regelmässig namhafte Mengen Hafer aus, besonders nach England, sowie kleinere Quantitäten Gerste nach England, Holland und Norwegen, während es Roggen und Mehl von Russland und Dänemark einfiihrt; demnach ist das Hauptgeschäft beim Import in Roggen und Roggenmehl, beim Export in Hafer.

Norwegen exportiert in geringen Mengen Hafer, während es von Russland, Dentschland, Dänemark und Nord-Amerika Weizen, Roggen und Gerste importiert.

Australien exportiert hauptsächlich nach England und zwar in erster Linic Weizen und dann zunächst Hafer und Gerste.

Aegypten sendet von dem Hauptplatz Alexandria aus die Hauptquantität seines Exportgetreides nach England; ausserdem aber auch nach Marseille und in nenerer Zeit nach Triest.

Das Land, welches des stärksten Getreideimportes bedarf, ist England, und lässt sich an seinem Import am besten del Anteil der verschiedenen Exportländer am Getreidehandel nachweisen

Der Bedarf Englands an Getreide ist noch immer im Steigen, denn er steht im Verhältniss zum Anwachsen der Bevölkerung, so stellte sich der jährliche Durclıschnittsimport in Hektolitern im Veleinigten Königreich, während der einem jeden Census rorausgehenden 10 Jahre, wie folgt:

\begin{tabular}{l|c|c|c|c|c|c|c}
\hline & $\begin{array}{c}1801-1811 \\
\end{array}$ & 1821 & 1831 & 1841 & 1851 & 1861 & 1871 \\
& $h l$ & $h l$ & $h l$ & $h l$ & $h l$ & $h l$ & $h l$ \\
\hline $\begin{array}{l}\text { Weizen } \\
\text { Andr. Getr. }\end{array}$ & 1700000 & 1305000 & 1537000 & 2610000 & 8549200 & 14587000 & 21058400 \\
986000 & 1334000 & 1827000 & 1261150 & 7969200 & 11544900 & 19479300
\end{tabular}


Das wichtigste Importgetreide Englands ist unzweifelhaft der Weizen und soll in nachfolgender Tabelle der Zuwachs des Weizenimportes mit der Zunahme der Bevölkerungszahl verglichen werden.

\begin{tabular}{|c|c|c|c|c|c|}
\hline 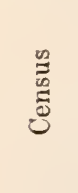 & $\begin{array}{l}\text { Zunahme d. } \\
\text { Bevölkerung } \\
\text { seit d. letzten } \\
\text { Census }\end{array}$ & $\begin{array}{l}\text { Zunahme d. } \\
\text { jhıl. Einfuhr, } \\
\text { vergl. mit d. } \\
\text { letzten } 10 \mathrm{~J} \text {. } \\
\text { nach } \mathrm{ll}\end{array}$ & $\begin{array}{l}\text { Durchschnitts } \\
\text { völkerung, we } \\
\text { J. unterhalten } \\
\text { ausländischen } \\
\text { Weizen }\end{array}$ & $\begin{array}{l}\text { lahl der Be- } \\
\text { lche in jedem } \\
\text { wurden durch } \\
\text { d. Produkt } \\
\text { d. Landes }\end{array}$ & $\begin{array}{l}\text { Bevölkerungs- } \\
\text { zahl d. König- } \\
\text { reichs b. jedem } \\
\text { Census. }\end{array}$ \\
\hline $\begin{array}{l}1811 \\
1821 \\
1831 \\
1841 \\
1851 \\
1861 \\
1871\end{array}$ & $\begin{array}{r}2200000 \\
2980000 \\
3150000 \\
2700000 \\
697000 \\
1540000 \\
2538000\end{array}$ & $\begin{array}{c}-\overline{-} \\
\text { Eine Abnahme } \\
232000 \\
783000 \\
8825700 \\
6037800 \\
9761400\end{array}$ & $\begin{array}{r}800000 \\
600000 \\
706000 \\
1200000 \\
3930000 \\
6706000 \\
11061000\end{array}$ & $\begin{array}{l}16000000 \\
18890000 \\
21850000 \\
24280000 \\
23255000 \\
21600000 \\
19278000\end{array}$ & $\begin{array}{l}18006000 \\
20983000 \\
24132000 \\
26833000 \\
27533000 \\
29070000 \\
31610000\end{array}$ \\
\hline
\end{tabular}

Hiernach hat also die Getreideproduktion in England mit dem Bevölkerungszuwachs nicht gleichen Schritt gehalten, vielmehr scheint der Höhepunkt der Getreideproduktion in England iiberschritten zu sein, indem man sich, wo es die Verhältnisse irgend gestatten, dem unrentablen Getreidebau abwendet und den billiger producierenden Ländern die Deckung des Getreidebedarfes iiberlässt.

Dass thatsächlich die mit Weizen bebaute Fläche in Grossbritannien und Irland abnimmt, dagegen der Weizenkonsum pro Kopf zunimmt, so dass bei der starken Bevölkerungszunahme der Weizenimport sehr erheblich wachsen muss, zeigt die nachfolgende $\mathrm{Zu}$ sammenstellung ${ }^{1}$ ).

Tabelle über Anbauflächen, Produktion, Import und Konsumtion des Weizens.

\begin{tabular}{l|c|c|c|c|c|c}
\hline & $\begin{array}{c}\text { Anbau- } \\
\text { fläche } \\
\text { des } \\
\text { Weizens }\end{array}$ & $\begin{array}{c}\text { Er- } \\
\text { trag } \\
\text { pro } \\
\text { in ha }\end{array}$ & $\begin{array}{c}\text { Ge- } \\
\text { sammt- } \\
\text { ploduk- } \\
\text { tion in }\end{array}$ & $\begin{array}{c}\text { Import } \\
\text { (ohne } \\
\text { Export) }\end{array}$ & $\begin{array}{c}\text { Bevölke- } \\
\text { rungszahl }\end{array}$ & $\begin{array}{c}\text { Konsum- } \\
\text { tion pro } \\
\text { Kopf in }\end{array}$ \\
& ha & hl & hl & hl & & hl \\
\hline $1852-59$ & 1636864 & 25.14 & 41501259 & 13493074 & 28067170 & 1.84 \\
$1860-67$ & 1324744 & 25.59 & 3859681623483507 & 29606462 & 2.00 \\
$1868-75$ & 1517054 & 23.89 & 3682755031 & 162147 & 31787143 & 2.04 \\
$1876-78$ & 1306534 & 24.34 & 3223903939731119 & 33709425 & 2.06 \\
$1852-78$ & 152.1466 & 24.78 & 3822674424603820 & 30252383 & 1.97
\end{tabular}

1) Farmer's Magaz. 1880 pg. 431. 
Eine Weizenmebreinfuhr begann in England schon 1750 und dauerte bis 1850, von welchem Zeitpunkt ab die Nureinfubr (also ein höchst geringfïgiger Export bei sehr starkem Import) zu verzeichnen ist. In den ersten Jahrzehnten dieses Jahrhunderts importierten die nächstgelegenen Länder nach England die grösste Weizenmenge, doch zogen sich die Kreise der exportierenden Gebiete mit der Verbesserung der Kommunikationsmittel immer weiter und weiter, bis schliesslich in diesem Augenblick die entferntesten Länder sich an der Konkurrenz nicht nur beteiligen können, sondern sogar die Hauptimporteure sind.

So beteiligte sich z. B. im Jahre 1830 an dern Weizeniniport nach England, Dentschland mit 45 Proc., Russland mit 12 Proc., Nord-Amerika mit 9 Proc., Canada und Frankreich mit 5 Proc.; während hingegen in dem Zeitraum von 1858-1872 Deutschland nur noch mit 17 Proc., Frankreich mit 9 Proc., Canada mit, 5 Proc., Russland mit 24 Proc., Nord-Anerika mit 27 Proc. und andere Länder mit 16 Proc. participierten und 1873 hatte sich dies Verbältnis für Anerika noch viel giinstiger gestaltet, denı cs lieferte in diesem Jahre 44 Proc., während der Anteil Russlands anf 21 Proc. herabging.

Nachfolgende Uebersicht zeigt die Beteiliging der einzelnen Länder zur Deckung des englischen Weizenbedarfes. Die Angaben sind in englischen Centnern ( $1 \mathrm{Cwt}=50.8 \mathrm{~kg}$ ) gemacht.

\begin{tabular}{|c|c|c|c|c|c|c|c|}
\hline Jahr & $\begin{array}{c}\text { Vereinigte } \\
\text { Staaten } \\
\text { von Nord- } \\
\text { Amerika } \\
\text { Cwt. }\end{array}$ & $\begin{array}{c}\text { Russland } \\
\text { Cwt. }\end{array}$ & $\begin{array}{l}\text { Deutsch- } \\
\text { land } \\
\text { Cwt. }\end{array}$ & $\begin{array}{c}\text { Frank- } \\
\text { reich } \\
\text { Cwt. }\end{array}$ & $\begin{array}{l}\text { Britisch- } \\
\text { Amerika } \\
\text { Cwt. }\end{array}$ & $\begin{array}{c}\text { Andere } \\
\text { Länder } \\
\text { Cwt. }\end{array}$ & $\begin{array}{l}\text { Total } \\
\text { Cwt. }\end{array}$ \\
\hline 1858 & 4782785 & 2653883 & 4210117 & 5581064 & 702838 & 5270254 & 23201941 \\
\hline 59 & 430504 & 3837454 & 4561521 & 8124978 & 170821 & 4372456 & 21497734 \\
\hline 60 & 9315125 & 5659971 & 6904819 & 4583412 & 1310652 & 4067947 & 31841926 \\
\hline 61 & 15610472 & 4540483 & 6658462 & 1359882 & 3387949 & 6089457 & 37646701 \\
\hline 62 & 21765087 & 5755785 & 7930849 & 1961835 & 5118698 & 7510140 & 50042394 \\
\hline 63 & 11869179 & 4538934 & 5728626 & 1857403 & 3198187 & 3695563 & 30887892 \\
\hline 64 & $\begin{array}{lll}10 & 077431\end{array}$ & 5129410 & 6842721 & 2854421 & 1831897 & 2101320 & 28837203 \\
\hline 65 & 1498579 & $8093989^{\circ}$ & 7224371 & 6058902 & 528456 & 2439255 & 25843552 \\
\hline 66 & 986229 & 9181432 & 6801657 & 8023530 & 59601 & 4319230 & 29371679 \\
\hline 67 & 5091733 & 14166794 & 7873216 & 2140832 & 835006 & 9029199 & 39136780 \\
\hline 68 & 6753389 & 10055338 & 7224597 & 846863 & 798505 & 10827353 & 36506045 \\
\hline 69 & 15320257 & 9187236 & 7546688 & 2153350 & 3396511 & 6843730 & 44447772 \\
\hline 70 & 15057236 & 10326844 & 4487773 & 1060120 & 3402690 & 2571452 , & 36906115 \\
\hline 71 & 15625331 & 15689943 & 4258823 & 182262 & 3782776 & 4823092 & 44362227 \\
\hline 72 & 9634349 & 17938977 & 5183601 & 4553781 & 2157170 & 8145018 & 47612896 \\
\hline 73 & 22007764 & 10503801 & 2153857 & 1170522 & 3767330 & 10414826 & 50018100 \\
\hline 74 & 23048552 & 5714488 & 3053680 & 300299 & 3807174 & 5555267 & 41479460 \\
\hline 75 & 23463910 & 9995295 & 5615984 & 1296920 & 3604610 & 7809674 & 51786393 \\
\hline 76 & 19301785 & 8769260 & 3318348 & 407010 & 1121978 & 9586217 & 42404598 \\
\hline 77 & 21308667 & 10838000 & 5455763 & 1494783 & 2912178 & 12153497 & 54162888 \\
\hline 78 & 28963901 & 9032930 & 5118135 & 11200 & 2603586 & 4081891 & 49811643 \\
\hline
\end{tabular}


Von den überseeischen Ländern ${ }^{1}$ ) beteiligen sich ausser Amerika auch noch Britisch-Indien uud Australien recht ansehnlich an der Verproviantiernug Englands.

Die wichtigsten Kornmärkte des rereinigten Königreichs sind: London. Lirerpool, Hull, Southampton, Glasgow und Leith.

Die Getreidepreise auf diesen Märkten sind für die kontinentalen Märkte in hohem Grade massgebend.

England wotierte bis 31. December 1878 gesetzlich das Getreide per Imperial-Quarter oder Bushel.

Diesen Hohlmassen wurden bestimmte Durchschnittsgewichte, je nach der Qualität, snbstituiert und uach diesen wurde das Getreide zugewrogen.

Dicse Durchsehnittsgewichte waren per Imperial-Quarter:

bei Weizen 50t, 500, 496, 492 und 480 englische Pfunde,

"Roggen 480, 472, 464 und 456 ,

"Gerste $448,432,416$ und 400 ,

"Hafer 336,320 und 300 ,

, Mais 496 und 480 englische Pfunde.

Mit dem 1. Jannar 1879 ist aher das amerikanische Cental i 100 englische Pfunde die gesetzliche Gewichtseinheit im Getreideund Mehlbandel geworden.

In Frankreich notiert man grösstenteils per $100 \mathrm{~kg}$ in Fraues und sind bedeutende Plätze Paris, Marseille, Hâre und Dunkerque; in den beiden letztereu Plätzen wird das Hauptgeschäft in Weizen, Mais und Hafer gemacht.

Deutschland importiert in erster Liuie ans Oesterreieh-Ungarn, dann ans Russland, Belgien, den Niederlanden und iiber die Ostseehäfen, und Mehl aus Frankreich. Das Getreide wird nur nach Gewicht verkauft.

Hauptplätze sind folgende:

1) Berlin mit sehr bedeutendem Termingeschäft.

2) Breslau, bedcutendes Getreidegeschäft.

3) Stettin. Hauptgeschäft in Roggen. Grosse Verschiffungen finden nach Grossbritaunien statt, namentlich nach Hull: ebenso nach Frankreich (Hârre), und uach Schweden und Norwegen.

4) Danzigr. Hauptsächlich in Weizen, welcher nach England, Hollaud, Schweden und Norwegen rerschifft wird.

5) Königsberg. Bedentendes Getreiảegeschäft nach England, Frankreich und Holland.

6) Hamburg. Bedeutendes Getreidegeschäft in Weizen und

1) Nonthly Rep. of the Departm. of Agric. Washington 1873 u. Journal of the Agric. Soc. of Engl. 1879. 
Roggen. Hauptplatz für den Export ron Gerste nach England und fiir den Import ron Mais.

7) Bremen. Hauptgesehäft in Roggen.

8) Mannheim. Bedeutender Getreidehandel in Weizen.

9) Köln. Berleutendes Getreidegeschäft in Weizen und Roggen.

In Belgien wird das Getreide nach Gewicht verkauft und sind dic Hauptgetreidemärkte Antwerpen und Brüssel.

In der Schweiz wird Getreide ebenfalls nach Gewicht verkauft. Das Hauptgeschäft findet in Weizen, Mais, Gerste und Hafer statt, während Roggen nur wenig inportiert wird. Die Hauptplätze sind: Zürich. Romaushorı mit seinen grossen Lagerhäusern und Basel für das rheinaufwärts ron Rotterdan kommende amerikanische Getreide.

In den Niederlanden wird das Getrcide nur nach Gewicht verkauft und das Hauptgeschüft fiudet in Amsterdam und Rotterdam in Roggen und Weizen statt.

Sic importieren nicht nur beträchtliche Mengen für den eigenen Bedarf, sondern auch zur Proviautirung der Seefahrer und zur Hefeund Spirituosen-Fabrikation. Ausserdem exportieren sie rheinaufwairts und nach dem Nordwesten Europas.

Die Hauptplätze Italiens sind Genua, welches Weizen ans der Levante importiert und Livorno. Das Getreide wird teils nach Mass, teils nach Gewicht verkanft.

Die vorliegenden Betrachtungen über die Getreideproduktion und den Getreidehandel haben unwiderlegbar die enorme Konkurrenz dargethan, welche Amerika namentlich den west- und mitteleuropäisehen Landwirten bietet, daher es auch für den deutschen Landwirt von Wichtigkeit sein duirfte, die Ursachen dicser stannenswerten Konkurrenzfähigkeit zu ergründen, und wenden wir uns zu diesem Zweck zunächst deu klimatischen und Boden-Verhältnissen zu, wobei wir hauptsächlich dem lehrreichen Buch Semler's, „Dic wahre Bedeutung und die wirklichen Ursachen der nordamerikanischen Kon-

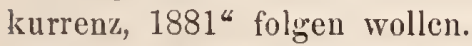

Der Major Powel teilt dnreh eine Linie, welche von Norden nach Siiden durch die Mitte von Kansas, dem Indianerterritorium und Texas läuft, die Vereinigten Staaten in eine trockenc westlichc und eine feuchte östliche Hälfte. In ersterer ist der Regenfall für die Zwecke des Ackerbaues nicht immer geniigend, doch besitzt sie Oasen, die grosse Fruclitbarkeit zeigen, scbald sie genügend bewässert werden kömuen. Sie umfasst ein Gebiet von 1487387 engl. Quadratmeilen, wovon 700000 Quadratneilen der wasserlosen und daher kulturunfahigen Weideregion, 310000 Quadratmeilen der Gebirgsregion, 75000 Quadratmeilen der. Waldregion und 175000 Quadratimeilen dem 'Tafel- und Lavalande angehören; 100000 Quadratmeilen sind sogenanntes schlechtes Land mit wïstenähnlichem Cha- 
rakter und 125000 Quadratmeilen wirkliches Wiistenland. In der feuchten Abteilung genuigt der Regenfall dem Ackerbau und gibt es gute und weniger gute Böden, gerade wie in Europa. Die klimatischen Verlültnisse sind ebenfalls nicht besser, sondern vielmehr weit extremer als in Europa und nehmen in einzelnen Gebieten vollständig den Charakter des Steppenklimas an.

Hieraus scheint hervorzugehen, dass die Konkurrenzfähigkeit Amerikas nicht durch ganz besonders günstige klimatische und Bodenverhältnisse Deutschland gegeniiber bedingt wird. Allerdings geniesst der Landwirt des amerikanischen Westens den Vorteil, dass er seine Ernte ohne Dungaufwand und olne sich an eine geordnete Fruchtfolge zu binden, einem an Pflanzennährstoffen noch reichen Boden, also durch Raubbau entnehmen kann, und hierauf griindet sich auch die leichte Vergrösserung des Arcals fiir eine gewisse Fruchtart, deren Konjunkturen giinstig geworden sind. Es liegt hierin ein Vorteil, jedoch anch zugleich eine gewisse Gefahr, denn eigentlich werden ja nur zwei Früchte, Weizen und Mais, im grossen Umfange angebaut, von denen die eine oder andere leicht einc Missernte bringen kann; ist aber das z. B. zum Weizenbau herangezogene Arcal zu gross und hat Europa eine gute Ernte gemacht, so ist nicht abzusehen, welche Physiognomie bei dieser Massenproduktion dem amerikanischen Ackerbau und dem ganzen Lande aufgenötigt wird, da ein grosser Teil der Ernte geradezu unverkäuflich wird.

Der natirliche Reichtum neu anfgebrochenen Landes ist aber auch nicht unzerstörbar, und in den älteren Staaten des Ostens hat die Erschöpfung des Bodens schon vielfach zu intensiverem Wirtschaftssystem mit Viehhaltung und Stallmistdüngung gefuihrt. Schlagende Beispiele dieser Bodenerschöpfung berichtet G. C. Carey in seinen Briefen an den Präsidenten der Vereinigten Staaten, worin derselbe, nach einer Berechnung der ungeheuren Menge Phosphorsäure und Kali, welche ohne Ersatz den Feldern jährlich entzogen wird, anführt, dass im Staate New-York der durchschnittliche Weizenertrag, der vor 80 Jahren 25-30 Bushel pro Acre betrug, auf 12 Bushel zuriickgegangen sei. In Ohio, einem Staate, der vor 80 Jahren noch eine Wildnis war, ist der durchschnittliche Weizenertrag noch nnter 12 Bushel und nimmt $a b$ anstatt zu. In Virginien gibt es eine ausgebreitete Landstrecke, welche, früher die reichste im Staate, heutzutage einen Weizendurchschnittsertrag von weniger als 7 Bushel crzeugt; in Nord-Carolina wird Land bebaut, welches weniger mehr an Mais aufbringt. In Virginien und Kentucky wurde so lange Tabak gebaut, bis der Boden erschöpft war; und in den Baumwollbezirken begegnen wir einem Erschöpfungszustande, welcher hinsichtlich der kurzen Zeit seines Entstehens nicht seines gleichen auf der Erde findet. Mit der Zeit nimmt auch der Reichtum und damit 
die Konkurrenzfähigkeit des im Westen aufgebrochenen Landes $a b$, und da besseres Land, das an Verkehrswegen liegt, immer seltener wird, so wird sich auch die Bodenerschöpfung auf dem weniger guten Lande zeitiger einstellen.

Wir haben jedoch zur Zeit mit gegebenen Grössen zll rechnen, also hier mit der Getreideproduktion bei sehr extensiver Wirtschaft und ohne Dungaufwand. Es ist fraglich, ob sich in Deutschland Ernteertrag und Getreidepreis un so viel höher stellen, dass der Mehraufwand der intensiven Kultur gedeckt wird.

Semler fuihrt nun folgendes Beispiel dafïr an, dass der deuttsche Landwirt für seinen Weizen einen böheren Preis als der amerikanishe erbält. Er sagt: In Norddeutschland kostete 1880 mittelguter Weizen loco Bahnhof $22 \mathscr{M}$ und zu gleicher Zeit in San Francisco $13.20 \mathscr{M}$ per $100 \mathrm{~kg}$; die Versandkosten berechnen sich durchschnittlich in den dichter besiedelten Counties bei mässiger Entfernung des Abnahmeortes auf 1 W per $100 \mathrm{~kg}$, und die Fracht kann sich bei sebr weiten Entfernungen immerhin so hoch stellen, dass sie den Nutzen des Landwirts verzehrt, oder bei billigen Preisen die Versendung überhaupt unmöglich macht. Bei Annahme der Versandkosten von 1 th wird der Preis von $100 \mathrm{~kg}$ auf 12,20 M herabgedrückt. Ausserdem verkauft der Landwirt seinen Weizen mit den Säcken, woraus sich eine Ausgabe von 80 if ergiebt, daher der Preis auf $11.40 \mathscr{M}$ hinabgeht. Die Fracht von San Francisco nach Liverpool beträgt jedoch mehr als von Chicago aus; sie kann bei den äusserst mässigen Frachtsätzen uı $3.20 \mathscr{M}$ und mit den Ersparnissen an Versicherung und Zinsen um $3.50 \mathscr{H}$ billiger sein, so bleiben zu ginnsten des deutschen Landwirtes, da sich un diese Summe der Weizenpreis in Chicago erhöhen könnte, $7.10 \leadsto$ per $100 \mathrm{~kg}$, welche wohl die Mehrausgaben der intensiven Wirtschaft decken könnten.

Die Konkurrenzfähigkeit Amcrikas wird aber auch nicht durch höhere Erträge erzielt, denn durchselınittlich sind dieselben erheblich geringer als im europäischen Westen.

Vielfach wird nun anch behauptet, dass der niedrigc Landpreis von $1 \frac{1}{2}-5$ Dollars fïr den Acre die Konkurrenzfähigkeit Amerikas bedinge. Nun liegt allerdings die Thatsache vor, dass Land zu obengenannten Preisen ìn Westen, denn im Osten nähıern sich die Preise den europäischen, verkauft wird, doch ist dasselbe vollkommen unkultiviert und fern jeglicher Verkehrsader gelegen, weshalb der Preis unmöglich mit dem Preise gut kultivierten deutschen Landes verglichen werden kann, das auch niemals allzu weit von den Verkehrswegen abliegt. Vergleichbar dürfte nur gut kultiviertes, in der Nähe von Verkehrswegen gelegenes Farmland mit mittelgutem Weizenboden und deutsches Land von derselben Qualität sein: Land dieser 
Art ist zul' Zeit in Deutschland zum Preise von $1200 \mathscr{M}$ pro Hektar $\mathrm{zu}$ erhalten.

Nach Semler stellen sich der Preis und die Kosten der Urbarmachung in Amerika mindestens auf 520 / pro Hektar, wobei jedoch zu bemerken ist. dass in Amerika der Zinsfuss weit höher als in Deutsehland steht, denı derselbe beträgt an der Atlantisehen Küste 7 Proe., im Mississippithal 8-10 Proe., in den Paeifiestaaten 10-12 Proc. und im Durehschnitt etwa 8 Proe, während derselbe in Deutschland etwas mehr als die Hälfte ausmacht. Hierzu gesellt siclı noch eine beträchtlich höhere Steuerbelastung des Grund und Bodens als in Deutschland.

In den getreidebauenden Staaten Amerikas stellt sich diese Steuerquote auf 2-5 Proc, wird, wie dies in jenen Staaten der Fall ist, ein Acre auf 50 Dollar eingeschätzt, so beträgt die Stener nngefähr 10 \# pro Hektar, während in Deutschland Güter mit mittelgutem Weizenboden 4-5 $\mathscr{H}$ zahlen. Natnrgemäss sind hierin dic persönlichen Abgaben nicht mit einbegriffen; bekanntlich stellen sich aber dic indirekten Stemern in Amerika viel lıöher als in Deutschland, denn es entfallen pro Kopf der Berölkerung, nach der Denkschrift des Reichskanzlers, in Dentschland 10.4, in den Vereinigten Staaten dagegen 26.3 M. Werden alle diese Verhältnisse in Betracht gezogen, so seheint es, dass auch in Betreff der Bodenpreise Deutschlands und Amerikas grosse Untersehiede nicht bestehen.

Was nun den Arbeitslohn angeht, so ist derselbe weit höher als in Deutsehland und werden in den Pacificstaaten an Arbeiter fuir knrze Frist täglich $1 \frac{1}{2}$ und in der Ernte $2-2^{1 / 2}$ Dollar bei freier Beköstigung gezahlt, auf längere Frist monatlich 26-30 Dollar cinschliesslich Bekiostigung, in den östlichen Staaten 12-15 und in den Suidstaaten 7 I)ollar. Ferner hat der Landwirt scine Bedirfnisse sehr tener zu bezahlen, z. B. Handwerker, Arzt, Apotheker, Kleidung, Kolonialwaren u. s. w. Im fernen Westen, weit von Verkehrswegen entfernt, kann der Laudwirt seine Erzeugnisse bäufig nur dadurch umsetzen, dass er den Betrag des Erlöses wieder in Waren berausnimnt, und es bedarf zuweilen einer ganzen Wagenladung roll Produkte, um dafür einige Pfund Kaffee, Zucker und die sonst für den alläglichen Gebrauch einer Haushaltung notwendigen Gegenstände einzukaufen.

Schliesslich wire noch herrorzuheben, dass der amerikanische Landwirt bei seinem einseitigen Getreidebau und der extensiven Wirtschaft mit weit zahlreicheren und geführlicheren Pflanzenfeinden, als da sind: Unkräuter, Heuschrecken, Heerwiirmer n. s. w., welche nicht selten seine Ernten rernichten, zu kämpfen hat.

Aus allen diesen Thatsachen geht klar herror, dass der amerikanische Landwirt nicht besonders glïcklichen Umständen seine Kon- 
kurrenzfähigkeit zu danken hat, sondern dass derselben wesentlieh andere Ursachen zu Grunde liegen miissen. Allerdings geht aber auch aus ihnen hervor, dass Amerika, selbst bei mittelmässigen Ernten, in Folge seiner sehwaehen Besiedlung ausfuhrfähig bleiben und also anch die Getreidepreise in Westemropa und Dentschland mehr oder weniger driieken kann, dass aber diese Konkmrenzfähigkeit wesentlich geringer ist, als es namentlieh im Jahre 1879 den Anschein gewann, in welehem Jahre fast alle Länder der Welt, mit Ausuahme der Vereinigten Staaten, wenig befriedigende Eruten erzielten. Ausserdem kaun der Raubbau auf die Dauer nicht bestehen und dureh die Einführung intensiverer Wirtsehaftsweisen gehen den amerikanischen Landwirten viele Vorteile uns gegenïber verloren.

Ferner ist zu beachten, dass leicht kulturfähige, den Verkehrswegen geniigend nahegelegene Ländereien grösstenteils sehon in Besitz genommen sind und zur Aufsehliessung anderer Gegenden dureh neue Verkehrswege selı viel Kapital gehört, sodass sieh ein solcher Vorgaug und aneh in Hinbliek auf die allmähliche Vermelırung der Bevölkernng vergleiehsweise nur langsam vollziehen kann. „Die Urbarmaehung sehleehten Landes, namentlieh wenn dasselbe mit Nadelholz besetzt ist, oder troekene Ländereien zu bewaissern und versumpfte zu entwässern sind, verursaeht Unkosten, die zur Zeit noeh nieht dureh den Ertrag gedeckt werden können.

Die Ursaehen nun, denen Amerika seine Konkırrenzfahigkeit verdank wiehtig ist, weil sie vielleieht eine Handhabe zur Bekämpfung jener Konkurrenz bieten, seheinen folgende zu sein.

Zuvörderst gehört hierhin die Arrondirung der Güter, die in Amerika, seien sie gross oder klein, jedenfalls Rechtecke bilden, während der Besitz in Deutsehland vielfach arg zersplittert ist, wodurel ausserordentlieh viel Zeit und Kraft vergeudet wird. Ferner zeiehnet sich die amerikanische Bewirtschaftung der Güter dureh eine stark ausgeprägte Arbeitsteilung aus, wobei jedoeh $z u$ beachten, dass dieselbe nur dureh die Möglichkeit des Raubbaues in voller Strenge durehfiburbar ist; so baut eine Farm nur Weizen oder Tabak eine andere treibt Jungviehzueht oder Milehwirtschaft, Mastungu.s.w. Unsere intensivere und auf Düngung begrindete Wirtsehaftsweise lässt nun eine solehe strenge Durchführung der Arbeitsteilung nieht $\mathrm{zu}$, vielleicht lässt sieh aber der Grundsatz derselben bei uns etwas mehr zur Anwendung bringen.

Einen wesenthichen Vorsprung hat der Anerikaner vor dem Deutsehen als praktischer Gesehäftsmann voraus, sowie als Kraftund Zeitersparer, indem er immer im Ange hat, dass sich aus rielen kleinen Vorteilen ein grosser zusammensetzt. So vermeidet er ängstlich jegliche unnütze Arbeitsunterbrechung, weshalb z. B. während 
der Arbeit nicht Tabak geraucht werden darf; er versieht seine Arbeiter mit leichten praktischen Geräten, benutzt, wo es nur angeht, gute Maschinen, fordert in der Arbeitszeit auch von seinen Zugtieren die böchste Leistung und sinnt fortwährend darauf, Verbesserungen einzufuihren, welche Kraft und Zeit ersparen.

Das landwirtschaftliche Vereinswesen in den Vereinigten Staaten ist es aber, das den praktischen Sinn, die grössere Thatkraft und den schwunghafteren Unternehmung'sgeist der Amerikaner bekundet. In den Vereinen Deutscblands findet vorwiegend ein theoretischer Meinnngsaustausch und Belehrung statt; seltener werden gemeinsame praktische Werke beraten und auch wirklich durchgeführt, während der Amerikaner seine Thätigkeit vorzngsweise der praktischen Seite zuwendet und durch Eröffnung nener Absatzquellen, Grïndung von Verbänden zur Erreichung praktischer '/wecke u.s.w. sein Gewerbe zu förderu sncht.

Die vorzügliche Organisation des Handels und die Billigkeit der Frachten sind weitere schwerwiegende Ursachen, welche die Ausfuhrfähigkeit Amerikas bedingen. Während der europäische Landwirt den Verkauf seiner Prodnkte auf dem nächstgelegenen Markte selbst besorgt und sich nur nach der Auskunft richtet, die er iiber den Tagespreis an Ort und Stelle erhält, ist dieses Geschäft in Amerika ganz verschieden.

Sobald das Getreide gedroschen ist, wird es nach dem nächstliegenden Giiterbahnhof gefahren, un daselbst in dem Elevator des Ortes anfgespeichert zu werden. Dort befindet sich ein Agent der grossen Getreidehäuser, der stets bereit ist, zum Tagespreis zn kaufen. Die Preise werden von dem Verkänfer nach den in den Zeitungen veröffentlichten kontroliert, welche in Amerika infolge des allgemeinen Gebrauchs, den man von den Telegraphen macht, in Wirklichkeit die neuesten Preise sind. Das Getreide wird gegen bar gekauft; demnächst geht es durch den Elevator, um klassificiert, gewogen, gereinigt und mittels Lieferungsscheins zur Verfügung des Känfers gestellt zu werden.

Was die Seetrachten anbetrifft, so stellen sich dieselben äusserst billig. Nach einer Mitteilung der Times rom 30. August 1880 kaun amerikanischer Weizen wie folgt in Liverpool verkauft werden:

Die Produktionskosten im Westen einschliesslich Lieferung an das Lokaldepot betragen fiir $100 \mathrm{~kg} 13 \mathscr{M}-$ s Fracht nach Chicago Von dort nach New-York Seefracht nach Liverpool Behandlung in Amerika Spesen in Liverpool

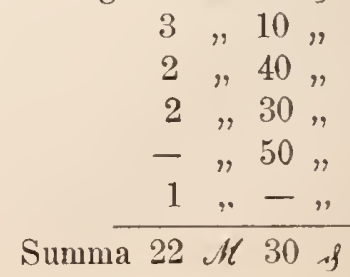


Weniger bewunderungswürdig scheint das Eisenbahnwesen zu sein. Es werden über dasselbe vielerlei Klagen erhoben, da die Gesellschaften als ganz selbständige Körperschaften jeder Staatsaufsicht entriickt sind; heute z. B. sehen einzelne Gesellschaften ein, dass sie die hohen Tarife nicht aufrecht erhalten können, wenn sie überhaupt Frachten bekommen wollen; sie schreiten daher zu Ermässigungen; ihre Konkurrenten suchen sic sofort zu überbieten, und sehliesslich vereinigen sich alle wieder unter einen Hut, um dem Publikum neue Daumschrauben anzusetzen, sodass also der an sich unstete Preis auf den Getrcidemärkten dadurch um so mehr beeinflusst werden muss, weil bei den grossen Entfernungen \%wischen dem Westen und den Hafenplïitzen die Versandkosten bedeutend in die Wagschale fallen. Denn werden die Frachtpreise um 75-100 Proc., wie dies nicht selten vorkomint, plötzlich in die Höhe getrieben, so wird dadurch dem Landwirt der Ertrag seiner Ernte um ebensoviel verringert.

Wir sahcn, dass die Konkurrenzfähigkeit Amerikas zu einem grossen Teil auf den selbstgeschaffenen Vorteilen beruht, und suchen wir in Deutschland uns dieser zu bemächtigen, so wird es mit Hiilfe einer geregelten Buchführung, eines vorsichtigeren Ankaufs der Guiter, einer den Verhältnissen besser entsprechenden Festsetzung der Pachtpreise und teilweisen Neugestaltung unserer Wirtschaften wohl gelingen, uns kräftiger als bisher dieser Konkurrenz zu crwehren.

Was die Wirtschaftsreorganisation anbetrifft, so wïrde es sich empfellen, dort, wo Wiesen und Weiden am Platze sind, die Viehhaltung zu vermehren. Gemcinhin wird durch die vermehrte Viehhaltung, welche eine grössere Dungmasse und bei rationeller Ernährung auch einen wertvolleren Dünger liefert, der Kornertrag auf der Flächencinhcit in solchem Grade gesteigert werden, dass der Getreidebau, weil die Produktionskosten nicht im gleichen Verhältnisse mit der Mehrproduktion wachsen, cinträglicher werden kann. Unter passenden Verlältnissen würde auch der Anbau von Zuckerriiben und Handelsgewächsen einen höheren Reinertrag als der Getreidebau ergeben, auch würde in manchen Fällen es wohl zu iiberlegen sein, ob nicht fiur den Futter- und Getreidebau gleich ungeeignete Flächen vorteilhaft forstwirtschaftlich zu benutzen seien. Als Mittel aber, den Getreidebau konkurrenzfähiger zu machen, bleibt hauptsächlieh die Herstellung besserer Getreidequalitäten und die Vermehrung der Quantität auf der Flächeneinheit.

Eine bessere Kornqualität lässt sieh dureh eine den Verhältnissen entsprechende richtige Sortenauswahl und durch eine möglichst sorgsame Reinigung der Handelsware bewirken. Welcher Wert im Handel auf gut gereinigtes Getreide gelegt wird, zeigt sich in Amcrika, wo die Reinigung der Körner mittels Walzbürsten geschieht, wodurch 
sie von Staub befreit werden, Glanz bekommen und als bessere Handelsware einen höhern Preis erzielen.

In betreff der tierischen Produkte sollte es als Regel gelten, immer feinste Qualitäten, wo dies nur irgend angeht, zu erzeugen.

Fin Getreidezoll schiitzt gegenüber dieser Konkurrenz nicht, denn iibersteigt das Angebot die Nachfrage, so zahlt Amerika den Zoll; anderenfalls wird das Brot in Europa tenrer, weil dann der Konsument den Zoll extra zu zahlen hat, und dies wiirde die ärmeren Klassen,der Berölkelnng am meisten treffen und aufregen, weshalb die Zolltarife nicht so hoch gegriffen werden können, dass sie der ausländischen Konkurrenz wirksam entgegentreten. Jedenfalls haben wir den Trost, dass die iiberseeische Produktion das brotbedurftige Europa auf lange Zeiträume vor Hungersnot bewahren wird. 


\title{
Besonderer Teil.
}

\author{
Weizen. \\ Triticum vulgare $\mathrm{L}$. \\ Einteilung.
}

\section{Unterart: 1. Triticum vulgare L. Eigentlicher Weizen.}

A. Kolbenweizen. Muticum Al.

Varietät: Triticum vulgare albidum Al.

Aehren kahl, weiss oder gelb; Körner weiss oder gelblich.

\section{Sorten:}

Frankensteiner-Weizen. (3)

Aehre: blassgelb, lang, locker, schmal; Aehrchen $1.3 \mathrm{~cm}$ breit, 2-körnig. - Stroh: gelb, fest. - Frucht: Original schön blassgelb, klein (6 mm lang, 31/2 mm breit, 276 Körner wiegen $10 \mathrm{gr}$ ), rundlich, schön geformt, weich, mehlig, sehr feinschalig; nachgebaut: leicht degenerierend, indem sie meist glasig wird.

Herbstblatt schmal, kraus, dunkelgrün; Frühjahrsvegetation spät; Bestockung sehr stark, 5.2 Schösslinge (bei $100 \mathrm{qcm}$ Wachsraum sogar 18.6 Sehösslinge) spät schossend und blühend; Halmhöhe in der Blüte $130 \mathrm{~cm}$ (Max. $155 \mathrm{~cm}$ ), Halmdicke $0.49 \mathrm{~cm}$, Blattzahl 4; mittlere Blattlänge $26.92 \mathrm{~cm}$, Blattbreite $1.15 \mathrm{~cm}$, mithin beträgt die Blattoberfläche beider Seiten $247.68 \mathrm{qcm}$, die Halmfläche $191.10 \mathrm{qcm}$ und die Gesammtfläche $438.78 \mathrm{qcm}$.

Junge Aehre gelbgrün, spät reifend, $13 \mathrm{~cm}$ (Max. $16 \mathrm{~cm}$ ) lang, 20 Aehrchen und 40 Früchte enthaltend.

Es kommen auf 1 qm 700 Halme oder 135 Pflanzen, von denen jede Pflanze $74.1 \mathrm{qcm}$ Raum einnimmt, und auf $1 \mathrm{qm}$ Bodenfl̈̈che ca. $30.71 \mathrm{qm}$ Blattläche.

Auf $1 \mathrm{hl}(=82 \mathrm{~kg})$ entfallen 1749000 Früehte, daher sich das Saatquantum $(1 / 3$ Verlust) auf $1.16 \mathrm{hl} \mathrm{p}$. ha beläuft.

Es wiegen 100 Halme $650 \mathrm{gr}$ und davon die Früchte $240 \mathrm{gr}$.

Seine eigentliche Heimat in Schlesien ist eine eng begrenzte, nämlich das Hügelland des Quell- und Flussgebietes der Ohlau und zwar im Süden 
der Quelle und auf der linken westlichen Seite des Flusses im Münsterberger Kreise, wo er auf dem roten milden Lehmboden der Ausartung nicht unterworfen ist, während er in andere Verhältnisse gebracht, leicht degeneriert, weil das Korn seine schöne blassgelbe Farbe und Mehligkeit verliert und dafür rötlich und glasig wird, weshalb bei seinem Anbau in anderen Gegenden ein häufiger Saatwechsel stattfinden muss.

Wie empfindlich dieser hochgeschätzte Weizen betreffs der Konstanz seines Kornes ist, geht daraus hervor, dass unter sonst gleichen Terhältvissen iun Muinsterberger- und Frankensteiner-Kreise eine geringe Abweichung in der Bodenqualität schon hinreicht, um rotes liorn zu erzeugen. Dieses eigentümliche Verhalten hat eine Reihe von Bodenuntersuchungen ${ }^{1}$ ) veranlasst, aus denen hervorzugehen scheint, dass an Talkerde reicher Bodell weissen Weizen erzeugt, während auf dem an Talkerde armen Boden der Weizen rot und glasig wird.

Am besteu eignet sich dieser Weizen für das Kontinentalklima und einen tiefgrüindigen, kulturvollen Lehmboden.

Die Frucht liefert ein vorzügliches, sehr gesuchtes Mehl; das Stroh ist von fester Textur und lagert uur auf sehr reichell Alluvialböden, und leidet wenig durch Rost.

Dieser Weizen hat sich in Poppelsdorf als durchaus winterfest erwiesen.

Eiue Reihe grösstenteils durch uns * ausgeführter Kulturversuche, ergab folgende Erträge p. ha.

*Abtshagen, Teu-Torpommern, Lehmboden, I $868.1784 \mathrm{~kg} 2848 \mathrm{~kg} 376 \mathrm{~kg}$ *Fldena " " sand. Lehm " 1888,4960 "360 " Waldau, Ost-Preussen schwerer Weizenboden 1861. $1960 " 4968$ " 880 " Proskau, Schlesien, humoser Thonboden 1872. 2803 " 7387 " 409 ", *Poppelsdorf, Rheinprovinz, milder Lehm 1873. 1936 „, 4883 , 752 "

Den Namell „Fraukensteiner-Weizen" hat er von der Stadt Frankenstein in Schlesien erhalten, die seit alten Zeiten einen viel besuchten Getreidemarkt besass, auf dem rorzugsweise dieser Weiss-Weizen verbandelt wurde.

\section{Kujavischer weisser Weizen.}

Aehre: blassgelb, etwas locker, schmal, lang; Aehrchen $1.5 \mathrm{~cm}$ breit, weiss, 3-körnig. - Stroh: hellgelb, ziemlich lang, fest. - Frucht: Original fast weiss, und mehlig, klein (6 mm lang, $3^{1} / 2 \mathrm{~mm}$ breit, 216 Früchte $\left.=10 \mathrm{gl}^{\circ}\right)$, sehr feinschalig; nachgebaut: viele rötlich und glasig; weich.

Herbstblatt dunkelgrün, breit, roggenähnlich; Frïhjahrsvegetation zeitig, Bestockung mittelstark, 4 Schösslinge, mittelfrüh schossend, spät blühend.

Halmlänge $130 \mathrm{~cm}$ (MIax. $155 \mathrm{~cm}$ ), Halmdicke $0.42 \mathrm{~cm}$, Blattzahl 3.3, Blattlänge $27.68 \mathrm{~cm}$, Blattbreite $1.12 \mathrm{~cm}$, Blattoberfläche $204.6 \mathrm{qcm}$, Halmfläche $163.8 \mathrm{qcm}$, Gesammtfläche $368.4 \mathrm{qcm}$.

Junge Aehren gelbgrïn, spät reifend, $12 \mathrm{~cm} \mathrm{lang,} \mathrm{(Мax.} 14 \mathrm{~cm}$ ):

1) Vergl. E. Peters, Chem. Ackersm. 1860 pr. 22. R. H of $f m a n n$, Jahresbericht, Jahrg. VI pg. 34. Schlesische landw. Zeit. No. 38. Verhandl. d. landw. Vereins in Schweidnitz. 
mit 21 Aehrchen und 60 nicht leicht ausfallenden Früchten, von denen 1749600 auf $1 \mathrm{hl}=81 \mathrm{~kg}$ gehen.

Auf $1 \mathrm{qm}$ wachsen 800 Halme oder 200 Pflanzen, mithin beträgt der Raum für eine Pflanze $50 \mathrm{qcm}$, die Blattfläche p. qm Bodenfläche $29.5 \mathrm{qm}$ und das Saatquantum $1.7 \mathrm{hl}$.

Es wiegen 100 Halme $405 \mathrm{gr}$ und davon die Früchte $211 \mathrm{gr}$. Es ist ein echter, durchaus sicherer Winterweizen, denn als Sommerweizen kultiviert, trieb er keine Halme; liefcrt ein vorzügliches Melll, lagert nicht leicht, und ist auf den schweren, reichen Weizenböden sehr ertragreich.

Er lieferte nachfolgende Erträge in $\mathrm{kg} \mathrm{p}$. ha:

Provinz Ort Jahr Boden Korn Stroh Spreu

*F'ornmern, Eldena, 1868, sandiger Lehm $\quad \begin{array}{cccc}\mathrm{kg} & \mathrm{kg} & \mathrm{kg} \\ & 2836 & 4644 & 336\end{array}$

Preussen, Waldau, 1861, schwerer Weizenboden $2816 \quad 7440 \quad 120$

Schlesien, Proskau, 1872, schwerer Lehm 13954275405

Seine Heimat ist die Landschaft Kujavien, welche in der Provinz Posen und dem Königreich Polen, an der westpreussischen Grenze, auf beiden Ufern der Weichsel gelegen ist.

Für das nordöstliche Deutschland ist dieser Weizen von grossem Wert.

\section{Kulmer-Weizen. (2)}

Aehre: fast weiss, sich stark verjüngend und grannenspitzig, locker, auf $11 \mathrm{~cm}$ Länge entfallen 50 Früchte; Aehrchen $1.4 \mathrm{~cm}$ breit. 2-3. körnig. - Stroh: blassgelb. - Frncht: weiss, mehlig, kurz, rund $(61 / 4 \mathrm{~mm}$ lang, $4 \mathrm{~mm}$ breit), schön, schwer, Mehlqualität hoch geschätzt.

Dieser Weizen stammt aus dem sog. Kulmer Ländchen in der Weichselniederung und verlangt guten Boden; unter ungünstigen Verhältnissen angebaut, degeneriert er leicht.

\section{Schlesischer Gebirgs-Weizen. (2)}

Aehre: schwach rötlich-weiss, geschlossen, sich nach Spitze verjüngend, grannenspitzig; mittellang, breit; Aelıren $1.8 \mathrm{~cm}$ breit, 3 und 4körnig. - Stroh: rötlichgelb, fest. - Frucht: blassgelb, meist mehlig, rundlich ( $5 \mathrm{~mm}$ lang, $4 \mathrm{~mm}$ breit, 195 Früchte $=10 \mathrm{gr}$ ), schön, feinschalig.

Herbstblatt dunkclgriin, schmal, kraus; Entwickelung mittelfrüh, 2.7 Sprosse, mittelfrüh schossend und blühend. Halmlänge $150 \mathrm{~cm}$ (Max. $170 \mathrm{~cm}$ ), Halmdicke $0.47 \mathrm{~cm}$, Blattzahl 5, Blattlänge $32.3 \mathrm{~cm}$, Breite $0.93 \mathrm{~cm}$, mittlere Blattfläche $150.40 \mathrm{qcm}$, Halmfläche $211.15 \mathrm{qcm}$, Gesammtfäche $361.90 \mathrm{qcm}$.

Junge A ebre gelblich grün, mittelfriih reifend, $11 \mathrm{~cm}$ lang (Max. $13 \mathrm{~cm}$ ) mit 20 Aehrchen und 72 Früchten, von denen $1 \mathrm{hl} 84 \mathrm{~kg}$ wiegt, und 1438000 Frïchte enthält.

Es wachsen 800 Halme oder ca. 300 Pflanzen p. qm, mithin entfallen pro Pflanze $33.3 \mathrm{qcm}$ Raum, und auf $1 \mathrm{qm}$ Bodenfläche $28.96 \mathrm{qm}$ Blattfläche.

Das Aussaatquantum beträgt bei 3000000 Pflanzen $3.1 \mathrm{hl} \mathrm{p}$. ha. 100 Halme wiegen $650 \mathrm{gr}$ und davon die Frïchte $430 \mathrm{gr}$.

Dieser Weizen widersteht dem Lagern und Rost ziemlich gut, doch fallen die Früchte leicht aus.

Er zeigte sich in Poppelsdorf vollkommen winterfest und scheint für gute Lelımböden sehr geeignet zu sein. 


\section{Weisser Weizen von Gilmannsdorf, Schlesien. (3)}

Aehre: blassgelb, sehr locker, grannenspitzig, schmal; Aehrchen $1.5 \mathrm{~cm}$ breit, 3-körnig. - Stroh: gelb, dünnwandig. - Frucht: blassgelb, mehlig, länglich ( $7 \mathrm{~mm}$ lang, $31 / 2 \mathrm{~mm}$ breit), feinschalig.

Herbstblatt blaugrün, kraus, schmal; Frühjahrsvegetation sehr spät, Bestockung sehr stark, 8.4 Schösslinge, spät schossend und blühend. Halm $150 \mathrm{~cm}$ (Max. $175 \mathrm{~cm}$ ) lang, $0.38 \mathrm{~cm}$ dick, Blattzahl 4.4, Blätter $25.5 \mathrm{~cm}$ lang, $1.0 \mathrm{~cm}$ breit, Blattoberflüche $224.4 \mathrm{qcm}$, Halmfläche $1.71 \mathrm{qcm}$, Gesammtfläche $395.4 \mathrm{qcm}$.

Junge Aehre blaugrün, spät reifend, $12 \mathrm{~cm}$ lang, (Max. $16 \mathrm{~cm}$ ), mit 18 Aehrchen und 54 Früchten.

Es kommen auf $1 \mathrm{qm} 900$ Halme oder 107 Pflanzen, hiernach stellt sich der Raum pro Pflanze auf $93,4 \mathrm{qcm}$ und die Blattfläche pro qm Bodenfläche auf 35.59 qm.

Es wiegt $1 \mathrm{hl}=84 \mathrm{gr}$ und enthält 1776000 Körner, mithin beträgt das Saatquantum $(1 / 3$ Verlust $) 0.9 \mathrm{hl}$ p. ha. Es wiegen 100 Halme $578 \mathrm{gr}$ und davon die Früchte $178 \mathrm{gr}$.

Der Weizen zeigte sich vollkommen winterfest, lagerte nicht leicht und widerstand dem Rost, weshalb er für gute Lehmböden des Kontinentalklimas hoch beachtenswert erscheint.

\section{Schönermark's Weizen.}

Aehre: fast weiss, sich wenig verjüngend, ziemlich geschlossen, mittelbreit; Aehrchen $1.5 \mathrm{~cm}$ breit, 3-körnig. - Stroh: gelb, ziemlich kräftig. - Frucht: blassgelb, mehlig, rund (6 $\mathrm{mm}$ lang, $3 \frac{1}{2} \mathrm{~mm}$ breit, 276 Früchte $=10 \mathrm{gr}$ ), feinschalig.

Herbstblatt blaugrün, etwas niederliegend; Frühjahrsvegetation zeitig; Bestockung etwas schwach, 3, 4 Schösslinge, mittelfrüh schossend und blühend. Halmlänge $130 \mathrm{~cm}$ (Max. $155 \mathrm{~cm}$ ), Halmdicke $0.4 \mathrm{~cm}$; Blattzahl 3.5, mittlere Blattlänge $28.5 \mathrm{~cm}$, Blattbreite $0.8 \mathrm{~cm}$, mittlere Blattoberfläche $159.60 \mathrm{qcm}$, Halmfläche $156 \mathrm{qcm}$, Gesammtfläche $315.60 \mathrm{qcm}$.

Junge Aehre blaugrün, spät reifend, $10 \mathrm{~cm}$ lang (Max. $15 \mathrm{~cm}$ ) mit 16 Aehrchen und 50 nicht leicht ausfallenden Früchten.

Es wachsen pro qm 900 Halme oder 265 Pflanzen, also beansprucht eine Pflanze $37.7 \mathrm{qcm}$ Raum, und pro qm Bodenfläche entfallen $28.4 \mathrm{qm}$ Blattfläche.

Auf $1 \mathrm{hl}(=82 \mathrm{~kg})$ entfallen 2263200 Früchte, mithin stellt sich das Saatquantum auf $1.8 \mathrm{hl} \mathrm{p}$. ha.

Es wiegen 100 Halme $650 \mathrm{gr}$ und davon die Früchte $220 \mathrm{gr}$.

Dieser Weizen neigt etwas zum Lagern und befällt stark mit Rost, ist jedoch in Deutschland vollkommen winterfest. Für gute kulturvolle Lehmböden geeignet. za Halle.

Wir erhielten diesen Weizen 1877 aus dem ök.-botanischen Garten

\section{White Essex-Wheat. (2)}

Französisch: Blé blanc d' Essex.

Deuts ch: Weisser Essex-Weizen.

Aehre: blassrötlichweiss, sich nach der Spitze verjüngend, ziemlich geschlossen, mittellang. Aehrchen ziemlich breit $(1.5 \mathrm{~cm})$, meist 3-körnig. - Stroh: rötlichgelb, lang, fest, ziemlich blattreich. - Frucht: 
mehlig und blassgelb; nachgebaut: häufig glasig und blassrötlich, breit, klein, rundlich (6 $\mathrm{mm}$ lang, $3^{1} / 2 \mathrm{~mm}$ breit), feinschalig, halbhart, Bruch halb mehlig.

Herbstblatt gelbgrün, kahl oder oberwärts sehr schwach behaart, breit, lang, aufrecht, kräftig. Frühjahrsentwickelıng nittelfrüh; $\mathrm{Be}$ stockung sehr stark, 5.7 Sprossen, mittelfrüh schossend und blühend, Halm $130 \mathrm{~cm}$ (Max. $150 \mathrm{~cm}$ ) lang, $0.4 \mathrm{~cm}$ dick, Blätter $25.8 \mathrm{~cm}$ lang, $1 \mathrm{~cm}$ breit, mithin bei 4.1 Blättern die Blattfläche $211.56 \mathrm{qcm}$, die Halmfläche $156 \mathrm{qcm}$, und die Gesammtfläche 367.56 qcm beträgt.

Junge Aehre gelbgrün, $9 \mathrm{~cm}$ (Max. $12 \mathrm{~cm}$ ) lang, mit 16 Aehrchen und 50 etwas lose sitzenden Früchten.

Es wiegt $1 \mathrm{hl} 84 \mathrm{~kg}$ und enthält 1906800 Früchte, mithin, wenn 800 Halme oder 140 Pflanzen p. qm wachsen können, ein Aussaatquantum von $1.7 \mathrm{hl}$ nötig ist.

Jede Pflanze beansprucht eine Bodenfläche ron $71 \mathrm{qcm}$ und auf 1 qm Bodenfläche berechnet sich eine Blattfläche von $29.4 \mathrm{qm}$.

Es wogen 100 Halme $540 \mathrm{gr}$ und davon die Körner $180 \mathrm{gr}$.

Ungünstiger Witterung widersteht er im Allgcmeinen gut, auch ist er dem Lagern wenig ausgesetzt, leidet aber stark durch Rost, weshalb feuchte, indurchlassende, schwere Böden sich für ihn nicht eignen. Es scheint, dass er die Stanmform des „Blé blanc de Flandres" ist.

\section{Brodie's white Wheat. (2)}

Syn.: Engl.: Oxford prize.

Franz.: Blé blanc d'Oxford.

Deutsch: Brodie's weisser Kolbenweizen, Preisweizen von Oxford.

Aehre: weiss, aufrecht, lang, etwas locker, breit; Aehrchen $1.6 \mathrm{~cm}$ breit, 3-körnig. - Stroh: rötlichgelb, kräftig, fest, steif. - Frucht: weiss, mehlig, voll, schön, gross $(7 \mathrm{~mm}$ lang, $4 \mathrm{~mm}$ breit, 250 Früchte $=10 \mathrm{gr})$; nachgebaut: nach wenigen Jahren glasig, rötlich und grösser (8 $\mathrm{mm}$ lang, $4 \mathrm{~mm}$ breit, 199 Früchte $=10 \mathrm{gr}$ ) weich, Bruch halbmehlig.

Herbstblatt blaugrün, schmal, kraus, beiderseits schwach behaart; Frihjahrsvegetation mittelfriih, Bestockung mittelstark, 4.6 Schösslinge (bei $100 \mathrm{qcm}$ Raum p. Pflanze 13.3 Schösslinge). Mittelfrïh blühend; Halmlänge $125 \mathrm{~cm}$ (Max. $155 \mathrm{~cm}$ ), Halmdicke $0.43 \mathrm{~cm}$, Blattzahl 3.3, mittlere Blattlänge $31.8 \mathrm{~cm}$, Blattbreite $1.13 \mathrm{~cm}$, Blattoberfläche $237.14 \mathrm{qcm}$, Halmfläche $161.25 \mathrm{qcm}$ und Gesammtfläche eines Halmes $398.39 \mathrm{qcm}$.

Junge Aehre gelbgriin, blau bereift, ziemlich früh reifend, reif $12 \mathrm{~cm}$ lang (Max. $16 \mathrm{~cm}$ ) mit 20 Aehrchen und 60 in der Reife leicht ausfallenden Friichten.

Es wachsen 992 Halme oder 216 Pflanzen pro Quadratmeter, mithin eine Pflanze einen Raum von $46.3 \mathrm{qcm}$ einnimmt, während die Blattfläche pro qm Bodenfläche 39.52 qm beträgt.

Es zählen sich pro hl (= $82.7 \mathrm{~kg}) 1645730$ Früchte aus, demzufolge das Saatquantum ( $1 / 3$ Verlust) 2 hl beträgt.

Es wiegen 100 Halme $540 \mathrm{gr}$ und davon die Früchte $183 \mathrm{gr}$.

Es ist dies ein schöner, ertragreicher und gegen ungünstige Witterung wenig empfindlicher Weizen, der wegen seines steifen Strohes selten lagert, doch ziemlich stark dem Rost unterworfen ist. 
Auf guten, reichen Weizenböden stellen sich seine Korn- und Stroherträge beträchtlich hoch, so brachte derselbe auf gutem Weizenboden in Frankreich, Departm. Indre $\left.{ }^{1}\right) 30.80 \mathrm{hl}$ Korn à $74 \mathrm{~kg}$ und $2330 \mathrm{~kg}$ Stroh.

Dieser in Grossbritamien, namentlich in Berwickshire früher stark gebaute Weizen, wird auch vielfach in Frankreich und Deutschland, hier namentlich in Pommern kultiviert.

Nach seinem Züchter, Mr. Brodie zu Orniston, 1821, erhielt er seinen Namen; 1839 wurde dem Weizen zu Oxford von der englischen Landwirtschaftsgesellschaft ${ }^{2}$ ) ein erster Preis zuerkannt, und seit dieser Zeit hat sich für ibn auch der Name ,Oxford prize" eingebürgert.

\section{Hunter's white Wheat. (2)}

Deatsch: Hunter's weisser Winterweizen.

Französisch: Blé de Hunter.

Soll nach Heuzé mit dem alten weissen schottischen StandardWeizen (White Standard-Wheat; Blé Standard blanc) identisch sein.

Verbesserte Formen: Hallet's pedigree Hunter's white Wheat; Webb's selected Hunters white.

Aehre: blassgelb, aufrecht, geschlossen, mittellang, sich nach der Spitze etwas verjüngend, grannenspitzig. Aehrchen breit $(1.7 \mathrm{~cm})$, meist 3-körnig. - Stroh: rötlich-weiss, lang, fest. - Erucht: Original mattweiss, mehlig, in der Mitte am dicksten, sich nach Basis und Spitze verjüngend, rundlich (6 mm lang, $3 \frac{1}{2} \mathrm{~mm}$ breit, 230 Früchte wiegen $10 \mathrm{gr}$ ), Textur feim, schwer wiegend. Nachgebaut: schon in erster Ernte neist glasig und blassrötlich, auch grösser ( $7 \mathrm{~mm}$ lang, $4 \mathrm{~mm}$ breit), 194 Früchte wiegen $10 \mathrm{gr}$, demnach Frucht nicht konstant; feinschalig, halbweich, Bruch haibmehlig.

Herbstblatt ziemlich breit, beiderseits schwach beliaart, aufreclit, blaugriin, Bestockung mittelstark, 3.5 Sprossen, Fruhjahrsvegetation zeitig, doch tritt das Schossen und Blühen mittelfrüh und die Ernte spät ein. Halm $130 \mathrm{~cm}$ (Max. $150 \mathrm{~cm}$ ) lang, $0.45 \mathrm{~cm}$ dick, Blattzahl 3. Mittlele Blattlänge $30.77 \mathrm{~cm}$, Blattbreite $1.13 \mathrm{~cm}$, hiernach beträgt die Blattfläche 208.62 q cm, die Halmfläche $175.50 \mathrm{qcm}$ und die Gesammtfläche 384.12 qcm.

Auf $1 \mathrm{qm}$ Bodenfläche können 800 Halme oder 229 Pflanzen wachsen, mithin beträgt der Raum pro Pflanze $43.7 \mathrm{qcm}$ und die Gesammtoberfläche aller Pflanzen $30.73 \mathrm{qm}$.

Aehre jung gelbgriin, leif $10 \mathrm{~cm}$ (Max. $13 \mathrm{~cm}$ ) lang, Zahl der Aehrchen 18, mit 50 Friichten, die etwas lose in den Spelzen sitzen.

Es wiegen 100 Halme $700 \mathrm{gr}$ und davon die Friuchte $225 \mathrm{gr}$.

Das Hektolitergewicht stellt sich auf $83.3 \mathrm{~kg}$ und $1 \mathrm{hl}$ enthält 1616000 Frïchte, mithin stellt sich das Saatquantum (bei 33 Proc. Verlust), wenn 2290000 Pflanzen pro ha wachsen können, auf $1.42 \mathrm{hl}$.

Dieser Weizen eignet sich, da er nicht leicht lagert, für reiche Weizenböden, jedoch mit der Einschränkung, dass das Klima mild ist. In Poppelsdorf und auch sonst in Nord-Deutschland erwies er sich als nicht winterfest ${ }^{3}$ ), doch ziemlich widerstandsfähig gegen Rost.

Er ist eine der ältesten und geschätztesten Weizensorten Schottlands,

1) Journ. d'Agric. 1857. 'T. I pg. 93.

2) Morton. Cyclop. of Agric. Vol. II pg. 1127 etc.

3) Vergl. Metz, Berichte über neuere Nutzpfl. 1859. 
wo er um 1830 durch Mr. Hunter zu Tynefield bei Dunbar, EastLothian eingeführt wurde, auch hat er sich in Schottland trotz Einführung vieler never Sorten noch eine grosse Verbreitung erhalten. Die Samenhandlung von Peter Lawson hat namentlich, zu seiner weiteren Verbreitung sehr viel beigetragen.

In neuerer Zeit ist er dureh Mr. Hallet nach seinem System verbessert worden, und wird dieser verbesserte Weizen in Grossbritannien und Nord-Frankreich angebaut und zwar als „Hallet's Pedigree Hunter's white Wheat."

Ein mehrjähriger Anbau dieses Weizens und eine sorgfältige Vergleichung mit dem nicht verbesserten "Hunter's Wheat" hat gezeigt, dass allerdings die Bestockung kräftiger ist (4.1 Sprossen), die Aehrchen breiter und meist 4-körnig sind, ïberhaupt sich die Pflanze robuster entwickelt.

Von diesem wiegen 100 Halme $740 \mathrm{gr}$ und davon das Korn $290 \mathrm{gr}$. Die Aehren enthalten bei einer durchschnittlichen Länge von $12 \mathrm{~cm}$ mit 20 A ehrchen 70 Früchte und Mr. Lawes ${ }^{1}$ ) in Rothamsted erzielte auf gutem Weizenboden bei sechsjährigen Kulturversuchen $33.07 \mathrm{hl}$ p. ha. Die Körner liefern ein vortreffliches von den Bäckern sehr geschätztes Mehl.

Hin und wieder wird dieser Weizen auch versuchsweise in Deutschland und Italien kultiviert.

Im Uebrigen stimmt er vollständig mit „Hunter's Wheat“ überein.

Gleiches lässt sich von dem durch den englischen Samenhändler Webb verbesserten "Selected Hunters white" sagen.

\section{Whittington Wheat. (2)}

Syn.: Englisch: Eley's Giant-Wheat.

Französisch: Blé Whittington, Blé de Whittingham; Blé géant d'Eley.

Deutsch: Whittington's weisser Weizen; Eley's Riesenweizen.

Aehre: weiss, mit schwachrötlichem Schimmer, locker, lang, sich nach Spitze verjuingend und grannenspitzig. Aehrchen mittelbreit $(1.5 \mathrm{~cm})$, meist 3-körnig. - Strolı: rötlichgelb, ziemlich lang. - Frucht: blassgelb mehlig, sehr kleinkörnig ( $6 \mathrm{~mm}$ lang. $31 / 2 \mathrm{~mm}$ breit), $310 \mathrm{Körner} \mathrm{wiegen}$ $10 \mathrm{gr}$; nachgebaut grösser und dicker (6 $\mathrm{mm}$ lang, $4 \mathrm{~mm}$ breit), zuweilen auch glasig und rötlich; Bruch mehlig, weich.

Herbstblatt dunkelgrün, niederliegend, schmal, oberseits ziemlich sclıwacl behaart, unterseits kahl. Die Frühjahrsvegetation, das Schossen, die Blüte und die Ernte treten spät ein. Die junge Aehre ist gelbgrün.

Es wiegen 100 Halme $479 \mathrm{gr}$ und davon die Körner $160 \mathrm{gr}$. Frucht in der Reife leicht ausfallend.

Das Stroh ist weich, lagcrt daher auf reichem Boden etwas leicht, doch zeigt es sich gegen Rost widerstandsfähig.

Dieser Weizen zeigte sich vollständig winterfest, auch gehörte er zu den wenigen Sorten, welche den Winter von 1870/71 überstanden.

Seine Bodenansprüche sind gering, so bringt er selbst noch auf sandigen Lehmböden recht befriedigende Erträge.

Ir. Whittington of Whitmore-house near Ripley soll ibn 1830 aus der Schweiz nach England eingeführt und seit 1836 davon verkauft

1) Farmer's Miagazine 1876, pg. 433 u. „Journ. de l'Agric.“ 1878. I. 
haben. Fast gleichzeitig (1832) wurde unter dem Namen Eley's Riesenweizen durch Charles Eley, Sion-Hill near Isleworth ein Weizen verbreitet, der unzweifelhaft mit dem von Whittington gezüchteten identisch ist, denn nicht nur Jühlke behauptete dies schon im Eldenaer Archiv 1856 pg. 96, sondern auch unsere Untersuchungen bestätigten dies. Mr. Darblay führte ihn 1840 nach Frankreich ein.

Der Whittington-Weizen ist durch $\mathrm{Krausche}$ in neuerer Zeit verbessert worden, der vergleichende Anbau dieser drei Formen ergab nachfolgende Resultate:

\begin{tabular}{|c|c|c|c|}
\hline & Whittington & Eley & $\begin{array}{l}\text { Verbesserter } \\
\text { Whittington }\end{array}$ \\
\hline $\begin{array}{l}\text { Anzahl der Schossen } \\
\text { Halmlänge } \\
\text { Halmdicke } \\
\text { Blattzahl } \\
\text { Blattlänge } \\
\text { Blattbreite } \\
\text { Blattoberfläche } \\
\text { Halmfläche } \\
\text { Gesammtfäche } \\
\text { Aehrenlänge } \\
\text { Anzahl der Aehrchen } \\
\text { pro Aehre } \\
\text { Fruchtzahl } \\
\text { Halme pro qm } \\
\text { Blattfläche pro qm } \\
\text { Bodenfläche } \\
\text { Anzahl der Pflanzen } \\
\text { pro qm } \\
\text { Raum pro Pflanze } \\
\text { Hektolitergewicht } \\
\text { Körnerzahl pro hl } \\
\text { Aussaatquantum pro ha }\end{array}$ & \begin{tabular}{|c|}
6.0 \\
$120 \mathrm{~cm}($ Max. $150 \mathrm{~cm})$ \\
$0.33 \mathrm{~cm}$ \\
3.4 \\
$23.8 \mathrm{~cm}$ \\
$0.81 \mathrm{~cm}$ \\
$131 \mathrm{qcm}$ \\
$12078 \mathrm{qcm}$ \\
$251.78 \mathrm{qcm}$ \\
$11 \mathrm{~cm}$ Max. $15 \mathrm{~cm})$ \\
11 \\
42 \\
970 \\
$24.42 \mathrm{qcm}$ \\
162 \\
$61.7 \mathrm{qcm}$ \\
$79.6 \mathrm{~kg}$ \\
1767000 \\
$1.6 \mathrm{hl}$
\end{tabular} & \begin{tabular}{|c|}
6.0 \\
$135 \mathrm{~cm}($ Iax. $155 \mathrm{~cm})$ \\
$0.4 \mathrm{~cm}$ \\
3 \\
$27.3 \mathrm{~cm}$ \\
$1.18 \mathrm{~cm}$ \\
$193.26 \mathrm{qcm}$ \\
$162 \mathrm{qcm}$ \\
$355.26 \mathrm{qcm}$ \\
$12 \mathrm{~cm}($ Max. $15 \mathrm{~cm})$ \\
18 \\
54 \\
936 \\
\\
$33.25 \mathrm{qcm}$ \\
156 \\
$64.1 \mathrm{qcm}$ \\
$81 \mathrm{~kg}$ \\
1903500 \\
$1.63 \mathrm{hl}$
\end{tabular} & $\begin{array}{c}7.5 \\
130 \mathrm{~cm}(\text { Max. } 150 \mathrm{~cm}) \\
0.42 \mathrm{~cm} \\
4 \\
24.5 \mathrm{~cm} \\
1.06 \mathrm{~cm} \\
207.76 \mathrm{qcm} \\
163.8 \mathrm{qcm} \\
371.56 \mathrm{qcm} \\
12 \mathrm{~cm}(\text { Max. } 16 \mathrm{~cm}) \\
18 \\
54 \\
900 \\
33.44 \mathrm{qm} \\
120 \\
83.3 \mathrm{qcm} \\
80.6 \mathrm{~kg} \\
1636180 \\
1.81 \mathrm{hl}\end{array}$ \\
\hline
\end{tabular}

Früher wurde dieser Weizen sehr ausgedehnt in England und Schottland kultiviert, doch geht sein Anbau jetzt immer mehr auf Böden von geringerer Fruchtbarkeit über, auf denen Lagerfrucht nicht zu fürchten. Ebenso ist auch in Nord-Deutschland seine Kultur fast ganz aufgegeben worden, da er sehr leicht degenerieren soll. Sein Anbau wurde naınentlich in Pommern und Westpreussen ziemlich stark betrieben, und soll dieser Weizen beim Export nach England die höchsten Preise erzielt haben.

\section{White Chiddam Wheat. (2)}

Syn.: Cheltham, Chidham.

Franz.: Blé blanc de Chiddam; Blé Chiddam d'automne à épi blane.

Aehre: blassgelb, locker, schmal, etwas grannenspitzig, aufrecht, mittellang; Aehrchen $1.5 \mathrm{cln}$ breit, 3-körnig. - Stroh: orangegelb, wenig blattreich, ziemlich dick $(0.35 \mathrm{~cm})$, steif, lang $(150 \mathrm{~cm})$. - Frucht: Original weiss, mehlig; nachgebaut, viele glasig, klein, rundlich (6 mm lang, 
$4 \mathrm{~mm}$ breit, 237 Früchte $=10 \mathrm{gr}$ ), sehr schwer, feinschalig; halbweich, Bruch halb mehlig.

Aehre reift früh, bis $12 \mathrm{~cm}$ lang, mit 60 leicht ausfallenden Früchten, deren Mehl geschätzt ist, doch leidet ihre Qualität in feuchten Jahren. Das Strob lagert nicht leicht, befällt aber stark mit Rost.

Dieser Weizen bestockt sich nur schwach, und ist nicht ganz winterfest, so soll er selbst noch im nördlichen Frankreich auswintern; auch sind seine Bodenansprïche sehr hoch, und obgleich der Weizen ziemlich ergiebig ist, entspricht er selten den Erwartungen, welche sein üppiger Wuchs erzeugt. Lawes ${ }^{1}$ ) in Rothamsted, Eugland, erntete ron ihm im sechsjährigen Durchschnitt, auf Lehmboden $31.39 \mathrm{hl}$ p. ha.

Dieser Weizen ist eine alte englische Sorte, welche häufig in den besseren Weizenregionen Englands, so in Kent, Surrey und Middlesex, aber auch in Schottland und im nördlichen Frankreich, namentlich in der Brie, gebaut wird.

Er wurde zuerst 1835 durch Robb zu Georgie-Mains bei Edinburgh unter seinem jetzigen Namen weiter verbreitet.

Nach Heuzé soll er 1840 von de Gourcy, dagegen nach einer von Vaury in der französischell Abteilung der Pariser Weltausstellung 1878 ausgelegten Mitteilung erst 1856 von Darblay de Corbeil aus England nach Frankreich eingefuihrt worden sein. $\mathrm{Er}$ gelangte 1851 von England aus als Chidham-Wheat nacl Nord-Amerika ${ }^{2}$ ).

In Fraukreich ${ }^{3}$ ) liat er sich jetzt ein enormes Gebiet erobert und werden im Departement Seine inférieure als Erträge p. ha angegeben:

\begin{tabular}{|c|c|c|c|c|c|c|}
\hline auf & Thonboden & 2400 & $\mathrm{~kg}$ & Kor & - & Stroh. \\
\hline & Lehmboden & 2100 & . & $"$ & 3500 & \\
\hline$"$ & $"$ & 1600 & & $"$ & 4000 & \\
\hline " & $"$ & 1720 & & $"$ & 5000 & \\
\hline & , & 1950 & & ", & 3600 & \\
\hline
\end{tabular}

\section{Hopetoun-Wheat. (2)}

Syn: Hopetoun-Weizen.

Fran z.: Blé Hopetoun.

Aehre: blassgelb, mit einigen kurzen Grannen an der Spitze, aufrecht, ziemlich dick, bis $13 \mathrm{~cm}$ lang, mit 75 lose sitzenden Früchten; Aehrchelı meist 4-körnig, 2 cm breit. - Stroh: blassgelb, sehr kräftig, doch Stroh und Spreu weich, etwas leicht lagernd, bis $150 \mathrm{~cm}$ lang, $0.47 \mathrm{~cm}$ breit. - Frucht: Original blassgelb, mehlig, doch nachgebaut leicht glasig, etwas plump ( $61 / 2 \mathrm{~mm}$ lang, $3^{1} / 2 \mathrm{~mm}$ breit, 256 Friichte $=10 \mathrm{gr}$ ), schwer, feinschalig, halbweich, Bruch halbmehlig.

Herbstblatt gross, aufrecht, Bestockung mittelstark, Wuchs beträchtlich kräftiger als bei "Hunter's white", doch spät blühend, und für Deutschland nicht genügend winterfest. sollte.

Ertrag selten so gross, als man nach dem üppigen Wuchs vermuten

Die zweijährigen Durchschnittserträge stellten sich p. ha in

1) Farmer's Magaz. V. 80.1876 pg. 433.

2) Transactions of the New-York st. $1853 \mathrm{pg} .174$.

3) Dreis ch, Paris. Weltausst.-Berichte 1878 pg. 247. 
England (schwerer Lehm) auf $2450 \mathrm{~kg}$ Korn, $3548 \mathrm{~kg}$ Stroh

Poppelsdorf (milder Lehm) „, 2320 ," " 5200 , ,

Er eignet sich nur für einen kräftigen, in guter Kultur befindlichen Boden und für ein nildes Klima.

Alexander Douglas, der Verwalter der Farm Drem, East Lothian, fand 1832 eine Aehre dieses Weizens, welche er dem Mr. Shirreff zu Mungowells $z \mathfrak{u}$ weiterer Ziichtung übergab, der 1846 beim Verlassen seines Gutes die ganze Produktion dem Besitzer ron Drem, Mr. Reid, überliess.

Original in der landw. Akademie zu Poppelsdorf.

\section{Vipound's white Wheat. (2)}

A ehre: fast weiss, sich nach spitze verjuingend und grannenspitzig, etwas locker. Aehrchen schmal $(1.3 \mathrm{~cm}$ breit), 2-körnig. - Stroh: rötlich-gelb, derbwandig, blattreich. - Frucht: Original weiss, mehlig, nach einigen Ernten rötlich und meist glasig, mittelgross, rundlich $(61 / 2 \mathrm{~mm}$ lang, $3^{1 / 2} \mathrm{~mm}$ breit), feinschalig; Bruch mehlig, weich.

Herbstblatt schmalblättrig, kahl, blaugrün, kraus. Die Frühjahrsvegetation tritt spät ein, Bestockung etwas schwach, 3.1 Sprossen. Halm $120 \mathrm{~cm}$ (Мax. $140 \mathrm{~cm}$ ) lang, $0.38 \mathrm{~cm}$ dick. Die Blätter $29.25 \mathrm{~cm}$ lang, $1.13 \mathrm{~cm}$ breit, Blattzahl 3.3, Blattfläche $218.2 \mathrm{qcm}$. Halmfläche $136.8 \mathrm{qcm}$, Gesammtfäche $355 \mathrm{qcm}$.

Junge Aehre gelbgrün mit bläulichem Anflug, $11 \mathrm{~cm}$ (Мax. $15 \mathrm{~cm}$ ) lang, mit 20 Aehrchen und 40 etwas leicht ausfallenden Früchten.

Es wachsen 830 Halme oder 270 Pflanzen pro qm, mithin sich die Bodenfläche pro Pflanze auf $37 \mathrm{qcm}$ stellt, während die Blattfläche pro qm Bodenfläche 29.47 qm beträgt.

Es wiegt $1 \mathrm{hl} 82 \mathrm{~kg}$ und lassen sich 1 i22 000 Frïchte auszählen, mithin das Saatquantum ( $1 / 3$ Verlust) $2 \mathrm{hl}$ ausmacht.

Das Stroh lagert nicht leicht, doch befällt es mit Rost.

100 Halme wiegen $580 \mathrm{gr}$ und davon die Körner $200 \mathrm{gr}$.

In Schottland auf gutem Weizenboden geschätzt.

\section{Archer's prolific. (2)}

Deutsch: Archer's ergiebiger Weizen.

Aehre: gelblich-weiss, kurz, viereckig, ziemlich geschlossen, an der Spitze kurz begrannt; Aehrchen mittelbreit $(1.5 \mathrm{~cm})$, meist 3-körnig. Stroh: gelb, dickwandig, kräftig. - Frucht: Original weiss, mehlig, rundlich (6 mm lang, $4 \mathrm{~mm}$ breit, 245 Früchte wiegen $10 \mathrm{gr}$ ) sehr schön; nachgebaut: von gleicher Grösse, doch meist rötlich-weiss und dann glasig, Form schön, feinschalig, weich.

Herbstblatt blaugriin, ziemlich schmal, kraus; Frühjahrsvegetation ziemlich zeitig; Bestockung etwas schwach, 3,2 Sprossen, doch spät schossend und bliihend. Halmlänge $115 \mathrm{~cm}$ (Max. $145 \mathrm{~cm}$ ), Halmdicke $0.44 \mathrm{~cm}$, Blattzahl 3.3, mittlere Blattlänge $30.85 \mathrm{~cm}$, Breite $1.15 \mathrm{~cm}$, Blattoberfäche $234.17 \mathrm{qcm}$, Halmfläche $151.80 \mathrm{qcm}$, Gesammtfläche $385.97 \mathrm{qcm}$. A uf $1 \mathrm{qm}$ wuchsen 800 Halme oder 250 Pflanzen, mithin stellt sich die Bodenfläche pro Pflanze auf $40 \mathrm{qcm}$ und die Blattfläche pro $1 \mathrm{qm}$ Bodenfläche auf $30.88 \mathrm{qm}$.

Es kommen auf $1 \mathrm{hl}(=81.7 \mathrm{~kg}) 2001650$ Früchte, mithin sich las Saatquantum $(1 / 3$ Verlust $)$ auf $1.9 \mathrm{l}$ l p. ha stellt. 
Junge Aehre gelbgrün, spätreifend, $9 \mathrm{~cm}$ (Max. $11 \mathrm{~cm}$ ) lang, mit 18 Aehrchen und 54 Friichten, welche locker in den Spelzen sitzen.

Dieser in England auf mildem, kulturvollem Boden kultivierte Weizen wurde früher auch in Mittel-Deutschland und namentlich in der Provinz Sachsen angebaut, doch ist seine Kultur in neuerer Zeit zurückgegangen, da er leicht auswintert; derselbe erfror 1870/71 in Poppelsdorf vollständig.

Das Stroh lagert nicht leicht und befällt selten mit Rost.

Es wiegen 100 Halme $460 \mathrm{gr}$ und davon die Früchte $211 \mathrm{gr}$.

\section{White Trump. (2)}

Syn.: Franz.: Blé blanc de Trump.

Deutsch: Trump-Weizen.

Aehre: blassgelb, geschlossen, aufrecht, lang, breit; Aehrchen $2 \mathrm{~cm}$ breit, meist 4-körnig. - Stroh: schwach rötlich-gelb, lang, fest, ziemlich feinhalmig. - Frucht: Original blassgelb, mehlig, wenige glasig und rötlich; mittelgross ( $7 \mathrm{~mm}$ lang, $4 \mathrm{~mm}$ breit, 220 Früchte $=10 \mathrm{gr}$.) feinschalig, weich, Bruch mehlig; nachgebaut: konstant geblieben.

Herbstblatt dunkelgrün, gross, Frühjahrsvegetation zeitig, 2.8 Schösslinge, demnach Bestockung schwach, zeitig schossend und blühend; Halmlänge $105 \mathrm{~cm}$ (Max. $120 \mathrm{~cm}$ ), Halmdicke $0.37 \mathrm{~cm}$, Blattzahl 4, Blattlänge $26.3 \mathrm{~cm}$, Blattbreite $1.0 \mathrm{~cm}$, Blattoberfläche $210.40 \mathrm{qcm}$, Halmfläche $116.55 \mathrm{qcm}$, Gesammtfläche eines Halmes $326.95 \mathrm{qcm}$.

Junge Aehre gelbgrün, zeitig reifend, $10 \mathrm{~cm}$ (Max. $13 \mathrm{~cm}$ ) lang, mit 15 Aehrchen und 60 Früchten, welche leicht ausfallen.

Auf $1 \mathrm{qm}$ wachsen 840 Halme oder 300 Pflanzen, mithin eine Pflanze einen Raum von $33.3 \mathrm{qcm}$ einnimmt nnd anf $1 \mathrm{qn}$ Bodenfläche $27.46 \mathrm{qm}$ Blattfläche entfallen.

Auf $1 \mathrm{hl}(=82.5 \mathrm{~kg})$ kommen 1815000 Früchte, mithin beträgt das Saatquantum $(1 / 3$ Verlust) $2.5 \mathrm{hl}$.

Es wiegen 100 Halme $550 \mathrm{gr}$ und davon die Früchte $210 \mathrm{gr}$.

Dieser Weizen ist winterfest, leidet wenig durch Rost und Lagern, ist jedoch, wenn der Boden nicht sehr reich, wenig ergiebig.

Heimat: England.

\section{White Champion Wheat. (2)}

Deutsch: Weisser siegreicher Kolbenweizen.

Aehre: blassgelb, fast weiss, locker, ziemlich schmal, lang; Aehrchen $1.5 \mathrm{~cm}$ breit, 3- und 4-körnig. - Stroh: gelb, steif, lang, dickwandig, blattreich. - Frucht: Original fast weiss, mehlig, wenige glasig, sehr klein (6 mm lang, $3^{1 / 1} \mathrm{~mm}$ breit, 280 Früchte $\left.=10 \mathrm{gr}\right)$, nachgebaut: schon in 3. Tracht vollständig glasig und grösser $(232$ Früchte $=10 \mathrm{gr})$, feinschalig; weich.

Herbstblatt dunkelgrün, lang, breit, aufrecht; Frühjahrsvegetation zeitig, Bestockung schwach, 3 Schösslinge, mittelfrüh schossend und blühend. Halmlänge $130 \mathrm{~cm}$ (Max. $145 \mathrm{~cm}$ ), Halmdicke $0.44 \mathrm{~cm}$, Blattzahl 4, Blattlänge $27.75 \mathrm{~cm}$, Blattbreite $1.11 \mathrm{~cm}$, Blattoberfläche $246.4 \mathrm{qcm}$, Halmfläche 171.6 qcm, Gesammtfläche 418 q $\mathrm{cm}$.

Junge Aehre blaugrün, spät reifend, $11 \mathrm{~cm}$ (Max. $13 \mathrm{~cm}$ ) lang, mit 16 Aehrchen und 56 lose sitzenden Früchten, von denen 1948800 auf $1 \mathrm{hl}=84 \mathrm{~kg}$ gehen. 
Auf $1 \mathrm{qm}$ wachsen 800 Halme oder 267 Pflanzen, mithin nimmt eine Planze einen Ranm ron $37.5 \mathrm{qcm}$ ein, die Blattfläche beträgt $\mathrm{p}$. $q \mathrm{~m}$ Bodenfläche $33.4 \mathrm{qm}$, and das Saatquantum $2 \mathrm{hl} \mathrm{p.} \mathrm{ha.}$

Es wiegen 100 Halme $420 \mathrm{gr}$ und daron die Früchte $190 \mathrm{gr}$.

Dieser Weizen verlangt einen kräftigen, reichen Boden und ein mildes Klima, denn in Poppelsdorf erwies er sich als nicht winterfest.

In England, seiner Heimat, soll er sich durch grosse Ertragsfähigkeit, die er in Poppelsdorf keineswegs gezeigt hat, auszeichnen, so dass er auf vielen Ausstellungen, auch wegen der guten Qualität seines Kornes, Preise errungen hat, die ihm den Namen "Champion" d. h. Sieger eingetragen haben.

In Poppelsdorf im Frihjahr ausgesäet, zeigte er sich als echter Winterweizen.

\section{White Victoria. (2)}

Franz.: Blé Tictoria blanc, Blé blanc de la Sarthe, Blé blanc de la Mayenne ${ }^{1}$ ).

Terbesserte Folmen:

Hallet's Pedigree white Victoria wheat (Blé Hallet's pedigree white Tictoria, franz.). Webb's "C'hallenge“ White Wheat (Webb's herausfordernder weissähriger Kolbenweizen, deutsch).

Aehre: fast weiss, dicht, lang, breit, sich wenig verjuingend, Aehrchen bis $2 \mathrm{~cm}$ breit, 3-, 4- und 5-körnig. - Stroh: rötlich-gelb, fest, starkhalmig. - Frucht: Original blassgelb oder fast weiss, mehlig, wenige glasig und rötlich, rund, klein $(6 \mathrm{~mm}$ lang, $4 \mathrm{~mm}$ breit, 244 Früchte = $10 \mathrm{gr}$ ), weich, Bruch mehlig; nachgebaut: rötlich und meist glasig, feinschalig.

Herbstblatt dnnkelgrün, sehr kräftig, gross, aufrecht, beiderseits behaart; Frühjahrsvegetation zeitig, Bestockung mittelstark, 3.8 Schösslinge, mittelfrül schossend, spät blühend. Halm $125 \mathrm{~cm}$ (Max. $155 \mathrm{~cm}$ ) lang, $0.4 \mathrm{~cm}$ dick, Blattzahl 4, Blätter $28.12 \mathrm{~cm}$ lang, $1.0 \mathrm{~cm}$ breit, Blattoberfläche $224.96 \mathrm{qcm}$, Halmfläche $150 \mathrm{qcm}$, Gesammtfläche $374.96 \mathrm{qcm}$.

Junge Aehre gelbgriun, spät reifend, $11 \mathrm{~cm}$ (Max. $15 \mathrm{~cm}$ ) lang, mit 15 Aehrchen und 60 ziemlich fest sitzenden Friichten, ron denen 1912500 auf $1 \mathrm{hl}(=85 \mathrm{~kg}$ ) entfallen.

Auf $1 \mathrm{qm}$ wachsen 722 Halme oder 190 Pflanzen, mithin beansprucht 1 Pflanze einen Raum ron $52.7 \mathrm{qcm}$. Das Saatquantmu beträgt $1.49 \mathrm{hl} \mathrm{p}$. ha.

Es wiegen 100 Halme $675 \mathrm{gl}^{\circ}$ nnd daron die Früchte $270 \mathrm{gr}$. Dieser Weizen verlangt reiche, knlturvolle Bödell, milde Winter, sowie zeitige Aussaut und ist widerstandsfähig gegen Lagern und Rost.

Sechsjährige Kulturversnche $(1871 / 76)$ des Mr.Lawes ${ }^{2}$ ) zu Rothamsted, England, ergaben auf Lehmboden einen Durchschnittsertrag von 35.44 hl p. ha.

Dieser Weizen wird ziemlich ausgedehnt in England und in Frankreich namentlich in Maine und einem Teil der Bretagne gebaut. In neuerer Zeit ist er anch in Australien und am Niederrlsein verbreitet, doch ist

1) Vilmorin, Les meilleurs Blés.

2) Farmer's Magaz. Vol. 80. 1876. pg. 433. 
er für das östliche Deutschland zu weich, obgleich er nach Vilmorin ${ }^{\mathbf{1}}$ ) ursprünglich von der Südküste der Ostsee stammen soll.

Diese Sorte ist nach Hallet'schem System durch Mr. Hallet, Manorhouse, Brighton, sowie durch Mr. Webb, Wordsley, Stourbridge, England verbessert worden, indem nicht allein der Habitus der Pflanze (Gesammtfäche pro Halm $467.91 \mathrm{qcm}$ ) sondern auch die Frucht (210 Früchte $=10 \mathrm{gr}$ ) vergrössert wurde.

Originalsaat erhielten wir durch Mr. Hallet und Mr. Webb.

\section{Mungowells Wheat ${ }^{2}$ ). (2)}

Syn.: Priory, East Barns, Murray's, Fraser's, Lady-Hall, AlliasWheat.

Französisch: Blé Mungowells.

Aehre: schwach rötlich-weiss, locker, etwas in sich gebogen, sich wenig verjüngend, und wenig grannenspitzig, $11 \mathrm{~cm}$ lang, mit 23 Aehrchen und 60 Früchten. Aehrchen $1.2 \mathrm{~cm}$ breit, meist 3-körnig. - Stroh: rötlich-weiss, blattreich, fest, $160 \mathrm{~cm}$ lang, $0.45 \mathrm{~cm}$ dick. - Frucht: fast weiss; mehlig oder glasig, klein, rundlich (6 mm lang, $3 \mathrm{~mm}$ breit), sehr schön, feinschalig.

Patrick Shirreff fand 1819 diesen dem Hunters-wheat sehr ähnlichen Weizen auf der Farm Nungowells, in Haddingtonshire, wo eine einzelne Pflanze sich durch kräftiges Aussehen in einem schlecht durch den Winter gekommenen Weizenfelde auszeichnete. Diese Pflanze wurde weiter kultiviert und der Same verbreitet, doch hat ihre Kultur keine grosse Ausdehnung gewonnen, obgleich dieser Weizen frihreifer und ertragreicher als Hunter's sein sollte.

Der Ertrag stellte sich in Schottland auf schwerem Boden im zweijährigen Durchschnitt auf: $2481 \mathrm{~kg}$ Korn und $3597 \mathrm{~kg}$. Stroh p. ha.

\section{Hard-Castle. (2)}

Französisch: Blé de Hard-Castle.

Aehre: blassgelb, grannenspitzig, locker, bis $12 \mathrm{~cm}$ lang mit 55 leicht ausfallenden Früchten, aufrecht; Aehrchen 3-körnig. - Stroh: blassgelb, blattarm, ziemlich feinhalmig, fest, bis $130 \mathrm{~cm}$ lang. - Frucht: gelblich-weiss, mehlig, klein (6 mm lang, $3^{1 / 2} \mathrm{~mm}$ breit, 279 Früchte $=$ $10 \mathrm{gr}$ ).

Dieser Weizen ist nicht besonders ertragreich, stellt dafür aber nur geringe Ansprüche an den Boden.

Nach den Versuchen von Lawes in Rothamsted lieferte er auf Lehmboden im sechsjährigen Durchschnitt 38.92 hl Korn p. ha.

Original in der Sammlung der landw. Akademie zu Poppelsdorf.

\section{Lord Western-Wheat. (2).}

Aehre: fast weiss, locker, enthält 18 Aehrchen mit 50 Früchten, sich wenig verjüngend, etwas grannenspitzig, pyramidal, ein wenig gebogen, $10 \mathrm{~cm}$ lang; Aehrchen $1.3 \mathrm{~cm}$ breit, meist 3-körnig. - Stroh: röt-

1) Les meilleurs Blés pg. 30 .

2) P. Shirreff, Improvem. of Cer. 1873. 
lich-gelb, ziemlich blattreich, bis $160 \mathrm{~cm}$ lang, $0.4 \mathrm{~cm}$ breit. - Frucht: fast weiss, meist mehlig, gross, rundlich ( $7 \mathrm{~mm}$ lang, $4 \mathrm{~mm}$ breit) feinschalig.

Original im landw. Museum zu Berlin.

\section{Blé blanc Charles. (2)}

Aehre: fast weiss, ziemlicl dicht, $9 \mathrm{~cm}$ lang, mit 19 Aehrchen und 48 Früchten, sich stark verjüngend und grannenspitzig; $1.3 \mathrm{~cm}$ breit, 2- und 3-körnig. - Stroh: rötlich-weiss, ziemlich fest, $150 \mathrm{~cm}$ lang, $0.45 \mathrm{~cm}$ dick. - Frucht: blassgelb, mehlig, oder rötlich-weiss und glasig, klein $\left(6^{1} / 2 \mathrm{~mm}\right.$ lang, $3^{1} / 2 \mathrm{~mm}$ breit), feinschalig.

Original im landw. Museun zu Berlin.

\section{Hatherton's-Wheat. (2)}

Französisch: Froment ou Touzelle Hatherton.

Aehre: blassgelb, dicht, bei $12 \mathrm{~cm}$ Länge 23 Aehrchen und 56 Früchte enthaltend, sich wenig verjiingend; Aehrchen $1.2 \mathrm{~cm}$ breit, meist 3-körnig; Klappen lang und spitz. - Stroh: rötlich-weiss, ziemlich blattreich, fest, $160 \mathrm{~cm}$ lang, $0.45 \mathrm{~cm}$ dick. - Frucht: hellrötlich, glasig, länglich, klein ( $7 \mathrm{~mm}$ lang, $3 \mathrm{~mm}$ breit), feinschalig.

Original im landw. Museum zu Berlin.

\section{Lord Ducie. (2)}

Französisch: Froment de Lord Ducie.

Aelire: blassgelb, breit, ziemlich dicht, $10 \mathrm{~cm}$ lang, mit 20 Aehrchen und 55 Früchten; Aehrchen meist 3-körnig. - Stroh: blassgelb, sehr dick, Durchmesser $0.5 \mathrm{~cm}$ bei $130 \mathrm{~cm}$ Länge, rohrartig, fest. - Frucht: blassgelb, melilig, klein, feinsclialig.

Original im landw. Museum zu Berlin.

\section{Volunteer-Wheat. (2)}

Aehre: fast weiss, dünn, etwas locker, $8 \mathrm{~cm}$ lang, mit 15 Aehrchen und 28 Frichten, sich verjüngend, grannenspitzig; Aehrchen $1 \mathrm{~cm}$ breit, 2-körnig. - Stroh: blassgelb, dünnhalmig, blattarm, weich, bis $130 \mathrm{~cm}$ lang, $0.33 \mathrm{~cm}$ dick. - Frucht: blassgelb, mehlig, fein, schmal, klein (6 $\mathrm{mm}$ lang, $3 \mathrm{~mm}$ breit), feinschalig.

Original im landw. Museum zu Berlin.

\section{Nairn prize. (2)}

Aehre: blassgelb, sich etwas verjüngend, mit wenigen Grannenspitzen, locker, $9 \mathrm{~cm}$ lang, mit 30 Früchten; Aehrchen $1.5 \mathrm{~cm}$ breit, 2und 3-körnig, Klappen gezahnt. - Stroh: blassgelb, fest, kräftig, $110 \mathrm{~cm}$ lang, $0.4 \mathrm{~cm}$ breit, befällt leicht mit Rost. - Frucht: blassgelb, mehlig, klein (6 mm lang, $3^{1 / 2} \mathrm{~mm}$ breit) oval, feinschalig.

Original im landw. Museum zu Berlin. 


\section{Eclipse dwarf Wheat. (2)}

Aehre: blassgelb, schmal, sich wenig verjiingend, an der Spitze kurz begrannt, dicht, kurz, auf $8 \mathrm{~cm}$ Lünge entfallew 50 Früchte; Aehrchen $1 \mathrm{~cm}$ breit, 2- und 3-körnig, - Stroh: blassgelb, ziemlich blattreich, fest, $130 \mathrm{~cm}$ lang, $0.4 \mathrm{~cm}$ dick. - Frucht: blassgelb, mehlig, oval $(6 \mathrm{~mm}$ lang, $4 \mathrm{~mm}$ breit), feinschalig.

Original im landw. Muscum zu Berlin.

\section{Casey's White. (2)}

A ehre: unrein weissgelb, sich wenig verjüngend und wenige Grannenspitzen zeigend, sehr dicht, auf $12 \mathrm{~cm}$ Länge kommen 80 Früchte; A ehrchen $1.5 \mathrm{~cm}$ breit, 3-, 4- und 5-körnig. - Stroh: gelb, fest, nicht leicht lagernd. Frucht: weiss, mellig, klein, rundlich ( $6 \mathrm{~mm}$ lang, $3 \frac{1}{2} / \mathrm{mm}$ breit), feinschalig.

Lawes ${ }^{1}$ ) erntete in sechsjährigen Durchschwitt auf gutem Lehmboden in Rothamsted, England, $36.90 \mathrm{hl}$ Korn p. ha.

\section{White egg-shell. (2)}

Syn: Weisser eierschaliger Weizen.

Aehre: weiss. - Stroh: rötlich-weiss. - Fruclit weiss, etwas leicht ausfallend, Mell wciss, doch Schale ein wenig dick.

Eine alte englische Sorte, welche schon von John Mills $\left.{ }^{2}\right) 1762$ erwähnt wird, zu welcher Zeit sie auf leichtem Boden in Essex im Gemenge mit Roggen gebaut wurde, und sich durch Frühreife auszeichnete.

\section{White Swan. (2)}

Aehre: blassgelb, etwas locker, $12 \mathrm{~cm}$ lang mit 66 ziemlich leicht ausfallenden Früchten, breit; Aehrchen $1.7 \mathrm{~cm}$ breit, 4-körnig. - Stroh: rötlich-gelb, bis $130 \mathrm{~cm}$ lang, blattarm, ziemlich feinhalmig, weich, etwas leicht lagernd. - Frucht: weiss, mehlig, selı schön, klein (6 mm lang, $3 \mathrm{~mm}$ breit, 256 Früchte $=10 \mathrm{gr}$ ), feinschalig.

Verlangt kulturvollen Lehmboden zum Gedeihen.

Original in der Sammlung der landw. Akademie zu Poppelsdorf.

\section{Cluster dwarf white wheat.}

Aehre: gelblich-weiss, fast viereckig, sehr geschlossen, aufrecht, grannenspitzig. - Stroh: lellgelb, kurz, fest. - Frucht: gclblich-weiss, gross, doch kurz, feinschalig.

Vielfach auf reichem, humosem Boden, auf dem andere Sorten leicht lagern, in England angebaut.

1) Farmer's Magaz. Vol. 80.1876 p. 433.

2) A new and complete Syst. of prakt. Husb. Vol. I p. 366. 
Nahe mit ihm verwandt, ist Tall cluster (Syn.: Dudney), nur länger im Stroh und deshalb leichter lagernd.

Der Name "Cluster" bezeichnet eine traubige Aehrenform.

\section{Henton-Wheat. (2)}

Aehre: hellgelb, ziemlich dicht, $10 \mathrm{~cm}$ lang, mit 55 wenig fest sitzenden Früchten; Aehrchen ziemlich breit $(1.8 \mathrm{~cm})$, meist 4 -körnig. Stroh: rötlich-gelb, fest, ziemlich blattreich, dick, $110 \mathrm{~cm}$ lang, steif. Frucht: blassgelb, mehlig, einige glasig, klein $6 \mathrm{~mm}$ lang, $3 \mathrm{~mm}$ breit, 242 Früchte $=10 \mathrm{gr})$, feinschalig.

Nicht besonders ergiebig, doch für leichteren Boden geeignet.

Original in der Sammlung der landw. Akademie zu Poppelsdorf.

\section{Broad-leaf Cape-Wheat. $\odot$ u. (2)}

Syn.: Französisch: Blé du Cap à larges feuilles; Blé du Cap sans barbes. Blé d'Abondance.

Deutsch: Grossblättriger, weisser Kapweizen.

Aehre: weiss, mit rötlichem Anflug, ein wenig locker, sich nach Spitze verjüngend, grannenspitzig; Aehrchen breit $(1.4-1.7 \mathrm{~cm}), 2-3-$, selten 4-körnig. - Stroh: rötlich-gelb, derbwandig, fest. - Frucht: gelblich-weiss, mehlig; nachgebaut: meist glasig, gross $(8 \mathrm{~mm}$ lang, $4 \mathrm{~mm}$ breit, 180 Körner $=10 \mathrm{gr}$; Sommerfrucht: $7 \mathrm{~mm}$ lang, $4 \mathrm{~mm}$ breit, 200 Körner $=10 \mathrm{gr}$ ), schön, schwer, feinschalig; Bruch halb-mehlig, halb-weich.

Wintersaat: Herbstblatt gelbgriin, breit, aufrecht, Frübjahrsvegetation zeitig, Bestockung mittelstark, 4.4 Schösslinge, zeitig scbossend und blühend. Junge Aehre blaugrün. Sommersaat: Blatt gelbgrün, aufrecht, sehr kräftig, sehr zeitig schossend und blühend, Bestockung für Sommersaat stark, 3 Schösslinge. Die Ausmessung ergab folgende Resultate:

\begin{tabular}{|c|c|c|}
\hline & Sommersaat & Wintersaat. \\
\hline $\begin{array}{l}\text { Halmlänge } \\
\text { Halmdicke } \\
\text { Blattzahl } \\
\text { Blattlänge } \\
\text { Blattbreite } \\
\text { Blattoberfläche } \\
\text { Halmfäche } \\
\text { Gesammtläche } \\
\text { Aehrenlänge } \\
\text { Anzahl der Aehrchen pro Aehre } \\
\text { Fruchtzahl } \\
\text { Halme p. qm } \\
\text { Blattfäche p. qm Bodenfläche } \\
\text { Anzahl der Pflanzen p. qm } \\
\text { Raum p. Pflanze } \\
\text { Hektolitergewicht } \\
\text { Früchte in 1 hl } \\
\text { Aussaatquantum p. ha } \\
\text { loo Halme wogen } \\
\text { Die Früchte in } 100 \text { Halmen wogen }\end{array}$ & \begin{tabular}{|c|}
$117 \mathrm{~cm}($ Iax. $135 \mathrm{~cm})$ \\
$0.33 \mathrm{~cm}$ \\
3.2 \\
$27.6 \mathrm{~cm}$ \\
$0.9 \mathrm{~cm}$ \\
$158.98 \mathrm{qcm}$ \\
$133.38 \mathrm{qcm}$ \\
$292.36 \mathrm{qcm}$ \\
$8 \mathrm{~cm}$ (.ax. $12 \mathrm{~cm})$ \\
12 Aehrchen \\
40 \\
900 \\
$26.31 \mathrm{qm}$ \\
300 \\
$33.3 \mathrm{qcm}$ \\
$80 \mathrm{~kg}$. \\
1680000 \\
$2.7 \mathrm{hl}$ \\
$470 \mathrm{gr}$ \\
$170 \mathrm{gr}$
\end{tabular} & $\begin{array}{c}120 \mathrm{~cm} \text { (Max. } 145 \mathrm{~cm}) \\
0.43 \mathrm{~cm} \\
3.7 \\
28.08 \\
1.06 \\
220.22 \mathrm{qcm} \\
154.80 \mathrm{qcm} \\
375.02 \mathrm{qcm} \\
10 \mathrm{~cm} \text { (Max. } 13 \mathrm{~cm}) \\
15 \text { Aehrchen } \\
45 \\
840 \\
31.5 \\
191 \\
52.4 \mathrm{qcm} \\
81.7 \mathrm{~kg} \\
1524460 \\
1.9 \mathrm{hl} \\
500 \mathrm{gr} \\
190 \%\end{array}$ \\
\hline
\end{tabular}


Dieser Weizen ist nicht winterfest; so winterte derselbe 1870/71 in Poppelsdorf vollständig aus. Das Stroh lagert nicht leicht, leidet jedoch durch Rost. Die Früchte sitzen ziemlich fest in den Spelzen.

Für den kulturvollen, mergelhaltigen Lehıboden im milden Klima geeignet.

Seine Kultur erstreckt sich vornehmlich über Frankreich und Süd. England. Die Heimat ist das Kap der guten Hoffnung.

\section{White Tuskan-Wheat ${ }^{1}$ ). (2)}

Süd-A ustralien: Red-beds. (Rotfüssig wie Roggen).

De utsch: Weisser toskanischer und australischer Kolben-Weizen.

Französisch: Blé de Toscane.

Aehre: rötlich-weiss, sehr locker, sich nach der Spitze stark verjüngend und grannenspitzig, schmal; Aehrchen $1.4 \mathrm{~cm}$ breit, 2 und 3-körnig. Stroh: rötlichweiss, mittellang, ziemlich derbwandig, fest. - Frucht: Original: rötlichweiss, meist glasig, weniger blassgelb und mehlig, $\left(61 / 2 \mathrm{~mm}\right.$ lang, $3 \frac{1}{2} \mathrm{~mm}$ breit, 212 Früchte $\left.=10 \mathrm{gr}\right)$ sehr schön, feinschalig, halbhart, Bruch halbstahlig; nachgebaut: grösser (158 Früchte $=10 \mathrm{gr})$.

Herbstblatt blaugriin; Halm am Fuss rötlich, roggenähnlich; breit, aufrecht, schwach behaart, sehr kräftig; Frühjahrsvegetation sehr zeitig, Bestockung schwach, 2.8 Schösslinge, zeitig schossend und blühend. Halmlänge $110 \mathrm{~cm}$ (Max. $140 \mathrm{~cm}$ ), Halmdicke $0.38 \mathrm{~cm}$, Blattzahl 3.3. Mittlere Blattlänge $22.2 \mathrm{~cm}$, Blattbreite $0.98 \mathrm{~cm}$, mithin beträgt die Blattoberfläche $143.62 \mathrm{qcm}$, die Halmfläche $125.40 \mathrm{qcm}$ und die Gesammtfläche $269.02 \mathrm{qcm}$.

Junge Aehre blaugrïn, zeitig reifend, $12 \mathrm{~cm}$ lang (Max.: $15 \mathrm{~cm}$ ), mit 18 Aehrchen und 45 Früchten, welche ziemlich fest von den Spelzen ilmschlossen werden.

Es kommen auf $1 \mathrm{qm} .984$ Halme oder 351 Pflanzen, demnach stellt sich der Raum für eine Pflanze auf $28.5 \mathrm{qcm}$, und die Blattfläche pro $\mathrm{qm}$ Bodenfläche auf $26.47 \mathrm{qm}$.

Auf $1 \mathrm{hl}(=85.3 \mathrm{~kg})$ entfallen 1347740 Früchte, mithin sich das Saatquantum $(1 / 3$ Verlust) auf $1.7 \mathrm{hl} \mathrm{p}$. ha berechnet. Es wiegen 100 Halme $380 \mathrm{gr}$ und davon die Früchte $130 \mathrm{gr}$.

In Poppelsdorf mehrfach als Sommerweizen kultiviert, zeigte er sich als echter Winterweizen, denn es trieben nur relativ wenige Halme Aeliren. Als Winterweizen war er nicht winterfest, so erfror derselbe 1876 total.

Für gute, mergelhaltige Lehmböden im trocknen, milden Klima ist dies ein vortrefflicher, ertragreicher Weizen, dessen Früchte ein vorzügliches Mehl liefern; auf sehr reichem Boden und im feuchten Klima lagert er leicht, widersteht jedoch recht gut dem Rost.

Ursprünglich stammt dieser Weizen aus Toskana und wurde in England in Kultur genommen, von wo er $1837^{2}$ ) in den Siidstaaten der nordamerikanischen Union, sowie in Australien zum Anbau gelangte und in dem milden Klima dieser Länder vorzügliche Resultate lieferte. Der

1) Katalog von Haage \& Schmidt, Erfurt, als ,Australischer TekanWeizen" aufgeführt (1872).

2) Departm. of Agric. 1862. 
nordamerikanische Gesandte, Mr. Wright, sandte 1858 Proben dieses Weizens an das landwirtschaftliche Ministerium nach Berlin, und wurden mit ihm Anbau-Versuche gemacht, doch ist über den Erfolg nicht viel bekannt geworden.

In Holstein soll sich nach Metz (Berichte 1863 p. 2) sein Anbau bewährt haben.

In dem trocknen Klima Sïd-Australiens wird jetzt eine verbesserte Form „Frame's White Tuscan Wheat" angebaut. Adelaide.

Einsender: Schomburgk, Direktor des botanischen Gartens zu

\section{Callaby's Purple-Straw-wheat, Australien. (2)}

Aehre: blassgelb, mittellang, grannenspitzig, Klappen gezahnt und lederartig, ziemlich dicht; Aehrcben: 3- und 4-körnig. - Stroh: rötlichgelb, bis riolett, fest. - Frucht: Original gelblichweiss, mehlig, oval, sehr gross, $7 \mathrm{~mm}$ lang, $4 \mathrm{~mm}$ breit, $3.8 \mathrm{~mm}$ dick, 176 Früchte $=10 \mathrm{gr}$, feinschalig; nachgebaut: blassrot, meist glasig, halbhart.

Herbstblatt blaugrün, schwach behaart, aufrecht, ziemlich lang, 3.7 Schösslinge, Vegetation zeitig, ebenso das Schossen und Blühen; Halmlänge $120 \mathrm{~cm}$ (Max. $140 \mathrm{~cm}$ ), Halmdicke $0.4 \mathrm{~cm}$, Blattzahl 3.2, Blätter $24.3 \mathrm{~cm}$ lang, $1.3 \mathrm{~cm}$ breit, Blattfläche $202.2 \mathrm{qcm}$, Halmfläche $144 \mathrm{qcm}$, Gesammtfläche 346.2 qcm.

Zeitig reifend. Aehre blaugrïn, $10 \mathrm{~cm}$ (Max. $13 \mathrm{~cm}$ ) lang, mit 19 Aehrchen und 66 ziemlich fest sitzenden Früchten, von denen 1425600 auf $1 \mathrm{hl}(=81 \mathrm{~kg})$ entfallen.

Wenig durch Lagern und Rost leidend.

Von Schomburgk, Direktor des bot. Gartens zu Adelaide, 1881 nach Poppelsdorf gesandt.

\section{Weizen aus Monnt-Barker, Austrailen $\odot$ u. (2).}

Aehre: gelblichweiss, sich etwas rerjüngend, grannenspitzig, ziemlich geschlossen, mittellang, ziemlich breit; Aehrchen $1.6 \mathrm{~cm}$ breit, meist 3-körnig. - Stroh: rötlichgelb, fest, derbwandig. - Frucht: gelblichweiss, glasig, gross $(7 \mathrm{~mm}$ lang, $4 \mathrm{~mm}$ breit, 197 Früchte $=10 \mathrm{gr})$, feinschalig; Bruch halbmehlig, halbweich.

Herbstblatt blaugrü, breit, aufrecht; Frühahrsvegetation sehr zeitig, Bestockung schwach, 2.5 Sprosse, sehr zeitig schossend und blïhend. Junge Aehre blau-grïn, sehr zeitig reifend.

Die Entwickelung der Sommer- und Wintersaat ist folgende:

\begin{tabular}{l|c|c}
\hline & Sommersaat & Wintersaat. \\
\hline Halmiänge & $115 \mathrm{~cm}($ Max. $135 \mathrm{~cm})$ & $120 \mathrm{~cm}$ (Nax. $145 \mathrm{~cm})$ \\
Halmdicke & $0.38 \mathrm{~cm}$ & $0.37 \mathrm{~cm}$ \\
Blattzahl & 4 & 4 \\
Blattlänge & $25.0 \mathrm{~cm}$ & $24.0 \mathrm{~cm}$ \\
Blattbreite & $0.84 \mathrm{~cm}$ & $0.74 \mathrm{~cm}$ \\
Blattoberfläche & $168.0 \mathrm{qcm}$ & $142.08 \mathrm{qcm}$
\end{tabular}




\begin{tabular}{|c|c|c|}
\hline & Sommersaat & Wintersaat \\
\hline $\begin{array}{l}\text { Halmfläche } \\
\text { Gesammtfläche } \\
\text { Aehrenlänge } \\
\text { Anzahl der Aehrchen pro Aehre } \\
\text { Fruchtzahl pro Aehre } \\
\text { Halme pro qm } \\
\text { Raum pro Pflanze } \\
\text { Hektolitergewicht } \\
\text { Fruchtzahl in hl } \\
\text { Aussaatquantum pro ha } \\
\text { 100 Halme wogen } \\
\text { Die Früchte in } 100 \text { Halmen wogen } \\
\text { Anzahl der Pflanzen pro qm } \\
\text { Blatttläche pro qm Oberfläche }\end{array}$ & 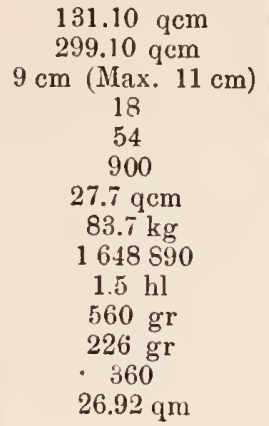 & $\begin{array}{c}133.20 \mathrm{qcm} \\
275.28 \mathrm{qcm} \\
10 \mathrm{~cm}(\mathrm{Max} .14 \mathrm{~cm}) \\
18 \\
54 \\
900 \\
27.7 \mathrm{qcm} \\
83.7 \\
1648890 \\
1.5 \mathrm{hl} \\
- \\
- \\
360 \\
24.78 \mathrm{q} \mathrm{m}\end{array}$ \\
\hline
\end{tabular}

Dieser Weizen ist gegen Lagern und Rost sehr widerstandsfähig, auch sitzen die Früchte fest in der Aehre. Sehr weichlich, denn in Poppelsdorf winterte er in 10 Jahren viermal aus; als Sommerweizen ist er im milden Klima und für milde Lehmböden sehr beachtenswert.

\section{(hili-wheat. $\odot$ u. (2).}

Syn: Large et small club wheat; Oregon wheat; Chili white Spring-wheat.

Französisch: Blé du Chili, Petit blé de mars du Chili.

Deutsch: Weisser Chile-Sommerweizen aus Oregon (U. S.), Californischer Sommerweizen.

Aehre: blassgelb, sehr geschlossen, fast 4eckig, kurz, grannenspitzig, breit, Aehrchen (1.4 cm breit) 3-4-samig. - Stroh: rötlichgelb, derbwandig, fest. - Frucht: gelblichweiss, mehlig, doch meist glasig und dann rötlich, klein, rundlich $\left(5^{1 / 2} \mathrm{~mm}\right.$ lang, $3^{1 / 2} \mathrm{~mm}$ breit, 300 Früchte $=10 \mathrm{gr}$ ), sehr feinschalig, weich.

Blätter dunkelgrün, Vegetationsperiode 130 Tage umfassend, Bestockung schwach, 2 Schösslinge, Halm $95 \mathrm{~cm}$ (Max. $105 \mathrm{~cm}$ ) lang, $0.33 \mathrm{~cm}$ breit, Blattzahl 3 , Blätter $25.3 \mathrm{cn}$ lang, $1.0 \mathrm{~cm}$ breit, mithin beträgt die Blattfläche $151.8 \mathrm{qcm}$, die Halmfläche $94.05 \mathrm{qcm}$, und die Gesammtfläche eines Halnes $245.85 \mathrm{qcm}$. Junge Aehre blaugrün, $8 \mathrm{~cm}$ lang, mit durchschnittlich 17 Aehrchen und 60 nicht leicht ausfallenden Früchten.

Es kommen auf 1 qm 1000 Halme oder 500 Pflanzen und stellt sich demnach die Bodenfläche p. Pflanze auf $20 \mathrm{qcm}$ und die Blattfläche auf $24.59 \mathrm{qm}$.

Auf $1 \mathrm{hl}$ (=84 kg) gehen 2520000 Früchte, mithin beträgt das Saatquantum (1/3 Verlust) $3 \mathrm{hl} \mathrm{p.} \mathrm{ha.}$

100 Halme wogen $370 \mathrm{gr}$ und davon die Früchte $160 \mathrm{gr}$.

In trocknen, warmen Jahren liess sein Stand in Poppelsdorf nichts zu wünschen, während er in fẻuchten, kühlen Jahrgängen nur kümmerlich gedieh. Ein milder Lehmboden, sowie ein warmes, mehr trocknes Klima scheint zu seinem Gedeihen notwendig zu sein. Er liefert wenig Stroh. 
Die ursprïngliche Form dieses Weizens ist der Californische SommerWeizen aus Chile, der unter .,Triticum compactum Humboldti“" beschrieben ist, nur sind die Aehrchen länger geworden, weshalb er nicht mehr zu den Binkel-Weizen zu rechnen ist, doch hat er mit letzterem noch gemein, dass sich die Aehren nach der Spitze zu häufiger verbreitern und auch geschlossener werden.

Das Strob lagert nicht leicht, leistet jedoch dem Roste nur geringen Widerstand. Dieser Weizen wird häufig in Californien und Oregon, aber auch sonst im westlichen Tordamerika und zuweilen in Frankreich und Deutschland kultiviert.

Nach Tilmorin lässt er sich im milden Klima als Wechselweizen anbauen.

\section{Virginia white. (2)}

Syn: White May.

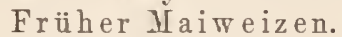

Aehre: fast weiss, mittellang, halblocker, sich stark verjüngend, grannenspitzig, dïnn; Aehrchen $1.3 \mathrm{~cm}$ breit, 2-3-körnig. - Stroh: rötlichgelb, unter mittellang, steif. - Frucht: Original fast weiss, mehlig, wenige glasig, halbweich, schön, länglich, $1 \mathrm{~mm}$ lang, $3^{1} / 4 \mathrm{~mm}$ breit, klein, 341 Früchte $=10 \mathrm{gr}$; nachgebaut: rötlichweiss, glasig, grösser, $2 \triangleleft 0$ Früchte $=10 \mathrm{gr}$; feinschalig.

Herbstblatt hellgrün, feinblättrig, ziemlich aufrecht, Entwickelung zeitig, doch mittelfrüh schossend und blïhend, 3 Schösslinge; Halmlänge $100 \mathrm{~cm}$ (Max. $111 \mathrm{~cm}$ ), Halmdicke $0.3 \mathrm{~cm}$, Blattzahl 4, Blätter $18 \mathrm{~cm}$ lang, $0.7 \mathrm{~cm}$ breit, Blattfläche $100.8 \mathrm{qcm}$, Halmfläche $90 \mathrm{qcm}$, Gesammtfläche $190.8 \mathrm{qcm}$.

Junge Aehrchen gelbgrün, zeitig reifend, $9 \mathrm{~cm}$ (Мax. $11 \mathrm{~cm}$ ) lang, mit 18 Aehrchen und 75 ziemlich fest sitzenden Früchten, von denen 3043000 auf $1 \mathrm{hl}$ (=89.5 kg. sehr schwer) entfallen.

Diese gegen Rost und Lagern widerstandsfähige Sorte gehört mit zu den besten Weizen von Tirginien und Tennessee U.S. und erhielten wir sie 1880 rom Agr. Coll. zu Missouri.

\section{Amerikanischer Sandweizen. (2)}

Syn: Chicago-Weizen.

Aehre: fast weiss, etwas locker, dünn, sich stark rerjüngend, grannenspitzig, mittellang: Aehrchen $1.5 \mathrm{~cm}$ breit, 2- nnd 3-körnig. Stroh: blassgelb, feinhalmig, fest, iiber mittellang. - Frucht: Original gelblichweiss, mehlig; nachgebaut: viele glasig, rundlich, klein $(6 \mathrm{~mm}$ lang, $4 \mathrm{~mm}$ breit, 209 Friichte $=10 \mathrm{gr})$, schwer, feinschalig; Bruch halbmehlig, hart.

Herbstblatt blaugrün, schmal, kabl, kraus: Frühjabrsvegetation sehr spät, Bestockung sehr stark, 6.7 Schösslinge, spät schossend und blühend; Halme gelbgriin $130 \mathrm{~cm}$ (Max. $155 \mathrm{~cm}$ ) lang, $0.35 \mathrm{~cm}$ dick, Blattzahl 3.6 , Blätter $26 \mathrm{~cm}$ lang, $0.9 \mathrm{~cm}$ breit, Blattfläche $168.48 \mathrm{qcm}$, Halmfläche 136.5 qcm, Gesammtfläche 304.98 qcm.

Junge Aehre gelbgrün, spät reifend, $11 \mathrm{~cm}$ (Max. $15 \mathrm{~cm}$ ) lang, mit 16 Aehrchen und 40 leicht ausfallenden Frichten, von denen 1755600 auf $1 \mathrm{hl}(=81 \mathrm{~kg})$ entfallen. 
Auf 1 qm wachsen 1000 Halme oder 150 Pflanzen, mithin beträgt das Saatquantum $1.3 \mathrm{hl}$ p. ha.

Es wiegen 100 Halme $400 \mathrm{gr}$, und davon die Früchte $162 \mathrm{gr}$.

Dieser Weizen bringt auf den leichteren Böden verhältnissmässig hohe Erträge, und lässt sich auch noch, da er spät in Vegetation tritt, sehr unempfindlich gegen ungünstige Witterung und durchaus winterfest ist, auf Thonboden kultivieren. Seine Widerstandsfähigkeit gegen Rost darf als vortrefflich angesehen werden, doch neigt er auf fruchtbarem Boden zum Lagern.

Den Chicago-Weizen erhielt Oekonomierat Gr üt tn er, Westpreussen, 1875 aus Chicago, doch fand sich in Poppelsdorf nach genauer Untersuchung, dass der schon frïher eingeführte amerikanische Sandweizen mit ihm identisch ist, wenngleich Grïttner anderer Ansicht zu sein scheint.

Dieser Weizen hat sich durch seine geringen Boderansprïche, durch seine hohen Erträge, sowie durch die vortreffliche Qualität seines Kornes und Strohes schon beträchtlich, namentlich in den Provinzen Preussen und Schlesien, verbreitet.

\section{Defiance Spring-wheat. $\odot$}

Aehre: fast weiss, mit schwach rötlichem Anflug, sich etwas verjüngend und grannenspitzig, mässig locker, aufrecht, mittellang; Aehrchen $1.5 \mathrm{~cm}$ breit, 3- und 4-körnig. - Stroh: rötlichgelb, fest, kurz. Frucht: gelblichweiss, mehlig, doch meist hellrötlich und glasig, klein (6 $\mathrm{mm}$ lang, $3 \mathrm{~mm}$ breit, 328 Früchte $=10 \mathrm{gr})$, sehr feinschalig, halbweich, Bruch halbmehlig.

Junges Blatt blaugriin, sehr kurz und schwach behaart, Bestockung mittelstark, 2.4 Schösslinge, etwas spät schossend und blïhend. Halme $100 \mathrm{~cm}$ (Xax. $112 \mathrm{~cm}$ ) lang, $0.3 \mathrm{~cm}$ dick, Blattzahl 4.4, Blätter $13.8 \mathrm{~cm}$ lang, $0.7 \mathrm{~cm}$ breit, Blattfläche $85 \mathrm{qcm}$, Halmfläche $90 \mathrm{qcm}$, Gesammtfläche $175 \mathrm{qcm}$.

Junge Aehre blaugrün, in 122 Tagen reifend, $10 \mathrm{~cm}$ (Uax. $12 \mathrm{~cm}$ ) lang, mit 16 Aehrchen, von denen 2722400 auf $1 \mathrm{hl}$ (=83 kg) entfallen.

Es wiegen 100 Halme 358 gr und davon die Scheinfriichte $158 \mathrm{gr}$.

Dieser Weizen gedeiht in Nord-Amerika sehr sicher.

Mr. Pringle soll diesen Weizen 1871 aus einer Kreuzung mit dem harten Klubweizen und einer der weissesten Sorten an der Küste des stillen Oceans erhalten haben.

In Poppelsdorf zeigte er einen schönen Stand, lagerte nicht und litt wenig durch Rost. Bezugsquelle: H. Frommer, Budapest.

\section{White Tradewell-wheat. (2)}

Aehre: weiss, mittellang, sich verjüngend, grannenspitzig, ziemlich dicht, schmal; Aehrchen meist 3-körnig. Stroh: blassgelb, unter mittellang, steif. - Frucht: Original rötlichweiss, meist glasig, wenige weiss und mehlig $\left(6^{1} / 2 \mathrm{~mm}\right.$ lang, $3^{1} \frac{1}{4} \mathrm{~mm}$ breit, 290 Früchte $\left.=10 \mathrm{gr}\right)$; nachgebaut: grösser, 195 Früchte $=10 \mathrm{gr}$; feinschalig, halbhart, Bruch halbstahlig.

Herbstblatt hellgrün, fein, niederliegend, 3 Schösslinge, spät schossend und blühend; Halmlänge $105 \mathrm{~cm}$ (Yax. $120 \mathrm{~cm}$ ), Halmdicke $0.33 \mathrm{~cm}$, Blattzahl 4.2, Blätter $15 \mathrm{~cm}$ lang, $0.86 \mathrm{~cm}$ breit, Blattfläche $108.4 \mathrm{qcml}$, Halmfläche $104 \mathrm{qcm}$, Gesammtfläche $212.4 \mathrm{qcm}$. 
Junge Aehre blaugrün, bereift; mittelfrüh reifend, $10 \mathrm{~cm}$ (Max. $13 \mathrm{~cm}$ ) lang, mit 20 Aehrchen und 50 Früchten, von denen 2552000 auf 1 hl (=88 kg) entfallen.

Ziemlich rostfrei und leicht lagernd. Original 1880 vom Missouri Agric. Coll., Nord-Amerika, erhalten.

\section{Arnold's Victor. (2)}

Aehre: blassgelb, quadratisch (Hicklingform), etwas grannenspitzig, dicht, kurz; Aehrchen 3-kölnig. - Stroh: rötlichgelb, steif, unter mittellang. - Frucht: Original fast weiss, mehlig, wenige rötlich und glasig, oval, $5^{1} / 2 \mathrm{~mm}$ lang, $3^{1} / 4 \mathrm{~mm}$ breit, 310 Früchte $=10 \mathrm{gr}$, klein, feinschalig; nachgebaut: rötlichweiss, meist glasig, grösser, 208 Früchte $=$ 10 gr; halbhart, Bruch halbmehlig.

Herbstblatt dunkelgrün, fast aufrecht, ziemlich gross; 2 Schösslinge, spät schossend und blüliend; Halmlänge 100 cm (Max. $110 \mathrm{~cm})$, Halmdicke $0.4 \mathrm{~cm}$, Blattzahl 4.6, Blätter $16.6 \mathrm{~cm}$ lang, $1 \mathrm{~cm}$ breit, Blattfläche $152.7 \mathrm{qcm}$, Halmfläche $120 \mathrm{qcm}$, Gesammtfläche $272.7 \mathrm{qcm}$.

Junge Aehre gelbgrün, rot umrändert, mittelfrüh reifend, $7 \mathrm{~cm}$ (Max. $8 \mathrm{~cm}$ ) lang, mit 17 Aehrchen und 50 festsitzenden Früchten, von denen 2728000 auf $1 \mathrm{hl}(=88 \mathrm{~kg}$ ) entfallen.

Leidet weder durch Lagern noch Rost.

Diese in den Nordweststaaten der amerikanischen Union häufig gebaute Sorte erhielten wir 1880 vom Missouri Agric. Coll. U. S.

\section{Washington-Glass. (2)}

Aehre: blassgelb, mittellang, sich verjüngend, etwas grannenspitzig, ein wenig locker; Aehrchen 3-körnig. - Stroh: rötlichgelb, reichblättrig, unter mittellang, steif. - Frucht: Original blassgelb mit rötlichem Schimmer, halbmehlig. halbweich, schlank, $7 \mathrm{~mm} \mathrm{lang,} 3^{1 / 4} \mathrm{~mm}$ breit, 270 Früchte $=10 \mathrm{gr}$; nachgebaut: rötlich, glasig, grösser, 182 Früchte $=10 \mathrm{gr}$, feinschalig.

Herbstblatt dunkelgriin, ziemlich gross, fast aufrecht, 2.4 Schösslinge, mittelfrüh schossend und blïhend; Halm $105 \mathrm{~cm}$ (Max. $115 \mathrm{~cm}$ ) lang, $0.33 \mathrm{~cm}$ dick, Blattzahl 5.6, Blätter $15.4 \mathrm{~cm}$ lang, $1.1 \mathrm{~cm}$ breit, Blattfläche $189.7 \mathrm{qcm}$, Halmfläche $104 \mathrm{qcm}$, Gesammtfläche $293.7 \mathrm{qcm}$.

Junge Aehre bläulichgrün, mittelfrüh reifend, $9 \mathrm{~cm}$ (Мax. $12 \mathrm{~cm}$ ) lang, mit 16 Aehrchen und 45 ziemlich fest sitzenden Früchten, von denen 2430000 auf $1 \mathrm{hl}(=90 \mathrm{~kg}$, sehr schwer) entfallen.

Diesen schönen, gut durchwinternden, rostfreien Weizen erhielten wir 1880 vom Agric.-Coll. zu Missouri.

\section{Tappahannock-wheat. (2)}

Syn: Early Boughton.

Aehre: weiss mit schwach rötlichem Schimmer, sich stark verjüngend, grannenspitzig, halblocker, unter mittellang, schmal, aufrecht; Aehrchen weiss, 3-körnig. - Stroh: rotgelb-violett, steif, unter mittellang. - Frucht: Original weiss, mehlig, weich, wenige glasig, voll, oval, $6 \mathrm{~mm}$ lang, $31 / 2 \mathrm{~mm}$ breit, 310 Früchte $=10$ gr; nachgebaut: meist rötlich-weiss, glasig, grösser, 210 Früchte $=10 \mathrm{gr} ;$ feinschalig. 
Herbstblatt hellgrïn, aufrecht, gross, 3 Schösslinge, Vegetation tritt zeitig ein, ebenso das Schossen und Blühen; Halmlänge $100 \mathrm{~cm}$ (Max. $120 \mathrm{~cm}$ ), Halmdicke $0.3 \mathrm{~cm}$, Blattzahl 3.4, Blätter $14 \mathrm{~cm}$ lang, $0.8 \mathrm{~cm}$ breit, Blattfläche $71.7 \mathrm{qcm}$, Halmfläche $90 \mathrm{qcm}$, Gesammtfläche $161.7 \mathrm{qcm}$.

Junge Aehre blaugrïn, zeitig reifend, $8 \mathrm{~cm}$ (Max. $11 \mathrm{~cm}$ ) lang, mit 16 Aehrchen und 45 ziemlich fest sitzenden Früchten, von denen 2728000 auf $1 \mathrm{hl}(=88 \mathrm{~kg})$ entfallen.

Dieser Weizen widersteht harten Wintern nicht gut, wird daher besonders in den Südstaaten Nord-Amerikas, z. B. in Nord-Carolina und Virginien gebaut. Durch Sturme leidet er wenig; Rost ist selten. Gedeiht auf sandigen Lehmböden noch recht gut, und soll in Amerika auf rejchem Boden Erträge von $22-36$ hl p. ha aufbringen.

Durch den amerikanischen Gesandten, Mr. Wright ${ }^{1}$ ), gelangte dieser vortreffliche Weizen 1858 an das landw. Ministerium zu Berlin.

Wir erhielten ihn 1830 vom Missouri Agric. College U. S.

\section{Blue-Stem. (2)}

Syn: White Maryland-Wheat.

Deutsch: Blauhalm-Weizen.

Aehren: weiss, kurz, dicht, etwas gebogen, Frucht von den Spelzen fest umschlossen. - Stroh: einige Tage vor Eintritt der Reife nimmt der obere Halmteil eine purpurrote oder bläuliche Färbung an, kurz, fest. Frucbt: weiss, gross, dick, feinschalig.

Alte ertragreiche, amerikanische Weizensorte, die nicht leicht lagert, wenig durch Rost leidet, sich stark bestockt und ein vorzügliches Mehl liefert.

Häufig in Virginien, Maryland, Ohio etc. angebaut.

Sie wurde 1858 durch den amerikanischen Gesandten, Mr. Wright, zur Prüfung an das preussische landw. Ministerium gesandt and in Proskau und Waldau angebaut, ohne hier besonders hervorragende Resultate zu liefern.

\section{North Carolina-wheat. (2)}

Syn: Früher weisser Nord-Carolina-Winterweizen.

Franz.: Blé de la Caroline du Nord.

Aehre: blassgelb, sich verjüngend, grannenspitzig, meist aufrecht, schmal, Aehrchen $1.2 \mathrm{~cm}$ breit; Aehre $10 \mathrm{~cm}$ lang, mit 20 Aehrchen und 45 Fruichten. - Stroh: blassgelb oder violett, schilfartig, lang (120$165 \mathrm{~cm})$. - Frucht: weiss, mehlig, nachgebaut: gelblich, mehlig und glasig, klein, $6 \mathrm{~mm}$ lang, $3 \mathrm{~mm}$ breit, feinschalig.

Nicht leicht lagernd, doch gegen Rost wenig widerstandsfähig, Bestockung stark, fruihreif.

Der amerikanische Gesandte, Mr. W right, sandte diese Sorte 1858 an das preussische landw. Ministerium.

In Proskau und Waldau kultiviert, zeigte sie sich für die Verhältnisse Nord-Deutschlands nicht besonders anbauwürdig. Original im landw. Museum zu Berlin. 


\section{Original white Flint-wheat. (2)}

Syn: Rochester; Winter Canada Flint-wheat.

Verbesserte Form: General Harmon's improved White-Flint.

Aehre: weiss, kurz, dick, reif etwas gebogen, grannenspitzig, Frucht von Spelzen fest umschlossen, voll, 30-40 Früchte pro Aehre. - Stroh: weiss, mittellang, blattarm. - Frucht: sehr weiss, glänzend, dem Quarzglanz (Flint) ähnlich, hart, oblong, 61/2 mm lang, $3 \mathrm{~mm}$ breit.

Das Korn soll wegen seiner Härte nicht leicht auswachsen und ein in den Nord-Staaten Nord-Amerikas sehr geschätztes Mehl liefern, auch nicht leicht durch Lagern oder Rost leiden.

In den nördlichen Staaten Anfang September, im mittleren und südlichen Ohio Anfang Oktober gesäet, bringt diese Sorte einen Ertrag von $18-26 \mathrm{hl}$, und sogar $61 \mathrm{hl}$ pro ha.

Grössere Früchte hat Mr. Harmon ${ }^{1}$ ) durch Auswahl des besten Saatgutes und Kultur auf reichem Boden erzielt.

Diese Sorte soll 1823 aus Spanien in die Vereinigten-Staaten eingeführt worden sein.

\section{Yorkshire-wheat. (2)}

Syn: English Flint; Soule's Wheat.

Aehre: weiss, halblocker, aufrecht, ein wenig verjünt, mittellang $(8 \mathrm{~cm})$; Aehrchen meist 2-körnig; 17 Aehrchen mit 30 Früchten. - Stroh: blassgelb, steif, $120 \mathrm{~cm}$ lang. - Frucht: weiss, sehr schön, mehlig, feinschalig.

Viel in Michigan U. S. gebaut.

\section{Indiana-wheat. $\odot$}

Syn: Large-wheat.

Aehre: weiss, sich etwas verjüngend, grannenspitzig: - Stroh: gelblich-weiss, lang. - Frucht: weiss, gross, halbhart, Bruch halbstahlig.

Auf schwerem Boden sehr ertragreich.

Führt den Namen vom Staate Indiana, in welchen diese Sorte 1830 eingeführt wurde.

\section{Sonora-Weizen. (2)}

Aehre: weiss, dünn, kurz, - Stroh: blassgelb, unter mittellang. Frucht: weiss, mehlig, klein, rund, voll; weich. Aeusseres sehr schön, doch nicht besonders kleberreich.

In Californien und Oregon hoch geschätzt. Aussaat im December, Ernte im Juli.

1) Dr. Emmons, Classificat. and Analys. of. Wheat, in Dep. of Agric. Rep. 1862 U. S. 


\section{Trigo de Nueva-Holanda, $\odot$ u. (2)}

Syn: Trigo de Australia, Chile.

Aehre: blassgelb, mittellang, sich verjüngend, ein wenig grannenspitzig, locker; Aehrchen $1.4 \mathrm{~cm}$ breit, meist 3-körnig. - Stroh: rötlichgelb, fest, steif, unter mittellang. - Frucht: Original weiss, mehlig, etwas bauchig, gross $(7 \mathrm{~mm}$ lang, $4 \mathrm{~mm}$ breit, 193 Frïchte $=10 \mathrm{gr})$, prachtvoll, feinschalig; nachgebant: rötlich, glasig, grösser, 170 Früchte $=10 \mathrm{gr}$; halbhart, Bruch halbmehlig.

Als Winterweizen gebaut, stark gelitten; Herbstblatt dunkelgrün, ziemlich gross, aufrecht, 2.2 Schösslinge, mittelfrüh schossend und blühend, spät reifend.

Im kälteren, gemässigten Klima nur Sommerweizen; junges Blatt dunkelgrïn, gross, lang, aufrecht, 2.8 Schösslinge, inittelfriih schossend und blïhend, mittelfriih, in 120 Tagen reifend.

Früchte fest von den Spelzen umschlossen. Nicht leicht durch Lagern und Rost leidend.

\begin{tabular}{l|c|c}
\hline \multicolumn{1}{c|}{ Mittlere } & Winterweizen & Sommerweizen \\
\hline & 100 (Max.: 120) & 110 (Max.: 125) \\
Halmlänge cm & 0.35 & 0.35 \\
Halmdicke cm & 4 & 4 \\
Blattzahl & 19 & 22.3 \\
Blattlänge cm & 0.8 & 0.9 \\
Blattbreite cm & 121.6 & 160.6 \\
Blattfläche qcm & 105 & 115.5 \\
Halmfläche qcm & 226.6 & 276.1 \\
Gesammtfäche qcm & $9($ Max.: 13) & $10($ Max.: 13) \\
Aehrenlänge cm & 18 & 18 \\
Darin Aehrchen & 54 & 54 \\
Früchte in der Aehre & &
\end{tabular}

Diese Sorte wurde 1880 durch v on Gülich an das landw. Museum zu Berlin aus Chile eingesandt.

\section{Trigo de Tesoro, Chile $\odot$.}

Deutsch: Schatz-Weizen aus Chile.

A ehre: fast weiss, prachtvoll, sich etwas nach Spitze verjüngend, etwas locker, breit; A ehrchen (1.6 cm breit) 2-körnig. - Stroh: goldgelb, sehr fest und derbwandig. - Frucht: gelblichweiss und mehlig, meist glasig und rötlich, etwas plump, gross $(7 \mathrm{~mm}$ lang, $4 \mathrm{~mm}$ breit, 150 Früchte $=10 \mathrm{gr}$ ) die Früchte am schönsten und grössten von allen weissen Sommerweizen; feinschalig, halbhart, Bruch halbmehlig.

Blätter blaugrün, 2.4 Schösslinge, Vegetationszeit 130 Tage. Halmlänge $115 \mathrm{~cm}$ (Max. $125 \mathrm{~cm}$ ), Halmdicke $0.33 \mathrm{~cm}$, Blattzahl 4, durchschnittliche Blattlänge $21.5 \mathrm{~cm}$, Blattbreite $0.99 \mathrm{~cm}$, Blattoberfläche 170.32 qcm, Halmfläche $113.85 \mathrm{qcm}$, Gesammtfläche $284.17 \mathrm{qcm}$.

Junge Aehre blaugrïn, reif $10 \mathrm{~cm}$ lang (Max. $14 \mathrm{~cm}$ ), mit 15 Aehrchen und 30 ziemlich leicht ausfallenden Früchten.

Auf I qm können 925 Halme oder 385 Pflanzen wachsen, demnach nimmt eine Pflanze eine Bodenfläche von $26 \mathrm{qcm}$ ein, und die Blattfläche stellt sich pro qm der Bodenfläche auf $26.29 \mathrm{qm}$. 
Es zählt $1 \mathrm{hl}(=84.7 \mathrm{~kg}) 1270500$ Früchte aus, wonach das Saatquantum ( $1 / 3$ Verlust) $4.5 \mathrm{hl}$ beträgt.

Es wiegen 100 Halme $480 \mathrm{gr}$ und davon die Friichte $190 \mathrm{gr}$.

Auf den guten Lehmböden im milden Klima bringt dieser Weizen hohe Erträge: das Mehl gilt als vorzüglich, auch lagert er nicht leicht, doch befiel er in Poppelsdorf ziemlich stark mit Rost.

Dieser schöne Weizen wurde von der Wiener-Ausstellung 1873 durch Wittmack nach Poppelsdorf gesandt, wo er sich mit Ausnahme der Früchte, die in feuchten Jahrgängen glasig wurden, konstant gezeigt hat. Heimat: Chile.

\section{Trigo de Talavera (2) u. $\odot$.}

Syn: Engl.: Talavera-wheat.

Franz.: Froment ou Blé de Talavera; Blé anglais voisin du Talavera, Blé de Pologne ou de Varsovie, Blé d'Espagne et Blé d'Espagne de Mars (Vilmo rin, Journ. d'Agric. prat. 1851 pg. 454 u. 455 ); Blé Talavera de Printemps.

Deutsch: Weisser Talavera-Weizen.

Verbesserte Form: Blé Talavera de Bellevue.

Aehre: fast weiss, lang, sehr locker, schlaff, sich stark verjüngend, grannenspitzig; Aehrchen mittelbreit $(1.5 \mathrm{~cm}), 2-$ und 3-körnig. - Stroh : gelb, fest, biegsam, mittellang. -- Frucht: Original weiss, meist mehlig, oval ( $7 \mathrm{~mm}$ lang, $4 \mathrm{~mm}$ breit) gross, feinschalig; nachgebaut: konstant geblieben, 190 Früchte wiegen $10 \mathrm{gr}$, Bruch halbmehlig, halbweich.

Herbstblatt hellgrün, lang, breit, aufrecht; Frühjahrsvegetation zeitig, Bestockung mittelstark, 4.5 Sprosse, zeitig schossend und blühend. Mittlere Halmlänge $125 \mathrm{~cm}$ (Max. $145 \mathrm{~cm}$ ), Halmdicke $0.4 \mathrm{~cm}$, Blattzahl 3,5, mittlere Blattlänge $25 \mathrm{~cm}$, Blattbreite $1.0 \mathrm{~cm}$, Blattoberfläche beider Seiten $175 \mathrm{qcm}$, Halmfläche $150 \mathrm{qcm}$, Gesamintfläche eines Halmes $325 \mathrm{qcm}$.

Auf 1 qm wachsen 1000 Halme oder 222 Pflanzen, mithin stellt sich die Bodenfläche p. Pflanze auf $45 \mathrm{qcm}$, und die Blattfläche pro $1 \mathrm{qm}$ Bodenfläche auf $32.50 \mathrm{qm}$.

Es kommen auf $1 \mathrm{hl}$ (= $83 \mathrm{~kg}) 1577000$ Früchte, demnach beträgt das Saatquantum ( $1 / 3$ Verlust) $2.1 \mathrm{hl} \mathrm{p}$. ha.

Junge Aehre gelbgrün, zeitig reifend, $11 \mathrm{~cm}$ lang (Max. $16 \mathrm{~cm}$ ), mit 18 Aehrchen und 45 lose sitzenden F'rüchten.

Es wiegen 100 Halme $450 \mathrm{gr}$ und davon die Früchte $225 \mathrm{gr}$. Lagert leicht.

Dieser Weizen eignet sich für humose oder warme gute Lehmböden, doch nicht für schwere Clayböden.

Sein Anbau wird stark in Süd-England (Surrey) und anf den Kanalinseln, sowie im nördlichen Frankreich betrieben, doch hat man in Frankreich in neuerer Zeit seine Kultur vielfach aufgegeben, weil er nicht genügend ertragreich ist und zu leicht auf nicht sehr reichen Böden degeneriert.

Für Nord-England und Deutschland ist diese Sorte zu weichlich, doch lässt er sich als Sommerweizen, Aussaat im Februar, anbauen, und schätzt man ihn als solchen namentlich in Nord-Amerika.

Er stammt ursprünglich aus Spanien und gelangte 1814 von dort nach England, sowie auch sehr bald nach Frankreich und 1817 nach 
Wien ${ }^{1}$, wo er sich in der Umgegend trefflich bewährte. Vorzugsweise verbreitete ihn Peter Lawson, Edinburgh.

Der bekannte Landwirt Le Couteur ${ }^{2}$ ), zu Bellevue, Insel Jersey, kultivierte Talavera-Weizen $183^{\circ}$ und verbesserte $\mathrm{ihn}$, und wurde dieser namentlich von Vilmorin als Blé Talavera de Bellevue in den Handel gebracht.

\section{Trigo salmonado (2).}

Syn: Blé saumon.

Lachsfarben er Weizen, Salmons-Weizen.

Aehre: blassgelb, sehr dicht, breit, ein wenig gebogen, mittellang.Stroh: rötlichgelb, lang, fest. - Frucht: schön blassgelb, mehlig, viele rötlich und glasig, rundlich, klein $\left(7 \mathrm{~mm}\right.$ lang, $3 \frac{1}{1} / 2 \mathrm{~mm}$ breit, 255 Früchte $=10 \mathrm{gr}$ ) feinschalig, halblart.

Herbstblatt blaugrïn, niederliegend; Entwicklung mittelfrüh, Bestockung stark, 7 Schösslinge, spät schossend und blühend; Halm $140 \mathrm{~cm}$ (Max. $160 \mathrm{~cm}$ ) lang, $0.35 \mathrm{~cm}$ dick, Blattzahl 4.5, Blätter $27.8 \mathrm{~cm}$ lang, $0.95 \mathrm{~cm}$ breit, Blattfläche $237.7 \mathrm{qcm}$, Halmfä̈che $147 \mathrm{qcm}$, Gesammtfläche $384.7 \mathrm{qcm}$.

Junge Aehre gelbgrïn, spät reifend, $11 \mathrm{~cm}$ (Max. $14 \mathrm{~cm}$ ) lang.

Auf $1 \mathrm{hl}(=85 \mathrm{~kg})$ entfallen 2167500 Früchte.

In Spanien auf reichem Boden gebaut.

\section{Trigo candeal desraspado de Murcia $\odot$ u. (2).}

Syn: Deutsch: Weisser Kolbenweizen aus Murcia.

Aehre: fast weiss, etwas locker, schlank, sich nach der Spitze verjüngend, grannenspitzig, breit; A ehrchen $1.7 \mathrm{~cm}$ breit, häufig 4-körnig. - Stroh: blassgelb, fest, ziemlich derbwandig. - Frucht: schwach rötlich-weiss, mehlig, weich; nachgebaut: meist glasig und rötlich. mittelgross $(7 \mathrm{~mm}$ lang, $3 \frac{1}{2} \mathrm{~mm}$ breit, 220 Friichte wiegen $10 \mathrm{gr}$ ), schlank, feinschalig.

Herbstblatt blaugrün, breit, aufrecht, Frühjahrsvegetation sehr zeitig, Bestockung schwach, bei Wintersaat 3 Schösslinge, bei Sommersaat 1.7 Schösslinge; sehr zeitig schossend und blïhend.

Junge Aehre blaugrün, reif $10 \mathrm{~cm}$ lang (Max. $14 \mathrm{~cm}$ ) mit 14 Aehrchen und $\mathbf{5} 6$ Früchten.

Als Sommerfrucht gebaut, schosste und blühte der Weizer spät und zeigte fast genau denselben Habitus wie die Wintersaat; Halmlänge $110 \mathrm{~cm}$ (Max. $125 \mathrm{~cm}$ ), Halmdicke $0.4 \mathrm{~cm}$, Blattzahl 3.3, Blattoberfläche $145.33 \mathrm{qcm}$, Halmfläche $132 \mathrm{qcm}$, Gesammtfläche eines Halmes $277.33 \mathrm{qcm}$.

Auf $1 \mathrm{qm}$ können 880 Halme oder 293 Pflanzen wachsen, mithin jede Pflanze 34.1 qcm Raum beansprucht.

Es wiegt $1 \mathrm{hl}=84 \mathrm{~kg}$ und enthält 1848000 Früchte, demnach beträgt das Saatquantum ( $1 / 3$ Verlust) $2.4 \mathrm{hl} \mathrm{p.} \mathrm{ha.}$

Es wiegen 100 Halme $463 \mathrm{gr}$ und davon die Früchte $150 \mathrm{gr}$.

Dieser Weizen ist nicht winterfest, denn er erfror seit $1870 \mathrm{mehr}$ mals in Poppelsdorf.

Dem Rost und Lagern unterliegt er nur in geringem Grade.

1) Fraas, Geschichte d. Landw. 1852, pg. 427.

2) Journ. of the Royal Agric. Soc. of England 1840, p. 119. 
Der Weizen wurde 1867 durch den Berliner Akklimatisations-Verein nach Deutschland aus Spanien eingeführt. (Zeitschr. f. Akklim. 1869. No. X-XII pg. 157.) achtenswert.

Für ein mildes Klima und einen kulturrollen Lehmboden be-

\section{Ble blanc de Marenil. (2)}

Syn: Blé blanc à paille pleine.

Aehre: gelblichweiss mit schwach rötlichem Anflug, etwas locker, doch ziemlich breit, Aehrchen $1.8 \mathrm{~cm}$ breit, meist 3-körnig, - Stroh: rötlichweiss, oder rotgrau, stark. - Frucht: blassgelb meist mehlig, wenn glasig, so rötlich, gross ( $7 \mathrm{~mm}$ lang, $4 \mathrm{~mm}$ breit. 157 Früchte $=10 \mathrm{gr})$. feinschalig, halbweich, Bruch halbmehlig.

Herbstblatt dunkelgrün, sehr lang und breit. aufrecht; Frühjabrsvegetation sehr zeitig, sehr kräftig, Blätter kahl oder oberseits äusserst schwach behaart; Bestockung mittelstark, 4.2 Schösslinge. Mittelfrüh schossend, Halm $138 \mathrm{~cm}$ (Max. $155 \mathrm{~cm}$ ) lang; Halmdicke $0.4 \mathrm{~cm}$, Blattzahl 4.4, Blattlänge $29.3 \mathrm{~cm}$, Blattbreite $1.13 \mathrm{~cm}$, mithin beträgt die Blattfläche eines Halmes $291.37 \mathrm{qcm}$, die Fläche eines Halmes $165.60 \mathrm{qcm}$ und die Gesammtfläche $456.97 \mathrm{qcm}$.

Die Aehre $10 \mathrm{~cm}$ (Max.: $13 \mathrm{~cm}$ ) lang, ist jung gelb-griin, reif entbält sie 14 Aehrchen mit 40 festsitzenden Früchten.

Auf $1 \mathrm{qm}$ entfallen 9/0 Halme oder 200 Pflanzen, mithin stellt sich die Bodenfläche p. Pflanze auf $50 \mathrm{qcm}$ und die Blattfläche auf $41.13 \mathrm{qm}$.

Die Zahl der Früchte berechnet sich pro hl $(=84 \mathrm{~kg})$ auf 1318800 Stiick und das Saatquantum ( $1 / 3$ Verlust) auf $2.3 \mathrm{hl} \mathrm{p}$, ha.

Es wiegen 100 Halme $750 \mathrm{gr}$ und davon die Früchte $240 \mathrm{gr}$.

Dieser Weizen bringt auf den mittleren Böden Nord-Frankreichs gute Erträge, lagert nicht leicht und ist auch gegen ungünstige Witterungsverhältnisse recht widerstandsfähig, doch leidet er durch Nässe.

\section{Blé blanc de Hongrie (2) u. $\odot$.}

Syn.: Französ isch: Blé anglais blanc; Blé anglais du Blaisois; Blé anglais des environs de Blois; Blé Chevalier; Albuin densum.

Spanisch: Candeal chamorro de Hungria.

Englisch: White Hungarian Wheat.

Deutsch: Weisser ungarischer Kolbenweizen.

Aehre: gelblichweiss, fast quadratisch, kurz, $8 \mathrm{~cm}$ lang, mit 35 Früchten; Aehrchen meist 2 -körnig, $1.5 \mathrm{~cm}$ breit. - Stroh: blassgelb, fest, steif, nicht leicht lagernd, feinhalmig, $115 \mathrm{~cm}$ lang. - Frucht: blassgelb, mehlig, wenige glasig, klein (6 mm lang, $3 \mathrm{~mm}$ breit), Qualität vortrefflich; halbweich.

Dieser allerdings wenig ergiebige Weizen macht nur geringe Ansprüche an den Boden, verlangt jedoch ein mildes Klima und reift zeitig.

Nach Heuzé ${ }^{1}$ ) führte ihn 1810 Vilmorin-Vater aus Ungarn

1) A. a. $0 . p g \cdot 54$. 
in Frankreich ein, wo er namentlich in Mittel- und Westfrankreich ziemlich umfangreich auf leichteren Böden kultiviert wird. Diesem entgegen gibt Peter Lawsoll ${ }^{1}$ ) all, dass 1830 dieser Weizen aus England in die Gegend von Blois eingefuihrt worden sei und spricht auch hierfür die Bezeichnung ,Blé anglais", so dass wohl anzunehmen ist, dass auch nach England diese Sorte importjert und von dort später wiederum nach Frankreich gelangt sei. Uebrigens führt Vilmorin ${ }^{2}$ ) selbst an, dass Mr. Rattier diesen Weizen in die Umgegend von Blois eingeführt habe.

Von Frankreich aus verbreitete sich seine Kultur iiber Spanien und in neuerer Zeit auch ïber die Siidstaaten der nordamerikanischen Union, wo er meist als Sommerweizen angebaut wird.

Nahe mit dieser Sorte ist „Blé de Hongrie à épi long" verwandt, die sich durch längere und schlaffere Aehre von ihr unterscheidet, auch Blé free trade und Blé club zeigen eine nahe Verwandtschaft, werden aber verhältnismässig selten kultiviert.

Dieser Weizen ist für das mittlere Frankreich mit seinem mehr trockenen Klima und seinen leichtereı, kalkreicheı Böden sehr geeignet.

\section{Blé Rosean. (2)}

Deutsch: Schilfweizen.

A ehre: blassgelb, kurz, dick, quadratisch, die zweizeilige Seite sehr in die Augen fallend, sehr geschlossen, der Aehre dem Hickling-Weizen sehr ähnlich, doch kïrzer, aber noch nicht so kurz wie beim Binkelweizen; Aehrchen sehr breit (2 cm), 3- und 4-körnig. - Stroh: gelb, kräftig, reich beblättert. Frucht: Original (Vilmorin) gelblich-weiss, mehlig, weich, gross $\left(7 \mathrm{~mm} \mathrm{lang,} 3^{3} / 4 \mathrm{~mm}\right.$ breit, 196 Früchte $=10 \mathrm{gr}$ ), schwer, feinschalig; nachgebaut: teilweise rötlichweiss und dann glasig.

Herbstblatt dunkelgrün, sehr lang und breit, aufrecht; Frïhjahrsvegetation mittfrül, Bestockung kräftig, 5 Schösslinge, nittelfrüh schossend und blühend. Mittlere Halmhöhe $130 \mathrm{~cm}$ (Max. $150 \mathrm{~cm}$ ), Halndicke $0.4 \mathrm{~cm}$, Blattzahl 4.5. Blattlänge $30.5 \mathrm{~cm}$, Blattbreite $1.0 \mathrm{~cm}$, mithin beträgt die Blattoberfläche beider Seiten eines Halmes $274.5 \mathrm{qcm}$, die Halmfläche $156 \mathrm{qcm}$ und die Gesammtfläche $430.5 \mathrm{qcm}$.

Junge Aehre gelbgriin, mittelfrüh reifend, $8 \mathrm{~cm}$ lang (Max. $9 \mathrm{~cm}$ ), mit 17 Aehrchen und 60 etwas lose sitzenden Früchten.

Auf $1 \mathrm{qm}$ wachsen $650 \mathrm{Halme}$ oder 130 Pflanzen, mithin jede Pflanze einen Raum von $77 \mathrm{qcm}$ einnimmt und auf $\mathrm{l} \mathrm{qm}$ Bodenfläche ca. $28 \mathrm{qm}$ Blattfläche entfallen.

Es enthält $1 \mathrm{hl}(=83.7 \mathrm{~kg}) 1640520$ Früchte, demnach stellt sich das Saatquantum $(1 / 3$ Verlust) auf $1.3 \mathrm{hl}$.

Es wiegen 100 Halme $670 \mathrm{gr}$ und davon die Früchte $240 \mathrm{gr}$.

Dieser Weizen wird auf den sehr fruchtbaren Alluvialböden, namentlich des nördlichen Fuankreichs kultiviert, doch lagerte er in Poppelsdorf auf reichem Lehmboden, hielt sich dabei jedoch ziemlich rostfrei. Für ein rauhes Klima eignet sich dieser Weizen nicht.

Nach Vilmorin soll er im nördlichen Frankreich einen Ertrag bis zu $50 \mathrm{hl}$ p. ha, obne sich zu lagern, aufgebracht haben.

1) Agric. Manual 1836, pg. 7 .

2) Les meilleurs Blés, pg. 38 . 


\section{Blé tendre. (2)}

Syn.: Italien: Grano tenero o Grano gentile bianco. Spanisch: Trigo tierno.

Aehre: fast weiss, geschlossen, an Basis breit, sich nach der Spitze zu stark verjüngend und grannenspitzig; Aehrchen sehr breit $(1.8 \mathrm{~cm})$, 2-3-körnig. - Stroh: gelb, dïnnwandig. - Frucht: blassgelb, wenige mehlig, meist glasig und rötlich, lang, etwas eingefallen $(7 \mathrm{~mm}$ lang, $3 \mathrm{~mm}$ breit, 256 Friichte $=10 \mathrm{gr}$ ), feinschalig, halbweich, Bruch halbmehlig.

Herbstblatt d unkelgrün, ziemlich schmalblättrig, Blätter beiderseits äusserst schwach behaart oder kahl: Frülijahrsentwickelung mittelfrüh, spät schossend, Bestockung mittelstark, 4 Schösslinge, spät blühend. Halmlänge $130 \mathrm{~cm}$ (Max.: $160 \mathrm{~cm}$ ), Halmdicke $0.38 \mathrm{~cm}$, Blattzahl 3.8, mittlere Blattlänge $27.5 \mathrm{~cm}$, Blattbreite $0.94 \mathrm{~cm}$, Blattoberfläche $196.46 \mathrm{qcm}$, Halmfläche $148.20 \mathrm{qcm}$, Gesammtoberfläche eines Halmes $344.66 \mathrm{qcm}$.

Junge Aehre gelbgrïn, spät reifend, $10 \mathrm{~cm}($ Max. $13 \mathrm{~cm})$ lang, mit 20 Aehrchen und 50 nicht leicht ausfallenden Früchten.

Es wachsen $9(10$ Halme oder 225 Pflanzen pro $q m$, mithin die Pflanze einen Raum von $44.4 \mathrm{qcm}$ einnimmt, während die Blattlläche pro qm Bodenfläche $31.02 \mathrm{qm}$ ausmacht.

Auf 1 bl $(=825 \mathrm{~kg})$ entfallen 2112000 Früchte, mithin beträgt das Saatquantum $1.6 \mathrm{hl}$.

Es wiegen 100 Halme $474 \mathrm{gr}$ und davon die Früchte $200 \mathrm{gr}$.

Dieser Weizen widersteht unseren Wintern recht gut, doch zeigt er auf reichem Boden im feuchten Knlima Neigung zum Lagern und geringe Widerstandsfähigkeit gegen Rost.

Im trocknen, milden Klima und auf Lehmboden scheint derselbe am besten zu gedeihen.

Nach Metz (Berichte über neuere Nutzpflanzen, pg. 99. 1858) soll er aus Oran als Sommerweizen eingeführt sein und sich sehr ergiebig gezeigt haben. In Poppelsdorf bekundete sich derselbe jedoch als echter Winterweizen.

Er wir̂̀ in Algier, Süd-Frankreich, Spanien und in Italien, namentlich um Foggia gebaut; höchst wahrscheinlich wird er in jenen sïdlichen Ländern im Laufe des Winters ausgesäet. Bezugsquelle: oek.-botanischer Garten zu Halle.

\section{Blé Chiddam blanc de Mars. $\odot$}

Syn.: Englisch: White Chiddam Spring-wheat.

Deutsch: März-Chiddam-Sommerweizen.

Aehre: blassgelb, lang, schmal, locker, sich nach der Spitze verjüngend und grannenspitzig, Aehrchen $1.4 \mathrm{~cm}$ breit, meist 2-, selten 3körnig. - Stroh: rötlichgelb, derbwandig. - Frucht: gelblichweiss, wenn mehlig, doch meist glasig und rötlichweiss, rundlich, klein $(6 \mathrm{~mm}$ lang, $3 \frac{1}{2} \mathrm{~mm}$ breit, $10 \mathrm{gr}=240$ Früchte), schwer, feinschalig, weich.

Pflanze blaugrün, Bestockung mittelgut, 2.8 Schösslinge, etwas spät bliilhend und reifend, Vegetationszeit 133 Tage; Halmlänge $110 \mathrm{~cm}$ (Max. $125 \mathrm{~cm}$ ), Halmdicke $0.3 \mathrm{~cm}$, Blattzahl 4, Blattlänge $24.25 \mathrm{~cm}$, Blattbreite 
$0.7 \mathrm{~cm}$, mithin beträgt die Blattfläche beider Seiten eines Halmes $135.84 \mathrm{qcm}$ die Halmfläche $99 \mathrm{qcm}$ und die Gesammtoberfläche $234.44 \mathrm{qcm}$.

Die Aehre, $10 \mathrm{~cm}$ lang (Max. $13 \mathrm{~cm}$ ), enthält 16 Aehrchen und 36 ziemlich leicht ausfallende Frichte,

Es kommen auf $1 \mathrm{qm} 1000$ Halme, oder 360 Pflanzen, mithin stellt sich die Bodenfläche pro Pflanze auf $27.7 \mathrm{qcm}$ und die Blattfläche auf $23.4 \mathrm{qm}$.

Die Zahl der Früchte berechnet sich pro hl (=84.3 kg) auf 2023200 Stück, und das Saatquantum (1/3 Verlust) auf $2.7 \mathrm{hl} \mathrm{p.} \mathrm{ha.}$

Es wiegen 100 Halme $420 \mathrm{gr}$ und davon die Früchte $145 \mathrm{gr}$.

Dieser Sommerweizen scheint die guten Eigenschaften des WinterChiddam-Weizens zu besitzen, aus dem er durch Auswahl von M. Garnot (Hilaire), Landwirt zu Ville-la-Roche, um 1860 geziichtet wurde und sich schnell in der Brie verbreitete.

Sein Korn steht dem des Winterweizens im Preise gleich, und bringt derselbe auf den besten kulturvollen Böden der Brie, $11 \mathrm{~m}$ Mitte März gesäet, einen Durchnitts-Ertrag von $30 \mathrm{hl}$ p. ha, doch ernteten M. M. Mathieu \& Candeliez ${ }^{1}$ ) bei Dükirchen sogar 48 hl p. ha.

Dieser Weizen wird auch vielfach in Italien angebaut.

\section{Froment blanc de Brosson.}

Aehre: blassgelb, ziemlich dicht, 25 Aehrchen mit 70 Früchten enthaltend, sich etwas verjüngend, grannenspitzig, bis $11 \mathrm{~cm}$ lang; A ehrchen $1.4 \mathrm{~cm}$ breit, meist 3-körnig. - Stroh: rötlich-gelb, blattreich, fest, $150 \mathrm{~cm}$ lang, $0.4 \mathrm{~cm}$ breit. - Frucht: blassgelb, mehlig, klein, oval (6 mm lang, $4 \mathrm{~mm}$ breit), feinschalig.

Original im landw. Museum zu Berlin.

\section{Blé saus barbe sorti du Siaisse d'Arles ou Narbonne blanc. (2)}

Aehre: weiss mit schwach rötlichem Anflug, sich stark verjüngend, an der Spitze kurzgrannig, schmal, locker, bei $10 \mathrm{~cm}$ Länge mit 35 Fruichten; Aehrchen $1.2 \mathrm{~cm}$ breit, 2- und 3-körnig. - Stroh: rötlich-weiss, feinhalmig, ziemlich blattreich, fest, $150 \mathrm{~cm}$ lang, $0.35 \mathrm{~cm}$ dick. - Frucht: rötlich-weiss, meist glasig, oval, klein ( $6 \mathrm{~mm} \mathrm{lang,} 3^{1} / 2 \mathrm{~mm}$ breit), schön, feinschalig.

Nach Vilmorin ${ }^{2}$ ) ist dieser allerdings noch stark grannenspitzige Kolbenweizen aus einem zu Tr. vulgare graecum gehörigen Bartweizen „Siaisse d'Arles, ou Narbonne (Syn.: Blé de Roussillon, Saisette de Tarascon, Siaisse blanche ou de Béziers) hervorgegangen.

Original im landw. Museum zu Berlin.

1) Vilm. Journ. d'Agric. prat. 1865. T. I pg. 179.

2) Vilm. Essai a. a. O. 1850. Section 29. 


\section{Touzelle blanche sans barbe $\odot$ und (2).}

Syn.: Froment commun sans barbes, blanc et glabre ${ }^{1}$ ).

Nord-Amerika: White Oregon-Wheat; Touzelle, Saisette. Süd-Amerika: Trigo del Oregon, Trigo Americano Chile.

Aehre: blassgelb. etwas schmal, sich rerjüngend, grannenspitzig, halblocker; Aehrehen $1.5 \mathrm{~cm}$ breit, 2-3-körnig. - Stroh: blassgelb, unter mittellang. - Frucht: Original weiss, mehlig, weich, wenige rötlich und glasig, oval, gross ( $7 \mathrm{~mm}$ lang, $4 \mathrm{~mm}$ breit, 193 Friichte $=10 \mathrm{gr}$ ). feinschalig; nachgebaut: alles glasig, ein wenig grösser, 169 Friichte $=10 \mathrm{gr}$, schwer, $1 \mathrm{hl}$ wiegt $88 \mathrm{~kg}$.

Winterfrucht: Herbstblatt dunkelgrün, ziemlich lang, schmal, fast aufrecht; Entwickelung ziemlich früh, 2.1 Schösslinge, mittelfrüh schossend und blühend. Junge Aehre blaugrün, mittelfrüh reifend.

Sommerfrucht: Junges Blatt dunkelgrün, gross, aufrecht, 2.8 Schüsslinge, zeitig schossend und blühend; in 116 Tagen reifend.

\begin{tabular}{l|c|c}
\hline Mittlere & Winterweizen & Sommerweizen \\
\hline Halmlänge cm & 100 (Max. 120) & 110 (Max. 130) \\
Halmdicke cm & 0.35 & 0.37 \\
Blattzahl & 4 & 3.9 \\
Blattlänge cm & 19.4 & 19.1 \\
Blattbreite cm & 0.8 & 1.0 \\
Blattfläche qcm & 124.2 & 149.0 \\
Halmfläche qcm & 105.0 & 122.1 \\
Gesammtfläche qcm & 229.2 & 271.1 \\
Aehrenlänge cm & $9($ Max. 13$)$ & $9($ Max. 13) \\
Darin Aehrchen: & 17 & 17 \\
Früchte in den Aehren & 42 & 42 \\
Fruchtzahl pro hl & 1698400 & 1672000 \\
& &
\end{tabular}

Im kälteren gemässigten Klima nicht winterfest, leidet wenig durch Lagern und Windschlag, stärker durch Rost.

Auf in nicht zu holer Kultur befindlichen Böden und im trocknen Klima angebaut. so in Sïd-Frankreich, der Schweiz. Oregon, Californien, Chile etc., in welchen Ländern derselbe in hohem Grade geschätzt wird.

\section{Blé d'Ostende. (2)}

Aehre: fast weiss, sehr dicht, bei $9 \mathrm{~cm}$ Länge 22 Aehrchen und 66 Früchte enthaltend, sich wenig verjüngend, wenig grannenspitzig, prismatisch, aufrecht; Aehrchen $1.4 \mathrm{~cm}$ breit, 3- und 4-körnig. - Stroh: fast weiss, mehlig, klein, oval (6 $\mathrm{mm}$ lang, $3.5 \mathrm{~mm}$ breit), feinschalig.

Heimath: Belgien.

Original im landw. Museum zu Berlin.

1) Seringe, Monogr. des céréales de la Suisse 1818, pg. 92. 


\section{Blé blane de Flandres. (2)}

Syn.: Französisch: Blé de Zélande; Blé de Bergues; Blé blanc Zée; Blé blazé de Lille; Blé blanzé; Blé suisse. Nach Vilmorin(Journ. Agric. prat. $1851 \mathrm{pg} .452$ ) sind auch identisch: Ble de Tiflis; Blé blanc du Loudunais; Blé blane du Nord.

Holländisch: Zeeuwsch witte Tarwe.

Dentsch: Zeeländer-Weizen; weisser Weizen aus Flandern ; weisser Winterweizen aus Belgien.

Engliseh: White Flanders Wheat.

Spanisch: Trigo de Bergues.

Italienisch: Grano di Zelanda.

Aehre: blassgelb, geschlossen, fast quadratiseh, sich wenig nach der Spitze verjüngend. Aehrehen breit $(1.8 \mathrm{~cm})$, meist 3-körnig. - Stroh: rötlich-gelb, hohl, etwas dünnwandig. - Frucht: Original blassgelb, mehlig, weich, wenige glasig, rundlich $\left(6^{1} / 2 \mathrm{~mm}\right.$ lang, $3^{1} / 2-4 \mathrm{~mm}$ breit $)$, feinschalig. Nachgebant schou in erster Ernte meist glasig, grösser ( $7 \mathrm{~mm}$ lang, $4 \mathrm{~mm}$ breit).

Herbstblatt dunkelgrün, sehr breit, kräftig, aufrecht. Bestockung stark, 4.5 Sprossen, und die absolute Bestockungsfähigkeit stellt sich bei $100 \mathrm{qcm}$ Raum auf 13.5 Schösslinge. Das Schossen, die Blüte und die Reife treten mittelfrül ein und erreicht der Halm während der Blüte $0.44 \mathrm{~cm}$ Dicke, $133 \mathrm{~cm}$ (Max. $165 \mathrm{~cm}$ ) Länge, mittlere Zahl der B]ätter 4.2, Blätter $29.3 \mathrm{~cm}$ lang, $1.04 \mathrm{~cm}$ breit, mithin die Blattfäche eines Halmes $304.72 \mathrm{qcm}$, die Halmfläche $175.56 \mathrm{qm}$ und die Gesammtfläche $480.28 \mathrm{qcm}$ ausmacht.

Es wachsen pronqm Bodenfläche 640 Halme oder 142 Pflanzen, demnach jede Pflanze einen Raum von $70.4 \mathrm{qcm}$ einnimmt und die Blattfläche aller Pflanzen $30.74 \mathrm{qm}$ beträgt.

Die junge gelbgrüne Aehre erreicht in der Reife eine mittlere Länge von $11 \mathrm{~cm}$ (Max. $15 \mathrm{~cm}$ ) und befinden sich an derselben 20 Aehrchen mit 60 Früchten, von diesen wiegt $1 \mathrm{hl} 82.87 \mathrm{~kg}$ und enthält 1779200 Stïck, und stellt sich demnach das Saatgut ( $1 / 3$ Verlust), da 1420000 Pflanzen pro ha wachsen können, auf $1.67 \mathrm{hl}$. $210 \mathrm{gr}$.

In Poppelsdorf wogen 100 Halme $625 \mathrm{gr}$ und davon die Körner

Der Hauptverbreitungsbezirk dieser Weizensorte erstreckt sich auf das französische und belgische Flandern, sowie auf die holländischen Provinzen Seeland, Nord- und Süd-Holland.

In vorzuiglicher Qualität gedeiht er auf den schweren Böden des in Seeland gelegenen Gutes "Wilhelmina Polder", doch wird er auf den besseren, drainirten Böden Hollands durch "White 'Essex und Rough chaffed Essex" (Dikkop tarwe) immer mehr verdrängt, weil diese höhere Erträge und besseres Mehl liefern, doch ist seine Kultur auf den schweren, feuchten Böden noch ziemlich stark verbreitet.

Auf leichteren Böden degeneriert er sowohl im Korn wie Stroh sehr leicht, so dass häufiger frische Saat von reichen, humosen Böden zu beziehen ist.

In Poppelsdorf seit 1869 kultiviert, winterte er nur in dem ungünstigen Winter 1870 teilweis aus, lagerte jedoch leicht und befiel stark mit Rost. Unter solchen Umständen ist seine Kultur für Nord-Deutschland kaum zu empfehlen. 
Im Dep. Seine inférieure ${ }^{1}$ ) stellte sich der Ertrag

p. ha auf Lehmbodell auf: $1640 \mathrm{~kg}$ Körner $3000 \mathrm{~kg}$ Stroh

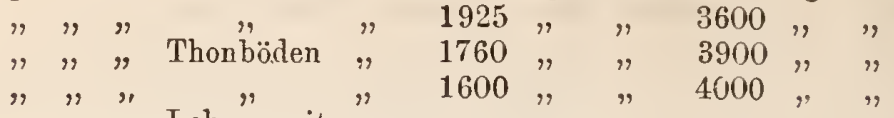

$", "$, Lehm mit undurchlassendem Unter-

grund auf:

$1620, \quad, 5000, "$,

Peter Laws on führt in seinem Agric. Manual 1836 "an, dass dieser Weizen nur sehr wenig von "White Essex" verschieden sei und ihn wahrscheinlich nur klimatische Einfliisse verändert hätten. Dies mag im Allgemeinen zutreffell, doch ist das Korn von "White Esscx" klciner unil die Pflanze weniger robust.

\section{Vulgo Grano bianco. Ex Apulia. (2)}

Syn.: Italienisch: Bianchetto; Grano carosella.

Französisch: Blé Richelle blanche de Naples, Blé blanc de Naples; Richelle blanche de Provence; Blé de Lado; Blé espagnol sans barbes; Blé blanc de Rome.

Spaniscli: Trigo richello; Trigo rico de Napoles.

Englisch: White Naples Wheat.

Deutsch: Weisser reichtragender Neapolitaner-Weizen.

Aehre: weiss, mit rötlichem Schimmer, ein wenig hängend, lang, schmal, sich stark verjüngend und grannenspitzig, locker. Aehrchen schnal $(1.5 \mathrm{~cm})$, Klappen und Spelzen mit stark nach Innen gekrümmtem Zahn, 2-3-körnig. - Stroh : rötlich-gelb, lang, fest, terbwandig. - Frucht: Original gelblich-weiss, doch schon erste Ernte alle Körner glasig und rötlich; gross ( $8 \mathrm{~mm}$ lang, $4 \mathrm{~mm}$ breit), schwer, sehr feinschalig; Bruch halbmehlig, halbweich.

Herbstblatt blaugrün, roggenähnlich, breit, anfrecht; Bestockung schwach, 3 Schösslinge. Frühjahrsvegetation zeitig. Halm $115 \mathrm{~cm}$ (Max. $130 \mathrm{~cm}$ ) lang, $0.4 \mathrm{~cm}$ dick, Blätter $26 \mathrm{~cm}$ lang, $1.04 \mathrm{~cm}$ breit, Blattoberfläche $162.24 \mathrm{qcm}$, Halmfläche $138 \mathrm{qcm}$, Gesammtfläche $300.24 \mathrm{qcm}$. Junge Aehre gelbgriin, $13 \mathrm{~cm}$ (Max. $18 \mathrm{~cm}$ ) lang, 20 Aehrchen mit 50 ziemlich fest von den Spelzen umschlossenen Früchten. Von letzteren wiegt $1 \mathrm{hl} 84.6 \mathrm{~kg}$ und zählt 1395900 Stuick aus.

Wachsen pro qm 936 Halme oder 312 Pflanzen, so kommen auf jede Pflanze $32 \mathrm{qcm}$ Bodenfläche, und das Aussaatquantum stellt sich auf $3 \mathrm{hl} \mathrm{p}$. ha. Die Blattfläche berechnet sich pro $1 \mathrm{qm}$ Bodenfläche anf $28.1 \mathrm{qm}$.

Diese Weizensorte zeigte sich in Poppelsdorf sehr empfindlich, indem sie leicht erfror; das Stroh lagert nicht leicht, ist jedoch dem Roste unterworfen. Das Melnl gilt als feinstes weisses Luxusmehl.

Nach Vilmorin soll dieser Weizen anch Sommerfrucht sein, doch hat er sich hier als echter Winterweizen erwiesen, im Frühjahr gesäet, wurden die Pflanzen, welche iiberhaupt geschosst hatten, erst Ende August reif. 
Es wogen 100 Halme $590 \mathrm{gr}$ und davon die Körner $244 \mathrm{gr}$.

Seine Heimat findet sich auf den reichen J,ehmböden Süd-Italiens, und namentlicl in der Ebene von Neapel, von wo ihn M. Darblay nach Frankreich einführte, und erfreut er sich in Siid-Frankreich einer weiten Verbreitung, während er für Nord-Frankreich schon $z u$ weich ist.

Auch in Spanien und den Siid-Staaten der nordamerikanischen Union wird er vielfach angebaut.

Den Originalsamen sandte Herr Pedecino aus Portici nach Poppelslorf. Am besten soll dieser Weizen zn Barbetta, Cerignola, Manfredonia und Taranto in Italien gedeihen.

\section{Weizen von Missolunghi, Griechenland. $\odot$ u. (2)}

Aehre: fast weiss, schmal, unansehnlich, etwas locker, sich stark verjuingend und grannenspitzig; Aehrehen $1.3 \mathrm{~cm}$ breit, 3-körnig. Stroh: rötlich-gelb, ziemlich lang. - Frucht: weissgelb, wenn mehlig, meist glasig und rosa, länglich, schmal $\left(7 \mathrm{~mm}\right.$ lang, $3^{\mathrm{x}} / 2 \mathrm{~mm}$ breit, 250 Früchte $=10 \mathrm{gr}), 1 \mathrm{hl}$ wiegt $86 \mathrm{~kg}$, feinschalig, lualbhart, Bruch halbmehlig.

Dieser Weizen lässt sich als Wechselweizen kultivieren und zwar verdiente derselbe in Poppelsdorf als Sommerweizen den Vorzug und einige Beachtung, wenngleich seine Ernte erst spät, Ende August, eintritt.

Dic jungen Blätter sind dunkelgrün, schmal und kraus; die Frühjahrsvegetation tritt zeitig ein, sowie auch das Schossen (5.2 Schösslinge), die Blite und Ernte. Der Sommerweizen treibt nur 4.2 Schösslinge, schosst und blüht spät.

\begin{tabular}{l|c|c}
\hline & Winterweizen & Sommerweizen \\
\hline & & \\
Halmlänge & $115 \mathrm{~cm}($ Max.: $130 \mathrm{~cm})$ & $135 \mathrm{~cm}($ Max.: $150 \mathrm{~cm})$ \\
Halmdicke & $0.3 \mathrm{~cm}$ & $0.43 \mathrm{~cm}$ \\
Blattzahl & 2.8 & 3.8 \\
Blattlänge & $22.3 \mathrm{~cm}$ & $263 \mathrm{~cm}$ \\
Blattbreite & $0.85 \mathrm{~cm}$ & $0.92 \mathrm{~cm}$ \\
Aehrenlänge & $10 \mathrm{~cm}($ Max.: $14 \mathrm{~cm})$ & $10 \mathrm{~cm}($ Max.: $13 \mathrm{~cm})$ \\
Zahl der Achrchen & 16 & 16 \\
, "Früchte & 42 & 42 \\
& &
\end{tabular}

Der Weizen gedieh als Sommcr- und Winterfrucht 1879 und 1880 recht gut, lagerte nicht leicht und befiel wenig mit Rost. Es wiegen 100 Halme Winterweizen $285 \mathrm{gr}$ und davon die Frïchte $124.6 \mathrm{gr}$.

Importeur und Uebersender ist Itzenplitz, Köln, 1878.

\section{Kostroma-Weizen. (2)}

Aehre: hellgelb, lang; Aehrchen schmal (1.3 cm breit), 2-körnig. Stroh: gelb, selır dünnwandig. - Frucht: Original weiss, meist mellig; nachgebaut rötlich-weiss, meist glasig, rundlich, mittelgross (6 mm lang, $4 \mathrm{~mm}$ breit), schwer, schön, feinschalig, halbweich, Bruch halbmelılig. 
Herbstblatt blaugrün, schmal, kraus, niederliegend; Frühjahrsvegetatiou etwas spät; Bestockung stark, 5.3 Sprossen, spät schossend und blühend. In der Blïte beträgt die Halmhöhe $150 \mathrm{~cm}$ (Мax. $190 \mathrm{~cm}$ ), die Halmdicke $0.32 \mathrm{~cm}$, die Blattzahl 4.5 ; Blätter $21 \mathrm{~cm}$ lang, $0.8 \mathrm{~cm}$ breit, Blattoberfläche 151.20 qcm, Halmoberfläche 144 qcm, Gesammtfläche 295.20 qciu.

Jumge Aehre gelbgrün, mittelfrüh reifend, $11 \mathrm{~cm}$ lang (Max. $14 \mathrm{~cm}$ ), mit 17 Aelurchen und 34 etwas locker sitzenden Früchten.

Es kommen auf 1 qm 950 Halme oder ca. 180 Pflanzen, mithin stellt sich die Bodenfläche pro Pflanze auf $55.5 \mathrm{qcm}$ und die Blattfläche pro $1 \mathrm{qm}$ Bodenfläche auf $28.04 \mathrm{qm}$.

Es enthält $1 \mathrm{hl}$ ( $84.8 \mathrm{~kg}$ wiegend) 1837000 Früchte, mithin sich das Saatquantum (bei $1 / 3$ Verlust) anf $1.47 \mathrm{hl} \mathrm{p}$. ha stellt.

Es wiegen 100 Halme $470 \mathrm{gr}$ und davon die Frichte $160 \mathrm{gr}$.

Der Weizen ist in Kontinentalklima und auf gnten Lehmböden ohne grossen Dungreichtum sehr ertragreich, da sonst das Stroh leicht lagert; doch ist er widerstandsfähig gegen Rost; aucl zeigte er sich in Poppelsdorf durchaus winterfest und degeneriert nicht leicht.

Seine ursprüngliche Heimat ist das russische Gouvernement Kostroma, doch hat er sich seit langer Zeit in Polen eingebiirgert, wo er hoch geschätzt wird.

\section{Urtoba-Weizen. (2)}

Aehre: blassgelb, fast weiss, sich stark verjüngend, doch ohne Grannenspitzen, locker, nittelbreit; Aehrchen $1.5 \mathrm{~cm}$ breit und 2- und 3-kürnig. - Stroh: rötlich-gelb, fest. - Frucht: Original wachsgelb, meist mehlig, wenige glasig, letztere rötlich, rundlich $\left(6 \mathrm{~mm}\right.$ lang, $3^{1} / 2 \mathrm{~nm}$ breit, 220 Körner $=10 \mathrm{gr})$, nachgebaut meist glasig.

Herbstblatt blaugrün, kraus, schmal; Blätter äusserst schwach behaart oder unterseits kahl. Frühjahrsvegetation sehr spät, Bestockung sehr stark, 6.8 Schösslinge, spät schossend und blühend.

Halmlänge $140 \mathrm{~cm}$ (Max. $165 \mathrm{~cm}$ ), Haludicke $0.4 \mathrm{~cm}$, Blattzahl 3.5. Mittlere Blattlänge $26 \mathrm{~cm}$, Blattbreite $1 \mathrm{~cm}$, Blattoberfläche $182 \mathrm{qcm}$, Halmfläche $168 \mathrm{qcm}$, Gesammtfläche $350 \mathrm{qcm}$.

Junge Aehre gelbgrün, mit bräunlichen oder gelben Staubbeuteln, spät reifend, $10 \mathrm{~cm}$ lang ( die ziemlich fest sitzen.

Es wuchsen pro qu 900 Halme oder 132 Pflanzen, mithin beansprucht jede Pflanze einen Raum von $75.7 \mathrm{qcm}$, und die Blattfläche beträgt pro qin Bodenfläche $31.5 \mathrm{qm}$.

Es kommen auf $1 \mathrm{hl}(=84 \mathrm{~kg}) 1848000$ Früchte, demnach stellt sich das Saatquantum auf $1.1 \mathrm{hl}$.

Es wiegen 100 Halme $524 \mathrm{gr}$ und davon die Frïchte $200 \mathrm{gr}$.

Dieser Weizen soll nur geringe Bodenansprüche stellen, sich nicht lagern, dem Rost wilerstelen, und ein vorzïgliches Mehl liefern.

Auf dem reichen Boden in Poppelsdorf zejgte er jedoch Neigung zum Lagern.

Die Heimat dieses Weizens soll Russland sein, wenigstens will ihn der Samenbändler Ernst Bahlsen in Prag von dort 1576 bezogen und weiter verbreitet haben. Von der Filiale dieser Samenhandlung in Berlin, Markgrafenstrasse 15, Vertreter: Julins Bahlsen, erhielten wir diesen IV eizen \%ugesandt. 
Nach einer Notiz der Wiener landw. Zeit. 1877 No. 36 rg. 412 soll derselbe mit dem von Metzger beschriebenen l)lauen englischen oder russischen Weizen identisch sein, doch beruht dies auf einem Irrtum, indem der von Metzger ${ }^{1}$ ) beschriebene ein Tr. turgidum ist.

\section{Tham-wheat. $\odot$}

Syn.: Sibirischer Weizen. züglich.

Aehre: weiss. - Stroh: kurz. - Frucht: weiss, schön, Mehl vor-

Frühreif, nicht leicht durch Lagern oder Rost leidend.

Einer der besten Sommerweizen der Neu-England-Staaten und des Nordens des New-York-Staates.

\section{Smogger-Weizen. (2)}

Aehre: blassgelb, fast weiss, locker, sicl verjüngend, grannenspitzig, dünn; Aehrchen $1.5 \mathrm{~cm}$ breit, meist 3-körnig. - Stroh: rötlich-gelb bis orange, sehr schön, fest. - Frucht: Original gelblich-weiss, mehlig; nachgebaut: meist glasig und rötlich; klein (6 mu lang, $3 \frac{1}{2} \mathrm{~mm}$ breit, 233 Früchte $=10 \mathrm{gr}$ ), feinschalig.

Herbstblatt blaugrün, schnal, kraus; Frühjahrsvegetation sehr spät, Bestockung stark, 5.8 Schösslinge, spät schossend und blühend. Haln1länge $110 \mathrm{~cm}$ (Max. $140 \mathrm{~cm}$ ), Halmdicke $0.37 \mathrm{~cm}$, Blattzahl 4. Mittlere Blattlänge $26.02 \mathrm{~cm}$, Blattbreite $0.93 \mathrm{~cm}$, Blattoberfläche $193.6 \mathrm{qcm}$, Halmfläche $122.1 \mathrm{qcm}$, Gesammtfläche eines Halınes 315,7 qcm.

Junge Aehre gelbgriun, mittelfriih reifend, $11 \mathrm{~cm}$ lang (Max. $15 \mathrm{~cm}$ ), mit 14 Aehrchen und 50 ziemlich leicht ausfallenden Frïliten.

Es kommen auf 1 qm 900 Halme oder 155 Pflanzen, hieraus ergiebt sich ein Raum pro Pflanze von $64.7 \mathrm{qcm}$, und eine Blattfläche pro qm Bodenfläche von $28.41 \mathrm{qm}$.

Es enthält $1 \mathrm{hl}(=78.3 \mathrm{~kg}) 1863540$ Früchte, mithiu stellt sich das Saatquantum auf $1.3 \mathrm{hl}$ p. ha.

Es wiegen 100 Halme $470 \mathrm{gr}$ und davon die Frïchte $170 \mathrm{gr}$.

Er gedeiht vorzïglich im Kontinentalklima mit heissen Sommern und strengen Wintern und auf mildem Lehmboden, auch lagert er nicht leicht und hält sich fast rostfrei.

Das Mehl dieses ertragreichen ungarisehen Weizens ist vortrefflich. Als Sommerweizen kultiviert, erwies er sich als echter Winterweizen.

Durch Haage \& Schmidt, Erfurt, 1876 erhalten.

\section{Weisser Kolbenweizen aus der Berberei. $\odot$ u. (2)}

Aelıre: blassgelb, locker, düın, mittellang; Aehrehen $1.2 \mathrm{~cm}$ breit, 2-körnig. - Stroh: blassgelb, fest. - Frucht: gelblich-weiss, mehlig, meist jedoch glasig, scliön, gross ( $7 \mathrm{~mm}$ lang, $4 \mathrm{~mm}$ breit, 179 Früchte $=10 \mathrm{gr}$ ); Bruch halbmehlig.

Herbstblatt blaugriin, schmal; Frühahrsvegetation sehr zeitig; Be-

1) Metzger, landw. Pflanzenkunde, pg. 82. 
stockung schwach, 2.7 Schösslinge, zeitig schossend und blühend, zeitig reifend, junge Aehre blaugrün, reif $10 \mathrm{~cm}$ lang (Max. $13 \mathrm{~cm}$ ), mit 15 Aehrchen und 30 Früchten.

Die Sommersaat entwickelte sich etwas spät, doch zeigte auch diese eine schwache Bestockung, 1.2 Schösslinge.

Die Ausmessung blühender Halme der Sommer- und Winterfrucht ergab nachfolgende Resultate:

\begin{tabular}{l|c|c}
\hline & Sommersaat & Wintersaat \\
\hline Halmlänge & $105 \mathrm{~cm}($ Max.: $120 \mathrm{~cm})$ & $115 \mathrm{~cm}$ (Max.: $140 \mathrm{~cm}$ ) \\
Halmdicke & $0.34 \mathrm{~cm}$ & $0.36 \mathrm{~cm}$ \\
Blattzahl & 3 & 3 \\
Blattlänge & $23.8 \mathrm{~cm}$ & $24.9 \mathrm{~cm}$ \\
Blattbreite & $1.0 \mathrm{~cm}$ & $1.02 \mathrm{~cm}$ \\
Blattoberfläche & $142.8 \mathrm{qcm}$ & $152.4 \mathrm{qcm}$ \\
HalmHäche & $107.1 \mathrm{qcm}$ & $124.2 \mathrm{qcm}$ \\
Gesammtfläche & $249.9 \mathrm{qcm}$ & $276.6 \mathrm{qcm}$ \\
Halme pro qun & 1000 & 928 \\
Raum pro Pflanze & 12.5 & $29.1 \mathrm{qcm}$ \\
Anzahl der Pflanzen pro qm & 830 & 344 \\
Blattfläche pro qm Bodenfläche & $25 \mathrm{qm}$ & $25.67 \mathrm{qm}$ \\
Hektolitergewicht & 85 & 85 \\
Fruchtzahl in 1 hl & 1521500 & 1521500 \\
Aussaatquantum p. ha & $8 \mathrm{hl}$ & $3.3 \mathrm{hl}$ \\
100 Halme wogen: & $460 \mathrm{gr}$ & - \\
Die Früchtc in j00 Halmen wogen: & $175 \mathrm{gr}$ & - \\
& &
\end{tabular}

Der Weizen ist nicht winterfest, su erfror derselbe in Poppelslorf seit 1870 mehrere Male; doch zeigte er sich gegen Rost und Lagern ziemlich widerstandsfühig.

Für ein mildes Klima usd milde Lehmböden scheint er beachtenswert zu sein.

Der Berliner Akklinatisations-Verein führte ihn 1867 zur Kultur in Deutschland ein. (Zeitschr. f. Akklim. 1869 No. X. XII pg. 158.)

\section{Aegyptischer Weizen. (2)}

Aehre: fast weiss, ein wenig locker, sich stark verjüngend, grannenspitzig, $10 \mathrm{~cm}$ lang, mit 50 Früchten; Aehrchen 2-3-körnig, $1.5 \mathrm{~cm}$ breit. - Strolı: fast weiss, feinhalmig. - Frucht: fast weiss, inehlig, prachtvoll, ( $7 \mathrm{~mm}$ lang, $3^{3} / 4 \mathrm{~mm}$ breit), feinschalig. Original in der Sanmlung des Dr. Dreisch, Poppelsdorf.

\section{Weisser Winter-Kolbenweizen aus Ostindien. (2)}

Aehre: fast weiss, sehr lang, etwas locker, sich wenig verjiingend und spärlich mit Grannenspitzen besetzt, etwas schmal; Aehrchen $1.5 \mathrm{~cm}$ breit, 3-körnig. - Stroh: rötlich-gelb, fest, ziemlich kräftig. - Frucht: fast weiss und mehlig, oder gelb und glasig, oval $\left(6 \mathrm{~mm}\right.$ lang, $3^{3} / 4 \mathrm{~mm}$ breit, 211 Frïchte $=10 \mathrm{gr}$ ), feinschalig, halbwcich; Bruch halbmehlig. 
Herbstblatt dunkelgrün, ziemlich kräftig; Bestockung mittelstark, 5 Schösslinge, spät schossend und blühend; Halmlänge $85 \mathrm{~cm}$ (Max. $110 \mathrm{~cm}$ ), Halmdicke $0.38 \mathrm{~cm}$, Blattzahl 5 , Blattlänge $22 \mathrm{~cm}$, Blattbreite $1 \mathrm{cml}$, Blattfläche eines Halmes 220 q $\mathrm{cm}$, Halmfläche 96.9 qcm, Gesammtfläche $316.9 \mathrm{qcm}$.

Junge Aehre blaugrïn, frühreifend, $12 \mathrm{~cm}$ (Max. 15 cm) lang, mit 21 Aehrchen und 60 leicht ausfallenden Früchten, von denen 1734600 auf $1 \mathrm{hl}=82.6 \mathrm{~kg}$ entfallen.

Es wiegen 100 Halme $543 \mathrm{gr}$ und davon die Früchte $234 \mathrm{gr}$.

Der Weizen durchwinterte $1879 / 80$ gut, blieb aufrecht und ziemlich rostfrei. Uebersender: Bundten, Amsterdam.

\section{Man-zi. (2)}

Syn.: Chinesischer Man-zi-Weizen. Franz.: Blé Chinois.

Aehre: fast weiss, kurz, dicht, fast quadratisch, bis $7 \mathrm{~cm}$ lang mit 20 A ehrchen und 50 Früchten; Aehrcheu 2- und 3-körnig; Spelzen kurz, die Frucht nicht ganz deckend. - Stroh: fast weiss, blattarm, fest, bis $150 \mathrm{~cm}$ lang, $0.4 \mathrm{~cm}$ dick; Blätter gelbgrŭn. - Frucht: weiss, mehlig, klein, oval. Soll durch Hott's ${ }^{1}$ ) über Moskau 1834 nach Frankreich aus China eingefuihrt sein.

Original im landw. Museum zu Berlin.

\section{Blé de l'Inde:}

Sy n.: Blé de la Chine.

Aehre: fast weiss, pyramidal, graunenspitzig. doch Grannenspitzen nach abwärts gebogen, dicht, kurz, $7.5 \mathrm{~cm}$ lang mit 18 Aehrchen und 50 Friichten; Aehrchen 3-körnig. - Stroh: blassgelb, weich, blattreicl, kurz, düunhalmig, bis $100 \mathrm{~cm}$ lang; Blätter dunkelgriin. - Frucht: blassgelb, meist mehlig, klein (6 $\mathrm{mm}$ lang, $3 \mathrm{~mm}$ breit), feinschalig.

Heimat: Ostiudien.

Original im landw. Museum zu Berlin.

\section{Weizen aus Tasmanien. (2)}

Aehre: schmutzig-weiss, compakt, pyramidal, $9 \mathrm{~cm}$ lang, mit 20 Aehrchen und 56 Früchten; Aehrchen $1.4 \mathrm{~cm}$ breit, 3-körnig. - Stroh: gelb, blattarm, steif, $100 \mathrm{~cm}$ lang. - Frucht: blassgelb, mehlig, klein, rundlich ( $6 \mathrm{~mm}$ lang, $3.5 \mathrm{~mm}$ breit), sehr schön, feinschalig.

Original im landw. Museum zu Berlin.

1) Vilmorin, Essai d'un cat. méthod. et syn. des Froments. Paris 1850. 


\section{Varietät: Triticum vulgare lutescens Al.}

Aehren kahl, weiss oder gelb; Körner rot.

\section{Sorten:}

\section{Weissähriger Probsteier-Weizen. (2)}

A tehre: fast weiss, lang, schmal, locker, sich wenig verjüngend; A ehrchen $1.3 \mathrm{~cm}$ breit, meist 2-körnig. - Stroh: rötlich-gelb, derbwandig. lang. - Frucht: gelbrot, mehlig, länglich, gross (7 mm lang, $4 \mathrm{~mm}$ breit), feinschalig, weich.

Herbstblatt dunkelgrün, beiderseits äusserst kurz behaart, ziemlich fein, kraus; Frühjahrsvegetation mittelfrüh, Bestockung mittelstark, 5 (bei 100 qcm Raum) 13.8 Schösslinge, spät schossend und blühend, Halmlänge $145 \mathrm{~cm}$ (Max. $165 \mathrm{~cm}$ ), Halmdicke $0.4 \mathrm{~cm}$, Blattzahl 4.2, Blattlänge $30.3 \mathrm{~cm}$, Blattbreite $1.0 \mathrm{~cm}$, Blattoberfläche $254.52 \mathrm{qcm}$, Halmfläche $174 \mathrm{qcm}$, GesammtAläche $428.52 \mathrm{qcm}$.

Junge Aehre gelbgrün, spät reifend, $10 \mathrm{~cm}$ (Max.14 cm) lang, mit 20 Aehrchen und 40 etwas lose sitzenden Früchten, von denen 1776000 auf $1 \mathrm{hl}(=82 \mathrm{~kg})$ gehen.

Es wachsen 800 Halme oder 160 Pflanzen auf $1 \mathrm{qm}$, mithin beträgt der Raum für eine Pflanze $62.5 \mathrm{qcm}$, die Blattfäche p. qm Bodenfläche $34.28 \mathrm{qm}$ und das Saatquantum $1.4 \mathrm{hl} \mathrm{p}$. ha.

Dieser Weizen ist vollkommen winterfest, befällt jedoch leicht mit Rost, und lagert auf sehr reichem Boden. Für den guten Lehmboden Nord-Deutschlands eignet er sich vortrefflich, doch wird ihm im Allgemeinen der rotährige Probsteier (Trit. vulg. miltura) vorgezogen, der ertragreicher sein soll.

Heimat: Die Probstei in Holstein, von wo aus der Originalsame in plombierten Säcken versandt wird.

\section{Kaiser-Weizen. (2)}

Syn.: Biddle's Imperial-Wheat ${ }^{1}$, in Australien gebant, und entsprechend dem dortigen warmen, trocknen Klima im Habitus kleiner geworden.

Aehre: blassgelb, mit schwach rötlichen Schimmer, dicht, lang, breit; Aehrchen $2 \mathrm{~cm}$ breit, 3-4-körnig. - Stroh: gelb-orange, über mittellang, sehr fest, derbwandig. - Frucht: gelbrot, mittelgross, rundlich, $6 \mathrm{~mm}$ lang, $4 \mathrm{~mm}$ breit, feinschalig; Bruch halbinehlig, halbweich.

Herbstblatt gelbgrün, kahl, breit, aufrecht, Vegetation mittelfrüh, bei Biddle's Imperial-Wheat waren merkwürdigerweise die Blätter kurz

1) Original 1880 aus bot. Garten zu Adelaide erhalten. 
aber dicht behaart, eine Erscheinung, welche wohl mit der Trockenheit des australischen Klimas im Zusammenhang steht.

\begin{tabular}{l|c|c}
\hline \multicolumn{1}{c|}{ Mittlere } & Kaiser-Weizen & Biddle's Imperial \\
\hline & & \\
Zahl der Schösslinge & 5.8 & 2.2 \\
Halmlänge cm & 125 Max.: 140) & $120($ Max.: 140) \\
Halmdicke cm & 0.44 & 0.4 \\
Blattzahl & 3.7 & 4 \\
Blattlänge cm & 31.18 & 28 \\
Blattbreite cm & 1 & 1 \\
Blattoberfläche qcm & 230.73 & 224 \\
Halmfläche qcm & 165 & 144 \\
Gesammtoberfläche qcm & 395.73 & 368 \\
Aehrenlänge cm & $12($ Max.: 15) & $10($ Max.: 12) \\
Zahl der Aehrchen & 18 & 15 \\
F" Früchte & 60 & 50 \\
Fruchtzahl pro 1 hl & 2074600 & 2720000 \\
Hektolitcrgewicht in kg & 80 & 85 \\
& &
\end{tabular}

Vom Kaiser*Weizen wachseu 148 Pflauzen pro $1 \mathrm{qm}$, mithin sich ein Saatquantun von $1.1 \mathrm{hl}$ pro ha berechuet.

Junge Aehre olivengrün, mittelfriil reifend; Frïchte zientlich fest von den Spelzen umschlossen.

Sehr widerstandsfähig gegen ungünstige Witterung, so dass er selbst $1870 / 71$ nicht auswinterte, also in einem Winter, in welchem fast alle Sorten stark litten.

Fïr einen sehr humosen, dem Auffrieren ausgesetzten Boden geeignet, weil er sich aussergewöhnlich kräftig bewurzelt, ihm daher das Abreissen von Wurzeln weniger als anderen Sorten schadet.

Auf guten Weizenböden, und selbst auf dem sandigen Lehm, sind seine Erträge verhältnismässig hoch und stellen sich denen des Kessingland-Weizens an die Seite.

Sechsjährige Durchschnittserträge ergaben in Poppelsdorf $2400 \mathrm{~kg}$ Korn und $5000 \mathrm{~kg}$ Stroh p. ha, in Eldena, Pommern, auf sandigem Lehmboden 2248 Korn, $3304 \mathrm{~kg}$ Stroh und $304 \mathrm{~kg}$ Spreu.

Das derbe, feste Stroh lagert nicht leicht, doch wird das Korn vou den Müllern nicht besonders hoch geschätzt.

Seine Kultur findet sich stellenweise in Nord-Deutschland verbreitet.

\section{Rheinischer-Kling-Weizen. (2)}

Aehre: fast weiss, mittcllang, sich ein wenig verjiingend, grannenspitzig, etwas in sich gebogen; Aehrchen 2- und 3-körnig. - Stroh: blassgelb, fest, mittellang. - Frucht: Original rot, glasig, einige gelbrot, mehlig, länglich, klein $\left(6^{1} / 4 \mathrm{~min}\right.$ lang, $3^{1} / 4 \mathrm{~mm}$ breit, 260 Friichte $=10 \mathrm{gr}$ ), feinschalig, halbhart, Bruch halbstahlig.

Herbstblatt dunkelgrün, feinblättrig, aufrecht; Entwickelung zeitig, 3 Schösslinge, Halme $125 \mathrm{~cm}$ (Max. $135 \mathrm{~cm}$ ) lang, $0.38 \mathrm{~cm}$ dick, Blattzahl 3.8, Blätter $26.3 \mathrm{~cm}$ lang, $1 \mathrm{~cm}$ dick, Blattfläche $199.9 \mathrm{qcm}$, Halmfläche 141.5 qcm, Gesammtfläche 342.4 qcm. 
Junge Aehre bläulich, mittelfriil reifend, nit 17 Aelrrchen und 45 Früchten, die ausserordentlich leicht ausfallen, und wobei durch das Aufspringen der Spelzen ein eigentiimlicher Klang (Klingweizen) sich hören lässt. Auf $1 \mathrm{hl}(=85.5 \mathrm{~kg})$ entfallen 2223000 Körner.

Landweizen am Mittel- und Niederrhein ziemlich rostfrei, nicht leicht lagernd, wenig ertragreich.

\section{Juli-Weizen. (2)}

Aehre: blassgelb, ziemlich locker, grannenspitzig, mittellang; Aehrchen 3- und 4-körnig, $1.5 \mathrm{~cm}$ breit, $1.2 \mathrm{~cm}$ hoch, schmal. - Stroh: blassgelb, fest, unter mittellang. - Fruclit: rotgelb, mehlig, viele rot und glasig, rundlich, klein (6 $\mathrm{mm}$ lang, $3^{3} /{ }_{4} \mathrm{~mm}$ breit, $3 \mathrm{~mm}$ dick; 283 Früchte $=$ $10 \mathrm{gr})$; feinschalig, halbhart.

Herbstblatt blaugriin, fein, niederliegend; Entwickelung mittelfrüh, 4 Schösslinge, zeitig schossend und bliihend; Halm $110 \mathrm{~cm}$ lang (Max. $130 \mathrm{~cm}$ ), $0.35 \mathrm{~cm}$ dick, Blattzahl 4, Blätter $23.3 \mathrm{~cm}$ lang, $0.8 \mathrm{~cm}$ breit, Blattfläche $149.1 \mathrm{qcm}$, Halmfläche $115.5 \mathrm{qcm}$, Gesammtfläche 264.6 qcnl. Junge Aehre gelbgrüu, mittelfriih reifend, $10 \mathrm{~cm}$ (Max. $13 \mathrm{~cm}$ ) lang, mit 13 Aehrchen und 55 Früchten.

Winterfest, leidet wenig durch Rost.

In Anhalt gezüchtet. (Kat. v. Metz \& Co. 1881 Herbst.)

\section{Hasselburger-Weizen. (2)}

Aehre: blassgelb, breit, dicht, mittellang; Aehrchen $1.4 \mathrm{~cm}$ breit, 3-körnig. - Stroh: rötlich-gelb, mittellang, fest. - Frucht: rotgelb, meist mehlig, gross $(6 \mathrm{~mm}$ lang, $4 \mathrm{~mm}$ breit, 220 Früchte $=10 \mathrm{gr}$ ), oval; etwas dickschalig, weich.

Herbstblatt fein, niederliegend; Entwickelung spät, 3.4 Schösslinge, spät schossend und bliihend; Halm $115 \mathrm{~cm}$ (Xax. $135 \mathrm{~cm}$ ) lang, $0.43 \mathrm{~cm}$ dick, Blattzahl 4.8, Blätter $23.6 \mathrm{~cm}$ lang, $1 \mathrm{~cm}$ breit, Blattfläche $226.6 \mathrm{qm}$, Halmfläche $148.4 \mathrm{qcm}$, Gesammttläche $375 \mathrm{qcm}$.

Junge Aehre bläulich, spät reifend̆, $11 \mathrm{~cm}$ (Max. $14 \mathrm{~cm}$ ) lang, mit 21 Aehrchen und 60 sehr fest sitzenden Früchten, von denen 1848000 auf $1 \mathrm{hl}(=81 \mathrm{~kg})$ entfallen.

Winterfest, fast rostfrei; nicht leicht lagernd, ertragreich.

Bezugsquelle: Wilh. Werner \& Co., Berlin.

\section{Weissspelziger-Winterweizen. (2)}

Aehre: fast weiss, sich verjüngend, etwas locker, lang; Aehrchen $1.4 \mathrm{~cm}$ breit, 2- und 3-körnig. - Stroh: Halme vor der Reife dunkelbraun, später gelb- und blaugrau, fest. - Original ziemlich hell, meist glasig; nachgebaut: gelbrot, mehlig, oder rot und glasig; kurz, rund $(6 \mathrm{~mm}$ lang, $4 \mathrm{~mm}$ breit); feinschalig, halbhart, Bruch halbstahlig.

Herbstblatt blaugriin, schınal, kraus; Friihjahrsvegetation spät, Bestockung mittelstark, 4.9 Schösslinge, spät schossend und blühend. Halmlänge $110 \mathrm{~cm}$ (Max. $130 \mathrm{~cm}$ ), Halmdicke $0.33 \mathrm{~cm}$, Blattzahl 3.7 , Blattlänge $26.18 \mathrm{~cm}$, Blattbreite $1.02 \mathrm{~cm}$, Blattoberfläche $232.51 \mathrm{qcm}$, Halmfläche $108.9 \mathrm{q} \mathrm{cm}$, Gesammtfläche $341.41 \mathrm{qcm}$.

Junge Aehre gelbgriin, spät reifend, $11 \mathrm{~cm}($ Мax. $15 \mathrm{~cm})$ lang, mit 
19 Aehrchen und 50 etwas lose sitzenden Früchten, von denen 1844000 auf $1 \mathrm{hl}(=82.3 \mathrm{~kg})$ entfallen.

Auf $1 \mathrm{qm}$ wachsen 1000 Halme oder 204 Pflanzen, mithin beträgt der Raum für eine Pflanze $49 \mathrm{qcm}$, die Blattfläche p. qm Bodenfläche $34 \mathrm{qm}$, und das Saatquantum $1.66 \mathrm{hl} \mathrm{p}$. ha.

Es wiegen 100 Halme 587 gr und davon die Früchte 242 gr.

Ziichter und Uebersender: Rimpau, Schlanstedt.

\section{Bundhorster-Mischweizen. (2)}

Aehre: gelb oder blassrot, doch Mehrzahl gelb, daher zu Triticum vulgare lutescens gehörig, dicht; Aehrehen $1.6 \mathrm{~cm}$ breit, 3- und 4-körnig. Stroh: rötlich-gelb oder gelb, blattreich, sehr stark und schön. - Frucht: Original hellgelbrot, mehlig; nachgcbaut: meist rot und glasig, wenige mehlig, in Poppelsdorf 3 Jahre hinter einander verschrumpft und mnvollkommen entwickelt, während die Kornqualität anderer Sorten von Tr. vulgare befriedigte; mittelgross (7 $\mathrm{mm}$ lang, $4 \mathrm{~mm}$ breit), sehr leicht, ( $1 \mathrm{hl}=76 \mathrm{~kg}$ und 235 Früchte wiegen $10 \mathrm{gr}$ ), dickschalig, halbweich.

Herbstblatt blaugrïn, breit, aufrecht. Frühjahrsvegetation spät, Bestockung schwach, 3.9 Schösslinge, spät schossend und blühend. Halmlänge $120 \mathrm{~cm}$ (Max. $150 \mathrm{~cm}$ ), Halmdicke $0.46 \mathrm{~cm}$, Blattzahl 4, Blattlänge $30.68 \mathrm{~cm}$, Blattbreite $1.25 \mathrm{~cm}$, Blattoberfläche $306.8 \mathrm{qcm}$, Halmfläche $165.6 \mathrm{qcm}$, Gesammtfläche eines Halmes $472.4 \mathrm{qcm}$.

Auf 1 qm wachsen 800 Halme oder 205 Pflanzen, demnach beträgt der Raum pro Pflanze $49 \mathrm{qcm}$, und die Blattfläche pro qm Bodenfläche $37.79 \mathrm{qm}$.

Junge Aehren meist bläulich-grün, wenige gelb-grün und rot reifend, $13 \mathrm{~cm}$ (Max. $17 \mathrm{~cm}$ ) lang, mit 22 Aehrelien und 70 ziemlich fest sitzenden Früchten. Spät reifend. Auf $1 \mathrm{hl}(=76 \mathrm{~kg})$ entfallen 1786000 Früchte, mithin sich die Saatquantität $(1 / 3$ Verlıst) auf $1.8 \mathrm{hl}$ p. ha stellt.

Es wiegen 100 Halme $700 \mathrm{gr}$ und davon die Früchte $220 \mathrm{gr}$.

Dieser Weizen ist gegen Lagern und Rost sehr widerstandsfähig, doch scheint er zur guten Fruchtreife eines temperierten Seeklimas zu bedürfen, wie er denn auch in Holstein auf mergelhaltigen Lehmböden gute Erträge bringen soll. Er erwies sich als echter Winterweizen.

Züchter dieses Weizens ist Graf von Dürkheim auf Bundhorst in Holstein. Verbreitet wurde der Weizen 1875 durch die Samenhandlung von Metz \& Co. in Berlin.

\section{Zwätzener (Jena) Sommerweizen. $\odot$}

A ehre: fast weiss, sich verjiingend, grannenspitzig, dicht; Aehrehen 2- und 3-körnig. - Stroh: goldgelb, fest. - Frucht: rot und glasig, wenige gelbrot und mehlig, klein $\left(6 \mathrm{~mm}\right.$ lang, $3 \frac{1}{2} / 2 \mathrm{~mm}$ breit, 280 Frïchte $=10 \mathrm{gr}$ ); halbhart, Bruch halbmehlig.

Halme dunkelgrün, Bestockung schwach, 2 Schösslinge, zeitig schossend und blühend. Halmlänge $125 \mathrm{~cm}(\operatorname{Max} .140 \mathrm{~cm})$, Halmdicke $0.28 \mathrm{~cm}$, Blattzahl 3, Blattlänge $20.7 \mathrm{~cm}$, Blattbreite $0.88 \mathrm{~cm}$, Blattoberfläche 109.3 qcm, Halmfläche $105 \mathrm{qcm}$, Gesammtfläche $214.3 \mathrm{qcm}$.

Auf 1 qm stehen 1200 Halme oder 600 Pflanzen, mithin beträgt 
der Raum für eine Pflanze $16.7 \mathrm{qcm}$ und die Blattfäche p. qm Bodenfläche $25.68 \mathrm{qm}$.

Junge Aehre blangrün, zeitig reifend, $10 \mathrm{~cm}$ lang (Max. $12 \mathrm{~cm}$ ), mit 18 Aehrchen und 45 etwas leicht ausfallenden Friichten, von denen 2332400 auf $1 \mathrm{hl}$ ( $=83.3 \mathrm{~kg}$ ) gehen, mithin sich das Aussaatquantum $(1 / 3$ Verlust) auf $3.9 \mathrm{hl}$ p. ha stellt.

Es wiegen 100 Halme $480 \mathrm{gr}$ und davon die Frïchte $150 \mathrm{gr}$.

Für leichtere Weizenböden scheint sich diese Sorte wohl zu empfehlen, zimmal sie widerstandsfähig gegen Rost ist und nur auf sehr reichem Boden lagert.

Uebersender: Prof. Dr. Oehmichen, Jena.

\section{SommerTeizen ron Angermünde. $\odot$}

Aehre: rötlich-weiss, locker, sich verjiingend und grannenspitzig, mittellang, etwas schmal; Aelirchen $1.5 \mathrm{~cm}$ breit, 2- und 3-körnig. Stroh: rötlich-gelb, von fester Textmr, fein. - Frucht: rot, glasig. klein, rundlich ( $6 \mathrm{~mm}$ lang, $3 \mathrm{~mm}$ breit); feinschalig, halbhart, Bruch halbstahlig.

Bestockung schwach, 2.3 Schösslinge, mittelfrüh schossend und bliihend. Halmlänge $107 \mathrm{~cm}$ (Max. $115 \mathrm{~cm}$ ), Halmdicke $0.33 \mathrm{~cm}$, Blattzahl 3,7, mittlere Blattlänge $26.5 \mathrm{~cm}$, Blattbreite $0.8 \mathrm{~cm}$, Blattoberfläche 156.88 q cm, Halmfläche $105.93 \mathrm{qcm}$, Gesammtfiäche eines Halmes $261.81 \mathrm{qcm}$.

Auf 1 qm wachsen 1000 Halme oder 435 Pflanzen, mithin pro Pflanze ein Ranm von $23 \mathrm{qcm}$ und eine Blattläche von $26.2 \mathrm{qm} \mathrm{p}$. qm Bodentläche enthält.

Junge Aehre gelbgriun, reifte in 121 Tagen (Poppelsdorf), $9 \mathrm{~cm}$ (Max. $10 \mathrm{~cm}$ ) lang, mit 14 Aehrchen und 10 ziemlich leicht ausfallenden Früchten, von denen $1 \mathrm{hl}(=84.3 \mathrm{~kg}), 2360000$ Früchte enthält, mithin sich das Saatquantum $(1 / 3$ Terlust) auf $2.8 \mathrm{hl}$ stellt.

Dieser vortreffliche Sommerweizen, dessen Ergiebigkeit und Qualität auf gutem Mergelboden sehr geschätzt wird, zeichnet sich durch seine Widerstandsfähigkeit gegen Lagern und Rost aus.

Es wiegen 100 Halme $470 \mathrm{gr}^{\circ}$ und davon die Früchte $160 \mathrm{gr}$.

\section{Goldradt-Sommerweizen. $\odot$}

Aehre: schwach, rötlich-gelb, sehr locker, $9 \mathrm{~cm}$ lang, mit $40 \mathrm{sehr}$ lose sitzender Früchten; Aehrchen 2-3-körnig. - Frucht: rot, glasig, klein ( $6 \mathrm{~mm}$ lang, $3 \mathrm{~mm}$ breit), feinschalig.

Im Königreich Sachsen gebaut.

\section{Sommerweizen ans der Eifel (Bitburg). $\odot$}

Aehre: blassgelb, sich stark verjüngend, grannenspitzig, schmal, kur'z, etwas locker, $7 \mathrm{~cm}$ lang mit 20 leiclit ausfallenden Früchten; Aehrchen 1 cm breit, meist 2-körnig. - Stroh: blassgelb, blattarn, feinhalmig, $10 \mathrm{~cm}$ lang. - Frucht: rot, glasig, klein (6 mm lang, $3 \mathrm{~mm}$ breit), feiuschalig.

Original im landw. Museum zu Berlin. 


\section{Yellow Lammas Wheat. (2)}

Syn.: Franz.: Blé Lamma.

Dentsch: Lammas Winterweizen mit gelben Aehren; gelber Angustweizen.

Aehre: gelb, geschlossen, gross; Aehrehcn meist 4-körnig, $2 \mathrm{~cm}$ hreit. - Stroh : gelb, kräftig, derbwandig. - Frucht: gelbrot, mehlig, zuweilen rot, glasig, gross ( $7 \mathrm{~mm}$ lang, $4 \mathrm{~mm}$ breit, 212 Körner $=10 \mathrm{gr}$ ), ziemlich feinschalig, weich.

Herbstblatt dunkelgriin, breit, aufrecht; Frühjahrsvegetation zeitig, Bestockung selır kräftig, 6 Schösslinge, mittelfriih schossend und blühend. Mittlere Halmlänge $135 \mathrm{~cm}$ (Max. $150 \mathrm{~cm})$, Halmdicke $0.38 \mathrm{~cm}$ : Blattzalıl 4.4, Blattlänge $24.3 \mathrm{~cm}$, Blattbreite $0.91 \mathrm{~cm}$, Blattoberfläche 192.83 $q \mathrm{c} \cdot \mathrm{m}$, Halmfläche $153.90 \mathrm{qcm}$, Gesammtfläche $346.73 \mathrm{qcm}$.

Auf $1 \mathrm{qm}$ kommen 860 Halme oder 140 Pflanzen, mithin beträgt der Raum pro Pflanze $71.4 \mathrm{q} \mathrm{cm}$, und die Blattfläche p. qm Bodenfläche $29.82 \mathrm{qm}$.

Junge Aehre gelbgrïin, mit bläulichem Anflug, mittelfrüh reifend, $11 \mathrm{~cm}$ (Nax. $15 \mathrm{~cm}$ ) lang, mit 20 Aehrchen und gegen 80 Friichten, die nicht in der Gelbreife, wohl aber in der Vollreife leicht ausfallen.

Es entliält $1 \mathrm{hl}$ (= $82.7 \mathrm{~kg}) 1753000$ Früchte, mithin sich das Saatquantum $(1 / 3$ Verlust $)$ auf $1.5 \mathrm{hl}$ p. ha stellt.

Es wiegen 100 Halme $620 \mathrm{gr}$ und davon die Früchte $226 \mathrm{gr}$.

Dieser Weizen ist in Grossbritannien und Nord-Frankreich für mittlere und selbst noch fïr geringere Weizenböden sehr geschätzt.

Für Deutschland scheint er zu weichlich zn sein, denn in Poppelsdorf war er nicht ganz winterfest.

Er liefert namentlich reiche Stroherträge, lagert dabei nicht leicht und besitzt gegen Rost eine bedeutende Wilerstandsfähigkeit.

Dieser Weizen ist eine sehr alte cnglische Sorte, die schon Mor is on, hist. pl. oxon. tom III, anno 1699 pg. 175 sect. 8. wie folgt, beschreibt: "Trit. Spica mntica albicante granis rufescentibus sive Trit. mixtum: Mixt Lammas Wheat."

Den Namen "Lammas" scheint er in Schottland erlalten zu haben, denn der Name bedeutet dort „Petri-Kettenfeier", welche auf den 1. Angust fällt, zu einer Zeit, in welcher für gewölnnlich dieser Weizon in Schottland reift.

\section{Red strawed Wheat. (2)}

Aehre: blassgelb, sehr lang, sich wenig verjïingend, geschlossen; Aehrchen $1.7 \mathrm{~cm}$ breit, meist 3-körnig. - Stroh: gegen die Reife lin erhält es eine schöne rote Farbc, etwas weich. - Frucht: meist gelbrot und mehlig, wenn glasig, so rot, kmrz, dick, rund (6 mm lang, $4 \mathrm{~mm}$ breit, 172 Früchte $=10 \mathrm{gr}$ ), etwas grobschalig; weich.

Herbstblatt blaugrün, schmal, kraus, schwach behaart; Friihjahrsvegetation zeitig, Bestockung schwach, 3.3 Sclı̈sslinge, zeitig schossend und bliihend. Halmlänge $120 \mathrm{~cm}$ (Max. $150 \mathrm{~cm}$ ), Halmdicke $0.43 \mathrm{~cm}$, Blattzahl 3.7, Blattlänge $21.8 \mathrm{~cm}$, Blattbreite $1.07 \mathrm{~cm}$, Blattoberfläche $172.64 \mathrm{qcm}$, Halmfläche $154.8 \mathrm{qcm}$, Gesammtfläche eines Halmes $327.44 \mathrm{qcm}$.

Es zählen sich p. qu 900 Ifalme oder 280 Pflanzen aus, mithin 
betrïgt der Raum für eine Pflanze 35.9 q cm, und die Blattfläche p. qm Bodenfläche $29.43 \mathrm{qm}$.

Junge Aehre blaugriin, mittelfrïh reifend, $11 \mathrm{~cm}$ (Max. $15 \mathrm{~cm})$ lang, mit 22 Aehrchen und 60 Früchten.

In $1 \mathrm{hl}(=83 \mathrm{~kg})$ zählen sich 1427600 Friichte aus, mithin betrïgt das Saatquantum $3 \mathrm{hl} \mathrm{p}$. ha.

Es wiegen 100 Halme $911 \mathrm{gr}$ und davon die Friichte $350 \mathrm{gr}$.

Dieser Weizen erwies sich in Poppelsdorf nicht als winterfest, auch zeigte er Neigung zum Lagern, und litt ziemlich stark durch Rost.

In England auf guten Weizenböden häufig gebaut und seines hohen Ertrages und guten Mehles wegen geschätzt. Uelrigens ist er eine alte englische Sorte, so beschreibt ihn schon Mo r is on, Professor der Botanik zu Oxford, 1699 in seiner hist. pl. oxon. tom. III sect. 8 pg. 175 wie folgt: Wheat."

„Trit. culmo rubro aut purpurescente, granis rubris. Red strawed

\section{Hallet's Pedigree red Wheat ${ }^{1}$ ). (2)}

Deutsch: Hallet's Stammbaum, genealogischer oder Pedigree-Weizen.

Franz.: Blé généalogique, Blé géant.

Aelure: fast weiss, lang, etwas locker, sich wenig verjiingend, breit; Aelircheu sehr breit (2 cm), 3-körnig. - Stroh: gclb-rötlich, blattreich, dickwandig, lang. - Frucht: Original goldgelb, meist mehlig, plump, gross ( $7 \mathrm{~mm}$ lang, $4 \mathrm{~mm}$ breit, 203 Friichte $=10 \mathrm{gr}$ ), nachgebaut: etwas glasiger, sonst konstant; ein wenig dickschalig; Bruch halbmehlig, weich.

Herbstblatt blaugrün, kräftig, etwas niederliegend; Frühjahrsvegetation mittelfrüh; Bestockung stark, 5 Schösslinge (bci 100 qcm Wachsraum 12 Schösslinge).

Halm $140 \mathrm{~cm}$ (Max. $175 \mathrm{~cm}$ ) lang, $0.4 \mathrm{~cm}$ dick, Blattzahl 3.3, Blätter $30.15 \mathrm{~cm}$ lang, $1.19 \mathrm{~cm}$ breit; Blattoberfläche $236.81 \mathrm{qcm}$, Halmfläche 168 qcm, Gesammtfläche 404.81 qcm.

Spät schossend und blühend; auf 1 ha wachsen 1.42 Millionen Pflanzen, mithin beträgt das Saatquantum, da 1624000 Körner auf $1 \mathrm{hl}$ $(=80 \mathrm{~kg})$ entfallen, $1.2 \mathrm{hl}$.

Junge Aehre bläulich-griin, spät reifend, $13 \mathrm{~cm}$ (Max. $15 \mathrm{~cm}$ ) lang, mit 24 Aehrchen und bis 70 leicht ausfalienden Frücliten.

Es wiegen $100 \mathrm{Halme} 630 \mathrm{gr}$ und davon die Früchte $230 \mathrm{gr}$.

Die Erträge stellen sich auf reichen Böden und inı feuchten, milden Klima selir hoch, auch lagert er nicht leicht und ist gegen Rost ziemlich widerstandsfähig. Leider driickt die Kleberarmut des Kornes die Qualität des Mehles, das für sich allein kaum verbackbar ist, sehr lierunter. In Poppelsdorf winterte er 1870 vollständig aus, ist also gegen ungünstige Witterung einpfindlich.

Nur unter den güinstigsten klimatisehen und Boden-Verhältnissen artet er nicht aus und bringt seine geriihmten lohen Erträge, so erntete L a w es in Rothansted unter glcichen Boden- und Kulturverliältnissen p. ha.

1873

$32.74 \mathrm{hl}$
1874

39.26 lil
1875

$23.40 \mathrm{hl}$
1878 durchschnittlich

$36.11 \mathrm{hl} \quad 32.88 \mathrm{hl}$.

1) On "Perligree" in Wheat, Journ. of the Roy. Agric. Soc. 1861, 
und in Poppelsdorf anf kulturvollem, mildem Lehmboden wurden 1873 p. ha geerntet:

Drillweite $31.4 \mathrm{~cm}, 2350 \mathrm{~kg}$ Korn, $3917 \mathrm{~kg}$ Stroh, $783 \mathrm{~kg}$ Spreu. " 15.7 " 2068 " " 2900 , , 815 " "

"F. Hallet, Manorhouse, Brighton, ziichtete ihn 1857, „. h. "verbesserte ihn durcl Innzucht, indem er die zwei besten Aehren des von ihm gebauten Weizens heraussuchte, aus diesen die besten und feinschaligsten Früchte entuahm und in so weiten Entfernungen ansdibbelte, dass sich die Pflanzen selır vollkommen entwickehn nnd stark bestocken konnten.

Durch dieses Verfahren wurden in den ersten Jahren nachfolgende Resultate crzielt:

\section{Länge der Aehren. Zahl der Körner Zahl der Aehren.} in der Aehre.

$\begin{array}{rrrr}1857 & 11.44 \mathrm{~cm} & 47 & - \\ 58 & 16.34 & 79 & 10 \\ 59 & 20.27 & 94 & 17\end{array}$

60 wegen zu nasser Witterung unvollkommen entwickelt.

$61 \quad 22.28 \mathrm{~cm} \quad 123 \quad 52$.

Durch sorgfåltigc Auswahl des Saatgntes bei sehr giinstigen Boden- und Kulturverhältnissen sind sehr robustc Pflanzen, mit reicher Bestockung nnd langen, jedoch lockeren Aehren crzeugt worden. Sind aber nicht alle Verhältnisse dicsem Weizen sehr gïnstig, so degeneriert er ausserordentlich schnell.

Diese Weizensorte wird vielfach, ausser in Eugland, auf den reichen Weizenböden Nord-Deutschlands nnd Nord-Frankreichs gebant, anch sind in Ober-Italicn Versuche mit ihrer Kultur angestellt worden.

\section{Shiriff's Square-headed-Wheat. (2)}

\section{Syn.: Blé à ćpi carré Vilm., Blé de Scholey.} Dänischer Weizen von Bogense.

Aehre: blassgelb, schr dicht, kmrz, die zweizeilige Seite füllt durch ihre Brcitc sehr in's Auge, wie Hickling Uebergang zil den Binkelweizen bildend, ein wenig grannenspitzig; Aelurchen $1.8 \mathrm{~cm} \mathrm{breit,} \mathrm{3-,} \mathrm{4-} \mathrm{und} \mathrm{5-}$ körnig. - Stroh: rötlich-gelb, mittellang, sehr fest und steif. - Frncht: Original meist rot und glasig, wenige gelbrot und mehlig, oval, $61 / 2 \mathrm{~mm}$ lang, $4 \mathrm{~mm}$ breit, 218 Friichte $=10 \mathrm{gr}$; nachgebant: fast konstant; ziemlich feinschalig, halbweich, Bruch halbmelılig.

Herbstblatt dunkelgrüin, anf beiden Seiten relativ stark behaart, ziemlich breit, aufrecht; Frühjahrsvegetation mittelfriih; Bestocknng schwach, 3 Schösslinge, etwas spät schossend nud bliihend. Halme $115 \mathrm{~cm}$ (Hax. $160 \mathrm{~cm}$ ) lang, $0.4 \mathrm{~cm}$ dick, Blattzahl 4.5 , Blätter $20.6 \mathrm{~cm}$ lang, $1.1 \mathrm{~cm}$ breit, Blattfläche $203.9 \mathrm{qcm}$, Halmfläche $138 \mathrm{qcm}$, Gesammtfläche $341.9 \mathrm{qcm}$.

Auf 1 ha wachsen 2 Millionen Pflanzen, mithin beträgt das Saatquantum, da auf $1 \mathrm{hl}(=84 \mathrm{~kg}) 1831200$ Früchte entfallen, $1.6 \mathrm{hl}$ bei Drillsaat.

Junge Aehre blänlich-grün, mittelfrüh reifend, $8.5 \mathrm{~cm}$ (Max. $11 \mathrm{~cm}$ ) lang mit 21 Aehrehen nnd 75 festsitzcnden Frïclten.

Es wiegen 100 Halme $822 \mathrm{gr}$ nnd davon die Früchte $346 \mathrm{gr}$.

Dieser schöne Weizen wintertc in Poppelsdorf nicht ans, lagerte 
nicht, und zeigte sich fast rostfrei; doch sind seine Ansprüche an den Boden und die Kulturverhältnisse hoch, und scheint derselbe namentlich für reiche Böden im Seeklima vortrefflich geeignet zu sein; in Schottland, England, Dänemark und auch in Deutschland (Schleswig-Holstein, Rheinprovinz), bringt er sehr hohe Erträge, welche sich nach verschiedenen glaubwürdigen Angaben ${ }^{1}$ ) für Dänemark auf 38.84 hl und für Deutschland auf $31.88 \mathrm{hl}$ stellen sollen, bei guter Qualität der Körner; daher bei Müllern und Bäckern beliebt. Züchter dieses Weizens ist: Mr. Samnel D. Shiriff, Saldcoats, Drem, Haddingtonshire, Schottland.

In den trocknen Distrikten Süd-Australiens, wo dieser Weizen ebenfalls zum Anbau gelangt, wird das Korn kleiner, länglicher und unansehnlicher.

Uebersender: Mr. Shiriff.

\section{Hickling's prolific Wheat. (2)}

Syn.: Engl.: King William, Thick-set, Incledon's prolifie, Courtney's six rowed Chevalier, Norfolk ${ }^{2}$ ).

Franz.: Blé Hickling.

De utsch: Hickling's ergiebiger Weizen.

Aelıre: blassgelb, quadratisch, sehr dicht, kurz, grannenspitzig, Uebergang zum Binkelweizen bildend. Aelirchen $1.6 \mathrm{~cm}$ breit, 3- und 4körnig. - Stroh: rötlich-gelb, mittellang, fest. - Frucht: gelbrot, meist rot und glasig, rundlich, mittelgross (6 mm lang, $4 \mathrm{~mm}$ breit), leicht, etwas grobschalig, halbhart, Bruch halbiuehlig.

Herbstblatt blaugriin, ziemlich breit, beiderseits schwach behaart; Friihjalırsvegetation ziemlich zeitig, Bestockung mittelstark 3.8 Schösslinge, mittelfriih schossend und bliihend. Halnlänge $130 \mathrm{~cm}$ (Max. $165 \mathrm{~cm}$ ), Halm dicke $0.44 \mathrm{~cm}$, Blattzalıl 4, Blattlänge $30 \mathrm{~cm}$, Blattbreite $1.17 \mathrm{~cm}$, Blattoberfläche $280.8 \mathrm{qcm}$, Halmfläche $171.6 \mathrm{qcm}$, Gesammtfäche $452.4 \mathrm{qcm}$.

Junge Aehre gelbgrün, mittelfrüh reifend, $7 \mathrm{~cm}$ (Max. $10 \mathrm{~cm}$ ) lang, mit 24 Aehrchen und 73 festsitzenden Früchten, von denen 1716780 auf $1 \mathrm{hl}(=80.6 \mathrm{~kg})$ gehen.

Es wachsen auf 1 qm 830 Halme oder 218 Pflanzen, mithin beträgt der Raum für eine Pflanze $46 \mathrm{qcm}$, die Blattfäche $\mathrm{p}$. qm Bodenfläche $37.6 \mathrm{qm}$, und das Saatquantum $2 \mathrm{hl}$ p. ha.

Es wiegen 100 Halme $850 \mathrm{gr}$ und davon die Früchte $211 \mathrm{gr}$.

Dieser Weizen ist nicht winterfest und leidet leicht, so erfror derselbe 1870/71 vollständig; auch zeigte er sich auf reichem Boden gegen Lagern und Rost wenig widerstandsfähig. Im Allgemeinen degeneriert auf kulturvollem Boden diese Sorte leicht, in welchem Falle die Aehren länger, lockerer und schlaffer werden, wie dies sein Abkömmling, der Blé du Mesnil St. Firmin, zeigt.

Er wird vielfach in Grossbritannien und Irland, in Nord-Frankreich und in Deutschland, und zwar vorzugsweise häufig in Westpreussen, Pommern, Brandenburg und Schlesien angebaut.

In milden Klina und auf reichem Boden bringt er reiche Erträge, doch befriedigen dieselben anch noch auf nicht ganz kulturlosen und

1) Jensen. Landsmands-Blade, übersetzt durch die deutsche Landw. Presse II. Jahrg. No. 75 und Biedermann's Centralbl. 1878, Heft 1.

2) Vergl. P. I, awson, Synops, of the reget. products of Scotl. 1852. 
genügend feuchten Sandböden. In Poppelsdorf erwies er sich als echter Winterweizen, weshalb „Blé Hickling de Mars" wohl von ihm stammt, doch nicht identisch ist.

Züchter ist: Samuel Hickling, welcher 1830 zu Cawston bei Aylsham, Norfolk drei Weizenpflanzen fand, aus denen er seinen Hickling's prolific erzog.

\section{Kessingiand-Wheat. (2)}

Deutsch: Kessingland-Weizen.

Französisch: Blé doré ou Victoria rose.

Aehre: blassgelb, viereckig, ziemlich dicht geschlossen, lang. Aehrchen sehr breit ( $2 \mathrm{~cm}), 3$ - und 4-körnig. - Stroh: gelb, über mittellang, kräftig, derbwandig, fest. - Frucht: Original gelbrot, mehlig, doch traten nach einigen Ernten oft glasige Früchte auf, mittelgross, rundlich, (6 $\mathrm{mm}$ lang, $4 \mathrm{~mm}$ breit), etwas dickschalig, weich.

Herbstblatt schmal, teilweis niederliegend, kraus, blaugrün; Frühjahrsvegetation sehr spät eintretend; Bestockung stark, 4.7 Schösslinge, absolute Bestockungsfähigkeit bei $100 \mathrm{qcm}$ Raum 11.8 Schösslinge. Halm $120 \mathrm{~cm}$ (Max. $200 \mathrm{~cm}$ ) lang, $5 \mathrm{~cm}$ dick, also sehr starkhalmig; Blattzahl 4.7, Blätter $27.18 \mathrm{~cm}$ lang, $1.21 \mathrm{~cm}$ breit, Gesammtoberfläche beider Seiten $309.17 \mathrm{qcm}$, Halmfläche $180 \mathrm{qcm}$, Gesammtfläche $489.17 \mathrm{qcm}$. Auf $1 \mathrm{qm}$ wachsen 640 Halme oder 136 Pflanzen, mithin jede Pflanze einen Raum von $73.5 \mathrm{qcm}$ eimnimmt und auf $1 \mathrm{qm}$ Bodenfläche $31.3 \mathrm{qm}$ Blattfläche entfallen.

Junge Aehre blaugrün, $12 \mathrm{~cm}$ (Max. $15 \mathrm{~cm}$ ) lang, mit 18 Aehrchen und 65 fest in den Spelzen sitzenden Friichten, weshalb sich dieser Weizen schwer mit dem Flegel drischt, aber bei Wind in der Vollreife nicht ausfällt. Reift spät. Das Hektolitergewicht beträgt $82.3 \mathrm{~kg}$ und $1 \mathrm{hl}$ enthält 1711840 Körner, da sich nun 1360000 Pflanzen p. ha berechmen lassen, und unter der Annahme, dass sich 67 Proc. der Samenkörner entwickeln, wird an Saatgut $1.2 \mathrm{hl}$ p. ha gebraucht.

Seine Vorzüge gipfeln in den sehr hohen Korn- und Stroherträgen; so stellen sich z. B. die 5jährigen Durchschnittserträge in Poppelsdorf auf $2417 \mathrm{~kg}$ Korn, $5124 \mathrm{~kg}$ Stroh, $841 \mathrm{~kg}$ Spreu p. ha, in dem kräftigen sich nicht leicht lagernden und gegen Rost widerstandsfähigen Stroh, sowie in den nicht hohen Bodenansprïchen, da sich selbst noch auf sandigem, gut geduingtem Lehmboden hohe Erträge erzielen lassen. Die Nachteile liegen in der geringen Qualität des Kornes, dass sich auffallend kleberarm erweist, und in dem leichten Auswintern; so kamen 1868 in Eldena und 1870 in Poppelsdorf nur wenige kümmerliche Pflanzen durch den Winter, wenngleich dieser Nachteil durch die hohen Erträge in günstigen Jahren annähernd ausgeglichen wird. Es wiegen 100 Halme $490 \mathrm{gr}$ und davon die Früchte $213 \mathrm{gr}$.

Er wird ausser in England ziemlich stark in der Provinz Sachsen, in Pommern, am Rhein und in Frankreich gebaut.

\section{White Golden-Drop. (2)}

Deutsch: Weissähriger Goldtropfen.

Verbesserte Form: Webb's selected Golden-Drop wheat.

Aehre: weiss, lang, etwas locker; Aehrchen $1.8 \mathrm{~cm}$ breit, meist 3-körnig. - Stroh: blassgelb, mittellang. - Frucht: gelbrot, mehlig, grobschalig, gross, rundlich (7 $\mathrm{mm}$ lang, $4 \mathrm{~mm}$ breit), weich. 
Herbstblatt schmal, fast niederliegend, blaugrün; Bestockung schwach, 3.3 Schösslinge, mittelfrüh schossend und blühend. Halmlänge $120 \mathrm{~cm}$ (Max. $140 \mathrm{~cm}$ ), Halmdicke $0.43 \mathrm{~cm}$, Blattzahl 4, Blattlänge $29.58 \mathrm{~cm}$, Blattbreite $1.18 \mathrm{~cm}$, Blattoberfläche eines Halmes $279.2 \mathrm{qcm}$, Halmoberfläche $154.8 \mathrm{qcm}$, Gesammtfläche $434 \mathrm{qcm}$.

Junge Aehre blaugrün, mittelfrüh reifend, $11 \mathrm{~cm}$ laug ( $(1 a x .15 \mathrm{~cm}$ ), mit 20 Aehrchen und 50 fest sitzenden Friichten, von denen 1465000 auf $1 \mathrm{hl}(=84.2 \mathrm{~kg})$ gehen.

Auf 1 qm können 700 Halme oder 210 Pflanzen wachsen, mithin beträgt der Raum für eine Pflanze $50 \mathrm{qcm}$, die Blattläche p. qm der Bodenfläche $30.33 \mathrm{qm}$ und das Saatquantum (1/3 Verlust) $2.1 \mathrm{hl}$ p. ha.

Es wiegen 100 Halme $850 \mathrm{gr}_{\mathrm{r}}$ und davon die Früchte $290 \mathrm{gr}$.

Da das Mehl kleberarm, das blattreiche, weiche Stroh zu sehr dem Rost und Lagern ausgesetzt und iiberdem der Weizen nicht winterfest ist, so schwindet in Deutschland scine Kultur mehr und mehr, obwohl er auf nahrungsreichen Böden recht hohe Erträge zu liefern vermag.

Seine Heimat ist England, und fand ihn $1 \$ 34$ Mr. Gorrie zwischen anderem Weizen auf einem Felde vor und kultivierte ihn weiter.

In neuerer Zeit durch den englischen Samenbändler Webb verbessert, und als "Selected Golden Drop Wheat" in den Handel gebracht.

\section{Doweston's new Wheat. (2)}

Syn.: Doweston's neuer Weizen.

Aehre: blassrötlichgelb, sich nach der Spitze verjüngend, mitteldicht, schlank; Aehrchen $1.6 \mathrm{~cm}$ breit, meist 3-körnig. - Strolı: rötlich-gelb, kräftig, blattreich, fest. - Frucht: hellrot, glasig, sehr wenige mehlig und gelbrot, schön, länglich $\left(7 \mathrm{~mm}\right.$ lang, $3^{1} / 2 \mathrm{~mm}$ breit, 234 Früchte $=$ $10 \mathrm{gr}$ ), sehr schwer, feinschalig, halbhart, Bruch balbstahlig.

Herbstblatt gelbgriin, kräftig, ziemlich aufrecht, beiderseits schwach behaart; Frühjahrssegetation mittelfrüh, Bestockung stark, 5.5 Schösslinge, mittelfriih schossend und blühend. Halmlänge $130 \mathrm{cnı}$ ( (Yax. $150 \mathrm{~cm}$ ), Halmdicke $0.4 \mathrm{~cm}$, Blattzahl 4, Blattlänge $25.3 \mathrm{~cm}$. Blattbreite $0.85 \mathrm{~cm}$, Blattoberflïche $172.04 \mathrm{qcn}$, Halmđläche $156 \mathrm{qcm}$, Gesammtfläche eines Halmes $328.04 \mathrm{q} \mathrm{cm}$.

Auf $1 \mathrm{qm}$ entfallen 900 Halme oder 164 Pflanzen, demnach beträgt der Raum pro Pflanze $61 \mathrm{qcm}$, und die Blattfläche pro q1n Bodenfläche $29.52 q \mathrm{~m}$.

Junge Aehre blaugrün, mittelfrüh reifend, $9 \mathrm{~cm}$ (Max. $13 \mathrm{~cm}$ ) lang, mit 20 Aehrchen und 60 nicht leicht ausfallenden Früchten, von denen

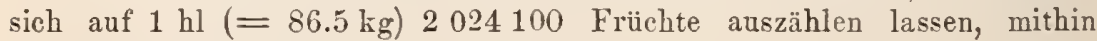
die Saatquantität $1.2 \mathrm{hl} \mathrm{p}$. ha beträgt.

Es wiegen 100 Halme $680 \mathrm{gr}$ und davon die Früchte $233 \mathrm{gr}$.

In Poppelsdorf zeigte sich dieser Weizen winterfest, auch widerstandsfähig gegen Lagern und Rost, so dass derselbe, bei den vortrefflichen Eigenschaften seiner Früchte, für gute Lehmböden höchst beachtenswert erscheint.

Die Heimat ist England; nach Poppelsdorf sandte ihn der ök.-bot. Garten zu Halle. 


\section{Farwer's Wheat, (2)}

Syn.: Deutsch: Farwer's Winterweizen.

Aehre: gelb, bisweilen rötlich, sich etwas verjüngend, locker, schmal; Aehrchen $1.5 \mathrm{~cm}$ breit, 2 und 3-körnig. - Stroh: rötlich-gelb, dünnwandig, weich. - Frucht: gelbrot, mehlig, rundlich ( $6 \mathrm{~mm}$ lang, $4 \mathrm{~mm}$ breit) etwas grobschalig, weich.

Herbstblatt blaugrün, kraus, schmal; Blätter beiderseits schwach behaart, Frïhjahrsvegetation spät; Bestockung stark, 5.1 Schösslinge, mittelfrüh schossend und bliihend.

Halmlänge $120 \mathrm{~cm}$ (Max. $175 \mathrm{~cm}$ ), Halmdicke $0.38 \mathrm{~cm}$, Blattzahl 3.3, mittlere Blattlänge $25,9 \mathrm{~cm}$, Blattbreite $0.98 \mathrm{~cm}$, Blattoberfläche $167.84 \mathrm{qcm}$, Halmfläche 136.8 qcm, Gesammtfläche eines Halmes $304.64 \mathrm{qcm}$.

Auf $1 \mathrm{qm}$ wachsen 900 Halme oder 176 Pflanzen, mithin beträgt der Raum pro Pflanze $57 \mathrm{qcm}$ und die Blattfläche pro qm Bodenfläche $27.42 \mathrm{qm}$.

Junge Aehre gelbgriin, mittelfriih reifend, $12 \mathrm{~cm}$ (Max. $17 \mathrm{~cm}$ ) lang, nit 20 Aehrchen und 50 etwas leicht ausfallenden Früchten.

Es wiegt $1 \mathrm{hl}=83 \mathrm{~kg}$ und enthält 1881000 Früchte, demnach ist ein Saatquantum von $1.4 \mathrm{hl}$ p. ha erforderlich.

In Poppelsdorf erwies sich dieser Weizen als vollständig winterfest, doch gegen Lagern und Rost wenig widerstandsfähig. In England and Holstein soll er vielfach auf gutem Lehmboden gebaut werden.

\section{Mummy-Wheat. (2)}

Franz.: Blé Mummy.

Deusch: Mumien-Weizen.

Aehre: fast weiss, quadratisch, dicht, kurz; Aehrchen 3-körnig, $1.7 \mathrm{~cm}$ breit. - Stroh: gelb, derbwandig, steif, mittellang. - Frucht: gelbrot und mehlig, zuweilen rot und glasig, oval $(7 \mathrm{~mm}$ lang, $4 \mathrm{~mm}$ breit), feinschalig, halbweich, Bruch halbmehlig.

Herbstblatt blaugrün, schmal, ziemlich anfrecht; Friibjahrsvegetation mittelfrüh, Bestockung schwach, 3.6 Schösslinge, mittelfrül schossend und blühend. Halmlänge $120 \mathrm{~cm}$ (Max. $140 \mathrm{~cm}$ ), Halmdicke $0.4 \mathrm{~cm}$, Blattzahl 3.3, Blattlänge $28.58 \mathrm{~cm}$, Blattbreite $1.04 \mathrm{~cm}$, Blattoberfläche $196.15 \mathrm{qcm}$, Halmfläche $144 \mathrm{qcm}$, Gesammtfläche $340.15 \mathrm{qcm}$.

Junge Aehre gelbgrün, mittelfrüh reifend, $8 \mathrm{~cm}$ (Max. $11 \mathrm{~cm}$ ) lang, mit 18 Aehrchen und 52 nicht leicht ausfallenden Früchten, von denen 2000000 auf $1 \mathrm{hl}(=80 \mathrm{~kg})$ gehen.

Auf $1 \mathrm{qm}$ wachsen 850 Halme oder 236 Pflanzen, mithin beträgt der Raum für eine Pflanze $42.4 \mathrm{qcm}$, die Blattoberfläche pro qm Bodenfläche $2.9 .9 \mathrm{qm}$ und das Saatquantum $1.8 \mathrm{hl}$ p. ha.

Dieser Weizen lagert nicht leicht, ist aber nicht winterfest.

Heimat: England.

\section{Hartswood's-Wheat (2)}

Aehre: blassgelb, sich stark verjüngend, grannenspitzig, dicht; Aehrchen $1.7 \mathrm{~cm}$ breit, meist 3-körnig. - Stroh: gelb und blaugrün, kräftig. - Frucht: meist rot und glasig, wenige gelbrot und mehlig, 
klein $\left(6^{1} / 2 \mathrm{~mm}\right.$ lang, $3^{1} / 2 \mathrm{~mm}$ breit, 230 Früchte $\left.=10 \mathrm{gr}\right)$, feinschalig, halbhart, Bruch halbmehlig.

Herbstblatt dunkelgrün, lang, aufrecht; Frühjahrsvegetation spät, Bestockung sehr stark, 7.5 Schösslinge, spät schossend und blühend. Halmlänge $120 \mathrm{~cm}$ (Max. $140 \mathrm{~cm}$ ), Halmdicke $0.4 \mathrm{~cm}$, Blattzahl 4, mittlere Blattlänge $24.5 \mathrm{~cm}$, Blattbreite $1.0 \mathrm{~cm}$, Blattoberfläche $196 \mathrm{qcm}$, Halmfläche $144 \mathrm{qcm}$, Gesammtfläche eines Halmes $340 \mathrm{qcm}$.

Auf $1 \mathrm{qm}$ entfallen 900 Halme oder 120 Pflanzen, also an Raum pro Pflanze $83.3 \mathrm{qcm}$, und an Blattfläche pro qm Bodenfläche $30.6 \mathrm{qm}$.

Junge Aehre gelbgruin, mit braunen oder gelben Staubbeuteln, spät reifend, $9 \mathrm{~cm}$ (Мax. $15 \mathrm{~cm}$ ) lang, mit 20 Aehrchen und 60 etwas lose sitzenden Friichten.

In $1 \mathrm{hl}(=85 \mathrm{~kg})$ sind 1955000 Früchte enthalten, mithin das Saatquantum (1/3 Verlust) $0.9 \mathrm{hl}$ pro ha ausmacht.

Es wiegen 100 Halme $570 \mathrm{gr}$ und davon die Friiclite $202 \mathrm{gr}$.

Dieser Weizen verlangt einen reichen Boden, ist gegen ıngünstige Witterung recht widerstandsfähig und ebenso gegen Lagern und Rost.

Die urspriingliche Heimat ist England.

Aus dem ök.-bot. Garten zu Halle erhalten.

\section{Golden-Swan. (2)}

Aehre: rötlich-weiss, sich verjüngend, locker, dünn; Aehrehen $1.5 \mathrm{~cm}$ breit, 2-3-körnig. - Stroh: gelb oder graublau, kräftig. - Frucht: gelbrot und mehlig, oder rot und glasig, klein ( $6 \mathrm{~mm}$ lang, $31 / 2 \mathrm{~mm}$ breit), feinschalig, halbweich, Bruch halbmehlig.

Herbstblatt blaugriill, kraus, Blätter beiderseits äusserst schwach behaart; Frühjahrsvegetation mittelfriill, Bestockung stark, 6 Schösslinge, spät schossend lund blühend. Halmlänge $125 \mathrm{~cm}$ (Max. $150 \mathrm{~cm}$ ), Halmdicke $0.42 \mathrm{~cm}$, Blattzahl 4, Blattlänge $30.3 \mathrm{~cm}$, Blattbreite $1.04 \mathrm{~cm}$. Blattoberfläche $378.14 \mathrm{qcm}$, Halmfläche $157.5 \mathrm{qcm}$, Gesammtfläche $535.64 \mathrm{qcm}$.

Auf $1 \mathrm{qm}$ kommen 780 Halme oder 125 Pflanzen, mithin stellt sich pro Pflanze der Raum auf $80 \mathrm{qcm}$ und die Blattfäche pro qm Bodenfläche auf $40.2 \mathrm{qm}$.

Junge Aehre blaugrün, spät reifend, $12 \mathrm{~cm}($ Мax. 15 cm) lang, mit 20 Aehrchen und 50 etwas lose sitzenden Frïchten.

Es enthält $1 \mathrm{hl}(=79 \mathrm{~kg}) 1659000$ Früchte, demnach beträgt das Saatquantum $1.1 \mathrm{hl}$ pro ha.

Es wiegen 100 Halme $533 \mathrm{gr}$ und davon die Früchte $191 \mathrm{gr}$.

Dieser englische Weizen verlangt einen kräftigen reichen Boden, wenn er ergiebig sein soll.

Das Stroh ist dem Lagern, doch wenig dem Rost ausgesetzt.

Aus dem ök.-bot. Garten zu Halle erhalten.

\section{Langley's red. (2)}

Aehre: blassgelb, sich stark rerjüngend und grannenspitzig, $15 \mathrm{~cm}$ lang, mit 65 ziemlich leicht ausfallenden Früchten, Aehrehen $1.5 \mathrm{~cm}$ breit, meist 3-körnig. - Stroh: rötlich-gelb, sehr blattreich, kräftig, $130 \mathrm{~cm}$ lang. - Frucht: rot, glasig, klein ( $6 \mathrm{~mm}$ lang, $3 \frac{1}{2} \mathrm{~mm}$ breit), feinschalig.

Original im landw. Museum zu Berlin. 


\section{Allerton-Wheat. (2)}

Aehre: fast weiss, dicht, sich wenig verjüngend, etwas grannenspitzig, bei $9 \mathrm{~cm}$ Länge 60 Fruichte enthaltend; Aehrchen $1.5 \mathrm{~cm}$ breit, 3-körnig. - Stroh: weiss. - Frucht: rötlich-gelb, mehlig, fast kuglig, klein (6 mm lang, $4 \mathrm{~mm}$ breit), ziemlich feinschalig.

Original in der Sammlung des Dr. Dreisch zu Poppelsdorf.

\section{Woodley's superb. (2)}

Aehre: blassgelb, ziemlich dicht, bei $13 \mathrm{~cm}$ Länge 70 etwas lose sitzende Früchte entbaltend; Aehrchen $2 \mathrm{~cm}$ breit, meist 4-körnig. - Stroh: gelb, blattreich, bis $150 \mathrm{~cm}$ lang, $4 \mathrm{~cm}$ dick, weich. - Frucht: Original gelbrötlich, mehlig, doch viele rot und glasig, klein, rundlich, (6 $\mathrm{mm}$ lang, $3 \mathrm{~mm}$ breit, 252 Friichte $=10 \mathrm{gr}$ ), grobschalig.

Diese Sorte hat nur geringe Verbreitung, obwohl im milden Klima die Erträge befriedigen sollen.

Original in der Sammlung der landw. Akademie zu Poppelsdorf.

\section{Irish-Wheat. (2)}

Syn.: Old white Irisll-Wheat.

Deutsch: Weissähriger irischer Winterweizen.

Aehre: weiss, sich verjüngend, grannenspitzig, locker, Frucht lose sitzend, sehr lang. - Stroh: gräulich-weiss, mehr Roggen- als Weizenstroh gleichend, sehr lang. - Frucht: braun, gross, länglich; Qualität geschätzt.

Herbstblatt klein, kraus; Bestockung stark; spätreif; winterfest.

Dieser Weizen soll auf Mittelboden sehr ertragreich sein, wächst aber auf reichem Boden zu sehr in's Stroh.

In neuerer Zeit wird er, ausser in Irland, vielfach in Ohio und auch sonst woll in der nordamerikanischen Union angebaut.

\section{Amber Winter-Wheat. (2)}

Syn.: German Amber, Red Winter Wheat from New-Orleans.

Deutsch: Bernsteinfarbener Winter-Weizen aus Nord-Amerika.

Aelre: blassgelb, fast weiss, lang, diinn, halblocker, sich stark verjüngend, grannenspitzig; Aehrchen schmal, $1.1 \mathrm{~cm}$ breit, meist 3-körnig. - Stroh: gelb, kurz, derbwandig. - Frucht: gelbrot, meist mehlig, klein, rundlich (51/2 mm lang, $3 \mathrm{~mm}$ breit, 292 Früchte $=10 \mathrm{gr})$, feinschalig; nachgebaut: rot, glasig, grösser, 265 Früchte $=10 \mathrm{gr}$, halbhart, Bruch halbstahlig.

Herbstblatt gelbgrün, aufrecht, gross; Frühjalırsvegetation zeitig, Bestockung schwach, 2.6 Schösslinge; zeitig sclossend und bliihend; Halm $95 \mathrm{~cm}$ (Max. $120 \mathrm{~cm}$ ) lang, $0.3 \mathrm{~cm}$ dick, Blattzahl 4.5 , Blätter $17 \mathrm{~cm} \mathrm{lang,}$ $0.82 \mathrm{~cm}$ breit, Blattfläche $125.5 \mathrm{qcm}$, Halmfläche $85.5 \mathrm{qcm}$, Gesammtfläche $211 \mathrm{qcm}$.

Frühreif; junge Aehre gelbgrïn, mit 17 Aehrchen und 50 etwas lose sitzenden Friichten.

Auf $1 \mathrm{hl}(=87.5 \mathrm{~kg})$ entfallen 2555000 Frichte.

Es wiegen 100 Halme $291.5 \mathrm{gr}$ und davon die Früchte $126.5 \mathrm{gr}$. 
Dieser Weizen unterlag in Poppelsdorf sehr stark dem Rost, lagerte jedoch nicht, und überwinterte gut.

Wird viel in Ohio, aber auch in den Nord-Weststaaten der Union gebaut. Sehr geschätzt.

Original 1879 durch Diirselen in Neuss, Abladung New.York, und durch Missouri, Agric. Coll. 1880 erhalten.

\section{Fultz Winter-Wheat. (2)}

Aehre: fast weiss, kurz, sich stark verjüngend, kurzgrannig, dünn; Aehrehen $1.2 \mathrm{~cm}$ breit, meist 3-körnig. - Stroh: rötlich-gelb, zuweilen violett, fest, unter mittellang. - Frucht: Original gelbrot, mehlig, wenige rot und glasig, dick, kurz, klein $\left(5 \frac{1}{2} \mathrm{~mm}\right.$ lang, $3^{3} / 4 \mathrm{~mm}$ breit, 330 Früchte $=10 \mathrm{gr})$; nachgebaut: grösser $(239$ Früchte $=10 \mathrm{gr})$, feinschalig, weich, Bruch inehlig.

Herbstblatt dunkelgrïn, feinblättrig, ziemlich aufrecht; Entwickelung mittelfrïh, 2.8 Schösslinge, zeitig schossend und blühend; Halm $100 \mathrm{~cm}$ (Max. $110 \mathrm{~cm}$ ) lang, $0.3 \mathrm{~cm}$ dick, Blattzahl 4.6, Blätter $15.7 \mathrm{~cm}$ lang, $0.8 \mathrm{~cm}$ breit, Blattfläche $115.6 \mathrm{qcm}$, Halmfläche $90 \mathrm{qcm}$, Gesammtfläche $205.6 \mathrm{qcm}$.

Junge Aehre gelbgruin, mittelfrüh reifend, $8 \mathrm{~cm}$ (Max. $10 \mathrm{~cm}$ ) lang, mit 16 Aehrchen und 45 fest sitzenden Früchten, von denen 2871000 auf $1 \mathrm{hl}(=87 \mathrm{~kg})$ entfallen.

Winterfest, nicht leicht lagernd, doch stark mit Rost befallen.

Wurde 1862 durch $\mathrm{Mr}$. Abram Fultz in Mifflin-County, Penns. aus 3 schönen Aehren, welche er unter "Old-Lancaster wheat" fand, geziichtet.

Tiel in den Nordweststaaten der Union angebaut und hoch geschätzt. Bezugsquelle: Missouri Agric. Coll. 1880. U. S.

\section{Walker-Wheat. (2)}

Aehre: blassgelb, mittellang, sich verjüngend, locker, dünu, Spelzen gezahnt; Aehrchen ziemlich breit $(1.5 \mathrm{~cm})$, meist 3-körnig. - Stroh: gelbrot, steif, mittellang. - Frucht: Original gelbrot, mehlig, einige rot und glasig, rundlich, klein $\left(6 \mathrm{~mm}\right.$ lang, $3^{1} \frac{1}{2} \mathrm{~mm}$ breit, 306 Früchte $\left.=10 \mathrm{gr}\right)$; nachgebaut: rot, glasig, grösser $(220$ Früchte $=10 \mathrm{gr})$, feinschalig, halbweich, Brucb halbmehlig.

Herbstblatt hellgrïn, ziemlich aufrecht, breit, kurz; Entwickelung zeitig, 3.3 Schösslinge, zeitig schossend und blühend; Halme $120 \mathrm{~cm}$ (Max. $140 \mathrm{~cm}$ ) lang, $0.33 \mathrm{~cm}$ dick, Blattzahl 4.8, Blätter $17 \mathrm{~cm}$ lang, $1 \mathrm{~cm}$ breit, Blattfläche $163.2 \mathrm{qcm}$, Halmfläche $118.8 \mathrm{qcm}$, Gesammtfä̈che 282 q $\mathrm{cm}$.

Junge Aehre bläulich-grün, zeitig reifend, $10 \mathrm{~cm}$ (Max. $14 \mathrm{~cm}$ ) lang. mit 17 Aehrchen und 40 etwas lose sitzenden Friichten, von denen 2646900 auf $1 \mathrm{hl}(=86.5 \mathrm{~kg})$ entfallen.

Winterfest, sehr widerstandsfähig gegen Rost. In den Nordstaaten der Union gebaut.

Bezugsquelle: Missouri Agric. Coll. 1880 U. S. 


\section{Muskingum. (2)}

Aehre: fast weiss, sich wenig verjüngend, halblocker, unter mittellang, dünn; Aehrchen $1.3 \mathrm{~cm}$ breit, 2- und 3-körnig. - Stroh: blassgelb, steif, unter mittellang. - Frucht: Original gelbrot, mehlig, oval, klein $\left(5 \mathrm{~mm}\right.$ lang, $3^{1} / 2 \mathrm{~mm}$ breit, 322 Früchte $\left.=10 \mathrm{gr}\right)$; nacligebaut: meist rot, glasig, grösser (220 Früchte $=10 \mathrm{gr}$ ), schwer, feinschalig, halbweich, Bruch halbmehlig.

Herbstblatt hellgrün, breit, kurz, aufrecht; 3.8 Schösslinge, mittelfrüh schossend und blühend; Halm $108 \mathrm{~cm}$ (Max. $120 \mathrm{~cm}$ ) lang, $0.3 \mathrm{~cm}$ dick, Blattzahl 4.4, Blätter $16.3 \mathrm{~cm}$ lang, $0.75 \mathrm{~cm}$ breit, Blattfläche $195.6 \mathrm{qcm}$, Halmfläche $97.2 \mathrm{qcm}$, Gesammtfläche $292.8 \mathrm{qcm}$.

Junge Aehre gelbgrün, rot umrandet, zeitig reifend, $8 \mathrm{~cm}$ (Max. $10 \mathrm{~cm}$ ) lang, mit 17 Aehrchen und 40 Früchten, von denen 2833600 auf $1 \mathrm{hl}(==88 \mathrm{~kg})$ entfallen.

Winterfest; ziemlich rostfrei.

Bezugsquelle: Missouri Agric. Coll. 1880 U. S.

\section{Arnold's Hybrid. (2)}

Aehre: gelb, sich verjüngend, locker, mittellang; Aelırchen meist 3-körnig. - Stroh: gelb, fest, unter mittellang. - Frucht: Original gelbrot, mehlig, einige rot, glasig, oval, klein $(6 \mathrm{~mm}$ lang, $31 / 2 \mathrm{~mm}$ breit, 312 Früchte $=10 \mathrm{gr}$ ); nachgebaut: grösser 221 Früchte $=10 \mathrm{gr}$, feinschalig, halbhart, lialbmehlig.

Herbstblatt hellgrün, aufrecht, ziemlieh breit; 3 Schösslinge, sehr zeitig sehossend, mittelfrüh blühend; Halm $100 \mathrm{~cm}$ (Max. 125 cm) lang, $0.3 \mathrm{~cm}$ dick, Blattzahl 4.4, Blätter $15.4 \mathrm{~cm}$ lang, $0.6 \mathrm{~cm}$ breit, Blattläche $81.3 \mathrm{qcm}$, Halmfläche $90 \mathrm{qcm}$, Gesammtfläche $171.3 \mathrm{qcm}$.

Junge Aelıre blaugrün, mittelfrüh reifend, $10 \mathrm{~cm}$ (Max. $13 \mathrm{~cm}$ ) lang, mit 15 Aehrchen und 45 ziemlich leicht ausfallenden Früchten, von denen 2745600 anf $1 \mathrm{hl}(=88 \mathrm{~kg})$ entfallen.

Winterfest, nicht leicht lagernd, doch stark rostig.

Bezugsquelle: Missouri Agric. Coll. 1880 U. S.

\section{Odessa. (2)}

Aehre: blassgelb, unter mittellang, sich verjüngend, gran»enspitzig, locker, Aehrchen $1.3 \mathrm{~cm}$ breit, meist 3-körnig. - Stroh: meist violett, steif, fein, unter mittellang. - Frucht: Original gelbrot, mehlig, rundlich, klein $\left(5^{3} / 4 \mathrm{~mm}\right.$ lang, $3 \frac{1}{2} \mathrm{~mm}$ breit, 300 Früchte $\left.=10 \mathrm{gr}\right)$; nachgebaut: dunkelrot, glasig, grösser (224 Fruchte $=10 \mathrm{gr})$, feinschalig, halbhart, Bruch halbmehlig.

Herbstblatt dunkelgrün, niederliegend; Entwickelung mittelfrüh, 4 Schösslinge; Halm $100 \mathrm{~cm}$ (Max. $112 \mathrm{~cm}$ ) lang, $0.3 \mathrm{~cm}$ dick, Blattzahl 4.6, Blätter $18 \mathrm{~cm}$ lang, $0.74 \mathrm{~cm}$ breit, Blattfäche $222,5 \mathrm{qcm}$, Halmfläche $90 \mathrm{qcm}$, Gesammtfläche $312.5 \mathrm{qcm}$.

Junge Aehre blaugrün, Antheren rosa, mittelfrüh reifend, $9 \mathrm{~cm}$ (Max. $10 \mathrm{~cm}$ ) lang, mit 16 Aehrehen und 45 festsitzenden Früchten, von denen 2610000 auf $1 \mathrm{hl}(=\varepsilon 8 \mathrm{~kg})$ entfallen.

Winterfest; stark rostig. 
Bezugsquelle: Missouri Agric-Coll. 1880 U. S.

Wahrscheinlich aus einem südrussischen Weizen in N. Amerika weiter gezüchtet.

\section{Kentucky-Wheat. (2)}

Aehre: fast weiss, sich rerjüngend, etwas grannenspitzig, ziemlich dicht, unter mittellang; Aehrchen 3-körnig. - Stroh: rötlich-gelb, unter mittellang, feinhalmig. - Frucht: gelbrot, mehlig, oval, klein $(51 / 2 \mathrm{~mm}$ lang, $31 / 2 \mathrm{~mm}$ breit, 302 Früchte $=10 \mathrm{gr}$ ); nachgebaut: rot, meist glasig, grösser (222 Früchte $=10 \mathrm{gr}$ ), feinschalig, halbweich, Bruch halbmehlig.

Herbstblatt hellgrün, ziemlich aufrecht; Entwickelung zeitig, 4 Schösslinge, mittelfrüh schossend und biübend; Halm $105 \mathrm{~cm}$ (Max. $120 \mathrm{~cm}$ ) lang, $0.3 \mathrm{~cm}$ dick, Blattzahl 4, Blätter $15.7 \mathrm{~cm}$ lang, $1 \mathrm{~cm}$ breit, Blattfläche $125.6 \mathrm{qcm}$, Halmfläche $94.5 \mathrm{qcm}$, Gesammtfläche $220.1 \mathrm{qcm}$.

Junge Aehre bläulich, zeitig reifend, mit 16 Aehrchen und 45 lose sitzenden Früchten, voul denen 2612300 auf $1 \mathrm{hl}$ (=86.5 kg) entfallen.

Winterfest, nicht selten stark rostig. Vorzugsweise in Kentucky, Nord-Amerika, gebant.

Bezugsqueile: Missouri Agric. Coll. 1880 U. S.

\section{Democrat. (2)}

Aehre: fast weiss, sich wenig verjüngend, halblocker, dünn, kurz; Aehrchen 2- und 3-körnig, $1.3 \mathrm{~cm}$ breit. - Stroh: blassgelb, sehr fest, unter mittellang. - Frucht: Original gelbrot und mehlig, riele rot und glasig, oval, klein $\left(5^{1} / 2 \mathrm{~mm}\right.$ lang, $3^{1 / 2} \mathrm{~mm}$ breit, 336 Frïchte $\left.=10 \mathrm{gr}\right)$; nachgebaut: grösser (231 Früchte $=10 \mathrm{gr})$, schr schwer, feinschalig, halbweich, Bruch halbmehlig.

Herbstbiatt gelbgrün, ziemlich aufrecht, doch fein; 3 Schösslinge, mittelfrüb schossend und blühend; Halm $100 \mathrm{~cm}$ (Max. $110 \mathrm{~cm}$ ) lang, $0.33 \mathrm{~cm}$ dick, Blattzahl 4, Blätter $18.5 \mathrm{~cm}$ lang, $0.8 \mathrm{~cm}$ breit, Blattfläche $118.2 \mathrm{qcm}$, Halmfläche $99 \mathrm{qcm}$, Gesammtfläche $217.2 \mathrm{qcm}$.

Junge Aehre bläulich, rot umrändert, $8 \mathrm{~cm}$ (J「ax. $10 \mathrm{~cm}$ ) lang, kurz, mit 17 Aehrchen und 40 Friuchten, vou denen 2990400 auf 1 hl $(=89 \mathrm{~kg})$ entfallen.

Zeitig reifend, fast rostfrei, nicht lagernd.

Bezugsquelle: Missouri Agric. Coll. U. S.

Viel in den Nordstaaten der Vereinigten Staaten gebaut.

\section{Deihl-Wheat. (2)}

Aehre: fast weiss, sich stark verjüngend, halblocker, mittellang, grannenspitzig; Aehrchen 1.5 cm breit, 3- und 4-körnig. - Stroh: gelbrot bis violett, steif, unter mittellang. - Frucht: Original gelbrot, mehlig, oval, klein $\left(5^{1} / 2 \mathrm{~mm}\right.$ lang, $3^{1} / 2 \mathrm{~mm}$ breit, 286 Frïchtc $\left.=10 \mathrm{gr}\right)$; nachgebaut: rot, glasig, grösser 225 Früchte $=10 \mathrm{gr}$, feinschalig, halbhart.

Herbstblatt hellgrün, ziemlich aufrecht, gross; Entwickelung zeitig, 4 Schösslinge, zeitig schossend und blühend, Halm $100 \mathrm{~cm}$ (Max. $120 \mathrm{~cm}$ ) lang, $033 \mathrm{~cm}$ dick, Blattzahl 4, Blätter $18 \mathrm{~cm}$ lang, $0.8 \mathrm{~cm}$ breit, Blattfläche 115.2 qcm, Halmfläche $99 \mathrm{qcm}$, Gesammtfläche $214.2 \mathrm{qcm}$.

Junge Aehre blaugrün, zeitig reifend, $9 \mathrm{~cm}$ (Max. $13 \mathrm{~cm}$ ) lang, mit 
19 Aehrchen und 60 ziemlich festsitzenden Früchten, von denen 2508220 auf $1 \mathrm{hl}(=87.7 \mathrm{~kg})$ entfallen.

Winterfest, doch rostig. geschätzt.

In den Nordweststaaten der Union und in Canada gebaut. Sehr

Bezugsquelle: Missouri Agric. Coll. 1880. U. S.

\section{Chili square wheat. (2)}

Syn.: Franz.: Blé de Chile, ou carré de Chili.

Deu ts ch: Chile-Weizen.

Aehre: blassgelb, kurz, dicht, viereckig, breit; Aelırchen $2 \mathrm{~cm}$ breit, meist 4-körnig. - Stroh: rötlich-gelb, derbwandig, steif. - Frucht: hellbraun, halb-mehlig, rund, klein ( $6 \mathrm{~mm}$ lang, $4 \mathrm{~mm}$ breit), schön, schwer, etwas grobschalig, halbhart.

Herbstblatt gelbgrün, ziemlich breit, aufrecht. Frühjahrsvegetation zeitig, Bestockung stark, 5.2 Schösslinge, mittelfrüh schossend, spät blühend. Halmlänge $130 \mathrm{~cm}$ (Max. $160 \mathrm{~cm}$ ), Halmdicke $0.4 \mathrm{~cm}$, Blattzahl 4, Blattlänge $22.3 \mathrm{~cm}$, Blattbreite $0.8 \mathrm{~cm}$, Blattoberfläche $153.92 \mathrm{qcm}$, Halmfläche $156 \mathrm{qcm}$, Gesammtfläche eines Halmes $309.92 \mathrm{qcm}$.

Auf $1 \mathrm{qm}$ wachsen 940 Halme oder 180 Pflanzen, demnach beträgt der Raum für eine Pflanze $55.5 \mathrm{qcm}$ und die Blattfläche p. qm Bodenfläche $29.1 \mathrm{qm}$.

Junge Aelıre gelbgrün, mittelfrüb reifend, $10 \mathrm{~cm}$ lang (Max. $15 \mathrm{~cm}$ ), mit 22 Aehrchen und 80 etwas leicht ausfallenden Friichten, von denen auf $1 \mathrm{hl}(=84 \mathrm{~kg}) 1876000$ Friichte entfallen, wonach sich das Saatquantum $(1 / 3$ Verlust) auf $1.44 \mathrm{hl}$ p. ha stellt.

Es wiegen 100 Halme 600 gr und davon die Früchte $200 \mathrm{gr}$.

In Poppelsdorf zeigte sich dieser schöne, ergiebige und weder durch Lagern noch Rost stark leidende Weizen nicht ganz winterfest, doch ist derselbe für reiche Weizenböden im milden Klima wohl zu beachten.

Heimat: Santiago de Chile. kultiviert.

Er wird ausser in Chile vielfach in den Südstaaten der Union

\section{Festal-Pedigree-Wheat. (2)}

Syn.: Fest-Pedigree-Weizen.

Aehre: blassgelb, fast weiss, viereckig und zwar die zweizeilige Seite breit und wie bei Hickling in die Augen fallend, sehr dicht, mittellang; Aehrchen $1.6 \mathrm{~cm}$ breit, meist 3-körnig. — Stroh: rötlich-gelb oder orange, blattreich, rohrartig, mittellang. - Frucht: Original gelbrot, mehlig, einige rot und glasig, gross $(7 \mathrm{~mm}$ lang, $4 \mathrm{~mm}$ breit, 213 Frürhte $=$ $10 \mathrm{gr})$, etwas grobschalig, weich.

Herbstblatt blaugrün, oberseits stark und lang, unterseits schwächer und kürzer behaart, breit, aufrecht; Entwickelung ziemlich zeitig, Bestockung etwas schwach, 3.5 Sclösslinge, doch spät schossend und blühend. Halme $120 \mathrm{~cm}$ (Max. $150 \mathrm{~cm}$ ) lang, $0.45 \mathrm{~cm}$ dick, Blattzahl 4.4 , Blätter $22.6 \mathrm{~cm}$ lang, $1.06 \mathrm{~cm}$ breit, Blattfläche $210.85 \mathrm{qcm}$, Halmfläche $162 \mathrm{qcm}$, Gesammtfläche $372.85 \mathrm{qcm}$

Junge Aehre gelbgrün, reift spät, $9 \mathrm{~cm}$ (Max. $12 \mathrm{~cm}$ ) lang, mit 60 festsitzenden Früchten, von denen 1804110 auf $1 \mathrm{hl}(=84.7 \mathrm{~kg})$ entfallen. 
Auf 1 qm wachsen 700 Halme oder 200 Pflanzen, mithin beträgt der Raum für eine Pflanze $50 \mathrm{qcm}$, die Blattfläche p. qm Bodenfläche $26.1 \mathrm{qm}$, und das Saatquantum $1.7 \mathrm{hl}$ p. ha.

Es wiegen 100 Halme $702 \mathrm{gr}$ und davon die Scheinfrüchte $221 \mathrm{gr}$.

Diese Weizensorte wurde aus Spanien nach England eingeführt und nach dem Verfahren des Capitain William Delf, Great-Bentley, bei Colchester, in Essex verbesscrt und auf der Weltausstellung von Philadelphia prämijert.

Dieser Weizen lagert selten, leidet wenig durch Rost und ist gegen ungünstige Witterungsverhältnisse recht widerstandsfähig. Die Kornquälität wird gerühmt, doch eignet er sich nur für kulturvolle Lehmböden.

Uebersender: W. Delf.

\section{Amerikanischer Prairieweizen. $\odot$}

Aehre:rötlich-weiss, sich verjüngend, an der Spitze kurzgrannig, locker, dünn, schmal; Aehrchen $1.3 \mathrm{~cm}$ breit, 2- und 3-körnig. - Stroh: rötlichweiss, fest. - Frucht: blassgelbrot, mellig; nachgebaut: meist rötlich und glasig, schwer, rundlich $\left(6^{1} / 2 \mathrm{~mm}\right.$ lang, $3^{1} / 2 \mathrm{~mm}$ breit, 245 Früchte $=10 \mathrm{gr}$ ), klein, feinschalig, Bruch halbstahlig, hart.

Halme blaugrïn, 2.8 Schösslinge, mittelfrïh schossend und blülıend. Fialmlänge $90 \mathrm{~cm}$ (Max. $115 \mathrm{~cm}$ ), Halmdicke $0.3 \mathrm{~cm}$, Blattzahl 3, Blattlänge $27.3 \mathrm{~cm}$, Blattbreite $0.83 \mathrm{~cm}$, Blattoberfläche $135.96 \mathrm{qcm} ; \mathrm{Halm-}$ fläche 81 qcm, Gesammtfläche eines Halmes 216.96 qcm.

Auf 1 qm stehen 1200 Halme oder 430 Pflanzen, mithin beträgt der Raum für eine Pflanze 23.3 qcm und die Blattfïche p. qm BodenHäche 26.04 qm.

Junge Aehre blaugrün, mittelfrïh reifend, $9 \mathrm{~cm}$ (Мax. $11 \mathrm{~cm}$ ) lang, mit 16 Aehrchen und 40 etwas lose sitzenden Früchten, von denen 2033500 Stiick auf $1 \mathrm{hl}(=83 \mathrm{~kg})$ gehen, wonach sich das Saatquantum $(1 / 3$ Verlust) auf $3 \mathrm{hl}$ p. lia stellt.

Es wiegen 100 Halme $420 \mathrm{gr}$ und davon die Frichte $150 \mathrm{gr}$.

Dieser Weizen hält sich fast rostfrei und lagert selten. Seine vorzügliche Kornqualität und die Fähigkeit auf leichtem Boden noch befriedigende Ernten zu bringen, machen ihn beachtenswert. Der Weizen wurde von $\mathrm{Metz} \& \mathrm{Co}$. bezogen.

\section{Nova-scotia. $\odot$ u. (2)}

Deutsch: Weizen aus Neu-Schottland, Canada.

Aehre: fast weiss, etwas locker, dünn, sich verjüngend und an der Spitze für einen Kolbenweizen anffallend lang begrannt; Aehrchen schmal, $1.2 \mathrm{~cm}$ breit, 2-körnig. - Stroh: rötlich-gelb, dünnwandig. - Frucht: rot, glasig, wenige mehlig, länglich $\left(7 \mathrm{~mm}\right.$ lang, $3^{1 / 2} \mathrm{~mm}$ breit, 238 Früchte $=10 \mathrm{gr}$ ), feinschalig, Bruch halbmehlig, halbhart.

Er scheint sich wenig als Wintersaat zu eignen, denn er zeigte sich in Poppelsdorf nicht winterfest, erfror z. B. $1870 / 71$ vollständig.

Die Somncrsaat besitzt ein gelbgrünes, langes, aufrechtes und sehr kräftiges Blatt, einc schwache Bestockung, 2.4 Schösslinge, und scbosst und blülıt zeitig.

Halmlänge $120 \mathrm{~cm}$ (Max. $140 \mathrm{~cm}$ ), Halmdicke $0.35 \mathrm{~cm}$, Blattzahl 3.6 , Blattlänge $22.3 \mathrm{~cm}$, Blattbreite $0.88 \mathrm{~cm}$, Blattobcrfläche $140.29 \mathrm{qcm}$, Halmfiäche 126 qcin, Gesammtflächc 266.29 qcm. 
Junge Aehre gelbgrün, in 120 Tagen reifend, mit 18 Aehrchen und 36 ziemlich fest sitzenden Früchten, von denen 1999200 auf 1 hl $(=84 \mathrm{~kg})$ gehen.

Es wiegen 100 Halme dieses Sommerweizens $420 \mathrm{gr}$ und davon die Friichte $140 \mathrm{gr}$.

Für einen sehr reichen Boden ist dieser Weizen nngeeignet, da er sehr leicht lagert.

Das landwirtschaftliche Ministerium sandte ihn 1869 nach Poppelsdorf.

\section{Grano di Napoli. (2)}

Syn.: Deutsch: Winterweizen von Neapel.

Aehre: blassgelb, lang, grannenspitzig, ziemlich dicht; Aehrchen $1.5 \mathrm{~cm}$ breit, 2 - und 3-körnig. - Stroh : rötlich-weiss, orange, mittellang, fest. - Frucht: rot und glasig, wenige gelbrot und mehlig, klein $(6 \mathrm{~mm}$ lang, $3 \mathrm{~mm}$ breit, 265 Früchte $=10 \mathrm{gr}$ ), feinschalig, hart, Bruch halbstahlig.

Herbstblatt schmal, kraus, kahl oder schwach behaart; Frühjahrsvegetation spät, Bestockung schwach, 3.6 Schösslinge, spät schossend und blühend. Halmlänge $120 \mathrm{~cm}$ (Max. $145 \mathrm{~cm}$ ), Halmdicke $0.4 \mathrm{~cm}$, Blattzahl 4, Blattlänge $27.16 \mathrm{~cm}$, Blattbreite $0.91 \mathrm{~cm}$; BlattoberHäche $197.76 \mathrm{qcm}$, Halnfläche $144 \mathrm{qcm}$, Gesammtfäche eines Halmes $341.76 \mathrm{qcm}$.

Auf 1 qm entfallen 900 Halme oder 250 Pflanzen, mithin beträgt der Raum für eine Pflanze 40 q em, nnd die Blattfläche p. qun Bodenfläche 30.76 qm.

Junge Aehre gelbgrüı mit bläulichem Anflug, spät reifend, $12 \mathrm{~cm}$ (Max. $15 \mathrm{~cm}$ ) lang, mit 20 Aehrchen und 50 lose sitzenden Früchten, von denen 2120000 auf $1 \mathrm{hl}(=80 \mathrm{~kg}$ ) gehell, und das Saatquantum $(1 / 3$ Verlust $) 1.8 \mathrm{hl}$ beträgt.

100 Halme wiegen $435 \mathrm{gr}$ nnd davon die Früchte $160 \mathrm{gr}$.

In Poppelsdorf, im Frühjahr gesäct, erwies er sich als echter Winterweizen, der nicht leicht lagert, oder durch Rost leidet, doch zu seinem Gedeihen ein mildes Klima und einen guten Weizenboden erfordert.

\section{Blé d'hiver ordinaire. (2)}

Syn.: Blé de saison, de Crépi, bladette sans barbes, de Nérac, du Cayran, grissard de Donai, roux d'Armentières, de Pomeranie, blane des coteanx.

Span is ch: Trigo de Crepi.

Deutsch: Weissühriger, rotkörniger, französischer Landweizen.

Aehre: blassgelb mit leicht rötlichem Anflug, diinn, sich verjüngend, grannenspitzig, locker, auf $14 \mathrm{~cm}$ Länge entfallen 48 zicmlich lose sitzende Früchte; Aehrchen $1 \mathrm{~cm}$ breit, also schmal, Klappen und Spelzen mittelgross, 2-körnig. - Stroh: rötlich-weiss, biegsam, blattarm, feinhalmig, bis $150 \mathrm{~cm}$ lang. - Frucht: rötlich-gelb, meist glasig, klein, länglich (6 $\mathrm{mm}$ lang, $3 \mathrm{~mm}$ breit), Qualität geschätzt, feinschalig, halbhart, halbstahlig.

Für kalkreiche, trockne Mittelböden geeignet und liefert derselbe in Nord- und Mittel-Frankreich recht befriedigende Erträge. Als „Blé de Crépi" wird er stark in der Umgegend von Paris gebaut. 
In neuerer Zeit ist er auch nach Spanien eingeführt worden. Original im landw. Museum zu Berlin.

\section{Blé de l'île de Noé. (2) ○}

Deutsch: Früher gelber Noëscher-Weizen.

Spanisch: Noé pelado (geschorener).

Franz.: Blé bleu; Blé debout; Blé de Noé; Blé turc.

A merikanisch: Early Noé wheat.

Aehre: fast weiss, mit schwach rötlichem Anflug, lang. locker; Aehrchen breit $(1.7 \mathrm{~cm})$, meist 3-körnig. - Stroh: rötlich-gelb, derbwandig, mittellang, fest. - Frucht: Original gelbrötlich, mehlig; nachgebaut: schon in erster Ernte rot und meist glasig, etwas eingefallen, feinschalig, gross ( $7 \mathrm{~mm}$ lang, $4 \mathrm{~mm}$ breit), weich.

Als Wechselweizen kultiviert, besass der Sommerweizen ein blaugrünes, krauses Blatt, 2.9 Schösslinge, also etwas schwache Bestockung, schosste und bluihte spät.

Herbstblatt beim Winterweizen breit, lang, aufrecht, gelbgrün; Frühjahrsvegetation zeitig, Bestockung schwach, 3.2 Sprossen.

Die weitere Entwickelung gestaltet sich wie folgt:

\begin{tabular}{|c|c|c|}
\hline & beim Winterweizen & beim Sommerweizen \\
\hline $\begin{array}{l}\text { Jalmlänge } \\
\text { llalmdurchmesser } \\
\text { Blattzahl am Halm } \\
\text { Durchschnittliche Blattlänge } \\
\qquad, \quad \text { Blattbreite } \\
\text { blattoberfläche } \\
\text { beider "Seiten } \\
\text { Durchschnittliche Halmfläche } \\
\text { Gesammtfäche } \\
\text { Aelirenlänge } \\
\text { Aehrenzahl pro Achre } \\
\text { Fruchtzahl " " " } \\
\text { Halme pro qm pm } \\
\text { Blattfläche pro qm Bodenfläche } \\
\text { Anzahl der Pflanzen pro qm } \\
\text { Raum pro Pflanze } \\
\text { Hektolitergewicht } \\
\text { Körnerzahl pro hl } \\
\text { Aussaatquantum (33 Proc. Ver- } \\
\text { lust) pro ha }\end{array}$ & \begin{tabular}{|c|}
$110 \mathrm{~cm}($ Max. $130 \mathrm{~cm})$ \\
$0.4 \mathrm{~cm}$ \\
4 \\
$24.32 \mathrm{~cm}$ \\
$1.04 \mathrm{~cm}$ \\
\\
$202.32 \mathrm{qcm}$ \\
$132.00 \mathrm{qcm}$ \\
$334.32 \mathrm{qcm}$ \\
$11 \mathrm{~cm} \mathrm{(Max.} 15 \mathrm{~cm})$ \\
14 \\
50 \\
880 \\
$29.42 \mathrm{qm}$ \\
280 \\
$35.8 \mathrm{qcm}$ \\
$82.32 \mathrm{~kg}$ \\
1507500 \\
\\
$2.4 \mathrm{hl}$
\end{tabular} & $\begin{array}{c}125 \mathrm{~cm}(\text { Max. } 140 \mathrm{~cm}) \\
0.36 \mathrm{~cm} \\
3.8 \\
24.60 \mathrm{~cm} \\
0.90 \mathrm{~cm} \\
\\
168.26 \mathrm{qcm} \\
135.00 \mathrm{qcm} \\
303.26 \mathrm{qcm} \\
11 \mathrm{~cm}(M \mathrm{ax} .15 \mathrm{~cm}) \\
14 \\
50 \\
800 \\
24.26 \mathrm{qm} \\
276 \\
36.2 \mathrm{qcm} \\
84.00 \mathrm{~kg} \\
1344000\end{array}$ \\
\hline
\end{tabular}

Junge Aehre vor der Reife so intensiv dunkelblaugrün gefärbt, (die meisten anderen Sorten sind mehr olivengrün), dass diese Färbung den Namen „Blé bleu" veranlasst hat. Die Reife tritt zeitig beim Winterweizen ein, und erfolgt beim Sommerweizen nach 130 Tagen. Seit 1870 zeigtc er sicl bis auf das Glasigwerden der Körner konstant.

Seine Vorzüge beruhen auf dem mehlreichen, wenig Kleie liefernden Korn, sowie in den hohen Erträgen, sobald Kilima und Boden ihm zusagen. Für Deutschland ist er als Winterweizen zu empfindlich, so winterte er 
1870 und 1876 vollständig aus; mehr empfiehlt sich seine Kultur als Sommerweizen, doch liessen seine Erträge am Rhein, wo er vom Gutsbesitzer Limbourg in Bitburg eingeführt worden ist, $1877 \mathrm{sehr} z u$ wünschen, und scheint sein Anbau wieder aufgegeben zu werden, denn er stellt an Boden und Klima zu hohe Ansprüche, degeneriert leicht im Korn und das feste derbwandige Stroh eignet sich nicht als Viehfutter, dafür lagert er jedoch nicht leicht, weshalb ihm in Frankreich die Benennung "Blé debout" geworden ist, auch zeigt er grossc Widerstandsfähigkeit gegen Rost; die Früchte sitzen nur lose in den Spelzen.

In Poppelsdorf wogen 100 Halme Wintersaat $530 \mathrm{gr}$ und davon die Körner $200 \mathrm{gr}$, bei der Sommersaat die Halme $530 \mathrm{gr}$ und die Körner $180 \mathrm{gl}^{\circ}$.

In Frankreich, wo er vorzugsweise in Haute Loire kultiviert wird, bringt er Erträge von 20,22 bis $29 \mathrm{hl}$ p. ha. In Italien, Nord-Amerika und Spanien wird er ebenfalls angebaut.

Bei einem Spaziergange in der Ebene von Lectoure bemerkte Graf Frank de $\mathrm{N}_{0} \mathrm{e}^{1}$ ) diesen Weizen und baute ihn auf seinem Gute ,Beauce“" unter dem Namen „Blé de Noé“ an. Wie sich später zeigte, war dieser Weizen dureh M. Planté zu Nérac, Depart. Lot-et-Garonne 1826 aus Odessa bezogen und unter dem Namen „Blé turc", welcher Name sich noch vielfach erhalten hat, angebaut worden, doch wurde er in SüdFrankreich vielfach „Blé bleu“" genannt. Später bezog M. Pérès von der dem Grafen de Noé gehörigen Farm Caumont, die in Isle-de-Noé gelegen, Samen und verbreitete ihn 1842 unter dem Namen Isle-de-Noé.

\section{Blé Pictet. $\odot$ u. (2)}

Syn.: Frauz.: Blé Fellenberg; Blé Gagarin.

De utsch: Sommerweizen von v. Fellenberg.

Aehre: blassgelb, aufrecht, locker, lang, dünn; Aehrchen $1.5 \mathrm{~cm}$ breit, 2- und 3-körnig. - Stroh: rötlich-gelb-graublau, derbwandig. Frucht: rot, glasig, klein (6 $\mathrm{mm}$ lang, $3 \mathrm{~mm}$ breit), feinschalig, halbhart, halbstahlig.

Herbstblatt blaugrün, breit, aufrecht; Frühjahrsvegetation zeitig, Bestockung schwach, 2.9 Schösslinge, zeitig schossend und reifend. In Poppelsdorf seit einigen Jahren erfolgreich als. Winterweizen kultiviert, wenngleich die Pflanze strenge Winter $(1870 / 71)$ nicht erträgt. Ursprünglich kam er von Hofwyl in der Schweiz als Sommerweizen (Blé Pictet de Mars) nach Frankreich. Im Allgemeinen ist der Habitus der Sommerund Winterfrucht konform, und lieferte die Untersuchung des Sommerweizens nachfolgende Resultate:

Zahl der Schösslinge 2, mittelfrüh schossend nnd blühend. Halmlänge $120 \mathrm{~cm}$ (Max. $155 \mathrm{~cm}$ ), Halmdicke $0.4 \mathrm{~cm}$, Blattzahl 3.3, mittlere Blattlänge $30.15 \mathrm{~cm}$, Blattbreite $1.02 \mathrm{~cm}$, Blattoberfläche $202.95 \mathrm{qcm}$, Halmfläche $144 \mathrm{qcm}$, Gesammtfläche eines Halmes $346.95 \mathrm{qcm}$.

Auf $1 \mathrm{qm}$ wachsen 900 Halne oder 450 Pflanzen, so dass sich für jede ein Raum von 22.2 q $\mathrm{cm}$, und eine Blattfläche p. qm Bodenfläche von $31.23 q \mathrm{~m}$ berechnet.

1) Bulletin de la société botanique de France. T. IV. Paris 1857, pg. 288. 
Junge Aehre blaugrün, mittelfrüh reifend, $10 \mathrm{~cm}$ (Max. $12 \mathrm{~cm})$ lang, mit 16 Aehrchen und 50 etwas leicht ausfallenden Früchten.

Es enthält $1 \mathrm{hl}(=82 \mathrm{~kg}) 2296600$ Früchte, mithin sind als Saatquantum $3.2 \mathrm{hl}$ p. ha notwendig.

Es wiegen 100 Halme $520 \mathrm{gr}$ und davon die Früchte $150 \mathrm{gr}$.

Seine Widerstandsfähigkeit gegen Lagern und Rost ist bemerkenswert.

Soll wegen der Kleinheit der Körner in Frankreich (nach Heuzé) nur noch wenig kultiviert werden.

Von Fellenberg in Hofwyl, Schweiz, sandte ihn zuerst zur Kultur nach Frankreich.

\section{Blé Hickling de Mars. $\odot$}

Dentsch: Hickling's Sommerweizen.

Aehre: blassgelb und etwas lockerer, länger und schmäler als „Hickling's prolific", ziemlich stark grannenspitzig; Aehrchen $1.3 \mathrm{~cm}$ breit, 3- und 4-körnig. - Stroh: rötlich-gelb, fest, mittellang. - Frucht: meist rot und glasig. rundlich, mittelgross (6 mm lang, 4 mm breit), etwas grobschalig, halbhart, Bruch halbmehlig.

Junges Blatt und Halme blaugrïn, Bestockung ziemlich kräftig, 2.5 Schösslinge, spät schossend und blühend, mittelfrüh in 130 Tagen reifend. Halmlänge $115 \mathrm{~cm}$ ( Yax. $125 \mathrm{~cm}$ ). Halmdicke $0.37 \mathrm{~cm}$, Blattzahl 4, Blattläuge $28.8 \mathrm{~cm}$, Blattbreite $0.88 \mathrm{~cm}$, Blattoberfläche $202.72 \mathrm{qcm}$, Halmfläche 127.65 qcm, Gesammtfäche $330.37 \mathrm{qcm}$.

Junge Aehre gelbgriin, $9 \mathrm{~cm}$ (Мax. $11 \mathrm{~cm}$ ) lang, mit 21 Aehrchen und 70 etwas lose sitzenden Früchten, ron denen 1694000 auf $1 \mathrm{hl}$ (= $=7 \mathrm{~kg})$ gehen.

Es wachsen auf 1 qm 900 Halme oder 360 Pflanzen, mithin beträgt der Raum für eine Pflanze $28 \mathrm{qcm}$, die Blattfläche p. qm Bodenfiäche $29.73 \mathrm{qcm}$, und das Saatquantum $3.2 \mathrm{hl} \mathrm{p}$. ha.

Es wiegen 100 Halme $451 \mathrm{gr}$ und davon die Früchte $183 \mathrm{gr}$.

Im milden Klima lässt sich dieser Weizen schon im Februar und Närz anbauen, ist ertragreich, lagert nicht leiclit, unterliegt jedoch sehr stark dem Rost. Der milde, kalkreiche Lehmboden sagt ihm am meisten zu.

Wahrscheinlich ist dieser Weizen aus "Hickling prolific" im nördlichen Frankreich, wo er auch zur Zeit noch am häufigsten kultiriert wird, gezüchtet worden.

\section{Blé de Vilmorin. (2)}

Syn.: Deutsch: Tilmorin's Weizen.

Aehre: fast weiss, etwas locker, mittelbreit; Aehrchen $1.7 \mathrm{~cm}$ breit, 3-körnig. - Stroh: rötlich-gelb, sehr derbwandig, steif, lang. - Frucht: Original hellrot, mehlig; nachgebaut: hellrot, meist glasig, etwas eingefallen, länglich, gross $(71 / 2 \mathrm{~mm}$ lang, $4 \mathrm{~mm}$ breit), feinschalig, schwer, halbhart. Bruch halbmehlig.

Herbstblatt gelbgrün, sehr breit, anfrecht; Frülijahrsvegetation sehr zeitig und kräftig. Bestockung mittelstark, 4 Schösslinge, mittelfrüh schossend und bliihend. Halmlänge $135 \mathrm{cnl}$ (Max. $165 \mathrm{~cm}$ ), Halmdicke $0.4 \mathrm{~cm}$, Blattzahl 4.2, Blattlänge $24.5 \mathrm{~cm}$, Blattbreite $0.8 \mathrm{~cm}$, Blattoberfläche $97.44 \mathrm{qcm}$, Halmfläche $162 \mathrm{qcm}$, GesammtAäche $259.44 \mathrm{qcm}$.

Auf 1 qm können 1000 Halme oder 250 Pflanzen wachsen, mithin 
stellt sich der Raum für eine Pflanze auf $40 \mathrm{qcm}$ und die Blattfäche p. qm der Bodentläche auf 25.9 qm.

Junge Aehre gelbgrün, mittelfrüh reifend, $10 \mathrm{~cm}$ (Max. $15 \mathrm{~cm}$ ) lang, mit 18 Aehrchen und 54 Früchten, welche etwas leicht ausfallen, und von denen 1496000 auf $1 \mathrm{hl}$ (=85 kg) kommen, mithin das Saatquantum ( $1 / 3$ Verlust) $2.5 \mathrm{hl}$ beträgt.

100 Halme wiegen $415 \mathrm{gr}$ und daron die Früchte $170 \mathrm{gr}$.

Dieser Weizen zeigte sich in Poppelsdorf nicht winterfest, aber widerstandsfähig gegen Lagern und Rost.

Im südlichen England und Frankreich wird er vielfach, der Giite der Körner und seiner Ergiebigkeit wegen, auf kräftigem Boden kultiviert.

Vilmorin ist Zuichter dieser Sorte und hat sie auch verbreitet.

\section{Blé du Mesnil Saint-Firmin. (2)}

Syn.: Franz.: Blé du Mesnil, Ble à grain jaune de M. Bazin, Blé de Saint-Firmin, Garreau, Saumon, Blé Saumon de M. Monnot-Leroy, Somon, Pomon ${ }^{1}$ ).

Aehre: blassgelb, ziemlich dicht, sich etwas verjüngend, grannenspitzig, lang; Aehrchen $1.5 \mathrm{~cm}$ breit, 3- und 4-körnig. - Stroh: rötlichgelb, fest, blattreich. - Frucht: rot, glasig, wenige gelbrot, mehlig, rundlich, mittelgross ( $7 \mathrm{~mm}$ lang, $4 \mathrm{~mm}$ breit), etwas grobschalig, Bruch halbstahlig, halbhart.

Herbstblatt blaugriin, ziemlich breit, beiderseits schwach behaart; Frühjahrsvegetation zeitig, Bestockung schwach, 3.4 Schösslinge, mittelfrüh schossend und blühend. Halmlänge $115 \mathrm{~cm}$ (Wax. $140 \mathrm{~cm}$ ), Halmdicke $0.14 \mathrm{~cm}$, Blattzahl 4, Blattlänge $30.58 \mathrm{~cm}$, Blattbreite $1.3 \mathrm{~cm}$, Blattoberfläche $318 \mathrm{qcm}$, Halmfläche $151.8 \mathrm{qcm}$, Gesammtfläche $469.8 \mathrm{qcm}$.

Junge Aehre gelbgrïn, mittelfrüh reifend, $12 \mathrm{~cm}$ (Max. $15 \mathrm{~cm}$ ) lang, mit 21 Aehrchen und 70 ein wenig lose sitzenden Früchten, von denen 1508900 auf I hl (=79 kg) gehen.

Auf 1 qm wachsen 776 Halme oder 228 Pflanzen, mithin beträgt der Raum für eine Pflanze $44 \mathrm{qcm}$ und die Blattfäche p. qnı Bodenfläche $36.47 \mathrm{qm}$, und das Saatquantum $2.3 \mathrm{hl} \mathrm{p}$. ha.

Dieser Weizen trägt seinen Namen "Mesnil Saint Firmin“ von einer Ackerbauschule in Frankreich (Oise), deren Direktor, M. Bazin, 1838 in einem Weizenfelde zwei durch Grösse und Fruchtreichtum (91 Früchte) ausgezeichnete Aehren fand, welche er sorgfältig weiter züchtete, und auf diese Weise eine konstante Sorte erzielte, welche eine nahe Verwandtschaft mit dem Hickling-WVeizen zeigte, der im Allgemeinen leicht degeneriert, indem auf gutem Boden die Aehren länger, lockerer und schlaff werden, demnach steht zu vermuten, dass diese neue Sorte vom Hickling abstamint und auf fruchtbarem, kalkreichen Lehm- und Aueboden in diese Form übergegangen ist. Er erzielte auf diesem Boden Erträge ron 35 und selbst $40 \mathrm{hl} \mathrm{p}$. ha.

Leider zeigte sich dieser Weizen in Poppelsdorf nicht winterfest und erfror $1870 / 71$ vollständig, doch lagert er nicht leicht und widersteht dem Rost.

1) Vergl. Vilmorin, Journ. d'Agric. prat. 1851, pg. 454 und Essai 1850. 


\section{Blé Victoria d'automne. (2)}

Syn.: Französisch: Blé de Mr. Reiset; Blé géant de la Tréhonnais. Spanisch: Trigo Victoria de Otoño.

Englisch: Haigh-Wath prolific wheat.

Deutsch: Victoria Winterweizen.

Aehre: fast weiss, mit schwach rötlichem Schimmer, ziemlich dicht, breit; Aehrchen $2 \mathrm{~cm}$ breit, 3-körnig. - Stroh: rötlich-weiss, derbwandig. - Frucht: gelbrot, mehlig, nicht selten glasig, rundlich (6 inm lang, $4 \mathrm{~mm}$ breit), feinschalig, schön, halbhart.

Herbstblatt blaugrün, mittelbreit, ziemlich aufrecht; Frühjahrsvegetation zeitig, Bestockung schwach, 3 Schösslinge, mittelfrüh schossend und blühend. Halmlänge $120 \mathrm{~cm}$ (Max. $145 \mathrm{~cm}$ ), Halmdicke $0.45 \mathrm{~cm}$, Blattzahl 3.7, mittlere Blattlänge $28.75 \mathrm{~cm}$, Blattbreite $1.13 \mathrm{~cm}$, Blattoberfläche $240.43 \mathrm{qcm}$, Halmfläche $162 \mathrm{qcm}$, Gesammttäche eines Halmes $402.43 \mathrm{q} \mathrm{cm}$.

Auf 1 qm können 840 Halme oder 280 Pflanzen wachsen, mithin beträgt der Raum für jede Pflanze $35.7 \mathrm{qcm}$ und die Blattfläche $\mathrm{p}$. qm Bodenfläche $33.8 \mathrm{qm}$.

Junge Aehre gelbgriin mit bläulichem Anflug, mittelfrüh reifend, $12 \mathrm{~cm}$ (Max. $16 \mathrm{~cm}$ ) lang, mit 22 Aehrchen und 64 Früchten, die wenig fest in den Spelzen sitzen.

Es enthält $1 \mathrm{hl}(=82 \mathrm{~kg}) \quad 1886000$ Früchte, demzufolge das Saatquantum ( $1 / 3$ Verlust) $2.3 \mathrm{hl} \mathrm{p}$. ha beträgt.

Es wiegen 100 Halme $720 \mathrm{gr}$ und davon die Früchte $220 \mathrm{gr}$.

In Poppelsdorf erwies sich dieser Weizen als nicht winterfest, so erfror er 1870/71 vollständig, und kam in anderen Jahrgängen häufig nur mit wenigen kümmerlichen Pflanzen durch den Winter.

Aus diesen Gründen empfiehlt sich seine Kultur nur in sehr mildem Klima, wie es das westliche Frankreich und Spanien, wo er auch hauptsächlich gebaut wird, besitzen.

Gegen Lagern und Rost zeigte er sich in hohem Grade widerstandsfähig und auf reichen Böden stehen anch gute Erträge in Aussicht.

\section{Blé de Saumur d'antomne. (2)}

Syn.: Französisch: Blé gris de St. Laud, Blé de St. Laud, Blé d'Anjou, Gros blé de Saumur ${ }^{1}$ ).

Englisch: Saumur yellow Wheat.

Spanisch: Chamorro ${ }^{2}$ ) de Saumur.

Deutsch: Roter Winterweizen von Saumur.

Aehre: blassgelb, ziemlich dicht, lang, dünn, sich verjüngend; Aehrchen $1.3 \mathrm{~cm}$ breit, 2-körnig. - Stroh: rötlich-gelb, dickwandig, fest, lang. - Frucht: rot, glasig, länglich, gross ( $\mathrm{mm}$ lang, $31 \frac{1}{2} \mathrm{~mm}$ breit), eingefallen, dickschalig, Bruch halbstahlig, halbhart.

Herbstblatt blaugrün, schmal, aufrecht; Frühjahrsvegetation mittelfrüh, Bestockung mittelstark, 4.6 Schösslinge, mittelfriih schossend und

1) Vilmorin, Catal. 1877.

2) Kahlkopf, hier unbegrannter oder Kolbenweizen. 
blühend. Halmlänge $130 \mathrm{~cm}$ (Max. $150 \mathrm{~cm}$ ), Halmdicke $0.4 \mathrm{~cm}$, Blattzahl 4, Blattlänge $26.68 \mathrm{~cm}$, Blattbreite $0.99 \mathrm{~cm}$, Blattoberfläche $211.28 \mathrm{qcm}$, Halmfläche $151 \mathrm{q} \mathrm{cm}$, Gesammttläche $367.28 \mathrm{qcm}$.

Junge Aehre gelbgrïin, mittelfriih reifend, $10 \mathrm{~cm}$ (Max. $14 \mathrm{~cm}$ ) lang, mit 20 Aehrchen und 40 ziemlich leicht ausfallenden Früchten, von denen 1494000 auf $1 \mathrm{hl}(=83 \mathrm{~kg})$ gehen.

Es wachsen auf $1 \mathrm{qm} 800$ Halme oder 174 Pflanzen, mithin beträgt der Raum für eine Pflanze 57.5 qcm, die Blattoberfläche p. qm Bodenfläche 29.36 qm und das Saatquantum 1.7 hl p. ha.

Dieser Weizen ist ziemlich winterfest, so erfror derselbe 1870/71 nur zu einem geringen Teil, ferner zeigte er sich seit 1870 konstant, widerstelit dem Rost und Lagern vortrefflich und ist ergiebig.

Er findet sich namentlich auf den guten Weizenböden in Anjou ${ }^{1}$ ), Frankreich, wird aber auch in neuerer Zeit in Deutschland und Spanien gebaut.

\section{Blé de Saumur de Mars. $\odot$}

Syn.: Franz: Blé de Mars rouge de Brie.

Engl.: Sanmur Spring wheat.

Deutsch: Roter Märzweizen von Saumur.

Aehre: blassgelb, etwas locker, diinn; Aehrchen $1.5 \mathrm{~cm}$ breit, 2-körnig. - Stroh: rötlich-gelb, sehr dickwandig, wenig blattreich. Frucht: rotbraun, halbmehlig, rundlich (7 $11 \mathrm{~m}$ lang, $4 \mathrm{~mm}$ breit), feinschalig, halbhart.

Jnnges Blatt dunkelgrün, schmal, aufrecht; 2.5 Schösslinge, spät schossend und blühend. Halmlänge $125 \mathrm{~cm}$ (Max. $145 \mathrm{~cm}$ ), Halmdicke $0.4 \mathrm{~cm}$, Blattzahl 3, Blattlänge $26.3 \mathrm{~cm}$, Blattbreite $0.8 \mathrm{~cm}$, Blattoberfläche $126.24 \mathrm{qcm}$, Halmfläche $150 \mathrm{qcm}$, Gesammtfläche $276.24 \mathrm{qcm}$.

Die Aehre reift mittelfrüh, in 130 Tagen, und enthält bei $10 \mathrm{~cm}$ (Max. $14 \mathrm{~cm}$ ) Länge 18 Aelirchen mit 40 lose sitzenden Früchten, von denen 1735000 auf 1 hl (=82.6 kg) gehen.

Nach Vilmorin soll er auch als Winterweizen benutzt werden können, doch erfror derselbe 1870/71 in Poppelsdorf vollständig, daher er auch nicht mit dem ziemlich winterfesten ",Blé de Saumur d'automne“ identisch sein kann.

Dieser Sommerweizen ist ergiebig, leidet wenig durch Rost und Lagern und entstammt den Thälern von Anjou, und wird vorzugsweise im Distrikt von Orleans, La Beauce und der Brie, sowie auch im Weichbilde von Paris sehr ausgedehnt, in neuester Zeit auch in den mittleren Staaten der Vereinigten Staaten erfolgreich kultiviert.

\section{Blé de pays du Gâtinais ${ }^{2}$ ).}

şy n.: Blé de Revel, fin de Toulouse, de Carône (Vienne), Chicot blanc (Caën).

Aehre: fast weiss, mit schwach rötlicbem Anflug, sich wenig verjüngend, Spitze kurzgrannig, breit, 10 cm lang mit 60 Früchten; Aehrchen $1.5 \mathrm{~cm}$ breit, 3- und 4-körnig. - Stroh: rötlich-gelb, sehr fest,

1) Gasparin, Cours d'Agric. III, 604.

2) Vilmorin, Essai d'un catal. méthod. et syn. d. Froments. Paris 1850. 
kräftig, $120 \mathrm{~cm}$ lang. - Frucht: rot, glasig, gross (7 mm lang, $4 \mathrm{~mm}$ breit), ziemlich feiuschalig.

Original im landw. Museum zu Berlin.

\section{Blé Napoléon. (2)}

Aehre: rötlich-weiss, sich wenig verjüngend, etwas locker, lang und dick; Aehrchen $2 \mathrm{~cm}$ breit, 3- und 4-körnig. - Stroh: rötlich-gelb, sehr kräftig. blattreich. - Frucht: rotgelb, mehlig; nachgebaut: meist rot und glasig, plump, gross $(8 \mathrm{~mm}$ lang, $4 \mathrm{~mm}$ breit, 170 Früchte $=$ $10 \mathrm{gr}$ ); etwas dickschalig, weich.

Herbstblatt dunkelgrïn, ziemlich breit, aufrecht; Bestockung schwach, 3.5 Schösslinge, mittelfrüh schossend und blühend. Halmlänge $150 \mathrm{~cm}$ (Max. $165 \mathrm{~cm}$ ), Halndicke $0.5 \mathrm{~cm}$, Blattzahl 5.4 , Blattlänge $34.8 \mathrm{~cm}$, Blattbreite $1.15 \mathrm{~cm}$, Blattoberfläche $432.22 \mathrm{q} \mathrm{cm}$, Halmfläche $225 \mathrm{q} \mathrm{cm}, \mathrm{Ge}$ sammtfläche eines Halmes $657.22 \mathrm{qcm}$.

Auf $1 \mathrm{qm}$ entfallen 600 Halme oder 170 Pflanzen, mithin nimmt eine Pflanze einen Raum ron $59 \mathrm{qcm}$ ein, und die Blattfläche beträgt $\mathrm{p}$. qm der Bodenfl̈̈che $39.44 \mathrm{qm}$.

Junge Aehre gelbgrüin oder bläulich, mittelfrüh reifend, $12 \mathrm{~cm}$ (Max. $14 \mathrm{~cm}$ ) lang, mit 20 Aehrchen und 70 etwas lose sitzenden Früchten, ron denen 1428000 auf $1 \mathrm{hl}$ (= $8 t \mathrm{~kg}$ ) gehen, mithiu sich das Saatquantum $(1 / 3$ Verlust) auf $1.7 \mathrm{hl}$ p. ha stellt.

Es wiegen 100 Halme $860 \mathrm{gr}$ und daron die Früchte $320 \mathrm{gr}$.

Dieser Weizen ist dem Lagern unterworfen, doch fast rostfrei. Nur auf sehr reichen Böden im milden Seeklima sind ron diesem Weizen gute Resultate zu erwarten. Sein Aubau scheint vorzugsweise in NordFrankreich verbreitet $\mathrm{zu}$ sein, doch sind auch im Rheinthal mit ihm erfolgreiche Versuche angestellt worden, so ron Gutsbesitzer Herstatt in Marsdorf bei Köln.

\section{Blé Drouillard. (2)}

A ehre: blassgelb, Hicklingform, dicht, kurz, breit, grannenspitzig; Aehrchen meist 2-körnig. - Stroh: rötlich-weiss, ziemlich blattreich, fest, bis $150 \mathrm{~cm}$ hoch. $0.4 \mathrm{~cm}$ breit. - Frucht: rot, glasig, klein $(6 \mathrm{~mm}$ lang, $3 \mathrm{~mm}$ breit). feinschalig, lialbhart, Bruch halbstahlig.

Durchschnittlich enthält die Aehre 20 Aehrchen und 40 Früchte. Original im landw. Museum zu Berlin.

\section{Blé Chiddam de mars à grain rouge. ( ) u. (2)}

Syn.: Deutsch: Chiddam Sommerweizen mit rotem Korn.

Aehre: weiss, Klappen rot umrandet, dicht und breit, grösser als bei anderen Sommerkolbenweizen; Aehrchen $1.8 \mathrm{~cm}$ breit, 3-körnig. Stroh: rötlich-gelb, derbwandig, fest. - Frucht: gelbrot, halbmehlig, kurz, rund, dick (6 mm lang, $4 \mathrm{~mm}$ breit, 190 Früchte $=10 \mathrm{gr}$ ), feinschalig, schwer, halbhart.

Pflanze blau bereift, spät schossend, 2.7 Schösslinge, spät blühend. Halmlänge $115 \mathrm{~cm}$ (Iax. $125 \mathrm{~cm}$ ), Halmdicke $0.43 \mathrm{~cm}$, Blattzahl 4, Blattlänge $26 \mathrm{~cm}$, Blattbreite $1.05 \mathrm{~cm}$, Blattoberfläche $218.40 \mathrm{qcm}$, Halmfläche $148.35 \mathrm{qcm}$, Gesammtfläche eines Halmes $366.75 \mathrm{qcm}$. 
Auf 1 qm kommen 900 Halme oder 333 Pflanzen, mithin beträgt der Raum für eille Pflanze 33.3 q cm, und die Blattfläche p. qm Bodenfläche $33 \mathrm{qm}$.

Die Reife tritt nach einer Vegetationsperiode von 128 Tagen ein; Aehre $10 \mathrm{~cm}$ lang (Max. $13 \mathrm{~cm}$ ), mit 16 Aehrchen und 50 lose sitzenden Früchten, von denen auf 1 lil (= $=85 \mathrm{~kg}) 1615000$ Stiick gehen, demnach stellt sich das Saatquantum $(1 / 3$ Verlust) auf $3 \mathrm{hl} \mathrm{p.} \mathrm{ha.}$

100 Halme wiegen $571 \mathrm{gr}$ und davon die Frïchte $220 \mathrm{gr}$.

Fïr fruchtbare Weizenböden sehr geeignet, namentlich da er nicht leicht lagert und wenig durch Rost leidet; auch lässt er sicl im milden Klima als Winterweizen kultivieren.

Sein Anbau verbreitet sich hauptsächlich iiber Nord-Frankreich; in nenerer Zeit sind auch in Dcutschland und Italien erfolgreiche Anbauversuche ausgeführt worden.

Originalsaat ist von Vilmorin \& Andrieux, Paris, zu bezielen.

\section{Roode 'Tarwe Roozendaal. (2)}

Identisch sind nachfolgende holländische Weizensorten:

Roode Tarwe Haarlemermeer, Provinz Holland;

,,$\quad$ Arnhem, Provinz Gelderland.

Aehre: fast weiss, sicl stark verjïngend, grannenspitzig, locker, lang, dünn; Aehrchen $1.5 \mathrm{~cm}$ breit, meist 3-körnig. - Stroh: rötlichgelb, feinhalmig, doch fest. - Frucht: rot, mcist glasig, wenn mehlig, so gelbrot, klein, rundlich $\left(6 \mathrm{~mm}\right.$ lang, $3 \frac{1}{2} \mathrm{~mm}$ breit, 246 Früchte = $10 \mathrm{gr})$, feinschalig, halbhart, Bruch lialbmehlig.

Herbstblatt dunkelgrïn, beiderseits schwach behaart, etwas schmal, aufrecht; Bestockung stark, 5 Schösslinge. Frühjahrsvegetation mittelfrüh, spät schossend und blühend.

Halmlänge $140 \mathrm{~cm}$ (Max. $165 \mathrm{~cm}$ ), Halmdicke 0,38 cm, Blattzalıl 4, Blattlänge $32.5 \mathrm{~cm}$, Blattbreite $0,8 \mathrm{~cm}$, Blattoberfläche $208 \mathrm{qcm}$, Halmfläche 159,6 qcm, Gesammtfläche eines Halmes $367,6 \mathrm{qcm}$.

Es kommen auf 1 qm 900 Halme oder 180 Pflanzen, mithin beträgt der Raum für eine Pflanze $55.5 \mathrm{qcm}$, und die Blattfläche p. qm Bodenfläche 33,08 qm.

Junge Aehre gelbgrïn, mittelfüh reifend, $11 \mathrm{~cm}$ (Max. $14 \mathrm{~cm}$ ) lang, mit 18 Aehrchen und 54 ziemlich festsitzenden Früchten.

Aus $1 \mathrm{hl}(=83 \mathrm{~kg})$ zählen sich 2041800 Frïchte aus, und beträgt demnach das Saatquantum $1.3 \mathrm{hl} \mathrm{p.} \mathrm{ha.}$

Fis wiegen 100 Halme $605 \mathrm{gr}$ und davon die Früchte $225 \mathrm{gr}$.

Dieser Weizen erwies sich in Poppelsdorf als winterfest und eignet sich für leichtere Böden (sandiger Lehm) vorziiglich.

Uebersender: Dampfmühle zu Rotterdam.

\section{Galizischer Sommerweizen. $\odot$ u. (2)}

Aehre: blassgelb, etwas locker, grannenspitzig, dünn; Aehrchen $1.2 \mathrm{~cm}$ breit, 2- und 3-körnig. - Stroh: rötlich-gelb, derbwandig, fest. Frucht: rot, glasig oder halbmehlig, rund (6 mm lang, $4 \mathrm{~mm}$ breit), feilschalig: halbhart, Bruch halbstahlig.

Spät schossend, 3.5 Schösslinge und spät blühend. Halmlänge $90 \mathrm{~cm}$ (Max. $120 \mathrm{~cm}$ ), Halmdicke $0.35 \mathrm{~cm}$, Blattzahl 3, Blattlänge 
$18.22 \mathrm{~cm}$, Blattbreite $0.62 \mathrm{~cm}$, Blattoberfläche $67.8 \mathrm{qcm}$, Halmfläche 94.5 qcm, Gesammtfläche 162.3 qcm.

Auf $1 \mathrm{qm}$ wachsen 1500 Halme oder 430 Pflanzen, mithin beträgt der Raum für eine Pflanze $23.3 \mathrm{qcm}$ und die Blattläche p. qnı Bodenfläche $24.35 \mathrm{qm}$.

Junge Aehre gelbgrün, in 130 Tagen reifend, $8 \mathrm{~cm}$ (Мax. $12 \mathrm{~cm}$ ) lang, mit 18 Aehrchen und 45 leicht ausfallenden Frichten, von denen anf $1 \mathrm{hl}(=83.6 \mathrm{~kg}) 2069300$ gehen. mithin sich das Saatquantum auf $3,1 \mathrm{hl}$ p. ha stellt.

Es wiegen 100 Halme $430 \mathrm{gr}$ und davon die Früchte $140 \mathrm{gr}$.

In Eldena und Waldau wurden sehr hohe Erträge erzielt:

Ertrag p. ha in fiorn stroh Spreu

Waldau, schwerer Weizenboden (1861) $2012 \mathrm{~kg} \quad 4528 \mathrm{~kg} 992 \mathrm{~kg}$

Eldena, sandiger Lehm (1868) $2280,, 4480,592$,

Die Qualität des Kornes ist vorzüglich, und ausserdem ist das Korn so gross, dass im Handel dieser Weizen als Winterweizen durchgeht.

Ferner lagert er nicht leicht, zeigt sich gegen Rost widerstandsfähig and lässt sich anch als Winterweizen kultivieren.

Für die Lehmböden des feuchteren Klimas, namentlich des Gebirges, scheint sich dieser Weizen, dessen ursprüngliche Heimat Galizien ist, der jedoch auch viel in Ungarn, Siebenbürgen und Deutschland angebaut wird, zu eignen.

\section{Rnmänischer Weizen. (2)}

Aehre: fast weiss, mit schwachrötlichem Anflug, sich stark verjüngend, grannenspitzig, etwas locker, dünn; Aehrchen $1.3 \mathrm{~cm}$ breit, 2-körnig. - Stroh: rötlich-gelb, Testur fest, ziemlich blattreich. - Frucht: rot. glasig, selten gelbrot und mehlig, sehwer, klein (6 mm lang, $3 \mathrm{~mm}$ breit, $24 \%$ Früchte $=10 \mathrm{gr}$ ), feinschalig, Bruch halbstahlig, halbhart.

Herbstblatt blaugrün, schmal, kraus; Frühjabrsvegetation mittelfrüh, Bestockung stark, 4.5 Srhösslinge, mittelfrüh schossend und blühend. Halmlänge $125 \mathrm{~cm}$ (Мах, $150 \mathrm{~cm}$ ), Halmdicke $0.4 \mathrm{~cm}$, Blattzahl 3.7, Blattlänge $23.32 \mathrm{~cm}$, Blattbreite $1.08 \mathrm{~cm}$, Blattobertläche $186.55 \mathrm{qcm}$, Halmfläche $150 \mathrm{qcm}$, Gesammtfläche eines Halmes $336.55 \mathrm{qcm}$.

Es kommen auf $1 \mathrm{qm} 856$ Halnıe oder 190 Pflanzen, mithin beträgt der Raum für eine Pflanze $52.6 \mathrm{qcm}$, und die Blattflïche p. qm Bodenfläche $28.76 \mathrm{qm}$.

Junge Aebre gelbgrün, ziemlich zeitig reifend, $11 \mathrm{~cm}$ (Мas. $15 \mathrm{~cm}$ ) lang, mit 20 Aehrchen und 40 Früchten.

Es enthält $1 \mathrm{hl}(=82 \mathrm{~kg}) 2025400$ Früchte, mithin stelit sich das Sammtquantum auf $1.4 \mathrm{hl}$ p. ha.

Es wiegen 100 Halme $516 \mathrm{gr}^{\circ}$ und davon die Früchte $160 \mathrm{gr}$.

Der Weizen erwies sich als vollständig winterfest, zeigte wenig Neigung zum Lagern und Rost, und ist derselbe fiir gate Lehmböden im Kontinental-Klima des östlichen Europas vortrefflich geeignet, zumal das harte, slasige Korn eine vortreffliche Exportwaare ist.

Das prenssische landwirtschaftliche Ministerium sandte 1869 diesen Weizen nach Poppelsdorf ein.

\section{Weissähriger roter Kolbenweizen rom Altai. $\odot$}

Aehre: blassgelb, lang, locker, dünn, sich verjüngend und grannenspitzig; Aehrchen schmal, $1 \mathrm{~cm}$ breit, 2-körnig. - Stroh: blassgelb, fest, 
mittellang. - Frucht: rot, glasig, rundlich, sehr klein (51/2 mm lang, $3 \mathrm{~mm}$ breit, 340 Früchte $=10 \mathrm{gr}$ ), schön, feinschalig, hart, Bruch stahlig.

Jungès Blatt blaugrün, behaart, Bestockung ziemlich stark, 3 Schösslinge, etwas spät schossend und blühend, Halmlänge $105 \mathrm{~cm}(\operatorname{Max} .115 \mathrm{~cm})$, Halmdicke $0.3 \mathrm{~cm}$, Blattzahl 4, Blattlänge $14.5 \mathrm{~cm}$, Blattbreite $0.58 \mathrm{~cm}$, Blattoberfläche 67.28 q cm, Halmffäche $94.5 \mathrm{qcm}$, Gesammtfläche $161.78 \mathrm{qcm}$.

Junge Aehre blangrün, in 120 Tagen reifeud, $9 \mathrm{~cm}$ (Max. $13 \mathrm{~cm}$ ) lang, mit 17 Aehrchen und 32 lose sitzenden Früchten, von denen 2856000 auf $1 \mathrm{hl}(=8+\mathrm{kg})$ gehen.

Es wiegen 100 Halme $239 \mathrm{gr}$ und davon die Früchte $109 \mathrm{gr}$.

Dieser Weizen leidet wenig durch Rost und lagert nicht.

Heimat: das Quellgebiet des Ob im Altaigebirge.

Uebersender: Dr. Finsch und Graf Zeil 1879.

\section{Weissähriger roter Kolbenweizen ans Ostindien. $\odot$}

Aehre: blassgelb, mittellang $(9 \mathrm{~cm})$, locker, sich stark verjüngend, dünn, grannenspitzig; Aehrchen $1.1 \mathrm{~cm}$ breit, 2- und 3-körnig; 38 Früchte in einer Aehre. - Stroh: rötlich-gelb, feinhalmig, fest. - Frucht: rot, meist glasig, lang, $7 \mathrm{~mm}$ lang, 31/2 mm breit, feinschalig, 192 Früchte $=10 \mathrm{gr}$, halbhart, Bruch halbstahlig.

Es wiegen 100 Halme $330 \mathrm{gr}$, und davoll die Friichte $161 \mathrm{gr}$.

Spätreif.

\section{Weizen aus Brasilien. (2)}

Aehre: gelb, grannenspitzig, dicht, $10 \mathrm{~cm}$ lang mit 60 Früchten; Aehrchen 3-körnig, $1.5 \mathrm{~cm}$ breit. - Stroh : gelb, steif, nicht leicht lagernd. Frucht: rot, glasig, klein, rundlich (6 $\mathrm{mm}$ lang, $3^{1 / 4} \mathrm{~mm}$ breit, ) feinschalig.

Original im landw. Museum zu Berlin.

\section{Varietät: Triticum vulgare alborubrum Kcke.}

Aehren kahl, rot; Körner weiss oder gelblich.

\section{Sorten:}

\section{Dantzic red chaffed-wheat. (2)}

Syn: Franz.: Blé red chaff de Dantzick, Blé Jersey-Dantzick, Blé Le Couteur-Dantzick, Blé blanc de Dantzick.

Aehre: sehr hellrot, dicht, viereckig, lang, aufrecht, breit; Aehrchen $2 \mathrm{~cm}$ breit, 3- bis 4-körnig. - Stroh: blassgelb, biegsam, fest und schön. - 
Frucht: Original gelblich-weiss, mehlig, klein, rund; nachgebaut: viele glasig ( $6 \mathrm{~mm}$ lang, $4 \mathrm{~mm}$ breit, 270 Früchte $=10 \mathrm{gr}$ ), feinschalig, halbhart, Bruch halbmehlig.

Herbstblatt blaugriin, beiderseits behaart, ziemlich breit, aufrecht; Friihjahrsvegetation sehr zeitig, Bestockung schwach, 3.5 Schösslinge, mittelfriih schossend, doch ziemlich spät reifend. Halmlänge $120 \mathrm{~cm}$ (Max. $140 \mathrm{~cm}$ ), Halmdicke $0,47 \mathrm{~cm}$, Blattzahl 3.3, Blattlänge $30.98 \mathrm{~cm}$, Blattbreite $1.14 \mathrm{~cm}$, Blattoberfläche $233.11 \mathrm{~cm}$, Halmfläche $169.2 \mathrm{~cm}$, Gesammtfläche $402.31 \mathrm{qcm}$.

Junge Aehre gelbgrïn, $11 \mathrm{~cm}$ (Мax. $14 \mathrm{~cm}$ ) lang, mit 19 Aehrchen und 65 etwas lose sitzenden Friichten, von denen 2160000 auf $1 \mathrm{hl}$ (= $83 \mathrm{~kg})$ gehen.

Auf $1 \mathrm{qm}$ wachsen 900 Halme oder 260 Pflanzen, mithin beträgt der Raum für eine Pflanze $38.5 \mathrm{qcm}$, die Blattfläche p. qm Bodenfläche $40 \mathrm{qm}$, und das Saatquantum $1.8 \mathrm{hl}$ p. ha.

Es wiegen $100 \mathrm{Halme} 580 \mathrm{gr}$ und davon die Friichte $180 \mathrm{gr}$. Stroh zu Flechtwerk geeignet.

Unter gleichen Boden- und. Kulturverhältnissen erntete Lawes, Rothamsted, im vierjährigen Durchschnitt (1873/76) $36.5 \mathrm{hl}$ p. ha.

Im siidlichen England wird er mit Erfolg auf den leichteren aber kulturvollen Böden knltiviert; auf den reichen Böden erreicht das Stroh eine sehr bedeutende Iänge, in Folge dessen es leicht lagert und stark durch Rost leidet.

In Poppelsdorf erwies sich diese Sorte als nicht winterfest, auch soll sie schon für das nördliche Frankreich zu weich sein. Der Weizen wurde durch Colonel Le Couteur ${ }^{2}$ ) auf der Insel Jersey in aus Danzig importiertem Getreide gefunden und weiter kultiviert. Wahrscheinlich stammt er ursprünglich vom Sandomir-Weizen ab, welcher mit der Zeit durch den Einfluss des milderen und feuchteren Klimas üppiger, aber auch weichlicher geworden ist.

\section{Fenton white Wheat. (2)}

Syn: Deutsch: Weisser Winter-Fenton-Weizen.

Aehre: blassrot, ziemlich dicht, grannenspitzig, lallg, etwas schmal; Aehrchen $1.7 \mathrm{~cm}$ breit, 3-körnig. - Stroh: rötlich-gelb, derbwandig, steif, häufig ungleich hoch. - Frucht: Original meist mehlig, gelblichweiss, sehr schön, länglich $\left(6^{1} / 2 \mathrm{~mm}\right.$ lang, $3^{1 / 2} \mathrm{~mm}$ breit, 227 Früchte $=10 \mathrm{gr})$; nachgebaut: Frichte kleiner $(259=10 \mathrm{gr})$, doch in der Beschaffenheit konstant geblieben, weich.

Herbstblatt blaugriin, schmal, kraus; Frühjahrsvegetation spät, Bestockung stark, 6 Sprosse, spät schossend und blühend. Halmlänge $125 \mathrm{~cm}$ (MIax. $150 \mathrm{~cm}$ ), Halmdicke $0.4 \mathrm{~cm}$, Blattzahl 4, Blattlänge $22.5 \mathrm{~cm}$, Blattbreite $0.89 \mathrm{~cm}$, Blattoberfläche $160.20 \mathrm{qcm}$, Halmfläche $150 \mathrm{qcm}$, Gesammtblattfläche $310.20 \mathrm{qcm}$.

Junge Aehre gelbgriin, Spelzen rot umrandet, etwas spät reifend, $10 \mathrm{~cm}$ lang (Max: 14 cm) mit 20 Aehrchen und 56 leicht ausfallenden Früchten, von denen 2162650 anf $1 \mathrm{hl}$ (=83.5 kg) gehen, mithin sich das Saatquantum auf $1.1 \mathrm{hl}$ stellt.

1) Journ. of the Roy. Agric. Soc. 1840. Vol. I, pag. 115. 
Auf 1 qm entfallen 1000 Halme oder 167 Pflanzen, demnach beträgt der Raum für eine Pflanze $60 \mathrm{qcm}$ und die Blattoberfläche p. qm. Bodenfläche $31 \mathrm{qm}$. 100 Halme wiegen $386 \mathrm{gr}$ und die Früchte $180 \mathrm{gr}$.

Für Deutschland ist dieser Weizen nicht winterfest genug, so winterte derselbe in Schlesien ${ }^{1}$ ), Posen und Brandenburg 1857/58 aus.

Da dieser Weizen sclbst bei reicher Düngung auf gutem Lehmboden selten lagert, wird er in England lıäufig dem Hunter's Weizen vorgezogen.

Robert Hope fand ihn $\mathbf{1 8 3 5}$ in einem Basalt-Steinbruche zu Fenton Barns, East-Lothian und verbreitete ihn scit 1841.

Auf schwerem Lehmboden in Nord-England soll $\mathrm{cr}$ im zweijährigen Durchschnitt $2727 \mathrm{~kg}$ Korn und $3492 \mathrm{~kg}$ Stroh p. ha geliefert haben.

Dieser Weizen scheint selır nahe init ,Dantzik red chaffed-wheat" verwandt zu sein.

\section{Red strawed white Wheat. (2)}

Aelire: hellrot, ziemlich dicht und lang, $12 \mathrm{~cm}$ lang mit 70 festsitzenden Früchten; Aehrchen $1.8 \mathrm{~cm}$ breit, 3 - und 4-körnig. - Stroh: der obere Halmtcil nimmt vor der Reife Purpur-oder rote Farbe an, stark, $137 \mathrm{~cm}$ lang, nicht leicht lagernd, Strolertrag hoch. - Frucht: Original weiss, rund, schön $(6 \mathrm{~mm}$ lang, $4 \mathrm{~mm}$ breit, 226 Friichte $=$ $10 \mathrm{gr}$ ), die Frucht wird jedoch grobschalig und plump, sobald das Wetter nasskalt oder der Boden sehr humos ist, daher sich sein Anbau nur für Lehm- und Thonböden empfiehlt.

Er wurde durch Mr. John Morton, Whitfield, Gloucestershire, zur Kultur eingefübrt. Original in Poppelsdorf.

\section{Compfsane Prize. (2)}

Syn.: Deutsch: Winterweizen aus Canada.

Aehre: blassrot, ziemlich dicht, sich etwas verjüngend, schmal; Aehrchen $1.3 \mathrm{~cm}$ breit, 2- und 3-körnig. - Stroh: rötlich-gelb, fest. Frucht: Original weiss, meist mehlig; nachgebaut: meist glasig, rund, klein ( $6 \mathrm{~mm}$ lang, $3 \frac{1}{2} \mathrm{~mm}$ breit, 287.5 Frichte $=10 \mathrm{gr}$ ), feinsclalig, halbhart, Bruch halbmehlig.

Herbstblatt blaugriin, schmal, kraus; Frihjahrsvegetation zeitig; Bestockung mittelstark, 4.2 Schösslinge; zeitig schossend und bliibend. Halm länge $115 \mathrm{~cm}$ (Max. $140 \mathrm{~cm}$ ), Halmdicke $0.4 \mathrm{~cm}$, Blattzahl $3.3 \mathrm{~cm}$, Blattlänge $26.33 \mathrm{~cm}$, Blattbreite $0.99 \mathrm{~cm}$, Blattoberfläche $172.06 \mathrm{qcm}$, Halmfläche $138 \mathrm{qcm}$, Gesammtfï̈che $310.06 \mathrm{qcm}$.

Junge Aehre gelbgrïn, zeitig reifend, $10 \mathrm{~cm}$ (Max.: $15 \mathrm{~cm}$ ) lang, mit 20 Aehrchen und 50 ziemlich leicht ausfallenden Frichtell.

Es kommen auf $1 \mathrm{qm} 900$ Halme oder 215 Pflanzen, mithin beträgt der Raum für eine Pflanze $46.5 \mathrm{qcm}$, und die Blattfläche p. qun der Bodenfläche 27.9 qm.

Es entfallen pro hl $(=81.7 \mathrm{~kg}) 2348875$ Frïichte, mithiu stellt sich das Saatquantum (1/3 Verlust) auf $1.4 \mathrm{hl}$ p. ha.

Es wiegen 100 Halme $410 \mathrm{gr}$, und davon die Frichte $171 \mathrm{gr}$.

Fïr einen mergelhaltigen Lehmboden scheint sich dieser ertragreiche,

1) Vergl. Metz, Berichte 1881, pag. 51. 
nicht leicht durch Lagern oder Rost leidende Weizen am meisten zu empfehlen.

Seine Heimat ist Canada.

\section{Old-Genesee-Red-Chaff, Nord-Amerika. (2)}

Syn.: Red-chaff Bald.

Aehre: blassrot, sich verjiingend, grannenspitzig, dünn, locker, mittellang; Aehrchen schmal $(1.1 \mathrm{~cm}$ breit), 2- und 3-körnig. - Stroh: rötlich- oder blassgelb, fest, kurz. - Frucht: Original weiss, meist mehlig, klein, $(6 \mathrm{~mm}$ lang, $31 / 2 \mathrm{~mm}$ breit, 255 Frïchte $=10 \mathrm{gr}$ ); nachgebaut: meist rötlich und glasig, grösser $(200$ Früchte $=10 \mathrm{gr})$, feinschalig, weich.

Herbstblatt blaugrün, kraus; Entwickelung mittelfrüh, 2.9 Schösslinge, zeitig schossend und blühend; Halm $95 \mathrm{~cm}$ (Max. $105 \mathrm{~cm}$ ) lang, $0.38 \mathrm{~cm}$ dick, Blattzahl 4.4, Blätter $17.5 \mathrm{~cm}$ lang, $0.9 \mathrm{~cm}$ breit, Blattfläche $138.69 \mathrm{~cm}$, Halmfläche $108.3 \mathrm{qcm}$, Gesammttläche $246.9 \mathrm{qcm}$.

Junge Aehre blaugrïn, rot umrandet, mittelfrïh reifend, $10 \mathrm{~cm}$ (Max.: $12 \mathrm{~cm}$ ) lang, mit 16 Aehrchen und 36 etwas lose sitzenden Früchten, von denen 2244000 anf $1 \mathrm{hl}(=88 \mathrm{~kg}$ ) entfallen.

Selten lagernd.

Alte Sorte ${ }^{1}$ ), schon 1798 westlich ron New-York kultiviert, sehr geschätzt, auch viel im südlichen und östlichen Pennsylvanien und Californien gebaut. York.

Bezugsquelle: Diirselen in Neuss, Ernte 1879, Abladung New-

\section{Clawson. (2)}

Aehre: hellrot, locker, mittellang, dïun, grannenspitzig; Aehrchen $1.5 \mathrm{~cm}$ breit, 3-körnig. - Stroh: fast weiss, fest, unter mittellang. Frucht: Original fast weiss, mehlig, wenige rötlich und glasig, oval, mittelgross $\left(6^{1 / 4} \mathrm{~mm}\right.$ lang, $3^{1 / 2} \mathrm{~mm}$ breit, 268 Friichte $\left.=10 \mathrm{gr}\right)$; 11 achgebaut: grösser, 196 Friichte $=10 \mathrm{gr})$, feinschalig, weich, Bruch mehlig.

Herbstblatt dunkelgrün, ziemlich aufrecht, feinblättrig; Entwickelung mittelfrüh, 3 Schösslinge, spät schossend und blühend; Halm $100 \mathrm{~cm}$ (Max. $115 \mathrm{~cm}$ ) lang, $0.3 \mathrm{~cm}$ dick, Blattzahl 4.2, Blätter $16.5 \mathrm{~cm}$ lang, $0.85 \mathrm{~cm}$ breit, Blattoberfläche $117.8 \mathrm{qcm}$, Halmfläche $90 \mathrm{qcm}$, Gesammtfläche $207.8 \mathrm{qcm}$.

Junge Aehre bläulich, rot umrandet, $9 \mathrm{~cm}$ (Мax. $12 \mathrm{~cm}$ ) lang, mit 15 Aehrchen und 40 Früchten, ron dencn 2304800 auf $1 \mathrm{hl}$ (=86 kg) entfallen.

Unterliegt stark dem Rost, winterfest und nicht leicht lagernd.

Bezugsquelle: Missouri Agric.-Coll. U. S.

\section{White Mammoth. $\odot$}

Deuts ch: Weisser Mammuth-Sommer-Weizen.

Aehre: blassrot, etwas locker, lang, diinn; Aehrchen $1.5 \mathrm{~cm}$ breit,

1) Allen, The americ. Farm-book. 1856. 
2-körnig. - Stroh: rötlich-gelb, fest, lang. - Frucht: hellgelb, glasig, länglich, voll, sehr gross ( $8 \mathrm{~mm}$ lang, $4 \mathrm{~mm}$ breit), feinschalig, halbhart, Bruch halbstahlig.

Junges Blatt dunkelgrün, aufrecht, breit, 2.9 Schösslinge, spät schossend und blühend; Halm $130 \mathrm{~cm}$ (Max. $150 \mathrm{~cm}$ ) lang, $0.43 \mathrm{~cm}$ dick, Blattzahl 3.4, Blätter $28.8 \mathrm{~cm}$ lang, $0.85 \mathrm{~cm}$ breit, Blattoberfläche 166.5 q cm, Halmfläche 167.7 q $\mathrm{cm}$, Gesammtflächc 334.2 qcm.

Aehre in 126 Tagen reifend, $11 \mathrm{~cm}$ (Max. $15 \mathrm{~cm}$ ) lang, mit 36 leicht ausfallenden Frichten, von denen 1815000 auf $1 \mathrm{hl}(=82.5 \mathrm{~kg})$ entfallen.

Wenig durch Rost und Lagern leidend.

In den Vereinigten Staaten, namentlich in Oregon gebant.

Bezugsquelle: Wiener Ausstellung 1873.

\section{Oregon-Club. (2)}

Syn.: Club-Wheat; Louisiana-Wheat.

Aehre: rot mit violettem Anflug, ein wenig grannenspitzig, dicht. knrz, Form gleich Hickling; Aehrchen 3- bis 4-körnig. Stroh: rötlichgelb, steif. - Frucht: Original fast weiss, mehlig, oval. voll, dick, klein $\left(5 \frac{1}{2} \mathrm{~mm}\right.$ lang, $3^{1} / 2 \mathrm{~mm}$ breit, 320 Friichte $\left.=10 \mathrm{gr}\right)$; nachgebaut: meist rötlich-weiss, glasig, grösser, 235 Früchte $=10 \mathrm{gr}$, feinschalig, halbhart, Bruch halbmehlig.

Herbsthlatt dunkelgrün, aufrecht, breit; Entwickelung zeitig, 2.8 Schösslinge, mittelfrüh schossend und blühend; Halm $90 \mathrm{~cm}$ (Max. 110 cm) lang, $0.4 \mathrm{~cm}$ dick, Blattzahl 4.4, Blätter $14.6 \mathrm{~cm}$ lang, $1 \mathrm{~cm}$ breit, Blattfläche 128.5 qcm, Halmfläche 108 qcm, Gesammtfläche 236.5 qcm.

Junge Aehre gelblich-grün, rot umrandet, mittclfriil reifend, $7 \mathrm{~cm}$ (Max. $9 \mathrm{~cm}$ ) lang, mit 20 Aehrehen und 70 fest sitzenden Frichten, von denen 2880000 auf $1 \mathrm{hl}(=90 \mathrm{~kg})$ entfallen.

Dieser häufig im Westen Nord-Amerikas angebaute Weizen lagert nicht, ist aber ausserordentlich stark dem Rost unterworfen.

Bezugsquelle: Missouri Agric.-Coll. [T. S.

\section{Trigo blaneo, Chile. $\odot$ n. (2)}

Aehre: blassrot, halblocker, sich verjüngend, kurzgrannig, schmal; Aehrchen lang, $1 \mathrm{~cm}$ breit, 3-körnig. - Strol: rötlich-gelb, fest. Frucht: Original fast weiss, meist mehlig, länglich, gross (7 mm lang, $3 \frac{1}{2} \mathrm{~mm}$ breit, 196 Erüchte $\left.=10 \mathrm{gr}\right)$; nachgebaut: rötlich, glasig, ein wenig grösser, 172 Früchte $=10 \mathrm{gr}$, feinschalig, halbhart, halbmehlig.

Junges Blatt dunkelgrïn, fein, aufrecht, 2 Schösslinge, mittelfrüh schossend und bliihend; Halm $110 \mathrm{~cm}$ (Max. $125 \mathrm{~cm}$ ) lang, $0.35 \mathrm{~cm}$ dick, Blattzahl 4, Blätter 24,5 cm lang, $1 \mathrm{~cm}$ breit, Blattfläche $196 \mathrm{qcm}$, Halmfläche 155 qcm, Gesammtfäche $351 \mathrm{qcm}$.

Junge Aehre blaugrün, spät reifend; $10 \mathrm{~cm}$ (Max. 14 cm) lang, mit 18 Aehrchen und 50 Früchten, ron denen 1764000 auf $1 \mathrm{hl}(=90 \mathrm{~kg})$ entfallen.

Im Herbst angebaut, kamen nur wenige Pflanzen durch den Winter. Widersteht dem Lagern und Rost sehr gut.

Bezugsquelle: durch von Gülich 1880 aus Chile gesandt. 


\section{Blé Chiddam d'automne à épi rouge. (2)}

Syn: Winter-Chiddam-Weizen mit roter Aehre.

Aehre: blassrot, mittellang, ziemlich quadratisch, sich wenig verjüngend, etwas grannenspitzig, dicht, ziemlich breit; Aehrchen $1.6 \mathrm{~cm}$ breit, meist 3-körnig. - Stroh: rötlich-gelb, blattreich, sehr fest. Frucht: Original (Vilmolin etc., Paris) gelblich-weiss, mehlig; nachgebaut: Mehrzahl glasig und rötlich, klein, rundlich $\left(6 \mathrm{~mm}\right.$ lang, $3^{1 / 2} \mathrm{~mm}$ breit, 219 Früchte $=10 \mathrm{gr}$, sehr schön, feinschalig, schwer, halbhart, Bruch halbmehlig.

Herbstblatt gelbgrün, breit, behaart, aufrecht; Frühjahrsvegetation ziemlich zeitig, doch spät schossend, 3.7 Schösslinge und spät blühend. Halmlänge $125 \mathrm{~cm}$ (Max. $145 \mathrm{~cm}$ ), Halmdicke $0.38 \mathrm{~cm}$, Blattzahl 4.3, Blattlänge $27 \mathrm{~cm}$, Blattbreite $0.96 \mathrm{~cm}$, Blattoberfläche $222.91 \mathrm{qcm}, \mathrm{Halm}$ fläche $142.5 \mathrm{qcm}$, Gesammtfläche $365.41 \mathrm{qcm}$.

Junge Aehre gelbgrün mit rot umrandeten Spelzen, spät reifend, $9 \mathrm{~cm}$ (Max. $13 \mathrm{~cm}$ ) lang, mit 20 Aehrchen und 60 ziemlich fest sitzenden Früchten, von denen 1883400 auf $1 \mathrm{hl}(=86 \mathrm{~kg})$ gehen.

Auf 1 qm können 860 Halne oder 233 Pflanzen wachsen, mithin nimmt eine Pflanze einen Raum von $43 \mathrm{gcm}$ ein und beträgt die Blattfläche p. qm Bodenfläche $31.4 \mathrm{qm}$ und das Saatquantum (1/3 Verlust) $1.8 \mathrm{hl} \mathrm{p.} \mathrm{ha.}$

Es wiegen 100 Halme $750 \mathrm{gr}$ und davon die Früchte $300 \mathrm{gr}$.

Dieser Weizen zeichnet sich durch seine vorzügliche Fruchtqualität aus und lagert nicht leicht, befällt aber stark mit Rost und scheint für rauhe Klimate nicht genügend winterfest zu sein.

Zu seiner Kultur sind milde, kulturvolle Lehmböden am geeignetsten. In Frankreich lässt er sich bis in den December hinein aussäen.

\section{Blé Ronsselin. $\odot$ u. (2)}

Aehre: hellrot, sich ziemlich stark verjüngend, locker, lang, schmal; Aehrchen $1.3 \mathrm{~cm}$ breit, 2- und 3-körnig. - Stroh: schön gelb, fest, kräftig. - Frucht: Original weiss, mehlig; nachgebaut: meist rötlich und glasig, rundlich, gross ( $71 / 2 \mathrm{~mm}$ lang, $4 \mathrm{~mm}$ breit, 140 Frïchte $=10 \mathrm{gr}$ ), feinschalig, halbweich, Bruch halbmehlig. Die Früchte des Sommerweizens etwas kleiner (165 Früchte $=10 \mathrm{gr}$ ).

Herbstblatt gelbgrün, schmal, aufrecht, sehr zeitig schossend, blühend und reifend, als Sommerweizen spät, denn er reifte in einer Vegetationsperiode von 137 Tagen aus.

Entwickelung der Winter- und Sommersaat:

\begin{tabular}{l|c|c}
\hline & Wintersaat & Sommersat \\
\hline & $130 \mathrm{~cm}($ Max. $150 \mathrm{~cm})$ & $130 \mathrm{~cm}$ (Max. $155 \mathrm{~cm})$ \\
Halmlänge & $0.38 \mathrm{~cm}$ & $0.4 \mathrm{~cm}$ \\
Halmaicke & 4.4 & 4 \\
Blattzahl & $28.3 \mathrm{~cm}$ & $35 \mathrm{~cm}$ \\
Mittlere Blattlänge & $1.13 \mathrm{~cm}$ & $0.9 \mathrm{~cm}$
\end{tabular}




\begin{tabular}{|c|c|c|}
\hline & Wintersaat & Sommersaat \\
\hline $\begin{array}{l}\text { Blattoberfläche } \\
\text { Halmflāche } \\
\text { Gesammtfläche } \\
\text { Anzahl der Schösslinge } \\
\text { Auf } 1 \text { qm wachsen } \\
\text { do } \\
\text { Auf } 1 \text { qm Bodenfläche kommen } \\
\text { Raum für eine Pflanze } \\
\text { Aehrenlänge } \\
\text { Anzahl der Aehrchen pro Aehre } \\
\text { Früchte in einer Aehre } \\
\text { Hektolitergewicht } \\
\text { Fruchtzahl in } 1 \text { hl } \\
\text { Aussaatquantum pro ha }\end{array}$ & $\begin{array}{c}281.42 \mathrm{qcm} \\
148.20 \mathrm{qcm} \\
429.62 \mathrm{qcm} \\
2.4 \\
700 \text { Halme } \\
290 \text { Pflauzen } \\
30.07 \text { qm Blattfläche } \\
34.5 \text { qcm } \\
11 \mathrm{~cm} \text { (Max. } 15 \mathrm{~cm} \text { ) } \\
16 \\
40 \\
82 \mathrm{~kg} \\
1148000 \\
3.8 \mathrm{hl}\end{array}$ & 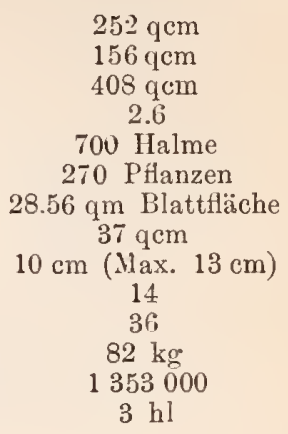 \\
\hline
\end{tabular}

Es wiegen 100 Halme der Wintersaat $540 \mathrm{gr}$, die Früchte $180 \mathrm{gr}$. " " " ", Sommersaat 530 " , " 180 , Hieraus geht hervor, dass, mit Ausnahme einer geringeren Grösse der Friichte der Sommersaat, die Entwickelung dieselbe ist, also dieser Weizen als echter Wechselweizen angesehen werden kann, zunal derselbe gegen ungünstige Witterung sich wenig empfindlich zeigte; doch ist er gegen Lagern weniger widerstandsfähig als gegen Trockenheit und Rost.

Für reiche Weizenböden scheint dieser Weizen sehr empfehlenswert zu sein.

Originalsamen versendet Vilmorin \& Andrieux, Paris.

\section{Sandomirska Pszenica. (2)}

A merikanisch: Sandomirka oder Sandomir wheat.

Deutsch: Sandomir-Weizen, auch Sandomierz-Weizen.

Aehre: hellrot, etwas locker, sich nach der Spitze zu verjüngend und kurz begrannt, lang, schmal; Aehrchen im Original $1 \mathrm{~cm}$ breit und 2-körnig; nachgebaut: $1.5 \mathrm{~cm}$ breit und meist 3-körnig. — Stroh: rötlichgelb, fest, geschmeidig, schön, dünn, kurz; nachgebaut: länger und kräftiger. - Frucht: Original weissgelb, mehlig, oval, klein (6 mm lang, $3 \mathrm{~mm}$ breit, 376 Früchte $=10 \mathrm{gr}$ ); nachgebaut: viele glasig und hellrötlich, grösser $(6 \mathrm{~mm}$ lang, $4 \mathrm{~mm}$ breit, 231.3 Früchte $=10 \mathrm{gr})$, Textur fest, feinschalig, hart, Bruch stahlig.

Herbstblatt blaugrün, fein, kraus, Frïhjahrsvegetation sehr spät, Bestockung sehr stark, 5.6 Schösslinge, bei 100 qcm Raum ergaben sich 18 Schösslinge p. Pflanze; mittelfriih schossend und blühend.

Die aus dem Originalsamen in 1. Tracht gewonnene Pflanze verhielt sich zu der nachgebauten Pflanze (6. Tracht) wie folgt: 


\begin{tabular}{l|c|c}
\hline & Originalpflanze & Nachgebaut \\
\hline Halmlänge & $95 \mathrm{~cm}$ (Max.110 cm) & $125 \mathrm{~cm}$ (Max. 140 cm) \\
Halmdicke & $0.3 \mathrm{~cm}$ & $0.38 \mathrm{~cm}$ \\
Blattzahl & 3 & 4 \\
Blattlänge & $17.2 \mathrm{~cm}$ & $25.08 \mathrm{~cm}$ \\
Blattbreite & $0.72 \mathrm{~cm}$ & $1.03 \mathrm{~cm}$ \\
Blattoberfläche & $74.30 \mathrm{qcm}$ & $166.58 \mathrm{qcm}$ \\
Halmfläche & $85.50 \mathrm{qcm}$ & $142.50 \mathrm{qm}$ \\
Gesammtfläche & $159.80 \mathrm{qcm}$ & $309.08 \mathrm{qcm}$ \\
Aehrenlänge & $10 \mathrm{~cm}(\mathrm{Max} .13 \mathrm{~cm})$ & $11 \mathrm{~cm}(\mathrm{Max} .14 \mathrm{~cm})$ \\
Aehrchenzall & 15 & 18 \\
Früchte in einer Aehre & 30 & 50 \\
Fruchtzahl in hl & 3083200 & 1863000 \\
Hektolitergewicht & $8.2 \mathrm{~kg}$ & $81.7 \mathrm{~kg}$ \\
100 Halme wiegen & $310 \mathrm{gr}$ & $390 \mathrm{gr}$ \\
Körner wiegen & $141.5 \mathrm{gr}$ & $185.6 \mathrm{gr}$ \\
& &
\end{tabular}

Junge Aehre gelbgrün, rot umrandet, mittelfrülı reifend. vom liost.

Das Stroh lagert nur auf sehr reichem Boden und leidet wenig

Der Weizen ist vollkommen winterfest.

Seine eigentliche Heimat liegt $\mathrm{mm}$ die im Königreich Polen gelegene Stadt Sandomierz als Mittelpunct herum, und reicht das Gebiet nach Norden bis Lublin, nach Osten bis Zamosc, nach Westen bis Olkusz und nach Süden bis nach Galizien hinein; aber auch in West- und Ostpreussen wird dieser Weizen wegen seiner vortrefflichen Qualität und Widerstandsfähigkeit gegen ungünstige Witterung sehr ausgedehnt kultiviert, und namentlich zeigt sich der um Graudenz in der Weichselniederung gebaute von gleicher Güte wie der Originalweizen.

In Westeuropa, so in Frankreich und England degeneriert er leicht und muss häunger frisches Saatgut bezogen werden.

Auf den guten Niederungsböden au den norddeutschen Flissen liefert er sehr befriedigende Erträge und schöne Kornqualität, auch auf den nahrungsreicheı sandigen Lehmböden befriedigt sein Anbau, vorausgesetzt, dass ihm keine sehr starke Stallmistdiungung gegeben wird, weil er in diesem Falle selır stark in's Stroh wächst und dickschalige Körner liefert.

Für das nordöstliche Deutschland und Polen ist dieser Weizen höchst beachtenswert, so lieferte derselbe auf der Domaine Waldau in Ostpreussen 1861 auf schwerem Weizenboden folgende Erträge p. ha:

$2608 \mathrm{~kg}$ Korn, $6184 \mathrm{~kg}$ Stroh, $840 \mathrm{~kg}$ Spreu.

Die Qualität dieses Weizens ist vortrefflich und namentlich der Klebergehalt sehr hoch; so fand won Lukowitz ${ }^{1}$ ) bei Weizen aus der Lycker-Gegend den sehr hohen Gehalt an frischem Kleber von 33 pc.

Ferner liegen Analysen der Versuchsstation zu Insterburg ${ }^{2}$ ) und von $\mathrm{Krocker}$ und Horsdorf aus Hohenheim vor.

1) Vergl. r. Lukowitz, Weizen- und Weizenmehluntersuchungen, Vortrag gehalten zu Königsberg 1879.

2) Georgine, 1880, No. 3 u. 4. 


\begin{tabular}{|c|c|c|c|}
\hline & \multicolumn{2}{|c|}{ Krocker \& Horsdorf } & \multirow{2}{*}{$\begin{array}{l}\text { Insterburg } \\
\text { Seit } 15 \text { Jahren } \\
\text { auf gutem } \\
\text { Mittelboden } \\
\text { gebaut. }\end{array}$} \\
\hline & Original & $\begin{array}{l}\text { In } \\
\text { Hohenheim } \\
\text { gebaut }\end{array}$ & \\
\hline Wasser & 13.2 & 15.48 & 15.06 \\
\hline Eiweiss & 21.5 & 17.15 & 10.02 \\
\hline Stärke & 55.1 & 53.37 & 57.70 \\
\hline Fett & 1.5 & - & 2.17 \\
\hline Asche & - & 2.40 & 1.68 \\
\hline Extraktstoffe & 6.8 & - & - \\
\hline
\end{tabular}

Seine Kultur ist auch erfolgreich in Amerika ${ }^{1}$ ) eingeführt worden. Charkow.

Tebersender des Originalsamens ist Professer Saykewitsch zu

\section{Rotähriger weisser Kolben-Weizen ans Ostindien. (2)}

Aehre: blassrot, sich verjiingend, grannenspitzig, schmal, dünn; Aehrchen 2-körnig. - Stroh: blassgelb, kräftig. - Frucht: blassgelb und mehlig; schön, rund, klein (6 mm lang, $4 \mathrm{~mm}$ breit, 215 Früchte $=$ $10 \mathrm{gr}$ ), halbhart; nachgebaut: meist glasig und rötlich.

Herbstblatt dnnkelgrün, krans; Bestockung mittelstark, 4 Schösslinge, mittelfrüh schossend nnd blühend. Halmlänge $135 \mathrm{~cm}$ (Iax. $150 \mathrm{~cm}$ ), Halmdicke $0.45 \mathrm{~cm}$, Blattzahl 5. Mittlere Blattlänge $25.8 \mathrm{~cm}$, Blattbreite $0.95 \mathrm{~cm}$, Blattoberfläche $245.1 \mathrm{qcm}$, Halmfläche $182.25 \mathrm{qcm}$, Gesammtfläche $427.35 \mathrm{qcm}$.

Aehre mittelfriih reifend, $11 \mathrm{~cm}$ (Max. $14 \mathrm{~cm}$ ) lang, mit 20 Aehrchen und 40 etwas lose sitzenden Friichten, von denen 1784500 auf $1 \mathrm{hl}$ $(=83 \mathrm{~kg})$ entfallell.

Auf 1 qm können 900 Halme oder 225 Pflanzen wachsen, demnach beträgt der Raum für eine Pflanze $44.4 \mathrm{qcm}$ und die Blattoberfläche p. $q \mathrm{~m}$ Bodenfläche $38.46 \mathrm{qm}$, und das Saatquantum ( $1 / 3$ Verlust) $1.8 \mathrm{hl}$.

100 Halme wiegen $411 \mathrm{gr}$ und davon die Frïchte $160 \mathrm{gr}$. leicht.

Das Stroh leidet etwas durch Rost und lagert auf reichem Boden

Dieser Weizen wurde 1879 als Sommerweizen kultiviert, doch erwies er sich als echter Winterweizen, der auch den harten Winter 1879/80 vortrefflich überstand.

\section{Australischer Wechsel-Weizen. (-) u. (2)}

Syn.: Blé d'Anstralie blanc rond.

Aehre: sehr blassrot, ziemlich dicht, mittellang, schmal, sich etwas verjüngend, grannenspitzig; A ehrchen $1.2 \mathrm{~cm}$ breit, 2 - bis. 3 -körnig. - Stroh: rötlich-gelb, mittellang. - Frucht: fast weiss, meist mehlig, einige rötlich 
und glasig, rundlich, ziemlich gross $\left(6 \frac{1}{2} \mathrm{~mm}\right.$ lang, $3 \frac{3}{4} \mathrm{~mm}$ breit, 226 Früchte $=10 \mathrm{gr}$ ), feinschalig, halbweich, Bruch halbmehlig.

Herbstblatt blaugrün, aufrecht, beiderseits schwach sammetig; Entwickelung zeitig, Sommerfrucht 2.6, Winterfrucht 5 Schösslinge, spät schossend und blühend, Halm $120 \mathrm{~cm}$ (Max. $145 \mathrm{~cm}$ ) lang, $0.4 \mathrm{~cm}$ dick, Blattzahl 4, Blätter $18 \mathrm{~cm}$ lang, $1 \mathrm{~cm}$ breit, Blattfläche $144 \mathrm{qcm}$, Halmfläche $144 \mathrm{qcm}$, Gesammtfläche $288 \mathrm{qcm}$.

Junge Aehre bläulich, spät reifend, $11 \mathrm{~cm}$ (Max. $14 \mathrm{~cm}$ ) lang, mit 21 Aehrcheu und 55 ziemlich fest sitzenden Früchten, von denen 1898400 auf $1 \mathrm{hl}(=84 \mathrm{~kg})$ entfallen. terung.

Lagert nicht leicht, leidet wenig durch Rost und schlechte Wit-

Original im landw. Museum zu Berlin.

\title{
Varietät: Triticum vulgare miltura AI.
}

\author{
Aehren kahl, rot; Körner rot.
}

\section{Sorten:}

\section{Rotstroh- oder Dessauer-Weizen. (2)}

Aehre: rot, fast quadratisch, dicht, lang; Aehrchen $1.7 \mathrm{~cm}$ breit, 3- und 4-körnig. - Strolı: hellrot, fest, lang. - Frucht: dunkelrot, glasig, liurz, etwas plump $\left(6^{1} / 2 \mathrm{~mm}\right.$ lang, $4 \mathrm{~mm}$ breit, 175 Früchte $=$ $10 \mathrm{gr}$ ), etwas grobschalig, Bruch halbstahlig, halbhart.

Herbstblatt blaugrün, kraus; Frỉhjahrsvegetation etwas spät, Bestockung mittelstark, 4.7 Schösslinge, mittelfriih schossend und blïhend. Halmlänge $120 \mathrm{~cm}$ (Max. $145 \mathrm{~cm}$ ), Halmdicke $0.4 \mathrm{~cm}$, Blattzahl 3.3, Blattlänge $28.88 \mathrm{~cm}$, Blattbreite $1.03 \mathrm{~cm}$, Blattoberfläche $196.35 \mathrm{qcm}$, Halmfläche $144 \mathrm{qcm}$, Gesammtfläche $340.35 \mathrm{qcm}$.

Junge Aehre gelbgrün, mittelfrüh reifend, $10 \mathrm{~cm}$ (Max. $13 \mathrm{~cm}$ ) lang, mit 20 Aehrehen und 65 ziemlich fest sitzenden Früchten, von denen 1412250 auf $1 \mathrm{hl}(=80.7 \mathrm{~kg})$ gehen.

Auf $1 \mathrm{qm}$ wachsen 900 Halme oder ca. 200 Pflanzen, mithin beträgt der Raum für eine Pflanze $50 \mathrm{qcm}$, die Blattoberfläche p. qm Bodenfläche $30.6 \mathrm{qm}$, und das Saatquantum $2.1 \mathrm{hl}$ p. ha.

Es wiegen 100 Halme $450 \mathrm{gr}$ und davon die Friichte $199 \mathrm{gr}$.

Dieser Weizen ist eine alte, winterfeste und fruher sehr verbreitete Sorte, welche auf gutem Lehmboden, so namentlich in Dessau, gute Erträge lieferte, doch leidet sie vom Rost und neigt zum Lagern. 


\section{Rotähriger Probsteier-Weizen. (2)}

Aehre: blassrot, ziemlich geschlossen, sich nach der Spitze etwas verjüngend. Aehrchen mittclbreit $(1.5 \mathrm{~cm})$, meist 3-körnig. - Stroh: rötlich-gelb, blattreich, etwas weich. - Frucht: Original gelbrot, mehlig; nachgebaut: viele Frichte glasig und dunkler, ziemlich gross, länglich ( $7 \mathrm{~mm}$ lang, $3 \frac{1}{2} \mathrm{~mm}$ brcit), ziemlich feinschalig, Bruch halbmehlig.

Herbstblatt ziemlich breit, aufrecht, blaugrün, Bestockung stark, 4.2 Schösslinge. Vegetation mittelfrüh. Halm $0.46 \mathrm{~cm} \mathrm{dick,} 125 \mathrm{~cm}$ (Yax. $140 \mathrm{~cm}$ ) lang, Blattzall 4, Blätter $25.85 \mathrm{~cm}$ lang, $1.12 \mathrm{~cm}$ breit, Blattfläche 231.6 qcn, Halnıfläche 172.5 qcm, Gesammtfläclıe 404.1 qcm.

Wachsen auf $1 \mathrm{qm}$ Bodenfläche 800 Halme oder 190.5 Pflanzen, so beträgt der Raum pro Pflanze $52.5 \mathrm{qcm}$ und die Gesammtblattfäche der Pflanzen $32.33 \mathrm{qm}$.

Junge Aehre gelbgriin, $11 \mathrm{~cm}$ (Max. 14cm) lang, mit 18 Aehrchen und 60 etwas lose sitzenden Früchten. Die Reifezeit fällt Ende Juli.

Es wiegt $1 \mathrm{hl} 79.2 \mathrm{~kg}$, ist also relativ leicht, und enthält 1603800 Körner, mithin ergiebt sich bei 33 Proc. Verlust ein Saatquantum von $1.8 \mathrm{hl} \mathrm{p.} \mathrm{ha.}$

Dieser Weizen ist im Stroh- und Korncrtrag selir ergiebig und winterfest, doch lagert sich das blattreiche, weiche Strol bei feuchter Witterung etwas leicht und zeigt sich auch gegen Rost nicht besonders widerstandsfähig.

Für gute Lehm- und Nergelböden in Nord-Deutscliland vorzüglich geeignet.

Es wurdeu p. ha geerntet: in

\begin{tabular}{|c|c|c|}
\hline & $\begin{array}{l}\text { Poppelsdorf } \\
\text { (4jähriger Durchschnitt) }\end{array}$ & $\begin{array}{c}\text { Proskau } \\
\text { (humoser Thonboden) }\end{array}$ \\
\hline Körner & $2100 \mathrm{~kg}$ & $2621 \mathrm{~kg}$ \\
\hline Stroh & 5172, & 7580, \\
\hline Spreu & 1090 & 810, \\
\hline
\end{tabular}

Seine eigentliche Heimat ist die Probstei in Holstein, und ist dieser rotährige Probsteier im Allgemeinen exgiebiger, als der ihm sonst sehr ähnliclıe, ebenfalls in der Probstei kultivierte, weissälırige Probsteier (Trit. vulg. lutescens).

\section{Roter dentscher Woizen. (2)}

Aehre: liellrot mit bläulichem Anflug, ziemlich dicht, au derselben komnien erblich einige monströse, doppelte Aehrchen, teils rudimentär, teils gut ausgebildet vor; Aelırchen meist 3-körnig. - Stroh: schön hellgelb, derbwandig. - Original graurot, glasig, gross und schön ( $7 \mathrm{~mm}$ lang, $4 \mathrm{~mm}$ breit, 179 Friichte $=10 \mathrm{gr}$ ), ziemlich feinsclialig; nachgebaut: einige gelbrot und mehlig, sonst dem Original gleich; Bruch halbstahlig, halbliart.

Herbstblatt blaugrün, schmal, kraus; Frühjahrsvegetation mittelfrüh, Bestockung stark, 5.5 Schösslinge, mittelfrüh schossend und blühend. Halmlänge $135 \mathrm{~cm}$ (Max. $150 \mathrm{~cm}$ ), Halmdicke $0.4 \mathrm{~cm}$, Blattzalı 3.7 , Blattlänge $25.75 \mathrm{~cm}$, Blattbreite $0.99 \mathrm{~cm}$, Blattoberfäche eines Halmes $188.63 \mathrm{qcm}$, Halmfläche $162 \mathrm{qcm}$, Gesammitfäche $350.63 \mathrm{qcm}$.

Junge Aehre gelbgrïn, mittelfrüh reifend, $11 \mathrm{~cm}$ (Max. $15 \mathrm{~cm}$ ) lang, 
mit 18 Aehrchen und 50 wenig fest sitzenden Früchten, von denen 1503600 auf $1 \mathrm{hl}(=84 \mathrm{~kg}$ ) entfallen.

Auf 1 qun kommen S00 Halme oder 146 Pflanzen, mithin beträgt der Raum für eine Pflanze ca. 70 qcm, die Blattfläche p. qn Bodenfläche $28 \mathrm{qm}$, und das Saatquantum (1/3 Verlust) 1.45 lil p. ha.

Es wiegen 100 Halme $580 \mathrm{gr}$ und davon die Frïchte $191 \mathrm{gr}$.

Dieser Weizen neigt selbst auf reichen Lehmböden wenig zum Lagern, zeigt sich gegen Rost widerstandsfähig, und ist ertragreich.

Er wurde seit 1873 von Wilhelm Rimpau in Schlanstedt, Provinz Sachsen, gezogen, und 1875 nach Poppelsdorf gesandt.

\section{Roter schlesischer Gebirgsweizen. (2)}

Aehre: blassrot, dicht, quadratisch, sehr dicht, lang. - Stroh: rötlich-gelb, fest, lang. - Frucht: gelbrot, mehlig, auch rot und glasig, gross, plump ( $7 \mathrm{~mm}$ lang, $4 \mathrm{~mm}$ breit), grobschalig, halbhart, Bruch halbmehlig.

Herbstblatt dunkelgrïn, schmal, kraus; Oberseite der Blätter mit kurzen Härehen, aber nicht sammetig; Frühjahrsvegetation mittelfriih, Bestockung mittelstark, 3.8 Schösslinge, mittelfrüh schossend und blühend. Halmlänge $150 \mathrm{~cm}$ (Max. $165 \mathrm{~cm}$ ), Halmdicke $0.4 \mathrm{~cm}$. Blattzahl 5, Blattlänge $28.8 \mathrm{~cm}$, Blattbreite $1.0 \mathrm{~cm}$, Blattoberfläche $288 \mathrm{qcm}$, Halmfläche 180 qcm, Gesammtfläche 463 qcm.

Junge Aehre gelbgriin, Klappen und Spelzen rot umrandet, spät reifend, $10 \mathrm{~cm}$ (Max. $14 \mathrm{~cm}$ ) lang, mit 22 Aehrchen und 60 nicht leicht ausfallenden Friichten, von deneu 1760000 auf $1 \mathrm{hl}(=80 \mathrm{~kg}$ ) gehen. Diese Weizensorte ist winterfest und leidet wenig durch Lagern und Rost, doch befriedigt die Kornqualität nicht.

\section{Kurzähriger dentscher Winterweizen. (2) Zucht von Rimpau, Schlaustedt.}

Aehre: rostfarben, dickährig, aber nicht eigentlich kurzährig, quadratisch, ziemlich dicht; Aehrchen $1.8 \mathrm{~cm}$ breit, 3- und 4-körnig. Stroh: gelb, kräftig, fest, lang. - Frucht: rot, glasig, oval $(6 \mathrm{~mm}$ lang, $3^{1} / 2 \mathrm{~mm}$ breit), leicht, ziemlich feinschalig, Bruch halbmehlig, halbweich.

Herbstblatt dunkelgrün, kurz und schwach behaart, breit, aufrecht; Frihjahrsentwicklung mittelfriih, Bestockung stark, 6 Schösslinge, doch spät schossend und blühend. Halmlänge $130 \mathrm{~cm}$ (Max. $145 \mathrm{~cm}$ ), Halmdicke $0.4 \mathrm{~cm}$, Blattzahl 4.2, Blattlänge $29.3 \mathrm{~cm}$, Blattbreite $0.9 \mathrm{~cm}$, Blattoberfläche $221.5 \mathrm{qcm}$, Halmfläche $156 \mathrm{qcm}$, Gesammtfläche $377.5 \mathrm{qcm}$.

Junge Aehre gelbgrün, spät reifend, $10 \mathrm{~cm}$ (Max. $12 \mathrm{~cm}$ ) lang, mit 19 Aehrchen und 65 fest sitzenden Frïchten, von denen 1980000 auf $1 \mathrm{hl}(=78.2 \mathrm{~kg})$ gehen.

Auf 1 qm wachsen 900 Halme oder 150 Pflanzen, mithin beträgt der Raum für eine Pflanze 66.6 qcm, die Blattfäche p. qm Oberfläche $34 \mathrm{qm}$, und das Saatquantum $1.1 \mathrm{hl} \mathrm{p}$. ha.

Es wiegen 100 Halme $520 \mathrm{gr}$ und davon die Früchte $220 \mathrm{gr}$. Das Stroh lagert niclit leicht und leidet wenig vom Rost, namentlich viel weniger als der gemeine deutsche Winterweizen von Rimpau. In Poppelsdorf erwies er sich durchaus winterfest und auf reichem Boden ertragreich. 
Rimpau ${ }^{1}$ ), Schlanstedt fand ihn 1871 in dem gemeinen deutschen Winterweizen und kultivierte ihn weiter.

Uebersender: Rimpau.

\section{Halberstädter-Weizen. (2)}

Aehre: rot, sich verjüngend, dünn, $11 \mathrm{~cm}$ lang mit 60 Früchten; Aehrchen $1.3 \mathrm{~cm}$ breit, 3-körnig. - Stroh: rötlich-gelb. - Frucht: rot, glasig, klein ( $6 \frac{1}{2} \mathrm{~mm}$ lang, $3 \mathrm{~mm}$ breit), feinschalig.

\section{Braunschweiger-Weizen. (2)}

Aehre: rot, ein wenig grannenspitzig und sich verjüngend, ziemlich dicht, $10 \mathrm{~cm}$ lang mit 50 Früchten; Aehrchen $1.4 \mathrm{~cm}$ breit, 2- und 3-körnig. - Stroh: rötlich-gelb. - Frucht: rotgelb, mehlig, $\left(6^{1} / 2 \mathrm{~mm}\right.$ lang, $3^{1 / 2} \mathrm{~mm}$ breit).

\section{Roter Wechselẉeizon aus Böhmen. $\odot$ u. (2)}

Aehre: rostrot, sich verjüngend, grannenspitzig, kurz, dicht, schmal ; Aehrchen $1.3 \mathrm{~cm}$ breit, 2- und 3-körnig. -- Stroh: rötlich-gelb, feinhalmig. - Erucht: gelbrot, mehlig, länglich, klein $\left(6^{1 / 2} \mathrm{~mm} \mathrm{lang,} 3^{1 / 2} \mathrm{~mm}\right.$ breit), sehr schwer, feinschalig, halbhart, Bruch halbmehlig; nachgebaut: meist dunkelrot und glasig.

Herbstblatt blaugrün, kraus; Frühahrsvegetation mittelfrüh, doch spät schossend und blühend. Junge Aehre blaugrün. Als Sommerweizen betrug seine Vegetationsperiode 130 Tage.

Die Entwickelung der Pflanze ist folgende:

\begin{tabular}{|c|c|c|}
\hline & Wintersaat & Sommersaat \\
\hline $\begin{array}{l}\text { Halmlänge } \\
\text { Halmdicke } \\
\text { Blattzahl } \\
\text { Mittlere Blattlänge } \\
\text { Blattbreite } \\
\text { Blattoherfäche } \\
\text { Halmfläche } \\
\text { Gesammtfläche } \\
\text { Anzahl der Schösslinge } \\
\text { Auf } 1 \text { qm wacliscn } \\
\text { Aof } 1 \text { qm Bodenfläche kommen } \\
\text { Raum für eine Pflanze } \\
\text { Aelrenlänge } \\
\text { Anzahl der Aehrchen pro Aehre } \\
\text { Früchte in einer Aehre } \\
\text { Hektolitergewicht } \\
\text { Fruchtzali in } 1 \text { hl } \\
\text { Aussaatquantum p. ha } \\
100 \text { Halme wiegen: } \\
\text { In } 100 \text { Halmen wiegen die Früchte }\end{array}$ & \begin{tabular}{|c|}
$115 \mathrm{~cm}$ (Max. $130 \mathrm{~cm})$ \\
$0.32 \mathrm{~cm}$ \\
4 \\
$17.8 \mathrm{~cm}$ \\
$0.75 \mathrm{~cm}$ \\
$106.8 \mathrm{qcm}$ \\
$110.4 \mathrm{qcm}$ \\
$217.2 \mathrm{qcm}$ \\
4.6 \\
1200 Halme \\
260 Pflanzen \\
$26 \mathrm{qcm}$ Blattfäche \\
$38.4 \mathrm{qcm}$ \\
$7 \mathrm{~cm} \mathrm{(Max.} 10 \mathrm{~cm})$ \\
16 \\
40 \\
$88 \mathrm{~kg}$. \\
$2156 \mathrm{on0}$ \\
$1.8 \mathrm{hl}$ \\
$390 \mathrm{gr}$ \\
$180 \mathrm{gr}$
\end{tabular} & $\begin{array}{c}115 \mathrm{~cm}(\text { Max. } 130 \mathrm{~cm}) \\
0.3 \mathrm{~cm} \\
4 \\
28.8 \mathrm{~cm} \\
0.83 \mathrm{~cm} \\
151.39 \mathrm{qcm} \\
103.50 \mathrm{qcm} \\
254.89 \mathrm{qcm} \\
3.0 \\
1200 \text { Halme } \\
400 \text { Pfanzen } \\
30.6 \text { qm Blattfläche } \\
25 \text { qcm } \\
8 \mathrm{~cm} \text { (Max. } 11 \mathrm{~cm}) \\
16 \\
40 \\
88 \mathrm{~kg} \\
2332000 \\
2.6 \mathrm{hl} \\
380 \mathrm{gr} \\
150 \%\end{array}$ \\
\hline
\end{tabular}

1) Vergl. Landw. Jahrb. VI. 1877, p. 229.

Koernicke u. Werner, Handb. d. Getreidebau' II. 
Dieser schöne, für einen milden Lehmboden geeignete Weizen, zeigte sich in Poppelsdorf winterfest und gegen Rost widerstandsfähig, doch lagerte er leicht.

Die fast gleiche Entwicklung der Winter- und Sommersaat beweist, dass er ein echter Wechselweizen ist.

\section{Old red Lammas. (2)}

Syn.: Englisch: Red english Wheat, Lammas red, Old red, Red Kent ${ }^{1}$, Red. Burwell.

Französisch ${ }^{2}$ ): Blé Lammas, Blé rouge anglais, Blé Joannet de Châtellérault, Blé grand rouge, Blé Saint-Pierre.

Deutsch: Lammas-Winterweizen, Roter August ${ }^{3}$ )-Weizen.

Aehre: dunkelrot, mittellang, ziemlich dicht, etwas überhängend, ziemlich breit; Aehrchen $1.7 \mathrm{~cm}$ breit, 3-körnig. - Stroh: gelb, lang, kräftig. - Frucht: Original gelbrot, mehlig, mittelgross (7 mm lang, $3 \frac{1}{2} \mathrm{~mm}$ breit, $\left.230 \mathrm{Früchte}=10 \mathrm{gr}\right)$; nachgebaut: mehr dunkelrot und glasig, wenige mehlig, etwas eingefallen (242 Fruichte $=10 \mathrm{gr}$ ), grobschalig, weich.

Herbstblatt dunkelgrün, behaart, breit, aufrecht ; Frïhjahrsvegetation mittelfrüh; Bestockung sehr stark, 9 Schösslinge; mittelfrüh schossend und blühend. Halmlänge $130 \mathrm{~cm}$ (Hax. $150 \mathrm{~cm}$ ), Halmdicke $0.38 \mathrm{~cm}$, Blattzahl 4, Blattlänge $27.3 \mathrm{~cm}$, Blattbreite $0.98 \mathrm{~cm}$, Blattoberfläche eines Halmes $214 \mathrm{qcm}$. Halmfläche $148.2 \mathrm{qcm}$, Gesammtfläche $362.20 \mathrm{qcm}$.

Junge Aehre gelbgrün, mittelfrüh reifend, $10 \mathrm{~cm}$ (Max. $13 \mathrm{~cm}$ ) lang, mit 20 Aehrchen und 60 Früchten, welche in der Vollreife leicht ausfallen, doch in der Gelbreife von den Spelzen fest umschlossen werden, und von denen 1936000 auf $1 \mathrm{hl}(=80 \mathrm{~kg})$ gehen.

Auf 1 qm kommen 900 Halme oder 100 Pflanzen, mithin beträgt der Raum für eine Pflanze $100 \mathrm{qcm}$, die Blattfäche p. qm Bodenfläche $32.58 \mathrm{qm}$, und das Saatquantum (1/3 Terlust) $0.8 \mathrm{hl}$ p. ha.

In Poppelsdorf zeigte sich dieser Weizen nicht winterfest, auch nicht genügend widelstandsfähig gegen Rost und Lagern.

Es ist dies ein sehr alter englischer Weizen, den schon Morison in seiner hist. pl. oxon. tom. III anno $1699 \mathrm{pg} .175$ wie folgt beschreibt:

"Trit. spica rubra et granis etiam rubris aut fuscis, culmo luteolo. Hoc frequentissime est, quod "Red Wheat appellatus."

Schon 1797 importierte ihn M. We at Chr off nach Calvados, Frankreich, wo er jedoch in neuerer Zeit an Wichtigkeit verloren hat, da ex auch selbst dort zu häufig áuswintert.

Für mittlere Weizenböden gehörte er in England und Schottland zu den geschätztesten roten Weizensorten seines hohen Ertrages wegen, obgleich die Mü̈ller das Mehl nicht lieben, doch geht sein Anbau in der Neuzeit auch in seiner alten Heimat zurück.

Original in der Sammlung der Akademie Poppelsdorf.

Der in dem Kirchspiel Burwell, Cambridgeshire und in der Graf-

1) Vergl. Tha er, engl. Landw. Bd. I, pg. 357. 1800.

2) Vergl. Vilmorin. Journ. d'Agric. prat. 1851, pg. 456.

3) Lammas = Petri-Kettenfeier, weil 1. August reif. 
schaft Kent gebaute Lammas-Weizen scheint ein etwas kürzeres, steiferes Stroh zu besitzen, und demzufolge weniger leicht zu lagern.

Mr. Lawes '1), Rothamsted, erhielt im sechsjährigen Durchschnitt auf Lehmboden $34.76 \mathrm{hl} \mathrm{p.} \mathrm{ha.}$

\section{Hallet's red Nursery. (2)}

Deutsch: Hallet's genealogischer Nursery-Weizen.

Aehre: rot, etwas locker, lang, breit; Aehrchen bis $2 \mathrm{~cm}$ breit, meist 3-körnig. - Stroh: gelb, sehr kräftig, lang. - Frucht: rot, mehlig, einige glasig; nachgebaut: meist glasig, länglich (7 $\mathrm{mm}$ lang, $3^{1 / 2} \mathrm{~mm}$ breit, 220 Früchte $=10 \mathrm{gr}$ ), ziemlich feinschalig, weich.

Herbstblatt blaugriin, breit, aufrecht; Frilijahrsvegetation zeitig, Bestockung mittelstark, 4 Schösslinge (bei $100 \mathrm{qcm}$ Raum betrug die Zahl der Schösslinge 10.8), mittelfrüh schossend und blïhend. Halmlänge $120 \mathrm{~cm}$ (Max. $150 \mathrm{~cm}$ ), Halmdicke $0.4 \mathrm{~cm}$, Blattzahl 4, Blattlänge $26.68 \mathrm{~cm}$, Blattbreite $1.01 \mathrm{~cm}$, Blattoberfläche $215.6 \mathrm{qcm}$, Halmfläche 144 qcm, Gesammtfläche 359.6 qcm.

Junge Aehre gelbgrïn, spät reifend, $10 \mathrm{~cm}$ (Max. $13 \mathrm{~cm}$ ) lang. mit 21 Aehrchen und 60 ziemlich leicht ausfallenden Früchten, von denen 1775400 auf $1 \mathrm{hl}(80.7 \mathrm{~kg})$ gehen.

A uf $1 \mathrm{qm}$ wachisen 800 Halme oder 200 Pflanzen, mithin beträgt der Raum für eine Pflanze $50 \mathrm{qcm}$, die Blattfläche p. qm Bodenfläche 29 qm und das Saatquantum $1.7 \mathrm{hl}$ p. ha.

Dieser an Korn und Stroh sehr ertragreiche Weizen verlangt einen sehr reichen Boden und mildes Klima.

In Poppelsdorf zeigte er sich fast rostfrei und wenig zum Lagern geneigt.

In England, aber auch vielfach in Deutschland kultiviert.

Die sechsjährigen Kulturversuche $(1871 / 76)^{1}$ ) von Mr. Lawes in Rothamsted, England, ergaben einen Durchschnittsertrag von $33.64 \mathrm{hl}$ p. ha.

Original in der Sammlung der Akademie Poppelsdorf.

\section{Spaldings prolific Wheat. (2)}

Deutsch: Spalding's ergiebiger Weizen, auch Sandweizen, in Sachsen englischer Sandweizen genannt.

Französiscli: Blé Spalding.

Aehre: blassrot, etwas locker, mittellang; Aehrchen ziemlich breit (1.8 cm) 3- und 4-körnig. - Stroh : rötlichgelb, blattreich, dickwandig. Frucht: Original gelbrot, mehlig, doch auch viele glasig, diese dann dunkler, gross ( $7 \mathrm{~mm}$ lang, $4 \mathrm{~mm}$ breit), etwas dickschalig. Seit 1871 konstant geblieben, halbweich, Bruch halbmehlig.

Herbstblatt breit, etwas aufrecht, blaugrün; Frühjahrsvegetation zeitig, Bestockung mittelstark, 3.6 Schösslinge, die Bestockungsfähigkeit bei $100 \mathrm{qcm}$ Raum beträgt 14.3 Schösslinge pro Pflanze.

Junge Aehre gelbgrïn, mittelfrüh, Halm $130 \mathrm{~cm}$ (Max. $150 \mathrm{~cm}$ ) lang, $0.4 \mathrm{~cm}$ dick, Blätter $29.3 \mathrm{~cm}$ lang, $0.95 \mathrm{~cm}$ breit, Blattzahl 4,

2) Farmer's Magaz. Vol. 80 1876, pg. 433. 
Blattoberfläche $222.72 \mathrm{qcm}$, Halmfläche $156 \mathrm{qcm}$, Gesammtfläche $378.72 \mathrm{qcm}$. Wachsen p. qm 872 Halme oder 242 Pflanzen, so entfallen auf jede Pflanze $41.3 \mathrm{qcm}$ Raum und auf $1 \mathrm{qm}$ Bodenfläche $33 \mathrm{qm}$ Blattfläche. Diese Sorte reift mittelfrüh (Ende Juli). Aehre $10 \mathrm{~cm}$ (Max. $14 \mathrm{~cm}$ ) lang, mit 14 Aehrchen und 50 ziemlich lose sitzenden Frïchten.

Es wiegen 100 Halme $950 \mathrm{gr}$ und davon die Körner $410 \mathrm{gr}$.

Das Hektolitergewicht beträgt $83 \mathrm{~kg}$ und $1 \mathrm{hl}$ enthält 1882000 Körner.

Wachsen 2420000 Pflanzen p. ha, so stellt sich ein Saatbedürfnis, bei 33 Proc. Verlust, von 1.9 hl p. ha heraus.

Die Torzüge gründen sich auf die geringen Bodenanspriiche, da selbst noch auf leichteren, sandigen Lehmböden befriedigende Erträge erzielt werden. Ferner lagert das Stroh nur auf sehr reichem Boden und befällt nicht leicht mit Rost. Doch zeigte er sich in Poppelsdorf gegen ungünstige Witterung empfindlich, denn 1871 und 1876 trat starkes Auswintern ein, aber auch in Mecklenburg und Schleswig-Holstein ist er demselben unterworfen.

Dreijährige Durchschnittserträge lieferten in Poppelsdorf $2360 \mathrm{~kg}$ Korn, $5037 \mathrm{~kg}$ Stroh, $1120 \mathrm{~kg}$ Spreu p. ha. Vielfach wird er in NordDeutschland, am Rhein, in Westfalen und Sachsen kultiviert, während im östlichen Deutschland, weil zu empfindlich, sein Anbau grösstenteils wieder aufgegeben worden ist. In England, so namentlich in Lincolnshire, wird er gern auf Moorboden gebaut, auf dem er zuerst entstanden sein soll, aber auch auf Clayboden schätzt man ihn.

\section{Red Marigold-Wheat. (2)}

Syn.: Franz.: Blé red Marigold.

Deutsch: Goldblumen-, Ringelblumen- oder Blumen-Weizen.

Aehre: rot mit bläulichem Anflug, mittellang, schmal, locker; Aehrchen $1.5 \mathrm{~cm}$ breit, 3-körnig. - Stroh: rötlich, ziemlich derbwandig. - Frucht: Original gelbrot, mehlig, wenige dunkler und glasig (6 mm lang, $3^{1} / 2 \mathrm{~mm}$ breit, 247 Früchte $=10 \mathrm{gr}$ ); nachgebaut: meist dunkelrot und glasig, grösser ( $7 \mathrm{~mm}$ lang, $4 \mathrm{~mm}$ breit, 210 Friichte $=10 \mathrm{gr}$ ), ziemlich feinschalig, halbweich.

Herbstblatt blaugrün, schmal, kraus; Frühjahrsvegetation ziemlich spät; Bestockung stark, 5 Schösslinge, spät schossend und blühend. Halmlänge $120 \mathrm{~cm}$ (Max. $155 \mathrm{~cm}$ ), Halmdicke $0.4 \mathrm{~cm}$, Blattzahl 4.2, Blattlänge $22 \mathrm{~cm}$, Blattbreite $0.95 \mathrm{~cm}$, Blattoberfläche eines Halmes $175.56 \mathrm{qcm}$, Halmfläche $144 \mathrm{qcm}$, Gesammtfläche $319.56 \mathrm{qcm}$.

Junge Aehre gelbgrün, rot umrandet, mittelfrüh reifend, $10 \mathrm{~cm}$ (Max. $13 \mathrm{~cm}$ ) lang, mit 20 Aehrchen und 54 leicht ausfallenden Früchten, von denen 1743000 auf $1 \mathrm{hl}(=83 \mathrm{~kg})$ gehen.

Auf $1 \mathrm{qm}$ kommen 970 Halme oder 194 Pflanzen, mithin beträgt der Raum für eine Pflanze $51.5 \mathrm{qcm}$, die Blattoberfläche $\mathrm{p}$. qm Bodenfläche $31.04 \mathrm{qm}$ und das Saatquantum (1/3 Verlust) $1.7 \mathrm{hl}$ p. ha.

Es wiegen 100 Halme $580 \mathrm{gr}$, und davon die Früchte $206 \mathrm{gr}$.

Dieser Weizen zeigte sich vollkommen winterfest, so erfror derselbe in Poppclsdorf 1870/71 nicht, und widersteht sowohl dem Lagern wie dem Rost.

Für die leichteren Weizenböden Deutschlands ist dieser ertragreiche Weizen, der auch ein gutes Mehl liefert, wohl zu empfehlen, und wird 
derselbe auch vielfach in Mecklenburg, Schlesien und im Königreich Sachsen kultiviert.

\section{Clover's red Wheat. (2)}

Syn.: Deutsch: Clover's roter Weizen.

Französisch: Froment rouge de Burrel ou du duc de Portland.

Aehre: blassrot, lang, ziemlich geschlossen. Aehrchen breit $(1.8 \mathrm{~cm})$ 3-körnig. - Stroh: gelb, derbwandig, dick, fest. - Frucht: Original blassrot, mehlig, voll, schwer, rundlich $\left(6^{1} / 2 \mathrm{~mm}\right.$ lang, $4 \mathrm{~mm}$ breit $)$; nachgebaut: konstant, mehlig und gut gestaltet geblieben, weich.

Herbstblatt schmal, die Blattseiten beiderseits schwach behaart, grösstenteils aufrecht, blaugrüin, Bestockung stark, 4.1 Schösslinge; Vegetation tritt zeitig im Frühjahr ein, Halm $125 \mathrm{~cm}$ (Max. $145 \mathrm{~cm}$ ) lang, $0.42 \mathrm{~cm}$ dick; Blattzahl 3.3 , Blätter $23.9 \mathrm{~cm}$ lang, $1.01 \mathrm{~cm}$ breit, Blattoberfläche $159.32 \mathrm{qcm}$, Halmfläche $157.5 \mathrm{qcm}$, Gesammtfläche $316.82 \mathrm{qcm}$.

Auf $1 \mathrm{qm}$ Bodenfläche wachsen 800 Halme, oder 242 Pflanzen, somit beträgt der Raum pro Pflanze $41.3 \mathrm{qcm}$ und die Gesammtfläche der Pflanze $25.32 \mathrm{qm}$.

Junge Aehre gelbgrün, Ende Juli, also mittelfrüh reifend, und wiegen 100 Halme $400 \mathrm{gr}$ und davon die Frïchte $130 \mathrm{gr}$. Aehre $13 \mathrm{~cm}$ (Max. $17 \mathrm{~cm}$ ) lang, mit 18 Aehrchen und 60 Früchten.

Es wiegt $1 \mathrm{hl} 80.6 \mathrm{~kg}$ und enthält 1370200 Früchte, daher das Saatquantum sich bei 2420000 Pflauzen auf $1.56 \mathrm{hl}$ p. ha berechnet.

Auf gutem Lehmboden und im milden Klima liefert er recht hohe Erträge, auch leidet sein Stroh wenig durch Rost; dagegen wintert er zuweilen, so 1876 in Poppelsdorf, total aus; auch ist sein Mehl kleberarm und nicht beliebt.

Mr. John Clover fand ihn in Suffolk in einem mit Suffolk-redWheat bestelltem Felde und kultivierte ihn weiter. Zur Zeit wird er in England noch stark in Suffolk gebaut. In Deutschland scheint er vorzugsweise in Schlesien Verbreitung gefunden zu haben.

Original in der Sanmlung der Akademie Poppelsdorf.

\section{Browick red Wheat. (2)}

Syn.: Engl. Thick-set club.

De uts ch: Roter Browick Winterweizen.

Franz.: Blé Browick.

Aehre: blassrot, mittellang, kompakt, ziemlich dicht, sich etwas verjüngend, mittellang, mittelbreit; Aehrchen $1.6 \mathrm{~cm}$ breit, 3-körnig. Stroh : rötlich-gelb, lang, sehr blattreich. - Frucht: Original meist gelbrot. mehlig, wenige dunkelrot und glasig, rundlich, gross $\left(6^{3} / 4 \mathrm{~mm}\right.$ lang, $4 \mathrm{~mm}$ breit, 200 Früchte $=10 \mathrm{gr}$ ); nachgebaut: etwas grösser geworden (183 Frïchte $=10 \mathrm{gr}$ ), sonst konstant geblieben, feinschalig, weich, Bruch mehlig.

Herbstblatt gelbgrün, breit, aufrecht, schwach behaart; Frühjahrsvegetation zeitig: Bestockung schwach, 3.9 Schösslinge, doch spät schossend und blïhend. Halmlänge $145 \mathrm{~cm}$ (Max. $170 \mathrm{~cm}$ ), Halmdicke $0.43 \mathrm{~cm}$, Blattzahl 4.4, Blattlänge $25 \mathrm{~cm}$, Blattbreite $1.14 \mathrm{~cm}$, Blattoberfläche eines Halmes 250,8 qcm, Halmfläche $187.05 \mathrm{qcm}$, Gesammtfläche $437.85 \mathrm{qcm}$. 
Junge Aehre gelbgrïn, Spelzen rot umrandet, Staubbeutel "bräunlich, mittelfrüh reifend, $11 \mathrm{~cm}$ (Max. $14 \mathrm{~cm}$ ) lang, mit 20 Aehrchen und 54 fest sitzenden Früchten, von denen 1537200 auf $1 \mathrm{hl}(=84 \mathrm{~kg})$ gehen.

Auf $1 \mathrm{qm}$ kommen 860 Halme oder 220 Pflanzen, mithin beträgt der Raum pro Pflanze $46 \mathrm{qcm}$, die Blattläche pro $\mathrm{qm}$ der Bodenfläche $37.58 \mathrm{qm}$ und das Saatquantum $2.1 \mathrm{hl} \mathrm{p.} \mathrm{ha.}$

Es wiegen 100 Halme $605 \mathrm{gr}$ und davon die Früchte $195 \mathrm{gr}$ und Mr. Lawes ${ }^{1}$ ), Rothamsted, England, erhielt auf Lehmboden im sechsjährigen Durchschnitt 36.45 hl p. ha.

Das Stroh zeigt gegen Lagern und Rost eine bedeutende Widerstandsfähigkeit, so dass dieser ertragreiche Weizen auf sehr reichen Böden erfolgreich zu kultivieren ist. Leider ist er nicht ganz winterfest, weshalb seine früher in der Rheinprovinz weit verbreitete Kultur beträchtlich abgenommen hat.

Heimat: England.

Mr. Robert Banham ${ }^{2}$ ) fand diese Sorte in einigen Aehren zwischen anderem Weizen 1844 auf seiner Farm Browick im Kirchspiel Wymondham, er kultivierte sie weiter und brachte dieselbe 1848 in den Handel.

Original in der Sammlung der Akademie Poppelsdorf,

\section{Red Golden-Drop. (2)}

Deutsch: Roter Goldtropfen.

Franz.: Blé Pluie d'or.

Verbesserte Form: Hallet's pedigree Golden-Drop.

Verwandte Form: Purple stalked Golden-Drop.

Aehre: rotbräunlich, sich verjüngend, ein wenig locker, doch breit; Aehrchen $1.8 \mathrm{~cm}, 3-4$-körnig. - Stroh: rötlich-gelb, häufig unterhalb der Aehre graublau, lang, fest. - Frucht: Original gelbrot, mehlig; nachgebaut: meist rot und glasig; rundlich $\left(6 \frac{1}{2} \mathrm{~mm}\right.$ lang, $4 \mathrm{~mm}$ breit, 193 Früchte $=10 \mathrm{gr}$ ), feinschalig, weich.

Herbstblatt blaugrün, schwach behaart, kraus, etwas schmal; Frühjahrsvegetation spät; Bestockung stark, 7 Schösslinge, spät schossend und blühend. Halmlänge $130 \mathrm{~cm}$ (Max. $155 \mathrm{~cm}$ ), Halmdicke $0.4 \mathrm{~cm}$, Blattzahl 4.2 , Blattlänge $27.5 \mathrm{~cm}$, Blattbreite $1 \mathrm{~cm}$, Blattoberfläche eines Halmes $231 \mathrm{qcm}$, Halmfläche $156 \mathrm{qcm}$, Gesammt fläche $387 \mathrm{qcm}$.

Junge Aehre gelbgriin, spät reifend, $10 \mathrm{~cm}$ lang (Max. $13 \mathrm{~cm}$ ), mit 16 Aehrchen und 54 ziemlich fest sitzenden Früchten, von denen 1582600 auf $1 \mathrm{hl}(=82 \mathrm{~kg})$ gehen.

Auf 1 qm kommen 900 Halme oder 129 Pflanzen, mithin entfallen auf eine Pflanze $77.5 \mathrm{qcm}$, an Blättfläche p. qm Bodenfläche $34.83 \mathrm{qm}$ und an Saatgut $1.3 \mathrm{hl} \mathrm{p}$. ha.

Es wiegen 100 Halme 554 gr und davon die Früclite 208 gr.

Mr. Lawes ${ }^{3}$ ) erhielt zu Rothamsted, England, im sechsjährigen Durchschnitt auf gutem Lehmboden $40.72 \mathrm{hl}$ p. ha.

In Deutschland wurde dieser Weizen besonders häufig in der Pro-

1) Farmer's Magaz. Vol. 80. 1876, pg. 433.

2) Gardener's Chronicle 1869, pg. 1192.

3) Farmer's Magaz. Vol. 80. 1876, pg. 433. 
vinz Sachsen und am Mittelrhein gebaut, doch geht seine Kultur zurück, da er sich nicht als vollkommen winterfest erwiesen hat, und auch die Qualität der Früchte, weil kleberarm, zu wünschen lässt. In Poppelsdorf befriedigte die Widerstandsfähigkeit des Strohes gegen Lagern und Rost.

In den nordfranzösischen Departements, welche sich durch milde Winter und reiche Böden auszeichnen, ist sein Anbau weit verbreitet und sollen sich hier Mittelerträge ${ }^{\mathbf{l}}$ ) von $2040 \mathrm{~kg}$ Korn und $4050 \mathrm{~kg}$ Stroh p. ha ergeben.

Dieser Weizen hat in England wiederum dadurch an Beliebtheit gewonnen, dass ilın Mr. Hallet nach seinem System rerbessert und ergiebiger gemacht hat, weshalb sich "Hallet's pedigree Golden-Drop" einer bedeutenden Kultur erfreut.

Ihm nahe verwandt ist "Purple stalked Golden-Drop", der eine dunklere, kompaktere Aehre, purpurfarbenes Stroh, sowie eine grössere Frühreife besitzt.

Red Golden-Drop wurde in Grossbritannien zuerst durch Mr. Gorrie, Annat-Garden, 1834 gezüchtet, und vorzugsweise häufig in den Grafschaften Kent und Middlesex kultiviert, wo er Erträge bis zu 29 hl p. ha aufbrachte.

\section{Haigh's prolific Wheat. (2)}

Syn: Deutseh: Haigh's ergiebiger Weizen.

Französisch: Blé Haigh's prolific.

Aehre: blassrot, mittellang; Aehrchen ziemlich breit $(1.8 \mathrm{~cm})$ 3-körnig. - Strolı: gelb, lang, derbwandig. - Frucht : rotgrau, meist mehlig, länglich, gross ( $7 \mathrm{~mm}$ lang, $3 \frac{1 / 2}{\mathrm{~mm}}$ breit), etwas grobschalig, weich.

Herbstblatt blaugrün, fein, zum Teil niederliegend, schmal. Frühjahrsvegetation ziemlich spät, Bestockung sehr stark, 5.3 Schösslinge. Die Pflanze schosst und blüht mittelfrüh. Halm $145 \mathrm{~cm}$ (Max. $165 \mathrm{~cm}$ ) lang, $0.38 \mathrm{~cm}$ dick, Blattzahl 4.5, Blätter $24 \mathrm{~cm}$ lang, $1.1 \mathrm{~cm}$ breit, Blattoberfläche beider Seiten $237.6 \mathrm{~cm}$, Halmfläche $165.3 \mathrm{qcm}$, Gesammt fläche 402.9 qcm. Es wachsen pro qm 900 Halme oder 170 Pflanzen, mithin beträgt der Raum für jede Pflanze 59 qcm und die Blattfläche pro qm Bodenfläche $36.26 \mathrm{qm}$.

Junge Athre gelbgrïn, $10 \mathrm{~cm}$ (Max. $15 \mathrm{~cm}$ ) lang, mit 16 Aehrchen und 50 Früchten, welche leicht ausfallen. 100 Halme ergaben ein Gewicht von $713 \mathrm{gr}$ und betrug davon das Korngewicht $23.8 \mathrm{gr}$.

Es wiegt $1 \mathrm{hl} 82 \mathrm{~kg}$ und enthält 1858000 Früchte; wachsen 1700000 Pflanzen 1). ha, so beträgt die Aussaatquantität 1.33 hl.

In Poppelsdorf zeigte sich dieser Weizen nicht winterfest, so winterte er 1870 bis auf wenige liummerlicle Pflanzen aus. Das Stroh lagert nicht leicht und die Reife tritt Ende Juli ein.

Auf reichen Böden und in dem milden Klima Englands und NordFrankreichs werden hohe Erträge erzielt. Zuweilen wird er auch im nordwestlichen Deutschland kultiviert.

1) Dreis ch, Berichte über d. landw. Teil d. Pariser Ausst. 1878, pg. 248. 


\section{Blood red. (2)}

Syn: Franz.: Blé rouge d'Ecosse, Blé blood red. Spanisch: Trigo rojo de Escocia.

Deutsch: Roter schottischer Weizen.

Aehre: hellrot bis braun, lang, sich etwas verjüngend, ein wenig locker; Aehrchen breit, bis $2 \mathrm{~cm}, 2-, 3$ - und selbst 4-körnig. - Stroh: rötlich-gelb, derb, fest, blattreich. - Frucht: aus England bezogen gelbrot, mehlig; nachgebaut: viele rot und glasig, rundlich $\left(66^{1} / 2 \mathrm{~mm}\right.$ lang, $4 \mathrm{~mm}$ breit, 190 Früchte $=10 \mathrm{gr}$ ), ziemlich gross, etwas grobschalig, weich.

Herbstblatt blaugrün, breit, aufrecht; Frühjahrsvegetation zeitig, Bestockung schwach, 3.9 Schösslinge, mittelfrüh schossend und blühend. Halmlänge $135 \mathrm{~cm}$ (Мax. $160 \mathrm{~cm}$ ), Halmdicke $0.44 \mathrm{~cm}$, Blattzahl 3.7, Blattlänge $29.5 \mathrm{~cm}$, Blattbreite $1.2 i \mathrm{~cm}$, Blattoberfläche $277.28 \mathrm{qcm}$, Halmfläche $178.2 \mathrm{qcm}$, Gesammtfäche $455.48 \mathrm{qcm}$.

Aehre $11 \mathrm{~cm}\left(M_{\mathrm{ax}} 15 \mathrm{~cm}\right)$ lang, mit 19 Aehrchen und 50 ziemlich fest ron den Spelzen umschlossenen Früchten, von denen 1539000 auf

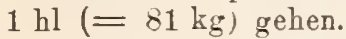

Auf $\mathrm{J}$ qm wachsen 700 Halme oder 180 Pflanzen, mithin beträgt der Raum für eine Pflanze $55.5 \mathrm{qcm}$, die Blattfläche p. qm Bodenfläche $31.85 \mathrm{qm}$ und das Saatquantum $1.75 \mathrm{hl} \mathrm{p}$. ha.

Es wiegen 100 Halme $590 \mathrm{gr}^{\circ}$ und davon die Früchte $265 \mathrm{gr}$.

Der Weizen ist nicht winterfest, so erfror derselbe $1570 / 71$ fast vollständig, reift spät, befällt leicht mit Rost und liefert ein ron den Bäckern sehr gering geschätztes $\$ ehl; dagegen macht er verhältnismässig geringe Bodenanspriiche, ist ertragreich und lagert selten.

Um 1830 verbreitete er sich rom Londoner Markte aus in EastLothian ${ }^{1}$ ). von wo sich seine Kultur bald über die meisten Weizendistrikte Schottlands ausdehnte, doch hat sein Anbau in neuerer Zeit wegen der schlechten Qualität des Kornes sehr nachgelassen.

Auch in Deutschland, Frankreich und Spanien wird derselbe vieltach angebaut.

\section{Talavera red Wheat. (2)}

Deutsch: Roter Winter-Talarera-Weizen.

Aelire: rot mit bläulichem Anflug, locker, lang; Aehrchen $1.5 \mathrm{~cm}$ breit, 3-körnig. - Stroh: gelb, derbwandig. - Frucht: rot, glasig, oval, gross (7 mm lang, $4 \mathrm{~mm}$ breit), feinschalig, halbweich.

Herbstblatt blaugrün, schmal, niederliegend; Frühjahrsvegetation spät, Bestockung sehr stark, 8.2 Schösslinge, spät schossend und blühend. Halmlänge $130 \mathrm{~cm}$ ( \ax. $160 \mathrm{~cm}$ ), Halmdicke $0.33 \mathrm{~cm}$, Blattzahl 4, Blattlänge $25 \mathrm{~cm}$, Blattbreite $0.9 \mathrm{~cm}$; Blattoberfläche $180 \mathrm{qcm}$, Halmfläche $128.7 \mathrm{qcm}$, Gesammtfläche eines Halmes $308.7 \mathrm{qcm}$.

Junge Aehre gelbgrün, spät reifend, $10 \mathrm{~cm}$ (Max. $14 \mathrm{~cm}$ ) lang, mit 18 Aehrchen und 50 Früchten, von denen 1677000 auf $1 \mathrm{hl}(=83 \mathrm{~kg})$ entfallen.

Es wiegen 100 Halme $500 \mathrm{gr}$ und daron die Früchte $250 \mathrm{gr}$. 
In Poppelsdorf zeigte sich dieser Weizen winterfest und widerstandsfähig gegen Lagern und Rost.

\section{Prince Albert Wheat. (2)}

Syn: Engl.: Red Rostock; Oxford red. Franz.: Blé rouge Prince Albert. Deutsch: Prinz Albert-Weizen.

Aehre: rot mit bläulichem Anflug, locker, schmal, lang; Aehrchen $1.5 \mathrm{~cm}$ breit, 3-körnig. - Stroh: rötlich-gelb, kräftig, lang. - Frucht: Original gelbrot, meblig; nachgebaut: meist rot und glasig, länglich (7 $\mathrm{mm}$ lang, $3^{1 / 2} \mathrm{~mm}$ breit), ziemlich feinschalig.

Herbstblatt gelbgrïn, breit, aufrecht; Frühjahrsvegetation zeitig, Bestockung schwach, 3.5 Schösslinge, mittelfrüh schossend und blühend. Halmlänge $120 \mathrm{~cm}$ (Max. $140 \mathrm{~cm}$ ), Halmdicke $0.35 \mathrm{~cm}$, Blattzahl 4, Blattlänge $29.8 \mathrm{~cm}$, Blattbreite $0.9 \mathrm{~cm}$, Blattoberfläche $214.56 \mathrm{qcm}$, Halmfläche $136.8 \mathrm{qcm}$, Gesammtfäche $351.36 \mathrm{qcm}$.

Junge Aehre gelbgrïn, mittelfrüh reifend, $10 \mathrm{~cm}$ (Max. $16 \mathrm{~cm}$ ) lang, mit 16 Aehrchen und 45 nicht leicht ausfallenden Früchten, von denen 1663000 auf $1 \mathrm{hl}(=81.8 \mathrm{~kg})$ gehen.

Dieser Weizen ist ziemlich winterfest und ertragreich, auch leidet er wenig durch Lagern und Rost, und macht nur geringe Bodenansprüche. Lawes ${ }^{1}$ ) erntete zu Rothamsted, England, auf Lehmboden im Durchschnitt von 6 Jahren $38.59 \mathrm{hl} \mathrm{p}$. ha.

Diese Sorte ist unzweifelhaft durch Auswahl aus Red Rostock oder Oxford red, die vollkommen identisch sind, hervorgegangen.

\section{Baxter's Wheat. (2)}

Deutsch: Baxter's Winterweizen.

Aehre: rot, ziemlich dicht, mittellang; Aehrchen $1.5 \mathrm{~cm}$ breit, 3-körnig. - Stroh: gelbrot-orange, feinhalmig, spröde, Aehre leicht abbrechend. - Frucht: rot, glasig, etwas eingefallen, gross, plunp $\left(7 \frac{1}{2} \mathrm{~mm}\right.$ lang, $4 \mathrm{~mm}$ breit, 183 Friuchte $=10 \mathrm{gr}$ ), etwas grobschalig.

Herbstblatt dunkelgrün, beiderseits behaart oder unterscits kahl, schmal, kraus; Frühjahrsvegetation mittelfrüh, Bestockung stark, 7.8 Schösslinge; mittelfrüh schossend, doch spät blühend. Halmlänge $125 \mathrm{~cm}$ (Max. $150 \mathrm{~cm}$ ), Halmdicke $0.32 \mathrm{~cm}$, Blattzahl 4.3 , Blattlänge $21.5 \mathrm{~cm}$, Blattbreite $0.82 \mathrm{~cm}$, Blattoberfläche eines Halmes $151.62 \mathrm{qcm}$, Halmfläche $120 \mathrm{qcm}$, Gesammttläche $271.62 \mathrm{q} \mathrm{cm}$.

Junge Aehre gelbgriin, rot umrandet, spät reifend, $8 \mathrm{~cm}$ (Max. $11 \mathrm{~cm})$ lang, mit 16 Aehrchen und 45 ziemlich festsitzenden Früchten, voll denen 1464000 auf $1 \mathrm{hl}$ gehen.

Auf $1 \mathrm{qm}$ können 1000 Halınc oder 130 Pflanzen wachsen, mithin beträgt der Raum für eine Pflanze $78 \mathrm{qcm}$, die Blattfläche p. qm Bodenfläche $27.16 \mathrm{qm}$ und das Saatquantum $1.3 \mathrm{hl} \mathrm{p.} \mathrm{ha.}$

Es wiegen 100 Halme $450 \mathrm{gr}$ und davon die Früchte $280 \mathrm{gr}$.

Diese Sorte scheint nur für leichtere Weizenböden geeignet zu sein,

1) Farmer's Magaz. V. 80. 1876, pg. 433 . 
da sie leicht lagert und gegen Rost nur eine geringe Widerstandsfäligkeit besitzt.

\section{Hontlop's prolific. (2)}

Aehre: hellrot, dicht, $11 \mathrm{~cm}$ lang, mit 60 etwas lose sitzenden Früchten, aufrecht; Aehrchen $1.9 \mathrm{~cm}$ breit, 3- und 4-körnig. - Stroh: rötlich-gelb, ziemlich fest, blattreich, bis $135 \mathrm{~cm}$ hoch. - Frucht: Original rotbraun, mehlig, einige glasig, gross ( $7 \mathrm{~mm}$ lang, $4 \mathrm{~mm}$ breit, 217 Früchte $=10 \mathrm{gr}$ ), ziemlich feinschalig.

Original in der Sammlung der landw. Akademie zu Poppelsdorf.

\section{Standard red. (2)}

Franz.: Blé Standard rouge.

Aehre: blassrot, sich verjüngend, grannenspitzig, schmal, ziemlich dicht, $10 \mathrm{~cm}$ lang mit 20 Aehrchen und 50 Früchten; Aehrchen $1.2 \mathrm{~cm}$ breit, 2- und 3-körnig. - Stroh: rotgelb, blattreich, weich, $150 \mathrm{~cm} \mathrm{lang.} \mathrm{-}$ Frucht: rot, klein, länglich ( $6 \mathrm{~mm}$ lang, $3 \mathrm{~mm}$ breit), feinschalig.

Original im landw. Museum zu Berlin.

\section{Crimson-red. (2)}

Aehre: rot, sehr dicht, pyramidal, $9 \mathrm{~cm}$ lang mit 21 Aehrchen und 60 Früchten; Aehrchen $1.5 \mathrm{~cm}$ breit, 3-körnig. - Stroh: blassgelb, fest, $150 \mathrm{~cm}$ lang. - Frucht: gelbrot, mehlig ( $7 \mathrm{~mm}$ lang, $4 \mathrm{~mm}$ breit), etwas grobschalig.

Original im landw. Museum zu Berlin.

\section{Red-Wonder. (2)}

Aehre: rot, sich verjüngend, grannenspitzig, locker, $11 \mathrm{~cm}$ lang mit 63 Friichten; Aehrehen 3- und 4-körnig. - Stroh: rötlich-gelb. - Frucht: rot, glasig, länglich ( $7 \mathrm{~mm}$ lang, $3 \mathrm{~mm}$ breit), etwas grobschalig.

Lawes erntete im sechsjährigen Durchschnitt zu Rothamsted, England, 36.67 hl p. ha.

In der Sammlung des Dr. Dreisch, Poppelsdorf.

\section{Bole's prolific. (2)}

Aehre: lellrot, sich verjüngend, ein wenig grannenspitzig, locker, $13 \mathrm{~cm}$ lang, mit 60 Früchten; Aehrchen $1.5 \mathrm{~cm}$ breit, 3-körnig. - Stroh: gelb. - Frucht: rot, glasig, einige mehlig ( $7 \mathrm{~mm}$ lang, $3 \frac{1}{2} \mathrm{~mm}$ breit), feinschalig.

Lawes erntete im sechsjährigen Durchschnitt zu Rothamsted, England, $38.25 \mathrm{hl} \mathrm{p.} \mathrm{ha.}$

In der Sammlung des Dr. D reisch, Poppelsdorf.

Red Langham. (2)

Aehre: hellrot, sich wenig verjüngend und schwach grannenspitzig, sehr locker, $15 \mathrm{~cm}$ lang mit 70 Früchten, Aehrchen $2 \mathrm{~cm}$ breit, 3- und 
4-körnig. - Stroh: rötlich-gelb, kräftig. - Frucht: rot, glasig $(71 / 2 \mathrm{~mm}$ lang, $3 \frac{3 / 4}{\mathrm{~mm}}$ breit), etwas grobschalig.

Lawes erntete im sechsjährigen Durchschnitt zu Rothamsted, England, $35.89 \mathrm{hl} \mathrm{p.} \mathrm{ha.}$

In der Sammlung des Dr. Dreisch, Poppelsdorf.

\section{Red Berwick. (2)}

Aehre: hellrot, ziemlich dicht, $10.5 \mathrm{~cm}$ lang mit 65 ziemlich festsitzenden Früchten, steif; Aehrchen $2 \mathrm{~cm}$ breit, meist 4-körnig. - Stroh: blassgelb, blattreich, fest, nicht leicht lagernd, bis $140 \mathrm{~cm}$ lang. Frucht: Original rot, mehlig, mittelgross $(7 \mathrm{~mm}$ lang, $4 \mathrm{~mm}$ breit, 203 Früchte $=10 \mathrm{gr}$ ), ziemlich feinschalig.

Dieser Weizen beansprucht ein mildes Klima und kräftigen Boden. Original in der Sammlung der landw. Akademie zu Poppelsdorf.

\section{Creeping-red.}

Aehre: hellrot, sich stark verjuingend, locker, $13 \mathrm{~cm}$ lang mit 50 ziemlich festsitzenden Früchten; Aehrchen $1.5 \mathrm{~cm}$ breit, 2- und 3-körnig. Stroh: rotgelb, etwas weich und leicht lagernd, ziemlich blattreich, feinhalmig, $150 \mathrm{~cm}$ lang. - Frucht: rot, mehlig, wenige glasig, klein, rundlich ( $6 \mathrm{~mm}$ lang, $4 \mathrm{~mm}$ breit, 252 Früchte $=10 \mathrm{gr}$ ), etwas grobschalig. Für geringere Böden geeignet, doch ziemlich aus der Kultur, namentlich wegen des groben Mehles, verschwunden.

Original in der Sammlung der landw. Akademie Poppelsdorf.

\section{Harvey's prolific. (2)}

Aehre: rostrot, sehr dicht, $10 \mathrm{~cm}$ lang, mit 60 leicht ausfallenden Früchten, bei fortgesetztem Anbau war die Aehre etwas lockerer geworden; Aehrchen $2 \mathrm{~cm}$ breit, 3- und 4-körnig. - Stroh: rötlich-gelb, sehr blattreich, $140 \mathrm{~cm}$ lang, starkhalmig, doch ziemlich leicht lagernd. - Frucht: Original rot, voll, mehlig oder glasig, ziemlich plump (7 mm lang, $4 \mathrm{~mm}$ breit, 212 Früchte $=10 \mathrm{gr}$ ), grobschalig.

Dieser Weizen bestockt sich stark, bringt aber nur mittelmässige Erträge.

Original in der Sammlung der landw. Akademie zu Poppelsdorf.

\section{Chancellor red wheat. (2)}

A ehre: rot, sich wenig verjüngend, mit einigen Grannenspitzen, etwas locker, sehr lang $(15 \mathrm{~cm})$, mit 23 Aehrchen und 75 Früchten, aufrecht; Aehrchen $1.6 \mathrm{~cm}$ breit, 3- und 4-körnig. - Stroh: rotgelb, kräftig, fest, nicht leicht lagernd, $140 \mathrm{~cm}$ lang. - Frucht: rot, meist glasig $(7 \mathrm{~mm}$ lang, $3.5 \mathrm{~mm}$ breit).

Original im landw. Museum zu Berlin.

\section{Striped chaff. (2)}

Franz.: Blé à balles panachées.

Aehre: blassrot, Ränder der Klappen und Spelzen dunkelrot, daher 
gestreift aussehend, sich stark verjüngend, grannenspitzig, $9 \mathrm{~cm}$ lang mit 45 Frïchten; Aehrchen $1.2 \mathrm{~cm}$ breit, meist 2-körnig. - Stroh: blassgelb, blattreich, ziemlich reich, $140 \mathrm{~cm}$ lang. - Frucht: rot, glasig, klein (6 $\mathrm{mm}$ lang, $3 \mathrm{~mm}$ breit), feinschalig.

1850 auf.

Diese Sorte führt Loudon 1836 und Tilmo rin in seinem Essai ron

Original im landw. Museum zu Berlin.

\section{Drouved's new-wheat. (2)}

Syn: Drouved's neuer Weizen.

Aehre: rot, ziemlich dicht, breit, lang. - Stroh: rötlich-gelb, kräftig, mittellang. - Frucht: gelbrot, mehlig, viele rot, glasig, etwas eingefallen, rundlich, ziemlich gross $\left(7 \mathrm{~mm}\right.$ lang, $3 \frac{1}{2} \mathrm{~mm}$ breit, 227 Früchte $=10 \mathrm{gr}$ ); etwas grobschalig.

Herbstblatt dunkelgruin, beiderseits schwach behaart, oder unterseits kahl, ziemlich niederliegend; Entwickelung zeitig, 5 Schösslinge, spät schossend und blühend; Halm $120 \mathrm{~cm}$ (Jax. $145 \mathrm{~cm}$ ) lang, $0.4 \mathrm{~cm}$ breit, Blattzahl 4.2, Blätter $27.8 \mathrm{~cm}$ lang, $0.8-\mathrm{cm}$ breit, Blattfläche $204.6 \mathrm{qcm}$, Halmfläche 144 qcm. Gesammttäche 348.6 q cun.

Junge Aehre blaugrün, spät reifend, $10 \mathrm{~cm}$ (Мax. $13 \mathrm{~cm}$ ) lang.

Diese englische Weizensorte wurde 1877 durch J. Kühn, Halle, eingesandt.

\section{Virginian-3Iay. (2)}

Syn: Virginian-Wheat.

Roter Maiweizen.

Aehre: blassrot, mittellang. - Stroh: rötlich-gelb, lang. - Frucht: rot.

Frihreif, wenig empfindlich gegen schlechte Witterung und widerstandsfähig regen Rost.

Diese alte amerikanische Sorte wird seit 1800 um die ChesapeakeBay und in neverer Zeit auch in Oregon und Californien kultiviert und hoch geschätzt.

\section{Grass-Wheat. (2)}

Aehre: rot mit violettem Anfug, diinn, unter mittellang, sich stark verjüngend, grannenspitzig, halblocker; Aehrchen 3-körnig. - Stroh: meist violett, steif, unter mittellang. - Frucht: Original dunkelrot, glasig, oval, sehr klein ( $5 \mathrm{~mm}$ lang, $3 \mathrm{~mm}$ breit, 441 Frïchte $=10 \mathrm{gr}$ ); nachgebaut: riel grösser, 260 Früchte $=10 \mathrm{gr}$, sehr schwer, feinschalig, hart, Bruch stahlig.

Herbstblatt blaugrün, fein, kraus. Entwickelung spät, 5.6 Schösslinge, spät schossend und blïhend; Halm $110 \mathrm{~cm}$ (Max. $125 \mathrm{~cm}$ ) lang, $0.3 \mathrm{~cm}$ dick, Blattzahl 4.4, Blätter $15.6 \mathrm{~cm}$ lang, $0.8 \mathrm{~cm}$ breit, Blattläche $109.8 \mathrm{qcm}$, HaJmfläche 99 q cm, Gesammtfläche $208.8 \mathrm{qcm}$.

Junge Aehre bläulich, rot umrandet, mittelfrïh reifend, $9 \mathrm{~cm}$ (Max. $14 \mathrm{~cm})$ lang, mit 17 Aehrchen und 48 ziemlich lose sitzenden Frichten, von denen 3969000 auf $1 \mathrm{hl}(=90 \mathrm{~kg}$ ) entfallen.

Sehr widerstandsfähig gegen Rost und Lagern. Ein vorzüglicher Steppenweizen, der im Nordwesten der Vereinigten Staaten vielfach gebaut wird.

Bezugsquelle: Missouri Agric. Coll. 1880 U. S. 


\section{Gold-Dust. (2)}

Aehre: rot, sehr locker, sich verjüngend, grannenspitzig; Aehrchen $1.5 \mathrm{~cm}$ breit, meist 3-körnig. - Stroh: rötlich-gelb, unter mittellang, fest. - Frucht: Original rot, glasig, wenige gelbrot und mehlig, schlank, (7 mm lang, $3 \mathrm{~mm}$ breit. 287 Früchte $=10 \mathrm{gr}$ ), selır feinschalig; nach. gebaut: ein wenig grösser 200 Früchte $=10 \mathrm{gr}$, halbhart, Bruch halbmehlig.

Herbstblatt hellgrün, niederliegend; Entwickelung ziemlich zeitig, 2.6 Schösslinge, mittelfrüh schossend und bliihend; Halm $112 \mathrm{~cm}$ (Max. $140 \mathrm{~cm}$ ) lang, $0.33 \mathrm{~cm}$ dick, Blattzahl 4.2 , Blätter $16.6 \mathrm{~cm}$ lang, $0.84 \mathrm{~cm}$ breit, Blattfläche $117.1 \mathrm{qcm}$, Halmfläche $110.9 \mathrm{qcm}$, Gesammtfläche $228.0 \mathrm{qcm}$.

Junge Aehre bläulich-grïn, rot umrandet, zeitig reifend, $10 \mathrm{~cm}$ (Max. $14 \mathrm{~cm}$ ) lang, mit 18 Aehrchen und 50 lose sitzenden Früchten.

Befällt wenig durch Rost.

Für die Steppe geeignet.

Bezugsquelle: Missouri, Agric. Coll. U. S.

\section{Smooth Mifiterranean. (2)}

Aehre: blassrot, dünn, locker, sich stark verjüngend, kurz; Aehrchen 2- und 3-körnig, $1.3 \mathrm{~cm}$ breit, Spelzen mit Zahn. - Stroh: blassgelb, unter mittellang, steif. - Frucht: Original gelbrot, mehlig, wenige glasig, oval $\left(6^{1} / 4 \mathrm{~mm}\right.$ lang, $3^{1} / 2 \mathrm{~mm}$ breit, 264 Früchte $\left.=10 \mathrm{gr}\right)$; nachgebaut: ein wenig grösser 230 Früchte $=10 \mathrm{gr}$, rot, glasig; feinschalig, halbhart, halbstahlig.

Herbstblatt hellgriin, fein, niederliegend, Entwickelung ziemlich zeitig, 3 Schösslinge, mittelfrüh schossend und blühend; Halm $112 \mathrm{~cm}$ (Max. $125 \mathrm{~cm}$ ) lang, $0.3 \mathrm{~cm}$ dick, Blattzahl 4.4, Blätter $16.2 \mathrm{~cm}$ lang, $0.74 \mathrm{~cm}$ breit, Blattfläche $105.5 \mathrm{qcm}$, Halmfläche $100.8 \mathrm{qcm}$, Gesammtfläche $206.3 \mathrm{qcm}$.

Junge Aehre bläulich-grïn, rot umrandet, zeitig reifend; $8 \mathrm{~cm}$ (Max. $12 \mathrm{~cm}$ ) lang, mit 15 Aehrchell und 36 Früchten, von denen 2376000 auf $1 \mathrm{hl}(=90 \mathrm{~kg})$ entfallen.

Leidet wenig durch Rost und Lagern.

Die Beschaffenheit der Körner vorzüglich.

Angebaut in den Nordweststaaten Nord-Amerikas.

Bezugsquelle: Missouri-Agric. Coll. 1880 U.S.

\section{Shumaker. (2)}

Aehre: rot mit violettem Anflug, dünn, locker, sich verjüngend, grannenspitzig; Aehrchen $1.3 \mathrm{~cm}$ breit, 2- und 3-körnig. - Stroh: meist violett, unter inittellang, steif. - Frucht: Original gelbrot, meist mehlig, einige rot und glasig, länglich $\left(6^{1} / 2 \mathrm{~mm}\right.$ lang, $3 \frac{1}{4} \mathrm{~mm}$ breit, 26.3 Friichte $=10 \mathrm{gr}$ ), feinschalig; nachgebaut: alles glasig, etwas grösser, 200 Früchte = $10 \mathrm{gr}$, halbhart, Bruch halbmehlig.

Herbstblatt gelbgriin, aufrecht, lang doch schmal; 3 Schösslinge, sehr zeitig schossend, mittelfrüh blühend; Halm $100 \mathrm{~cm}$ (Max. $115 \mathrm{~cm}$ ) lang, $0.3 \mathrm{~cm}$ dick, Blattzahl 4.2, Blattlänge $15 \mathrm{~cm}$, Blattbreite $0.84 \mathrm{~cm}$, Blattfläche $105.8 \mathrm{qcm}$, Halmfläche $90 \mathrm{qcm}$, Gesammtfläche $195.8 \mathrm{qcm}$. 
Junge Aehre gelbgrün, rot umrandet, zeitig reifend; $9 \mathrm{~cm} \mathrm{(Max.}$ $11 \mathrm{~cm}$ ) lang, mit 17 Aehrchen und 40 Früchten, von denen 2261800 auf $1 \mathrm{hl}(=86 \mathrm{~kg})$ entfallen.

Lagert nicht, fast rostfrei.

In den Nordwest-Staaten Amerikas gebaut.

Bezugsquelle: Missouri Agric. Coll. 1880. U. S.

\section{Red (hatf. (2)}

Aehre: rot mit violettem Anflug, locker, dünn, unter mittellang, grannenspitzig; Aehrchen $1.3 \mathrm{~cm}$ breit, 2- und 3-körnig. - Stroh: blassgelb, steif, unter mittellang. - Frucht: Original gelbrot, mehlig, rundlich, klein ( $6 \mathrm{~mm}$ lang, $31 / 4 \mathrm{~mm}$ breit, 294 Früchte $=10 \mathrm{gr})$; nachgebaut: fast alles glasig, grösser $238 \mathrm{Körner}=10 \mathrm{gr}$, feinschalig, weich.

Herbstblatt dunkelgriin, halb niederliegend, fein, schmal; Entwickelung mittelfrïh, 5 Schösslinge; mittelfrüh schossend und bliihend; Halm $110 \mathrm{~cm}$ (Мах. $120 \mathrm{~cm}$ ) lang, $0.3 \mathrm{~cm}$ dick, Blattzahl 4.3, Blätter $15.8 \mathrm{~cm}$ lang, $0.9 \mathrm{~cm}$ breit, Blattläche $122.3 \mathrm{qcm}$, Halmfläche $99 \mathrm{qcm}$, Gesammtfläche $221.3 \mathrm{qcm}$.

Junge Aehre gelbgrün, rot umrandet, zeitig reifend, $9 \mathrm{~cm}$ (Мax. $12 \mathrm{~cm}$ ) lang, mit 18 Aehrchen und 45 etwas lose sitzenden Früchten, von denen 2601900 auf $1 \mathrm{hl}(=88.5 \mathrm{~kg})$ entfallen.

Leidet wenig durch Rost und Lagern.

Heimat: Nordweststaaten Nord-Amerikas und hochgeschätzt in Oregon und Californien.

Bezugsquelle: Missouri Agric. Coll. 1880 U. S.

\section{Triticum subfragile, Palermo. $\odot$}

Aebre: blassrot, sich verjüngend und grannenspitzig, locker, lang; Aebrchen ziemlich breit, $1.5 \mathrm{~cm}, 3-\mathrm{körnig}$. - Stroh: vor der Reife dunkelbraun, reif rötlich-grau oder graublau, dickwandig, fest. - Frucht: meist hellrot und glasig, wenige gelbrot und mehlig, oval, klein $(6 \mathrm{~mm}$ lang, $3 \frac{1}{2} \mathrm{~mm}$ breit, 260 Früchte $=10 \mathrm{gr}$ ), feinschalig, halbhart, Bruch halbmehlig.

Junges Blatt dunkelgrün, aufrecht, ziemlich breit; Bestockung schwach, 2.4 Schösslinge, mittelfrüh schossend und blühend. Halmlänge $128 \mathrm{~cm}$ (Hax. $150 \mathrm{~cm}$ ), Halmdicke $0.36 \mathrm{~cm}$, Blattzahl 3.7, Blattlänge $24.8 \mathrm{~cm}$, Blattbreite $0.9 \mathrm{~cm}$, Blattoberfläche $165.17 \mathrm{qcm}$, Halmfläche $138.24 \mathrm{qcm}$, Gesammtfläche $303.41 \mathrm{qcm}$.

Junge Aebre gelblich-grün, in 124 Tagen reifend, $10 \mathrm{~cm}$ (Max.14 cm) lang, mit 17 Aehrchen und 48 leicht in der Vollreife ausfallenden Frïchten, von denen 1957100 auf $1 \mathrm{hl}(=83.3 \mathrm{~kg})$ gehen.

Es wiegen 100 Halme $312 \mathrm{gr}$ und daron die Früchte $134 \mathrm{gr}$.

Dieser Weizen eignet sich nur für trockne, kalkreiche Böden, da er leicht durch Rost leidet und lagert. Das Korn liefert ein vorzügliches Irehl.

Dieser rote Weizen aus Palermo war unter dem Namen „Triticum subfragile" 1873 auf der Wiener Weltausstellung ausgestellt und wurde durch Dr. Wittmack nach Poppelsdorf gesandt. 


\section{Touzelle ronge sans barbes. (2) u. $\odot$}

Syn.: Franz.: Blé rouge de Provence.

Deutsch: Braunroter französischer Landweizen.

Aehre: braunrot, sich verjüngend, grannenspitzig, kurz, dicht, dünn; Aehrchen $1.4 \mathrm{~cm}$ breit, 3-körnig. - Stroh: gelb, nach der Aehre zu häufig blaugrau, fein und weich. - Frucht: rot, glasig, sehr schön, rundlich, klein $\left(6 \mathrm{~mm}\right.$ lang, $3^{3} / 4 \mathrm{~mm}$ breit, 257 Früchte $\left.=10 \mathrm{gr}\right)$, sehr feinschalig, halbhart, Bruch halbstahlig.

Herbstblatt blaugrïn, behaart, schmal, kraus; Frühjahrsvegetation etwas spät, Bestockung stark, Schösslinge, mittelfrüh schossend und blühend. Halmlänge $120 \mathrm{~cm}$ (Max. $130 \mathrm{~cm}$ ), Halnıdicke $0.33 \mathrm{~cm}$, Blattzahl 3.7, Blattlänge $24.8 \mathrm{~cm}$, Blattbreite $0.8 \mathrm{~cm}$, Blattoberfläche eines Halmes $146.8 \mathrm{qcm}$, Halmfläche $118.8 \mathrm{q} \mathrm{cm}$, Gesammtfläche $265.6 \mathrm{qcm}$.

Aehre jung gelbgrün, mittelfrüh reifend, $8 \mathrm{~cm}$ (Max. $13 \mathrm{~cm}$ ) lang, mit 18 Aehrchen und 50 Früchten, von denen sich 2158800 auf $1 \mathrm{hl}$ $(=84 \mathrm{~kg})$ berechnen.

Auf $1 \mathrm{qm}$ kommen 1000 Halme oder 167 Pflanzen, mithin stellt sich der Raum für eine Pflanze auf $60 \mathrm{qcm}$, die Blattfläche $\mathrm{p}$. qm der Bodenfläche auf $26.56 \mathrm{qm}$ und das Saatquantum (1/3 Verlust) auf $1.2 \mathrm{hl}$ p. ha.

Es wiegen 100 Halme $457 \mathrm{gr}$ und davon die Früclite $143 \mathrm{gr}$.

Dieser Weizen leidet stark durch Lagern und Rost.

Es ist eine der besten im sïdlichen Frankreich einheimischen Sorten, welche schon für die Ungegend von Paris zu weichlich und als Sommerweizen schon im Februar auszusäen ist.

In der Provence und dem Languedoc zeigt sich dieser Weizen auf den leichteren, durchlassenden, kalkreichen Böden sehr lohnend und das Korn von vorzüglicher Qualität.

Der Name "Touzelle" findet sich schon bei Dalechamp, hist. gen. pl. 1 (1586) p. 376 und bezeichnete einen ausgezeichnet guten roten Weizen, welcher zwischen der Rhône und Isère gebaut wurde.

\section{Blé de Mars ronge de Noé. $\odot$}

Deutsch: Roter Sommerweizen von Noé.

Aehre: dunkelrot, sich verjüngend, grannenspitzig, ziemlich dicht, mittellang; Aehrchen $1.6 \mathrm{~cm}$ breit, meist 3-körnig. - Stroh: blassrötlichgelb, feinhalmig, fest, hohl, aber mit markigem Rande. - Frucht: gelbrot, meist mehlig, rundlich, dick, gross $\left(6^{1 / 2} \mathrm{~mm}\right.$ lang, $4 \mathrm{~mm}$ breit, 186 Früchte $=10 \mathrm{gr}$ ), ziemlich feinschalig, Bruch halbmehlig, halbweich.

Junges Blatt dunkelgrüin, lang, breit, 2.3 Schösslinge, sehr spät schossend und blühend. Halmlänge $125 \mathrm{~cm}$ (Max. $145 \mathrm{~cm}$ ), Halmdicke $0.33 \mathrm{~cm}$, Blattzahl 4.5, Blattlänge $22.8 \mathrm{~cm}$, Blattbreite $1.04 \mathrm{~cm}$, Blattoberfläche eines Halmes $213.41 \mathrm{qcm}$, Halmfläche $123.75 \mathrm{qcm}$, Gesammtfläche 337.16 qcm.

Junge Aehre gelbgrün, sehr spät reifend, $9 \mathrm{~cm}$ lang (Мax. $12 \mathrm{~cm}$ ) mit 16 Aehrchen und 45 nicht leicht ausfallenden Früchten, von denen 1562400 auf $1 \mathrm{hl}(=84 \mathrm{~kg})$ gehen.

Auf $1 \mathrm{qm}$ wuchsen 700 Halme oder 300 Pflanzen, mithin betrïgt der Raum für eine Pflanze $33.3 \mathrm{qcm}$, die Blattfläche $\mathrm{p}$. qm Bodenfläche $23.59 \mathrm{qm}$ und das Saatquantum (1/3 Verlust) $2.9 \mathrm{hl} \mathrm{p.} \mathrm{ha.}$

Es wiegen 100 Halme $560 \mathrm{gr}$ und davon die Früchte $210 \mathrm{gr}$. 
In Poppelsdorf gedieh auf reichem Lehmboden dieser Weizen vortrefflich, doch fordert seine lange Vegetationsperiode (140 Tage) warme, lange Sommer. Das Stroh lagert nicht leicht und widersteht dem Rost vortrefflich. Heimat: Mittel-Frankreich.

\section{Blé rouge de St. Laud.}

\section{Syn. Franz.: Blé de Mars à épi rouge.}

Deutsch: Rotähriger Sommerweizen, Roter Weizen von St. Laud.

A ehre: hellrot mit bläulichem Anflug, ziemlich kompakt, dicht, kurz, grannenspitzig; Aehrehen $1.5 \mathrm{~cm}$ breit, 3- und 4-blütig. - Stroh: rötlichgelb, sehr derbwandig. - Frucht: gelbrot, mehlig; nachgebaut: meist rot und glasig; klein ( $6 \mathrm{~mm}$ lang, $3^{1 / 2} \mathrm{~mm}$ breit, 275 Körner $\left.=10 \mathrm{gr}\right)$, feinschalig, Brach halbmehlig, halbweich.

Halme blaugrün, 2.4 Schösslinge, Halmlänge $110 \mathrm{~cm}$ (Max. $135 \mathrm{~cm}$ ), Halmdicke $0.33 \mathrm{~cm}$, Blattzahl 3.7 , Blattlänge $30.75 \mathrm{~cm}$, Blattbreite $0.89 \mathrm{~cm}$, Blattoberfläche eines Halmes $202.54 \mathrm{qcm}$, Halmfläche $108.9 \mathrm{qcm}$, Gesammtfläche $311.44 \mathrm{q} \mathrm{cm}$.

Junge Aehre gelbgrïn, Spelzen rot umrandet, spät reifend, $8 \mathrm{~cm}$ lang (Max. $10 \mathrm{~cm}$ ) mit 18 Aebrchen und 60 ziemlich fest sitzenden Früchten, ron denen 2200000 auf $1 \mathrm{hl}$ (=80 kg) gehen.

Auf $1 \mathrm{qm}$ wachsen 900 Halme oder 275 Pflanzen, mithin nimmt eine Pflanze einen Raum von $36.5 \mathrm{qcm}$ ein, die Blattfläche p. qm Bodenfläche beträgt $28 \mathrm{qm}$, und das Saatquantum $1.8 \mathrm{hl}$ p. ha.

Es wiegen 100 Halme 620 gr und davon die Früchte $230 \mathrm{gr}$.

Dieser Weizen verlangt warme Sommer, wenn die Qualität der Früchte befriedigen soll. Das Stroh lagerte nicht leicht und zeigte eine bedeutende Widerstandsfähigkeit gegen Rost.

Dieser ertragreiche Sommerweizen empfiehlt sich für reiche Lehmböden und ein mildes Klima, in welchem Fall sich derselbe auch als Winterweizen braucherı lässt.

Wahrscheinlich ist er aus einem Binkelweizen (Trit. comp. creticum) durch Kultur auf reichem Boden lervorgegangen.

Diese Sorte wurde von Vilmorin \& Andrienx, Paris, bezogen.

Die ursprüngliche Heimat dieser Sorte liegt im Thal der Loire und wird der Anbau rorzugsweise stark in der Umgegend von Angers betrieben.

\section{Blé vert bâtard. (2)}

Deutsch: Neuer Bastard.

Aehre: blassrot, dicht, sich nach der Spitze verjüngend, mittellang, doch etwas schmal; Aehrchen $1.4 \mathrm{~cm}$ breit, meist 3-körnig. - Stroh: blassgelb, etwas weich, lang. - Frucht: rot, glasig, wenige gelbrot und mehlig, voll, oval, schön, gross $(7 \mathrm{~mm}$ lang, $33 / 4 \mathrm{~mm}$ breit, 193 Früchte $=10 \mathrm{gr})$, ziemlich feinschalig, halbweich, Bruch halbmehlig.

Herbstblatt dunkelgrün, beiderseits behaart, ziemlich breit, aufrecht; Friihjahrsentwickelung mittelfrïh, Bestockung mittelstark, 4.3 Schösslinge, mittelfriih schossend und blühend. Halmlänge $135 \mathrm{~cm}$ (Max. $160 \mathrm{~cm}$ ), Halmdicke $0.4 \mathrm{~cm}$, Blattzahl 4.1, Blattlänge $18.3 \mathrm{~cm}$, Blattbreite $0.94 \mathrm{~cm}$, Blattoberfläche $141 \mathrm{qcm}$, Halmfläche $162 \mathrm{qcm}$, Gesammtfläche $303 \mathrm{qcm}$.

Junge Aehre gelbgrïn, mittelfrüh reifend, $8 \mathrm{~cm}$ (Max. $12 \mathrm{~cm}$ ) lang, 
mit 20 Aehrchen und 56 festsitzenden Früchten, von denen 1544000 auf $1 \mathrm{hl}(=80 \mathrm{~kg})$ gehen.

Es wiegen 100 Halme $520 \mathrm{gr}$ und davon die Früchte $192 \mathrm{gr}$.

Dieser Weizen ist nicht ganz winterfest, lagert leicht und ist gegen Rost sehr wenig widerstandsfähig.

Für leichtere Böden im milden Klima scheint er sich zu eignen.

\section{Blé rouge inversable. $\odot$ u. (2)}

Syn.: Franz.: Blé de Bordeaux; Blé rouge de Lectoure; Bladette de Lesparre.

Deutsch: Nicht lagernder roter Wechselweizen.

Aehre: rotblau, sich wenig verjünend, etwas locker, mittellang und schmal; Aehrchen $1.5 \mathrm{~cm}$ breit, meist 3-körnig. - Stroh: rötlich-gelb bis orange, blattreich, mittellang, sehr fest. - Frucht: Original (Vilmorin \& Andrieux, Paris) hellgelbrot, mehlig, plump, gross $(7 \mathrm{~mm}$ lang, $4 \mathrm{~mm}$ breit); nachgebaut: konstant geblieben, ein wenig grobschalig, weich, Bruch mehlig.

Herbstblatt dunkelgriin, breit, lang, aufrecht. Sommer- und Winterfrucht stimmen im Habitus vollständig mit einander übereir. Frühjahrsvegetation sehr zeitig; Bestockung schwach, 3.5 Schösslinge, zeitig schossend und blühend. Halmlänge $115 \mathrm{~cm}$ (Max. 135 cm), Halmdicke $0.37 \mathrm{~cm}$, Blattzahl 4.3, Blattlänge $29.8 \mathrm{~cm}$, Blattbreite $0.94 \mathrm{~cm}$, Blattoberfläche eines Halınes 240.89 qem, Halmflächc 127.65 qcm, Gesammttläche $368.54 \mathrm{qcm}$.

Junge Aehre bläulich-grün, zeitig reifend, $9 \mathrm{~cm}$ (Max. $13 \mathrm{~cm}$ ) lang, mit 15 Aehrchen und 45 festsitzenden Früchten, von denen 1445000 auf $1 \mathrm{hl}(=85 \mathrm{~kg})$ gehen.

Es wachsen auf $1 \mathrm{qm} 900$ Halme oder 257 Pflanzen, mithin stellt sich der Raum für eine Pflanze auf $40 \mathrm{qcm}$, die Blattfläche p. qm Bodenfläche auf $33.12 \mathrm{qm}$ und das Saatquantum auf $2.6 \mathrm{hl} \mathrm{p}$. ha.

$\begin{array}{ccc} & \text { Winterfrucht } & \text { Sommerfrucht } \\ \text { Es wiegen } 100 \text { Halme } & 587 \mathrm{gr} & 620 \mathrm{gr} \\ \text { und davon die Früchte } & 230 \% & 200 \mathrm{M}\end{array}$

Nach Vilmorin wird dieser Weizen in der Niederung der Garonne kultiviert, und ist für den an Dürre leidenden Mittelboden Frankreichs sehr wichtig, weil er dieser vortrefflich widersteht.

In Poppelsdorf zeichnete er sich durch seinen vortrefflichen Stand, sein festes, weder Lager noch Rost zeigendes Stroh aus, doch scheint er hier nicht ganz winterfest zu sein, so litt er im Winter 1879/80 nicht unerheblich.

\section{Blé de Rampillon. (2)}

Syn.: Froment rouge de M. Van Malders ${ }^{1}$ )

Aehre: blassrot, sich stark verjüngend, meist kurzgrannig, locker, etwas schlaff, $11 \mathrm{~cm}$ lang, mit 40 Früchten, Aehrchen $1 \mathrm{~cm}$ breit, meist 2-körnig. - Stroh: rötlich-gelb, kräftig, blattreich, $150 \mathrm{~cm}$ lang. Frucht: gelbrot, mehlig oder rot und glasig, klein, länglich $(6 \mathrm{~mm}$ lang, $3 \mathrm{~mm}$ breit), feinschalig.

Original im landw. Museum zu Berlin.

1) Vilm. Essai a. a. O. 1850. 


\section{Blé Rafford. (2)}

Aehre: rot, dicht, kurz, der des Binkelweizens sehr ähnlich, nur schmäler, $8 \mathrm{~cm}$ lang mit 40 Frïchten; Aehrchen $1.2 \mathrm{~cm}$ breit, 2 - und 3-körnig. - Stroh: blassgelb, steif, feinhalmig, kurz, $90 \mathrm{~cm}$ lang. Frucht: gelbrot, mehlig, länglich ( $7 \mathrm{~mm} \mathrm{lang,} 31 / 2 \mathrm{~mm}$ breit).

Original im landw. Museum zu Berlin.

\section{Froment Chouroute. (2)}

Aehre: blassrot, sich stark verjïngend, grannenspitzig, ziemlich dicht, $9 \mathrm{~cm}$ lang mit 18 Aehrehen und 50 Früchten; Aehrchen $1.3 \mathrm{~cm}$ breit, 2- und 3-körnig. — Stroh: rötlich-gelb, blattreich, kräftig, $150 \mathrm{~cm}$ lang. - Frucht: rot, glasig, länglich (61/2 $\mathrm{mm}$ lang, $3 \mathrm{~mm}$ breit), feinschalig.

Original im landw. Museum zu Berlin.

\section{Blé du Languedoc. (2)}

Syn.: Blé de Caucase rouge sans barbes.

Aehre: rot, dünn, locker, $11 \mathrm{~cm}$ lang, mit 17 Aehrchen und 42 Früchten, sich stark verjüngend, kurzgrannig; Aehrchen $1.2 \mathrm{~cm}$ breit, 2- und 3-körnig. - Stroh: rötlich-weiss, ziemlich blattreich, fest, $140 \mathrm{~cm}$ lang. - Frucht: rot, glasig, länglich, gross (7 mm lang, $31 / 2 \mathrm{~mm}$ breit). Original im landw. IIusenm zu Berlin.

\section{Blé rouge de Bretagne ${ }^{1}$ ).}

Sy n.: Marselage grisâtre, Blé Raton. Engl.: Red Britannia.

Aehre: blassrot, sich verjüngend, kurzgrannig, dünn, locker, mittellang, $9 \mathrm{~cm}$ lang, mit 35 leicht ausfallenden Friichten; Aehrchen $1.2 \mathrm{~cm}$ breit, meist 2-körnig. - Stroh: rötlich-gelb, feinhalmig, blattreich, etwas weich, 130-160 cm lang. - Frucht: rot, glasig, klein, 61/2 mm lang, $3 \mathrm{~mm}$ breit, feinschalig.

Häufig im Norden und Nordwesten Frankreichs auf kulturvollem Boden gebant.

Original im landw. Museum zu Berlin.

\section{Blé rouge de l'Aigle. (2)}

Syn.: Blé Paquêt.

Aehre: blassrot, dicht, sich wenig verjüngend, grannenspitzig, doch Spitzen meist nach innen gebogen, kurz, $8 \mathrm{~cm}$ lang mit 45 Früchten; Aehrchen $1.1 \mathrm{~cm}$ breit, 2- und 3-körnig. - Stroh: rotgelb, blattreich, fest, $150 \mathrm{~cm}$ lang. — Frucht: graurot, meist glasig (7 mm lang, 31/2 mm breit), länglich, etwas grobschalig.

Original im landw. Museum zu Berlin.

1) Vilm. Essai a. a. 0. 1850. 


\section{Blé Chicot rouge de Caën. (2)}

Syn.: Franz.: Blé rouge Touzard, Blé Petit rouge Desvaux, Blé reçu de la Nouvelle-Zélande ${ }^{1}$ ).

Aehre: rot, sich verjüngend, grannenspitzig, etwas locker, $10 \mathrm{~cm}$ lang mit 17 Aehrchen und 56 Früchten; Aehrchen $1.3 \mathrm{~cm}$ breit, meist 3-körnig. - Stroh: goldgelb, ziemlich blattreich, fest, $160 \mathrm{~cm}$ lang. Frucht: gelbrot, mehlig, schlank $(61 / 2 \mathrm{~mm}$ lang, $3 \mathrm{~mm}$ breit $)$, feinschalig.

Diese Sorte ist vorzugsweise im westlichen und nordwestlichen Frankreich verbreitet, und verlangt guten Boden.

Original im landw. Museum zu Berlin.

\section{Blé Monterosier. (2)}

Aehre: blassrot, sich stark verjüngend, kurzgrannig, locker, $10 \mathrm{~cm}$ lang, mit 18 Aehrchen und 36 Früchten, dünn; Aehrehen $1.2 \mathrm{~cm}$ breit, meist 2-körnig. - Stroh: blassgelb, fest, blattarm, $120 \mathrm{~cm}$ lang. Frucht: gelbrot, mehlig, (6 $\mathrm{mm}$ lang, $3 \mathrm{~mm}$ breit), feinschalig.

Original im landw. Museunı zu Berlin.

\section{Blé Jacquin. (2)}

Aehre: rot, aufrecht, sich wenig verjüngend, ziemlich dicht, $9 \mathrm{~cm}$ lang, mit 60 leicht ausfallenden Früchten; Aehrchen $1.7 \mathrm{~cm}$ breit, 3- und 4-körnig. - Stroh: gelb, blattarm, steif, mittellang, $100 \mathrm{~cm}$ lang. Frucht: dunkelrot, glasig, ziemlich plump, rundlich, gross $(7 \mathrm{~mm}$ lang, $4 \mathrm{~mm}$ breit).

Auf reichen Niederungsböden in Frankreich gebaut.

Original im landw. Museum zu Berlin.

\section{Roode Tarwe kaalarige Tiel. (2)}

Aehre: rot; ziemlich dicht, sich verjüngend; Aehrchen 2-3-körnig. Stroh: rotgelb-orange, fest. - Frucht: rot, glasig, klein, rundlich $(6 \mathrm{~mm}$ lang, $3^{1} / 2 \mathrm{~mm}$ breit, 250 Früchte $=10 \mathrm{gr}$ ), schwer, feinschalig, halbhart, Bruch halbmehlig.

Herbstblatt gelbgrün, breit, aufrecht; Frühjahrsvegetation mittelfrüh; Bestockung stark, 6 Schösslinge, spät schossend und blühend. Halmlänge $145 \mathrm{~cm}$ (Max. $165 \mathrm{~cm}$ ), Halmdicke $0.4 \mathrm{~cm}$, Blattzahl 3.7, Blattlänge $29 \mathrm{~cm}$, Blattbreite $1 \mathrm{~cm}$, Blattoberfläche $214.6 \mathrm{qcm}$, Halmfläche $174 \mathrm{qcm}$, Gesammtfläche $388.6 \mathrm{qcm}$.

Junge Aehre gelbgrün, mittelfrüh reifend, $10 \mathrm{~cm}$ (Max. $14 \mathrm{~cm}$ ) lang, mit 20 Aehrchen und 50 Früchten, von denen 2150000 auf $1 \mathrm{hl}$ $(=86 \mathrm{~kg})$ gehen.

Es kommen auf 1 qm 840 Halme oder 140 Pflanzen, mithin beträgt der Raum pro Pflanze $71.4 \mathrm{qcm}$, die Blattfläche p. qm Bodenfläche $32,6 \mathrm{qm}$ und das Saatquantum $(1 / 3$ Verlust) $1 \mathrm{hl} \mathrm{p.} \mathrm{ha.}$

1) Vilm. Essai a. a. O. 1850. 
Es wiegen 100 Halme $430 \mathrm{gr}$ und davon die Früchte $160 \mathrm{gr}$.

Dieser schöne Weizen leidet wenig durch Lagern, Rost und Auswintern.

Heimat: Provinz Gelderland, Holland, auf leichterem Boden.

Bezugsquelle: Dampfmühle zı Rotterdam.

\section{Roter Kolbenweizen von Missolunghi, Griechenland $\odot$ u. (2)}

Aehre: blassrot, ziemlich dicht, sich verjüngend und grannenspitzig, lang; Aehrchen $1.5 \mathrm{~cm}$ breit, lang, 3-körnig. - Stroh: gelb, weich. Frucht: rot, mehlig oder glasig, nicht schön, sehr eingefallen, lang, gross, verhältnismässig leicht ( $8 \mathrm{~mm}$ lang, $4 \mathrm{~mm}$ breit). $1 \mathrm{hl}$ wiegt $79 \mathrm{~kg}$ und enthält 1619500 Früchte, ziemlich feinschalig, halbhart, Bruch halbmehlig.

Junges Blatt blaugrün, schmal, kraus; Friihjalırsvegetation zeitig, zeitig schossend und blühend, mittelfriih reifend, die Sommersaat dagegen in der Entwickelung sehr spät und zwar am spätesten von allen Sommerweizen schossend und blühend, in 135 Tagen reifend. wie folgt:

Sommer- und Wintersaat verhielten sich in demselben Jahre geerntet,

\begin{tabular}{l|l|l}
\hline & Winterweizen & Sommerweizen \\
\hline
\end{tabular}

\begin{tabular}{l|c|c} 
Halmlänge & $120 \mathrm{~cm}($ Max.: $140 \mathrm{~cm})$ & $140 \mathrm{~cm}($ Max. $155 \mathrm{~cm})$ \\
Halmdicke & $0.38 \mathrm{~cm}$ & $0.38 \mathrm{~cm}$ \\
Blattlänge & $20 \mathrm{~cm}$ & $21.8 \mathrm{~cm}$ \\
$\begin{array}{l}\text { Blattbieite } \\
\text { Blattzahl }\end{array}$ & $0.85 \mathrm{~cm}$ & $0.85 \mathrm{~cm}$ \\
$\begin{array}{c}\text { Aehrenlänge } \\
\text { Fruchtzahl in einer }\end{array}$ & $9 \mathrm{~cm}($ Max.: $12 \mathrm{~cm})$ & $11 \mathrm{~cm} \mathrm{(Max.:} 14 \mathrm{~cm})$ \\
$\begin{array}{c}\text { Achre } \\
\text { Gesammtoberfläche } \\
\text { eines Halmes }\end{array}$ & 48 & 60 \\
& $272.8 \mathrm{qcm}$ & $315.3 \mathrm{qcm}$
\end{tabular}

Es wiegen 100 Halme

Winterweizen. Sommerweizen.

Davon die Früchte

$\begin{array}{ll}540 \mathrm{gr} & 364 \mathrm{gr} \\ 209 & 178\end{array}$

In Poppelsdorf lagerte der Winterweizen, während sich der Sommerweizen aufrecht hielt; die Widerstandsfähigkeit gegen Rost war bedeutend.

Dieser Weizen wurde 1878 von der Samenhandlung Itzenplitz \& Co., Köln, eingefïhrt.

\section{Roter Winter-Kolbenweizen aus dem Vispthal, Schweiz. (2)}

Aehre: rostfarben, sich stark verjüngend, oft mit kurzen Grannen oder stark grannenspitzig, schmal, lang; Aehrchen 2- und 3-körnig. - Stroh: rötlich-gelb. - Frucht: Original blass-rot, glasig, lang, schmal $(71 / 2 \mathrm{~mm}$ lang, $3 \mathrm{~mm}$ breit, 225 Früchte $=10 \mathrm{gr}$ ), feinschalig, hart, halbstahlig.

Herbstblatt blaugrün, lang, fein, niederliegend; Frühjahrsvegetation mittelfrüh, Bestockung stark, 6 Schösslinge, deren Fuss rot, gleich Roggen, gefärbt ist, zeitig schossend und blühend. Halmlänge $130 \mathrm{~cm}$ (JIax. 
$150 \mathrm{~cm}$ ), Halmdicke $0.39 \mathrm{~cm}$, Blattzahl 3.7, Blattlänge $22 \mathrm{~cm}$, Blattbreite $0.89 \mathrm{~cm}$, Blattoberfläche $144.89 \mathrm{qcm}$, Halmfläche $152.1 \mathrm{qcm}$, Gesammtfläche $296.99 \mathrm{qcm}$.

Junge Aehre gelbgriin, mit rot umrandeten Klappen und Spelzen, $10 \mathrm{~cm}$ (Max. $15 \mathrm{~cm}$ ) lang, mit 18 Aehrchen und 45 ziemlich leicht in der Vollreife ausfallenden Früchten, von denen 1822500 auf $1 \mathrm{hl}(=$ $81 \mathrm{~kg}$ ) gehen.

Die Reife trat in Poppelsdorf am zeitigsten voll allen Winterweizen ein, schon vom 13. Juni $1878 \mathrm{ab}$ bräunten sich die Aehren.

Es ist ein echter Winterweizen, der sich als vollkommen winterfest bewährte.

Es wiegen 100 Halme $370 \mathrm{gr}$ und davon die Früchte $160 \mathrm{gr}$.

Das Stroh befiel wenig mit Rost, zeigte aber Neigung zum Lagern.

Fr. Körnicke sammelte im Augnst 1876 diesen Weizen im Vispthale unterhalb Zermatt, Wallis, Schweiz in der Höhe von ca. $1440 \mathrm{~m}$ ii. M.

\section{Roter Sommerweizen aus Charkow, (Ghirka), Sïd-Russland. $\odot$}

Aehre: schnutzig hellrot, sich stark verjüngend, grannenspitzig, locker, mittellang; Aehrchen $1.5 \mathrm{~cm}$ breit, 2- und 3-körnig. - Stroh: gelb, mittellang. - Frucht: Original rot, glasig, wenige mehlig und gelbrot, klein $\left(5 \frac{1}{2} \mathrm{~mm}\right.$ lang, $3 \mathrm{~mm}$ breit, 400 Früchte $\left.=10 \mathrm{gr}\right)$, sehr schwer, feinschalig, hart, Bruch halbstahlig.

Jung'es Blatt blaugrin, oberseits sehr kurz behaart, schmal, aufrecht, 3.6 Schösslinge, zeitig schossend und bliihend. Halm $110 \mathrm{~cm}$ (Max. $135 \mathrm{~cm}$ ) lang, $0.38 \mathrm{~cm}$ dick, Blattzahl 3.4, Blätter $29.8 \mathrm{~cm} \mathrm{lang,} 0.8 \mathrm{~cm}$ breit, Blattfläche $162.11 \mathrm{qcm}$, Halmfläche $125.4 \mathrm{qcm}$, Gesammtfläche $287.51 \mathrm{qcm}$.

Junge Aehre blaugrün, $9 \mathrm{~cm}$ ( von denen 3680000 auf $1 \mathrm{hl}(=92 \mathrm{~kg})$ entfallen.

Es wiegen 100 Halme $242 \mathrm{gr}$, nnd davon die Früchte $108 \mathrm{gr}$.

Dieser Weizen ist auf reichem Boden stark dem Rost und Lagern unterworfen.

Original durch Professor Saykewitsch, Charkow, erhalten.

\section{Sommerweizen von Jekaterinoslaw, Süd-Russland.}

A ehre: bläulich-rot; locker, sich verjüngend und grannenspitzig, dünn, lang; Aehrehen $1.3 \mathrm{~cm}$ breit, 2- und 3-körnig. - Stroh: gelb oder grau-blau, fest, fein, lang. - Frucht: Original gelbrot, glasig und eingefallen, sehr klein ( $51 / 2 \mathrm{~mm}$ lang, $3 \mathrm{~mm}$ breit), Bruch stahlig, hart; nachgebaut: Frucht viel grösser geworden, wie nachfolgende Znsammenstellung zeigt:

Original $18761 \mathrm{hl}$ wiegt $86.5 \mathrm{~kg}$ und enthält 4800750 Früchte.

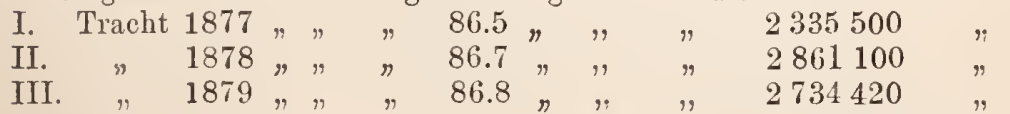

Junges Blatt "Blaugrün, sehr fein, "kraus, Bestockung ziemlich stark, 3.3 Schösslinge, spät schossend und blühend, Halmlänge $105 \mathrm{~cm}$ (Max. $135 \mathrm{~cm}$ ), Halmdicke $0.3 \mathrm{~cm}$, Blattzahl 4, Blattlänge $25.25 \mathrm{~cm}$, Blattbreite $0.8 \mathrm{~cm}$, Blattoberfläche $161.6 \mathrm{qcm}$, Halmfläche $94.5 \mathrm{qcm}$, Gesammtfläche $256.1 \mathrm{qcm}$. 
Junge Aehre gelbgruin, Spelzen rot umrandet, Vegetationszeit 120 Tage, also mittelfrüh reifend, $10 \mathrm{~cm}$ lang, mit 17 Aehrchen und 40 ziemlich lose sitzenden Friichten.

Es wiegen 100 Halme $301 \mathrm{gr}$ und davon die Früchte $139 \mathrm{gr}$.

Das Stroh lagert nicht leicht and wird wenig durch Rost angegriffen.

Die Heimat des Weizens ist das vom Dniepr durchströmte südrussische Gouvernement Jekaterinoslaw, das sich durch seinen aus Schwarzerde bestehenden Boden auszeichnet und ein ausgesprochenes Steppenklima besitzt.

Uebersender: Gutsbesitzer Degtiareff (1876), Jekaterinoslaw.

\section{Weizen ron Berdjansk, am Asow'schen Meere. Süd-Russland. ()}

Syn.: Ital. Frumento Berdianscha.

Aehre: bläulich-rot, halblocker, unter mittellang $(8-10 \mathrm{~cm})$, sich stark verjüngend, grannenspitzig; Aehrchen 3-körnig, in einer Aehre 22 Aehrchen mit 54 Früchtell. - Stroh: rötlich-gelb, fest, unter mittellang. - Frucht: rot, glasig, klein, feinschalig, hart, Bruch stahlig.

Viel in Süd-Russland gebaut, und neuerdings erfolgreich in Polesine (Venetien) eingefülırt.

Kornqualität hoch geschätzt.

In Italien nachgebaut, von der Ausstellung zu Mailand 1881 erhalten.

\section{Pererodka. (2)}

Syn.: regenerierter südrussischer harter Weizen, eine besondere und konstante Sorte aus dem Distrikt Keharkow.

Aehre: rot, dïnn, locker, sich verjüngend und stark grannenspitzig oder kurzgrannig, mittellang; Aehrchen $1.1 \mathrm{~cm} \cdot$ breit, 2 und 3-körnig. Stroh: blassgelb, diinnhalmig, mittellang, fest. - Frucht: Original rot, giasig, einige gelbrot und mehlig, klein, länglich $(6 \mathrm{~mm}$ lang, $3 \mathrm{~mm}$ breit, 305 Friichte $=10 \mathrm{gr}$ ), feinschalig, Bruch halbstahlig, hart.

Junges Blatt gelblich-grün, aufrecht, dicht und ziemlich lang behaart; Bestockung ziemlich stark, 4 Schösslinge, mittelfrüh schossend und blühend. Halm $110 \mathrm{~cm}$ (Max. $125 \mathrm{~cm}$ ) lang, 0,3 cm dick, Blattzahl 4, Blätter $18.5 \mathrm{~cm}$ lang, $0.75 \mathrm{~cm}$ breit, Blattläche $111 \mathrm{qcm}$, Halmfläche 99 qcm, Gesammtfläche $210 \mathrm{qcm}$.

Junge Aehre bläulich-griun, in 123 Tagen reifend, $10 \mathrm{cn}$ (Max. $15 \mathrm{~cm})$ lang mit 16 Aehrchen und 40 lose sitzenden Früchten, von denen 2623000 anf $1 \mathrm{hl}(=86 \mathrm{~kg})$ entfalleu.

Es wiegen 100 Halme $236 \mathrm{gr}$, und davon die Früchte $108 \mathrm{gr}$. Original durch Prof. Saykewitsch, Charkow; erhalten.

\section{Roter Sommer-Kolbenweizen von Kupjansk, Russland. $\odot$}

Aehre: rot, sich verjïngend, grannenspitzig, locker, dünn, mittellang; Aehrchen $1.2 \mathrm{~cm}$ breit, 2- und 3 -körnig. — Stroh: rötlich-gelb, fest, blattarm. - Frucht: Original rot, glasig, klein, oval $\left(6^{1} / 2 \mathrm{~mm}\right.$ lang, $3^{1} / 2 \mathrm{~mm}$ breit, 265 Friichte $\left.=10 \mathrm{gr}\right)$, schön, feinschalig, hart, Bruch stahlig.

Junges Blatt blaugriiı, selır schmal, Bestockung ziemlich stark, 2.4 Schösslinge, sehr spät schossend und blïhend. Halmlänge $110 \mathrm{~cm}$ 
(Max. $125 \mathrm{~cm}$ ), Halmdicke $0.38 \mathrm{~cm}$, Blattzahl 3.6, Blattlänge $23 \mathrm{~cm}$, Blattbreite $0.83 \mathrm{~cm}$, Blattoberfläche $137.23 \mathrm{qcm}$, Halmfläche $125.4 \mathrm{qcm}$, Gesammtfläche $262.63 \mathrm{qcm}$.

Reift sehr spät, die Vegetationszeit umfasst 140 Tage. Die Aebre, $10 \mathrm{~cm}$ lang, besitzt 16 Aehrehen mit 40 ziemlich fest sitzenden Friichten, von denen 2279000 auf $1 \mathrm{hl}(=86 \mathrm{~kg})$ entfallen.

Es wiegen 100 Halme $279 \mathrm{gr}^{\circ}$ und davon die Früchte $111 \mathrm{gr}$. Das Stroh ist gegen Lagern und Rost ziemlich widerstandsfähig.

Heimat: Umgegend der Stadt Kupjansk am Oskol im Gouvernement Charkow. Uebersender: Professor Saykewitsch zu Charkow (1879).

\section{Kaukasus-Weizen. (2)}

Aehrc: rot, diclit, pyramidal, gramenspitzig, kurz. - Stroh: rötlichgelb bis violett, steif, unter mittellang. - Frucht: rot, glasig, oval, klein, (6 $\mathrm{mm}$ lang, $33 / 4 \mathrm{~mm}$ breit, 226 Körner $=10 \mathrm{gr}$ ), feinschalig, hart, Bruch stahlig.

Herbstblatt dunkelgriin, fein, kraus; Entwickelung spät, 3.4 Schösslinge, spät schossend und blühend; Halm $100 \mathrm{~cm}$ (Iax. $130 \mathrm{~cm}$ ) lang, $0.3 \mathrm{~cm}$ dick, Blattzahl 4, Blätter $17.4 \mathrm{~cm}$ lang, $0.7 \mathrm{~cm}$ breit, Blattfläche $97.4 \mathrm{qcm}$, Halmfl̈̈che $90 \mathrm{gcm}$, Gesammtfläche $187.4 \mathrm{qcm}$.

Junge Aehre blau, spät reifend, $8 \mathrm{~cm}$ (Max. $10 \mathrm{~cm}$ ) lang, mit 20 Aehrchen und 50 festsitzenden Früchten, von denen 1864500 auf 1 hl $(=82.5 \mathrm{~kg})$ entfallen.

Winterfest, nicht leicht lagernd.

Wurch das preussische landw. Ninisterinm 1880 erhalten.

\section{Roter Kolbenweizen vom Altai. $\odot$}

Aehre: rostrot, sich stark verjuingend und grannenspitzig, lang, sehr locker, schnal; Aehrchen 1.1 cm breit, 2- und 3-körnig. - Stroh: rotgelb, fest, lang, blattarm. - Frucht: rot, glasig, rundlich, klein (6 mm lang, $3 \frac{3}{4} \mathrm{~mm}$ breit, 285 Früchte $=10 \mathrm{gr}$ ), seln schön und feinschalig, hart, Bruch stahlig.

Junges Blatt blaugriin, lang, schmal; Bestockung stark, 2.8 Sehösslinge, zeitig schossend und blühend. Halmlänge $125 \mathrm{~cm}$ (Max. $145 \mathrm{~cm}$ ), Halmdicke $0.38 \mathrm{~cm}$, Blattzahl 3, Blattlänge $27.8 \mathrm{~cm}$, Blattbreite $0.8 \mathrm{~cm}$, Blattoberfläche $133.44 \mathrm{qcm}$, Halmfläche $1+2.5 \mathrm{qcm}$, Gesammtfläche eines Halmes 275.94 q $\mathrm{cm}$.

Reift mittelfriih, in 120 Tagen, und ist ein cchtes Sommergetreide, denn die Wintersaat ging in Poppelsdorf vollkommen ein. Die Aehre, $12 \mathrm{~cm}$ lang, entlält 18 Aehrchen und 45 nicht leicht ausfallende Früchte, von denen 2394000 auf $1 \mathrm{hl}(=84 \mathrm{~kg})$ gehen.

Es wiegen 100 Halme $360 \mathrm{gr}$ und davon die Früchte $130 \mathrm{gr}$. Das Stroh lagert nicht, leidet jedoch stark durch Rost.

Heimat: Altaigebirge im siidwestlichen Sibirien.

Uebcrsender: die Reisendeu Dr. Finsch und Graf Zeil (1879).

\section{Rumänischer Weizen. (2)}

Aelı'e: rotblan, sich nach der Spitze stark verjüngend, kurz begrannt, mittellang, locker, schmal; Aehrchen $1.2 \mathrm{~cm}$ breit, 2- und 3-körnig. - 
Stroh: gelb, oder unterhalb der Aehre rotgrau, feinhalmig. - Frucht: rot, glasig, klein ( $6 \mathrm{~mm}$ lang, $3 \mathrm{~mm}$ breit, 310 Früchte $=10 \mathrm{gr}$ ), feinschalig, hart, Bruch halbstahlig.

Herbstblatt blaugrün, kraus; Frühjahrsvegetation spät, Bestockung sehr stark, 9 Schösslinge, spät schossend und blühend. Halmlänge $110 \mathrm{~cm}$ (Max. $135 \mathrm{~cm}$ ), Halmdicke $0.3 \mathrm{~cm}$, Blattzahl 4, Blattlänge $20 \mathrm{~cm}$, Blattbreite $0.8 \mathrm{~cm}$, Blattoberfläche eines Halmes $128 \mathrm{qcm}$, Halmfläche $99 \mathrm{qcm}$, Gesammtfläche $227 \mathrm{qcm}$.

Junge Aehre gelbgrüu, mittelfrüh reifend, $8 \mathrm{~cm}$ (Max. $11 \mathrm{~cm}$ ) lang, mit 16 Aehrehen und 40 Früchten, von denen 2480000 auf $1 \mathrm{hl}(=84 \mathrm{~kg})$ entfallen.

Auf 1 qm wachsen 1200 Halme oder 133 Pflanzen, mithin nimmt eine Pflanze einen Raum von $75.2 \mathrm{qcm}$ ein; die Blattfläche beträgt p. qm Bodenfläche $27.24 \mathrm{qm}$ und das Saatquantum (1/3 Verlust) $0.9 \mathrm{hl}$ p. ha.

Es wiegeu 100 Halme $320 \mathrm{gr}$ und davon die Früchte $120 \mathrm{gr}$.

Auf reichem Boden lagert das Stroh und leidet stark durch Rost.

Der Weizen eignet sich für lehmige, in geringer Dungkraft stehende Böden des Koutinentalklimas. Er ist durchans winterfest.

\section{Sommerweizen aus Serbien. $\odot$}

Aehre: hellrot, etwas locker, schmal, stark grannenspitzig, kurz; Aełrchen $1 \mathrm{~cm}$ breit, 2-körnig. - Stroh: gelb, sehr feinhalmig, fest, steif, kurz. - Frucht: Original rot, glasig, klein $\left(5 \frac{1}{2} \mathrm{~mm}\right.$ lang, $3 \mathrm{~mm}$ breit, 435 Früchte $=10 \mathrm{gr}$ ), feinschalig, hart, Bruch halbstahlig.

Junges Blatt blaugriin, kurz aber dicht behaart, schmal, aufrecht, Bestockung mittelstark, 2.4 Schösslinge, zeitig schossend und blühend. Halme $80 \mathrm{~cm}$ (Max. 95 cm) lang, $0.23 \mathrm{~cm}$ dick, Blattzahl 4, Blätter $14.3 \mathrm{~cm}$ lang, $0.6 \mathrm{~cm}$ dick, Blattfä̈che $68.64 \mathrm{qcm}$, Halmfläche $55.2 \mathrm{qcm}$, Gesammtfläche 1:3.84 qcm.

Junge Aehre gelbgrïn. reift in 122 Tagen, $7 \mathrm{~cm}$ (Max. $8 \mathrm{~cm}$ ) lang, mit 13 Aehrchen und 24 Frïchten, von denen 3741000 auf $1 \mathrm{hl}(=86 \mathrm{~kg})$ entfallen.

Es wiegen 100 Halme $187 \mathrm{gr}$ und davon die Früchte $83 \mathrm{gr}$.

Original durch Professor Pancic, Belgrad, 1880 erhalten.

\section{Lappländischer-Weizen. (2)}

Aehre: hellrot, mittellang, ziemlich dicht, sich wenig verjüngend, ziemlich breit; Aehrchen $1.7 \mathrm{~cm}$ breit, meist 3-körnig. - Stroh: blassgelb, kräftig, fest. - Frucht: gelbrot und glasig, wenige mehlig, etwas plump, gross (7 $\mathrm{mm}$ lang, $4 \mathrm{~mm}$ breit, 190 Früchte $=10 \mathrm{gr}$ ), grobschalig, halbhart, Bruch halbmehlig.

Herbstblatt dunkelgrün, schmal, kraus; Frülijahrsvegetation spät, Bestockung sehr stark, 7 Schösslinge, spät schossend uud blïhend. Halmlänge $140 \mathrm{~cm}$ (Max. $165 \mathrm{~cm}$ ), Halmdicke $0.4 \mathrm{~cm}$, Blattzahl 3.6, Blattlänge $24 \mathrm{~cm}$, Blattbreite $0.9 \mathrm{cu}$, Blattoberfläche $155.52 \mathrm{qcm}$, Halmfläche $168 \mathrm{qcm}$, Gesammtfläche $323.52 \mathrm{qcm}$.

Junge Aelıre gelbgrün, spät reifend, $11 \mathrm{~cm}$ (Max. $15 \mathrm{~cm}$ ) laug, mit 20 Aehrchen mnd 54 Früchten, die etwas lose sitzen und von denen 1577000 auf $1 \mathrm{hl}(=83 \mathrm{~kg})$ geheu.

Es kommen auf 1 qm 900 Halme oder 129 Pflanzen, mithin beträgt 
der Raum für eine Pflanze 77.5 qcm, die Blattfläche p. qm Bodenfläche $29 \mathrm{qm}$, und das Aussaatquantum ( $1 / 3$ Verlust) $1.2 \mathrm{hl}$ p. ha.

Es wiegen 100 Halme $550 \mathrm{gr}$ und davon die Früchte $180 \mathrm{gr}$.

Dieser Weizen ist durchaus winterfest und leidet nur unbedeutend durch Lagern und Rost.

Diese Sorte wurde vom Versuchsfelde zu Proskau eingesandt.

\section{Rotel Weizen ans Ustindien. $\odot$}

Aehre: blassrot, schmal, dünn, sich verjüngend, granneuspitzig kurz; Aehrchen $1 \mathrm{~cm}$ breit, 2-körnig. - Stroh: gelb, fest, mittellang. - Frucht: rot, glasig, klein ( $6 \mathrm{~mm}$ lang, $3 \mathrm{~mm}$ breit, 292 Früchte $=10 \mathrm{gr}$ ), feinschalig, hart, Bruch halbmehlig.

Junges Blatt blaugriin, beiderseits behaart, schmal, aufrecht, 2.4 Schösslinge, sehr zeitig schossend und blühend. Halm $100 \mathrm{~cm}$ (Max. $110 \mathrm{~cm}$ ) lang, $0.28 \mathrm{~cm}$ dick, Blattzall 3.2 , Blätter $20 \mathrm{~cm} \mathrm{lang,} 0.7 \mathrm{~cm}$ breit, Blattfläche $89.6 \mathrm{qcm}$, Halnfläche $84 \mathrm{qcm}$, Gesammtfläche $173.6 \mathrm{qcm}$.

Junge Aehre blaugrion, in 120 Tagen reifend, $7 \mathrm{~cm}$ (Max. $8 \mathrm{~cm}$ ) lang, mit 14 Aehrchen und 26 Frichten, von denen 2496600 auf 1 hl $(=85.5 \mathrm{~kg})$ entfallen.

Es wiegen 100 Halme $270 \mathrm{gr}$, und davon die Früchte $121 \mathrm{gr}$.

Dieser Weizen leidet leicht durch Rost, und ist ein echter Sommerweizen.

\section{Varietät: Triticum vulgare lencospermum Kcke.}

Aehren sammetig, weiss; Körner weiss oder gelblich.

\section{Sorten:}

\section{Tunstall 'Thick-chaffed Wheat. (2)}

Syn.: Englisch: White Velvet or Woolly-eared Wheat; Hoary white Wheat; Stuffed Wheat; Hedge Wheat; Downy Kent-IVheat.

Franz.: Blé blanc à duvet ou velouté; Blé Tunstall; Blé de Haie; Blé Blanchard.

Spanisch: Trigo cerrado de Tunstall.

Deutsch: Heckenweizen, Bismarck-Weizen.

Identisch nach Vilmorin ${ }^{1}$ ), Triticum Koeleri ${ }^{6:}$.

Aehre: weiss, stark sammetig, kurz, dicht, quadratisch; Aehrchen

1) Journ. d'Agric. prat. 1851, pg. 455. 
breit $(1.8 \mathrm{~cm})$, ङ- und 4-körnig. - Stroh: rötlich-gelb, mittellang, kräftig. - Frucht: Original blassgelb, mehlig, nach sechsjähriger Kultur rötlich, meist glasig, länglich, mittelgross ( $7 \mathrm{~mm}$ lang, $3 \frac{1}{2} \mathrm{~mm}$ breit), feinschalig, weich.

Herbstblatt breit, fast aufrecht; Frühjahrsregetation zeitig, Bestockung mittelstark, 3.7 Schösslinge, bei 100 q cm Raum 7.1 Schösslinge, also schwach.

Halm $120 \mathrm{~cm}$ lang. $0.45 \mathrm{~cm}$ dick, Blattzahl 4, Blätter $29 \mathrm{~cm} \mathrm{lang,}$ $1 \mathrm{~cm}$ breit. Blattfläche $232 \mathrm{qcm}$, Halmfläche 162 q $\mathrm{cm}$, Gesammtfläche $394 \mathrm{qcm}$.

Es wachsen 736 Halme oder 200 Pflanzen auf $1 \mathrm{qcm}$, mithin nimmt jede Pflanze einen Raum von $50 \mathrm{qcm}$ ein, und auf $1 \mathrm{qm}$ Bodenfläche berechnen sich $29 \mathrm{qm}$ Blattfläche.

Junge Aehre gelbgrün, wegen starker Behaarung schwach bläulich, mittelfuih reifend, $9 \mathrm{~cm}$ (Мax. $13 \mathrm{~cm}$ ) lang mit 20 Aehrchen und 70 etwas lose sitzendell Früchten, von denen 2000000 auf $1 \mathrm{hl}(=82,3 \mathrm{~kg})$ gehen; Aussaat $1.33 \mathrm{hl}$.

Es wiegen 100 Halme $587.5 \mathrm{gr}$ und daron die Fruichte $244 \mathrm{gr}$. Das Korn liefert ein weisses, bei den Londoner Müllern sehr beliebtes Mehl; auch lagert der Weizen nicht leicht.

Leider erwies er sich nicht winterfest, indem er 1870 total auswinterte und 1876 beträchtlich litt; auch rerzögert sich bei feuchter Witterung die Einerntung und wuchs derselbe leicht aus, weil in Folge der starken Behaarung der Aehre die Feuchtigkeit nicht leicht verdunstet.

In mildem Klima mit trocknen Herbsten und auf warmen, kulturvollen, kalkueichen Lehmböden bringt er reiche Erträge.

Diese sehr alte englische Sorte verlor zeitweise in England an Anbauterrain, um dann wiederum unter anderem Namen in Kultur genommen zu werden. Diesbezüglich teilt A. Young mit, dass es A rbuthnot, als er die Kultur dieses Weizens 1779 wieder aufnehmen wollte, Schwierigkeiten verursachte, ihn zu erhalten, bis er denselben bei seinem ehemaligen Schüler, Mr. Chambers, angebaut fand.

Nach Loudon ${ }^{1}$ ) fand Mr. Wood 1790 eine Aehre dieser Sorte in einer Hecke in der Grafschaft Sussex stehend, baute ihn an, und verbreitete ihn später unter dem Namen "Hedge Wheat". Im Jahre 1839 empfahl auch Sir Francis A. II. Kenzi e ${ }^{2}$, Bart. of Gairloch, seinen Anbau unter dem Namen, Tunstall Thick-chaffed- Wheat". Unter der Bezeichnung ,White velvet or hoary white Wheat" war er auch rielfach in England verbreitet, und beschreibt ihn darunter schon Boys in seinem ,General View of the Agric. of Kent", und unter diesem Namen empfahl ihn auch Thae ${ }^{3}$ ) für Deutschland. Colonel Le Couteur ${ }^{4}$ ) führte ihn in seinem Werk über den Weizen als, White downy or hoary the Vélouté: auf.

Auf der Pariser Ausstellung 1867 wurde er als bester Weizen prämiiert, und brachte ihn Dr. Eisbein, indem er ihm den Namen ,Bismarck-Weizen" beilegte, zur Kultur an den Rhein, doch befriedigte er nicht, weil er nicht winterfest war, leicht lagerte, sehr bald im Korn degenerierte und Treissweizen von den rheinischen Müllern ungern geliauft werden.

1) Encyclop. Deutsch II pg. 161, 1833.

2) Synopsis of the veget. prod. P. Lawson 1852.

3) Engl. Landwirtsch. Bd. I, pg. 357. 1806.

4) Journ. of the Roy. Agric. Soc. of Engl. I. p. 113. 1840. 
Zur Zeit ist seiue Kultur ziemlich ansgedehnt in den Grafschaften Essex, Sussex und Kent, und nach Heuzé schon seit einem Jahrhundert in Boulonnais, Flandern und in der Normandie verbreitet.

Vielfach wird er auch in Belgien und nenerdings in Spanien angebaut.

La we s in Rothaunsted erzielte im 6jährigen Durchschnitt 36.79 hl p. hl.

Original in der Sammlung der Akademie Poppelsdorf, durch Dr. Eis be in erhalten.

\section{Rough chaffed Lssex. (2)}

Sy u.: Engl.: Taunton-Dean, Club-headed.

Franz.: Blé blanc d'Essex, Blé auglais de Bricquebec ${ }^{1}$ ).

Holl: Witte tarwe Wilhelmina-Polder, Zeeland, Holland. Dikkop-tarwe.

Deutsch: Sammetiger Essex-Weizen, Dikkop-(Dickopf-) Weizen ${ }^{2}$ ).

Aelire: blassgelb, sehr dicht, quadratisch, sammetig, mittellang, breit; Aehrchen $1.8 \mathrm{~cm}$ breit, 3- u. 4- körnig. - Stroh: gelb, mittellang, fest, steif. - Frucht: weiss, wenn mehlig, wenige rötlich und glasig, mittelgross $\left(6^{1} / 2 \mathrm{~mm}\right.$ lang, $3 \frac{1}{2} \mathrm{~mm}$ breit, 234 Frïchtc $\left.=10 \mathrm{gr}\right)$, feinschalig, halbweicli, Bruch halbmehlig.

Herbstblatt blaugriin, behaart, nittelbreit, ziemlich aufrecht; Frïhjahrsvegetation mittelfrüh, Bestockung mittelstark, 5 Scliösslingc, Bestockungsfähigkeit bci 100 qcm Pflauraum 12 Schösslinge. Mittelfrül schossend und blithend; Halmlänge $120 \mathrm{~cm}$ (Max. 140), Halmdicke, $0.38 \mathrm{~cm}$, Blattzahl 3.4. Blattläuge $27 \mathrm{~cm}$, Blattbreite $0.96 \mathrm{~cm}$, Blattoberfläcle eines Halmes $176.26 \mathrm{qcm}$, Halmfläche $136.8 \mathrm{qcm}$, Gesammtfläche $313.06 \mathrm{qcm}$.

Junge Aehre gelbgrün, aber wegen der starken Bchaarung etwas bläulich, mittelfriih reifend, $9 \mathrm{~cm}$ (Max. $12 \mathrm{~cm}$ ) lang mit 20 Aehrchen und 70 nicht leicht ausfallenden Erïchten, von denen 1,895400 auf $1 \mathrm{hl}$ $(=81 \mathrm{~kg})$ entfallen.

Auf 1 qun waclisen 900 Halme oder 180 Pflanzen, mithin stellt sich der Raum für eine Pflanze auf $55.5 \mathrm{qcm}$, die Blattfläche beträgt p. qm Bodeufläche 28.17 qm, und das Saatquantum (1/3 Verlust) 1.t hl. p. ha.

Es wiegen 100 Halme $465 \mathrm{gr}$, und davon die Frichte $183 \mathrm{gr}$.

Fiir den schwcren, fruchtbaren Boden und ein nicht zu rauhes Klima eignet sich dieser nicht leicht lagernde und fast rostfreie Weizen vortrefflich, doch wächst er wegen der Behaarung seiner Spelzen, die das Abtrocknen erschwert, leicht aus.

Es wird auch angegeben, dass sich dieser Weizen noch zeitig im Frühjahr, im MIonat Februar oder Anfang März erfolgreich anssäen lasse, doch scheint dies nur in einem sehr milden Klima zulässig zu sein, denn schon in Poppelsdorf befriedigte die Sommersaat nicht.

Was die Verbreitnng dieses englischen Weizcns unter holländischem Namen angeht, so ist dieselbe folgende: Der Bürgcrmeister van Wecl auf der holländischen Insel Flakkee erliclt 1853 einen englischen WVeizen zum Anbau, iu dem er fremde Aelren fand und diese von 1857 ab weiter kultivierte und diese Sorte wegen ihrer dicken Aehre, ,Dikkop" taufte. Von dort aus gelangte sie 1865 nacl dem Wilhelmina-Polder, und von diescm \ugenblick an datiert eigentlich crst der Aufschwung ihrer Kultur in Hollant. Im Wilhelmina-Polder lieferte dieser Wcizen bis 54.30 hl. p. ha

1) Vergl. Vilmorin. Journ'. d'Agric. prat. 1851, pg. 454.

2) Zuweilen fälschliseh ,Piccap- oder Pickub-Weizen" genannt. 
and rerdrängte den einheimischen Zeeländer-Weizen immer mehr auf die sehr schweren undrainirten Böden. Um die weitere Terbreitung dieses schönen Weizens bemiiht sich namentlich die Samenhandlung ran den Bosch ${ }^{1}$ ) in Goes, Prorinz Zeelaud, Holland.

Je nach dem Standort rerändert sich der Weizen, so ist er im Wilhelmina-Folder massiger und grosskörnigcr, als auf weniger reichen im Kontinental-Klima gelegeuen Böden.

\section{Pearl Wheat. (2)}

Syn.: Engl.: Uxbridge.

Franz.: Blé Perle.

Deut sch: Perlweizen.

Aehre: blassgelb, sammetig, fast quadratisch, mit einigen Grannenspitzen, dicht, mittellang; Aehrchen $1.4 \mathrm{~cm}$ breit, meist 3 -körnig. Stroh: blassgelb und rötlich-gelb, steif, lang. - Frucht: Original blassgelb, mehlig, oval, klein ( $6 \mathrm{~mm}$ lang, $3^{1 / 2} \mathrm{~mm}$ breit, 255 Frïchte $=10 \mathrm{gr}$ ); nachgebaut: rötlich und glasig, bauchiger, grösser (206 Früchte $=10 \mathrm{gr})$; schön, schwer, feinschalig, halbhart.

Herbstblatt dunkelgriin, schmal, lang; Frühjahrsvegetation mittelfrüh, Bestockung mittelstark, 4.5 Schösslinge, mittelfrïh schossend und blïhend. Halmlänge $125 \mathrm{~cm}$ ( Max. $140 \mathrm{~cm}$ ), Halmdicke $0.4 \mathrm{~cm}$, Blattzahl 4.7, Blattlänge $26.5 \mathrm{~cm}$, Blattbreite $0.86 \mathrm{~cm}$, Blattoberfläche $214.23 \mathrm{qcm}$, Halmfläche $150 \mathrm{qcm}$, Gesammtiäche $364.23 \mathrm{qcm}$.

Junge Aehre blangriin, mittelfriil reifend, $8.5 \mathrm{~cm}$ (Мax. $11 \mathrm{~cm}$ ) lang, mit 18 Aehrchen und 50 festsitzenden Früchten, von denen 2091000 auf $1 \mathrm{hl}(=82 \mathrm{~kg})$ entfallen.

Auf $1 \mathrm{qm}$ wachsen 900 Halme oder 200 Pflanzen, mithin beträgt der Ranm für eime Pflanze $50 \mathrm{qcm}$, die Blattfläche p. qn Bodenfläche $32.8 \mathrm{qm}$, und das Saatquantum $1.4 \mathrm{hl} \mathrm{p}$. ha.

Es wiegen 100 Halme $630 \mathrm{gr}$ und daron die Früchte $230 \mathrm{gr}$. Lagert nicht leicht, befällt jedoch stark mit Rost.

Für dicsen Weizeu eignet sich nur der reiche, thätige Boden, und da er nicht winterfest ist, ein mildes Klima. Obgleich nicht besonders ertragreich, baut man ihn in England regen der feinen Qualität seines Kornes an, auch soll er sich als Sommerweizen kultivieren lassen.

Unter ungünstigeu Terhältuissen kultiviert, degeneriert derselbe in der Beschaffenheit des Kornes sehr schmell.

Original in der Sammlung der Akademie Poppelsdorf.

\section{Pringle's white Wheat. (2)}

Aehre: schmutzig-blassgelb, sammetig, kompakt, fast quadratisch, sich wenig rerjüngend, $9 \mathrm{~cm}$ lang mit 20 Aehrchen und 60 Früchten, Aehrchen $1.4 \mathrm{~cm}$ breit, meist 3-körnig. - Stroh: gelbrot, sehr blattreich, ziemlich weich, $135 \mathrm{~cm}$ lang. - Frucht: blassgelb, meist mehlig, länglich, klein ( $6 \mathrm{~mm}$ lang, $3 \mathrm{~mm}$ breit), feinschalig.

Heimat: Nord-Amerika.

Original im landw. Museum zu Berlin.

1) Yergl. Fühling's, Neue landw. Zeit. 1873, pg. 60. 


\section{White Lammas-Iheat. (?)}

Syn.: Trigo white Lammas; Trigo Ingles, Chile.

Aehre: blassgelb, sammetig, unter mittellang, ziemlich dicht, fast quadratisch, sich nur wenig verjüngend, grannenspitzig; Aehrchen $1.4 \mathrm{~cm}$ breit, meist 3-körnig. - Stroh: blassgelb, fest, unter mittellang. Frucht: weiss, meist mehlig, länglich, mittelgross $\left(7 \mathrm{~mm}\right.$ lang, $3 \frac{1}{2} \mathrm{~mm}$ breit, 196 Frïchte $=10 \mathrm{gr}$ ), schön, feinschalig, weich.

Herbstblatt dunkelgrïn, fein, ziemlich aufrecht; Entwickelung spät, 2.4 Schösslinge, mittelfrüh schossend und blühend; Halm $100 \mathrm{~cm}$ (Max. $115 \mathrm{~cm}$ ) lang, $0.35 \mathrm{~cm}$ dick, Blattcahl 4.5 , Blätter $19 \mathrm{~cm}$ lang, $0.85 \mathrm{~cm}$ breit, Blattfläche $145 .+\mathrm{qcm}$, Halmfläche $105 \mathrm{qcm}$, Gesammtfläche $250.4 \mathrm{qcm}$.

Junge Aehre blaugrün, mittelfrüh reifend, $8 \mathrm{~cm}$ (Max. $13 \mathrm{~cm}$ ) lang, mit 18 Aehrchen und 45 festsitzenden Früchten, von denen 1666000 auf $1 \mathrm{hl}(=85 \mathrm{~kg})$ entfallen.

Nicht winterfest, wenngleich echtes Wintergetreide.

Bezugsquelle: durch von Giilich 1880 aus Chile erhalten.

\section{Trigo candeal vellosa de Talavera. (2)}

Syn.: Franz.: Blé velu de Talavéra.

Engl.: Hoary white Talavera.

Deutsch: Sammetiger Talavera-IVeizen.

Aehre: fast weiss, ziemlich dicht, sammetig, mittellang; Aehrchen $1.5 \mathrm{~cm}$ breit, meist 3-körnig. - Stroh: rötlich-gelb-orange, fest. - Frucht: gelblich-weiss, mehlig, einige rötlich und glasig, länglich, klein $(61 / 2 \mathrm{~mm}$ lang, $3 \frac{1}{2} \mathrm{~mm}$ breit, 217 Frïchte $=10 \mathrm{gr}$ ), feinschalig, halbhart, Bruch halbmehlig.

Herbstblatt gelbgrün, sehr gross, aufrecht; Frühjahrsvegetation etwas spät; Bestockung stark, 10 Schösslinge, mittelfrüh schossend und blühend. Halmlänge $110 \mathrm{~cm}$ ( Мax. $125 \mathrm{~cm}$ ), Halmdicke $0.4 \mathrm{~cm}$, Blattzahl 4, Blattlänge $23.8 \mathrm{~cm}$, Blattbreite $0.99 \mathrm{cnl}$, Blattoberfläche eines Halmes $188.48 \mathrm{qcm}$, Halmfläche $132 \mathrm{~cm}$, Gesammtfäche $320.48 \mathrm{qcm}$.

Aehre mittelfrüh reifend, $11 \mathrm{~cm}$ (Max. $15 \mathrm{~cm})$ lang, mit 20 Aehrchen und 60 fest sitzenden Früchten, von denen 1801100 auf $1 \mathrm{hl}(=83 \mathrm{~kg})$ entfallen.

Auf 1 qm kommen 900 Halme oder 90 Pflanzen, mithin stellt sich der Raum für eine Pflanze auf $111 \mathrm{qcm}$; die Blattläehe beträgt $\mathrm{p} . \mathrm{qm}$ Bodenfläche $28.8 \mathrm{qm}$, und das Saatquantum $0.75 \mathrm{hl} \mathrm{p}$. ha.

Es wiegen 100 Halme 500 gr und davon die Frïchte $190 \mathrm{gr}$.

Der Weizen zeigte sich in Poppelsdorf nicht winterfest, das Stroh jedoch ziemlich rostfrei und nicht lagernd.

Diese schöne Sorte wird in Spanien, Frankreich und England gebaut.

\section{Blé de Touzelle anone $\left.{ }^{1}\right)$. (2)}

Franz.: Touzelle blanche (Vilm.).

Aehre: gelb, sammetig, quadratisch, sehr regelmässig, sich etwas

1) Anone ist die Bezeichnung nur für diese französische Weizensorte. Touzelle kommt vom altfranzösischen touze $=$ tondu oder razé, geschoren $=$ unbegrannt, also Kolbenweizen. 
nach der Spitze verjüngend, äussere Spelze mit Zahnfortsatz versehen. ziemlich dicht, mittellang; Aehrchen $1.5 \mathrm{~cm}$ breit, 3-körnig. - Stroh: rötlichgelb, fest, steif, blattreich. - Frucht: blassgelb, mehlig, einige rötlich und glasig, schön, ziemlich gross ( $7 \mathrm{~mm}$ lang, $4 \mathrm{~mm}$ breit, 197.5 Friichte $=10 \mathrm{gr}$, feinschalig, halbhart, Bruch halbmehlig.

Herbstblatt gelbgriin, mittelbreit, aufrecht: Frühjahrsvegetation zeitig, Bestockung mittelstark, 5 Schösslinge, mittelfrïh schossend und blühend. Halmlänge $130 \mathrm{~cm}$ (Max. $150 \mathrm{~cm}$ ), Halmdicke $0.39 \mathrm{~cm}$, Blattzalıl 4.3, Blattlänge $26.4 \mathrm{~cm}$, Blattbreite $1.05 \mathrm{~cm}$, Blattoberfläche eines Halmes $238.39 \mathrm{qcm}$, Halmfläche $152.1 \mathrm{qcm}$, Gesammtfläche $390.49 \mathrm{qcm}$.

Junge Aehre gelbgrün, doch wegen der starken Behaarung etwas bläulich, mittelfrüh reifend, $10 \mathrm{~cm}$ lang (Max. $13 \mathrm{~cm}$ ), mit 18 Aehrchen und 50 leicht ausfallenden Früchten, voll denen 1659000 auf 1 hl $=$ $84 \mathrm{~kg})$ gehen.

Auf 1 qm kommen son Halme oder 160 Pflanzen, mithin beträgt der Raum für eine Pflanze 62.5 qcm, die Blattoberfläche p. qm Bodenfäche $31.2 \mathrm{qm}$, und das Saatquantum $1.4 \mathrm{hl} \mathrm{p}$. ha.

$100 \mathrm{Halme}$ wiegen $640 \mathrm{gr}$ und daron die Frïchte $250 \mathrm{gr}$.

In Poppelsdorf lagerte der Weizen nicht und litt wenig durch Rost, doch zeigte er sich nicht winterfest, so winterte er $1870 / 71$ völlig aus. lassen.

Nach Tilmorin soll er sich auch als Sommerweizen benutzen

Heuz é führt an, dass dieser Weizen schon seit 1785 in dem Languedoc gebaut, sich durch die Schönheit seiner Früchte und die Guite seines Mehles, welches letztere nach ihm ,Tuzello" genannt werde, auszeichne, aber weichlich sei, und sich als Winterweizen selbst nicht mehr in NordFrankreich bauen liesse.

\section{N euseeländer-Weissweizen. (2)}

Aehre: weiss, sammetig, quadratisch, sehr dicht, kurz; Aehrchen $1.5 \mathrm{~cm}$ breit, 3-körnig. - Stroh: gelb, unter mittellang, fest. - Frucht: Original fast weiss, mehlig, wenige glasig und rötlich, fast kugelrund, (5 mm lang, $4 \mathrm{~mm}$ breit, 228 Früchte $=10 \mathrm{gr}$ ); nachgebaut: konstant geblieben, 215 Friichte $=10 \mathrm{gr}$, selı schön, feimschalig, halbweich, Bruch halbmehlig.

Herbstblatt blaugrü, ziemlich fein, doch aufrecht; Entwickelung spät, 2 Schösslinge, sehr spät schossend und blühend; Halm $100 \mathrm{~cm}$ (Max. $110 \mathrm{~cm}$ ) lang, $0.38 \mathrm{~cm}$ dick, Blattzahl 4.2, Blätter $16 \mathrm{~cm} \mathrm{lang,}$ $1 \mathrm{~cm}$ breit, Blattfläche $134.4 \mathrm{qcm}$, Halmfläche $114 \mathrm{qcm}$, Gesammtfläche 248.4 qcm.

Junge Aehre blau, spät reifend, $8 \mathrm{~cm}$ (Max. $10 \mathrm{~cm}$ ) lang, mit 20 Aehrchen und 55 fest sitzenden Früchten, von denen 1892400 auf $1 \mathrm{hl}$ $(=83 \mathrm{~kg})$ entfallen.

Nicht ganz winterfest; widerstandsfähig gegen Rost und Lagern.

Bezugsquelle: Samenhandlung ron J. W is inger, Berlin. 


\title{
Varietiit: Triticum vulgare villosum Al.
}

\author{
Aeliren sammetig, weiss; Körner rot.
}

\section{Sorten:}

\section{Goldene Ane-Weizen. (2)}

Aelıre : schuutzig-blassgelb, sammetig, fast quadratisch, ziemlich dicht, lang, ziemlich breit; Aehrehen $1.7 \mathrm{~cm}$ breit, 2- und 3-körnig. - Stroh : gelb und rotgrau, derb, fest. - Frucht: gelbrot, meist mehlig, plump (7 mm lang, $4 \mathrm{~mm}$ breit, 205 Früchte $=10 \mathrm{gr}$ ), grobschalig, halbweich, Bruch halbmehlig.

Herbstblatt blaugrün, schmal, krans; Frühjalırsvegetation spät, Bestockung sehr stark, 9 Schösslinge, spät schossend und blühend. Halmlänge $130 \mathrm{~cm}$ (Max. $155 \mathrm{~cm}$ ), Halmdicke $0.44 \mathrm{~cm}$, Blattzahl 4, Blattlänge $33.5 \mathrm{~cm}$, Blattbreite $1.12 \mathrm{~cm}$, Blattoberfläche eines Halmes $300.16 \mathrm{qcm}$, Halmfläche $171.6 \mathrm{qcm}$, Gesammtfläche $471.76 \mathrm{qcm}$.

Junge Aehre blaugrün mit braunen Staubbenteln, spät reifend, $11 \mathrm{~cm}$ (Max. $15 \mathrm{~cm}$ ) lang, mit 24 Aelhrehen und 60 ziemlich festsitzenden Friichten, von denen 1640000 auf $1 \mathrm{hl}(=80 \mathrm{~kg})$ entfallen.

Auf $1 \mathrm{qm}$ kommen 700 Halme oder 78 Pflanzen, mithin betrïgt der Raum für eine Pflanze $129 \mathrm{qcm}$, die Blattoberfläche p. qm Bodenfläche $33 \mathrm{qm}$, und das Saatquantum ( $1 / 3$ Verlust) $0.7 \mathrm{hl} \mathrm{p}$. ha.

Es wiegen 100 Halme $570 \mathrm{gr}$ und davon die Früchte $200 \mathrm{gr}$.

Dieser Weizen zeigte sich gegen Lagern und Rost sehr widerstandsfähig und scheint auch winterfest zu sein.

Er wird vielfach auf den reichen humosen Lehmböden der Provinz Sachsen angebaut.

Diese Sorte wurde 1877 durch Hage \& Schmidt in Erfurt bezogen.

\section{Uanchester Wheat. (2)}

Dentsch: Manchester-Weizen, gelber Mecklenburger Sammetweizen.

Aehre: blassgelb, behaart, etwas locker, mittellang, schmal; Aehrchen $1.3 \mathrm{~cm}$ breit, 3- und 4-körnig. - Stroh: gelb, derbwandig, fest. - Frucht: Original sehr hell, gelbrot, mehlig; nachgebaut: schon in zwei Ernten rot und glasig, rundlich, klein (6 $\mathrm{mm}$ lang, $3 \mathrm{~mm}$ breit), halbweich, Bruch halbmehlig.

Herbstblatt blaugrün, kräftig, kraus; Frühjahrsvegetation spät, Bestockung stark, 5.2 Schösslinge, spät schossend und blühend. Halmlänge $120 \mathrm{~cm}$ (Max. $150 \mathrm{~cm}$ ), Halmdicke $0.4 \mathrm{~cm}$, Blattzahl 4.4, Blattlänge $20.5 \mathrm{~cm}$, Blattbreite $0.82 \mathrm{~cm}$, Blattoberfläche eines Halmes $147.93 \mathrm{qcm}$, Halmfläche $144 \mathrm{qcm}$, Gesammtfläche $291.93 \mathrm{qcm}$.

Junge Aehre blaugrïn, spät reifend, $10 \mathrm{~cm}$ (Max. $14 \mathrm{~cm}$ ) lang, mit 16 Aehrchen und 50 ziemlich lose sitzenden Früchten, von denen 1926000 auf $1 \mathrm{hl}(=83 \mathrm{~kg})$ gehen. 
Auf 1 qm kommen 1000 Halme oder 192 Pflanzen, mithin beträgt der Raum für eine Pflanze 52 qcm, die Blattfläche p. q1n Bodenfläche $29.13 \mathrm{qm}$, und das Saatquantum $1.5 \mathrm{hl}$ p. ha.

Es wiegen 100 Halme $600 \mathrm{gr}$ und die Früchte $210 \mathrm{gr}$.

Der Weizen lagert nicht leicht. widersteht dem Rost, ist winterfest und eignet sich noch für leichtere Böden, z. B. für den sandigen Lehmboden.

Der Ertrag betrug in Proskau auf Lehmboden:

$1944 \mathrm{~kg}$ Korn, $7128 \mathrm{~kg}$ Stroh, $680 \mathrm{~kg}$ Spreu.

In Mecklenburg, Pommern und Holstein ist diese Sorte sehr beliebt. Heimat: England.

\section{Richmond's Giant or Prize Wheat. (2)}

Deuts ch: Richmond's Riesen- oder Preisweizen.

Aehre: fast weiss, sammetig, dicht, sich nach der Spitze verjüngend, lang; Aehrchen $1.5 \mathrm{~cm}$ breit, meist 3-körnig. - Stroh: gelb, dickwandig, sehr lang. - Frucht: rot, mellig und glasig, dick, oval (6 mm lang, $4 \mathrm{~mm}$ breit, 225 Früchte $=10 \mathrm{gr}$ ), schwer, feinschalig, halbweich, Bruch halbmehlig.

Herbstblatt blaugruin, breit, aufrecht; Fruhjahrsvegetation zeitig, Bestockung mittelstark, 3.6 Schösslinge, zeitig schossend und blühend. Halmlänge $140 \mathrm{~cm}$ (Max. $160 \mathrm{~cm}$ ), Halmdicke $0.43 \mathrm{~cm}$, Blattzahl 3.3 , Blattlänge $28.75 \mathrm{~cm}$, Blattbreite $1.07 \mathrm{~cm}$, Blattoberfläche $203.02 \mathrm{qcm}$, Halmfläche 180.6 qcm, Gesammtfäche 383.62 qcm.

Junge Aehre gelbgrün, wegen starker Behaarung etwas bläulich, mittelfrüh reifend, mit 22 Aehrchen und 60 festsitzenden Früchten, von denen 1881000 auf $1 \mathrm{hl}(=83.6 \mathrm{~kg})$ gehen.

Es wiegen 100 Halme $430 \mathrm{gr}$ und davon die Früchte $175 \mathrm{gr}$.

Die Stroherträge sind hoch, doch lassen die Kornerträge auf gutem Weizenboden zu wünschen.

Heimat: England.

\section{Dorking glory. (2)}

Aehre: fast weiss, sammetig, etwas locker, lang; Aehrchen $1.4 \mathrm{~cm}$ breit, 2-körnig: - Stroh: rötlich-gelb, ziemlich fest, lang. - Frucht: rot, glasig, länglich, gross $\left(7 \mathrm{~mm}\right.$ lang, $3^{1} / 2 \mathrm{~mm}$ breit, 200 Friichte $=$ $10 \mathrm{gr}$ ), feinschalig.

Herbstblatt blaugrïn, schmal; Frühjahrsvegetation spät, Bestockung sehr stark, 5.6 Schösslinge, mittelfrüh schossend und blühend. Halmlänge $130 \mathrm{~cm}$ (Мах.: $150 \mathrm{~cm}$ ), Halmdicke $0.38 \mathrm{~cm}$, Blattzahl 3.3, Blattlänge $28.5 \mathrm{~cm}$, Blattbreite $0.99 \mathrm{~cm}$, Blattoberfläche $186.25 \mathrm{qcm}$, Halmfläche $148.2 \mathrm{qcm}$, Gesammtfläche $334.45 \mathrm{qcm}$.

Junge Aehre gelbgriin, doch wegen der starken Behaarung etwas bläulich, mittelfrüh reifend, mit 20 Aehrchen und 40 Friichten, von denen 1674000 auf $1 \mathrm{hl}(=83.7 \mathrm{~kg})$ gehen.

Es wiegen 100 Halme $320 \mathrm{gr}$ und die Früchte $143 \mathrm{gr}$.

Für mittlere Weizenböden passend, und auf diesen nicht lagernd.

Heimat: England. 


\section{Böhmischer sammetiger Kolbenweizen. (2)}

Syn: De utsch: Weisser Winter-Kolbenweizen mit sammetiger Aehre. Franz: Froment commun sans barbes, velouté, blanc; Blé de Bohêmc; Froment grisâtre, épi velouté (DC. Fl. fr. 3. p. 81 var. du Nr. 165 $b^{\circ}$ ).

Aehre: schmutzig-gelb, sammetig, lang, sclimal, sich vcrjüngend, grannenspitzig, etwas locker; Aehrchen $1.3 \mathrm{~cm}$ breit, 2- und 3-körnig. Stroh: rötlich-gelb bis orange, ziemlich derb. - Frucht: goldgelb, mehlig und glasig, schön, ziemlich gross (7 $\mathrm{mm}$ lang, $4 \mathrm{~mm}$ breit), feinschalig, halbweich, Bruch halbmehlig.

Herbstblatt dunkelgrün, beirlerscits schwach behaart, krüftig, aufrecht; Frühjahrsvegetation ziemlich zeitig, Bestockung mittelstark, 5 Schösslinge, spät schossend und blühend. Halmlänge $130 \mathrm{~cm}$ (Max. $160 \mathrm{~cm}$ ), Halmdicke $0.38 \mathrm{~cm}$, Blattzahl 4, Blattlänge $25.6 \mathrm{~cm}$, Blattbreite $0.92 \mathrm{~cm}$, Blattoberfläche eines Halmes $188.42 \mathrm{qcm}$, Halmfläche $148.2 \mathrm{qcm}, \mathrm{Ge}-$ sammtfläche $336.62 \mathrm{qcm}$.

Junge Aehre gelbgrün, spät reifend, $10 \mathrm{~cm}$ (Max. $14 \mathrm{~cm}$ ) lang, mit 20 Aehrchen und 50 lose sitzenden Frïchten, von denen 1845000 auf $1 \mathrm{hl}(=82 \mathrm{~kg})$ gehen.

Auf 1 qm entfallen 900 Halme oder 180 Pflanzen, mithin beträgt der Raum für eine Pflanze $55.5 \mathrm{qcm}$, die Blattoberfläche $\mathrm{p}$. q $\mathrm{m}$ Bodenfläche $30.25 \mathrm{qm}$, und das Saatquantum $1.5 \mathrm{hl} \mathrm{p}$. ha.

Es wiegen 100 Halme $580 \mathrm{gr}$ und davon die Früchte $173 \mathrm{gr}$.

Der Weizen zeigte sich in Poppelsdorf weder ganz winterfest, denn $1870 / 71$ winterte cr bis auf einige Pflanzen aus, noch widerstandsfähig gegen Rost und Lagern.

In Böhmen, Süd-Deutschland, in der französischen Schweiz ${ }^{1}$ ), sowie in Mittel- und Süd-Frankreich auf Lehm- und Mergelböden gebaut.

\section{Weissähriger holländischer Weizen mit gelbem Korn. (2)}

Aehre: gelb, sammetig, ziemlich dicht, mittellang, schmal; Aehrchen $1.2 \mathrm{~cm}$ breit, 2 -körnig. - Stroh : gelb, dünnwandig, doch fest. - Frucht: rötlichgelb, mehlig, länglich ( $7 \mathrm{~mm}$ lang, $4 \mathrm{~mm}$ breit), feinschalisg, weich; nachgebaut meist rot und halbglasig.

Herbstblatt blaugriin, oberseits sehr kurz behaart, sonst kahl, schmal, kraus; Frühjahrsvegetation spät; Bestockung stark, 6 Schösslinge, spät schossend und blühend. Halmlänge $130 \mathrm{~cm}$ (Max. $160 \mathrm{~cm}$ ), Halmdickc $0.38 \mathrm{~cm}$, Blattzahl 4.5, Blattlänge $31 \mathrm{~cm}$, Blattbreite $0.95 \mathrm{~cm}$, Blattoberfläche eines IIalmes $265.05 \mathrm{qcm}$, Halmfläche $148.20 \mathrm{qcm}$, Gesammtfäche $413.25 \mathrm{qcm}$.

Junge Aehre blaugrün, spät reifend, $10 \mathrm{~cm}$ (Max. $13 \mathrm{~cm}$ ) lang, mit 20 Aehrchen und 40 leicht ausfallenden Früchten, von denen 2050000 auf $1 \mathrm{hl}(=82 \mathrm{~kg})$ gehen.

Auf 1 qm wachsen 800 Halme oder 133 Pflanzen nehmen einen Raum von $75.2 \mathrm{qcm}$ ein. Die Blattfläche beträgt p. qm Bodenfläche $33 \mathrm{qm}$ und das Saatquantum (1/3 Verlust) $1 \mathrm{hl}$ p. ha.

1) Seringe pg. 92. Monogr. d. Céréal. de la Suisse 1818. 
Es wiegen 100 Halme $520 \mathrm{gr}$ und davon die Früchte $170 \mathrm{gr}$.

Der Weizen zeigte sich in Poppelsdorf winterfest und sowohl gegen Lagern wie Rost widerstandsfähig.

Für reiche Alluvialböden acheint diese Sorte beachtenswert zu sein. Bezugsquelle: Haage \& Schmidt, Erfurt.

\section{Winterweizen ron Srartlo. (2)}

Aehre: fast weiss, stark behaart, dicht, sich nach der Spitzc verjüngend, mit ziemlich grossen Zahnfortsätzen an den äusseren Spelzen, ziemlich lang; Aehrchen $1.6 \mathrm{~cm}$ breit, Aehrchen an der Basis 3-4-körnig, an der Spitze nur 2-körnig. - Stroh: rötlich, derbwandig, ziemlich blattreich, lang. - Frucht gelbrot, meist dunkelrot und glasig, rundlich, klein, (51/2 mm lang, $4 \mathrm{~mm}$ breit, 270 Früchtc $=10 \mathrm{gr})$, etwas grobschalig, halbweich, Bruch halbmehlig.

Herbstblatt tief dunkelgrün, roggenähnlich; Frühjahrsregetation mittelfrüh; Bestockung mittelstark, 4.6 Schössliuge, mittelfrüh schossend und blühend. Halmlänge $135 \mathrm{~cm}$ (Max. $155 \mathrm{~cm}$ ), Halmdicke $0.4 \mathrm{~cm}$, Blattzahl 4, Blattlänge $26.48 \mathrm{~cm}$, Blattbreite $1.07 \mathrm{~cm}$, Blattoberfläche eines Halmes $226.64 \mathrm{qcm}$, Halmfläche $162 \mathrm{qcm}$, Gesammtfläche $388.64 \mathrm{qcm}$.

Junge Aehre gelbgrïn, wegen der starken Behaarung bläulich, mittelfrüh reifend, $11 \mathrm{~cm}$ (IIax. $14 \mathrm{~cm}$ ) lang, mit 22 Aehrchen und 70 Früchten, welche fest vou den Spelzen umschlossen werden und ron denen 2187000 auf $1 \mathrm{hl}(=81 \mathrm{~kg})$ entfallen.

Auf $1 \mathrm{qm}$ wachsen 800 Halme oder 174 Pflanzen, mithin beträgt der Raum für eine Pflanze $57.5 \mathrm{qcm}$, die Blattfläche p. qm Bodenfläche $31 \mathrm{qm}$ und das Saatquantum ( $1 / 3$ Terlust) $1.2 \mathrm{hl}$ p. ha.

Es wiegen 100 Halme $575 \mathrm{gr}$ und davon die Früchte $200 \mathrm{gr}$.

In Poppelsdorf winterte dieser Weizen nicht aus, lagerte nicht und litt nur wenig durch Rost.

Dr. Wittmack erhielt diese hochnordische Sorte aus Boden (Svartlo), Norbottenlän, Schweden und sandte dieselbe 1873 nach Poppelsdorf.

Für einen schweren Lehmboden und rauhes Klima scheint dieser Weizen beachtenswert zu sein.

\section{Varietät: Triticum vulgare Delfii Kcke.}

Aehren sammetig, rot; Körner weiss oder gelblich.

\section{Sorten:}

\section{Mainstay-Wheat. (2)}

Deutsch: Mainstay-Weizen.

Aehre rotbräınlich, samnetig, fast quadratisch, sich wenig verjüngend, dicht, mittellang; Aehrchen $1.5 \mathrm{~cm}$ breit, meist 3-körnig. - Stroh: rötlich- 
gelb, blattreich, schön. - Frucht: Original gelblich-weiss, mehlig (6 mm lang, $4 \mathrm{~mm}$ breit, 220 Früchte $=10 \mathrm{gr}$ ); nachgebaut: meist glasig und dann rötlich-weiss, voll, schön, rund, 196.5 Friichte $=10 \mathrm{gr}$, feinschalig, lalbhart, Bruch halbmehlig.

Herbstblatt schmal, kraus, beiderseits behaart; Friihjahrsvegetation spät, Bestockung mittelstark, 4 Schösslinge, spät schossend und blühend, Halmlänge $130 \mathrm{~cm}$ (Max. $155 \mathrm{~cm}$ ), Halmdieke $0.45 \mathrm{~cm}$, Blattzahl 4, Blattlänge $29.08 \mathrm{~cm}$, Blattbreite $1,19 \mathrm{~cm}$, Blattoberfläche eines Halmes $276.88 \mathrm{qcm}$, Halmfläche 175,5 q cm, Gesamntfä̈che 452.38 qem.

Junge Aehre gclbgrïn, mittelfrüh-reifend, $10 \mathrm{~cm}$ (Max. $13 \mathrm{~cm}$ ) lang, mit 20 Aehrchen nud 60 fest von den Spelzen umschlossenen Frïchten, von denen 1768000 auf $1 \mathrm{hl}(=85 \mathrm{~kg})$ entfallen.

Auf $1 \mathrm{qm}$ kommen 740 Halme oder 185 Pflanzen, mithin beträgt der Raum für eine PHanze $54 \mathrm{qcm}$, die Blattoberfläche p. qm Bodenfläche $33.45 \mathrm{qm}$, und das Saatquantum ( $1 / 3$ Verlust) $1.6 \mathrm{hl} \mathrm{p.} \mathrm{ha.}$

Es wiegen 100 Halme $665 \mathrm{gr}$ und davon die Frïchte $260 \mathrm{gr}$.

Es scheint, dass dieser vortreffliche Weizen, der sich durch Schwere und Schönheit der Früchte, sowie durch sein festes, steifes, nicht lagerndes und gegen Rost sehr widerstandsfähiges Stroh auszeichnet, ziemlich winterfest ist und $m$ r unter sehr unguinstigen Witterungsverhältnissen leidet. Demnach ist dieser Weizen, der anch auf der Weltausstellung zu Philadelphia prämiiert wurde, für die reichen Alluvialböden im hohen Grade zu empfehlen.

Ziichter ist Kapitain William Delf zu Great Bentley, Colchester, England, welcher diesc schöne Sorte 1869 zïchtete, und zwar im Allgemeinen nach Hallet'schem System, doch darin von letzterem abweichend, dass er nicht die grössten, sondern die specifisch schwersten Körner zur Saat benutzte, und zur Erlangung dieses Saatgutes eine eigene Sortiermaschine erfand.

Der Name "Mainstay" soll wahrscheinlich „Hauptstiitze" bedeuten, weil er der beste Weizen der Zuchten des Mr. Delf ist.

Uebersender: Mr. Delf.

\section{Triticum aestivum, Portici. $\odot$ u. (2)}

Aelire: rotgrau, sammetig, sich verjiingend, grannenspitzig, locker, etwas schmal, lang; Aehrchen $1.5 \mathrm{~cm}$ breit, 2-3-körnig. - Stroh: gelb, fest, ziemlich lang. - Frucht: rötlich-gelb, glasig, oval $(61 / 2 \mathrm{~mm}$ lang, $31 / 2 \mathrm{~mm}$ breit, $190 \mathrm{Früchte}=10 \mathrm{gr}$ ), gross, schön, feinschalig.

Junges Blatt dunkelgrün, sehr schmal, lang; Bestockung schwach, 2 Schösslinge, sehr spät schossend und blülıend. Halmlänge $115 \mathrm{~cm}$ (Max. $135 \mathrm{~cm}$ ), Halndicke $0.38 \mathrm{~cm}$, Blattzahl 4.8, Blattlänge $22 \mathrm{~cm}$, Blattbreite $0.8 \mathrm{~cm}$, Blattoberfläche $168.96 \mathrm{qcm}$, Halıufläche $131.1 \mathrm{q} \mathrm{cm}$, Gesammtfläche $300.06 \mathrm{qcm}$.

Junge Aehre blaugrün, in 130 Tagen reifend, mit 17 Aehrehen und und 48 fest sitzenden Früchten, von denen 1596000 auf $1 \mathrm{hl}(=84 \mathrm{~kg})$ entfallen.

Es wiegen 100 Halme $450 \mathrm{gr}$ und davon die Früchte $180 \mathrm{gr}$.

Dieser Weizen lässt sich im milden Klima auch als Winterweizen kultivieren und leidet wenig durch Rost und Lagern, sobald der Boden nicht zu den sehr reichen Alluvialböden gehört. Er wurde 1876 durch Dr. Pedieino aus Portici, Italien, dem ökonomisch-botanischen Garten zu Poppelsdorf iibersandt. 


\section{New Sindh Thoree-Wheat: $\odot$ od. (2)}

Syn. Weisskörniger New Sindh Thoree-Weizen aus Ostindien über Kurrachee als Handelsware gesandt.

Aehre: blassrot, sammetig, sich wenig verjüngend, schwach grannenspitzig, ziemlich dicht, mittellang; Aehrchen $1.2 \mathrm{~cm}$ breit, Klappen gezahnt, meist 3-körnig. - Stroh: gelb, fein, steif, feinhalmig. - Frucht: Original weiss, mehlig; nachgebaut: rötlich, glasig; klein $\left(6^{1 / 4} / 4 \mathrm{~mm}\right.$ lang, $3 \frac{1}{4} \mathrm{~mm}$ breit, 242 Früchte $=10 \mathrm{gr}$ ), feinschalig, hart. halbmehlig.

Junges Blatt sehr hellgrün, behaart, aufrecht, 3 Schösslinge, sehr zeitig schossend und blühend. Halme $80 \mathrm{~cm}$ ( Мax. $90 \mathrm{~cm}$ ) lang, $0.3 \mathrm{~cm}$ dick, Blattzahl 3.4, Blätter $17.5 \mathrm{~cm}$ lang, $0.8 \mathrm{~cm}$ breit, Blattfläche $95.2 \mathrm{qcm}$, Halmfläche $72 \mathrm{qcm}$, Gesammtfläche $167.2 \mathrm{qcm}$.

Junge Aehre blaugrün, reift in 122 Tagen, $8 \mathrm{~cm}$ (Max. $10 \mathrm{~cm}$ ) lang, mit 13 Aehrchen und 32 Früchten, von denen 2042800 auf $1 \mathrm{hl}(=84 \mathrm{~kg})$ entfallen.

Es wiegen 100 Halme $206 \mathrm{gr}$ und davon die Früchte $117 \mathrm{gr}$.

Als Winterweizen kultiviert, zeigte er einen sehr kümmerlichen Stand.

Durch Hub. Dürselen, Neuss a. Rh., erhalten.

\section{Varietät: Triticum vulgare pyrothrix Al.}

Aehren sammetig, rot; Körner rot.

\section{Sorten:}

\section{Roter sammetiger Kolbenweizen. (2)}

Aehre: rotblan, sammetig, sich nach der Spitze stark verjüngend, ziemlich dicht, lang; Aehrchen $1.3 \mathrm{~cm}$ breit, meist 3-körnig. - Stroh: rötlich, lang, ziemlich derbwandig, blattarm. - Frucht: rot, glasig, klein, oval ( $6 \mathrm{~mm}$ lang, $3^{1} / 2 \mathrm{~mm}$ breit, 236 Früchte $\left.=10 \mathrm{gr}\right)$, ctwas grobschalig, halbhart, Bruch halbstahlig.

Herbstblatt blaugrün, schmal, kraus; Frühjalırsvegetation ziemlich zeitig, Bestockung sehr stark, 5.3 Schösslinge, mittelfrüh schossend und blühend. Halmlänge $125 \mathrm{~cm}$ (Max. $160 \mathrm{~cm}$ ), Halmdicke $0.38 \mathrm{~cm}$, Blattzahl 2.3, Blattlänge $24.53 \mathrm{~cm}$, Blattbreite $1.09 \mathrm{~cm}$, Blattoberfläche $123 \mathrm{qcm}$, Halmfläche $142.5 \mathrm{qcm}$, Gesammtfläche $265.59 \mathrm{qcm}$.

Junge Aehre gelbgrün mit bläulichem Anflug, mittelfrüh reifend, $10 \mathrm{~cm}$ (Max. $14 \mathrm{~cm}$ ) lang, mit 20 Aehrchen und 45 ziemlich fest sitzenden Früchten, von denen 1925760 auf $1 \mathrm{hl}=81.6 \mathrm{~kg}$ gehen.

Diese ziemlich winterfeste Sorte neigt wenig zum Lagern, befällt jedoch sehr leicht und stark mit Rost.

Der ökonomisch-botanische Garten zu Poppelsdorf erhielt diesen Weizen 1871 vou Hohenheim und zeigte sich derselbe konstant. 


\section{Golden rough-chaff. (2)}

Aehre: rotgrau, sammetig, etwas grannenspitzig, locker, $14 \mathrm{~cm} \mathrm{lang}$ mit 54 Früchten; Aehrchen $1.5 \mathrm{~cm}$ breit, 3-körnig. - Stroh: rötlich-gelb oder rotgrau. - Frucht: lelliot, glasig, länglich (7 mm lang, $3 \mathrm{~mm}$ breit).

Lawes erntete in Rothamsted, England, auf Lehmboden im sechsjährigen Durchschnitt 36 hl p. ha.

\section{Bristol-red. (2)}

Aehre: schmutzig-rotgrau, sammetig, sich stark verjüngend, locker, $14 \mathrm{~cm}$ lang mit 70 Früchten; Aehrchen $1.3 \mathrm{~cm}$ breit, 3- und 4-körnig. Stroh: rötlich-gelb. - Frucht: rot, glasig, klein.

Lawes ${ }^{1}$ ) erntete in Rothamsted, England, auf Lehmboden im sechsjährigen Durchschnitt 36.11 hl p. lia.

\section{Early Michigan. (2)}

Syn.: Bull-Wheat.

Aehre: blassrot mit schwach violettem Anflug, kurz, sammetig, halblocker, sich verjüngend, grannenspitzig, dünn; A ehrchen $1.3 \mathrm{~cm}$ breit, 2und 3-körnig. - Stroh: rötlich-gelb, kurz, steif. - Fruclıt: Original rot, meist glasig, schlank, klein $\left(6^{1} / 2 \mathrm{~mm}\right.$ lang, $3 \mathrm{~mm}$ breit, 306 Früchte $=$ $10 \mathrm{gr})$; nachgebaut: 243 Früchte $=10 \mathrm{gr}$, feinschalig, hart, Bruch stahlig.

Herbstblatt hellgrün, lang, schmal; Entwickelung zeitig, 2.3 Schösslinge, am zeitigsten von allen Sorten schossend und blühend; Halm $78 \mathrm{~cm}$ (Max. $100 \mathrm{~cm}$ ) lang, 0.33 dick, Blattzahl 4.8, Blätter $15 \mathrm{~cm} \mathrm{lang,}$ $0.7 \mathrm{~cm}$ brcit, Blattfläche $100.8 \mathrm{qcm}$, Halmfläche $77.2 \mathrm{qcm}$, Gesammtfläche $178 \mathrm{qcm}$.

Junge Aehre blaugrïn, am zeitigsten von Allen reifend, $7.5 \mathrm{~cm}$ (Max. $10 \mathrm{~cm}$ ) lang, mit 16 Aehrchen und 46 ziemlich fest sitzenden Früchten, von denen 2692800 auf $1 \mathrm{hl}(=88 \mathrm{~kg}$ ) entfallen.

Scheint winterfest zu scin; unterliegt dem Rost sehr stark, nicht leicht lagernd.

In den Nordstaaten Amerikas gebaut.

Bezugsquelle: Missouri Agric. Coll. 1880. U. S.

\section{Blé seigle. $\odot$ u. (2)}

Syn.: Franz.: Blé roux grand grillé (Anjou).

Deutseh: Roggenweizen.

Aehre: rotblau, schwach sammetig, locker, schınal, lang; Aehrchen $1.4 \mathrm{~cm}$ breit, 2-körnig. - Stroh: rötlich-gelb, blattarm, weich, - Frucht: gelbrot, mehlig; nachgebaut meist rot und glasig, länglich (7 mm lang, $3^{1 / 2} \mathrm{~mm}$ breit,) gross, feinschalig, halbweich, Bruch halbmehlig.

Herbstblatt dunkelgriin, aufrecht, breit, dem des Roggens ähnlich;

1) Farmer's Mag. V. 80. 1876, pg. 433. 
Frühjahrsvegetation zeitig; Bestockung schwach, 3.5 Schösslinge, zeitig schossend und blühend. Halmlänge $130 \mathrm{~cm}$ (Max. 150), Halmdicke $0.38 \mathrm{~cm}$, Blattzahl 3, Blattlänge $24.2 \mathrm{~cm}$, Blattbreite $1.13 \mathrm{~cm}$, Blattoberfläche eines Halmes $164.1 \mathrm{qcm}$, Halmfläche $148.2 \mathrm{qcm}$, Gesammtfläche $312.3 \mathrm{qcm}$.

Junge Aehre gelbgrün, niit bläulichem Anflug, zeitig reifend, $12 \mathrm{~cm}$ (Max. $15 \mathrm{~cm}$ ) lang, mit 24 Aehrchen und 50 ziemlich fest sitzenden Früchten, von denen 1413450 auf 1 lil (= $83 \mathrm{~kg}$ ) gehen.

Auf $1 \mathrm{qm}$ wachsen 900 Halme oder 260 Pflanzen, mithin beträgt der Raum für eine Ptlanze $38.5 \mathrm{qcm}$, die Blattfläche p. qm Bodenfläche 28 qm und das Saatquantum (1/3 Verlust) $2.8 \mathrm{hl}$ p. ha.

Es wiegen 100 Halme $580 \mathrm{gr}$ und davon die Fruichte $190 \mathrm{gr}$.

Der Weizen ist nicht winterfest, und das Stroh lagert sehr leicht, leidet indessen nicht allzusehr durch Rost.

In Poppelsdorf als Sommerweizen kultiviert, erwies er sich als solcher.

Diese Weizensorte soll nocl gut auf Mittelböden gedeihen, und empfahl sie der Graf von Gourcy unter dem Namen Roggenweizen für Sandböden. Vielfach findet sich die Kultur dieser Sorte in dem sandigen Teil des Loirethales zwischen Orléans und Angers.

\section{Varietät: Triticum vulgare cyanothrix Keke.}

Aehren sammetig, graublau; Kïrner weiss oder geblich.

\section{Sorte:}

\section{Graublauer Kolbenweizen. (2)}

Aehre: auf rötlichcm Grunde graublau, stark behaart, dicht, sich stark verjüngend, schmal, mittellang; Aehrehen $1.3 \mathrm{~cm}$ breit, 2- und 3körnig, äussere Soelze mit grannenartigem Zahnfortsatz. - Stroh: rötlichgelb, ziemlich derbwandig. - Frucht: gelblich, glasig, länglich ( $7 \mathrm{~mm}$ lang, $31 / 2 \mathrm{~mm}$ breit, 252 Früchte $=10 \mathrm{gr}$ ), feinschalig.

Herbstblatt blaugriin, beiderseits behaart, ziemlich schınal, kraus; Frihjahrsvegetation zeitig, Bestockung stark, 5 Schösslinge, mittelfrüh schossend und blühend. Halmlänge $140 \mathrm{~cm}$ (Max. $160 \mathrm{~cm}$ ), Halmdicke $0.37 \mathrm{~cm}$, Blattzahl 2.3, Blattlänge $22.33 \mathrm{~cm}$, Blattbreite $1.01 \mathrm{~cm}$, Blattoberfläche $103.73 \mathrm{qcm}$, Halmfläche $155.4 \mathrm{qcm}$, Gesammtflächc $259.13 \mathrm{qcm}$.

Junge Aehre blaugrün, $9 \mathrm{~cm}$ (Мax. $13 \mathrm{~cm}$ ) lang, mittelfrïh reifend, mit 22 Aehrchen und 55 Früchten von denen 2116800 auf $1 \mathrm{hl}$ (= $84 \mathrm{~kg}$ ) gehen.

Es wiegen 100 Halme 340 gr und davon die Früchte $137 \mathrm{gr}$.

Dieser Weizen zeigt wenig Neigung zum Lagern, bcfällt jedoch leicht mit Rost, auch ist er nicht ganz winterfest. 


\section{B. Bartweizen. Aristatum Al.}

\section{Varietät: Triticnm vulgare graecum Kcke.}

Aehren kahl, wciss; Körner weiss oder gelblich.

\section{Sorten:}

\section{Shirrefl's bearded White. (2) $1 . \odot$}

Franz.: Blé blane Shirreff.

Deuts ch: Shirreff"s weisser Bartweizen.

Aehre: schwach rötlich-weiss, sich wenig verjüngend, dünn, mittellang; Aehrchen $1.5 \mathrm{~cm}$ breit, 2- und 3-körnig; Grannen fast weiss, gespreizt, $10 \mathrm{~cm}$ lang. - Stroh: rötlich-gelb bis orange, lang, kräftig. Frucht: gelblich-weiss, mehlig und glasig; nachgebaut: grösstentheils Mehligkeit bewahrt, sehr schön, rundlich (7 $\mathrm{mm}$ lang, $4 \mathrm{~mm}$ breit, 210 Früchte $=10 \mathrm{gr}$ ), sehr schwer und feinschalig, weich.

Herbstblatt gellgrüun, beiderseits behaart, etwas schmal; Frühjahrsregetation mittelfrüh, Bestockung mittclstark, 4.4 Schösslinge, spät schossend und blühend. Halmlänge $140 \mathrm{~cm}$ (Max. $150 \mathrm{~cm}$ ), Halmdicke $0.4 \mathrm{~cm}$, Blattzahl 4.6, Blattlänge $30.5 \mathrm{~cm}$, Blattbreitc $1.0 \mathrm{~cm}$, Blattoberfläche eines Halmes 280.6 qcm, Halmfläche 168 qcm, Gesammtfläche $448.6 \mathrm{gcm}$.

Junge Achre gelbgrün, nnittelfrüh reifend, $9 \mathrm{~cm}$ (Max. $12 \mathrm{~cm}$ ) lang, mit 18 Aehrchen und 45 etwas lose sitzenden Früchten, von denen 1806000 auf $1 \mathrm{hl}(=86 \mathrm{~kg})$ gehen.

Auf $1 \mathrm{qm}$ wachsen 800 Halme oder 182 Pflanzen, mithin beträgt der Raum für eine Pflanze $55 \mathrm{qcm}$, die Blattfläche p. qm Oberfläche $35.8 \mathrm{qm}$ und das Saatquantum $1.5 \mathrm{hl}$ p. ha.

Es wiegen 100 Halme $628 \mathrm{gr}$ und die Früchte $200 \mathrm{gr}$.

Als Sommerweizen angebaut, erwies er sich als solcher.

Dieser schöne Weizen, der nicht leicht lagert und fast rostfrei bleibt, ist als Winterweizen leider selbst für West-Deutschland noch zu weichlich. In Poppelsdorf gelang seine Kultur als Sommerweizen vortrefflich, und ist er als solcher wohl zu beachten. Der Sommerweizen besitzt eine sehr schöne, doch ctwas kleinere Frucht, denn erst 320 Früchte wiegen $10 \mathrm{gr}$.

Züchter ist: Mr. Shirreff, Mnngowells, Haddingtonshire, Schottland.

\section{Cape wheat. $\odot$ u. (2)}

Syn: Franz.: Blé du cap; nach Vilmorin identisch mit: Blé barbu Pictet (Desvaux).

Deutsch: Weisser Bartweizen vom Cap.

Aehre: fast weiss, sich verjüngend, locker; Aehrchen $1.5 \mathrm{~cm}$ breit, 3- und 4-körnig, 3-grannig, mittelste Granne kurz, Klappen mit ziemlich 
langen Grannenspitzen, Grannen blassgelb, gespreizt, $8 \mathrm{~cm}$ lang, ziemlich leicht abbrechend. - Stroh: hellgelb, selır derbwandig, doch hohl, fest. Frucht: blassgelb, mehlig; nachgebaut: rötlich, glasig, eingefallen, sehr schön, länglich ( $7 \mathrm{~mm}$ lang, $3 \frac{1}{2} \mathrm{~mm}$ breit, 225 Früchte $=10 \mathrm{gr}$ ), schwer, feinschalig, halbweich, halbmehlig.

Blätter und Halme dunkelgriin, 3 Sclösslinge, zeitig schossend und blühend. Halmlänge $115 \mathrm{~cm}$ (Max. $135 \mathrm{~cm}$ ), Halmdicke $0.38 \mathrm{~cm}$, Blattzahl 4, Blattlänge $34.3 \mathrm{~cm}$, Blattbreite $0.8 \mathrm{~cm}$, Blattobcrfläche eines Halmes 219.52 qcm, Halmfläche 131.1 qcm, Gesammtfläche 350.62 qcm.

Junge Aehre blaugrün, in 130 Tagen reifend, $10 \mathrm{~cm}$ (Max. $13 \mathrm{~cm}$ ) lang, mit 14 Aehrchen und 45 ziemlich leicht ausfallenden Früchten, vou denen 1890000 auf $1 \mathrm{hl}(=84 \mathrm{~kg})$ gehen.

Auf $1 \mathrm{qm}$ wachsen 90 ) Halme oder 300 Pflanzen, mithin beträgt der Raum für eine Pflanze $33.3 \mathrm{qcm}$. die Blattfliche p. qm Bodenfläche $31.5 \mathrm{qm}$, und das Saatquantum (1/3 Terlust) 2.4 hl p. ha.

Es wiegen 100 Hlalme $420 \mathrm{gr}^{\circ}$ und davon die Frijchte $170 \mathrm{gr}$.

In Poppelsdorf gedieh dieser Weizen vortrefflich, das Stroh lagerte nicht und blieb fast rostfrei.

In Frankreich gchört diese Sorte zu den besten Sommerweizen und wird im Süden auch als Winterweizen gesäet, doch degeneriert dieselbe in Nord-Frankreich sehr leicht. Durch Commodore Perry kam diese wohl urspriinglich französische Sorte rom Cap der guten Hoffnung, nach den Südstaaten der Union und wird rort jetzt vielfach kultiviert.

Fïr trockne, kalkreiche Lehmböden im milden Klima ist dieser Weizen entschieden ron Bedentung.

Bezugsquelle: Vilmorin \& Andrieux, Paris.

\section{Hichigan-Trick. (2)}

Aehre: rötlich-weiss, unter mittellang, sich verjüngend, etwas locker; Aehrchell meist 3-körnig und 2-grannig; Gramell hell, gespreizt, bis $7 \mathrm{~cm}$ lang. - Stroh: rötlich-gelb, fest, unter mittellang. - Frucht: Original weiss, meist mehlig, schlank, klein (7 mm lang, $3^{1 / 4} \mathrm{~mm}$ breit, 320 Früchte $=10 \mathrm{gr})^{\circ}$; nachgebaut: glasig, grösser, 221 Früchte $=10 \mathrm{gr}$ ); feinschalig, halbweich, Bruch halbmehlig.

Herbstblatt dunkelgriin, fein, kraus; Fintwickelung spät, 3 Schösslinge, mittelfrüh schossend und blïhend; Halm $100 \mathrm{~cm}$ (Max. $115 \mathrm{~cm}$ ) lang, $0.3 \mathrm{~cm}$ dick, Blattzahl 4.6, Blätter $16.3 \mathrm{~cm}$ lang, $0.8 \mathrm{~cm}$ brcit, Blattfläche $120 \mathrm{qcm}$, Halmfäche 90 qcm. Gesammtfäche 210 qcm.

Junge Aehre bläulich-griin, mittelfrüh reifend, $9 \mathrm{~cm}$ (Max. $12 \mathrm{em}$ ) lang, mit 19 Achrolien und 57 ziemlich leicht ausfallenden Früchten, ron denen 2816000 auf $1 \mathrm{hl}(=88 \mathrm{~kg})$ cntfallen.

Winterfest, doch stark rostig.

Heimat: Vereinigte Staaten.

Bezugsquelle: Missouri Agric. Coll. 1880.

\section{Jeming's White. (2)}

Aehre: weiss, fast quadratisch, sich ein wenig verjingend, dicht, unter mittellang; Aelırchen 3-körnig, 3-gramig, doch inittlere Granne meist liürzer; Grannen hell, fast aufreclıt, $6 \frac{1}{2} \mathrm{~cm}$ lang. - Stroh: gclb, fest, mnter mittellang. - Frucht: Original fast weiss, mehlig, oval 
$(61 / 2 \mathrm{~mm}$ lang, $3 * \mathrm{~mm}$ breit, 320 Früchte $=10 \mathrm{gr})$; nachgebaut: glasig, nur wenige mehlig, grösser, 196 Früchte $=10 \mathrm{gr}$, schön, feinschalig, weich.

Herbstblatt hellgrïn, gross, aufrecht; Entwickelung zeitig, 3 Schösslinge, mittelfriih schossend und bliihend; Halm $100 \mathrm{~cm}$ (Max. $115 \mathrm{~cm}$ ) lang, $0.3 \mathrm{~cm}$ breit, Blattzahl 4.6 , Blätter $16.8 \mathrm{~cm}$ lang, $0.88 \mathrm{~cm}$ breit, Blattfläche $136 \mathrm{qcm}$, Halmfläche $90 \mathrm{qcm}$, Gesammitläche $226 \mathrm{qcm}$.

Junge Aehre bläulich-grün, ziemlich zeitig reifend, $9 \mathrm{~cm}$ (Max. $12 \mathrm{~cm}$ ) lang, mit 21 Aehrehen und 60 Früchten, von denen 2832000 auf $1 \mathrm{hl}$ $(=88.5 \mathrm{~kg})$ entfallen.

Nicht ganz winterfest und auffallend stark durch Rost leidend.

Heimat: Vereinigte Staaten.

Bezugsquelle: Missouri Agric. Coll. 1880.

\section{White Rogers. (2)}

Aehre: fast weiss, kurz, sich verjüngend, etwas locker; Aehrchen 3-körnig, 3-grannig, Klappen gezahnt; Grannen hell, gespreizt. - Stroh: rötlich-gelb, unter mittellang, steif. - Frucht: Original fast weiss, mehlig, einige glasig, sehr schön, oval (6 mm lang, $3 \frac{11}{2} \mathrm{~mm}$ breit, 268 Früchte $=10 \mathrm{gr})$; nachgebaut: glasio, ein wenig grösser, 213 Früchte $=10 \mathrm{gr}$, sehr schwcr, feinschalig, hallhart, halbmehlig.

Herbstblatt hellgrïn, gross, aufrecht; Entwickelung zeitig, 3.2 Schösslinge, spit schossend und blühend, $H a l m 100 \mathrm{~cm}$ (Max. $110 \mathrm{~cm}$ ) lang, $0.3 \mathrm{~cm}$ dick, Blattzalıl 4, Blitter $15.2 \mathrm{~cm}$ lang, $0.8 \mathrm{~cm}$ breit, Blattfläche $97.3 \mathrm{qcm}$, Halmfläche $90 \mathrm{qcm}$, Gesammtfläche $187.3 \mathrm{qcm}$.

Junge Aelıre gelbgrün, ziemlich zeitig reifend, $8 \mathrm{~cm}$ (Max. 9 cm) lang, mit 19 Aehrchen und 55 leicht ausfallenden Früchten, von denen 2412000 auf $1 \mathrm{hl}(=90 \mathrm{~kg})$ entfallen.

Winterfest, niclit leicht lagernd, doch stark dem Rost ausgesetzt.

In den Vereinigten Staaten kultiviert.

Bezugsquelle: Missouri Agric. Coll. 1880.

\section{Post-Wheat. (2)}

Aehre: blassgelb, kurz, sich verjüngend, ziemlich dicht; Aelırchen 3-körnig, 3-graunig, Klappen mit Zahn; Grannen leell, gespreizt. - Stroh: blassgelb, unter mittellang, weich. - Frucht: Original blassgelb, mehlig, oder glasig, schlank (7 mm lang, $3 \mathrm{~mm}$ breit, 265 Friichte $=10 \mathrm{gr}$ ); nach gebaut: grösser, 178 Frïchte $=10 \mathrm{gr}$, sehr schön, feinhalniig, halbhart, halbmehlig.

Herbstblatt dunkclgrün, ziemlich fein, aufrecht; Entwickclung ziemlich zeitig, 4 Schüsslinge, spät schossend und blühınd; Halı $100 \mathrm{~cm}$ (Max. $110 \mathrm{~cm}$ ) lang, $0.33 \mathrm{~cm}$ dick, Blattzahl 4, Blätter $21 \mathrm{~cm}$ lang, $1.1 \mathrm{~cm}$ breit, Blattfläche $184.8 \mathrm{qcm}$, Halmfläche $99 \mathrm{qcm}$, Gesammtfläche $283.8 \mathrm{qm}$.

Junge Aelre bläulich, ziemlich zeitig reifend, $8 \mathrm{~cm}$ (Max. $9 \mathrm{~cm}$ ) lang, mit 17 Aehrchen und 48 lcicht ausfallenden Früchten, von denen $2226(100$ auf $1 \mathrm{hl}(=84 \mathrm{~kg})$ entfallen.

Winterfest, neigt zum Rost.

In den Vereinigten-Staaten kultiviert.

Bezugsquelle: Missouri Agric. Coll. 1880. 


\section{Sanford-Wheat. (2)}

Aehre: fast weiss, kurz. ziemlich dicht, sich rerjüngend; Aebrehen meist 3-körnig. 3-grannig. Klappen mit Zahn, $1.3 \mathrm{~cm}$ breit; Grannen hell, ziemlich gespreizt, bis $6^{1}$ 2 $\mathrm{cm}$ lang. - Stroh: rötlich-gelb, steif, unter mittellang. - Frucht: Original fast meiss, mehlig, oral, klein $(5 \mathrm{~mm}$ lang, $3 \mathrm{~mm}$ breit, 300 Früchte $=10 \mathrm{gr}$; feinschalig, weich; nachgebaut: rötlich, glasig, grösser, 221 Früchte $=10 \mathrm{gr}$.

Herbstblatt hellgriin, ziemlich aufrecht, mittelgross; Entwickelung zeitig, 3.2 Schösslinge, spät schossend und blïhend; Halm $100 \mathrm{~cm}$ (Iax. $110 \mathrm{~cm}$ ) lang, $0.33 \mathrm{~cm}$ dick, Blattzahl 4.4, Blätter $15 \mathrm{~cm}$ lang. $0.9 \mathrm{~cm}$ breit, Blattfläche 118.8 qcm, Halmfläche 99 q cm, Gesammtfäche $217.8 \mathrm{qcm}$.

Junge Aehre bläulich, mittelfrüh reifend, $8 \mathrm{~cm}$ (Max. $10 \mathrm{~cm}$ ) lang, mit 18 Aehrchen und 50 lose sitzenden Früchten, von denen $26 r 0$ c00 auf $1 \mathrm{hl}(=89 \mathrm{~kg})$ entfallen.

Winterfest, nicht leicht lagernd, doch leicht rostig.

Kultiviert in der mittleren Region der Tereinigten Staaten.

Bezugsquelle: Missonri Agric. Coll. 1880.

\section{Pio Grande Spring-Wheat. $\odot$}

Aehre: weiss, 8-10 cm lang. - Stroh: blass-gelb, bis $1 \mathrm{~m}$ hoch. Frucht: hellrot, klein, glasig.

Durch ron Gerold 1855 aus Wisconsin U. S. an das preussische Landes-Oek.-Colleg. eingesandt.

\section{White Californian. $\odot$ и. (2)}

Syn: Deutsch: Califormischer weisser Bartweizen. Span isch: Trigo de California.

Aehre: blassgelb, locker, breit, mittcllang; Aehrchen $1.5 \mathrm{~cm}$ breit, 3-körnig Spindel zähe, Aehre nicht leicht abbrechend; Grannen abstehend, zähe. - Stroh: rötlich-gelb, derbwandig, fest, mittellang. Frucht: Original weiss, mehlig, sehr schön, gross; nachgebaut: meist hellrötlich und glasig. Wenige weiss und mehlig $\left(7^{1} / 2 \mathrm{~mm}\right.$ lang, $4 \mathrm{~mm}$ breit, 185 Früchte $=10 \mathrm{gr}$ ), auffallend schwer, feinschalig, weich, Bruch laltumehlig.

Herbstblatt blaugrün, sehr schmal, kraus; Frühjahrsvegetation zeitig, Bestockung sehr stark, 6 Schösslinge (bei Sommersaat nur 2 Schösslinge). Der Habitus der Pflanzen der Sommer- und Wintersaat wich nicht ron einander $\mathrm{ab}$ und zeigte sich, wie folgt:

Halmlänge $120 \mathrm{~cm}$ (YIax. $135 \mathrm{~cm}$ ), Halmdicke $0.37 \mathrm{~cm}$, Blattzahl 4, Blattlänge $23 \mathrm{~cm}$. Blattbreite $0.9 \mathrm{~cm}$, Blattoberfäche eines Halmes 164.4 qcm, Halmfläche 133.2 qcm, Gesammtfläche $297.6 \mathrm{qcm}$.

Jnnge Aehre blaugrün, mittelirüh reifend, als Sommersaat betrug die Tegetationsdauer 121 Tage, $9 \mathrm{~cm}$ (Max. $13 \mathrm{~cm}$ ) lang, mit 16 Aehrchen und 50 Früchten, von denen 1665000 auf 1 hl $(=90 \mathrm{~kg})$ entfallen.

Die Wintersaat war in Poppelsdorf nicht winterfest, auch litt der Weizen, obgleich er nicht lagerte, ziemlich hochgradig durch Rost. Ferner ergab sich, dass er nach 3 jährigem Anbau schon beträchtlich im 
Korn und Stroh degeneriert war, so dass er die Hoffuung nicht erfüllte, zu welcher die Schönheit seiner Früchte berechtigte.

Es wiegen 100 Halme $550 \mathrm{gr}$ und davon die Früchte $215 \mathrm{gr}$.

Für einen kalkreichen Lehmboden und ein mildes Klima scheint er sehr empfehlenswerth zu sein.

Uebersender: Landrat a. I. Thilmany zu Bonn, der ihn von seinem Sohn aus Californien erhielt, und von Gïlich, der ihn 1880 aus Chile an das landw. Nuseum in Berlin einsandte, welches Proben nach Poppelsdorf abgab.

\section{Trigo candealense, Madrid. $\odot$}

Aehre: gelblichweiss, mittellang, dïnn, locker; Aehrchen 2- und 3-körnig, mit 2 langen und 1 kurzen Granne, Grannen gelb, bis $10 \mathrm{~cm}$ lang. - Stroh: rötlich-gelb, fein, fest, mit markigem Rande (trotzdem nicht zu Trit. durum zu stellen). - Frucht: Original gelblich-weiss, mehlig; nachgebaut: im ersten Jahre meist rötlich und glasig, gross (8 mu lang, $\$ \mathrm{~mm}$ breit), sehr schwer, schön, feinschalig, halbhart, Bruch halbinehlig.

Halme blaugrün, 2.5 Schösslinge; Halmlänge $100 \mathrm{~cm}$ (Мax. $130 \mathrm{~cm}$ ), Halmdicke $0.33 \mathrm{~cm}$, Blattzahl 4, Blattlänge $26.75 \mathrm{~cm}$, Blattbreite $0.94 \mathrm{~cm}$, Blattoberfläche eines Halmes 201.2 q $\mathrm{cm}$, Halmfläche $99 \mathrm{qcm}$, Gesammtfläche 300.2 q $\mathrm{cm}$.

Junge Aehre blaugrün, in 131 Tagen reifend, $10 \mathrm{~cm}$ (Max. $13 \mathrm{~cm}$ ) lang, mit $16^{2}$ Aehrchen und 40 leicht ausfallenden Friichten, vou denen 1630000 auf $1 \mathrm{hl}(=85.8 \mathrm{~kg})$ entfallen.

Auf $1 \mathrm{qm}$ wachsen $1000 \mathrm{Halme}$ oder 400 Pflanzen, mithin beträgt der Raum für eine Pflanze 25 qcm, die Blattoberfäche p. q⿴囗 Bodenfläche $30 \mathrm{qml}$, und das Saatquantum $(1 / 3$ Verlust) $3.7 \mathrm{hl} \mathrm{p}$. ha.

Es wiegen 100 Halme $420 \mathrm{gr}$ und davon die Friichte $170 \mathrm{gr}$.

Dieser Weizen zeigte selbst in dem kühlen Sommer 1879 einen prächtigen Stand, und scheint für trockne bündige Böden im milden Klima als Sominerweizen beachtenswert zu sein, zumal das Stroh fast rostfrei blieb und wenig zum Lageru neigte.

Dieser Weizen wird in Spanien, namentlich in Murcia, als Sommerweizen gebaut.

Uebersender: Dr. Wittmack, der den Samen auf der Wiener Weltausstellung 1873 erhielt.

\section{Grano gentile binnco dei Toseani. (2)}

Syn.: Bartweizen aus Livorno.

Aehre: rötlich-weiss, sich etwas verjüngend, ziemlich dicht, mittellang, etwas schnnal; Aehrcheı $1.4 \mathrm{~cm}$ breit, 2-3-körnig; Grannen blassgelb, abstehend. - Stroh : rötlich-gclb, sehr fest. - Frucht: meist hellrötlich und glasig, wenige mehlig und weiss, rundlich $(6 \mathrm{~mm}$ lang, $4 \mathrm{~mm}$ breit, 212 Früchte $=10 \mathrm{gr})$, schön, sehr feinschalig, hart, Bruch halbmehlig.

Herbstblatt dunkelgrün, lang, aufrecht, Frühjahrsvegetation zeitig; Bestockung mittelstark, 4 Schösslinge, mittelfrüh schossend und blïhend. Halmlänge $110 \mathrm{~cm}$ (MIax. $130 \mathrm{~cm}$ ), Halmdicke $0.35 \mathrm{~cm}$, Blattzahl 3.8 , Blattoberfläche eines Halmes $142.35 \mathrm{qcm}$, Halmfläche $115.5 \mathrm{qcm}$, Gesammtfläche $257.85 \mathrm{qgm}$. 
Junge Aehre bläulich-grün, mittelfrüh reifend, $9 \mathrm{~cm}$ (Max. $12 \mathrm{~cm}$ ) lang, mit 18 Achrchen, und 45 lose sitzenden Früchten, von denen 1770200 auf $1 \mathrm{hl}(=83.5 \mathrm{~kg})$ entfallen.

Auf $1 \mathrm{qm}$ wachsen 1000 Halme oder 250 Pflanzen, mithin beträgt der Raum für eine Pflanze $40 \mathrm{qcm}$, die Blattfäche p. qm Bodenfläche $25.79 \mathrm{qm}$ und das Saatquantum ( $1 / 3$ Verlust) $2.1 \mathrm{hl} \mathrm{p}$, ha.

Es wiegen 100 Halme $500 \mathrm{gr}$ und davon die Früchte $210 \mathrm{gr}$.

Das Stroh ist fest und widerstandsfähig gegen Rost, der Weizen nicht winterfest. Halle.

Bezugsquelle: Ausstellung zu Mailand 1881 u. ök.-bot. Garten zu

\section{Blé du Cancase barbu. () и. (2)}

Syn.: Franz.: Blé du Caucase amélioré. (Verbessert durch Tilmorin-Tater).

Engl.: Caucasian-Wheat.

Deutsch: Kaukasischer- oder verbesserter kaukasischer Bartweizen.

Aehre: blassgelb, fast weiss, aufrecht, ziemlich dicht, lang; Aelrchen $1.7 \mathrm{~cm}$ breit, 3- und 4-kïmig; Grannen blassgelb, wenig gespreizt, bis $9.5 \mathrm{~cm}$ lang. - Stroh: rötlich-gelb. ziemlich blattreich; Spelzen hart und dick. - Frucht: Original graulich-weiss, ziemlich mehlig, sehr gross; nachgebant: rötlich-gelb, glasig, länglich $(8 \mathrm{~mm}$ lang, $4 \mathrm{~mm}$ breit, 165 Früchte $=10 \mathrm{gr}$ ), etwas eingefallen, hallweich, Bruch halbmehlig.

Herbstblatt blaugrïn, breit, kräftig, ziemlich aufrecht; Frïhjahrsvegetation mittelfrüh, Bestockung stark, 5.4 Schösslinge, mittelfrüh

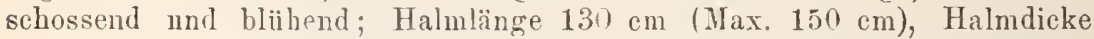
$0.4 \mathrm{~cm}$, Blattzabl 4, Blattlänge $33.3 \mathrm{~cm}$, Blattbreite $1.18 \mathrm{~cm}$, Blattoberfläcbe eines Halmes $314.64 \mathrm{qcm}$, Halmfläche $156 \mathrm{q} \mathrm{cm}$, Gesammtfl̈che $470.6 \pm \mathrm{q} \mathrm{cm}$.

Junge A ehre blaugriin, mittelfruih reifend, $10 \mathrm{~cm}$ (Max. $13 \mathrm{~cm}$ ) lang, mit 18 Aehrchen und 60 ziemlich festsitzcnden Früchten, ron denen 1369500 auf $1 \mathrm{hl}(=83 \mathrm{~kg})$ gehen.

- Auf 1 qun komnien 800 Halme oder 148 Pflanzen, mithin nimmt eine Pflanze einen Raum von $68 \mathrm{qqm}$ ein; die Blattfläche beträğt p. qm Bodenfläche $37.6 \mathrm{qm}$, nnd das Saatquantum $1.6 \mathrm{hl} \mathrm{p}$. ha.

Es wiegen 100 Halme $55+\mathrm{gr}$ und lavon die Früchte $185 \mathrm{gr}$.

Dieser Weizen zeigte sich in Poppelsdorf nicht winterfest, doch, zeitig gesäct, als Somnerweizen kultivierbar. Er neigt etwas zum Lagern, leidet aber wenig rom Rost.

Nach Heuzé wurle er 1820 rom Kaukasus nach Franlreich eingeführt; durch Vilnorin Vater verbessert und weiter verbreitet. Im Allgemeinen ist dieser. Weizcn nicht produltir und als Winterweizen bereits für Nordfrankreich zu weich.

\section{Bartweizen aus Zaracos, Griechenland. (2)}

Aehre: blassgelb mit rötlichem Schimmer, lang, sehr locker, schmal; Achrehen $1.2 \mathrm{~cm}$ brcit, 3-lsörnig; Grannen rötlich-weiss, $9 \mathrm{~cm}$ lang. Stroh: rötlich-gelb, dickwandig, mittellang. - Frucht: gchblich-weiss, mehlig; nachgebaut: meist rötlich und glasig, länglich $(71 / 2 \mathrm{~mm}$ lang, 
$3 \mathrm{~mm}$ breit, 198 Früchte $=10 \mathrm{gr}$ ), schwer, schön, feinschalig, halbhart, Bruch halbinellig.

Herbstblatt gelbgrün, hreit, anfrecht, Bestockung mittelstark, 5 Schösslinge, zeitig schossend und blühend. Halnnlänge $110 \mathrm{~cm}(\operatorname{Max} .130 \mathrm{~cm})$, Halmdicke $0.38 \mathrm{~cm}$, Blattzahl 4, Blattlänge $24.7 \mathrm{~cm}$, Blattbreite $1.23 \mathrm{~cm}$; Blattoberfläche eines Halmes $242.72 \mathrm{qcm}$, Halmfläche $125.4 \mathrm{qcm}$, Gesammtfläche $368.12 \mathrm{qcm}$.

Junge Aehre gelbgrün, zeitig reifend, $11 \mathrm{~cm}$ (Max. $15 \mathrm{~cm}$ ) lang, mit 14 Aelrchen und 40 festsitzenden Früchten, von denen 1702800 auf $1 \mathrm{hl}(=86 \mathrm{~kg})$ gehen.

Auf $1 \mathrm{qm}$ wachsen 900 Halme oder 180 Pflanzen, mithin beträgt der Raum für eine Pflanze 55.5 qcm, die Blattfläche p. qm Oberfläche $33.12 \mathrm{qm}$ und das Saatquantım (1/3 Verlıst) $1.6 \mathrm{hl} \mathrm{p.} \mathrm{ha.}$

Es wiegen 100 Halme $350 \mathrm{gr}$ und davon die Früchte $130 \mathrm{gr}$.

Dieser Weizen ist nicht winterfest und degeneriert leicht, doch zcigte er gegen Lagern und Rost eine bedeutende Widerstandsfähigkeit.

Als Sommerweizen 1878 ausgesäet, verhielt er sich wie Winterweizen, während er in dem kühlen Sommer 1879 merkwürdigerweise erfolgreich als Sommerweizen kultiviert wurde.

Für Dcutschland hat sein Anbau wohl kaum Bedeutung, da seine Ansprüche an das Klima sehr hoch sind.

Dieser Weizen wurde 1869 vom preussischen landw. Ministerium zur Prüfung nach Poppelsdorf überwiesen.

\section{Weisser, kahler Bartweizen von Karystos, Euboea, Griechenland. $\odot$ и. (2)}

Aehre: weiss oder gelblich, etwas locker, lang, sich wenig verjüngend; Aehrchen $1.2 \mathrm{cnl}$ breit, meist 2-körnig; Grannen fast weiss, wenig gespreizt. - Stroh: rötlich-gelb, sehr derbwandig, blattreich, mittellang. - Frucht: ineist rötlich und glasig, wenige weiss und mehlig, lang $\left(71 / 2 \mathrm{~mm}\right.$ lang, $3 \frac{1}{2} \mathrm{~mm}$ breit, 185 Früchte $\left.=10 \mathrm{gr}\right)$, schön, sehr feinschalig, halbhart, Bruch halbglasig.

Junges Blatt gelbgrün, schmal, aufrecht; Frühjahrsvegetation zeitig, Bestockung mittelstark, 4 Sprosse, zeitig schossend und blühend. Halmlänge $110 \mathrm{~cm}$ (Max. $130 \mathrm{~cm}$ ), Halmdicke $0.37 \mathrm{~cm}$, Blattzahl 4, Blattlängo $24 \mathrm{~cm}$, Blattbreite $1.01 \mathrm{~cm}$, Blattoberfläche $193.92 \mathrm{qcm}$, Halmfläche $122.1 \mathrm{qcm}$, Gesammtfäche $316.02 \mathrm{qcm}$.

Aehre zeitig reifend, mit 16 Aehrchen und 30 sehr fest in den Spelzen sitzenden Früchten, von denen 1517000 auf $1 \mathrm{hl}(=82 \mathrm{~kg})$ gehen.

Die Herbstsaat ist wenig winterfest.

Im Frühjahr gesäet, zeigte dieser Weizen den nämlichen Habitus, jedoch eine sehr schwache Bestockung (2 Schösslinge pro Pflanze).

Das Stroh befällt stark mit Rost, lagert jedoch nicht leicht. Co., Köln.

Importeur und Uebersender ist die Samenbandlung Itzenplitz \&

Für Deutschland hat sein Anbau keine Bedeutung. 


\section{Griechischer Sommerweizen ron Atalanti. $\odot$}

Aehre: blassgelb, fast weiss, etwas locker, sich verjüngend, mittellang, düun; Aehrchen $1.2 \mathrm{~cm}$ breit, meist 3-körnig, 3-grannig (eine Granne kurz); Grannen fast weiss, zähe, gespreizt, $9 \mathrm{~cm}$ lang. -- Stroh: goldgelb, sehr derbwandig. - Frucht: gelblich-weiss, mehlig; nachgebaut: wenige rötlich und glasig, lang, schmal, gross $18 \mathrm{~mm}$ lang, $4 \mathrm{~mm}$ breit, 200 Friichte $=10 \mathrm{gr}^{\mathrm{r}}$ ), feinschalig, Bruch halbwehlig, halbhart.

Halme gelbgriin, 2.4 Schösslinge, sehr zeitigr schossend und blühend; Halmlänge $80 \mathrm{~cm}$ (Max. $85 \mathrm{~cm}$ ), Halmdicke $0.23 \mathrm{~cm}$, Blattzahl §. Blattlänge $24 \mathrm{~cm}$, Blattbreite $0.78 \mathrm{~cm}$, Blattoberfläche eines Halmes $112.32 \mathrm{qcm}$. Halmfläche $55.2 \mathrm{qm}$, Gesammtfläche $167.52 \mathrm{qcm}$.

Junge Aehre blaugrün, in 125 Tagen reifend, $9 \mathrm{~cm}$ ( Мах. $11 \mathrm{~cm}$ ) lang, mit 14 Aehrchen und 40 sehr festsitzenden Früchten, rou denen 1600000 auf $1 \mathrm{hl}(=80 \mathrm{~kg})$ entfailen.

Es wiegen 100 Halme $330 \mathrm{gr}$ und daron die Früchte 11 gr.

In Poppelsdorf befriedigte der Stand nicht, auch zeichnete er sich mehrere Jahre durch seine grosse Empfänglichkeit fuir Rost aus.

Für Deutschland hat diese Sorte keine Bedeutung.

\section{Weisser begrannter Winterweizen aus Serbien. (2)}

Aehre: fast weiss, mittellang, sich stark rerjüingend, sehr locker; Aehrchen meist 3-körnig, 3-grannig, mittlere Granne kurz; Grannen hell, gespreizt, bis $9 \mathrm{~cm}$ lang. - Stroh: rötlich-gelb bis violett, unter mittellang, steif. - Frucht: Original fast weiss, mehlig, klein, rundlich $6 \mathrm{~mm}$ lang. $3^{1 / 2} \mathrm{~mm}$ breit, 281 Friichte $=10 \mathrm{gr}$ ); nachgebant: rötlich, glasig, grösser 189 Frïchte $=10 \mathrm{gr}$, in der Form sehr verändert, feinschalig, weich.

Herbstblatt dunkelgrün, fein, niederliegend; Entwickelung ziemlich zeitig, 3.3 Schösslinge, mittelfriih schossend und blühend; Halm $110 \mathrm{~cm}$ (Мax. $120 \mathrm{~cm}$ ) lang, $0.33 \mathrm{~cm}$ dick, Blattzahl 3.5 , Blätter $18.3 \mathrm{~cm}$ lang, $0.8 \mathrm{~cm}$ breit, Blattfläche $102.5 \mathrm{qcm}$, Halmfläche $108.9 \mathrm{qcm}$, Gesammtfläche 211.4 qcm.

Junge Aelıre bläulich, Antheren rot, zeitig reifend, $10 \mathrm{~cm}$ (Мax. $14 \mathrm{~cm}$ ) lang, mit 16 Aehrchen und t5 lose sitzenden Früchten, von denen $2+08000$ auf $1 \mathrm{hl}(=86 \mathrm{~kg})$ entfallen.

Echter Winterweizen, winterfest, nicht leicht lagernd, fast rostfrei. Bezugsauelle: Prof. Pantschitsch, Belgrad.

\section{Turkestanischer weisser Sommer-Weizen aus Wjernoje, am Fusse des Ala-Tau. $\odot$}

Aehre: gelb, locker, sich etwas rerjüngend, kurz, schmal; Aehrchen $1.3 \mathrm{~cm}$ breit, meist 3-körnig; Grannen hellgelb, $7 \mathrm{~cm} \mathrm{lang.} \mathrm{-} \mathrm{Stroh:}$ rötlich-weiss, sehr feinhalmig, kurz, blattarn. - Frucht: Original rein weiss, länglich, mehlig, prachtroll $\left(7 \mathrm{~mm}\right.$ lang, $3^{1 / 2} \mathrm{~mm}$ breit, 220 Früchte $=10 \mathrm{gr})$; nachgebaut: meist glasig und diese dann rötlich, soust konstant geblieben, feinschalig, halbhart, halbmehlig.

Blatt hellgriin, aufrecht, breit, beiderseits behaart, sehr zeitig schossend und blühend, 1.8 Schösslinge; Halmlänge $85 \mathrm{~cm}$ (Max. $100 \mathrm{~cm}$ ), 
Halmdicke $0.28 \mathrm{~cm}$, Blattzahl 3.6 , Blattlänge $20.3 \mathrm{~cm}$, Blattbreite $0.6 \mathrm{~cm}$, Blattoberfläche eines Halmes $87.7 \mathrm{qcm}$, Halmfläche 71.4, Gesammtfläche $159.1 \mathrm{qcm}$.

Aehre in 130 Tagen reifend, $8.5 \mathrm{~cm}$ (Max. $10 \mathrm{~cm}$ ) lang, mit 14 Aehrchen und 40 Friichten, von denen 1760000 auf $1 \mathrm{hl}(=80 \mathrm{~kg})$ entfallen.

Es wiegen 100 Halme $330 \mathrm{gr}$ und davon die Früchte $160 \mathrm{gr}$.

Dieser Weizen zeigte keine Neigung zum Lagern, dagegen geringe Widerstandsfähigkeit gegen Rost. Als Winterweizen kultiviert, erfror er fast vollständig.

Durch F'tisow gesammelt, wurde er durch E. Regel 1879 an den ök.-bot. Garten zu Poppelsilorf gesandt.

\section{Weisser Weizen ans dem Thal des Juldus, Turkestan. $\odot$}

Aelıre: blassgelb, sich wenig verjüngend, breit, ziemlich dicht, mittellang; Aehrchen $1.4 \mathrm{~cm}$ breit, 3- und 4-körnig, 5-grannig, da aucl die Klappen ebenso lange Grannen als die Spelzen besitzen; Grannen gespreizt, bis $10 \mathrm{~cm}$ lang. - Stroh: rötlich-gelb, hohl, fest, kaum mittellang. - Frucht: rötlich-gelb, glasig, wenige mehlig, stark eingefallen, gross, länglich $\left(7 \mathrm{~mm}\right.$ lang, $3 \frac{1}{2} \mathrm{~mm}$ breit, 228 Friichte $=10 \mathrm{gr}$ ), feinschalig, halbhart, lalbmehlig.

Junges Blatt blaugriin, beiderseits behaart, aufrecht, 3 Schösslinge, spät schossend und blühend. Halme $95 \mathrm{~cm}$ (Max. 105 cm) lang, $0.3 \mathrm{~cm}$ dick, Blattzahl 4, Blätter $14 \mathrm{~cm}$ lang, $0.73 \mathrm{~cm}$ breit, Blattfläche $83.51 \mathrm{qcm}$, Halmfäche 85.5 qcm, Gesammtfläche $169.01 \mathrm{qcm}$.

Junge Aehre blaugrün. in 120 Tagen reifend, $10 \mathrm{~cm}$ (Мax. $13 \mathrm{~cm}$ ) lang, mit 17 A ehrehen und 55 festsitzenden Früchten, von denen 1892400 auf $1 \mathrm{hl}(=83 \mathrm{~kg})$ entfallen.

Es wiegen 100 Halme $433 \mathrm{gr}$ und davon die Früchte $191 \mathrm{gr}$.

Dieser Weizen wurde durch den Reisenden Fetisow gesammelt, und durch E. Regel 1879 dem ök.-bot. Garten zu Poppelsdorf iibersandt.

\section{Weisser Bartweizen aus Persien. $\odot$}

Aehre: fast weiss, aufrecht, dünn, sich verjüngend, mittellang, sehr locker; Aehrchen $1.3 \mathrm{~cm}$ breit, 3-körnig, 3-grannig, Klappen lang, gezahnt; Grannen $7.5 \mathrm{~cm}$ lang, gespreizt. - Stroh: rötlich-gelb, feinhalmig, steif, Innenrand markig. - Frucht: rötlich-weiss, meist glasig, rundlich $\left(6^{1} / 4 \mathrm{~mm}\right.$ lang, $3 \frac{1}{4} \mathrm{~mm}$ breit, 240 Früchte $=10 \mathrm{gr}$ ), feinschalig, hart, halbstahlig.

Junges Blatt bläulich-grün, oberseits kurz behaart, aufrecht, sehr zeitig schossend und blühend. Halme $75 \mathrm{~cm}$ (Max. $85 \mathrm{~cm}$ ) lang, $0.3 \mathrm{~cm}$ dick, Blattzahl 3.6, Blätter $19.8 \mathrm{~cm}$ lang, $0.8 \mathrm{~cm}$ breit, Blattfläche $114.05 \mathrm{qcm}$, Halmfläche $67.5 \mathrm{qcm}$, Gesammtfäche $181.55 \mathrm{qcm}$.

Junge Aehre gelbgrün, reift in 120 Tagen, $7 \mathrm{~cm}$ (Max. $9 \mathrm{~cm}$ ) lang, mit 26 Früchten, von denen 2068800 auf $1 \mathrm{hl}(=86.2 \mathrm{~kg})$ entfallen.

Es wiegen 100 Halme $230 \mathrm{gr}$ und davon die Früchte $109 \mathrm{gr}$.

Erhalten durch die Rotterdan'sche Stoom-rystpeel Meelmolen 1877. 


\section{Weisser Bartweizen ans Calcntta. $\odot$}

Aehre: fast weiss, kurz, sehr locker; Aehrchen $1.5 \mathrm{~cm}$ breit, $2-$ und 3-körnig; Grannen etwas gespreizt, $9 \mathrm{~cm}$ lang. - Stroh: gelb, feinhalmig. - Frucht: Original weiss, glasig und mehlig, rundlich, klein $(6 \mathrm{~mm}$ lang, $4 \mathrm{~mm}$ breit, 255 Frïchte $=10 \mathrm{gr})$; nachgebaut: konstant geblieben, feinschalig, halbhart, Bruch halbmehlig.

Blatt hellgrün, oberseits behaart, aufrecht, breit, 1.5 Schösslinge, sehr zeitig schossend und blühend. Halmlänge $85 \mathrm{~cm}($ Max. $100 \mathrm{~cm}$ ), Halmdicke $0.3 \mathrm{~cm}$, Blattzahl 3, Blattlänge $20.3 \mathrm{~cm}$, Blattbreite $0.88 \mathrm{~cm}$, Blattoberfläche eines Ilalmes 107.18 qcm, Halmfläche $76.5 \mathrm{qcm}$, Gesammtfläche $183.68 \mathrm{qcm}$.

Junge Aehre gelbgrün, in 127 Tagen reifend, mit 14 Aehrchen und 35 ziemlich festsitzenden Früchten, von denen 2065500 auf $1 \mathrm{hl}$ $(=81 \mathrm{~kg})$ gehen.

Es wiegen 100 Halme $300 \mathrm{gr}$ und daron dic Früchte $130 \mathrm{gr}$. lagernd.

In Poppelsdorf zeigte sich dieser Weizen stark rostig und etwas

Uebersender: Rotterdam'sche Stoom-rystpecl en Meelnoolen.

Für Deutschland scheint er ohne Bedeutung zu sein.

\section{Delhie-Weizen ans 0stindien. $\odot$ u. (2)}

Aehre: blassgelb, ziemlich dicht, kurz; Aehrchen $1.3 \mathrm{~cm}$ breit, 3-körnig, 3-grannig; Granne hell, gespreizt, $7.5 \mathrm{~cm}$ lang. - Stroh: gelb; steif, sehr kurz. - Frucht: weiss, mehlig, oder hellrötlich und glasig, länglich $(61 / 2 \mathrm{~mm}$ lang, $3 \mathrm{~mm}$ breit, 224 Früchte $=10 \mathrm{gr})$, schwer, schön, feinschalig, halbbart, Bruch halb mehlig.

Blätter gelblich-grün, beiderseits kurz behaart, 3 Schösslinge, sehr zeitig schossend und blühend. Halme $55 \mathrm{~cm}$ (МГax. $75 \mathrm{~cm}$ ) lang, $0.25 \mathrm{~cm}$ dick, Blattzahl 3, Blätter $13.3 \mathrm{~cm}$ lang, $0.6 \mathrm{~cm}$ breit, Blattfläche $47.88 \mathrm{qcm}$, Halmfläche $40.25 \mathrm{qcm}$. Gesammtfäche $88.13 \mathrm{qcm}$.

Junge Aehre gelbgrün, sehr zeitig, in 110 Tagen reifend, $6 \mathrm{~cm}$ (Max. $8 \mathrm{~cm}$ ) lang, mit 11 Aehrchen und 30 Früchten, von denen 1948800 auf $1 \mathrm{hl}(=87 \mathrm{~kg})$ entfallen.

Es wiegen 100 Halme $181 \mathrm{gr}$ und davon die Früchte $100 \mathrm{gr}$.

Als Winterweizen kultiviert kam er nur kümmerlich durch den Winter. Er leidet sehr stark durch Rost.

Durch Hub. Dürselen, Neuss a. Rh., 1879 erhalten. 


\title{
Varietät: Triticum vulgare erythrospermum Kcke.
}

\author{
Aehren kahl, weiss; Körner rot.
}

\section{Sorten:}

\section{Victoria Sommerweizen.}

E 11 g l.: Victoria red Spring.

Franz: Blé de Victoria; Blé de la Trinité; Blé des lles Barbades; Blé Victoria de Mars; Blé de soixante-dix jours; Blé de la Colombie; Blé de Caracas.

Aehre: goldgelb, sich etwas verjüngend, locker, mittellang; A ehrchen $1.5 \mathrm{~cm}$ breit, 3- und 4-körnig und grannig, zwei Grannen lang, zwei kurz, Klappen mit sehr langen Grannenspitzen; Grannen hellı̈̈tlich-gelb, absteliend, bis $13 \mathrm{~cm}$ lang, nicht leicht abbrechend. - Stroh: gelb, feinhalmig, sehr derbwandig, fest, mittellang. - Frucht: gelbrot, mehlig; nachgebaut: dunkelrot, glasig, etwas eingefallen ( $7 \mathrm{~mm}$ lang, $3 \frac{1}{2} \mathrm{~mm}$ breit), selır schwer, feinhalnig, hart, Bruch halbstahlig.

Blätter blaugrün, aufrecht, 2.5 Schösslinge, spät schossend und blühend. Halmlänge $115 \mathrm{~cm}$ (Max. $125 \mathrm{~cm}$ ), Halndicke $0.3 \mathrm{~cm}$, Blattzahl 4, Blattlänge $24 \mathrm{~cm}$, Blattbreite $0.62 \mathrm{~cm}$, Blattoberfläche eines Halmes 119.04 q $\mathrm{cm}$, Halmfläche $103.5 \mathrm{q} \mathrm{cm}$, Gesammtfläche $222,54 \mathrm{qcm}$.

Junge Aehre blaugrüı, in 140 Tagen, also spät reifend, $10 \mathrm{~cm}$ (Max. $13 \mathrm{~cm}$ ) lang, mit 14 Aehrchen und 50 ziemlich festsitzenden Früchten, von denen 2165000 Früchte auf $1 \mathrm{hl}(=866 \mathrm{~kg})$ gehen.

Auf $1 \mathrm{qm}$ wachsen 1300 Halme oder 520 Pflanzen, mithin beträgt der Raum für eine Pflanze 19.2 q cm, die Blattoberfläche p. qm Bodenfläche $28.86 \mathrm{qm}$ und das Saatquantull $3.6 \mathrm{hl} \mathrm{p.} \mathrm{ha.}$

Es wiegen 100 Halme $450 \mathrm{gr}$ und davon die Früclite $150 \mathrm{gr}$.

Für Südeuropa auf Lehmboden eignet sich dieser Weizen besser zur Kultur als in Deutschland, für dessen Klima er zu zart ist.

Nach Heuzé soll diese Sorte in 70 Tagen ausreifen, sehr wenig ergiebig sein und 'leicht degenerieren, während sich in Poppelsdorf der Weizen als spätreif und ergiebig erwies. Zur Kontrolle liessen wir von Vilmorin \& Andrieux, Paris, frische Saat kommen, die sich jedoch genau so verhielt, wie die bisher angebaute.

Das Stroh lagerte in Poppelsdorf nicht leicht, befiel jedoch sehr stark mit Rost.

Dieser Weizen wurde durch $\mathrm{A}$. von $\mathrm{Humboldt}$ bei Victoria in der Provinz Caracas, Venezuela, unter $10^{\circ} 3^{\prime}$ nördl. Breite und in einer Höhe von 500-600 m gefunden und wegen seiner Ergiebigkeit und Frühreife, denn er reifte hier in seiner Heimat in 70-75 Tagen, zum Anbau empfohlen.

Der Garteninspector E. tt $^{1}{ }^{1}$ ), der in den 30er Jahren die Provinz

1) Eldenaer Archiv pg. 75. 1856. 
Caracas bereiste, sandte ron diesem Weizen an $J$ ühlke, in Eldena, der ihn weiter verbreitete. In England liess sich Dr. $\mathrm{H}$ a milto ${ }^{2}$ ) in Plymouth 1834 von Sir R. K. Porter Samen schicken und verteilte denselben in kleinen Quantitïten, so z. B. erhielt P. Lawson, der anerkannt grösste Samenhändler jener Zeit, 125 Körner.

\section{Goldgelber Winter-Rartweizen. (2)}

Aehre: gelb, mit rötlichem Schimmer, mittellang, sehr locker, sich verjüngend; Aehrchen schmal, $1 \mathrm{~cm}$ breit, 2-körnig; Grannen hell, fast aufrecht, bis $7 \mathrm{~cm}$ lang. - Stroh: rötlich-gelb, unter mittellang, weich. Frucht: rot, glasig, länglich, gross ( $8 \mathrm{~mm}$ lang, $4 \mathrm{~mm}$ breit, 190 Früchte $=10 \mathrm{gr})$, feinschalig.

Herbstblatt gelbgriin, schmal, niederliegend; Vegetation zeitig, Bestockung stark, 5.4 Schösslinge; Halm $110 \mathrm{~cm}$ (Iax. $135 \mathrm{~cm}$ ) lang, 0,37 cm dick, Blattzahl 3.3 , Blätter $27.32 \mathrm{~cm}$ lang, $0.86 \mathrm{~cm}$ breit, Blattfläche $155.1 \mathrm{qcm}$, Halmfläche $122.1 \mathrm{qcm}$, Gesammtfläche 277.2 q $\mathrm{cm}$.

Junge Aehre gelbgrün, zeitig reifend, $10 \mathrm{~cm}$ (Wax. $12 \mathrm{~cm}$ ) lang, mit 30 festsitzenden Früchten, von denen 1647300 auf $1 \mathrm{hl}(=86.7 \mathrm{~kg})$ entfallen.

Nicht ganz winterfest, stark durch Lagern und Rost leidend.

Ziemlich ausgedehnt in Norddeutschland kultiviert.

\section{Somner-Blumenweizen.}

Aehre: blassgelb, sich verjüngend, etwas locker, dünn; Aelurchen 2- und 3-körnig, $1.4 \mathrm{~cm}$ breit, 2- und 3-grannig, davon eine kurz, Grannen blassgelb, bis $10 \mathrm{~cm}$ lang. - Stroh: gelb, fest, feinhalmig. - Frucht: schön, gelbrot, meist mehlig, wenige glasig und rot, klein $(6 \mathrm{~mm} \mathrm{lang,}$ $3 \mathrm{~mm}$ breit, 244 Früchte $=10 \mathrm{gr}$ ), feinschalig, halbweich, Bruch halbmehlig.

Junges Blatt dunkelgrün, schmal, lang, 2.8 Schösslinge, zeitig schossend und blühend. Halmlänge $120 \mathrm{~cm}$ (Max. $130 \mathrm{~cm}$ ), Halndicke $0.28 \mathrm{~cm}$, Blattzahl 3, Blattlänge $21.7 \mathrm{~cm}$, Blattbreite $0.88 \mathrm{~cm}$, Blattoberfläche 114.58 qcm, Halmtläche 100.8 q cm, Gesammtfläche 215.38 qcm.

Junge Aehre gelbgriin, in 130 Tagen reifend, $9 \mathrm{~cm}$ (Max. $11 \mathrm{~cm}$ ) lang. Strolı niclıt leicht lagernd, doch durch Rost leidend.

Es wiegen 100 Halme $354 \mathrm{gr}$ und davon die Frïchte $172 \mathrm{gr}$.

\section{Sommerweizen ron von Langsdorfi:. $\odot$}

Aehre: rötlich-gelb, dünn, etwas locker, lang; Aehrchen $1.5 \mathrm{~cm}$ breit, 3-körnig, 3-grannig, Mlittelgranne kurz; Grannen rötlich-gelb, zähe, gespreizt, bis $9 \mathrm{~cm}$ lang. - Stroh: rötlich-gelb, fest, kräftig, lang. Frucht: rot, glasig, etwas eingefallen, sehr gross ( $8 \mathrm{~mm}$ lang, $4 \mathrm{~mm}$ breit), feinschalig.

Junges Blatt gelbgrün, schmal, lang; 2 Schösslinge, mittelfrüh schossend und blülzend. Halm $135 \mathrm{~cm}$ (Max. $150 \mathrm{~cm}$ ) lang, $0.4 \mathrm{~cm}$ dick,

1) Loudon's Gardener's Mag. Vol. IX, pg. 700. 
Blattzahl 3.5, Blätter $26.3 \mathrm{~cm}$ lang, $0.9 \mathrm{~cm}$ breit, Blattfläche $165.69 \mathrm{qcm}$, Halmfläche $162 \mathrm{qcm}$, Gesammtfläche $327.69 \mathrm{qcm}$.

Junge Aehre bläulich-grün, reift in 123 Tagen, $12 \mathrm{~cm}$ (Max. $15 \mathrm{~cm}$ ) lang, mit 50 sehr leicht ausfallenden Friichten, von denen 1619000 auf $1 \mathrm{hl}(=85.2 \mathrm{~kg})$ entfallen.

Auf $1 \mathrm{qm}$ wachsen 900 Halme oder 450 Pflanzen, mithin beträgt das Saatquantum $4.2 \mathrm{bl}$ p. ha.

Es wiegen 100 Halme $503 \mathrm{gr}$ und davon die Frïchte $191 \mathrm{gr}$.

Für reichen Niederungsboden ist dieser gegen Rost und Lagern sehr widerstandsfähige Weizen zu empfeblen.

\section{Zborower-Weizen. (2)}

Aehre: blassgelb, mit rötlichem Schimmer, sich stark verjüngend, locker; Aelirchen meist 2-körnig, 2-grannig, $1.2 \mathrm{~cm}$ breit; Grannen hell, gespreizt, bis $5 \mathrm{~cm}$ lang. - Stroh: rötlich-gelb, unter mittellang, fein, fest. - Frucht: rot, glasig, lang, gross ( $81 / 2 \mathrm{~mm}$ lang, $4 \mathrm{~mm}$ breit), grobschalig, halbhart, Bruch halbmehlig.

Herbstblatt gelbgrün, aufrecht, breit; Entwickelung zeitig, 2 Schösslinge, sehr zeitig schossend, mittelfrüh blühend; Halm $100 \mathrm{~cm}$ (Max. $115 \mathrm{~cm})$ lang, $0.3 \mathrm{~cm}$ dick, Blattzahl 4.2 , Blätter $17 \mathrm{~cm}$ lang, $0.8 \mathrm{~cm}$ breit, Blattfläche $114.2 \mathrm{qcm}$, Halmfläche $90 \mathrm{qcm}$, Gesammtfläche $204.2 \mathrm{q} \mathrm{cm}$.

Aehre spät reifend, $9 \mathrm{~cm}$ (Max. $14 \mathrm{~cm}$ ) lang, mit 13 Aehrchen und 26 Früchten, von denen 1 ll l (= $77 \mathrm{~kg})$ wiegt.

Ein sehr mittelmässiger in Zborow, Böhmen, gezüchteter Weizen, welchen wir 1880 durch das preussische landw. Ministerium erhielten.

\section{Roode Tarwe Ruwarige Tiel, Provinz Gelderland,} Holland. (2)

Identisch sind: Roode Tarwe Roozendahl und Haarlemermeer.

A ehre: gelb, sich verjüngend, locker, ziemlich breit, lang; Aehrchen 1.6 cin breit, 2- und 3-körnig; Grannen gelblich-weiss, abstehend. Stroh: gelb, fest, derbwandig. - Frucht: rot, meist glasig, wenige gelbrot und mehlig, länglich, klein $(61 / 2 \mathrm{~mm}$ lang, $3 \mathrm{~mm}$ breit, 233 Früchte $=10 \mathrm{gr}$ ), feinschalig, halbweich, Bruch halbmehlig.

Herbstblatt dunkelgrün, schwach behaart, ziemlich breit, aufrecht; Frühjahrsvegetation mittelfrüh, Bestockung mittelstark, 4 Schösslinge, mittelfruih schossend und bliihend; Halmlänge $130 \mathrm{~cm}$ (Max. $150 \mathrm{~cm}$ ), Halmdicke $0.4 \mathrm{~cm}$, Blattzahl 4.2 , Blattlänge $30 \mathrm{~cm}$, Blattbreite $0.94 \mathrm{~cm}$, Blattoberfläche eines Halmes 228.48 qcm, Halmfläche $156 \mathrm{qcm}$, Gesammtfläche 384.48 qcm.

Junge Aehre gelbgrün mit bläulichem Anflug, mittelfrüh reifend, $12 \mathrm{~cm}$ (Max. $18 \mathrm{~cm}$ ) lang, mit 20 Aehrchen und 50 nicht leicht ausfallenden Früchten, von denen 1957200 auf $1 \mathrm{hl}(=84 \mathrm{~kg})$ gehen.

Auf $1 \mathrm{qm}$ kommen 800 Halme oder 200 Pflanzen, mithin beträgt der Raum für eine Pflanze $50 \mathrm{qcm}$, die Blattoberfläche p. qm Bodenfläche $30.72 \mathrm{qm}$ und das Saatquantum (1/3 Verlust) $1.5 \mathrm{hl} \mathrm{p}$. ha.

Es wiegen 100 Halme $700 \mathrm{gr}$ und davon die Früchte $270 \mathrm{gr}$.

Dieser schöne Weizen erwies sich in Poppelsdorf vollständig winterfest, lagerte nur wenig, und wurde nur geringfügig mit Rost befallen.

Für reiche Weizenböden ist dieser Weizen wohl zu beachten.

Bezugsquelle: Dampfmïhle in Rotterdam. 


\section{Ungarischer Winterweizen (2) und Ungarischer Sommerweizen.}

\section{Verbelsserte Form: Mokry-Weizen.}

Aehre: rötlich-gelb, dünn, sich nach der Spitze verjiingend, ziemlich dicht; Aehrchen $1.1 \mathrm{~cm}$ breit, 2- und 3-köruig: jedes Aehrchen mit 2 vollentwickelten und eiuer verkümmerten Granne, Graunen gelb, mässig gespreizt, bis $15 \mathrm{~cm}$ lang. - Stroh: rötlich-gelb, fest, steif, dünnbalmig, blattarm, mittellang. - Frucht: hellrot, meist glasig, wenn mehlig, so gelbrot, klein ( $6 \mathrm{~mm}$ lang, $3 \mathrm{~mm}$ breit, $3 \pm 0$ Friichte $=10 \mathrm{gr}$ ), schwer, sehr feinsehalig, meist hart, Bruch stahlig.

Herbstblatt blaugriin, sehr fein, kraus, niederliegend. Frühjahrsvegetation uicht vorschnell; Bestockung mittelstark, 4.5 Sehösslinge. Beim Sommerweizen ist das Blatt dınkelgriin und schmal, Bestockung ziemlich stark, 3 Schösslinge.

Bei der stark treibenden Kraft des ungarischen Frühjahrs vollendet sich die Vegetation, also Schossen, Bliihen, Reifen verhältnismässig zeitig. Junge Aehre gelbgrïn, Spelzen und Klappen rot umrandet, reif $8 \mathrm{~cm}$ lang, enthält beim Banater Weizen 14 Aehrchen und 30 Früchte.

Die gelbährigen begrannten rotkörnigen Landweizen Ungarns scheinen sämmtlich aus einem gemeinsamen Typus hervorgegangen zu sein und weichen sehr wenig in ihrer Beschaffenheit von einander ab, wie dies schon der Steppencharakter bedingt. Als Typus des ungarischen Weizens ist der Banater anzusehen und die geringen Abweichungen anderer Sorten ergeben sich aus nebenstehender Uebersicht.

Eine sehr grosse Uebereinstimmung der in Poppelsdorf gebauten Sorten mit dem Original-Banater ist hiernach nicht zu verkennen, denn sie unterscheiden sich von ihm nur durch grössere Körner und üppigeren Habitus, eine Folge des feuchteren Klimas und kultivierteren Bodens. Ferner unterscheiden sich auch in Uugarn die in den feuchteren Gebirgsgegenden wachsenden Sorten, z. B. der sog. nord-nngarische, Füleker etc., dadurch, dass sie mehligere, weichere Körner und üppigeren Habitns besitzen, voll den in den Steppengegenden gebauteu Sorten, so zeichnen sich vorzugsweise der Banater- und Theissweizen durch kleine, harte, kleberreiche Körner aus, weshalb sich auch diese Weizen als rorzüglich backfähige Exportweizen eines hohen Rufes erfreuen.

Sämmtliche Sorten sind vollkommen winterfest, lagern nicht leicht und leiden wenig durch Rost.

Der Banater-Weizen ist nun von Mokry ${ }^{1}$ ) zu Gerendás in Bekescher Comitat, Poststation Apácza, veredelt worden und hat derselbe dariiber, um allen Anfragen zu genügen, 1875 in ungarischer Sprache eine Schrift, wclche bei Ludwig Aigner in Budapest erschienen ist, veröffentlicht.

Mokry sucht seinen Weizen so zu vervollkommnen, dass cr unter gleichen Verhältnissen einen bedeutend höheren Ertrag als der gewölnliche liefert. Wie uns Herr II okry mitteilte, gleirht sein Veredelungsverfahren dem $\mathrm{Hallct}$ 's, nur mit der Abweichung, dass mehr Rücksicht auf die Länge und den Fruchtreichtum der Aehre, als auf die Bestockung genommen werde.

Die Teredelung geschieht nun in der Weisc, dass sehr vollkommene

1) Vergl. Landw. Jahrb. 1880. Werner, Studienreise durch Ungarn. 


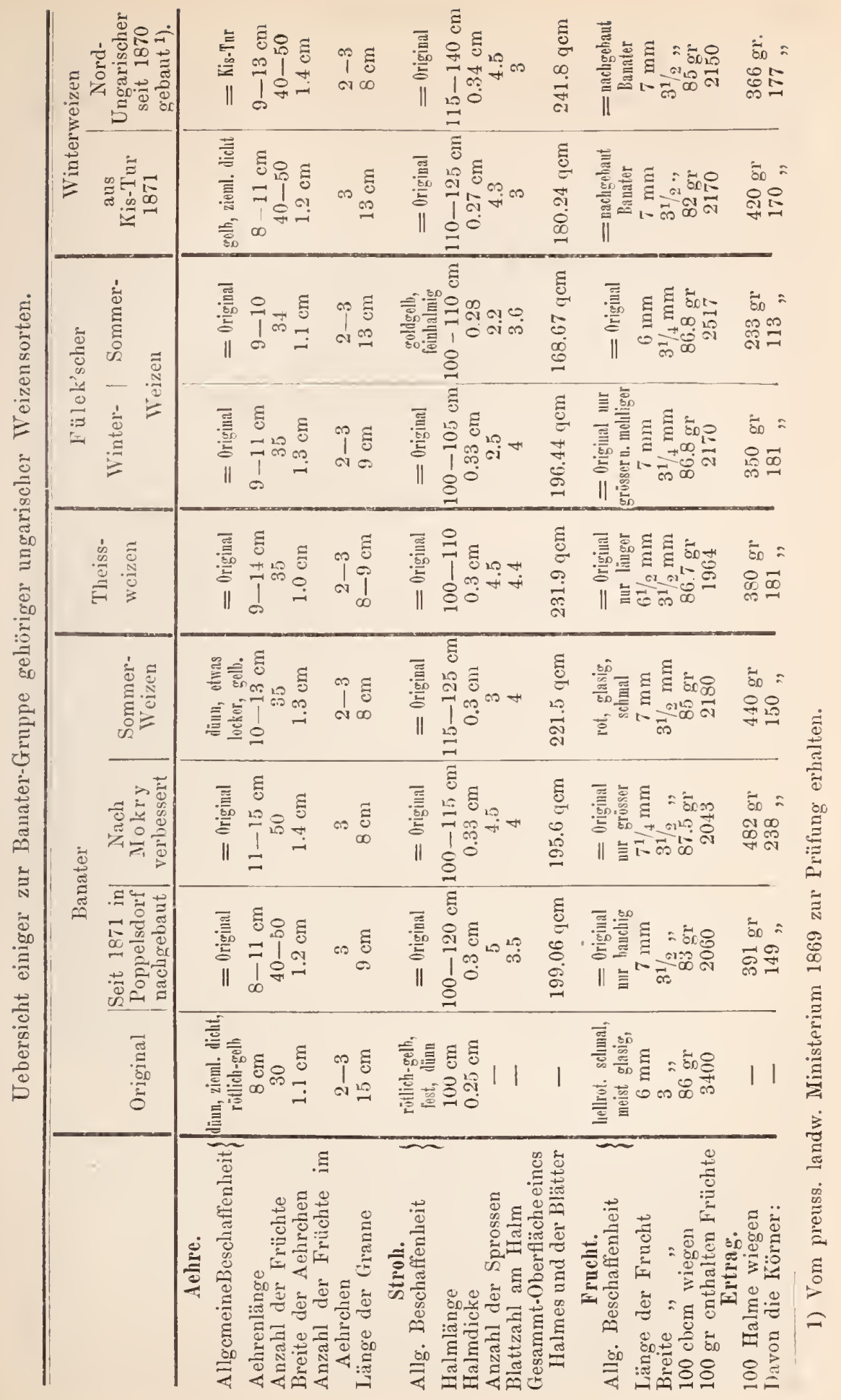


Aehren des gewöhnlichen Weizens ausgesucht und von diesen wieder die besten Körner ausgelesen und auf einer tief umgegrabenen und stark gediingten Parzelle (ca. $50 \mathrm{qkm}$ ) in einfüssiger Reihenentfernung und sechszölliger Entfernung in der Reihe ausgesäet und die Zwischenräume im Laufe der Vegetationsperiode zweinal behackt werdeu.

Die besten Körner aus den längsten Aehren dieser Parzelle werden nun im nächsten Jahre in derselben Weise ausgesäet und bildet diese Parzelle dann die erste Pflanzschule.

Sämmtliches Saatgut dieser ersten Pflanzschule wird dann im Herbst auf ähnlich gut vorbereitetem Boden (3 Joch à 1100 Quadratklafter) in einfüssiger Entfernung ausgedrillt, so dass sich die Aussaat per Joch auf $7 \mathrm{l}$ stellt, und im Frihjahr ebenfalls behackt. Der Ernteertrag hiervon gelangt nun wiederum unter gleicher Kultur zur Aussaat, nur dass etwas enger gedrillt wird, indem 251 per Joch entfallen.

Die dritte Pflanzschule liefert nun das Saatgut für die gewölnnliche Aussaat, zu welcher der Acker anf 4 bis 6 Zoll gepflügt und die übliche Aussaat beim gewöhnlichen Weizen von 50-60 Ltr. per Joch mit der dreizehnreihigen Drillmaschine bewirkt wird. Das Behacken fällt hier fort.

Dieses von Mokry seit 15 Jalıren verfolgte Verfahren hat zu überraschenden Erfolgen geführt und kommen Landwirte aus nah und fern, um sich nicht bloss den Weizen in der Pflanzschule, sondern auch auf dem Felde anzusehen, und um den Unterschied recht hervortreten zu lassen, ist gewöhnlicher Weizen neben veredeltem kultiviert. Im Jahre 1875 besuchte auf Veranlassung des Ackerbau-Ministeriums, das Herrn Mokry aus freien Stücken für das Unternehmen eine jährliche Staatsbeihülfe von 600 H. gewährt hat, eine Kommission der landwirtschaftlichen Gesellschaft des Bekescher Komitats die Felder, und eine eingehende Untersuchung ergab, dass durchschnittlich eine Aehre des veredelten Weizens 46.6 Körner und eine solche des unter gleichell Verhältnissen angebauten gewöhnlichen Weizens nur 28.3 Körner enthielt, ein Erfolg der ausserordentlich ist, und auf das ganze Land bereclinet, einen sehr bedeutenden Mehrertrag in Aussicht stellen würde, vorausgesetzt, dass auch die Kulturverhältnisse überall entsprechende wären, doch beweist dieses Beispiel sehr schlagend die Notwendigkeit der Anwendung des allerbesten Saatguts, zur Erzielung hoher Durchschnittserträge.

In Folge der Teredelung verlängerte sich die Aehre, so dass sie von anfänglich 18 Aehrchen in der Aehre auf $32 \mathrm{kam}$, und anstatt der bisherigen 3 Körner sich in den besten Aehrchen häufig fünf Körner entwickelten. Entsprechend länger und stärker wurden auch Halm und Blätter.

In dem Steppenklima Ungarns scheint aber gerade dieser üppige Wuchs, da er Spätreife, also eine Verlängerung der V'egetationsperiode veranlasst, diese Veredelung in Frage zu stellen. In Pflanzschule I. verlängerte sich die Vegetationsperiorle um 14 Tage, in II. um 10 Tage, in III. um 8 Tage und bei dem üblich dicht gesäeten Weizen um 6 Tage. Diese 6 Tage werden aber nicht selten dem Weizen verderblich, weil geradc zur Reifezeit im Steppenklinı häufig sengende Hitze eintritt, durch welche die Körner vor der Ausreife, also vorzeitig zusammenschrumpfen und leichter werden; nun verschlingt aber ein Jahr, in welchem der veredelte Weizen total zusammenschrumpft, wiederum den Mehrertrag vieler Jahre. Leider ist nun die Umwandlung zu einer frihhreifen Sorte einem Terzicht auf die bisher errungenen Torteile gleich zu setzen. 
Für das Steppenklima ist deshalb dieser veredelte Mokry-WVeizen weniger zu empfehlen, als fiir das etwas feuchtere Klima der Gebirgsgegenden, indem hier eine Verzögerung der Reife weniger schadet, und in der That haben wir vielfarh diese Methode in den Gebirgsgegenden, so um Fülek verbreitet gefunden, während die Landwirte der Ebene das Verfahren zum Teil verwerfen.

Durch die Veredelung vergrössert sich auch das Korn, was jedoch eine Verringerung der Qualität nach sich zieht, indem ans dem harten Banater Weizen ein weicherer erzeugt wird, der weniger kleberreich ist. Da nun aber zur Erzeugung backfähigen Mehles der kleberreiche Weizen der Steppen zur Vermischung mit den westeuropäischen Sorten sehr erwiunseht ist, so verliert derselbe als Exportwaare an WVert, sobald sich der Kleberrcichtum vermindert.

Diese ungarischen Landweizen werden fast ausschliesslich in der Ebene und vielfach in den Gebirgsgegenden Ungarns gebaut.

\section{Wallachischer Weizen. (2)}

Syn.: Franz.: Blé rouge roumain.

Aelure: blassgelb, sich verjiingend, locker, dümm; Aehrchen $1.3 \mathrm{~cm}$ breit, 2-und 3-körnig; Granıen holl, gespreizt, bis $8 \mathrm{~cm}$ lang. - Stroh: rötlich-gelb, ziemlich blattreich. - Frucht: rot, glasig, länglich, klein $\left(6^{1 / 2} \mathrm{~mm}\right.$ lang, $3^{1 / 4}$ min breit, 237 Früchte $\left.=10 \mathrm{gr}\right)$, feinschalig, schwer, hart, Bruch halbstahlig.

Herbstblatt blaugrün, schmal, kraus; Frühjahrsvegetation zeitig, Bestockung mittelstark, 4 Schösslinge, zeitig schossend und blühend. Halmlänge $110 \mathrm{~cm}$ ( Max. $130 \mathrm{~cm}$ ), Halmdicke $0.35 \mathrm{~cm}$, Blattzahl 3.7, Blattlänge $25.68 \mathrm{~cm}$, Blattbreite $0.91 \mathrm{~cm}$, Blattoberfläche $172.2 \mathrm{qcm}$, HalmHäche 115.5 qcm, Gesainmtoberfläche $287.7 \mathrm{qcm}$.

Junge Aehre gelbgrün, zeitig reifend, $10 \mathrm{~cm}$ (Nax. $13 \mathrm{~cm}$ ) lang, mit 16 Aehrchen und 35 Früchten, von denen 2061900 auf $1 \mathrm{hl}(=87 \mathrm{~kg}$ ) gehen.

Auf $1 \mathrm{qm}$ wachsen 1200 Halme oder 300 Pflanzen, mithin beträgt der Raum für eine Planze 33.3 qem, die Blattoberfäche p. qu Bodenfläche $34.5 \mathrm{qm}$ und das Saatquantum $2.2 \mathrm{hl} \mathrm{p}$. lia.

Es wiegen 100 Halme $326 \mathrm{gr}$ und davon die Friichte $172 \mathrm{gr}$.

Auf hochkultiviertem, reichem Boden lagert dieser Steppenweizen leicht, winterfest.

Vaterland: Rumänien.

Diese Weizensorte ist sehr nahe mit dem Banater Weizen verwandt.

\section{Froment d'Afrigue. (2)}

Aehre: hellgelb, zuweilen mit schwach rötlichem Schimmer, lang, sich wenig verjüngend, etwas locker; Aehrchen $1.5 \mathrm{~cm}$ breit, meist 3-körnig; Grannen hell, gespreizt, bis $10 \mathrm{~cm}$ lang. - Stroh: rötlich-gelb, fest, blattarm, lang. - Frucht: Original gelbrot, mehlig, nach erster Tracht fast Alles glasig und rot, länglich $\left(7 \mathrm{~mm}\right.$ lang, $3 \frac{1}{2} \mathrm{~mm}$ breit, 230 Köruer $=10 \mathrm{gr}$ ), etwas eingefallen, sehr feinschalig.

Herbstblatt blaugrün, fein, kraus, Frühjahrsvegetation mittelfrüh, Bestockung mittelstark, 4.2 Schösslinge, niittelfrüh schossend und blühend. Halmlänge $120 \mathrm{~cm}$ (Max. $145 \mathrm{~cm}$ ), Halmdicke $0.34 \mathrm{~cm}$, Blattzahl 3, Blatt- 
länge $24.77 \mathrm{~cm}$, Blattbreite $0.93 \mathrm{~cm}$, Blattoberfläche $138.24 \mathrm{qcm}, \mathrm{Halm}$ fläche 122.4 qcm, Gesammtfäche 260.64 qcm.

Junge Aehre blaugrïn, mittelfriil reifend, $11 \mathrm{~cm}$ (Max. $14 \mathrm{~cm}$ ) lang, mit 18 Aehrchen und 50 ziemlich festsitzenden Friichten, von denen 1994100 auf $\mathrm{l}$ hl (= $86.7 \mathrm{~kg})$ gehen.

Es wiegen 100 Halme $403 \mathrm{gr}^{\circ}$ und davon die Frïchte $194 \mathrm{gr}$. Das Stroll lagert selten, auch ist dieser Weizen winterfest.

Er wurde 1870 durch die Füstin $\mathbb{T}^{\mathrm{T}} \mathrm{ed}$ als eine in Rumänien gebaute Weizensorte dem hiesigen ökonomisch-botanischen Garten übelmittelt.

Sehr nahe dem Banatcr IVeizen verwandt.

\section{Blé Rab. (2)}

Aelire: blassgelb, fast weiss, mittellang. ziemlich dick, doch etwas locker; Aehrchen $1.4 \mathrm{~cm}$ breit, meist 3-körnig; Grannen gelb, wenig gesprcizt, bis $10 \mathrm{~cm}$ lang. - Stroh: rötlich-gclb, fest, wenig blattreich, lang. -- Frucht: Original gelbrot, mehlig, schon in erster Tracht glasig, etwas eingefallen, oval, ziemlich gross $\left(7 \frac{1}{2} \mathrm{~mm}\right.$ lang, $4 \mathrm{~mm}$ breit, 189 Frichte $=10 \mathrm{gr}$ ), feinschalig. halbhart, halbmchlig.

Herbstblatt blaugrïn, fein, kraus; Friiljahrsvegetation zeitig, Bestockung schwach, 3.9 Schösslinge, zeitig schossend und blühend. Halmlänge $125 \mathrm{~cm}$ (Yโax. $150 \mathrm{~cm}$ ), Halndicke $0.37 \mathrm{~cm}$, Blattzahl 3.3, Blattlänge $23.7 \mathrm{~cm}$, Blattbreite $0.86 \mathrm{~cm}$, Blattoberfläche $134.51 \mathrm{qcm}$, Halmfläche $\mathbf{1 3 8 . 7 5} \mathrm{qcm}$, Gesammtfäche $273.26 \mathrm{qcm}$.

Junge Aelire blaugriin, zeitig reifend, $9 \mathrm{~cm}$ (Max. $14 \mathrm{~cm}$ ) lang, mit 14 Aelirchen und 45 nicht leicht ausfallenden Früchten, von denen 1619730 auf $1 \mathrm{hl}(=85.7 \mathrm{~kg})$ gehen.

Es wiegen 100 Halme $400 \mathrm{gr}$ und davon die Früchte $196 \mathrm{gr}$.

Diescr Weizen lagert nicht leicht und ist ziemlich winterfest.

Er wurle 1870 durcli die Fïrstin TV ied als eine in Rumänien gebaute Weizcnsorte dem hicsigen ökonomisch-botanischen Garten übermittelt.

Sehr nale dem Banater Weizcn verwandt.

\section{Froment de Tiflis. (2)}

Aehre: blassgelb, fast weiss, sich verjuingend, locker, mittellang; Aehrchen meist 3-körnig; Grannen fast weiss, gesprcizt, bis $9 \mathrm{~cm}$ lang. Stroh: rötlich-gelb, fest. - Frueht: Original gelbrot, mellig, später auch glasig und rot, länglich ( $7 \mathrm{~mm}$ lang, $3 \frac{1}{2} \mathrm{~mm}$ breit, 215 Friichte $=10 \mathrm{gr}$ ), schwer, schr feinschalig, halbhart, Bruch halbmehlig.

Herbstblatt blaugriin, selur fein, kraus; Frülijalırsvegetation ziemlich zeitig, Bestockung mittelstark, 4.7 Schösslinge, ziemlich zeitig schossend und blïhend. Halmlänge $115 \mathrm{~cm}$ ( $Г a x .135 \mathrm{~cm}$ ), Halmdicke $0.3 \mathrm{~cm}$, Blattzahl 3, Blattoberfläche 115.2 qcm, Halmfläche 103.5 q cm, Gesammtfäche $218.7 \mathrm{qcm}$.

Junge Aehre blaugriin, ziemlich zeitig reifend, 9 cm (Мax. $12 \mathrm{~cm}$ ) lang, mit 15 A elıchen und 40 ziemlich festsitzenden Frïchten, von denen 1870500 auf 1 hl (= $87 \mathrm{~kg})$ gehen.

Es wiegen 100 Halme $330 \mathrm{gr}$ und davon die Früchte $161 \mathrm{gr}$. 
Da dieser Weizen winterfest und fruihreif ist, so darf er als vortrefflicher Steppenweizen gelten, auch lagert er nicht auf trocknem Lehmboden. Sein Mehl wird sehr geschätzt.

Fr wurde 1870 durch die Fürstin Wied als eine in Rumänien gebaute Weizensorte dem hiesigen ökonomisch-botanischen Garten übermittelt.

Sehr nahe dem Banater Weizen verwandt.

\section{Weizen (Jarica) aus Serbien. $\odot$}

Syn: Triticum vernum, Serbien.

Aehre: fast weiss, sich stark verjüngend, dïnn, ziemlich locker, kurz; Aehrchen 3-körnig, 3-grannig, mittlere kurz, 1 cm breit; Grannen hell, gespreizt, bis $8 \mathrm{~cm}$ lang. - Stroh: rötlich-gelb, kurz, steif. Frucht: Original rot, glasig, schr kleinkörnig $(387$ Früchte $=10 \mathrm{gr}$, $5 \mathrm{~mm}$ lang, $3 \mathrm{~mm}$ lreit); nacligebaut: grösser, 278 Frïchte $=10 \mathrm{gr}$, feinschalig, hart, Bruch stahlig.

Junges Blatt blaugrin, fein, kurz aber dicht behaart, zeitig schossend und bliihend, 2.4 Schösslinge; IIalm $80 \mathrm{~cm}$ (Max. $95 \mathrm{~cm})$ lang, $0.23 \mathrm{~cm}$ dick, Blattzahl 4, Blätter $14.3 \mathrm{~cm}$ lang, $0.6 \mathrm{~cm}$ breit, Blattfläche $68.6 \mathrm{cqcm}$, Halmfläche 55.2 q $\mathrm{cm}$, Gesammtflïche 123.8 q $\mathrm{cm}$. Früchten.

Junge Achre gelbgrün, mit 15 Achrchen und 42 lose sitzenden

\section{In 115 Tagen reifend.}

Bezugsquelle: Prof. Pantschits ch Belgrad, Serbien.

\section{Weissähriger roter Bartweizen ans Kastamuni, Türkei, Ílein-Asien. $\odot$ u. (2)}

Aehre: fast weiss, sehr schmal, locker; Aehrchen $1 \mathrm{~cm}$ breit, meist 2-körnig; Grannen lıcll, bis $9 \mathrm{em}$ lang, wenig gespreizt. - Stroh: gelb, dünnwandig, feinhalnnig. - Frucht: rot, glasig, länglich (7 mm lang, $3^{1} / 2 \mathrm{~mm}$ breit, 210 Körner $=10 \mathrm{gr}$ ), feinsehalig, halbhart, halbstahlig.

Herbstblatt blangriin, sehr fein, kraus; H'rïhjahrsvegetation mittelfrüh, Bestockung sehr stark, 8.3 Schösslinge, zeitig schossend nnd bJïhend. Halnılänge $110 \mathrm{~cm}$ (Max. $130 \mathrm{~cm}$ ), Halmdicke $0.28 \mathrm{~cm}$, Blattzahl 3.3, Blattlänge $21.68 \mathrm{~cm}$, Blattbreite $0.8 \mathrm{~cm}$, Blattoberfäche $114.44 \mathrm{qcm}, \mathrm{Halm}$ fläche $92.4 \mathrm{qcm}$, Gesammtfläche $206.84 \mathrm{qcm}$.

Als Sommerweizen gesäet, schosste, blïhte und reifte er mittelfriih, stand kräftig und schön und der Halm erreichte eine Maximallänge von $135 \mathrm{~cm}$.

Junge Aehre blaugriin, mittelfriih reifend, $9 \mathrm{~cm}$ (Max. $13 \mathrm{~cm}$ ) lang, mit 18 Aehrchen und 36 Früchten, von denen 1806000 auf 1 hl $(=86 \mathrm{~kg})$ gehell. $160 \mathrm{gr}$.

Es wiegen 100 Halme der Wintersaat $350 \mathrm{gr}$ und davon die Früchte

Das Stroh lagert ziemlich leicht, bleibt jedoch rostfrei.

Dieser Weizen ist nicht winterfest, so erfror derselbe in Poppelsdorf $1870 / 71$ vollständig.

Heimat: die Umgegend der Stadt Kastamuni in Pontischen Gebirge $850 \mathrm{~m}$ ii. M., in Klcin-Asien gelegen. 


\section{Weissähriger roter Bartweizen aus Haffkani, T'ürkei. (2)}

Aehre: blassgelb, fast weiss, sich verjügend, locker; Aehrchen $1.4 \mathrm{~cm}$ breit, 2- und 3-körnig; Grannen fast weiss, gespreizt, bis $8 \mathrm{~cm}$ lang. - Stroh: gelb, weich. - Frucht: rot, meist glasig, gross, plump, eingefallen $\left(7^{1} / 2 \mathrm{~mm}\right.$ lang, $4 \mathrm{~mm}$ breit, $\left.185 \mathrm{Körner}=10 \mathrm{gr}\right)$, etwas grobschalig, halbhart, Bruch halbstahlig.

Herbstblatt blaugrün, schmal, niederliegend; Frühjahrsvegetation mittelfrüh, Bestockung mittelstark, 4.6 Schösslinge, spät schossend und blühend. Halmlänge $130 \mathrm{~cm}$ (Max. $155 \mathrm{~cm}$ ), Halmdicke $0.35 \mathrm{~cm}$, Blattzahl 2.3, Blattlänge $26.23 \mathrm{~cm}$, Blat tbreite $0.92 \mathrm{~cm}$, Blattoberfläche $111 \mathrm{qcm}$, Halmfläche $148.2 \mathrm{qcm}$, Gesammtläche $259.2 \mathrm{qcm}$.

Junge Aehre blaugrin, spät reifend, $11 \mathrm{~cm}$ (Маx. $13 \mathrm{~cm}$ ) lang, mit 17 Aehrcheu und 40 ziemlich lose sitzenden Früchten, von denen 1631000 auf $\mathrm{l} \mathrm{hl}(=86 \mathrm{~kg})$ gehen.

Es wiegen 100 Halme $320 \mathrm{gr}$ und daron die Früchte $163 \mathrm{gr}$.

Das Stroh zeigt Neigung zum Lagern, daher sich diese Sorte nur für lëichtere, kalkreiche Böden eignet, auch verlangt sie ein mildes Klima.

Das landwirtschaftliche Ministerium schickte diesen Weizen 1\&69 zur Prïung ein.

\section{Gelbähriger roter Bartweizen aus Bigha, Ḱlein-Asien. $\odot$ u. (2)}

Aehre: weiss mit schwachrötlichem Schimmer, sich etwas verjüngend, sehr locker, mittellang; Aehrchen $1.2 \mathrm{~cm}$ breit, meist 2-körnig; Grannen blassgelb, abstehend, bis $8 \mathrm{~cm}$ lang. - Stroh: gelb, feinhalmig, weich, mittellang. - Frucht: rot, glasig, länglich $\left(7 \mathrm{~mm}\right.$ lang, $3^{1 / 2} \mathrm{~mm}$ breit, 220 Frichte $=10 \mathrm{gr}$ ), feinschalig, hart, Bruch halbstahlig.

Herbstblatt gelbgrün, breit, aufrecht; Frühjahrsvegetation zeitig, Bestockung schwach, 3 Schösslinge, zeitig schossend und blïhend. Halmlänge $115 \mathrm{~cm}$ (Jax. $135 \mathrm{~cm}$ ), Halmdicke $0.28 \mathrm{~cm}$, Blattzahl 3, Blattlänge $21.66 \mathrm{~cm}$, Blattbreite $0.86 \mathrm{~cm}$, Blattoberfläche eines Halmes $111.78 \mathrm{qcm}$, Halmfläche 96.6 qcm, Gesammtfläche 208.38 qcm.

Junge Aehre blaugrïn, frühreif, $9 \mathrm{~cm}$ (Мax. $13 \mathrm{~cm}$ ) lang, mit 16 Aehrehen und 30 festsitzenden Früchten, voll denen 1914000 auf $1 \mathrm{hl}$ $(=87 \mathrm{~kg})$ gehen.

Es wiegen 100 Halme $330 \mathrm{gr}$ und davon die Frïchte $150 \mathrm{gr}$.

Als Sonmerweizen kultiviert, zeigte er sich als solcher.

Für Deutschland ist dieser Weizen zu weichlich, lagert zu leicht und ist nicht genügend ertragreich.

\section{Champlain. $\odot$}

Aehre: fast weiss, sich verjüngend, aufrecht, locker, mittellang; Aehrchen meist 3-körnig und 3-grannig, Mittelgrannen kurz; Grannen fast weiss, gespreizt, bis $7 \mathrm{~cm}$ lang. - Stroh: goldgelb, fest, kaum mittellang. - Frucht: meist rot, glasig. wenn mehlig, so rötlich-gelb, rundlich, klein ( $6 \mathrm{~mm}$ lang, $3 \mathrm{~mm}$ breit, 289 Friichte $=10 \mathrm{gr}$ ), feinschalig, halbhart, Bruch halbmehlig.

Junges Blatt blaugrtin, ziemlich stark behaart; Bestockung mittel- 
stark, 2.4 Schösslinge; zeitig schossend und blühend. Halme $95 \mathrm{~cm}$ (Max. $105 \mathrm{~cm}$ ) lang, $0.32 \mathrm{~cm}$ dick, Blattzahl 3.8 , Blätter $14.8 \mathrm{~cm}$ lang, $0.8 \mathrm{~cm}$ breit, Blattlläche $90 \mathrm{qcm}$, Halmfläche $91.2 \mathrm{qcm}$, Gesammtfläche $181.2 \mathrm{qcm}$.

Junge Aehre bläulich-grün, reift in 122 Tagen, $9 \mathrm{~cm}$ (Max. $12 \mathrm{~cm}$ ) lang, mit 50 Früchten, von denen 2508520 anf $1 \mathrm{hl}(=86.8 \mathrm{~kg})$ entfallen.

Es wiegen 100 Halme $370 \mathrm{gr}$ und davon die Friichte $161 \mathrm{gr}$.

Diese beachtenswerte Sorte soll 1870 durch Mr. Pringle in Amerika aus einer Kreuzung des „Schwarzenmeer-Weizens", zu Trit. durum gehörig, mit dem "Golden-Drop" erzengt worden sein, doch ist dies im höchsten Grade unwahrscheinlich, denn Nichts erinnert bei diesem Kreuzungsprodukte an Trit. durum.

Bezugsquelle: Frommer in Budapest.

\section{Turkey-Wheat. (2)}

Syn: Turkish flint-wheat $\left.(\text { Olymp })^{1}\right)$.

Aehre: fast weiss, mit rötlichem Schimmer, halblocker, sich verjüngend, düun, kurz; Aehrehen 3-körnig, 3-grannig, $1.3 \mathrm{~cm}$ breit, Klappen gezahnt; Granuen hell, gespreizt, bis $9 \mathrm{~cm}$ lang. - Stroh: fast weiss, fein, sehr fest, kurz. - Frucht: Original rot, glasig, klein $(6 \mathrm{~mm}$ lang, $3 \mathrm{~mm}$ breit, 376 Früchte $=10 \mathrm{gr}$ ); nachgebaut: grösser, 245 Früchte $=10 \mathrm{gr}$, feinschalig, halbhart, Bruch halbstahlig.

Herbstblatt blangrïn, sehr fein, niederliegend; Entwickelung spät, 3.6 Schösslinge; Halm $95 \mathrm{~cm}$ (Max. $111 \mathrm{~cm}$ ) lang, $0.3 \mathrm{~cm}$ dick, Blattzahl 3.6, Blätter $15.3 \mathrm{~cm}$ lang, $0.7 \mathrm{~cm}$ breit, Blattlläche $77.1 \mathrm{qcm}$, Halmfläche $85.5 \mathrm{qcm}$, Gesammtfläche $162.6 \mathrm{qcm}$.

Junge Aehre bläulich-grün, zeitig reifend, $8 \mathrm{~cm}$ (Max. $11 \mathrm{~cm}$ ) lang, mit 15 Aehrchen und 40 Früchten, von denen 3384000 auf $1 \mathrm{hl}(=90 \mathrm{~kg})$ entfaller.

Winterfest, rostfrei, und in den mittleren Staaten der Union ergiebig, wo er seit 1850 kultiviert wird und von der Balkanhalbinsel (Olymp) stammt.

Bezugsquelle: Missouri Agric. Coll. 1880.

\section{Egyptian-Wheat. (2)}

Aehre: blassgelb, mittellang, sich verjüngend, locker; Aehrchen 3-körnig, 3-grannig, Klappen gezahnt; Granneu hell, gespreizt, bis $61 / 2 \mathrm{~cm}$ lang. - Stroh: rötlich-gelb, unter mittellang, sehr fest. - Frucht: Original gelbrot, mehlig, oval, klein (6 $\mathrm{mm}$ lang, $31 / 4 \mathrm{~mm}$ breit, 279 Früchte $=10 \mathrm{gr}$ ); nachgebant: glasig, grösser, 210 Früchte $=10 \mathrm{gr}$, feinhalmig, halbhart, Bruch halbmehlig.

Herbstblatt hellgrün, gross, aufrecht; Entwickelung zeitig, 3.4 Schösslinge, sehr zeitig schossend, mittelfrüh blülend; Halm $110 \mathrm{~cm}$ (Max. $125 \mathrm{~cm}$ ) lang, $0.38 \mathrm{~cm}$ dick, Blattzahl 4.6 , Blätter $20.8 \mathrm{~cm}$ lang, $0.9 \mathrm{~cm}$ breit, Blattfäche $172.2 \mathrm{qcm}$, Halmfläche $125.4 \mathrm{qcm}$, Gesammtfläche $297.6 \mathrm{qcm}$.

Junge Aehre blaugrün, zeitig reifend, $10 \mathrm{~cm}$ (11ax. $13 \mathrm{~cm})$ lang, mit

1) Transact. of the Americ. Inst. of the city of N. Y. 1854 p. 589. 
17 Aehrchen und 48 lose sitzenden Früchten, von denen 2469150 auf $1 \mathrm{hl}(=88.5 \mathrm{~kg})$ entfallen.

Winterfest, doch zum Rost neigend.

Kultiviert in den mittleren Staaten der Union. Aegyptischer Abstammung.

Bezugsquelle: Missouri Agric. Coll. 1881.

\section{Trigo jejár de Valencia.}

Syn.: A inerika: Geja wheat.

Deutsch: Weissähriger roter Bartweizen aus Talencia.

Aehre: weiss mit schwach rötlichem Anflug, sich verjingend, etwas locker, breit; Aehrehen $1.6 \mathrm{~cm}$ breit, 3-körnig und 3-grannig, davon eine kurz, hell, bis $10 \mathrm{~cm}$ lang, Klappen kurzgramig. - Stroh: rötlich-gelb, fest, aufrecht. - Frucht: rot, glasig, länglich $(7 \mathrm{~mm}$ lang, $3 \mathrm{~mm}$ breit, 230 Früchte $=10 \mathrm{gr})$, schön, feinsclialig, halbhart, Bruch halbstahlig.

Junges Blatt hellgrün, kraus, Bestockung zicmlich stark, 3.2 Schösslinge, zeitig schossend und blïhend. Halmlänge $120 \mathrm{~cm}$ (Max. $140 \mathrm{~cm}$ ), Halmdicke $0.33 \mathrm{~cm}$, Blattzahl 4, Blattlänge $32 \mathrm{~cm}$, Blattbreite $1.0 \mathrm{~cm}$, Blattoberfläche $256 \mathrm{qcm}$, Halmfl̈̈che $118.8 \mathrm{qcm}$, Gesammtläche $374.8 \mathrm{qcm}$.

Junge Aehre gelbgriin, in 130 Tagen reifend, $9 \mathrm{~cm}$ (Max. $11 \mathrm{~cm}$ ) langg, mit 15 Aehreken und 42 uicht leicht ausfallenden Früchten, ron denen 1978000 auf $1 \mathrm{hl}(=86 \mathrm{~kg}$ ) entfallen.

Es wiegen 100 Halme $344 \mathrm{gr}$ und davon die Früchte $166 \mathrm{gr}$. Das Stroh lagert nicht leicht.

Die eigentliche Heimat dieses Weizens ist Spanien, von wo aus derselbe zur Kultur nach Nord-Amerika gelangte und dort vielfach gebaut wird.

Ueberseuder der Originalsaat ist Gutsbesitzer Pfeiffer, Ossendorf bei Köln, 1878 .

\section{Trigo candeal tremesino marzal de raspa. $\odot$}

Syn.: Dreimonatweizen aus Spanien.

Aehre: rötlich-blassgelb, mittellang, dünn, sehr locker; Aehrchen 3--4-körnig, $1.5 \mathrm{~cm}$ breit; Grannen lell, zähe, bis $8 \mathrm{~cm}$ lang. - Stroh: rötlich-gelb, unter inittellang, fast markig. - Frucht: rotbraun, glasig, länglich, gross ( $8 \mathrm{~mm}$ lang, $3^{1 / 2} \mathrm{~mm}$ breit), feinschalig, halbhart, Bruch halbstahlig.

Junges Blatt dunkel blaugrün; spät schossend und blïhend, 2.8 Schösslinge; Halı $110 \mathrm{~cm}$ (Nax.: $135 \mathrm{~cm}$ ) lang, $0.3 \mathrm{~cm}$ dick, Blattzahl 4, Blätter $27 \mathrm{~cm}$ lang, $0.83 \mathrm{~cm}$ breit, Blattfläche $179.3 \mathrm{qcm}$, Halmfläche $99 \mathrm{qcm}$, Gesammtfläche $278.3 \mathrm{qcm}$.

Junge Aelıre blangrün, spät, in 127 Tagen reifend, $11 \mathrm{~cm}$ (Max. $14 \mathrm{~cm}$ ) lang, mit 40 leicht ausfallenden Früchten, von denen 1490000 auf $1 \mathrm{hl}(=82.8 \mathrm{~kg})$ entfallen.

Befällt leicht mit Rost.

Fïr das wärmere, gemässigte Klima geeignet und namentlich in Spanien gebaut.

Es wiegen 100 Halme $230 \mathrm{gr}$ und davon die Körner $172 \mathrm{gr}$.

Bezugsquelle: Wiener Ausstellung 1873. 


\section{Weissähriger roter Bartweizen aus Valencia mit beharten Halmknoten. $\odot$}

Aehre: dunkelgelb, sich rerjüngend. locker, mittellang; Aelirchen $1.2 \mathrm{~cm}$ breit, 3-körnig, 3-grannig, Nittelgrannen liurz, Klappen kurzgrannig: Grannen hell, wenig gespreizt, 9 cm lang. - Stroh: blassgelb, fest, mit markigem Rande oder ganz markig, Halmknoten dicht mit riickwärts stehenden Haaren, ganz wie bei Trit. monococcum besetzt, mittellang. Frucht: rot, glasig, ziemlich gross ( $7 \mathrm{~mm}$ lang, $3 \frac{3}{4} \mathrm{~mm}$ breit), feinschalig, halbliart, Bruch glasig.

Junges Blatt blaugriin, beiderseits kurz behaart, ziemlich schmal; 2.4 Schösslinge, zeitig schossend und bliihend. Halme $100 \mathrm{~cm}$ (Max. $110 \mathrm{~cm}$ ) lang, $0.3 \mathrm{~cm}$ dick, Blattzahl 4.4, Blätter $20 \mathrm{~cm} \mathrm{lang,} 0.7 \mathrm{~cm}$ breit, Blattflache $123.2 \mathrm{qcm}$, Halmfläche $90 \mathrm{qcm}$, Gesammtfläche $213.2 \mathrm{qcm}$.

Junge Aehre blaugrün, reift in 121 Tagen, $8 \mathrm{~cm}$ (IIax. $10 \mathrm{~cm}$ ) lang, mit 35 Friichten, voll denen 1746000 auf $1 \mathrm{hl}(=87.3 \mathrm{~kg}$ ) entfallen.

Es wiegen 100 Halme $300 \mathrm{gr}$, und davon die Ścheinfrüchte $139 \mathrm{gr}$. halten.

Original durch Gutsbesitzer Pfe iffer, Ossendorf bei Köln, 1878 er-

\section{Blat de Montjuich.}

Aehrc: blassgelb mit rötlichem Schimmer, sich verjiingend, halblocker, kurz; Aehrchen 3-körnig, 3-gramnig, mittlere Grannc kurz, Klappen gezahrit; Grannen hell, gespreizt, $7.5 \mathrm{~cm}$ lang. - Stroh: gclbrot, steif, kurz. - Frucht: Original gelbrot, mehlig, rundlich $\left(6^{1} / 2 \mathrm{~mm}\right.$ lang, $3^{1} / 2 \mathrm{~mm}$ breit, 249 Friichte $=10 \mathrm{gr}$ ), feinschalig.

Junges Blatt gelbgrün, fein, lang, aufrecht, 1.1 Schössling, sehr zeitig schossend und bliihend; Aehre $6 \mathrm{~cm}$ (Max. $8 \mathrm{~cm}$ ) lang, in 117 Tagen reifend; mit 11 Aehrchen und 30 leicht ausfallenden Früchten.

In Spanien kultiviert.

Bezugsquelle: Antonio Cipriano Costa, Barcelona 1881.

\section{Trigo ribeiro, Benavente, Portugal. $\odot$}

Aehre: blassgelb, ziemlich dicht, kurz; Aehrchen 3-4-körvig, 3glannig, mittlere knrz: Grannen hell, gespreizt, bis $22 \mathrm{~cm}$ lang. - Stroh: goldgelb, fein, unter mittellang, hohl. - Frncht: Original gelbrot, meist mehlig, doch einige rot und glasig, klein, schlank $\left(6^{1} / 2 \mathrm{~mm}\right.$ lang, $3 \mathrm{~mm}$ breit, 320 Friichte $=10 \mathrm{gr}$ ); nachgebaut: nur grösser, sonst konstant, 222 Körner $=10 \mathrm{gr}$, feinschalig, halbhart, Bruch halbstahlig.

Junges Blatt dunkelgrïn, fein, lang, aufrecht, zeitig schossend und bliilıend, 1.2 Schösslinge; Halın $105 \mathrm{~cm}$ (Yax. $120 \mathrm{~cm}$ ) lang, $0.3 \mathrm{~cm}$ dick, Blattzahl 4, Blätter $25 \mathrm{~cm}$ lang, $0.8 \mathrm{~cm}$ breit, Blattflüche $160 \mathrm{qcm}$, Halmtäche $94.5 \mathrm{qcm}$, Gesammtfläche $254.5 \mathrm{qcm}$.

Junge Aehre gelbgrïn, in 127 Tagen reifend, $7 \mathrm{~cm}$ (Max. 10 cm) lang, mit to Früchten, von denen 2742400 auf $1 \mathrm{hl}(=85.7 \mathrm{~kg})$ entfallen.

Leidet wenig durch Rost.

Es wiegen 100 Halme $241 \mathrm{gr}$, davon die Früchte $172 \mathrm{gr}$. Bezugsquelle: Prof. Jnl. Henriquez, Coïmbra, Portugal. 


\section{Trigo marzal da Corilhã, Portugal. $\odot$}

Aehre: rötlich-gelb, etwas locker; Aehrchen $1.6 \mathrm{~cm}$ breit, 3 - und 4-körnig, 3-grannig, Nittelgranne kurz; Grannen hell, gespreizt, zähe, bis $7 \mathrm{~cm}$ lang. - Stroh: rötlich-gelb bis goldgelb, fest, feinlialmig. - Frucht: rot, glasig, wenige mehlig, etwas eingefallen, länglich ( $7 \mathrm{~mm} \mathrm{lang,} 3^{1 / 2} \mathrm{~mm}$ breit), feinschalig.

Junges Blatt gelbgrün, aufrecht, kräftig, Bestockung schwach, 1.6 Schösslinge, sehr zeitig schossend und blühend. Halmlänge $90 \mathrm{~cm}$ (Max. $100 \mathrm{~cm}$ ), Halmdicke $0.28 \mathrm{~cm}$, Blattzahl 3, Blattlänge $18.8 \mathrm{~cm}$, Blattbreite $0.75 \mathrm{~cm}$, Blattoberfläche $84.6 \mathrm{qcm}$, Halmfläche $75.6 \mathrm{qcm}$, Gesammtfläche 160.2 qcm.

Junge Aehre bläulich-grün, sehr zeitig, in 115 Tagen reifend, $7.5 \mathrm{~cm}$ (Max. $10 \mathrm{~cm}$ ) lang, mit 13 Aehrchen und 45 Friuchten, von denen 2073000 auf $1 \mathrm{hl}(=84.6 \mathrm{~kg})$ gehen.

Das Stroh lagert nicht leicht, befällt jedoch mit Rost.

Es wiegen 100 Halme $298 \mathrm{gr}$ und davon die Früchte $139 \mathrm{gr}$.

Taterland: Am Fusse der Sierra da Estrella, Provinz Beira. baixa, Portugal.

\section{Grano marzuolo (Marzolano).}

Franz.: Blé de mars barbn de Toscane, Blé de chapeau de Toscane.

Engl.: Leghorn or Tuscany-wheat.

A merikanisch: Italian Spring-wheat.

De utsch: Toskanischer Sommerweizen.

Aehre: fast weiss, mittellang, etwas locker, diinn; Aehrchen $1.3 \mathrm{~cm}$ breit, 2- und 3-körnig, mit 2 längeren und einer kürzeren Granne; Grannen blassgelb, bis $13 \mathrm{~cm}$ lang. - Stroh: rötlich-gelb, lang, blattarm, dünnwandig, doch von sehr fester Textur, geschmeidig. - Frucht: rot, halbmehlig oder glasig, klein, länglich ( $7 \mathrm{~mm}$ lang, $31 \% \mathrm{~mm}$ breit), feinschalig, hart, Bruch halbstahlig.

Junges Blatt dunkelgrün, ziemlich schmal, aufrecht; 3 Schösslinge, zeitig schossend und blühend. Halmlänge $135 \mathrm{~cm}$ (Max. $145 \mathrm{~cm}$ ), Halmdicke $0.38 \mathrm{~cm}$, Blattzahl 3, Blattlänge $30.8 \mathrm{~cm}$, Blattbreite $0.78 \mathrm{~cm}$, Blattoberfläche eines Halmes 144.14 qcm, Halmfläche 153.9 qcm, Gesammtfläche 298.04 qcm.

Junge Aehre blaugrün, spät reifend, $10 \mathrm{~cm}$ (Max. $13 \mathrm{~cm}$ ) lang, mit 20 Aehrchen und 45 leicht ausfallenden Früichten, von denen 2402000 auf $1 \mathrm{hl}$ (= $85.8 \mathrm{~kg})$ gehen.

Auf 1 qm wachsen 1000 Halme oder 333 Pflanzen, mithin beträgt der Raum für eine Pflanzc 33.3 qcm, die Blattfläche p. qm Bodenfläche $29.8 \mathrm{qm}$ und das Saatquantum (1/3 Terlust) $1.1 \mathrm{hl} \mathrm{p.} \mathrm{lia.}$

Es wiegen 100 Halme $480 \mathrm{gr}$ und davon die Früchte $160 \mathrm{gr}$.

Als Winterweizen kultiviert, erwies er sich in Poppelsdorf als echter Sommerweizen.

Auf trocknen Lelımböden im Kontinental-Klima lagert dieser Weizen nicht und bleibt rostfrei.

In Italien ist das Mehl dieses Weizens wegen seines hohen Klebergehaltes zur Makaronifabrikation sehr geschätzt, doch wird er in Italien und vorzugsweise in einem Umkreise von $30-35 \mathrm{klm}$ um Sigma und Brozzi bei Florenz auch seines zur Strohhutfabrikation höchst verwendbaren Strohes wegen in bedeutendem Umfange angebaut. 
Zum Zwcck der Gewinnung von Hutstroh ${ }^{1}$ ) (paglia da capelli) wird dieser Weizen auf leichtem, sandigem, wenig fruchtbarem Boden im Thal des Arno kultiviert. Die Aussaat erfolgt im Februar in der Stärke von 8-10 hl p. ha, welche starke Aussaat zur Erziclung eines feinen Strohes notwendig ist. Subald der Weizen Ende Mai oder Anfang Juni seine kleine Aehre entwickelt hat, und die Halme eine Iänge von $30-40 \mathrm{~cm}$ erlangt haben, werden sie vorsichtig gerauft und darauf gebleicht. Der Ertrag stellt sich auf $7-8000 \mathrm{~kg}$ trocknes Stroh p. ha. Das gebleichte Stroh ist sehr fein, biegsam, glänzend und von schön weisser Farbe. Die Fabrikation und der Export nach Frankreich, Deutschland und anderen Ländern begann 1812, nnd die Dörfer, in welchen dieser Fabrikationszweig vorzugsweise betrieben wird, sind: Prato, Campi und Sesto.

Zum Zweck der Strohhutfabrikation wurde dieser Weizen auch nach England eingefuhrt, doch erwies sich das Produkt weniger gut als iu Italien und wurde daher durch Roggenstroh verdrängt.

Nach Amerika ${ }^{2}$ ) wurde zur Kornproduktion dieser kleberreiche Weizen 1831 durch J. B. Carbonari aus Florenz und zwar nach Oneida County eingefübrt, wo er sich seit dieser Zeit einer beträchtlichen Verbreitung erfreut.

Ausser in Mittel-Italien wird er gern im Gebirge angebaut, so in Piemont noch bis zu Höhen von $1400 \mathrm{~m}$.

\section{Grano comune. (2)}

Syn: Frumento nostrano.

Aehre: fast weiss, mit schwach rötlichem Schimmer, mittellang, sehr locker, sich stark verjüngend, dünn; Aehrchen 3-körnig, 3-grannig, mittlere Granne kurz, Klappen kurzgrannig; Grannen hell, gespreizt, bis $8 \mathrm{~cm}$ lang. - Stroh: rötlich-Weiss, kurz, fest. - Frucht: rotbrann, glasig, bauchig, etwas eingefallen, gross $\left(7^{3} / 4 \mathrm{~mm}\right.$ lang, $3^{1 / 2} \mathrm{~mm}$ breit, 189 Friichte $=10 \mathrm{gr}$ ); nachgebaut: konstant geblieben, hart, Bruch stahlig.

Herbstblatt dunkelgrïn, fein, anfrecht, beiderseits sammetig; Entwickelung spät, 2.2 Schösslinge, mittelfriih schossend und bliihend; Halm $90 \mathrm{~cm}$ (Max. $110 \mathrm{~cm}$ ) lang, $0.33 \mathrm{~cm}$ dick, Blattzahl 3.5, Blätter $21 \mathrm{~cm}$ lang, $0.8 \mathrm{~cm}$ breit, Blattfäche $117.6 \mathrm{qcm}$, Halmfläche $89.1 \mathrm{qcm}$, Gesammtfläche $206.7 \mathrm{qcm}$.

Junge Aehre bläulich, spät reifend, $10 \mathrm{~cm}$ (Max. $12 \mathrm{~cm}$ ) lang, mit 15 Aelrchen und 40 ziemlich leicht ausfallenden Früchten. Ziemlich winterfest und gegen Rost widerstandsfähig.

In Nord-Italien namentlich in Piemont, Toskana, Umbrien und den Marken gebaut; ertragreicher als Grano gentile bianco, doch seiu Mehl weniger beliebt.

- Bezugsquelle: Pariser Ausstellnng 1878 und Mailänder Ausstellung 1881 .

1) Vergl. Marchese Teodoro Ducessois, Monografia della Paglia da Capelli. Firenze 1878.

2) Henry Randal1, Transactions of the New York State Agric. Soc. Vol. I, 1842, pg. 360 . 


\section{Grano maiorica rossa di Puglia.}

Aehre: gelb mit schwachrötlichem Schimmer, aufrecht, ziemlich dicht, kaum mittellang; Aehrchen $1.5 \mathrm{~cm}$ breit, meist 3-körnig und 3-grannig; Grannen blassgelb, gespreizt, bis $9 \mathrm{~cm}$ lang. - Stroh: blassgelb, fest, feinhalmig, mittellang. - Frucht: rotbraun, glasig, gross, länglich $\left(8 \mathrm{~mm}\right.$ lang, $3^{3 / 4} \mathrm{~mm}$ breit, 189 Früchte $\left.=10 \mathrm{gr}\right)$, etwas grobschalig, halbhart.

Junges Blatt blaugrün und schwach sammetig; Bestockung stark, 4 Schösslinge, sehr zeitig schossend und bliihend. Halm $100 \mathrm{~cm}$ (Мax. $110 \mathrm{~cm}$ ) lang, $0.27 \mathrm{~cm}$ dick, Blattzahl 4.4, Blätter $19.3 \mathrm{~cm}$ lang, $0.77 \mathrm{~cm}$ breit, Blattfläche $124 \mathrm{qcm}$, Halmfläche $81 \mathrm{qcm}$, Gesainmtfläche $205 \mathrm{qcm}$.

Junge Aehre blangriin, reift in 123 Tagen, $8 \mathrm{~cm}$ (Max. $10 \mathrm{~cm}$ ) lang, mit 15 Aehrehen und 42 Früchten, von denen 1587600 auf $1 \mathrm{hl}(=$ $84 \mathrm{~kg}$ ) entfalle1.

Es wiegen 100 Halme $400 \mathrm{gr}$, und davon die Friichte $172 \mathrm{gr}$.

Dieser Weizen zeigte etwas Neigung zum Lagern und geringe Widerstandsfähigkeit gegen Rust.

Er wird vorzugsweise in Süd-Italien und auf Sicilien kultiviert.

Original von der Pariser Weltausstellung 1878 erhalten.

\section{Grano rosso. Ex Apulia. $\odot$}

Aehre: gelb, sich verjiingend, dünn, mittellang; Aehrchen $1.3 \mathrm{~cm}$ breit, 2- und 3-körnig und grannig; Grannen hell, gespreizt, $9 \mathrm{~cm}$ lang. Stroh: rötlich-weiss, ziemlich blattreich, fest, Innenrand markig, lang. Frucht: rot, glasig, länglich (7 $\mathrm{mm}$ lang, $3 \frac{1}{2} \mathrm{~mm}$ breit), etwas eingefallen, feinschalig, hart, halbstahlig.

Junges Blatt blangriin, ziemlich lang; 3.0 Schösslinge, mittelfrüh schossend und blühend. Halne $115 \mathrm{~cm}$ ( $\left({ }_{a x} .140 \mathrm{~cm}\right.$ ) lang, $0.35 \mathrm{~cm}$ dick, Blattzahl 4.2, Blätter $27.8 \mathrm{~cm}$ lang, $0.8 \mathrm{~cm}$ breit, Blattfläche $186.82 \mathrm{qcm}$, Halmfläche $120.75 \mathrm{qcm}$, Gesammtfläche $307.57 \mathrm{qcm}$.

Junge Aehre bläulich-griin, reift in 123 Tagen, $9 \mathrm{~cm}$ (Max. $14 \mathrm{~cm}$ ) lang, mit 14 Aehrchen und 28 ziemlich fest sitzenden Früchten, von denen 1740000 auf $1 \mathrm{hl}(=87 \mathrm{~kg})$ entfallen.

Auf 1 qm wachsen 900 Halme oder 300 Pflanzen, mithil beträgt das Saatquantum $2.6 \mathrm{hl} \mathrm{p}$. ha.

Es wiegen 100 Halme $415 \mathrm{gr}$, und davon die Früchte $145 \mathrm{gr}$.

Diese italienische Sorte wurde 1876 durch Dr. Pedecino aus Portici eingesandt.

\section{Grano Serino. $\odot$}

Aehre: blassgelb mit rötlichem Schimmer, sich ein wcnig verjüngend, mittellang; Aehrchen $1.2 \mathrm{~cm}$ breit, 3-körnig, 3-grannig, Mittclgranne kurz; Klappen gramenspitzig; Grannc hell, etwas gespreizt, $7.5 \mathrm{~cm}$ lang. Stroh: gelb, fest, steif, kaum mittellang. - Frucht: rot, glasig, zuweilen gelbrot und mehlig, gross $(71 / 2 \mathrm{~mm}$ lang, $4 \mathrm{~mm}$ breit, 148 Früchte $=$ $10 \mathrm{gr}$ ). etwas grobschalig, halbweich, Bruch halbmellig.

Junges Blatt blaugriin, oberseits zerstrent kurzhaarig; Bestockung stark, 4 Schösslinge, zeitig schossend und blühend. Halme $90 \mathrm{~cm}$ (Max. 
$105 \mathrm{~cm}$ ) lang, $0.33 \mathrm{~cm}$ dick, Blattzahl 5, Blätter $17.4 \mathrm{~cm}$ lang, $08 \mathrm{~cm}$ breit, Blattfläche 139.2 qcm, Halmfläche $89.1 \mathrm{qcm}$, Gesammtfläche $228.3 \mathrm{qcm}$.

Junge Aehre blaugrün, in 123 Tagen reifend, $8 \mathrm{~cm}$ (Max. $11 \mathrm{~cm}$ ) lang, mit 12 Aehrchen und 32 lose sitzenden Früchten, von denen 1284640 auf $1 \mathrm{hl}(=86.8 \mathrm{~kg})$ entfallen.

Es wiegen 100 Halme $381 \mathrm{gr}$, und davon die Friichte $170 \mathrm{gr}$.

Original von der Pariser Weltausstelluug 1878 und Mailänder Ausstellung 1881 erhalten.

\section{Vulgo Granillo e Salerno. $\odot$}

Deutsch: Gelbähriger, roter Sommer-Bartweizen aus Salerno.

Aehre: rötlich-gelb, sehr locker, mittellang, dünn; Aehrchen $1.5 \mathrm{~cm}$ breit, 2- und 3-körnig und mit 2 langen und 1 kurzen Granne; Grannen rötlich-gelb, etwas abstehend, bis $9 \mathrm{~cm}$ lang, nicht leicht abbrechend. Stroh: rötlich-gelb, derbwandig, mittellang. - Frucht: Original gelbrot, klein, mehlig; nachgebaut: rot, glasig, eingefallen, plump (7 mm lang, $4 \mathrm{~mm}$ breit), sehr schwer, feinschalig.

Blätter dunkelgrün, 2.2 Schösslinge, mittelfrüh schossend und blühend, Halmlänge $105 \mathrm{~cm}$ (Max. $135 \mathrm{~cm}$ ), Halmdicke $0.3 \mathrm{~cm}$, Blattzahl 3.7 , Blattlänge $22.75 \mathrm{~cm}$, Blattbreite $0.69 \mathrm{~cm}$, Blattfläche eines Halmes $116.18 \mathrm{qcm}$, Halmfläche $94.5 \mathrm{qcm}$, Gesammtfläche $210.68 \mathrm{qcm}$.

Junge Aebre gelbgrün, in 127 Tagen reifend, $10 \mathrm{~cm}$ (Max. $13 \mathrm{~cm}$ ) lang, mit 16 Aehrchen und 40 sehr leicht ausfallenden Früchten, von denen 1992000 auf $1 \mathrm{hl}$ (=86.6 kg) gehen.

Auf 1 qm wachsen 1300 Halme oder 600 Pflanzen, mithin beträgt der Raum für eine Pflanze $16.7 \mathrm{qcm}$, die Blattfläche p. qm Bodenfläche $27.3 \mathrm{qm}$ und das Saatquantum $4.5 \mathrm{hl} \mathrm{p}$. ha.

Es wiegen 100 Halme $310 \mathrm{gr}$ und davon die Friichte $120 \mathrm{gr}$.

Im trocknen, warmen Klima und für Lehmboden ist dies ein schöner, ertragreicher Weizen, der ein sehr kleberreiches Mehl liefert. Auf dem reichen Boden zu Poppelsdorf zeigte er Neigung zum Lagern, wurde aber nur wenig durch Rost befallen.

Uebersender: Prof. Pedecino in Portici, Italien.

\section{Frumento di Rieti. (2)}

Aehre: weiss, mit schwach rötlichem Anflug, dünn, locker; Aehrchen 3- und 4-körnig, 3-grannig, Grannen hell, gespreizt, bis $8 \mathrm{~cm} \mathrm{lang.} \mathrm{-}$ Stroh: rötlich-gelb, mittellang, fest. - Frucht: rot, glasig, mittelgross, schlank, sebr schön, feinschalig, hart, Bruch stahlig.

Aehre $12 \mathrm{~cm}$ lang, mit 22 Aehrchen und 60 Früchten.

Heimat: Sabiner-Gebirge in Umbrien.

Hat in den letzten Jahren grossen Ruf und weite Verbreitung durch Italien erhalten.

Saatgetreide wird vom "Comizio agrario Sabino di Rieti" abgegeben. Bezugsquelle: Mailänder Ausstellung 1881.

\section{Frumento detto grosso. (2)}

Aehre: blassgelb, sehr locker, lang; Aehrchen $1.5 \mathrm{~cm}$ breit und $1.5 \mathrm{~cm}$ hoch, meist 3-körnig; Klappen gezahnt; Grannen gespreizt, $6 \frac{1}{2} \mathrm{~cm}$ 
lang. - Stroh: rötlich-gelb, mittellang, fest. - Frucht: rot, etwas eingedrückt, lang, gross $\left(8 \mathrm{~mm}\right.$ lang, $3 \frac{1}{2} \mathrm{~mm}$ breit und dick, 175 Früchte $=10 \mathrm{gr})$, feinschalig, halbhart, Bruch halbstahlig.

Herbstblatt blaugriin, sehr lang, breit; Entwickelung sehr zeitig, 3 Schösslinge; Halm $125 \mathrm{~cm}$ ( Wax. $140 \mathrm{~cm}$ ) lang, $0.4 \mathrm{~cm}$ dick, Blattzahl 4, Blätter $20.8 \mathrm{~cm} \mathrm{lang,} 1 \mathrm{~cm}$ breit, Blattfläche $164.6 \mathrm{qcm}$, Halmfläche $150 \mathrm{qcm}$, Gesammtfl̈̈che $314.6 \mathrm{qcm}$.

Junge Aehre blä ulich, mittelfrüh reifend, $12 \mathrm{~cm}$ (Мax. $15 \mathrm{~cm}$ ) lang, mit 50 Früchten.

Widerstandsfähig gegen Lagern und Rost. Kultiviert in Italien. Bezugsquelle: Pariser Ausstellung 1878.

\section{Griechischer Sommerweizen ron Petali. $\odot$}

Aehre: weiss, mit rötlichem Schimmer, dicht, kurz; Aehrchen $1.8 \mathrm{~cm}$ breit, 4-körnig; Grannen gespreizt, zerbrechlich, bis $17 \mathrm{~cm}$ lang. - Stroh: rötlich-gelb, steif, markig, unter mittellang. - Frucht: rot, glasig, wenige mehlig, stark eingefallen, plump, sehr gross ( $7 \mathrm{~mm}$ lang, $4 \mathrm{~mm}$ breit), feinschalig, halbhart, Bruch halbmehlig.

Junges Blatt hellgriin, fein; 2.2 Schösslinge, sehr zeitig schossend und blühend; Halm $100 \mathrm{~cm}$ (Max. $125 \mathrm{~cm}$ ) lang, $0.37 \mathrm{~cm}$ dick, Blattzahl 4,4, Blätter $24.4 \mathrm{~cm}$ lang, $0.8 \mathrm{~cm}$ breit, Blattfläche 171.8 q $\mathrm{cm}$, Halmfläche $111 \mathrm{qcm}$, Gesammtfläche $292.8 \mathrm{qcm}$.

Junge Aehre blaugrün, in 128 Tagen reifend, $8 \mathrm{~cm}$ (Max. $9 \mathrm{~cm}$ ) lang, mit 60 sehr fest ron den Spelzen umschlossenen Frïchten, von denen 1696000 auf $1 \mathrm{hl}(=84.8 \mathrm{~kg})$ entfallen.

Bezugsquelle: Haage \& Schmidt, Erfurt.

\section{Griechischer Weizen aus Messenien. () u. (2)}

Aehre: fast weiss, sich wenig verjüngend, locker, lang, breit; 3und 4-körnig; Grannen fast weiss, etwas abstehend, bis $10 \mathrm{~cm}$ lang. Stroh: gelb oder rotblau, kräftig, sehr lang. - Frucht: rot, glasig, etwas eingefallen, länglich, gross $\left(\tau^{1} / 2 \mathrm{~mm}\right.$ lang, $3^{1} / 2 \mathrm{~mm}$ breit, 205 Früchte (= $10 \mathrm{gr}$ ), feinschalig, hart, Bruch glasig.

Blätter dunkelgrün, schmal, kraus, 4.4 Schösslinge, selır zeitig schossend und blühend. Halmlänge $145 \mathrm{~cm}$ (Max. $155 \mathrm{~cm}$ ), Halmdicke $0.4 \mathrm{~cm}$, Blattzahl 5, Blattlänge $25.5 \mathrm{~cm}$, Blattbreite $1.0 \mathrm{~cm}$, Blattoberfläche eines Halmes $255 \mathrm{qcm}$, Halmfläche $174 \mathrm{qcm}$, Gesammtfläche $429 \mathrm{q} \mathrm{cm}$.

Junge Aehre bläulich-grün, in 120 Tagen reifend, $13 \mathrm{~cm}$ (Маx. $15 \mathrm{~cm})$ lang, mit 18 Aehrchen und 60 etwas lose sitzenden Früchten, von denen 1722000 auf $1 \mathrm{hl}(=84 \mathrm{~kg})$ gehen.

Es wiegen 100 Halme $490 \mathrm{gr}$ und daron die Früchte $200 \mathrm{gr}$.

Das Stroh lagert nicht leicht, befällt jedoch mit Rost.

Diese Sorte wurde $1879 / 80$ als Winterweizen erfolgreich kultiviert.

Für trockne Lehmböden im süd-westlichen Deutschland ist dieser Weizen vielleicht beachtenswert.

Bezugsquelle: Itzenplitz, Köln. 


\section{Ghirka ostistaja. $\odot$}

Syn.: Gelbähriger roter Bartweizen von Kupjansk, am Oskol, Gouvernement Charkow, Russland.

Aehre: fast weiss, ziemlich dicht, sich etwas verjüngend; Aehrchen $1.3 \mathrm{~cm}$ breit, meist 3-körnig; Grannen weiss, abstehend, bis $11 \mathrm{~cm}$ lang. - Stroh: gelb, fest, blattarm. - Frucht: Original rot, glasig, schön, sehr klein ( $6 \mathrm{~mm}$ lang, $3 \mathrm{~mm}$ breit, 375 Früchte $=10 \mathrm{gr}$ ), hart, Bruch stahlig.

Blatt dunkelgrün, schmal, 1.2 Schösslinge, sehr spät schossend und blïhend. Halmlänge $115 \mathrm{~cm}$ (Max. $130 \mathrm{~cm}$ ), Halmdicke $0.33 \mathrm{~cm}$, Blattzahl 3.4 , Blattlänge $22.3 \mathrm{~cm}$, Blattbreite $0.88 \mathrm{~cm}$, Blattoberfläche eines Halmes $133.44 \mathrm{qcm}$, Halmfläche $113.85 \mathrm{qcm}$, Gesammtfläche $247.29 \mathrm{qcm}$.

Junge Aehre gelbgriin, in 140 Tagen, also sehr spät reifend, $8.5 \mathrm{~cm}$ (Max. $11 \mathrm{~cm})$ lang, mit 14 Aehrchen und 40 ziemlich fest sitzenden Früchten, von denen 3150000 auf $1 \mathrm{hl}(=84 \mathrm{~kg})$ gehen.

Es wiegen 100 Halme $400 \mathrm{gr}$ und davon die Früchte $170 \mathrm{gr}$.

Dieser vorzügliche südrnssische Steppenweizen lagert nicht und leidet wenig durch Rost:

Uebersender: Prof. Saykewits ch, Charkow.

\section{Saksonka. $\odot$}

Syn.: Sächsischer Weizen aus den deutschen Kolonieen der Gouvernements Saratow und Samara, Russland.

Aehre: fast weiss mit schwach rötlichem Anflug, sich nach der Spitze verjüngend, schmal, dünn, aufrecht, sehr locker, mittellang; Aehrchen $1.1 \mathrm{~cm}$ breit, meist 3-körnig und 3-grannig, Mittelgrannen kürzer; Granne blassgelb, gespreizt, bis $10 \mathrm{~cm}$ lang. - Stroh: blassgelb, feinhalmig, fest, kaum mittellang. - Frucht: Original rot, glasig, sehr klein, $\left(6 \mathrm{~mm}\right.$ lang, $2 \frac{1}{2} \mathrm{~mm}$ breit, 512 Früchte $\left.=10 \mathrm{gr}\right)$; nachgebaut: grösser und rundlicher, mehliger, auf $10 \mathrm{gr}$ gehen nur 284 Früchte, feinschalig, hart, Bruch stahlig.

Junge Blätter und Blattscheiden graugrün, stark sammetig behaart; Bestockung ziemlich stark, 3 Schösslinge, spät schossend und blühend. Halme $85 \mathrm{~cm}$ (Max. $100 \mathrm{~cm}$ ) lang, $0.3 \mathrm{~cm}$ dick, Blattzahl 3.4, Blätter $15 \mathrm{~cm}$ lang, $0.7 \mathrm{~cm}$ breit, Blattfläche $71.4 \mathrm{qcm}$, Halmfläche $76.5 \mathrm{qcm}$, Gesammtfläche $147.9 \mathrm{qcm}$.

Junge Aehre blaugrün, in 123 Tagen reifend, $9 \mathrm{~cm}$ (Max. 12 cm) lang, mit 12 Aehrchen und 34 etwas lose sitzenden Früchten, von denen 4403200 auf $1 \mathrm{hl}(=86 \mathrm{~kg})$ entfallen.

Es wiegen 100 Halme $215 \mathrm{gr}$ und davon die Früchte $96 \mathrm{gr}$.

Diese Sorte gehört zu den russischen Weichweizen und wurde 1880 durch Professor Saykewitsch, Charkow eingesandt.

\section{Weissähriger roter Bartweizen rom Altai. $\odot$}

Aehre: fast weiss, sich verjüngend, dünn, locker, mittellang; Aehrchen $1 \mathrm{~cm}$ breit, 3-körnig, 3-grannig, Mittelgranne kurz, Klappen mit Zahn; Grannen hell, gespreizt, $8 \mathrm{~cm}$ lang. - Stroh: goldgelb, fest, feinhalmig, mittellang. - Frucht: gelbrot, mehlig, einige rot und glasig, 
rundlich, kleìn $\left(5^{1 / 2} \mathrm{~mm} \text { lang, } 31 / 4 \mathrm{~mm} \text { breit, } 324 \text { Früchte }=10 \mathrm{gr}\right)_{\text {r }}$ feinschalig, halbhart, Bruch halbstahlig.

Junges Blatt blaugrtin, dicht aber kurz behaart, schmal, aufrecht; 2.2 Schösslinge, spät schossend und blühend. Halm $110 \mathrm{~cm}($ Wax. $130 \mathrm{~cm})$ lang, $0.39 \mathrm{~cm}$ dick, Blattzahl 3, Blätter $23 \mathrm{~cm}$ lang, $1.08 \mathrm{~cm}$ breit, Blattfläche $149.04 \mathrm{qcm}$, Halmfläche $128.7 \mathrm{qcm}$, Gesammtfläche $277.74 \mathrm{qcm}$.

Junge Aehre blaugrün, reift in 121 Tagen, $10 \mathrm{~cm}$ (Max. $12 \mathrm{~cm}$ ) lang, mit 19 Aehrchen und 54 Früchten, von denen 2637360 auf 1 hI $(=81.4 \mathrm{~kg})$ entfallen.

Es wiegen 100 Haliue $200 \mathrm{gr}$ und davon die Früchte $88 \mathrm{gr}$.

Als Winterfrucht kultiviert, kommen nur wenige kümmerliche Pflanzen durch den Winter, auch befällt dieser Weizen stark mit Rost.

Uebersender Dr. Finsch und Graf Z eil 1879.

\section{Weissähriger roter Weizen aus Turkestan. $\odot$}

Aehre: blassrot, im Original kurz, doch in 1. Tracht -mittellang geworden, sich verjuingend; Aehrchen $1.2 \mathrm{~cm}$ breit, 3-körnig, 3-grannig, Klappen kurzgrannig; Grannen hell, bis $8 \mathrm{~cm}$ lang. - Stroh: schön gelb, fest, mittellang. - Frucht: Original blassrot, mehlig; nachgebaut: rot, fast Alles glasig, länglich ( $7 \mathrm{~mm}$ lang, $3^{1} / 4 \mathrm{~mm}$ breit, 227 Früchte $=10 \mathrm{gr}$ ), schön, feinschalig, hart, Bruch halbmehlig.

Junges Blatt hellgrün, beiderseits stark behaart, breit; 2.5 Schösslinge, zeitig schossend und blühend. Halm $100 \mathrm{~cm}$ ( Мax. 130 cm) lang, $0.35 \mathrm{~cm}$ dick, Blattzahl 3, Blätter $27 \mathrm{~cm}$ lang, $0.8 \mathrm{~cm}$ breit, Blattfläche $129.6 \mathrm{qcm}$, Halmfläche $105 \mathrm{qcm}$, Gesammtfläche $234.6 \mathrm{qcm}$.

Junge Aehre blaugrün, reift in 121 Tagen, $9 \mathrm{~cm}$ (Nax. $11 \mathrm{~cm}$ ) lang, mit 16 Aehrehen und 46 fest sitzenden Früchten, von denen 1847780 auf $1 \mathrm{hl}(=81.4 \mathrm{~kg})$ entfallen.

Es wiegen 100 Halme $320 \mathrm{gr}$ und davon die Früchte $148 \mathrm{gr}$.

Als Winterweizen gebaut, kamen nur einige Pflanzen durch den Wiuter, er ist daher ein echter Sommerweizęn, der etwas leicht dem Rost und Lagern unterliegt. erhalten.

Original durch den Reisenden Dr. Alb. R egel aus Turkestan

\section{Bartweizen aus Nepal (Himalaya). (2) u. $\odot$}

Aehre: fast weiss, sich etwas verjüngend, locker; Aehrchen 2- und 3-körnig, $1.5 \mathrm{~cm}$ breit; Grannen weiss, seitlich abstehend, bis $8 \mathrm{~cm}$ lang. Stroh: gelb, wenig blattreich, mittellang. - Frucht: rot, meist glasig, etwas eingefallen, länglich ( $7 \mathrm{~mm}$ lang, $3 \frac{1}{2} \mathrm{~mm}$ breit, 214 Früichte $=10 \mathrm{gr}$ ), schwer, feinschalig, hart, Bruch halbstahlig.

Herbstblatt dunkelgrün, kräftig, aufrecht; Frühjahrsvegetation zeitig, Bestockung stark, 5.3 Schösslinge, mittelfrüh schossend und blühend; Halmlänge $100 \mathrm{~cm}$ (Max. $120 \mathrm{~cm}$ ), Halmdicke $0.27 \mathrm{~cm}$, Blattzahl 3.5, Blattlïnge $20.8 \mathrm{~cm}$, Blattbreite $0.76 \mathrm{~cm}$, Blattoberfläche eines Halmes $110.67 \mathrm{qcm}$, Halmfläche $81 \mathrm{qcm}$, Gesammtfläche $191.67 \mathrm{qcm}$.

Junge Aehre gelbgrün, zeitig reifend, $9 \mathrm{~cm}$ (Max. $13 \mathrm{~cm}$ ) lang, mit 16 Aehrchen und 45 leicht ausfallenden Früchten, von denen 1840400 auf $1 \mathrm{hl}(=86 \mathrm{~kg})$ gehen.

Es wiegen 100 Halme $480 \mathrm{gr}$ und davon die Früchte $175 \mathrm{gr}$. 
Der Weizen ist ziemlich winterfest, zeigt jedoch auf reichen Boden Neigung zum Lagern und befällt sehr stark mit Rost, so dass er für Deutschland wohl keine Bedeutung hat.

Als Sommerweizen kultiviert, erwies er sich als solcher.

Uebersender: Oek.-bot. Garten zu Halle.

\section{Weissähriger roter Bartweizen aus Ostindien. $\odot$}

Aelıre: blassgelb mit schwach rötlichem Schimmer, dünn, sich verjüngend, etwas locker, kurz; Aehrchen $1 \mathrm{~cm}$ breit, 3-körnig, 3-grannig, Mittelgranne kurz, Klappen mit Zahn; Grannen hell, wenig gespreizt, $5 \mathrm{~cm}$ lang. - Stroh: gelb, Innenrand markig, aufrecht, kurz. - Frucht: rot, glasig, oval, klein ( $6 \mathrm{~mm}$ lang, $3^{1} / 2 \mathrm{~mm}$ breit, 280 Früchte $\left.=10 \mathrm{gr}\right)$, feinschalig, hart, Bruch halbstahlig.

Junges Blatt gelbgrün, oberseits behaart, aufrecht, 3.2 Schösslinge, zeitig schossend und blühend. Halme $65 \mathrm{~cm}$ (Max. $75 \mathrm{~cm}$ ) lang, $0.25 \mathrm{~cm}$ dick, Blattzahl 3, Blätter $11.8 \mathrm{~cm}$ lang, $0.53 \mathrm{~cm}$ breit, Blattfläche 37.52 qcm, Halmfläche $48.75 \mathrm{qcm}$, Gesammtfläche $86.27 \mathrm{qcm}$.

Junge Aehre gelbgrün, reift in 120 Tagen, $6 \mathrm{~cm}$ (Jax. $7 \mathrm{~cm}$ ) lang, mit 12 Aehrchen und 32 ziemlich fest sitzenden Früchten, von denen 1371600 auf $1 \mathrm{hl}(=84.7 \mathrm{~kg})$ entfallen.

Es wiegen 100 Halme $180 \mathrm{gr}$ und davon die Früchte $96 \mathrm{gr}$.

Der Weizen befällt sehr stark mit Rost, in Folge dessen das Stroh sehr mürbe wird.

\section{Varietät: Triticum vulgare erythroleucon Kcke.}

Aehren kahl, rot; Körner weiss oder gelblich.

\section{Sorten:}

\section{Rotähriger weisser Bartweizen aus Turkestan. $\odot$}

Aehre: blassrot, bläulich bereift, aufrecht, sich verjüngend, locker, mittellang; Aehrchen $1.2 \mathrm{~cm}$ breit, an der Spindel etwas schräg angesetzt, 3-körnig, 3-grannig, Mittelgranne kurz, Spelzen dick, Klappen ziemlich langgrannig; Granne hell, gespreizt, bis $9 \mathrm{~cm}$ lang. - Stroh: rötlich-gelb, fest, kurz. - Frucht: rötlich-gelb, glasig, gross $\left(7 \mathrm{~mm}\right.$ lang, $3 \frac{1}{2} \mathrm{~mm}$ breit, 194 Früchte $=10 \mathrm{gr}$ ), feinschalig.

Junges Blatt blaugrün, behaart, 2.2 Schösslinge, spät schossend und blühend. Halm $85 \mathrm{~cm}$ (Max. $95 \mathrm{~cm}$ ) lang, $0.3 \mathrm{~cm}$ dick, Blattzahl 4, Blätter $16.5 \mathrm{~cm}$ lang, $0.83 \mathrm{~cm}$ breit, Blattfläche $109.56 \mathrm{qcm}$, Halmfläche $76.5 \mathrm{qcm}$, Gesammtfläche $186.06 \mathrm{qcm}$.

Junge Aehre blaugrün, in 120 Tagen reifend, $8 \mathrm{~cm}$ (Max. $10 \mathrm{~cm}$ ) lang, mit 13 Aehrchen und 35 fest sitzenden Früchten, von denen 1668400 auf $1 \mathrm{hl}(=86 \mathrm{~kg})$ entfallen.

Es wiegen 100 Halme $349 \mathrm{gr}$ und daron die Früchte $169 \mathrm{gr}$.

Der Weizen unterliegt sehr leicht dem Rost.

Von Fetisow gesammelt und durch E. Regel übersandt. 


\section{Rotähriger weisser Bartweizen aus Persien. $\odot$}

Aehre: blassrot, sich verjüngend, aufrecht, dünn, locker, mittellang; Aehrchen $1.1 \mathrm{~cm}$ breit, meist 3-körnig und 3-grannig, Mittelgranne kurz, Klappen mit Zahn, Spelzen lederartig; Granne hell, gespreizt, bis $6 \mathrm{~cm}$ lang. - Stroh: gelb, steif, kurz. - Frucht: blassrötlich, glasig, klein (6 $\mathrm{mm}$ lang, $3 \mathrm{~mm}$ breit, 314 Früchte $=10 \mathrm{gr}$ ), feinschalig.

Junges Blatt hellgrïn, aufrecht; 2 Schösslinge; Halme $80 \mathrm{~cm}$ (Max. $95 \mathrm{~cm}$ ) lang, $0.33 \mathrm{~cm}$ dick, Blattzahl 3.2 , Blätter $24 \mathrm{~cm}$ lang, $0.85 \mathrm{~cm}$ breit, Blattfläche $130.56 \mathrm{qcm}$, Halmfläche $79.2 \mathrm{qcm}$, Gesammtfläche $209.76 \mathrm{qcm}$.

Junge Aehre gelbgrün, reift in 125 Tagen, $8 \mathrm{~cm}$ (Max. $10 \mathrm{~cm}$ ) lang, mit 13 Aehrchen und 35 Früchten, von denen 2700400 auf $1 \mathrm{hl}$ $(=86 \mathrm{~kg})$ entfallen.

Es wiegen 100 Halme $190 \mathrm{gr}$ und davon die Früchte $85 \mathrm{gr}$.

\section{Rotähriger weisser Winter-Bartweizen aus Ostindien. (2)}

Aehre: rot, mit bläulichem Anflug, sich stark verjüngend, ziemlich dicht, lang; Aehrehen schmal, $1 \mathrm{~cm}$ breit, Klappen mit Zahn, 3-grannig, davon 1 Granne kurz; Grannen hellrötlich, gespreizt, bis $8 \mathrm{~cm}$ lang. Stroh: blassrötlich-gelb, fest. - Frucht: gelb, glasig, klein (6 $1 / 2 \mathrm{~mm}$ lang, $3^{1 / 2} \mathrm{~mm}$ breit, 210 Frïchte $=10 \mathrm{gr}$ ), feinschalig.

Herbstblatt dunkelgrün, schmal; Frühjahrsvegetation mittelfrüh, Bestockung mittelstark, 4 Schösslinge, mittelfrüh schossend und blühend. Halmlänge $90 \mathrm{~cm}$ (Max. $110 \mathrm{~cm}$ ), Halmdicke $0.33 \mathrm{~cm}$, Blattzahl 4.4, Blattlänge $20.2 \mathrm{~cm}$, Blattbreite $0.88 \mathrm{~cm}$, Blattoberfläche $156.43 \mathrm{qcm}, \mathrm{Halm}$ fläche $89.1 \mathrm{qcm}$, Gesammtfläche $245.53 \mathrm{qcm}$.

Junge Aehre gelbgrün, Staubbeutel braun, zeitig reifend, $10 \mathrm{~cm}$ (Max. $12 \mathrm{~cm}$ ) lang, mit 18 Aehrchen und 50 lose sitzenden Friichten, von denen 1816500 auf $1 \mathrm{hl}(=86.5 \mathrm{~kg})$ gehen.

Es wiegen 100 Halme $457 \mathrm{gr}$ und davon die Frïchte $209 \mathrm{gr}$.

Auf reichem Boden lagert der Weizen, befällt leicht mit Rost und ist nicht ganz winterfest. Er ist ein echter Winterweizen.

\section{Varietät: Triticum valgare ferruginenm Al.}

Aehren kahl, rot; Körner rot.

\section{Sorten:}

\section{Clever-Hochland-Weizen. (2)}

Syn.: Holländisch: Roode Tarwe Westland.

Aehre: rot, lang, etwas locker, schmal, Aehrchen mittelbreit $(1.5 \mathrm{~cm})$, 2- und 3-körnig; Grannen rostrot, mittellang $(8-9 \mathrm{~cm})$, abstehend. Stroh: rötlich-gelb, derb, hoch. - Frucht: gelbrot und dann mehlig, 
viele auch glasig und dann rot, ]änglich, gross ( $7 \mathrm{~mm}$ lang, $3^{1} / 2 \mathrm{~mm}$ breit), sehr feinschalig, halbhart, Bruch halbmehlig.

Herbstblatt schmal, kraus, blaugrün, niederliegend. Frühjahrsvegetation spät; Bestockung stark, 4.6 Schösslinge, während sich die Bestockungsfähigkeit bei $100 \mathrm{qcm}$ Raum mit 18 Schösslingen als sehr stark erwies. Halm $145 \mathrm{~cm}$ (Max. $160 \mathrm{~cm}$ ) lang, $0.4 \mathrm{~cm}$ dick, Blattzahl 4, Blätter $28.8 \mathrm{~cm}$ lang, $0.97 \mathrm{~cm}$ breit, Blattfläche 223.20 qcm, Halmfläche $174 \mathrm{qcm}$, Gesammtfläche $397.20 \mathrm{qcm}$. Ferner wachsen 180 Pflanzen oder 828 Halme pro $\mathrm{qm}$, mithin auf jede Pflanze $55.5 \mathrm{qcm}$ Raum und auf 1 qm Bodenfläche 32.9 qm Blattläche entfallen.

Junge Aehre gelbgrün, spät blühend und reifend, $14 \mathrm{~cm}$ (Max. $16 \mathrm{~cm}$ ) lang, mit 20 Aehrchen und 50 ziemlich lose sitzenden Früchten. 100 Halme wiegen $535 \mathrm{gr}$ und davon die Körner $190 \mathrm{gr}$.

Ein Hectoliter wiegt $84 \mathrm{~kg}$, also schwer, und enthält 1839500 Früchte, mithin die Saatquantität bei 1800000 Pflanzen $1.47 \mathrm{hl}$ p. ha ausmacht.

Diese in Holland und in den nördlichen an Holland grenzenden Distrikten der Rheinprovinz einheimische Sorte zeichnet sich sowohl durch hohe Erträge als auch durch eine vorzügliche Qualität des Kornes aus, so dass $100 \mathrm{~kg}$ um 75 Pfg. bis 1 Mark höher bezahlt werden als englische Sorten.

In Poppelsdorf brachte er iiberraschend hohe Erträge, nämlich im zweijährigen Durchschnitt $2980 \mathrm{~kg}$ Korn und $8180 \mathrm{~kg}$ Stroh p. ha, ausserdem zeigte er sich winterfest.

Auf sehr reichem Boden lagert er etwas leicht, aber auf den besseren Lehmböden werden seine Erträge sehr befriedigen. Es wiegen 100 Halme $489.9 \mathrm{gr}$ und davon die Frïchte $213 \mathrm{gr}$.

Seine Kultur ist, ausser in Holland, in Nord-Deutschland und namentlich in den östlichen Provinzen und am Rhein verbreitet.

\section{Fuchsweizen. (2)}

Syn.: Westerwälder Weizen, Ahrweizen, Brauner Grannenweizen.

Aehre: dunkel- bis blaurot, etwas locker, sich stark verjüngend; Aehrchen $1.5 \mathrm{~cm}$ breit, 2- und 3-körnig; Grannen rötlich, abstehend, bis $10 \mathrm{~cm}$ lang. - Stroh: rötlich-gelb, fest. - Frucht: tiefrot, glasig, eingefallen, mittelgross $(61 / 2 \mathrm{~mm}$ lang, $4 \mathrm{~mm}$ breit, 192 Früchte $=10 \mathrm{gr})$ feinschalig, hart, halbstahlig.

Herbstblatt blaugrün, schmal, kraus, Frühjahrsvegetation mittelfruih, Bestockung stark, 5 Schösslinge, zeitig schossend und blühend; Halmlänge $120 \mathrm{~cm}$ (Max. $150 \mathrm{~cm}$ ), Halmdicke 0.4, Blattzahl 4, Blattlänge $23.4 \mathrm{~cm}$, Blattbreite $1.0 \mathrm{~cm}$, Blattoberfläche eines Halmes $187.2 \mathrm{qcm}$, Halmfläche $144 \mathrm{qcm}$, Gesammtfläche $331.2 \mathrm{qcm}$.

Junge Aehre gelbgrün, mittelfrül reifend, $10 \mathrm{~cm}$ (Max. $15 \mathrm{~cm}$ ) lang, mit 18 Aehrchen und 50 etwas lose sitzenden Früchten, von denen 1612800 auf $1 \mathrm{hl}(=84 \mathrm{~kg})$ gehen.

Auf $1 \mathrm{qm}$ wachsen 900 Halme oder 180 Pflanzen, mithin beträgt der Raum für eine Pflanze $55.5 \mathrm{qcm}$, die Blattoberfläche p. qm Bodenfläche $29.8 \mathrm{qm}$ und das Saatquantum (1/3 Verlust) $1.7 \mathrm{hl}$ p. ha.

Es wiegen 100 Halme $505 \mathrm{gr}$ und davon die Früchte $207 \mathrm{gr}$.

Dieser schöne Weizen, dessen Korn sich durch Kleberreichtum auszeichnet, eignet sich für ein rauhes Gebirgsklima und Lehmboden vortreff- 
lich, auch wird er vom Wilde und von Sperlingen seiner starken Grannen wegen nicht leicht angegangen. Lagert auf sehr reichem Boden.

Diese Weizensorte wird in der Wetterau, zumal bei Wiesbaden, „Fuchsweizen"1) genannt, und dort, sowie iberhaupt in Nassau seit geraumer Zeit gebaut.

\section{Langähriger roter kahler Bartweizen. (2)}

Aebre: hellrot, sich wenig verjüngend, etwas locker, lang; Aehrchen $1.5 \mathrm{~cm}$ breit, meist 3-körnig; Grannen blassrot, bis $7 \mathrm{~cm}$ lang, etwas abstehend. - Stroh: blassgelb, fest. - Frucht: rot, halbmehlig oder glasig: gross ( $7 \mathrm{~mm}$ lang, $4 \mathrm{~mm}$ breit), feinschalig, halbhart, Bruch halbmehlig.

Herbstblatt blaugrïn, mittelbreit, ziemlich aufrecht, Bestockung stark, 6 Schösslinge, spät schossend und blïhend. Halmlänge $135 \mathrm{~cm}$ (Max. $150 \mathrm{~cm}$ ), Halmdicke $0.4 \mathrm{~cm}$, Blattzahl 3.3 , Blattlänge $27.65 \mathrm{~cm}$, Blattbreite $1.05 \mathrm{~cm}$, Blattoberfläche eines Halmes $191.6 \mathrm{qcm}$, Halmfläche $162 \mathrm{qcm}$, Gesammtfläche $353.6 \mathrm{qcm}$.

Junge Aehre gelbgrün, spät reifend, $11 \mathrm{~cm}$ (Max. $14 \mathrm{~cm}$ ) lang, mit 18 Aehrchen und 50 ziemlich lose sitzenden Frïchten, ron denen 1740000 auf $1 \mathrm{hl}(=87 \mathrm{~kg})$ gehen.

Auf 1 qm wachsen 900 Halme oder 150 Pflanzen, mithin beträgt der Raum für eine Pflanze $66.6 \mathrm{qcm}$, die Blattfläche p. qm Bodenfläche $31.8 \mathrm{qm}$ und das Saatquantum ( $1 / 3$ Verlust) $1.3 \mathrm{hl}$ p. ha.

Es wiegen 100 Halme $529 \mathrm{gr}$ und davon die Früchte $172 \mathrm{gr}$.

Dieser nicht leicht lagernde, ertragreiche Weizen eignet sich für reichen Treizenboden.

\section{Dentscher Grannenweizen aus der Zucht von Rimpau, Schlanstedt. (2)}

Aehre: dunkelrot, sehr locker, lang, mittelbreit; Aehrchen $1.8 \mathrm{~cm}$ breit. 3-körnig; Grannen rot, $6.7 \mathrm{~cm}$ lang, zähe. - Stroh: rötlich, dickwandig. - Frucht: rot, meist glasig, rund (7 mm lang, $4 \mathrm{~mm}$ breit), etwas grobschalig, schwer, hart, Bruch halbstahlig.

Herbstblatt dunkelgriin, mittelbreit, aufrecht; Frühjahrsvegetation mittelfrüh, Bestockung mittelstark, 4.5 Schösslinge, spät schossend und blühend. Halmlänge $130 \mathrm{~cm}$ (Max. $155 \mathrm{~cm}$ ), Halmdicke $0.4 \mathrm{~cm}$, Blattzahl 4.4, Blattlänge $32 \mathrm{~cm}$, Blattbreite $91 \mathrm{~cm}$, Blattoberfläche eines Halmes $256.26 \mathrm{qcm}$, Halmfläche $156 \mathrm{qcm}$, Gesammtfläche $412.26 \mathrm{qcm}$.

Junge Aehre gelbgrủu, spät reifend, $10 \mathrm{~cm}$ (Max. $15 \mathrm{~cm}$ ) lang, mit 18 Aehrchen und 50 ziemlich fest sitzenden Frïchten, von denen 1751000 auf $1 \mathrm{hl}(=86.3 \mathrm{~kg})$ entfallen.

Auf 1 qm wachsen 900 Halne oder 200 Pflanzen, mithin beträgt der Raum fuir eine Pflanze $50 \mathrm{qcm}$, die Blattoberfläche p. qm Bodenfläche $37.08 \mathrm{qm}$ und das Saatquantum $1.7 \mathrm{hl} \mathrm{p}$. ha.

Es wiegen 100 Halme $533 \mathrm{gr}$ und davon die Früchte $133 \mathrm{gr}$.

1) Vergl. Metzger, Landw. Pflanzenkunde I 1811, pg. 58. 
Diese Sorte ist nach Rimpail $\left.{ }^{1}\right) 1871$ aus dem gemeinen deutschen Winterwcizen entstanden und hält sie der Züchter, da sie sehr leicht lagert und mit Rost befällt, für wertlos.

In Poppelsdorf befiel sie mit Rost und lagerte auch, doch im Verhältnis zu vielen anderen gleichzeitig kultivierten Sorten nicht allzustark, so dass Versuche mit ihrer Kultur auf nicht allzureichen Lehmböden im Kontinentalklima nicht unterlassen werden sollten, da dieser Weizen vollkommen winterfest ist und sich durch schweres Korn auszeichnet.

\section{Johannis-Weizen. (2) u. $\odot$}

Aehre: hellrot, sehr locker, hängend, sehr lang; Aelirchen 2- und 3-körnig, $1.6 \mathrm{~cm}$ breit; Grannen gelb, $9 \mathrm{~cm}$ lang. - Stroh: rötlich-gelb, fest, lang. - Frucht: gelbrot, mchlig; nachgebaut: rot, glasig, etwas eingefallen, länglich ( $7 \mathrm{~mm}$ lang, $3^{1} / 2 \mathrm{~mm}$ breit, 227.5 Früchte $\left.=10 \mathrm{gr}\right)$, feinschalig, halbhart, Bruch mehlig.

Herbstblatt blaugriin, schwach behaart, breit, aufrecht; Friihjalırsvegetation sehr zeitig, Bestockung sehr schwach, 2.6 Schösslinge, zeitig schossend und blühend; Halnlänge $130 \mathrm{~cm}$ (Max. $150 \mathrm{~cm}$ ), Halmdicke $0.42 \mathrm{~cm}$, Blattzahl 3.7, Blattlänge $26.75 \mathrm{~cm}$, Blattbreite $1.1 \mathrm{~cm}$, Blattfläche eines Halmes $217.78 \mathrm{qcm}$, Halmfläche $163.8 \mathrm{qcm}$, Gesammtfläche $381.58 \mathrm{qcm}$.

Junge Aehre gelbgriin, zeitig reifend, $14 \mathrm{~cm}$ (Max. $17 \mathrm{~cm}$ ) lang, mit 16 Aehrchen und 40 leicht ausfallenden Friichten, von denen 1933750 auf $1 \mathrm{hl}(=85 \mathrm{~kg})$ gehen.

Es kommen 840 Halme oder 323 Pflanzen auf $1 \mathrm{qm}$, mithin nimmt eine Pflanze einen Raum von $31 \mathrm{qm}$ ein. Die Blattfläche beträgt p. qm Bodenfläche $32 \mathrm{qm}$ und das Saatquantum $2.5 \mathrm{hl} \mathrm{p}$. ha.

Es wiegen 100 Halme $522 \mathrm{gr}$ und davon die Frïchte $155 \mathrm{gr}$.

Dieser Weizen war nicht winterfest, wohl aber widerstandsfähig gegen Lagern und Rost.

Als Sommerweizen angebaut, erwies er sich als solcher.

Der Weizen erträgt eine sehr frühe Aussaat, in welchem Fallc er sich auch stark bestockt und lässt sich dann wie Johannis-Roggen im Herbst abmähen oder abweiden. Naturgemäss wird sich dieser Weizen nur auf reichem Boden in dieser Weise benutzen lassen.

\section{Graf Walderdorff's regenerierter Weizen. (2)}

Aehre: rot, schmal, locker, lang; Aehrchen $1.3 \mathrm{~cm}$ breit, 3-körnig; Grannen rot, sehr gespreizt, $7-8 \mathrm{~cm}$ lang. - Stroh: rötlich-gelb und rotblau, fein, fest, lang. - Fruhct: rot, mehlig, oder glasig, etwas bauchig, rundlich ( $7 \mathrm{~mm}$ lang, $4 \mathrm{~mm}$ breit), etwas grobschalig, halbweich, Bruch mehlig.

Herbstblatt dunkelgriin, schmal, etwas niederliegend; Frühjahrsvegetation sehr spät, Bestockung ausserordentlich stark, 8 Schösslinge, mittelfrüh schossend und blühend. Halmlänge $135 \mathrm{~cm}$ (Мax. $155 \mathrm{~cm}$ ), 
Halmdicke $0.33 \mathrm{~cm}$, Blattzahl 4, Blattlänge $22.5 \mathrm{~cm}$, Blattbreite $0.86 \mathrm{~cm}$, Blattoberfläche $154.8 \mathrm{qcm}$, Halmfläche $133.65 \mathrm{qcm}$, Gesammtfäche $288.45 \mathrm{qcm}$.

Junge Aehre gelbgrün, mittelfrüh reifend, $10 \mathrm{~cm}$ (Max. $14 \mathrm{~cm}$ ) lang, mit 18 Aebrchen und 50 nicht leicht ausfallenden Früchten, von denen 1731000 auf $1 \mathrm{hl}(=78.8 \mathrm{~kg})$ gehen.

Es wiegen 100 Halme $515 \mathrm{gr}$ und davon die Früchte $200 \mathrm{gr}$.

Diese Sorte ist winterfest, nicht leicht lagernd und wenig durch Rost leidend, und soll durch Graf Walderdorff, Klafterbrunn bei Wien, Ober-Oestreich, genealogisch aus Banater-Weizen gezüchtet worden sein. Letzterer gehört zu T. v. erythrospermum, doch kommen bei ihm auch rötliche dehren vor, so dass die Züchtung aus dem Banater-Weizen nicht unwahrscheinlich ist.

\section{Hunderttägiger Sommerweizen.}

Aehre: bläulich-rot, sich verjüngend, ein wenig locker, mittellang, dünn; Aehrchen $1.3 \mathrm{~cm}$ breit, 3-körnig, 3-grannig (2 Grannen lang); Grannen rot, fächerförmig abstehend, bis $8 \frac{1}{2} \mathrm{~cm}$ lang, zähe. - Stroh: blassgelb, mittellang, fest. - Frucht: rot, meist glasig, schön, klein, rundlich ( $6 \mathrm{~mm}$ lang, $3 \frac{1}{2} \mathrm{~mm}$ breit, 280 Früchte $=10 \mathrm{gr}$ ), feinschalig, hart, halbstahlig.

Halme gelbgrün, 2 Schösslinge, zeitig schossend und blühend. Halmlänge $100 \mathrm{~cm}$ (Wax. $110 \mathrm{~cm}$ ), Halmdicke $0.27 \mathrm{~cm}$, Blattzahl 3.7, Blattlänge $22.5 \mathrm{~cm}$, Blattbreite $0.8 \mathrm{~cm}$, Blattoberfläche eines Halmes $133.2 \mathrm{qcm}$, Halmfläche $81 \mathrm{qcm}$, Gesammtfläche $214.2 \mathrm{qcm}$.

Junge Aehre blaugrün, zeitig, in 120 Tagen reifend, $9 \mathrm{~cm}$ (Max. $10 \mathrm{~cm}$ ) lang, mit 14 Aehrchen und 40 leicht ausfallenden Früchten, von denen 2408000 auf $1 \mathrm{hl}(=86 \mathrm{~kg})$ gehen.

Es wachsen auf $1 \mathrm{qm} 1200$ Halme oder 600 Pflanzen, mithin beträgt der Raum für eine Pflanze $16.6 \mathrm{qcm}$, die Blattoberfäche $p . q \mathrm{~m}$ Bodenfläche $25.68 \mathrm{qm}$ und das Saatquantum $(1 / 3$ Verlust $) 3.7 \mathrm{hl} \mathrm{p}$. ha.

Es wiegen 100 Halme 300 gr und davon die Früchte 130 gr.

Dieser Weizen lagert nicht leicht, ist aber nicht ganz rostfrei, doch scheint er sich sowohl für bündige wie für leichtere Bodenarten in rauhen Lagen zu eignen.

\section{Sandweizen aus Münster. (2)}

Id entisch: Bartweizen aus England.

A ehre : dunkelrot, sich stark verjüngend, ziemlich dicht, lang; Aehrchen meist 2-körnig; Grannen rötlichgrau, bis $7 \mathrm{~cm}$ lang. - Stroh: rötlich-gelb, blattreich, lang. - Frucht: gelbrot, mehlig; nachgebaut: rot, glasig, etwas eing efallen, rundlich, ( $6 \mathrm{~mm}$ lang, $3^{1} / 2 \mathrm{~mm}$ breit), feinschalig, halbhart, Bruch mehlig.

Herbstblatt blaugrün, schmal, kraus; Frühjahrsvegetation mittelfrüh, Bestockung mittelstark, 4.5 Schösslinge, mittelfrüh schossend und blühend. Halmlänge $135 \mathrm{~cm}$ (Мах. $150 \mathrm{~cm}$ ), Halmdicke $0.4 \mathrm{~cm}$, Blattzahl 4, Blattlänge $25.08 \mathrm{~cm}$, Blattbreite $1.04 \mathrm{~cm}$, Blattoberfläche eines Halmes $208.64 \mathrm{qcm}$, Halmfäche $162 \mathrm{qcm}$, Gesammtfläche $370.6+\mathrm{qcm}$.

Jinge Aehre gelbgrün, zeitig reifend, $11 \mathrm{~cm}($ Max. $14 \mathrm{~cm})$ lang, mit 20 Aehrchen und 40 ziemlich leicht ausfallenden Früchten, von denen 1734000 auf $1 \mathrm{hl}(=85 \mathrm{~kg})$ gehen. 
Auf $1 \mathrm{qm}$ wachsen 900 Halme oder 200 Pflanzen, mithin beträgt der Raum für eine Pflanze $50 \mathrm{qcm}$, und die Blattfläche p. qm Bodenfläche $33.3 \mathrm{qm}$ und das Saatquantum $1.7 \mathrm{hl} \mathrm{p.} \mathrm{ha.}$

Dieser Weizen gedeiht auf niedrig gelegenem Sardboden, dem es also nicht an der nötigen Feuchtigkeit fehlt, recht gut, reift früh und bringt verhältnismässig hohe Erträge. Neigung zum Lagern zeigt das Stroh nur auf sehr reichem Boden.

Diese Sorte erwies sich durchaus winterfest und winterte selbst nicht $1870 / 71$ aus.

Es wiegen 100 Halme $401 \mathrm{gr}$ und davon die Körner $181.6 \mathrm{gr}$.

\section{Roter Winter-Tagaurog-Bartweizen. (2)}

Aehre: rosenrot, sich wenig verjüngend, seitlich zusammengedrückt, etwas locker, lang; Aehrchen $1.6 \mathrm{~cm}$ breit, 2- und 3-körnig, 2-grannig; Granuen rötlich, stark gespreizt, bis $10 \mathrm{~cm}$ lang. - Stroh: schön rotgelb, ziemlich blattreich, lang. - Frucht: rot, glasig, klein $\left(6 \frac{1}{2} \mathrm{~mm}\right.$ lang, $3 \frac{1}{2} \mathrm{~mm}$ breit, 244 Früchte $=10 \mathrm{gr}$ ), schön, feinschalig, hart, halbstahlig.

Herbstblatt blaugrün, fein, aufrecht; Frühjahrsvegetation spät, Bestockung sehr stark, 5.7 Schösslinge, spät schossend und bliihend. Halmlänge $125 \mathrm{~cm}$ (Max. $155 \mathrm{~cm}$ ), Halmdicke $0.38 \mathrm{~cm}$, Blattzahl 4.3, Blattlänge $25 \mathrm{~cm}$, Blattbreite $0.75 \mathrm{~cm}$, Blattoberfläche $161.25 \mathrm{q} \mathrm{cm}$, Halmfläche $148.5 \mathrm{qcm}$, Gesammtfläche $309.75 \mathrm{qcm}$.

Junge Aehre gelbgrïn, mittelfrüh reifend, $11 \mathrm{~cm}$ (Max. $14 \mathrm{~cm}$ ) lang, mit 18 Aehrchen und 45 etwas lose sitzenden Frïchten, von denen 2049600 auf $1 \mathrm{hl}(84 \mathrm{~kg}$ ) gehen.

Es wiegen 100 Halme $400 \mathrm{gr}$ und davon die Frichte $220 \mathrm{gr}$.

Dieser im Gebiete der Don'schen Kosaken verbreitete Steppenweizen wird uber Taganrog am Azow'schen Meer vorzugsweise exportiert.

\section{Fern-April or Awny-Wheat. $\odot$ и. (2)}

Syn.: Deutsch: Fern- oder Aprilweizen.

Franz.: Blé Fern.

Aehre: blassrot, mit schwach bläulichem Anflug, lang, schmal; Aehrchen 3- und 4-körnig, $1.3 \mathrm{~cm}$ breit; sich nach der Spitze stark verjüngend, locker. Granuen blassrot, mittellang $(8 \mathrm{~cm})$, gespreizt. - Stroh: rötlich-gelb, mittellang, ziemlich derbwandig, dem Roggenstroh ähnlich. Frucht: Original rot, glasig, länglich, klein ( $6 \mathrm{~mm}$ lang, $3 \frac{1}{2} \mathrm{~mm}$ breit), Bruch halbmehlig, halbhart. Seit 1871 konstant. Winterfrucht und Sommerfrucht zeigten keinen specifischen Unterschied.

Herbstblatt breit, aufrecht, blaugrün, beiderseits schwach behaart. Beginn der Frihjahrsvegetation sehr zeitig. Bestockung schwach, 3.5 Schösslinge bei der Wintersaat, 2.3 bei der Sommersaat.

Die weitere Entwickelung gestaltet sich wie folgt: 
Halmlänge

Aehrenlänge

Anzahl der Aehrchen

Früchte in einer Aehre

Halmdurchmesser

Blattzahl am Halm

Durchschnittliche Blattlänge

Blattfläche

$$
\text { Blattbreite }
$$

Halmfläche

Gesammtfäche

A uf $1 \mathrm{qm}$ Bodenfläche entfallen:

Blattflächc

Auf $1 \mathrm{qm}$ wachsen do

Raum pro Pflanze

Hektolitergewicht

Körnerzahl pro hl

Aussaatquantum pro ha
$120 \mathrm{~cm}$ (Мax. $145 \mathrm{~cm}) 110 \mathrm{~cm}$ (Max. $120 \mathrm{~cm})$ $13 \mathrm{~cm}(\operatorname{Max} .17 \mathrm{~cm}) \quad 10 \mathrm{~cm}(\operatorname{Max} .14 \mathrm{~cm})$

16
55
$3.8 \mathrm{~mm}$
4
$25.5 \mathrm{~cm}$
$1.0 \mathrm{~cm}$
$204.0 \mathrm{qcm}$
$140.4 \mathrm{qcm}$
$344.4 \mathrm{qcm}$
$30.3 \mathrm{qcm}$
$880 \mathrm{Halme}$
$251 \mathrm{Pffanzen}$
$40 \mathrm{qcm}$
$84 \mathrm{~kg}$
$2234 \mathrm{v00}$
$1.5 \mathrm{hl}$

12
45
$3.8 \mathrm{~mm}$
3
$26.66 \mathrm{~cm}$
1.1
$174.98 \mathrm{qcm}$
$125.4 \mathrm{qcm}$
$301.38 \mathrm{qcm}$
$25.6 \mathrm{qcm}$
$850 \mathrm{Halme}$
370 Pflanzen
$27 \mathrm{qcm}$
$81 \mathrm{~kg}$
2234000
$2.2 \mathrm{hl}$

Die in der Jugend blaugrüne Aehre lässt in der Reife die Körner leicht ausfallen. Seit 1871 blieb dieser Weizen vollkommen konstant, so dass das ron einigen Seiten behauptete leichte Degenerieren hier nicht zutrifft.

Die Stroherträge treten beim Sommerweizen gegen die des Winterweizens zurück, doch ist dies nicht immer in Betreff des Kornes der Fall.

Dieser sehr zeitig reifende Weizen zeigt sich gegen ungünstige Witterung, so gegen Nässe und Dürre nnempfindlich.

Es wiegen 100 Halme Wintersaat $480 \mathrm{gr}$, Sommersaat $400 \mathrm{gr}$ und in beiden Fällen die Früchte $150 \mathrm{gr}$.

Dieser Weizen wurde 1829 von Mr. James Ross, Moorhall, Carse of Gowrie, in Grossbritannien eingefuihrt, welcher ihn von dem Kornhäudler Mr. Fern zuerst erhielt. Er wird jetzt viel in Schottland, aber auch häufig in Deutschland, so in der Provinz Sachsen nach Zuckerriben gebaut.

\section{Amber-Straw-Wheat. (2)}

Aehre: rot mit violettem Anflug, kurz, dïnn, locker, sich stark verjüngend; Aehrchen 2- und 3-körnig und grannig, Klappen gezahnt; Grannen blassrot, gespreizt, bis $6 \mathrm{~cm}$ lang. - Stroh: violett, mittellang, sehr fest. - Frucht: Original gelbrot, mehlig, wenige rot und glasig, schlank ( $7 \mathrm{~mm}$ lang, $3 \mathrm{~mm}$ breit, $258 \mathrm{Fr}$ üchte $=10 \mathrm{gr}$ ); nachgebaut: alles glasig, 184 Früchte $=10 \mathrm{gr}$, feinschalig, halbhart, Bruch halbstahlig.

Herbstblatt gelbgriun, aufrecht, lang, schmal; Entwickelung zeitig, 2.3 Schösslinge, zeitig schossend und blühend; Halm $115 \mathrm{~cm}$ (Max. $130 \mathrm{~cm}$ ) lang, $0.33 \mathrm{cml}$ dick, Blattzahl 4, Blätter $16.5 \mathrm{~cm}$ lang, $0.85 \mathrm{~cm}$ breit, Blattfläche 112.2 q cm, Halmfläche $113.89 \mathrm{qcm}$, Gesammtfläche $226 \mathrm{qcm}$. - Junge Aehre gelblich-grïn, rot umrandet, zeitig reifend, $9 \mathrm{~cm}$ (Max. 
$12 \mathrm{~cm})$ lang, mit 13 Aehrehen und 30 Früchten, von denen 2257500 auf $1 \mathrm{hl}(=87.5 \mathrm{~kg})$ entfallen.

Winterfest, doch leicht durch Rost leidend.

In den Vereinigten Staaten gebaut.

Bezugsquelle: Missouri Agric.-Coll. U. S.

\section{Longberried Winter-Wheat. (2)}

\section{Syn.: Langkörniger Winterweizen.}

Aehre: hellrot, sich stark verjüngend, ein wenig locker, mittellang; Aehrchen $1.3 \mathrm{~cm}$ breit, 3-körnig, 3-grannig; Grannen hell, gespreizt, 7-8 cm lang. - Stroh: rötlich-gelb, fest, mittellang, dünnhalmig. Frucht: Original hellrot, meist glasig, wenige gelbrot und mehlig, schmal ( $7 \mathrm{~mm}$ lang, $3 \mathrm{~mm}$ breit, 245 Früchte $=10 \mathrm{gr}$ ); nachgebaut: in erster Tracht rot, glasig, gross $(18+$ Früchte $=10 \mathrm{gr}, 71 / 2 \mathrm{~mm}$ lang, $31 / 4 \mathrm{~mm}$ breit), schön, feinschalig, halbhart, Bruch halbmehlig.

Herbstblatt blaugrïn, schmal, lang, aufrecht; Frühjahrsvegetation zeitig, Bestockung schwach, 2.4 Schösslinge, zeitig schossend und bliihend. Halmlänge $100 \mathrm{~cm}$ ( (Iax. $112 \mathrm{~cm}$ ), Halmdicke $0.3 \mathrm{~cm}$, Blattzahl 4.6, Blattlänge $17 \mathrm{~cm}$, Blattbreite $0.8 \mathrm{~cm}$, Blattoberfläche $125.12 \mathrm{qcm}$, Halmfläche 90 qcm, Gesamintfläche 115.12 qcm.

Junge Aehre gelbgrün, Spitzen rot umrandet, frühreif, $9 \mathrm{~cm}$ (Max. $12 \mathrm{~cm})$ lang, mit 15 Aehrchen und 42 leicht ausfallenden Früchtell, von denen 2002500 auf $1 \mathrm{hl}(=85 \mathrm{~kg})$ entfallen.

Es wiegen 100 Halme $387 \mathrm{gr}$ und davon die Friichte $186 \mathrm{gr}$.

Diese schöne Weizensorte wird vielfach in den Nordstaaten der Vereinigten Staaten angebaut, ist ertragreich, winterfest und bringt auf trocknen, kulturarmen Lehmböden noch relativ hohe Erträge.

Uebersender: Hub. Dürselen, Neuss a/Rh.

\section{Dott-Wheat. $\odot$}

Aehre: blassrot, kurz, sich stark verjüngend, dünn, locker; Aehrchen meist 3-körnig und grannig, Klappen gezahnt; Grannen hell, gespreizt, bis $7 \mathrm{~cm}$ lang. - Stroh: blassgelb, unter mittellang, steif. - Frucht: gelbrot, mehlig, oder rot und glasig, schlank $\left(6^{3} / 4 \mathrm{~mm}\right.$ lang, $3 \mathrm{~mm}$ breit, 281 Früchte $=10 \mathrm{gr}$ ); nachgebaut: grösser, 190 Friichte $=10 \mathrm{gr}$, feinschalig, halbhart, Bruch halbstahlig.

- Herbstblatt hellgrün, aufrecht, gross; Entwickelung zeitig, 2.2 Schösslinge; sehr zeitig schossend, zeitig blühend; Halm $108 \mathrm{~cm}$ (Мax. $120 \mathrm{~cm}$ ) lang, $0.3 \mathrm{~cm}$ dick, Blattzahl 4.3 , Blätter $15.6 \mathrm{~cm}$ lang, $0.8 \mathrm{~cm}$ breit, Blattfläche $107.3 \mathrm{qcm}$, Halmfläche $97.2 \mathrm{qcm}$, Gesaunmtfläche $204.5 \mathrm{qcm}$.

Junge Aehre bläulich, zeitig reifend, $8 \mathrm{~cm}$ (Miax. $12 \mathrm{~cm}$ ) lang, mit 14 Aehrchen und 40 leicht ausfallenden Früchten, von denen 2430650 auf $1 \mathrm{hl}(=86.5 \mathrm{~kg})$ entfallen.

Winterfest; befällt leicht mit Rost.

In den mittleren Staaten der Union gebaut.

Bezngsquelle: Missouri Agric. Coll. 1880. U. S. 


\section{Early Lancaster. (2)}

Aehre: rot, sich verjüngend, locker, kurz; Aehrchen 2-grannig, 2und 3-körnig; Grannen blassrot, gespreizt, bis $7 \mathrm{~cm}$ lang: - Stroh: meist violett, unter mittel, fest. - Frucht: rot, meist glasig, lang, ziemlich gross ( $7 \mathrm{~mm}$ lang, $3 \frac{1}{4} \mathrm{~mm}$ breit, 260 Fruichte $=10 \mathrm{gr}$ ); nachgebaut: ein wenig grösser (198 Früchte $=10 \mathrm{gr}$ ), feinschalig, halbhart, Bruch halbmehlig.

Herbstblatt dunkelgrün, lang, schmal, aufrecht; Entwickelung zeitig, 2.8 Schösslinge; zeitig schossend, mittelfrih bliihend; Halm $100 \mathrm{~cm}$ (Max. $115 \mathrm{~cm}$ ) lang, $0.3 \mathrm{~cm}$ dick, Blattzahl 4, Blätter $15.3 \mathrm{~cm}$ lang, $0.8 \mathrm{~cm}$ breit, Blattfläche $97.9 \mathrm{qcm}$, Halmfläche $90 \mathrm{qcm}$, Gesammtfläche $187.9 \mathrm{qcm}$.

Junge Aehre bläulich-grün, zeitig reifend, $8 \mathrm{~cm}$ (Мax. $10 \mathrm{~cm}$ ) lang, mit 14 Aehrchen und 40 leicht ausfallenden Früchten, von denen 2210000 auf $1 \mathrm{hl}(=85 \mathrm{~kg})$ entfallen.

Winterfest; zum Rost neigend; ertragreich.

Stark in Maryland gebaut.

Bezugsquelle: Missouri Agric-Coll. 1880. U. S.

\section{Red bearded Mediterranean-Wheat. (9)}

Aehre: rot, sich verjüngend, halblocker; kurz; Aehrchen 3-körnig, 3-grannig; Grannen blassrot, gespreizt, bis $6 \mathrm{~cm}$ lang. - Stroh: meist violett, unter mittellang, steif. - Frucht: Original gelbrot, mehlig, einige dunkelrot, glasig, schlank ( $7 \mathrm{~mm}$ lang. $3 \mathrm{~mm}$ breit, 258 Früchte $=10 \mathrm{gr}$ ); nachgebaut: Alles glasig, grösser, 186 Früchte $=10 \mathrm{gr}$, ziemlich grobschalig, hart, Bruch stahlig.

Herbstblatt gelbgrün, aufrecht, lang, schmal; Entwickelung zeitig, 2 Schösslinge; sehr zeitig schossend, mittelfrüh blühend; Halm $100 \mathrm{~cm}$ (Max. $115 \mathrm{~cm}$ ) lang, $0.4 \mathrm{~cm}$ dick, Blattzahl 4. Blätter $17 \mathrm{~cm} \mathrm{lang,} 0.8 \mathrm{~cm}$ breit, Blattfläche $108.8 \mathrm{qcm}$, Halınfläche $120 \mathrm{qcm}$, Gesammtfläche $228.8 \mathrm{qcm}$.

Junge Aehre gelbgrün, zeitig reifend, $8 \mathrm{~cm}$ (Max. $10 \mathrm{~cm}$ ) lang, mit 40 leicht ausfallenden Früchten, von denen 2296200 auf hl (= $89 \mathrm{~kg}$ ) entfallen.

Winterfest, fast rostfrei. Mehl nicht besonders geschätzt, doch ertragreich.

Wurde 1819 durcl John Gordon ${ }^{1}$ ), Wilmington, Delaware, aus Genua bezogen.

Wird viel in Ohio und Pennsylvanien gebaut.

Bezugsquelle: Missouri Agric. Coll. 1880. U. S.

\section{Cartagena rojo aristado. $\odot$}

Deutsch: Roter Bartweizen aus Cartagena, Spauien.

Aehre: bläulich-rot, sich verjüngend, locker, kurz, dünn; Aehrchen 2- und 3-körnig; Grannen rot, abstehend, zähe. - Stroh: gelb, feinhalmig, fest. - Frucht: rot, glasig, etwas eingefallen, länglich ( $7 \mathrm{~mm}$ lang, $3^{1 / 2} \mathrm{~mm}$ breit), feinschalig, sehr hart, Bruch glasig. 
Halme gelbgrün, sehr zeitig schossend und blühend, 2 Schösslinge; Halmlänge $95 \mathrm{~cm}$ (Max. $130 \mathrm{~cm}$ ), Halmdicke $0.3 \mathrm{~cm}$, Blattzahl 3, Blattlänge $29 \mathrm{~cm}$, Blattbreite $0.78 \mathrm{~cm}$, Blattoberfläche eines Halmes $135.72 \mathrm{qcm}$, Halmfläche $85.5 \mathrm{qcm}$, Gesammtfläche $221.22 \mathrm{qcm}$.

Junge Aehre blaugrün, bereift; Vegetationsdauer bis zur Reife 120 Tage, also frühreif, $8 \mathrm{~cm}$ (Max. $12 \mathrm{~cm}$ ) lang, mit 13 Aehrchen und 30 Früchten, von denen 2038000 auf $1 \mathrm{hl}(=81.5 \mathrm{~kg})$ gehen.

Das Stroh lagert nur auf reichem Boden; gegen Rost widerstandsfähig.

Es wiegen 100 Halme $370 \mathrm{gr}$ und davon die Früchte $150 \mathrm{gr}$.

Diese Sorte hat nur für Süd-Europa Bedeutung.

Der Berliner Akklimatisations-Verein führte diesen Weizen 1867 in Deutschland ein.

\section{Trigo piche, Cadiz, Spanien. $\odot$}

Aehre: rot, sich wenig verjüngend, locker, kurz; Aehrchen $1.3 \mathrm{~cm}$ breit, 3- und 4-körnig, 3-grannig, mittlere kurz; Grannen hellrot, $8.5 \mathrm{~cm}$ lang, gespreizt. - Stroh: gelb, kurz, steif. - Frucht: Original gelbrot, mehlig, ein wenig zusammengedrückt, klein $\left(6^{1} / 2 \mathrm{~mm}\right.$ lang, $2 \frac{1}{2} \mathrm{~mm}$ breit, 286 Früichte $=10 \mathrm{gr}$ ); nachgebaut: rot, Alles glasig, grösser, 197 Früchte $=10 \mathrm{gr}$, feinschalig.

Junges Blatt gelbgrün, Fuss rot, sehr fein, kurz; zeitig schossend und blühend, 1.2 Schösslinge; Halm $85 \mathrm{~cm}$ (Max. $100 \mathrm{~cm}$ ) lang, $0.3 \mathrm{~cm}$ dick, Blattzahl 3.3. Blätter $21 \mathrm{~cm}$ lang, $0.8 \mathrm{~cm}$ breit, Blattfäche $110.9 \mathrm{qcm}$, Halmfläche $76.5 \mathrm{qcm}$, Gesammtfläche $187.4 \mathrm{qcm}$.

Junge Aehre blau, bereift, in 120 Tagen reifend, mit 13 Aehrchen und 40 fest sitzenden Früchten.

Uebergang zu Triticum durum.

Nur für ein warmes, trocknes Klima geeignet.

\section{Blat del país, Granja de Barcelona, Spanien. $\odot$}

Aehre: blassrot, locker, sich verjüngend, kurz; Aehrchen 2- und 3-körnig, 2-grannig, Klappen gezahnt; Grannen blassrot, gespreizt, $61 / 2 \mathrm{~cm}$ lang. - Stroh: gelbrot, dünnhalmig, kurz. - Fruclit: Original gelbrot, mehlig, einige glasig, rundlich ( $7 \mathrm{~mm}$ lang, $3 \frac{3}{4} \mathrm{~mm}$ breit, 231 Früchte $=10 \mathrm{gr}$ ) ; nachgebaut: Alles glasig, ein wenig grösser, 200 Früchte $=10 \mathrm{gr}$; ziemlich feinschalig, halbhart, Bruch halbmehlig.

Junges Blatt gelbgrün, sehr lang, doch schmal, aufrecht; 1 Schössling, sehr zeitig schossend und blühend; junge Aehre blaugrün, in 117 Tagen reifend, $6 \mathrm{~cm}$ (Max. $8 \mathrm{~cm}$ ) lang, mit 12 Aehrchen und 30 lose sitzenden Früchten.

Im nordöstlichen Spanien kultiviert.

Bezugsquelle: Ant. Cipr. Costa, Barcelona, 1881.

1) Zeitschr. f. Akklim. 1869, No. X-XII. 


\section{Xexa.}

Aehre: rauchbrann, dünn, locker, unter mittellang; Aehrchen 2-und 3-körnig, 2-grannig, Klappen kurzgrannig; Grannen rotbraun, bis $8 \mathrm{~cm}$ lang. - Stroh: gelbrot, fest, unter mittellang. - Frucht: Original gelbrot, glasig, länglich ( $7 \mathrm{~mm}$ lang, $31 / 4 \mathrm{~mm}$ breit, 241 Früchte $=10 \mathrm{gr}$ ); ein wenig grobschalig.

Aehre in 121 Tagen reifend, $10 \mathrm{~cm}$ lang, mit 14 Aehrchen und 35 fest sitzenden Früchten, von denen $1 \mathrm{hl}$ (= $84 \mathrm{~kg}$ ) wiegt.

Heimat: Vich, (Catalüna) Spanien.

Bezugsquelle: Ant. Cipr. Costa Barcelona, mis. 1881.

\section{Tosetto rosso. (2)}

Syn.: Pisano; Frumento fiorentino.

Aehre: sehr blassrot, sich stark verjüngend, locker, mittellang; Aehrchen 2- und 3-körnig und grannig, Klappen gezahnt; Grannen hellrot, gespreizt. - Stroh: gelbrot, unter mittellang, steif. - Frucht: rot, glasig, gross, länglich ( $81 / 2 \mathrm{~mm}$ lang, $3^{3} / 4 \mathrm{~mm}$ breit, 134 Früchte $=10 \mathrm{gr}$ ), etwas grobschalig, halbhart, Bruch halbstahlig.

Herbstblatt hellgriin, sehr gross, aufrecht; Friihjahrsblatt roggenähnlich, Fnss rot; Entwickelung sehr zeitig, 3 Schösslinge, zeitig schossend und blühend; Halm $110 \mathrm{~cm}$ (Max. $115 \mathrm{~cm}$ ) lang, $0.38 \mathrm{~cm}$ dick, Blattzahl 3.6, Blätter $19 \mathrm{~cm}$ lang, $0.9 \mathrm{~cm}$ breit, Blattfläche $123.1 \mathrm{qcm}$, Halmfläche $125.4 \mathrm{qcm}$, Gesammtfiäche $248.5 \mathrm{qcm}$.

Junge Aehre blaugrün, zeitig reifend, $10 \mathrm{~cm}$ (Max. 14 cm) lang, mit 14 Aehrchen und 35 fest sitzenden Friichten, von denen 1152400 auf $1 \mathrm{hl}(=86 \mathrm{~kg})$ entfallen.

Nicht ganz winterfest, ziemlich rostfrei; bei Rovigo und in Toskana häufig zur Gewinnung von Hutstroh im Frühjahr gebaut.

Bezugsquelle: Pariser Ausstellung 1878.

\section{Froment commun, barbu, roux et glabre ${ }^{1}$ ). (2)}

Syn.: Franz.: Touzelle rouge, barbue; Saisette de Tarascon.

Ita 1.: Frumento rosso comune.

Deutsch.: Roter, kahler Winterbartweizen.

Aehre: blaurot, sich verjïngend, locker, lang; Aehrchen $1.3 \mathrm{~cm}$ breit, meist 3-körnig; Grannen rötlich, bis $9 \mathrm{~cm}$ lang, abstehend. - Stroh: rötlich-gelb, unterhalb der Aehre bläulich, fest, lang. - Frucht: hellrot, glasig, länglich, klein (6 $\mathrm{mm}$ lang, $3 \mathrm{~mm}$ breit, 240 Früchte $=\mathrm{gr}$ ), feinschalig, schwer, halbhart, Bruch halbstahlig.

Herbstblatt gelbgrïn, sehr breit, aufrecht, Bestockung schwach, 3.8 Schösslinge, sehr zeitig schossend und blühend. Halmlänge $120 \mathrm{~cm}$ (Мax. $145 \mathrm{~cm}$ ), Halmdicke $0.36 \mathrm{~cm}$, Blattzahl 4, Blattlänge $18 \mathrm{~cm}$, Blattbreite $1 \mathrm{~cm}$, Blattoberfläche $144 \mathrm{qcm}$, Halmfläche $129.6 \mathrm{qcm}$, Gresammtfläche $273.6 \mathrm{qcm}$.

Junge Aehre blaugrün, selır zeitig reifend, $10 \mathrm{~cm}$ (Щax. $12 \mathrm{~cm}$ )

1) Vergl. Seringe, Monogr. des céréales de la Suisse 1818, pg. 90. 
lang, mit 12 Aehrchen und 36 ziemlich leicht ausfallenden Früchten, von denen 2088000 auf $1 \mathrm{hl}(=87 \mathrm{~kg})$ gehen.

Auf 1 qm wachsen 1000 Halme, oder 263 Pflanzen, mithin beträgt der Raum für eine Pflanze $38 \mathrm{qcm}$, die Blattfäche p. qin Bodenfläche $32.27 \mathrm{qm}$ und das Saatquantum (1/3 Verlust) $2 \mathrm{hl}$ p. ha.

Es wiegen 100 Halme $491 \mathrm{gr}$ und davon die Früchte $151 \mathrm{gr}$.

Dieser Weizen war in Poppelsdorf nicht winterfest, lagerte aber nicht. Zuweilen in der Schweiz, im süd-östlichen Frankreich und in Ober-Italien auf milden Lehmböden angebaut.

\section{Weizen von der Insel Andros, Kykladen, Griechenland. (2)}

Aehre: dunkelrot, sich etwas verjüngend, ziemlich dicht, sehr lang; Aehrchen meist 3-körnig; Grannen hellrot, gespreizt, bis $9 \mathrm{~cm} \mathrm{lang.} \mathrm{-}$ Stroh: hellgelb, weich, lang. - Frucht: rot, glasig, wenige mehlig, länglich ( $7 \mathrm{~mm}$ lang, $3^{1} / 2 \mathrm{~mm}$ breit, 210 Früchte $=10 \mathrm{gr}$ ), schön, feinschalig, halbhart, halbmehlig.

Herbstblatt blaugriin, schmal, kraus; Frihjahrsvegetation mittelfrüh, Bestockung stark, 5.3 Schösslinge, mittelfrüh schossend und blühend. Halmlänge $135 \mathrm{~cm}$ (Max. $160 \mathrm{~cm}$ ), Halmdicke $0.4 \mathrm{~cm}$, Blattzahl 4.3, Blattlänge $26.46 \mathrm{~cm}$, Blattbreite $1.06 \mathrm{~cm}$, Blattoberfläche $241.23 \mathrm{qcm}$, HalmHläche 162 qcm, Gesammtfläche 403.23 qcm.

Junge Aehre gelbgrïn, mittelfrüh reifend, $12 \mathrm{~cm}$ (Max. $15 \mathrm{~cm}$ ) lang, mit 22 Aehrchen und 60 lose sitzenden Früchten, von denen 1795500 auf $1 \mathrm{hl}(=85.5 \mathrm{~kg})$ entfallen.

Auf 1 qm wachsen 760 Halme oder 143 Pflanzen, mithin beträgt der Raum p. Pflanze $70 \mathrm{qcm}$, die Blattoberfläche p. qm Bodenfläche $30.4 \mathrm{qm}$ und das Saatquantum $1.2 \mathrm{hl}$ p. ha.

Es wiegen 100 Halme $480 \mathrm{gr}$ und davon die Früchte $217 \mathrm{gr}$.

Diese hochfeine griechische Sorte erhielt 1867 auf der Pariser Weltausstellung einen ersten Preis. Sie eignet sich zur Kultur für ein mildes Klima und einen trocknen Lehmboden, da sie auf sehr reichem Boden leicht lagert.

Bezugsquelle: Haage \& Schmidt, Erfurt (1871).

\section{Blê de Jassy. (2)}

Aehre: hellrot, sich verjüngend, locker, lang; Aehrchen $1.3 \mathrm{~cm}$ breit, meist 2-körnig; Grannen hell, bis $7 \mathrm{~cm}$ lang, etwas gespreizt. Stroh: rötlich-gelb, weich, ziemlich lang. - Frucht: Original gelbrot, mehlig, in 1. Tracht bereits glasig und rot, klein $\left(6 \mathrm{~mm}\right.$ lang, $3^{1 / 2} \mathrm{~mm}$ breit, 219 Frichte $=10 \mathrm{gr}$ ), etwas eingefallen, feinschalig, halbhart, Bruch halbmehlig.

Herbstblatt blaugrün, schmal, kraus; Fruhjahrsvegetation sehr spät, Bestockung stark, 5 Schösslinge, mittelfrüh schossend und blühond. Halmlänge $110 \mathrm{~cm}$ (Max. $135 \mathrm{~cm}$ ), Halmdicke $0.37 \mathrm{~cm}$, Blattzahl 3, Blattlänge $26.12 \mathrm{~cm}$, Blattbreite $0.92 \mathrm{~cm}$, Blattoberffäche $144.18 \mathrm{qcm}$, Halmfläche $122.1 \mathrm{qcm}$, Gesammtfläche $266.28 \mathrm{qcm}$.

Junge Aehre gelbgrün, ziemlich zeitig reifend, $11 \mathrm{~cm}$ (Мax. $15 \mathrm{~cm}$ ) lang, mit 20 Aehrchen und 40 Fruchten, von denen 1828650 auf 1 hl $(=83.5 \mathrm{~kg})$ gehen.

Es wiegen 100 Halme $350 \mathrm{gr}$ und davon die Früchte $178 \mathrm{gr}$.

Koernicke u. Werner, Hanab. a. Getreidebau's Il. 
Auf reichem Alluvialboden leicht lagernd, dagegen für das Steppenklima und den trocknen Steppenboden vorzüglich geeignet.

Diese rumänische Weizensorte wurde 1870 durch die Fürstin Wied dem hiesigen ökonomisch-botanischen Garten zugesandt.

\section{Ghirka. (2)}

Syn.: Krasnaja ostistaja.

A merik a: Red-Russian.

Aehre: rot, dünn, locker, sich verjüngend, kurz; Aehrchen $1.1 \mathrm{~cm}$ breit, 2- und 3-körnig, 3-grannig, 1 Granne sehr kurz; Klappen mit grannenartigem Zahn; Grannen gespreizt, 7-9 cm lang. - Stroh: rötlichgelb oder violett, kurz. - Frucht: Original rot, meist glasig, wenige gelbrot und mehlig, schlank, klein $\left(6 \frac{1}{2} \mathrm{~mm}\right.$ lang, $3 \mathrm{~mm}$ breit, 273 Früchte $=10 \mathrm{gr}$ ); nachgebaut: grösser, 215 Früchte $=10 \mathrm{gr}$, feinschalig, halbhart, Bruch stahlig.

Herbstblatt blaugrün, schmal, niederliegend; Frühjahrsentwickelung mittelfrüh; 3.8 Schösslinge, mittelfrüh schossend und blühend; Halm $90 \mathrm{~cm}$ (Max. $115 \mathrm{~cm}$ ) lang, $0.3 \mathrm{~cm}$ dick, Blattzahl 4, Blätter $20.5 \mathrm{~cm}$ lang, $0.75 \mathrm{~cm}$ breit, Blattfläche $123 \mathrm{qcm}$, Halmfläche $81 \mathrm{qcm}$, Gesammtfläche $204 \mathrm{qcm}$.

Junge Aehre gelbgrün, rot umrandet, mittelfrüh reifend, $8 \mathrm{~cm}$ (Max. $11 \mathrm{~cm})$ lang, mit 15 Aehrchen und 36 ziemlich fest sitzenden Friichten, von denen 2331420 auf $1 \mathrm{hl}(=85.4 \mathrm{~kg})$ entfallen.

Es wiegen 100 Halme $330 \mathrm{gr}$ und davon die Früchte $147 \mathrm{gr}$.

Winterfest; echtes Wintergetreide; ziemlich rostfrei, nicht leicht lagernd.

Die Heimat dieses vorzüglichen Steppenweizens liegt im südlichen Russland am kaspischen Meere und wird in Süd-Russland von allen Sorten vielleicht am häufigsten gebaut und meist ïber Odessa nach Konstantinopel, Smyrna, Griechenland, Spanien, Süd-Frankreich und England als sehr beliebter Weizen ausgeführt.

Von Süd-Russland gelangte derselbe nach den Nordweststaaten Amerikas, wo er als "Red-Russian" stark gebaut wird.

Original durch Prof. Saykewitsch, Charkow, und Red-Russian durch Missouri Agric. Coll. 1880 erhalten.

\section{Roter Bartweizen aus Wjernoje, am Fusse des Ala-Tau, Turkestan.}

Aehre: rot, blau bereift, sich wenig verjüngend, ziemlich dicht, breit, ziemlich lang; Aehrchen $1.5 \mathrm{~cm}$ breit, meist 3-körnig und 3-grannig, Grannen der Klappen fast so lang als die der Spelzen; Granne stark gespreizt, bis $10 \mathrm{~cm}$ lang. - Stroh: blassgelb, sehr fest, kaum mittellang. - Frucht: dunkelrot, glasig, stark eingefallen, länglich, gross ( $7 \mathrm{~mm}$ lang, $31 / 2 \mathrm{~mm}$ breit, 184 Früchte $=10 \mathrm{gr}$ ), grobschalig, sehr hart, stahlig.

Junges Blatt blaugrün, dicht behaart, aufrecht, 2.2 Schösslinge, sehr spät schossend und blühend. Halme $90 \mathrm{~cm}$ (Max. $105 \mathrm{~cm}$ ) lang, $0.4 \mathrm{~cm}$ dick, Blattzahl 3.4, Blätter $26 \mathrm{~cm}$ lang, $1 \mathrm{~cm}$ breit, Blattfäche $176.8 \mathrm{qcm}$, Halmfläche $108 \mathrm{qcm}$, Gesammtfäche $284.8 \mathrm{qcm}$.

Junge Aehre gelbgriin, in 130 Tagen reifend, $10 \mathrm{~cm}$ (Max. 14 cm) 
lang, mit 15 Aehrehen und 45 sehr fest sitzenden Früchten, von denen 1582400 auf $1 \mathrm{hl}(=86 \mathrm{~kg})$ entfallen.

Es wiegen 100 Halme $370 \mathrm{gr}$ und davon die Früchte $177 \mathrm{gr}$.

Von Fetisow gesammelt und furch E. Regel ïbersandt.

\section{Roter Bartweizen vom Altai. $\odot$}

Aehre: blassrot, etwas locker, sich verjüngend, schmal, dünn, zienlich lang; Aehrehen $0.9 \mathrm{~cm}$ breit, 2- und 3-körnig und grannig, Klappen mit Zahn; Grannen gespreizt, $8.5 \mathrm{~cm}$ lang. - Stroh: blassgelb, fest, mittellang. - Frucht: rot, glasig, sehr klein, oval (6 mm lang, $3 \mathrm{~mm}$ breit, 409 Frïchte $=10 \mathrm{gr}$ ), feinschalig, halbhart, Bruch halbstahlig.

Junges Blatt blaugrün, beiderseits dicht behaart, aufrecht; 2.2 Schösslinge, Halm $105 \mathrm{~cm}$ (Max. $120 \mathrm{~cm}$ ) lang, $0.3 \mathrm{~cm}$ dick, Blattzahl 3.7 , Blätter $20 \mathrm{~cm}$ lang, $0.62 \mathrm{~cm}$ breit, Blattfläche $91.76 \mathrm{qcm}$, Halmfläche $94.5 \mathrm{qcm}$, Gesamintfläche $186.26 \mathrm{qcm}$.

Junge Aehre blaugrün, reift in 119 Tagen, $9 \mathrm{~cm}$ (Max. $11 \mathrm{~cm}$ ) lang, mit 17 Aehrchen und 40 Früchten, von denen 3558300 auf 1 hl (= $87 \mathrm{~kg}$ ) entfallen.

Es wiegen 100 Halme $278 \mathrm{gr}$, und davon die Früchte $150 \mathrm{gr}$.

Durch Dr. Finseh und Graf Zeil erhalten.

\section{Roter Sommer-Bartweizen aus dem Bezirk „Irkutsk", Sibirien. $\odot$}

Aehre: rot, dünn, ziemlich dicht, kurz; Aehrehen meist 3-köruig und grannig, $1.2 \mathrm{~cm}$ breit. Klappen gezahnt; Grannen hellrot, wenig gespreizt, bis $5.5 \mathrm{~cm}$ lang. - Stroh: rotgelb, kurz, fest. - Frucht: rot, glasig, sehr klein (550 Früchte $=10 \mathrm{gr}, 51 / 2 \mathrm{~mm} \mathrm{lang,} 2^{1 / 2} \mathrm{~mm}$ breit); nachgebaut: grösser 418 Früchte $=10 \mathrm{gr}$, hart, Bruch stahlig.

Junges Blatt hellgrïn, schwach sammetig, sehr feinblättrig, lang, aufrecht, Fuss rötlich; Entwickelung zeitig, 2 Schösslinge; sehr zeitig schossend, blïhend und reifend; Halm $90 \mathrm{~cm}$ (Max. $100 \mathrm{~cm}$ ) lang, $0.3 \mathrm{~cm}$ dick, Blattzahl 3, Blätter $21.3 \mathrm{~cm}$ lang, $0.7 \mathrm{~cm}$ breit, Blattfliiche $89.5 \mathrm{qcm}$, Halmfï̈che $81 \mathrm{qcm}$, Gesammtfäche $170.5 \mathrm{qcm}$.

Junge Aehre blaugrün, Antheren rot, in 106 Tagen reifend, mit 16 Aehrchen und 40 ziemlich fest sitzenden Früchten.

Bezugsquelle: durch Anatol von Fa dejeff vom landw. Versuchsfeld zu Petrowsk bei Moskau Originalsaat erhalten.

\section{Roter Bartweizen von den Aland-Inseln. (2)}

Aehre: schmutzig-rot, dünn, mittellang; Aehrchen 3-4-körnig; Grannen gespreizt. - Stroh: rötlich-gelb, dick, fest. — Frucht: rot, mehlig oder glasig, schlank, $8 \mathrm{~mm}$ lang, $3 \mathrm{~mm}$ breit.

Aehre $11 \mathrm{~cm}$ (Max. $14.5 \mathrm{~cm}$ ) lang, mit 22 Aehrehen und 65 Früchten.

Bezugsquelle: durch Pastor Molin auf Eckero, einer von den Aland-Inseln.

\section{Roter Bartweizen aus Umea, Schweden. $\odot$}

Aehre: rot, locker, dünn, mittellang; Aehrehen $1.5 \mathrm{~cm}$ breit, 3-kïrnig und 3-grannig (2 Grannen lang) Grannen rot, abstehend bis $8 \mathrm{~cm}$ 
lang, zähe. Stroh: rötlich-gelb, feinschalig, blattarm, fest, mittellang. Frucht: rot, glasig, etwas eingefallen, plump, mittelgross $(7 \mathrm{~mm}$ lang, $3 \frac{1}{2} \mathrm{~mm}$ breit) schwer, feinschalig, halbhart, Bruch halbstahlig.

Halm blaugriin, schosst und blüht zeitig, 2.1 Schösslinge, Halmlänge $105 \mathrm{~cm}$ (Max. $125 \mathrm{~cm}$ ), Halmdicke $0.33 \mathrm{~cm}$, Blattzahl 3, Blattlänge $28.3 \mathrm{~cm}$, Blattbreite $0.88 \mathrm{~cm}$, Blattoberfläche eines Halınes $149.4 \mathrm{qcm}$, Halmfläche $103.95 \mathrm{qcm}$, Gesammtfläche $253.35 \mathrm{qcm}$.

Junge Aehre blaugrün, sehr zeitig in 115 Tagen reifend, also 5 Tage früher als der aus Süd-Spanien stammende Cartagena rojo aristado. Reife Aehre $9 \mathrm{~cm}$ (Max. $11 \mathrm{~cm}$ ) lang, mit 14 Aehrchen und 40 leicht ausfallenden Frïchten, von denen 1827000 auf 1 hl (= $87 \mathrm{~kg}$ ) gehen.

Es wiegen 100 Halme $330 \mathrm{gr}$ und davon die Früchte $150 \mathrm{gr}$.

Das Stroh lagert nicht leicht, doch befällt es stark mit Rost.

Für Deutschland ist dieser Weizen bedeutungslos.

Uebersender: L. Wittmack, Berlin 1874.

\section{Roter Winter-Bartweizen aus Ostindien. (2)}

Aehre: rostrot, blau bereift, sich stark verjüngend, locker, lang; Aehrchen $1.4 \mathrm{~cm}$ breit meist 3-körnig; Grannen hell, gespreizt. - Stroh: rötlich-gelb, fest, fein, mittellang. - Frucht: rot, glasig, länglich (7 mm lang, $31 / 2 \mathrm{~mm}$ breit, 220 Früchte $=10 \mathrm{gr}$ ), feinschalig, sehr schwer, hart, Bruch stahlig.

Herbstblatt dunkelgrün, fein, kraus, Frühjahrsvegetation zeitig, Bestockung mittelstark, 4.2 Schösslinge, zeitig schossend und blühend. Halmlänge $100 \mathrm{~cm}$ (Mlax. $120 \mathrm{~cm}$ ), Halmdicke $0.25 \mathrm{~cm}$, Blattlänge $18.5 \mathrm{~cm}$, Blattbreite $0.85 \mathrm{~cm}$, Blattoberfläche $157.25 \mathrm{qcm}$, Halmfläche $75 \mathrm{qcm}, \mathrm{Ge}-$ sammtfläche $232.25 \mathrm{qcm}$.

Junge Aehre gelblich-grün, mittelfrüh reifend, $10 \mathrm{~cm}$ (Мax. $15 \mathrm{~cm}$ ) lang, mit 16 Aehrchen und 42 Früchten, von denen 1914000 auf 1 hl $(=87 \mathrm{~kg})$ entfallen.

Es wiegen 100 Halme $400 \mathrm{gr}$ und davon die Früchte $188 \mathrm{gr}$.

Diese ostindische l'echt beachtenswerte Sorte, leidet ziemlich stark durch Rost, jedoch wenig durch Lagern und überwinterte 1879/80 vortreflich.

\section{Varietät: Triticnm vulgare caesium Al.}

Aehre kahl, graublau; Körner rot.

\section{Sorte:}

\section{Blauähriger Sommer-Bartweizen. $\odot$}

Aehre: meist schwarzblau, einige rotblau, sich verjüngend, schlaff, etwas locker, mittellang, dünn; Aehrchen $1.5 \mathrm{~cm}$ breit, 3- und 4-körnig, und 3-grannig (davon 2 lang), Klappen mit Grannenspitzen; Grannen graublau, stark gespreizt, bis $12 \mathrm{~cm}$ lang, leicht abbrechend. Stroh: gelbgran, mittellang, blattarm, derbwandig, doch feinhalmig. fest. 
Frucht: dunkelrot, glasig, etwas eingefallen, klein $(6 \mathrm{~mm}$ lang, $3 \mathrm{~mm}$ breit), feinschalig, schwer.

Halm dunkelgrün, mittelfrüh schossend und blïhend, 2.2 Schösslinge Halmlänge $105 \mathrm{~cm}$ (Max. $115 \mathrm{~cm}$ ), Halmdicke $0.3 \mathrm{~cm}$, Blattzahl 3, Blattlänge $26 \mathrm{~cm}$, Blattbreite $0.9 \mathrm{~cm}$, Blattoberfläche eines Halmes $140.4 \mathrm{qcm}$, Halmfläche $94.5 \mathrm{qcm}$, Gesammtfläche $234.9 \mathrm{qcm}$.

Junge A ehre blaugrün, Reifezeit 125 Tage, reif $10 \mathrm{~cm}$ (Max. $12 \mathrm{~cm}$ ) lang, mit 14 Aehrchen und 50 ziemlich leicht ausfallenden Früchten, von denen 2279000 auf $1 \mathrm{hl}(=86 \mathrm{~kg})$ gehen.

Auf $1 \mathrm{qm}$ wachsen 1000 Halme oder 455 Pflanzen, mithin beträgt der Raum für eine Pflanze $22 \mathrm{qcm}$, die Blattoberfläche p. qm Bodenfläche $23.49 \mathrm{qm}$, und das Saatquantum ( $1 / 3$ Verlust) $3 \mathrm{hl}$ p. ha.

Es wiegen 100 Halme $390 \mathrm{gr}$ und davon die Früchte $170 \mathrm{gr}$.

Dieser Weizen, da er sehr hart ist, auch wenig durch Lagern oder Rost leidet, empfiehlt sich für rauhe Lagen und schweren, feuchten Thonboden.

Metzger ${ }^{1}$ ) versuchte diesen Weizen an Stelle des Spelzes in die Spelzbau treibenden Gegenden Südwestdeutschlands einzuführen, doch mit geringem Erfolg, indem die Bauern meist wieder zum Spelz zurückkehrten.

\section{Varietät: Triticum vulgare meridionale Kcke.}

Aehre sammetig, weiss; Körner weiss oder gelblich.

\section{Sorte:}

\section{Weisser sammetiger Bartweizen aus Karystos, Euboea, Griechenland. $\odot$ u. (2)}

Aehre: weiss, sammetig, schmal, dicht, ziemlich lang; Aehrchen $1.1 \mathrm{~cm}$ breit, 2- und 3-körnig, 2-grannig, Klappen gezahnt und gekielt: Grannen wenig gespreizt, bis $7 \mathrm{~cm}$ lang. - Stroh: gelb, fest, mittellang. Frucht: weisslich-gelb, glasig, einige mehlig, gross, oval $\left(7^{3} / 4 \mathrm{~mm}\right.$ lang, $4 \mathrm{~mm}$ breit, 208 Früchte $=10 \mathrm{gr}$ ), feinschalig.

Herbstblatt dunkelgrün, kräftig, 3 Schösslinge, sehr zeitig schossend und blühend, Halmlänge $100 \mathrm{~cm}$, (Max. $110 \mathrm{~cm}$ ), Halmdicke $0.39 \mathrm{~cm}$, Blattzahl 4, Blättlänge $24.5 \mathrm{~cm}$ Blattbreite $1.0 \mathrm{~cm}$, Blattoberfläche $196 \mathrm{qcm}$, Halmfläche 114 qcm, Gesammtfläche $310 q \mathrm{~cm}$.

Junge Aehre blaugrün, mittelfrüh reifend, mit 14 Aehrchen und 35 Früchten, von denen 1726400 auf $1 \mathrm{hl}$ (=83 kg) gehen.

Für Deutschland ist dieser Weizen nicht winterfest genug, doch lässt er sich auch als Sommerweizen aussäen, lagert aber leicht und leidet sehr stark durch Rost.

Es wiegen 100 Halme $290 \mathrm{gr}$ und davon die Früchte $144 \mathrm{gr}$.

1) Landw. Pflanzenkunde 1841 pg. 58. 


\section{Varietät: Triticum vulgare velutinum $\mathrm{Al}$.}

Aehre sammetig, weiss; Körner rot.

\section{Sorte:}

\section{Weisser sammetiger Bartweizen. (2)}

Syn.: Froment commun, barbu, blanc et velouté ${ }^{1}$ ).

Aehre: blassgelb mit schwach rötlichem Anflug, sich nach der Spitze verjüingend, stark sammetig, locker; Aehrchen $1.2 \mathrm{~cm}$ breit, 3-körnig, Grannen hell, gespreizt, $6-7 \mathrm{~cm}$ lang. - Frucht: rot, mehlig oder glasig, etwas bauchig, gross, ( $8 \mathrm{~mm}$ lang, $4 \mathrm{~mm}$ breit), eingefallen, feinschalig.

Herbstblatt blaugrün, kräftig; Frühjahrsvegetation sehr spät, Bestockung stark, 5 Schösslinge, spät schossend und blühend. Halmlänge $145 \mathrm{~cm}$ (Max. $160 \mathrm{~cm}$ ) Halmdicke $0.33 \mathrm{~cm}$, Blattzahl 4.8, Blattlänge $26 \mathrm{~cm}$, Blattbreite $0.9 \mathrm{~cm}$, Blattoberfläche $224.64 \mathrm{qcm}$, Halmfläche $143.55 \mathrm{qcm}$, Gesammtfläche 368.19 qcm.

Junge Aehre blaugrüin, Spelzen violett umrandet, mittelfrüh reifend, mit 16 Aehrchen und 45 Früchten von denell 1709000 auf $1 \mathrm{hl}=$ $78.4 \mathrm{~kg}$ gehen.

Es wiegen 100 Halme $570 \mathrm{gr}$, und davon die Früchte $190 \mathrm{gr}$.

Diese Weizensorte wurde nach Seringe auch in der Schweiz, wenngleich nur selten gebaut; sie ist nicht ganz winterfest, so erfror dieselbe $1870 / 71$ in Poppelsdorf bis auf einige wenige kümmerliche Pflanzen, doch widersteht sie dem Rost gut und lagert selten.

\section{Varietät: Triticum vulgare turcicum Kcke.}

Aehre sammetig, rot: Körner weiss oder gelblich.

\section{Sorte:}

Turkestanischer rotähriger, weisser, sammetiger Bartweizen. $\odot$

Aehre: schmutzig-rot, sammetig, ziemlich dicht, aufrecht, lang; Aehrchen $1.2 \mathrm{~cm}$ breit, meist 3-körnig und 3-grannig, Spelzen dick, Klappen kulzgranuig; Granne hell, gespreizt, $8 \mathrm{~cm}$ lang. - Stroh: rötlich-gelb, fest, lang. - Frucht: Original fast weiss, mehlig; nachgebaut: blassrötlich, glasig, ziemlich gross $(7 \mathrm{~mm}$ lang, $3 \mathrm{~mm}$ breit, 275 Früchte $=10 \mathrm{gr})$, feinschalig.

Junges Blatt blaugriin, beidcrseits stark behaart, 2.8 Schösslinge, spät schossend und blühend. Halme $120 \mathrm{~cm}$ ( Мax. $135 \mathrm{~cm}$ ) lang, $0.38 \mathrm{~cm}$

1) Seringe, Mongr. des céréales de la Suisse 1818, pg. 89. 
dick, Blattzahl 3, Blätter $25.8 \mathrm{~cm}$ lang, $0.9 \mathrm{~cm}$ breit, Blattfläche $139.32 \mathrm{qcm}$, Halmfläche $136.8 \mathrm{qcm}$, Gesammtfläche 276.12 q $\mathrm{cm}$.

Junge Aehre bläulich-grün, reift in 122 Tagen, $10 \mathrm{~cm}$ (Max. $13 \mathrm{~cm}$ ) lang, mit 17 Aehrchen und 50 Früchten, von denen 2255000 auf $1 \mathrm{hl}$ $(=82 \mathrm{~kg})$ entfallen.

Es wiegen 100 Halme $312 \mathrm{gr}$ und davon die Früchte $128 \mathrm{gr}$.

Durch Dr. Alb. Regel 1875 Originalsaat erhalten.

\section{Varietät: Triticum vulgare subvelntinum Keke.}

Aehre schwach sammetig, rot; Körner rot.

\section{Sorte:}

\section{Roter, schwach sammetiger Bartweizen. (2)}

Aehre: blassrot, schwach sammetig, sich verjüngend, mittellang, schmal; Aehrchen $1.2 \mathrm{~cm}$ breit, meist 2-körnig; Grannen rötlich, gespreizt, bis $5 \mathrm{~cm}$ lang. - Stroh : rötlich-gelb, mittellang. - Frucht: rot, glasig, wenige gelbrot, mehlig, klein (61/2 $\mathrm{mm}$ lang, $3^{1 / 2} \mathrm{~mm}$ breit), feinschalig.

Herbstblatt blaugrün, schmal, sehr kurz, kraus, schwach behaart; Entwickelung sehr spät, Bestockung stark, 6.3 Schösslinge, spät schossend und blühend; Halm $125 \mathrm{~cm}$ (Max. $150 \mathrm{~cm}$ ) lang, $0.35 \mathrm{~cm}$ dick, Blattzahl 3.7, Blätter $23.5 \mathrm{~cm}$ lang, $0.87 \mathrm{~cm}$ breit, Blattfläche $151.33 \mathrm{qcm}$, Halmfläche $131.25 \mathrm{qcm}$, Gesammtfläche $282.58 \mathrm{qcm}$.

Junge Aehre gelbgrün, spät reifend, $10 \mathrm{~cm}$ (Max. $13 \mathrm{~cm}$ ) lang, mit 40 Früchten, von denen 2076000 auf $1 \mathrm{hl}(=83.7 \mathrm{~kg}$ ) entfallen.

Winterfest, nicht leicht lagernd, doch stark durch Rost leidend.

\section{Varietät: Triticum vulgare barbarossa Al.}

Aehre sammetig, rot; Körner rot.

\section{Sorten:}

\section{Kurzähriger, sammetartiger Bartweizen. (2)}

Aehre: bläulich-rot, ziemlich breit, doch kurz, Uebergang zu den Igelweizen bildend, fast quadratisch, dicht; Aehrchen 3-körnig, Grannen bläulich-rot, wenig gespreizt, bis $8 \mathrm{~cm}$ lang. - Stroh: rötlich-gelb, nach Aehre zu rotblau, lang, dickwandig, steif. - Frucht: gelbrot, meist glasig, etwas bauchig, länglich ( $7 \mathrm{~mm}$ lang, $3 \frac{1}{2} \mathrm{~mm}$ breit), schwer, etwas eingefallen, feinschalig, halbhart, Bruch halbmehlig. 
Herbstblatt blaugrïn, schmal, kraus; Frïhjahrsvegetation zeitig, Bestockung schwach, 3.8 Schösslinge, mittelfrüh schossend und blühend. Halmlänge $120 \mathrm{~cm}$ (Max. $140 \mathrm{~cm}$ ), Halmdicke $0.37 \mathrm{~cm}$, Blattzahl 3.7 , Blattlänge $23.52 \mathrm{~cm}$, Blattbreite $1.01 \mathrm{~cm}$, Blattoberfläche $175.82 \mathrm{qcm}$, Halmfläche $133.2 \mathrm{qcm}$, Gesammtfläche $309.02 \mathrm{qcm}$.

Junge Aehre bläulich-griin, etwas spät reifend, mit 15 Aehrchen und 45 nicht leicht ausfallenden Früchten, von denen 1960000 auf $1 \mathrm{hl}$ $(=84.5 \mathrm{~kg})$ gehen.

Es wiegen 100 Halme $483 \mathrm{gr}$ und davon die Früchte $151 \mathrm{gr}$.

Diese Weizensorte erwies sich winterfest, lagerte nicht, litt jedoch stark durch Rost.

\section{Velvet-Chaff. (2)}

Syn.: Velvet Beard; Crate Wheat.

Aehre: rot, sammetig, halblocker, sich wenig verjüngend, unter mittellang. Aehrchen $1.5 \mathrm{~cm}$ breit, 3-körnig, 2-grannig; Grannen blassrot, wenig gespreizt (bis $6 \mathrm{~cm} \mathrm{lang).} \mathrm{-} \mathrm{Stroh:} \mathrm{rotgelb,} \mathrm{bis} \mathrm{violett,} \mathrm{steif,} \mathrm{unter}$ mittellang. - Frucht: Original gelbrot, mehlig, länglich, klein $(61 / 4 \mathrm{~mm}$ lang, $3^{1 / 4} \mathrm{~mm}$ breit, 316 Früchte $\left.=10 \mathrm{gr}\right)$; nachgebaut: rot, glasig, grösser, 204 Frïchte $=10 \mathrm{gr}$, schwer, feinschalig, halbhart, Bruch mehlig.

Herbstblatt hellgrün, etwas niederliegend, feinblättrig; Entwickelıng mittelfrüh, 3.4 Schösslinge, zeitig schossend, mittelfrüh blühend; Halm $100 \mathrm{~cm}$ (Max. $112 \mathrm{~cm}$ ) lang, $0.3 \mathrm{~cm}$ dick, Blattzahl 4.4, Blätter $15.6 \mathrm{~cm}$ lang, $0.75 \mathrm{~cm}$ breit, Blattfläche $103 \mathrm{qcm}$, Halmfläche $90 \mathrm{qcm}$, Gesammtfläche $193 \mathrm{qcm}$.

Junge Aehre blaugrün, zeitig reifend, $9 \mathrm{~cm}$ (Мax. $12 \mathrm{~cm}$ ) lang, mit 18 Aehrchen und 50 ziemlich fest sitzenden Früchten, von denen 2780800 auf $1 \mathrm{hl}(=88 \mathrm{~kg})$ entfallen.

Winterfest; rostig, nicht leicht lagernd, ertragreich und für schweren Boden geeignet.

Soll ursprünglich eine englische Sorte sein, welche 1830 nach den Tereinigten Staaten eingeführt wurde.

Bezugsquelle: Missouri Agric. Coll. 1880.

\section{Froment commun, barbu, roux et veloute ${ }^{1}$ ).}

Deutsch: Roter sammetiger Grannenweizen.

Aehre: dunkelrot, sammetig, halblocker, diinn, sich verjüngend, unter mittellang; Aehrchen $1.3 \mathrm{~cm}$ breit. 3-körnig; Granmen rotgrau, gespreizt (bis $10 \mathrm{~cm}$ lang). - Stroh: rötlich-gelb, meist nach der Aehre zu rotgrau, mittellang. - Frucht: dunkelrot, glasig, bauchig, $7 \mathrm{~mm}$ lang, $3 \mathrm{~mm}$ breit, etwas grobschalig, halbhart, Bruch halbstahlig.

Herbstblatt dunkelgrïn, kräftig, aufrecht; Entwickelung sehr zeitig, 3 Schösslinge, mittelfrüh schossend und blühend; Halm $110 \mathrm{~cm}$ (Max. $130 \mathrm{~cm}$ ) lang, $0.34 \mathrm{~cm}$ dick, Blattzahl 4, Blätter $18.8 \mathrm{~cm} \mathrm{lang,} 0.9 \mathrm{~cm}$ breit, Blattfläche $\mathbf{1 3 5 . 4}$ qcm, Halmfläche 112.2 qcm, Gesammtfläche $147.6 \mathrm{qcm}$.

1) Seringe, Monogr. des céréal. de la Suisse 1818 pg. 90. 
Junge Aehre blaugrün, rot gestreift, zeitig reifend, $9 \mathrm{~cm}$ (Max. $11 \mathrm{~cm}$ ) lang, mit 45 Friichten, von den 1926000 auf $1 \mathrm{hl}$ (=86 kg) entfallen.

Winterfest, neigt zım Lagern, wenig widerstandsfähig gegen Rost.

Zuweilen in Mitteleuropa, so z. B. in der Schweiz gebaut.

\section{Roter, sammetartiger Bartweizen aus Kastamuni. (2) u. $\odot$}

Aehre: schmutzig-graurot, schmal, ziemlich dicht, lang. - Aehrchen $1.2 \mathrm{~cm}$ breit, 3-körnig und 3-grannig, eine Granne kurz; Grannen rötlich, ziemlich gespreizt, bis $8 \mathrm{~cm}$ lang. - Stroh: rotgrau, oder gelbrot, weich. Frucht: blassrot, meist glasig, lang, schmal $\left(7^{1} / 2 \mathrm{~min}\right.$ lang, $3 \frac{1}{4} \mathrm{~mm}$ breit, 235 Früchte $=10 \mathrm{gr}$ ), feinschalig, halbhart, Bruch halbmehlig.

Herbstblatt gelbgrün, schmal, ziemlich aufrecht; Friihjahrsvegetation zeitig, Bestockung stark, 5.2 Schösslinge, zeitig schossend und blühend. Halmlänge $100 \mathrm{~cm}$ (Max. $120 \mathrm{~cm}$ ), Halmdicke $0.28 \mathrm{~cm}$, Blattzahl 3.3 , Blattlänge $23.8 \mathrm{~cm}$, Blattbreite $0.8 \mathrm{~cm}$, Blattoberfläche $125.66 \mathrm{qcm}$, Halmfläche $84 \mathrm{qcm}$, Gesammtfläche $209.66 \mathrm{qcm}$.

Junge Aehre bläulich-griin, mittelfriih reifend, $10 \mathrm{~cm}$ (Max. $12 \mathrm{~cm}$ ) lang, mit 19 Aehrchen und 54 lose sitzenden Früchten, von denen 1903500 auf $1 \mathrm{hl}(=81 \mathrm{~kg})$ gehen.

Es wiegen 100 Halme $350 \mathrm{gr}$ und davon die Früchte $139 \mathrm{gr}$.

Dieser Weizen eignet sich nur zum Anbau für leichteren Boden, da das Stroh sehr leicht lagert und sehr wenig Widerstandsfäligkeit gegen Rost besitzt.

Er lässt sich auch als Sommerweizen benutzen, reift aber in diesem Falle etwas spät, denn seine Vegetationsperiode betrug 135 Tage.

Heimat: Bezirk Kastamuni im Pontischen Gebirgssystem, KleinAsien, Türkei.

\section{Roter, sammetiger Bartweizen aus dem Thale des Juldus in Turkestan.}

Aehre: schmutzig-rot, sammetig, locker, dünn, mittellang; Aehrchen schmal, $1 \mathrm{~cm}$ breit, meist 3-körnig und 3-grannig, Mittelgranne kurz, Granne der Klappen sehr lang; Granne wenig gespreizt, bis $8 \mathrm{~cm}$ lang. Stroh: gelb, fest, steif, kurz. - Frucht: rot, glasig, länglich $\left(6 \frac{1}{2} \mathrm{~mm}\right.$ lang, $3 \mathrm{~mm}$ breit, 375 Früchte $=10 \mathrm{gr}$ ), schmal, feinschalig, hart, stahlig.

Junges Blatt gelblich-griin, beiderseits behaart und Basis der Blätter graublau, 2 Schösslinge, mittelfrüh schossend und blühend. Halme $80 \mathrm{~cm}$ (Max. $95 \mathrm{~cm}$ ) lang, $0.3 \mathrm{~cm}$ dick, Blattzahl 3.6 , Blätter $15 \mathrm{~cm}$ lang, $0.6 \mathrm{~cm}$ breit, Blattfläche $64.8 \mathrm{qcm}$, Halmfläche 72 q $\mathrm{cm}$, Gesammtfläche $136.8 \mathrm{qcm}$.

Junge Aehre bläulich-grün, reift in 119 Tagen, $10 \mathrm{~cm}$ (Max. $11 \mathrm{~cm})$ lang, mit 16 Aehrchen und 45 Frücliten, von denell 3150000 auf $1 \mathrm{hl}$ $(=84 \mathrm{~kg})$ entfallen.

Es wiegen 100 Halme $275 \mathrm{gr}$ und davon die Früchte $113 \mathrm{gr}$.

Von Fetisow 1878 gesammelt und durch E. Regel eingesandt. 


\section{Varietät: Triticum vulgare coeruleo-velutinum Kcke.}

Aehre sammetig, graublau; Körner rot.

\section{Sorten:}

\section{Graublauer sammetartiger Bartweizen. (2)}

Aehre: dunkelgraublau, stark behaart, sehr locker, schmal, lang; Aehrchen $1 \mathrm{~cm}$ breit, meist 3-körnig; Granne hell, 8-10 cm lang. Stroh: rötlich-gelb, sehr dickwandig, lang. - Frucht: rot, meist glasig, lang, schmal ( $8 \mathrm{~mm}$ lang, $3 \mathrm{~mm}$ breit), sehr schwer, eingefallen.

Herbstblatt gelbgriin, schwach behaart, ziemlich breit, aufrecht; Frübjahrsvegetation sehr zeitig, Bestockung schwach; 3.5 Schösslinge, mittelfrüh schossend und bliihend. Halmlänge $115 \mathrm{~cm}$ (Max. $140 \mathrm{~cm}$ ), Halmdicke $0.38 \mathrm{~cm}$, Blattzahl 4, Blattlänge $25 \mathrm{~cm}$, Blattbreite $0.9 \mathrm{~cm}$, Blattoberfläche $180 \mathrm{qcm}$, Halmfläche $131.1 \mathrm{qcm}$, Gesammttläche $311.1 \mathrm{qcm}$.

Junge Aehre blaugriin, mittelfrüh reifend, $10 \mathrm{~cm}$ (Max. $13 \mathrm{~cm}$ ) lang, mit 15 Aehrchen und 40 lose sitzenden Früchten, von denen 1853000 auf $1 \mathrm{bl}(=85 \mathrm{~kg})$ gehen.

Es wiegen 100 Halme $400 \mathrm{gr}$ und davon die Früchte $161 \mathrm{gr}$.

Diese nicht ganz winterfeste Sorte lagert nicht leicht, leidet aber stark durch Rost.

\section{Graublauer sammetiger Sommer-Bartweizen ans Wjernoje.}

Aehre: fast weiss mit schwach bläulichem Anflug, sammetig, halblocker, schmal, unter mittellang; Aehrchen $1 \mathrm{~cm}$ breit, meist 3-körnig, 3-grannig; Klappen mit Zahn; Grannen hell, gespreizt, bis $10 \mathrm{~cm}$ lang. Stroh: blassgelb, unter mittellang. - Frucht: gelbrot, mehlig, rundlich $(7 \mathrm{~mm} \text { lang, } 4 \mathrm{~mm} \text { breit, } 179 \text { Früchte }=10 \mathrm{gr})^{2}$, feinschalig.

Junges Blatt blaugriin, aufrecht, dicht behaart; 2.8 Schösslinge, spät schossend und blühend; Halm $100 \mathrm{~cm}$ (Max. $110 \mathrm{~cm}$ ) lang, $0.3 \mathrm{~cm}$ dick, Blattzahl 4, Blätter $19 \mathrm{~cm}$ lang, $0.77 \mathrm{~cm}$ breit, Blattfläche $117 \mathrm{qcm}$, Halmfläche $90 \mathrm{qcm}$, Gesammttläche $207 \mathrm{qcm}$.

Junge Aehre blaugrün, $9 \mathrm{~cm}$ (Мax. $12 \mathrm{~cm}$ ) lang, mit 13 Aehrchen und 32 Früchten, von denen 1557300 auf $1 \mathrm{hl}$ (=87 kg) entfallen.

Es wiegen 100 Halme $330 \mathrm{gr}$ und davon die Früchte $143.5 \mathrm{gr}$.

Leidet stark durch Rost. Von Fetisow gesammt.

\section{Varietät: Triticum vulgare fuliginosum Al.}

Aehre sammetig, schwarz; Körner rot.

\section{Sorte:}

\section{Blauer sammetiger Bartweizen. (2)}

Aehre: auf blassgelbem oder rötlichgelbem Grunde und zwar namentlich an den Rändern der Klappen, am Zahn und Kiel blau gefärbt, mittellang (10 cm lang), viereckig, aufrecht; Aehrchen 2- und 3-körnig; Grannen schwärzlich, gespreizt, bis $9 \mathrm{~cm}$ lang. Zahl der Aehrchen 24, der Früchte 60. - Stroh: rötlich-gelb, mittellang. - Frucht: gelbrot, meist mehlig, oval, mittelgross, $7 \mathrm{~mm}$ lang, $4 \mathrm{~mm}$ breit. 


\section{Unterart: 2. Triticum compactum Host. Binkel- und Igelweizen.}

\section{A. Binkelweizen.}

Varietät: Triticum compactum Humboldtii Kcke.

Aehre kahl, weiss; Körner weiss oder gelblich.

\section{Sorten:}

\section{Gelbähriger Binkelweizen. $\odot$ u. (2)}

Aehre: gelb, seitlich zusammengedrïckt, sehr dicht, kurz; Aehrehen $1.2 \mathrm{~cm}$ breit, 3-körnig, Aehrchen sich gegenüberstehend. - Stroh: rötlichgelb, steif, mittellang. - Frucht: blassroth, glasig, plump, rundlich, klein (6 $\mathrm{mm}$ lang, $3^{1} / 2 \mathrm{~mm}$ breit, 275 Frïchte $=10 \mathrm{gr}$ ), etwas grobschalig, halbhart, Bruch halbstahlig.

Dieser Weizen ist ein Wechselweizen und zeigten Sommer- und Winterweizen den gleichen Habitus.

Herbstblatt blaugriin, schmal, Bestockung schwach, 3 Schösslinge, mittelfriih schossend und blühend; Halmlänge $110 \mathrm{~cm}$ (Max. $130 \mathrm{~cm}$ ), Halmdicke $0.38 \mathrm{~cm}$, Blattzahl 3.7, Blattlänge $22.92 \mathrm{~cm}$, Blattbreite $0.98 \mathrm{~cm}$, Blattoberfläche eines Halmes 166.2 qcm, Halmfläche 125.4 qcm, Gesammtfläche $291.6 \mathrm{qcm}$.

Junge Aehre blaugrün, Wintersaat mittelfrïh, Sommersaat in 124 Tagen reifend. Aehre $5.5 \mathrm{~cm}$ (Max. $8 \mathrm{~cm} \mathrm{lang),} \mathrm{mit} 16$ Aehrchen und 45 Früchten, von denen 2266000 auf $1 \mathrm{hl}(=82.4 \mathrm{~kg})$ gehen.

Auf $1 \mathrm{qm}$ wachsen 900 Halme oder 300 Pflanzen, mithin beträgt der Raum für eine Pflanze $33.3 \mathrm{qcm}$, die Blattoberfläche p. qm Bodenfläche $26.1 \mathrm{qm}$, und das Saatquantum (1/3 Verlust) $2.2 \mathrm{hl} \mathrm{p.} \mathrm{ha.}$

Es wiegen 100 Halme $380 \mathrm{gr}$, und davon die Früchte $120 \mathrm{gr}$.

Der Weizen lagerte in Poppelsdorf nicht, befiel jedoch stark mit Rost und zeigte sich winterfest.

Im Allgemeinen scheint dieser Weizen eine geringere Kultur zu beanspruchen, und auf leichteren Böden, z. B. auf lehmigem Sand und leichterem sandigen Lehm, gute Erträge zu bringen.

\section{Walla-Walla Spring-Wheat. $\odot$}

Syn.: Sommerweizen aus Walla-Walla, Vereinigte Staaten.

Aehre: blassgelb, sehr dicht und klein, $6 \frac{1}{2} \mathrm{~cm}$ lang mit 45 Érüchten; Aehrchen $0.7 \mathrm{~cm}$ breit, 2- und 3-körnig. - Stroh: gelb, steif. - Frucht: blassröthlich, klein, (51/2 mm lang, $2^{1 / 2} \mathrm{~mm}$ breit), feinschalig.

Original in der Sammlung von Dreisch, Poppelsdorf. 


\section{Carter's fill measure. (2)}

A ehre schmutzig-weissgelb, quadratisch, sehr dicht, kurz, $8 \mathrm{~cm} \mathrm{lang,}$ mit 70 Früchten; Aehrchen $1.5 \mathrm{~cm}$ breit, 4-körnig. - Stroh: gelb, sehr fest, steif. - Frucht: fast weis, mehlig, oval, klein $(6.4 \mathrm{~mm}$ lang, $4 \mathrm{~mm}$ breit), feinschalig. In der Sammlung von Dreiscll.

\section{Trigo blanquillo, Chile. $\odot$}

Syn.: Californischer Weizen aus Chile.

Aehre: blassgelb, aufrecht, sehr dicht, an der Spitze kurzgrannig; Aehrchen $1.3 \mathrm{~cm}$ breit, 2-, 3- und 4-körnig. - Frucht: Original weiss, mehlig; nachgebaut: rötlich und glasig, seitlich zusammengedrückt, klein $\left(6 \mathrm{~mm}\right.$ lang, $3^{1 / 2} \mathrm{~mm}$ breit, 246 Früchte $\left.=10 \mathrm{gr}\right)$, feinschalig halbweich Bruch halbmehlig.

Halme dunkelgrün, 1.8 Schösslinge, mittelfrüh schossend und blühend. Halmlänge $80 \mathrm{~cm}$ (Max. $95 \mathrm{~cm}$ ), Halmdicke $0.27 \mathrm{~cm}$, Blattzahl 4, Blattlänge $22.5 \mathrm{~cm}$, Blattbreite $0.82 \mathrm{~cm}$, Blattoberfläche eines Halmes $147.6 \mathrm{gcm}$, Halmfläche $64.8 \mathrm{qcm}$. Gesammtfläche $214.4 \mathrm{qcm}$.

Junge Aehre blaugrün, mittelfrüh, in 130 Tagen reifend, $5 \mathrm{~cm}$ (Max. $6 \mathrm{~cm}$ ) lang, mit 14 Aehrehen und 40 ziemlich fest sitzenden Früchten, von denen 2115600 auf $1 \mathrm{hl}(=86 \mathrm{~kg})$ gehen.

Auf 1 qm wachsen 1000 Halme oder 555 Pflanzen, somit beträgt der Raum für eine Pflanze $18 \mathrm{qcm}$, die Blattoberfläche $\mathrm{p}$. qm Bodenfläche $21.44 \mathrm{qm}$ und das Saatquantum $(1 / 3$ Verlust $) 4 \mathrm{hl} \mathrm{p}$. ha.

Es wiegen 100 Halme 500 gr und darum die Früchte 170 gr.

Die ursprüngliche Heimat dieses Weizens ist Chile, von wo er nach Californien zum Anbau auf trockenem Lehmboden gelangte. Wahrscheinlich ist aus ihm durch Verlängerung und Lockerwerden der Aehre der weisse Chile-Sommerweizen und der mit diesem identische Californische Sommerweizen unter 'Trit. vulg. albidum entstanden.

Der Weizen lagert nicht, befiel jedoch in Poppelsdorf stark mit Rost.

Uebersender: L. Wittmack, von der Wiener Weltausstellung 1873. Trigo blanquillo durch v. Giilich 1880 aus Chile erhalten.

\section{Trigo mocho, Chile. $\odot$ u. (2)}

Aehre: blassgelb, 2-zeilig, sehr dicht, kurz, grannenspitzig; Aehrchen $1.4 \mathrm{~cm}$ breit, meist 4-köruig. - Stroh: blassgelb, mittellang, steif. Frucht: Original weiss, mehlig, viele rötlich, glasig, rundlich, klein $\left(5^{3 / 4}\right.$ $\mathrm{mm}$ lang, $3^{1 / 4} \mathrm{~mm}$ breit, 254 Früchte $=10 \mathrm{gr}$ ); nachgebaut: glasig, grösser, 218 Früchte $=10 \mathrm{gr}$, sehr schön, feinschalig, halbweich, Bruch halbmehlig.

Herbstblatt dunkelgrün, schwach aufrecht, 2 Schösslinge, mittelfrüh schossend und blühend; Halm $90 \mathrm{~cm}$ (Max. $100 \mathrm{~cm}$ ) lang, $0.4 \mathrm{~cm}$ dick, Blattzahl 3.5, Blätter $19.3 \mathrm{~cm}$ lang, $0.8 \mathrm{~cm}$ breit, Blattfläche $108.1 \mathrm{qcm}$, Halmfläche $108 \mathrm{qcm}$, Gesammtfläche 216, $1 \mathrm{qcm}$. Der Sommerweizen verhielt sich im Habitus wie der Winterweizen.

Junge Aehre blaugrün, mittelfrüh reifend, う cu (Мax.6 cm) lang. Nicht winterfest; etwas durch Rost leidend.

Bezugsquelle: durch von Gülich 1880 aus Chile erhalten. 


\section{Weisser Malorca-Weizen. (2)}

Aehre: blassgelb mit schwach rötlichem Schimmer, platt, sehr dicht, kurz, $5 \mathrm{~cm}$ lang mit 16 Aehrchen und 45 Früchten; Aehrchen $1.2 \mathrm{~cm}$ breit, 3-körnig. - Stroh: blassgelb, blattarm, steif, bis $80 \mathrm{~cm}$ lang. Frucht: fast weiss, mehlig, sehr schön $(7 \mathrm{~mm}$ lang, $3.5 \mathrm{~mm}$ breit), feinschalig.

Original im landw. Museum zu Berlin.

\section{Varietät: Triticum compactum Wernerianum Kcke.}

Aehre kahl, weiss; Körner rot.

\section{Sorte:}

\section{Weissähriger roter Binkelweizen aus Sicilien. $\odot$}

Aehre: fast weiss, compakt, mit kurzen Grannenspitzen, kurz; A ehrchen $1.1 \mathrm{~cm}$ breit, 3-körnig. - Stroh: rötlich-gelb, hohl, fest, steif. Frucht: dunkelrot, glasig klein $(6 \mathrm{~mm}$ lang, $3 \mathrm{~mm}$ breit, 282 Früchte $=10 \mathrm{gr}$ ), feinschalig, hart, Bruch stahlig.

Junges Blatt gelblich-grün, beiderseits kurz aber dicht behaart, gross, aufrecht, 2.5 Schösslinge, zeitig schossend und blühend. Halm $115 \mathrm{~cm}$ (Max. $130 \mathrm{~cm}$ ) lang, $0.4 \mathrm{~cm}$ dick, Blattzahl 3, Blätter $31 \mathrm{~cm}$ lang, 0.93 $\mathrm{cm}$ breit, Blattfäche $172.98 \mathrm{q} \mathrm{cm}$, Halmfläche $138 \mathrm{qcm}$, Gesammtfläche $310.98 \mathrm{qcm}$.

Junge Aehre blaugrün, reift in 120 Tagen, $6 \mathrm{~cm}$ (Max. $7 \mathrm{~cm}$ ) lang, mit 17 A ehrchen und 50 ziemlich festsitzenden Früchten, von denen 2312400 auf $1 \mathrm{hl}(=82 \mathrm{~kg})$ entfallen.

Es wiegen 100 Halme $283 \mathrm{gr}$, und davon die Früchte $118 \mathrm{gr}$.

Varietät: Triticum compactum creticum Al.

Aehre kahl, rot; Köruer rot.

\section{Sorte i:}

\section{Chub-Wheat. (2)}

Syn.: Dickköpfiger-Weizen.

Aehre: blassrot, quadratisch, etwas grannenspitzig, kurz, dick, selrr dicht, $8 \mathrm{~cm}$ lang mit 80 Früchten; Aehrchen $1.4 \mathrm{~cm}$ breit, 4-körnig. Stroh: rötlich-gelb, fest, steif. - Frucht: rot, glasig, rundlich, klein (6 mm lang, $3^{3 / 4} \mathrm{~mm}$ breit), feinschalig.

Lawes ${ }^{1}$ ) erzielte auf Lehmboden im Rothamsted, England, im sechsjährigen Durchschnitt p. ha. 34.99 hl.

\section{Blé hérisson sans barbe. $\odot$}

Aehre: rot mit bläulichem Anflug, platt, sehr dicht, sehr kurz; Aehrchen $1.6 \mathrm{~cm}$ breit, 3- und 4-körnig. - Stroh: rötlich-gelb, steif. Frucht: Original gelbrot, mehlig, rundlich, klein; nachgebaut: schon in 
der ersten Ernte Alles rot und glasig ( $5 \mathrm{~mm}$ lang, $3 \mathrm{~mm}$ breit), etwas bauchig, feinschalig, sehr schwer, halbhart, Bruch halbmehlig.

Halme blaugrün, 2 Schösslinge, spät schossend und blühend; Halmlänge $80 \mathrm{~cm}$ (Max. $90 \mathrm{~cm}$ ), Halmdicke $0.3 \mathrm{~cm}$, Blattzahl 4, Blattlänge $25 \mathrm{~cm}$, Blattbreite $0.85 \mathrm{~cm}$, Blattoberfläche eines Halmes $170 \mathrm{qcm}, \mathrm{Halm}$ fläche $72 \mathrm{qcm}$, Gesammtfläche $242 \mathrm{qcm}$.

Junge Aehre blaugrün, mittelfrüh reifend, Vegetationszeit 127 Tage, $4.5 \mathrm{~cm}$ (Max. $5 \mathrm{~cm}$ ) lang, mit 14 Aehrchen und 50 ziemlich fest sitzenden Früchten, von denen 2448000 auf $1 \mathrm{hl}$ (=89 kg) gehen.

Auf $1 \mathrm{qm}$ kommen 1100 Halme oder 550 Pflanzen, mithin beträgt der Raum für eine Pflanze 18.2 qcm, die Blattfläche p. qm Bodenfläche $26.6 \mathrm{qm}$ und das Saatquantum (1/3 Verlust) $3.4 \mathrm{hl}$ p. ha.

Es wiegen 100 Halme $480 \mathrm{gr}$ und davon die Früchte $200 \mathrm{gr}$.

Dieser Weizen soll auch als Winterweizen kultivierbar sein, doch nur im milden Klima. Das Stroh lagert nicht leicht und wird wenig rom Rost angegriffen.

Diese Sorte stammt ursprünglich aus Aegypten und wurde durch L. Wittmack 1876 nach Poppelsdorf gesandt, ebenfalls auch durch Vilmorin et Andrieux, Paris.

\section{Blé carré de Sicile. (2) u. $\odot$}

$\begin{aligned} \text { Syn.: Franz.: } & \text { Blé de Mars carré de Sicile. } \\ & \text { Blé carré de mars à épi blanchâtre (Vilm) }{ }^{1} \text { ). } \\ & \text { Blé de Crète (Seringe). } \\ & \text { Blé Mottu de Crète (Vilm). } \\ & \text { Blé de Phalsbourg (Tessiel). } \\ & \left.\text { Froment d'Alsace }(\text { DC. })^{2}\right) \text {. }\end{aligned}$

Engl.: Square Sicilian Spring Wheat.

Piper's Thickset ${ }^{3}$ ).

Deutsch: Hartsamiger sicilianischer Sommerweizen.

Cretischer Weizen.

Sommerweizen aus Esula (Morell) $\left.{ }^{4}\right)$.

Aehre: rosenrot mit bläulichem Anflug, an der Spitze kurz begrannt, platt, sehr dicht, kurz; Aehrchen schmal, $1.2 \mathrm{~cm}$ breit, 2- und 3-körnig. Stroh: rötlich-gelb bis orange, hohl, derb, steif, lang. - Frucht: rot, glasig, etwas eingefallen, rund, klein ( $6 \mathrm{~mm}$ lang, $3 \mathrm{~mm}$ breit), ziemlich feinschalig, hart, Bruch halbstahlig.

Herbstblatt blaugriin, kräftig, ziemlich aufrecht, doch etwas schmal und beide Seiten behaart, Bestockung mittelstark, 4.2 Schösslinge, spät schossend und blühend, mittelfrüh reifend.

Blatt der Sommersaat dunkelgrïn, etwas schmal, lang, aufrecht, 2.6 Schösslinge, mittelfrüh schossend und blühend, Reifezeit 127 Tage.

Das steife feste Stroh lagert nur unter sehr ungiinstigen Witterungsverhältnissen, doch lässt die Widerstandsfähigkeit gegen Rost zu wünschen.

Die Wintersaat zeigte sich nicht ganz winterfest, denn 1870/71 erfror der Weizen bis auf wenige kümmerliche Pflanzen.

1) Vilmorin, Journ. d'Agric. prat. 1851, pg. 456.

2) De Candolle, Fl. fr. 3 pg. 80.

3) Peter Lawson, Synops. of the reget. Products of Scotland, 1852.

4) More1l, Collect. de Céríales du .Musée d'hist. nat. de Berne. 
Winter- und Sommersaat entwickelten sich wie folgt:

\begin{tabular}{|c|c|c|}
\hline & Wintersaat & Sommersaat \\
\hline $\begin{array}{l}\text { Halmlänge } \\
\text { Halmdicke } \\
\text { Blattzahl } \\
\text { Mittlere Blattlänge } \\
\text { Bl, Blattbreite } \\
\text { Blattoberfläche } \\
\text { Halmfläche } \\
\text { Gesammtläche } \\
\text { Auf } 1 \text { qm wachsen } \\
\text { do. } \\
\text { Auf } 1 \text { qm Bodenfläche lommen } \\
\text { Raum für eine Pflanze } \\
\text { Aehrenlänge } \\
\text { Anzahl der Aehrchen pro Aehre } \\
\text { Früchte in einer Aehre } \\
\text { Hektolitergewicht } \\
\text { Fruchtzahl in } 1 \text { hl } \\
\text { Aussaatquantum pro ha }\end{array}$ & \begin{tabular}{|c|}
$120 \mathrm{~cm}$ (Max. $140 \mathrm{~cm})$ \\
$0.38 \mathrm{~cm}$ \\
4.4 \\
$29.5 \mathrm{~cm}$ \\
$0.9 \mathrm{~cm}$ \\
$233.64 \mathrm{qcm}$ \\
$13680 \mathrm{qcm}$ \\
$370.44 \mathrm{qcm}$ \\
900 Halme \\
212 Pflanze \\
33.3 qm Blattfläche \\
47.1 qcm \\
$5.5 \mathrm{~cm} \mathrm{(Max.} 7 \mathrm{~cm})$ \\
16 \\
40 \\
$81 \mathrm{~kg}$ \\
2177000 \\
$1.5 \mathrm{hl}$
\end{tabular} & $\begin{array}{c}115 \mathrm{~cm}(\text { Max. } 130 \mathrm{~cm}) \\
0.33 \mathrm{~cm} \\
3 \\
23.8 \mathrm{~cm} \\
0.85 \mathrm{~cm} \\
121.38 \mathrm{qcm} \\
113.85 \mathrm{qcm} \\
235.23 \text { qcm } \\
1200 \text { Halme } \\
462 \text { Pflanzen } \\
28.2 \text { qm Blattfläche } \\
21.7 \text { qm } \\
5.5 \mathrm{~cm} \text { (Max. } 7 \mathrm{~cm}) \\
16 \\
40 \\
81 \mathrm{~kg} \\
2130300 \\
3.2 \mathrm{hl}\end{array}$ \\
\hline
\end{tabular}

Es wiegen 100 Halme der Wintersaat $522 \mathrm{gr}$, die Früchte $201 \mathrm{gr}$ $" \quad " \quad, \quad$ " Sommersaat $301, "$ " 120 ,

Auf gutem, reichem Boden, so z. B. auf Neubruch, auf dem andere Sorten leicht lagern würden, empfiehlt sich der Anbau; die besten Friichte liefert er jedoch auf Kalkboden.

In Frankreich, namentlich aber auch im Elsass, in der Schweiz nud in Württemberg wird er gern als einer der frühesten Sommerweizen kultiviert. Seine Kultur als Winterweizen empfiehlt sich selbst in diesen Gegenden nicht, weil er häufiger auswintert, doch lässt sich die Sommersaat $^{1}$ ) schon im Februar ausführen.

Diese Sorte ist, da die Aehre in der Vollreife leicht abbricht, in der Gelbreife zu mähen.

\section{Bentel-Jinthel, Palermo. $\odot$}

Aehre : rot, platt, grannenspitzig, sehr dicht, kurz; Aehrchen $1.2 \mathrm{~cm}$ breit, 2- und 3-körnig. - Stroh: goldgelb, fest, mittellang. - Frucht: graurot, glasig, klein $\left(5^{1} / 2 \mathrm{~mm}\right.$ lang, $3 \mathrm{~mm}$ breit, 295 Früchte $\left.=10 \mathrm{gr}\right)$, feinschalig, hart, Bruch halbstahlig.

Junges Blatt. blaugrün, sehr lang, breit, 2.9 Schösslinge, mittelfriih schossend und blühend. Halmlänge $115 \mathrm{~cm}$ (Max. $140 \mathrm{~cm}$ ), Halmdicke $0.34 \mathrm{~cm}$, Blattzahl 3, Blattlänge $27.8 \mathrm{~cm}$, Blattbreite $0.93 \mathrm{~cm}$, Blattoberfläche eines Halmes 155.12 qcm, Halmfläche $117.3 \mathrm{qcm}$, Gesammtfläche $272.4 \mathrm{qcm}$.

Junge Aehre blaugrün, sehr zeitig, in 116 Tagen reifend, $6 \mathrm{~cm}$ (Max. $8 \mathrm{~cm}$ ) lang, mit 14 Aehrchen und 35 Früchten, von denen 2466000 auf $1 \mathrm{hl}(=83.6 \mathrm{~kg})$ gehen.

1) Metzger, Ccrealien pg. 11 u. 12. 
Auf $1 \mathrm{qm}$ wachsen 1000 Halme oder 345 Pflanzen, mithin beträgt der Raum für eine Pflanze $29 \mathrm{qcm}$, die Blattoberfläche p. $q \mathrm{~m}$ Bodenfläche $27.24 \mathrm{qm}$ und das Saatquantum $2.1 \mathrm{hl}$ p. ha.

Es wiegen 100 Halme $450 \mathrm{gr}$ und davon die Früchte $165 \mathrm{gr}$.

Der Weizen lagert nicht leicht und leidet wenig durch Rost. Die Aehre bricht in der Vollreife sehr leicht ab. stellung.

Uebersender: L. Wittmack 1873, von der Wiener Weltaus-

Varietät: Triticum compactum linaza Kcke. Aehre sammetig, blassgelb; Körner weiss oder gelblich.

\section{Sorte : \\ Trigo linaza, Chile. $\odot$ u. (2)}

Syn.: Weissähriger sammetiger Binkelweizen mit weissem Korn.

Aehre: blassgelb, sammetig, sehr dicht, 2-zeilig, kurz; Aehrchen $1.3 \mathrm{~cm}$ breit, 3-körnig. - Stroh: gelbrot, steif, kurz. - Frucht: Original blassgelb, mehlig, einige rötlich, glasig, rundlich, klein (6 mm lang, $3^{1 / 2} \mathrm{~mm}$ breit, 306 Früchte $\left.=10 \mathrm{gr}\right)$; nachgebaut: grösser, 220 Früchte $=10 \mathrm{gr}$, schön, feinschalig.

Herbstblatt dunkelgrün, schmal, aufrecht; Entwickelung spät, 2 Schösslinge; Halm $75 \mathrm{~cm}$ (Мax. $85 \mathrm{~cm}$ ) lang, $0.35 \mathrm{~cm}$ dick, Blattzahl 3.5, Blätter $18 \mathrm{~cm}$ lang, $1 \mathrm{~cm}$ breit, Blattlä̈che $126 \mathrm{qcm}$, Halmfläche $78.8 \mathrm{qcm}$, Gesammtfläche $204.8 \mathrm{qcm}$. Sommerweizen $\nabla$ on gleichem Habitus.

Junge Aehre gelblich-grün, mittelfrüh reifend, $4 \mathrm{~cm}$ (Max. $6 \mathrm{~cm}$ ) lang, mit 17 Aehrchen und 50 fest sitzenden Früchten.

Nicht winterfest; widerstandsfähig gegen Rost.

Bezugsquelle: durch von Gülich 1880 aus Chile.

Varietät: Triticum compactum Wittmackianum Kcke.

Aehre sammetig, blassgelb; Körner rot.

\section{Sorte:}

\section{Weissähriger sammetiger Binkelweizen.}

Aehre: blassgelb, sammetig, sehr dicht, platt, kurz; Aehrchen 3- uud 4-körnig, $1.2 \mathrm{~cm}$ breit. - Stroh: rötlich-gelb oder rötlich-grau, steif, mittellang. - Frucht: rot, glasig, etwas eingefallen, klein $(6 \mathrm{~mm}$ lang, $3 \mathrm{~mm}$ breit, 245 Früchte $=10 \mathrm{gr}$ ), feinschalig, hart, Bruch halbstahlig.

Herbstblatt blaugrün, sehr schmal, kraus; Frühjahrsvegetation ziemlich spät, Bestockung stark, 6 Schösslinge, mittelfrüh schossend und blühend. Halmlänge $115 \mathrm{~cm}$ (Max. $130 \mathrm{~cm}$ ), Halmdicke $0.38 \mathrm{~cm}$, Blattzahl 3, Blattlänge $24.76 \mathrm{~cm}$, Blattbreite $0.93 \mathrm{~cm}$, Blattoberfläche $138.18 \mathrm{qcm}$, Halmfläche 131.1 q cm, Gesammtfläche $269.28 \mathrm{qcm}$.

Junge Aehre blaugrün, zeitig reifend, $5 \mathrm{~cm}$ (Иаx. $6 \mathrm{~cm}$ ) lang, mit 17 Aehrchen und 60 fest sitzenden Friichten, von denen 2033500 auf $1 \mathrm{hl}(=83 \mathrm{~kg})$ entfallen.

Es wachsen auf 1 qm 1100 Halme oder 183 Pflanzen, mithin beträgt der Raum für eine Pflanze $54.6 \mathrm{qcm}$, die Blattfläche p. qm Bodenfläche $29.7 \mathrm{qcm}$ und das Saatquantum $1.4 \mathrm{hl} \mathrm{p}$. ha. 
Es wiegen 100 Halme $500 \mathrm{gr}$ und davon die Früchte $199 \mathrm{gr}$.

Dieser Weizen neigt auf reichem Boden etwas zum Lagern, leidet jedoch wenig durch Rost.

\section{Varietät: Triticum compactum clavatum Al. \\ Aehre sammețig, rot; Körner rot.}

\section{Sorte:}

\section{Blauroter sammetiger Binkelweizen. (2) n. $\odot$}

\section{Syn.: Keulen-Binkelweizen.}

Aehre: blaurot, sammetig, quadratisch, sehr dicht, leicht an der Basis abbrechend, trägt an der Basis eine oder einige ganz rudimentäre Aehrchen, oder der beteffende Spindelabschnitt ist nackt; Aehrchen $1.2 \mathrm{~cm}$ breit, meist 3-körnig. - Stroh: rötlich-gelb, steif, fein, mittellang, hohl. - Frucht: dunkelrot, glasig, sehr klein, rundlich $(5 \mathrm{~mm}$ lang, $3 \mathrm{~mm}$ breit, 360 Früchte $=10 \mathrm{gr}$; Sommerfrucht noch kleiner, $5 \mathrm{~mm}$ lang, $2^{3} / 4 \mathrm{~mm}$ breit, 430 Früchte $=10 \mathrm{gr}$ ). feinschalig, hart, Bruch stalılig.

Herbstblatt gelbgrün, schmal, fast aufrecht; Frühjahrsvegetation zeitig, Bestockung schwach, 3.3 Schösslinge; als Sommerweizen gebaut, Halm blaugrün, 3.2 Schösslinge, spät schossend und blühend.

Habitus des Winter- und Sommerweizens gleich. Halmlänge $115 \mathrm{~cm}$ (Max. $135 \mathrm{~cm}$ ), Halmdicke $0.3 \mathrm{~cm}$, Blattzahl 3.3, Blattlänge $21.5 \mathrm{~cm}$, Blattbreite $0.95 \mathrm{~cm}$, Blattoberfläche $134.77 \mathrm{qcm}$, Halmfläche $103.5 \mathrm{qcm}, \mathrm{Ge}-$ sammtfläche $238.27 \mathrm{qcm}$.

Junge Aehre bläulich-grün, stark blau bereift, $5 \mathrm{~cm}$ (Max. $7 \mathrm{~cm}$ ) lang, mit 20 Aehrchen und 56 fest sitzenden Früchten; von diesen gehen beim Winterweizen 2952000 auf $1 \mathrm{hl}(=82 \mathrm{~kg})$ und beim Sommerweizen 3483000 auf $1 \mathrm{hl}(=81 \mathrm{~kg})$.

Dieser Weizen ist nicht ganz winterfest, jedoch gegen das Lagern sehr widerstandsfähig.

Durch die rudimentären Aehrchen an der Basis der Aehre crhält dieselbe ein keulenartiges Ansehen.

\section{B. Igelweizen.}

Varietät: Triticum compactum splendens Al. Aehre kahl, weiss; Körner weiss oder gelblich.

\section{Sorten:}

\section{Gelber Sommer-Igelweizen.}

Aehre: blassgelb, platt, sehr dicht, sehr kurz; Aehrchen $1.3 \mathrm{~cm}$ breit, 3-körnig, 3-grannig; Grannen hellgelb, kurz, bis $5 \mathrm{~cm}$ lang, zähe und steif. - Stroh: gelb, derbwandig, doch weniger steif und fest als von anderen Igelweizen. - Frucht: gelblichweiss, mehlig, viele rötlich und glasig, eingefallen, plump, klein ( $6 \mathrm{~mm}$ lang, $3 \frac{1}{2} \mathrm{~mm}$ breit), feinschalig, halbweich, halbmehlig.

Junges Blatt gelbgrün, sehr lang, breit, 3 Schösslinge, sehr zeitig schossend und blühend; Halmlänge $100 \mathrm{~cm}$ (Max. $110 \mathrm{~cm}$ ), Halmdicke $0.38 \mathrm{~cm}$, Blattzahl 3.5, Blattlänge $27 \mathrm{~cm}$, Blattbrẹite $0.8 \mathrm{~cm}$, Blattober- 
fläche eines Halmes $151.2 \mathrm{qcm}$, Halmfläche $114 \mathrm{qcm}$, Gesammtfläche $265.2 \mathrm{gcm}$.

Junge Aehre blaugrün, zeitig, in 124 Tagen reifend, $4.5 \mathrm{~cm}$ (Max. $6 \mathrm{~cm}$ ) lang, mit 14 Aehrchen und 40 fest sitzenden Früchten, ron denen

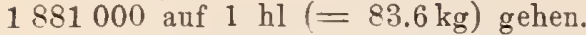

Auf 1 qm wachsen 100 Halme oder 333 Pflanzen, mithin eine Pflanze einen Raum von $33.3 \mathrm{qcm}$ einnimmt, die Blattoberfläche beträgt pro qm Bodenfläche 26.5 qm und das Saatquantum (1/3 Terlust) $2.8 \mathrm{hl} \mathrm{p}$. ha.

Es wiegen 100 Halme $340 \mathrm{gr}$ und daron die Früchte $120 \mathrm{gr}$.

Auf reichem Boden lagert der Weizen und befällt auch stark mit Rost, doch scheint er fiir armen, trocknen Boden beachtenswert zu sein, so wird derselbe z. B. vielfach in der Schweiz, und nach Alefeld anch in Baden kultiviert.

\section{Canada Club Spring-Wheat. $\odot$}

Syn.: Kentucky Thite Chaff; Hutchinson; Bearded or Canada Flint; Club-wheat.

Aehre: blassgelb, bis $5 \mathrm{~cm}$ lang, dick, schwer, Frucht lose von den Spelzen umschlossen. - Stroh: rötlich-gelb, kurz, bis $1 \mathrm{~m}$ hoch. Frucht: gelblich-weiss, kurz, rundlich, klein, halbhart, Bruch halbstahlig, Mehl geschätzt.

Bestockt sich wenig; ertragreich.

Wurde durch Mr. Hutchinson aus Cayuga-County in den Vereinigten Staaten verbreitet, und um 1840 ziemlich allgemein im Westen ron New-York und riel in Canada gebaut.

Im Jahre 1855 sandte ihn F. Gerold aus Wisconsin zur Prïfung an das preussische Landes-Oek.-Collegium.

\section{Trigo de la Viuda, Chile. $\odot$ u. (2)}

Aehre: fast weiss mit schwach rötlichem Schimmer, 2-zeilig, sehr dicht, kurz; Aehrchen $1.3 \mathrm{~cm}$ breit, Klappen mit Zahn, 3-körnig, 2-grannig; Grannen hell, aufrecht, bis 5 cm lang. - Stroh: rötlich-weiss, steif, kurz. - Frucht: Original rötlich-weiss, glasig, bauchig, ziemlich klein $\left(6^{1} / 2 \mathrm{~mm}\right.$ lang, $3^{1} / 2 \mathrm{~mm}$ breit, 230 Friichte $\left.=10 \mathrm{gr}\right)$; nachgebaut: grösser, 173 Friichte $=10 \mathrm{gr}$, feinschalig, hart, Bruch glasig.

Herbstblatt hellgrün, fein, aufrecht, 2 Schösslinge, mittelfrüh schossend und blühend; Halm $70 \mathrm{~cm}$ ( Мax. $80 \mathrm{~cm}$ ) lang, $0.33 \mathrm{~cm}$ dick, Blattzahl 3.5, Blätter $18.3 \mathrm{~cm}$ lang, $0.8 \mathrm{~cm}$ breit, Blattlläche $102.5 \mathrm{qcm}$, Halmfläche 69.3 qcm, Gesammtlläche $171.8 \mathrm{qcm}$. Der Sommerweizen zeigte den gleichen Habitus.

Junge Aehre blaugrün, mittelfrüh reifend, $4 \mathrm{~cm}$ (МГax. $4.5 \mathrm{~cm}$ ) lang, mit 16 Aehrchen und 45 fest sitzenden Früchten.

Nicht winterfest, auch lejcht durch Rost leidend.

Heimat: Chile, 1880 durch von Gülich erhalten.

\section{Trigo Carbillo, Chile $\odot$ u. (2)}

Aehre: blassgelb, platt, 2-zeilig, sehr dicht, kurz; Aehrchen 3-körnig, 3-grannig, mittlere beträchtlich kürzer, $1.5 \mathrm{~cm}$ breit; Grannen hell, gespreizt, bis $5 \mathrm{~cm}$ lang. - Stroh: rötlich-gelb, fest, steif, kurz. - Frucht: Original weiss, mehlig, rundlich, klein $(51 / 2 \mathrm{~mm}$ lang, $3 \mathrm{~mm}$ breit, 285 
Früchte $=10 \mathrm{gr}$ ); nachgebaut: etwas kleiner, 206 Früchte $=10 \mathrm{gr}$, wenige glasig, feinschalig, halbhart, Bruch halbmehlig.

Herbstblatt hellgrün, aufrecht, fein, 2 Schösslinge, mittelfrüh schossend und blühend; Halm $75 \mathrm{~cm}$ (Max. $85 \mathrm{~cm}$ ) lang, $0.38 \mathrm{~cm}$ dick, Blattzahl 3.5, Blätter $17 \mathrm{~cm}$ lang, $0.9 \mathrm{~cm}$ breit, Blattfläche $107.1 \mathrm{qcm}$, Halmfläche $85.5 \mathrm{qcm}$, Gesammtfläche $192.6 \mathrm{qcm}$. Sommerfrucht voll gleichem Habitus wie die Winterfrucht.

Junge Aehre blaugrün, mittelfrüh reifehd, $4 \mathrm{~cm}$ (Max. $5 \mathrm{~cm}$ ) lang, mit 16 Aehrchen und 48 Früchten, von denen 2308500 auf $1 \mathrm{hl}$ (= $81 \mathrm{~kg}$ ) entfallen.

Widerstandsfähig gegen Rost; nicht winterfest.

Heimat: Chile; durch von Gülich 1880 aus Chile erhalten.

\section{Trigo chinense, Palermo. $\odot$}

Franz.: Blé carré de Chine.

Spanisch: Trigo de la China, de la India.

Deutsch: Chinesischer Igelweizen.

Aehre: blassgelb, quadratisch, compakt, kurz; Aehrchen $1.2 \mathrm{~cm}$ breit, meist 3-körnig und 3-grannig; Grannen blassgelb, ziemlich aufrecht, leicht abbrechend, $6 \frac{1}{2} \mathrm{~cm}$ lang. - Stroh: rötlich-gelb, steif, kurz. - Frucht: rot, glasig, etwas eingefallen, oval, klein $\left(6 \mathrm{~mm} \mathrm{lang,} 3^{1 / 2} \mathrm{~mm}\right.$ breit, 254 Früchte $=10 \mathrm{gr})$, feinschalig, hart, Bruch halbstahlig.

Junges Blatt und Halm dunkelblaugrün, Bestockung schwach, 2 Schösslinge, spät schossend und blühend. Halmlänge $90 \mathrm{~cm}$ (Max. $100 \mathrm{~cm}$ ), Halmdicke $0.37 \mathrm{~cm}$, Blattzahl 3.3 , Blattlänge $24.8 \mathrm{~cm}$, Blattbreite $0.9 \mathrm{~cm}$, Blattoberfläche $147.31 \mathrm{qcm}$, Halmfläche $99.9 \mathrm{qcm}$, Gesammtfläche $247.21 \mathrm{qcm}$.

Junge Aehre blaugrün, mittelfrüh in 130 Tagen reifend, $5 \mathrm{~cm}$ (Max. $7 \mathrm{~cm}$ ) lang, mit 16 Aehrchen und 45 fest sitzenden Früchten, von denen 2033100 auf $1 \mathrm{hl}(=81 \mathrm{~kg}$ ) gehen.

Es wiegen 100 Halme $329 \mathrm{gr}$ und davon die Früchte $149 \mathrm{gr}$.

Diese Sorte lagert nicht, befällt jedoch leicht mit Rost und wird in Italien, Spanien und Süd-Frankreich gebaut.

Auf der Wiener Weltausstellung 1873 von Italien ausgestellt, wurde sie durch L. Wittmack an den ökonomisch-botanischen Garten in Poppelsdorf gesandt.

Eignet sich nur für trocknen, wenig kulturvollen Lehinboden und warmes Klima.

Varietät: Triticum compactum icterinum Al.

Aehre kahl, weiss; Körner rot.

\section{Sorten :}

\section{Neuer sehr ertragreicher Sommerweizen. $\odot$}

Aehre: unrein blassgelb, platt, sehr dicht; Aehrchen $1.8 \mathrm{~cm}$ breit, 4- und 5-körnig; Grannen gelb, $8^{1 / 2} \mathrm{~cm} \mathrm{lang,} \mathrm{zähe.} \mathrm{-} \mathrm{Stroh:} \mathrm{gelb} \mathrm{oder}$ graublau, steif, mittellang. - Frucht: dunkelrot, glasig, nur wenige gelbrot und mehlig (6 $\mathrm{mm}$ lang, $3 \mathrm{~mm}$ breit), feinschalig, sehr schwer, hart, Bruch stalilig.

Junges Blatt gelbgrün, ziemlich breit, lang; 2.5 Schösslinge, zeitig schossend und blïhend; Halmlänge $115 \mathrm{~cm}$ (Max. $130 \mathrm{~cm}$ ), Halmdicke 
$0.33 \mathrm{~cm}$, Blattzahl 3.5, Blattlänge $24.5 \mathrm{~cm}$, Blattbreite $0.95 \mathrm{~cm}$, Blattoberfläche eines Halmes $162.93 \mathrm{qcm}$, Halmfläche $113.85 \mathrm{qcm}$, Gesammtfläche $276.78 \mathrm{qcm}$.

Junge Aehre blaugrün, $7 \mathrm{~cm}$ (Max. $9 \mathrm{~cm}$ ) lang, zeitig, in 120 Tagen ausreifend, mit 14 Aehrchen und 60 in der Vollreife sehr leicht ausfallenden Früchten, von denen 2608000 auf $1 \mathrm{hl}(=88.4 \mathrm{~kg}$ ) gehen.

Auf $1 \mathrm{qm}$ kommen 1000 Halme oder 400 Pflanzen, mithin beträgt der Raum für eine Pflanze $25 \mathrm{qcm}$, die Blattoberfläche p. qm Bodenfläche $27.67 \mathrm{qm}$ und das Saatquantum (1/3 Verlust) $2.3 \mathrm{hl}$ p. ha.

Es wiegen 100 Halme 440 gr und davon die Früchte 231 gr.

Das Stroh zeichnet sich durch grosse Festigkeit und Widerstandsfähigkeit gegen Rost aus.

\section{Blé hérisson ${ }^{1}$ ). (2)}

Syn.: Franz.: Blé barbu compact, Blé hérisson brun et court $\left.(\text { Vilm })^{2}\right)$; Blé de Taganrock compact, salonique, à quatre côtes, de Flandre à épi court, comprimé barbu, hérisson rouge, de Tiflis, d'Odessa barbu à épi court $\left(\right.$ Heuzé) ${ }^{3}$ ).

Engl isch: Flander's short-eared Wheat.

Deutsch: Igelweizen.

Aehre: blassgelb mit graublauenı Anflug, platt, sehr dicht, kurz; Aehrchen $1.6 \mathrm{~cm}$ breit, meist 3-körnig; Grannen gelb, abstehend, kurz, bis $6 \frac{1}{2} \mathrm{~cm}$ lang. Stroh: gelb oder graublau, derbwandig, steif, mittellang. - Frucht: meist rot, glasig oder gelbrot und mehlig, schwer, klein ( $5 \mathrm{~mm}$ lang, $3 \mathrm{~mm}$ breit, 244 Früchte $=10 \mathrm{gr}$ ), feinschalig, hart, Bruch halbstahlig.

Herbstblatt blaugriin, breit, ziemlich aufrecht; Frühjahrsvegetation zeitig, Bestockung schwach, 3.2 Schösslinge, nnittelfrüh schossend und blühend; Halmlänge $110 \mathrm{~cm}$ ( Мax. $140 \mathrm{~cm}$ ), Halmdicke $0.42 \mathrm{~cm}$, Blattzahl 4, Blattlänge $26.47 \mathrm{~cm}$, Blattbreite $0.96 \mathrm{~cm}$, Blattoberfläche eines Halmes $203.28 \mathrm{qcm}$, Halmfläche $138.6 \mathrm{qcm}$, Gesammtfläche $341.88 \mathrm{qcm}$.

Junge Aehre blaugrüı, oft bereift, etwas spät reifend, $6 \mathrm{~cm}$ (Max. $8 \mathrm{~cm}$ ) lang, mit 16 Aehrchen und $45 \mathrm{sehr}$ fest sitzenden Früchten, von denen 2098400 auf $1 \mathrm{hl}$ (=86 kg) gehen.

Auf $1 \mathrm{qm}$ wachsen 800 Halme oder 250 Pflanzen, mithin beträgt der Raum für eine Pflanze $40 \mathrm{qcm}$, die Blattfäche p. qm Bodenfläche $27.2 \mathrm{qm}$ und das Saatquantum (1/3 Verlust) $1.8 \mathrm{hl}$ p. ha. Es wiegen 100 Halme $735 \mathrm{gr}$ und davon die Früchte $322 \mathrm{gr}$.

Da dieser Weizen nicht lagert und wenig durch Rost leidet, wird er in Frankreioł auf sehr reichem Boden häufig kultiviert, so empfiehlt ihn de Guaita zu Agréez für schweren, reichen Thonboden auch als Sommerweizen und gibt nachfolgende Ernteerträge p. ha an:

$$
\begin{array}{llll}
1861 & 3671 & \mathrm{~kg} & \text { Korn } \\
1862 & 2064 & " & " \\
1863 & 2392 & " & " \\
1864 & 2145 & &
\end{array}
$$

Im Allgemeinen wird er "nach" Vilmorin selten als Sommerweizen

1) Hérisson $=$ Igel.

2) Vilmorin, Journ. d'Agric. prat. 1851 pg. 457.

3) Heuzé, Les plantes alimentaires pg. 82 . 
gebaut, weil er häufig missrät, doch gedeiht er mit Sicherheit als Winterweizen nur in Süd-Frankreich, so vorzugsweise un Avignon. Er erfror auch 1870/71 in Poppelsdorf vollständig.

Nach Heuzé stamint diese Sorte ursprünglich aus Syrien und von den Inseln des Archipels.

Bezugsquelle: Vilmorin et Andrieux, Paris.

\section{Gelber kahler Winter-Igelweizen. (2)}

Franz.: Blé ordinaire varieté à épi compact et barbu.

Aehre: gelb, quadratisch, sehr dicht, kurz; Aehrchen $1.5 \mathrm{~cm}$ breit, 3-körnig; Grannen hell, 5-7 cm lang, aufrecht. - Stroh: gelb, feinhalmig, mittellang, sehr steif. - Frucht: rot, glasig, einige gelbrot und mehlig, etwas bauchig, rundlich, klein ( $6 \mathrm{~mm}$ lang, $3 \mathrm{~mm}$ breit), schwer, feinschalig, halbhart, Bruch halbmehlig.

Herbstblatt gelbgriin, breit, aufrecht; Frïhjahrsvegetation sehr zeitig, Bestockung sehr schwach, 2 Schösslinge, zeitig schossend und blühend. Halmlänge $110 \mathrm{~cm}$ (Max. $120 \mathrm{~cm}$ ), Halmdicke $0.3 \mathrm{~cm}$, Blattzahl 3, Blattlänge $21.23 \mathrm{~cm}$, Blattbreite $0.96 \mathrm{~cm}$, Blattoberfläche $122.28 \mathrm{qcm}$, Halmfläche $99 \mathrm{qcm}$, Gesammtfläche $221.28 \mathrm{qcm}$.

Junge Aehre bläulich-grün, zeitig reifend, $5 \mathrm{~cm}$ (Max. $7 \mathrm{~cm}$ ) lang, mit 18 Aehrchen und 50 Frïchten, von denen 2227000 auf $1 \mathrm{hl}$ ( $87 \mathrm{~kg}$ ) gehen.

Auf $1 \mathrm{qm}$ wachsen 1200 Halme oder 600 Pflanzen, mithin beträgt der Raum für eine Pflanze $16.6 \mathrm{qcm}$, die Blättfläche p. qm Bodenfläche $27.5 \mathrm{qm}$ und das Saatquantum $4 \mathrm{hl}$ p. ha.

Es wiegen 100 Halme $406 \mathrm{gr}$ ind davon die Früchte $190 \mathrm{gr}$.

Dieser winterfeste Weizen eignet sich besonders, da die Spelzen die Früchte sehr fest umschliessen, für rauhe und stürmische Lagen, und auch für einen kulturlosen Boden besser als irgend eine Sorte von Trit. vulgare. Ferner lagert er niclit, befällt aber stark mit Rost. Wegell seiner kräftigen Grannell wird er auch vom Wilde nicht gern angenommen.

Die Qualität des Mehles ist sehr gut.

Im Frühjahr kultiviert, erwies er sich als echter Winterweizen.

\section{Trigo Sennaar, Palermo. $\odot$}

Identisch: Braunsamiger Sommer-Igelweizen.

Aehre: graulich, platt, sehr dicht, kurz; Aehrchen meist 3-körnig, 3-grannig, Aehrchen entsprechen in der Stellung der von Triticum vulgare, $1.5 \mathrm{~cm}$ breit, Klappen mit Zahnfortsatz; Grannen gelb, an Basis mit bläulichem Anflug, sehr lang $(8 \mathrm{~cm})$, gespreizt, zähe. - Stroh: gelb oder rotgrau, derbwandig, steif. - Frucht dunkelbraun, glasig, einige gelbrot und mehlig, klein ( $5 \frac{1}{2} \mathrm{~mm}$ lang, $3 \mathrm{~mm}$ breit, 290 Früchte $=10 \mathrm{gr}$ ), feinschalig, halbhart, Bruch halbmehlig.

Halme blaugrïn, 2.2 Schösslinge, sehr zeitig schossend und blühend Halmlänge $110 \mathrm{~cm}$ (Max. $125 \mathrm{~cm}$ ), Halmdicke $0.3 \mathrm{~cm}$, Blattzahl 3.8 , Blattlänge $23 \mathrm{~cm}$, Blattbreite $0.8 \mathrm{~cm}$, Blattfläche eines Halmes $139.84 \mathrm{qcm}$, Halmfläche 99 qcm, Gesammtfläche 238.84 qcm.

Junge Aehre blaugrün, in 124 Tagen, also zeitig reifend, $6 \mathrm{~cm}$ (Max. $8 \mathrm{~cm}$ ) lang, mit 10 Aehrchen und 30 fest sitzenden Früchten, von denen 2537500 auf $1 \mathrm{hl}(=87.5 \mathrm{~kg})$ gehen.

Auf 1 qm wachsen 1100 Halme oder 500 Pflanzen, mithin beträgt 
der Raum für eine Pflanze $20 \mathrm{qcm}$, die Blattoberfläche p. qm Bodenfläche 26.29 qm, und das Saatquantum (1/3 Verlust) $3 \mathrm{hl} \mathrm{p.} \mathrm{ha.}$

Diese Weizensorte sandte $1873 \mathrm{~L}$. Wittmack von der Wiener Ausstellung als "Trigo Sennaar" ein, und fand sich hier die Identität mit dem braunsamigen Sommer-Igelweizen.

Der Weizen lagert nicht, wird wenig mit Rost befallen und zeichnet sich durch ein sehr schweres Korn aus.

\section{Gelber, kahler, rotköruiger Sommer-Igelweizen aus Kupjansk, Gouveruemeut Charkow, Süd-Russland. $\odot$}

Aehre: schmutzig-gelb, ziemlich lang, ziemlich dicht; Aehrchen 3-4-körnig, 3-grannig, mittlere kurz, Klappen kurzgranuig, Grannen hell, stark gespreizt, $8 \mathrm{~cm}$ lang. - Stroh: gelb, kurz, steif. - Frucht: dunkelbraun, glasig, doch viele hellbraun, mehlig, klein, 270 Früchte $=10 \mathrm{gr}$, rundlich, schwer, feinschalig, halbhart, Bruch halbmehlig.

Junges Blatt gelbgrün, aufrecht, beiderseits kurz behaart, 3.4 Schösslinge, mittelfrüh schossend und blühend; Halm $95 \mathrm{~cm}$ (Max. $110 \mathrm{~cm}$ ) lang, $0.3 \mathrm{~cm}$ dick, Blattzahl 4, Blätter $14 \mathrm{~cm}$ lang, $0.75 \mathrm{~cm}$ breit, Blattfläche 84 q cm, Halmfläche 85.5 q cm, Gesammtfläche 169.5 q $\mathrm{cm}$.

Junge Aehre blaugrün, in 120 Tagen reifend, $6 \mathrm{~cm}$ (Max. $10 \mathrm{~cm}$ ) lang, mit 14 Aehrchen und 56 fest sitzenden Früchten, von denen 2362500 auf $1 \mathrm{hl}(87.5 \mathrm{~kg})$ entfallen.

Durch Rost leidend.

Bezugsquelle: Prof. Saykewitsch, Charkow.

\section{Weissähriger roter Igelweizen aus 0stindien. $\odot$}

Aehre: blassgelb mit bläulichem Schimmer, quadratisch, sehr dicht, kurz; Aehrchen 3- und 4-körnig, 3-grannig, Mittelgrannen kurz; Grannen hell, bis $9 \mathrm{~cm}$ lang, gespreizt. - Stroh: graugelb, fest, steif. - Frucht: rot, glasig, rundlich, klein ( $6 \mathrm{~mm}$ lang, $3 \mathrm{~mm}$ breit, 315 Fruichte $=10 \mathrm{gr}$ ), feinschalig, hart, Bruch halbstahlig.

Junges Blatt gelbgrïn, sehr schwach und kurz behaart, 2.8 Schösslinge, mittelfriih schossend und blühend. Halme $80 \mathrm{~cm}$ (Max. $95 \mathrm{~cm}$ ) lang, $0.3 \mathrm{~cm}$ dick, Blattzahl 3, Blätter $12.4 \mathrm{~cm}$ lang, $0.62 \mathrm{~cm}$ breit, Blattfläche $46.13 \mathrm{qcm}$, Halmfläche $72 \mathrm{qcm}$, Gesammtfläche $118.13 \mathrm{qcm}$.

Junge dehre blaugrün, bereift, reift in 122 Tagen, $5 \mathrm{~cm}$ (Max. $6 \mathrm{~cm}$ ) lang, mit 15 Aehrchen und 52 Früchten, von denen 2646000 auf $1 \mathrm{hl}$ $(=84 \mathrm{~kg})$ entfallen.

Es wiegen 100 Halme $260 \mathrm{gr}$ und davon die Friichte $116 \mathrm{gr}$.

Varietät: Triticum compactum hystrix Kcke.

Aehre kahl, graublau; Körner rot.

Sorte :

\section{Langgranniger Sommer-Igelweizen.}

Aehre: graulich, platt zusammengedrückt, dicht, kurz; Aehrchen 2- und 3-körnig, $1.5 \mathrm{~cm}$ breit, 3-grannig (2 Grannen lang); Grannen graulich, $7 \frac{1}{2} \mathrm{~cm}$ lang. - Stroh: graulich, derbwandig, steif. - Frucht: gelbrot, glasig, klcin ( $6 \mathrm{~mm}$ lang, $3 \mathrm{~mm}$ breit), sehr schwer, feinschalig.

Junges Blatt gelbgrün, lang, breit, 2.6 Schösslinge, zeitig schossend und blühend. Halmlänge $125 \mathrm{~cm}$ (Max. $145 \mathrm{~cm}$ ), Halndicke $0.34 \mathrm{~cm}$, 
Blattzahl 3.5, Blattlänge $25.3 \mathrm{~cm}$, Blattbreite $0.93 \mathrm{~cm}$, Blattoberfläche eines Halmes $164.7 \mathrm{qcm}$, Halıfläche $127.5 \mathrm{qcm}$, Gesammtfläche $292.2 \mathrm{qcm}$.

Junge Aelire blaugriin, sehr zeitig, in 124 Tagen reifend, $6 \mathrm{~cm}$ (Max. $8 \mathrm{~cm}$ ) lang, mit 14 Aehrchen und 35 etwas lose sitzenden Friichteu, von denen 2691000 auf $1 \mathrm{hl}(=86.8 \mathrm{~kg}$ ) gehen.

Es wiegen 100 Halme $400 \mathrm{gr}$ und davon die Frïchte $150 \mathrm{gr}$.

Da das Stroh selteu lagert und nicht leicht mit Rost befällt, eignet sich diese Sorte für sehr reiche Böden.

Varietät: Triticum compactum Fetisowii Kcke.

Aehre kahl, rot; Körner weiss oder gelblich.

\section{Sorte:}

\section{Rotähriger kahler Igelweizen aus Wjernoje, Turkestan. (2)}

Aehre: blassrot mit bläulichem Anflug, 2-zeilig, sehr dicht; Aehrchen 3- und 4-körnig und grannig, von denen 2 Grannen lang, 2 kurz, Klappen kurzgrannig; Grannen hell, gespreizt, bis $6.5 \mathrm{~cm}$ lang. - Stroh: gelb, steif, sehr derbwandig, ziemlich lang. - Frucht: blassrot, glasig, sehr plump, etwas eingefallen, gross $\left(7 \mathrm{~mm}\right.$ lang, $3^{3} / 4 \mathrm{~mm}$ breit, 202 Früchte $=10 \mathrm{gr}$ ), schwer, feinschalig, hart, Bruch stahlig.

Herbstblatt dunkelgrün, Unterseite sammetig, schmal, lang; Entwickelung ziemlich frïh, 2 Schösslinge, mittelfrïh schossend und blühend; Halm $90 \mathrm{~cm}$ (Max. $100 \mathrm{~cm}$ ) lang, $0.3 \mathrm{~cm}$ dick, Blattzahl 3, Blätter $18.5 \mathrm{~cm}$ lang, $1 \mathrm{~cm}$ breit, Blattfäche $111 \mathrm{qcm}$, Halmfläche $81 \mathrm{qcm}$, Gesammtfläche 192 qcm.

Jange Aehre gelbgrïn, spät reifend, $5 \mathrm{~cm}$ (Max. $6 \mathrm{~cm}$ ) lang, mit 20 Aehrchen und 70 fest sitzenden Friichten, von denen 1777800 auf $1 \mathrm{hl}(=88 \mathrm{~kg}$ ) entfallen.

Winterfest; durch Rost leidend.

Bezugsquelle: durch Fetisow aus Turkestan erhalten.

Varietät: Triticum compactum erinaceum Keke.

Aehre kahl, rot; Körner rot.

\section{Sorte:}

\section{Roter Igelweizen aus Wjernoje, Turkestan. $\odot$}

Aehre: blassrot, blau bereift, sehr compakt, zweizeilig, kurz; Aehrchen $0.8 \mathrm{~cm}$ breit, 3-körnig, 5-grannig, da die Grannen der Klappen und die der Spelzen gleich lang sind; Grannen hell, bis $7 \mathrm{~cm} \mathrm{lang.} \mathrm{-} \mathrm{Stroh:} \mathrm{gelb,}$ steif, fest, mittellang. - Frucht: rot, sehr klein $\left(5^{1 / 2} \mathrm{~mm}\right.$ lang, $2 \frac{1}{2} \mathrm{~mm}$ breit), ziemlich feinschalig, hart, Bruch stahlig.

Junges Blatt blaugriin, dicht und lang behaart, ausgebreitet, breit; 3 Schösslinge, etwas spät schossend und bliihend. Halme $100 \mathrm{~cm}$ (Nax. $110 \mathrm{~cm}$ ) lang, $0.35 \mathrm{~cm}$ dick, Blattzalıl 3.8, Blätter $18.5 \mathrm{~cm}$ lang, $1.1 \mathrm{~cm}$ breit, Blattfläche 154.66 q cm, Halmfläche $105 \mathrm{qcm}$, Gesammtfläche $259.66 \mathrm{qcm}$.

Junge Aehre blaugrün, Staubbeutel braun, in 125 Tagen reifend, $5 \mathrm{~cm}$ (Max. $6 \mathrm{~cm}$ ) lang, nit 16 Aehrchen und 45 festsitzenden Früchten, von denen 2645000 auf $1 \mathrm{hl}(=82 \mathrm{~kg}$ ) entfallen.

Dieser Weizen leidet stark durch Rost.

Wurde von Fetisow gesammelt und durch E. Regel iibersandt. 
Varietät: Triticum compactum sericeum Al. Aehren sammetig, weiss; Körner weiss oder gelblich.

\section{Sorte :}

\section{Weissähriger sammetiger Igelweizen mit weisslichem Korn. (2)}

Aehre: schmutzig-rötlich-gelb, schwach sammetig, sehr dicht, ziemlich lang; Grannen hell, gespreizt, 5-6 cm lang. - Stroh: rötlich-blassgelb, fest, lang. - Frucht: rötlich-weiss, glasig, rundlich, klein (6 mm lang, $3 \frac{1}{2} \mathrm{~mm}$ breit, $3 \frac{1}{2} \mathrm{~mm}$ dick, 249 Früchte $=10 \mathrm{gr}$ ); schön, feinschalig, hart, Bruch halbstahlig.

Herbstblatt blaugrün, lang, schmal; Entwickelung mittelfrüh, 6 Schösslinge; mittelfrüh schossend und bliihend; Halm $100 \mathrm{~cm}$ (Max. $115 \mathrm{~cm}$ ) lang, $0.4 \mathrm{~cm}$ dick, Blattzahl 4, Blätter $26 \mathrm{~cm}$ lang, $1.1 \mathrm{~cm}$ breit, Blattfäche $228.8 \mathrm{qcm}$, Halmfäche $120 \mathrm{qcm}$, Gesammtfäche $348.8 \mathrm{qcm}$.

Junge Aehre bläulich-grün, spät reifend, $7 \mathrm{~cm}$ (Мax. $9 \mathrm{~cm}$ ) lang, mit 24 Aehrchen nnd 60 Friichten.

Winterfest; fast rostfrei.

Varietät: Triticum compactum albiceps Kcke. Aehre sammetig, weiss; Körner rot.

\section{Sorte:}

\section{Weissähriger, sammetiger Igelweizen mit rotem Korn. (2)}

Aehre: weiss mit schwach rötlichem Schimmer, sammetig, 2-zeilig, sehr dicht, kurz; Aehrchen $1.3 \mathrm{~cm}$ breit, 3-körnig, 2-grannig; Grannen hell, bis $7,5 \mathrm{~cm}$ lang. - Strob: rötlich-gelb, bis violett, sehr fest, lang. Frucht: dunkelrot, glasig, dick, rundlich $\left(6^{1} / 2 \mathrm{~mm}\right.$ lang, $3 \frac{1}{2} \mathrm{~mm}$ breit, 226 Früchte $=10 \mathrm{gr}$ ), feinschalig, hart, Bruch halbstahlig.

Herbstblatt dınkelgrün, fein, kraus; 4 Schösslinge, mittelfrüh schossend und blühend; Halm $110 \mathrm{~cm}$ ( Blattzahl 4, Blätter $19.5 \mathrm{~cm}$ lang, $0.8 \mathrm{~cm}$ breit, Blattlä̈che $124.8 \mathrm{qcm}$, Halmfläche $108.9 \mathrm{qcm}$, Gesammtfläche $233.7 \mathrm{qcm}$. Frïchten.

Junge Aehre gelbgrün, spät reifend, mit 19 Aehrchen und 55

Varietait: Triticum compactum echinodes Keke.

Aehre sammetig, rot; Körner rot.

\section{Sorten:}

\section{Roter sammetiger Winter-Igelweizen. (2)}

Aehre: dunkelrotgrau, sammetig, fast quadratisch, sehr dicht, mittellang; Aehrchen $1.5 \mathrm{~cm}$ breit, meist 3-körnig, 3-grannig, mittlere kürzer; Grannen rotgrau, gespreizt, bis $8.5 \mathrm{~cm}$ lang. - Stroh: rotgrau bis violett, fest, ziemlich lang. - Frucht: rot, glasig, klein ( $6 \mathrm{~mm}$ lang, $3 \mathrm{~mm}$ breit, 231 Frïchte $=10 \mathrm{gr}$ ), feinschalig, schwer, hart, Bruch stahlig.

Herbstblatt gelbgrün, gross, anfrecht, 4.8 Schösslinge, zeitig schossend und blühend; Halm $115 \mathrm{~cm}$ (Max. $125 \mathrm{~cm}$ ) lang, $0.4 \mathrm{~cm}$ dick, Blattzahl 4.5, Blätter $21.8 \mathrm{~cm}$ lang, $1 \mathrm{~cm}$ breit, Blattfläche $196.2 \mathrm{qcm}$, Halmfläche $138 \mathrm{qcm}$, Gesammtflärhe 334.2 qem. 
Junge Aehre gelbgrün, $7 \mathrm{~cm}$ (Max. $9 \mathrm{~cm}$ ) lang, zeitig reifend, 20 Aebrchen mit 60 fest sitzenden Früchten, von denen 1951950 auf $1 \mathrm{hl}(=84.5 \mathrm{~kg})$ entfallen.

Winterfest und ecliter Winterweizen, doch leicht durch Rost leidend.

\section{Roter sammetiger Igelweizen aus Palermo. $\odot$}

Aehre: blassrot, bereift, dicht, seitlich zusammengedrückt, sammetig; Aehrchen $1.5 \mathrm{~cm}$ breit, meist 3-körnig, 3-grannig, mittelste Granme kürzer, Klappen mit plötzlich aufgesetzter, mittellanger Granne; Grannen blassrot, in der oberen Hälfte der Aelıre länger und nach aussen gespreizt, bis zur Basis rauh, $8 \mathrm{~cm}$ lang. -- Stroh: blassgelb, fein, für Igelweizen etwas lang. - Frucht: hellrot, glasig, länglich, klein (7 $\mathrm{nm}$ lang, $31 \frac{1}{2} \mathrm{~mm}$ breit, 253 Früchte $=10 \mathrm{gr}$ ), feinschalig, hart, Bruclı glasig.

Junges Blatt gelbgrün, lang, schmal, 2 Schösslinge, 'sehr spät schossend und blühend; Halmlänge $115 \mathrm{~cm}$ (Max. $140 \mathrm{~cm}$ ), Halmdicke $0.34 \mathrm{~cm}$, Blattzalıl 4, Blattlänge $28.5 \mathrm{~cm}$, Blattbreite $0.96 \mathrm{~cm}$, Blattoberfläche eines Halmes 218.88 q cm, Halmfläche 117.3 qcm, Gesammtfläche $336.18 \mathrm{qcm}$.

Junge Aehre blaugrün, spät, in 135 Tagen reifend, $7 \mathrm{~cm}$ (Max. $9 \mathrm{~cm})$ lang, mit 16 Aehrehen und 45 fest sitzenden Frïchten, von denen 2031590 auf $1 \mathrm{hl}(=80.3 \mathrm{~kg})$ gehen.

Auf $1 \mathrm{qm}$ wachsen 850 Halme oder 425 Pflanzen, mithin beträgt der Raum für eine Pflanze $23.5 \mathrm{qcm}$, die Blattfläche p. qm Bodenfläche $28.56 \mathrm{qm}$ und das Saatquantun $(1 / 3$ Verlust) $3.1 \mathrm{hl}$ p. ha.

Es wiegen 100 Halme $420 \mathrm{gr}$ und davon die Früchte $150 \mathrm{gr}$. rostfrei.

In Poppelsdorf lagerte der Weizen nicht leicht und zeigte sich

Unterart: 3. Triticum turgidum L. Englischer oder banchiger Weizen.

A. Aehren einfach.

Varietät: Triticum turgidum lusitanicum Kcke.

Aehre kahl, weiss; Körner weiss oder gelblich; Grannen hell.

\section{Sorten :}

\section{. Trigo de Ejipto, Chile. (2)}

Aelrre: weiss mit schwach rötlichem Sclimmer, pyranidal, dicht, kurz; Aehrchen 3-körnig, 2-grannig; Grannen hell, bis $12 \mathrm{~cm}$ lang, sehr leicht abfallend. - Stroh: fast weiss, Inneurand markig, doch schmal, kurz. - Frucht: Original weiss, mellig, wenige glasig, rundlich, voll 
$(7 \mathrm{~mm}$ lang, $4 \mathrm{~mm}$ breit, 190 Früchte $=10 \mathrm{gr})$; nachgebaut: grösser, 125 Früchte $=10 \mathrm{gr}$ ), ziemlich feinschalig.

Herbstblatt blaugrün, schwach sammetig, sehr fein, kraus; Entwickelung spät, 3 Schösslinge, spät schossend und blühend; Halm $115 \mathrm{~cm}$ (Max. $135 \mathrm{~cm}$ ) lang, $0.35 \mathrm{~cm}$ dick, Blattzahl 5, Blätter $20 \mathrm{~cm}$ lang, $1 \mathrm{~cm}$ breit, Blattfläche 200 qcm, Halmfläche $120.8 \mathrm{qcm}$, Gesammttläche $320.8 \mathrm{qcm}$.

Junge Aehre blaugrün, bereift, $8 \mathrm{~cm}$ (Max. $10 \mathrm{~cm}$ ) lang, mit 23 Aehrchen und 60 Früchten, von denen 1491500 auf $1 \mathrm{hl}$ (=78.5 kg) entfallen.

Spät reifend; gut durchwintert.

Bezugsquelle: von Gi ii lich, 1880, Chile.

\section{Frumento grosso. (2)}

Aehre: weiss mit schwach rötlichem Schimmer, pyramidal, mittellang, dicht; Aehrchen 3-körnig, 3-grannig, mittlere Granne kurz; Grannen weiss, fast aufrecht, stark, bis $12 \mathrm{~cm}$ lang, sehr leicht abbrechend. Stroh: gelb, Innenrand markig, mittellang. - Frucht: blassgelb, mellig, bauchig, gross $(71 / 2 \mathrm{~mm}$ lang, $4 \mathrm{~mm}$ breit, 154 Früchte $=10 \mathrm{gr})$, ziemlich feinschalig.

Herbstblatt blaugrün, sammetig, kräftig; Entwickelung spät, 4 Schösslinge, spät schossend und blühend; Halm $120 \mathrm{~cm}$ (Max. 130 cm) lang, $0.4 \mathrm{~cm}$ dick, Blattzahl 4.5, Blätter $25 \mathrm{~cm}$ lang, $1.2 \mathrm{~cm}$ breit, Blattfläche $270 \mathrm{qcm}$, Halmfläche $144 \mathrm{qcm}$, Gesammttläche $414 \mathrm{qcm}$.

Junge Aehre blaugrün, spät reifend, $10 \mathrm{~cm}$ (Max. $15 \mathrm{~cm}$ ) lang, mit 26 Aehrchen und 65 Früchten.

Erwies sich als echter Winterweizen.

Heimat: Italien.

Bezugsquelle: Pariser Ausstellung 1878.

\section{Blé garagnon blanc. (2)}

Syn.: Blé garagnon blanc de la Lozère, du Languedoc, Poulard géant à épi blanc.

Aehre: gelblich-weiss, pyramidal, wenig dicht, sehr regelmässig; Aehrchen sehr gross, Klappen stark gekielt; Grannen lang, hell, zuweilen an der Basis grau. - - Stroh: mittellang. - Frucht: rötlich-gelb, oder gelb, mittelgross, schön.

Ertragreich; in mittleren Frankreich kultiviert.

Beschrieben durch Heuzé, Pl. aliment.pg. 96.

\section{Blé hybrid de Galland (2) 1 . $\odot$}

Syn.: Franz.: Poulard blano à barbes caduques, blane anglais, de St. Laud, géant de Lille, blanc sans barbes, doré de Russie, blane d'Australie, des Hautes-Alpes, touzelle des Alpes; Blé Galland, de Sibérie, de la Providence, grossau blane, poulard du Nord, sans barbes de Russie, géant d'Alger, Aubron blanc, Aubanie blanche; Froment lisse d'Odessa, tendre d'Afrique.

Ital. Grano Gallandt, o Grano ibrido di Galland.

Engl. White Rivet.

Deutsch: Galland-Weizen.

Aehre: fast weiss, mit rötlichem Schimmer, kahl, pyramidal, lang, 
sehr dicht, breit; Aehrchen $1.8 \mathrm{~cm}$ breit, meist 3-körnig, Klappen grannenspitzig; Grannen weiss, bis $10 \mathrm{~cm}$ lang, der Aehre anliegend und nur an der Spitze ein wenig gespreizt, fast gänzlich zur Reifezeit abfallend. Stroh: rötlich-gelb, mit markigem Innenrande, oder ganz markig, selır robust, sehr lang. - Frucht: weiss and mehlig, wenige rötlich und glasig, Farbe überraschend schön, bauchig, plump, sehr gross $(9 \mathrm{~mm}$ lang, $4^{1 / 2} \mathrm{~mm}$ breit, 128 Früchte $=10 \mathrm{gr}$ ), leicht, etwas grobschalig.

Herbstblatt dunkelgrün, äusserst kurz und schwach sammetig, sehr breit, aufrecht; Frühjahrsvegetation zeitig, Bestockung mittelstark, 4.8 Schösslinge, mittelfrüh schossend und spät blühend. Als Sommerweizen gebaut, schosste er sehr spät $(28 / 7.79)$ und wurde so spät reif, dass nur im wärmeren Klima seine Kultur erfolgreich sein kann.

Halmlänge $160 \mathrm{~cm}$ (Max. $180 \mathrm{~cm}$ ), Halmdicke $0.5 \mathrm{~cm}$, Blattzahl 5.3, Blattlänge $30 \mathrm{~cm}$, Blattbreite $1.26 \mathrm{~cm}$, Blattoberfläche eines Halmes $400.68 \mathrm{qcm}$, Halmfläche $240 \mathrm{qcm}$, Gesammtfläche $6+0.68 \mathrm{qcm}$.

Junge Aehre blaugrïn, spät reifend, $12 \mathrm{~cm}$ (Max. 14 cm) lang, mit 24 Aehrchen und 72 fest sitzenden Früchten, von denen 1024000 auf $1 \mathrm{hl}(=80 \mathrm{~kg})$ gehen.

Auf $1 \mathrm{qm}$ wachsen 560 Halme oder 117 Pflanzen, mithin nimmt eine Pflanze einen Raum von $85.5 \mathrm{qcm}$ ein; die Blattoberfläche beträgt p. qm Bodenfläche $35.84 \mathrm{qm}$, und das Saatquantum (1/3 Verlust) $1.7 \mathrm{hl}$ p. ha.

Dieser nicht lagernde und rostfreie Weizen zeigte sich nicht winterfest, so winterte derselbe $1878 / 79$ total aus.

Seine Erträge an Korn und Stroh sind anf reichem Boden in Frankreich ${ }^{1}$ ) enorm hoch, so sollen von 7 ha à 2 hl Aussaat, 326 hl Weizen geerntet worden sein. $482 \mathrm{gr}$.

In Poppelsdorf wogen 100 Halme $1280 \mathrm{gr}$ und davon die Frïchte

Das Mehl dieses Weizens ist etwas grau und durch Mangel an Kleber schwer verbackbar; auf Kalkboden soll die Qualität sich verbessern.

Durch die grossen Erfolge in Frankreich und England anfmerksam geworden, liess die italienische Regierung 1874 von Vilmorin \& Andrieux, Paris, Saatgut kommen und Versuche mit diesem Weizen anstellen, welche sich glänzend bewährt haben, so dass zur Zeit in Frankreich, England, Italien und Spanien der Anbau immer weitere Verbreitung findet.

Nach den Angaben des landwirtschaftlichen Museums in Berlin soll dieser Weizen ursprünglich aus Aepypten "Ghézireh" stammen, nach Dreisch ${ }^{2}$ ) jedoch vom Senegal.

Zur Geschichte dieses vortrefflichen Weizens ist jedoch Nachfolgendes bemerkenswert.

Es sandte 1854 der Freiherr vou Richthofen ${ }^{3}$ ) auf Brechelshof an den akademischen Gärtner Jühlke zu Eldena einen Weizen, der 1853 in Bordeaux anf der landwirtschaftlichen Industrie-Ausstellung von einem Gärtner Galland zu Ruffec, Vendée gezüchtet und als „Blé Galland ì gros grain blane, forte paille, très productif" ausgestellt worden war;

1) Journ. de l'Agric. 1873. 'T. I, pg. 243.

2) Vergl. Berichte über die Pariser Ausst. 1878, pg. 249.

3) Eldenaer Archiv 1855, pg. 97. 
weiter bemerkt er, dass Galland schon seit 1815 Kreuzungsversuche gemacht und in Bordeaux eine Sammlung neuer gekreuzter Sorten ausgestellt habe.

Wenngleich nun Freiherr von Richthofen diesen Weizen für einen weissen Kolbenweizen hält, so scheint derselbe doch mit dem hier besprochenen zu Turgidum gehörigen Weizen identisch zu sein, da es unter Umständen dem Laien nicht leicht ist, die Unterschiede zwischen Triticum vulgare und turgidum festzustellen, und weil die Grannen meist vollständig abfallen, so dass man ihn sehr leicht für einen Kolbenweizen halten kann.

Bezugsquelle: Vilmorin \& Andrieux, Paris.

Varietät: Triticum turgidum melanatherum Kcke.

Aehre kahl, weiss; Körner weiss oder gelblich; Grannen schwarz.

\section{Sorte :}

\section{Pétanielle noire de Nice. $\odot$ u. (2)}

Syn.: Ital.: Grano moro.

Span.: Blat de Sesia; Blat mitaden.

Aehre: blassgelb, doch Ränder der Spelzen und Klappen blauschwarz, pyramidal, kurz; Aehrchen $1 \mathrm{~cm}$ breit, 3-körnig, 2-grannig, Klappen gezahnt; Grannen an Basis schwarzblau, nach oben heller, bis $13 \mathrm{~cm}$ lang, abfallend. - Stroh: blassgelb, fest, kräftig, mit markigem Innenrande, lang. - Frucht: gräulichweiss, am Keim bräunlich, glasig, einige gelb und mehlig, gross, bauchig $(8 \mathrm{~mm}$ lang, $4 \mathrm{~mm}$ breit, 140 Früchte $=10 \mathrm{gr})$, ziemlich feinschalig.

Junges Blatt blaugrïu, sammetig; 3 Schösslinge, mittelfrüh schossend und blühend. Halme $130 \mathrm{~cm}$ (Max. $155 \mathrm{~cm}$ ) lang, $4 \mathrm{~cm}$ dick, Blattzahl 4.5, Blätter $22.6 \mathrm{~cm}$ lang, $0.92 \mathrm{~cm}$ breit, Blattfläche $187.13 \mathrm{qcm}$, Halmfläche $156 \mathrm{qcm}$, Gesammttläche $343.13 \mathrm{qcm}$.

Junge Aehre blaugrün, reift in 140 Tagen, $6.5 \mathrm{~cm}$ (Max. $8 \mathrm{~cm}$ ) lang, mit 14 Aehrchen und 40 Frïchten, von denen 1120000 auf $1 \mathrm{hI}$ $(=80 \mathrm{~kg})$ entfallen.

Es wiegen 100 Halme $557 \mathrm{gr}$ und davon die Früchte $232 \mathrm{gr}$.

In Süd-Frankreich, Italien und Spanien entweder im Herbst oder Frühjahr angebaut.

Varietät: Triticum turgidum gentile $\mathrm{Al}$.

Aehre kahl, weiss; Körner rot; Grannen hell.

\section{Sorten:}

\section{Pisana. $\odot$}

Aehre: fast weiss, ziemlich dicht, quadratisch, mittellang; Aehrchen 3-körnig, 3-grannig, mittlere Granne kurz; Graunen hell, an Basis schwärzlich, bis $15 \mathrm{~cm}$ lang. - Stroh: weiss, mit rötlichenı Anflug, Innenrand narkig, mittellang. - Frucht: Original weiss, meist mehlig, bauchig, sehr gross ( $8 \mathrm{~mm}$ lang, $4^{1} / 4 \mathrm{~mm}$ breit, 169 Früichte $=10 \mathrm{gr}$ ); nachgebaut: fast Alles glasig, ziemlich feinschalig.

Junges Blatt blaugriin, sammetig, kräftig, aufrecht, sich spät entwickelnd, 3 Schösslinge; Halm $125 \mathrm{~cm}$ (Max, $150 \mathrm{~cm}$ ) lang, $0.5 \mathrm{~cm}$ dick, 
Blattzahl 4.5, Blätter $28 \mathrm{~cm}$ lang, $1 \mathrm{~cm}$ breit, Blattfäche $252 \mathrm{qcm}$, Halmfläche $187.5 \mathrm{qcm}$, Gesammtfläche $439.5 \mathrm{qcm}$.

Junge Aehre blaugrün, kaum in Poppelsdorf reifend, $10 \mathrm{~cm}$ (Max. $14 \mathrm{~cm})$ lang, mit 20 Aehrchen nnd 57 Früchten.

Heimat: Vich, Cataluña, Spanien.

Bezugsquelle: Antonio Cipriano Costa, Barcelona 1881.

\section{Blé poulard blanc lisse ou carré. (2)}

Syn.: Franz.: Blé de Taganrock, Poule (Touraine) blane de Châtellerault, blane Locar, blane de la Vienne, buisson; Poulard blane du Blaisois, blanc de Touraine, barbu de Russie, blanc de la Seine-Inférieure, blanc comprimé; Gros blé blanc; Epaule blanche du Gâtinais ${ }^{1}$ ).

Engl.: Taganrock smooth white Wheat.

Deuts c h: Weissähriger, rotsamiger Winter-Taganrock-Weizen.

Aehre: fast weiss, mit rötlichem Schimmer, dicht, quadratisch, mittellang; Aehrchen $1.5 \mathrm{~cm}$ breit, meist 2-körnig; Grannen blassgelb, $16 \mathrm{~cm}$ lang. - Stroh: rötlich-gelb, holıl, mit markigem Innenrande, fest, lang. - Frucht: gelbrot und mehlig, doch auch rot und glasig, bauchig, Junzelig, klein ( $6 \mathrm{~mm}$ lang, $4 \mathrm{~mm}$ breit), etwas grobschalig.

Herbstblatt blaugrün, sammetig, breit, aufrecht; Frühjahrsvegetation mittelfrüh, Bestockung schwach, 3.8 Schösslinge (11.6 Schösslinge bei $100 \mathrm{qcm}$ Raum), mittelfrüh schossend und blühend. Halmlänge $135 \mathrm{~cm}$ (Max. $160 \mathrm{~cm}$ ), Halmdicke $0.4 \mathrm{~cm}$, Blattzahl 4, Blattlänge $25.82 \mathrm{~cm}$, Blattbreite $1.14 \mathrm{~cm}$, Blattoberfläche eines Halmes $235.44 \mathrm{qcm}$, Halınfläche $162 \mathrm{q} \mathrm{cm}$, Gesammtfläche $397.44 \mathrm{qcm}$.

Junge Aehre blaugrün, spät reifend, $10 \mathrm{~cm}$ (Max. $13 \mathrm{~cm}$ ) lang, nit 22 Aehrchen und 48 Früchten, von denen 2058000 auf $1 \mathrm{hl}(=84 \mathrm{~kg})$ gehen.

Auf $1 \mathrm{qm}$ wachsen 760 Halme oder 200 Pflanzen, mithin kommt auf eine Pflanze ein Raum von $50 \mathrm{qcm}$; die Blattfläche stellt sich auf $30.17 \mathrm{qm}$ und das Saatquantum auf $1.4 \mathrm{hl} \mathrm{p.} \mathrm{ha.}$

Es wiegen 100 Halme $1063 \mathrm{gr}$ und davon die Früchte $475 \mathrm{gr}$.

Das Korn ist von ziemlich guter Qualität und von allen TurgidumSorten am geschätztesten, auch ist dieser Weizen auf gutem, schweren Weizenboden im hohen Grade ergiebig, lagert nicht und hält sich ziemlich rostfrei, doch ist er leider nicht winterfest, so erfror derselbe 1870/71 vollständig.

Er wird vielfach in Gâtinais, Anjou, um Avignon, in Savoyen, in der Schweiz und unter französisclıer Bezeichnung auch in Italien kultiviert.

Ursprünglich stammt dieser Weizen aus Süd-Russland und wurde durch einen hervorragenden Züchter, Mr. Le Blanc du Plessis ${ }^{2}$ ) veredelt und unter dem Namen „Blé de Taganrock" in den Handel gebracht.

\section{Blé pétanielle de Nice. (2)}

Syn.: Blé pétanielle d'Orient, Blé de la Mongolie chinoise ${ }^{3}$ ). Aehre: blassgelb, fast weiss, pyramidal, sehr dicht, lang; Aehrchen

1851, pg. 485 .

2) $\mathrm{M}$ a i son rust. I, pg. 370 .

3) Heuzé, Les plantes alimentaires. 
$1.2 \mathrm{~cm}$ breit, 3-körnig, meist 3-grannig; Grannen fast weiss, sehr lang $(14 \mathrm{~cm})$, wenig gespreizt; Klappenkiel zuweilen schwärzlich oder braun. Stroh: rötlich-gelb, markig, sehr fest, sehr lang. - Frucht: gelbrot, mehlig, bauchig, mittelgross ( $7 \mathrm{~mm}$ lang: $4 \mathrm{~mm}$ breit, 198 Frïchte $=10 \mathrm{gr}$ ), grobschalig.

Herbstblatt blaugrün, breit, aufrecht; Frühjahrsvegetation spät, Bestockung mittelstark, 4.4 Schösslinge, spät schossend und blühend. Halmlänge $150 \mathrm{~cm}$ (Nax. $170 \mathrm{~cm}$ ), Halmdicke $0.42 \mathrm{~cm}$, Blattzahl 5, Blattlänge $26.4 \mathrm{~cm}$, Blattbreite $1.06 \mathrm{~cm}$, Blattoberfiäche $279.8 \mathrm{qcm}$, Halmfläche $189 \mathrm{qcm}$, Gesammtfläche $468.8 \mathrm{qcm}$.

Aehre sehr spät reifend, $10 \mathrm{~cm}$ ( $\amalg a x .13 \mathrm{~cm}$ ) lang, mit lederartigen Spelzen. Auf $1 \mathrm{hl}(=81.5 \mathrm{~kg})$ entfallen 1613700 Früchte, die für Turgidum zur Reifezeit etwas leicht ausfallen.

Das Stroh lagert nicht, doch erwies sich dieser Weizen in Poppelsdorf als nicht winterfest.

Im südöstlichen Frankreich wird er noch auf leichteren Böden angebaut.

\section{Normandie-Weizen. (2)}

Aehre: fast weiss, sich wenig rerjüngend, fast quadratisch, mittellang; Aehrchen $1.5 \mathrm{~cm}$ breit, meist 3-körnig; Grannen weiss, bis $11 \mathrm{~cm}$ lang, gespreizt. - Stroh: blassrot, derbwandig. - Frucht: rot und meist glasig, wenn mehlig, so gelbrot, bauchig, gross $(7 \mathrm{~mm}$ lang, $41 / 2 \mathrm{~mm}$ breit, 147 Früchte $=10 \mathrm{gr}$ ), ziemlich feinschalig.

Herbstblatt gelbgrün, sehr kurzsammetig, sehr lang und breit, anfrecht; Frühjahrsvegetation mittelfrüh, Bestockung stark, 7.5 Schösslinge, spät schossend und blühend. Halmlänge $150 \mathrm{~cm}$ (Мrax. $165 \mathrm{~cm}$ ), Halmdicke $0.4 \mathrm{~cm}$, Blattzahl 4, Blattlänge $31.3 \mathrm{~cm}$, Blattbreite $1.12 \mathrm{~cm}$, Blattoberfläche eines Halmes 280.48 qcm, Halmfläche $180 \mathrm{qcm}$, Gesammtfläche $460.48 \mathrm{qcm}$.

Junge Aehre bläulich-grün, $10 \mathrm{~cm}$ (Max. $13 \mathrm{~cm})$ lang, mit $24 \mathrm{Aehr}$ chen und 72 fest sitzenden Früchten, von denen 1176000 auf $1 \mathrm{hl}$ $(=80 \mathrm{~kg})$ gehen.

Auf $1 \mathrm{qm}$ wachsen 650 Halme oder 87 Pflanzen, mithin beträgt der Raum für eine Pflanze $115 \mathrm{qcm}$, die Blattoberfläche p. qm Bodenfläche $30.8 \mathrm{qm}$ und das Saatquantum $1.1 \mathrm{hl} \mathrm{p}$. ha.

Es wiegen 100 Halme $950 \mathrm{gr}$ und davon die Frïchte $400 \mathrm{gr}$.

Dieser Weizen eignet sich fïr schweren, kulturrollen Boden und ein mildes Klima, denn schon für Poppelsdorf war er zu weichlich. Er lagert nicht leicht und leidet wenig durch Rost.

Seine ursprüngliche Heimat ist die Normandie.

Bezugsquelle: Versuchsfeld zu Proskan.

Varietät: Triticum turgidum nigrobarbatum Desv.

Aehren kahl, weiss; Körner rot; Grannen schwarz.

\section{Sorte:}

\section{Blé poulard blanc à barbes noires. $\odot$}

Syn.: Franz.: Blé garagnon de Grignon, Blé de la Lozère à barbes noires, Blé touzelle de Sardaigne, Blé garagnon du Languedoc. 
Spanisch: Trigo arisnegro.

Deutsch: Englischer Weizen mit gelben Aehren und schwärzlichen Grannen.

A ehre blassgelb, pyramidal, dicht, kurz; Aelırchen $1.2 \mathrm{~cm}$ breit, 4-körnig, 2-grannig; Grannen färben sich zur Reifezeit schwärzlich, bis $12 \mathrm{~cm}$ lang, aufrecht, nicht leicht abbrechend. - Stroh: rötlich-gelb, markig, fest, blattreich, mittellang. - Frucht: gelbrot, mellig, einige glasig, bauchig, gross ( $8 \mathrm{~mm}$ lang, $4 \mathrm{~mm}$ breit), grobschalig.

Junges Blatt dunkelgrün, sammetig, kräftig; 2.5 Schösslinge, mittelfrüh schossend und blühend. Halmlänge $110 \mathrm{~cm}$ (Max. $130 \mathrm{~cm}$ ), Halmdicke $0.38 \mathrm{~cm}$, Blattzahl 5.4, Blattlänge $24 \mathrm{~cm}$, Blattbreite $1.0 \mathrm{~cm}$, Blattoberfläche $259.2 \mathrm{qcm}$, Halmfläche $125.4 \mathrm{qcm}$, Gesammtfläche $384.6 \mathrm{qcm}$.

Junge Aehre blaugrün, $7.5 \mathrm{~cm}$ (Max. $9 \mathrm{~cm}$ ) lang, mittelfrüh, in 128 Tagen reifend, mit 19 Aehrchen und 75 fest sitzenden Früchten, von denen 1787000 auf $1 \mathrm{hl}(=82 \mathrm{~kg})$ gehen.

Diese Sorte wird hauptsächlich im Süden und Südosten Frankreichs, sowie in Spanien auf leichteren Böden kultiviert.

Varietät: Triticum turgidum Dreischianum Kcke.

Aehren kahl, rot; Körner weiss oder gelblich; Grannen hell.

\section{Sorte :}

\section{Frumento bianco. (2)}

Aehre: kahl, rot, dicht, viereckig, bis $9 \mathrm{~cm}$ lang; Aehrchen 3- und 4-körnig, $1.5 \mathrm{~cm}$ breit; Grannen hell, wenig gespreizt, bis $13 \mathrm{~cm}$ lang. Stroh: rötlich-gelb, markig oder nur mit markigem Innenrand, fest, nittellang. - Frucht: blassgelb, mehlig, bauchig $(8 \mathrm{~mm}$ lang, $4 \mathrm{~mm}$ breit, $4 \mathrm{~mm}$ dick), $1 \mathrm{hl}=74 \mathrm{~kg}$, grobschalig.

\section{Varietät: Triticum turgidum speciosum Al. Aehren kahl, rot; Körner rot.}

\section{Sorte :}

\section{Pole Rivet wheat of England. (2) u. $\odot$}

Syn.: Franz.: Poulard rouge bleu, d'Auvergne à épillets élargis, gros rouge, rouge de la Limagne, rouge lisse de Beauce, doré de Bourgeois; Gros blé rouge. de Grenoble; Blé pétanielle rouge, rouge de Montpellier.

It al.: Andriolo rosso.

Spanisch: Trigo redondillo rubio recio.

De utsch: Roter, kahler Entenschnabelweizen.

Aehre: rot-bräunlich, bis beinahe dunkelrot, blau bereift, sehr dicht, abgeplattet, etwas unregelmässig, lang; Aehrchen $1.5 \mathrm{~cm}$ breit, 3-körnig, Spelzen geschnäbelt; Grannen rötlich, nach Basis zu schwarzrot, $11 \mathrm{~cm}$ lang, gespreizt, aber nach der Spitze der Aehre zu etwas zusammengezogen, zur Reifezeit leicht abfallend. - Stroh: rötlich-gelb, sehr fest. - Frucht: rot, für Turgidum auffallend glasig, bauchig, gross $(7 \mathrm{~mm}$ lang, $4 \mathrm{~min}$ breit, 195 Früchte $=10 \mathrm{gr}$ ), grobschalig.

Herbstblatt gelbgrün, kurz, sammetig, breit, aufrecht, Bestockung schwach, 3.5 Schösslinge, mittelfrül schossend und blühend, als Sommer- 
weizen kultiviert, schosste und bliihte er auffallend spät, wurde jedoch 1879 noch reif, trotzdem wohl nur in wärmeren Klimaten als Sommerweizen benutzbar.

Halmlänge $135 \mathrm{~cm}$ (Маx. $160 \mathrm{~cm}$ ), Halmdicke $0.47 \mathrm{~cm}$, Blattzahl 3.7, Blattlänge $32.15 \mathrm{~cm}$, Blattbreite $1.17 \mathrm{~cm}$, Blattoberfläche eines Halmes $278.39 \mathrm{qcm}$, Halmfläche $190.35 \mathrm{qcm}$, Gesanmtfläche $468.74 \mathrm{qcm}$.

Junge Aehre blangrün, mittelfrüh reifend, $10 \mathrm{~cm}$ (Max. 14 cm) lang, mit 26 Aehrchen und 78 fest sitzenden Früchten, von denen 1638000 auf $1 \mathrm{hl}(=84 \mathrm{~kg})$ gehen.

Auf 1 qm kommen 650 Halme oder 186 Pflanzen, mithin beträgt der Raum für eine Pflanze $53.8 \mathrm{qcm}$, die Blattoberfläche p. qm Bodenfläche $30.49 \mathrm{qm}$ und das Saatquantum $1.8 \mathrm{hl}$ p. ha.

Es wiegen 100 Halme $750 \mathrm{gr}$ und davon die Frïchte $270 \mathrm{gr}$.

In Poppelsdorf erwies sich dieser Weizen weder winterfest, noch gegen Rost widerstandsfähig, doch lagerte er nicht leicht.

Er wird rorzugsweise auf den strengen Böden des mittleren und südlichen Englands, zuweilen in Süd-Frankreich, z. B. im Depart. Yonne, Loiret, Nièrre, sowie in Spanien und Italien kultiviert.

Die Kornqualität lässt sehr zu wünschen iibrig, dagegen stellen sich die Erträge sehr hoch.

\section{Varietät: Triticum turgidum megalopolitanum Kcke.}

Aehre sammetig, weiss; Körner weiss oder gelblich; Grannen hell.

\section{Sorte : \\ Blé pétanielle blanche.}

Syn.: Franz.: Blé de Constantine, renflé à barbes blanches, du Dauphiné, pétanielle d'Orient, blanc de Montpellier; Poulard blanc de Montauban.

Ital.: Grano tenero bianco; Grano grosso; Frumento bianco. $\mathrm{Sp}$ an is ch: Trigo redondillo relloso blanco.

Chile: Trigo pulardo blanco Español.

Deutsch: Weisser elglischer Sammetweizen.

Aehre: weiss, schwach behaart, ein wenig platt, dicht, etwas kurz; Aehrchen $1.8 \mathrm{~cm}$ breit, 3- und 4-körnig; Grannen weiss, nur an Basis schwarzbläulich, bis $12 \mathrm{~cm}$ lang, etwas gespreizt, fein, zähe. - Stroh: blassgelb, markig, steif. - Frucht: blassgelb, mehlig, zuweilen rötlich und glasig, plump, sehr gross ( $8 \mathrm{~mm}$ lang, $4 \mathrm{~mm}$ breit), ziemlich feinschalig.

Halm blaugrün, 2.5 Schösslinge, spät schossend und blühend; Halmlänge $110 \mathrm{~cm}$ (Max. $125 \mathrm{~cm}$ ), Halmdicke 0.4 , Blattzahl 5, Blattlänge $23.4 \mathrm{~cm}$, Blattbreite $1.2 \mathrm{~cm}$, Blattoberfläche eines Halmes $280.8 \mathrm{qcm}$, Halmfläche $132 \mathrm{qcm}$, Gesammtfläche $412.8 \mathrm{qcm}$.

Aehre $7 \mathrm{~cm}$ (Max. $9 \mathrm{~cm}$ ) lang, mit 18 Aehrchen und 60 nicht leicht ausfallenden Früchten, von denen 1348750 auf $1 \mathrm{hl}(=83 \mathrm{~kg})$ gehen.

In Süd-Frankreich, Spanien, Italier, zuweilen in der Schweiz (Canton Waadt) ${ }^{1}$ ) und in Süd-Amerika kultiviert.

Im Herbst gesäet, erwies èr sich als echter Sommerweizen.

Bezugsquelle: Pariser Ausstellung 1878 und von Gülich aus Chile 1880.

1) Séringe, Mongr. des céréales de la Suisse pg. 98. 


\section{Varietät: Triticum turgidum Salomonis Kcke.}

Aehre sammetig, weiss; Körner weiss oder gelblich; Grannen schwarz.

\section{Sor te : \\ Englischer Weizen aus Catanien, Sicilien.}

Aehre: auf weissem Grunde blauschwarz, doch zuweilen Färbung nur angedeutet, kurz, dick, schwach sammetig, 5.5-7 cm lang; Grannen schwarz. - Halm: rötlich-gelb, mit schmalem, markigem Innenrande. Frucht: rötlich-gelb, einige mehlig, die anderen glasig.

Blätter sammetig.

Uebersender: Gius eppe Salom one, Catania.

Varietät: Triticum turgidum buccale $\mathrm{Al}$.

Aehre sammetig, weiss, Körner rot; Grannen hell.

\section{Sorte:}

\section{Cone Rivet or Antifly-Wheat. (2)}

Syn.: Engl.: German Thickset-Wheat.

Franz.: Poulard blauc velu de Touraine, prolific cone, Aubaine blanche, Blé blauc de Décaze, Poulard velu de Taganrock, Poulard blanc velu du Gâtinais.

Aehre: blassgelb mit schwach blaurötlichem Anflug, weiss behaart, konisch, sehr dicht, sehr regelmässig, mittellang; Aehrchen $1.5 \mathrm{~cm}$ breit, 3- und 4-körnig, nur an der Spitze 2-körnig, Klappen mit langer, gebogener Spitze; Grannen hell, 4 Granuenreiben sitzen an del 4 Kanten der Aehre, und 2 kürzere an der breiten Aehrenseite, bis $10 \mathrm{~cm}$ lang, gespreizt, leicht abbrechend. - Stroh: blassgelb, markig, steif. - Frucht: goldgelb, klein, länglich ( $7 \mathrm{~mm}$ lang, $3^{1} / 2 \mathrm{~mm}$ breit, 253 Frïchte $\left.=10 \mathrm{gr}\right)$, grobschalig.

Herbstblatt blaugrïn, sammetig, breit, aufrecht; Frühjahrsvegetation zeitig, Bestockung mittelstark, 4.2 Schösslinge (bei 100 qcm Raum 11.7 Schösslinge), spät schossend und blühend. Halmlänge $135 \mathrm{~cm}$ (Max. $155 \mathrm{~cm}$ ), Halmdicke $0.47 \mathrm{~cm}$, Blattzahl 3.7, Blattlänge $28.8 \mathrm{~cm}$, Blattbreite $0.99 \mathrm{~cm}$, Blattoberfläche eines Halınes $210.97^{\sharp} \mathrm{q} \mathrm{cm}$, Halmfläche 190,35 qcm, Gesammtfläche $401.32 \mathrm{qcm}$.

Junge Aehre blaugrün, spät reifend, $9 \mathrm{~cm}(\mathrm{Max} .211 \mathrm{~cm})$ lang, 'mit 20 Aehrchen und 70 Früchten, von denen 2074600 auf $1 \mathrm{hl}(=82 \mathrm{~kg})$ gehen.

Auf $1 \mathrm{qm}$ wachseu 750 Halme oder 180 Pflanzen, mithin beträgt der Raum für eine Pflanze $55.5 \mathrm{qcm}$, die Blattoberfläche p. qm, Bodenfläche $30 \mathrm{qm}$, das Saatquantum $1.3 \mathrm{hl} \mathrm{p}$. lia.

Der Weizen ist ziemlich winterfest, ein echter Winterweizen, dessen Strob nicht leicht lagert, oder durch Rost befällt, aber dessen Früchte wegen der groben Qualität des Mehles und ibrer Kleberarmut nicht beliebt sind.

Ziemlich umfangreich in Schottland auf den schwersten Clayböden, in England (Oxfordshire), in Deutschland, namentlich in der Provinz Sachsen, in Suid-Frankreich und Spanien gebaut.

Ausser auf den sehr schweren Böden wird er noclı erfolgreich auf 
leichteren Böden kultiviert, doch verliert er dann naturgemäss bedeutend an seiner hohen Ertragsfähigkeit.

Den Namen "Antifly-Wheat" hat er davon erhalten, dass er weniger als andere Sorten durch die Hessenfliege gelitten haben soll.

Es ist dies eine sehr alte Sorte Grossbritanniens, denn Morison beschreibt sie schon 'in seiner hist. pl. oxon. tom. III a. 1699 pg. 176 sect. 8. T. 1, Fig. 13 als "Cone wheat rusticis" wie folgt: „Trit. spica villosa quadrata longiore, aristis munitum. Glumis hirsutis cinereis in longissimas asperrimasque aristas desinentibus. Semina praebent pollen longe candidissimum.

\section{Varietät: Triticum turgidum dinura Al.}

Aehre sammetig, rot; Körner rot; Grannen hell.

\section{Sorten:}

\section{Blé géant de Sainte-Hélène. (2)}

Syn.: Franz.: Blé Nonette de Lausanne ${ }^{1}$ ), de la Mecque, de Dantzic, poulard roux velu, souris, mitadin, des gouttières, poulard roux d'Australie; Froment de Silistrie; Pétanielle rousse veloutée; Poulard d'Auvergne à épi long, géant du Milanais, roux de la Limagne, roux pubescent, velu de la Beauce; Ponlage rouge du Mont d'Or; Gros blé roux. Ebenfalls identisch, doch verbesserte Formen mit grösserer breiterer Aehre, sind: Blé gros turquet, poulard carré velu, pétanielle rousse, turquet à six rangs, roux de Montpellier, grossaille de la Gironde, brousse; Gros blé de l'Ardèche.

Span.: Blat Nonette de Lausanne.

Ital.: Andriolo rosso peloso; Grano di Losanno; Pilosella auf Sicilien.

Engl.: Giant St. Helena Wheat.

Dentsch: Helena-Weizen, Wispelweizen (Provinz Sachsen), Glockenweizen, Aegyptischer-, Marokkanischerund Türkischer-Weizen. Am Rhein auch schottischer oder englischer Grannenweizen genannt.

Aehre: bläulich-rot, rauhhaarig, fast quadratisch, doch ein wenig unregelmässig, dicht, mittellang; Aehrchen $1.7 \mathrm{~cm}$ breit, 4-körnig; Grannen bläulich, 12-17 cm lang, wenig gespreizt. - Stroh: blassgelb, markig, steif, sehr lang. - Frncht: gelbrot, mehlig oder glasig, banchig, runzelig, gross ( $7 \mathrm{~mm}$ lang, $4 \mathrm{~mm}$ breit), grobschalig.

Herbstblatt dunkelgrün, breit, aufrecht; Frühjahrsvegetation zeitig, Bestockung mittelstark, 4 Schösslinge, Bestockungsfähigkeit bei $100 \mathrm{qcm}$ Raum 15.5 Schösslinge, mittelfriih schossend und bliihend.

Halmlänge $145 \mathrm{~cm}$ ( Мax. $165 \mathrm{~cm}$ ), Halmdicke $0.49 \mathrm{~cm}$, Blattzahl 4, Blattoberfläche eines Halmes $250.96 \mathrm{qcm}$, Halmfläche $213.15 \mathrm{qcm}, \mathrm{Ge}-$ sammtfläche $464.11 \mathrm{qcm}$.

1) Vergl. Vilmorin, Journ. d'Agric. prat. 1851, pg. 487; Oscar LeclercThouin et Vilmorin, Maison rust. I pg. 360 etc. Heuzé, Les plantes aliment. 
Junge Aehre blaugrün, spät reifend, $8 \mathrm{~cm}$ (Max. $11 \mathrm{~cm}$ ) lang, mit 16 Aehrchen und 60 nicht leicht ausfallenden Früchten, von denen 1498000 auf $1 \mathrm{hl}(=81.5 \mathrm{~kg})$ gehen.

Auf $1 \mathrm{qm}$ wachsen 650 Halme oder 162 Pflanzen, demnach beträgt der Raum für eine Pflanze $61.3 \mathrm{qcm}$, die Blattoberfläche p. qm Bodenfläche $30 \mathrm{qm}$ und das Saatquantum (1/3 Verlust) 1.t hl p. ha.

Es wiegen 100 Halme $901 \mathrm{gr}$ und davon die Frïchte $278 \mathrm{gr}$.

Der Helenaweizen ist nicht ganz winterfest, so winterte derselbe 1870/71 auf dem Versuchsfelde zu Poppelsdorf grösstentheils aus, obgleich er seit ca. 20 Jahren aus hier geerntetem Saatgut erwachsen war.

In Poppelsdorf stellten sich die Erträge im Durchschnitt dreier Jahre auf $2800 \mathrm{~kg}$ Korn und $4200 \mathrm{~kg}$ Stroh p. ha.

Nach Heuzél) soll der Helenaweizen zuerst durch Tessier aus Genf nach Frankreich gebracht worden sein, und später soll ihn Noisette als "Blé géant de St. Hélène" von St. Helena bezogen haben.

Zur Zeit wird er vielfach in Frankreich (Gascogne), in der Schweiz (Bern, Waadt), in Spanien, Italien, Nord-Deutschland (Rheinprovinz und Provinz Sachsen), in England und sogar in Finnland auf reichem Boden kultiviert.

Der Weizen besitzt die gute Eigenschaft, nicht leicht zu degenerieren, so wurde derselbe ohne Saatwechsel anf ein und demselben Felde in Poppelsdorf ${ }^{2}$ ) 22 Jahre hindurch gebant, ohne dass sich eine markante Veränderung in den Eigenschaften gezeigt hätte.

\section{Tunesischer Weizen. (2)}

Aelrre: bläulich-rot, sammetig, quadratisch, sehr diclit, mittellang; Aehrchen 1.5 cm breit, 3-körnig; Grannen blassrot. wenig gespreizt, bis $9 \mathrm{~cm}$ lang, zur Reifezeit leicht abbrechend. Stroh: rötlich-gelb, nit markigem Innenrande, fest, sehr lang. - Fruclit: gelbrot,' mehlig oder glasig, etwas eingefallen, bauchig, plump, $(8 \mathrm{~mm}$ lang, $4 \mathrm{~mm}$ breit), verhältnismässig feinschalig.

Herbstblatt auffallend hell-gelbgrün, sammetig, sehr breit, aufrecht; Frühjahrsvegetation sehr zeitig, Bestockıng mittelstark, 4 Schösslinge; spät schossend und blülıend. Halmlänge $160 \mathrm{~cm}($ Max. $170 \mathrm{~cm})$ Halmdicke $0.37 \mathrm{~cm}$, Blattzahl 4.3, Blattlänge $29.32 \mathrm{~cm}$, Blattbreite $1.03 \mathrm{~cm}$, Blattoberfläche eines Halmes $259.72 \mathrm{qcm}$, Halmfläche $177.6 \mathrm{qcm}$, Gesammtfläche $437.32 \mathrm{qcm}$.

Junge Aehre blaugriin, spät reifend, $8 \mathrm{~cm}$ (Max. $12 \mathrm{~cm}$ ) lang, mit 20 Aelirchen und 60 sehr fest sitzenden Früchten, vou denen 1218000 auf $1 \mathrm{hl}(=84 \mathrm{~kg})$ gehen.

Auf $1 \mathrm{qm}$ wachsen 700 Halme oder 175 Pflanzen, mithin beträgt der Raum für eine Pflanze $57 \mathrm{qcm}$, die Blattoberfäche $p$. qun Bodenfläche $30.6 \mathrm{qm}$ und das Saatquantum $2.2 \mathrm{hl} \mathrm{p}$. ha.

Der Weizen lagert nicht, widersteht dem Rost, ist auf reichem Boden sehr ertragreich, doch in Deutschland nicht winterfest.

1) Vergl. Les plantes aliment.

2) Methode Lois-Weedon. 


\section{Gros blé de Montauban. (2)}

Syn.: Franz.: Blé grossagne de Nérac.

$" \quad$ " des Basses-Pyrénées.

" pétanielle de Lavaur.

$"$ gouape de l'Anjou.

$"$ à six carrés.

Spanisch: Trigo redondillo velloso rubio recio.

Deutsch: Roter sammetiger englischer Bartweizen.

Aehre: rot oder rötlich-grau, ein wenig hängend, stark behaart, quadratisch, dicht, breit; Aehrchen $1.7 \mathrm{~cm}$ breit, 3-körnig, Klappen grannenspitzig; Grannen blassrot, an Basis schwärzlich, $16 \mathrm{~cm}$ lang. - Stroh: gelb, innerer Rand markig, fest. - Frucht: gelbrot, meist mehlig, zuweilen rot und glasig, etwas eingefallen, bauchig, plump, gross $(8 \mathrm{~mm}$ lang, $4 \mathrm{~mm}$ breit), grobschalig.

Herbstblatt dunkelgriin, sehr kurzsammetig, breit, aufrecht; Frïhjahrsvegetation zeitig; Bestockung mittelstark, 4 Schösslinge, spät schossend und blühend. Halmlänge $155 \mathrm{~cm}$ (Мax. $175 \mathrm{~cm}$ ), Halmdicke $0.48 \mathrm{~cm}$, Blattzahl 5.5, Blattlänge $30 \mathrm{~cm}$, Blattbreite $1.0 \mathrm{~cm}$, Blattoberfläche eines Halmes $330 \mathrm{qcm}$, Halmfläche $223.20 \mathrm{qcm}$, Gesammtfläche $553.2 \mathrm{qcm}$.

Junge Aehre blaugriin, spät reifend, $10 \mathrm{~cm}$ (Max. $12 \mathrm{~cm}$ ) lang, mit 24 Aehrehen und 70 Früchten, von denen 1109700 auf $1 \mathrm{hl}(=81 \mathrm{~kg})$ gehen.

Es wiegen 100 Halme $1044 \mathrm{gr}$ und davon die Früchte $463 \mathrm{gr}$.

Für Deutschland zu weichlich; doch wird diese sehr ertragreiche Sorte auf fruchtbarem Boden im westlichen und südwestlichen Frankreich und in Spanien (Navarra) angebaut.

\section{Roter sammetiger Weizen. (2)}

Aehre: blassrot, oft mit bläulichem Anflug, sammetig, relativ schmal, pyramidal, ziemlich dicht, lang; Aehrchen $1.5 \mathrm{~cm}$ breit, 3-körnig, 2-grannig; Grannen hell, doch an Basis hellblau bereift, aufrecht, bis $17 \mathrm{~cm}$ lang. - Stroh: gelb, markig, steif, mittellang. - Frucht: hellbraun, mehlig, stark bauchig, runzelig ( $7 \mathrm{~mm}$ lang, $3 \mathrm{~mm}$ breit, 234 Frïchte $=10 \mathrm{gr})$, grobschalig.

Herbstblatt dunkelblaugrün, sammetig, schmal, kraus; Frühjahrsvegetation spät, Bestockung mittelstark, 4.8 Schösslinge, mittelfrüh schossend und blühend. Halmlänge $110 \mathrm{~cm}$ ( $\lceil a x .120 \mathrm{~cm}$ ), Halmdicke 0.38, Blattzahl 4.2, Blattlänge $23.8 \mathrm{~cm}$. Blattbreite $0.9 \mathrm{~cm}$, Blattoberfläche $179.9 \mathrm{qcm}$, Halmfläche $125.4 \mathrm{qcm}$, Gesammtfläche $305.3 \mathrm{qcm}$.

Junge Aehre blaugrün, spät reifend, $10 \mathrm{~cm}$ (Мax. $14 \mathrm{~cm}$ ) lang mit 22 Aehrchen und 65 fest sitzenden Früchten, von denen 1900080 auf $1 \mathrm{hl}(=81.2 \mathrm{~kg})$ gehen.

Diese Sorte lagert nicht, widersteht dem Rost vorzüglich, nimmt mit leichterem Boden vorlieb und ist ziemlich winterfest.

Es wiegen 100 Halme $580 \mathrm{gr}$ und davon die Früchte $276 \mathrm{gr}$. 


\title{
Varietät: Triticum turgidum rubroatrum Keke.
}

Aehre sammetig, rot; Körner rot; Grannen schwarz.

\section{Sorte: \\ Grano Serino di Sesto-Aurunca. $\odot$}

Syn.: Franz.: Blé pétannielle noire; Poulard brun de la Vienne, Blé bleuâtre l'Aveyron; Blé noir de Montpellier'; Blé touzelle noir velouté.

Aehre: schmutzig-rot, stark sammetig, dicht, fast quadratisch, kurz; Aehrchen $1.5 \mathrm{~cm}$ breit, 4-körnig, 4-grannig, die beiden mittleren Grannen kurz; Grannen schwarz, mässig gespreizt, bis $13 \mathrm{~cm}$ lang, leicht abbrechend. - Stroh: blassgelb, mit schmalem, markigem Innenrande, lang. - Frucht: rotgelb, mehlig, länglich $\left(71 / 2 \mathrm{~mm}\right.$ lang, $3 \frac{1}{2} \mathrm{~mm}$ breit, 188 Früchte $=10 \mathrm{gr}$ ), etwas grobschalig.

Junges Blatt dunkelgruin, sammetig, sehr spät schossend, 5 Schösslinge, Mitte Juli blühend; Halm $150 \mathrm{~cm}$ (Max. $170 \mathrm{~cm}$ ) lang, $0.5 \mathrm{~cm}$ dick, Blattzahl 5, Blätter $22.4 \mathrm{~cm}$ lang, $1.1 \mathrm{~cm}$ breit, Blattfläche $246.4 \mathrm{qcm}$, Halmfläche $225 \mathrm{qcm}$, Gesammtfläche $471.4 \mathrm{qcm}$.

Junge Aehre gelbgrün, sehr spät reifend, $7 \mathrm{~cm}$ (Max. $9 \mathrm{~cm}$ ) lang.

Es wiegen 100 Halme $741 \mathrm{gr}$ und davon die Früchte $297 \mathrm{gr}$.

Nur für das wärmere, gemässigte Klima.geeignet.

Bezugsquelle: Pariser Ausstellung 1878.

Varietät: Triticum turgidum jodura Al.

Aehre sammetig, blau; Körner rot.

\section{Sorten:}

\section{Blauer sammetiger englischer Weizen (aus Heidelberg).}

\author{
Syn.: Deutsch: Russischer Weizen (nach Metzger). \\ Franz.: Blé gris de Russie. \\ Blé brun d'Heidelberg.
}

Aehre: blassrötlich mit blauem Anflug, sammetig, stark zusammengedrïckt, die breitere Seite ähnlich Trit. dicoccum, dicht, lang; Aehrchen $2 \mathrm{~cm}$ breit, 3- und 4-körnig; Grannen blau, an Basis dunkel, bis $16 \mathrm{~cm}$ lang, zerbrechlich. - Stroh: gelb, markig, kräftig. - Frucht: braun, mehlig, doch auch viele glasig, runzelig, stark bauchig, gross $(8 \mathrm{~mm}$ lang, $4 \mathrm{~mm}$ breit, 175 Früchte $=10 \mathrm{gr}$ ), grobschalig.

Herbstblatt blaugrün, kurz, sammetig, ziemlich breit und aufrecht; Frühjahrsvegetation zeitig, Bestockung mittelstark, 4.2 Schösslinge, mittelfrüh schossend und bliihend.

Halmlänge $150 \mathrm{~cm}$ (Max. $175 \mathrm{~cm})$, Halmdicke $0.45 \mathrm{~cm}$, Blattzahl 4, Blattlänge $34 \mathrm{~cm}$, Blattbreite $1 \mathrm{~cm}$, Blattoberfläche eines Halmes $272 \mathrm{qcm}$, Halmfläche $202.5 \mathrm{qcm}$, Gesammtfläche $474.5 \mathrm{qcm}$.

Junge Aehre blaugrün, zeitig reifend. $11 \mathrm{~cm}$ (Max. $14 \mathrm{~cm}$ ) lang, mit 20 Aehrchen und 70 fest sitzenden Früchten, von denen 1431000 auf $1 \mathrm{hl}(=81.3 \mathrm{~kg})$ gehen.

Auf $1 \mathrm{qm}$ wachsen 600 Halme oder 145 Pflanzen, mithin beträgt der Raum fiir eine Pflanze $70 \mathrm{qcm}$, die Blattoberfläche p. qm Bodenfläche $28.44 \mathrm{qm}$ und das Saatquantum ( $1 / 3$ Verlust) $1.5 \mathrm{hl} \mathrm{p}$. ha. 
Es wiegen 100 Halme $780 \mathrm{gr}$ und davon die Früchte $320 \mathrm{gr}$.

Dieser Weizen erwies sich als winterfest, lagerte nicht, befiel aber stark mit Rost. Sein Mehl wird wenig geschätzt. angebaut.

Zuweilell in den Ostseeprovinzen, in Deutschland und Frankreich

\section{Common Rivet wheat of England. (2)}

Syn.: Deuts ch: Schwarzblauer, dickähriger, sammetiger Bartweizen; Schottischer rauher Weizen (Provinz Sachsen); Australischer gelber Weizen; Rivet's Grannenweizen.

Franz.: Blé bleuâtre d'Égypte; Blé de Poméranie; Blé poulard velu d'Australie (Vilmorin).

Aehre: auf rotem Grunde blau, graublau oder rötlich, behaart, fast quadratisch, sich wenig verjüngend, in der Reife etwas gebogen, sehr dicht, mittellang; Aehrchen $1.5 \mathrm{~cm}$ breit, 3- zuweilen 4-körnig; Grannen blassrot, etwas gespreizt, $10-12 \mathrm{~cm}$ lang, stark, zum Teil in der Reife abfallend. - Stroh: hellgelb, sehr derbwandig, innerer Rand markig, zuweilen vollkommen markig, fest. - Frucht: goldgelb ${ }^{1}$ ), mehlig, wenige glasig, weniger plump als andere zu Turgidum gehörige Sorten, gross ( $7 \mathrm{~mm}$ lang, $4 \mathrm{~mm}$ breit, 170 Früchte $=10 \mathrm{gr}$ ), grobschalig.

Herbstblatt blaugrün, kurz, sammetig, ziemlich breit, aufrecht; Frühjahrsvegetation mittelfrüh, Bestockung mittelstark, 5 Schösslinge, Bestockungsfähigkeit bei $100 \mathrm{qcm}$ Raum 10.3 Schösslinge; etwas spät schossend und blüheıd. Halmlänge $135 \mathrm{~cm}$ (Max. $160 \mathrm{~cm}$ ), Halmdicke $0.46 \mathrm{~cm}$, Blattzahl 4, Blattlänge $27.7 .2 \mathrm{~cm}$, Blattbreite $1.0 \mathrm{~cm}$, Blattoberfläche eines Halmes $221.76 \mathrm{qcm}$. Halmfläche $186.3 \mathrm{q} \mathrm{cm}$, Gesammtfläche $408.06 \mathrm{qcm}$.

Junge Aehre blaugriin, Spelzen rötlich umrandet, spät reifend, $10 \mathrm{~cm}$ (Max. $12 \mathrm{~cm}$ ) lang, mit 22 Aehrchen und 70 Früchten, von denen 1428000 auf $1 \mathrm{hl}(=84 \mathrm{~kg})$ gehen.

Auf $1 \mathrm{gm}$ wachsen 700 Halme oder 140 Pflanzen, mithin beträgt der Raum für eine Pflanze 71 qcm, die Blattfläche p. qm Bodenfläche $28.6 \mathrm{qm}$ und das Saatquantum (1/3 Verlust) $1.5 \mathrm{hl} \mathrm{p.} \mathrm{ha.}$

Es wiegen 100 Halme $908 \mathrm{gr}$ und davon die Früchte 405 gr.

Dieser. Weizen zeigte sich in Poppelsdorf nicht ganz winterfest, denu $1870 / 71$ und $1875 / 76^{\circ}$ erfror derselbe vollständig, doch lagert er nicht und widersteht dem Rost vortrefflich. Das Korn wird von den Müllern nicht geliebt, da das Mehl grau ist und sich aus Mangel an gutem Kleber schlecht verbackt.

Als Sommerweizen kultiviert, bewies er sich als echter Winterweizen.

In England wird dieser sehr ertragreiche Weizen auf den schwersten Böden kultiviert und erntete Mr. Law es ${ }^{2}$ ) auf Lehmboden in Rothamsted im 6 jährigen Durchschnitt 46.35 hl p. lia. Von England aus gelangte diese alte englische Sorte, die sich nach s'sirreff ${ }^{3}$ ) schon länger als ein Jahrhundert konstant erhalten hat, nach Frankreich, wo sie auf frucht-

1) Nach Rimpau soll das Korn durch cinc bräunliche Stelle in der Nähe des Embryo leicht kenntlich sein. Wir konnten dies jedoch nicht konstatieren.

2) Farmer's Magaz. Vol. 80, 1876, pg. 433.

3) Gardener's Chronicle 1858 pg. 722. 
barem Thonboden angebaut wird; ebenso auch nach Deutschland, und hat sich hier vorzugsweise auf den guten Rübenböden der Provinz Sachsen ausgebreitet. Nach Australien ist sie ebenfalls von England aus importiert worden.

\section{Paines defiance. (2)}

Deutsch: Unverdrossen herausfordernder Weizen.

Aehre: dunkelblau in's Rote iibergehend, sammetig, quadratisch, dicht, mittellang; Aelirchen $1.5 \mathrm{~cm}$ breit, 3- und 4-körnig; Grannen rot, zerbrechlich, wenig gespreizt, bis $11 \mathrm{~cm}$ lang. - Stroh: hellgelb, lang, fest, sehr derbwandig. - Frucht: gelbrot, mehlig, plump $(61 / 2 \mathrm{~mm}$ lang, $4 \mathrm{~mm}$ breit, 210 Früchte $=10 \mathrm{gr})$, grobschalig.

Herbstblatt gelbgrün, sammetig, ziemlich breit, aufrecht; Frühjahrsvegetation zeitig, Bestockung schwach, 3.9 Schösslinge, mittelfrüh schossend und blühend. Halmlänge $140 \mathrm{~cm}$ (Max. $150 \mathrm{~cm}$ ), Halmdicke $0.42 \mathrm{~cm}$, Blattzahl 3.3, Blattlänge $26.42 \mathrm{~cm}$, Blattbreite $0.94 \mathrm{~cm}$, Blattoberfläche eines Halmes 163.88 q cm, Halmfläche $176.4 \mathrm{qcm}$, Gesammtfläche $340.28 \mathrm{qcm}$.

Junge Aehre blaugrïn, mittelfrüh reifend, $10 \mathrm{~cm}$ (Max. $12 \mathrm{~cm}$ ) lang, mit 20 Aehrchen und 70 fest sitzenden Früchten, von denen 1774500 auf $1 \mathrm{hl}(=84.5 \mathrm{~kg})$ gehen.

Auf 1 qm wachsen 800 Halme oder 205 Pflanzen, mithin nimmt eine Pflanze einen Raum von $49 \mathrm{qcm}$ ein; die Blattoberfläche beträgt p. qm Bodenfläche $27.2 \mathrm{qm}$ und das Saatquantum ( $1 / 3$ Verlust) $1.8 \mathrm{hl}$ p. ha. rostfrei.

Der Weizen ist nicht winterfest, lagert jedoch nicht und hält sich

Der Ertrag im Durchschnitt von 3 Jahren stellte sich in Poppelsdorf auf $3078 \mathrm{~kg}$ Korn und $5000 \mathrm{~kg}$ Stroh p. ha.

Für reiche, humose Lehmböden eignet sich dieser ertragreiche Weizen sehr gut und wird auch in England vielfach auf solchen kultiviert, für Deutschland ist er jedoch zu empfindlich.

\section{Blue Rivet. (2)}

Deutsch: Blauer englischer Weizen.

Franz.: Blé poulard bleu, bleu de Rivet, bleu d'Égypte, bleu conique, bleu d'Australie, locar de la Picardie, gris sonris.

Aehre: rötlich-blau, Klappen mit schwärzlichen Ränderı, sehr rauhhaarig, quadratisch, sich etwas verjiingend, dicht, aufrecht; Aehrchen $1.5 \mathrm{~cm}$ breit, 3- und 4-körnig; Grannen blau, bis $13 \mathrm{~cm}$ lang, gedrängt, in der Reife zum Teil abfallend. - Stroh: gelb, derb, markig, steif. Frucht: gelbrot, meist glasig, stark bauchig, runzelig, gross ( $8 \mathrm{~mm}$ lang, $4 \mathrm{~mm}$ breit), grobschalig.

Herbstblatt blaugriin, sammetig, sehr breit, aufrecht; Frühjahrsvegetation zeitig, Bestockung mittelstark, 4 Schösslinge, mittelfrüh schossend und blühend. Halmlänge $145 \mathrm{~cm}$ (Max. $170 \mathrm{~cm}$ ), Halmdicke $0.42 \mathrm{~cm}$, Blattzahl 3, Blattlänge. $27.96 \mathrm{~cm}$, Blattbreite $1.06 \mathrm{~cm}$, Blattoberfläche eines Halmes 177.84 qcm, Halmfläche 182.7 qcm, Gesanmtfläche $360.54 \mathrm{qcm}$.

Junge Aehre blaugrün und Klappen nit schwärzlichen Rändern, mittelfrüh reifend, $9 \mathrm{~cm}$ (Max. $13 \mathrm{~cm}$ ) lang, mit 20 Aehrchen und 70 fest sitzenden Früchten, von denen 1492000 auf $1 \mathrm{hl}(=82.5 \mathrm{~kg}$ ) entfallen.

Auf $1 \mathrm{qm}$ wachsen 800 Halme oder 200 Pflanzen, mithin beträgt der Raum für eine Pflanze $50 \mathrm{qcm}$, die Blattoberfläche p. qm Bodenfläche $28.8 \mathrm{qm}$, das Saatquantum ( $1 / 3$ Verlust) $2 \mathrm{hl}$ p. ha. 
Es wiegen 100 Halme $930 \mathrm{gr}$ und davon die Früchte $400 \mathrm{gr}$.

Dieser nicht leicht lagernde Weizen zeigte sich in Poppelsdorf ziemlich winterfest.

Er wird vielfach in England und Frankreich auf schwerem Boden kultiviert.

\section{Frumento Veneto. (2)}

Syn.: Spanisch: Blat morisco.

Aehre: blauschwarz, sammetig, pyramidal, ziemlich dicht, kurz; Aehrchen 3-körnig, 2-grannig: Grannen blauschwarz, gespreizt, sehr lang $(16 \mathrm{~cm})$. - Stroh: rötlich-gelb, Innenrand markig, kräftig, mittellang. Frucht: gelbrot, mehlig, viele rot, glasig; eingefallen, gross $(8 \mathrm{~mm}$ lang, $4 \mathrm{~mm}$ breit, 126 Früchte $=10 \mathrm{gr}$ ), grobschalig.

Herbstblatt blaugrün, fein, schwach, sammetig, bereift, Entwickelung spät, 4 Schösslinge, spät schossend und blühend. Halm $130 \mathrm{~cm}$ (Мax. $145 \mathrm{~cm})$ lang, $0.4 \mathrm{~cm}$ dick, Blattzahl 4, Blätter $28 \mathrm{~cm}$ lang, $1.2 \mathrm{~cm}$ breit, Blattfäche $268.8 \mathrm{qcm}$, Halmfläche $156 \mathrm{qcm}$, Gesammtfläche $424.8 \mathrm{qcm}$.

Junge Aehre blaugrün, bereift, spät reifend, $8 \mathrm{~cm}$ (Max. $12 \mathrm{~cm}$ ) lang, mit 19 Aehrchen und 50 Früchten, von denen 1033200 auf 1 hl $(=80 \mathrm{~kg})$ entfallen.

Nicht winterfest, aber echter Winterweizen. Verlangt reichen Boden.

In Italien, Spanien etc. gebaut.

Bezugsquelle: Pariser Ausstellung 1878.

\section{B. Aehren verästelt.}

Varietät: Triticum turgidum pseudo-cervinum Kcke.

Aehre kahl.

\section{Sorte :}

\section{Trigo rubio, Castilien, Spanien. $\odot$}

Deuts ch: Roter, kahler Wunderweizen;

Sommerwunderweizen (hort. Halle).

Aehre: blassrot mit bläulichem Anflug, kahl, in sich gebogen, stark verästelt, mittellang; Aehrchen $1 \mathrm{~cm}$ breit, 2-körnig, 2-grannig; Grannen rötlich, an Basis dunkel, bis $9 \mathrm{~cm}$ lang. - Stroh: rötlich-gelb, bis orange; hohl, doch mit markigem Innenrande, fest, mittellang. - Frucht: schön blassgelb, oft eingefallen, glasig und mehlig, klein $(6 \mathrm{~mm}$ lang, $3 \mathrm{~mm}$ breit).

Halme blaugrün, Blätter sammetig, 2.5 Schösslinge, zeitig schossend und blühend; Halmlänge $110 \mathrm{~cm}$ (Max. $125 \mathrm{~cm}$ ), Halmdicke $0.43 \mathrm{~cm}$, Blattzahl 5, Blattlänge $25.4 \mathrm{~cm}$, Blattbreite $0.95 \mathrm{~cm}$, Blattoberfläche eines Halmes $241.3 \mathrm{qcm}$, Halmfläche $141.9 \mathrm{qcm}$, Gesammtfäche $383.2 \mathrm{qcm}$.

Junge Aehre blaugrün, spät, in 132 Tagen reifend, $9 \mathrm{~cm}$ lang, $21 / 2 \mathrm{~cm}$ breit (Max, $11 \mathrm{~cm}$ lang, $3 \mathrm{~cm}$ breit), mit 100 nicht leicht ausfallenden Früchten, von denen 1776000 auf $1 \mathrm{hl}(=80 \mathrm{~kg})$ gehen.

Es wiegen 100 Halme $644 \mathrm{gr}$ und davon die Früchte $255 \mathrm{gr}$.

Der Weizen lagert nicht, wird jedoch stark durch Rost befallen und degeneriert auf armem Boden sehr leicht, indem seine Aehre einfach wird.

Bisweilen in Süd-Europa und Nord-Afrika kultiviert. 
Varietät: Triticum turgidum mirabile Keke.

Aehre sammetig, rot.

\section{Sorte:}

\section{Roter sammetiger Wunderweizen.}

Aehre: blassrot mit bläulichem Anflug, bis gegen die Spitze stark verästelt, sammetig; Aehrchen $1 \mathrm{~cm}$ breit, klein, 2-körnig, Grannen rötlich, gespreizt, bis $12 \mathrm{~cm}$ lang. -.. Stroh: rötlich-gelb, schilfartig, narkig. - Frucht: rötlich-gelb, mehlig und durch kürzere, abgerundetere Form von allen übrigen Trit. turgidum verschieden $(51 / 2 \mathrm{~mm}$ lang, $3 \mathrm{~mm}$ breit, 255 Früchte $=10 \mathrm{gr}$ ).

Herbstblatt blaugrün, sammetig, breit, aufrecht, Frühjahrsvegetation spät, Bestockung sehr stark, 8.5 Schösslinge, spät schossend und blühend. Halmlänge $145 \mathrm{~cm}$ (Max. $170 \mathrm{~cm}$ ), Halmdicke $0.34 \mathrm{~cm}$, Blattzahl 4.7, Blattlänge $26.44 \mathrm{~cm}$, Blattbreite $1.28 \mathrm{~cm}$, Blattoberfläche eines Halmes $318.1 \mathrm{qcm}$, Halmfläche $147.9 \mathrm{qcm}$, Gesamintfläche $466 \mathrm{qcm}$.

Junge Aehre gelbgrün, spät reifend, $9 \mathrm{~cm}$ lang, $2.5 \mathrm{~cm}$ breit (Max. $12 \mathrm{~cm}$ lang, $5 \mathrm{~cm}$ breit), mit 100-150 Früchten, von denen 2162400 auf $1 \mathrm{hl}(=84.8 \mathrm{~kg})$ gehen.

In Poppelsdorf erwies sich dieser Weizen als echter Winterweizen, doch nicht winterfest und das Stroh fast rostfrei.

Dieser Weizen kann nur auf sehr reichem Boden, ohne zu degenerieren, angebaut werden. Seine Kultur scheint namentlich in den Mittelmeerländern verbreitet zu sein, wenngleich er nirgend eine dominierende Stellung einnimmt.

\section{Unterart: 4. Triticum durum Desf. Hartweizen.}

Varietät: Triticum durum leucura Al. Aehre kahl, weiss;..Körner weisslich; Grannen hell.

\section{Sorten:}

\section{Trigo berberisco, Moruno, Spanien. $\odot$}

Syn.: Spanisch: Trigo candeal negro, Chile.

Portugal: Trigo mourisco.

Franz.: Blé dur de Barbarie.

It al.: Frumento di Barberia.

Deutsch: Hartweizen aus der Berberei.

Aehre: blassgelb oft mit schwärzlichem Anflug, kurz und dick, Aehr-

1) Country Gentleman's Magaz. Ill 420, 1869. 
chen 3- und 4-körnig, $2 \mathrm{~cm}$ breit, 3-grannig; Grannen gelb, bis $21 \mathrm{~cm}$ lang. - Stroh: rötlich-gelb, fest, steif, meist hohl, am Rande markig, seltener ganz markig, kurz. - Frucht: weisslich, glasig, plump, länglich, zusammengedrickt ( $9 \mathrm{~mm}$ lang, $31 / 2 \mathrm{~mm}$ breit), feinschalig.

Halm dunkelgrün, 2 Schösslinge, zeitig schossend und blühend; Halmlänge $80 \mathrm{~cm}$ (Max. $85 \mathrm{~cm}$ ), Halmdicke $0.43 \mathrm{~cm}$, Blattzahl 4, Blattlänge $29.5 \mathrm{~cm}$, Blattbreite $1.05 \mathrm{~cm}$, Blattoberfläche eines Halmes $247.84 \mathrm{qcm}$, Halmfläche $103.2 \mathrm{qcm}$, Gesammtfläche $351.04 \mathrm{qcm}$.

Junge Aehre blaugrün, zeitig, in 120 Tagen reifend, $7 \mathrm{~cm}$ (MIax. $8 \mathrm{~cm})$ lang, mit 14 Aelirchen und 50 ziemlich fest sitzenden Früchten, von denen 1840000 auf $1 \mathrm{hl}(=81.2 \mathrm{~kg})$ gehen.

Es wiegen 100 Halme $602 \mathrm{gr}$ und davon die Früchte $252 \mathrm{gr}$.

In Poppelsdorf lagerte der Weizen nicht, befiel jedoch stark mit Rost.

Dieser Weizen ist vorzugsweise in Tunis, Sicilien, Aegypten, Chile und Spanien und zwar nach Will ko m m ${ }^{1}$ j hier nur in Granada verbreitet, und wahrscheinlich, wie die Mehrzahl der Hartweizen durch die Mauren eingefülırt worden, woher der in jener Provinz gebräuchliche Vulgärname "Trigo Moruno" und bei Malaga "Trigo berberisco" kommen mag.

Nach Seringe ${ }^{2}$ ) liess die Berner Regierung 1817 Samen dieses Weizens zu Kulturversuchen, welche der Pastor Steck im Simmenthal leitete, aus Aegypten kommen, derselbe wurde reif, doch ist später nichts weiter darüber bekannt geworden.

Auch 1867 führte der Akklimatisations-Verein ${ }^{3}$ ) zu Berlin diesen Weizen nach Preussen ein, wie es scheint, ohne besondere Erfolge zu erzielen.

In neuerer Zeit wird er erfolgreich in Mittel-Italien kultiviert.

Als Trigo candeal negro erhielten wir ihn 1880 durch von $\mathrm{G}$ ülich aus Chile und fanden ihn als „Frumento di Barberia“ 1881 auf der Ausstellung zu Maailand,

\section{Trigo Mesclilla de Sevilla, Spanien: $\odot$}

Syn.: Trigo blanquillo, Cadiz.

Aehre: blassgelb mit schwach-rötlichem Anflug, dicht, kurz; Aehrchen 3- und 4-körnig, Klappen gezahnt, 3-grannig, mittlere kurz; Grannen hell, bis $20 \mathrm{~cm}$ lang, gespreizt. - Stroh: rötlich-gelb, markig, fest. Frucht: Original meist hellrötlich, glasig, doch einige blassgelb, mehlig, etwas eingefallen, plump, gross $\left(8 \mathrm{~mm}\right.$ lang, $3 \frac{1}{2} \mathrm{~mm}$ breit, 211 Früchte $=10 \mathrm{gr}$ ); nachgebaut: Alles glasig, grösser 142 Früchte $=10 \mathrm{gr}$ ), feinschalig.

Junges Blatt dunkelgrün, ziemlich kräftig aufrecht, 1.2 Schösslinge, zeitig schossend und blühend; Halm $90 \mathrm{~cm}$ (Max. $115 \mathrm{~cm}$ ) lang, $0.33 \mathrm{~cm}$ dick, Blattzahl 3.5, Blätter $20 \mathrm{~cm}$ lang, $0.8 \mathrm{~cm}$ breit, Blattfläche 112 qcm, Halmfläche $89.1 \mathrm{qcm}$, Gesammtfläche $201.1 \mathrm{qcm}$.

Junge Aehre blaugrün, bereift, $7 \mathrm{~cm}$ (Max. $9 \mathrm{~cm}$ ) lang, mit $15 \mathrm{Aehr}$ chen und $45 \mathrm{Früchten}$, von denen 1856800 auf $1 \mathrm{hl}(=88 \mathrm{~kg})$ entfallen. Bezugsquelle: Antonio Cipriana Costa in Barcelona.

1) Agron. Zeit. 1852, pg. 36

2) Monogr. des céréales de la Suisse $1818 \mathrm{pg} \cdot 108$.

3) Zeitschr. f. Akklimat. 1869 No. X-XII, pg. 158. 


\section{Trigo rojal (royal), Valencia.}

Syn.: Deutsch: Hartweizen aus Valencia.

Aehre: etwas rötlich, sich stark verjüngend, locker, mittellang; Aehrchen $1.3 \mathrm{~cm}$ breit, 3- und 4-körnig, 3-grannig; Grannen blassrot, bis $16 \mathrm{~cm}$ lang, aufrecht. - Stroh: gelb, Innenrand markig, lang, steif, sehr fest. - Frucht: weisslich, glasig, seitlich zusammengedrückt, sehr gross ( $8 \mathrm{~mm}$ lang, $3 \mathrm{~mm}$ breit, 165 Früchte $=10 \mathrm{gr}$ ), schön, feinschalig.

Junges Blatt dunkelgriin, breit, aufrecht, 2.6 Schösslinge, zeitig schossend und blühend; Halmlänge $140 \mathrm{~cm}$ (Max. $150 \mathrm{~cm}$ ), Halmdicke $0.43 \mathrm{~cm}$, Blattzahl 3.2, Blattlänge $30 \mathrm{~cm}$, Blattbreite $1.0 \mathrm{~cm}$, Blattoberfläche einesHalmes 192 qcm, Halmfläche $294 \mathrm{qcm}$, Gesammtfläche $486 \mathrm{qcm}$.

Junge Aelhre blaugrün, Klappen und Spelzen rot umrandet, $9 \mathrm{~cm}$ (Max. $12 \mathrm{~cm}$ ) lang, mit 16 Aehrchen und 56 fest sitzenden Früchten, von denen 1386000 auf $1 \mathrm{hl}(=84 \mathrm{~kg})$ gehen. Reift zeitig in 125 Tagen.

Es wiegen 100 Halne $620 \mathrm{gr}$ und davon die Früchte $240 \mathrm{gr}$.

Vielfach in Spanien, namentlich in Valencia und Jaen und in Portugal kultiviert. Uebersender: Pfeiffer in Ossendorf bei Köln.

\section{Trigo á laga, Soria, Spanien. (2)}

Syn.: Spanisch: Trigo la Rioja, Trigo mayor in Leon. Portugal: Trigo durazio rijo.

Deutsch: Spelzartiger Hartweizen.

Aehre: blassgelb, mit schwach bläulichem Anflug, sehr grossährig, locker, lang; Aehrchen $1.9 \mathrm{~cm}$ breit, 2- und 3-körnig, 2-grannig; aufrecht, Spindel zerbrechlich; Grannen hell, bis $23 \mathrm{~cm}$ lang. - Stroh: rötlich-gelb, markig, steif, lang. - Frucht: hellgelbrot, glasig, gross, plump und sehr lang (10 $\mathrm{mm}$ lang, $31 / 2 \mathrm{~mm}$ breit), feinschalig.

Junges Blatt dunkelgriin, schmal, lang, 1.3 Schösslinge, sehr spät (am spätesten von Tr. durum) schossend und blühend. Halmlänge $120 \mathrm{~cm}$ (Max. $150 \mathrm{~cm}$ ), Halmdicke $0.4 \mathrm{~cm}$, Blattzahl 5, Blattlänge $27 \mathrm{~cm}$, Blattbreite $1 \mathrm{~cm}$, Blattoberfläche $270 \mathrm{qcm}$, Halmfläche $144 \mathrm{qcm}$, Gesammtfläche $414 \mathrm{q} \mathrm{cm}$.

Junge Aehre blaugrün, sehr spät reifend, $11 \mathrm{~cm}$ (Max, $13 \mathrm{~cm}$ ) lang. Auf $1 \mathrm{hl}(=82 \mathrm{~kg})$ entfallen 1230000 Frïchte.

Er leidet weder durch Rost woch Lagern. Willko mm ${ }^{1}$ ) fiihrt ihn als zur Art Tr. Gaertıerianum Lagasca (Tr. album Gaertn.) gehörig auf.

Dieser sehr grossährige, kräftige Weizen wird hauptsächlich in Leon und Altcastilien, Spanien, gebaut.

Durch Wittmack 1873 von der Wiener Weltansstellung erhalten.

\section{Trigo de Jerez, Spanien. $\odot$}

Syn.: Ital.: Saragolla di Calabria, Frumento duro di Prglia.

Franz.: Blé ou Plat de Xérès, Blé d'Andalousie, égyptien, dacca youssfi.

Deutch: Hartweizen von Xeres.

Aehre: gelb, mit hellbläulichem Anflug, quadratisch, dicht; Aehrchen 1,3 cm breit, 3- und 4-körnig, 3-grannig, mittelste Granne kurz;

1) Agron. Zeit. 1852, pg, 36. 
Grannen gelb, bis $15 \mathrm{~cm}$ lang, gespreizt, zähe. - Stroh: rötlich-gelb, markig, ziemlich blattreich, steif, doch spröde und zerbrechlich, mittellang. - Frucht: weisslich, glasig, einige mehlig und gelbweiss, eingefallen, zusammengedrückt, gross ( $9 \mathrm{~mm}$ lang, $4 \mathrm{~mm}$ breit, 177 Früchte $=10 \mathrm{gr}$.$) ,$ Qualität geschätzt, feinschalig.

Halme dunkelgrün, 2 Schösslinge, zeitig schossend und blühend, Halmlänge $100 \mathrm{~cm}$ (Max. $117 \mathrm{~cm}$ ), Halmdicke $0.3 \mathrm{~cm}$, Blattzahl 4, Blattlänge $23 \mathrm{~cm}$, Blattbreite $0.94 \mathrm{~cm}$, Blattoberfläche eines Halmes $172.96 \mathrm{qcm}$, Halmfläche $90 \mathrm{qcm}$, Gesammtfläche $262.96 \mathrm{qcm}$.

Junge Aehre blaugrün, mittelfrüh, in 130 Tagen reifend, $7 \mathrm{~cm}$ (Max. $9 \mathrm{~cm})$ lang, mit 14 Aehrchen und 45 nicht leicht ausfallenden Früchten, von denen 1416000 auf $1 \mathrm{hl}(=80 \mathrm{~kg})$ gehen.

Es wiegen 100 Halme $733 \mathrm{gr}$ und davon die Früchte $300 \mathrm{gr}$.

Dieser Hartweizen ist in Süd-Europa und Aegypten verbreitet.

\section{Grano scorsonera. $\odot$}

Syn.: Grano duro Saragolla.

Aehre: blassgelb mit rötlichem Schimmer, ziemlich dicht, quadratisch, kurz; Aehrchen $1.2 \mathrm{cin}$ breit, 3-körnig, 3-grannig, Mittelgranne kurz; Granne hell, aufrecht, zähe, bis $18 \mathrm{~cm}$ lang. - Stroh: gelb, markig, nur wenige mit markigem Innenrande, kaum mittellang. - Frucht: röthlich-gelb, glasig, sehr gross, zusammengedrückt, $9 \mathrm{~mm}$ lang, $3^{3} / 4 \mathrm{~mm}$ breit, 129 Früchte $=10 \mathrm{gr}$, feinschalig.

Junges Blatt gelbgrïn, aufrecht; Bestockung stark, 4 Schösslinge, zeitig schossend und blühend. Halme $95 \mathrm{~cm}$ (Max. $110 \mathrm{~cm}$ ) lang, $0.3 \mathrm{~cm}$ dick, Blattzahl 4.8, Blätter $17 \mathrm{~cm}$ lang, $0,7 \mathrm{~cm}$ breit, Blattfäche 114.24 q cm, Halmfläche $85.5 \mathrm{qcm}$, Gesammtfläche $199.74 \mathrm{qcm}$.

Junge Aehre blaugrün, reift in 123 Tagen, $7 \mathrm{~cm}$ (Max. $10 \mathrm{~cm}$ ) lang, mit 13 Aehrchen und 36 Früchten, von denen 1038450 auf $1 \mathrm{hl}(=$ $80.5 \mathrm{~kg}$ ) entfallen.

Es wiegen 100 Halme $530 \mathrm{gr}$ und davon die Früchte $226 \mathrm{gr}$. halten.

Von der italienischen Abteilung der Pariser Weltausstellung er-

Heimat: Sicilien, und vorzugsweise in der Provinz Catania gebaut.

\section{Trigo Candeal de la Mancha, Spanien. $\odot$}

Aehre: weiss, kahl, dünn, locker; Aehrchen 3-körnig, 3-grannig, davon 1 Granne kurz, Klappen mit Zahn; Grannen hell, aufrecht, bis $9 \mathrm{~cm}$ lang. - Stroh: gelbrot, markig. - Frucht: Original weiss, glasig oder mehlig, schmal, 320 Früchte $=10 \mathrm{gr}, 7 \mathrm{~mm}$ lang, $3 \mathrm{~mm}$ breit; nachgebaut; Alles rötlich und glasig, grösser $205 \mathrm{Körner}=10 \mathrm{gr}$.

Junges Blatt dunkelgrün, kraus, 3 Schösslinge, Halm $80-100 \mathrm{~cm}$ lang. Junge Aehre bläulich bereift, 8-9 cm lang, mit 12 Aehrchen und 35 Früchten.

Uebersender: Antonio Cipriano Costa.

\section{Grano sammartinara. $\odot$}

Aehre: fast weiss, schmal, etwas locker, mittellang; Aehrchen $1.2 \mathrm{~cm}$ breit, 3-körnig, 2-grannig, Klappen mit starkem Zahu und Kiel; Grannen hell, zähe, wenig gespreizt, bis $15 \mathrm{~cm}$ lang. - Stroh: rötlich- 
gelb, Innenrand markig oder ganz markig, mittellang. - Frucht: weisslich, glasig. lang $\left(9 \mathrm{~mm}\right.$ lang, $3^{1} / 2 \mathrm{~mm}$ breit, 160 Früchte $\left.=10 \mathrm{gr}\right)$, sehr schön, feinschalig.

Junges Blatt gelbgrün, aufrecht; 2.8 Schösslinge, zeitig schossend und blühend. Halme $100 \mathrm{~cm}$ (Max. $110 \mathrm{~cm}$ ) lang, $0,3 \mathrm{~cm}$ dick, Blattzahl 4, Blätter $21.3 \mathrm{~cm}$ lang, $0,7 \mathrm{~cm}$ breit, Blattfläche $119.28 \mathrm{qcm}$, Halmfläche $90 \mathrm{qcm}$, Gesammtfläche $209.28 \mathrm{qcm}$.

Junge Aehre blaugrün, stark bereift, in 122 Tagen reifend, $8 \mathrm{~cm}$ (Max. $11 \mathrm{~cm}$ ) lang, mit $14 \mathrm{Aehrchen}$ und 48 etwas lose sitzenden Früchten, von denen 1280000 auf $1 \mathrm{hl}(=80 \mathrm{~kg})$ entfallen.

Es wiegen 100 Halme $363 \mathrm{gr}$, und davon die Früchte $172 \mathrm{gr}$.

Dieser Weizen scheint dem Trit. candidissimun Arduini nach BayleBarelle 42, tab. 2, Fig. 3 zu entsprechen.

Von der Wiener Weltausstellung 1873 erhalten.

Vaterland: Italien, und, namentlich auf Sicilien gebaut.

\section{Froment de Medeah. $\odot$}

Aehre: fast weiss, sehr dicht, quadratisch, kurz; Aehrchen meist 3-körnig, " unregelmässig begrannt, normal sind 3 Grannen, doch häufig fehlen 1 oder 2, Klappen stark gekielt, mit hakig gebogener Spitze; Grannen fast weiss, bis $18 \mathrm{~cm}$ lang, gespreizt. - Stroh: rötlich-gelb, markig, selten hohl, fest, lang. - Frucht: hellrot, glasig, einige mehlig und dann gelblich-weiss, eingefallen, länglich, gross $\left(8 \mathrm{~mm} \mathrm{lang,} 3^{3} / 4 \mathrm{~mm}\right.$ breit, 148 Friichte $=10 \mathrm{gr}$ ), feinschalig.

Junges Blatt dunkeldrün, breit, sehr lang, 2.3 Schosslinge, sehr zeitig schossend und blühend; Halmlänge $120 \mathrm{~cm}$ (Max. $145 \mathrm{~cm}$ ), Halmdicke $0.35 \mathrm{~cm}$, Blattzahl 3.6, Blattlänge $26.3 \mathrm{~cm}$, Blattbreite $1.0 \mathrm{~cm}$, Blattoberfläche eines Halmes $189.36 \mathrm{qcm}$, Halmfläche $126 \mathrm{qcm}$, Gesammtfläche $315 \mathrm{qcm}$.

Junge Aehre blaugrü, zeitig, in 120 Tagen reifend, $7 \mathrm{~cm}$ (Max. $9 \mathrm{~cm})$ lang, mit 14 Aehrchen und 45 fest sitzenden Frichten, von denen 1243200 auf $1 \mathrm{hl}(=84 \mathrm{~kg})$ gehen.

Es wiegen 100 Halme $820 \mathrm{gr}$ und davon die Friichte $330 \mathrm{gr}$. werden.

In Afrika, namentlich in Tunis, soll dieser Weizen stark kultiviert

Uebersender: L. Wittma ck, Berlin.

\section{Hartweizen aus Persien. $\odot$}

Aehre: fast weiss, dicht, quadratisch, kurz; Aehrchen $1.5 \mathrm{~cm}$ breit, 3-körnig, 3-grannig, mittlere Granne kurz; Grannen hell, $10 \mathrm{~cm}$ lang, aufrecht. - Stroh : rötlich-gelb, Rand markig, steif. - Frucht weisslich, glasig, zusammengedruickt, eingefallen, gross $(8 \mathrm{~mm}$ lang, $3 \mathrm{~mm}$ breit, 177 Frïchte $=10 \mathrm{gr})$, feinschalig.

Junges Blatt gelbgriin, aufrecht, mittelfriih schossend und bliihend, 2.5 Schösslinge; Halm $100 \mathrm{~cm}$ (Max. $110 \mathrm{~cm}$ ) lang, $0.37 \mathrm{~cm}$ dick, Blattzahl 4, Blätter $17 \mathrm{~cm}$ lang, $0.9 \mathrm{~cm}$ breit, Blattfläche $122.4 \mathrm{qcm}$, Halmfläche $111 \mathrm{qcm}$, Gesammtfläche $233.4 \mathrm{qcm}$.

Junge Aehre blaugrün, $6 \mathrm{~cm}$ (Max. $7 \mathrm{~cm}$ ) lang, mit 14 Aehrchen und 50 Früchten; in 124 Tagen reifend. 
Varietät: Triticum durum campylodon Keke.

Aehren kahl, weiss, Körner rot; Grannen hell; Klappen mit stark nach Innen gebogenem Zahn.

\section{Sorte :}

\section{Krummzahniger Hartweizen aus Palermo. $\odot$}

Aehre: blassgelb, quadratisch, dicht, kurz, Spindel zerbrechlich; Aehrchen $1.5 \mathrm{~cm}$ breit, 3-körnig, 2-grannig, Spelzen und Klappen mit stark nach Innen gebogenem Zahn; Grannen hell, an Basis schwärzlich, wenig gespreizt, unterer Teil oft bajonettförmig gebogen, sehr lang (14 cm). - Stroh: rötlich-gelb, hohl, mit markigem Rand, steif, mittellang. - Frucht: braun, glasig, plunp, lang ( $8 \mathrm{~mm}$ lang, $3 \mathrm{~mm}$ breit), stark verschrumpft und daher leicht.

Das erste Blatt auffallend dunkel, braungrün, behaart, Bestockung schwach, 2 Schösslinge; Halm dunkelgrün, $100 \mathrm{~cm}$ (Max. $130 \mathrm{~cm}$ ) lang, Halmdicke $(1.33 \mathrm{~cm}$, Blattzahl 4 . Blattlänge $32.5 \mathrm{~cm}$, Blattbreite $0.94 \mathrm{~cm}$. Blattoberfläche $244.4 \mathrm{qcm}$, Halmfläche $99 \mathrm{qcm}$, Gesammtfläche $343.4 \mathrm{qcm}$.

Junge Aehre blaugrün, zeitig, in den ersten Tagen des August, für Tr. durum sehr früh, reifend. Aehre $7 \mathrm{~cm}$ (Wax. $9 \mathrm{~cm}$ ) lang, mit 18 Aehrchen und 50 Früclıten, von denen 1469000 auf $1 \mathrm{hl}(=77.3 \mathrm{~kg})$ gehen.

Es wiegen 100 Halıne $219 \mathrm{gr}$ und davon die Früchte $98 \mathrm{gr}$.

Der Weizen lagert nicht und widersteht dem Rost, doch ist derselbe für Deutschland ohne Bedeutung.

Varietät: Triticum durum affine Kcke. Aehren kahl, weiss; Körner rot; Grannen hell.

\section{Sorten:}

\section{Dünnähriger Bartweizen.}

Aehre: blassgelb, dicht, quadratisch, einer vierzeiligen Gerstähre nicht unähnlich, kurz; Aehrchen $1.5 \mathrm{~cm}$ breit, 3-körnig und 3-grannig, eine Granne sehr kurz, Klappen mit kurzen, doch breiten Grannenspitzen; Grannen sehr lang, hell, bis $18 \mathrm{~cm}$, aufrecht, zähe. - Stroh: rötlich-gelb, feinhalmig, sehr derbwandig oder vollständig markig, fest, ziemlich lang. Frucht: rot, glasig. einige gelbrot und mehlig, roggenähnlich, lang $(8 \mathrm{~mm}$ lang, $4 \mathrm{~mm}$ breit), etwas grobschalig. Uebergangsform zu Tr. vulg. erythrospermum.

Junges Blatt hellgrün, schmal, aufrecht; Bestockung schwach, 2 Schösslinge, sehr zeitig schossend und blülend. Halmlänge $115 \mathrm{~cm}$ ( \ax. $135 \mathrm{~cm}$ ), Halındicke $0.33 \mathrm{~cm}$, Blattzahl 4, Blattlänge $26.3 \mathrm{~cm}$, Blattbreite $0.75 \mathrm{~cm}$, Blattoberfläche $15 \tau .8 \mathrm{qcm}$, Halmfläche $113.85 \mathrm{qcm}$, Gesammtfläche $271.65 \mathrm{qcm}$.

Junge Aehre blau- oder gelbgrün, $7 \mathrm{~cm}$ (Max. $9 \mathrm{~cm}$ ) lang, zeitig, in 124 Tagen reifend, mit 18 Aehrchen und 50 fest sitzenden Früchten, von denen 2135000 auf $1 \mathrm{hl}(=85.4 \mathrm{~kg})$ entfallen.

Dieser Weizen lagert nicht leicht und blieb sonst rostfrei.

Es wiegen 100 Halme $420 \mathrm{gr}$ und davon die Früchte $198 \mathrm{gr}$. 


\section{Trigo Tremes.}

Syn.: Spanisch: Tremesino.

Ital.: Triminia, Grano marzatico, Tumminia (Neapel), Timilia o Tremilia (Sicilien).

Franz.: Blé trimenia, trémois, trimenia de Sicile, de niars de l'Ardèche ${ }^{1}$ ), de Géorgie, de Salerne, sicilien; Blé dur de Vendôme, de Desfontaines, d'Alger.

Dell tsch: Dreimonatweizen. Triticum tumonia (bot. Gärten). Will ko $\mathrm{mm}^{2}$ ) fiihrt ihn fälschlich als zur Art „Tr. Gaertnerianum Lagasca“ (Trit. album Gärtn.) gehörig auf.

A lte $\mathrm{Namen}{ }^{3}$ ): Puros Trimenaios (Theophrast); Trimenon (Griechenland); Trimestri (Plinius); Trimestre (Columella).

Aehre: blassgelb mit rötlichem Anflng, etwas schlaff, pyramidal, regelmässig, dicht, kurz; Aehrchen $1.5 \mathrm{~cm}$ breit, meist 3-körnig, 2-grannig; sehr lang begrannt, Grannen bis $16 \mathrm{~cm}$ lang, wenig gespreizt, blassgelb, ziemlich zähe. - Stroh: rötlich-gelb, nach oben rot oder rotgrau, steif, hart, hohl mit markigem Innenrande, zuweilen markig. - Frucht: rot, glasig, wenige graugelb und mehlig, eingefallen, seitlich zusammengedrückt, lang, schmal $\left(71 / 2 \mathrm{~mm}\right.$ lang, $3^{1} / 2 \mathrm{~mm}$ breit), hart, feinschalig.

Junges Blatt dunkelgrün, schmal, spitz, 1.5 Schösslinge, zeitig schossend und blühend. Halmlänge $100 \mathrm{~cm}$ (Max. $120 \mathrm{~cm}$ ), Halmdicke $0.3 \mathrm{~cm}$, Blattzahl 3.5, Blattlänge $26 \mathrm{~cm}$, Blattbreite $0.85 \mathrm{~cm}$, Blattoberfläche eines Halmes $154.7 \mathrm{qcm}$, Halmfläche $90 \mathrm{qcm}$, Gesammttläche $244.7 \mathrm{qcm}$.

Junge Aehre blaugrün, zeitig, in 120 Tagen reifend, mit $14 \mathrm{Aehr}$ chen und 42 fest sitzenden Früchten, von denen 1660000 auf $1 \mathrm{hl}$ $(=83 \mathrm{~kg}$ ) gehen.

Auf $1 \mathrm{qm}$ wachsen 1000 Halme oder 666 Pflanzen, mithin beträgt der Raum für eine Pflanze $15 \mathrm{qcm}$, die Blattoberfläche p. qm Bodenfläche $24.5 \mathrm{qm}$ und das Saatquantum $6.6 \mathrm{hl} \mathrm{p}$. ha.

Es wiegen 100 Halme $510 \mathrm{gr}$ und davon die Früchte $220 \mathrm{gr}$.

Dieser Weizen wird stark in der Ebene von Sevillat) kultiviert und namentlich im Alluvium des Guadalquivir, wo er der einzige Weizen sein soll, welcher diesen ïberreichen Boden auszunutzen vermag, ohne sich zu lagern; seine Aussaat geschieht Ende Februar und bei giinstiger Witterung wird er Mitte Mai, also nach 70-75 Tagen geerntet.

In anderen Ländern, so in Portugal, Afrika, in Italien und hier namentlich in der Provinz Salerno in Calabrien, auf Sicilien und in Frankreich soll er erfolgreich auf den leichteren und wenig tiefgründigen Böden angebaut werden.

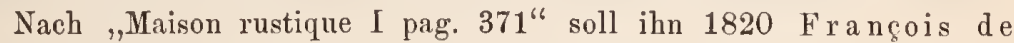
Neufchâteall nach Frankreich eingeführt habell, doch führt Heuzé, Les plantes alimentaires pag. 3 an, dass er schon 1638 in der Beauce, Touraine, Auvergne, Provençe und in Savoyen kultiviert worden sei, mit-

1) Heuzé, Les plantes aliment.

2) Agron. Zeit. 1852, pg. 36.

3) Ob die Namen der Alten dieselbe Sorte bezeichnen, ist jedoch fraglich.

4) Wolffenstein, Landw. Jahrb. VI 1877, pg. 709 . 
bin es sich im ersteren Falle nur um Neueinführung und Verbreitung gehandelt haben kann. $\mathrm{mack}$.

Uebersender: Dr. Wolffenstein, Malaga, durch Dr. Witt-

\section{Trigo obispado, Cadiz. $\odot$}

Aehre: blassgelb mit schwachrötlichem Anflug, compakt, kurz; Aehrchen 3- und 4-körnig, 3-grannig, mittlere kurz; Grannen hell, bis $15 \mathrm{~cm}$ lang, fast aufrecht. - Stroh: blassgelb, kurz, markig, steif. Frucht: Original dunkelrot, glasig, schmal (7 mm lang, $3 \mathrm{~mm}$ breit, 271 Früchte $=10 \mathrm{gr}$ ); nachgebaut: grösser, $185 \mathrm{Körner}=10 \mathrm{gr}$, einige mehlig.

Junges Blatt dunkelgrün, lang, aufrecht, 2 Schösslinge, zeitig schossend und blühend; Halm $80 \mathrm{~cm}$ (Max. $100 \mathrm{~cm}$ ) lang, $0.3 \mathrm{~cm}$ dick, Blattzahl 4, Blätter $23.5 \mathrm{~cm}$ lang, $0.9 \mathrm{~cm}$ breit, Blattfläche $169.2 \mathrm{qcm}$, Halmfläche $72 \mathrm{qcm}$, Gesammtfläche $241.2 \mathrm{qcm}$.

Junge Aehre bläulich, bereift, in 120 Tagen reifend, $7 \mathrm{~cm}$ (Max. $8 \mathrm{~cm}$ ) lang, mit 13 Aehrchen und 40 Frïchten, von denen 2249300 auf $1 \mathrm{hl}(=83 \mathrm{~kg})$ entfallen.

Heimat: Spanien, aus Cadiz 1880 erhalten.

\section{Weissähriger Hartweizen. $\odot$}

Syn.: Franz.: Blé de Mogador, Constantine, Manfredonia.

Aehre: graulich-gelb, quadratisch, etwas locker, kurz, aufrecht, Spindel sehr leicht zerbrechlich; Aehrchen $1.5 \mathrm{~cm}$ breit, 3- und 4-körnig, 3-grannig, Klappen stark gekielt, in eine durchsichtige Spitze endigend, bauchiger und stärker als bei der nahe verwandten "Trimenia“; Grannen gelb, bis $17 \mathrm{~cm}$ lang, fein, aufgerichtet. - Stroh: gelb, blattreich, dem der Gerste ähnlich, nur Halm sehr derbwandig und häufig markig, steif, doch spröde und leicht zerbrechlich. - Frucht: braunrot, glasig, zuweilen mehlig und gelbrot, plump, bauchig, etwas eingefallen $(8 \mathrm{~mm}$ lang, $3 \mathrm{~mm}$ breit), ziemlich grobschalig.

Junges Blatt dunkelgrün, sehr schmal, lang, 1.4 Schösslinge, mittelfrüh schossend und blühend. Halmlänge $95 \mathrm{~cm}$ (Max. $110 \mathrm{~cm}$ ), Halmdicke $0.3 \mathrm{~cm}$, Blattzahl 4, Blattlänge $235 \mathrm{~cm}$, Breite $1 \mathrm{~cm}$, Blattoberfläche eines Halmes $180 \mathrm{qcm}$, Halmfläche $85.5 \mathrm{qcm}$, Gesammtfläche $265.5 \mathrm{qcm}$.

Junge Aehre blaugrün, in 125 Tagen reifend, $7 \mathrm{~cm}$ (Max. $10 \mathrm{~cm}$ ) lang, mit 14 Aehrchen und 50 Früchten, von denen 1557000 auf $1 \mathrm{hl}$ $(=86.5 \mathrm{~kg})$ gehen.

Es wiegen 100 Halme 600 gr und davon die Frïchte 257 gr.

Dieser Hartweizen wird in Süd-Italien, Sicilien, Spanien und NordAfrika gebaut und sein Mehl in Italien zur Macaronifabrikation geschätzt.

\section{Varietät: Triticum durum leucomelan Al.}

Aehren kahl, weiss; Körner weisslich; Grammen dunkel.

\section{Sorten:}

\section{Trigo azul o azuleuco. $\odot$}

Syn.: Span.: Trigo azulejo in Granada; Trigo arisnegro in Jaen. Aehre: fast weiss, nit bläulichem Anflug, pyramidal, itdicht, ¿auf- 
recht, kurz; Aehrchen 3-körnig, 3-grannig, davon eine Granne kurz; Grannen an Basis schwärzlich, sonst bräunlich, bis $16 \mathrm{~cm}$ lang, aufrecht. - Stroh: rötlich-gelb, markig, lang, fest, - Frucht: Original zum Teil mehlig und gelblich-weiss, doch überwiegend blassrötlich und glasig; nachgebaut Alles glasig, zusammengedruickt, gross $\left(8^{1 / 4} \mathrm{~mm}\right.$ lang, $31 / 2 \mathrm{~mm}$ breit), feinschalig.

Junges Blatt gelbgrün, schmal, lang; Bestockung sehr schwach, 1.4 Schösslinge, zeitig schossend und blühend. Halmlänge $120 \mathrm{~cm}$ (Max. $140 \mathrm{~cm}$ ), Halmdicke $0.4 \mathrm{~cm}$, Blattzahl 5, Blattlänge $28.2 \mathrm{~cm}$, Blattbreite $1.0 \mathrm{~cm}$, Blattoberfläche $282 \mathrm{qcm}$, Halmfläche $144 \mathrm{qcm}$, Gesammtfläche $426 \mathrm{qcm}$.

Junge Aehre blaugrün, zeitig, in 124 Tagen reifend, mit 15 Aehrchen und 42 etwas lose sitzenden Früchten, von denen 1424000 auf 1 hl $(=80 \mathrm{~kg})$ gehen.

Es wiegen 100 Halme $363 \mathrm{gr}$ und davon die Früchte $176 \mathrm{gr}$. Dieser Weizen lagert nicht leicht und ist für Rost wenig empfänglich.

Er wird vorzugsweise in Granada, Spanien kultiviert.

L. Wittmack sandte ihn 1873 von der Wiener Weltausstellung nach Poppelsdorf.

\section{Blé dur de Medeah. $\odot$}

Aehre: gelb, mit schwarzbläulichem Anflug, verdriickt, viereckig, sehr dicht, mittellang. Aehrchen bis $2 \mathrm{~cm}$ breit, 4-5-körnig, 3-gramnig; Gramen an Basis schwarzblau, sonst bräunlich, sehr lang (20 cul), zïhe, kräftig, etwas abstehend; Spindel zähc. - Stroh: rötlich-gelb, mit markigem Innenrande, oder markig, fest, kurz. - Frucht: blassrot, glasig, stark eingefallen, zusammengedriickt, gross (9 mm lang, $4 \mathrm{~mm}$ breit, 156 Frïchte $=10 \mathrm{gr}$ ), feinschalig.

Junges Blatt blaugrün, Bestockung ziemlich kräftig, 2.3 Schösslinge, zeitig schossend und blühend. Halmlänge $90 \mathrm{~cm}$ (Max. $100 \mathrm{~cm}$ ), Halmdicke $0.37 \mathrm{~cm}$, Blattzahl 4, Blattlänge $30.25 \mathrm{~cm}$, Blattbreite $1.1 \mathrm{~cm}$, Blattoberfläche $266.24 \mathrm{qcm}$, Halmfläche $99.9 \mathrm{qcm}$, Gesammtfläche $366.14 \mathrm{qcm}$. Junge Aehre blaugrün, zeitig, in 123 Tagen reifend, $8 \mathrm{~cm}$ (Max. $9 \mathrm{~cm})$ lang, mit 17 Aehrcheu und 60 fest sitzenden Früchtell, von denen 1279200 auf $1 \mathrm{hl}(=82 \mathrm{~kg})$ entfallen.

Es wiegen 100 Halme $446 \mathrm{gr}$ und davon die Früchte $153 \mathrm{gr}$. fähig.

Dieser Weizen lagert nicht leicht und ist gegen Rost widerstands-

\section{Blé de Tunis. $\odot$}

Syn.: Eranz.: Blé de la Calédonie, d'Ismaël à barbes noires, d'Egypte à barbes noires, d'Alexandrie.

Deutsch: Hartweizen aus Tunis.

Aehre: gelb, mit schwarzbläulichem Anflug, quadratisch, schr dicht, Spindel zähe, kurz; Aehrchen $1.6 \mathrm{~cm}$ breit, 3-körnig, 3-grannig; Grannen an Basis schwarzblau, sonst bräunlich, sehr stark, nicht lcicht abbrechend, bis $17 \mathrm{~cm}$ lang, gespreizt. - Stroh: rötlich-gelb, mit markigem Innenrande oder markig, sehr steif, fest, kurz. - Frucht: rot, glasig, gross ( $8 \mathrm{~mm}$ lang, $4 \mathrm{~mm}$ breit. 146 Früchte $=10 \mathrm{gr}$ ), eingefallen, feinschalig.

Junges Blatt blaugrün, Bestockung ziemlich stark, 2.3 Schösslinge, zeitig schossend und blühend. Halmlänge $90 \mathrm{~cm}$ (Max. $110 \mathrm{~cm}), H a l m-$ 
dicke $0.33 \mathrm{~cm}$, Blattzahl 3.5, Blattlänge $24.5 \mathrm{~cm}$, Blattbreite $0.99 \mathrm{~cm}$, Blattoberfläche $169.82 \mathrm{qcm}$, Halmfläche $89.1 \mathrm{qcm}$, Gesammtflächc 258.92 qcm.

Aehre zeitig, in 123 Tagen reifend, $6 \mathrm{~cm}$ (Max. $9 \mathrm{~cm}$ ) lang, mit 15 Aehrchen und 40 fest sitzenden Früchten, von denen 1197200 auf $1 \mathrm{hl}$ $(=82 \mathrm{~kg})$ entfallen.

Es wiegen 100 Halme $437 \mathrm{gr}$ und davon die Früchte $211 \mathrm{gr}$.

Diese Sorte wird in Nord-Afrika, und namentlich in Aegypten, wo sie als sehr ergiebig gilt, angebant, doch wird sie auch schon seit langer Zeit im Süilen Europas kultiviert.

Varietät: Triticum durum Reichenbachii Keke. Aehre kahl, weiss; Körner rot; Gramncn dunkel.

Sorte :

Triticum durum meianocus h. Dersden 1872. $\odot$

Aehre: weiss, dicht, aber nicht seln dick, kurz, Klappen mit grannenartigem Zahn; Grannen lang, an Basis schwar\%. - Stroh: gelb, markig, ziemlich lang, doch dünnhalmig. - Frucht: grau-rot, glasig, einige Stellen gelbrot und mehlig, gross ( $8 \mathrm{~mm}$ lang, $33 / 4 \mathrm{~mm}$ breit), geschrumpft.

Junges Blatt dunkelgruin, sehr lang, schmal, spitz, 2.1 Schösslinge, mittelfriih schossend und bliihend. Halmlänge $110 \mathrm{~cm}$ ( $Г a x .125 \mathrm{~cm}$ ), Halmdicke $0.3 \mathrm{~cm}$, Blattzahl 3.5, Blattlänge $26.3 \mathrm{~cm}$, Blattbreite $0.95 \mathrm{~cm}$, Blattoberfläche 174.9 qcm, Halmfläche $99 \mathrm{qcm}$, Gesammtfläche $273.9 \mathrm{qcm}$. Junge Aehre blaugrün, in 120 Tagen reifend, $7 \mathrm{~cm}$ (Max. 9 cm) lang. Auf $1 \mathrm{hl}(=83 \mathrm{~kg})$ entfallen 1826000 Früchte.

Es wiegen 100 Halme $380 \mathrm{gr}$ und davon die Friichte $175 \mathrm{gr}$.

Das Stroh neigt etwas zum Lagern und leidet durch Rost.

Varietait: Tritienm durum hordeïforme Host.

Aehre kahl, rot; Körner weisslich; Gramıen hell.

\section{Sorten:}

\section{Gerstenweizen. $\odot$}

Achre: hellrot, mit schwach blïulichem Anflug, ziemlich dick, etwas locker, fast quadratisch, aufrecht, mittellang; Aehrchen $1.3 \mathrm{~cm}$ breit, Klappen mit zugespitztem Zahn, 3- und 4-körnig, 3-grannig; Grannen hell, anliegcnd, bis $15 \mathrm{~cm}$ lang; Spindel zähe. - Stroh: gelb, blattreich, steif, kräftig, Halm hohl, doch immer mit schmalem, marligem Rande, steif, kurz. - Frucht: weisslich und glasig, wenigstens die 1870 ausgesäeten Frïchte, 1871 fanden sich ziemlich viele hellgelbe mehlige und von da ab hïufig, so 1878 bis zum vierten Teile mehlige Früchte, dies beweist, dass die Glasigkeit ein durchschlagendes Charakteristicum von Trit. durum nicht ist; zusammengedrückt, gross ( $8 \mathrm{~mm}$ lang, $31 / 2 \mathrm{~mm}$ breit), schwer, sehr feinschalig.

Junges Blatt blaugrïn, Bestockung ziemlich kräftig, 2.3 Schösslinge, zeitig schossend und bliihend. Halınlänge $95 \mathrm{~cm}$ (Max. $100 \mathrm{~cm}$ ), Halmdicke $0.37 \mathrm{~cm}$, Blattzahl 5, Blattlänge $22.8 \mathrm{~cm}$, Blattbreite $0.97 \mathrm{~cm}$, Blattoberfäche $221.2 \mathrm{qcm}$, Halmfliche $105.45 \mathrm{qcm}$, Gesammtfläche 326.65 q $\mathrm{cm}$. 
Junge Aehre blaugrün, zeitig, in 124 Tagen reifend, $8 \mathrm{~cm}$ (Max. $10 \mathrm{~cm}$ ) lang, mit 12 Aehrchen und 40 fest in den Spelzen sitzenden Frïchten, von denen 1560000 auf $1 \mathrm{hl}(=86,2 \mathrm{~kg})$ gehen.

Es wiegen 100 Halme $620 \mathrm{gr}$ und davon die Früchte $370 \mathrm{gr}$.

Dieser Weizen leidet wenig durch Rost und Lagern.

\section{Trigo dorado de lifurcia. $\odot$}

Deutsch: Goldgelber Hartweizen aus Murcia.

Aehre: gelblich-rot mit schwach bläulichem Anfug, quadratisch, kompakt, aufrecht, kurz; Aehrchen $1.5 \mathrm{~cm}$ breit, 3- und 5-körnig, 2- und 3-grannig; Grannen hell, aufrecht, bis $18 \mathrm{~cm}$ lang, leicht abbrechend; Spindel zähe. - Stroh: rötlich-gelb, markig, steif, lang. - Frucht: weisslich, glasig, plump, gross (9 $\mathrm{mm}$ lang, $3 \frac{1}{2} \mathrm{~mm}$ breit), etwas eingefallen. feinschalig.

Halme dunkelgrün, 2.5 Schösslinge, mittelfriih schossend und blühend. Halmlänge $120 \mathrm{~cm}$ (Max. $130 \mathrm{~cm}$ ), Halmdicke $0.33 \mathrm{~cm}$, Blattzahl 4, Blattlänge $25 \mathrm{~cm}$, Blattbreite $0.91 \mathrm{~cm}$, Blattoberfläche $182 \mathrm{qcm}$, Halmfläche $118.8 \mathrm{qcm}$, Gesammtlläche $300.8 \mathrm{qcm}$.

Aehre mittelfruih reifend, $7 \mathrm{~cm}$ (Max. $10 \mathrm{~cm}$ ) lang, mit 13 Aehrchen und 50 fest sitzenden Früchten, von denen 1389300 auf 1 lll (=84.2 kg) entfallen.

Dieser Weizen lagert nicht und leidet wenig durch Rost.

Er wurde 1867 durch den Akklinatisationsverein ${ }^{1}$ ) in Berlin nach Preussen eingeführt und in Eldena angebaut und zwar auch als Winterweizen.

\section{Trigo trobat de Valencia. $\odot$}

Deutsch: Hartwcizen aus Valencia, Spanien.

Aehre: blassrot, ziemlich schmal und locker, ähnlich manchem Tr. vulgare; Aehrchen $1.3 \mathrm{~cm}$ breit, 3- und 4-körnig, 2-grannig; Grannen hell, aufrecht, bis $16 \mathrm{~cm}$ lang. - Stroh: rötlich-gelb, mit markigem Innenrand, lang, dünn. - Frucht: weisslich, meist glasig, einige gelblich-weiss und mellig, zusammengedrückt, mittelgross ( 7 mm lang, $3 \frac{1}{2} \mathrm{~mm}$ breit), schön, schwer.

Junges Blatt dunkelgrün, breit, aufrecht, sehr lang, Bestockung ziemlich kräftig, 2.6 Schösslinge, zeitig schossend und bliihend. Halmlänge $135 \mathrm{~cm}$ (Max. $150 \mathrm{~cm}$ ), Halmdicke $0.33 \mathrm{cml}$, Blattzahl 3, Blattlänge $25.5 \mathrm{~cm}$, Blattbreite $0.8 \mathrm{~cm}$, Blattoberfläche $122.4 \mathrm{qcm}$, Halmfläche $133.7 \mathrm{qcm}$, Gesammtfläche $256.1 \mathrm{qcm}$.

Junge Aehre bläulich-grïn, zeitig, in 124 Tagen reifend, $8 \mathrm{~cm}$ (Max. $10 \mathrm{~cm}$ ) lang, mit 12 Aehrchen und 42 etwas lose sitzenden Frïchten, von dencn 1785000 auf $1 \mathrm{hl}(=85 \mathrm{~kg})$ entfallen.

Es wiegen 100 Halme $490 \mathrm{gr}$ und davon die Früchte $206 \mathrm{gr}$.

Dieser Weizen zeigte sich fast rostfrei und widersteht dem Lagern ziemlich gut.

Uebersender: Gutsbesitzer Pfeiffer, Ossendorf bei Köln, der iln 1878 in Valencia sammelte.

1) Zeitschr. f. Akklim. 1869, No. X-XII, pg. 157. 


\section{Trigo recio de pastas. $\odot$}

Aehre: gelblich-rot, Kiel der Klappen mit bläulichem Anflug, dicht, quadratisch; Aehrchen 3- und 4-körnig, 2-grannig, Klappen gezahnt; Grannen hell, bis $18 \mathrm{~cm}$ lang; Spindel zerbrechlich. - Stroh: rötlichgelb, bis $90 \mathrm{~cm}$ lang, $0.35 \mathrm{~cm}$ dick, markig, ziemlich blattreich. - Frucht: weisslich, glasig, einige hellgelb, mehlig, plump, bauclig, lang, gross $(9 \mathrm{~mm}$ lang, $4 \mathrm{~mm}$ breit, 195 Früclite $=10 \mathrm{gr})$.

Junge Aehre blaugrün, oft bereift, $9.5 \mathrm{~cm}$ lang, mit 50 Früchten; in 128 Tagen reifend.

Heimat: Spanien, wo das Mehl vorzugsweise zur Nudelfabrikation benutzt wird. erhalten.

Bezugsquelle: durch Wittmack 1873 von der Wiener Ausstellung

\section{Trigo candeal redondo, Chile. $\odot$}

Aehre: blassrot, fast pyramidal, dicht, kurz; Aehrchen $1.3 \mathrm{~cm}$ breit, 3- und 4-körnig, 3-grannig, mittlere kurz; Grannen hell, aufrecht, bis $18 \mathrm{~cm}$ lang. - Stroh: rötlich-gelb, markig. - Frucht: Original weisslich, glasig, einige fast weiss und mellig, etwas eingefallen, bauchig, rundlich, gross ( $8 \mathrm{~mm}$ lang, $4 \mathrm{~mm}$ breit, 180 Früchte $=10 \mathrm{gr}$ ); nachgebaut: Alles glasig, ein wenig grösser, 163 Friichte $=10 \mathrm{gr}$ ), feinschalig.

Junges Blatt dunkelgrïn, schmal, aufrecht, 1.3 Schösslinge, zeitig schossend und blühend; Halm $100 \mathrm{~cm}$ (Max. $115 \mathrm{~cm}$ ) lang, $0.35 \mathrm{~cm}$ dick, Blattzahl 4, Blätter $20.5 \mathrm{~cm}$ lang, $0.9 \mathrm{~cm}$ breit, Blattfläche $147.6 \mathrm{qcm}$, Halmfläche $105 \mathrm{qcm}$, Gesammtfläche $252.6 \mathrm{qcm}$.

Junge Aehre bläulich, schwach bereift, in 120 Tagen reifend, $6 \mathrm{~cm}$ (Max. $8 \mathrm{~cm}$ ) lang, mit 13 Aehrehen und 40 Früchten, von denen 1584000 auf $1 \mathrm{hl}(=88 \mathrm{~kg})$ entfallen.

Bezugsquelle: durch von Gülich 1880 aus Chile erlalten.

\section{Trigo Nomorado de Carralho, Fronteira. $\odot$}

Syn.: Spaniseh: Trigo candeal amarillo largo, Chile.

Franz.: Blé dur dit $\mathrm{St}^{a}$ Martha.

Portugal: Trigo amarello de Santa Martha.

Aehre: blassrot, mit bläulichem Anflug, dicht, aufrecht, fast quadratisch, mittellang; Aehrchen $1.5 \mathrm{~cm}$ breit, 3- und 4-körnig, 2-grannig, Klappen mit zugespitztem Zahn; Gramen hell, lang (bis $20 \mathrm{~cm}$ ), aufrecht; Spindel zähe. - Stroh: rötlich-gelb, teils hohl, doch immer mit markigem Rande, teils markig, fest, lang. - Frucht: Original weisslich, glasig, gross ( $9 \mathrm{~mm}$ lang, $31 / 2 \mathrm{~mm}$ breit), etwas eingefallen, feinschalig.

Junges Blatt gelbgrün, etwas schmal, lang; Bestockung ziemliclı stark, 2.4 Schösslinge, zeitig schossend und blühend. Halmlänge $130 \mathrm{~cm}$ (Max. $150 \mathrm{~cm}$ ), Halmđicke 0,38 cm, Blattzahl 3.8, Blattlänge $27.8 \mathrm{~cm}$, Blattbreite $1.0 \mathrm{~cm}$, Blattoberfläche $211.28 \mathrm{qcm}$, Halnfläche $148.2 \mathrm{qcm}$, Gesammttläche $359.48 \mathrm{qcm}$.

Junge Aehre blaugrün, zeitig, in 124 Tagen reifend, $8 \mathrm{~cm}$ (Мax. $10 \mathrm{~cm}$ ) lang, mit 17 Aehrchen und 60 Früchten, von denen 1565600 auf $1 \mathrm{hl}(=82.4 \mathrm{~kg})$ entfallen.

Dieser Weizen lagert nicht leicht und bleibt fast rostfrei. Stand schön und kräftig. 
E1 wird in Spanien, Portugal, Chile und Siid-Frankreich kultiviert.

L. Wittmack sandtc ihn 1873 von der Wiener Weltausstellung, I'rof. Henriques 1881 aus Coümbra, Portugal und von Giilich 1880 aus Chile uach Poppelsdorf.

\section{Beloturka oder Kubanka. $\odot$}

Syn.: Deutseh: Kuban-Weizen.

Franz.: Blé Kubanka.

Aehre: rosa, dicht, quadratisch, kurz; Aehrchen $1.1 \mathrm{~cm}$ breit, meist 3-körnig, 3-grannig, Mittelgranne kurz; Grannen hell, zähe, aufrecht, bis $15 \mathrm{~cm}$ lang. - Stroh: gelb, steif, mittellang, Innenrand markig, oder ganz markig. - Frucht: Original weisslich, glasig, einige fast weiss, mehlig, $\left(71 / 2 \mathrm{~mm}\right.$ lang, $3^{1} / 4 \mathrm{~mm}$ breit, 235 Frïchte $\left.=10 \mathrm{gr}\right)$; nachgebaut: grösser (201 Frïchte $=10 \mathrm{gr}$ ) und mehliger, feinschalig.

Junges Blatt gelbgrün, aufrecht; Bestockung ziemlich stark, 3.3 Schösslinge, zeitig schossend und blühend. Halm $100 \mathrm{~cm}$ (Max. $115 \mathrm{~cm}$ ) lang, $0.3 \mathrm{~cm}$ dick, Blattzahl 4, Blätter $17.3 \mathrm{~cm}$ lang, $0.75 \mathrm{~cm}$ breit, Blattfläche 103.8 q cm, Halnfläche $90 \mathrm{qcm}$, Gesammtfläche $193.8 \mathrm{qcm}$.

Junge Aehre blaugriin, bereift, reift in 123 Tagen, $6 \mathrm{~cm}$ (Max. $8 \mathrm{~cm}$ ) lang, mit 14 Aehrchen und 43 fest sitzenden Friichten, von denen 2011600 auf i hl $(=86.5 \mathrm{~kg})$ entfallen.

Es wiegren 100 Halme $391 \mathrm{gr}$ und davon die Früchte $192 \mathrm{gr}$.

Dieser Weizen liefert ein vortreffliches Mehl und ist gegen Lagern und Rost widerstandsfähig.

Nach Vilmorin lässt er sich in der Umgegend von Paris, olnne Schaden zu nehmen, selbst im Herbst aussäen und scheint sich für SüdFrankreich und Algier sein Anbau zu empfehlen.

Professor Saykewitsch, Charkow, sandte ihn 1880 als „Beloturka“ aus dem Distrikt Saratow, und als "Kubanka" aus dem Gebiet der Kubanskischen Kosaken ein.

\section{Aidurka. $\odot$}

Syn.: Weissgranniger Aidurka-Weizen.

Aehre: rosa, dicht, pyramidal, kaum mittellang, doch länger als bei Beloturka; Aehrchen $1.3 \mathrm{~cm}$ breit, 3- und 4-körnig, 3-granuig, Mittelgranne kurz; Grannen fast weiss, aufrecht, bis $15 \mathrm{~cm}$ lang. - Stroh: rötlich-gelb, steif, Innenrand markig, kaum mittellang. - Frucht: Original weisslich, glasig, einige mehlig, länglich $(7 \mathrm{~mm}$ lang, $3 \mathrm{~mm}$ breit, 262 Friichte $=10 \mathrm{gr})$, sehr schwer, feinschalig.

Junges Blatt gelbgriin, aufrecht; Bestockung stark, 4 Schösslinge, mittelfriih schossend nnd bluihend; Halme $95 \mathrm{~cm}$ (Max. $109 \mathrm{~cm}$ ) lang, $0.3 \mathrm{~cm}$ dick, Blattzahl 3.4 , Blättcr $21.3 \mathrm{~cm}$ lang, $0.6 \mathrm{~cm}$ breit, Blattfläche $86.9 \mathrm{qcm}$, Halmfläche $85.5 \mathrm{qcm}$, Gesammtfläche $172.4 \mathrm{qcm}$.

Junge Aehre blangriin, bereift, in 123 Tagen reifend, $7 \mathrm{~cm}$ (Max. $9 \mathrm{~cm}$ ) lang, mit $16^{3}$ Aelirchen und 54 Früchten, von denen 2358000 auf $1 \mathrm{hl}(=90 \mathrm{~kg})$ entfallen.

Es wiegen 100 Halme $463 \mathrm{gr}$ nnd davon die Früchte $226 \mathrm{gr}$.

Von Prof. Saykewitsch, Charkow, 1880 aus dem Distrikt Starbielsk, Russland, erhalten. 


\section{Arnantka oder Garnowka. $\odot$}

Syn.: Deutsch: Arnautischer Weizen, Schwarzmeer-Weizen, Taganrog-Bartweizen.

A merika: Arnautka-wheat; Black-sea wheat.

Aehre: hellrot, blau bereift, quadratisch, dicht, aufrecht, mittellang; Achrchen $1.4 \mathrm{~cm}$ breit, 3- und 4-körnig, 3-grannig; Grannen hellrot, sehr lang, bis $20 \mathrm{~cm}$ lang, anliegend. - Stroh: rötlich-gelb, blattarm, hohl, Innenrand nicht markig, fest. - Frucht: Original weisslich, glasig, lang, schmal ( $8 \mathrm{~mm}$ lang, $3 \mathrm{~mm}$ breit, 210 Früchte $=10 \mathrm{gr}$ ); nachgebaut: in 1. Tracht schon einige mehlige, fast weisse und halbmehlige Frichte, grösser $\left(8 \mathrm{~mm}\right.$ lang, $3^{1} / 2 \mathrm{~mm}$ breit, 160 Früchte $\left.=10 \mathrm{gr}\right)$, schön, feinschalig.

$J$ unges Blatt dunkelgrün, schmal, lang, aufrecht, 2.4 Schösslinge, zeitig schossend und blüliend; Halmlänge $130 \mathrm{~cm}$ (Max. $150 \mathrm{~cm}), \mathrm{Halm}-$ dicke $0.4 \mathrm{~cm}$, Blattzahl 3, Blattlänge $27.3 \mathrm{~cm}$, Blattbreite $0.98 \mathrm{~cm}$, Blattoberfläche eines Halmes $160.52 \mathrm{qcm}$, Halmfläche $156 \mathrm{qcm}$, Gesammtfläche $316.52 \mathrm{qcm}$.

Junge Aehre blaugriin, in 125 Tagen reifend, $8 \mathrm{~cm}$ lang (Max. $11 \mathrm{~cm}$ ), mit 18 Aehrehen und 60 fest sitzenden Früchten, von denen 1591000 auf $1 \mathrm{hl}(=86 \mathrm{~kg})$ gehen.

Es wiegen 1010 Halme $520 \mathrm{gr}$ und davon die Früchte $240 \mathrm{gr}$.

Dieser Steppenweizen Süd-Russlands lagerte in Poppelsdorf nicht und zeigte sich rostfrei, überhaupt liess der Stand selbst in dem fenchten und kiihlen Sommer 1879 nichts zu wïnschen.

Dieser beliebteste Hartweizen Russlands wurde 1864 von Odessa aus nach Amerika eingefuihrt, wo sein Anbau bedeutende Fortscliritte macht, auch soll er in den Staaten des Sïd-Westens erfolgreich als Winterweizen kultiviert worden sein. Bietet in Amerika das beste Material für die Griesmüllerei.

Seine Heimat sind die Gegenden am schwarzen Meere. Wird gern zur Nudelfabrikation benutzt.

Uebersender: Professor Saykewitseh zu Charkow.

\section{Hartweizen von Kupjansk, Gourernement Charkow, liussland. $\odot$}

Aelre: rosenrot, blau bereift, quadratisch, dicht, kurz; Aehrchen $1.5 \mathrm{~cm}$ kreit, 3- und 1-körnig, 2-grannig; Grannen blassrötlich, aufrecht, bis $16 \mathrm{~cm}$ lang. - Stroh: gelb, hohl, gar nicht markig, brüchig. Frucht: weisslich, glasig, einige mehlig und blassgelb, stark zusammengedrückt, gross ( $8 \mathrm{~mm}$ lang, $3^{2} / 2 \mathrm{~mm}$ breit), feinschalig, sehr schwer.

Blätter dunkelgrün, schmal, kurz, 2.5 Schösslinge, spät schossend und blühend; Halmlänge $125 \mathrm{~cm}$ (Max. $140 \mathrm{~cm}$ ), Halmdicke $0.4 \mathrm{~cm}$, Blattzahl 3,4, Blattlänge $30 \mathrm{~cm}$, Blattbreite $1 \mathrm{~cm}$, Blattoberffäche eines Halmes $204 \mathrm{qcm}$, Halmfläche $150 \mathrm{qcm}$, Gesammtfläche $354 \mathrm{qcm}$.

Junge Aehre gelblich-grün, Spelzen rot umrandet, selır spät, in 140 Tagen reifend, $7 \mathrm{~cm}$ (Max. $9 \mathrm{~cm}$ ) lang, mit 14 Aehrchen und 50 sehr fest sitzenden Friichten, von denen 1740000 auf $1 \mathrm{hl}(=87 \mathrm{~kg})$ gehen.

Es wiegen 100 Halme $510 \mathrm{gr}$ und davon die Früchte $220 \mathrm{gr}$.

Dicser südrussische Steppenweizen zeichnete sich in Poppelsdorf durclı schönen Stand, und dadurch, dass er fast rostfrei blieb, aus, doch zeigte er Neigung zum Lageru.

Uebersender: Professor Saykewitsel zu Cliarkow. 


\section{Hartweizen vom Altai. $\odot$}

Aehre: blassrot, blau bereift, quadratisch, dicht, mittellang; Aehrchen $1.5 \mathrm{~cm}$ breit, meist 3- und 4-körnig, 2-grannig; Grannen seln lang, bis $21 \mathrm{~cm}$ lang, rötlich-gelb, aufrecht, ziemlich leicht abbrechend. Stroh: rötlich-gelb, blattarm, ctwas briichig, lang. - Frucht: weisslich, glasig, zusammengedruickt, lä̈nglich, schön, gross ( $8 \mathrm{~mm}$ lang, $31 / 2 \mathrm{nmm}$ breit, 210 Früchte $=10 \mathrm{gr}$ ), in dem feuchten, kuihlen Sommer 1879 traten vereinzelt hellgelbe, inellige Friichte auf.

Junges Blatt runkelgriin, schmal, 2.8 Schösslinge, spät schossend und blïhend; Halmlänge $120 \mathrm{~cm}$ (Max. $140 \mathrm{~cm}$ ), Halmdicke $0.4 \mathrm{~cm}$, Blattzahl 3.3 , Blattlänge $30 \mathrm{~cm}$, Blattbreite $0.94 \mathrm{~cm}$, Blattoberfläche eines Halmes 186.12 q cm, Halmfläche $144 \mathrm{qcm}$, Gesammtfläche $330.12 \mathrm{qcm}$.

Junge Aehre gelbgrün, Spelzen rot umrandet, spät reifend, Reifezeit 140 Tage, $8 \mathrm{~cm}$ lang (Max. $10 \mathrm{~cm}$ ), mit 18 Aehrchen und $60 \mathrm{sehr}$ fest sitzenden Früchten, von denen 1722000 auf $1 \mathrm{hl}(=82 \mathrm{~kg})$ gehen.

Es wiegen 100 Halme $665 \mathrm{gr}$ und davon die Friichte $280 \mathrm{gr}$.

Der Stand dieses Weizens war selbst in dem kühlen und feuchten Sommer von 1879 schön, auch lagerte derselbe wenig, und zeigte sich fast rostriei.

Heimat: das Altai-Gebirge an der sibirisch-chinesischen Grenze, dem Qnellgebiet des $\mathrm{Ob}$.

Uebersender: die Reisenden Dr. Finsch und Graf Zeil.

\section{Griechischer Hartweizen vou Volo. $\odot$}

Aehre: hellrot, zuweilen mit bläulichem Anflug, quadratisch, dicht, aufrecht, kaum mittelang; Aehrchen $1.4 \mathrm{~cm}$ breit, 2- und 3-körnig, 2-grannig, Klappen mit zugespitztem Zahn; Grannen blassrot, bis $18 \mathrm{~cm}$ lang, aufrecht, Spindel zerbrechlich. - Stroh: rötlich-gelb, lang, unarkig, fcst. - Frucht: weisslich, glasig, einige mehlig und gelblich-weiss, selrr lang und schmal (10 $\mathrm{mm}$ lang, $3 \mathrm{~mm}$ breit), zusammengedriickt und bauchig, feinschalig.

Junges Blatt dunkelgrün, lang, schmal, 2.7 Schösslinge, zeitig schossend und bliihend; Halmlïnge $130 \mathrm{~cm}$ (Max. $150 \mathrm{~cm}$ ), Halmdicke $0.35 \mathrm{~cm}$, Blattzahl 4, Blattlänge $24 \mathrm{~cm}$, Blattbreite $1 \mathrm{~cm}$, Blattoberfläche eines Halmes $192 \mathrm{qcm}$, Halmfäche $136.5 \mathrm{qcm}$, Gesammtfläche $328.5 \mathrm{qcm}$.

Junge Aelıre gelbgriin, blau bereift, Spelzen rot umrandet, in $\mathbf{1 2 5}$ Tagen, also zeitig reifend, $7.5 \mathrm{~cm}$ lang (Max. $9 \mathrm{~cm}$ ), mit 14 Aehrchen und 36 fest sitzenden Friichten, von denen 1237500 anf $1 \mathrm{hl}(==82.5 \mathrm{~kg})$ gehen.

Es wiegen 100 Halme $585 \mathrm{gr}$ und davon die Frïchte $241 \mathrm{gr}$.

In Poppelsdorf zeigte diese Sorte einen kräftigen Stand, sowie wenig Lager und Rost.

Heimat: die Umgegend von Volo in Thessalien.

\section{Griechischer Hartweizen von Atalantis. $\odot$}

Aehre: blassrot, blau bereift, dicht, zweizeilig, kurz; Aehrchen 3-körnig, 3-gramnig; Granncn hell, mittellang ( $15 \mathrm{~cm}$ ), aufrecht. - Stroh: rötlich-gelb, markig oder holı, doch mit sehr breitem, markigem Inmenrande, starkhalmig, mittellang. - Frucht: weisslich, glasig, einige gelblich-weiss und mehlig, zusammengedrückt, gross ( $8 \mathrm{~mm}$ lang, $4 \mathrm{~mm}$ breit), sehr schön, feinschalig. 
Junges Blatt dunkelgruin, Bestockung stark, 3.6 Schösslinge, sehr zeitig schossend, mittelfrüh blühend. Halmlänge $100 \mathrm{~cm}$ (Max. $120 \mathrm{~cm}$ ), Halmdicke $0.38 \mathrm{~cm}$, Blattzahl 4, Blattlänge $25.5 \mathrm{~cm}$, Blattbreite $0.8 \mathrm{~cm}$, Blattoberfläche 163.2 qcm, Halmflächc 114 qcm, Gesammtfläche 277.2 qcm.

Junge Aehre blaugriin, Klappen und Spelzen rot umrandet, sehr spät, in 140 Tagen reifend, $7 \mathrm{~cm}$ (Max. $10 \mathrm{~cm}$ ) lang, mit 19 Aehrchen und 54 Friichten, von denen 1499400 auf $1 \mathrm{hl}$ (=83.3 kg) entfallen.

Es wiegen 100 Halme $483 \mathrm{gr}$ und davon die Frïchte $178 \mathrm{gr}$.

Importeur und Uebersender: Samenhändler Itzenplitz, Köln, 1878.

Varietät: Triticum durum murciense Kcke.

Aehre kahl, rot; Körner rot; Grannen hell.

\section{Sorten:}

\section{Hartweizen aus Murcia, Spanien. $\odot$}

Aehre: blassrot mit schwach bläulichem Anflug, dicht, quadratisch, kurz; Aehrchen $1 \mathrm{~cm}$ breit, 3-körnig, 2-grannig; Grannen hell, aufrecht, bis $15 \mathrm{~cm}$ lang. - Stroh: rötlich-gelb, markig, feinhalmig, mittellang. Frucht: dunkelrot, glasig, eingefallen, länglich $(7 \mathrm{~mm}$ lang, $3 \mathrm{~mm}$ breit, 228 Frichte $=10 \mathrm{gr}$ ), feinschalig.

Junges Blatt gelbgrïn, aufrecht, 2.2 Schösslinge, zeitig schossend und bliihend. Halme $105 \mathrm{~cm}$ (Max. $120 \mathrm{~cm}$ ) lang, $0.28 \mathrm{~cm}$ dick, Blattzahl 3.5, Blätter $20 \mathrm{~cm}$ lang, $0.8 \mathrm{~cm}$ breit, Blattfläche 112 q $\mathrm{cm}$, Halmfläche $88.2 \mathrm{q} \mathrm{cm}$, Gesammtfläche $200.2 \mathrm{qcm}$.

Junge Aehre blangrün, bereift, $6 \mathrm{~cm}$ (Max. $9 \mathrm{~cm}$ ) lang, mit 15 Aehrchen und 42 Früchten, von denen 1949400 auf 1 hl (=85.5 kg.) entfallen.

Es wiegen 100 Halme $370 \mathrm{gr}$ und davon die Früchte $175 \mathrm{gr}$.

\section{Roter Hartweizen aus dem Altai. $\odot$}

Aehre: blassrot, blaı bereift, kompakt, kurz; Aehrehen $1.3 \mathrm{~cm}$ breit, 3- und 4-körnig, 3-grannig, Mittelgranne kurz; Grannen hell, aufrecht. bis $15 \mathrm{~cm}$ lang. -- Stroh: gelb, entweder Innenrand oder ganz markig, ziemlich lang. - Frucht: ziemlich dunkelrot, glasig, einige halbmehlig, länglich $(71 / 4 \mathrm{~mm}$ lang, $31 / 2 \mathrm{~mm}$ breit, 181 Friichte $=10 \mathrm{gr})$, feinschalig.

Junges Blatt gelbgrïn, aufrecht; 2.2 Schösslinge, mittelfrüh schossend und blïhend, Halme $112 \mathrm{~cm}$ (Max. $130 \mathrm{~cm}$ ) lang, $0.35 \mathrm{~cm}$ dick, Blattzahl 5, Blätter $22.5 \mathrm{~cm}$ lang, $0.8 \mathrm{~cm}$ breit, Blattfläche $180 \mathrm{qcm}$, Halmfläche $117.6 \mathrm{qcm}$, Gesammtfärhe $297.6 \mathrm{qcm}$.

Junge Aehre blangrün, bereift, in 122 Tagen reifend, $7 \mathrm{~cm}$ (Max. $10 \mathrm{~cm}$ ) lang, mit 17 Aehrchen und 56 Friichten, von denen $148 \pm 200$ auf $1 \mathrm{hl}(=82 \mathrm{~kg}$ ) entfallen.

Es wiegen 100 Halme $545 \mathrm{gr}$ und davon die Früchte $234 \mathrm{gr}$.

Original von Dr. Finseh und Graf Zeil erhalten.

\section{Hartweizen aus Persien. $\odot$}

Aelire: rosa, fast quadratisch, dicht, kurz; Aehrchen $1.3 \mathrm{~cm}$ breit, meist 3-körnig, 2-granuig, Klappen mit starkem Kiel und Zahn; Granne hell, wenig gespreizt, zerbrechlich, bis $11 \mathrm{~cm}$ lang. - Stroh: rötlich-gelbInenrand markig, steif, kurz. - Frucht: rot, glasig, zusammengedrückt, 
verschrumpft, ziemlich gross $\left(7 \frac{1}{2} \mathrm{~m} \mathrm{n}\right.$ lang, $3 \frac{1}{4} \mathrm{~mm}$ breit, 220 Früchte $=10 \mathrm{gr})$, grobschalig.

Junges Blatt gelbgrün, aufrecht; 3.4 Schösslinge, zeitig schossend und blühend. Halme $75 \mathrm{~cm}$ (Max. $85 \mathrm{~cm}$ ) lang, $0.25 \mathrm{~cm}$ dick, Blattzahl 3.2 , Blätter $15 \mathrm{~cm}$ lang, $0.6 \mathrm{~cm}$ breit, Blattfläche $57.6 \mathrm{qcm}$, Halmfläche $56.25 \mathrm{qcm}$, Gesammtfläche $113.85 \mathrm{qcm}$.

Junge Aehre gelbgriin, reift in 120 Tagen, $5 \mathrm{~cm}$ (Max. $6 \mathrm{~cm}$ ) lang, mit 13 Aehrchen und 36 fest sitzenden Früchten, von denen 1716000 auf $1 \mathrm{hl}(=78 \mathrm{~kg})$ entfallen.

Es wiegen 100 Halme $263 \mathrm{gr}$, und davon die Früchte $126 \mathrm{gr}$.

\section{Varietät: Triticum durum erythromelan Kcke.}

Aehre kahl, rot; Körner weisslich; Grannen dunkel.

\section{Sorte:}

\section{Blé Taganrock rouge. $\odot$}

Syn.: Franz: Blé aubaine de Languedoc, rouge de Marianopoli, rouge d'Afrique, d'Égypte, d'Anatolie, de Sicile, de Toscane.

Spanisch: Trigo Marianopoli.

Ital.: Frumento Taganrock, o Grano duro di Realforte (Sicilien).

D eutsch: Rotblauer Hartweizen.

Triticum sordidulum h. Dresden.

Aehre: hellrot mit schwarzbläulichem Anflug, quadratisch, dicht, kaum mittellang; Aehrehen $1.6 \mathrm{~cm}$ breit, 3- und 4-körnig, 3-grannig, mittelste Granne kurz; Grannen an Basis schwarzblau, nach oben rötlich, etwas gespreizt, bis $18 \mathrm{~cm}$ lang, sehr stark, zähe. - Stroh: blassrötlich, hohl, Innenrand markig, reichblätterig, fest, lang. - Frucht: weisslich, glasig, stark eingefallen, gross ( $8 \mathrm{~mm}$ lang, $4 \mathrm{~mm}$ breit), feinschalig.

Junges Blatt gelbgrün, aufrecht, kräftig, 3 Schösslinge, zeitig schossend und blïhend; Halmlänge $120 \mathrm{~cm}$ (Max. $135 \mathrm{~cm}$ ), Halmdicke $0.4 \mathrm{~cm}$, Blattzahl 3.8, Blattlänge $26.2 \mathrm{~cm}$, Blattbreite $1.15 \mathrm{~cm}$, Blattoberfläche eines Halmes 229 qcm, Halmfläche 144 qcm, Gesammtfläche $373 \mathrm{qcm}$.

Junge Aehre blaugrün, zeitig, in 123 Tagen reifend, $8 \mathrm{~cm}$ (Max. $9 \mathrm{~cm}$ ) lang, mit 14 Aehrchen und 45 nicht leicht ausfallenden Früchten, von denen 1440000 auf $1 \mathrm{hl}(=80 \mathrm{~kg})$ gehen.

Es wiegen 100 Halme $780 \mathrm{gr}$ und davon die Früchte $300 \mathrm{gr}$.

Dieser Hartweizen zeigte in Poppelsdorf einen guten Stand, lagerte nicht und blieb fast rostfrei.

In Frankreich, namentlich in dem Languedoc, in Italien und zwar hauptsächlich auf Sicilien, in Toscana und in der Emilia, in Spanien und anderen Mittelmeerländern, sowie in der Argentinischen Republik vielfach gebaut. Er gehört mit zu den in Frankreich verbreitetsten Hartweizen. 


\section{Varietät: Triticum durum alexandrinum Kcke. Aehre kahl, rot: Körner rot; Grannen dunkel.}

\section{Sorte:}

\section{Froment de la Basse-Égrote.}

Aehre: blassrot, kahl, pyramidal, dicht; Aelirchen meist 4-kï̈rnig, 2-grannig; Granne an Basis schwarzbraun, nach Spitze heller, aufrechî, bis $14 \mathrm{~cm}$ lang. - Stroh: rötlich, steif, hohl mit markigem Inncnrand, 80-90 cm lang. - Frucht: dunkelrot, glasig, gross $(8 \mathrm{~mm}$ lang, $4 \mathrm{mn}$ breit), verschrumpft, 171 Körner $=10 \mathrm{gr}$, Qualität schlecht.

Blätter hellgriin, breit, aufrecht, 1.6 Schösslinge, sehr zeitig schossend und blühend; junge Aehre gelblichgriin, reif 5-6 cm lang, mit 14 Aehrchen und 45 Früchten.

Stroh unterliegt sehr leicht dem Rost.

Varietiit: Triticum durnm provinciale Al.

Aehre kahl, schwarzblau; Körner weisslich; Grannen dunkel.

S o r te n :

\section{Trigo Fuerte de Sevilla.}

Sy n.: Trigo Macolo, Cadiz.

Aelire: Klappen violett mit dunkelviolettem Kiel und Zahn, Spelzen blassgelb, pyramidal, zicmlich dicht, kurz; Aehrchen $1.2 \mathrm{~cm}$ breit, 3-körnig, 3-grannig, mittlere kurz; Grannen blauschwarz, stark, bis $17 \mathrm{~cm}$ lang, wenig gespreizt. - Stroh: rötlich-gelb, stcif, markig. - Frucht: Original weisslich, glasig, schlank ( $7 \mathrm{~mm}$ lang, $3 \mathrm{~mm}$ breit, $25 \%$ Früchte $=.10 \mathrm{gr})$; nachgebant: grösser, 143 Früchte $=10 \mathrm{gr}$, selır feinschalig.

Junges Blatt hellgrün, ziemlich fein, lang, aufrecht, 1.6 Schösslinge, zeitig schossend und blühend; Halnı $90 \mathrm{~cm}$ (Max. $110 \mathrm{~cm}$ ) lang, $0.3 \mathrm{~cm}$ dick, Blattzahl 3.3, Blätter $21 \mathrm{~cm}$ lang, $0.9 \mathrm{~cm}$ breit, Blattfläche $124.7 \mathrm{qcm}$, Halmfläche $81 \mathrm{qcm}$, Gesammtfäche $205.7 \mathrm{qcm}$.

Junge Aehre bläulich, violett unırandet, bereift, $6 \mathrm{~cm}$ (JIax. $8 \mathrm{~cm}$ ) lang, mit 15 Aehrchen und 42 Friichten, von denen 2176000 auf $1 \mathrm{hl}$ $(=85 \mathrm{~kg})$ entfallen.

Zeitig, in 120 Tagen reifend.

Heimat: Spanien.

Bezugsquelle: Antonio Cypriano Costa in Barcelona, 1881.

\section{Trigo nero o rubion. $\odot$}

Syn.: Deutsch: Schwarzer oder goldgelber Hartweizen.

Aehre: grauweiss, Klappen und Spelzen schwarzblau umrandet, kurz, quadratisch, dicht; Aehrchen 3- und 4-körnig, meist 2-, selten 3-grannig, $1.5 \mathrm{~cm}$ breit; Grannen an Basis schwarz, nach oben hell, sehr lang, bis 17 cm lang. - Stroh: rötlich-gelb, markig, selır fest, steif. - Frucht: weisslich, glasig, zusammengedrückt, sehr gross $\left(8^{3} / 4 \mathrm{~mm}\right.$ lang, $4 \mathrm{~mm}$ breit, 170 Früchte $=10 \mathrm{gr}$ ), feinschalig.

Junge Blätter dunkelgrïin, schmal, lang, 1.6 Schösslinge, sehr zeitig schossend und bliihend; Halmlänge $100 \mathrm{~cm}$ (Max. $110 \mathrm{~cm}$ ), Halmdicke 
$0.4 \mathrm{~cm}$, Blattzahl 4, Blattlänge $25.4 \mathrm{~cm}$, Blattbreite $0.92 \mathrm{~cm}$, Blattoberfläche eines Halmes $186.94 \mathrm{qcm}$, Halmfläche $120 \mathrm{qcm}$, Gesammtfläche $306.94 \mathrm{qcm}$.

Junge Aehre blaugrün, in 125 Tagen, also ziemlich zeitig reifend, $7 \mathrm{~cm}$ (Max. $8 \mathrm{~cm}$ ) lang, mit 14 Aehrchen und 50 nicht leicht ausfallenden Frïchten, von denen 1394000 auf $1 \mathrm{hl}$ (=82 kg) gehen.

Es wiegen 100 Halme $650 \mathrm{gr}$ und davon die Früchte $270 \mathrm{gr}$.

Dieser Hartweizen wird in Spanien, Italien und zuweilen in SiidFrankreich kultiviert.

In Poppelsdorf befriedigte der Stand und das Stroh lagerte nicht und blieb fast rostfrei.

Varietät: Triticum durum ohscurum Kcke.

Aehre kahl, schwarzblau; Körner rot; Grannen dunkel.

\section{Sorte :}

\section{Trigo azulejo, Spanien. $\odot$}

Syn.: Portugal: Trigo aza de corvo.

It a 1.: Grano duro nero.

Franz.: Blé dur noir, noir d'Afrique, noir de Sicilie, Taganrock noir, hybride de Russie; Froment dur violet.

De utsch: Blauer kahler Hartweizen.

Aehre: schwarzblau, quadratisch, dicht, kurz; Aehrchen $1.7 \mathrm{~cm}$ breit, 3- und 4-körnig, 2-grannig, Klappen mit lang zugespitztem Zahn oder kurzer Grame; Grannen an Basis schwarzblau, nach Spitze heller, bis $14 \mathrm{~cm}$ lang, aufrecht, leicht abbrechend. - Stroh : rötlich-gelb, mittellang, hohl, nur Innenrand markig, fest. - Frucht: dunkelrot, glasig, eingefallen (7 $\mathrm{mm}$ lang, $4 \mathrm{~mm}$ breit), etwas grobschalig.

Halme blaugrün, 2.5 Schösslinge, mittelfriih schossend und blühø̨n; Halmlänge $100 \mathrm{~cm}$ (Max. $120 \mathrm{~cm}$ ), Halmdicke $0.37 \mathrm{~cm}$, Blattzahl 4, Blattlänge $33 \mathrm{~cm}$, Blattbreite $1.05 \mathrm{~cm}$, Blattoberfläche eines Halmes 277.2 qcm, Halmfläche $111 \mathrm{qcm}$, Gesammtfläche 388.2 q cm.

Junge Aehre blaugrün, Spelzen braun umrandet, zeitig, in 125 Tagen reifend, 6 cu (Max. $9 \mathrm{~cm}$ ) lang, mit 14 Aehrchen und 50 fest sitzenden Friichten, von denen 1722000 auf $1 \mathrm{hl}(=82 \mathrm{~kg})$ gehen.

Es wiegen 100 Halme $600 \mathrm{gr}$ und davon die Früchte $280 \mathrm{gr}$.

Dieser Weizen zeigte einen schönen Stand, lagerte nicht leicht und blieb fast rostfrei, doch verschrumpte in kühlen Sommern das Korn stark. Sein Anbauge biet erstreckt sich iiber Spanien, Portugal, Sïd-Frankreich (Provençe), Süd-Italien, Sicilien und Nord-Afrika.

\section{Varietät: Triticum durum Valenciae Kcke.}

Aehre sammetig, weiss; Körner weisslich; Grannen hell.

\section{Sorten :}

\section{Hartweizen aus Valencia. $\odot$}

Aehre: blassgelb mit rötlichem Schimmer, sammetig, sehr dicht, quadratisch, kurz; Aehrchen $1.2 \mathrm{~cm}$ breit, 3-körnig, 3-grannig, Mittelgranne kurz, Klappen mit Zahn und Kiel; Granne hell, uur an Basis 
schwärzlich, zähe, aufrecht, bis $15 \mathrm{~cm}$ lang. - Stroh: rötlich-gelb, an Basis markiger Innenrand, nach oben zu ganz markig. mittellang, steif. Frucht: weisslich, glasig, stark eingefallen, zusammengedrückt, gross $(8 \mathrm{~mm}$ lang, $3^{1 / 2} \mathrm{~mm}$ breit, 154 Früchte $=10 \mathrm{gr}$ ), feinschalig.

Junges Blatt dunkelgriin, ausgebreitet; 3 Schösslinge, spät schossend und blühend. Halm $100 \mathrm{~cm}$ (Max. $110 \mathrm{~cm}$ ) lang, $0.33 \mathrm{~cm}$ dick, Blattzahl 4.2, Blätter $17.9 \mathrm{~cm}$ lang, $0.9 \mathrm{~cm}$ breit, Blattfläche $134.57 \mathrm{gcm}$, Halmfläche $99 \mathrm{gcm}$, Gesammtfläche $233.57 \mathrm{qcm}$.

Junge Aehre blaugrün, reift in 123 Tagen, $7 \mathrm{~cm}$ (Max. $9 \mathrm{~cm}$ ) lang, mit 16 Aehrchen und 45 fest sitzenden Frïchten, von denen 1293600 auf $1 \mathrm{hl}(=84 \mathrm{~kg})$ entfallen.

Es wiegen 100 Halme $514 \mathrm{gr}$ und davon die Früchte $225 \mathrm{gr}$. erhalten.

Original durch Gutsbesitzer Pfeiffer in Ossendorf bei Köln 1878

\section{Blé d'Ismaël. $\odot$}

Syn.: Blé Tripet.

Aehre: blassgelb, sammetig, fast quadratisch, dicht, kurz; Aehrchen $1.1 \mathrm{~cm}$ breit, 3-körnig, Mittelgrannen kurz, Klappen ein wenig kurz, doch lang gezahnt; Grannen hell, an Basis etwas bräunlich, ein wenig gespreizt, zähe, bis $14 \mathrm{~cm}$ lang. - Stroh: rötlich-gelb, feinhalmig, markig, kaum mittellang. - Frucht: weisslich, glasig, einige gelb und mehlig, bauchig, lang $\left(8^{3} / 4 \mathrm{~mm}\right.$ lang, $4 \frac{1}{2} \mathrm{~mm}$ breit, 169 Friichte $\left.=10 \mathrm{gr}\right)$, ziemlich feinschalig.

Junges Blatt gelb, aufrecht; 3.6 Schösslinge, zeitig schossend und blühend. Halme $90 \mathrm{~cm}$ (Max. $100 \mathrm{~cm}$ ) lang, $0.3 \mathrm{~cm}$ dick, Blattzahl 4, Blätter $18 \mathrm{~cm}$ lang, $0.75 \mathrm{~cm}$ breit, Blattfläche $135 \mathrm{q} \mathrm{cm}$, Halmfläche $81 \mathrm{qcm}$, Gesammtfläche 216 qcm.

Junge Aehre blaugrün, reift in 123 Tagen, $6 \mathrm{~cm}$ (Max. $8 \mathrm{~cm}$ ) lang, mit .lose sitzenden Frichten, von denen 1436500 anf 1 hl (= $85 \mathrm{~kg}$ ) cntfallen.

Es wiegen 100 Halme $380 \mathrm{gr}$ und davon die Früchte 183 gr.

Dieser Hartweizen wird im Norden Afrikas, namentlich in Aegypten, und in einzelnen Gegenden Italiens nud des südlichen Frankreichs angebant.

\section{Weisser sammetiger Hartweizen aus dem Gouvernement Charkow, Russland. $\odot$}

Aehre: blassgelb, mit rötlichem Schimmer, sammetig, quadıatisch, dicht, kurz; Aehrchen $1.2 \mathrm{~cm}$ breit, 3-körnig, 3-grannig, davon eine Granne kurz; Grannen hell, anfrecht, bis $13 \mathrm{~cm}$ lang. - Stroh; rötlich-gelb, mit markigem Iınemrande, mittellang. - Frucht: weisslich, glasig, einigc mehlig und beinahe weiss, lang ( $8 \mathrm{~mm}$ lang, $3^{1} / 2 \mathrm{~mm}$ breit, 210 Friichte $=10 \mathrm{gr}$ ), sehr feinschalig.

Junges Blatt dunkelgriin, lang, schmal, aufrecht, 2.4 Schösslinge, sehr zeitig schossend und blühend, Halmlänge $100 \mathrm{~cm}$ (Max. $120 \mathrm{~cm}$ ), Halmdicke $0.38 \mathrm{~cm}$, Blattzahl 4, Blattlänge $28.3 \mathrm{~cm}$, Blattbreite $0.8 \mathrm{~cm}$, Blattoberfläche 181.12 qcm, Halmfläche $114 \mathrm{qcm}$, Gesammtfl̈̈che $295.12 \mathrm{qcm}$. Junge Aehre blaugriin, Spelzen rot umrandet, $6 \mathrm{~cm}$ ( $\left(\mathrm{ax}_{\mathrm{x}} 7 \mathrm{~cm}\right.$ ), zeitig, in 122 Tagen reifend, mit 15 Aehrchen und 42 fest sitzenden Frichten, von denen 1806000 auf 1 lil $(=86 \mathrm{~kg})$ entfallen. 
Es wiegen 100 Halme $460 \mathrm{gr}$ und davon die Frïchte $236 \mathrm{gr}$.

Mit Ausnahme des Arnautischen Weizens wïrde dies für Deutschland der beachtenswerteste Hartweizen sein.

Durch Prof. Saykewitsch, Charkow, 1880 erhalten.

Varietät: 'Triticum durum fastuosum Lag. Aehre sammetig, weiss; Körner rot; Grannen hell.

\section{Sorte:}

\section{T'rigo fanfarrón blanco, Spanien. •}

Syn.: Ital.: Frumento mazzocchio.

Franz.: Blé durelle fastucuse, fastuosum; Froment de Taganrock d'Espagne.

Deutsch: Schmalähriger, sammetiger Hartweizen.

Aehre: łlassgclb, sammetig, locker, schmal, mittellang; Aehrchen $1.5 \mathrm{~cm}$ breit, 3-körnig, klappen kurzgrannig; Grannen gelblich-weiss, lang. Strolı: blassgelb, fast weiss, hohl, Innenrand markig, fest. - Frucht: rot, glasig, zusammengedrïckt, eingefallen, länglich (7 mm lang, $3^{1 / 2} \mathrm{~mm}$ breit), feinschalig.

Halme blaugrïn, bereift, 2.4 Schösslinge, zeitig schossend und blühend; Halmlänge $117 \mathrm{~cm}$ (Max. $130 \mathrm{~cm}$ ), Halmdicke $0.3 \mathrm{~cm}$, Blattzahl 4, Blattlänge $33 \mathrm{~cm}$, Blattbreite $0.9 \mathrm{~cm}$, Blattoberfläche eines Halmes 237.6 q cin, Halmfläche $105.3 \mathrm{qcm}$, Gesammtfläche $342.9 \mathrm{qcm}$.

Junge Aelsre blangriin, zeitig, in 123 Tagen reifend, $10 \mathrm{~cm}$ (Max. $11 \mathrm{~cm}$ ) lang, mit 14 Aehrchen und 40 wenig fest sitzenden Früchten, von denen 1782000 auf $1 \mathrm{hl}(=81 \mathrm{~kg})$ gehen.

Es wiegen 100 Halme 530 gr und davon die Früchte $200 \mathrm{gr}$.

Dieser Hartweizen zeichnete sich durch vorzüglichen Stand aus, scheint sehr ertragreich zu sein, nicht leicht zu lagern oder mit Rost zu befallen, und sich noch zur Kultur in Deutschland zu eignen.

Dieser Weizen sielst mehr einem Trit. vulgare velutinum als Trit. durum ähnlich, was auch bei den Abbildungen Metzger's Tab. IV, A der Fall ist, (Cerealien 1824), Link stellte iln zu Trit. durum.

Willko mm ${ }^{1}$ ), durch die Schönheit der Körner verführt, importierte ihn aus Spanien 1844 in die Umgegend von Zittau, wo er vortrefflich gedieh.

In den Gebirgsgegenden Süd-Spaniens wird dieser Weizen häufig gebaut, so reicht er in Granada bis zu Höhen von $1850 \mathrm{~m}$, und in manchen Thälern der Sierra nevada sogar bis $2000 \mathrm{~m}$ hinauf, doch wird er auch in der Ebene von Albacete in Murcia, und häufig in anderen Ländern Sïd-Europas und Nord-A frikas gebaut.

In Italien findet seine Kultur hauptsächlich in Toscana statt, wie dies dic Ausstellung in Mailand 1880 lehrte.

1) Willkomm, Agron. Zeit. 1852 pg. 26 u. 36 . 


\section{Varietät: Triticum durum circumflexum Kcke.}

Aehre sammetig, weiss; Körner rot; Grannen hell und gebogen.

\section{Sor t e :}

\section{Hartweizen aus Palermo mit bajonnetförmig gekrümmten Grannen. $\odot$}

Aehre: blassgelb mit bläulichem Schimmer, schwach sammetig, quadratisch, die zweizeilige Seite der Aehre mehr oder weniger breit, sehr dicht, kurz; Aehrchen $1.5 \mathrm{~cm}$ breit, 3- und 4-körnig, meist 2-grannig, Zahn der Klappen kurz, stark nach innen gebogen; Grannen fast weiss oder ein wenig schwärzlich, ron mässiger Länge, bis $14 \mathrm{~cm}$ lang, parallel der Aehre, an der Basis bajonnetförmig gekrümmt, nämlich in einem abgerundet rechten, oder von innen abgerundet spitzlichen Winkel nach unten und dann perpendikulär nach oben gekrümmt. - Stroh: dunkelgelb, hohl, mit schmalem markigem Rande, mittellang, fest, steif. - Frucht: graurot, glasig, zusammengedrückt, plump ( $7^{1} / 2 \mathrm{~mm}$ lang, $3^{1} / 2 \mathrm{~mm}$ breit), grobschalig, eingefallen und in kühlen Sommern verschrumpft.

Junges Blatt dunkelgrün, schmal, lang, aufrecht, 3.4 Schösslinge, zeitig schossend und blühend; Halmlänge $115 \mathrm{~cm}$ (Max. 135 cm), Halmdicke $0.33 \mathrm{~cm}$, Blattzahl 3 , Blattlänge $30 \mathrm{~cm}$, Blattbreite $0.94 \mathrm{~cm}$, Blattoberfläche eines Halmes $169.2 \mathrm{qcm}$, Halnfläche $113.85 \mathrm{q} \mathrm{cm}$, Gesammtfläche $283.05 \mathrm{qcm}$.

Junge Aehre blaugrün, zeitig, in 125 Tagen reifend, $7 \mathrm{~cm}$ (Max. $8 \mathrm{~cm})$ lang, mit 12 Aehrchen und 45 fest sitzenden Früchten, von denen 1757600 auf $1 \mathrm{hl}(=84.5 \mathrm{~kg})$ gehen.

Es wiegen 100 Halme $550 \mathrm{gr}$ und davon die Früchte $200 \mathrm{gr}$.

In Poppelsdorf lagerte dieser Weizen nicht und zeigte wenig Rost.

Heimat: Sicilien; Uebersender: L. Wit tmack, der 1873 von der Wiener Ansstellung Weizen aus Palermo sandte, zwischen dem sich diese Varietät fand.

\section{Varietät: Triticum durum melanopus Al.}

Aehre sammetig, weiss; Körner weisslich; Grannen dunkel.

\section{Sorten:}

\section{Trigo Alouso, Cadiz. $\odot$}

Syn.: Trigo salmerone.

Aelire: blassgelb mit rötlichem Anflug, Kiel und Zalın der Klappen schwärzlich, sammetig, fast pyramidal, dicht, kurz; Aehrchen $1.3 \mathrm{~cm}$ breit, 3- und 4-köruig, 3-grannig, mittlere kurz; Grannen schwarzbraun, lang, wenig gespreizt, $15 \mathrm{~cm}$ lang. — Stroh: rötlich-grelb, markig. - Frucht: Original meist weisslich, glasig, einige blassgelb, mehlig, zusammengedrückt, lang ( $71 / 2 \mathrm{~mm}$ lang, $3 \mathrm{~mm}$ breit, 221 Früchte $=10 \mathrm{gr})$; nachgebaut: Alles glasig, grösser, 166 Früchte $=10 \mathrm{gr}$, feinschalig.

Junges Blatt hellgrïn, ziemlich kräftig, lang, aufrecht, 1.4 Schösslinge, zeitig schossend und blühend; Halm $90 \mathrm{~cm}$ (Max. $105 \mathrm{~cm}$ ) lang, 0.33 cm dick, Blattzalıl 4, Blätter $21.8 \mathrm{~cm}$ lang, $0.9 \mathrm{~cm}$ breit, Blattfläche $157 \mathrm{qcm}$, Halmfläche $89.1 \mathrm{q} \mathrm{cm}$, Gesammtfläche $246.1 \mathrm{qcm}$. 
Aehre $5 \mathrm{~cm}$ (Max. $7 \mathrm{~cm}$ ) lang, mit 12 Aehrchen und 40 Früchten, von denen 1322700 anf $1 \mathrm{hl}(=87 \mathrm{~kg})$ entfallen.

Zeitig, in 120 Tagen reifend.

In Salmeron, Ort am Guadalajara, sowie um Sevilla, in Almeria und Granada kultiviert.

Wurde 1867 durch den Akklimatisations-Verein in Berlin zur Prüfung in Eldena gebaut. Fiir Deutschland ungeeiguet.

\section{Trigo cortesano, Spanien. $\odot$}

Aehre: blassgelb, sammetig, quadratisch, dick, kurz; A ehrchen $2 \mathrm{~cm}$ breit, 3-und 5-körnig, 3-grannig, Klappe lang zugespitzt oder lang begrannt; Grannen an Basis schwarzbraun, nacl oben heller, bis $17 \mathrm{~cm}$ lang; Spindel zerbrechlich. - Stroh: rötlich-gelb, innerer Rand markig, häufig auch ganz markig, mittcllang. - Frucht: weisslich, glasig, einige mehlig, plump, gross (8 mım lang, $4 \mathrm{~mm}$ breit), feinschalig.

Junges Blatt dunkelgrïn, aufrecht, ziemlich, breit, kräftig, 1.2 Schösslinge, mittelfrüh schossend und blühend; Halmlänge $100 \mathrm{~cm}$ (Max. $120 \mathrm{~cm}$ ), Halmdicke $0.38 \mathrm{~cm}$, Blattzahl 3.6, Blattlünge $28 \mathrm{~cm}$, Blattbreite $1.04 \mathrm{~cm}$, Blattoberfläche einer Pflanze 209.67 qcm, Halmfläche $114 \mathrm{qcm}$, Gesammtfläche $323.67 \mathrm{qcm}$.

Junge Aehrc blaugrün, zeitig, in 125 Tagen reifend, $6 \mathrm{~cm}$ (Max. $7 \mathrm{~cm}$ ) lang, 12 Aehrchen mit 50 fest sitzenden Friichten, von denen 1486000 anf $1 \mathrm{hl}(=83.5 \mathrm{~kg})$ gehen.

In Poppelsdorf wiegen 100 Halme $750 \mathrm{gr}$ und davou die Früchte $280 \mathrm{gr}$, auch hielt sich das Stroh fast rostfrei und lagerte nicht.

Uebersender: L. Wittmack von der Wiener Weltausstellung 1873.

\section{Sieruschka. $\odot$}

Sy 1.: Kuban'scher Weizen mit grauen Grannen.

Mit obiger Form identisch, nur Grannell schwarz, ist ein als "Tschernuschka" am Kuban bezeichneter Weizen.

Aehre: unrein blassgelb mit schwach rötlichem Schimmer, sammetig, kompakt, kurz, Aehrchen $1.3 \mathrm{~cm}$ breit, meist 4-körnig, 3-grannig, Mittelgranne kurz; Granne schwärzlich-grau, wenig gespreizt, bis $20 \mathrm{~cm}$ lang. Stroh: gelb, Innenrand markig, einige ganz markig, fest, mittellang. Frucht: weisslich, glasig, länglich ( $7 \mathrm{~mm}$ lang, $3 \frac{1}{2} \mathrm{~mm}$ breit), schön, feinschalig.

Junges Blatt gelbgrün, aufrecht; 3 Schösslinge, mittelfrüh schossend und blühend. Halm $100 \mathrm{~cm}$ (Max. $120 \mathrm{~cm}$ ) lang, $0.3 \mathrm{~cm}$ dick, Blattzahl 4, Blätter $20.3 \mathrm{~cm}$ lang, $0.75 \mathrm{~cm}$ breit, Blattfläclie $121.8 \mathrm{qcm}$, Halmfläche $90 \mathrm{qcm}$, Gesammtfläche $211.8 \mathrm{qcm}$.

Junge Aehre blaugriin, reift in 123 Tagen, $6.5 \mathrm{~cm}$ (Max. $9 \mathrm{~cm}$ ) lang, mit 14 Aehrchen und 56 festsitzenden Friichten, von deuen 17.3 800 auf $1 \mathrm{hl}(=84.5 \mathrm{~kg})$ entfallen.

Es wiegen 100 Halıne $402 \mathrm{gr}$ und davon die Früchte $191 \mathrm{gr}$.

Von Professor Saykewitsch, Charkow, 1880 aus dem Gouvernement Jekaterinoslaw, Distrikt Slawianoserbsk, erhalten. 
Varietät: Triticum durum africanum Kcke.

Aehre sammetig, weiss; Körner rot; Grannen dunkel.

\section{Sorten:}

\section{Trigo fanfarrón velloso raspinegro. $\odot$}

Syn.: Blé Taganrock velouté, de la Mongolie, dur velouté d'Algerie.

Aehre: grauweiss, Klappen mit braunem Kiel, schwach sammetig, kurz, quadratisch, sehr dicht; Aehrchen $1.6 \mathrm{~cm}$ breit, meist $4 \cdot \mathrm{körnig}$, 2-grannig, seltener eine 3. kleine Granne; Grannen bis $17 \mathrm{~cm}$ lang, zähe, Basis schwarz, nach Spitze zu fast weiss. - Stroh: rötlich-gelb, ziemlich blattreich, steif, markig. - Frucht: rot, sehr gross, plump, zusammengedrückt, eingefallen, lang $\left(91 / 2 \mathrm{~mm}\right.$ lang, $3^{1} / 2 \mathrm{~mm}$ breit, 177 Früchte $=10 \mathrm{gr}$ ); etwas grobschalig.

Junge Aehre blaugrün, in 130 Tagen reifend, $6 \mathrm{~mm}$ lang mit 50 fest 'sitzenden Früchten, von denen 1456710 auf $1 \mathrm{hl}$ (=82.3 kg) entfallen.

In Spanien, auf Sicilien und in Nord-Afrika gebaut.

\section{Hartweizen aus Bigha, Ḱlein-Asien, Türkei. $\odot$}

Aehre: blassgelb, sammetig, dicht, fast, quadratisch, kurz; Aehrchen $1.6 \mathrm{~cm}$ breit, 3·körnig, 3-grannig, davon eine Granne kurz, Klappen mit spitzem Zahn; Grannen schwarzbraun an Basis, nach Spitze zu heller werdend, bis $14 \mathrm{~cm}$ lang, zähe. - Stroh: rötlich-gelb, meist markig, steif, mittellang. - Frucht: rotbräunlich, glasig, etwas plump, zusammengedrückt, gross (9 mm lang, $4 \mathrm{~mm}$ breit), etwas eingefallen, ziemlich feinschalig, sehr schwer.

Halme dunkelgrün, Bestockung ziemlich stark, 2.6 Schösslinge, mittelfrüh schossend und blühend. Halmlänge $100 \mathrm{~cm}$ (Мax. $115 \mathrm{~cm}$ ), Halmdicke $0.37 \mathrm{~cm}$, Blattzahl 4, Blattlänge $26.75 \mathrm{~cm}$, Blattbreite $1.05 \mathrm{~cm}$, Blattoberfläche $224.72 \mathrm{qcm}$, Halmfäche $111 \mathrm{qcm}$, Gesammtfläche $335.72 \mathrm{qcm}$.

Junge Aehre $6 \mathrm{~cm}$ lang, blaugrün, in 123 Tagen reifend, mit 15 Aehrchen und 40 Früchten, von denen 1505000 auf $1 \mathrm{hl}$ (=88.5 $\mathrm{kg}$ ) entfallen.

Es wiegen 100 Halme $330 \mathrm{gr}$ und davon die Früchte $157 \mathrm{gr}$.

Für Deutschland wertlos.

\section{Varietät: Triticum durum italicum Al.}

Aehre sammetig, rot; Körner weisslich; Grannen hell.

\section{Sorten:}

\section{Trigo fanfarrón velloso rubion. Valencia. $\odot$}

Sy n.: Rotähriger, sammetiger Hartweizen aus Valencia.

Aehre: rot, sammetig, wenig dicht, lang, schmal; Aelırchen $1 \mathrm{~cm}$ breit, 3-körnig, 2-grannig; Grannen hell, bis $13 \mathrm{~cm}$ lang, aufrecht. Stroh: rötlich-gelb, steif, lang, Innenrand markig. - Frucht: weisslich, glasig, einige mehlig und fast weiss, länglich $\left(8 \mathrm{~mm}\right.$ lang, $3 \frac{1}{2} \mathrm{~mm}$ breit, 200 Früchte $=10 \mathrm{gr}$ ), sehr schön, feinschalig.

Junges Blatt aufrecht, äusserst kur'z aber dicht behaart, jedoch leicht zu übersehen; 2 Schüsslinge, sehr zeitig schossend und blühend. Halme 
$140 \mathrm{~cm}$ (Max. $160 \mathrm{~cm}$ ) lang, $0.45 \mathrm{~cm}$ dick, Blattzahl 3.2, Blätter $35 \mathrm{~cm}$ lang, $1.1 \mathrm{~cm}$ breit, Blattfläche $246.4 \mathrm{qcm}$, Halmfläche 189) qcm, Gesammtfläche $435.4 \mathrm{qcm}$.

Junge Aehre gelbgrün, in 123 Tagen reifend, $9 \mathrm{~cm}$ (Max. $12 \mathrm{~cm}$ ) lang, mit 13 Aehrchen und 36 Früchten, von denen 1706000 auf $1 \mathrm{hl}$ $(=85.3 \mathrm{~kg})$ entfallen.

Es wiegen 100 Halme $450 \mathrm{gr}$ und davon die Früchte $192 \mathrm{gr}$.

\section{Rotähriger, sammetiger Hartweizen aus Apulien. $\odot$}

Aehre: blassrot, dicht, viereckig, kurz, schwach sammetig; Aelırchen 3- und 4-körnig, meist 3-grannig, $1.8 \mathrm{~cm}$ breit; Grannen blassrot, an Basis schwarzbraun, wenig gespreizt, zähe, bis $18 \mathrm{~cm}$ lang. - Stroh: rötlich-gelb, Rand markig, ziemlich lang. - Frucht: weisslich, glasig, eingefallen, plump ( $8 \mathrm{~mm}$ lang, $4 \mathrm{~mm}$ breit, 140 Früchte $=10 \mathrm{gr}$ ).

Junges Blatt dunkelgrün, lang, schmal, 1.2 Schösslinge, zeitig schossend und blühend; Halm $100 \mathrm{~cm}$ (Max. $125 \mathrm{~cm}$ ) lang, $0.4 \mathrm{~cm}$ dick, Blattzahl 3, Blätter $23 \mathrm{~cm}$ lang, $1 \mathrm{~cm}$ breit, Blattfläche $138 \mathrm{qcm}$, Halm甘läche $120 \mathrm{qcm}$, Gesammtfläche $258 \mathrm{qcm}$.

Junge Aehre bläulich, in 125 Tagen reifend, $6 \mathrm{~cm} \mathrm{(Max.} 8 \mathrm{~cm}$ ) lang, mit 50 Früchten.

Varietät: Triticum durum apulicum Kcke.

Aehre sammetig, rot; Körner weisslich; Grannen dunkel.

\section{Sorten:}

\section{Grano duro ex Apulia. $\odot$}

Aehre: blassºt, sammetig, dicht, kurz; Grannen dunkel, bis $15 \mathrm{~cm}$ lang. - Stroh: rötlich-gelb, mit markigem Innenrande oder markig, lang. - Frucht: weisslich, plump, gross $(81 / 2 \mathrm{~mm}$ lang, $4 \mathrm{~mm}$ breit, 125 Früchte $=10 \mathrm{gr}$ ).

Junges Blatt gelbgrün, aufrecht, breit, 2 Schösslinge, zeitig schossend und blühend; Halm $135 \mathrm{~cm}$ (Max. $150 \mathrm{~cm}$ ) lang, $0.4 \mathrm{~cm}$ dick, Blattzahl 3.6, Blätter $23.3 \mathrm{~cm}$ lang, $1.1 \mathrm{~cm}$ breit, Blattfläche $184.5 \mathrm{qcm}$, Halmfläche $162 \mathrm{qcm}$, Gesammtfäche $346.5 \mathrm{qcm}$.

$9 \mathrm{~cm})$ lang.

Junge Aehre bläulich-grün, in 130 Tagen reifend, $7 \mathrm{~cm}$ (Max.

\section{Trigo claro de Raspa negra. La Mancha, Spanien. $\odot$}

Syn.: Deutsch: Roter, sammetiger Hartweizen mit dunklen Grannen aus Spanien.

Aehre: blassrot, schwach sammetig, dicht, kurz; Aehrchen $1.5 \mathrm{~cm}$ breit, meist 3-körnig, 2-grannig; Grannen an Basis schwarzbraun, nach oben heller, bis $16 \mathrm{~cm}$ lang, gespreizt, zähe. -- Stroh: blassgelb, reich beblättert, lang, Innenrand markig, spröde. - Frucht: weisslich, glasig, eingefallen, plump, zusammengedrückt ( $8 \mathrm{~mm}$ lang, $4 \mathrm{~mm}$ breit, 170 Früchte $=10 \mathrm{gr})^{2}$, feinschalig.

Junges Blatt dunkelgrün, aufrecht, lang, schmal, 3 Schösslinge, zeitig schossend und blühend; Halmlänge $120 \mathrm{~cm}$ (Max. $130 \mathrm{~cm}$ ), Halmdicke $0.37 \mathrm{~cm}$, Blattzahl 4, Blattlänge $22.3 \mathrm{~cm}$, Blattbreite $1.0 \mathrm{~cm}$, Blattober- 
fläche eines Halmes $178.4 \mathrm{qcm}$, Halmfläche 133.2 qcm, Gesammtfläche $311.6 \mathrm{qcm}$.

Junge Aehre blaugriin, in 120 Tagen, also zeitig reifend, $6 \mathrm{~cm}$ (Max. $8 \mathrm{~cm}$ ) lang, mit 14 A ehrchen und 40 fest sitzenden Früchten, von denen 1394000 auf $1 \mathrm{hl}(=82 \mathrm{~kg})$ gehen.

Es wiegen 100 Halme 600 gr und davon die Früchte 260 gr.

\section{Trigo chapado vellosa $\left.{ }^{1}\right)$. $\odot$}

Syn.: Spanisch: Patianchuclo, Trigo cuchareta (löfflig).

Deutsch: Stolzer, sammetiger, dickähriger Hartweizen.

Aehre: rot, sammetig, fast kugelig, weil die einzelnen Aehrchen sämmtlich nach einer Seite hin gewendet stehen, also Aehre konkav, viereckig, dicht; Aelırchen 4-körnig, 3-grannig, $1.8 \mathrm{~cm}$ breit, Aehre bis $7 \mathrm{~cm}$ lang und 40 Früchte enthaltend. - Stroh: rötlich-gelb, eingefallen, blattreich, markig. - Frucht: rötlich, glasig, gross $(8 \mathrm{~mm}$ lang, $3 \mathrm{~mm}$ breit, 225 Friichte $=10 \mathrm{gr}$ ). Reift in 122 Tagen. beschrieben.

Schon durch Lagasca als Triticum cochleare (löflliger Weizen)

Nach Willkomm nur in Granada gebaut.

Varietät: Triticum durum niloticum Kcke.

Aehre sammetig, rot; Körner rot; Grannen dunkel.

\section{Sorte:}

\section{Roter sammetiger Weizen mit dunklen Grannen aus Aegypten. $\odot$}

Aehre: blassrot, blau bereift, sammetig, pyramidal, selrr dicht, kurz; Aehrchen $1.8 \mathrm{~cm}$ breit, 3- und 4-körnig; Grannen rot, an Basis dunkel, bis $16 \mathrm{~cm}$ lang, aufrecht. - Strolı: rötlich-gelb, mit markigem Innenrand, feinhalmig, kurz. - Frucht: dunkelrot, glasig, sehr gross $\left(8^{1} / 2 \mathrm{~mm}\right.$ lang, $4 \mathrm{~mm}$ breit, 140 Früchte $=10 \mathrm{gr}$ ), plump, verschrumpft, dickschalig.

Junges Blatt hellgrün, breit, aufrecht, 2.2 Schösslinge, sehr zeitig schossend und bliihend, Halmlänge $75 \mathrm{~cm}$ (Мax. $85 \mathrm{~cm}$ ), Halmdicke $0.3 \mathrm{~cm}$, Blattzahl 4, Blattlänge $24.3 \mathrm{~cm}$, Blattbreite $1.07 \mathrm{cn}$, Blattoberfläche $208 \mathrm{qcm}$, Halmfläche $67.5 \mathrm{qcm}$, Gesammtfläche $275.5 \mathrm{qcm}$.

Junge Aehre bläulich-grün, $6 \mathrm{~cm}$ (Max. $8 \mathrm{~cm}$ ) lang, zeitig, in 120 Tagen reifend, mit 15 Aehrchen und 40 fest sitzenden Früchten, von denen 1050000 auf $1 \mathrm{hl}(=75 \mathrm{~kg})$ gehen.

Es wiegen 100 Halme $372 \mathrm{gr}$ und davon die Früchte $170 \mathrm{gr}$.

Dieser Weizen litt sehr stark durch Rost, so dass das Korn verschrumpfte und das Stroh brüchig wurde.

1) Willkomm. Agron. Zeit. 1852, pg. 36 . 
Varietät: Triticum durum taganrocense Desv.

Aehre sammetig, schwarzblau; Körner weisslich.

\section{Sorten:}

\section{Trigo canalvo o patta, Spanien. $\odot$}

Syn.: Ital.: Grano Siciliano di Alghero.

Franz.: Blé d'Espagne noir, d'Afrique noirâtre, noir de Russie, noir de Galand, noir de Sicile.

Aehre: schwarzblau, sammetig, dicht, kurz; Aehrchen $1.4 \mathrm{~cm}$ breit, meist 3-körnig, 2- und 3-grannig, Klappen mit zugespitztem oder in eine kurze Granne verlängertem Zahn; Grannen an Basis dunkelbraun, nach oben heller, bis $17 \mathrm{~cm}$ lang, zähe. - Stroh: gelb, Innenrand oder ganz markig, fest, inittellang. - Frucht: weisslich, glasig, einige gelblich-weiss und mehlig, seitlich zusammengedrückt, gross (183 Früchte $=10 \mathrm{gr})$, $8 \mathrm{~mm}$ lang, $3^{3} / 4 \mathrm{~mm} \cdot$ breit, bauchig, etwas eingefallen, feinschalig, sehr schwer.

Junges Blatt dunkelgrün, aufrecht, schmal, lang, 1.2 Schösslinge, mittelfrüh schossend und blühend. Halmlänge $100 \mathrm{~cm}$ (Max. $115 \mathrm{~cm}$ ), Halmdicke $0.33 \mathrm{~cm}$, Blattzahl 4, Blattlänge $26.3 \mathrm{~cm}$, Blattbreite $1.1 \mathrm{~cm}$, Blattoberfläche eines Halmes $231.44 \mathrm{qcm}$, Halmfläche $99 \mathrm{qcm}$, Gesammtfläche $330.44 \mathrm{qcm}$.

Junge Aehre blaugrün, Spelzen dunkelviolett umrandet, mittelfrüh, in 130 Tagen reifend, $7 \mathrm{~cm}$ (Max. $9 \mathrm{~cm}$ ) lang, mit 16 Aehrchen und 45 fest sitzenden Früchten, von denen 1628700 auf $1 \mathrm{hl}(=89 \mathrm{~kg})$ gehen.

Es wiegen 100 Halme $670 \mathrm{gr}$ und davon die Früchte $260 \mathrm{gr}$.

Das Stroh lagert nicht leicht und ist gegen Rost widerstandsfähig. kultiviert.

Dieser Weizen wird vorzugsweise in Sicilien, Spanien und Afrika

Uebersender: L. Wittmack, Wiener Ausstellung 1873.

\section{Trigo candeal del Carmen, Chile. $\odot$}

Syn.: Chile: Trigo candeal de barba negra.

Portugal: Trigo candial.

Aehre: dunkelblau, Ränder violett, bereift, quadratisch, sehr dicht, kurz; Aehrchen 3- und 4-körnig, $1.5 \mathrm{~cm}$ breit, 3-grannig, mittlere kurz; Grannen an Basis scliwarzblau, nach der Spitze zu heller, bis $20 \mathrm{~cm}$ lang, sehr kräftig. - Stroh: rötlich-gelb, steif, markig. - Frucht: Original weisslich, einige rötlich-gelb, inehlig, zusammengedrückt, etwas eingefallen, glasig ( $8 \mathrm{~mm}$ lang, $4 \mathrm{~mm}$ breit, 152 Früchte $=10 \mathrm{gr}$ ), feinschalig.

Junges Blatt dunkelgrün, schmal, lang, aufrecht, 1.3 Schösslinge, zeitig schossend und blühend; Halm $90 \mathrm{~cm}$ (Max. $105 \mathrm{~cm}$ ) lang, $0.35 \mathrm{~cm}$ dick, Blattzahl 3.8 , Blätter $21 \mathrm{~cm}$ lang, $0.5 \mathrm{~cm}$ breit, Blattfläche $79.8 \mathrm{qcm}$, Halmfläche 94.5 qcm, Gesammtfläche $174.3 \mathrm{qcm}$.

Junge Aelire blaugrün, $6 \mathrm{~cm}$ (Max. $7 \mathrm{~cm}$ ) lang, mit 13 Aehrchen und 40 Früchten, in 120 Tagen reifend.

Bezugsquelle: durch von Gül ich 1880 aus Chile erhalten.

\section{Mazzocchio. $\odot$}

Syn.: Frumento farro.

Aehre: schwarzblau, sammetig, kurz, kompakt; Aehrehen $1.5 \mathrm{~cm}$ breit, 3- und 4-körnig, 3-grannig, Klappen mit starkem Zahn; Grannen an 
Basis schwarzblau, gespreizt, bis $20 \mathrm{~cm}$ lang, zähe; Spindel brüchig. - Stroh: gelb, mürbe, Innenrand markig, kaum mittellang. - Frucht: weisslich, bauchig, etwas eingefallen, gross $(8 \mathrm{~mm}$ lang, $4 \mathrm{~mm}$ breit, 166 Früchte $=10 \mathrm{gr}$ ), feinschalig.

Junges Blatt bläulich-grün, kahl, aufrecht, sehr zeitig schossend und blïhend, Bestockung stark, 4 Schösslinge, Halme $90 \mathrm{~cm}$ (Max. 105 cm) lang, $0.3 \mathrm{~cm}$ dick, Blattzahl 4, Blätter $21 \mathrm{~cm}$ lang, $0.8 \mathrm{~cm}$ breit, Blattfläche $134.4 \mathrm{qcm}$, Halmfläche $81 \mathrm{qcm}$, Gesammtfläche $215.4 \mathrm{qcm}$.

Junge Aehre blaugrün, bereift, $6 \mathrm{~cm}$ (Max. $8 \mathrm{~cm}$ ) lang, mit 12 Aehrchen und 50 fest sitzenden Früchten, von denen 1361200 auf $1 \mathrm{hl}$ $(=82 \mathrm{~kg})$ entfallen.

Es wiegen 100 Halme $436 \mathrm{gr}$ und davon die Früchte $171 \mathrm{gr}$.

Ton der Pariser Weltausstellung 1878 erhalten.

Heimat: Süd- und Mittel-Italien.

\section{Unterart: 5. Triticum Spelta L. Spelz.}

\section{A. Kolbenspelz.}

Varietät: Triticum Spelta album Al.

Aehre kahl, weiss.

\section{Sorten:}

\section{Weisser Winter-Kolbenspelz. (2)}

Syn.: Franz.: Épeautre ordinaire blanche sans barbes; Épeautre commune; Grand épeautre; Blé de Jerusalem.

Nach Morison: Zea spica mutica dicoccos vel major. (Moris. Hist. 3 p. 204. S. 8. T. 6 fig. 1. 1699.)

Aehre: blassgelb, schmal, sehr locker, schlaff, sich nach der Spitze verjüngend, sehr lang; A ehrchen $0.7 \mathrm{~cm}$ breit, 2-körnig. - Stroh: rötlichweiss, derbwandig, hohl, lang. - Frucht: hellbraun, mehlig, etwas zugespitzt, gefurcht, schmal, lang ( $7 \mathrm{~mm}$ lang, $3 \mathrm{~mm}$ breit), ziemlich feinschalig. $100 \mathrm{~kg}$ Veesen enthalten $75 \mathrm{~kg}$ Kernen.

Herbstblatt blaugrïn, kraus, schmal; Frühjahrsvegetation spät, Bestockung sehr stark, 6 Schösslinge, spät schossend, mittelfrüh blühend. Halmlänge $120 \mathrm{~cm}$ (Max. $140 \mathrm{~cm}$ ), Halmdicke $0.4 \mathrm{~cm}$, Blattzahl 4, Blattlänge $26 \mathrm{~cm}$, Blattbreite $1.0 \mathrm{~cm}$, Blattoberfläche $208 \mathrm{qcm}$, Halmfläche 144 qcm, Gesammtfläche $352 \mathrm{qcm}$.

Junge Aehre blaugrün, mittelfrüh reifend, $14 \mathrm{~cm}$ (Max. $18 \mathrm{~cm}$ ) lang, mit 23 Veesen und 45 Kernen, von denen $1 \mathrm{hl}(=43 \mathrm{~kg}) 452000$ Veesen und 796000 Kernen enthält.

Auf $1 \mathrm{qm}$ wachsen 900 Halme oder 150 PAlanzen, mithin beträgt 
der Raum für eine Pflanze 66.7 qcm, die Blattoberfläche p. qm Bodenfläche $31.7 \mathrm{qm}$ und das Saatquantum 2.8 hl p. ha.

Es wiegen 100 Halme $478 \mathrm{gr}$ und davon die Veesen $287 \mathrm{gr}$.

Diese Sorte lagert nicht leicht, ist winterfest und wird vorzllgsweise in Württemberg, am Oberrhein, in der Scliweiz und zwar vorzugsweise in Canton Bern ${ }^{1}$ ), sowie in Süd-Frankreich kultiviert. In einigen Gegenden dieser Länder tritt diese ergiebige, ein sehr feines Schwingmehl liefernde Sorte als dominierende Brotfrucht auf und wird auch läufig, so in der Eifel, im Gemenge mit. Roggen (Mischelfrucht) gebaut.

Sie verlangt $\mathrm{zu}$ ihrem guten Gedeihen einen milden Lchmboden in warmer Lage.

\section{Weisser Sommer-Kolbenspelz. $\odot$}

Aehre: weiss, locker, schmal, lang; Aehrchen $0.7 \mathrm{~cm}$ breit, 2-körnig. - Stroh: rötlich-gelb, dünnlalmig, hohl, mittellang. - Frucht: hellbraun, glasig, sehr lang, schmal (9 $\mathrm{mm}$ lang, $3 \mathrm{~mm}$ breit), feinschalig; es enthalten $100 \mathrm{~kg}$ Veesen $78.5 \mathrm{~kg}$ Kernen.

Junges Blatt und Halme blaugrïn, Blätter schmal, kahl, an Basis schwach gewimpert, Scheiden kahl; Bestockung stark, 4 Schösslinge, mittelfrüh schossend, zeitig blühend. Halmlänge $110 \mathrm{~cm}$ (Мax. $120 \mathrm{~cm}$ ), Halmdicke $0.33 \mathrm{~cm}$, Blattzahl 4, Blattlänge $26.75 \mathrm{~cm}$, Blattbreite $0.74 \mathrm{~cm}$, Blattoberfläche $158.4 \mathrm{qcm}, H_{a}$ lmfläche $108.9 \mathrm{qcm}$, Gesammtfläche $267.3 \mathrm{qcm}$.

Junge Aelre blaugriin, ca. 10 Tage später als Winterspelz, nämlich in 120 Tagen, also zeitig reifend, $13 \mathrm{~cm}$ (Max. $16 \mathrm{~cm}$ ) lang, mit 18 Veesen und 35 Kernen, von denen $1 \mathrm{hl}(=47 \mathrm{~kg}) 352500$ Veesen oder 752000 Kernen enthält.

Es wiegen 100 Halme $490 \mathrm{gr}$ und davon die Veesen $250 \mathrm{gr}$.

Anf $1 \mathrm{qm}$ wachsen 1000 Halme oder 250 Pflanzen, mithin beträgt der Raum für eine Pflanze $40 \mathrm{qcm}$, die Blattoberfläche p. qm Bodenfläche $26.73 \mathrm{qm}$ und das Saatquantum $5 \mathrm{hl}$ Veesen p. ha.

Auf kalkreichen Gebirgsböden in Schwaben, Frankreich, seltener in der Eifel (Rheinprovinz) gebaut.

\section{Schlegel-Dinkel. (2)}

Aehre: blassgelb, locker, schmal, lang; Aehrchen $0.7 \mathrm{~cm}$ breit, 2-körnig. - Stroh: rötlich-gelb, hohl, geschmeidig, fest, inittellang. Frucht: blassrot, mehlig oder glasig, selir lang, schmal (10 mm lang, $3 \frac{1}{2} \mathrm{~mm}$ breit), etwas eingefallen, feinschalig. $100 \mathrm{~kg}$ Veesen enthalten $73.26 \mathrm{~kg}$ Kernen.

Herbstblatt blaugrïn, kahl, breit, aufrecht; Frïhjahrsvegetation mittelfrüh, Bestockung auffallend stark, 9.0 Schösslinge, mittelfrül schossend, zeitig blühend. Halmlänge $110 \mathrm{~cm}$ (Max. $125 \mathrm{~cm}$ ), Halmdicke $0.35 \mathrm{~cm}$, Blattzahl 4, Blattlänge $27.3 \mathrm{~cm}$, Blattbreite $0.98 \mathrm{~cm}$, Blattoberfläche $214 \mathrm{qcm}$, Halmfläche $115.5 \mathrm{qcm}$, Gesammtfläche $329.5 \mathrm{qcm}$.

Junge Aehre blaugriin, zeitig reifend, etwa 7 Tage früher als der weisse Winter-Kolbenspelz, $10 \mathrm{~cm}$ (Max. $15 \mathrm{~cm}$ ) lang, mit 16 Veesen und 30 Kernen lund es enthält $1 \mathrm{hl}(=45.3 \mathrm{~kg}$ ) 272000 Veesen und 498000 Kernen.

Auf 1 qm wachsen 900 Halme oder 100 Pflanzen, mithin beträgt

1) Seringe, Monogr. des céréales de la Suisse pg. 121. 1818. 
der Raum für eine Pflanze 100 q cm, die Blattoberfläche p. qm Bodenfläche $32.9 \mathrm{gm}$ und das Saatquantum $3 \mathrm{hl} \mathrm{p.} \mathrm{ha.}$

Es wiegen 100 Halme $475 \mathrm{gr}$ und davon die Veesen $280 \mathrm{gr}$.

In Holenheim ${ }^{1}$ ) stellte sich der vierjährige Durchschnittsertrag auf $1990 \mathrm{~kg}$ Kernen und $5501.5 \mathrm{~kg}$ Stroh p. ha.

In Poppelsdorf erwies sich diese Sorte als nicht winterfest, so erfror sie $1870 / 71$ fast vollständig, lagerte jedoch nicht und litt nur wenig durch Rost.

Der trockne, warme Boden scheint sich am besten für sie zu eiguen, doch ist ihr Anbau im Rückgange begriffen.

\section{Voegeles-Dinkel. (2)}

Aehre: fast weiss, für Spelz ziemlich dicht, sich verjüngend, an der Spitze kurz begrannt, lang; Aehrchen $0.8 \mathrm{~cm}$ breit, 2-körnig. - Stroh: graugelb oder rötlich-gelb, fest, blattreich, lang. - Frucht: rot, mittellang, schmal ( $7 \mathrm{~mm}$ lang, $3 \mathrm{~mm}$ breit), sehr feinschalig. $100 \mathrm{~kg}$ Veesen enthalten $76.5 \mathrm{~kg}$ Kernen.

Herbstblatt blaugrüin, schmal, kraus; Frühjahrsvegetation spät, Bestockung sehr stark, 7 Schösslinge, mittelfrüh schossend und bliilhend. Halnlänge $125 \mathrm{~cm}$ ( Max. $140 \mathrm{~cm}$ ), Halmdicke $0.37 \mathrm{~cm}$, Blattzahl 4, Blattlänge $25.85 \mathrm{~cm}$, Blattbreite $0.92 \mathrm{~cm}$, Blattoberfläche $190.24 \mathrm{qcm}$, Halmfläche 138.75 q cm, Gesanmtfläche 328.99 qcm.

Junge Aehre blaugrün, mittelfrüh reifend, $12 \mathrm{~cm}$ (Max. $17 \mathrm{~cm}$ ) lang, mit 19 Veesen und 40 Kernen, von denen $1 \mathrm{hl}(=48.3 \mathrm{~kg}$ ) 483000 Veesen oder 893550 Kernen enthält.

Auf $1 \mathrm{qm}$ wachsen 1000 Halme oder 143 Pflanzen, mithin beträgt der Raum für eine Pflanze $70 \mathrm{qcm}$, die Blattoberfläche p. qm Bodenfläche $32.9 \mathrm{qm}$ und das Saatquantum $2.4 \mathrm{hl}$ p. ha.

Im Jahre 1836 fand A. Münchenmaier aus Hengenberg in einem Weinberge des Neckarthales eine einzelne schöne Dinkelpflanze, welche er unter dem Namen "Voegeles-Dinkel" weiter kultivierte, indem er annahm, nur Vögel könnten den Samen in den Weinberg gcbracht haben. Durch seine Ergiebigkeit und vorzïgliche Qualitït des IIehles hatte er seit 1840 im Neckarthale eine sehr weite Verbreitung erlangt, doch ist seine Kultur in neuerer Zeit nahezu verschwunden.

Dieser Spelz lagert nur ausnahmsweise, befällt jedoch, wenn auch nicht hochgradig, mit Rost.

\section{Varietät: Triticum Spelta rufum Al. \\ Aelıre kalıl, rot.}

\section{Sorten:}

\section{Roter Winter-Kolbenspelz. (2)}

Franz.: Épeautre sans barbes rousse et glabre; Épeautre blond.

Aehre: rot, sehr locker, sehr lang, schmal, Spindel ziemlich zähe; Aehrchen $0.9 \mathrm{~cm}$ breit, 2-körnig. - Stroh: rötlich-gelb, hohl, lang. Frucht: hellbraun, glasig, lang, schmal ( $8 \mathrm{~mm}$ lang, $3 \frac{1}{2} \mathrm{~mm}$ breit), fein-

1) Wochenbl. f. Land- u. Forstw. Württemberg. No. 11. 1876. 
schalig. $100 \mathrm{gr}$ Veesen enthalten $72.5 \mathrm{gr}$ Kernen; 185 Kernen wiegen 10 gr.

Herbstblatt blaugrün, schmal, kraus; Frïhjahrsvegetation sehr spät, Bestockung sehr stark, 5.6 Schösslinge, spät schossend und bliihend. Halmlänge $125 \mathrm{~cm}$ (Max. $150 \mathrm{~cm}$ ), Halmdicke $0.42 \mathrm{~cm}$, Blattzahl 4, Blattlänge $29.15 \mathrm{~cm}$, Blattbreite $0.93 \mathrm{~cm}$, Blattoberfläche $216.88 \mathrm{qcm}$, Halmfläche $157.5 \mathrm{qcm}$, Gesammtfläche $374.38 \mathrm{qcm}$.

Junge Aehre blaugrün, einige Tage später als der weisse Winterkolbenspelz reifend, $15 \mathrm{~cm}$ (Max. $17 \mathrm{~cm}$ ) lang, mit 19 Veesen und 35 Kernen. Es enthält $1 \mathrm{hl}(=49 \mathrm{~kg}) 343000$ Veesen und darin 583100 Kernen.

Auf $1 \mathrm{qm}$ wachsen 850 Halme oder 150 Pflanzen, mithin beträgt der Raum für eine Pflanze $66.6 \mathrm{qcm}$, die Blattfläche p. qm Bodenfläche $31.8 \mathrm{qm}$ und das Saatquantum ca. $4 \mathrm{hl} \mathrm{p}$. ha.

Es wiegen 100 Halme $465 \mathrm{gr}$ und davon die Veesen $232 \mathrm{gr}$.

Kulturbedingung und ökonomischer Wert stimmen mit dem beim weissen Winterkolbenspelz Gesagten nabezu überein.

In der Schweiz auf niedrigen Bergen kultiviert, z. B. am Züricher See, zeigt er sich kräftiger und liefert mehr Mehl als der weisse Kolbenspelz.

Auf feuchtem Boden in den Niederungen soll er nach Seringe leicht degenerieren.

$\mathrm{Da}$ er vollkommen winterfest, ertragreich und nur auf reichem Boden lagert, so baut man ihn vielfach in Süd-Deutschland an.

\section{Roter Sommer-Kolbenspelz. $\odot$}

Aehre: rosenrot, locker, leicht zerbrechlich, schmal, lang; Aehrehen $0.7 \mathrm{~cm}$ breit, 2-körnig. - - Stroh: graugelb, hohl, dünnhalmig, lang. Frucht: hellbraun, glasig, schmal, lang ( $8 \mathrm{~mm}$ lang, $3 \mathrm{~mm}$ breit), schwer, feinsehalig. Es enthalten $100 \mathrm{gr}$ Veesen $74.75 \mathrm{gr}$ Kernen.

Junges Blatt dunkelgriin, schmal, lang; Bestockung stark, 4 Schösslinge, spät schossend und blühend. Halmlänge $120 \mathrm{~cm}$ (Max. $145 \mathrm{~cm}$ ), Halmdicke $0.33 \mathrm{~cm}$, Blattzahl 4, Blattlänge $24.75 \mathrm{~cm}$, Blattbreite $0.93 \mathrm{~cm}$, Blattoberfläche $184.16 \mathrm{qcm}$, Halmfläche $118.8 \mathrm{qcm}$, Gesammtfläche $302.96 \mathrm{qcm}$.

Junge Aehre blaugrïn, $12 \mathrm{~cm}$ (Max. $16 \mathrm{~cm}$ ) lang, in 126 Tagen und zwar 10 Tage später als der rote Winterkolbenspelz reifend, mit 18 Veesen und 35 Kernen. Es enthält $1 \mathrm{hl}(=53.7 \mathrm{~kg}) 483300$ Veesen und 966600 Kernen.

Auf $1 \mathrm{qm}$ wachsen 1000 Halme oder 250 Pflanzen, mithin beträgt der Raum für eine Pflanze $40 \mathrm{qcm}$, die Blattoberfläche p. qm Bodenfläche $30.3 \mathrm{qm}$ und das Saatquantum $4 \mathrm{hl}$ p. ha.

Dieser Spelz lagert nicht leicht und widersteht dem Rost.

Es wiegen 100 Halme $468 \mathrm{gr}$ und davon die Veesen $221 \mathrm{gr}$.

\section{Varietät: Triticum Spelta Alefeldii Keke.}

Aehre sammetig, graublau.

Sorte:

Blauer Winter-Kolbenspelz. (2)

I ta l.: Grano rosso.

Aehre: graublau, sammetig, locker, Sdpinel leicht zerbrechlich, 
schmal, lang; Aehrchen $0.8 \mathrm{~cm}$ breit, 2-körnig. - Stroh: gelbgrau oder gelb, hohl, sehr lang, fest. - Frucht: hellbraun, glasig, lang, schmal $(8 \mathrm{~mm}$ lang, $31 / 2 \mathrm{~mm}$ breit), feinschalig; $100 \mathrm{gr}$ Veesen enthalten $74 \mathrm{gr}$ Kernen.

Herbstblatt blaugrün, schmal, kraus; Frühjahrsvegetation spät, Bestockung stark, 5 Schösslinge, mittelfrüh schossend und blühend. Halmlänge $135 \mathrm{~cm}$ (Max. $145 \mathrm{~cm}$ ), Halmdicke $0.35 \mathrm{~cm}$, Blattzahl 3.7 , Blattlänge $24.25 \mathrm{~cm}$, Blattbreite $0.84 \mathrm{~cm}$, Blattoberfläche $150.74 \mathrm{qcm}$, Halmfläche $141.75 \mathrm{qcm}$, Gesammtfläche $292.49 \mathrm{q} \mathrm{cm}$.

Junge Aehre gelblich-grün, ziemlich zeitig reifend, mit 16 Veesen und 30 Kernen, $10 \mathrm{~cm}$ (Max. $15 \mathrm{~cm})$ lang. Es enthält $1 \mathrm{hl}(=46 \mathrm{~kg})$ 345000 Veesen und darin 667000 Kcrnen.

Auf $1 \mathrm{qm}$ wachsen 900 Halme oder 180 Pflanzen, mithin beträgt der Raum für eine Pflanze 55.5 qcm, die Blattoberfläche p. qm Bodenfläche $26.3 \mathrm{qm}$ und das Saatquantum $4 \mathrm{hl}$ p. ha.

Es wiegen 100 Halme $295 \mathrm{gr}$ und davon die Veesen $168 \mathrm{gr}$.

Dieser Spelz lagert nicht leicht und befällt wenig mit Rost, doch ist er nicht ganz winterfest und auch sein ökonomischer Wert soll hinter dem des roten und weissen Spelzes zurückstehen, indem der Mehlertrag geringer ist.

Wird vielfach in Italien kultiviert.

\section{B. Grannenspelz.}

Varietät: Triticum Spelta Arduinii Al.

Aehre kahl, weiss.

\section{Sorten:}

\section{Weisser Winter-Grannenspelz. (2)}

Franz.: Épeautre ordinaire blanche barbue.

I tal.: Farro bianco a spigarada.

Aehre: fast weiss, locker, sich nach der Spitze verjüngend, schlaff, lang; Aehrchen oval, platt, $0.9 \mathrm{~cm}$ breit, 2-, zuweilen 3-körnig, 2-grannig; Grannen hell, rauh, zugespitzt, gespreizt. - Stroh: gelb, hohl, dünnhalmig, fest, ziemlich lang. - Frucht: hellbraun, glasig, nach Metz ger ${ }^{1}$ ) mehr mehlig als glasig, sehr lang, schmal (10 mm lang, $4 \mathrm{~mm}$ breit, 187 Kernen $=10 \mathrm{gr}$ ), feinschalig. Es enthalten $100 \mathrm{gr}$ Veesen $77 \mathrm{gr}$ Kernen.

Herbstblatt blaugrün, schmal, kraus; Frühjahrsvegetation spät, Halmblätter kahl, Bestockung seh» stark, 5.6 Schösslinge, mittelfrüh schossend, zeitig blühend. Halmlänge $115 \mathrm{~cm}$ (Max. $135 \mathrm{~cm}$ ), Halmdicke $0.33 \mathrm{~cm}$. Blattzahl 4, Blattlängc $24 \mathrm{~cm}$, Blattureite $0.86 \mathrm{~cm}$, Blattoberfläche $165.12 \mathrm{qcm}$, Halmfläche $113.85 \mathrm{qcm}$, Gesammtfläche $278.97 \mathrm{qcm}$.

Junge Aehre bläulich-grün, zeitig reifend, $11 \mathrm{~cm}$ (Max. $15 \mathrm{~cm}$ ) lang, mit 20 Veesen und 40 Kernen. Es enthält $1 \mathrm{hl}(=49 \mathrm{~kg}) 465500$ Veesen und darin 684285 Kernen.

Auf $1 \mathrm{qm}$ wachsen 1100 Halme oder 200 Pflanzen, mithin beträgt

1) Metzger, Cerealien pg. 26. 
der Raum für eine Pflanze $50 \mathrm{qcm}$, die Blattoberfläche p. qm Bodenfläche $30.7 \mathrm{qm}$ und das Saatquantum $4.4 \mathrm{hl}$ p. ha.

Dieser Spelz ist vollkommen winterfest und lagert nicht leicht.

Er wird in Sïd-Deutschland, Frankreich, der Schweiz, Italien und Spanien gebaut, wenn auch nicht in dem gleichen Umfange, wie der weisse Kolbenspelz, da er geringere Erträge bringt.

Wagin ${ }^{1}$ ) hält ihn für die Stammform des Spelzes. Andrée Michaux fand einen wildwachsenden Spelz in der Gegend von Hamadan in Persien und Metzger glaubt, dass dies der weisse Wintergrannenspelz gewesen sei.

\section{Weisser Sommer-Grannenspelz. $\odot$}

Aehre: blassgelb, locker, Spindel sehr leicht brechend, schmal, lang; Aehrchen $0.8 \mathrm{~cm}$ breit, 2-körnig, 2-grannig; Grannen hell, 7-8 cm lang. - Stroh: blassgelb, hohl, mittellang. - Frucht: hellrot, glasig, schmal, lang ( $8 \mathrm{~mm}$ lang, $3 \mathrm{~mm}$ breit), feinschalig. Es enthalten $100 \mathrm{gr}$ Veesen 76.5 gr Kernen.

Junges Blatt dunkelgrün, Bestockung ziemlich stark, 3.3 Schösslinge. Halmlänge $100 \mathrm{~cm}$ (Max. $117 \mathrm{~cm}$ ), Halmdicke $0.37 \mathrm{~cm}$, Blattzahl 3, Blattlänge $27 \mathrm{~cm}$, Blattbreite $1 \mathrm{~cm}$, Blattoberfläche $162 \mathrm{qcm}$, Halmfläche $111 \mathrm{qcm}$, Gesammtfläche $273 \mathrm{qcm}$.

Junge Aehre blaugriin, 12 Tage später als der Wintergrannenspelz und zwar in 120 Tagen reifend, $12 \mathrm{~cm}$ (Max. $15 \mathrm{~cm}$ ) lang: mit 18 Veesen und 35 Kernen. Kernen.

Es enthält $1 \mathrm{hl}(=47.4 \mathrm{~kg}) 308000$ Veesen und darin 616000

Auf $1 \mathrm{qm}$ wachsen 1100 Halme oder 333 Pflanzen, mithin beträgt der Raum für eine Pflanze $30 \mathrm{qcm}$, die Blattoberfläche p. qm Bodenfläche $30 \mathrm{qm}$ und das Saatquantum $8 \mathrm{hl} \mathrm{p.} \mathrm{ha.}$

Es wiegen 100 Halme $308 \mathrm{gr}$ und davon die Veesen $167 \mathrm{gr}$.

Diese Spelzsorte lagert nicht leicht und widersteht dem Rost. gemein.

Sie hat den Verbreitungsbezirk mit dem weissen Wintergrannenspelz

\section{Varietät: Triticum·Spelta vulpinum Al. \\ Aehre kahl, rot.}

\section{Sorte:}

\section{Roter kahler Wintergrannen- oder Fuchsspelz. (2)}

Franz: Épeautre rouge barbu.

Aehre: blassrot, locker, schmal, lang; Aehrchen $0.9 \mathrm{~cm}$ breit, 2-körnig, untere Aehrchen oft hoch hinauf verkümmert; Grannen blassrot, 7-8 cm lang. - Stroh: rötlich-gelb, hohl, dünnwandig, weich, lang. Frucht: blassrot, lang, schmal ( $8 \mathrm{~mm}$ lang, $3 \frac{1}{2} \mathrm{~mm}$ breit), feinschalig. Es enthalten $100 \mathrm{~kg}$ Veesen $79.92 \mathrm{~kg}$ Kernen und $20.08 \mathrm{~kg}$ Spelzen.

Herbstblatt blaugrün, lang, schmal; Frühjahrsvegetation mittelfrüh, Bestockung sehr stark, 5.3 Schösslinge, mittelfrüh schossend und bliihend; Halmblätter kahl. Halmlänge $130 \mathrm{~cm}$ (Max. $150 \mathrm{~cm}$ ), Halmdicke $0.34 \mathrm{~cm}$, 
Blattzahl 3, Blattlänge $20.2 \mathrm{~cm}$, Blattbreite $0.85 \mathrm{~cm}$, Blattoberfläche $103.02 \mathrm{qcm}$, Halmfläche $132.6 \mathrm{qcm}$, Gesammtfläche $235.62 \mathrm{qcm}$.

Junge Aehre gelblich-grün, etwas spät reifend, $12 \mathrm{~cm}$ (Мax. $17 \mathrm{~cm}$ ) lang, mit 21 Veesen und 40 Kernen. Es enthält $1 \mathrm{hl}(=49.6 \mathrm{~kg}) 347000$ Veesen und 743000 Kernen.

Auf 1 qm wachsen 1100 Halme oder 200 Pflanzen, mithin beträgt der Raum für eine Pflanze $50 \mathrm{qcm}$, die Blattoberfläche p. qm Bodenfläche $26 \mathrm{qm}$ und das Saatquantum $4 \mathrm{hl}$ p. ha. Es wiegen 100 Halme $490 \mathrm{gr}$ und davon die Veesen $260 \mathrm{gr}$.

Dieser Grannenspelz ist vollkommen winterfest, lagert jedoch leicht auf reichem Boden und leidet stark durch Rost.

Im Ertrag steht er den meisten Kolbenspelzen nach, doch scheint er sich für leichten Boden und rauhe Lagen vertrefflich zu eignen.

\section{DunkeIroter Winter-Grannenspelz. (2)}

Aehre: rotbraun, schmal, locker, lang; Aehrchen $0.9 \mathrm{~cm}$ breit, 2-körnig; Grannen rot, $7-8 \mathrm{~cm}$ lang. - Stroh: gelb, hohl, mittellang. Frucht: hellbraun, glasig, schmal, sehr lang (9 mm lang, $3 \frac{1}{2} \mathrm{~mm}$ breit), feinschalig. $100 \mathrm{gr}$ Veesen enthalten $63.5 \mathrm{gr}$ Kernen.

Herbstblatt gelbgrün, breit, aufrecht; Frühjahrsvegetation zeitig, Bestockung mittelstark, 3.8 Schösslinge, mittelfrüh schossend und blühend. Halmlänge $110 \mathrm{~cm}$ (Max. $120 \mathrm{~cm}$ ), Halmdicke $0.37 \mathrm{~cm}$, Blattzahl 4.4, Blattlänge $28.5 \mathrm{~cm}$, Blattbreite $1.1 \mathrm{~cm}$, Blattoberfiäche $275.88 \mathrm{qcm}$, Halmfäche $122.10 \mathrm{qcm}$, Gesanımtfäche $397.98 \mathrm{qcm}$.

Junge Aehre blaugrïn, etwas spät reifend, $12 \mathrm{~cm}$ (Max. $16 \mathrm{~cm}$ ) lang, mit 18 Veesen und 35 Kernen. Es enthält $1 \mathrm{hl}(=47 \mathrm{gr})+70000$ Veesen und darin 893.000 Kernen.

Es wachsen auf 1 qm 800 Halme oder 210 Pflanzen, mithin beträgt der Raum für eine Pflanze $48 \mathrm{qcm}$, die Blattoberfläche p. qm Bodenfläche $31.8 \mathrm{qm}$ und das Saatquantum $3.5 \mathrm{hl}$ p. ha.

Dieser Spelz lagert selten, befällt wenig mit Rost und ist winterfest.

\section{Varietät: Triticum Spelta albovelutinum Kcke.}

Aehre sammetig, weiss.

\section{Sorte:}

\section{Weisser sammetiger Wintergrannenspelz. (2)}

Franz.: Épeautre barbu, blanc et velouté.

Aehre: fast weiss, oft schwach hellblau, sammetig, locker, sehr lang, schmal, Spiudel ziemlich zähe; Aehrchen $0.8 \mathrm{~cm}$ breit, 2-körnig; Grannen hell, kurz, 7-8 cm lang. - Stroh: rötlich-gelb, hohl, doch derbwandig, fest, sehr lang. - Frucht: rot, mehlig, lang, schmal (8 mm lang, $3 \mathrm{~mm}$ breit), feinschalig. $100 \mathrm{~kg}$ enthalten $76.66 \mathrm{~kg}$ Kernen.

Herbstblatt blaugrün, schmal, ziemlich aufrecht; Frühjhrsvegetation ziemlich zeitig, Bestockung mittelstark, 3.4 Schösslinge, Blätter am Halm ziemlich breit, oberseits selır schwach behaart, unterseits kahl, mittelfriih schossend und blïhend. Halmlänge $140 \mathrm{~cm}$ (Max. $150 \mathrm{~cm}$ ), Halmdicke $0.4 \mathrm{~cm}$, Blattzahl 3, Blattlänge $25.97 \mathrm{~cm}$, Blattbreite $1.12 \mathrm{~cm}$, Blattoberfläche 174.54 qcm, Halmfläche 168 qcm, Gesammtfläche 342.54 qcm. 
Junge Aehre blaugrün, mittelfrüh reifend, $15 \mathrm{~cm}$ (Max. 20 cm) lang, mit 21 Veesen und 40 Kernen. Es enthält $1 \mathrm{hl}(=42.7 \mathrm{~kg}) 354000$ Veesen und 637000 Kernen.

Auf $1 \mathrm{qm}$ wachsen 850 Halme oder 250 Pflanzen, mithin beträgt der Raum für eine Pflanze $40 \mathrm{qcm}$, die Blattoberfläche p. qm Bodenfläche $29.1 \mathrm{qm}$ und das Saatquantum $6 \mathrm{hl} \mathrm{p}$. ha.

Diese Sorte lagert nicht leicht und leidet wenig durch Rost.

\section{Varietät: Triticum Spelta rubrovelutinum Kcke.}

Aehre sammetig, rot.

\section{Sorten:}

\section{Rötlicher, sammetiger Winter-Grannenspelz. (2)}

Aehre: blassrot mit bläulichem Anflug, sammetig, für Spelz ziemlich dicht, Spindel ziemlich zähe, schmal, lang; Aehrchen $0.8 \mathrm{~cm}$ breit, 2-körnig; Grannen blassrot, zähe, $7-8 \mathrm{~cm}$ lang. - Stroh: rötlich-gelb, holll, kräftig, mittellang. - Frucht: hellbraun, glasig, lang, schmal ( $8 \mathrm{~mm}$ lang, $3 \mathrm{~mm}$ breit), feinschalig. $100 \mathrm{gr}$ Veesen enthalten $76.66 \mathrm{gr}$ Kernen.

Herbstblatt blaugrün, schmal, kraus, Frühjahrsvegetation zeitig, Halmblätter beiderseits schwach behaart, Bestockung mittelstark, 4.1 Schösslinge, zeitig schossend und blühend. Halmlänge $115 \mathrm{~cm}$ (Max. $130 \mathrm{~cm}$ ), Halmdicke $0.4 \mathrm{~cm}$, Blattzahl 4, Blattlänge $24.6 \mathrm{~cm}$, Blattbreite $0.92 \mathrm{~cm}$, Blattoberfläche $181.04 \mathrm{qcm}$, Halmfliche $138 \mathrm{qcm}$, Gesammtfläche $319.04 \mathrm{qcm}$.

Junge Aehre blaugrün, zeitig reifend, $11 \mathrm{~cm}$ (Max. $14 \mathrm{~cm}$ ) lang, mit 24 Veesen und 45 Kernen. Es enthält $1 \mathrm{hl}(==49 \mathrm{~kg}) 456000$ Veesen und 766000 Kernen.

Auf 1 qm wachsen 850 Halme oder 207 Pflanzen, mithin beträgt der Raum für eine Pflanze $48.3 \mathrm{qcm}$, die Blattfläche p. qm Bodenfläche $27 \mathrm{qm}$, und das Saatquantum $4 \mathrm{hl}$ p. ha.

Dieser Spelz ist winterfest, ertragreich und lagert nicht leicht.

\section{Rötlicher, sammetiger Sommer-Grammenspelz.}

Syn.: Triticum pretiosum Jessen, h. Dresden 1872.

Aehre: blassrot, kurz behaart, sehr lang, sich nach der Spitze verjüngend, Spindel nicht leicht zerbrechlich, locker; Aehrchen $1 \mathrm{~cm}$ breit, häufig 3-körnig und 3-grannig; Grannen blassrot, gespreizt, bis $9 \mathrm{~cm}$ lang. - Stroh: rötlich-gelb, sehr kräftig, fest, mittellang. - Frucht: hellrot, glasig, sehr lang (9 mml lang, $4 \mathrm{~mm}$ breit), feinschalig. $100 \mathrm{gr}$ Veesen enthalten $75 \mathrm{gr}$ Kernen.

Halme dunkelgrün, 3.0 Schösslinge, Halmlänge $115 \mathrm{~cm}$ (Max. $130 \mathrm{~cm}$ ), Halmdicke $0.4 \mathrm{~cm}$, Blattzahl 4, Blattlänge $31 \mathrm{~cm}$, Blattbreite $0.98 \mathrm{~cm}$, Blattoberfläche $243.04 \mathrm{qcm}$, Halmfläche $138 \mathrm{qcm}$, Gesammtfläche $381.04 \mathrm{qcm}$.

Aehre reift mittelfrüh, in 130 Tagen, $14 \mathrm{~cm}$ (Max. $18 \mathrm{~cm}$ ) lang, mit 20 Veesen oder 50 Kernen. Es enthält $1 \mathrm{hl}(==46.7 \mathrm{~kg}) 257000$ Veesen und 631000 Kernen.

Es wachsen auf 1 qcm 900 Halme oder 300 Pflanzen, mithin be- 
trägt der Raum für eine Pflanze $33.3 \mathrm{qcm}$, die Blattoberfläche $\mathrm{p} . \mathrm{qm}$ Bodenfläche $34.3 \mathrm{qm}$ und das Saatquantum $7 \mathrm{hl} \mathrm{p}$. ha.

Es wiegen 100 Halme $468 \mathrm{gr}$ und davon die Veesen $244 \mathrm{gr}$.

Dieser Spelz lagert nicht leicht.

\section{Roter, sammetiger Winter-Grannenspelz. (2)}

Aebre: bläulich-rot, schwach sammetig, locker, lang; Aehrchen $0.9 \mathrm{~cm}$ breit, 2-körnig. - Stroh: goldgelb, fest, lang. - Frucht: blassrot, glasig, gross und lang ( $8 \mathrm{~mm}$ lang, $4 \mathrm{~mm}$ breit), feinschalig. Es enthalten 100 gr Veesen 76.5 gr Kernen.

Herbstblatt blaugrün, schmal, aufrecht; Frühjahrsvegetation zeitig, Bestockung mittelstark, 3.5 Schösslinge, zeitig schossend und blühend. Halmlänge $120 \mathrm{~cm}$ (Max. $140 \mathrm{~cm}$ ), Halmdicke $0.43 \mathrm{~cm}$, Blattzahl 3, Blattlänge $28 \mathrm{~cm}$, Blattbreite $1.08 \mathrm{~cm}$, Blattoberfläche $181.44 \mathrm{qcm}$, Halmfläche $154.8 \mathrm{qcm}$, Gesammtfläche $336.24 \mathrm{qcm}$.

Junge Aebre blaugrün, $12 \mathrm{~cm}$ (Max. $15 \mathrm{~cm}$ ) lang, zeitig reifend, mit 19 Veesen und 36 Kernen. Es enthält $1 \mathrm{hl}(=49.5 \mathrm{~kg}) 317000$ Veesen und darin 719000 Kernen.

Auf $1 \mathrm{qm}$ wachsen 800 Halme oder 230 Pflanzen, mithin beträgt der Raum für eine Pflanze $43.5 \mathrm{qcm}$, die Blattoberfläche p. qm Bodenfläche $26.9 \mathrm{qm}$, und das Saatquantum $4.8 \mathrm{hl} \mathrm{p}$. ha.

Diese Sorte lagert nicht leicht, ist winterfest, widersteht dem Rost vortrefflich, und die Aehrenspindeln brechen bei Wind nicht leicht $a b$. Im Frühjahr kultiviert, erwies sie sich als echte Winterfrucht.

\section{Varietät: Triticum Spelta coeruleum Al.}

Aehre sammetig, blau.

\section{Sorte :}

\section{Blauer sammetiger Grannenspelz. $\odot$ u. (2)}

Syn.: Schwarzer Grannenspelz, Metzger ${ }^{1}$ ), Triticum pruinosum $h$. Dresden, 1872.

Franz.: Épeautre noire barbue, ou Épeautre barbue bleue et veloutée.

Aehre: blauschwarz, dunkel bereift, schwach-sammetig, sich nach der Spitze verjüngend, locker, Spindel ziemlich zähe, dünn, sehr lang; Aehrchen 0,9 cm breit, meist 3-körnig und 3-grannig; Grannen graulich, leicht zerbrechlich, bis $8 \mathrm{~cm}$ lang. - Stroh: blassgelb, kräftig, fest, mittellang. - Frucht: hellrot, glasig, etwas eingefallen, gross $(9 \mathrm{~mm}$ lang, $4 \mathrm{~mm}$ breit), feinschalig. $100 \mathrm{gr}$. Veesen des Sommerspelzes enthalten $74 \mathrm{gr}$ Kernen.

Herbstblatt blaugrün, breit, aufrecht; Frühjahrsvegetation zeitig, Bestockung schwach, 3.4 Schösslinge, beim Sommerspelz 3 Schōsslinge. Sommer- und Winterfrucht zeigten folgenden Habitus:

1) Cerealien pg. 28,1824 . 


\begin{tabular}{|c|c|c|}
\hline & Winterfrucht & Sommerfrucht \\
\hline $\begin{array}{l}\text { Halmlänge } \\
\text { Halmdicke } \\
\text { Blattzahl } \\
\text { Blattlänge } \\
\text { Blattbreite } \\
\text { Blattoberfläche } \\
\text { Halmfläche } \\
\text { Gesammtfäche } \\
\text { Aehrenlänge } \\
\text { Anzahl der Veesen in } \\
\text { einer Aehre } \\
\text { Anzahl der Kernen } \\
\text { Hektolitergewicht der } \\
\text { Veesen } \\
\text { Anzahl der Veesen in } 1 \mathrm{hl} \\
\quad \text { ", Kernen in } 1 \mathrm{hl}\end{array}$ & $\begin{array}{c}110 \mathrm{~cm}(\text { Max. } 125 \mathrm{~cm}) \\
0.43 \mathrm{~cm} \\
4 \\
29.5 \mathrm{~cm} \\
0.99 \mathrm{~cm} \\
233.68 \mathrm{qcm} \\
141.9 \mathrm{qcm} \\
375.58 \mathrm{qcm} \\
15 \mathrm{~cm} \mathrm{(Max.18} \mathrm{cm}) \\
23 \\
50 \\
47 \mathrm{~kg} \\
329000 \\
611000\end{array}$ & $\begin{array}{c}130 \mathrm{~cm} \text { (Max. } 145 \mathrm{~cm}) \\
0.38 \mathrm{~cm} \\
3.7 \\
26.3 \mathrm{~cm} \\
0.91 \mathrm{~cm} \\
177.08 \mathrm{qcm} \\
148.20 \mathrm{qcm} \\
325.28 \mathrm{qcm} \\
11 \mathrm{~cm}(\text { Max. } 16 \mathrm{~cm} \\
- \\
- \\
- \\
-\end{array}$ \\
\hline
\end{tabular}

Dieser Spelz blühte als Sommerfrucht von allen Spelzen am zeitigsten. Die junge Aehre ist blaugrün und reifte zeitig, nämlich in 125 Tagen.

Es wachsen 800 Halme oder 267 Pflanzen auf 1 qm, mithin beträgt der Raum für eine Pflanze $38 \mathrm{qcm}$, die Blattoberfläche $\mathrm{p} . \mathrm{qm}$ Bodenfläche $30 \mathrm{qm}$ und das Saatquantum $6.5 \mathrm{hl} \mathrm{p}$. ha. $282 \mathrm{gr}$.

Es wiegen 100 Halme Sommerspelz $600 \mathrm{gr}$ und davon die Veesen

\title{
Unterart: 6. Triticum dicoceum Schr. Emmer.
}

\author{
A. Aehren einfach. \\ Varietät: Triticum dicoccum farrum Bayle. \\ Aehre kahl, weiss. \\ Sorten: \\ Weisser Emmer. (2) u. $\odot$
}

Franz: Amidonnier blanc, Épeautre de Mars, Épeautre dı Cap d'hiver, Amidonnier de Tartarie.

Aehre: gelblich-weiss, regelmässig, platt, ziemlich dicht, lang; Aehrchen $0.8 \mathrm{~cm}$ breit, 2-körnig, 2-grannig; Spindel sehr leicht zerbrechlich; 
Grannen fast weiss, leicht abbrechend, bis $8 \mathrm{~cm}$ lang. - Stroh: fast weiss, sehr schön, derbwandig, fest. - Frucht: rot, glasig, dreikantig, länglich, klein ( $7 \mathrm{~mm}$ lang, $3 \mathrm{~mm}$ breit, 290 Früchte $=10 \mathrm{gr}$ ), feinschalig. Es enthalten $100 \mathrm{gr}$ Veesen $74 \mathrm{gr}$ Kernen.

Herbstblatt blaugrün, stark sammetig, schmal, aufrecht, Frühjahrsentwickelung zeitig, ebenso zeitig schossend, blühend und reifend.

Die Wachstumsverhältnisse der Sommer- und Wintersaat gestalteten sich wie folgt:

\begin{tabular}{|c|c|c|}
\hline & Winters & Sommersaat \\
\hline $\begin{array}{l}\text { Halmlänge } \\
\text { Halmdicke } \\
\text { Blattzahl } \\
\text { Blattlänge } \\
\text { Blattbreite } \\
\text { Blattoberfläche } \\
\text { Halmfläche } \\
\text { Gesammtfläche } \\
\text { Aehrenlänge } \\
\text { Anzahl der Veesen in einer Aehre } \\
\text { Anzahl der Halme pro qm } \\
\quad \text { " " Pflanzen," "Shösslinge pro Pflanze } \\
\text { Raum pro Pflanze } \\
1 \text { hl à } 42 \text { kg = } \\
\text { Saatquantum pro ha }\end{array}$ & $\begin{array}{c}110 \mathrm{~cm} \text { (Max. } 130 \mathrm{~cm}) \\
0.44 \mathrm{~cm} \\
3.3 \\
25.4 \mathrm{~cm} \\
1.02 \mathrm{~cm} \\
161.01 \mathrm{qcm} \\
145.3 \mathrm{qcm} \\
316.21 \mathrm{~cm} \\
10 \mathrm{~cm} \text { (Max. } 13 \mathrm{~cm}) \\
24 \text { Veesen und } \\
45 \text { Kernen } \\
850 \\
274 \\
3.1 \\
36.5 \mathrm{qcm} \\
650000 \text { Vesen, } \\
1118000 \text { Kernen } \\
3.7 \mathrm{hl}\end{array}$ & \begin{tabular}{|c}
$125 \mathrm{~cm}$ ( Max. $145 \mathrm{~cm})$ \\
$0.33 \mathrm{~cm}$ \\
4 \\
$25.5 \mathrm{~cm}$ \\
$1.05 \mathrm{~cm}$ \\
$214.2 \mathrm{qcm}$ \\
$142.5 \mathrm{qcm}$ \\
$356.7 \mathrm{qcm}$ \\
$10 \mathrm{~cm}$ (Max. $12 \mathrm{~cm})$ \\
24 Veesen und \\
45 Kernen \\
850 \\
315 \\
2.7 \\
$31.1 \mathrm{qcm}$ \\
- \\
$4 \mathrm{hl}$
\end{tabular} \\
\hline
\end{tabular}

Es wiegen 100 Halme der Sommerfrucht $600 \mathrm{gr}$ und davon die $\nabla$ eesen $321 \mathrm{gr}$.

Dieser Emmer lagert nicht leicht, ist jedoch weichlich, so winterte derselbe 1870/71 vollständig aus. Er eignet sich für leichtes, bergiges Land und wird viel in Baden und im Elsass gebaut.

\section{Reisdinkel. $\odot$ u. (2)}

Identisch: Épeautre double, Épeautre commune.

Aehre: fast weiss, ziemlich dicht, Spindel sehr Jeicht zerbrechlich, schmal, lang; Achrchen $1.2 \mathrm{~cm}$ breit, 2-körnig, 2-grannig, Klappenkiel in einen gebogenen Zahn ausgehend; Grannen fast weiss, in Vollreife leicht abbrechend, bis $10 \mathrm{~cm}$ lang. - Stroh: rötlich-gelb, sehr kräftig, hohl, derbwandig, fest, mittellang. - Frucht: rot, glasig, dreikantig, sehr lang, schmal, $10 \mathrm{~mm}$ lang, $3 \mathrm{~mm}$ breit, feinschalig. $100 \mathrm{gr}$ Veesen enthalten 77.5 gr Kernen.

Herbstblatt gelbgrün, lang, breit, kräftig. Bestockung schwach, 2.7 Schösslinge, Halmblätter sammetig; spät schossend, blühend und reifend. 


\begin{tabular}{|c|c|c|}
\hline & Sommersaat & Wintersaat \\
\hline $\begin{array}{l}\text { Halmlänge } \\
\text { Halmdicke } \\
\text { Blattzahl } \\
\text { Blattlänge } \\
\text { Blattbreite } \\
\text { Blattoberfläche } \\
\text { Halmfläche } \\
\text { Gesammtfläche } \\
\text { Aehrenlänge } \\
\text { Anzahl der Veesen in einer A ehre } \\
\text { Anzahl der Halme pro qm } \\
\text { ', " Pflanzen pro qm } \\
\text { Raun pro Pflanze } \\
\text { 1 hl à 47.3 kg enthält: } \\
\text { Saatquantum pro ha } \\
\text { 100 Halme wiegen } \\
\text { Davon die Veesen }\end{array}$ & \begin{tabular}{|c}
$110 \mathrm{~cm}(\mathrm{Max} .120 \mathrm{~cm})$ \\
$0.47 \mathrm{~cm}$ \\
4 \\
29.5 \\
$1.05 \mathrm{~cm}$ \\
$247.84 \mathrm{qcm}$ \\
$155.10 \mathrm{qcm}$ \\
$402.94 \mathrm{qcm}$ \\
$10 \mathrm{~cm}(\mathrm{M}$ \\
20 Veesen, \\
8 \\
3 \\
33.3 \\
591250 Veesen, \\
4 \\
54 \\
27
\end{tabular} & $\begin{array}{l}120 \mathrm{~cm}(\text { Max. } 145 \mathrm{~cm}) \\
0.38 \mathrm{~cm} \\
4.3 \\
24.8 \mathrm{~cm} \\
1.07 \mathrm{~cm} \\
265.36 \mathrm{qcm} \\
136.80 \mathrm{qcm} \\
402.16 \mathrm{qcm} \\
\text { Iax. } 12 \mathrm{~cm}) \\
40 \text { Kernen } \\
00 \\
00 \\
\text { qcm } \\
1135200 \text { Kernen } \\
\text { hl } \\
0 \mathrm{gr}\end{array}$ \\
\hline
\end{tabular}

Dieser vorzügliche, kräftige, ertragreiche Emmer erfordert eine zeitige Aussaat, liefert ein feines, weisses Mehl, lagert micht und widersteht dem Rost vorziiglich.

Die Erträge sollen sich in Schwaben auf $39-45 \mathrm{hl}$ p. ha belaufen. Metzger erntete 1823 nicht weniger als $44.2 \mathrm{hl}$ Kernen und $4380 \mathrm{~kg}$ Stroh und Spreu p. ha.

Sein Anbau ist vorzugsweise in Württemberg, der Schweiz, Frankreich, Italien und Oesterreich verbreitet.

Die beiden Sorten "Épeautre double et commune" erhielt L. Wittmack aus Aegypten, und sandte dieselben 1876 nach Poppelsdorf, wo sich ihre Identität mit dem Reisdinkel ergab.

Milde kalkreiche Lehmböden und warme Lagen sind für seinen Anbau am besten geeignet.

\section{Breitähriger Reisdinkel. $\odot$}

Franz.: Blé plat blanc, Blé de la Providence.

Aehre: fast weiss, dicht, breit und platt, gross; Aehrchen $1.3 \mathrm{~cm}$ breit, 2- zuweilen 3-körnig, 2-grannig; Spindel leicht zerbrechlich, in den Veesen sitzen viele Früchte sehr lose; Grannen fast weiss, in Vollreife leicht abbrechend, bis $11 \mathrm{~cm}$ lang. - Stroh: rötlich-gelb, mit markigem Innenrande, fest, mittellang. - Frucht: rot, glasig, dreikantig, lang, schmal (10 mm lang, $3 \frac{1}{2} \mathrm{~mm}$ breit), feinschalig. Es enthalten $100 \mathrm{gr} 78.35 \mathrm{gr}$ Kernen.

Halme blaugrün, Blätter beiderseits stark sammetig; Bestockung mittelstark, 3 Schösslinge, sehr spät schossend und blühend.

Halmlänge $100 \mathrm{~cm}$ (Max. $130 \mathrm{~cm}$ ), Halmdicke $0.37 \mathrm{~cm}$, Blattzahl 4, Blattlänge $24.5 \mathrm{~cm}$, Blattbreite $0.98 \mathrm{~cm}$, Blattoberfläche $192.08 \mathrm{qcm}$, Halmfläche $111 \mathrm{qcm}$, Gesammtfläche $303.08 \mathrm{qcm}$.

Junge Aehre blaugrün, sehr spät, in 135 Tagen, am spätesten von allen Dinkeln reifend, $10 \mathrm{~cm}$ (Max. $13 \mathrm{~cm}$ ) lang, mit 20 Veesen und 40 Kernen. Es enthält $1 \mathrm{hl}(=50.3 \mathrm{~kg}) 377250$ Veesen, 880250 Kernen. Es wachsen auf 1 qm 1000 Halme oder 333 Pflanzen, mithin be- 
trägt der Raum für eine Pflanze $30 \mathrm{qcm}$, die Blattoberfläche p. qm Bodenfläche $30.3 \mathrm{qm}$ und das Saatquantum $5.6 \mathrm{hl}$ p. ha.

Es wiegen 100 Halme $789 \mathrm{gr}$ und davon die Veesen $390 \mathrm{gr}$.

Dieser Emmer lagert nicht leicht, ist rostfrei und ertragreich, doch stellt er höhere Ansprüche an Boden und Klima, als der gewöhnliche Reisdinkel.

\section{Weisser Emmer (Krupnic) aus Serbien. $\odot$}

Aehre: blassgelb, dünn, schmal; Aehrchen $0.6 \mathrm{~cm}$ breit, 2-körnig, Mittelzahn der Klappen ganz kurz, stumpflich, also anders als bei Trit. dic. farrum, die obere Klappe des Endährchens zweispitzig; Aehrchenspindel kahl, an der Basis der Klappen und zwischen ihnen nur wenige kurze Härchen; Grannen hell, bis $12 \mathrm{~cm}$ lang, aufrecht; Grannen und Spindel leicht zerbrechlich. - Stroh: gelb, feinhalmig, Innenrand markig, kaum mittellang. - Frucht: hellrot, glasig, länglich $(8 \mathrm{~mm}$ lang, $3 \mathrm{~mm}$ breit), Veesen $13 \mathrm{~mm}$ lang, $61 / 2 \mathrm{~mm}$ breit, enthalten $78 \%$ Kernen.

Junges Blatt blaugrün, stark sammetig, mit einzelnen etwas längeren Haaren; 2.2 Schösslinge, mittelfrüh schossend und bliihend. Halme $95 \mathrm{~cm}$ (Max. $110 \mathrm{~cm}$ ) lang, $0.3 \mathrm{~cm}$ dick, Blattzahl 3.9 , Blätter $19.5 \mathrm{~cm}$ lang, $0.6 \mathrm{~cm}$ breit, Blattfläche $91.26 \mathrm{qcm}$, Halmfläche $85.5 \mathrm{qcm}$, Gesammtfläche $176.76 \mathrm{qcm}$.

Aehre reift in 123 Tagen, $6.5 \mathrm{~cm}$ (Max. $7.5 \mathrm{~cm}$ ) lang, mit 15 Veesen und 29 Früchten. Von den Veesen wiegt $1 \mathrm{hl}=52.5 \mathrm{~kg}$ und enthält 732000 Veesen oder 1415000 Früchte.

Es wiegen 100 Halme $190 \mathrm{gr}$ und davon die Früchte $111 \mathrm{gr}$.

Durch Professor Pantschitsch aus Belgrad 1880 erhalten.

\section{Varietät: Triticum dicoccum tricoccum Schübl.}

Aehre kahl, weiss; Aehrchen häufig 3-körnig.

\section{Sorte:}

\section{Aegyptischer Emmer. (2)- $\odot$}

Syn.: Triticum tricoccum Schübler, Russischer Spelz.

Franz.: Blé amidonnier à courtes barbes.

Aehre: blassgelb, matt glänzend, kahl, schlaff, platt, sehr dicht, lang; Spindel leicht zerbrechlich; Aehrchen $1 \mathrm{~cm}$ breit, 2- und 3-körnig. kurz begrannt; Grannen bis $4 \mathrm{~cm}$ lang. - Stroh: hellgelb, hohl, derbwandìg, lang. - Frucht: rötlich-gelb, mehlig, viele rötlich und glasig, 3-kantig, etwas eingefallen, gross $(9 \mathrm{~mm}$ lang, $4 \mathrm{~mm}$ breit, 149 Früchte $=10 \mathrm{gr}$ ), etwas grobschalig. Es enthalten $100 \mathrm{gr}$ Veesen $74 \mathrm{gr}$ Kernen.

Herbstblatt gelbgrün, breit, aufrecht. Frühjahrsvegetation sehr zeitig, so dass er wie eine Sommerfrucht erschien, doch im Frühjahr gesäet, erwies er sich als echte Winterfrucht; Bestockung mittelstark, 4.3 Schösslinge; Halme und Halmblätter gelbgrün, letztere beiderseits stark sammetig. Halmlänge $125 \mathrm{~cm}$ (Max. $150 \mathrm{~cm}$ ), Halmdicke $0.47 \mathrm{~cm}$, Blattzahl 4, Blattlänge $26 \mathrm{~cm}$, Blattbreite $1.16 \mathrm{~cm}$, Blattoberfläche $241.28 \mathrm{qcm}$, Halmfläche $176.25 \mathrm{qcm}$, Gesammtfläche $417.53 \mathrm{qcm}$. 
Junge Aehre bläulich-grün, mittelfiüh reifend, $10 \mathrm{~cm}$ (Max. $13 \mathrm{~cm})$ lang, mit 28 Veesen und 50 Kernen. Fs enthält $1 \mathrm{hl}(=45,5 \mathrm{~kg}) 273000$ Veesen, 499590 Kermen.

Es wiegen 100 Halme $662 \mathrm{gr}$ und davon die Veesen $301 \mathrm{gr}$.

Dieser Emmer lagerte nicht, blieb fast rostfrei, ist jedoch für Deutschland zu empfindlich, so dass er hier als nicht winterfest anzusehen ist. Er soll schon bei $10-12^{\circ}$ C. auswintern.

Er wird in Aegypten, Italien und im südlichen Frankreich kultiviert, verlangt einen kräftigen Boden und zeitige Aussaat im Herbst.

\section{Varietiit: Triticum dicoceum pyenura Al. Aehre kahl, rötlich, dicht.}

\section{Sorten:}

\section{Dichter, rötlicher Émmer.}

Franz.: Blé amidonnier roux compacte.

Aehre: rostrot, platt, sehr dicht, kur\%, Spindel sehr leicht zerurechlich; Aehrehen $1.4 \mathrm{~cm}$ breit, 2-körnig, 2-gramig, sehr abgestutzt, Klappen völlig kahl und auch nicht am unteren Rande weichhaarig; Grannen rötlich, bis $11 \mathrm{~cm}$ lang, leicht abbrechend. - Stroh: gelb, hohl, derbwandig, fest, kurz. - Frucht: rot, glasig, dreikantig, lang, schmal (8 mm lang, $3 \mathrm{~mm}$ breit), feinschalig. Es enthalten $100 \mathrm{gr}$ Veesen $76.1 \mathrm{gr}$ Keruen.

Halme blaugrün, Blatter beiderseits sammetig, Bestockung mittelstark, 3 Schösslinge, zeitig schossend und bliihend. Halmlänge $90 \mathrm{~cm}$ (Max. $115 \mathrm{~cm}$ ), Halmdicke $0,37 \mathrm{~cm}$, Blattzahl 5, Blattlänge $28.75 \mathrm{~cm}$, Blattbreite $1.09 \mathrm{~cm}$, Blattoberfläche $313.4 \mathrm{qcm}$, Halmfläche 99,9 qcm, Gesammtfläche 413.3 q $\mathrm{cm}$.

Junge Aehre bläulich-grün, zeitig, in 120 Tagen reifend, $7.5 \mathrm{~cm}$ (Max. $9 \mathrm{~cm}$ ) lang, mit 25 Veesen und 48 Kernen. Es enthält $1 \mathrm{hl}$ (= 42.3 kg) 465300 Veesen, und darin 803700 Kernen.

Auf $1 \mathrm{qm}$ wachsen 800 Halne oder 267 Pflanzen, mithin beträgt der Raum für eine Pflanze $38 \mathrm{qcm}$, die Blattoberflïche p. qm Bodenfläche $32.8 \mathrm{qm}$ und das Saatquantum 5 hl p. ha.

Es wiegen 100 Halme $450 \mathrm{gr}$ und davon die Veesen $183 \mathrm{gr}$.

Diese Sorte, welche in Allgemeinen wenig kultiviert wird, lagert nicht leicht, leidet jedoch etwas durch Rost.

\section{Breiter roter Sommer-Emmer. $\odot$}

Syn.: Triticum Cienfuegos Lagasea, gen. et sp. pl. (1816), p. 6, No. 83. Franz.: Blé plat roux; Amidonnier d'Heidelberg.

Aehre: blassrot mit bläulichem Anflug, platt, in der Mitte am breitesten, dicht, bis $6 \mathrm{~cm}$ lang, Spindel sehr leicht zerbrechlich; Aehrchen $2 \mathrm{~cm}$ breit, Klappen 2-zähnig, 2-körnig, 2-grannig; Grannen rötlich-gelb, bis $10 \mathrm{~cm}$ lang, leicht abbrechend. - Stroh: rötlich-gelb, ziemlich blattreich, $95 \mathrm{~cm}$ lang, Blätter beiderseits sammetig; Halm der meisten SommerEmmer hohl, doch hier meist, wenigstens im obersten Gliede markig. Frucht: rotbraun, glasig (10 $\mathrm{mm}$ lang, $3 \mathrm{~mm}$ breit); Veesen blassrot, Spelzen umschliessen Körner nicht fest, viele nackt; 1 hl Veesen wiegt $50 \mathrm{~kg}$ und enthält 450000 Veesen und 900000 Kernen; die Menge der Spelzen beträgt 21.25 Proc. vom Gewicht der Veesen. 
Junge Aehre blaugrün, in 120 Tagen reifend, mit 30 Kernen.

Leidet durch Rost.

Wird nach Willkomm $\mathrm{m}^{1}$ ) in Asturien gebaut, wo ihn die Bauern „Cienfuegos" nennen.

Bezugsquelle: l. Dresden.

Varietät: Triticum dicoccum brunneum Al.

Aehre kahl, rot.

\section{Sorten:}

\section{Roter Sommer-knmer. $\odot$}

Franz.: Amidonnier roux; Blé amidonnier rose, élevé, et de Tarascon.

Aehre: rosenrot, platt, dicht, aufrecht oder leicht geneigt, Spindel sehr leicht zerbrechlich, etwas kurz; Aehrchen $1.2 \mathrm{~cm}$ breit, 2-körnig, 2-grannig; Grannen blassrot, fein, bis $11 \mathrm{~cm}$ lang. - Stroh: rötlich-weiss, fest, hohl, duinnhalmig, mittellang. - Frucht: blassrot, glasig, schmal ( $7 \mathrm{~mm}$ lang, $3 \mathrm{~mm}$ breit), sehr feinschalig. $100 \mathrm{gr}$ Veesen enthalten $81 \mathrm{gr}$ Kernen.

Halmblatt dunkelgriin, beiderseits stark sammetig, 2.5 Schösslinge, spät schossend und blühend. Halmlänge $110 \mathrm{~cm}$ (Max. $120 \mathrm{~cm}$ ), Halmdicke $0.33 \mathrm{~cm}$, Blattzahl 5, Blattfläche 189.6 q $\mathrm{cm}$, Halmfläche 108.9 qcm, Gesammtfläche 298.5 q $\mathrm{cm}$.

Junge Aehre blaugrün, $12 \mathrm{~cm}$ (Max. $16 \mathrm{~cm}$ ) lang, spät, in 129 Tagen reifend, mit 16 Veesen und 30 Kermen. Es enthält $1 \mathrm{hl}(=53.6 \mathrm{~kg})$ 536000 Veesen und 992000 Kernen.

Auf $1 \mathrm{qm}$ wachsen 1000 Halme oder 400 Pflanzen. mithin beträgt der Raum p. Pflanze $25 \mathrm{qcm}$, die Blattoberfläche p. qm Bodenfläche $29.8 \mathrm{qm}$ und das Saatquantum $6 \mathrm{hl}$ p. ha.

Es wiegen 100 Halme $515 \mathrm{gr}$ und davon die Veesen $229 \mathrm{gr}$.

Diese Sorte lagert nicht leicht, bleibt rostfrei und wird hauptsächlich in Scliwaben und Siid-Frankreich angebaut, doch steht sie in Bezug auf Mehlreichtum hinter dem weissen Emmer zurück.

\section{Roter Sommer-Enmer aus Serbien. $\odot$}

Aehre: gesättigt rot, schmal, klcin ( $7 \mathrm{~cm}$ lang. $1 \mathrm{~cm}$ breit); Aehrchen $0.6 \mathrm{~cm}$ breit, 2-körnig, obere Klappe des Endährchens 2-spitzig, untere oft fehlend; Mittelzahn der Klappen kurz, stumpf. - Strolı: gclbrot, Rand markig. - Frucht: hellrot, glasig, länglich $(8 \mathrm{~mm}$ lang, $3 \mathrm{~mm}$ breit), dic Spelzen betragen von den Veesen $22 \%$.

Habitus sonst genan mit dem des weissen Emmers aus Serbien iibereinstimmend.

Bezugsquelle: Prof. Pantschitsch aus Belgrad 1880.

1) Agr. Zeit. 1852, pg. 24. 
Varietät: Triticum dicoccum majus Keke.

Aehre sammetig, weiss.

\section{Sorte: \\ Grosser weisser summetiger Winter-Emmer. (2)}

Syn.: Deutsch: Russischer Mehldinkel ${ }^{1}$ ).

Franz.: Blé amidonnier blanc à épi velouté.

Aehre: weiss, mit graubläulichem Anflug, platt, dicht, breit und zwar an der Basis am breitesten, steifer als die Aehre der kahlen, weissen Emmer, Spindel zerbrechlich; Achrchen 2- und 3-körnig, lang begrannt; Grannen sehwärzlich-dunkelbraun, bis $17 \mathrm{~cm}$ lang. - Stroh: gelb, hohl, sehr kräftig. lang. - Frncht: gelbrot und mehlig, oder blassrot und glasig, lang, schmal ( $8 \mathrm{~mm}$ lang, $31 / 2 \mathrm{~mm}$ breit), ziemlich feinschalig; es enthalten $100 \mathrm{gr}$ Veesen $73.5 \mathrm{gr}$ Kernen.

Herbstblatt blaugriin, schmal, kraus; Friihjalırsvegetation spät, Bestockung stark, 5 Schösslingc, Halmblätter beiderseits stark kurzsamıetig; spät sehossend und blühend, Halmlänge $140 \mathrm{~cm}$ (Max. $160 \mathrm{~cm}$ ), Halmdicke $0.5 \mathrm{~cm}$, Blattzahl 3.7 , Blattlänge $27.52 \mathrm{~cm}$, Blattbreite $1.26 \mathrm{~cm}$, Blatto berfläche $256.63 \mathrm{qcm}$, Halmfläche $210 \mathrm{qqcm}$, Gesammtfläche $466.63 \mathrm{qcm}$.

Junge Aehre blaugriin, spät reifend, $10 \mathrm{~cm}$ (Max. $14 \mathrm{~cm}$ ) lang, init 22 Teesen und 55 Kerncn, von denen ein Teil schon frei in den Veesen liegt. Es enthält $1 \mathrm{hl}(=37 \mathrm{~kg}) 204000$ Veesen und darin 501000 Kernen.

Auf 1 qm wachsen 700 Halme oder 140 Pflanzen, mithin beträgt der Raum für eine Pflanze $71.5 \mathrm{qcm}$, die Blattfläche p. qm Bodenfläche $32.6 \mathrm{qm}$ und das Saatquantum $4 \mathrm{hl} \mathrm{p.} \mathrm{ha.}$

Dieser sehr kräftige Emmer ist zwar eine echte Winterfrucht, jedoch schon für Poppelsdorf zu weichlich und erfordert ein milderes Klima, wie Süd-Europa es ihm bietet. Er lagert nicht leicht und leidet wenig durch Rost.

Varietät: Triticum dicoccum flexuosum Keke.

Aehre saminetig, weiss; Grannen gebogen.

\section{Sorte:}

\section{Emmer mit bajonnetförmig gebogenen Grannen. (2) u. $\odot$}

Aelre: weiss, stark sammetig, mittellang, schmäler als andere, doch iiberall von gleicher Breite; locker, so dass man zwischen den einzelnen Aehrchen lindurchseben kann; Zahn der Klappen einwärts gebogen; Granne hell, an Basis meist schwärzlich, bajonnetförmig gebogen oder geschlängelt, mittellang $(11 \mathrm{~cm})$, fast aufrecht, Spindel zerbrechlich; Aehrchen 2-körnig, 2-grannig; Frucht ziemlich lose in den Spelzen, alle Frïchte nackt; Stroh gelb, ganz markig oder mit breitem, markigem Innenrand. - Frucht: rot, glasig, eingefallen, gross $(71 / 2 \mathrm{~mm}$ lang, $31 / 2 \mathrm{~mm}$ breit).

Junges Blatt blaugrïn, breit, lang, dicht, sammetig.

Nicht winterfest.

1) Metzger, Landw. Pflanzenkunde pg. 116, 1811. 
Varietät: Triticum dicoccum Bauhinii Al.

Aehre sammetig, rot.

\section{Sorte : \\ Roter, sammetiger Emmer.}

Aehre: hellrot, sammetig, platt, dicht, an Basis haben einige Aehren schwache Neigung zum Verästeln, Spindel ziemlich zähe, lang; Aehrchen 2-körnig, untere Aehrchen 1-grannig, obere 2-grannig; Grannen rötlich, relativ kurz, bis $10 \mathrm{~cm}$ lang, ein wenig gespreizt. - Stroh: gelb, sehr lang, hohl, mit kaum markigem Inneurand, fest. - Frucht: meist gelbrot und mehlig, wenige rot und glasig, dreikantig, klein, kurz (7 mm lang, $3 \frac{1}{2} \mathrm{~mm}$ breit), ziemlich feinschalig, viele Kernen liegen frei in den Veesen, oder sind nur wenig fest umschlossen. Es enthalten $100 \mathrm{gr}$ Veesen $78 \mathrm{gr}$ Kernen.

Herbstblatt blaugrün, schmal, ziemlich kraus; Frühjahrsvegetation spät, Bestockung stark, 5 Schösslinge, Blätter am Halm gelbgrün, dicht sammetig; mittelfrüh schossend und blühend. Halmlänge $140 \mathrm{~cm}$ (Max. $155 \mathrm{~cm}$ ), Halmdicke $0.46 \mathrm{~cm}$, Blattzahl 3.7 . Blattlänge $25.25 \mathrm{~cm}$, Blattbreite $1.2 \mathrm{~cm}$, Blattoberfläche $324.22 \mathrm{qcm}$, Halmfläche $193.2 \mathrm{qcm}$, Gesammtfläche $517.42 \mathrm{qcm}$.

Junge Aehre gelbgrün, Staubbeutel rotbräunlich, spät reifend, $10 \mathrm{~cm}$ (MIax. $12 \mathrm{~cm}$ ) lang, mit 28 Veesen und 55 Kernen. Es enthält $1 \mathrm{hl}(=49.3 \mathrm{~kg}) 394400$ Veesen und darin 788800 Kernen.

Auf $1 \mathrm{qm}$ wachsen 600 Halme oder 120 Pflanzen, mithin beträgt der Raum für eine Pflanze $83.3 \mathrm{qcm}$, die Blattfläche p. qm Bodenfläche $31 \mathrm{qm}$ und das Saatquantum $2.3 \mathrm{hl} \mathrm{p}$. ha.

Es wiegen 100 Halme $798 \mathrm{gr}$ und davon die Veesen $411 \mathrm{gr}$.

Dieser Emmer ist nicht winterfest, jedoch ein echter Winteremmer; er lagert nicht und leidet wenig durch Rost. zu eignen.

Nur sehr reiche Böden und ein mildes Klima scheinen sich für ihn

Wahrscheinlich ist er mit "Triticum Bauhini Lagasca"1) identisch, der vielfach in Altcastilien und Burgos, Spanien, gebaut wird.

\section{Varietät: Triticum dicoccum semicanum Krause.}

Aehre sammetig, rot; Körner meist gelöst.

\section{Sorte:}

\section{Triticum amyleum semicanum villosum Kranse $\left.{ }^{2}\right)$.}

Aehre: blassrot, stark sammetig, schlank, $5 \mathrm{~cm}$ lang, $1.2 \mathrm{~cm}$ breit, schmal, locker, so dass man wie bei flexuosum zwischen den Aehrchen hindurchsehen kann; Grannen lang, gerade, an Basis schwarz. - Stroh: markig, mit enger Höhlung. - Frucht: hellrot, glasig, löst sich meist aus den Spelzen, sehr schön, feinschalig, $1 \mathrm{hl}=82 \mathrm{~kg}$.

Herbstblatt blaugrün, sammetig, mittelgross.

1) Vergl. Willk omm, Agron. Zeit. 1852, pg. 24.

2) Diese Varietät entspricht der Abbildung von $\mathrm{Kr}$ ause. Getreide, Heft 5 pg. 7 tab. 2 A. 


\section{Varietät: Triticum dicoccum atratum $\mathrm{Al}$. \\ Aehre sammetig, schwarzblau.}

\section{Sorte :}

\section{Schwarzer sammetiger Emmer ${ }^{1}$ ).}

Syn.: Triticum atratum Host., schwärzlicher Weizen, schwarzer Winterspelz aus Afrika.

Frauz.: Blé amidomier noirâtre, Amidomnier noir compacte, Blé plat d'Afrique, Blé plat brun ou noir.

A ehre: scliwarzblau, sammetig, dicht, steif, sich nach der Spitze verjüngend, platt, mittellang, sehr breit, an Basis am breitesten; Spindel leicht zerbrcchlich; Aehrchen 2-körnig; Grannen rotblau, bis $14 \mathrm{~cm}$ lang. - Stroh : rötlich-gelb, holıl, derbwandig, lang. - Frucht: braun, mehlig, sehr lang und schmal (10 $\mathrm{mm}$ lang, $3^{1 / 2} \mathrm{~mm}$ breit), ziemlich feinschalig, $1 \mathrm{hl}$ Kernen wiegt $78 \mathrm{~kg}$ und $100 \mathrm{gr}$ Veesen enthalten $76 \mathrm{gr}$ Kernen.

Herbstblatt blaugriin, schmal, kraus; Frülijahrsvegetation spät, Bestockung stark, 6 Schösslinge; Halmblätter beiderseits kurz sammetig; spät schossend und blïhend.

Halmlänge $135 \mathrm{~cm}$ (Max. $150 \mathrm{~cm}$ ), Halmdicke $0.44 \mathrm{~cm}$, Blattzahl 4.3, Blattlänge $22.18 \mathrm{~cm}$, Blattbreite $1.07 \mathrm{~cm}$, Blattoberfläche $324.31 \mathrm{qcm}$, Halmfläche $178.2 \mathrm{qcm}$, Gesammtfläche $502.51 \mathrm{qcm}$.

Junge Aehre erst gelbgrün, dann bläulich- und endlich blaugrün, spät reifend, $8 \mathrm{~cm}$ (Max. $10 \mathrm{~cm}$ ), mit 26 Veesen und 50 Kernen. Es enthält 1 hl $(=48.5 \mathrm{gr}) 364000$ Veesen und darin 607000 Kernen.

Es wiegen 100 Halme $833 \mathrm{gr}$ und davon die Veesen $305 \mathrm{gr}$.

Dieser sehr robuste echte Winteremmer ist nicht winterfest und gelıört in ein südliches Klima, so soll derselbe nach Heuzé in Sicilien, Afrika und auf den Balearen gebaut werden, während seine Kulturen in Siid-Frankreich nicht befriedigt haben.

Er lagert nicht leicht und befällt höchst selten mit Rost, doch ist sein Mehl etwas grau.

\section{B. Aehren ästig.}

\section{Varietät: Triticum dicoccum cladura Al. \\ Aehre kahl, rot.}

\section{Sorte :}

\section{Roter, kahler, ästiger Emmer. (2)}

Aehre: xot, kahl, verästelt, Spindel ziemlich zähe, dicht, mittellang; Aehrchen $0.9 \mathrm{~cm}$ breit, 2-körnig, kurz begrannt; Grannen $4-5 \mathrm{~cm}$ lang. hell, teilweis verkümmert. - Stroh: gelb, hohl, sehr derbwandig, dick, lang. - Frucht: gelbrot und mehlig, oder blassrot und glasig, eingefallen, klein, rundlich ( $6 \mathrm{~mm}$ lang, $3^{1} / 2 \mathrm{~mm}$ breit, 202.6 Frïchte $=10 \mathrm{gr}$ ),

1) In der wahrscheinlich von Metzger herrührenden Getreidesammlung des Bonner naturh. Ter. entspricht No. 49 dieser Varietät. 
etwas grobschalig. Es enthalten $100 \mathrm{gr}$ Veesen $76.5 \mathrm{gr}$ Kernen, von denen eimige frei sind.

Herbstblatt gelbgriin, bieit, aufrecht; Frühjahrsvegetation mittelfrüh, Bestockung mittelstark, 4.5 Schösslinge; Halme blaugrün, Halmblättex beiderseits stark sammetig; mittelfrüh schossend und blühend. Halınlänge $130 \mathrm{~cm}$ (Max. $150 \mathrm{~cm}$ ), Halmdicke $0.48 \mathrm{~cm}$, Blattzahl 3.7. Blattlänge $24.65 \mathrm{~cm}$, Blattbreite $1.25 \mathrm{~cm}$, Blattoberfläche 227.99 q $\mathrm{cm}$. Halmfläche $187.2 \mathrm{qcm}$, Gesammtfläche $415.19 \mathrm{qcm}$.

Junge Aehre bläulich-grün, Staubbeutel rotbraun, mittelfriih reifend, $9 \mathrm{~cm}$ (Max. $11 \mathrm{~cm}$ ) lang, mit 21 Teesen und 40 Kernell. Kernen.

Es enthält $1 \mathrm{hl}(=52 \mathrm{~kg}) 416000$ Teesen und darin $8070: 0$

Es wiegen 100 Halme $880 \mathrm{gr}$ und davon die Veesen $458 \mathrm{gr}$.

Dieser Emmer ist steif, fast rostfrei, doch nicht winterfest und fül. Deutschland in ökonomischer Beziehung wertlos.

\section{Varietät: Triticum dicoccum Krausei Kcke.}

Aehre sammetig, rot.

\section{Sorte: \\ Roter, sammetiger, ästiger Emmer. (2)}

Aehre: blassrot, sammetig, sich stark rerjüngend, an Basis mehrfach verästelt, selı dicht, Spindel zerbrechlich, lang; Aehrehen $0.8 \mathrm{~cm}$ breit, 2-körnig, meist nur eine Granne am Aehrchen entwickelt, Frucht im Aehrchen zum Teil frei; Grannen sehr blassrot, wenig gespreizt, leicht "erbrechlich. - Stroh: goldgelb, hohl, sehr derbwandig, fest, sehr lang. - Frucht: blassrot, meist glasig, einige rötlich-gelb und mehlig, oval, klein ( $7 \mathrm{~mm}$ lang, $3^{1 / 2} \mathrm{~mm}$ breit, 215.2 Früchte $=10 \mathrm{gr}$ ), ziemlich feinschalig. Es enthalten $100 \mathrm{gr}$ Veesen $79 \mathrm{gr}$ Kernen.

Herbstblatt dunkelgrün, schmal, kraus, Frühjahrsvegetation spät, Bestockung stark, 7,5 Schösslinge; Halmblätter sammetig; spät schossend und blühend. Halmlänge $140 \mathrm{~cm}$ ( Max. $155 \mathrm{~cm}$ ), Halmdicke $0.45 \mathrm{~cm}$, Blattzahl 4, Blattlänge 25.4.3 cm, Blattbreite $1.14 \mathrm{~cm}$, Blattoberfläch $231.92 \mathrm{qcm}$, Halıfläche $189 \mathrm{qcm}$. Gesammtfläche $420.92 \mathrm{qcm}$.

Junge Aehre gelbgriin. spät reifend, $10 \mathrm{~cm}$ (Max. $13 \mathrm{~cm}$ ) lang, nit 47 Veesen und 80 Kernen.

Es wiegt $1 \mathrm{hl}$ abgedrosehener. Teesen $70 \mathrm{~kg}$; dass der grösste Teil der Kernen schon durch das Abdreschen frei wird, bezeugt dies hohe Hektolitergewicht.

Es wiegen 100 Halme $780 \mathrm{gr}$ und davon die Veesen $430 \mathrm{gr}$.

Dieser Spelz ist nicht winterfest, lagert selten und leidet fast gar nicht durch Rost, doch verlangt derselbe, soll er nicht degenerieren, einen sehr reichen Boden und ein mildes Klima.

ILit diesem Emmer ist der ,rote, sammetige Emmer aus Heidelber"gr" nahe verwandt, nur dass bei diesem die Aehre lockerer ist, so dass auf eine Länge von $10 \mathrm{~cm} 36$ Teesen und 60 Kernen entfallen, ausserdem reift er 8 Tage früher und seine Halmblätter sind kahl; die übrigen Wachstumsverhältnisse sind denen des oben beschriebenen Emmers vollständig analog. 
Varietät: Triticum dicoccum melanura $\mathbf{~} \mathrm{l}$.

Aehre sammetig, blauschwarz.

\section{Sorte :}

\section{Schwarzer, sammetiger, ästiger Emmer. (2)}

Aehre: blauschwarz, schwach-sammetig, verästelt, namentlich an der Basis, platt, sehr dicht, Spindel in Vollreife sehr leicht zerbrechlich, nittellang, breit $\left(8^{1} / 2 \mathrm{~cm}\right.$ lang, $31 / 2 \mathrm{~cm}$ breit); Aehrchen $0.8 \mathrm{~cm}$ breit, 2-kz̈rnig; Grannen dunkelbraun, nach Spitze heller, bis $10 \mathrm{~cm}$ lang. Stroh: gelb, hohl, selır derbwandig, selır lang. - Frucht: gelbrot, mehlig, sehr schmal und lang ( $8 \mathrm{~mm}$ lang, $2 \mathrm{~mm}$ breit), ziemlich feinschalig; $100 \mathrm{gr}$ Veesen enthalten $80.7 \mathrm{gr}$ Kernen, die teilwcise schon frei in den Veesen liegen.

Herbstblatt blaugrün, lang, schmal kraus; Frühjahrsvegetation spät, Bestockung etwas schwach, 3.3 Schösslinge; Halmblätter beiderseits sainmetig, spät schossend und blühend. Halmlïnge $145 \mathrm{~cm}$ (Мax. 165 cm), Halmdicke $0.44 \mathrm{~cm}$, Blattzahl 4.7, Blattlänge $25.54 \mathrm{cml}$, Blattbreite $1.1 \mathrm{~cm}$, Blattoberffäche $264.05 \mathrm{qcm}$, Halmfläche $191.04 \mathrm{qcm}$, Gesammtfläche 455.09 qcin.

Junge Achre blaugrüin, spät reifend, $8.5 \mathrm{~cm}$ (MTax. $11 \mathrm{~cm}$ ) lang, mit iiber 100 Veesen und 200 Kernen. Es enthält $1 \mathrm{lll}(=42.7 \mathrm{~kg}) \$ 70000$ Veesen und darin 833000 Kernen.

Es wiegen 100 Halme $893 \mathrm{gr}$ und davon die Veesen $451 \mathrm{gr}$.

Dieser Einmer ist eine echte Winterfrucht, doch für Deutschland zu weichlich; er lagert nicht leicht und widersteht dem Rost vorziiglich.

\section{Unterart: 7. Triticum monococenm L. Einkorn.}

Varietät: 'Triticum monococcum Hornemanni Clem.

Aehre rot, Spelzen kurz behaart.

\section{Sorte:}

\section{Weichhaariges, rotes Einkorn. ( ) (2)}

Aehre: rot, etwas glänzend, Klappen kaum wahrnehmbar behaart, dagegen der obere hervorragende Teil der äusseren Spelze dicht weichhaarig, doch erst durch Lupe deutlich, platt, dicht, Spindel leicht zerbrechlich, ziemlich lang; Aehrchen 1-körnig, selten 2-körnig und 2-gramiig, mitunter die zweite Granne ziemlich lang, also nur eine im Allgemeinen kräftig entwickelt, Grannen bis $9 \mathrm{~cm}$ lang, hell. - Stroh: rötlich-gelb, hohl, diinnhalmig, fest, biegsam. - Frucht: blassrot, glasig, zusammen- 
gedrückt, lang und schmal (9 cm lang, $21 / 2 \mathrm{~cm}$ breit), feinschalig. Es enthalten $100 \mathrm{gr}$ Teesen $79 \mathrm{gr}$ Kernen.

Herbstblatt blaugrün, schınal, kraus; Frühjahrsvegetation sehr spät, Bestockung stark, 5.7 Schösslinge, als Sommerfrucht 3.5 Schösslinge; Halme gelbgrün, Halmblätter oberseits mit äusserst kurzen, kaum wahrnehmbaren, gleich langen, dichten Härchen besetzt; spät schossend und bliihend.

Sommersaat und Wintersaat verhalten sich wie folgt:

\begin{tabular}{l|l|l|l|}
\hline & Wintersaat & Sommersaat \\
\hline
\end{tabular}

Halmlänge

Halm dicke

Blattzahl

Blattlänge

Blattbreite

Blattoberfläche

Halmfläche

Gesammtfläche

Aehrenlänge

Anzahl der Veesen in einer Aehre
$120 \mathrm{~cm}$ (Max. $130 \mathrm{~cm}) 100 \mathrm{~cm}($ Max. $130 \mathrm{~cm})$ $0.28 \mathrm{~cm}$ 4

$21.3 \mathrm{~cm}$

$0.62 \mathrm{~cm}$

$104.84 \mathrm{gcm}$

$100.80 \mathrm{qcm}$

$205.64 \mathrm{qcm}$

$6 \mathrm{~cm}(\mathrm{Max} .8 \mathrm{~cm})$

24 Veesen, 26 Kernen 24 Veesen, 26 Kernen

Junge Aehre gelbgrün, Staubbeutel bräunlich, spät reifend.

Auf $1 \mathrm{qm}$ wachsen 1400 Halme, mithin bei der Wintersaat 246 und bei der Sommersaat 400 Pflanzen, da nun $1 \mathrm{hl}$ (= $49.7 \mathrm{~kg}$ ) Wintereinkorı 895000 Veesen und darin 970000 Kernen und $1 \mathrm{hl}(=51.5 \mathrm{~kg}$ ) Sommereinkoru 979000 Veesen und darin 1056000 Früchte enthält, so beträgt das Saatquantum $4 \mathrm{hl}$ resp. $6 \mathrm{hl}$ p. ha.

Es wiegen 100 Halme $382 \mathrm{gr}^{\circ}$ und davon die Treesen $181 \mathrm{gr}$.

Dieses Einkorn lagert nicht leicht, leidet wenig durch Rost und ist vollkommen winterfest.

In den siddeutschen Gebirgen und in der Schweiz als Winterfrucht, seltener als Sommerfruclit gebaut, da das Einkorn eine längere Vegetationsperiode als anderes Sommergetreide besitzt, doch lässt es sich selbst noch um. Weihnachten und im Februar aussäen und nimmt mit den sterilsten und rauhesten Lagen vorlieb.

Varietat: Triticum monococcum vulgare Kcke.

Aehre kahl, blassrot.

\section{Sorte :}

\section{Gemeines Einkorn. ( ) (2)}

Franz.: Engrain commum.

Aehre: blassrot, glänzend, kahl, kurz, Spindel leicht zerbrechlich; Aehrchen kleiner als bei den übrigen Varietäten, $0.5 \mathrm{~cm}$ breit, 1-körnig, zuweilen einige Aehrchen 2-körnig. - Stroh: rötlich-gelb, hohl, kurz, biegsam, feinhalmig. - Frucht: hellrot, glasig, flach zusammengedrückt, schmal (7 $\mathrm{mm}$ lang, $2 \mathrm{~mm}$ breit, 450 Früchte $=10 \mathrm{gr}$ ), feinschalig. Es enthalten $100 \mathrm{gr}$ Veesen $65 \mathrm{gr}$ Kernen.

Junges Blatt gelbgrün, fein, karz; 2.5 Schösslinge, sehr spät schossend 
und blühend. Halmlänge $85 \mathrm{~cm}$ (Max. $100 \mathrm{~cm}$ ), IIalmdicke $0.25 \mathrm{~cm}$, Blattzahl 4, Blattlänge $18.8 \mathrm{~cm}$, Blattbreite $0.67 \mathrm{~cm}$, Blattoberflächc $100.77 \mathrm{qcm}$, Halmfläche $63.75 \mathrm{qcm}$, Gesammtfläche $164.52 \mathrm{qcm}$.

Junge Aehre gelbgrïn, Staubbeutel gelb oder bräunlich, etwas später als bei den beiden anderen Varietüten, in 134 Tagen reifend, 5 cm (Max. $7 \mathrm{~cm}$ ) lang, mit 18 Veesen und 21 Kernen.

Es enthält $1 \mathrm{hl}(=48.3 \mathrm{~kg}) 1400000$ Veesen und darin 1456700 Kernen.

Auf $1 \mathrm{qm}$ waclisen 1500 Halme oder 600 Pflanzen, mithin beträgt der Raum für eine Pflanze $16.7 \mathrm{qcm}$, die Blattoberfäche p. qm Bodellfläche $24.6 \mathrm{qm}$ und das saatquantmon $6.2 \mathrm{hl} \mathrm{p}$. ha.

Dieses Einkorn lagert nicht leicht und bleibt fast rostfrei.

Es wird unter den gleichen Bedingungen wie das weichhaarige rote Finkorn in den süddeutschen Gebirgen als Winter- und Sommerfrucht gebaut.

Varietät: Triticum monococcum flarescens Kcke.

Aehre kahl, bleichgelblich

\section{Sorte :}

\section{Trigo escaña menor, Campina, Spanien. $\odot$}

Sy 11.: Franz.: Engrain double.

Aehre: bleichgelblich mit rötlichem Schimmer; Klappen und Spelzen unbehaart, aber nach oben etwas ranh, platt, dicht, kurz; mittlere Aehrchen meist 2-körnig; Spindel zerbrechlich; Grannen gelb, bis $8 \mathrm{~cm}$ lang, aufrecht. - Strolı: rötlich-gelb, sehr feinhalmig, fest, nittellang. Frucht: lellrot, glasig, 3-kantig, schmal ( $8 \mathrm{~mm}$ lang), feinschalig; $100 \mathrm{gr}$ Veesen enthalten $77.3 \mathrm{gr}$ Kernen.

Junges Blatt und Halm gelbgrün, Halmknoten zottig behaart, Bestockung ziemlich krïftig, 2.5 Schösslinge, zeitig schossend und blühend. Halmlänge $95 \mathrm{~cm}$ ( I ax. $125 \mathrm{~cm}$ ), Halmdicke $0.27 \mathrm{~cm}$, Blattzahl 4, Blattlänge $16.6 \mathrm{~cm}$, Blattbreite $0.7 \mathrm{~cm}$, Blattoberfläche $92.96 \mathrm{qcm}$, Halmfläche $76.95 \mathrm{qcm}$, Gesammtfläche $169.91 \mathrm{qcm}$.

Junge Aehre gelb, Staubbeutel gelb, zeitig und zwar bis 14 Tare vor Tr. monoc. Hornemanni Clem. reifend, $6 \mathrm{~cm}$ (Max. $8 \mathrm{~cm}$ ) lang, mit 20 Veesen und 24 Kerncn. Es enthält $1 \mathrm{hl}(=54 \mathrm{~kg}) 864000$ Veesen und 1134000 Kernen. Es wiegen 100 Halme 261 gr und davon die Veesen $130 \mathrm{gr}$.

In Poppelsdorf lagerte dieses Einkorn nicht und blieb rostfrei.

Nach Willk $\mathrm{om} \mathrm{m}^{1}$ ) wird dicses Einkorn in allen Provinzen Spaniens auf leichtem Boden schr häufig gebaut nnd fiihrt in Nord- und CentralSpanien den Namelı „Escaña menor", in Sürl-Spanien „Esprilla“ oder "Cardón", in Catalonien „Espelta" comuna". Von Spanien ans gelangte es 1850 nach Süd-Frankreich ${ }^{2}$ ) und wird auch jetzt in Algier angebaut.

Ausser dieser frilhen Sorte wurde im ök.-bat. Garten zn Poppelsdorf auch noch eine späte, aber sonst ihr völlig identische Sorte kultiviert. Bezugsquelle: durch Antonio Cipriano Costa 1881 erhalten.

1) Vergl. Landw. Jahrb. VI (18iT) p. 1044.

2) Agron. Zeit. 1852, pg. 21.

3) Heuzé, Pl. aliment. pg. 134. 


\section{Art: Triticnm polonicnm L. Polnischer Weizen.}

Varietät: Triticum polonicum rufescens Keke. Aehre länglich, kahl, rot; Körner rot.

\section{Sorte:}

\section{Schmalihriger, langgranniger, roter, polnischer Veizen. $\odot$}

Aehre: hellrot, lang, am schmalsten von allen übrigen; Aehrchen 1.5 cm breit, 3- und 4-körnig, 2-grannig, Klappen schr gross, $2.5 \mathrm{~cm}$ lang, meist das Aehrchen ganz einschliessend, sie endigen zuweilen in eine kurze Stachelspitze, welche neben sich einen Zahn hat, der mitunter gleich lang ist, stark gekielt; Grannen schwach rötlich, bis $15 \mathrm{~cm}$ lang, nicht leicht abbrechend; die Aelrrenspindel ist kahl, nur gegen die Aelrehen zu an den Kanten ist sie sehr kurz behaart. Begrannte Spelzen beinahe so lang wie die Klappen. - Stroh: rötlich-gelb, mit markigem Innenrand, oder ganz markig, fest. - Frucht: hellrot, glasig, etwas eingefallen, hart, seln lang und schmal (11 mm lang, $4 \mathrm{~mm}$ breit), feinschalig.

Junges Blatt dunkelgrün, etwas schmal und spitz, 2.5 Schösslinge, zeitig schossend und blïhend; Halnnlänge $105 \mathrm{~cm}$ (Max. $130 \mathrm{~cm}$ ), Halmdicke $0.3 \mathrm{~cm}$, Blattzahl 4, Blattlänge $27.25 \mathrm{~cm}$, Blattbreite $0.85 \mathrm{~cm}$, Blattoberfläche eines Halmes 185.28 q cm, Halmfläche $94.5 \mathrm{qcm}$, Gesamntfläche $279.78 \mathrm{qcm}$.

Junge Aehre blaugrün, bereift, $11 \mathrm{~cm}$ (Max. $15 \mathrm{~cm}$ ) lang, zeitig, in 126 Tagen reifend, nit 17 Aehrchen und 60 nicht leicht ausfallenden Früchten, von denen 1418000 auf $1 \mathrm{hl}(=77.8 \mathrm{~kg})$ gehen.

Es wiegen 100 Halme $600 \mathrm{gr}$ und davon die Früchte $221 \mathrm{gr}$.

Der Stand in Poppelsdorf war diinn, doch kräftig, das Stroh lagerte nicht, doch befiel dasselbe in beträchtlichem Grade mit Rost. Die Spreu erwies sich als selır hart.

Varietät: Triticum polonicum levissimum Haller.

Aebre kahl, weiss; Körner weisslich.

\section{Sorte:}

\section{Weisser polnischer Weizen. $\odot$}

Franz.: Blé de Pologne ou d'Astrakan.

Identisch mit: Metzger, Cerealien 23. A. Tab. V. Krause, Getreide. Heft IV Tab. 1.

Deina polonica var. alba Al. L. Fl. 336.

Aehre: weiss, breit, ein wenig locker, sehr lang; Aehrchen $3 \mathrm{~cm}$ breit, meist 4-körnig, 2- und 3-graming, eine der begrannten Spelzen in Achrchen länger als die Klappen (4.5 $\mathrm{cm}$ lang), Klappen flattrig, stark gekielt, bis $4 \mathrm{~cm}$ lang, endigen in eine kurze Stachelspitze, die neben sich einen spitzen Zalın hat. Grannen bis $16 \mathrm{~cm}$ lang, aufrecht, fast weiss. - 
Stroh : rötlich-gelb, blattrcich, lang, markig. - Frucht: hellrot, glasig, lang, eingefallen (10 mm lang, $4 \mathrm{~mm}$ breit), feinschalig.

Junges Blatt selır kräftig, lang, breit, 2.6 Sehösslinge, zeitig schossend und blïhend; Halnnlänge $125 \mathrm{~cm}$ (Max. $150 \mathrm{~cm}$ ), Halmdicke $0.35 \mathrm{~cm}$, Blattzahl 4, Blattlänge $30 \mathrm{~cm}$, Blattbreite $1 \mathrm{~cm}$, Blattoberfläche eines Halmes 240 q $\mathrm{cm}$, Halmfläche $131.25 \mathrm{qcm}$, Gesammttläche $371.25 \mathrm{qcm}$.

Junge Aehre gelbgriin, zeitig, in 126 Tagen reifend, $13 \mathrm{~cm}$ (Max. $20 \mathrm{~cm}$ ) lang, mit 18 Aehrehen und 70 nicht leicht ansfallenden Früchten, von denen 1590000 auf $1 \mathrm{hl}(=80 \mathrm{~kg})$ gehen.

Es wiegen 100 Halme $775 \mathrm{gr}$ und davon die Früchte $213 \mathrm{gr}$.

Vorzugsweise in Süd-Europa kultiviert.

Die eigentünliche Gestalt der Früchte der polnischen Weizen gab zu der irrtïnlichen Anffassung Veranlassung, dass sie Roggensorten seien, daher es nicht iiberraschen kann, dass dieser Weizen auf der Wiener Weltausstellnng 1873 von Seiten der nordamerikanischen Union als "Montana Rye from Mill-Creek in Montana, Madisson City, Pacific-Railway", also als Roggen ausgestellt werden konnte. Er zeichnete sich namentlich durch grosse Flattrigkeit der Spelzen ans, die sich jedoch nach längerem Anbau in Poppelsdorf beträchtlich verminderte.

Varietait: Triticum polonicum villosum Desr. Aehre sammetig, weiss; Körner weisslich.

\section{Sorte: \\ Sammetiger weisser polnischer Weizen.}

Syn.: Franz.: Blé de Pologne à épi velu.

Aehre: blassgelb, schwach behaart, schnal; Aehrehen 1.5 em breit, meist 3-körnig, 2-grannig; Grannen blassgelb, bis $12 \mathrm{~cm}$ lang; Klappen besitzen an der Spitze einen sehr kurzen Fortsatz, der neben sich einen deutlichen, stumpflichen Zishn hat; die begrannten spelzen sind beinale so lang als die Klappen $(2.8 \mathrm{~cm})$. - Stroh: rötlich-gelb, markig, fest. Frucht: weisslich, glasig, wenig eingefallen, gross (10 mm lang, $4 \mathrm{~mm}$ breit), feinschalig.

Junges Blatt dunkelgrün, breit, lang, 2.8 Schösslinge, zeitig schoskend und blühend; Halmlänge $110 \mathrm{~cm}$ (Max. $140 \mathrm{~cm}$ ), Halındicke 0.4, Blattzahl 4, Blattlänge $24.5 \mathrm{~cm}$, Blattbreite $0.95 \mathrm{~cm}$; Blattoberfläche eines Halmes $186.24 \mathrm{qcm}$, Halmoberfläche $120 \mathrm{qcm}$, Gesammtfläche $306.24 \mathrm{qc1n}$.

Junge Achre blaugrün, bereift, schmal, zeitig, in 125 Tagen reifend, $11 \mathrm{~cm}$ (Max. $14 \mathrm{~cm}$ ) lang, mit 15 Aelirclien und 45 fest sitzenden Friichten, von denen 1503300 auf 1 hl $(=81.7 \mathrm{~kg})$ gehen.

Es wiegen 100 Halme $556 \mathrm{gr}$ und davon dic Frïiclite $225 \mathrm{gr}$.

Dieser Weizen gedieh in Poppelsdorf recht gut, auch lagertc das Stroh nicht und blieb rostfrei; das Korn scheint das beste von allen Sorten zil sein.

Nach Alefeld soll diese Sorte schon in Mittel-Deutschland zun Teil seine Behaarung verlieren.

In Spanien wird dieser Weizen häufig gebaut. 1878 in der italienischen Abteilung der Pariser Weltausstellung und 1881 in Mailand ausgestellt. 


\section{Varietät: Triticum polonicum chrysospermum Kcke.}

Aehre sammetig, weiss; Korn rot.

\section{Sorte :}

\section{Sammetiger polnischer Weizen mit roten Körnern. $\odot$}

Aehre: weisslich-gelb, mit bläulichem Anflug, sammetig, lang, locker, flattrig, Klappen $3^{1 / 2} \mathrm{~cm}$ lang, länger als Spelzen; Aehrchen bis $3 \mathrm{~cm}$ breit, meist 3-körnig; Grannen bis $8 \mathrm{~cm}$ lang, hin- und hergebogen. Stroh: gelbrot bis orange, fest, markig, lang. - Frucht: graurot, glasig, einige mehlig und gelbrot, runzelig, lang, schmal, Roggenkörnern sehr ähnlich (9 $\mathrm{mm}$ lang, $3^{1 / 2} \mathrm{~mm}$ breit), etwas grobschalig.

Junges Blatt blaugrün, lang, breit, 2.2 Schösslinge, zeitig schossend und blühend; Halnnlänge $135 \mathrm{~cm}$ (Max, $150 \mathrm{~cm}$ ), Halmdicke $4 \mathrm{~cm}$, Blattzahl 4, Blattlänge $33.5 \mathrm{~cm}$, Blattbreite $1 \mathrm{~cm}$, Blattoberfläche eines Halmes $268 \mathrm{qcm}$, Halmfläche $162 \mathrm{qcm}$, Gesammtfläche $430 \mathrm{qcm}$,

Junge Aehre blaugriin, bereift, in 125 Tagen reifend, $11 \mathrm{~cm}$ (Max. $15 \mathrm{~cm})$ lang, mit 17 Aehrchen und 50 fest sitzenden Früchten, von denen 1603700 auf $\mathrm{r}$.hl $(=79 \mathrm{~kg})$ gehen.

Es wiegen 100 Halme $800 \mathrm{gr}$ und davon die Früchte $225 \mathrm{gr}$.

In Sïd-Europa angebaut.

\section{Varietät: Triticum polonicum compactum Kranse.}

Aehre kahl, weiss, halb oder kurz begrannt.

\section{Sorte :}

\section{Dichter polnischer Weizen. $\odot$}

Ident isch sind: Deina polonica clavata Al, L. Fl. 337.

Metzger, Cerealien pg. 25 E. tab. V. C. F.

Blé de Pologne compacte (Vilm.)

Blé d'Alger du général Galbois (Soc. d'agric. 1840).

Blé de Pologne mutique, Polonielle compacte.

A ehre: blassgelb, Klappen stark gekielt und Kiel gelb, dicht, aufrecht, an Spitze kurzgrannig, Aehre breit (2 cm); Aehrchen $1.5 \mathrm{~cm}$ breit, 2- und 3-körnig, mit 2 kurzen Grannen (5 cm lang); Klappen und Spelzen gleich lang $(3 \mathrm{~cm})$; Spindel zerbrechlich. - Stroh: rötlich-gelb, markig, blattreich, sehr fest. - Frucht: hellrot, glasig, etwas eingefallen, sehr lang, schmal, gefurcht, zugespitzt (11 mm lang, $4 \mathrm{~mm}$ breit), feinschalig.

Junges Blatt dunkelgrüin, schmal, 2.6 Schösslinge, mittelfrüh schossend und blühend; Halmlänge $100 \mathrm{~cm}$ (Nax. $125 \mathrm{~cm}$ ), Halmdicke $0.4 \mathrm{~cm}$, Blattzahl 4, Blattlänge $29.75 \mathrm{~cm}$, Blattbreite $1.17 \mathrm{~cm}$, Blattoberfläche eines Halmes $278.48 \mathrm{qcm}$, Halmfläche $120 \mathrm{qcm}$, Gesammtfläche $398.48 \mathrm{qcm}$.

Junge Aelire gelbgrün, schwach bereift, mittelfrüh, in 130 Tagen reifend, $9 \mathrm{~cm}$ (Max. $11 \mathrm{~cm}$ ) lang, mit 20 Aehrchen und 50 Früchten, von denen 1082000 auf $1 \mathrm{hl}(=74.6 \mathrm{gr})$ gehen.

Es wiegen 100 Halme $780 \mathrm{gr}$ und davon die Früchte $220 \mathrm{gr}$.

Das Stroh widerstand dem Rost selir wenig, lagerte jedoch nicht, auch soll diese Sorte sehr wenig ergiebig sein.

Dieser Weizen wird in Spanien und Nord-Afrika angebaut. 
Varietät: Triticum polonicum attenuatum Kcke.

Aehrc kahl, weiss, dick, sich nach oben verschmälernd, lang begrannt.

\section{Sorte:}

\section{Dickähriger langgranniger, polnischer Weizen. $\odot$}

Aehre: blassgelb, mit rotbläulichem Anflug, kahl, dicht, dick, sich nach oben verschmälernd, mittellang; Aehrchen $2 \mathrm{~cm}$ breit, 3 - 5-körnig; Klappen heinahe so lang als die Spelzen, sehr gross (3 cm lang), stark grekielt, nnd besitzen dieselben neben der stachlichen Spitze einen Zahn, dessen Länge aber, wie die der Stachelspitze selbst, veränderlich ist; Aehrchen 2-grannig; Granmen an Basis zuweilen schwärzlich, sonst blassgelb, sehr lang, bis $20 \mathrm{~cm}$ lang. Die Spindel ist auf den Flächen und Rändern kahl. - Stroh: gclb oder rötlich-gelb, mittellang, fest, oberstes Halmglied hohl, mit markigem Innenrande. - Frucht: hellrot, glasig, eingefallen, lang, ( $8 \mathrm{~mm}$ lang, $4 \mathrm{~mm}$ breit), feinschalig.

Junges Blatt blaugriin, lang, spitz, 2.3 Schösslinge, zeitig schossend und bliihend; Halmlänge $100 \mathrm{~cm}$ (Max. 110), Halmdicke $0.38 \mathrm{~cm}$, Blattzahl 4.2, Blattlänge $28.7 \mathrm{~cm}$, Blattbreite $1 \mathrm{~cm}$, Blattoberfläche eines Halmes $241.08 \mathrm{qcm}$, Halmfläche $114 \mathrm{qcm}$, Gesammtfläche $355.08 \mathrm{qcm}$.

Junge Aehre blaugriin, bereift, mittelfrül, in 130 Tagen reifend, $9 \mathrm{~cm}$ (Max. $13 \mathrm{~cm}$ ) lang, mit 15 Aehrchen und 60 fest sitzcnden Friichten, von denen 1393000 auf $\mathrm{l} \mathrm{hl}(=75.3 \mathrm{~kg})$ gehen.

Es wiegen 100 Halme $671 \mathrm{gr}$ und davon die Früchte $234 \mathrm{gr}$.

Das Stroh lagert nicht, befällt jedoch mit Rost.

In Süd-Europa kultiviert. 


\section{Die biologischen Verhältnisse des Weizens.}

Das bestc Saatgut liefern die absolut schwersten Samenkörner, denn die an Reservestofien reichsten Körner keimen am leichtesten und kräftigsten auf und erzeugen die vollkommensten Pflanzen, während minder schwere auch entsprechend schwächere Pflanzen herrorbringen, die nu unter selı günstigen Verhältnissen zu einer befriedigenden Prodnktivität gelangen.

Das absolute Gewicht selbst unter gleichen Verbältnissen erzeugter Körner der nämlichen Weizensorte kann aber sehr verschieden sein, wie Versuche von A. Mïller ${ }^{1}$ ) lehren, der nachwies, dass im sog. Hektolitergewicht Unterschiede wie $3: 2$ bestehen und die Zahl der Körner in gleichem Hollmaass, aber ron verschiedenem Gewicht, in dem Verhältnis ron 3:5 differieren können, sowie, dass das Einzelgewicht der schweren Körner das der leichten annähernd fiinfunal $z$ in iibertreffen vermag.

Dies beweist, wenn auch die procentische Zusammensetyung der Reservestoffe im Weizenkorn keine bedentenden Unterschiede zeigt. dass die schwereren Körner doch betrüichtlich reicher an Reservestoffen als die leichteren sind, nithin der jungen Pflanze crheblich mehr Bildungsmaterial zuführen, und demzufolge auch gewichtigere und flächenreichere Keimpflanzen erzeugen werdcn, wofür Versuche von Nobbe ${ }^{2}$ ) sprechen.

Dieser Forscher rerteilte die 27 Aehrchen einel Aehre nach ihrer Stellung an der Basis ( $\mathrm{Nr}^{\mathrm{r}}$ I), in der Mitte ( $\mathrm{Nr}^{\circ}$. II) und an der Spitze (Nr. III) auf drei gleiche Gruppen und bestimmte deren Gewichte, sowie nach der Keimung die Wurzellängen:

\begin{tabular}{|c|c|c|c|}
\hline I. & Aehrchen 1-9 & $\begin{array}{l}\text { Gewicht. } \\
153 \mathrm{mg}\end{array}$ & $\begin{array}{l}\text { Wurzellänge. } \\
223 \mathrm{mg}\end{array}$ \\
\hline II. & $10-18$ & 282 & 1094 \\
\hline III. & $19-27$ & 191 & $454 \quad$. \\
\hline
\end{tabular}

Hiernach kann es wohl niclit zweifellaft sein, dass die Körner von der Längenmitte der Spindel die schwersten sind, zugleich aber dic mächtigste Triebkraft besitzen.

Ferner stellte Nowacki die Thatsache fest. dass sich glasige

1) Journ. f. Landw. IT 1856, p. 25.

2) A. a. O. pg. 303. 
Körner, weil reieher an Proteïnstoffen als mehlige von gleichem absoluten Gewieht, selbst noch anf sehr reiehem Boden, also unter sehr günstigen Verhältnissen, vor mehligen Körnern derselben Sorte und Ernte dureh grössere Schmelligkeit und Kräftigkeit der Entwiekelıng. reiehliehere Bestockung, frühzeitigere Blïte, grössere Halmzahl und schwereres Gewicht der Pflanze auszeiehneten. Doeb ist hieraus noeh nieht der Sehluss berechtigt, dass unter allen Umständen die glasigen Weizenkörner das beste Saatgut seien. Die nachfolgenden Analysen zeigen den Unterschied mehliger und glasiger Körner im Proteïngehalt, und enthielten 100 lufttroekne Körner ron gleiehem Gesammtvolum und von derselben Sorte in Grammen:

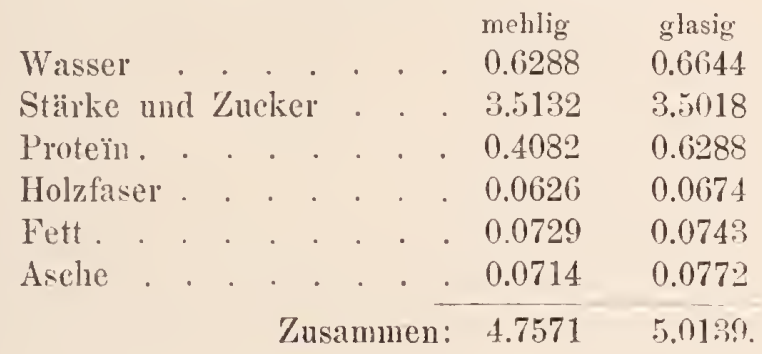

In 100 Teilen Körnermasse sind Teile:

$\begin{array}{llrrr}\text { Stärke und Zueker } & . & . & 73.8526 & 69.8410 \\ \text { Protcïn. . . . . . . . . } & \text {. } & 8.5819 & 12.5406 .\end{array}$

Die Unterarten des Weizens weichen stark in dem absoluten Gewieht ihrer Friiehte und Veesen von einander ab; so beträgt naelı unseren Ermittelungen das absolnte Gewicht eines Kornes des Saatgetreides bei

\begin{tabular}{|c|c|c|c|c|c|c|}
\hline Tritienm & vulgare & $\begin{array}{c}\text { interf } \\
46.0\end{array}$ & $\begin{array}{l}\text { ucht. } \\
\operatorname{lgg} .\end{array}$ & $\begin{array}{c}\text { So m me } \\
38.4\end{array}$ & $g r$ & (Friehte) \\
\hline , & compaetum. & 33.6 & , & 36.2 & " & , \\
\hline , & turgidnm & 55.0 & , & 58.0 & , & ״ \\
\hline , & dillum. & - & . & 51.5 & , & , \\
\hline , & polonieum & - &, & 55.5 & ,. & $"$ \\
\hline 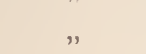 & molnoeoccum & 50.0 & , & 41.7 &, & (Veesen) \\
\hline " & dicoeeum & 51.6 & , & 49.0 & , & , \\
\hline , & Spelta . & 68.0 & , & 59.5 & $"$ & , \\
\hline
\end{tabular}

Nobbe gibt das absolnte Gewicht eines Weizenkornes der Handelsware (Tritieum vulgare) an:

$$
\begin{array}{clc}
\text { im Mittel auf } 37.567 \mathrm{mgr} \\
, \text { Maximum } & 45.819, \\
, \text { Minimum } & 15.238,
\end{array}
$$

Genauere Anlialtspunkte zur Beurteilung der Friiehte und V'eesen erhält man, wenn nieht nur das absolute Gewieht des ganzen Kornes, 
sondern auch das der einzelnen Teile erhoben wird; so betragen nach B locziszewski die Keime vom Gewicht der Frucht 2-3 Proc. und die Spelzen rom Gewicht der Veesen nach unseren Ermittelungen bei

\begin{tabular}{|c|c|c|c|c|c|}
\hline & & & $\begin{array}{r}\text { Max.: } \\
\text { Proc. }\end{array}$ & $\begin{array}{c}\text { Min.: } \\
\text { Proc. }\end{array}$ & $\begin{array}{l}\text { Mittel } \\
\text { Proc. }\end{array}$ \\
\hline Triticum & monococerim & (2) & 35.0 & 21.0 & 28.0 \\
\hline$"$ & $"$ & $\odot$ & - & - & 22.7 \\
\hline " & dicocenm & (2) & 26.5 & 19.3 & 23.6 \\
\hline$"$ & & $\odot$ & 23.9 & 19.0 & 21 \\
\hline$"$ & Spelta & (2) & 36.5 & 20.1 & \\
\hline$"$ & 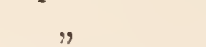 & $\odot$ & 25.2 & 21.5 & \\
\hline
\end{tabular}

Ferner ist zur Erzielung eines gleichmässigen Bestandes die Gleichförmigkeit der Samenkörner zu beachten, da sich nur aus einem Saatgut gleich schwerer Körner auch Pflanzen von gleichartiger Entwiekelung erwarten lassen.

Bei gewöhnlicher guter Aufbewahrung des Weizens auf Speichern dauert seine Keimfähigkeit 3 Jahre, d. h. bis zu diesem Zeitpunkt wird sich die grössere Körnerzahl keimfähig erhalten. doch erscheint es wirtschaftlich richtiger, möglichst frisches, doch nicht gedörrtes Saatgut zil verwenden.

Die Keimfähigkeit der Weizenkörner tritt schon in einen Entwickelungsstadium ein, das als "unreif" bezeichnet werden mnss; so säete Göppert am 20. Juni geerntete Weizenkörner (während die allgemeine Reife am 9. Juli eintrat) am 26. Jnni, gleichzeitig mit vorjährigen ans und sah erstere am fünften, letztere am dritten Tage keimen. Im Allgemeinen wird die Gelbreife des Weizens auch fiir den Saatweizen festzuhalten sein, wie sich aus einem umfassenden Vegetationsversuch ron $\mathrm{Nowacki}{ }^{1}$ ) mit Weizen ron ungleichem Reifezustande ergab.

Die äusseren Merkmalc zur Beurteilung der Keimfähigkeit des Weizens begründen sich nach Dimitrieviez ${ }^{2}$ ) daranf, dass die Keimlinge absolıt keimfähiger Weizenkörner eine schön gelblichgrine oder wachsgelb-grinliche Farbe besitzen, dagegen die geschwächten blassgelb oder schmutziggelb, die noch melr verdorbenen bräunlich bis braun und rotbraun sind.

Ausgewachsener Weizen, wenn die Plumula eine Länge von $15 \mathrm{~mm}$ noch nicht überschritten hat, lässt sich im Notfalle noch zur Saat verwenden, vorausgesetzt, dass zur Vermeidung von Leerstellen etwas stärker gesäet und auf weniger reichem Boden die jung'en Pflanzen durch Anwendung leicht löslicher stickstoffhaltiger Diinge-

1) Untersuchungen über das Reifen des Getreides.

2) Wissenschaftlich-pract. Unters. auf d. Gebiet d. Pflanzenbaues, Wien. II. Bd. 1877, p. 70 . 
mittel gekräftigt werden, um den stattgehabten Verlust der Samenkörner an Reservestoffen einigermassen auszugleichen.

Zur Zerstörung der an den Samenköruern etwa haftenden Brandsporen bedient man sich zweckmässig des schwefelsauren Kupferoxyds (Kupfervitriol), von dem nach J. K ii lu u'scher Vorschrift pro $1 \mathrm{hl}$ Saatkorn $180 \mathrm{gr}$ verwandt werden. Derselbe wird fein zerstossen, in heissem Wasser anfoelöst und hierauf zu so vielem kalten Wasser in einen Bottig gegossen, lass das Saatkorn noch eine Querhand hoch mit Kupferwasser bedeckt ist, damit beim Quellen die oberen Schichten nicht trocken liegen. Hierauf wird wicderholt umgerührt und alles auf der Oberflache schwimmende abgeschöpft. Nach 12-16 Stunden wird das Korn ausgeworfen, flach ansgebreitet, sowie fleissig gewendet, und kann hierauf schon in wenigen Stunden mit der Hand, und nach 24 Stunden mit der Maschine gesäet werden.

Die Beizc vermag aber die Keimkraft derjenigen Samenkörner, deren Fruchtschale beim Drusch beschädigt wurde, entweder gainzlich zu zerstören, oder doch die Keimungsenergie erheblich zu schwächcn. Glïcklicher Weise ist bei Verwendung nicht koncentrierter Lösungen von Kupfervitriol, wenn die Samenkörner in fenchte Ackererde kommen, die eine grosse Absorptionskraft für Kufer besitzt, der Procentsatz an in ilurer Keimkraft geschädigten Körneru relativ gering, namentlich weun das Saatgut durch Handdrusch oder durch Ausdrusch anf einer einfachen, nur mit Dreschtrommel versehencn und langsam arbeitenden Dreschmaschine grewonnen wurde.

Durch das Einquellen biissen die Samenkörner immerhin nicht unbedeutende Mengen an Trockensubstanz dureh Exosmose ein; so wies Haberlandt nach 24 stiindigem Einquellen einen Verlnst von 1.14 Proc. nach.

Die Volumenvergrösserung des eingeweichten Weizens beträgt nach Payen bei 5-10-15 Gewichtsprocenten Quellungswasser 15 $-25-25.5$ Proc.

Es ist nach unseren Versuchen aneh nicht unwahrscheinlieh, dass die Bestockungsfähigkeit der ans gebeizten Samenkörnern hervorgehenden Pflänzchen grösser als die der aus ungebeizten ist, wodurch einigermassen cin Ausfall an zerstörter Keimkraft ersetzt wird.

Nach Nobbe betrug bei gewöhnlicher Handelsware

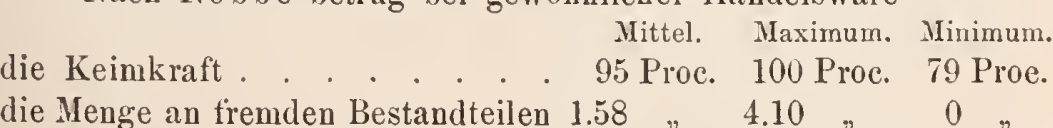

Zur Keimung hat sich zunächst das lufttrockne Samenkorn mit dem notwendigen Qnellungswasser, das 45-69 Proc. betragen kann, und welches auf endosmotischem Wege in 24 Stunden aus nicht 
ganz trockncm Ackerboden aufgenomnen werden kann, zu versehen. Die niedrigste Keimungstemperatur liegt bei $3-4.5^{\circ} \mathrm{C}$., dic maximale zwischen $30-32^{\circ} \mathrm{C}$. und die giunstigste bei $25^{\circ} \mathrm{C}$. Damit nun der zum Keimen erforderliche Sauerstoff dem keinienden Samenkorn in geniigender Quantität zuzufliessen vermag, ist die Tiefe der Unterbringung nach der Bindigkeit und dem Feuchtigkeitsgehalt des Bodens zu regnlieren, und hat sich herausgestellt, dass bei einer Tiefe von $21 \mathrm{~cm}$ dic Weizenkörner nicht mehr keimen und zur Erzielung einer kräftigen Pflanze die Tiefe der Unterbringung folgende Tieflagen nicht iibersehreiten darf, nämlich:

$$
\begin{array}{clr}
\text { auf schwerem Boden } & \multicolumn{2}{c}{\text { Mittelboden }} \\
\text { feucht } & \text { trocken } \\
2 \mathrm{~cm} & 2,5 \mathrm{~cm} & 4 \mathrm{~cm} .
\end{array}
$$

Nach Versuchen von Hosäus, welche in ganz trockenem Boden im trockenen Herbste 1874 mit Weizen gemacht wurden, waren vou je $100^{\circ}$ am 5 . Oktober gesäeten Weizenkörnern im Durchschnitt vou zwei Kontrollparzellen an Pflanzen vorbanden:

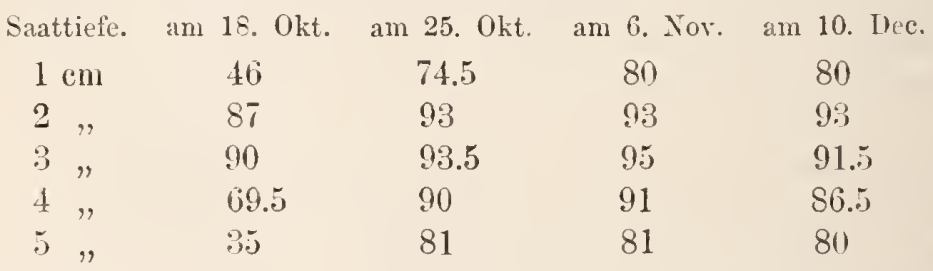

Aehnliche Ergebnisse erzielte anf lcichtem Boden J. Ekkert mit Weizen und Gerste, indem er den Samen ron 2 bis auf $15 \mathrm{~cm}$ Tiefe unterbrachte und folgendes Ergebnis fand: Je geringer die Saattiefe, desto friberes Aufgehen und desto friihere Ernte; sicheres Aufgehen; grössere Aehren- und Stengelzahl; grösseres Körnergewicht im Verhältnis zum Strohgewicht; grössere absolute Produktion. Die grösste Strohlänge wurde bei j cm Saattiefe erzielt. Die Versuche wurden bei Weizen und Saatgut von drei Qualitäten (100 Körner $=4.5 .50,2.808$ und $1.615 \mathrm{gr})$, bei Gerste mit solchem von zwei Qualitäten $(100 \mathrm{Körner}=5.24$ und $3.19 \mathrm{gr})$ gemacht und es ergab sich dabei, dass dic ungünstige Einwirknng der Tiefe bei geringeren Saatgrnt stäker ist als bei gutem. Je besser dasselbe und je geringer die Saattiefe, desto grösser die Ernte. Selbstrerständlich muss die Saat tief genug mit Erde bedeckt scin, um niclit von oben durch Austrocknen allzusehr beeinflusst zu werden. Die günstigste Tiefe scheint $2-3 \mathrm{~cm}$ zu sein.

Gemeinlin beginnt beim Weizen das Keimen bei $16-18^{\circ} \mathrm{C}$. in einem Tage und vollendet die grössere Hälftc der Körner dasselbe in drei Tagen, und zwar treten zunächst drei Primordialwurzeln hervor. 
Ueber den Einfluss der Mitteltemperaturen der Monate März, April, Mai und Juni auf die Keimnng nach 24 stïndigem Einquellen cler Körner geben die nachfolgenden Versnchsresnltate von Haberland t Aufschluss:

\begin{tabular}{|c|c|c|c|c|c|c|c|c|}
\hline & \multicolumn{4}{|c|}{$\begin{array}{c}\text { Die Keimung erfolgte mit dem } \\
\text { Sichtbarwerden desWürzelchens } \\
\text { in 'Tagen }\end{array}$} & \multicolumn{4}{|c|}{$\begin{array}{l}\text { Durchschnittliches Längen- } \\
\text { wachstum für einen Tag in mm. }\end{array}$} \\
\hline bei & \multicolumn{4}{|c|}{$4.38^{0}$ C. $10.25^{\circ}$ C. $15.75^{\circ}$ C. $119^{\circ}$ C. } & \multicolumn{4}{|c|}{$4.38^{\circ}$ C. $10.25^{\circ}$ C. $15.75^{\circ}$ C. $19^{0} \mathrm{C}$} \\
\hline Winter-Weizen & 6 & 3 & 2 & 1.75 & 1.40 & 3.07 & 6.54 & \\
\hline Sommer-Weizen & 6 & 4 & 2 & 1.75 & 1.35 & 3.14 & 6.28 & 7.85 \\
\hline
\end{tabular}

Hiernach sind die Fortschritte der Keimung bei der relativ niedrigen Temperatur von nur $4.38^{\circ} \mathrm{C}$. sehr erhcbliche, welche allein lurch die des Hafers übertroffen werden, und licgt hierin anch die Ursache, dass Herbstsaaten, die schwach in den Winter gekommen, häufig bei`guinstiger Witternng oder unter einer Schneedecke weiter vegetieren und im Frihjahr weit kräftiger erscheinen.

Mit dem Erscheinen des grünen Blattes an der Oberfläche beginnt nun die eigentliche Vegetation und beträgt der Zeitraum von der Anssaat des trocknen Samens bis zum Auflaufen bei einer Mitteltemperatur von $12-15^{\circ}$ C. Ind unter normalen Verhältnissen $10-1$ ? Tage.

Mit der weiteren Entwickehmg sterben die Primordialwurzehn $a b$, dic Kronenwurzeln an einem der unteren Knoten bilden sich und die Bestockung tritt ein. Doch ist hierbei zu beachten, dass die echten Winterweizen vor Vollendung der letzteren eine Ruhepause beansprnchen.

Bei zeitiger Aussaat, genügender Wärme und auf frnchtbarem Boden wird bei ihnen allerdings schon vor der Ruhepause die Bestockung ziemlich reichlich ausfallen können, doch gewöhnlich erscheint erst im Frühjahr die Mehrzahl der Schösslinge.

Die Notwendigkeit einer Ruhepanse scheint den echten Winterweizen in so hohem Grade innezuwohnen, dass selbst die günstigsten Vegetationsbedingungen nicht im Stavde sind, dieselbe aufzuheben, immer tritt ein Zeitpunkt ein, von wo ab bei verspäteter Aussaat ein Teil oder sämmtliche Pflanzen nicht mehr Fruchthalme zu entwickeln vermögen, wofür der von Körnicke in Poppelsdorf ausgefiihrte Versuch den Beweis liefern mag. 
Weisser Winterweizen aus Belgien 1877/78.

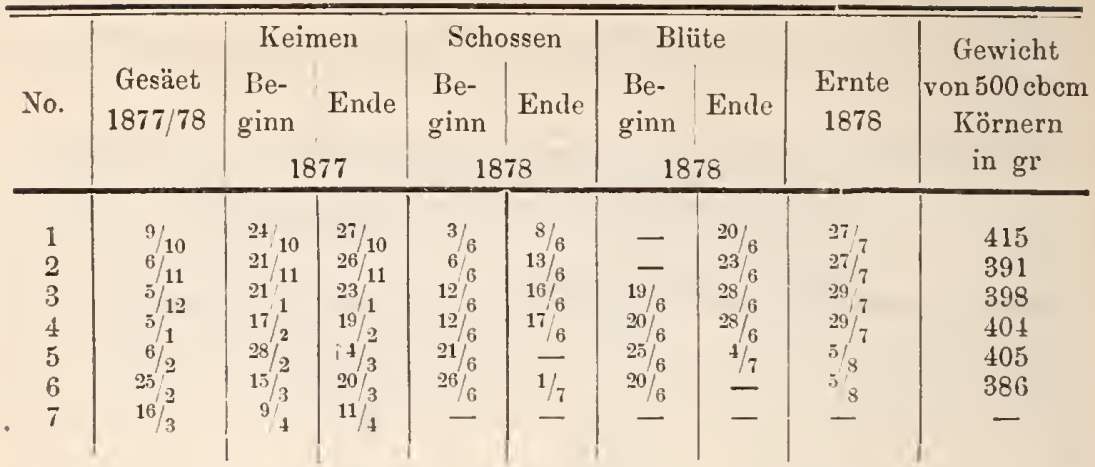

Nur No. 7 reifte nicht ans; eine Aussaat $13 / 6$ zeigte keine Halmbildung, aber iippige Blattbildung; $28 / 63$ Halme p. qm, Blätter sehr hoch und iippig; ${ }^{t} / 78$ Halme, die Blätter fallen um; $12 / 71$ Halm in Bliite. Es wurde nichts geerntet.

Bei Unterbrechung des Wachstums der Pflanzen 'im Winter stirbt ein 'Teil der Wurzeln und Blätter ab, um im Friihjahr durch nene ersetzt zu werden, nnd zugleich beginnt auch die Bestockung: von neuem, welche sieh in der kälteren, gemässigten Zone der Hauptsache nach bis Ende April resp. Anfang Mai vollzieht, und entwickelt der Winterweizen bei wirtsehaftlich dichten Stande 4-5, der Sommerweizen 2.5-4 Halme, doch kommen auch unter sehr guinstigen Bedingungen 50-100 und selbst 400 und mehr Halme pro Pflanze vor. Die Bestockung wird durch zeitige Aussaat, grossen Wachsraum, Fruchtbarkeit des Bodens, giinstige Witternng nud Ncignng. der Sorte zmr starken Bestockung gefördert. Von diesen Schösslingen erreichen nach unseren Beobachtungen gemeinhin 66 Proc. ihre normale Ausl)ildnng; während die anderen meist durch Ueberschattung: vor der Bliite \%u Grunde gehen.

Die ausgewachsenen kräftigen Halme wcisen durchschnittlich 5, seltener 6 Knoten und eine dieser Anzahl entsprechende Blattzahl zur Blïtezeit auf, doch ist $\mathrm{zu}$ dieser Zeit das unterste Blatt meist schon vergilbt oder vollständig eingetrocknet.

Die nachstehende Tabelle (Seitc 469) soll die Vegetationsverhältnisse des Weizens, wie sie sich im Allgemcinen bei unseren Kulturen in Poppelsdorf ergaben, vorfiibren.

Der Weizen gehört zu den Flachwurzlern oder sog. Krumepflanzen, da er den Hauptteil seiner Pflanzennährstoffe, die in leicht aufnehmbarer Form vorhanden sein miissen, aus der Ackerkrume entnimmt, und beweisen die Untersuchungen iber den Wurzeltiefgang und dic Wurzelausbreitung in der That, dass sich die Hauptmasse der aufnahmetähigen Wurzeln in der Ackerkrume, welche auf bes- 


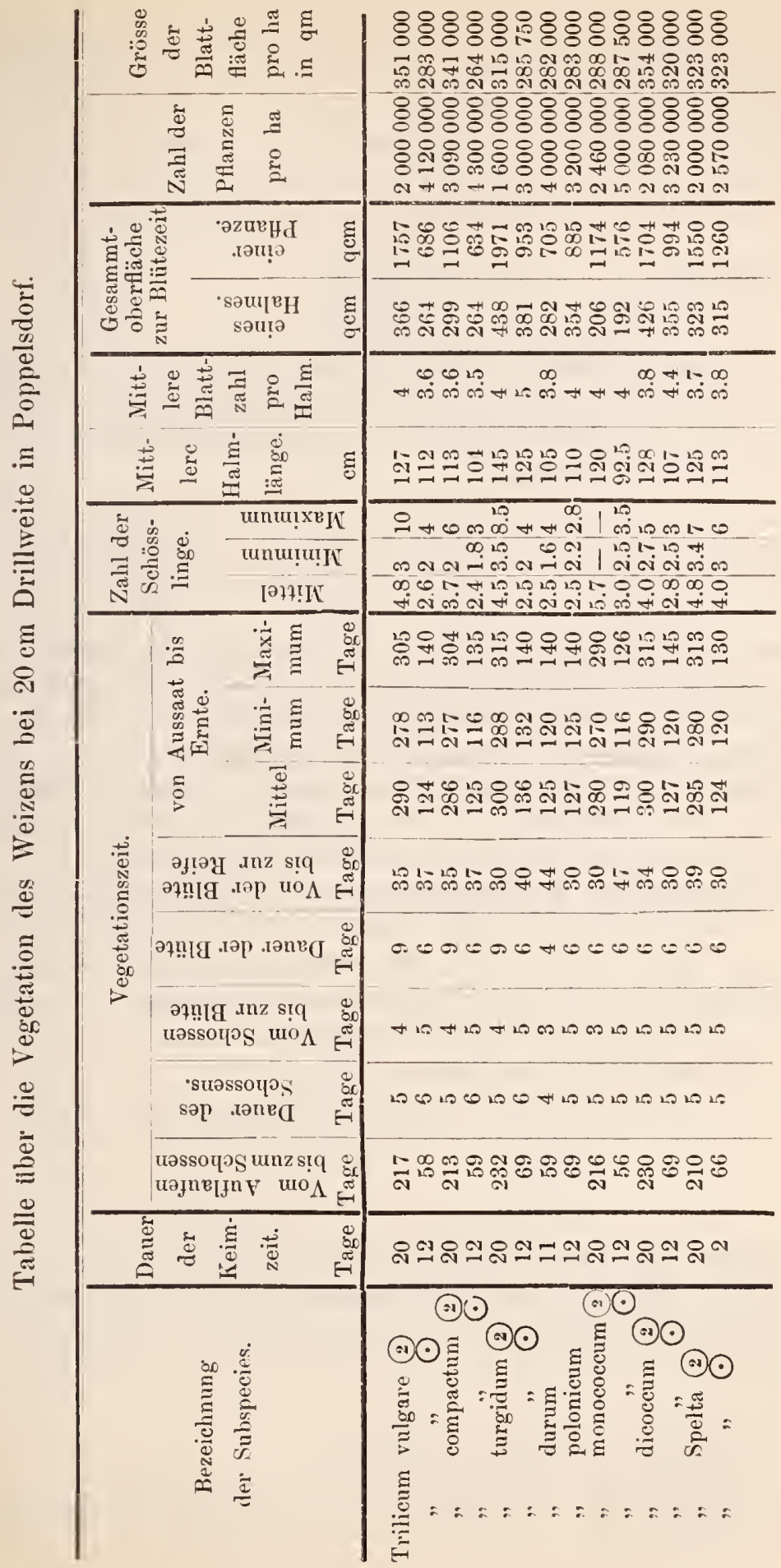


serem Weizenboden auf $26 \mathrm{~cm}$ angenommen werden kann, ausbreitet, worauf anch schon die Bildung der Kronenwurzeln dicht unter der Oberfläche hindeutet. Allerdings erreichten nach SchubarthGallentin ${ }^{1}$ ) einige Wurzeln auf sandigem Lehmboden einen Tiefgang von $2.3 \mathrm{~m}$, und auf bindigerem Boden von $2 \mathrm{~m}$, ferner

am 26. Septbr. gesäet und 30. April ausgegraben von $1.00 \mathrm{~m}$

\begin{tabular}{|c|c|c|c|c|c|c|}
\hline$n$ & $"$ & $"$ & 14. Mai & , & " & 1.22, \\
\hline Ende Oktober & $"$ & $"$ & 26. April & $"$ & $"$ & 0.91, \\
\hline$n$ &, & $"$ & 8. Juni &, & " & 1.14 \\
\hline
\end{tabular}

Dass aber trotzdem die Menge der aufnahmefähigen Wurzelı in der Ackerkrume grösser als im Untergrunde ist, bewies Stöckhardt durch die Untcrsuchung der am 8. Juni gegrabenen Wurzeln. Nach derselben kommen

von 100 Wurzeln auf:

Ackerkrume Untergrund

63
Trockne Wurzeln pro Mrg. in Pfunden: von 100 Teilen Stickstof der Wurzeln auf:

Ackerkrume Untergrund 55

mithin fällt nicht allein die grösste Zahl der Wurzeln, sondern auch die ihrer aufnahmefähigen Endigungen auf die Ackerkrume, was sich aus dem grösseren Stickstoffgehalt der Wurzeln, welcher vorzugsweise wachsenden, jüngeren Teilen zukommt, ergiebt.

Einzelue Wurzeln dringen aber immerhin bis zu beträchtlicher Tiefe in den Untergrund ein und scheinen der ununterbrochenen Wasserversorgung der Pflanze in trockner Zeit zu dienen.

Ueber die Zahl der Wurzelfasern in verschiedenen Tiefen liegen fiir Weizen auch die folgenden Angaben von Hellriegel ${ }^{2}$ ) vor:

Bodenprofil $\left\{\begin{array}{l}\text { lehn. Sand } 65 \mathrm{~cm} \text { \{ } \begin{array}{l}\text { davon Ackerkrume humushaltig } 34 \mathrm{~cm} \\ \text { Untergrund humuslos }\end{array} \\ \text { grober kiesartiger Diluvialsand. }\end{array}\right.$ Zahl der Wurzeln auf 400 qcm Flïche:

$$
\begin{aligned}
& \text { bei } 20 \mathrm{~cm} \text { Tiefe }=820 \text { Fasern } \\
& \text {, } 54, "=200 \text { " } \\
& " 78 ", "=26 " \\
& , 100, " \quad=0 \text { " },
\end{aligned}
$$

Ueber die Wurzelausbreitung gibt $\mathrm{Nobbe}^{3}$ ) folgenden Aufschluss: Er zählte an einer Weizenpflanze, die eben im Begriff war, ihre Aehre hervorzustrecken, 17 Nebenwurzeln 1. Ordnung, 2989 Nebenwurzeln 2. Ordnung, 7215 3. Ordnung und 513 Nebenwurzeln

1) Chemischer Ackersmann 1855, pg. 193.

2) Grundlagen d. Ackerb. pg. 257. 1883.

3) Jahresber. über d. Fortschr. auf d. Gesammtgebiete d. Agric.-Chenie 1868 und 1869, p. 218. 
4. Ordnung. Die Gesammtlänge aller ihrer Wurzeln betrug $520 \mathrm{n}$. Aus diesen Zahlen bereehnet nun Dr. Miiller, Thurgau, eine Gesammtoberfläche von 4.16 qm und eine aufnehmende, nit Wurzelfasern besetzte Fläehe von ea $1 \mathrm{qm}$, welche weit beträchtlieher ist, als die Gesammtfläche der transpirierenden Blätter einer Pflanze des Winterweizens, welehe naeh unseren Untersuehungen bei Tritieum vulgare nur 1757 qcm beträgt.

Im Allgemeinen ist das Wurzelvermögen des Weizens schwächer als das des Hafers und des Roggens, doch stärker als bei der Gerste, daher dem Weizen, sollen hohe Erträge erzielt werden, anf Bïden mit hoher Absorptionskraft leicht assimilierbare Nährstoffe in reiehlieher Fülle $z u$ bieten sind.

Dass das Wurzelvermögen des Weizens schwäeher als das des Roggens ist, scheint aus einer von uns gemachten Beobaehtung hervorzingehen.

Es wurde nämlich seit dem Jahre 1855 auf dem Versuehsfelde zu Proskau Weizen naelı dem Systenı von Smith ${ }^{1}$ ) zu Lois-Weedon kultiviert, welehes von der Drillkultur des Jethro Tull darin abwich, dass breite Zwvischenräume, welche während der Vegetationszcit des Weizens mit dem Spaten tief bearbeitet werden konnten, zwischen ebenso breiten Getreidestriehen lagen. Ein Jahr 1 m das andere wurde der Zwischenraum mit Weizen besäet, welehen demnach die Verwitterungsprodukte zweier Jahre, denn das Feld wurde niemals gredüngt, zur Verfügung standen.

Dass dies ein wirkliches Raubsystem ist und naeh Maassgabe des Bodenreichtums nur eine gewisse Zeit hindureh mit Vorteil betrieben werden kamn, liegt auf der Hand.

Diesc Kultur wurde auf Thonboden mit Thonmergeluntergrund auf einer 1/4 Morgen grossen Parzelle eine Reihe von Jahren durehgeführt und ergab sieh naehsteliendes Resultat:

Jahreszahl:

1855

1856

1857

1858

1859

1860

1861

1862

1863
Gesäet:

Englischer Bartweizen

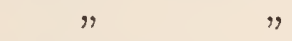

Sommerweizen, "weil Winter-

weizen ausgewintert

Frankenstciner Weizen

$\begin{array}{ll}" & " \\ " & "\end{array}$

Körnerernte :
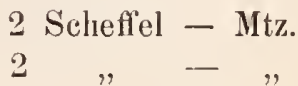

2

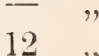

$1 \quad " \quad 12 "$

1) A Word in Season; or How to grow Wheat with Profit. 
Jahreszahl :

1864

1865

1866

1867
Gesäet:

Frankensteiner Weizen

Hernaeh zeigt sieh alljährlieh eine ziemlieh stetige Abuahme von ea. 4 Mtz. Weizen, so dass sehliesslieh überhaupt nur noeh eine Ernte von 4 Mtz. erzielt wurde und die Annahme gereehtfertigt erschien, dass nun eine fast vollstäulige Bodenersehöpfnng für Weizen eingetreten sei. Demzufolge wurde an Stelle des Weizens Roggen zur Einsaat verwandt, weleher folgende Ernten lieferte:

\begin{tabular}{|c|c|c|c|c|}
\hline $186^{\circ}$ & Göttinger Roggen & $\begin{array}{r}\text { Kör } \\
- \text { Sehffl. }\end{array}$ & $\begin{array}{l}\text { ner. } \\
15 \quad \text { Mtz. }\end{array}$ & $\begin{array}{l}\text { Stroh und Spreu. } \\
134 \mathrm{Pfd} \text {. }\end{array}$ \\
\hline 186 & 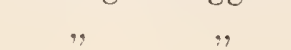 & 1 & $71 / 2 \quad$, & $242 \quad$.. \\
\hline 1870 & , & 1 & $3^{1 / 4}$ & 179 \\
\hline
\end{tabular}

Das ungünstige Resultat des Jahres 1868 ist als Folge sehr starken Auftreteus vou Rost anzuseheu.

Hieraus gelıt herror, dass für Roggen der Boden naeh 13jühriger Weizenkultur noch nielıt ersehöpft war, und 1869 ohne Düngung noeh 11 Seheffel $12 \mathrm{Mtz}$. Roggen und $1936 \mathrm{Pfd}$. Stroh pro Morgen erzeugt werden konnten. Diese Erseheinung glauben wir nur dadureh erklären zu können, dass die Wurzel des Roggens in der Nahrungsaufnahme eine stärkere Intensität, also ein grösseres Wn Wrzelveruögeu besitzt. als die des Weizens; denn dass der eine oder andere wiehtige Mineralbestandteil für Weizen nieht mehr im Boden vorhanden gewesen sein sollte, erscheint unwahrscheinlieh, da eine Rogrgenernte. gleieh grosse Ertrïge vorausgesetzt, dem Boden die wielutigsten Mineralbestandteile in annähernd denselben Qnantitäten wie der Weizen entzielit.

Der Weizen entnimmt dem Boden dureh eine Mittelerute pro ha an Nährstoffen:

\begin{tabular}{l}
\hline \\
\hline
\end{tabular}


Nach J. B. Lawes ${ }^{1}$ ) verbrancht del Weizen bis zur vollständigen Entwickelung durchschnittlich die 2000 fache Gewichtsmenge seiner assimilierten Aschenbestandteile an Wasser, und vürde dies einer mittleren Lösungskoncentration von 0.5 pro Mille entsprechen. Bis zur Reife verbranchte eine Pflanze durchschnittlich $43 \mathrm{gr}$ Wasser p. Tag in dem Seeklima Englands.

Risler berechnet den Wasserkonsum pro 100 qem Blattoberfläche und Stunde anf $0.175 \mathrm{gr}$ oder $4.2 \mathrm{gr}$ p. Tag, und Hellrieg'el den Wasserverbrauch pro Gramm producicrte Trockensubstanz für Sommerweizen auf $338 \mathrm{gr}$.

Da num die Pflanze täglich beträchtliche Quantitäten rohen Nahrungssaftes zu verarbeiten lat, muss auch die aufsangende Wurzeloberflïche zul der verdunstenden Fliiche der oberirdischen Teile in einem gewissen Verhältnis stehen, wobei jedoch zu beachten ist, dass die Pflanzen um so melir Wasser verdunsten, je jünger sie sind, wie dies anch die nachstehende Uebersicht ans Versuchen von Haberlandt bestätigt; doch ist zu bemerken, dass die P'flanzen bei diesem Versuch Wasser im Ueberfluss zugefïhrt erhielten, daher die gewonnencu Resultate den faktischen Verhältnissen nicht grenau entsprecheu.

\begin{tabular}{|c|c|c|c|c|c|}
\hline & $\begin{array}{c}\text { Ober } \\
\text { der } \\
\text { suc } \\
\text { pfla } \\
\text { I } \\
\text { qcm }\end{array}$ & $\begin{array}{l}\text { äche } \\
\text { Ver- } \\
\text { as- } \\
\text { zzen } \\
\text { II } \\
\text { qcm }\end{array}$ & $\mid \begin{array}{c}\text { Zahl der } \\
\text { Spaltöff- } \\
\text { nungen } \\
\text { auf der } \\
\text { unteren } \\
\text { Blattseite } \\
\text { pro qmm }\end{array}$ & $\begin{array}{l}\text { Verlältnis } \\
\text { des Trocken- } \\
\text { gewichts der } \\
\text { Wurzeln zu } \\
\text { jenem der } \\
\text { oberirdi- } \\
\text { schen Teile }\end{array}$ & $\begin{array}{l}\text { Ver- } \\
\text { dunstung } \\
\text { pro Tag } \\
\text { u.100qcm } \\
\text { (bei Was- } \\
\text { ser im } \\
\text { Ueber- } \\
\text { fluss) }\end{array}$ \\
\hline a. Junge Pflanze vor dem Schossen & 76 & 97 & 111 & $1: 0.673$ & 5.136 \\
\hline b. Mittlere Pflanze vor der Blïte & 154 & 283 & 95 & $1: 4.943$ & 2.802 \\
\hline c. Pflanze nach der Blïte & 220 & 387 & 75 & $1: 10.471$ & 2.657 \\
\hline
\end{tabular}

Hiernach verdunsten 100 qem pro Tag im Mittel $3.532 \mathrm{gr}$, und wird diese Verdunstungsgrösse bei den echten Getreidearten nul durel die der Gerste mit 3.794 gr uibertroffen.

- Ueber die Henge und Wanderung der organischen und unorganischen Stoffe in der Weizenpflauze liegen einige intercssante Untersuchungen vor, z. B. liat Heintich ${ }^{2}$ ) eine getrennte Bestimmung der stickstofffreicn organischen Substanz vorgenommen, die zu folgenden Resultaten fïhrte:

1) Experimental investing into the amount of water given of by plants during their growth. 1850 , citiert von Kresnik, Journ. f. Landwirthsch. XXXI, 1881, p. $32 \pi$.

2) St o ckhardt, Chem. Ackersm. 1867, p. 116. 
In 100 Teilen Trockensubstanz der Halme und Aehren wurden gefunden :

\begin{tabular}{|c|c|c|c|c|c|c|c|c|c|c|}
\hline \multirow[t]{2}{*}{ Entwiekelungsstadium ${ }^{1}$ ). } & \multicolumn{2}{|c|}{$\begin{array}{l}\text { Krümel- } \\
\text { zucker. }\end{array}$} & \multicolumn{2}{|c|}{$\begin{array}{l}\text { Rohr- } \\
\text { zucker. }\end{array}$} & \multicolumn{2}{|c|}{$\begin{array}{c}\text { Gummi- } \\
\text { artige } \\
\text { Substanz. }\end{array}$} & \multicolumn{2}{|c|}{$\begin{array}{c}\text { Stärke- } \\
\text { artige } \\
\text { Substanz. }\end{array}$} & \multicolumn{2}{|c|}{$\begin{array}{l}\text { Gesammt- } \\
\text { menge } \\
\text { von stick- } \\
\text { stofflosen } \\
\text { Stoffen. }\end{array}$} \\
\hline & 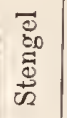 & $\stackrel{0}{\Xi}$ & $\begin{array}{l}\overrightarrow{0} \\
\infty 0 \\
\overrightarrow{0} \\
\vec{D}\end{array}$ & $\frac{2}{2}$ & 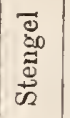 & $\frac{0}{\square}$ & $\begin{array}{l}\vec{D} \\
\dot{E} \\
\bar{D} \\
\dot{D}\end{array}$ & $\stackrel{巳}{\frac{\varrho}{2}}$ & $\begin{array}{l}\bar{D} \\
\frac{\delta 0}{\bar{J}} \\
\dot{d}\end{array}$ & 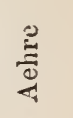 \\
\hline $\begin{array}{l}\text { 1. Pflanze ganz jung } \\
\text { 2. Pflanze mit beginnender }\end{array}$ & 8.2 & - & - & - & 26.9 & - & 一 & - & 35.1 & - \\
\hline lentwickel & 15.1 & - & 3.4 & - & 20.5 & - & - & - & 39.0 & - \\
\hline $\begin{array}{l}\text { 3. Anfang des Schossens } \\
\text { 4. Aehren aus der Blattum. }\end{array}$ & 12.3 & 9.3 & 6.5 & 8.2 & 18.9 & 26.0 & - & - & 37.7 & 43 \\
\hline büll & 10.8 & 9.5 & 8.7 & 6.9 & 14.7 & 11.6 & 3.0 & 11.4 & 37.2 & 39. \\
\hline 5. Blütezeit & 9.0 & 4.4 & 5.5 & 6.7 & 14.1 & 7.1 & 3.4 & 28.9 & 32.0 & 47. \\
\hline 6. Blüte vorübe & 7.7 & 1.4 & 4.7 & 2.3 & 9.7 & 4.7 & 4.5 & 54.4 & 26.6 & 62 \\
\hline e bleichen & 5.6 & Spur & 3.9 & Spur & 3.6 & 2.7 & 4.5 & 68.6 & 17.6 & 71. \\
\hline 8. $\mathrm{M}$ & 0 & 0 & 0 & 0 & 1.8 & 2.5 & 5.6 & 71.4 & 7.4 & 73. \\
\hline 9. Ueberreife & 0 & 0 & 1) & 0 & 1.7 & 2.4 & 5.0 & 73.1 & 6.7 & 75. \\
\hline
\end{tabular}

Dic stickstoffhaltigen organischen Substan\%en (Proteïnkörper) finden sich entweder im lebensthätigen Protoplasma, wie das Pflanzeneiweiss oder Pflanzenalbumin, während die iubrigen Proteïnkörper als Reservestoffe abgelagert werden und uuterscheidet man von ihnen nach Kitth a sen:

1) Para-Caseïn (Gluten-Caseïn) mit 16.0-16.1 Proc. Stickstoff

2) Pflanzenfibrin (Gluten-Fibrin) „ 16.9

3) Mucin (Mucediu)

4) Pflanzenleim (Glialdin)

"18.1

Diese Proteïnkörper fiihren auch den Kollectivnamen „Kleber“.

Die nachstehende Untersuchung von Heinrich sei ein Beispiel der Wanderung der Proteïnstoffe.

Proteïnstoffe in 100 Teilen Trockensubstanz:

Stengel Aehren

1) Pflanze ganz jung

18.5

2) Pflanze vor Beginn des Sehossens 5.5

20.7

3) Entwickelung der Bliite

$4.4 \quad 14.2$

4) Blütezeit

$4.0 \quad 11.0$

5) Ende der Bliite

$2.8 \quad 9.3$

6) Halbe Reife

$2.0 \quad 8.8$

7) Ganze Reife

1.9

8.0

1) Die ersten 2 Perioden beziehen sich auf die Blätter, die anderen 6 auf die Stengel und Aehren. 
Ueber die Wanderung der Mineralbestandteile der Weizenpflanze während der Entwickelung vom Fruchtkuoten bis zur Ucberreife hat Hein $\mathrm{rich}^{1}$ ) ebenfalls Untersuchungen bei 5 verschiedenen Entwickelungsstufen der Samenkörner angestellt, und zwar:

1) am 4. Juli. Dic Hälfte des Weizens, welcher als Untersuchungsmaterial diente, blühte zu dieser Zeit noch. Es wurden hier die Fruchtknoten fiir die Analysen gesammelt;

2) an 18. Juli, also 14 'Tage nach der Blite;

3) am 1. August, als der Weizen bereits za reifen begann;

4) am 8. August, als der Weizen reif war und gemiaht wurde;

5) an 23. August, also 14 Tage nach der Erute. Hier wurden die Mineralstoffe der überreifen Körner untersucht.

100 Teile der vollständig wasserfreien Körner zcigten sich zu den verschiedenen Zeiten der Untersuchung folgcudermassen zusammengesctzt:

Tabelle I.

\begin{tabular}{|c|c|c|c|c|c|}
\hline & 4. Juli & 18. Juli & 1. Aug. & 8. Aug. & 23. Aug. \\
\hline $\begin{array}{l}\text { Rohrzucker } \\
\text { Krümelzucker } \\
\text { Aetherauszug (Chlorophyll, } \\
\text { Wachs, Oel) } \\
\text { Gummi } \\
\text { Stärke } \\
\text { Proteïnstoffe } \\
\text { Zellstoff } \\
\text { Mineralstoffe } \\
\text { Kali } \\
\text { Natron } \\
\text { Kalk } \\
\text { Magnesia } \\
\text { Eisenoxyd } \\
\text { Schwefelsäure } \\
\text { Phosphorsäure } \\
\text { Chlor } \\
\text { Kieselsäure }\end{array}$ & \begin{tabular}{|c|}
6.97 \\
4.08 \\
\\
5.69 \\
12.64 \\
41.79 \\
14.15 \\
10.35 \\
4.33 \\
1312 \\
0.055 \\
0.412 \\
0.514 \\
0.024 \\
$-\overline{1.740}$ \\
0.326 \\
0.021
\end{tabular} & \begin{tabular}{|r|}
4.24 \\
1.27 \\
\\
2.25 \\
7.50 \\
61.44 \\
14.05 \\
6.77 \\
2.48 \\
0.768 \\
0.007 \\
0.166 \\
0.315 \\
0.016 \\
$\overline{1.100}$ \\
0114 \\
0.020
\end{tabular} & \begin{tabular}{|l} 
Spuren \\
\\
2.08 \\
5.86 \\
74.17 \\
12.21 \\
3.54 \\
2.14 \\
0.529 \\
0,016 \\
0.085 \\
0.283 \\
0.021 \\
$-\overline{118}$ \\
0.069 \\
0.034
\end{tabular} & \begin{tabular}{|r|}
- \\
1.90 \\
5.43 \\
75.66 \\
11.82 \\
3.22 \\
1.97 \\
0.483 \\
$-\overline{076}$ \\
0.250 \\
0.059 \\
$-\overline{019}$ \\
0.069 \\
0.039
\end{tabular} & $\begin{array}{c}- \\
- \\
1.90 \\
4.97 \\
76.38 \\
11.67 \\
3.20 \\
1.88 \\
0.453 \\
-\overline{0} \\
0.074 \\
0.023 \\
0.055 \\
-\overline{078} \\
0.064 \\
0.040\end{array}$ \\
\hline $\begin{array}{l}\text { Summa } \\
\text { Hiervon ab der dem Chlor } \\
\text { äquivalente Sauerstoff }\end{array}$ & $\begin{array}{l}4.404 \\
0.074\end{array}$ & $\begin{array}{l}2.506 \\
0.026\end{array}$ & $\begin{array}{l}2.155 \\
0.015\end{array}$ & $\begin{array}{l}1.985 \\
0.015\end{array}$ & $\begin{array}{l}1.894 \\
0.014\end{array}$ \\
\hline & 4.330 & 2.408 & 2.140 & 1.970 & 1.880 \\
\hline Summa & 100.00 & 100.00 & 100.00 & 100.00 & 100.00 \\
\hline
\end{tabular}

Bercehnet man, um einen Anhalt über die absoluten Mengen

1) Heinrich, Annal. Bd. 57, 1871. 
der einzelnen Stoffe in den Körnern zu haben, die Bestandteile auf die Körner von 100 Aehren (2600 Köruer), so erhält man die folgenden Zahlen:

Tabelle II.

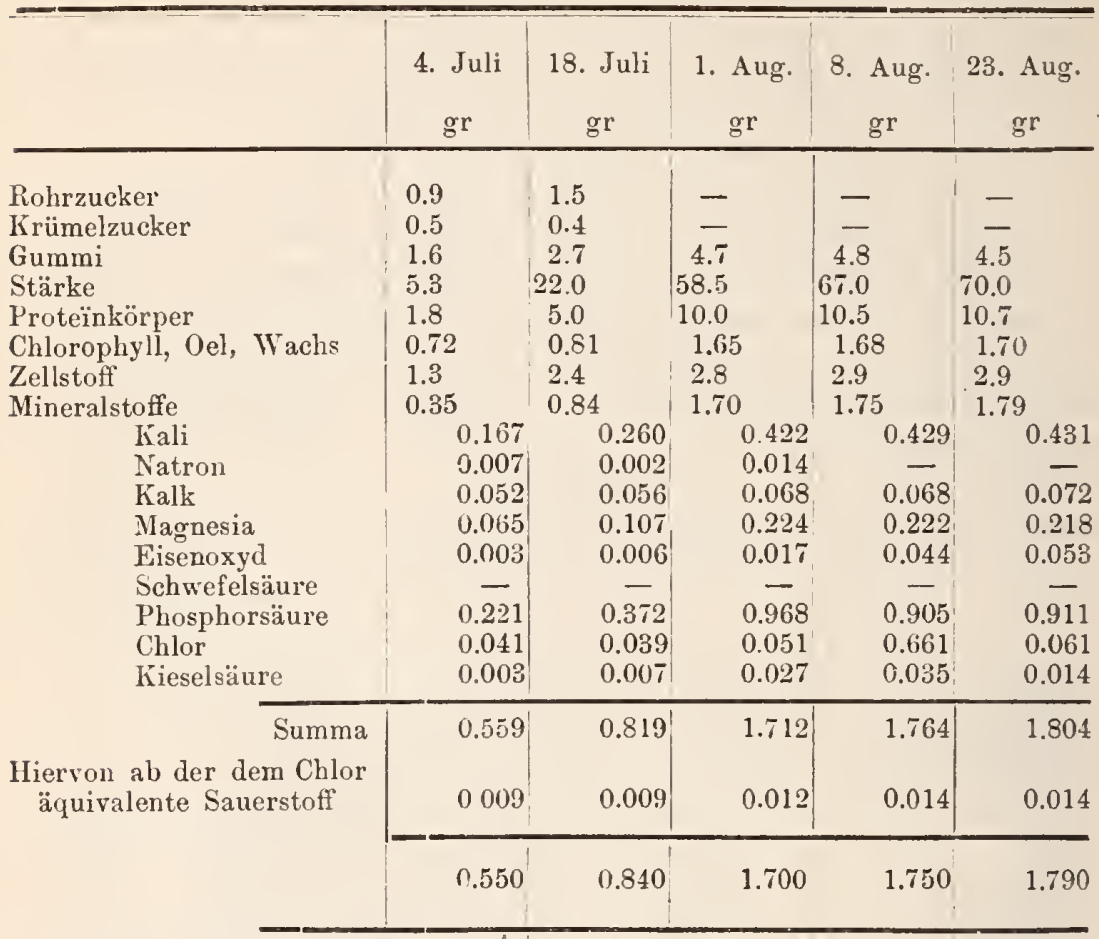

\begin{tabular}{l|l|l|l|l|l|l|l} 
Gewicht von 2600 Körnern & 12.7 & $\mathrm{gr}^{*}$ & 35.7 & $\mathrm{gr}^{*}$ & $79.4 \mathrm{gr}$ & $88.6 \mathrm{gr}$ & $91.6 \mathrm{gr}$
\end{tabular}

In der Zeit, welehe die rersehiedenen Untersuchungen einsehliesst, haben demzufolge 2600 Weizenkörner eine gesammte Hineralstoffzunahme erfahren ron $0.55-1.79 \mathrm{gr}$. Dieser Zunahme unterliegen alle Mineralstoffe mit Ausnahme ron Natron. Aus dem vollständigen Versehwinden des Natrons, ohne dass dies einen bemerkbaren Einfluss auf die Entwiekelung der Körner äussert, g'eht sehou dessen Unwesentlichkeit für dieselben hervor.

Die beiden vorwiegenden Bestandteile der Körner sind dagegen Phosphorsänre und Kali; diesen schliesst sieh der Quantitait nach die Magnesia an, für welehe eine physiologisehe Wirkung bisher aber noch nicht aufzufinden war. Nur soll nach Hellriegel${ }^{1}$ ) Maguesianangel ein flattriges Aussehen, begleitet von einer kränklichen, blassgelben Farbe, bei starkem Längenwaehstum der Pflanze bedingen.

1) Landw. Versuchsst. 1868, p. 105. 
Die genannten Bestandteile sammeln sieh nach und nach in den juingsten Teilen der Pflanze, den Körner'n an, wogegen die iibrigen Organe an den betreffenden Bestandteilen ärmer werden.

Es ist eine, dureh die genauesten Untersuehungen iiber die Vegetationsverhältnisse der Kulturpflanzen (z. B. Arndt, die Veget. d. Haferpfl., Leipzig 1859; D i etrieh. Unters. d. Rotklees, 2. Bericht d. Versuchsst. Heidau, 1864) bestätigte Thatsaehe, dass das Lelıen dieser Pflanzen schon mehrere Wochen vor der Samenreife fast $\mathrm{nmr}$ in einer inneren Thïtigkeit besteht, auf welche der Einfluss des Bodens als ermährendes Medium fast ganz authört. Nicht nü die Gesamntmasse der Mineralstoffe ist bis zu dieser Zeit vollständig von den Pflanzen anfgenommen, sondern sogar die Quantität der organischen Substanzen seheint sehon fertig gebildet zn sein, so dlass das vegetative Leben nur noch auf einer Translokation der einzelnen Stoffe beruht; aus den Blättern nud Stengelgliedern gehen die organisehen Stoffe naeh der Aehre und lagern sich hier fast aussehliesslieh in den Körneru ab.

Der Zeitpunkt der vollendeten Gewichtsaufiahme tritt naeh J. Pierre ungefäh 14 Tage naeh der Weizenbliite ein.

Ist es nun bekannt, dass die Pflanzen kur nach der Blite Nichts oder mu geringe Mengen aus dem Boden aufnehmen, so ist es interessant, die Bewegungen der hauptsïehlichsten Mincralstoffe in der Pflanze zu verfolgen, und zwar nach den Gewiehtsverhältnissen der versehiedenen Teile während der versehiedenen Entwickelnngsperioden, wie sie die Untersuehungen von J. Pierre ${ }^{1}$ ) ergeben haben, berechnet auf die Pflanzen von 1 ha.

Aus den Versuehen von 1864:

\begin{tabular}{|c|c|c|c|}
\hline Es wogen pro ha. & $\begin{array}{l}\text { Am 6. Juli } \\
\text { (14 Tage } \\
\text { nach der } \\
\text { Blüte) } \\
\text { kg }\end{array}$ & $\begin{array}{c}\text { Am 25. Juli } \\
\text { (Reifezeit) } \\
\text { kg }\end{array}$ & $\begin{array}{l}\text { Vermin- } \\
\text { derung des } \\
\text { Gewichts } \\
\text { kg }\end{array}$ \\
\hline $\begin{array}{l}\text { Die sämmtlichen Blätter } \\
\text { "des Halmes Internodien } \\
\text { die sämmtlichen Knoten des } \\
\text { Halmes }\end{array}$ & $\begin{array}{r}1594 \\
2253 \\
304\end{array}$ & $\begin{array}{r}1255 \\
1822 \\
259\end{array}$ & $\begin{array}{r}339 \\
431 \\
45\end{array}$ \\
\hline Gewicht der vollen Aehren & 4151 & 3336 & $\begin{array}{c}815 \\
\text { Vermehrung } \\
796\end{array}$ \\
\hline
\end{tabular}

1) Recherches expériment. sur le developpement du blé 1866 . 
Das Kali ist auf 1 ha in den cinzelnen Pflanzenteilen in folgender Menge enthalten:

\begin{tabular}{|c|c|c|c|c|}
\hline & $\begin{array}{c}\text { Am 3. Juni } \\
\text { (Aelire } \\
\text { entwickelt } \\
\text { sich) } \\
\mathrm{kg} \\
\end{array}$ & $\begin{array}{c}\text { Am 22. Juni } \\
\text { (Ende der } \\
\text { Blüte) } \\
\mathrm{kg}\end{array}$ & $\begin{array}{c}\text { Am } 6 . \\
\text { Juli } \\
\mathrm{kg}\end{array}$ & $\begin{array}{c}\text { Am } 25 . \\
\text { Juli } \\
\mathrm{kg}\end{array}$ \\
\hline $\begin{array}{ccl}\text { Die } & \text { volle Aehre } \\
, & \text { sämmtl. Internodien } \\
, & , & \text { Knoten } \\
, & , & \text { Blätter }\end{array}$ & $\begin{array}{r}4.43 \\
3.77 \\
3.23 \\
11.48\end{array}$ & $\begin{array}{r}2.55 \\
10.56 \\
4.41 \\
8.67\end{array}$ & $\begin{array}{r}10.00 \\
6.79 \\
5.44 \\
534\end{array}$ & $\begin{array}{r}13.79 \\
4.55 \\
4.05 \\
0.96\end{array}$ \\
\hline
\end{tabular}

Der Bedarf der Aehren (der Körner) an KO wurde also rollständig durch den Verlust, den die krautigen T'eile der Pflanze lieran erlitten, gedeckt.

Die Erschöpfung der einzchnen Organe an den für das Samenkorn wichtigen Stoffen, geht, wie es schcint, im abnehmenden Massc von unten nach oben zu.

Dies zeigt eine Zusammenstellung des Kaliverlustes fiir die einzelnen Blätter. Die Verluste betrugen nach Pierre:

für das oberste Blatt 95 Proc.

$\begin{array}{rrrrrr}" & , & 2 . & , & 86 & \\ " & " & 3 . & " & 92 & " \\ ", & , & 4 . & " & 96 & . \\ " & " & 5 . & " & 100 & ,\end{array}$

Von dieser Rerel zeigte also nur das oberste Blatt eine Aus. nahme; die anderen Blätter folgen ihr genau.

Die verschiedenen Organe mit einander verglichen, tragen relativ verschiedene Verluste an Kali. Es beträgt der Kaliverlust:

$$
\begin{array}{cccc}
\text { für die } & \text { Blätter } & 91 & \text { Proc. } \\
\text { ". } & \text { Internodien } & 57 & \\
, \quad, \quad \text { Knoten } & 26 &
\end{array}
$$

Für die Phosphorsäure stellen sich die Verhältnisse folgendermassen:

Auf 1 ha enthalten an Phosphorsaure:

\begin{tabular}{c|c|c|c|c}
\hline & 3. Juni & 22. Juni & 6. Juli & 25. Juli \\
& $\mathrm{kg}$ & $\mathrm{kg}$ & $\mathrm{kg}$ & $\mathrm{kg}$ \\
\hline & & & & \\
\hline
\end{tabular}

Auch an Phosphorsäure wurde der Bedarf der Aehre durch den 
Verlust des Krantes vollständig gedeekt und zwar sind hier wie beim Kali die Blätter für die Lieferung von höehster Bedeutung. Sie verlieren nicht nur relativ, sondern auch alsolut die neiste Plosphorsäure.

Auch für die Magnesia ergaben sich ähnliche Resultate:

Auf 1 ha enthalten an Magnesia.

\begin{tabular}{|c|c|c|c|c|c|}
\hline & $\begin{array}{l}\text { 11. Mai } \\
\mathrm{kg}\end{array}$ & $\begin{array}{l}\text { 3. Juni } \\
\mathrm{kg}\end{array}$ & $\begin{array}{c}\text { 22. Juni } \\
\mathrm{kg}\end{array}$ & $\begin{array}{l}\text { 6. Juli } \\
\mathrm{kg}\end{array}$ & $\begin{array}{l}\text { 25. Juli } \\
\mathrm{kg} \\
\end{array}$ \\
\hline $\begin{array}{l}\text { Die vollen Aelren } \\
, \quad \text { sämmtl. Internodien } \\
", \quad, \quad \text { Ínoten } \\
", \quad, \quad \text { Blätter }\end{array}$ & $\begin{array}{l}-\overline{39} \\
0.27 \\
1.67\end{array}$ & $\begin{array}{l}0.41 \\
0.62 \\
0.42 \\
2.07\end{array}$ & $\begin{array}{l}1.44 \\
1.82 \\
0.73 \\
3.37\end{array}$ & $\begin{array}{l}2.21 \\
085 \\
0.78 \\
2.80\end{array}$ & $\begin{array}{l}4.31 \\
0.79 \\
0.59 \\
1.64\end{array}$ \\
\hline
\end{tabular}

Es findet demnach eine langsame Bewegung der Stoffe statt, welehe als Endziel das Samenkoru liat. Jedoeh sehliessen sich nieht alle Mineralstoffe der Pflanze diesen Bewegungen in so ausgesprochenem Masse an, vorzugsweise sind es I'hosphorsäure, Kali und Magnesia, während sieh nur in geringen Mengen Kalk. Kisenoxyd ete. im Samenkorn finden.

Der Weizen wird unter Unständen durch Unkrant selı stark geschädigt nnd selbst vollständig unterdriekt. In solehen Fällen ist zur Vertilgung desselben auf Brachbearbeitung. zweckmässige Fruchtfolge und rationelle Haekliultnr zuriekzugreifen.

Bei der nachfolgenden Bespreehung der geführliehsten Unkräuter werde ich die speeiellen Vertilgungsurassregehn, welehe gegen dieselben zu ergreifen sind, anfiihren.

Auf den guten Lehmmergelböden tritt sehr hïufig. sowohl unter Sommer- wie auch Winterweizen der Klatsehmohu (Papaver Rhoeas I.) in grossen Masseu auf, weleher in diesem Fall vor der Bliite durel Jäten oder Hacken zu entfernen ist, damit nicht der Weizen unterdriiekt und dureh Samenausfall das Feld infieiert wird.

Als sehr lästiges Wurzelunkrant ist ferner die Feldkratzdistel (Cirsium arvense Seop.) zu erwähneu, welehe nieht nur die Entwiekelnng des Weizens liemunt und die Ernte ersehwert, sondern auch dem Boden sehr beträehtliche Mengen an Pflanzennährstoffen entzieht. Gegen dieses Unkraut lässt sieh nnr durch tiefes Grubbern. nnd Ausstechen ank:̈mpfen.

Sehr gefürehtet, namentlieh am Rhein und im mittleren und suidlichen Frankreieh, ist aueh der Flug-oder Wildhafer (Avena fatua L.), weleher nnter Sommer- und Winterweizen vorkomnit. Zur Vertilgung lässt sich die Verhinderung der Samenreife, die gute Reinigung des Saatgutes, sowie das Jäten und Haeken empfehlen.

Auf kalkarnen 'Thon- und Lehmböden erseheint unter Sommer- 
weizen auch die Saat-Wucherblnme (Chrysanthenum segetum L.), welche durch Jäten und Hacken zn vertilgen ist.

In Ländern nit mildem Winter tritt anf humosem Lehm oder Thon auch im Winterweizen der Ackersenf oder Bruchbederich (Sinapis arvensis L.) und auf leichterem Boden der Hederich (Raphanns Raphanistrum L.) als gefurchtetes Unkraut auf, da sie nicht nur die Nïhrstoffe der Ackerkrume stark in Anspruch nehmen, sondern auch das Getreide leicht ïberwachsen. Die Hederichjätemaschinen wendet man erfolgreich zur Vertilgung an.

Die gewöhnlichsten Unkränter auf den sandigen Lehm- und lehmigen Sandböden sind die Kornrade (Agrostemma Githago L.) und die Kornblume (Centaurea Cyanus L.), welche beide unter Winterweizen, aber auch unter zeitig gesäctem Sommerweizen vorkommen. Gelangen die Samen der ersteren mit dem Weizen zur Vermahlung, so erhält das Mehl eine schwärzliche Farbe und das daraus bereitete Brod gesundheitsschädliche Eigenschaften. Die Ausrottnng wird durch gute Reinigmng des Saatgutes, Eggen, Hackkultur, Ausstechen und Jäten angebahnt. Recht schädlich kann dem Winterweizen bei masscnhaftem Auftreten auch die ausdanerndc Ackerwinde (Convolvulus arvensis L.) dureh Entkräitung des Bodens, Niederziehen der Halme und Erschwerung der Ernte werden.

Zur Vertilgung wird das Ackern bei Diirre, namentlich das Grubbern, sowie dic Hackknltur enpfohlen.

Auch der gemeine Windhalm (Agrostis Spica venti L.) ist anf leichtem Boden mit feuchtem Untergrunde dem Weizen nachteilig und hilft gegen ilm nur Entwässerung und zweckmässige Ackerbestellung.

Auf den kalkreichen Mittelböden treten häutig zwei Schmarotzer als gefährliche Feinde des Weizens auf, weil sie bei häufigem Vorkommen den Weizenpflanzen ansehnliche Quantitäten rohen Nahrungssaftes entziehen, anch geben ihre Samen dem Mehl eine blaue Farbe und bitteren Geschmack; es sind dies der Feldwachtelweizen (Melampyrum arvense L.), sowie die grössere Klapper (Alectorolophus major Rehb.); beide lassen sich durch sorgfältiges Reinigen des Saatgutes, sowie durch Jäten oder Hackkultur entfernen.

Ein sehr lästiges Unkraut ist ferner die stinkcndc Hnndskanille (Anthemis Cotula L.), welche sich durch krïftiges Aufeggen der Wintersaat und Hackkultur ausrotten lïsst.

Unter Sommerweizen findet sieh die nebenblättrige Platterbse (Lathyrus Aphaca L.), und ist durch Jäten und Hackkultur zu vertilgen.

Ein Unkraut des Kalkbodens in Frankreich und Italien ist die traubige Bisambyacinthe (Muscari racemosum Mill.), die gern unter Sommerweizen auftritt. 
Auf feuchten Aeckern in Frankreich fand Lagrère-Fossat den rotblütigen Augentrost (Euphrasia odontites L.), auf Weizen schmarotzend, derselbe lässt sich dureh gute Entwiissermung des Ackers bald bescitigen.

Auf allen Bodenarten, wemn sich nur Mergel im Untergrunde findet, breitet sich der geneine Huflattich (Tussilago Farfara L.) als kaum zu vertilgendes Unkraut, nanentlich anf Aeckern in etwas feuchter Lage ans und wird als Vertilgungsuittel das B;achen, das Aussteclen und der Anbal stark schattender Blattgewächse empfohlen.

Der Weizen leidet auch mehr oder weniger durch parasitische Pilze. Zu diesen gehört der Faul-, Schmier- orer Steinbrand (Tilletia caries Tul.), daran kenntlich, dass das von seiner Frucht- nnd Samenhaut bedeckt bleibende Innere des Wcizenkorns, statt des Keimlings nit seincm Eiwciss, aus einer anfang's schmierigen, später staubartigen, nach Heringen (Trimcthylamin) riechenden schwarzen Masse, den Sporen eines Pilzes besteht, dessen Mycelium schon verschwunden ist.

Zur Verhuitung des Brandes beizt man, wie wir scholl when gesehen, das Saatgut mit Kupfervitriol ein, und bei richtiger Ausfiibrung werden anch die an Samenkorn haftenden Pilzsporen unbedingt getötet werden, wïhrend hingegen Aetzkalk, Salz, Arsenik, Steinkohlenteer, Asche etc. in ihrer Wirkung entweder uisicher oder vollständig unwirksam sind.

Trotz des Beizens tritt jedoch zuweilen der Brandpilz auf, weil seine Sporen dureh Stalldung oder wildwachsende Pflanzen verbreitet werden können.

Der Flug-, Russ- oder Stanbbrand (Ustilago Carbo Tul.) schädigt den Weizen in verhältnismässig geringem Unifange und dasselbe ist mit dem Mutterkornpilz (Claviceps purpurea Tul.) der Fall, weungleich häufiger deformierte, keimungsunfähige Körner rorkommen, welche nach Sorauer diesen Zustand einer friihen Entwickelungsstufe des Mutterkornpilzes, anf wclche derselbe verharrte, zu verdanken liaben.

Sehr gefühliclı, namentlich im feuchten lílima, siud zwei Arten des Rostpilzes, nänlich der Fleckenrost (Puccinia straninis Fuck.) und der lokal vorkommende Grasrost (Puecinia graminis Pers.), welche anf den oberirdischen Teilen der in ilırer kräftigsten Entwickelungsperiode befindlichen Weizenpflanze schmarotzen, indem sie den chlorophyllhaltigen Zellen dic bereits assimilierte Nalirung entziehen.

Da nun feuchtwarme Lagen und Lagergetreide die Pilzentwickelung fördern, so sollte der Weizen auf möglichst trocknem, hochgelegenem Boden und zur Vermeidung des Lagerns genügend weit gedrillt werden. Ferner verbreiten auch gewisse Pflanzen, z. B. solche aus 
der Familie der Boragineen, den Fleckenrost und die Berberitze den Grasrost, weshalb es angezeigt ist, auf die Vertilgnng dieser Pflanzen zu achten.

Anch ist darauf aufmerksam zu machen, dass sich die Weizensorten in Bezng anf die Disposition für die Rostkrankheit sehr verschicden verhalten, nithin auf den Anban widerstandsfähiger Sorten zu sehen ist und verweisen wir in dicser Bezichung auf die von uns gemachten Angaben bei der Beschreibung der einzelnen Sorten. Innerhalb der Unterart tritt der Rost an häufigsten bei 'Triticum vulgare, weniger häıfig bei den übrigen, \%. B. bei Tr. turgidnm anf.

Bei fenchtwarmer Witterung und sehr kräftig cntwickeltem Weizen stellt sich anch nicht selten als empfindlicher Feind der Mehltaupilz (Erysiphe graminis Lev.) ein.

Dic den Weizen schädigenden tierischen Feinde sind ebenfalls zahlreich und will ich mich, unter Hinweis auf das iiber dieselben bereits im ersten Bande Gesagte, darauf beschränken, dic an den einzelnen Pflanzenteilen vorkommenden Feinde aufzuführen.

Die Keime des Weizens werden von dem matten Aaskäfer (Silpha opaca L.), die Wurzeln von den Larren der Anisoplia horticola L. und den Raupen von Agriotes lincatus L., A. obscurus Gyllh., Agrotis crassa Hb., A. corticea Wien. Verz., A. cxelamationis L. Characas graminis L. angegriffen. Ferner sind anch Wurzelliuse, z. B. Schizoneura remista Pass. und Tychea trivialis Pass. beobachtet worden.

Durch Ausfressen der Terminalknospe, sowie durch Verletzung der jungen Blätter haben sich schädlich crwiesen: ein Blattkäfer (Pliyllotreta (Haltica) vittnla), die Larve und der Käfer von Lema melanopa L., die Raupen von Hadena basilinca Wien.Verz. und H. infesta Treischke, sowie von Agrotis tritici L., Plusia gramma L.; ferner die Maden von Anthomyia coaretata Fallén und Opomyza florum $\mathrm{Fb}$. In Lündern mit fenchtem. mildem Klima wird auch die grane Ackerschnecke (Limax agrestis L.) häufig sehr gefährlich.

Sehr schwer schädigen diejenigen Insekten, welche den Halm verletzen, so die Larve von Calamobins marginellus Fabr., Cephus pygmaeus L., Cecidomya destructor Say und Tipula cerealis Santer.

Die junge Aehre und weiche Frucht werden angegriffen dureh die Larve und den Käfer von Zabrus gibbus Fabricius, dessen Larve aber auch die weichen oberirdischen Pflanzenteile zerquetscht und aussaugt; durch den Kïfer von Anisoplia anstriaca Herbst und A. fruticola Fab.; ob dagegen der Getreideblasenfuss (Thrips cerealium Haliday) und seine Larve schädlich sind, ist noch nicht mit Sicherheit bezcugt; ferner schädigt die Raupe ron Hadena infesta Treischke, Lencania albilinea Guen. und L. unipuncta Haw., sowie 
die Larve von Tipula tritici Kirby, Chlorops taeniopus Meig. und Oscinis frit. L., auch kommt eine Blattlaus (Aphis granaria Kirby) vor.

Die sog. Getreidewanze (Micropus leucopterus Say) schädigt in Amerika (Chinch-bug) den Weizen in allen Entwickelungsstadien und ist in hohem Grade gefährlich.

Von dem reifen Weizenkorn leben folgende Käfer: Cucujus testacens, Silvanus surinamensis Steph. und Cureulio granarius L., sowie die Raupen von Tinea granella L. und T. cerealella Oliv. Eine eigentümliche Kornkrankheit (Gicht- oder Radenkrankheit) wird durch das Weizenälchen (Anguillula tritiei Needham) erzeugt.

\section{Klima.}

Die nördlichste Polargrenze des Weizens reicht in Norwegen ungefähr bis zum $64 .{ }^{\circ} \mathrm{n}$. Br., kann aber auch in günstigen Lagen überschritten werden, so soll nach Schubeler selbst noch unter $69^{\circ} 28^{\circ}$ in Skibotten Sommerweizen reifen, welcher am 9. Mai 1870 gesäet, am 23. Mai keimte und am 30. August, also nach 114 Tagen reifte, und betrugen die Mitteltemperaturen im Mai $5.16^{\circ} \mathrm{C}$., Juni $13.12^{0} \mathrm{C}$, Juli $13.13^{\circ} \mathrm{C}$., August $12.87^{\circ} \mathrm{C}$.

In diesen hohen Breiten lässt sich nur noch Sommerweizen bauen, da Winterweizen eine über 3 Monate ohne Unterbrechung dauernde Schneedecke nicht mehr erträgt. Der südlichste Punkt der Weizenkultur durfte wohl unter dem $50 .^{0}$ südl. Br. und zwar in der chilenischen Kolonie Punta Arenas de Magellanes, Amerika, liegen. von wo wir Weizen zugesandt erhielten.

Die Hauptverbreitung findet der Weizen in der kälteren und wärmeren gemässigten Zone, wenngleich er in letzterer schon häufig unter Wassermangel leidet, daher hier durch künstliche Bewässerung, z. B. in Italien, Spanien etc., die Erträge wesentlich erhöht und sicher gestellt werden; in noch weit höherem Grade tritt in der tropischen und subtropischen Zone das Wasserbedürfnis zu Tage, wie auch andererseits in der heissen Jahreszeit die Temperatur für den Weizen zu hoch wird, weshalb sich seine Kultur in der tropischen Zone auf die Wintermonate, so z. B. in Indien nach Royle ${ }^{1}$ ) auf die Monate Oktober bis März und in der subtropisehen Zone auf die Monate November bis Mai erstreckt.

1) Illustr of botany of the Himalaya etc. 1839 , pg. 418 . 
Nach Boussingault ${ }^{1}$ ) soll die Weizenkultur noch in allen denjenigen Tropenländern vorteillıaft scin, deren nittlere Temperatur $18-19^{\circ} \mathrm{C}$. beträigt.

Die äussersten Grenzen des Weizenbaues werden im Allgemeinen durch die mittleren Sommertemperaturen von $12-23.5^{\circ} \mathrm{C}$. bestimmt, und verlangt der Weizen in dem kälteren gemässigten Klima eine mittlere Sommertemperatur von $17.5^{\circ} \mathrm{C}$.

Die Höhengrenze des Weizens erreicht in Norwegen noch $300 \mathrm{~m}$, am Stidabhange der Alpen $1264 \mathrm{~m}$ und in Tibet sogar $4549 \mathrm{~m}$, doch verlängert sich entsprechend der Höhe auch die Vegetationszeit und fand Berghaus für Sachsen eine Verzögerung der Blite und Ernte bei einer Hühe von $335 \mathrm{~m}$ voll 22 Tagen.

Úeber die Wärmesumme des Weizens, welcher er voln Ersclieinen des ersten Blattes bis zur Reife bedarf, liegen naclifolgende Untersuchungen von Boussingault und Krutzsch vor:

Produkt aus der mittleren Temperatur' und der Vegetationszeit:

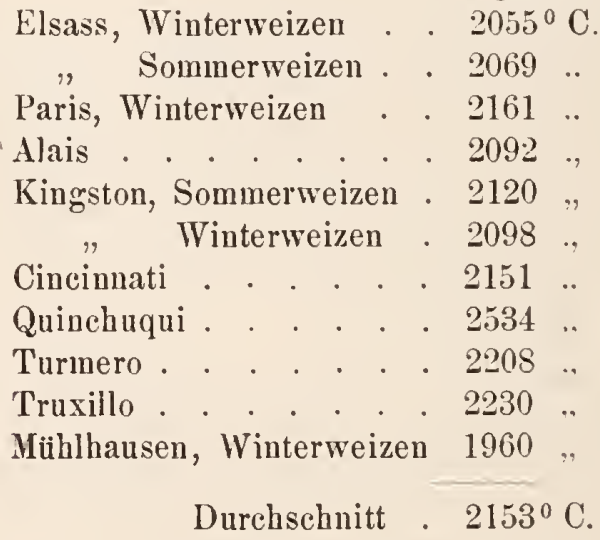

Sehr interessante Zahlen sind aber auch in Folge vergleichender Kulturen nit nordischem Sommerweizen aus Umea und einem Sommerweizen aus Angermünde erhalten worden; für diese wurden die verbrauchten Würmesummen für eine grössere Anzahl Stationen ermittelt und ergaben sich nachfolgende Resultate ${ }^{2}$ ):

1) D. Landwirtsch. etc. I, pg. 281.

2) Wittmack, Berichte über vergleichende Kulturen mit nord. Getreide, Landw. Jahrb. V $18 \overline{7} 6$. 


\begin{tabular}{|c|c|c|c|c|}
\hline Station & $\begin{array}{l}\text { Weizen- } \\
\text { sorte }\end{array}$ & $\begin{array}{c}\text { Vege- } \\
\text { tations- } \\
\text { zeit } \\
\text { Tage }\end{array}$ & $\left|\begin{array}{c}\text { Verbrauchte } \\
\text { mittlere } \\
\text { Wärme- } \\
\text { summe } \\
0 \mathrm{C} .\end{array}\right|$ & $\begin{array}{c}\text { Regenhöhe } \\
\text { mm }\end{array}$ \\
\hline $\begin{array}{l}\text { Mauen bei Königsberg } \\
\text { Proskau," Ober-Śchlesien } \\
\text { Posen ", } \\
\text { Eldena, bei Greifswald } \\
\text { Leipzig" ", } \\
\text { Göttingen } \\
\text { Poppelsdorf bei Bunn } \\
\text {,", ," } \\
\text { Verrières bei Paris } \\
\text { Rotlamsted, England } \\
\text {," ," }\end{array}$ & $\begin{array}{l}\text { Umea } \\
\text { Angermünde } \\
\text { Umea } \\
\text { Angermünde } \\
\text { Umea } \\
\text { Angermünde } \\
\text { Umea } \\
\text { Angermünde } \\
\text { Umea } \\
\text { Angermünde } \\
\text { Umea } \\
\text { Angermünde } \\
\text { Umea } \\
\text { Angermünde } \\
\text { Umea } \\
\text { Angermünde } \\
\text { Umea } \\
\text { Angermünde }\end{array}$ & $\begin{array}{r}104 \\
108 \\
97 \\
110 \\
91 \\
102 \\
116 \\
119 \\
102 \\
104 \\
109 \\
115 \\
113 \\
118 \\
121 \\
129 \\
148 \\
148\end{array}$ & $\begin{array}{l}1732.20 \\
1810.60 \\
1545.59 \\
1760.29 \\
1558.30 \\
1757.80 \\
1573.30 \\
1635.80 \\
175,2.00 \\
1799.30 \\
1625.40 \\
175260 \\
1616.20 \\
1699.21 \\
1847.30 \\
1983.70 \\
1955.00 \\
1955.00\end{array}$ & $\begin{array}{l}161.59 \\
162.52 \\
178.70 \\
210.70 \\
194.77 \\
198.02 \\
207.52 \\
207.52 \\
252.63 \\
252.63 \\
214.20 \\
228.70 \\
346.09 \\
349.21 \\
199.40 \\
211.90 \\
362.00 \\
362.00\end{array}$ \\
\hline
\end{tabular}

Im Allgemeinen ist anzunelmen, dass die Vegetationszeit beim Winterweizen 270-330 und im Mittel 290 Tage, bein Sommerweizen 90-150, in Mittel 125' Tage beträgt, und sieh die erforderliehen Wämesummen beim Winterweizen auf $1960-2534^{\circ}$ C., im Mittel $2180^{\circ} \mathrm{C}$. und beim Sommerweizen auf $1545-2120^{\circ} \mathrm{C}$., im Mittel aut $1740^{\circ} \mathrm{C}$. stellen, während das Maximnm der giinstigsten Bodenwärme bei $30^{\circ} \mathrm{C}$. liegt.

Das Gedeihen des Weizens hängt zu einem grossen Teil von der Gunst der Witterung ab, so kann dem Weizen der Winter verhängnisvoll werden, demn obwohl ihm auf troeknem, gut entwässertem Boden, sobald eine schützende Selineedeeke vorhanden ist, holie Kältegrade Niehts anhaben, leidet er doeh ungemein und kann selbst auswintern, sobald er namentlich auf feuehtem Boden einer ganz unvernittelt weehselnden kalten und milden Witterung ausgesetzt wird, wie dies sehr häufig in den vom Seeklima beeinflussten Gebieten West-Europas der Fall ist, indem er dureh mehrmaliges Auftauen und Einfirieren leieht zu Grunde geht, weun nieht sehr widlerstandsfahige Sorten angebant werden. So beobachteten wir in Poppelsdorf, dass sich in dem Zeitraum von 12 Jahren von 40 aus England stammenden Weizensorten 52.5 Proe. als nieht winterfest erwiesen.

Eine sehr kritisehe Epoehe ist aueh die Fribljalısentwiekelungsperiode, da in derselben der Weizen leieht dureh troekne, kalte Wiude, oder nasses, kiihles Wetter leidet, was sieh dureh Gelbfärbung (Chlorose) der Blätter bekundet, und auf ungenuigende Assimi- 
lation hindeuten lässt, während mässig feuchtes, warmes Wetter ein lebhaftes Grïn der Blätter und eine krättige Bestockung hervorruft, wodurch manche Liicke in den nicht gut durch den Winter gekommenen Pflanzen wieder geschlossen wird. Ferner verlangt auch der Weizen kurz vor dem Schossen, sowie nach der Blïte eine mässig feuchte Witterung und eine Temperatur von $16-17^{\circ} \mathrm{C}$, und zwar soll derselbe zn dieser Zeit von der Frühjahrsentwickelung an nach Gasparin $\left.{ }^{1}\right) 813^{\circ}$ C. oder beim Winterweizen incl. Herbstregetation $1413^{\circ} \mathrm{C}$. an Wärme empfangen haben. Ein kiihles, feuchtes Wettcr in der Bliitezeit liefert ein geringes, kleberarmes Korn, und kurz vor der Ausreife plötzlich bei trockenem Wetter eintretende sengende Hitze verschrumpfte leichte Körner, eine Erscheinung, die nur zu häufig im ausgesprochenen Kontinentalklima vorkommt.

Ferner ist der Einfluss des Klimas auf die Qualität der Frucht sehr bedeutend, und fand schon H. Davy, dass im Allgemeinen die unter wärmeren Himmelsstrichen gebauten Weizen mehr Kleber enthielten und specifisch schwerer waren, aber sich schwieriger, weil härter, mahlen liessen, als die Weizen Englands; und im Jahre 1857 teilte Ritthausen ${ }^{2}$ ) hieriber mit, dass in den nördlicheren und kälteren Himmelsstrichen, in nebel- nnd regenreichen Ländern ein an Stickstoff ärmeres Getreide als in siidlichen wärmeren Gegenden produciert werde, und die Weizen sehr siidlicher Länder meist hart und glisig sind und den Stickstoff fast ausschliesslich in Form von Kleber cnthalten, wogegen die nördlichen Länder häufiger weiche und mehlige Weizen erzeugen. in welchen sich neben relativ wenig Kleber viel Pflanzeneiweiss findet.

In Allgemeinen ist anzunehmen, dass das trockne, heisse Klima meist begranute, feinhalmige und blattarme Weizen erzeugt, deren Körner aber hart, glasig und reich an Stickstoff, der grösstenteils als Kleber auftritt, sind, während das kïhle, feuchte und namentlich das Seeklima gern unbegrannte, sich durch iippigen Wuchs auszeichnende Weizensorten, mit iiberwiegend weichen, mehligen Körnern erzeugt, die relativ arm an Stickstoff sind, welcher sich vorzugsweise in der Form von Pflanzeneiweiss findet, weshalb sich bei dem geringen Klebergehalt anch die Backfähigkeit der aus diesen Körıern gewonnenen Mehle sehr wesentlich vermindert.

Aber nicht nur das Klima ${ }^{3}$ ), sondern auch der Boden und die Kultur iiben einen wesentlichen Einfluss auf die Beschaffenheit des

1) Cours d'Agriculture III

2) Sitzung d. schlesischen Gesellsch. f. vaterl. Kultur in Breslau, Jahresbericht 1857 .

3) Vergl. Werner, Bericht uber eine landwirtsch. Studienreise durch Ungarn, Landw. Jahrb. 1880 pg. 591. 
Kornes aus, so trïigt der harte, von Natur reiche, ungedüngte Steppenboden vol"zugsiveise hartes und halbhartes Koru, während dasselbe Land bei reichlicherer Düngung und längerer Kultur weiche und grosse Körner erzeugt.

Ferner kann auch ein grö̈sserer Kleberreichtum mehr odler weniger in den Eigenschaften einer Sorte begrindet sein, denn es ist bekannt, dass die kleinkörnigen Sommerweizen meist reicher an Kleber als die Winterweizen sind und dass sich der Hartweizen (Tritieum durum) von allen dureh Kleberreiehtum auszeiehnet. Welchen Sehwankungen der Klebergehalt unterliegen kann, zeigen die nachstehẹnden Untersuchungen von Ritthausen ${ }^{1}$ ).

\begin{tabular}{|c|c|c|c|c|c|c|}
\hline \multirow{3}{*}{$\begin{array}{c}\text { Bezeichnung der } \\
\text { Weizensorten }\end{array}$} & \multicolumn{2}{|c|}{$\begin{array}{l}\text { Die Körner } \\
\text { enthalten: }\end{array}$} & \multicolumn{4}{|c|}{$\begin{array}{c}\text { Das Mehl derselben } \\
\text { enthält: }\end{array}$} \\
\hline & \multirow{2}{*}{ 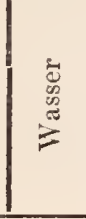 } & \multirow{2}{*}{ 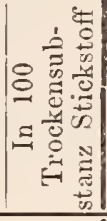 } & \multirow{2}{*}{ 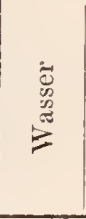 } & \multicolumn{2}{|c|}{$\begin{array}{c}\text { in } 100 \\
\text { Trockensub- } \\
\text { stanz }\end{array}$} & \multirow{2}{*}{ 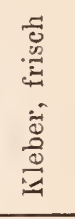 } \\
\hline & & & & $\begin{array}{l}\text { Pro- } \\
\text { teïn }\end{array}$ & 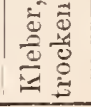 & \\
\hline Sommerweizen aus Jekaterinoslaw & 11.81 & 341 & 12.54 & 19.62 & 19.70 & 55.00 \\
\hline "Cherson & 13.11 & 3.07 & 13.10 & 17.04 & 16.00 & 42.70 \\
\hline Winterweizen & 12.90 & 2.51 & 13.41 & 15.18 & $14: 14$ & 38.96 \\
\hline , dem Banat & 12.62 & 3.08 & i3.81 & 18.42 & 16.87 & 42.80 \\
\hline Ungarischer Sommerweizen, & 13.78 & 2.57 & 1435 & 15.84 & 13.85 & 35.84 \\
\hline in Poppelsdorf gebaut & 14.81 & 2.50 & 15.28 & 14.58 & 14.80 & 37.67 \\
\hline Frankensteiner Weizen, Schlesien & 14.49 & 2.01 & 15.07 & 10.50 & $11.2 \tau$ & 25.50 \\
\hline Kujavischer Weizen, Posen. & 16.61 & 2.36 & 15.94 & 12.24 & 12.33 & 29.88 \\
\hline Kaiser-Weizen, Proskau & 15.42 & 2.01 & 1539 & 9.90 & 10.65 & 26.36 \\
\hline Aarweizen aus Nassau & 15.46 & 1.93 & 15.52 & 11.64 & 11.16 & 26.71 \\
\hline Kessingland, Poppelsdorf & 17.14 & 2.03 & 16.91 & 10.26 & 8.36 & 18.99 \\
\hline Hallet's genealogiseher, Pop & 15.53 & 1.92 & 15.83 & 10.68 & 10.41 & 24.11 \\
\hline
\end{tabular}

Entsprechend den vorgefiihrten Thatsachen wird in den wärmeren Klimaten, so in der subtropisehen und wärmeren gemässigten ' $/$ one, der sebr kleberreiche Hartweizen, und zwar' dem Klima angepasst, Ende Oktober bis in den Dezember hinein gesäet nud im Mai oder Juni geerntet. Trotzdessen ist dieser Weizen entsehieden ein Sommerweizen, der kalte Winter nicht verträgt, und der nur in Klimaten mit iiberaus milden Wintern kaum eine Unterbrechung des Waehstums erfährt; aueh wird dureh die Herbstaussaat verhindert, dass seine Ernte in die beisse trockene Jahreszeit fällt, welche der Körnerausbildung wenig förderlich ist. Gleiches Verhalten zeigt auch der in geringerem Umfange gebaute polnisehe Weizen.

Ferner kommen auch halbharte Igel- und Binkelweizen (Tr.

1) Die Eiweisskörper 1872. 
eompactum), sowie kleinkörnige Bartweizen (Triticum vulgare aristatum) vor.

Der kälteren gemäissigten Zone fallen hauptsächlieh die Weichweizen und zwar vorıugsweise dic Winter-Kolbenweizen (Triticum vulgare muticum) zu.

In allen Klimaten gelangen Sorten des euglischen oder bauehigeu Wcizens (Tr. turgidum), der sich als eehter Weicbweizen vou allen iibrigen Unterarten durch den geringsten Klebergchalt auszeichnet, zur Kultur, doeh rermehrt sieh sein Klebergehalt sebr wesentlieh, sobald er iu einem trocknen, warmen Klima zeitigt.

Die Spelzweizen werden hauptsäehlich iu rauben Gebirgslagen der kïlteren, gemässigten Zone kultiviert; dort also wo der Weizen rersagt, findet der Spelzweizen noch eine geniigende Sicherheit des Gedeihens, denn er verträgt frühen Eintritt des Winters, uud trockue, kalte Witterung im Frihjahl hesser als der Naektweizen.

Auf den siddeutsehen Gebirgen erreicht der Spelzweizen noch Höhen ron 600--1000 m und liegt der Hauptsitz der Kultur in Schwaben, Franken, der Sehweiz und der Rheingegend.

\section{Boden.}

Dic Betrachtung der biologisehen Verhältnisse des Weizens lehrte, dass er eines absorptionsfähigen und an fertiger Pflanzennabrung reichen Bodens zu seiner kräftigen Entwiekelung bedarf, oder letztere im Fall des Fehlens durch Diingung zu ersetzen ist.

Hicrnach ist ror Allem der Weizen das hauptsäiehlichste Getreide des frisch ungebroehenen jungfräulichen und an Nährstoffen iiberreiehen Bodens, z. B. der Steppen Siid-Russlands, der Pussten Ungarns, der Prairicen des nordamerikanisehen Westens ete. Hier wachsen jene gesehätzten kleinkörnigen, kleberreiehen W'cizeu, die einen seh" begehrten Exportartikel bilden.

Was die physikalische Beschaffenheit des Weizenbodens anbetrifft, so soll dersclbe bei einer gewissen Bindigkeit eine mässige Durchlässigkeit besitzen. Im Allgemeinen fordert der Weizen ciue um so grössele Bindirkeit, je wärmer und troekner das Klima ist, weshall, auch in der wärmeren gemässigten Zone und im Steppenklima dic schwereren Lehmböden hevorzugt werden, andererseits nimnt er im kiibleren, fenehteren Klima und vorzngsweise im Seeklima, wie dies die ausgedehnte Weizenkultur auf' den leichten Böden Norfolk's zeigt, mit verhältnismässig teichtem Boden, selbst mit leh- 
migem Sandboden vorlieb, sobald er der notwendigen Pflanzennährstoffe nieht entbehrt.

Im Kontinentalklima ist jedoch die Heranziehung soleher Böden zur Weizenkultur davon ablïngig, dass der Untergr'undwasserspiegel zur Erfrisehung der Aekerkrume boch genug steht, oder der Anbau von Mischelfrueht oder hoggen nicht höhere Reinerträg'e abwirft.

Wir sahen allerdings nit Hülfe einer iiberans kräftigen Düngung auf dem troeknen lehmigen Sandboden zu Lichtenberg bei Berlin einen selı befriedigenden Stand des Weizens, sind aber iiberzeugt, dass wohl nur ansuahmsweise unter solehen Umständen der Weizenban rentabel sein kaun.

Die Spelzweizen nelmen elıer mit einem wenig kräiftigen, leiclıten, aber aueh mit nasserem Boden als die Naektweizen vorlieb, und können selbst auf trocknem lialkboden noeh befriedigende Ernten liefern nnd sielı dabei die Kernen durch gute Qualitat auszeielnnen.

In Allgemeinen soll der Weizenboden bindig, frisch, kalkhaltig, bumusreich, aber säurefrei sein, jedoeh darf fur Winterweizen der Humusgehalt nicht so hoch steigen, dass die Saat durch Auffrieren leidet.

Demnach enpfiehlt es sich. den Weizen bei zweckmäissiger, den Bodenverhailtnissen angepasster Auswahl der Sorten, auf folgenden Bodenarten zu kultivieren:

1) lieicher, tiefer, milder Thon- und Aueboden; Weizenboden 1. $\mathrm{Kl}$.

Liefert hohe Erträge an Korn und Stroh, doch sind zur Verhiitung des Lagerus im feuehten Klima starkhahnige Weichweizen anzubauen.

2) Humoser, reicher, milder Lehmboden; Gerstenloden I. Kl.

Dieser Boden begiinstigt die Blattbildung sehr stark, weshall, der Weizen auf ihm leicht lagert, auch ist das Auffrieren des Bodens nicht ausgeschlossen, so dass auf ihm der Winterweizen leicht gesehädigt werden kann, sonst wie oben.

3) Schwerer, kräftiger Thonboden; Weizenboden II. Kl.

Im käilteren, genuissigten Klima fiir die weiehen Winter-Kolbenweizen, und in wärmeren, gemässigten und subtropischen Klima füi die halbharten lartweizen und die harten Weizen (Trit. durum uul polonicum), sowie für den hauchigen, weichen Weizen (Trit. turgidum) geeiguet. Liefert sehwere Körner.

4) Milder, tiefer, mergeliger, friseher Lehmboden und sandiger Lehmborlen; Gerstenboden II. Kl.

Bei guter Kultur in kïilteren, gemässigten Klima für Winterund in feuchteren Lagen fiur Sommerweizen vor zïglich passend. In rauhen Gebirgslagen liefern die Spelzweizen nach Quntitut und Qualität befriedigende Erträige. 
Im wärmeren, gemässigten Klima werden noeh Hartweizen, halbharte Bartweizen, sowie Igrel- und Binkelweizen (Trit. compaetum , letztere vorzugsweise bei sehr trockener Lage kultiviert.

5) Leichter sandiger Lehm- und lehmiger Sandboden; Roggenboden I. KI.

Dieser Boden wird gemeinhin vorteilhafter mit Roggen zu bestellen sein, und nur in feuchten Lagen mit Weizen und in rauhen Gebirgslagen mit Spelzweizen.

b) Kalter, zäher Thon- und Lehmboden; Weizenboden III. Kl.

Bei guter Entwässerung, Kultur und starker Dïngung bringt er noch befriedigende Erträge, wenngleieh die Qualität der Körner, da diese dicksehalig sind, zu wïnschen lässt. Aneh ist auf den Anbau wenig empfindlieher, gegen Nässe widerstandsfähiger Sorten zu aehten.

7) Strenger, zäher, nasskalter Thonboden ron lettenartiger Beschaffenheit; Haferboden I. Kl.

Wie Nro. 6, nur Erträge noch unsicherer, sowie nach Quantität und Qualität geringer.

\section{Diingung.}

Zum Gedeihen des Weizens gehört ein reicher Vorrat fertiger Pflanzennahrung im Boden, weshalb er auf Neuland, in alter Kraft stehenden oder stark zur Vorfrueht event. zur Braehe gediingten Böden reichere Ernten bringt, als auf ausgetragenem, wenn auch reichlieh mit Stallmist frisch gedüngtem Lande.

Von besonderer Wichtigkeit für die Produktion, sowohl nach Quantitiit wie Qualität befriedigender Körnerernten ist der Gehalt des Bodens an fein rerteilter, anfnehmbarer Phosphorsäure, weil der Proteïngehalt der Körner mit der durch die Pflanze aufgenommenen Phosphorsäure im Verhältnis steht, und von den Getreidearten der Weizen die grösste Menge davon beansprucht, denn eine mittlere Ernte entzieht dem Boden pro ha ca. $15.4 \mathrm{~kg}$ Phosphorsäure, doch dürfen aueh die äbrigen Pflanzennährstoffe zı einem befriedigenden Ertrage nieht fehlen, so berlarf der Weizen an Stickstoff $31.5 \mathrm{~kg}$, an Kali $19.9 \mathrm{~kg}$.

Diese Pflanzennährstoffe miissen der Pflanze vorzugsweise in ihrer Hauptregetationsperiode, nämlich bei Beginu des Schossens in aufnehınbarer Form zur Verfügung stehen, daher denn auch eine frische Stallmistdüngung zu Sommerweizen kurz vor der Einsaat gegegehen, verbältnismässig wenig ausgenutzt wird. 
Gemeinhin gilt der Stalldung zu Winterweizen als Hauptdiunger, der sich anch in der langen Zeit bis zum Eintritt des Schossens, zumal wenn er der Brache einverleibt wurde, noch genügend zersetzt.

Auf den Mittelböden wendet man gern Rindviehmist, auf den schweren Pferde- und Schafmist an, welche letzteren Dïnger, weil sehr stickstoffreich, kleberreiche Körner, und diese schr backf:ihiges Mebl lieferu, doch eignen sie sich zur Vermalzung weniger gont.

Die Stalldungmenge schwankt je nach den Verhältnissen zwischen 24000 und $50000 \mathrm{~kg}$ pro ha und ist dieselbe müglichst ggleichmässig bis zur vollen Tiefe der Ackerkrume zu verteilen.

Zur Unterstützung des Stallmistes lassen sich zur Herbstsaat häufig sehr vorteilhaft Kunstdünger verwenden, sobald es an cinem Hauptnährstoff im Boden besonder's fehlt und der Stalldung denselben nicht zur Geniige ersetzt.

Macht sich ein Mangel an Phosphorsäure fiihlbar, so gibt man pro ha 200-300 kg Superphospat, fehlt es aber auch zugleich an Stickstoff, dann empfiehlt sich das Ausstreuen ron $2-400 \mathrm{~kg}$ Knochenmehl, resp. $2-300 \mathrm{~kg}$ Peruguano. Auf sclu stickstofiarmeu Boden wendet man im Herbst auch scluwefelsaures Amuoniak an und hat namentlich Lawes ${ }^{1}$ ) durch $225-450 \mathrm{~kg}$ pro ha vortreffliche Erfolge bei seincn Dïngungsversuchen erzielt.

Diese Kunstdiinger werden am besten vor der Einsaat nntergepfliigt.

Als Kopflïngung zur Unterstïtzung einer kränkelnden oder schwachen Saat gibt man gern sehr stickstoffreiche, leicht assimilierbare Dünger und ist der unter ihnen am schnellsten wirkende jedenfalls der Chilisalpeter; doch hat seine Verwendung immer mit Vorsiclit zu geschehen, weil zı grosse Mengen wohl die Blattentwickelun." iibermässig fördern, aber die Ausbildung des Kornes zurïckhalten. Quantitäten von $100-160 \mathrm{~kg}$ werden bei geniigender Zerkleinerung und Vermischung mit Erde, damit eine möglichst sorgfältige Verteilung crzielt wird, selten Nachteile hervorrufen, zumal, wenn das Ausstreuen bei mässig fenchter Witterung und zwar beim Winterweizen kurz vor dem Schossen und beim Sommerweizen nach Entwickelung des dritten Blattes erfolg't.

Durch eine Stickstofflüngung wird der Gelalt des Kornes an Proteïnstoffen und namentlich an Kleber vermehrt, wic dies ein in Poppelsdorf angestellter Versuch von Rittla usen ${ }^{2}$ ) ïber den Einfluss stickstoffreicher Diingung auf den Weizen nachweist:

1) Journ, of the Agric, soc. of Engl, 1878. I, pg. 238.

2) Verhandl. d. Naturhist. Ver. in Bonn. I. pg. 16, 1873. 


\begin{tabular}{|c|c|c|c|c|}
\hline 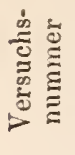 & Art der Düngung & \multicolumn{3}{|c|}{\begin{tabular}{c|c}
\multicolumn{2}{c}{ Procentgehalt an: } \\
Stickstoff & Protein | Kleber \\
hörner & Mehl
\end{tabular}} \\
\hline $\begin{array}{l}1-3 \\
4-6 \\
7 \\
8 \\
9 \\
10 \\
11 \\
12\end{array}$ & $\begin{array}{l}\text { Nicht gedüngt (Mittel) } \\
\text { Superphosphat (Mittel) } \\
\text { Schwefelsaures Ammoniak } \\
\text { Schwefels. Ammoniak u. Superphosphat } \\
\text { Chilisalpeter mit Superphosphat } \\
\text { Schwefels. Ammoniak mit Chlilisalpeter } \\
\text {," , "Superphosphat }\end{array}$ & $\begin{array}{l}2.60-2.76 \\
2.79-2.90 \\
3.59-3.64 \\
382-3.97 \\
3.38-3.56 \\
3.36-3.70 \\
3.48-3.70 \\
3.58-3.77\end{array}$ & $\begin{array}{l}16.6 \\
17.0 \\
21.8 \\
23.8 \\
21.3 \\
22.2 \\
22.2 \\
22.6\end{array}$ & $\begin{array}{l}16.2 \\
16.7 \\
22.9 \\
24.7 \\
22.5 \\
22.3 \\
22.6 \\
25.5\end{array}$ \\
\hline & Mittel: & $3.54-3.72$ & $2 \cdot .3$ & 23.4 \\
\hline
\end{tabular}

Demzufolge ist die Erhöhung des Proteïn- und nanentlich des Klebergehaltes ais eine sehr beträchtliche anzuerkennen, während die Anwending reiner Superphosphate nur eine geringfugige Erhöhnng: des Stickstoffgehaltes in Korn berbeifuhrte.

In England sncht man dic Nachtheile einer zu reichen Stickstofflüngung durch glcichzeitige Kochsalzdüngung fern zu halten, und soll sich aneh in der That die Qualität des Kornes darnach rerbessern nnd weniger Lagerkorn zn befürehten sein. Die anzuwendenden Qurantitaiten betragen $200-300 \mathrm{~kg}$ Kochsalz pro ha. Merkwiirdig ist es überhaupt, dass sich in Lngland relativ wenig Lagerfrucht findet und mag dies anf dem Gehalt der Atmosphäre an mechanisch aus dem Meerwasser mit emporgrerissenen Salzteilchen beruhcu. welche auf die Aecker gelangen.

\section{Fruchtfolge.}

Bekanntlich licht der Weizen einen in alter Kraft befindlichen, miuben Acker, der frei von Lnkräutern und namentlich Wurzelunkriintern. wie Quecken ist. Besitzt der Acker diese Eigenschaften nieht, so sollte man ihn nicht mit Weizen bestellen. Der Einfluss der Vorfincht anf die Iodenbeschaffenheit ist ferner von grösster Wichtigkeit, weshalb die Auswahl der Vorfrueht sehr sorgsam zu treffen ist und die hesten Vorfrïichte diejenigen sein werden, welehe den Naihrstoffvorrat der Ackerkrmme nicht erschöpfen, die physikalische Beschaffenheit des Bodens verbessern, ihn frei von Unkräutern zurieklassen und das Feld so zeitig räumen, dass dasselbe zur Einsaat des Weizens noeh geniigend vorbereitet werden kann. 
Je guinstiger die Bodenverhältnisse dem Weizenbau sind, um so weniger hängt sein Gedeihen von der Vorficht ab, mithin in diesem Fall der Kreis der Vorfrüchte erweitert werlen darf.

Auf den reiehen tiefen, milden, humosen Thon- und Lehnböden nach gediungten Hackfriichten oder Mais wird jedenfalls Sommerund in milden Klina Winter-Weizen folgen können. Aber auch Hanf, 'Tabaek etc., werden gute Vorfriiclite abgeben, da sie den Boden für Weizen noch genïgend reich an Nährstoffen nnd zngleich vortrefflich zubereitet übergeben.

Fine sehr vorziigliche Vorf'tucht ist Raps, nach dem der Weizen nicht leicht lagert und der Boden bei der zeitigen Ente desselben annähcrud eine Braehbearbeitung erfalıren kaun, weshalb gerade der Raps sich für etwas verunkrauteten boden als Vorfruelit empfielılt; reeht gnte Vorfirichte sind ferner die Schotenfriiclite (Erbsen, Wieken), welehe das Feld ebenfalls zeitig rämmen.

Dagegen eignet sicls der Potklee auf diesen Boden nicht besonders gut als Vorfurelit, weil der Weizen nach ihm zn iippig wäiehst, worunter nicht nur die Kornqualitiit leidet, sondern auch Lagern eintreten kann, wovon liauptsielılich die grosse Menge an stiekstoffreichen Stoppel- und Wurzelriickstiinden die Schuld trägt, welche der Aekerkiume durch die Rotkleestoppel einverleibt werden. Diese betragen ansser $10000 \mathrm{~kg}$ Trockensubstanz ea. $215 \mathrm{~kg}$ Stiekstoff, $90 \mathrm{~kg}$ Kali und $84 \mathrm{~kg}$ Phosphorsäure pro lı und reprïisentiert der Stiekstoff eine Stallmistmenge ron $40000 \mathrm{~kg}$, das Kali von $13000 \mathrm{~kg}$ und die Phosphorsäure von $26000 \mathrm{~kg} \mathrm{p}$. ha, mithin ist die Stickstoffdingung durch diese Rückstainde in zur reichliehen Masse geboten.

Anders verhält sich aber der Rotklee als Vorfrueht auf den schweren, kräftigen Thon- und Lehmböden. Hier wirkt der einjährige Klee bei diehtem Stande hanptsäehlieh auf die Zersetzung des Bodens und auf die Verbesserung des plysikaliselıen Zustandes hin, wie er aueh andererseits soviel Nährstoffe der Ackerkrume belässt, lass nach ihm ohne Düngung der Weizen gut gedeiht.

Gedüngte Grünwieken nähern sieh in ihrer Wirkung dem Klee und der Raps, weil nach ihm der sehwere Boden noeh eine Brachbearbeitung erfahren kann, wird fiul diesen Boden als eine der besten Vorfriiehte anzusehen sein. Diesem folgen gut bearbeitete Bohnen und in letzter Linie Wieken oder Erbsen zur Kormprodulition.

Gute Vorfriichte auf den milden Lehm- und sandigen Lehmböden sind gredïngte Kartoffeln, zwei- oder dreijälriger Kleedreseh und Luzerne, welche letztere den Aeker an Nabrstoffen bereichert und in günstigster physikalischer Beschaffenheit dem Weizen hinterlässt, so dass olne Dung eine oder zwei gute Weizenernten zu erwarten sind. Sollte jedoeh der Boden derart reieh sein, dass Lagerkorn zu befüreh- 
ten steht, dann ist anzuraten, zunächst eine Hackfrucht und darauf Teizen folgen zu lassen.

Auf den kalten zähen Thon- und Lehmböden ist als beste Vor. bereitung zu Weizen die reine, stark gedüngte Brache anzusehen, namentlich wemn sie gckalkt oder gemergelt wurde.

Eine sehr gute Vorfrucht auf diesen zähen Böden sind fermer dicht gedrillte und gut behackte Pferdebohnen, welche die Ackerkrume nicht erschöpfen, sondern physikalisch verbessern und von Unkraut reinigen.

Die schlechteste Vorfrucht ist unter allen Unständen das Halmgetreide, obwohl hier Modifikationen auftreten, z. B. ist Gerste eine weit sclilechtere Vorfurcht als Hafer, weil erstere grössere Anspriiche an die fertige Pflanzennahrung des Bodens macht und wenig Nährstoffe in iliren Stoppel- und Wurzelrïckständen in der Ackerkrume zuriicklässt.

Die Spclzweizen, weil sie geniigsamer und gegen späte Saat wenig empfindlich. anch mit sich selhst sehr verträglich sind, passen sich den Wirtschafissystemen leichter an.

In Allgemeinen ist auch der Weizen mit sich selbst ziemlich verträglich und lässt sich ohne Nachteil in 3 Jahren einmal und selbst cin Jahr um das andere anbauen.

Die Verträglichkeit des Weizens mit sich selbst illustriert nachstehender Versucl ron Lawes auf der Farm ron Rothamsted:

Verschiedene Parzellen wurden 30 Jahre ununterbrochen mit Weizen bestellt und ergaben sich bei verschiedenen Diingungen folgende Erträge pro ha:

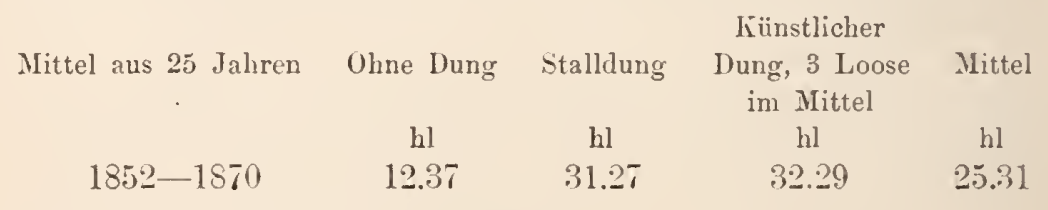

Nittel aus den letzten

10 Jahren

$\begin{array}{lllll}1866-1876 & 10.69 & 39.82 & 30.71 & 24.07\end{array}$

Hieraus geht hervor, dass in sehr langen Zeiträumen die Erträge zurïckgegangen sind, so in den letzten 10 Jahren um durchschnittlich 1 hl pro ha.

Der Weizen ist an und für sich keine gute Vorfrucht, da er den Boden erschöpft, weshalb denn auch nur in gediingter Brache gebauter Weizen fiir anderes Halmgetreide als gute Vorfrucht in den extensiven Wirtschaftssystemen, z. B. in der Dreifelder- und Koppelwirtschaft angesehen wird.

Nach unseren Untersuchungen hinterlässt auf kräftigem Thon- 
boden gewaehsener Weizen bis zu einer Tiefe von $26 \mathrm{~cm}$ an Stoppelund Wurzelriickständen pro ha:

$3888.3 \mathrm{~kg}$ Troekensubstanz, $26.4 \mathrm{~kg}$ Stiekstoff, $1218.7 \mathrm{~kg}$ Asche und darin $86.0 \mathrm{~kg}$ Kalkerde, $11.5 \mathrm{~kg}$ Magnesia, $20.7 \mathrm{~kg}$ Kali, $13.7 \mathrm{~kg}$ Natron, $8.4 \mathrm{~kg}$ Sehwefelsäure, $13.3 \mathrm{~kg}$ Phosphorsäure.

\section{Bodenbearbeitung.}

Auf guten Weizenböden erfordert die Herbstbestellung durchschnittlich weniger Sorgfalt als die anderer Getreidearten, da der Weizen keinen sehr lockeren Boden beansprneht, auch auf dem Acker verbleibende Erdschollen ihm nieht allein Schutz, sondern, dureh die Egge im Frïhjahr zertriimmert, auch frische Erde gewähren.

Die Frühjahrsbestellung hat dagegen mögliehst sorgsam zn geschehen.

Die Art der Vorbereitung des Ackers zur Herbstbestellung hängt hauptsächlieh von der Vorfrueht ab.

Jedenfalls erfähr't der Acker die beste Vorbereitung durch die Brache, welehe aueh die Saatfurehe sehon 3-4 Wochen vor der Einsaat zu geben gestattet, mithin der Aeker nieht nur Zeit hat, sich geniigend zu setzen, sondern aneh die in ihm noeh ruhenden Unkrautsamen zur Entwiekelnng kommen zu lassen, welche wiedernm dureh die Saatbestellung verniehtet werden.

Nach Haekfrïichten, Mais und während ilurer Vegetationszeit gut bearbeiteten Handelsgewächsen genügt gemeinhin eine bis zur vollen Tiefe der Aekerkrume sorgfültig gegebene Saatfurehe und empfiehlt es sieh, die Strïnke von Taback, Mais ete. in die Pflugfurchen z.n legen und tief genug unterzupflügen, so dass die Egge sie nieht wieder zu Tage fördert.

Nach Raps oder zeitigem Grünfutter pflügt man die Stoppen flach um, wartet mit dem Eggen bis das Unkraut anfgelaufen, eggt und walzt, und gibt, damit die Stoppeln des Rapses genïgend tief unterkommen, eine tiefe Furche, lässt darauf das Land sich wiederum begrünen, eggt und pflügt seicht zur Saat.

Die Stoppeln von Schotenfrüchten oder spätem Grïnfutter pflïgt man flach unter und walzt, damit sie schnell faulen; ist dann das Unkraut aufgelaufen, so eggt man und gibt die Saatfurche bis zur vollen Tiefe der Ackerki'ume.

Aehnlich verhält sich auch die Bestellunğ nach einjährigem 
Klee, dessen Stoppel ca. 4 Wochen vor der Einsaat am licsten, wenn der Acker nicht zu trocken ist, mit mehrseliarigen Pflügen flach umgebrochen und zum schnellen Faulen der Stoppeln gewalzt wird. Das Egren gesehieht kurz vor der Saatfurche, welche letztere möglichst sorgfültig gegeben wird.

Bei verspäteter Saat w'endet man das Doppelpflïgen oder einen Ticfpflug mit Schälschar an, und genügt dann eine Furche, denn die zuerst flach umgebrochenen Stoppeln werden durch den nachfolgenden Pflug tief genug in die Erde gebracht, als dass die Egge sie noch erreichen könnte.

Dagegen ist mehrjühriges Kleegras oder sog. Klecdresch häufig derart fest und dureh Quecken etc. vermnkrautet, dass zu seiner genïgenden Vorbereitung eine halbe Brache notwendig erscheint.

Soll zu Weizen noch gediingt werden. so fährt man zweckmässig den Dung auf den Klee und ist letzterer eine Hand lang bindurehgewachsen, dam pfliggt man ihn mit der ersten scichten Furche unter und walzt. In diesem Znstande rerbleibt der Acker bis drei Wochen vor der Einsaat, wo er dann tiiehtig abgeeggt und zur Saat gepfligt wird.

Mit Weizen zu besäende alte Luzemetelder erhalten am besten eine Sommerbrache.

Die Vorbereitung des Ackers für Sommerweizen gestaltet sich derart, dass die Stoppeln der Vorfrucht kurz nach der Iberntung umgebrochen werden, nach dem Auflaufeu des Unkrautes wird geeggt, ev. gewalzt und gediingt.

Hat sich dann der Acker wiederum begriint, so erhält er noch vor Winter eine tiefe Furehe und bleibt, mit Wasserfurchen versehen, iuber Winter in rauher Furche licgen. In Frühjahr nach dem Abtrockuen wird geeggt und gewalzt, über Kreuz gegrubbert, glatt geeggt und noch einmal gewalzt.

Durch diese Art der Vorbereitung lässt sich, was für Sommerweizen sehr wichtig ist, eine verhältuismässig frühe Einsaat erziclen, daher Ansnahmen uur danu stattfinden sollten, wenn der Boden in Folge eines frostlosen, regenreichen Winters stark rerschlämmt ist, in welchem Fall, anstatt gegrubbert, besser gepflight wird.

Die Spelzweizen erfabren im Allgemeineu dieselbe Vorbereitung des Feldes wie der gewöhnliche Weizen, doch ist bei ihnen erwiinscht, den Acker drei Wochen bis 14 Tage vor der Saat zu pflügeu, damit durch späteres Sichsetzen des Bodens das Entblössen der Wurzeln vermicden wird, auch das aufgelaufene Unkraut uoch eiumal zerstört werden kann. 


\section{Anssaat.}

Von der rechtzeitigen Aussaat des Winterweizens, in der für jede Gegend durch die klimatischen und Bodenverhältnisse bestimmten besten Saatzeit, hängt zu einem nicht geringen Teil sein Gedeihen ab.

Für die Sommersaat gilt die Regel, sie so zeitig, als es die Abtrocknung des Bodens nur gestattet, zu bewirken, indem Nachtfröste die jungen Pflanzen wenig schädigen, die Ertrïge besser ausfallen und die Reife später Sorten in eine günstigere Erntezeit fällt.

Die Erntezeit wird nun, abgesehen auch von anderen sich geltend machenden Einfliissen, hauptsäehlich dureh die Wärmezone oder Höhenlage bestimmt.

Sommerweizen wird vorzugsweise in der subarktischen und kälteren gemässigten Zone gebaut und geht seine Kultur mit der Wärmezunahme inmer mehr zurïck, oder die ilırer Natur nach zu den Sommerweizen zählenden Hartweizen und polnische Weizen müssen wie Winterweizen behandelt oder doch wenigstens im Laufe des Winters ausgesäet werden.

Im Allgemeinen fällt der Anbau des Winterweizens und des Sommerweizens in folgende Zciten.

In der tropischen und subtropischen Zone fällt die Herbstsaatzeit in den Oktober und November, in Aegypten je nach dem Zurücktreten des Nil in Ober-Aegypten in den November, im Delta in den November oder Jannar, in der wärmeren gemässigten Zone, z. B. in Italien, Spanien, Siid-Frankreich, in den Siudstaaten voll NordAmerika etc. Ende Oktober, November und Dezember, dic der Sommersaat in den Februar und März. In der kälteren gemässigten Zone und zwar inı Kontinental-Klima erfolgt die Herbstsaat in den Nordstaaten Amerikas im September, die Sommersaat im März und April, in Siid-Dentschland beim Wintergetreide ron Ende September bis Ende Oktober $\left(8-15^{\circ} \mathrm{C}\right.$.) und beim Sommergetreide Ende Februar bis Mitte April, in Nord-Deutschland von der Hälfte September bis Ende Oktober, und beim Sommergetreide im März und April. Im Seeklima dagegen wird viel später gesäet, am Niederrhein vom 10. Oktober bis 15. November, in den Niederlanden von Ende Oktober bis Anfang December und in England vom 20. Oktober bis 30. November. Da im Seeklima der Acker spät abtrocknet, kann die Sommersaat erst im März oder April eingesäet werden.

In der subarktischen Zone erfolgt die Aussaat des Wintergetreides sehr zeitig, Ende August, und die des Sommergetreides sebr spät, Ende April oder Anfang Mai.

Der Spelz wird auf den Gebirgen Sïd-Dentschlauds, je nach der 
Höhenlage und Bodenbeschaffenheit, ron Ende September bis Ende Oktober und die Sommersaat von April bis Mai gesäet.

Nun ist es aber nicht immer möglich, innerhalb dieser Zonen den richtigen Zeitpunkt zur Aussaat unter allen Umständen festzuhalten, da sich mancherlei Einflüsse geltend machen können; um jedoch in diesem Fall Nachteile möglichst zu vermeiden, sind hiernach die Saatquanta zu korrigieren; ist z. B. auf reichem Boden und im feuchten Klima die Winterbestellung sehr früh erfolgt, so wïrde, wenn keine Verminderung des Saatquantums rorgenommen worden wäre, schon im Herbst die Saat zu üppig stehen und möglicherweise im Winter ausfaulen, andererseits ist bei verspäteter Saat das Saatquantum zu vermehren, da die Bestockung weniger ausgiebig und die Pflanze verhältnismässig schwach entwickelt ist.

Um das hiel Gesagte zahlenmässig belegen zu können, führen wir einen Versuch von $H$. Thiel ${ }^{1}$ ) an, der auf einer Reihe ron Beeten alle 8 Tage je ein Beet mit einer gleichen Anzahl Körner in drei Reihen auf $18 \mathrm{~cm}$ Entfermung bedibbelte, bis der Frost eine Anssaat unmöglich machte.

Die erlangten Resultate (Kornerträge nicht bestimmt, weil zu sehr durch Sperlingsfrass gelitten) gibt nachfolgende Tabelle:

\begin{tabular}{|c|c|c|c|c|c|c|}
\hline $\begin{array}{l}\text { No. des } \\
\text { Beetes. }\end{array}$ & $\begin{array}{c}\text { Datum } \\
\text { der Saat. }\end{array}$ & $\begin{array}{c}\text { Anzahl } \\
\text { der aus- } \\
\text { gesäeten } \\
\text { Körner } \\
\text { pro Beet. }\end{array}$ & $\begin{array}{c}\text { Anzahl der } \\
\text { bei der Ernte } \\
\text { vorhandenen } \\
\text { Stöcke. }\end{array}$ & $\begin{array}{c}\text { Anzahl der } \\
\text { Aehren. }\end{array}$ & $\begin{array}{c}\text { Mithin } \\
\text { Aehren pro } \\
\text { Stock }\end{array}$ & $\begin{array}{c}\text { Strohlänge } \\
\text { in } \mathrm{cm} .\end{array}$ \\
\hline $\begin{array}{l}\text { I. } \\
\text { II. } \\
\text { III. } \\
\text { IV. } \\
\text { V. } \\
\text { VI. } \\
\text { VII. } \\
\text { VIII. }\end{array}$ & $\begin{array}{r}\text { 9. Okt. } \\
\text { 16. Okt. } \\
\text { 23. Okt. } \\
\text { 30. Okt. } \\
\text { 6. Nov. } \\
\text { 13. Nov. } \\
\text { 20. Nov. } \\
\text { 27. Nov. }\end{array}$ & 357 & $\begin{array}{l}334 \\
315 \\
286 \\
242 \\
230 \\
252 \\
194 \\
185\end{array}$ & $\begin{array}{l}4050 \\
4676 \\
5681 \\
4530 \\
4081 \\
2900 \\
2346 \\
2150\end{array}$ & $\begin{array}{l}12.1 \\
14.8 \\
19.8 \\
18.7 \\
17.7 \\
11.5 \\
12.1 \\
11.6\end{array}$ & $\begin{array}{l}130 \\
147 \\
140 \\
140 \\
126 \\
120 \\
116 \\
114\end{array}$ \\
\hline
\end{tabular}

Trotz der so weit auseinander liegenden Aussaat-Zeit war in dem Schossen der Halme und in der Bllite der einzelnen Beete nur eine Differenz voll einigen Tagen, so dass die Ernte gleichzeitig vorgenommen werden konnte. Hierin liegt der Hauptgrund des geringen Ertrages der spät gesäeten Pflanzen, soweit sie überhaupt am Leben geblieben sind. Sie fangen eben bei der entsprechenden Witterung im Fribjahr auch schon an zu schossen, obgleich sie noch nicht Zeit genug gehabt haben, zu einer kräftigen Entwickelung genügende Mengen von Bildungsstoffen zu assimilieren.

Es muss demgemäss die fehlende Bestockung durch Vermehrung der Individuen, also der Aussaatmenge ersetzt werden.

1) Rhein. Wochenschr. No. 41, 1872. 
Im Allgemeinen lässt sich annehmen, dass, sobald in einer Gegend die Aussaat 8 'Tage frïher erfolgt, als der richtige Zeitpunkt dies verlangt, das Aussaatquantum fïir je 8 Tage zu viel, um ein Zehntel verringert, und bei je 14 Tagen verspäteter Aussaat um ein Zehntel vermehrt werden muss.

Einen weiteren sehr erheblichen Einfluss auf die Bestimmung des Saatquantums iibt jedenfalls auch die Bodenbeschaffenheit aus, da sich nach ihr vorzugsweise der Habitus der Pflanze bildet.

Angenommen, das Saatquantum wäre auf sehr reichem Boden $=1 \mathrm{zu}$ setzen, so ist es auf Mittelboden $=1.5$ und auf leichtem Boden $=2$.

Ausserdem kommt die angebaute Sorte, ob sie gross- oder kleinkörnig, sich schwach oder stark bestockt, einen diinnen oder dicken Halm macht, in Betracht, sowie auch die Art der Kultur, Pflege etc.

Demnach ist die genaue Bestimmung des richtigen Saatquantums im konkreten Fall nicht leicht und wollen wir als Beispiel die mittleren Saatquanta der Unterarten des Weizens fiur den milden kräftigen Lehmboden hierunter folgen lassen. S. die Tabelle pg. 500.

In dieser Saattabelle erscheint vielleicht der Wachsraum von $50 \mathrm{qcm}$ ftir den Winterweizen (Trit. vulgare) zu karg bemessen, namentlich da ältere Autoren, z. B. Sprengel, den Wachsraum ciner Pflanze auf kräftigem Boden auf $54.7-61.6$ qem und Hlubeck sogar auf 68 q $\mathrm{cm}$ angeben, doch erklïrt sich dies aus dem Unistande, dass in Poppelsdorf auch die sehr feinhalmigen Sorten warmer Länder mit einbegriffen sind; wählt man jedoch die Sorten des kontinentalen Klimas Nord-Deutschlands und des Seeklimas der Niederlande und Englands aus, so muss sich der Wachsraum bedeutend vergrössern und die oben genannten Autoren werden diese starkhalmigen Sorten von Triticum vulgare bei der Bestimmung des Wachsraumes wohl im Auge gehabt haben.

Folgendes sind die Resultate unserer Untersuchungen:

Die Wachsräume und Saatquanta stellen sich in Poppelsdorf bei $20 \mathrm{~cm}$ Drillweite im Mittel für Winterkolbenweizen aus dem Kontinental-Klima Nord-Deutschlands wie folgt:

\begin{tabular}{|c|c|c|c|}
\hline $\begin{array}{l}\text { Wachsraum } \\
\text { pro Pfianze } \\
\text { in qcm }\end{array}$ & $\begin{array}{c}\text { Auf } 1 \text { qm Raum } \\
\text { entfallen an } \\
\text { Blattfläche } \\
\text { in qm }\end{array}$ & $\begin{array}{l}\text { Aussaatquan- } \\
\text { tum pro ha } \\
\text { in hl }\end{array}$ & $\begin{array}{l}\text { Gewicht p. } 1 \mathrm{hl} \\
\text { in } \mathrm{kg}\end{array}$ \\
\hline 62.5 & 33.7 & 1.5 & 81.3 \\
\hline
\end{tabular}

aus dem Seeklima der Niederlande und Englands: 


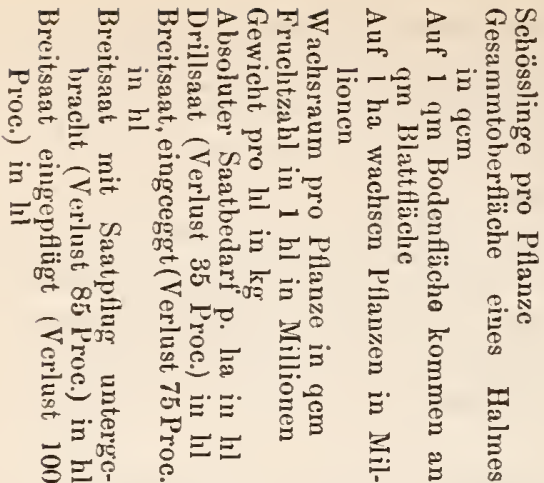

iv

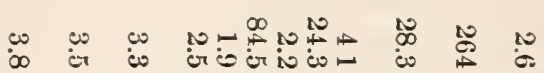

$\stackrel{N}{\infty} \stackrel{N}{N}$ i

a d c

Winter- $\overrightarrow{7}$



frucht

Sommer-

frucht

Winter-

frucht

Sommer-

frucht

$\stackrel{0}{\circ}$ ம

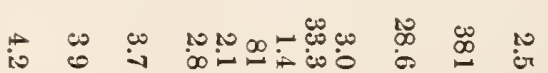

Winter-

frucht a

Sommer-

frucht

章蒙

T

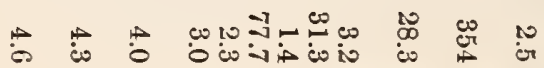

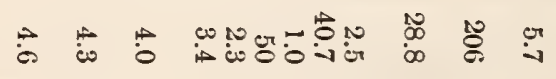

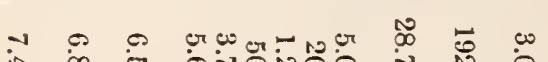

i $\infty$ or biriono

i

$: \stackrel{0}{0}$ i

Sommer-

ڤ

or $\rightarrow$ wntort

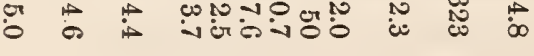

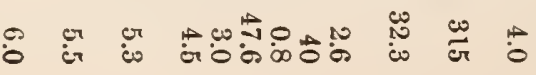

Sommer-
frucht 
Hiernach stimmt der Wachsraum der im Frühjahr vorhandenen Pflanzen nabezu mit den von Sprengel und Hlubek angegebenen Zahlen iberein.

In der Saattabelle sind nur die Mittelzahlen des Aussaatquantums der Sorten für jede Unterart angegeben, und finden sich die Aussaatquanta für jede Sorte bei der Beschreibung derselben meist mit aufgeführt, worauf wir hier verweisen müssen, um jedoch zu zeigen, in welchen weiten Grenzen bei dem gewöhnlichen Weizen (Trit. vulgare) dieselben schwanken können, fübren wir hierunter die Maximal- und Minimalzahlen für Poppelsdorf bei riehtiger Aussaatzeit und $20 \mathrm{~cm}$ Drillweite an:

\begin{tabular}{|c|c|c|c|c|}
\hline \multirow[b]{2}{*}{$\begin{array}{l}\text { Wachsraum pro Pflanze } \\
\text { Auf } 1 \text { qm Raum entfallen } \\
\text { an Blattfläche }\end{array}$} & \multicolumn{2}{|c|}{$\begin{array}{c}\text { Winterweizen. } \\
\text { Minimum | Maximum } \\
\text { an Wachsraum }\end{array}$} & \multicolumn{2}{|c|}{$\begin{array}{c}\text { Sommerweizen. } \\
\text { Minimum } \mid \text { Maximum } \\
\text { an Wachsraum }\end{array}$} \\
\hline & $\begin{array}{l}32 \mathrm{qcm} \\
28.1 \mathrm{qm}\end{array}$ & $\begin{array}{l}129 \mathrm{qcm} \\
33 \mathrm{qm}\end{array}$ & $\begin{array}{l}12.5 \mathrm{qcm} \\
25 \mathrm{qm}\end{array}$ & $\begin{array}{l}60 \mathrm{qcm} \\
26.6 \mathrm{qm}\end{array}$ \\
\hline Aussaatquantum pro ha & $3 \mathrm{hl}$ & $0.7 \mathrm{hl}$ & $8 \mathrm{hl}$ & $1.2 \mathrm{hl}$ \\
\hline
\end{tabular}

Zur Vergleichung diene nachfolgende Zusammenstellung der Aussaatquanta für breitwiurfige Saat von älteren Autoren. Es geben an für Winterweizen pro ha in hl: Thaer für Preussen $2.7 \mathrm{hl}$; Koppe $2.2 \mathrm{hl}$ und nur auf nasskaltem Boden bei verspäteter Saat $3.3 \mathrm{hl}$; Block 1.8-3.3 hl, im Mittel 2.5 hl; Hlubek $2.5 \mathrm{hl}$; Schweitzer 2.3-2.5 hl; Pabst $2.20 \mathrm{hl}$; Schmalz und Sehnee $2.5-2.7 \mathrm{hl}$; Boussingault für das Elsass $2 \mathrm{hl}$; Schwerz in Brabant auf Marsehboden 1.5-2 hl, in Flandern auf Sand- und gutem Mittelboden $1.5-18 \mathrm{hl}$, in den besten Gegenden Oesterreichs $1.87 \mathrm{hl}$ und im Marchfelde $3 \mathrm{hl}$; nach Heuzé in Frankreich auf sehr reichem Boden 1.8-2 lll, auf armem Bergland 3-4 hl, im Mittel $2.5 \mathrm{hl}$ und bei Drillsaat $(20-22 \mathrm{~cm}) 1.5-2 \mathrm{hl}$; nach A. Young in England 1.6 $-2 \mathrm{hl}$; nach Mc. Culloeh $2-2.25 \mathrm{hl}$, bei Drillsaat $(25-28 \mathrm{em})$ Drillweite) $1.5-2 \mathrm{hl}$; in Holland werden auf Wilhelmina-Polder (Zeeland) auf humosem Thon bei $22.5 \mathrm{~cm}$ Drillweite nach unseren Erkundigungen rom Zeelander-Weizen $1.4 \mathrm{hl}$ p. ha ausgesäet; nach Sewell und Pell im Westen der Vereinigten Staaten $1.6 \mathrm{hl} \mathrm{p.} \mathrm{ha.}$

Das Aussaatquantum für Sommerweizen gibt Block auf 1.8$2.7 \mathrm{hl}$ und Hlubek auf $2.7 \mathrm{hl}$ bei breitwürfiger Saat an.

Vom Spelz säet man naeh Schwerz in Württemberg auf den 
besseren und nicht zu hoeh gelegenen Feldern $3.5-5.62 \mathrm{hl}$ und im Oberland auf schwerem Boden bis $11.24 \mathrm{hl}$ p. ha aus, und ohne die übertriebene Aussaatmenge im Oberland im Mittel 4,42 hl. In Hohenheim werden $4.9 \mathrm{hl}$ und in der Pfalz $3.84 \mathrm{hl} \mathrm{p}$. ha gesäet.

Die Aussaatmethoden können sehr rersehiedene sein; ist z. B. das Getreide relativ billig und mensehliehe Arbeitskraft teuer, so werden, verbunden mit einer gewissen Saatversehwendung, die möglichst einfaebsten säemethoden zur Anwendung kommen, wie sich dies aus dem Berieht über den Agrikulturzustand der Vereinigten Staaten durch die beiden englisehen Parlamentsmitglieder Charl. Se well und Alb. Pell erkennen lässt.

Darnach folgt dort der Weizen gewöhnlich dem Mais und ist letzterer zwischen den Reihen leidlich rein gehalten worden, so wird der Winterweizen in den westlichen Staaten, ohne dass vorher das Land gepflügt wird, ausgesäet, und zuweilen erfolgt die Aussaat auf dem ungeschnittenen Mais, indem der Säemann von einem Pferde aus. dessen Ohren verbunden sind, den Weizensamen iber die Maisgipfel verstreut. Nach Beendigung der Maisernte wird eine eiserne Eisenbahnsehiene von ea. 9 nı Länge mit einem Schuh an jedem Ende von zwei Pferden itber die Reihen entlang gezogen, um die Stengel niederzubrechen, die darauf zusammengelesen und verbrannt werden.

In den mittleren und älteren Staaten wird meist, nachdem der Mais geschnitten und in Garben aufgestellt worden war, zwisehen den Reihen gepfiuigt und noch ehe die Maisernte entfernt ist, der Weizen gesäet.

Zur Sommersaat pfligt man das Land vor Winter und eggt im Frühjahr die rauhen Furehen nieder. Die Säemasehine, von zwei Pferden gezogen und von einem Manu bedient, säet die Körner breitwürfig aus, und ein einmaliges, besser ein zweimaliges Durcheggen vollendet die Operation.

In den europäisehen Ländern sucht man durch die Säemethode, namentlieh dureh Einführung der Drillkultur, am Saatgut zu sparen, und da die Arbeitslöhne billiger und die Wirtsehaftssysteme intensiver sind, wendet man sich auch immer melhr den besseren Säemethoden zu. Sehr häufig werden aber noeh Weizen und Spelz, sobald der Boden leieht, auf die rauhe saatfurehe und auf sehwererem Boden, nachdem vorgeegt worden ist, mit der Hand oder besser mit der Säemasehine (Saatersparnis 10 Proe.) ausgestreut und mit einigen Eggenstrichen untergeeggt, oder es wird auf das geeggte Ackerstück gesäet und dann die Unterbringung vermittelst der Krümmer, mehrseharigen Saatpfligge oder des gewöhnliehen Pfluges bewerkstelligt, worauf die Egge folgt.

Jedenfalls ist eine weit rationellere Methode als die genannten die Drillkultur, welehe zur Zeit vorzugsweise in England, Nord- 
Frankreich, Belgien, den Niederlanden, Nord-Deutschland, Dänemark und Ungarn Anwendung findet und sich auch immer mehr in den Vereinigten Staaten einbiirgert, denn es sollen schon 37 Proc. des gesammten Anbaues gedrillt werden.

Sie verlangt einen zur Saat vollkommen vorbereiteten Acker, also die Saatfurche muss klar geeggt und bei der Frühjahrsbestellung event. gewalzt sein; dass diese Vorbereitung vor der Einsaat greschehen muss, darf namentlich auf sehwerem Boden, auf dem narh der Saat das Festtreten durch die Zugtiere naehteilig ist, als ein Vorzug der Drilkultur angesehen werden; ferner bringt die Drillmaschine die Samenkörner in gleiche und zweckmässige Tiefen unter und verteilt sie gleichmässiger iuber den Acker, was eine gleielmässigere und kräftigere Entwickelung der Pflanzen znl Folge hat; mithin lässt sich durch ein verhältnismässig geringes Saatruantun ein höherer Kornertrag nach Quantität und Qualität und meist aueh ein höherer Strohertrag als bei der Breitsaat erzielen. Jedoch ist zu beachten, dass die Maximalerträge sich im konkreten Fall nur bei einer bestimmten Standdiehte erzielen lassen, mithin die Feststellung derselben durch Versuche sehr notwendig erseheint, doeh werden diesclben von vielen Faktoren, z. B. von der Weizcnsorte, vom Klima, von der Bodenbeschaffenheit, Düngung, Kulturart etc. beeinflusst.

Die Wichtigkeit derartiger Feststellungen ergiebt sich ans den beiden naehfolgenden Versuchen von Wollny und Jansen in Pros$\left.k^{2}{ }^{1}\right)$ und von uns in Poppelsdorf, welche zeigen, dass die engste Reihenweite den höchsten, unter anderen Verluältnissen abcr auch den niedrigsten Ertrag herbeiführen kann.

I. Versuch in Proskau mit Sandomir-Weizen:

\begin{tabular}{c|c|c|c|c}
\hline $\begin{array}{c}\text { Reihen- } \\
\text { entfernung. }\end{array}$ & $\begin{array}{c}\text { Aussaat- } \\
\text { quantum. }\end{array}$ & \multicolumn{2}{|c}{ Ernte pro ha in kg. } \\
cm & $\mathrm{kg}$ & Körner & Stroh & Spreu \\
\hline 15.7 & 128 & 2224.0 & 6384.0 & 838.4 \\
20.9 & 96 & 2108.8 & 6297.6 & 796.4 \\
26.2 & 74 & 2011.6 & 6118.8 & 822.4 \\
31.4 & 64 & 1904.0 & 6000.0 & 739.2
\end{tabular}

II. Versuch in Poppelsdorf mit Hallet's Pedigree-Weizen:

15.7

31.4

\begin{tabular}{|r|r|r|}
150 & 2068.0 & 2900.0 \\
75 & 2350.0 & 3917.0
\end{tabular}

815.0

783.0

1) Centralbl. f. Agric. Chemie II. Heft 9, pg. 164. 
In diesem Fall scheinen hauptsächlich die angebauten Sorten einen entscheidenden Einfluss ausgeübt zu haben, da sie beide im Habitus ausserordentlich abweichen, denn der Sandomir-Weizen wies in Poppelsdorf nur eine Gesammtfläche von $159.80 \mathrm{qcm}$ pro Halm und 5.6 Halme pro Pflanze, dagegen $\mathrm{H}$ all e t's Pedigree eine Gesammtfläche pro Halm ron $404.81 \mathrm{qcm}$ und 5 Halme pro Pflanze auf, mithin vermochte der Sandomir-Weizen in Proskau bei den weiten Stande von $314 \mathrm{~cm}$ den Boden nicht genügend zu decken, wohl aber der in Poppelsdorf gebaute Hallet's Pedigree.

$\mathrm{Zu}$ bemerken ist nur, dass schr grosse Drillweiten nicht ohne Einfluss auf die Qualität der Körner bleiben, denn diese werden voller, runder, stïrkemehlreicher und eignen sich in Folge dessen besser zur Vermalzung als zur Herstellung von Backmehl, denn für letzteres werden kleberreiche Körner verlangt.

Die Grenzen del Reihenentfernung liegen zwischen $10-30 \mathrm{~cm}$ (10-25 cm nach Nowacki), doch kann die Reihenentfernung ausnahmsweise, z. B. auf reichen im Seeklima gelegenen Poldern bis $50 \mathrm{~cm}$ elreiclien.

In England wird meist auf $25-30 \mathrm{~cm}$, in Belgien, den Niederlanden und Nord-Frankreich auf $20-221 / 2 \mathrm{~cm}$, in Nord-Deutschland auf $10-20$, seltener $30 \mathrm{~cm}$, und in Ungarn auf $10-15 \mathrm{~cm}$ gedrillt.

Dic Dibbelsaat oder das Auspflanzen des Weizens bringt im Allgemeinen noch höhere Erträge und Körner von grösserem absoluten Gewicht als die Drillsaat, vorausgesetzt, dass das Klima mild und event. auch eine Bewässerung der Pflanzen möglich ist, doch dürfte diese höchst intensive S̈̈emethode nur in solchen Ländern fiir die Kultır im Grossen vorteilhaft sein, welche eine sehr dichte Bevölkerung und niedere Arbeitslöhne bei hohen Getreidepreisen aufweisen, wie dies in vielen dicht bevölkerten Gegenden Ostasiens, z. B. in China und Japan, der Fall ist, welche demnach das Problem gelöst liaben, durch möglichst geringe Aussaat möglichst hohe Erträge zu erzielen. Die Dibbelsaat geschieht durch Herstellung kleiner Löcher mit Hülfe von Handhacken und die Pflanzung mittels des Pflanzstocks und zwar in China ${ }^{1}$ ) auf Entfernungen von $15-20 \mathrm{~cm}$.

In Europa macht man ron dieser Säemethode im Grossen nicht Gebrauch, weil sic zu kostspielig und auch in den strengeren Wintern des kälteren gemässigten Klimas diese Kulturen durch Auswintern zu sehr leiden, wenn auch zuweilen, bei sehr sorgsamer Kultur, überraschenci hohe Erträge erzielt werden können, wie ein solcher Versuch, in Proskau 1872, durch Wollny mit Chiddam-Weizen angestellt, zeigt:

1) Green, II. pg. 234. 


\begin{tabular}{l|c|c|c|c|c|c}
\hline & $\begin{array}{c}\text { Reihen- } \\
\text { ent- } \\
\text { fernung. }\end{array}$ & $\begin{array}{c}\text { Ausssaat- } \\
\text { quantum. }\end{array}$ & \multicolumn{3}{|c|}{ Ernte pro ha in kg. } \\
\cline { 3 - 7 } & $\mathrm{kg}$ & Brutto & Netto & Stroh. & Spreu. \\
\hline Drillsaat & $20.9 \mathrm{~cm}$ & 123.12 & 2306.4 & 2183.3 & 7478 & 818 \\
Dibbelsaat & $20.9 \mathrm{~cm} \mathrm{im}$ & 21.60 & 2476.0 & 2454.4 & 6967 & 802 \\
& Quadrat & & & & &
\end{tabular}

Diese enorme Saatersparnis wird einzig gedeekt dureh eine stärkere Bestoekung, zumal wenn, wie bei der Dibbelkultur, die Pflanzen einzeln stehen, und daher dureh den Kampf um das Dasein, in weit geringerem Grade an ihrer Bestoekungsfähigkeit gesehädigt werden, als die in den Drillreihen eng zusammenstehenden Pflanzen, daher im Verhältnis zum Wachsraum die gedibbelten Pflanzen eine stärkere Bestoekung zeigen werden.

Wir haben daraufhin in Poppelsdorf gedrillte (20 em Reihenweite) und gedibbelte Pflanzen untersueht nud folgende Resultate gefunden :

\begin{tabular}{|c|c|c|c|}
\hline Sorte & \begin{tabular}{|} 
Gedrillte Pfla \\
Grösse des \\
Wachsraumes \\
der im Frühjahr \\
noch vorhande- \\
nen Pflanzen \\
qcm
\end{tabular} & $\begin{array}{l}\text { Anzahl } \\
\text { der } \\
\text { Schöss- } \\
\text { linge }\end{array}$ & $\begin{array}{l}\text { Gedibbelte } \\
\text { Pflanzen } \\
\text { Auf } 100 \text { qcm } \\
\text { Wachsraum } \\
\text { entwickelten } \\
\text { die Pflanzen } \\
\text { Schösslinge }\end{array}$ \\
\hline $\begin{array}{l}\text { Hallet's Pedigree-Wheat } \\
\text { Kessingland } \\
\text { Probsteier } \\
\text { Hallet's red Nursery } \\
\text { Spalding's prolific Wheat } \\
\text { Tunstall } \\
\text { Rough chaffed Essex } \\
\text { Sandomir } \\
\text { Frankensteiner } \\
\text { Brodie's white Wheat } \\
\text { Blé géant de St. Hélène } \\
\text { Blé poulard blanc lisse } \\
\text { Common Rivet }\end{array}$ & $\begin{array}{l}70 \\
73.5 \\
62.5 \\
50 \\
40 \\
50 \\
55.5 \\
60 \\
74 \\
46 \\
61 \\
50 \\
71\end{array}$ & $\begin{array}{l}5 \\
4.7 \\
5 \\
4 \\
3.6 \\
3.7 \\
5 \\
5.6 \\
5.2 \\
6 \\
4 \\
3.8 \\
5\end{array}$ & $\begin{array}{l}12 \\
11.8 \\
13.8 \\
10.8 \\
14.3 \\
7.1 \\
12 \\
18 \\
18.6 \\
13.3 \\
15.5 \\
11.6 \\
10.3\end{array}$ \\
\hline
\end{tabular}

Zur Verbesserung und sehnellen Vermehrung einer Weizensorte bedient man sich mit Vorteil der Dibbelkultur, während sie sonst in Europa keine nennenswerte Verbreitung gefunden hat, so fuihrte Chateauvieu naeh Heuzé in der Sehweiz 1745 ein Art Dibbel- 
kultur (semer le blé en bouquets) mit einem von ihm erfundenen Handsieapparat ein, und das Pflanzen des Weizens wurde schon 1698 durch Abbé Fillizzio-Pizzichi bei Florenz versucht, doch sind befricdigende Resultate nicht crzielt worden.

\section{Pflege.}

Die Pflege des gedrillten Weizens beginnt sofort nach der Einsaat, indem mit einer leichten Egge ein Eggenstrich quer über die Drillreihen zur besseren Schliessung derselben, namentlich auf bindigem, etwas fenchtem Boden gegeben wird, um zu verhindern, dass die Samenkörner den Krähen, Sperlingen etc. zur Beute fallen, zugleich wird auch, und zwar rorzugsweise auf gewalztem Acker, die Oberfläche wiederum gelockert und das Wurzelunkraut zum Vertrocknen an die Oberfluche gebracht.

Die Wintersaat, seltener die Sommersaat, wird auf schwerem, oder nicht ganz ebenem Boden, zur Vermeidung der schädlichen Wirknugen stagnierenden Wassers, mit zweckmässig angelegten Wasserfurchen rersehen.

Sommerweizen, welcher sehr zeitig anf' einem mit Unkrautsamen erfiillten Boden ausgesäet werden musste, eggt man gern noch einmal, wenn der Weizen gekeimt ind schon bis $3 \mathrm{~cm}$ lange Würzelchen entwickelt hat, um das bereits aufgelaufene Unkraut wiederum zu vertilgen.

Hat die Sommersaat eine Höhe von $6-8 \mathrm{~cm}$ erreicht, so walzt man auf genügend abgetrocknetem Boden mit Ringel- oder kannelierten Walzen, wodurch die Bestockung gekräftigt, die Feuchtigkeit im Boden mehr der jungen Pflanze zugefuilht, eine gleichmässigere Entwickelung der Halme erzielt, sowie die Ernte durch das Eindrücken der Steine in den Boden und durch Zertrümmerung der Klösse elleichtert wird. Hingegen hat das Walzen der Winterung: im Herbst, weil sich der Boden zu leicht schliesst, in Folge dessen die jungen Pflanzen kränkeln, ausnahmslos zu unterblciben, zumal etwaige Klösse der Saat zum Schutz gereichen und durch den Frost zermiirbt, im Frühjahr beim Eggen der Weizensaat sehr leicht zerfallen. Letzteres sollte unter allen Umständen und selbst bei Reihensaat mit Behacken zur Anwendung kommen, sobald der Acker genügend abgetrocknet und der Weizen in Vegetation getreten ist. Die wirksamste Egge, wenn es sich um die Zertrümmerung der Klösse und das Brechen einer festen Kruste handelt, ist die Wiesenegge ron $\mathrm{How}$ a d d, zumal durch sie verhältnismässig kleine Pflanzen nicht leicht mit Erde be- 
deckt werden; später, solsald die Gefahr des Bedcekens nicht melır vorliegt, bedient man sich zı einer zweiten, ticferen Lockerung schiverer, scharfühnniger Eggen, z. B. der schottischen RhomboidalEggen und will man bei zu uppigen Wuchs, weleher Lagern vermuten lässt, die Pflanzen lichter stellen, dann greift man zu den schweren eisernen Eggen, z. B. der Brabanter Egge.

Ein starkes Aufeggen liebt auf schwerem Boden lauptsiichlich der Spelzweizen.

Auf sehr humosem Boden werden die etwa durch den Frost gehobenen Weizenpflanzen durch Inwalzen wiederum zu befestigen gesucht.

Im Allgeneinen zerstört man durch das Eggen der Wintersaat wenig Unkraut, weshalb die schlimmsten Unkräuter wie Kornrade, Kornblume, Disteln und zwar selbst bei Hackkultur die noch in den Reihen zwischen den Weizenpflanzen stehenden in Frühjahr auszustechen sind.

Schlecht durch den Winter gekommene oder durch Feinde geschädigte Saaten lassen sich durch Ueberdüngung mit unkrautfieiem, gut zersetztem, nährstoffreichem Kompost bei Beginn der Vegetation oder durch $100-160 \mathrm{~kg}$ Chilisalpeter kurz vor dem Schossen aufhelfen.

Grössere, durch Mäusefrass, Ausfaulen oder Auswintern entstandene Blössen sind durch Bepflanzen aus dichteren Beständen einigermassen zu schliessen.

Auf 20-30 cm Reihenweitc gedrillte Saaten können mit der Pferdehacke, engere mit der Handhacke, behackt werden. Eine hierzı iiberaus taugliche Pferdehacke ist die Salzminder von $13 \ddot{l} l$ te, deren bewegliche Messer sich dem Terrain vollkommen anschmiegen und eine Form besitzen, durch welche das Bewerfen der Pflanzen mit Erde. selbst wenn man bis dicht an die Pflanzcureilien heran lackt, vermieden wird. Aus diesem Grunde lässt sich bereits beim Beginn der Vegetation hacken, so dass, selbst bei schnell sich entwickclnden Sorten, meist noch kurz vor dem Schossen eine zweite, tieferc Hacke gegeben werden kann. Durch das Hacken wird der Boden der Luft erschlossen, die Feuchtigkeit besser zurïckgehalten und das Unkraut zerstört.

Steht Lagergetreide in Aussicht, so lässt sich durch Schröpfen des Weizens, bevor die Aehre in den Halm getreten ist, oder durch Walzen kurz vor dem schossen auf cinigen Erfolg hoffen weniger empfehlenswert ist dagegen das Beweiden der Saat, das aber, soll es ausgeführt werden, nur höchst vorsichtig und bei trocknem Wetter geschehen darf und verweise ich auf das im Kapitel iber Pfiege im allg. Teil dariber Gesagte.

In den warmen Zonen reicht der Regenfall nicht vollkommen 
aus, das Wasserbediirfnis der Weizenpflanze vollkommen zu decken, wenn lohe und sichere Erträge erzielt werden sollen, aus welchem Grunde hier vielfach künstliche Bewässerungen angetroffen werden.

In welchem Masse eine reichliche Bewässerung die Ernteerträge erböhen kann, indem die Pflanze gleichsam ihre volle Verdunstungsfähigkeit ausnützt, daron legen die Resultate, welche von der Versuchsstation in Montsouris, Frankreich, erhalten wurden, Zeugnis ab.

Diese Resultate sind folgende:

$\begin{array}{cc}\begin{array}{c}\text { Verbrauchte } \\ \text { Wassermenge }\end{array} & \begin{array}{c}\text { Producierte } \\ \text { Körnermenge }\end{array} \\ 1.616 & \mathrm{~kg} \\ 1.512 & 0.6 \\ 1.703 & 0.8 \\ 2.202 & 2.4 \\ 3.262 & 2.7 \\ 4.327 & 2.9 \\ 4.751 & 3.1 \\ 7.417 & 5.5 \\ 7.702 & 9.2 \\ & 10.6\end{array}$

Hauptsächlich muss die hohe Wirksamkeit und Verwertung des Wasser's zur Zeit der kräftigsten Entwickelung der Pflanze (doch nicht während der Blïte), der Ausbildung der Aehre, und der intensirsten Wărme wohl berieksichtigt werden, daher für binreichende Wasserzufuhr in dieser Zeit zu sorgen ist.

Selbstrerständlich ist das Feld zur Berieselung einzurichten, wozu es eines schwachen Gefälles und der Wasserverteilgräbchen bedarf. (Vergl. das Kapitel über die Pflege im allg. Teil.)

Gasparin ${ }^{1}$ ) fülurte die Bewässerung im Grossen zu Caraillon (Vaucluse, Frankreich) aus, und macht dariber folgende Mitteilungen:

Man gibt 4 Bewässerungen, die 1. ror der Saat, die 2. im April bei $+12{ }^{\circ}$ C., die 3. kurz ror der Blïte und die 4. einige Tage nach der Bliite; die beiden letzten Wässerungen sollen die beste Kornausbildung bewirken und wurden $3200-3680 \mathrm{~kg}$ p. ha an Körnern geerntet. Selbstrerständlich darf auf undurchlassendem Boden nicht gewässert werden, weil in diesem Falle der Weizen zu Grunde geht.

Geneinhin wässert man in Süd-Frankreich nur in trocknen Jahren und dann zweimal, im Mai und Juni, und gibt $1200 \mathrm{cbm}$ Wasser pro ha im Ganzell.

In Spanien wässert man fünfmal à $500 \mathrm{kbm}=2500 \mathrm{cbm}$ Wasser pro ha. 
In Italien wird während der Vegetationszeit pro ha und Sekunde ein Wasserquantum von 0.377 Ltr verwandt.

In Algier wird durehschnittlich dreimal gewässert und sollen pro ha im Ganzen $1000 \mathrm{cbm}$ Wasser verbraucht werden.

Der Winterweizen erbält in Indien 5 Bewässerungen nnd im Ganzen 2990 cbm Wasser pro ha.

In Mexico wird der Weizen ebenfalls bewissert nnd in dem Fall, dass Wasserzufluss nicht vorhanden ist, begiesst man, wenn irgend möglich, einmal nach dem Aufgehen und zweimal während des Schossens.

\section{Ernte, Ausdrusch und Aufbewahrung.}

Der zweckmässigste Reifezustand ${ }^{1}$ ) des Weizens als Saat- und Brotgetreide tritt mit der Gelbreife ein, in welcher sich das Korn über den Nagel brechen lïsst.

In diesen Znstande geerntet, wird nicht nur das höchste Erntegewicht, sondern auch die beste Kornqualität erzielt, wofür die Versuche von $\mathrm{Hannam}{ }^{2}$ ) und $\mathrm{Nowacki}$ sprechen.

Ersterer gelangte $\mathrm{zu}$ folgenden Resultaten:

\begin{tabular}{|c|c|c|c|c|c|}
\hline \multirow[b]{2}{*}{ No. } & \multirow{2}{*}{$\begin{array}{c}\text { Tag } \\
\text { des Mähens }\end{array}$} & \multirow[b]{2}{*}{ Reifegrad } & \multirow[b]{2}{*}{$\begin{array}{l}\text { Tag des } \\
\text { Einfahrens }\end{array}$} & \multicolumn{2}{|c|}{ Ernteerträge } \\
\hline & & & & $\begin{array}{c}\text { Korn } \\
\mathrm{kg}\end{array}$ & $\begin{array}{c}\text { Stroh } \\
\mathrm{kg}\end{array}$ \\
\hline $\begin{array}{l}1 \\
2 \\
3 \\
4 \\
5\end{array}$ & $\begin{array}{l}\text { 12. August } \\
\text { 19. " " } \\
26 . \text { " } \\
\text { 30. " " } \\
\text { 9. Septr. }\end{array}$ & $\begin{array}{l}\text { sehr grün } \\
\text { grün } \\
\text { unreif } \\
\text { ziemlich reif }\{\text { gelbreif } \\
\text { ganz reif }\end{array}$ & $\begin{array}{l}\text { 26. August } \\
\text { 31. " " } \\
\text { 5. Septbr. } \\
\text { 9. " " } \\
\text { 16. " }\end{array}$ & $\begin{array}{c}72.2 \\
67.4 \\
95.7 \\
100 \\
91\end{array}$ & $\begin{array}{l}137 \\
129.2 \\
125.5 \\
116.5 \\
109.5\end{array}$ \\
\hline
\end{tabular}

Der Weizen lieferte in den verschiedenen Proben:

\begin{tabular}{l|c|c|c}
\hline \hline No. & $\begin{array}{c}\text { Gutes Mehl } \\
\text { Proc. }\end{array}$ & $\begin{array}{c}\text { Schlechtes } \\
\text { Nehl } \\
\text { Proc }\end{array}$ & Kleien \\
Proc. \\
\hline 1 & $75^{1 / 6}$ & $7^{1} / 6$ & $17^{2} / 3$ \\
2 & $76^{2} / 3$ & $7^{1 / 6}$ & $16^{1 / 6}$ \\
3 & 81 & $5^{1 / 2}$ & $13^{1} / 2$ \\
4 & $77^{1} / 3$ & $72 / 3$ & 15 \\
5 & 73 & $11^{1 / 10}$ & $15^{9} / 10$
\end{tabular}

1) Schwerz, Anl. z. prakt. Ackerb. pg. 95, 1825.

2) Farmer's Mag. XXIV pg. 254, 1863. 
Ferner enthält das Stroh, in der Gelbreife gemähet, bedeutend mehr Nährstoffe als in der Vollreife, liefert demnach ein besseres Futterstroh. Nach Völker erleidet das Stroh durch die Ueberreife insofern eine Veränderung, als ein grosser Teil der Tiernährstoffe unlöslich wird; er fand z. B. im Stroh, in der Gelbreife geerntet. 0.5 Proc. lösliche Eiweisskörper und 1.62 Proc. unlösliche, in dem Stroh desselben Getreides in der Ueberreife gehauen, nur 0.06 Proc. lösliche und 2.06 Proc. unlösliche Eiweisskörper.

Ausserdem lässt sich durch das Mähen in der Gelbreife die Ernte mit grösserer Sicherheit und geringerem Körnerausfall bewirken.

Die Ernte beginnt in der tropischen Zone Anfang April (Ostindien!, in der subtropischen Ende April (Aegypten); in der wiirmeren gemässigten Zone wird der Winterweizen im Mai (Algier) oder in der ersten Hälfte des Juni (Spanien, Süd-Italien, Südstaaten NordAmerikas), oder in der zweiten Hälfte des Juni (Nord-Italien, SiidFrankieich) geerntet.

In der kälteren, gemässigten Zone ist der Ernteeintritt auch davon abhäugig, ob in dem betreffenden Landstrich das Binnen- oder Seeklima herrscht; im Allgemeinen fällt die Ernte in die Monate Juli und Angust. In den Nordstaaten der Vereinigten Staaten erntet man im Juli und August; Mitte Juli in Süd-Deutschland, Süd-Russland und Mittel-Frankreich; Ende Juli in Mittel-Deutschland; Ende Juli bis August in Nord-Frankreich, Belgien, den Niederlanden, Nordwest-Deutschland, Siid-England; Anfang August in Nord-Deutschlaud und Mittel-England; Ende August in Nord-Englaud.

In der subarktischen Zoue, z. B. in Mittel-Schweden, wird Anfang Angust, weiter nördlich bis Ende August gemähet.

Nicht selten stellt sich im ausgesprochenen Kontiueutal-Klima gerade zur Reifezeit sengende Hitze ein, wodurch die Körner rorzeitig zusammenschrumpfen und an Quantität wie Qualität eine beträchtliche Eiubusse erleiden.

Zur Verhuitung von Verlusten durch Wiud sollte für Abmähen in der Gelbreife und Anbau solcher Sorten Sorge getragen werden, deren Früchte im Reifezustande noch fest von den Spelzen unschlossen siud.

Bei nasser Erntewitterung wächst der Weizen und zwar selbst auf dem Halm aus; hiergegen hilft nur grosse Aufmerksamkeit auf die Erntearbeiten, verbesserte Erntemethoden und den Anbau solcher Sorten zu richten, welche weniger leicht auswachsen. Bekanntlich neigen hartkörnige, in der Aehre lockere und kahle Weizen weniger leicht zum Auswachsen als weichkörnige und behaarte, dichte Kolbenweizen.

Das Mähen des Weizens erfolgt in England, Nord-Frankreich, Nord-Deutschland und Ungarn meist mit der Mähemaschine, in den 
Vereinigten Staaten von Nord-Amerika, insofern Baumstimpfe im Boden ihre Anwendung nicht verbindern, vielfach mit der Bindemähemaschine, doch kommt auch in allen diesen Länderı noch häufig. die Bügelsense zur Anwendung und in Siid-Deutschland neben der Sense auch die Sichel. In Belgien und einigen daran grenzenden Landistrichen wird der Weizen iberwiegend mit dem Sichet abgebracht. In den wärmeren Zonen konmt fast ausnahmslos dic Sichel bei der Ernte zur Alwendung.

Findet sich unter dem Weizen nicht viel Kleegras oder saftiges Unkraut, daun hat zur Erhaltung ciner guten Qualitiit und Nachrcife, sowie zur Vermeidung des leichten Auswachsens bei feuchter Witterming sofort nach dem Schnitt das Aufbinden in Garben und Aufstellen in Hocken nder Stiegen, Puppen ctc. zu geschcheu. Häufig. hört man die Ansicht aussprechen, dass das Nachreifen des Weizens in Puppen dic Mchligkeit der Körner und das Liegen im Schwad die Glasigkeit befördere, doch konnte Nowacki für das feuchtere, gemässigte Klima den Nachweis der Richtigkeit nicht erbringen.

Der Ansdrusch erfolgt in den grösseren Wirtschaftsbetricben zur Zeit iiberwiegend mit Huilfe der Dreschmaschinen, und in den trockenen Klimaten meist sofort nach der Ernte auf dem Felde, z. B. in den Vereinigten Staaten, Ungarn, Siid-Russland, Italien etc.

Soll beim Ausdrusch das Stroh möglichst unversehrt bleiben, so wendet man gern Breitdreschmaschinen mit Schlagleisten an, doch werden ron diesen mehr Körner als durch die Stiftenmaschinen zerschlagen, durch letztcre jedoch mehr Aeluren abgerissen und das Stroh wird stärker zerknittert und zerrissen.

Zur Erzielung eines vollkommenen Reindrusches bei Anwendung des Flegels und namentlich beim Ausdrusch solcher Weizensorten, deren Spelzen das Korn f'est umschliessen, empfielılt es sich, Frostwetter abzuwarten, das Getreicle sehr gleichmässig und nie dicker als $16 \mathrm{~cm}$ loch anzulegen, auch vom Vorsatzbrette des Scheunenthores mindestens $30 \mathrm{~cm}$ entfernt $\mathrm{zu}$ bleiben, damit nicht zu viel Körner beim Ausdrusch darïber hinwegspritzen.

Die Reinigung geschieht entweder durch Wurfeln oder Getreidereinigungsmaschinen und werden dabei durchschnittlich 10 Proc. Hinterkorn erhalten.

In Bezug auf dic Erntemethoden, den Ausdrusch, die Reinigung und Aufbewahrung des Weizens verweise ich auf das im allgemeinen Teil in dem Kapitel iiber die Ernte Gesagte.

Weit schwieriger gestaltet sich dagegen die Ernte der Spelzweizen. Diese werden in der ersten Hälfte des August in SüdDeutschland, sobald der Halm vollständig weiss geworden ist, und sollte auch die Aehre noch nicht ganz reif, sondern nacli dem Sprachgebrauch "untergrïn" sein, geerntet. 
Der Ernte erwachsen nun dadurch Schwierigkciten, dass die Aehrenspindel zerbrechlich, in Folge dessen die Aehre nicht allein leicht in die einzelnen Aehrchen mit den daran befindlichen Teilen der Spindel (Veesen) zerfällt, sondern auch in der Vollreife die ganzen Aehren leicht abbrechen.

Diese Briichigkeit ist nun weit schlimmer als der Körnerausfall beinı Weizen und können bci raschem Ernteeintritt oder Notreife oft sehr grosse Verluste entstehen, die sich aber auch bei normaler Wittcrung, rechtzeitigem Schnitt, sowie durch Einfahren im Tau und Ausschlagen der Wagen mit Tiichern nie ganz vermeiden lassen.

Ferner wachsen die Spelzweizen weit leichter als die gewöhnlichen Weizen aus.

Nach Vossler ${ }^{1}$ ) empfiehlt sich nun die landesübliche Erntemethode in Wiurttemberg, dem klassischen Lande des Spelzbaues, nicht. Der abgesichelte und wegen der Briichigkeit der Aehren selten gemähte Spclzweizen bleibt in Gelegen oder Schwaden bis er trocken auf dem Felde liegen, wobci allerdings dic Vorsicht gebraucht wird, die Aehren erhöht auf die Stoppeln oder das Schnittende eines anderen Geleges zu bringen, damit sie auf dem sich häufig stark erwärmenden und feuchten Erdboden nicht auswachsen, was bei feuchtem Wetter auch bei dieser Massregel ohnehin leicht genug geschieht. Ist nun nach einigen Tagen der Spelz trocken, so wird erst nach dem Auftrocknen des Taues gegen 9 Uhr des Morgens mit dem Binden begonnen, was Zeitverlust zur Folge hat, und werden meist sehr grosse unhandliche Garben gebunden, die nicht aufgesctzt werden, sondern zerstreut auf dem Felde liegen bleiben, also beim Einfahren erst wieder tautrocken und nachler eingesammelt werden miussen, was wiederum mit Zeitverlust verbunden ist.

Weit empfehlenswerter scheint es uns, den Spelz sofort nach dem Mähen in kleine Garben zu binden und in Stiegen zum Trocknen aufzustellen. Die Stiege ist deshalb der Puppe vorzuziehen, weil in letzterer die Garben sich sehr fest ineinanderlegen und leicht die Aehren abbrechen, auch darf eine Sturzgarbe wegen der Brüchigkeit der Aehren nicht aufgesetzt werden.

Durch ein solches Verfahren würden die Aehren geschont werden und die Kernen, da die Aehren rom Boden entfernt sind, weniger leicht auswachsen.

Bei heissem Wetter und in der Vollreife wird er auch häufig zeitig des Morgens abgeschnitten, aufgebunden und am Abend desselben Tages eingefahren.

1) Wochenbl. f. Land- u. Forstwirtsch. No. 11, 1876. 


\section{Erträge und Nahrungsbestandteile.} folgt:

Die Weizenerträge stellen sich im Grossen und Ganzen wie Ertragstabelle.

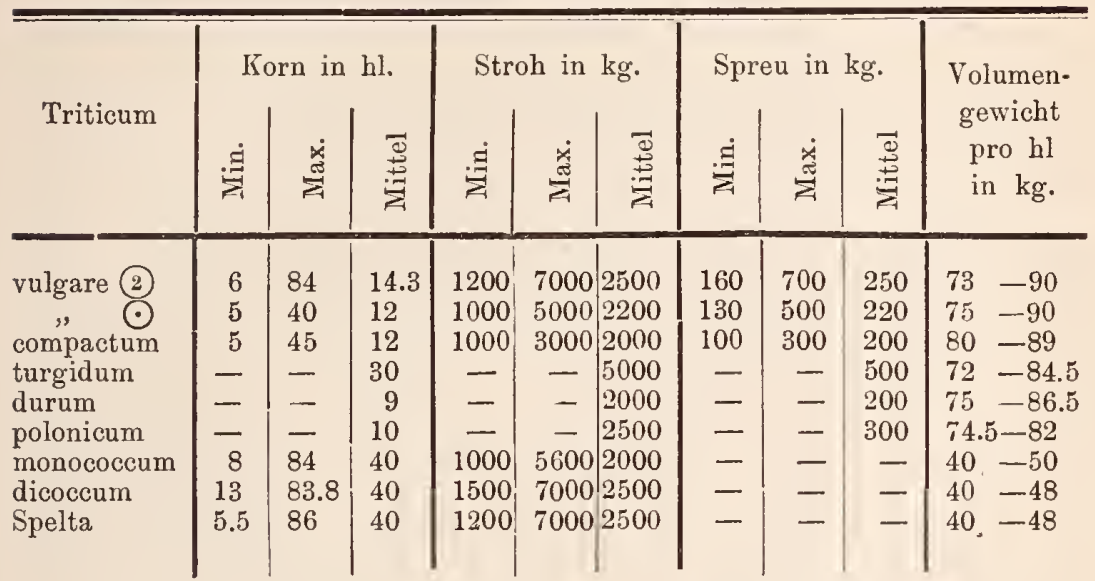

$\mathrm{Zu}$ dieser Tabelle ist zu bemerken, dass der Durchsehnittsertrag von $\mathrm{Tr}$. turgidum sich deshalb verhältnismässig hoch stellt, weil die sehr robuste Pflanze immer auf schweren, mehr oder weniger feuchten, gut gedüngten Böden angebaut wird. Anders verhalten sich Trit. durum, polonicum und compactum, die auf den von Natur nicht ganz armen, doch meist trocknen Böden und in den wärmeren Zonen zum Anbau gelangen, daher sich denn auch ihre Erträge relativ niedrig stellen.

Für Trit. durum ist del Durchschnittsertrag von $9 \mathrm{hl}$ pro ha aus Algier entnommen und zwar wird dieser Ertrag von den durch Europäer kultivierten Böden erzielt, während die Felder der Eingeborenen nur einen Mittelertrag von $5.8 \mathrm{hl}$ pro ha aufbringen.

Berechnet man den Mittelertrag aller an der Weizenkultur beteiligten Länder, so stellt sich derselbe auf $14.3 \mathrm{hl}$ Korn à $75 \mathrm{~kg}$ und $2500 \mathrm{~kg}$ Stroh und Spreu pro ha.

In nachfolgender Tabelle gelangt das Verhältnis der Körner zum Stroh zur Darstellung, wie sich dasselbe bei unseren siebenjährigen Kulturversuchen in Poppelsdorf herausstellte. 
Tabelle uber das Verhältnis der Körner zum Stroh (excl. Stoppeln).

\begin{tabular}{|c|c|c|c|c|c|c|}
\hline \multirow[b]{2}{*}{ Triticum } & \multicolumn{4}{|c|}{ Mittlere } & \multicolumn{2}{|c|}{ Gewichtsprocente. } \\
\hline & $\begin{array}{l}\text { Halm- } \\
\text { länge. } \\
\text { cm }\end{array}$ & $\begin{array}{l}\text { Blatt- } \\
\text { zahl pro } \\
\text { Halm. } \\
\text { Stück }\end{array}$ & $\begin{array}{c}\text { Aehren- } \\
\text { länge. } \\
\text { cm }\end{array}$ & $\begin{array}{l}\text { Frucht- } \\
\text { zahl in } \\
\text { einer } \\
\text { Aehre. } \\
\text { Stück }\end{array}$ & Korn & Stroh \\
\hline vulgare (2) & 127 & 4 & 10.5 & 54 & 36 & 64 \\
\hline " $\odot$ & 112 & 3.6 & 9.5 & 42.5 & 41 & 59 \\
\hline compactum (2) & 113 & 3.6 & 5.4 & 48 & 40 & 60 \\
\hline , & 104 & 3.5 & 5.6 & 43 & 40 & 60 \\
\hline turgidum (2) & 145 & 4 & 10 & 66 & 40 & 60 \\
\hline,$\quad$ C & 125 & 5 & 8 & 60 & 39 & 61 \\
\hline durum & 105 & 3.8 & 7 & 45 & 44 & 56 \\
\hline polonicum & 110 & 4 & 10.2 & 53 & $\begin{array}{c}32 \\
\text { Veesen }\end{array}$ & 68 \\
\hline monococcum (2) & 120 & 4 & 6 & 26 & 47 & 53 \\
\hline ," $\odot$ & 92.5 & 4 & 5.5 & 23.5 & 50 & 50 \\
\hline dicoccum (2) & 128 & 3.8 & 10 & 49 & 50 & 50 \\
\hline,$\quad \odot$ & $10 \pi$ & 4.4 & 10 & 41 & 47 & 53 \\
\hline Spelta (2) & $12 j$ & 3.7 & 12 & 39 & 53 & 47 \\
\hline,$\quad \odot$ & 113 & 3.8 & 13 & 40 & 51 & 49 \\
\hline
\end{tabular}

Durchschnittlich berechnen sich auf $100 \mathrm{~kg}$ Körner $250 \mathrm{~kg}$ Stroh und auf $100 \mathrm{~kg}$ Stroh $10 \mathrm{~kg}$ Spreu.

In der kälteren, gemässigten Zone ergeben sich für die Weizenböden nachfolgende Erträge an Winterweizen :

1) Reicher, tiefer, milder Thon- und Aueboden; Weizenboden I. Kl. $31-39 \mathrm{hl}=2277-2847 \mathrm{~kg}$ Korn, $5580-7000 \mathrm{~kg}$ Stroh p. ha.

2) Humoser, reicher, milder Lehmboden; Gerstenboden I. K1.

$28-32 \mathrm{hl}=2100-2400 \mathrm{~kg}$ Korn, $6000-7000 \mathrm{~kg}$ Stroh p. ha.

3) Schwerer, kräftiger Thonboden; Weizenboden II. Kl.

$26-30 \mathrm{hl}=1898-2190 \mathrm{~kg}$ Korn, $4680-5400 \mathrm{~kg}$ Stroh p. ha.

4) Milder, tiefer, mergeliger, frischer Lehmboden; Gerstenboden II.K1.

$21-26 \mathrm{hl}=1569-1898 \mathrm{~kg}$ Korn, $3780-4680 \mathrm{~kg}$ Stroh p. ha.

5) Leichter, sandiger Lehm und lehmiger Sandboden; Roggenboden I. Kl.

$18-20 \mathrm{hl}=1350-1500 \mathrm{~kg}$ Korn; $3000-3500 \mathrm{~kg}$ Stroh p. ha.

6) Kalter, zäher Thon- und Lehmboden; Weizenboden III. KI.

$17-19.5 \mathrm{hl}=1253-1424 \mathrm{~kg}$ Korn; $3060-3510 \mathrm{~kg}$ Stroh p. ha. 
7) Strenger, zäher, nasskalter Thonboden; Haferboden I. Kl.

$12-16 \mathrm{hl}=876-1168 \mathrm{~kg}$ Korn; $2160-2880 \mathrm{~kg}$ Stroh p. ha. Nach Block liefert der Sommerweizen etwa 25 Proc. weniger Körner und 20 Proc. weniger Stroh als der Winterweizen.

Den durch Unfälle veranlassten jährlichen Verlust schlägt B lock beim Winterweizen auf $1 / 12$, beim Sommerweizen auf $1 / 7$ des Ernteertrages an.

An Nahrungsbestandteilen (verdauliche und unverdauliche) befinden sich:

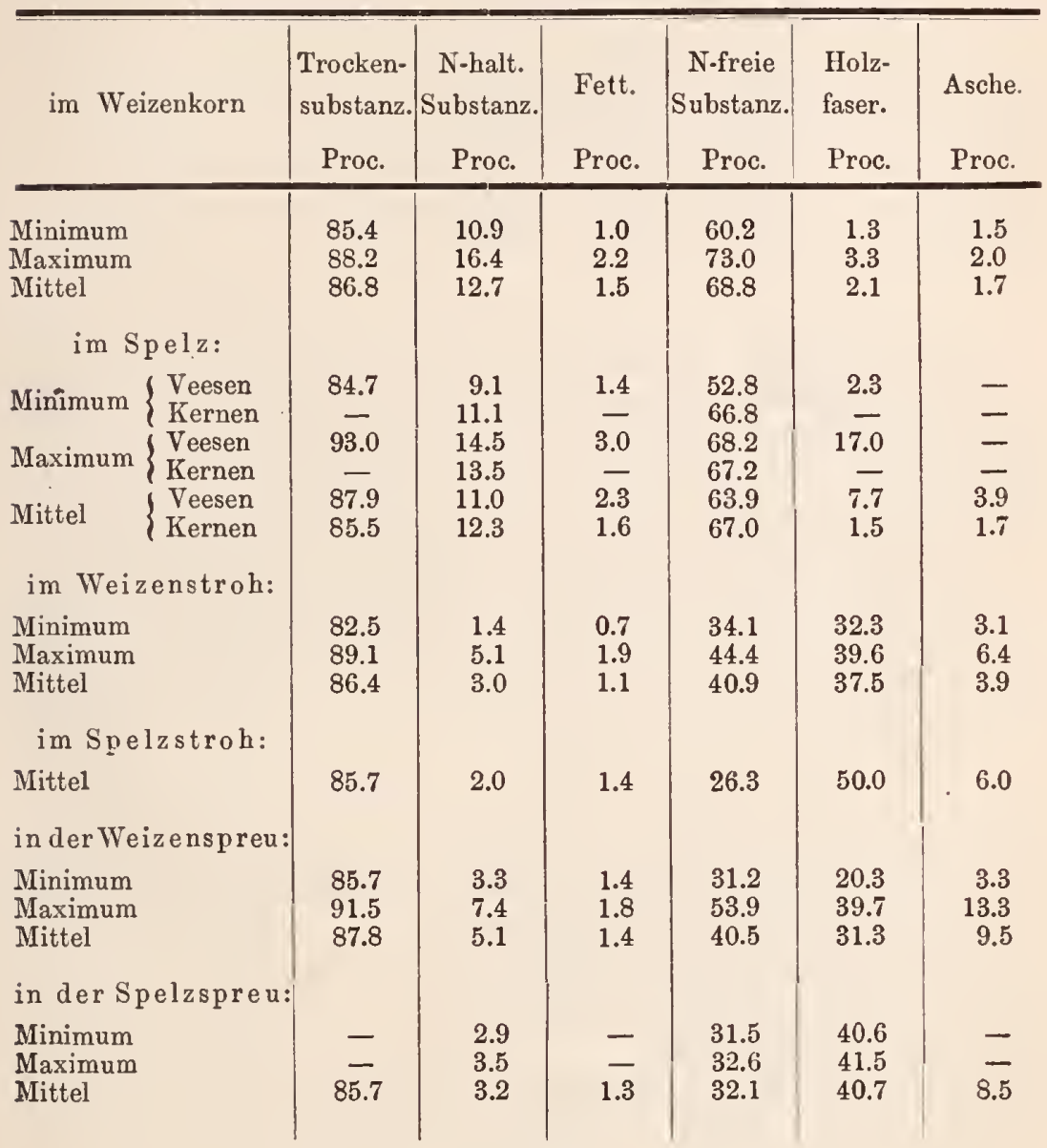


Der mittlere Procentgehalt an verdaulichen Nährstoffen beträgt nach E. Wolff:

\begin{tabular}{|c|c|c|c|c|c|c|c|c|}
\hline im & 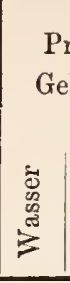 & $\begin{array}{l}0 \\
\text { d } \\
\text { 出 }\end{array}$ & an & 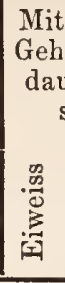 & 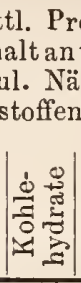 & $\begin{array}{l}\text { oc.- } \\
\text { ver- } \\
\text { ihr- } \\
\text { l. } \\
\underset{0}{ \pm}\end{array}$ & $\begin{array}{c}\text { Wahr- } \\
\text { scheinliches } \\
\text { Nährstoff- } \\
\text { verhältnis } \\
\text { wie } 1:\end{array}$ & $\begin{array}{l}\text { Geldwert pro } 100 \mathrm{~kg} \\
\quad \text { in Mark. } \\
1 \mathrm{~kg} \text { verdaul. } \\
\text { Protein }=40 \\
\text { Kohlehydrate }=8, \\
\text { Fett }=40, \\
\text { gerechnet. }\end{array}$ \\
\hline $\begin{array}{l}\text { Weizenkorn } \\
\text { Spelz (incl. Hülle) } \\
\text { Kernen } \\
\text { Weizenstroh } \\
\text { Spelzstroh } \\
\text { Weizenspreu } \\
\text { Spelzspreu }\end{array}$ & $\begin{array}{l}14.4 \\
14.8 \\
14.5 \\
14.3 \\
14.3 \\
14.3 \\
14.3\end{array}$ & $\begin{array}{l}1.7 \\
3.7 \\
1.7 \\
4.6 \\
5.0 \\
9.2 \\
8.3\end{array}$ & $\begin{array}{l}83.9 \\
81.5 \\
83.8 \\
81.1 \\
80.7 \\
76.5 \\
77.4\end{array}$ & $\begin{array}{r}11.7 \\
7.5 \\
9.8 \\
0.8 \\
0.7 \\
1.4 \\
1.1\end{array}$ & $\begin{array}{l}64.3 \\
42.7 \\
60.6 \\
35.6 \\
32.1 \\
32.8 \\
33.9\end{array}$ & $\begin{array}{l}1.2 \\
1.1 \\
1.3 \\
0.4 \\
0.4 \\
0.4 \\
0.4\end{array}$ & $\begin{array}{r}5.8 \\
6.1 \\
6.8 \\
45.8 \\
47.3 \\
24.1 \\
31.7\end{array}$ & $\begin{array}{r}10.30 \\
6.86 \\
9.68 \\
3.32 \\
3.00 \\
3.34 \\
3.32\end{array}$ \\
\hline
\end{tabular}

Die mittelguten Weizen liefern durchschnittlich von $100 \mathrm{~kg}$ Körnern $74 \mathrm{~kg}$ Mehl, $22 \mathrm{~kg}$ Kleie und $4 \mathrm{~kg}$ Verlust, doch steigert sich die Mehlmenge bei den besten Sorten auf $76-80 \mathrm{~kg}$, ja ausnahmsweise selbst auf $88 \mathrm{~kg}$, während andererseits die geringeren Qualitäten $61.5-68 \mathrm{~kg}$ und sogar nur $54-56 \mathrm{~kg}$ Mehl ausgeben.

Die Mehlausbeute wächst mit der Härte und Dichte, sowie mit der Feinheit der Schale der Körner und gleichzeitig, weil sich anch der Klebergehalt erhöht, gewinnt die Qualität des Mehles, wie dies die harten, glasigen und glänzenden Weizen in recht auffallender Weise zeigen

Nach Payen sollen enthalten:

Weichweizen (Winterkolbenweizen ${ }^{1}$ ) und die zu Trit. turgidum gehörigen Sorten) Halbweiche Weizen (Bart- und Sommerweizen im mässig feuchten Klima) Halbharte Weizen (Steppenweizen, sowie Igel- und Binkelweizen) Hartweizen (Trit. durum, polonicum)

Mehl Kleie Kleber 75 Proc. 25 Proc. 9 Proc. $80,20,11$, $\begin{array}{llllll}84 & \prime & 16 & \prime & 13 & \\ 88 & \prime & 12 & , & 15 & \end{array}$

Einige durch Despine ausgeführte Analysen von Handelsweizen bestätigen diese Angaben, ebenso die hier nachfolgenden Untersuchungen von Reiset, wie auch die wertvollen Arbeiten von

1) Die in diese Gruppen gehörigen eingeklammerten Varietäten sind durch den Autor hinzugefügt. 
Ritthausen, welche letzteren schon in dem Abschnitt uber das Klima weiter oben besprochen worden sind.

Nach Despine enthielten:

\begin{tabular}{l|c|c|c|c}
\hline \hline & Stärke. & Kleber. & Schale. & $\begin{array}{c}\text { Feuchtig- } \\
\text { keit. }\end{array}$ \\
\hline Blé touzelle rouge & 65.46 & 12.72 & 2.25 & 6.90 \\
" de Narbonne & 66.00 & 12.34 & 2.10 & 7.55 \\
" de Carcassonne & 64.15 & 14.45 & 2.20 & 6.91 \\
" fin de Toulouse & 69.56 & 14.00 & 2.20 & 6.90 \\
" de Brissac & 69.30 & 10.14 & 2.05 & 10.02 \\
" richelle de Naples & 65.36 & 13.03 & 2.90 & 8.90 \\
" tendre d'Odessa & 66.15 & 12.30 & 3.00 & 6.15 \\
" de Taganrock & 63.50 & 16.80 & 3.00 & 6.50 \\
" dur de Sicile & 63.00 & 16.35 & 2.90 & 6.60
\end{tabular}

Nach Reiset ${ }^{1}$ ):

\begin{tabular}{|c|c|c|c|c|c|c|}
\hline Name des Weizens. & Dichte & $\mid \begin{array}{cc}\text { Gewicht } \\
\text { p. } & \text { Liter } \\
\text { gr }\end{array}$ & $\begin{array}{l}\text { Wasser } \\
\text { bei } 100^{\circ}\end{array}$ & $\begin{array}{c}100 \mathrm{t} \\
\text { nen W } \\
\text { entha } \\
\text { Asche }\end{array}$ & $\begin{array}{l}\text { rock- } \\
\text { Veizens } \\
\text { alten } \\
\text { Stick- } \\
\text { stoff }\end{array}$ & $\begin{array}{c}\text { Kleber } \\
\text { oder } \\
\text { Albumin. }\end{array}$ \\
\hline $\begin{array}{l}\text { Poulard noir, laalbweich } \\
\text { Weisser weicher englischer }\end{array}$ & 1.290 & 739.6 & 14.10 & 2.14 & 1.71 & 10.68 \\
\hline Weizen & 1.347 & 767.4 & 14.47 & 1.88 & 1.88 & 11.75 \\
\hline $\begin{array}{l}\text { Weizen von Charmoise } \\
\text { Engl. Weizen, } 3 \text { Jahr nach der }\end{array}$ & 1.350 & 774.2 & 14.97 & 2.10 & 1.87 & 11.68 \\
\hline $\begin{array}{l}\text { Einfuhr in Frankreich } \\
\text { Barkers-Weizen, } 1851 \text { einge- }\end{array}$ & 1.358 & 791.6 & 15.64 & 1.92 & 1.97 & 12.31 \\
\hline $\begin{array}{l}\text { führt, reich } \\
\text { Weisser russischer Weizen }\end{array}$ & $\begin{array}{l}1.371 \\
1.378\end{array}$ & $\begin{array}{l}793.0 \\
816.0\end{array}$ & $\begin{array}{l}16.51 \\
15.00\end{array}$ & $\begin{array}{l}1.88 \\
1.97\end{array}$ & $\begin{array}{l}1.83 \\
2.03\end{array}$ & $\begin{array}{l}11.43 \\
12.68\end{array}$ \\
\hline $\begin{array}{l}\text { Herisson } \odot \text { Weizen } 1851 \\
\text { Blanche richelle de Naples }\end{array}$ & 1.380 & 795.6 & 13.48 & 2.19 & 2.87 & 17.93 \\
\hline 1851. $\odot$ Weizen & 1.381 & 801.1 & 14.13 & 2.11 & 2.23 & 13.93 \\
\hline Victoria $\odot$ Weizen & 1.381 & 745.4 & 15.49 & 2.02 & 2.45 & 15.31 \\
\hline Spalding 1851 gebaut & 1.382 & 782.3 & 14.69 & 2.03 & 1.98 & 12.37 \\
\hline Xeres-Weizen, sehr hart & 1.384 & 803.6 & 13.60 & 1.91 & 1.94 & 12.12 \\
\hline $\begin{array}{l}\text { Helena-Weizen } \\
\text { Albert-Weizen } 1851 \text { aus Eng- }\end{array}$ & 1.391 & 799.8 & 13.11 & 1.98 & 2.09 & 13.05 \\
\hline $\begin{array}{l}\text { land importiert } \\
\text { Polnischer Weizen, sehr hart }\end{array}$ & $\begin{array}{l}1.398 \\
1.407\end{array}$ & $\begin{array}{l}815.3 \\
746.2\end{array}$ & $\begin{array}{l}16.11 \\
12.20\end{array}$ & $\begin{array}{l}2.13 \\
2.18\end{array}$ & $\begin{array}{l}2.15 \\
2.61\end{array}$ & $\begin{array}{l}13.43 \\
16.31\end{array}$ \\
\hline
\end{tabular}

Ferner wiesen die Hartweizen aus dem Süden Europas nach Peligot auf:

1) Lüdersdorff's Annal. d. Landw. Bd. 23, pg. 386 . 


\begin{tabular}{|c|c|c|}
\hline & Stärke & Proteïr \\
\hline Blé de Pologne & 53.4 & 21.5 \\
\hline Blé poulard bleu conique & 58.9 & 18.1 \\
\hline Blé de Taganrock & 57.9 & 16.6 \\
\hline Blé d'Égypte & 59.4 & 20.6 \\
\hline Mit & 55.1 & 19.2 \\
\hline
\end{tabular}

Im Allgemeinen lässt sich wohl annehmen, dass die Weizen Englands und iiberhaupt des Seeklimas in der kälteren gemässigten Zone kaum über einen Klebergehalt von 10 Proc. hinausgehen, während im mässig feuchten Kontinental-Klima, namentlich in Frankreich und Deutschland, der Klebergehalt zwischen 10-15 Proc. schwankt und schliesslich erreicht er in der Steppe und wärmeren gemässigten Zone, also in den Weststaaten Amerikas, in Sïd-Russland, Rumänien, der Türkei, Ungarn, sowie in Süd-Europa und in der subtropischen Zone eine Höhe bis zu 20 Proc. und darüber.

Durchschnittlich enthält das Weizenmehl:

$\begin{array}{lcccccc} & \text { Proteïn } & \text { Zucker } & \text { Gummi } & \text { Fett } & \text { Stärke } & \text { Wasser } \\ \text { feines Weizenmehl } & 11.2 & 2.3 & 6.3 & 1.1 & 63.6 & 15.5 \\ \text { grobes } & 13.3 & 2.4 & 6.5 & 1.3 & 62.2 & 14.3\end{array}$

Im Weizenmehl beträgt die Asche 1.03 bis 1.5 Proc. und besteht aus 49.7 Proc. Phosphorsäure, 31.8 Proc. Kali, 14.7 Proc. Magnesia und 4.2 Proc. Kalk.

Die Spelzweizen sind an Kleber ein wenig ärmer als die Sorten von Trit. vulgare und liefern nach $S \mathrm{chwerz} 100 \mathrm{~kg}$ Veesen $71.6 \mathrm{~kg}$ Kernen, $23.8 \mathrm{~kg}$ Hülsen und $4.6 \mathrm{~kg}$ Abgang, und $100 \mathrm{~kg}$ Kernen geben nach Angaben des Kunstmiillers Kettner ${ }^{1}$ ) $81 \mathrm{~kg}$ Mehl, $15.25 \mathrm{~kg}$ Kleie und Nachmehl, $3.75 \mathrm{~kg}$ Abgang.

\section{Benutzung.}

Zur Gewinnung eines Ueberblickes über Produktion und Konsumtion des Weizens in den verschiedenen Ländern, möge die nachstehende Tabelle dienen:

1) Citiert von Vossler, Wochenbl. f. Land- und Forstw. No. 11. 1876. 


\begin{tabular}{l|c|c|c}
\hline \multicolumn{1}{c|}{ Land: } & $\begin{array}{r}\text { Produktion } \\
\text { des Landes } \\
\text { in Millionen } \\
\text { Hektoliter. }\end{array}$ & \multicolumn{2}{|c}{$\begin{array}{c}\text { Pro Kopf der Be- } \\
\text { völkerung: }\end{array}$} \\
& $\begin{array}{l}|c| \\
\text { Produktion. }\end{array}$ \\
\hline Ronsumtion. \\
Russland & 99.8 & 1.25 & 1.0 \\
Frankreich & 98.9 & 2.74 & 2.9 \\
Vereinigte Staaten & 93.7 & 1.83 & 1.2 \\
Italien & 51.8 & 1.90 & 2.0 \\
Spanien & 43.0 & 2.60 & 2.6 \\
Deutsches Reich & 36.5 & 0.85 & 0.9 \\
Grossbritannien und Irland & 36.4 & 1.10 & 2.8 \\
Oesterreich-Ungarn & 32.8 & 0.90 & 0.6 \\
Algier & $18.3 ?$ & $7.00 ?$ & $?$ \\
Canada & 13.2 & 3.00 & 1.6 \\
Belgien & 8.0 & 1.60 & 2.0 \\
Rumänien & 7.5 & 1.50 & 0.7 \\
Australien & 7.2 & 3.30 & 2.8 \\
Aegypten & 5.6 & 1.20 & 1.1 \\
Portugal & 2.8 & 0.60 & 0.8 \\
Griechenland & 1.8 & 1.40 & 1.5 \\
Niederlande & 1.6 & 0.45 & 0.6 \\
Schweiz & 1.5 & 0.60 & 1.1 \\
Dänemark & 1.5 & 090 & 0.8 \\
Schweden-Norwegen. & 1.2 & 0.30 & 0.28 \\
& & & \\
& & &
\end{tabular}

Nach unseren Ermittelungen scheint die gesammte Weizenproduktion der bekannten Erde 711.6 Millionen Hektoliter zu betragen.

Der Weizen gilt in Europa als Hauptfrucht und den Romanen und Engländern auch als Hauptbrotfrucht, während die germanischen und slavischen Völker sich mehr dem Roggen zuwenden, wie dies schon recht deutlich aus obiger Tabelle hervorleuchtet, wenn man die Spalte iiber den Konsum pro Kopf der Bevölkerung in den verschiedenen Ländern betrachtet.

Die Mehlbereitung aus dem Weizen steht oben an, und gegen diese Benutzungsweise treten alle ibrigen, wie z. B. die Malzbereitung zur Herstellung obergahrer Biere oder die Benutzung auf Weizenstärke weit in den Hintergrund. Doch eignen sich nicht alle Weizen gleich gut zur Brotmehlbereitung, da hierzu ein gut backfähiger, d. h. einen geniigenden Klebergehalt von guter Qualität besitzender Weizen erforderlich ist. Gute, feine, weisse Backmehle liefern die halbweichen und halbharten Weizen und auch Weichweizen, wenn sie trocken sind und geniugenden Klebergehalt aufwcisen.

Wie die Zusammensetzung guter Backmehle sein soll, zeigt die nachstehende Analyse, welche auf Veranlassung der Regierung der Vereinigten Staaten durch Beck ${ }^{1}$ ) von 71 amerikanischen Weizen-

1) E. Wolff, Die naturgesetzl. Grundl. d. Ackerbaus. 1852, pg. 355. 
mehlsorten gemacht wurde und zwar stimmten sie meist im Klebergehalt uberein, und enthielten im Mittel:

12.57 Proc. Wasser, 11.77 Proc. Kleber, 67.68 Proc. Stärke, 7.43 Proc. Dextrin und Zucker, 0.68 Proc. Holzfaser.

Anders rerhalten sich die ausgesprochenen Weichweizen und namentlich die zu Trit. turgidum gehörigen, zumal wenn sie im feuchten Klima und auf sehr fruchtbarem Boden angebaut werden, denn diese sind wohl reich an Stärkemehl, aber so arm an Kleber von geringer Qualität, dass sie ein häufig nicht backfähiges Mehl liefern, welches sich, nur mit kleberreichem Mehl gemischt, verbacken lässt. Dagegen eignen sich diese Weizen wegen ihres hohen Stärkegehaltes zur Malzbereitung und Stärkefabrikation.

Das Mehl der Hartweizen ist dagegen überreich an Kleber, weshalb die Backwaren zu fest werden, in Folge dessen man dasselbe gern zur Nudelfabrikation und die Körner zur Herstellung von Graupen und Grütze verwendet.

Nachstehende Tabelle bringt Untersuchungen von Krocker über den wechselnden Proteïn- und Klebergehalt der Körner und Mehle von Weizensorten verschiedener Gegenden, welche zur Bestätigung des Mitgeteilten dienen mögen.

Die Weizenkörner wurden auf einer Handmühle so lange gemahlen bis $60-70$ Proc. Feinmehl mittelst eines Siebes von Seidengaze erhalten wïrden.

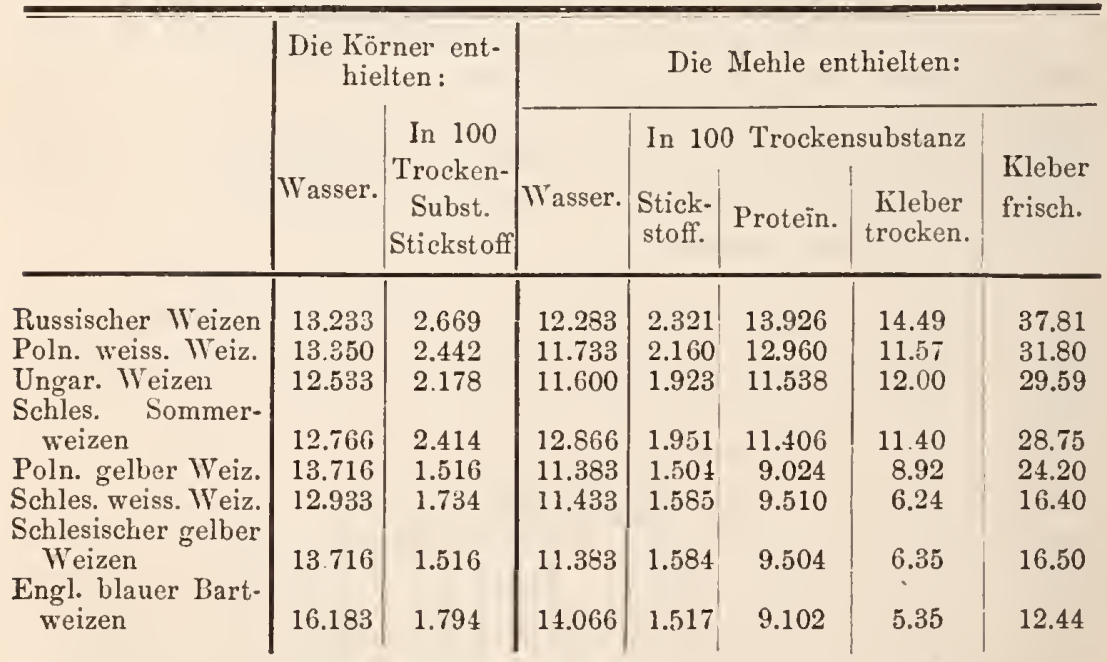

Ferner ist $\mathrm{zu}$ bemerken, dass in ein und demselben Weizen die vollkommeneren Körner mehr Wasser und weniger Kleber, als die mageren Körner besitzen, wie dics die nachstchende Untersuchung von $\operatorname{Re}$ is et ${ }^{1}$ ) zeigt.

1) Lüdersdorff's Annal. d. Landw. Bd. 23, p. 386. 


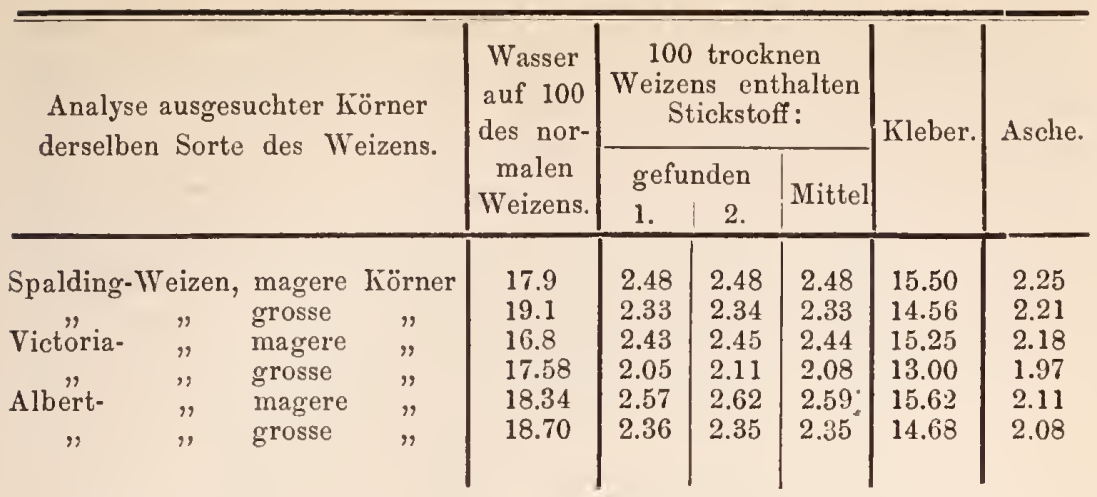

Der Klcbergehalt der Weizensorten nimmt auch zu, sobald Sorten des Seeklimas im Kontinentalklima angebaut werden und umgekchrt.

Die Qualität des Kornes bezüglich der Menge uud Qualität des vorbandenen Klebers lässt sich recht gut aus der Beschaffenheit der Bruchfläche der Kömer erkennen und führt E. Pekảr folgende Merkmale auf: Die Obcrfläche des Querschnittes ist bei dem glasharten und zumeist kleberreichen Trit. durum glatt, glasig, durchscheinend, bei dem harten, klcberreichen Weizen bester Kleberqualität, stalılig, doch in der dunklen Bruchfläche etwas rauh, bei dem weniger kleberreichen, oft sogar ganz kleberarmen weichen Weizen vollständig rauh, weiss und mehlig.

Der Kleber ist nun nicht gleichmässig durch die ganze Masse des Endosperms verteilt, sondern es sind die der Fruchtschale zunächst liegenden Zellenschichten daran am reichsten; wogegen derselbe in den mehr nach Innen liegenden Schichten weniger, am allerwenigsten in der Mitte zu finden ist.

Bei dem Vermahlen des Weizens soll nun die holzfaserreiche Fruchtschale von der darunter liegenden Kleberschicht und dem Mehlkörper überhaupt getrennt, also Mehl und Klcie gebildet werden.

Entsprechend der Mahlmethode gelingt diese Trennung mehr oder weniger vollkommen, doch nienıals vollständig; auch kann der Klebergehalt der aus denselben Körnern bereiteten Mehle ein sehr verschiedener sein, je nachdem feinere oder gröbere, also in letzterem Falle mit Schalenresten und Kleber reichlicher versehene Mehle erzeugt werden sollen.

Aus diesen Gründen ist auch die Kleie immer reicher an Proteïn als das Korn und selır viel reicher als das Mehl.

In der den härteren Weizen angepassten Hochmüllerei, wie sie in Ungarn, Oestcricich, Frankreich etc. besteht, wird weit weniger proteïnreiche Kleie als bei der Flachmüllerei Nord-Deutschlands und Englands crzielt.

Bei der Hochmüllerei wird das Korn zunächst gewisscrmassen 
geeschält und man erhält Weissmehl, Grütze und Kleie. Zwischen mehr genäherten Steinen wird diese Grütze noch mehrmals vermahlen, wobei sie eine gewisse Menge Mehl und Grütze liefert. Dagegen zelreibt man bei der Flachmüllerei den Weizen durch eine einzige Operation vollständig. Da hierbei die Steine aber selı genähert sind und mit grosser Geschwindigkeit rotieren müssen, so findet eine beträchtliche Wärmeentwickelung statt und sind, zur Vermeidung von Nachteilen, Abkühlungsvorrichtungen angebracht.

Nach Boussinggault ergaben 100 Teile Weizen bei:

Mehl zu Weissbrod Mehl zu Schwarzbrod Feine und grobe Kleie Flachmüllerei Hochmüllerei Abgang

\begin{tabular}{cc}
$\left.\begin{array}{c}58 \\
14\end{array}\right\} 72$ & 66 \\
26 & 8 \\
2 & 23 \\
100 & 3 \\
\hline 100
\end{tabular}

Die gute Backfähigkeit eines Mehles ist aber nicht allein von dem hohen Klebergehalt, sondern auch von der Qualität desselben abhängig, die sich nach seiner Dehnbarkeit und Zähigkeit richtet, denn um so grösser diese sind, um so stärker ist auch seine Steigkraft im Gebäck, während der bröckliche, wenig elastische Kleber auf eine geringe Steigkraft schliessen lässt.

Die geringere Steigklaft des Teiges bei kleberarmem Mehl lässt sich nur dadurch erklären, dass er zu wenig Zusammenhang besitzt, um die sich bildende Kohlensäure zuriickzuhalten, wodurch das Brot an Lockerheit und durch den fehlenden Kleber auch an Nahrhaftigkeit einbüisst.

Es ist nun wohl möglich, dass durch die Mahlmethoden die Quantität und Qualität des Klebers in den Mehlen beträchtlich heruntergedriickt werden kann, wenn nur die feinsten Produkte aus dem Innern des Kornes gewonnen werden.

Dementsprechend weisen die feinsten Produkte der Hochmullerei den geringsten Kleber- und grössten Stärkemehlgehalt auf, wie sich dies aus den folgenden Daten einer auf Liebig's Veranlassung unternommenen Analyse von Weizenmehl aus der Pester Walzmühle ergiebt.

Der zur Untersuchung verwendete Weizen enthielt in 100 Teilen:

$\begin{array}{ccccc}\text { Wasser } & \text { Asche } & \text { Kleber etc. } & \text { Stärke } & \text { Holzfaser und Fett } \\ 10.511 & 1.505 & 14.3 \check{2} & 6 \check{3.407} & 8.225\end{array}$

Die daraus erzeugten Mehle enthielten auf 100 Teile: 


\begin{tabular}{|c|c|c|c|c|c|c|c|}
\hline & & Wasser. & Stärke. & $\begin{array}{c}\text { Kleber } \\
\text { wasserfrei. }\end{array}$ & Asche. & $\begin{array}{l}\text { Stick- } \\
\text { stoff. }\end{array}$ & $\begin{array}{l}\text { Stickstoff } \\
\text { wasserfrei. }\end{array}$ \\
\hline $\begin{array}{c}\text { Gries } \\
\text { Mehl } \\
\text { ", } \\
", \\
" \\
" \\
" \\
" \\
,\end{array}$ & $\begin{array}{cc}\text { A. } & \cdot \\
\text { B. } & \cdot \\
\text { Nr. } & 0 \\
" & 1 \\
" & 2 \\
" & 3 \\
" & 4 \\
" & 5 \\
" & 6 \\
" & 7 \\
" & 8\end{array}$ & $\begin{array}{r}11.050 \\
11.545 \\
10077 \\
10.618 \\
10.492 \\
10.142 \\
10.421 \\
10.544 \\
10.748 \\
10.674 \\
9.527\end{array}$ & $\begin{array}{l}69.983 \\
69.530 \\
72.145 \\
71.017 \\
68.867 \\
68.386 \\
67.302 \\
67.176 \\
65.631 \\
61.773 \\
61.031\end{array}$ & $\begin{array}{l}13.396 \\
12.012 \\
12.891 \\
13.275 \\
13.378 \\
13.602 \\
14.179 \\
15.609 \\
16.737 \\
17.871 \\
16.474\end{array}$ & $\begin{array}{l}0.398 \\
0.386 \\
0.380 \\
0.416 \\
0.452 \\
0.481 \\
0.586 \\
0.611 \\
0.764 \\
1.171 \\
1.549\end{array}$ & $\begin{array}{l}1.858 \\
1.658 \\
1.808 \\
1.851 \\
1.868 \\
1.907 \\
1.981 \\
2.178 \\
2.329 \\
2.491 \\
2.375\end{array}$ & $\begin{array}{l}2.089 \\
1.874 \\
2.011 \\
2.071 \\
2.087 \\
2.122 \\
2.211 \\
2.435 \\
2.611 \\
2.788 \\
2.570\end{array}$ \\
\hline
\end{tabular}

Schliesslich kann aber auch bei der Flachmiillerei unter dem Einfluss von Wärme und Wasser eine chemische Umsetzung der Gemengteile des Klebers stattfinden, wodurch seine Qualität benachteiligt wird, was um so mehr in's Gewicht fallen muss, als die Flachmuillerei vorzugsweise in Gebieten angetroffen wird, deren Weizen kleberarm sind.

Um ein Bild von dem Klebergehalt und der Beschaffenheit des Klebers in sehr verschiedenen Weizenmehlen zu geben, führen wir bierunter Untersuchungen von $\mathrm{Krocke}^{1}$ ) an.

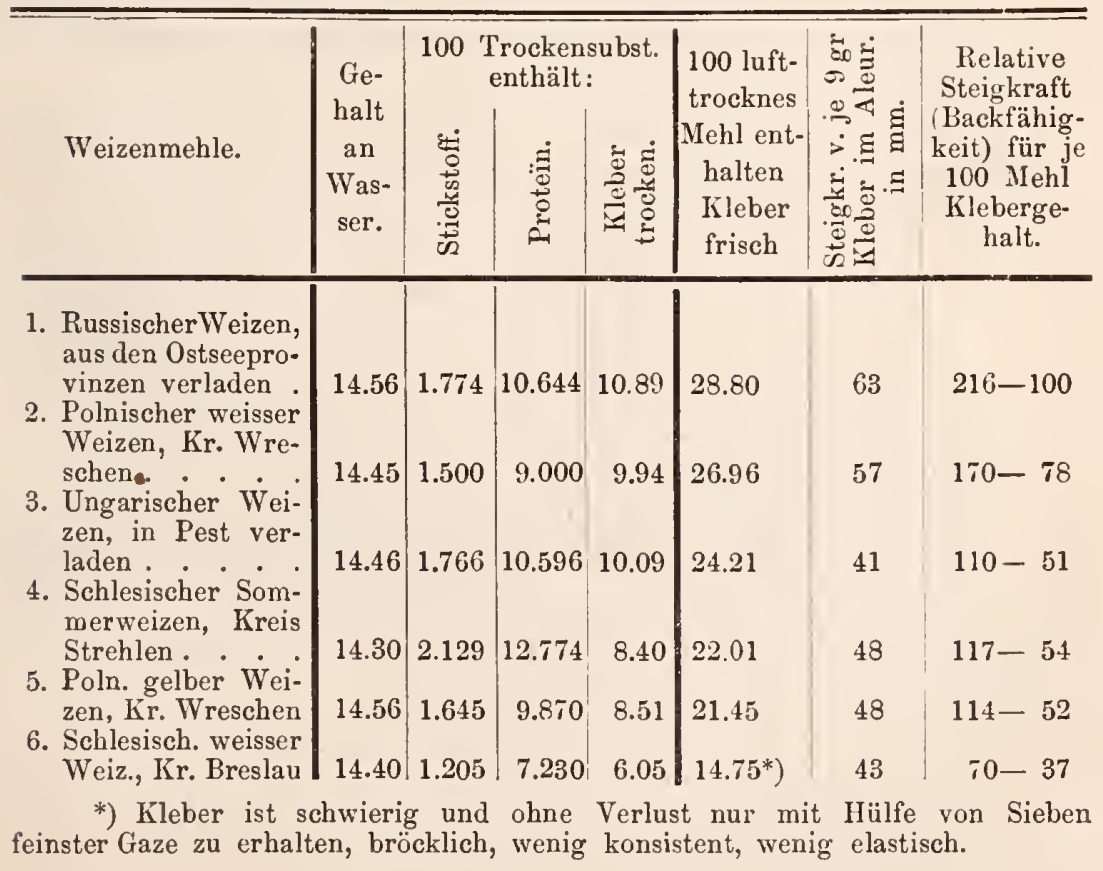

1) Vortrag des Prof. Dr. Krocker, Proskau, am 25. Juni 1879 zu Berlin. 


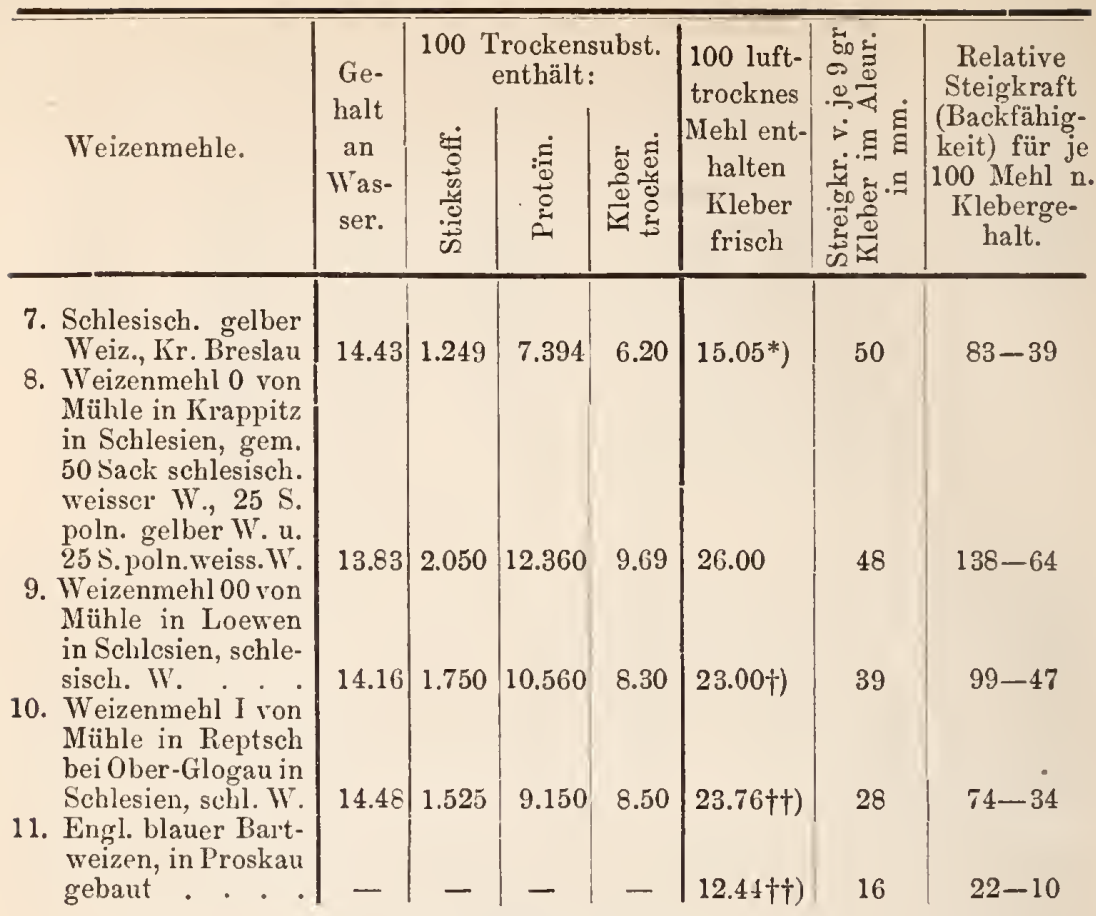

†) Kleber weich.

††) Kileber noch weniger konsistent und noch schwieriger $2 \mathrm{u}$ erbalten, als die mit *) bezeichneten.

Nach E. Milton enthielten in Frankreich und Algier erbaute Weizensorten an Stickstoff und Kleber ${ }^{1}$ ):

\begin{tabular}{|c|c|c|c|c|c|c|}
\hline & \multirow{2}{*}{$\begin{array}{l}\text { Was- } \\
\text { ser. }\end{array}$} & \multirow{2}{*}{$\begin{array}{l}\text { Stick- } \\
\text { stoff. }\end{array}$} & \multicolumn{3}{|c|}{$\begin{array}{l}\text { In } 100 \text { Trocken- } \\
\text { substanz: }\end{array}$} & \multirow{2}{*}{$\begin{array}{l}\text { Kleber } \\
\text { frisch. }\end{array}$} \\
\hline & & & $\begin{array}{l}\text { Stick- } \\
\text { stoff. }\end{array}$ & $\begin{array}{l}\text { Pro- } \\
\text { teïn. }\end{array}$ & $\begin{array}{l}\text { Kleber } \\
\text { trocken. }\end{array}$ & \\
\hline \multicolumn{7}{|l|}{$\begin{array}{l}\text { A. Weizen, in Jahre } 1948 \text { in der } \\
\text { Gegend von Lilla erbaut. }\end{array}$} \\
\hline 1. Spanischer Weizen, weiss, weich . & 16.5 & 1.936 & 2.30 & 13.80 & 11.90 & 29.70 \\
\hline 2. Englischer rother Weizen, weich . & 17.1 & 1.695 & 2.04 & 12.24 & 7.23 & 18.00 \\
\hline 3. $" . \quad " . \quad$. & 17.1 & 1.929 & 2.32 & 13.92 & 12.30 & 30.60 \\
\hline $\begin{array}{l}\text { 4. Bartweizen, weiss, weich } \\
\text { 5. Wunderweizen, Korn etwas horn- }\end{array}$ & 17.1 & 1.885 & 2.45 & 12.90 & 11.00 & 27.30 \\
\hline artiger Bruch $\cdot . \cdot{ }^{\circ} \cdot$ & 17.7 & 2.084 & 2.53 & 15.18 & 12.43 & 24.60 \\
\hline hornartiger Bruch . . . . & 17.7 & 1.975 & 2.40 & 14.40 & 14.24 & 35.16 \\
\hline
\end{tabular}

1) Der frische Kkleber ist zum Verglcich mit den früheren Tabellen aus dem trocknen Kleber berechnet; im Mittel enthält frischer Kleber 33.3\% trocknen Kleber, welcher zunächst für lufttrockne Substanz berechnet wurde. 
B. Weizen, im Jahre 1852 und 1853 in Umgegend von Algier und benachbarten Breitegraden erbant.

1. Weicher weisser Weizen . . .

2. Weizen bei Guytoville erbaut, die ausgelesenen weichen Körner haben 0 Kleber

3. Weicher Weizen von Mitidja, mit einigen halbharten Körnern .

4. Rötlicher weicher Weizen mit

5. Roter harter Weizen aus Provinz Weisser harter Weizen aus Provinz Constantine. . . . . .

7. Harter Weizen von Mitidja .

8. Harter Weizen von Odessa .

\begin{tabular}{|c|c|c|c|c|c|}
\hline \multirow{2}{*}{$\begin{array}{l}\text { Was- } \\
\text { ser. }\end{array}$} & \multirow{2}{*}{$\begin{array}{l}\text { Stick } \\
\text { stoff. }\end{array}$} & \multicolumn{3}{|c|}{$\begin{array}{l}\text { In } 100 \text { Trocken- } \\
\text { substanz: }\end{array}$} & \multirow{2}{*}{$\begin{array}{l}\text { Kleber } \\
\text { frisch. }\end{array}$} \\
\hline & & $\begin{array}{l}\text { Stick- } \\
\text { stoff. }\end{array}$ & $\begin{array}{l}\text { Pro- } \\
\text { tein. }\end{array}$ & $\begin{array}{r}\text { Kleber } \\
\text { trocken }\end{array}$ & \\
\hline 13.70 & 1.785 & 2.07 & 12.42 & 10.43 & 27.00 \\
\hline 12.23 & 1.588 & 1.81 & 10.86 & 5.47 & 14.40 \\
\hline 12.00 & 1.972 & 2.24 & 13.44 & 13.19 & 34.80 \\
\hline 13.01 & 1.874 & 2.15 & 12.90 & 14.40 & 37.56 \\
\hline 12.01 & 2.141 & 2.43 & 14.58 & 16.90 & 44.61 \\
\hline $\begin{array}{l}12.45 \\
12.67\end{array}$ & $\begin{array}{l}2.088 \\
2.210\end{array}$ & $\begin{array}{l}2.38 \\
2.53\end{array}$ & $\begin{array}{l}14.28 \\
15.16\end{array}$ & & $\begin{array}{l}41.79 \\
49.98\end{array}$ \\
\hline 12.67 & 2.729 & 3.12 & 18.72 & 19.92 & 52.40 \\
\hline
\end{tabular}

Ueber die Zusammensetzung der Mehle aus amerikanischem Weizen bringt das Septemberheft 1879 des "Deutsch-amerikanischen Müllers" in Chicago eine Reihe von Mehluntersuchungen, welche durch namhafte Chemiker ausgeführt wurden.

Alle Weizen waren nach dem System der Flachmüllerei vermahlen.

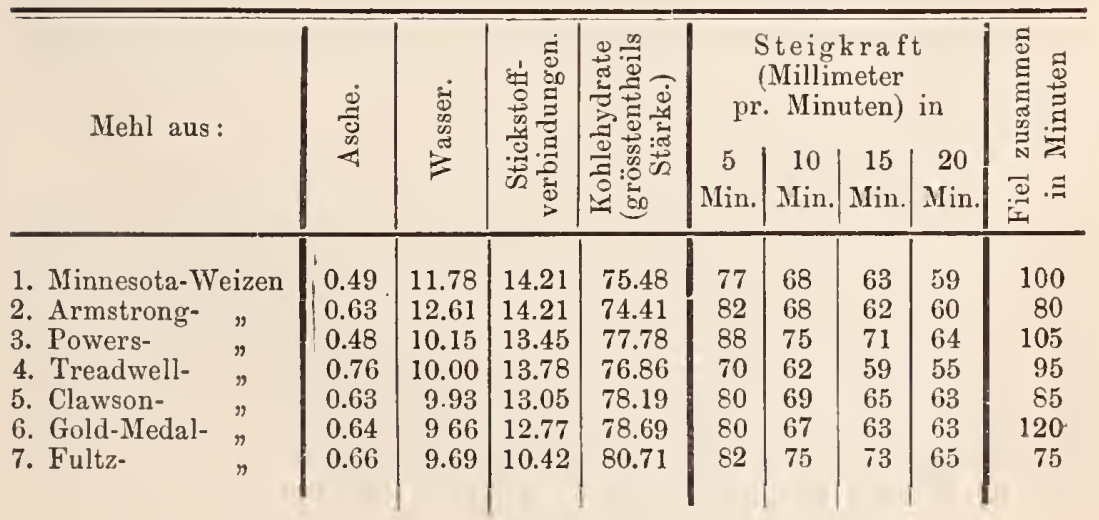

Aus dieser Tabelle geht aber auch hervor, dass die Steigkraft der Mehle nicht im gleichen Verhältnis zu ihrem Klebergehalt steht, also auch die Beurteilung des Weizens in Betreff der Backfähigkeit seines Mehles sich nicht lediglich auf den Gehalt an Kleber, sondern auch auf die Qualität desselben zu richten hat. 
Vielfach tritt nun von Seiten der deutschen Müller dass Bestreben hervor, die Landwirte zu bewegen, möglichst kleberreiche Weizen anzubauen, die aber auf hochkultiviertem Boden einen weit geringeren Ertrag als die englischen Weizensorten von Triticum vulgare und namentlich von Tr. turgidum aufbringen.

Als zahlenmässige Begründung für diese vielfältig bewährte Erfahrung sei hier ein 1872 auf dem Versuchsfelde zu Proskau von Wollny ${ }^{1}$ ) angestellter Versuch angefuhrt, welcher sich auf die Feststellnng des Einflusses der Sorten auf den Ertrag bezog.

Bci dicsem Versuch wurden vom Weizen 21 verschiedene Sorten in gleichen Aussaatmengen und unter gleichen Boden- und Kulturverhältnissen angebaut und deren Erträge genau festgestellt. Unter diesen 21 Sorten befanden sich 7 englische und 14 andere und zwar grösstenteils im mittleren und östlichen Kontinent heimische Weizen. Die pro Hektar berechnete Ernte ergab durchschnittlich:

bei den englischen

\begin{tabular}{ccccc} 
& & $\begin{array}{c}\text { pCt. der } \\
\text { Gesammternte }\end{array}$ & $\mathrm{kg}$ & $\begin{array}{c}\text { pCt. der } \\
\text { Gesammternte }\end{array}$ \\
an Körnern & 2667 & 27.90 & 1689 & 19.75 \\
Stroh & 6247 & 65.36 & 6233 & 72.88 \\
Spreu & 645 & 6.74 & 630 & 7.37 \\
\hline Zusammen & 9559 & 100.00 & 8552 & 100.00
\end{tabular}

Die englischen Weizen gaben also in diesem Falle durchschnittlich mindestens ebenso viel Stroh und Spreu, aber 57 Proc. Korn mehr als dic anderen Weizen.

Selbstrerständlich wird sich auch der niedere Gehalt an Kleber der englischen Weizen (Trit. turgidum) im Preise ausdrücken und fragt es sich, ob dieser niedere Preis nicht durch den höheren Ertrag aufgewogen wird, was zur Zeit vielfach behauptet wird.

Die Notierıng der Magdeburger Getreidebörse vom 15. Janıar 1881 gibt für $1000 \mathrm{~kg}$ Landweizen 206-216, für Rauhweizen (Trit. turgidum) $186-196 \mathscr{M}$ an, mithin besteht ein Unterschied im Preise von durchschnittlich $91 / 2$ Proc. zu Ungunsten des letzteren. Das lässt sich der Landwirt auch gern gefallen und die wissenschaftliche Untersuchung hat diesen Preisunterschied auch begründet. So untersuchte Dr. Neale im Laboratorium der Versuchsstation zu Halle kürzlich mehrere Mehlsorten und kam dabei zu folgendem Ergebnis:

In 100 Teilen Trockensubstanz des Mehles waren enthalten:

Bei südrussischem Ghirkameizen 16.50 Proteïnstoff, 88.13 Stärkemehl

„ havelländischem Weizen . . 11.56

, sächsischem Weizen ..... 9.44 86.46 89.13

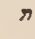

1) Zeitschr. d. landw. Ver. in Bayern, 1873. 
Bei Magdeburger Weissweizen • 9.00 Proteïnstoff, 90.78 Stärkemehl " englischem Raubweizen ... 7.94 n 91.04 "

Da nun die Baekfähigkeit des Weizenmehles seinem Gehalte an Kleber (der grösste Teil der Proteïnstoffe besteht aus Kleber) entsprieht, so ist der niedrigere Preis aueh vollkommen gereehtfertigt.

Demnach wird der Landwirt nur solehe Weizensorten anbauen, welehe ihm den höchsten Reinertrag siehern, ganz abgesehen davon, ob ihr Gehalt an Kleber den Miillern genehm ist oder nieht.

Der Benutzung und folglieh aueh dem Anban der Spelzweizen sind, dem Weizen gegeniiber, verhältnismässig enge Grenzen gesteekt, obgleieh sie in einzelnen Gebieten, wie in Württemberg, die dominierende Brotfrueht sind, denn im 15jälırigen Durehselınitt (1852-1866) nahm der Weizen eine Anbaufläche von nur 0.96 Proe. gegen 23.84 Proe. des Spelzes von der gesammten Aekerfläehe ein, doeh tritt auelı in Württemberg in neuerer Zeit mit dem Steigen der landwirtsehaftliehen Kultur das Bestreben hervor, den Spelzbau einzusehränken und führt Vossle ${ }^{1}$ ), ein genauer Kenner der wiirttembergischen Verlıältnisse, an, dass er vor dem Weizen unzweifelhafte Vorzuige nur auf geringem Boden, kleinem, zerstiekeltem Besitz und bei mittelmässiger Kultur habe, da er anspruehsloser, sieherer, verträglieher mit sieh selbst als der Weizen, auch weniger den Krankheiten und gar nieht den Angriffen der Sperlinge, was in der Nähe der Dörfer wiehtig, ausgesetzt ist.

Ferner ïberwinden die Arbeitskräfte der Familienmitglieder im Kleinbesitz dureh grössere Sorgfalt die Schwierigkeiten der Einerntung des Spelzes leiehter und da sie ihn der Hauptsache naeh aueh selbst verzehren, kommt seine geringe Handelsfäligkeit weniger in Betracht, zumal er im ungegerbten Zustande aueh als Pferdefutter dient.

Dagegen treten die Vorteile des Weizenbaues auf besserem Boden, in grösserem Besitz und bei rationeller Kultur sehr scharf hervor. Unter solehen Verhältnissen bringt der Weizen aueh höhere Erträge, selbst wenn Spelz und Weizen neben einander gebaut werden, wie dies in seehs wïrttembergisehen Oberämtern der Fall ist, denn im 10 jährigen Durehsehnitt ergaben sich $1169.1 \mathrm{~kg}$ Kernen gegen $1386.5 \mathrm{~kg}$ Weizen p. ha, also von letzterem $217.4 \mathrm{~kg}$ p. ha mehr. Dazu kommt, dass beim Weizen die Sehwierigkeiten der Spelzernte fortfallen, seine Handelsfähigkeit sehr viel grösser, sowie der notwendige Speicherraum geringer ist. Ausserdem kann der Weizen ohne weiteres vermahlen werden, während die Spelzweizen vorher zu gerben, also die Klappen und Spelzen zu entfernen sind; hierzu müssen aber die Mühlen mit einer Gerbvorriehtung versehen sein. Dureh das

1) Wochenbl. f. Land- und Forstwirtsch. No. 11. 1876. 
Gerben büssen jedoch die sog. „Kernen“ wesentlich an Haltbarkeit ein, wahrscheinlich weil sie beim Gerbprocess am Keimling Verletzungen davontragen.

Der Weizen gibt ausserdem ein glinstigeres Mahlresultat, als der Spelz und teilt z. B. Vos sler Resultate grosser Mahlungen des Kunstmiillers Kettner mit, aus denen sich bei einem Quantum von $1300000 \mathrm{~kg}$ Kernen eincrseits und $105946 \mathrm{~kg}$ Weizen andererseits folgendes procentische Verbältnis ergab:

\begin{tabular}{|c|c|c|c|c|}
\hline Mehlsorten & Kernen & Mehlsorten & & Weizen \\
\hline Nr. 1. - & 31.25 & Gries & - & 2.41 \\
\hline Nr. 2. - & 13.25 & Nr. 0. & - & 1.14 \\
\hline Nr. 3. - & 20.25 & Nr. 1. & - & 32.22 \\
\hline Nr. 4. - & 10.25 & Nr. 2. & - & 11.83 \\
\hline Nr. 5. - & 2.75 & $\mathrm{Nl} .3$. & - & 20.12 \\
\hline Nr. $6 . \quad-$ & 3.25 & Nr. 4. & - & 9.63 \\
\hline Kleie u.Nachmehl & 15.25 & Nr. 5. & - & .2 .41 \\
\hline Abgang - & 3.75 & Nr. 6. & 一 & 5.13 \\
\hline & & Kleie & - & 11.26 \\
\hline & & Abgang & - & 3.85 \\
\hline & 00.00 & & & 100.00 \\
\hline
\end{tabular}

Hiernach liefern an Weiss- und Brotmehl zusammen Kernen 81.00 und Weizen 84.89 Proc.

Der Stickstoffgehalt des Kernen ist im Allgemeinen nicht niedriger, als der des Weizenkorns; auch das Mehl zeigt bei beiden fast gleichen Stickstoffgehalt, dagegen ist in dem Kernen der Gehalt an Gummi und Zucker beträchtlich geringer und der Stärkegehalt entsprechend grösser und hierauf mag es beruhen, dass zu feinen Backwaaren dieses Mehl dem Weizenmehl vorgezogen wird, trotzdem man nach allgemeiner Erfahrung aus Weizen ein feineres und weisseres Mehl herstellt; denn das Mehl des Spelzes und noch mehr die Mehle von Emmer und Einkorn haben immer etwas gelbliche Färbung. Dagegen soll wegen seiner dünneren und feineren Schale Kernen weniger Kleie als Weizen liefern, eine Annahme, mit welcher die oben mitgeteilten Nahlresultate im Widerspruch stehen.

Endlich ist der Preis des Weizens durchschnittlich höher als der des Kernen.

Im Handel kommen auch sog. „grüne Kernen" vor und sind dies unreife und rasch gedörrte Kernen, die in Suppen verwandt werden.

Das aus dem Mehl der Kernen hergestellte Spelzbrot trocknet sehr leicht aus und wird daher früher spröder und unschmackhaftcr als das aus Weizenmehl bereitete.

Zuweilen kommen Betrügereien durch Oelen des Weizens vor, 
und werden bei diesem Verfahren entweder die Kornschaufeln vor dem Umsetzen des Weizens mit Rüböl bestrichen, oder es wird dasselbe mittels Spritze oder Giesskanne iiber den Weizen gebracht, welcher hierauf mehrfach umgestochen wird.

Durch das Oelen macht der Verküufer einen sehr beträchtlichen Gewinn zum Nachteil des Käufers, denn der geölte Weizen fühlt sich glatt und schön an und wiegt ca. $3 \mathrm{~kg}$ pro hl schwerer, hat also scheinbar 10-12 Proc. an Wert gewonnen, was einem Gewinn von 20-24 $\mathscr{N}$ pro $1000 \mathrm{~kg}$ entspricht, bei einer Auslage für $1 / 2-1 \mathrm{~kg}$ Rüböl pro $1000 \mathrm{~kg}$ zum Prcise von $30-50$ as und dem geringen Arbeitslohn, welchen das Durchschaufeln verursacht.

Die Zunahme des Volumengewichts beruht darauf, dass durch die Glätte des Weizens, eine grössere Körnerzahl in einen Hektoliter hineingeht.

Der geölte Weizen ist dem Mühlengewerbe sehr gefährlich, denn abgesehen von dem Minderwert wird auch die Ausmahlung benachteiligt.

Die bisher in Vorschlag gebrachten Erkennungsmittel von geöltem Weizen, wie Curcumapulver, Camphor, Behandlung mit Fett lösenden Agentien bewährten sich nicht, doch soll nach den Untersuchungen im Universitäts-Laboratorium zu Kiel 1878 ein von C. Himly empfohlenes Verfahren einen besseren Erfolg gehabt haben.

Bei diesem Verfahren wird der zu untersuchende Weizen in einem reinen, trocknen Gläschen mit einer kleinen Menge des zum Bedrucken vou Etiquetten etc. angewendeten sehr feinen Bronzepulvers geschüttelt. Darauf schüttet man auf trocknes Filtrirpapier den Weizen aus und reibt denselben damit. Vergoldet sich bei dieser Behandlung der Weizen, so ist er geölt, während sich von ungeöltem Weizen das Bronzepulver wieder abreiben lässt. 


\title{
Roggen.
}

\section{Secale cereale L.}

\author{
Einteilung.
}

Varietät: Secale cereale vulgare Kcke.

Aehre einfach, gelblich.

\section{Sorten:}

\section{Mehrblütiger Roggen ron Martiny. (2)}

Aehre: gelb, dicht, sehr breit, lang; Aehrehen $1 \mathrm{~cm}$ breit, meist 3-körnig; Grannen hell, 4-5 cm lang. - Stroh: gelb, sehr derb und kräftig. - Frucht: hellbraun, gross (9 mm lang, $3 \frac{1}{2} \mathrm{~mm}$ breit, 250 Früchte $\left.=10 \mathrm{gr}^{\circ}\right)$, ziemlich feinschalig.

Herbstblatt blaugrün, sehr kräftig, kraus; Frühjahrsvegetation mittelfruih, Bestockung mittelstark, 5 Schösslinge (bei $100 \mathrm{qcm}$ Raum 7.7 Schösslinge), mittelfrüh schossend und blühend. Halmlänge $151 \mathrm{~cm}$ (Max. $186 \mathrm{~cm}$ ), Halmdicke $0.46 \mathrm{~cm}$, Blattzahl 4, Blattlänge $20.8 \mathrm{~cm}$, Blattbreite $0.96 \mathrm{~cm}$, Blattfläche $159.76 \mathrm{qcm}$, Halmfläche $218.30 \mathrm{qcm}$, Gesammtfläche 378.06 q $\mathrm{cm}$.

Aehre spät, Ende Juli reifend, $13 \mathrm{~cm}$ (Max. $19 \mathrm{~cm}$ ) lang, mit 100 ziemlich fest sitzenden Früchten, von denen 1935000 auf $1 \mathrm{hl}(=75 \mathrm{~kg})$ entfallen.

Auf $1 \mathrm{qm}$ wachsen 800 Halme oder 160 Pflanzen, mithin beträgt der Raum für eine Pflanze $65.5 \mathrm{qcm}$, die Blattfläche $\mathrm{p}$. qm Bodenfläche $30.2 \mathrm{qm}$ und das Saatquantum $1.2 \mathrm{hl}$ p. ha.

Es wiegen 100 Halme $1042 \mathrm{gr}$ und davon die Früchte $365 \mathrm{gr}$.

In Proskau wurden 1872 p. ha erzielt: $3224 \mathrm{~kg}$ Korn, $5834 \mathrm{~kg}$ Stroh, $242 \mathrm{~kg}$ Spreu.

Dieser Roggen ist winterfest, lagert nicht leicht und leidet nur wenig durch Rost, doch degeneriert er binnen kurzer Zeit, wenn er nicht auf sehr reichem Boden kultiviert wird und bringt auch nur auf solchell Böden reichere Erträge als andere Sorten.

El wurde 1867 ron Martiny auf dem aus humosem Sande bestehenden Versuchsfelde des Hauptvereins westpreussischer Landwirte gezüchtet. 


\section{Roggen vom Westerwald bei Dierdorf. (2)}

Aehre: gelb, schmal, sehr lang; Aehrchen $0.8 \mathrm{~cm}$ breit, 2-körnig; Grannen $4-5 \mathrm{~cm}$ lang. - Stroh: gelb, fest, sehr kräftig, lang. - Frucht: hellbraun, gross $(81 / 2 \mathrm{~mm}$ lang, $3 \mathrm{~mm}$ breit, 263 Früchte $=10 \mathrm{gr})$. feinschalig.

Herbstblatt dunkelgrün, kräftig; Frühjahrsvegetation sehr spät, Bestockung mittelstark, 4.5 Schösslinge, spät schossend und blühend. Halmlänge $180 \mathrm{~cm}$ (Max. $200 \mathrm{~cm}$ ), Halmdicke $0.45 \mathrm{~cm}$, Blattzahl 4, Blattlänge $17.8 \mathrm{~cm}$, Blattbreite $1.03 \mathrm{~cm}$, Blattfläche $146.67 \mathrm{qcm}$, Halmfläche $243 \mathrm{qcm}$, Gesammtfläche $383.67 \mathrm{qcm}$.

Aehre reift spät, $16 \mathrm{~cm}$ (Max. $20 \mathrm{~cm}$ ) lang, mit 80 Früchten, von denen 2025100 auf $1 \mathrm{hl}(=77 \mathrm{~kg})$ entfallen.

Auf $1 \mathrm{qm}$ wachsen 800 Halme oder 171 Pflanzen, mithin beträgt der Raum für eine Pflanze $58.5 \mathrm{qcm}$, die Blattfläche p. qm Bodenfläche $30.6 \mathrm{qm}$ und das Saatquantum $1.3 \mathrm{hl} \mathrm{p}$. ha.

Es wiegen 100 Halme $748 \mathrm{gr}$ und davon die Früchte $246 \mathrm{gr}$.

Diese höchst beachtenswerte Roggensorte ist winterfest, lagert nicht leicht, leidet wenig durch Rost und liefert auf guten Roggenböden sehr hohe Erträge.

\section{Sächsischer Sommer-Staudenroggen. $\odot$}

Franz.: Seigle d'été de Saxe.

Aehre: blassgelb, etwas locker, dünn, ziemlich lang; Aehrchen 2-körnig, $0.9 \mathrm{~cm}$ breit; Grannen hell, bis $4 \mathrm{~cm}$ lang. - Stroh: gräulichgelb, ziemlich fest, lang. - Frucht: bräunlich-grau, kurz, plump $(8 \mathrm{~mm}$ lang, $31 / 2 \mathrm{~mm}$ breit, 350 Früchte $=10 \mathrm{gr}$ ), feinschalig, schön, schwer.

Junges Blatt dunkelgrün, schmal; Bestockung ziemlich stark, 3.1 Schösslinge, zeitig blühend. Halmlänge $135 \mathrm{~cm}$ (Max. $165 \mathrm{~cm}$ ), Halmdicke $0.28 \mathrm{~cm}$, Blattzahl 3.5 , Blattlänge $17 \mathrm{~cm}$, Blattbreite $0.63 \mathrm{~cm}$, Blattfläche $74.97 \mathrm{qcm}$, Halmfläche $113.4 \mathrm{qcm}$, Gesammtfläche $188.37 \mathrm{qcm}$.

Aelire reift spät, $10 \mathrm{~cm}$ (Max. $12 \mathrm{~cm})$ lang, mit 50 Fruichten, voll denen 2800000 auf $1 \mathrm{hl}(=80 \mathrm{~kg})$ entfallen.

Es wiegen 100 Halme 348 gr und davon die Früchte 117 gr.

Auf nicht zu armem Boden zeichnet sich dieser Roggen durch hohe Produktion aus, leider unterliegt er leicht dem Rost.

\section{Klafterbrunner Roggen. (2)}

Syn.: Graf Walderdorff's regenerierter Roggen.

Aehre: blassgelb, voll, dick, lang; Aehrchen 2-körnig, $1 \mathrm{~cm}$ breit, Grannen hell, 4-5 cm lang. - Stroh: graugelb, sehr lang, kräftig, fest. Frucht: grünlich-gelb, gross, schön $\left(10 \mathrm{~mm}\right.$ lang, $3 \frac{1}{2} \mathrm{~mm}$ breit, 251 Früchte $=10 \mathrm{gr}$ ), feinschalig.

Herbstblatt blaugrün, kraus, kräftig, Frühjahrsvegetation zeitig, Bestockung stark, 6 Schösslinge, zeitig schossend und Mitte Mai blühend.

Halmlänge $165 \mathrm{~cm}$ (Max. $210 \mathrm{~cm}$ ), Halmdicke $0.4 \mathrm{~cm}$, Blattzahl 5, Blattlänge $20.1 \mathrm{~cm}$, Blattbreite $0.93 \mathrm{~cm}$, Blattfläche $186.93 \mathrm{qcm}$, Halmfläche $198 \mathrm{qcm}$, Gesammtfläche $384.93 \mathrm{qcm}$.

Aehre spät, Ende Juli reifend, $14 \mathrm{~cm}$ (Max. $18 \mathrm{~cm}$ ) lang, mit 70 sehr fest sitzenden Friichten, von denen 1807200 auf $1 \mathrm{hl}(=72 \mathrm{~kg})$ entfallen. 
Auf $1 \mathrm{qm}$ wachsen 800 Halme oder 133.3 Pflanzen, mithin beträgt der Ranm für eine Pflanze $75 \mathrm{qcm}$, die Bodenfläche p. qm Blattfläche $30.8 \mathrm{qm}$ und das Saatquantum $1.1 \mathrm{hl}$ p. ha.

Es wiegen 100 Halme $645 \mathrm{gr}$ und davon die Früchte $260 \mathrm{gr}$.

Diese vortreffliche Roggensorte eignet sich für schwere, sehr nahrungsreiche Böden, zumal sie nicht leicht lagert und wenig durch Rost leidet.

Graf Walderdorff zu Klafterbrunn bei Wien hat diese Sorte verbessert.

\section{Roggen rom Hellweg, Westfalen. (2)}

Aehre: gelb, ziemlich breit, mittellang; Aehrchen $0.9 \mathrm{~cm}$ breit, 2-körnig; Grannen 4-5 cm lang. - Stroh: gelb, sehr kräftig, lang. Frucht: hellbraun, sehr schön, gross (10 mm lang, $3^{1 / 2} \mathrm{~mm}$ breit, 264 Friichte $=10 \mathrm{gr}$ ), feinschalig.

Herbstblatt blaugruin, ziemlich gross; Frühjahrsvegetation etwas spät, Bestockung sehr stark, 6.2 Schösslinge. spät schossend und blühend. Halmlänge $150 \mathrm{~cm}$ (Max. $180 \mathrm{~cm}$ ), Halmdicke $0.45 \mathrm{~cm}$, Blattzahl 5, Blattlänge $17.5 \mathrm{~cm}$, Blattbreite $0.75 \mathrm{~cm}$, Blattfläche $131.3 \mathrm{qcm}$, Halmfläche $202.5 \mathrm{qcm}$, Gesammtfläche $333.75 \mathrm{qcm}$.

Aehre reift spät, $13 \mathrm{~cm}$ (Мax. $16 \mathrm{~cm}$ ) lang, mit $6 \pm$ nicht leicht aus. fallenden Früchten, von denen 1940400 auf $1 \mathrm{hl}(=73.5 \mathrm{~kg}$ ) entfallen.

Auf $1 \mathrm{qm}$ wachsen 900 Halme oder 145 Pflanzen, mithin beträgt der Raum für eine Pflanze $70 \mathrm{qcm}$, die Blattfläche $\mathrm{p}$. qm Bodenfläche $30 \mathrm{qm}$ und das Saatquantum $1.1 \mathrm{hl}$ p. ha.

Es wiegen 100 Eialme $713 \mathrm{gr}$ und davon die Früchte $281 \mathrm{gr}$.

Der Roggen ist winterfest, lagert nicht und leidet wenig durch Rost.

Diese Sorte liefert auf den besseren Roggenböden hohe Erträge an Korn und Stroh.

\section{Probsteier-Winterroggen. (2)}

Aehre: blassgelb, voll, dick, lang; Aehrchen 2-körnig, $0.8 \mathrm{~mm}$ breit, Grannen kurz, 4-5 cm lang, schmutzig-gelb. - Stroh: graugelb, stark, derbwandig, mittellang. - Frucht: grünlich-gelb oder hellbraun, kurz, dick ( $8 \mathrm{~mm}$ lang, $3 \mathrm{~mm}$ breit), mehlreich, sehr schwer, feinschalig.

Herbstblatt gelbgrün, aufrecht. kräftig; Frühjahrsvecetation mittelfriih; Bestockung mittelstark, 5 Schösslinge (bei $100 \mathrm{qcm}$ Raum p. Pflanze 11 Schösslinge). Mittelfrüh, in der zweiten Hälfte des Mai blühend. Halmlänge $138 \mathrm{~cm}$ (Max. $200 \mathrm{~cm}$ ), Halmdicke $0.37 \mathrm{~cm}$, Blattzahl 4.7, Blattlänge $15 \mathrm{~cm}$, Blattbreite $0.75 \mathrm{~cm}$, Blattoberfläche $105.75 \mathrm{qcm}, \mathrm{Halm}$ fäche $153.18 \mathrm{qcm}$, Gesammtfläche $258.93 \mathrm{qcm}$.

Aehre Mitte bis Ende Juli, also etwas spät reifend, $12 \mathrm{~cm}$ (Max. $17 \mathrm{~cm}$ ) lang, mit 60 etwas lose sitzenden Früchten, von denen 2296000 auf $1 \mathrm{hl}(=80 \mathrm{~kg})$ entfallen.

Anf $1 \mathrm{qm}$ wachsen 1030 Halme oder 206 Pflanzen, mithin beträgt ler Raum für eine Pflanze $48.5 \mathrm{qcm}$, die Blattfläche p. qm Bodenfläche $26.67 \mathrm{qm}$ und das Saatquantum $1.34 \mathrm{hl}$ p. ha.

Es wiegen 100 Halme $655 \mathrm{gr}$, davon die Früchte $300 \mathrm{gr}$.

Das Stroh lagert nicht leicht und widersteht dem Rost ziemlich gut.

Der Probsteier Roggen verträgt strenge Winter, leidet aber zuweilen durch sehr wechselnde Frühahrswitterung. Die mergelhaltigen sandigen 
Lehmböden sagen ihm am meisten $\mathrm{zu}$, und degeneriert derselbe in kurzer Zeit, sobald er auf den leichteren Böden im Kontinentalklima kultiviert wird, weshalb ein häufiger Saatwechsel in diesem Falle geboten ist.

Es wurden erzielt:

in Weihen-Stephan 1866, sandiger Lehm . . . . $1652 \quad \begin{array}{ccc}16785 & 236\end{array}$

in Eldena ${ }^{1}$ ) 1868, sandiger Lehm . . . . . . 17003354289

in Knltnrverein Eldena 1868, Gesammtresultat mehrerer

unter sehr von eiuander abweichenden Ver-

hältuissen vorgenommener Versuche . . . 20324095254

in Proskau 1872, sandiger Lehm . . . . . . 19224536164

Der Probsteier-Roggen ist vielleicht in Deutschland eine der begehrtesten Sorten. Die ursprïngliche Heimat liegt in der Probstei, einer Landschaft in Holstein, von wo aus die grösseren Samenhändler Norddeutschlands in plombierten Säcken das Saatgut versenden.

\section{Rheinischer Roggen. (2)}

Aehre: blassgelb, voll, lang; Aehrchen 2-körnig, Grannen blassgelb, 4-5 cm lang. - Stroh: graugelb, kräftig, sehr lang. - Frucht: bräunlich, etwas kurz ( $8 \mathrm{~mm}$ lang, $3 \mathrm{~mm}$ breit), mittelgross, ziemlich feiuschalig.

Herbstblatt dunkelgrün, kraus, sehr kräftig; Frïhjahrsvegetation sehr zeitig; Bestockung stark, 5.3 Schösslinge (bei $100 \mathrm{qcm}$ Raum p. Pflanze 8.2 Schösslinge). Mittelfrüh, gegen Ende Mai blïhend, weshalb ihm Nachtfröste nicht leicht gefährlich werden. Halmlänge $146 \mathrm{~cm}$ (Max. $197 \mathrm{~cm}$ ), Halmdicke $0.35 \mathrm{~cm}$, Blattzahl 4.25 , Blattlänge $14.4 \mathrm{~cm}$, Blattbreite $0.73 \mathrm{~cm}$, Blattoberfläche $89.55 \mathrm{qcm}$, Halmfläche $153.3 \mathrm{qcm}$, Gesammtfläche $242.85 \mathrm{qcm}$.

Junge Aehre blangrïn, zeitig reifend, $11.2 \mathrm{~cm}$ (Max. $15 \mathrm{~cm}$ ) lang, mit 60 fest sitzendeu Frïchten, voll denen 2233000 auf 1 hl (= $77 \mathrm{~kg}$ ) entfallen.

Auf $1 \mathrm{qm}$ wachsen 1200 Halme oder 226 Pflanzeu, mithin beträgt der Raum fiir eine Pflanze 44.2 qcm, die Blattoberfläche p. qm Bodenfläche 29 qin und las Saatquantum $1.5 \mathrm{hl}$ p. ha.

Es wiegen 100 Halme $680 \mathrm{gr}$ und davon die Friichte $390 \mathrm{gr}$.

Auf lehmigem Saudboden wurden p. lia erzielt:

$\begin{array}{llccc} & & \begin{array}{c}\text { Korn } \\ \mathrm{kg}\end{array} & \begin{array}{c}\text { Stroh } \\ \mathrm{kg}\end{array} & \begin{array}{c}\text { Spreu } \\ \mathrm{kg}\end{array} \\ \text { Eldenaer-Versuchsfeld } & 1868 & 1919 & 4095 & 94 \\ \text { Proskauer- " } & 1871 & 2064 & 6912 & -\end{array}$

Dieser Roggen, der jetzt ziemlich ausgedehnt in Norddeutschland kultiviert wird, ist vor ca. 20 Jahren von Oekonomierat Dr. Rohde zu Eldena zuerst geziichtet worden, und zwar aus einem Roggen, welchen derselbe vom Rhein erhielt und der sich durch langes Stroh und zahlreiche Doppelähren auszeichnete.

1) Anbauversuche des Verfassers. 


\section{Garde du corps-Roggen. (2)}

Sy n.: Hessischer-Roggen, Wallburger-Roggen.

Aehre: schmutzig-blassgelb, voll, dick, lang; Aehrchen $0.9 \mathrm{~cm}$ breit, 2-körnig; Grannen hell, bis 5 cm lang. - Stroh: gräulich-gelb, rohrähnlich, sehr lang. - Frucht: graugelb, gross (9 mm lang, $3 \mathrm{~mm}$ breit), etwas grobschalig und Hektolitergewicht leicht.

Herbstblatt blaugrïn, sehr kräftig, aufrecht. Bestockung mittelstark, 5 Schösslinge (bei 100 qem Raum 10 Schösslinge). Frühjahrsvegetation spät. Halmlänge $175 \mathrm{~cm}$, Halmdicke $0.4 \mathrm{~cm}$, Blattzahl 4.4, Blattlänge $20.4 \mathrm{~cm}$, Blattbreite $0.93 \mathrm{~cm}$, Blattfläche $166.94 \mathrm{qcm}$, Halmfläche $210 \mathrm{qcm}$, Gesammtfläche $376.94 \mathrm{qcm}$.

Aehre reift Mitte Juli, $14 \mathrm{~cm}$ (Max. $18 \mathrm{~cm}$ ) lang, mit 60 etwas leicht ausfallenden Früchten, von denen 2136000 auf $1 \mathrm{hl}(=74 \mathrm{~kg})$ entfallen.

Auf 1 qm wachsen 800 Halme oder 160 Pflanzen, mithin beträgt der Raum für eine Pflanze 62.5 qcm, die Blattfäche p. qm Bodenfläche $30.15 \mathrm{qm}$ und das Saatquantum $1.12 \mathrm{hl}$ p. ha.

Es wiegen 100 Halme $752 \mathrm{gr}$ und davon die Früchte $302 \mathrm{gr}$.

Dieser Roggen eignet sich vorzugsweise für die reicheren Lehmböder, doch bringt derselbe auch auf leichterem Boden verhältnismässig hohe Stroherträge.

Die Kornerträge lassen nach Quantität und Qualität zll wünschen, wohingegen die Stroherträge sehr hoch sind, denn das Stroh dieses Staudenroggens kaun eine enorme Höhe erreichen, so sind von mir auf reichem Lehmboden in Elsdorf bei Bergheim, Rheinprovinz, Halme von $237 \mathrm{~cm}$ Höhe und $0.5 \mathrm{~cm}$ Durchmesser gefunden worden, wobei bemerkenswert, dass sich Lagerkorn nicht fand.

Seine Widerstandsfähigkeit gegen ungünstige Frühjahrswitterung ist bedeutend, doch leidet er leicht vom Rost. Am vorzüglichsten gedeilit er bei dem hessischen Dorf Wallburg, von wo aus sich derselbe weiter verbreitet hat.

\section{Westermarscher oder Lintelermarscher Winterroggen. (2)}

Aehre: rötlich-blassgelb, ziemlich dicht, sehr schön, lang; Aehrchen $0.9 \mathrm{~cm}$ breit, 2-körnig; Grannen sehr lang, bis $8 \mathrm{~cm}$ lang, etwas gespreizt. Stroh: rötlich-gelb, blattreich, kräftig, lang. - Frucht: Original hellgraublau oder hellbraun, kurz, dick ( $7 \mathrm{~mm}$ lang, $3 \mathrm{~mm}$ breit, 385 Früchte $=10 \mathrm{gr})$; nachgebaut: dunkler, länger $\left(8^{1} / 2 \mathrm{~mm}\right.$ lang, $3 \mathrm{~mm}$ breit, 266 Früchte $=10 \mathrm{gr}$ ), schwer, feinschalig.

Herbstblatt dunkelgrün; Frühjahrsvegetation spät, Bestockung stark, 5 Schösslinge, spät schossend und blïhend. Halm $130 \mathrm{~cm}$ (Max. $150 \mathrm{~cm}$ ) lang, $0.4 \mathrm{~cm}$ dick, Blattzahl 4.5, Blätter $18.5 \mathrm{~cm}$ lang, $1 \mathrm{~cm}$ breit, Blattfläche $166.5 \mathrm{qcm}$, Halmfläche $156 \mathrm{qcm}$, Gesammtfläche $322.5 \mathrm{qcm}$.

Aehre reift spät, $14 \mathrm{~cm}$ (Max. $18 \mathrm{~cm}$ ) lang, mit 38 Aehrchen und 72 Frïchten, von denen 2983750 auf $1 \mathrm{hl}(=77.5 \mathrm{~kg})$ entfallen.

Auf $1 \mathrm{qm}$ wachsen 900 Halme oder 180 Pflanzen, mithin beträgt der Raum für eine Pflanze $55.5 \mathrm{qcm}$, die Blattfäche p. qm Bodenfläche 29 qm und das Saatquantum ca. 1 hl p. ha.

Es wiegen 100 Halme $463 \mathrm{gr}$ und davon die Früchte $218 \mathrm{gr}$.

Dieser Roggen ist winterfest, lagert nicht leicht und befällt wenig mit Rost. 
Diese schöne, fiir reichen Boden höchst beachtenswerte Sorte entstammt den bei Norden in Ostfriesland gelegenen Marschen und wurde durch von Hülst, Vice-Präsident des landw. Vereins und Gutsbesitzer in Lintel bei Norden eingesandt.

\section{Pirnaer-Roggen. (2)}

Aehre: blassgelb, voll, lang; Aehrchen $1 \mathrm{~cm}$ breit, 2-körnig; Grannen hell, 4-5 cm lang. - Stroh: gelbgrau, fest, lang. - Frucht: braun, sehr lang, schmal (10 $\mathrm{mm}$ lang, $3 \mathrm{~mm}$ breit), etwas dickschalig.

Herbstblatt blaugrün, sehr kräftig, kraus; Frïhjahrsvegetation sehr zeitig, Bestockung stark, 6.5 Schösslinge (bei $100 \mathrm{qcm}$ Raum 9 Schösslinge); zeitig schossend, doch mittelfrüh, Ende Mai blühend. Halmlänge $155 \mathrm{~cm}$ (Max. $180 \mathrm{~cm}$ ), Halmdicke $0.37 \mathrm{~cm}$, Blattzahl 4, Blattlänge $15.4 \mathrm{~cm}$, Blattbreite $0.73 \mathrm{~cm}$, Blattfläche $89.92 \mathrm{qcm}$, Halmfläche $180.24 \mathrm{qcm}, \mathrm{Ge}$ sainmtfläche $270.16 \mathrm{qcm}$.

Aehre zeitig, gegen Mitte Juli reifend, $12 \mathrm{~cm}$ (Max. 15 cm) lang, mit 65 nicht leicht ausfallenden Früchten, von denen 2224300 auf 1 hl $(=76.7 \mathrm{~kg})$ entfallen.

Anf $1 \mathrm{qm}$ wachsen 1100 Halme oder 170 Pflanzen, mithin beträgt der Raum für eine Pflanze $59 \mathrm{qcm}$, die Blattfäche p. qin Bodenfläche $29.7 \mathrm{qm}$ und das Saatquantum $1.15 \mathrm{hl}$ p. ha.

Es wiegen 100 Halme $633 \mathrm{gr}^{\circ}$ und davon die Früchte $241 \mathrm{gr}$. befallend.

Winterfest, nicht leicht lagernd, doch ziemlich stark mit Rost

Diese Sorte begniigt sich mit leichtem Boden, hat sich aber auch für die Bruchböden des Oder- und Warthebruches bewährt, nur degeneriert sie auf diesem Boden leicht, so dass häufiger Saatwechsel stattfinden muss.

Heimat: das Gebirgsplateau bei Pirna im Königreich Sachsen.

\section{Mürkischer Stauden-Roggen. (2)}

Aehre: schmutzig-blassgelb, schlaff, Frucht meist halb unbedeckt, mittellang; Granne 4-5 cm lang. - Stroh: graugelb oder violett, kräftig, sehr lang. - Frucht: hellbraun, gross $(9 \mathrm{~mm}$ lang, $3 \mathrm{~mm}$ dick, 236 Früchte $=10 \mathrm{gr}$ ), etwas grobschalig.

Herbstblatt dunkelgrün, gross, breit, 4 Schösslinge, zeitig schossend und blühend; Halm $165 \mathrm{~cm}$ (Max. $210 \mathrm{~cm}$ ) lang, $0.4 \mathrm{~cm}$ dick, Blattzahl 5, Blätter $19.2 \mathrm{~cm}$ lang, $0.8 \mathrm{~cm}$ breit, Blattfläche $153.6 \mathrm{qcm}$, Halmfläche $198 \mathrm{qcm}$, Gesammtfläche $351.6 \mathrm{qcm}$.

Zeitig reifend, Aehre $13 \mathrm{~cm}$ (Max. $17 \mathrm{~cm})$ lang, mit 80 Friichten, von denen 1935200 auf $1 \mathrm{hl}(=82 \mathrm{~kg})$ entfallen.

Für guten Roggenboden geeignet. Winterfest.

Bezugsquelle: Haage \& Schmidt, Erfurt.

\section{Bestehorn's Riesen-Roggen. (2)}

Aehre: blassgelb, schlaff, lang, häufig mehr als 2, nämlich 3 Blütchen im Aehrchen; Grannen 4-5 cm lang. - Stroh: rötlich-gelb und graublau, sehr lang. - Frucht: schmutzig-hellbraun, schmal (7 mm lang, $21 / 2 \mathrm{~mm}$ breit, 378 Früchte $=10 \mathrm{gr}$ ), ein wenig grobschalig. 
Herbstblatt blaugrün, kräftig, 3.7 Schösslinge; Halm $150 \mathrm{~cm}$ (Max. $200 \mathrm{~cm}$ ) lang. $0.5 \mathrm{~cm}$ dick, Blattzahl 4, Blätter $19 \mathrm{~cm}$ lang, $1.1 \mathrm{~cm}$ breit. Blattfläche $167.2 \mathrm{qcm}$, Halmfläche $225 \mathrm{qcm}$, Gesammtfläche $392.2 \mathrm{qcm}$.

Aehre mittelfrüh reifend, $15 \mathrm{~cm}$ (Max. $21 \mathrm{~cm}$ ) lang, mit 70 Früchten, von deneu $1 \mathrm{hl}=77 \mathrm{~kg}$ wiegt.

Winterfest. Für sehr reichen Boden und zur Grünfuttererzeugung geeignet, da die Früchte verhältnismässig geringwertig sind.

Bezugsquelle: Metz \& Co., Berliu.

\section{Eldenaer Bastard-Roggen. (2)}

Aehre: blassrötlich-weiss, sehr lang, bis $18 \mathrm{~cm}$ lang, Grannen hell. 4-5 cm lang. - Stroh: rötlich.gelb, feinhalmig, doch steif und fest, $140 \mathrm{~cm}$ lang. - Frucht: Original hellbraun bis dunkelbraun, klein $(8 \mathrm{~mm}$ lang, $3 \mathrm{~mm}$ breit, 560 Früchte $=10 \mathrm{gr}$ ), mehlreich, feinschalig.

Dieser für leichten Boden geeignete, ertragreiche Roggen bestockt sich sehr stark, widersteht ungünstiger Witterung und dem Rost, lagert nicht und reift spät.

Er wurde voln $J$ ühlke 1842 in Eldena durch künstliche Befruchtung des gewölnnlichen pommerschen Landroggens mit einem Staudenroggen erzeugt.

\section{Guöttinger Roggen. (2)}

Aehre: gräulich-gelb, dick, voll, lang; Aehrchen $0.8 \mathrm{~cm}$ breit, 2-körnig; Grannen hell, $4-5$ cm lang. - Stroh: graugelb, kräftig, lang. Frucht: hellbräunlich, etwas plump (8 mm lang, $3 \frac{1}{2} \mathrm{~mm}$ breit, 359 Früchte $=10 \mathrm{gr})$, grobschalig.

Herbstblatt blaugrün, sehr kräftig, aufreclit; Frühjahrsvegetation zeitig, Bestockung mittelstark, 4 Schösslinge, mittelfrüh schossend und blühend. Halmlänge $137 \mathrm{~cm}$ (Max. $190 \mathrm{~cm}$ ), Halmdicke $0.4 \mathrm{~cm}$, Blattzahl 4, Blattlänge $13.92 \mathrm{~cm}$, Blattbreite $0.72 \mathrm{cru}$, Blattfäche $80.16 \mathrm{qcm}$, Halmfläche $172.23 \mathrm{qcm}$, Gesammtfläche $252.39 \mathrm{qcm}$.

Aehre reift mittelfrüh, $12 \mathrm{~cm}$ ( $(\Gamma \mathrm{ax} .16 \mathrm{~cm}$ ) lang, mit 70 nicht leicht ausfallenden Frïchten, von denerı 2800200 auf $1 \mathrm{hl}(=78 \mathrm{~kg})$ entfallen.

Auf $1 \mathrm{qm}$ wachsen 1200 Halme oder 300 Pflanzen, mithin beträgt der Raum für eine Pflanze $33.3 \mathrm{qcm}$, die Blattfläche p. qm Bodenfläche $30.2 \mathrm{qm}$ und das Saatquantum $1.6 \mathrm{hl}$ p. ha.

Es wiegen 100 Halme $727 \mathrm{gr}$ und davon die Früchte $300 \mathrm{gr}$.

Dieser Staudenroggen ist winterfest, lagert nicht leicht und leidet wenig durch Rost. Er liefert hohes Stroh, doch nicht übermässige Kiornerträge und verlangt zu seiner Kultur den besseren lehmigen Sandboden.

\section{Correns Staudemroggen. (2)}

Aehre: blassgelb, voll, dick, mittellang; Grannen hell, $4-5 \mathrm{~cm}$ lang; Aehrchen 2-körnig, $S \mathrm{~mm}$ breit. - Stroh: graugelb, kräftig, fest, lang. Frucht: bräunlich, breit, länglich (9 $\mathrm{mm}$ lang, $3 \mathrm{~mm}$ breit), feinschalig.

Herbstblatt gelbgrün, sehr kräftig, aufrecht; Frühjahrsregetation zeitig, Bestockung mittelstark, 4.5 Schösslinge (bei $100 \mathrm{qcm}$ Raum 9.7 Schösslinge), spät, Ende Mai blülıend. Halmlänge $144 \mathrm{~cm}$ (Max. $190 \mathrm{~cm}$ ), Halmdicke $0.35 \mathrm{~cm}$, Blattzahl 4.5, Blattlänge $13.3 \mathrm{~cm}$, Blattbreite $0.7 \mathrm{~cm}$. Blattoberfläclıe $83.97 \mathrm{qcm}$, Halmfläche $151.2 \mathrm{qcm}$, Gesammtfläche $235.17 \mathrm{qcm}$. 
Aehre reift Mitte Juli, $11 \mathrm{~cm}$ (Max. $16 \mathrm{~cm}$ ) lang, mit 60 ziemlich fest sitzenden Früchten, von denen $1 \mathrm{hl}(=76 \mathrm{~kg})$ 2 561200 Früchte enthält.

Auf $1 \mathrm{qm}$ wachsen 1250 Halme oder 278 Pflanzen, mithin beträgt der Raum für eine Pflanze $36 \mathrm{qcm}$, die Blattfäche p. qın Bodenfläche $29.4 \mathrm{qm}$ und das Saatquantum $1.63 \mathrm{hl} \mathrm{p}$. ha.

Da sich dieser Roggen, namentlich zeitig gesäet, stark bestockt und spät blïht, so leidet er selten durch Frühjahrsfröste und ist sonst vollkommen winterfest.

Sein Korn liefert ein vortreffliches Mehl; das schöne, feste Stroh lagert nicht leicht und zeigt sich auch gegen Rost sehr widerstandsfähig.

Es wiegen 100 Halme $511 \mathrm{gr}$ und davon die Früchte $220 \mathrm{gr}$.

Er empfiehlt sich vorzugsweise für den leichten sandigen Lehmboden, während der kalte schwere Boden ihm nicht zusagt und seine Degeneration hier sehr bald eintritt.

Seine Erträge stellten sich auf den sandigen Lehmböden wie folgt:

\begin{tabular}{|c|c|c|c|c|c|}
\hline & \multicolumn{3}{|c|}{ Ertrag per ha an } \\
\hline & & & $\begin{array}{c}\text { Korn } \\
\mathrm{kg}\end{array}$ & $\begin{array}{c}\text { Stroh } \\
\mathrm{kg}\end{array}$ & $\begin{array}{c}\text { Spreu } \\
\mathrm{kg}\end{array}$ \\
\hline Kulturverein & Eldena ${ }^{1}$ ) & 1868 & 2371 & 4735 & 281 \\
\hline Versuchsfeld & Eldena ${ }^{1}$ ) & 1868 & 1556 & 2848 & 160 \\
\hline n & Proskau & 1872 & 2016 & 5344 & 176 \\
\hline
\end{tabular}

Der Roggen wurde zuerst durch Elsner ron Gronow-Kalinowitz, Schlesien, auf sandigem Boden mit Kalkunterlage kultiviert und später weiter verbreitet. Die erste Probe erhielt derselbe 1849 von dem königl. Forstmeister Correns, der den Samen aus Amerika bezogen hatte.

Zur Zeit ist dieser Roggen namentlich in Schlesien, Pommern und Westpreussen verbreitet.

\section{Igelroggen von Prof. Dr. Wollny, München. (2)}

Aehre: Original schwach rötlich-gelb; Kiel der Spelzen borstig: zusammengedrückt, 2-zeilig, sich stark nach oben verjüngend, an Basis $2 \mathrm{~cm}$, an Spitze $0.7 \mathrm{~cm}$ breit, $9 \mathrm{~cm}$ lang, mit 68 Aehrchen und 56 Frücllten; aufrecht, sehr dicht; Grannen kurz, bis $3 \mathrm{~cm}$ lang. — Stroh: rötlichgelb, steif, kurz. - Frucht: selı hell, dick, $8 \mathrm{~mm}$ lang, $0.3 \mathrm{~mm}$ breit, 267 Körner $=10 \mathrm{gr}$.

E. Wolln $y^{2}$ ) beobachtete 1873 auf dem Versuchsfelde zu Mïnchen eine Aehre von nur $5.2 \mathrm{~cm}$ Länge, mit 39 Körnern und kurzen Grannen, und in ihrem Bau dem Igelweizen glich und sagt darüber:

"Bei fortgesetztem Bau verlor sich zwar die kurze Gestalt der Aehre, dagegen erhielt sich die kurze Begrannung, die deutlich ansgesprochene starke seitliche Kompression derselben, sowie der dichte Stand der Aehrchen und die kräftig ausgebildete borstige Bewimperung der Spelzenkiele."

Seit 8 Jahren zeigte sich diese Sorte konstant und gab im Mittel zahlreicher Messungen:

1) Versuche des Verfassers.

2) Vergl. Deutsche landw. Presse Jahrg. VIII, p. 56. 
Länge der Aehren Zahl der Aehrchen Zahl der Frïchte

Igel-Roggen $9.8 \mathrm{~cm}$ 41 82

Gewöhnl. schlaff-ähriger Roggen $18.2 \mathrm{~cm}$ 38 76

Der Originalsame lieferte in Poppelsdorf dichte und schlaffährige Aehren, erstere allerdings in der Mehrzahl.

Somit zeigte sich dieser Roggen in Poppelsdorf nicht konstant, auch ist zu bemerken, dass ähnliche Aehrenformen an den sekundären Halmen aller Roggensorten nicht ungewöhnlich sind.

Demnach scheint uns dieser Roggen nicht eine neue Varietät zu sein. Bezugsquelle: E. Wollny, München.

\section{Gewöhnlicher Sommerroggen. $\odot$}

Franz.: Seigle de printemps, de Mars, de tramis, de trois mois.

Aehre: blassgelb, dünn, mittellang; Aehrchen $0.7 \mathrm{~cm}$ breit, 2-körnig; Grannen hell, $3 \mathrm{~cm}$ lang. - Stroh: gräulich-gelb, feinhalmig, fest, biegsam, mittellang. - Frucht: grau bis braun, schmal, klein ( $8 \mathrm{~mm}$ lang, $21 / 2 \mathrm{~mm}$ breit, 305 Früchte $=10 \mathrm{gr}$ ), feinschalig.

Junges Blatt blaugrün, fein, 2.3 Schösslinge. Halmlänge $120 \mathrm{~cm}$ (Max. $150 \mathrm{~cm}$ ), Halmdicke $0.3 \mathrm{~cm}$, Blattzahl 3.3 , Blattlänge $20.18 \mathrm{~cm}$, Blattbreite $0.7 \mathrm{~cm}$, Blattfläche $93.26 \mathrm{qcm}$, Halmfläche $108 \mathrm{qcm}$, Gesammtfläche $201.26 \mathrm{qcm}$.

A ehre reift in 120 Tagen, $10 \mathrm{~cm}$ (М von denen 2287500 auf $1 \mathrm{hl}(=75 \mathrm{hg})$ entfallen.

Auf $1 \mathrm{qm}$ wachseu 1300 Halme oder 570 Pflanzen, mithin beträgt der Raum für eine Pflanze 17.5 qcm, die Blattfläche $p . q m$ Bodenfläche $26 \mathrm{qm}$ und das Saatquantum $3.8 \mathrm{hl} \mathrm{p}$. ha.

Es wiegen 100 Halme $315 \mathrm{gr}$ und davon die Früchte $11 \mathrm{tgr}$.

Für sehr leichte Böden geeignet.

\section{Winter-Giftkorn. (2)}

Aehre: grauweiss oder gräulich-blassgelb, sehr lang und dicht; A ehrchen $0.7 \mathrm{~cm}$ breit, 2-körnig; Grannen bis $6 \mathrm{~cm}$ lang. - Stroh: rötlich-gelb, kräftig, mittellang. - Frucht: graublau oder hellbraun, kurz, dick ( $7 \mathrm{~mm}$ lang, $2^{1} \frac{2}{\mathrm{~mm}}$ breit, 350 Früchte $\left.=10 \mathrm{gr}\right)$ schwer, sehr feinschalig.

Herbstblatt dunkelgrün, schmal, kraus; Frühjahrsvegetation spät, Bestockung stark, 5 Schösslinge, spät schossend und bliihend. Halm $135 \mathrm{~cm}$ (IIax. $160 \mathrm{~cm}$ ) lang, $0.35 \mathrm{~cm}$ dick, Blattzahl 4, Blätter $15.6 \mathrm{~cm}$ lang, $0.7 \mathrm{~cm}$ breit, Blattfläche $87.36 \mathrm{qcm}$, Halmfläche $141.75 \mathrm{qcm}, \mathrm{Ge}-$ sammtfläche 229.11 qcm.

Aehre reift spät, $15 \mathrm{~cm}$ (Max. $160 \mathrm{~cm}$ ) lang, mit 49 Aehrchen und 94 Früchten, von denen 2625000 auf $1 \mathrm{hl}(=75 \mathrm{~kg})$ entfallen.

Es wiegen 100 Halme $469 \mathrm{gr}$ und davon die Frïchte $210 \mathrm{gr}$.

Dieses winterfeste Giftkorn lagert nicht leicht und ist gegen Rost ziemlich widerstandsfähig. Es stammt aus Ehrenfriedendorf, Freiberg, Königr. Sachsen, von arsenikhaltigem Boden, auf dem Roggen bekanntlich sehr schöne, schwere und feinschalige Körner liefern soll. 


\section{Sommer-Giftkorn.}

Aehre : rötlich-blassgelb, sehr schön, lang, dicht; Aehrchen 2-körnig; Granne bis $6 \mathrm{~cm}$ lang. - Strolı: rötlich-gelb, fest, lang, feinhalınig. Frucht: hellbraun oder hellgrau, klein, dick $\left(6^{1 / 2} \mathrm{~mm}\right.$ lang, $2 \frac{1}{2} \mathrm{~mm}$ breit, 454 Früchte $=10 \mathrm{gr}$ ), schwer, sehr feinschalig.

Junges Blatt hellgrün, aufrecht; Bestockung mittelstark, 2.2 Schösslinge, zeitig schossend und blühend. Halm $135 \mathrm{~cm}$ (YIax. $155 \mathrm{~cm}$ ) lang, $0.25 \mathrm{~cm}$ dick, Blattzahl 4, Blätter $12.5 \mathrm{~cm}$ lang, $0.63 \mathrm{~cm}$ breit, Blattfläche $63 \mathrm{qcm}$, Halmfläche $101.25 \mathrm{q} \mathrm{cm}$, Gesammtfläche $164.25 \mathrm{qcm}$.

Aehre reift in 110 Tagen, $10 \mathrm{~cm}$ (Max. $14 \mathrm{~cm}$ ) lang, mit $31 \mathrm{Aehr}$ chen und 56 Früchten, von denen 3608150 auf $1 \mathrm{hl}(=79.3 \mathrm{~kg})$ entfallen.

Es wiegen 100 Halme $192 \mathrm{gr}$ und davon die Früchte $125 \mathrm{gr}$.

Diese Roggensorte lagert nicht leicht und zeigt sich gegen Rost sehr widerstandsfähig.

Das Giftkorn stammt aus Ehrenfriedendorf, Freiberg, Königr. Sachsen, von arsenikhaltigem Boden.

\section{Zeeländer Winterroggen. (2)}

Aehre: blassgelb, voll, lang; Aehrchen $0.9 \mathrm{~cm}$ breit, 2-körnig; Grannen hell, 4-5 cm lang. - Stroh: gelb, sehr kräftig, fest, lang. Frucht: graugelb, kurz, dick, plump, schwer ( $7 \mathrm{~mm}$ lang, $4 \mathrm{~mm}$ breit, 257 Friichte $=10 \mathrm{gr}$ ), etwas grobschalig.

Herbstblatt gelbgrün, kräftig, aufrecht; Frühjahrsvegetation sehr zeitig, Bestockung nittelstark, 4.5 Schösslinge (bei 100 qcin $=11.4$ Schösslinge), mittelfruih schossend und blühend. Ilalmlänge $155 \mathrm{~cm}$ (Max. $200 \mathrm{~cm}$ ), Halmdicke $0.42 \mathrm{~cm}$, Blattzahl 4, Blattlänge $17.94 \mathrm{~cm}$, Blattbreite $0.78 \mathrm{~cm}$, Blattfläche $111.92 \mathrm{qcm}$, Halmfläche $204.6 \mathrm{qcm}$, Gesammtfläche $316.52 \mathrm{qcm}$.

Aehre reift mittelfrüh, $13 \mathrm{~cm}$ (Max. $15 \mathrm{~cm}$ ) lang, mit 60 in der Vollreife fest sitzenden Früchten, von denen 1963480 auf $1 \mathrm{hl}$ (=76.4 kg) entfallen.

Auf $1 \mathrm{qm}$ wachsen 900 Halme oder 200 Pflanzen, inithin beträgt der Raum für eine Pflanze $50 \mathrm{qcm}$, die Blattfläche p. qm Bodenfläche $28.5 \mathrm{qm}$ und das Saatquantum $1.6 \mathrm{hl} \mathrm{p}$. ha.

Es wiegen 100 Halme $584 \mathrm{gr}$ und davon die Früchte $252 \mathrm{gr}$.

Auf dem Versuchsfelde zu Proskau wurden geerntet p. lia: im Jahre $1868=1950 \mathrm{~kg}$ Korn, $4867 \mathrm{~kg}$ Stroh

$$
1871=2436, \quad " 6512,
$$

Dieser Roggen degeneriert leicht, so dass sich seine Eigenschaften nur auf reichen Alluvial- und humosen Thonböden und im feuchten Klima erhalten lassen.

Er ist nicht ganz winterfest, lagert nicht leicht, leidet wenig durch Rost und fällt bei verzögerter Ernte nicht leicht aus.

Seine Heimat ist die holländische Provinz Zeeland, und wurde er durcb Josmann nach Deutschland eingeführt. 


\section{Campiner-Roggen. (2)}

Aehre: blassgelb, voll, dick, dicht, lang; Aehrchell $0.9 \mathrm{~cm}$ breit, 2 körnig; Grannen 5-8 cm lang. - Stroh: rötlich-gelb, fest, kräftig, lang. - Fruclit: hellgrau, schön, kurz (8 mm lang, $3 \mathrm{~mm}$ breit, 313 Früchte $=10 \mathrm{gr})$, mehlreich, sehr feinschalig.

Herbstblatt dunkelgriun, kräftig, aufrecht; Frühjahrsvegetation sehr zeitig, Bestockung mittelstark, 5 Schösslinge, zeitig schossend und Mitte Mai blühend. Halmlänge $145 \mathrm{~cm}$ (Max. $172 \mathrm{~cm}$ ), Halmdicke $0.4 \mathrm{~cm}$, Blattzahl 4, Blattlänge $22 \mathrm{~cm}$, Blattbreite $0.9 \mathrm{~cm}$, Blattfläche $158.4 \mathrm{qcm}, \mathrm{Halm}$ fläche $174 \mathrm{qcm}$, Gesammtfläche $332.4 \mathrm{qcm}$.

Aehre zeitig reifend, $15 \mathrm{~cm}$ (Max. $20 \mathrm{~cm}$ ) lang, mit 70 ziemlich fest sitzenden Früchten, von denen 2347500 auf $1 \mathrm{hl}(=75 \mathrm{~kg})$ entfallen.

Auf $1 \mathrm{qm}$ wachsen 900 Halme oder 180 Pflanzen, mithin beträgt der Ranm für 1 Pflanze $55.5 \mathrm{qcm}$, die Blattfläche p. qm Bodenfläche $29.9 \mathrm{qm}$ und das Saatquantum $1.2 \mathrm{hl} \mathrm{p.} \mathrm{ha.}$

Es wiegen 100 Halme $569 \mathrm{gr}$ und davon die Früchte $23.9 \mathrm{gr}$.

Anf saudigem Lchmboden wurden p. ha erzielt:

Eldena $\left.{ }^{1}\right) \quad 1868=1587 \mathrm{~kg}$ Korn, 4266 Stroh.
Proskau $1871=1409, ", " 4640 "$
Hohenheim $1866=2059, ", 4347 "$,

Dieser Roggen liefert auf den "abweichendsten Bodenarten gute Erträge, so gedeilıt er noch anf leichtem Sandboden; je kulturvoller und bindiger der Boden wird, um so höher stellen sich auch die Korn- und Stroherträge. $\mathrm{Er}$ ist winterfest und lagert nicht leicht.

Die Heimat ist die belgisehe Campine, wo er seit sehr langer Zeit gebaut und geschätzt wird, was bereits 1566 Dodonaeus ${ }^{2}$ ) bezeugt, indem er sagt (aus dem Lateinischen übersetzt), ,Roggen wächst sowohl in Deutschland als auch in Belgien fast auf allen Aeckern, wie in Brabantiae Campania, welche, obschon sie trocken und unfruchtbar ist, doch dieses Getreide in vorzüslicher Qualität erzeugt."

\section{Böhmischer Gebirgs-Standenroggen. (2)}

Aehre: blassgelb, roll, lang; Aehrchen $0.8 \mathrm{~cm}$ breit, 2-körnig; Grannen hell, 4-5 cm lang. - Stroh: gelb, etwas mürbe, lang. - Frucht: grau-gelb, plump, klein ( $7 \mathrm{~mm}$ lang, $3^{1} / 2 \mathrm{~mm}$ breit, 323 Frichte $=10 \mathrm{gr}$ ), etwas grobschalig.

Herbstblatt blaugriin, kraus, schmal; Frihjahrsvegetation spät, Bestockung mittelstark, 4.5 (bei 100 qcm 8.8) Schösslinge, spät schossend und bliubend. Halmlänge $145 \mathrm{~cm}$ (Max. $170 \mathrm{~cm}$ ), Halmdicke $0.36 \mathrm{~cm}$, Blattzahl 4.3, Blattlänge $16 \mathrm{~cm}$, Blattbreite $0.67 \mathrm{~cm}$, Blattfläche $92.2 \mathrm{qcm}$, Halmfläche $164.06 \mathrm{qcm}$, Gesammtfläche $256.26 \mathrm{qcm}$.

Aelıre reift spät, $13 \mathrm{~cm}$ (Max. $15 \mathrm{~cm}$ ) lang, mit 60 ziemlich fest sitzenden Früchten, von denen 2487100 auf $1 \mathrm{hl}(=77 \mathrm{~kg})$ gehen.

Auf $1 \mathrm{qm}$ wachsen 1200 Halme oder 266 Pflanzen, mithin beträgt der Raum für eine Pflanze 37.6 qcm, die Blattläche p. qm Bodenfläche $30.7 \mathrm{qm}$ und das Saatquantum $1.6 \mathrm{hl}$ p. ha.

1) Anbauversuch des Verfassers.

2) Dodonaeus, Frumentorum etc. hist. pg. 47, 1566. 
Es wiegen 100 Halme $551 \mathrm{gr}^{\circ}$ und davon die Früchte $204 \mathrm{gr}$.

Dieser Roggen ist winterfest, leidet wenig durch Rost und macht geringe Ansprüche an den Boden, weshalb er für rauhe Gegenden mit leichtem Boden wohl beachtenswert ist.

\section{Gewöhnlicher böhmischer Winterroggen. (2)}

Aehre: gelb, breit, sehr locker, lang; Aehrchen $1.0 \mathrm{~cm}$ breit, 2-körnig; Grannen hell, $4-5 \mathrm{~cm}$ lang. - Strolı: rötlich-gelb, fest, lang. Frucht: grünlich, gross (9 mm lang, $3 \mathrm{~mm}$ breit, 290 Früichte $=10 \mathrm{gr}$ ), feinschalig.

Herbstblatt breit, lang; Frühjahrsvegetation sehr zeitig, Bestockung mittelstark, 4 Schösslinge, sehr zeitig scliossend und blïhend. Halmlänge $150 \mathrm{~cm}$ (Max. $182 \mathrm{~cm}$ ), Halmdicke $0.33 \mathrm{~cm}$, Blattzahl 4, Blattlänge $18.5 \mathrm{~cm}$, Blattbreite $0.73 \mathrm{~cm}$, Blattfläche $108.0 \mathrm{qcm}$, Halmfläche $148.5 \mathrm{qcm}$, Gesainmtfläche $256.5 \mathrm{qcm}$.

Aehre sehr zeitig, gleich nach Johannisroggen und Roggen aus Italien reifend, mit 60 Früchten, von denen 2291000 auf $1 \mathrm{hl}(=79 \mathrm{~kg})$ entfallen.

Es wiegen 100 Halme $567 \mathrm{gr}$ und davon die Früchte $211 \mathrm{gr}$. dem Lagern.

Dieser Roggen wintert leicht aus, widersteht jedoch dem Rost und

\section{Winterroggen ans Ungarn. (2)}

Aehre: schmutzig-blassgelb, hängend, locker, schmal, lang; Aehrchen $0.7 \mathrm{~cm}$ breit, 2-körnig, Grannen hell, 4-5 cm lang. - Stroh: gräulich-gelb, fest, lang. - Frucht: Original hell, silbergrau oder hellbraun, klein, sehr schwer, feinschalig, so wogen einige der besten Sorten von 1877 und zwar:

\begin{tabular}{|c|c|c|c|}
\hline Name der Sorten. & Beschaffenbeit des Kornes. & $\begin{array}{l}\text { Körnerzahl } \\
\text { pro } 1 \mathrm{gr}\end{array}$ & $\begin{array}{l}100 \mathrm{cbcm} \\
\text { wiegen } \mathrm{gr}\end{array}$ \\
\hline $\begin{array}{l}\text { Pester-Boden-Roggen } \\
\text { Nyirer " " } \\
\text { Debrecziner } \quad " \\
\text { Kecskeméter } \quad "\end{array}$ & 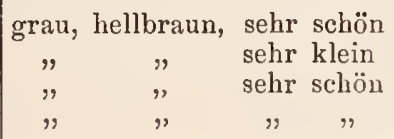 & $\begin{array}{l}40 \\
49 \\
45 \\
39\end{array}$ & $\begin{array}{l}82.0 \\
81.0 \\
81.0 \\
81.5\end{array}$ \\
\hline
\end{tabular}

In Poppelsdorf nachgebaut, wurde das Korn grösser (11 mm lang, $3 \mathrm{~mm}$ breit) und das Hektolitergewicht leichter, so ergaben nachgebaute Sorten folgendes Resultat:

$\begin{array}{lccc} & & \begin{array}{c}\text { Körnerzahl } \\ \text { pr. } 1 \text { gr }\end{array} & \begin{array}{c}100 \mathrm{cbcm} \\ \text { wiegen gr }\end{array} \\ \text { Ungarischer Winterroggen } & \text {. } & 33.65 & 73.8 \\ \text { Banater Roggen . . . . . . . } 31.00 & 72.5\end{array}$

Herbstblatt blaugrün, kraus; Frühjahrsvegetation ziemlich zeitig, Bestockung mittelstark, 4.3 Schösslinge, zeitig schossend, doch erst Ende Mai, also spät blühend.

Halmlänge $155 \mathrm{~cm}$ (Max. $175 \mathrm{~cm}$ ), Halmdicke $0.4 \mathrm{~cm}$, Blattzahl 4, Blattlänge $16.4 \mathrm{~cm}$, Blattbreite $0.72 \mathrm{~cm}$, Blattfläche $94.46 \mathrm{qcm}$, Halmfläche $186 \mathrm{qcm}$, Gesammtfläche $280.46 \mathrm{qcm}$. 
Aehre reift mittelfrüh, $12 \mathrm{~cm}$ (Max. $16 \mathrm{~cm}$ ) lang, mit 70 Früchten. Es wiegen 100 Halme $498 \mathrm{gr}$ und davon die Früchte $185 \mathrm{gr}$.

Der Roggen ist winterfest, leidet aber etwas durch Rost.

\section{Sommerroggen aus Ungarn. $\odot$}

Aehre: weissgrau, dünn, ziemlich diclit und lang; Aehrchen $0.9 \mathrm{~cm}$ breit, 2-körnig, Spelzen verhältnismässig gross; Grannen hell, bis $4.5 \mathrm{~cm}$ lang. - Stroh: graugelb, sehr feinhalmig, fest. - Frucht: graugelb bis hellbraun, lang, schmal (10 mm lang, $3 \mathrm{~mm}$ breit, 315 Frïchte $=10 \mathrm{gr}$ ), feinschalig, sehr schwer.

Halme blaugrün, 2.8 Schösslinge, mittelfrüh schossend und blühend. Halmlänge $110 \mathrm{~cm}$ (Nax. $140 \mathrm{~cm}$ ), Halmdicke $0.27 \mathrm{~cm}$, Blattzahl 3, Blattlänge $15.23 \mathrm{~cm}$, Blattbreite $0.69 \mathrm{~cm}$, Blattfläche $63.06 \mathrm{qcm}$, Halmfläche $89.1 \mathrm{qcm}$, Gesammtfläche $152.16 \mathrm{qcm}$.

Aehre $9 \mathrm{~cm}$ (Max. $11 \mathrm{~cm}$ ), in 120 Tagen reifend, mit 42 ziemlich fest sitzenden Früchten, von denen 2520000 auf $1 \mathrm{hl}(=80 \mathrm{~kg})$ entfallen.

Der Roggen lagert nicht leicht, befällt jedoch stark mit Rost.

\section{Roggen aus Rumänien. (2)}

Aehre: gräulich-gelb, voll, breit, lang; Aehrchen 2-körnig; Grannen hell, 5-6 cm lang. - Stroh: gräulich-gelb, kräftig, lang. - Frucht: grau, voll, kurz ( $8 \mathrm{~mm}$ lang, $3 \mathrm{~mm}$ breit, 348 Friichte $=10 \mathrm{gr}$ ), feinschalig.

Herbstblatt dunkelgrün, aufrecht; Friihjahrsvegetation zeitig, Bestockung sehr stark, 6.6 Schösslinge, zeitig schossend und bliihend. Halmlänge $150 \mathrm{~cm}$ ( (Max. $170 \mathrm{~cm}$ ), Halmdicke $0.4 \mathrm{~cm}$, Blattzahl 4.6, Blattlänge $18.6 \mathrm{~cm}$, Blattbreite $0.87 \mathrm{~cm}$, Blattfläche $148.86 \mathrm{qcm}$, Halmfläche $180 \mathrm{qcm}$, Gesammtfläche $328.86 \mathrm{qcm}$.

Aehre reift früh, $14 \mathrm{~cm}$ (Max. $17 \mathrm{~cm}$ ) lang, mit 70 Früchten, von denen 2610000 auf $1 \mathrm{hl}(=75 \mathrm{~kg})$ entfallen.

Auf $1 \mathrm{qm}$ wachsen 950 Halme oder 144 Pflanzen, mithin beträgt der Raum für eine Pflanze $70 \mathrm{qcm}$, die Blattfläche p. qm Bodenfläche $31.26 \mathrm{qm}$ und das Saatquantum $1 \mathrm{hl}$ p. ha.

Es wiegen 100 Halme $562 \mathrm{gr}$ und davon die Früchte $190 \mathrm{gr}$.

Diese Sorte lagert nicht, leidet wenig durch Rost und verlangt einen Boden mit natiirlichem Reichtum.

\section{Wechselroggen ans Serbiell. $\odot$ und (2)}

Aehre: grauweiss, schlaff, ziemlich locker; Grannen $4-5 \mathrm{~cm}$ lang. - Stroh: graugelb und gelbrot, mittellang. - Frucht: Original meist grau, schmal, auffallend klein $\left(7 \mathrm{~mm}\right.$ lang, $2 \frac{1}{2} \mathrm{~mm}$ breit, 570 Frichte $=$ $10 \mathrm{gr}$ ), feinschalig; nachgebaut: als Sommerfrucht 448 Früchte $=10 \mathrm{gr}$, als Winterfrucht: 331 Früchte $=10 \mathrm{gr}$.

Herbstblatt blaugrün, schmal, kurz, kraus, stark sammetig, mittelfrüh schossend, blühend und reifend; Sommerfrucht in 110 Tagen reifend. 


\begin{tabular}{|c|c|c|}
\hline & Winterfrucht & Sommerfrucht \\
\hline $\begin{array}{l}\text { Halmlänge } \\
\text { Halmdicke } \\
\text { Blattzahl } \\
\text { Blattlänge } \\
\text { Blattbreite } \\
\text { Blattfläche } \\
\text { Halmfläche } \\
\text { Gesammtfäche } \\
\text { Aehrenlängc } \\
\text { Anzahl der Aehrchen } \\
\qquad " \text { " Früchte } \\
\text { ", Schösslinge } \\
\text { Gewicht pro hl in kg }\end{array}$ & $\begin{array}{c}120 \mathrm{~cm} \mathrm{(Max.} 135 \mathrm{~cm}) \\
0.3 \mathrm{~cm} \\
4.8 \\
15.3 \mathrm{~cm} \\
0.6 \mathrm{~cm} \\
88.1 \mathrm{qcm} \\
108.0 \mathrm{qcm} \\
196.1 \mathrm{qcm} \\
12 \mathrm{~cm}(\text { Max. } 15 \mathrm{~cm}) \\
29 \\
54 \\
3.5 \\
82.5\end{array}$ & $\begin{array}{c}145 \mathrm{~cm} \text { (Max. } 170 \mathrm{~cm}) \\
0.4 \mathrm{cin} \\
4.5 \\
13.4 \mathrm{~cm} \\
0.7 \mathrm{~cm} \\
84.4 \mathrm{qcm} \\
174.0 \mathrm{~cm} \\
258.4 \mathrm{qcm} \\
12 \mathrm{~cm}(\text { Max. } 17 \mathrm{~cm}) \\
30 \\
58 \\
4.5 \\
80\end{array}$ \\
\hline
\end{tabular}

Winterfest; nicht leicht lagernd.

Bezugsquelle: Prof. Pantschitsch in Belgrad.

Beachtenswert für hohe, kalte Gebirgslagen, in denen es nicht immer glückt, die Wintersaat rechtzeitig zu bestellen.

\section{Roggen von Zermatt. (2)}

Aehre: Original ziemlich goldgelb oder etwas fuchs-rötlich, dicht, gedrungen, vollkörnig, kurz, 5-9 $\mathrm{cm}$ lang, Grannen 4-5 cm lang; nachgebaut: Aehren schon in 1. Tracht länger geworden (Max. $13.5 \mathrm{~cm}$, Mittel $11 \mathrm{~cm}$, Minimum $7 \mathrm{~cm}$ ) und ähneln dem gewöhnlichen Roggen, indem nur einige ihre ursprüngliche Form und Farbe erhalten haben. - Stroh: rötlich-gelb, feinhalmig, fest. - Frucht: graubraun, etwas hornartig gebogen $(81 / 2 \mathrm{~mm}$ lang, $3 \mathrm{~mm}$ breit, 362.5 Früchte $=10 \mathrm{gr})$, grobschalig.

Herbstblatt blaugrün, fein, aufrecht; Frühjahrsvegetation spät, 4 Schösslinge, doch gleichzeitig mit dem frühen Roggen aus Italien schossend, 1./5. 78 Schossen beendigt, sehr zeitig bluihend (10./5. 78), sehr zeitig reifend (5./7. 78), dies eigentümliche Verhalten entspricht vollkommen der hohen Lage (1620 m ü. M.). Halmlänge $138 \mathrm{~cm}$ (Max. $163 \mathrm{~cm}$ ), Halmdicke $0.3 \mathrm{~cm}$, Blattzahl 3.7 , Blattlänge $15.45 \mathrm{~cm}$, Blattbreite $0.72 \mathrm{~cm}$, Blattfläche 82.28 q $\mathrm{cm}$, Halmfläche 130.10 q $\mathrm{cm}$, Gesammtfläche $212.38 \mathrm{qcm}$.

Aehre $11 \mathrm{~cm}$ lang, mit 70 ziemlich fest sitzenden Früchten. Es enthält $1 \mathrm{ll} l(=74.5 \mathrm{~kg}) 2700625$ Früchte.

Es wiegen 100 Halme $405 \mathrm{gr}$ und davon die Frïchte $170 \mathrm{gr}$.

Dieser alpine Roggen ist winterfest, lagert nicht leicht und wird wenig durch Rost angegriffen.

Durch Körnicke (24./8. 76) in Zermatt, Canton Wallis, Schweiz, gesammelt.

\section{Roggen von Macugnaga, am Süd-Abfall des Monte-Rosa} (1559 m ü. M.). (2)

A ehre : graugelb, schmal, mittellang; Aehrchen $0.8 \mathrm{~cm}$ breit, 2-körnig; Grannen 4-5 cm lang. - Stroh: schön gelb, fest, sehr lang. - 
Frucht: hellbraun und grau, gross $\left(9 \mathrm{~mm}\right.$ lang, $3 \frac{1}{2} \mathrm{~mm}$ breit, 235 Früchte $=10 \mathrm{gr}$ ), feinschalig.

Herbstblatt gelbgrün, aufrecht; Frühjahrsvegetation zeitig, 4.6 Schösslinge, zeitig schossend und blühend. Halmlänge $160 \mathrm{~cm}$ (Max. $200 \mathrm{~cm}$ ), Halmdicke $0.35 \mathrm{~cm}$, Blattzahl 4.5, Blattlänge $18 \mathrm{~cm}$, Blattbreite $0.7 \mathrm{~cm}$, Blattfäche $113.4 \mathrm{qcm}$, Halmfäche $168 \mathrm{qcm}$, Gesammtfläche $281.4 \mathrm{qcm}$.

Aehre reift zeitig, $12 \mathrm{~cm}$ (Max. $18 \mathrm{~cm}$ ) lang, mit 65 sehr leicht ausfallenden Früchten, von denen 1729600 auf $1 \mathrm{hl}$ (=73.6 kg) entfallen.

Es wiegen 100 Halme $568 \mathrm{gr}$ und davon die Früchte $169 \mathrm{gr}$.

Dieser alpine Roggen wurde 1878 durch Körnicke gesammelt.

\section{Roggen ans dem Livinenthale unterhalb Airolo bei der Galerie, (1179 m ii. M.), Schweiz. (2)}

Aehre: graugelb, ziemlich breit, mittellang; Aehrchen $0.9 \mathrm{~cm}$ breit, 2- zuweilen 3-körnig; Grannen 4-5 cm lang. - Stroh: gelb, kräftig, lang. - Frucht: hellgrau oder hellbraun, gross $(9 \mathrm{~mm}$ lang, $3 \mathrm{~mm}$ breit, 255 Frïchte $=10 \mathrm{gr}$ ), feinschalig.

Herbstblatt dunkelgrün, klein; Frühjahrsvegetation spät, Bestockung stark, 6 Schösslinge, spät blühend, 21./5. 79 noch keine Aehre heraus, volle Blüte 11./6. 79. Halmlänge $160 \mathrm{~cm}$ (Мax. $180 \mathrm{~cm}$ ), Halmdicke $0.4 \mathrm{~cm}$, Blattzahl 3.5, Blattlänge $15.3 \mathrm{~cm}$, Blattbreite $0.7 \mathrm{~cm}$, Blattfläche $74.97 \mathrm{qcm}$, Halmfläche $192 \mathrm{q} \mathrm{cm}$, Gesammtfläche $266.97 \mathrm{qcm}$.

A ehre spät (28./7. 79) reifend, $12 \mathrm{~cm}$ (Max. $16 \mathrm{~cm}$ ) lang, mit 70 nicht leicht ausfallenden Früchten, von denen 1938000 auf $1 \mathrm{hl}(=76 \mathrm{~kg})$ entfallen.

Es wiegen 100 Halme $556 \mathrm{gr}$ und davon die Früchte $245 \mathrm{gr}$.

Dieser Roggen widersteht dem Rost und Lagern vortrefflich.

Durch Körnicke 1878 gesammelt.

\section{Roggen aus Saas im Grund. (2)}

Aehre: gelbbräunlich, schmal, ziemlich kurz, dicht, Aehrchen $0.7 \mathrm{~cm}$ breit, 2-körnig; Grannen 4-5 cm lang. - Stroh: gelb, fest, derb. Frucht: hellbraun, ziemlich gross ( $10 \mathrm{~mm}$ lang, $3 \mathrm{~mm}$ breit, 262.5 Früchte $=10 \mathrm{gr}$ ), etwas grobsehalig.

Herbstblatt gelbgrün, aufrecht; Frühjahrsvegetation zeitig, Bestockung stark, 5 Schösslinge, zeitig schossend und blühend. Halmlänge $160 \mathrm{~cm}$ (Max. $190 \mathrm{cin}$ ), Halmdicke $0.4 \mathrm{~cm}$, Blattzahl 4, Blattlänge $15.4 \mathrm{~cm}$, Blattbreite $0.9 \mathrm{~cm}$, Blattfläche $110.88 \mathrm{qcm}$, Halmfläche $192 \mathrm{qcm}$, Gesammtfläche $302.88 \mathrm{qcm}$.

Aehre reift zeitig, $10 \mathrm{~cm}$ (Max. $14 \mathrm{~cm}$ ) lang, mit 60 etwas leicht ausfallenden Früchten, von denen 1916250 auf $1 \mathrm{hl}(=73 \mathrm{~kg})$ entfallen.

Es wiegen 100 Halme $465 \mathrm{gr}$ und davon die Früchte $153 \mathrm{gr}$.

Dieser alpine Roggen wurde 1876 durch Körnicke in Saas im Grund, Canton Wallis, Schweiz (1562 m ï. M.) gesammelt.

\section{Riesenstaudenroggen. (2)}

Syn.: Engl.: Tyrolese or Giant-Rye.

Franz.: Seigle géant ou tyrolien.

Aehre: schmutzig-gelb, ziemlich dicht, lang; Aehrchen $0.9 \mathrm{~cm}$ breit, 2-körnig; Grannen länger als bei vielen anderen Sorten, bis $6 \mathrm{~cm}$ lang. - 
Stroh: rötlich-gelb, fest, lang. - Frucht: silbergrau oder hellbraun, schmal (9 mm lang, $3 \mathrm{~mm}$ breit, 356 Früchte $=10 \mathrm{gr}$ ); nachgebuut: grösser, 265 Früchte $=10 \mathrm{gr}$, feinschalig.

Herbstblatt blaugrün, sehr kräftig, aufrecht, Frühjahrsvegetation ziemlich zeitig, Bestockung stark, 6 Schösslinge, zeitig schossend, mittclfrïh blühend. Halmlänge $160 \mathrm{~cm}$ (Max. $185 \mathrm{~cm}$ ), Halmdicke 0.4, Blattzahl 5, Blattlänge $17,6 \mathrm{~cm}$, Blattbreite $0.83 \mathrm{~cm}$, Blattfläche $145.1 \mathrm{qcm}$, Halmfläche $192 \mathrm{qcm}$, Gesammtfläche $337.1 \mathrm{qcm}$.

Aehre reift in der 1. Hälfte des Juli, $15 \mathrm{~cm}$ (Max. $18 \mathrm{~cm}$ ) lang, mit 80 Früchten, von denen 2670000 auf $1 \mathrm{hl}(=75 \mathrm{~kg}$ ) entfallen.

Es wiegen 100 Halme $598 \mathrm{gr}$ und davon die Früchte $249 \mathrm{gr}$.

In England wird dieser Roggen wegen seiner zeitigen und kräftigen Entwickelung vielfach als Grünfutter kultiviert, auch leidet derselbe wenig durch Rost.

\section{Champagner-Staudenroggen. (2)}

Syn.: Champagner-Hybrid, Vielstengliger Staudenroggen.

Aehrc: rötlich-blassgelb, locker, lang; Aehrchen $0.9 \mathrm{~cm}$ breit, 2 -körnig; Grannen hell, lang $(6 \mathrm{~cm})$. - Stroh: rötlich-rgelb, lang, Textur etwas locker. - Frucht: hellgrau oder hellbraun, gross, schmal $(91 / 2 \mathrm{~mm}$ lang, $3 \mathrm{~mm}$ breit, 265 Früchte $=10 \mathrm{gr}$ ), feinschalig.

Herbstblatt dunkelgrün, kräftig, aufrecht; Frïhjahrsvegetation zeitig, Bestockung mittelstark, 4.5 Schösslinge (bei $100 \mathrm{qcm}$ Raum 10.8 Schösslinge), zeitig schossend und blühend. Halmlänge $150 \mathrm{~cm}$ (Max. $180 \mathrm{~cm}$ ), Halmdicke $0.4 \mathrm{~cm}$, Blattzahl 5, Blattlänge $16.5 \mathrm{~cm}$, Blattbreite $0.8 \mathrm{~cm}$, Blattfläche $132 \mathrm{qcm}$, Halmfläche $180 \mathrm{qcm}$, Gesammtfläche $312 \mathrm{qcm}$.

Aehre reift mittelfrüh, $15 \mathrm{~cm}$ (Max. $22 \mathrm{~cm}$ ) lang, mit 40 Aehrchen und 74 Friichten, von denen 1934500 auf $1 \mathrm{hl}(=73 \mathrm{~kg})$ entfallen.

Auf $1 \mathrm{qm}$ wachsen 900 Halme oder 200 Pflanzen, mithin beträgt der Raum für eine Pflanze $50 \mathrm{qcm}$, die Blattfläche p. qm Bodenfläche $28 \mathrm{qm}$ und das Saatquantum $1.6 \mathrm{hl} \mathrm{p}$. ha.

Es wiegen 100 Halme $593 \mathrm{gr}$ und davon die Friichte $232 \mathrm{gr}$.

In Proskau wurden 1872 auf gutem Roggenboden p. ha erzielt: $1724 \mathrm{~kg}$ Korn, $4992 \mathrm{~kg}$ Stroh, $228 \mathrm{~kg}$ Spreu.

In Poppelsdorf erwies er sich als nicht ganz winterfest, neigte zum Lagern uud litt stark durch Rost.

Diese Roggensorte wird vielfach in den nördlichen Departements Frankreichs kultiviert.

\section{Schilfroggen. (2)}

Sjn.: Riesenstaudenroggen. Secale arundinaceum.

Franz. : Seigle roseau.

Aehre: gelb, dick, sehr dicht, kurz; Aehrchen 2- und 3-körnig, $0.9 \mathrm{~cm}$ breit; Grannen hell, $4-5 \mathrm{~cm}$ lang. - Stroh: gelb, rohrartig, sehr lang. - Frucht: gelblich-grün, etwas bauchig (9 mm lang, $31 / 2 \mathrm{~mm}$ breit), gross, grobschalig.

Herbstblatt kräftig, aufrecht, gelbgrün; Bestockung sehr stark, Halme dicker und härter als von anderen Sorten und bis $2 \mathrm{~m}$ hoch, auch nach dem Schossen zeigen die Blätter eine hellgrüne Farbe.

Aehre reift zeitig, bis $15 \mathrm{~cm}$ lang, mit 90 Früchten, die tief in den 
Spelzen stecken und sich fest an die Spindel anpressen. Es wiegt $1 \mathrm{hl}$ $=75.5 \mathrm{~kg}$.

In Proskau brachte er 1871 auf reichem Boden $2136 \mathrm{~kg}$ Korn und $6424 \mathrm{~kg}$ Stroh p. ha.

F. W. von Tra utyetter empfahl in einer Broschüre, „Der Schilfroggen" (Secale arundinaceum) Dresden und Leipzig 1840 diese Roggensorte, welche er 1830 erhalten hatte, doch führt er seine Bezugsquelle nicht an.

Bei früher Aussaat auf reichen, namentlich auf humusreichen Alluvialböden bringt er hohe Griinfuttererträge.

\section{Seigle des Alpes ou de Iontagne. (2)}

Sy ll.: Montagner- oder Alpen-Roggen.

Verbesserte Form: Montagner regenerierter Roggen.

Aehre: graulich-gelb, voll, ziemlich lang; Aehrchen $1 \mathrm{~cm}$ breit, 2-körnig; Grannen hell, bis $6 \mathrm{~cm}$ lang. - Stroh: gelb, fest, feinhalmig, ziemlich kurz. - Frucht: grünlich-gelb, dick ( $8 \mathrm{~mm}$ lang, $31 \frac{1}{2} \mathrm{~mm}$ breit), feinschalig.

Herbstblatt blaugrüu, aufrecht; Frühjahrsvegetation zeitig.

Diese Sorte ist in Deutschland, namentlich in Böhmen vielfach angebaut und verbessert worden und wird als „Montagner regenerierter Roggen" empfohlen.

Die Originalsorte verhält sich nun zu der verbesserten wie folgt:

\begin{tabular}{l|l|l}
\hline \hline Regeneriert \\
\hline
\end{tabular}

Halmlänge

Halmulicke

Blattzahl

Blattlänge

Blattbreite

Blattfläche

Halmfläche

Gesammtflächc

Aehrenlänge

Anzahl der Früchte in einer Aehre

Hektolitergewicht

Anzahl der Früchte in $1 \mathrm{hl}$

$\begin{array}{ll}" & \quad \text { Schössling c } \\ \text { " } & \text { Halme p. qm } \\ \text { Saatquantum p. ha } & \text { Pflanzen qm }\end{array}$

$130 \mathrm{~cm}(\operatorname{Max} .150 \mathrm{~cm}) 145 \mathrm{~cm}($ Max. $170 \mathrm{~cm})$ $0.38 \mathrm{~cm}$

4.4

$14.8 \mathrm{~cm}$

$0.9 \mathrm{~cm}$

$116.16 \mathrm{qcm}$

$148.20 \mathrm{qcm}$

$26436 \mathrm{qcm}$

$13 \mathrm{~cm}$ (Max. $18 \mathrm{~cm}$ )

65

$70.83 \mathrm{~kg}$

2069000

5 (Max. 9.2)

1100

220

$1.6 \mathrm{hl}$
$0.4 \mathrm{~cm}$

\section{5}

$18.2 \mathrm{~cm}$

$0.77 \mathrm{~cm}$

$301.4 \mathrm{qcm}$

$174.0 \mathrm{qcm}$

$475.4 \mathrm{qcm}$

$15 \mathrm{~cm}$ (Max. $20 \mathrm{~cm}$ )

88

$75.3 \mathrm{~kg}$

2161111

6.2

620

100

$0.7 \mathrm{hl}$

Es wiegen 100 Halme des regenerierten Roggens $622 \mathrm{gr}$ und daron die Früchte $258 \mathrm{gr}$.

Die ursprüngliche Heimat des Alpen-Roggens liegt in den Gebirgsländern des südwestlichen Europas und namentlich ist derselbe in der Dauphiné sehr geschätzt.

Er eignet sich für die leichteren Böden der rauhen Gebirgslagen vortrefflich, denn er zeigt sich gegen ungünstige Witterungsverhältnisse und Rost unempfindlich, lagert nicht leicht, reift ziemlich zeitig und die 
Friichte werden von den Spelzen noch in der Vollreife fest umschlossen, so dass der Wind oder eine verzögerte Ernte erhebliche Verluste durch Fruchtausfall nicht herbeiführen.

Der regenerierte Roggen hat sich diese guten Eigenschaften grösstenteils erhalten, doch beansprucht er reichere Böden, wenn er nicht wieder degenerieren soll.

\section{Spanischer Doppel-Roggen. (2)}

Syn.: Franz.: Seigle d'Espagne double, ou d'hiver de Saxe.

Aehre: blassgelb, locker, lang; Aehrchen $0.8 \mathrm{~cm}$ breit, 2-körnig, kurz begranut, Grannen hell, 4-5 cm lang. - Stroh: graugelb, kräftig, lang. - Frucht: Original hell- bis dunkelbraun, gross (9 $\mathrm{mm}$ lang, $3 \mathrm{~mm}$ hreit, 366 Friuchte $=10 \mathrm{gr}$ ); nachgebaut: grösser, 260 Früchte $=10 \mathrm{gr}$, mehlreich, schwer, ziemlich feinschalig.

Herbstblatt blaugrün, kräftig, kraus; Frühjahrsvegetation zeitig, Bestockung mittelstark, 4.5 Schösslinge (und bei $100 \mathrm{qcm}$ Raum 10.6 Schösslinge), zeitig schossend und in der zweiten Hälfte des Mai bliihend. Halmlänge $165 \mathrm{~cm}$ (Max. $180 \mathrm{~cm}$ ), Halmdicke $0.45 \mathrm{~cm}$, Blattzahl 4.4, Blattlänge $18 \mathrm{~cm}$, Blattbreite $0.92 \mathrm{~cm}$, Blattoberfläche $145.73 \mathrm{~cm}$, Halmfläche $222.75 \mathrm{qcm}$, Gesammtfläche $368.48 \mathrm{qcm}$.

Junge Aehre blangriin, zeitig reifend, $14 \mathrm{~cm}$ (Max. $21 \mathrm{~cm}$ ) lang, mit 31 Aehrchen und 60 in der Vollreife leicht ausfallenden Friichten, von denen $1 \mathrm{hl}$ (=76.3 kg) 2208900 Frïchte enthält.

Auf $1 \mathrm{qm}$ wachsen 800 Halme oder 177 Pflanzen, mithin beträgt der Rauın fürr eine Pflanze 56.5 qcm, die Blattoberfläche p. qm Bodenfläche $29.5 \mathrm{qm}$ und das Saatquantum $1.2 \mathrm{hl}$.

Es wiegen 100 Halme $900 \mathrm{gr}$ und davon die Friichte $400 \mathrm{gr}$.

Auf den in guter Kultur befindlichen Lehmböden, den humusreichen Sandböden und den reichen Moorböden lassen sich von ihm, da er nicht leicht lagert, hohe Erträge erzielen, und selbst anf den leichteren Sandböden befriedigen seine Erträge, wenngleich auf diesen Böden nach einigen Jahren Degeneration eintritt, sobald nicht für frisches Saatgut gesorgt wird.

Dieser vollkommen winterfeste, prachtvolle Roggen ist leider gegelı Rost nicht ganz widerstandsfähig.

Nach sicheren Ernteangaben stellen sich seine Erträge wie folgt:

1) Eldenaer Kulturverein 1868, sandiger Lehm

1) " " " lehmiger Sand

1) Proskauer-Versuchsfeld 1869, sandiger Lehm

\begin{tabular}{ccc}
\multicolumn{4}{c}{ Ertrüge per ha an } \\
$\begin{array}{c}\text { Korn } \\
\text { kg }\end{array}$ & $\begin{array}{c}\text { Stroh } \\
\text { kg }\end{array}$ & $\begin{array}{c}\text { Spreu } \\
\text { kg }\end{array}$ \\
2075 & 4602 & 257 \\
1841 & 4836 & 108 \\
2496 & 5280 & - \\
1400 & 3622 & - \\
1979 & 4957 & -
\end{tabular}

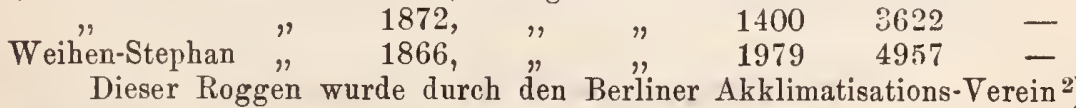
1861 aus Spanien bezogen und später durch die Samenhandlung von Wilh. Werner \& Co, in Berlin in Deutschland weiter verbreitet.

1) Anbauversuche des Verfassers.

2) Zeitschr. f. Akklimat. 1866, p. 180. 


\section{Roggen ans Evora, Portugal. (2) und $\odot$}

Aehre: gelb, schmal, sehr lang ; Aehrchen $0.8 \mathrm{~cm}$ breit, 2-körnig; Grannen hell, $4-5 \mathrm{~cm}$ lang. - Stroh: gelb, fest, kräftig, lang. Frucht: Original hell, sehr oft gelbrötlich, weizenfarbig, lang, schmal (9 $\mathrm{mm}$ lang, $3 \frac{1}{2} \mathrm{~mm}$ breit), feinschalig; nachgebaut: in 1. Tracht kurz, dick, braun ( $8 \mathrm{~mm}$ lang, $3 \mathrm{~mm}$ breit), etwas grobschalig.

Herbstblatt gelbgrïn, kräftig, Frühjahrsvegetation sehr zeitig, Bestockung stark, auffallend zeitig schossend, was seine Natur als Sommerroggen bekundet, zumal derselbe ausserordentlich empfindlich ist, demzufolge als Sommerroggen gebaut, erwies er sich als solcher. Blite und Reife treten sehr zeitig ein, Anfang Juli reift der Winterroggen und in 130 Tagen der Sommerroggen.

\begin{tabular}{|c|c|c|}
\hline & Winterroggen & Sommerroggen \\
\hline $\begin{array}{l}\text { Halmlänge } \\
\text { Halmdicke } \\
\text { Blattzahl } \\
\text { Blattlänge } \\
\text { Blattbreite } \\
\text { Blattfläche } \\
\text { Halmfläche } \\
\text { Gesammtfläche } \\
\text { Aehrenlänge } \\
\text { Anzahl der Früchte in einer Aehre } \\
\text { Hektolitergewicht der Früchte } \\
\text { Anzahl der Früchte p. hl } \\
\text { 100 Halme wiegen } \\
\text { Darin die Früchte } \\
\text { Anzahl der Schösslinge }\end{array}$ & $\begin{array}{c}147 \mathrm{~cm}(\text { Max. } 200 \mathrm{~cm}) \\
0.4 \mathrm{~cm} \\
3 \\
18 \mathrm{~cm} \\
0.85 \mathrm{~cm} \\
91.80 \mathrm{qcm} \\
184.80 \mathrm{qcm} \\
276.60 \mathrm{qcm} \\
14 \mathrm{~cm}(1 \mathrm{Max} .19 \mathrm{~cm}) \\
80 \\
79.3 \mathrm{~kg} \\
2537600 \\
568 \mathrm{gr} \\
199 \mathrm{gr} \\
5\end{array}$ & \begin{tabular}{|c|c}
$145 \mathrm{~cm}($ Max. $185 \mathrm{~cm})$ \\
$0.28 \mathrm{~cm}$ \\
3.5 \\
$16.8 \mathrm{~cm}$ \\
$0.7 \mathrm{~cm}$ \\
$82.32 \mathrm{qcm}$ \\
$121.80 \mathrm{qcm}$ \\
$204.12 \mathrm{qcm}$ \\
$10 \mathrm{~cm}(\mathrm{Max} .15 \mathrm{~cm})$ \\
55 \\
$77.2 \mathrm{~kg}$ \\
2856400 \\
$381 \mathrm{gr}$ \\
$162 \mathrm{gr}$ \\
3.4
\end{tabular} \\
\hline
\end{tabular}

\section{Sẻgol, Vich (Cataluña).}

Aehre: schmutzig-blassgelb, halbhängend, kurz, $7 \mathrm{~cm}$ (Max. $10 \mathrm{~cm}$ ) lang, mit 40 Früchten; Grannen $4-5 \mathrm{~cm}$ lang. - Stroh: rotgelb bis rotgrau, sehr feinhalmig, doch fest. - Frucht: hellbraun oder graublau, lang $\left(9^{1 / 2} \mathrm{~mm}\right.$ lang, $21 \% 2 \mathrm{~mm}$ breit, 302 Früchte $\left.=10 \mathrm{gr}\right)$; nachgebaut: 296 Früchte $=10 \mathrm{gr}$.

Junges Blatt dunkelgrün, schmal, lang, aufrecht, sammetig, 1.2 Schösslinge; Halm $100 \mathrm{~cm}$ (Max. $130 \mathrm{~cm}$ ) lang, $0.3 \mathrm{~cm}$ dic̉k, Blattzahl 4, Blätter $11 \mathrm{~cm}$ lang, $0.5 \mathrm{~cm}$ breit, Blattfläche $44 \mathrm{qcm}$, Halmfläche $90 \mathrm{~cm}$, Gesammtfläche $134 \mathrm{qcm}$.

Bezugsquelle: Antonio Cipriano Costa, Barcelona 1881.

\section{Sommerroggen ans Minho (Portugal). $\odot$}

Aehre: rötlich-gelb, aufrecht, Spelzen lang, Aehre $6 \mathrm{~cm}$ (Max. $9 \mathrm{~cm}$ ) lang, mit 30 Früchten; Grannen etwas gespreizt, $4-5 \mathrm{~cm}$ lang, - Stroh: rötlich-gelb oder rotgrau, sehr feinhalmig, doch fest, kurz. - Frucht: hellbraun, lang, sehr schön, gross $\left(10^{1 / 2} \mathrm{~mm}\right.$ lang, $3 \mathrm{~mm}$ breit, 224 Früchte $=10 \mathrm{gr}$ ), sehr feinschalig. 
Junges Blatt aufrecht, schmal, lang, dunkelgrün, sammetig, 1.2 Schösslinge; Halm $105 \mathrm{~cm}$ (Max. $115 \mathrm{~cm}$ ) lang, $0.25 \mathrm{~cm}$ dick, Blattzahl 4.2, Blätter $11 \mathrm{~cm}$ lang, $0.44 \mathrm{~cm}$ breit, Blattfläche $40.7 \mathrm{qcm}$, Halmfläche $78.8 \mathrm{qcm}$, Gesanmtfläche $119.5 \mathrm{qcm}$.

\section{Centeio barazzo. $\odot$}

Syn.: Sommerrogen aus Portugal.

Aehre: fast weiss, dünn, ziemlich dicht, mittellang; Aehrchen $1.2 \mathrm{~cm}$ breit, 2-körnig, Granuen grauweiss, bis $4 \mathrm{~cm}$ lang. - Stroh: gelb, dünnhalmig, fest. - Frucht: heller, als bei den übrigen gebauten Sommerroggen, gross $(10 \mathrm{~mm}$ lang, $3 \mathrm{~mm}$ breit, 257 Früchte $=10 \mathrm{gr})$, feinschalig.

Halme blaugrün, 2 Schösslinge, mittelfrüh schossend und blühend. Halmlänge $120 \mathrm{~cm}$ (Max. $160 \mathrm{~cm}$ ), Halmdicke $0.27 \mathrm{~cm}$, Blattzahl 4, Blattlänge $14.24 \mathrm{~cm}$, Blattbreite $0.63 \mathrm{~cm}$, Blattfläche $71.76 \mathrm{qcm}$, Halmfläche $97.2 \mathrm{qcm}$, Gesammtfläche $168.96 \mathrm{qcm}$.

Aebre in 120 Tagen reifend, $8 \mathrm{~cm}$ (Max. $13 \mathrm{~cm}$ ) lang, mit 40 ziemlich fest sitzenden Frïchten, von denen 2030300 auf $1 \mathrm{hl}(=79 \mathrm{~kg})$ entfallen.

Es wiegen 100 Halme $176 \mathrm{gr}$ und davon die Früchte $124 \mathrm{gr}$.

Diese Sorte ist ertragreich und sehr beachtenswert. Sie lagert nicht leicht, befällt aber stark mit Rost.

\section{Römischer Roggen. (2)}

Franz.: Seigle de Rome, ou à gros grains.

Aehre: schmutzig-blassgelb, voll, sehr breit, lang; Aehrchen $1 \mathrm{~cm}$ breit, 2-körnig; Grannen hell, $4-5 \mathrm{~cm}$ lang. - Stroh: graugelb, fest, lang. - Frucht: gelbgrau, dick ( $7 \mathrm{~mm}$ lang, $31 / 4-4 \mathrm{~mm}$ breit), schwer, feinschalig.

Herbstblatt blaugrün. kräftig, ziemlich breit, aufrecht: Frühjahrsvegetation zeitig, Bestockung mittelstark, 4.5 Schösslinge (bei $100 \mathrm{qcm}$ Raum 13.6 Schösslinge), zeitig schossend, Mitte Mai blühend. Halmlänge $170 \mathrm{~cm}$ (Max. $190 \mathrm{~cm}$ ), Halmdicke $0.4 \mathrm{~cm}$, Blattzahl 4.8, Blattlänge $21.5 \mathrm{~cm}$, Blattbreite $0.9 \mathrm{~cm}$, Blattfläche $185.76 \mathrm{qcm}$, Halmfläche $204 \mathrm{qcm}$, Gesammtfläche $389.76 \mathrm{qcm}$.

Aehre rcift etwas ungleich, Mitte Juli; $14 \mathrm{~cm}$ (Max. $17 \mathrm{~cm}$ ) lang, mit 65 ziemlich fest sitzenden Früchten, von denen 1617000 auf 1 hl $(=77 \mathrm{~kg})$ entfallen.

Es wachsen auf $1 \mathrm{qm} 800$ Halme oder 177 Pflanzen, mithin beträgt der Raum für eine Pflanze $56.5 \mathrm{qcm}$, die Blattfläche p. qm Bodenfläche $31.18 \mathrm{qm}$ und das Saatquantum $1.64 \mathrm{hl}$.

Es wiegen 100 Halme $780 \mathrm{gr}$ und davon die Früchte $335 \mathrm{gr}$.

Diese Roggensorte ist sehr genügsam, da sie selbst noch auf leichterem Sandboden verhältnismässig hohe Erträge bringt, die sich entsprechend auf den schwereren Böden steigern.

Das selir starkhalmige Stroh lagert selten, doch ist der Roggen gegen Rost nicht besonders widerstandsfähig.

Diesen Roggen führte nach Heuzél) M. d'Oncien de Chaffor-

1) Plant. aliment. p. 410. 
don nach Frankreich ein, wo ihn M. Trochu zu Belle-Isle-en Mer weiter verbreitete. Auch soll er sich in Frankreich als Sommerroggen kultivieren lassen, doch erwies er sich in Poppelsdorf, obwohl einige Halme schossten, als echter Winterroggen.

\section{Roggen aus Italien. (2)}

Aehre: blassgelb, lang, breit, etwas locker, voll; Aehrchen 2-kör. nig. - Stroh: gelb, feinhalmig, mittellang. - Frucht: gelblich-grïn, sehr hell, gross (9 $\mathrm{mm}$ lang, $3 \frac{1}{2} \mathrm{~mm}$ breit, 281 Früchte $=10 \mathrm{gr}$ ), etwas grobschalig.

Herbstblatt ziemlich kräftig, Frühjahrsvegetation sehr zeitig, Bestockung mittelstark, 3.2 Schösslinge, sehr zeitig schossend und blïhend. Halmlänge $115 \mathrm{~cm}$ ( Мax. $142 \mathrm{~cm}$ ), Halmdicke $0.31 \mathrm{~cm}$, Blattzahl 3, Blattlänge $20.7 \mathrm{~cm}$, Blattbreite $0.7 \mathrm{~cm}$, Blattfläche $86.94 \mathrm{qcm}$, Halmfläche $111.55 \mathrm{qcm}$, Gesammtfäche $198.49 \mathrm{qcm}$.

Aehre reift sehr zeitig (16/7.77, 5/7. 78), $12 \mathrm{~cm}$ (Max. $20 \mathrm{~cm}$ ) lang, mit 65 fest sitzenden Früchten, von denen 2107500 auf $1 \mathrm{hl}$ $(=75 \mathrm{~kg})$ entfallen.

Es wiegen 100 Halme $516 \mathrm{gr}$ und davon die Früchte $211 \mathrm{gr}$.

Im Friihjahr gesäet, erwies er sich als echter Winterroggen. Leidet wenig durch Lagern, doch stark durch Rost.

Wahrscheinlich ist dies eine ursprünglich alpine Sorte, welche in Nord-Italien zum Anbau gelangt ist.

\section{Sommer-Staudenroggen aus Palermo. $\odot$}

Aehre: blassgelb, dünn, lang, etwas locker; Aehrchen $0.9 \mathrm{~cm}$ breit, 2-körnig, Grannen $4-5 \mathrm{~cm}$ lang. - Stroh: graulich-gelb, feinhalmig, fest, ziemlich lang. - Frucht: silbergrau und hellbraun, sehr lang $(10 \mathrm{~mm}$ lang, $3 \mathrm{~mm}$ breit, 342 Früchte $=10 \mathrm{gr}$ ), sehr schwer, feinschalig.

Junges Blatt gelbgrün, schmal, kraus; 2 Schösslinge, zeitig blühend. Halmlänge $135 \mathrm{~cm}$ (Max. $165 \mathrm{~cm}$ ), Halmdicke $0.27 \mathrm{~cm}$, Blattzahl 3.5, Blattlänge $15.8 \mathrm{~cm}$, Blattbreite $0.7 \mathrm{~cm}$, Blattfläche $77.42 \mathrm{qcm}$, Halmfläche $109.35 \mathrm{qcm}$, Gesammtfläche $186.77 \mathrm{qcm}$.

Aehre reift in 120 Tagen, $10 \mathrm{~cm}$ (Max. $15 \mathrm{~cm}$ ) lang, mit 40 Früchten, von denen 2736000 auf $1 \mathrm{hl}(=80 \mathrm{~kg})$ entfallen.

Es wiegen 100 Halme $300 \mathrm{gr}$ und davon die Früchte $109 \mathrm{gr}$.

Dieser Roggen leidet stark durch Rost.

\section{Roggen aus der Türkei. (2)}

Aehre: blassrötlich-gelb, dünn, lang; Aehrchen $0.7 \mathrm{~cm}$ breit, 2-körnig; Grannen hell, 4-5 cm lang. - Stroh: graugelb, kräftig, lang. - Frucht: graubraun, lang (9 $\mathrm{mm}$ lang, $3 \mathrm{~mm}$ breit, 332 Früchte $=10 \mathrm{gr}$ ), feilschalig.

Herbstblatt blaugrün, kräftig, kraus; Frühjahrsvegetation zeitig, Bestockung mittelstark, 4.8 Schösslinge, zeitig schossend und blïhend.

Halmlänge $170 \mathrm{~cm}$ (Max. $190 \mathrm{~cm}$ ), Halmdicke $0.4 \mathrm{~cm}$, Blattzahl 5.4, Blattlänge $21.6 \mathrm{~cm}$, Blattbreite $0.83 \mathrm{~cm}$, Blattfläche $193.64 \mathrm{qcm}$, Halmfläche $204 \mathrm{qcm}$, Gesammttläche $397.64 \mathrm{qcm}$. 
Aehre reift zeitig, erste Hälfte des Juli, $14 \mathrm{~cm}$ (Max. $18 \mathrm{~cm}$ ) lang, mit 80 Früchten, von denen 2357200 auf $1 \mathrm{hl}(=71 \mathrm{~kg})$ entfallen.

Es wiegen 100 Halme $545 \mathrm{gr}$ und davon die Friichte $203 \mathrm{gr}$.

Diese Roggensorte lagert nicht leicht und leidet wenig durch Rost.

\section{Roggen aus Erzerum, Klein-Asien. (2)}

Aehre: blassgelb, dünn, sehr locker, lang; Aehrehen $0.8 \mathrm{~cm}$ breit; Grannen hell, 4-5 cm lang. - Stroh: graulich-gelb, fest, mittellang. Frucht: hellgraublau, etwas plump $\left(10 \mathrm{~mm}\right.$ lang, $3 \frac{1}{2} \mathrm{~mm}$ breit, 363 Friichte $=10 \mathrm{gr}$ ), leicht, feinschalig.

Herbstblatt blaugruin, fein, weizenähnlich; Frühjahrsvegetation etwas spät, Bestockung sehr stark, 7 Schösslinge, spät schossend und blühend. Halmlänge $128 \mathrm{~cm}$ (Max. $140 \mathrm{~cm}$ ), Halmdicke $0.35 \mathrm{~cm}$, Blattzahl 4, Blattlänge $22.25 \mathrm{~cm}$, Blattbreite $0.77 \mathrm{~cm}$, Blattfäche 137.04 qcm, Hahmfläche $140.8 \mathrm{qcm}$, Gesammtfäche $277.84 \mathrm{qcm}$.

Aehre etwas spät, in der 2. Hälfte des Juli reifend, $14 \mathrm{~cm}$ (Max. $18 \mathrm{~cm}$ ) lang, init 60 fest sitzenden Früchten, ron denen 2577300 auf $1 \mathrm{hl}(=71 \mathrm{~kg}$ ) entfallen.

Es wiegen 100 Halme $555 \mathrm{gr}$ und davon die Friichte $241 \mathrm{gr}$.

Diese beachtenswerte Roggensorte lagert nicht leicht und leidet wenig durch Rost.

\section{Schwedischer Stauden-Roggen. (2)}

Aehre: blassgelb, fast weiss, dicht, voll, schön, lang; Aelırchen $0.8 \mathrm{~cm}$ breit, 2-körnig; Grannen hell, 4-5 cm lang. - Stroh: graugelb, fest, lang. - Frucht: braungrau, gross, schön ( $81 / 2$ mm lang, $3 \mathrm{~mm}$ breit, 312.5 Früchte $=10 \mathrm{gr}$ ), schwer, feinschalig.

Herbstblatt blaugriin, kraus; Friihjahrsvegetation spät, sich im Allgemeinen wie Johannis-Roggen verhaltend, Bestockung stark, 5 (bci 100 qcm 14) Schösslinge, mittelfrïh schossend und bluihend. Halmlänge $144 \mathrm{~cm}$ (Max. $165 \mathrm{~cm}$ ), Halmdicke $0.38 \mathrm{~cm}$, Blattzahl 4, Blattlänge $18.5 \mathrm{~cm}$, Blattbreite $0.92 \mathrm{~cm}$, Blattfläche $136.16 \mathrm{qcm}$, Halmfläche $171.98 \mathrm{qcm}$, Gesammtfläche 308.14 qcin.

Aehre reift mittelfrüh, $14 \mathrm{~cm}$ (Max. $17 \mathrm{~cm}$ ) lang, mit 80 etwas leicht ausfallenden Früchten, von denen 2406250 auf $1 \mathrm{hl}(=77 \mathrm{~kg}$ ) entfallen.

Es wachsen auf 1 qm 1000 Halme, oder 200 Pflanzen, mithin beträgt der Raum für eine Pflanze $50 \mathrm{q} \mathrm{cm}$, die Blattoberfläche $\mathrm{p}$. qm Bodellfläche $30.8 \mathrm{qm}$ und das Saatquantum $1.2 \mathrm{hl} \mathrm{p}$. ha.

Es wiegen 100 Halme $703 \mathrm{gr}$ und davon die Früchte $262 \mathrm{gr}$.

Diese Roggensorte ist vollkommen winterfest, lagert nicht leicht, wird wenig durch Rost angegriffen und bringt auf den besseren Roggenbüden, selbst im rauhen Klima, hohe Korn- und Stroherträgc.

\section{Roggren aus Umei, Schweden. (2)}

Aehre: gelb, schmal, lang; Aehrchen $0.9 \mathrm{~cm}$ breit, 2-köruig, Grannen $4-5 \mathrm{~cm}$ lang. - Stroh: rötlich-gelb, fest, lang. - Frucht: braun, klein, dick ( $8 \mathrm{~mm}$ lang, $3 \mathrm{~mm}$ breit, 359 Fruchte $=10 \mathrm{gr}$ ), etwas grobschalig.

Herbstblatt blaugriin, schmal, kraus; Frïhahrsvegetation spät, Blatt schmal, Bestockung mittelstark, 4.5 Schösslinge (bei 100 qcm Raum 12 
Schösslinge), mittel(rüh schossend und blühend (20/5. 78), zeitig $11 /$ 万. 78 (gleichzeitig mit Roggen aus Italien) reifend. Dies Verhalten entspricht vollkommen dem nordischen Getreide, welches erst spät in Vegetation und Blüte tritt, dann aber in der Reife nicht selten südliche Sorten überholt, in dieser Beziehung stimm' sein Terhalten mit den alpinen Roggen ïberein, nur dass bei ihm die Periode $\mathrm{z}$ wischen Blüte und Reife kürzer ist.

Halmlänge $140 \mathrm{~cm}$ (Max. $167 \mathrm{~cm}$ ), Halmdicke $0.36 \mathrm{~cm}$, Blattzahl 4, Blattlänge $20.6 \mathrm{~cm}$, Blattbreite $0.87 \mathrm{~cm}$, Blattfläche $143.36 \mathrm{qcm}$, Halmfäche 151.2 qcm, Gesammtfläche $294.56 \mathrm{qcm}$.

Aehre $15 \mathrm{~cm}$ (Max. $20 \mathrm{~cm}$ ) lang, mit 75 ziemlich leicht ausfallenden Früchten, von denen 2699680 Früchte auf $1 \mathrm{hl}(=75.2 \mathrm{~kg})$ entfallen.

Es wiegen 100 Halme $618 \mathrm{gr}$ und davon die Früchte $249 \mathrm{gr}$.

Diese Sorte lagert nicht leiclit, leidet jedoch durch Rost.

\section{Schwedischer Roggen. (2)}

Syn.: Schneeroggen.

Aehre: rötlich-gelb, voll, dünn, verhältnismässig kurz; Aehrchen $0.8 \mathrm{~cm}$ breit, 2-körnig, Grannen hell, 4-5 cm lang. -- Stroh: schön, rötlich-gelb, sehr fest, feinhalmig, sehr lang. - Frucht: Original hellbräunlich, klein (6 $\mathrm{mm}$ lang, $1 \frac{1}{2} \mathrm{~mm}$ breit); nachgebaut: in 4. Tracht grösser und schöner geworden, doch immerhin noch sehr schmal $(9 \mathrm{~cm}$ lang, $21 / 2 \mathrm{~mm}$ breit, 310 Früchte $=10 \mathrm{gr}$ ), etwas leicht, ziemlich feinschalig.

Herbstblatt blaugrün, schmal, krans; Frühjahrsvegetation sehr spät, Bestockung schwach, 3 Schösslinge, sehr spät schossend, Ende Mai blühend. Halmlänge $152 \mathrm{~cm}$ (Max. $210 \mathrm{~cm}$ ), Halmdicke $0.3 \mathrm{~cm}$, Blattzahl 4.7 , Blattlänge $19.7 \mathrm{~cm}$, Blattbreite $0.7 \mathrm{~cm}$, Blattfäche $129.62 \mathrm{qcm}$, Halmfläche $143.31 \mathrm{qcm}$. Gesammtfläche $272.93 \mathrm{qcm}$.

Aehre spät reifend, $11 \mathrm{~cm}$ (Max. $17 \mathrm{~cm}$ ) lang, mit 40 Aehrchen und 75 ziemlich lose sitzenden Früchten, ron denen 2263000 auf $1 \mathrm{hl}$ $(=73 \mathrm{~kg})$ entfallen.

Es wiegen 100 Halme $798 \mathrm{gr}$ und davon die Früchte $27 \mathrm{ggr}$.

Dieser Roggen ist durchaus winterfest, leidet wenig durch Lagern und Rost, und eignet sich zum Anbau für nördliche Gegendell oder sehr rauhe Lagen vortrefflich und verträgt namentlich noch eine sehr späte Aussaat im December, weshalb ihm der Name „Schneeroggen " mit Recht zukommt.

Im nilden Klima und auf gutem Boden gewinnt er beträchtlich an Quantität und Qualität des Ertrages.

L. Wittmack erhielt ihn durch Paul Andersson in Oestersuud $\left(63^{0} 10^{\prime} 58^{\prime \prime}\right.$ nördl. Br.), Jemtlands-Län, Schweden, und sandte ihn 1875 nach Poppelsdorf.

\section{Schwedischer Sandroggen. (2)}

Aehre: blassgelb, schmal, dicht, rollkörnig, lang; Aehrchen $0.3 \mathrm{~cm}$ breit, 2-körnig; Grannen 4-5 cm lang. - Stroh: gelb, fest, ziemlicb feinhalmig, lang. - Frucht: hellbraun, ziemlich kurz ( $7 \mathrm{~mm}$ lang, $21 / 2 \mathrm{~mm}$ breit, 471 Früchte $=10 \mathrm{gr}$ ), etwas grobschalig; nachgebaut: nur 280 Früchte $=10 \mathrm{gr}$.

Herbstblatt blaugrün, kräftig; Bestockung sehr stark, 6 Schösslinge; 
Frühjahrsvegetation spät, spät schossend und blühend (11/b. 79). Halm $150 \mathrm{~cm}$ (Мax. $175 \mathrm{~cm}$ ) lang, $0.38 \mathrm{~cm}$ dick, Blattzahl 4, Blätter $19.3 \mathrm{~cm}$ lang, $0.85 \mathrm{~cm}$ dick, Blattfläche $164.05 \mathrm{qcm}$, Halmfläche $171 \mathrm{qcm}$, Gesammt甘läche $335.05 \mathrm{qcm}$.

A ehre reift spät, $13 \mathrm{~cm}$ (Мax. $16 \mathrm{~cm}$ ) lang, mit 70 nicht leicht ausfallenden Früchten, von denen 3687930 auf $1 \mathrm{hl}(=78.3 \mathrm{~kg})$ entfallen.

Es wiegen 100 Halme $569 \mathrm{gr}$ und davon die Früchte $248 \mathrm{gr}$.

Dieser durchaus winterfeste Roggen eignet sich für rauhe Lagen und geringe Böden.

Bezngsquelle: Haage \& Schmidt, Erfurt.

\section{Alands-Roggen. (2)}

Aehre: blassgelb, schlaff, schön, etwas locker, lang; Grannen bis $6 \mathrm{~cm}$ lang. - Stroh: gelbgrau bis violett, sehr fest, mittellang. - Frucht: hellbraun, schmal (9 $\mathrm{mm}$ lang, $2 \frac{1}{2} \mathrm{~mm}$ dick, 410 Früchte $=10 \mathrm{gr}$ ), feinschalig.

Herbstblatt blaugrün, kurz, stark sammetig, Vegetation spät, 4 Schösslinge, spät schossend und blühend, zeitig reifend; Halm $120 \mathrm{~cm}$ (Max. $145 \mathrm{~cm}$ ) laug, $0.45 \mathrm{~cm}$ dick, Blattzahl 4.8 , Blätter $16.5 \mathrm{~cm}$ lang, $1 \mathrm{~cm}$ breit, Blattfläche $158.4 \mathrm{Gcm}$, Halmfläche $162 \mathrm{qcm}$. Gesammtfläche $320.4 \mathrm{qcm}$.

Aehre $13 \mathrm{~cm}$ (Max. $18 \mathrm{~cm}$ ) lang, mit 80 Früchtel, von denen $1 \mathrm{hl}$ $=78 \mathrm{~kg}$ wiegt.

Winterfest. Für einen guten Roggenboden im rauhen Klima sehr geeignet.

Original durch Pfarrer Molin volı der Alands-Insel Eckero̊ erhalten.

Ein Alands-Roggen von der Firma Ernst Bahlsen in Prag bezogen, zeigte sich in seinen Wachstumsverhältnissen nicht als nordischer Roggen, weshalb wir zur Prüfung direkt von den Alands-Inseln Roggen bezogen.

Der Roggen von E. Bahlsen bat ein hellgrïnes, aufrechtes, kräftiges Blatt und entwickelt sich sehr zeitig und stimmt in dieser Beziehung mit dem italienischen Roggen überein, während der von uns bezogene Originalroggen vollkommen die Eigenschaften nordischen Getreides besitzt.

\section{Winterroggen aus Norwegen. (3)}

A ehre: gräulich-gelb, schmal, lang; Aehrchen $0.7 \mathrm{~cm}$ breit, 2-körnig; Grannen heil, 4-5 cm lang. - Stroh: rötlich-gelb, kräftig, fest, sehr lang. - Frucht: hellgrau bis graubraun, lang $\left(8^{1} / 2 \mathrm{~mm}\right.$ lang, $3 \mathrm{~mm}$ breit, 305 Frïchte $=10 \mathrm{gr}$ ), feinschalig.

Herbstblatt blaugrïn, kraus; Frühjahrsvegetation spät, Bestockung stark, 6 Schösslinge, spät 15/5. 78 schossend, 30/5. 78 blïhend und mittelfruih 15/7. 78 reifend, hiermit zeigt er das Verhalten der nordischen Roggen.

Halmlänge $160 \mathrm{~cm}$ (Max. $200 \mathrm{~cm}$ ), Halmdicke $0.37 \mathrm{~cm}$, Blattzahl 4.5, Blattlänge $22 \mathrm{~cm}$, Blattbreite $0.78 \mathrm{~cm}$, Blattfläche $154.44 \mathrm{qcm}$, Halmfläche $177.60 \mathrm{qcm}$, Gesammtfläche $332.04 \mathrm{qcm}$.

Aehre $14 \mathrm{~cm}$ ( Мax. $18 \mathrm{~cm}$ ) lang, mit 90 Früchten, von denen 2348500 auf $1 \mathrm{hl}(=77 \mathrm{~kg})$ entfallen.

Auf $1 \mathrm{qm}$ wachseu 900 Halme oder 150 Pflanzen, mithin beträgt 
der Raum für eine Pflanze $66.6 \mathrm{qcm}$, die Blattläche p. qm Bodenfläche $30 \mathrm{qm}$ und das Saatquantum $1 \mathrm{hl}$ p. ha.

Es wiegen 100 Halme 591 gr und davon die Früchte 230 gr. tenswert.

Diese Roggensorte ist winterfest und für rauhe Lagen sehr beach-

\section{Astrachan'scher Roggen. (2)}

Syn.: Jerusalemer Roggen.

Aehre: rötlich-gelb, dünn, hängend, lang; Aehrchen 2-körnig; Grannen hell, 4-5 cm lang. - Stroh: rötlich-gelb, fest, im Mittel $140 \mathrm{~cm}$ (Max. über $200 \mathrm{~cm}$ ) lang. - Frucht: grünlich-gelb, von schlechtem Aussehen. Gervicht leicht, schmal (9 $\mathrm{mm}$ lang, $2 \frac{1}{2} \mathrm{~mm}$ breit).

Herbstblatt blaugriin, ziemlich lang, kraus, Bestockung stark und tritt vorzugsweise im Frühjahr ${ }^{1}$ ) ein; Friihjahrsvegetation spät, sie beginnt 14 Tage später als beim Probsteier Roggen, ebenso tritt die Bliite 8 Tage später ein, reift jedoch mit dem Probsteier gleichzeitig.

Die Erträge, namentlich an Stroh, sind auf kräftigem Boden reich.

In Eldena wurden erzielt nach einer Düngung und bei einer Aussaat ron $150 \mathrm{~kg}$ p. ha, rom

Jerusalemer . . . $2135 \mathrm{~kg}$ Korn, $5058 \mathrm{~kg}$ Stroh, $187 \mathrm{~kg}$ Spreu.

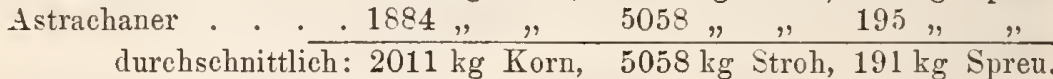

Durchschnitt vom Prob-

steier Roggen zum

Tergleich: . . . $2100 \mathrm{~kg}$ Korn, $46 \pi 2 \mathrm{~kg}$ Stroh, $193 \mathrm{~kg}$ Spreu.

Bei zeitiger Aussaat und kräftigem, gut kultiviertem Boden empfiehlt sich die Roggensorte, namentlich in stroharmen Wirtschaften, zun Anbau.

Das preussische Landes-Oekonomie-Collegium veranlasste $185 \mathrm{l}$ in Folge einer sehr giinstig lautenden Nitteilung durch den Kammerrat Kleinwäehter über den in der Umgegend von Oels in Schlesien gebauten Roggen die Anstellung von Versuchen an dell landwirthschaftlichen Lehranstalten.

\section{Podolischer Standenroggen. (2)}

Aehre: schnutzig-gelb, voll, schmal, lang; Aehrchen $0.9 \mathrm{~cm}$ breit, 2-körnig, doch zuweilen ein 3. Blütchen entwickelt; Grannen hell, 4-5 cm lang. - Stroh: rötlich-gelb, kräftig, mittellang. - Frucht: hellgraublau oder hellbraun, schön ( $8 \mathrm{~mm}$ lang, $3 \mathrm{~mm}$ breit, 315 Früchte $=10 \mathrm{gr}$ ), feinschalig.

Herbstblatt blaugrün, sehr kräftig, aufrecht; Frühjahrsvegetation etwas spät, mittelfrüh schossend und blühend. Halmlänge $135 \mathrm{~cm}$ (Max. $160 \mathrm{~cm})$, Halmdicke $0.4 \mathrm{~cm}$, Blattzahl 5, Blattlänge $19.6 \mathrm{~cm}$, Blattbreite $0.91 \mathrm{~cm}$, Blattfäche $178.40 \mathrm{qcm}$, Halmfläche $162 \mathrm{qcm}$, Gesammtfläche $340.40 \mathrm{qcm}$.

Aehre reift ziemlich zeitig in der 1. Hälfte des Juli, 15 cin (Max. $20 \mathrm{~cm})$ lang, mit 80 Früchten, von denen 2394000 auf $1 \mathrm{hl}(=76 \mathrm{~kg})$ entfallen.

1) Landw. Centralbl 1853, pg. 311 . 
Es wiegen 100 Halme 572 gr und davon die Früchte 232 gr.

Diese für rauhe Lagen sehr beachtenswerte Roggensorte lagert nicht leicht und ist winterfest, doch leidet sie etwas stark durch Rost.

Bezugsquelle: Oek.-botanischer Garten zu Halle, 1877.

\section{Kolossal-Roggen ron Azow. (2)}

Aehre: blassgelb, schlaff, lang; Granmen $6-7 \mathrm{~cm}$, also verhältnismässig lang. - Stroh: rötlich-gelb, lang, rohrartig. - Frucht: hell- bis dunkelbramn oder blaugrau, spitz, klein ( $7 \mathrm{~mm}$ lang, $2 \mathrm{~mm}$ breit, 413 Früchte $=10 \mathrm{gr})$, feinschalig.

Herbstblatt dunkelgrün, zeitig schossend und blühend, 4.5 Schösslinge; Halm $150 \mathrm{~cm}$ (Max. $180 \mathrm{~cm}$ ) lang, $0.45 \mathrm{~cm}$ dick, Blattzahl 4.6, Blätter $17.5 \mathrm{~cm}$ lang, $0.9 \mathrm{~cm}$ breit, Blattfläche 144.9 qem, Halmfläche 202.5 qem, Gesammtfläche $347.4 \mathrm{qcm}$.

Aehre $12 \mathrm{~cm}$ (Max. $16 \mathrm{~cm}$ ) lang, mit 80 Frïchtell.

Dieser Roggen wurde 1878 durch Gutsbesitzel* Ram bousek in Zborow bei Forbes nach Böhmen eingeführt.

Dieser Staudenroggen erwies sich als vollkommen winterfest und namentlich im Stroh ertragreich, während der Kornertrag und die Qualität der Körner zu wiinschen lassen, wie dies uberhaupt immer bei sehr kräftigen Staudenroggen der Fall ist.

Bezugsquelle: Zborow.

\section{Petersburger Roggen. (2)}

Aehre blassgelb, voll, dick, mittellang; Aeluchen $1 \mathrm{~cm}$ breit, 2-körnig; Grannen hell, 4-5 cm lang. - Stroh: gelb, sehr kräftig, lang. Frucht: graugelb, kurz, lick ( $8 \mathrm{~mm}$ lang, $3^{1 / 2} \mathrm{~mm}$ breit, 306 Früchte $=$ $10 \mathrm{gr}$ ), feinschalig.

Herbstblatt dunkelgrïn, breit, aufrecht; Frühjahrsvegetation ziemlich zeitig, Bestockung stark, 5 Schösslinge (bei 100 qem Raum 11.9 Schösslinge, also sehr stark), zeitig schossend und blïhend. Halmlänge $165 \mathrm{~cm}$ (Max. $200 \mathrm{~cm}$ ), Halmdicke $0.45 \mathrm{~cm}$, Blattzahl 4, Blattlänge $18.3 \mathrm{~cm}$, Blattbreite $0.9 \mathrm{~cm}$, Blattfläche $131.76 \mathrm{qcm}$, Halmfläche $222.75 \mathrm{qcm}$, Gesammtfläche $354.51 \mathrm{qcm}$.

Aehre reift mittelfrüh, $14 \mathrm{~cm}$ (Max. $17 \mathrm{~cm}$ ) lang, mit 70 Früchten, von denen 2203200 auf $1 \mathrm{hl}(=72 \mathrm{~kg})$ entfallen.

Auf 1 qm wachsen 800 Halme oder 160 Pflanzen, mithin beträgt der Raum für eine Pflanze $62.5 \mathrm{qcm}$, die Blattfläche p. qm Bodenfläche $28.4 \mathrm{qm}$ und das Saatquantum $1.1 \mathrm{hl} \mathrm{p}$. ha.

Dieser kräftige Staudenroggen wird vielfach auf reichem Boden in den russischen Ostseeprovinzen gebaut.

\section{Grosser russischer Roggen. (2)}

Sy n.: Kolossal-Roggen, Aulock'scher Staudenroggen.

Franz.: Seigle grand de Russie.

Aehre: hellgelb, etwas locker, lang; Aelirchen $0.9 \mathrm{~cm}$ breit, 2-körnig; Grannen hell, 4-5 cm lang. - Stroh: rötlich-gelb, kräftig, etwas mürbe, lang. - Frucht: graubraun, mittelgross ( $8 \mathrm{~mm}$ lang, $3 \mathrm{~mm}$ breit), etwas grobschalig.

Herbstblatt dunkelgrün, breit, lang, kräftig; Frühjahrsvegetation 
zeitig, Bestockung mittelstark, 5 Schösslinge, zeitig schossend, doch erst Ende Mai blühend. Halmlänge $143 \mathrm{~cm}$ (Max. $180 \mathrm{~cm}$ ), Halmdicke $0.4 \mathrm{~cm}$, Blattzahl 4, Blattlänge $17 \mathrm{~cm}$, Blattbreite $0.73 \mathrm{~cm}$, Blattfläche $99.28 \mathrm{qcm}$, Halmfläche $179.8 \mathrm{qcm}$, Gesammtfläche $279.08 \mathrm{qcm}$.

Die Aehre reift ziemlich zeitig, Mitte Juli, $12 \mathrm{~cm}$ (Max. $18 \mathrm{~cm}$ ) lang, mit 70 leicht ausfallenden Friichten, von denen 2590250 auf $1 \mathrm{hl}$ $(=79.7 \mathrm{~kg})$ entfallen.

Auf 1 qm wachsen 1000 Halme oder 200 Pflanzen, mithin beträgt der Raum für eine Pflanze $50 \mathrm{qcm}$, die Blattoberfläche p. qm Bodenfläche $27.91 \mathrm{qm}$ und das Saatquantum $1.2 \mathrm{hl}$ p. ha.

Es wiegen 100 Halme $553 \mathrm{gr}$ und davon die Früchte $222 \mathrm{gr}$.

Diese Roggensorte eignet sich für die schwereren Böden und für nördliche Gegenden, da sie weder leicht in der Blüte erfriert, noch auswintert. Auf leichtem Boden artet sie jedoch sehr schnell aus, so dass in diesem Falle alle 3 Jahre mit dem Saatgut gewechselt werden muss.

Die Korn- und namentlich die Stroherträge stellen sich sehr hoch, doch ist das Stroh miirbe, lagert leicht und ist dem Rost stark ausgesetzt. Es soll auf reichen Böden eine Länge von 2-2.50 m erreichen kömnen.

Erträge auf sandigen Luehmböden.

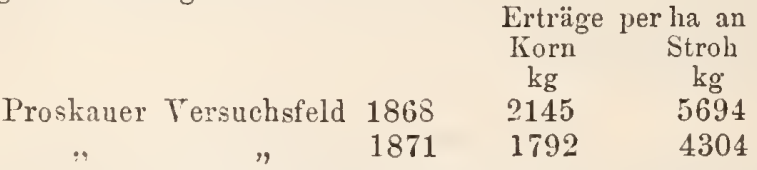

Den Namen Aulock'scher Roggen trägt er voll einem seiner Anbauer in Ober-Schlesien, dem Herru voll A ulock.

Nach Frankreich wurde er durch M. Moll eingeführt.

\section{Finnländischer Wasa-Winter-Roggen. (2)}

Aehre: rötlich-gelb, dicht, $11 \mathrm{~cm}$ lang, mit 40 Aehrchen und 75 Früchten; Grannen hell, $4-5 \mathrm{~cm}$ lang. - Stroh: gelb, feinhalmig, fest, $140 \mathrm{~cm}$ lang. - Frucht: dunkel, braun, kurz, $7 \mathrm{~mm}$ lang, $21 / 2 \mathrm{~mm}$ breit, etwas grobschalig, Qualität wenig befriedigend, doch besser als rom $\mathrm{Ny}$ land-Roggen.

Er wurde 1861 rom Perliner Akklimatisationsverein in Preussen eingeführt; erwies sich in Allgemeinen weniger ertragreich als NylandRoggen. tiviert.

Diese Roggensorte wird sehr häufig im nördlichen Russland kul-

Original im landwirtschaftlichen Museum zu Berlin.

\section{Finnländischer Nyland-Winter-Roggen. (2)}

Aehre: rötlich-gelb, dicht, $14 \mathrm{~cm}$ lang, mit 35 Aehrchen und 68 Friichten; Grannen hell, 4-5 cm lang. - Stroh: rötlich-gelb, feinhalmig, fest, $140 \mathrm{~cm}$ lang. - Frucht: hellbräunlich oder grünlich-gelb, lang, mager.

Er wurde 1861 vom Berliner Akklimatisationsverein in Preussen eingefiihrt, hat jedoch keine grosse Verbreitung gefunden.

Original im landwirtschaftlichen Mruseum zu Berlin. 


\section{Roggen aus der Ukraine. (2)}

Aehre: blassgelb, dick, voll, lang; Aehrchen $1 \mathrm{~cm}$ breit, 2-körnig; Grannen 4-5 cm lang. - Stroh: rötlich-gelb, lang, feinhalmig, fest. Frucht: gelb mit grünlichem Anflug, sehr dick, sehr gross (10 mm lang, $31 / 2 \mathrm{~mm}$ breit, 260 Früchte $=10 \mathrm{gr}$ ), schwer, mehlreich, feinschalig.

Herbstblatt dunkelgrün, kräftig, Frühjahrsvegetation zeitig, Bestockung stark, 5.4 Schösslinge (bei 100 qcm Raum 9.5 Scliösslige), zeitig schossend und Mitte Mai blühend. Halmlänge $155 \mathrm{~cm}$ (Max. $170 \mathrm{~cm}$ ), Halmdicke $0.3 \mathrm{~cm}$, Blattzahl 4, Blattlänge $17 \mathrm{~cm}$, Blattbreite $0.87 \mathrm{~cm}$, Blattfläche $118.32 \mathrm{qcm}$, Halmfläche $139.5 \mathrm{qcm}$, Gesammtfläche $257.82 \mathrm{qcm}$.

Aehre zeitig reifend, $14 \mathrm{~cm}$ (Max. $17 \mathrm{~cm}$ ) lang, mit 65 ziemlich fest sitzenden Früchten, von denen 2002000 auf $1 \mathrm{hl}(=77 \mathrm{~kg})$ entfallen.

\section{Roggen aus Jekaterinoslaw, Siid-Russland. (2)}

Aehre: blassgelb, dünn, lang; Aehrchen 2-körnig, $0.7 \mathrm{~cm}$ breit; Grannen hell, 4-5 cm lang. - Stroh: grangelb, fest, feinhalmig, lang. - Frucht: Original auffallend hell, grünlich-gelb, klein und spitz $(6 \mathrm{~mm}$ lang, $2 \mathrm{~mm}$ breit), feinschalig. A uf $10 \mathrm{gr}$ entfielen 659 Friüchte der Originalsaat, 352 Früclite der 1. Tracht, 363 Früchte der 2. Tracht und 365 Früchte der 3. Tracht.

Herbstblatt blaugrün, sehr fein, kraus; Frühjahrsvegetation sehr spät, die Bodenblätter sind viel dunkelgrüner und schnnäler als bei allen übrigen kultivierten Roggensorten, Bestockung nittelstark, 4.2 Schösslinge, sehr spät schossend, denn als der frühe Roggen aus Italien schon blühte, war die Aehre noch nicht hervorgetreten, am spätesten von allen Sorten, gegen Mitte Juni blühend, doch Reife wenig später als beim Roggen aus Italien, nämlich in der 2. Hälfte des Juli eintretend.

Halmlänge $150 \mathrm{~cm}$ (Маx. $180 \mathrm{~cm}$ ), Halmdicke $0.33 \mathrm{~cm}$, Blattzahl 5.3, Blattlänge $14.8 \mathrm{~cm}$, Blattbreite $0.76 \mathrm{~cm}$, Blattfläche $119.25 \mathrm{qcm}$, Halmfläche $148.5 \mathrm{qcm}$, Gesammtfläche $267.75 \mathrm{qcm}$.

Aehre $12 \mathrm{~cm}$ (Max. $16 \mathrm{~cm}$ ) lang, mit 70 ziemlich fest sitzenden Friichten, von denen beim Original 5345000 anf $1 \mathrm{hl}(=81 \mathrm{~kg})$ gehen.

Es wiegen 100 Halme $592 \mathrm{gr}$ und davon die Früchte $212 \mathrm{gr}$.

Dieser Steppenroggen lagert nicht leicht und leidet wenig durch Rost.

Für Dentschland scheint seine Kultur wertlos zu sein.

Bezugsquelle: Gutsbesitzer Dégtiareff, Jekaterinoslaw.

\section{Saksonka. (2)}

Aehre: schmutzig-blassgelb, lang; Aehrchen $0.9 \mathrm{~cm}$ breit, 2-körnig, Grannen lell, bis $4 \mathrm{~cm}$ lang. - Stroh: rötlich-gelb, fest, fein, mittellang. - Frucht: Original grünlich-grau, spitz, lang $\left(8 \mathrm{~mm}\right.$ lang, $2^{1} / 2 \mathrm{~mm}$ breit, 369 Friichte $=10 \mathrm{gr}$ ); nachgebaut: dunkeler und grösser, $81 / 2 \mathrm{~mm}$ lang, $2^{3} / 4 \mathrm{~mm}$ breit, 281 Frïchte $=10 \mathrm{gr}$, schwer, feinschalig.

Herbstblatt blaugrün, schmal; Frühjahrsvegetction spät, Bestockung stark, 5 Schösslinge, spät schossend und bliihend. Halmlänge $1: 5 \mathrm{~cm}$ (Max. $140 \mathrm{~cm}$ ), Halmdicke $0.33 \mathrm{~cm}$, Blattzahl 4, Blätter $18.3 \mathrm{~cm}$ lang, $0.77 \mathrm{~cm}$ breit, Blattfläche $112.73 \mathrm{q} \mathrm{cm}$, Halmfläche $123.75 \mathrm{qcm}$. Gesammtfläche $236.48 \mathrm{qcm}$.

Aehre reift spät, $12 \mathrm{~cm}$ (Max. $16 \mathrm{~cm}$ ) lang, mit 39 Aehrchen und 
76 etwas lose sitzenden Früchten, von denen 2874900 Früchte auf $1 \mathrm{hl}$ $(=77.7 \mathrm{~kg})$ entfallen.

Es wiegen 100 Halme $362 \mathrm{gr}$ und davon die Früchte $174 \mathrm{gr}$.

Dieser winterfeste Roggen lagert nicht leicht, ist aber gegen Rost wenig widerstandsfähig.

Er entstammt delı deutschen Kolonieen Süd-Russlands und wurde durch Prof. Saykewitsch, Charkow, uibersandt.

\section{Johannis-Roggen ${ }^{1}$ ).}

Syn.: Waldkorn'), Klebkorn ${ }^{3}$ ), Eisroggen, russischer Roggen.

Franz.: Seigle de la Saint-Jean, multicaule, des forêts, du Nord, buisson, d'Archangel.

Engl.: St. John's day or Midsummer-Rye.

Ital.: Segola S. Giovanni.

Aehre: graulich-gelb, lang, schmal; Aehrchen $1 \mathrm{~cm}$ breit, 2-körnig; Grannen hell, 4-5 cm lang. - Stroh: graulich-gelb, kräftig, fest, sehr lang. - Frucht: graubraun, spitz, schmal, sehr klein $\left(7 \mathrm{~mm}\right.$ lang, $2^{1} / 2 \mathrm{~mm}$ breit, 396 Früchte $=10 \mathrm{gr}$ ), feinschalig.

Herbstblatt blaugriin, fein, schmal, aufrecht; Frühjahrsvegetation bei um Johannis ausgesäetem Roggen zeitig, Anfang Oktober gesäet, verhielt er sich wie nordischer Roggen, d. h. die Frühjahrsvegetation trat spät ein. In gleicher Weise zeigte sich je nach der Aussaatzeit seine Bestockungsfähigkeit sehr verschieden gross. Johannis gesäet, erzeugten sich bei $200 \mathrm{qcm}$ Bodenfläche für jede Pflanze bis 40 Schösslinge und bei der Oktobersaat nur 13.8 Schösslinge.

Die Bestockungsfähigkeit verglichen mit Probsteier-Roggen bei $20 \mathrm{~cm}$ Drillweite und normalem Stande, ergab folgende Resultate:

\begin{tabular}{|c|c|c|c|c|c|}
\hline \multirow[b]{2}{*}{ Zeit der Aussaat } & is - Roggen. & & \multicolumn{3}{|c|}{ Probsteier-Roggen. } \\
\hline & $\begin{array}{c}\text { Tag der } \\
\text { Untersuchung }\end{array}$ & 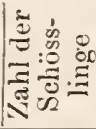 & Zeit der Aussaat & $\left|\begin{array}{c}\text { Tag der } \\
\text { Untersuchung }\end{array}\right|$ & 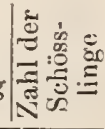 \\
\hline ang Juli 1876 & il 1877 & 12 & - & - & - \\
\hline "Oktober " & 10. & 10 & Anfang Oktob. 1876 & 6 10. April 1877 & 5 \\
\hline 27. November & 10. & 4 & 27. November $"$ & 10. $"$, & 3 \\
\hline $27 . \quad n$ & 25. Mai & 5 & 27. & 25. Mai & 4 \\
\hline 23. Januar & 10. April & 2.8 & 23. Januar & 10. April & 2 \\
\hline $23 . \quad$, & 25. Mai & 5.2 & $23 . \quad$, & 25. Mai ", & 3.1 \\
\hline 5. Februar , & 10. April " & 1 & ๊. Februar & 10. April " & 1 \\
\hline 5. $\quad$, & 25. Hai , & 3.4 & 5. $\quad$, & 25. Mai " & 3.2 \\
\hline
\end{tabular}

Hieraus ergiebt sich, dass nur bei sehr zeitiger Aussaat und bei geniigend grossem Pflanzraum die Bestockungsfähigkeit des JohannisRoggens eine aussergewöhnliche ist.

1) Ausführliches findet sich in: Werner, Handb. d. Futterbaues auf $d$. Ackerlande, pg. 529 u. flgde. 1875.

2) Schober, Zeitschr. f. deutsche Landw. 1860 , p. 13.

3) Medicus, Landw. Centralbl. 1855. No. II, pg. 66. 
Die Möglichkeit diesen Roggen, ohne ihn zu erschöpfen, im Aussaatjahre, und selbst in dem Falle, dass die Aussaat im Frïhjahr erfolgte, als Grïnfutter, und in darauf folgenden Jahre ohne Neuansaat zur Kornproduktion zu benutzen, beruht darauf, dass er im Aussaatjahre keine Neigung zeigt, Fruchthalme zu treiben, sondern er verwendet das Nährstoffmaterial zur Bestockung und Bewurzelung, welche Eigentümlichkeit ihm durch das nordische Klima, dem er entstanmt, eingeimpft ist.

Die Triebe, welche der Johannis-Roggen im Aussaatjahre entwickelt, erreichen auf kräftigem Boden nicht selten eine Länge von $40-50 \mathrm{~cm}$, sind also gut mähbar. Im nächsten Frïhjahr treiben die Fruchthalme, sobald die Einsaat um Johannis erfolgte, sehr zeitig hervor, und ebenso tritt auch die Blüte und Reife sehr zeitig ein, während bei gewöhnlicher Herbstsaat das Schossen spät, die Blüte und Reife dagegen mittelfrüh erfolgt.

Vergleichende Versuche haben nun erwiesen, dass der Habitus der Fruchthalme von der Aussaatzeit unabhängig ist, und nur ihre Zahl pro Pflanze variirt. Es ergaben sich nachfolgende Ausmessungsresultate:

\begin{tabular}{|c|c|c|}
\hline & \multicolumn{2}{|c|}{ Aussatzeit: } \\
\hline & Anfang Juli 1876. & Anfang Oktober 1876. \\
\hline Halmlänge & $150 \mathrm{~cm}(\operatorname{Max} .180 \mathrm{~cm})$ & $150 \mathrm{~cm}$ (Мax. $170 \mathrm{~cm})$ \\
\hline Halmulicke & $0.4 \mathrm{~cm}$ & $0.38 \mathrm{~cm}$ \\
\hline Blattzahl & 5.3 & 5.1 \\
\hline Blattlänge & $19 \mathrm{~cm}$ & $17.3 \mathrm{~cm}$ \\
\hline Blattbreite & $0.86 \mathrm{~cm}$ & $0.9 \mathrm{~cm}$ \\
\hline Blattfläche & $173.2 \mathrm{qcm}$ & $158.81 \mathrm{qcm}$ \\
\hline Halmfläche & $188.6 \mathrm{qcm}$ & $171.00 \mathrm{qcm}$ \\
\hline Gesammtfläche & $361.8 \mathrm{gcm}$ & $329.81 \mathrm{gcm}$ \\
\hline Aehrenlänge & $14 \mathrm{~cm}(\operatorname{Max} .18 \mathrm{~cm})$ & $14 \mathrm{~cm}($ Max. $18 \mathrm{~cm})$ \\
\hline
\end{tabular}

Auf 1 qm wachsen 1000 Halıe, also bei Herbstsaat (10 Schösslinge) 100 Pflanzen, mithin beträgt der Raum für eine Pflanze $100 \mathrm{qcm}$, die Blattfläche p. qm Bodenfläche ca. $34 \mathrm{qm}$ und das Saatquantum, wenn $1 \mathrm{hl}$ (=74.5 kg) 2940200 Frïchte enthält, $0.5 \mathrm{hl}$.

In Poppelsdorf erwies sich dieser Roggen als echter Winterroggen, der durchaus winterfest ist, nicht zum Lagern neigt, doch durch Rost leidet.

Es wiegen 100 Halme $556 \mathrm{gr}$ und davon die Früchte $203 \mathrm{gr}$.

Der Johannis-Roggen steht in seinen Korn- und Stroherträgen hinter den besseren Roggensortell nicht zurück, auf dem Versuchsfelde zu Proskau lieferte z. B. am 2. Juli 1871 gesäeter Johannis-Roggen, nachdem er vorher $6920 \mathrm{~kg}$ Grïfutter erbracht hatte, und am 8. September gesäeter und wie gewöhnlicher Roggen behandelter Johannis-Roggen nachstehende Erträge :

\begin{tabular}{|c|c|c|c|}
\hline aat & Körner & Stroh & $\mathrm{Sp}$ \\
\hline . Ju & $2408 \mathrm{~kg}$ & $6512 \mathrm{~kg}$ & $113 \mathrm{~kg}$ \\
\hline ptembe & 2080 & 6108 & 114 \\
\hline
\end{tabular}

Der Johannis-Roggen gedeiht selbst auf sehr humosen und sehr feuchten Böden, auf welchen andere Roggensorten versagen, noch verhältnismässig gut, weil seine ausserordentlich grosse Bewurzelungsfähigkeit 
die etwa ihm durch das Anffrieren zngefügten Schäden leichter überwinden lässt. Ausserdem schadet ihm ein fenchter, kalter Boden im Frühjahr weniger als anderen Roggensorten, weil er, entsprechend den Verhältnissen seiner nordischen Heimat, dagegen nnempfindlich ist.

Den Grünfntterschnitt im Herbst verträgt der Johannis-Roggen vorzüglich nnd zieht derselbe auch keine Ertragsverminderung der Kornproduction nach sich, sobald der Boden genügend reich an Pflanzennährstoffen ist.

Das Grünfutter eignet sich vortrefflich znr Milchproduktion und ersetzt in den Milchwirtschaften im Herbst sehr gnt den teuren Grünmais, dagegen ist jedoch das Korn wegen seiner Kleinheit nnd seines geringeren Nahrungswertes weniger geschätzt.

Seine Anssaatzeit lässt sich anf jeden Monat des Jahres verlegen, so säet man das Klebkorn von November-Februar und Johannis-Roggen in allen übrigen Mronaten. Ferner lassen sich zur Grünfuttergewinnung Gemenge von Hafer, Wicken und Johannis-Roggen mit vorzüglichem Erfolg aussäen.

Eine sich sehr stark bestockende Form ist ferner der jnnri-oder Wurzelroggen ${ }^{1}$ ), der in Finnland auf abgebolzten Flächen, wie bei uns das Waldkorn, ausgesäet wird.

Eine Form des Johannisroggens ist der Murawieffkaroggen, welcher von Murawieff aus dem sog. wilden sibirischen perennirendell Rog;en, den Komercienrat von Papoff aus Irkutsk in Sibirien über Russland verbreitete, gezogen, indem er denselben bei Petersburg in vorzüglich gediungtem Boden anbaute und ihn bedeutend veredelte. Der Gutsbesitzer von L ï zo ${ }^{2}$ ) bei 'osen bante dann diesen Roggen in den 40 er Jahren an.

Der Johannis-Roggen gelangte höchst wahrscheinlich aus den rnssischen Ostseeprovinzen nach Deutschland und dem westlichen Europa.

Znerst wird er 1779 in der physik.ök. Gesellschaft in Bern ${ }^{3}$ ), später durch Riem 1785 in seiner praktisch-ökonomischen Encyclopädie erwähnt und nach Heuzé4) warde er 1785 durch Le Bréton nach Frankreich eingeführt, wo er jetzt vielfach in den Bergen von Briançonnais und der Anvergne angebaut wird. Auch Seringe ${ }^{5}$ ) erwähnt seiner und führt zur Empfehlung einen günstigen Bericht der Musterwirtschaft zu Krignac (Morbihan), nnd des MI. Ch. Drouet aus dem Jahre 1840 an.

Die Kultur des Johannis-Roggens bietet unter Umständen in gewissen wirtschaftlichen Verhältnissen sehr beachtenswerte Vorzüge gegenüber dem Anban gewöhnlichen Roggens, und zwar durch bequeme Bestellung, Verringernng der Herbstbestellungsarbeiten, Saatersparnis, Benutzung ungünstiger Böden, verhältnismässig grosse Sicherheit des Ertrages und Benutznng zur Grünfuttergewinnung im Herbst.

Der Johannis-Roggen, wie uns dies langjährige Kulturen zur Genüge bewiesen haben, lässt sich durch Kultur aus gewöhnlichem Staudenroggen bei nns nicht erzeugen, auch wandelt er sich bei darauf abzielender Kultur nicht in Staudenroggen nm, sobald eine gegenseitige Bestaubung zwischen Johannis- nnd Standen-Roggen vermieden wird.

1) Mittheil. d. kais. r. ök. Gesellsch. z. Petersburg 1858, p. 178.

2) Agron. Zeit. III. p. 427. 1848. $299-304$

3) Neue Samml. phys.-ök. Schrift. d. ök. Ges. in Bern. I. Bd. 1779. pg。

4) Heuzé, Les plantes aliment. pg. 409.

5) Descript. et fig. d. ceréal. europ. IV, 1841, p. 371. 
Demnach ist der Johannis-Roggen als keine leicht veränderliche „Züchtungs-Varietät" anzusehen, wie dies früher von Sturm und in neuerer Zeit von Blomeyer ${ }^{1}$ ), und zwar von letzterem gestïtzt auf in Leipzig durchgefiilhrte Kulturversuche, behauptet wurde. Die Blomeyer'schen Versuche können deshalb nicht als entscheidend betrachtet werden, weil der Anbau des Johannis- und Stauden-Roggens in so unmittelbarer Nähe stattfand, dass eine gegenseitige Bestaubung und deshalb die Bildung von Kreuzungsprodukten keinesweges ausgeschlossen war.

\section{Russisches Schneekorn. (2)}

Syn.: Livländischer Staudenroggen.

Aehre: blassgelb, lang, schmal, ziemlich dicht; Aehrehen $0.8 \mathrm{~cm}$ breit, 2-körnig; Granmen hell, bis 5 cm lang. - Stroh: gelb, fest, ziemlich lang. - Frucht: brann, dick, kurz (8 mm lang, $3 \mathrm{~mm}$ breit, 355 Früchte $=10 \mathrm{gr}$ ), etwas grobschalig.

Herbstblatt blaugriin, kräftig, kraus; Frühjahrsvegetation sehr spät, Bestockung stark, 5 Schösslinge, ziemlich zeitig schossend, zeitig bliihend. Halnnlänge $140 \mathrm{~cm}$ (Max. $150 \mathrm{~cm}$ ), Halmdicke $0.37 \mathrm{~cm}$, Blattzahl 4, Blattlänge $20 \mathrm{~cm}$, Blattbreite $0.78 \mathrm{~cm}$, Blattfläche $124.8 \mathrm{qcm}$, Halmfläche $155.4 \mathrm{qcm}$, Gesammtfläche $280.2 \mathrm{qcm}$.

Aelire reift mittelfrüh, $12 \mathrm{~cm}$ (Max. $18 \mathrm{~cm}$ ) lang, mit 76 fest sitzenden Friichten, von denen 2744150 auf $1 \mathrm{hl}(=77.3 \mathrm{~kg}$ ) entfallen.

Dieser Roggen ist durchaus winterfest, lagert nicht leicht, befällt jedoch stark mit Rost.

Er wird vorzugsweise in den Ostseeprovinzen, zuweilen auch in den rauheren Lagen Nord-Deutschlands kultiviert, und lässt sich ähnlich wie Johannis-Roggen, dem er nahe verwandt ist, anbauten.

Es wiegen 100 Halme $615 \mathrm{gr}$ und davon die Friichte $293 \mathrm{gr}$.

\section{Winterroggen aus dem Bezirk Irkutsk, Sibirien. (2)}

Aehre: schmutzig-blassgelb, lang, schlaff, dïnn; Grannen $4-5 \mathrm{~cm}$ lang. - Stroh: rotgrau bis violett, fest. - Frucht: Original hellbraun, schlank, sehr klein, $7 \mathrm{~mm}$ lang, $2 \mathrm{~mm}$ breit, $10 \mathrm{gr}=692$ Frïchte; nachgebaut: viele graublan, grösser, 440 Früchte $=10 \mathrm{gr}$, sehr feinschalig.

Herbstblatt blaugrün, sehr fein, kraus; 4 Schösslinge, Entwickelung spät, erst 1/6. 80 schossend und 18/6. 80 blühend, 14/7. 80 reifend, während die meisten anderen Roggensorten schon 1/6. abgeblülit hatten. Halm $150 \mathrm{~cm}$ (Max. $175 \mathrm{~cm}$ ) lang, $0.4 \mathrm{~cm}$ dick, Blattzahl 5, Blätter $14.2 \mathrm{~cm}$ lang, $0.8 \mathrm{~cm}$ breit, Blattfläche $113.6 \mathrm{qcm}$, Halmfläche $180 \mathrm{qcm}$, Gesammtfiäche $293.6 \mathrm{qcm}$.

Aehre enthält 120 Früchte, von denen $1 \mathrm{hl}=80 \mathrm{~kg}$ wiegt.

Winterfest. Für leichten Boden in sehr rauhen Lagen zu einpfehlen.

Bezugsquelle: durch Anatol von Fadejeff ans der Sammlung zu Petrowsk bei Moskan erhalten.

\section{Sommerroggen aus dem Bezirk Irkutsk, Sibirien. $\odot$}

Aehre: schmutzig-gelb, halbhängend, dünn, 9-13 cm lang mit 50 Früchten. - Stroh: rotgelb bis rotgrau, steif, kurz. - Frucht: Original 
hellbräunlich oder grünlich, sehr klein $\left(6 \frac{1}{2} \mathrm{~mm}\right.$ lang, $12 \mathrm{~mm}$ breit, 577 Früchte $=10 \mathrm{gr}$ ); nachgebaut: grösser, 383 Friichte $=10 \mathrm{gr}$ ), feinschalig.

Junges Blatt bläulich-grün, schmal, sammetig, aufrecht, 1.2 Schösslinge; Halm $105 \mathrm{~cm}$ (Max. $130 \mathrm{~cm}$ ) lang, $0.3 \mathrm{~cm}$ dick, Blattzahl 4, Blätter $15 \mathrm{~cm}$ lang, $0.5 \mathrm{~cm}$ breit, Blattfläche $60 \mathrm{qcm}$, Halmfläche $94.5 \mathrm{qcm}$, Gesammtfläche $154.5 \mathrm{qcm}$.

Bezugsquelle: durch Anatol ron Fadejeff ans der Sammlung zu Petrowsk bei Moskau erhalteu.

\section{Roggen rom Altai, Süd-Sibirien. (2)}

Aehre: graulich-gelb, lang, dünn, hängend; Aehrchen sehr schnıal, $0.5 \mathrm{~cm}$ breit, 2-körnig; Grannen hell, kurz, $4 \mathrm{~cm}$ lang. - Stroh: rötlichgelb, mittellang, ziemlich kräftig, - Frucht: graublau oder hellbraun, klein, spitz, schmal (7 mm lang, $2 \mathrm{~mm}$ breit, 588 Früchte $=10 \mathrm{gr}$ ), feinschalig.

Herbstblatt blaugrün, kraus, Vegetation sehr spät, Bestockung stark, 6 Schösslinge, sehr spät, erst Ende Mrai sehossend und sehr spät blühend. Halm $115 \mathrm{~cm}$ (Max. $130 \mathrm{~cm}$ ) lang, $0.35 \mathrm{~cm}$ dick, Blattzahl 4.5, Blätter $17.4 \mathrm{~cm}$ lang, $0.85 \mathrm{~cm}$ breit, Blattfläche $133.11 \mathrm{qcm}$, Halmfläche $120.75 \mathrm{qcm}$, Gesammtfläche $253.86 \mathrm{qcm}$.

Aehre viel später als alle übrigen Winterroggen, erst Anfang Angust reifend, $13 \mathrm{~cm}$ (Iax. $17 \mathrm{~cm}$ ) lang, mit 45 Aehrchen und 84 Friichten, von denen 4292400 auf $1 \mathrm{hl}(=73 \mathrm{~kg}$ ) entfallen.

Rost leidet.

Es ist ein echter Winterroggen, der nicht lagert und wenig durch

Uebersender: die Reisenden Dr. Finsch und Graf Zeil.

\section{Abessinischer Stauden-Roggen.}

Aehre: schmutzig-blassgelb, hängend, dünn, lang; Aehrchen $0.8 \mathrm{~cm}$ breit, 2-körnig; Grannen 4-5 cm lang. - Stroh: graugelb und rötlichgelb, fest, lang. - Frucht: Original hellbraun und silbergrau, klein ( $8 \mathrm{~mm}$ lang, $3 \mathrm{~mm}$ breit, 495 Früchte $=10 \mathrm{gr}$ ); nachgebaut: grösser, 330 Früchte $=10 \mathrm{gr}$, etwas grobschalig.

Herbstblatt blangrün, sehr kräftig, aufrecht; Frühjahrsvegetation mittelfrüh, Bestockung mittelstark, 4 Schösslinge, mittelfrüh schossend und blühend. Halmlänge $150 \mathrm{~cm}$ (JIax. $170 \mathrm{~cm}$ ), Halmdicke $0.4 \mathrm{~cm}$, Blattzahl 4.7, Blattlänge $18.6 \mathrm{~cm}$, Blattbreite $0.84 \mathrm{~cm}$, Blattfläche $146.83 \mathrm{qcm}$, Halmfläche 180 qcm, Gesammtfläche 326.83 q $\mathrm{cm}$.

Aehre reift mittelfrüh, $13 \mathrm{~cm}$ (Max. $20 \mathrm{~cm}$ ) lang, mit 65 Friichten, ron denen 2531100 auf $1 \mathrm{hl}(=76.7 \mathrm{~kg})$ entfallen.

Es wiegen 100 Halme $553 \mathrm{gr}$ und daron die Früchte $211 \mathrm{gr}$.

Diese Sorte lagert nicht leicht und wird wenig durch Rost angegriffen.

\section{Centeno de Colonia de Punta Arenas, Magellanes, Chile. $\odot$}

Aehre: schmutzig-blassgelb, $8 \mathrm{~cm}$ lang, Grannen $4-5 \mathrm{~cm}$ lang. Stroh: rotgrau, fest, feinhalmig, bis $100 \mathrm{~cm}$ lang. - Frucht: hellbraun, kurz, dick ( $7 \mathrm{~mm}$ lang, $21 / 2 \mathrm{~mm}$ breit, 381 Friichte $=10 \mathrm{gr}$ ), feinselalig; 40 Früchte in einer Aehre. 
Winterte $1880 / 81$ vollkommen aus; als Sommerrogen 1881 gesäet, liefen nur wenige Pflanzen auf, weil der Same schon grösstenteils die Keimkraft verloren hatte.

Bezugsquelle: Dureh Ministerresident von Giilich aus Chile an das landwirtschaftliche Museum zu Berlin gesandt und von dort erhalten.

\section{Western-Rye. (2)}

Aehre: graulich-weiss, lang; A ehrchen $0.8 \mathrm{~cm}$ breit, 2-körnig; Grannen hell, bis $4 \mathrm{~cm}$ lang. - Strolı: gelbrot, fest, lang. - Frucht: Original sehr hellbraun, lang (9 $\mathrm{mm}$ lang, $2 \frac{1}{2} \mathrm{~mm}$ breit, 479 Früchte $=10 \mathrm{gr}$ ); nachgebaut: grösser, 300 Frïchte $=10 \mathrm{gr}$, sehr feinschalig.

Herbstblatt dunkelgrüin, schmal; Frühjahrsvegetation spät, Bestockung stark, 5 Schösslinge, spät schossend nnd blühend. Halmlänge $135 \mathrm{~cm}$ (Max. $150 \mathrm{~cm}$ ), Halmdicke $0.4 \mathrm{~cm}$, Blätter $19.8 \mathrm{~cm}$ lang, $0.69 \mathrm{~cm}$ breit, Blattfläche $131.16 \mathrm{qcm}$, Halmfläche $162 \mathrm{qcm}$, Gesammtfläche $293.16 \mathrm{qcm}$.

Aelıre reift spät, $14 \mathrm{~cm}$ (Max. $16 \mathrm{~cm}$ ) lang, mit 37 Aehrehen und 70 Friichten, von denen 2379000 anf $1 \mathrm{hl}(=79.3 \mathrm{~kg})$ entfallen.

Es wiegen 100 Halme $432 \mathrm{gr}$ und davon die Früchte $178 \mathrm{gr}$.

Dieser Roggen lagert nur selten, leidet jedoch etwas durch Rost.

Er stammt aus den Weststaaten der amerikanischen Union.

Uebersender: Hnb. D ii rselen, Neuss.

\section{Northern-Rye. (2)}

Aehre: grauweiss, roll, lang; Aehrchen $0.9 \mathrm{~cm}$ breit, 2-körnig; Grannen 4-5 cm lang, hell. - Stroh: rötlich-graugelb, sehr derb, fest, lang. - Frucht: Original selrr hellbraun, schön, klein $(7 \mathrm{~mm}$ lang, 21/2 $\mathrm{mm}$ breit, 391 Früchte $=10 \mathrm{gr}$ ); nachgebaut: etwas grösser, 330 Frïchte $=10 \mathrm{gr}$, feinschalig.

Herbstblatt dunkelgrün; Frühjahrsvegetation spät, Bestockung schwach, 3 Schösslinge, spät schossend und blülıend. Halmlänge $130 \mathrm{~cm}$ (Max. $150 \mathrm{~cm}$ ), Halmdicke $0.4 \mathrm{~cm}$, Blattzahl 4.6, Blätter $19 \mathrm{~cm}$ lang, $1.05 \mathrm{~cm}$ breit, Blattfläche $183.54 \mathrm{qcm}$, Halmfläche $156 \mathrm{qcm}$, Gesammtfläche $339.54 \mathrm{qcm}$.

Aehre reift spå̆t, $13 \mathrm{~cm}$ (Max. $16 \mathrm{~cm}$ ) lang, mit 75 Frïchten, ron denen 2971600 auf $1 \mathrm{hl}(=76 \mathrm{~kg})$ entfallen.

Es wiegen 100 Halme 502 gr und davon die Frïchte $206 \mathrm{gr}$.

Dieser Roggen lagert nicht leicht, wird jedoch leicht rostig.

$\mathrm{Er}$ stammit aus den Nordstaaten der amerikanischen Union.

Uebersender: Hub. Dür selen, Neuss.

\section{Weisser Roggen aus Pennsylvanien, Vereinigte Staaten. (2)}

Aehre: blassgelb, breit, ziemlich dicht, $15 \mathrm{~cm}$ lang, 2-körnig, mit 80-90 Früchten; Grannen hell, $4-5 \mathrm{~cm}$ lang. - Stroh: graulich-gelb, kräftig, fest lang. - Frucht: sehr hell, fast weizenfarbig, schön, gross (9 $\mathrm{mm}$ lang, $3^{1 / 2} \mathrm{~mm}$ breit), 1 hl wiegt $76 \mathrm{~kg}$, feirschalig.

Zeitig, Mitte Juli reifend.

Der Roggenhau ist in Nord-Amerika am meisten in Pennsylvanien verbreitet. 


\section{Canada-Rye. (2)}

Aehre: fast weiss, etwas locker, lang; Aehrchen $0.9 \mathrm{~cm}$ breit, 2körnig; Grannen bis $5 \mathrm{~cm}$ lang. - Stroh: rötlich-gelb, kräftig, mittellang. - Frucht: Original hellbraun, klein, schmal (71/2 mm lang, $21 / 2 \mathrm{~mm}$ breit, 482 Früchte $=10 \mathrm{gr}$ ); nachgebaut: länger, 307 Frïchte $=10 \mathrm{gr}$, feinschalig.

Herbstblatt dunkelgrün, dem des Weizens ähnlich, schmal; Frühjahr'svegetation spät, Bestockung stark, 5 Schösslinge, spät schossend und blühend. Halm $115 \mathrm{~cm}$ (Max. $130 \mathrm{~cm}$ ) lang, $0.4 \mathrm{~cm}$ dick, Blattzahl 4.2 , Blätter $13.8 \mathrm{~cm}$ lang, $0.63 \mathrm{~cm}$ breit, Blattläche 73 qcm, Halmfläche $138 \mathrm{qcm}$, Gesammtfläche $211 \mathrm{qcm}$.

Aehre reift spät, $13 \mathrm{~cm}$ (Max. $17 \mathrm{~cm}$ ) lang, mit 33 Aehrchen und 64 leicht ausfallenden Früchten, von denen 3518600 auf $1 \mathrm{hl}$ (= 73 lig) entfallen.

Es wiegen 100 Halme $414 \mathrm{gr}$ und davon die Früchte $187 \mathrm{gr}$.

Dieser Roggen ist winterfest, leidet etwas durch Rost und lagert nicht leicht.

Heimat: Canada.

Uebersender: Hub. Dürselen, Neuss.

\section{Roggen aus Ostindien. (2)}

Aehre: blassgelb, schlaff, lang; Klappen lang, etwas locker; Grannen 5-6 cm lang. - Stroh: rotgelb, sehr fest. - Frucht: blaugrau und hellbraun, ziemlich gross, etwas verschrumpft, $10 \mathrm{~mm}$ lang, $21 / 2 \mathrm{~mm}$ breit, 250 Früchte $=10 \mathrm{gr}$.

Herbstblatt dunkelgrün, aufrecht, lang, breit; Entwickelung viel später als bei allen übrigen Roggen, 4 Schösslinge, spät bliihend; Halm $150 \mathrm{~cm}$ (Маa. $180 \mathrm{~cm}$ ) lang, $0.4 \mathrm{~cm}$ dick, Blattzahl 4, Blätter $20.6 \mathrm{~cm} \mathrm{lang,}$ $0.7 \mathrm{~cm}$ breit, Blattfläche $115.4 \mathrm{qcm}, \mathrm{Halmfläche} 180 \mathrm{qcm}$, Gesammtfäche $295.4 \mathrm{qcm}$.

Yittelfrüh reifend, Aehre $15 \mathrm{~cm}$ (Max. $17 \mathrm{~cm}$ ) lang, mit 80 Früchtell, von denen $1 \mathrm{hl}=79 \mathrm{~kg}$ wiegt. Wahrscheinlich ist er ein Gebirgsroggell.

\section{Winterroggen aus Tasmanien, Australien. (2)}

Aehre: graulich-gelb, dïnn, mittellang, $10 \mathrm{~cm}$ lang, 24 Aehrchen und 45 Friichte enthaltend; Grannen hell, 4-5 cm lang. - Stroh: gelb, feinhalmig, fest, bis $110 \mathrm{~cm}$ lang. - Frucht: graugelb, lang und schmal, $8^{1 / 2} \mathrm{~mm}$ lang, $2^{1 / 2} \mathrm{~mm}$ breit.

Original im landwirtschaftlichen Museum zu Berlin.

Varietät: Secale cereale vulpinum Kcke.

Aehre einfach, fuchsrot.

\section{Sorte :}

\section{Fuchsiger Roggen aus Erzerum, Klein-Asien. (2)}

Aehre: fuchsrot, locker, mittellang; Aehrchen $1 \mathrm{~cm}$ breit, 2- und 3körnig; Grannen schmutzig-rot, 4-5 cin lang. - Stroh: gelb, krüftig, 
mittellang. - Frucht: bräunlich, sehr sehmal (8 unm lang, $21 / 2 \mathrm{~mm}$ breit, 358 Früchte $=10 \mathrm{gr}$ ), ziemlich feinschalig.

Herbstblatt gelbgrün, schmal, etwas kraus; Frühjahrsvegetation zeitig, 5.4 Schösslinge, spät schossend und blühend. Halmlänge $136 \mathrm{~cm}$ (Max. $157 \mathrm{~cm}$ ), Halmdicke $0.38 \mathrm{~cm}$, Blattzahl 4, Blattlänge $17.8 \mathrm{~cm}$, Blattbreite $0.8 \mathrm{~cm}$, Blattfläche $113.92 \mathrm{qcm}$, Halmfläche $162.42 \mathrm{qcm}, \mathrm{Ge}$ sammtfläche eines Halmes $276.34 \mathrm{qcm}$.

Aelire reift spät, $12 \mathrm{~cm}$ (Max. $17 \mathrm{~cm}$ ) lang, ruit 70 fest sitzenden Friichtelı, von denen 2778080 auf $1 \mathrm{hl}(=77.6 \mathrm{~kg})$ entfallen.

Es wiegen 100 Halme $665 \mathrm{gr}$ und davon die Früchte $278 \mathrm{gr}$.

Diese Roggensorte lagert nicht leicht, leidet aber ziemlich stark durch Rost.

Bezugsquelle: Landw. Schule Strickh of bei Ziirich 1870.

\section{Varictüt: Secale cereale fuscum Kcke.}

A ehre einfach, braun.

\section{Sor te:}

\section{Bramer Roggen aus Erzerum, Klein-Asien, (2)}

Achre: schmutzig-braun, ziemlich dicht, lang; Aehrchen $0.8 \mathrm{~cm}$ breit, 2-köruig; Gramen bräunlich, 4- $5 \mathrm{~cm}$ lang. - Stroh: gelbbraun, kräftig, ziemlich lang. - Frucht: etwas dunkel-roggenfarbig, manche ziemlich braun ( $8 \mathrm{~mm}$ lang, $3 \mathrm{~mm}$ breit, 344 Früchte $=10 \mathrm{gr}$ ), grobschalig.

Herbstblatt sehr fein, weizenähnlich; Frühjahrsvegetation etwas spät, Bestockung mittelstark, 4.5 Schösslinge, spät schossend und blühend. Halnuänge $147 \mathrm{~cm}$ (Max. $175 \mathrm{~cm}$ ), Halndicke $0.36 \mathrm{~cm}$, Blattzahl 4.3, Blattlänge $19.2 \mathrm{~cm}$, Blattbreite $0.79 \mathrm{~cm}$, Blattfläche $130.46 \mathrm{qcm}, \mathrm{Halm}$ fläche $158.76 \mathrm{qcm}$, Gesammtfächc $289.22 \mathrm{q} \mathrm{cm}$.

Aehre reift spät, $14 \mathrm{~cm}$ (Max. $16 \mathrm{~cm}$ ), mit 70 sehr fest sitzenden Fruichten, von denen 2463040 auf $1 \mathrm{hl}(=71.6 \mathrm{~kg}$ ) entfallen.

Diese Roggensorte lagert nicht leicht, befällt jedoch stark mit Rost. Bezugsquelle: Landw. Schule Stricklof bei Zïrich 1870.

Varietät: Secale cereale duplofuscum Kcke.

Aehre einfach, dunkelbraun.

\section{Sorte :}

\section{Dunkelbrauner Roggen aus Erzerum, Klein-Asien. (2)}

Aehre: dunkel-schmutzigbraun, ziemlich dicht, lang; Aehrchen $0.8 \mathrm{~cm}$ breit, 2-körnig; Grannen braun, $4-5 \mathrm{~cm}$ lang. - Stroh: gelb, kräftig, fest, mittellang. - Frucht: dunkelbraun, lang $(9 \mathrm{~mm}$ lang, $3 \mathrm{~mm}$ breit, 302 Friichte $=10 \mathrm{gr}$ ), grobschalig.

Herbstblatt kräftig, kraus; Eriilhjahrsvegetation spät, 5 Schösslinge, spät schossend und bliihend. Halmlänge $130 \mathrm{~cm}$ (Max. $160 \mathrm{~cm}$ ), Halm- 
dicke $0.4 \mathrm{~cm}$, Blattzahl 4, Blattlänge $18.7 \mathrm{~cm}$, Blattbreite $1.0 \mathrm{~cm}$, Blatt甘äche $149.6 \mathrm{qcm}$, Halmfläche $156 \mathrm{qcm}$, Gesammtfläche $305.6 \mathrm{qcm}$.

Aehre reift sehr spät, $14 \mathrm{~cm}$ (Max. $18 \mathrm{~cm}$ ), lang, mit 70 sehr fest sitzenden Früchten, von denen 2325400 auf 1 hl (= $77 \mathrm{~kg})$ entfallen.

Es wiegen 100 Halme $560 \mathrm{gr}$ und davon die Friichte $225 \mathrm{gr}$.

Diese für Deutschland bedeutungslose Roggensorte lagert nicht leicht, leidet jedoch stark durch Rost.

Bezugsquelle: Landw. Schule Strickhof bei Zürich 1870.

Varietät: Secale cereale monstrosum Kcke.

Aehre verästelt.

\section{Sorte :}

\section{Aestiger Roggen aus der 'Türkei. (2)}

Aehre: graulich-gelb, meist dick, verästelt, mittellang, Grannen kurz, bis $3 \mathrm{~cm}$ lang. - Stroh: rötlich-gelb, kräftig, lang. - Frucht: graubraun, klein verkïmmert.

Herbstblatt weizenähnlich; Frühjahrsvegetation spät, 4.5 Schösslinge, Halmlänge $150 \mathrm{~cm}$ (Max. $170 \mathrm{~cm}$ ), Halmdicke $0.44 \mathrm{~cm}$, Blattzahl 4, Blattlänge $21 \mathrm{~cm}$, Blattbreite $0.84 \mathrm{~cm}$, Blattfläche $141.12 \mathrm{qcm}$, Halmfläche $207.43 \mathrm{qcm}$, Gesammtfläche $348.55 \mathrm{qcm}$.

Aehre reift mittelfrüh, $11 \mathrm{~cm}$ ( $\left(\mathrm{Lax}_{\mathrm{a}} 13 \mathrm{~cm}\right.$ ) lang.

Dieser Roggen darf nicht mit Secale compositum Lam. verwechselt werden, bei welchem die Aehrenspindeln verästelt sind, und der in der Anssaat mit sehr seltenen Ausnahmen nur einfache Aehren liefert.

Bezugsquelle: Landw. Schule Strickh of bei Zürich 1870. 


\section{Die biologischen Verhältnisse des Roggens.}

In der Praxis herrscht die weit verbreitete Ansicht, dass das Saatkorn des Roggens vollständiger ausgereift sein solle, als das der übrigen echten Getreidearten und schien auch ein Versuch von Lucanu s ${ }^{1}$ ) dies zu rechtfertigen, welcher fand, dass in der Vollreife gemähter Roggen reicher an Proteïnstoffen und Kohlehydraten ist, als in der Gelbreife. Nowacki dagegen, gestiutzt auf seine Versuche über das Reifen des Getreides, widersprach dieser Ansicht und führte die Differenzen in del Zusammensetzung des in der Gelb- und Vollreife gemähten Roggens in dem Versuch von Lu canus auf Ungleichmässigkeit des Materials zuriick. Demnach empfiehlt es sich, auch für das Saatkorn des Roggens, wie für das der ubrigen Getreirlearten, die Gelbreife als die beste Periode der Ernte anzunehmen.

Die Zusammensetzung des Roggens variiert nach der Beschaffenheit des Kornes sehr beträchtlich und kann derselbe enthalten an

\begin{tabular}{lcccccc} 
& $\begin{array}{c}\text { Trocken- } \\
\text { substanz }\end{array}$ & Stickstoff- & \multicolumn{3}{c}{ Stickstofffreie } \\
& Procstanz & Fett & Extraktstoffc & Holzfaser & Asche \\
Minimum & 81.7 & 10.9 & 1.0 & 60.2 & Proc. & Proc. \\
Maximum & 88.2 & 16.4 & 2.2 & 73.0 & 3.3 & 1.5 \\
Mittel & 86.8 & 12.7 & 1.5 & 68.8 & 2.1 & 1.7
\end{tabular}

Da nun die absolut schwersten Samenkörner die an Reservestoffen reichsten sind, hat man dieselben auch als Saatgut zu verwenden.

Dass die kleineren Körner ein und derselben Roggensorte für die junge Pflanze erheblich weniger Mutternahrung liefern als die grossen, daher sich, namentlich auf armem Boden und bei ungünstiger Witterung, die junge Pflanze auch weniger uippig entfalten wird, beweisen die Untersuchungen von $A$. $\mathrm{M} u ̈ l \mathrm{lel}$ an Winterroggen, danach betrug beim

\begin{tabular}{|c|c|c|}
\hline & grossen Kiorn & klcinen Korn \\
\hline $\begin{array}{l}\text { Hektolitergewicht } \\
\text { Kornzahl pro hl } \\
\text { Gewicht pro Korn } \\
\text { Specifisches Gcwicht } \\
\text { Volumen eines Kornes }\end{array}$ & $\begin{array}{c}77.0 \mathrm{~kg} \\
2817606 \\
25.8 \mathrm{mg} \\
1.39 \\
18.6 \mathrm{cbmm}\end{array}$ & $\begin{array}{c}62.4 \mathrm{~kg} \\
4537215 \\
12.9 \mathrm{mg} \\
1.39 \\
9.3 \mathrm{cbmrn}\end{array}$ \\
\hline
\end{tabular}

1) Landw. Versuchsst. IV. 165. 


\begin{tabular}{|c|c|c|c|}
\hline & grossen Korn & kleinen & n Korn \\
\hline Bestandteile: & & & \\
\hline $\begin{array}{l}\text { Tasser } \\
\text { Holzfaser } \\
\text { Asche } \\
\text { Proteïnstoffe } \\
\text { Fett } \\
\text { Zucker } \\
\text { Stärke }\end{array}$ & $\begin{array}{rc}18.34 & \text { Proc. } \\
3.52 \quad " \\
1.40 \quad " \\
9.05 \quad " \\
2.33 \quad " \\
0.36 \quad " \\
64.97 \quad ",\end{array}$ & $\begin{array}{r}16.46 \\
4.64 \\
1.80 \\
10.06 \\
2.81 \\
0,62 \\
63.61\end{array}$ & $\begin{array}{c}\text { Proc. } \\
\quad " \\
", \\
", \\
" \\
"\end{array}$ \\
\hline
\end{tabular}

Bei dell eimzelnen Roggensorten, und zwä ansgesuchtes Saatgut derselben mit einander verglichen, variiert das absolute und das Volumengewicht nach unseren Untersuchungen in sehr erheblichem Grade, wie wachfolgende Zusammenstellung zeigt:

a. Winterroggen.

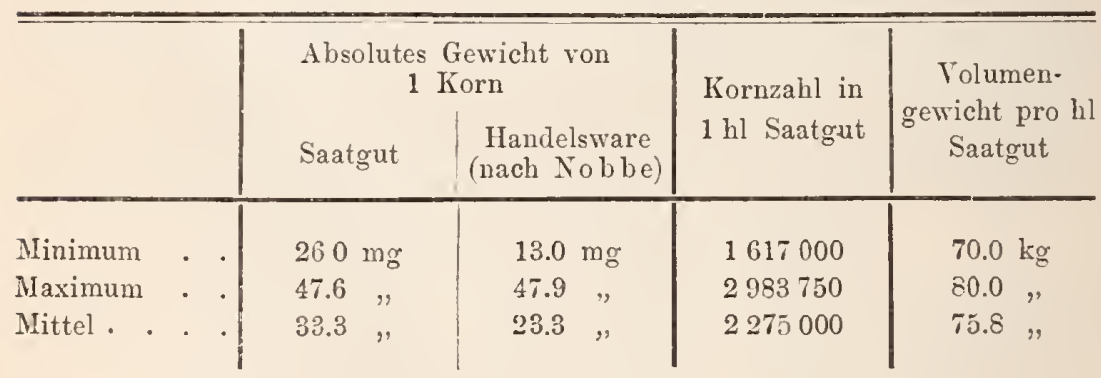

b. Sommerroggen.

\begin{tabular}{|c|c|c|c|c|}
\hline Minimum & $22.0 \mathrm{mg}$ & - & 2030000 & $72.2 \mathrm{~kg}$ \\
\hline Maximum & $39.0 \quad$, & - & 3608150 & 80.0 \\
\hline Mittel. & $29.0 \quad "$ & - & 2700000 & 78.0 \\
\hline
\end{tabular}

Der Saatroggen darf nicht künstlich getrocknet sein, da im lufttrocknen Zustande schon Temperaturen von $+60^{\circ} \mathrm{C}$. und im feuchten ron $+50^{\circ} \mathrm{C}$. fül seine Keinfähigkeit bedenklich sind.

Schliesslich soll Saatroggen nicht iiber ein Jahr alt und nicht multrig sein, indem Roggen bei schlechter Aufbewahrung seine Keimkraft viel leichter als Weizen oder gar Hafer verliert, es sei denn, dass uberjühriger, mit Spreu vermengt, dünu auf einem luftigen Boden gelagert hat.

Kommt iiberjähriger Roggen zur Aussaat, was z. B. beim Johannis-Roggen nicht iibergangen werden kaun, so keimt derselbe, weil mehr vơhärtet und deshalb mehr' Zeit zur Quellung beanspruchend, etwas langsamer als neuer Roggen.

Nach 3-4 Jahren rerliert der Roggen seine Keimfähigkeit, 
weshalb es wichtig ist, angekauften Saatroggen auf seine Keinfaihigkeit und zugleich auf seine sonstige Beschaffenheit $\mathrm{zu}$ untersuchen.

Nach Nobbe betrugen Keimkraft und fremde Beimengungen in der Handelsware:

$\begin{array}{lccc} & \text { Mittel } & \text { Maximum } & \text { Minimum } \\ \text { Proc. } & \text { Proc. } & \text { Proc. } \\ \text { Keimkraft rou 100 reinen Samen } & 89 & 100 & 17 \\ \text { fremde Bestandteile } & 1.67 & 6.37 & -\end{array}$

Nach Dimitrieviez ${ }^{1}$ ) besitzt der mittels eines scharfen Rasiermessers ansgeschnittene Embryo unter einer $5-6$ mal vergrössernden Lupe bei absolut keimfähigen Samenkörnern eine gelblichgrüne, grüngelbe bis erdwachsgelbgriune Färbung. Die Keimlinge der schwach oder nicht keimfähigen Samen sind fahl, mit einem Stich in's Bläuliche, brïunlich Braune und bläulich Weisse.

Ausgewachsene und später wieder getrocknete Körner, welche nur die Wurzelkeime entwickelt hatten, keimen grösstenteils, haben aber dabei einen Teil ihrer Reservestoffe eingebiisst und liefern eine entsprechend schwächere P'flanze.

Der Roggen benötigt zum Keimen nach Hoffma nn 57.7 Proc., nach Haberlandt 85 Proc. Quellungswasser, welches in 24-48 Stunden anfgenommen wird. Von allen echten Getreidearten scheint der Roggen den bedeutendsten Sauerstoffzufluss beim Keimen zu beanspruchen, demzufolge er eine tiefe Unterbringumg am wenigsten verträgt; gemeinhin schwankt die Tiefe zwischen 1.3-2.5 und höchstens $7 \mathrm{~cm}$. Nach Tietschert ${ }^{2}$ ) gingen ron 100 Saatkörnern auf:

\begin{tabular}{c|c|c|c|c}
\hline $\begin{array}{c}\text { Saattiefe } \\
\mathrm{cm}\end{array}$ & $\begin{array}{c}\text { Sand- } \\
\text { boden }\end{array}$ & $\begin{array}{c}\text { Humoser } \\
\text { Boden }\end{array}$ & $\begin{array}{c}\text { Lehm- } \\
\text { boden }\end{array}$ & $\begin{array}{c}\text { Thon- } \\
\text { boden }\end{array}$ \\
\hline & & & & \\
2.6 & 81.8 & 809 & 84.5 & $72 . \overline{1}$ \\
5.2 & 77.3 & 73.6 & 86.4 & 73.6 \\
7.9 & 77.3 & 75.5 & 77.3 & 63.6 \\
10.4 & 78.2 & 67.3 & 69.1 & 33.6 \\
13.0 & 27.3 & 60.0 & 20.0 & 6.4 \\
15.6 & 7.3 & 5.5 & 12.7 & 1.8
\end{tabular}

Zunächst treten bei der Keimung 4 Würzelchen hervor und hierauf erscheint das Stengelchen. Nobbe fand, dass die Keimung bei $16-18^{\circ} \mathrm{C}$. in einem 'Tag' begann und die Mehrzahl der Saatkörner nach 3 Tagen gekeimt hatte.

Nach 24stundiger Einquellung' ausgesäet, erfolgten Keimung und 1877. p. 71.

1) Wissenschaftl.-prakt. Unters. auf d. Gebiet d. Pflanzenbaus. Wien II.

2) Keimungsversuche mit Roggen und Raps bei rerschieden tiefer Unterbringung. Halle 1872 . 
Wachstum nach Haberlandt mit dem Sichtharwerden des Würzelchens

Winterroggen in Tagen

Sonmerroggen in Tagen bei $4.38^{\circ} \mathrm{C} .10 .25^{\circ} \mathrm{C} .15 .75^{\circ} \mathrm{C}$. $19^{\circ} \mathrm{C}$.

3

4

2

1.75

1.75

Liingenwachstum des Stengelehens

fiir einen Tag in $\mathrm{mm}$

Winterroggen

Sonmerroggen

1.68

3.82

6.54

Unter guinstigen Keimungsbedingungen erschienen in Poppelsdorf die Pflanzen bei $9-12^{\circ}$ C. in 8-27 Tagen und im Durchschnitt 16 Tage nach Legung des trocknen Samens an der Oberfliiche.

Die Bestockung des Winterroggens vollzieht sich der Hauptsache nach im Herbst, nnd ist die Zahl der Schösslinge von der Sorte, der Grösse des Pflanzraumes, der Tiefe der Unterbringung des Saatkorns, sowie ron der Beschaffenheit des Bodens und der Witterung ablängig:

Auf dem reichen, milden Lehmboden in Poppelsdorf betrug bei $20 \mathrm{~cm}$ Drillweite die Zahl der Schösslinge im siebenjährigen Dnrchschnitt pro Pflanze:

beim Winterroggen 5 Schösslinge, Minimum 4, Мaximum 6.6 " Sommerroggen $2.1 \quad$, $\quad 1.2$, - 3.4 .

Eine Ausnahme macht im Juli gesäeter Johannis-Roggen mit 12 Schösslingen.

Betrefis der Einwirkung der Wachsraumgrösse auf die Bestockung ist ein Versuch von Haberlandt mit 1876 am 29. September in Wien ausgesäetem Roggen anzufiihren, danach erzeugte eine Pflanze:

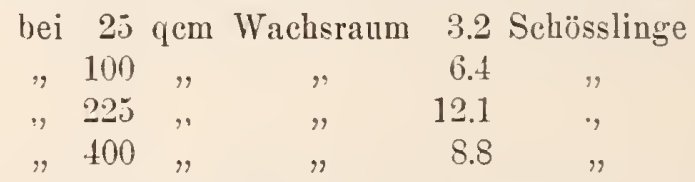

Bei sonst giinstigen Keimungsverhältnissen bestocken sich die aus flach untergebrachten Saatkörnern hervorgegangenen Pflanzen am stärksten, weil die in geringer Tiefe entwickelten Pflanzen auch die geringsten Verluste an Reservestoffen erfahren haben, also krüiftigere Pflanzen mit reicherer Bestockung erzengen können.

Ferner wird sich auf reichem Boden und bei geniigend warmer und fenchter Wittermug die relativ kräftigste Bestockung bei jeder Sorte zeigen müssen.

Die Halme beginnen im Frühjahr ihre Entwickelung relativ zeitig, wenn dic Temperatur sich auf $+6^{0} \mathrm{C}$. erhölıt hat, und tritt bei einer Durchschnittstemperatur ron $14^{\circ} \mathrm{C}$. die Blïte ein. Die gavze Aehre blïht dann mit weit geöffneten Blütchen gleichzeitig ab 
und da Fremdbestäubung die Regel ist, leidet der Roggen in dieser Phase sehr stark, sobald ungiinstige Witterungsverhältnisse obwalten, daher viel Regen, heftige Winde odcr Nachtfröste taube oder schartige Aehren erzeugen, mithin für den Ertrag beim Roggen zu einem grossen Teil ein günstiger Verlauf der Bliite entscheidet. Die Befruchtung vollzieht sich am besten bei mässig feuchtem, warmem Wetter, das mit sonnigen Perioden abwechselt, dann erheben sich bei leisem Luftzuge Wolken von Bluitenstaub in den Roggenfeldern, welcher sich senkend die Narben befruchtet. Durchschnittlich rerläuft die Blüte innerhalb 10 Tagen.

Um auch bei nicht ganz günstigen Witterungsverhältnissen eine ausgiebigere Befruchtung zu erzielen, suchte in den sechsziger Jahren Hooibrenk durch Ueberziehen der Saaten während ihrer Bliitezeit mit einer aus Wollfäden hergestellten Befruchtungsfranse eine rollständigere Uebertragung des Pollens auf die Narben zu bewirken, doch hat sich trotz zahlreicher und ausgedehnter Versuche ein giinstiger Erfolg nicht gezeigt.

In der nachfolgenden Tabelle ist eine Uebcrsicht der Vegetationsverhältnisse gegeben, wie sie sich in Poppelsdorf bei einer Drillweite von $20 \mathrm{~cm}$ und einer grossen Zahl von angebauten Roggensorten durchschnittlich gestalteten.

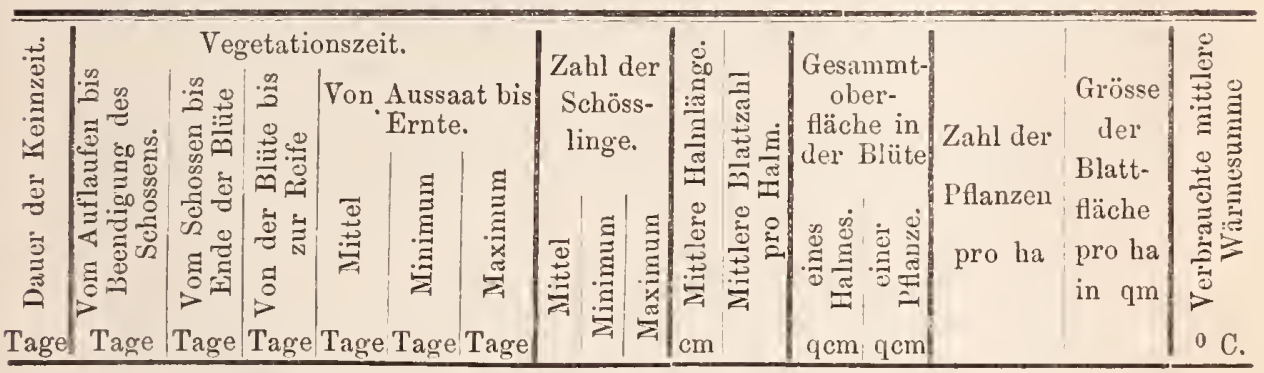

a. Wint erroggen.

$16|189| 22|38| 265|233| 300|5| 4|6.6| 150|4.3| 312|1560| 2000000|312000| 2276$ b. Sommerroggen.

$16|-|-|-| 120|110| 130|2.1| 1.2|3.4| 130|3.5| 181|380| 6000000|228000| 1500$

Im Allgemeinen beansprucht der Roggen bis zum Auflaufen eine Wärme von $117-150^{\circ} \mathrm{C}$, bis zur Bliite, die regetationslose Zeit ausgenommen, $1225-1425^{\circ} \mathrm{C}$. und bis zur Ernte $1700-2400^{\circ} \mathrm{C}$. In obiger Tabelle ist auf die gebränchliche Einteilung des Roggens in gewöhnlichen Land- und sog: Staudenroggen (nach 
Springer 1765 Ic pg. 104 zuerst aus der Walachei nach Deutschland gelangt), keine Riicksicht genommen.

Der Staudenroggen unterscheidet sich rom Landroggen durch eine längere Vegetationsperiode, stärkere Bestockung, höhere Kornund Strohertrïge, mithin durch kräftigeren Habitus, weshalb er sich auch zur Verwendung als Grinfutter empfiehlt. Dagegen stelit seine Kornqualität, namentlich auf sehr reichen Böden, hinter der des gewöhnlichen Landroggens zurïck. Diese Eigenschaften gehen jedoch mehr oder minder verloren, wenn seine Kultur nicht auf reichem, frischem Boden stattfindet, er nähert sich dann dem gewöhnlichen Landroggen und da sich nun bei dieser Veränderlichleit des Habitus nicht mit Sicherheit angeben lässt, ob eine Sorte der einen oder anderen Abteilung zuzuzählen ist, habe ich gänzlich von einer solchen Einteilung Abstand genommen.

Der Roggen ist als Flachwurzler oder Krumepflanze anzusehen, denn obwohl Schubart-Gallentin cinen recht beträchtlichen Wurzeltiefgang bei seinen Untersuchungen fand, bezieht sich derselbe doch̉ nur auf eine verhäiltnismässig geringe Anzahl Wurzeln, die, in grössere Tiefen dringend, dem Wasser nachgehen.

Schubart fand, dass am 16. September gesïeter Winterroggen, am 29. April ausgegraben, Wurzeln von $1.17 \mathrm{~cm}$ Länge getrieben hatte, doch kamen nach den Untersuchungen Stöekhardt's von der gesammten Wurzelmasse 141 Teile auf die Ackerkrume $(23.5-26 \mathrm{~cm}$ tief) und nur 51 Teile auf den Untergrund, aber auch die grösste Zahl der aufuahmefuhigen Wurzelendigungen fand sich in der Ackerkrume, wenn man aus dem gefundenen Stickstoffgehalt auf ihre Zahl schliessen darf, demn auf die Wurzelmasse der Ackerkrume entfielen $13.2 \mathrm{~kg}$ und auf die des Untergrundes $10.8 \mathrm{~kg}$ Stickstoff pro ha.

Ebenso bestätigen die Untersuchungen Hellriegels ${ }^{1}$ ), dass sich die grösste Zahl der Faserwurzeln in der Ackerkrume ausbrcitet. Er fand bei Untersuchung des Winterroggens folgende Zahlen:

\section{anf Feld a.}

Bodenprofil $\left\{\begin{array}{l}\text { lehm. Sand } 66 \mathrm{~cm}\left\{\begin{array}{l}\text { daron } \Lambda \text { ckerkrume humushaltig } 35 \mathrm{~cm} \\ \text { Untergrund humuslos }\end{array}\right. \\ \text { grober roter Diluvialsand. }\end{array}\right.$

Zahl der Wurzeliasern auf 400 qem Fläche:

bei $25 \mathrm{~cm}$ Tiefe (in der Ackerkrume) 600 Fasern

" 50, " (im lehmigen Sande) 376 "

1) Grundl. đ. Ackerb. pg. 25i, 1883. 


\section{auf Feld b.}

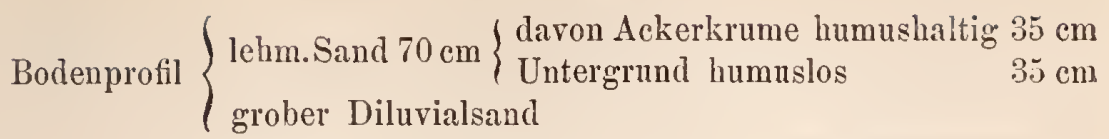
bei $25 \mathrm{~cm}$ Tiefe (in der Ackerkrume) 634 Fasern

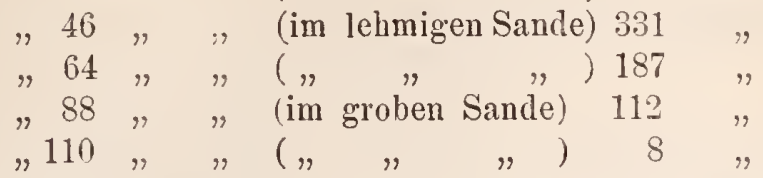

Es kann hiernach keineswegs zweifelhaft sein, dass der Roggen die Hauptsumme seiner Nährstoffe aus der Ackerkrume bezieht. Anch scheint es, wie schon beim Weizen dargethan, dass sein Wurzelvermögen nicht unbeträchtlich grösser als das des Weizens ist, weshalb er selbst anf armem Sandc noch relativ hohe Erträge zu liefern vermag; freilich kommt ihm hierbei seine Bestockung im Herbst und der zeitige Eintritt der Vegetation im Frühjahr za statten, denn zu diesen Jahreszeitell steht ihm auf den leichten Böden meist geniigend Fenchtigkeit zur Verfügung.

Der Ernteentzug an wichtigen Pflanzennährstoffen ist, gleich hohe Ernteerträge beim Weizen und Roggen voransgesetzt, bei beiden annähernd gleich, und entnimmt sogar der Roggen dem Boden beträchtlich grössere Kalimengen als der Weizen.

Der Ernteentzug einer Mittelernte des Roggens stellt sich wie folgt:

\begin{tabular}{|c|c|c|c|c|c|c|c|c|c|c|}
\hline & $\begin{array}{l}\text { Mittel- } \\
\text { ernte } \\
\text { pro ha } \\
\text { in } \mathrm{kg} \text {. }\end{array}$ & 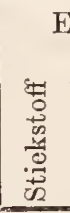 & $\begin{array}{l}0 \\
0 \\
0 \\
\frac{0}{4}\end{array}$ & $\begin{array}{l}\because \approx \\
\approx=\end{array}$ & 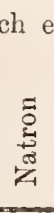 & $\begin{array}{l}\text { ine } 1 \\
\text { in } \mathrm{kg} \\
= \\
=\end{array}$ & 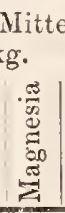 & 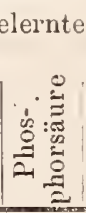 & pro & 恶 \\
\hline \multirow{2}{*}{$\begin{array}{cl}\text { Winterroggen, } & \text { Korn } \\
\text { do. } & \text { Stroh } \\
\text { Winterroggen im }\end{array}$} & $\begin{array}{l}1060 \\
3300\end{array}$ & $\begin{array}{r}17.6 \\
7.9\end{array}$ & $\begin{array}{r}17.3 \\
134.3\end{array}$ & $\begin{array}{r}5.4 \\
25.1\end{array}$ & $\begin{array}{l}0.3 \\
4.3\end{array}$ & $\begin{array}{r}0.5 \\
10.2\end{array}$ & $\begin{array}{l}1.9 \\
4.3\end{array}$ & $\begin{array}{l}8.2 \\
6.3\end{array}$ & $\begin{array}{l}0.4 \\
2.6\end{array}$ & $\begin{array}{r}0.3 \\
78.2\end{array}$ \\
\hline & Ganzen : & 25.5 & 151.6 & 30.5 & 4.6 & 107 & 6.2 & 14.5 & 3.0 & 78.5 \\
\hline \multirow{2}{*}{$\begin{array}{cc}\text { Sommerroggen, Korn } \\
\text { do. } & \text { Stroh } \\
\text { Sommerroggen im }\end{array}$} & $\begin{array}{r}880 \\
2200\end{array}$ & $\begin{array}{r}15.5 \\
5.3\end{array}$ & $\begin{array}{r}15.2 \\
104.7\end{array}$ & $\begin{array}{r}4.8 \\
22.4\end{array}$ & $\begin{array}{l}03 \\
2.9\end{array}$ & $\begin{array}{l}0.4 \\
9.7\end{array}$ & $\begin{array}{l}1.7 \\
2.9\end{array}$ & $\begin{array}{l}6.2 \\
6.8\end{array}$ & $\begin{array}{l}0.4 \\
2.6\end{array}$ & $\begin{array}{r}0 . \\
58.5\end{array}$ \\
\hline & Ganzen: & 20.8 & 119.9 & 27.2 & 3.2 & 10.1 & 4.6 & 13.0 & 3.0 & 58.8 \\
\hline
\end{tabular}

Ferner verdunstet der Roggen von den Getreidearten nach Risler die geringsten Wassermengen, denn es wurdc die mittlere Verdunstung der Pflanzen durch einen Niederschlag gedeckt, del täglich beim Roggen $2.26 \mathrm{~mm}$, beim Weizen $2.67-2.8 \mathrm{~mm}$ und beim Hafer $3.9-4.9 \mathrm{~mm}$ betrug.

Auch fand Hellriegel, dass der Sommerroggen zur Eizielung von $1 \mathrm{gr}$ Trockensubstanz der oberirdischen Teile $338 \mathrm{gr}$ und zwa* 
$28 \mathrm{gr}$ Wasser mehr als Sommergerste und weniger als die iibrigen echten Getreidearten rerdunstete.

Nach einem Versuch ron Haberlan $\mathrm{dt}^{1}{ }^{1}$ ) ergiebt sich fïr Sommerroggen in drei verschiedenen Entwickelungsperioden nachfolgende Wasserverdunstung.

\begin{tabular}{|c|c|c|c|c|c|}
\hline \multirow[t]{2}{*}{ Entwickelungsstadium. } & \multicolumn{2}{|c|}{$\begin{array}{l}\text { Oberfläche } \\
\text { der Ver- } \\
\text { suchs- } \\
\text { pflanzen }\end{array}$} & \multirow{2}{*}{$\begin{array}{l}\text { Zahl der } \\
\text { Spaltöff- } \\
\text { nungen } \\
\text { auf der } \\
\text { unteren } \\
\text { Blattseite } \\
\text { pro qmm }\end{array}$} & \multirow{2}{*}{$\begin{array}{l}\text { Verhältnis } \\
\text { des Trocken- } \\
\text { gewichts der } \\
\text { Wurzeln zu } \\
\text { jenem der } \\
\text { oberirdi- } \\
\text { schen Teile }\end{array}$} & \multirow{2}{*}{$\begin{array}{l}\text { Ter- } \\
\text { dunstung } \\
\text { pro Tag } \\
\text { u.100qcm } \\
\text { (bei Was- } \\
\text { ser im } \\
\text { Ueber- } \\
\text { fluss) }\end{array}$} \\
\hline & $\begin{array}{c}\text { I } \\
\mathrm{qcm}\end{array}$ & $\begin{array}{c}\text { II } \\
\text { qcm }\end{array}$ & & & \\
\hline a. Junge Pflanze ror dem Schossen & 66 & 166 & 124 & $1: 1.075$ & 3.765 \\
\hline b. Mittlere Pflanze vor der Blüte & 104 & $15 \tau$ & 105 & $1: 7.171$ & 2.611 \\
\hline c. Pflanze nach der Blüte & 102 & 126 & 83 & $1: 12.2 S 8$ & 2.172 \\
\hline
\end{tabular}

Demzufolge verdunsten die Pflanzen pro $100 \mathrm{qcm}$ Oberfläche um so mehr Wasser, je jünger sie sind, und dementsprechend hält auch die Entwickelung der Wurzeln und oberirdischen Organe nicht gleichen Schritt, sondern die aufsaugende Wurzeloberfläche ist im Verbältnis zu den oberirdischen Teilen um so grösser, je jünger die Pflanzen sind.

Die Zahl der unter Sommer- und Winterroggen vorkommenden Unkräuter ist bäufig so gross, dass zu ihrer Vertilgung zur Brachbearbeitung oder Hackkultur gegriffen und eine zweckmässige Frucht= folge eingerichtet werden muss.

Auf den Lehmmergelböden treten nahezı die nämlichen Unkräuter, welche schon beim Weizen besprochen wurden, wie die Feldkratzdistel (Cirsium arrense Scop), der Klatschmohn (Paparer Rhoeas L.), der Wildhafer (Arena fatua L.), auf, ausserdem aber auch der gemeinc Knöterich (Polygonum Persicaria L.), der sich nur durch genaue Reinigung des Saatgutes, Jäten, sowie rechtzeitiges Pflügen und Eggen des Saatlandes rernichten lässt.

Eines der gefährlichsteı Unkräuter, namentlich in nassen Jabrgängen, ist die Roggentrespe (Bromus secalinus L.), welche nicht nur den Ertrag wesentlich schmälert, sondern es wird auch, wenn die Entfernung ihrer Samen aus den Roggenkörnern unterbleibt, und bekanntlich lassen sie sich nur mit Hiilfe der Trespensiebe ausscheiden,

1) Den Pflanzen wurde Wasser im Ueberfluss zugeführt, daher sicl voraussichtlich unter normalen Verhältnissen eine weit geringere Verdunstungsgrösse ergeben wird. 
das aus diesem verunreinigten Roggen hergestellte Brod schwär»lich, bleibt feucht, und soll betäubende Wirkungen besitzen; ähnlich rerhält sich auch der Taumellolch (Lolium tcmulentum L.), dessen Samen narkotisch wirken.

Nur durch genauc Reinigung des Saatgutes und indirckte Vertilgungsmittel lässt sich der Ausbreitung dieser Unkräuter entgegentreten.

Sehr gefährliche Unkräuter des sandigen Lehm- und lehmigen Sandbodens sind auch dic beim Weizen schon erwähnte Kornrade (Agrostemma Githago L.) und Kornblume (Centaurea Cyanus L.); durch die Samen der ersteren nimmt clas Melıl eine schwärzliche Färbung an und das daraus belcitete Brod zeigt gesundheitsschädliche Eigenschaften. Ferner sind noch anzufiihren: die ausdauernde Ackerwinde (Convolrulus arvensis L.), und auf leichtem Boden mit fenchtem Untergrunde der gemeine Windhalm (Agrostis spica venti L.). Ein sehr gefährlicher Feind dieser Bodenarten ist aber jedenfalls die Quecke (Triticum repens L.) und sollte ein Feld niemals mit Roggen bestellt werden, welches nicht durch zweckmässigc Behandlung von der Queckenplage befreit worden ist.

Auf den kalkreichen Lchmböden schädigen auch zwei Schmarotzer, der Feldwachtelweizen (Melampyrum arvense L.) und die grössere Klapper (Alectorolophus major Rehb.), welche nicht nur den Ernteertrag "sehr beträchtlich vermindern, sondern die Samen dersclben verleihen dem Mehl eine blaue Farbe und unangenehmen Geschmack. Ein sehr lästiges Unkraut ist auch die stinkende Hundskamille (Anthemis Cotula L.).

Auf sandigen Bodenarten mit Mergel im Untergrunde tritt dic bläuliche Brombeere (Rubus caesius L.) unter Roggen häufig als sehr lästiges Unkraut auf, das sich nur durch wiederholtes Abschneiden. Hackfruchtbau, Brache und Ausjäten entfernen lässt.

Ebenfalls schr schädlich und in gleicher Weisc schwer vertilgbar ist der Ackerschachtelhalm (Equisetum arvense L.).

Auf den leichten Sandböden kommen unter Sommer- und Winterroggen vor: Feldrittersporn (Delphinium Consolida L.), Sandmohn (Papaver Argemone L.); unter Winterroggen: Gemeine Vogelwicke (Vicia cracca L.), zottige Wicke (Vicia villosa Roth), Kreuzkraut (Senecio vernalis W. K.); unter Sommerroggen: Feldspörgel (Spergula arvensis L.), bunter Daun (Galeopsis versicolor Curt), und kleiner Sauerampfer (Rumex Acetosella L.); diese Unkräuter lassen sich am besten durch rechtzcitigen Stoppelumbruch, besommerte Brache, gute Reinigung des Saatkornes und Hackkultur vertilgen.

Ein lästiges Unkraut der Sandfelder ist ferner der Acker- oder Sandlauch (Allium arenarium L.), dessen Blütenzwiebeln leicht unter den Körnern verbleiben und dann dem Mehl einen penetranten, knob- 
lanchsartigen Gernch und Geschmack mitteilen, hiergegen hilft nur gename Reinigung des Saatgutes und Spatpflügen zum Vergraben der Zwiebeln.

Auf allen Bodenarten mit Kalk im Untergrunde stellt sich auch der gemeine Huflattich (Tussilago Farfara L.) ein und wird vorzugsweise im Seeklima sehr lästig.

Der Roggen ist einer grossen Zahl von Pilzkrankheiten unterworfen, die sich aber anch grösstenteils bei anderen echten Getreidearten finden.

Zuvörderst sind zwei dem Roggen eigentümliche Krankheiten, der Roggenkornbrand ('Tilletia secalis Keke.) und der Roggenstengelbrand (Urocystis neculta Rabli.) zn erwähnen.

Der Roggenkornbrand zerstört den Frnchtknoten in ähnlicher Weise wie der Steinbrand des Weizens, und laisst sich durch Beizen mit Kupfervitriol die Ausbreitung des Pilzes einschränkeı. In Mittelenropa tritt diese Krankheit sehr selten auf.

Der Roggenstengelbrand kommt gliicklicherweise meist nur vereinzelt vor und entzieht sich um so leichter der Wahrnehmung, als er nicht immer eine gleich intensive Erkrankung hervorrult.

Bei intensiverem Anftreten wird auch der Halm und die Aehre mehr oder weniger stark in Mitleidenschaft gezogen und in den ungïnstigsten Fällen kommt die Aebre entweder gar nicht zur Entwicklung oder ist doch durch den Brand verulstaltet, während der Halm nicht nur Brandstreifen wahrnehmen lässt, sondern in seinem obern Teile sogar aufspringt und seine innere mit Brandstaub bedeckte Fläche zeigt. Dieses verschiedene Maass der Ausbildnng hängt zum Teil von der Stärke der Infektion, ganz besonders aber von dem Verlaufe der Witterung ab.

Die Mittel gegen diesen Feind sind bei intensivem Anftreten folgende :

Zunächst mähe man die stark befallenen Felder in der Gelbreife. Je später gemälit wird, um so zahlreicher wcrden die Sporen von den erkrankten und an den Brandstellen zum Teil anfspringenden Pflanzen anf benachbarte Aecker durch den Wind verbreitet. Kommit auf diese im nächsten Jahre Roggen, dann ist eine Iufektion höchst wahrscheinlich.

Ferner muss vermieden werden, dass durch das Stroh des befallenen Roggens die Sporen in den Diinger und durch dicsen auf das Feld gelangen. Man verwende daher brandiges Roggenstroh nicht zü Einstreu, wenn Diinger bereitet wird, der zn Roggen oder zu einer Frucht Verwendung finden soll, anf die Roggen folgt, denn die sporen bewahren ïber zwei Jahre ibre Keimfähigkeit und können daher auch später folgendem Roggen noch gefährlich werden.

Endlich ist zu beriicksichtigen, dass bei dem Dreschen aneh 
die verstïnbenden Sporen zum Teil an den Körnern hängen bleiben. Durch derartiges Saatgut wird dic Neuinfektion am sichersten und unfehlbarsten bewirkt. Deshalb ist es rätlich, den Saatroggen in einer $1 / 2$ procentigen Kupfervitriollösung einzuweichen. Man verwendet anf 100 Liter Wasser $1 / 2 \mathrm{~kg}$ Kupfervitriol und achtet larauf, dass diese Lösung etwa eine Querhand hoch iiber den in einem Bottich einzuquellenden Roggenkörnern steht. Es genügt eine Einweichungsdauer von 5 Stunden.

As hervorragendster Feind des Roggeens gilt der Rost, welcher namentlich im Seeklima, sowic in feuchten Lagen und in grösster Fille im Lagergetreide bei feuchtwarmer Witterung im Nai und Juni erscheint, aber auch bei zeitig gesäetem Roggen schon im Herbst auftreten kann. Ist die Witterung der Entwickelung des Pilzes günstig, dann befällt nicht selten der Roggen derart hochgradig, dass die Hälfte der Körnerernte verloren geht und ansserdem das Korn verschrumpft und unansehnlich, das Stroh niïrbe und nissfarben wird, daher als Viehfutter nicht mehr geeignet, anch arm an Nährstoffen ist.

Hauptsïchlich erzeugt diese Krankheit der Fleckenrost (Puccinia straninis Fuck.), seltener der Grasrost (Puccinia graminis Pers.).

Ton dem Fleckenrost kommt die Aecidienform auf Pflanzen aus der Familie der Boragineen, und von dem Grasrost auf der Berberitze vor und wies schon Schwerz 1821 auf den nachteiligen Einfluss hin, welchen in der Nähe von Roggenfeldern stehende Berberitze ansiubt.

Demnach sind zur Einschränkung dicser Krankheit die Träger der Aecidienform möglichst aus dem Felde zu entfernen, sowie Roggensorten auszuwählen, welche gegen Rost und Lagern eine grosse Widerstandsfahigkeit besitzen, und schliesslich sollte die Roggenkultur in möglichst freier Lage, sowie auf passendem Boden geschelien.

Bei feuchtwarmer Witterung tritt auf ippig entwickeltem Roggen nicht selten der Mehltaupilz (Erysiphe graminis Lev.) verderbenbringend auf. Sein Mycel überzieht mit weisslichem Ueberzng Blätter und Halme gerade zur Zeit des kräftigsten Wachstunıs der Pflanze, weshalb letztere durch Entziehung bereits organisierten Bildnngsmaterials erheblich leidet.

Sehr häufig zeigt sich auch beim Roggen das Mutterkorn (Claviceps purpurea Tul.), und gibt dieser Pilz seine Anwesenheit zunächst durch Austreten einer ölartigen Flïssigkeit („Honigtau") in den Spelzen einiger Blüten kund, die sich aus einem weissen Myceliun am Grunde des Fruchtknotens absondert und mit Konidien erfüllt ist; wird nun hiervon durch Insekten etwas auf eine andere Blite gebracht und diese inficiert, so entsteht die Ueberwinterungsform des 
Pilzes „das Mutterkorn". Dasselbe wirkt als scharf narkotisches, heftig wirkendes Gift durch zwrei in demselben enthaltene Alkaloide, das Ergotin und das Ekbolin und durch eine Säurc, die Ergotsäure, und sind die durch den Genuss ron Brod, welches Mutterkorn enthält, auftretenden Krankheiten zweierlei Art. Die eine wird Kriebelkrankheit genannt, weil sich bei dersclben als charakteristisches Symptom ein Kriebeln in der Haut einstellt, begleitet ron Uebelkeit und Taubheit; die andere Art beginnt mit Krämpfen ete. und endigt mit dem Brandigrerden einzelner Glieder. Beide Arten der Krankheit können den T'od zur Folge haben.

Wenngleich nun die durch das Ifutterkorn bewirkten Krankbeiten zur Zeit nur selten rorkommen, da es jetzt durch die rervollkommneten Reinigungsmaschinen grösstenteils von den schweren Getreidekörnern alogesondert wird, so hat der Landwirt doch stets auf das Vorkommen des Mutterkorns im Roggen sorgfältig zu achten und auf Vertilgung: und Verhiitung dieses der menschlichen Gesundhcit schädlichen Pilzes sein Augenmerk zu richten.

Ausnelımend zahlreich sind die Feinde aus dem Tierreich, so werden die Wurzeln des Roggens durch dic Raupen von Agriotes lincatus L., A. obscurus Gyllh., Igrotis crassa Hb., A. exelanationis L. und Characas graminis L. beschädigt.

Die Terminalknospen und jungen Blitter fressen ab: ein Blattkäfer (Phyllotreta vittula), die Larve und der Käfer ron Lema mclanopa L., die Raupe ron Hadena basilinea Wien. Verz., Agrotis segetum Wien. T'erz.. A. tritici L., A. funosa Wien. Verz. und Plusia gamma L.; ferncr die Made von Anthomyia coarctata Fall.; auch richtet im warmen und feuchten Klima die graue Ackerschnecke (Limax agrestis L.) bedeutende Verheerungen an, gegen wclche man sich durch Bestrenen der Feldränder mit Kalk oder Häcksel einigermassen zu schïtzen vermag, wenn es gleich nach der Einsaat geschicht.

Die den Haln angreifenden Insekten sind ausnehmend gefährlich, so die Larre von Calamobius marginellus Fabr., Cephus pygmaeus L., Tipula cerealis Sauter und Pyralis secalis L.

Die junge Aehre, weiche Frucht und iberhaupt dic weichen, oberirdischen Pflanzenteile werden häufig sehr umfangreich durch die Larve und den Käfer von Zabrus gibbus Fabr. zerstört. Die Befruchtungsorgane und das breiige Korn greifen an: die Larve ron Tipula tritici Kirby; der Käfer von Anisoplia austriaca Herbst, A. fruticola Fab.; die Raupe ron Leucania albilinca Guen. und Ochsenheimeria taurelli Schiff; die Larre von Chlorops taeniopus Meig., Oscinis frit L., Siphonella pumilionis Bjerkander; die Schildwanze Aelia acuminata F. Der zur Aehre aufsteigende Nahrungssaft wird dagegen von der Getreide-Blattlaus (Aphis granaria Kirby) aufgesogen 
und hierdurch die Entwickelung der Körner geschädigt. Das trockne, aufgespeicherte Korn wird durch die Käfer von Silvanus surinamensis Steph., Curculio granarius L., sowie durch die Raupen voll Tinea granella L. und T. cerealella Oliv, angegriffen.

Ausserordentlich gefährlich, so dass unter Umständen in grossen Bezirken der Roggenban unmöglich wird, erweist sich das Roggenoder Stockälchen (Anguillula devastatrix J. Kühn), indem es die jungen Roggenpflanzen durch Aussaugung des Bildungsmaterials zum Absterben bringt.

Schliesslich sei noch erwähnt, dass unter allen Getreidearten der Roggen am meisten durch Mäusefrass leidet, da er sich schon im Herbst kräftig bestockt und entwickelt, also rcichliche Nahrung bietet.

\section{Klima.}

Im Allgemeinen lässt sich annehmen, dass der Sommerroggen während einer mittleren Vegetationszeit von 125 Tagen durchschnittlich einer Temperatur von $12^{\circ} \mathrm{C}$. zu seiner Entwickelung bedarf, was die Versuche von Krutzsch in Sachsen in nachstehender Uebersicht bestätigen:

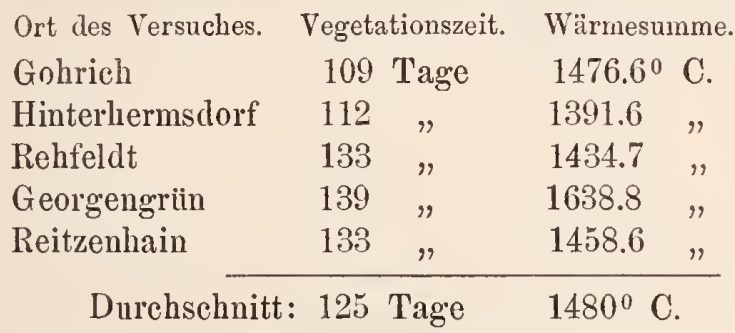

Der Winterroggen beanspruchte in Poppelsdorf bei einer mittleren Vegetationszeit von 265 Tagen $2276^{\circ} \mathrm{C}$; gemeinhin nimmt man für Winterroggen eine Wärmesumme von $1700-2400^{\circ} \mathrm{C}$. und für Sommerroggen von $1400-1800^{\circ}$ C. an.

Entsprechend dieser niederen Wachstumstemperatur wird nach Schübeler in Norwegen Sommerroggen noch bis zum $68^{\circ} 49^{\prime}$ und Winterroggen bis zum $69^{\circ} 38^{\prime} \mathrm{n}$. Br., in Innerrussland bis zum $65^{\circ}$ n. Br., auf der sủdlichen Erdhälfte, noch in Punta Arenas de Magellanes, unter dem $50^{\circ}$ südl. Br. und in der Schweiz bis zu Höhen von $1700-1950 \mathrm{~m}$ gebaut.

In Gegenden mit hohem Schneefall, in dencn der Schnee länger 
als 3 Monate den Boden unausgesetzt deckt, ist anstatt des Winterroggens Sommerroggen zu bauen.

Die Vegetationsperiode verkürzt sich bis zu einer gewissen Grenze mit dem Steigen der Durchschnittstemperatur. Das Maximum der guinstigsten Bodenwärme beträgt $20^{\circ} \mathrm{C}$.

Der Roggen gehört in die kältere gemässigte und subarktische Zone, also in das Winter- und Sommergetreideklima, zumal er in seiner Jugend strenge Kälte vorzüglich erträgt und nur im Friihjahr leidet, wenn auf kaltem, nassem Boden Frost- und Tanwetter bei Sonnenschein mit einander wiederholt abwechseln.

Noch kritischer ist jedoch die Periode des Schossens und Bliihens, inden die junge Aehre kurz vor dem Hervortreten leicht gänzlich oder doch an ihrer Spitze erfriert, mitunter aber auch nur einige Bliten leiden, welche taub bleiben und die Aehre schartig machen.

Zur Bliitezeit wird die Bestaubung durch starke Regengüsse oder nasskalte Witterung nicht selten sehr erheblich gestört.

Der Winterroggen widersteht der Dürre ganz vortrefflich und zwar nicht nur, weil er eine relativ geringe Verdunstungsgrösse aufweist, sondern er vermag wegen seines sehr zeitigen Vegetationseintrittes im Frühjahr, zur Zeit seiner üppigsten Wachstumsperiode noch aus der vorhandenen Winterfeuchtigkeit Vorteil zu ziehen.

Gleiches gilt auch, weil sehr zeitig gesäet, vom Sommerroggen, der in der Regel bei Eintritt der trocknen Zeit seine Wurzeln hinlänglich vertieft hat, um selbst auf leichtem Boden der Trockenheit widerstehen zu können.

\section{Boden.}

Der Roggen nimmt bei sonst günstigen Düngungs- und Kulturverhältnissen fast mit allen Bodenarten, sowohl Thon- und Lehmböden, als auch relativ armen Sand-, Humus- und Moorböden vorlieb, doch sagen ihm die schweren, sehr bindigen, feuchten Böden am wenigsten zu, und empfiehlt es sich, dieselben möglichst von seiner Kultur auszuschliessen, zumal die Produktionskosten der Getreidearten annähernd gleich hoch sind.

Auf den bindigen, wenig durehlassenden Böden ist die Roggenpflanze dem Auswintern unterworfen, und hat sie die Nässe und Kälte des Winters leidlich iiberstanden, so hält der nasskalte Boden 
im Frühjahr ihre Entwickelung zuriick, in Folge diessen ungenügende Erträge in Aussicht stehen.

Ueberhaupt liebt der Roggen die Nässe nicht, z. B. widersteht er der Inundation weit weniger gut als der Weizen, auch bringen die Niederungsböden wohl viel Stroh, aber eine weniger befriedigende Qualität der Körner, denn diese sind weit weniger voll und feinschalig, daher ärmer an Mehl, als die auf trocknen, sandigen Bodenarten geernteten Körner, welche nach Schwerz häufig cin Mehrgewicht von $8 \mathrm{~kg}$ pro hl aufweisen.

Seine höchsten Erträge und Körner vorziiglicher Qualität spendet der Roggen unzweifelhaft auf den kalkhaltigen, im richtigen Grade das Wasser durchlassenden und in gutem Kulturzustand befindlichen Lehmböden. Verhältnismässig sicher, weil zeitig in Vegetation tretend, gedeiht er auch auf den trocknen Sandböden, insofern diese nicht Mangel an Phosphorsäure und Kalk leiden, weshalb der Roggen auch cine hohe nationalökonomische Bedeutung hat, da dicse leichten Sandböden vorzugsweise durch seine Kultur noch einen genügenden Reinertrag abwerfen; auch vermag er bei nicht zu trockner Witterung sogar auf leerem, magerem Sande die Produktionskosten zu decken.

Auf entwässerten Haide-, Moor- und Bruchböden, namentlich aber, wenu dieselben mit Sand, Mergel oder Kalk befahren wurden, gedeiht der Roggen verhältnismässig gut.

Besonders beachtenswert ist die Melioration des Moorbodens durch Sandaufbringung, wie dies die Rimpan'sehen Moordammkulturen bewcisen, auf denen vortrefflicher Roggen wächst, während sonst der schlammige, lose Moorboden so stark zum Auffrieren neigt, dass mit Ausnahme vielleicht des Johannis-Roggens keine andere Winterroggensorte auf ihm gedeiht. Die sehr starke Bewurzelungsfähigkeit des Johannis-Roggens schützt ihn bedeutend gegen das Anffrieren, da seine zahlreichen Wurzeln nicht leicht sämmtlich abgerissen werden, sich daher die Pflanze im Friihjahr wiederum leichter zu bewurzeln vermag; auch schadet ihm ein fenchter, kalter Boden im Frihjahr weniger, als anderen Roggensorten.

Ueberhaupt empfiehlt es sich, eine den Bodenverhältnissen entsprechende Auswahl der Roggensorten zu treffen, z. B. sind die Sorten des gewöhnlichen Landrogyens auf die leichteren Böden, die des Staudenroggens auf die fruchtbareren, bindigeren, feuchteren Böden zu bringen.

Die für die Roggenkultur g'eeigneten Bodenarten sind folgende:

1) Reicher, tiefer, milder Thon- und Aueboden; Weizenboden I. Kl.

Auf diesem Boden liefern die Staudenroggen reiche Korn- und Strohernten, doch ist gemeinhin die Kultur des Weizens vorteilhafter. 
2) Humoser, reicher, milder Lehm; Gerstenboden I. Kl. Der Roggen liefert viel Stroh, doch lässt die Quantität und Qualität der Körner zu wünschen; auch neigt der Boden zum Auffrieren. daher Winterung nicht ganz sicher ist.

3) Scliwerer, kräftiger Thon; Weizenboden II. Kl.

Fiir Weizen weit besser als für Roggen geeignet.

4) Milder, tiefer, frischer Lehm und sandiger Lehmboden; Gerstenboden II. Kl.

Nicht selten besser für Roggen als Weizen geeignet. Quantität und Qualität der Körnerernte vorziigglich.

5) Milder Humusboden mit schwacher Lehm- und Sandbeimischnng. Für Winterung weniger geeignet, weil der Boden aufziehende Eigenschaften besitzt.

6) Leichter sandiger Lehm- und lehmiger Sandboden; Rogrgenboden I. Kl.

7) Leichter magerer Sandboden und dürftiger lehmiger Sand; Roggenboden II. Kl.

8) Saurer. sandiger Humusboden. Gnt entwässert, so zur Roggenkultur verwendbar.

9) Armer Sand- und Kiesboden. Roggenboden III. Kl.

In Folge der diurren Krume und des trocknen Untergrundes bremnen die Pflanzen leicht aus.

10) Saurel Haidehnmus mit Sand.

Bei entsprechender Kultur noch zum Roggenbau heranzuziehen.

11) Loser Sand, Grand, Kies.

Diese Böden geringster Ertragsfähigkeit können noch mit Rogggen bestellt werden, doch ist es häufig fraglich, ob die Erträge auch die Produktionskosten decken.

12) Mooriger, sanrer Torfboden. Genügend entwässert und sonst melioriert, trägt er noch Roggen, wenngleich die Winterung wegen der aufziehenden Eigenschaften misslich ist. Jedoch ist dieselbe bei Anwendung der Moordammkultur durchaus sicher und ertragreich.

\section{Dïngnng.}

Der Roggen gedeiht als Flachwurzler am besten in einer mit fertiger Pflanzennahrung erfüllten Ackerkrume, also in einem Boden mit „alter Kraft" oder auf Neubruch, während im abtragenden Schlag" auf einen bohen Ertrag nicht zu rechuen ist.

Der Winterroggen nutzt aber auch eine direkte Düngung noch 
gut aus, während zum Sommerroggen möglichst die Vorfrucht geedingt werden sollte.

Auf den leiehteren Sandböden, die an und fïr sieh Mangel an Phosphorsäure zeigen, ist für die Zuführung dieser vorzugsweise Sorge zu tragen, da der Roggen grosser Mengen an Phosphorsäure bedarf, und wendet man auf diesen Böden gern $200-300$ und $400 \mathrm{~kg}$. Knoebenmehl oder Bakerguano an, und bringt diese Kunstdiinger im Herbst vor der Saat $15-20 \mathrm{~cm}$ tief unter. Zur Stallinistcliingung sollte vorzugsweise ein guter Rindviehlung in Quantititen bis zu $20000 \mathrm{~kg}$ p. ha zur Anwendung gelangen und wirkt derselbe namentlich in Verbintlung mit einer Mergelung vortrefflieh. Anf sehr leiehtenı Boden kann jedoch häufig eine Düngung mit Moder oder eine Griindüngung von besseren Erfolgen als eine Stallmisttüngung begleitet sein. Ebenso gerät der Ruggen naeh einer im Herbst oder Winter gegebenen Kopfdüngung mit Kompost oder gut verrottetem Rindviehmist vortrefflieh, denn die hierdureh gegebene Bodendeckung verhindert ein zu sehnelles Austrocknen und Ausschwemmen der Pflanzemuährstoffe in den Untergrund, und ausserdem wird die Bodengahre gefördert. Sehr vorteilhaft erseheint es auch, den soeben ausgesäieten Roggen auf losem Sande mit Sehafen zn bepferehen, wodureh dieser Boden eine grössere Bindigkeit nehen Nährstoffzufuhr erhält.

Bei der Roggenkultur auf stark humosen Bïden empfiehlt sieh die Auffuhr von Sand und kalkreichem Mergel ubd nanentlich die Anwendung von Kalisalzen z. B. $200 \mathrm{~kg} 3$ fach koneentriertes Kalisalz mit bis zu 35 Proe. Kali, um das diesen Böden meist fehlende Kali hineinzubringen.

Von trefflieher Wirkung auf die Zersetzung und Verbesserung dieser Böden ist ferner die Dïngung mit Pferde- oder Sclatufung. Fehlt es dem Boden weiter an Phosplorsänre, so ist dieselbe in Form nieht leicht lossicher Phosphate zu geben, um die Auswaschung der Phosphorsäure in den Untergrund zu vermeiden.

Für die Mittelböden empfiehlt sich am meisten eine Düngung nit $24000-30000 \mathrm{~kg}$ Rindviehmist, während eine gleieh starke Düngung mit sehr stickstoffreiehem Schaf- oder Pferdenist Lagerkorn herbeiführt, wolureh die Körnerernte quantitativ und qualitativ geschïdigt w ird.

Dagegen wendet man auf den sehweren Thonböden, zur Verbesserung ihrer physikalisehen Eigenschaften, gern Kalkdiungung und grosse Quantitititen (bis $48000 \mathrm{~kg}$ ) frisehen Pferde- oder Nehafmist an.

Die sehr reiehen Alluvialböden werden zu Roggen, zur Verhütung des Lagerns, meist nieht direkt gediingt.

Auf den besseren, bindigen Böden, welchen es an Phosphor- 
säure mangelt, gibt man diese gern in Form hoehproeentiger Superphosphate, ron denen man $150-300 \mathrm{~kg}$ p. ha vor der Saat streut; bei Stickstoffmangel wendet man $100 \mathrm{~kg}$ schwefelsaures Ammoniak oder $150-250 \mathrm{~kg}$ Peruguano an.

Kümmerlich durch den Winter gekommenen Saaten wird mit einer kur' vor dem Schossen verabfolgten Kopfdüngung ron $80-100 \mathrm{~kg}$ Chilisalpeter pro ha, oder auf leichtem Boden durch Jauchedüngung wieder aufgeholfen.

\section{Fruchtfolge.}

Die besten Vorfriiehte des Roggens sind diejenigen, welehe dem Boden durch dichte Beschattung eine vorzügliche Gahre erteilen, das Unkraut unterdriicken, ihre Nährstoffe grösstenteils dem Untergrunde und der Lnft entnehmen, die Ackerkrume durch ihre Stoppel- und Wurzelriickstände bereichern und das Feld zu zweckentsprechender Vorbereitung für die Roggeneinsaat genügend zeitig räumen.

Fïr die schwereren Böden sind als vortreffliche Vorfrüchte für Roggen, obgleich der Anbau des Weizens nach ihnen auf diesem Boden meist vorteilhafter sein wiirde, folgende anzusehen:

Gedüngter Raps oder Riibsen; naeh diesen gerät, mit Ausnahme der gedïngten Brache, der Roggen an besten, da diese Früchte meist eine Brachbearbeitung erfahren, schr reich geduingt werden, den Boden gut beschatten und reichliehe Mengen an Stoppel- und Wurzelrückständen der Ackerkrume zuriicklassen.

Nach Rotklee gibt der Roggen auf kräftigem Boden aueh ohne Düngung eine gute Ernte, während auf weniger reichem Boden eine halbe Düngung oder eine Beidüngung mit künstlichem Dung verabfolgt werden muss.

Vorzügliche Vorfriichte sind ferner gedüngte, namentlieh aber gedrillte und behackte Pferdebohnen, da sie nicht allein die Hauptmenge ihrer Nährstoffe aus dem Untergrunde und der Atmosphäre bezichen, sondern anch viel Riickstände und eine gelockerte, unkrantfreie Ackerkrume hinterlassen, ebcnso gedüngte, dicht stehende Erbsen und Wicken, und zwar bauptsäehlieh dann, wenn sie als Grünfutter benutzt werden, also den Boden am wenigsten ersehöpfen.

Auf den Lehmmergel- und kalkreiehen sandigen Lehmböden kommen ausser den eben genannten als Vorfriichte noch dic Luzerne, Kleegrasgemenge und Tabak vor. Durch die Luzerne erfährt die Ackerkrume nicht nur eine erhebliehe Bereicherung an Pflanzennähr- 
stoffen, sondern auch eine vortreffliche Bodengahre, so dass selbst auf leichten Böden der Poggen nach ihr ohne Dung gut gedeiht und auf den von Natur reichen Böden leicht Lagerkorn entsteht.

Das Kleegrasgemenge erschöpft die Ackerkrume weit mehr als Rotklee, daher mit Ausnahme auf reichem Boden zu Roggen noch gediingt werden sollte.

Nach Tabak steht der Roggen immer sehr schön, weil der Boden fleissig hearbeitet, stark gedüngt und durch die grosse Menge untergepfligter Tabaksstengel die Ackerkrume bereichert wird.

Auf den Kalkböden und kalkreichen leichten Sandböden ist die Esparsette aus denselben Grinden wie die Luzerne eine empfehlenswerte Vorfrucht.

Auf den leichten Sand- und Haideböden ist der Buchweizen, wenn zu Roggen mit Stallmist oder Kompost gediungt wird, eine vortreffliche Vorfrucht; auch wächst nach grün untergepflügtem Buchweizen guter Roggen. Wundklee, Serradella, Weissklee und Hoifenluzerne sind, wenn diese Pflanzen abgeweidet wurden, ebenfalls als gute Vorfrïchte anf nicht ganz kalkarmem Sandboden anzusehen.

Die beste Vorfrucht des sehr leichten, kalkarmen Sandbodens ist jedenfalls die Lupine, denn sie beschattet nicht nur den Boden sehr stark, sondern bereichert die Ackerkrume auch an Nährstoffen. Nach griin untergepflügten Lupinen wächst der Roggen häufig besser als nach ciner Stallmistdungung.

Der Roggen gedeiht in der Regel sehr gut anf einer umgebrochenen Grasnarbe, und nimmt in diesem Falle selbst mit einem ziemlich rohen Boden und noch nicht vollständig zersetzter Grasnarbe vorlieb. Auf frisch gerodetem Waldboden, wie dies die Hackwaldwirtschaft der Gebirgsgegenden zur Genïge zeigt, wächst er ebenfalls vortreffich.

Der beste loggen und sicherste Ertrag wird jedenfalls nach gediungter Brache, namentlich auf bindigen und verunkrauteten oder sehr leichten Böden erzielt, denn nicht nur, dass heträichtliche Nährstoffmengen für den Roggen durch die Brachbearbeitung aufnahmefähig werden, sondern es gestaltet sich die Ackerkrume auch physikalisch giinstiger und das Unkraut wird zerstört.

Ungüustige Vorfriichte des Roggens sind die echten Getreidearten, da sie nahezı ans den nämlichen Bodenschichten wie der Roggen die Nährstoffe in einem Zustande entnehmen, der auch der Roggenpflanze zusagt; ferner unterliegen sie einer gleichartigen Kultur und beschattell den Boden nur mässig, in Folge dessen sich die Feinde des Roggens, welche grösstenteils auch die der ïbrigen Getreidearten sind, stark vermehren und der Boden leicht erhärtet. Aus allen diesen Grïnden wird nur auf reichem, physikalisch giinstigem Boden ein befriedigender Ertrag nach anderen Halmfriichten, und zwar noch am ehesten nach Hafer, von dem Roggen zu erhoffen sein. 
Gediingte Hackfrïchte, namentlich Runkelrüben und Kartoffeln, weniger Weissrüben und Mohrrüben, sind für Sommerroggen gute, dagegen firr Winterroggen sehr schlechte Vorfrüchte, und liegt der Grund hierfïr darin, dass der sich schon im Herbst bestockende Winterroggen nicht zeitig genug gesäet werden kam, und in Folge dessen sich ungenügend hestockt; auch ist, namentlich nach Kartoffeln, der Boden sehr stark gelockert, mithin zum Zusammenschlämmen geneigt, worunter die junge Pflanze leidet; schliesslich wird die Entwickelung des Roggens dadurch hauptsäichlich gestört, dass beim Sichsetzen des Bodens die Kronenwurzeln der Roggenschösslinge von Erde entblösst werden und eventuell zu Grunde gehen können.

Sehr selten gerät der Roggen nach Hanf und Lein, selbst wemn zu diesen stark gedingt wurde. Wahrscheinlich nehmen sie die fertige Pflanzennahrmug und lauptsächlich die phosphorsauren Salze zn stark in Anspruch, wozu noch tritt, dass sie mitsammt den Wurzeln ausgerauft werden, also Stoppel- und Wurzelriickstände der Ackerkrume nicht belassen.

Nach einer Düngung wächst jedoch der Roggen recht gut, ein Beweis dafür, dass nur der Nährstoffentzug die Schuld an dem Nichtgedeihen trägt.

Mit sich sellost ist der Roggen im hohen Grade verträglich, wie dies die Fruclitfolgen sehr leichter Böden beweisen, in welchen der Roggen nicht selten mehrere Jahre hindurch nur im Wechsel mit Lnpinen gebaut wird.

Roggen, namentlich Grinfutterroggen, ist im Allgemeinen als eine bessere Vorfiucht als irgend eine andere echte Getreideart anzusehen, was wohl nicht zum geringsten Teil den an stickstoff, Kali und Phosphorsäure überaus reichen stoppel- und Wurzelrückständen zuzuschreiben ist, welche dieselben der Ackerkrume hinterlassen, und welche nur von denen der kleeartigen Gewächse übertroffen werden.

Nach unseren Ermittelnngen hinterliess reifer Roggen in einer Ackerkrume von $26 \mathrm{~cm}$ Tiefe auf sandigem Lehmboden in Proskau bei normalem stande in seinen Stoppel- und Wurzelriickständen an Nährstoffen p. ha:

Gesammtmenge der Stoppel- und Wurzelrückstände $5887 \mathrm{~kg}$ Darin an Stickstoff

" $"$ der "Asche:

$$
\text { Asche. }
$$

73.2, 1842.7

an Kalkerde

.. Nagnesia

. Kali

"Natron .

"Schwefelsäure

.. Phosphorsäure 
Diese Rückstände erhöhen sieh beträchtlich beim Grünfutterroggen, weleher daher das Land in noch besserem Zustande hinterlässt. Da letzterer sehr zeitig das Feld räunt. können ihm roch gepflanzte Runkel- und Kohlrüben, Mais, Wickengemenge, Raps, Rlibsen, weisser Senf, Sommergetreide etc. folg'en.

Nach gediingten reifen Roggen gedeihen Erbsen, Kartoffeln und event. Gerste und Hafer; als Nachfriichte fiir den Herbst können in die Stoppel im milden Klima Inkarnatklee, Stoppelriben, weisser Senf ete. gebracht werden; auch eignet er sich als Ueberfrucht für Kleegras, Serradella, Mohrriben etc.

\section{Bodenbearbeitung.}

Bei Vorbereitung des Ackers für die Wintersaat ist durchaus an dem Grundsatz festzuhalten, die Saatfurche mindestens 14 Tage, besser 3 bis 4 Wochen vor der Einsaat zu geben, weil das Gedeihen des Roggens zu einem grossen Teil davon abbängt, dass er auf gelagertem Acker ausgesäet wird.

Der Hauptsache naeh riehtet sich die Vorbereitung nach der Beschaffenheit des Ackers und nach der Vorfrueht. Im Allgemeinen wird auf einem erhärteten, mit Unkraut und namentlich Wurzelunkraut erfiillten Acker am besten die Brachbearbeitung platzgreifen.

Ist leichterer Boden durch die Vorfrucht stark beschattet worden, dann genügt eine bis zur vollen Tiefe durch einen mit einem Sehälschar versehenen Pflng gegebene Saatfurche, oder es wird gleich nach der Ernte die Stoppel flach gestiirzt und zum schnclleren Faulen der Stoppeln gewalzt, darauf der Acker nach dem Auflaufen des Unkrantes gnt vereggt und tief zur Saat gepflügt.

Dagegen verlangt der Roggen auf dem bindigeren Boden, und namentlich nach einer Vorfrucht, unter welcher derselbe erhärtete und verunkrautete, drei Pflugfurchen. Nach Kleegras schält man die Narbe am besten flach ab, walzt, und sobald die Narbe bis zu solchem Grade verfault ist, dass sie durch Eggen leicht zerreisst. wird scharf durchgeeggt und hierauf eine tiefe Saatfurche gegebell. Dies Verfahren lässt sich jedoch auf Luzerne- oder Esparsette-Aeckern nicht gut anwenden, da die starken Wurzeln dem Pfluge einen zu grossen Widerstand entgegensetzen. Hier empfiehlt sich mehr, nur einen Schnitt zu nehmen, flach zu schälen, damit die Wurzeln, ihrer oberirdischen Teile beraubt, faulen, dam abzueggen, und eine zweite etwas tiefere Furche zu geben, um sehliesslich nach dem Abeggen 
der letzteren eine bis zur vollen Tiefe der Ackerkrume sich erstreckende Saatfurche folgen zu lassen.

Behunfs Anbau des Sommerroggens wird im Herbst möglichst bald nach der Ernte der Vorfrucht die Stoppel flach gestiirrt, und nach dem Auskeimen des Unkrautes kräftig geeggt, hierauf gibt man vor Winter eine tiefe Saatfurche, zieht die nötigen Wasserfurchen und lässt das Land bis zum Frühahr in der rauhen Furche liegen.

Nach dem Abtrocknen wird auf leichtem Boden der Acker zur Einsaat einfach abgeeggt, sobald derselbe nicht durch Wurzelunkräuter verunreinigt oder stark verschlämmt ist, in welchen Fällen sich nach denı Abeggen das Grubbern iiber Kreuz empfiehlt.

\section{Aussaat.}

Die Aussaat des Roggens in der für jede Gegend zweckmässigsten Saatzeit darf für sein Gedeihen als wesentlich angesehen werden. Jedenfalls wird die Aussaat des Winterroggens so zeitig zu erfolgen haben, dass sich die Pflanzen noch im Herbst geniigend zu bestocken und Reservestoffe für die kräftige Entwickelung im Frïhjahr aufzunehmen vermögen, doch nicht eine Ueppigkeit erreichen, die Ausfaulen oder Lagerkorn befiirchten lässt.

Die Saatzeit des Sommerroggens richtet sich in Allgemeinen nach dem Abtrocknen des Bodens im Friihjahr, da ihn Friihjahrsfröste kaum schädigen, tind es auf den sehr leichten Bören wichtig ist, dass ihm noch die Winterfeuchtigkeit des Bodens zu Gute kommt.

In Seeklima der kälteren gemässigten Zone Europas fällt die Saatzcit des Winterroggens Anfang bis Ende Oktober, im KontinentalKlima Europas in den September, jedoch in Nord-Amerika in die Zeit rom 20. August bis 20. September.

Der Sommerroggen kommt im März bis Mitte April zur Aussaat.

In der subarktischen Zone wird der Winterroggen schon Ende August gesäet, und der sehr ausgedehnt angebaute Sommerroggen erst Ende April und sclbst noch Anfang Mai. Diese Angaben reichen selbstverständlich nicht fuir einen konkreten Fall aus, der, entsprechend den obwaltenden Verhältnissen, auch die Einsaat zu einer bestimunten Zeit fordert, welche genau festzustellen Sache des ausiibenden Landwirts ist. Es kann nun aber vorkommen, dass die wirtschaftlichen Verhältnisse eine Abweichung ron der rechtzeitigen Aussaatzeit gebieterisch fordern, und ist dann folgender Grundsatz festzuhalten: säet man 8 Tage zu früh, so ist das gewöhnliche Aussaatquantum um $1 / 10$ zu verringern, und bei um 14 Tage verspäteter Saat um 1/10 
zu erhöhen, in Rücksicht darauf, dass sich die Bestockungsfähigkeit ändert.

Um hierfür einen Ausdruck in Zahlen geben zu können, führe ich hierunter einen Versuch mit verschiedener Aussaatzeit, den wir 1876 in Poppelsdorf mit auf $20 \mathrm{~cm}$ gedrilltem Roggen anstellten, vor.

\begin{tabular}{|c|c|c|}
\hline Zeit der Aussaat. & $\begin{array}{l}\text { Tag der Unter- } \\
\text { suchung. }\end{array}$ & $\begin{array}{c}\text { Zahl der Schösslinge bei } \\
\text { Johannis- } \mid \text { Probsteier- } \\
\text { foggen. }\end{array}$ \\
\hline $\begin{array}{l}\text { Anfang Juli } 1876 \\
\text { Oktob. " } \\
27 . \text { November " } \\
\text { 27. " " " } \\
\text { 23. Januar ", } \\
\text { 23. F" " } \\
\text { 5. Februar ", } \\
5 . \quad ",\end{array}$ & $\begin{array}{l}\text { 10. April } 1877 \\
\text { 10. " " } \\
\text { 10. M" " } \\
\text { 25. Mai " } \\
\text { 10. April ", } \\
\text { 25. Mai " } \\
\text { 10. April ", } \\
\text { 25. Mai " }\end{array}$ & $\begin{array}{l}12 \\
10 \\
4 \\
5 \\
2.8 \\
5.2 \\
1 \\
3.4\end{array}$ \\
\hline
\end{tabular}

Das Saatquantum wird ferner noch in sehr hervorragender Weise durch die Bodenbeschaffenheit beeinflusst; nimmt man z. B. auf sehr reichem Boden das Saatquantum $=1$ an, so kann dasselbe auf Mittelboden $=1.5$ und auf sehr leichtem Boden $=2$ sein, weil mit dem Bodenreichtum auch zugleich die kräftige Entwickelung abnimmt, wenngleich die Kultur und Pflege der Pflanzen, sowie die Körnergrösse der verschiedenen Sorten auf die Feststellung des Saatquantums ebenfalls einwirken.

Zur Gewinnung eines Anhaltes für die Bestimmung der Saatmenge lasse ich die Aussaatmengen folgen, wie sie sich im Durchschnitt aus den hier gebauten Roggensorten berechnen liessen.

Aussaattabelle des Roggens.

\begin{tabular}{|c|c|c|c|c|}
\hline & & & Winterfrucht & Sommerfrucht \\
\hline $\begin{array}{l}\text { Schösslinge pro Pflanze . } \\
\text { Halmlänge } \\
\text { Blattzahl pro Halm } . \text {. } \\
\text { Blattoberfläche pro Halm } \\
\text { Auf } 1 \text { qm Bodenfläche kommt } \\
\text { Auf } 1 \text { ha wachsen Pflanzen } \\
\text { Wachsraum pro Pflanze } \\
\text { Fruchtzahl pro hl . . . } \\
\text { Gewicht pro hl . . . . }\end{array}$ & 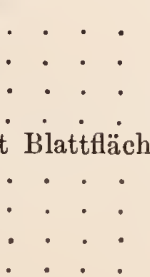 & 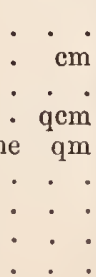 & $\begin{array}{c}5 \\
150 \\
4.3 \\
312 \\
31.2 \\
2000000 \\
50 \\
2275000 \\
75.8\end{array}$ & $\begin{array}{c}2.1 \\
130 \\
3.5 \\
181 \\
22.8 \\
6000000 \\
17 \\
2700000 \\
78\end{array}$ \\
\hline
\end{tabular}


Winterfrucht Sommerfrucht

Absoluter Samenbedarf pro ha in hl

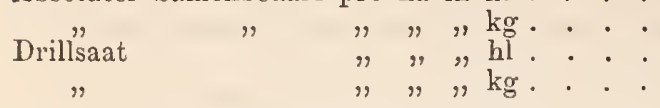

Breitwürfige Saat:

a) Durch Egge untergebracht in h

b) " Saatpflüge " gewöhnliche P̈lüge untergebracht in hi

\begin{tabular}{l|l}
0.9 & 2.2 \\
68 & 172 \\
1.2 & 3.0 \\
92 & 234 \\
& \\
& \\
1.6 & 3.8 \\
1.7 & 4.1 \\
1.8 & 4.4
\end{tabular}

In welchem Maasse die Saatquanta der cinzelnen Sorten je nach ihrem Habitns von den oben angeführten Durchschnittssätzen abweichen können, crgiebt sich darans, dass in Poppelsdorf der Klafterbrunner-Winterroggen pro Pflanze einen Wachsranm von $75 \mathrm{qcm}$ und $1.1 \mathrm{hl}$ Aussaat erforderte, während der Göttinger $33.3 \mathrm{qcm}$ und $1.6 \mathrm{hl}$ an Saat beanspruchte.

Znu Vergleichung mit den in der Saattabelle angegebenen Zahlen mögen die nachfolgenden Angaben anderer Autoren dienen. Saat in

Nach Schwerz beträgt das Aussaatquantum für breitwirfige

Brabant, lehmiger Sand

$1.40 \mathrm{hl} \mathrm{p.} \mathrm{ha}$

" Marschboden

$1.80, ", .$.

$" \quad$ Sand (Campine)

in der Pfalz .

$1.50, "$,

in England

$1.75, ",$,

„, Oesterreich

$1.70,,, \quad$,

"Hohenheim

2.10

1.75

Nach Heuzé in Frankreich:

anf reichem Boden.

"sehr armem Boden

im Mittel

Nach Block

im Mittel

Thaer, schweitzer

Hlubek

Kre issig.

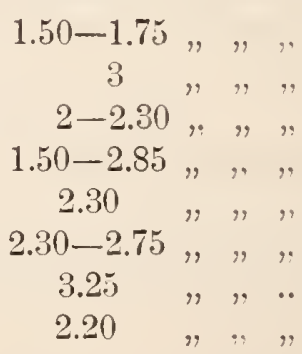

Für Sommerroggen geben an:

Block

$1.60-2.45,,,,$.

Kорие

$1.90-2.20, ",$,

Schweitzer

2.50

$3.80 \quad " .$,

Hlubek.

Zur Ermittelung der Saatquanta für die Drillsaat ist im konkreten Fall die passendste Drillweite durch Versuche herauszufinden, 
und wird dieselbe je nach der anzubauenden Sorte, dem Klima, der Bodenbeschaffenlicit, dem Düngungszustande, der Aussaatzeit 11nd ob der Roggen während der Vegetationsperiode der Bearbeitung unterliegt oder nicht, sehr versehieden sein.

Die Grenzen der Reihenentfernung scliwanken im Allgemeinen zuvischen 10 nnd $26 \mathrm{~cm}$ mit 2 resp. 1 hl Aussat pro ha, docl kommen im Secklima anf sehr fruchtbarem Boden Fälle vor, in denen die Reihenentfernung weiter zu greifen ist; so sahen wir in Badhoeve. Haarlemermecr, Holland auf stark gedüngtem sandig-lehmigem Humusboden eine Reilıcnentfernung von $50 \mathrm{~cm}$ bei $0.40 \mathrm{hl}$ Aussaat pro ha.

Demnach stelle man die Reihen unter

$$
\text { giunstigen mittleren weniger giinstigen }
$$

\section{Verhältnissen}

anf . 20-26 cm $15-20 \mathrm{~cm} \quad 10-15 \mathrm{~cm}$.

Dass nun in der That auch heim Roggen unter günstigen Verhältnissen die weitere Reihenentfernung ebenso wic bein Weizen hölere Erträge in Aussicht stellt, bewcisen die Versuche von Wollny ${ }^{1}$ ). der folgende Resultate erhielt:

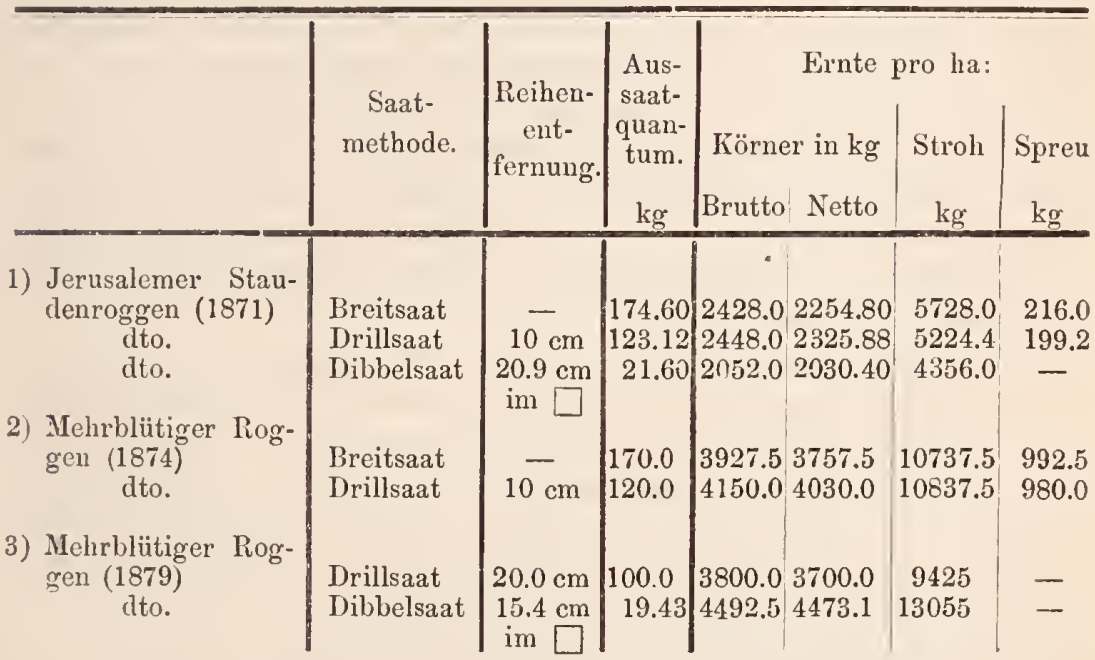

Trotzdem die Dibbelsaat bei einem grossen Wachsraum pro Pflanze überraschend hohe Ertrïge gebracht hat, ist dieselbe doch nieht zu empfehlen, da sich der Roggen niclit verpflanzen lässt, also event. ausgewinterte Stöcke sich nicht wieder ergänzen lassen, aueh nur besonder's kräftig sich entwickelnde Sorten und auf selır reichem Boden höliere Erträge zu bringen vermögen.

Nicht selten tritt auch an Stelle der Reinsaat des Roggens ein

1) Journ. f. Landw. 1881. pg. $493 \mathrm{ff}$. 
Gemenge von Roggen und Weizen oder Spelz, wenn sich Boden und Klima nicht sonderlich für Reinsaaten eignen. Auf cinem etwas schweren, feuchten Boden, und in einem rauhen Klima, z. B. im Ge. birge, werden von diesen Gemengesaaten auch bessere Erträge als von Reinsaaten zu erhoffen sein, weil die Ungunst der Verhältnisse durch den Anbau mehrerer Pflanzenspecies, deren Anspriiche sich nicht vollkommen mit einander decken, bis zu einem gewissen Grade ausgeglichen wird.

Fül diese Gemenge berechnet man das Aussaatquantum im konkreten Fall nach den Procentsätzen, in welchen die Getreidearten vertreten sind, doch hat zuvor der Landwirt die gegebenen Verhältnisse genau zu erwägen und je nach dem Befunde sich darüber zu entscheiden, wie das Gemenge zusammengesetzt sein soll. Da ein Hektar 100 Are umfasst, drücken die Procentsätze die Anzahl der Are aus, welche jede Getreideart für sich in Anspruch nimmt.

Die Mengung hat für jede Aussaat immer ron Neuem zu geschehen, weil die Jahreswitterung das eine oder andere Getreide mehr begünstigen kann, wodurch sich der Procentsatz an Korn im Ernteerzeugnisse ändert. Diese Gemenge säet man ein wenig später als den Roggen, und erntet dasselbe zur vollen Reife des Roggens. denn in diesem Fall wird sich eine frühreife Weizensorte auch schon in der Gelbreife befinden, und eine vortreffliche Kornqualität lieferu. In dem Gemenge lässt sich das vollkommen entrickelte Weizenkorn durch Getreidesortiermaschinen oder passende Siebe rom Roggen trennen, während der im Roggen zurückgebliebene feinkörnige Weizen die Qualität als Brotkorn rerbessert. Noch leichter lässt sich der Spelz vom Roggen scheiden.

Uebrigens gilt die Gemengefrucht von Roggen und Weizen in Süd-Deutschland und Frankrcich als vortrefflich für Brotmehl geeignet.

Dergleichen Gemengesaaten sind namentlich in Sïd-Deutschland und am Rhein, als "Mischel", sowie in Belgien und Frankreich verbreitet, wo sie ansser dem Namen „Méteil" noch die Namen "Mescle" in dem Languedoc, "Cossegail" in der Provence, "Conceau" in der Bretagne, "Muison" in Burgund führen.

In den gebirgigen Teilen von Piemont kommen sie unter dem Namen "Barbariato" und in Toscana als "Segolato" vor.

Die Aussaat des Roggens anf nassem Boden ist zu rermeiden, weil er das Einschmicren durchaus nicht verträgt.

Ferner darf derselbe auf schwerem Boden nur $2 \mathrm{~cm}$, auf feuchtem Mittelboden $2.5 \mathrm{~cm}$, auf trockuem $4 \mathrm{~cm}$ und auf leichtem Sandboden höchstens $7 \mathrm{~cm}$ tief untergebracht werden.

Hänfig säet man den Roggen auf leichtem Boden in die rauhe Furche und eggt ihn ein, oder in vorgeeggtes Land und bringt ihn 
mit g'ewöhnlichen Pfligen unter, Verfahren, welehe nur zur Saatrerschwendung und zu ungleichmässigem Stande führen.

Hiergegen empfiehlt sieh weit mehr die Aussaat auf vorgeeggtem Lande und die Unterbringung durch Saatpflïge oder Kriimmereggen.

Jedenfalls ist bei der breitwiirfigen waat die Masehinensaat der Handsaat vorzuziehen.

Auf den schwereren Böden wird zunäehst die rauhe Furche vereggt, hierauf gesäet und das Saatkorn eingeeggt, und sieht man es gern, wenn das Winterroggenfeld etwas sehollig liegen bleibt.

Auf dem gebrannten Boden der Hoehmoore, welche häufig mehrere Jahre hinter einander Roggen tragen, säet man ihn in die noch warme Asche und eggt ihn ein, doeh ist zu seiner Bestellung inmer ein troekner Herbst notwendig.

Die beste Saatmethode für Roggen, obgleich sich Stimmen aneh dagegen erheben, ist die Drillkultur, welche auf Guitern mit intensiverer Kultur und nieht zu leichtem Boden immer mehr an Ausdehnung gewinnt. Das Drillen erfolgt auf' vollständig vorbereiteten Saatacker, danit die Drillmaschinen exakt zn arbeiten vermögen. Nach der Einsaat werden die Drillreihen dureh einen Eggenstrieh quer uiber dieselben vollkommen gesehlossen.

Ob auf sehr leiehtem Boden die Drillkultur empfehlenswert ist, steht noeh dahin; vielfach wird dagegen angeführt, der Wind entblösse die Pflanzenwurzeln in den Drillreihen leichter von Erde, worunter dieselben litten. In Allgemeinen seheint dieser Grund nieht stichhaltig zu sein, wenigstens nieht den grossen Vorteil der gleiehmässig tiefen Unterbringung des Saatkornes aufzuwiegen.

\section{Pflege.}

Naeh dem Keimen des Sommerroggens eggt man zur Zerstörung des Unkrautes oder einer Kruste, und walzt, sobald die jungen Pflanzen eine Höhe von $6-8 \mathrm{~cm}$ erreicht haben, in der Absielt, die Bestockung zu kräftigen, den Boden zu befestigen und durch Eindrücken der Steine und Zerstörung der Schollen die Erntc zu elleiehtern.

Bei dem Winterroggen besteht die erste Pflege in der Anlage von Wasserfurehen, da derselbe bekanntlich auf feuchtem Boden leieht auswintert.

Sobald der Aeker im Friihjahr genügend abgetrocknet, wird zur Brechung der Kruste an besten mit einer Wiesenegge geeggt, und folgt diesem Eggstriehe ein zweiter mit einer seharfzinkigen 
Egge nach, wenn die Pflanzen hoch genug erwaehsen sind, um nicht mehr dureh Erde bedeckt zu werden. Dies Eggen hat den Zweek, die Oberfläche wiedernm zu loekern und das Unkraut mögliehst zu zerstören, denn einzelne Unkräuter, wie Rade, Kornblume, Distel lassen sich nur dureh Jäten, Ausstechen oder Hackkultnr entfernen. Letztere wird nur auf den bindigeren, reieheren Bodenarten platzgreifen können, weil sieh hier genïgend weite Entfernungen den Drillreihen geben lassen. Uebrigens wird das Haeken bei der sehr zeitigen Vegetation des Roggens selten häufiger als einmal auszuführen sein.

Die auf hnmosem Boden dureh den Frost gehobenen Pflanzen werden dureh Walzen oder Uebertreiben einer Sehafheerde wiederum nen befestigt.

Zur Vermeidung des Lagerns empfiehlt sieh das Schröpfen oder anch Walzen ${ }^{1}$ ) kurz vor dem Sehossen, weniger dagegen das Beweiden mit Sehafen. Ebenso lässt sieh mit Erfolg dann die Walze anwenden, wenn der Roggen in seinen Haupthalmen im Frühjahr spitz emporsehiesst und die Seitenhalme zurïckbleiben, wie dies bei kalter Witterung und auf kraftlosem Boden häufig geschieht. In diesem Fall wird selbst bei $13-16 \mathrm{em}$ hohem Roggen die Walze anzuwenden sein, um die Haupthalme zu knieken, demzufolge den Seitenhalmen mehr Bildungsmaterial zufliesst und sie Zeit und Kraft erhalten, die Haupthalme im Waehstum einzuholen.

\section{Ernte, Ausdrusch und Anfbewahrung.}

Die Sehnittreife des Roggens tritt ebenso wie beim Weizen in der sog. Gelbreife ein, also zu einer Zeit, in weleher die Saftberregung im Halm aufgehört hat und letzterer gebleieht erseheint, doch das Korn noeh eine waehsweiche Besehaffenheit besitzt. Zu diesem Zeitpunkt gemäht, steht nieht nur der höchste Ertrag an Quantität, zumal auch der Körnerausfall auf ein Minimum beschränkt ist, sondern auch eine gute Qualität des Kornes in Anssieht.

Die Ernte beginnt in der wärmeren gemässigten Zone, so in den Ebenen Italiens Anfang Juni, am Südabhange der Alpen, in den Bergen des siidliehen Frankreiehs, Spaniens und Portugals Ende Juni, $i_{n}$ der kälteren, gemässigten Zone Anfang bis Ende Juli, und in der subarktisehen Zone im August.

Sehliesslieh ist jedoeh noch zu bemerken, dass in Kontinental-

1) Sprengel, Meine Erfahrungen in Gebiete d. allg. u. speciell. Pfl.Kultur. $1847, \mathrm{pg} .215$. 
klima nieht selten kurz vor der Reife eine intensive Hitze eintritt, die das Korn zum Verschrumpfen bringt, es also notreif macht, und beträchtliche Verluste durch Verringerung der Quantität, sowie Versehlechterung der Qualität herbeiführt.

Zu Grünfutter sollte der Schnitt vor dem Erscheinen der Aehre, Mitte April, beginnen und der Roggen in 3-4 Wochen abgefüttert werden; was dann zu hart, bleibt zur Kornproduktion stehen; will man aber zweimal schneiden, dann erfolgt der zweite Sehnitt 4-6 Wochen später, wenngleich eine solehe Benutzung bei der schwachen Reproduktionskraft des Roggens kaum anzuraten wäre.

Der Roggen darf nicht im Schwad trocknen, es sei denn, dass durel Unkraut oder Kleegras ihm viele saftige Pflanzen beigemengt sind. Am zweckmässigsten wird er sofort nach dem Mähen in Garben gebunden und zum Troeknen in Stiegen oder Puppen aufgestellt, weil dann jedenfalls der Körnerausfall, sowie die Gefahr des Auswachsens und Verregnens am geringsten und die Hoffnung auf eine gute Qualität am grössten ist.

In Bezug auf den weiteren Verlauf der Ernte, des Ausdrusehes und der Aufbewahrung verweise ich auf das entsprechende Kapitel im allgemeinen Teil.

\section{Erträge und Nahrungsbestandteile.}

Die Roggenerträge stellen sich im Allgemeinen pro ha wie folgt:

\begin{tabular}{c|c|c|c|c|c|c|c|c|c|c|c|c}
\hline & \multicolumn{2}{|c|}{ Korn in hl } & \multicolumn{3}{c|}{ Stroh in kg } & \multicolumn{2}{c|}{$\begin{array}{c}\text { Spreu in kg } \\
\text { Molumenge- } \\
\text { wicht pro h } \\
\text { in kg }\end{array}$} \\
\hline $\begin{array}{c}\text { Winter- } \\
\text { roggen .. }\end{array}$ & 4.3 & 53.4 & 14.5 & 900 & 7000 & 3000 & 100 & 700 & 300 & $68-80$ \\
$\begin{array}{c}\text { Sommer- } \\
\text { roggen... }\end{array}$ & 4.0 & 30.0 & 12.0 & 750 & 4600 & 2000 & 78 & 460 & 200 & $68-78$
\end{tabular}

Bereehnet man den Mittelertrag aller an der Roggenkultur beteiligten Länder, so beträgt derselbe $14.5 \mathrm{hl}$ Korn pro ha.

Das Verhältnis der Körner zum Stroh stellte sich in Poppelsdorf folgendermassen: 


\begin{tabular}{l|c|c|c|c|c|c}
\hline \hline & $\begin{array}{c}\text { Halm- } \\
\text { länge } \\
\mathrm{cm}\end{array}$ & $\begin{array}{c}\text { Blattzahl } \\
\text { pro Halm } \\
\text { Stiück }\end{array}$ & $\begin{array}{c}\text { Aehren- } \\
\text { länge } \\
\mathrm{cm}\end{array}$ & $\begin{array}{c}\text { Frucht- } \\
\text { zahl in } \\
\text { 1 Aehre } \\
\text { Stück }\end{array}$ & Korn & Stroh \\
\hline Winterroggen & 150 & 4.3 & 13 & 67 & 44 & 56 \\
Sommerroggen & 130 & 3.5 & 10 & 48 & 40.5 & 59.5
\end{tabular}

Das Stroh verhält sich nach den Angaben älterer Autoren zu den Körnern wie:

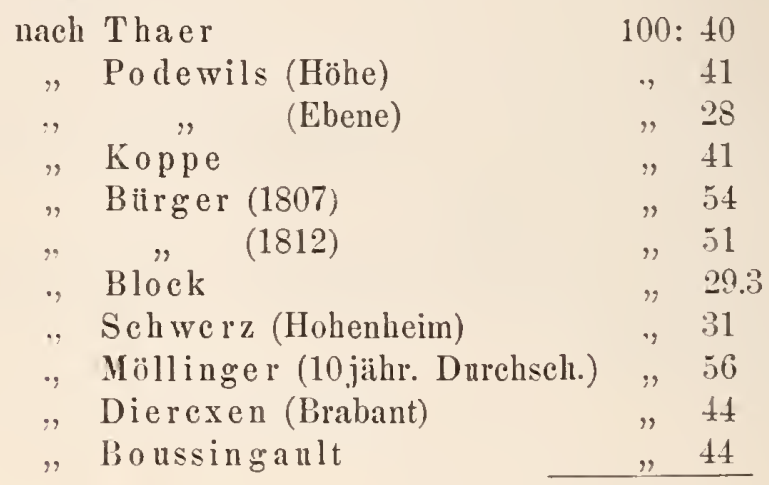

Durchschnitt: 100:41

Nach Gasparin enthalten 1000 Tcile 244 Teile Körner, Teile Stroh und Spreu und 161 Teile Stoppeln.

Durchschnittlich lassen sich im kälteren gemässigten Klima an $100 \mathrm{~kg}$ Korn $225-275 \mathrm{~kg}$. Stroh und anf $100 \mathrm{~kg}$ Stroh $5 \mathrm{~kg}$ Spreu, sowie nachfolgende Erträge pro ha annehmen:

1) Reicher, tiefer, milder Thon- und Aneboden; Weizenboden I. Kl. $31-39 \mathrm{hl}=2277-2847 \mathrm{~kg}$ Korll, $6820-8580 \mathrm{~kg}$ Stroh.

2) Schwerer, kräftiger Thonboden; Weizenboden II. K1. $26-30 \mathrm{hl}=1898-2190 \mathrm{~kg}$ Korn, $5720-6600 \mathrm{~kg}$ Stroh.

3) Milder, frischer Lehm; Gerstenboden II. Kl. $26-30 \mathrm{hl}=1898-2190 \mathrm{~kg}$ Korn, $4680-5400 \mathrm{~kg}$ Stroh.

4) Leichter, sandiger Lehm; Roggenboden I. Kl. $21-26 \mathrm{hl}=1569-1898 \mathrm{~kg}$ Korn, $3780-4680 \mathrm{~kg}$ Stroh.

5) Leichter, magerer Sand: Roggenboden II. Kl. 13-17 hl $-949-1240 \mathrm{~kg}$ Korn, $2340-3060 \mathrm{~kg}$ Stroh.

6) Saurer, sandiger Humusboden.

$13-17 \mathrm{hl}-949-1240 \mathrm{~kg}$ Korn, $2340-3060 \mathrm{~kg}$ Stroh.

7) Armer Sand und Kicsboden; Roggenboden III. Kl. $11-13 \mathrm{hl}=803-949 \mathrm{~kg}$ Korn, $1980-2340 \mathrm{~kg}$ Stroh.

8 ) Saurer Haidelumus, Flugsand und Grund. $4-6.5 \mathrm{hl}=292-474.5 \mathrm{~kg}$ Korn, $720-1170 \mathrm{~kg}$ Stroh. 
Der Sommerroggen bleibt etwa 25 Proc. in den Körnern und 20 Proc. im Stroh gegen den Winterroggen zurlick.

Die Grïnfuttererträge können sich durchschnittlich anf $10000 \mathrm{~kg}$, unter sehr giinstigen Verliältnissen sogar auf $18000 \mathrm{~kg}$ p. ha stellen.

Der Winterroggen ist einc sichere Frucht und bestätigt dies Block, der angiebt, man könne bei zweckentsprechendem Aubau die in einem Zeitraume von 20 Jahren zu gewinnenden Roggenernten mit Sieberheit auf 19 ganz vollkommene veranschlagen; dagegen erachtet er den Somnerroggen für weit weniger sicher, indem er in 6 Jahren nur auf 5 vollkommene Ernten reclnet.

An Nalırungsbestandteilen (verdaulichen und unverdaulichen) sind vorhanden im

\begin{tabular}{|c|c|c|c|c|c|c|}
\hline Iorn: & $\begin{array}{c}\text { Trocken- } \\
\text { substanz } \\
\text { Proc. }\end{array}$ & $\begin{array}{c}\text { N-haltige } \\
\text { Substanz } \\
\text { Proc. }\end{array}$ & $\begin{array}{l}\text { Fett } \\
\text { Proc. }\end{array}$ & $\begin{array}{c}\text { N.freie } \\
\text { Substanz } \\
\text { Proc. }\end{array}$ & $\begin{array}{c}\text { Holzfaser } \\
\text { Proc. }\end{array}$ & $\begin{array}{l}\text { Asche } \\
\text { Proc. }\end{array}$ \\
\hline Minimum & 81.7 & 9.1 & 0.9 & 62.5 & 1.8 & 1.4 \\
\hline Maximum & 87.3 & 17.4 & 2.5 & 66.9 & 3.5 & 2.7 \\
\hline Mittel & 85.1 & 13.3 & 2.0 & 65.2 & 2.7 & 1.9 \\
\hline Stroh: & & & & & & \\
\hline Minimum & 84.1 & 1.9 & 1.1 & 23.4 & 38.9 & 3.1 \\
\hline Maximum & 89.2 & 4.6 & 1.8 & 37.5 & 53.9 & 5.5 \\
\hline Mittel & 87.0 & 3.6 & 1.4 & 33.4 & 44.6 & 4.0 \\
\hline Spreu: & & & & & & \\
\hline Minimuın & 一 & 3.5 & 1.2 & 28.0 & 41.5 & - \\
\hline Maximum & - & 3.7 & 1.8 & 31.5 & 466 & - \\
\hline Mittel & 85.7 & 3.6 & 1.4 & 29.7 & 43.5 & 7.5 \\
\hline
\end{tabular}

Der mittlere Procentgehalt an verdaulichen Nährstoffen beträgt nach E. Wolff:

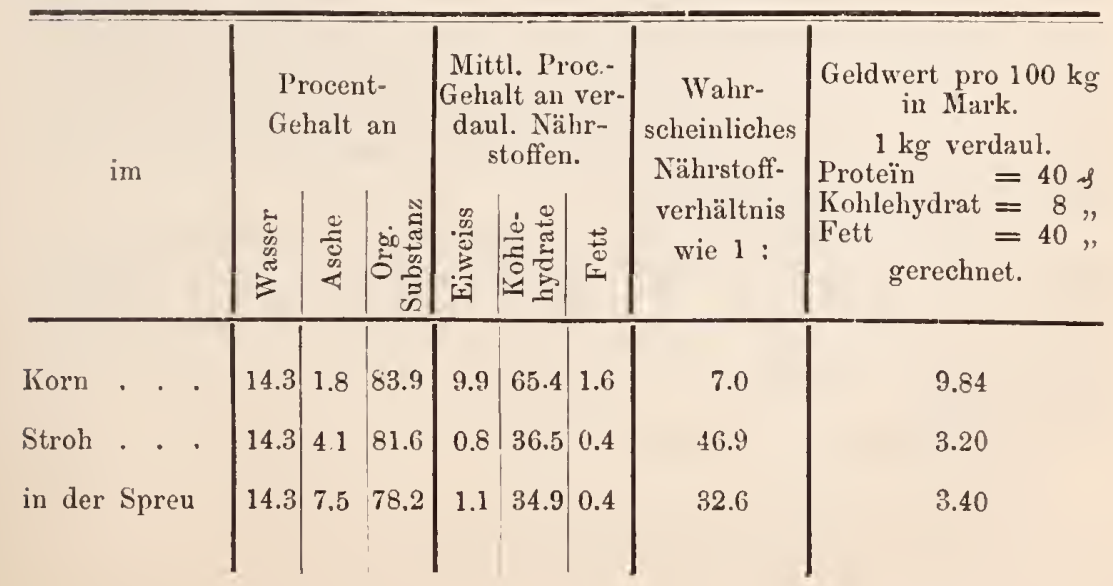


Je nach dem Mahlverfahren und der Konstruktion der Miuhle erhält man aus $100 \mathrm{~kg}$ Körnern $75-85 \mathrm{~kg}$ Mehl, 9-23.5 kg Kleie, $1.5-6 \mathrm{~kg}$ Abgang.

Durchschnittlich enthält das Roggenmehl:

$\begin{array}{ccccccc} & \begin{array}{c}\text { Proteïnkörper } \\ \text { Proc. }\end{array} & \begin{array}{c}\text { Zucker } \\ \text { Proc. }\end{array} & \begin{array}{c}\text { Gummi } \\ \text { Proc. }\end{array} & \begin{array}{c}\text { Fett } \\ \text { Proc. }\end{array} & \begin{array}{c}\text { Stärke } \\ \text { Proc. }\end{array} & \text { Wasser } \\ \text { fein } & 11.8 & 3.5 & 4.1 & 1.8 & 64.2 & 14.6 \\ \text { grob } & 13.3 & 3.0 & 6.3 & 2.5 & 60.3 & 14.5\end{array}$

\section{Benutzung.}

Der Roggen ist die Hauptbrotfrucht der germanischen und slavischen Völker und dementsprechend überragt seine Benutzung zu Brotmehl sehr erheblich alle übrigen Benutzungsweisen.

Das Roggenmehl besitzt eine bläulich-weisse Farbe, und das daraus bereitete Brot, wenn die Kleie aus ihm entfernt ist, immer eine graue Farbe. Mit der Kleie verbacken, wird das Brot nahrhafter, da dicht unter der Fruchtschale wie beim Weizen die kleberreichen Zellen liegen. Dieses Schwarzbrot fuihrt jedoch gelinde ab.

Der Roggen euthält ein nach Veilchen riechendes ätherisches Oel, welches dem Brote einen angenehmen Geschmack und Geruch mitteilt; ferner wird das Brot nicht leicht altbacken und lässt sich daher mehrere Wochen in einem Raum mit nicht zu trockner Luft frisch erhalten.

Das Roggenbrot wird selten mit Hülfe der Hefe, sondern meist mit Sanerteig hergestellt und liefert feines Roggenmehl gemeinhin ebensoviel Brot als Weizenmehl; nach Knapp ${ }^{1}$ geben $100 \mathrm{~kg}$ Mehl $163.3 \mathrm{~kg}$ Teig und $143.3 \mathrm{~kg}$ Brot; immer hängt das Gewicht des Brotes aus einer gewissen Quantität Mehl nicht allein von der Beschaffenheit des Mehles und seinem Wassergehalt, sondern auch von dem üblichen Backverfahren ab.

Nach der Ansicht von Till ${ }^{2}$ ) könnten noch mehr Procente an Mehl aus dem Roggen als bisher gezogen werden, und fiuhrt derselbe an, dass die Ausbeute zur Zeit nur 65-75 Proc. zur Broterzengung taugliches Mehl betrïgt und der Rest aus schwarzem Futtermehl und Kleie bestehe.

Innerhalb dieser 10 Procent mehr oder weniger Ausbeute bewegt

1) Lehrb. d. chem. Technologie Bd. II, pg. 109.

2) Till, Die Lösung der Brotfrage. Graz, 2. Aufl. 1878. 
sich aber die Konkurrenz der Müller und Bäcker, denn derjenige, weleher 75 Proe. Mehl gewinnt, wird bei einem bestimmten Brotpreise noch seinen Nutzen baben, während bei 65 Proc. Schaden erwäehst; daher sich die Verschiedenheit der Brotpreise nicht allein nach dem Getreidepreise, sondern in weit hölerem Masse nach der Leistungsfähigkeit der Mühlen richtet. Schliesslich hält er es für möglieh, wenn nur die Fruchtschale geschält und das übrige Korn vermahlen wird, bis 96 Proc. Mehl zu gewinnen, wenn man die von ibm erfundene Schälmaschine benutzt, durch welche die Schalen ohne Verletzung des Kornes auf trocknem Wege entfernt werden. Er selbst will mit Hülfe dieser Maschine an gutem Mehle 92.6 Proc., an Schälkleie 6 Proc. gewonnen und nur 1.4 Proc. durch Verstaubung verloren haben. In wieweit sich diese Mühleneinrichtung praktisch bewährt, bleibt abzuwarten, wenngleich nicht zu lcugnen ist, dass eine so hohe Ausbeute wesentlieh zur Erniedrigung der Brotpreise beitragen würrle.

In zweiter Linie steht die Verwendung des Roggens zur Erzeugung von Alkohol und liefert derselbe 3.6-4.2 Proc. Im Allgemeinen geben $66 \mathrm{~kg}$ Roggen und $34 \mathrm{~kg}$ Gerste $25-26$ Ltr Alkohol zu $95^{0}$.

Geröstet, dient der Roggen auch als Kaffesmrrogat; und in Russland bereitet man aus dem Roggen auch eine Art Bicr (Kwas).

Der griune Roggen bietet den Tieren im Herbst oder im zeitigen Frühjahr ein sehr nahrhaftes, die Milchsekretion förderndes Futter, und sind im Durchschnitt darin enthalten:

$\begin{array}{cccccc}\text { Wasser } & \text { Eiweiss } & \text { Kohlehydrate } & \text { Fett } & \text { Holzfaser } & \text { Asche } \\ \text { Proc. } & \text { Proc. } & \text { Proc. } & \text { Proc. } & \text { Proc. } & \text { Proc. } \\ 72.9 & 3.3 & 14.0 & 0.9 & 7.3 & 1.6\end{array}$

Nach E. Wolff finden sich an verdaulichen Nährstoffen in $100 \mathrm{~kg}$ Grünfutterroggen $1.9 \mathrm{~kg}$ Eiweiss, $11.0 \mathrm{~kg}$ Kohlchydrate, $0.4 \mathrm{~kg}$ Fett und ergiebt sich ein Nährstoffverhältnis wie 1:6.3, und der Futterwert stellt sich auf $1.80 \mathscr{M}$. pro $100 \mathrm{~kg}$.

Das Stroh dient seiner Festigkeit, Feinheit und Biegsamkeit wegen vielfach zu industriellen Zwecken, wie namentlich zur Herstellung von Geflechten, z. B. Strohhüten.

Weniger brauchbar, weil hart und nicht besonders reich an Nährstoffen, ist es als Futterstroh, weshalb seine hauptsächliche Verwendung in der Landwirtsehaft auf die Benutzung als Streu-, Bandund Dachstroh abzielt. 


\title{
Gerste.
}

\section{Hordeum vulgare $\mathrm{L}$.}

\author{
Einteilung.
}

\section{Unterart: Hordenm hexastichum L. Sechszeilige Gerste.}

Varietiat: Hordeum hexastichum brachyatherum Kcke.

Aehre blassgelb, Grannen kurz.

\section{Sorte:}

\section{líurzgrannige sechszeilige Gerste aus Japan. (2)}

Aehre: blassgelb, kurz, dicht; Grannen kurz, nur $4 \mathrm{~cm}$ lang, aufrecht, hell; Grannen und Spindel sehr zerbrechlich. - Stroh: rotgelb, $60-75 \mathrm{~cm}$ hoch. - Scheinfrucht: blassgelb, klein, voll $(8 \mathrm{~mm}$ lang, $31 / 2 \mathrm{~mm}$ breit, $3 \mathrm{~mm}$ dick, 241 Scheinfrüchte $=10 \mathrm{gr})$, ziemlich feinschalig.

Herbstblatt blaugriin, fein, kraus, 4 Schösslinge; Aehre reif $4-6 \mathrm{~cm}$ lang, mit 40 Scheinfriichten.

Winterfest, doch stark rostig.

Varietät: Hordeum hexastichum pyramidatum Kcke.

Aehre pyramidal; Granuen lang.

\section{Sorten:}

Kurze sechszeilige Wintergerste. (2) $\mathbf{u}^{*} \odot$

Engl.: Pomeranian or Six-rowed-White Winter-Barley.

Aehre: gelb, dicht, kurz, pyramidal, leicht abbrechend; Grannen hell, gespreizt, bis $15 \mathrm{~cm}$ lang. - Stroh: gelb, sehr kräftig, blattreich, fest, lang. - Scheinfrucht: gelb, lang (10 $\mathrm{mm}$ lang, $3 \frac{1}{2} \mathrm{~mm}$ breit), etwas dickschalig.

Herbstblatt blaugriin, kraus, sehr kräftig; Entwickelung gegen die sechs- und vierzeiligen Wintergersten in Fribjahr sehr spät, doch reifte sie am frühesten. Bestockung inittelstark, 4.5 Schösslinge. Halme $110 \mathrm{~cm}$ (Max. $125 \mathrm{~cm}$ ) lang, $0.5 \mathrm{~cm}$ dick, Blattzahl 5, Blätter $22.34 \mathrm{~cm}$ lang, $1.14 \mathrm{~cm}$ breit, Blattfläche $255.7 \mathrm{qcm}$, Halmfläche $165 \mathrm{qcm}$, Gesammtfläche $42.07 \mathrm{qcm}$. 
Aehre reift zeitig, Anfang Juli; $5 \mathrm{~cm}$ (Max. $7 \mathrm{~cm}$ ) lang, mit 60 Scheinfriichten, von denen 1643775 auf $1 \mathrm{hl}(=70.7 \mathrm{~kg})$ entfallen.

Auf $1 \mathrm{qm}$ wachsen 800 Halme oder 180 Pflanzen, mithin beträgt der Raum für eine Pflanze $55.5 \mathrm{qcm}$, die Blattfläche p. qm Bodenfläche $33.6 \mathrm{qm}$ und das Saatquantum $1 \mathrm{hl}$ p. ha.

Es wiegen 100 Halme $837 \mathrm{gr}$ und davon die Scheinfrüichte $448 \mathrm{gr}$.

Diese Gerste leidet wenig durch Rost, lagert nicht leicht, ist winterfest und als Sommergerste kultivierbar, so wird sie z. B. in Ostfriesland auf reichem Boden unter dem Namen „Märzgerste“ Ende Februar oder Anfang März ausgesäet und ist sehr ertragreich.

Häufig dient sie auch in den Marschen als Ersatzfrucht für ausgewintertell Raps.

Sie soll vielfach in den Marschen an der Nordsee, im nördlichen Frankreich, in England und Schottland gebaut werdell.

Aussaatzeit: September bis Oktober.

\section{Kurze sechszeilige Sommergerste. $\odot$}

Syn.: Ordi, (Vich, Cataluña), Spanien.

Aelıre: gelb, sich nach der Spitze stark verjüngend, leicht abbrechend, dicht, aufrecht; Grannen hell, gespreizt, bis $16 \mathrm{~cm}$ lang. - Stroh: gelb, sehr kräftig, blattreich, kurz. -- Seheinfrucht: graulich, an Basis bräunlich, nach beiden Enden stark zugespitzt, gross (9 mm lang, 4 mm breit), sehr leicht und dickschalig.

Halme blaugrün, 22 Schösslinge, nittelfriih schossend und blühend, $55 \mathrm{~cm}$ (Max. $60 \mathrm{~cm}$ ) lang, $0.43 \mathrm{~cm}$ dick, Blattzahl 4.3, Blätter $24 \mathrm{~cm}$ lang, $1.1 \mathrm{~cm}$ breit, Blattfläche $227.04 \mathrm{q} \mathrm{cm}$, Halmfläche $69.95 \mathrm{qcm}$, Gesammtfläche $296.99 \mathrm{qcm}$.

Aehre reift mittelfrüh, $5 \mathrm{~cm}$ (Max. $6 \mathrm{~cm}$ ) lang, mit 48 Scheinfriichten, von denen 1339000 auf $1 \mathrm{hl}(=68.3 \mathrm{~kg})$ entfallen.

Auf $1 \mathrm{qm}$ wachsen 900 Halme oder 410 Pflanzen, mithin beträgt der Raum für eine Pflanze 24.4 qcm, die Blattfläche p. qm Bodenfläche $27 \mathrm{qm}$ und das Saatquantum $4 \mathrm{hl}$ p. ha.

Es wiegen 100 Halme $570 \mathrm{gr}$ und davon die Scheinfrüchte $323 \mathrm{gr}$.

In Proskau wurden 1872 auf humosem Thonboden p. ha erzielt: $3474 \mathrm{~kg}$ Korn, $3328 \mathrm{~kg}$ Stroh, $582 \mathrm{~kg}$ Spreu und in Dänemark sollen sich auf reichem Boden die Erträge auf $25--40$ hl p. ha stellen.

Diese Gerste, welche nicht leicht lagert und wenig durch Rost leidet, verlangt zu ihrem Gedeihen einen kräftigen Boden und ein mildes Klima; da sie jedoch ihrer Dickschaligkeit wegen als Braugerste nicht verwendbar ist, findet ihre Kultur nur in sehr beschränktem Umfange statt. Kultiviert in Dänemark, Spanien ete.

Bezugsquelle: Antonio Cipriano Costa, 1881.

\section{Lange sechszeilige Wintergerste. (2)}

Aehre: fast weiss, dicht, Reihen parallel, nicht leicht abbrechend; Grannen hell, zerbrechlich, bis $17 \mathrm{~cm}$ lang. - Stroh: gelb, blattreich, kräftig, sehr weich. - Scheinfrucht: fast weiss, schmal, spitz, gross (10 mm lang, $4 \mathrm{~mm}$ breit), leicht, dickschalig.

Herbstblatt gelbgrün, breit, 4.2 Schösslinge, spät schossend und blühend. Halme $108 \mathrm{em}$ (Max. $130 \mathrm{~cm}$ ), $0.45 \mathrm{~cm}$ dick, Blattzahl 4, Blätter 
$18.4 \mathrm{~cm}$ lang, $1.12 \mathrm{~cm}$ breit, Blattfläche $164.88 \mathrm{qcm}$, Halınfläche $152.75 \mathrm{qcm}$, Gesammtfläche $317.63 \mathrm{qcm}$.

Aehre reift sehr spät, Ende Juli, $6 \mathrm{~cm}$ (Max. $9 \mathrm{~cm}$ ) lang, mit 80 Scheinfritichten, von denen 1800000 anf 1 hl $(=60 \mathrm{~kg})$ entfallen.

Auf $1 \mathrm{qm}$ wachsen 940 Halme oder 224 Pflanzen, mithin beträgt der Raum für eine Pflanze 44.6 q cm, die Blattfäche p. qm Bodenfläche $30 \mathrm{qm}$ und das Saatquantum $1.7 \mathrm{hl}$ p. ha. leicht.

Diese ergiebige Gerste verlangt einen reichen Boden, lagert aber

\section{Lange sechszeilige Sommergerste. $\odot$}

Aehre: schmutzig-gelb, anfrecht, dicht, kurz, Reihen parallel; Klappen pfriemenförmig, kahl; Grannen lıell, breit, obere Grannen kürzer als die unteren, letztere doppelt so lang als die Aehre, bis $15 \mathrm{~cm} \mathrm{lang,} \mathrm{ge-}$ spreizt. - Stroh: gelb, kräftig, mittellang. - Scheinfrucht: schmutziggelb, gefurcht, nach beiden Enden zugespitzt (9 $\mathrm{mm}$ lang, $4 \mathrm{~mm}$ breit), leicht, dickschalig.

Halme blaugrïn, bereift, 3.3 Schösslinge, spät schossend und blühend, $80 \mathrm{~cm}$ (Max. $90 \mathrm{~cm}$ ) lang, $0.47 \mathrm{~cm}$ dick, Blattzahl 4, Blätter $22.73 \mathrm{~cm}$ lang, $1.1 \mathrm{~cm}$ breit, Blattfläche $200 \mathrm{qcm}$, Halmfläche $112.8 \mathrm{qcm}$, Gesammtfläche $312.8 \mathrm{qcm}$.

Aehre in 115 Tagen reifenr, $6 \mathrm{~cm}$ (Max. $7 \mathrm{~cm}$ ) lang, mit 60 Scheinfrichten, von denen 1547000 anf $1 \mathrm{hl}(=70 \mathrm{~kg}$ ) entfallen.

Auf $1 \mathrm{qm}$ wachsen 800 Halme oder 242 Pflanzen, mithin beträgt der Ramm für eine Pflanze $41 \mathrm{qcm}$, die Blattfläche p. qm Bodenfläche $25 \mathrm{qm}$ und das Saatquantum $2.1 \mathrm{hl}$ p. ha.

Diese Gerste leidet leicht durch Rost und besitzt für Deutschland nur geringen ökonomischell Wert.

\section{Varietät: Hordeum hexastichum parallelum Kcke. Aehre parallel; Granuen lang.}

\section{Sor te :}

\section{Japanische sechszeilige Wintergerste. (2)}

Aehre: fast weiss, dicht, Reihen parallel, nicht leicht aborechend; Graunen fast weiss, kiirzer als bei pyramidatum, aufrecht. - Stroh: hellgelb, blattreich, steif. - Scheinfruclit: gelb, an Basis bräunlich, spitz (231 Scheinfrüchte $=10 \mathrm{gr}, 8 \mathrm{~mm}$ lang, $31 / 2 \mathrm{~mm}$ breit).

Junges Blatt hellgrün, bereift, aufrecht; 4.5 Schösslinge, Halme $90 \mathrm{~cm}$ (Max. $100 \mathrm{~cm}$ ) lang, $0.4 \mathrm{~cm}$ dick, Blattzahl 5, Blätter $16.7 \mathrm{~cm}$ lang, $1 \mathrm{~cm}$ breit, Blattfläche $167 \mathrm{qcm}$, Halmfläche $108 \mathrm{qcm}$, Gesammtfläche $275 \mathrm{q} \mathrm{cns}$.

Aehre reift in der zweiten Hälfte des Juli, $6 \mathrm{~cm}$ (Max. $7 \mathrm{~cm}$ ) lang, mit 72 Scheinfriicliten, von denen 1533840 auf $1 \mathrm{hl}(=66.4 \mathrm{~kg})$ entfallen.

Es wiegen 100 Halme $500 \mathrm{gr}$ und davon die Scheinfrüclite $300 \mathrm{gr}$.

Sie ist eine echte Wintergerste, die ein mildes Klima verlangt, denn in Poppelsdorf kamen nur wenige lebensfähige Pflanzen durch den Winter. 


\section{Unterart: Hordeum tetrastichum Kcke. Vierzeilige Gerste.}

\section{A. Körner beschalt.}

Varietät: Hordeum tetrastichum pallidum Sér.

Aehre blassgelb, Grannen gerade.

\section{Sorten:}

\section{Gemeine vierzeilige Wintergerste. (2)}

Syn.: Perlgerste, Bärengerste, Rettema d. h. „Rettet den Manu“, weil sie zeitiges Brot liefert.

Fran z.: Orge carrée d'hiver.

Engl.: White Four-rowed Winter-Barley.

It al.: Orzo vernino, comune d'autunno.

Dänisch: Winterbyg.

Schwedisch: Korn.

Aehre: hellgelb, ziemlich dicht, fast quadratisch, doch etwas gebogen, kurz; Spindel zerbrechlich; Grannen hell, zerbrechlich, anliegend, bis $15 \mathrm{~cm}$ lang. - Stroh: rötlich-gelb, kräftig, blattreich, lang. - Scheinfrucht: goldgelb, voll (10 mm lang, $4 \mathrm{~mm}$ breit), feinschalig.

Junges Blatt gelbgriin, kräftig, aufrecht; Friiljahrsvegetation sehr zeitig, Bestockung stark, 6 Schösslinge (bei 100 qcm Raum 17.2 Schösslinge), bestockt sich nur im Herbst, daher zeitig säen, sehr zeitig schossend und blühend (zweite Hälfte Juni). Halm $120 \mathrm{~cm}$ (Max. $140 \mathrm{~cm}$ ) lang, $0.4 \mathrm{~cm}$ dick. Blattzahl 4.2, Blätter $19.5 \mathrm{~cm}$ lang, $1 \mathrm{~cm}$ breit, Blattfläche $163.8 \mathrm{qcm}$, Halınfläche $144 \mathrm{qcm}$, Gesammtfäche $307.8 \mathrm{qcm}$.

Aehre reift sehr zeitig, in den ersten Tagen des Juli, $5 \mathrm{~cm}$ (Max. $8 \mathrm{~cm})$ lang, mit 50 Scheinfrüchten, von denen 1836000 auf $1 \mathrm{hl}(=68 \mathrm{~kg})$ entfallen.

Auf $1 \mathrm{qm}$ wachsen 900 Halme oder 150 Pflanzen, mithin beträgt der Raum für eine Pflanze 66.6 q $\mathrm{cm}$, die Blattfläche $\mathrm{p}$. qm Bodenfläche $27.7 \mathrm{qm}$ und das Saatquantum $1.1 \mathrm{hl} \mathrm{p}$. ha.

Es wiegen 100 Halme $470 \mathrm{gr}$ und davon die Scheinfriichte $277 \mathrm{gr}$.

Sie ist eine ziemlich winterfeste und frühreife echte Wintergerste, denn im August gesäet, reift sie schon Ende Juni, im September gesäet, Anfang Juli. Ausserdem leidet sie wenig durch Rost und lagert nicht leicht, daher ein sehr reicher Boden zu ihrer Kultur benutzt werden kanu, zumal schwaches Lagern bei ihrer Frïhreife den Ertrag kaum verringert. Ausserdem lässt sich diese Gerste bei Sommerstallfiitterung als zeitiges Grünfutter verwenden und wird weniger leicht hart als Roggen, und da sie ferner sehr zeitig reift und vicl Stroh erzeugt, so ist sie anch aus diesem Grunde für die Sommerstallfütterung sehr beachtenswert. In England wird sie anch häufig im Frühjahr zur Sehafweide benutzt. Als Braugerste ist sie dagegen wegen ihres kleberreichen Kornes wenig geschätzt.

Auf reichem Marschboden liefert sie nicht selten $3800-4500 \mathrm{~kg}$ Korn; in Proskau erbrachte sie 1872 auf humosem Thonboden p. ha: $3959 \mathrm{~kg}$ Korn, $3558 \mathrm{~kg}$ Stroh. 
Bei vergleichenden Versuchen im Königreich Sachsen lieferte sie folgende Ertrige p. ha:

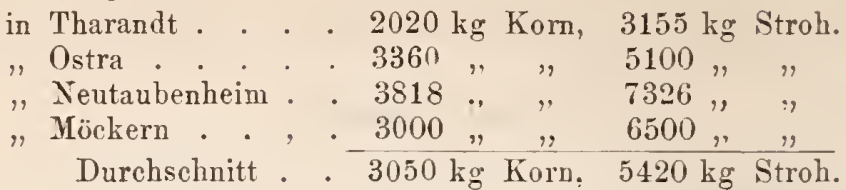

Diese Wintergerste wird rorzugsweise in England, Dänemark, Schweden, Nord-Frankreich, Belgien, Holland, am Niederrhein, in den deutschen Marschen, in einigen Teilen Westfalens, sowie iiberhaupt in Tord-Deutschland und hier uamentlich in Königreich Sachsen knltiviert.

\section{Gemeine vierzeilige Gerste. $\odot$}

Syn.: Kleine Sandgerste.

Franz.: Orge d'été à quatre rangs.

It a l.: Orzo comune di primavera, marzuolo.

Englisch: Common Bere or Big; Rough Barley.

Dänisch: Byg almindeligt, Korn, Sommerbyg.

Sch w ed is ch: Korn, Bjugg.

Aelne: gelb, etwas locker, schlaff; Spindel zerbrechlich; Gramnen gelb, anliegend, nicht dicht an Scheinfrucht abbrechend, bis $18 \mathrm{~cm}$ lang. - Stroh: rötlich-gelb, blattreich, ziemlich kräftig, mittellang. - Scheinfrucht: gelb, klein ( $8 \mathrm{~mm}$ lang, $4 \mathrm{~mm}$ breit), etwas grobschalig.

Junges Blatt gelbgrïn, kurz, breit, kräftig; 2.5 Schösslinge, zeitig schossend und blïhend. Halme $80 \mathrm{~cm}$ (Iax. $100 \mathrm{~cm}$ ) lang, $0.4 \mathrm{~cm}$ dick, Blattzahl 4, Blätter $18.5 \mathrm{~cm}$ lang, $1.0 \mathrm{~cm}$ breit, Blattfläche $148 \mathrm{qcm}$, Halmfliche $96 \mathrm{qcm}$, Gesammttläche $244 \mathrm{qcm}$.

Aehre roift sehr zeitig, in 100 Tagen, $7 \mathrm{~cm}$ (Max. $10 \mathrm{~cm}$ ) lang, mit 48 Scheinfrichten, von denen 1617000 auf $1 \mathrm{hl}(=70.3 \mathrm{~kg}$ ) entfallen.

Auf $1 \mathrm{qm}$ wachsen 1000 Halme oder 400 Pflanzen, mithin beträgt der Raum für eine P'flanze $25 \mathrm{qcm}$, die Blattfläche p. q in Bodenfläche $24.4 \mathrm{qm}$ und das Saatquantum $3.3 \mathrm{hl}$ p. ha.

Es wiegen 100 Halme $467 \mathrm{gr}$ und davon die Scheinfrüchte $278 \mathrm{gr}$.

Diese Gerste lagert nicht leicht, befällt aber stark mit Rost.

Sie wurde früher in Deutschland sehr allgemein angebaut, ist jedocl in neuerer Zeit durch die zweizeiligen Gerstensorten stark verdrängt worden, da sie diesen auf nicht allzuarmem Boden und bei besserer Feldkultur nachstelit. Wegen ihrer kurzen Tegetationsperiode wird sie mit Torliebe im Sorden Enropas, so in Scliweden und Norwegen, Finnland, im nördlichen Russland, in den schottischen Hochlanden etc. kultiviert. Auf geringen Böden bringt sie aber auch in allen Ländern Europas höhere Erträge als die zweizeilige Gerste, welche grösscre Bodenansprüche macht.

\section{Lange gemeine Wintergerste. (2)}

Aehre: liellgelb, dicht, schlaff, lang; Spindel zerbrechlich; Grannen hell, leicht zerbrechlich, anliegend, bis $15 \mathrm{~cm}$ lang. - Stroh: gelb, sehr kräftig, blattreich, lang. - Scheiufrucht: hellgclb, selır lang (12 mm lang, $4 \mathrm{~mm}$ breit), etwas grobschalig. 
Herbstblatt blaugriin, schmal; Fruihjahrsentwickelung spät, Bestockung stark, 5 Schösslinge, spät schossend und blïhend. Halme $120 \mathrm{~cm}$ (Max. $140 \mathrm{~cm}$ ) lang, $0.52 \mathrm{~cm}$ dick, Blattzahl 4.3, Blätter $25.54 \mathrm{~cm} \mathrm{lang,}$ $1.3 \mathrm{~cm}$ breit, Blattfläche 285.52 qcm, Halmfläche 187.2 qcm, Gesammtfläche 472.72 qem.

Aehre spät, Mitte Juli reifend, $9 \mathrm{~cm}$ (Max. $11 \mathrm{~cm}$ ) lang, mit 60 Scheinfrichten, von denen 1863200 auf $1 \mathrm{hl}(=68 \mathrm{~kg})$ entfallen.

Auf $1 \mathrm{qm}$ wachsen 700 Halme oder 140 Pflanzen, mithin beträgt der Raum für eine Pflanze $71 \mathrm{qcm}$, die Blattfläche p. qm Bodenfläche $33 \mathrm{qm}$ und das Saatquantuṇ $1 \mathrm{hl}$ p. ha.

Es wiegen 100 Halme $704 \mathrm{gr}$ nnd davon die Scheinfrüchte $402 \mathrm{gr}$.

Sie ist eine echte Wintergerste, jedoch nicht ganz winterfest, so erfror sie $1870 / 71$ in Poppelsdorf bis auf wenige Pflanzen; sie lagert nicht leicht, leidet wenig dureh Rost und verlangt ein mildes Klima und einen sehr kräítigen Boden.

\section{Schlesische Zeilgerste. $\odot$}

Aehre: gelb, dicht, lang, längend; Spindel zerbrechlich; Grannen hell, anliegend, bis $16 \mathrm{~cm}$ lang. - Stroh: rötlich-gelb, kräftig, mittellang. - Scheinfrucht: gelb, klein (9 mm lang, $4 \mathrm{~mm}$ breit), etwas grobschalig.

Junges Blatt hellgrün, breit, kräftig, Bestockung schwach, 1.8 Schösslinge, zeitig schossend und blühend. Halme $75 \mathrm{~cm}$ (Маa. $100 \mathrm{~cm}$ ) lang, $0.4 \mathrm{~cm}$ dick, Blattzahl 3.6, Blätter $22.3 \mathrm{~cm}$ lang, $1 \mathrm{~cm}$ breit, Blattfläche $160.56 \mathrm{qcm}$, Halmfläche $90 \mathrm{qcm}$, Gesammtfläche $250.56 \mathrm{qcm}$.

Junge Aehre gelbgrïn, in 107 Tagel reifend, $9 \mathrm{~cm}$ (Max. $14 \mathrm{~cm}$ ) lang, mit 68 Scheinfrichten, von denen 1680000 auf $1 \mathrm{hl}(=71.5 \mathrm{~kg})$ entfallen.

Auf $1 \mathrm{qm}$ wachsen 1000 Halme oder 555 Pflanzen, mithin beträgt der Raum für 1 Pflanze $18 \mathrm{qcm}$, die Blattfäche p. qm Bodenfläche $25 \mathrm{qm}$ und das Saatquantum $4.4 \mathrm{hl}$ p. ha.

Es wiegen 100 Halme $550 \mathrm{gr}$ und davon die Scheinfrüchte $311 \mathrm{gr}$.

Diese Gerste liefert auf nicht ganz geringem Boden hohe Erträge, so wurden, allerdings auf sehr reichem humosen Thonboden, in Proskau 1872 p. ha erzielt:

$3224 \mathrm{~kg}$ Korn, $2912 \mathrm{~kg}$ Stroh, $770 \mathrm{~kg}$ Spreu.

Ausserdem zeigt sie sich gegen Rost und Lagern sehr widerstandsfähig.

\section{Vierzeilige Gerste aus dem Oderbruch. $\odot$}

Aehre: graulich-weiss, etwas locker, hängend, mittellang; Śpindel zerbrechlich; Grannen hell, sehr lang (20 cm), anliegend, zerbrechlich, doch nicht dicht an Scheinfrucht abbrechend. - Stroh: rötlich-gelb, sehr kräftig, blattreich, mittellang. - Scheinfrucht: graulich-weiss, mittelgross (9 $\mathrm{mm}$ lang, $4 \mathrm{~mm}$ breit), ziemlich feinschalig.

Halme gelbgrün, 1.8 Schösslinge, ziemlich früh schossend und blühend, $85 \mathrm{~cm}$ (Iax. $110 \mathrm{~cm}$ ) lang, $0.47 \mathrm{~cm}$ dick, Blattzahl 4, Blätter $22.93 \mathrm{~cm}$ lang, $1.33 \mathrm{~cm}$ breit, Blattfäche $244 \mathrm{qcm}$, Halmfläche $119.85 \mathrm{qcm}$, Gesammtfläche 363.85 qem.

Junge Aehre gelbgriun, zeitig in 110 Tagen reifend, $8 \mathrm{~cm}$ (Max. 
$11 \mathrm{~cm})$ lang, mit 60 Scheinfriichten, von denen 2059500 anf $1 \mathrm{hl}(=73 \mathrm{~kg})$ entfallen.

Auf $1 \mathrm{qm}$ wachsen 720 Halme oder 400 Pflanzen, mithin beträgt das Saatquantum $1.6 \mathrm{~h} l \mathrm{p}$. ha.

Es wiegen 100 Halme $525 \mathrm{gr}$ und davon die Scheinfrüchte $319 \mathrm{gr}$.

Diese Gerste lagert nicht leicht, leidet fast gar micht durch Rost und wird vielfach im Oderbritch auf den besseren Gerstenböden angcbaut.

\section{Kleine Warthebruchgerste. $\odot$}

Aehre: graulich-weiss, aufrecht, mittellang; Spindel zerbrechlich; Gramnen hell, zerbrechlich, bis $18 \mathrm{~cm}$ lang. - Stroh: rötlich-gelb, kräftig, mittellang. - Scheinfrucht: graulich-weiss, gross, spitz (10 mm lang, $4 \mathrm{~mm}$ breit).

Halme gelbgriin, ziemlich zeitig blühend, 2.3 Schösslinge, $80 \mathrm{~cm}$ (Wax. $100 \mathrm{~cm}$ ) lang, $0.38 \mathrm{~cm}$ breit, Blattzahl 3.7, Blätter $20.38 \mathrm{~cm}$ lang, $1.02 \mathrm{~cm}$ breit, Blattfäche $153.85 \mathrm{qcm}$, Halmfläche $91.2 \mathrm{qcm}$, Gesammtfläche $245.05 \mathrm{qcm}$.

Aehre reift in 110 Tagen, $8 \mathrm{~cm}$ (Max. $9 \mathrm{~cm}$ ) lang, mit 60 Scheinfrïichten, von denen 1574000 auf $1 \mathrm{lll}(=73.2 \mathrm{~kg})$ entfallen.

Auf $1 \mathrm{qm}$ wachsen 1000 Halme oder 435 Pflanzen, mithin beträgt das Saatquantum 3.7 hl p. ha.

Es wiegen 100 Halme 541 gr und davon die Scheinfriichte 300 gr.

Diese Gerste entwickelt sich schnell, degeneriert nicht leicht (seit 1872 in Poppelsdorf gebaut), lagert nicht leicht, leidet wenig durch Rost und ist ertragreich.

Bezugsquelle: Metz \& Co., Berlin.

\section{Gerste von Borknm. $\odot$}

Aehre: grauweiss, etwas locker, unter mittellang; Spindel zerbrechlich; Grannen hellgelb, bis $20 \mathrm{~cm}$ lang, wenig gespreizt, leicht zerbrechlich. - Stroh: rötlich-gelb, ziemlich lang. - Scheinfrucht: grauweiss, klein (9 $\mathrm{mm}$ lang, $4 \mathrm{~mm}$ breit, 214 Scheinfrüchte $=10 \mathrm{gr}$ ), feinschalig.

Junges Blatt gelbgrün, kräftig; Entwickelung zeitig, 1.7 Schösslinge, zeitig schossend und blühend, Halm $85 \mathrm{~cm}$ (Max. $100 \mathrm{~cm}$ ) lang, $0.45 \mathrm{~cm}$ dick, Blattzahl 4.3 , Blätter $26 \mathrm{~cm}$ lang, $1.2 \mathrm{~cm}$ breit, Blattfläche $268.32 \mathrm{qcm}$, Halmfläche $114.75 \mathrm{qcm}$, Gesammtfläche $383.1 \mathrm{q} \mathrm{cm}$.

Reift in 110 Tagen, Aehre $7 \mathrm{~cm}$ (Max. $9 \mathrm{~cm})$ lang, mit 50 Scheinfriichten.

\section{Karrierte Gerste.}

Aehre: blassgelb, nit rötlichem Schimmer; Granne anliegend, sehr lang $(15 \mathrm{~cm})$. - Stroll : rotgelb, steif. - Scheinfrucht: weisslich mit schwach rötlichem Schimmer, ziemlich voll $\left(9 \mathrm{~mm}\right.$ lang, $3^{1} / 2 \mathrm{~mm}$ breit, 311 Scheinfrïchte $=10 \mathrm{gr})$, feinschalig.

Junges Blatt gelbgrün, 2 Schösslinge, Halme $80 \mathrm{~cm}$ (Max. $90 \mathrm{~cm}$ ) lang, $0.4 \mathrm{~cm}$ dick, Blattzahl 5, Blätter $12.6 \mathrm{~cm}$ lang, $0.9 \mathrm{~cm}$ breit, Blattfläche $113.4 \mathrm{qcm}$, Halmfläche $96 \mathrm{qcm}$, Gesammtfläche $209.4 \mathrm{qcm}$.

Aehre reift in 97 Tagen und enthält 60 Scheinfrüchte, von denen 2208000 auf $1 \mathrm{hl}(=71 \mathrm{~kg})$ entfallell.

Es wiegen 100 Halme $357 \mathrm{gr}$ und davon die Schcinfriichte $214 \mathrm{gr}$.

Bezugsquelle: Frommer, Budapest. 


\section{Orge carrée de printemps. $\odot$}

Syn.: Escourgeon de Mars.

Aehre: fast weiss, sehr dicht, luängend, verläuft ziemlich spitz, indem die oberen Aelrchen taub werden; oft an der Spitze schwach gekrümmt. Manche Aehrchen werden an der Spitze exakt 4-zeilig, indem hier die Seitenährchen genal unter (oder iiber) den Seitenährchen des nächsten Drillings stehen und daher vom Mittelährchen eine Distance von $90^{\circ}$ lraben. Die Mittelälırchen liegen dort der Spindel fest an, die Seitenährchen springen dagegen viel mehr nach aussen, weil hier in derselben Längsebene die doppelte Zahl der Aehrchen liegt; die Aehre erscheint daher an dieser Stelle wie zweizeilig, Spindel leicht zerbrechlich, lang; Grannen hell, wenig gespreizt, zerbrechlich, doch nicht dicht an Scheinfrucht abbrechend, bis $20 \mathrm{~cm}$ lang. - Stroh: rotgelb bis orange, sehr kräftig, blattreich, mittellang. - Scheinfrucht: fast weiss, ziemlich voll (9 $\mathrm{mm}$ lang, $4 \mathrm{~mm}$ breit), ziemlich feinsclalig.

Halme dunkelgrün, bereift, Entwickelung von allen Gersten dieser Varietät am langsamsten, Bestockung stark, 3 Schösslinge, spät schossend und blühend. Halme $85 \mathrm{~cm}$ (Max. $100 \mathrm{~cm}$ ) lang, $0.47 \mathrm{~cm}$ dick, Blattzahl 4.7, Blätter $25.94 \mathrm{~cm}$ lang, $1.43 \mathrm{~cm}$ breit, Blattfläche $345.65 \mathrm{qcm}$, Halmfläche $119.85 \mathrm{qcm}$, Gesammtfäche $468.5 \mathrm{qcm}$.

Aehre reift spät, in 124 Tagen, $10 \mathrm{~cm}$ (Max. $12 \mathrm{~cm}$ ) lang, mit 80 Scheinfrichten, von denen 1449000 auf $1 \mathrm{hl}(=69 \mathrm{~kg})$ entfallen.

Auf 1 qu wachsen 600 Halme oder 200 Pflanzen, mithin beträgt der Raum für eine Pflanze $50 \mathrm{qcm}$, die Blattfläche p. q1n Bodenfläche $28 \mathrm{qm}$ und das Saatquantum $1.9 \mathrm{hl}$ p. ha.

Es wiegen 100 Halme $504 \mathrm{gr}$ und davon die Scheinfriichte $272 \mathrm{gr}$.

Diese auf besseren Gerstenböden sehr ertragreiche Sorte lagert nicht leicht und leidet sehr wenig durch Rost.

Bezugsquelle: Vilmorin \& Andrieux, Paris.

\section{Gerste aus Apulien. $\odot$}

Aehre: blassgelb, etwas hängend, locker, kurz; Spindel zähe; Grannen fast weiss, anliegend, bis $20 \mathrm{~cm}$ lang, zähe. - Stroh: gelb, kurz, blattreicl, weich. - Scheinfrucht: blassgelb, an Basis häufig violett, lang, schmal (12 cm lang, $4 \mathrm{~mm}$ breit, 168 Frïchte $=10 \mathrm{gr}$ ), grobschalig.

Junges Blatt und Halme blaugrün, 4.5 Schösslinge, spät blühend; Halm $70 \mathrm{~cm}$ (MFax. $90 \mathrm{~cm}$ ) lang, $0.38 \mathrm{~cm}$ dick, Blattzahl 5, Blätter $17.16 \mathrm{~cm}$ lang, $0.76 \mathrm{~cm}$ breit, Blattfläche $130.4 \mathrm{qcm}$, Halmfläche $79.8 \mathrm{qcm}$, Gesammtfäche 210.2 q $\mathrm{cm}$.

Reift spät, in 121 Tagen, Aehre $7 \mathrm{~cm}$ (Max. $8 \mathrm{~cm}$ ) lang, mit 50 Scheinfrüchten.

\section{Sommergerste von Zea. $\odot$}

Aehre: blassgelb, etwas locker, hängend, lang; Spindel zerbrechlich; Grannen hell, zähe, bis $15 \mathrm{~cm}$ lang. - Stroh: rotgelb, kräftig, mittellang. - Scheinfrucht: blassgelb, ziemlich voll, mittelgross $(8 \mathrm{~mm}$ lang, $4 \mathrm{~mm}$ breit).

Halme gelbgrün, 2.8 Schüsslinge, mittelfrüh schossend und blühend, $80 \mathrm{~cm}$ (Max. $90 \mathrm{~cm}$ ) lang, ().45 cm dick, Blattzahl 4, Blätter $19 \mathrm{~cm}$ lang, 
$1.13 \mathrm{~cm}$ breit, Blattfäche $171.76 \mathrm{qcm}$, Halmftäche 108 q cm, Gesammtfläche $279.76 \mathrm{qcm}$.

Aehre reift in 110 Tagen, $9 \mathrm{~cm}$ (Max. $12 \mathrm{~cm}$ ) lang, mit 60 Scheinfrüchten, von denen 1541000 auf $1 \mathrm{hl}(=71 \mathrm{~kg})$ entfallen.

Es wiegen 100 Halme $578 \mathrm{gr}$ und davon die Sicheinfrüchte $299 \mathrm{gr}$. Diese Gerste lagert nicht leicht und bleibt fast rostfrei.

\section{Victoria Big. $\odot$}

Deutsch: Victoria-Gerste.

Franz.: Orge Victoria.

Aelre: gelb, etwas locker, lang, hängend; Spindel zerbrechlich; Grannen hell, $16 \mathrm{~cm}$ lang, anliegend, zerbrechlich. - Stroh: gelb, kräftig, blattreich, mittellang. - Scheinfruclit: gelb, mittelgross (9 $\mathrm{mm}$ lang, $4 \mathrm{~mm}$ breit), etwas grossschalig.

Halme blaugrün, Bestockıng ziemlich stark, 2.2 Schösslinge, zeitig schossend und bliihend, $80 \mathrm{~cm}$ (Max. $100 \mathrm{~cm}$ ) lang, $0.4 \mathrm{~cm}$ dick, Blattzahl 4.3, Blätter $17.66 \mathrm{~cm}$ lang, $1.09 \mathrm{~cm}$ breit, Blattfläche $165.55 \mathrm{qcm}$, Halmfläche $96 \mathrm{q} \mathrm{cm}$, Gesammtfläche $261.55 \mathrm{qcm}$.

Aehre reift zeitig, in 109 Tagen, $8 \mathrm{~cm}$ (Max. $11 \mathrm{~cm}$ ) lang, mit 50 Scheinfrüchten, von denen 1645000 auf $1 \mathrm{hl}(=71.5 \mathrm{~kg})$ entfallen.

Es wiegen 100 Halme $570 \mathrm{gr}$, und daron die Scheinfrüchte $270 \mathrm{gr}$; und in Proskau wurden 1872 auf humosem Thonboden p. ha geerntet: $2995 \mathrm{~kg}$ Korn, $3037 \mathrm{~kg}$ Stroh, $665 \mathrm{~kg}$ Spreu.

Diese Gerste lagert nicht leicht und ist gegen Rost ziemlich widerstandsfähig, und da sie ansserdem sehr frühreif, sowie gegen ungünstige Witterung wenig enpfindlich ist, empfiehlt sich ihr Anbau für die nordischen Gegenden und das Gebirge.

Sie wurde 1857-59 durch Mr. Fulton in Ayrshire verbreitet, der sie 1836 ans dem botanischen Garten zu Belfast erhalten hatte.

\section{Kurländische Gerste. $\odot$}

Aehre: fast weiss, $7 \mathrm{~cm}$ lang mit 60 Scheinfriichten; Grannen selır lang $(15 \mathrm{~cm})$. - Stroh: sehr hellgelb, feinhalmig. - Scheinfrucht: fast weiss, schön, voll (10 cn lang, $3 \frac{1}{1} / 2 \mathrm{~mm}$ breit), feinschalig.

\section{Gerste vom Altai, Südwest-Sibirien. $\odot$}

Aehre: fast weiss, etwas locker, ziemlich lang, Scheinfurcht seln" leicht abfallend; Spindel zerbrechlich; Grannen hell, leicht zerbrechlich, bis $15 \mathrm{~cm}$ lang. - Stroh: rotgelb, kräftig, sehr blattreich, lang. - Scheinfrucht: fast weiss, roll, lang $\left(10 \mathrm{~mm}\right.$ lang, $3 \frac{1}{2} \mathrm{~mm}$ breit $)$, feinschalig.

Junges Blatt blaugrïn, breit, sehr kräftig̨, Bestockung schwach, 1.6 Schösslinge, selı zeitig schossend und blühend. Halme $90 \mathrm{~cm}$ (Max. $100 \mathrm{~cm}$ ) lang, $0.48 \mathrm{~cm}$ dick, Blattzahl 5.2, Blätter $22.6 \mathrm{~cm}$ lang, $1 \mathrm{~cm}$ breit, Blattfläche $235.04 \mathrm{qcm}$, Halmfläche $129.6 \mathrm{qcm}$, Gesammtfläche $364.64 \mathrm{qcm}$.

Aehre reift zeitig, $9 \mathrm{~cm}$ ( $(\mathrm{ar} .12 \mathrm{~cm}$ ) lang, mit 60 Scheinfrüchten, von denen 1292000 auf $1 \mathrm{hl}(=68 \mathrm{~kg})$ entfallen.

Es wiegen 100 Halme $498 \mathrm{gr}$ und davon die Scheinfrüchte $249 \mathrm{gr}$.

Diese Gerste lagert nicht, leidet wenig durch Rost, jedoch stark durch Windbruch.

Sie wurde durch Dr. Finsch und Graf Zeil am Altai gesammelt und 1879 an den ök.-bot. Garten zu Poppelsdorf gesandt. 


\section{Vierzeilige sibirische Gerste ans Irkutsk.}

Aehre: graulich-weiss, dicht, aufrecht, kurz, $6 \mathrm{~cm}$ lang mit 45 Scheinfrüchten; Spindel zerbrechlich; Grannen hell, $15 \mathrm{~cm}$ lang, sehr zerbrechlich. - Stroh: rötlich gelb, feinhalmig, kurz, $75 \mathrm{~cm}$ lang, blattrcich, 4.5 Blätter. - Scheinfrucht: Original graulich-weiss, voll, klein $181 / 2 \mathrm{~mm}$ lang, $3^{1 / 2} \mathrm{~mm}$ breit, $2 \frac{1}{2} \mathrm{~mm}$ dick, 374 Früchte $\left.=10 \mathrm{gr}\right), 1 \mathrm{hl}$ wiegt $74 \mathrm{~kg}$, feinschalig.

Reift sehr zeitig, in 99 Tagen.

Bezugsquelle: durch Prof. Anatol von Fadejeff zu Petrowsk, Moskau erhalten.

\section{Gerste aus Turkestan. $\odot$}

Aehre: gelb, aufrecht, mittellang; Spindel zähe; Grannen rötlichgelb, bis $16 \mathrm{~cm}$ lang. - Stroh: rötlich-gelb, blattreich, mittellang. Scheinfrncht: gelb, an Basis rötlich, voll, etwas klein $(9 \mathrm{~mm} l a n g, 31 / 2 \mathrm{~mm}$ breit), Spelzen häufig wenig mit Frucht verwachsel1, so dass sie den Uebergang zn den nackten Gersten bildet.

Junges Blatt gelbgruin, breit, kurz, 3 Schösslinge, zeitig schossend und blïhend. Halme $80 \mathrm{~cm}$ (Max. $100 \mathrm{~cm}$ ) lang, $0.43 \mathrm{~cm}$ dick, Blattzahl 4.5, Blätter $19.3 \mathrm{~cm}$ lang, $1 \mathrm{~cm}$ breit, Blattfläche $173.7 \mathrm{qcm}$, Halmfläche $103.2 \mathrm{qcm}$, Gesammtfläche $276.9 \mathrm{qcm}$.

Aehre reift in 110 Tagen, also zeitig, $8 \mathrm{~cm}$ (Max. $10 \mathrm{~cm}$ ) lang, mit 60 Scheinfrüchten, von denen 1620000 auf $1 \mathrm{hl}$ (=72 kg) entfallen.

Es wiegen 100 Halme $472 \mathrm{gr}$ und davon die Scheinfrüchte $260 \mathrm{gr}$.

Diese Gerste lagerte nicht leicht und blieb rostfrei.

Sie wurde 1878 am Fluss Urtaksary (ca. $2300 \mathrm{~m}$ hoch) durch Dr. Albert Regel gesammelt und an den hiesigen ökon.-botanischen Garten gesandt.

\section{Mandschurei-Gerste. $\odot$}

Syn.: Hordeum vulgare mandschuricum.

Aehre: gelb, dicht, lang, hängend; Spindel zerbrechlich; Grannen hell, leicht, doch nicht dicht an Scheinfrucht abbrechend; bis $16 \mathrm{~cm}$ lang. - Stroh: rötlich-weissgelb, kräftig, blattreich, lang. - Scheinfrucht: gelb, klein, voll (9 $\mathrm{mm}$ lang, $4 \mathrm{~mm}$ breit).

Junges Blatt gelbgrïn, breit, kurz; Bestockung etwas schwach, 2 Schösslinge, zeitig schossend und bliihend. Halme $90 \mathrm{~cm}$ ( lang, $0.43 \mathrm{~cm}$ dick, Blattzahl 4, Blätter $20.8 \mathrm{~cm}$ lang, $1.04 \mathrm{~cm}$ breit, Blattfläche $173.04 \mathrm{qcm}$, Halmfläche $116.1 \mathrm{~cm}$, Gesammtfläche $289.14 \mathrm{qcm}$.

Junge Aehre gelbgrïn, sehr zeitig in 100 Tagen und auf leichtem Boden noch friiher reifend. Nach $\mathrm{B} u \mathrm{chwald}$ reifte sie in Waldau nach 93 Tagen, und gehört unzweifelhaft zll den frühreifsten Gerstensorten. Aehre $9 \mathrm{~cm}$ (Max. $12 \mathrm{~cm}$ ) lang, mit 60 Scheinfriichten, von denen 1828000 auf $1 \mathrm{hl}(=71.7 \mathrm{~kg})$ entfallen.

Auf $1 \mathrm{qm}$ wachsen 1000 Halme oder 500 Pflanzen, mithin beträgt das Saatquantum $3.7 \mathrm{hl}$ p. ha.

Es wiegen 100 Halme $500 \mathrm{gr}$, und davon die Scheinfriichte $300 \mathrm{gr}^{\mathrm{r}}$; in Proskau lieferte 1872 ein humoser Thonboden p. ha:

$2808 \mathrm{~kg}$ Korn, $2704 \mathrm{~kg}$ Stroh, $624 \mathrm{~kg}$ Spreu.

Diese Gerste ist gegen nasskalte Friihjahrswitterung, sowie gegen 
Dürre unempfindlich, leidet aber durch Nachtfröste, weshalb sich eine nicht zu zeitige Aussaat empfiehlt; sie lagert nicht leicht, ist aber dem Rost ausgesetzt.

Thre Erträge sind sehr befriedigend, und durch die sehr kurze Vegetationszeit empfiehlt sie sich zum Anbau in den nordischen Ländern.

Maximowicz brachte diese Gerste 1856 vom Amur nach Petersburg, und ron dort führte sie Körnicke 1859 nach Deutschland ein; auch wurde sie 1859 von Dr. Regel in Petersburg an Jühlke ${ }^{1}$ ) in Eldena gesandt und erfolgreich auf humosem Boden auf dem Akademiegute angebaut.

In Poppelsdorf erwies sie sich seit 1870 konstant.

\section{Gerste aus Umeả, Westerbotten, Schweden $\left(64^{0}\right.$ n. Br.). $\odot$}

Aehre: gelb, etwas hängend, locker, mittellang; Spindel zerbrechlich; Grannen hell, zerbrechlich, 'bis $16 \mathrm{~cm}$ lang, anliegend. - Stroh: rötlich-gelb, kräftig, kurz. - Scheinfrucht: gelb, mittelgross (9 mm lang, $4 \mathrm{~mm}$ breit), ziemlich grobschalig.

Halue gelbgruin, 2 Schösslinge, sehr zeitig schossend und blühend, $75 \mathrm{~cm}$ (Max. $80 \mathrm{~cm}$ ) lang, $0.43 \mathrm{~cm}$ dick, Blattzahl 4, Blätter $19.25 \mathrm{~cm}$ lang, $1.15 \mathrm{~cm}$ breit, Blattfläche $177.12 \mathrm{qcm}$, Halınfläche $96.75 \mathrm{qcm}, G e-$ sammtfl̈̈che $273.87 \mathrm{qcm}$.

Junge Aehre gelbgrün, reift sehr zeitig, in 105 Tagen, 8 cm (Max. $10 \mathrm{~cm})$ lang, mit 50 Scheinfrüchtell, von denen 1443000 auf $1 \mathrm{hl}$ $(=62.75 \mathrm{~kg})$ entfallen.

Es wiegen 100 Halme 411 gr und davon die Scheinfrüchte $250 \mathrm{gr}$.

\section{Gerste aus Luleå, Schweden. $\odot$}

Aehre: graulich-weiss, etwas locker, hängend, nittellang; Grannen hell, bis $15 \mathrm{~cm}$ lang, zerbrechlich; Spindel ziemlich zähe. - Stroh: gelb, kräftig, kurz. -- S'cheinfrucht: graulich-weiss, gross (10 mm lang, $4 \mathrm{~mm}$ breit), ziemlich feinschalig.

Halıne gelbgriin, 2 schösslinge, sehr zeitig schossend und blühend, $75 \mathrm{cur} \mathrm{(Max.} 85 \mathrm{~cm}$ ) lang, $0.4 \mathrm{~cm}$ dick, Blattzahl 4, Blätter $20.75 \mathrm{~cm}$ lang, $1.23 \mathrm{~cm}$ breit, Blattläche $204.16 \mathrm{qcm}$, Halmfläche $90 \mathrm{qcm}$, Gesamuitfläclıe 294.16 q $\mathrm{cm}$.

Junge Aehre gelbgruin, zeitig in 105 Tagen reifeud, mit 50 Scheinfrüchten, von denen 1563000 auf $1 \mathrm{hl}(=72.7 \mathrm{~kg})$ entfallen.

Es wiegen 100 Halme $500 \mathrm{gr}$ und davon die Scheinfrichte $286 \mathrm{gr}$.

Diese Gerste lagert nicht leicht, ist jedoch dem Rost ziemlich stark ausgesetzt.

Heimat: Luleå, Norrbotten, unter $66^{\circ} \mathrm{n} . \mathrm{Br}$.

\section{Gerste aus Dalekarlien, Schweden. $\odot$}

Aehre: fast weiss, dicht, hängend, mittellang; Spindel ziemlich zähe; Grannen hell, sehr zerbrechlich, bis $16 \mathrm{~cm}$ lang. - Stroh: gelb oder orange, kräftig, blattreich, mittellang. - Scheinfrucht: fast weiss, schön, voll (9 $\mathrm{mm}$ lang, $4 \mathrm{~mm}$ breit), ziemliclı feinschalig.

1) Eldenaer Archiv 1859, p. 173. 
Halme gelbgrün, 2 Schösslinge, sehr zeitig schossend und blühend, $80 \mathrm{~cm}$ (Max. $100 \mathrm{~cm}$ ) lang, $0.4 \mathrm{~cm}$ dick, Blattzahl 4, Blätter $18 \mathrm{~cm} \mathrm{lang,}$ $1.2 \mathrm{~cm}$ breit, Blattfläche $172.8 \mathrm{qcm}$, Halmfläche $96 \mathrm{qcm}$, Gesammtfläche $268.8 \mathrm{qcm}$.

Junge Aehre gelbgrïn, in 106 Tagen reifend, $8 \mathrm{~cm}$ (Max. $10 \mathrm{~cm}$ ) lang, mit 50 Scheinfruichten, von denen 1381000 auf $1 \mathrm{hl}(=72.7 \mathrm{~kg}$ ) entfallen.

Es wiegen 100 Halme $443 \mathrm{gr}$ und davon die Scheinfrüchte $282 \mathrm{gr}$.

Diese ertragreiche und in der Qualität des Kornes hervorragende Gerste stammt aus Mora (Dalekarlien), $200 \mathrm{~m}$ ü. M. unter dem $61 .{ }^{0} \mathrm{n}$. Br., sie lagert nicht leicht, leidet wenig durch Rost, und ist daher für rauhe Lagen in Deutschland selır beachtenswert.

\section{Gerste aus Svartló, Norrbottenlän, Schweden. $\odot$}

Aehre: gelb, ziemlich dicht, etwas hängend; Spindel zerbrechlich; Grannell gelb, zerbrechlich, bis $15 \mathrm{~cm}$ lang. - Stroh: gelb, blattreich, mittellang. - Scheinfrucht: gelb, schmal (9 mm lang, $31 / 2 \mathrm{~mm}$ breit).

Junges Blatt bläulichgrün, breit; 1.2 Schösslinge, zeitig blühend; Halme gelbgrün, $65 \mathrm{~cm}$ (Max. $75 \mathrm{~cm}$ ) lang, $0.33 \mathrm{~cm}$ dick, Blattzahl 4, Blätter $17.35 \mathrm{~cm}$ lang, $1.02 \mathrm{~cm}$ breit, Blattfäche $141.6 \mathrm{qcm}$, Halmfläche $64.35 \mathrm{qcm}$, Gesammtfläche $205.95 \mathrm{qcm}$.

Aelıre reift in 102 Tagen, $7 \mathrm{~cm}$ (Max. $11 \mathrm{~cm}$ ) lang, mit 60 Scheinfrichten, vou denen 1831000 auf $1 \mathrm{hl}(=71.8 \mathrm{~kg})$ entfallen.

Es wiegen 100 Halme $433 \mathrm{gr}$, und davon die Scheinfrüchte $251 \mathrm{gr}$.

\section{Grosse norwegische Gerste. $\odot$}

Aehre: fast weiss, mittellang, hängend; Spindel zerbrechlich; Grannen zerbrechlich, bis $20 \mathrm{~cm}$ lang. - Stroh: rötlich-gelb, wenig blattreich, feinhalmig, fest, lang. - Scheinfrucht: fast weiss, an Basis bräunlich oder schwach violett, mittelgross ( $9 \mathrm{~mm}$ lang, $4 \mathrm{~mm}$ breit).

Junges Blatt gelbgrün, sehr kxäftig, breit, 1.3 Schösslinge, zeitig schossend und blühend.

Halme $90 \mathrm{~cm}$ (Max. $100 \mathrm{~cm}$ ) lang, $0.35 \mathrm{~cm}$ dick, Blattzahl 3.8, Blätter $18.4 \mathrm{~cm}$ lang, $1.1 \mathrm{~cm}$ breit, Blattfläche $76.91 \mathrm{qcm}$, Halmfläche $94.5 \mathrm{qcm}$, Gesammtfläche $171.41 \mathrm{qcm}$.

Junge Aehre gelbgrün, zeitig in 105 Tagen reifend, $8 \mathrm{~cm}$ (Max. $10 \mathrm{~cm})$ lang, mit 60 Scheinfrüchten, von denen 1806000 auf $1 \mathrm{hl}$ $(=73.7 \mathrm{~kg})$ entfallen.

Es wiegen 100 Halme $405 \mathrm{gr}$ und davon die Scheinfrüchte $232 \mathrm{gr}$. Leidet wenig durch Lagem oder Rost.

\section{Canadisch $\theta$ Mammuth-Wintergerste. (2)}

Aehre: hellgelb, dicht, lang und hierin von keiner Wintergerste übertroffen, Grannen hell, anliegend, bis $15 \mathrm{~cm}$ lang. - Stroh: gelb, kräftig, lang. - Scheinfrucht: hellgelb, voll, lang (12 $\mathrm{mm} \mathrm{lang,} 4 \mathrm{~mm}$ breit), ziemlich feinschalig.

Herbstblatt blaugriin, schmal, ausgebreitet, Frühjahrsentwickelung spät, Bestockung stark, 5.4 Schösslinge, mittelfrüh schossend und blühend. Halme $120 \mathrm{~cm}$ (Max. $135 \mathrm{~cm}$ ) lang, $0.47 \mathrm{~cm}$ dick, Blattzahl 4.8, Blätter $19.6 \mathrm{~cm}$ lang, $1.3 \mathrm{~cm}$ breit, Blattfläche $244.61 \mathrm{qcm}$, Halmfläche $169.20 \mathrm{qcm}$, Gesammtfläche $413.81 \mathrm{qcm}$. 
Aehre reift Anfang Juli, $10 \mathrm{~cm}$ (Max. $13 \mathrm{~cm}$ ) lang, mit 60 Scheinfrüchten, von denen 1272600 auf $1 \mathrm{hl}(=70.7 \mathrm{~kg})$ entfallen.

Auf 1 qm wachsen 700 Halme oder 130 Pflanzen, mithin beträgt der Raum für eine Pflanze $80 \mathrm{qcm}$, die Blattfläche p. qm Bodenfläche $29 \mathrm{qm}$, und das Saatquantum $1.4 \mathrm{hl}$ p. ha.

Es wiegen 100 Halme $728 \mathrm{gr}$ und davon die Scheinfrïchte $399 \mathrm{gr}$.

Im Frühjahr ansgesäet, erwies sie sich als echte Wintergerste, die jedoch nicht ganz winterfest ist, denn $1870 / 71$ erfror sie bis auf wenige kümmerliche Pflanzel.

Diese Gerste wurde 1862 durch Ingenieur William Wagner aus dem westlicben Canada, und zwar aus der Nähe der Stadt Ottawa an den Berliner Akklimatisations-Verein gesandt, der sie prüfte und diese ertragreiche, nicht leicht lagernde und sich stark bestockende Gerste weiter verbreitete.

\section{Chilenische Gerste. $\odot$}

Syn.: Hordeum vulgare chilense.

Aehre: grauweiss, etwas hängend, ziemlich dicht, kurz; Spindel sehr leicht zerbrechlich; Grannen hell, fast weiss, anliegend, fein, bis $16 \mathrm{~cm}$ lang, sehr leicht zerbrechlich. - Stroh: gelb, mittellang. - Scheinfrucht: grauweiss, an Basis zuweilen bläulich, klein $\left(9 \mathrm{~mm}\right.$ lang, $3^{1} / 2 \mathrm{~mm}$ breit, 268 Frïchte $=10 \mathrm{gr}$ ), etwas grobschalig.

Junges Blatt gelbgruin, 2.4 Schösslinge; Halm $75 \mathrm{~cm}$ (Max, $90 \mathrm{~cm}$ ) lang, $0.33 \mathrm{~cm}$ dick, Blattzahl 4, Blätter $18.56 \mathrm{~cm} \mathrm{lang,} 1.02 \mathrm{~cm}$ breit, Blattfläche $151.44 \mathrm{qcm}$, Halmfläche $74.25 \mathrm{qcm}$, Gesammtfläche $225.7 \mathrm{qcm}$.

In 110 Tagen reifend; Aehre $6 \mathrm{~cm}$ (Max. $8 \mathrm{~cm}$ ) lang mit 50 Scheinfrüchten.

\section{Gerste aus Japan. $\odot$}

Aehre: fast weiss, ziemlich dicht, etwas hängend, mittellang; Spindel zerbrechlich; Grannen hell, schwach, zerbrechlich, doch nicht dicht an Scheinfrucht abbrechend, ein wenig gespreizt, sehr lang $(20 \mathrm{~cm})$. - Stroh: fast weiss, sehr blattreich, mittellang. - Scheinfrucht: fast weiss, an Basis rötlich, lang, schmal (10 $\mathrm{mm}$ lang, $3 \frac{1}{2} \mathrm{~mm}$ breit), ziemlich feinschalig.

Halme gelbgrün, 3 Schösslinge, mittelfrüh blühend, $80 \mathrm{~cm}$ (Max. $95 \mathrm{~cm}$ ) lang, $0.4 \mathrm{~cm}$ dick, Blattzahl 5, Blätter $23.46 \mathrm{~cm} \mathrm{lang,} 1.04 \mathrm{~cm}$ breit, Blattfläche $244 \mathrm{qcm}$, Halmfläche $96 \mathrm{qcm}$, Gesammtfläche $340 \mathrm{qcm}$.

Aehre mittelfrüh in 115 Tagen reifend, $8 \mathrm{~cm}$ (Max. $10 \mathrm{~cm}$ ) lang, mit 60 Scheinfruichten, von denen 1574820 anf $1 \mathrm{hl}(=67.3 \mathrm{~kg})$ entfallen.

Es wiegen 100 Halme $430 \mathrm{gr}$ und davon die Scheinfruichte $183 \mathrm{gr}$. Diese Gerste lagert nicht und bleibt fast rostfrei.

Garten-Inspektor B ou ché zu Poppelsdorf erhielt sie 1876 aus Japan.

\section{Chinesische Gerste. $\odot$}

Syn.: Hordeum vulgare chinense.

Aehre: weiss, ein wenig hängend, ziemlich dicht, $6-8 \mathrm{~cm}$ lang, mit 40 Scheinfrüchten; Spindel leicht zerbrechlich; Grannen weiss, fein, anliegend, bis $15 \mathrm{~cm}$ lang, sehr leicht zerbrechlich. - Stroh: fast weiss, 
kurz, weich, blattreich. - Scheinfrucht: weiss, an Basis zuweilen bläulich, klein ( $9 \mathrm{~mm}$ lang, $3 \frac{1}{2} \mathrm{~mm}$ breit, 238 Scheinfrüchte $\left.=10 \mathrm{gr}\right), 1 \mathrm{hl}$ wiegt $66 \mathrm{~kg}$, feinschalig.

Reift in 113 Tagen.

\section{Gerste aus der Provinz Siout, Aegypten. $\odot$}

A ehre: blassgelb, $5 \mathrm{~cm}$ lang mit 36 Scheinfriichten; Grannen fast weiss, bis $14 \mathrm{~cm}$ lang. - Stroh: fast weiss, steif. - Scheinfrucht: blassgelb, an Basis hellbräunlich (10 mm lang, $4 \mathrm{~mm}$ breit), etwas grobschalig.

Original in der Sammlung des Dr. Dreisch, Poppelsdorf.

Varietät: Hordeum tetrastichum coerulescens Sér.

A ehre blaugraulich.

\section{Sorten:}

\section{Orzo di Firenze. $\odot$}

Syn.: Bläuliche Gerste voll Florenz.

Aehre: graulich-gelb, aufrecht, kurz; Spindel zähe; Grannen gelb, anliegend, zerbrechlich, bis $20 \mathrm{~cm}$ lang. - Stroh: graulich-gelb, feinhalmig, kurz. - Scheinfrucht: graulich-gelb, selır gross (12 mm lang, $4 \mathrm{~nm}$ breit), voll, grobschalig.

Halme gelbgrïn, bereift, fast rostfrei, doch leicht lagernd, 2.5 Schösslinge, $75 \mathrm{~cm}$ (Max. $90 \mathrm{~cm}$ ) lang, $0.33 \mathrm{~cm}$ dick, Blattzahl 5, Blätter 21.36 $\mathrm{cm}$ lang, $0.87 \mathrm{~cm}$ breit, Blattfläche $185.8 \mathrm{qcm}$, Halmfläche $74.25 \mathrm{qcm}, \mathrm{Ge}-$ sammtfläche $260.05 \mathrm{qcm}$.

Junge Aehre hellgelbgrün, spät, in 120 Tagen reifend, $8 \mathrm{~cm}$ (Max. $10 \mathrm{~cm})$ lang. mit 50 Scheinfrïchten, von denen 1183000 auf $1 \mathrm{hl}(=$ $65.7 \mathrm{~kg}$ ) entfalle».

Es wiegen 100 Halme $487 \mathrm{gr}$ und davon die Scheinfrüchte $268 \mathrm{gr}$.

Sie ist eine echte Sommergerste, die 1872 von Delpino aus Florenz nach Poppelsdorf gesandt wurde.

\section{Orzo di Leonforte. $\odot$}

Syn.: Bläuliche Gerste aus Leonforte, Sicilien. Bläuliche Gerste ans Portici.

Aehre: graugelb, ein wenig längend, mittellang; Spindel zähe; Grannen gelb, sehr lang $(23 \mathrm{~cm})$. - Stroh: gelb, fest, ziemlich blattreich, mittellang. - Scheinfrucht: graugelb, voll, sehr gross (12 mm lang, $4 \mathrm{~mm}$ breit), grobschalig.

Junges Blatt gelbgrün, kräftig, ausgebreitet, 2.2 Schösslinge, zeitig sclossend und bliuhend. Halme $85 \mathrm{~cm}$ (Max. $100 \mathrm{~cm}$ ) lang, $0.37 \mathrm{~cm}$ dick, Blattzahl 4, Blätter $25.5 \mathrm{~cm}$ lang, $1.06 \mathrm{~cm}$ breit, Blattfläche $270.3 \mathrm{qcm}$, Halmfläche $94.35 \mathrm{qcm}$, Gesammtfläche $364,65 \mathrm{qcm}$.

Junge Aehre gelbgriin, in 110 Tagen reifend, $7 \mathrm{~cm}$ (Max. $10 \mathrm{~cm})$, lang, mit 42 Scheinfrüichten, von denen 1056000 auf $1 \mathrm{hl}(=69 \mathrm{~kg})$ entfallen.

Es wiegen 100 Halme $540 \mathrm{gr}$ und davon die Scheinfrüchte $278 \mathrm{gr}$. 
Diese Gerstensorte war 1873 auf der Wiener Weltausstellung ausgestellt und wurde durch L. Wittmack nach Poppelsdorf gesandt; 1876 durch Pedecino aus Portici erhalten.

\title{
Hordeum rulgare minus, vulgo ,Orzola“. E Samnio. $\odot$
}

\author{
Gerste aus Samnio, Süd-Italien.
}

Aehre: blaugrau, mittellang; Blattscheiden sehr oft bis über Basis der Aehren reichend; Spindel zerbrechlich; Grannen graulich-gelb, sehr zähe, aufrecht. bis $15 \mathrm{~cm}$ lang. - Stroh: gelb, sehr blattreich, kräftig, kurz. - Scheinfrucht: graulich-gelb, an Basis mit violettem Anflug. gross (10 mm lang, $4 \mathrm{~mm}$ breit), grobschalig.

Halme blaugrün, 2.7 Schösslinge, spät schossend und blühend, $75 \mathrm{~cm}$ (Max. $110 \mathrm{~cm}$ ) lang, $0.43 \mathrm{~cm}$ breit, Blattzahl 5.7, Blätter $23.45 \mathrm{~cm}$ lang, $1.04 \mathrm{~cm}$ breit, Blattfläche $278.05 \mathrm{qcm}$, Halmfläche $96.75 \mathrm{qcm}$, Gesammtfläche 374.8 qcm.

Aehre reift spät, in 124 Tagen, $8 \mathrm{~cm}$ (Мax. $10 \mathrm{~cm}$ ) lang, mit 55 Scheinfrüchten, von denen 1089000 auf $1 \mathrm{hl}(=70.7 \mathrm{~kg})$ entfallen.

Es wiegen 100 Halme $674 \mathrm{gr}$ und davon die Scheinfrüchte $332 \mathrm{gr}$.

Sie wurde 1876 von Pedecino aus Portici an den ök.-bot. Garten zu Poppelsdorf gesandt.

\section{Bläuliche gemeine Gerste. $\odot$}

Syn.: Franz.: Orge commune bleuâtre.

spanisch: Hordi comń, aus Granja de Barcelona; Cebada comun aus Chile und Spanien.

Aehre: blaugraulich, kurz, aufrecht, etwas locker; Spindel zähe; Grannen graulich-gelb, zähe, bis $15 \mathrm{~cm}$ lang. - Stroh: gelb, zuweilen oberhalb der Knoten mit blaugraulichem Anfug, fest, sehr blattreich, kurz. - Scheinfrucht: Original blaugraulich, Spelzen an Basis oft braun oder blau, am dunkelsten von allen Sorten der Varietät H. v. coerulescens; sehr gross, dick (10 mm lang, $4 \mathrm{~mm}$ breit, 185 Scheinfrïchte $=10 \mathrm{gr}$ ), grobschalig.

Halme dunkelgriin, bereift, Bestockung stark, 3 Schösslinge, mittelfrüh bliihend. Halme $60 \mathrm{~cm}$ (Max. $80 \mathrm{~cm}$ ) lang, $0.4 \mathrm{~cm}$ dick, Blattzahl 5 , Blätter $21 \mathrm{~cm}$ lang, $1.16 \mathrm{~cm}$ breit, Blattfläche $243.6 \mathrm{qcm}$, Halmfläche $72 \mathrm{qcm}$, Gesammtfläche $315.6 \mathrm{qcm}$.

Aehre mittelfrüh in 115 Tagen reifend, $6 \mathrm{~cm}$ (Max. $9 \mathrm{~cm}$ ) lang, mit 36 Scheinfrüchten, von denen 1252450 auf $1 \mathrm{hl}(=67.7 \mathrm{~kg})$ entfallen.

Auf $1 \mathrm{qm}$ wachsen 900 Halme oder 300 Pflanzen, mithin beträgt der Raum für eine Pflanze 33.3 q cm, die Blattfäche p. qm Bodenfläche $28.3 \mathrm{qm}$ und das Saatquantum $4.2 \mathrm{hl}$ p. ha.

Es wiegen 100 Halme $424 \mathrm{gr}$ und davon die Scheinfrüchte $253 \mathrm{gr}$.

Diese Gerste lagert nicht, leidet wenig durch Rost, ist ertragreich and eine echte Sommergerste.

Vorzugsweise in Spanien und Süd-Amerika kultiviert.

Bezugsquelle: 1871 aus Hohenheim, 1880 durch von Gülich aus Chile und José Perez Lara aus Jerez de la Fronteira und 1881 durch Cost a, Barcelona, erhalten. 


\section{Gerste aus Coïmbra, Portugal. $\odot$}

Syn.: Gerste aus Aveiro und Benavente.

Aehre: blassgelb mit schwach bläulichem Schimmer, aufrecht, kurz; Spindel ziemlich zähe; Grannen hell, fast aufrecht, bis $12 \mathrm{~cm}$ lang. Stroh: blassrot, $60-70 \mathrm{~cm}$ lang, feinhalmig, fest. - Scheinfrucht: blassgelb mit bläulichem Schimmer und hellbräunlicher Basis, Grannen lang abbrechend, $10 \mathrm{~mm}$ lang, $4 \mathrm{~mm}$ breit, $3 \mathrm{~mm}$ dick, 211 Scheinfrüchte $=$ $10 \mathrm{gr}$; nachgebaut: 175 Scheinfrüchte $=10 \mathrm{gr}$ ), ziemlich feinschalig.

In 100 Tagen reifend, Aehre $6 \mathrm{~cm}$ lang, mit 40 Scheinfrüchten.

In Spanien und Portugal im Oktober ausgesäet und im Mai geerntet, in Deutschland nur Sommergerste.

Bezugsquelle: Prof. Jul. Henriques, Coömbra, Portugal, 1881.

\section{Aegina-Gerste, von der Insel Aegina, Griechenland. $\odot$}

Aehre: graugelb, dicht, kurz, aufrecht; Grannen fast weiss, zähe, bis $20 \mathrm{~cm}$ lang, aufrecht. - Stroh: gelb, steif, fest, kurz. - Scheinfrucht: gelbgrau und violett gestreift, an Basis violett, dunkel, sehr lang (14 $1 / 2 \mathrm{~mm}$ lang, $4 \mathrm{~mm}$ breit), grobschalig.

Junges Blatt gelbgrün, ziemlich breit, 1.5 Schösslinge, mittelfrüh schossend und bliihend. Halme $65 \mathrm{~cm}$ (Max. $75 \mathrm{~cm}$ ) lang, $0.38 \mathrm{~cm}$ dick, Blattzahl 4, Blätter $15.3 \mathrm{~cm}$ lang, $0.7 \mathrm{~cm}$ breit, Blattfäche $85.68 \mathrm{qcm}$, Halmfläche $74.1 \mathrm{qcm}$, Gesaunmtfäche $159.78 \mathrm{qcm}$.

Junge Aehre gellgrün, zeitig, in 108 Tagen reifend, $5 \mathrm{~cm}$ (Max. $7 \mathrm{~cm})$ lang, mit 30 Scheinfrüchten, von denen 882000 anf $1 \mathrm{hl}(=63 \mathrm{~kg})$ entfallen.

Es wiegen 100 Halme $388 \mathrm{gr}$ und davon die Scheinfrüchte $269 \mathrm{gr}$. Bezugsquelle: Haage \& Schmidt, Erfurt.

\section{Gerste von Bigha, Klein-Asien. $\odot$}

Aehre: bläulich-gelb, etwas locker, anfrecht, kurz; Spindel ziemlich zähe; Grannen blassgelb, anliegend, leicht abbrechend, bis $17 \mathrm{~cm}$ lang. Stroh: rötlich-gelb, derbwandig, blattreich, kurz. - Scheinfrucht: graugelb, an Basis violett, gross, dick (10 mm lang, $4 \frac{1}{2} \mathrm{~mm}$ breit), grobschalig.

Halme dunkelgrün, bereift, spät blühend, Bestockung stark, 3 Schösslinge, $60 \mathrm{~cm}$ (Max. $70 \mathrm{~cm}$ ) lang, $0.43 \mathrm{~cm}$ dick, Blattzahl 5, Blätter $18.5 \mathrm{~cm}$ lang, $0.95 \mathrm{~cm}$ breit, Blattfläche $155.8 \mathrm{qcm}$, Halmfäche $77.4 \mathrm{qcm}$, Gesammtfläche $233.2 \mathrm{qcm}$.

Junge Aehre gelbgrün, in 115 Tagen reifend, $6.5 \mathrm{~cm}$ (Max. $8 \mathrm{~cm}$ ) lang, mit 40 Scheinfrüchten, von denen 1103720 auf $1 \mathrm{hl}(67.3 \mathrm{~kg})$ entfallen.

Es wiegen 100 Halme $616 \mathrm{gr}$ und davon die Scheinfrïchte $367 \mathrm{gr}$. Diese Gerste lagert nicht leicht und befällı wenig mit Rost.

\section{Gerste aus Tunis. $\odot$}

Aehre: graulich-gelb, locker, etwas hängend, kurz; Spindel zähe; Grannen gelb, sehr zähe, bis $15 \mathrm{~cm}$ lang. - Stroh: gelb, kräftig, blattreich, kurz. - Scheinfrucht: graulich-gelb, Basis violett, leicht, gross (12 mm lang, $4 \mathrm{~mm}$ breit), grobschalig. 
Halme tief blaugrün, bereift, 3.1 Schösslinge, mittelfrüh blühend, $70 \mathrm{~cm}$ (Max. $75 \mathrm{~cm}$ ) lang, $0.42 \mathrm{~cm}$ dick, Blattzahl 5, Blätter $21 \mathrm{~cm}$ lang, $0.92 \mathrm{~cm}$ breit, Blattfläche $193.2 \mathrm{qcm}$, Halmfläche $88.2 \mathrm{qcm}$, Gesammtfläche $281.4 \mathrm{qcm}$.

Junge Aehre gelbgrün, sehr spät, in 125 Tagen reifend, $7 \mathrm{~cm}$ (Max. $8.5 \mathrm{~cm}$ ) lang, mit 40 Scheinfrüchten, von denen 1060490 auf $1 \mathrm{hl}$ (= $61.3 \mathrm{~kg}$ ) entfallen.

Fs wiegen 100 Halme $420 \mathrm{gr}$ und davon die Scheinfrüchte $290 \mathrm{gr}$. gesandt.

Diese Gerste wurde 1876 durch L. Wittmack nach Poppelsdorf

\section{Orge de la basse Égypte. $\odot$}

Syn.: Orge de la haute Égypte.

Aehre: gelbbräunlich, sehr dicht, aufrecht, kurz; Spindel sehr leicht zerbrechlich; Grannen gelb, zerbrechlich, bis $14 \mathrm{~cm}$ lang. - Stroh: gelb, steif, blattreich, sehr kurz. - Schcinfrucht: schmutzig-gelb mit bräunlichem Anflug an der Basis und den Leisten der Spelzen, lang (11 mm lang, $3 \frac{1}{2} \mathrm{~mm}$ breit), schmal, leicht, grobschalig.

Halme gelbgrün, leicht rostig, 1.7 Schösslinge, sehı zeitig, am frühesten von allen Gersten blühend, $45 \mathrm{~cm}$ (Max. $50 \mathrm{~cm}$ ) lang, $0.4 \mathrm{~cm}$ dick, Blattzahl 4, Blätter $21.6 \mathrm{~cm}$ lang, $1.04 \mathrm{~cm}$ breit, Blattfläche $179.68 \mathrm{qcm}$, Halmfläche $54 \mathrm{qcm}$, Gesammtfläche $233.68 \mathrm{qcm}$.

Aehre in 105 Tagen reifend, $5 \mathrm{~cm}$ lang, mit 30 Scheinfrüchten, von denen 1386000 auf $1 \mathrm{hl}(=63 \mathrm{~kg})$ entfallen.

Es wiegen 100 Halme $290 \mathrm{gr}$ und davon die Scheinfrüchte $179 \mathrm{gr}$. gesandt.

Diese Gerste wurde 1876 durch L. Wittmack nach Poppelsdorf

\section{Cebada de 6-hileras, Chile. $\odot$}

Aehre: graulich-weiss, ziemlich dick, kurz; Spindel zerbrechlich; Grannen hell, wenig gespreizt, bis $13 \mathrm{~cm}$ lang, zälıe. - Stroh: rötlichgelb, steif, mittellang. - Scheinfrucht: Original graulich-weiss, lang, schmal (11 mm lang, $3 \frac{1}{2} \mathrm{~mm}$ breit, $184 \mathrm{Körner}=10 \mathrm{gr}$ ); nachgebaut: 165 Körner $=10 \mathrm{gr}$, ziemlich feinschalig.

Junges Blatt gelbgrün, fein, lang, aufrecht, 1.5 Schösslinge; Halın $75 \mathrm{~cm}$ lang, $0.33 \mathrm{~cm}$ dick, Blattzall 5, Blätter $13.8 \mathrm{~cm}$ lang, $0.75 \mathrm{~cm}$ breit, Blattfläche $103.5 \mathrm{qcm}$, Halmfläche $74.2 \mathrm{qcm}$, Gesammtfläche $177.7 \mathrm{gcm}$.

Aehre $5.5 \mathrm{~cm}$ (Max. $7 \mathrm{~cm}$ ) lang, mit 36 Scheinfrücliten, reift in 110 Tagen.

Bezugsquelle: Durch von Gülich 1881 aus Chile eingesandt.

\section{Cebada, semilla del país; Colonia de Punta Arenas, Magellanes, Chile.}

Aehre: schmutzig-gelb, aufrecht, mittcllang; Spindel ziemlich zähe; Grannen hell, leicht und lang abbrechend, aufrecht, bis $20 \mathrm{~cm}$ lang. Stroh: rötlich-gelb, fest, lang. - Scheinfrucht: Original schmutzig-gelb, an Basis hellbräunlich, gross (11 mm lang, $4 \mathrm{~mm}$ breit, 176 Körner $=^{\circ}$ $10 \mathrm{gr})$; nachgebaut: grösser 140 Körner $=10 \mathrm{gr})$, dickschalig. 
Junges Blatt dunkelgrün, schmal, fein, kurz, 2 Schösslinge, spät schossend und blühend; Halm $80 \mathrm{~cm}$ (Max. $100 \mathrm{~cm}$ ) lang, $0.4 \mathrm{~cm}$ dick, Blattzahl 4.6, Blätter $17.2 \mathrm{~cm}$ lang, $1 \mathrm{~cm}$ breit, Blattfläche $158.2 \mathrm{qcm}$, Halmfläche $96 \mathrm{qcm}$, Gesammtfläche $254.2 \mathrm{qcm}$. früchten.

Aehre in 110 Tagen reifend, $6 \mathrm{~cm}$ (Max. $8 \mathrm{~cm}$ ) lang, mit 60 Schein-

Fast rostfrei und niclit leicht lagernd.

Bezugsquelle: Durch Ministerresident von Gülich aus Chile 1880 eingesandt.

\section{Gerste aus 0stindien. $\odot$}

Aehre: graulich-gelb, sehr locker, kurz; Spindel leicht zerbrechlich; Grannen hell, aufrecht, zähe, bis $12 \mathrm{~cm}$ lang. - Stroh: blassgelb, sehr kurz. - Scheinfrucht: graulich-gelb, an Basis bräunlich, mittelgross ( $9^{1 / 2} \mathrm{~mm}$ lang, $3^{3} / 4 \mathrm{~mm}$ breit), grobschalig.

Blatt dunkelgrün, schmal, 1.8 Schösslinge, zeitig blühend. Halme $50 \mathrm{~cm}$ (Max. $66 \mathrm{~cm}$ ) lang, Halmdicke $0.33 \mathrm{~cm}$, Blattzahl 4, Blätter $15 \mathrm{~cm}$ lang, $0.8 \mathrm{~cm}$ breit, Blattfläche $96 \mathrm{qcm}$, Halmfläche $49.5 \mathrm{qcm}$, Fesammtfläche 145.5 q $\mathrm{cm}$.

Aehre reift in 110 Tagen, $5 \mathrm{~cm}$ (Max. $7 \mathrm{~cm}$ ), lang, mit 32 Scheinfrüchten, von denen 1736000 auf $1 \mathrm{hl}(=i 0 \mathrm{~kg})$ entfallen.

Es wiegen 100 Halme $192 \mathrm{gr}$ und davon die Scheinfrüchte $112 \mathrm{gr}$.

Unter Weizen aus Ostindien erlalten.

\section{Varietät: Hordeum tetrastichum nigrum Willd.}

Aehre schwarz, Grannen raul.

\section{Sorte n:}

\section{Schwarze gemeine Wintergerste oder Russgerste. (2)}

Syu.: Franz.: Orge commune à épi noir, carrée noire, de Russie, blene; Escourgeon noir, Orge d'Amérique.

Eng l.: Black Winter-Barley.

It a l.: Orzo di America (Piemont).

Dänis ch: Firtaxet Byg.

Aehre: schwarzblau, dicht, mittellang; Klappen anliegend, weichhaarig; Granuen graublau, leicht abbrechend, an Rande rauh, bis $15 \mathrm{~cm}$ lang. - Stroh: blassgelb, kräftig, sehr blattreich, fest, lang. - Scheinfrucht: schwarzblau, gross (10 $\mathrm{mm}$ lang, $4 \mathrm{~mm}$ breit), leicht, grobschalig.

Herbstblatt blaugrün, kraus; Frühjalırsvegetation spät, Bestockung stark, 6 Schösslinge, spät schossend, doch verhältnismässig zeitig bliihend. Halme $125 \mathrm{~cm}$ (MIax. 140 $\mathrm{cm}$ ) lang, $0.46 \mathrm{~cm}$ dick, Blattzahl 5, Blätter $24.1 \mathrm{~cm}$ lang, $1.11 \mathrm{~cm}$ breit, Blattfläclse $267.5 \mathrm{qcm}$, Halmfläche $172.5 \mathrm{qcm}$, Gesammtfläche $440 \mathrm{q} \mathrm{cm}$.

Aehre zeitig, Anfang Juli reifend, $7 \mathrm{~cm}$ (Max. $10 \mathrm{~cm}$ ) lang, mit 50 Scheinfrüchten, von denen 1861750 auf $1 \mathrm{hl}(=67.7 \mathrm{~kg})$ entfallen.

Auf $1 \mathrm{qm}$ wachsen 720 Halme oder 120 Pflanzen, mithin beträgt 
der Raum für eine Pflanze 83.3 qcm, die Blattoberfläche p. qm Bodenfläche $31.68 \mathrm{qm}$ und das Saatquantum $0.9 \mathrm{hl} \mathrm{p.} \mathrm{ha.}$

Es wiegen 100 Halme $520 \mathrm{gr}$ und davon die Scheinfriichte $278 \mathrm{gr}$.

Im Frühjahr ausgesäet, erwies sich diese Gerste als echte Wintergerste, die härter als die weisse vierzeilige Wintergerste ist.

In Frankreich wird sie häufig schon im Juni oder Juli gesäet, um noch im Herbst mit Schafen beweidet zu werden.

Auf reichem Boden sehr ertragreich, auch nicht leicht lagernd und gegen Rost widerstandsfähig. Aussaatzeit: September bis Oktober.

\section{Schwarze Sommergerste. $\odot$}

It a l.: Orzo quadrato nero.

Aehre: grauschwarz, mittellang, Klappen anliegend, weichhaarig; Grannen gelblichbraun, rauh. - Stroh: graulich-gelb, blattreich, kräftig, kurz. - Scheinfrucht: grauschwarz, schwach bereift, gross $(9 \mathrm{~mm}$ lang, $4 \mathrm{~mm}$ breit), grobschalig.

Junges Blatt graugrün, ausgebreitet, während alle tubrigen Sommergersten aufrecht und gelb- bis dunkelgrün sind, Bestockung schwach, 1.T Schösslinge, spät schossend und blühend. Halme $65 \mathrm{~cm}$ (Мrax. $80 \mathrm{~cm}$ ) lang, $4.0 \mathrm{~cm}$ dick, Blattzahl 5, Blätter $22.6 \mathrm{~cm}$ lang, $1 \mathrm{~cm}$ breit, Blattfläche 226 q $\mathrm{cm}$, Halmfläche 89.7 qcm, Gesammtfläche $315.7 \mathrm{qcm}$.

Aehre spät, in 133 Tagen reifend, $8 \mathrm{~cm}$ (Max. $11 \mathrm{~cm}$ ) lang. Auf $1 \mathrm{hl}(=67.5 \mathrm{~kg})$ entfallen 1755000 Scheinfrüchte.

\section{Schwarze Wintergerste ans Tiflis. (2)}

Aehre: bräunlich-schwarz, blau bereift, bis $10 \mathrm{~cm}$ lang, mit 66 Scheinfrüchten; Klappen kahl; Grannen rauh, grau, anliegend, bis $15 \mathrm{~cm}$ lang. - Stroh: rötlich-weiss, steif, bis 10 cm lang. - Seheinfrucht: bräunlich-schwarz, blauer bereift als die der übrigen schwarzen Wintergersten, klein $\left(81 / 2 \mathrm{~mm}\right.$ lang, $3^{1} / 2 \mathrm{~mm}$ breit, 284 Seheinfrüchte $\left.=10 \mathrm{gr}\right)$, etwas dickschalig.

Nicht winterfest, doch echte Winterfrucht.

\section{Schwarze Gerste ans Persien. $\odot$}

Aehre: schwarzbraun, locker; Spindel zerbrechlich; Grannen meist hell, aufrecht, bis $13 \mathrm{~cm}$ lang; Klappen kahl. - Stroh: rötlich-gelb, kurz. - Seheinfrucht: schwarzbraun, lang schmal $\left(10 \mathrm{~mm}\right.$ lang, $3 \frac{1}{1} \mathrm{~m} \mathrm{~mm}$ breit, 222 Scheinfrüchte $=10 \mathrm{gr}$ ).

Junges Blatt dunkelgrün, schmal, aufrecht; 2 Schösslinge, sehr zeitig blühend. Halme $65 \mathrm{~cm}$ (Max. $75 \mathrm{~cm}$ ) lang, $0.3 \mathrm{~cm}$ dick, Blattzahl 4, Blätter $14.3 \mathrm{~cm}$ lang, $0.5 \mathrm{~cm}$ breit, Blattfläche 57.2 qem, Halmfläche 58.5 qcm, Gesammtfläche $115.7 \mathrm{qcm}$.

Junge Aehre gelbgrïn, in 112 Tagen reifend, $6 \mathrm{~cm}$ (Max. $8 \mathrm{~cm}$ ) lang, mit 30 Scheinfrüchten, von denen 1476300 auf $1 \mathrm{hl}$ (=66.5 kg) entfallen. Es wiegen 100 Halme $233 \mathrm{gr}$ und davon die Scheinfrïelite $189 \mathrm{gr}$.

Zwischen Weizen aus Persien erhalten. 
Varietät: Hordeum tetrastichum leiorrhynchum Kcke. Aehre schwarz; Grannen glatt.

\section{Sorte : \\ Schwarze glattgrannige, vierzeilige Gerste. $\odot$}

Aehre: blauschwarz, 4-zeilig, aufrecht, kurz; Spindel zerbrechlich; Klappen kahl; Grannen ziemlich hell, meist grau, aufrecht, glatt. Stroh: rötlich-gelb, kurz, blattreich. - Scheinfrucht: blauschwarz, bereift, voll, gross $(10 \mathrm{~mm}$ lang, $4 \mathrm{~mm}$ breit, 200 Früchte $=10 \mathrm{gr})$, dickschalig.

Junges Blatt dunkelgrïn, Halm stark blau bereift, 3 Schösslinge; Halm $70 \mathrm{~cm}$ (Max. $80 \mathrm{~cm}$ ) lang, $0.35 \mathrm{~cm}$ dick, Blattzahl 5, Blätter $20.4 \mathrm{~cm}$ lang, $0.7 \mathrm{~cm}$ breit, Blattfäche $142.8 \mathrm{qcm}$, Halmfäche $73.5 \mathrm{qcm}$, Gesammtfläche $216.3 \mathrm{qcm}$.

\section{B. Körner nackt.}

Varietät: Hordeum tetrastichum coeleste L. Aehre blassgelb, lang, schmal; Körner schlank.

\section{Sorte:}

\section{Himmelsgerste. $\odot$}

Syn.: Jerusalemergerste, Davidskorn, ägyptisches Korn, walachisches Korn, Thorgerste, nackte Nepaul-Gerste, nackte Reisgerste, Weizen- oder Edelgerste, Nampto-Gerste, nackte Gerste von Risso ${ }^{1}$, nackte schottische Gerste, nackte peruanische Gerste.

Engl.: Himalaya naked Barley, Kintbury-Barley.

Dänisch: Himmelbyg, Himmelkorn, Hevedebyg, Egyptik Rugeller Korn.

Norweg.: Davidsbyg, Thorebyg.

Franz.: Orge de Guimalaya, de Nampto, céleste, Petite orge nue, Orge d'Égypte, de Jérusalem, du Pérou, de David, de Valachie, de Sibérie.

Ital.: Orzo nudo, 0 . monstarolo, 0 . monde.

Aehre: blassgelb, schlank, ziemlich dicht, etwas hängend, mittellang; Klappen schwach anliegend, behaart; Spindel zähe; Grannen blassgelb, sehr leicht abbrechend, weich, bis $20 \mathrm{~cm}$ lang, anliegend. - Stroh: hellgelb, kräftig, blattreich, weich, kurz. - Frucht: hellbraun, lanzettlich, klein ( $8 \mathrm{~mm}$ lang, $4 \mathrm{~mm}$ breit), feinschalig.

Junges Blatt gelbgrün, kurz, fein: Bestockung mittelstark, 2.3 Schösslinge; Halme dunkelgrün, bereift, mittelfrüh schossend und blühend, $78.5 \mathrm{~cm}$ (Max. $100 \mathrm{~cm}$ ) lang, $0.44 \mathrm{~cm}$ dick, Blattzahl 4.3, Blätter

1) Durch Risso in Ober-Italien kultiviert. 
$21.4 \mathrm{~cm}$ lang, $1.15 \mathrm{~cm}$ breit, Blattfäche $209.18 \mathrm{qcm}$, Halmfläche 103.62 qcm, Gesammtläche $312.8 \mathrm{qcm}$.

Junge Aehre gelbgrün, in 110 Tagen reifend, $8 \mathrm{~cm}$ (Jiax. $12 \mathrm{~cm}$ ) lang, mit 60 leicht ausfallenden Früchten, von denen 2106770 auf $1 \mathrm{hl}$ $(=83.4 \mathrm{~kg})$ entfallen.

Auf $1 \mathrm{qm}$ wachsen 900 Haime oder 400 Pflanzen, mithin beträgt der Raum für eine Pflanze $25 \mathrm{qcm}$, die Blattfäche pro qm Bodenfläche $28 \mathrm{qm}$ und das Saatquantum $2.5 \mathrm{hl} \mathrm{p}$. ha.

Es wiegen 100 Halme $471 \mathrm{gr}$ und davon die Früchte $226 \mathrm{gr}$.

Diese Gerste verlangt einen reichen Boden und da sie gegen Frühjahrsfröste unempfindlich ist, auch eine zeitige Aussaat zur kräftigen Bestockung. Diese Cnempfindlichkeit ist es auch, welche ihren Anbau in sehr rauhen Lagen gestattet, so soll sie im Orient und in Himalaya bis zu Höhen ron $4700 \mathrm{~m}$ kultiviert werden, aber auch in den Alpen wird diese Gerste noch in sehr bedeutender Höhe angebaut. Körnicke fand dieselbe 1878 bei Macugnaga am Süd-Abfall des Monte-Rosa, $1560 \mathrm{~m}$ ii. M. Auch geht sie sehr hoch nach Norden, z. B. wird sie in Schottland, Schweden, Norwegen und seit 1838 auch in Russland ${ }^{1}$ ) vielfach angebaut. In günstigeren Lagen hält sie jedoch die Konkurrenz mit den beschalten Gersten nicht ans, indem sie diesen meist im Ertrage und zur Nalzbereitung nachsteht; doch eignet sie sich vorzüglich zur Graupen-, Gries- und Mehlbereitung. Ausserdem lagert sie nicht leicht und bleibt fast rostfrei, doch brechen die Aehren durch Wind in der Tollreife leicht $\mathrm{ab}$.

In Deutschland empfahl namentlich von Trautvetter ${ }^{2}$ ) 1840 ihre Kultur, ohne dass jedoch diese Empfehlung zu ihrer Verbreitung verholfen hätte.

Höchst wahrscheinlich stanımt diese Gerste aus den höheren $\mathrm{Ge}$ birgsgegenden des Himalaya ${ }^{3}$ ) und musste es auffallen, dass sie auch den Namen ,nackte peruanische Gerste" führt, doch scheint diese Bezeichnung bedeutungslos zu sein, da aus einem Bericht des preussischen Geschäftsträgers, Herrn v. Gülich, an das Landes-Oekonomie-Kollegium hervorgeht (Annal. d. Landw. Bd. 28. 1856. p. 190), dass eine nackte Gerste in Peru vollkommen unbekannt ist.

\section{Varietät: Hordeum tetrastichum himalayense Rittig.}

Aehre blassgelb, kurz; Körner dick, graublau.

\section{Sorte:}

\section{Sackte Gerste ans 0stindien. $\odot$}

Aehre: fast weiss, quadratisch, kompakt, aufrecht, kurz; Spindel leicht zerbrechlich; Grannen hell, aufrecht, zerbrechlich, bis $16 \mathrm{~cm}$ lang.

1) St. Petersburger kaiserl. akad. Zeit. 1838.

2) Anleit. z. gedeihlichsten Bau der Fofältig tragenden Himalaya-Gerste (H. coel. himalayense).

3) Vergl.: Royle, Illustratiuns of botany of the Himalaya and Cashmere pg. 418. London 1839. 
- Stroh: gelb, steif, blattreich, sehr kurz. - Frucht: graublau, sehr hell, oval, klein $\left(6^{1 / 2} \mathrm{~mm}\right.$ lang, $3^{1 / 2} \mathrm{~mm}$ breit), feinschalig.

Junges Blatt dunkelgrün, kurz, kraus, Bestockung schwach, 1.8 Schösslinge, zeitig schossend und bliihend. Halme $65 \mathrm{~cm}$ (Max. $80 \mathrm{~cm}$ ) lang, $0.35 \mathrm{~cm}$ dick, Blattzahl 4, Blätter $16 \mathrm{~cm}$ lang, $0.88 \mathrm{~cm}$ breit, Blattfläche $112.64 \mathrm{qcm}$, Halmfläche $68.25 \mathrm{qcm}$, Gesammtfläche $180.89 \mathrm{qcm}$.

Aehre reift in 103 Tagen, $6 \mathrm{~cm}$ (Nax. $7 \mathrm{~cm}$ ) lang, mit 54 Früchten, von denen 3825000 auf $1 \mathrm{hl}(=85 \mathrm{~kg})$ entfallen.

Es wiegen 100 Halme 255 gr und davon die Früchte $142 \mathrm{gr}$.

Diese Gerste lagert nicht, unterliegt aber stark dem Rost.

\section{Varietät: Hordeum tetrastichum Walpersii Kcke.}

Aehre blassgelb, kurz; Körner gelbbräunlich, schlank.

\section{Sorte:}

\section{Dr. Walper's Gerste. $\odot$}

Syn.: Deutsch: Wundergerste aus Spanien. Span.: Cebada - sin Cáscara, aus Costa in Catalonien.

Aehre: graulich-gelb, dicht, kurz, dicklich, ein wenig hängend; Spindel ziemlich zähe; Klappen anliegend, behaart, Spelzen allmählich zugespitzt; Grannen hellgelb, etwas gespreizt, wenig zerbrechlich, am Rande sehr rauh, rauher als bei den ïbrigen nackten Gersten und namentlich H. v. coeleste, bis $15 \mathrm{~cm}$ lang. - Stroh: rötlich-gelb, feinhalmig, blattreich, kurz. - Frucht: Original kaffeebraun mit violettem Anflug, aber anch hellere gelbbräunliche und längere Früchte kommen vor, sie variieren je nach dem Jahrgange, denn ausgesäet, können wieder dunklere erzielt werden, oval, Spitze zusammengedriickt nnd kurz, klein $(7 \mathrm{~mm}$ lang, $4 \mathrm{~mm}$ breit, 275 Früchte $=10 \mathrm{gr}$ ), .feinschalig.

Junges Blatt gelbgrün, breit, lang; Bestockung mittelstark, 2 Schösslinge, zeitig schossend und blühend; Halme gelbgrün, bereift, $60 \mathrm{~cm}$ (Max. $80 \mathrm{~cm}$ ) lang, $0.33 \mathrm{~cm}$ dick, Blattzahl 4, Blätter $19.4 \mathrm{~cm}$ lang, $0.95 \mathrm{~cm}$ breit, Blattfäche $147.44 \mathrm{qcm}$, Halmfläche $59.4 \mathrm{qcm}$, Gesammtfläche $206.84 \mathrm{qcm}$.

Junge Aehre gelbgriin, in 104 Tagen reifend, $5 \mathrm{~cm}$ (Nax. $7 \mathrm{~cm}$ ) lang, mit 36 fest sitzenden Früchten, von denen 2133500 auf $1 \mathrm{hl}$ (= $84.5 \mathrm{~kg}$ ) entfallen.

Auf 1 qm wachsen 1200 Halme oder 600 Pflanzen, mithin beträgt der Raum für eine Pflanze 16.6 qm, die Blattfläche p. qm Bodenfläche $24.7 \mathrm{qm}$ und das Saatquantum $3.8 \mathrm{hl}$ p. ha.

Es wiegen 100 Halme $312 \mathrm{gr}$ und davon die Früchte $170 \mathrm{gr}$.

Von den vierzeiligen Gersten wird in Spanien ${ }^{1}$ ) vorzugsweise diese nackte, weniger die bespelzte Gerste gebaut.

In der wärmeren, gemässigten Zone wird diese Gerste häufig schon im November ausgesäet.

Bezugsquelle: Antonio Cipriano Costa 1881 und Prof. Jul. Henriques in Coïmbra.

1) Willkomm, Agr. Zeit 1852, p. 72 . 


\section{Varietät: Hordeım tetrastichum violaceum Kcke.}

Aehre grauriolett.

\section{Sorte :}

\section{Nackte violette Gerste. $\odot$}

Syn.: Deutsch: Schwarze Gerste aus Ekholmen, Östergothland Schweden.

Franz.: Orge nue violette.

Aehre: grau, violett, mit gelben Flecken und Streifen, sehr dicht, kurz, aufrecht; Klappen anliegend, behaart; Spindel zerbrẹchlich; Grannen gelb und mehr oder weniger violett, etwas gespreizt, zähe, am Rande rauh, an Basis der Aelıre am längsten, bis $15 \mathrm{~cm}$ lang. - Stroh: gelbgrau, an den Knoten mit violettem Anflug, kräftig, kurz. - Frucht: kaffeebraun mit violettem Anflug, voll, gross ( $8 \mathrm{~mm}$ lang, $4 \mathrm{~mm}$ breit), grobschalig.

Junges Blatt gelbgrün, breit, kräftig, Bestockung schwach, 1.6 Schösslinge, mittelfrüh schossend und blühend. Halm $75 \mathrm{~cm}$ (Max. $90 \mathrm{~cm}$ ) lang, $0.43 \mathrm{~cm}$ dick, Blattzahl 4.5 , Blätter $14 \mathrm{~cm}$ lang, $1.1 \mathrm{~cm}$ breit, Blattfläche $138.6 \mathrm{qcm}$, Halmfläche $96.75 \mathrm{qcm}$, Gesammtfläche $235.35 \mathrm{qcm}$.

Junge Aehre violett, in 110 Tagen reifend, $6 \mathrm{~cm}$ (Max. $8 \mathrm{~cm}$ ) lang, mit 40 leicht ausfallenden Früchten, von denen 1688250 auf $1 \mathrm{hl}$ $(=83 \mathrm{~kg})$ entfallen.

Es wiegen 100 Halme $334 \mathrm{gr}$ und davon die Früchte $182 \mathrm{gr}$; im Allgemeinen liefert sie selır geringe Erträge, die auf sehr gutem Boden im milden Klima kaum $1900 \mathrm{~kg}$ Korn p. ha überschreiten; doch lagert die Gerste nicht und zeigt sich fast rostfrei.

\section{Varietät: Hordeum tetrastichum trifurcatum Schl.}

Aehre unbegrannt; Spelzen monströs.

\section{Sorte:}

\section{Ziegenhorn- oder Gabel-Gerste. $\odot$}

Syn.: Deutsch: Nepal- oder Nepaul-Gerste.

It al.: Orzo di Nepaul, trifurcato, dell' Himalaya.

Engl.: Nepaul-Wheat; Nepaul naked Barley.

Franz.: Orge trifurquée, bifurquée, crochue, du Népaul, sans barbes de l'Himalaya.

Span.: Hordiate polau y verd.

Aehre: schmutzig-gelb, sich nach der Spitze verjüngend, aufrecht, dicht, kurz; Grannen dreizackig umgebogen und rerkümmert, 1877 zeigten sich in Poppelsdorf an einer Anzahl Aehren einzelne Aehrchen, bei denen die äussere Spelze einfach langgegrannt war. - Stroh: fast weiss oder blassrot, kräftig, blattreich, kurz. - Frucht: gelbbräunlich, dick (8 mm lang, $4 \mathrm{~mm}$ breit).

Halme blaugrün, 1.8 Schösslinge, zeitig schossend und blühend, $70 \mathrm{~cm}$ (Max. $90 \mathrm{~cm}$ ) lang, $0.4 \mathrm{~cm}$ dick, Blattzahl 4, Blätter $20.8 \mathrm{~cm}$ lang, 
$1.32 \mathrm{~cm}$ breit, Blattfläche $219.68 \mathrm{qcm}$, Halmfläche $84 \mathrm{qcm}$, Gesammtfläche $303.68 \mathrm{q} \mathrm{cm}$.

Aehre reift in 107 Tagen, $7 \mathrm{~cm}$ (Max. $8 \mathrm{~cm}$ ) lang, mit 50 Scheinfrüchten, von denen 2104000 Früchte auf $1 \mathrm{hl}$ (=82.5 kg) entfallen.

Es wiegen 100 Halme $380 \mathrm{gr}$ und davon die Früchte $170 \mathrm{gr}$.

Diese Gerste ist im Himalaya-Gebirge ${ }^{1}$ ) heimisch und soll unter dem Namem Nepaul-Wheat 1817 vom Himalaya nach England eingeführt worden sein; später verbreitete die hamburger Samenhandlung von Booth diese Gerste und 1844 wurde sie zuerst auf ihren ökonomischen Wert auf dem Versuchsfelde der k. k. steiermärkischen Landwirtschafts-Gesellschaft geprüft.

Sie steht im Ertrage andereu Sorten sehr nach.

\section{Unterart: Hordenm distichum L. Zweizeilige Gerste.}

\section{A. Körner beschalt.}

Varietät: Hordeum distichum nutans Schübl.

Aehre blassgelb; Grannen anliegend, rauh.

\section{Sorten:}

\section{Probsteier-Gerste. $\odot$}

Syn.: Franz.: Orge du Holstein.

A merika: Probstier-Barley.

Aehre: blassgelb, hängend, lang; Grannen fast weiss, anliegend, dicht an Scheinfrucht abbrechend, bis $20 \mathrm{~cm}$ lang. - Stroh: rötlich-gelb, kräftig, ziemlich blattreich, fest, lang. - Scheinfrucht: blassgelb, voll, gross (10 mm lang, $4 \frac{1}{2} \mathrm{~mm}$ breit), ziemlich feinschalig.

Junges Blatt gelbgrïn, ziemlich breit, lang; Bestockung mittelstark, 2.5 Schösslinge, zeitig schossend und bliilıend. Halılänge $100 \mathrm{~cm}$ (Max. $115 \mathrm{cn})$, Halmdicke $0.38 \mathrm{~cm}$, Blattzahl 4, Blätter $21.5 \mathrm{~cm} \mathrm{lang,} 0.79$ cm breit, Blattfäche 135.88 qcm, Halmfläche 114 qcm, Gesammtfläche $249.88 \mathrm{qcm}$.

Aehre reift früh, in 113 Tagen, $11 \mathrm{~cm}$ (Max. $15 \mathrm{~cm}$ ) lang, mit 25 Scheinfrichten, von denen 1565000 auf $1 \mathrm{hl}(=74.5 \mathrm{~kg})$ entfallen.

Auf $1 \mathrm{qm}$ wachsen 1000 Halme oder 400 Pflanzen, mithin beträgt der Raum für eine Pflanze $25 \mathrm{qcm}$, die Blattfläche p. qm Bodenfläche $25 \mathrm{qm}$ und das Saatquantum $3.4 \mathrm{hl} \mathrm{p}$. ha.

1) Royle, Illustr. of bot. of the Himalaya and Cashmere, London 1839 , pg. 418, Abbildung auf Tab. 97 . 
Es wiegen 100 Halme $311 \mathrm{gr}$ und davon die Scheinfrüchte $150 \mathrm{gr}$.

Diese schöne Gerste eignet sich vortrefflich für feuchtes Klima und guten Lehmboden, da sie wenig durch Lagern und Rost leidet. Auf milden, kalkreichen Lehmböden liefert sie eine gute Braugerste.

Ihre Heimat ist die Probstei, Holstein, von wo sie als Saatgerste in plombierten Säcken über ganz Nord-Deutschland versandt wird. Auch in den Vereinigten Staaten und namentlich in Ohio wird sie vielfach angebaut. geerntet:

In Poppelsdorf wurden auf mildem Lehmboden durchschnittlich p. ha $2433 \mathrm{~kg}$ Korn, $4166 \mathrm{~kg}$ Stroh, $509 \mathrm{~kg}$ Spreu.

\section{Bergsträsser-Gerste.}

Aehre: blassgelb, hängend, lang; Grannen hell, bis $18 \mathrm{~cm}$ lang. Stroh: rötlich-gelb, blattreich, kräftig, mittellang. - Scheinfrucht: blassgelb, gross, voll (10 mm lang, $5 \mathrm{~mm}$ breit), schwer, feinschalig.

Junges Blatt dunkelgrün, schmal, lang; Bestockung mittelstark, 2.5 Schösslinge; sehr zeitig schossend und blühend. Halm $85 \mathrm{~cm}$ (Max. $100 \mathrm{~cm}$ ) lang, $0.38 \mathrm{~cm}$ dick, Blattzahl 5.4, Blätter $21 \mathrm{~cm} \mathrm{lang,} 0.8 \mathrm{~cm}$ breit, Blattfäche $181.44 \mathrm{qcm}$, Halmfläche 96.9 qcm, Gesammtfäche $278.34 \mathrm{qcm}$.

Aehre zeitig in 110 Tagen reifend, $10 \mathrm{~cm}$ (Max. $13 \mathrm{~cm}$ ) lang, mit 28 Scheinfrüchten, von denen 1280000 auf $1 \mathrm{hl}(=75.3 \mathrm{~kg})$ entfallen.

Auf $1 \mathrm{qm}$ wachsen 1000 Halme oder 400 Pflanzen, mithin nimmt jede Pflanze einen Raum von $25 \mathrm{qcm}$ ein; die Blattfläche beträgt p. qm Bodenfläche $27.8 \mathrm{qm}$ und das Saatquantum $4.2 \mathrm{hl}$ p. ha.

Es wiegen 100 Halme $303 \mathrm{gr}$ und davon die Scheinfrüchte $142 \mathrm{gr}$.

Für kalkreiche Lehmböden ist dies eine vorzügliche Braugerste. welche vielfach an der Bergstrasse gebaut wird, fast rostfrei ist und wenig zum Lagern neigt.

\section{Fruihreife Poppelsdorfer-Gerste. $\odot$}

Aehre: blassgelb, hängend, mittellang; Grannen hell, bis $20 \mathrm{~cm}$ lang, aufrecht. - Stroh: rötlich-gelb, sehr blattreich, kräftig, lang. - Scheinfrucht: blassgelb, gross, voll (10 mm lang, $4 \mathrm{~mm}$ breit), schwer, feinschalig.

Junges Blatt hellgrün, schmal, lang; Bestockung sehr stark, 3.2 Schösslinge, zeitig schossend und bliihend. Halm $90 \mathrm{~cm}$ (Мax. $100 \mathrm{~cm}$ ) lang, $0.4 \mathrm{~cm}$ dick, Blattzahl 5.6, Blätter $19.5 \mathrm{~cm}$ lang, $0.92 \mathrm{~cm}$ breit, Blattfläche $200.9 \mathrm{qcm}$, Halmfläche $108 \mathrm{qcm}$, Gesammtfläche $308.9 \mathrm{qcm}$.

Aehre sehr früh, meist 8 Tage früher als die meisten Sorten von H. distichum reifend, $10 \mathrm{~cm}$ (Hax. $13 \mathrm{~cm}$ ) lang, mit 24 Scheinfrüchten, von denen 1328000 auf $1 \mathrm{hl}(=72 \mathrm{~kg})$ entfallen.

Es wiegen 100 Halme $250 \mathrm{gr}$ und davon die Scheinfrüchte $133 \mathrm{gr}$.

Diese vortreffliche Sorte lagert nicht leicht und bleibt fast rostfrei. 


\section{Hellweg-Gerste, Westfalen.}

Aehre: blassgelb, hängend, lang; Spindel zälıe; Grannen blassgelb, bis $20 \mathrm{~cm}$ lang. - Stroh: rötlich-gelb, kurz. - Scheinfrucht: blassgelb, an Basis zuweilen violett oder hellbräunlich, kurz, voll ( $8 \mathrm{~mm}$ lang, $3^{1} / 2 \mathrm{~mm}$ breit, 200 Körner $=10 \mathrm{gr}$ ), feinschalig.

Junges Blatt hellgriin, fein, kurz, kraus; 1.8 Schösslinge, mittelfrüh schossend und blühend; Halm $85 \mathrm{~cm}$ (Hax. $110 \mathrm{~cm}$ ) lang, $0.43 \mathrm{~cm}$ dick, Blattzahl 4, Blätter $22.3 \mathrm{~cm}$ lang, $1 \mathrm{~cm}$ breit, Blattfläche 178.4 qcm, Halmfläche $109.6 \mathrm{qcm}$, Gesammtfläche $288 \mathrm{qcm}$.

Aehre $12 \mathrm{~cm}$ (Max. $15 \mathrm{~cm}$ ) lang, mit 34 Scheinfrüchten, von denen 1520000 auf $1 \mathrm{hl}$ (=76 kg) entfallen.

Für leichteren Boden eine höchst beachtenswerte Braugerste.

Bezugsquelle: Ackerbauschule Füchten, Westfalen 1878.

\section{Erfurter feinste weisse Brangerste.}

Aehre: blassgelb, hängend, lang; Klappen anliegend, behaart; Grannen hell, dicht an Scheinfrucht abbrechend, am Rande raul, bis $22 \mathrm{~cm}$ lang. - Stroh: rötlich-gelb, weich, mittellang. - Scheinfrucht: blassgelb, an Basis schwach-rötlich, gross, voll (10 mm lang, $4 \mathrm{~mm}$ breit), feinschalig.

Halm blaugriin, bereift, Bestockung mittelstark, 2.5 Schösslinge, mittelfrüh schossend und blühend. Halm $75 \mathrm{~cm}$ (Max. $90 \mathrm{~cm}$ ) lang, $0.38 \mathrm{~cm}$ dick, Blattzahl 4, Blätter $24.5 \mathrm{~cm}$ lang, $0.96 \mathrm{~cm}$ breit, Blattfläche $188.16 \mathrm{qcm}$, Halmflïche $85.5 \mathrm{qcm}$, Gesammtfliche $273.66 \mathrm{qcm}$.

Aehre $12 \mathrm{~cm}$ (Max. 14 cm) lang, rcift mittelfrüh, in 120 Tagen, mit 30 Sclieinfrïchten, von denen 1440000 anf $1 \mathrm{hl}(=72 \mathrm{~kg})$ entfallen.

Auf $1 \mathrm{qm}$ wachsen 900 Halme oder 360 Pflanzen, mithin beträgt der Raum für eine Pflanze $30 \mathrm{qcm}$, die Blattlläche p. qm Bodenfläche $24.7 \mathrm{qm}$ und das Saatquantum $3.3 \mathrm{hl}$ p. ha.

Es wiegen 100 Halme $292 \mathrm{gr}$ und die Scheinfrüchte $133 \mathrm{gr}$.

Diese Gerste hat sich in Poppelsdorf immer wenig ertragreich erwiesen, auch liess die Qualität des Kornes, sowie die Widerstandsfähigkeit gegen Lagern und Rost sehr zu wünschen.

\section{Kalina-Gerste. $\odot$}

Aehre: blassgelb, hängend, sehr lang; Grannen hell, bis $20 \mathrm{~cm}$ lang. - Stroh: rötlich-gelb, sehr kräftig und fest, blattarm, lang. Scheinfrucht: hellgelb, gross (10 mm lang, $4^{1} / 2 \mathrm{~mm}$ breit, 185 Scheinfrüchte $=10 \mathrm{gr}$ ), feinschalig.

Halme blaugrün, bereift, Bestockung sehr stark, 3.5 Schösslinge, mittelfrüh schossend und blühend. Halm $105 \mathrm{~cm}$ (Max. $120 \mathrm{~cm}$ ) lang, $0.4 \mathrm{~cm}$ dick, Blattzahl 4, Blätter $23.5 \mathrm{~cm}$ lang, $0.98 \mathrm{~cm}$ breit, Blattfäche $184.24 \mathrm{qcm}$, Halmfläche $126 \mathrm{qcm}$, Gesammtfläche $310.24 \mathrm{qcm}$.

Aehre reift mittelfrüh, in 113 Tagen, $14 \mathrm{~cm}$ (Max. $20 \mathrm{~cm}$ ) lang, mit 30 Scheinfrüchten, von denen 1375000 auf $1 \mathrm{hl}(=74.3 \mathrm{~kg}$ ) entfallen.

Auf I qm wachsen 800 Halme oder 230 Pflanzen, mithin beträgt 
der Raum für eine Pflanze $43.4 \mathrm{qcm}$, die Blattfläche p. qm Bodenfläche $24.8 \mathrm{qm}$ und das Saatquantum $2.2 \mathrm{hl}$ p. ha.

$175 \mathrm{gr}$.

Es wiegen 100 Halme $298 \mathrm{gr}$ und davon die Scheinfruichte

Für sandige Lehmböden, aber auch für reichen Boden eignet sich diese Gerste rortrefflich, da sie nicht leicht lagert und auch wenig durch Rost leidet, und ist als gute Braugerste gesucht.

Sie ist durch Elsner von Gronow auf Kalinowitz bei Oppeln in Schlesien geziichtet worden und wird auf den leichteren Böden NordDeutschlands luäufig kultiviert.

\section{Voigtländer feine zweireihige Gerste. $\odot$}

Aehre: hellgelb, hängend, lang; Grannen hell, bis $20 \mathrm{~cm}$ lang. Stroh: rötlich-gelb, etwas mürbe, lang. - Scheinfrucht: blassgelb, voll (10 $\mathrm{mm}$ lang, $4^{1} / 2 \mathrm{~mm}$ breit), feinschalig.

Junges Blatt dunkelgrün, etwas schmal, lang, Bestockung mittelstark, 2.4 Schösslinge, sehr zeitig schossend und blühend. Halm $95 \mathrm{~cm}$ (Max. 105 cm) lang, $0.4 \mathrm{~cm}$ breit, Blattzahl 4.6, Blätter $20.8 \mathrm{~cm} \mathrm{lang,}$ $0.84 \mathrm{~cm}$ breit, Blattfläche $160.74 \mathrm{qcm}$. Halmfläche $114 \mathrm{qcm}$, Gesammtfläche $274.74 \mathrm{qcm}$.

Aehre reift zeitig, in 110 Tagen, $12 \mathrm{~cm}$ (Max. $14 \mathrm{~cm}$ ) lang, mit 30 Scheinfrüchten, von denen 1456000 auf $1 \mathrm{hl}(=72.8 \mathrm{~kg})$ cntfallen.

Auf 1 qin wachsen 900 Halme odcr 400 Pflanzen, mithin beträgt der Raum für eine Pflanze $25 \mathrm{qcm}$, die Blattflächc pro qm Bodenfläche $24.75 \mathrm{qm}$ und das Saatquantum $3.7 \mathrm{hl} \mathrm{p}$. ha.

Es wiegen 100 Halme $320 \mathrm{gr}$ und daron die Scheinfrüchte $161 \mathrm{gr}$.

Diese für leichteren Boden passende Brangerste lagert niclit leicht und bleibt fast rostfrei.

\section{Zuckergerste ans Sachsen.}

A ehre: gelb, $11.5 \mathrm{~cm}$ lang, nit 26 Scheinfrichten; Granne blassgelb, bis $16 \mathrm{~cm}$ lang. - Strolı: gelb. - Scheinfrucht: gelb, an Basis violett, roll, $11 \mathrm{~mm}$ lang, $4 \mathrm{~mm}$ breit, etwas grobschalig.

\section{Sandgerste aus Sachsen. $\odot$}

Aehre: gelb, $12 \mathrm{~cm}$ lang, mit $2 \mathrm{~S}$ Scheinfrüchten; Granne blassgelb, bis $16 \mathrm{~cm}$ lang. - Stroh: gelb. - Scheinfrucht: gelb, an Basis hellbraun, voll, $10^{1} / 2 \mathrm{~mm}$ lang: $4 \mathrm{~mm}$ breit, etwas grobschalig.

\section{Phoenix-Gerste. $\odot$}

Aehre: blassgelb, liängend, lang; Spindel zälıe; Grannen blassgelb, aufrecht, $12 \mathrm{~cm}$ lang. - Stroh: rötlich-gelb, kurz. - Scheinfrucht: blassgelb, an Basis bläulich, voll, gross (10 $\mathrm{mm}$ lang, $4 \frac{1}{2} \mathrm{~mm}$ breit), feinschalig.

Junges Blatt gelbgriin, breit, aufrecht; mittelfriih schossend und blühend; 2 Schösslinge; Halı $70 \mathrm{~cm}$ (M Iax. $80 \mathrm{~cm}$ ) lang, $0.33 \mathrm{~cm}$ dick, Blattzalıl 4, Blätter $12 \mathrm{~cm}$ lang, $0.6 \mathrm{~cm}$ breit, Blattfläche $57.6 \mathrm{~cm}$, Halmfläche $69.3 \mathrm{qcm}$, Gesammtfläche $126.9 \mathrm{qcm}$. 
Aehre $9 \mathrm{~cm}$ (Max. $12 \mathrm{~cm}$ ) lang, mit 30 Scheinfrüchten, von denen 1488000 auf $1 \mathrm{hl}(=76.7 \mathrm{~kg})$ entfallen; reift in 120 Tagen.

Für gute sandige Lehmböden empfehlenswert; verträgt Trockenheit vorzüglich.

Die Erträge stellten sich in Proskau pro ha:

auf sandigem Lehm 1871, $1991 \mathrm{~kg}$ Korn, $1864 \mathrm{~kg}$ Stroh. auf humosem Thon 1872, 3286 " " 4160 , "

Diese beachtenswerte Gerstensorte wurde schon von Metzger in Karlsrule kultiviert.

\section{Goldgerste. $\odot$}

Aehre : rötlich-weiss, liängend, lang; Grannen hell, bis $22 \mathrm{~cm}$ lang. - Strolı: rötlich-gelb, sehr kräftig, blattreich, gutes Futterstroh, lang. Scheinfrucht: blassgelb, voll (9 $\mathrm{nm}$ lang, $4 \mathrm{~mm}$ breit), feiuschalig.

Junges Blatt dunkelgrïn, Bestockung mittelstark, 2.2 Schösslinge, mittelfruil s schossend und blühend. Halm $100 \mathrm{~cm}$ (Max. $110 \mathrm{~cm}) \cdot \operatorname{lang}, 0.4 \mathrm{~cm}$ dick, Blattzahl 5.4, Blätter $24.6 \mathrm{~cm}$ lang, $1.04 \mathrm{~cm}$ breit, Blattfläche $266.3 \mathrm{qcm}$, Halmfläche $120 \mathrm{qcm}$, Gesammtfläche $386.3 \mathrm{qcm}$. Aehre mittelfrüh, in 120 Tagen reifend, $12 \mathrm{~cm}$ (Max. $14 \mathrm{~cm}$ ) lang, mit 32 Scheinfrüchtell, von denell 1759000 auf $1 \mathrm{hl}(=73.3 \mathrm{~kg})$ entfallen.

Es wiegen 100 Halme $422 \mathrm{gr}$ und davon die Scheinfrüichte $171 \mathrm{gr}$.

In Proskau wurden 1872 auf humosem Thonboden p. la geerntet: $3141 \mathrm{~kg}$ Korn, $3640 \mathrm{~kg}$ Strol,, $332 \mathrm{~kg}$ Spreu.

Diese Gerste lagert nicht leicht und bleibt fast rostfrei.

\section{Grosse Gerste von Falster. $\odot$}

Aehre: fast weiss, $12 \mathrm{~cm}$ lang; Granne weiss, aufrecht, bis $17 \mathrm{~cm}$ lang. - Stroh: fast weiss, kräftig, bis $90 \mathrm{~cm}$ lang. - Scheinfrucht: fast weiss, an Basis hellbräunlich, $9 \mathrm{~mm}$ lang, $4 \mathrm{~mm}$ breit, schön und voll.

Original im landw. Museum zu Berlin.

\section{Jütländische zweizeilige Gerste. $\odot$}

A ehre: blassgelb, hängend, lang; Granneu hell, kurz, bis $14 \mathrm{~cm}$ lang, dicht an der Scheinfrucht abbrechend. - Stroh: rötlich-gelb bis orange, weich, sehr lang. - Scheinfrucht: blassgelb, voll (10 mm lang, $4 \mathrm{~nm}$ breit, 195 Scheinfrüchte $=10 \mathrm{gr})$, ziemlich feinschalig.

Junges Blatt gelbgriin, breit, sehr lang; Bestockung stark, 3 Schösslinge, zeitig schossend und blühend. Halm $110 \mathrm{~cm}$ (Max. $120 \mathrm{~cm}$ ) lang, $0.38 \mathrm{~cm}$ dick, Blattzahl 3.5 , Blätter $27.5 \mathrm{~cm}$ lang, $1.0 \mathrm{~cm}$ breit, Blattfläche $192.5 \mathrm{qcm}$, Halmfläche $125.4 \mathrm{qcm}$, Gesammtfläche $317.9 \mathrm{qcm}$.

Junge Aehre gelbgrün, reift zeitig, in 110 Tagen, $11 \mathrm{~cm}$ (Max. $16 \mathrm{~cm}$ ) lang, mit 28 Scheinfrüchten, von denen 1448850 auf $1 \mathrm{hl}$ $(=74.3 \mathrm{~kg})$ entfallen.

Es wiegen 100 Halme $352 \mathrm{gr}$ und davon die Scheinfrïclıte $191 \mathrm{gr}$. Diese Gerste leidet sehr stark durch Lagern, weniger durch Rost.

\section{Gerste aus Zermatt, Schweiz. $\odot$}

Aehre: fast weiss, etwas hängend; Klappen anliegend, behaart; Grannen am Rande rauh, fast weiss, kurz, bis $12 \mathrm{~cm}$ lang, leicht abbrechend. - Stroh: rötlich-gelb, blattarm, fest, mittellang. - Soheinfrucht: 
gelb, an Basis schwach bräunlich, etwas spitz $(91 / 2 \mathrm{~mm}$ lang, $4 \mathrm{~mm}$ breit, 205 Scheinfrüchte $=10 \mathrm{gr})$, ziemlich feinschalig.

Junges Blatt gelbgrün, lang, etwas schmal; 1.4 Schösslinge, am frïhesten von allen hier kultivierten Gersten schossend und blïhend. Halme $65 \mathrm{~cm}$ (Max. $75 \mathrm{~cm}$ ) lang, $0.33 \mathrm{~cm}$ dick, Blattzahl 3, Blätter $16 \mathrm{~cm}$ lang, $0.7 \mathrm{~cm}$ breit, Blattfläche $67.2 \mathrm{qcm}$, Halmfläche 64.35 qcin, Gesanmtfläche $131.55 \mathrm{qcm}$.

Junge Aehre gelbgriin, sehı zeitig, in 110 Tagen reifend, $9 \mathrm{~cm}$ (Max. $11 \mathrm{~cm}$ ) laug, mit 20 Scheinfrüchten, von denen 1353000 auf 1 hil $(=66 \mathrm{~kg})$ entfallen.

Es wiegen 100 Halme $180 \mathrm{gr}$ und davon die Scheinfrüchte $120 \mathrm{gr}$. Von Körnicke 1876 gesammelt.

\section{Gerste aus Saas im Grund, Canton Wallis, Schweiz. $\odot$}

Aehre: blassgelb, ziemlich dicht, lang; Grannen hell, zähe, bis $16 \mathrm{~cm}$ lang. - Stroh: rötlich-weiss, weich, mittellang. - Scheinfrucht: blassgelb, an Basis hellbraun bis violett, ziemlich voll $(91 / 2 \mathrm{~mm}$ lang, $4 \mathrm{~mm}$ breit), ziemlich grobschalig.

Junges Blatt dunkelgrün, schınal, Bestockung mittelstark, 2.6 Schösslinge, sehr zeitig schossend und blühend. Halm $85 \mathrm{~cm}$ (Мax. $95 \mathrm{~cm}$ ) lang, $0.4 \mathrm{~cm}$ dick, Blattzahl 4, Blätter $19.3 \mathrm{~cm}$ lang, $0.95 \mathrm{~cm}$ breit, Blattfäche $146.68 \mathrm{qcm}$, Halmfläche $102 \mathrm{qcm}$, Gesammtfläche $248.68 \mathrm{qcm}$.

Aehre reift zeitig, in 110 Tagen, $10 \mathrm{~cm}$ (Max. $13 \mathrm{~cm}$ ) lang. mit 24 Scheinfrüchten, von denen 1184960 auf $1 \mathrm{hl}(=74 \mathrm{~kg}$ ) entfallen.

Es wiegen 100 Halme $248 \mathrm{gr}$ und davon die Scheinfrüchte $130 \mathrm{gr}$.

Diese alpine Gerste wurde 1876 durch Körnicke in Saas im Grund (1562 m ü. MI.) gesammelt.

\section{Hannakische Gerste. $\odot$}

Aehre: blassgelb, hängend; Grannen hell, bis $20 \mathrm{~cm}$ lang. - Strob: rötlich-gelb, kräftig, blattreich, lang. - Scheinfrucht: blassgelb, an Basis zuweilen etwas bläulich, gross (10 $\mathrm{mm}$ lang, $4 \mathrm{~mm}$ breit), feinschalig.

Junges Blatt dunkelgriin, schmal, lang; Bestockung stark, 3.2 Schösslinge, sehr zeitig schossend und blühend. Halm $95 \mathrm{~cm}$ (Max. $105 \mathrm{~cm}$ ) lang, $0.38 \mathrm{~cm}$ dick, Blattzahl 5.2, Blätter $21.6 \mathrm{~cm}$ lang, $0.8 \mathrm{~cm}$ breit, Blattfläche $179.71 \mathrm{qcm}$, Halmfläche $108.3 \mathrm{qcm}$, Gesammtfläche $288.01 \mathrm{qcm}$.

Aehre reift in 110 Tagen, $11 \mathrm{~cm}$ (Max. $14 \mathrm{~cm}$ ) lang, mit 35 Scheinfrücliten, von denen 1391000 auf $1 \mathrm{hl}(=74 \mathrm{~kg})$ entfallen.

Auf $1 \mathrm{qm}$ wachsen 1000 Halme oder 313 Pflanzen, mithin beträgt der Raum für eine Pflanze $32 \mathrm{qcm}$, die Blattfäche p. qm Bodenfläche $29 \mathrm{qm}$ und das Saatquantum $3 \mathrm{hl}$ p. ha.

Es wiegen 100 Halme $298 \mathrm{gr}$ und daron die Scheinfrüchte $129 \mathrm{gr}$.

Diese schöne, beachtenswerte Gerste lagerte nicht und zeigte sich fast rostfrei.

Heimat: Niederungen an der Hanna und der March in Mähren.

\section{Gerste ans Ungarn. $\odot$}

Aehre: blassgelb, hängend, lang; Grannen hell, kurz an der Scheinfrucht abbrechend, bis $23 \mathrm{~cm}$ lang. - Stroh: rötlich-gelb, kräftig, lang. - 
Scheinfrucht: blassgelb, sehr gross (11 mm lang, $5 \mathrm{~mm}$ breit), sehr schön, feinschalig.

Junges Blatt blaugruin, sehr schmal und lang; Bestockung sehr stark, 3.4 Schösslinge, zeitig schossend und bliihend. Hahn $95 \mathrm{~cm}$ (Max. $110 \mathrm{~cm}$ ) lang, $0.4 \mathrm{~cm}$ dick, Blattzahl 5, Blätter $24.4 \mathrm{~cm}$ lang, $0.8 \mathrm{~cm}$ breit, Blattfläche $195.2 \mathrm{q} \mathrm{cm}$, Halmfläche $114 \mathrm{qcm}$, Gesammtfläche $309.2 \mathrm{qcm}$.

Aehre zeitig, in 110 Tagen reifend, $10 \mathrm{~cm}$ (Max. $12 \mathrm{~cm}$ ) lang, mit 28 Scheinfrüchten, von denen 1314000 auf $1 \mathrm{hl}(=73 \mathrm{~kg})$ entfallen.

Auf $1 \mathrm{qm}$ wachsen 900 Halne oder 265 Pflanzen, mithin beträgt der Raun für einc Pflanze 38 qcm, die Blattfäche p. qm Bodenfläche $27.8 \mathrm{qm}$ und das Saatquantum $2.6 \mathrm{hl}$ p. ha.

Es wiegen 100 Halme $269 \mathrm{gr}$ und davon die Früchte $134 \mathrm{gr}$.

Diese Sorte, welche sich seit 1869 konstant erhalten hat, wurde vom landwirtschaftlichen Ministerium zur Prüfung eingesandt und gehört mit zu den schönsten Braugersten, die auf mildem Lehmboden vorzügliche Qualitäten erzeugen; auch leidet sie wenig durch Lagem und Rost.

Die Qualität der Gerste ist in Ungarn ausserordentlich verschieden und als Braugerste in Allgemeinen nur in solchen Gegenden anzusehen, die weniger unter dem excessiven Steppenklima zu leiden haben, oder deren Bodenbeschaffenheit, sowie Düngungs- und Kulturverhältnisse dem Gerstenbau ansnahmsweise günstig sind. Allerdings spielt das Klima bei Erzeugung der Braugersten die Hauptrolle, denn sobald ziemlich regelmässig gegen die Reife hin trockene, heisse Witterung eintritt, verschrumpfen die Körner und werden dickschalig und glasig, Qualitäten, welche man fiir Braugersten nicht wünscht.

Die Untersuchung nachfolgender Gerstensorten der $1877 \mathrm{er}$ Ernte (Originalgersten) ergab als Resultat:

\begin{tabular}{l|l|l}
\hline Name der Sorten & Beschaffenheit des Kornes & $\begin{array}{c}100 \text { cbem } \\
\text { wiegen gr }\end{array}$ \\
\hline
\end{tabular}

Weissenburger Gerste

Waitzener

Alföld

Pressburger

Ober-Ungarn

Graner

Neuhäusler

Donau

Theiss

Pester-Boden
Braugerste, sehr weiss fast weiss, sehr schön, voll 78.0 75.0 75.0 72.5 72.0 72.0 71.0 710 70.2 680

\section{Zweizeilige (ierste (1)voredac) aus Serbien. $\odot$}

Aehre: fast weiss, Klappen behaart; Granne aufrecht, bis $15 \mathrm{~cm}$ lang, leicht und kurz an Scheinfrucht abbrechend. - Stroh: rötlich-gelb, steif. - Scheinfrucht: fast weiss, etwas schmächtig $\left(81 / 2 \mathrm{~mm} \mathrm{lang}, 3^{1} / 2 \mathrm{~mm}\right.$ breit, 270 Scheinfriichte $=10 \mathrm{gr}$ ), etwas grobschalig.

Junges Blatt bläulichgriin, aufrecht, sehr schmal; 2.5 Schösslinge, zeitig blïhend; Halue $75 \mathrm{~cm}$ (Max. $85 \mathrm{~cm}$ ) lang, $0.3 \mathrm{~cm}$ dick, Blattzahl 5 , Blätter $13.7 \mathrm{~cm}$ lang, $0.7 \mathrm{~cm}$ breit, Blattfläche 95.9 qcm, Halmfläche $67.5 \mathrm{qcm}$, Gesammtfläche $163.4 \mathrm{qcm}$. 
Aehre reift in 100 Tagen, $10 \mathrm{~cm}$ (Max. $12 \mathrm{~cm}$ ) lang, mit 24 Scheinfrüchten, von denen 2084500 anf $1 \mathrm{hl}(=73.5 \mathrm{~kg})$ entfallen.

Es wiegen 100 Halme $180 \mathrm{gr}$ und davon die Scheinfrüchte $106 \mathrm{gr}$.

Von Professor Pantschitsch, Belgrad, 1880 erhalten.

\section{Gerste von Jekaterinoslaw, Süd-Russland. $\odot$}

Aehre: grauweiss, hängend, mittellang; Klappen anliegend, weichhaarig; Grannen hell, sebr fein, auffallend leicht zerbrechlich, bis $22 \mathrm{~cm}$ lang. - Stroh: fast rötlich-weiss, sehr fest, blattarm, inittellang. Scheinfrucht: hellgelb, voll (9 $\mathrm{mm}$ lang, $4 \mathrm{~mm}$ breit); nachgebaut: grösser, und schwerer.

Es wog $1 \mathrm{hl}$ Originalsaat $71.0 \mathrm{~kg}$ und enthielt 1400000 Scheinfrüchte

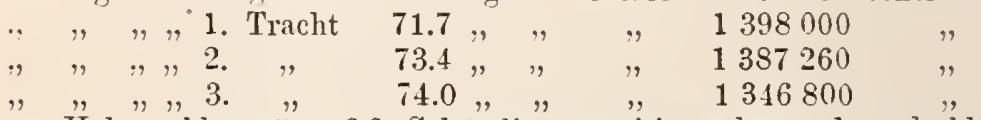

Halme blaugrïin, 2.2 Schösslinge, zeitig schossend und blühend. Halm $75 \mathrm{~cm}$ (Max. $95 \mathrm{~cm}$ ) lang, $0.34 \mathrm{~cm}$ dick, Blattzabl 3.7, Blätter $18.6 \mathrm{~cm}$ lang, $0.82 \mathrm{~cm}$ breit, Blattfläche $112.85 \mathrm{qcm}$, Halmfläche $76.5 \mathrm{qcm}$, Gesammtfläche $189.35 \mathrm{qcm}$.

A ehre zeitig, in 110 Tagen reifend, $9 \mathrm{~cm}$ (Max. $11 \mathrm{~cm}$ ) lang, mit 24 Friichten.

Es wiegen 100 Halme $294 \mathrm{gr}$ und davon die Scheinfriichte $177 \mathrm{gr}$.

Diese Gerste wurde 1876 durcl Gutsbesitzer Dégtiareff aus dem Gebiete der Schwarzerde von Jekaterinoslaw eingesandt.

\section{Upländische Gerste.}

Aelıre: hellgelb, hängend, lang; Grannen hell, bis $20 \mathrm{~cm}$ lang. Stroh: rötlich-gelb, kräftig, lang. - Scheinfrucht: hellgelb, sehr gross (10) $\mathrm{mm}$ lang, $5 \mathrm{~mm}$ breit), schwer, doch etwas dickschalig.

Junges Blatt dunkelgrïin, sehr schmal; Bestockung stark, 3 Schösslinge, spät schossend und blühend. Halm $90 \mathrm{~cm}$ (Max. $110 \mathrm{~cm}$ ) lang, $0.4 \mathrm{~cm}$ dick, Blattzahl 4, Blätter $24.2 \mathrm{~cm}$ lang, $0.9 \mathrm{~cm}$ breit, Blattfläche $174.24 \mathrm{qcm}$, Halmfläche $108 \mathrm{qcm}$, Gesammtflïche $282.24 \mathrm{qcm}$.

Aehre reift zeitig, in 113 Tagen, $11 \mathrm{~cm}$ (Max. $15 \mathrm{~cm}$ ) lang, mit 30 Scheinfrüchten, von denen 1347000 auf $1 \mathrm{hl}(=77 \mathrm{~kg})$ entfallen.

Es wiegen 100 Halme $404 \mathrm{gr}$ und davon die Scheinfruichte $182 \mathrm{gr}$.

Diese ergiebige nordische Gerste zeigt eine bedeutende Widerstandsfähigkeit gegen Rost und Lagern.

Die Periode von der Blüte bis zur Reife umfasst nur eine relativ kurze Spanne Zeit und entspricht dies Verhalten dem nordischen Klima vollkommen.

Heimat: Alte Landschaft Upland am Mälarsee in Schweden $\left(60^{\circ} \mathrm{n} . \mathrm{Br}\right.$.).

\section{Common or early english-barley.}

Syn.: Englische Frühgerste.

Nahe verwandt: Dunlop-barley.

A ehre: blassgelb, unter mittellang, ziemlich dicht, $9 \mathrm{~cm}$ lang, mit 26-30 Scheinfrüchten; Grannen blassgelb, fast anfrecht, lang. - Stroh: rötlich-gelb, bis $90 \mathrm{~cm}$ lang. - Scheinfrucht: blasagelb, voll, feinschalig. 
Lieferte in Proskau 1872 auf humosem Thonboden:

$3328 \mathrm{~kg}$ Korn, $3993 \mathrm{~kg}$ Stroh, $769 \mathrm{~kg}$ Sprell.

Diese Sorte ist im mittleren und südlichen England sehr weit verbreitet, wo sie in 90-110 Tagen ausreift.

Dunlop-barley ist kürzer und kompakter in der Aehre, etwas länger $(100 \mathrm{~cm})$ im Stroh, doch zarter, sich weniger gut gegen Wind und Wetter kurz vor der Ernte haltend.

\section{Chevalier-Barley. $\odot$}

Syn.: Deutsch: Chevalicr- orler Rittergerste.

Franz.: Orge Chevalier.

Chile: Cebada malting-barley ${ }^{1}$ ).

Verbeserte Formen:

Hallet's Pedigree-Chevalier-Barley.

We bb's Kinver-Chevalier-Barley.

Scholey's warp Grown-Chevalier-Barley.

Bestehorn's verbesserte Chevalier-Gerste.

Aehre: blassgelb, hängend, lang; Grannen hell, aufrecht, dicht und leicht an der Scheinfrucht abbrechend, bis $22 \mathrm{~cm}$ lang. - Stroh: tieforangegelb, sehr kräftig, fest, lang. - Scheinfrucht: blassgelb, an Basis dunkler, rundlich, sehr voll (9 $\mathrm{mm}$ lang, $4 \frac{1}{2} \mathrm{~mm}$ breit), sehr feinschalig.

Jumges Blatt blaugrün, lang, krïftig; mittelfrüh scliossend und blühend.

Die verschiedenen Formen verhalten sich zu einander wie folgt:

\begin{tabular}{|c|c|c|c|c|c|}
\hline & $\begin{array}{l}\text { Chevalier- } \\
\text { Gerste }\end{array}$ & $\begin{array}{l}\text { Hallet's } \\
\text { Pedi- } \\
\text { gree }\end{array}$ & $\begin{array}{l}\text { Webb's } \\
\text { Kinver }\end{array}$ & $\begin{array}{l}\text { Scho- } \\
\text { ley's } \\
\text { warp } \\
\text { Grown }\end{array}$ & $\begin{array}{c}\text { Beste- } \\
\text { horn's } \\
\text { ver- } \\
\text { besserte }\end{array}$ \\
\hline Anzahl der Schösslinge & 2.4 & 2.6 & 2.6 & 2.5 & 2.0 \\
\hline . . . $\mathrm{cm}$ & 95 (Max. 115) & $95(115)$ & $95(115)$ & $95(110)$ & $85(105)$ \\
\hline Halmdicke & 0.45 & 0.48 & 0.4 & 0.4 & 0.4 \\
\hline Blattzahl . & 4.2 & 4.2 & 4. & 5 & 4.0 \\
\hline Blattlänge & 24.3 & 27.6 & 25.3 & 27 & 23.3 \\
\hline Blattbreite . . $\mathrm{cm}$ & 1.12 & 1.1 & 0.9 & 0.8 & 1.0 \\
\hline Blattfläche . . q qcm & 228.61 & 255.02 & 200.38 & 216.00 & 186.40 \\
\hline Halmfläche . . qem & 128.25 & 136 & 114 & 114.00 & 102.00 \\
\hline Gesammtfläche . . qcm & 356.86 & 391.82 & 314 & 330.00 & 288.40 \\
\hline & $12(\operatorname{Max} .15)$ & $12(15)$ & $12(15)$ & $12(15)$ & $11(15)$ \\
\hline $\begin{array}{l}\text { Scheinfrüchte pro Aehre } \\
\text { Gewicht oro hl iu ko }\end{array}$ & $\begin{array}{l}34 \\
75\end{array}$ & $\begin{array}{c}35 \\
75\end{array}$ & 34 & $\begin{array}{l}32 \\
76\end{array}$ & 30 \\
\hline & 3200000 & 3000000 & 3200000 & 3200000 & $\begin{array}{c}75 \\
3500000\end{array}$ \\
\hline Scheinfrüchte pro hl. & 1290000 & 1295000 & 1530000 & 1428000 & 135000 \\
\hline Saatquantum pro ha in $\mathrm{hl}$ & 3.3 & 3 & 3 & 3 & 3.5 \\
\hline $\begin{array}{l}100 \text { Halme wiegen. "gr } \\
\text { Davon die Scheinfriichte }\end{array}$ & 418 & 404 & 410 & 410 & - \\
\hline $\mathrm{gr}$ & 16 & 19 & 20 & 19 & - \\
\hline VegetationsdauerinTagen & 116 & 119 & 121 & 117 & - \\
\hline
\end{tabular}

Das Korn ist schwerer und mehlreicher als das der Annatgerste und da sie ausserdem schnell und sehr gleichmässig kcimt, wird sie letz-

1) Identisch, nur weniger robust, als die im nordwestlichen Europa gebaute Gerste. 
terer auf dell gute Gerstenböden vorgezogen und überhaupt zur Zeit als die beste Malzgerste angesehen, zumal sie bei der festen Textur ihrer Halme nicht leicht lagert oder mit Rost befällt.

Gegen kalte Frïhjahrswitterung und Dürre ist die Cheralier-Gerste wenig empfindlich, doch rerlangt sie, wenn sie hohe Erträge bringen und nicht degenerieren soll, einen reichen Lehm- oder Humusboden, mindestens aber in guter Kultur befindliche sandige Lehmböden. Bei früher Aussaat und passenden Böden bringt diese Gerste die reichsten Körner und Stroherträge.

\section{Erträge der Cheralier-Gerste pro ha}

Proskan 1872 humoser Thonboden, $21 \mathrm{~cm}$ Drillweite

Proskau 1872 humoser Thonboden, Pedigree-Gerste

Waldau 1861 sandiger Lehm

Crüssow bei Stargardt, 1868 sandiger Lehm

Eldena, Versuchsfeld 1868 , sandiger Lehm, holie Kultur, Drillweite $26 \mathrm{~cm}$.

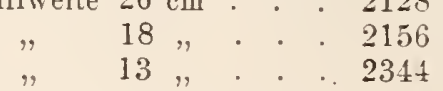

Poppelsdorf 1873 , milder Lehm, Drillweite

$$
\begin{gathered}
\text { Korn } \\
\mathrm{kg}
\end{gathered}
$$$$
2912
$$

2974

1294

1836

2128

2344

\section{Stroh $\mathrm{kg}$}

3473

3661

269 !

2016

2908

2424

3080
Kaff

$\mathrm{kg}$

347

416

515

334

472

400

440

\section{$15.70 \mathrm{~cm}$

Die Cheralier-Gerste hat sich ihrer rortrefflichen Eigenschaften wegen über alle Länder der Erde, welche erfolgreich Braugerste kultirieren, rerbreitet.

Im Elsass hat man versucht. obwohl zweizeilige Gerstensorten nicht Wiutergersten sind, dieselbe im November in der Stärke von $2.2-2.5 \mathrm{hl}$ p. ha ausznsäen, und will mau hierdurch nicht nur ein höheres Quantum, sondern auch eine bessere Qualität erzielt haben; hierzı will ich bemerken, dass auch der Anbau als Winterfrucht bereits mehrere Jahre hindurch in Poppelsdorf gelungen ist.

Sehr wichtig ist die Herbstaussaat für das Steppenklima, in welchem die Frühjahrssaat sehr leicht in der Qualität des Kornes durch zur unrechten Zeit eintretende Dürre und Hitze geschädigt werden kanu, weshalb man auch auf der Herrschaft Bellye in Ungarn Tersuche mit der Herbstaussaat angestellt hat, in der Hoffnung, dass bei einer Aussaat im Norember die Gerste noch im Herbst keimt und sich im Frïhjahr so zeitig zu entwickeln rermag, dass die Reife ror dem Eintritt der Dürre und Hitze erfolgt, mithin die Körner dem Verschrumpfen entgehen.

Der Züchter dieser Gerste ist der Engländer Chevalier, welcher auf einem Gerstenacker ein Kiorn fand, das ihm durch Dicke und Schwere auffiel, weshalb er dasselbe aussäete und weiter züchtete. Diese neue Sorte vererbte sich sehr vortrefflich und ihr Ruf als Braugerste rerbreitete sich sehr schnell, als 1832 Lord Leicester ihre Kultur im grösseren Massstabe betreiben liess.

Hieranf reredelte $\mathrm{Mr}$. Hallet nach seinem System, also durch sorgfältige Samenauswahl und Kultur diese Gerste, welchem Beispiel der engliche Samenhändler Mr. W eb zu Wordsley, Stourbridge folgte, der ihre Zucht auf seiner Farm „Kinver Hill" betrieb; auch die ron ihm empfohlene „New-Beardless Barley" ist ebenfalls eine Cheralier-Gerste, nur dass sie leicht die Grannen rerliert. In Deutschland verbesserte sie 
der Gutsbesitzer Bestehorn zu Bewitz bei Koennern. In neuester Zeit komnt fuir die reichsten Böden eine durch Scholey verbesserte Form in den Handel, welche von den überaus fruchtbaren Schlammböden in Yorkshire bezogen wird und für die Narschen Englands und Frankreichs sehr gesucht ist.

Diese verbesserten Formen der Chevalier-Gerste besitzen ein grosses, schweres und volles Korn und sind sehr robust, doch degenerieren sie, unter ärmlicheren Verhältnissen angebaut, sehr leicht, so dass nicht selten ein Jahr um das andere mit dem Samen gewechselt werden muss, doch werden gemeinhin die hicrdurch erwachsenden Kosten durch höhere Erträge und bessere Kornqualität wiedcr reichlich aufgewogen.

\section{Annat-Barley. $\odot$}

Syn.: Australien: Scotch-Barley.

Franz: Orge d'Annat, du Portugal, de Lord Western.

Deutsch: Schottische Annat-Gerste.

Aehre: liellgelb, lang, hängend; Klappen anliegend. behaart; Grannen hell, lang $(20 \mathrm{~cm})$, dicht und leicht an der Scheinfrucht abbrechend, am Rande sehr rauh. - Stroh: rötlich-gelb, sehr kräftig, blattreich, fest, lang. - Scheinfrucht: hellgelb, an Basis mit bläulichem Anflug, gross, voll (10 mm lang, 41/2 min breit), feinschalig.

Junge Pflanze dunkelgrün, Bestockung stark, 3 Schösslinge, mittelfrüh schossend und blïhend. Halm $90 \mathrm{~cm}$ (Max. $115 \mathrm{~cm})$ lang, $0.4 \mathrm{~cm}$ dick, Blattzahl 4.7, Blätter $25.9 \mathrm{~cm}$ lang, $0.95 \mathrm{~cm}$ breit, Blattflïche $231.33 \mathrm{qcm}$, Gesammtflïche 339.33 qcm.

A ehre reift zeitig, in 115 Tagen, $12 \mathrm{~cm}$ (Max. $15 \mathrm{~cm}$ ) lang, mit 36 Scheinfrüchten, von denen 1574000 auf $1 \mathrm{hl}(=73.2 \mathrm{~kg})$ entfallen.

Auf $1 \mathrm{qm}$ wachsen 900 Halme oder 300 Pflanzen, mithin beträgt der Raum für eine Pflanze $33.3 \mathrm{qcm}$, die Blattfläche p. qm Bodenfläche $30.5 \mathrm{qm}$, und das Saatquantum $2.5 \mathrm{hl}$ p. ha.

Es wiegen 100 Halne $380 \mathrm{gr}$, davon die Scheinfriichte $200 \mathrm{gr}$, und in Proskau wurden 1871 auf Lelmboden $3074 \mathrm{~kg}$ Korn, $3420 \mathrm{~kg}$ Stroh p. ha geerntet. In England sollen auf Clayboden schon $49.39 \mathrm{hl}$ Korn p. ha erzielt worden sein. und Morton ${ }^{\mathbf{1}}$ ) führt an, dass sie 38.6 Proc. Korn, 7.8 Proc. Spreu, 40.7 Proc. Strol, sowie 12.9 Proc. Stoppelrückstände liefere.

Die Körner, welche sich etwas schwer abdreschen, sind sehr ausgeglichen und feinschalig, weshalb sie sich fast so gut wie die der CheralierGerste zum Mälzen und ganz vorzüglich zur Graupenbereitung eignen.

Das nicht leicht lagernde, blattreiche Stroh liefert in rostfreien Jahren ein vorziigliches Futterstroh; doch unterliegt die Gerste leicht dem Rost.

Fruchtbare, milde Lehmböden eignen sich am besten zu ihrer Kultur, während sehr leichte und sehr schwere Böden für sie nicht benutzbur sind, auch rerträgt sie Nässe im Frühjahr, aber nicht rauhe Lagen, da in solchen ihr Ertrag sehr unsicher wird. Unter nicht passenden Verhältnissen degeneriert sie leicht. In Poppelsdorf hat sie sich seit 1870 konstant gezeigt.

Dicse schöne Gerste wurde 1835 zuerst ron Mr. Gorrie zu Annateottage, Carse of Gowrie, in Schottland kultiviert und gelangte ron dort um 1840 nach Deutschland.

Sie wird jetzt in Europa, Nord-Amerika und Australien angebaut.

1) Cyclop. of Agric. Yol. I, p. 176. 


\section{fiolden-drop Barley. $\odot$}

Deuts ch: Goldtropfen-Gerste.

Aehre: blassgelb, hängend, langälurig; Klappen anliegend, behaart; Grannen hell, $20 \mathrm{~cm}$ lang, dicht an Scheinfrucht abbrecliend, anı Rande rauh. - Stroh: blassgelb, kräftig, fest, dem des Sonımerweizens ähnlich, lang. - Scheiufrucht: blassgelb, an Basis mit rötlichem Anflug, voll $10 \mathrm{~mm}$ lang, $4^{1 / 2} \mathrm{~mm}$ breit), feinschalig.

Halme blaugrün, bereift; Bestockung mittelstark, 2.5 Schüsslinge; mittelfrüh schossend und blühend. Halm $90 \mathrm{~cm}$ (Max. $100 \mathrm{~cm}$ ) lang, $0.42 \mathrm{~cm}$ dick, Blattzalıl 5, Blätter $25.64 \mathrm{~cm}$ lang, $0,95 \mathrm{~cm}$ breit, Blattfläche $243.6 \mathrm{qcm}$, Halmfläche $113.4 \mathrm{qcm}$, Gesammtfläche $357 \mathrm{qcm}$.

Aehre mittelfrüh, in 120 Tagen reifend, $14 \mathrm{~cm}$ (Max. $16 \mathrm{~cm}$ ) lang, mit 36 Frïchten, von denen 1292000 auf $1 \mathrm{hl}(=76 \mathrm{~kg}$ ) entfallen.

Auf i qm wachsen 800 Halme oder 320 Pflanzen, mithin beträgt Jer Raum für eine Pflanze $31.2 \mathrm{qcm}$, die Blattfläche p. qm Bodenfläche $28.6 \mathrm{qm}$, und das Saatquantum $3.3 \mathrm{hl} \mathrm{p}$. ha.

Es wiegen 100 Halme $290 \mathrm{gr}$ und davon die Früclite $147 \mathrm{gr}$.

Diese Sorte, welche vielfach im siidlichen England angebaut wird, verlangt mit der Chevalier-Gerste gleiche Anbauverhältnisse, kommt ihr aber in diesem Falle in Qualität und Quantität des Ertrages sehr nahe, auch lagert sie nicht leicht, leidet aber etwas durch Rost.

\section{Golden Melon-Pedigree-Barley. $\odot$}

Deutsch: Gold-Melone, Stammbaum-Gerste.

Aehre: hellgelb, hängend, gross; Spindel zähe; Grannen hcll, anliegend, bis $21 \mathrm{cnl} \mathrm{lang.} \mathrm{-} \mathrm{Stroh:} \mathrm{hellgelb,} \mathrm{blattreich,} \mathrm{kräftig,} \mathrm{aufrecht.} \mathrm{-}$ Scheinfrucht: Original goldgelb, voll, gross (9 $\mathrm{mm}$ lang, $4^{1 / 2} \mathrm{~mm}$ breit, 226 Scheinfrüchte $=10 \mathrm{gr}$ ), feinschalig; nachgebaut: grösser (20t Scheinfriichte $=10 \mathrm{gr}$ ), und dichsehaliger.

Halme blaugrün, bereift; Bestockung stark, 2.8 Schösslinge, spät schossend und bliihend. Halmlänge $100 \mathrm{~cm}$ (Мax. $115 \mathrm{~cm}$ ), Halmdicke $0.48 \mathrm{~cm}$, Blattzahl 4.7, Blattlänge $31.4 \mathrm{~cm}$, Blattbreite $1.16 \mathrm{~cm}$, Blattfläche 342.35 qcu, Halmfläche $144 \mathrm{qcm}$, Gesammtfläche $486.35 \mathrm{qcm}$.

Aehre reift spät, in 131 Tagen, $13 \mathrm{~cm}$ (Max. $17 \mathrm{~cm}$ ) lang, mit 30 Scheinfrüchten, von denen 1595560 auf $1 \mathrm{hl}(=70.6 \mathrm{~kg})$ entfallen.

Auf I qm wachsen 600 Halme oder 214 Pflanzel, mithin beträgt der Raum für eine Pflanze $47 \mathrm{qcm}$, die Blattfläche p. qm Bodenfläche $29 \mathrm{qm}$ und das Saatquantum $1.8 \mathrm{hl} \mathrm{p.} \mathrm{ha.}$

Es wiegen 100 Halme $433 \mathrm{gr}$ und daron die Scheinfrüchte $250 \mathrm{gr}$.

Diese Gerste lagert nicht leicht, ist gegen Rost ziemlich widerstandsfähig und das blattreiche Stroh zu Futterstroh geeignet.

Nach zwei Ernten waren auf dem etwas schweren Poppelsdorfer Lehmboden die Scheinfrüchte grösser und dickschaliger geworden, mithin wohl kalkreichere, milde Lehmböden sich besser zu ihrer Kultur eignen dürften.

Diese in Philadelphia 1876 prämiierte Gerste ist eine Pedigree-Gerste des Captain William Delf, Great-Bentley, Colchester, Essex, England, dessen Züchtungsprincip von dem $\mathrm{Hallet}$ 'schen insoferm abweicht, als el nicht die grössten, sondern vielmehr die dem Gewichte nach schwersten Körner zur Aussaat rerwendet, welche auf einer ron ihm hierzu lronstruierten Sortiermaschine sortiert werden. 
Diese Gerste wird schon vielfach von englischen Landwirten als Braugerste kultiviert und von den Nälzern gesucht, doch ist durch sorgfältige Auswahl der Körner und des Bodens, sowie durch aufmerksame Kultur der Pedigree-Charakter festzuhalten, wenn man nicht zn hänfigem Samenwechsel schreiten will.

Bezugsquelle: Original vom Ziichter erhalten.

\section{Prima-Donna Barley.}

Deutsch: Prima-Donna-Gerste.

Aehre: blassgelb, lang, hängend; Grannen fast weiss, anliegend, dicht an der Scheinfrucht abbrechend, sehr lang $(25 \mathrm{~cm})$. - Stroh: blassgelb, steif, lang. - Scheinfrucht: weisslich-gelb, voll, schön (8 mm lang, $4 \mathrm{~mm}$ breit, 230 Scheinfrüchte $=10 \mathrm{gr}$ ), feinschalig; nachgebant in 1. Tracht grösser (197.5 Scheinfrüchte $=10 \mathrm{gr}$ ), doch grobschaliger und dunkler.

Halme blaugrïin, bereift; Bestockung stark, 2.8 Schösslinge, spät schossend und bliihend. Halm $100 \mathrm{~cm}$ (Max. $115 \mathrm{~cm}$ ) lang, Halmdicke $0.44 \mathrm{~cm}$, Blattzahl 3.7, Blattlänge $30.3 \mathrm{~cm}$, Blattbreite $1.19 \mathrm{~cm}$, Blattfläche $265.84 \mathrm{qcm}$, Halmfäche $132 \mathrm{qcm}$, Gesammtfläche $397.84 \mathrm{qcm}$.

Aehre reift spät, in 131 Tagen, $13 \mathrm{~cm}$ (Max. $16 \mathrm{~cm}$ ) lang, mit 30 Scheinfrüchten, von denen 1679000 auf $1 \mathrm{hl}(=73 \mathrm{~kg})$ entfallen.

Es wiegen 100 Halme $406 \mathrm{gr}$ und davon die Scheinfrïclite $223 \mathrm{gr}$.

Auf $1 \mathrm{qm}$ wachsen 700 Halme oder 250 Pflanzen, mithin beträgt der Raum für, eine Pflanze $40 \mathrm{qcm}$, die Blattfläche p. qm Bodenfäcche $27,9 \mathrm{qm}$ und das Saatquantum $2 \mathrm{hl} \mathrm{p.} \mathrm{ha.}$

Das blattarme und sich wenig zum Verfüttern eignende Strolı lagert nicht leicht und ist gegen Rost sehr widerstandsfähig.

Diese schöne Gerste, welche 1876 in Philadelphia prämiier wurde, stammt ursprünglich aus Amerika, wurde in England durch Captain Delf veredelt und gilt als gute Braugerste, vorausgesetzt, dass sie auf einem milden, kalkreichen, gut kultivierten Lehmboden angebaut wird, da sic anderenfalls leicht degeneriert.

Bezugsquelle: Captain W. Delf, Great-Bentley, Colchester, Essex, England. Züchtungsprincip siehe bei Golden-Melon.

\section{Chesney-Barley. $\odot$}

Deutsch: Chesney-Gerste.

Aehre: blassgelb, hängend, etwas locker, schr lang; Klappen anliegend, behaart; Grannen hell, am Rande rauh, dicht an der Scheinfrucht abbrechend, bis $22 \mathrm{~cm}$ lang. - Stroh: rötlich-gelb, blattreich, fest, lang. - Scheinfrucht: blassgelb, an Basis dunkler, voll, schön, gross (10 nım lang, $4^{1 / 2} \mathrm{~mm}$ breit), feinschalig.

Halme blaugrün, bereift, Bestockung mittelstark, 2.3 Schösslinge, spät schossend und blühend. Halm $90 \mathrm{~cm}$ (Max. $110 \mathrm{~cm}$ ) lang. $0.35 \mathrm{~cm}$ dick, Blattzabl 4.3, Blätter $21.7 \mathrm{~cm}$ lang, $0.77 \mathrm{~cm}$ breit, Blattfläche $143.71 \mathrm{qcm}$, Halmfläche $94.5 \mathrm{qcm}$, Gesammtfläche $238.21 \mathrm{qcm}$.

Aehre reift spät, in 125 Tagen, $13 \mathrm{~cm}$ (IIax. $15 \mathrm{~cm}$ ) lang, mit 34 Scheinfrïchten, von denen 1686000 auf $1 \mathrm{hl}(=73.3 \mathrm{~kg}$ ) entfallen.

Auf 1 qm wachsen 1150 Halme oder 300 Pflanzen, mithin beträgt der Raum für eine Pflanze $20 \mathrm{qcm}$, die Blattfläche p. qm Bodenfläche $27.4 \mathrm{qm}$ und das Saatquantum $4 \mathrm{hl}$ p. ha. 
Es wiegen 100 Halme $380 \mathrm{gr}$ und daron die Ścheinfrüchte $203 \mathrm{gr}$.

Diese sehr ertragreiche Braugerste eignet sich für leichtere Böden lagert nicht leicht und leidet wenig durch Rost.

\section{Long eared Barley.}

Deutsch: Lange zweizeilige Gerste.

Aehre: blassgelb, locker, hängend, lang; Klappen anliegend, behaart; Grannen fast weiss, etwas gespreizt, am Rande rauh, dicht an del Scheinfrucht abbrechend, bis $16 \mathrm{~cm}$ lang. - Stroh: gelb, ziemlich feinhalmig, blattreich, mittellang. - Scheinfrucht: blassgelb, an Basis rötlich, ziemlich lang und spitz (10 $\mathrm{mm}$ lang: $4 \mathrm{~mm}$ breit, 198 Scheinfrüchte $=10 \mathrm{gr})$, ziemlich feinschalig.

Junge Pflanze blaugriin, bereift; Bestockung mittelstark, 2.4 Schösslinge, mittelfrüh schossend und blülend. Halm $80 \mathrm{~cm}$ (Max. $100 \mathrm{~cm}$ ) lang, $0.36 \mathrm{~cm}$ dick, Blattzahl 5, Blätter $23.14 \mathrm{~cm}$ lang, $1.01 \mathrm{~cm}$ breit, Blattfläche $233.7 \mathrm{qcm}$, Halmfläche $86.4 \mathrm{qcm}$, Gesammtfläche $320.1 \mathrm{qcm}$.

Aehre reift mittelfrüh, in 118 Tagen, $11 \mathrm{~cm}$ (Мax. $14 \mathrm{~cm}$ ) lang, mit 30 Scheinfrüchten, ron denen 1471140 auf 1 hl (=74.3 kg) entfallen.

Auf 1 qm wachsen 900 Halme odel 375 Pflanzen, mithin beträgt der Raum für eine Pflanze $26.6 \mathrm{qcm}$, die Blattfläche $\mathrm{p}$. q $\mathrm{m}$ Bodenfläche 28.8 qul, und das Saatquantum $3.4 \mathrm{hl}$.

Es wiegen $100 \mathrm{Halme} 250 \mathrm{gr}$ und daron die Frïchte $126 \mathrm{gr}$.

Diese Gerste ist mehrere Jahre erfolgreich als Wintergerste in Poppelsdorf gebaut worden. Sie leidet durch Lagern und Rost.

\section{Porter-Barley. $\odot$}

Deutsch: Englische Porter-Gerste.

A ehre: hellgelb, hängend, langährig; Spindel zälıe; Gramnen hell, dicht an der Scheinfrucht abbrechend, aufrecht, bis $20 \mathrm{~cm}$ lang. - Strohgelb, kräftig, ziemlich blattreich, sehr lang. - scheinfrucht: hellgelb gross, voll (10 $\mathrm{mm}$ lang, $4 \frac{1}{2} \mathrm{~mm}$ breit, 188 Früchte $\left.=10 \mathrm{gr}\right)$, fein: schalig.

Halme blaugrün, aufrecht, Bestockung stark, 3 Schösslinge. Halm* länge $100 \mathrm{~cm}$ (Max. $115 \mathrm{~cm}$ ), Halmdicke $0.44 \mathrm{~cm}$, Blattzahl 4, Blattlänge $28.4 \mathrm{~cm}$, Blattbreite $1.12 \mathrm{~cm}$, Blattfläche $254.48 \mathrm{qcm}$, Halmfläche $132 \mathrm{qcm}$, Gesaumtfäche 386.48 qcm.

Aclue reift mittelfrïh, in 120 Tagen, $13 \mathrm{~cm}$ (Мax. $16 \mathrm{~cm}$ ) lang, mit 30 Scheinfrüchten, von denen 1259600 auf $1 \mathrm{hl}(=67 \mathrm{~kg})$ entfallelı.

Auf $1 \mathrm{qm}$ wachsen 630 Halme oder 210 Pflanzen, mithin beträgt der Raum für eine Pflanze $48 \mathrm{qcm}$, die Blattfläche p. qm Bodenfläche $24.4 \mathrm{qm}$ und das Saatquantum $2.3 \mathrm{hl}$ p. ha.

Es wiegen 100 Halme $385 \mathrm{gr}$ und daron die Scheinfrüchte $180 \mathrm{gr}$.

Diese Gerste lagert nicht, ist auf mildem, fruchtbarem Boden sehr ertragreich und als gute Braugerste in England geschätzt.

\section{Gerste aus Reading.}

Aelıre: blassgelb, hängend, mittellang; Spindel zähe; Grannen blassgelb, bis $20 \mathrm{~cm}$ lang. - Stroh: rötlich-gelb, kurz, fest. - Schein- 
frucht: blassgelb, kurz, sehr voll und dick (9 $\mathrm{mm}$ lang, $4 \frac{1}{2} \mathrm{~mm}$ breit); feinschalig.

Junges Blatt hellgrün, lang, schmal, 2.2 Schösslinge, sehr zeitig schossend und blühend; Halm $85 \mathrm{~cm}$ (Max. $100 \mathrm{~cm}$ ) lang, $0.4 \mathrm{~cm}$ dick, Blattzahl 5.6, Blätter $25.8 \mathrm{~cm}$ lang, $0.8 \mathrm{~cm}$ breit, Blattfläche $231.2 \mathrm{qcm}$, Halmfläche $102 \mathrm{qcm}$, Gesammtfläche $333.2 \mathrm{qcm}$.

Aehre $11 \mathrm{~cm}$ (JIax. $14 \mathrm{~cm}$ ) lang mit 30 Scheinfrüchten, von denen 1451000 auf 1 ha $(=75.2 \mathrm{~kg})$ entfallen. Reift in 115 Tagen.

Widerstandsfähig gegen Rost und Lagern.

Für in guter Kultur befindliche lumose Lehmböden sehr beachtenswert. Stammt von Sutton \& Sons, Samenhändler zu Reading bei London.

\section{Page's prolific Barley. $\odot$}

Deutsch: Page's ergiebige Gerste.

Aelıre: blassgelb, hängend, lang; Grannen hell, sehr lang $(25 \mathrm{~cm})$, zähe. - Stroh: rötlich-weiss, kräftig, blattreich, lang. - Scheinfrucht: hellgelb, an Basis bräunlicl,, voll, rundlich $(81 / 4 \mathrm{~mm}$ lang, $4 \mathrm{~mm}$ breit, 181 Scheinfrüchte $=10 \mathrm{gr}$ ), feinschalig.

Junges Blatt gelbgrün, ziemlich breit, lang; Bestockung schwach, 1.5 Schösslinge, mittclfrüh schossend und blühend. Halm $90 \mathrm{~cm}$ (Max. $100 \mathrm{~cm}$ ) lang, $0.4 \mathrm{~cm}$ dick, Blätter $23.6 \mathrm{~cm}$ lang, $1.1 \mathrm{~cm}$ breit, Blattzahl 4.8, Blattfläche $249.2 \mathrm{qcm}$, Halmfläche $108 \mathrm{qcm}$, Gesammtfläche $357 \mathrm{qcm}$.

Aehre mittelfriih, in 120 Tagen reifend, $11 \mathrm{~cm}$ (Max. $14 \mathrm{~cm}$ ) Jang, mit 30 Scheinfrüchten, von denen 1375600 auf $1 \mathrm{hl}(=76 \mathrm{~kg})$ entfallen.

Es wiegen 100 Halme $330 \mathrm{gr}$ und davon die Scheinfrüchte $169 \mathrm{gr}$.

Diese in England auf milden Lehmböden gebaute Gerste lagert wenig und zeigt sich auch gegen Rost ziemlich widerstandsfähig.

\section{Gerste von Florenz. $\odot$}

Aehre: blassgelb, hängend, lang; Klappen anliegend, behaart; Grannen hell, dicht an der Scheinfrucht abbrechend, am Rande rauh, bis $20 \mathrm{~cm}$ lang. -- Stroh: hellgelb, blattreich, fest, mittellang. - Scheinfrucht: fast weiss, voll (10 mm lang, $5 \mathrm{~mm}$ breit), prachtvoll, sehr schwer, feinschalig.

Halme blangrün, Bestockung mittelstark, 2 Schösslinge, inittelfrüh schossend und blühend. Halm $80 \mathrm{~cm}$ (Max. $110 \mathrm{~cm}$ ) lang, $0.4 \mathrm{~cm}$ dick, Blattzahl 4.3 , Blätter $21.54 \mathrm{~cm}$ lang, $0.85 \mathrm{~cm}$ breit, Blattfläche $157.47 \mathrm{qcm}$, Halmfläche $96 \mathrm{qcm}$, Gesammtfläche $253.47 \mathrm{qcm}$.

Aelire reift mittelfrüh, in 115 Tagen, $11 \mathrm{~cm}$ (Nax. $15 \mathrm{~cm}$ ) lang, mit 30 Scheinfrüchten, von denen 1474000 Scheinfrüchte auf $1 \mathrm{hl}$ $(=77.6 \mathrm{~kg})$ entfallen.

Auf $1 \mathrm{qm}$ wachsen 1000 Halme oder 500 Pflanzen, mithin beträgt der Raum für eine Pflanze $20 \mathrm{qcm}$, die Blattfläche p. qm Bodenfläche $25.3 \mathrm{qm}$ und das Saatquantum $4.5 \mathrm{hl}$ p. ha.

Es wiegen 100 Halme $354 \mathrm{gr}$ und davon die Scheinfrüchte $203 \mathrm{gr}$.

Diese höchst beachtenswerte Braugerste wurde von Prof. Delpino aus Florenz an den ökon.-botanischen Garten zu Poppeldorf 1876 eingesandt. 


\section{Tramasó (Vich, Cataluña), Spanien. $\odot$}

Aehre: bläulich-meiss, aufrecht, kurz; Spindel zähe; Grannen blassgelb, bis $17 \mathrm{~cm}$ lang, wenig gespreizt, zähe. - Stroh: gelbrot, steif, nnter mittellang. - Scheinfrucht: Original bläulich-weiss, mit hellbräuilicher Basis (10 mm lang, $4 \mathrm{~mm}$ breit, 206 Scheinfrüchte $=10 \mathrm{gr}$ ); nachgebaut: 150 Scheinfrüchte $=10 \mathrm{gr}$, grobschalig.

Junges Blatt dunkelgrün, fein, aufrecht, 1.5 Schösslinge; Halm $85 \mathrm{~cm}$ (MIax. $95 \mathrm{~cm}$ ) lang, $0.38 \mathrm{~cm}$ dick, Blattzahl 4, Blätter $21.4 \mathrm{~cm}$ lang, $0.8 \mathrm{~cm}$ breit, Blattfäche $137 \mathrm{q} \mathrm{cm}$, Halmfläche $97 \mathrm{qcm}$, Gesammtfläche $234 \mathrm{qcm}$. friichten.

Aehre reift in 100 Tagen, $8 \mathrm{~cm}$ (Yax. $13 \mathrm{~cm}$ ) lang, mit 21 Schein-

Bezugsquelle: Antonio Cipriano Costa, Barcelona, 1881.

\section{Persische Gerste. $\odot$}

Aehre: blassgelb, klein; Grannen hell, rauh, etwas gespreizt, bis $15 \mathrm{~cm}$ lang, nicht leicht abbrechend. - Stroh: rötlich-weiss, kurz, feinhalmig. - Scheinfrucht: granlich-weiss, an Basis leicht bräunlich, schlank $\left(9^{1} / 2 \mathrm{~mm}\right.$ lang, $3 \mathrm{~mm}$ breit, 245 Scheinfrüchte $=10 \mathrm{gr}$ ), dickschalig.

Junges Blatt blaugriin, klein, sehr schmal, 3.2 Schösslinge, mithin Bestockung sehr stark, zeitig sehossend und bliihend. Halm $65 \mathrm{~cm}$ (Jax. $75 \mathrm{~cm})$ lang, $0.33 \mathrm{~cm}$ dick, Blattzahl 4, Blätter $19.8 \mathrm{~cm}$ lang, $0.9 \mathrm{~cm}$ breit, Blattfäche $142.56 \mathrm{qcm}$, Halmfläche $64.35 \mathrm{qcm}$, Gesammtfläche $206.91 \mathrm{qcnl}$. Aussaat zeitig, weil sie sich sonst wie Wintergetreide verhält.

Aehre reift zeitig, in 105 Tagen, $7 \mathrm{~cm}$ (Iax. $8 \mathrm{~cm}$ ) lang, mit 18 Scheinfrüchten, von denen 1715000 auf $1 \mathrm{hl}(=70 \mathrm{~kg}$ ) entfallen.

Es wiegen 100 Halme $190 \mathrm{gr}$ und davon die Früchte $97 \mathrm{gr}$.

Bezugsquelle: Rotterdamsche stoom-rystpeel en MIoelmolen und zwar unter Weizen aus Persien.

\section{Brangerste aus Oregon, Vereinigte Staaten. $\odot$}

Aehre: fast weiss, dicht, lang; Grannen hell, nicht leicht abbrechend, sehr lang $(25 \mathrm{~cm})$. - Stroh: rötlich-weiss, sehr kräftig, blattreich, lang. - Scheinfrucht: fast weiss, an Basis mit bräunlichem Anflug, voll, gross, (10 mm lang, $4 \frac{1}{4} \mathrm{~mm}$ breit, 165 Scheinfrüchte $\left.=10 \mathrm{gr}\right)$, schwer, feinschalig.

Junges Blatt dunkelgrün, etwas schmal, lang; Bestockung stark, 3 Schösslinge, spät schossend und blühend. Halm $90 \mathrm{~cm}$ (Мax. $110 \mathrm{~cm}$ ) lang, $0.43 \mathrm{~cm}$ dick, Blattzahl 4.8 , Blätter $25.4 \mathrm{~cm}$ lang, $0.96 \mathrm{~cm}$ breit, Blattfläche 234.09 qcm, Halmfläche $116.1 \mathrm{qcm}$, Gesammtfläche $350.19 \mathrm{qcm}$.

Aehre spätreif, in 130 Tagen reifend, $12 \mathrm{~cm}$ (Маx. $15 \mathrm{~cm}$ ) lang, mit 32 Scheinfrüchten, von denen 1254000 auf $1 \mathrm{hl}(=76 \mathrm{~kg})$ entfallen.

Es wiegen 100 Halme $450 \mathrm{gr}$ und davon die Scheinfrüchte $222 \mathrm{gr}$.

Diese Braugerste ist auf mildem Lehmboden in hohem Grade beachtenswert, lagert selten und bleibt fast rostfrei. 


\section{Gerste aus Uruguay.}

Aehre: gelb, $13 \mathrm{~cm}$ lang mit 33 Scheinfrüchten, Grannen anliegend, bis $21 \mathrm{~cm}$ lang. - Stroh: blassgelb, blattreich, sehr kräftig, bis $100 \mathrm{~cm}$ hoch. - Scheinfrucht: gelb, an Basis schwach riolett, $9 \mathrm{~mm}$ lang, $4 \mathrm{~mm}$ breit. - Original im landw. Museum zu Berlin.

\section{Cape Barley.}

\section{Syn.: Z/weizeilige Gerste aus Australien.}

Aehre: fast weiss, stark liängend, dicht, lang; Grannen hell, auffallend leicht und dicht an der Scheinfrucht abbrcchend, bis $20 \mathrm{~cm}$ lang. Stroh: rötlich-blassgelb, etwas weich, lang. - Scheinfrucht: fast weiss, an Basis mit schwach rötlichem Anflug, kurz, roll (81/2 $\mathrm{mm}$ lang, $4 \mathrm{~mm}$ breit), feinschalig.

Junges Blatt gelbgrün, etwas schmal, lang, Bestockung mittelstark, 2.2 Sehösslinge, zeitig schossend und blïhend. Halm $110 \mathrm{~cm}$ (Max. $120 \mathrm{~cm}$ ) lang, $0.38 \mathrm{~cm}$ dick, Blattzahl 3.6, Blätter $24.8 \mathrm{~cm} \mathrm{lang,} 1.03 \mathrm{~cm}$ breit, Blattfläche $232.13 \mathrm{q} \mathrm{cm}$, Halmfläche $114 \mathrm{qcm}$, Gesaumtfläche 346,13 qem.

Junge Aehre gelbgrün, mittelfriih, in 115 Tagen reifend, $11 \mathrm{~cm}$ (Max. $15 \mathrm{~cm}$ ) lang, mit 32 Scheinfriichten, von denen 1420800 auf $1 \mathrm{hl}$ $(=74 \mathrm{~kg})$ entfallen.

Auf $1 \mathrm{qm}$ wachsen 840 Halme oder 420 Pflanzen, mithin beträgt der Paum für eine Pflanze $24 \mathrm{qcm}$, die Blattfläche p. qm Bodenfläche $29 \mathrm{qm}$ und das Saatquantum $4 \mathrm{hl}$ p. ha.

Es wiegen 100 Halme $310 \mathrm{gr}$ und davon die Früchte $175 \mathrm{gr}$.

Diese für kalkreichen Lehmboden beachtenswerte Gerste lagert leider etwas leicht und ist gegen Rost wenig widerstandsfähig. Adelaide.

Einsender: Schomburgk, Direktor des botanischen Gartens zu

\section{Gerste aus Adelaide, Australien.}

Aehre: fast weiss, etwas locker, mittellang, Spindel zähe; Klappen angedrückt, behaart; Gramnen fast weiss, wenig gespreizt, zerbrechlich, bis $22 \mathrm{~cm}$ lang. - Stroh: rötlich-gelb, unter mittellang, derb. - Scheinfrucht: fast weiss, voll, gross ( $10 \mathrm{~mm}$ lang, $4 \frac{1}{2}$, $14 \mathrm{~m}$ breit, 163 Scheinfrïchte $=10 \mathrm{gr} \mathbf{r}^{\circ}$, feinschalig.

Junges Blatt gelbgrïn, kräftig, mittelfrüh schossend und blïhend; 1.8 Schösslinge; Halm $75 \mathrm{~cm}$ (Max. $95 \mathrm{~cm}$ ) lang, $0.33 \mathrm{~cm}$ dick, Blattzahi 4, Blätter $21.82 \mathrm{~cm}$ lang, $0.9 \mathrm{~cm}$ breit, Blattfläche 157.1 qcm, Halmfläche $84.3 \mathrm{qcm}$, Gesammtfläche $241.4 \mathrm{qcm}$.

Aehre $9 \mathrm{~cm}$ (Max. $11 \mathrm{~cm}$ ) lang mit 24 Scheinfrüchten; reift in 110 Tagen. Es kommen auf $1 \mathrm{hl}(=75 \mathrm{~kg}) 1222500$ Scheinfrüchte.

Fìr sandigen Lehmboden im milden Klima beachtenswert. 
Varietät: Hordeum distichum medicum Kcke. Aehre blassgelb; Grannen anliegend, glatt.

\section{Sorte:}

\section{Glattgrannige zweizeilige Gerste ans Persien.}

Aehre: blassgelb, zweizeilig, kurz, aufrecht, locker; Klappen schwach behaart; Grannen hell, mittellang $(15 \mathrm{~cm})$, anliegend, glatt, zähe. - Strolı: gelbrot, sehr feinhalmig, kurz. - Scheinfrucht: graulich, lang aber nicht voll (10 $\mathrm{mm}$ lang, $4 \mathrm{~mm}$ breit, 190 Scheinfrüchte $=10 \mathrm{gr}$ ), dickschalig.

Junges Blatt blaugrün, schmal, kahl, kraus; 2 Schösslinge; Halm $80 \mathrm{~cm}$ lang, $0.25 \mathrm{~cm}$ dick, Blattzahl 4.5, Blätter $19 \mathrm{~cm}$ lang, $1 \mathrm{~cm}$ breit, Blattläche $171 \mathrm{qcm}$, Halmfläche $60 \mathrm{q} \mathrm{cm}$, Gesammtfläche $231 \mathrm{qcm}$.

Aehre $6 \mathrm{~cm}$ lang, in 110 Tagen reifend, 14 Scheinfrüchte, von denen $1 \mathrm{hl}=75 \mathrm{~kg}$ wiegt. Ist zeitig zu säen, da sie sich sonst wie Wintersetreide verhält.

Bezugsquelle: Rotterdamsche stoom-rystpeel en Moelmolen, unter Weizen aus Persien.

Varietät: Hordeum distichum nigrescens Keke.

Aehre schwärzlich.

\section{Sorte:}

\section{Schwärzliche Gerste. $\odot$}

Aehre: graublau, wenig hängend; Grannen blassgelb, fast weiss, leicht und kurz an Scheinfrucht abbrechend. - Stroh: gelb, fest, mittellang. - Scheinfrucht: graublau, gross (12 mm lang, $4 \frac{1}{1} / 2 \mathrm{~mm}$ breit, 144 Scheinfrüchte $=10 \mathrm{~kg}$ ), grobschalig.

Junges Blatt gelbgrün, aufrecht, schmal, 2.2 Schösslinge, mittelfrül blühend. Halme $85 \mathrm{~cm}$ (Max. $95 \mathrm{~cm}$ ) lang, $0.34 \mathrm{~cm}$ dick, Blattzahl 3.6 , Blätter $23.8 \mathrm{~cm}$ lang, $0.95 \mathrm{~cm}$ breit, Blattfäche $162.79 \mathrm{qcm}$, Halmfläche $86.7 \mathrm{qcm}$, Gesammtfläche $249.49 \mathrm{qcm}$.

Junge Aehre gelbgrün, violett gestreift, reift in 119 Tagen, $10 \mathrm{~cm}$ (Max. $14 \mathrm{~cm}$ ) lang, mit 30 Scheinfrüchten, von denen 1041120 auf $1 \mathrm{hl}$ $(=72.3 \mathrm{~kg})$ entfallen.

Es wiegen 100 Halme $437 \mathrm{gr}$, und davon die Scheinfrüchte $170 \mathrm{gr}$.

Varietät: Hordeum distichum nigricans Sér.

Aehre schwarz; Grannen rauh.

\section{Sorten:}

\section{Orge d'Abyssinie. $\odot$}

Syn.: Franz.: Orge noire à deux rangs.

Eng l.: Abyssinian Black-Barley.

Deutsch: Schwarze abessinische Gerste.

Aehre: blauschwarz, etwas locker, hängend, mittellang; Klappen 
schwach anliegend, behaart; Grannen dunkel, nach der Spitze heller, am Rande rauh, aufrecht, bis $20 \mathrm{~cm}$ lang. - Stroh: gelbgrau bis blaugrau, etwas weich, mittellang. - Scheinfrucht: blauschwarz, gross (11 mm lang, $4 \mathrm{~mm}$ breit), grobschalig.

Halme gelbgrün, Bestockung mittelstark, 2.2 Schösslinge; zeitig schossend und blihhend. Halm $80 \mathrm{~cm}$ (Max. $100 \mathrm{~cm}$ ) lang, $0.37 \mathrm{~cm}$ dick, Blattzahl 3.7, Blätter $25.85 \mathrm{~cm}$ lang, $1.01 \mathrm{~cm}$ breit, Blatṭlläche $193.21 \mathrm{qcm}$, Halmfläche 88.8 qcm, Gesammtfläche $282.01 \mathrm{qcm}$.

Junge Aehre mit schwach violettem Anflug, reift zeitig, in 110 Tagen, $10 \mathrm{~cm}$ (Max. $12 \mathrm{~cm}$ ) lang, mit 26 Scheinfrüchten, von denen 1181000 Frïchte auf $1 \mathrm{hl}(=70.7 \mathrm{~kg}$ ) entfallen.

Auf $1 \mathrm{qm}$ wachsen 1000 Halme oder 455 Pflanzen, mithin beträgt der Raum für eine Pflanze $22 \mathrm{qcm}$, die Blattfläche $p$. $q \mathrm{~m}$ Bodenfläche $28 \mathrm{qm}$ und das Saatquantum $5 \mathrm{hl}$.

Es wiegen 100 Halme. $380 \mathrm{gr}$ und davon die Früchte $202 \mathrm{gr}$.

In Proskau wurden 1872 auf humosem Thonboden p. ba geerntet: $3224 \mathrm{~kg}$ Korn, $3619 \mathrm{~kg}$ Stroh, $728 \mathrm{~kg}$ Spreu.

Diese Gerste wird wenig in Deutschland, und in Frankreich nach Heuz é zu Paillerols in Basses Alpes kultiviert.

Schimper sandte sie zuerst aus Abessinien nach Deutschland; auch soll sie der Franzose Lejeune 1854 direkt aus Abessinien nach Frankreich eingeführt haben.

\section{Ordu negrn, Rumänien.}

Aehre: blauschwarz, bereift, hängend, ziemlich dicht, mittellang; Klappen anliegend, behaart; Grannen blauschwarz, nach der Spitze zu heller, wenig abstehend, am Rande rauh, dicht an Scheinfrucht abbrechend, bis $15 \mathrm{~cm}$ lang. - Stroh: gelb bis blaugrau, sehr blattreich, duinnlialmig, doch fest, mittellang. - Scheinfrucht: blauschwarz, bereift, gross (10 mm lang, $4 \mathrm{~mm}$ breit, 161 Scheinfrüchte = $10 \mathrm{gr}$ ), grobschalig.

Halme blaugrün, bereift, 2.6 Schösslinge, mittelfrüih schossend und blühend. Halm $80 \mathrm{~cm}$ (Max. $90 \mathrm{~cm}$ ) lang, $0.3 \mathrm{~cm}$ breit, Blattzahl 4.7, Blätter $23.54 \mathrm{~cm}$ lang, $0.77 \mathrm{~cm}$ breit, Blattfläche 170.33 qcm, Halmfläche 72 qcm, Gesammtfläche 242.33 q cm.

Junge Aehre mit violettem Anflug, reift in 113 Tagen, $9 \mathrm{~cm}$ (Max. $11 \mathrm{~cm})$ lang, mit 24 Scheinfrüchten, von denen 1154370 auf $1 \mathrm{hl}$ $(=71.7 \mathrm{~kg})$ entfallen.

Es wiegen 100 Halme $312 \mathrm{gr}$ und davon die Früchte $181 \mathrm{gr}$. Uebersandt durch Frau Fürstin Wied.

\section{Varietät: Hordeum distichum persicum Kcke.}

Aehre schwarz; Grannen glatt.

\section{Sorte:}

\section{Zweizeilige schwarze persische Gerste mit glatten Grannen. $\odot$}

Aehre: schwarz oder schwarzbraun, 2-zeilig, kurz; Grannen schwärzlich, aufrecht, glatt, nur nach der Spitze zu schwach rauh, zähe, bis $14 \mathrm{~cm}$ lang; Klappen kahl oder sehr schwach behaart und hierdurch von 
"nigricans" unterschieden. - Stroh: rötlich-gelb, sehr feinhalmig, doch fest, kurz. - Scheinfrucht: schwarz oder sehr schwärzlich, $1881 \mathrm{mehr}$ dunkelkaffebraun, $9 \mathrm{~mm}$ lang, $3 \frac{1}{2} \mathrm{~mm}$ breit, $2 \frac{1}{2} \mathrm{~mm}$ dick, 220 Körner $=10 \mathrm{gr}$, etwas grobschalig.

Blätter mehr bläulich-grïn als bei anderen Sorten von H. distichum, kahl; Entwickelung sehr zeitig; 4 Schösslinge; Halm $60 \mathrm{~cm}$ (Мrax. $72 \mathrm{~cm}$ ) lang, $0.3 \mathrm{~cm}$ dick, Blattzahl 4, Blätter $21.5 \mathrm{~cm}$ lang, $0.8 \mathrm{~cm}$ breit, Blattfläche $137.6 \mathrm{qcm}$, Halmfläche $54 \mathrm{qcm}$, Gesammtfläche $191.6 \mathrm{qcm}$. früchten.

Aehre in 100 Tagen reifend, $5 \mathrm{~cm}$ (Max. $6 \mathrm{~cm}$ ) lang, mit 15 Schein-

Widerstandsfähig gegen Rost.

Bezugsquelle: Rotterdamsche stoom-rystpeel en Mloelmolen und zwar unter Weizen aus Persien.

\section{Varietät: Hordeum distichum erectum Schiibl.}

Aehre blassgelb, dicht, breit.

\section{Sorten:}

\section{Italian Barley. $\odot$}

Syn.: Engl.: Golden-Barley, Alpine-Barley.

Deutsch: Italienische Gerste.

Franz.: Orge à deux rangs d'Italie, Orge plate d'Italie, Orge des Alpes.

Aehre: blassgelb, selrr dicht, sich etwas rerjüngend, aufrecht; Spindel ziemlich zähe; Klappen anliegend, behaart; Grannen hell, gespreizt, am Rande raull, bis $18 \mathrm{~cm}$ lang, dicht an Scheinfrucht abbrechend. Stroh: rötlich-weiss, kräftig, steif, mittellang. - Scheinfrucht: fast weiss, sehr gross, voll (11 mm lang, 41/2 mm breit), feinschalig, schwer.

Halm gelbgrün, 3 Schösslinge, zeitig schossend und blühend. Halm $90 \mathrm{~cm}$ (Max. $110 \mathrm{~cm}$ ) lang, $0.4 \mathrm{~cm}$ dick, Blattzahl 4, Blätter $24.52 \mathrm{~cm}$ lang, $0.98 \mathrm{~cm}$ breit, Blattfläche $192.24 \mathrm{qcm}$, Halmfläche $108 \mathrm{q} \mathrm{cm}$, Gesammtfläche $300.24 \mathrm{qcm}$.

Aehre mittelfrüh, in 120 Tagen reifend, $9 \mathrm{~cm}$ (Max. $11 \mathrm{~cm}$ ) lang, mit 34 Scheinfrüchten, welche ziemlich fest sitzen und von denen 1323000 auf $1 \mathrm{hl}(=76.5 \mathrm{~kg})$ entfallen.

Auf $1 \mathrm{qm}$ wachsen 900 Halme oder 300 Pflanzen, mithin beträgt der Raum für eine Pflanze $33.3 \mathrm{qcm}$, die Blattfäche p. qm Bodenfläche $27 \mathrm{qm}$ und das Saatquantum $3 \mathrm{hl} \mathrm{p}$. ha.

Es wiegen 100 Halme 398 gr und davon die Scheinfrüchte 150 gr.

In England sollen Erträge bis zu $46.7 \mathrm{hl} \mathrm{p}$. ha erreicht werden.

Diese Gerste ${ }^{1}$ ) gelangte um 1830 als "Italian Barley" von den Süd-Abhängen der Alpen (Alpine-Barley) nach Ayrshire; in der Umgegend von Stirling wird sie auch "Golden-Barley" genannt.

1) P. Lawson, The Agriculturist's Manual 1836. 


\section{Jerusalemer-Gerste. $\odot$}

Sy n.: Imperial- oder Kaiser-Gerste, Zeilen-, Spiegelgerste.

Aehre: fast weiss, aufrecht, sich etwas, jedoch weniger als die Pfauengerste verjüngend, dicht, platt; Spindel zähe; Klappen anliegend, behaart; Grannen hell, gespreizt, am Rande rauh, bis $18 \mathrm{~cm}$ lang. Stroh: hellgelb, kräftig, blattreich, steif, lang. - Scheinfrucht: fast weiss, voll, gross (10 mm lang, $4 \mathrm{~mm}$ breit), feinschalig.

Junges Blatt gelbgrün, sehr breit; Bestockung sehr stark, 3.3 Schösslinge, zeitig schossend und blühend; Halm blaugrïn, bereift, $100 \mathrm{~cm}$ (Max. $115 \mathrm{~cm}$ ) lang, $0.45 \mathrm{~cm}$ dick, Blattzahl 4, Blätter $22.5 \mathrm{~cm}$ lang, $1 \mathrm{~cm}$ breit, Blattfläche $180 \mathrm{qcm}$, Halmfläche $135 \mathrm{qcm}$, Gesammtfläche $315 \mathrm{qcm}$.

Junge Aelıre gelbgrün, in 110 Tagen reifend, $8 \mathrm{~cm}$ (Max. $11 \mathrm{~cm}$ ) lang, mit 30 Scheinfrüchten, welche ziemlich fest sitzen und von denen 1285000 auf $1 \mathrm{hl}(=75 \mathrm{~kg})$ entfallen.

Auf $1 \mathrm{qm}$ wachsen 800 Halme oder 242 Pflanzen, mithin beträgt der Raum für eine Pflanze $41.3 \mathrm{qcm}$, die Blattfläche p. qm Bodenfläche $25.2 \mathrm{qm}$ und das Saatquantum $2.5 \mathrm{hl} \mathrm{p}$. ha.

Diese Gerste zeichnet sich durch ein mehlreiches Korn, das sich vorzüglich zur Graupenbereitung und zum Mälzen eignet, aus, lagert nicht, leidet aber durch Rost.

Die Erträge stellen sich auf den milden, gut kultivierten Lehm. böden im milden Klima recht hoch, lassen aber in hohem Grade nach, sobald die Verhältnisse für den Anbau nicht ganz günstige sind, wodurch eine weite Verbreitung beträchtlich verhindert wird.

Wir erzielten 1867 auf kulturvollem, sandigem Lehmboden in 1) Eldena und auf mildem, fruchtbarem Lehmboden in 2) Poppelsdorf p. ha :

$$
\text { 1) } 3024 \mathrm{~kg} \text { Korn, } 3800 \mathrm{~kg} \text { Stroh, } 832 \mathrm{~kg} \text { Spreu. }
$$

Die sog. Imperial-Gerste wurde zuerst 1867 von den Samenhändlern Metz \& $\mathrm{C}_{0}$. in Berlin unter diesem Namen verbreitet, und soll dieselbe von einer durch Knauer in Gröbers bei Halle a. S. gebauten Gerste stammen, docl ist dieselbe mit der seit langer Zeit angebauten JerusalemerGerste vollkommen identisch.

Ausser in Deutschland ist diese Gerste namentlich in Russland sehr verbreitet und beliebt.

\section{Varietät: Hordeum distichum zeocrithum L.}

Aehre blassgelb, nach der Spitze zu verschmälert; Grannen fächerförmig spreizend.

\section{Sorte :}

\section{Pfauengerste.}

S yn.: Fächer-, Bart-, Wucher-, Riemen-, türkische-, Peters- und Dinkelgerste, Hammelkorn, deutscher Reis.

Franz.: Orge éventail, riz, pyramidale, de Russie, faux-riz, à large épi, du Japon, de Paon, Riz rustique, Riz d'Allemagne. 
Engl.: Spread, Battledore, Fan, Putney, Fulham barley, Peacock's barley.

Ita 1.: Orzo di Germania, a mazzarella, a spiga lunga, a ventaglio, maschio.

Spanisch: Espelta de cebada, Arroz de Alemania, Cebada de abanico, Hordi vano (catalonisch).

Schwedisch: Skyffelkorn, Plumagekorn, Bredkorn.

Dänisch: Risbyg.

Holl.: Speltige gerst, Baard gerst.

Böhmisch: Spalda.

Polnisch: Jéczmien ryzowy.

Abessinien: Sigam guanhe tengai (Schimper).

Aehre: hellgelb: kurz, dicht, aufrecht, sich stark nach der Spitze verjüngend, platt; Spindel zerbrechlich; Klappen anliegend, behaart; Grannen hell, gespreizt wie ein Pfauenrad, am Rande ranh, zähe, bis $17 \mathrm{~cm}$ lang. Stroh: gelb, kräftig, blattreich, steif, kurz. - Scheinfrucht: fast weiss, voll, sehr gross (10 mm lang, $4 \mathrm{~mm}$ breit), nach beiden Enden zugespitzt, feinschalig.

Junges Blatt dunkelgrün, schmal; Bestockung stark, 3 Schösslinge, spät schossend und bliihend; Halm blaugrün, bereift, $70 \mathrm{~cm}$ (Max. $80 \mathrm{~cm}$ ) lang, $0.4 \mathrm{~cm}$ dick, Blattzahl 4, Blätter $21.92 \mathrm{~cm}$ lang, $0.98 \mathrm{~cm}$ breit, Blattfläche $171.84 \mathrm{qcm}$, Halmfläche $84 \mathrm{qcm}$, Gesammtfläche $255.84 \mathrm{qcm}$.

Junge Aehre gelbgrün, reift spät, in 125 Tagen, $8 \mathrm{~cm}$ (Max. $9 \mathrm{~cm}$ ) lang, mit 30 Scheinfrüchten, von denen 1350000 auf $1 \mathrm{hl}(=70.3 \mathrm{~kg})$ entfallen.

Auf 1 qm wachsen 1000 Halme oder 333 Pflanzen, mithin beträgt der Raum für eine Pflanze $33.3 \mathrm{qcm}$, die Blattfläche p. qm Bodenfläche $25.6 \mathrm{qm}$ und das Saatquantum $3.3 \mathrm{hl} \mathrm{p}$. ha.

Es wiegen 100 Halme $220 \mathrm{gr}$ und davon die Scheinfrüchte $117 \mathrm{gr}$.

Diese Gerste widersteht vorzüglich der Dürre, weshalb sie gern auf den leichteren Gerstenböden angebaut wird, leidet wenig durch Rost, lagert nicht, und die kräftigen Grannen gewähren Schutz gegen Vogelfrass, doch lassen die Erträge zu wünschen, während die Qualität des Kornes gelobt wird, denn es liefert feines Mehl, gute Graupen und keimt sehr gleichmässig, weshalb diese Gerste in England als Malzgerste gesucht ist, doch darf sie nicht mit anderer Gerste beim Mälzen vermischt werden, da ein solches Gemenge ungleichmässig keimt.

Diese Gerste wird nur relativ selten in England, Italien, Frankreich, in Central- und Südspanien, sowie in Deutschland gebaut; während sie nach Viborg besonders stark in Dänemark und Schleswig-Holstein kultiviert werden soll.

Schon Bock ${ }^{1}$ ) erwähnt dieser Gerste als im Wasgau und Westrich angebaut, mithin ihre Kultur in Deutschland mindestens schon seit 300 Jahren besteht und wird sie "deutscher Reis" genannt.

$\mathrm{Zu}$ Hof Geisberg bei Wiesbaden wurde 1853 durch Dr. Thomae ${ }^{2}$ ) auch eine ästige Fächergerste gefunden, welche den Namen „Hordeum Zeocrithum ramosum" erhielt.

1) New Kreütter-Buch 1539.

2) Agron. Zeit. 1855, p. 9. 


\section{B. Körner nackt.}

Varietät: Hordeum distichum nudum L.

Aehre blassgelb; Kïriner nackt.

\section{Sorte:}

\section{Nackte zweizeilige Gerste. $\odot$}

Syn.: Nackte Kaffeegerste, Himmelsgerste, Himalayagerste, grosse neue nackte Gerste, nackte Gerste aus Ungarn, nackte Gerste aus Charkow, nackte Gerste aus Serbien.

Franz.: Orge à café, du Pérou, d'Espagne, céleste de Constantine, de Sibérie, de Russie, nue à deux rangs, grosse orge nue, moudée, du 'Thibet, de Jérusalem, Pamelle nue, Orge fromentacée, peliet ou pelée.

Ital.: Orzo da caffe, Scandella monda di Firenze.

Engl.: Siberian or Haliday Barley.

Norweg isch: Thorebyg, Noegent taradetbyg, Himelbyg.

Rumänisch: Ordu golazu.

Serbisch: Niski Goli Jécam.

Aehre: fast weiss, selten schwach rötlich, locker, hängend, mittellang; Grannen fast weiss, anliegend, kräftig, am Rande rauh, $18-22 \mathrm{~cm}$ lang; Klappen anliegend, behaart. - Stroh : gelb oder rötlich-gelb, kräftig, steif, kurz, ziemlich blattreich. - Frucht: gelbbraun oder kaffeebraun, mit leicht violettem Anflug, lanzettlich, voll, sehr gross $(9 \mathrm{~mm}$ lang, $5 \mathrm{~mm}$ breit), scliwer, feinschalig.

Junges Blatt gelbgriin, kurz, doch sehr breit; Bestockung schwach, 1.8 Schösslinge, Blattscheiden nach unten bräunlich; Halme bläuliclı-grün, $75 \mathrm{~cm}$ (Max. $85 \mathrm{~cm}$ ) lang, $0.4 \mathrm{~cm}$ dick, Blattzahl 4, Blätter $19 \mathrm{~cm}$ lang, $1.06 \mathrm{~cm}$ breit, Blattfläche 161.12 qcm, Haln fläche $90 \mathrm{qcm}$, Gesammtfläche $251.12 \mathrm{qcm}$.

Aehre reift zeitig, in 110 Tagen, $9 \mathrm{~cm}$ (Max. $13 \mathrm{~cm}$ ) lang, mit 20 nicht leicht ausfallenden Frïchten, von denen 1211946 auf 1 hl $(=84 \mathrm{~kg})$ entfallen.

Auf 1 qm wachsen 1000 Halme od̉er 555 Pflanzen, mithin beträgt das Saatquantum $6 \mathrm{hl} \mathrm{p}$. ha.

Es wiegen 100 Halme $277 \mathrm{gr}$ und davon die Früchte $143 \mathrm{gr}$.

In Proskau wurden 1872 auf humosem Thonboden p. ha geerntet: $2080 \mathrm{~kg}$ Korn, $1664 \mathrm{~kg}$ Stroh, $582 \mathrm{~kg}$ Spreu.

Diese Gerste steht auf gutem Gerstenboden in Mitteleuropa anderen Gersten im Ertrage nach, woraus sich ihre verhältnismässig geringe Verbreitung erklärt. Da sie jedoch gegen ungünstige Witterungsverhältnisse im hohen Grade unempfindlich ist, so wird sie sowohl in suidlichen wie in nordischen Ländern, so z. B. in Algier, aber auch in den hochgelegenen Distrikten Schottlands, Irlands und Norwegens gebaut, und zwar in den letzteren Ländern ihres guten Mehles wegen, das dem Brotmehl zugesetzt wird; auch leidet sie in jenen Ländern wenig durch Lagern oder Rost. 
Halida $y^{1}$ ) führte 1767 diese Gerste nach Grossbritannien ein, wo sie Peter Law son namentlich in Schottland verbreitete.

Die Mehrzahl der aufgeführten Synonyme sind hier geprüft worden, doch hat sich evident herausgestellt, dass alle diese unter den verschiedensten Namen vorkommenden Sorten vollkommen identisch sind.

Ihre Heimat ist der Himalaya ${ }^{2}$ ) und steigt sie dort von allen Gerstensorten am höchsten hinauf.

\section{Varietät: Hordeum distichum compositum Kcke.}

Aehre verästelt; Seitenährchen normal.

\section{Sorte:}

\section{Verästelte zweizeilige Gerste.}

Spanisch: Cebada ramosa, castilianisch; Hordi romós, catalonisch.

Aehre: blassgelb, verästelt, und zwar vorzugsweise am unteren Aehrenteile; Grannen, wo Aehre verästelt, geschlängelt, sonst aufrecht, bis $15 \mathrm{~cm}$ lang, dicht an Scheinfrucht abbrechend. - Stroh: rötlich-gelb. Scheinfrucht: blassgelb mit rötlichem Schimmer, wo verästelt klein, sonst kurz, rund, voll $\left(8 \mathrm{~mm}\right.$ lang, $3 \frac{1}{2} \mathrm{~mm}$ breit, 299 Scheinfrüchte $=10 \mathrm{gr}$ ), etwas grobschalig.

Junges Blatt bläulich-grün, schmal, aufrecht; 2.8 Schösslinge, spät schossend und blühend. Halme $90 \mathrm{~cm}$ lang, $0.4 \mathrm{~cm}$ dick, Blattzahl 5, Blätter $18 \mathrm{~cm}$ lang, $0.74 \mathrm{~cm}$ breit, Blattfläche $133.2 \mathrm{qcm}$, Halmfläche 108 qcm, Gesammtfläche 241.2 qcm.

Aehre reift in 118 Tagen; $10 \mathrm{~cm}$ lang mit 48 Scheinfrüchten, von denen $1 \mathrm{hl}=74.8 \mathrm{~kg}$ wiegt.

Es wiegen 100 Halıe $375 \mathrm{gr}$ und davon die Scheinfrüchte $186 \mathrm{gr}$. Von W. Rimpau, Schlanstedt, 1879 erhalten.

1) Metzger, Landw. Pflkde. 1841, p. 67.

2) Royle, Illustr. of bot. of the Himalaya etc. London 1839, p. 35. 


\section{Die biologischen Verlıältnisse der Gerste.}

Bei der Kultur der Gerste ist namentlich, sobald es sich um Produktion von Braugerste handelt, zu beachten, dass möglichst gleich kräftige und gleichzeitig reifende Pflanzen, mit gleich grossen, stärkereichen Körnern erzeugt werden.

Zur Erreichung dieses Zieles ist aber die Beschaffenheit des Saatgutes von erbeblichem Einfluss. Die Körner sollen voll, banchig, und feinschalig sein, ein möglichst hohes absolutes und Volumengewicht, sowie die charakteristischen Eigenschaften der Sorte besitzen. Diese wïnschenswerte Beschaffenheit des Saatkornes lässt sich nur unter giunstigen Kulturbedingungen, durch Ernte in der Gelbreife und Auswahl der schwersten Körner erreichen.

In einem solchen Saatgut cnthält jedes Korn einen fast gleichgrossen Vorrat an Reservestoffen, wodurch eine gleichmässigc Entwickelung der Pflanzen zu erwarten steht.

Die Wichtigkeit einer guten Qualität des Saatkornes tritt aber besonders scharf hervor, sobald dic Witterungs-, Boden- und Kulturverhältnisse der Saat nicht ganz giïnstig sind, weil die grössere. Nahrungsmenge, welche den jungen Pflänzchen zufliesst, auch ilıre Wachstumsenergie und Widerstandsfähigkeit gegen ungiinstige Vegetationsbedingungen erhöht.

In wclchem bedentenden Grade die Bestandteile der Gerste wechseln können, zeigt nachfolgende Zusammenstellung ${ }^{1}$ ):

\begin{tabular}{lcccccc} 
& \multicolumn{3}{c}{ Stickstoffh. } & \multicolumn{3}{c}{ Stickstofffr. } \\
Masser & Substanz & Fett & Extraktstoffe & Holzfaser & Asche \\
Maximum & 11.34 & 8.75 & 1.29 & 61.25 & 2.31 & 1.77 \\
Mittel & 16.90 & 15.72 & 2.85 & 69.82 & 8.17 & 4.35 \\
\hline 13.07 & 12.09 & 2.09 & 64.97 & 5.14 & 2.64
\end{tabular}

Die Grössenunterschiede von Körnern derselben Sorte können bei der Gerste sehr erheblich sein, wie die nachfolgende Untersuchung von $\mathrm{Wunder}{ }^{2}$ ) zeigt:

1) Dietrich \& König, Zusammens. und Verdaulichk. d. Futterstoffe 1874.

2) Ueber d. Zusammens. d. Getreideart. b. versch. Scheffelgewicht, Landw. Centralbl. I, p. 332. 1857. 


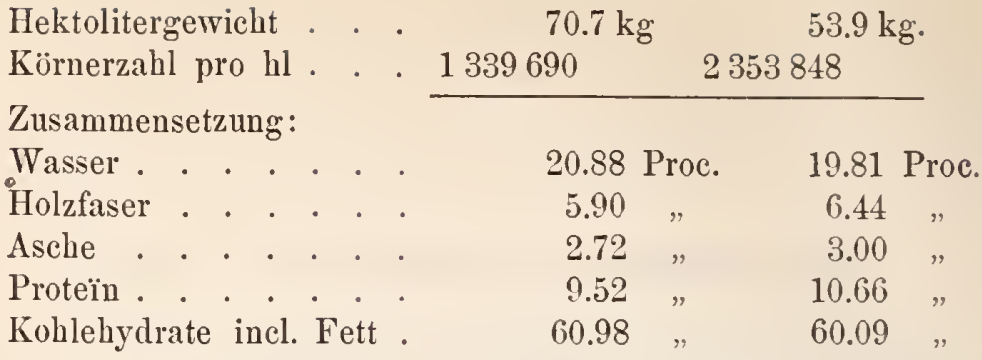

Hiernach kann die Anzahl der Körner ein und derselben Gerstensorte in der Masseinheit um 100 Proc. differieren.

Obwohl wir nun sahen, dass zwar die chemische Zusammensetzung grosser und kleiner Körner nur unerheblich schwankt, indem erstere etwas reicher an Wasser und Kohlehydraten, letztere an Eiweisskörpern, Holzfaser und Asche sind, so wird doch in den kleinen Körnern der Gesammtgehalt an Reservestoffen wesentlich geringer als in den grossen sein, weshalb sie auch entsprechend schwächere Pflanzen erzeugen werden, mithin aus einem Gemenge grosser und kleiner Körner auch nur auf ungleiches Aufgehen, ungleichen Stand, ungleiche Blïte und Reife zu rechnen ist.

Dass nun in der That die Wachstumsenergie leichterer Körner erheblich geringer als dic schwererer ist, zeigen die komparativen Versuche mit Gerste, welche Hellriegel ${ }^{1}$ ) anstellte. Sie ergaben folgende Resultate:

Schwere des Samens $\mathrm{mgr}$

50
Ernte, 15 Tage nach der Sant. Gewicht der Pflanze.

\begin{tabular}{cc}
\multicolumn{2}{c}{ mgr } \\
grün & trocken \\
267 & 29 \\
477 & 46 \\
575 & 55 \\
797 & 70
\end{tabular}

Das Gewicht der jungen Pflanze stand somit in geradem Verhältnis zum Gewicht des Samens und betrug iiberall das 1.7 fache. Nach unseren Ermittelungen beträgt das absolute Gewicht der Körner ron zur Saat bestimmter Gerste im Mittel bei:

\section{Sommerfrucht Winterfrucht}

Hordeum distichum

$$
\begin{aligned}
& \text { beschalt . . . . } 51.0 \mathrm{mgr} \\
& \text { nackt . . . } 50.0 \%
\end{aligned}
$$

1) Norddeutsche 1. Ztg. 1869. 
Sommerfrucht Winterfrucht

Hordeum tetrastichum

\begin{tabular}{|c|c|c|c|}
\hline & gewöhuliche Gerste & $44.4 \mathrm{mgr}$ & $37.6 \mathrm{mgr}$ \\
\hline & bläuliche Gerste & $57.5 \quad$, & - \\
\hline & nackt & $39.5 \quad$ & - \\
\hline lordeum & hexastichum. & 48.0 & 39.6 \\
\hline
\end{tabular}

Das absolute Gewicht eines Gerstenkornes gewöhnlicher Handelsware beträgt nach Nobbe

im Mittel $40.987 \mathrm{mgr}$
" Max. 48.925 "
" Min. 27.730 "

Bei Beurteilung des Saatgutes darf auch seine Keimfähigkeit, welche sich durch die Keimprobe feststellen lässt, nicht ausser Acht gelassen werden.

Nobbe ${ }^{1}$ ) fand bei 68 untersuchten Proben eine mittlere Keimfähigkeit von 88 Proc., während das Maximum 100 Proc. und das Minimum 32 Proc. ausmachte.

Als äusseres Kennzeichen guter Keimfähigkeit wird die der Sorte charakteristische Farbe der Spelzen resp. der Fruchthaut, ein frischer, gesunder Geruch, und dic vollkommene lufttrockne Beschaffenheit des Kornes angesehen. Diese letztere Eigensehaft lässt sich in der Praxis dadurch einigermassen feststellen, dass sich bcim Hineingreifen in den Hanfen die Gerste nicht kalt anfühlen darf, vielmehr wie trockner grobkörniger Sand durch die Finger rinnen soll, was zugleich anch eine wünschenswerte Feinschaligkeit des Kornes anzeigt.

Diese vollkommene Lufttrockne, welche chemische Processe in den Körnern, sowie Pilzbildung ausschliesst und ihnen die volle Keimkraft bewahrt, lässt sich nur bei trockner Einerntung und Aufbewahrung in trocknen Räumen erreichen, da sie in feuchten binnen relativ kurzer Zcit so viel Wasser anziehen, z. B. nach Haberlandt in 31 Tagen bis zu 22.15 Proc., dass sie feucht, multrig und missfarbig werden und Pilze auftreten, deren rötliche Sporen die Samenkörner belegen. Bei näherer Untersuchung werden sich dann auch die Kcimlinge geschwächt erweisen, daran kenntlich, dåss sie blass, fahl, bräınlich oder braun gefärbt sind, oder auch dunkelgriinliche, bläuliche oder blaue Schnittflächen zeigen; solehe Körner sind jedenfalls als Saatgut zu verwerfen.

Wenn nun auch, wie Heiden ${ }^{2}$ ) nachgewiescn, Reife und Keimfähigkeit bei der Gerste nicht zusammenfallen, vielmehr letztere der

1) A. a. O. pg. 517 .

2) Heiden, Ueber die Lebensfähigkeit gekeimter und darauf getrockneter Früchte der Cerealien. Eldenaer Archiv 1861, p. 6 u. flgde. 
ersteren um ungefähr rier Wochen voraneilt, also das Korn noch grïn sein kann, so sind doch diese unvollkommen entwickelten Körner nicht als Saatgut zu benutzen, weil sie aus Mangel an Reservestoffen nur höchst kümmerliche Pflanzen erzeugen, auch eine viel längere Zeit als reife Samen zum Keimen beansprucheu.

Die Keimfähigkeit rollkommen reifer und lufttrocknel Gerstenkörner nimmt mit zunehmendem Alter immer mehr ab, und zwar keimten, wie Haberlandt nachwies, ron 100 keimfähigen Körnern nach zehn Jahren nur noch 26 Proc.

Bei sehr sorgfältiger Aufbewahrung lassen sich allerdings nach 3 und 4 Jahren noch so hohe Procentsätze keimfähig erhalten, dass die Körner ohne grosse Verlnste znr Aussaat verwandt werden können, doch empfiehlt es sich, zur Erzielnng eines gleichmässigen und kräftigen Pflanzenbestandes, nur Saatgut der letzten Ernte zu verwenden.

Die Keimfähigkeit kann aber auch durch Trocknen der Körner bei relativ hohen Temperaturen zn Grunde gehen, weshalb gedörrte nicht als Saatgut rerwendet werden sollten.

Nach Sachs ${ }^{1}$ ) biisste lufttrockene Gerste, eine Stunde lang auf $63^{\circ} \mathrm{C}$. erwärmt, ibre Keimkraft ein, während sie, mit Wasser vollgesogen, schon bei $53-54^{\circ} \mathrm{C}$. getödtet wurde.

Gegen bohe Kältegrade verhält sich dagegen das trockne Gerstenkorn vollkommen unempfindlich, während mit Wasser imbibiert, nach den Versuchen ron Haberlandt ${ }^{2}$ ), die nackte Gerste bei $-10^{\circ} \mathrm{C}$. und die bespelzte bei $-24^{\circ} \mathrm{C}$. erfriert.

In dem Saatgut lürfen sich ferner nicht zerschlagene Körner vorfinden, weil die keimlose Hälfte derselben verloren geht und die andere nur eine schwächliche Pflanze erzeugt; schliesslich soll es frei ron Unkrautsamen und anderen Vermnreinigungen sein.

Nobbe ${ }^{3}$ ) fand in 16 Proben im Mittel 0.84, im Maximum 2.20 und im Minimum 0.30 Proc. an fremden Bestandteilen.

Das Gerstenkorn keimt in Folge des Znsammenwirkens ron Wasser, Wärme und Sauerstoff und scheint die Menge des notwendigen Quellnngswassers, je nach der Beschaffenheit der Körner, starken Abweichungen zu nnterliegen, so betrug nach Heiden das Wasserquantnm bei Körnern von

1) Handbuch der Experimental-Physiologie 1865, p. 66 und Lehrbuch d. Botanik.

2) A. a. O. p. 70 .

3) Nobbe, a. a. O. p. 431. 
Hordeum distichum .

55.58 Proc.

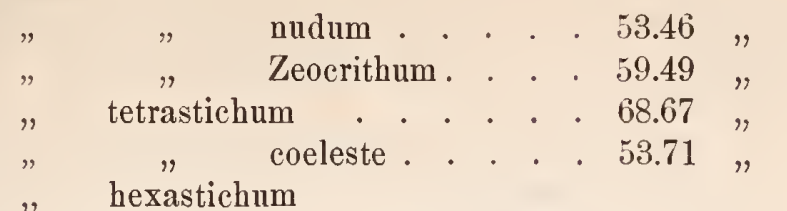

a. kurze chinesische 6 zeilige Gerste 72.45 ,

b. Gemeine 6 zeilige Gerste . . . 70.18 ,

Durchschnitt: 61.93 Proc.

Durch diese Wasseraufnahme vergrössert sich das Volumen beträchtlich, z. B. fand Payer bei einer Gewichtszunahme durch Wasser

von 5 Proc. eine Volumenzunahme von 10 Proc.

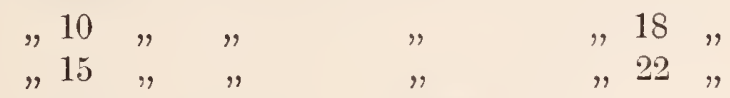

Die Keimung kann erfolgen, sobald die Wärme $3-4.5^{\circ} \mathrm{C}$. im Minimum, $28-38^{\circ} \mathrm{C}$. im Maximum beträgt, während die günstigste Keimtemperatur (das Optimum) zwischen $16-20^{\circ}$ C. liegt. Die keimende Gerste bedarf ferner einer gewissen Sauerstoffnenge, die nach de Saussure 1/10 des Gewichtes vom Samenkorn betragen soll, weshalb für ungehinderten Luftzutritt zu sorgen ist, demgemäss die Körner nicht tiefer als $2 \mathrm{~cm}$ auf schwerem Boden, $3 \mathrm{~cm}$ auf feuchtem Mittelboden, $4 \mathrm{~cm}$ auf trocknem Mittelboden und bis $7 \mathrm{~cm}$ auf leichtem Sandboden unterzubringen sind, zumal bei flacherer Unterbringung für die kräftige Entwickelung des Keimes und Bildung zahlreicher Kronenwurzeln jedem Saatkorn ein grösseres Quantum an Reservestoffen als bei tieferer Unterbringung verbleibt.

Nach 12-24 Stunden hat es sich gemeinhin auf nicht zu trocknem Boden mit dem notwendigen Quellungswasser versehen und feblen die übrigen Bedingungen nicht, so beginnt das Keimen bei einigen Körnern schon nach 1-2 Tagen und bei der grösseren Hälfte nach 3-4 Tagen. Die Zellennenbildung beim Keimen gescbieht mit Hïlfe der Reservestoffe des Endosperms, welche durch die sich bildende Diastase, nach Dubrunfa ut ${ }^{1}$ ) "Maltin" genannt, aufgelöst werdeñ, und dem Keimling zuströmen. In Folge dieser Zellenneubildung zerreisst die Samen- und Fruchthaut und tritt zunächst das Wurzelende hervor, welcher Vorgang mit, Aeugeln, Stechen oder Spitzen" bezeichnet wird, später erscheint der Blattkeim und schiebt sich zwischen Epicarpium und Mesocarpium der Fruchthaut gegen die Spitze des Kornes empor, und es treten 5-8 Würzelchen hervor.

1) Dingler, polyt. Journ. Bl. 187, p. 491. 
Der weitere Verlauf der Keimung richtet sich vornämlich nach der Bodentemperatur, z. B. erfolgte bei Sommer- und Wintergerste die Keimung mit dem ersten Sichtbarwerden des Würzelchens (Haberlandt):

$$
\begin{array}{cccccc}
\text { bei } & 4.38^{\circ} \mathrm{C} . ; & 10.25^{\circ} \mathrm{C} . ; & 15.75^{\circ} \mathrm{C} . ; & 19^{\circ} \mathrm{C} \\
\text { in } 6 \text { Tagen } & 3 & 2 & 1.75,
\end{array}
$$

und das durchschnittliche Längenwachstum des Stengelchens betrug pro Tag in $\mathrm{mm}$

$\begin{array}{cllll}\text { bei Wintergerste } & 1.35 \mathrm{~mm} & 3.20 & 7.48 & 7.85, \\ " \text { Sommergerste } 1.40, & 3.07 & 5.84 & 7.48 .\end{array}$

Hiernach lässt sich, selbst bei der relativ niederen Temperatur von $4.38^{\circ} \mathrm{C}$., ein immerhin bedeutendes Wachstum des Stengelchens, das sich allerdings mit zunehmender Wärme erheblich zu steigern vermag, nicht verkennen.

Gemeinhin erscheint das erste griine Blatt bei $12-15^{\circ} \mathrm{C}$. in 10-15 Tagen an der Oberfläche.

Mit dem Beginn der Bestockung sterben nunmehr die Keimwurzeln ab, und bilden sich als Ersatz an einem der untersten Knoten zahlreiche Kronenwurzeln aus, von denen einige wenige recht wohl Längen ron $2 \mathrm{~m}$ erreichen können.

Hierauf erfolgt nach geraumer Zeit das Schossen, und sobald die Aehre vollstïndig entwickelt ist, das Abblühen.

Nachfolgende Tabelle (Seite 653) soll die Vegetationsverhältnisse der Gerste, wie sie sich bei den hauptsächlichsten Varietäten derselben in Poppelsdorf gestalteten, zur Anschauung bringen.

Die Gerste beansprucht von allen echten Getreidearten die kürzeste Vegetationszeit und die geringsten Wärmesummen. Bialoblocki fand, dass bei genügender Feuchtigkeit das Maximum der günstigsten Bodenwärme $25^{\circ} \mathrm{C}$. beträgt, jedoch bei einer konstanten Temperatur von $10^{\circ} \mathrm{C}$. sich die Gerste rollkommen, sowie stämmig und breitblättrig entwickelt, während sie bei $30^{\circ} \mathrm{C}$. allerdings noch zur Körnerentwickelung gelangt, jedoch nur einen schwächlichen Habitus aufweist.

Da nun innerhalb ciner relativ kurzen Zeit im Mittel zu erzeugen sind:

$\begin{array}{cccc}\text { bei Wintergerste } & 4100 \mathrm{~kg} \text { Trockensubstanz pro ha, } \\ \text { " zweizeiliger Gerste } & 3200 " & " & ", \\ \text { "vierzeiliger " } & 2250 " & ",\end{array}$
so hat sie täglich recht beträchtliche Quantitäten rohen Nahrungssaftes aufzunehmen und zu verarbeiten, weshalb die Pflanzennährstoffe, da die Gerste den Flachwurzlern angehört, vorzugsweise in der Ackerkiume und zwar in leicht aufnehmbarem Zustande vorhanden sein miissen. 
Die biologischen Verhältnisse der Gerste.

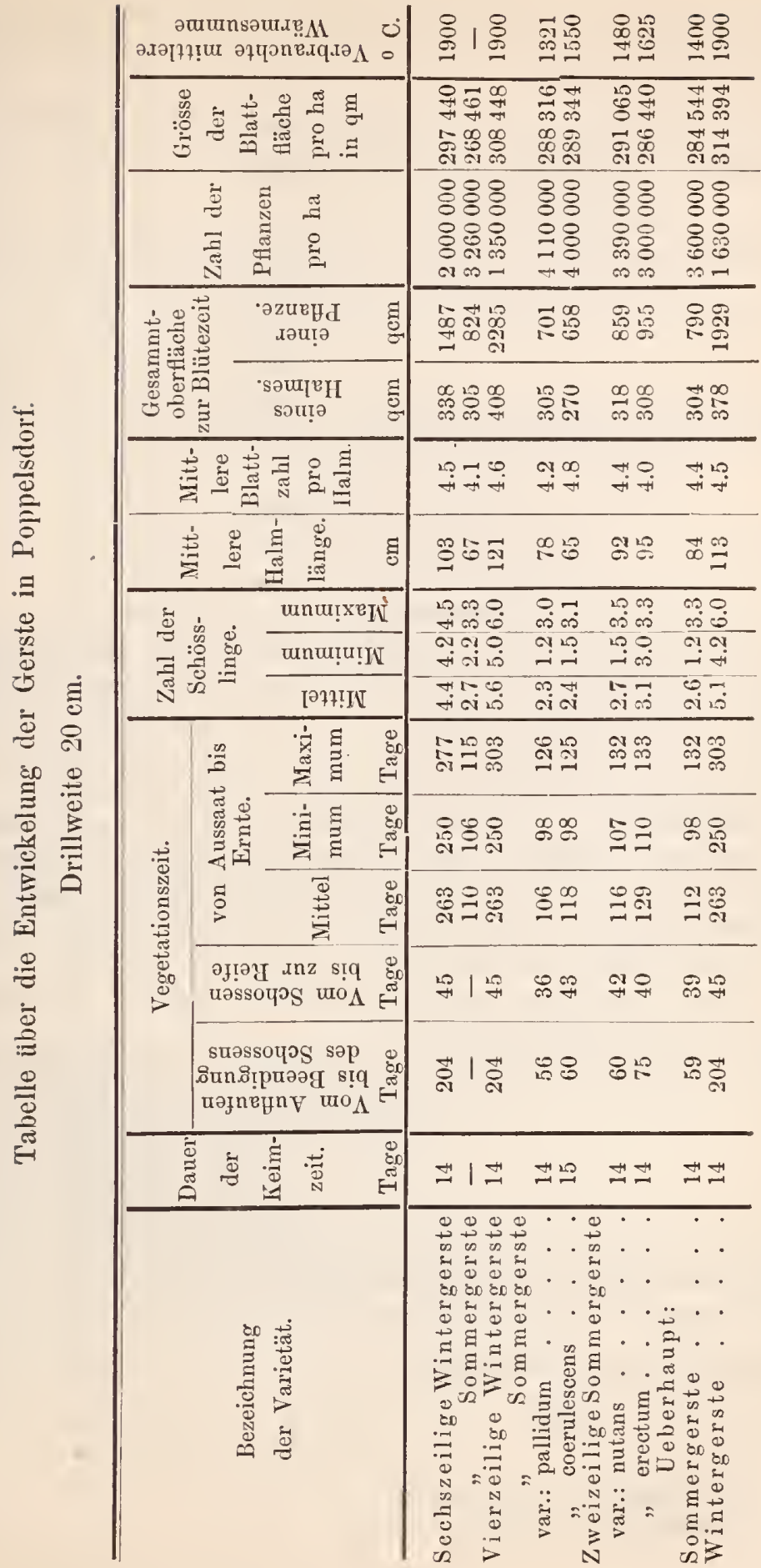


Nach Hellinegel ${ }^{1}$ ) betrug die Zahl der Wurzelfasern auf einer Fläche von $400 \mathrm{qcm}$ bei rerschiedener Tiefe und unter nachstehenden Bodenverhältnissen:

Bodenprofil $\left\{\begin{array}{l}\text { lehm. Sand } 62 \mathrm{~cm}\left\{\begin{array}{l}\text { daronAckerkrume humushaltig } 33 \mathrm{~cm} \\ \text { Untergrund humuslos }\end{array}\right. \\ \text { grober Diluvialsand. }\end{array}\right.$ auf Feld a.

auf Feld b.

bei $25 \mathrm{~cm}$ Tiefe 348 Fasern bei $25 \mathrm{~cm}$ Tiefe 615 Fasern

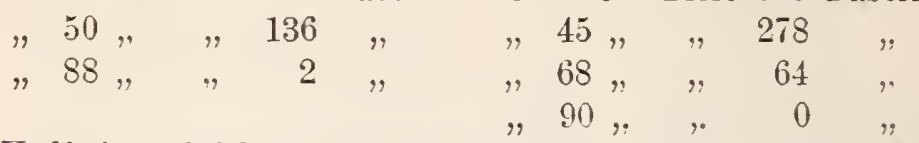

Hell riegel fiihrt auch an, dass die Gesammtlänge aller Wurzelfasern einer Gerstenpflanze im Mittel betrage, in:

Periode I, Pflanzen jung . . . . $566 \mathrm{~cm}$

$" \quad$ II, Beginn des Schossens . 1492,

$" \quad$ III, Erscheinen der Aehren . $2772,$.

" IV, Beginn des Kornansatzes 2817 "

$"$ V, Pflanzen reif . . . 2957,

Ferner hat die aufsaugende Wurzeloberfläche mit der verdunstenden Blattoberfläche in einem gewissen Verhältnis zu stehen, derart, dass je jiinger die Pflanze ist, die Wurzeloberfläche im Verhältnis zur Blattoberfläche um so grösser sein muss, weil letztere in der Jugend pro qem mehr Wasser als später rerdunstet.

Hieraus erklärt sich auch die Erscheinung, dass nach beendigter Keimung das Wachstum der Blätter nicht eher erheblich fortschreitet, bis die Wurzeln eine geniigende Ausbildung erreicht haben, ron welchem Zeitpunkt ab sich dann das Verhältnis zwischen Wurzelund Blattoberfläche nach und nach erweitert.

Diese Verhältnisse werden durch einen Versuch ron Haberlandt ${ }^{2}$ ), wie folgt, illustriert:

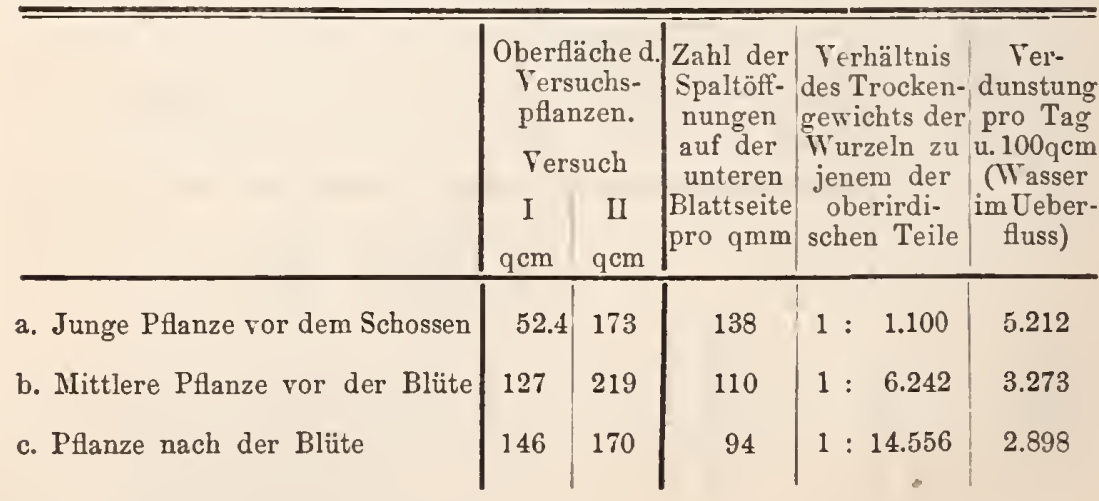

1) Grundlagen d. Ackerb. pg. 257 .

2) Landw. Jahrb. F, 1876. 
Hiernach verdunsten $100 \mathrm{qcm}$ Oberfläche im Mittel pro Tag $3.794 \mathrm{gr}$ Wasser, eine Verdunstungsgrösse, hinter welcher die der anderen echten Getreidearten zurücksteht.

Schliesslich sei noch angeführt, dass nach Hellriegel die Sommergerste zur Erzielung von $1 \mathrm{gl}$ Trockensubstanz der oberirdischen Organe $310 \mathrm{gr}$ Wasser verdunstete.

Sonst güustige Verhältnisse voransgesetzt, wächst die Gerste freudig, sobald sie einige Zeit nach der Einsaat, in der Periode des Schossens und Kornansatzes ausgiebigen Regen erhält.

Ueber den Nährstoffentzug durch eine Mittelernte geben nachfolgende Zahlen Aufschluss:

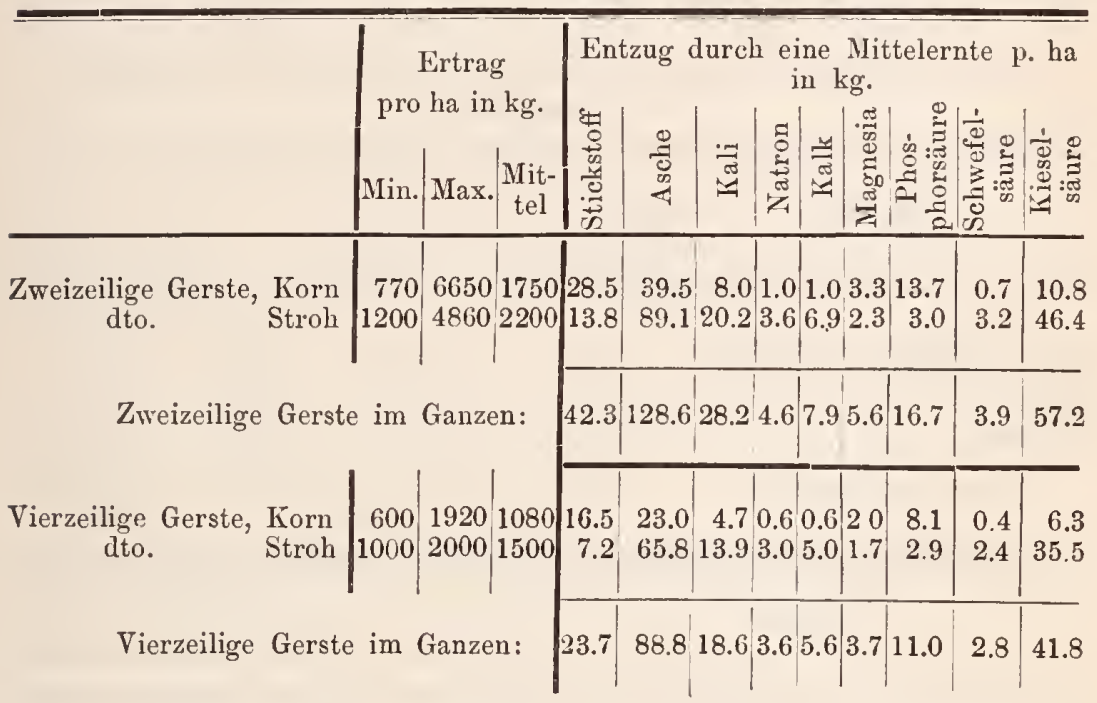

Die hierunter folgende Untersuchung von Scheven soll einen Ueberblick über die Menge und Wanderung der hauptsächlichsten Bestandteile der Pflanze während ihrer verschiedenen Entwickelungsphasen gewähren.

Die Gerste wurde in sandigem Lehmboden als zweite Frucht nach einer schwachen Düngung im Jahre 1852 gebaut, dessen Sommer sich durch viele Regentage auszeichnete. Die Untersuchung fand in vier verschiedenen Perioden statt. Das Wachstum war üppig und kräftig.

1) Chem. Ackersm. 1868, pg. 28. 
Nährstoffe in $100 \mathrm{~kg}$ der ganzen (wasserfreien) Gerstenpflanze.

\begin{tabular}{|c|c|c|c|c|}
\hline & $\begin{array}{l}1 . \\
\text { Beginn des } \\
\text { Schossens }\end{array}$ & $\begin{array}{l}2 . \\
\text { Volle Blüte }\end{array}$ & $\begin{array}{c}3 . \\
\text { Halbe Reife }\end{array}$ & $\begin{array}{l}4 . \\
\text { Volle Reife }\end{array}$ \\
\hline $\begin{array}{l}\text { Stickstoffhaltige Bestandteile } \\
\text { Stickstofffreie Extraktstoffe } \\
\text { Fett etc. } \\
\text { Rohfaser }\end{array}$ & $\begin{array}{r}19.4 \\
37.6 \\
3.4 \\
27.6\end{array}$ & $\begin{array}{r}11.0 \\
40.0 \\
3.9 \\
37.7\end{array}$ & $\begin{array}{r}8.3 \\
48.0 \\
2.0 \\
34.8 \\
\end{array}$ & $\begin{array}{r}8.2 \\
50.5 \\
1.4 \\
33.8 \\
\end{array}$ \\
\hline Summa der Nährstoffe: & 60.4 & 54.9 & 58.3 & 60.1 \\
\hline $\begin{array}{l}\text { Auf } 1 \text { ha kommen hl } \\
\text { Phosphorsäure in } 100 \mathrm{~kg} \text {. } \\
\text { Kalk in } 100 \mathrm{~kg} \text {. }\end{array}$ & $\begin{array}{l}2.1 \\
1.30 \\
0.95\end{array}$ & $\begin{array}{l}4.0 \\
0.75 \\
0.47\end{array}$ & $\begin{array}{l}6.0 \\
0.66 \\
0.33\end{array}$ & $\begin{array}{l}6.3 \\
0.70 \\
0.22\end{array}$ \\
\hline
\end{tabular}

Nährstoffe in $100 \mathrm{~kg}$ der (wasserfreien) Blätter und Stengel der Gerste.

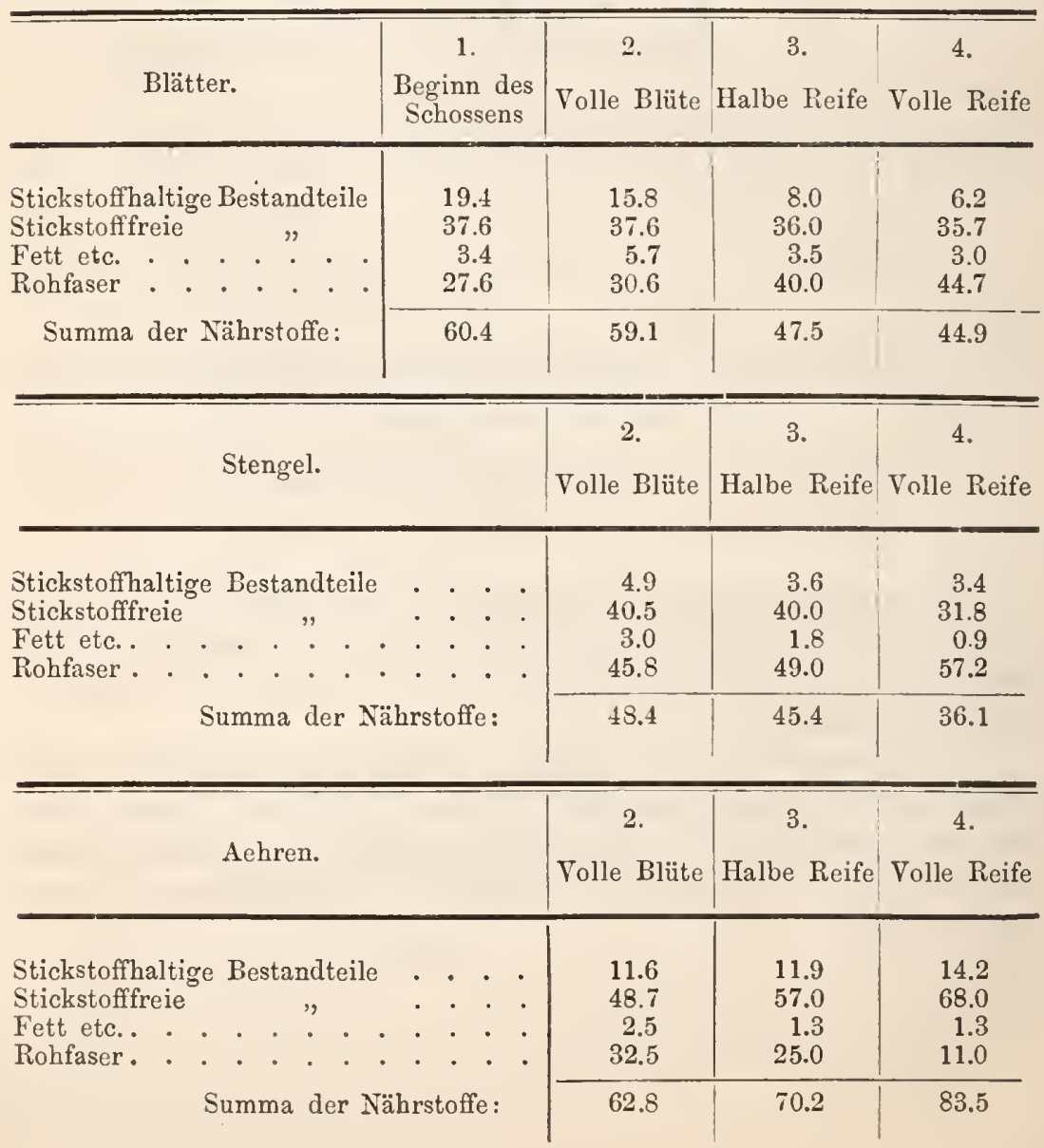


Diese Untersuehungen lehren, dass die jüngeren Blätter und Stengel reicher an Kohlehydraten, Eiweissstoffen und Salzen sind, als die älteren, und sich von der Bliite ab eine starke Auswanderung. der kornbildenden Bestandtcile nach der Aehre zu geltend macht.

Die Feinde der Gerste sind sehr zahlreich und wollen wir zunächst die Unkräuter, welche vorzugsweise den Ertrag schädigen, einer Besprechung unterzichen.

Die Hauptfeinde der Kultur der Sommergerste sind Unkräuter aus der Familie der Crueiferen und zwar auf Bruchboden, liumosem Lehm- und Thonboden der Ackersenf oder Bruchlhederich (Sinapis arvensis L.) und auf den leichteren Böden der Hederieh (Raphanus Raphanistrum L.); etwas weniger schädlieh treten das Feld-Pfennigkraut (Thlaspi arvense L.), sowie das gemeine Täselielkrant (Capsella [Thlaspi] bursa pastoris Mnch.) auf.

Diese Cruciferen entwickeln sich sehr sehnell, überwachsen daher mit ihren breiten Blättern die Gerste ungemein leielıt, entzielıen ihr Lieht und Luft, sowie die assimilationsfähigen Naihrstoffe der Ackerkrume, in Folge dessen das Wachstum der Gerste aro gesehädigt wird.

Aehnlieh verhält sich auf leiehtem Sandhoden der Feldspörgel (Spergula arvensis L.), und auf den bindigeren Lehmböden der gemeine Knötcrieh (Polygonum Persiearia L.), sowie die Saatwucherblume (Chrysanthenum segetum L.).

Die grössere Klapper (Alectorolophlıs major Rehb.) stellt sich häufig in grosser Zahl unter Gerste auf Mittelboden ein und behindert dann, da die Pflanze sehmarotzt, dureh Entnahme des rohen Nahrungssaftes aus den Wurzeln der Gerstenpflanzen deren freudige Entwickelung, weshalb dieses Unkraut durch Jäten oder Hackkultur entfernt werden sollte.

Die loekeren, leiehteren, aber in guter Dungkraft stelienden Böden werden selı häufig dureh die Queeke ('Triticum repens L.) heimgesueht, welehe der Gerste dadureh gefährlieh wird, dass sie der Ackerkrume die fertige Pflanzennahrung in grosser Menge entnimnt.

Auf den fruehtbaren Lehm- und Thonböden findet sich im milden Klima unter Gerste nicht selten der Flugliafer (Avena fatua L.) ein, wäehst mit ihr gleiehzeitig auf, und sebmälert ihr durel üppige Vegetation nicht nur den Raum, sondern nimmt aueh cinen grossen Teil der Pflanzennährstoffe für sieh in Ansprueh. Da sich dieses Unkraut im jugendliehen Alter sehwer von der Gerste unterseheiden lässt, so ist ihm dureh Jäten kaum, dagegen besser dureh Haekfruehtbau beizukommen.

Die Feldkratzdistel (Cirsium arvense Seop.) ist für Sommer- wie Winter-Gerste auf besserem Boden ein sehr unangenehmes Unkraut, 
weil sie den Boden an Pflanzennährstoffen erschöpft, dem Getreide den Platz raubt, und die Erntearbeiten, sowie das Trocknen erschwert.

Sehr nachteilig ist ferner fü die Wintergerste der gemeine Huflattich (Tussilago Farfara L.), welcher hauptsächlich im Seeklima auf fast allen nicht ganz kalkarmen Bodenarten angetroffen wird.

Auf guten Lehmböden erscheint auch nicht selten unter ITintergerste die Klatschrose (Paparer Rhoeas L.).

Was nun die Feinde der Gerste unter den Kryptogamen anbetrifft, so ist als sehr gefährlich zunächst der Fleckenrost (Puccinia straminis Fuck) herrorzuheben, welcher in feuchtwarmen Jahren oder Lagen epidemisch auftritt und Missernten erzeugen kann, indem die Gerste notreif und das Stroh bei starkem Befallensein so mürbe wird, dass es noch stehend zusammenbricht und seinen Futterwert verliert.

Weit weniger gefährlich, weil seine Verbreitung stets nur örtlich, ist der Gras- oder Streifenrost (Puccinia graminis Pers.).

Alljährlich, wenn auch selten in bedenklicher Teise, befällt die Gerste nit dem Staub-, Russ- oder Flugbrand (Ustilago Carbo Tul.), welcher dureh Zerstörung einiger Aehreu meist nur geringfügigen Schaden hervolrnft, und dasselbe ist von dem Mutterkorn (Clariceps purpurea Tul.) zu sagen.

Es ist als Präservatirmittcl gegen diesc Krankheiten vor allen Dingen die Kultur der Gerste in trockner, luftiger Lage rorzunehmen, und auf dic Vertilgung jener Unkränter, wie Lycopsis, Echium, Anchusa, Berberis zu achten, welche Träger der Aecidienform sind, wenngleich auch das Hycel ron P. straminis auf dem Wintergetreide zu iiberwintern vermag.

Dic tierischen Feinde können der Gerste ebenfalls sehr nachteilig werden, so zuweilen der Getreide-Laufkäfer (Zabrus gibbus Fabricins), dessen Larve die weichen oberirdischen Pflauzenteile zerquetscht und anssaugt, während der Käfer dic noch weichen Körner ausfrisst.

Die Larve des Saatschncllkäfers, der berüchtigte Drahtwurm (Agriotes [Elater] segetis Fabr.) frisst die jungen Wurzeln ab oder benagt den weichen Halm dicht unterhalb der Ackerkrume und zwar findet diese Schädigung bei der Wintergerste im Oktober und Norember, bei (ler Sommergerste vor Eintritt ${ }^{-}$der Bestockung statt, und kann die Verwüstung bei warmem, trocknem Wetter und auf Mittelboden grossartige Dimensionen annehmen, welche man durch Walzen der Saat, möglichst frühe Aussaat und eine Kopfdüngung von $4-5 \mathrm{hl}$ Kochsalz p. ha einzuschräinken sucht.

In Schreden soll auch ein Blattkäfer (Phyllotreta [Haltica] vittula) durch Abfressen ganz junger Pflanzenteile schädlich werden.

Die Larven der Hesscnfliege (Cecidomyia destructor Say) saugen Ende Mai bis Anfang Juni an den untersten Halmknoten die Halme 
aus, so dass diese abwelken und eingehen, wodurch bei massenhaftem Vorkommen sehr ausgedehnte Verwiistungen veranlasst werden können.

Als Gegenmittel empfiehlt sich das Verbrennen ev. das Unterpflügen der Stoppeln und später des Gerstenauflaufs.

Die im Mai und Juni fliegende Mücke des Getreideschänders (Tipula cerealis Sauter) legt ihre Eier zwischen Blattscheide und Halm dicht über den untersten Knoten ab, aus denen nach 14 Tagen die Larven auskriechen, wclche den Halm anfressen und zum Absterben bringen.

Bei grossen Verheerungen bleibt weiter nichts als das Abmähen und Verfüttern der grïnen Gerstenpflanzen übrig, wenn dem Uebel Einbalt gethan werden soll.

Auch die Larve der Kornfliegen (Chlorops taeniopus Meig. und Herpinii Guér.) schädigt durch Benagen der Aehre von oben her bis zum obersten Halmknoten. Darauf verpuppt sie sich Ende Juni in der Fressfurche und vor der Ernte erscheint die Fliege der zweiten Generation, setzt auf den Blättern der Wintersaat ihre Eier ab und die ausschlüpfende Larve dringt in die Terminalknospe ein, das Herzblatt zerstörend.

Demnach wird durch die Sommergeneration der Ertrag geschädigt und durch die Wintergeneration die Wintersaat verwiistet.

Gegen diesen Feind hilft nur Kräftigung der Saat durch Kopfduingung, Walzen, Eggen und Beweiden der Wintersaat, sowie die Vertilgung des Getreideauflaufs und der Quecke.

Aehnlich der obigen verhält sich auch die Larve der Fritfliege (Oscinis frit L.), indem sich die Larven der Sommergeneration von dem weichen Korn, die der Wintergeneration an den Terminalknospen der Wintersaat ernähren.

Die Larve von Phytomyza cinereïformis Hardy und Hydrellia griseola Fall., welche in den jungen Blättern der Gerste minieren, können bei starkem Auftreten bedeutende Verwüstungen anrichten, wie wir dies 1867 in Eldena bei Hydrellia beobachteten. Als Mittel lässt sich nur die Stärkung der Pflanzen durch stickstoffhaltigen Kopfdung empfehlen.

In neuester Zeit ist in Ungarn, Süd-Russland und Italien auch eine Wurzellaus, Schizoneura venusta Pass., an den Wurzeln saugend, gefunden worden.

\section{Klima.}

Bekanntlich erfreut sich der Anbau der Gerste unter allen Getreidearten der grössten geographischen Verbreitung, doch ergiebt 
ergiebt sich bei genauerer Betrachtung, dass die Ansprủche der einzelnen Varietäten an das Klima sehr verschiedene sind, weshalb wir die bauptsächlich angebauten Varietäten daraufhin prüfen wollen.

Von allen reicht die weisse vierzeilige Gerste (Hordeum tetrastichum pallidum) am weitesten nach den Polen hin (bis zum $700^{\circ}$ n. Br.), indem sie, dank ihrer sehr kurzen Vegetationsperiode und geringen Empfindlichkeit in ihrer Jugend gegen rauhe Witterung und Nachtfröste, in den zwar kurzen aber heissen Sommern, wenn eine passende frühreife Sorte ausgewählt wird, vollkommen ausreift. Nach Dr. Unande $\mathbf{r}^{1}$ ) wird sie um Umeå anı 30. Mai in der Regel gesäet und gegen den 25. August geerntet, so dass ihre Vegetationszeit 85-90 Tage umfasst.

Wie $\mathrm{H}$ of $f m a n n^{2}$ ) beobachtete, wächst diese Gerste noch bei einer Bodentemperatur von etwas iiber $0^{0}$ und bei einer durchschnittlichen Lufttemperatur unter $0^{\circ}$, die sich nur einmal während des Tages ein Paar Grade über $0^{0}$ erhob. Sobald die hohe Sommertemperatur eintritt, schiesst sie in den nordischen Gegenden schnell in den Halnı und reift binnen kurzer Frist, doch ist das Korn dickschalig und glasig.

In gemässigten Klima angebaut, verträgt sie wegen ihrer kurzen Vegetationsperiode Hitze und Dürre vortrefflich, leidet aber in ihrer Jugend dureh nasskalte Witterung.

Die weisse zweizeilige Gerste (Hordeum distichum nutans) verlangt dagegen bei beträchtlich längerer Vegetationsperiode (107-132 Tage), ein gemässigtes Klima, und zum gleichmässigen Verlauf der Entwickelung jederzeit cin gewisses Mass von Bodenfeuchtigkeit, auch dïrfen die Sommer weder zu kiihl noch zu nass sein, weil die Gerste dann ungleich reift, und das Korn schmächtig, glasig, dickschalig und missfarben wird, Eigenschaften, welche Braugerste, denn solche liefert sie hauptsächlich, nicht besitzen darf, deren Korn viclmehr bauchig, voll, gleich gross, im Innern weiss, mehlig, sowie feinschalig sein soll, denn je dicker die Huilse ist, um so mehr verliert mit Zunahme des Gewichtsprocentes der Spelzen die Braugerste an Wert.

Demnach werden im milderen Kontinental-Klima Deutschlands und in nicht zu nassen Jahren auch im Seeklima Dänemarks, der Niederlande und Englands gute Braugersten gedeihen.

Die Sorten der bläulichen Gerste (Hordenm tetrastichum coerulescens) finden sich in den warmen, trocknen Kilimaten, so z. B. gehören die meisten Sorten Siid-Europas, Klein-Asiens und Afrikas dieser Varietät an. Sie bleiben bei relativ langer Vegetationsperiode (118 Tage im Mittel in Poppelsdorf) kurz im Stroh, und liefern kleber-

1) Landw. Jahrb. V, 1876.

2) Jahrb. f. Agrik.-Chemie 1860-61, pg. 68 u. ff. 
reiche, sehr dickschalige Körner, welche vorzugsweise als Viehfutter dienen.

Der Wintergerste sagt am meisten das Seeklima oder feuchte Lage im Kontinentalklima der gemässigten Zone zu und steigt sie noch zu beträchtlichen Höhen an, so in der Schweiz bis zu $1700 \mathrm{~m}$ (Sprengel), wo sie lange Zeit unter dem Schnee vergraben liegt.

Die Wintergerste bestockt sich nur im Herbst und erfordert daher eine entsprechend zeitige Aussaat, weil anderenfalls der Frost der Bestockung ein zu schnelles Ende bereitet.

Ueber die Vegetationsdauer und die in derselben verbrauchte Wärmesumme liegt eine grosse Anzahl von Versuchen vor, doch ist leider nicht immer die Varietät, welche untersucht wurde, festzustellen.

Die hierunter folgende Zusammenstellung bringt die gesammte Vegetationszeit von der Aussaat bis zur Ernte und die verbrauchte Wärmesumme.

\begin{tabular}{|c|c|c|c|c|}
\hline Name der Varietät. & Beobachtungsort. & $\begin{array}{c}\text { Vege- } \\
\text { tations- } \\
\text { zeit. } \\
\text { Tage } \\
\end{array}$ & $\begin{array}{c}\text { Ver- } \\
\text { brauchte } \\
\text { Wärme- } \\
\text { summe. } \\
0 \mathrm{C} .\end{array}$ & $\begin{array}{c}\text { Name des } \\
\text { Beobachters. }\end{array}$ \\
\hline $\begin{array}{c}\text { Ne uere Beobach- } \\
\text { tung. } \\
\text { Vierzeilige Gerste. } \\
\text { (H. t. pallidum) } \\
\text { ", } \\
\text { ", } \\
\text { ", } \\
\text { ", } \\
\text { ", } \\
\text { H. t. coerulescens } \\
\text { Zweizeilige Gerste. } \\
\text { (H. dist. nutans) } \\
\text { " , erectum }\end{array}$ & \begin{tabular}{|c|} 
Freysing \\
Regensburg \\
Elsass \\
Alais \\
Mülhausen \\
Kingston \\
Cumbal \\
Santa Fé de Bogota \\
A egypten \\
Upsala \\
Bechelbronn \\
Reval \\
Mauen, Ostpr. \\
Proskau \\
Zabikowo (Posen) \\
Eldena \\
Berlin \\
Göttingen \\
Poppelsdorf \\
München \\
Verrières, Paris \\
Montpellier \\
Rothamsted \\
Poppelsdorf \\
do. \\
do.
\end{tabular} & $\begin{array}{l}100 \\
- \\
\overline{-} \\
\overline{92} \\
168 \\
122 \\
\overline{-} \\
\overline{92} \\
\\
90 \\
97 \\
85 \\
95.5 \\
96.5 \\
96 \\
97.2 \\
106 \\
90.5 \\
96 \\
85 \\
127.5 \\
118 \\
116 \\
129\end{array}$ & $\begin{array}{l}1725 \\
1525 \\
1710 \\
1795 \\
1790 \\
1738 \\
1798 \\
1793 \\
1890 \\
1589 \\
1748 \\
1288 \\
1604 \\
1321 \\
1329 \\
1353 \\
1174 \\
1303 \\
1321 \\
1593 \\
1519 \\
1642 \\
1585 \\
1550 \\
1480 \\
1625\end{array}$ & 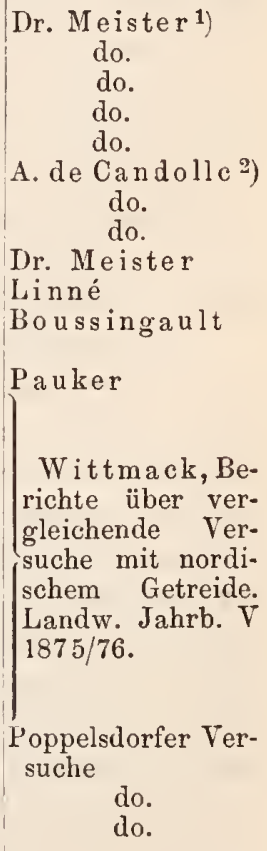 \\
\hline
\end{tabular}

1) Flora No. 401819 , p. 625 u. 628.

2) Géogr. bot. Bd. 2, p. 51 u. 52. 
Ueberhaupt verlangt:

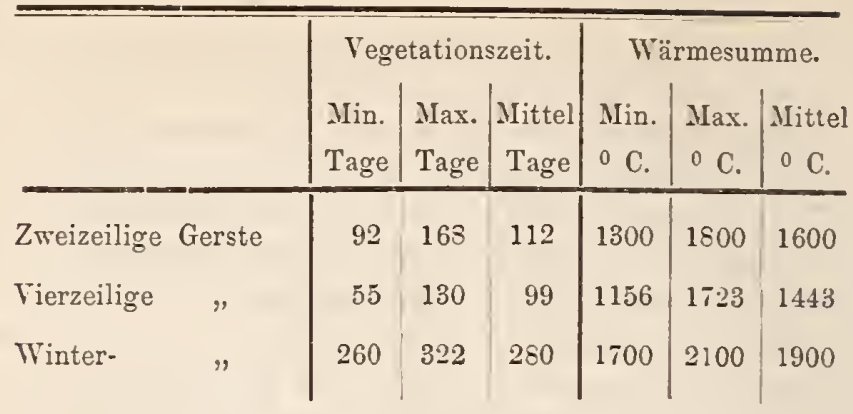

\section{Boden.}

Im Allgemeinen gedeiht die Gerste auf kulturlosem Boden nicht, da sie in Folge ihrer kurzen Vegetationsperiode leicht aufnahmefähige Nährstoffe in der Ackerkrume finden muss; ebenso kümmert sie auf den undurchlassenden, schweren, sowie auf den eisenschüssigen Böden, den reinen Sand, nicht entsäuerten Humus- und Haideböden.

Leichtere Böden, z. B. der lehmige Sand, renn nicht ganz kulturlos, eignen sich noch für die kleine weisse vierzeilige Gerste; die bläuliche Gerste nimmt mit weniger kulturvollen Böden, wie sie die extensive Kultur der warmen Zonen mit sich bringt, vorlieb, sobald dieselben einer gewissen Bindigkeit, wie sie kalkreichen Lehmböden eigentuimlich, nicht entraten.

Die zweizeilige Gerste stellt die höchsten Ansprüche an die Bodenbeschaffenheit, namentlich sobald es sich um die Produktion ron Braugerste handelt, denn diese fordert einen in alter Kraft befindlichen, nicht zu leichten Boden und wird der beste Gerstenboden die Eigenschaften des geborenen Rübenbodens zeigen. Diese Böden zeichnen sich durch einen milden, humosen Lehm in der Ackerkrume mit einer darunter stehenden Lehm- oder Nergelschicht, auf welche eine durchlassende Sandlage folgt, aus. Es sind dies also keineswegs schwere, sondern sichere, leicht ackerbare, aber rermöge ihres Lehm-, Kalk- und Humusgehaltes hohc Absorptionsfähigkeit besitzende Böden, welche grosse Mengen an Pflanzennälirstoffen fixieren und der Pflanze anch physikalisch einen höchst güinstigen Standort bieten. Aber auch humose sandige Lehmböden liefern bei geeigneter Kultur nach Qualität und Quantität rortreffliche Erträge.

Ein Haupterfordernis des guten Gerstenbodens ist ein gewisser Grad ron Durchlässigkeit seines Untergrundes, demn feuchte, kalte 
Aecker lassen sich nicht rechtzeitig bestellen, werden bei Dürre leicht rissig, worunter die Entwickelung nicht nur der jungen Pflänzchen leidet, sondern es wird auch das Korn weniger voll, stärkereich und feinschalig. Durch Drainage lassen sich solche Felder häufig gerstenfähig machen.

Die Wintergerste verträgt einen leichten Boden noch relativ gut, da sie von der Winterfeuchtigkeit profitiert und von dem Regenfall des Sommers, da sie zeitig reift, weniger abhängig als Sonmergerste ist, doch verlangt sie ebenfalls einen erheblichen Reichtum an Pflanzennährstoffen, wenn sie hohe Erträige bringen soll.

Demnach empfiehlt es sich, dic Gerste auf folgenden Bodenarten zu kultivieren:

1) Reicher, tiefer, milder Thon- und Aueboden; Weizenboden I. Kl. Dieser Boden bringt hohe Erträge nnd vorzïgliche Kornqualität.

2) Humoser, reicher, milder Lehmboden; Gerstenboden I. Kl.

Für Gerste auf's Vorzüglichste geeignet.

3) Milder, ticfer, mergliger, frischer Lehm und sandiger Lehm; Gerstenboden II. Kl.

Bei relativ geringen Stroherträgen stellt sich der Kornertrag nach Quantitait und Qualitait hoch.

4) Milder, thoniger oder lehmiger Humus- und Aueboden.

Stroherträge hoch, doch Kornerträge quantitativ und qualitativ wenig befriedigend.

5) Leichter, sandiger Lehm und lehmiger Sand; Roggenboden I. Kl.

Bei Kultur und Mergelung noch für kleinc, vierzeilige Gerste gut geeignet.

\section{Dïngung.}

Der Düngungszustand der Ackerkrume beeinflusst bei der Gerstenkultur sehr wesentlich die Quantität und Qualität der Ernte, namentlich der Braugerste, welche volle, dünnschalige, an Kohlehydraten also an Extrakt reiche, sowie möglichst glcichmässig ausgncreifte Körner, die voraussichtlich auch gleichmässig keimen, liefern soll. Eine solche Ernte lässt sich nur auf einem in alter Kraft stehenden Boden erzielen, weleher mit leicht aufnahmefähigen und schr gleichmässig rerteilten Pflanzennährstoffen erfülit ist, deren die Gerste bei ihrem schnellen Wachstum und ihrer verhältnismässig geringen Wurzel- und Blattentwickelung zur Produktion möglichst vollkommener Körner bedarf. 
Diese alte Kraft kann durch eine frische Stallmistdungung nicht ersetzt werden, denn letztcre lässt eine gleichmässige, feine Verteilung der Nährstoffe nicht zu, zcrsetzt sich ungleichmässig und führt der regeticrenden Pflanze die Nährstoffe erst zu, wenn ihr Wachstum auf der Höhe der Entwickelung angelangt ist. Die Folge hiervon wird ein ungleiches Ausreifen und die Verlängerung der Vegetationsperiode sein, wodurch sich die Blattentwickelung kräftiger gestaltet, während die Körnerernte quantitativ und qualitativ vermindert wird; auch lagert die Gerste leichter und nicht selten gelangen auch Unkrautsamen mit in den Acker.

Von allen Stalldüngern wirkt Schafmist am nachteiligsten, weil sichı nach ihm die Körner sehr ungleich entwickeln, eine dunkle Farbe und dicke Schale, sowie einen in Verhältnis zu den Kohlehydraten zu hohen Eiweissgehalt aufweisen.

Weit geeigneter zur Düngung ist dagegen verrotteter Rindriehmist, der kcine crhebliche Gärung im Boden melır durchzumachen hat, namentlich, sobald derselbe schon im Herbst untergebracht wird, also die Bodenpartikelchen Gelegenheit erhalten, sich nach Möglichkeit mit fertigen Pflanzennährstoffen zu rersehen.

Den Volzug rerdienen jedoch unzweifelhaft leicht assimilierbare, sich gleichmässig und schnell im Boden verteilende Dünger, und empfiehlt sich für leichtere Böden hinreichend zersetzter, aus menschlichen und tierischen Excrementen, Kalk ete. bereiteter Kompost, der reich an fertiger Pflanzennahrung ist.

Nicht minder zusagend ist auch eine im Herbst gegebene schwache Pferchdiingung.

Vorzüglich wirken auch Kunstdünger, namentlich wenn sie als Kopflünger einer schwächlichen Saat aufhelfen sollen, doch darf gerade bei ihrer Verwendung nicht ausser Acht gelassen werden, dass die Gerste, bei verhältnismässig kurzer Vegetationszeit, schon im ersten Drittel derselben den grössten Teil der Nährstoffe, welche der Boden liefert, aufnimmt, also in dieser Zeit für reichliche Nahrung zu sorgen ist, wenn die Düngung erfolgreich sein soll.

Als Stickstoffdiunger steht der Chilisalpeter in erster Linic, weil er den Pflanzen zunächst den Stickstoff in der zusagendsten Form liefert, wie dies aus Versuchen mit kleiner Gerste in Dahme ${ }^{1}$ ) herrorzugehen scheint, denn es ergab sich, dass Nitrate die vorzüglichste Wirkung zeigten, während z. B. saures, phosphorsaures Ammon, wenn die Zeit und die Bedingungen zur Nitrification nicht vorhanden sind, die am wenigsten geeignete Verbindungsform des Stickstoffs ist, also als Kopfdiungung nicht rerwandt werden sollte.

Ferner ubertrifft den Chilisalpeter kein anderes Düngemittel an

1) Dr. Hässelbarth, Landw. Versuchsst. p. 394. XX 1877 u. XXI 1878. 
Schnelligkeit und Intensität der Wirkung, daher er ein echter Friihjahrsdünger ist, welcher den Pflanzen den zum kräftigen Gedeihen und zur leichteren Ueberwindung der Fïhlichkeiten des späteren Wachsthums so nötigen Stickstoff liefert, denn bei Mangel an demselben bleibt die Gerste kicin, reift vorzeitig und bringt nul geringen Ertrag und schmächtige Körner. Seine Anwendung hat jedoch vorsichtig zu geschehen, damit nicht Lagerfrucht entsteht, zumal die Bestimmung der Quantität auf Schwicrigkeiten stösst, z. B. kann dieselbe Quantität bei guinstiger Witterung zu gross, bei ungïnstiger zu klein sein, und wird man sich am besten nach dem Düngungszustande des Feldes und dem Stande der Saat richten. Meist gibt man auf stickstoffarmen Böden 100-160 kg. Chilisalpeter p. ha.

Im Allgemeinen empfiehlt es sich, den Chilisalpeter erst beim Eintritt lebhafterer Vegetation, wenn die Gerstenpflanzen drei Blätter getrieben haben und die Bildnng der nächsten zwei Blätter nahe bevorsteht, möglichst zerkleinert, recht gleichmässig zu verteilen.

Soll jedoch bei einer reichen Stickstoffdingung nicht die Körnerbildung benachteiligt werden, so fügt man dem Chilisalpeter auf phosphorsäurearmem Boden noch hochgradige superphosphate mit leicht löslicher Phosplırsäure bei, denn die Phosphorsäure drängt auf Samenbildung und gute Kornqualität hin, und hebt demnach bei etwa zu stark gegriffencr Stickstoffdüngung die nachieiligen Folgen derselben einigermassen auf; es genügen hierzu 100-200 kg superphosphat p. ha.

Ist eine Kopfdüngung nicht erwiinscht, dann können im Herbst Knochenmehl und Superphosphat, im Frülijahr Peruguano in Verbindung mit Superphosphaten. oder aufgeschlossener Guano mit Anmoniak-Superpliaten in Quantitäten ron $290-300 \mathrm{~kg}$ p. ha eingestreut und entweder untergepfliigt, eingekrümmert oder nur cingeegogt werden.

\section{Fruchtfolge.}

Die Gerste, nnd am meisten die Brangerste, beansprucht einen mürben, reichlich mit fertiger Pflanzennahrung versehenen, unkrautfreien Standort, weshalb gut gediingte und rationell kultivierte Hackfrïchte anch die vortrefflichsten Vorfriichte sind; doch weichen sie in soferu von einander ab, als diejenigen unter ihnen, welche dem Acker die anfuahmefühigen Nährstoffe mit grosser Energie entziehen, wie die Brach- und Mohrrüben, sich weniger gut als die Runkelriiben, namentliclı aber die Kartoffeln und Kohlriben zur Vorfiucht eignen. 
Auf deu guten Gerstenböden ist auch gediingter Wiuterweizen, doch besser Winterroggen, oder auch Dinkel eine gute Vorfrucht.

Jede andere Stellung der Gerste in der Fruchtfolge ist unsicherer und teurer.

Hervorzuheben wäre noch, dass niemals vor ihrer Kultur Stoppelriiben gebaut werden diurfen. da diese den Boden an den leicht aufnehmbaren Nährstoffen derart erschöpfen, dass die Gerste nach ihnen hohe Erträge nicht aufzubringen vermag.

Für die Wintergerste sind Grünfutter, Inkarnatklee, Raps etc. geeignete Vorfriichte.

Im Allgemeinen erschöpft die Gerste den Boden an Pflanzennährstoffen in weit lıöherem Grade als Wintergetreide und lässt von allen Halm- und Blattfiüchten auch die geringsten Mengen an Stoppelund Wurzelrückständen zuriick, so dass sie als sehr schlechte Vorfrucht, namentlich fiir anderes Halmgetreide angesehen wird.

Nach unsereu in Proskau angestellten Untersuchungen blieben auf sandigem Lehmboden bei normal stehender zweizeiliger Gerste bis zur Tiefe ron $26 \mathrm{~cm}$ an Stoppel- und Wurzelrückstainden p. ha zurück:

$2-26.9 \mathrm{~kg}$ Trockensubstanz, $25.7 \mathrm{~kg}$ Stickstoff, $425.1 \mathrm{~kg}$ Asche und darin an $13.5 \mathrm{~kg}$ Phosphorsäure, $10.9 \mathrm{~kg}$ Kali, $47.4 \mathrm{~kg}$ Kalk, $6.2 \mathrm{~kg}$ Magnesia, $6.2 \mathrm{~kg}$ Schwefelsänre und $3.9 \mathrm{~kg}$ Natron.

Aus diesen Griinden folgt nach Gerste am besten eine stark gediingte Hackfrucht oder auf gutem Boden Rotklee, doch ist zu beachten, dass auf schr reichem Boden die zweizeilige Gerste leicht lagert und ein Knie macht, d. h. das unterste Interuodium legt sich dicht an cien Boden, so dass z. B. cingesäeter Rotklee darunter leicht ersticken kaun.

\section{Bodenbearbeitung.}

Die Gerste rerlangt einen mürben, unkrautfreien Acker, weshalb man die Pflugfurchen gern vor Winter gibt. Denuzufolge wird nach Hackfrüchten noch im Herbst die Ackerkrume bis zur rollen Tiefe gepflïgt, wïhrend nach Getreide sofort nach der Ernte die Stoppeln flach umgebrochen, später nach dem Auflaufen des Uukrautes geeggt und kurz vor dem Einfrieren eine zweite tiefe Furche gegeben wird.

Der Acker bleibt nun, nit zweckmässig gezogenen Wasserfurchen rersehen, uber Winter in rauler Furche liegen, um nach dem Abtrockuen im Friilujahr zunächst geeggt und darauf am besten über Kreuz gegrubbert zu werden. 
Hierdurch erfaihrt dersclbe nicht nur eine vortreffliche Lockerung, sondern es werden auch die Wurzelunkräuter an die Oberfläche geebracht, während die in den tieferen Bodenschichten ruhenden Unkrautsamen dort verbleiben, also nicht zum Anskeimen gelangen.

Ausserdem bewahrt der Acker seine zum schnellen und gleichmässigen Auskeimen der Samenkörner notwendige Feuchtigkeit und die Bestellung kann zeitiger als nach einer im Frühjahr gegebencn Pflugfurche geschehen.

Kurz vor der Einsaat wird dann glatt geeggt und ev. gewalzt.

Zur Wintergerste empfiehlt sich entweder cine Brachbearbeitung, oder es wird nach rechtzeitig abgeernteten Vorfrichten dic Stoppel umgebrochen, nach dem Auflaufen des Unkrautes der Acker abgceggt und kurz vor der Einsaat eine tiefe Saatfurche gegeben.

\section{Anssaat.}

Die Aussaatzeit richtet sich im Allgemeincn nach den Wärmezonen oder der Höhenlage des Landes, demgemäss für die wärmere, gemässigte Zonc $\left(34-45^{0} \mathrm{n}\right.$. und $\mathrm{s} . \mathrm{Br}$.), in welcher vorwiegend bliuliche Gerste gebaut wird, die zweckmässige Aussaatzeit in den Herbst und nur in höheren Gebirgslagen in das Frülijahr fällt, wählıend in der kälteren, gemässigten Zone $\left(45-58^{\circ} \mathrm{n}\right.$. und s. Br.) die zwveizcilige Gerste, seltener die vierzeilige Sommergerste gebaut und bei Temperaturen zwischen $3.5-9^{\circ} \mathrm{C}$. von Mitte März bis Mitte Mai und die vierzeilige Wintergerste bei $10.5-16.5^{\circ} \mathrm{C}$. von Ende August bis Ende September ausgesäet wird. In der subarktischen Zone $\left(58-66^{\circ} \mathrm{n}\right.$. Br.) gelangt die vierzeilige gemeine Sommergerste gemeinhin erst in den letzten Tagen des Mai zur Aussaat.

Innerhalb dieser Zonen hängt aber die zeitigere oder spätere Aussaatzeit wiederum von mancherlei Umständen ab.

Jedenfalls hat bezïglich der Braugerste der Grundsatz zu gciten, die Einsaat möglichst zeitig zu bewirken, weil dann die Gerste weniger in's Stroh, also stämmiger wächst, weniger leicht lagert und bei höherem Kornertrage auch eine bessere Kornqualität als spät gesäete in Aussicht stellt; doch auch die vierzeilige Gerste gedeiht bei frïher Aussaat besser, wird aber durch späte Aussaat bei ihrer kürzeren Vegetationsperiode und ihrem geringeren Wasserbediurfnis weniger leicht geschädigt.

Nachtfröste, welche die Gerste in nicht zu feuchton Lagen treffen, schaden ihr, zumal wenn sie schon das dritte Blatt entwickelt hat, weit weniger als dem Hafer, nur dadurch, dass ihre Blattspitzen er- 
frieren, wird sie in der Vegetation etwas zurückgehalten; doch rerhält sie sich ganz anders, sobald sie auf feuchtem, zu bindigem Boden längere Zeit einer kalten Witterung ausgesetzt ist, in diesem Fall färbt sie sich gelb, kümmert, und dieser nachteilige Einfluss in der Jugend gelangt auch später durch geringeren Ernteertrag zum Ausdruck.

Vorausgesetzt, dass der Boden vollständig zur Aufnahme der Saat vorbereitet und die Witterung die Aussaat erlaubt, wird dieselbe um so zeitiger erfolgen, je leichter der Boden ist, damit die Gerste noch ron der Winterfeuchtigkeit Vorteil ziehen kann. Doch hat als Regel zu gelten, niemals die Gerste einzuschmieren, sondern das Abtrocknen des Bodens abzuwarten, denn das Samenkorn umgibt sich leicht mit einer fiur den Sauerstoff undurchdringlichen Kruste, und weil mit Wasser imbibiert, fault es aus Mangel an Sauerstoff leicht. Ebenso wird das Herrorspriessen der zarten Blättchen durch die Krustenbildung behindert.

Die Feststellung des zur Erzielung einer nach Quantität und Qualität befriedigenden Ernte notwendigen Saatquantums ist im konkreten Falle je nach der Beschaffenheit des Klimas und Bodens, sowie nach der Art der Kultur, der Grösse der Saatkörner ete. zu treffen und können hierítir Recepte nicht gegeben werden; doch ist als leitender Grundsatz festzuhalten, sich namentlich nicht bei der Braugerste auf das Bestocken zu verlassen, sondern von vornherein das Saatquantum so hoch zu greifen, dass auch ohne starke Bestockung ein gentigend dichter Bestand erzielt wird, weil solche. Pflanzen gleichmässiger wachsen und reifen, auch durchschnittlich vollkommenere Körner als dïun stehende liefern, die sich allerdings stärker bestocken, deren secundäre Schösslinge sich aber ungleichmässiger entwickeln, wodurch bei ungünstiger Frühjahrswitterung leicht Zweischürigkeit entsteht.

Im Allgemeinen ist das Saatquantum, je nach der Bodenkraft, den klimatischen Verhältnissen, der Kulturart, der Grösse des Saatkorns, dem Habitus und der Bestockungsfähigkeit der Sorte ete. beträchtlichen Schwankungen unterworfen.

In welchem hohen Grade diese letzteren Faktoren das Saatquantum beeinflussen können, soll in der nachfolgenden Saattabelle (S. 669) zum Ausdruck gebracht werden.

Das in Poppelsdorf auf $20 \mathrm{~cm}$ Drillwcite ausgesäete Saatquantum erscheint im Allgemeinen etwas hoch gegriflen, doch ist daranzu erinnern, dass nur Samenkörver von schr hohem absoluten Gewicht Verwendung gefunden haben.

Zur Vergleichung diene nachfolgende Zusammenstellung der Saatquanta, welche von älteren Autoren herrühren, so gibt Tha er 2.5-3 hl, Schwerz $3-3.9$ hl, Koppe $2.7-3.4$ hl, Burger $2.5-3 \mathrm{hl}$, 


\begin{tabular}{|c|c|c|c|c|}
\hline \multirow{2}{*}{ 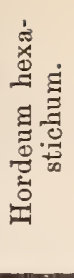 } & 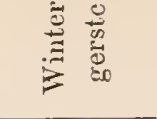 & स⿻ & $\stackrel{\oplus}{-i} \vec{i}$ & $\stackrel{\mathrm{ci}}{\mathrm{S}} \mathrm{i}$ \\
\hline & 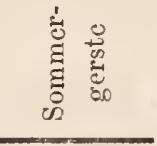 & 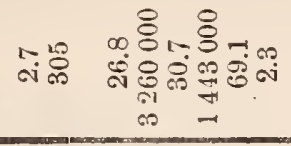 & के & $\stackrel{\text { in }}{*}$ \\
\hline \multirow{4}{*}{ 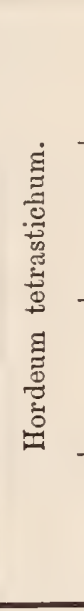 } & 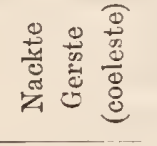 & ↔i & $\begin{array}{l}\text { कृco } \\
\text { जi के }\end{array}$ & 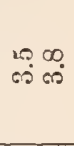 \\
\hline & 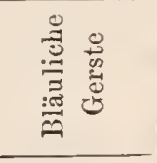 & 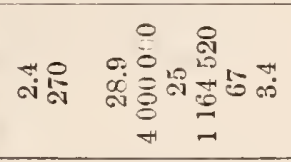 & ث̊. & \begin{tabular}{c}
$\infty$ \\
\hdashline \\
\hdashline
\end{tabular} \\
\hline & 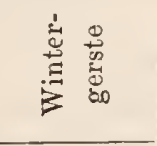 & 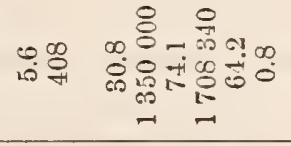 & 윰 & $\stackrel{\leftrightarrow}{-\infty}$ \\
\hline & 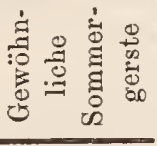 & 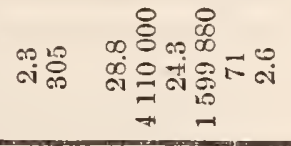 & 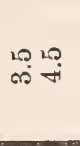 & 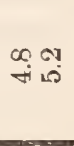 \\
\hline \multirow{3}{*}{ 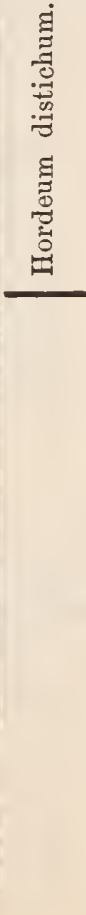 } & 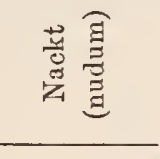 & 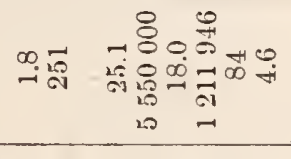 & $\begin{array}{l}\text { No } \\
\omega \infty \\
\infty\end{array}$ & $\begin{array}{ll}5 . \\
\infty\end{array}$ \\
\hline & 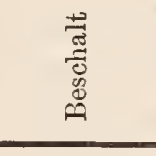 & 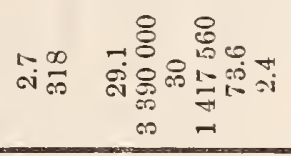 & 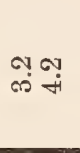 & 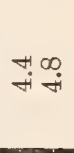 \\
\hline & & 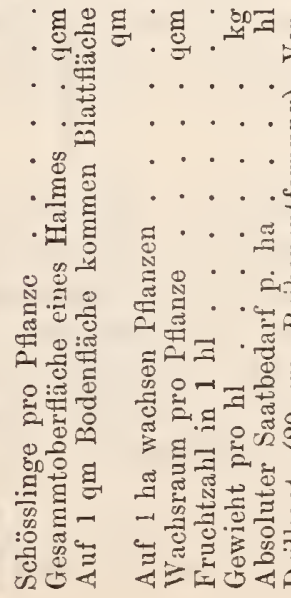 & 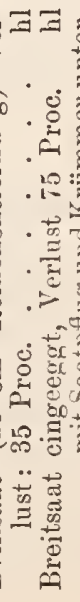 & 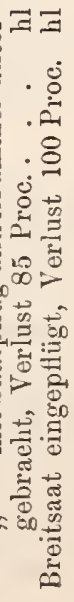 \\
\hline
\end{tabular}


Block 1.9-3 hl, Hlubek 3-3.7 hl, Schmalz 2.5-2.7 hl und Sprengel $3.3-3.4$ hl bei breitwürfiger Aussaat als anzuwendende Saatquanta pro ha an. Für England berechnet sich die Saatmenge nach A. Young auf 2.7, 3.6-4.8 hl p. ha, und nach Heuzé in Frankreich auf reichem Boden auf $2.5-3 \mathrm{hl}$, auf weniger gutem Boden auf 3.5-4 hl p: ha.

Von den Kulturarten verdient die Reihensaat, zumal für Braugerste, den Vorzug, denn bei verhältnismässig geringem Saatquantum fällt der Korn- und nicht selten anch der Strohertrag höher und die Kornqualitiit besser als bei Breitsaat ans. Ferner lagert die Gerstc weniger leicht, und zur Verkrustung neigende, oder rerunkrautete Aecker lassen sich bei genügender Reihenweite mit Hülfe der Hackkultnr in einer dem Gedeihen der Gerste günstigeren Beschaffenheit erhalten.

Noch grösserc Vorzuige würde die Dibbelsaat aufweisen, wenn nicht die Kulturkosten zu hoch wären, weshalb sie nur zur Erzeuzeugung von Saatgut Beachtung verdient.

Wie sich die Breit-, Drill- und Dibbelsaat betreffs ihrer Erträge zu einander verhalten, zeigen die im Jahre 1871 durch Wolln $y^{1}$ ) vorgenommenen Versuche mit Annat-Gerste.

Versuch von Wollny.

\begin{tabular}{l|c|c|c|c|c|c} 
& $\begin{array}{c}\text { Reihen- } \\
\text { ent- } \\
\text { fernung. }\end{array}$ & $\begin{array}{c}\text { Aussaat- } \\
\text { quantum. }\end{array}$ & \multicolumn{3}{|c|}{ Ernte pro ha in $\mathrm{kg}}$. \\
\hline
\end{tabular}

Die Entfernuug der Drillreihen richtet sich nun nicht allein nach den die Vegetation beeinflussenden Faktoren, sondern auch darnach, ob während der Vegetationszeit eine Bearbeitung stattfinden soll oder nicht, denn die Pferdehacke arbeitet erst bei einer Reihenweite von $16 \mathrm{~cm}$. Im Allgemeinen schwanken die Drillweiten zwischen 8 und $28 \mathrm{~cm}$ und werden namentlich solche von $24-28 \mathrm{~cm}$ häufig in England angetroffen.

1) Journ. f. Landw. 1881, pg. 493 ff. 
Von grosser Wichtigkeit ist es jedoch, im konkreten Fall durch kleine Versuche die passendsten Drillweiten festzustellen, weil durch letztere die Höhe der Erträge bedeutend bceinflusst werden kann, wie z. B. nachfolgender Versuch mit Chevalier-Gerste, von uns auf sandigem Lehmboden in Eldena ausgeführt, beweist:

Ertrag pro ba an:

$\begin{array}{ccccc} & & \text { Korn } & \text { Stroh } & \text { Spreu } \\ \text { Drillweite } & 26 \mathrm{~cm} & 2128 \mathrm{~kg} & 2908 \mathrm{~kg} & 472 \mathrm{~kg} \\ " & 18 & 2156, & 2424, & 400 " \\ " & 13, & 2344, & 3080 " & 440 ",\end{array}$

Vor dem Eindrillen ist der Acker durch Glatteggen resp. Walzen vollständig zur Saat herzurichten, so dass nur auf den bindigeren Böden durch Eggen mit leichten schottischen oder Zickzack-Eggen quer iiber die Drillreihen letztere besser geschlossen werden; auf sehr leichtem Boden walzt man nach der Einsaat gern mit kannelierten oder Ringelwalzen, damit die Fläche raul licgt, also weniger leicht durch starken Regen verschwemmt, noch durch Wind der Sand verweht werden kann.

Die Breitsaat geschieht am vorteilhaftesten und gleichmässigsten mit der Säemaschine, auch ist die Anssant anf die rauhe Furche zu vermeiden, weil sich nur in diesem Falle die Tiefe der Unterbringung cinigermassen gleichmässig gestaltet.

Auf feuchterem Boden bringt man das Saatkorn mit Hülfe der Egge, anf trocknerem durch Krümmereggen oder Saatpflüge unter, während gewöhnliche Pflïge zu vermeiden sind, da deren Tiefgang: nicht genügend gleichmässig ist, auch durch dieselben die Arbeit verteuert wird.

In allen diesen Fällen sollte jedoch das Fertigeggen erst stattfinden, nachdem die Gerste ihre Wurzcln einige Centimeter lang hervorgetrieben hat und der Graskeim die Schale durchbricht, weil dann durch nochmaliges Eggen das aufgelaufene Unkraut vertilgt und eine etwa vorhandene Kruste gebrochen wird.

\section{Pflege.}

Nacbdem die junge Pflanze die Länge eines Fingerss erreicht hat, walzt man noch einmal mit kannelierten oder Ringelwalzen. Hierdnrch zerstört man eine etwa gebildete Kruste, erschliesst also den Boden der Einwirkung der Atmosphäre und zertrümmert die 
Schollen. Ferner wird auch der Haupttrieb der Pfianzen ctras gequetscht und hierdurch in der Entwickelung ein wenig zurückgehalten, daher die Nebensprossen zur kräftigeren Entwickelung Zeit gewinnen und demzufolge eher gleichzcitig mit dem Haupttrieb reifen.

Läuft nach dem Walzen noch viel Unkraut, z. B. Hederich, auf, so ist dasselbe bei breitwiirfiger Saat vor dem Erscheinen der Aehren entweder mit der Hand oder mit der Jätemaschine za entfernen, und gelangt letztere zur Anwendung, sobald der Hederich die Gerste uiberragt.

Bei der Drillkultur und hinreichend weiten Drillreilsen hackt man mit der Pferdehacke, was sich bei dem schnellen Wachstum der Gerste meist nur einmal ausfïhren lïsst.

Durch kalte regnerische Witterung kränkelt die junge Gerstenpflanze sehr leicht und ninmt eine gelbe Färbung an; es ist dann an der Zeit durch kleine Quantitäten Chilisalpeter als Kopfdung ilır Wachstum zu unterstuitzen.

Einem zu iippigen Wuchs, der Lagerkorn befuirchten lässt, tritt man am besten durch rechtzeitiges Schröpfen entgegen.

Die Gerste und vor'unsweise die ron allen Getreidearten am zeitigsten reifende Wintergerste leidet, und zwar hauptsächlich in der Nähe der Gehöfte, bäufig sehr stark durch Sperlingsf́rass, weshalb man sich durch Vertilgen der Sperlinge und Ablaltung derselben durch Schiessen möglichst dieser ungebetenen Gäste zu erwehren hat.

\section{Ernte, Ansdrusch nnd Auflewahrung.}

Die Gerste ist mähereif, sobald die Körner die charakteristische Farbe der Sorte zeigen, doch noch wachsweich sind, und sich die Aehren gegen den Halm neigen, welcher letztere schon seine grüne Farbe verloren hat, aber noch nicht vollständig ausgetrocknet ist.

In diesem Stadium gemäht, zeichnen sich die Körner durch Feinschaligkeit und gute Qualität aus, olnc eine Ertragsvermindesung zu erfahren, während sich bei längerem Verbleiben auf dem Halm, also in der Vollreife, die Schale des Kornes verdickt, auch durch Wind die zerbrechlichen Spindeln der vierzeiligen Gerstensorten leicht zerschlagen werden und bei den zweizeiligen Gerstensorten die Aehre durch Knicken des Halmes dicht unter derselben leicht abbricht.

Im wärmeren. gemässigten Klima erfolgt die Ernte im Mai oder Juni, im käiteren Ende Juli bis Anfang dugust, und in der subarktischen Zone Ende August. 
Im Süden Europas und auch in Süddeutschland geschieht das Mähen meist mit der Sichel, in den nördlichen Lä̈ndern entweder mit der Gestellsense oder der Mähemaschinc.

Da nun die in der sog. "Gelbreife" gemähte Gerste noch viel Feuchtigkeit enthält, lässt man sie zunächst im Schwad trocknen, bis der grösste Teil der Feuchtigkeit verdunstet ist, meist wird sie dann aufgebunden und wenn die Körner erhärtet sind, eingefahren.

Feucht eingebrachte Gerste nimmt sehr bald einen multrigen Geruch und eine rötliche durch Pilzbildungen erzengte Farbe an, ein Zeichen, dass eine lebhafte Zersetzung stattfindet, durch welche die Qualität des Kornes und Strohes erheblich geschädigt werden kann. Ebenso leidet auch, bei der stark hygroscopischem Eigenschaft des Strohes, die Gerste durch Beregnen und wächst schliesslich, wenn auch nicht leicht, aus, weshalb konstantes Erntewetter, namentlich für die Einerntung der Braugerste, sehr wesentlich ist. Bei sehr günstiger Witterung kann sie nach $3-4$ Tagen, in der Regel nach 5-6 Tagen, eingebracht werdeu.

Wird die Gerste in Schwad durch Regen getroffen, so lüftet man die Schwade, um die vom Regen zur Erde niedergcschlagenen Aehren an die Luft zu bringen, mit dem Rechenstiele oder der Gabel. Dieses Verfahren reicht meist zum Abtrocknen aus und wird hierbei das Stroh weniger geknickt und zerbrochen als beim Umkehren der Schwade, durch welches Verfahren, wenn es öfters wiederholt wcrden muss, das Stroh so weich wird, dass sich die Achren an den Boden legen und die Körner bei feuchter Witterung auswachsen.

In Ländern mit feuchter, kühler Witterung, z. B. in Eugland, Dänemark, Nord-Deutschland etc. wird die zweizeilige Gerste, nachdem sie einige Tage im Schwad getrocknet hat, mit dem eignen Stroh in Garben aufgebunden und zum weiteren Austrockmen in sog. Hocken oder Stiegen aufgestellt. In Lündern mit giinstigerer Erntcwitterung, in denen auch gemeinhin die Gerste im Stroh kiirzer bleibt und letzteres leichter bricht, bindet man mit Wintergetreidestroh oder Weidenruten. In Süd-Deutschland lässt man sie in del Regel im Schwad vollkommen trocknen und bringt sie dann auf kleine Haufen, welche auf mit Erntetiichern ausgeschlagenen Wagen eingefahren werden; zuweilen wird sie auch wie der Dinkel in sog. Kapellen zum Trocknen aufgestellt und kurz vor dem Einfahren gebunden.

Die Aufbewahrung geschieht am besten in den feuchteren Klimaten in Scheunen, da die Qualität der Gerste in den Feimen sehr leicht leidet.

Der Ausdrusch erfolgt entweder mit der Dreschmaschine oder dem Dreschflegel. Durch letzteren werden die geringsten Procentsätze 
keimungsunfähiger, zerschlagener Körner erzielt, dafür ist aber diese Arbeit erheblich teurer.

Beim Maschinendrusch zerschlagen die mit Schlagleisten versehenen Maschinen mehr Körner als die Stiftenmaschinen, doch werden durch letztere mehr Aehren abgerissen, die entweder noch einmal die Maschine passieren miissen oder mit dem Flegel abzudreschen sind.

Die unteren Teile der Grannen, wenn sie trotz des Drusches an den Körnern verblieben sind, werden zur Herstellung einer guten Verkaufsware entweder mit dem Flegel nachträglich abgedroschen oder mit Hülfe einer Maschine entfernt.

Ein vorzüglicher Gerstenentgranner ist die $\mathrm{H}$ en sm ann'sche Handdreschmaschine, welche bei richtiger Stellung, ohne Verletzung der Körner, alle Grannen abschlägt und $5-6$ hl Körner in der Stunde entgrannt.

In England und Nord-Frankreich wendet man eine eigene für diesen Zweck bestimmte Maschine, den Grannenbrecher von G a rret, an.

In Ländern mit trocknem Klima ist dieses Entgrannen nicht nötig, da die Grannen spröder sind und leichter abbrechen.

Die Herstellung einer staub- und unkrautfreien Verkaufsware ist ferner im hohen Grade za beachten, sowie auch bei den Braugersten das Entfernen aller Schmachtkörner und der beim Drusch zerschlagenen Körner, welche unter Umständeu bis 10 Proc. betragen können. Demnach empfiehlt es sich, die letztc Reinigung der Braugerste auf Getreidesortiermaschinen vorzunehmen.

\section{Erträge und Nahrungsibestandteile.}

Die Gerste bringt an Körnern und Stroh nachfolgende Erträge pro ha auf:

Ertragstabelle.

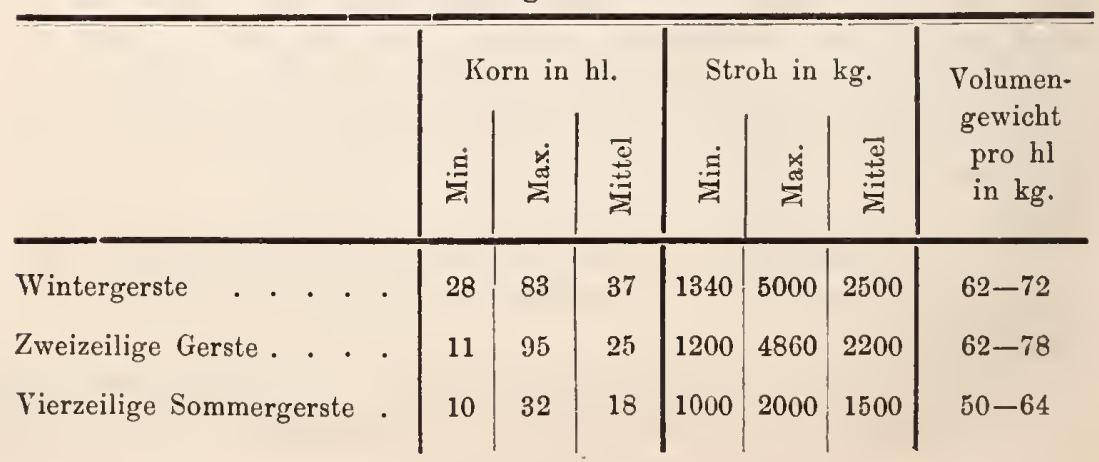


Der Mittelertrag aller an der Gerstenkultur teilnehmenden Länder stellt sich auf $20 \mathrm{hl} \mathrm{à} 64 \mathrm{~kg}=1280 \mathrm{~kg}$ Korn und $1800 \mathrm{~kg}$ Stroh.

Ueber das Verhältnis der Körner zum Stroh bei den wichtigsten Gerstenvarietäten gibt nachfolgende Tabelle Auskunft, und basieren die darin angeführten Zahlen auf unseren in Poppelsdorf angestellten Untersuchungen.

Tabelle über das Verhältnis der Körner zum Stroh (excl. Stoppeln).

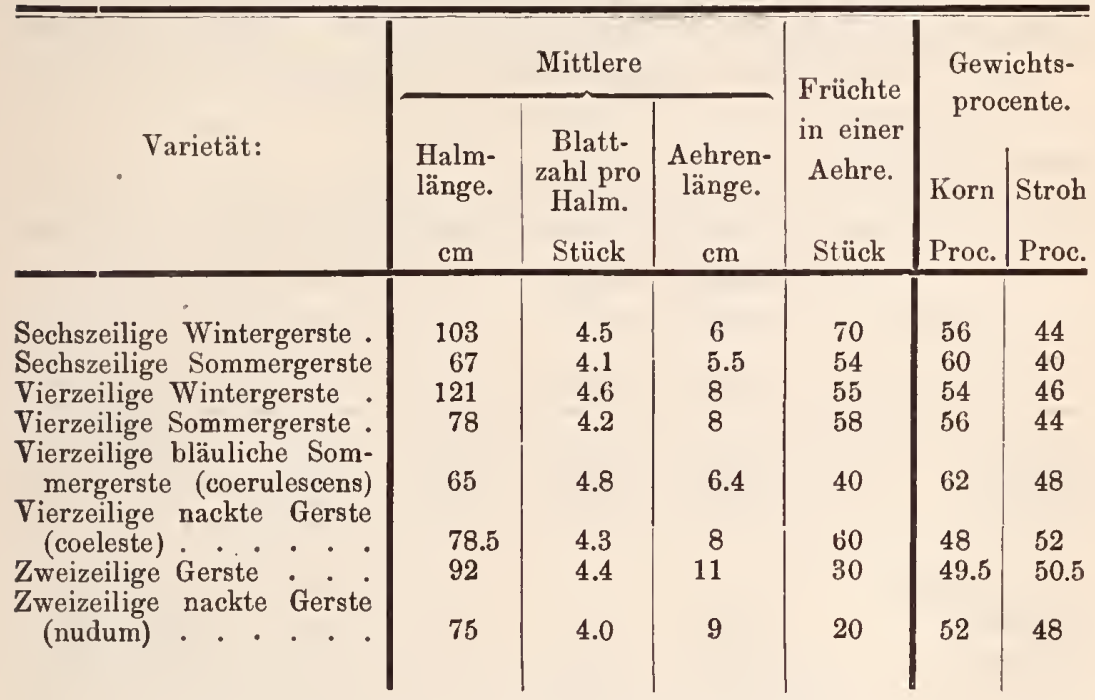

Diese Zahlen stimmen in überraschender Weise mit den von Haxton aufgestellten überein, wie nachfolgende Uebersicht zeigt:

Zweizeilige- vierzeilige- sechszeilige Gerste

Korn 45.4 Proc. 59.9 Proc. 51.0 Proc.

Halme und Blätter (lufttrocken) . . . . . . Aehrenspindel und Grannen Stoppeln und Wurzeln . .

\begin{tabular}{|c|c|c|c|}
\hline 38.1 & 38.0 & " & 32.0 \\
\hline 6.6 & 5.7 & , & 5.0 \\
\hline 9.9 & 5.4 & ” & 12.0 \\
\hline
\end{tabular}

Selbstverständlich wird in feuchten Klimaten das Gewichtsverhältnis des Strohes zum Korn grösser sein als in trocknen.

Block ${ }^{1}$ ) nimmt an, dass die grosse Gerste nur auf ganz angemessenem Boden in 7 Jahren 6 vollkommene Ernten und die kleine sogar in 5 Jahren nur 4 mittelmässige Ernten bringt.

Im kälteren, gemässigten Klima ergeben sich für diejenigen Böden, auf denen erfolgreich Gerste gebaut werden kann, nachfolgende Erträge:

1) Mitteilungen landw. Erfahrungen Bd. I, T. 68 und 78. 1837. 
1) Reicher, tiefer, milder Thon- und Aueboden. Weizenboden I. Kl. $35-44 \mathrm{hl}=2210-2816 \mathrm{~kg}$ Korn, $3850-4860 \mathrm{~kg}$ Stroh p. ha.

2) Humoser, reicher, milder Lehmboden. Gerstenboden I. Kl. $33-40 \mathrm{hl}=2022-2560 \mathrm{~kg}$ Korn, $3300-4000 \mathrm{~kg}$ Stroh p. ha.

3) Milder, tiefer, mergliger, frischer Lehm und sandiger Lehm. Gerstenboden II. Kl.

$26-33 \mathrm{hl}=1664-2022 \mathrm{~kg}$ Korn, $2600-3300 \mathrm{~kg}$ Stroh p. ha.

4) Milder, thoniger oder lehmiger Humus- und Auebnden.

$26-33 \mathrm{hl}=1664-2022 \mathrm{~kg}$ Korn, $2860-3630 \mathrm{~kg}$ Stroh p. ha.

5) Lcichter sandiger Lehm und lehmiger Sand. Roggenboden I. Kl. $22-26 \mathrm{hl}=1408-1664 \mathrm{~kg}$ Korn, $1980-2340 \mathrm{~kg}$ Stroh p. ha.

Die Gerste enthält an Nahrungsbestandteilen (verdaulichen und unverdauliclien):

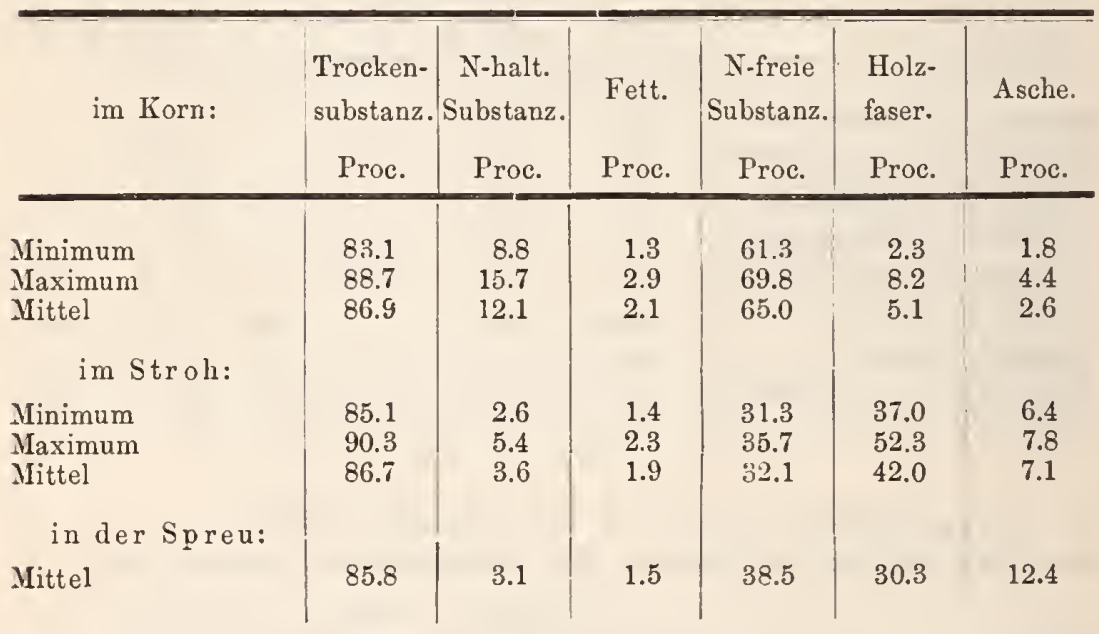

Der mittlere Procentgehalt an verdaulichen Nährstoffen beträgt nach E. Wolff:

\begin{tabular}{|c|c|c|c|c|c|}
\hline & Eiweiss & $\begin{array}{l}\text { Kohle- } \\
\text { hydrate }\end{array}$ & Fett & $\begin{array}{l}\text { Nähr- } \\
\text { stoffver- } \\
\text { hältnis } \\
\text { wie 1: }\end{array}$ & $\begin{array}{l}\text { Geldwert p. } 100 \mathrm{~kg} \text { in } \text { the } \\
1 \mathrm{~kg} \text { Eiweiss aे } 40 \text { s } \\
1 \text { "Fett } \\
1 \text { "Kohlehydrate, } 80 \text { " }\end{array}$ \\
\hline im Korn & 8.0 & 58.9 & 1.7 & 7.9 & 8.60 \\
\hline "Stroh & 1.3 & 40.6 & 0.5 & 32.2 & 3.96 \\
\hline
\end{tabular}

Durchschnittlich erbält man aus $100 \mathrm{~kg}$ Gerste $68.6 \mathrm{~kg}$ Mehl, $18.4 \mathrm{~kg}$ Kleie und $13 \mathrm{~kg}$ Wasser.

Die Kleie kann aber, je nach dem Gewichtsprocent an vor- 
handenen Spelzen, in sehr hohem Grade schwanken, denn während die nackten Gersten nur 3-4 Proc. Holzfaser enthalten, beziffert sich dieselbe bei den beschalten um das Zwei- bis Vierfache höher. Da nun offenbar der Wert der bespelzten Früchte auch von dem Gewichtsverhältnisse zwischen den Spelzen und der von diesen eingeschlossenen nackten Frucht abhängig ist, so mögen die von $\mathrm{Holk}^{\mathrm{k}}$ und Klos e gefundenen Gewichtsprocente der Spelzen einiger Gerstensorten hierunten eine Stelle finden, doch stammen die Angaben iiber dic Varietät der dort angeführten Sorten von uns, und sind gemacht, um das Verhalten der verschiedenen Varietäten zu einander bezüglich der Beschaffenheit ihrer Fruchtschale zu zeigen.

Gewichtsprocent der Spelzen

1. Gerste aus Schweden (wahrscheinlich H. dist. nutans) 7.18

2. Gerste aus Oestr.-Schle-

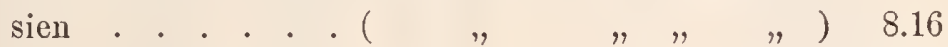

3. Gerste aus Australien ( $, \quad, \quad, \quad, \quad$ ) 8.17

4. " "Baiern. . ( " " " , " ) 8.95

5. Imperial-Gerste aus

Böhmen . . . . . (wahrscheinl. H. dist. erectum) 7.84

6. Gerste a. Württemberg (wahrscheinlich H. v. pallidum) 10.05

7. " "Russland . ( " " " ) 10.38

8. Wintergerste aus Württemberg . . . ( " " ", 10.63

9. Wintergerste a. Ungarn ( $", ", 12.54$

10. Gerste aus Spanien . (wahrscheinl.H.v. coerulescens) 10.94

11. " "Aegypten . " " " " " ) 12.00

12. " "Griechenl. ( " " " " ) 14.86

Die Schwankungen innerhalb der Sorten betragen hiernach mehr als das Doppelte, und besitzen die feuchteren Gegenden entstammenden Sorten der Varietäten H. dist. nutans und erectum das geringste Spelzengewicht, die Sorten der Varietät H. v. coerulescens aus der wärmeren, gemässigten Zone das grösste, und die zu H. v. pallidum gehörigen Sorten ein mittleres Spelzengewicht.

\section{Benutzung.}

Zur Herbeifuihrung einer den realen Verhältnissen möglichst Rechnung tragenden Anschauung iiber die Benutzung der Gerste in den verschiedenen Ländern empfiehlt es sich, die Gesammtproduktion 
an Gerste, sowie ihre Produktion und Konsumtion pro Kopf der Bevölkerung zu erheben, wie dies in nachfolgender Zusammenstellung geschehen ist:

\begin{tabular}{l|c|c|c}
\hline \multicolumn{1}{c|}{ Land: } & $\begin{array}{r}\text { Produktion } \\
\text { des Landes } \\
\text { in Millionen } \\
\text { Hektoliter. }\end{array}$ & \multicolumn{2}{|c}{$\begin{array}{c}\text { Pro Kopf der Be- } \\
\text { völkerung: }\end{array}$} \\
& \begin{tabular}{l|c}
$|c|$ \\
Produktion.
\end{tabular} \\
& Konsumtion. \\
\hline & 48.5 & 0.6 & 0.57 \\
Russland & 35.1 & 0.8 & 0.9 \\
Deutschland & 33.6 & 1.0 & 1.3 \\
England & 26.4 & 1.3 & 0.8 \\
Oesterreich-Ungarn & 20.0 & 1.2 & 1.2 \\
Spanien & 18.0 & 0.5 & 0.5 \\
Frankreich & 10.8 & 0.2 & 0.2 \\
Vereinigte Staaten & 9.3 & 2.1 & $?$ \\
Canada & 7.7 & 4.3 & $?$ \\
Dänemark & 6.4 & 1.5 & 1.4 \\
Skandinavien & 6.3 & 1.3 & 0.8 \\
Rumänien & 3.9 & 0.8 & 0.8 \\
Aegypten & 3.4 & 0.13 & 0.13 \\
Italien & 1.5 & 0.7 & $?$ \\
Schweiz & 1.5 & 0.4 & 0.6 \\
Niederlande & 1.3 & 0.25 & $?$ \\
Belgien & 0.9 & 0.44 & $?$ \\
Portugal & 0.8 & 0.4 & $?$ \\
Griechenland & 0.2 & 0.1 & 0.1 \\
Australien & & & \\
& & &
\end{tabular}

Die gesammte Gerstenproduktion beträgt annähernd 270 Millionen Hektoliter, von denen in Europa und Amerika ca. 60 Millionen Hektoliter verbraut werden, und beteiligen sich die nachstehenden Länder daran wie folgt:

Grossbritannien und Irland mit 20 Millionen hl

Deutsches Reich . . . , 19 , ,

Oesterreich-Ungarn . . . , 6 , ,

Amerika . . . . . . , 5 " ,

Belgien . . . . . . " 3.5 ,

Frankreich . . . . . , $3.5, "$

Russland . . . . . . " 1.0 , "

Niederlande . . . . . , 0.7 , ,

Dänemark . . . . . . "

Schweden und Norwegen ., 0.5,

Schweiz . . . . ., $0.3 \pi$,

Die beste Braugerste liefern Sorten der Varietäten Hordeum distichum nutans und erectum, doch ist hierbei zu bemerken, dass ein Gemenge dieser Varietäten nicht vermalzt werden darf, da die Körner von H. d. erectum etwas langsamer keimen. 
Bei der Auswahl der Braugerste ist das Hauptgewicht auf die Beschaffenheit des Mehlkörpers, des Keimlings und der Spelzen zu legen.

Beim Keimen des Kornes wird aus dem Eiweiss des Mehlkörpers Diastase erzeugt, die ihrerseits das Stärkemebl desselben in Dextrin und Zucker umwandelt, worauf der Hauptsache nach der Brauprocess beruht, und ist diejenige Braugerste die beste, welche sich bei nicht zu hohem Eiweissgehalt durch einen möglichst bohen Stärkegehalt auszeichnet.

Erfahrungsgemäss wird ein mittlerer Eiweissgehalt der Gerste von 10.5 Proc. für hinreichend zur sicheren Erzeugung cines guten Bieres betrachtet, und lieferte eine grössere Anzahl Analysen von Reischauer ${ }^{1}$ ) nachfolgende Procentsätze an Reservestoffen:

In 100 Teilen Trockensubstanz fanden sich:

Eiweiss Asche Phosphorsäure Kieselsäure Eisenoxyd Kalkerde

Max.

$\begin{array}{llllll}17.85 & 3.34 & 1.145 & 0.845 & 0.0694 & 0.151\end{array}$

Min.

$8.00 \quad 2.12$

0.614

0.460

0.0019

0.043

Mittel

$\begin{array}{lll}10.804 & 2.799 & 0.902\end{array}$

0.641

0.0200

0.068

Die äusseren Merkmale einer guten Braugerste kennzeichnen sich durch ein möglichst schweres Volumengewicht, denn dasselbe setzt auch ein hohes absolutes Gewicht der Körner, einen bedeutenden Stärkegehalt und Feinschaligkeit voraus. Ferner soll das Korn bauchig, voll, gleich gross, im Innern weiss, mellig und nicht glasig' sein.

Bei Beurteilung der Brangerste ist sie auf ihre Keimfahigkeit zu prüfen und gelten als äussere Zeichen guter Keimfähigkeit eine hell- oder lichtgelbe Farbe, doch gestattet dieselbe keinen sicheren Schluss auf die Keimfähigkeit, denn es lässt sich dieselbe auch durch künstliches Bleichen mittels Schwefeldampf herstellen; zı dem Zweck feuchtet man die Gerste an, bringt sie auf einc Darre und lässt sie hier langsam bei Schwcfeldämpfung trocknen und bleichen. Die Feuchtigkeit und das nachherige Dänıfen bewirken Anschwellung der Gerste und geben ihr ein volleres Aussehen. Gleichzeitig wird die dunkle oder gar schon schwärzliche Farbe der einzelnen Körner in die hellgelbe, welche schöner Gerste eigen ist, verwandelt. Die Keimkraft der Gerste erleidet durch einen solchen Blcichprocess keinen Abbruch, doch wird verdorbene, nicht mehr keimfähige Gerste zu besserem Ansehen gebracht.

Ferner ist sich feucht anfühlende und dumpfig riechende Gerste wegen mangelhafter Keimfähigkeit zur Malzbereitung untauglich; doch darf ausgewachsene Gerste nicht ohne weiteres verworfen werden, da ein geringer Procentsatz auf dem Halm gewachsencr Körner nur wenig schadet.

1) Zeitschr. f. d. gesammte Brauwesen. 4. Jahrg. 1881. Nr. 15, p. 353-363. 
Halbe Kömer dürfen sich dagegen nicht in der Gerste finden, weil sich die keimlosen Kornhälften der Vermälzung entziehen, und bei zahlreichem Vorhandensein zur Schimmelbildıng fiihren.

Schliesslich soll die Gerste frei von Unkrautsamen sein, denn, obwohl dieselben einen nachteiligen Einfluss auf die Bierbereitung nieht haben, führen sie doch zu Geldverlust.

Ausser zur Bierbereitung werden erhebliche Qnantitäten Gerste zur Malzbereitnug fiur die Brennereien verwandt.

In den Ländern der wärmeren Zone ersetzt die Gerste den Hafer als Pferdefutter, wie in Spanien, Süd-Italien, Nord-Afrika, Klein-Asien etc., und in der kälteren gemässigten Zone ist sie ein den Sehweinen und dem Rindvieh sehr zusagendes Futter.

Das Gerstenmehl liefert ein schwach rötliches, trockenes, hartes, fades, schlecht anfgehendes und wenig schmackhaftes Brot, das sich jedoch durch Beimischnng kleberreicher Mehlsorten, z. B. des Weizens zu 25-33-66 Proc. wie im Elsass, sehr wesentlich verbessern lässt. Das Gerstenbrot hat sich in West- nnd Mittelenropa nur wenig erhalten und ist dem Weizen- und Roggenbrot gewichen, doch liegt dies anders für den Norden Europas, wo namentlich in der subarktischen Zone noch hanptsächlich Gerstenbrot genossen wird, weshalb man hier die Gerste auch schlechtweg "Korn“ nennt.

Das Gerstenmehl ist zwar leich an Proteïnstoffen, doch arm an gutem Kleber und wie folgt zusammengesetzt:

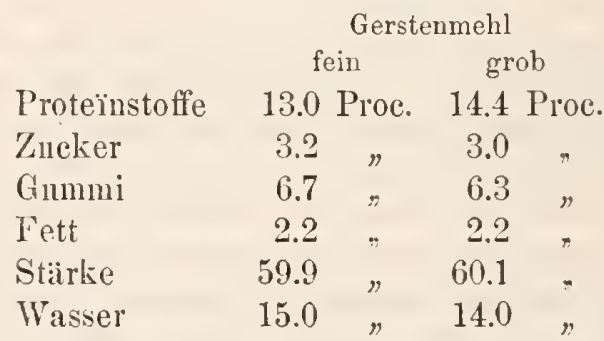

Einer sehr allgemeinen Verwendung erfreut sich ferner die Gerstengriitze und Grampe.

Das Gerstenstroh ist weich und verhältnismässig nährstoffreich, weshalb es gern als Häcksel oder Langfutter dem Rindvieh gereicht wird, während die Gerstengrannen ein gesundheitsschädliches Futtermittel sind, da sie bei Schafen nnd Rindern schwere Erkrankungen und selbst den Tod herbeifülıren können. Die Gerstengrannen vermögen nämlich die Schlcimhäıte des Verdauungskanals, und namentlich des Blättermagens zu durchdringen, was Entzündung und Verdanungsstörnng zur Folge hat, auch setzen sie sich in den Darmfalten zu grösseren Ballen fest; und behindern die Fortschaffung der Kotmassen. 


\title{
Hafer.
}

\author{
Avena sativa $\mathrm{I}$.
}

\author{
Einteilung.
}

\section{Unterart: Avena sativa patula Al. Rispenhafer.}

Varietät: Avena sativa mutica Al.

Unbegrannt; Spelzen blassgelblich.

\section{Sorten:}

\section{Oderbruch-Hafer. $\odot$}

Rispe: blassgelb, ausgebreitet, mittellang (24 cm), reichsamig, 240 Scheinfrüchte; Aehrchen 2-körnig, Klappen blassgelb, $2.5 \mathrm{~cm}$ lang, $0.7 \mathrm{~cm}$ breit. -- Stroh: rötlich-gelb, nittellang und kräftig $(125 \mathrm{~cm}$ hoch, $0.4 \mathrm{~cm}$ dick), steif. - Scheinfrucht: blassgelb, kurz, schön, voll (grosses Korn $16 \mathrm{~mm}$ lang, $3^{1 / 2} \mathrm{~mm}$ breit, kleines $12 \mathrm{~mm}$ lang, $3 \mathrm{~mm}$ breit, 267 Scheinfrüchte $=10 \mathrm{gr}$ ); feinschalig, Gewichtsprocent der Spelzen 23 Proc. vom Korn. Sehr frühreif, in 105 Tagen reifend; ertragreich; Scheinfrüchte nicht leicht ausfallend; widerstandsfähig gegen Lagern. Für reichen Boden gceignet.

Bezugsquelle: Haage \& Schmidt, Erfurt.

\section{Warthebruchhafer. $\odot$}

Rispe: ausgebreitet, kurz, reichsannig; Aehrchen 2-, zuweilen 3-körnig; Klappen blassgelb, bis $3 \mathrm{~cm}$ lang, $0.6 \mathrm{~cm}$ breit. - Stroh: grünlichgelb, blattreich, weich, feinhalmig, ziemlich kurz. - Scheinfrucht: gelb, lang, spitz, schmal (grosses Korn $2 \mathrm{~cm}$ lang, $0.3 \mathrm{~cm}$ breit, kleines $1.6 \mathrm{~cm}$ lang, $0.25 \mathrm{~cm}$ breit), leicht, Schalc mittelfein, $100 \mathrm{gr}$ enthalten $74.2 \mathrm{gr}$ Früchte, $25.8 \mathrm{gr}$ Spelzcn.

Junges Blatt dunkelgriin, Bestocknng mittelstark, 2.5 Schösslinge, sehr zeitig schossend und blühend; Halm $100 \mathrm{~cm}$ (Max. $120 \mathrm{~cm}$ ) lang, $0.35 \mathrm{~cm}$ dick, Blattzahl 4, Blätter $21 \mathrm{~cm}$ lang, $0.8 \mathrm{~cm}$ breit, Blattfläche $134.4 \mathrm{qcm}$, Halmfläche $105 \mathrm{qcm}$, Gesammtfïche $239.4 \mathrm{qcm}$.

Früllhafer in 113 Tagen reifend; Rispe $20 \mathrm{~cm}$ (Max. $25 \mathrm{~cm}$ ) lang, mit 180 Scheinfrüchten, von denen 1494000 auf $1 \mathrm{hl}(=41.5 \mathrm{~kg})$ entfallen. 
Auf 1 qm wachsen 1500 Halme oder 600 Pflanzen, mithin beträgt der Raum für eine Pflanze 16. $\mathrm{qcm}$, die Blattlläche p. $\mathrm{qm}$ Bodenfläche $36 \mathrm{qm}$ und das Saatquantum $5.5 \mathrm{hl} \mathrm{p.} \mathrm{ha.}$

Es wiegen 100 Halme $290 \mathrm{gr}$ und daron die Scheinfrichte $151 \mathrm{gr}$.

Dieser Hafer, der fast rostfrei bleibt und nicht leicht lagert, empfiehlt sich für sehr humose, feuchte Böden und selbst für Torfboden.

\section{Probsteier-Hafer. $\odot$}

Rispe: ausgebreitet, reichsamig, lang; Aehrchen 2-körnig; Klappen gelb (2.5 cm lang, $0.7 \mathrm{~cm}$ breit). - Stroh: gelb, kräftig, fest, blattreich, mittellang. - Scheinfrucht: blassgelb, selten begrannt, länglich, ziemlich voll, grosses Korn $1.5 \mathrm{~cm}$ lang, $0.35 \mathrm{~cm}$ breit, kleines $1.1 \mathrm{~cm}$ lang, $0.3 \mathrm{~cm}$ breit, Schale mittelfein, $100 \mathrm{gr}$ enthalten $71.5 \mathrm{gr}$ Frïchte, $28.5 \mathrm{gr}$ Spelzen.

Junges Blatt dunkelgrün; Bestockung stark, 3 Schösslinge, mittelfriih schossend und blïhend. Halme $120 \mathrm{~cm}$ (Max. $145 \mathrm{~cm}$ ) lang, $0.4 \mathrm{~cm}$ dick, Blattzahl 5.2, Blätter $21.4 \mathrm{~cm}$ lang, $0.9 \mathrm{~cm}$ breit, Blattfläche $200.3 \mathrm{qcm}$, Halmfläche $144 \mathrm{qcm}$, Gesammtfläche $344.3 \mathrm{qcm}$.

Frühhafer in 113 Tagen reifend, $25 \mathrm{~cm}$ (Max. $30 \mathrm{~cm}$ ) lang, mit 250 etwas leicht ausfallenden Scheinfrüchten, von denen 1479000 auf $1 \mathrm{hl}$ $(=43.5 \mathrm{~kg})$ gehen.

Auf $1 \mathrm{qm}$ wachsen 1000 Halme oder 333 Pflanzen, mithin beträgt der Raum für eine Pflanze $30 \mathrm{qcm}$, die Blattliäche $\mathrm{p} 0^{\circ} \mathrm{qm}$ Bodenfläche $34.4 \mathrm{qm}$ und das Saatquantum $3.3 \mathrm{hl}$ p. ha.

Es wiegen 100 Halme $508 \mathrm{gr}$ und davon die Scheinfrüchte $276 \mathrm{gr}$.

Dieser Hafer eignet sich vortrefflich für feuchte Klimate, Lehmund sandige Lehmböden und selbst für lehmige Sandböden. Er lagert nicht leicht, leidet wenig durch Rost; das Stroh liefert ein vorzügliches Futterstroh, und die Erträge stellen sich hoch, weshalb dieser Hafer in Nord-Deutschland, in den Ostseeprovinzen, Dänemark und Holland sehr geschätzt ist.

In Poppelsdorf wurden auf mildem, reichem Lehmboden nach gedüngtem Roggen und bei $15.7 \mathrm{~cm}$ Drillweite p. ha erzielt:

$2478 \mathrm{~kg}$ Korn, $2957 \mathrm{~kg}$ Stroh, $548 \mathrm{~kg}$ Spreu.

Heimat: Probstei in Holstein.

\section{Weisser Friesländischer Hafer.}

Eng 1.: Friesland or Dutch-Oat.

Rispe: ziemlich ausgebreitet, kurz, reichsamig; Aehrchen 2-körnig; Klappen blassgelb (2.5 cm lang, $0.6 \mathrm{~cm}$ breit). - Stroh: gelb, fest, etwas kurz. - Scheinfrucht: gelb, schmal, spitz (grosses Korn $1.6 \mathrm{~cm} \mathrm{lang,}$ $0.3 \mathrm{~cm}$ breit, kleines $1.2 \mathrm{~cm}$ lang, $0.25 \mathrm{~cm}$ breit), zuweilen begrannt, grobschalig, $100 \mathrm{gr}=703 \mathrm{gr}$ Früchte, $29.7 \mathrm{gr}$ Spelzen.

Junges Blatt dunkelgrün, Bestockung stark; 3 Schösslinge, mittelfrïh schossend und blühend. Halme $100 \mathrm{~cm}$ (Max. $125 \mathrm{~cm}$ ) lang, $0.4 \mathrm{~cm}$ dick, Blattzahl 4.4, Blätter $22.5 \mathrm{~cm}$ lang, $0.85 \mathrm{~cm}$ breit, Blattfläche $168.52 \mathrm{qcm}$, Halmfläche $120 \mathrm{qcm}$, Gesammtfläche $288.52 \mathrm{qcm}$.

Frühhafer, Rispe $20 \mathrm{~cm}$ (Max. $25 \mathrm{~cm}$ ) lang, mit 160 Scheinfrüchten, von denen 1732000 auf $1 \mathrm{hl}(=43.3 \mathrm{~kg})$ entfallen.

Es wiegen $100 \mathrm{Halme} 380 \mathrm{gr}$ und daron die Scheinfrüchte $214 \mathrm{gr}$.

Dieser Hafer ist unempfindlich, fast rostfrei, und auf gutem Lehm- 
and Marschboden ertragreich, doch reift er ungleich und besitzt ein geringwertiges Korn, weshalb er in neuerer Zeit weniger geschätzt wird.

Nach Versuchen von Melvin in England lieferte er p. ha nach einjähriger Weide auf drainirtem Lehmboden:

$61.06 \mathrm{hl}$ Korn $(1 \mathrm{hl}$ à $56 \mathrm{~kg}$ ) und $5147 \mathrm{~kg}$ Stroh.

Seine eigentliche Heimat ist Friesland, doch wurde er früher stark in England ${ }^{1}$ ) namentlich in Perthshire und in Amerika gebaut.

\section{Rügen'scher Hafer. $\odot$}

Rispe: kompakt, reichsamig, kurz; Aehrchen meist 3-körnig; Klappen blassgelb (2.5 cm lang, $0.7 \mathrm{~cm}$ breit). - Stroh: gelb, fest, ziemlich blattreich, mittellang. - Scheinfrucht: blassgelb, voll, lang (grosses Korn $2 \mathrm{~cm}$ lang, $0.35 \mathrm{~cm}$ breit, mittleres $1.5 \mathrm{~cm}$ lang, $0.25 \mathrm{~cm}$ breit, kleines $1 \mathrm{~cm}$ lang, $0.2 \mathrm{~cm}$ breit), etwas leicht, Schale mittelfein, $100 \mathrm{gr}=73 \mathrm{gr}$ Korn, 27 gr Spelzen.

Blätter blaugrün, schmal, Bestockung etwas schwach, 1.7 Schösslinge; Halm $120 \mathrm{~cm}$ (Max. $135 \mathrm{~cm}$ ) lang, $0.43 \mathrm{~cm}$ dick, Blattzahl 4.6, Blätter $29.2 \mathrm{~cm}$ lang, $0.9 \mathrm{~cm}$ breit, Blattfläche $241.78 \mathrm{qcm}$, Halmfläche $154.8 \mathrm{qcm}$, Gesammtfläche $396.58 \mathrm{qcm}$.

Frühhafer reift in 114 Tagen; Rispe $20 \mathrm{~cm}$ (Max. $25 \mathrm{~cm}$ ) lang, mit 150 Scheinfrüchten, von denen 1512000 auf $1 \mathrm{hl}$ (= $42 \mathrm{~kg}$ ) entfallen.

Auf $1 \mathrm{qm}$ wachsen 900 Halme oder 530 Pflanzen, mithin beträgt der Raum für eine Pflanze $19 \mathrm{qcm}$, die Blattfläche p. qm Bodenfläche $35.6 \mathrm{qm}$ und das Saatquantum $4.7 \mathrm{hl}$ p. ha.

Es wiegen 100 Halme $480 \mathrm{gr}$ und davon die Scheinfrïchte $263 \mathrm{gr}$.

In Poppelsdorf wurden 187;3 auf reichem Lehmboden nach gedüngtem Roggen und bei $15.7 \mathrm{~cm}$ Drillweite p. ha erzielt:

$2115 \mathrm{~kg}$ Korn, $3564 \mathrm{~kg}$ Stroh, $407 \mathrm{~kg}$ Spreu.

Dieser fast rostfreie, nicht leicht lagernde Hafer bringt auf der Halbinsel Wittow der Insel Ruigen auf mergelhaltigem Lehmboden sehr hohe Erträge, degeneriert jedoch leicht in Kontinentalklima und auf leichterem Boden.

\section{Rheinischer Hafer. $\odot$}

Rispe: ziemlich ausgebreitet, etwas armsamig, kurz; Aehrchen 2-körnig; Klappen blassgelb, schmal (2.8 cm lang, $0.7 \mathrm{~cm}$ breit). Stroh: rötlich-gelb, sehr kräftig, mittellang. - Scheinfrucht: tief gelb, ziemlich lang, schmal, doch voll (grosses Korn $1.3 \mathrm{~cm}$ lang, $0.28 \mathrm{~cm}$ breit, kleines $1 \mathrm{~cm}$ lang, $0.25 \mathrm{~cm}$ breit), feinschalig, $100 \mathrm{gr}=77.5 \mathrm{gr}$ Früchte, $22.5 \mathrm{gr}$ Spelzen.

Junges Blatt dunkelgrün, schmal, 2.5 Schösslinge. spät schossend und bliihend. Halm $120 \mathrm{~cm}$ (Max. $140 \mathrm{~cm}$ ) lang, $0.57 \mathrm{~cm}$ dick, Blattzahl 4.8, Blätter $38.8 \mathrm{~cm}$ lang, $1.25 \mathrm{~cm}$ breit, Blattfläche $465.6 \mathrm{qcm}, \mathrm{Halm}$ fläche 205.2 qcm, Gesammtfläche $670.8 \mathrm{qcm}$.

Späthafer reift in 125 Tagen; Rispe $20 \mathrm{~cm}$ (Max. $25 \mathrm{~cm}$ ) lang, mit 110 fest sitzenden Scheinfrüchten, von denen 1488000 auf $1 \mathrm{hl}(=46.5 \mathrm{~kg}$ ) entfallen.

Auf 1 qm wachsen 550 Halme oder 220 Pflanzen, mithin beträgt

1) Thaer, Engl. Landw. Bd. I, 1806. 
der Raum für eine Pflanze $45.5 \mathrm{qcm}$, die Blattfläche p. qm Bodenfläche $36.85 \mathrm{qm}$ und das Saatquantum $2 \mathrm{hl}$ p. lia.

Es wiegen 100 Halme $815 \mathrm{gr}$ und daron die Scheinfrüchte $390 \mathrm{gr}$.

Auf reichen Lehmböden bringt dieser selten lagernde und ziemlich gegen Rost widerstandsfälige Hafer namentlich hohe Stroherträge.

\section{Weisser Westerwälder-Hafer. $\odot$}

Rispe : ausgebreitet, locker, kurz, sehr armsamig; Rispenäste hängend; Aehrchen 2-körnig; Klappen blassgelb, fast weiss (2.3 cm lang). - Stroh: rötlich-gelb, sehr stark. fest, lang. - Scheinfrucht: graulich-meiss, sehr kurz und dick (grosses Kioln $1 \mathrm{~cm}$ lang, $0.3 \mathrm{~cm}$ breit, kleines $0.85 \mathrm{~cm}$ lang, $0.25 \mathrm{~cm}$ breit), ziemlich feinschalig, $100 \mathrm{gr}=76 \mathrm{gr}$ Fruchte, $24 \mathrm{gr}$ Spelzen.

Junges Blatt blaugrün, schmal, kurz; Bestockung mittelstark, 2.6 Schösslinge; Halm $130 \mathrm{~cm}$ (Max. $160 \mathrm{~cm}$ ) lang, $0.53 \mathrm{~cm}$ dick, Blattzahl 5, Blätter $31.5 \mathrm{~cm}$ lang, $1.22 \mathrm{~cm}$ breit, Blattfläche $384.3 \mathrm{qcm}$, Halmfläche $206.7 \mathrm{qcm}$, Gesammtfläche $591 \mathrm{qcm}$.

Späthafer reift in 125 Tagen; Rispe $20 \mathrm{~cm}$ (Max. $30 \mathrm{~cm}$ ) lang, mit 110 nicht leicht ausfallenden Sclieinfrichten, von denen 1376000 auf $1 \mathrm{hl}$ $(=43 \mathrm{~kg})$ entfallen.

Auf 1 qm wachsen 600 Halme oder 230 Pflanzen, mithin beträgt das Saatquantum $2.2 \mathrm{hl} \mathrm{p}$. ha.

Es wiegen 100 Halme $700 \mathrm{gr}$, daron die Scheinfrüchte $320 \mathrm{gr}$.

\section{Friilhafer von Kanen.}

Rispe: ausgebreitet, kurz, reichsamig; Aehrchen 2- bis 3-körnig; Klappen blassgelb, derb $(2.2 \mathrm{~cm}$ lang, $0.7 \mathrm{~cm}$ breit). - Stroh: rötlichgelb, kräftig, fest, etwas kurz. - Scheinfrucht: blassgelb, voll, sehr schwer, ziemlich gross (grosses Korn $1.6 \mathrm{~cm} \mathrm{lang,} 0.3 \mathrm{~cm}$ breit, kleines $1.4 \mathrm{~cm}$ lang, $0.25 \mathrm{~cm}$ breit), sehr feinschalig, $100 \mathrm{gr}=79 \mathrm{gr}$ Früchte, $21 \mathrm{gr}$ Spelzen.

Halme blaugrün, 2.6 Schösslinge, mittelfrüh blühend, $100 \mathrm{~cm}$ (Max. $120 \mathrm{~cm}$ ) lang, $0.47 \mathrm{~cm}$ dick, Blattzahl 4.3, Blätter $27 \mathrm{~cm} \mathrm{lang,} 1.36 \mathrm{~cm}$ breit, Blattläche $315.79 \mathrm{qcm}$, Halmfläche $141 \mathrm{qcm}$, Gesammtfläche 456.79 qcm.

Rispe reift in 120 Tagen, $20 \mathrm{~cm}$ (Max. $25 \mathrm{~cm}$ ) lang, mit 150 fest sitzenden Scheinfruichten, von denen 1492400 auf $1 \mathrm{hl}(=52 \mathrm{~kg})$ entfallen.

Auf $1 \mathrm{qm}$ wachsen 800 IJalme oder 310 Pflanzen, mithin beträgt der Raum für eine Pflanze $32 \mathrm{qcm}$, die Blattfäche p. qm Bodenfläche $36.6 \mathrm{qm}$ und das Saatquantum $3 \mathrm{hl} \mathrm{p}$. ha.

Es wiegen 100 Halme $986 \mathrm{gr}$ und davon die Scheinfrüchte $530 \mathrm{gr}$.

Dieser auf gut kultiviertem Wittelboden sehr ertragreiche Hafer ist gegen Lagern und Rost sehr widerstandsfähig.

\section{Schlesischer Friihhafer. $\odot$}

Rispe: etwas zusammengezogen, reichsamig, kurz; Aehrchen 2- und 3-körnig; Klappen gelb (2.8 cm lang, $0.6 \mathrm{~cm}$ breit). - Stroh: grüngelb, steif, ziemlich lang. - Scheinfrucht: gelb, Scheidenspelze rötlich, lanzett- 
lich, voll, ziemlich klein (grosses Korn $1.3 \mathrm{~cm}$ lang, $0.3 \mathrm{~cm}$ breit, kleines $1 \mathrm{~cm}$ lang, $0.25 \mathrm{~cm}$ breit), Schale mittelfein $100 \mathrm{gr}=73.5 \mathrm{gr}$ Frïchte, 26.5 gr Spelzen.

Junges Blatt dunkelgrïn, breit, lang, sehr kräftig; Bestockung sehr schwach, 1.2 Schösslinge, zeitig schossend und blïhend. Halm $125 \mathrm{~cm}$ (Max. $155 \mathrm{~cm}$ ) lang. $0.43 \mathrm{~cm}$ dick, Blattzahl 4, Blätter $29.3 \mathrm{~cm} \mathrm{lang,}$ $1.1 \mathrm{~cm}$ breit, Blattfläche $257.84 \mathrm{q} \mathrm{cm}$, Halmfläche $161.25 \mathrm{qcm}$, Gesammtfläche 419.09 qcm.

Rispe in 118 Tagen reifend, $20 \mathrm{~cm}$ (Max. $25 \mathrm{~cm}$ ) lang, mit 150 nicht leicht ausfallenden Scheinfrïchten, von denen 1550000 auf 1 hl $(=50 \mathrm{~kg})$ entfallen.

Auf $1 \mathrm{qm}$ wachsen 800 Halme oder 666 Pflanzen, mithin beträgt der Raum für eine Pflanze $15 \mathrm{qcm}$, die Blattfläche $p . q \mathrm{~m}$ Bodenfläche $33.5 \mathrm{qm}$ und das Saatquantum $6 \mathrm{hl}$ p. ha.

Es wiegen 100 Halme $905 \mathrm{gr}$ nnd davon die Scheinfriichte $503 \mathrm{gr}$.

In Poppelsdorf wurden auf reichem Lelımboden 187.3 nach gediingtem Roggen und bei einer Drillweite von $15.7 \mathrm{~cm} \mathrm{p}$. ha geerntet:

$1802 \mathrm{~kg}$ Korn, $3231 \mathrm{~kg}$ Stroh, $529 \mathrm{~kg}$ Spreu.

Dieser Hafer lagert nicht leicht und bleibt fast rostfrei.

\section{Sommer-Gabelhafer.}

Rispe: ausgebreitet, armsamig, gross; Aehrchen 2-körnig; Klappen blassgelb, gross, ïber $2 \mathrm{~cm}$ lang, breit. - Stroh: orangegelb, fest, mittellang, ziemlich blattreich. - Scheinfruclst: blassgelb, ziemlich dick, kurz (1.3 cm lang, $0.3 \mathrm{~cm}$ breit); mitunter ganze Rispen begrannt, Grannen gelb, über $2 \mathrm{~cm}$ lang; schwer, feinschalig, $100 \mathrm{gr}=76.5 \mathrm{gr}$ Früchte, 23.5 gr Spelzen.

Blätter gelbgrïn, 2.2 Schösslinge, Halme $115 \mathrm{~cm}$ (Max. $135 \mathrm{~cm}$ ) lang, $0.4 \mathrm{~cm}$ dick, Blattzahl 4, Blätter $27 \mathrm{~cm}$ lang, $0.9 \mathrm{~cm}$ breit, Blattfläche $194.4 \mathrm{qcm}$, Halmfläche $138 \mathrm{qcm}$, Gesammtfläche $332.4 \mathrm{qcm}$.

Frihhafer, Rispe reift in 115 Tagen, $30 \mathrm{~cm}$ (Max. $35 \mathrm{~cm}$ ) lang, mit 160 Scheinfruichten, von denen 2332000 auf $1 \mathrm{hl}(=50.7 \mathrm{~kg}$ ) entfallen. Es wiegen 100 Halme $382 \mathrm{gr}$ und davon die Scheinfriichte $198 \mathrm{gr}$. Für leichtere Böden geeignet.

\section{Hafer von Borkum. $\odot$}

Rispe: etwas zusammengezogen, kurz, ziemlich reichsamig; Aehrchen 2-körnig; Klappen fast weiss $(2.4 \mathrm{~cm}$ lang, $0.5 \mathrm{~cm}$ breit). - Stroh: hellgelb, fest, sehr kurz. - Scheinfrucht: blassgelb, kurz, Spitze abgestutzt, wie abgerissen (grosses Korn $1.2 \mathrm{~cm}$ lang, $0.35 \mathrm{~cm}$ breit, kleines $0.9 \mathrm{~cm}$ lang, $0.3 \mathrm{~cm}$ breit), grobschalig, $100 \mathrm{gr}$ enthalten $65.5 \mathrm{gr}$ Frucht, $34.5 \mathrm{gr}$ Spelzen, leicht, selten begrannt.

Halme blaugrün, 2.3 Schösslinge, mittelfrüh blühend, $95 \mathrm{~cm}$ (Max. $110 \mathrm{~cm}$ ) lang, $0.4 \mathrm{~cm}$ dick, Blattzahl 4, Blätter $27.6 \mathrm{~cm}$ lang, $1.04 \mathrm{~cm}$ breit, Blattfläche 229.6 qcm, Halmfläche 114 qcm, Gesammtfläche 343.6 qcm.

Rispe mittelfriih, in 123 Tagen reifend, $20 \mathrm{~cm}$ (Max. $30 \mathrm{~cm}$ ) lang, mit 130 sehr fest sitzenden Scheinfrïchten, von denen 1395200 auf 1 hl $(=43.6 \mathrm{~kg})$ entfallen.

Es wiegen 100 Halme $527 \mathrm{gr}$ und davon die Scheinfrïchte $278 \mathrm{gr}$.

Für stürmische Gegenden und leichten Boden am Meere durchaus geeignet. 


\section{Frühhafer von Gilmannsdorf bei Neisse in Schlesien. $\odot$}

Rispe: ausgebreitet, ziemlich reichsamig, kurz; Aehrchen 2-körnig; Klappen fast weiss $(2.2 \mathrm{~cm}$ lang, $0.65 \mathrm{~cm}$ breit). - Stroh: graulich-gelb, blattreich, kräftig, fest, mittellang. - Scheinfrucht: tief gelb, länglich, voll, gross (grosses Korn $1.4 \mathrm{~cm}$ lang, $0.35 \mathrm{~cm}$ breit, kleines $1.2 \mathrm{~cm} \mathrm{lang,}$ $0.25 \mathrm{~cm}$ breit), schwer, feinschalig, $100 \mathrm{gr}$ enthalten $75.6 \mathrm{gr}$ Frucht, $24.4 \mathrm{gr}$ Spelzen.

Halme blaugrün, 2.5 Schösslinge, zeitig schossend, $115 \mathrm{~cm}$ (Max. $130 \mathrm{~cm}$ ) lang, $0.47 \mathrm{~cm}$ dick, Blattzahl 5.3, Blätter $29.5 \mathrm{~cm} \mathrm{lang,} 1.1 \mathrm{~cm}$ breit, Blattfläche $343.97 \mathrm{qcm}$, Halmfläche $162.15 \mathrm{qcm}$, Gesammtfläche $506.12 \mathrm{qcm}$.

Rispe in 120 Tagen reifend, $20 \mathrm{~cm}$ (Max. $27 \mathrm{~cm}$ ) lang, mit 120 etwas lose sitzenden Scheinfrüchten, von denen 1590000 auf $1 \mathrm{hl}(=53 \mathrm{~kg})$ entfallen.

Auf $1 \mathrm{qm}$ wachsen 750 Halme oder 300 Pflanzen, mithin beträgt der Raum für eine Pflanze $33.3 \mathrm{qcm}$, die Blattfläche p. qm Bodenfläche $38 \mathrm{qm}$ und das Saatquantum $2.5 \mathrm{hl}$ p. ha.

Es wiegen 100 Halme $566 \mathrm{gr}$ und davon die Scheinfrichte $318 \mathrm{gr}$.

Für sandigen Lehmboden eignet sich diese Sorte vortrefflich.

\section{Ligowo-Hafer. $\odot$}

Syn.: Rispenhafer aus Ligowo.

Rispe: ausgebreitet, locker, etwas armsamig, mittellang; Aehrchen 2-körnig; Klappen blassgelb (2.2 cm lang, $0.7 \mathrm{~cm}$ breit). - Stroh: gelb, sehr kräftig, blattreich, lang. - Scheinfrucht: blassgelb, zuweilen doch selten begrannt; Granne bräunlich, bis $3 \frac{1}{2} \mathrm{~cm}$ lang; kurz, plump (grosses Korn $1.5 \mathrm{~cm}$ lang, $0.35 \mathrm{~cm}$ breit, kleines $1 \mathrm{~cm}$ lang, $0.25 \mathrm{~cm}$ breit), etwas grobschalig, $100 \mathrm{gr}=71.1 \mathrm{gr}$ Früchte, $28.5 \mathrm{gr}$ Spelzen.

Junges Blatt blaugrün, lang, kräftig, breit; Bestockung schwach, 1.6 Schösslinge; Halme $140 \mathrm{~cm}$ (Max. $160 \mathrm{~cm}$ ) lang, $0.7 \mathrm{~cm}$ dick, Blattzahl 5, Blätter $37 \mathrm{~cm}$ lang, $1.7 \mathrm{~cm}$ breit, Blattfläche 629 q cm, Halmfläche $294 \mathrm{qcm}$, Gesammttläche $923 \mathrm{qcm}$.

Späthafer, Rispe $25 \mathrm{~cm}$ (Max. $30 \mathrm{~cm}$ ) lang, mit 150 Scheinfrüchten, von denen 1812000 auf $1 \mathrm{hl}(=45.3 \mathrm{~kg})$ entfallen.

Es wiegen 100 Halme $928 \mathrm{gr}$ und davon die Scheinfrüchte $476 \mathrm{gr}$.

Auf reichem Boden ist diese fast rostfreie und nicht lagernde Sorte sehr ergiebig und empfiehlt sich vorzugsweise zur Grünfuttererzeugung. fraglich.

Diese Hafersorte soll aus den Pyrenäen stammen, doch ist dies

\section{Dublauer-Frühhafer. $\odot$}

Rispe: ausgebreitet, lang $(26 \mathrm{~cm})$, armkörnig (100 Scheinfrïchte); Aehrchen 2-körnig; Klappen blassgelb (2 cm lang, $0.6 \mathrm{~cm}$ breit). Stroh: blassgelb. - Scheinfrucht: fast weiss, voll, kurz (grosses Korn $1.2 \mathrm{~cm}$ lang, $0.25 \mathrm{~cm}$ breit, kleines $0.8 \mathrm{~cm} \mathrm{lang,} 0.2 \mathrm{~cm}$ breit).

Original in der Sammlung des Dr. Dreis ch, Poppelsdorf. 


\section{Luher-Hafer. $\odot$}

Rispe: fast weiss, ausgebreitet, ziemlich armsamig, unter mittellang; Aehrchen 2-körnig, Klappen fast weiss, $2 \frac{1}{2} \mathrm{~cm}$ lang, $0.7 \mathrm{~cm}$ breit. Stroh: rotgelb, fest, kurz. - Scheinfrucht: fast weiss mit rötlicher Scheidespelze, kurz (grosses Korn $15 \mathrm{~mm}$ lang, $2.5 \mathrm{~mm}$ breit, kleines $11 \mathrm{~mm}$ lang, $2 \mathrm{~mm}$ breit, 300 Scheinfrüchte $=10 \mathrm{gr}$ ), grobschalig, Spelzengewicht 32.5 Proc.

Junges Blatt dunkelgrün, schmal; 1.8 Schösslinge; Halm $100 \mathrm{~cm}$ lang, $0.4 \mathrm{~cm}$ dick, Blattzahl 4, Blätter $27 \mathrm{~cm}$ lang, $1 \mathrm{~cm}$ breit, Blattläche $216 \mathrm{qcm}$, Halmfläche $120 \mathrm{qcm}$, Gesammtfläche $336 \mathrm{qcm}$.

Rispe $20 \mathrm{~cm}$ lang, mit 86 Scheinfrüchten, von denen 1541000 auf $1 \mathrm{hl}(=51.7 \mathrm{~kg})$ entfallen.

Frühhafer in 105 Tagen reifend, Quantität und Qualität des Ertrages nicht hervorragend.

Bezugsquelle: durch das preussische landw. Ministerium 1881 aus Zborow, Böhmen, erhalten.

\section{Mährischer Hafer. $\odot$}

Rispe: sehr ausgebreitet, locker, weitschweifig, armsamig, gross; Aehrchen 1- und 2-körnig; Klappen blassgelb (2 cm lang, $0.65 \mathrm{~cm}$ breit). - Stroh: grüngelb oder rötlich-gelb, sehr fest, lang. - Scheinfrucht: blassgelb, sehr voll, kurz (grosses Korn $1.2 \mathrm{~cm}$ lang, $0.3 \mathrm{~cm}$ breit, kleines $0.8 \mathrm{~cm}$ lang, $0.25 \mathrm{~cm}$ breit), zuweilen begrannt, sehr schwer, Schale mittelfein, $100 \mathrm{gr}=72.5 \mathrm{gr}$ Früchte, $27.5 \mathrm{gr}$ Spelzen.

Junges Blatt dunkelgrün, lang, etwas schmal, Bestockung etwas schwach, 2.4 Schösslinge, mittelfrüh schossend und blühend; Halme $130 \mathrm{~cm}$ (Max. $150 \mathrm{~cm}$ ) lang, $0.4 \mathrm{~cm}$ dick, Blattzahl 4.6, Blätter $28.5 \mathrm{~cm}$ lang, $1 \mathrm{~cm}$ breit, Blattfäche $262.2 \mathrm{qcm}$, Halmfläche $156 \mathrm{qcm}$, Gesammtfläche $418.2 \mathrm{qcm}$.

Frühhafer reift in 117 Tagen; Rispe $25 \mathrm{~cm}$ (Max. $35 \mathrm{~cm}$ ) lang, mit 120 ziemlich fest sitzenden Scheinfrüchten, von denen 1596000 auf $1 \mathrm{hl}$ $(=57 \mathrm{~kg})$ entfallen.

Es wiegen 100 Halme 833 gr, und davon die Scheinfrüchte $417 \mathrm{gr}$.

Für einen armen, flachgrundigen Gebirgsboden eignet sich dieser Hafer vortrefflich; wenig dureh Rost und Lagern leidend.

\section{Belgischer Rispenhafer. $\odot$}

Rispe: etwas zusammengezogen, kurz, armsamig; Aehrehen 2-körnig; Klappen gelb $(2.3 \mathrm{~cm}$ lang, $0.7 \mathrm{~cm}$ breit). - Stroh: gelbgrün, fest, lang, blattarm. - Scheinfrucht: blassgelb, schmal, spitz (grosses Korn $1.8 \mathrm{~cm}$ lang, $0.3 \mathrm{~cm}$ breit, kleines $1.3 \mathrm{~cm}$ lang, $0.25 \mathrm{~cm}$ breit), Schale mittelfein, $100 \mathrm{gr}=72.7 \mathrm{gr}$ Früchte, $27.3 \mathrm{gr}$ Spelzen.

Junges Blatt hellgrün, breit, kräftig; Bestorkung schwach, 1.8 Schösslinge, zeitig schossend und blühend, $\operatorname{Halm} 135 \mathrm{~cm}$ (Max. $165 \mathrm{~cm}$ ) lang, $0.4 \mathrm{~cm}$ breit, Blattzahl 4.2 , Blätter $30.5 \mathrm{~cm}$ lang, $1.05 \mathrm{~cm}$ breit, Blattfläche $269.01 \mathrm{qcm}$, Halmfläche $162 \mathrm{qcm}$, Gesammtfläche $431.01 \mathrm{qcm}$.

Frülhafer, reift in 118 Tagen; Rispe $20 \mathrm{~cm}$ (Max. $30 \mathrm{~cm}$ ) lang, mit 100 Scheinfrüchten, welche etwas locker sitzen, und von denen 1574000 auf $1 \mathrm{hl}(=46.3 \mathrm{~kg})$ entfallen. 
Es wiegen 100 Halme $809 \mathrm{gr}$ und davon die Scheinfriichte $445 \mathrm{gr}$.

Dieser nicht leicht lagernde und wenig durch Rost leidende Hafer wird in Belgien für Moorboden empfohlen.

\section{Early-Angus-0at. $\odot$}

Syn.: Erüher schottischer Angus-Hafer.

Rispe: ausgebreitet, armsamig, mittellang; Aehrchen 2-körnig; Klappen blassgelb, Basis dunkler $(2.2 \mathrm{~cm}$ lang, $0.75 \mathrm{~cm}$ breit). - Stroh: rötlich-gelb, feinhalmig, fest, mittellang. - Scheinfrucht: rötlich-blassgelb, länglich, gross, voll (grosses Korn $1.6 \mathrm{~cm}$ lang, $0.35 \mathrm{~cm}$ breit, kleines $1.1 \mathrm{~cm}$ lang, $0.3 \mathrm{~cm}$ breit), spitz, grobschalig, $100 \mathrm{gr}=63.8 \mathrm{~kg}$ Früichte, $36.2 \mathrm{~kg}$ Spelzen.

Halm gelbgrün, Bestockung mittelstark, 2.5 Schösslinge, sehr zeitig blühend, $110 \mathrm{~cm}$ (Max. $120 \mathrm{~cm}$ ) lang, $0.37 \mathrm{~cm}$ dick, Blattzahl 4, Blätter $28.25 \mathrm{~cm}$ lang, $1.05 \mathrm{~cm}$ breit, Blattfläche $237.28 \mathrm{qcm}$, Halmfläche $122.1 \mathrm{qcm}$, Gesammtfläche $359,38 \mathrm{qcm}$.

Frühreif, in 108 Tagen reifend, $25 \mathrm{~cm}$ (Max. $30 \mathrm{~cm}$ ) lang, mit 120 ziemlich fest sitzenden Scheinfrichten, von denen 1557600 auf $1 \mathrm{hl}$ $(=47.2 \mathrm{~kg})$ entfallen.

Auf $1 \mathrm{qm}$ wachsen 1000 Halme oder 400 Pflanzen, mithin beträgt das Saatquantum $3.4 \mathrm{hl}$ p. ha.

Es wiegen 100 Halme $538 \mathrm{gr}$ und davon die Scheinfriichte $256 \mathrm{gr}$.

Mitchell erzielte 1848 in England nach einjähriger Weide auf drainiertem Lehmboden p. ha 65.55 hi Korn à $55 \mathrm{~kg}, 2 \mathrm{hl}$ Hinterkorn, $4949 \mathrm{~kg}$ Stroh.

Sein Anbau empfiehlt sich nur für reiches Land, unter weniger günstigen Bodenverhältuissen degeneriert er leicht; wegen seiner Frïhreife wird er gern in Schottland, und namentlich viel in Angus, aber auch in den Vereinigten Staaten gebaut.

Diese vortreffliche Sorte wurde 1864 von Shirreff in Mungowells gezuichtet, und erhielt dieselbe vielfach erste Prämien und zu Dalkeith die Preismedaille der ,Highland Society".

\section{Late Angus-0at. $\odot$}

Syn.: Common late Oat.

Deutsch: Später schottischer Angus-Hafer.

Nahe verwandt: Grey Angus-Oat.

Rispe: ausgebreitet, etwas locker, mittellang, etwas armsamig; Aehrchen 2-körnig; Klappen fast weiss, an Basis dunkler, ziemlich derb (2.2 cm lang, $0.6 \mathrm{~cm}$ breit). - Stroh: rötlich-gelb oder orange, kräftig, mittellang. - Scheinfrucht: schmutzig-weiss, lang, voll (grosses Korn $1.5 \mathrm{~cm}$ lang, $0.35 \mathrm{~cm}$ breit, kleines $1 \mathrm{~cm}$ lang, $0.27 \mathrm{~cm}$ breit), schwer, feinschalig, $100 \mathrm{gr}=76 \mathrm{gr}$ Früchte, $24 \mathrm{gr}$ Spelzen. Auf leichtem Boden kommt zuweilen eine Granne vor.

Halme blaugrün, Bestockung stark, 2.9 Schösslinge, spät blühend, $120 \mathrm{~cm}$ (Max. $130 \mathrm{~cm}$ ) lang. $0.43 \mathrm{~cm}$ dick, Blattzahl 4.3, Blätter $31.7 \mathrm{~cm}$ lang, $1.2 \mathrm{~cm}$ breit, Blattfläche $327.14 \mathrm{qcm}$, Halmfläche $154.8 \mathrm{qcm}$. Gesammtfläche $481.94 \mathrm{qcm}$.

Frïhreif, in 116 Tagen, aher 8-14 Tage später als ,Early Angus"; Rispe $25 \mathrm{~cm}$ (Max. $30 \mathrm{~cm}$ ) mit 120 nicht leicht ausfallenden Scheinfrüchten, von denen 1654400 auf $1 \mathrm{hl}(=51.7 \mathrm{~kg})$ gehen. 
Auf $1 \mathrm{qm}$ wachsen 800 Halme oder 275 Pflanzen, mithin beträgt das Saatquantum $2.2 \mathrm{hl}$ p. ha.

Es wiegen 100 Halme $683 \mathrm{gr}$ und davon die Scheinfrïchte $336 \mathrm{gr}$.

Auf kalkhaltigem Thonboden wurden 1872 in Proskau geerntet:

$1781 \mathrm{~kg}$ Korn, $2500 \mathrm{~kg}$ Stroh, $207 \mathrm{~kg}$ Spreu.

Mr. Mitchell erzielte in England nach Weide auf drainiertem Lehmboden p. ha:

$\begin{array}{lcccc} & \text { Vorderkorn } & \text { Gewicht p. hl } & \text { Hinterkorn Stroh } \\ 1847 \text { (2-jährige Weide) } & 49.62 \mathrm{hl} & 54.5 \mathrm{~kg} & 3.86 \mathrm{hl} 4392 \mathrm{~kg} \\ 1848 \text { (1-jährige Weide) } & 67.80, & 52.5, " & 2.69,26492, "\end{array}$

Für kalte, feuchte, lochgelegene Gegenden und für schweren Thonboden eignet sich diese Hafersorte vortrefflicl, und wird deshalb in Schottland, namentlich in Angus, so allgenıein gebaut, dass er hier schlechthin als "Common late Oat" bezeichnet wird; doch soll er auch auf leichterem Boden, in trockner Lage noch recht befriedigende Ernten bringen.

Diesem Hafer sehr ähnlich, nur dass die Scheinfrüchte mehr graulich gefärbt und etwas grösser sind, ist der für Clayboden sehr geschätzte „Grey Angus-Oat".

\section{Hopetonn-0at. $\odot$}

Syn.: Hopetoun-Hafer.

Rispe: ausgebreitet, ziemlich reichsamig, mittellang; Aehrchen 2körnig; Klappen an Basis gelb, nach oben weisslich $(2.4 \mathrm{~cm}$ lang, $0.7 \mathrm{~cm}$ breit). - Stroh: rötlich-gelb, sehr lang, fest, ziemlich blattreich, kräftig. - Scheinfrucht: unrein blassgelb, Scheidenspelze hellrot (charakteristisch), schmal, lang (grosses Korn $1.7 \mathrm{~cm}$ lang, $0.3 \mathrm{~cm}$ breit, kleines $1.3 \mathrm{~cm}$ lang, $0.25 \mathrm{~cm}$ breit), spitz, etwas leicht, ziemlich grobschalig, $100 \mathrm{gr}=$ $71 \mathrm{gr}$ Früchte, $29 \mathrm{gr}$ Spelzen.

Junges Blatt dunkelgrün, sehr lang, doch schmal, Bestockung schwach, 2 Schösslinge, zeitig schossend und blühend. Halm $145 \mathrm{~cm}$ (Max. $165 \mathrm{~cm}$ ) lang, $0.5 \mathrm{~cm}$ dick, Blattzahl 4, Blätter $36.5 \mathrm{~cm}$ lang, $1.21 \mathrm{~cm}$ breit, Blattfläche 353.32 qcm, Halmfläche $217.5 \mathrm{qcm}$, Gesammtfläche $570.82 \mathrm{qcm}$.

Frühhafer, reift in 120 Tagen, Rispe $25 \mathrm{~cm}$ (Max. $35 \mathrm{~cm}$ ) lang, mit 180 ziemlich fest sitzenden Scheinfrüchten, von denen 1935000 auf 1 h1 $(=43 \mathrm{~kg})$ entfallen.

Auf $1 \mathrm{qm}$ wachsen 650 Halme oder 325 Pflanzen, mithin beträgt der Raum für eine Pflanze $30.8 \mathrm{qcm}$, die Blattfläche p. qun Bodenfläche $37 \mathrm{qm}$, und das Saatquantum $2.3 \mathrm{hl}$ p. ha.

Es wiegen 100 Halme $1000 \mathrm{gr}$ und davon die Scheinfrüchte $500 \mathrm{gr}$.

Die Erträge stellen sich p. ha in England wie folgt:

Nach den Versuchen von Mitchell wurden nach zweijähriger Weide auf drainiertem Lehmboden p. ha gewonnen:

1847: $51.19 \mathrm{hl}$ Vorderkorn à $54.5 \mathrm{~kg}, 2.47 \mathrm{hl}$ Hinterkorn, $3459 \mathrm{~kg}$ Stroh 1848: 56.13 ," à 55.0 " 2.00 " $"$ Mach einjähriger Weide durch "Mr. Me

1848: $44.90 \mathrm{hl}$ Vorderkorn à $56.5 \mathrm{~kg}, 14.37 \mathrm{hl}$ Hinterkorn, $5771.6 \mathrm{~kg}$ Stroh.

In Deutschland wurden geerntet p. ha auf

\begin{tabular}{|c|c|c|c|}
\hline in 1 & $\begin{array}{l}\text { Korn } \\
1316 \mathrm{~kg}\end{array}$ & $\begin{array}{c}\text { Stroh } \\
3680 \mathrm{~kg}\end{array}$ & $\begin{array}{c}\text { Spreu } \\
280 \mathrm{~kg}\end{array}$ \\
\hline in $\mathrm{P}$ & 2074, & 4228, & $242 "$ \\
\hline . $\mathrm{T}$ & 0781 & 3525, & 509 \\
\hline
\end{tabular}


Dieser Hafer leidet selbst auf reichem Boden weder durch Lagern noch Rost, doch wachsen die Halme meist sehr ungleich auf, so dass man, um Zweischürigkeit zu vermeiden, auf möglichst gleichartige Beschaffenheit des Saatguts und auf Drillkultur Bedacht zu nehmen hat.

Er eignet sich vortrefflich für Moorboden und Neuland, aber auch für leichteren Boden im Kontinentalklima, wenugleich die reichen Lehmböden im Seeklima die löchsten Erträge bringen.

Zucht: Patrick Shirreff fand 1824 zu Mrungowells, East-Lothian, eine hohe Haferpflanze, welche er weiter kultivierte und um 1830 davon Samen abgab.

Dieser Hafer ist namentlich in England, in den Ostseeländern und in Amerika verbreitet.

\section{Sandie or Sandy-0at. $\odot$}

Syn.: Australian Cape-Oat.

Deutsch: Sandy-Hafer.

Rispe: etwas zusammengezogen, reichsamig, lang; Klappen blassgelb, an Basis rötlich, nach Spitze heller ( $1.9 \mathrm{~cm}$ lang, $0.5 \mathrm{~cm}$ breit), weich. Stroh: blassgelb, steif, kräftig, blattreich, lang. - Scheinfrucht: blassgelb mit rötlichem Anflug, zuweilen tritt eine schwache rötliche Granne auf, schmal, klein (grosses Korn $1.5 \mathrm{~cm}$ lang, $0.3 \mathrm{~cm}$ breit, kleines $1 \mathrm{~cm}$ lang, $0.25 \mathrm{~cm}$ breit), ziemlich feinschalig, $100 \mathrm{gr}=76 \mathrm{gr}$ Früchte, $24 \mathrm{gr}$ Spelzen.

Junges Blatt blangrün, schmal, kurz; Halm dunkelgrün, Bestockung stark, 3.2 Schösslinge, etwas spät blühend, Halm $130 \mathrm{~cm}$ (Max. $160 \mathrm{~cm}$ ) lang, $0.5 \mathrm{~cm}$ dick, Blattzahl 5, Blätter $32.6 \mathrm{~cm}$ lang, $0,96 \mathrm{~cm}$ breit, Blattfläche $313 \mathrm{qcm}$, Halmfläche $195 \mathrm{qcm}$, Gesammtfläche $508 \mathrm{qcm}$.

Späthafer, in 130 Tagen reifend; Rispe $30 \mathrm{~cm}$ (Max. $35 \mathrm{~cm}$ ) lang, mit 240 ziemlich fest sitzenden Scheinfrüchten, von denen 2076900 auf $1 \mathrm{hl}(=48.3 \mathrm{~kg})$ entfallen.

Es wiegen 100 Halme $710 \mathrm{gr}$ und davon die Scheinfrüchte $294 \mathrm{gr}$.

Auf drainiertem Lehmboden nach Weide wurden in England p. ha erzielt:

\begin{tabular}{lllll} 
& \multicolumn{4}{c}{ Vorderkorn Gewicht Hinterkorn Stroh } \\
1847 nach Mitchell (2-jähr. Weide) & $49.62 \mathrm{hl}$ & $55.5 \mathrm{~kg}$ & $4.14 \mathrm{hl}$ & $4936 \mathrm{~kg}$ \\
1848 & 60.84 & 56.0 & 2.69 & 5905
\end{tabular} 1848 " " $" 60.84, \quad 56.0, \quad 2.69,5905$, 1848 " Melvin (1-jährige Weide) $46.70 " 55.5 ", 12.57 " 7532 "$

Diese Hafersorte ist unempfindlich gegen ungünstige Witterung, und eignet sich sowohl für nassen schweren, als auch für leichten Boden. Er wird vorzugsweise durch ganz Schottland, vielfach in den Vereinigten Staaten und zuweilen in Deutschland kultiviert.

Nach Peter Lawson wurde sie 1824 oder 1825 auf der Farm Miltoun of Noth, Aberdeenshire, Schottland, durch einen Hirtenknaben Alexander (schottische Abkürzung "Sandy") Thomson auf dem Felde gefunden und von seinem Herrn, Mr. Pirie, weiter kultiviert. Mr. P. Shirreff ${ }^{1}$ ) vermutet nun, dass dieser Hafer ein am Ende des vorigen Jahrhunderts in East-Lothian von Mr. Brodie zu Upper-Keith kultivierter Hafer sei, den dieser für die höheren Gegenden Schottlands empfohlen habe, und der zu Anfang dieses Jahrhunderts noch wenig genannt wurde. In Deutschland soll er durch Jühlke in Eldena bekannt

1) The Country Gentleman's Magaz. Vol. V, p. 247. 1870. 
geworden sein. Wahrscheinlich ist er auch von England nach Anstralien gelangt, denn der dort gebaute "Australian Cape-oat" erwies sich nach unserer Untersuchung fast vollständig identisch mit ihm, nur dass die vom Direktor des botanischen Gartens zu Adelaide, Herrn Schomburgk, eingesandten Scheinfrüchte, wahrscheinlich in Folge des wärmeren, trockneren Klimas, eine mehr rötlich-gelbe Färbung besassen.

\section{Potato-0at. $\odot$}

Syn.: Englischer Kartoffelhafer.

Franz.: Avoine patate.

Rispe: ausgebreitet, klein, bis $22 \mathrm{~cm}$ lang, ziemlich reichsamig; Aehrchen 2-körnig; Klappen blassgelb (2.2 cm lang, $0.6 \mathrm{~cm}$ breit). Stroh: blassgelb, fest, blattreich, mittellang. - Scheinfrucht: gelb, voll, schwer, kurz (grosse Körner $1.6 \mathrm{~cm}$ lang, $0.35 \mathrm{~cm}$ breit, kleine $1.2 \mathrm{~cm}$ lang, $0.3 \mathrm{~cm}$ breit), etwas grobschalig, denn $100 \mathrm{gr}$ enthalten $69 \mathrm{gr}$ Korn, $31 \mathrm{gr}$ Spelzen.

Junges Blatt dunkelgruin, lang, schmal; Bestockung mittelstark, 2.8 Schösslinge, mittelfrüh schossend und blühend. Halm $130 \mathrm{~cm}$ (Max. $140 \mathrm{~cm}$ ) lang, $0.48 \mathrm{~cm}$ dick, Blattzahl 4.3, Blätter $32 \mathrm{~cm}$ lang, $1 \mathrm{~cm}$ breit, Blattfläche $275.2 \mathrm{qcm}$, Halmfläche $187.2 \mathrm{qcm}$, Gesammtfläche $462.4 \mathrm{qcm}$.

Frühhafer, in 120 Tagen reifend, Rispe $22 \mathrm{~cm}$ lang, mit 140 in der Vollreife leicht ansfallenden Scheinfrichten, voll denen 1333000 auf $1 \mathrm{hl}$ $(=43 \mathrm{~kg})$ entfallen.

Auf 1 qu wachsen 900 Halme oder 320 Pflanzen, mithin beträgt der Raum für eine Pflanze $31.2 \mathrm{qcm}$, die Blattfläche p. qn Bodenfläche $41.6 \mathrm{qm}$, und das Saatquantum $3.2 \mathrm{hl}$ p. ha.

Es wiegen 100 Halme $888 \mathrm{gr}$ und davon die Scheinfrüchte $438 \mathrm{gr}$. erzielt:

In Eldena wurden 1868 auf sandigem Jehm voln Verfasser p. ha

\section{$2134 \mathrm{~kg}$ Korn, $3222 \mathrm{~kg}$ Stroh, $250 \mathrm{~kg}$ Spreu.}

Die Erträge sollen sich in England, wo er sehr ausgedehnt kultiviert wird, auf $40-70 \mathrm{hl}$ p. ha, je nach der Bodenbeschaffenleit belaufen, so erzielte Mitchell auf drainiertem Lehmboden nach zweijähriger Weide p. ha:

$$
71.39 \mathrm{hl}(1 \mathrm{hl}=55 \mathrm{~kg}) \text { Korn und } 5368 \mathrm{~kg} \text { Stroh. }
$$

Dieser Hafer eignet sich vorzugsweise für ein mildes Klima und thätigen, reichen Humus- oder Lehmboden, auf armem Boden artet er leicht aus, indem das Korn länger, flacher, grobschaliger wird und sich begrannt.

Er lagert nicht leicht und bleibt fast rostfrei.

Ausser in England wird er in Deutschland, Frankreich und ziemlich stark in Amerika kultiviert.

Nach Peter Lawson wurde 1788 die erste Pflanze zu Cumberland in einem Kartoffelfelde gefunden und weiter kultiviert; doch gibt ein Anonymus im Farmer's Magazine von 1803 an, dass dieser Hafer von Süd-Amerika mit Kartoffeln, zwischen denen sich einige Haferkörner befunden hätten, importiert worden sei.

\section{Berwick-0at. $\odot$}

Syn.: Schottischer Berwick-Hafer.

Rispe: etwas zusammengezogen, reichsamig, mittellang; Aehrchen 
2-körnig, Aehrchenstiele schwärzlich ołer bläulich; Klappen gelb, nach der Spitze zn heller, weich, aufgeblasen ( $2 \mathrm{~cm}$ lang, $0.6 \mathrm{~cm}$ breit). - Stroh: rötlich-gelb, kräftig, fest, blattreich, ziemlich lang. - Scheinfrucht: schmutzig blass-gelb, Scheidenspelze rötlich, etwas spitz, klein (grosses Korn $1.3 \mathrm{~cm}$ lang, $0.3 \mathrm{~cm}$ breit, kleines $1 \mathrm{~cm}$ lang, $0.25 \mathrm{~cm}$ breit), schwer, Schale mittelfein, $100 \mathrm{gr}=72,5 \mathrm{gr}$ Früchte, $27.5 \mathrm{gr}$ Spelzen.

Halme blaugriin, spät blïhend, Bestockmng sehr stark, 3.3 Schösslinge, $125 \mathrm{~cm}$ (Max. $135 \mathrm{~cm}$ ) lang, $0.5 \mathrm{~cm}$ dick, Blattzahl 4.3, Blätter $31.4 \mathrm{~cm}$ lang, $1.24 \mathrm{~cm}$ breit, Blattfläche $334.8 .5 \mathrm{qcm}$, Halmfläche $187.5 \mathrm{qcm}$, Gesammtfäche $522.38 \mathrm{qcm}$.

Späthafer, reift sehr gleichmässig in 130 Tagcn, Rispe $25 \mathrm{~cm}$ (Max. $30 \mathrm{~cm}$ ) lang, mit 230 sehr leicht ausfallenden Scheinfriichten, von denen 2350000 auf $1 \mathrm{hl}(=50 \mathrm{~kg}$ ) entfallen.

Anf $1 \mathrm{qm}$ wachsen 700 Halme oder 212 Pflanzen, mithin beträgt der Rarm für eine Pflanze $47 \mathrm{qcm}$. die Blattläche p. qm Bodenfläche $36.5 \mathrm{qm}$, und das Saatquantum $1.2 \mathrm{hl} \mathrm{p}$. ha.

Es wiegen 100 Halme $545 \mathrm{gl}$ und davon die Scheinfrichte $263 \mathrm{gr}$.

In Proskan wurden 1872 auf kalkhaltigem Thonboden p. ha geerntet: $2143 \mathrm{~kg}$ Korn, $3110 \mathrm{~kg}$ Stroh, 265 kg Spreu.

Dieser Hafer liebt zeitige Aussaat, feuchtes Klina und reichen Moor- oder Lehmboden, wenngleich er anch anhaltende Trockenheit verträgt und anf leichterem Boden noch befriedigende Ernten liefert.

In Schottland, England, Holland und häufig in Norddeutschland, so namentlich in Holstein und Mecklenburg kultiviert.

\section{Long Fellow-0at. $\odot$}

Syn.: Schottischer ,Iong Fellow" Hafer.

Rispe: ausgebreitet, gross, reichsamig; Aehrchen 2-körnig; Klappen blassgelb (2.2 cm lang, $0.7 \mathrm{~cm}$ breit). -- Stroh: hellgelb, wenig blattreich, sehr lang, sehr kräftig, fest. -- Schcinfrucht: gelb, selten kurz begrannt, klein (grosses Korn $1.5 \mathrm{~cm}$ lang, $0.3 \mathrm{~cm}$ breit, kleines $0.8 \mathrm{~cm}$ lang, $0.25 \mathrm{~cm}$ breit), knrz, plump, feinschalig, $100 \mathrm{gr}=76.5 \mathrm{gr}$ Früchte, $23.5 \mathrm{gr}$ Spelzen.

Junges Blatt dunkelgriun, lang, etwas schmal; dieser Hafer entwickelt sich zuerst langsam, wächst jedoch nach dem Schossen schnell nach; Bestockung etwas schwach, 2.5 Schösslinge, ziemlich spät blühend. Halme $150 \mathrm{~cm}$ (Max. $180 \mathrm{~cm}$ ) lang, $0.5 \mathrm{~cm}$ dick, Blattzahl 5, Blaitter $36.8 \mathrm{~cm}$ lang, $1.36 \mathrm{~cm}$ breit, Blattfäche $500.48 \mathrm{qcm}$, Halmfläche $225 \mathrm{qcm}, G e-$ sammtfläche $725.48 \mathrm{qcm}$.

Späthafer, in 125 Tagen reifend, Rispe $30 \mathrm{~cm}$ (Мax. $40 \mathrm{~cm}$ ) lang, mit 250 Scheinfrüchten, von denen 2231000 auf $1 \mathrm{hl}(=50.7 \mathrm{~kg}$ ) entfallen.

Auf $1 \mathrm{qm}$ wachsen 550 Halme oder 220 Pflanzen, mithin beträgt das Saatquantum $1.3 \mathrm{hl}$ p. ha.

Es wiegen 100 Halme $913 \mathrm{gr}$ und davon die Scheinfrüchte $388 \mathrm{gr}$.

Diese durch ihr langes Stroh (daher auch "Long Fellow" = langer Bruder) bemerkenswerte Hafersorte ist ertragreich, leidet nicht leicht durch ungünstige Witternng, widersteht sowohl dem Lagern, als anch dem Rost, und eignet sich zur Grünfutterbenutzing.

Sie wurde 1862 von P. Shireff ${ }^{1}$ ) durch Aehrenauswahl gewonnen, und mit ihr noch zwei andere Sorten und zwar:

1) Shirreff, Improvem. of Cercals ctc. 187 ? 
„Early Fellow", vielleicht die früheste der in den Lothians kultivierten Sorten, denn sie reift noch 5-6 Tage vor dem Kartoffelhafer; das Stroh ist 5--6 cm höher und das leicht ausfallende Korn schwerer, kiirzer und plumper.

„Fine Fellow" ist ebenfalls friiher als der Kartoffelhafer und bis $25 \mathrm{~cm}$ länger: die Spelzen sind hellgelb, und die Scheidenspelze besitzt, ähnlich dem Hopetoun-Hafer, cinen roten Strich.

\section{Kildrummie-Oat.}

Syn.: Halkerton-Oat.

Rispe: etwas zusammengezogen, armsamig, mittellang; Aehrchen 2-körnig; Klappen gelb (2.5 cm lang, $0.3 \mathrm{~cm}$ breit). - Stroh: gelb, lang, kräftig, fest. - Scheinfrucht: gelb, dick, Schale mittelfein, $100 \mathrm{gr}=$ $72 \mathrm{gr}$ Friichte, $28 \mathrm{gr}$ Spelzen.

Halne dunkelblaugrïn, Bestockung ziemlich schwach, 2.4 Schösslinge, etwas spät bliihend, $125 \mathrm{~cm}$ (Max. $150 \mathrm{~cm}$ ) lang, $0.47 \mathrm{~cm} \mathrm{dick,}$ Blattzahl 5, Blätter $32.2 \mathrm{~cm}$ lang, $1.19 \mathrm{~cm}$ breit, Blattfläche $383.2 \mathrm{qcm}$, Halmfläche 176.25 qcm, Gesammtfläche $559.45 \mathrm{qcm}$.

Frühhafer, reift in 120 Tagen; Rispe $25 \mathrm{~cm}$ (Max. $35 \mathrm{~cm}$ ) lang, mit 120 Scheinfrüchten, von denen 1425000 auf 1 lil $(=47.5 \mathrm{~kg})$ entfallen.

Es wiegen 100 Halme $1000 \mathrm{gr}$ und davon die Scheinfruichte $471 \mathrm{gr}$.

Ex eignet sich fïr leichten Boden, auf dem er sich jedoch nach längerer Kultur begrannt, weshalb ein häufigerer Saatwechsel mit auf schwererem Boden gewachsenem Hafer zu empfehlen ist. rostfrei.

Er liefert hohe Stroherträge, lagert nicht leicht und bleibt fast

In England ist der Name ,Halkerton-Oat" der verbreitetere, während er in Schottland, Kildrummie" nach einem Distrikt im nördlichen Aberdcenshire, wo man ihn stark anbaut, genannt wird. breitet.

Ansser in Grossbritannien ist seine Kultur vielfach in Amerika ver-

\section{Old Poland or Tom Finlay's 0at. $\odot$}

Syn.: Deutsch: Weisser polnischer Hafer.

Franz.: Avoine de Pologne.

A inerika: Poland-Oat.

Rispe: wenig ausgebreitet, etwas armsamig, mittellang; A ehrchen 2-körnig; Klappen fast weiss (25 cm lang, $06 \mathrm{~cm}$ breit). - Strolı: hellgelb, kräftig, blattreich, inittcllang. - Scheinfrucht: blassgelb, lang (grosses Korn $1.7 \mathrm{~cm}$ lang, $0.3 \mathrm{~cm}$ breit, kleines $1.2 \mathrm{~cm}$ lang, $0.25 \mathrm{~cm}$ breit), etwas leicht, Schale mittelfein, $100 \mathrm{gr}=73.7 \mathrm{gr}$ Früchte, $26.3 \mathrm{gr}$ Spelzen.

Jlnges Blatt blaugrün, Bestockung mittelstark, 2.5 Schösslinge, zeitig schossend und blühend; Halme $120 \mathrm{~cm}$ (MLax. $140 \mathrm{~cm}$ ) lang, $0.4 \mathrm{~cm}$ dick, Blattzahl 5, Blätter $30 \mathrm{~cm}$ lang, $0.8 \mathrm{~cm}$ breit, Blattfäche $240 \mathrm{qcm}$, Halmfläche $144 \mathrm{qcm}$, Gesammtfläche $394 \mathrm{qcm}$.

Friihhafer, Rispe $25 \mathrm{~cm}$ (Max, $30 \mathrm{~cm}$ ) lang, nit 150 leicht ausfallenden S'cheinfrüchten, von denen 1299000 auf $1 \mathrm{hl}(=43.3 \mathrm{~kg})$ cntfallen.

Es wiegen 100 Halme $521 \mathrm{gr}$ und davon die Scheinfrüchte $332 \mathrm{gr}$. Dicser Hafer ist gegen unginstige Witterung sehr unempfindlich, 
lagert nicht leicht und befällt wenig mit Rost, doch lässt die Qualität des Kornes, namentlich auf schwerem, kaltem Boden, auf dem er sehr grobschalig wird, zu wünschen.

Ursprünglich stammt diese Sorte aus Polen und wurde zuerst durch Thomas Finlay in Ayrslire verbreitet und in Schottland und England ${ }^{1}$ ) friber stark angebaut, aber auch über Frankreich und Amerika dehnte sich seine Kultur aus.

\section{Shirreff's 0at. $\odot$}

Sy n.: Schottischer früher Shirreff's-Hafer.

Weisser schwedischer Shirreff-Hafer.

Rispe: ausgebreitet, armsamig, lang; Aehrchen 2-körnig; Klappen blassgelb (2.2 cm lang, $0.6 \mathrm{~cm}$ breit). - Stroh: gelb, fest, lang. Scheinfrucht: blassgelb, Scheidenspelze rot, lanzettlich, voll, klein (grosses Kön $1.5 \mathrm{~cm}$ lang, $0.35 \mathrm{~cm}$ breit, kleines $1 \mathrm{~cm}$ lang, $0.25 \mathrm{~cm}$ breit); zuweilen begrannt, feinschalig, $100 \mathrm{gr}=76 \mathrm{gr}$ Früchte, $24 \mathrm{gr}$ Spelzen.

Halme dunkelgrün, etwas spät blühend, 2.8 Schösslinge, $130 \mathrm{~cm}$ (Max. $150 \mathrm{~cm}$ ) lang, $0.5 \mathrm{~cm}$ dick, Blattzahl 5, Blätter $28.6 \mathrm{~cm}$ lang, $1.08 \mathrm{~cm}$ breit, Blattfläche 308.9 q cm, Halmfläche $195 \mathrm{qcm}$, Gesammtfläche $503.9 \mathrm{qcm}$.

Frühhafer, reift in 120 Tagen, Rispe $30 \mathrm{~cm}$ (Max. $35 \mathrm{~cm}$ ) lang, mit 160 Scheinfrüchten, welche in der Vollreife fest sitzen, und von denen 1839000 auf $\mathrm{l} \mathrm{hl}(=45.3 \mathrm{~kg})$ entfallen.

Es wiegen 100 Halme $457 \mathrm{gr}$ und davon die Scheinfrüchte $259 \mathrm{gr}$.

Nach Mr. MI lvin wurden nach einjähriger Weide und auf drainiertem Lehmboden 1848 in England p. ha erzielt:

$53.88 \mathrm{hl}$ Vorderkorn à $54 \mathrm{~kg}, 17.96 \mathrm{hl}$ Hinterkorn, $5147 \mathrm{~kg}$ Stroh.

Dieser nicht leicht lagernde, fast rostfreie Hafer eignet sich für reiche, etwas feuchte Böden und soll unter solchen Unständen schon bis $90 \mathrm{hl} \mathrm{p.} \mathrm{ha} \mathrm{geliefert} \mathrm{haben.}$

Zuichter ist Mr. Slsirreff ${ }^{2}$ ) in Mungowells, East-Lothian.

Sein Anbau hat kcine weite Verbreitung gefunden; gewöhnlich erscheint er auf den Märkten von Dalkeith und Kelso unter dem Namen "Mlake him rich".

\section{Milton-0at. $\odot$}

S y n.: Milton-Hafer.

Rispe: etwas zusammengezogen, kurz, reichsamig; Aehrchen meist dreikörnig; Klappen schmutzig gelbgelb (2.5 $\mathrm{cm}$ lang, $0.7 \mathrm{~cm}$ breit). Stroh: griin-gelb, sehr kräftig, sehr fest, lang. - Scheinfrucht: schmutzig blassgelb, dick, voll, kurz (grosses Korn $1.3 \mathrm{~cm}$ lang, $0.3 \mathrm{~cm}$ breit, kleines $1.1 \mathrm{~cm}$ laug, $(1.25 \mathrm{~cm}$ breit), schwer, Schale mittelfein, $100 \mathrm{gr}$ enthalten 72. $\mathrm{gr}$ Frucht, 27.5 gr Spelzen. Bildet Uebergang zll A. s. praegravis.

Junges Blatt blaugriin, breit, lang; Bestockung mittelstark, 2.8 Schösslinge, zeitig schossend und blühend. Halme $135 \mathrm{~cm}$ (MIax. $165 \mathrm{~cm}$ ) lang, $0.6 \mathrm{~cm}$ breit, Blattzahl 5, Blätter $38.8 \mathrm{~cm}$ lang, $1.2 \mathrm{~cm}$ breit, Blattfläche $465.6 \mathrm{qcm}$, Halmfläche $243 \mathrm{qcm}$, Gesamıntfäche $7118.6 \mathrm{qcm}$.

1) Thaer, Engl. Landw. Bd. I, 1806.

2) Vergl. Improvem. of Cereals etc. 1879 
Frühhafer, Rispe $20 \mathrm{~cm}$ (Max. $25 \mathrm{~cm}$ ) lang, mit 155 Scheinfruichten, von denen 1309500 auf $1 \mathrm{hl}(=4.5 \mathrm{~kg}$ ) entfallen.

Es wiegen 100 Halme $1060 \mathrm{gr}$ und davon die Scheinfruichte $552 \mathrm{gr}$.

Zur Grünfuttererzeugung scheint dieser gegen Rost und Lagern sehr widerstandsfähige, sowie selır schnellwüchsige nnd robuste Hafer beachtenswert zu sein.

Heimat: Minnesota, Nord-Amerika.

\section{Barbachlow-0at. $\odot$}

Rispe: ausgebreitet, kurz, ziemlich reichsamig; Aehrchen 2-, zuweilen 3-körnig; Klappen blassgelb (2.8 cm lang, $0.7 \mathrm{~cm}$ breit). - Stroh: gelb, kräftig, lang, fest, blattreich. - Scheinfrucht: blassgelb mit graulichem Anflug, Sclieidenspelze graubraun, länglich, spitz, gross (grosses Korn $2 \mathrm{~cm}$ lang, $0.35 \mathrm{~cm}$ breit, kleines $1.5 \mathrm{~cm}$ lang, $0.25 \mathrm{~cm}$ breit), nicht selten begrannt; Grannen an Basis schwarzbraun, nach oben hellbraun; ziemlich feinschalig, $100 \mathrm{gr}=76 \mathrm{gr}$ Früchte, $24 \mathrm{gr}$ Spelzen.

Blätter blaugrün, schmal, kurz, Bestockung schwach, 2 Schösslinge, zeitig schossend und blühend. Halm $125 \mathrm{~cm}$ (Max. $110 \mathrm{~cm}$ ) lang, $0.5 \mathrm{~cm}$ dick, Blattzahl 5, Blätter $32.8 \mathrm{~cm}$ lang, $1.2 \mathrm{~cm}$ breit, Blattfläclie $393.6 \mathrm{qcm}$, Halmfläche $187.5 \mathrm{qcm}$, Gesammtfläche $581.1 \mathrm{qcm}$.

Frühhafer, in 120 Tagen reifend; Rispe $20 \mathrm{~cm}$ (Max. $30 \mathrm{~cm}$ ) lang, mit 150 nicht leicht ausfallenden Scheinfrüchten, von denen 1419000 auf $1 \mathrm{hl}(=47.3 \mathrm{~kg})$ entfallen.

Es wiegen 100 Halme $790 \mathrm{gr}$, und davon die Scheinfriichte $402 \mathrm{gr}$.

Dieser Hafer ist wenig empfindlich, ertragreich in Korn und Stroh, widerstandsfähig gegen Lagern und Rost, und für hochgelegene, leichtere aber in guter Kultur befindliche Aecker, namentlich auch zur Grünfuttererzeugung geeignet.

Ursprünglich wurde er auf der Farm Barbachlow in der Nähe von Bathgate, Schottland, gezüchtet, und zugleich mit ibm ein schwarzer Hafer, der jedoch geringwertiger ist.

\section{Providence-0at. $\odot$}

Syn.: Schottischer Providence-Hafer.

Rispe: ausgebreitet, ziemlich reichsamig, mittellang; Aehrchen 2-, zuweilen 1-körnig; Klappen blassgelb (2 cm lang, $0.6 \mathrm{~cm}$ breit). - Stroh: orange-gelb, fest, lang. - Scleinfruclit: blassgelb, zuweilen begrannt, klein, dick (grosses Korm $1.3 \mathrm{~cm}$ lang, $0.3 \mathrm{~cm}$ breit, kleines $0.8 \mathrm{~cm}$ lang, $0.25 \mathrm{~cm}$ breit), lanzettlich, schwer, sehr feinschalig, $100 \mathrm{gr}=78 \mathrm{gr}$ Früchte, 22 gr Spelzen.

Junges Blatt dunkelgrïn, lang, kräftig, 2.4 Schösslinge, mittelfrüh schossend nnd bliihend. Halm $125 \mathrm{~cm}$ (Max. $150 \mathrm{~cm}$ ) lang, $0.5 \mathrm{~cm}$ dick, Blattzahl 4.4, Blätter $30.6 \mathrm{~cm}$ lang, $1.14 \mathrm{~cm}$ breit, Blattfläche $306.98 \mathrm{qcm}$, Halmfläche $187.5 \mathrm{qcm}$, Gesammtfläclıe $494.45 \mathrm{qcm}$.

Friihreif, in 117 Tagen reifend; Rispe $25 \mathrm{~cm}$ (Max. $35 \mathrm{~cm}$ ) lang, mit 150 Scheinfriichten, vou denen 2890000 auf $1 \mathrm{hl}(=50.7 \mathrm{~kg})$ entfallen.

Es wiegen 100 Halme $852 \mathrm{gr}$ und davon die Scheinfriichte $375 \mathrm{gr}$.

Im Allgemeinen älınelt er dem englischen Kartoffelhafer, nur ist das Korn noch kleiner und dicker.

Dieser nicht leicht lagernde und fast rostfreie Hafer eignet sich für Mittelboden. 


\section{Scotch Dwarf-0at. $\odot$}

Syn.: Schottischer Zwerghafer.

Rispe: wenig ausgebreitet, sehr kurz, ziemlich reichsamig; Aehrchen 2-körnig; Klappen gelb (2.5 cm lang, $0.6 \mathrm{~cm}$ breit). - Stroh: gelbgruin, fest, mittellang. - Scheinfrucht: blassgelb, rund, voll, klein (grosses Korn $1.7 \mathrm{~cm}$ lang, $0.35 \mathrm{~cm}$ breit, kleines $0.7 \mathrm{~cm}$ lang, $0.3 \mathrm{~cm}$ breit), schwer, sehr feinschalig, $100 \mathrm{gr}$ enthalten $77 \mathrm{gr}$ Früchte, $23 \mathrm{gr}$ Spelzen.

Junges Blatt blaugrüll, kräftig, schmal, lang, Bestockung mittelstark, 2.4 Schösslinge. Halm $110 \mathrm{~cm}$ (Max. $120 \mathrm{~cm}$ ) lang, $0.4 \mathrm{~cm}$ dick, Blattzahl 4.6, Blätter $32.5 \mathrm{~cm}$ lang. $0.5 \mathrm{~cm}$ breit, Blattfläche $149.5 \mathrm{qcm}$, Halmfläclıe $132 \mathrm{qcm}$, Gesammtfläche $281.5 \mathrm{q} \mathrm{cm}$.

Frühhafer, Rispe $15 \mathrm{~cm}$ (Max. $25 \mathrm{~cm}$ ) lang, mit 100 ziemlich fest sitzenden Scheinfrücliten, von denen 1831600 auf $1 \mathrm{hl}$ (= $48.2 \mathrm{~kg}$ ) entfallen.

Es wiegen 100 Halme $460 \mathrm{gr}$ und davon die Scheinfrüchte $243 \mathrm{gr}$.

Er lagert nicht leicht, bleibt fast rostfrei, und eignet sich für leichteren Boden.

Erhalten aus h. Eldena 1872.

\section{Blainslie-0at.}

Rispe: ansgebreitet, sehr armsamig (60 Scheinfriichte), kurz; Klappen gelb, lang, schmal ( $2 \mathrm{~cm}$ lang, $0.6 \mathrm{~cm}$ breit); Aelirchen: 2-körnig. Stroh: gelb, kurz (90 cm lang), fest, steif. - Scheinfrucht: blassgelb (grosses Korn $1.5 \mathrm{~cm}$ lang, $0.3 \mathrm{~cm}$ breit, kleines $1.2 \mathrm{~cm}$ lang, $0.2 \mathrm{~cm}$ breit).

Dieser frïhreife Hafer trïgt seinen Namen von einer schottischen Farm. auf der er, wie iberliaupt in dem sïdöstlichen Sclottland viel gebaut wurde. In neuerer Zeit ist er jedoch durch andere friihreife Sorten vielfach verdrängt worden. bringen.

Auf gutem Baden soll er reiche Ernten an Körnern und Stroh

Original: im landw. Museum zu Berlin.

\section{White or Conmon-0at. $\odot$}

Sy n.: Euglischer weisser Hafer.

Rispe: blassgelb, etwas zusammengezogen, mittelgross, $25 \mathrm{~cm}$ lang, mit 110 Scheinfrüchten; Aehrchen meist 3-körnig, Klappen blassgelb und gross, $3 \mathrm{~cm}$ lang, $0.7 \mathrm{~cm}$ breit. - Strolı: gelb, fest, kräftig $(0.4 \mathrm{~cm}$ dick), blattreich, $140 \mathrm{~cm}$ hoch. - Scheinfrucht: blassrötlichıelb, gross, $20 \mathrm{~mm}$ lang, $3 \mathrm{~mm}$ breit, mittlere Scheinfrucht $13 \mathrm{~mm}$ lang, $2.5 \mathrm{~mm}$ breit, kleine $9 \mathrm{~mm}$ lang, $2 \mathrm{~mm}$ breit; ein wenig dickschalig, da die Spelzen 27.8 Proc. alsmachen. Auf $1 \mathrm{hl}$ (= $44.5 \mathrm{~kg}$ ) entfallen 1335000 Scheiufruichte.

Frühlafer in 130 Tagen reifend.

In England, Schottland und stark in Nord-Amerika gebaut.

\section{Cumberland early white 0at. $\odot$}

Rispe: ausgebreitet. - Strolı: gelb, länger als bein Kartoffellıfer, his $150 \mathrm{~cm}$ lang. - Scheinfrucht: dunlielgelb, leichter, schmaler und geringwertiger als die des Kartoffelhafers. 
Sehr friihreif und stark in Schottland kultiviert.

Wurde 1833/34 aus einer einzigen in Cumberland gefundenen Pflanze, die sich durch Frïhreife auszeichnete, gezogen.

\section{0rkney-0at. $\odot$}

Rispe: ausgebreitet, mit 50 Aehrchen und 90 Scheinfrüchten; Klappen fast weiss $(2.2 \mathrm{~cm}$ lang, $0.7 \mathrm{~cm}$ breit). - Stroh: gelb, kräftig, $100 \mathrm{~cm}$ lang. - Scheinfrucht: blassgelb, zuweilen besitzt das grosse Korn eine helle, gebogene Granne, schmal (grosses Korı $1.5 \mathrm{~cm}$ lang, $0.2 \mathrm{~cm}$ breit, kleines $1 \mathrm{~cm}$ lang, $0.15 \mathrm{~cm}$ breit).

Heimat: Orkney-Inseln.

Original im landw. Museum zu Berlin.

\section{('nbian-0at. $\odot$}

Rispe: ausgebreitet, mittellang $(25 \mathrm{~cm})$, ziemlich reichsamig (180 Scheinfrüchte); Aehrchen 2-körnig; Klappen gelb (2 cm lang, $0.5 \mathrm{~cm}$ breit). - Strolı: rötlich-gelb, kräftig, etwas kurz (100 cm lang). - Scheinfrucht: gelb, schmal (grosses Korn $1.5 \mathrm{~cm}$ lang, $0.2 \mathrm{~cm}$ breit, kleines $1.1 \mathrm{~cm}$ lang, $1.5 \mathrm{~cm}$ breit).

Original: im landw. Museum zu Berlin.

\section{Waterlo0-0at. $\odot$}

Rispc: ausgebreitet, ziemlich reichsamig, kurz; Aehrchen 2- und 3-körnig; Klappen gelb (2.5 cm lang, $0.7 \mathrm{~cm}$ breit). - Stroh: griinlichgelb, feinhalınig, etwas iiber mittellang. - Scheinfrucht: blassrötlich-gelb, an Basis einige Borsten, meist unbegrannt, lang, spitz, doch voll (grosses Korn $1.8 \mathrm{~cm}$ lang, $0.35 \mathrm{~cm}$ breit, kleines $1.3 \mathrm{~cm}$ lang, $0.3 \mathrm{~cm}$ breit), ziemlich feinschalig, $100 \mathrm{gr}=72.8 \mathrm{gr}$ Frïchte, $27.2 \mathrm{gr}$ Spelzen.

Junges Blatt dunkelgriin, lang, breit; Bestockıng sehr schwach, 1.5 Schösslinge, zeitig schossend und bliihend. Halm $125 \mathrm{~cm}$ (Max. $145 \mathrm{~cm}$ ) lang, $0.4 \mathrm{~cm}$ dick, Blattzahl 4.7, Blätter $30 \mathrm{~cm}$ lang, $1.03 \mathrm{~cm}$ breit, Blattfäche 290.46 qcm, Halınfläche 150 qcm, Gesammtfläche $440.46 \mathrm{qcm}$.

Frïhhafer, reift in 118 Tagen; Rispe $20 \mathrm{~cm}$ (Max. $25 \mathrm{~cm}$ ) lang, mit 120 ziemlich fest sitzenden Scheinfriichten, von denen 1593000 auf $1 \mathrm{hl}(=45.5 \mathrm{~kg})$ entfallen.

Es wiegen 100 Halme $833 \mathrm{gr}$ und davon die Scheiufrüchte $451 \mathrm{gr}$.

Dieser Hafer, der durch Lagern und Rost" wenig leidet, eignet sich fuir sandige Lelım- und lehmige Sandböden, und ist in nenerer Zeit von England nach Amerika eingefïhrt worden, wo er namentlich in Ohio kultiviert wird.

\section{Norway-0at. $\odot$}

Risje: etwas zusammengezogen, kur\% $(18 \mathrm{~cm})$, sehr armsamig, mit 30 Aehrchen und 55 Scheinfrüchten; Klappen fast weiss, länger als Scheinfrucht. - Stroh: rötlich-gelb, fest, knrz $(100 \mathrm{~cm})$. - Scheinfrucht: rötlich-gelb, voll, klein (grosses Korn $1.3 \mathrm{~cm}$ lang, $0.25 \mathrm{~cm}$ breit, kleines $0.9 \mathrm{~cm}$ lang, $0.2 \mathrm{~cm}$ breit).

Original im landw. Museum zu Berlin. 


\section{American Potato-0at. $\odot$}

Syn.: Deutsch: Amerikanischer Kartoffel-Hafer.

Franz.: Avoine patate jaune.

Rispe: wenig ausgebreitet, locker, ziemlich reichsamig, mittellang; Aehrchen 2-körnig, höchst selten begrannt; Klappen goldgelb $(2.5 \mathrm{~cm}$ lang, $0.6 \mathrm{~cm}$ breit). - Stroh: grünlich-gelb, kräftig, lang. - Scheinfrucht: blassgelb, etwas schmal, mittelgross (grosses Korn $1.2 \mathrm{~cm}$ lang, $0.3 \mathrm{~cm}$ breit, kleines $0.8 \mathrm{~cm}$ lang, $0.25 \mathrm{~cm}$ breit), sehr feinschalig, $100 \mathrm{gr}$ enthalten $78.7 \mathrm{gr}$ Korn, $21.3 \mathrm{gr}$ Spelzeu, schwer.

Junges Blatt blaugruin, ziemlich breit, kräftig, Bestockung schwach, 2 Schösslinge. Halm $150 \mathrm{~cm}$ (Мax. $165 \mathrm{~cm}$ ) lang, $0.5 \mathrm{~cm}$ breit, Blattzahl 4.6, Blätter $30 \mathrm{~cm}$ lang, $1.13 \mathrm{~cm}$ breit, Blattfläche $311.88 \mathrm{qcm}$, Halmfläche $225 \mathrm{qcm}$, Gesammtfläche 536.88 qem.

Späthafer, in 130 Tagen reifend; Rispe $25 \mathrm{~cm}$ lang, mit 200 ziemlich fest sitzenden Scheinfrüchten, von denen 1612100 auf $1 \mathrm{hl}(=49 \mathrm{~kg})$ entfallen.

Es wiegen 100 Halme $830 \mathrm{gr}$ und davon die Scheinfrüchte $486 \mathrm{gr}$.

Diese höchst beachtenswerte anerikanische Sorte wird auch vielfach im suidlichen Russland, so in Gouvernement Charkow, gebaut und verlangt einen nahrungsreichen Boden.

\section{Excelsior-0at. $\odot$}

Rispe: blassgelb, ein wenig zusammengezogen, mittelgross; Aehrchen meist 3-körnig. - Stroh: rötlich-gelb, bis $150 \mathrm{~cm}$ lang, selır kräftig, steif. - Scheinfrucht: fast weiss, gross, voll, feinschalig.

Frühreif, Bestockung sehr stark; ertragreich, und in Nord-Amerika in grosser Ausdehnung auf reichem, aber auch auf armem Boden gebaut.

Wurde $1868^{1}$ ) von Bristol aus nach Nord-Amerika eingeführt.

\section{White Schönen or Beautiful-oat. $\odot$}

Rispe: blassgelb, ausgebreitet, mittelgross; Aehrchen meist 3-körnig. - Stroh: rötlich-gelb, steif, fest. - Scheinfrucht: blassgelb, sehr schön, feinschalig.

Weniger frühreif als „Excelsior", doch ebenso ertragreich, und stellten sich die Erträge in Nord-Amerika auf $56-67 \mathrm{hl}$ p. ha.

Dieser ursprüinglich aus Schweden stammende Hafer wurde $1868^{2}$ ) über Hamburg nach Nord-Amerika importiert, wo er jetzt sehr beliebt ist.

\section{Arena, Colonia de Punta Arenas, Magellanes, Chile. $\odot$}

Rispe: gelb, etwas zusammengezogen, kurz, ziemlich reichsamig; Aehrchen meist 3-körnig. - Stroh: rotgelb, fest, kurz. - Scheinfruclit: hellgelb, voll, sehr schön, ziemlich lang (grosses Korn $19 \mathrm{~mm}$ lang, $3 \mathrm{~mm}$ breit, kleines $9 \mathrm{~mm}$ lang, $2.3 \mathrm{~mm}$ breit, 279 Scheinfrüchte $=10 \mathrm{gr}$ ); znweilen tritt eine Granne auf, bis $4 \mathrm{~cm}$ lang, gekniet und gedreht, an Basis schwarz-braun, nach oben heller.

Junges Blatt dunkelgrün, sehr kräftig; Entwickelung spät; Halm

1) Annual Rep. of the U. S. Hepartm. of Agric. 1871, pg. 135.

2) Annual Rep. of the U. S. Departm. of Agric. 1871, pg. 136. 
$100 \mathrm{~cm}$ lang, $0.48 \mathrm{~cm}$ dick, Blattzahl 4.5 , Blätter $28.4 \mathrm{~cm}$ lang, $1.1 \mathrm{~cm}$ breit, Blattfläche 271.2 qcm, Halmfläche $144 \mathrm{qcm}$, Gesammtfläche 495.2 q cm.

In 145 Tagen reifend; Späthafer.

Bezugsquelle: Ministerresident von Gülich, Chile, 1880.

\section{Avena marzuola, Arezzo, Italien. $\odot$}

Rispe: ausgebreitet, lang $(26 \mathrm{~cm})$; Aehrchen 2-körnig; Klappen rötlich-gelb ( $2 \mathrm{~cm}$ lang, $0.6 \mathrm{~cm}$ breit). - Stroh: tief gelb. - Scheinfrucht: bräunlich-gelb, mit hellbräunlicher Scheidenspelze (grosses Korn $1.5 \mathrm{~cm}$ lang, $0.25 \mathrm{~cm}$ breit, kleines $1.2 \mathrm{~cm}$ lang, $0.2 \mathrm{~cm}$ breit).

Original auf der Pariser Ausstellung 1878.

\section{Civada blanca, Granjà de Barcelona. $\odot$}

Rispe: ausgebreitet, armsamig, kurz; Aehrchen 1- und 2-körnig, Klappen unrein blassgelb, $2.5 \mathrm{~cm}$ lang, $0.7 \mathrm{~cm}$ breit. - Stroh: blass-rot, fest, unter mittellang. - Scheinfrucht: schwach graulich, kurz, voll (grosses Korn $12 \mathrm{~mm}$ lang, $2.5 \mathrm{~mm}$ breit, 340 Scheinfrüchte $=10 \mathrm{gr}$ ); zuweilen begrannt; ziemlich feinschalig, 24 Proc. Spelzen.

Junges Blatt dunkelgrün, schmal, 1.5 Schösslinge; Halm $100 \mathrm{~cm}$ lang, $0.33 \mathrm{~cm}$ dick, Blattzahl 4.5, Blätter $24 \mathrm{~cm}$ lang, $0.8 \mathrm{~cm}$ breit, Blattfläche $172.8 \mathrm{qcm}$, Halmfläche $99 \mathrm{qcm}$, Gesammtfläche $271.8 \mathrm{qcm}$. früchten.

Rispe $17 \mathrm{~cm}(M a x .25 \mathrm{~cm})$ lang, mit 25 Aehrchen und 45 Schein-

Frühhafer, in 110 Tagen reifend.

Bezugsquelle: Ant. Cipr. Costa, 1881. Barcelona.

\section{Hafer aus Umeå. $\odot$}

Rispe: ausgebreitet, mittellang, sehr reichsamig; Aehrchen 2-körnig; Klappen gelb, nach der Spitze zu heller (2.7 cm lang, $0.65 \mathrm{~cm}$ breit), weich. - Stroh: rötlich-gelb bis orange, rohr-artig, sehr fest, blattarm. - Scheinfrucht: rötlich-gelb, zuweilen mit graulichen Streifen und Flecken, lang, etwas spitz (grosses Korn $1.7 \mathrm{~cm}$ lang, $0.35 \mathrm{~cm}$ breit, kleines $1.3 \mathrm{~cm}$ lang, $0.25 \mathrm{~cm}$ breit), grobschalig, $100 \mathrm{gr}$ enthalten $67.8 \mathrm{gr}$ Korn, $32.2 \mathrm{gr}$ Spelzen.

Halme blaugrün, 2.8 Schösslinge, sehr zeitig blühend, $115 \mathrm{~cm}$ (Max. $140 \mathrm{~cm}$ ) lang, $0.6 \mathrm{~cm}$ dick, Blattzahl 3.7 , Blätter $30 \mathrm{~cm}$ lang, $1.09 \mathrm{~cm}$ breit, Blattfläche $241.98 \mathrm{qcm}$, Halmfläche $207 \mathrm{qcm}$, Gesammtfläche $448.98 \mathrm{qcm}$.

Frühhafer, Rispe in 106 Tagen reifend, $25 \mathrm{~cm}$ (Max. $30 \mathrm{~cm}$ ) lang, mit 270 etwas leicht ausfallenden Scheinfrüchten, von denen 1620000 auf $1 \mathrm{hl}(=45 \mathrm{~kg})$ entfallen.

Es wiegen 100 Halme $689 \mathrm{gr}$ und davon die Scheinfrïchte $334 \mathrm{gr}$.

Heimat: Umeå, Westerbotten, Schweden $\left(64^{0} \mathrm{n}\right.$. Br. $)$.

\section{Hafer aus Högen, Âmål, Dalsland, Schweden.}

Rispe: ausgebreitet, locker, mittellang (26 cin), mit 55 Aehrchen und 85 Scheinfrüchten; Klappen nach der Spitze fast weiss, nach der Basis zu schön gelb ( $1.5 \mathrm{~cm}$ lang, $0.6 \mathrm{~cm}$ breit). - Stroh : rötlich-blassgelb. Scheinfrucht: blassgelb, voll $(1.3 \mathrm{~cm}$ lang, $0.25 \mathrm{~cm}$ breit).

Original in der Sammlung des Dr. Dreisch in Poppelsdorf. 


\section{Lappländischer Hafer. $\odot$}

Rispe: ausgebreitet, ziemlich reichsamig, kurz; Aehrchen meist 3-liörnig; Klappen bräunlich-weiss $(2.4 \mathrm{~cm}$ lang, $0.6 \mathrm{~cm}$ breit). - Stroh: goldgelb, sehr fest. blattarm, lang. - Scheinfrucht: sclinutzig-gelb, lanzettlich, schmal, zuweilen begrannt, klein (grosses Korn $1.3 \mathrm{~cm}$ lang, $0.25 \mathrm{~cm}$ breit, kleines $0.9 \mathrm{~cm}$ lang, $0.2 \mathrm{~cm}$ breit), ziemlich grobschalig, $100 \mathrm{gr}=$ $70.9 \mathrm{gr}$ Früchte, $29.1 \mathrm{gr}$ Spelzen.

Junges Blatt gelbgrün, ziemlich lang und breit; zeitig schossend, Bestockung inittelstark, 2.7 Schösslinge; Halme $140 \mathrm{~cm}$ (Max. $155 \mathrm{~cm}$ ) lang, $0.4 \mathrm{~cm}$ dick, Blattzahl 4.2 , Blätter $38.3 \mathrm{~cm}$ lang, $0.9 \mathrm{~cm}$ breit, Blattfläche $289.55 \mathrm{qcm}$, Halmfläche $168 \mathrm{qcm}$, Gesamintfläche $457.55 \mathrm{qcm}$. Frühhafer, reift in 118 Tagen; Rispe $22 \mathrm{~cm}$ (Max. $30 \mathrm{~cm}$ ) lang, mit 200 fest sitzenden Scheinfriichten, von denen 1984400 auf $1 \mathrm{hl}$ $(=48.4 \mathrm{~kg})$ entfallen.

Es wiegen 100 Halme $975 \mathrm{gr}$ und davon die Scheinfrüchte $525 \mathrm{gr}$.

Diese Sorte, welche der Akklimatisations-Verein an Berlin in NordDeutschland einfuihrte, zeichnet sich auf gutem Bodel durch hohe Ertrïge und grosse Widerstandsfähigkeit gegen Lagern und Rost aus.

\section{Kaukasischer Hafer. $\odot$}

Rispe: blassgelb, stark zusammengezogen, doch näher zu "Patula“ als ,Orientalis" stehent, also den Uebergang bildend, mittellang; Aehrchen 2-, selten 3-körnig, Klappen blassgelb, $2.7 \mathrm{~cm}$ lang, $0.7 \mathrm{~cm}$ breit. -.- Stroh: grünlich-gelb, blattreich, fest, unter mittellang. -- Scheinfrucht: blassgelb, höchst selten begrannt, leicht, sehr lang, schmal (grosses Korn $20 \mathrm{~mm}$ lang. $3 \mathrm{~min}$ breit, kleines $15 \mathrm{~mm}$ lang, $2.5 \mathrm{~mm}$ breit), sehr grobschalig, Spelzen 34.6 Proc. ausmachend.

Junges Blatt dunkelgrün, schmal, lang, aufrecht; Halm $100 \mathrm{~cm}$ lang, $0.4 \mathrm{~cm}$ dick, Blattzahl 4.5, Blätter $25 \mathrm{~cm}$ lang, $1.1 \mathrm{~cm}$ breit, Blattfläche $247.5 \mathrm{qcm}$, Halmfläche $120 \mathrm{qcm}$, Gesammtfläche $367.5 \mathrm{qcm}$.

Rispe $25 \mathrm{~cm}$ lang nit 140 Scheinfrüchten, von denen 1392000 auf $1 \mathrm{hl}(=43.5 \mathrm{~kg})$ คntfallen.

Späthafer, 130 Tagen reifend. Ertrag nach Quantität und Qualität geringwertig.

\section{Hafer aus Jekaterinoslaw, Süd-Russland. $\odot$}

Rispe: ausgebreitet, kurz, armsamig; Aehrchen 2-körnig; Klap’en blassgelb (2.3 cm lang, $0.65 \mathrm{~cm}$ breit). - Strolı: orange-gelb, blattarm, fest, mittellang. - - Scheinfrucht: blassgelb, selten begrannt, schmal (grosses Korn $1.8 \mathrm{~cm}$ lang, $0.3 \mathrm{~cm}$ breit, kleines $1.3 \mathrm{~cm}$ lang, $0.3 \mathrm{~cm}$ breit), schwer, Schale mittelfein, $100 \mathrm{gr}$ enthalten $73 \mathrm{gr}$ Korn, $27 \mathrm{gr}$ Spelzen.

Halm dunkelgrün, 2.6 Schösslinge, spät blühend, $110 \mathrm{~cm}$ (Мах. $150 \mathrm{~cm}$ ) lang, $0.35 \mathrm{~cm}$ dick, Blattzahl 5 , Blätter $25.6 \mathrm{~cm}$ lang, $1 \mathrm{~cm}$ breit, Blattfläche $256 \mathrm{qcm}$, Halmfläche $105 \mathrm{qcm}$, Gesanmmtfläche $361 \mathrm{qcm}$. Späthafer, in 125 Tagen reifend, Rispe $20 \mathrm{~cm}$ (Max. $30 \mathrm{~cm}$ ) lang, mit 100 ziemlich fest sitzenden Scheinfrichten, von denen 1948800 auf $1 \mathrm{hl}(=48 \mathrm{~kg})$ entfallen. 
Es wiegen 100 Halme $913 \mathrm{gr}$ und davon die Scheinfriichte $438 \mathrm{gr}$.

Diescr nicht leicht lagemule, fast rostfreic und ertragreiche Hafer entstammt der russischen Schwarzerde des Gouvernements Jekaterinoslaw und wurde uns dureh Gutsbesitzer Degtiareff 1875 cingesandt.

\section{Hafer aus Charkow, Süil-Russland. $\odot$}

Rispe: sehr ausgebreitet, Aelure lang, locker, armsamig, mittellang; Aehrchen 1- bis 2-köınig; Klappen blassgelb (2 cm lang, $0.6 \mathrm{~cm}$ breit). - Stroh: grüngelb, kräftig, ziemlich reichblättrig, lang. - Soheinfrucht: gelb, kurz, doch dick (grosses Korn $1.25 \mathrm{~cm}$ lans, $0.3 \mathrm{~cm}$ breit, kleines $1 \mathrm{~cm}$ lang, $0.25 \mathrm{~cm}$ breit); zuweilen begrannt; Schale mittelfein, $100 \mathrm{gr}$ $=72 \mathrm{gr}$ Fruichte, $28 \mathrm{gr}$ Spelzen.

Junges Blatt blangriin, lang, ziemlich breit, Bestockung schwach, 2.2 Schösslinge; Halm 140 $\mathrm{cm}$ (Max. $160 \mathrm{~cm}$ ) lang, $0.5 \mathrm{~cm}$ dick, Blattzahl 4.6, Blätter $39.5 \mathrm{~cm}$ lang, $1.3 \mathrm{~cm}$ breit, Blattfä̈lıe $472.42 \mathrm{qcm}$, Halmfläche 210 q $\mathrm{cm}$, Gesammtfläche $682.42 \mathrm{qcm}$.

Späthafer, reift in 130 Tagen; Rispe $25 \mathrm{~cm}$ (Max. $30 \mathrm{~cm}$ ) lang, mit 150 Scheinfrüchten, von denen 1757400 auf 1 hl $(==50.5 \mathrm{~kg})$ entfallen.

Es wiegen 100 Halme $870 \mathrm{gr}$ und davon die Scheinfriichte :881 gr.

Dieser Hafer ist gegen Lagern und Rost nicht ganz widerstandsfälig und verlangt einen reichen Boden.

Uebersender: Professor Saykewitsch zu Charkow.

\section{Hafer von Tula, Russland. $\odot$}

Syn.: Schatilowsky-Hafer.

Rispe: blassiötlich, sehr ausgebreitet, locker, armsamig; Aelıchen 2-körnig, Klappen fast weiss, $2 \mathrm{~cm}$ lang, $0.6 \mathrm{~cm}$ breit. - Strolı: blassrot, kurz, fest. - Scheinfrucht: Original fast weiss mit blassrötlichem Schimner, zuweilen tritt eine gebogene, an der Basis schwärzliche Granne auf, klein, schmal (grosses Korn $12 \mathrm{~mm}$ lang, $2.8 \mathrm{~mm}$ breit, kleines $10 \mathrm{~mm}$ lang, $2 \mathrm{~mm}$ breit); 344 Scheinfriichte $=10 \mathrm{gr}$, ziemlich dickschalig, Spelzen 30 Proc. ausmachend.

Junges Blatt dunkelgrün, selımal, 1.5 Schösslinge; Halm $100 \mathrm{~cm}$ lang, $0.38 \mathrm{~cm}$ dick, Blattzahl 4, Blätter $23 \mathrm{~cm}$ lang, $0.85 \mathrm{~cm}$ breit, Blattfläche $156.4 \mathrm{qcm}$, Halmfläche $114 \mathrm{qcm}$, Gesammtflächc $270.4 \mathrm{qcm}$.

Rispe mit 80 Scheinfriichten, von denen 1857600 auf $1 \mathrm{l} l(=54 \mathrm{~kg}$ ) entfallen.

Friihhafer; sehr zeitig, in 110 Tagen reifend.

Soll ursprünglich aus Flandern stammen. Bezugsquelle: Kaiserl. fr. ̈̈k. Gesellsch. zu St. Petersburg, 1880.

\section{Irbit-Hafer, Russland. $\odot$}

Rispe: wenig ausgebreitet, kurz, armsanig; Aelırchen meist 2-körnig; Klappen goldgelb, gross (2.5 $\mathrm{cm}$ lang, $0.8 \mathrm{~cm}$ breit). - Stroh: goldgelb, fest, lang, sehr stark. - Scheinfruclut: blassgelb, ziemlich gross (grosses Korn $1.3 \mathrm{~cm}$ lang, $0.3 \mathrm{~cm}$ breit, kleines $1 \mathrm{~cm}$ lang, $0.25 \mathrm{~cm}$ breit), grobschalig, $100 \mathrm{gr}=67.5 \mathrm{gr}$ Friichte, $32.5 \mathrm{gr}$ Spelzen.

Blätter blaugrün, kräftig, breit, Bestockung ziemlich schwach, 2.4 Schösslinge, zeitig schossenl und blïlsend, Halm $135 \mathrm{~cm}$ (Max. $160 \mathrm{~cm}$ ) 
lang, $0.53 \mathrm{~cm}$ dick, Blattzahl 4, Blätter $29.3 \mathrm{~cm}$ lang, $1.08 \mathrm{~cm}$ breit, Blattfläche $253,15 \mathrm{qcm}$, Halmfläche $214.65 \mathrm{qcm}$, Gesammtfäche $467.8 \mathrm{qcm}$.

Rispe reift mittelfrüh, in 120 Tagen, $20 \mathrm{~cm}$ ( Max. $30 \mathrm{~cm}$ ) lang, mit 110 fest sitzenden Scheinfrüchten, von denen 1324400 auf $1 \mathrm{hl}(=47.3 \mathrm{~kg})$ entfallen.

Es wiegen 100 Halme $600 \mathrm{gr}$ und davon die Scheinfrüchte $302 \mathrm{gr}$.

Soll noch auf den ärmsten Böden zufriedenstellende Erträge liefern und für rauhe Lagen in hohem Grade geeignet sein, auch leidet er wenig durch Rost und Lagern.

Heimat: Nord-Russland.

Bezugsquelle: Samenhandlung von Frommer in Budapest.

\section{Hafer aus Finnland. $\odot$}

Rispe: etwas zusammengezogen, reichsamig, mittellang; Aehrchen 2-körnig; Klappen gelb. - Stroh: gelbgrïn, etwas feinhalmig, steif, lang. - Scheinfrucht: schmutzig-gelb, Scheidenspelze rotgrau, lanzettlich, voll, mittelgross (grosses Korn $1.4 \mathrm{~cm}$ lang, $0.3 \mathrm{~cm}$ breit, kleines $0.9 \mathrm{~cm}$ lang, $0.25 \mathrm{~cm}$ breit), ziemlich feinschalig, $100 \mathrm{gr}=74 \mathrm{gr}$ Früchte, $26 \mathrm{gr}$ Spelzen.

Junges Blatt gelbgruin, ziemlich lang, breit; mittelfrüh schossend, Bestockung schwach, 2 Schösslinge; Halme 125 cin (Max. $150 \mathrm{~cm}$ ) lang: $0.38 \mathrm{~cm}$ dick, Blattzahl 4, Blätter $27.6 \mathrm{~cm}$ lang, $1 \mathrm{~cm}$ breit, Blattfäche $220.8 \mathrm{qcm}$, Halmfläche $145.5 \mathrm{qcm}$, Gesammtfläche $366.3 \mathrm{qcm}$.

Frühhafer, reift in 118 Tagen; Rispe $25 \mathrm{~cm}$ (Max. $35 \mathrm{~cm}$ ) Jang, mit 220 nicht leicht ausfallenden Scheinfrüchten, von denen 1659900 auf $1 \mathrm{hl}(=50.3 \mathrm{~kg})$ entfallen.

Es wiegen 100 Halme $857 \mathrm{gr}$ und davon die Scheinfrüchte $457 \mathrm{gr}$. Erhalten $18 \bar{i} \mathrm{~T}$ aus h. Halle.

\section{Hafer aus Irkutsk, Sibirien. $\odot$}

Rispe: gelb, ausgebreitet, armsamig; Aehrchen 2-körnig, Klappen weiss, $2.5 \mathrm{~cm}$ lang, $0.7 \mathrm{~cm}$ breit. - Stroh: gelbrot, dünn, kurz, doch fest. - Scheinfrucht: Original gelb, Scheidenspelze rötlich, klein, schmal (grosses Korn bis $13 \mathrm{~mm}$ lang, $2.5 \mathrm{~mm}$ breit, kleines $9 \mathrm{~mm}$ lang, $2 \mathrm{~mm}$ breit, 513 Scheinfrüchte $=10 \mathrm{gr}$ ), grobschalig, Spelzen 35.6 Proc. ausmachend.

Junges Blatt dunkelgrün, aufrecht, 2.2 Schösslinge; Halm $90 \mathrm{~cm}$ lang, $0.33 \mathrm{~cm}$ dick, Blattzahl 3.5, Blätter $24 \mathrm{~cm}$ lang, $0.8 \mathrm{~cm}$ breit, Blattfläche $134.4 \mathrm{qcm}$, Halmfläche $89.1 \mathrm{qcm}$, Gesammtfläche $223.5 \mathrm{qcm}$.

Rispe $15 \mathrm{~cm}$ lang mit 60 Scheinfrüchten.

Sehr frühreif, in 95-100 Tagen reifend.

Diesen aus 11 Gemeindevorratshäusern des Bezirkes Irkutsk entnommenen Hafer erhielten wir durch Prof. Anatol von "Fadejeff, rom landw. Versuchsfeld zu Petrowsk bei Moskau.

\section{Sibirischer Omsk-Hafer. $\odot$}

Rispe: gelb, ausgebreitet, armsamig, unter mittellang; Aehrchen 2-körnig, Klappen fast weiss. - Stroh: rotgelb, sehr fest, mittellang. Scheinfrucht: graulich-gelb, Scheidenspelze rötlich, ziemlich roll (grosses 
Korn $16 \mathrm{~mm}$ lang, $3 \mathrm{~mm}$ breit, kleines $11 \mathrm{~mm}$ lang, $2 \mathrm{~mm}$ breit, 311 Scheinfrüchte $=10 \mathrm{gr}$ ), zuweilen tritt eine helle Granne auf; sehr feinschalig, Spelzengewicht 25 Proc.

Junges Blatt dunkelgrün, kräftig, 1.8 Schösslinge; Halm $120 \mathrm{~cm}$ lang, $0.4 \mathrm{~cm}$ dick, Blattzahl 4, Blätter $30 \mathrm{~cm}$ lang, $1 \mathrm{~cm}$ breit, Blattfäche $240 \mathrm{qcm}$, Halmfläche $144 \mathrm{q} \mathrm{cn}$, Gesammtfläche $384 \mathrm{q} c \mathrm{~cm}$.

Frühreif, in 110 Tagen reifend.

Bildet Uebergang zu "Aurea".

Von keiner Bedeutung für Mitteleuropa.

Bezugsquelle: durch das preussische landw. Ministerium 1881 aus Zborow, Böhmen erhalten.

\section{Sibirischer Frühhafer. $\odot$}

Syn.: Engl.: Siberian early white Oat.

Franz.: Avoine hâtive de Sibérie.

Ital.: Avena di Sibiria.

Rispe: ausgebreitet, ziemlich reichsamig, mittellang (25 cm); Aehrchen 2-körnig; Klappen fast weiss $(2.5 \mathrm{~cm}$ lang, $0.6 \mathrm{~cm}$ breit). - Stroh: gelb, kräftig, fest, mittellang. -- Scheinfrucht: blassgelb, auf leichtem, armem Boden zuweilen begrannt; Granne an der Basis schwärzlich; kurz, dick (grosses Korn $1.3 \mathrm{~cm}$ lang, $0.35 \mathrm{~cm}$ breit, kleines $1 \mathrm{~cm}$ lang, $0.25 \mathrm{~cm}$ breit), schwer, Schale mittelfein, $100 \mathrm{gr}$ enthalten $72.4 \mathrm{gr}$ Korn, $27.6 \mathrm{gr}$ Spelzen.

Halm blaugrïn, 2.3 Schösslinge, sehr zeitig schossend und bliihend, $120 \mathrm{~cm}$ (Max. $150 \mathrm{~cm}$ ) lang, $0.43 \mathrm{cnl}$ dick, Blattzahl 4.7, Blätter $29.8 \mathrm{~cm}$ lang, $1.17 \mathrm{~cm}$ breit, Blattfäche $327.78 \mathrm{qcm}$, Halmfläche $154.8 \mathrm{qcm}, \mathrm{Ge}-$ sammtfläche $482.58 \mathrm{qcm}$.

Frühhafer, in 110 Tagen also sehr früh reifend, $25 \mathrm{~cm}$ (Max. $30 \mathrm{~cm}$ ) lang, mit 150 etwas leicht ausfallenden Scheinfrüchten, von denen 1758000 auf $1 \mathrm{hl}(=51.7 \mathrm{~kg})$ entfallen.

Auf $1 \mathrm{qm}$ wachsen 800 Halme oder 350 Pflanzen, mithin beträgt der Raum für eine Pflanze $28.6 \mathrm{qcm}$, die Blattfläche p. qm Bodenfläche $38.6 \mathrm{qm}$ und das Saatquantum $2.7 \mathrm{hl}$ p. ha.

Es wiegen 100 Halme $763 \mathrm{gr}$ und davon die Scheinfrüchte $411 \mathrm{gr}$.

Auf reichem Boden, namentlich auf Moorbodeu, bringt er, da er nicht lagert, sehr hohe Erträge, und lässt sich, weil sehr frühreif und wenig empfindlich, weit nach Norden, z. B. noch im nördlichen Schottland erfolgreich kultivieren; ausserdem ist seine Kultur im nördlichen Frankreich, Deutschland und den Vereinigten Staaten weit verbreitet. In neuerer Zeit wird er auch in Nord-Italien und zwar hauptsächlich als Grünfutter angebaut.

Nach Mitchell's Versuchen lieferte er auf drainiertem Lehmboden nach zweijähriger Weide p. ha in England:

$$
65,76 \mathrm{hl} \text { Korn }(1 \mathrm{hl}=58 \mathrm{~kg}), 4585 \mathrm{~kg} \text { Stroh. }
$$

Dieser Hafer empfiehlt sich auf reichem Boden auch als Grünfutter, da er ein sehr kräftiges Blatt besitzt und vor Austritt der Rispe gemäht, neue Halme treibt, und wenı auch etwas spät, an diesen einen befriedigenden Kornertrag bringt.

Nach Heuzél${ }^{1}$ ) soll schon Buchoz 1775 auf ihn aufmerksam ge-

1) A. a. O. Vol. I, p. 508. 
macht haben; fest steht, dass er durch die Samenhandlung von Booth \& Co. in Hamburg 1839 aus Russland bezogen und iiber England und Jeutschland verbreitet wurde, ferner, dass 1858 der Berliner Akklimatisations-Verein neue Saat aus Russland kommen liess.

\section{Kamtschatka-Hafer. $\odot$}

Franz.: Avoine du Kamtschatka.

Rispe: wenig ausgebreitet, etwas armsamig; kurz; Aehrchen 2-körnig; Klappen gelb, $2.2 \mathrm{~cm}$ lang, $0.6 \mathrm{~cm}$ breit. - Stroh: gelb, sehr lang, fest. - Scheinfrucht: blassgelb, doch an der Stelle, wo sich die Spitze stark verjüngt, hellbräunliche Flecken zeigend, länglich, spitz (grosses Korn $1.6 \mathrm{~cm}$ lang, $0.25 \mathrm{~cm}$ breit, kleines $1.1 \mathrm{~cm}$ lang, $0.2 \mathrm{~cm}$ breit), se]ten begrannt, ziemlich feinschalig, $100 \mathrm{gr}=74.5 \mathrm{gr}$ Früchte, $25.5 \mathrm{gr}$ Spelzen.

Junges Blatt dunkelgriin, lang, schmal, kräftig, Bestockung schwach, 1.7 Schösslinge, mittelfriih schossend und blühend. Halme $150 \mathrm{~cm}$ (Max. $200 \mathrm{~cm}$ ) lang, $0.43 \mathrm{~cm}$ dick, Blattzahl 4.6, Blätter $30.4 \mathrm{~cm} \mathrm{lang,} 1.1 \mathrm{~cm}$ breit, Blattfäche 307.65 qcm, Halmfläclıe $193.5 \mathrm{qcm}$, Gesammtfläche $501.15 \mathrm{qcm}$.

Frühhafer, reift in 118 Tagen; Rispe $20 \mathrm{~cm}$ (Max. $25 \mathrm{~cm}$ ) lang, mit 110 Scheinfrüchten, von denen 1680000 auf $1 \mathrm{hl}$ (=42 kg) entfallen.

Es wiegen 100 Halme $957 \mathrm{gr}$ und davon die Scheinfriichte $457 \mathrm{gr}$.

Auf kräftigen Alluvial- und guten humosen Lehm- und Thonböden sollen Erträge bis zu $52 \mathrm{hl}$ erzielt worden sein; auch lagert dieser Hafer nicht und zeigt sich fast rostfrei.

Zur Grünfuttererzeugung scheint dieser Hafer, da er auch der Dürre gut widersteht, im hohen Grade geeignet zu sein.

Seine Herkunft aus Kamtschatka ist nicht genïgend bezeugt; fest steht, dass er durch J. G. Bnoth in Hamburg von England aus nach Deutschland gelangt ist.

Im suidlichen Schweden soll sich seine Kultur ebenfalls vorzïglich bewährt haben.

\section{Sommerhafer aus Algier.}

Rispe: ausgebreitet, armsamig, mittellang; Aehrchen 1- und 2-körnig; Klappen blassgelb (2.2 cm lang, $0.6 \mathrm{~cm}$ breit). — Stroh: hellgelb, fest, wenig blattreich, mittellang. - Scheinfrucht: blassrötlich-gelb, schmal, kurz (grosses Korn $1.5 \mathrm{~cm}$ lang, $0.25 \mathrm{~cm}$ breit, kleines $0.8 \mathrm{~cm}$ lang, $0.2 \mathrm{~cm}$ breit), zuweilen kurz begrannt, feinschalig, $100 \mathrm{gr}=77 \mathrm{gr}$ Friichte, $23 \mathrm{gr}$ Spelzen.

Halm gelbgrün, Bestockung stark, 3.3 Schösslinge, spät blühend, $120 \mathrm{~cm}$ (Max. $145 \mathrm{~cm}$ ) lang, $0.4 \mathrm{~cm}$ dick, Blattzahl 4.3 , Blätter $27.2 \mathrm{~cm}$ lang, $1.04 \mathrm{~cm}$ breit, Blattfläche $243.29 \mathrm{qcm}$, Halmfläche $144 \mathrm{qcm}$, Gesammtfläche $387.29 \mathrm{qcm}$.

Rispe reift etwas spät, in 125 Tagen, $25 \mathrm{~cm}$ (Max. $30 \mathrm{~cm}$ ) lang, mit 120 ziemlich fest sitzenden Scheinfriichten, von denen 1915000 auf $1 \mathrm{hl}(=46.7 \mathrm{~kg})$ entfallen.

Es wiegen 100 Halme $670 \mathrm{gr}$ und davon die Scheinfriichte $283 \mathrm{gr}$. Fïr trockne lehmige Böden im milden Klima zu beachten. 


\section{White Australian 0at. $\odot$}

Syn.: Deutsch: Weisser australischer Hafer.

Franz.: Aroine blanche d'Adélaïde,

Rispe: ausgebreitet, gross, armsamig; Aehrchen 2-körnig; Klappen fast weiss oder schön gelb ( $3 \mathrm{~cm}$ lang, $0.7 \mathrm{~cm}$ breit). - Stroh : orange-gelb, kräftig, blattreich, fest, ziemlich kurz. - Scheinfrucht: blassgelb, gross (grosse Scheinfrucht $2 \mathrm{~cm}$ lang, $0.35 \mathrm{~cm}$ breit, kleine $1.5 \mathrm{~cm} \mathrm{lang,} 0.3 \mathrm{~cm}$ breit), feinschalig, denn $100 \mathrm{gr}$ enthalten $75 \mathrm{gr}$ Frucht, $25 \mathrm{gr}$ Spelzen.

Junges Blatt dunkelgrün, schmal, Bestockung mittelstark, 2.i Schösslinge, spät schossend und blühend. Halme $100 \mathrm{~cm}$ (Max. $120 \mathrm{~cm}$ ) lang, $0.38 \mathrm{~cm}$ dick, Blattzahl 4, Blätter $25.3 \mathrm{~cm}$ lang, $0.8 \mathrm{~cm}$ breit, Blattfläche $161.92 \mathrm{qcm}$, Halmfläche $114 \mathrm{qcm}$, Gesammtfläche $275.92 \mathrm{qcm}$.

Rispe reift spät, nit 180 Scheinfrichten, voll denen 1111000 auf $1 \mathrm{hl}(=46.3 \mathrm{~kg})$ entfallen.

Es wiegen 100 Halme $220 \mathrm{gr}$ und davon die Scheinfrïchte $112 \mathrm{gr}$.

Auf reichem, humosen Niederungsboden soll er nach Löbe ${ }^{1}$ ) Erträge bis zu $40 \mathrm{hl}$ p. ha in Frankreich geliefert und sich durch eine sehr starke Bestockung ausgezeichnet haben. griffen.

Dieser Hafer lagert nicht leicht und wird wenig durch Rost ange-

Varietät: Avena sativa praegravis Langethal.

Unbegrannt; Spelzen blassgelb; Scheinfrucht bauchig.

\section{Sorten:}

\section{Neuer Gersthafer. $\odot$}

Rispe: zusammengezogen, ziemlich reichsamig, lang; Aehrchen 2 körnig; Klappen gelb, lederartig (2.3 cm lang, $0.7 \mathrm{~cm}$ breit). Strolı: hellgelb, kräftig, blattarm, lang. - Scheinfrucht: blassgelb, aufgeblaseu, die äussere Spelze der grossen Scheinfrucht umfasst die kleine so vollständig, dass beide wie eine Scheinfrucht von $1.2 \mathrm{~cm}$ Länge und $0.4 \mathrm{~cm}$ Breite erscheinen, ausserordentlich grobschalig, $100 \mathrm{gr}=51 \mathrm{gr}$ Früchte, $49 \mathrm{gr}$ Spelzen.

Junges Blatt hellgriin, sehr kräftig; Bestockung mittelstark, 2.5 Schösslinge; Halm $130 \mathrm{~cm}$ (Max, $140 \mathrm{~cm}$ ) lang, $0.5 \mathrm{~cm}$ dick, Blattzahl 3.3, Blätter $29.5 \mathrm{~cm}$ lang, $1.25 \mathrm{~cm}$ brcit, Blattfïche $243.41 \mathrm{qcm}$, Halmfläche $195 \mathrm{qcm}$, Gesammtfïche $438.41 \mathrm{qcm}$.

Frühlafer, reift in 120 Tagen; Rispe $30 \mathrm{~cm}$ (Max. $35 \mathrm{~cm}$ ) lang, mit 170 sehr fest sitzenden Scheinfrüchten, von denen 2462400 auf $1 \mathrm{hl}$ $(=51.3 \mathrm{~kg})$ entfallen.

Auf 1 qu wachsen 800 Halme oder 320 Pflanzen, mithin beträgt das Saatquantum $1.8 \mathrm{hl} \mathrm{p.} \mathrm{ha.}$

Heimat: die Niederlande, wo dieser Hafer erfolgreich auf Torfboden gebaut wird, und trotz der geringen Qualität der Körner sein Ertrag befriedigt.

Vorstermann von Oyen hatte ihn 1873 auf der Wiener Weltausstellung ausgestellt.

1) Kulturpflanzen 1879. 


\section{Scotch Berlie-0at. $\odot$}

Syn.: Engl.: Scotch Barley-Oat ${ }^{1}$ ).

Deutsch: Schottischer Berlie- oder Gersthafer.

Franz.: Avoine d'Écosse.

Rispe: ausgebreitet, sehr locker, etwas armsamig, mittellang; Aehrchen 2-, häufig 1-körnig; Klappen gelb, an der Basis dunkler. - Stroh: grüngelb, kräftig, blattarm, lang. - Scheinfrucht: blassgelb, zuweilen begrannt, Basis borstig, klein, dick (grosses Korn $1.5 \mathrm{~cm}$ lang, $0.35 \mathrm{~cm}$ breit, kleines $0.9 \mathrm{~cm}$ lang, $0.3 \mathrm{~cm}$ breit), sehr schwer, Schale zähe, grob, $100 \mathrm{gr}=67.5 \mathrm{gr}$ Früchte, $32.5 \mathrm{gr}$ Spelzen.

Junges Blatt blaugruin, schmal, lang; Bestockung schwach, 1.4 Schösslinge, zeitig schossend und blühend. Halm $130 \mathrm{~cm}$ (Мax. $140 \mathrm{~cm}$ ) lang, $0.53 \mathrm{~cm}$ dick, Blattzahl 3.2, Blätter $31 \mathrm{~cm}$ lang, $1.3 \mathrm{~cm}$ breit, Blattfläche $257.92 \mathrm{qcm}$. Halmfläclıe $206.7 \mathrm{qcm}$, Gesammtfläche $464.62 \mathrm{qcm}$.

Friihhafer, Rispe $25 \mathrm{~cm}$ (Max. $30 \mathrm{~cm}$ ) lang, mit 120 Scheinfrüchten, von denen 1575000 auf $1 \mathrm{hl}(=54.3 \mathrm{~kg})$ entfallen.

Es wiegen 100 Halme $962 \mathrm{gr}$ und davon die Scheinfrüchte $500 \mathrm{gr}$.

Man unterscheidet nach John $\mathrm{Haxton}^{2}$ ) zwei Sorten, the english and the scotch Berlie-Oat". Die erstere wurde um 1837 von England nach Aberdeenshire gebracht, während die letztere vielleicht 50 Jahre vorher kultiviert worden war.

Der englische Berlie-Hafer ist sehr frühreif, lässt nicht leicht die Scheinfrüchte ausfallen und eignet sich für reichen Boden. Der schottische Berlie-Hafer ist ertragreicher, weniger frühreif, passt besser für leichteren Boden, und da seine Körner auch ein vorzügliches Mehl liefern und das Stroh geschätzt wird, so ist dieser alte schottische Hafer namentlich in Aberdeen und Banff sehr beliebt.

Mr. Mitchell erzielte 1848 auf drainiertem Lehmboden und nach zweijähriger Weide p. ha $59.94 \mathrm{hl}$ Vorderkorn à $55.5 \mathrm{~kg}, 2.25 \mathrm{hl}$ Hinterkorn, $5719 \mathrm{~kg}$ Stroh.

\section{Scotch Potato-0at.}

Syn.: Schottischer Kartoffel-Hafer.

Rispe: etwas zusammengezogen, etwas armsamig, kurz; Aehrchen 1- und 2-körnig; Klappen gelb (2 cm lang, $0.9 \mathrm{~cm}$ breit). - Stroh: gelb, sehr kräftig, lang. - Scheinfrucht: schmutzig-gelb, Scheidenspelze hellbräunlich, Spelzen lederartig, plump (grosses Korn $1 \mathrm{~cm}$ lang, $0.35 \mathrm{~cm}$ breit, kleines $0.8 \mathrm{~cm}$ lang, $0.3 \mathrm{~cm}$ breit), grobschalig, $100 \mathrm{gr}=65.5 \mathrm{gr}$ Früchte, $34.5 \mathrm{gr}$ Spelzen.

Junges Blatt dunkelgrïn, sehr lang, breit; Bestockung ziemlich schwach, 2.1 Schösslinge, zeitig schossend und blühend; Halm $135 \mathrm{~cm}$ (Max. $155 \mathrm{~cm}$ ) lang, $0.53 \mathrm{~cm}$ dick, Blattzahl 4, Blätter $30.8 \mathrm{~cm}$ lang, $1.3 \mathrm{~cm}$ breit, Blattfäche $320.32 \mathrm{qcm}$, Halmfläche $214.65 \mathrm{qcm}$, Gesammtfläche $534.97 \mathrm{qcm}$.

Frühhafer, reift in 118 Tagen; Rispe $20 \mathrm{~cm}$ (Max. $30 \mathrm{~cm}$ ) lang, mit 110 ziemlich fest sitzenden Scheinfrüchten, von denen 1346800 auf $1 \mathrm{hl}(=51.8 \mathrm{~kg})$ entfallen.

1) Journ. of the Roy. Agric. Soc. 1851, p. 117.

2) Morton, Cyclop. of Agric. Vol. II, p. 482. 
Es wiegen $100 \mathrm{Halme} 1043 \mathrm{gr}$ und davon die Scheinfrüchte $557 \mathrm{gr}$. Dieser Hafer leidet wenig durch Lagern und Rost.

Bezugsquelle: Ha ge \& Schmidt in Erfurt.

\section{Georgian-0at. $\odot$}

Syn.: White Canadian-oat ${ }^{1}$ ).

Franz. ${ }^{2}$ ): Avoine du Banat - des Canaries - du comte Baudissin - du Kamtschatka - de M. Pstross blanche de Russie - du Canada; Avoine d'Amerique (Heuzé).

Deutsch: Georgischer oder weisser canadischer Hafer.

Verbesserte Formen:

Hallet's pedigree white Canadian-oat;

Webb's "Challenge" (Herausforderer) white Canadian-oat.

Rispe: blassgelb, etwas zusammengezogen, mittelgross; Aehrchen 1-2-körnig, zuweilen begrannt, Klappen blassgelb, an Basis gelb, weich, $2 \mathrm{~cm}$ lang, $0.6 \mathrm{~cm}$ breit. - Stroh: gelbrot-orange, mittellang, steif. Scheinfrucht: blassgelb, aufgeblasen, kurz (grosses Korn $14 \mathrm{~mm}$ lang, $3.5 \mathrm{~mm}$ breit, kleines $9 \mathrm{~mm}$ lang, $2.5 \mathrm{~mm}$ breit), 270 Scheinfriiclite = $10 \mathrm{gr}$; Spelzen dick, lederartig.

Junges Blatt dunkelgrïn, sehr breit, kräftig, lang; Entwickelung sehr schnell, daher Bestockung schwach, 1.8 Schössling; sehr zeitig schossend und blühend, und weil sehr kräftig, vorzüglich zur Grünfutterproduktion geeignet.

Die weitere Entwickelung zeigt sich wie folgt:

\begin{tabular}{|c|c|c|c|}
\hline & Gcorgian-oat & $\begin{array}{l}\text { Hallet's } \\
\text { pedigree }\end{array}$ & $\begin{array}{l}\text { Webb's } \\
\text { challenge }\end{array}$ \\
\hline Halmlänge & $125($ Max. 150) & $125(145)$ & $125(145)$ \\
\hline Halmdicke . . . $\mathrm{cm}$ & 0.6 & 0.5 & 043 \\
\hline Blattzahl . . . . . . & 3 & 3.3 & 4.3 \\
\hline Blattlänge . . . $\mathrm{cm}$ & 32.3 & 30 & 30.2 \\
\hline Blattbreite . . $\mathrm{cm}$ & 1.3 & 1.2 & 1.0 \\
\hline Blattfläche . . . qcm & 126 & 118.8 & 129.9 \\
\hline Halmfläche . . . qcm & 225 & 187.5 & 161.3 \\
\hline Gesammtfläche . . qcm & 351 & 306.3 & 291.2 \\
\hline Mittlerc Rispenlänge cm & 25 & 25 & 25 \\
\hline Fruchtzall pro Rispe . & 140 & 120 & 150 \\
\hline ", $\mathrm{hl}$. & 1323000 & 1443000 & 1395900 \\
\hline Gewicht pro hl in $\mathrm{kg}$ & 49 & 55.5 & 51.7 \\
\hline Grosses Korn lang $\mathrm{mm}$ & 16 & 14 & 12 \\
\hline ,, dick $\mathrm{mm}$ & 3 & 3.5 & 4 \\
\hline Kleines ", lang & 10 & 0.9 & 9.5 \\
\hline , $\quad$ dick $\mathrm{mm}$ & 2 & 2.5 & 3 \\
\hline Procentc an Spelzen. . & 34.5 & 32 & 34.1 \\
\hline
\end{tabular}

Frühhafer, reift sehr zeitig, in 120 Tagen, für rauhes Klima, namentlich in hohen Gebirgslagen und auf Torf- und Moorböden beachtenswert.

1) Vergl. Shirreff, Improvem. of cereals 1873, wonach „Georgian oat" in neuercr Zeit aucl "Canadian oat" genannt wird.

3) Vianne, Prairies et pl. 1870. 
Stroh grob, daher kein gutes Futterstroh, doch nicht leicht lagernd und wenig durch Rost leidend. Kornertrag hoch, doch Qualität wegen der lederartigen Spelzen gering; aus diesem Grunde in England jetzt noch wenig gebaut, mehr geschätzt in Frankreich und namentlich im Norden der Vereinigten Staaten nnd in Canada.

Ursprüngliche Heimat wahrscheinlich Süd-Russland; in Frankreich 1823 durch Yvart und de Thury (Gas parin, Cours d'agric. III T09), in England um 1825 durch Capt. Barclay of Urie (P. Lawson, Agric. manual, 1836) verbreitet.

In Eldena, Pommern, lieferte er 1868 auf sandigem Lehm $1830 \mathrm{~kg}$ Korn, $2550 \mathrm{~kg}$ Stroh, $484 \mathrm{~kg}$ Spreu p. lia.

Bezugsquelle: F. Hallet, Manorhouse, Brighton; Webb \& Sons, Wordsley, Stourbridge. Canadian-Oat aus deutschen Samenhandlungen bezogen.

\section{Avoine d'hiver (2) u. $\odot$}

Syn.: Avoine de Provence.

Rispe: bleichgelblich, ein wenig zusammengezogen, mittellang, armsamig; Aehrchen 1-und 2-körnig, Klappen kurz, $2 \mathrm{~cm}$ lang, $0.6 \mathrm{~cm}$ breit. - Stroh: rotgelb, rohrartig, fest, lang. - Scheinfrucht: bleichgelblich mit schwach graulichem Schimmer, klein (grösstes Korn $12 \mathrm{~mm}$ lang, $2.5 \mathrm{~mm}$ breit, 441 Scheinfrüchte $=10 \mathrm{gr}$ ); nachgebaut: grösser, 242 Scheinfrüchte $=10 \mathrm{gr}$, sehr dickschalig, Spelze» 40 Proc. ausmachend, zuweilen begrannt.

Als Sommer- und Winterfrucht gebaut. Entwickelung wie folgt:

\begin{tabular}{|c|c|c|}
\hline & Sommerfrucht & Winterfrucht \\
\hline $\begin{array}{l}\text { Halmlänge } \\
\text { Halmdicke } \\
\text { Blattzahl } \\
\text { Blattlänge } \\
\text { Blattbreite } \\
\text { Blattfläche } \\
\text { Halmfläche } \\
\text { Gesammtfläche } \\
\text { Rispenlänge } \\
\text { Anzahl der Aehrchen p. Rispe } \\
\text { V" " Scheinfrüchte p. Rispe } \\
\text { Vegetationszeit }\end{array}$ & $\begin{array}{c}120 \mathrm{~cm} \text { (Max. } 135 \mathrm{~cm}) \\
0.4 \mathrm{~cm} \\
4 \\
25 \mathrm{~cm} \\
1.1 \mathrm{~cm} \\
220 \mathrm{qcm} \\
144 \mathrm{qcm} \\
364 \mathrm{qcm} \\
20 \mathrm{~cm}(\operatorname{Max} .30 \mathrm{~cm}) \\
60 \\
100 \\
120\end{array}$ & \begin{tabular}{|c}
$145 \mathrm{~cm}$ (Max. $175 \mathrm{~cm})$ \\
$0.55 \mathrm{~cm}$ \\
4.4 \\
$26.5 \mathrm{~cm}$ \\
$1.4 \mathrm{~cm}$ \\
$326.5 \mathrm{qcm}$ \\
$239.3 \mathrm{qcm}$ \\
$565.8 \mathrm{qcm}$ \\
$25 \mathrm{~cm}($ Max. $45 \mathrm{~cm})$ \\
75 \\
85 \\
$18 / 10-18 / \mathrm{T}$
\end{tabular} \\
\hline
\end{tabular}

Die Winterung hatte stark gelitten, obgleich der Winter 1882/83 so milde war, dass Sommerhafer nicht erfror, doch hatte sich die Saat im Juni soweit erholt, dass der Stand ziemlich normal war. Die Sommersaat gedieh vortrefflich. Bei zeitiger Aussaat im milden Klima des westlichen Frankreichs (Wintersaat September und Oktober, Sommersaat Januar und Februar) vortrefflich zu Grünfutter geeignet.

Bezugsquelle: Vilmorin, Paris. 


\section{Walla-Walla-0at. $\odot$}

Rispe: etwas zusammengezogen, armsamig, mittellang; Aehrchen 1und 2-körnig; Klappen gelb, bis $2 \mathrm{~cm}$ lang. - Stroh: rötlich-gelb, kräftig, mittellang. - Scheinfrucht: blassgelb, sehr dick, aufgeblasen, kurz (grosses Korn $1.2 \mathrm{~cm} \mathrm{lang,} 0.35 \mathrm{~cm}$ breit, kleines $0.8 \mathrm{~cm}$ lang, $0.25 \mathrm{~cm}$ breit), schwer, grobschalig, $100 \mathrm{gr}=65 \mathrm{gr}$ Frichte, $35 \mathrm{gr}$ Spelzen.

Junges Blatt dunkelgriin, schmal; Bestockung schwach, 1.6 Schösslinge, zeitig schossend und blühend. Halm $120 \mathrm{~cm}$ (Max. $140 \mathrm{~cm}$ ) lang, $0.53 \mathrm{~cm}$ dick, Blattzahl 4, Blätter $27.8 \mathrm{~cm}$ lang, $1.3 \mathrm{~cm}$ breit, Blattfläche $289.12 \mathrm{qcm}$, Halmfläche $190.8 \mathrm{qcm}$, Gesammtfläche $479.92 \mathrm{qcm}$.

Frühhafer, reift in 115 Tagen; Rispe $25 \mathrm{~cm}$ (Max. $35 \mathrm{~cm}$ ) lang, mit 130 nicht leicht ausfallenden Scheinfriichten, von denen 1456000 auf $1 \mathrm{hl}(=52 \mathrm{~kg})$ entfallen.

Es wiegen 100 Halme $798 \mathrm{gr}$ nnd davon die Scheinfrüchte $416 \mathrm{gr}$.

Diese Sorte widersteht dem Lagern und Rost vortrefflich.

Heimat: Washington-Territory, Vereinigte Staaten.

\section{0regon-0at.}

Rispe: etwas zusammengezogen, dicht, armsamig, kurz; Aehrchen 2-körnig; Klappen gelb, $2 \mathrm{~cm}$ lang. - Stroh: rötlich-gelb, kräftig, lang. - Scheinfrucht: blassgelb, kurz, dick (grosses Korn $1.2 \mathrm{~cm} \mathrm{lang,}$ $0.35 \mathrm{~cm}$ breit, kleines $0.8 \mathrm{~cm}$ lang, $0.25 \mathrm{~cm}$ breit), schwer, grobschalig, $100 \mathrm{gr}=68 \mathrm{gr}$ Frïchte, $32 \mathrm{gr}$ Spelzen.

Junges Blatt dunkelgrün, sehr breit, lang; Bestockung schwach, 2 Schösslinge, sehr zeitig schossend und blühend. Halm $135 \mathrm{~cm}$ (Max. $150 \mathrm{~cm}$ ) lang, $0.5 \mathrm{~cm}$ dick, Blattzahl 4, Blätter $34.4 \mathrm{~cm}$ lang, $1.24 \mathrm{~cm}$ breit, Blattfläche $426.56 \mathrm{qcm}$, Halmfläche $202.5 \mathrm{qcm}$, Gesammtfläche $629.06 \mathrm{qcm}$.

Späthafer, reift in 125 Tagen; Rispe $20 \mathrm{~cm}$ (Max. $30 \mathrm{~cm}$ ) lang, mit 100 fest sitzenden Scheinfrichten, von denen 1237500 auf $1 \mathrm{hl}(=49.5 \mathrm{~kg}$ ) entfallen.

Es wiegen 100 Halme $850 \mathrm{gr}$ und davon die Scheinfriichte $463 \mathrm{gr}$.

Dieser Hafer leidet wenig durch Lagern und Rost und zeigte einen kräftigen, als Griinfutter sehr beachtenswerten Habitus.

Heimat: Oregon, Vereinigte-Staaten.

\section{Helena-Montana-0at. $\odot$}

Rispe: etwas zusamnengezogen, sehr armsamig, kurz; Aehrchen 1und 2-körnig; Klappen gelb, bis $1.8 \mathrm{~cm}$ lang. - Stroh: gelb, kräftig, mittellang. - Scheinfrucht: blassgelb, knrz, dick (grosses Korn $1.1 \mathrm{~cm}$ lang, $0.33 \mathrm{~cm}$ breit, kleines $0.9 \mathrm{~cm}$ lang, $0.27 \mathrm{~cm}$ breit), grobschalig, $100 \mathrm{gr}=67.5 \mathrm{gr}$ Frichte, $32.5 \mathrm{gr}$ Spelzen.

Junges Blatt blaugriin, lang, kräftig; 2.2 Schösslinge, zeitig schossend und bliihend. Halm $120 \mathrm{~cm}$ (Max. $135 \mathrm{~cm}$ ) laug, $0.5 \mathrm{~cm}$ dick, Blattzahl 4, Blätter $30.8 \mathrm{~cm}$ lang, $1.13 \mathrm{~cm}$ breit, Blattfläche $278.43 \mathrm{qcm}$, Halmfläche $180 \mathrm{qcm}$, Gesammtfläche $458.43 \mathrm{qcm}$.

Friihhafer, reift in 115 Tagen, Rispe $20 \mathrm{~cm}$ (Max. $25 \mathrm{~cm}$ ) lang, mit 110 fest sitzenden Scheinfrichten, von denen 1268800 auf $1 \mathrm{hl}(=48.8 \mathrm{~kg}$ ) entfallen.

Es wiegen 100 Halme $708 \mathrm{gr}$ und davon die Scheinfrüchte $369 \mathrm{gr}$. Amerika.

Heimat: Territorium Montana der Vereinigten Staaten von Nord- 


\section{Surprise-0at. $\odot$}

Rispe: ausgebreitet; Aehrchen 1- und 2-körnig, 75 Aehrchen mit 110 Scheinfrüchten; Klappen hellgelb, $2 \mathrm{~cm}$ lang, $0.7 \mathrm{~cm}$ breit. - Stroh: hellgelb. - Scheinfrucht: blassgelb, kurz, dick, aufgeblasen (grosses Korn $1.3 \mathrm{~cm}$ lang, $0.3 \mathrm{~cm}$ breit, kleines $0.9 \mathrm{~cm}$ lang, $0.2 \mathrm{~cm}$ breit); grobschalig.

Heimat: Vereinigte Staaten von Nord-Amerika.

Original in der Sammlung des Dr. Dreisch, Poppelsdorf.

\section{Später Podolischer-Hafer.}

Rispe: ausgebreitet, sehr gross, reichsamig; Aehrchen 2-körnig, zuweilen begrannt; Klappen hellgelb, bis $2.2 \mathrm{~cm}$ lang. - Stroh: hellgelb, kräftig, blattarm, kaum mittellang. - Scheinfrucht: blassgelb, kurz, aufgeblasen (grosses Korn $1.3 \mathrm{~cm}$ lang, $0.4 \mathrm{~cm}$ breit, kleines $0.8 \mathrm{~cm}$ lang, $0.25 \mathrm{~cm}$ breit), Schale grob, lederartig, $100 \mathrm{gr}=66.5 \mathrm{gr}$ Früchte, $33.5 \mathrm{gr}$ Spelzen.

Junges Blatt hellgrïn, gross; Bestockung schwach, 2 Schösslinge, Halm blaugrün, spät blïhend, $115 \mathrm{~cm}$ (Max. $130 \mathrm{~cm}$ ) lang, $0.47 \mathrm{~cm}$ dick, Blattzahl 3, Blätter $31.66 \mathrm{~cm}$ lang, $1.5 \mathrm{~cm}$ breit, Blattfläche $284.94 \mathrm{qcm}$, Halmfläche $162.15 \mathrm{qcm}$, Gesammt fäche $447.09 \mathrm{qcm}$.

Späthafer, reift in 135 Tagen; Rispe $30 \mathrm{~cm}$ (Max. $40 \mathrm{~cm}$ ) lang, mit 210 ziemlich locker sitzenden Scheinfriichten, von denen 1636800 auf $1 \mathrm{hl}(=52.8 \mathrm{~kg})$ entfallen.

Es wiegen 100 Halme $278 \mathrm{gr}$ und davon die Scheinfrüchte $133 \mathrm{gr}$.

\section{Neuer australischer Hafer aus Port-Adelaïde. $\odot$}

Rispe: ziemlich ansgebreitet, reichsamig, mittellang; Aelırchen 2-, häufig 1-körnig; Klappen gelb (2 cm lang, $0.6 \mathrm{~cm}$ breit). — Stroh: gelbgrün, kräftig, lang. - Scheinfrucht: blassgelb, aufgeblasen (grosses Korn $1.5 \mathrm{~cm}$ lang, $0.4 \mathrm{~cm}$ breit, kleines $1 \mathrm{~cm}$ lang, $0.3 \mathrm{~cm}$ breit), Schale lederartig, $100 \mathrm{gr}=69 \mathrm{gr}$ Frïchte, $31 \mathrm{gr}$ Spelzen.

Junges Blatt duukelgriin, lang, breit, sehr kräftig; Bestockung schwach, 2 Schösslinge, zeitig schossend und blühend. Halme $135 \mathrm{~cm}$ (Max. $160 \mathrm{~cm}$ ) lang, $0.5 \mathrm{~cm}$ dick, Blattzahl 4.3, Blätter $32.2 \mathrm{~cm}$ lang, $1.26 \mathrm{~cm}$ breit, Blattfläche $348.92 \mathrm{qcm}$, Halmfläche $202.5 \mathrm{qcm}$, Gesammtfläche $551.42 \mathrm{qcm}$.

Frühhafer, Rispe $25 \mathrm{~cm}$ (Max. $35 \mathrm{~cm}$ ) lang, mit 180 etwas leicht ausfallenden Scheinfrüchten, von denen 1590000 auf $1 \mathrm{lll}(=53 \mathrm{~kg})$ entfallen.

Auf $1 \mathrm{qm}$ wachsen 700 Halme oder 350 Pflanzen, mithin beträgt das Saatquantum $3 \mathrm{hl} \mathrm{p.} \mathrm{ha.}$

Es wiegen 100 Halme $1450 \mathrm{gr}$ und davon die Scheinfrïchte $783 \mathrm{gr}$.

Diese Sorte wurde durch Rud. Samm \& Co. ${ }^{1}$ ) in Berlin 1870 direkt importiert.

\section{Hafer aus T'asmanien, Australien. $\odot$}

Rispe: ausgebreitet; Klappen rötlich-gelb $(2 \mathrm{~cm}$ lang, $0.9 \mathrm{~cm}$ breit). Stroh: rötliclı-gelb, ziemlich feinhalmig, fest, $90 \mathrm{~cm}$ lang. - Scheinfrucht:

1) Akklimat. Verein Bd. IX, 15il, p. 55. 
rötlich-gelb, beide Scheinfrüchte des Aehrchens werden von der äusseren Spelze der grösseren Scheinfrucht fast vollständig umgeben $(1.5 \mathrm{~cm}$ lang, $0.35 \mathrm{~cm}$ breit), voll, Schale grob, lederartig.

Original im landwirtschaftlichen Museum zu Berlin.

\section{Weisser neuseeländischer Rispenhafer. $\odot$}

Rispe: blassgelb, ausgebreitet, gross; Aehrchen meist 2-körnig, Klappen blassgelb, $2.5 \mathrm{~cm}$ lang, $0.7 \mathrm{~cm}$ breit. - Stroh: rötlich-gelb, sehr kräftig, mittellang. - Scheinfrucht: blassgelb, ziemlich voll, kurz (grosses Korn $9 \mathrm{~mm}$ lang, $3 \mathrm{~mm}$ breit, kleines $8 \mathrm{~mm}$ lang, $2.5 \mathrm{~mm}$ breit), 289 Scheinfriichte $=10 \mathrm{gr}$ ); zuweilen tritt eine helle kurze Granne auf; grobschalig, Spelzen 33 Proc. ausmachend.

Junges Blatt dunkelgrün, kräftig, 1.5 Schösslinge; Halm $120 \mathrm{~cm}$ (Max. $130 \mathrm{~cm}$ ) lang, $0.5 \mathrm{~cm}$ dick, Blattzahl 4.5, Blätter $29 \mathrm{~cm}$ lang, $1.3 \mathrm{~cm}$ breit, Blattfläche $338.3 \mathrm{qcm}$, Halmfläche $180 \mathrm{qcm}$, Gesammtfläche $518.3 \mathrm{qcm}$.

Rispe $24 \mathrm{~cm}$ (Max. $30 \mathrm{~cm}$ ) lang mit 110 Aehrchen und 200 Scheinfrüchten, von denen 1641000 auf $1 \mathrm{hl}(=54.7 \mathrm{~kg})$ entfallen.

Frïhhafer, in 110 Tagen reifend.

Bezugsquelle: Metz \& Co., Berlin.

\section{Hafer aus Nagpore, Ostindien. $\odot$}

Rispe: ausgebreitet, armsamig, kurz, (bis $26 \mathrm{~cm}$ lang), Aehrchen 1-körnig; Klappen gelb (2.2 cm lang, $0.7 \mathrm{~cm}$ breit); 50 Scheinfrüchte. Stroh: gelb, fest, kurz, nicht leicht lagernd. -- Scheinfrucht: blassgelb, kurz, dick, aufgeblasen (1.3 cm lang, $0.3 \mathrm{~cm}$ breit); zuweilen begrannt, Granne an der Basis schwarzbraun, nach oben hell, gekniet, $2.5 \mathrm{~cm}$ lang.

Original in der Sammlung des Dr. Dreisch, Poppelsdorf.

\section{Varietät: Avena sativa aristata Krause. \\ Begrannt; Spelzen blassgelblich.}

\section{Sorten:}

\section{Weisser gegrannter Rispenhafer.}

Syı.: Avena sativa pennsylvanica h. Dresden.

Franz.: Avoine ordinaire blanche et barbue.

Rispe: ausgebreitet, ziemlich reichsamig, mittellang; Aehrchen 2-, selten 3-körnig, an der Basis borstig; Klappen hellgelb $(2.5 \mathrm{~cm} \mathrm{lang,}$ $0.7 \mathrm{~cm}$ breit). - Stroh: rötlich-gelb, kräftig, blattreich, mittellang. Scheinfrucht: hellrötlich-gelb, länglich, spitz (grosses Korn $2 \mathrm{~cm}$ lang, $0.3 \mathrm{~cm}$ breit, kleines $1.5 \mathrm{~cm}$ lang, $0.25 \mathrm{~cm}$ breit); immer begrannt, Granne an der Basis schwarzbraun, nach oben heller, gekniet, bis $3 \mathrm{~cm}$ lang; ziemlich feinschalig, $100 \mathrm{gr}=75 \mathrm{gr}$ Früchte, $25 \mathrm{gr}$ Spelzen.

Junges Blatt blaugrün, kurz, schmal, Bestockung zicmlich schwach, 2.3 Schösslinge; Halme gelbgrün, etwas spät blühend, $120 \mathrm{~cm}$ (Max. $130 \mathrm{~cm}$ ) lang, $0.43 \mathrm{~cm}$ dick, Blattzahl 4.7, Blätter $31.6 \mathrm{~cm} \mathrm{lang,} 1.22 \mathrm{~cm}$ breit, Blattfläche $362.37 \mathrm{qcm}$, Halmfläche $154.8 \mathrm{qcm}$, Gesammtfläche $517.17 \mathrm{qcm}$. 
Späthafer, reift in 125 Tagen: Rispe $25 \mathrm{~cm}$ (Max. $30 \mathrm{~cm}$ ) lang, mit 140 leicht ansfallenden Scheinfriichten, von denen 1291000 auf $1 \mathrm{hl}$ $(=44.5 \mathrm{~kg})$ entfallen.

Auf 1 qm wachsen 750 Halme oder 326 Pflanzen, mithin beträgt das Saatquantum $3.4 \mathrm{hl}$ p. ha.

Es wiegen 100 Halme $1162 \mathrm{gr}$ und davon die Scheinfrüchte $575 \mathrm{gr}$.

Auffallend ist, dass dieser gegrannte Hafer in Deutschland aus der Ebene ganz oder fast ganz verdrängt ist, während er vor 50 Jahren die am meisten, ja an manchen Orten die fast allein gebaute Varietät war. Metzger (Cer. 1824 p. 50) schreibt: ,Dieser Hafer ist am allgemeinsten ïber einen grossen Teil der Erde verbreitet", während er von unserem jełzt gewöhnlichen Hafer (var. mutica) sagt: „Er wird in den Rheingegenden häufig angebaut." Dass der weisse, gegrannte Hafer frïher allgemein gebaut wurde, bestätigt auch Krause (Getr. Heft 7 S. 6 anno 1837). Er schreibt, dass es hauptsächlich dieser Hafer sei, den die agronomischen Schriftsteller bei ihren Mittheilungen über Haferbau im Auge gehabt hätten. Ferner: "Er ist am weitesten verbreitet. Indessen haben neuerlich einige grosskörnige, sehr mehlhaltige und darunter eine grannenlose Sorte, besonders in England ihm den Rang streitig gemacht."

Es scheint hieraus hervorzugehen, dass die jetzt in ganz Deutschland herrschende unbegrannte Varietät (var. mutica) ihren Weg von Westen nach Osten genommen hat.

\section{Gegrannter Hafer rom Westerwalde. $\odot$}

Syn.: Granniger Rispenhafer aus Manderscleid, Eifel, Rheinprovinz.

Rispe: sehr ausgebreitet, armsamig. lang; Aehrchen 2-körnig, 1grannig; Granne gekniet, an der Basis schwarzbraun, bis $3.5 \mathrm{~cm}$ lang; Klappen fast weiss ( $2 \mathrm{~cm}$ lang, $0.5 \mathrm{~cm}$ breit). - Stroh: rötlich-gelb, fest, lang. - Scheinfrucht: schwach rötlich-gelb, voll, kur'z (grosses Korn $1.3 \mathrm{~cm}$ lang, $0.32 \mathrm{~cm}$ breit, kleines $1 \mathrm{~cm}$ lang, $0.23 \mathrm{~cm}$ breit), feinschalig, $100 \mathrm{gr}=75.2 \mathrm{gr}$ Frïchte, $24.8 \mathrm{gr}$ Spelzen.

Halm blaugrïn, Bestockung stark, 3.3 Schösslinge, $150 \mathrm{~cm}$ (Max. $170 \mathrm{~cm}$ ) lang, $0.5 \mathrm{~cm}$ dick, Blattzahl 4.3, Blätter $29 \mathrm{~cm}$ lang, $0.93 \mathrm{~cm}$ breit, Blattfläche $231.94 \mathrm{qcm}$, Halmfläche $185 \mathrm{qcm}$, Gesammtfläche $416.94 \mathrm{qcm}$.

Späthafer, reift in 125 Tagen; Rispe $30 \mathrm{~cm}$ (Max. $40 \mathrm{~cm}$ ) lang, mit 200 fest sitzenden Scheinfrüchten, von denen 1842250 auf $1 \mathrm{hl}(=45.2 \mathrm{~kg})$ entfallen.

Auf 1 qm wachsen 900 Halme oder 273 Pflanzen, mithin beträgt das Saatquantum $2 \mathrm{hl}$ p. ha.

Es wiegen 100 Halme $906 \mathrm{gr}$ und davon die Scheinfrichte $438 \mathrm{gr}$.

Dieser nicht leicht lagernde, fast rostfreie Hafer eignet sich für rauhes Klima und Gebirgsboden.

\section{Cluster-Oat.}

Rispe: ausgebreitet, begrannt, mittellang, ziemlich reiclısamig; A elırchen 2-körı́ng, hlappeu fast weiss, $2 \mathrm{~cm}$ lang, $0.7 \mathrm{~cm}$ brcit. - Śtroh: rötlich-gelb, kurz. - Scheinfrucht: rötlich-weiss, Scheidenspelze rötlich, bauchig wie „praegravis", an der Basis borstig, kurz, 390 Scheinfriichte = $10 \mathrm{gr}$; Granne an der Basis schwarzbraun, gekniet, $2.5 \mathrm{~cm}$ lang; ziemlich feinschalig, Spelzen 27.2 Proc. ausmachend. 
Junges Blatt blaugrïn, breit, aufrecht, 2.1 Schösslinge; Halm $80 \mathrm{~cm}$ (Max. $100 \mathrm{~cm}$ ) lang, $0.45 \mathrm{~cm}$ dick, Blattzahl 4.5, Blätter $24.4 \mathrm{~cm} \mathrm{lang,}$ $1.2 \mathrm{~cm}$ breit, Blattfläche $353.5 \mathrm{qcm}$, Halmfläche $108 \mathrm{qcm}$, Gesammtfläche $461.5 \mathrm{qcm}$. früchten.

Rispe $20 \mathrm{~cm}$ (Max. $25 \mathrm{~cm}$ ) lang, nit 75 Aehrchen und 150 Schein-

Frühhafer, in 105 Tagen reifend.

\section{Avena comune di Viterbo. $\odot$}

Rispe: ausgebreitet, locker, bis $23 \mathrm{~cm}$ lang; Aehrchen 2-körnig, begrannt; Klappen blassrötlich-weiss ( $3 \mathrm{~cm}$ laner, $0 .(i \mathrm{~cm}$ breit). - Stroh: blassgelb. - Scheinfrucht: blassrötlich-weiss, an der Basis borstig (grosses Korn $1.6 \mathrm{~cm}$ lang, $0.25 \mathrm{~cm}$ breit, kleines $1.2 \mathrm{~cm}$ lang, $0.2 \mathrm{~cm}$ breit); Granne gebogen, blassrot, bis $2.5 \mathrm{~cm}$ lang.

Original von der Pariser Weltausstellung 1878.

\section{Varietät: Avena sativa trisperma Schübler et Mart.}

Begrannt; Spelzen blassgelb; dreikörnig.

\section{Sorten:}

\section{Gegrannter, dreikörniger Rispenhafer. $\odot$}

Syn.: Avena trisperma Schübler et Martens.

Doppelhafer, Klumphafer, Gabelshafer (Schiibler).

Engl.: Three grained white Oat.

Franz.: Avoine à trois graines.

Rispe: ausgebreitet, etwas armsamig, mittellang; Aehrchen 3-körnig, nur die erste Blïthe begraunt; Granne sehr rauh, gebogen, bis $3 \mathrm{~cm}$ lang, gelb, an der Basis dunkelgrau; Klappen, gelb (2.4 cm lang, $0.7 \mathrm{~cm}$ breit). - Stroh: gelb, blattreich, ziemlich kurz. - Scheinfrucht: blassgelb, schmal (grösstes Korn $1.9 \mathrm{~cm}$ lang, $0.3 \mathrm{~cm}$ breit, kleinstes $0.8 \mathrm{~cm}$ lang, $0.2 \mathrm{~cm}$ breit), grobschalig, $100 \mathrm{gr}=69 \mathrm{gr}$ Frïchte, $31 \mathrm{gr}^{\circ}$ Spelzen.

Halm dunkelblau, 2.3 Schösslinge, sehr spät blïhend, $105 \mathrm{~cm}$ (Max. $130 \mathrm{~cm}$ ) lang, $0.43 \mathrm{~cm}$ dick, Blattzahl 5, Blätter $29.2 \mathrm{~cm} \mathrm{lang,} 1,14 \mathrm{~cm}$ breit, Blattfläche 332.9 qcm, Halmfläche 135.45 q cm, Gesammtfläche $468.35 \mathrm{q} \mathrm{cm}$.

Späthafer, reift in 135 Tagen; Rispe: $25 \mathrm{~cm}$ (Max. $30 \mathrm{~cm}$ ) lang, mit 120 fest sitzenden Scheinfrichten, von denen 1131840 auf 1 hl $(=39.3 \mathrm{~kg})$ entfallen.

Auf $1 \mathrm{qm}$ wachsen 800 Halme oder 348 Pflanzen, mithin beträgt der Raum für eine Pflanze $29 \mathrm{qcm}$, dic Blattfäche p. qm Bodenfläche $37.4 \mathrm{qm}$, und das Saatquantum $4.1 \mathrm{hl} \mathrm{l}$. ha.

Seine Kultur ist selır wenig verbreitet. 


\section{Dreikörniger Hafer ans Umeå, Westerbotten $\left(64^{0} \mathrm{n}\right.$. Br. $)$, Schweden. $\odot$}

Rispe: ausgebreitet, reichsamig, mittellang; Aehrchen meist 3-körnig und 1-grannig; Klappen blassgelb (2.8 cm lang. $0.7 \mathrm{~cm}$ breit). Stroh: rötlich-gelb oder orange, fest, wenig blattreich, ziemlich kurz. Scheinfrucht: blassgelb, schmal (grösstes Korn $2 \mathrm{~cm}$ lang, $0.3 \mathrm{~cm}$ breit, kleinstes $1.1 \mathrm{~cm}$ lang, $0.2 \mathrm{~cm}$ breit), leicht, grobschalig, $100 \mathrm{gr}=65.5 \mathrm{gr}$ Früchte, 33.5 gr Spelzen.

Halın gelbgrün, 2 Schösslinge, sehr zeitig blühend, $110 \mathrm{~cm}$ (Max. $120 \mathrm{~cm}$ ) lang, $0.47 \mathrm{~cm}$ dick, Blattzahl 3, Blätter $30.3 \mathrm{~cm}$ lang, $1.53 \mathrm{~cm}$ breit, Blattfläche 278.16 qcm, Halmfläche 155.1 qcm, Gesammtfläche $433.26 \mathrm{qcm}$.

Friihhafer, reift in 104 Tagen; Rispe $25 \mathrm{~cm}$ (Max. $30 \mathrm{~cm}$ ) lang, mit 150 nicht leicht ausfallenden Scheinfriichten, von denen 1461000 auf $1 \mathrm{hl}(=40 \mathrm{~kg})$ entfallen.

Auf $1 \mathrm{qm}$ wachsen 800 Halme oder 400 Pflanzen, mithin beträgt das Saatquantum $3.7 \mathrm{hl} \mathrm{p.} \mathrm{ha.}$

Es wiegen $100 \mathrm{Halme} 1120 \mathrm{gr}$, und davon die Scheinfrüchte $698 \mathrm{gr}$.

Dieser Hafer wurde 1876 durch L. Wittmack an den ök.-bot. Garten zu Poppelsdorf gesandt.

\section{Dreikörniger Hafor aus Lappland. $\odot$}

Rispe: ziemlich ausgebreitet, mittellang; Aehrchen meist 3-körnig, und grösstes Korn mit an der Basis dunkelbrauner, geschlängelter, gedrehter $3.5 \mathrm{~cm}$ langer Granne, Klappen goldgelb, $2.5 \mathrm{~cm}$ lang, $0.7 \mathrm{~cm}$ breit. - Stroh: grünlich-gelb, sehr fest, lang. - Scheinfrucht: blassgelb, klein, schmal (grosses Korn $13 \mathrm{~cm}$ lang, $2.5 \mathrm{~cm}$ breit, mittleres $10 \mathrm{~cm}$ lang, $2.2 \mathrm{~cm}$ breit, kleines $8 \mathrm{~cm}$ lang, $2 \mathrm{~cm}$ breit, 392 Scheinfrüchte $=10 \mathrm{gr}$ ); etwas grobschalig, 29.5 Proc. Spelzen.

Junges Blatt hellgrün, schmal, 2.2 Schösslinge; Halm $135 \mathrm{~cm}$ (Max. $150 \mathrm{~cm}$ ) lang, $0.5 \mathrm{~cm}$ dick, Blattzahl 4.3 , Blätter $30 \mathrm{~cm}$ lang, $1.1 \mathrm{~cm}$ breit, Blattfä̈che $283.8 \mathrm{qcm}$, Halmfläche $202.5 \mathrm{qcm}$, Gesammtfläche $486.3 \mathrm{qcm}$.

Rispe $20 \mathrm{~cm}$ (Max. $25 \mathrm{~cm}$ ) lang, mit 150 ziemlich fest sitzenden Scheinfrüchten.

Späthafer, in 140 Tagen reifend.

Bezugsquelle: Versuchsfeld zu Halle.

\section{Avena di Palermo.}

Rispe: ausgebreitet, bis $26 \mathrm{~cm}$ lang; Aehrchen meist 3-körnig, davon 2 Blütchen gegrannt, Granne goldgelb, bis $2.5 \mathrm{~cm}$ lang; Klappen rötlich-gelb ( $2.5 \mathrm{~cm}$ lang, $0.6 \mathrm{~cm}$ breit). - Stroh: rötlich-gelb. - Schei:1frucht: rötlichgelb, an der Basis borstig (grösstes Korn $2 \mathrm{~cm}$ lang, $0.3 \mathrm{~cm}$ breit, mittelstes $1.5 \mathrm{~cm}$ lang, $0.2 \mathrm{~cm}$ breit, kleinstes $0.7 \mathrm{~cm} \mathrm{lang,} 0.15 \mathrm{~cm}$ breit).

Original in der Sammlung des Dr. Dreisch, Poppelsdorf. 


\section{Varietät: Avena sativa aurea Kcke.}

Unbegrannt; Spelzen goldgelb.

\section{Sorten:}

\section{Grosser gelber Hafer. $\odot$}

Rispe: etwas zusammengezogen, ziemlich reichsamig, kurz; Aehrchen häufig 3-körnig; Klappen goldgelb $(2.5 \mathrm{~cm}$ lang, $1.3 \mathrm{~cm}$ breit). Stroh: gelb, kräftig, lang. _- Scheinfrucht: goldgelb, gross, schwer (grosses Korn $1.8 \mathrm{~cm}$ lang, $0.35 \mathrm{~cm}$ breit, kleines $1 \mathrm{~cm}$ lang, $0.25 \mathrm{~cm}$ breit), ziemlich feinschalig, $100 \mathrm{gr}=74 \mathrm{gr}$ Früchte, $26 \mathrm{gr}$ Spelzeu.

Junges Blatt blaugrïn, lang, schmal; Bestockung mittelstark, 2.3 Schösslinge, mittelfrüh schossend und blühend. Halm $125 \mathrm{~cm}$ (Мax. $150 \mathrm{~cm}$ ) lang, $0,43 \mathrm{~cm}$ dick, Blattzahl 4.4, Blätter $31.4 \mathrm{~cm}$ lang, $1.1 \mathrm{~cm}$ breit, Blattfläche $203.95 \mathrm{qcm}$, Halmfläche $161.25 \mathrm{qcm}$, Gesammtfläche $365.2 \mathrm{qcm}$.

Rispe in 118 Tagen reifend, $20 \mathrm{~cm}$ (Max. $25 \mathrm{~cm}$ ) lang, mit 130 Scheinfrüchten, von denen 1461000 auf $1 \mathrm{hl}(=48.7 \mathrm{~kg})$ entfallen.

Auf $1 \mathrm{qm}$ wachsen 1000 Halme oder 434 Pflanzen, mithin beträgt das Saatquantum $4 \mathrm{hl} \mathrm{p.} \mathrm{ha.}$

Es wiegen 100 Halme $943 \mathrm{gr}$ und davon die Scheinfrüchte $513 \mathrm{gr}$.

Er leidet wenig durch Lagern und Rost.

\section{Hoher Goldhafer. $\odot$}

Rispe: etwas zusammengezogen, armsamig, kurz; Aehrchen 2-körnig; Klappen sattgelb, weich ( $2 \mathrm{~cm}$ lang, $0.5 \mathrm{~cm}$ breit). - Stroh: hellgelb, mittellang, kräftig, blattreich, fest - Scheinfrucht: goldgelb, unbegrannt, ziemlich klein, schmal, spitz (grosses Korn $1.5 \mathrm{~cm}$ lang, $0.25 \mathrm{~cm}$ breit, kleines $1.1 \mathrm{~cm}$ lang, $0.2 \mathrm{~cm}$ breit), Schale mittelfein, $100 \mathrm{gr}=73.2 \mathrm{gr}$ Früchte, $26.8 \mathrm{gr}$ Spelzen.

Halm dunkelblangrün, Bestockung mittelstark, 2.5 Schösslinge, zeitig blühend, $120 \mathrm{~cm}$ (Max. $127 \mathrm{~cm}$ ) lang, $0.47 \mathrm{~cm}$ dick, Blattzahl 4.7, Blätter $28.4 \mathrm{~cm}$ lang, $1.09 \mathrm{~cm}$ breit, Blattfläche 291.02 qcm, Halmfläche $169.2 \mathrm{qcm}$, Gesammtfläche $460.22 \mathrm{qcm}$.

Späthafer, reift in 130 Tagen; Rispe $20 \mathrm{~cm}$ (Nax. $27 \mathrm{~cm}$ ) lang, mit 100 fest sitzenden Scheinfrüchten, von denen 2033900 auf $1 \mathrm{hl}$ $(=47.3 \mathrm{~kg})$ entfallen.

Auf 1 qm wachsen 900 Halme oder 360 Pflanzen, mithin beträgt der Raum für eiue Pflanze $27.8 \mathrm{qcm}$, die Blattfläche p. qm Bodenfläche $41.4 \mathrm{qm}$ und das Saatquantum $2.4 \mathrm{hl} \mathrm{p}$. ha.

Es wiegen 100 Halme $450 \mathrm{gr}$ und davon die Scheinfrüchte $236 \mathrm{gr}$.

\section{Sauerländer-Hafer.}

Rispe: ausgebreitet, reichsamig, kuız; Aehrcheıl meist 2-körnig, Klappen gelb $(2.5 \mathrm{~cm}$ lang, $0.7 \mathrm{~cm}$ breit). - Strob: gelbgrün, rohrartig, lang. - Scheinfrucht: goldgelb, spitz, schmal, klein (grosses Korn $1.4 \mathrm{~cm}$ lang, $0.25 \mathrm{~cm}$ breit, kleines $1 \mathrm{~cm}$ lang, $0.25 \mathrm{~cm}$ breit), grobschalig, $100 \mathrm{gr}$ $=68.3 \mathrm{gr}$ Früchte, $31.7 \mathrm{gr}$ Spelzen.

Blätter blaugruin, schmal, kurz, 2 Schösslinge, Halm $125 \mathrm{~cm}$ (Max. $145 \mathrm{~cm}$ ) lang, $0.53 \mathrm{~cm}$ dick, Blattzahl 5, Blätter $36.6 \mathrm{~cm}$ lang, $1.5 \mathrm{~cm}$ 
breit, Blattfläche 549 q $\mathrm{cm}$, Halmfläche $198.75 \mathrm{q} \mathrm{cm}$, Gesammtfläche $747.75 \mathrm{q} \mathrm{cm}$.

Späthafer, reift in 125 Tagen; Rispe $20 \mathrm{~cm}$ (Max. $25 \mathrm{~cm}$ ) lang, mit 150 fest sitzenden Sclıeinfrüchten, von denen 1358000 auf 1 lil $(=48.5 \mathrm{~kg})$ entfallen.

Es wiegen 100 Halme $1122 \mathrm{gr}$ und davon die Scheinfrüchte $560 \mathrm{gr}$.

Dieser wenig durch Lagern oder Rost leidende Hafer ist als Grünfutter im hohen Grade beachtenswert.

\section{Kartoffel-Goldhafor. $\odot$}

Rispe: ein wellig zusammengezogen, ziemlich reichsamig, kurz; Aehrchen 2-körnig; Klappen goldgelb $(1.8 \mathrm{~cm}$ lang, $0.7 \mathrm{~cm}$ breit). Stroh: gelb, fest, etwas feinhalmig, mittellang. - Scheinfrucht: goldgelb, ziemlich kurz, plump (grosses Korn $1.5 \mathrm{~cm}$ lang, $0.35 \mathrm{~cm}$ breit, kleines $1.1 \mathrm{~cm}$ lang, $0.3 \mathrm{~cm}$ breit), schwer, Schale mittelfein, $100 \mathrm{gr}=72 \mathrm{gr}$ Frïchte, $28 \mathrm{gr}$ Spelzen.

Blätter dunkelgrün, schmal; Bestockung schwach, 1.3 Schösslinge, mittelfriih schossend und blïhend. Halm $120 \mathrm{~cm}$ (Max. $140 \mathrm{~cm}$ ) lang, $0.43 \mathrm{~cm}$ dick, Blattzahl 4.2 , Blätter $32 \mathrm{~cm}$ lang, $1.3 \mathrm{~cm}$ breit, Blattfäche $349.44 \mathrm{qcm}$, Halmfläche $154.8 \mathrm{qcm}$, Gesammtfläche $504.24 \mathrm{qcm}$.

Späthafer, reift in 125 Tagen; Rispe $20 \mathrm{~cm}$ (Max. $25 \mathrm{~cm}$ ) lang, mit 130 ziemlich fest sitzenden Scheinfrüchten, von denen 1436000 auf $1 \mathrm{hl}(=49.5 \mathrm{~kg})$ entfallen.

Es wiegen 100 Halme $900 \mathrm{gr}$ und davon die Scheinfrïchte $443 \mathrm{gr}$. Dieser beachtenswerte Hafer lagert nicht und bleibt fast rostfrei.

\section{Grosser gelber Thüringer-Hafer. $\odot$}

Rispe: ausgebreitet, locker, armsamig, kurz; Aehrchen 2-körnig; Klappen gold- oder blassgelb $(2.5 \mathrm{~cm}$ lang, $0.6 \mathrm{~cm}$ breit $)$. - Stroh: gelb oder orange, feinhalmig, kurz. - Scheinfrucht: goldgelb, länglich, etwas spitz doch voll (grosses Korn $1.8 \mathrm{~cm}$ lang, $0.3 \mathrm{~cm}$ breit, kleines $1.2 \mathrm{~cm}$ lang, $0.25 \mathrm{~cm}$ breit); zuweilen begramnt, Grannen bis $2.5 \mathrm{~cm}$ lang, bräunlich; ziemlich schwer, etwas grobschalig, $100 \mathrm{gr}=72 \mathrm{gr}$ Früchte, $28 \mathrm{gr}$ Spelzen.

Halın dunkelblaugrün; Bestockung stark, 3 Schösslinge, sehr spät bliihend, $105 \mathrm{~cm}$ (Max. $130 \mathrm{~cm}$ ) lang, $037 \mathrm{~cm} \mathrm{dick,} \mathrm{Blattzahl} \mathrm{4.3,} \mathrm{Blätter}$ $31.4 \mathrm{~cm}$ lang, $086 \mathrm{~cm}$ breit, Blattfläche $232.2 \mathrm{qcm}$, Halmfläche $116.55 \mathrm{qcm}$, Gesammtfläche $348.75 \mathrm{qcm}$.

Späthafer, reift in 137 Tagen; Rispe $18 \mathrm{~cm}$ (Max. 22 cm) lang, mit 100 Scheinfriichten, von denen 1607000 auf $1 \mathrm{hl}(=48.7 \mathrm{~kg})$ entfallen.

Auf $1 \mathrm{qm}$ wachsen 900 Halme oder 300 Pflanzen, mithin beträgt das Saatquantum $1.3 \mathrm{hl}$ p. ha.

Es wiegen 100 Halme $400 \mathrm{gr}$ und davon die Scheinfriichte $183 \mathrm{gr}$.

\section{Ungarischer Goldhafer. $\odot$}

Rispe: ausgebreitet, ziemlich reichsamig, mittellang; Aehreheu 2-, selur selten 3-köruig; Klappen goldgelb $(2.5 \mathrm{~cm}$ lang, $0.6 \mathrm{~cm}$ breit). - Stroh: gelb, sehr kräftig, fest, blattreich, lang. - Scheinfrucht: goldgelb, läng- 
lich, etwas spitz docl voll (grosses Korn $1.9 \mathrm{~cm}$ lang, $0.3 \mathrm{~cm}$ breit, kleines $1.4 \mathrm{~cm}$ lang, $0.25 \mathrm{~cm}$ breit); znweilen begrannt, Granne bräunlich, an der Basis dunkler, bis $3 \mathrm{~cm}$ lang; ziemlich feinschalig, $100 \mathrm{gr}=$ 74.5 gr Früchte, 25.5 gr Spelzen.

Blätter blaugrün, schmal, Bestockung schwach, 1.8 Schösslinge, spät blühend. Halm $135 \mathrm{~cm}$ (Max. $165 \mathrm{~cm}$ ) lang, $0.63 \mathrm{~cm}$ breit, Blattzahl 5, Blätter $35.2 \mathrm{~cm}$ lang, $1.5 \mathrm{~cm}$ breit, Blattfläche $528 \mathrm{qcm}$, Halmfläche $255.15 \mathrm{qcm}$, Gesammtfliche $783.15 \mathrm{qcm}$.

Späthafer, reift in 130 Tagen; Rispe $25 \mathrm{~cm}$ (Max. $30 \mathrm{~cm}$ ) lang, mit 140 zicmlich fest sitzenden Schcinfrïchten, vou denen 1426000 anf 1 hl $(=46 \mathrm{~kg})$ entfallen.

Es wiegen 100 Halıne $943 \mathrm{gr}$ und davon die Scheinfriichte $415 \mathrm{gr}$.

Dieser Hafer lagert kaum auf den reichsten Böden, leidet relativ wenig durch Rost, eignet sich zu Grünfutter und bringt sehr hohe Stroherträge.

\section{Podolischer Goldhafer. $\odot$}

Rispe: ausgebreitet, armsamig, kurz; Aehrchen 2-, selten 3-körnig; Klappen goldgelb (2.7 cm lang, $0.6 \mathrm{~cm}$ breit). -- Stroh: gelb, ziemlich blattarm, lang. - Scheinfrucht: goldgelb, schmal, sehr lang (grosses Korn $2 \mathrm{~cm}$ lang, $0.3 \mathrm{~cm}$ breit, kleines $1.4 \mathrm{~cm}$ lang, $0.25 \mathrm{~cm}$ breit), sehx leicht, Schale mittelfein, $100 \mathrm{gr}=73 \mathrm{gr}$ Frichte, $27 \mathrm{gr}$ Spelzen.

Blätter blaugrün, schmal, larg; Bestockung schwach, 1.6 Schösslinge, spät blühend; Halm $130 \mathrm{~cm}$ (Max. $140 \mathrm{~cm}$ ) lang, $0.5 \mathrm{~cm}$ dick, Blattzahl 4, Blätter $35 \mathrm{~cm} \mathrm{lang,} 1.08 \mathrm{~cm}$ breit, Blattfläche $302.4 \mathrm{qcm}$, Halmfläche $195 \mathrm{qcm}$, Gesammtfläche $497.4 \mathrm{qcm}$.

Späthafer, in 125 Tagen reifend; Rispe $20 \mathrm{~cm}$ (Max. $30 \mathrm{~cm}$ ) lang, mit 100 Seheinfrüchten, von denen 1230000 auf $1 \mathrm{hl}(=41 \mathrm{~kg})$ entfallen.

Es wiegen 100 Halme $408 \mathrm{gr}$ und davon die Scheinfriichte $276 \mathrm{gr}$. Er lagert seiten und widersteht dem Rost.

\section{Ossetinischer-Hafer. $\odot$}

Syn.: Hafer aus St. Petersburg.

Rispe: ziemlich stark zusammengezogen, etwas armsamig, kurz; Aehrchen 2-körnig; Klappen goldgelb ( $2 \mathrm{~cm}$ lang, $0.6 \mathrm{~cm}$ breit). - Strolı: gelb, kräftig, lang. - Scheinfrucht: goldgelb, spitz, schmal (grosscs Korn $1.5 \mathrm{~cm}$ lang, $0.3 \mathrm{~cm}$ breit, kleines $1.1 \mathrm{~cm}$ lang, $0.25 \mathrm{~cm}$ breit), leicht, Schale mittelfein, $100 \mathrm{gr}=72 \mathrm{gr}$ Früclite, $28 \mathrm{gr}$ Spelzen.

Blätter dunkelgruin, schmal, 2.4 Schösslinge; Halm $125 \mathrm{~cm}$ (Max. $140 \mathrm{~cm})$ lang, $0.58 \mathrm{~cm}$ dick, Blattzalıl 4, Blätter $38 \mathrm{~cm} \mathrm{lang,} 1.3 \mathrm{~cm}$ breit, Blattfläche 395.2 qcm, Halmfläche $217.5 \mathrm{qcm}$, Gesammtfläche $612.7 \mathrm{qcm}$. Frühhafer, Rispe $20 \mathrm{~cm}$ (Max. $30 \mathrm{~cm}$ ) lang, mit 110 Scheinfrüchtell, von denen 1712000 anf $1 \mathrm{ll}(=42.8 \mathrm{~kg})$ entfallen.

Er leidet wenig durch Rost, lagert jedoch leicht.

Heimat: Kaukasien, Umgebung des Kasbek.

\section{Hafer vom Altai, Südwest-Sibirien.}

Rispe: wenig ausgebreitet, reichsamig, mittellang; Aehrchen 2- und 3-körnig; Klappen sattgelb $(2.5 \mathrm{~cm} \mathrm{lang,} 0.7 \mathrm{~cm}$ breit). - Stroh: grün- 
lich-gelb, sehr kräftig, fest, blattarm, lang. - Scheinfrucht: goldgelb, ziemlich lang, doch schmal (grosses Korn $1.5 \mathrm{~cm}$ lang, $0.25 \mathrm{~cm}$ breit, kleines $1 \mathrm{~cm}$ lang, $0.22 \mathrm{~cm}$ breit), ziemlich feinschalig, $100 \mathrm{gr}=76.5 \mathrm{gr}$ Früchte, 23.5 gr Spelzen.

Blätter blaugrün, ziemlich lang, schmal; Bestockung mittelstark, 2.4 Schösslinge, sehr zeitig schossend und blühend. Halme $130 \mathrm{~cm}$ (Мax. $150 \mathrm{~cm}$ ) lang, $0.63 \mathrm{~cm}$ dick, Blattzalı 3.9 , Blätter $37.3 \mathrm{~cm}$ lang; $1.23 \mathrm{~cm}$ breit, Blattläche $357.86 \mathrm{qcm}$, Halmfläche $245.7 \mathrm{qcm}$, Gesammtfläche $603.56 \mathrm{qcm}$.

Rispe reift in 120 Tagen, $25 \mathrm{~cm}$ (Max. $30 \mathrm{~cm}$ ) lang, mit 250 ziemlich fest sitzenden Scheinfrücliten, von denen 1458600 auf $1 \mathrm{hl}(=44.2 \mathrm{lg})$ entfallen.

Es wiegen 100 Halme $1220 \mathrm{gr}$ und davon die Scheinfrüchte $640 \mathrm{gr}$.

Er lagert nicht leicht und widersteht dem Rost.

Er wurde von den Reisenden Dr. Finsch und Graf Zeil eingesandt.

\section{Drummond-0at. $\odot$}

Syn.: Hafer von Drummond.

Rispe: etwas zusammengezogen, armsamig, mittellang; Aehrchen 2körnig; Klappen gelb (2.4 cm lang, $0.6 \mathrm{~cm}$ breit). - Stroh: grünlichgelb, blattreich, mittellang, fest. - Scheinfrucht: goldgelb, lang, schmal, etwas spitz (grosses Korn $1.7 \mathrm{cn}$ lang, $0.3 \mathrm{~cm}$ breit, kleines $1.2 \mathrm{~cm}$ lang, $0.25 \mathrm{~cm}$ breit), auf armem Lande zuweilen begrannt, ziemlich feinschalig, $100 \mathrm{gr}=74.3 \mathrm{gr}$ Früchte, $25.7 \mathrm{gr}$ Spelzen.

Halme dunkelblaugrün, Bestockung mittelstark, 2.6 Schösslinge, spät blühend, $125 \mathrm{~cm}$ (Max. $140 \mathrm{~cm}$ ) lang, $0.4 \mathrm{~cm}$ dick, Blattzahl 5, Blätter $32.2 \mathrm{~cm}$ lang, $1.2 \mathrm{~cm}$ breit, Blattfläche $386.4 \mathrm{qcm}$, Halmfläche $150 \mathrm{qcm}$, Gesammtfläche $536.4 \mathrm{qcm}$.

Späthafer, in 130 Tagen reifend; Rispe $25 \mathrm{~cm}$ (ㄷa. $30 \mathrm{~cm}$ ) lang, mit 110 fest sitzenden Scheinfrüchten, von denen 1481800 auf $1 \mathrm{hl}$ $(=47.8 \mathrm{~kg})$ entfallen.

Es wiegen 100 Halme $420 \mathrm{gr}$ und davon die Scheinfriichte $231 \mathrm{gr}$.

Dieser Hafer wird in England nnd Mittel-Schottland vielfach auf schwerem Clayboden angebaut und liefert einen etwas geringeren Ertrag als "Late Angus-Oat".

\section{Aroine jaune de Flandre. $\odot$}

Syn.: Franz.: Avoine du Nord, des Salines.

Eng l.: Flemish-Oat.

Ital.: Avena flandrese.

Deutsch: Gelber flandrischer Hafer, ostfriesischer Goldhafer.

Rispe: ein wenig zusammengezogen, ziemlich reichsamig, mittellang; Aehren 2-, selten 3-körnig; Klappen blassgelb ( $2.5 \mathrm{~cm}$ lang, $0.6 \mathrm{~cm}$ breit). - Stroh: rötlich-gelb, rohrartig, fest, blattreich. - Scheinfrucht: goldgelb, etwas spitz, doch ziemlich voll (grosses Korn $1.7 \mathrm{~cm}$ lang, $0.3 \mathrm{~cm}$ breit, kleines $1.2 \mathrm{~cm}$ lang, $0.25 \mathrm{~cm}$ breit), viele begrannt, Grannen gelb, an Basis schwarzbraun, bis $2.5 \mathrm{~cm}$ lang, leicht, ziemlich feinschalig, $100 \mathrm{gr}$ $=74.8 \mathrm{gr}$ Früchte, $25.2 \mathrm{gr}$ Spelzen.

Halm dunkelblaugruin, Bestockung mittelstark, 2.5 Schösslinge, mittelfriilı blühend. Halm $130 \mathrm{~cm}$ (Max. $140 \mathrm{~cm}$ ) lang. $0.5 \mathrm{~cm}$ dick, Blatt- 
zahl 5, Blätter $34 \mathrm{~cm}$ lang, $1.2 \mathrm{~cm}$ breit, Blattfläche 409 qcm, Halmfläche $195 \mathrm{qcm}$, Gesammtfläche $603 \mathrm{qcm}$.

Späthafer, in 125 Tagen reifend; Rispe $25 \mathrm{~cm}$ (Max. $30 \mathrm{~cm}$ ) lang, mit 120 ziemlich leicht ausfallenden Scheinfrïchten, von denen 1610000 auf $1 \mathrm{hl}(=46 \mathrm{~kg})$ entfallen.

Auf $1 \mathrm{qm}$ wachsen 600 Halme oder 240 Pflanzen, mithin beträgt das Saatquantum $2 \mathrm{hl}$ p. ha.

Es wiegen 100 Halme $600 \mathrm{gr}$ und davon die Scheinfrichte $333 \mathrm{gr}$.

Mr. Melvin erzielte in England auf Lehmboden nach einjähriger Weide p. ha:

$44.9 \mathrm{hl}$ Vorderkorn ¿ $52.5 \mathrm{~kg}, 21.55 \mathrm{hl}$ Hinterkorn, $7532.4 \mathrm{~kg}$ Stroll.

Dieser ertragreiche und zu Grünfutter sich vortrefflich eignende Hafer verlangt einen kräftigen humosen Lehmboden.

Er wird vorzugsweise an der Nordseeküste in Belgien, im nördlichen Frankreich und Deutschland, sowie in England und versuchsweisc zu Monza in Italien kultiviert.

\section{Avoine jaune de Bourbourg. $\odot$}

Syn.: Goldhafer von Bourbourg, Frankieich.

Rispe: ausgebreitet, ziemlich reichsamig, mittellang; Aehrchen 2körnig, die oberen lang, die unteren kurz oder kaum begrannt; Klappen goldgelb, an der Spitze weisslich $(2.3 \mathrm{~cm}$ lang, $0.6 \mathrm{~cm}$ breit). - Stroh: gelb, sehr kräftig, wenig blattreich, fest, lang. - Scheinfrucht: goldgelb, voll, lang (grosses Koin $1.8 \mathrm{~cm}$ lang, $0.25 \mathrm{~cm}$ breit, kleines $1.3 \mathrm{~cm}$ lang, $0.25 \mathrm{~cm}$ breit), wenn begrannt, so Grannen gelb, an Basis bräunlich, bis $3 \mathrm{~cm}$ lang, schwer, ziemlich feinschalig, $100 \mathrm{gr}=75 \mathrm{gr}$ Frichte, $25 \mathrm{gr}$ Spelzen.

Junges Blatt hellgriin, ziemlich lang, breit, kräftig; Bestockung mittelstark, 2.5 Schösslinge, sehr spät schossend und blïhend. Halm $140 \mathrm{~cm}$ (Max. $160 \mathrm{~cm}$ ) lang, $0.5 \mathrm{~cm}$ dick, Blattzalıl 4.8, Blätter $33.9 \mathrm{~cm}$ lang, $1.27 \mathrm{~cm}$ breit, Blattfläche $413.31 \mathrm{qcm}$, Halmfläche $210 \mathrm{qcm}, \mathrm{Ge}-$ sammtfläche $623.31 \mathrm{qcm}$.

Späthafer, reift in 125 Tagen; Rispe $25 \mathrm{~cm}$ (Max. $30 \mathrm{~cm}$ ) lang, mit 140 Scheinfriichten, von denen 1546000 auf $1 \mathrm{hl}(=48.3 \mathrm{~kg}$ ) entfallel.

Auf $1 \mathrm{qm}$ wachsen 600 Halme oder 240 Pflanzen, mithin beträgt der Raum für eine Pflanze $83.3 \mathrm{qcm}$, die Blattfläche p. qm Bodenfläche $37.4 \mathrm{qm}$ und das Saatquantum $2 \mathrm{hl}$ p. ha.

Es wiegen 100 Halme 1156 gr und davon die Scheinfrüchte 514 gr.

Dieser Hafer ist auf reichem Boden in hohem Grade ertragreich, leidet weder durch Lagern noch durch Rost und erwies sich seit 1870 konstant.

Er wurde 1869 durch das preussische landw. Ministerium zur Prüfung eingesandt.

Varietiat: Avena sativa Krausei Keke.

Begrannt; Spelzen goldgelb.

\section{Sorte:}

\section{Gegrannter Goldhater. $\odot$}

Rispe: ausgebreitet, armsamig, mittellang; Aehrchen 2-körnig, 1grannig; doch fehlt mitunter, namentlich bei den Aehrchen an der Basis 
der Rispe die Granne; Klappen gelb. - Stroh: grünlich-gelb, sehr kräftig, blattreich, lang. - Scheinfrucht: goldgelb, lanzettlich, schmal, doch ziemlich voll (grosses Korn $1.4 \mathrm{~cm}$ lang, $0.3 \mathrm{~cm}$ breit, kleines $0.9 \mathrm{~cm}$ larg, $0.2 \mathrm{~cm}$ breit), grobschalig, $100 \mathrm{gr}=65.5 \mathrm{gr}$ Früichte, $34.5 \mathrm{gr}$ Spelzen.

Junges Blatt dunkelgriin, schmal, lang; Bestockung schwach, 1.8 Schösslinge, spät schossend und blühend. Halm $135 \mathrm{~cm}$ (Мax. $155 \mathrm{~cm}$ ) lang, $0.5 \% \mathrm{~cm}$ dick, Blattzahl 5, Blätter $37 \mathrm{~cm}$ lang, $1.24 \mathrm{~cm}$ breit, Blattflïche $458.8 \mathrm{qcm}$, Halmfläche $234.9 \mathrm{qcm}$, Gesammtfläche $693.7 \mathrm{qcm}$.

Späthafer, reift in 125 Tagen; Rispe $25 \mathrm{~cm}$ (Мax. $30 \mathrm{~cm}$ ) lang, mit 110 ziemlich fest sitzenden Scheinfrüchten, von denen 1255500 anf $1 \mathrm{hl}(=46.5 \mathrm{~kg})$ entfallen.

Es wiegen 100 Halme $1172 \mathrm{gr}$ und davon die Scheinfrüchte $600 \mathrm{gr}$.

Das Stroh lagert nicht leicht und bleibt fast rostfrei.

Nach Krause ${ }^{1}$ ) war er Mitte der dreissiger Jahre fast ausschliesslich die einzige Rispenhafersorte, welche man in Thüringen baute, doch scheint dieselbe dort zur Zeit fast ganz verschwunden und unbekannt zu sein und nur zufällig fand sie Körnicke unter einer Probe vom grossen gelben Thïringer-Hafer.

\section{Varietät: Arena sativa grisea Kcke. \\ Unbegraunt; Spelzen grau.}

\section{Sorte : \\ Grauer ungegramuter Winterhafer. (2) und $\odot$}

Franz.: Avoine grise.

Ital.: Avena grigia d'inverno.

Rispe: ansgebreitet, armsamig, kaum mittellang; Aehrchen 2-körnig, zuweilen begrannt; Klappen blassgelb $(2.5 \mathrm{~cm}$ lang, $0.8 \mathrm{~cm}$ breit). Strolı: gelb, blattarm, kräftig, lang. - Scheinfrucht: bläulichgrau, gross, dick (grosses Korn $1.7 \mathrm{~cm}$ lang, $0.35 \mathrm{~cm}$ breit, kleines $1.1 \mathrm{~cm}$ lang, $0.25 \mathrm{~cm}$ breit), Granne braun, selı schwer, sehr feinschalig, $100 \mathrm{gr}=$ $79.8 \mathrm{gr}$ Früchte, $20.2 \mathrm{gr}$ Spelzen.

Herbstblatt hellgrüı, aufrecht, schmal; Bestockung als Winterfrucht schwach, 3.6 Schösslinge (Sommerfrucht stark, 3 Schösslinge). Frühjahrsvegetation beginnt Anfang April, die Blüte tritt 14 Tage nach der des Roggens ein. Halm $130 \mathrm{~cm}$ (Max. $150 \mathrm{~cm}$ ) lang, $0.42 \mathrm{~cm}$ dick, Blattzahl 4, Blätter $28 \mathrm{~cm}$ lang, $1.25 \mathrm{~cm}$ breit, Blattflïche $280 \mathrm{qcm}$, Haimfläche $163.8 \mathrm{q} \mathrm{cm}$, Gesammtfläche $443.8 \mathrm{qcm}$.

Reift in der zweiten Hälfte des Juli und als Sommerhafer nach 125 Tagen; Rispe $24 \mathrm{~cm}$ (IIax. $30 \mathrm{~cm}$ ) lang. mit 100 ziemlich fest sitzenden Scheinfrüchten, von denen 1590000 auf $1 \mathrm{hl}(=51 \mathrm{~kg})$ entfallen.

Es wiegen 100 Halme $1295 \mathrm{gr}$ und davon die Scheinfrüchte $577 \mathrm{gr}$.

Dieser sehr ertragreiche Hafer verlangt einen reichen Boden und ein mildes Klima, vorzugsweise wird er in Sïd-Frankreich, Spanien, Italien und hier namentlich in den Maremmen und der Provinz Torino kultiviert.

Er liefert ein zeitiges, kräftiges Grünfutter.

1) Vergl. Getreidearten Heft 7 p. 11. 
Varietät: Avena sativa cinerea Kcke.

Begrannt; Spelzen grau.

\section{Sorte:}

\section{Grauer gegramnter Winterhafer. (2) und $\odot$}

Rispe: wenig ausgebreitet, kurz, etwas armsamig; Aehrchen meist 3-körnig und meist begrannt; Ḱlappen gelb ( $3 \mathrm{~cm}$ lang, $0.6 \mathrm{~cm}$ breit). Stroh: gelb, wenig blattreich, fest, lang. - Scheinfrucht: grau, lang (grosses Korn $2.3 \mathrm{~cm}$ lang, $0.35 \mathrm{~cm}$ breit, mittleres $1.8 \mathrm{~cm}$ lang, $0.3 \mathrm{~cm}$ breit, kleines $1.1 \mathrm{~cm}$ lang, $0.25 \mathrm{~cm}$ breit); Granne schwarzbraun, gedreht, bis $6 \mathrm{~cm}$ lang; Schale mittelfein, $100 \mathrm{gr}=72.5 \mathrm{gr}$ Früchte, $27.5 \mathrm{gr}$ Spelzen.

Herbstblatt dunkelgrün, kurz; Frühjahrsvegetation zeitig, Bestockung mittelstark, 4.5 Schösslinge, 14 Tage nach dem Roggen blühend. Halm $130 \mathrm{~cm}$ (Max. $145 \mathrm{~cm}$ ) lang, $0.4 \mathrm{~cm}$ dick, Blattzahl 4, Blätter $24.18 \mathrm{~cm}$ lang, $1.02 \mathrm{~cm}$ breit, Blattfläche $232.13 \mathrm{qcm}$, Halmfläche $156 \mathrm{qcm}, \mathrm{Ge}-$ sammtfläche $388.13 \mathrm{qcm}$.

Reift in der zweiten Hälfte des Juli und als Sommerhafer in 130 Tagen; Rispe $22 \mathrm{~cm}$ (Max. $25 \mathrm{~cm}$ ) lang, mit 100 leicht ausfallenden Scheinfriichten, von denen 1176000 auf $1 \mathrm{hl}(=49 \mathrm{~kg})$ entfallen.

Auf $1 \mathrm{qm}$ wachsen 1000 Halme oder 222 Pflanzen, mithin beträgt das Saatquantum $2.5 \mathrm{hl} \mathrm{p.} \mathrm{ha.}$

Es wiegen 100 Halme $1117 \mathrm{gr}$ und davon die Scheinfrüchte $500 \mathrm{gr}$.

In Poppeldorf wurden 1872/73 nach gedüngtem Raps auf mildem Lehmboden p. ha. geerntet:

\begin{tabular}{|c|c|c|c|c|}
\hline & & & & \\
\hline Aussa: & Art der Bestellung & Korn & & Spreu \\
\hline $\begin{array}{l}\text { 2. Oktober, } \\
\text { do. }\end{array}$ & $\begin{array}{l}15.7 \mathrm{~cm} \text { gedrillt, } \\
\text { breitwürfig }\end{array}$ & $\begin{array}{l}3737 \mathrm{~kg} \\
4406, "\end{array}$ & $\begin{array}{l}3839 \mathrm{~kg} \\
3917 "\end{array}$ & $\begin{array}{l}842 \mathrm{~kg} \\
587,\end{array}$ \\
\hline April & breitwürfig & 3339 & 4309 & 490 \\
\hline
\end{tabular}

Der Winterhafer lagert nicht leicht und leidet wenig durch Rost, doch ist derselbe wenig winterfest, eignet sich daher nur für Gegenden mit mildem Winter und verlangt einen reichen Boden. Er wird vorzugsweise in Frankreich, Spanien und Italien kultiviert.

Bezugsquelle: Wiener Ausstellung 1873 aus Spanien.

Varictät: Avena sativa brunuea Kcke.

Unbegrannt; Spelzen braun.

\section{Sorten:}

\section{Brauner ungegrannter Rispenhafer. $\odot$}

Syn.: roter Bruch- oder Moorhafer.

Rispe: ausgebreitet, mittellang, reichsamig; Aehrchen 2-körnig; Klappen blassgelb (2.5 cm lang, $0.6 \mathrm{~cm}$ breit). - Stroh: gelb, weich, blattreich, lang. - Scheinfrucht: braun, an der Basis am dunkelsten, nach oben zu heller, länglich, etwas spitz (grosses Korn $1.6 \mathrm{~cm}$ lang, 
$0.3 \mathrm{~cm}$ breit, kleines $1.3 \mathrm{~cm}$ lang, $0.25 \mathrm{~cm}$ breit), leicht, zuweilen begrannt, Granne an der Basis schwarzbrann, nach oben bräunlich, bis $3 \mathrm{~cm}$ lang, Schale mittelfein, $100 \mathrm{gr}=72 \mathrm{gr}$ Früchte, $28 \mathrm{gr}$ Spelzen.

Junges Blatt dunkelgrïn, sehr lang, ziemlich breit. Bestockung stark, 3 Schösslinge, zeitig schossend und blühend. Halm $130 \mathrm{~cm}$ (Max. $145 \mathrm{~cm}$ ) lang, $0.58 \mathrm{~cm}$ breit, Blattzahl 5, Blätter $37 \mathrm{~cm}$ lang, $1.1 \mathrm{~cm}$ breit, Blattfläche $407 \mathrm{qcm}$, Halmfläche $226.2 \mathrm{qcm}$, Gesammtfläche $633.2 \mathrm{qcm}$.

Friihhafer, in 120 Tagen reifend, Rispe $25 \mathrm{~cm}$ (Max. $30 \mathrm{~cm}$ ) lang, mit 210 etwas leicht ausfallenden Scheinfriichten, von denen 1665000 auf $1 \mathrm{hl}(=42,7 \mathrm{~kg})$ entfallen.

Es wiegen 100 Halme $1270 \mathrm{gr}$ und davon die Scheinfriichte $617 \mathrm{gr}$.

Dieser Hafer lagert nicht leicht, ist sehr ertragreich an Stroh und Korn, liefert vortreffliches Futterstroh und empfiehlt sich für Moor-, Bruch- oder gerodeten Waldboden zum Anbau.

\section{Common Dun or red 0at. $\odot$ und (2)}

Syn.: Schottischer Dun- (dunkelbranner) Hafer.

Rispe: ausgebreitet, gross; Aehrchen 2-körnig; Klappen blassgelb. - Stroh: rötlich-gelb, steif, 1.6-2 m lang. - Scheinfrucht: an der Basis schwarzbraun und weiss gemischt, in der Mitte dunkelbraun, an der Spitze weisslich; gross, lang, dick, schwer; Schale mittelfein.

Auf Clayland mit undurchlassendem Untergrund bewahrt er die charakteristische Farbe und Form der Scheinfrüchte, nur auf leichtem, trocknem Boden degeneriert er leicht, indem die Scheinfrüchte heller und schlanker werden.

Dieser Hafer ist gegen ungünstige Witterung vollkommen unempfindlich, liefert viel und gutes Mehl, sowie ein vortreffliches Futterstroh, welches dem des "Tartarian-Oat" vorgezogen wird, und nicht leicht lagert.

Er wird sehr stark in Schottland und in England hauptsächlich in den Mooren von Cheshire, Derbyshire und Staffordshire angebaut.

Er ist ein Späthafer und lässt sich in Süd-England, Irland, sowie im Westen und Nord-Westen Frankreichs, in September gesäet, als Winterfrucht'(Winter Dun-Oat, Avoine d'hiver) benutzen und reift dann zeitig im Juli, wird er, wie dies zuweilen geschieht, im Friihjahr durch Schafe beweidet, so verzögert sich die Sommerreife um einige Wochen.

Seine Kultur hat sich auch vielfach in Nord-Amerika bewährt.

\section{Rousse couronné. $\odot$}

Syn.: Avoine rougeâtre ou ronge.

Rispe: ziemlich dicht, reichsamig, kurz; Aehrchen 2- selten 3-körnig; Klappen blassgelb (2.7 cm lang, $0.6 \mathrm{~cm}$ breit). - Stroh: gelb oder orange, blattreich, fest, kaum mittellang. - Scheinfrucht: hellbraun, an der Basis dunkler und borstig, selten begrannt, lang, schmal, spitz (grosses Korn $1.8 \mathrm{~cm}$ lang, $0.25 \mathrm{~cm}$ breit, kleines $1.3 \mathrm{~cm}$ lang, $0.25 \mathrm{~cm}$ breit), Schale mittelfein, $100 \mathrm{gr}=73 \mathrm{gr}$ Frïchte, $27 \mathrm{gr}$ Spelzen.

Halm blaugrün, mittelfrüh blühend, 2.6 Schösslinge, $110 \mathrm{~cm}$ (Max. $120 \mathrm{~cm}$ ) lang, $0.47 \mathrm{~cm}$ dick, Blattzahl 5, Blätter $31.8 \mathrm{~cm}$ lang, $1.16 \mathrm{~cm}$ breit, Blattfläche $368.9 \mathrm{qcm}$, Halmfäche $155.1 \mathrm{qcm}$, Gesammtfl̈che $525 \mathrm{qcm}$.

Frühhafer, Rispe $20 \mathrm{~cm}$ (Max. $25 \mathrm{~cm}$ ) lang, mit 140 etwas lose sitzenden Scheinfrüchten, von denen 1935000 auf $1 \mathrm{hl}(=45 \mathrm{~kg})$ entfallen. 
Es wiegen 100 Halme $587 \mathrm{gr}$ und davon die Scheinfrüchte $316 \mathrm{gr}$.

Dieser in Frankreich stark kultivierte Hafer ist ertragreich und lagert nicht leicht.

\section{Avoine grise de Houdan. $\odot$}

Syn.: Avoine noire de Beauce, grise de Perche, de Pithiviers.

Rispe: ziemlich ausgebreitet, armsamig, mittellang; Aehrchen 2-körnig, nur sehr selten begrannt; Klappen dunkelgelb, weich $(2.2 \mathrm{~cm}$ lang, $0.5 \mathrm{~cm}$ breit). - Stroh: dunkelgelb, blattreich, fest, kaum mittellang. Scheinfrucht: schwarzbraun, nach der Spitze zu heller, lanzettlich, ziemlich lang (grosses Korn $1.5 \mathrm{~cm}$ lang, $0.3 \mathrm{~cm}$ breit, kleines $1.1 \mathrm{~cm} \mathrm{lang,} 0.25 \mathrm{~cm}$ breit), schwer, feinschalig, $100 \mathrm{gr}=76.8 \mathrm{gr}$ Früchte, $23.2 \mathrm{gr}$ Spelzen.

Halm blaugrün, dnnkler als vom Avoine de Brie, Bestockung stark, 3 Schösslinge, mittelfrüh blühend, $110 \mathrm{~cm}$ (Max. $125 \mathrm{~cm}$ ) lang, $0.4 \mathrm{~cm}$ dick, Blattzahl 4.7, Blätter $28.1 \mathrm{~cm}$ lang, $0.9 \mathrm{~cm}$ breit, Blattfläche $237.73 \mathrm{qcm}$, Halmfläche $132 \mathrm{qcm}$, Gesammtfläche $369.73 \mathrm{qcm}$.

Späthafer, reift in 125 Tagen, Rispe $25 \mathrm{~cm}$ (Max. $30 \mathrm{~cm}$ ) lang, mit 100 leicht ausfallenden Scheinfrüchten, von denen 1809500 auf $1 \mathrm{hl}$ $(=51.7 \mathrm{~kg})$ entfallen.

Auf $1 \mathrm{qm}$ wachsen 900 Halme oder 300 Pflanzen, mithin beträgt das Saatquantum $2.2 \mathrm{hl}$ p. ha.

Es wiegen 100 Halme $744 \mathrm{gr}$ und davon die Scheinfrüchte $378 \mathrm{gr}$.

Dieser nicht leicht lagernde, fast rostfreie Hafer verlangt reiche, fruchtbare Böden, wenn er hohe Erträge liefern soll.

Er bildet den Uebergang zur Varietät Avena sativa nigra, doch ist die Scheinfrucht für dieselbe zu schlank.

Heimat: Frankreich.

\section{Aroine Picarde. $\odot$}

Rispe: ausgebreitet, $25 \mathrm{~cm}$ lang, etwas armsamig (130 Scheinfrüchte in 75 Aehrchen); Klappen unrein blassgelb (2 cm lang, $0.8 \mathrm{~cm}$ breit). Stroh: goldgelb, sehr kräftig, fest. - Scheinfrucht: braun, nach der Spitze $\mathrm{zu}$ heller (grosses Korn $1.7 \mathrm{~cm}$ lang, $0.3 \mathrm{~cm}$ breit, kleines $1.3 \mathrm{~cm}$ lang, $0.25 \mathrm{~cm}$ breit), zuweilen kurz begrannt.

Original im landw. Museum zu Berlin.

\section{Brauner Hafer aus Umei, Schweden.}

Rispe: blassgelb, ausgebreitet, gross, reichsamig; Aehrchen 2-körnig, Klappen blassgelb, $2.6 \mathrm{~cm}$ lang, $0.6 \mathrm{~cm}$ breit. - Stroh: orange bis violett blattreich, mittellang, sehr fest. - Scheinfrucht: schwarzbraun, nach der Spitze heller, selten begrannt, klein (grosses Korn $12 \mathrm{~mm}$ lang, $2.5 \mathrm{~mm}$ breit, kleines $10 \mathrm{~mm}$ lang, $2 \mathrm{~mm}$ breit, 411 Körner $=10 \mathrm{gr}$ ); ziemlich feinschalig, Spelzen 26.1 Proc. ausmachend.

Junges Blatt blaugrün, kräftig, 2.3 Schösslinge; Halm $115 \mathrm{~cm}$ (Max. $125 \mathrm{~cm}$ ) lang, $0.55 \mathrm{~cm}$ dick, Blattzahl 4, Blätter $27 \mathrm{~cm} \mathrm{lang,} 1.25 \mathrm{~cm}$ breit, Blattfläche $270 \mathrm{qcm}$, Halmfläche $189.8 \mathrm{qcm}$, Gesammtfiäche $459.8 \mathrm{qcm}$. Rispe $25 \mathrm{~cm}$ (Max. $30 \mathrm{~cm}$ ) lang, mit 214 Scheinfrüchten, von denen 1767300 auf $1 \mathrm{hl}(=43 \mathrm{~kg})$ entfallen.

Mittelfrüh, in 120 Tagen reifend. 


\section{Branner Rispenhafer ans Norwegen. $\odot$}

Rispe: rötlich-gelb, ausgebreitet, unter mittellang; nicht selır reichsamig; Aehrchen 2-körnig, Klappen rötlich-blassgelb, $2.3 \mathrm{~cm}$ lang, $0.6 \mathrm{~cm}$ breit. - Stroh: rötlich-gelb, fest, rohrartig, lang. - Scheinfrucht: rein braun, selten gegraunt, schmal, klein (grosses Korn $17 \mathrm{~mm}$ lang, $3 \mathrm{~mm}$ breit, kleines $13 \mathrm{~mm}$ lang, $2.5 \mathrm{~mm}$ breit, 409 Scheinfrüchte $=10 \mathrm{gr}$ ), ziemlich feinschalig, Spelzen 28 Proc. ausmachend.

Junges Blatt blaugrün, kräftig; 2.6 Schösslinge, spät blühend; Halm $125 \mathrm{~cm}$ (Max. $140 \mathrm{~cm}$ ) lang, $0.5 \mathrm{~cm}$ dick, Blattzahl 5, Blätter $40.4 \mathrm{~cm}$ lang, $1.22 \mathrm{~cm}$ breit, Blattfläche $492.9 \mathrm{qcm}$, Halmfläche $187.5 \mathrm{qcm}$, Gesammtfläche $680.4 \mathrm{qcm}$.

Rispe $20 \mathrm{~cm}$ (Max. $27 \mathrm{~cm}$ ) mit 100 Scheinfrüchten, von denen 2012280 auf $1 \mathrm{hl}(=49.2 \mathrm{~kg})$ entfallen. Scheinfrichte nicht leicht ausfallend.

Späthafer, in 130 Tagen reifend. Stroh.

$\mathrm{Zu}$ Grünfutter vorziiglich geeignet, auch ertragreiclı in Korn und

Bezugsquelle: Wiener Ausstellung 1873. Aussteller: Landw. Schule Aas bei Christiania.

\section{New-Brunswick-0at. $\odot$}

Rispe: ausgebreitet, unbegrannt, $22 \mathrm{~cm}$ lang, armsamig (70 Scheinfrüchte in 40 Aehrchen); Klappen blassgelb ( $2 \mathrm{~cm}$ lang, $0.8 \mathrm{~cm}$ breit). -Stroh: rötlich-weiss, feinhalmig, fest. - Scheinfrucht: braun, nach der Spitze zu heller (grosses Korn $1.5 \mathrm{~cm}$ lang, $0.3 \mathrm{~cm}$ breit, kleines $1 \mathrm{~cm}$ $0.25 \mathrm{~cm}$ lang, breit).

Heimat: Canada.

Original im landw. Museum zu Berlin.

\section{Varietät: Avena sativa nigra Krause.}

Unbegrannt; Spelzen schwarz.

\section{Sorten:}

\section{Avoine hâtive d'Etampes.}

Syn.: Franz.: Avoine hâtive de Beauce, hâtive d'Outarville, hâtive de Normandie, hâtive d'Angerville ${ }^{1}$ ).

Deutsch: Schwarzer Hafer von Etampes.

Rispe: etwas zusammengezogen, zwischen Patula und Orientalis die Mitte haltend, also den Uebergang bildend, mittellang, ziemlich reichsaniig; Aehrchen 2-köruig, unbegranut; Klappen weisslich $(2.5 \mathrm{~cm}$ lang, $0.65 \mathrm{~cm}$ breit). - Stroh: gelbgrüu, kräftig, fest, mittellang. — Scheinfrucht: schwarzbraun, lanzettlich, zuweilen borstig, voll (grosses Korn $1.6 \mathrm{~cm}$ lang, $0.35 \mathrm{~cm}$ breit, kleines $1 \mathrm{~cm}$ lang, $0.3 \mathrm{~cm}$ breit), schwer, ziemlich feinschalig, $100 \mathrm{gr}=75.5 \mathrm{gr}$ Früchte, $24.5 \mathrm{gr}$ Spelzen.

J) Vergl. Ileuzé, Pl. aliment. und Vianne, Prairies et pl. fourrag. 1870. 
Junges Blatt blaugriin, fein; Bestockung mittelstark, 2.8 Schösslinge, ziemlich spät schossend und bliihend; Halme $125 \mathrm{~cm}$ (Max. $145 \mathrm{~cm}$ ) lang, $0.43 \mathrm{~cm}$ dick, Blattzahl 5, Blätter $28 \mathrm{~cm}$ lang, $1 \mathrm{~cm}$ brcit, Blattfäche $280 \mathrm{qcm}$, Halmfläche $161.25 \mathrm{qcm}$, Gesammtfläche $441.25 \mathrm{qcm}$.

Friihhafer, reift in 120 Tagen; Rispe $25 \mathrm{~cm}$ (Max. $30 \mathrm{~cm})$ lang, mit 140 Scheinfrüchten, von denen 1500000 auf $1 \mathrm{hl}(=50 \mathrm{~kg})$ entfallen.

Auf 1 qm wachsen 800 Halne oder 300 Pflanzen, mithin beträgt das Saatquantum $3 \mathrm{hl}$ p. ha.

Es wiegen 100 Halme $868 \mathrm{gr}$ und davon die Scheinfrüchte $429 \mathrm{gr}$.

Dieser nicht leicht lagernde, ziemlich rostfreie Hafer ist vielleicht die beste Sorte des nördlichen Frankreichs, welche auf leichten und Moorböden noch sehr hohe Erträge bringt.

\section{Avoine noire de printemps des Côtes-du-Nord.}

Rispe: ansgebreitet, nittellang, mit 45 Aehrchen und 90 Scheinfriichten; Klappen blassgelb oder unrein-weiss $(2.4 \mathrm{~cm}$ lang, $0.8 \mathrm{~cm}$ breit). - Stroh: rötlich-gelb, fest, blattarm, $110 \mathrm{~cm}$ lang. - Scheinfrucht: schwarzbraun, nach der Spitzc zu heller, gross, dick (grosses Korn $1.5 \mathrm{~cm}$ lang, $0.35 \mathrm{~cm}$ breit, kleines $1 \mathrm{~cm}$ lang, $0.3 \mathrm{~cm}$ breit), zuweilen begrannt, Granne gekniet, an Basis schwarzbraun, nach oben heller, bis $3 \mathrm{~cm}$ lang, feinschalig.

Original im landw. Mnseum zu Berlin.

\section{Avoine Joanette. $\odot$}

Syn.: Franz.: Avoine de Chenailles, d'Orłéans, noire de trois mois, brune hâtive.

Deutsch: Sehr früher Joanette-Hafer.

Rispe: ausgebreitet, locker, armsamig, kurz; Aehrchen 2-körnig, selten begrannt; Klappen blassgelb, an Basis dunkler $(2.3 \mathrm{~cm} \mathrm{lang,} 0.7 \mathrm{~cm}$ breit). - Stroh: gelb, feinhalmig, kurz. - Scheinfrucht: sehr dunkelbraunschwarz, kurz, dick, voll (grosses Korn $1.5 \mathrm{~cm}$ lang, $0.35 \mathrm{~cm}$ breit, kleines $1 \mathrm{~cm}$ lang, $0.3 \mathrm{~cm}$ breit), schwer, sehr feinschalig, $100 \mathrm{gr}=78.5 \mathrm{gr}$ Frïchte, $21.5 \mathrm{gr}$ Spelzen.

Halm gelbgrün, schr zeitig blühend, Bestockung stark, 3.4 Schösslinge, $95 \mathrm{~cm}$ (Max. $117 \mathrm{~cm}$ ) lang, $0.3 \mathrm{~cm}$ dick. Blattzahl 4, Blätter $26.2 \mathrm{~cm}$ lang, $0.9 \mathrm{~cm}$ breit, Blattfl̈̈che 188.64 qcm, Halmfläche $85.5 \mathrm{qcm}$, Gesammtfläche $274.14 \mathrm{q} \mathrm{cm}$.

Frühreif, reift in 115 Tagen, Rispe $20 \mathrm{~cm}$ (Max. $25 \mathrm{~cm}$ ) lang, mit 60 sehr leicht ausfallenden Scheinfrüchten, von denen 1695110 auf $1 \mathrm{hl}$ $(=50.3 \mathrm{~kg})$ entfallen.

Auf 1 qm wachsen 1200 Halme oder 363 Pflanzen, nithin beträgt das Saatquantum $3 \mathrm{hl} \mathrm{p.} \mathrm{ha.}$

Es wiegen 100 Halme $450 \mathrm{gr}$ und davon die Scheinfrüchte $222 \mathrm{gr}$.

Da dieser Hafer früh reift, säet man ihn gern auf feuchte, kalte Böden, doch gehört er eigentlich auf den mageren, hochgelegenen Boden, wo er allerdings, wem derselbe den Winden ausgesetzt ist, wegen des leichten Ausfallens der Körner zeitig gemähet werden muss. Er widersteht lem Rost recht gut, lagert sich jedoch anf schwerem Boden.

Als A. de Chenailles, piner durch M. Bobée, Besitzer von Chenailles, verbesserten Form, wird er liäufig in Orléanais und rorzugsweise zwischen Gien und Orléans gebaut. 


\section{Avoine noire d'hiver de Bretagne. (2)}

Rispe: blassgelb, ein wenig zusammengezogen, armsamig, lang; Aehrchen 1- und 2-körnig; Klappe blassgelb, $2.2 \mathrm{~cm}$ lang, $0.7 \mathrm{~cm}$ breit. Stroh: rötlich-gelb, fest, lang. - Scheinfrucht: Original schwarzbraun, an Basis borstig; Granne gekniet und gedreht, an Basis schwarzbraun, nach der Spitze zu heller; voll, mittelgross (grosses Korn $13 \mathrm{~mm}$ lang, $3 \mathrm{~mm}$ breit, kleines $10 \mathrm{~mm}$ lang, $2 \mathrm{~mm}$ breit, 248 Scheinfrüchte $=10 \mathrm{gr}^{\circ}$; nachgebaut: 201 Scheinfrüchte $=10 \mathrm{gr}$; sehr feinschalig, Spelzen nur 20 Proc. ausmachend.

Herbstblatt blaugrün, aufrecht, schmal, Bestockung stark, 4.8 Schösslinge; Halm $130 \mathrm{~cm}$ (Max. $165 \mathrm{~cm}$ ) lang, $0.45 \mathrm{~cm}$ dick, Blattzalıl 5, Blätter $24.5 \mathrm{~cm}$ lang, $1.1 \mathrm{~cm}$ breit, Blattfläche $269.5 \mathrm{qcm}$, Halmfläche $175.5 \mathrm{qcm}$, Gesammtfläche $445 \mathrm{qcm}$.

Rispe $25 \mathrm{~cm}$ (Max. $35 \mathrm{~cm}$ ) lang, mit 40 Aehrchen und 60 ziemlich leicht ausfallenden Scheintrüchten.

Schon zu weich für das Klima von Paris. Es scheint ein echter Winterhafer zu sein, denn im Frïhjahr gesäet, entwickelte er sich sehr spät, so dass nur wenige Halme ausreiften.

Bezugsquelle: Vilm orin, Paris.

\section{Avoine noire de Brie. $\odot$}

Syn.: Franz,: Avoine de Coulommiers, de Soissons, de Meaux, noire de Saint-Lô, brune tardive, noire de Chanpagne, noire des trois lunes, double, fourchue.

It a l.: Avena nera di Brie.

Deutsch: Schwarzer Hafer aus der Brie.

Rispe: sehr ausgebreitet, Rispenäste sehr lang, armsamig, Rispe mittellang; Aehrchen 2-körnig, sehr selten begrannt; Klappen blassgelb (2.5 cm lang, $0.8 \mathrm{~cm}$ breit). - Stroh: gelb, ziemlich blattreich, kräftig, kaum mittellang. - Scheinfrucht: meist tiefschwarzbraun, nach der Spitze zl etwas heller, zuweilen auf leichtem Boden weniger dunkel, voll, länglich (grosses Korn $1.5 \mathrm{~cm}$ lang, $0.35 \mathrm{~cm}$ breit, kleines $1 \mathrm{~cm}$ lang, $0.3 \mathrm{~cm}$ breit), schwer, sehr feinschalig, $100 \mathrm{gr}=77.2 \mathrm{gr}$ Friichte, $22.8 \mathrm{gr}$ Spelzen.

Halm blaugrün, 3 Schösslinge, spät bliihend, $110 \mathrm{~cm}$ (Max. $135 \mathrm{~cm}$ ) lang, $0.45 \mathrm{~cm}$ dick, Blattzahl 4.5, Blätter $30.6 \mathrm{~cm}$ lang, $1.2 \mathrm{~cm}$ breit, Blattfläche $330.18 \mathrm{qcm}$, Halmfläche $148.5 \mathrm{qcm}$, Gesammtfläche $478.98 \mathrm{qcm}$.

Späthafer, reift in 130 Tagen; Rispe $25 \mathrm{~cm}$ (MIax. $35 \mathrm{~cm}$ ) lang, mit 85 sehr lose sitzenden Scheinfriichten, von denen 1579000 auf $1 \mathrm{hl}$ $(=51 \mathrm{~kg})$ entfallen.

Auf $1 \mathrm{qm}$ wachsen 800 Halme oder 267 Pflanzen, mithin beträgt das Saatquantum $2.2 \mathrm{hl}$ p. ha.

Es wiegen 100 Halme $549 \mathrm{gr}$ und davon die Scheinfriichte $253 \mathrm{gr}$.

Jieser Hafer, der sich durch ein mehlreiches sehr geschätztes Korn, sowie durch Ergiebigkeit auszeichnet, empfiellt sich fiir leichte, arme, trockne Böden, aber auch für mooriges Neuland zum Anbau, und ist derselbe sehr stark in der Brie, Champagne und Picardie verbreitet. Nach Vilmorin ist der Hafer von Coulommiers nur ein schöner Brie-Hafer, dessen Korn etwas hell doch voller, und dessen Habitus kräftiger ist. 
Nach P. Law son ${ }^{1}$ ) stammt der Hafer aus der Brie von den alten, schwal'zen, schottischen Hafer (Common or old Black-Oat) ab und ist mit ihm identisch, doch ist dies fraglich, da letzterer frühreif sein soll.

\section{Common or old Black-0at. $\odot$}

Syn.: Alter, schwarzer, schottischer Hafer.

Rispe: ausgebreitet, lang, schwer, Aehrchen 2-körnig. - Stroh: etwas kurz, nicht leicht lagernd. -- Scheinfrucht: schwarzbraun, kurz, schwer und in der Vollreife nicht leicht ausfallend. Mehl wegen seiner Güte geschätzt.

Für mooriges Neuland vorziiglich geeignet und noch eine Woche früher als der englische Kartoffelhafer reifend.

\section{Schwarzer Hafer aus der Moldau. $\odot$}

Rispe: zusammengezogen, ziemlich reichsamig, mittellang; Aehrehen 2-körnig, unbegrannt; Klappen weisslich (2 cm lang, $1.2 \mathrm{~cm}$ breit). Stroh : gelb, blattreicl, fest, lang. - Scheinfrucht: scliwarzbraun, nach der Spitze zu heller, voll, ziemlich dick (grosses Korn $1.6 \mathrm{~cm} \mathrm{lang,} 0.35 \mathrm{~cm}$ breit, kleines $1.2 \mathrm{~cm}$ lang, $0.25 \mathrm{~cm}$ breit), Schale mittelfein, $100 \mathrm{gr}=$ $72.5 \mathrm{gr}$ Friichte, $27.5 \mathrm{gr}$ Spelzen.

Junges Blatt blaugrün, fein; Bestockung schwach, 2 Schösslinge, mittelfrüh scliossend und blühend. Halm $130 \mathrm{~cm}$ (Max. $150 \mathrm{~cm}$ ) lang, $0.4 \mathrm{~cm}$ dick, Blattzahl 5, Blätter $27.6 \mathrm{~cm}$ lang, $1 \mathrm{~cm}$ breit, Blattfläche $276 \mathrm{qcm}$, Halınfläche $156 \mathrm{qcm}$, Gesammtfläche $432 \mathrm{qcm}$.

Späthafer, reift in 125 Tagen; Rispe $25 \mathrm{~cm}$ (Max. $30 \mathrm{~cm}$ ) lang, mit 140 Scheinfruichten, von denen 1703000 auf $1 \mathrm{hl}(=47.3 \mathrm{~kg})$ entfallen.

Es wiegen 100 Halme $763 \mathrm{gr}$ und davon die Scheinfriichte $365 \mathrm{gr}$.

Dieser Hafer wurde 1869 vom preussischen landw. Ministerium zur Prïfung an den ök.-bot. Garten zu Poppelsdorf gesandt.

\section{Schwarzer Hafer aus Schweden.}

Rispe: ein wenig zusammengezogen, mittellang; Aehrchen 2-körnig, Klappen graulich-gelb, $2.5 \mathrm{~cm}$ lang, $0.7 \mathrm{~cm}$ breit. - Stroh: meist rot, sehr kräftig, blattreich, mittellang. - Schcinfrucht: schwarzbraun, einige begrannt, Grannen gekniet und gedreht, an Basis schwarzbraun, bis $3.5 \mathrm{~cm}$ lang, klein, grosses Korn $11 \mathrm{~mm}$ lang, $3 \mathrm{~mm}$ breit, kleines $8 \mathrm{~mm}$ lang, $2.5 \mathrm{~mm}$ breit, 385 Scheinfrüchte $=10 \mathrm{gr}$.

Junges Blatt dunkelgriin, kräftig, 1.5 Schösslinge; Halm $100 \mathrm{~cm}$ lang, $0.4 \mathrm{~cm}$ dick, Blattzalı 4.5, Blätter $26.3 \mathrm{~cm}$ lang, $1 \mathrm{~cm}$ breit, Blattfläche 236.7 qcu, Halmfläche $120 \mathrm{qcm}$, Gesammtfläche $356.7 \mathrm{qcm}$.

Rispe $20 \mathrm{~cm}$ lang, mit 55 Aehrehen und 110 fest sitzenden Scleinfriichten, von denen 1878800 auf $1 \mathrm{lll}$ (=48.8 kg) entfallen.

Frühhafer, in 115 Tagen reifend.

Bezugsquelle: Metz \& Co., Berlin.

1) Agric. Manual 1836 
Varietät: Avena sativa montana $\mathrm{Al}$.

Begrannt; Spelzen dunkel.

\section{Sorte:}

\section{Berghafer. $\odot$}

Syn.: Schwarzer gegrannter Rispenhafer (Metzger); rauher Eichelund Waldhafer; Hafer aus Umeå, Schweden.

Rispe: ausgebreitet, ziemlich reichsamig, mittellang; Aehrchen 2-, zuweilen 3-körnig, 1-grannig; Klappen blassgelb $(2.5 \mathrm{~cm}$ lang, $0.6 \mathrm{~cm}$ breit). - Strolı: rötlich-gelb, ziemlich blattreich, kräftig, kaum mittellang. - Scheinfrucht: schwarzbraun, lang (grosses Korn $2 \mathrm{~cm}$ lang, $0.3 \mathrm{~cm}$ breit, kleines $1.3 \mathrm{~cm}$ lang, $0.25 \mathrm{~cm}$ breit), Schale mittelfein, $100 \mathrm{gr}=71.3 \mathrm{gr}$ Friichte, $28.7 \mathrm{gr}$ Spelzen. Granne schwarzbraul, nach oben heller, stark gekniet und gedreht, bis $4 \mathrm{~cm}$ lang.

Junges Blatt gelbgrün, ziemlich lang, breit, Bestockung mittelstark, 2.5 Schösslinge, Halm gelbgrün, etwas spät blühend, $110 \mathrm{~cm}$ (Max. $140 \mathrm{~cm}$ ) lang, $0.5 \mathrm{~cm}$ dick, Blattzahl 5, Blätter $34.4 \mathrm{~cm}$ lang, $1.4 \mathrm{~cm}$ breit, Blattfläche $481.6 \mathrm{qcm}$, Halmfläche $165 \mathrm{qcm}$, Gesammtfläche $646 \mathrm{qcm}$.

Rispe reift in 120 Tagen, $25 \mathrm{~cm}$ (Max. $30 \mathrm{~cm}$ ) lang, mit 150 ziemlich fest sitzenden Scheinfrüchten, von denen 1678300 auf $1 \mathrm{hl}(=45.2 \mathrm{~kg}$ ) entfallen.

Auf 1 qm wachsen 600 Halme oder 240 Pflanzen, mithin beträgt das Saatquantum $2 \mathrm{hl} \mathrm{p}$. ha.

Es wiegen 100 Halme $788 \mathrm{gr}$ und davon die Scheinfrüchte $406 \mathrm{gr}$.

Dieser Hafer eignet sich für wenig kultivierten oder frisch gerodeten Boden.

Varietät: Avena sativa rubida Kcke.

Begrannt; Spelzen rötlich.

\section{Sorten:}

Avena del Llobregat, (Catalnña), Spanien. $\odot$

Rispe: ausgebreitet, sehr armsamig, sehr kurz; Aehrchen 2-körnig, 1-grannig, Klappen blassrot, $2.5 \mathrm{~cm}$ lang, $0.7 \mathrm{~cm}$ breit. - Stroh: hellrot, steif, kurz. - Scheinfrucht: graurot, kurz, voll. klein, grosses Korn $11 \mathrm{~mm}$ lang, $2.5 \mathrm{mn}$ breit, 420 Scheinfrüchte $=10 \mathrm{gr}$; Granne gekniet, $\$ \mathrm{~cm}$ lang, an Basis schwarzbraun; ziemlich feinschalig, 25 Proc. Spelzen.

Junges Blatt dunkelgrün, schmal; Halm $80 \mathrm{~cm}$ lang, $0.33 \mathrm{~cm}$ dick, Blattzahl 4, Blätter $20 \mathrm{~cm}$ lang, $0.8 \mathrm{~cm}$ breit, Blattfläche $64 \mathrm{q} \mathrm{cm}$, Halmfläche $79.2 \mathrm{qcm}$, Gesammtfläche $143.2 \mathrm{qcm}$. frïchten.

Rispe $15 \mathrm{~cm}$ lang mit 15 Aehrchen und 30 fest sitzenden Scheil-

Frühhafer, in 100 Tagen reifend.

Bezugsquelle: Antonio Cipriano Costa, Barcelona, 1881.

\section{Hafer aus Abrantes, Portugal. $\odot$}

Rispe: ausgebreitet, armsamig; Aehrchen 2-körnig, 1-grannig, Klappen auffailend lang, rötlich-blassgelb. - Stroh: rötlich-gelb, kurz. - 
Scheinfrucht: rot mit schwarzgrauen Flecken, auffallend platt, grosses Korn $15 \mathrm{~mm}$ lang, $3 \mathrm{~mm}$ breit, kleines $10 \mathrm{~mm}$ lang, $2.5 \mathrm{~mm}$ breit, 298 Scheinfrüchte $=10 \mathrm{gr} ;$ Granne des grossen Korns klein und bei Reife meist abgebrochen, daher leicht zu ubersehen.

Bezugsquelle: Prof. Jul. Henriques, Coïmbra, Portugal, 1881.

\section{Avena di Ruvo di Puglia. $\odot$}

Rispe ausgebreitet, sehr kurz, armsanig; Aehrchen 2-körnig; Klappen blassgelb, Basis dunkler (3.2 cm lang, $0.6 \mathrm{~cm}$ breit). - Strolı: rötlich-gelb, steif, mittellang. - Scheinfrucht: blassgelbrot, sehr lang, spitz, schmal (grosses Korn $1.9 \mathrm{~cm}$ lang, $0.3 \mathrm{~cm}$ breit, klcines $1.4 \mathrm{~cm} \mathrm{lang,}$ $0.25 \mathrm{~cm}$ breit); grosses Korn begrannt, Granne blassgelbrot, $2.5 \mathrm{~cm}$ lang; Schale mittelfein, $100 \mathrm{gr}=73 \mathrm{gr}$ Früchte, $27 \mathrm{gr}$ Spelzen.

Halme blaugriin, mittelfriih schossend und bliihend, Bestockung sehr stark, 5.4 Schösslinge, $115 \mathrm{~cm}$ (Max. $140 \mathrm{~cm}$ ) lang, $0.4 \mathrm{~cm}$ dick, Blattzahl 4.7, Blätter $26.8 \mathrm{~cm}$ lang, $0.96 \mathrm{~cm}$ breit, Blattfläche $241.86 \mathrm{qcm}$, Halmfläche 138 qcm, Gesammtfläche $379.86 \mathrm{qcm}$.

Späthafer, reift in 128 Tagen; Rispe $18 \mathrm{~cm}$ (Max. 25 cm) lang, mit 90 ziemlich fest sitzenden Scheinfruchten, von denen 1116000 auf $1 \mathrm{hl}(=45 \mathrm{~kg}$ ) entfallen.

Es wiegen 100 Halme $850 \mathrm{gr}$ und davon die Scheinfrüchte $425 \mathrm{gr}$.

Diesen Hafer erhielt $1873 \mathrm{Körnicke} \mathrm{von} \mathrm{der} \mathrm{italienischen} \mathrm{Abtei-}$ lung der Wiener Weltausstellung.

Heimat: Apulien in Italien.

\section{Hafer aus Apulien. $\odot$}

Rispe: ausgebreitet, sehr armsamig, sehr kurz; Aehrchen 2-, selten 3-körnig, 1-grannig; Klappen rötlich-blassgelb, an der Basis dunkler, lang und schmal (3 cm lang, $0.6 \mathrm{~cm}$ breit). - Stroh: rötlich-gelb, feinhalmig kurz. - Scheinfrucht: blassgelbrot, lang, breit, an der Basis stark borstig (grosses Koln $2 \mathrm{~cm}$ lang, $0.4 \mathrm{~cm}$ breit, kleines $1.5 \mathrm{~cm}$ lang, $0.3 \mathrm{~cm}$ breit); Granne blassrot, an der Basis dunkler, gebogen, bis $3 \mathrm{~cm}$ lang; grobschalig, $100 \mathrm{gr}=69 \mathrm{gr}$ Friichte, $31 \mathrm{gr}$ Spelzen.

Junges Blatt dunkelgrüı, Bestockung stark, 3 Schösslinge, sehr zeitig schossend und blïlıend. Halme $100 \mathrm{~cm}$ (Max. $110 \mathrm{~cm}$ ) lang, $0.33 \mathrm{~cm}$ dick, Blattzalıl 4.4, Blätter $14 \mathrm{~cm}$ lang, $0,65 \mathrm{~cm}$ breit, Blat+fläche $80.08 \mathrm{qcm}$, Halmfläche $99 \mathrm{qcm}$, Gesammtflïche $179.08 \mathrm{qcm}$.

Friilhafer, in 102 Tagen reifend; Rispe $15 \mathrm{~cm}$ (Max. $20 \mathrm{~cm}$ ) lang, nit 40 fest sitzenden Scheinfriichten, von denen 122.4760 anf $1 \mathrm{hl}(=45.7 \mathrm{~kg})$ entfallen.

In Apulien auf leichtem, trocknem Borlen wachsend, aber auch in Parma, Livorno, Avellino ete. kultiviert.

Original durch Pedecino in Portici 1876 erhalten. 


\title{
Unterart: Avena sativa orientalis I. Fahnenhafer.
}

\author{
Varietät: Avena orientalis obtusata Al. \\ Unbegrannt; Spelzen weiss.
}

\section{Sorte:}

\section{Avoine blanche de Hongrie. $\odot$}

Syn.: Franz.: Avoine de Podolie, blanche de Turquie, blanche de Russie.

Deutsch: Weisser ungarischer Fahnenhafer.

Rispe: zusammengezogen, kompakt, einseitig hängend, reichsamig, lang; Aehrchen 2-körnig, unbegrannt; Klappen gelb $(2.3 \mathrm{~cm}$ lang, $0.7 \mathrm{~cm}$ breit). - Strob: gelb, kräftig, blattreich, lang. - Scheinfrucht: dunkelgelb mit bräunlichem Anflug, länglich, spitz, doch ziemlich voll (grosses Korn $1.7 \mathrm{~cm}$ lang, $0.35 \mathrm{~cm}$ breit, kleines $1.2 \mathrm{~cm}$ lang, $0.3 \mathrm{~cm}$ breit), ziemlich schwer, feinschalig, $100 \mathrm{gr}=75.5 \mathrm{gr}$ Früchte, $24.5 \mathrm{gr}$ Spelzen.

Halme dunkelgrün, Bestockung mittelstark, 2.5 Schösslinge, spät blühend, $125 \mathrm{~cm}$ (Max. $140 \mathrm{~cm}$ ) lang, $0.5 \mathrm{~cm}$ dick, Blattzahl 5, Blätter $35 \mathrm{~cm}$ lang, $1.12 \mathrm{~cm}$ breit, Blattfläche $382 \mathrm{qcm}$, Halmfläche $187.5 \mathrm{qcm}$, Gesammtfläche $569.5 \mathrm{qcm}$.

Späthafer, reift in 125 Tagen; Rispe $30 \mathrm{~cm}$ (Max. $35 \mathrm{~cm}$ ) lang, mit 200 sehr fest sitzenden Scheinfrüchten, von denen 1466000 auf 1 hl $(=47.3 \mathrm{~kg})$ entfallen.

Auf 1 qm wachsen 725 Halme oder 250 Pflanzen, mithin beträgt das Saatquantum $2.6 \mathrm{hl}$ p. ha.

Es wiegen 100 Halme $1000 \mathrm{gr}$ und davon die Scheinfrüchte $425 \mathrm{gr}$.

Dieser Hafer ist für reiche, humose Böden vortrefflich geeignet, lagert nicht leicht, bleibt fast rostfrei, und zeigt sich gegen Nässe und Dürre gleich widerstandsfähig.

Seine Heimat liegt im suidöstlichen Europa, wo er auch jetzt noch mehr oder weniger stark angebaut wird, und ist er namentlich auch in Frankreich schon seit langer Zeit in Kultur und geschätzt. Nach Heuzé ${ }^{1}$ ) erwähnt Buchoz seiner 1775 .

\section{Varietät: Avena orientalis Metzgerii Kcke.}

Begrannt; Spelzen weiss.

\section{Sorte:}

\section{Common white Tartarian 0at. $\odot$}

Syn.: Deutsch: Weisser gegrannter englischer Fahnenhafer. Franz.: Avoine blanche de Tartarie.

Rispe: zusammengezogen, kompakt, einseitig hängend, ziemlich

1) Heuzé, a a. O. Vol. J, p. 513. 
reichsamig, mittellang; Aehrchen 2- und 3-körnig, 1-grannig, und zwar fast sämmtliche Aehrchen begrannt, nur auf sehr reichem Boden nimmt die Zahl der unbegrannten zu; Klappen gelb, sehr lang (3 cm lang, $0.6 \mathrm{~cm}$ breit). - Stroh: gelb, reichblättrig, sehr kräftig, kaum mittellang. - Scheinfrucht: gelb, lang (grösstes Koln $2 \mathrm{~cm}$ lang, $0.35 \mathrm{cn}$ breit, kleinstes $0.7 \mathrm{~cm}$ lang, $0.2 \mathrm{~cm}$ breit), Granne bräunlich, an der Basis schwarzbraun, bis $3 \mathrm{~cm}$ lang, leicht, ziemlich feinschalig, $100 \mathrm{gr}=71 \mathrm{gr}$ Früchte, $29 \mathrm{gr}$ Spelzen.

Halme blaugriùn, 2 Schösslinge, sehr spät blïhend, $110 \mathrm{~cm}$ (Max. $125 \mathrm{~cm}$ ) lang, $0.55 \mathrm{~cm}$ dick, Blattzahl 5, Blätter $38 \mathrm{~cm}$ lang, $1.26 \mathrm{~cm}$ breit, Blattfläche $478.8 \mathrm{qcm}$, Halmfläche $181.5 \mathrm{qcm}$, Gesammtfläche $660.3 \mathrm{qcm}$.

Späthafer, reift in 132 Tagen; Rispe $25 \mathrm{~cm}$ (Max. $30 \mathrm{~cm}$ ) lang, mit 150 Sicheinfïichten, von denen 1385600 auf $1 \mathrm{hl}(=43.3 \mathrm{~kg})$ entfallen.

Auf 1 qm wachsen 500 Halme oder 250 Pflanzen, mithin beträgt das Saatquantum $3 \mathrm{hl} \mathrm{p.} \mathrm{ha.}$

Es wiegen 100 Halme $1287 \mathrm{gr}$ und davon die Scheinfriichte $540 \mathrm{gr}$.

Diese S'orte bringt auf reichem, humosem, tief bearbcitetem Boden hohe Korn- und Stroherträge, zumal Lagerfrucht zu den grössten Ausnahmen gehört, und selbst noch anf Torfboden werden die Erträge gerihmt.

Dieser Hafer wird ziemlich häufig, wenn anch nicht so allgemein als ,Black Tartarian-Oat", in England und Schottland kultiviert. In Frankreich und namentlich auch in der Levante, welche seine Heimat sein soll, erfreut er sich eines ausgedehnten Anbaues. Ebenso wird derselbe vielfach in Australien kultiviert.

\section{Varietät: Avena orientalis flava Kcke. Unbegrannt; Spelzen goldgelb.}

\section{Sorte:}

\section{Goldfahnenhafer. $\odot$}

Rispe: zusammengezogen, einseitig hängend, mittellang, reichsamig; Aehrchen 2-körnig, sehr selten begrannt; Klappen goldgelb oder blassgelb (2 cm lang, $0.6 \mathrm{~cm}$ breit). - Stroh: gelb, kräftig, lang. - Scheinfrucht: goldgelb, klein, schmal, spitz (grosses Korn $1.5 \mathrm{~cm}$ lang, $0.25 \mathrm{~cm}$ breit, kleines $1.2 \mathrm{~cm}$ lang, $0.2 \mathrm{~cm}$ breit), grobschalig, $100 \mathrm{gr}=69 \mathrm{gr}$ Korn, $31 \mathrm{gr}$ Spelzen.

Junges Blatt dunkelgriin, lang, ziemlich breit; Bestockung schwach, 1.6 Schösslinge, sehr spät schossend und bliihend; Halme $135 \mathrm{~cm}$ (Max. $150 \mathrm{~cm}$ ) lang, $0.43 \mathrm{~cm}$ dick, Blattzahl 5.3, Blätter $28.2 \mathrm{~cm} \mathrm{lang,} 1.1 \mathrm{~cm}$ breit, Blattfläche $328.81 \mathrm{qcm}$, Halmfläche 174.15 qcm, Gesammtfläche 502.96 qcm.

Späthafer, reift in 125 Tagen, Rispe $25 \mathrm{~cm}$ (Max. $30 \mathrm{~cm}$ ) lang, mit 170 Scheinfriichten, von denen 2170700 anf $1 \mathrm{hl}(=44.3 \mathrm{~kg})$ entfallen.

Es wiegen 100 Halme $1187 \mathrm{gr}$ und davon die Scheinfruichte $590 \mathrm{gr}$.

Dieser fast rostfrcie, nicht leicht lagernde Hafer eignet sich für humose Böden, und liefert namentlich grosse Grünfuttererträge. 
Varietät: Avena orientalis tristis Al.

Unbegrannt; Spelzen schwarzbraun.

\section{Sorten:}

\section{Neffly-0at. $\odot$}

Syn.: Neffly-Hafer.

Rispe: sehr zusammengezogen, einseitig hängend, sehr kurz, ziemlich reichsamig; Aehrchen 2-körnig; Klappen gelb, bis $2.4 \mathrm{~cm}$ lang. Stroh: grünlich-gelb, blattreich, ziemlich fest, mittellang. - Scheinfrucht: schwarzbraun, meist unbegrannt, kommt Granne vor, so braun und bis $2 \mathrm{~cm}$ lang, lang, schmal, spitz (1.2 cm lang, $0.25 \mathrm{~cm}$ breit), feinschalig, $100 \mathrm{gr}=77 \mathrm{gr}$ Friichte, $23 \mathrm{gr}$ Spelzen.

Junges Blatt dunkelgrün, schmal, lang; Bestockung mittelstark, 2.4 Schösslinge, mittelfriih schossend und blühend. Halme 120 $\mathrm{cm}$ (Max. $140 \mathrm{~cm}$ ) lang, $0.4 \mathrm{~cm}$ breit, Blattzahl 4.8 , Blätter $26.6 \mathrm{~cm}$ lang, $0.9 \mathrm{~cm}$ breit, Blattfläche $229.82 \mathrm{q} \mathrm{cm}$, Halmfläche $141 \mathrm{qcm}$, Gesammtfläche $373.82 \mathrm{qcm}$.

Frühhafer, in 117 Tagen reifend; Rispe $15 \mathrm{~cm}$ (Max. $25 \mathrm{~cm}$ ) lang, mit 80 Scheinfriichten, von denen 1720000 auf $\mathrm{l} \mathrm{hl}(=43 \mathrm{~kg}$ ) entfallen.

Es wiegen 100 Halme $763 \mathrm{gr}$ und davon die Scheinfrüchte $375 \mathrm{gr}$.

Für leichten und trocknen Boden oder für Torfboden geeignet.

\section{Avoine noire de Hongrie. $\odot$}

Syn.: Franz.: Avoine noire de Russie, de Turquie, d'Orient.

Deutsch: Schwarzer oder brauner ungarischer, und Westerwälder Trauer- oder Fahnenhafer.

Ital.: Avena nera d'Ungheria.

Rispe: stark zusammengezogen, einseitig hängend, ziemlich reichsamig, mittellang; Aehrchen 2-, zuweilen 3-körnig, meist unbegrannt; Klappen blassgelb, an der Basis dunkler (2.5 cm lang, $0.6 \mathrm{~cm}$ breit). Stroh: etwas kur\%, kräftig, gelbgriin, fest. - Scheinfrncht: schwarzbraun, doch auch viele heller, bis gelbbraun, schmal, spitz (grosses Korn $1.8 \mathrm{~cm}$ lang, $0.25 \mathrm{~cm}$ breit, kleines $1.4 \mathrm{~cm}$ lang, $0.2 \mathrm{~cm}$ breit), selten begramnt, Granne hellbraun, bis $2.5 \mathrm{~cm}$ lang, feinschalig, $100 \mathrm{gr}=75.82 \mathrm{gr}$ Korm, 24.18 gr Spelzen.

Junges Blatt dunkelgriin, schmal, lang: Bestockung stark, 3 Schösslinge, Halme dunkelgriin, mittelfrüh blühend, $110 \mathrm{~cm}$ (Max. $125 \mathrm{~cm}$ ) lang, $0.44 \mathrm{~cm}$ dick, Blattzahl 4, Blätter $30.2 \mathrm{~cm}$ lang, $1 \mathrm{~cm}$ breit, Blattfläche 241.6 qcm, Halmfläche 145.2 qcm, Gesammtfläche 386.8 qcm.

Späthafer, in 125 Tagen reifend; Rispe $25 \mathrm{~cm}$ (Max. $33 \mathrm{~cm}$ ) lang, mit 150 etwas lose sitzenden Scheinfriichten, von denen 1678500 auf $1 \mathrm{hl}(=43.5 \mathrm{~kg})$ entfallell.

Auf $1 \mathrm{qm}$ wachsen 900 Halme oder 300 Pflanzen, mithin beträmt das Saatquantum $2.4 \mathrm{hl} \mathrm{p.} \mathrm{ha.}$

Es wiegen 100 Halme $971 \mathrm{gr}$ und davon die Scheinfrüchte $480 \mathrm{gr}$.

Diese Sorte eignet sich für Torf- und Moorböden vorzüglich und bringt anf reichem Boden hohe Erträge, ist gegen Diirre und Nässe unempfindlich, widerstandsfähig gegen Rost und lagert nicht leicht. 
Seine Heimat liegt im südöstlichen Europa und wird er namentlich im südlichen Russlarid, in der Moldau, in Bulgarien und Ungarn gebaut, doch scheint es, dass er in neuerer Zeit nur noch selten in letzterem Lande kultiviert wird, da wir ihn dort trotz eingehendster Erkundigungen nicht auffinden konnteu.

$\mathrm{Zu}$ Anfang dieses Jahrhunderts durch Morel de Vindé ${ }^{1}$ ) nach Frankreich eingeführt, erfreut er sich daselbst einer grossen Verbreitung. Gasparin ${ }^{2}$ ) versuchte ibn in Süd-Frankreich als Winterhafer zu kultivieren, doch erfror er im Winter 1819/20 vollståndig.

Varietät: Avena orientalis pugnax Al.

Begrannt; Spelzeu schwarzbraun.

Sor te n :

\section{Black Tartarian 0at. $\odot$}

Syn.: Deutsch: Schwarzer oder brauner tatarischer Fahnenhafer. Franz.: Avoine de Tartarie.

Verbesserte Formen mit etwas vollerem Korn und weniger Grannen sind:

Hallet's Pedigree Black Tartarian-Oat (verbessert durch Mr. Hallet und Original von ihm erhalten).

Prolific Black Tartarian-Oat (durch Webb \& Sons, The Queen's Seedsmen, Wordsley, Stourbridge, England erhalten).

Rispe: stark zusammengezogen, kompakt, einseitig hängend, sehr reichsamig, mittellang; Aehrchen 2-körnig, begranut, doch bei den verbesserten Formen weniger läufig begrannt; Klappen blassgelb (2.5 cm lang, $0.7 \mathrm{~cm}$ breit). - Stroh: griinlich-gelb, ziemlich lang, rohrartig, fest. - Scheinfrucht: meist schwarzbraun, nach der Spitze zu heller, doch kommen auch in derselben Rispe braune Scheinfriichte vor, Granne an der Basis schwarzbraun, nach oben heller, gekniet, bis $3 \mathrm{~cm}$ lang, lanzettlich, doch voll (grosses Korn $1.8 \mathrm{~cm}$ lang, $0.35 \mathrm{~cm}$ breit, kleines $1.2 \mathrm{~cm}$ lang, $0.3 \mathrm{~cm}$ breit), etwas grobschalig, $100 \mathrm{gr}=69.2$ Frïchte, $30.8 \mathrm{gr}$ Spelzen.

Junges Blatt blaugrün, lang, ziemlich breit; Bestockung mittelstark, 2.6 Schösslinge, spät schossend und blühend. Halme $125 \mathrm{~cm}$ (Max. $160 \mathrm{~cm}$ ) lang, $0.55 \mathrm{~cm}$ dick, Blattzalıl 5, Blätter $34.8 \mathrm{cnı} \mathrm{lang,} 1.2 \mathrm{~cm}$ breit, Blattfäche $417.6 \mathrm{qcm}$, Halmfläche $206.25 \mathrm{qcm}$, Gesammtfläche $623.85 \mathrm{qcm}$.

Fribhafer, reift in 120 Tagen; Rispe $25 \mathrm{~cm}$ (Max. $30 \mathrm{~cm}$ ) lang, mit 260 Scheinfricliten, von denen 1750230 auf $1 \mathrm{hl}(=47.2 \mathrm{~kg})$ entfallen.

Auf 1 qm wachsen 600 Halme oder 231 Pflanzen, mithin beträgt das Saatquantum $1.8 \mathrm{hl}$ p. ha.

Es wiegen 100 Halme $918 \mathrm{gr}$ und davon die Scheinfrüchte $429 \mathrm{gr}$.

In England sollen sich die Frträge auf reichem Boden liäufig auf $90 \mathrm{hl} \mathrm{p.} \mathrm{ha} \mathrm{belaufen,} \mathrm{und} \mathrm{beträgt} \mathrm{das} \mathrm{Hektolitergewicht} \mathrm{auf} \mathrm{Torfboden}$ $44.5-48.2 \mathrm{~kg}$, auf Marschboden $51.8 \mathrm{~kg}$.

1) Mémoire de la Soc. roy. d'Agric. 1817, p. 387.

2) Cours d'Agric. HII, p. 709. 
Auf reichen, humosen Böden werden von dieser Sorte sehr hohe Erträge an Korn und Stroh erzielt, zumal sie höchst selten lagert und sehr wenig durch Rost leidet, nur ist zu bemerken, dass das Stroh wegen seiner rohrartigen Beschaffenheit als Futter nur geringen Wert besitzt.

Längere Zeit auf feuchten, humosen Böden angebaut, degeneriert er leicht, was sich dadurch bekundet, dass sich die Scheinfruichte an der Spitze weisslich färben, schlanker werden und die Grannen sich vermehren, wälırend auf trocknem, reichem Boden die Scheinfrüchte dunkler, voller und weniger begrannt auftreten. In der Regel nimmt man auf Torfboden jedes zweite Jahr einen Saatwechsel mit Samen von trocknem Boden vor.

In England wird er sehr ausgerlehnt als Pferdefutter und in neuerer Zeit auch vielfach in Nordamerika kultiviert.

\section{Neuer gegrannter Fahnenhafer aus Italien.}

Rispe: sehr zusammengezogen, kompakt, reichsamig, kurz; Aehrchen 2-körnig, begrannt; Klappen hellgelb, weich (2.4 cm lang, $0.65 \mathrm{~cm}$ breit). - Stroh: grünlich-gelb, kaum mittellang, blattreich, sehr kräftig. Scheinfrucht: braunschwarz, nach der Spitze zu heller, gross, voll (grosses Korn $1.4 \mathrm{~cm}$ lang, $0.3 \mathrm{~cm}$ breit, kleines $1 \mathrm{~cm}$ lang, $0.25 \mathrm{~cm}$ breit), Granne an Basis dunkelbraun, nach oben heller, gedreht, bis $3 \mathrm{~cm}$ lang, schwer, Schale mittelfein, $100 \mathrm{gr}=73.2 \mathrm{gr}$ Frïchte, $26.8 \mathrm{gr}$ Spelzen.

Halme blaugrün, 2.5 Schösslinge, mittelfrüh blühend, $110 \mathrm{~cm}$ (MFax. $135 \mathrm{~cm}$ ) lang, $0.6 \mathrm{~cm}$ dick, Blattzahl 5, Blätter $34.4 \mathrm{~cm}$ lang, $1.36 \mathrm{~cm}$ breit, Blattfläche $467.8 \mathrm{qcm}$, Halmfläche $198 \mathrm{qcm}$, Gesammtfläche $665.8 \mathrm{qcm}$.

Friihhafer, reift in 120 Tagen; Rispe $20 \mathrm{~cm}$ (Max. $25 \mathrm{~cm}$ ) lang, mit 200 nicht leicht ausfallenden Scheinfrüchten, von denen 1818000 auf $1 \mathrm{hl}(=50.5 \mathrm{~kg})$ entfallen.

Es wiegen 100 Halme $945 \mathrm{gr}$ und davon die Scheinfriichte $533 \mathrm{gr}$.

Dieser nicht lagernde, wenig durch Rost leidende, sehr ertragreiche Hafer empfiehlt sich für Moor- und reichen Niederungsboden.

\section{Schwarzer gegrannter oder Streit-Fahmenhafer. $\odot$}

Rispe: zusammengezogen, einseitig hängend, ziemlich armsamig, kurz; 2-körnig, meist begrannt; Klappen blassgelb $(2.2 \mathrm{~cm}$ lang, $0.5 \mathrm{~cm}$ breit). - Stroh: gelb, feinhalmig, blattreich, mittellang. - Scheinfrucht: sehr dunkel schwarzbraun, klein, spitz, schmal (grosses Korn $1.8 \mathrm{~cm}$ lang, $0.3 \mathrm{~cm}$ breit, kleines $1.5 \mathrm{~cm}$ lang, $0.25 \mathrm{~cm}$ breit), Granne an Basis schwarzbraun, nach oben zu heller, bis $3 \mathrm{~cm}$ lang, feinschalig, $100 \mathrm{gr}=$ $77.5 \mathrm{gr}$ Früchte, $22.5 \mathrm{gr}$ Spelzen.

Blätter dunkelgriin, Bestockung stark, 3.2 Schösslinge; Halme blaugrüu, ziemlich zeitig blühend, $120 \mathrm{~cm}$ (Max. $160 \mathrm{~cm}$ ) lang, $0.4 \mathrm{~cm}$ dick, Blattzahl 5, Blätter $28.5 \mathrm{~cm}$ lang, $1.0 \mathrm{~cm}$ breit, Blattfläche $28.5 \mathrm{qcm}$, Halmfläche $144 \mathrm{qcm}$, Gesammtfläche $4: 29 \mathrm{qcm}$.

Frühhafer, reift in 117 Tagen; Rispe $20 \mathrm{~cm}$ (IIax. $25 \mathrm{~cm}$ ) lang, mit 110 Scheinfrüchten, von denen 1793000 auf $1 \mathrm{hl}(=42.7 \mathrm{~kg})$ entfallen.

Auf 1 qm wachsen 800 Halmc oder 250 Pflanzen, mithin beträgt das Saatquantum $2 \mathrm{hl} \mathrm{p.} \mathrm{ha.}$ 
Es wiegen 100 Halme 1033 gr und davon die Scheinfrüchte 517 gr.

Dieser Hafer lagert nicht leicht, bleibt rostfrei und empfiehlt sich für sehr armen und leichten oder Torfboden.

\section{Brauner tatarischer gegranuter Fahnenhafer.}

Syn.: Franz.: Avoine noire de Tartarie.

Ital.: Avena tartarica.

Rispe: stark zusammengezogen, mittellang; Aehrchen 2-körnig, 1grannig, Klappen fast weiss, $2.5 \mathrm{~cm}$ lang, $0.7 \mathrm{~cm}$ breit. - Stroh: grünlich-gelb, sehr lang $(150 \mathrm{~cm})$, fest, doch weich und blattreich. - Scheinfrucht: rot- bis schwarzbraun, klein, schmal (grosses Korn $13 \mathrm{~mm}$ lang, $2.5 \mathrm{~mm}$ breit, kleines $9 \mathrm{~mm}$ lang, $2 \mathrm{~mm}$ breit, 385 Scheinfrüchte $=10 \mathrm{gr}$ ), Grannen stark gekniet, an Basis schwarzbraun, $3 \frac{1}{2} \mathrm{~cm}$ lang, grobschalig, 31.5 Proc. Spelzen.

Rispe $25 \mathrm{~cm}$ lang, mit 200 fest sitzenden Scheinfriichten.

Es wiegen 100 Halme $1075 \mathrm{gr}$, davon die Körner $468 \mathrm{gr}$.

Späthafer, in 130 Tagen reifend.

\section{Unterart: Avena sativa nuda Al. Nackter Hafer.}

Varietait: Avena sativa inermis Keke.

Rispe ausgebreitet; unbegrannt; Spelzen blassgelb.

\section{Sorten:}

\section{Grosser nackter Hafer. $\odot$}

Syn.: Engl.: Large naked Oat.

Franz.: Avoine nue grosse.

Rispe: ausgebreitet, locker, sebr reichsamig, mittellang; Aehrchen 3- und 4-körnig, flattrig, grösser als bei den übrigen nackten Varietäten; Blüten meist nicht weit aus den Spelzen hervorragend; äussere Spelze an der untersten Blüte mit einer graden, feinen, nicht in die Augen fallenden Granne versehen, innere Spelze halb so lang; Aehrchen durch helle, blassgelbe Farbe der Klappen und Spelzen ausgezeichnet. - Stroh: gelb, kaum nittellang, fest. - Frucht: hellgelb, anliegend behaart (grösstes Korn eines Aehrchens $0.9 \mathrm{~cm}$ lang, $0.3 \mathrm{~cm}$ breit, kleinstes $0.5 \mathrm{~cm}$ lang, $0.2 \mathrm{~cm}$ breit), im Allgemeinen grösser als bei den übrigen nackten Varietäten.

Halme gelbgrün, 2.3 Schösslinge, mittelfrüh blühend, $110 \mathrm{~cm}$ (Max. $150 \mathrm{~cm}$ ) lang, $0.43 \mathrm{~cm}$ dick, Blattzahl 4, Blattfläshe $231.84 \mathrm{gcm}$, Halmfläche $141.2 \mathrm{qcm}$, Gesammtfäche $373.74 \mathrm{qcm}$. 
Rispe $25 \mathrm{~cm}$ (Max. $30 \mathrm{~cm}$ ) lang, mit 200 leicht ausfallenden Früchten, von denen 3360000 anf $1 \mathrm{hl}(=70 \mathrm{~kg})$ entfallen. Reift in 123 Tagen.

Es wiegen 100 Halme $643 \mathrm{gr}$ und davon die Früchte $228 \mathrm{gr}$.

Auf $1 \mathrm{qm}$ wachsen 900 Halme oder 400 Pflanzen, mithin beträgt das Saatquantum $1.7 \mathrm{hl}$ p. ha.

Diese Sorte ist die gewöhnlichste Form der Nackthafer, welche zuweilen in England, Schottland, Spanien, Oesterreich, Rumänien, Russland, in der Schweiz, weniger dagegen in Deutschland gebaut, und deren Früchte als Graupen verwandt werden.

Ihre Kultur scheint schon selır alt zu sein, demu Gerard, der 1597 iiber Landwirtschaft schrieb, fiihrt an, dass ,unhulled or naked oats, were cultivated in Norfolk and Suffolk."

\section{Nackter kleiner Hafer. $\odot$}

Engl.: Small naked Oat.

Franz.: Avoine nue petite.

Rispe: ausgebreitet, locker, schlaff, lang, zjemlich reichsamig: Aehrchen 3-, 4- und 5-körnig, unbegrannt; Spelzen und Klappen blassgelb (2.4 cm lang, $0.6 \mathrm{~cm}$ breit), weich. - Strolı: gelb, blattreich, mittellang, fest. - Frucht: klein (grösstes Korn $0.8 \mathrm{~cm}$ lang, $0.25 \mathrm{~cm}$ breit, kleinstes $0.5 \mathrm{~cm}$ lang, $0.15 \mathrm{~cm}$ breit).

Halme gelbgrün, 2.5 Schösslinge, mittelfrüh blühend, $120 \mathrm{~cm}$ (Max. $130 \mathrm{~cm}$ ) lang, $0.5 \mathrm{~cm}$ dick, Blattzahl 5, Blätter $30.5 \mathrm{~cm} \mathrm{lang,} 0.98 \mathrm{~cm}$ breit, Blattfläche $298.9 \mathrm{qcm}$, Halmfläche $180 \mathrm{qcm}$, Gesammtfläche $478.9 \mathrm{qcm}$.

Späthafer, in 126 Tagen reifend; Rispe $30 \mathrm{~cm}$ (Max. $35 \mathrm{~cm}$ ) lang, mit 150 ziemlich fest sitzenden Scheinfrüchten, von denen 4185000 auf $1 \mathrm{hl}(=67.5 \mathrm{~kg}$ ) entfallen.

Auf $1 \mathrm{qm}$ wachsen 750 Halme oder 300 Pflanzen, mithin beträgt das Saatquantum 1 hl p. ha.

Es wiegen 100 Halme $744 \mathrm{gr}$ und davon die Früchte $278 \mathrm{gr}$.

Dieser Hafer ist wenig ertragreich und hat für Deutschland keine wirtschaftliche Bedentung.

\section{Hafer aus Peking und der Iongolei. $\odot$}

Rispe: nach einer Seite hängend, ziemlich lang; Aehrchen 3-5körnig, Spelzen und Klappen blassgelb. - Stroh: gelb, mittellang. Frucht: blassgelb ( $8 \mathrm{~mm}$ lang, $2 \mathrm{~mm}$ breit, 505 Früchte $=10 \mathrm{gr}$ ).

Junges Blatt dunkelgrün, kahl, gross, 4.5 Schösslinge; Halm $115 \mathrm{~cm}$ (Max. $130 \mathrm{~cm}$ ) lang, $0.43 \mathrm{~cm}$ dick, Blattzahl 4, Blätter $26.8 \mathrm{~cm}$ lang, $1 \mathrm{~cm}$ breit, Blattfäche $214.4 \mathrm{qcm}$, Halmfläche $148.4 \mathrm{qcm}$, Gesammtfl̈̈che $362.8 \mathrm{qcm}$.

Rispe $20 \mathrm{~cm}$ (Max. $25 \mathrm{~cm}$ ) lang, mit 35 Aehrchen und 120 Früchten, von denen 3636000 auf $1 \mathrm{hl}(=72 \mathrm{~kg})$ entfallen.

Frühhafer, 14 Tage früher als alle iibrigen Nackthafer.

Bezugsquelle: hort. Petersburg durch Bretschneider 1879. 
Varietät: Avena sativa chinensis Fisch.

Rispe ausgcbreitet; Aehrchen begrannt.

Sor te:

Chinesischer Nackthafer. $\odot$

Syn.: Franz.: Avoine de Chine, Avoine chinoise.

Eng 1.: China Oat.

Rispe: ausgebreitet, etwas einseitig entwickelt, mittellang, ziemlich reichsamig; Aelırchen traubig, 3-, 4- und 5-körnig, Spelzen grauschwarz oder gelb, die grösste Spelze im Aelhrchen begrannt, Granne gelb, an der Basis grauschwarz, $3.5 \mathrm{~cm}$ lang; Spelze bis $2 \mathrm{~cm}$ lang; Klappen blassgelb, $2 \mathrm{~cm}$ lang, $0.6 \mathrm{~cm}$ breit). - Stroh: gelb oder orange, kurz, blattreich, dick. - Frucht: nackt, doch bleibt beim Dreschen der grösste Teil der Spelze lose um das Korn. (Grösstes Korn $1 \mathrm{~cm}$ lang, $0.25 \mathrm{~cm}$ breit).

Halme gelbgrün, sehr spät blühend, 2.5 Schösslinge, $100 \mathrm{~cm}$ (Max. $145 \mathrm{~cm}$ ) lang, $0.45 \mathrm{~cm}$ dick, Blattzahl 5, Blätter $27.8 \mathrm{~cm}$ lang, $1.04 \mathrm{~cm}$ breit, Blattfäche 289.1 qcm, Halmfläche 135 qcm, Gesammtfl̈chc $424.1 \mathrm{qcm}$.

Späthafer, reift in 130 Tagen; Rispe $27 \mathrm{~cm}$ (Max. $35 \mathrm{~cm}$ ) lang, mit 120 Früchten, von denen vollkommen ausgeschält 3990000 auf $1 \mathrm{hl}$ $(=70 \mathrm{~kg}$, zum Teil Früchte noch im Kaff $=55.4 \mathrm{~kg})$ entfallen.

Auf $1 \mathrm{qm}$ wachsen 800 Halme oder 320 Pflanzen, mithin beträgt das Saatquantum $1 \mathrm{hl} \mathrm{p.} \mathrm{ha.}$

Es wiegen 100 Halme $883 \mathrm{gr}$ und davon die F'rüchte $250 \mathrm{gr}$.

Für Deutschland hat diese Sorte keine wirtschaftlichc Bedeutung. In China ist sie nach $B$ unge ${ }^{1}$ ) die nur allein kultivierte Sorte; in neuerer Zeit wird sie auch in den Vereinigten Staaten angebaut.

\section{Varietät: Avena orientalis gymnocarpa Kcke.}

Rispe zusammengezogen; unbegrannt; Spelzen blassgelb.

\section{Sorte:}

\section{Grosser nackter Fahnenhafer. $\odot$}

Rispe: einseitig hängend, kurz; Aehrchen oft 5-körnig, Scheidenspelze hellbraun; oft tritt an den Basalblütchen eine Granne auf, auch sind deren Spelzen länger als die Klappen; Klappen und Spelzen blassgelb, $2 \mathrm{~cm}$ lang, $0.5 \mathrm{~cm}$ breit. - Stroh : rötlich-gelb, kurz. - Frucht: blassgelb, halbmehlig (grosses Korn $8 \mathrm{~mm}$ lang, $2^{1 / 2} \mathrm{~mm}$ breit, kleines $51 / 2 \mathrm{~mm}$ lang, $2 \mathrm{~mm}$ breit, 519 Friichte $=10 \mathrm{gr}$ ).

Junges Blatt dunkelgrün, schmal, aufrecht, 2.4 Schösslinge, Halm $90 \mathrm{~cm}$ (Max. $125 \mathrm{~cm}$ ) lang, $0.3 \mathrm{~cm}$ dick, Blattzahl 4.5, Blätter $21 \mathrm{~cm}$ lang, $0.7 \mathrm{~cm}$ breit, Blattfäche $132.3 \mathrm{qcm}$, Halmfläche $81 \mathrm{qcm}$, Gesammtfläche $213.3 \mathrm{qcm}$.

1) L'enumération des pl. du Nord de la Chine. 
Rispe $15 \mathrm{~cm}$ (Max. $25 \mathrm{~cm}$ ) lang, mit 25 Aehrchen und 100 ziemlich fest sitzenden Früchten.

späthafer, in 130 Tagen reifend.

Varietät: Arena sativa nuda L.

Rispe zusammengezogen; begrannnt; Spelzen blassgelb.

\section{Sorte:}

\section{Kleiner nackter Fahnenhafer. $\odot$}

Syn.: Deutsch: Tatarischer Gritzhafer.

Rispe: zusammengezogen, straff, einseitig hängend, kurz, etwas armsamig; Aehrchen 2-körnig und die Bliiten ron den Klappen eingeschlossen, oder 3- und 4-körnig mit herausragenden oberen Bliiten, Aehrchen 2-grannig; Granne braun, an der Basis schwarzbraun, stark gekniet und gedreht, $2.5 \mathrm{~cm}$ lang; Spelzen und Klappen blassgelb, letztere $2 \mathrm{~cm}$ lang, $0.5 \mathrm{~cm}$ breit, weich. - Stroh: gelbgriin, kurz, feinhalmig. - Frucht: bräunlich, klein, schmal, spitz (grösstes Korn $0.7 \mathrm{~cm}$ lang, $0.15 \mathrm{~cm}$ breit).

Junges Blatt sehr schmal, Bestockung stark, 3 Schösslinge, Halme dunkelgruin, sehr spät blühend, $85 \mathrm{~cm}$ (Max. $110 \mathrm{~cm}$ ) lang, $0.23 \mathrm{~cm}$ dick, Blattzahl \&, Blätter $16.5 \mathrm{~cm}$ lang, $0,5+\mathrm{cm}$ breit, Blattfläche $71.2 \mathrm{~S} q \mathrm{~cm}$, Halmfläche $58.65 \mathrm{qcm}$, Gesammtfl̈che $129.93 \mathrm{qcm}$.

Späthafer, reift in 130 Tagen; Rispe $18 \mathrm{~cm}$ (Мax. $25 \mathrm{~cm}$ ) lang, mit 80 noch verhältnismässig fest in den Spelzen sitzenden Früchten, von denen 7700000 auf $1 \mathrm{hl}(=77 \mathrm{~kg})$ entfallen.

Es riegen 100 Halme $340 \mathrm{gr}$ und davon die Früchte $125 \mathrm{gr}$.

Fir Deutschland ist diese Sorte wirtschaftlich ron keiner Bedeutung.

\section{Arena subspontanea Kcke. Halbwilde Hafer.}

Art: Arena brevis Roth.

\section{Kurzhafer. $\odot$}

Syn.: Franz.: Aroine courte.

Engl.: Short-Oat.

Rispe: hellgelb, ziemlich ausgebreitet, kurz, reichsamig; Aehrchen 2-körnig, 2-grannig, Klappen klein, $1.5 \mathrm{~cm}$ lang, $0.4 \mathrm{~cm}$ breit; Grannen an der Basis sclıwarzbraun, gekniet, bis $2 \mathrm{~cm}$ lang. Stroh: gelblich-grün, kräftig, mittellang. - Scheinfrucht: gelb oder hellgrau, Scheidenspelze grau, klein (grosses Korn $8 \mathrm{~mm}$ lang, $2 \mathrm{~mm}$ breit, kleines $61 / 2 \mathrm{~mm}$ lang, $11 / 2 \mathrm{~mm}$ breit, 760 Scheinfrüchte $=10 \mathrm{gr}$ ), ziemlich feinschalig, 26.7 Proc. Spelzen.

Junges Blatt gelbgrün, sehr schmal, lang, 3 Schösslinge, ganze Pflanze weich behaart; Halm $120 \mathrm{~cm}$ (Мax. $140 \mathrm{~cm}$ ) lang, $0.4 \mathrm{~cm}$ dick, Blattzahl 4, Blätter $24.3 \mathrm{cnl}$ lang, $1 \mathrm{~cm}$ breit, Blattfläche $194.4 \mathrm{qcm}$, Halmfläche $14+\mathrm{qcm}$, Gesamutfläche $338.4 \mathrm{qcm}$. 
Rispe $15 \mathrm{~cm}$ (Max. $20 \mathrm{~cm}$ ) lang, mit 120 Früchten, von denen 3192000 auf $1 \mathrm{hl}(=42 \mathrm{~kg}$ ) entfallen.

Es wiegen 100 Halme $400 \mathrm{gr}$ und davon die Scheinfrüchte $163 \mathrm{gr}$.

Späthafer, in 125 Tagen reifend.

Ausser dieser Varietät mit kaller Scheinfrucht giebt es noch eine mit borstiger Scheinfrucht.

Zuweilen in armen Sand- oder Gebirgsgegenden der kälteren und wärmeren gemässigten Zone gebaut.

\section{Art: Avena strigosa Schreb.}

\section{Rauh- oder Sandhafer. $\odot$}

Syn.: Franz.: Avoine strigueuse.

Engl.: Meagre oat, Bristle-pointed-oat.

Rispe: ein wenig zusammengezogen, fast einseitswendig, lang; Aehrchen 2-körnig, 2-grannig, kahl; Blïthen auf dem Rücken mit geknieter Granne, letztere an der Basis schwarzbraun und bis $3 \mathrm{~cm}$ lang, Klappen blassgelb, $2.2 \mathrm{~cm}$ lang, $0.5 \mathrm{~cm}$ breit. - Stroh: gelbgrün, feinhalmig, blattarm, lang. - Scheinfrucht: gelbgrau, klein, schmal (grosses Korn 11 mm lang, $2 \mathrm{~mm}$ breit, 689 Scheinfriichte $=10 \mathrm{gr}$ ); grobschalig, 31.3 Proc. Spelzen.

Junges Blatt gelbgrün, schmal, kurz, 2.7 Schösslinge; $H a l m ~ 120 \mathrm{~cm}$ (Max. $130 \mathrm{~cm}$ ) lang, $0.35 \mathrm{~cm}$ dick, Blattzalıl 3.5, Blätter 20,8 cm lang, $0.8 \mathrm{~cm}$ breit, Blattfäche $116.5 \mathrm{qcm}$, Halmfläche $126 \mathrm{qcm}$, Gesammtfläche $242.5 \mathrm{qcm}$.

Rispe $20 \mathrm{~cm}$ (Max. $25 \mathrm{~cm}$ ) lang, mit 100 Scheinfrüchten, von denen 2466620 auf $1 \mathrm{hl}(=35.8 \mathrm{~kg}$ ) entfallen.

Es wiegen 100 Halme $375 \mathrm{gr}$ nd davon die Scheinfrüchte $155 \mathrm{gr}$.

Späthafer, in 125 Tagen reifend.

Zuweilen auf sehr armen Böden gebaut, wo die besseren Hafer versagen, z. B. in Mecklemburg und Holstein. Auch in Portugal.

\section{A n hang.}

Gemisch von Avena brevis und strigosa.

Fliegenfuss. $\odot$

Syn.: Franz.: Avoine pied de Mouche, à fourrage.

Engl.: Animal or Fly-Oat.

Rispe: zusammengezogen, fast einseitswendig, reichsamig, lang; Aehrchen meist 2-körnig und 2-grannig; Grannen gedreht und gekniet, an der Basis schwarzbraun; Klappen schmutzig-blassgelb, $2 \mathrm{~cm}$ lang, $0.4 \mathrm{~cm}$ breit. - Stroh: grünlich-gelb, steif, sehr lang. - Scheinfrucht: gelbgrau, klein, schmal, sehr kurz (grosses Korn $10.5 \mathrm{~mm}$ lang, $2 \mathrm{~mm}$ breit, kleines $7 \mathrm{~mm}$ lang, $1.5 \mathrm{~mm}$ breit, 720 Scheinfrüchte $=10 \mathrm{gr}$ ); ziemlich feinschalig, 26 Proc. Spelzen.

Junges Blatt gelbgrün, schmal, 2.7 Schösslinge; Halm $135 \mathrm{~cm}$ (Max. $160 \mathrm{~cm}$ ) lang, $0.38 \mathrm{~cm}$ breit, Blattzahl 4.5 , Blätter $18.8 \mathrm{~cm}$ lang, $0.8 \mathrm{~cm}$ breit, Blattfläche $135.4 \mathrm{qcm}$, Halınfläche $153.9 \mathrm{qcm}$, Gesammtfläche $289.3 \mathrm{qcm}$. 
Rispe $20 \mathrm{~cm}$ ( ax, $25 \mathrm{~cm}$ ) lang, mit 120 Scheinfrüchten, von denen 2736000 auf $1 \mathrm{hl}(=38 \mathrm{~kg}$ ) entfallen.

Es wiegen 100 Halme 462 gr nnd davon die Scheinfrüchte $201 \mathrm{gr}$.

Frühhafer, in 120 Tagen reifend.

Auf leichten Böden hügliger Terrains auf der pyrenäischen Halbinsel, Frankreichs und Deutschlands kultiviert und 1804 von Deutschland aus nach England eingeführt.

Diese Pflanze bringt ein gutes Grünfutter und Heu, welches dem des Reygrases sehr ähnlich ist, daher zur Futtergewinnung in vielen Berggegenden kultiviert, z. B. in der Auvergne und dem Mont-Dore, sowie in Forez, Frankreich, in Spanien etc., wo er mit den schlechtesten Böden vorlieb nimmt.

\section{Die biologischen Verhältnisse des Hafers.}

Die Verwendung an Reservestoffen reicher und dabei möglichst gleichartiger Körner zur Saat ist besonders beim Hafer von grösster Wichtigkeit, weil er in demselben Aehrehen regelmässig Körner von sehr ungleichem absoluten Gewicht erzengt, die ausgesäet, auch sehr ungleichartige Pflanzen hervorbringen, von denen die schwächeren, zumal bei kübler, trockner Witterung im Frühjalır und auf den ärmeren Feldern in ihrer Entwickelung zurückbleiben, in Folge dessen der Bestand leicht der Zweischürigkeit anheimfällt.

Gemeinhin steht nun das Gewicht der jungen Pflanze im geraden Verhältnis zum Gewicht des Saatkornes, will man daher Pflanzen ron bedeutender Wachstumsenergie und Widerstandsfähigkeit gegen ungïnstige Verbältnisse erzielen, dann empfiehlt sich die ${ }^{\mp}$ Aussaat der grössten und absolut schwersten Körner, welche mit Hülfe einer Getreidesortiermaschine leicht auszusondern sind.

Dass nun aber das absolut schwerere Korn von gleicher Herkunft auch wirklich das an Reservestoffen reichere ist, ergiebt sich aus Untersuchungen ron A. Müller an Weisshafer, denn es stellte? sich die procentische Zusammensetzung der Körner wie folgt:

Bei einem Gewicht von $30.5 \mathrm{mg}-27.9 \mathrm{mg}$ fanden sich:

$\begin{array}{llrrr}\text { an Wasser } & 14.70 & \text { Proc. } & 14.64 & \text { Proc. } \\ \text { "Holzfaser } & 8.46 & 10.74 & \\ \text { "Asche } & 2.74 & & 2.68 & \\ \text { "Protein } & 9.00 & & 8.52 & \end{array}$




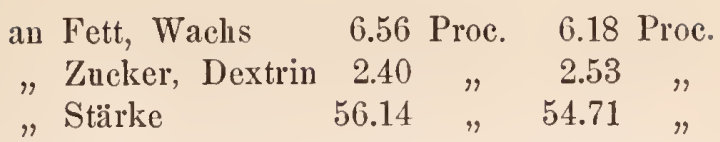

Welchem Wechsel iiberhaupt die Reservestoffmengen in Hafer unterworfen sein können, zeigen nachstchende Angaben uiber das Maximum und Minimum derselben:

$\begin{array}{lrrrcrr} & \text { Wasser } & \text { Proteïn } & \text { Fett } & \text { Stickstofffr. Subst. } & \text { Holzfaser } & \text { Asche } \\ & \text { Proc. } & \text { Proc. } & \text { Proc. } & \text { Proc. } & \text { Proc. } & \text { Proc. } \\ \text { Minimum } & 7,66 & 8.56 & 4.40 & 47.98 & 7.16 & 2.50 \\ \text { Maximum } & 15.67 & 18.50 & 7.11 & 61.69 & 16.09 & 5.14 \\ \text { Mittel } & 12.52 & 12.66 & 6.09 & 54.30 & 11.01 & 3.42\end{array}$

Das absolute Gewicht eines Kornes, die Anzahl der Körner, welche auf 1 hl gehen, das Volumengewicht, und schliesslich der Procentsatz an Spelzen, welehe die Frucht umschliessen, weichen bei den einzelnen Varietäten des Hafers beträchtlich von cinander ab, wic sich dies aus meinen in Poppelsdorf angestellten Untersuchungen, deren Resultate auf Seite 742 zusammengestellt sind, ergiebt.

Vorzugsweise beachtenswert in dieser Tabelle ist der procentische Gchalt an Spelzen, der in hervorragendem Grade die Menge der Reservestoffe des Kormes beeinflusst.

Nobbe gibt das Gewicht eines Kornes der Handelsware im Mittel auf $28.777 \mathrm{mg}$ an, während das Maximum $54.090 \mathrm{mg}$ und das Minimum $14.700 \mathrm{mg}$ beträgt; diese Zahlen stimmen mit denen unserer Varietät "Avena sativa mutica", und Körner dersclben werden seinen Untersuchungen wohl meist zu Grunde gelegen haben, recht gut tiberein.

Die Keimkraft des Hafers betrug nach Nobbe bei 87 untersuchten Proben im Durehsehnitt 74 Proc., mindestens 45 Proc. und höchstens 100 Proc.

Als Zeichen einer befriedigenden Keimfähigkeit, wie überhaupt guten Qualitiit, sieht man eine hornige Beschaffenheit des Kornes, sowie die charakteristische Farbe und den eigentumlichen Glanz der Sorte an, auch darf das Korn weder multrig noch feucht, oder ausgewachsen sein. Hat das Korn an seiner Keimfähigkeit Schaden gelitten, so sind nach Dimitrievicz die Embryonen der nicht keimfähigen Körner missfarbig, braungelb bis rotbraun, während bei den schwach keimfähigen die gesunde gelbgrüne Färbung noch nicht ganz verwischt ist.

Uebrigens ist das Haferkorn, weil wenig hygroscopiseh, dem Verderben in geringerem Masse als das der Gerste ausgesetzt. 


$1111 \quad 11111$

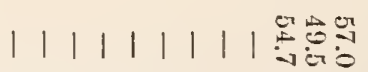

1111

| | | |

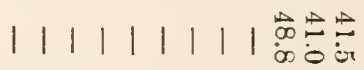

V

- Nーール

궁휴:

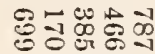

๕๕:

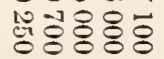

ロ -

๘

\section{-}

$\begin{array}{llllllll}1 & 1 & 1 & 1 & 1 & 1 \\ 1 & 1 & 1 & 1 & 1 & 1\end{array}$

$\longrightarrow$

\begin{tabular}{|c|c|c|}
\hline 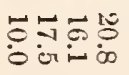 & 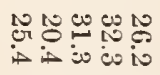 & 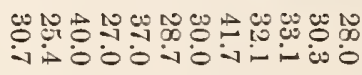 \\
\hline 1111 & 11111 & |||||||| $\mid \overbrace{0}^{\infty} e_{0}^{\infty}$ \\
\hline $1|1|$ & 11111 & 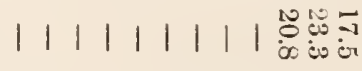 \\
\hline 1111 & 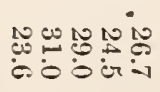 & 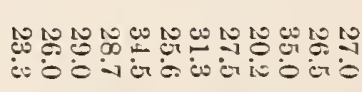 \\
\hline
\end{tabular}

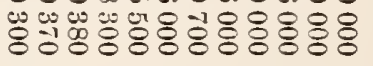


Was nun die Keimfähigkeit anbetrifft, so fand Haberlandt, dass von 100 keimfähigen Körnern noch keimten:
nach 6 Jahren
4 Jahren
3 Jahien
2 Jahren
$1 \mathrm{Jahr}$
48 Proc.
72 Proc.
32 Proc.
80 Proc. 96 Proc.

und bewahrt der Hafer, mit Ausnahme des Mais, von den Getreidearten seine Keimkraft am längsten, doch ist anzuraten, möglichst nur Körner der letzten Ernte als Saatkorn zu verwenden.

Bei höheren Temperaturen künstlich getrocknete Körner, namentlich sobald sie vor dem Trocknen sehr fencht waren, sollten ebenfalls nicht zur Saat verwandt werden, denn von 100 Körnern keimten nur

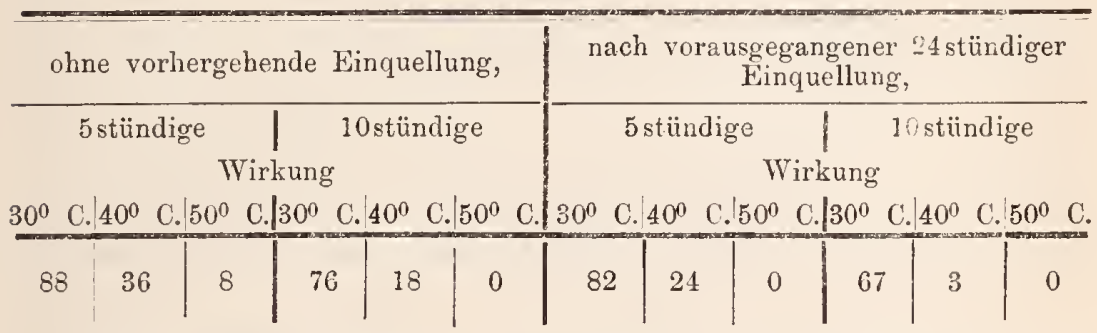

Die in gutem Saatgut vorkommende Unreinigkeit ist meist gering, und fand Nobbe in 29 Proben im Mittel nur 1.02 Proc., im Maximum 4.80 Proc. und im Minimum 0.06 Proc.

Der Hafer benötigt nach Hoffmann 59.8 Proc., nach Haberlandt 76 Proc. Qnellungswasser zum Keimen, jedenfalls aber nicht unbeträchtlich mehr als Weizen und Gerstc, und bei einer Gewichtszunahme von 10 Proc. durch aufgenommenes Wasser vermehrt sich nach Payen das Volumen um 22 Proc.

Dieses Quellungswasser entnimmt das lufttrockene Samenkorn einem genügend feuchten Boden in 12-24 Stunden, und fehlt es nicht an Sauerstoff und Wärme, so beginnt das Keimen nach Nobbe bei $16-18^{\circ} \mathrm{C}$. in $1-2$ Tagen und hat die grössere Hälfte dasselbe nach 5-6 Tagen beendet. Im Allgemeinen beträgt die niedrigste Keimungstemperatur $4-5^{0} \mathrm{C}$, die höchste $30^{\circ} \mathrm{C}$, die giinstigste $25^{\circ} \mathrm{C}$., und liegt hiernach das Minimum $1-2^{\circ} \mathrm{C}$. höher als bei den übrigen echten Getreidearten.

Sollen nun die Keimungsfaktoren ausgiebig auf das Samenkorn einwirken, so ist dasselbe auf schwercm Boden nur $2 \mathrm{~cm}$, auf feuchtem Mittelboden $3 \mathrm{~cm}$, auf trocknem Mittelboden $5 \mathrm{~cm}$ und auf sehr leichtem Boden $7 \mathrm{~cm}$ tief unterzubringen. Durch eine tiefere Unterbringung wird nicht nur die schnelle Kcimung, sondern auch das energische Wachstum und die Bildıng zahlreicher Kronenwurzeln und Schösslinge behindert.

Zunächst entwickeln sich beim Keimen die drei ersten Würzel- 
chen, und darauf erscheint der Blattkeim. Wie sehr nun die Keimung und die Entwickelung des Blattkeimes ron der Bodentemperatur abhängt, ergiebt sich aus einem Versuch ron Haberlandt. Nach demselben erfolgte die Keimung mit dem ersten Sichtbarwerden des Wiirzelchens

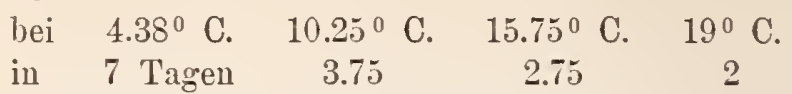

und das durchschnittliche Längenwachstum des Stengelchens betrug pro Tag in $\mathrm{mm}$
$\mathrm{mm} \quad 1.22$
2.75
5.41
6.54

Es verbrancht hiernach das Haferkorn zum Keimen und zur Entwickelung des Blattkeimes mehr Wärme und Zeit als die uibrigen echten Getreidearten und insbesondere die Gerste, weshalb es gemeinhin geratener ist, vor dem Hafer erst die Gerste auszusäen, zumal nach unseren Beobachtungen, entgegen denen ron Sprengel und Schwerz, die junge Haferpflanze gegen kalte Frühjahrswitterung empfindlicher als die junge Gerstenpflanze ist.

In der Regel erfolgt das Hervortreten des ersten Blattes an die Oberfläche bei $12-15^{\circ} \mathrm{C}$. in 12-15 Tagen.

Die jetzt assimilationsfähige junge Pflanze beginnt zunächst ihre Kronenwurzeln zu bilden und sich zu bestocken.

Das Wurzelausbreitungsrermögen und der Wurzeltiefgang ist bei der Haferpflanze im Allgemeinen weit grösser als bei den anderen echten Getreidearten; so fand Hein r ich eine Wurzellänge ron $2.27 \mathrm{~m}$ und bei der Gerste nur eine solche ron $1.90 \mathrm{~m}$, und ein Gewicht der lufttrocknen Wurzeln einer Haferpflanze von $43.75 \mathrm{gr}$, dagegen bei einer Gerstenpflanze ron nur $27.50 \mathrm{gr}$.

Naturgemäss unterliegt diese Wurzelentwickelung, je nach der angebauten Sorte, der Bodenbeschaffenheit und des Düngungszustandes der Felder, sehr erheblichen Schwankungen und geben hieruber die Untersuchungen von Hosaeus ${ }^{1}$ ) einige Aufklärung, deren Resultate folgen :

1) Der Einfluss der Sorte anf das Verhältnis der Wurzeln zu den oberirdischen Organen, zeigt sich wie folgt:

$\begin{array}{cc}\text { Potatoe-Hafer } & 1: 2.5 \\ \text { Gabel-Hafer } & 1: 2.4 \\ \text { " } & 1: 3.3 \\ \text { Australischer Hafer } & 1: 5.6 \\ \quad \text { " }, & 1: 5.0\end{array}$

2) Der Einfluss des Bodens auf das Terhältnis zwischen Wurzeln und oberirdisehen Organen:

1) Neue landw. Zeit. Heft 6. 1873, pg. 427. 


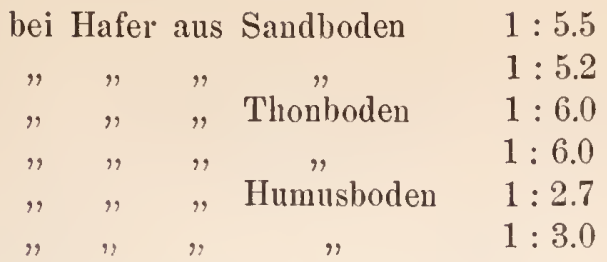

3) Der Einfluss des Düngung'szustandes anf das Verbältnis zwischen Wurzeln und oberirdischen Organen:

$$
\begin{aligned}
& \text { Hafer aus armem Boden } 1: 4.5
\end{aligned}
$$

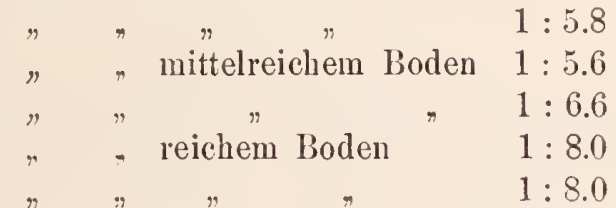

Aus diesen letzten Resultaten geht unzweifelhaft hervor, dass die Wurzeln im nahrungsicichen Boden eine viel geringerc Ausdehnung im Verhältnis zu den oberirdischen Teilen crreichen, als im nahrungsarmen, und liegt wohl der Grund hierfür darin, dass die Wurzel zur Beschaffung der Pflanzennährstoffe in nahrungsarmen Boden eine grössere Oberfläche besitzen muss, weil erst ein relativ grosses Bodenvolumen die notwendige Nährstoffmenge zu liefern vermag. Diese stärkere Wurzelentwickelung wird aber auf Kosten der oberirdischen Organe geschehen, weil der Wurzel viel organisiertes Nährstoffmaterial zufliesst, woraus eine schwächere Entwickelung dieser Teile auf nahrungsarmem Boden resulticrt.

Betreffs der Verbreitung der Wurzeln im Boden liegt ein Versuch von Hellriegel vor, der folgende Resultate ergab:

$$
\text { Bodenprofil }\left\{\begin{array}{l}
\text { lehmiger Sand } 62 \mathrm{~cm}\left\{\begin{array}{l}
\text { Ackerkrume } 30 \mathrm{~cm} \\
\text { humushaltig }
\end{array}\right. \\
\text { grober roter Diluvialsand. }
\end{array}\right.
$$

\begin{tabular}{|c|c|c|c|c|}
\hline bei & $22 \mathrm{~cm}$ & Tiefe & 271 & Fasern \\
\hline$\eta$ & 44 & $"$ & 231 & . \\
\hline & $66 \eta$ & $\pi$ & 82 & $"$ \\
\hline & $87 n$ & 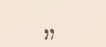 & 16 & n \\
\hline & $104 n$ & & 0 & $\pi$ \\
\hline
\end{tabular}

Zahl der Wurzeln auf 400 qem Fläche:

Ueber den Verlauf der Entwickelung der Haferpflanze geben die Zahlen der nachstehenden Tabelle (siebenjälıriger Durchschnitt der in Poppelsdorf kultivierten Sorten) Aufschluss: 


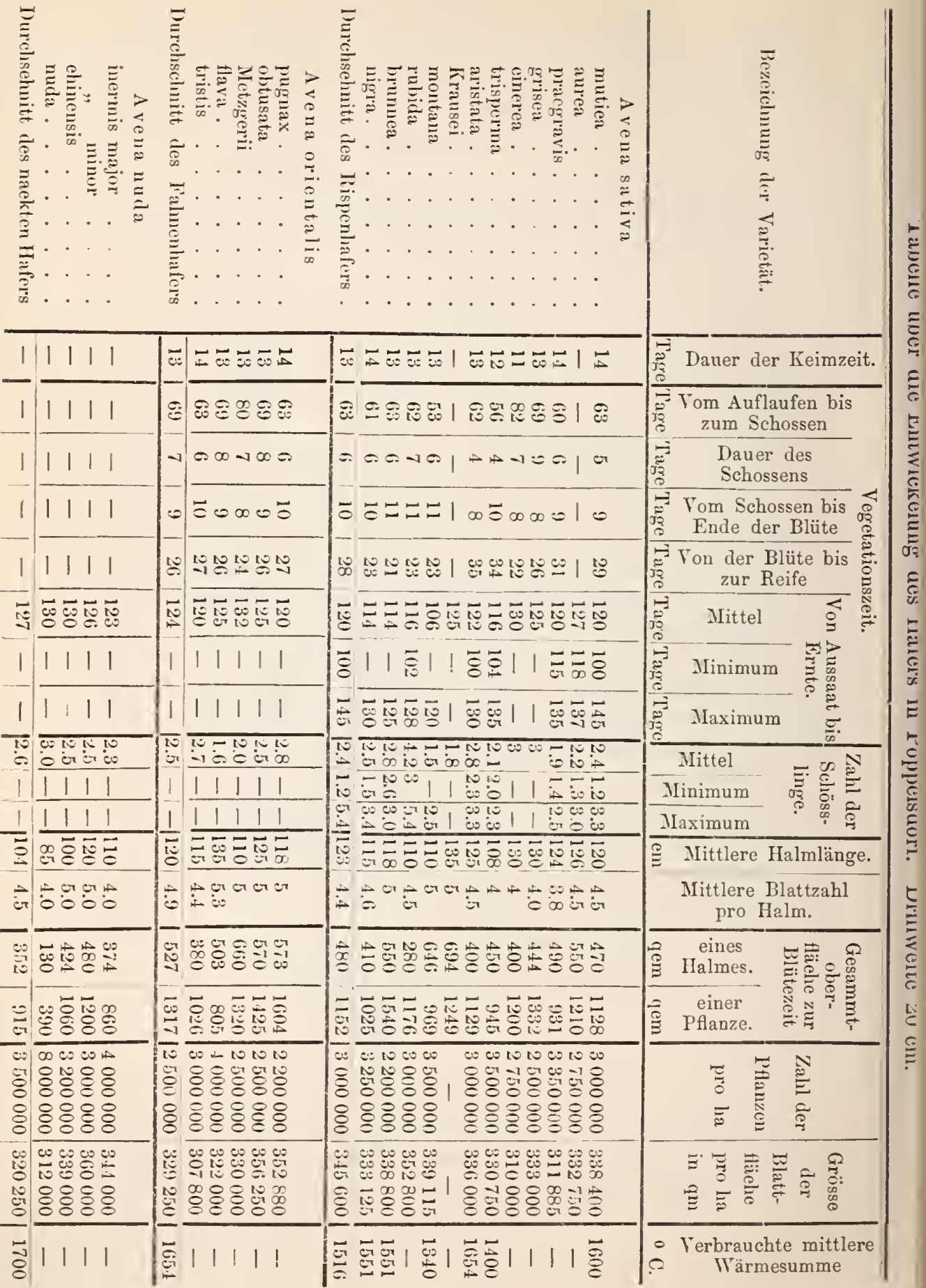


Aus dieser Tabelle geht deutlich hervor, wie sehr dic Varietäten des Hafers in ihrem Habitus und Wärmeverbrauch von einander abweichen, was auch durch das Gewicht der Ernte bestätigt wird, so wogen 100 Halme vom

Rispenhafer 785 gr, davon Körner 400 gr oder 51 Proc.

Fahnenhafer 1013 " , 486 " , 48 "

Nackthafer 652.5 " " " 222 " " 33.6 "

mithin erzengt der spätreife Fahnenhafer die kräftigsten Pflanzen, jedoch im Verhältnis zum Stroh weniger Korn als der Rispenhafer. Die Nackthafer zeigen entschieden die schwächste Entwickelung und im Verhältnis zum Stroh auch die geringste Kornproduktion.

Innerhalb der Varietäten kommen jedoch zwischen den friihund spätreifen Sorten ebenfalls grosse Verschiedenhciten vor, und kann hier als Grundsatz gelten, dass, je geringer die Wärmesumme ist, welche eine Varietät bis zur Ausreife beansprucht, sich um so mehr das Erntegewicht und zwar vorzugsiveise das des Strohes vermindert, so ergaben unsere Untersuchungen an der am meisten gebauten Varietät „mutica“, dass von 100 Halmen die Ernte betrug beim

$$
\text { Späthafer Frïhhafer }
$$

(über 120 Tage Vegetationszeit)

$\begin{array}{lrl}\text { Gesammternte } & 770 \mathrm{gr} & 700 \mathrm{gr} \\ \text { davon Korn } & 300 \text { " } & 365 \text { " } \\ \text { oder } & 39 \text { Proc. } & 52 \text { Proc. }\end{array}$

Hiernach liefert der Frihhafer eine geringere Gesammternte als der Späthafer, doch im Verhältnis zum Stroh mehr Korn. Vielfach wird auch angegeben, dass die Körner des Frühhafers diinnschaliger als die des Späthafers sein sollen, doch bestätigten dies unsere Untersuchnngen nicht, denn diese ergaben für Früh- und Späthafer die gleichen Procentsätze an Spelzen; auch soll das Mehl des Friihhafers besser sein, was jedoch noch der Bestätigung bedarf.

Im Allgemeinen lagern die Späthafer dureh ibren kräftigen Habitus nicht leicht, und vertragen eine ungünstige Witterung und schweren, feuchten Boden besser als die Friilhafer.

Bekanntlich hat die aufsaugende Wurzeloberfläche mit der verdunstenden Blattoberfläche in cinem gewissen Verhältnis zu stehen und gibt hieriiber cin Versuch von Haberlandt Aufschluss; darnach betrug: 


\begin{tabular}{|c|c|c|c|c|c|}
\hline & $\begin{array}{c}\text { Ober } \\
\text { der } \\
\text { suc } \\
\text { pla } \\
\text { Ter } \\
\text { I } \\
\text { qcm } \\
\end{array}$ & $\begin{array}{l}\text { äche } \\
\text { Ver- } \\
\text { as- } \\
\text { azen } \\
\text { uch } \\
\text { II } \\
\text { qcm } \\
\end{array}$ & \begin{tabular}{|c} 
Zahl der \\
Spaltöff- \\
nungen \\
auf der \\
unteren \\
Blattseite \\
pro qmm
\end{tabular} & $\begin{array}{l}\text { Terhältnis } \\
\text { des Trocken- } \\
\text { gewichts der } \\
\text { Wurzeln zu } \\
\text { jenem der } \\
\text { oberirdi- } \\
\text { schen Teile }\end{array}$ & $\begin{array}{c}\text { Ver- } \\
\text { dunstung } \\
\text { pro Tag } \\
\text { u.100qcm } \\
\text { bei W'asser } \\
\text { im Ueber- } \\
\text { fluss } \\
\text { in gr } \\
\end{array}$ \\
\hline a. Junge PHanze vor dem Schossen & 158 & 170 & 96 & $1: 1.208$ & 3.272 \\
\hline b. Mittlere PAlanze ror der Blüte & 229 & 191 & 75 & $1: 4.319$ & 2.438 \\
\hline c. Pflanze nach der Blüte & 310 & 291 & 62 & $1: 16.914$ & $2.2 s \S$ \\
\hline
\end{tabular}

Es rerdunstet die Haferpflanze rermöge ihrer grossen Blattoberfäche ron allen Sommergetreidearten am meisten, doch ist die Verdunstung ron der Flächeneinheit am wenigsten intensir, denn dieselbe stellte sich pro $100 \mathrm{qcm}$ pro Tag im Mittel

$$
\begin{aligned}
& \text { auf } 3.794 \mathrm{gr} \text { bei der Gerste } \\
& \text { " 3.532 ", , dem Weizen } \\
& \text { "2.849 ", " Roggen } \\
& \text { "2.666 " ". Hafer. }
\end{aligned}
$$

Nach den Untersuchungen Hellriegel's ergab sich als durchschnittlicher Wasserverbrauch pro Gramm prođucierter oberirdischer

\begin{tabular}{|c|c|c|c|c|c|c|c|c|c|c|c|c|c|}
\hline & Ertras & pro ha & in $\mathrm{kg}$. & Mittel & 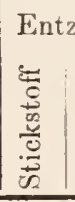 & $\begin{array}{l}\text { zug du } \\
\stackrel{0}{\frac{0}{0}} \\
\frac{\infty}{4}\end{array}$ & $\begin{array}{l}\operatorname{arch} \\
= \\
=\end{array}$ & eine & $\begin{array}{l}\text { Mitte } \\
\text { 关 }\end{array}$ & 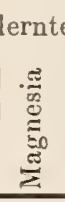 & 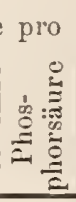 & 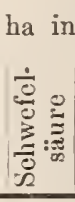 & 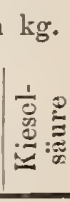 \\
\hline Iiorn & $\cdot$ & 363 & 7130 & 1100 & 21.1 & 29.0 & 4.6 & 1.1 & 1.1 & 2.0 & 6.1 & 0.4 & 13.5 \\
\hline Stroh & . & 1200 & 5500 & 2500 & 10.0 & 110.0 & 24.3 & 5.8 & 9.0 & 4.5 & 9.0 & 3.8 & 53.0 \\
\hline im $\mathrm{Ga}$ & anzen & 1568 & 12630 & 3600 & 31.1 & 139.0 & 28.9 & 6.9 & 10.1 & 6.5 & 15.1 & 4.2 & 66.5 \\
\hline
\end{tabular}
Trockensubstanz $376 \mathrm{gr}$.

Der Entzug an Pflanzennährstoffen durch eine mittlere Haferernte stellt sich pro ha wie folgt:

Gegen die Reife hin wandert der grösste Teil der wichtigsten Pflanzennälırstoffe zur Bildung des Kornes der Aehre zu und möge das folgende Beispiel ${ }^{1}$ ) die Wanderung der Proteïnkörper näher darthun.

1) Chemischer Ackersm. 1867, pg. 110. 


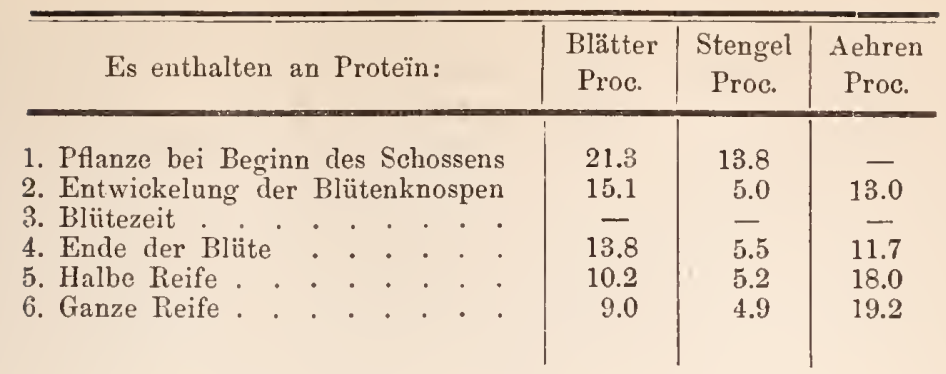

Als Feinde des Hafer's sind zunächst die Unkräuter anzufiihren und zwar auf Bruchboden, sowie auf den feuchten lumosen Thonböden der Ackersenf (Sinapis arvensis L.), der Ackerhahnenfuss (Ranunculus arvensis L.), der gemeine Knöterich (Polygonum Persicaria L.), und der Wasserpfeffer (Polygonum Hydropiper L.). Die Lehmmergel-, Lehm- und sandigen Lehmböden bieten der Feldkratzdistel (Cirsium arvense Scop.), dem Wildhafer (Avena fatua L.), der Quecke (Triticum repens L.), der Saatwucherblume (Chrysanthemum segetum L.), sowie auch dem schon erwähnten gemeinen Knö̈terich einen sehr günstigen Standort. Ferner ist als ein dem Hafer sehr gefährliches Unkraut der Hederich (Raphanus Raphanistrum L.) zu erwähnen, der ihn namentlich auf den leichten lehmigen Sandböden zu unterdriicken vermag.

Auf den Sandböden kommen vor: Feldrittersporn (Delphinium Consolida L.), Feldspörgel (Spergula arvensis L.), stinkende Hundskamille (Anthemis Cotula L.), Kreuzkraut (Senecio vernalis W. K.), rauhhaarige Hanfnessel (Galeopsis Tetrahit L.), bunter Daun (Galeopsis versicolor Curt.), und kleiner Sauerampfer (Rumex Acetosella L.). Ist der Sandboden jedoch kalt und feucht, so findet sich häufig in grossen Massen der gemeine Windhalm (Agrostis Spica renti L.) ein.

Die Pflanzenkrankheiten des Hafers, welche durch Pilze erzeugt werden, sind im Allgemeinen denen der Gerste identisch. Gefährlicher als der Gerste ist ihm der Rost und treten Gras- oder Streifenrost (Puccinia graminis Pers.) und der am häufigsten vorkommende Kronenrost (Puccinia coronata Corda) auf, und wird die Aecidienform dieses Pilzes auf dem Faulbaum (Rhamnus Frangula) und dem Kreuzdorn (Rhamnus eathartica) erzeugt, daher diese Pflanzen aus der Nähe der Haferfelder zu entfernen sind.

Nach Sprengel wird durch diese Rostpilze der Ertrag zuweilen um 66 Proc. vermindert, ausserdem wird das Stroh stark befallenen Hafers derart mürbe, dass es auf dem Halme zusammenbricht und schliesslich seinen Futterwert verliert, während die Körner verkümmern. 
Von allen Getreidearten befällt der Hafer am meisten mit dem Russ- oder Flugbrand (Ustilago Carbo Tul.), der in der Regel sämmtliche Schösslinge einer Pflanze ergreift und deren Aehrchen zerstört, doch lält sich auch bei ihm der Schaden meist in mässigen Grenzen, und eine Zerstörung des achten Teils der Pflanzen, wie Sprengel anführt, habe ich niemals beobachten können. Bei einer solchen hochgradigen Infektion dürfte es sich empfehlen, das Saatkorn in derselben Weise wie bcim Weizen mit schwefelsanrem Kupferoxyd zu beizen.

Sehr selten erscheint dagegen das Mutterkorn (Clariceps purpurea Tul.).

Als Präservatir gegen diese Krankheiten empfiehlt sich die Kultur des Hafers in luftiger, trockner Lage, sowie die Entfernung derjenigen Pflanzen ans der Nähe der Haferfelder, welche die Aecidienform der Rostpilze zu erzeugen vermögen.

Die Anzahl der den Hafer schädigenden tierischen Feinde ist verhältnismässig gering. Die Wurzeln werden durch die Larven des Maikäfers (Melolontha rulgaris F.), des Saatschnellkäfers (Agriotes lineatus L. und obscurus Gyllh.), sowie durch die Maulwurfsgrille (Gryllotalpa vulgaris Latreille), und die Raupe der Graseule (Charaeas graminis L.) angegriffen. Finden sich Rubennematoden (Heterodera Schachtii) in einem Felde, so können diese auf den Hafer übergehen, und dureh Aussaugen des Saftes an den Wurzeln es dahin bringev, dass die Pflanzen kümmern oder eingehen, also die sog. „Hafermüdigkeit" des Feldes erzeugen.

Die jungen Pflanzenteile werden in Schweden durch einen Blattkäfer (Phyllotreta vittula) und in Nord-Amerika durch die Raupe ron Lencania obsoleta Hübn. abgefressen. Durch Saugen des Saftes in den Blattscheiden erwies sich in Poppelsdorf eine Milbe (Phytoptus) sehr nachteilig und scheint der sog. Senger des Hafers durch sie hervorgebracht zu werden. Durch Aussaugen des Saftes in den Blattscheiden und an der Oberseite der Blätter schädigt auch, wenngleich selten erheblich, die Hafer-Blattlaus (Aphis Arenae Fabr.).

Sehr gefährlich und auch "Hafermiidigkeit" des Bodens veranlassend, sind die Stockälchen (Anguillula derastatrix J. Kühn), welche in den Geweben des jungen Pflänzchens leben.

Die Blätter werden durcl Abschaben der Oberhant durch Käfer und Larven des rothalsigen Getreidehähnehens (Lema melanopus L.) und durch Minieren in den jungen Blättern von Seiten der Larre ron Hydrellia griseola Fall. verletzt. Die Körner frisst auf dem Kornboden die Larre der Kornmotte (Tinea granella L.) aus. 


\section{Klima.}

Die Verbreitnngszone des Hafers ist weit weniger ausgedehnt als die der Gerste, denn sehon in der wärmeren, gemässigten Zone findet sieh, mit Ausnahme der höheren Gebirgslagen, Haferbau verhältnismässig selten, weil ihm ein trocknes Klima nit hoher Sommertemperatur wenig zusagt; und andererseits reieht er, da seine Vegetationsperiode länger als die der Gerste ist, weniger weit als diese in die arktisehe Zone linein.

Die Vegetationsperiode des Hafers schwankt zwischen 88 und 150 Tagen, und bezeichnen wir diejenigen Sorten, welehe in Deutsehland binnen 120 Tagen ausreifen, als Frühhafer. Selbstverständlich sind die nordischen Hafersorten Frühhafer, denen die Tendenz innewohnt, verhältnismässig sehncll, allerdings auf Kosten der Produktion, auszureifen. Je länger jedoeh die Sommer und je geringer die Schwankungen der Tagestcmperaturen einer Gegend sind, um so mehr vergrössert sich der Habitus der Pflanzen und verlängert siclı die Vegetationszeit.

Letzteres bestätigen die naehfolgenden Zahlen, welehe aus Beriehten des Dr. Wittmaek ${ }^{1}$ ) iber vergleiehende Kulturen mit nordischem Getreide entnommen sind, und zwar diente ein hochnordischer Hafer ans Umeå, und ein deutscher Hafer aus Nauen zur Vergleiehmug.

\begin{tabular}{|c|c|c|c|}
\hline Ort des Versuches. & Hafersorte & $\begin{array}{c}\text { Temperatur- } \\
\text { summen } \\
0 \mathrm{C} \text {. }\end{array}$ & $\begin{array}{c}\text { Vegetations- } \\
\text { dauer } \\
\text { in Tagen }\end{array}$ \\
\hline \multirow[t]{2}{*}{ Mauen bei Königsberg } & Umeå & 1406.06 & 86 \\
\hline & Nauen & 1694.56 & 107 \\
\hline \multirow[t]{2}{*}{ Proskau in Schlesien. } & Umeå & 1610.37 & 98 \\
\hline & Nauen & 1758.50 & 107 \\
\hline \multirow[t]{2}{*}{ Zabikowo, Posen } & Umeả & 1486.05 & 93 \\
\hline & Nauen & 1628.87 & 101 \\
\hline \multirow[t]{2}{*}{ Eldena bei Greifswald } & Umeå & 1404.37 & 103 \\
\hline & Nauen & 1518.52 & 113 \\
\hline \multirow{2}{*}{ Leipzig . . . . . . } & Umeå & 1612.05 & 95 \\
\hline & Nauen & 1679.35 & 98 \\
\hline \multirow{2}{*}{ Göttingen . . . . . } & Umeå & 1585.90 & 108 \\
\hline & Nauen & 1771.30 & 117 \\
\hline \multirow[t]{2}{*}{ Poppelsdorf bei Bonn } & Umeå & 1533.10 & 106 \\
\hline & Nauen & 1629.81 & 113 \\
\hline \multirow[t]{2}{*}{ Verrières bei Paris . } & Umeå & 1715.90 & 101 \\
\hline & Nauen & 2060.20 & 113 \\
\hline \multirow[t]{2}{*}{ Kothamsted, England } & Umeå & 1708.20 & 134 \\
\hline & Nauen & 1708.20 & 134 \\
\hline
\end{tabular}

1) Landw. Jalırb. V, 1876. 
Das Klima der kälteren, gemässigten Zone sagt dem Hafer unstreitig am meisten zu, namentlich sobald es nicht an Feuchtigkeit fehlt. In diesem Klima gedeihen die kräftigsten Hafersorten und liefern die schwersten und feinschaligsten Körner.

Die Ansprïche der Hafersorten sind in Bezug auf das Klima sehr verschieden, z. B. werden in der wärmeren, gemässigten Zone, wie in der Türkei, in Italien, Spanien, Portugal etc. vorzugsweise Sorten der Varietäten Arena sativa rubida, trisperma und aristata gebaut, auch gedeihen, soweit die Olivenkultur reicht, die sehr weichlichen Winterhafer von A. s. grisea und cinerea. In den Länderı del kälteren, gemässigten Zone präralieren auf gutem Boden und im Seeklima die besten weissen Rispenhafer der Varietät A. s. mutica, doch werden auch vielfach, namentlich im nordwestlichen Frankreich Sorten von A. s. brunnea, nigra und aurea, und in Schottland, den nordwestlichen Staaten der amerikanischen Union, sowie in Canada häufig Sorten von A. s. praegravis kultiviert. Seltener tritt in diesen Gebieten der Fahnenhafer (Avena orientalis) auf, doch findet sich derselbe auf den guten Böden des südöstlichen Europas und hauptsächlich in Rumänien verbreitet. In rauhen Gebirgslagen wird auch noch in Deutschland A. s. aristata und montana und in den Bergen der Auvergne (1000-1300 m hoch), Avena brevis und strigosa gebaut.

In den höheren Gebirgslagen und je mehr sich die Kultur der subarktischen Zone nähert, treten sehr frïhreife Sorten der Varietäten A. s. mutica und aristata auf, weil in jenen Gcbieten die Haferernte durch Spätfröste, wenn der Frost den Hafer im Milchsaft trifft, geschädigt wird, und die Ernte in die regenreiche, kïhle Witterung des Spätherbstes fallen würde.

Im Allgemeinen ist die junge Haferpflanze vor der Bestockung gegen nasskalte Witterung auch empfindlicher als dic Gerstc.

Die Kultur der Nackthafer tritt nur sebr vereinzelt innerhalb der kälteren gemässigten Zone auf und erstreckt sich vornehmlich auf Ostasien, namentlich auf China und Japan.

\section{Boden.}

Der Hafer ist die einzige Getreideart, deren Kultur sich auf alle Bodenarten erstreckt, und selbst noch in Folge seines grossen Wurzelund Blattvermögens auf an Pflanzennährstoffen armen Böden verhältnismässig hohe Erträge bringt, weshalb man ihn mit Vorliebe auf den ausgetragenen und armen Ländereien kultiviert. Andererseits wirft er 
auf len kräftigen, reichen Böden nicht selten höhere Brutto- und aneh Reinerträge $a b$, als die iibrigen Getreidcarten. Ferner befähigt ibn seine verhältnismässig lange Vegetationsperiode und sein bedeutendes Wurzelverınögen, die sich im Boden zersetzenden Pflanzenreste auszunutzen, weshalb er gern anf friseh umgebrochenes Weide- und Luzerneland oder Klecdresch gebracht wird, anch sagen ihm sehr humose und an Nälırstoffen reiehe Böden besonders zil, z. B. Neubrueh und Moorland, auf denen er sich mehrere Jahre hintereinander mit dem besten Erfolge bauen lässt.

Der Hafer verträgt aber auch die verschiedenartigste physikalisehe Beschaffenheit des Bodens, was zur Genüge ans seinem Verhalten auf den sehr feuehten, selbst sehwammigen und sauren Humusund Torfböden hervorgeht, welehe sich hänfig nur dureh ihn vorteilhaft benutzen lassen. Andererseits liefert er auf den sehr leichten Sand- und Kalkböden, wenn diese zur Saatzeit nieht zu trocken sind, und während des Sehossens einen ausgiebigen Regen crhalten, noch befriedigende Ernten, vorausgesetzt, dass mit der ungiinstigeren Gestaltung der Produktionsfaktoren auch eine erhölite Sorgfalt in der Kultur gleiehen Sehritt hält. Ebenso lässt sich dureh Meliorationen auf diesen extremen Bodenarten viel helfen, z. B. auf den nassen Thon- oder humosen Böden dureh eine zweekmässige Entwässerung, auf Thonboden durch Kalkung, auf Humusboden dureh Uebererdung, und auf den loekeren Sandböden dureh Mergelung, Befahrung mit Thon, Lehm oder Humns zur Vermehrung der wasserfassenden nud wasserhaltenden Kraft des Bodens und iiberhaupt zur Förderung seiner Produktionskraft.

Giinstige Ernteergebnisse lassen sieh aber nur dann erwarten, wenn auch den Bodenansprüchen der Sorten entsprechend Rechnung gretragen wird, da sie in dieser Beziehung sehr erheblieh von einander abweichen.

Die höehsten Anforderungen an den Boden stellen sonder Zweifel die Winterhafer, da sie nur auf durchlässigen, warmen. nieht zu losen und an Nährstoffen reiehen Böden gedeihen. Holıe Anspriiehe erheben aneh die spätreif'en, weissen, ungegrannten Rispenhafer, die ibre höchste Vollkommenheit nur auf den nahrungsreichen Lehmböden erreichen. Die im Habitus sehr kräftigen, viel Stroh, wenn auch verhältnisnässig weniger Körner erzeugenden, daher vielfach zur Grinfintterproduktion dienenden Fahnen- und Goldhafer gelangen am besten auf den reichen humosen und sehweren Thonböden zur Kultur.

Die diekkörnigen Sorten der Varietät „A. s. praegravis" sind auf den von Natur reiehen und humosen Böden der Steppen, z. B. in Nord-Amerika zu kultivieren, wenngleich sie anch auf sehr humosem Boden, selbst Torfboden gedeihen. 
Für sehr leiehte oder troekne Böden passen die frühreifen weissen Rispenhafer, sowie die Sorten der Varietäten „A. s. aristata, montana und rubida".

Mit besonders guten Erfolge kommen auf den Moor-, Bruchnnd gerodeten Waldböden die braunen und sehwarzen Sorten der Tarietäten „A. s. brumea und nigra" zur Kultur.

Da sieh nun der Hafer. wie sehon oben herrorgehoben wurde. auf allen Bodenarten, wenugleieh nieht immer mit gleieh gutem Erfolge anbanen lässt, so rerweise ieh auf das schon im „Allgemeinen Teil" über den Boden Gesagte.

\section{Dïngnng.}

Obrohl ron allen Getreidearten der Hafer noch am besten auf entkräftetem Boden gedeiht, ist er doeh für alte Bodenkraft, sehneli wirkende Kunstdiinger, Kompost, sogal für frisehe Stallmist- und Grïndüngung sehr dankbar, weshalb unter Umständen eine Düngung nioht nur für den Ertrag. sondern aueh für die Krafterhaltung des Bodens ron grossem Nutzen sein kann.

Der Hafer verträgt, olne zu lagern oder stark mit Rost zu befallen, relatir leicht einen sehr reiehen Boden, wie seine Kultur auf dem Sehlamm abgelassener Fisehteiehe, auf umgebrochenem Weideund Luzerneland bereist.

Auf des Dunges bedürftigen Aeekern lässt sieh, namentlieh auf leiehten Böden, gnt zersetzter Kompost sehr erfolgreich verwenden, sobald derselbe entweder zeitig im Frïhjahr eingegrubbert oder gleiehzeitig mit der Saat untergebraeht wird. Er stellt dann der jungen Pflanze einen reichliehen Vorrat leieht aufnehmbarer Pflanzennährstoffe zur Terfiugung, in Folge dessen sieh der Halm und die Bestoekung kräftigt und die Pflanze leichter nachteiligen Titterungseinfliissen zu widerstehen vermag, während eine tiefere Unterbringung weniger für die erste kritisehe Jugendzeit der Pflanze nutzt. In ähnlieher Weise wie der Kompost wirkt auf leiehtem Boden aueh die Pferehdingung.

Soll der Aeker dureh Kunstdünger gekräftigt werden, so wendet man im Herbst oder zeitig im Früljahr auf leiehtem Boden Knoehenmehl, auf sehwerem Ammoniak-Superphosphat in Quantitäten ron $200-300 \mathrm{~kg}$ p. ha an, und bringt sie durch Krimmern, flaehes Unterplftigen oder Eineggen unter.

Auf den sehr lumosen Böden gibt man $200-300 \mathrm{~kg}$ Knochenmehi und $20 \mathrm{~kg}$ Kalisa! 
Eine Kopfdïngung ist für kränkelnde Saaten ebenfalls im hohen Grade empfehlenswert und steht hierfür der Stickstoffdiinger in Form des Chilisalpeters in erster Reihe, ron dem auf stickstoffarmem Boden bis $160 \mathrm{~kg}$, für gewöhnlich jedoch nur $100 \mathrm{~kg}$ p. ha möglichst zerkleinert und sorgfältig iiber den Hafer, sobald er das dritte Blatt gebildet hat, gestreut werden. Bei gleichzeitig hervortretendem Mangel an Phosphorsäure verwendet man auf den absorptionsfähigen Böden als Kopfdüngung zur besseren Ausbildung der Körner $100-200 \mathrm{~kg}$ hochgradige Superphosphate pro Hektar.

Der frische Dung kommt im Allgemeinen dem Hafer noch zu statten, wenn derselbe vor Winter aufgebracht und womöglich untergepflügt wurde, damit er Zcit zur Zersetzung erhält, also der jungen Pflanze eine reichliche Menge von Pflanzennährstoffen während ihrer Vegetationszeit zugeführt wird; geschieht aber die Düngung und Unterbringung spät, dann kommt der Dung zu wenig zur Geltung, auch wächst und reift darnach der Hafer leicht ungleich.

Eine schwache Stallmist-Dïngung wirkt namentlich auf den armen, leichten Böden, wenn nicht eine stark geduingte Frucht denı Hafer roranging, in hervorragender Weise und lässt sich, da der Hafer für dieselbe sehr dankbar ist, nur empfehlen, zumal auf diesen leichten Bodenarten Kunstduinger relativ wenig leisten.

Aber auch die Grïndïngung sagt auf sandigen Feldern dem Hafer besonders zu. Man säet hier zweckmässig unter Roggen, dem der Hafer häufig folgt, im Frihjahr Serradella und Lupinen, oder nach dem Umbruch der Roggenstoppel weissen Senf, der, wenn der Boden nicht zu arm ist, his zur Zeit des Unterpfligens, Ende Oktober, noch eine recht beträchtliche Höhe erreichen kann.

\section{Fruchtfolge.}

Dic besten Vorfrïchte des Hafers sind unstreitig stark gedüngte und gut bearbeitete Hackfriichte, z. B. auf leichtem Boden die Kartoffeln, auf Humusboden die Kohlrïben, auf Lehmboden die Runkelrüben und auf Thonboden dic Pferdebohnen; ferner gedeiht der Hafer nach Rotklee oder Kleedresch vortrefflich, wenn der Klce nicht in den abtragenden Schlag, sondern dicht nach einer Düngung eingesäet wurde, und auch dementsprechend einen dichten Bestand aufwics. Nach solchen Vorfiüchten findet der Hafer eine reichliche Menge leicht aufnehmbarer Näbrstoffe, sowie einen ron Unkraut 
nahezu freien und gut zermürbten Boden vor, also Bedingungen, die sein Wachstum wesentlich fördern. Recht gute Vorfrüchte sind auch gedüngte Hiilsenfrüchte, Grïnfuttergewächse und Wintergetreide.

Folgt der Hafer, wie dies läufig in der Koppelwirtschaft der Fall ist, im abtragenden Schlag nach Gerste, so wird sein Ertrag: bei den hohen Ansprüchen der Gerste an die Bodenkraft wenig befriedigen, und dasselbe ist mit seiner Stellung nach Stoppelriiben der Fall.

Der Hafer ist num auf nicht zu armem Boden keincswegs als schlechte Vorfrucht fiur gediungte Winterung oder Kleegras zu erachten, denn bei dichtem Stande hinterlässt er ein reines, lockeres Land und recht anschnliche Quantitäten an Stoppel- und Wurzelrückständen, die an wertvollen Pflanzeunährstoffen, z. B. an Phosphorsïure, die der anderen Getreidearten iibertreffen, und fauden sich nach unseren Untersuchungen in Proskau bis zu einer Ticfe rou $26 \mathrm{~cm}$ pro ha in $\mathrm{Kg}$ vor: an wasserfreien Stoppel- und Wurzelriickständeu $3725.7 \mathrm{~kg}$, Stickstofi $30.0 \mathrm{~kg}$, Asche $1614.6 \mathrm{~kg}$ und darin an: Kalk $95.9 \mathrm{~kg}$, Magnesia $13.6 \mathrm{~kg}$, Kali $27.9 \mathrm{~kg}$, Natron $20.3 \mathrm{~kg}$, Schwefelsäure $9.9 \mathrm{~kg}$, und Phosphorsäure $33.5 \mathrm{~kg}$.

Auch ist zu beachten, dass sich der Hafer mit Hiilfe seines grossen Wurzelvermögens die Pflanzennährstoffe aus grösseren Tiefen leichter anzueignen vermag, als die tibrigen Getreidearten, daher derselbe auch weit weniger als z. B. die Gerste die oberste Schicht der Ackerkrume an fertiger Pflanzennahrung erschöpft.

Mit sich selbst ist der Hafer sehr verträglich, in Folge dessen el sich auf' reichem Boden, z. B. in abgelassenen Fischteichen, auf Neuland etc. sehr gut obne wesentliche Ertragsminderung mehrmals hinter cinander anbanen lässt; in der Regel bringt man ihn jedoch erst nach 4-5-6 Jahreu auf dasselbe Feld zurïck.

Wegen seines bedeutenden Wurzel- und Blattvernöigens, welche ihn in den Stand setzen, noch spärlich vorhandene Nährstoffreste aufzusammeln und sich anzueignen, säet man ihn auch in den abtragenden Schlag, wic dies z. B. in den Koppelwirtschaften gebräuchlich ist, wo nicht selten auf Weizen und Gerste der Hafer folgt.

\section{Bodenbearbeitung.}

Dic Bodenbearbeitung ist in der Weise durchzufiihren, dass die licstellung nöglichst zeitig im Frühjahr geschehen kaun, der Acker uicht zu locker ist und ihm namentlich auf leichtem Boden die zum grleichmässigen Auflaufen und kräftigen Wachstum der jungen Pflanzc 
notwendige Feuchtigkeit erhalten bleibt, sowie auch cine möglichst durchgreifende Zerstörung der Samen- und Wurzelunkräuter erzielt wird.

A us allen diesen Griinden sollte es Grundsatz sein, die Pflugarbeit stets vor Winter zu beenden, so dass im Frühjahr nur noch Grubber, Egge und Walze in Thätigkeit treten.

Der Hauptsache nach sollte sich die Bearbeitung zu Hafer nach der Bodenbeschaffenheit und der Vorfrucht richten, und auf eine gute Bearbeitung Wert gelegt werden, denn obwohl der Hafer vou allen Cerealien die wenigst gute Bearbeitung noch am besten verträgt, ist er doch andererseits für eine sorgsame Vorbereitung des Bodens äusserst dankbar.

Nach Hackfrüchten bricht man das Feld vor Winter bis zur vollen Tiefe der Ackerkrunı um, und eggt im Frübjahr, wodurch der leichte oder humose Boden geniigend zur Saat vorbereitet wird, während auf schwerem, bindigem Boden im Frîhjahr ein einmaliges und selbst zweimaliges Grubbern über Kreuz folgen muss, um den zu sehr geschlossenen Boden wiederum zu lockern. Nach Klec oder Kleedresch wird im Herbst die Kleenarbe am besten mit mehrscharigen Pflitgen umgerissen und mit einer schweren Walze zum besseren Verwesen der Pflanzenriuckstände an den Boden angedriickt, hierauf wird kurz vor Eintritt des Winters geeggt, event. noch einmal gewalzt und die Saatfurche gegeben. Aebnlich ist die Bearbeitung alten Gras- und Weidelandes, nur dass man dasselbe im Herbst gern mit Hülfe des Doppelpflügens umbricht, d. h. es laufen zwei Pflüge hintereinander in derselben Furche, von denen der erste die Narbe nur auf $8 \mathrm{~cm}$ schält, und der zweite diesclbe mit frischer Erde, und zwar zum schnellen Verwesen $12-15 \mathrm{~cm}$ hoch bedeckt. Ein gleich gutes Resultat lässt sich auch durch Verwendung von Rajolpflïgen mit Schälschaar erreichen. Dic an die Oberfläche gebrachte frische Ercle wird über Winter durch den Frost gelockert und zermürbt, während der Rasen verwest, so dass nach dem Abtrocknen des Feldes im Frülijahr dic Aussaat sofort erfolgen kann.

Auf Lehmböden, wenı der Hafer einer Hülsen- oder Halmfrucht folgt, stürzt man die Stoppeln möglichst bald nach der Ernte, und eggt nach dem Auflaufen der Unkrautsamen; hierauf bleibt das Feld liegen, bis es sich von netem begrünt hat, um dann noch vor Winter bis zur vollen Tiefe der Ackerkrume die Saatfurche zu geben, im Frühjahr, namentlich wenn Wurzelunkraut zu fuirchten, wird geeggt, und uber Kreuz gegrubbert. Auf Sandboden ist die Bodenbearbeitung dieselbe, nur fällt das Grubbern im Frühjahr meist fort, wenn der Boden nicht verschlämmt oder verqueckt ist. 


\section{Aussaat.}

Die Zeit der Aussaat richtet sich in der Hauptsache nach der Wärmezone, der Höhenlage, der Witterung und der Bodenbeschaffenheit. Gemeinhin wird in der wärmeren, gemässigten Zone, in welcher relatir wenig Hafer, und vorzugsweise Sorten der Varietäten A. s. rubida, grisea und cinerea gebaut werden, der Somnierhafer im Februar und März, der Winterhafer von September bis Mitte December gesäet, wenngleich die späte Saat rom November ab unsicher ist, weil die noch sehr jungen Pflanzen zu leicht unter starken Herbstregen und Nachtfrösten leiden.

Im kälteren, gemässigten Klima fällt die Aussaatzeit in der Regel in die Monate März und April und nur in sehr rauhen Lagen, oder auf schwerem Boden und bei ungunstiger Witterung ausnahms. weise in den Mai.

Im westlichen und suidlichen Frankreich z. B. in der Bretagne und den Ebenen des Languedoc säet man den Winterhafer (Heuzè) ron Anfang Scptember bis Anfang November, den Sommerhafer auf leichtem Boden im Februar und März, während auf den schweren Böden des nördlichen Frankreichs, beispielsweise in der Brie und den Poldern Flanderns die Aussaat in der zweiten Hälfte des April bis Anfang Mai bewirkt wird. In Grossbritannien und Irland säet man ron Anfang März bis Ende April, und wird die Zeit bis Mitte März für dic günstigste gehalten. Ausnahmsweise kommt in SüdEngland die Aussaat Ende Februar vor.

In der subarktischen Zone tritt die Saatzeit, je nach Boden und Witterung, im April und Mai ein.

Im Allgemeinen gilt für den Hafer derselbe Grundsatz wie für die Gerste, seine Aussaat, den Umständen gemäss, möglichst zeitig zı bewirken, weil die Erträge im Korn und Stroh sich nach Quantität und Qualität günstiger als bei später Saat gestalten, denı früh gesäeter Hafer leidet namentlich auf leichtem Boden weniger durch die Trockenheit und widersteht auch besser dem Rost, weil seine Blätter beim Auftreten desselben schon kräftiger sind und daher eine geringere Krankheitsdisposition besitzen. Die Riicksicht auf die Nachtfröste kann für die Aussaatzeit nicht nussgebend scin, zumal häufig gerade die späte Aussaat, weil die Pflänzchen bei spät eintretenden Frösten noch sehr klein sind, weit mehr als dic friihe Aussaat leidet.

Fordern die wirtschaftlichen Verhältnisse einen späten Eintritt der Ernte, so lässt sich dies durch richtige Auswahl einer späten Hafersorte erreichen, welche bei frübel Aussaat in der Regel böhere Erträge als späit gesäeter Friihhafer abwirft. 
Ueber die grossen Vorteile friiher Aussaat gibt ein interessanter Versuch von $\mathrm{Crampe}{ }^{1}$ ) Aufschluss, welcher auf den Versuchsfelde z, Proskan sechs englische Hafersorten zu vier verschiedenen Aussaatzeiten anbaute und fand, dass, trotzdem die erste Saat erheblich durch Frost beschädigt wurde, denn wenigstens ein Drittel der Pflanzen war eingegangen, sich doch herausstellte, dass die Erträgc an Körnern, Stroh und Spreu in demselben Masse abnahmen, als sich die Vegetationszeit des Hafers verkürzte, wie dies dic nachstehende Uebersicht zeigt:

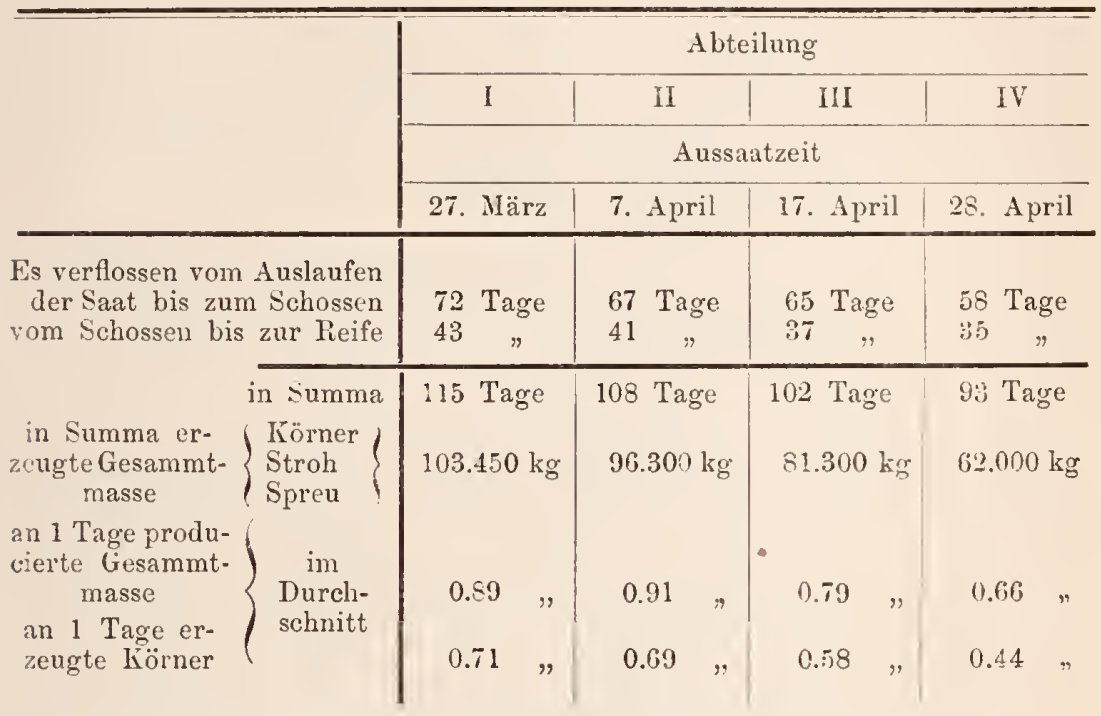

Die Höhe der Erträgc sowohl an Gesammtmasse, als auch an Körnern cntspricht bei den Abteilungen I und II genau de: Länge der Vegetationszeit der damit bestellen Friichte, bei beiden kommt auf einen Tag Vegetationszeit fast cin ganz gleiches Quantum an producierter Gesammtnasse resp. an erzengten Körnern; jeder Tag späterer Bestellung wird durch cinen Verlnst an Stroh, Spren und Körvern gebüsst. Diese Verluste gestalten sich bei den ubrigen Abteilungen um so grösser, je weiter hinaus die Bestellung geschoben und je mehr dadurch die Vegetationszeit der Pflanze rerkiirzt wird.

Aber nicht genug an dem, dass der Ertrag an Gesanmtmasse ein geringerer wird, auch das Verhältnis zwischen derselben und den producierten Körnern gestaltet sich zu Ungunsten der späten Saat. Bei der am 27. März bestellten Abtcilıng waren dem Hafer 115 Tage Vegetationsdaner zugemessen, der Ertrag an Körnern beträğ 30 Proc. der Gesammtmasse. Bei Abteilung II, bestellt am 7. April, Kommen

1) Der Landwirt No. 86. 1873. 
bei 108 Tagen Vegetationsdauer gleichfalls 30 Proc. der Gesanmtmasse auf Körner.

Auf Abteilung III, bei 102 Tagen Vegetationsdauer der Frucht, kommt nicht allein auf den Tag nur eine Production von 0.79 Kilo Gesammtmasse, statt 0.89 Kilo bei Abteilung I, sondern der Ertrag an Körnern beträgt nur 26.5 Proc. der Gesammternte. Noch ungünstiger stellt sich dieses Verhältnis auf Abteilung IV dar, hier sind in der Ernte nur 25 Proc. Körner enthalten.

Die Saatquanta des Hafers wechseln je nach den Witterungsund Bodenverhältnissen, nach der Kulturart, der Grösse des Saatkorns, dem Habitus und der Bestockungsfähigkeit der Sorte in erheblichem Massc, und schwankte z. B. der Wachsraum der Pflanze in Poppelsdorf unter gleichen klimatischen und Bodenverhältnissen bei den beschalten Hafervarietäten zwischen 30 und $45 \mathrm{qcm}$, bei den nackten zwischen 12.5 und $33.3 \mathrm{qcm}$.

In der auf Seite 761 für Poppelsdorf entworfenen Saattabelle werden die mittleren Saatquanta der rerschiedenen Hafervarietäten anfgeführt und bemerken wir zu derselben, dass die Drillweite $20 \mathrm{~cm}$ betrug.

Dieser Tabellc ist hinzuzufiigen, dass im konkreten Falle die Saatquanta auch durch die Aussaatzeit mit bestinmt werden und dass eine um 14 Tage gegen die nolmale Aussaatzeit verspätete Aussaat das Saatquantum um cin Zehntel zu vermchren ist. Von sehr viel bedeutenderem Einfluss ist ferner die Bodenbeschaflenheit, weil sie hauptsächlich den Habitns der Pflanzen bestimmt, und lïsst sich annehmen, dass, wenn auf sehr reichem Boden das Saatquantum $=1$ ist, dasselbe auf Mittelboden schon $=1.5$ und auf leichtem Boden $=2$ sein kanı, wobei jedoch selbstrerständlich noch Kulturart und Pflege zu beriicksichtigen sind.

Zur Vergleichung der Saatquanta unserer Tabclle mit denen älterer Autoren, diene folgende Znsammenstellung: Es empfehlen zur Aussaat: Burger auf sehr gutem oder frisch gedüngtem Boden p. ha $2.85 \mathrm{hl}$, in zweiter Tracht $4.28 \mathrm{hl}$ und in schlechtester Lage $5.70 \mathrm{hl}$; Podewils (langjähriger Durchschnitt auf Bruchboden) $5 \mathrm{hl}$; Koppe auf sandigem Lehm $3.3 \mathrm{hl}$, Thonboden $4.4 \mathrm{hl}$; Schweitzer $3.3-3.8 \mathrm{hl}$; Block im Mittel $2.75 \mathrm{hl}$; Thacr $8 \mathrm{hl}$; Veit $3.8 \mathrm{hl}$ und Hlubek 4 hl. In England säet man nach $A$. Young auf reichem Boden 3.5-4.3 hl, auf armem Boden $5.35 \mathrm{hl}$ bis $7 \mathrm{hl}$. Nach Schwerz werden auf den in hoher Kultur stehenden Böden der Niederlande gesäct: auf reichem Saudboden $2.25 \mathrm{hl}$, in den Poldern $2.75-3 \mathrm{hl}$, auf dem Sand der Kampine $3.4 \mathrm{hl}$. Die Saatquanta stellen sich nach Heuzć in Frankreich für reichen Boden auf $2.5-3.2 \mathrm{hl}$, für armen Boden und späte Saat auf $5.0-6.0 \mathrm{hl}$ und für Drillsaat $(16 \mathrm{~cm}$ Reihenentfernung) auf $1.5-2 \mathrm{hl}$. 


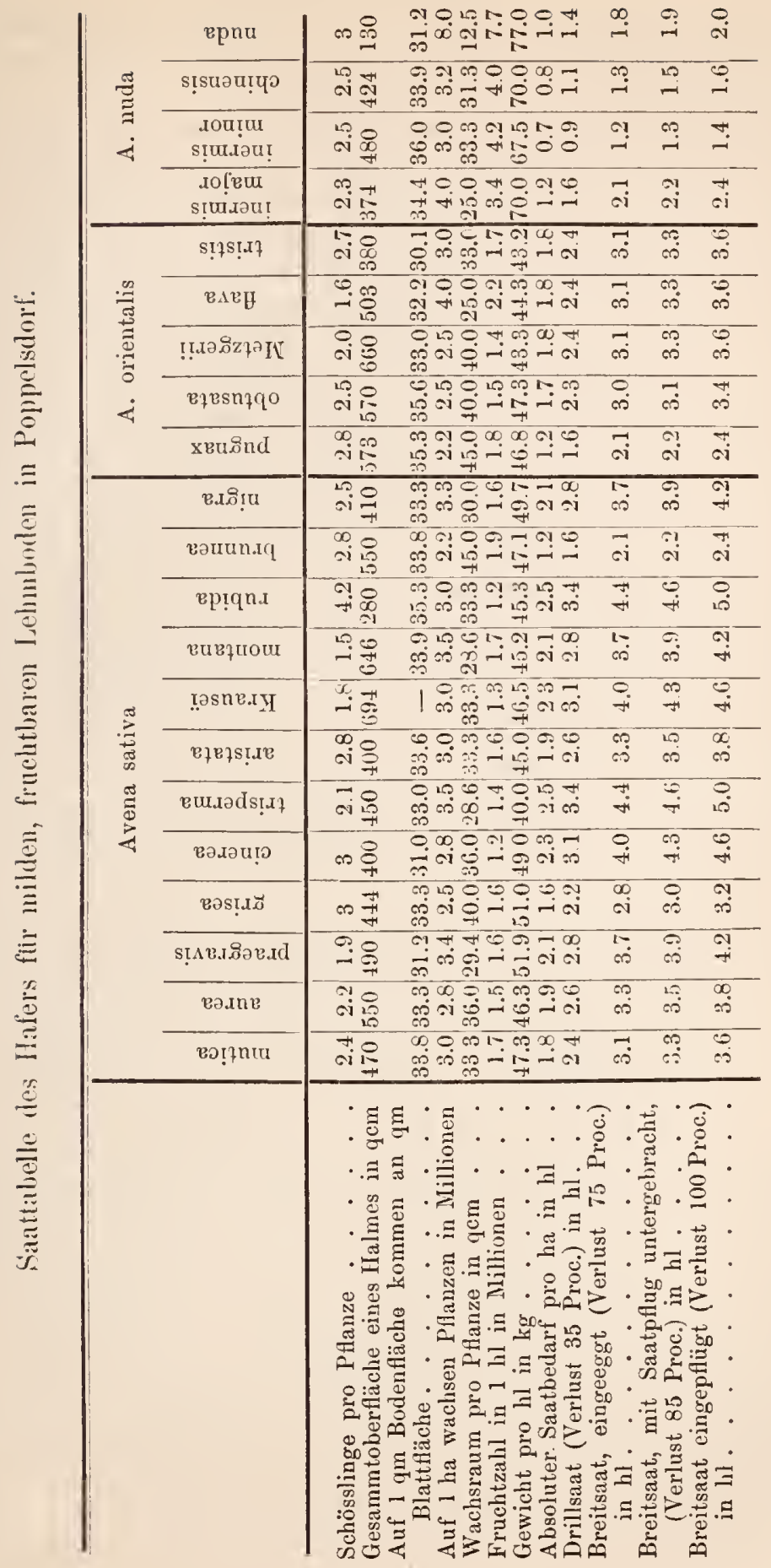


Bein Winterlafer richtet sich die Saatmenge hauptsächlich naeh dem Zeitpunkt der Aussaat und werden bei frïher Saat 2.5$3 \mathrm{hl}$ und bei später $3.5-4 \mathrm{hl}$ p. ha gesäet.

In Betreff der Säemethoden ist zu bemerken, dass auf leichtem Boden der Hafer sehr häufig breitwürfig mit der Hand auf die rauhe Furche gesäet und durch Eineggren untergebracht wird, ein Verfahren, dass nur zur Saatverschwendung. sowie zu ungleichem Auflaufen der Samenkörner und mngleichem Wachstum der Pflanzen führt, demnach zu verwerfen nnd höchstens mur auf selir verrasten Böden, z. B. auf Neulaurl anwendbar ist. Weit mehr empfiehlt es sich, auf den leichten Sand- nnd miłden Lehmböden die Aussaat auf das glattgeegrgte, beziehungsweise gewalzte Land durch eine Breits:ienaschine zu berrirken, und die Samenkörner mit Hiilfe von Krümmereggen oder mehrschaarigen Saatpflïgen bis zur wiinschenswerten 'Tiefe nnterzubringen, und später zur besseren Vertilgung der aufgelaufenen Unkräuter und event. zur Brechung der Kruste, wenn der Graskein schon einige Centimeter lang ist, glatt zu eggen. Durch dieses Verfahren werden die Samenkörner weit gleichmässiger als auf́ die rauhe Furche ansgesäet und untergebracht, was fiir die gleichmässige Entwickelung nnd den normalen Stand der Pflanzen ron grösster Wichtigkeit ist. Ebenso darf auch anf den schweren, feuehten Böden die Aussant niemals auf die rauhe Furche erfolgen, sondern nur auf gut rorgeeggtcm Lande, da hier eine genügende Tiefe der Unterbringung; dureh Eineggen mit eisernen Egren erzielt werden kann.

Die empfehlenswerteste Kulturmethode bleibt aber unzweifelhaft die Drillkultur, welehe vorzngsweise in England, den Niederlanden, Belgien, Nord-Frankreich, Nord-Deutsehland und Dänemark immer mchr, nlit Ausuahme auf den sehr leiehten Sandböden oder den nuit vielen nuzersetzten Pflanzenresten verschenen Humusböden, zur Anwendung gelangt.

In der Regel dirillt man anf dem glatt geeggten nnd gewalzten Lande quer iiber die PAlugfurehen und gibt dann nach beendigter Einsaat zur besseren Schliessung der Drillreihen quer über dieselben einen Eggenstrich. Durch die głeichmässige Tiefe der Saatunterbringung und Pflanzenvertcilung beim Drillen wird nicht allein erheblich an Saatgut gespart, sondern auch die gleiehmïssige und kräftige Entwiekelung der Pflanzen gefördert, was wiederum eine vermehrte Widerstandsfihigkeit gegen Lagern und Pflanzenkrankheiten, sowie auch einen besseren Ertrag an Quantitit und Qualität nicht nur im Korn, sondern auch im Stroh gegenïber der breitwürfigen Aussaat zur Folge hat, sehliesslich auch das Gedeiben etwaiger Untersaten, z. B. des Kleegrases fördert.

Durch die Drillkultur lassen sich die angeführten Vorteile aber nur 
dann erzielen, wenn im konkreten Falle die Entfernung der Drill:cilien von einander genau ermittelt wird, wobci die Witterung, der Kuiturzustand des Bodlens, die Entwickelungsfïhigkcit der anzubauenden Hafersorte und ob eine Bearbeitung der Zwischenrüume wälrend der Vegetationszeit stattfinden soll oder nieht, wohl zu beachten ist.

Im Allgemeinen können die Reihenweiten zwischen 10 und $50 \mathrm{~cm}$ schwanken und fanden wir die letztere Weite von $50 \mathrm{~cm}$, bei $1.5 \mathrm{hl}$ Aussaat, auf dem stark gedüngten sandig-lehmigen Humusboden des Gutes Badhoeve im Harlemermeer.

Meistenteils wählt man unter güunstigen Verlältnissen in Deutsehland Reihenweiten von $15-20 \mathrm{~cm}$ (z. B. in Poppelsdorf $20 \mathrm{~cm}$ ), unter weniger giinstigen $10-12 \mathrm{~cm}$ und im Mittel $15 \mathrm{~cm}$.

Im Seeklina und auf gutem Boden wird dic Entfermung der Drillrcihen weiter gegriffen, z. B. drillt man in England auf 25$30 \mathrm{em}$, in den Niederlanden auf $20-22.5 \mathrm{em}$ und fanden wir $22.5 \mathrm{~cm}$ Drillweite auf hunosem Thonboden zu Wilhelmina-dorp in Zeeland.

Wie sieh zwischen der Breitsaat einerseits und der Drill- und Dibbelsaat andererseits die Saatquanta und Ernteerträge gestalten, zeigen die komparativen Versuche von $\mathrm{Wollng}^{1}$ ), welche derselbe 1872 mit Kamtschatka-Hafer ausfïhrte.

\begin{tabular}{|c|c|c|c|c|c|c|}
\hline & $\begin{array}{l}\text { Reihen- } \\
\text { ent- } \\
\text { fernung. }\end{array}$ & $\begin{array}{c}\text { Aus- } \\
\text { saat- } \\
\text { quan- } \\
\text { tum. } \\
\text { kg } \\
\end{array}$ & \begin{tabular}{|c} 
Körne \\
Brutto \\
kg
\end{tabular} & $\begin{array}{l}\text { Ernte } \\
\text { in kg } \\
\text { Netto } \\
\mathrm{kg}\end{array}$ & $\begin{array}{c}\text { pro ha: } \\
\text { Stroh } \\
\mathrm{kg}\end{array}$ & $\begin{array}{c}\text { Spreu } \\
\mathrm{kg} \\
\end{array}$ \\
\hline Breitsaat & - & 162.00 & 2923.2 & 2761.2 & 54360 & 256.8 \\
\hline Drillsaat & $15.7 \mathrm{~cm}$ & 123.00 & 3196.8 & 3073.8 & 5642.0 & 286.0 \\
\hline Dibbelsaat & $\begin{array}{l}20.9 \mathrm{~cm} \\
\mathrm{im} \square\end{array}$ & 12.85 & 2342.4 & $23 \div 95$ & 4672.0 & 230.0 \\
\hline
\end{tabular}

Hiernach stellte sich beim Hafer die Drillsaat am günstigsten.

\section{Pflege.}

Die Pflege des Hafers beginut auf́ den leichteren Böden und bei trockner Witterung mit der Erhaltung der zum gleichmässigen Aufkeimen notwendigen Feuchtigkeit in der Ackerkrume und zwar

1) Journ. f. Landw. 1881. pg. $493 \mathrm{ff}$. 
durch Walzen knrz nach der Einsaat. Hierdurch wird die oberste Schicht der Ackerkrume angedrickt, in welche jetzt durch kapillare Strömung Wasser ron unten eintritt. Bei ganz glatten Flächen würde sich jedoch an der Oberfläche wiederum eine sehr starke Verdunstung geltend machen, weshalb man gern kannelirte oder Ringelwalzen benutzt, event. auch mit einer leichten Egge wiederum eine lockere Isolierschicht herstellt.

Auf durch schwcren Regen festgeschlagenen und rerkrusteten Böden rerwendet man diese letzteren Walzen ebenfalls zul Erzielung eines rollkommeneren Luftzutrittes.

Gewöhnlich läuft nach dem Walzen riel Unkraut, das in den Erdschollen eingeschlossen war, auf, welches am besten durch Eggen, sobald der Hafer eine Lünge ron $7-8 \mathrm{~cm}$ erreicht hat, zerstört wird.

Bei einer Höhe der Pflanzen ron $15 \mathrm{~cm}$ walzt man zur Förderung der Bestockung gern noch einmal.

Die Pflege der Drillsaaten, sobald sie nicht behackt werden, was schon bei eincr Drillweite ron $16 \mathrm{~cm}$ möglich ist, gestaltet sich wie die der Breitsaaten.

Durclı die Anwendung der Hederichjätemaschine kurz ror dem Schossen des Hafers wird der grösste Teil der schnellwachsenden Cruciferen und namentlich der Hederich beseitigt.

Kränkelt auf kaltem, feuchten Boden der Hafer, so gibt man eine Kopfdiugung mit Chilisalpeter.

Der Winterhafer wird in Frühjahr zur Zerstörung des Unkrautes und Lockerung des Bodens bei Drillkultur behackt und bei Breitsaat mit eiscrnen Eggen tiichtig bearbeitet.

\section{Ernte, Ausdrasch and Aufbewahrang.}

Im Allgemcinen reift der Hafer etwas unglcich, und da bei vielen Hafersorten dic reifen Körner sehr leicht ausfallen und dies gerade dic vollkommensten Körner sind, schreitet man gern zur Ernte, sobald sich die Mehrzahl der Halme als mähercif erweist. Allerdings lassen sich die weniger reif gewordenen Körner mit dem Flegel etwas schwer ausdreschen, doch ist dies jetzt nebensächlich geworden, da dic Dreschmaschinen in ausgiebigster Weise zur Anwendung gelangen und diese rein ausdreschen, auch kommt das leichte im Futterstroh noch befindliche Korn dem Vieh zu Gute.

Der Hafer wird als reif erachtet, sobald das Korn die charakteristische Farbe der Sorte anzunehmen beginnt, aber noch so weich ist, dass es sich über den Nagel biegen lässt, also sein Inhalt eine 
wachsweiche Konsistenz besitzt, und laben zu dicsem Zeitpunkt auch gewöhnlich die Halme, Blätter und Rispen eine gelbliclıe Färbung angenommen. In diesem Stadium gemälıet, erzielt man die höchsten Erträge, sowie ein relativ schweres Kón und nahrungsreiches Futterstroh.

In der wärmeren, gemässigten Zone tritt die Ernte des Sommerhafers gewöhnlich im Juni ein, in der kälteren von Mitte Jnli bis Ende August, jedoch im Seeklima und in rauhen Lagen häufig erst Anfang September; und in der subarktischen Zone Ende August und Anfaug September.

Der Winterhafer wird in Italien, Spanien, in der Provence und in den Ebcnen des Languedoc Ende Mai oder Anfang Juni, und in der Vendée, in Anjou und in der Bretagne bis Mitte Juli geerntet.

Das Schneiden des Hafers geschieht im Suiden Europras, zuwcilen aber auch in Suid-Deutschland, Frankreich und Belgien mit der Sichel, dagegen im Norden meist mit der Gestellsense oder Mähemaschine. Ist der Hafer sehr blattreich, oder findet sich viel saftreiches Unkraut oder Kleegras in ihm, dann lässt man ilın gern auf dem Schwad liegen, bis die griinen Pfianzen abgewclkt sind, worauf man ihn mit dem eignen Stroh, wenn hierzu der Hafer genügend lang und zähe ist, in Garben bindet. Durch anhaltenden Regen, welcher den Hafer im Schwade trifft, wird namentlich auf an und für sich feuchtem Boden das Stroh leicht mürbe und die schwersten Körner fallen aus, zumal, wenn behufs des Trocknens die Schwade mehrmals umzulegen sind. Aus diesen Griinden bindet man den blattarmen und wenig mit saftigen Unkräutern vermischten Hafer gerı sofort nach dem Mähen auf, wcil er dann im Stande ist, schlechter Witterung, ohne auszufallen, besser Widerstand zu leisten; auch setzt man ihn wohl im feuchten Gebirgsklima ungebunden wie den Spelz nach dem Mähen in sog. Kapellen auf, in denen er rollkommen trocknet und erst kurz vor dem Einfahren gebunden wird.

Bei gutem Wetter lässt sich reiner Hafer schon nach $3-4$ Tagen, mit saftreichen Pflanzen vermischter nach 5-6 Tagen einfahren, und in Scheunen, aber auch sehr gut in Feimen, in denen er sich vortrefflich hält, einbansen.

Mit Hülfe der Dreschnaschine wird jede Hafersorte vollkommen rein ausgedroschen, was vom Flegeldrusch nicht immer gilt.

Von allen Getreidearten erfordert der Hafer die geringste Aufmerksamkeit in Betreff seiner Aufbewahrung auf den Kornspeichern. Sorgt man für frische Luft und reitweises Umstechen, so bleibt er vollkommen gesund.

Seine Reinigung auf Getreidereinigungsmaschinen geht leicht von statten, nur zur Herstellung eines gleichförmigen Saatgutes ist eine Getreidesortiermaschine unbedingt erforderlich. 


\section{Erträge und Nahrungsbestandteile.}

Der Korn-, Stroh- und Sprenertrag des Hafers stellt sich pro ha wie folgt:

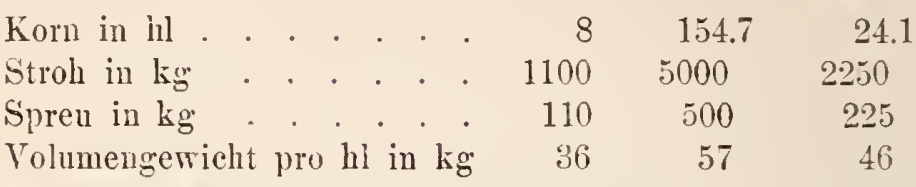

Wird der Mittelertrag aller an der Haferkultur beteiligten Länder berticksichtigt, so ergiebt sich eine Produlition pro ba ron $24.1 \mathrm{hl}$ Korn und $2250 \mathrm{~kg}$ Stroh.

Ueber das Verhältnis der Körner zum Stroh aller Hafervarietäten greben die von uns in Poppelsdorf angestellten Untersuchungen Aufschliss und sind die Resultate derselben in der nachstehenden Tabelle niedergelegt.

Tabelle iiber das Verluältnis der Körner zum Stroh (excl. Stoppeln).

\begin{tabular}{|c|c|c|c|c|c|c|c|c|}
\hline \multirow{2}{*}{\multicolumn{2}{|c|}{ Varietät: }} & \multicolumn{3}{|c|}{ Mittlere } & \multirow{2}{*}{\begin{tabular}{|} 
Früchte \\
an einer \\
Rispe \\
Stück
\end{tabular}} & \multirow{2}{*}{$\begin{array}{l}\text { Anzahl } \\
\text { der } \\
\text { unter- } \\
\text { suchten } \\
\text { Sorten }\end{array}$} & \multicolumn{2}{|c|}{$\begin{array}{l}\text { Gewichts- } \\
\text { procente }\end{array}$} \\
\hline & & $\begin{array}{c}\text { Halm- } \\
\text { länge } \\
\mathrm{cm}\end{array}$ & $\begin{array}{c}\text { Blattzahl } \\
\text { pro } \\
\text { Halm }\end{array}$ & $\begin{array}{c}\text { Rispen- } \\
\text { länge } \\
\mathrm{cm}\end{array}$ & & & $\begin{array}{l}\text { Korn } \\
\text { Proc. }\end{array}$ & $\begin{array}{l}\text { Stroh } \\
\text { incl. } \\
\text { Spreu } \\
\text { Proc. }\end{array}$ \\
\hline $\begin{array}{l}\text { Avena sati } \\
\text { mutica. } \\
\text { aurea } \\
\text { praegravis } \\
\text { grisea. } \\
\text { cinerea } \\
\text { trisperma. } \\
\text { aristata } \\
\text { Krausei } \\
\text { montana. } \\
\text { rubida. } \\
\text { brunnea } \\
\text { nigra. }\end{array}$ & $\begin{array}{l}\text { a } \\
: \\
: \\
: \\
: \\
: \\
: \\
:\end{array}$ & \begin{tabular}{|l}
120 \\
126 \\
124 \\
130 \\
130 \\
108 \\
125 \\
135 \\
110 \\
110 \\
118 \\
115 \\
\end{tabular} & $\begin{array}{l}4.5 \\
4.5 \\
3.8 \\
4 \\
4 \\
4 \\
4.5 \\
5 \\
5 \\
4.5 \\
5 \\
4.6 \\
\end{array}$ & $\begin{array}{l}23 \\
21 \\
24 \\
24 \\
22 \\
25 \\
27 \\
25 \\
25 \\
16 \\
23 \\
24 \\
\end{array}$ & $\begin{array}{r}150 \\
130 \\
140 \\
100 \\
100 \\
135 \\
170 \\
110 \\
150 \\
65 \\
150 \\
106\end{array}$ & $\begin{array}{r}40 \\
13 \\
8 \\
1 \\
1 \\
1 \\
2 \\
1 \\
1 \\
2 \\
3 \\
4 \\
\end{array}$ & $\begin{array}{l}50 \\
49 \\
53 \\
44.6 \\
44.5 \\
62.3 \\
50 \\
53 \\
51.5 \\
50 \\
50 \\
48 \\
\end{array}$ & $\begin{array}{l}50 \\
51 \\
47 \\
55.4 \\
55.2 \\
37.7 \\
50 \\
47 \\
48.5 \\
50 \\
50 \\
52 \\
\end{array}$ \\
\hline Durchschnitt & . & 123 & 4.4 & 22 & 140 & 77 & 51 & 49 \\
\hline $\begin{array}{l}\text { Avena orien } \\
\text { pugnax. } \\
\text { obtusata } \\
\text { Metzgerii } \\
\text { flava } \\
\text { tristis } .\end{array}$ & : & $\begin{array}{l}118 \\
125 \\
110 \\
135 \\
115 \\
\end{array}$ & $\begin{array}{l}5 \\
5 \\
5 \\
5.3 \\
4.4 \\
\end{array}$ & $\begin{array}{l}22 \\
30 \\
25 \\
25 \\
20 \\
\end{array}$ & $\begin{array}{l}190 \\
200 \\
150 \\
170 \\
115 \\
\end{array}$ & $\begin{array}{l}3 \\
1 \\
1 \\
1 \\
2\end{array}$ & $\begin{array}{l}51 \\
42.5 \\
42 \\
50 \\
49 \\
\end{array}$ & $\begin{array}{l}49 \\
57.5 \\
58 \\
50 \\
51 \\
\end{array}$ \\
\hline Durchschnitt & - & 120 & 4.9 & 23 & 165 & 8 & 48 & 52 \\
\hline
\end{tabular}




\begin{tabular}{|c|c|c|c|c|c|c|c|}
\hline \multirow[b]{2}{*}{ Varietät: } & \multicolumn{3}{|c|}{ Mittlere } & \multirow{2}{*}{$\begin{array}{c}\text { Früchte } \\
\text { an einer } \\
\text { Rispe } \\
\text { Stück } \\
\end{array}$} & \multirow{2}{*}{$\begin{array}{l}\text { Anzahl } \\
\text { der } \\
\text { unter- } \\
\text { suchten } \\
\text { Sorten }\end{array}$} & \multicolumn{2}{|c|}{$\begin{array}{l}\text { Gewichts- } \\
\text { procente }\end{array}$} \\
\hline & $\begin{array}{c}\text { Halm- } \\
\text { länge } \\
\mathrm{cm}\end{array}$ & $\mid \begin{array}{c}\text { Blattzahl } \\
\text { pro } \\
\text { Halm }\end{array}$ & $\begin{array}{c}\text { Rispen- } \\
\text { länge } \\
\mathrm{cm}\end{array}$ & & & $\begin{array}{l}\text { Iiorn } \\
\text { Proc. }\end{array}$ & $\begin{array}{l}\text { Stroh } \\
\text { incl. } \\
\text { Spreu } \\
\text { Proc. }\end{array}$ \\
\hline $\begin{array}{l}\text { Avena uuda } \\
\text { inermis major } \\
\text { chinensis.. } \\
\text { nuda... }\end{array}$ & $\begin{array}{l}110 \\
120 \\
100 \\
85\end{array}$ & $\begin{array}{l}4 \\
5 \\
5 \\
4\end{array}$ & $\begin{array}{l}25 \\
30 \\
27 \\
18\end{array}$ & $\begin{array}{r}200 \\
150 \\
120 \\
80\end{array}$ & $\begin{array}{l}1 \\
1 \\
1 \\
1\end{array}$ & $\begin{array}{l}35.4 \\
37.4 \\
28.3 \\
37.0\end{array}$ & $\begin{array}{l}64.6 \\
62.6 \\
71.7 \\
63.0\end{array}$ \\
\hline Durchschnitt . & 104 & 4.5 & 25 & 140 & 4 & 33.6 & 66.4 \\
\hline
\end{tabular}

Aus dieser Tabelle ergiebt sich ein anffallend hoher Procentsatz an Korn, der fiir gewöhnlich nicht vorkommt, und sich nur dađurch erklären lässt, dass sich der Poppelsdorfer milde Lehmboden in ganz vorziiglicher Weise zur Kornprodnktion eignet, und dass nur Halme mittlerer Länge zur Untersuchung dienten, dementsprechend gibt die Tabellc auch nur darüber Auskunft, wie sich die einzelnen Varietäten in ihren Gewichtsprocenten an Korn und Stroh zu einander verhalten.

Man kann wohl im Grossen und Ganzen annehmen, obgleich die einzeinen Sorten erheblich von einander abweichen und anch andere Umstände z. B. die Witterung und Bodenbeschaffenheit auf das Verhäinis zwischen Korn und Stroh erheblich einwirken, dass sich das Stroh zu den Körnem verhält wie $100: 100$ bis $100: 33$ und im Mittel wie 100:66; und was die Spreu anbetrifft, so dürfte sie 6-25 Proc. und im Mittel 10 Proc. des Stroherzeugnisses ausmachen.

Diese Angaben werden recht gut durch nachstehenden Kulturversuch von Fühling in St. Nicolas, Rheinprovinz, illustriert:

\begin{tabular}{l|c|c|c|c|c}
\hline \hline Hafersorte: & \multicolumn{2}{|c|}{ Verhältnis des } & \multicolumn{2}{|c|}{$\begin{array}{c}\text { Verhältnis } \\
\text { des }\end{array}$} & $\begin{array}{c}\text { Die Kör- } \\
\text { ner geben }\end{array}$ \\
& Korns : & Strohs & Strohs : & Spreu & Spelzen \\
Proc.
\end{tabular}


Der Hafer ist eine sehr siehere Frueht, welehe in dieser Beziehung namentlieh auf den geringeren Böden und auf Neubruch jedes andere Getreide in den Sehatten stellt, und nimmt Bloek ron 10 Ernten 9 als vollkommen an.

In k:ilteren genässigten Klima werden pro ha naelistehende Erträge erzielt:

1) Reieher, tiefer, milder Thon- und Aueboden; Weizenboden I. Kl. $44-55 \mathrm{hl}=2024-2530 \mathrm{~kg}$ Korn, $4000-5000 \mathrm{~kg}$ Stroh.

2) Humoser, reieher. milder Lehmboden; Gerstenboden I. Kl. $35-44 \mathrm{hl}=1610-2024 \mathrm{~kg}$ Korn, 3200-4000 kg Stroh.

3) Sehwerer, kräftiger Thonboden; Weizenboden II. Kil. $35-44 \mathrm{hl}=1610-2024 \mathrm{~kg}$ Korm, $3200-4000 \mathrm{~kg}$ Stroh.

4) Milder, tiefer, mergeliger, friseher Lehm- und sandiger Lehmboden; Gerstenboden II. Kl.

$30.5-35 \mathrm{hl}=1403-1010 \mathrm{~kg}$ Korn, $2520-2880 \mathrm{~kg}$ Stroh.

5) Leiehter, sandiger Lehm und lehmiger Sandboden; Rogrgenboden I. $\mathrm{Kl}$.

$28-33 \mathrm{hl}=1288-1518 \mathrm{~kg}$ Korn; 2080-2400 kg Stroh.

6) Kalter, zäher Thon- und Lehmboden; Weizenboden III. Kl. 22-26 hl = 1012-1196 kg Korn; $1800-2160 \mathrm{~kg}$ Stroh.

7) Leiehter, magerer Sand, dürftiger lehmiger Sandboden. Roggenbuden II. Kl.

$17-22 \mathrm{hl}=782-1012 \mathrm{~kg}$ Korn, $1280-1600 \mathrm{~kg}$ Stroh.

8) Strenger, zäher, lettenartiger Thonboden; Haferboden I. Kl. $17-22 \mathrm{hl}=782-1012 \mathrm{~kg}$ Koln; $1410-1800 \mathrm{~kg}$. Stroh.

9) Armer Sand und Kiesboden; Roggenboden III. Kl. $15-19.5 \mathrm{hl}=690-897 \mathrm{~kg}$ Korn, $1120-1440 \mathrm{~kg}$ Stroh.

10) Töpferthon, loser Sand, Grand etc.; Haferboden II. und III Kl. $11-13 \mathrm{hl}=506-598 \mathrm{~kg}$ Korn, 900-1080 k $\mathrm{k}^{\circ}$ Stroh.

11) Milder, thoniger Humusboden.

$26-30.5 \mathrm{hl}-1196-1610 \mathrm{~kg}$ Korn, 2400-2800 kg Stroh.

12) Milder Humus mit wenig Lehm und Sand.

$19.5-22 \mathrm{hl}=897-1012 \mathrm{~kg}$ Korn, $1800-2000 \mathrm{~kg}$ Stroh.

13) Saurer, sandiger Humusboden.

$11-15 \mathrm{hl}-506-690 \mathrm{~kg}$ Korn, $900-1260 \mathrm{~kg}$ Stroh.

14) Saurer Haidehumus mit Sand.

$13-17 \mathrm{hl}=598-782 \mathrm{~kg}$ Korn, $1080-1440 \mathrm{~kg}$ Stroh.

15) Mooriger, saurer Torfboden.

$11-13 \mathrm{hl}=506-598 \mathrm{~kg}$ Korn, $900-1080 \mathrm{~kg}$ Stroh.

Der Hafer enthält an verdauliehen und unverdauliehen Nahrungsbestanclteilen: 


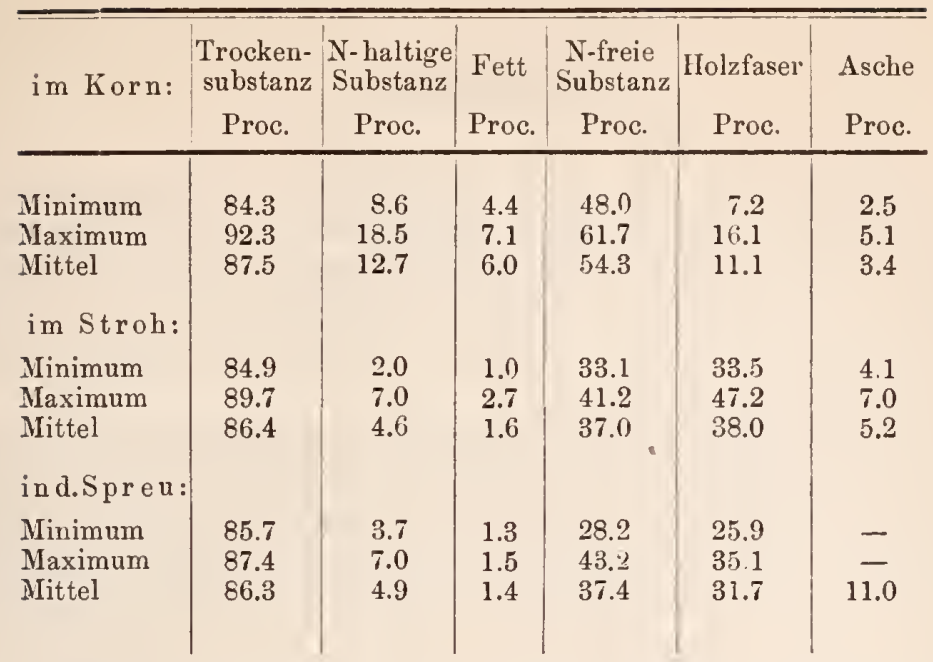

Der mittlere Gehalt an verdaulichen Nährstoffen beträgt nach E. Wolff:

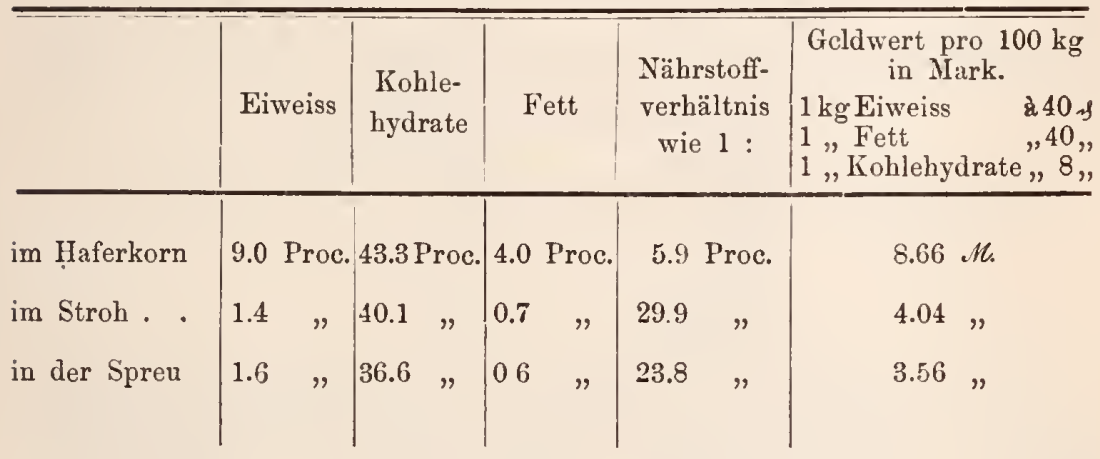

Durchschnittlich liefern $100 \mathrm{~kg}$ Körner $65-75$ Proc. Mehl und 25-35 Proc. Kleie und Abgang.

Der Wert des Haferkorns ist aber auch von dem Gehalt an Spelzen abhängig, und verweise ich in dieser Beziehung auf meine oben angeführten Untersuchungen, nach denen der Gehalt an Spelzen bei den verschiedenen Hafersorten zwischen 21 und 49 Proc. schwanken kann. 


\section{Benutzang.}

Der Hauptsache nach dient das Haferkorn als Pferdefutter und eignet sich durch seine leichte Verdaulichkeit, sein enges Nährstoffverhältnis und seinen hohen Fettgehalt ganz besonders für die Ernährung von Arbeitstieren, aber auch jungen Tieren, z. B. den Kälbern und Lämmern, sowie männlichen Tieren in der Brunst ist er in hohem Grade zuträglich.

Die eigentïmlich anregende Wirkung des Hafers, welche andere Futtermittel nicht erzielen lassen, soll auf dem Vorhandensein eines aromatischen Körpers beruhen, der nach Journet ${ }^{1}$ ) mit der Vanille identisch sein soll. Sanson stellt ihn jedoch unter die Alkaloïde und schlägt vor, denselben, „Avenin" zu nennen. Nach seinen Untersuchungen enthält namentlich der schwarze Hafer das Avenin am reichlichsten, doch wird dasselbe durch Quetschen des Hafers in seiner anregenden Kraft abgeschwächt.

Das Mehl des Hafers ist fast weiss und enthält:

\begin{tabular}{lrr} 
& \multicolumn{2}{c}{ Mehl } \\
& fein & grob \\
Proteïnkörper & 16.1 & 19.5 \\
Zucker & 2.2 & 2.2 \\
Gummi & 3.5 & 2.5 \\
Fett & 6.8 & 5.7 \\
Stärke & 59.1 & 58.4 \\
Wasser & 12.3 & 11.7
\end{tabular}

Das aus dem Mehl bereitete Brot ist schlecht und wenig zur menschlichen Nahrung geeignet und wird zur Zeit nur noch in hochnordischen Länderu bereitet. Weit verbreiteter ist dagegen der Haferbrei, der schon bei den alten Deutschen die Hauptkost gebildet haben soll.

Die Griitze wird zur Herstellung schleimiger Suppen oder Breie und in der Heilkunst nicht selten zu warmen Umschlägen verwandt.

Zuweilen vermalzt man den Hafer zur Herstellung von Bier, z. B. soll die Braunschweiger Mumme aus Hafer, Weizen und Pferdebohnen gebraut werden.

Nach Mulder enthält:

1) Heuzé, Plant. alim. pg. 520. 


\begin{tabular}{l|r|r}
\hline & Haferkorn & Malz \\
\hline Stärke & 47.0 & 37.3 \\
Zucker & - & 0.4 \\
Dextrin & 5.0 & 7.1 \\
Fett & 5.4 & 4.1 \\
Eiweiss & 12.1 & 13.3 \\
Cellulose & 14.5 & 22.6 \\
Asche & 2.8 & 3.1 \\
Wasser & 13.2 & 12.1
\end{tabular}

Das Haferstroh ist weich, geschmeidig, blattreicher als Weizenoder Roggenstroh, und, gut geerntet, von angenehmem Geruch und etwas bitterem Geschmack, auch soll es, verfüttert, ein wenig adstringierend wirken. Bleibt das Stroh bei schlechtem Wetter längere Zeit auf dem Felde, so wird es missfarben und dem Vieh weniger gedeihlich.

Die Haferspreu ist ebenfalls ein nahrhaftes, weiches, dem Rindvieh sehr zuträgliches Futter.

Vielfach wird der Hafer auch zur Grïnfutterung verwandt und sollte zu diesem Zwecke in einem noch milchigen Zustande der Körner geschnitten werden, weil mit der weiter vorgeschrittenen Reife die Haferpflanzen an Nahrungswert verlieren.

Es enthielt nach Völker:

\begin{tabular}{lr|r|r|r|r}
\hline & \multicolumn{2}{|c|}{ reifer Hafer } & \multicolumn{2}{|c}{ grüner Hafer } \\
& \multicolumn{2}{|c|}{ Versuch } & \multicolumn{2}{c}{ Versuch } \\
& I & II & I & II \\
\hline in den Körnern an Proteïn & 14.92 & 15.87 & 17.93 & 17.81 \\
im Stroh,$"$, & 8.31 & 8.62 & 10.87 & 11.25
\end{tabular}

auch gibt Völker an, es sei mehrfach die Erfahrung gemacht worden, dass der noch griine Hafer ein Viertel mehr Futterwert als der völlig reife besass.

Die Ursache dieser Erscheinung liegt nun nicht allein in dem höheren Eiweissgehalt des grünen Hafers, sondern auch in seiner grösseren Weichheit und leichteren Verdaulichkeit. 


\section{M a i s. \\ Zea Mais $\mathrm{L}$.}

Einteilung.

\section{Gruppe I. Excellens Al. Ansgezeichneter Mais.}

Varietät: Zea Mais tunicata Larranhaga.

Sorten:

Pinsingallo bei Buenos-Ayres.

Kolben: konisch, einem Pinienzapfen ähnlich, 10-12-reihig, Reihen etwas unregelmässig, $17 \mathrm{~cm}$ lang, $3.5 \mathrm{~cm}$ an der Spitze, $5.5 \mathrm{~cm}$ an der Basis breit, 23 Früchte in der Reihe. - Scheinfrucht: von braunen Spelzen umgeben; Frucht gelb, Krone rund, etwas zugespitzt, grösste Breite $71 / 2 \mathrm{~mm}$, geringste $5 \mathrm{~mm}, 9 \mathrm{~mm}$ lang, $5 \mathrm{~mm}$ dick, 38 Früchte $=10 \mathrm{gr}$; selten gebaut, Früchte schwer zu enthülsen. - Halm 2-3 m hoch.

Heimat: St. Hilaire erhielt sie aus Paraguay, Bonafous (Zea eryptosperma) aus Buenos-Ayres.

In der Poppelsdorfer-Sammlung.

\section{A n h a n g.}

\section{Rocky Mountain-corn.}

Syn.: Texas-corn; California-corn; Forage-corn; Wild-corn ${ }^{1}$ ).

Kolben: konisch, einem Pinienzapfen ähnlich, $22 \mathrm{~cm}$ lang; Spindel weiss oder rot; meist 2 Kolben pro Halm. - Scheinfrucht: von braunen Spelzen umgeben; Frucht weiss, gelb, rot oder purpurn. - Halm $2.5-3 \mathrm{~m}$ hoch, Blattzahl 9.

Nach Salisbury ${ }^{2}$ ) ist dies eine wilde Maisform, welche bei guter Kultur allmählich die Spelzen verlieren soll.

Die Früchte enthielten:

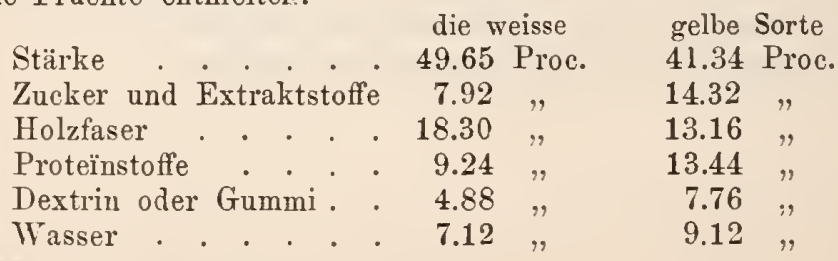

1) Landwirt Nr. 99 Jahrg. 1879. VIII, 1848.

2) Salisbury, Maiz or Indian-corn; Transact. of the N. Y. st. Vol. 


\section{Varietät: Zea Mais macrosperma Kl.}

\section{Sorten:}

\section{Weisser Cuzco-Mais.}

Franz.: Mais de Cuzco blanc.

Ital.: Mais Cuzco bianco.

Kolben: konisch, verhältnismässig breit, \&-reihig; Spindel weiss. Frucht: zart mattweiss, noch stärker als beim Pferdezahn zusammengedrückt, unregelmässiger, aber länger und breiter, sehr gross (20 mm lang, $15 \mathrm{~mm}$ breit, $6 \mathrm{~mm}$ dick, 11 Körner $=10 \mathrm{gr}$ ), oval, Bruch mehlig. Halm sehr gross, in Peru bis $3.50 \mathrm{~m}$ hoch, in Frankreich ${ }^{1}$ ) als Grünfutter $3 \mathrm{~m}$ hoch und $8-21 \mathrm{~cm}$ im Umfang.

Ausser dem weissen Cuzko-Mais gibt es noch einen gelben mit roten Streifen und roter Spindel (mirabilis Kcke.).

Heimat: Cuzco in Peru und dort die ergiebigste Maissorte. Sehr spätreif, so dass er in Europa nirgends reift; Heuzé fülırt zwar an, dass er in Spanien reife, doch ist dies sehr fraglich, da er bei Neapel, wohin ihn Körnicke zur Kultur sandte, nicht ausreifte.

Körnicke erhielt Originalfrüchte vom Consul Reinecke aus Cuzko 1872, durch Vermittelung von Th. v. Bunsen.

In der Sitzung der naturforschenden Freunde zu Berlin am 19. Angust 1851 zeigte Dr. Klotzsch Frïchte dieser Maissorte vor, welche A. v. Humboldt aus Cuzco, Süd-Peru, erhalten und schlug für dieselbe den Namen "Zea macrosperma" vor.

Varietit: Zea Mais acuminata Kcke.

\section{Sorten:}

\section{Gelber geschnäbelter Mais.}

Span.: Maiz picudo (Chile).

Ital.: Granturco a becco.

Franz.: Mais jaune à bec, épineux, pointu.

Engl.: Beaked maize.

Kolben: sattgelb, konisch, einem Pinienzapfen ähnlich, 16-20 cm lang, $3 \frac{1}{2}-4 \mathrm{~cm}$ an der Basis breit, 14-16-reihig, regelmässig, 30 Früchte p. Reihe, Spindel weiss. - Fruclit: Original sattgelb, geschnäbelt, oval, etwas zusammengedrückt $(9 \mathrm{~mm}$ lang, $6 \mathrm{~mm}$ breit, $5 \mathrm{~mm}$ dick, 85 Früchte $=10 \mathrm{gr}), 1 \mathrm{hl}$ wiegt $72.5 \mathrm{~kg}$, feinschalig.

Die Kultur in Poppelsdorf bei $50 \mathrm{~cm}$ Reihenweite und $25 \mathrm{~cm}$ Entfernung in der Reihe, ergab folgendes Resultat: Aussaat 20/5., Auflaufen 7/6., Blütezeit 16/8.; männliche Blüte, 1 pro Pflanze, gelbgrün, Staubbeutel gelbgriü oder rot; weibliche Blüte, 3.1 pro Pflanze, Griffel hellgrün, oder rosa. Bestockungstriebe 1.15 pro Pflanze, Halme $130 \mathrm{~cm}$ (Max. $170 \mathrm{~cm}$ ) lang, $1.8 \mathrm{~cm}$ dick, Blattzahl 10.2 , Blätter $60 \mathrm{~cm}$ lang, $5.5 \mathrm{~cm}$ breit, Blattfläche $6732 \mathrm{qcm}$, Halmfläche $702 \mathrm{qcm}$; Gesammtfläche $7434 \mathrm{qcm}$.

1) Goffart, Man. de la Cult. et de l'ensilage des Mais 1877, pg. f. 
Reifezeit 12/10, 1.8 fruchtbare Kolben p. Pflanze, und von 100 reifen Pflanzen wurden geerntet: $17.500 \mathrm{~kg}$ Kolben, $3.100 \mathrm{~kg}$ Hüllen, in den Kolben $12.500 \mathrm{~kg}$ Körner, $5 \mathrm{~kg}$ Spindeln; $19.500 \mathrm{~kg}$ Stroh.

Vaterland: Suid-Amerika.

Original 1880 durch $\nabla$ on Gülich aus Chile, Hacienda de Colina, Dept. de Santiago erhalten.

Dieser Mais zeichnet sich durch Frühreife aus, so dass er sich in Süd-Deutschland erfolgreich anbauen lässt.

\section{Kleiner spitzkörniger chinesischer Hais.}

Franz.: Maïs petit de la Chine.

Kolben: hellgelb, stark konisch, $17-20 \mathrm{~cm}$ lang, $3 \frac{1}{2}-4 \mathrm{~cm}$ an der Basis breit, 18-20-reihig, locker, unregelmässig, 32 Früchte p. Reihe; Spindel weiss. - Frucht: Original hellgelb, mit hakig gekrümmter Spitze, länglich-rundlich (10 mm lang, $5 \mathrm{~mm}$ breit, $4 \mathrm{~mm}$ dick, 99 Früchte $=10 \mathrm{gr}$ ), sehr feinschalig.

Die Kultur in Poppelsdorf bei $50 \mathrm{~cm}$ Reihenweite und $25 \mathrm{~cm}$ Entfernung in der Reihe, ergab folgendes Resultat: Aussaat 20/5. 1878, Erscheinen der Pflanzen 7/6., Blïtezeit 29/8, männliche Blüte 1.25 p. Pflanze, Staubbeutel pfirsich-grün, weibliche Blüte 3.25 p. Pflanze. Schösslinge 2 p. Pflanze, Halme $150 \mathrm{~cm}$ (Max. 200 cm) lang, $2.3 \mathrm{~cm}$ dick, Blattzahl 9, Blätter $65.3 \mathrm{~cm}$ lang, $6.1 \mathrm{~cm}$ breit, Blattfläche $7169.94 \mathrm{qcm}$, Halmfläche $1035 \mathrm{qcm}$, Gesammtfläche $8204.94 \mathrm{qcm}$.

In Poppelsdorf reift er nur in sehr heissen Sommern in einigen Kolben aus; da er aber feinhalmig, buschig und blattreich ist, empfiehlt er sich vielleicht als Grünfutter. Es betrug das mittlere Frischgewicht blühender Halme $450 \mathrm{gr}$ (Мax. $1000 \mathrm{gr}$ ).

Original in der Sammlung zu Poppelsdorf.

Bezugsquelle: Vilmorin, Paris.

Varietät: Zea Mais pungens Kcke.

Sorte:

Roter spitzkörniger Mais.

Franz.: Maïs rouge à bec.

Ital.: Granturco rostrato rosso.

Kolben: rot, ziemlich cylindrisch, $10 \mathrm{~cm}$ lang, $3 \mathrm{~cm}$ an der Basis breit; 14-reihig, unregelmässig, 24 Früchte p. Reihe; Spindel rot. Halm bis $2 \mathrm{~m}$ hoch. - Frucht: braunrot, zugespitzt (10 mm lang, $5 \mathrm{~mm}$ breit, $5 \mathrm{~mm}$ dick, 98 Früchte $=10 \mathrm{gr}$ ), sehr feinschalig.

Dieser Mais ist etwas weniger frühreif als Quarantino, und wirả vielfach in Frankreich, Italien und namentlich Spanien kultiviert.

Original in der Poppelsdorfer Sammlung. 


\title{
Gruppe II. Saccharata Kcke. Znckermais.
}

\author{
Varietät: Zea Mais rugosa Bonaf.
}

\section{Sorten:}

\section{Briggs Large early Sweet-corn.}

Kolben: farblos, schwach konisch, $13 \mathrm{~cm}$ lang, $3.5 \mathrm{~cm}$ dick, 8-reihig, regelmässig, 28 Früchte p. Reihe; Spindel weiss. - Frucht: farblos, zuweilen blassrötlich, hornig, runzelig $(11 \mathrm{~mm}$ lang und breit, $5 \mathrm{~mm}$ dick), sehr zart und suiss.

Die Kultur in Poppelsdorf, bei $50 \mathrm{~cm}$ Reihenweite und $20 \mathrm{~cm}$ Entfernung in der Reihe, ergab folgendes Resultat: Aussaat 20/5. 78, Erscheinen der Pflanzen 7/6., Blütezeit 12/8.; männliche Blüte 1 p. Pflanze, rot, Staubbeutel gelb; weibliche Blüte hellgrün, $1.6 \mathrm{p}$. Pflanze; Schösslinge $1.1 \mathrm{p}$. Pflanze, Halme $80 \mathrm{~cm}$ (Max. $110 \mathrm{~cm}$ ) lang, $1.5 \mathrm{~cm}$ dick, Blattzahl 8, Blätter $37.5 \mathrm{~cm}$ lang, $3.6 \mathrm{~cm}$ breit, Blattfäche $2160 \mathrm{qcm}$, Halmfläche $360 \mathrm{qcm}$, Gesammtfläche $2520 \mathrm{qcm}$.

Zur Reifezeit (12/10.) 1 Kolben pro Pflanze und 100 trockne Halme lieferten $6.670 \mathrm{~kg}$ Kolben, $1.330 \mathrm{~kg}$ Hüllblätter, $5.325 \mathrm{~kg}$ Früchte, $1.345 \mathrm{~kg}$ Spindeln, 2.000 Stroh.

Dieses frühe, grosskolbige Suisskorn wird als zeitiges Gemüse sehr vielfach in Nord-Amerika kultiviert.

Von Thilmany, Bonn, erhalten, der dasselbe von der Firma Briggs \& Brother, Rochester, N. York, bezog.

\section{Large Rhode-Island Sweet.}

Syn.: Rhode Island Asylum.

Kolben: farblos, schwach konisch, 13-21 cm lang, Durchmesser an der Spitze $5 \mathrm{~cm}$, an der Basis $3 \frac{1}{2} \mathrm{~cm}, 8-10$-reihig, auf $20 \mathrm{~cm}$ Länge 40 Friichte p. Reihe; Spindel weiss. - Frucht: farblos, hornig, runzelig, gross (10 $\mathrm{mm}$ lang, $8-13 \mathrm{~mm}$ breit, $4.5 \mathrm{~mm}$ dick, 44.2 Früchte = $10 \mathrm{gr})$.

Nach Salisbury ${ }^{1}$ ) erreichte er in der Blüte im Staate New-York eine Höhe von $1.73 \mathrm{~m}$, in der Peife, welche nach 127 Tagen (Aussaat 12/5.) eintrat, $2.06 \mathrm{~m}$, mit 3 Kolben und 10 Blättern, und der Ertrag stellte sich p. ha auf $4972.8 \mathrm{~kg}$ Früchte, $1372 \mathrm{~kg}$ Spindeln, $1492.96 \mathrm{~kg}$ Blütenhüllen, $3112.48 \mathrm{~kg}$ Blätter und Scheiden, $3557.12 \mathrm{~kg}$ Halme.

Ergiebig, von vortrefflichem Geschmack, spätreif.

\section{Large eight rowed Sweet-Corn.}

Kolben: farblos, bis $22 \mathrm{~cm}$ lang, $4 \mathrm{~cm}$ dick, 8 -reihig, mit 40 Früchten p. Reihe; Spindel weiss. - Frucht: farblos, hornig, stark runzelig (9 $\mathrm{mm}$ lang, $13 \mathrm{~mm}$ breit, $6 \mathrm{~mm}$ dick).

Original in der Poppelsdorfer Sammlung.

1) Transact. of the N. Y. st. Vol. VIII, 1848. 


\section{Brill's early Dwarf Sugar.}

Frucht: farblos, kurz, hornig, platt, runzelig; $10 \mathrm{~mm}$ lang, $12 \mathrm{~mm}$ breit, $3 \frac{1}{2} \mathrm{~mm}$ dick, 47 Früchte $=10 \mathrm{gr}$.

Wird namentlich in Massachusetts in $94 \mathrm{~cm}$ Reihenweite und 26$30 \mathrm{~cm}$ Entfernung in der Reihe kultiviert und ist früh, zart und ergiebig.

Erbalten durch van Treeck 1872 aus New-York.

\section{Varietät: Zea Mais dulcis Kcke.}

\section{Sorten:}

\section{Darling's early sugar.}

Kolben: farblos, $18 \mathrm{~cm}$ lang, an der Basis $4 \mathrm{~cm}$, an der Spitze $2.5 \mathrm{~cm}$ dick, 8-reihig, 42 Früchte pro Reihe; Spindel weiss. - Frucht: farblos, hornig, platt, runzelig $(10 \mathrm{~mm}$ lang, $10 \mathrm{~mm}$ breit, $4 \mathrm{~mm}$ dick, 38.7 Früchte $=10 \mathrm{gr}$ ).

Dies ist eine sehr feine, ertragreiche Sorte des Zuckermaises, die in Nord-Amerika Anfang Mai gepflanzt, schon Anfang Juli als Gemüse benutzt wird.

Heimat: Connecticut.

Wurde 1872 durch van Treeck aus New-York eingesandt.

\section{Maïs sucré ridé.}

Sy n.: Farbloser runzliger Zuckermais.

Kolben: farblos, knnisch, $20 \mathrm{~cm}$ lang, $5 \mathrm{~cm}$ dick, 14-reihig, sehr regelmässig, 37 Früchte pro Reihe; Spindel weiss. - Halm sehr zuckerreich, 150-200 cm lang. - Frucht farblos, hornig, abgeplattet, runzelig $(15 \mathrm{~mm}$ lang, $11 \mathrm{~mm}$ breit, $4 \mathrm{~mm}$ dick, 40.6 Früchte $=10 \mathrm{gr})$, sehr zuckerreich.

Die Kultur in Poppelsdorf bei $50 \mathrm{~cm}$ Reihenweite und $30 \mathrm{~cm}$ Entfernung in der Reihe, ergab folgendes Resultat: Aussaat 20/5. 1878, Erscheinen der Pflanzen $7 / 6$., Blütezeit 30/8.; männliche Blüte 1.1 p. Pflanze, grün, rot gestreift, Staubbeutel rot; weibliche Bliite 2.15 p. Pflanze; Schösslinge 1.15 p. Pflanze, Halm $150 \mathrm{~cm}$ (Max. $200 \mathrm{~cm}$ ) lang, $2.3 \mathrm{~cm}$ dick, Blattzahl 13.5, Blätter $66.2 \mathrm{~cm}$ lang, $6.4 \mathrm{~cm}$ breit, Blattfläche $11439.36 \mathrm{qcm}$, Halmfläche $1035 \mathrm{qcm}$, Gesammtfläche $12474.36 \mathrm{qcm}$.

In Poppelsdorf reift er nur in sehr heissen Sommern, 1878 lieferte er an Frischgewicht p. Halm $630 \mathrm{gr}$ (Max. $820 \mathrm{gr}$ ), 100 trockne Halme lieferten $32.500 \mathrm{~kg}$ Kolben, $8.500 \mathrm{~kg}$ Hüllblätter, $18.650 \mathrm{~kg}$ Früchte, $13.850 \mathrm{~kg}$ Spindeln, $24.000 \mathrm{~kg}$ Stroh.

In Amerika werden die unreifen Früchte, wie grüne Erbsen zubereitet, gegessen, und würde sich zur Bereicherung unserer Küche der Anbau wohl empfehlen.

Die Ueppigkeit ihres Wachstums, sowie ihr Zuckerreichtum machen diese Sorte zur Futtermaiskultur sehr empfehlenswert.

Bezıgsquelle: Vilmorin, Paris. 
Varietät: Zea Mais uberior Kcke.

\section{Sorten:}

\section{Stowel's Evergreen Sugar-corn.}

Kolben: farblos, fast cylindrisch, $20 \mathrm{~cm}$ lang, $4^{1} / 2-5 \mathrm{~cm}$ breit, 12-14-16-reihig, 39 Früchte p. Reihe; Spindel weiss, schmal. - Halm kurz, reichkolbig, 3-5 Kolben. - Frucht: farblos, hornig, runzelig, platt, in der Form dem Zahnkornmais sehr ähnlich, gross (14 mm lang, $7-10 \mathrm{~mm}$ breit, $3^{1} / 2 \mathrm{~mm}$ dick, 43.3 Früchte $\left.=10 \mathrm{gr}\right)$.

Diese Sorte ist die spätreifste aber süsseste, bleibt grün bis zum Eintritt des Frostes, und wird daher auch häufig als spätes Grünfutter benutzt, zu gleicher Zeit mit frühreifen Sorten in $1 \mathrm{~m}$ Reihenweite und $30 \mathrm{~cm}$ Entfernung der Horste (à 4-5 Pflanzen) ausgelegt, versorgt sie in Nord-Amerika noch in Oktober den Tisch mit frischem Gemuise. Sie ist sehr ertragreich, und wurde zuerst durch $\mathrm{M}$ r. Stowel gezogen und nach Philadelphia zu Markt gebracht. Reift in Poppelsdorf nicht.

Durch van Treek 1872 aus New-York erhaltell.

\section{Twelve rowed Sweet-corn.}

Verbesserte Form: Burr's Mammoth.

Aehre: farblos, fast cylindrisch, $23 \mathrm{~cm}$ lang, $4-5 \mathrm{~cm}$ breit, $12-$ 16-reihig, mit 50 Früchten p. Reihe. - Frucht: farblos, hornig, runzelig, in der Form dem Zahnkorn ähnlich, platt $(10 \mathrm{~mm}$ lang, 6-10 $\mathrm{mm}$ breit, $4 \mathrm{~mm}$ dick), feinschalig.

Diese sehr grosse, ergiebige, unempfindliche und sehr spätreife Sorte hat ihre Heimat in Massachusetts.

Varietät: Zea Mais flavodulcis Keke.

\section{Sorte :}

\section{Maiz azucarado arrugado, Chile.}

Kolben: fast cylindrisch, schlank, $20 \mathrm{~cm}$ lang, $3.5 \mathrm{~cm}$ dick, 10-reihig, 40 Früchte in der Reihe. - Frucht: blassgelb, durchsichtig, verschrumpft, $10.5 \mathrm{~mm}$ lang, $9.5 \mathrm{~mm}$ breit, $4.5 \mathrm{~mm}$ dick, 47 Früchte $=10 \mathrm{gr}$. - Halm: $185 \mathrm{~cm}$ lang, $2.5 \mathrm{~cm}$ dick, 4 Schösslinge, Rispe $35 \mathrm{~cm}$ lang, 1 Kolben pro Halm, weibliche Blüte schön rot; Blattzahl 11, Blätter $67 \mathrm{~cm}$ lang, $7.7 \mathrm{~cm}$ breit, Blattfläche $11349.8 \mathrm{qcm}$, Halmfläche $1387.5 \mathrm{qcm}$, Gesammtfläche $12737.3 \mathrm{qcm}$.

Sehr spätreif.

Bezugsquelle: durch v. Gülich aus Hacienda de Colina, Chile, 1880. 


\section{Varietät: Zea Mais rubentidulcis Kcke.}

\section{Sorte :}

\section{Early Narraganset.}

Kolben: rosenrot, Spindel rot, 8- und 10-reihig, schwach konisch (an der Spitze $3 \mathrm{~cm}$, an der Basis $4 \mathrm{~cm}$ Durchmesser), $17 \mathrm{~cm}$ lang, mit 296-370 (37 p. Reihe) Früchten. - Halme kurz. - Frucht: rosenrot, durchsichtig, runzelig, platt (12 $\mathrm{mm}$ breit, $10 \mathrm{~mm}$ lang, $4 \mathrm{~mm}$ dick), 38.5 Früchte $=10 \mathrm{gr}$.

Dieser Zuckermais zeiclnet sich durch sehr feine Qualität, Frühreife und Ergiebigkeit aus; die nicht ausgereiften Kolben werden in New-York gern als Gemüse benutzt.

Er wird vorzugsweise auf leichtem Boden in Connecticut kultiviert.

Varietät: Zea Mais rubrodulcis Kcke.

\section{Sorte:}

\section{Roter Zuckermais von Philadelphia.}

Kolben: braunrot, konisch, $11-16 \mathrm{~cm}$ lang, $4-4.5 \mathrm{~cm}$ dick, $10-$ reihig mit 40 Früchten p. Reihe; Spindel hellrot. - Frucht: braunrot, runzelig ( $8 \mathrm{~mm}$ lang, $11 \mathrm{~mm}$ breit, $3^{1} / 2 \mathrm{~mm}$ dick, 53.4 Früchte $=10 \mathrm{gr}$ ), feinschalig.

Original in der Poppelsdorfer Sammlung.

Varietät: Zea Mais coeruleodulcis Kcke.

\section{Sorte:}

\section{Black Mexican Sweet-Corn.}

Kolben: bläulich, konisch, $15-17 \mathrm{~cm}$ lang, $3 \frac{1}{2} \mathrm{~cm}$ dick, 10-reihig, mit 25 locker sitzenden Frïchten p. Reihe; Spindel weiss. - Frucht: graublau, runzelig ( $8 \mathrm{~mm}$ lang, $10 \mathrm{~mm}$ breit, $3 \frac{1}{2} \mathrm{~mm}$ dick), platt, 47 Früchte $=10 \mathrm{gr}$.

Durch van Treeck 1872 aus New-York erhalten.

Varietät: Zea Mais chilena Kcke.

\section{Sorte :}

\section{Maiz uguye, Chile.}

Kolben: konisch, lang, schmal, 18-reihig, Reihen sehr regelmässig. - Frucht: hellgelb, im Kronenteil verschrumpft und durchsichtig, also gleich Zuckermais, unterer Teil undurchsichtig, Form des Zahnkornmaises, gross, $12 \mathrm{~mm}$ lang, $7 \mathrm{~mm}$ breit, $3.5 \mathrm{~mm}$ dick, 65 Früchte $=10$ gr. Halm $175 \mathrm{~cm}$ lang, $2.3 \mathrm{~cm}$ dick, 4 Schösslinge, 1 Kolben p. Halm, Rispe $35 \mathrm{~cm}$ lang; Blattzahl 12, Blätter $54 \mathrm{~cm}$ lang, $6 \mathrm{~cm}$ breit, Blattläche $7776 \mathrm{qcm}$, Halmfläche $1207.5 \mathrm{qcm}$, Gesammtfläche $8983.5 \mathrm{qcm}$.

Original durch von Gülich aus Hacienda de Colina, Chile 1880. 


\title{
Gruppe III. Dentiformis Kcke. Pferdezahnmais.
}

\author{
Varietät: Zea Mais leucodon Al.
}

\section{Sorten:}

\section{White Dent.}

Syn.: White tooth-corn (St. Louis), Gourdseed, Keutucky white Dent, North Carolina-corn, Devereaux.

Franz.: Mais blanc dent de cheval.

Ital.: Granturco a dente di cavallo.

Spanisch: Maiz diente de Caballo; Maiz Blanco Regalo de Llobregat, Cataluña; Maiz americano blanco, Chile; Maiz comun Chile.

Kolben: weiss, konisch, sehr gross, 18-26 cm lang, $5-6.5 \mathrm{~cm}$ dick, 12-18-reihig, mit 36 Friichten p. Reihe, sehr regelmässig; Spindel weiss. - Halm sehr gross, blattreich. - Frucht: weiss, perlmutterartig glänzend, platt, an der Krone oft etwas ausgehöhlt, mit einem scharfen Zahn, $12 \mathrm{~mm}$ lang, $7-10 \mathrm{~mm}$ breit, $3.5 \mathrm{~mm}$ dick, 22.5 Früchte $=10 \mathrm{gr}$.

Dieser Mais wurde 1877 in Poppelsdorf durch Kreusler und 1878 durch mich gepriuft und ergaben sich nachfolgende Resultate:

\begin{tabular}{|c|c|c|}
\hline & 1877 & 1878 \\
\hline $\begin{array}{l}\text { Pflanzraum } \\
\text { Aussaat } \\
\text { Blütezeit } \\
\text { Zahl der Triebe p. Pflanze } \\
\text { " " männlichen Blüten } \\
\text { " " weiblichen } \\
\text { Halmlänge } \\
\text { Halmdurchehtbaren Kolben } \\
\text { Blattzahl p. Halm } \\
\text { Blattlänge } \\
\text { Blattbreite } \\
\text { Blattflächc beider Seiten } \\
\text { Halmfläche } \\
\text { Gesammtfläche }\end{array}$ & $\begin{array}{c}750 \mathrm{qcm} \\
11 / 5 \\
24 / 8 \\
1.03 \\
1 \\
1.8 \\
1.1 \\
302 \mathrm{~cm}(\mathrm{Max} .350 \mathrm{~cm}) \\
16.1 \mathrm{~cm}(\operatorname{Max} .20 \mathrm{~cm}) \\
- \\
16516 \mathrm{qcm} \\
-\end{array}$ & $\begin{array}{c}1500 \mathrm{qcm} \\
20 / 5 \\
28 / 8 \\
1 \\
1 \\
1.3 \\
1.1 \\
170 \mathrm{~cm} \mathrm{(Max.} 220 \mathrm{~cm}) \\
2.7 \mathrm{~cm}(\operatorname{Max} .3 \mathrm{~cm}) \\
13 \\
68.4 \mathrm{~cm}(\operatorname{Max} .71 .3 \mathrm{~cm}) \\
6.4 \mathrm{~cm}(\operatorname{Max} .8 \mathrm{~cm}) \\
11381.76-14830.4 \mathrm{~cm} \\
1377.00-1980.0 \quad " \\
12758.76-16810.4 \quad "\end{array}$ \\
\hline
\end{tabular}

Nach den Untersuchungen von Kreusler 1877 betrug p. Pflanze am 24. August das Frischgewicht $1377.30 \mathrm{gr}$, Trockengewicht $163.140 \mathrm{gr}$. 28. September, 1380.60 , 5. October " 1174.20 267.82, 248.19,

Von der Bliitezeit an gestalteten sich die Blattfächen p. Pflanze einseitig gemessen, wie folgt: 


\begin{tabular}{|c|c|c|c|c|c|c|c|}
\hline $\mathrm{m}$ & 24. & August & betrug & dle & Blattfacche & 8. & qc1 \\
\hline$"$ & 31. & $"$ & $"$ & 13 & $"$ & 7090 & " \\
\hline$"$ & 7. & September & $"$ & $"$ & $"$ & 9200 & \\
\hline "3 & 15. & " & $"$ & $"$ & $\eta$ & 5838 & \\
\hline$"$ & 21. & $"$ & ", & $"$ & $"$ & 7071 & \\
\hline 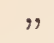 & 28. & 7 & $"$ & " & $"$ & 5610 & \\
\hline$"$ & 5 & ktober & " & $"$ & ", & & \\
\hline
\end{tabular}

Bis zum 5. Oktober zeigte sich eine sehr geringe Kornentwickelung und betrug das Trockengewicht der Körner uur 11,64 gr p. Pflanze.

In Mitteleuropa werden die Frïchte nur selten reif, und da sie auch leicht degenerieren, so ist das Saatgut für diesen nur als Grünfutter bei uns zu kultivierenden Mais aus Nord-Amerika zu beziehen.

In seiner Heimat wird dagegen das Korn hoch geschätzt und grob geschrotet in Milch gekocht, verzehrt.

Im Allgemeinen ist nach Salisbur. ${ }^{1}$ ) der Zahnkornmais viel ärmer an Oel als die Flintkornsorten, wie nachstehende Analyse zeigt.

$$
\text { Zucker }
$$

Stärke und Extrakt Holzfaser Eiweiss Oel Dextrin Wasser

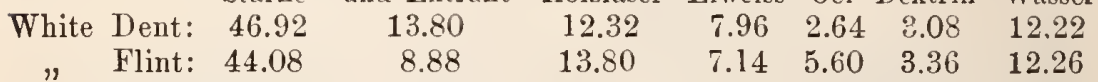

Stark angebaut in Kentucky, N. Carolina, Ohio, New-Jersey und Süd-Amerika. Ferner gedeilt er gut in Algier und Spranien.

\section{Caragua-Mais.}

Franz.: Maïs géant Caragua.

It al.: Frumentone gigante-Caragua.

Kolben: weiss, sich wenig verjüngend, $16 \mathrm{~cm}$ lang, 16-20-reihig, mit 30 resp. 35 Früchten p. Reihe; Spindel weiss. - Frucht: weiss, perlmutterfarbig, wenig durchscheinend, Mehl sehr weiss; in der Form mit Zahnkorn identisch (12 mm lang, 8-12 $\mathrm{mm}$ breit, $4 \mathrm{~mm}$ dick), 292.8 Frïchte $=100 \mathrm{gr}$. - Halm: Stengel und Hüllblätter mit violetten Streifen, Stengel und Blätter noch üppiger als beim Pferdezahn, 2.3$3 \mathrm{~m}$ locll.

Die Kultur in Poppelsdorf bei $50 \mathrm{~cm}$ Reihenweite und $30 \mathrm{~cm}$ Entfernung in der Reilse ergab folgendes Resultat: Aussaat 20/5. 78, Erscheinen der Pflanzen 7/6., Bliitezeit 20/9.; männliche Blüte 1.1 p. Pflanze, hellgrün, Staubbeutel grünlichgelb; weibliche Blüte 1.6 p. Pflanze, Griffel blassrosa. Bestockungstriebe 1.55 p. Pflanze, Halme $180 \mathrm{~cm}$ (Max. $220 \mathrm{~cm}$ ) lang, 21/2 cm (Max. $3 \mathrm{~cm}$ ) dick, Blattzall 18, Blätter $63 \mathrm{~cm}$ lang, $8 \mathrm{~cm}$ breit, Blattfläche $18144 \mathrm{qcm}$, Halmfläche $1350 \mathrm{qcm}$, Gesammtfläche $19494 \mathrm{qcm}$.

Dieser Mais gewährt noch ein viel späteres Grünfutter, zu gleicher Zeit gepflanzt, wie der Zahnkornmais, und ist selbst noch kräftiger und buschiger als die gelven Zahnkornsorten. $1030 \mathrm{gr}$

Das Frischgewiclit stellte sich bei einem Halm mittlerer Grösse auf

Goffart zu Burtin in der Sologne, Frankreich, erntete von ihm $100000 \mathrm{~kg}$ Sauerfutter p. ha.

$\mathrm{Da}$ er im Siidwesten Frankreichs reift, so ist von dorther ein

1) Transact. of the N. Y. st. V. VIII, 1848. p. 833. 
leichter Samenbezug möglich. Geerntet werden von 100 Kolben $12-$ $22^{1 / 2} \mathrm{~kg}$ Körner.

In Algier wird dieser Mais sehr geschätzt und ausgedehnt gebaut, und in neuerer Zeit ist seine Kultur auch in Ober-Italien eingeführt.

Ueber den Ursprung des Caragua-Maises besteht eine Kontroverse zwischen M. Goffart und M. Vilmorin ${ }^{1}$ ). Goffart behauptet, Vilmorin habe den "Caragua-Mais" durch einen Kommissionär Mïller aus New-York erhalten, und sei dies der als Woodrow oder Moka in den Vereinigten Staaten bekannte Mais, der vielfach in N. Carolina, Georgia und Maryland als Futtermais angebaut werde, während dagegen Vilm oriu anführt, er habe ihn aus einer Pflanzenschule Algiers erhalten, wohin er ursprünglich aus Nicaragua in Süd-Amerika gekommen, demnach der Name "Caragua" nur die Abkiirzung von ,Nicaragua" sei.

$\mathrm{Zu}$ bemerken ist, dass dieser Nais nicht mit dem "Curagua" (Zea curagua Molina) in Chile identisch ist.

Bezugsquelle: Vilmorin, Paris.

\section{Rhode Island Cap.}

Kolben: weiss, fast cylindrisch, $13-16 \mathrm{~cm}$ lang, 76.3 Proc. machen die Früchte und 23.7 Proc. die Spindeln aus. - Halm: $2.8 \mathrm{~m}$ hoch, mit 1-3 Kolben. - Frucht: weiss, in der Form, "White Dent" ähnelnd, gross (10 mm lang, $9-10 \mathrm{~mm}$ breit, $4.8 \mathrm{~mm}$ dick).

Nach Salisbur ${ }^{2}$ ) wurde dieser Mais am 12/5. im Staate NewYork ausgelegt, lief am 20/5. auf, trat am 25/7. in Blite und reifte nach einer Vegetationszeit von 126 Tagen, nämlich am 15/9. In der Bliute erreichte er eine Hölıe von $1.96 \mathrm{~m}$, in der Reife von $2.66 \mathrm{~m}$, die durchschnittliche Blattzahl betrug 10. Der Ertrag stellte sich p. ha auf $7459.2 \mathrm{~kg}$ Früchte, 2287.04 kg Spindeln, 6161.12 kg Blätter uid Kolbenhïllen und $5589.92 \mathrm{~kg}$ Stengel.

Das Korn zeigte nachfolgende Zusammensetzung:

$$
\text { Zucker Zeï Dextrin }
$$

Stärke u. Extrakt Holzfaser Eiweiss Kaseïn u. Glutin Oel u. Gummi Wasser $\begin{array}{lllllllll}50.36 & 6.56 & 10.48 & 5.84 & 0.76 & 5.40 & 4.76 & 3.38 & 12.49 .\end{array}$

Ursprünglich stammt diese frühreife Sorte aus Canada, und wird jetzt vielfach in den nördlichen und östlichen Staaten der Union kultiviert, und wïrde sich vielleicht auch erfolgreicl in Süd-Deutschland anbauen lassen.

\section{Adam's early-corn.}

Kolben: weiss, stark konisch, $12-18$ cin lang, Durchmesser an der Basis $4 \frac{1}{2} \mathrm{~cm}$, an der Spitze $3 \mathrm{~cm}, 10$-reihig mit $36-40$ Früchten p. Reihe. - Halm: mittelgross. - Frucht: weiss, Kunden selır tief, schwach transparent, gross (11 min lang, $10 \mathrm{~mm}$ breit, $4 \mathrm{~mm}$ dick).

Diesen Speisemais ziichtete Mr. Walker aus Columbia.

Nach Salisbury enthält das Korn: Zucker

Dextrin

Stärke und Extract Holzfaser Proteïn Oel und Gummi Wasser

$\begin{array}{lllllll}57.18 & 9.30 & 6.60 & 10.34 & 4.16 & 0.32 & 11.45\end{array}$

1) Journ. de l'Agric. 1876. 4. Bd. p. 17 und 305.

2) Transact. of the N. Y. st. V. VIII 1848. p. 830. 


\section{Sheep's tooth-corn or Sheep's dent.}

Syn.: Franz.: Maïs dent de mouton.

Deutsch: Schafszahnkornmais.

Kolben: konisch, 18-20-22-reihig, immer 2 Reihen dicht zusammen stossend, 60 Früchte p. Reihe, $25 \mathrm{~cm}$ lang, $5 \frac{1}{1} / 2 \mathrm{~cm}$ dick. Frucht: weiss, lang, schmal, ein wenig länger und schmaler als vom Pferdezahn, soust in der Form dem Pferdezahn gleich; glasig, an der Spitze mehlig (14 $\mathrm{mm}$ lang, $7 \mathrm{~mm}$ breit, $3 \mathrm{~mm}$ dick, 176 Früchte $=10 \mathrm{gr}$ ). - Halm $300 \mathrm{~cm}$ hocl,, $3 \mathrm{~cm}$ dick, Blattzahl 18, Blätter $72 \mathrm{~cm}$ lang, $8.6 \mathrm{~cm}$ breit, Blattfläche $2229 \mathrm{qcm}$, Halmfläche $900 \mathrm{qcm}$, Gesammtfläche 3129 qcm; 2 Kolben pro Halm.

Diese Sorte wird seit einiger Zeit in den Vereinigten Staaten kultiviert und tritt mit dem Pferdezahnmais, von dem sie nur eine andere Form ist, in Rivalität. Sie unterscheidet sich von dieser Form durch kleinere und scbmälere Körner, sowie durch grösseren Blattreichtum, daher sie mehr Grünfutter als Zahnkorn-Mais liefert.

Bezugsquelle: Tilin orin, Paris.

Varietiit: Zea Mais alborubra Kcke.

\section{Sorte:}

\section{Weisser Pferdezahnmais mit rothen Spelzen.}

Kolben: cylindrisch, $18 \mathrm{~cm}$ lang, $5 \mathrm{~cm}$ dick, 12-16-reihig, 32-36 Früchte p. Reihe; Spindel rot. - Frucht: oben weiss, nach unten zu blass-rötlich, Kunden oval (12 $\mathrm{mm}$ lang, $6-8 \mathrm{~mm}$ breit, $4 \mathrm{~mm}$ dick, 31.4 Fruichte $=10 \mathrm{gr}$ ).

Original in der Poppelsdorfer Sammlung.

\section{Varietät: Zea Mais xanthodon Al.}

\section{Sorten:}

\section{Maiz diente de Caballo amarillo, Chile.}

Syn.: Orangegelber Pferdezahnmais.

Kolben: fast cylindrisch, $25 \mathrm{~cm}$ lang, 4-5 cm dick, 14-16-reihig; Reihen regelmässig, mit 55-60 Früchten in der Reihe; Spindel weiss. - Halm bis $2 \mathrm{~m}$ hoch. - Frucht: orangefarben, Spitze etwas breit, schmal, lang, Seiten eingedrückt, Kunden ziemlich tief (12 mm lang, $7-9 \mathrm{~mm}$ breit, $4-5 \mathrm{~mm}$ dick, 26 Früchte $=10 \mathrm{gr}$ ).

Vaterland: Süd-Amerika.

Ton der Hacienda de Colina, Dept. de Santiago, Chile, durch Herrn von Gülich (landw. Museum zu Berlin) erhalten.

\section{IIaiz chico lijero, Chile.}

Kolben: konisch, 32-reihig, regelmässig. - Frucht: Original schwefelgelb und durchsichtig, Form des Pferdezahnmaises mit tiefen Kunden, gross, $14 \mathrm{~mm}$ lang, $8 \mathrm{~mm}$ breit, $5 \mathrm{~mm}$ dick 40 Früchte $=10 \mathrm{gr}$. - 
Halm $200 \mathrm{~cm}$ lang, $3 \mathrm{~cm}$ dick, 3 Schösslinge, Rispe $40 \mathrm{~cm}$ lang, weibliche Blüte grünlich-gelb; Blattzahl 11, Blätter $77 \mathrm{~cm}$ lang, $9.9 \mathrm{~cm}$ breit, Blattfläche $16770.6 \mathrm{qcm}$, Halmfiäche $1800 \mathrm{qcm}$, Gesammtfläche $18570.6 \mathrm{qem}$.

Sehr spätreif. 1880.

Bezugsquelle: Durch von Gülich aus Hacienda de Colina, Chile,

\section{Maiz precoz, Chile.}

Kolben: klein, 20-reihig. - Frucht: Original schwefelgelb, undurchsichtig, Form des Pferdezahnes, $11 \mathrm{~mm}$ lang, $6 \frac{1}{2} \mathrm{~mm}$ breit, $4 \mathrm{~mm}$ dick, 62 Früchte $=10 \mathrm{gr}$. - Halın: $165 \mathrm{~cm}$ lang, $2.5 \mathrm{~cm}$ dick, 1.5 Schösslinge, Rispe $25 \mathrm{~cm}$ lang, 1 Kolben pro Halm, weibliche Blüte grüngelb; Blattzahl 13, Blätter $55 \mathrm{~cm}$ lang, $6.6 \mathrm{~cm}$ breit, Blattfläche $9448 \mathrm{qcm}$, Halmfläche $1237.5 \mathrm{qcm}$, Gesammtfläche $10685.5 \mathrm{qcm}$.

Spätreif. 1880 .

Bezugsquelle: Durch von Gülich aus Hacienda de Colina, Chile,

\section{Maiz Llampo, Chile.}

Kolben: konisch, 24-reihig. - Frucht: hellgelb, Form des Pferdezahnes, verhältnismässig lang, $13 \mathrm{~mm}$ lang, $6.5 \mathrm{~mm}$ breit, $4 \mathrm{~mm}$ dick, 58 Früchte $=10 \mathrm{gr}$. - Halm: rotbraun, $250 \mathrm{~cm}$ lang, $3 \mathrm{~cm}$ dick, Rispe $45 \mathrm{~cm}$ lang, 3 Schösslinge, rotbraun; Blattzahl 15, Blätter $73 \mathrm{~cm}$ lang, $6.2 \mathrm{~cm}$ breit, Blattfäche $13578 \mathrm{qcm}$, Halmfläche $2250 \mathrm{qcm}$, Gesammtfläche $15828 \mathrm{qcm}$.

Sehr spätreif. 1880.

Bezugsquelle: Durch von Gülich aus Hacienda de Colina, Chile,

Varietät: Zea Mais flavorubra Kcke.

Sorten:

\section{Penusylvania Dent.}

Syn.: Clinton-Corn.

Franz.: Maïs de Pennsylvanie, géant de Chine.

Ital.: Grantureo gigante.

Portug.: Milho gigantil.

Spanisch: Maiz americano gigante, Chile.

Kolben: in der Mitte häufig am dicksten, sich nach der Spitze stark verjüngend, doch endet dieselbe plötzlich; $15-21 \mathrm{~cm}$ lang, $3.5-5 \mathrm{~cm}$ dick, 8-10-12-reihig, selır regelmässig, dicht, bis 50 Früchte in der Reihe; Spindel blassrot. - Frucht: fleischfarben am Zahn, gelb in der Mitte, hellgelb an der Krone, platt, sehr gross (10 mm lang, 5-10 mm breit, 2.5-4 mm dick, 26 Früchte $=10 \mathrm{gr}$ ). - Halm $2.5 \mathrm{~m}$, ausnalımsweise in den Südstaaten der Union 3-4 m hoch.

Nach Salisbury ${ }^{1}$ ) erschien im Staate New-York am 12/5. gelegter

1) A. а. 0. 1848 p. 832 . 
Mais am 21/5., trat am 28/7. in Blüte und reifte nach 126 Tagen am 15/9. Die Halme erreichten in der Blüte eine Höhe von $1.96 \mathrm{~m}$, in der Reife von $2.77 \mathrm{~m}$, hesassen 10 Blätter und 1 Kolben. Der Ertrag stellte sich p. ha auf $5376 \mathrm{~kg}$ Früchte, $1968.96 \mathrm{~kg}$ Spindeln, $4827.2 \mathrm{~kg}$ Blätter und Kolbenhüllen und $24858.2 \mathrm{~kg}$ Stengel. centen:

Die Analyse der Früchte ergab folgende Zusammensetzung in Pro-

$$
\begin{array}{ccccccc} 
& \text { Zucker } & & & \multicolumn{3}{c}{\text { Dextrin }} \\
\text { Stärke } & \text { und Extrakt } & \text { Holzfaser } & \text { Protein } & \text { Oel } & \text { und Gummi } & \text { Wasser } \\
45.52 & 14.36 & 13.68 & 9.36 & 3.68 & 3.28 & 10.23
\end{array}
$$

Nach Gasparin ${ }^{1}$ ) liefern 100 Kolben $22-25 \mathrm{~kg}$ Korn, von dem $1 \mathrm{hl}=75 \mathrm{~kg}$ wiegt, und beansprucht dieser Mais eine Wärmesumme von $4400^{\circ}$. Er reift nicht mehr in Frankreich, wohl aber in Piemont, Spanien, Portugal, in den Südstaaten der Union und in Süd-Amerika.

Original in der Sammlung zu Poppelsdorf, und von der Hacienda de Colina, Dept. de Santiago, Chile, durch Herrn von Gülich (landw. Museum zu Berlin) erhalten.

\section{Large yellow Gourd-seed, with red cob.}

Kolben: cylindrisch, sehr gross, 15-23 $\mathrm{cm}$ lang, $6-7 \mathrm{~cm}$ dick, 22-26-reihig; Frucht mittelfest sitzend, nicht selten liefert ein Kolben bis zu $500 \mathrm{gr}$ an Früchten: Spindel tief-rot. - Halm sehr gross, oft $4.5 \mathrm{~m}$ hoch. - Frucht: rötlich-gelb an den Seiten, hellgelb an der Krone, sehr stark gezahnt, 4-eckig, gross (11 mm lang, $8-9 \mathrm{~mm}$ breit, $4.5 \mathrm{~mm}$ dick).

Diese Sorte ist aus einer Kreuzung ${ }^{2}$ ) des "Southern Big Yellow“ mit "White Gourd-seed" hervorgegangen.

In den Südstaaten der Union sehr ertragreich, doch ist seine Vegetationsperiode für New-York schon zu lang.

Zuweilen findet sich dieser Mrais auch in Ober-Italien, z. B. in der Provinz Verona angebaut.

\section{Large Ohio Dent or Gourd-seed.}

Franz.: Maïs jaune de l'Ohio.

Kolben: cylindrisch, $21-36 \mathrm{~cm}$ lang, $5-6 \mathrm{~cm}$ dick, 12-reihig; Spindel hellrot. - Frucht: tief-gelb an den Seiten, hellgelb an der Krone, sehr stark gezahnt, gross (11-13 $\mathrm{mm}$ lang, 7-10 $\mathrm{mm}$ breit, $4 \mathrm{~mm}$ dick).

Gehört mit zu den grössten aber am spätesten reifenden Maissorten der Südweststaaten der Union.

In Ohio wird diese Sorte neben dem weissen Pferdezahn seines hohen Ertrages wegen am meisten gebaut.

Nach Salisbury ${ }^{3}$ ) besitzen die Früchte nachfolgende Zusammensetzung in Procenten:

Stärke Zucker und Extrakt Holzfaser Proteïn Oel Dextrin Wasser

$\begin{array}{llllllll}54.00 & 6.80 & 10.16 & 8.60 & 3.90 & 5.36 & 10.36\end{array}$

1) Cours d'agric. III 748 .

2) Salisbury, Transact. of the N. Y. st. V. VIII 1848 p. 833.

3) A. a. O. V. VIII pag. 833 . 


\section{Virginia Yellow-Dent.}

Kolben: schwach konisch, $15-26 \mathrm{~cm}$ lang, $5 \mathrm{~cm}$ dick, 16-reihig, etwas unregelmässig, 24-30 Früchte p. Reihe; Spelzen rot. - Halm gelbgrün, hoch. - Frucht: gelblich-rot an den Seiten, tief gelb an der Krone; mässig gezahnt, namentlich sind die Früchte an der Basis und Spitze kaum gezahnt $(10 \mathrm{~mm}$ lang, $5-8 \mathrm{~mm}$ breit, $4 \mathrm{~mm}$ dick, 47 Körner $=10 \mathrm{gr}$ ).

In Poppelsdorf erfolgte bei einem Pflanzraum von $1500 \mathrm{qcm}$ die Aussaat am 20/5. 78, die Pflänzchen zeigten sich am 7/6., und die Blüte begann am 5/9. Jede Pflanze entwickelte nur einen Halm, eine männliche Blüte mit goldgelben Staubbeuteln, und eine weibliche Blite mit blassrosa gefärbten Griffeln, doch gelangte sie kaum zum Fruchtansatz.

Halme $200 \mathrm{~cm}$ (Max. $250 \mathrm{~cm}$ ) lang, $3 \mathrm{~cm}$ dick, Blattzahl 12, Blätter $64.4 \mathrm{~cm}$ lang, $7.2 \mathrm{~cm}$ breit, Blattfläche 11368.32 q cm, Halnfläche $1800 \mathrm{qcm}$, Gesammtfläche 13168.32 qcm. Das Frischgewicht eines Halmes betrug $930 \mathrm{gr}$.

Nach Salisbury ${ }^{1}$ ) ist sie eine der nährstoffreichsten Sorten der Südstaaten und enthält die Frucht in Procenten:

Stärke Zucker und Extrakt Holzfaser Proteïn Oel Dextrin Wasser

$\begin{array}{llllllll}41.54 & 15.40 & 12.70 & 11.62 & 5.20 & 6.64 & 7.26 .\end{array}$

Diese Sorte ist nahe mit „Large Ohio Dent“ verwandt.

Varietät: Zea Mais crocodon Kcke.

\section{Sorte:}

\section{Safliranfarbener Pferdezahnmais.}

Kolben: cylindrisch, gross, $17 \mathrm{~cm}$ lang, $4 \mathrm{~cm}$ dick, 12-reibig, Reihen sehr regelmässig, weit von einander entfernt, locker, 35 Früchte in der Reihe; Spindel rot. - Frucht: Einsenkung in der Krone (Kunde) oval, gelb, undurchsichtig, sonst saffranfarben, sich nach der Basis zu versclımälernd (10 $\mathrm{mm}$ lang, $6-8 \mathrm{~mm}$ breit, $3 \frac{1}{2} \mathrm{~mm}$ dick, 39.3 Früchte $=10 \mathrm{gr}$ ).

Original in der Sammlung zu Poppelsdorf.

\section{Varietät: Zea Mais crococeras Kcke:}

\section{Sorte :}

\section{Saffranfarbener, spitziger Pferdezahnmais.}

Kolben: gross, cylindrisch, $20-25 \mathrm{~cm}$ lang, $5-5 \frac{1}{2} \mathrm{~cm}$ breit, 16 reihig, Reihen regelmässig, locker, 37-40 Früchte in der Reihe. Spindel rot. - Frucht: saffranfarben mit auffallend langem Zahn, platt (12 $\mathrm{mm}$ lang, $6-8 \mathrm{~mm}$ breit, $4 \mathrm{~mm}$ dick, 39.6 Früchte $=10 \mathrm{gr}$ ).

Original in der Sammlung zu Poppelsdorf.

1) Transact. of the N. Y. st. Vol. VIII 1848 p. 833.

Koernicke u. Werner, Handb. d. Getreidebau's $1 I$. 


\section{Varietät: Zea Mais pyrodon Al.}

\section{Sorten:}

\section{Maiz morado comun, Chile.}

Kolben: stark konisch, $18 \mathrm{~cm}$ lang, $4 \mathrm{~cm}$ breit, 18-20-reihig, 50 Früchte in der Reihe. - Frucht: Original dunkelrot, länglich, sich verjüngend, Form des Zahnkorumaises, Kunden schwach, $12 \mathrm{~mm}$ lang, $9 \mathrm{~mm}$ breit, $4.5 \mathrm{~mm}$ dick, 50 Früchte $=10 \mathrm{gr}$. - Halm: $270 \mathrm{~cm}$ lang, $3.2 \mathrm{~cm}$ dick, 3.3 Schösslinge, 2 Kolben, Rispe $40 \mathrm{~cm}$ lang; Blattzahl 14, Blätter $67.5 \mathrm{~cm}$ lang, $9.6 \mathrm{~cm}$ breit, Blattfläche $18144 \mathrm{qcm}$, Halmfläche $2592 \mathrm{qcm}$, Gesammttläche $20736 \mathrm{qcm}$.

Spätreif. 1880.

Bezugsquelle: Durch ron Gülich aus Hacienda de Colina, Chile,

\section{Red-Dent.}

Franz.: Maïs rouge dent de cheval.

Deutsch: Roter Pferdezahnmais.

Kolben: gross, cylindrisch, $17-20 \mathrm{~cm}$ lang, 4-4.5 cm dick, 14reiliig, Reihen regelmässig, locker, 40 Früchte in der Reihe; Spindel rot. - Frucht: braunrot, Kunden sehr tief, länglich, abgeplattet $10 \mathrm{~mm}$ lang, 7-10 $\mathrm{mm}$ breit, $5 \mathrm{~mm}$ dick, $28.2 \mathrm{Körner}=10 \mathrm{gr})$. - Halm sehr hoch. Spätreife Sorte, die sich ausser in den Südstaaten der Union nur in Süd-Europa kultivieren lässt.

Original in der Sammlung zu Poppelsdorf.

Varietät: Zea Mais striatidens Kcke.

Sorte:

\section{Gestreifter Mais ans Indiana.}

Kolben: fast cylindrisch, $18-20 \mathrm{~cm}$ lang, $5 \mathrm{~cm}$ dick, 12-15-reihig, Reihen etwas unregelmässig, 30 Früchte in der Reihe; Spindel rötlichweiss. - Frucht: auf weissem Grunde rotbraune Streifen, Kunden rund und tief, Zahn schwach ( $8 \mathrm{~mm}$ lang, $8 \mathrm{~mm}$ breit, $4 \mathrm{~mm}$ dick, 46.3 Früchte $=10 \mathrm{gr}$.)

Original in der Sammlung zu Poppelsdorf.

Varietät: Zea Mais rubrostriata Kcke.

\section{Sorte:}

\section{Gallischer Mais.}

Kolben: einem Pinienzapfen gleichend, $14-16 \mathrm{~cm}$ lang, $5-5.5 \mathrm{~cm}$ dick, 14-reihig, Reihen sehr regelmässig, 30 Früchte in der Reihe; Spindel weiss. - Frucht: anf mehr oder weniger sattgelbem Grunde, der 
Länge nach dunkelrote Streifen, Einsenkung in der Krone (Kunde) wenig sichtbar, Zahn kräftig, abgeplattet, gross, lang (15 $\mathrm{mm}$ lang, 5-10 $\mathrm{mm}$ breit, $4 \mathrm{~mm}$ dick, 33.5 Frïchte $=10 \mathrm{gr}$ ).

Original in der Sammlung zu Poppelsdorf.

Varietät: Zea Mais rubrorelata Kcke.

Sorte:

Maiz tierno colorado, Chile.

Kolben: 24-30-reihig, Reihen unregelmässig, Spelzen rot, Hüllblätter rotbraun. - Frucht: Original blassgelb mit dunkelroten Streifen, Form des Pferdezahnes, $12 \mathrm{~mm}$ lang, $8 \mathrm{~mm}$ breit, $4 \mathrm{~mm}$ dick, 52 Körner $=10 \mathrm{gr}$. - Halm: rotbraun, $200 \mathrm{~cm}$ lang, $3.3 \mathrm{~cm}$ dick, 4 Schösslinge, 3 Kolben; Blattzahl 11, Blätter $62.5 \mathrm{~cm}$ lang, $9.6 \mathrm{~cm}$ breit, Blattfäche $13200 \mathrm{qcm}$, Halmfläche $1980 \mathrm{qcm}$, Gesammtfläche $15180 \mathrm{qcm}$.

Spätreif. In Poppelsdorf Frucht milchig, also nicht gereift. 1880.

Bezugsquelle: Durch vou Gülich aus Hacienda de Colina, Chile,

\section{Gruppe IV. Microsperma Kcke. Kleinkörniger Mais.}

Varietät: Zea Mais oryzoides Kcke.

\section{Sorte:}

\section{Rice Pop-Corn.}

Kolben: konisch, Reihen in sehr verschieden grosser Zahl, an der Basis oft bis 20 vorhanden, doch unregelmässig, Früchte aus den Reihen hervortretend, 5-10-13 cm lang, 2-3 cm dick; Spindel weiss. Frucht: weiss, sich nach der Basis verjüngend, Krone elliptisch, sehr zart, klein $(7 \mathrm{~mm}$ lang, $4 \mathrm{~mm}$ breit, $3 \mathrm{~mm}$ dick, 115.2 Früchte $=10 \mathrm{gr}$ ), feinschalig. - Halm bis $150 \mathrm{~cm}$ hoch, buschig, 3-4 Halme p. Pflanze, Stengel und Blattscheiden zeigen rote Färbung, feinhalmig, bis $1.3 \mathrm{~cm}$ dick.

Sehr spätreif, in Poppelsdorf war die Frucht Mitte Oktober noch sehr weich und wenig entwickelt.

Die Frucht ist reich an Oel und Proteïn, jedoch arm an Stärke, was auch die unten stehende Analyse von Salisbury ${ }^{1}$ ) beweist, nach dieser besitzt die Frucht in Procenten:

Zucker

Stärke und Extrakt Holzfaser Proteïn

$37.72 \quad 12.40$

12.40

14.72

Dextrin

Oel und Gummi Wasser

4.324 .64

12.22 
Das Mehl soll sehr trocken sein, und lässt sich allein nicht zu Brot verwenden, doch eignen sich die Körner, ihrer Grösse und Zusammensetzung nach, als Geflügelfutter ganz vorzüglich. Wenig ergiebig.

Heimat: Pennsylvanien.

Varietät: Zea Mais leucornis Al.

Sorten:

\section{Maiz moracho perla, Chile.}

Kolben: konisch; 20-reihig, Reihen regelmässig, mit 33 Früchten; $16 \mathrm{~cm}$ lang, $3.5 \mathrm{~cm}$ dick. - Frucht: weiss, transparent, Krone rundlich, sich verjüngend, Seiten zusammengedrückt, $10 \mathrm{~mm}$ lang, $7 \mathrm{~mm}$ breit, $4 \mathrm{~mm}$ dick, 55 Frïchte $=10 \mathrm{gr}$. - Halm: $230 \mathrm{~cm}$ lang, $3 \mathrm{~cm}$ dick, 4 Schösslinge, Rispe $40 \mathrm{~cm}$ lang, 1.5 Kolben pro Halm; Blattzahl 12, Blätter $71 \mathrm{~cm}$ lang, $7 \mathrm{~cm}$ breit, Blattflächc $11928 \mathrm{qcm}$, Halmfläche $2070 \mathrm{qcm}$, Gesammtfläche 13998 qcm.

Spätreif. 1880 .

Bezugsquelle: Durch von Gïlich aus Hacienda de Colina, Chile,

\section{Maiz curagua blanca.}

Kolben: konisch, 18-reihig, klein (17 cm lang, $3 \mathrm{~cm}$ breit), Reihen regelmässig, 45 Früchte pro Reihe. - Frucht: gelblich-weiss, transparent, klein, länglich, Krone 4-eckig, sich nach der Basis verjüngend, 91 Körner $=10 \mathrm{gr}$. - Halm: 3.5 Schösslinge, $220 \mathrm{~cm}$ lang, $3 \mathrm{~cm}$ dick, Rispe $45 \mathrm{~cm}$ lang, Blattzahl 14, Blätter $74 \mathrm{~cm}$ lang, $8.5 \mathrm{~cm}$ breit, Blattfläche $17612 \mathrm{qcm}$, Halmfläche $1980 \mathrm{qcm}$, Gesammtfläche $19592 \mathrm{qcm}$.

Die Aufstellung der Art ,Zea Curagua" durch Molina gründet sich vornehmlich auf die etwas gezahnten Blattränder (Culmo humili, foliis serratis, Molina). Die Blätter der aus Originalfrüchten gezogenen Pflanzen zeigten sich in Poppelsdorf nicht stärker gezahnt als die anderer Maissorten. Auch Burger ${ }^{1}$ ) weist die von Molina gebildete Species, wie er solche in seinem „Versuch einer Naturgeschichte von Chili, aus dem Ital. übersetzt von Brandis $1786^{\text {" }}$ aufstellt, ebenfalls zurück, zumal die Beschreibung sehr kurz und hingeworfen und ïberdies nicht ganz gleichstimmig ist, einmal spricht er von "Curagua, foliis serratis" und später von "foliis denticulatis". Bonafous liess dagegen diese Species bestehen.

Die Bezeichnung Maiz curagua der Chilenen bedeutet, von der Härte der Körner hergeleitet „Steinmais'. Derselbe liefert ein vorzügliches Mrehl.

Seine Vegetationszeit unfasst in Chile 5 Monate. Ausser dieser Sorte gibt es in Süd-Amerika noch zahlreiche, hauptsächlich nur ander's gefärbte Sorten, die zum Teil bei den betreffenden Varietäten beschrieben sind.

Bezugsquelle: Durch von Gülich aus Hacienda de Colina, Chile.

1) Naturgesch., Kult. u. Benutz. d. Mais 1809 pg. 21. 


\section{New-Joint Parching.}

Syn.: Amerikan.: Pop or Parching-corn.

Deutsch: Puffkorn oder Röstmais.

Kolben: schwach konisch, $15 \mathrm{~cm}$ lang, $31 / 2 \mathrm{cml}$ dick, 18-reihig, Reihen nicht ganz regelmässig, 43 Früchte in der Reihe. - Frucht: weiss, transparent, keilförmig, abgeplattet, klein $(7 \mathrm{~mm}$ lang, $3-5 \mathrm{~mm}$ breit, $3.5 \mathrm{~mm}$ dick). - Halm buschig, feinhalmig, bis $180 \mathrm{~cm}$ hoch, 8-10 Kolben an einem Halm.

In Poppelsdorf am 20/5. ausgelegt, Pflanzraum $1500 \mathrm{qcm}$, trat die Blüte erst am 30/8. ein, mithin diese Sorte sehr spätreif ist und hier nicht mehr reift.

Die Zahl der männlichen Blüten (Staubbeutel hellrot), betrug $1 \mathrm{p}$. Halm, die der weiblichen (Griffel hellrot oder rot), 1.7. Halme $160 \mathrm{~cm}$ (Hax. $180 \mathrm{~cm}$ ) lang, $2.5 \mathrm{~cm}$ dick, Blattzahl 10, Blätter $66.8 \mathrm{~cm}$ lang, $6 \mathrm{~cm}$ breit, Blattfläche $8016 \mathrm{qcm}$, Halmfäche $1200 \mathrm{qcm}$, Gesammtfläche $9216 \mathrm{qcm}$.

Das Frischgewicht eines Halmes stellte sich auf $420-500 \mathrm{gr}$.

Diese Sorte, da das Korn weich, zart und von ausgezeichnetem Geschmack ist, eignet sich vorzüglich zum Rösten, doch wird es auch vielfach zum Futtern des Federviehs benutzt. Sie ist sehr ergiebig.

Heimat; New-York state.

Original in der Poppelsdorfer-Sammlung.

Varietät: Zea Mais gracillima Kcke.

Sorte:

Zea gracillima aus Nord-Amerika.

Syn.: Spanisch: Blat de moro.

Kolben: klein, fast cylindrisch, 9-14 $\mathrm{cm}$ lang, $2.5 \mathrm{~cm}$ dick, 16reihig, Reihen regelmässig, 30-45 Früchte in einer Reihe. - Frucht: blassgelb, transparent, meisselförmig, platt, sehr klein (6 mm lang, 2.5$4 \mathrm{~mm}$ breit, $2.5 \mathrm{~mm}$ dick, 194 Früchte $=10 \mathrm{gr})$. Halm niedrig, nur $70-90 \mathrm{~cm}$ hoch, doch einen umfangreichen Busch bildend.

Diese Sorte ist sehr spätreif und entwickelte sich in Poppelsdorf nicht einmal bis zur Blüte, doch ist sie vielleicht zur Grünfutternutzung, da ihr Anbau wenig Saatgut erfordert, die Halme blattreich und fein sind, und das Futter noch spät weich bleibt, geeignet.

Halm $170 \mathrm{~cm}$ lang, $2.5 \mathrm{~cm}$ dick, Blattzahl 24, Blätter $70 \mathrm{~cm}$ lang, $7.7 \mathrm{~cm}$ breit, Blattfläche $25872 \mathrm{qcm}$, Halmfläche $1275 \mathrm{qcm}$, Gesammtfläche $27147 \mathrm{qcm}$. Anzahl der Schösslinge 5.

Original in der Poppelsdorfer-Sammlung und „Blat de moro" durch Ant. Cipr. Costa, aus der Granja de Barcelona 1881 erhalten. 
Varietät: Zea Mais xanthornis Kcke.

\section{Sorten:}

\section{Iaiz curagua, Chile.}

Syn.: Zea Curagua Molina ${ }^{1}$.

Yais Curahua ${ }^{2}$ ).

Franz.: Mais de pierre.

It al.: Granoturco di pietra.

Deutsch: Kuragua- oder Steinmais.

Kolben: konisch, $15 \mathrm{~cm}$ lang, $4 \mathrm{cn}$ breit, 1-reihig mit 35 Früchten pro Reihe. - Frucht: sattgelb, Krone fast 4-eckig, sich nach der Spitze verjüngend, länglich, klein $(10 \mathrm{~mm}$ lang, $5 \mathrm{~mm}$ breit, $4 \mathrm{~mm}$ dick, 89 Früchte $=10 \mathrm{gr}) . \quad$ - Halm: $160 \mathrm{~cm}$ lang, $2.5 \mathrm{~cm}$ dick, Blattzahl 12, Rispe $30 \mathrm{~cm}$ lang, Narben rosa, 2 Kolben, Anfang August blühend; Blätter $58.3 \mathrm{~cm}$ lang, $7.8 \mathrm{~cm}$ breit, BlattAläche $10913.8 \mathrm{qcm}$, Halm丹läche $1200 \mathrm{qcm}$, Gesammttäche $12113.8 \mathrm{qcm}$.

In Poppelsdorf nicht reif geworden.

Bezugsquelle: Durch Ministerresident von Gülich 1880 erhalten, welcher diese Sorte an das landw. Mruseum in Berlin von der Hacienda de la Rinconada, Dept. del Parral, Chile, einsandte.

\section{Iaiz curagua alpiste, Chile.}

Kolben: konisch, 16-reihig. - Frucht: Original schwach rötlichgelb, transparent, Krone 4-eckig, sich meisselförmig verjüngend, klein $(8.5 \mathrm{~mm}$ lang, $3.5 \mathrm{~mm}$ breit und dick, 138 Früchte $=10 \mathrm{gr})$. - Halm: 6 Schösslinge, $200 \mathrm{~cm}$ lang, $2.5 \mathrm{~cm}$ dick, Rispe $30 \mathrm{~cm}$ lang, Mitte September blühend, 2 Kolben, Narben gelblich-grün, Blattzahl 11, Blätter $62 \mathrm{~cm}$ lang, $8.2 \mathrm{~cm}$ breit, Blattfläche $11184.8 \mathrm{qcm}$, Halmfäche $1500 \mathrm{qcm}$, Gesammtfäche $12684.8 \mathrm{qcm}$.

Sehr spätreif, in Poppelsdorf Korn kaum angesetzt.

Bezugsquelle: Durch v. Gülich aus der Hacienda de Colina, Dept. de Santiago, 1850, Chile.

\section{Maiz curagua amarillo coman.}

Kolben: schwach konisch, $22 \mathrm{~cm}$ lang, $4.5 \mathrm{~cm}$ dick, 16-18-22-reihig, mit 45 Frïchten in der Reihe. - Frucht: Original orangegelb, wenig transparent, Krone 4-eckig, sich meisselförmig verjüngend, klein (10 mm lang, $6 \mathrm{~mm}$ breit, $3 \mathrm{~mm}$ dick, 85 Früchte $=10 \mathrm{gr}$ ). - Halm: 4 Schösslinge, $200 \mathrm{~cm}$ lang, $2.5 \mathrm{~cm}$ dick, Blattzahl 14, Rispe $35 \mathrm{~cm}$ lang, Anfang August blühend, 3 Kolben; Blätter $60 \mathrm{~cm}$ lang, $7.9 \mathrm{~cm}$ breit, Blattfläche $13272 \mathrm{qcm}$, Halınfläche $1500 \mathrm{qcm}$, Gesammtfläche $14772 \mathrm{qcm}$.

Ziemlich frühreif, meist nahezu ausgereift.

Bezugsquelle: Durch v. Gülich aus der Hacienda de Colina, Dept. de Santiago 1880, Chile.

1) Molina, Chili ed. germ. pg. 107.

2) Bonafous, Hist. nat. Agric. et écon. du Mais. 


\section{Maiz curagua de Aconcagua, Chile.}

Kolben: konisch, 14-reihig, Reihen unregelmässig, $15 \mathrm{~cm} \mathrm{lang,} 3 \mathrm{~cm}$ dick, 35 Früchte in der Reihe. - Frucht: Original schwefelgelb, Krone 4-eckig, sich nach der Basis meisselförmig verjüngend, transparent, klein (10 $\mathrm{mm}$ lang, $5 \mathrm{~mm}$ breit, $4 \mathrm{~mm}$ dick, 90 Früchte $=10 \mathrm{gr})$. - Halm: 4 Schösslinge, $200 \mathrm{~cm}$ lang, $3 \mathrm{~cm}$ dick, Blattzahl 13, Rispe $30 \mathrm{~cm}$ lang, 2 Kolben; Blätter $58 \mathrm{~cm}$ lang, $8 \mathrm{~cm}$ breit, Blattfläche $12064 \mathrm{qcm}$, Halmfläche $1800 \mathrm{qcm}$, Gesammtfläche $13 \& 64 \mathrm{qcm}$.

Nur unvollkommen ausgereift.

Bezugsquelle: Durch von Gïlich ans Hacienda de Colina, Dept. de Santiago, Chile.

\section{Maiz, Ponte da Sìr, Portugal.}

Kolben: schwach konisch, $18 \mathrm{~cm}$ lang, $4.5 \mathrm{~cm}$ breit, 18-reihig, ziemlich regelmässig, 30 Früchte in der Reihe. - Frucht: schön gelb, glasig, Krone gerundet, sich verjuingend, Seiten platt, Keim eingedrückt, mittelgross, $8 \mathrm{~mm}$ lang, $8 \mathrm{~mm}$ breit, $4 \mathrm{~mm}$ dick, 55 Frïchte $=10 \mathrm{gr}$. - Halm: $145 \mathrm{~cm}$ lang, $2 \mathrm{~cm}$ dick, 1.3 Schösslinge, 2 reife Kolben, weibliche Blïte grïnlich-gelb, Rispe $30 \mathrm{~cm}$ lang, Blattzahl 11, Blätter $53 \mathrm{~cm}$ lang, $7.5 \mathrm{~cm}$ breit, Blattfäclıe $8745 \mathrm{qcm}$, Halmfläche $870 \mathrm{qcm}$, Gesammtfläche $9615 \mathrm{qcm}$.

Frühreif, in Poppelsdorf ziemlich gut im September ausreifend.

Bezugsquelle: Prof. Jul. Henriques, Coïmbra, Portugal.

\section{Chicken-Corn, Amerika.}

Syn.: Deutsch: Hühnermais.

Engl.: Poultry-Maize, Little yellow Pop-corn.

Franz.: Maïs à poulet, Mraïs nain.

It a l.: Granotureo nano.

Kolben: fast cylindrisch, diinn, abgerundet, klein, oft nur $8 \mathrm{~cm}$ (Max. $12 \mathrm{~cm}$ ) lang, 8-16-reihig, doch meist 10-reihig, Reihen regelmässig, dicht, mit 20 fest sitzenden Früchten in der Reihe. - Frucht: hellgelb, rundlich, glasig, klein $(7 \mathrm{~mm}$ lang, $7 \mathrm{~mm}$ breit, $5 \mathrm{~mm}$ dick, 83.3 Früchte $=10 \mathrm{gr}, 1 \mathrm{hl}=75 \mathrm{~kg}$ ).

In den Jahren $1875 / 78$ von $\mathrm{Krensler}$ und mir durchgeführte Kulturen ergaben im Durchschnitt nachfolgende Resultate:

Pflanzenraum 1000 q cm, Aussaat Mitte Mrai, Blïte Ende Juli, männliche Blüte 1 p. Pflanze (Staubbeutel grün), weibliche Blüte 2.7 (Griffel rot). Bestockungstriebe p. Pflanze 1.4, Halm $108 \mathrm{~cm}$ (MIax. $160 \mathrm{~cm}$ ) lang, $2.2 \mathrm{~cm}$ dick, Blattzahl 15, Blätter $34.5 \mathrm{~cm}$ lang, $4.4 \mathrm{~cm}$ breit, Blattfläche 4554 qcm, Halmfläche 712.8 qcm, Gesammtfläche $5266.8 \mathrm{qcm}$. Die Reife erfolgte in 120 Tagen und lieferten 100 Halme $9.600 \mathrm{~kg}$ Kolben ohne Kolbenhüllen, $1.900 \mathrm{~kg}$ Kolbenhüllen, $7.525 \mathrm{~kg}$ Früclite, $2.075 \mathrm{~kg}$ Spindeln, und $8.000 \mathrm{~kg}$ Stroh.

Der Kornertrag stellte sich auf $5897.32 \mathrm{~kg}$ p. ha.

Es ist dies eine kleine, sehr zeitige, doch auch wenig ergiebige Sorte, die noch auf Nittelboden gut gedeilht, sich für Mittel-Deutschland noch recht gut eignet, und als Hühnerfutter geschätzt ist.

In Italien reift dieser Mais in 2-3 Monaten. 
Varietät: Zea Mais haematornis Al.

\section{Sorte n:}

\section{Maiz curagua Argentina.}

Kolben: konisch, 15-reihig. - Frucht: hellrot, transparent, Krone 4-eckig, sich nach der Basis rerjüngend, klein, 110 Körner $=10 \mathrm{gr}$. Halm: $300 \mathrm{~cm}$ lang, $4 \mathrm{~cm}$ dick, 5 Schösslinge, Rispe $40 \mathrm{~cm}$ lang, 2 Kolben, Blattzahl 15, Blätter $86 \mathrm{~cm}$ lang, $9 \mathrm{~cm}$ breit, Blattfläche $23220 \mathrm{qcm}$, Halmfläche $3600 \mathrm{qcm}$, Gesammtfäche $26820 \mathrm{qcm}$.

Sehr spätreif, in Poppelsdorf unreif.

Bezugsquelle: Durch ron Gülich aus Hacienda de Colina, Chile.

\section{The large 12-14- and 16-rowed Hematite.}

Syn.: Blood-red.

Kolben: cylindrisch, $18-30 \mathrm{~cm}$ lang, 12-14- und 16-reihig, Reihen locker; Spindel rot. - Frucht: dunkelrot, eckig (9 mm lang, 4.9-9 mm breit, $5 \mathrm{~mm}$ dick).

\section{Dunkelroter Hühnermais.}

Kolben: konisch, klein, $11 \mathrm{~cm}$ lang, $3 \mathrm{~cm}$ breit, 14-reihig, Reihen ziemlich regelmässig, 32 Früchte in der Reihe; Spindel rot. - Frucht: dunkelrot, platt, spitz zulaufend, klein $\left(6 \mathrm{~mm}\right.$ lang, $3 \frac{1}{2}-6 \mathrm{~mm}$ breit, $21 / 2 \mathrm{~mm}$ dick).

Original in der Poppelsdorfer Sammlung.

Varietait: Zea Mais melanornis Keke.

\section{Sorte :}

\section{Rotschwarzer Hühnermais.}

Kolben: wenig cylindrisch, $10 \mathrm{~cm}$ lang, $2 \frac{1}{2} \mathrm{~cm}$ breit, 14-reihig, mit 30 Früchten in der Reihe, Reihen regelmässig; Spindel hellrot. Frucht: rotschwarz, rundlich, sehr klein ( $5 \mathrm{~mm}$ lang, $5 \mathrm{~mm}$ breit, $3 \frac{1}{2} \mathrm{~mm}$ dick).

Original in der Poppelsdorfer Sammlung.

Varietät: Zea Mais rosea Kcke.

\section{Sorten:}

\section{Rosafarbener Mais aus Siebenbürgen.}

Kolben: stark konisch, klein, $10 \mathrm{~cm}$ lang, $31 / 2 \mathrm{~cm}$ breit, 11-16reihig, Reihen unregelmässig, 20-25 Früchte in einer Reihe; Spindel 
weiss. - Frucht: rosa, kuglig, klein (7 $\mathrm{mm}$ lang, $6 \mathrm{~mm}$ breit, $5 \mathrm{~mm}$ dick, 92.3 Früchte $=10 \mathrm{gr}$.$) .$

Original in der Poppelsdorfer Sammlung.

\section{Maiz rosado, Chile.}

Kolben: fast cylindrisch, $18 \mathrm{~cm}$ lang, $3.5 \mathrm{~cm}$ dick, 10-14-reihig, 38 Früchte in der Reihe. - Fruclit: Original rosa, halb transparent, zusammengedrïckt, $10 \mathrm{~mm}$ lang, $8 \mathrm{~mm}$ breit, $4 \mathrm{~mm}$ dick, 45 Früchte = $10 \mathrm{gr}$. - Halm: rotbraun, $240 \mathrm{~cm}$ lang, $3 \mathrm{~cm}$ dick, 5 Scliösslinge, Rispe $35 \mathrm{~cm}$ lang, 2 Kolben pro Halm; Blattzahl 14, Blätter $73 \mathrm{~cm} \mathrm{lang,} 9 \mathrm{~cm}$ breit, Blattfläche $18396 \mathrm{qcm}$, Halmfläche 2160 qcm, Gesammtfläche 20556 qcm.

Spätreif.

Bezugsquelle: Durch v. Gülich aus Hacienda de Colina, Chile, 1880.

Varietat: Zea Mais glaucornis Al.

Sor te :

\section{Blauer Hühnermais.}

Kolben: stark konisch, 11-13 cm lang, 21/2 cm dick, 16-reihig, Reihen ziemlich regelmässig, Früchte dicht und $30-35$ in der Reihe; Spindel weiss. - Frucht: blau, spitzlich, sehr klcin (6 mm lang, $4 \mathrm{~mm}$ breit, $3 \mathrm{~mm}$ dick), 168.5 Friiclite $=10 \mathrm{gr}$.

Original in der Poppelsdorfer Sammlung.

\section{Gruppe V. Vulgaris Kcke. Gemeiner Mais.}

Varietät: Zea Mais alba Al.

\section{Sorten:}

\section{Weisser Oberländer-Mais aus Baden.}

Kolben: konisclı, $20 \mathrm{~cm}$ lang, $5 \mathrm{~cm}$ dick, 8-reilig, Reihen regelmässig, 34 Früchte in der Reihe; Spindel weiss. - Frucht: weiss, glänzend, Krone konvex (10 mm lang, $10 \mathrm{~mm}$ breit, $6 \mathrm{~mm}$ dick). sultate:

Die Kultur dieses Maises ergah in Poppelsdorf nachstehende Re-

Pflanzenraum $1250 \mathrm{qcm}$, Aussaat 20/5., Blüte 20/7., männliche Blüte $1 \mathrm{p}$. Pflanze (Staubbeutel rostrot), weibliche Blüte $2.35 \mathrm{p}$. Pflanze 
(Griffel gelb-grün). Schösslinge p. Pflanze 1.25 , Halme $130 \mathrm{~cm}$ (Max. $180 \mathrm{~cm}$ ) lang, $2 \mathrm{~cm}$ dick, Blattzahl 10, Blätter $45 \mathrm{~cm}$ lang, $6 \mathrm{~cm}$ breit, Blattfläche $5400 \mathrm{qcm}$, Halmfläche $780 \mathrm{qcm}$, Gesammtfläche $6180 \mathrm{qcm}$.

Zahl der fruchtbaren Kolben 1.6, Reifezeit 15/9., mithin Dauer der Vegetationsperiode 118 Tage.

Das Frischgewicht der Halme betrug in der Blüte $350 \mathrm{gr}$.

Nach Kreusler betrug das Trockengewicht bei der Reife am 15. September:

$$
\begin{aligned}
& \text { der Blätter } 10785 \mathrm{gr} \text {, } \\
& \text { "Stengel } 32116 \text { " } \\
& \text { "Körner } 43352 \text {," }
\end{aligned}
$$

Diese im hohen Grade beachtenswerte Sorte wird in Poppelsdorf wohl in jedem Jahre reif.

Nach einer Analyse des Laboratoriums zu Karlsruhe ${ }^{1}$ ) enthielt das Korn nachfolgende Bestandteile:

$\begin{array}{lccccccc}\text { Stärke } & \text { Zucker } & \text { Holzfaser } & \text { Proteïn } & \text { stickstofffreie Stoffe } & \text { Oel } & \text { Asche } & \text { Wasser } \\ 67.00 & \text { Spur } & 5.94 & 5.82 & 3.57 & 5.60 & 2.91 & 9.16\end{array}$

Demnach ist dieser Mais sehr reich an Stärkemehl und Oel, doch arm an Proteïnstoffen.

\section{Mais aus dem Ober-Innthale.}

Kolben: stark konisch, $18-22 \mathrm{~cm}$ lan:, $5-5.5 \mathrm{~cm}$ dick, 8-12-reihig, etwas unregelmässig, 42 Frïchte in der Reihe; Spindel weiss. - Frucht: weiss, mit perlmutterartigem Glanz, abgeplattet, Krone halbkreisförmig, gross (10 mm lang, $10 \mathrm{~mm}$ breit, $4 \mathrm{~mm}$ dick, 23.4 Früchte $=10 \mathrm{gr}$ ).

Original in der Poppelsdorfer Sammlung.

\section{Weisser grobkörniger Murecker-Mais.}

Kolben: konisch, 18-20 cm lang, $6 \mathrm{~cm}$ dick, 12-16-reihig, Reihen ziemlich regelmässig, mit 30 dicht stehenden Früchten. - Frucht: gelblichweiss, hornig, trapezoïdisch, platt, gross (10 mm lang, $11 \mathrm{~mm}$ breit, $5 \frac{1}{2} \mathrm{~mm}$ dick, 24.6 Früchte $=10 \mathrm{gr}, 1 \mathrm{hl}=75 \mathrm{~kg}$ ).

Die Kultur in Poppelsdorf ergab 1878 folgende Resultate:

Pflanzenraum $1250 \mathrm{qcm}$, Aussaat 20/5., Blütezeit 9/8, männliche Blüte $1 \mathrm{p}$. Pflanze (Stanbbeutel hellgelb), weibliche Blüte $1.85 \mathrm{p}$. Pflanze (Griffel hellrot oder grünlichgelb); Triebe p. Pflanze 1.07, Halm $125 \mathrm{~cm}$ (Max. $175 \mathrm{~cm}$ ) lang, $2 \mathrm{~cm}$ dick, Blattzahl 10, Blätter $51 \mathrm{~cm}$ lang, $5 \mathrm{~cm}$ breit, Blattfläche $5100 \mathrm{qcm}$, Halmfläche $750 \mathrm{qcm}$, Gesammtfläche $5850 \mathrm{qcm}$.

Zahl der fruchtbaren Kolben p. Pflanze 1.4, Reifezeit 4/10., mithin beträgt die Dauer der Tegetationsperiode 137 Tage.

Das Frischgewicht eines mittleren Halmes betrug zur Blütezeit $290 \mathrm{gr}$ (Max. $490 \mathrm{gr}$ ). Der Ertrag von 100 Halmen belief sich auf $17.000 \mathrm{~kg}$ Kolben, $10.810 \mathrm{~kg}$ Körner, $6.190 \mathrm{~kg}$ Spindeln, $3.600 \mathrm{~kg}$ Hüllen, $12.900 \mathrm{~kg}$ Stroh.

Diese aus dem unteren Jurthal in Steiermark stammende Sorte ist wahrscheinlich dieselbe, welche Burger ${ }^{2}$ ) durch Kreuzung einer einhei-

1) Fühling, Landw. Zeit. 1872. 75.

2) Burger, Mais 1809, pg. 60. 
mischen Sorte mit dem weissen Cinquantino 1804 erzielte, und die jetzt neben dem gelben Murecker-Mais fast ausschliesslich dort gebaut wird. langen.

In Poppelsdorf dürfte er wohl meist zur vollen Ausreife ge-

Von Professor Wilhelm 1878 aus Graz erhalten.

\section{White King Philip.}

Syn.: Amerikan.: Smith early White-corn.

Franz.: Mails King-Philip blanc.

Deutsch: Weisser König-Philip.

Verbcsserte Form: Improved King-Philip.

Kolben: konisch, $20 \mathrm{~cm}$ lang, $4-4^{1 / 2} \mathrm{~cm}$ dick, 8-10-reihig, Reihen regelmässig, locker, 35 Früchte in der Reihe; Spindel weiss. Frucht: weiss, perlmutterfarben, Krone konvex, abgeplattet (8 mm lang, $11 \mathrm{~mm}$ breit, $6 \mathrm{~mm}$ dick, 33 Früchte $=10 \mathrm{gr}, 1 \mathrm{hl}=73 \mathrm{~kg})$. - Halm $150-200 \mathrm{~cm}$ hoch.

Die Kultur in Poppelsdorf ergab 1878 folgende Resultate:

Pflanzenraum $1250 \mathrm{qcm}$, Aussaat 20/5., Blite 12/8., männliche Blüte 1.5 p. Pflanze (Staubbeutel dunkelrot), weibliche Bluite 2.3 p. Pflanze (Griffel hellgrün oder blassrot), Schösslinge p. Pflanze 1.42, Halme $120 \mathrm{~cm}$ (Wax. $170 \mathrm{~cm}$ ) lang, $2 \mathrm{~cm}$ dick, Blattzahl 11, Blätter $44 \mathrm{~cm}$ (Max. $56.5 \mathrm{~cm}$ ) lang, $3.8 \mathrm{~cm}$ (Wax. $5.5 \mathrm{~cm}$ ) breit, Blattfläche $3678.4 \mathrm{qcm}$, Halmfläche $720 \mathrm{qcm}$, Gesammitfäche $4398.4 \mathrm{qcm}$.

Zahl der fruchtbaren Kolben 1.35 p. Pflanze, Reifezeit 4/10., mithin Dauer der Vegetationsperiode 137 Tage.

Es lieferten 100 Halme $20.250 \mathrm{~kg}$ Kolben, darin $13.020 \mathrm{~kg}$ Körner, $7.230 \mathrm{~kg}$ Spindeln, und $2.250 \mathrm{~kg}$ Kolbenhüllen, $22.500 \mathrm{~kg}$ Strol.

Das Frischgewicht der Halme betrug in der Bliitezeit im Mittel $200 \mathrm{gr}$ (Мax. $465 \mathrm{gr}$ ).

Dieser \ais ist ertragreich, liefert viel Futter und lässt sich noch im mittleren Deutschland und nördlichelı Frankreich anbauen, auch wird diese neue Sorte besonders stark in Canada kultiviert.

Die verbesserte Form unterschied sich in nichts von der gewöhnlichen.

\section{Granturco maggengo bianco o Granturco bianco di Padora.}

Sỷn.: Deutsch: Paduaner oder gewöhnlicher weisser Mrais.

Franz.: Blanc de Padoue.

Kolben: konisch, $20 \mathrm{~cm}$ lang, $4-5 \mathrm{~cm}$ dick, 8-10-14-reihig, ziemlich regelmässig, locker, 35 Früchte in der Reihe; Spindel weiss. Frucht: gelblich-weiss, rundlich, gross $\left(8 \mathrm{~mm}\right.$ lang, $8 \mathrm{~mm}$ breit, $5^{1} / 2 \mathrm{~mm}$ dick, 28 Früchte $=10 \mathrm{gr}, 1 \mathrm{hl}=72.5 \mathrm{~kg}$ ).

In Poppelsdorf ergab 1878 ein von dem Verfasser durcligeführter Kulturversuch nachstehendes Resultat:

Pflanzenraum $1250 \mathrm{qcm}$, Aussaat 20/5., Blüte 9/8., männliche Blüte 1 p. Pflanze (Staubbeutel pfirsichgrün), weibliche Blüte 1.8 p. Pflanze (Griffel hellgrün, oder rot). Triebe p. Pflanze 1.05, Halm $100 \mathrm{~cm}$ (Max. $155 \mathrm{~cm}$ ) lang, $1.6 \mathrm{~cm}$ dick, Blattzahl 9.5 (Hax. 11), Blätter $43 \mathrm{~cm}$ lang, $5 \mathrm{~cm}$ breit, Blattfläche $4085 \mathrm{qcm}$, Halmfläche $480 \mathrm{qcm}$, Gesamintfläche $4565 \mathrm{qcm}$.

Zahl der fruchtbaren Kolben 1.2, Ernte 4/10., mithin betrug die 
Vegetationsperiode $13 \mathrm{~T}$ Tage. Es lieferten $100 \mathrm{Halme} 16.000 \mathrm{~kg}$ Kolben, $10.575 \mathrm{~kg}$ Körner, $5.425 \mathrm{~kg}$ Spindeln, $5.900 \mathrm{~kg}$ Kolbenhüllen, $15.600 \mathrm{~kg}$ Stroh.

Diese Sorte lässt sich in Suid-Fraukreich, Ober-Italien und Ungarn, aber auch recht gut in Siid-Deutschland anbauen.

In Ungarn wird er seiner Frühreife und Grosskörnigkeit wegen geschätzt und im gekochten Zustande am Kolben, mit Salz bestreut, genosseu.

\section{Maïs blanc hâtif des Landes.}

Syn.: Franz.: Mrais blanc de la Bresse, de Saverduu.

Span.: Milho de Vianna.

Deutsch: Weisser Mais von Landes.

Kolben: konisch, mittelgross, $17-20 \mathrm{~cm}$ lang, $4.5-5.5 \mathrm{~cm} \mathrm{dick,}$ 12-14-reihig, ziemlich regelmässig, locker, 25-30 Früchte in der Reihe; Spindel weiss. - Fruclit: weiss, perlmutterfarben, Krone konrex, Seiten platt, in der Mitte eingedrückt, mittelgross $(8 \mathrm{~mm}$ lang, $10 \mathrm{~mm}$ breit, $6 \mathrm{~mm}$ dick, 20.6 Früchte $=10 \mathrm{gr}, 1 \mathrm{hl}=74.6 \mathrm{~kg}$ ), grobschalig. Halm in den Landes $160-180 \mathrm{~cm}$ hoch, blattreich.

Die Kultur in Poppelsdorf 1878 ergab folgende Resultate:

Pflanzenraum 1500 qcm, Aussaat 20/5̃., Bliite 30/7., männliche Blüte 1. p. Pflanze (Staubbeutel gelbgrün), weibliche Blüe $1.25 \mathrm{p}$. Pflanze (Griffel rosa), Triebe p. Pflanze 1.08, Halme $100 \mathrm{~cm}$ (Max. $140 \mathrm{~cm}$ ) lang, $2.5 \mathrm{~cm}$ dick, Blattzahl 10. Blätter $46 \mathrm{~cm}$ (Max. $58.4 \mathrm{~cm}$ ) lang, $4.6 \mathrm{~cm}$ (Max. $6.4 \mathrm{~cm}$ ) breit, Blattfläche $4232 \mathrm{qcm}$, Halmfläclie $750 \mathrm{qcm}$, Gesammt. fläche $4982 \mathrm{qcm}$.

Zahl der fruchtharen Kolben 1.15, Reifezeit 1/10., mithin Dauer der Vegetationsperiode 134 Tare.

Es lieferten 100 Halme $16.100 \mathrm{~kg}$ Kolben, darin $10.500 \mathrm{~kg}$ Körner, $5.600 \mathrm{~kg}$ Spindeln, $2.550 \mathrm{~kg}$ Kolbenhuilleu und $17.000 \mathrm{~kg}$ Stengel.

Diese Sorte ist die ertragreichste in den Landes und wird auch in Spanien gebaut.

Die in Poppelsdorf erzielten Kolben standen nur wenig hinter dem Original zurück, und scheint dieser Mais für das Weinklima Deutschlands beachtenswert zu sein.

Das Frischgewicht der Halme betrug in der Blüte $250-450 \mathrm{gr}$, demnach sich auch der Anbau zur Gewinnung zeitigen Grünfutters empfehlen lässt.

Bezugsquelle: Tilmorin, Paris.

\section{Maïs blanc gros.}

Kolben: Lonisch, 20 cu lang, 5 cuu dick, 10-12-reihig, 30 Früchte in der Reihe; Spindel weiss. - Frucht: gelblich-weiss, perlmutterfarben, Krone konvex, platt, gross $(9 \mathrm{~mm}$ lang, $11 \mathrm{~mm}$ breit, $5 \mathrm{~mm}$ tief, 1 Frucht wiegt $0.38 \mathrm{gr}, 1 \mathrm{hl}=71 \mathrm{~kg})$.

Die Kultur in Poppelsdorf ergab 1878 folgende Resultate:

Pflauzenraum $1500 \mathrm{qcm}$, Aussaat 20/5., Bliitezeit 18/8., männliche Bliite 1 p. Pflanze (Staubbeutel schmutzig-grüngelb), weibliche Blite 2.75 p. Pflanze (Griffel hellgrün). Triebe p. Pflanze 1.2, Halıne $150 \mathrm{~cm}$ (Max. $180 \mathrm{~cm}$ ) lang, $2.3 \mathrm{~cm}$ dick, Blattzahl 11, Blätter $56.2 \mathrm{~cm}$ lang, $5.4 \mathrm{~cm}$ breit, Blattfäche $6676.56 \mathrm{qcm}$, Halmfläche $1035 \mathrm{qcm}$, Gesammtfläche $7711.56 \mathrm{qcm}$. 
Die Ernte erfolgte am 18/10, jedoch wird dieser Mais nur in sehr warmen Sommern in Poppelsdorf vollkommen reif.

Das Frischgewicht eines mittleren Halmes betrug zur Blütezeit $470 \mathrm{gr}$ (Max. $760 \mathrm{gr}$ ).

Die Fruchternte ergab auf 100 Halme $29.000 \mathrm{~kg}$ Kolben, darin $15.080 \mathrm{~kg}$ Körner, $13.920 \mathrm{~kg}$ Spindeln, ferner $11.000 \mathrm{~kg}$ Kolbenhüllen und $38.000 \mathrm{~kg}$ Stroh.

Vorzugsweise im siidlichen Frankreich knltiviert, und fiir Deutschland vielleicht als zeitiges Grünfutter zn empfehlen.

Bezugsquelle: Vilmorin, Paris.

\section{Maïs géant hybride de la Breille.}

Kolben: sehr gross, konisch, $20 \mathrm{~cm}$ (MIax. $25 \mathrm{~cm}$ ) lang, $7 \mathrm{~cm}$ dick, 14-18-reihig, Reihen regelmässig, nmr etwas spiralig gewunden, 32 Frïchte in der Reihe; Spindel wciss. - Frucht: weiss, perlmutterfarben, an den Seiten abgeplattet, gross $(11 \mathrm{~mm}$ lang, $9 \mathrm{~mm}$ breit, $4 \mathrm{~mm}$ dick), 1 Korn wiegt $0.31 \mathrm{gr}, 1 \mathrm{hl}=73 \mathrm{~kg}$.

Die Kultur in Poppelsdorf ergab 1878 folgende Resnltate:

Pflanzenraum $1500 \mathrm{qcm}$, Aussaat 20/5., Bliitezeit 22/8., männliche Blïte 1.1 (Staubbeutel grïngelb), weibliche Bliite 2.6 (Griffel hellgrün); Triebe p. Pflanze 1.5, Halme $160 \mathrm{~cm}$ (Nax. $250 \mathrm{~cm}$ ), $2.3 \mathrm{~cm}$ dick, Blattzahl 11, Blätter $66.4 \mathrm{~cm}$ lang, $6.4 \mathrm{~cm}$ breit, Blattfläche $9349,12 \mathrm{qcm}$, Halmfläche $1104 \mathrm{q} \mathrm{cm}$, Gesammtfläche $10453.12 \mathrm{qcm}$.

Die Ernte erfolgte am 18/10., jedoch ist anzinehmen, dass nur in sehr warmen Sommern in Poppelsdorf dieser Mais vollkommen ansreift, doch liefert er ein vorzügliches zeitiges Grünfutter und betrug das Frischgewicht mittlerer Halme $700 \mathrm{gr}$ ( $(\mathrm{I}$ ax. $900 \mathrm{gr}$ ).

Die Fruchternte ergab auf 100 Halme $32.000 \mathrm{~kg}$ Kolben, darin $17.950 \mathrm{~kg}$ Körner, $14.050 \mathrm{~kg}$ Spindelı, ferner $10.000 \mathrm{~kg}$ Kolbenhüllen und $47.000 \mathrm{~kg}$ Stroh.

Wird in Süd-Frankreich a uf reichem Boden angebaut und seines hohen Ertrages wegen selır geschätzt.

Bezugsquelle: Vilmorin, Paris.

\section{Blat de moro blanch, Hospitalet, Spanien.}

Kolben: konisch, $25 \mathrm{~cm}$ lang, $5 \mathrm{~cm}$ dick, 8-12-reilig, 35 Früchte in einer Reihe. - Original weiss, abgerundet, zuweilen etwas eingedrückt, glasig, gross, $9 \mathrm{~mm}$ lang, $12 \mathrm{~mm}$ breit, $5 \mathrm{~mm}$ dick, 21.4 Früchte $=10 \mathrm{gr}$. - Halm $190 \mathrm{~cm}$ lang, $3 \mathrm{~cm}$ dick, Rispe $35 \mathrm{~cm}$ lang, 2 Kolben, Blattzahl 20.2, Blätter sehr leicht zerbrechlich, $62.6 \mathrm{~cm}$ lang, $10 \mathrm{~cm}$ breit, Blattfläche 13772 qcm, Halmfläche $1710 \mathrm{qcm}$, Gesammtfläche $15482 \mathrm{qcm}$.

Ziemlich frühreif, in warmen Sommern in Poppelsdorf reifend.

Bezugsquelle: Ant. Cipr. Costa, Barcelona 1881.

\section{Maiz Blanco-Redondo de Lecano del Llobregat, Cataluña, Spanien.}

Kolben: stark konisch, $25 \mathrm{~cm}$ lang, $5 \mathrm{~cm}$ dick, 10-reihig, Reihen regelmässig, mit 40 Friichten. - Frucht: weiss, glasig, gerundet, gross, $10 \mathrm{~mm}$ lang, $12 \mathrm{~mm}$ breit, $8 \mathrm{~mm}$ dick, 22 Früchte $=10 \mathrm{gr}$. - Halm: $215 \mathrm{~cm}$ lang, $3 \mathrm{~cm}$ dick, 1.3 Schösslinge, Rispe $40 \mathrm{~cm}$ lang, 2 weibliche 
Blüten mit grünlich-gelben Griffeln, 1 reifer Kolben pro Halm; Blattzahl 18, Blätter $66 \mathrm{~cm}$ lang, $7.7 \mathrm{~cm}$ breit, Blattfäche $18295.2 \mathrm{qcm}$, Halmfläche $1935 \mathrm{qcm}$, Gesammtfäche $20230.2 \mathrm{qcm}$.

Spätreif.

Bezugsquelle: Ant. Cipr. Costa, Barcelona, 1881.

\section{Weisser Mais aus Minho, Portugal.}

Kolben: konisch, $20 \mathrm{~cm}$ lang, $4 \mathrm{~cm}$ breit, 10-12-reihig, 40 Früchte pro Reihe. - Frucht: Original weiss, glasig, gerundet, doch im Allgemeinen sehr rerdrückt und rerschiedenartig geformt, $9 \mathrm{~mm}$ lang, $8 \mathrm{~mm}$ breit, $6 \mathrm{~mm}$ dick, 374 Frïchte $=10 \mathrm{gr}$. - Halm: 4 Schösslinge, $250 \mathrm{~cm}$ lang, $3 \mathrm{~cm}$ dick, Rispe $35 \mathrm{~cm}$ lang, Anfang August blühend, 2-3 Kolben; Blattzahl 12, Blätter $63 \mathrm{~cm}$ lang, $3 \mathrm{~cm}$ breit, Blattfläche $12096 \mathrm{qcm}$, Halmfläche $2250 \mathrm{qcm}$, Gresamtfläche $14346 \mathrm{qcm}$.

Bezugsquelle: Prof. Jul. Henriques, Coïmbra, Portugal.

\section{Granturco cinquantino bianco.}

Syn.: Weisser Cinquantino Metzger. Zea mais quinquantina $\mathrm{Al}$.

Kolben: konisch, $17 \mathrm{~cm}$ lang, $4 \mathrm{~cm}$ dick, 16-18-reihig, Reihen sehr regelmässig, mit 40 Früchten, etwas locker. - Frucht: weiss, hornig, meisselförmig, Seiten stark eingedrückt ( $9 \mathrm{~mm}$ lang, $4-7^{1} / 2 \mathrm{~mm}$ breit, $4 \mathrm{~mm}$ dick, 60.8 Früchtc $=10 \mathrm{gr}, 1 \mathrm{hl}=75 \mathrm{~kg}$ ).

Die Kultur in Poppelsdorf ergab 1878 folgende Resultate:

Pflanzraum $1250 \mathrm{qcm}$, Aussaat 20/5., Blütezeit 20/8., männliche Bliite 1 p. Pflanze (Staubbeutel grïnlich-gelb), weibliche Blüte $1.8 \mathrm{p}$. Pflanze (Griffel hellrot). Schösslinge p. Pflanze 1.15 , Halme $130 \mathrm{~cm}$ (Max. 160 cm) lang, $2.3 \mathrm{~cm}$ dick, Blattzahl 11, Blätter $56.2 \mathrm{~cm}$ lang, $4.5 \mathrm{~cm}$ breit, Blattfläche $5563.8 \mathrm{qcm}$, Halmfläche $897 \mathrm{qcm}$, Gesammtfläche $6460.8 \mathrm{gcm}$.

Zahl der fruchtbaren Kolben P. Pflanze 1.6, Reifezeit 12/10. Im Allgemeinen ist nur in warmen Somnern in Poppelsdorf auf eine genügende Ausreife zu rechien.

Das Frischgewicht eines mittleren Halmes betrug zur Blütezeit $450 \mathrm{gr}$ ( $\mathrm{Max} .550 \mathrm{gr}$ ).

Die Fruchternte stellte sich für 100 Halme auf $14.400 \mathrm{~kg}$ Kolben, $10.325 \mathrm{~kg}$ Körner, $4.075 \mathrm{~kg}$ Spindeln, $3.450 \mathrm{~kg}$ Kolbenhüllen und $14.000 \mathrm{~kg}$ Stroh.

Dieser Mais mird lläufig in Ober-Italien und Süd-Oesterreich, namentlich in Steiermark gebaut, wohin ihn Burger ${ }^{1}$ ) 1802 aus Vicenza einführte.

Das Mehl ist rein weiss und wird daher in Italien gern dem Weizenbrotmehl zugesetzt.

\section{Weisser Mais aus Abrantes, Portugal.}

Syn.: Mais aus Areiro und Benarente.

Kolben: stark konisch, mittelgross, $16 \mathrm{~cm}$ lang, $3^{1} / 2-4 \mathrm{~cm}$ dick,

1) Burger, Мais 1509 p. 60. 
10-14-reihig, Reihen regelmässig, mit 30 Früchten. - Frucht: Original weiss, transparent, Krone gerundet, Seiten platt, Keim vertieft, $7 \mathrm{~mm}$ lang, $8 \mathrm{~mm}$ breit, $4 \mathrm{~mm}$ dick, 56.8 Körner $=10 \mathrm{gr}$. Halm: $140 \mathrm{~cm}$ lang, $2 \mathrm{~cm}$ dick, mit 2 Kolben; Rispe $25 \mathrm{~cm}$ lang, Mitte Juli erscheinend, Ende Juli blühend, weibliche Blüte rosa; Blattzahl 8, Blätter $50 \mathrm{~cm}$ lang, $7 \mathrm{~cm}$ breit, Blattfläche $5600 \mathrm{qcm}$, Halmfläche $840 \mathrm{qcm}$, Gesammtfläche 6440 qcm.

Frühreif, in warmen Sommern in Poppelsdorf reifend.

Bezugsquelle: Prof. Jul. Henriques, Coïmbra, Portugal, 1881.

\section{Maïs nain hâtif.}

Portugiesisch: Milho blanco de arneiros.

Kolben: konisch, kurz, $13-15 \mathrm{~cm}$ lang, $4-4 \frac{1}{2} \mathrm{~cm}$ dick, 14-reihig, Reihen regelmässig, 23 Friichte in der Reihe; Spindel weiss. - Frucht: weiss, transparent, trapezoïdisch, klein (9 $\mathrm{mm}$ lang, $7 \mathrm{~mm}$ breit, $5 \mathrm{~nm}$ dick). - Halme blattreich, $1.50-1.70 \mathrm{~cm}$ lang.

Auf leichtem Boden erfolgreich in Languedoc, Spanien und Portugal kultiviert. Ergiebig.

Original in der Poppelsdorfer Sammlung.

\section{Varietät: Zea Mais virginica Bonaf.}

\section{Sorte in:}

\section{Large Virginia White Flint.}

Syn.: Deutsch: Grosser weisser Flintkornmais aus Virginien. Franz.: Maïs de Virginie.

Kolben: cylindrisch, 20-36 cm lang, $5 \mathrm{~cm}$ dick, 14-reihig, Reihen regelmässig mit $45-50$ Frichten; Spindel weiss. - Frucht: sehr weiss, transparent, abgeplattet, sehr gross $(10 \mathrm{~mm}$ lang, $13 \mathrm{~mm}$ breit, $5 \mathrm{~mm}$ dick, 29 Fruichte $=10 \mathrm{gr})$, Mehl geschätzt. - Halm bis $3.50 \mathrm{~m}$ hoch, Blätter gross.

Es ist eine der besten weissen Elintkornsorten der Südstaaten NordAmerikas, die sich in Europa noch in Spanien, Sü-Frankreich, Italien und Ungarn kultivieren lässt.

Nach Salisbur ${ }^{1}$ ) zeigte das Korn nachfolgende Zusammensetzung in Procenten:

$\begin{array}{ccccccc} & \text { Zucker } & & & \text { Dextrin } & \\ \text { Stärke } & \text { und Extrakt } & \text { Iolzfaser } & \text { Proteïn } & \text { Oel } & \text { und Gummi } & \text { Wasser } \\ 34.04 & 11.80 & 17.70 & 15.50 & 4.60 & 5.28 & 10.36 . \\ \text { Original in der Sammlung zu Poppelsdorf. } & & & \end{array}$

\section{Small White-Flint.}

Syn.: Kleiner weisser Flintkorn-Mais.

Kolben: fast cylindrisch, $15-23 \mathrm{~cm}$ lang, $4 \mathrm{~cm}$ dick, 6-8-reihig, Reihen sehr regelmässig, mit 45-56 Früchten. Ein Kolben enthält 78.7 Proc. Korn, 21.3 Proc. Spindel; Spindel weiss. - Frucht: weiss (8-9 mm lang, 9-12 mm breit, $4 \mathrm{~mm}$ dick). MIchl geschätzt.

1) Transact. of the N. Y. st. VIII $1848, \mathrm{p} .834$. 
Salisbury's ${ }^{1}$ ) Knltur im Staate New-York ergab folgende Resultate:

Anssaat 12/5., Erscheinen der jungen Pflanzen 20/5., Blüte 10/8., Reife 29/9., mithin beträgt die Vegetationsperiode 140 Tage; Halme in der Blüte $214 \mathrm{~cm}$, in der Reife $277 \mathrm{~cm}$ hoch, Blattzahl 10, Zahl der fruchtbaren Kolben p. Pflanze 3.

Der Ertrag stellte sich p. ha auf $63 \varsigma 4 \mathrm{~kg}$ Früchte, $1714.72 \mathrm{~kg}$ Spindeln, $7209.44 \mathrm{~kg}$ Blätter und Kolbenhüllen, $6606.88 \mathrm{~kg}$ Stengel.

Die procentische Zusammensetzung des Kornes ergab: Zucker
Zeïn
Dextrin

Stärke u. Extrakt Holzfaser Proteïn u. Glutin Oel und Gummi Wasser $\begin{array}{llllllll}56.35 & 12.30 & 6.83 & 4.48 & 3.63 & 4.60 & 3.35 & 8.56\end{array}$

Sie ist eine der ergiebigsten weissen Flintmaissorten und wird vorzugsweise in New-Jersey kultiviert.

\section{Long Island, or Rhode Island white flint, or Douglass.}

Syn.: Weisses Flintkorn von Rhode-Island.

Kolben: fast cylindrisch, gross, $20-36 \mathrm{~cm}$ lang, $3-4 \mathrm{~cm}$ dick, 40 Früchte in der Peihe; Spindel weiss. - Frucht weiss (10 mm lang, $9-15 \mathrm{~mm}$. breit, $4.5 \mathrm{~mm}$ dick). - Halm $2.50-3-4 \mathrm{~m}$ hoch, mit $1 \frac{1}{4}$ $1 \frac{1}{2}$ Kolben.

Nach Salisbury ${ }^{2}$ ) ergaben im Staate New-Tork dnrchgeführte Versuche nachstehendes Resultat:

Aissaat 12/5., Erscheinen der jungen Pflänzchen 23/5., Blütezeit 10/8., Reifezeit 29/9. (140 Tage), Halme in der Blite $2.64 \mathrm{~m}$, in der Reife $3.20 \mathrm{~m}$ hoch, Blattzahl 10, Anzahl der fruchtbaren Kolben 3. Geerntet wirden p. ha: $5443.20 \mathrm{~kg}$ Früchte, $1714.72 \mathrm{~kg}$ Spindeln, $6268.64 \mathrm{~kg}$ Blätter und Kolbenhüllen, $9655.52 \mathrm{~kg}$ Stengel.

Die Früchte enthielten in Procenten:

Stärke Extrakt Holzfaser Eiweiss Caseïn Glutin oel Dextrin u. Wasser $\begin{array}{lllllllll}44.08 & 8.88 & 13.80 & 6.74 & 0.4 t & 4.36 & 5.60 & 3.36 & 12.26\end{array}$

Hiernach zeichnen sie sich besonders durch Oelreichtum aus.

Die ausgedehnteste Kultur hat diese Maissorte auf Long-Island, wohin sie durch Mr. Douglass eingeführt worden ist. Sie gehört zu den grössten und spätesten Sortel und reift nicht immer vollkommen in den nördlichen, mittleren und westlichen Teilen des Staates New-York. In Europa würde sie noch in Italien, Spanien und Süd-Frankreich anzu* banen sein.

\section{Large white Pop.}

Kolben: cylindrisch, $8-15 \mathrm{~cm}$ lang, $2.5-3 \mathrm{~cm}$ dick, S-reihig, Reihen regelmässig, 45-50 Früchte in der Reihe, Spindel weiss. - Frucht: weiss, $7 \mathrm{~mm}$ lang, $4-8 \mathrm{~mm}$ breit, $3.5 \mathrm{~mm}$ dick.

Nach Salisbury ${ }^{3}$ ) ergab die Kultur im Staate New-York folgende Resultate :

Aussant 12/5., Erscheinen an der Oberfläche 22/5., Blütezeit 28/7.,

1) Transact. etc. p. 829 .

2) Transact. of the X. Y. st. VIII 1818. p. 828.

3) Transact. of the New-York st. Vol. VIII 1818, p. $\$ 30$. 
Reifezeit 10/9., mithin beträgt die Vegetationsdauer 121 Tage. Halme in der Blüte $1.57 \mathrm{~m}$, in der Reife $1.88 \mathrm{~m}$ hoch, Blattzahl 10, Zahl der fruchtbaren Kolben p. Pflanze 3. Ertrag p. ha 5241.6 kg Früchte, $1778.86 \mathrm{~kg}$ Spindeln, 5368.16 kg Blätter und Kolbenhüllen, $5463.36 \mathrm{~kg}$ Stengel.

Analyse der Früchte:

Zucker

$\begin{array}{ccccccc}\text { Stärke } & \text { und Extrakt } & \text { Holzfaser } & \text { Proteï } & \text { Oel } & \text { und Gummi } & \text { Wasser } \\ \text { Proc. } & \text { Proc. } & \text { Proc. } & \text { Proc. } & \text { Proc. } & \text { Proc. } & \text { Proc. } \\ 39.20 & 10.60 & 15.20 & 14.10 & 6.98 & 3.40 & 10.56 .\end{array}$

Heimat: New-Jersey.

Diese Sorte würde sich wegen ihrer Frühreife noch zum Anbau in Süd-Deutschland eignen.

\section{Small White Pop.}

Kolben: fast cylindrisch, 8-12 $\mathrm{cm}$ lang, $2 \mathrm{~cm}$ dick, 12-16-reihig; Spindel weiss. - Frucht: weiss, klein (5 mm lang, $3-5 \mathrm{~mm}$ breit, $2.5 \mathrm{~mm}$ dick). - Halm mit $3-7$ Kolben besetzt.

\section{Early Canada White Flint.}

Syn.: Früher canadischer weisser Flintkornmais.

Kolben: fast cylindrisch, $13-23 \mathrm{~cm}$ lang, $4 \mathrm{~cm}$ dick, 8-reihig, Reihen sehr regelmässig, mit 38-42 Früchten; Spindel weiss. - Frucht: gelblich-weiss, hornig, halbkreisförmig in der Krone, platt (7 mm lang, 7-10 mm breit, $4 \mathrm{~mm}$ dick, 1 Frucht wiegt $0.47 \mathrm{gr}$ ). - Halm $1.50 \mathrm{~m}$ hoch.

Diese Maissorte reifte noch, am 10. Juni im südlichen Canada ausgesäet, in 110 Tagen, und wird wegen ihrer Frühreife häufig auch in den Vereinigten Staaten zur Erzielung zeitigen Grünkorns als Gemüse ausgesäet, auch liefert sie ein sehr zeitiges Grünfutter.

Sie wurde 1862 durch Ingenieur William Wagner aus Canada dem Aklimatisationsverein zu Berlin übersandt, und reifte dieselbe bei Berlin und Danzig vollkommen aus.

Original in der Sammlung zu Poppelsdorf.

\section{Squaw-Corn.}

Kolben: weiss, cylindrisch $10-21 \mathrm{~cm}$ lang, $3-4 \mathrm{~cm}$ dick, 8-reihig, Reihen etwas locker (77.9 Proc. Korn, 22.1 Proc. Spindel); Spindel weiss. - Frucht: weiss, gross (10 mm lang, $8.5-12 \mathrm{~mm}$ breit, $4.8 \mathrm{~mm}$ dick). Resultate:

Salisbury's ${ }^{1}$ ) Kultur im Staate New-York ergab nachfolgende

Aussaat 12/5., Erscheinen der jungen Pflanzen 21/5., Blütezeit 25/7., Reifezeit 6/9., mithin beträgt die Vegetationsperiode nur 117 Tage; Halme in der Blüte $165 \mathrm{~cm}$, in der Reife $183 \mathrm{~cm}$ hoch, Blattzahl 10, Zahl der fruchtbaren Kolben p. Pflanze 3.

Der Ertrag stellte sich p. ha auf $4838.4 \mathrm{~kg}$ Früchte, $1372 \mathrm{~kg}$ Spindeln, $3557.12 \mathrm{~kg}$ Blätter und Kolbenlıüllen, 3811.36 Stengel. 
Die procentische Zusammensetzung des Kornes ergab: Zucker Zeïn Dextrin

Stärke u. Extrakt Holzfaser Proteïn und Glutin Oel und Gummi Wasser $\begin{array}{llllllll}38.98 & 11.12 & 18.96 & 8.10 & 4.08 & 4.50 & 5.04 & 8.72 .\end{array}$

Ursprünglich wurde dieser Mais von den Indianern am MichiganSee kultiviert.

\section{Chinese Tree-Corn.}

\section{Syn.: Deutsch: Chinesisches Baumkorn.}

Franz.: Maiis arbre de la Chine.

Kolben: in der Mitte dicker als an der Basis, 21-30 cm lang, 3-5 cm dick, 10-reihig, Reihen dicht; Spindel weiss. - Frucht: weiss, an der Spitze abgerundet, lang, keilförmig, abgeplattet, zuweilen leicht eingedriickt, sehr gross $(10-12 \mathrm{~mm}$ lang, grösste Breite $11-13 \mathrm{~mm}$, geringste $4-7 \mathrm{~mm}, 4 \mathrm{~mm}$ dick).

Diese häufig in Nord-Amerika angebaute Sorte ist sehr ertragreich, beansprucht jedoch eine so lange Vegetationsperiode, dass sie im Staate New-York nicht in allen Jahrgängen ausreift.

Das Mehl wird sehr geschätzt und wegen seines angenehmen Geruches gern zu Suppen verwandt.

Ursprünglich soll das erste Saatkorn in Amerika in einer chinesischen Theekiste gefunden und weiter kultiviert worden sein, und zwar wurde diese Maissorte zuerst durch Grant Thornburn zu Astoria in der Nähe von New-York 1845 bekannt gemacht.

Durch J. L. Husted, Greenwich, Connecticut, gelangte dann 1860 eine verbesserte Form in den Handel.

Nach Salisbury ${ }^{1}$ ) besitzt die Frucht folgende procentische $\mathrm{Zu}$ sammensetzang:

\begin{tabular}{ccccccc}
\multicolumn{3}{c}{ Zucker } & & & \multicolumn{3}{c}{ Dextrin } \\
Stärke & und Extrakt & Holzfaser & Protein & Oel & und Gummi & Wasser \\
47.64 & 9.12 & 11.80 & 9.44 & 3.80 & 3.76 & 13.52
\end{tabular}

Varietät: Zea Mais erythrolepis Bonaf.

Sorte:

\section{Early Tuscarora-Corn.}

Syn.: Deutsch: Tuscarora-Mais.

Franz.: Maïs tuscarora.

Kolben: cylindrisch, $18-26 \mathrm{~cm}$ lang, $3.5-5 \mathrm{~cm}$ dick, 8-12-reihig, 35-40 festsitzende Früchte in der Reihe; sie enthalten 66.7 Proc. Korn, 33.3 Proc. Spindel; Spelzen rot. - Frucht: milchweiss mit durchweg mehligem Eiweisskörper, an der Krone abgerundet, von trapezoïder Gestalt, platt, sehr gross $(10-11 \mathrm{~mm}$ lang, $11-16 \mathrm{~mm}$ breit, $4 \mathrm{~mm}$ dick, 23 Frïchte $=10 \mathrm{gr}$ ) ; Yehl fein, weiss. - Halme $2.50 \mathrm{~m}$ und darïber hoch, blattreich.

1) Transact. of the Y-.Y. st. VIII, 834. 

sultate:

Salisbury's ${ }^{1}$ ) Kultur im Staate New-York ergab folgende Re-

Aussaat 12/5., Erscheinen der jungen Pflanzen 21/5., Blïtezeit 28/7., Reifezeit 15/9., mithin umfasst die Vegetationszeit 126 Tage; Halme in der Blüte $187 \mathrm{~cm}$, in der Reife $252 \mathrm{~cm}$, Blattzahl 10 .

Der Ertrag stellte sich p. ha auf $4099.2 \mathrm{~kg}$ Früchte, $2032.8 \mathrm{~kg}$ Spindeln, 5335.68 kg Stengel, 5017.16 kg Blätter und Blütenhüllen.

Die Analyse ergab in Procenten: Zucker

Stärke und Extrakt Holzfaser Proteïn Oel und Gummi Wasser

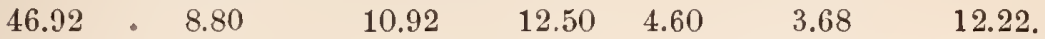
werden.

Das Mehl soll leicht dumpf und gern zur Stärkebereitung benutzt

Diese Maissorte wird vielfach nach einer Vegetationszeit von $60-$ 75 Tagen als Grünkorn gekocht, und da sie mittelfrüh ist, lässt sie sich mit Erfolg noch in der südlichen Schweiz, in der Provence, Ober-Italien, Ungarn und Rumänien kultivieren.

Sie soll zuerst von den Tuscarora-Indianern gezüchtet und später lange Zeit von den Onondagas kultiviert worden sein. zur Zeit wird sie vorzugsweise in Pennsylvanien angebaut.

Nach Heuzé (Pl. alim. 36) soll auch ein Tuscarora-Mais mit weisser Spindel vorkommen.

Varietät: Zea Mais vulgata Kcke.

\section{Sorten:}

\section{The golden Sioux, or large Yellow-Flint.}

Syn.: Large yellow Dutton-corn, Early Dutton-corn, Small yellow Dutton-Corn (verbesserte Formen).

Kolben: fast cylindrisch, $20-30 \mathrm{~cm}$ lang, $3.5-5 \mathrm{~cm}$ dick, $12-18$ reihig, Reihen regelmässig, doch sind zwei und zwei Reihen durch grössere Entfernung getrennt, 50 Früchte in der Reihe, 78.26 Proc. Korn, 21.74 Proc. Spindel. - Frucht: gelb, halbkreisförmig, gross, (10 mm lang, 9-10 $\mathrm{mm}$ breit, $4.5 \mathrm{~mm}$ dick), ölreich, ein vorzügliches Mehl und Viehfutter abgebend. sultate:

Salisbury's ${ }^{2}$ ) Kultur im Staate New-York ergab folgende Re-

Aussaatzeit 12/5., Erscheinen an der Oberfläche 20/5., Blüte 25/7., Rieife 4/9., mithin beträgt die Vegetationsperiode 115 Tage.

Der Ertrag stellte sich p. ha auf $7996.8 \mathrm{~kg}$ Früchte, $2223.2 \mathrm{~kg}$ Spindeln, 5526.08 kg Blätter und Kolbenhüllen, 2885.2 kg Stengel.

Die Analyse ergab in Procenten:

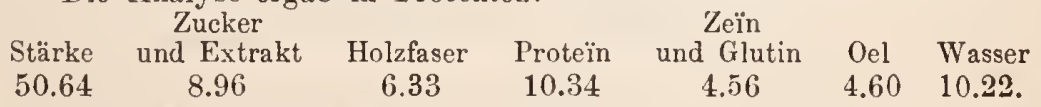

Diese Maissorte erreicht eine Höhe von $209 \mathrm{~cm}$ in der Blüte und $251 \mathrm{~cm}$ in der Reife. Ihre grosse Frühreife würde die Kultur vielleicht schon in Süd-Deutschland gestatten.

1) Transact. of the N.-Y. st. VIII, 835.

2) Transact. of the N.-Y. st. VIII, 825. 
Ursprünglich wurde dieser Mais von den Sioux-Indianern kultiviert, und 1818 machte Mr. Salmon Dutton, Cavendish in Vermont, verbesserte Formen bekannt, von denen jede einen gewissen Wert beanspruchen darf.

Large Yellow Dutton-corn stimmt mit Golden-Sioux in den Formen überein, nur ist die Frucht orangefarben und liefert ein sehr feines Mehl.

Early Dutton-corn ist kleiner und frühreifer, Kolben 12-reihig, $18 \mathrm{~cm}$ lang, $3 \frac{1}{2} \mathrm{~cm}$ dick; Frucht sattgelb, platt $(6 \mathrm{~mm}$ lang, $6 \mathrm{~mm}$ breit, $5 \mathrm{~mm}$ dick).

Small yellow Dutton-corn. Kolben etwas konisch, 20-2.5 cm lang, $4 \mathrm{~cm}$ dick, 12-reihig, 45 Früchte in der Reihe; Frucht $(9 \mathrm{~mm} \mathrm{lang,} 9 \mathrm{~mm}$ breit, $4 \mathrm{~mm}$ dick), gelb, platt.

\section{Large eight-rowed Yellow-Flint-corn.}

Kolben: schwach konisch, fein, sehr lang, 20-30 cm lang, 2.5$4 \mathrm{~cm}$ dick, 8-reihig, Reihen regelmässig, bei $25 \mathrm{~cm}$ Länge mit 50 Früchten besetzt, liefert 79.74 Proc. Korn, 20.26 Proc. Spindel; Spindel weiss. Frucht: orangefarben, halbkreisförmig, platt $(10 \mathrm{~mm}$ lang, 9-12 $\mathrm{mm}$ breit, $4.5 \mathrm{~mm}$ dick, 30 Früchte $=10 \mathrm{gr}$.) sultate:

Salisbury's ${ }^{1}$ ) Kultur im Staate New-York ergab folgende Re-

Aussaat 12/5., Erscheinen der Pfänzchen 23/5., Blütezeit 25/7., Reifezeit 15/9., mithin beträgt die Vegetationszeit 126 Tage. Die Halme erreichten in der Blüte eine Höhe von $195 \mathrm{~cm}$, in der Reife von $239 \mathrm{~cm}$, Blattzahl 10, fruchtbare Kolben 2.

Der Ertrag stellte sich p. ha auf: $7862.4 \mathrm{~kg}$ Früchte, $2001.44 \mathrm{~kg}$ Spindeln, 5908.00 kg Blätter und Kolbenhüllen, 5082.56 kg Stengel.

Die Analyse ergab in Procenten:

$$
\text { Zucker }
$$

\begin{tabular}{cccccc}
\multicolumn{2}{c}{ Zucker } & \multicolumn{2}{c}{ Zeīn } & Dextrin & \\
Stärke u. Extrakt & Holzfaser & Proteïn u. Glutin & Oel u. Gummi Wasser
\end{tabular} $\begin{array}{llllllll}42.03 & 12.52 & 9.80 & 6.58 & 7.32 & 4.35 & 6.28 & 11.18 \text {. }\end{array}$

Es ist eine der besten gelben Flintkornsorten und wird sehr ausgedehnt im Staate New-York kultiviert; zum Anbau für Süd-Frankreich, Ober-Italien und Ungarn geeignet.

\section{Large Yellow eight-rowed Pop.}

Kolben: 15-25 cm lang, 2.5-4 cm dick, 8-reihig, mit 48 Früchten in der Reihe; liefert 81.66 Proc. Früchte, 18.34 Proc. Spindel; Spindel weiss. - Frucht: gelb, rundlich, klein (7 mm lang, 7-9 mm breit, $4 \mathrm{~mm}$ dick), grobschalig. Resultate:

Nach Salisbury ${ }^{2}$ ) ergab die Kultur im Staate New-York folgende

Aussaat 12/5., Blütezeit 15/7., Höhe in der Blüte $161 \mathrm{~cm}$, Reifezeit (30/8.) nach 110 Tagen, Höhe in der Reife $195 \mathrm{~cm}$, Zahl der reifen Kolben 4 p. Pflanze.

In Poppelsdorf reifte er selbst noch in dem kühlen Sommer 1879 vollkommen aus, und betrug die Zahl der Triebe 1.4, der fruchtbaren Kolben 1.4 p. Pflanze. Halme $200 \mathrm{~cm}$ (Max. $250 \mathrm{~cm}$ ) lang, $2 \mathrm{~cm}$ dick, 
Blattzahl 8, Blätter $64 \mathrm{~cm}$ lang, $5 \mathrm{~cm}$ breit, Blattfäche $5120 \mathrm{qcm}$, Halmfläche $1200 \mathrm{qcm}$, Gesammtfläche $6320 \mathrm{qcm}$.

Nach Salisbury stellt sich der Ertrag p. ha auf $7526.4 \mathrm{~kg}$ Früchte, $1683.36 \mathrm{~kg}$ Spindeln, $4480 \mathrm{~kg}$ Blätter und Kolbenhüllen, $2858.24 \mathrm{~kg}$ Stengel.

Noch frühreifer ist die verwandte Sorte "Small Yellow", deren Kolben nur eine Länge von $4--8 \mathrm{~cm}$ und $1-2 \mathrm{~cm}$ Dicke und eine Höhe von 60-90 cm erreichen. Diese reift in 90 Tagen.

\section{Middle sized eight-rowed Yellow-Flint.}

Kolben: kurzer und cylindrischer als bei „Large Yellow-Flint", $15-26 \mathrm{~cm}$ lang, $3-4.5 \mathrm{~cm}$ breit, etwas locker, 8-reihig, bei $26 \mathrm{~cm}$ Länge 56 Friichte in der Reihe; liefert 75.78 Proc. Früchte, 24.22 Proc. Spindel; Spindel weiss. - Frucht: gelb, halbkreisförmig, platt, sehr gross (10 $\mathrm{mm}$ lang, 10-13 mm breit, $4.5 \mathrm{~mm}$ dick).

Resultate:

Nach Salisbury ${ }^{1}$ ) ergab die Kultur im Staate New-York folgende

Aussaat 12/5., Erscheinen der jungen Pflanzen 22/5., Blïtezeit 25/7., Höhe in der Blüte $190 \mathrm{~cm}$, Blattzahl 10, Reifezeit 15/9., mithin umfasste die Vegetationsperiode 126 Tage, Höhe in der Reife $239 \mathrm{~cm}$, Zahl der Kolben 2 p. Pflanze.

Ertrag p. ha: $8064.00 \mathrm{~kg}$ Friichte, $2128 \mathrm{~kg}$ Spindeln, $4416.16 \mathrm{~kg}$ Blätter nnd Kolbenhüllen, $3493.28 \mathrm{~kg}$ Stengel.

Die Analyse ergab im Korn in Procenten:

$$
\text { Zucker }
$$

Zeïn

Dextrin

Stärke u. Extrakt Molzfaser Proteïn und Glutin Oel und Gummi Wasser $\begin{array}{llllllll}42.62 & 10.40 & 5.56 & 10.04 & 5.30 & 4.40 & 5.92 & 11.23 .\end{array}$ Geschätzt und stark im Norden der Vereinigten Staaten gebaut. Original in der Sammlung zu Poppelsdorf.

\section{Early eight-rowed Canada.}

Syn.: Canadian early Yellow-Flint.

Kolben: fast cylindrisch, schmal, $13-20 \mathrm{~cm}$ lang, $2-4 \mathrm{~cm}$ dick, 82.3 Proc. Korn, 17.7 Proc. Spindel liefernd; 8-reihig, Reihen etwas locker, 20 Fruichte in der Reihe. - Frucht: sattgelb, halbkreisförmig, platt, mittelgross $(8 \mathrm{~mm}$ lang, $7-10 \mathrm{~mm}$ breit, $4 \mathrm{~mm}$ dick, 27 Früchte $=10 \mathrm{gr})$. grobschalig.

In Poppelsdorf betrug die Zahl der Schösslinge 1.5, die der männlichen Blüten 1.5, die der weiblichen 1.3.

Halıne $200 \mathrm{~cm}$ (Max. $260 \mathrm{~cm}$ ), $2 \mathrm{~cm}$ dick, Blattzahl 9. Blätter $71 \mathrm{~cm}$ lang, $6.6 \mathrm{~cm}$ breit, Blattläche $8434.8 \mathrm{qcm}$, Halmfläche $1200 \mathrm{qcm}, \mathrm{Ge}-$ sammtfläche $9634.8 \mathrm{qcm}$. Zahl der fruchtbaren Kolben 1.1, Reifezeit 140 Tage.

Nach den Versuchen von Salisbury ${ }^{2}$ ) im Staate New-York stellte sich die Halmhöhe auf $168 \mathrm{~cm}$ in der Blïte, und $192 \mathrm{~cm}$ in der Reife, die

1) Transact. of the N.-Y. st. VIII 826.

2) Transact. of the N.-Y. st. VIII, p. 827. 
Blattzahl auf 11, die Kolbenzahl auf 2, die Vegetationszeit auf 117 Tage, und der Ertrag p. ha auf $5913.6 \mathrm{~kg}$ Früchte, $1270.08 \mathrm{~kg}$ Spindeln, $4565.12 \mathrm{~kg}$ Blätter und Kolbenhüllen, $2985.92 \mathrm{~kg}$ Stengel.

Die Analyse ergab nachfolgende Bestandteile in Procenten: Zucker

Zeïn

Dextrin

Stärke u. Extrakt Holzfaser Proteïn und Glutin Oel und Gummi Wasser $\begin{array}{llllllll}42.62 & 11.76 & 6.12 & 11.40 & 4.66 & 5.20 & 4.76 & 12.22 \text {. }\end{array}$

Nach dieser Zusammensetzung erweist sich das Korn als besonders ölreich, und liefert, namentlich für Geflügel und Schweine, ein sehr wertvolles Futter und wird auch unreif als Gemüse geschätzt.

Diese frühreife Maissorte wird vorzugswcise in Canada und im Norden des Staates New-York, wie überhaupt in den Nord-Staaten der Union, wo die grösseren Sorten nicht mehr gedeihen, gebaut.

Nach Berichten der Samenhandlung von MLetz ${ }^{1}$ ) in Berlin reifte er in warmen Sommern noch in der Mark Brandenburg und Sachsen.

\section{Iaiz moracho amarillo, Chile.}

Kolben: $\mathrm{sch}$ wach konisch, $20 \mathrm{~cm}$ lang, $2.5 \mathrm{~cm}$ dick, 14 -reihig, 45 Früchte in der Reihe. - Frucht: Original orangegelb, transparent, Krone abgerundet, sonst zusammengedrückt, $11 \mathrm{~mm}$ lang, $9 \mathrm{~mm}$ breit, $5 \mathrm{~mm}$ dick, 38 Früchte $=10 \mathrm{gr}$. - Halm: $260 \mathrm{~cm}$ lang, $2.5 \mathrm{~cm}$ dick, 4.5 Schösslinge, Rispe $40 \mathrm{~cm}$ lang, 1.5 Kolben, weibliche Blüte gelbgrün; Blattzahl 15, Blätter $77.4 \mathrm{~cm}$ lang, $7.4 \mathrm{~cm}$ breit, Blattfläche $17182.8 \mathrm{qcm}$, Halmfläche $2000 \mathrm{qcm}$, Gesammtfläche 19182.8 qcm.

Sehr spätreif.

Bezugsquelle: Durch von Gülich aus Hacienda de Colina, Dept. de Santiago, Chile, 1880.

\section{Maiz de Argon, Spanien.}

Kolben: lang, dünn, schwach konisch, 8-reihig, je 2 Reihen enger stehend, $25 \mathrm{~cm}$ lang, $5 \mathrm{~cm}$ breit, 40 Früchte pro Reihe. - Frucht: Original gelb, halbkreisförmig, platt, transparent, gross, $10 \mathrm{~mm}$ lang, $12 \mathrm{~mm}$ breit, $4 \mathrm{~mm}$ dick, 28.6 Früchte $=10 \mathrm{gr}$. - Halm: 1 Schössling, $240 \mathrm{~cm}$ lang, $3.5 \mathrm{~cm}$ dick, Rispe Anfang August blühend, Narbe rosa, Blattzahl 13, Blätter $70 \mathrm{~cm}$ lang, $10.5 \mathrm{~cm}$ breit, Blattfläche $19.110 \mathrm{qcm}, H a l m-$ Häche $2520 \mathrm{qcm}$, Gesammtfläche $21630 \mathrm{qcm}$.

Frühreif, in Poppelsdorf in warmen Sommern ausreifend.

Bezugsquelle: Ant. Cipr. Costa, Barcelona 1881.

\section{Maiz amarillo de Ampurdan, Prov. Gerona, Cataluña, Spanien.}

Kolben: schwach konisch, gross, $22 \mathrm{~cm}$ lang, $6 \mathrm{~cm}$ dick, 12-14-16reihig, 35 Früchte pro Reihe. - Frucht: Original schön dunkelgelb, trapezoïdisch, transparent, gross, $9 \mathrm{~mm}$ lang, $11 \mathrm{~mm}$ breit, $6 \mathrm{~mm}$ breit, 29.3 Früchte $=10 \mathrm{gr} .-$ Halm: 2 Schösslinge, $200 \mathrm{~cm}$ lang, $3.5 \mathrm{~cm}$ dick, männliche Rispe Anfang August blühend, Narbe gelblich-grün, $40 \mathrm{~cm}$ 
lang, $11 / 2$ Kolben, Blattzahl 13, Blätter $66 \mathrm{~cm}$ lang, $11 \mathrm{~cm}$ breit, Blattfläche $18876 \mathrm{qcm}$, Halmfläche $2100 \mathrm{qcm}$, Gesammtfläche $20976 \mathrm{qcm}$.

Frühreif, in warmen Sommern in Poppelsdorf reifend.

Bezugsquelle: Ant. Cipr. Costa, Barcelona 1881.

\section{Mais aus Benavente, Portugal.}

Kolben: schwach konisch, $15 \mathrm{~cm}$ lang, Reihen regelmässig, dicht, 8-reihig, 30 Früchte in der Reihe. - Frucht: Original orangegelb, transparent, gerundet, an den Seiten platt, Keimling vertieft, über Mittelgrösse, $8 \mathrm{~mm}$ lang, $9 \mathrm{~mm}$ breit, $4 \mathrm{~mm}$ dick, 39.2 Früchte $=10 \mathrm{gr}$. - Halm: 3 Schösslinge, $130 \mathrm{~cm}$ lang, $1.5 \mathrm{~cm}$ dick, 6 blühende und 2 reife Kolben, Rispe $25 \mathrm{~cm}$ lang, Narbe grünlich-gelb, Mitte Juli blühend; Blattzahl 7, Biätter $52 \mathrm{~cm}$ lang, $7 \mathrm{~cm}$ breit, Blattfläche $5096 \mathrm{qcm}$, Halmfläche $585 \mathrm{qcm}, \mathrm{Ge}-$ sammtfläche $5681 \mathrm{qcm}$.

Sehr friihreif.

Bezugsquelle: Prof. Jul. Henriques, Coïmbra, Portugal.

\section{Granturco Quarantino, oder nostrano basso precoce.}

\section{Syn.: Ital.: Agostanella (Form mit etwas kleineren Früchten).}

Franz.: Maïs quarantain jaune, Maïs précoce, Maïs d'Onona, Maïs hâtif de Thourout.

Spanisch: Maiz cuarenteno, Maiz tremés, Olate colorado (Mexico).

Eng l.: Old Forty-days maize.

Kolben: schwach konisch, 10--16 cm lang, 8-10-14-reihig, 24-34 Früchte in der Reihe, diclit; Spindel weiss. - Frucht: hellgelb, zuweilen orange, rundlich (6 $\mathrm{mm}$ lang, $7 \mathrm{~mm}$ breit, $6 \mathrm{~mm}$ dick, 1 Frucht wiegt $0.167 \mathrm{gr}$ und $1 \mathrm{hl}=76 \mathrm{~kg}$ ), Frucht ein wenig grösser als vom Hühnermais, doch Schale feiner; Mehl gelb, von angenehmen Geruch, geschätzt.

Die Kultur in Poppelsdorf ergab folgende Resultate: Pflanzraum $1000 \mathrm{qcm}$, Aussaat 20/5. 78, Erscheinen der jungen Pflanzen 7/6., Blüte 29/7, männliche Blüte (Staubbeutel olivengrün oder rot) 1.115, weibliche (Griffel hellrot) 2.2 p. Pflanze; Zahl der Triebe 1.16 p. Pflanze. Halme $78 \mathrm{~cm}$ (Max. $110 \mathrm{~cm}$ ) lang, $2 \mathrm{~cm}$ dick, Blattzahl 10, Blätter $35 \mathrm{~cm}$ lang, $3.6 \mathrm{~cm}$ breit, Blattfläche $2520 \mathrm{qcm}$, Halmflïche $468 \mathrm{qcm}$, Gesammtfläche $2988 \mathrm{qm}$. gefärbt.

Halm, Blattscheiden, Blattrippen und Blattränder sind dunkel-violett

Zalıl der fruchtbaren Kolben 2, Reifezeit 20/9., mithin Dauer der Vegetationsperiode 123 Tage.

Frischgewicht des Halmes in der Blüte $120 \mathrm{gr}$ (Мax. $360 \mathrm{gr}$ ).

Es lieferten 100 Halme $8.900 \mathrm{~kg}$ Kolben, darin $7.275 \mathrm{~kg}$ Körner, $1.625 \mathrm{~kg}$ Spindeln, ferner $2.100 \mathrm{~kg}$ Kolbenhüllen, $7.250 \mathrm{~kg}$ Stengel.

Dieser sehr frühreife Mais wird in den höheren Lagen Piemonts gewöhnlich um Johannis gesäet und Martini geerntet; bei Danzig reifte er 1862 in 163 Tagen noch vollkommen aus.

Nach Gasparin ${ }^{1}$ ) reift er in Süd-Frankreich, bis zum 20. Juni gesäet, noch Ende Oktober aus und beansprucht $3300^{\circ}$ Wärme.

1) Cours d'Agric. III, p. $74 \pi$. 
In der Lombardei ${ }^{1}$ ) soll der „Agostanella“ durchschnittlich 30-35 hl à $68-72 \mathrm{~kg}$ und der ,Quarantino" $25-30 \mathrm{bl} \mathrm{p}$. ha aufbringen und beträgt seine Vegetationszeit $3^{1 / 2}$ Monate.

Es ist ein alter in Italien einheimischer Mais, den schon Dalechamp $\left.{ }^{2}\right) 1587$ erwähnt.

\section{Cinquantino.}

Syn.: Ital.: Granturco d'estate, Meliga ostenga, agostana, Fromentone di steola, di stoppia.

Franz.: Maïs cinquantain, d'août, d'été à grain jaune ${ }^{3}$ ).

Ungarn: Czéndery oder Banater-Mais.

A merika: Mohaw's-Corn ${ }^{4}$ ).

Kolben: schwach konisch, 11--21 cm lang, 3-4 cm dick, 12-14-16reihig, Reihen regelmässig, sehr dicht, mit $24-38$ fest sitzenden Früchten in der Reihe; Spindel weiss. - Frucht: gelb bis goldgelb, in der Form eine gewisse Aehnlichkeit mit dem Zahnkorn, klein, abgeplattet $(8 \mathrm{~mm}$ lang, $4-6 \mathrm{~mm}$ breit, $3^{1} / 2-4 \mathrm{~mm}$ dick, 93.9 Früchte $=10 \mathrm{gr}, 1 \mathrm{hl}=$ $78 \mathrm{~kg}$ ), Mehl blassgelb, sehr geschätzt. - Stengel $120 \mathrm{~cm}$ hoch.

Die Kultur in Poppclsdorf ergab folgende Resultate: Pflanzraum $1000 \mathrm{qcm}$, Aussaat 20/5. 78, Erscheinen der Pflanzen 7/6., Blüte 1/8., männliche Blüte (Staubbeutel schmutzig-gelb) 1 p. Pflanze, weibliche 2 p. Pflanze. Halme $100 \mathrm{~cm}$ (Max. $130 \mathrm{~cm}$ ) lang, $1.6 \mathrm{~cm}$ dick, Blattzahl 10, Blätter $33 \mathrm{~cm}$ lang, $4.5 \mathrm{~cm}$ breit, Blattlï̈che $2970 \mathrm{qcm}$, Halmfläche $480 \mathrm{qcm}$, Gesammtfläche $3450 \mathrm{qcm}$.

Zahl der Triebe 1.2 und der fruchtbaren Kolben 1.39 p. Pflanze, Reifezeit 28/9., mithin betrug die Dauer der Vegetationszeit 132 Tage, während sie in Ungarn 120 Tage, in Ober-Italien 70-80 Tage und in Amerika 90 Tage umfassen soll.

Das Frischgewicht stellt sich p. Halm in der Blüte auf $190 \mathrm{gr}$ (Max. $280 \mathrm{gr}$ ).

Es lieferten in Poppelsdorf $100 \mathrm{Halme} 10.400 \mathrm{~kg}$ Kolben, darin $8.475 \mathrm{~kg}$ Körmer, $1.925 \mathrm{~kg}$ Spindeln, ferner $2.350 \mathrm{~kg}$ Kolbenhüllen, $9.250 \mathrm{~kg}$ Stengel.

Zur Zeit Burger's (1609) soll er ausser in Spanien und Italien im übrigen Europa noch unbekannt gewesen sein, wälırend er sich jetzt über Burgund, die Franche-Comté, über einen Teil Siid-Deutschlands, die Schweiz, Kärnten, Krain, Steiermark, namentlich aber über Rumänien, Serbien und Ungarn verbreitet liat. In Ungarn wurde er zuerst auf der Herrschaft Czéndery im Banat gebaut, weshalb er den Namen Czéndery oder Banater Mais führt. In Üngarn ist derselbe seiner Ergiebigkeit und der Guite seines blassgelben Xehles wegen sehr geschätzt; in den Preisnotierungen figuriert er als der schwerste und am höclisten bezahlte Mais Ungarns. Er wird in Ungarn in der Regel auf $63 \mathrm{~cm}$ Reihenweite und $30 \mathrm{~cm}$ Entfernung in der Reihe gedrillt, verträgt die Dürre des Steppenklimas vorzüglich und gibt noch Kolben, wenn der spätreife „Pignoletto" schon unter derselben leidet, ausserdem erlaubt es seine Fruhreife, nacl ihm noclı Wintergetreide anssäen zu können. Die Namen

1) Ital. Catal. Pariser Ausst. 1878.

2) Heuzé, Pl. aliment, II. p. 26.

3) Bonafous, Hist. nat. Agr. et écon. du Mais 1836.

4) Burger, Mais p. 53. 
„Fromentone di steola" oder ,di stoppia" hat er in Italien erhalten, weil er, in die Stoppel des Wintergetreides gesäet, noch ausreift. pro ha.

Der Durchschnittsertrag stellt sich auf $45-50$ hl à $75-78 \mathrm{~kg}$

\section{Helia invernenga.}

Syn.: Ital.: Meliga invernenga o di otto fili dell' Abbadia; Maggengo; Grano tureo d'autunno.

Portug.: Milho grosso.

Franz.: Maïs d'automne à grain jaune ${ }^{1}$ ), Maïs jaune gros.

Deutseh: Grosser, gelber Mais.

Kolben : fast cylindrisch, gross, $22-28 \mathrm{~cm}$ lang, $5 \mathrm{~cm}$ dick, $8-10-$ 12-reihig, Reihen ziemlich dicht, 35 Früchte in der Reihe; 100 Kolben liefern 17-23 kg Früchte; Spindel weiss. - Fruclit: citronengelb, voll, ein wenig abgeplattet, gross (10) $\mathrm{mm}$ lang, $13 \mathrm{~mm}$ breit, $6 \mathrm{~mm}$ dick, $1 \mathrm{hl}$ wiegt $78 \mathrm{~kg}$ ). - Stengel bis $2 \mathrm{~m}$ hoch, in Italien und Portugal bewässert, erreicht er $3-4 \mathrm{~m}$.

Die Vegretationszeit dauert $4 \frac{1}{2}$ Nonat und gehört er zu den ertragreichsten gelben Maissorten Siid-Europas, so bringt er in Ober-Italien ${ }^{2}$ ) $65-75 \mathrm{hl}$ à $72-75 \mathrm{~kg}$ p. ha auf.

Diese Sorte wird vorzugsweise in Italien. und $\mathrm{zwar}$ in Piemont, der Lombardei und Toscana, in Spanien, Portugal und Süd-Frankreich kultiviert.

Die Aussaatzeit fällt in Italien in den April.

\section{Granturco bergamascone.}

Syn.: Ital.: Fromentone oro, Franz.: Haïs doré, orange, de Grèce.

Portug.: Milho temporao.

Kolben: schwach konisch, mittelgross, Reihen ziemlich unregelmässig. - Frucht: goldgelb oder orange, gross, an der Spitze abgerundet, Seiten ein wenig platt, rundlich $11 \mathrm{~mm}$ lang, $11 \mathrm{~mm}$ breit, $5 \mathrm{~mm}$ dick, 27 Früchte $=10$ gr. - Halm $130-140 \mathrm{~cm}$ hoch.

Viel in der Gegend von Bergamo, doch auch in Portugal, Spanien, z. B. bei Jerez de la Fronteira gebaut, widersteht der Trockenheit vortrefflich, aber selbst weniger als Quarantino ertragreich.

Bezugsquelle: Ausstellung zu Mailand 1881.

\section{Maïs d'Auxonne.}

Syn.: Jaune hâtif d'Auxolnne.

Kolben: mittelgross, ziemlich cylindrisch, doch oft platt, bis $15 \mathrm{~cm}$ lang, $3 \frac{1}{2}-4 \frac{1}{2} \mathrm{~cm}$ dick, 12 -reihig, Reihen ziemlich dicht, regelmässig, bis 25 Früchte enthaltend, Spindel weiss. - Frucht: gelb, platt, länglich und etwas spitz (9 $\mathrm{mm}$ lang, $4-8 \mathrm{~mm}$ breit, $5 \mathrm{~mm}$ dick, 1 Korn wiegt $0.156 \mathrm{gr}, 1 \mathrm{hl}=74.5 \mathrm{~kg}$ ), \ehl blassgelb, geschätzt, feinschalig.

Die Kultur in Poppelsdorf ergab folgende Resultate:

1) Bonafous, Hist. nat. Agric. et écun. du Mais 1836.

2) Ital. Cat. zur Paris. Ausst. 1878. 
Pflanzraum $1250 \mathrm{qcm}$, Aussaat 20/5. 78, Erscheinen der Pflanzen $7 / 6$, Blüte 10/8., männliche Bliite (Staubbeutel gelb) 1.25, weibliche (Griffel grünlich-gelb oder blassrot) 2.15 p. Pflanze, Schösslinge p. Pflanze 1.2. Halme $130 \mathrm{~cm}$ (Мax. $160 \mathrm{~cm}$ ) lang, $2.2 \mathrm{~cm}$ dick, Blattzahl 10, Blätter $52.7 \mathrm{~cm}$ lang, $5.8 \mathrm{~cm}$ breit, Blattfläche $6113.2 \mathrm{qcm}$, Halmfläche $858 \mathrm{qcm}$, Gesammtfläche $6971.2 \mathrm{pcm}$.

Zahl der fruchtbaren Kolben 1.6 p. Pflanze, Reifezeit 4/10., mithin Dauer der Vegetationsperiode 137 Tage.

Frischgewicht eines Halmes in der Blïte $450 \mathrm{gr}$ (Max. $680 \mathrm{gr}$ ).

Es lieferten 100 Halme $19.000 \mathrm{~kg}$ liolben, darin $12.900 \mathrm{~kg}$ Körner, $6.100 \mathrm{~kg}$ Spindeln, ferner $6.000 \mathrm{~kg}$ Kolbenhüllen und $22.500 \mathrm{~kg}$ Stengel.

Diese ergiebige Maissorte reifte 1862 noch am 20/10. (Aussaat 10/5.) bei Danzig, sowie bei Berlin, und wird vorzugsweise in Burgund und in der Franche-Comté kultiviert.

Bezugsquelle: Tilmorin, Paris.

\section{Kukuricza.}

Syn.: Deutsch: Gelber ungarischer Mais.

Franz.: Maïs jaune de Hongrie.

Kolben: Original schwach konisch, $25 \mathrm{~cm}$ lang, $5^{1 / 2} \mathrm{~cm}$ dick, $12-14$ reihig, 37 Früchte in der Reihe; Spindel weiss. - Frucht: gelb, platt, gross (9 $\mathrm{mm}$ lang, $9-10 \mathrm{~mm}$ breit, $6 \mathrm{~mm}$ dick), $1 \mathrm{hl}$ wiegt $73 \mathrm{~kg}$ und 39.4 Körner gehen auf $10 \mathrm{gr}$.

Die Kultur in Poppelsdorf stellte sich 1878 wie folgt:

Pflanzraum $1250 \mathrm{qcm}$, A ussaat 20/5., Erscheinen der jungen Pflanzen 7/6., Blütezeit 14/8., männliche Blüte (Staubbeutel pfirsich-grün) 1, weibliche (Griffel hellgrün) 2.15 p. Pflanze; Zahl der Triebe 1.33, der fruchtbaren Kolben 1.25 p. Pflanze. Halme $115 \mathrm{~cm}$ ( Мax. $160 \mathrm{~cm}$ ) lang, $2 \mathrm{~cm}$ dick, Blattzahl 11, Blätter $55 \mathrm{~cm}$ lang, $5.4 \mathrm{~cm}$ breit, Blattfläche $6534 \mathrm{qcm}$, Halmfläche $690 \mathrm{qcm}$, Gesammtlläche $7224 \mathrm{qcm}$.

Das Frischgewicht betrug in der Blüte $530 \mathrm{gr}$ (Мax. $670 \mathrm{gr}$ ).

Die Reife erfolgte 12/10., also nach einer Vegetationszeit von 145 Tagen und wurden von 100 Halmen geerntet: $22.500 \mathrm{~kg}$ Kolben, darin $13.685 \mathrm{~kg}$ Körner, $8.815 \mathrm{~kg}$ Spindeln, ferner $4.400 \mathrm{~kg}$ Kolbenhüllen, 20.600 $\mathrm{kg}$ Stengel.

Dieser sehr allgemein in Ungarn angebaute und in 150 Tagen dort reifende Mais wird, je nach den Boden- und Kulturverhältnissen, auf 63-75 cm Reihenweite und $50 \mathrm{~cm}$ Entfernung in der Reihe kultiviert.

Sehr häufig wird er jedoch bei Einführung der Fruchtwechselwirtschaft durch den frühreifen Cinquantino verdrängt, weil dieser noch den Anbau von Winterung nach Jais gestattet, und die Qualität seines Kornes höher geschätzt wird.

\section{Früher gelber Badener Mais.}

Kolben: cylindrisch, $20 \mathrm{~cm}$ lang, $4 \frac{1}{2} \mathrm{~cm}$ dick, konstant 8-reihig, 33 Früchte in der Reihe. - Frucht: sattgelb, rundlich, gross $10 \mathrm{~mm}$ lang, $12 \mathrm{~mm}$ breit, $7 \mathrm{~mm}$ dick, 48 Frïchte $=10 \mathrm{gr}$ ), grobschalig.

Die Kultur in Poppelsdorf stellte sich im vierjährigen Durchschnitt $1875 / 78$ wie folgt:

Pflanzraum 1250 qcm, männliche Blüte (Staubbeutel gelb oder dunkel- 
rot) 1.03, weibliche (Griffel meist hellgrün, zuweilen blassrot) 2.3; Zahl der Triebe 1.02, der fruchtbaren Kolben $1.3 \mathrm{p}$. Pflanze.

Halme $170 \mathrm{~cm}$ (Max. $240 \mathrm{~cm}$ ) lang, $0.2 \mathrm{~cm}$ dick, Blattzahl 10, Blätter $57 \mathrm{~cm}$ lang, $5 \mathrm{~cm}$ breit, Blattfläche $5700 \mathrm{qcm}$, Halmfläche $1020 \mathrm{qcm}$, Gesammtfläche $6720 \mathrm{qcm}$. $765 \mathrm{gr})$.

Das Frischgewicht in der Blïte betrug p. Halm 355 gr (Max.

Die Reife erfolgte nach einer Vegetationszeit von 140 Tagen und wurden von 100 Halmen geerntet: $21.900 \mathrm{~kg}$ Kolben, darin $15.375 \mathrm{~kg}$ Früchte, $6.525 \mathrm{~kg}$ Spindeln, ferner $4.600 \mathrm{~kg}$ Kolbenhüllen, $21.000 \mathrm{~kg}$ Stengel.

Dieser Mais wird vorzugsweise in Baden kultiviert und dort alljährlich reif.

\section{Ellwanger-Mais.}

Kolben: schwach konisch, 12-20 cm lang, 8-10-12-reihig, mit 28-32 fest sitzenden Früchten in der Reihe; Spindel weiss. - Frucht: hellgelb, halbkreisförmig (10 mm breit, $9 \mathrm{~mm}$ lang, $4 \mathrm{~mm}$ tief, 39 Früchte $=10 \mathrm{gr}, 1 \mathrm{hl}$ wiegt $75 \mathrm{~kg}$ ).

Die Kultur in Poppelsdorf ergab folgende Resultate:

Pflanzraum $1000 \mathrm{qcm}$, Aussaat 20/5. 78, Erscheinen der Pflanzen 7/6., Blüte 28/7., männliche Blüte 1.03, weibliche 1.65 und Triebe 1.34 p. Pflanze. Halme in der Blüte $70 \mathrm{~cm}$ (Max. $100 \mathrm{~cm}$ ) lang, $2.5 \mathrm{~cm}$ dick, Blattzahl 10, Blätter $43 \mathrm{~cm}$ lang, $4.45 \mathrm{~cm}$ breit, Blattfläche $3827 \mathrm{qcm}$, Halmfläche $525 \mathrm{qcm}$, Gesammtfläche $4352 \mathrm{qcm}$.

Zahl der fruchtbaren Kolben 1.65 p. Ptlanze, Reifezeit 20/9., mithin Dauer der Vegetationszeit 123 Tage.

Das Frischgewicht eines Halmes betrug $120 \mathrm{gr}$ (Max. $250 \mathrm{gr}$ ).

Es lieferten 100 Halme $14.350 \mathrm{~kg}$ Kolben, darin $9.725 \mathrm{~kg}$ Körner, $4.625 \mathrm{~kg}$ Spindeln; $2.400 \mathrm{~kg}$ Kolbenhüllen und $9.750 \mathrm{~kg}$ Stengel.

Diese Maissorte ist zweifellos aus dem Cinquantino hervorgegangen, welcher ihm auch vorzuziehen ist.

In Württemberg und namentlich bei Ellwangen häufig gebaut.

Original von Prof. Vossler, Hohenheim, erhalten.

\section{Cannstatter-Mais.}

Kolben : schwach konisch, 15-22 cm lang, 8-10-reihig, Reihen regelmässig mit 24 sehr fest und dicht sitzenden Früchten; Spindel weiss. Frucht: gesättigt gelb, halbkreisförmig, gross $(10 \mathrm{~mm}$ lang, $11 \mathrm{~mm}$ breit, $6 \mathrm{~mm}$ dick, 32.6 Früchte $=10 \mathrm{gr}, 1 \mathrm{hl}=75 \mathrm{~kg}$.)

Die Kultur in Poppelsdorf ergab folgende Resultate:

Pflanzraum $1000 \mathrm{qcm}$, Aussaat 20/5. 78, Erscheinen der Pflanzen 7/6., Blüte 26/7., männliche Blüte 1 (Staubbeutel roth), weibliche $1.6^{\circ}$ (Griffel rosa) und Triebe 1.57 p. Pflanze. Halm in der Blüte $70 \mathrm{~cm}$ (Max. $135 \mathrm{~cm}$ ) lang, $2 \mathrm{~cm}$ dick, Blattzahl 7, Blätter $44 \mathrm{~cm}$ lang, $4.5 \mathrm{~cm}$ breit, Blattfläche $2772 \mathrm{qcm}$, Halmfläche $420 \mathrm{qcm}$, Gesammtfläche $3192 \mathrm{qcm}$.

Zahl der fruchtbaren Kolben 1.1 p. Ptlanze, Reifezeit 20/9., mithin Dauer der Vegetationsperiode 123 Tage.

Das Frischgewicht eines Halmes betrug $170 \mathrm{gr}$ (Max. $600 \mathrm{gr}$ ).

Es lieferten 100 Halme $13.900 \mathrm{~kg}$ Kolben, darin $10.225 \mathrm{~kg}$ Körner, $3.675 \mathrm{~kg}$ Spindeln; $2.850 \mathrm{~kg}$ Kolbenhüllen, $9.250 \mathrm{~kg}$ Stengel. 
Dieser Mais wird allenthalben im Neckarthal angebaut und bildet mit dem Ellwanger die beiden specifisch württembergischen Maissorten.

Original ron Prof. Tossler, Hohenheim, 1878 erhalten.

\section{Heinemann's September-Mais.}

Kolben: dünn, fast cylindrisch, $20 \mathrm{~cm}$ lang, $4 \frac{1}{2} \mathrm{~cm}$ dick, S-reihig, 35 Früchte in der Reihe; Spindel weiss. - Frucht: hellgelb, halbkreisförmig, platt, hornig (9 $\mathrm{mm}$ lang, $11 \frac{1}{2} \mathrm{~mm}$ breit, $5 \mathrm{~mm}$ dick, 37 Früchte wiegen $10 \mathrm{gr}$ ). wie folgt:

Die Kultur stelite sich in dem sehr kühlen Sommer von 1879

Pflanzraum 1000 qcm, Aussaat 20/5., Zahl der männlichen Blïten 1.6, der weiblichen 1.3, ler fruchtbaren Kolben 1, der Triebe 1.8. Halme $170 \mathrm{~cm}$ (Мax. $200 \mathrm{~cm}$ ), $5 \mathrm{~cm}$ dick, Blätter $57 \mathrm{~cm}$ lang, $5 \mathrm{~cm}$ breit, Blattzahl 7, Blattfläche 3990 q cm, Halmfläche 765 qcm, Gesanımtfläche $4755 \mathrm{qcm}$.

Diese Sorte reifte am frihhesten von allen gleichzeitig angebauten Sorten und wurde selbst noch in diesem ausnahmsweise kiihlen Sommer gegen den 12. Oktober hin reif, also nach einer Tegetationszeit ron 145 Tagen.

Fiir Mitteldeutselland scheint diese Maissorte selı passend zu sein, wenn es sich bewahrheitet, dass ihre Ertragsfähigkeit eine ausgezeichnete ist.

Bezugsquelle: F. C. Hein emann, Eifurt.

\section{Varietät: Zea Mais turgida Bonaf.}

\section{Sorte ll:}

\section{Pignoletto.}

Syn.: Reichtragender Syrmier.

Kolben: stark konisch, $17 \mathrm{~cm}$ lang, $5 \mathrm{~cm}$ dick, vielreihig $(18-24), 40$ Früclıte in der Reihe, Reilıen an der Basis häufig unregelıässig; Spindel weiss. - Frucht: prachtroll, orangefarben, platt, glasig, klein $(6 \mathrm{~mm}$ lang, 5-71/2 mm breit, $4 \mathrm{~mm}$ dick, 73.9 Früchte $=10 \mathrm{gr}, 1 \mathrm{hl}$ wiegt $74 \mathrm{~kg})$.

In Poppelsdorf gestaltete sich seine Kultur 1878 wie folgt:

Pflanzraum 1250 qem. Aussaat 20/5., Erscheinen der Pflanzen 7/6., Blütezeit 20/8., männliche Bliite (Staubbeutel gelb) 1, weibliche (Griffel hellrot) 1.9 p. Pflanze. Zahl der Triebe 1.05; Halme $120 \mathrm{~cm}$ (Max. $160 \mathrm{~cm}$ ) lang, $2 \mathrm{~cm}$ dick, Blattzahl 12, Blätter $46 \mathrm{~cm}$ lang, $4.6 \mathrm{~cm}$ breit, Blattfläche $5078.4 \mathrm{qcm}$, Halmfläche $720 \mathrm{qcm}$, Gesammtfläche $5798.4 \mathrm{qcm}$.

Zalıl der reifen Kolben 1.5, Entezeit 12/10., mithin erfolgte die Reife nach 145 Tagen, und wurden von 100 Halmen erzielt: $15.100 \mathrm{~kg}$ Kolben, darin 9.62 i kg löörner, $5.475 \mathrm{~kg}$ Spindeln, ferner $6.000 \mathrm{~kg}$ Kolbenhüllen, $21.400 \mathrm{lig}$ Stengel.

Dieser Mais zeichnet sich durch Ergiebigkeit und volzügliche Qualität der Friichte aus, weshalb er auf den rationeller bewirtschafteten Gütern Lngarns dem gewöhnlichen gelben ungarischen Mais vorgezogen wird, doch verträgt er die Dürre weniger gut und ist auch spätreifer als der Cinquantino, der in trocknen Jahren einen höherell Ertrag bringt, und 
dem Winterung folgen kann, daher meist diese beiden Maissorten auf grösseren Gütern angebaut werden, und zwar in der Regel auf $63 \mathrm{~cm}$ Reihenweite und $50 \mathrm{~cm}$ in der Reihe, die Vegetationsdauer umfasst 150-160 Tage.

Ausser in Ungarn wird diese vorzügliche Sorte noch in Rumänien und Ober-Italien gebaut.

Bezugsquelle: Samenhandlung von A. Frommer, Budapest.

\section{Allerfrühester Szekler-Kukuruz.}

Kolben: stark konisch, Basis sehr breit, $16 \mathrm{~cm} \mathrm{lang,} 5 \mathrm{~cm}$ dick, 12-16-reihig, 25 Früchte in der Reihe; Spindel weiss. - Frucht: lichtgelb, rundlich, mittelgross $(8 \mathrm{~mm}$ lang, $10 \mathrm{~mm}$ breit, $9 \mathrm{~mm}$ dick, $1 \mathrm{hl}$ wiegt $75-77 \mathrm{~kg}, 37$ Frïchte $=10 \mathrm{gr})$.

In Siebenbürgen am 28. Mai ansgesäet, trat die volle Reife am 10. September, also nach 105 Tagen ein, auch in Poppelsdorf bewährte sich 1879 in dem kühlen Sommer seine Frühreife, da er zu den frühreifsten (Ernte 12/10.) der ausgesäeten Sorten gehörte.

Die Zahl der Triebe betrug 1.1, der männlichen Blüten 1.1, der weiblichen Blüten 1.2, der fruchtbaren Kolben 1.15 p. Pflanze.

Halme $185 \mathrm{~cm}$ (Max. $220 \mathrm{~cm}$ ) lang, $1.5 \mathrm{~cm}$ dick, Blattzahl 10, Blätter $60.5 \mathrm{~cm}$ lang, $5.0 \mathrm{~cm}$ breit, Blattfläche $6050 \mathrm{qcm}$, Halmfläche $990 \mathrm{qcm}$, Gesammtfläche $7040 \mathrm{qcm}$.

Durch Kreuzung des Cinquantino mit einer frühen Sorte des SzeklerLandes in Siebenbürgen ist diese durch grosse Frühreife sich auszeichnende Sorte von Arpad Szentskiralyi ${ }^{1}$ ) erzeugt worden.

Diese Sorte eignet sich vorziiglich für rauhere Gebirgslagen.

Bezugsquelle: Samenhandlung A. Frommer, Budapest.

\section{Maïs jaune très-hâtif des Motteaux.}

Kolben: stark konisch, $12-\mathbf{1 5 - 1 7} \mathrm{cm}$ lang, an der Basis $5-5.5 \mathrm{~cm}$ dick, 16-20-reihig, Reihen etwas unregelmässig, dicht, 25 Früchte in der Reihe; Spindel weiss. - Frucht: gesättigt gelb, rund; oben breit, nach unten spitz; klein $(7 \mathrm{~mm}$ lang, $7 \mathrm{~mm}$ breit, $6 \mathrm{~mm}$ dick, 31.8 Früchte $=10 \mathrm{gr}, 1 \mathrm{hl}=76.5 \mathrm{~kg}$ ).

Die Kultur in Poppelsdorf ergab folgende Resultate:

Pflanzraum $1000 \mathrm{qcm}$, Aussaat 20/5. 78, Erscheinen der jungen Pflanze 7/6., Blütezeit 1/8., männliche Blüte (Staubbeutel hell bis dunkelrot), 1 p. Pflanze, weibliche (Griffel blassrosa) 1.8 p. Pflanze; Triebe 1.19 p. Pflanze. Halm in der Blüte $90 \mathrm{~cm}$ (Max. $130 \mathrm{~cm}$ ) lang, $1.5 \mathrm{~cm}$ dick, Blattzahl 9, Blätter $38.8 \mathrm{~cm}$ lang, $4 \mathrm{~cm}$ breit, Blattfläche $2793.6 \mathrm{qcm}$, Halmfläche $405 \mathrm{qcm}$, Gesammtfläche $3198.6 \mathrm{qcm}$.

Zahl der fruchtbaren Kolben 1.25 p. Pflanze, Reifezeit 30/9., mithin Dauer der Vegetationsperiode 133 Tage.

Frischgewicht eines Halmes in der Bluite ca. $200 \mathrm{gr}$ (Max. $360 \mathrm{gr}$ ).

Es lieferten 100 Halme $12.750 \mathrm{~kg}$ Kolben, und darin $9.075 \mathrm{~kg}$ Körner, $3.675 \mathrm{~kg}$ Spindeln; $2.250 \mathrm{~kg}$ Kolbenhüllen, $11.000 \mathrm{~kg}$ Stengel.

Bezugsquelle: Vilmorin, Paris.

1) Oesterreichisch. Wochenbl. Nr. 4, 1878. 


\section{Gelber grobkörniger Murecker-Mais.}

Kolben: stark konisch, $22 \mathrm{~cm}$ lang, 6-7 cm dick, 14-24-reihig, regelmässig, ziemlich dicht, 35 Frïchte in der Reihe; Spindel weiss. - Frucht: sattgelb, undurchsichtig, trapezoïdisch, platt, gross $(10 \mathrm{~mm}$ lang, $10 \mathrm{~mm}$ breit, $6 \mathrm{~mm}$ dick, 31.2 Früchte $=10 \mathrm{gr}, 1 \mathrm{hl}$ wiegt $70 \mathrm{~kg}$ ).

Die Kultur ergab 1878 in Poppelsdorf folgende Resultate:

Pflanzraum $1250 \mathrm{qcm}$, Aussaat 20/5., Blütezeit 16/8., männliche Blüte (Staubbeutel gelb) 1.1, weibliche (Griffel blassrot) 1.4 p. Pflanze; Zahl der Triebe 1.1, der fruchtbaren Kolben 1.05 p. Pflanze.

Halme $120 \mathrm{~cm}$ (Max. $160 \mathrm{~cm}$ ) lang, $2 \mathrm{~cm}$ dick, Blattzahl 10, Blätter $53.2 \mathrm{~cm}$ lang, $5.3 \mathrm{~cm}$ breit, Blattfäche 5639.2 q cm, Halmfläche $720 \mathrm{qcm}$, Gesammtfläche $6359.2 \mathrm{qcm}$.

Es lieferten 100 Halme $25.000 \mathrm{~kg}$ Kolben, darin $13.535 \mathrm{~kg}$ Körner, $11.465 \mathrm{~kg}$ Spindeln, ferner $5.000 \mathrm{~kg}$ Kolbenhüllen und $18.000 \mathrm{~kg}$ Stengel.

Die Reife erfolgte 4/10., also nach 137 Tagen.

Diese Sorte gehört zu den im Murthale meist gebauten.

Erhalten durch Güterdirektor Weck zu Brunnsee im Murthal.

Varietät: Zea Mais gilra Kcke.

Sorte :

\section{Isabellfarbener Mais.}

Kolben: cylindrisch klein, $12 \mathrm{~cm}$ lang, $3 \frac{1}{2} \mathrm{~cm}$ dick, 10-reihig, 22 Früchte in der Reihe; Spindel weiss. - Frucht: isabellfarben, rundlich, gross ( $8 \mathrm{~mm}$ lang, $8 \mathrm{~mm}$ breit, $5 \mathrm{~mm}$ dick).

Original in der Poppelsdorfer Sammlung.

Varietät: Zea Mais Philippi Kcke.

\section{Sorte:}

\section{Early King-Philip.}

Syn.: A merikan.: Improver King-Philip, Brown-Corn. (Verbesserte Formen.)

Franz.: Haïs du roi Philippe.

Deutsch: König Philip-Mais.

Kolben: fast cylindrisch, $20-30 \mathrm{~cm}$ lang, $3^{1} / 2-4 \mathrm{~cm}$ dick, 8-reihig, doch soll er auf sehr gutem Boden auch 12-reihig werden können, Reihen dicht, je zwei Reihen durch einen weiteren Zwischenraum getrennt, sehr regelmässig, bei $20 \mathrm{~cm}$ Länge 40 Früchte in der Reihe; Spindel schmal, weiss. - Frucht: hellgelbbraun ins Rötliche spielend, Krone halbkreisförmig, platt, gross $(9 \mathrm{~mm}$ lang, $11 \mathrm{~mm}$ breit, $5.5 \mathrm{~mm}$ dick, 26.1 Früchte $=10 \mathrm{gr}, 1 \mathrm{hl}$ wiegt $71.5 \mathrm{~kg})$. - Halm: schlank, $150-200 \mathrm{~cm}$ hoch.

In Poppelsdorf ergab 1878 die Kultur dieses Maises folgende Resultate:

Pflanzraum $1250 \mathrm{qcm}$, Aussaat 20/5., Erscheinen der Pflanzen 7/6., Blütezeit 12/8., nünnliche Blüte (Staubbeutel rot) 1.55, weibliche (Griffel hellgrün) 2.T p. Pflanze, Zahl der Triebe 1.65. Halme $120 \mathrm{~cm}$ (Max. $165 \mathrm{~cm}$ ) lang, 2 cm dick, Blattzahl 11, Blätter $53.4 \mathrm{~cm}$ lang, $4.5 \mathrm{~cm}$ breit. Blattfläche 5286.6 qcm, Halmfläche 720 qcm, Gesammtfläche 6006.6 qcm, 

$550 \mathrm{gr}$ ).

Das Frischgewicht eines Halmes zur Bliitezeit betrug $250 \mathrm{gr}$ (Max.

Die Reife erfolgte 4/10., also nach 137 Tagen und fanden sich 1.15 fruchtbare Kolben p. Pflanze.

Es lieferten 100 Halme $21.000 \mathrm{~kg}$ Kólben, darin $13.650 \mathrm{~kg}$ Körner, $7.350 \mathrm{~kg}$ Spindeln, ferner $5.400 \mathrm{~kg}$ Kolbenhiillen, 21.250 Stengel.

Dieser harte, ertragreiche, frühreife Mais ist in den Nordstaaten der Union, namentlich in den Neu-England-Staaten, sowie in den Berggegenden von Virginien, Maryland und Pennsylvanien sehr geschätzt.

Im Weinklima Deutschlands und in Frankreich bis Paris lässt er sich noch erfolgreich kultivieren.

Den Namen „King Philip“ hat er nach einem berühmten Häuptling der Wampanoag-Indianer erhalten. Diese Sorte wurde durch Mr. John B rown, Long-Island, am Winnipiseogee-See verbessert, indem er den Ertrag (bis $122 \mathrm{hl} \mathrm{p.} \mathrm{ha)} \mathrm{und} \mathrm{Oelreichtum} \mathrm{steigerte,} \mathrm{und} \mathrm{Früchte} \mathrm{dieser}$ verbesserten Sorte wurden durch den preussischen Gesandten in Washington, $\mathrm{v}$ on Gerolt, 1855 an das Landes-Oekonomie-Kollegium in Berlin gesandt, welches Versuche an den preussischen landwirtschaftlichen Lehranstalten, welche günstig ausfielen, anstellen liess.

\section{Varietät: Zea Mais rubropaleata Kcke.}

\section{Sorten:}

\section{Maiz anaranjado, Chile.}

Kolben: fast cylindrisch, 18-reihig, Reihen sehr regelmässig mit 50 Früchten; Spelzen rot. -- Frucht: Original orangegelb, halbdurchsichtig, $10 \mathrm{~mm}$ lang, $9 \mathrm{~mm}$ breit, $5 \mathrm{~mm}$ dick, 38 Früchte $=10 \mathrm{gr}$. - Halm $220 \mathrm{~cm}$ lang, $2.5 \mathrm{~cm}$ dick, 4 Schösslinge, 2 Kolben, Rispe $40 \mathrm{~cm}$ lang; Blattzahl 14, Blätter $67 \mathrm{~cm}$ lang, $9.1 \mathrm{~cm}$ breit, Blattfläche $16471.6 \mathrm{qcm}$, Halmfläche $1650 \mathrm{qcm}$, Gesammtfläche 18121.6 qcm.

Spätreif.

Bezugsquelle: durch vo on Giilich aus Hacienda de Colina, Chile 1880.

\section{Citronengelber Iais mit roten Spelzen.}

Ital.: Granturco giallo ranciato a stelo rosso.

Kolben: konisch, gross, $20 \mathrm{~cm}$ lang, $4 \mathrm{~cm}$ breit, 10-reihig, Reihen etwas unregelmässig, locker, 32 Früchte in der Reihe; Spelzen rot, Frucht: citronengelb, rundlich, etwas gedrückt, gross ( $8 \mathrm{~mm}$ lang, $7 \mathrm{~mm}$ breit, $7 \mathrm{~mm}$ dick).

Original in der Poppelsdorfer Sammlung.

Varietät: Zea Mais rubropunctata Keke.

\section{Sor te :}

\section{Gelber Mais mit roten Griffelpunkten.}

Kolben: konisch, etwas gebogen, mittellang, $20 \mathrm{~cm} \mathrm{lang,} 31 / 2 \mathrm{~cm}$ breit, 8-10-reihig, 32 Früchte in der Reihe; Spindel rot. - Frucht: sattgelb, Griffelpunkt rot, gerundet ( $7 \mathrm{~mm}$ lang, $9 \mathrm{~mm}$ breit, $5 \mathrm{~mm}$ dick, 47 Früchte $=10 \mathrm{gr}$ ). 


\section{Varietät: Zea Mais rubra Bonaf.}

\section{Sorte 11:}

\section{Red Indian-corn.}

Syn.: Deutsch: Roter Mais.

Franz.: Мaïs rouge, gros, ’̀ grain de corail (Bonafous).

Ital.: Granturco rossiccio o rosso.

Portug.: Wilho sequeiro.

Kolben: dick, $20 \mathrm{~cm}$ lang, $5 \mathrm{~cm}$ dick, 8-14-reihig, 30-3j Früchte in der Reihe; Spindel rot. - Frucht: Runkelrot, Krone gerundet, etwas abgeplattet, dick, gross $(9 \mathrm{~mm}$ lang, $12 \mathrm{~mm}$ breit, $8 \mathrm{~mm}$ dick, 29 Früchte $=10 \mathrm{gr}, 1 \mathrm{hl}$ wiegt $73 \mathrm{~kg}$ ). Halm $175-200 \mathrm{~cm}$ hoch.

Die Kultur in Poppelsdorf ergab 1878 folgende Resultate:

Pflanzraum $1250 \mathrm{qcm}$, Aussaat 20/5, Erscheinen der Pflanzen $7 / 6$, Blütezeit 10/8, männliche Blüte 1, weibliche 1.9 p. Pflanze, Zahl der Triebe 1.2. Halme $130 \mathrm{~cm}$ (Max. $170 \mathrm{~cm}$ ) lang. 2 em dick, Blattzahl 10, Blätter $58.8 \mathrm{~cm}$ lang, $5.5 \mathrm{~cm}$ breit, Blattfläche $6468 \mathrm{qcm}$, Halmfläche $780 \mathrm{qcm}$, Gesammtfläche $7248 \mathrm{qcm}$. $930 \mathrm{gr})$

Das Frischgewicht eines Halmes in der Blüte betrug $364 \mathrm{gr}$ (Max.

Die Reife erfolgte (12/10.) nach 145 Tagen und entfielen 1.05 fruchtbare Kolben p. Pflanze.

Es lieferten 100 Halme $22.750 \mathrm{~kg}$ Kolben, darin $13.310 \mathrm{~kg}$ Körner, $9.440 \mathrm{~kg}$ Spindeln, ferner $5.000 \mathrm{~kg}$ holbenhü̈llen und $18.750 \mathrm{~kg}$ Stengel.

Diese Sorte ist gegen ungünstige Witterungsverhältnisse auffallend unempfindlich, so ertrug sie, obgleich eine späte Sorte, den kühlen und sehr feuchten Sommer von 1879 von den angebauten Sorten mit am besten.

Dieser Mais wird besonders in Süd-Frankreich, Portugal, NordAfrika und namentlich in Aegypten, dagegen wenig in Italien gebaut. Europa.

Er gelangte in der Mitte des 18. Jahrhunderts von Amerika nach

Bezugsquelle: Vilm orin, Paris.

\section{Fancy Pop-corn.}

Kolben: schmal, fast cylindrisch, $20 \mathrm{~cm}$ lang, $3 \mathrm{~cm}$ breit, 8-reihig, 45 Früchte in der Reihe. - Frucht: dunkelrot, Seiten platt, Krone gerundet $(6 \mathrm{~mm}$ lang, $10 \mathrm{~mm}$ breit, $5 \mathrm{~mm}$ dick, 50.8 Früchte $=10 \mathrm{gr})$.

Original in der Sammlung zu Poppelsdorf.

\section{Twelve rowed-Flesh-color.}

Kolben: 18-28 cm lang, 3-4 cm dick, liefert 78.32 Proc. Frucht, 21.6S Proc. Spindel. - Frucht: rötlich-gelb, grobschalig. - Halm: $200-250 \mathrm{~cm}$ lang, mit 2, zuweilen 3 Kolben.

Nach Salisbury ${ }^{1}$ ) reifte er im Staate New-York in 116 Tagen, und der Ertrag stellte sich p. ha auf: $7123.2 \mathrm{~kg}$ Früchte, $1958.96 \mathrm{~kg}$ Spindeln, $4764.48 \mathrm{~kg}$ Blätter und Kolbenhiillen, $3335.36 \mathrm{~kg}$ Stengel.

Die Körner zeigten nachfolgende Zusammensetzung in Procenten:

1) Transact. of the N.-Y. st. VIII, 828. 
Zucker

Zeïn

Dextrin

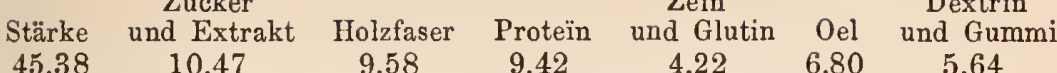

$\begin{array}{cccccc}45.38 & 10.47 & 9.58 & 9.42 & 4.22 & 6.80 \\ \text { Hiernach sind die } & \text { Körner im hohen Grade ölreich. }\end{array}$

Diese Maissorte ist ein Bastard des achtreihigen Flesh und des Sioux, erzeugt durch Mr. Salisbury zu Cortland, Vereinigte Staaten.

Varietät: Zea Mais nigra Al.

\section{Sorte :}

\section{Grano turchino nero.}

Syn.: Deutsch: Rotschwarzer Mais.

Franz. : Maïs noir.

Kolben : ziemlich cylindrisch, kurz, 10-15 cm lang, $3 \mathrm{~cm}$ dick, 20-25 Früchte in der Reihe; Spindel rot. - Frucht: tief dunkelbraun, Krone abgerundet, Seiten platt (10 $\mathrm{mm}$ lang, $9 \mathrm{~mm}$ breit, $5 \mathrm{~mm}$ dick, 34.8 Früchte $=10 \mathrm{gr}$ ).

Original in der Sammlung zu Poppelsdorf.

Varietät: Zea Mais violacea Keke.

\section{Sorte:}

\section{Maïs noir de Chine, ou de Canton.}

Syn.: Violetter Mais mit weissen Spelzen.

Kolben: ziemlich konisch, 14-17 cm lang, $4 \mathrm{~cm}$ dick, 12-18-reihig, Reihen etwas unregelmässig, 36 Früchte in der Reihe. - Frucht: violett, nach der Spitze zu heller, Krone gerundet, Seiten platt, klein $(7 \mathrm{~mm}$ lang, 4-6 $\mathrm{mm}$ breit, $4 \mathrm{~mm}$ dick, 50.2 Früchte $=10 \mathrm{gr}$.

Nach Heuzél ${ }^{1}$ ) ist diese Sorte in China verbreitet und 1812 durch Mr. L u puy im botanischen Garten zu Bordeaux zuerst kultiviert worden.

Varietät: Zea Mais caesia Al.

\section{Sorte:}

\section{Blue-Pop.}

Kolben: cylindrisch, $7.5-15 \mathrm{~cm}$ lang, 3-4 cm dick, 8-12-reihig, Spindel weiss, liefert 79.6 Proc. Friichte, 20.4 Proc. Spindel. - Frucht: schmutzig-blau, hornig, gerundet ( $8 \mathrm{~mm}$ lang, $8 \mathrm{~mm}$ breit, $4 \mathrm{~mm}$ dick), Mehl von guter Beschaffenheit. Halm: bis $2 \mathrm{~m}$ hoch, mit 3 Kolben. Nach einer Vegetationszeit von 116 Tagen erzielte Salis b ury ${ }^{2}$ ) im Staate New-York p. ha $6921.6 \mathrm{~kg}$ Früchte, $1778.56 \mathrm{~kg}$ Spindeln, $4954.88 \mathrm{~kg}$ Blätter und Kolbenhüllen, 5716.48 kg Stengel.

Diese Sorte eignet sich noch für Süd-Deutschland.

1) Pl. aliment. II. 38 .

2) Transact. of the N.-Y. st. Vol. VIII, 831.

Koernicke u. Werner, Handb. d. Getreidebau's. II. 


\section{Varietät: Zea Mais rubrocaesia Kcke.}

Sorte:

\section{Früher schmutzigblauer Mais mit roten Spelzen.}

Kolben: 14-16 cm lang, $3 \mathrm{~cm}$ breit, Reihen ziemlich regelmässig, 8-reihig, 25 Früchte in der Reihe; Spindel rot. - Frucht: schmutzigblau, abgerundet $(8 \mathrm{~mm}$ lang, $9 \mathrm{~mm}$ breit, $6 \mathrm{~mm}$ dick, 39.3 Früchte $=10 \mathrm{gr}$ ).

Original in der Sammlung zu Poppelsdorf.

Varietät: Zea Mais striata Al.

Sorte:

\section{Calico-corn, Nord-Amerika.}

Syn.: Spanisch: Mais moracho jaspeado (Chile), Süd-Amerika.

A merika: Speckled-corn.

Franz.: Maïs jaspé.

Deutsch: Gefleckter Mais.

Kolben: fast cylindrisch, $15-23 \mathrm{~cm}$ lang, 3-4 cm dick, 8-14reihig, Reihen dicht; Spindel weiss. - Frucht: gelb, mit roten Streifen, jaspisartig gebändert, undurchsichtig, hart, ziemlich gross $(10 \mathrm{~mm}$ lang, $7-11 \mathrm{~mm}$ breit, $4 \mathrm{~mm}$ dick, 45 Früchte $=10 \mathrm{gr}$ ), Wehlkörper sehr weiss und fest. - Halm: $150 \mathrm{~cm}$ lang, mit 1 Kolben.

Mittelfrüh; wenig in Nord- und Siid-Anerika kultiviert.

Original von der Hacienda de Colina, Dept. de Santiago, Chile, durch Herrn von Gïlich 1879 erhalten.

Varietät: Zea Mais dierythra Kcke.

\section{Sorte:}

\section{Pfantenmais.}

Kolben: ziemlich eylindrisch, 13-15 $\mathrm{cm}$ lang, 8-12-reihig, 30 Früchte in der Reihe. - Frucht: auf hellgelbem Grunde gehen von einem Punkte aus nach der Basis zu hell bis dunkelrote Streifen, rundlich, mittelgross $(7 \mathrm{~mm}$ lang, $9 \mathrm{~mm}$ breit, $6 \mathrm{~mm}$ dick, 65.1 Früchte $=10 \mathrm{gr}$ ).

Original in der Sammlung zu Poppelsdorf.

Varictät: Zea Mais alboflava Kcke.

Sorte:

\section{Weissgelber Mais.}

Kolben: cylindrisch, klein, schmal, $15 \mathrm{~cm}$ lang, $21 / 2 \mathrm{~cm}$ breit, 8-reihig, Reihen regelmässig, ziemlich dicht, $30-34$ Früchte in der Reihe. Frucht: weiss oder hellgelb, hornig, rundlich, Seiten platt $(7 \mathrm{~mm}$ lang, $8 \mathrm{~mm}$ breit, $4 \mathrm{~mm}$ dick, 42.5 Früchte $=10 \mathrm{gr}$ ).

Original in der Sammlung zu Poppelsdorf. 
Varietät: Zea Mais multicolor Al.

\section{So r te:}

\section{Pearl-corn.}

Syn.: Deutsch: Perlmais.

Franz.: Maïs perle.

Spanis ch: Maiz multicolor (Chile).

Kolben: ziemlich cylindrisch, mittelgross, $16 \mathrm{~cm}$ lang, $3-4 \frac{1}{2} \mathrm{~cm}$ dick, 10-reihig, 34 Früchte in der Reihe. - Frucht: in der Farbe rot, braun, gelb, rosa, weiss, bläulich, schwärzlich sehr verschieden und in gleicher Weise auch in Form und Grösse, halbglasig, 45 Früchte $=10 \mathrm{gr}$. Halm: bis $175 \mathrm{~cm}$ hoch, blattreich, mit 2 Kolben.

In Poppelsdorf ergab die Kultur folgende Resnltate:

Halme $160 \mathrm{~cm}$ lang, $2.3 \mathrm{~cm}$ dick, Blattzahl 11, Blätter $56 \mathrm{~cm}$ lang, $6.3 \mathrm{~cm}$ breit, Blattfläche $7761.6 \mathrm{qcm}$, Halmfläche $1104 \mathrm{qcm}$, Gesammtfläche $8865.6 \mathrm{qcm}$. Die Reife erfolgte in 140 Tagen.

In Amerika wird er vielfach als Röstkorn benutzt.

\section{Die biologischen Verhältnisse des Maises.}

Der sorgfältigen Auswahl des Saatgutes ist besondcre Aufmerksamkeit zu schenken, weil in nicht vollkommen trocken gewordenen Maiskörnern bei unzweckmässiger Aufbewahrung leicht Zersetzungsprocesse auftreten, welche die Keimkraft zerstören, was auch schon durch geringfügige äussere Verletzungen des Keimlings geschehen kann.

Ferner werden durch zu nahe Kultur verschiedener Maissorten Kreuzungsprodukte erzeugt, weshalb man bei der Reinzucht das Saatgut von solchen Pflanzen auszuwählen hat, welche der Kreuzungsgefahr am wenigsten ausgesetzt waren und deren Früchte die charakteristischen Eigenschaften der gewtinschten Sorte besitzen.

Das beste Saatgut liefern die reifsten, vollkommensten, am Halm zu unterst stehenden, verhältnismässig kurzen und dicken Kolben.

Gewöhnlich sind nach Wilhel $\mathrm{m}^{1}$ ) die im unteren Drittel des Kolbens befindlichen Früchte die schwersten und zugleich keimfähigsten.

1) Oesterr. landw. Wchbl, 1875, p. 173. 
Die zur Lieferung des Saatkornes bestimmten Kolben hängt oder bewahrt man zweckmässig zum Austrocknen der Spindel an einem luftigen Ort auf, wodurch die Keimfähigkeit der Früchte 3 und 4 Jahre bewahrt bleibt.

Die Entkörnung der Kolben, welche Saatfrucht liefern sollen, geschieht erst kurz vor der Aussaat und zwar ohne Hülfe einer Entkörnungsmaschine oder eines harten Instrumentes, weil die Keimlinge $\mathrm{zu}$ leicht beschädigt werden.

Zur Gewinnung der besten Körner aus dem mittleren Teil des Kolbens bricht man zunächst die oberen und unteren Enden desselben ab und rebbelt nun mit Hulfe einer entkörnten Maisspindel, indem man durch Drïcken nach abwärts die Körner zu lösen sucht, letztere ab.

In den Handel gelangt auch sehr viel Saatgut, das bei feuchter Witterung oder verspäteter Reife künstlich getrocknet wurde, also leicht an seiner Keimkraft Schaden gelitten haben kann, denn nach Sachs reicht bei feuchten Maiskörnern eine einstündige Einwirkung einer Temperatur von ca. $50^{\circ} \mathrm{C}$. und bei trocknen von $65^{\circ} \mathrm{C}$. vollkommen zur Zerstörung der Keimkraft des grössten Teiles der Körner aus.

Der Mangel an Keimkraft lässt sich sehr bald erkennen, wenn man das untere Ende des Maiskorns mit einem scharfen Messer derart durchschneidet, dass der Keimling, welcher ziemlich gross ist und 10-14 Proc. des ganzen Kornes beträgt, halbiert wird; ist derselbe hell und weiss, mit einem grünlichen Schimmer und dunklem Rand, so darf er als keimfähig angesehen werden. Bei nicht keimfähigem ist dagegen der Keim dunkel.

Demnach erscheint es geboten, angekauftes Saatgut stets auf die Keimfähigkeit und Menge der fremden Bestandteile zu prüfen, und fand Nobbe in Handelsware:

\begin{tabular}{l|c|c|c}
\hline & $\begin{array}{c}\text { Mittel } \\
\text { Proc. }\end{array}$ & $\begin{array}{c}\text { Min. } \\
\text { Proc. }\end{array}$ & $\begin{array}{c}\text { Max. } \\
\text { Proc. }\end{array}$ \\
\hline Unreinigkeit & 1.53 & 0 & 7.51 \\
keimfähige Körner & 70 & 23 & 97
\end{tabular}

Das absolute Gewicht der Maiskörner ist je nach der Sorte, welcher sie entstammen, ausnehmend verschieden, wie dies unsere Untersuchung an 90 Maissorten bezeugt; darnach betrug das Gewicht eines Kornes im Mittel $179 \mathrm{mgr}$, mindestens $51 \mathrm{mgr}$ (Zea gracillima), höchstens $909 \mathrm{mgr}$ (Cuzco-Mais).

Die von Nobbe untersuchte Handelsware ist viel gleichmässiger im Korn, weil die für technische Zwecke verkauften Sorten meist nur den über mittelgrossen Sorten angehören, so wog von 22 unter- 
suchten Proben ein Korn im Mittel $282.7 \mathrm{mgr}$, höchstens $382.9 \mathrm{mgr}$ und mindestens $114.5 \mathrm{mgr}$.

Die Grösse der Körner einer Sorte, von denen auch die Grösse der Kolben abhängt, charakterisiert auch bis zu einem gewissen Grade die daraus entstehenden Pflanzen, d. h. die kleinkörnigen Sorten sind auch im Habitus klein, die grosskörnigen gross.

Nach Bona fous ${ }^{1}$ ) macht das Episperma 6.00 Proc., das Perisperma 79.95 Proc., der Cotyledon 12.53 Proc. und der Embryo 1.52 Proc. des Kornes aus.

Von den Getreidearten variieren die Maiskörner in ihrer Zusammensetzung am stärksten, und zeichnen sich durch einen relativ niederen Proteïn-, aber hohen Fettgehalt aus, wie aus folgender Tabelle ersichtlich:

\begin{tabular}{l|c|c|c|c|c|c}
\hline & $\begin{array}{r}\text { Trocken- } \\
\text { substanz. }\end{array}$ & $\begin{array}{c}\text { Nubstanz } \\
\text { Sultige }\end{array}$ & Fett & $\begin{array}{c}\text { N-freie } \\
\text { Extraktst. }\end{array}$ & $\begin{array}{c}\text { Holz- } \\
\text { faser }\end{array}$ & Asche \\
& Proc. & Proc. & Proc. & Proc. & Proc. \\
\hline Minimum & 80.9 & 5.8 & 4.1 & 59.0 & 1.5 & 1.1 \\
Maximum & 90.8 & 15.1 & 9.2 & 70.6 & 8.5 & 4.1 \\
Mittel & 87.6 & 9.9 & 5.6 & 65.4 & 4.5 & 2.5
\end{tabular}

Das Endosperm ist am reichsten an Kohlehydraten, der Embryo an Fett (Samenlappe ca. 63 Proc.) und Eiweisskörpern, das Episperm an Holzfaser ca. 47.5 Proc.

$\mathrm{Zur}$ Erlangung einer Maximalernte erscheint es nun sehr wichtig, nicht verletzte, sondern ganze Körner auszulegen, namentlich, wenn die Anbauverhältnisse nicht besonders günstig sind, also die jungen Pflänzchen der gesammten Mutternahrung zur kräftigen Entwickelung benötigen. In dieser Beziehung hat nun Blocziszewski ausserordentlich belehrende Versuche angestellt, welche nachstehendes Resultat lieferten.

1) Hist, nat. du Mais 1836. 


\begin{tabular}{|c|c|c|c|c|c|}
\hline Ausgelegt wurden: & 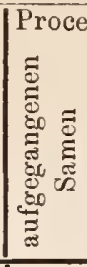 & 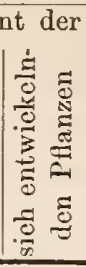 & 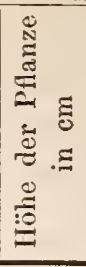 & 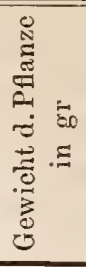 & $\begin{array}{l}\text { Gewicht dersel- } \\
\text { ben Pflanze auf } \\
\text { 100Gewächsteile } \\
\text { der Pflanze aus } \\
\text { ganzen Samen } \\
\text { berechnet }\end{array}$ \\
\hline Embryonen mit dem Schildchen & 76 & 75 & 170 & 819 & 56.33 \\
\hline$" \quad \quad 1 / 4$ Endosperm & 92 & 90 & 172 & 819 & 58.61 \\
\hline Hälften quer durchschnittener Samen & 76 & 75 & 171 & 1036 & 71.36 \\
\hline Ganze Samen & 92 & 90 & 172 & 1452 & 100.00 \\
\hline
\end{tabular}

Das Samenkorn beansprucht zum Keimen eine verhältnismässig geringe Quantität Quellungswasser, welche Hof fmann auf 44 Proc. und Haberlandt auf 49.7 Proc. vom Gewicht des Kornes angibt, doch wird dasselbe nicht sehr schnell anfgenommen, z. B. brauchte das Maiskorn nach den Untersuchungen von Haberlandt 7 Tage zur Aufnahme von 42.2 Proc. Wasser, wenn das Quellen in reinem Wasser geschah, und verlor dabei durch Exosmose nach 24 stiindigem Einquellen 1.0j Proc. an Substanz, welcher Verlust sich nach 5 Tagen bei Wasser ron $7^{\circ} \mathrm{C}$. auf 4.34 Proc. und von $18^{\circ} \mathrm{C}$. auf 5.45 Proc. steigerte.

In stagnierendem Wasser bäufen sich die ausgelaugten Stoffe an, in Folge dessen Bakterienbildung, also Fäulnis eintritt, daher es zur Erhaltung der Kieimkraft nicht rätlich ist, länger als 24 Stunden einzuquellen. Andererseits wird in fliessendem Wasser die Keimkraft mehrere Tage voll erhalten, und fanden von Schlag und Bressler nach 40 tägigem Einquellen noch 28 Proc. keimfähiger Körner.

Dem Einquellen behufs Erleichterung der Keimung ist kaum das Wort zu reden, denn wir sehen, dass das Maiskorn in mässig feuchtem Boden schon nach 3 höchstens 6 Tagen bei genügend boher Temperatur keimt, mithin sich mit dem notwendigen Quellungswasser schnell versieht und gleichzeitig einen sehr wichtigen Faktor der Keimung, den Sauerstoff mit anfnimmt, was bei dem Quellen unter Wasser nicht der Fall ist.

In einem beim Auslegen noch sehr trocknen Boden keimt das mit Wasser imbibierte Korn, ohne dass für das junge Pfänzchen die genügende Fenchtigkeit im Boden zu finden wäre, wie andererseits anch auf schwerem, feuchtem Boden viel leichter ein Ausfaulen als beim Legen trockner Körner vorkommt, und schliesslich kann bei zu langer Dauer des Einquellens, wenn z. B. durch ungünstige Witterung die Aussaat verzögert wurde, das Saatgut seine Keimkraft ver- 
lieren, wenn das Wasser nicht häufig erneuert oder fliessendes Wasser verwendet wird.

Die niedrigste Keimungstemperatur liegt nach Sachs sehr hoch, nämlich bei $9.4^{\circ} \mathrm{C}$, nach Haberlandt zwischen $8-10^{\circ} \mathrm{C}$, das Maximum bei $40-44^{\circ}$ und das Optimum bei $32-35^{\circ} \mathrm{C}$. Die Keimung vollzieht sich aber bei $8-10^{\circ} \mathrm{C}$. ausserordentlich langsam, weshalb es rätlich erscheint, erst bei höherer Temperatur zur Aussaat zu schreiten, weil dann durch schnelles Keimen und Aufwachsen die verlorene Zeit wieder eingebracht und das Saatkorn weniger Fährlichkeiten ausgesetzt wird.

Zur Bekräftigung des Gesagten mögen die Untersuchungen von Haberlandt dienen, nach denen die Keimung mit dem Sichtbarwerden des Wiilzelchens erfolgte

\begin{tabular}{l|c|c|c}
\hline \hline & bei $10.25^{0} \mathrm{C}$. & $15.75^{0} \mathrm{C}$. & $19^{0} \mathrm{C}$. \\
\hline in Tagen & 11.25 & 3.25 & 3 \\
$\begin{array}{l}\text { und das durchschnittliche Längenwachs- } \\
\text { tum des Stengelchens pro Tag in mm } \\
\text { betrug: }\end{array}$ & 0.2 & 2.4 & 6.5
\end{tabular}

Hiernach scheint es wohl empfehlenswert, erst bei einer Bodenerwärmung von $16-18^{\circ} \mathrm{C}$. mit der Aussaat zu beginnen, zumal dann auch das Gelbwerden (Clilorose) der jungen Pflanzen vermieden wird, welches sich bei früher Saat und nicht genügend hoher Temperatur leicht zum grossen Nachteile für die jungen Pflanzen einstellt.

Zur schnellen Keimung und kräftigen Entwickelung der Pflanzen darf aber auch die zweckmässigste Tiefe des Auslegens der Samenkörner, welche sich nach der Grösse der Körner, dem Boden, der Witterung etc. richtet, nicht ausser acht gelassen werden.

Ueber die Tiefe der Unterbringung stellte schon Burger folgenden Versuch an:

Bei einer Tiefe von $2.6 \mathrm{~cm}$ lief die Saat auf nach $81 / 2$ Tagen

\begin{tabular}{|c|c|c|c|c|c|c|c|c|c|c|c|}
\hline " & $"$ & $"$ & " & 4.0 & $n$ & $"$ & $n$ & $"$ & " & $"$ & $91 / 2$ \\
\hline$"$ & $"$ & $"$ & $"$ & 5.3 & $"$ & $"$ & " & " & $"$ & $"$ & 10 \\
\hline$"$ & $"$ & $"$ & $"$ & 6.5 & $"$ & $"$ & $"$ & $"$ & $"$ & " & $11^{1} / 2$ \\
\hline$"$ & $"$ & $"$ & $"$ & 8.0 & $"$ & $"$ & $"$ & $"$ & $"$ & $"$ & 12 \\
\hline$"$ & $"$ & ", & $"$ & 9.2 & $"$ & $"$ & $"$ & $"$ & $"$ & $"$ & 13 \\
\hline$"$ & $"$ & $"$ & $"$ & 10.6 & $"$ & $"$ & $"$ & $"$ & $"$ & $"$ & $13^{1} / 2$ \\
\hline " & $"$ & $" n$ & $"$ & 12.0 & $"$ & $"$ & $"$ & $"$ & $"$ & $"$ & $171 / 2$ \\
\hline$"$ & $"$ & $"$ & $"$ & 0 & $"$ & $n$ & $"$ & $"$ & $"$ & " & \\
\hline
\end{tabular}

Hiernach sind Maiskörner mittlerer Grösse auf schwerem Boden nicht tiefer als $3-4 \mathrm{~cm}$, auf leichtem $6-8 \mathrm{~cm}$ tief unterzubringen. 
Mit dem Beginn der Keimung tritt zunächst ein Würzelchen hervor, später die Plumula. Darüber, welche chemischen Processe nun zur weiteren Entwickelung des Embryo zum jungen Pflänzchen vor sich gehen, geben die chemischen Untersuchungen über das Wachstum der Maispflanze von Hornberger ${ }^{1}$ ) in Poppelsdorf Aufschluss; er fand, dass bei der Keimung in den ersten zwei Wochen nach der Aussaat der Verlust der Körner an Mineralstoffen, namentlich Phosphorsäure und Kali, relativ grösser als der an organischer Substanz ist. In der zweiten Woche bemerkt man eine ausgiebige Bildung von Amid- etc. Verbindungen aus Eiweiss. Der grösste Verlust an Stickstoff und organischer Substanz fällt in die dritte Woche, auch Phosphorsäure geht reichlicher ab, Kali nur noch in geringem Masse.

Schon in der dritten Woche beziehen die Keimpflänzchen den uiberwiegenden Teil ihrer anorganischen Nahrung aus dem Boden, während der organische Zuwachs nur halb so gross ist als der gleichzeitige Verlust der Körner. Die Stickstoffabgabe und -zunahme befindet sich ungefähr im Gleichgewicht. In der vierten Woche überwiegt auch hinsichtlich der organischen Substanz die Zunahme der Pflänzchen und beziehen dieselben vou jetzt ab ihren Bedarf an Stickstoff und Aschenbestandteilen aus dem Boden.

Ungefähr 8-18 Tage nach dem Auslegen der Samenkörner erscheint das Maispflänzchen mit einem dütenförmig zusammengerollten Blatt an der Oberfläche, worauf eine Wachstumsverzögerung eintritt, welche bei kühler Witterung nicht selten 14 Tage dauern kann. Während dieser scheinbaren Ruhepause des Pflänzchens entwickeln sich jedoch die Wurzeln um so schneller, was namentlich auf leichtem Boden sehr wichtig ist, damit den später sehr energisch wachsenden oberirdischen Teilen auch die nötigen Nährstoffe und das Vegetationswasser nicht fehlen. In der Regel besitzt das Pflänzchen nach 30 Tagen 2-3 Blätter und ist in seiner Ernährung vom Samenkorn unabhängig geworden.

Mit Eintritt der intensiveren Boden- und Lufterwärmung geht auch die kräftigere Entwickelung der oberirdischen Organe Hand in Hand, vorausgesetzt, dass in dicser Periode die Witterung nicht zu kühl ist, und Chlorose auftritt, welche das Wachstum in hohem Grade zurïckhält.

Der Stengel treibt in dieser Periode empor und zeigt am unteren Ende eine mehr runde, am oberen eine zusammengedruickte Form, es spriessen auch in schräger Richtung Schösslinge hervor, deren Zahl je nach Sorte, Boden, Kulturart etc. wechselt, doch im Allgemeinen 
geringer als bei den echten Getreidearten ist; so betrug in Poppelsdorf die Zahl der Halme pro Pflanze im Durchschnitt 1.2, mindestens 1 und höchstens 5, dagegen stellt sich die Blattzahl pro Halm zur Blütezeit verhältnismässig hoch, nämlich im Mittel auf 10, im Minimum 7 und im Maximum 15 Blätter, bei einer Stengelhöhe von $0.7-6.0$ und im Mittel $1.40 \mathrm{~m}$.

Mit der Entwickelung der oberirdischen Organe hält aber auch die der Wurzeln gleichen Schritt, indem sich zahlreiche Kronenwurzeln bilden, welche zum Teil auf bindigem, reichem Boden $0.5-1 \mathrm{~m}$, auf leichtem Boden sogar $3-4.7 \mathrm{~m}^{1}$ ) tief einzudringen vermögen, doch bleibt die Hauptmasse in der Ackerkrume, wie dies ein Versuch von Thiel zeigt, bei dem sich auf einem Bodenquerschnitt von $900 \mathrm{qcm}$ und bei einer Tiefe von

$\begin{array}{lllc}10 & \mathrm{~cm} & 68 & \text { Wurzeln } \\ 20 & & 32 & \\ 30 & " & 33 & " \\ 40 & " & 23 & " \\ 50 & " & 23 & " \\ 60 & " & 14 & " \\ 70 & " & 6 & " \\ 80 & " & 2 & " \\ 90 & " & 0 & \end{array}$

ergaben, mithin der Mais als Flachwurzler anzusehen ist.

Der Mais sucht ferner seine Bewurzelung noch dadurch zu verstärken, dass er aus dem ersten und auch zweiten Knoten seines Stengels oberhalb der Erde Wurzeln durch die Luft bis in den Boden sendet, wo sie sich zu wirklichen Wurzeln umgestalten, doch sollen diese Adventivwurzeln der Hauptsache nach dem schweren Stengel als Stiutze dienen, der sonst allzusehr durch Windbruch leiden würde, hierzu sei bemerkt, dass bis zur Halbreife der Kolben, die Stengelknoten noch soviel Quellungsfähigkcit besitzen, den niedergelegten Stengel wieder aufzurichten.

Bei der sehr bedeutenden Blatt- und Stengeloberfläche der Maispflanzen darf wohl auch auf eine sehr starke Transpiration und dieser entsprechend wohl auch auf ein sehr beträchtliches Wurzelvermögen geschlossen werden. Nach Rissler verdunsten $100 \mathrm{qcm}$ Blattfläche in 1 Stunde $0.16 \mathrm{gr}$, beim Hafer nur $0.14 \mathrm{gr}$ Wasser.

Vom Auflaufen bis zur Blïte beansprucht der Mais je nach Sorte, Witterung, Bodenbeschaffenheit etc. 45-105 und im Mittel 68 Tage, und ist in dieser Periode eine feuchtwarme Witterung erwiunscht.

1) Johnson, Wie die Feldfr. wachsen. 1871 pg. 263. 
Mit dem Erscheinen der männlichen Blütenrispe ist auch die Vegetation am lebhaftesten und nicht selten wächst der Halm in dieser Periode binnen 24 Stunden um $17-20 \mathrm{~cm}$.

Die Klappen der Rispe fangen an sich zu öffnen, wenn sich in den Acliseln des Halmes die Spitzen der Deckblättel der Kolben zeigen.

Die Befruchtung beansprucht eine lange Zeit, meist 18 Tage, da sich die männlichen Blüten nur allmählich öffnen und die Griffel sich auch erst nach und nach entwickeln.

In der Regel wird nur eine kleine Zahl der Kolben eines Halmes befruchtet, doch geniigen 1-2 Kolben schon zur Erzielung eines hohen Ertrages, anch kann der Halm selten eine grössere Anzahl ernähren.

Nach dem Abblïhen verliert die Rispe ihren Glanz und nimmt eine rötliche oder bräunliche Farbe an, und nun beginnt dic Fruchtbildung im Kolben, wobei unmittelbar nach dem Beginn eine sehr erhebliche Verzögerung der Assimilationstbätigkeit eintritt, welche sich aber nach kurzer Zeit wiederum lebhaft steigert, und dürfte diese Erscheinung nicht auf äussere, sondern vielmehr auf innere Ursachen zurïckzufiihren sein und nimmt Hornberger an, dass dieselben in der nach anderen Zielen gerichteten und anssergewöhnliche Oxydationsverluste erheischenden Stoffwanderung bezw. Stoffmetamorphose zu suchen wären. In der Periode des Reifens ist trocknes, war'mes Wetter höchst willkommen.

Es vergingen von der Blitte bis zur Reife in Poppelsdorf 40-80 und im Mittel 60 Tage und die gesammte Vegetationszeit schwankte zwischen 80-183 Tagen und betrug im Mittel 140 Tage.

Zur besseren Beurteilung der Vegetationsrerhältnisse lasse ich auf Seite 827 zwei Tabellen folgen, von denen die erste die Resultate eines von mir in Poppelsdorf angestellten Versuches und die zweite (Seite 828) solche von Salisbury im Staate New-York bringt.

Die Wachstumserscheinungen bestehen aber auch in der Gewichtszunahme an Trockensubstanz, weshalb ich auf Seitc 829 die Trockengewichtsbestimmungen von Kreusler ${ }^{1}$ ) folgen lassen will.

1) Landw. Jahrb 1877 pg. 759. 
Die biologischen Verhältnisse des Maises.

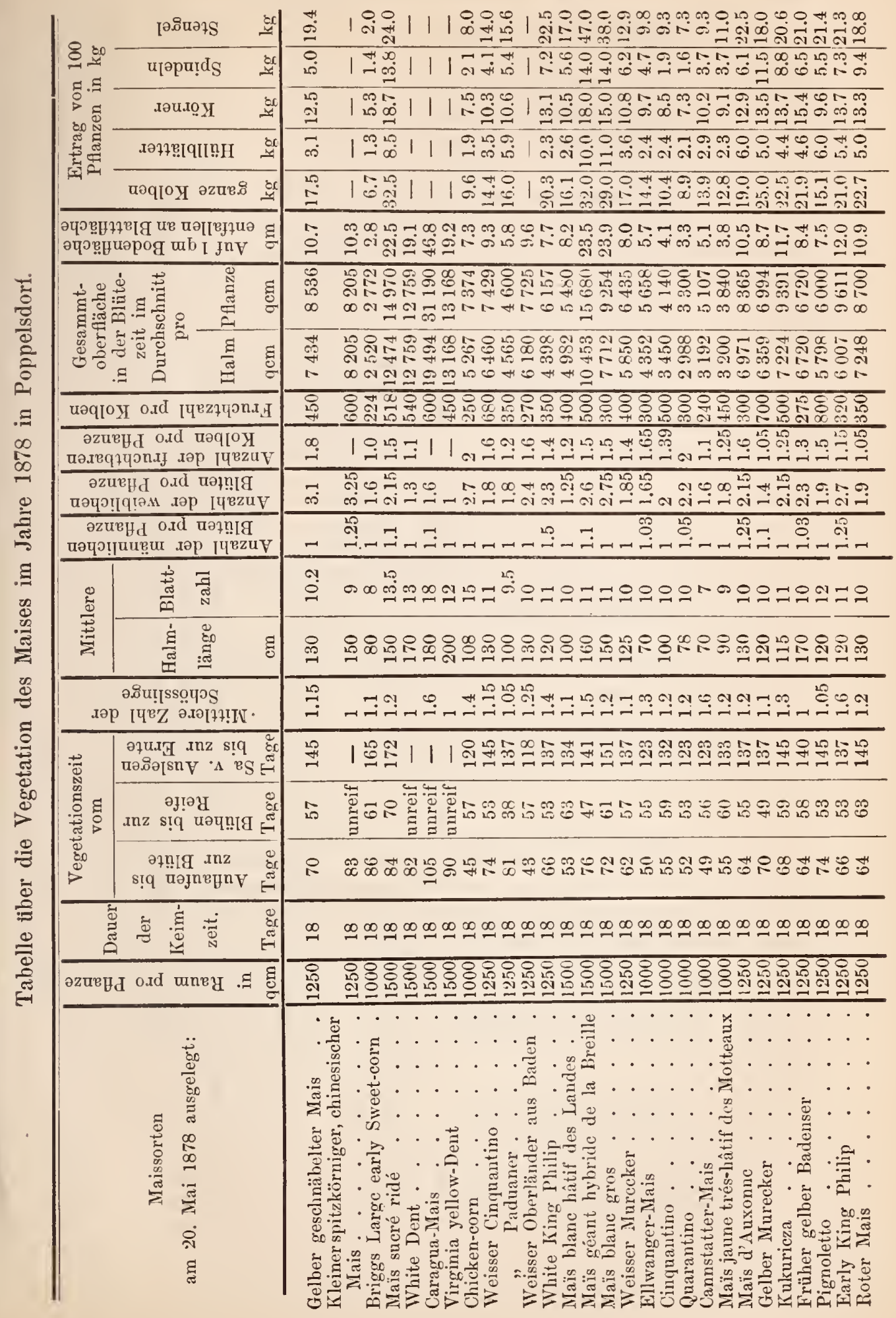




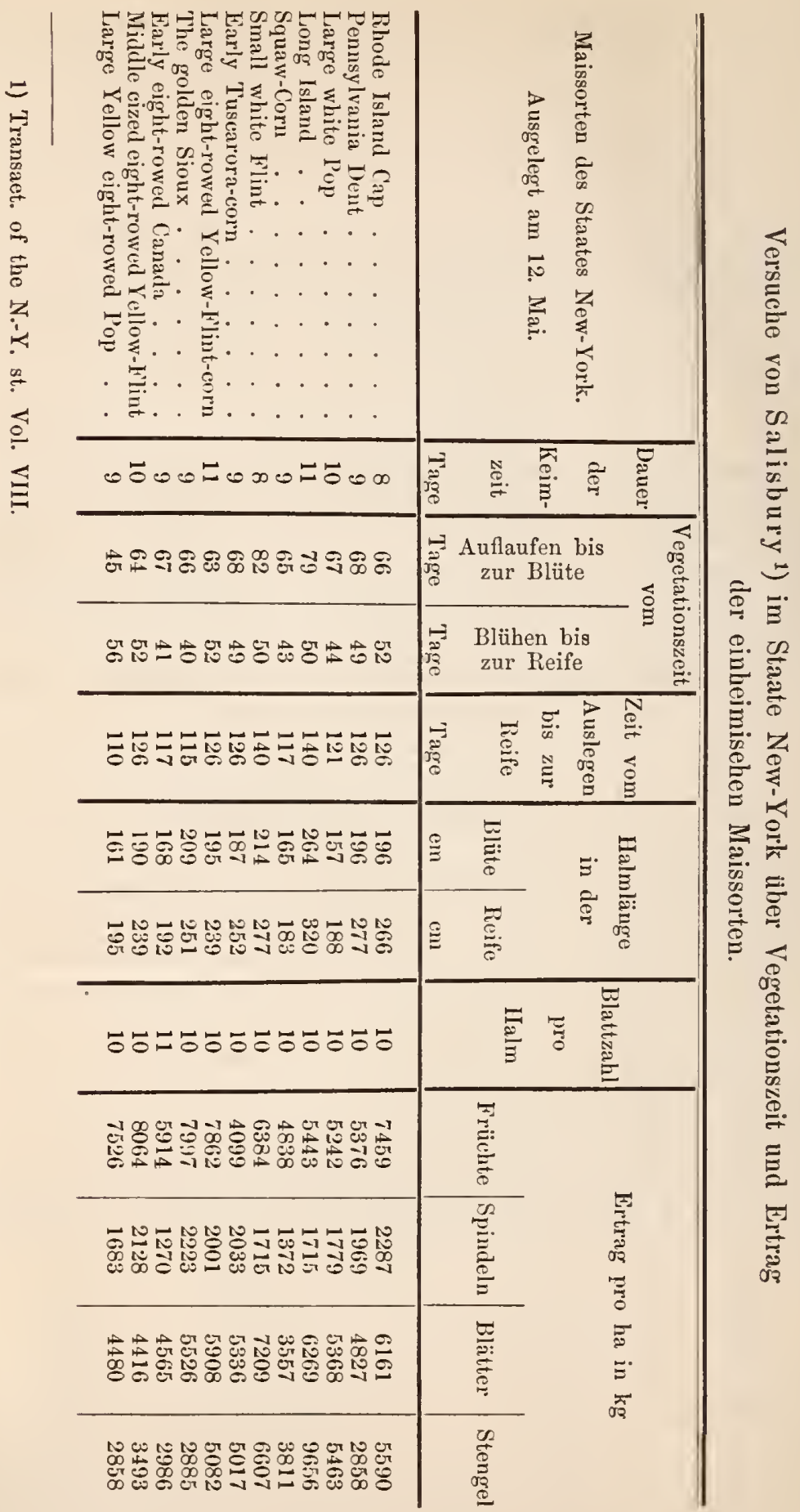




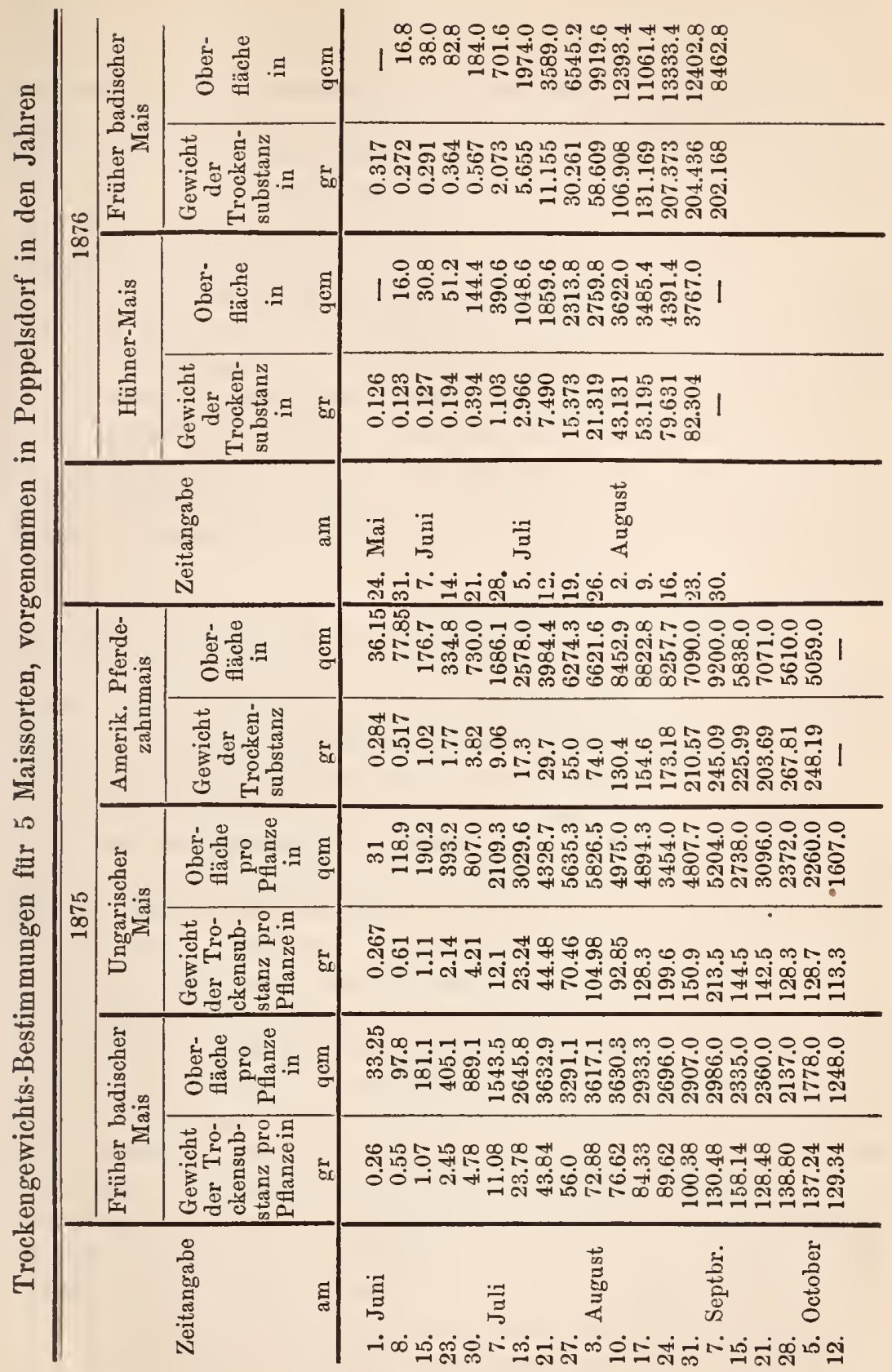


Aus den Zahlen der Trockengewichtsbestimmungen lässt sich folgern:

a) Dass eine Periode gesteigerter Trockensubstanzvermehrung, welche sich von Anfang Juli bis iiber Mitte August erstreckt, eintritt.

b) Dass mit der plötzlichen Vergrösserung der Blattoberfläche auch die Trockensubstanzerzeugung gleichen Schritt hält und gleich grosse Blattoberflächen bei den verschiedenen Maissorten ziemlich gleich grosse Trockensubstanzmengen producieren.

c) Dass die Trockensubstanzmengen ein und derselben Sorte, je nach Witterung, Kultur etc. sehr verschieden sein können, wie dies der frühe badische Mais in vorzitglicher Weise zeigt, der am 31. August 1875 erst 100.38 gr Trockensubstanz bei $2907 \mathrm{qcm}$ Blattoberfläche produciert hatte, während 1876 am 30. August $202.168 \mathrm{gr}$ bei $8462.8 \mathrm{qcm}$ Blattoberfläche pro Pflanze erzeugt worden waren.

Zur Vervollständigung des Bildes fügen wir diesen Untersuchungen über die Trockensubstanz, auch die Endresultate der chemischen Untersuchungen ron Horn be $\mathrm{r}^{\mathrm{g}}$ e $\mathrm{r}^{1}$ ) bei, welche derselbe an am 20. Nai ausgelegten Badischen Frühmais in Poppelsdorf durchführte.

El fand folgendes:

Die Massenzunahme der Pflanze erreicht mehrere Wochen vor der Körnerreife ihr Ende und fällt die weitaus grösste Gewichtsvermehrung in die Zeit nach der Blüte, doch trifft dieselbe rorzugsweise die Stengel, während die Blätter nur noch geringe Zunahme zeigen.

Die absolute Zunahme an Rohfaser erreicht gleichzeitig mit der Trockensubstanzvermehrung ihr Ende, ihr Maximum ebenfalls zu gleicher Zeit wie diese. Den höchsten relativen Gehalt zeigen die Wurzeln, die Blïten und die stetig zunehmenden Spindeln, den niedrigsten die Körner. Die grössten absoluten Mengen finden sich ror der Blitte in den Blättern, hernach in den Stengeln.

An Fett wird die Pflanze relativ ärmer bis zur Vollendung des Körneransatzes, worauf der procentische Gehalt wieder zunimmt. Der höchste relative Fettgehalt befindet sich in den Körnern, der niedrigste in den Spindeln. Die Stengel sind procentlich ärmer an Fett als die Blätter. Bis zur Zeit des ersten Kolbenansatzes ist die absolute Hauptmasse des Fettes in den Blättern, hierauf durch einige Wochen in den Stengeln, schliesslich in den Körnern enthalten. Die Pflanze fährt noch nach Beendigung der Trockengewichtszunahme Fett zu bilden fort, welches ausschliesslich den Körnern zukommt, ausserdem geben auch die übrigen Organe noch Fett an die Körner ab.

An stickstofffreien Extraktstoffen nimmt die Pflanze relativ und beständig $\mathrm{zu}$ und werden noch gebildet, wenn die Pflanze nicht

1) Landw. Jahrb. 1882 pg. 359. 
mehr an Gewicht zunimmt und wandern die Kohlehydrate aus den Blättern in die Stengel, von da später durch die Spindeln in die Körner.

Der relative Stickstoffgehalt der Maispflanze nimmt mit fortschreitender Entwickelung beständig ab. Bis zur Blïte enthalten die Blätter nahezu $2 / 3$, die Stengel $1 / 3$ des Gesammtstickstoffs und von da ab vergrössert sich in den Stengeln die Zunahme derart, dass sie mit dem Auftreten befruchteter Kolben fast dreimal so gross ist als die der Blätter, welche nur noch spärliche Stickstoffzufuhr erhalten.

Der Stickstoffzuwachs kommt, ebenso wie der an Fett und Kohlehydraten, schliesslich nur den Körnern zu Gute, während die iibrigen Organe Stickstoff verlieren.

Auch der procentische Aschengehalt ist in der jungen Pflanze höher als in der entwickelteren, und sind die Blätter, in welchen derselbe von der Bluite an zunimmt, das mineralstoffreichste Organ, die Spindeln das ärmste. In den Stengeln vermindert sich der Aschegehalt im Allgemeinen mit dem Alter, sehr beträchtlich aber mit Eintritt der Bliite (auf $2 / 3$ ), zu welcher Zeit auch die Blätter und Wurzeln Abnahme zeigen. Körner und Spindeln nehmen beständig ab. Die Aschenaufnahme nimmt ihr Ende mit dem Aufhören der Trockengewichtszunahme.

Von den wichtigeren Mineralstoffen sind es die Phosphorsäure und das Kali, welche uns besonders interessieren und ist der Phosphorsäuregehalt in der jungen Pflanze am höchsten, später weisen den höchsten Gehalt die Körner, den niedrigsten die Wurzeln und von oberirdischen Teilen die Spindeln auf; während die Blätter daran reicher als die Stengel sind.

Die Phosphorsäure ist der einzige Mineralstoff, der von der Pflanze noch aufgenommen wird, nachdem eine Trockensubstanzzunahme nicht mehr stattfindet.

Was das Kali anbetrifft, so ist der Procentgehalt der Stengel unmittelbar vor der Blïte am höchsten und mit dem Auftreten der ersten Blüten vermindert sich derselbe um $2 / 3$, was zum Teil von der reichlichen Abgabe an die Blitten herkommt, denn diese sind procentisch sehr reich an Kali, ebenso die ersten Kolben; auch ist die Asche der Pflanze bei Beginn der Blïte am kalireichsten. Das Kali findet aber, im Gegensatz zu sämmtlichen Mineralstoffen, in der Zeit der höchsten Assimilation keine Aufnahme mehr in die Blätter und ist eine Rückwanderung von Kali in den Boden wahrscheinlich.

Der Mais stellt beziiglich des Nährstoffreichtums an den Boden sehr hohe Ansprïche, so entnimmt derselbe in einer Mittelernte aus dem Boden eine grössere Menge wichtiger Pflanzennährstoffe als vielleicht mit alleiniger Ausnahme des Reises irgend eine andere Getrei- 
deart, wobei zu bemerken, dass namentlich ïberraschend grosse Mengen an Kali und Phosphorsäure verbraucht werden.

Eine Mittelernte entzieht dem Boden pro ha in $\mathrm{kg}$ :

\begin{tabular}{|c|c|c|c|c|c|c|c|c|c|c|}
\hline im & $\begin{array}{c}\text { Mittelernte } \\
\text { pro ha } \\
\mathrm{kg}\end{array}$ & 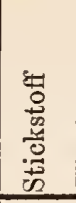 & $\begin{array}{l}\stackrel{\Xi}{0} \\
\stackrel{0}{4}\end{array}$ & intzug & 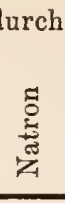 & 营 & 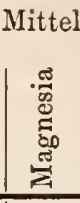 & 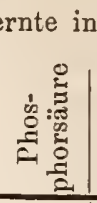 & 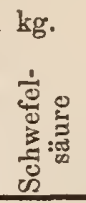 & 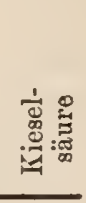 \\
\hline Korn & 1190 & 19.3 & 14.8 & 3.9 & 0.2 & 0.4 & 2.2 & 6.6 & 0.1 & 0.4 \\
\hline Stroh etc. & 7000 & 33.6 & 329.0 & 116.2 & 3.5 & 35.0 & 18.2 & 26.6 & 17.5 & 125.3 \\
\hline \multicolumn{2}{|l|}{ Im Ganzen: } & 52.9 & 343.8 & 120.1 & 3.7 & 34.4 & 20.4 & 33.2 & 17.6 & 125.7 \\
\hline
\end{tabular}

\section{Die Feinde des Maises.}

Wie wir gesehen, entwickelt sich der Mais in seinen ersten Jugendstadien ausnehmend langsam, daher schnell vegetierende, blattreiche Unkräuter ihn leicht $z u$ überwachsen und zu unterdrücken vermögen, wenn sie nicht durch Jäten oder Hacken rechtzeitig ausgerottet werden.

Auf den leichteren Böden werden vorzugsweise der Hederich (Raphanus Raphanistrum L.), die Hühner-Hirse (Panicum Crus-galli L.) und die Bluthirse (Panicum sanguinale L.) gefährlich, während auf den fruchtbaren, feuchten Lehmböden der gemeine Knöterich (Polygonum Persicaria L.), der windenartige Knöterich (Polygonum Convolvulus L.), die Ackerwinde (Convolvulus arvensis L.) und der Ackersenf (Sinapis arvensis L.), letzterer auch gern auf humosem Boden, vorkommen.

En field ${ }^{1}$ ) schlägt vor, vermittelst Kochsalzdiungung das Unkraut zu schrecken, auch werde durch eine solche Düngung auf schwerem Boden der Ertrag erhöht.

Durch Pilzkrankheiten leidet der Mais nur wenig, am gefürchtetsten ist der Mais-Flugbrand oder Beulenbrand (Ustilago Maydis

1) Edw. Enfield, Indian-Corn, New-York 1860. 
Tul), weleher die jungen Kolben vollständig zerstört, aueh ist derselbe von $\mathrm{Kiihn}$ an Stengeln und Blattrippen und neuerdings von

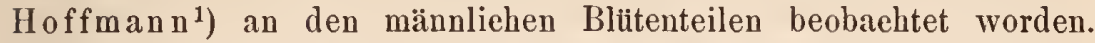
Gegen diesen Pilz wird von Kühn das Beizen der Samenkörner mit Kupfervitriollösung empfohlen. Hierbei sei bemerkt, dass naeh den Beobachtungen von Haubner und $\mathrm{Haselbach}$ diejenigen Kühe verkalbten, welehe mit von Mais-Beulenbrand befallenem Griinmais gefüttert worden waren.

In feuehten Lagen und bei Bewässerung tritt nieht selten ein Pilz (Sporisorium Maydis Ces.) auf, der sieh äusserlieh am Korn als grüner Fleek oder Ring bemerkbar maeht, weshalb man aueh die Krankheit Grünspan (Verdet franz.) genannt hat.

Sehr häufig findet sieh dieser Pilz in Nord-Italien und soll derselbe, wie Pisani, Bolardini, Costellat und Andere behaupten, was jedoeh noeh nieht bewiesen ist, die Ursache jener furchtbaren Hautkrankheit, der Pellagra, sein.

Sehliesslich soll, wenn auch nur höehst selten, das Mutterkorn vorkommen.

Weit zahlreicher und gefährlicher als diese Feinde aus dem Pflanzenreieh, sind die tierisehen Feinde, welche den Mais heimsuchen.

Unter ihnen ragen zur Zeit der Maisaussaat ganz besonders die Vögel hervor, z. B. Saatkrähen, Elstern, Sehwarzdrosseln und Häher, welche nieht allein die ungeniigend mit Erde bedeekten Körner auflesen, sondern auch den soeben die Oberfläehe durchbrechenden Pfänzehen nachspüren und mit diesen das Saatkorn herausziehen, was so lange betrieben wird, bis die im Korn aufgespeicherten Reservestoffe zur Bildung der jungen Pflanze verwandt sind. Gegen diese arge Sehädigung hat man die versehiedenartigsten Mittel angewandt, ohne vollkommen durchgreifende Erfolge erzielt zu haben.

Die Aufstellung von Windklappern und Seheusalen hilft wenig, während bessere Erfolge durch Schiessen und Aufhängen der toten Vögel, sowie dureh Ueberziehen des Feldes mit groben Fäden, die an Stäben $15 \mathrm{em}$ über den Boden befestigt werden, crzielt worden sind. Auch hat man versueht, wenngleieh mit zweifelhaftem Erfolge, die Samenkörner mit giftigen oder den Tieren unangenehmen Substanzen einzubeizen, wodureh nieht nur die Vögel, sondern aueh Mäuse, Eiehhörnehen, Insekten etc. abgehalten werden sollen.

In Amerika wendet man bei der Beizung ${ }^{1}$ ) folgendes Verfahren an:

1) Oester. landw. Wchbl. 1870 p. 470.

2) Rep. of the Commissioner of Agric. 1866 und Enfield, Indian-Corn New-York 1866. 
Nachdem das Saatkorn 10-12 Stunden eingeweicht worden ist, setzt man auf $1 \mathrm{hl}$ ungefähr $3 / 4$ Ltr. Kohlen- oder Gasteer $z u_{\text {, }}$ welcher sich in warmem Wasser gut rerteilt, hierauf wird das Korn herausgenommen und mit trockner Asche, gepulrertem Kalk oder Gips bestreut, um das Zusammenbacken zu vermeiden. Das Einbeizen geschieht aber auch mit Salpeter, Kupfervitriol, Holzasche, Guano, Chlorkalk, schwefelsaurem Ammoniak und Urin.

Nach Burger weicht man den Mais in Roussillon 24 Stunden lang in Coloquintenabsud (Cucumis colocynthis L.) und in Amerika nach $\mathrm{Halle \textrm {r } ^ { 1 } )}$ über Nacht in dem gesättigten Absud der weissen Niesswurz (Veratrum album L.) ein, wonach, kurz nach dem Genuss, die $\Gamma$ ögel in einen taumelnden Zustand geraten und leicht erlegt werden können. Ein gleiclıer Erfolg lässt sich nach Sprengel auch durch einen Absud ron Stechapfelsamen (Datura Stramonium L.) erzielen. Sehr gute Erfolge will man ferner durch das stinkende Tieröl (Oleum animale foctidım) erzielt haben; ron diesem werden auf $1 \mathrm{hl}$ Samenkörner $4 \mathrm{gr}$ in Alkohol oder Terpentinöl aufgelöst und in soviel Wasser, als zur Anfenchtung notwendig, rerteilt. Der Geruch soll den Vögeln derart zuwider sein, dass sie die Maiskörner unberührt lassen.

Alle diese Mittel helfen jedoch wenig zur Fernhaltung der Insektenlarven etc., da sie den wachsenden jungen Teilen des Embryo nicht anhaften.

Die Maiskeime frisst der Aaskäfer (Silpha opaca L.), und die jungen Pfänzehen in Nord-Amerika die Larve und der Käfer ron Systema blanda Melsch.. eine Henschrecke, Caloptenus femur-rubrum Har., und in Süd-Europa die Wanderheuschrecke (Gryllus italicus L.), die Raupe der überall rorkommenden Agrotis segetum, clandestina, fumosa, exclamationis, Ypsilon und praecox, sowie in Nord-Amerika die Raupe ron Celaena herbimacula Green.

An den Maiswurzeln leben in Amerika die Larven ron Anisoplia horticola L., in Europa und Amerika die Larren von Agriotes lineatus und obscurus und in Ungarn die des Melanotus niger Fabr., in Frankreich und Italien des Crypticus quisquilius; an den $\Pi$ urzeln saugend finden sich: Aphis Mayis Harris, Aphis Zeae und Coceus Zeae maydis.

Im Stengel des Maises leben die Larren ron Sphenophorus cariosus Oliv. und Sp. Zeae, von Botys nubilalis Hub. und es saugt am Stengel Aphis Maïdis Fitsch.

Die Blätter werden hauptsächlich und zwar sehr häufig in Amcrika durch mehrere Heuschreckenarten verzehrt, auch kommt eine Blattlaus (Aphis Zeae Bonaf.) darauf vor.

1) Hist. stirpium Helvetiae, Bernae 1768 tom. II pg. 98. 
Die Hüllblätter werden ausser den bei den Blättern schon erwähnten Feinden noch durch die Raupe der Leucania Zeae Dup. angegriffen.

Durch Fressen an den Kolben verursacht ein Glanzkäfer (Nitidula atrata.Lat.) in Frankreich erheblichen Schaden und im Marke der Spindel lebt die Raupe von Botys quadripunctalis Schiff.

Die Anzahl der die Maiskörner heimsuchenden Feinde ist sehr gross, und kommen vor:

Larve und Käfer von Pityophagus 4-guttatus Say, Trogosita caraboides F. und corticalis Mels., Cucujus minutus Oliv, Silvanus surinamensis Steph., Ptinus Zeae Nob., Anobium paniceum Fabr.; Tribolium ferrugineum Fabr., Curculio oryzae L. und granarius L., ferner die Raupe von Heliothis armigera Hub. und Gelechia pyrophagella Koll. Im Mehl finden sich: die Larven und Käfer von Tenebrio molitor L., T. obscurus; die Raupe von Asopia farinalis L. und Tinea Zeac, beide in Amerika einheimisch.

Sebr gefährlich ist ferner in Amerika eine Getreideraupe, Chinchbug genannt, welche nicht nur in allen Entwickelungsstadien, sondern auch an allen Teilen dem Mais erheblichen Schaden zufügt.

\section{Klima.}

Die Anbauzone des Maises ist nach der der Gerste die grösste, weshalb denn auch die Maissorten sowohl in ihrem Habitus als auch in ihren Wärmeansprüchen sehr verschieden sind.

In Amerika reicht der Maisbau vom $40^{\circ}$ südl. Br. bis zu Cumberland-House in Canada unter dem $54^{0}$ nördl. Br. Es ist selbstverständlich, dass unter diesem hohen Breitengrade nur frühreife Sorten angebaut werden, welche in den langen warmen trocknen Herbsten, und auf dem reichen jungfräulichen Boden bei einer mittleren Sommertemperatur von $15^{\circ}$ C. ausreifen können. In Europa geht die Grenze des Kornmaisbaues weit weniger hoch nach Norden und bildet nach $\mathrm{De} C \mathrm{Candolle}$ dieselbe eine Linie, welche man sich von der Vendée, $47^{\circ}$ n. Br. über Paris $48^{\circ} 50^{\prime}$, Coblenz $50^{\circ} 20^{\prime}$, die Bukowina $49^{\circ}$, Charkow $50^{\circ} \mathrm{n}$. Br. gezogen denkt. In Asien weicht diese Grenzlinie noch weiter nach Süden zurtick, denn Bunge fand z. B. bei Peking $40^{\circ}$ n. Br. Maisbau nicht mehr vor.

Im Allgemeinen fällt die nördliche Grenze des Maisbaues in Europa mit der Kultur des Weinstockes zur Weinbereitung zusammen. 
Die grösste Verbreitung hat aber der Maisbau in fast allen Ländern der subtropischen und wärmeren gemässigten Zone gefunden, wo er seine vollkommenste Entwickelung erreicht.

Je nach Sorte, Klima, Bodenbeschaffenheit etc. beträgt die Vegetationszeit 70-183 und im Mittel 140 Tage, so dass bei einer mittleren Sommertemperatur von $20-25^{\circ}$ C. der Mais vom Auslegen bis zur Reife eine Wärmesumme von $1700-3500^{\circ}$ C. beansprucht.

Nach Boussingault verlangt der Mais im

Vegetationszeit mittl. Temperatur Totalwärme

Elsass

Kingston

153 Tage

Magdalena (Siid-Amerika)

122 "

- $20.9^{\circ} \mathrm{C}$

$3198^{\circ} \mathrm{C}$.

Santa-Fé (Hochebene)

$92 "$

28.4,

3465 ,

34.4 "

3165

183

18.4

3367

In der subtropischen Zone, z. B. in Mexico erreicht der Mais, je nach der Sorte und Lage, eine Höhengrenze von $700-3000 \mathrm{~m}$ und in der wärmeren gemässigten Zone von $600-900 \mathrm{~m}, \mathrm{z}$. B. in Italien bei günstiger Lage $900 \mathrm{~m}$.

In den Thälern von Steiermark und Friaul, dann bei Lienz in Tirol wird noch Mais in Höhen bis zu $567 \mathrm{~m}$, im Rheinthal zu Trons bis $\mathrm{zu} 880 \mathrm{~m}$ und in den Karpathen bis $670 \mathrm{~m}$ kultiviert.

Wie alle subtropischen Gewächse widersteht auch der Mais der Trockenheit sehr gut, was die Möglichkeit seines Anbaues im Steppenklima, z. B. in Ungarn, Italien, im Westen Nord-Amerikas bekundet. Seine grosse Widerstandsfähigkeit gegen Trockenheit bezeugt auch $\mathrm{Humbold}$, welcher in den westlichen Cordilleren nach langer Trockenheit Mais fand und ihn verloren glaubte, als er nach eingetretenem Regen mit erstaunlicher Kraft von Neuem zu wachsen begann. Gewöhnlich sind die grossen Maissorten gegen Dürre widerstandsfähiger als die kleinen und mag dies mit dem grösseren Tiefgang ihrer Wurzeln in Verbindung stehen.

Uebrigens genügen schon verhältnismässig geringe Niederschläge zur Belebung seines Wachstums, da die breiten Blätter das Regen- und Tauwasser sammeln und am Stengel zu den Wurzeln hinabgleiten lassen.

Die vollkommenste Entwickelung erreicht er jedoch in feuchtwarmen Sommern, oder wenn im warmen Klima, wie in Italien, einzelnen Gegenden Spaniens etc. für eine ausreichende Bewässerung. gesorgt wird; auch erträgt der Mais bei hinreichend warmer Witterung eine längcre Zeit andauernde Inundation des Bodens weit besser als die iibrigen Getreidearten.

Erhält der Mais bis zur Blïtezeit genügend Regen und begünstigt dann ein trockner, warmer Herbst die Ausreife, so wird er sichere und bohe Erträge aufbringen, vorausgesetzt, dass an den Grenzen seines Anbaues für reichliche Düngung auf nicht zu schweren 
Böden und Schutz gegen rauhe, kalte Winde und gute Kultur Sorge getragen wird.

Gegen Nachtfröste im Fruihjahr ist die junge Maispflanze sehr empfindlich und erfriert leicht, allerdings schlägt sie von Neuem aus und kann auch immerhin in einem warmen Klima noch befriedigende Erträge aufbringen, was in der kälteren gemässigten Zone selten der Fall ist, weil hier der durch Frost beschädigte Mais nur ausnahmsweise zum Blühen kommt, wenn die Entwickelung der Pflänzchen bereits weit vorgeschritten war, oder im besten Falle der Ertrag nur sehr gering ausfällt; daher eine nicht zu frühe Aussaat die erste Bedingung für eine gute Körnerernte ist. Ferner können aber auch Friihfröste im Herbst das Ausreifen des Maises an den Grenzen seiner Kulturzone verhindern.

Als Grünfuttermais lässt er sich in der kälteren gemässigten Zone wohl noch überall anbauen.

\section{Boden.}

Der Mais stellt, mit Ausnahme des Reises, von den Getreidearten die höchsten Ansprüche an den Nährstoffreichtum des Bodens und verlangt insbesondere viel Kali und Phosphorsäure, während andererseits seine Anspriche an die physikalische Beschaffenheit des Bodens verhältnismässig gering sind, woher es kommt, dass derselbe, ausgenommen den sterilen Sand-, den sauren Moor- und Haideboden, sowie den undurchlassenden zähen Thonboden, auf allen Bodenarten wächst, sobald sie reich an fertiger Pflanzennahrung sind.

Da nun der Mais in seiner ersten Jugendzeit gegen Nässe und Kälte sehr empfindlich ist, so liegt es nahe, dass in dem kälteren gemässigten Klima die leichteren, durchlassenden Böden für den Maisball ausgesucht werden, und ausserdem eine nach Suden geneigte Lage wegen der stärkeren Erwärmung des Bodens gewählt wird, während man im warmen Klima den schweren und von Natur reichen Böden den Vorzug einräumt.

Ferner producieren feuchte Lagen hohe, blattreiche Pflanzen mit grossen Kolben, trockne dagegen die schwersten und schönsten Körner.

Vortrefflich sind für den Maisbau die reichen Alluvialböden und die im richtigen Masse durchlassenden Lehmböden geeignet, wenn dieselben durch Humussuhstanzen warm, lose, porös sind und eine bedeutende Absorptionsfähigkeit besitzen. Da nun der Boden an Nährstoffen 
dem Mais nicht zu reich werden kann, derselbe auch dem Lagern nicht ausgesetzt ist, so bringt man ihn gern auf die allerreichsten Böden.

Vorzüglich gedeiht er im zweiten Jahre nach dem Umbruch auf Neuland, wenn Rasen seine Kultur nicht mehr behindern, und auf den frisch umgebrochenen mit leicht aufnehmbaren Pflanzennährstoffen erfüllten Prairieböden, auf der kalireichen Schwarzerde des sïdöstlichen Europas und in dem reichen Schlamm ausgetrockneter Seeen und Teiche.

\section{Düngung.}

In Folge seines grossen Nährstoffbedürfnisses fordert der Mais, mit Ausnahme auf den uiberreichen Böden, eine Düngung, welche nicht zu stark werden kann, denn sein Ertrag steht mit der Stärke der Düngung im Verhältnis, und andererseits stehen keinerlei Nachteile durch übermässige Dïngung, selbst nicht für die Nachfrucht, zu befürchten, denn der Mais entzieht dem Acker den grössten Teil der fertigen Pflanzennahrung.

Vom Stallmist, der in Quantitäten von $50.000 \mathrm{~kg}$ und darüber pro ha aufgebracht werden kann, empfiehlt sich namentlich für die mittleren Böden der Rindviehmist, für die schweren der Pferde- und Schafmist, und für die leichten Sandböden der Rindvieh- und Schweinemist.

Auf Böden mit genügender Absorptionsfähigkeit bringt man den Stallmist gern schon im Herbst bis zur vollen Tiefe der Ackerkrume unter, damit er sich bis zur Saatzeit hinreichend zersetzt; aber auch im Laufe des Winters aufgefahren und im Frühjahr untergepfligt, wird der Dung bei der langen Vegetationszeit des Maises immerhin noch gut ausgenutzt.

Selbstredend ist der Stallmist zur Erzielung befriedigender Ernten recht gleichmässig auszustreuen und durch exaktes Einpflugen und Eggen auch fein und gleichmässig in der Ackerkrume zu verteilen.

Für die leichten Sandböden eignet sich die Gründüngung oder die Verwendung eines reichen Kompostes, letzterer namentlich zur Lochdüngung, vortrefflich.

Von ausserordentlichem Erfolge sind ferner sich leicht zersetzende stickstoffreiche Dünger, z. B. menschliche Exkremente, Jauche, Guano und Chilisalpeter, letzteren verwendet man auch als Kopfdung, sobald die Pflanzen das dritte Blatt entwickelt haben, in der Stärke bis zu $160 \mathrm{~kg}$ p. ha. Auf an Phosphorsäure armen, doch bindigen Böden streut man im Friihjahr mit der Saatfurche 
$200-300 \mathrm{~kg}$ Superphosphat p. ha und auf sehr leichten oder humosen Böden schon im Herbst $200-400 \mathrm{~kg}$ Knochenmehl und auf den an Kali armen Böden bis $200 \mathrm{~kg}$ eines Kalisalzes aus.

In Amerika ${ }^{1}$ ) gibt man gern bei der Dibbelkultur an jeden Horst Kopfdünger heran, z. B. eine halbe Schaufel Kompost oder eine Hand voll gut kompostierten Baumwollensamen, 200-400 kg Guano in Prisen den Samenkörnern beigefügt, ferner auf leichtem Boden Holzasche.

In Amerika scheint man mit grosser Vorliebe auch Gips, Kochsalz und Kalk zur Maisdüngung zu verwenden, also hauptsächlich die Löslichmachung und Verteilung der Nährstoffe anf von Natur reichem Boden zu erstreben. Es werden 20-100 hl Kalk, 0.5-2 hl Gips oder 3-4 hl Kochsalz p. hl ausgestreut.

\section{Fruchtfolge.}

Die Vorfrucht ist für das Gedeihen des Maises weniger als bei anderen Getreidearten wichtig, da der Boden zur Maiskultur tief bearbeitet und stark gedüngt wird, doch wächst er nach Klee, Gras oder Neubruch gemeinhin am besten.

In der Regel soll der Mais eine Hackfrucht ersetzen, dementsprechend er gern zwischen zwei Halmfrüchten gebaut wird.

Hackfrüchte als Vorfrucht zu wählen, ist unrentabel, weil die Vorteile, welche der Hackfruchtbau bietet, besser durch anderes Getreide als Nachfrucht ausgebeutet werden, ausserdem scheint es, als wenn die Hackfrüchte deı Boden für Mais zu sehr entkräften, und liegen hierüber Beobachtungen von $\mathrm{Karmrodt}$ vor, der weissen Pferdezahnmais nach verschiedenen Vorfrüchten sonst aber unter gleichen Verbältnissen kultivierte und pro ha erzielte:

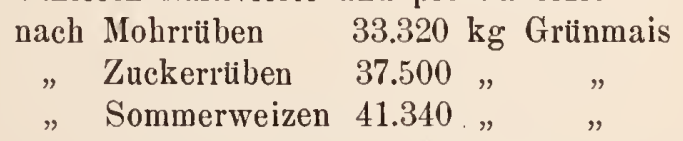

Zuweilen treten die frühreifen Maissorten in den wärmeren Klimaten noch als Stoppelfrucht auf, z. B. folgt in Ober-Italien nicht selten der Cinquantino auf Weizen, und in Valencia pflegt er die zweite Ernte des bewässerten Landes zu bilden, indem man den Weizenacker nach del Ernte im Juni mit jungem Mais bepflanzt, der

1) Rep. of the Commis. of Agric. Wash. 1866. Maiskultur in Amerika von Wolfinger, Penns. 
Ende September reift; in Zwischenkultur werden aber noch Kohl, Salat, Gurken, Melonen etc. angebaut, deren Ernte noch vor der des Maises fällt.

Diese Zwischenkulturen finden sich auch im Kleinbetriebe der kälteren gemässigten Zone, wo sich ihre Kultur noch bezahlt macht, und wird durch sie, da der Mais in seiner ersten Vegetationsperiode langsam wächst, der Raum vortrefflich ausgenutzt.

Hat der Mais und namentlich der Grünfuttermais in der kälteren, gemässigten Zone in seiner ersten Entwickelungsperiode durch Kälte, Vögel, Insekten etc. so stark gelitten, dass der Stand lïckig geworden ist, dann schreitet man zum Umbruch, oder wenn der Schaden nicht allzu bedentend ist, nach dem zweiten Hacken, also bis spätestens Mitte Juli, zu einer gleichmässigen, breitwürfigen Uebersaat von $1 \frac{1}{2}-2 \mathrm{~kg}$ p. ha Wasserrüben, und führt hieriiber J. Kühn an, die Wasserrübe wachse, wo sie stärker vom Mais beschattet wird, stark ins Krant, bilde sich aber normal dort aus, wo grössere kahle Stellen vorkommen. Selbstverständlich wird eine rolle Maisernte durch dieses Verfahren nicht ersetzt, wohl aber der Ausfall an Futter wesentlich rermindert.

Genügend dicht stehender Mais hinterlässt das Feld für die nachfolgenden Früchte in vorzïglichem Zustande, und bringt nach den friihreifeu Maissorten das Wintergetreide, nach sehr spätreifen das Sommergetreide hohe Erträge, doch liegt der Grund hierfür vornämlich nur in der guten Bodenbearbeitung, Dïngung und Pflege, welche dem Mais zu Teil geworden, und nicht etwa darin, dass er den Boden wenig angegriffen hätte, demn nicht gut bearbeiteter und gedüngter Mais hinterlässt auf nicht von Natur überreichen Böden das Land in sehr schlechtem Zustande.

In Deutschland wird der Grïnmais sporadisch in geringer Ausdehnung und Kornmais nur im siidlichen Deutschland, aber auch hier nur in kleinen Parzellen kultiviert, während er in Amerika, Italien, Ungarn und allen stark Mais bauenden Ländern die Hackfrucht ersetzt.

Im Westen Nord-Amerikas wechselt auf reichem, noch wenig erschöpftem Prairieboden der ungedüngte Mais in der Regel mit Weizen, während auf den schon mehr erschöpften Böden des Ostens zu ihm gediungt wird, selbst wenn Hackfrïchte in die Fruchtfolge aufgenommen sind, wie dies die nachfolgende interessante Fruchtfolge des Mr. Wright in Jowa U. S. zeigt: 1) Hackfrucht, 2) Mais*, 3) Winterung, 4) Hafer, 5-10) Kleegras.

Fruchtfolgen der Erzherzoglich Albrecht'schen Herrschaft Ungarisch-Altenburg in Ungarn für leichten Boden: 
I.

1) Mais, Rüben, Mohar*

2) Mohar, Mais

3) Roggen

4) Brache

5) Weizen

6) Hafer

7) Grünmais*

8) Weizen.
II.

1) Winterung

2) Mais, $1 / 2$ Riiben*

3) Mohar, Grünmais

4) Winterung

5) Brache*

6) Weizen

7) Hafer

8) Mais.

Die gebräuchlichen Fruchtfolgen in Italien und zwar auf hoch gelegenen Terrains um Verona sind:

1) Weizen und hierauf Cinquantino*, 2/3) Luzerne, 4) Weizen und hiernach Bohnen zur Gründüngung.

Auf wenig bewaisserten Terrains:

1) Weizen, 2) Mais*, 3) Hafer mit Luzerne, 4/5) Luzerne, 6) Weizen, 7) Wassermelonen*.

A uf gut bewässerten Terrains:

1) Reis*, 2) Mais*, 3) Weizen, 4) Rotklee.

\section{Bodenbearbeitung.}

Je zeitiger und sorgfältiger der Boden zu Mais vorbereitet wird, desto sicherer ist auf einen hohen Ertrag zu rechnen, da der Boden Zeit zur Verwitterung, also zur Gare erhält, und demzufolge ein poröser, all fertiger Pflanzennahrung reicher Boden dem Mais geboten wird. Bei reicher Düngung, oder auf Boden mit günstigem Untergrunde sollte wic zu Hackfriichten Tiefkultur betrieben und ein Untergrund von ungünstiger Beschaffenheit, den man also nicht gern mit der Ackerkrume vermischt, mit Hiilfe des Untergrundspfluges gelockert und bei schr hoch stehendem Untergrundwasserspiegel drainiert wcrden, damit den zum Teil tief in den Boden dringenden Wurzeln die Gelegenheit zu ihrer kräftigen Entwickelung nicht benommen wird.

Sehr wichtig ist die Tiefkultur im Steppenklima, in dem der Mais leicht clurch Trockenheit leidet, denn der tief gelockerte Boden bewahrt besser die Feuchtigkeit als der flach bearbeitete. Hierfür sprechen die Erfolge, welche mit der Dampfkultur resp. mit der tieferen Beackerung auf der Erzherzogl. Albrecht'schen Herrschaft „Bellye“ in Ungarn erreicht worden sind, wo seit Einführung der Dampfkultur nach dem übcreinstimmenden Urteil der Beamten, erheblich die Sicherheit und Höhe der Erträge zugenommen hat. 
Die Erfolge der tieferen und sorgfältigeren Bearbeitung sind aber so stark in die Augen fallend, dass selbst in den sebr extensiv betriebenen Wirtschaften auf dem Prairieboden Nord-Amerikas der Acker zu Mais schon im Sommer gebrochen, und im Herbst möglichst tief $(15-30 \mathrm{~cm})$ umgepflügt wird.

Im Allgemeinen und namentlich auf schwcreren Böden empfiehlt es sich, sofort nach Aberntung der Vorfrucht den Boden flach umzubrechen, nachdem das Unkraut aufgelaufen, zu eggen, darauf im Herbst noch den Dung aufzufahren und sorgfältig $\mathrm{zu}$ streuen und zur vollen Tiefe, bei günstigem Untergrunde bis $30 \mathrm{~cm}$ tief, zu pflügen, hierauf bleibt das Feld in rauher Furche bis zum Frühjahr liegen, wird nach dem Abtrocknen geeggt und kurz vor der Einsaat, damit die Samenkörner in einen frischen Boden kommen und schneller auflaufen, zur Saat gepflügt.

Auf leichtem Boden, der dem Austrocknen stark ausgesetzt und an und für sich locker ist, genügt es auch, an Stelle der Saatfurche zu grubbern.

Ist der Boden jedoch sehr flachgrindig, steht z. B. der Fels dicht unter der Ackerkrume an, oder liegt der Untergrundwasserspiegel zu hoch, so sollte man den Dung über Winter auffahren und das Land im Frühjahr mit Hülfe eines Hack-, Häufel- oder Kammpfluges in Kämme oder Dämme setzen, auf welche dann der Mais ausgelegt wird.

Soll der Acker eine sehr starke Düngung erhalten, dann kann es vorteilhaft erscheinen, die Hälfte des Dunges vor Winter mit der tiefen Furche unterzubringen, im Laufe des Winter's noch einmal zu düngen, ev. auch Janche aufzufahren, und diese Düngnng mit der Saatfirche der Ackerkrume einzuverleiben.

\section{Aussaat.}

Die Zeit der Aussaat des Maises ist zunächst von der Witterung abhängig, da sich der Boden auf $16-18^{\circ} \mathrm{C}$. erwärmt haben muss and Nachtfröste, welche die junge Pflanze zerstören könnten, nicht mehr in Aussicht stehen dürfen; gemeinhin wird der leichte warme Boden zeitiger als der schwere kalte zu besäen sein; ausserdem sind spätreife Sorten, wenn das Klima nicht in allen Fällen für sie passt, zuerst, frühreife später auszulegen, damit die spätreifen nicht im weichen Korn durch Frühfröste im Herbst getroffen werden.

Im subtropischen Klima, z. B. in Aegypten reift der Mais zweimal und wird im März und August gesäet. 
In Nord-Amerika säet man in den Sïdstaaten der Union vom 1. Februar bis 15. April, in den Mittelstaaten vom 15. April bis Ende Mai und in den nördlichen Staaten Maine und Minnesota, sowie auch in Canada im Juni. In Süd-Italien und Süd-Spanien währt die Saatzeit vom März bis Mitte April. In Nord-Italien und Nord-Spanien säet man die spätreifen Sorten im April, die mittelfrühen Anfang Mai und die frühreifen, wie Quarantino und Cinquantino, im Juni. In Frankreich, Ungarn, Kärnten, Steiermark wird im April und in der ersten Hälfte des Mai der Mais gelegt, in SüdDeutschland Ende April bis Ende Mai.

Da der Mais die Duirre gut erträgt, lässt er sich auch im Sommer zur Grïnfuttererzeugung aussäen, und gestattet daher in Ungarn, Ende April ausgesäet, indem er in der zweiten Hälfte des Juni schon eine Höhe von $1 \mathrm{~m}$ erreicht haben kann, noch eine zweite Aussaat auf demselben Felde, von dem der Grünmais im Oktober verfiittert oder zu Heu gemacht wird. Durchschnittlich stellten sich die Erträge einer Ernte auf $8000 \mathrm{~kg}$ Grünmais oder $2000 \mathrm{~kg}$ Heu pro ha.

In Nord-Deutschland lässt sich der Mais nur noch als Grünfutter erfolgreich verwenden, und säet man zu diesem Zweck von Mitte Mai ab in Zwischenräumen von 8 Tagen bis Ende Juli und selbst noch Anfang August, und erhält auf diese Weise von Mitte August an bis Mitte ev. Ende Oktober ein weiches und den Tieren zusagendes Futter.

Der Mais wird entweder gedibbelt oder gedrillt und nur ausnahmsweise bei sehr reinem Felde oder zur Gewinnung von Futtermais breitwürfig gesäet.

Der zur Erzielung eines möglichst hohen Rohertrages für eine Pflanze notwendige Wachsraum lässt sich nur im konkreten Falle genau feststellen, weil die Grösse desselben nicht nur vom Klima, der Bodenbeschaffenheit und Kulturart, sondern auch von dem Habitus der Sorten abhängt.

In Amerika, wo meist grosse Sorten angebaut und hauptsächlich eingedrillt werden, brauchen die Pflanzen im Allgemeinen den grössten Wachsraum, während in Europa meist die kleineren Sorten zum Anbau gelangen und vorzugsweise die Dibbelkultur Platz greift.

Die hierunter folgende Tabelle bringt Angaben iiber den notwendigen Wachsraum der Maispflanze in ihren Hauptproduktionsgebieten. 


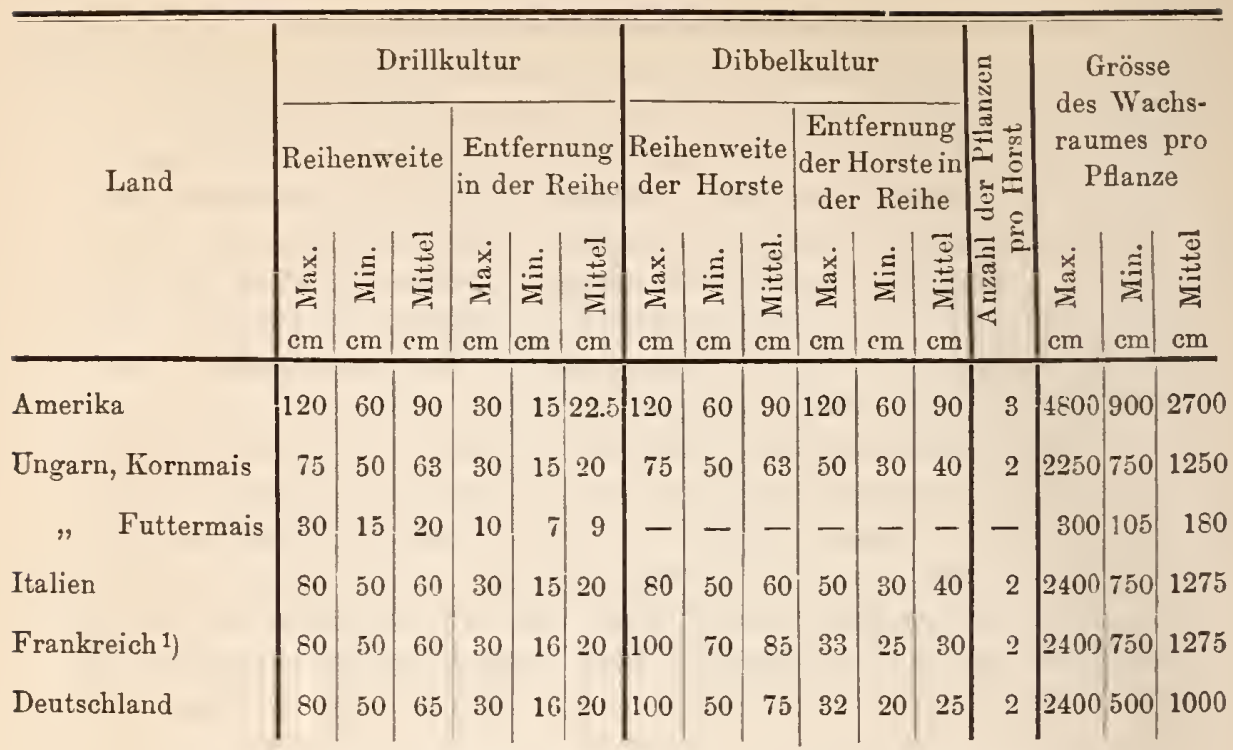

Die Aussaatmenge richtet sich im konkreten Fall einerseits nach dem Wachsraum der Pflanzen und andererseits nach dem Gewicht des Saatkornes, wobei jedoch nicht ausser acht zu lassen ist, dass der unvermeidlichen Verluste wegen sich das absolute Saatquantum mindestens um 30 Proc. zu erhöhen hat, so werden z. B. in Amerika bei der Dibbelkultur zur Erzielung ron 3 Pflanzen pro Horst 4-6 Samenkörner und in Europa für 2 zı erzielende Pflanzen pro Horst 3-4 Samenkörner ausgelegt.

Weil nun die Sorten, sowohl in ihrem Habitus, als auch im Gewicht ihrer Körner, erheblichen Schwankungen unterworfen sind, hat man sich das Saatquantum für jede Sorte selbst zu berechnen, und sollen als Beispiel für diese Berechnung die nachstehend aufgeführten Sorten dienen.

Saatquanta pro ha bei Drillkultur:

\begin{tabular}{|c|c|c|c|c|c|c|c|}
\hline Sorte & cm & $\begin{array}{c}\text { Entfer- } \\
\text { nung in } \\
\text { der Reihe } \\
\mathrm{cm}\end{array}$ & $\begin{array}{l}\text { Wachs- } \\
\text { raum pro } \\
\text { Pflanze } \\
\text { qcm }\end{array}$ & $\begin{array}{c}\text { Anzahl } \\
\text { der Pflan- } \\
\text { zen pro } \\
\text { ha }\end{array}$ & $\begin{array}{l}\text { Gewicht } \\
\text { eines } \\
\text { Kornes } \\
\\
\mathrm{gr}\end{array}$ & 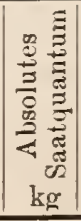 & 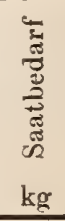 \\
\hline Grosse Sorten: & & & & & & & \\
\hline $\begin{array}{l}\text { Virginia Yellow Dent } \\
\text { Caragua . } \\
\text { White Dent : }\end{array}$ & $\begin{array}{l}120 \\
150 \\
120\end{array}$ & $\begin{array}{l}30 \\
20 \\
30\end{array}$ & $\begin{array}{l}3600 \\
4500 \\
3600\end{array}$ & $\begin{array}{l}27700 \\
22000 \\
27700\end{array}$ & $\begin{array}{l}0.21 \\
0.34 \\
0.40\end{array}$ & $\left|\begin{array}{r}9.8 \\
7.5 \\
11.0\end{array}\right|$ & $\begin{array}{r}7.7 \\
10.0 \\
14.6\end{array}$ \\
\hline
\end{tabular}

1) Dibbelkultur auf Kämmen (Billons). 


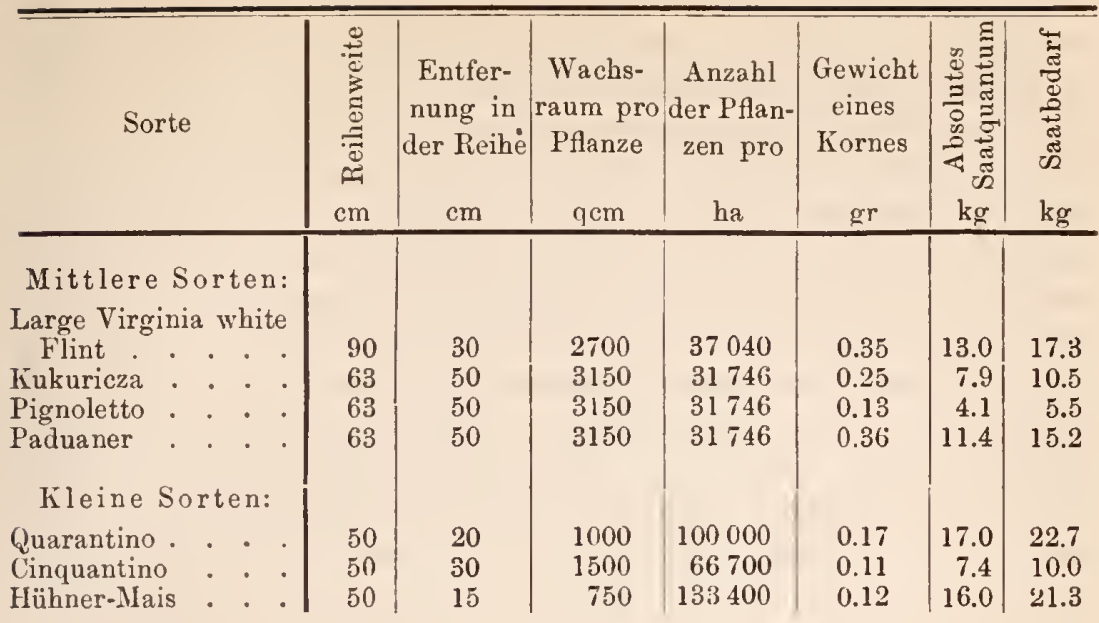

Was nun den Futtermais anbetrifft, so erhalten die grossen Sorten, welche hauptsächlich in Nord-Deutschland angebaut werden, meist eine Reihenweite von $50-70 \mathrm{~cm}$, bei einer Entfernung in der Reihe von 16-20 cm, nithin sich ein Wachsraum von 1000-1400 qcm pro Pflanze ergiebt. Diese Kultur setzt aber die kostspielige Bearbeitung der Zwischenräume voraus, und fragt es sich, ob sich dieselbe bei einer Pflanze rentiert, deren Nährstoffe einen relativ geringen Wert besitzen. Auch leiden die Pflanzen bei dieser Kultur durch Windbruch. Die Saat lässt sich nur mit Mühe durch Schiessen oder Ueberspannen des Bodens mit Fäden gegen die Krähen schützen. Es scheint demnach die breitwiirfige Saat oder sehr enges Drillen und fruhzeitiger Schnitt des Grünmaises mehr Vorteile zu bieten und namentlich auch seine Kultur für die leichtern Böden zu ermöglichen, da der Mais im allgemeinen gegen Trockenheit ziemlich widerstandsfähig ist.

Diese Art der Kultur ist schon allgemein in Ungarn verbreitet, wo dem Grünmais, damit der Halm fein bleibt, ein sehr dichter Stand gegeben wird, auch schneidet man ihn schon, sobald er eine Höhe von $1 \mathrm{~m}$ erreicht hat, doch wählt man seltener den Pferdezahnmais zur Aussaat, sondern benutzt dazu meistens den gelben ungarischen Mais und den Cinquantino. Gemeinhin drillt man den Mais sehr eng, sodass die Reihenweite nur $15-18 \mathrm{~cm}$ beträgt oder säet ihn breitwürfig aus, und zwar mit einem Wachsraum von $200-300$ q $\mathrm{cm}$ pro Pflanze, je nach dem Habitus der Maissorte.

Sehr häufig findet auch mit grossem Erfolge eine Uebersaat von Buchweizen und Wicken statt, welchem Gemenge aber auch noch andere Grünfuttergewächse beigemischt werden könnten, wie Erbsen, Saubohnen, Hafer u. s. w. Ein solches Gemenge gewährt offenbar 
den Vorteil, auf ärmeren und für Mais weniger gut vorbereiteten Böden noch gute Erträge zu erzielen und ausserdem ein Futter zu liefern, in welchem sich das Nährstoffverhältnis weit enger als im Mais gestaltet, da die im Gemenge befindlichen Leguminosen sich durch Eiweisreichtum auszeichnen; mithin würde, wenn die Menge des Grïnmais im Gemenge 50 Proc. nicht iibersteigt, ein vortreffliches Grünfutter bei geringeren Kosten erzielt werden können, zumal der Mais immer feinhalmig bleibt und deshalb weit nahrhafter ist, als die in die Blüte getretenen grobstengligen Sorten.

Schliesslich sei bemerkt, dass auch bei der Kornmaiskultur auf gutem Boden und hauptsächlich im Kleinbetriebe Zwischenkulturen vorkommen, so pflanzt man z. B. in Süd-Deutschland und im Alpengebiet in die Drillreihen, damit die Bearbeitung nicht gestört werde, nicht rankende Zwergbohnen, Kürbisse, seltener Rüben und Kartoffeln etc. hinein.

In Ungarn werden die Ränder der Maisfelder und ev. auch Lücken, denn obwohl sich der Mais verpflanzen lässt, unterlässt man die Auspflanzung der Lücken mit ihm, da er doch nur kümmerliche Pflanzen aufbringt, mit der Sonnenblume, die Speiseöl liefert, und der Besenhirse (Andropogon Sorghum technicus Keke.), deren Samen als Geflügelfutter und deren Rispen zur Besenfabrikation dienen, bepflanzt.

Die Säemethoden des Maises sind ausserordentlich mannigfaltig, und wollen wir die Besprechung derselben mit der einfachsten, der breitwürfigen beginnen. Die Aussaat lässt sich bei kleinkörnigen Sorten mittelst einer Breitsäemaschine, bei sehr grosskörnigen mit der Hand bewirken, und wird auf leichtem Boden mit dem Saatpflug, auf schwerem mit der Egge untergebracht.

Doch ist, namentlich zur Kornmaiserzielung diese Methode verwerflich, weil die Samenkörner sehr ungleich verteilt und ungleich durch Erde bedeckt werden.

Selbstverständlich muss auch der Acker sehr rein und unkrautfrei sein.

Den Nachteil nicht ganz gleichmässiger Unterbringung hat aber auch das Legen nach dem Pflug, was vielfach in Amerika, Italien (z. B. in Toskana) und in Siid-Deutschland (Elsass) gebräuchlich ist. Je 2-3 Körner werden auf die als zweckmässig erkannten Entfernungen (33-45 $\mathrm{cm}$ in Toskana und Suid-Deutschland) in die dritte Furche und zwar nicht auf die Sohle derselben, sondern in die lose Erde durch Menschenhände gelegt. Zur Erleichterung und Ersparung von Handarbeit sind auch Kombinationen zwischen Pflugen und Säemaschinen erfunden worden, die im Allgemeinen eine sehr befriedigende Arbeit leisten. $\mathrm{Zu}$ erwähnen ist eine Drillmaschine mit Pflugkörpern von Tomaselli in Cremona, Italien; doch finden sich 
in Italien auch noch anderc Konstruktionen, z. B. ist auf einem Häufelpflug eine kleine Löffeldrillmaschine direkt montiert, deren Welle dadurch bewegt wird, dass tiber ein Rad mit vier Hebelarmen, welche in den Boden greifen, also die Vorwärtsbewegung des Pfluges mitmachen, eine Kette ohne Ende läuft, welche diese Bewegung auf die Säewelle ïbcrträgt. Aehnliche Apparatc sind auch in Süd-Amerika in Anwendung und hatte auf der Pariser Weltausstellung 1878 Uruguay einen solchen Maispflanzer ausgestellt. Unmittelbar vor dem Sterzen auf dem Pflugbaum eines amerikanischen Adlerpfluges befindet sich ein Säekasten, aus welchem vermittelst einer mit peripherischen Einschnitten versehenen Scheibe, welche bei der Vorwärtsbewegung des Pfluges mit Hülfe der Uebertragung durch ein hinter demselben auf der Pflugsohle laufendes Rad sich dreht, die Maiskörner in eine viereckige Drillröhrc geworfen werden, so dass sie zwischen Sohle und Streichbrett auf die Pflugsohle gelangen.

In Nord-Amerika liefert der sog. „Keystone Planter" die beste Dibbelarbeit, und zwar in folgender Weise.

Die Saatreihen werden meist mit einem Markeur gezogen, der wie ein Schlitten konstruiert ist, mit so viel Kuffen, als man Linien zu ziehen beabsichtigt. Quer ab von diesem Gerät steht unter rechtem Winkel eine Stange, die nach Belieben auf die rechte oder linke Seitc ausgelegt werden kann. An das Ende derselben wird ein Stück Kettc gehängt, was auf dem Boden nachschleppt und somit auf der Seite eine Spur abzeichnet, die der Treiber beim Zurïckfahren als Richtschnur benutzt. Auf diese Weise, und da man den ersten Zug sorgfältig mit Stäben abvisiert, werden die Reihen ausserordentlich exakt und ein nach beiden Richtungen markicrtes Maisfeld sieht aus, als sci es mit Schnur, Winkelmass und Zirkel angelegt. Es ist diesc Regelmässigkeit von der grössten Wichtigkeit. Da bei dem holen Preise der Handarbeit an eine lohnende Verwendung für den Maisbau nicht zu denken, so muss durch regelmässige Aussaat die Möglichkeit gegeben sein, das Behäufeln und Reinhalten ausschliesslich mit Gespannwerkzeugen auszuführen. Ein Mann mit 2 Pferden markiert täglich 25-30 Acres je naclı der Reihenwcite.

Hieranf wird genau in den vorgezeichneten Linien die Aussaat mit dem zweispännigen „Planter" ${ }^{1}$ ) gemacht. Ein starkes, nach vorn und unten scharfes Drillschar durehschneidet Rasen und Wurzeln bis zur gewünschten Tiefe. Nach hinten erweitert es sich und ist hohl, so dass die Körner auf die Sohle der von ihm geöffneten Furche fallen und von dem nachbröckelnden losen Boden bedeckt werden

1) Gefertigt von Batchelder, Fabrik Ames Plow Co. in Worcester, Massach. Vertreter: Hammacher \& Delius, Hamburg. 
können. Auf dem Pfluggestell in der Mitte des Grindels befindet sich der Saatkasten, in dessen Boden ein beweglicher mit Löchern versehener Schieber angebracht ist. Während des Ganges wird derselbe durch eine gekröpfte Welle und Lenkerstange hin und her bewegt, wobei die Samenkörner durch die Schieberöffnungen fallen. Durch Anwendung von Schiebern mit verschieden grossen Oeffnungen lässt sich die Aussaatmenge in ziemlich weiten Grenzen regulieren.

Hinter dem unter dem Saatkasten befindlichen Schar folgt ein dreieckiger eiserner Streichapparat zu Beseitigung von Steinen etc., und endlich eine Walze, welche die von dem Schaar geöffnete Rille wieder zupresst. Von der Achse dieser Walze wird mittelst Zahnradübertragung die zwischen den Sterzen gelagerte Kurbelwelle, von welcher aus die Bewegung des Saatschiebers erfolgt, in Betrieb gesetzt.

Das Drillen des Maises lässt sich bei kleinkörnigen Sorten auclı ganz gut mit einer Getreidedrillmaschine und bei grosskörnigen mit dem Bohnendriller bewirken.

Bei der Dibbelsaat anf gut vorbereitetem, ebenem Lande wird der Acker uber Kreuz in den zweckmässig erscheinenden Entfernungen markiert und mit der Hand an den Kireuzungsstellen ein Gribchen ausgehöhlt, in welches $3-6$ Samenkörner gelegt und mit Erde, welche ein wenig angedrïckt wird, bedeckt werden. In Nord-Amerika dibbelt man auch mit Säestöcken.

Ist das Land in Kämmen aufgepflügt und nachher gewalzt, so wird behufs Erleichterung des Dibbelns quer über die Balken markiert, und dann durch Frauen in den Markierlinien das Auslegen bewirkt, oder es erhalten die Arbeiter kleine Stäbchen, von einer Länge, welche den Entfernungen der Horste entspricht, diese werden mit der linken Hand als Massstab auf den Kamm gelegt, während die rechte das Grübchen höhlt und die Samenkörner, aus Schïrze oder Sack entnommen, auslegt.

\section{Pflege.}

Nach der Einsaat folgt bei trocknem Wetter und auf leichtem Boden zur Beschleunigung des Auflaufens die Walze und von jetzt $a b$ ist das Hauptbestreben auf möglichst zeitige Zerstörung des Unkrautes oder eine die Oberfläche schliessende Kruste zu richten.

Dies sind die Gründe, welche das Eggen oder Hacken mit der Hand, selbst wenn die jungen Pflänzchen schon eine Länge von $3 \mathrm{~cm}$ erreicht haben, wünschenswert erscheinen lassen. 
Bei einer Höhe der Pflänzchen von $12-16 \mathrm{~cm}$ reinigt man mit der Pferdehacke und bei $35-40 \mathrm{~cm}$ werden die zu dicht stelicnden oder ganz unfruchtbaren Stengel und Schösslinge ausgeschnitten und später die iuberflïssigen Kolben ausgegeizt, so dass nur 2-3 Kolben an einem Halm verbleiben; hierauf wird schwach angehäufelt. Mit dem Hervortreten der Rispe häufelt man noch einmal und zwar stärker, indem dic Erde 8-10 $\mathrm{cm}$ hoch an den Fuss der Pflanze herangebracht wird, um dieselbe nicht nur zu erneuter Wurzelbildung anzuregen, sondern auch gegen Windbruch wirksamer zu schitzen.

Während der Blütezeit darf das Maisfeld nur im Notfall betreten werden, weil schon eine geringfügige Verletzung der Pistille hinreicht, den Kornertrag zu vermindern.

Zur Beschleunigung der Ausreife glaubt man den Mais gipfeln, d. h. nach dem Vertrocknen der Pistille den Halm bis dicht ïber den obersten Kolben abschneiden zu müssen, welche Teile dann als Viebfutter dienen.

Durch diese Entlaubung werden jedoch der Pflanze sehr beträchtliche Nährstoffquantitäten zur Ausbildung der Früchte entzogen, in Folge dessen sich der Kornertrag wesentlich verringert und das gewonnene Grünfutter nicht entfernt diese Verluste zu decken vermag; so will man in Amerika durch das Gipfeln $6-9$ hl Korn pro ha weniger geerntet haben, wozu noch die Unkosten des Gipfelns treten. Auch Haberlandt ${ }^{1}$ ) bat das Unvorteilhafte des Gipfelns nachgewiesen.

Dagegen dient zur Beschleunigung der Ausreife das Aufschlitzen und Herabbiegen der Hüllblätter des Kolbens, ungeführ 14 Tage vor der Reife, welches das leichtere Austrocknen der Spindel und das schnellere Erhärten der Früchte zur Folge hat.

Die etwa durch Sturm in der Bliitezeit geknickten Halme, denn später sind sie, wcil stärker verholzt, widerstandsfähiger, müssen wiedcrum aufgerichtet und die gänzlich abgebrochenen entfernt werden.

$\mathrm{Zu}$ dem Aufrichten dürfen jedoch nur umsichtige Leute verwandt werden, weil die jungen Kolben nicht berührt werden dïrfen; auch miissen die Stengel vollkommen frei von Regentropfen sein, da sie sich anderenfalls, durch das Gewicht des Wassers beschwert, wiederum herunterbiegen würden.

Durch Ticfkultur und nicht zu engen Stand lässt sich Windbruchschaden erheblich vermindern.

In Nord-Amerika spart man möglichst, weil zu teuer, an Handarbeit, weshalb sich hier die Pflege eigenartiger gestaltet.

1) Wie kann man die Reife des Maises beschleunigen? Allg. 1. u. f. Ztg. Wien, $1866 \mathrm{Nr} .35$.

Koernicke u. Werner, Handb. d. Getreidebau's II. 
Ist z. B. naeh dem Legen der Samenkörner mit dem "Planter" das Wetter troeken, bevor der Mais hoeh genug ist, um mit dem Kultivator befahren werden zu können, so wird das ganze Feld zuvor noeh gewalzt. Man thut das gern eine Woehe vor dem Befahren, damit die in den Boden gedruiekten Erdsehollen bis dahin noch Feuehtigkeit anziehen und mürbe werden.

Es sind zwar einspännige, zweischarige Kultivatoren noeh im Gebraueh, dasjenige Gerät jedoeh, ohne welehes sieh ein fortgeschrittener Maisfarmer nur selı sehwer behelfen würde, ist der zweispännige verbesserte „Selby Cultivator". Der Führer sitzt auf einem bequemen Sitze, regiert die Sehare mit den Füssen und die Zügel nit den Händen. Die Sehaufeln gehen bis dieht an die Pflanzen heran und maehen beide Seiten gleiehzeitig fertig.

Die Hauptsaehe für einen gewinnbringenden Maisbau ist, einen rechtzeitigen Vorsprung vor den Unkräutern zu gewinnen, da auf Naehhülfe durch Handarbeit nielıt gerechnet werden kann. Es muss also früh mit dem Befalıren begonnen und dureh $4-5$ Woehen dieses nindestens einmal die Woehe wiederholt werden. Diese Arbeit wird wesentlieh dureh das sehr gleiehmässige Auslegen der Körner erleichtert. Tritt bald naeh der Aussaat nasses Wetter ein, so dass reichliehes Unkraut früher da ist, als der Mais, so wird mit dem „Selby Cultivator" blind gearbeitet, da die Reihen durch die Radspur des "Planters" genugsam kenntlich sind. Alsdann erst wird, naehden die Unkräuter abgewelkt, geeggt und gewalzt, wie gewöhnlich.

Im wärmeren Klima und auf leichten Boden verlangt der Mais zur Sieherstellung und Erhöhung der Ernten einer periodisehen Bewässerung, die also erst platz greift, sobald sich ein effektiver Wassermangel einstellt, so dass, wie z. B. in Ober-Italien, in feuehten Jahren unter Umständen fast gänzlieh auf die Bewässerung verziehtet werden kann, wodıreh, da diese Geld kostet, nieht unerhebliehe Kosten erspart werden können.

Zur Bewässerung ist jedoeh das Aekerland besonders einzuriehten, und wird die Bestellung in Ober-Italien ${ }^{1}$ ) in der Weise vorgenommen, dass entweder schmale $1-1 \frac{1}{1} 2 \mathrm{~m}$ breite und gewölbte Beete, oder flaehe $3-4 \mathrm{~m}$ breite Beete in der Riehtung des grössten Gefälles aufgepflügt werden; in die Beetfurchen strömt dann von einem Verteilgräbehen aus, das parallel dem Bewässerungsgraben läuft, das Wasser langsam ein und sobald es am entgegengesetzten Ende angekonmen, wird meist die Bewässerung als genügend anzusehen sein. Auf den mit Mais bestellten Aeckern, werden aueh häufig

1) Vergl. Werne:, Landw. Reiseskizzen aus Ober-Italien. Landw. Jahrb. 1882. 
durch Häufelpflüge zwischen je zwei Reihen die Wasserfurchen aufgezogen. Während der Blütezeit und Ausbildung der Aehren darf jedoch niemals gewässert werden.

Der Wasserkonsum beträgt in Italien durchsehnittlich 0.377 Ltr., in Sïdfrankreich 0.300 Ltr., in Algier 0.930 Ltr. pro ha und Sekunde und in Valencia wird der Mais alle drei Tage unter Wasser gesetzt.

\section{Ernte, Entkörnung und Aufbewahrung.}

Der Mais ist reif, sobald sich die Kolben nach unten neigen, die Hüllblätter an den Spitzen einzutrocknen beginnen, sich gelb färben und aufspringen. $\mathrm{Zu}$ dieser Zeit zeigen die Körner ihre charakteristische Farbe, sind glänzend, und so hart, dass sie nur noch wenig dem Nageldruck nachgeben. Mit dem Erhärten der Körner werden die dunkelgrünen Blätter schmutzig-grün, und ibre glänzenden Oberflächen matt, schliesslich vertrocknet die ganze Pflanze, und färbt sich, vom Frost getroffen, fast weiss.

Die Reifezeit tritt in den Siidstaaten $\left(30-40^{\circ}\right.$ n. Br.) NordAmerikas Ende August ein, in den Mittelstaaten $\left(40-45^{\circ} \mathrm{n} . \mathrm{Br}\right.$.) Ende September bis Anfang Oktober und in den nördlichen Staaten und Canada im Laufe des Monat Oktober.

In Europa fällt die Ernte in der Türkei, Süd-Italien, Spanien und Portugal in den August, nur bei sehr späten Sorten in den September und Oktober; in Sïd-Frankreich und Nord-Italien in den September, wobei jedoch zu berïcksichtigen ist, dass frühreife nach Vorfrüchten gebaute und bewässerte spätreife Sorten häufig erst im Oktober und selbst noch im November geerntet werden. Im mittleren Frankrcich, Süd-Deutschland und Ungarn reift der Mais Ende September und Anfang Oktober.

In Algier erntet man im Juli und August, in Aegypten im Juli und November, wenn zwei Ernten genomnen werden.

Die Erntemethoden sind ausserordentlich verschieden, z. B. wird in Nord-Amerika der reife Mais, dessen Stengel ganz ausgetrocknet sind, mit der Sichel oder dem Messer tief am Grunde abgeschnitten, mit Stroh in Garben gebunden und diese dann in Feimen gefahren, um die Kolben bei gelegener Zeit auszubrechen. Sind die Stengel noch nicht vollkommen trocken, wie dies bäufig in den'nördlichen Staaten der Fall ist, so müssen die Garben zum Nachtrocknen aufgestellt werden, doch fällt die Qualität des Kornes um so geringer aus, je grüner die Blätter und Stengel bei der Ernte waren. 
Ein anderes sorgfältigeres Verfahren ${ }^{1}$ ) ist: Man geht strichweise die Maisfelder durch und schneidet die Stengel, deren Kolben völlig reif sind, nahe dem Boden ab und stellt sie in Schobern von mässigem Umfange zum Trocknen auf. Indem auf diese Weise das ganze Feld durchgegangen wird, kommt man nach etlichen Tagen an dieselben Stellen nochmals zurïck, denn da die Aberntung nicht übereilt zu werden braucht, kann man die Reife zurïckgebliebener Kolben abwarten und sammelt die bis dahin reif gewordenen Stengel ein. Hierdurch wird bei dem an und für sich ungleichmässigen Reifeeintritt des Maises eine möglichst gleichmässig reife Frucht geerntet. In extensiver betriebenen Wirtschaften bricht man wohl auch nur die besten reifen Kolben aus, und treibt zur Ausnutzung der verbliebenen Ernte das Vieh linein, welches sich die Kolben und zarteren Pflanzenteile heraussucht, und der Rest wird als Dung untergepflïgt.

Dieses Verfahren wird in Wirtschaften, welche die hinreichenden Arbeitskräfte zur Bergung der Ernte absolut nicht auftreiben können, noch weiter ausgedehnt, indem die ganze Ernte durch Vieh abgeweidet wird, wie dies z. B. anf der Besitzung des Mr. Sullivan²) in Illinois auf einer Fläche von 4000 ha geschieht, die unausgesetzt mit Mais bestellt wird.

Während hier die Ernte heranwächst und reift, gehen die Agenten nach Texas und kaufen halbwilde, magere Ochsen. Dieselben werden dann in kleinen Tagemärschen von reitenden Hirten der Besitzung zugetrieben, indem man sie unterwegs in den Waldungen und auf Wiesen weiden lässt. Sie kommen auf der Besitzung zur Reifezeit des Maises an, und werden alsdann in die Maisfelder getrieben, wo ihnen ein bestimmter Raum, der mit beweglichen starken Hürden eingeschlossen und mit einem Wasserbehälter versehen ist, überliefert wird. Die Ochsen treten die Pflanzen nieder und verzehren die Kolben. Wenn der Raum abgeweidet oder vielmehr die Pflanzen darin niedergetreten sind, werden die Ochsen in die anstossende Abteilung gebracht und in der ersten durch eine Heerde Schweine ersetzt, welche die iibrig gelassenen Reste der Maiskolben verzehren. Den Schweinen folgt eine Heerde Welschhïhner, um die ausgefallenen Körner aufzulesen und sich damit zu mästen. In dieser Weise folgen sich drei Heerden von Thieren verschiedener Art von Abteilung zu Abteilung, verrichten die Ernte, mästen sich, düngen den Boden, und liefern sich schliesslich selbst auf den Markt von Chicago oder an die nächste Eisenbahnstation ab.

1) Vergl. Fleischmann, der nordamerik. Landw. 1852.

2) Vergl. Zeitschr. d. bayr. landw. Vereins 1878. 
Die ausgebrochenen und auf Haufen zusammengeworfenen Kolben müssen möglichst sehnell von ihren Hüllblättern befreit werden, weil sie sich leicht erhitzen und die Verderbnis sich auch dem Korn mitteilt. Dies erfordert viel Arbeit, daher man hierzu in neuerer Zeit in Amerika die Maisentblätterungsmaschine von $\mathrm{Philip}{ }^{1}$ ) verwendet, die auch zugleich das Ausbrechen der Kolben besorgen kann. Bei dieser Maschine gehen die Maispflanzen zwischen zwei am Umfange spiralförmig ausgekehlten Walzen hindurch, wobei die Kolben von dem Stengel gebrochen werden. Die Stengel fallen auf einen Elevator, die Kolben, welche nicht zwischen den Walzen hindnreh können, auf ein schrägliegendes zweites Walzenpaar mit spiralförmigen Nuten und korrespondierenden spitzen Stahlzähnen, welche bei der Drehung der Walzen die Deckblätter fassen, in die Nuten ziehen und beim Abwärtsgleiten der Kolben diese entblättern. Kolben und Hüllblätter gelangen auf besonderen Elevatoren aus der Maschine.

Dieser Apparat ist auch mit einer Maismähemaschine „American corn harvester and husker" kombiniert und zuerst in Philadelphia ausgestellt worden, und gibt Thallmayer ${ }^{2}$ ) von derselben nachfolgende Beschreibung:

Bei der Ernte wird mit der Maschine ähnlich wie mit einer Getreide-Erntemaschine um das Feld gefahren und eine Reihe nach der anderen abgemacht.

Zwei Cirkularsägen ähnliche Stahlblätter schneiden die Maispflanzen $a b$, sie fallen auf ein endloses Band, werden zweien horizontal liegenden Walzen zugeführt, zwischen welchen die Stengel durchrutsclien, von denen aber die Kolben unter glcichzeitiger $\mathbf{A b}$ streifung der Lischen abgerissen werden.

Ein Elevator entführt den Walzen die Kolben und bringt sie in einen Trog, von wo sie in einen neben der Maschine angebrachten Behälter fallen, der von Zeit zu Zeit entleert wird.

Die immer noch in der Spindel viel Feuchtigkeit enthaltenden, ihrer Hüllblätter beraubten Kolben werden ill den warmen Gegenden Nord-Amerikas entweder an der Solme getrocknet, oder zum Nachtrocknen in einen starken Luftzug gestattenden Behälter (Corn-crib) locker aufgehäuft, trocknen darin aus, und werden dann bei gelegener Zeit mit Hülfe der Maisentkörnungsmaschinen (Corn-shellers) entkörnt, und die leeren Spindeln, welche noch als Viehfutter dienen sollen, auf einer den Oelkuchenbrechern ähnlichen Maschine (Corn-cob-crusher) zerquetscht.

In Europa erntet man meistenteils durch Ausbrechen der Kolben,

1) Fritz, Handb. d. landw. Maschinen, 1880 pg. 479.

2) Oesterr. landw. Wchbl. 1876 pg. 279, Mais-Erntemaschine. 
entweder, dass vorher die Hullblätter mit der Hand oder dem Messer geöffnet und die Kolben ausgebrochen werden, oder man lässt die Hüllblätter am Kolben, um dieselben, wie häufig im Kleinbetriebe, an denselben zum Nachtrocknen aufhängen zu können. Selbstverständlich entnimmt man zunächst, da der Mais ungleich reift und sich die Ernte bis zum Eintritt des Frostwetters ausdehnen lässt, die reifsten Kolben, und hält später Nachlese.

Es ernten nach Burger 26-30 Weiber durch Ausbrechen der Kolben 1 ha täglich ab.

Das Nachtrocknen der noch feuchten Kolben geschieht in warmen Ländern, z. B. in Italien, auf der Dreschtenne an der Sonne oder wie in Ungarn in eigens zu diesem Zweck eingerichteten Trockenhäusern, welche im gemässigten Klima eigentlich erst die Maiskultur im Grossen ermöglichen. Selbstverständlich sind in diesen Fällen vor dem Trocknen dic Hüllblätter und die Reste der noch an den Kolben befindlichen Stengelteile zu entfernen, und hat dies möglichst bald zu geschehen, damit sich die Kolben nicht erhitzen, weshalb man täglich nicht mehr Kolben abbrechen sollte, als man an demselben Abend oder dem folgenden Vormittag zu entblättern vermag.

Die in Ungarn zur Trocknung und Aufbewabrung bis zur Entkörnung dienenden sog. Maisszartaken ${ }^{1}$ ) sind eigentlich nur lange Kästen mit Fussboden und Dach, während die Seiten aus Lattenwänden hergestellt sind. In der Regel liegt der Fussboden $1 \frac{1}{2} \mathrm{~m}$ über der Erde, die Breite beträgt $1 \frac{1}{3} \mathrm{~m}$, und Höhe, sowie Länge können beliebige Dimensionen aufweisen. Die Entfernung der Latten von einander ist, zur Hervorrufung einer energischen Ventilation, möglichst weit zu greifen, doch richtet sich dieselbe auch einigermassen nach der Körnergrösse der Maissorten; bei sehr weiten Entfernungen schädigen auch die Krähen durch Entkörnen der dicht an den Latten befindlichen Kolben. Meist beträgt die mittlere Entfernung der Latten $2 \mathrm{~cm}$. Ein weit nach den Seiten überstehendes Schindeldach schützt den Mais gegen Regen.

Sollen die Kolben, wie dies im Kleinbetriebe in Frankreich, Italien, Steiermark, Kärnten, Süd-Deutschland üblich, aufgehangen werden, dann belässt man am Kolben $3-4$ der innersten Blätter, und verknüpft mit ihrer Hiilfe mehrere Kolben zu einem Bündel, das sich bequem an einem luftigen Ort aufbängen lässt. Dieses Verfahren soll nach Burger schon von den Ureinwohnern Amerikas geübt worden sein.

Die auf dem Felde verbliebenen Stengel werden abgeschnitten und mit Hülfe von Strohbändern zu Garben gehunden und zum Aus-

1) Vergl. Werner, Bericht über eine landw. Studienreise durch Ungarn. Landw. Jahrb. 1880 pg. 597. 
trocknen immer 5 aufrecht gegen einander gestellt. Feucht eingebracht schimmeln sie sehr leicht und sind dem Vieh nachteilig.

Nach dem Austrocknen der Kolben und am besten nach einem starken Frost, beginnt man mit der Entkörnung und zwar bei zu Saatkorn bestimmten Kolben mit der Hand, sonst mit dem Dreschflegel, oder noch besser mit Maschinen, den sog. Maisreblern, welche in vorzïglicher Qualität für Hand-, Göpel- und Dampfbetrieb, nach amerikanischem Princip konstruiert, von der Firma Clayton \& Shuttleworth in Wien, sowie von einer grossen Zahl ${ }^{1}$ ) anderer Fabrikanten geliefert werden.

Bei den Handreblern werden die Maiskolben einzeln oben in den Apparat eingefulhrt und die Körner zwischen zwei rotierenden Scheiben, wovon die eine gezahnt, die andere gerippt ist, abgerebelt. Die leeren Spindeln werden durch eine seitwärts angebraclite Oeffnung ausgeworfen, während die Körner durch die untere Spalte zu Boden fallen.

Die für Dampf- oder Göpelbetrieb ${ }^{2}$ ) eingerichteten Maisrebler können feststehend oder transportabel sein und sind mit Putzwerk und Einsackungs-Vorrichtung versehen.

Mit einer Lokomobile von vier Pferdekräften werden mittelst des grössten Apparates in 10 Stunden 420-500 hl Maiskörner abgerebelt, während ein kleinerer, durch vierpferdigen Göpel getrieben, 150-185 hl ausgiebt.

Der im warmen Klima entkörnte Mais wird genıeinhin noch an der Sonne nachgetrocknet und kommt dann auf Malta, Sicilien, in Spanien und an der afrikanischen Küste in Silos wie anderes Getreide und bält sich darin sehr gut. Im kälteren, gemässigten Klima dürfen die Körner, wenn sie nicht vorher gedörrt wurden, nicht über $20 \mathrm{~cm}$ hoch, selbst auf einen luftigen Speicher aufgeschiittet werden, und sind zur Verhïtung der Verderbnis mindestens alle 3 Tage einmal umzuschaufeln.

Unreif geernteter Mais ist zu dörren, weil er sich sonst nicht aufbewahren lïsst.

Die Ernte des Grünfuttermaises geschieht am zweckmässigsten mit dem Erscheinen der männlichen Rispe, weil er dann noch weich und den Tieren angenelm ist, auch meist die grösste Menge verdaulicher Nährstoffe von der Flächeneinheit liefert.

Die Benutzung des Maises als Grïnfutter und auch als Sauerfutter ist der als Heu vorzuziehen, denn die Heuwerbung des Maises ist sehr schwierig und gelingt es niemals, die Fenchtigkeit

1) Vergl. Fritz, Handb. d. I. Maschinen pg. 476.

2) Werner, Bericht über eine landw. Studienreise durch Ungarn p. 598. 
aus den starken Maisstengeln soweit zu entfernen, dass er sich in geschlossenen Räumen, ohne schimmlig zu werden, aufbewahren lässt.

Um Mais zu Heu zu werben und im Freien aufzuberwahren, empfiehlt van Laer ${ }^{1}$ ) folgende Nethode.

Der abgeschnittene Mais wird in zuckerhutförmigen Haufen auf dem Felde aufgestellt, so zwar, dass im Innern ein freier Raum, der unten einen Durchmesser von 1-1.3 m hat, bleibt. Um einem solchen Haufen die nötige Festigkeit zu' geben, wird vorher ein sogenanntes „Pferd" gebunden. Man wählt dazu 8-12 Maishalme aus, welche nicht abgeschnitten werden; dieselben miissen unter sich ein Viereck bilden, d. h. in 4 Büscheln ungefähr $1.3 \mathrm{~m}$ von einander entfernt stehen.

Es werden nun je 2 soleher Biischel in der Diagonal-Richtung zusammengeflochten, so dass das Ganze ein Kreuz von ca. 1-1.3 m bildet, welches eine grosse Festigkeit besitzt. In die Winkel dieses Kreuzes wird der abgeschnittene Mais gelehnt; dann wird der ganze Haufen oben mit einem Strohseil sehr fest gebunden und erlangt dadurch eine solche Festigkeit, dass ihn kein Sturm umwirft.

Je nach dem Stande des Maises genïgen p. ha 96-160 Haufen. In diesen Haufen kann er, ohne Schaden zu nehmen, bis zum Friuhjahr stehen bleiben. Die äusseren Blätter werden zwar gelb, aber im Innern behalten sie ihre grïne Farbe und verlieren nur äusserst wenig an ihrem Futterwerte.

Eine der besten Methoden der Maiskonservierung ist die in Ungarn gebräuchliche, welche auch Corvis art in Chateauneuf (Cher), Frankreich adoptiert zu habei scheint. Zu dieser Sauerfutteroder richtiger gesagt Braunheubereitung wird eng gedrillter, nicht zu starker Grïinmais gewählt.

Nachdem der Mais mit der Mähemaschine oder Sense abgemähet, lässt man ihn abwelken und bringt ihn sodann in $2 \mathrm{~m}$ tiefe und $4 \mathrm{~m}$ breite und belicbig lange Gruben, in welche er fest eingetreten wird. Nachdem die Grube bis zum Rande gefiullt ist, wird der Mais weiterhin dachförmig aufgeschichtet, sodass er sich nicht selten noch reichlich $3 \mathrm{~m}$ iiber die Grubenwand erhebt; dann wird er mit Erde bedeckt; mit dem Beginn der Gärung sinkt jedoch diese Erhöhung inmer mehr zusammen, weshalb die in der Erdbedeckung entstehenden Risse immer wieder sorgfältig zugeschlagen werden müssen. Dieser Mais besitzt in seinen oberen Schichten den angenehmen Geruch und die Farbe des Braunheves und nur in den unteren nimmt er mehr den Charakter des Sauerfutters an.

Bei dem Lecouteux'schen Verfahren in Cercay, Frankreich,

1) Zeitschr. des landw. Central-Vereins der Provinz Sachsen 1870 p. 210.

2) Schmitz, die Kultur und Aufbewahrung des Grünmais 1880. 
sind die Gruben ebenfalls in blosser Erde angelegt, doch die Wände stark geneigt und die Ecken abgerundet.

Der Mais kommt klein geschnitten hinein, wird mit einem Zehntel Kaff oder Häcksel vermischt ind erhält anfangs eine Erdbedeckung von $50 \mathrm{~cm}$, welche nach 6 Wochen auf $1 \mathrm{~m}$ verstärkt wird.

Wähırend des Einfüllens haben mehrere Arbeiter das Maishäcksel, besonders in den Ecken und die Ränder entlang, energisch festzutreten. Dicses Festtreten wird auch fortgesetzt, bis eine Maismasse von derselben Figur, wie der Inhalt der Grube, aus der Erde herausragt. Die Erdbedeckung wird direkt auf den Mais gebracht, nachdem derselbe zuerst mit einem Lehmbrei überzogen worden. Der Mais gärt nun und die Erdbedeckung erhält Risse, welehe anfangs täglich mehrmals zugeschlag'en werden. Der Haufen sinkt langsam zusammen, bis nach etwa sechs Wochen statt eines $2.50 \mathrm{~m}$ hohen Haufens nur mehr eine dachförmige, flache Erhöhung über dem Boden stehen bleibt. Der Mais kann nun zur Fiitterung benutzt werden.

Wir kommen jetzt zur dritten, der Goffart'schen Methode ${ }^{1}$ ). Sie erfordert gemanterte Behälter von $12 \mathrm{~m}$ Länge, $5 \mathrm{~m}$ Breite und $5 \mathrm{~m}$ Tiefe, welche zur Hälfte in der Erde liegen. Die Figur eines solchen Behälters erscheint von oben gesehen als ein Parallelogramm von $7 \mathrm{~m}$ Länge, dessen schmale Seiten in je einen Halbkreis von $2.50 \mathrm{~m}$ Radius ausgeschweift sind. Durch diese Form sind alle Ecken vermieden, dic Wände stehen lotrecht und sind äusserst glatt verputzt, um der Masse, wclehe auf genau $1 \mathrm{~cm}$ geschnitten ist, beim Herabsinken den kleinstmöglichen Widerstand entgegenzusetzen. Auf den möglichst geebneten Mais kommt als Decke eine $4 \mathrm{~cm}$ dicke Schicht Strohhäcksel oder Fichtennadeln, hierauf schmale dünne Bretter, lose in die Quere neben einander gelegt und sehliesslich schwere Gegenstände, welche auf den Quadratıncter einen Druck von $500 \mathrm{~kg}$ ausüben. Die Grube ist zilm Abhalten des Regenwassers überdacht. Ein solcher Behälter enthält das Futter fiir fünfzehn Stuick Rindvieh von $500 \mathrm{~kg}$ lebend Gewicht auf ein Jahr.

Das Zerschneiden des Maises findet mit eincr Häckselmaschine von Richmond \& Chandler statt, und wird dieses Häcksel mit soviel Strohbäcksel vermischt, dass sich der Wassergehalt des Maises von 85 Proc. auf 75 Proc. erniedrigt.

1) Goffart, Manuel de la Cult. et de l'ensilage du Maïs, 1877. 


\section{Erträge und Nahrungsbestandteile.}

Den höchsten Durehschnittsertrag der Mais bauenden Länder liefern die Vereinigten Staaten von Nord-Amerika mit 20 hl pro ha, während der Durchschnittsertrag für Italien 18.3, Australien 18, Rumänien 16.5, Frankreich 16.4, Portugal 13.6, Oesterreich-Ungarn 12.7 und Algier sogar nur 7.2 und der Durchsehnittsertrag aller Länder $15.3 \mathrm{hl} \mathrm{à} 78 \mathrm{~kg}$ ausmacht. Die Grenze der Produktion mit $225 \mathrm{hl}^{1}$ ) erreichte ebenfalls Nord-Amerika.

Die Maiscrträge stellen sich im Allgemeinen pro ha wie folgt:

$\begin{array}{lrcc} & \text { Min. } & \text { Max. } & \text { Mittel } \\ \text { Körner } & 7 \mathrm{hl} & 225 \mathrm{hl} & 15.3 \mathrm{hl} \\ \text { Stroh } & 730 \mathrm{~kg} & 20000 \mathrm{~kg} & 2500 \mathrm{~kg} .\end{array}$

Diese Ertragszusammenstellung zeigt recht deutlich, in welchen ausserordentlich weiten Grenzen, je nach Sorte, Klima, Bodenbeschaffenheit, Kulturart etc., die Erträge beim Mais schwanken können. Ausserdem erscheint es eigentuimlich, dass Maximal- und Durchschnittsertrag in so auffälliger Weise verschieden sind, was sich wohl darauf zurückführen lässt, dass die Hauptproduktionsländer des Maises dem warmen, trocknen Klima und den Gebieten extensiver landwirtschaftlicher Kultur angehören, mithin sich der Durchsehnittsertrag verhältnismässig niedrig stellen muss, während andererseits durch intensivere Kultur oder Wasserzufuhr bei Dürre eine aussergewöhnliche Ertragssteigerung erzielt werden kann.

So erhöhten sieh z. B. durch intensivere Kultur bei den Versuchen von Salisbury mit 13 versehiedenen amerikanischen Sorten im Staate New-York die Erträge auf $6240 \mathrm{~kg}=80 \mathrm{hl}$ Körner, $1800 \mathrm{~kg}$ Spindeln, $1754 \mathrm{~kg}$ Hüllblätter, $3570 \mathrm{~kg}$ Blätter und $4600 \mathrm{~kg}$ Stengel pro ha, während der Durchschnittsertrag in den Vereinigten Staaten nur 20 hl Körner p. ha beträgt.

In welcher Weise sich durch intensive Kultur die Roh- und Reinerträge heben lassen, ergiebt sich aus nachfolgender Uebersicht der Produktionskosten und der Ernteresultate bei rersehiedenartiger Kultur in den Vereinigten Staaten ${ }^{2}$ ).

1) Enfield, Indian-Corn 1866 pg. 54.

2) Enfield, a. a. 0. 
a. Produktionskosten bei extensiver Kultur.

$$
\begin{aligned}
& \text { Pflugen pro acre . . . . . . } 2.00 \text { Dollars } \\
& \text { Markiercn, Säen, Same . . . } 2.00 \text { " } \\
& \text { Erntekosten . . . . . . . } 3.00 \text { " } \\
& \text { Bodenrente . . . . . . } 5.00 \text { " } \\
& \text { Sa.: . } 12.00 \text { Dollars. }
\end{aligned}
$$

Davon der Wert der Stengel ab 3.60 ,

$$
\text { Ertrag } 15 \text { bushel }=8.40 \text { Dollars, }
$$

mithin stellen sich die Produktionskosten pro 1 bushel auf 56 cents.

b. Weniger extensive Kultur, jedoch noch ohne Düngung.

$$
\begin{aligned}
& \text { Zweimal pfliugen und eggen . . } 4.50 \text { Dollars } \\
& \text { Säen etc. . . . . . . . . . } 2.00 \text { ” } \\
& \text { Pflege . . . . . . . . . . } 4.00 \text { ” } \\
& \text { Ernte . . . . . . . . . } 3.50 \text { \% } \\
& \text { Rente . . . . . . . } 5.00 \text { " } \\
& \text { Sa.: . } 19.00 \text { Dollars. }
\end{aligned}
$$

Davon der Wert der Stengel ab: 7.20

$$
\text { Ertrag } 30 \text { bushel }=11.80 \text { Dollars, }
$$

mithin betragen die Produktionskosten pro 1 bushel $=39$ cents.

c. Intensive Kultur.

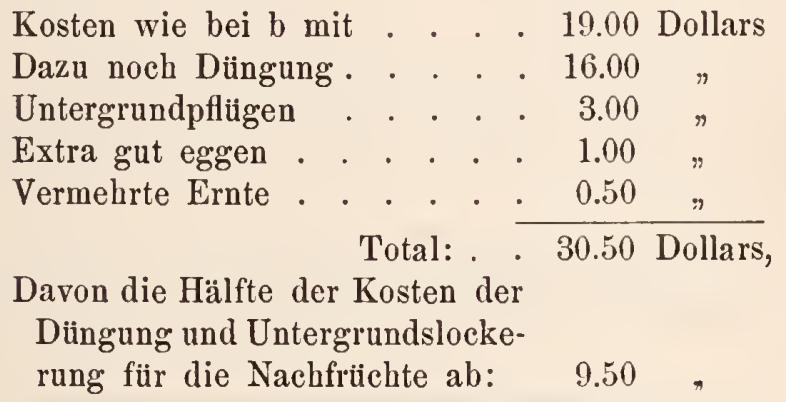

$$
\begin{aligned}
& \text { bleiben } 30.00 \text { Dollars. } \\
& \text { Wert der Stengel } 16.80 \pi n \\
& \text { Ertrag } 70 \text { bushel }=13.20 \text { Dollars, }
\end{aligned}
$$
mithin betragen die Produktionskosten pro 1 bushel 19 cents.

Unter sehr gïnstigen Bedingungen rechnet man in Ohio auf $80-90 \mathrm{hl}$, in Jowa auf $35 \mathrm{hl}$, in Indiana auf $27 \mathrm{hl}$ und eine sehr gute Ernte beträgt $54 \mathrm{hl}$, während früher bis $72 \mathrm{hl}$ erzielt wurden, Erträge, welche in diesem Staate durch den unausgesetzt betriebenen Maisbau nicht mehr vorkommen; in Italien werden bis 50 und $60 \mathrm{hl}$, in Portugal und Spanien 30-40 hl, in Ungarn 24-30 hl, in SüdDeutschland (Baden) 15-35 hl und im Mittel $22.5 \mathrm{hl}$ und in Brasilien $90 \mathrm{hl}$ pro ha produciert. 
Ueber das Verhältnis der Körner zu den Stengeln, Blättern, Hüllblättern und Spindeln geben die Versuchsresultate ron Salisbury in New-York und die von mir in Poppelsdorf angestellten Versuche mit italienischen, französischen, ungarischen, frühreifen amerikanischen und süddeutschen Sorten Aufschluss.

Es betringen an Gewichtsprocenten

bei 13 Sorten in

Früchte Spindeln Hüllblätter Blätter Stengel

New-York . 35 Proc. 10 Proc. 9.8 Proc. 20 Proc. 25.2 Proc. bei 23 Sorten in

Poppelsdorf .

$29,16,11.0$,

44 Proc.

im Durchschnitt: 32 Proc. 13 Proc. 10.4 Proc.

44.6 Proc.

Ueber die Frage, ob in Suid-Deutschland der Anbau des Maises noch lohnt, oder ob dies nicht der Fall, lässt sich folgendes sagen. Setzt man die Kulturkosten für Mais und Weizen gleich hoch und nimmt man den milden, tiefen, mergligen, frischen Lchmboden an, auf dem Mais und Weizen im Klima Süd-Deutschlands hohe Kornerträge aufbringen, nämlich durchschnittlich 23 hl (Baden) Weizen und 2.2.5 hl Nais (Baden), so stellt sich der mittlere Durchschnittsertrag für Weizen noch ein wenig höher als für Mais und wird der höhere Weizenpreis berücksichtigt, dann ergiebt sich durch Weizenbau ein nicht unerheblich höherer Reinertrag, ganz abgesehen von der besseren Verwendbarkeit des Wcizenstrohes.

Doch soll hierdurch nicht behauptet werden, dass die Kultur des Kornmaises in Verbindung mit Zwischenkulturen im Kleinbetriebe, sobald die Arbeit sehr gering berechnet wird, nicht lohnender als der Weizenbau sei.

Die Erträge an Futtermais schwanken zwischen 33.000 und $150.000 \mathrm{~kg}$ und belaufen sich im Mittel auf $80.000 \mathrm{~kg}$ pro ha.

An Nahrungsbestandteilen (verdaulichen und unverdaulichen) befinden sich:

\begin{tabular}{l|c|c|c|c|c|c}
\hline \hline \multirow{2}{*}{ im Maiskorn: } & $\begin{array}{c}\text { Trocken- } \\
\text { substanz. }\end{array}$ & $\begin{array}{c}\text { Nubstanz. } \\
\text { Sult. }\end{array}$ & Fett. & $\begin{array}{c}\text { N-freie } \\
\text { Substanz. }\end{array}$ & $\begin{array}{c}\text { Holz- } \\
\text { faser. }\end{array}$ & Asche. \\
& Proc. & Proc. & Proc. & Proc. & Proc. & Proc. \\
\hline Minimum & 80.5 & 5.8 & 4.1 & 59.0 & 1.5 & 1.1 \\
Maximum & 90.8 & 15.1 & 9.2 & 70.6 & 8.5 & 4.1 \\
Mittel & 87.6 & 9.9 & 5.6 & 63.4 & 4.2 & 2.5 \\
in den Spindeln: & & & & & & \\
Minimum & 85.6 & 1.2 & 0.1 & 45.3 & 36.1 & - \\
Maximum & 88.5 & 2.3 & 0.7 & 47.6 & 38.3 & 1.3 \\
Mittel & 87.0 & 1.8 & 0.4 & 46.5 & 37.2 & 1.3 \\
& & & & & &
\end{tabular}




\begin{tabular}{|c|c|c|c|c|c|c|}
\hline im Stroh: & $\begin{array}{c}\text { Trocken- } \\
\text { substanz } \\
\text { Proc. }\end{array}$ & $\begin{array}{c}\text { N-haltige } \\
\text { Substanz } \\
\text { Proc. }\end{array}$ & $\begin{array}{l}\text { Fett } \\
\text { Proc. }\end{array}$ & $\begin{array}{c}\text { N-freie } \\
\text { Substanz } \\
\text { Proc. }\end{array}$ & $\begin{array}{c}\text { Holzfaser } \\
\text { Proc. }\end{array}$ & $\begin{array}{l}\text { Asche } \\
\text { Proc. }\end{array}$ \\
\hline $\begin{array}{l}\text { Mittel } \\
\text { im Futtermais: }\end{array}$ & 86.0 & 3.0 & 1.1 & 37.9 & 40.0 & 4.0 \\
\hline $\begin{array}{l}\text { Minimum } \\
\text { Maximum } \\
\text { Mittel }\end{array}$ & $\begin{array}{l}12.81 \\
18.86 \\
15.00\end{array}$ & $\begin{array}{l}1.21 \\
2.23 \\
1.85\end{array}$ & $\begin{array}{l}0.24 \\
0.82 \\
0.56\end{array}$ & $\begin{array}{r}5.76 \\
10.59 \\
7.18\end{array}$ & $\begin{array}{l}3.29 \\
5.49 \\
4.39\end{array}$ & $\begin{array}{l}0.72 \\
1.48 \\
1.01\end{array}$ \\
\hline
\end{tabular}

Hiernach sind die Maiskörner nach dem Weizen am reichsten an Stärkemehl, und von allen Getreidearten am fettreichsten, doch am ärmsten an stickstoffhaltiger Substanz.

Im Allgemeinen enthält das Maiskorn mehr Wasser, und weniger Fett, Dextrin und Kleber, je nördlicher der Anbau erfolgt, nach Heuzé gebaut

$$
\text { im Elsass in Pisa in Ohio }
$$

Wasser . . . . . 17.00 Proc. 14.60 Proc. 10.00 Proc.

Eiweiss und Fett . . 7.00 " 11.16 " 12.37 "

Dextrin und Zucker . 1.50 " 8.60 , 14.40 "

Eine auffallende Erscheinung ist das Zusammenschrumpfen der Frïchte des Zuckermaises beim Austrocknen und führt Salisbury ${ }^{1}$ ) als Ursache desselben an, dass die Friichte sehr viel Albumin und Dextrin enthielten (ca. 28 Proc.), die reich an Wasser seien, so dass sie beim Trocknen ungefähr 85 Proc. ihrer Masse, also $1 / 6-1 / 7$ verlören. Aus diesem Grunde seien die Früchte vor der Reife noch vollkommen turgescent, schrumpfen aber durch den starken Wasserverlust beim Trocknen zusammen.

Den Beweis hierfür sucht er durch eine Analyse der Früchte zu erbringen, und stellen wir zur Vergleichung derselben eine Analyse des unter gleichen Verhältnissen gewachsenen, nicht lunzligen Tuscarora-Maises gegenuiber.

$$
\text { Zucker u. Zeï u. Dextrin u. }
$$

Large Rhode-

Stärke Extrakt Holzfaser Albumin Glutin Oel Gummi Wasser Island-Sweet-

$\begin{array}{lrrrrrrrr}\text { corn } & 15.16 & 20.80 & 13.04 & 15.64 & 3.68 & 9.92 & 12.32 & 10.22 \\ \text { Tuscarora } & 46.92 & 8.80 & 10.92 & 8.02 & 4.48 & 4.60 & 3.68 & 12.22 \text {. }\end{array}$

1) Salisbury, Maize or Indian-corn, Transact. of the N. Y. st. 1848. Vol. VIII, p. 836. 
Der mittlere Procentgehalt an verdaulichen Nährstoffen beträgt nach E. Wolff:

\begin{tabular}{|c|c|c|c|c|c|c|c|c|}
\hline \multirow{2}{*}{ im } & \multicolumn{3}{|c|}{$\begin{array}{c}\text { Procent-Gehalt } \\
\text { an }\end{array}$} & \multicolumn{3}{|c|}{$\begin{array}{l}\text { Mittl. Procentgeh. } \\
\text { an verdaul. Nähr- } \\
\text { stoffen }\end{array}$} & \multirow{2}{*}{$\begin{array}{l}\text { Wahr- } \\
\text { scheinl. } \\
\text { Nähr- } \\
\text { stoffver- } \\
\text { hältnis } \\
\text { wie 1: }\end{array}$} & \multirow{2}{*}{$\begin{array}{l}\text { Geldwert pro } 100 \mathrm{~kg} \\
\quad \text { in Mark. } \\
1 \mathrm{~kg} \text { verdaul. } \\
\text { Proteïn }=40 \\
\text { Kohlehydrate }=8, \\
\text { Fett }=40 "\end{array}$} \\
\hline & $\begin{array}{l}\text { Was- } \\
\text { ser }\end{array}$ & Asche & $\begin{array}{l}\text { Urg. } \\
\text { Sub- } \\
\operatorname{stanz}\end{array}$ & $\begin{array}{l}\text { Ei- } \\
\text { weiss }\end{array}$ & 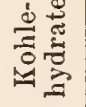 & Fett & & \\
\hline Maiskorn & 14.4 & 1.5 & 84.1 & 8.4 & 60.6 & 4.8 & 8.6 & 10.12 \\
\hline Spindeln & 13.0 & 1.3 & 85.7 & 0.6 & 41.7 & 0.4 & 71.2 & 3.74 \\
\hline Stengel & 15.0 & 4.2 & 80.8 & 1.1 & 37.0 & 0.3 & 34.4 & 3.52 \\
\hline Grünmais & 82.9 & 1.3 & 16.8 & 0.7 & 8.4 & 0.3 & 13.0 & 1.08 \\
\hline Sauermais & 79.3 & 1.5 & 19.2 & 0.6 & 10.3 & 0.5 & 19.3 & 1.26 \\
\hline
\end{tabular}

Durchschnittlich erhält man aus $100 \mathrm{~kg}$ Maiskörnern $93 \mathrm{~kg}$ Mehl, $5 \mathrm{~kg}$ Kleie und $2 \mathrm{~kg}$ Verlust, und es enthält dasselbe $11.5 \mathrm{~kg}$ Proteïnkörper, $67.1 \mathrm{~kg}$ Stärke, $13.4 \mathrm{~kg}$ Wasser und der Rest besteht aus Zucker, Fett und Gummi.

\section{Benutzung.}

Das Maismell dient zur Bereitung von Brot und Maisbrei, wovon sich ein grosser Teil der Bevölkerung Amerikas, Italiens, Portugals, Spaniens, des südwestlichen Frankreichs und südöstlichen Europas ernährt.

Gewöhnlich zieht man das Mehl der halbharten weissen Maissorten, dem der gelben vor.

Das nur aus Maismehl bereitete Brot ist jedoch altbacken, trocken und spröde, da der Klebergehalt des Mehles nicht zur Brotbereitung genẗgt, und dazu bäufig widerlich suiss.

Aus diesen Gründen lässt sich nur mit Hülfe einer Beimischung kleberreichen Roggen- oder Weizenmehles ein schmackhaftes, nährstoffreiches und sich genügend lange Zeit frisch erhaltendes Brot herstellen. In dieser Hinsicht empfiehlt sich die ron Bahr in Ungarn angewandte Methode. Bei dieser wird das Brot aus einem Drittel 
Mais- und zwei Dritteln Roggenmehl bereitet und soll 15 Proc. mehr Brot geben als reines Roggenmehl, da das Maismehl eine grössere Fähigkeit zur Wasseraufnahme besitzt; dabei soll die Preisersparnis gleichfalls 15 Proc. betragen und der höhere Nährwert sich auf $3 \frac{1}{2}$ Proc. beziffern.

Ueber dieses Brot äussert sich Birnbaum ${ }^{1}$ ) wie folgt:

${ }_{n}$ Vor einem Roggenbrot und einem Weizenbrot zeichnet sich Bahr's Brot ans durch seinen bedeutenden Gehalt an Fett, und ist dieses Brot in Bezug auf stickstoffhaltige Nährsubstanzen reinem Roggenbrot mindestens gleich, in Bezug auf stickstofffreie Nährstoffe - namentlich in Bezug auf Fett - ist es dem reinen Roggenbrot entschieden überlegen.

In Frankreich vermischt man 1 oder 2 Teile Maismehl mit 3 oder 4 Teilen Weizenmehl und stellt aus $100 \mathrm{~kg}$ Mehl $135-140 \mathrm{~kg}$ wohlschmeckendes, haltbares Brot her.

Ein Uebelstand beim Maismehl ist, dass es, in grösseren Partieen aufbewahrt, wegen seines hohen Fettgehaltes leicht ranzig wird und eine gelbliche Färbung annimmt, worunter der Gebrauchswert leidet. Durch Entfernung des Maiskeimes, der sehr ölhaltig ist, nach Verfahren von $\mathrm{Chiozza}{ }^{2}$ ) und H. Cavaye, wird ein reines, weisses, sich nicht leicht zersetzendes, ölfreies Mehl gewonnen, und zwar in der Gesammtquantität von 67 Proc. mit 78 Proc. Stärke, 6 Proc. Eiweisskörpern und 0.6 Proc. Asche. Ausserdem werden 10 Proc. Keimlinge erzielt, die 4-9 Proc. gut verwendbares Oel und als Ruickstand Maiskeimölkuchen liefern, die als Viehfutter geschätzt sind.

Der Mehlkörper wird auf Gries, Mehl und Stärke, oder auf fuselfreien Alkohol verarbeitet.

In weit ausgedehnterem Maasse als zur Brotbereitung findet das Mehl in der Herstellung des Maisbreis in Italien "Polenta", in Rumänien "Mamaliga", in Siebenbürgen „Paluchos", in Mexico "Atolli" oder "Atole“ genannt, Verwendung.

In der Regel rechnet man auf $1 \mathrm{~kg}$ Maismehl $2^{3 / 4}$ bis 3 Ltr. Wasser, doch ist es wichtig, wenn die Polenta die wünschenswerte Konsistenz erhalten soll, das richtige Verhältnis zwischen Mehl und Wasser zu finden, da nicht jedes Mehl die gleiche Absorptionsfähigkeit besitzt. Der Topf, in welchem die Polenta bereitet werden soll, darf höchstens bis zu zwei Drittteilen, da das Mehl stark quillt, mit Wasser gefullt und muss konisch sein, damit die Speise leicht herausgestürzt werden kann. In das kochende Wasser wird das Mehl unter stetem Umrühren hineingeschüttet, etwas Salz hinzugefügt und zehn

1) Das Brotbacken, Lehrb. der rat. Praxis der landw. Gewerbe, Bd. 29.

2) Journ. de l'Agric. 1876, I, pg. 286. 
Minuten lang gekocht. Hiernach lässt man den Brei ohne zu rühren noch so lange kochen, bis er sich vom Topfe ablöst und ausschïtten lässt. Die Polenta sieht alsdann wie ein Napfkuchen aus, lässt sich aber nicht mit dem Messer schneiden, sondern nur mit einem Faden oder Draht teilen. Genossen wird die Polenta mit Käse, Fett, brauner Butter, Fruchtsauce etc. Will man die Polenta als Reiseproviant verwenden, so schneidet man dieselbe in fingerdicke Scheiben, welche auf heissen Steinen geröstet werden und alsdann wie Schiffszwieback schmecken. In dieser Form werden die Kuchen in Rumänien „Mamaley" genannt, welche jeder Bauer unterwegs mit sich führt.

Bei der Billigkeit des Maises durfte diese nahrhafte Speise auch für Deutschland noch eine Zukunft baben.

Leider ist in denjenigen Ländern, in welchen die Polenta fast ausschliesslich zur Nahrung der ärmeren Bevölkerungsklassen dient, wie in Nord- und Mittel-Italien, im nördlichen Spanien, dem siidwestlichen Frankreich, im Banat und Rumänien eine schreckliche und abstossende Hautkrankheit unter dem Namen "Pellagra" bekannt.

Diese Krankheit trat in Europa zuerst 1735 in Spanien, 1740 in Italien, 1818 in Frankreich und seit 1829 in Rumänien auf und herrscht in allen diesen Ländern noch heutigen Tages und zwar über eine zwischen dem 42. und $46 .{ }^{\circ} \mathrm{n}$. Br. begriffenen Zone. Aeusserlich erscheint sie dem Beobachter als eine Hautkrankheit, die zunächst an denjenigen Teilen des Körpers auftritt, welche der Luft und der Sonne ausgesetzt sind - aber diese Krankheit der Haut ist nur das äussere Zeichen eines schweren inneren Leidens, welches alle Organe in Mitleidenschaft zieht und langsames, qualvolles Hinsterben des Betroffenen, nicht selten den Verlust der Vernunft zur Folge hat. Während des Winters scheint das schreckliche Uebel zu ruhen; kommt aber mit dem Frühling die heisse Sonne wieder, so wird an den Händen, im Gesicht, am Nacken die Epidermis erst rot und blättert ab, dann werden Lippen, Gaumen und Kehle in ähnlicher Wcise befallen und es stellt sich zugleich hartnäckige, keinem Mittel weichende Diarrhöe ein, welche den Patienten aller Kräfte beraubt. So kann man die Armen in der Lombardei, die ron der Pellagra befallen sind, umherschleichen sehen, matt und abgezehrt, fahl und erdfarben, als wären sie von der Malaria ergriffen. Das ist aber erst die erste Stufe der Krankheit. Im nächsten Jahre gesellen sich noch schlimmere Wirkungen hinzu: furchtbarer Kopfschmerz nebst heftigstem Fieber, Atemsnot und die Erscheinungen hochgradigen Skorbuts. Wirkt die Krankheit an sich nicht gleich tödlich, so zerrüttet sie den Körper doch in solchem Maasse, dass es nur des geringsten anderweitigen Anstosses bedarf, um einen tödlichen Ausgang herbeizuführen. 
Die Provinzialkommission von Mantua ${ }^{1}$ ) hat in einem besonderen Berichte iiber das Wesen und die Ausdehnung der Pellagra die Aufmerksamkeit der italienischen Regierung und Bevölkerung auf diese Krankheit gerichtet. Die Regierung Lat daraufhin zunächst eine statistische Erhebung im ganzen Lande angeordnet, und das Ministerium für Ackerbau und Handel ist damit beschäftigt, die Ergebnisse dieser Erhebung zu veröffentlichen. Es zeigt sich dabei, dass das Uebel viel weiter verbreitet ist, als man glaubte, dass nicht allein die Lombardei und Veneticn, sondern auch in beträchtlichem Masse die Emilia so wie mit geringeren Bruchteilen Toscana, die Marken und Umbrien, Ligurien, Piemont und endlich auch Latium betroffen sind. Die in der Lombardei im Jahre 1879 festgestellten chronischen Krankheitsfälle beziffern sich auf mehr als 40000 und bilden Ziveifünftel der Gesammtsumme für das ganze Königreich. Die Lombardei mit ihren unabsehbaren Mais- und Reisfeldern weist anch die grösste Procentzahl auf (11.76 auf 1000 Einwohner), ihr ganz nahe kommt Venetien (11.08), dann die Emilia mit 8.86, worauf die Procentzahl bei Toscana schon auf 2.21 sinkt, um endlich in Latium (0.09) ihren niedrigsten Stand zu erreiclien.

Der stete Genuss von Mais scheint die Hauptursache der Krankheit zu sein, denn die einzige Bedingung, wclche allen diesen inficierten Gebieten gemeinsam, ist die ausgedehnte Maiskultur und der Genuss des Maises als ausschliessliche Nahrung der ärmeren Bevölkerung. Merkwürdigerweise ist nun Ungarn, ein ebenfalls stark Mais bauendes Land, mit Ausnahme des Banats, von der Pellagra verschont geblieben, doch dient der Mais hier weniger als in anderen Ländern zur alleinigen Nahrung, sondern man benutzt ihn als Viehfutter und setzt ihn namentlich gern in Schweinefleisch um.

Ebenso ist es bemerkenswert, dass die Einführung der Maiskultur stets um einige Generationen dem Zeitpunkte vorausging, wo in den genannten Ländern die ersten Erkrankungsfălle beobachtet wurden.

Man hat angenommen, dass dem Körper durch Mais zu wenig Eiweiss zugeführt werde, denn da der Mais durchschnittlich nur 10 Proc. Eiweiss entbält und ein Erwachsener $120 \mathrm{gr}$ und bei schwerer Arbeit $130 \mathrm{gr}$ bedarf, müissten $1300 \mathrm{gr}$ Maismehl aufgenommen werden, ein Quantum, welches bcinahe Niemand zu iiberwältigen vermag und gewöhnlich wird kaum mehr als die Hälfte aufgenommen. Aehnliches findet aber auch bei der ausschliesslichen Reisnahrung der Inder und der Kartoffelnahrung der Irläinder statt, und dennocb wurde diese Krankheit hier nicht beobachtet.

1) La pellagra nella provincia di Mantova. Relazione della Commissione provinciale, Firenze 1878. 
Neuerdings behauptet nun Professor Lombroso in Turin, dass nur ranzig gewordenes Maismehl die Krankheit erzeuge, und erinnert daran, dass Mittel-Amerika deshalb die Krankheit nieht kenne, weil man nur gesundes Mehl verwende, auch glaubt er in einem alkoholisehen Extrakt das Gift "Pelagroseïn" gefunden zu haben. Ferner bestreitet er die Annahme, dass der Genuss brandigen Maises, der mit den Sporen von Ustilago Maydis DC oder mit einem Sehimmelpilz (Penicillium glaucum) behaftet sei, die Ursache zur Erzeugung der Krankheit abgebe.

Da dureh Trennung der Keimlinge vom Endosperm aus dem letztcren sich ein gut haltbares Mehl erzielen lässt, so sollten mit dem entölten Mehl Versuche angestellt werden, denn aus allem geht hervor, dass die eigentliche Ursache der Krankheit noch keineswegs erkannt ist.

In Mittel-Amerika werden aus dem Maismehl die von den Spaniern "Tortillas" genannten Kuchen hergestellt, indem man zuerst die Körner in Wasser mit wenig Kalk kocht, bis sie weich werden und sie dann enthülst. Hierauf verreibt man sie zwischen flachen Steinen zu einer feinen Masse, aus welcher runde, sehr diinne Kuchen geformt und auf einer erhitzten Thonplatte gebacken werden. Diese Tortillas werden warm verzehrt, weil sie dann am schmackhaftesten sein sollen.

Ein sehr wertvolles Produkt der Maiskörner ist die Maisstärke oder Maizena, welche jetzt in grossen Quantitäten in Nord-Amerika dargestellt wird und der Weizen- und Kartoffelstärke in Europa eine schwerwiegende Konkurrenz bercitet.

In Amerika gelten auch geröstetc Maiskörner als beliebte Speise und eignen sich zum Rösten besonders schnell aufspringende Sorten (Pop-Corn). Die reif gewordenen Körner werden in einen ringsum gesehlossenen Behälter von lïnglich-runder Form aus feingeflochtenem Eisendraht gebracht, dieser bis zur Hälfte gefüllt und unter fortwährendem Drehen und Schiitteln der Hitze glïhender Holzkoblen ausgesetzt. Die Körner platzen und rergrössern dabei ihren Umfang so beträchtlich, dass sie den ganzen Raum ausfüllen. Mit Leimwasser oder Gummi arabicum, und einem Zusatz ron Zueker oder Sirup vermischt, gibt man der Masse beliebige Formen und wird dieselbe als Naschwerk verkauft.

Ein ganz allgemein in Amerika geschätztes Gemiise liefert das Süss- oder Gartenkorn (Swect-eorn), dessen Zubercitung als Tafelgericht folgende ist. Die Kolben werden in der Halbreife, bevor das Korn anfängt hart zu werden, was jedoch Gesehmacksache ist, denn von Vielen wird reiferes Korn rorgezogen, gcerntet. Die vou ibren Hiullen befreiten Kolben werden mit etwas Salz gar gekocht, beiss aufgetragen und mit Butter und Gewïrzen genossen. 
Das Süsskorn säet man in den südlichen Staaten von Anfang Mai bis zum Juli, in den südlichsten sogar bis zum August in vierzehntägigen Zwischenräumen, so dass alle vierzehn Tage frisches Siisskorn geerntet werden kann.

Auch in Ungarn, Rumänien etc. findet junger Mais die gleiche Verwendung, wenngleich hier weniger die Sïsskornsorten, sondern gewöhnliche Maissorten in noch weichem Zustande gekocht, mit Salz bestreut und event. mit Butter bestrichen vom Kolben heruntergegessen werden.

Die Zubereitung geschieht in der Weise, dass der Boden eines Topfes mit den voll den Kolben gelösten Hüllblättcrn bedeckt wird, und hierauf legt oder stellt man die Kolben hinein, giesst kaltes Wasser auf und legt oben wiederum Hüllblätter auf. In der Regel ist daun nach zweistündigem Kochen der Mais wcich. Arme Leute essen auch den ganzen Winter über reif gewordenen Mais, doch ist derselbe, soll er einigermassen weich werden, vorher einzuquellen und einen halben Tag lang zu kochen.

Die jungen Maiskolben eignen sich, sobald die Pistille eingetrocknet sind, vorzïglich zun Einmachen. Zunächst werden sie von den Blättern und Hüllen befreit und von den Stielen abgeschnitten, darauf in Salzwasser weichgekocht und nach dem Herausnehmen auf ein trocknes Tuch gelegt, damit die Fenchtigkeit bald abziehen kann. Nachdem sie in Glasbüchsen gethan, wird guter Weinessig, der mit Zucker, etwas Zimmet und Gewürznelken abgekocht ist, darüber gegossen. Nach dem Abkühlen werden die Bïchsen verkorkt und verlackt und an einem kühlen Orte bis zum Verbrauch aufbewahrt.

Das Süsskorn kommt auch als Präserve vor. Zu dem Zweck werden die Körner, nachdem sie mit etwas Salz halb gar gekocht sind, abgeschnitten resp. mit einer Maschine von den Kolben abgeschält, in eine Blechbüchse gebracht, und diese in Wasser ron $110^{\circ}$ C. gestellt und verlötet. Zum Gebrauch wird das Korn erwärmt und mit den nötigen Zuthaten versehen.

Aus der Maisstärke bereitet man auch Zucker oder Sirup und zwar geben die besten Maiskornsorten auf $100 \mathrm{~kg}$ Korn ca. $56 \mathrm{~kg}$ Stärke und diese bis zu $60 \mathrm{~kg}$ Zucker oder Sirup.

Diese Produktc werden von Bierbrauern, Weinbändlern, Konditoren etc. rerbraucht, auch stellt man durch Hinzufügung anderer Stoffe, wahrscheinlich durch Rohrzucker, einen wohlschmeckenden Tafelsirup her.

Ferner wird der Maissirup zum Vermischen mit Californiahonig verkauft, weil er mit diesem in Farbe und anderen Eigenschaften Aehnlichkeit hat. Es wird einer Gallone Honig mindestens eine Gallone Maissirup zugesetzt; diese Mischung wird dann als Honig 
nicht bloss an die Konsumenten im Inlande abgesetzt, sondern auch nach Europa versohifft.

Diese Maiszuckerfabrikation aus Maisstärke gewinnt einen immer bedeutenderen Umfang und kann der Rohrzuckerindustrie nicht gleichgiiltig sein.

Die Darstellung von Sirup aus dem Saft des Maisstengels, welche schon den alten Mexikanern bekannt war und auf die vielfach zu Ende des vorigen und Anfang dieses Jahrhunderts aufmerksam gemacht wurde, scheint nicht wieder anfleben zu wollen, da sie sich nicht rentiert, denn, wenn $\mathrm{Bur} \mathrm{ger}^{1}$ ) anführt, dass 1 ha kastrierter Maisstengel 1600 Pfund Sirup geliefert und Ries in Ofen p. ha 160-225 Pfund Zucker erhalten hätte, so ist dies gegen die 50-60 Ctr. Zucker aus Zuckerriben so wenig, dass eine Konkurrenz nicht möglich ist.

Ferner bereitet man in Mexiko aus den Maisstengeln ein gegorenes Getränk, namens Pulque. In Siid-Amerika braut man ans Mais das sog. Maisbier (Chicha oder Chica). In Portugal wird zur Bierbereitung neben anderem Getreide ebenfalls Mais verwandt.

In neverer Zeit wird der Mais vielfach in Dentschland an Stelle des teuren Roggens in grossen Quantitäten zur Spiritusbereitung benutzt und liefern $100 \mathrm{~kg}$ Maismehl ca 26-28 Ltr. sehr reinschmeckenden feinen Sprit und ca. 2.5 Ltr. Oel, das zum allgemeinen Gebrauch dienen kann.

Schliesslich gewinnt man eine Hefe, welche die Bierhefe ersetzen soll.

Was nun die Fitterung unserer Haustiere mit Maiskörnern anbetrifft, so lässt sich darüber kurz folgendes mitteilen.

Den Pferden wird der Mais in grob geschrotenem Zustande gereicht und hat sich gezeigt, dass die Maisfütterung bis zur Hälfte des zu gebenden Körnerfutters bei reichlich ernährten Tieren, ron welchen eine gleichmässige Zngarbeit verlangt wird, ohne besonders hervortretenden Nachteil durchgeführt werden kann, während sie fül minder reichlich gefütterte Pferde, von denen zeitweise eine das gewöhnliche Arbeitsmass bedeutend überschreitende Dienstleistung gefordert wird, also besonders für Soldatenpferde, nicht geeignet ist.

Für Rindvieh schrotet man den Mais und brïht ihn mit heissem Wasser an. Den Schafen reicht man die Körner gern in gequollenem Zustande, und weicht sie zu diesem Zweck 24 Stunden in Salzwasser ein.

Für Mastschweine ist der Mais eines der besten Futtermittel, denn er liefert einen kernigen Speck. Am zweckmässigsten wird er den Schweinen in Schrotform und wo möglich angebriht, gegeben.

1) Naturg. d. Mais 1809. 
Ebenso ist der zerkleinerte Mais auch für Geflügel ein beliebtes und wirksames Futter. Die Hühner verzehren mit Begierde die kleinkörnigen Maissorten und legen darnach fleissig.

Die Maisspindeln werden rom Rindvieh, wenn in Salzwasser 24-48 Stunden eingeweicht, gern gefressen; in Amerika zerreisst man sie vorher.

Das Stroh wird den Tieren zur Nahrung vorgelegt und suchen sich dieselben danu die feineren nahrhafteren Teile heraus. Als Streumaterial ist dasselbe jedoch wertlos.

Aus der Holzfaser der Hüllblätter, aber auch der gewöhnlichen Blätter und Stengel, wird namentlich in Oesterreich ein recht gutes Papier gefertigt. Am besten ist das Papier aus den Hüllblättern, von denen $100 \mathrm{~kg}$ ca. $20 \mathrm{~kg}$ Papier liefern; auch werden aus ihnen in Amerika Hiite, und in Guatemala und Cuba Cigarrenhüllen hergestellt.

In Frankreich benutzt man die Spindeln als Feueranzünder, indem man sie eine Minute lang in ein Bad von 60 Teilen Harz und 40 Teilen Teer taucht und trocknen lïsst.

Sehr wichtig ist ferner die Verwendung des grünen Futtermaises in den warmen, häufig an Dürre leidenden Ländern als Viehfutter, weil hier die Wiesen und Weiden fehlen; aber auch im feuchteren, kälteren, gemässigten Klima liefert er im Herbst ein beachtenswertes Futter.

Der Grünmais wird seines Zuckergehaltes wegen von allem Vieh ausserordentlich gern gefressen und bietet er nicht allein, bei Herstellung eines passenden Nährstoffverhältnisses durch Kraftfuttermittel, ein vorzügliches auf die Qualität und Quantität der Milch gunstig wirkendes Futter, sondern auch Mastfutter und wird ihm nachgerühmt, dass er sehr schmackhaftes Fleisch erzeuge. Kühe verzehren 50 bis $60 \mathrm{~kg}$ Grïnmais pro Tag.

Zur Unterhaltung der Stallfütterung, namentlich in den Monaten August, September und Oktober, ist er im hohen Grade verwendbar.

Bekanntlich lässt sich der Grünmais nur sehr schwierig zu Heu werben, weshalb meist sog. Sauerfutter aus ihm bereitet wird, wobei durch die eintretende Gährung Verluste an leicht verdaulichen Nährstoffen entstehen, und zwar nicht nur an Kohlehydraten, sondern auch an Eiweissstoffen, wie die Untersuchungen Stutzer's ${ }^{1}$ ) ubereinstimmend zeigten, indem der überwiegend grösste Teil der Stickstoff-Substanz aus Zersetzungsprodukten der Eiweissstoffe bestand, welche im Nährwerte den Eiweissstoffen nicht an die Seite gestellt werden können, und betrug die Menge der leicht verdaulichen Eiweissstoffe nur 
einige Zehntel Procent. Demnach liegt es auf der Hand, dass der Mais durch das Einsäuern an Nährkraft bedeutend verliert.

Aus diesen Gründen ist bei Verfütterung des den Tieren wohlschmeckenden Sauermaises die Zugabe an Eiweissstoffen richtig zu bemessen, um jeglicher Futterverschwendung vorzubengen, und wird der Eiweisszusatz entsprechend dem geringen Eiweissgehalt des Sauermaises, sehr hoch zu stellen sein.

Auf $1000 \mathrm{~kg}$ leb. Gewicht nimmt das Rindvieh $120 \mathrm{~kg}$ Sauermais auf.

Nach einer Zusammenstellung von König ${ }^{1}$ ) finden sich im Sauermais und im Braunmais (Griinmais abgewelkt eingemacht):

\begin{tabular}{|c|c|c|c|c|c|c|c|}
\hline & $\begin{array}{c}\text { Was- } \\
\text { ser } \\
\text { Proc. }\end{array}$ & $\begin{array}{l}\text { Roh- } \\
\text { proteïn } \\
\text { Proc. }\end{array}$ & $\begin{array}{l}\text { Roh- } \\
\text { fett } \\
\text { Proc. }\end{array}$ & $\begin{array}{c}\text { N-freie } \\
\text { Extrakt- } \\
\text { stoffe } \\
\text { Proc. }\end{array}$ & $\begin{array}{l}\text { Holz- } \\
\text { faser } \\
\text { Proc. }\end{array}$ & $\begin{array}{l}\text { Asche } \\
\text { Proc. }\end{array}$ & $\begin{array}{l}\text { Sand } \\
\text { Proc. }\end{array}$ \\
\hline Grünmais frisch & 79.35 & 0.90 & 0.76 & 10.82 & 6.67 & 0.63 & 0.87 \\
\hline Als Sauermais aus $42 \mathrm{~cm}$ Tiefe & 57.69 & 1.86 & 1.88 & 7.48 & 18.32 & 1.90 & 1.84 \\
\hline " $\quad 84, \quad$, & 77.84 & 1.06 & 1.08 & 7.48 & 10.38 & 1.01 & 1.21 \\
\hline Als Braunmais „ $85 \mathrm{~cm}$ Tiefe & 78.10 & 1.18 & 1.25 & 10.40 & 7.63 & 0.88 & 0.56 \\
\hline$" \quad, 170, "$, & 80.40 & 0.87 & 0.95 & 9.85 & 6.39 & 0.80 & 0.84 \\
\hline
\end{tabular}

1) Ueber den Grünmais etc. Deutsche 1. Presse 1882 Nr. 31. 


\title{
Rispenlirse.
}

\section{Panicum miliaceum L.}

\author{
Einteilung.
}

\section{Gruppe I. Effusum Al. Rispenhirse.}

\section{Varietät: Panicum miliaceum candidum Kcke.}

\section{Weisse Rispenhirse.}

Rispe: unreif grüngelb, reif rötlich-gelb, mit sehr langen Aesten, deren überhängende Spitzen ein wenig zusammengezogen sind, locker, armsamig, gross, $25 \mathrm{~cm}$ (Max. $30 \mathrm{~cm}$ ) lang. - Stroh: gelbgrün bis orange, ziemlich blattreich, fest, kaum mittellang. - Scheinfrucht: gelblich-weiss und rein weiss, oval (3 $\mathrm{mm}$ lang, $2 \mathrm{~mm}$ breit), glänzend.

Halme gelbgrün, diese, sowie die Blattscheiden mit wagerecht abstehenden Haaren besetzt, die Blattspreiten weniger behaart; 1.9 Schösslinge, Halm $90 \mathrm{~cm}$ (Max. $110 \mathrm{~cm}$ ) lang, $0.63 \mathrm{~cm}$ dick, Blattzahl 5.5, Blätter $30 \mathrm{~cm}$ lang, $1.7 \mathrm{~cm}$ breit, Blattfäche $561 \mathrm{qcm}$, Halmfläche $170 \mathrm{qcm}$, Gesammtfäche $731 \mathrm{qcm}$.

Spät schossend und blühend (in 88 Tagen), etwas spät nach 110 Tagen reifend. Scheinfrüchte leicht ausfallend.

Auf 1 ha wachsen 2.5 Millionen Pflanzen, mithin beträgt das Saatquantum, da 15 Millionen Körner auf $1 \mathrm{hl}$ (= $70 \mathrm{~kg}$, leicht, weil nicht ganz reif geworden) entfallen, bei Drillsaat $0.23 \mathrm{hl}$ p. ha.

Diese Hirse wird nur im wärmeren gemässigten Klima erfolgreich kultiviert, so in Süd-Russland, Italien, Süd-Frankreich, Spanien und Portugal und erhielten wir aus letzterem Lande eine mit dieser identische Sorte durch Prof. Jul. Henriques aus Coïmbra zugesandt.

Varietät: Panicum miliaceum cinereum Al.

\section{Graue Rispenhirse.}

Eng 1.: Grey-seeded-Millet.

Franz.: Millet gris verdâtre.

Rispe: reif rötlich-gelb, sonst grüngelb, sehr ausgebreitet, locker, im Mittel $25 \mathrm{~cm}$ (Max. $30 \mathrm{~cm}$ ) lang; Aehrchen oval, 1-samig, mit bauchiger, gestreifter Klappe, unbegrannt. - Stroh: gelbgrün, fest. - Scheinfrucht: aschgrau, gestreift, oval, glänzend.

Halme gelbgrün, Halme und Blattscheiden mit wagerecht abstehen- 
den Haaren bedeckt, obere Blattspreite fein behaart, untere kahl; 3.2 Schösslinge, Halm $100 \mathrm{~cm}$ (Max. $120 \mathrm{~cm}$ ) lang, $0.5 \mathrm{~cm}$ dick, Blattzahl 5, Blätter $25.2 \mathrm{~cm}$ lang, $1.4 \mathrm{~cm}$ breit, Blattfläche $352.8 \mathrm{qcm}$, Halmfläche $150 \mathrm{qcm}$, Gesammtfläche zur Blütezeit $502.8 \mathrm{qcm}$.

Zeitig schossend und blühend (nach 66 Tagen), mittelfrüh nach 105 Tagen reifend. Scheinfrüchte ziemlich leicht ausfallend.

Auf 1 ha wachsen 2 Millionen Pflanzen, mithin beträgt das Saatquantum, da 15.2 Millionen Körner auf $1 \mathrm{hl}(=78.5 \mathrm{~kg})$ entfallen, bei Drillsaat $0.18 \mathrm{hl}$ p. ha.

Diese Hirse zeigte sich konstant in Rispen und Frïchten, soll sich wild in Indien ${ }^{1}$ ) finden, und wird, soweit das Weinklima reicht, so in Baden, Hessen, Baiern, Oesterreich-Ungarn, Süd-Russland und in Italien kultiviert.

In Proskau wurden 1871 auf Sandboden nach gedüngtem Roggen geerntet :

$26 \mathrm{hl}=1664 \mathrm{~kg}$ Köörner, $2550 \mathrm{~kg}$ Stroh, $246 \mathrm{~kg}$ Spreu.

Varietät: Panicum miliaceum flavum Kcke.

\section{Gelbe Rispenhirse.}

Engl.: Common Millet.

Rispe : rötlich-gelb, ein wenig zusammengezogen, überhängend, $25 \mathrm{~cm}$ (Max. $30 \mathrm{~cm}$ ) lang. - Stroh: schmutzig-gelbgrin, fest. - Scheinfrucht: blassgelb (gerundeter und dunkler als bei subvar. bosnicum), oval ( $3 \mathrm{~mm}$ lang, $2 \mathrm{~mm}$ breit), glänzend.

Halme gelbgruin mit 1-2 Seitensprossen; Halme und Blattscheiden rauhhaarig, Blattspreiten schwach behaart; Schösslinge 1.S, Halm $25 \mathrm{~cm}$ (Max. $30 \mathrm{~cm}$ ) lang, $0.5 \mathrm{~cm}$ dick, Blattzahl 5, Blätter $23.6 \mathrm{~cm} \mathrm{lang,} 1.4 \mathrm{~cm}$ breit, Blattfläche $330.4 \mathrm{qcm}$, Halmfläche $142.5 \mathrm{qcm}$, Gesammtfläche zur Blütezeit $472.9 \mathrm{qcm}$. reifend.

Mittelfrüh schossend und blühend (in 76 Tagen), nach 102 Tagen

Auf 1 ha wachsen 4 Millionen Pflanzen, mithin beträgt das Saatquantum, da 17.8 Millionen Körner auf $1 \mathrm{hl}(=78 \mathrm{~kg})$ entfallen, bei Drillsaat $0.31 \mathrm{hl}$ p. ha.

\section{Gelbe Rispenhirse aus Bosnien.}

Rispe: grün, an der Spitze rötlich, etwas zusammengezogen, $25 \mathrm{~cm}$ (Max. $30 \mathrm{~cm}$ ) lang. - Stroh: gelbgrïn, kräftig. - Scheinfrucht: blassgelb, oval, (3 mm lang, $2 \mathrm{~mm}$ breit), glänzend.

Halme gelbgrïn, rauhhaarig, nur Blattspreite etwas weniger stark behaart; zuweilen Seitensprossen auftretend; 2.2 Schösslinge, die kräftigsten, bestentwickelten Pflanzen erreichten eine Höhe von $130 \mathrm{~cm}$ (Max. $140 \mathrm{~cm}$ ), und $0.8 \mathrm{~cm}$ Dicke, Blätter $33 \mathrm{~cm} \mathrm{lang,} 2 \mathrm{~cm}$ breit, Blattzahl 9, Blattläche $1178 \mathrm{qcm}$, Halmfläche $312 \mathrm{qcm}$, Gesammtfläche zur Blütezeit $1490 \mathrm{qcm}$.

Sehr spät, meist erst Ende September schossend und nach 108

1) Metzger, Landw. Pflkunde. I. 1841 pg. 201. 
Tagen blühend; die wenigen Pflanzen, welche in Poppelsdorf zur Reife gelangten, gebrauchten eine Vegetationszeit von 140 Tagen.

Auf 1 ha wachsen 1.2 Millionen Pflanzen, mithin beträgt das Saatquantum, da $1 \mathrm{hl} 14.6$ Millionen Körner enthält, bei Drillsaat $0.11 \mathrm{hl}$ $(1 \mathrm{hl}=75 \mathrm{~kg})$ p. ha.

Diese Hirse wurde 1869 rom preussischen, landwirtschaftlichen Ministerium zur Untersuchung eingesandt, und ist dieselbe nur für SüdEuropa von Wert, wo sie in grossem Umfange angebaut wird.

Wir erhielten vollständig identisehe Formen als Mijo del Llobregat und Mill Hospitalet durch Antonio Cipriano Costa aus Barcelona und durch Jul. Henriques aus Coïmbra, Portugal, als „Hirse aus Ponte da Sòr" zugesandt.

\section{Varietät: Panicum miliaceum laetum Kcke.}

\section{Hellrote Rispenhirse.}

Rispe: reif rötlich-gelb, ausgebreitet, sehr locker, im Mittel $20 \mathrm{~cm}$ (Max. $25 \mathrm{~cm}$ ) lang; Klappen rötlich; Stroh: gelbgrün, steif. - Scheinfrucht: hellrot, oval ( $3 \mathrm{~mm}$ lang, $2 \mathrm{~mm}$ breit), glänzend.

Halme gelbgrün, mit 1-2 Seitensprossen, und abstehenden, langen Haaren besetzt, Blätter auf dcr Unterseite sehr schwach, auf der Oberseite stärker behaart; 1.2 Schösslinge, Halm $70 \mathrm{~cm}$ (Max. $80 \mathrm{~cm}$ ) lang, $0.43 \mathrm{~cm}$ dick, Blattzahl 6, Blätter $22.3 \mathrm{~cm}$ lang, $1.35 \mathrm{~cm}$ breit, Blattfäche $361.26 \mathrm{qcm}$, Halmfläche $90.3 \mathrm{qcm}$, Gesammtfläche zur Blütezeit $451.56 \mathrm{qcm}$. reifend.

Zeitig schossend und blühend (in 74 Tagen), zeitig nach 96 Tagen

Auf 1 ha wachsen 6 Millionen Pflanzen, mithin beträgt das Saatquantum, da 15 Millionen Körner auf $1 \mathrm{hl}(=78 \mathrm{~kg})$ entfallen, bei Drillsaat $0.54 \mathrm{hl}$ p. ha.

Wegen ihrer Frühreife wohl noch über die Grenzen des Weinklimas hinaus kultivierbar.

\section{Varietät: Panicum miliaceum coccineum Keke.}

\section{Rote Rispenhirse.}

Rispe: dunkelbraun, an der Spitze ein wenig zusammengezogen, überhängend, locker, $20 \mathrm{~cm}$ (Max. $30 \mathrm{~cm}$ ) lang. - Stroh: grünlich-gelb, teilweise dunkelblutrot, Blätter ebenfalls blutrot, mittellang. - Scheinfrucht: blassrot, am hellsten von allen rotfrïchtigen Sorten, oval (3 $\mathrm{mm}$ lang, $2 \mathrm{~mm}$ breit), glänzend.

Halme und Blattscheiden rauh behaart, Blattspreiten oben schwach behaart, unten fast kahl, meist blutrot umrandet. Halm mit $1-5$ Seitensprossen; Schösslinge 1.3, Halm $95 \mathrm{~cm}$ (Max. $140 \mathrm{~cm}$ ) lang, $0.4 \mathrm{~cm}$ dick, Blätter $22.2 \mathrm{~cm}$ lang, $1.4 \mathrm{~cm}$ breit, Blattzahl 6, Blattfläche $372.96 \mathrm{qcm}$, Halmfläche $141 \mathrm{qcm}$, Gesammtfläche zur Blütezeit $514 \mathrm{qcm}$.

Mittelfrüh schossend und blühend (in 76 Tagen), mittelfrüh nach 108 Tagen reifend. Scheinfrüchte weniger leicht als bei anderen Sorten ausfallend.

Auf 1 ha wachsen 5 Millionen Pflanzen, mithin beträgt das Saatquantum, da 17 Millionen Körner auf $1 \mathrm{hl}(=77 \mathrm{~kg})$ entfallen, bei Drillsaat $0.40 \mathrm{hl} \mathrm{p.} \mathrm{ha.}$ 
Eine rote Rispenhirse aus Ungarn, welche Körnicke 1873 auf der Wiener Ausstellung fand, verhielt sich im Habitus genau wie obige Sorte, doch variierte sie in der Farbe ihrer Scheinfrüchte, welche gesättigt orangerot und am dunkelsten von allen Sorten der Varietät coccineum war.

Diese Sorte wird wohl kaum noch in Nord-Deutschland mit Erfolg angebaut werden können.

In Proskau, Schlesien, lieferte sie 1871 auf Sandboden nach gedïntem Roggen:

$27.75 \mathrm{hl}=1776 \mathrm{~kg}$ Korn, $3120 \mathrm{~kg}$ Stroh, $276 \mathrm{~kg}$ Spreu.

\section{Varietät: Panicum miliaceum badium Kcke.}

\section{Braune Rispenhirse.}

Rispe: unreif grün, reif hellrötlich, sehr locker, lang, im Mittel $28 \mathrm{~cm}$ lang. - Stroh: gelbgrün, mittellang, steif. - Scheinfrüchte: rotbraun, oval (3 mm lang, $2 \mathrm{~mm}$ breit), glänzend.

Halme gelbgrün, mit 1-2 Seitensprossen, Blattscheiden und Halm mit wagerecht abstehenden, langen Haaren besetzt, Blattspreite an Oberund Unterseite dicht behaart; 2.7 Scnösslinge, Halm $90 \mathrm{~cm}$ lang, $0.38 \mathrm{~cm}$ dick, Blattzahl 5, Blätter $19 \mathrm{~cm}$ lang, $1.31 \mathrm{~cm}$ breit, Blattfläche $248.9 \mathrm{qcm}$, Halmfläche $102.6 \mathrm{qcm}$, Gesammtfläche zur Blütezeit $351.5 \mathrm{qcm}$.

Mittelfrüh schossend und blühend (in 80 Tagen), etwas spät, in 110 Tagen reifend. Scheinfrïchte leicht ausfallend.

Auf 1 ha wachsen 3.5 Millionen Pflanzen, mithin beträgt das Saatquantum, da 13.4 Millionen Körner auf $1 \mathrm{hl}(=76 \mathrm{~kg}$ ) entfallen, bei Drillsaat $0.35 \mathrm{hl}$ p. ha.

In Poppelsdorf stand diese Hirse in warmen Sommern kräftig und schön, doch sind auch von ihr befriedigende Erträge nur im wärmeren, gemässigten Klima zu erlangen.

\section{Hohe braune Rispenhirse.}

Rispe: gelblich-grün oder blassrot, letztere Farbe, wenn gut ausgereift, sehr locker, $25 \mathrm{~cm}$ lang. - Stroh: gelblich-grün, selır lang und blattreich, kräftig. - Scheinfrucht glänzend braunschwarz, oval $(3 \mathrm{~mm}$ lang, $2 \mathrm{~mm}$ breit).

Halme und Blattscheiden rauhhaarig, Blattspreiten oben schwach behaart, unten kahI; 2.3 Schösslinge, Halm $130 \mathrm{~cm}$ (Max. $155 \mathrm{~cm}$ ) lang, Blattzahl 8, Blätter $36 \mathrm{~cm}$ lang, $1.8 \mathrm{~cm}$ breit, Blattfläche $1036.8 \mathrm{qcm}$, Halmfläche 253.5 qcm, Gesammtfläche zur Blütezeit $1290.3 \mathrm{qcm}$.

Sehr spät schossend und blühend (in 104 Tagen), selten in Poppelsdorf gut ausreifend, meist schosste die Pflanze erst Mitte August, einige reiften in warmen Sommern in einer Vegetationszeit von 130 Tagen.

Auf 1 ha wachsen 1.5 Millionen Pflanzen, mithin beträgt das Saatquantum, da 17.3 Millionen Körner auf $1 \mathrm{hl}(=75 \mathrm{~kg})$ entfallen, bei Drillsaat $0.12 \mathrm{hl} \mathrm{p}$. ha.

Nur für wärmere Klimate geeignet. 


\section{Varietät: Panicum miliaceum aereum Kcke.}

\section{Broncierte Rispenhirse.}

Rispe: unreif grün, reif grünlich-gelb bis hellrötlich, mit ziemlich langen Aesten, armsamig, locker, im Mittel $18 \mathrm{~cm}$ (Max. $27 \mathrm{~cm}$ ) lang. Stroh: gelbgrün, sehr kurz, steif. - Scheinfrucht: broncefarben, hell gestreift, oval ( $3 \mathrm{~mm}$ lang, $2 \mathrm{~mm}$ breit), glänzend.

Halme gelbgrün mit 2 Seitensprossen, Halme und Blattscheiden behaart, obere Blattspreite stark behaart, untere fast kahl; 1.6 Schösslinge, Halm $65 \mathrm{~cm}$ lang (Max. $75 \mathrm{~cm}$ ), $0.37 \mathrm{~cm}$ dick, Blattzahl 4, Blätter $18.7 \mathrm{~cm}$ lang, $1 \mathrm{~cm}$ breit, Blattflächc $149.6 \mathrm{qcm}$, Halmfläche 72.2 qcm, Gesammtfläche zur Blütezeit $221.8 \mathrm{qcm}$.

Ziemlich früh schossend und blühend (in 76 Tagen), mittelfrüh nach 104 Tagen reifend. Scheinfrüchte ziemlich leicht ausfallend.

Auf 1 ha wachsen 7 Millionen Pflanzen, mithin beträgt das Saatquantum, da 15.2 Millionen Körner auf $1 \mathrm{hl}(=79 \mathrm{~kg})$ entfallen, bei Drillsaat $0.63 \mathrm{hl}$ p. ha.

Diese Hirse bezog der Akklimatisations-Verein zu Berlin aus Frankreich und berichtet $\mathrm{Bouch} \mathrm{e}^{1}$ ) 1866 über dieselbe, dass sie, bei Berlin kultiviert, ertragreich und frühreif sei.

Im Allgemeinen scheint dieselbe vorzugsweise im wärmeren, gemässigten Klima kultiviert zu werden, und erhielten wir von Prof. Jul. Henriques zu Coïmbra, Portugal, eine dieser vollkommen identische Sorte.

\section{Varietät: Panicum miliaceum nigrum Al.}

\section{Schwarze Rispenhirse.}

Engl.: Black-seeded Millet.

Franz.: Millet noir.

Rispe: meist hellrötlich, wenn nicht ganz reif, dann braun, ausgebreitet, locker, im Mittel $20 \mathrm{~cm}$ (Max. $30 \mathrm{~cm}$ ) lang. - Stroh: schmutzig. gelbgrün, fest. - Scheinfrucht: grünlich-grauschwarz, oval, $3 \mathrm{~mm}$ lang, $2 \mathrm{~mm}$ breit, glänzend.

Halme gelbgrün, oft mit 2-3 Seitensprossen; Halme und Blatt. scheiden rauhhaarig. Haare wagerecht abstehend, obere Blattspreite behaart, untere fast unbehaart und glänzend; 1.6 Schösslinge, $H a l m ~ 100 \mathrm{~cm}$ (Max. $120 \mathrm{~cm}$ ) lang, 0,43 cm dick, Blattzahl 5, Blätter $21.6 \mathrm{~cm}$ lang, $1.3 \mathrm{~cm}$ breit, Blattfläche $280.8 \mathrm{qcm}$, Halmfläche $129 \mathrm{qcm}$, Gesammtfläche zur Blütezeit $409.8 \mathrm{qcm}$.

Zeitig schossend und blühend (in 66 Tagen), nach 95 Tagen reifend. Scheinfrüchte sehr leicht ausfallend.

Auf 1 ha wachsen 5 Millionen Pflanzen, mithin beträgt das Saatquantum, da 19 Millionen Körner auf $1 \mathrm{hl} \mathrm{(=76} \mathrm{kg)} \mathrm{entfallen,} \mathrm{bei}$ Drillsaat $0.35 \mathrm{hl}$ p. ha.

Sie lässt sich, soweit als das Weinklima reicht, und auf leichtem, warmem Boden noch darüber hinans, anbauen. In neuerer Zeit wird sie viel im östlichen Nord-Amerika kultiviert.

Konstant in Rispen und Früchten.

1) Annalen d. Landw. 1866 pg. 32. 


\section{Gruppe II. Contractum Al. Klumphirse.}

\section{Varietät: Panicum miliaceum album Al. \\ Weisse Klumphirse.}

Engl.: White seeded Millet.

Franz.: Millet à graines blanches.

Rispe: unreif grün, reif rötlich, ziemlich dicht zusammengezogen, überhängend, $20 \mathrm{~cm}$ (Max. $27 \mathrm{~cm}$ ) lang. - Stroh: gelblich-grün, blattreich, lang. - Scheinfrucht: weiss, einige schwach gelblich, oval (3 mm lang, $2 \mathrm{~mm}$ breit), glänzend.

Halme gelbgrïn, besitzen wenig Neigung zur Bildung vor Halmsprossen; Halme und Blattscheiden steif-borstig, Blätter unten fast kahl, oben mit wagerecht abstehenden Haaren besetzt; 2 Schösslinge, Halm $120 \mathrm{~cm}$ (Max. $150 \mathrm{~cm}$ ) lang, $0.6 \mathrm{~cm}$ dick, Blattzahl 8, Blätter $27.4 \mathrm{~cm}$ lang, $18 \mathrm{~cm}$ breit, Blattfläche $789.12 \mathrm{qcm}$, Halmfläche $216 \mathrm{qcm}$, Gesammtfläche zur Blütezeit $1005.12 \mathrm{qcm}$.

Spät schossend und blühend (in 85 Tagen) und nach 105 Tagen reifend. Scheinfrüchte ziemlich leicht ausfallend.

Auf 1 ha wachsen 2 Millionen Pflanzen, mithin heträgt das Saatquantum, da 14.8 Millionen Körner auf $1 \mathrm{hl}(=72 \mathrm{~kg})$ entfallen, bei Drillsaat $0.18 \mathrm{hl}$ p. ha.

Im Weinklima kultivierbar.

Varietät: Panicum miliaceum griseum Kcke.

\section{Graue Klumphirse.}

Rispe: grünlich-gelb bis hellrötlich, stark zusammengezogen, überhängend, $20 \mathrm{~cm}$ ( \ах. $25 \mathrm{~cm}$ ) lang. - Stroh: gelbgrün, mittellang. Scheinfrucht: grau und graugelb, oval ( $3 \mathrm{~mm}$ lang, $2 \mathrm{~mm}$ breit), glänzend.

Halme und Blattscheiden stark behaart, Blattspreiten fast kahl und Unterseite glänzend; 2 Schösslinge, $H a l m 110 \mathrm{~cm}$ (Мax. $130 \mathrm{~cm}$ ) lang, $0.53 \mathrm{~cm}$ dick, Blattzahl 5, Blätter $24.6 \mathrm{~cm}$ lang, $1.7 \mathrm{~cm}$ breit, Blattfläche $418.2 \mathrm{qcm}$, Halmfläche $174.9 \mathrm{qcm}$, Gesammtfläche zur Blütezeit $592.1 \mathrm{qcm}$.

Zeitig schossend und blühend (in 74 Tagen), nach 92 Tagen reifend. Scheinfrüchte weniger leicht als bei anderen Sorten ausfallend.

Auf 1 ha wachsen 3.5 Millionen Pflanzen, mithin beträgt das Saatquantum, da 16.8 Millionen Kö̈rner auf $1 \mathrm{hl}(=80 \mathrm{~kg})$ entfallen, $0.28 \mathrm{hl} \mathrm{p}$. ha bei Drillsaat.

Diese Sorte lässt sich wegen ihrer Frühreife noch in Nord-Deutschland recht gut kultivieren.

\section{Varietät: Panicum miliaceum aureum Kcke.}

\section{Gelbe Klumphirse.}

Rispe: unreif grün, reif rötlich, sehr dicht zusammengezogen, fast Compactum, überhängend, $25 \mathrm{~cm}$ (Max. $32 \mathrm{~cm}$ ) lang. - Stroh: gelb bis 
orange, blattreich, mittellang. - Scheinfrucht: gelb und zwar reiner als luteum, fast kugelrund ( $3 \mathrm{~mm}$ lang, $2^{1 / 2} \mathrm{~mm}$ breit), glänzend.

Halme und Blattscheiden gelbgriin, rauhhaarig, Blattspreite oben weich behaart, unten fast kahl; 1.8 Schösslinge, Halm $105 \mathrm{~cm}$ (Max. $148 \mathrm{~cm}$ ) lang, $0.57 \mathrm{~cm}$ dick, Blattzahl 5.5, Blätter $28.5 \mathrm{~cm} \mathrm{lang,} 1.53 \mathrm{~cm}$ breit, Blattfläche 523.32 qcm, Halmfläche $179.55 \mathrm{qcm}$, Gesammtfläche $702.87 \mathrm{qcm}$.

Mittelfrïh schossend und blühend (in 81 Tagen), nach 100 Tagen reifend. Scheinfrichte sehr leicht ausfallend.

Auf 1 ha wachsen 3 Millionen Pflanzen, mithin beträgt das Saatquantum, da 14.8 Willionen Körner anf $1 \mathrm{hl}(=78 \mathrm{~kg}$ ) entfallen, bei Drillsaat 0.27 hl p. ha.

Diese Hirse wird stark in Oesterreich, Schlesien, aber auch sonst in Nord-Deutschland gebaut.

\section{Varietät: Panicum miliaceum lutenm Kcke.}

\section{Lehmgelbe Klumphirse.}

Rispe: unreif grüngelb, reif rötlich-gelb, ein wenig locker, doch noch zu Contractum gehörig, überhängend, $22 \mathrm{~cm}$ (Max. $30 \mathrm{~cm}$ ) lang. Stroh: gelbgrïn oder orange, blattreich, mittellang. - Scheinfrucht: graugelb, oval (3 mm lang, $2 \mathrm{~mm}$ breit), glänzend.

Halme und Blattscheiden stark behaart, Blattspreite auf beiden Seiten sehr schwach behaart; 1.5 Schösslinge, Halm $90 \mathrm{~cm}$ (Max. $110 \mathrm{~cm}$ ) lang, $0.5 \mathrm{~cm}$ dick, Blattzahl 7, Blätter $20.4 \mathrm{~cm}$ lang, $1.2 \mathrm{~cm}$ breit, Blattfläche $342.72 \mathrm{qcm}$, Halmfläche $135 \mathrm{qcm}$, Gesammtfläche in der Blütezeit $477.72 \mathrm{qcm}$.

Mittelfrüh schossend und blühend (in 76 Tagen). doch zeitig nach 93 Tagen reifend. Scheinfrüchte leicht ausfallend.

Auf 1 ha wachsen 4.8 Millionen Pflanzen, mithin beträgt das Saatquantum, da 17.6 Nillionen Körner auf $1 \mathrm{hl} \mathrm{(=80} \mathrm{kg)} \mathrm{entfallen,} \mathrm{bei}$ Drillsaat $0.36 \mathrm{hl} \mathrm{p.} \mathrm{ha.}$

Lässt sich in Nord-Deutschland kultivieren.

\section{Varietät: Panicum miliaceum sanguineum Al.}

\section{Hellrote Klumphirse.}

Rispe: unreif grün, reif gelb, zusammengezogen, ïberhängend, $25 \mathrm{~cm}$ (Max. $30 \mathrm{~cm}$ ) lang. - Stroh: gelbgriin bis orange. - Scheinfrucht: hellorangerot, oval ( $3 \mathrm{~mm}$ lang, $2 \mathrm{~mm}$ breit), glänzend. Ist die hellste Sorte ihrer Varietät.

Halme gelbgrïn, mit 2-3 Seitensprossen; Halme und Blattscheiden stark behaart, Blattspreiten oben wenig behaart, unten fast kahl und glänzend; 2 Schösslinge, Halm $110 \mathrm{~cm}$ (Max. $125 \mathrm{~cm}$ ) lang, $0.5 \mathrm{~cm}$ dick, Blattzahl 6, Blätter $28 \mathrm{~cm}$ lang, $1.4 \mathrm{~cm}$ breit, Blattläche $470.4 \mathrm{qcm}$, Halmfläche $165 \mathrm{qcm}$, Gesammtfläche $635.4 \mathrm{qcm}$.

Zeitig schossend und blïhend (in 75 Tagen), nach 92 Tagen reifend. Scheinfrichte ziemlich fest sitzend.

Auf 1 ha wachsen 3 Millionen Pflanzen, mithin beträgt das Saat- 
quantum, da 15.8 Millionen Körner auf $1 \mathrm{hl}(=80 \mathrm{~kg}$ ) entfallen, bei Drillsaat $0.27 \mathrm{hl} \mathrm{p}$. ha. bauen.

Diese Sorte lässt sich erfolgreich noch in Nord-Deutschland an-

Varietät: Panicum miliaceum subsanguineum Kcke.

\section{Blutrote KInmphirse.}

Rispe: reif dunkelblutrot, zusammengezogen, $20 \mathrm{~cm}$ (Мax. $32 \mathrm{~cm}$ ) lang, überhängend. - Stroh: gelbgrün bis blutrot. - Scheinfrucht: orangerot, glänzend, spitzlich ( $3 \mathrm{~mm}$ lang, $2 \mathrm{~mm}$ breit).

Halme dunkelgrün mit blutroten Flecken, Halme und Blattscheiden stark, Blattspreiten an der Basis der Oberseite behaart, sonst fast kahl.

Es wurden 3 Sorten kultiviert, welche sich folgendermassen zu ein. ander verhielten:

\begin{tabular}{l|c|c|c}
\hline & $\begin{array}{c}\text { Bluthirse aus } \\
\text { Cngarn }\end{array}$ & $\begin{array}{c}\text { Gewöhnliche } \\
\text { Bluthirse }\end{array}$ & $\begin{array}{c}\text { Panicum violaceum } \\
\text { hort. Königsberg }\end{array}$ \\
\hline Halmlänge & $165 \mathrm{~cm}$ & $75 \mathrm{~cm}$ & $110 \mathrm{~cm}$ \\
Halmdicke & $0.76 \mathrm{~cm}$ & $0.5 \mathrm{~cm}$ & $0.53 \mathrm{~cm}$ \\
Blattzahl & 9 & 5 & 7 \\
Blattlänge & $31.22 \mathrm{~cm}$ & $23.6 \mathrm{~cm}$ & $29 \mathrm{~cm}$ \\
Blattbreite & $1.6 \mathrm{~cm}$ & $1.4 \mathrm{~cm}$ & $1.6 \mathrm{~cm}$ \\
Blattfläche & $899.1 \mathrm{qcm}$. & $330.4 \mathrm{qcm}$ & $619.6 \mathrm{qcm}$ \\
Halmfläche & $394.1 \mathrm{qcm}$ & $112.5 \mathrm{qcm}$ & $174.9 \mathrm{qcm}$ \\
Gesammtfläche & $1293.2 \mathrm{qcm}$ & $442.9 \mathrm{qcm}$ & $825.5 \mathrm{qcm}$ \\
Anzahl der Schösslinge & 1.5 & 2.6 & 2 \\
Vegetationszeit & $94 \mathrm{Tage}$ & $108 \mathrm{Tage}$ & $108 \mathrm{Tage}$ \\
Anzahl der Pflanzen p. ha. & 1.500 .000 & 3.500 .000 & 3.800 .000 \\
Hektolitergewicht p. hl & 13.000 .000 & 14.500 .000 & 11.200 .000 \\
Saatquantum & $73 \mathrm{~kg}$ & $78 \mathrm{~kg}$ & $70 \mathrm{~kg}$ \\
& $0.12 \mathrm{hl}$ & $0.32 \mathrm{hl}$ & $0.34 \mathrm{~kg}$ \\
& & &
\end{tabular}

Der Ertrag dieser Hirse soll sich in Tngarn ${ }^{1}$ ) auf 13 hl Körner und $2000 \mathrm{~kg}$ Stroh stellen.

Varietät: Panicum miliaceum atrum Kcke.

\section{Schwarze Kilumphirse.}

Rispe: unreif grün, reif rötlich-gelb, zusammengezogen, überhängend, $25 \mathrm{~cm}$ (Jax. $30 \mathrm{~cm}$ ) lang. - Stroh: schmutzig-gelhgrün, mittellang. Scheinfrucht: grauschwarz, gestreift, oral (3 $\mathrm{mm}$ lang, $2 \mathrm{~mm}$ breit), glänzend.

Halme gelbgrün, steif-borstig, Blätter unten wenig und kurz, oben lang und reichlicher behaart, 1-2 Halmsprossen; 1.5 Schösslinge, Halm $100 \mathrm{~cm}$ (Wax. $120 \mathrm{~cm}$ ) lang, $0.33 \mathrm{~cm}$ dick, Blattzahl 5, Blätter $17.5 \mathrm{~cm}$ lang, $1.2 \mathrm{~cm}$ breit, Blattfläche $210 \mathrm{qcm}$, Halmfläche $99 \mathrm{qcm}$, Gesammtfläche zur Blütezeit $309 \mathrm{qcm}$.

1) Allg. Land- und forstw. Ztg. Wien $1867 \mathrm{pg} .391$. 
Zeitig schossend und blühend (in 75 Tagen), nach 96 Tagen reifend. Scheinfrüchte ziemlich leicht ausfallend.

Auf 1 ha wachsen 6 Millionen Pflanzen, mithin beträgt das Saatquantum, da 15 Millionen Samenkörner auf $1 \mathrm{hl}(=78 \mathrm{~kg})$ entfallen, bei Drillsaat $0.54 \mathrm{hl}$.

Wegen ihrer Frühreife wohl noch über das Weinklima hinaus kultivierbar.

\section{Gruppe III. Compactum Keke. Dickhirse.}

Varietät: Panicum miliacenm dacicum Kcke.

\section{Mein roça, Rumänien.}

Rispe: unreif grün, reif hellrot, sehr dicht, aufrecht, $12 \mathrm{~cm}$ (JIax. $15 \mathrm{~cm}$ ) lang, bis $4.5 \mathrm{~cm}$ breit. - Stroh: schmutzig-gelbgrün, blattreich, unter mittellang. - Scheinfrucht: gelbbräunlich, am dunkelsten von allen gelbroten Sorten, gross (3.5 mm lang, $2.3 \mathrm{~mm}$ breit), glänzend.

Halme und Blattscheiden rauh behaart, Oberseite der Blattspreite wenig behaart, Unterseite kahl, viel Seitensprossen, durchschnittlich 4; Schösslinge 2.4, Halm $80 \mathrm{~cm}$ (Max, $106 \mathrm{~cm}$ ) lang, $0.53 \mathrm{~cm}$ dick, Blattzahl 5, Blätter $21 \mathrm{~cm}$ lang, $1.35 \mathrm{~cm}$ breit, Blattfläche $396.9 \mathrm{qcm}$, Halmfläche $143.1 \mathrm{qcm}$, Gesammtfläche $540 \mathrm{qcm}$.

Mittelfrüh schossend und blühend (in 81 Tagen) nach 103 Tagen reifend. Scheinfrüchte ziemlich leicht ausfallend.

Auf 1 ha wachsen 3 Millionen Pflanzen, mithin beträgt das Saatquantum, da 10.8 Millionen Körner auf $1 \mathrm{hl}(=73 \mathrm{~kg}$ ) entfallen, bei Drillsaat $0.4 \mathrm{hl}$.

Wir erhielten 1872 diese Hirse dureh Vermittelung der Frau Fïrstin Wied unter dem Namen „Mein roça“ (Millet rouge roumain) aus Rumänien, und 1876 durch Gutsbesitzer Detiareff aus Jekaterinoslaw.

\section{Die biologischen Verhältnisse der Rispenhirse.}

Das.Samenkorn soll vollkommen ausgereift, von hohem absoluten Gewicht, glänzend, und nicht multrig sein.

In dem käilteren, gemässigten Klima mit seiner für den Hirsebau relativ geringen Wärme und feuchten Atmosphäre ist auf die 
Qualität und Aufbewahrung der Samenkörner ein ganz besonderes Augenmerk zu richten, da die Hirse hier weniger gleichmässig ausreift und gut trocknet als in wärmeren und trockneren Klimaten. Aus diesem Grunde ist anzuraten, die Hirse sofort nach dem Schnitt zur Gewinnung der reifsten und vollkommensten Körner oberflächlich abzudreschen, letztere mit Spreu rermischt auf einem luftigen Boden dïnn aufzuschütten und häufiger umzurechen, weil sich sonst die nicht ganz trocknen Körner leicht erhitzen, schimmeln und in Folge dessen ihre Keimkraft, die an und für sich kaum länge: als 2 Jahre wïhrt, einbüssen.

Das Stroh, welches feucht eingebracht, ebenfalls leicht schimmelt, wird entweder in Garben gebunden und zum Trocknen in $\mathrm{H} \cdot \mathrm{cck}$ en aufgestellt, oder zur Herstellung von Braunheu in Feimen zusarmengefahren.

Im wärmeren gemässigten Klima reift die Hirse gleichmässiger und trocknet schneller, weil die Temperatur hierzu genügend hoch ist.

Gedörrte Samenkörner sollten ebensowenig wie bei anderen Getreidearten zur Saat Vcrwendung finden, denn schon nach fünfstündiger Einwirkung einer Temperatur von $30^{\circ} \mathrm{C}$. keimten nach Haberlandt von trocknen Samen nur 75 Proc., nach 24 stïndigem Einweichen und darauf folgendes Trocknen nur noch 66 Proc.

Die Quantität des zum Keimen nötigen Quellungswassers ist relativ gering und reichen nach $\mathrm{Hoffmann}$ durchschnittlich 25 Proc. des Korngervichtes hin; dagegen ist die erforderliche Wärmemenge sehr bedeutend, denn es erfolgte die Keimung mit dem Sichtbarwerden des Würzelchens bei

\begin{tabular}{l|c|c|c}
\hline \hline & $10.25^{\circ} \mathrm{C}$. & $15.75^{\circ} \mathrm{C}$. & $19.00^{\circ} \mathrm{C}$. \\
\hline $\begin{array}{c}\text { in Tagen } \\
\begin{array}{c}\text { Durchschnittliches Längenwachstum in } \\
\text { mm pro Tag }\end{array}\end{array}$ & 13.25 & 325 & 3.00 \\
& 0.15 & 2.33 & 6.33
\end{tabular}

Hiernach sollte man mit des Einsaat warten, bis sich der Boden auf $12-15^{\circ} \mathrm{C}$. erwärmt hat, zumal die junge Pflanze ausnehmend leicht durch Frost geschädigt und durch kaltes Wetter in der Vegetation zuriickgehalten wird.

Wegen der Kleinheit der Samenkörner diurfen dieselben auf Mittelboden nur $1 \mathrm{~cm}$, auf Sandboden nicht iiber $2.5 \mathrm{~cm}$ tief untergebracht werden.

Die Grösse des Wachsraumes einer Pflanze kann je naclı den angebauten Sorten, da diese in Betreff ihres Habitus sehr grossen Verschiedenheiten unterliegen, sowie nach Massgabe der Reschaffen- 
heit des Klimas, Bodens und der Kulturart erheblich von einander abweichen. In Poppelsdorf betrug der Wachsraum der unter gleichen Verhältnissen angebauten und auf $20 \mathrm{~cm}$ gedrillten Sorten zwischen 14 und $83 \mathrm{qcm}$, im Mittel $34 \mathrm{qcm}$.

Ueberhaupt gestalteten sich bei den in Poppelsdorf kultivierten Varietäten die Vegetationsverhältnisse, wie nebenstehende Tabelle Seite 882 sie zeigt.

Aehnlich dem Habitus weichen auch die Hirsesorten bezüglich der Dauer ihrer Vegetationsperiode sehr stark von einander ab, denn letztere kann zwischen 3 bis 5 Monaten betragen, daher denn auch die zum Wachstum notwendige Wärmesumme in weiten Grenzen, zwischen 1500 und $2500^{\circ} \mathrm{C}$. schwankt.

Die Hirse ist ein Flachwurzler und eine echte Krumepflanze, deren Kultur einen reichen Vorrat fertiger Pflanzennahrung in der Ackerkiume verlangt, denn eine mittlere Ernte von $1360 \mathrm{~kg}$ Korn und $2725 \mathrm{~kg}$ Stroh entzieht dem Acker pro ha mehr Pflanzennährstoffe als eine mittlere Weizenernte, nämlich $40 \mathrm{~kg}$ Stickstoff, $200 \mathrm{~kg}$ Mineralstoffe und in diesen $23.2 \mathrm{~kg}$ Kali, $12.4 \mathrm{~kg}$ Magnesia, $12 \mathrm{~kg}$ Kalkerde, $13.6 \mathrm{~kg}$ Phosphorsäure.

Die Wasserverdunstung der meist ziemlich dicht behaarten oberirdischen Organe steht gegen andere Getreidearten nicht unerheblich zuriick, z. B. verdunstete nach Haberlandt der Mais anf 100 qem Oberfläche pro Tag $2.16 \mathrm{gr}$, der Weizen $2.66 \mathrm{gr}$, die Hirse aber nur $1.91 \mathrm{gr}$, mithin die Pflanze mit einem relativ geringen Wasservorrat im Boden auszukommen vermag, was jedoch nicht ausschliesst, dass im wärmeren Klima, wie in Ober-Italien, Indien ete. durch die Bewässerung eine recht bemerkenswerte Ertragserhöhung erzielt wird.

Die Hirse entwickelt sich in ihrer ersten Jugendzeit verhältnismässig langsam, und wird daher durch Unkraut leicht iiberwachsen, wenn letzteres nicht rechtzeitig durch Jäten oder Hacken entfernt wird.

Auf den humusreichen Sandböden, welche im kälteren gemässigten Klima der Hirse sehr zusagen, gelten folgende Unkräuter als besonders gefăhrlich: Spörgel (Spergula arvensis L.), Ackersenf (Sinapis arvensis L.), Hederich (Raphanus Raphanistrum L.), Vogelmiere (Alsine media L.) Feld-Pfennigkraut (Thlaspi arvense L.), Täschelkraut (Capsella bursa pastoris Mnch.), gemeiner Knöterich (Polygonum Persicaria L.), sowie die Atriplex-Arten. Von den Wurzelunkräutern ist vorzugsweise die Quecke (Triticum repens L.) gefürchtet.

Die Hirse leidet an einer specifischen Krankheit, dem Hirsebrand (Ustilago destruens Schlecht.). Dieser Brandpilz befällt meist sämmtliche Rispen einer Pflanze, und werden dieselben schon in den Blattscheiden brandig, wo sie dann zusammengeknäulte, weissliche, dicke, 

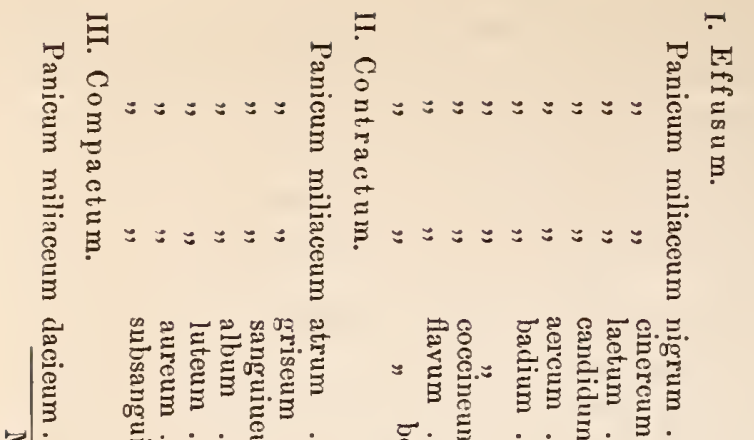

....$\cdot \cdot$

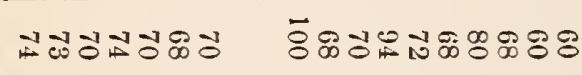

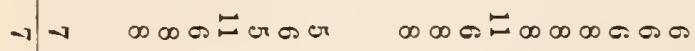
-

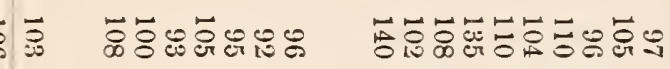

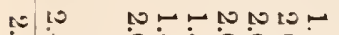

N

0

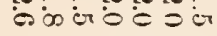

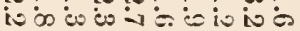

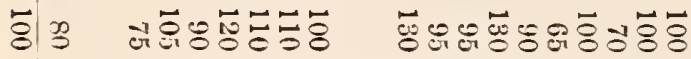

\begin{tabular}{|c|c|c|c|}
\hline 8 & g & 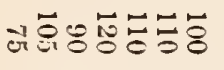 & 峁 \\
\hline$\Rightarrow$ & $\rightarrow$ & or er $\rightarrow \infty$ orer er & o er $\rightarrow \infty$ er er er er er $_{\text {er }}$ \\
\hline & r & 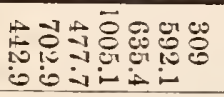 & 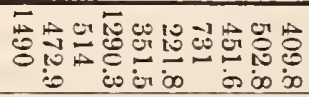 \\
\hline & $\begin{array}{l}\vec{c} \\
0 \\
0 \\
0 \\
0\end{array}$ & 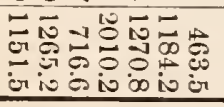 & 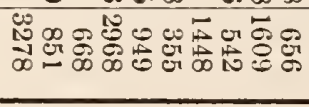 \\
\hline & $\omega$ & $\underset{\text { or }}{\omega} \underset{\infty}{\infty}$ ov & is \\
\hline & $b_{0}^{\infty}$ & 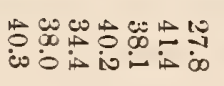 & 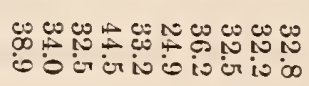 \\
\hline
\end{tabular}

§ Mittlere Halmlänge.

Aussaat bis Schossen

Schossen bis Blüte

Blüte bis Ernte Aussaat bis Ernte

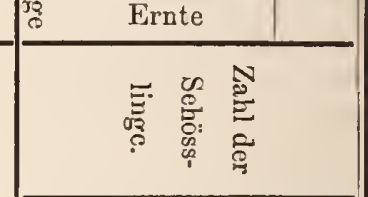

- eines $\forall \neq 0$

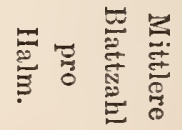
Halmes.

- einer Pflanze.

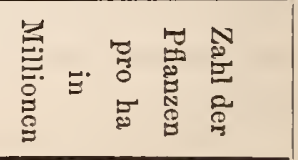

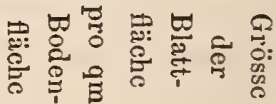


konische Körper bilden, welche in ihrem Innern die Brandsporen bergen; diese letzteren sind noch einmal so gross, als die des Flugbrandes, dabei unregelnässig-rund und dunkelbraun gefärbt. Das Einbeizen der Samenkörner mit Kupfervitriol soll gegen den Brandpilz schützen.

Von den der Pflanze eigentuimlichen tierischen Feinden ist nur die Raupe des Hirsezünslers (Botys nubilalis Hübner) anzuführen, welche sich in den Stengel einbohrt und die Hirse zum Absterben bringt. Durch Verbrennen der Stoppeln kann die Vermehrung dieses Feindes einigermassen gehemmt werden.

Ausserdem ist die reife Hirse stark dem Vogelfrass ausgesetzt, und sind die Vögel durch Bewachen der Felder und Schiessen zu ver'scheuchen.

\section{Klima.}

Die späten Hirsesorten sind in der subtropischen und wärmeren gemässigten Zone heimisch und nur solche, welche die mittlere Vegetationszeit von 106 Tagen nicht weit überschreiten, werden noch in der kälteren gemässigten Zone angebaut, denn obwohl die Vegetationszeit der späteren Sorten keineswegs an und für sich zu lang ist, können sie doch, weil gegen Friihjahrsfröste und feuchte, kalte Witterung sehr empfindlich, erst verhältnismässig spät ausgesäet werden, mithin späte Sorten im kälteren gemässigten Klima mit seinen kühlen und feuchten Sonmern zu ungleich und unsicher reifen, sowie nicht gehörig austrocknen. Frühreife Sorten gedeihen noch im Weinklima und in Nord-Deutschland auf sich leicht erwärmenden Böden, z. B. liumosem Sandboden, bis zum $53 .{ }^{0} \mathrm{n}$. Br.

Als Pflanze des Kontinental-Klimas erträgt sie ganz vorzüglich die Dürre.

\section{Boden.}

In den wärmeren Klimaten wächst die Hirse auf den von Natur reichen Lehmböden am besten, im kälteren gemässigten Klima dagegen auf den leichteren, warmen Böden, daher, je mehr sich die Hirse den Grenzen ihres Anbaues näbert, die physikalische Beschaffenheit des Bodens um so sorgsamer $\mathrm{zu}$ überwachen ist. Der geeignetste Boden wïrde bier ein in guter Dungkraft stehender leichter, lockerer, humoser, lehmiger Sand- oder Haideboden, also ein Roggenboden I. oder II. Klasse sein.

Auf den bindigen, eisenschüssigen Thonböden, oder den kalten, nicht gehörig entwässerten Bruch- und Moorböden wächst sie gar nicht; auch sagen ihr die Kalk- und Mergelböden wenig zu. 


\section{Dïngnng.}

Die Hirse ist eine Krumepflanze mit, wenigstens bei der Mehrzahl der Sorten, relativ kurzer Vegetationsperiode und setzt dies voraus, dass der Boden ,alte Kraft" also fertige Pflanzennahrung in reichlichem Masse besitzen muss, wenn sie gedeihen soll. Aus diesem Grunde liebt die Hirse auch sich zersetzende Grasnarbe, Neuland und Kleedresch, weil diese ihr leicht aufnehmbare Nahrung in genügender Menge zur Verfügung stellen, ebenso nährstoffreichen Kompost oder stark treibende stickstoffhaltige Düngemittel, wie Guano, Chilisalpeter, Ammoniaksuperphosphat, Schafpferch und Federviehmist. Eine starke Stickstoffdiingung erhöht den Ertrag bedeutend, ohne die Qualität zu schädigen oder Lagern hervorzurufen.

Eine Stallmistdüngung verwendet man zur Hirse niemals direkt, sondern diingt die Vorfrucht.

\section{Fruchtfolge.}

Die Hirse beansprucht einen nährstoffreichen und von Unkräutern freien Boden, weshalb als Vorfriichte, Hackfruichte, umgebrochenes Gras- oder Kleeland und gut gedüngte Wintergetreide den Vorzug verdienen.

Die besten Vorfrüchte sind jedenfalls stark gedüngte und gut bearbeitete Kartoffeln, und dicht stehender roter Klee, welcher die Ackerkrume nicht nur durch seine Stoppel- und Wurzelriickstände bereichert, sondern auch ihre physikalische Beschaffenheit giunstiger gestaltet.

Da die Aussaatzeit verhältnismässig spät erfolgt, so lassen sich im Weinklima auch Zwischenfrüchte, wie Inkarnatklee oder Grünfutterroggen anbauen.

Zuweilen wird die Hirse auf leichtem Boden, da sie der Dürre vortrefflich widersteht, auch im Gemenge mit Wickhafer, Buchweizen, Lupinen oder Mais ausgesäet.

Die Hirse entzieht dem Boden sehr viel Nährstoffe, weshalb ungedüngte Nachfrüchte sehr schlecht geraten, am besten gedeiht noch der Roggen.

\section{Bodenbearbeitnng.}

Die Hirse verlangt zu ihrem Gedeihen einen lockeren, unkrautfreien Boden, daher es rätlich erscheint, sofort nach der Ernte der Vorfrucht, wenn diese Getreide war, die Stoppeln umzubrechen und 
vor Winter noch einmal tief zu pflügen, im Frühjahr wird der Boden abgeeggt oder noch einmal gegrubbert. Nach Hackfriuchten gibt man vor Winter gern $110 \mathrm{ch}$ eine tiefe Furche, eggt im Frühjahr das Land ab, grubbert, eggt und walzt. Bei Zwischenfrüchten geniigt eine Furche. Der Kleedresch wird zweckmässig zeitig im Herbst geschält und gewalzt, darauf vor Winter die Narbe tief untergepflïgt und im Frühjalır zur Saat geeggt und gewalzt.

Jedenfalls ist, bei der Kleinheit der Samenkörner, das Saatland möglichst fein zu präparieren.

\section{Aussaat.}

Im tropischen Afrika wird die Rispenhirse bei Beginn der Regenperiode Anfang Juli bis Mitte Juli, und im nördlichen Indien ${ }^{1}$ ) im Oktober, inı südlichen Ende Mai und Anfang Juni gesäet. In Aegypten fällt die Aussaat nach dem Fallen des Nils in die Sommerperiode, also wie in der wärmeren gemässigten Zone in den April.

Die Aussaatzeit in der kälteren gemässigten Zone richtet sich nach dem Auftreten der Frühjahrsfröste sowie nach der Bodenerwärmung, da es sich empfiehlt, die Hirse nicht friiher zu säen, bis die Bodentemperatur $12-15^{\circ} \mathrm{C}$. erreicht hat; demzufolge säct man im Weinklima Anfang Mai und nördlich von dieser Zone von Mitte Mai bis Anfang Juni und selbst erst Mitte Juni. Selhstverständlich sind bei dieser späten Aussaat nur die frühreifsten Sorten zu wählen.

Zur Benutzung als Grünfutter lässt sie sicl zur Erzielung eines immer frischell Futters in 14-tägigen Perioden noch bis Anfang August aussäen.

In Poppelsdorf entfielen durchschnittlich 15.5 Millionen Samenkörner auf $1 \mathrm{hl}(=77 \mathrm{~kg}$ ), und da im Mittel 3.7 Millionen Pflanzen pro ha wuchsel, ergab sich eine mittlere absolute Saatmenge von $0.24 \mathrm{hl}(=18.5 \mathrm{~kg})$, bei Drillsaat $(20 \mathrm{~cm})$ von $0.33 \mathrm{hl}(=25.66 \mathrm{~kg})$, bei Breitsaat von $0.42 \mathrm{hl}(=32.34 \mathrm{~kg})$.

Die nebenstehende Saattabelle (Seite 886) gibt den Saatbedarf pro ha für alle in Poppelsdorf kultivierten Varietäten an.

Die Aussaat darf nicht auf feuchtem Boden, der schmiert, geschehen, weil die Hirse dies durchaus nicht verträgt, auch dürfen die Samenkörner nur 1-2.5 cm tief, je nach der Bodenbeschaffenheit, und zwar auf leichtem, trocknem Boden am tiefsten, untergebracht werden, zu dem Ende ist das Feld zur breitwürfigen Saat tüchtig vorzueggen, ev. zu walzen, worauf entweder mit der Säemaschine

1) Royle, Jllustr. of bot. of the Himalaya and Cashmere 1839 p. 418. 
Pflege, Ernte, Ausdrusch und Aufbewahrung der Rispenhirse.

oder mit der Hand über Kreuz die Aussaat erfolgt, worauf die Samenkörner mit leichten hölzernen oder eisernen Eggen untergebracht werden.

Am meisten empfiehlt sich jedoch die Drillkultur, indem nicht allein das Ausreifen gleichmässiger erfolgt, sondern sich anch der Ertrag nach Quantität und Qualität höher stellt, ausserdem wird die Arbeit des Jätens nicht selten vollkommen erspart, sobald die Drillreihen zum Behacken genügend weit gestellt werden. $\mathrm{Zu}$ diesem Zweck sind Entfernung von $20-30 \mathrm{~cm}$ zu geben, welche sich aber für die grössten Sorten auf $60-70 \mathrm{~cm}$ erweitern können.

\section{Pflege.}

Nach der Aussaat hat man zuvörderst darauf zu achten, dass der Acker an seiner Oberfläche nicht verkrustet, weil dies ein ungleichmässiges Auflaufen und einen ungleichen Stand nach sich zieht, weshalb mittels kannelierter oder Ringelwalzen die Kruste rechtzeitig zu brechen ist.

Ferner wird die Hirse wegen ihres langsamen Wachstums in der ersten Vegetationszeit sehr leicht durch Unkraut unterdrückt, wenn man nicht in Kleinbetriebe durch Jäten nach dem Erscheinen des zweiten Blattes, und im Grossbetriebe durch nochmaliges Eggen, sobald die junge Pflanze 3-4 Blätter entwickelt hat, und bei Drillkultur durch mehrmaliges Hacken bis kurz vor dem Schossen das Unkraut entfernt.

Bei kümmerlichem Stande lässt sich auch mit Hïlfe stickstoffhaltiger schnellwirkender Kopfdünger ein besseres Ernteresultat erzielen.

\section{Ernte, Ansdrusch und Anfbewahrung.}

Der zweckmässigste Reifezustand scheint bei dem ungleichen Reifen und leichten Ausfallen der Hirse gekommen zu sein, sobald Stengel und Blätter sich gelb färben und die Mehrzahl der Körner die charakteristische Färbung der Sorte angenommen hat.

Im tropischen Afrika tritt die Ernte in der Regel Mitte November bis Ende December, im nördlichen Indien im Februar, im südlichen Anfang September, in der wärmeren gemässigten Zone im Juli und August, und schliesslich in der kälteren gemässigten Zone im August und September ein.

Zur Grïnfuttergewinnung mähet man sie anı zweckmässigsten vor der Blüte, weil sie dann die grösste Masse verdaulicher Substanz liefert, und unter Umständen noch einen zweiten Schnitt abwirft.

Die reife Hirse, deren Stroh immer noch viel Vegetationswasser 
enthält, wird entweder mit der Sichel und Sense, oder mit einer Mähemaschine abgemäht, dann am besten sofort gedroschen und das Stroh in Garben gebunden zum Nachtrocknen aufgestellt, oder man lässt die gemähte Hirse ${ }^{1)}$ 1-2 Tage auf dem Schwad abwelken, bindet sie dann in Garben auf und fährt sie in grosse Feimen zusammen. In diesen erwärmt sie sich und färbt sich braun (Braunheu), die Körner lassen sich dann leicht ausdreschen und können zu Ernährungszwecken, jedoch nicht zur Saat verwandt werden.

Das Einfahren der reifen Hirse geschieht zweckmässig, zur Vermeidung von Körnerverlusten, anf mit Plantïchern ausgeschlagenen Wagen.

Die ausgedroschenen noch frischen Hirsekörner sind im warmen Klima nach der Ernte sehr sorgfältig in dünnen Lagen an der Sonne zu trocknen, während sie im kälteren, gemässigten Klima am besten mit Spreu vermischt, auf einem luftigen Speicherraum dünn aufgeschiittet und häufig umgerecht werden, damit sie schnell austrocknen und nicht verderben.

\section{Erträge und Nahrungsbestandteile.}

Die Erträge der Rispenhirse stellen sich im Allgemeinen wie folgt:

\begin{tabular}{l|r|r|r}
\hline & Min. & Max. & Nittel \\
\hline Körner (l hl à $i \tau \mathrm{kg}$ ) . & $8 \mathrm{hl}$ & $35 \mathrm{hl}$ & $20 \mathrm{hl}$ \\
Stroh . . . . . . . . & $1000 \mathrm{~kg}$ & $4000 \mathrm{~kg}$ & $2500 \mathrm{~kg}$ \\
Spreu . . . . . . . . & $90 \mathrm{~kg}$ & $350 \mathrm{~kg}$ & $225 \mathrm{~kg}$
\end{tabular}

Nach Block ${ }^{2}$ ) gibt die Hirse in 4 Jahren im kälteren gemässigten Klima 3 ziemlich vollkommene Ernten, welche sich durchschnittlich auf $17 \mathrm{hl}$ (= $1312 \mathrm{~kg}$ ) Korn und $1800 \mathrm{~kg}$ Stroh stellen, doch lassen sich innerhalb des Weinklimas unter sonst günstigen Kulturverhältnissen bis zu $30 \mathrm{hl}$ Korn und $3000 \mathrm{~kg}$ Stroh aufbringen, während sich für das wärmere gemässigte Klima Erträge von 30 bis 35 hl pro ha ergeben.

Der Grünfutterertrag berechnet sich auf $10.000-15.000 \mathrm{~kg} \mathrm{p}$. ha.

1) Vergl. Sprengel, a. a. O. pg. 263.

2) A. a. O. I. pg. 98 . 
Die Körner enthalten an Nährstoffen:

\begin{tabular}{|c|c|c|c|c|c|c|}
\hline & $\begin{array}{c}\text { Trocken- } \\
\text { substanz. } \\
\text { Proc. }\end{array}$ & $\begin{array}{c}\text { Stickstoff- } \\
\text { Substanz. } \\
\text { Proc. }\end{array}$ & $\begin{array}{l}\text { Fett } \\
\text { Proc. }\end{array}$ & $\begin{array}{c}\mathrm{N} \text {-freie } \\
\text { Extraktst. } \\
\text { Proc. }\end{array}$ & $\begin{array}{l}\text { Holz- } \\
\text { faser } \\
\text { Proc. }\end{array}$ & $\begin{array}{l}\text { Asche } \\
\text { Proc. }\end{array}$ \\
\hline Minimum & 86.0 & 10.9 & 3.0 & 56.9 & 6.4 & - \\
\hline Maximum & 86.9 & 14.5 & 3.4 & 59.1 & 13.1 & - \\
\hline Mittel & 86.5 & 12.7 & 3.3 & 58.0 & 9.5 & 3.0 \\
\hline
\end{tabular}

Nach Horky und Klose beträgt das Spelzengewicht im Mittel 16.8 Proc., wobei zu bemerken ist, dass das Spelzengewicht der Hirsen der wärmeren Klimate am geringsten ist.

Nach von Bibra enthalten:

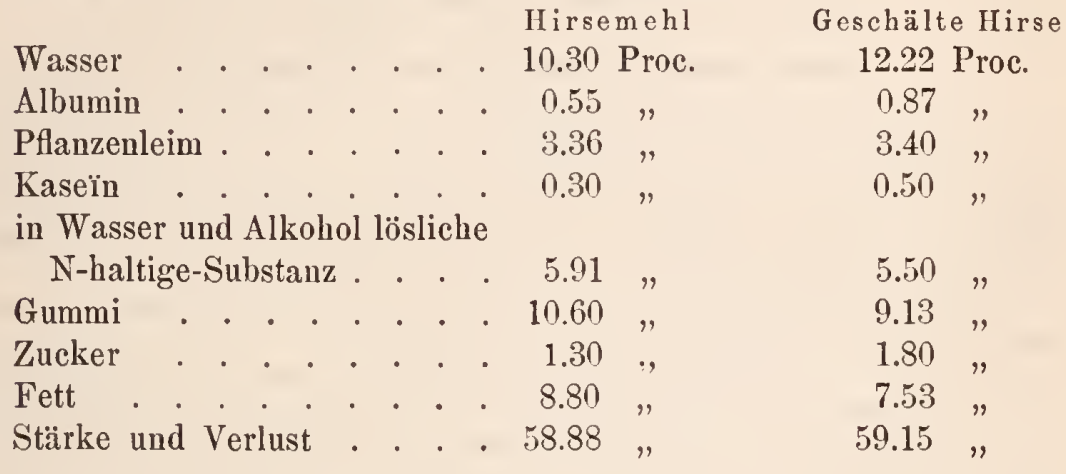

\section{Benutzung.}

Das Korn wird anf besonderen Mühlvorrichtungen geschält und als Grittze verwandt, wobei dem Volumen nach 50 Proc. und dem Gewichte nach 40 Proc. verloren gehen, doch lässt sich diese Grütze nicht lange Zeit aufbewahren.

Die Hirse ist sehr nahrhaft, aber etwas schwer verdaulich, auch kann sie vermahlen, nicht allein, sondern nur nach Vermischung mit gleich viel Weizenmehl zu Brot verbacken werden.

Ferner dienen die Körner als Mastfutter für Geflugel und das Grlinfutter zur Ernährung des Rindviehs, wodurch, weil ein gutes Milchfutter, auf Ieichtem Sandboden die Durchführung der Sommerstallfütterung unterstuitzt wird. Das Stroh ist geschätzter als Gerstenstroh.

Der Preis der Hirse hält sich meist höher als der des Weizens. 


\title{
Kolbenhirse.
}

\author{
Panicum italicum L.
}

Einteilung.

\section{Gruppe I. Maximum Al. Grosse Kolbenhirse.}

\author{
Varietät: Panicum italicum lobatum Kcke.
}

\section{Grosse gelappte italienische Kolbenhirse.}

Rispenähre: gelb, mit langen schmalen Seitenzweigen, sehr lappig, sehr gross, $24 \mathrm{~cm}$ lang, $4 \mathrm{~cm}$ breit, Seitenzweige $3-4 \mathrm{~cm}$ lang; Borsten ziemlich lang $(1 \mathrm{~cm})$, grünlich. - Stroh: schmutzig-gelbgrün, sehr lang, blattreich, markig. - Scheinfrucht: gelb, matt, gerundet, ziemlich gross $\left(2^{1} / 2 \mathrm{~mm}\right.$ lang, $2 \mathrm{~mm}$ breit).

Zahl der Schösslinge 2.5, Halmlänge $150 \mathrm{~cm}$, Blattzahl 10, Gesammtfläche einer mittleren Pflanze $1500 \mathrm{qcm}$.

Sehr spät, in 110 Tagen schossend und blübend, nach 160 Tagen notdürftig reifend.

Auf 1 ha wächst 1 Million Pflanzen, mithin beträgt das Saatquantum, da 27 Millionen Scheinfrüchte auf $1 \mathrm{hl}(=73 \mathrm{~kg}$ ) entfallen, bei Drillsaat $0.05 \mathrm{hl}$.

Diese Varietät ist eine Parallelform von P. it. gigas Kcke., und soll ihre ursprüngliche Heimat Ostindien sein.

Wir erhielten davon eine Sorte von Professor Deininger in Ungar.Altenburg als Setaria germanica Nr. 41.

Nur für ein warmes Klima geeignet.

\section{Varietät: Panicum italicum longisetım Döll.}

\section{Grosse langborstige Kolbenhirse mit gelben Samen,}

Rispenähre: grünlich-gelb bis orangegelb, etwas lappig, fuchsschwanzartig, sehr lang, $15 \mathrm{~cm}$ lang (Мax. $25 \mathrm{~cm}) 2.3 \mathrm{~cm}$ breit, dicht, nickend, sehr reichsamig; Aehrchen von den Hüllborsten weit überragt, letztere grün, bis $1.5 \mathrm{~cm}$ und darüber lang. - Stroh: gelbgrün, blattreich, schilfartig, meist markig. - Scheinfrucht: gelb, rundlicb, verhältnismässig gross $(21 / 2 \mathrm{~mm}$ lang, $2 \mathrm{~mm}$ breit), glatt.

Halme gelbgrün, von der Blattscheide fast ganz umschlossen, Blatt rauh; Bestockung mittelstark, 2.5 Schösslinge; der Halm mittlerer Pflanzen $124 \mathrm{~cm}$ lang, Blattzahl 8, Gesammtfläche $964 \mathrm{qcm}$ pro Halm. 
Durchschnittlich entwickelten sich die Pflanzen, weil es ihnen an Wärme in Poppelsdorf fehlte, nur kümmerlich, weshalb wir von den hier gebauten Sorten dieser Varietät in Nachfolgendem eine Uebersicht des Habitus der grössten und kräftigsten Pflanzen bringen wollen.

\begin{tabular}{|c|c|c|c|c|}
\hline & $\begin{array}{c}\text { Grosse } \\
\text { langborstige } \\
\text { Kolbenhirse } \\
\text { mit gelben } \\
\text { Samen. }\end{array}$ & $\begin{array}{l}\text { Setaria ita- } \\
\text { lica major } \\
\text { longiseta } \\
\text { h. Heidel- } \\
\text { berg. }\end{array}$ & $\begin{array}{l}\text { Paniso del } \\
\text { valles } \\
\text { Cataluña. }\end{array}$ & $\begin{array}{c}\text { Panis } \\
\text { Llano del } \\
\text { Llobregat. }\end{array}$ \\
\hline 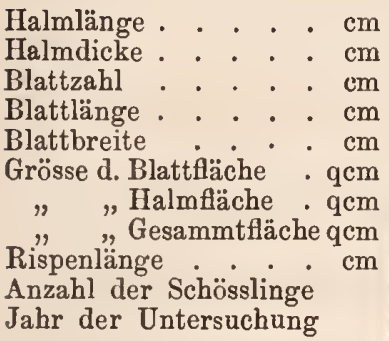 & $\begin{array}{c}146 \\
0.7 \\
8 \\
34.4 \\
1.6 \\
880.64 \\
321.20 \\
1201.84 \\
21 \\
2 \\
1876\end{array}$ & $\begin{array}{c}135 \\
0.5 \\
7 \\
28 \\
2 \\
784 \\
202.5 \\
986.5 \\
25 \\
1.8 \\
1877\end{array}$ & $\begin{array}{c}115 \\
0.6 \\
9 \\
33 \\
1.5 \\
891 \\
207 \\
1098 \\
15 \\
3 \\
1881\end{array}$ & $\begin{array}{c}115 \\
0.6 \\
9 \\
30 \\
1.5 \\
810 \\
207 \\
1017 \\
15 \\
3 \\
1881\end{array}$ \\
\hline
\end{tabular}

Sehr spät, in 96 Tagen schossend und blühend, nach 140 Tagen sehr notdürftig reifend.

Auf 1 ha wachsen 1.4 Millionen Pflanzen, und beträgt das Saatquantum, da 26.9 Millionen Samen auf $1 \mathrm{hl}(=73 \mathrm{~kg}$ ) entfallen, bei Drillsaat $0.07 \mathrm{hl}$.

Nach Metzger (Landw. Pflanzenkunde. 1841 pg. 195), soll sie in Süd-Carolina 2.6-3.3 m hoch werden. Soll wild in Indien vorkommen; kultiviert: in Italien, Süd-Carolina, in der Gegend von Genf, im Kanton Waadt und im südlichen Frankreich.

Wir erhielten die vollkommen identischen Formen „Paniso de valles, Cataluña und Panis, Llano del Llobregat durch Ant. Cipr. Costa, aus Barcelona, so dass diese Varietät innerhalb der wärmeren gemässigten Zone, also im südlichen Europa anzutreffen ist.

Selbst für Süd-Deutschland kann sie wegen ihrer Ertragsunsicherheit in kühlen, feuchten Sommern einen Wert kaum beanspruchen.

\section{Varietät: Panicum italicum californicum Kcke.}

\section{Kalifornische Kolbenhirse.}

Franz.: Moha de Hongrie vert de Californie.

It a l.: Miglio verde di California.

Rispenähre: grün, aufrecht, etwas nickend, etwas lappig, walzlich, $10 \mathrm{~cm}$ (M̆ax. $18 \mathrm{~cm}$ ) lang, $1.5 \mathrm{~cm}$ (Max. $2 \mathrm{~cm}$ ) breit; Borsten grün, mittellang. - Stroh: gelbgrün, blattreich, kxäftig, lang. - Scheinfrucht: bleich-gräulich-gelb, unter der Lupe oft gefleckt, fein querrunzelig, etwas spitzlich, gross ( $3 \mathrm{~mm}$ lang, $2 \mathrm{~mm}$ breit).

Halme gelbgrün, Zahl der Schösslinge 3.

Mittlere und grösste Halme zeigen folgenden Habitus: 


$\begin{array}{lcc} & \text { Mittel } & \text { Maximum } \\ \text { Halmlänge } & 110 \mathrm{~cm} & 150 \mathrm{~cm} \\ \text { Halmdicke } & 0.4 \mathrm{~cm} & 0.46 \mathrm{~cm} \\ \text { Blattzahl } & 8 & 8 \\ \text { Blattlänge } & 25 \mathrm{~cm} & 34.63 \mathrm{~cm} \\ \text { Blattbreite } & 1 \mathrm{~cm} & 1.36 \mathrm{~cm} \\ \text { Blattfläche } & 400 \mathrm{qcm} & 793.44 \mathrm{qcm} \\ \text { Halmfläche } & 132 ", & 217 \\ \text { Gesammtfläche } & 532 ", & 1010.44 "\end{array}$

Ausserdem fanden sich am grössten Halm noch 3 Seitensprossen mit einer Gesammtfl̈̈che von $274.3 \mathrm{qcm}$, so dass sich die Gesammtfläche des grössten Halmes auf $1284.74 \mathrm{qcm}$ stellt.

Zeitig, in 75 Tagen schossend und blühend, nach 118 Tagen reifend.

Auf 1 ha wachsen 2.5 Millionen Pflanzen, mithin beträgt das Saatquantum, da 25.9 Yillionen Samen auf $1 \mathrm{hl}(=77 \mathrm{~kg})$ entfallen, bei Breitsaat $0.13 \mathrm{hl}$ pro ha.

Diese Pflanze ist weit kräftiger und gibt mehr Futter als der Mohar, weshalb sich ihr Anbau im Steppenklima und auf leichtem Boden empfiehlt. gebaut.

In neuerer Zeit wird sie häufig in Italien zur Futterproduktion

Variétät: Panicum italicum erythrospermum Kcke.

\section{Grünborstige rotkörnige Kolbenhirse.}

Rispenähre: reif rotgelb, sich nach der Spitze kolbig verdickend, $14 \mathrm{~cm}$ (Max. $27 \mathrm{~cm}$ ) lang, $2 \mathrm{~cm}$ dick, die grossen nickend; Borsten an der Spitze der Rispe meist hellfuchsig, sonst grün, $1.5 \mathrm{~cm}$ lang. Stroh: gelb bis orange, ziemlich blattreich, mittellang, markig. - Scheinfrucht: orangerot, aber dunkler als bei P. it. aurantiacum, unreif gelb, klein ( $2 \mathrm{~mm}$ lang, $11 / 2 \mathrm{~mm}$ breit).

Anzahl der Schösslinge 2.2, Halme gelbgrün, $110 \mathrm{~cm}$ (Yax. $122 \mathrm{~cm}$ ) lang, $0.4 \mathrm{~cm}$ dick, Blattzahl 8 , Blätter $24.6 \mathrm{~cm}$ lang, $1.3 \mathrm{~cm}$ breit, Blattfläche 511.68 qcm, Halmfläche 132 qcm, Gesammtfläche $643.68 \mathrm{qcm}$.

Zeitig, in 75 Tagen schossend und blühend, nach 113 Tagen reifend.

Auf 1 ha wachsen 2.5 Millionell Pflanzen, mithin beträgt das Saatquantum, da 32.6 Yillionen Samen auf $1 \mathrm{hl}(=77.5 \mathrm{~kg})$ entfallen, bei Drillsaat $0.11 \mathrm{hl}$, bei Breitsaat $0.14 \mathrm{hl}$ pro ha.

Die Frühreife dieser Hirse erlaubt noch ihre Kultur im südlichen Deutschland.

Körnicke erbielt sie 1873 als S. it. major und breviseta aus h. Heidelberg.

Varietät: Panicum italicum rubrum Kcke.

\section{Braunborstige rotkörnige Kolbenhirse.}

Rispenähre: rot bis orange, walzlich, weniger lappig, dicht, meist aufrecht, mittellang, $14 \mathrm{~cm}$ (Max. $18 \mathrm{~cm}$ ) lang, $1.8 \mathrm{~cm}$ (Max. $2 \mathrm{~cm}$ ) breit; Borsten im jungen und reifen Zustande braun, kurz, 6-7 mm lang, länger und dichter als bei aurantiacum. - Stroh: schmutzig-gelbgrün, 
unter mittellang, ziemlich blattreich, markig. - Scheinfrucht: hellorangerot, doch dunkler als bei P. it. aurantiacum, grösser als bei den übrigen rotfrüchtigen Sorten ( $3 \mathrm{~mm}$ lang, $2 \mathrm{~mm}$ breit), gerundet.

Zahl der Schösslinge 3, Halme gelbgrïn.

Die mittleren und grössten Halme zeigten folgenden Habitus:

$\begin{array}{lcc} & \text { Mittel } & \text { Maximum } \\ \text { Halmlänge } & 92 \mathrm{~cm} & 115 \mathrm{~cm} \\ \text { Halmdicke } & 0.43 \mathrm{~cm} & 0.56 \mathrm{~cm} \\ \text { Blattzahl } & 8 & 8 \\ \text { Blattlänge } & 29 \mathrm{~cm} & 39.37 \mathrm{~cm} \\ \text { Blattbreite } & 1.3 \mathrm{~cm} & 1.67 \mathrm{~cm} \\ \text { Blattfläche } & 603.2 \mathrm{qcm} & 1052 \mathrm{qm} \\ \text { Halmfläche } & 108 " & 196 ", \\ \text { Gesammttläche } & 711.2 " & 1248,\end{array}$
reifend.

Mittelfrüh, in 80 Tagen schossend und blühend, nach 121 Tagen

Auf 1 ha wachsen 1.7 Millionen Pflanzen, mithin betrügt das Saatquantum, da 28.5 Millionen Samen auf $1 \mathrm{hl}(=73 \mathrm{~kg}$ ) entfallen, bei Breitsaat $0.11 \mathrm{hl}$, bei Drillsaat $0.08 \mathrm{hl}$ p. ha.

Die Kultur dieser Hirse ist noch in warmen Lagen im Weinklima möglich.

\section{Varietät: Panicum italicum nigrum Kcke.}

\section{Grosse schwarze Kolbenhirse.}

Franz.: Panis noir.

Rispenähre: dunkel-grüngelb, sich nach der Spitze kolbig verdickend, mittellang, $10 \mathrm{~cm}$ (Max. $17 \mathrm{~cm}$ ) lang, an der dicksten Stelle $2 \mathrm{~cm}$ breit, grössere nickend; Borsten $1 \mathrm{~cm}$ lang, unreif grün, reif bräunlich oder etwas fuchsig. - Stroh: schmutzig-grüngelb, blattreich, doch feinhalmig. - Scheinfrucht: unreif gelb, reif schwarz, d. h. unter der Lupe schwarzbraun oder auf gelbem Grunde schwarzbraun gefleckt, fein querrunzelig, mittelgross ( $2 \mathrm{~mm}$ lang, $1.5 \mathrm{~mm}$ breit).

Zahl der Schösslinge 2, Halme gelbgrün, $90 \mathrm{~cm}$ (Max. $110 \mathrm{~cm}$ ) lang, $0.33 \mathrm{~cm}$ dick, Blattzahl 9, Blattlënge $22.7 \mathrm{~cm}$, Blattbreite $0.9 \mathrm{~cm}$, Blattfläche $475.74 \mathrm{qcm}$, Halmfläche $89.10 \mathrm{qcm}$, Gesammtfläche $564.84 \mathrm{qcm}$.

Zeitig, in 75 Tagen schossend und blühend, in 112 Tagen reifend.

Auf 1 ha wachsen 3.5 Millionen Pflanzen, mithin beträgt das Saatquantum, da 33 Millionen Samen auf $1 \mathrm{hl}(=75 \mathrm{~kg})$ entfallen, bei Drillsaat 0.13 , bei Breitsaat $0.18 \mathrm{hl}$ pro ha.

Körnicke erhielt sie 1867 aus Ungar.-Altenburg als grosse Kolbenhirse aus Ungarn.

In ihren Eigenschaften gleicht sie dem Mohar.

\section{Varietät: Panicum italicum brevisetum Döll.}

\section{Kleinere kurzborstige Kolbenhirse.}

Rispenähre: grünlich-gelb, lappig, kleine Rispen aufrecht, grosse nickend, dicht; Hüllborsten bräunlich, wenig zahlreich, vor den Aehrchen überragt, daher wenig bemerkbar. Rispe $11 \mathrm{~cm}$ ( Мax. $22 \mathrm{~cm}$ ) lang, $1.7 \mathrm{~cm}$ 
(Max. $2 \mathrm{~cm}$ ) breit. - Stroh: gelbgrün, blattreich, mittellang, kräftig, fast markig. - Scheinfrucht: blassgelb, mittelgross $(21 / 2 \mathrm{~mm}$ lang, $2 \mathrm{~mm}$ breit), gerundet.

Zahl der Schösslinge 1.5; Halme gelbgrün, $110 \mathrm{~cm}$ (Max. $165 \mathrm{~cm}$ ) lang, $0.44 \mathrm{~cm}$ dick, Blattzahl 9, Blätter $22 \mathrm{~cm}$ lang, $1.2 \mathrm{~cm}$ breit, Blattfläche $475.2 \mathrm{qcm}$, Halmfläche $141.9 \mathrm{qcm}$, Gesammtfläche $617.1 \mathrm{qcm}$.

In Poppelsdorf wurden 3 Sorten kultiviert, von denen die grössten Halme folgenden Habitus aufwiesen:

\begin{tabular}{l|c|c|c}
\hline \multicolumn{1}{c|}{ Maximum: } & $\begin{array}{c}\text { Kolbenhirse } \\
\text { aus New-York. }\end{array}$ & Setaria pumila. & $\begin{array}{c}\text { Kleine } \\
\text { Kolbenhirse ohne } \\
\text { Borsten. }\end{array}$ \\
\hline Halmlänge & $147 \mathrm{~cm}$ & $165 \mathrm{~cm}$ & $145 \mathrm{~cm}$ \\
Halmdicke & $0.5 \mathrm{~cm}$ & $0.5 \mathrm{~cm}$ & $0.43 \mathrm{~cm}$ \\
Blattzahl & 9 & 9 & 10 \\
Blattlänge & $26.66 \mathrm{~cm}$ & $29.55 \mathrm{~cm}$ & $27.7 \mathrm{~cm}$ \\
Blattbreite & $1.41 \mathrm{~cm}$ & $1.57 \mathrm{~cm}$ & $1.4 \mathrm{~cm}$ \\
Blattfäche & $676.62 \mathrm{qcm}$ & $835.02 \mathrm{qcm}$ & $775.6 \mathrm{qm}$ \\
Halmfläche & $220.5 \mathrm{qcm}$ & $201.70 \mathrm{qcm}$ & $187.0 \mathrm{~cm}$ \\
Gesammtfläche & $897.12 \mathrm{qcm}$ & $1036.72 \mathrm{qcm}$ & $962.6 \mathrm{qcm}$
\end{tabular}

Zeitig, in 75 Tagen schossend und blühend, nach 113 Tagen reifend. Auf 1 ha wachsen 3.5 Millionen Pflanzen, mithin beträgt das Saatquantum, da 32.9 Millionen Samen auf $1 \mathrm{hl}$ (=75 kg) entfallen, $0.13 \mathrm{hl}$ bei Drillsaat und $0.18 \mathrm{hl}$ bei Breitsaat.

Nur für wärmeres Kontinental-Klima geeignet.

Subrar.: maximum Keke.

\section{Grössere kurzborstige Kolbenhirse.}

Rispenähre: grünlich-gelb, lappig, nickend, dicht, gross, $20 \mathrm{~cm} \mathrm{lang,}$ $2.5 \mathrm{~cm}$ dick. Hüllborsten bräunlich, kurz, wenig bemerkbar. - Stroh: gelbgrün, sehr lang, kräftig, sehr blattreich, markig. - Scheinfrucht: hellgelb, gross $(21 / 2 \mathrm{~mm}$ lang, $2 \mathrm{~mm}$ breit), gerundet.

Zahl der Schösslinge 1.2; Halme $170 \mathrm{~cm}$ lang, $0.8 \mathrm{~cm}$ dick, Blattzahl 13, Blätter $35.5 \mathrm{~cm}$ lang, $3 \mathrm{~cm}$ breit, Blattfläche $2544 \mathrm{qcm}$, Halmfläche $408 \mathrm{qcm}$, Gesammtfläche $2952 \mathrm{qcm}$.

Spät, in 110 Tagen schossend und blühend, erst nach 160 Tagen notdürftig reifend.

Auf 1 ha wächst 1 Million Pflanzen, mithin beträgt das Saatquantum, da 26.6 Millionen Samen auf $1 \mathrm{hl}(=73 \mathrm{~kg})$ entfallen, bei Drillsaat $0.05 \mathrm{hl}$, bei Breitsaat $0.07 \mathrm{hl}$ pro ha.

Diese Hirse wurde aus Minhos, Portugal durch Jul. Henriques aus Coïmbra eingesandt, und eignet sich nur für warme Klimate.

Subrar:: insigne Kcke.

\section{Grosse kurzborstige Kolbenhirse mit gelben Samen.}

Rispenähre: grünlich-gelb, lappig, nickend, ausserordentlich gross (30 cm lang, $4 \mathrm{~cm}$ breit); Borsten sehr kurz, wenig zahlreich, daher verschwin- 
dend. - Stroh: schmutzig-gelbgrün, sehr kräftig, blattreich, markig. Scheinfrucht: grünlich-gelb bis blassgelb, überall feinrunzelig, gerundet, verhältnismässig gross ( $3 \mathrm{~mm}$ lang, $2 \mathrm{~mm}$ breit).

Halme und Blätter gelbgrün, bestockte sich in Poppelsdorf nicht. Halme $150 \mathrm{~cm}$ lang, $1.1 \mathrm{~cm}$ dick, Blattzahl 13, Blätter $41 \mathrm{~cm}$ lang, $2.63 \mathrm{~cm}$ breit, Blattoberfläche $2804.1 \mathrm{qcm}$, Halmfläche $495 \mathrm{qcm}$, Gesammtfläche $3299.1 \mathrm{qcm}$.

Sehr spät, in 120 Tagen schossend und blühend, erst nach 165 Tagen konnten einige notreife Scheinfrichte geerntet werden.

Auf 1 ha wächst 1 Million Pflanzen, da 25.6 Millionen Scheinfrüchte auf $1 \mathrm{hl}(=73 \mathrm{~kg})$ entfallen, so beträgt das Saatquantum bei Drillsaat $0.05 \mathrm{hl}$.

Wir erhielten diese Hirse als ,Millet d'Jtalie" von der Fürstin Wied aus Rumänien.

$\mathrm{Zu}$ ihrer Ausreife verlangt sie heisse Sommer, bringt daher erst im wärmeren, gemässigten Klima befriedigende Ernten.

\section{Verietät: Panicum italicum aurantiacum Kcke.}

\section{Orangenfarbige Kóolbenhirse.}

Franz.: Panis orange.

Rispenähre: rot, sehr lappig, ziemlich dicht, nickend; Borsten braun, kurz, 5-6 mm lang, spärlich. - Stroh: gelbgriü oder orangefarben, ziemlich kurz, ziemlich blattreich, markig. - Scheinfrucht: orangerot, heller als P. it. erythrospermum, unreif gelb, spitzlich, sehr klein (2 mm lang, $1.05 \mathrm{~mm}$ breit).

Angebaut wurden 4 Sorten, die sich im Habitus wie folgt unterschieden:

\begin{tabular}{|c|c|c|c|c|c|c|}
\hline & & \multicolumn{3}{|c|}{ Mittlerer Halm } \\
\hline & & $\begin{array}{l}\begin{array}{c}\text { Setaria } \\
\text { folia } \\
\text { h. Dresc }\end{array} \\
\text { Mittl. } \\
\text { Halm }\end{array}$ & $\begin{array}{l}\text { a brevi- } \\
\text { Jahn } \\
\text { den } 1872 . \\
\text { Grösster } \\
\text { Halm }\end{array}$ & $\begin{array}{l}\text { Setaria ita- } \\
\text { lica var. } \\
\text { dilatata von } \\
\text { Haage \& } \\
\text { Schmidt, } \\
\text { Erfurt } 1870 .\end{array}$ & \begin{tabular}{|c|} 
Panicum \\
eriogonum, \\
Algier, von \\
der Wiener \\
Ausstellung \\
1873.
\end{tabular} & $\begin{array}{c}\text { Setaria } \\
\text { persica } \\
\text { von Haage } \\
\& \text { Schmidt, } \\
\text { Erfurt. }\end{array}$ \\
\hline $\begin{array}{l}\text { Rispenlänge : } \\
\text { Rispenbreite } \\
\text { Anzahl der Sch } \\
\text { Halmlänge } \\
\text { Halmdicke : } \\
\text { Blattzahl : } \\
\text { Blattlänge: } \\
\text { Blattbreite : } \\
\text { Blattfläche : } \\
\text { Halmfläche : } \\
\text { Gesammtfläche }\end{array}$ & 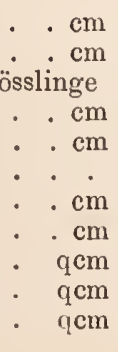 & $\begin{array}{c}12 \\
1.5 \\
1.3 \\
90 \\
0.4 \\
7.8 \\
28.1 \\
1.6 \\
701.22 \\
108.0 \\
809.22\end{array}$ & \begin{tabular}{|c|}
18 \\
2.5 \\
2.5 \\
120 \\
0.6 \\
10 \\
34.2 \\
1.66 \\
1135.4 \\
226.3 \\
1361.7
\end{tabular} & $\begin{array}{c}16 \\
1.8 \\
1 \\
85 \\
0.43 \\
8 \\
27.5 \\
1.67 \\
735.2 \\
109.7 \\
844.9\end{array}$ & $\begin{array}{c}12 \\
1.5 \\
2 \\
75 \\
0.5 \\
10 \\
23.7 \\
1.3 \\
616.2 \\
115.7 \\
731.9\end{array}$ & $\begin{array}{c}17 \\
2 \\
3 \\
95 \\
0.6 \\
8 \\
32 \\
1.5 \\
768 \\
171 \\
939\end{array}$ \\
\hline
\end{tabular}
reifend.

Mittelfrüh, in 85 Tageu schossend und blühend, nach 125 Tagen 
Auf 1 ha wachsen 2 Millionen Pflanzen, mithin beträgt das Saatquantum, da 38.3 Millionen Samen auf $1 \mathrm{hl}(=75 \mathrm{~kg}$ ) entfallen, bei Drillsaat $0.07 \mathrm{hl}$, bei Breitsaat $0.09 \mathrm{hl}$ pro ha.

Diese Hirse eignet sich für das wärmere gemässigte und subtropische Klima.

\section{Varietät: Panicum italicum gigas Kcke.}

\section{Grosse Kolbenhirse ohne Borsten.}

Rispenähre: rot, lappig, nickend, ausserordentlich gross, bis $25 \mathrm{~cm}$ lang, $4 \mathrm{~cm}$ dick, ohne (d. h. mit sehr kurzen) Borsten, letztere wenig zahlreich, hell, nicht in die Augen fallend. - Stroh: schmutzig-gelbgrün, blattreich, markig, sehr lang und kräftig. - Scheinfrucht: orangerot, ziemlich gerundet, feinrunzelig auf allen Seiten, dadurch von den Scheinfriichten des Panic. it. aurantiacum zu unterscheiden, schlecht ausgebildete Scheinfrüchte gelb, gross $(21 / 2 \mathrm{~mm}$ lang, $2 \mathrm{~mm}$ breit).

Halm an der Basis rötlich, Basis der Blattspreite und der Nittelnerv rot, sonst Alles dunkelgrün. 2.5 Schösslinge und ein Halm mittlerel Grösse besass eine Gesammtoberfläche von $1511.16 \mathrm{qcm}$, während ein Halm der grössten Pflanze folgenden Habitus aufwies; Halmlänge $155 \mathrm{~cm}$, Halmdicke $0.9 \mathrm{~cm}$, Blattzahl 13, Blätter $43.3 \mathrm{~cm}$ lang, $1.94 \mathrm{~cm}$ breit, Blattfläche $2184 \mathrm{qcm}$, Halmfläche $438.43 \mathrm{qcm}$, Gesammtfläche $2622.43 \mathrm{qcm}$.

Sehr spät, in 110 Tagen schossend und blühend, nach 160 Tagen erst notdürftig reifend.

Auf 1 ha wächst 1 Million Pflanzen, mithin heträgt das Saatquantum, da 27 Nillionen Scheinfrüchte auf $1 \mathrm{hl}(=73 \mathrm{~kg})$ entfallen, bei Drillsaat $0.05 \mathrm{hl}$.

Diese Hirse eignet sich selbst für das Weinklima nicht mehr, sondern gedeiht nur in wärmeren Klimaten, so in Italien, Spanien etc.

\section{Grappe II. Germanicam Roth. Kleine Kolbenhirse (Iohar).}

Varietät: Panicum italieum Metzgerii Keke.

\section{Mohar.}

Sy n.: Kleine Kolbenhirse mit gelben Samen aus Ungarn.

Franz.: Moha de Hongrie.

Rispenähre: bräunlich, wegen der dunkelbraunen langen Borsten und braunen Klappen, walzlich, dicht, aufrecht, klein, $7.5 \mathrm{~cm}$ (Мax. $11 \mathrm{~cm}$ ) lang, $1.2 \mathrm{~cm}$ (Max. $1.8 \mathrm{~cm}$ ) breit; Spindel und Blütenstiel behaart; Borsten lang $(7 \mathrm{~mm})$. - Stroh: gelbgrün, blattreich, kurz, markig. - Scheinfrucht: gelb, etwas spitzlich, klein ( $2 \mathrm{~mm}$ lang, $1.5 \mathrm{~mm}$ breit).

Zahl der Schösslinge 2.4; Halme gelbgrün, $80 \mathrm{~cm}$ (Hax. $127 \mathrm{~cm}$ ) lang, $0.28 \mathrm{~cm}$ (Max. $0.33 \mathrm{~cm}$ ) dick, Blattzahl 7.5 (Мax. 9), Blätter $18.9 \mathrm{~cm}$ (Max. $29.77 \mathrm{~cm}$ ) lang, $1.14 \mathrm{~cm}$ (Мax. $1.22 \mathrm{~cm}$ ) breit, Blattfä̈che $323.25 \mathrm{gcm}$ (Max. $653.76 \mathrm{qcm}$ ), Halmfläche $97.2 \mathrm{qcm}$ (Max. $131.72 \mathrm{qcm}$ ), Gesammtfläche $420.45 \mathrm{qcm}$ (Max. $785.48 \mathrm{qcm}$ ); ferner besass der grösste Haln 
noch 2 Halmsprossen von 81 und $58 \mathrm{~cm}$ Länge, mit 6 resp. 4 Blättern, welche Blattflächen von $242.6 \mathrm{qcm}$ und $169.66 \mathrm{qcm}$ aufwiesen, mithin sich die Gesammtfläche des grössten Halmes auf $1197.74 \mathrm{acm}$ stellt.

Zeitig, in 80 Tagen schossend und blühend, nach 122 Tagen reifend.

Auf 1 ha wachsen 3.5 Millionen Pflanzen, mithin beträgt das Saatquantum, da 33.5 Millionen Samen auf $1 \mathrm{hl}$ (=78 kg) entfallen, bei Drillsaat $0.15 \mathrm{hl}$, bei Breitsaat $0.19 \mathrm{hl}$ pro ha.

Die eigentliche Heimat des Mohar ist Ungarn, doch wird er auch viel in Illyrien, Oesterreich und Italien, sehr selten in der Schweiz, in Schlesien und Baden gebaut. Nach . Frankreich wurde derselbe durch Graf von Gourcy 1815, und durch Borda 1820 in die Umgebung von Metz eingeführt, letzterer sandte von dem Samen an Vilmorin, Paris, der ihn namentlich in Siid-Frankreich auf den kalkhaltigen trocknen Lehm- und Sandböden verbreitete.

In dem Steppenklima Ungarns bringt er selbst auf ganz leichtem Boden sichere Erträge. Tom Mai, ab bis Mitte August wird er breitwürfig zur Grünfuttererzeugung ausgesäet, und da die Saatquantität gering, so kommt dieselbe billiger als die des Maises und Wickfutters zu stehen. Er ist in Ungarn wohl überall in die Fruchtfolgen ${ }^{1}$ ) der Sandregionen wegen seiner relativ hohen Erträge an Futter (3600 bis $4500 \mathrm{~kg}$ Heu pro ha) und Widerstandsfähigkeit gegen Dürre, wodurch er als sehr wesentliche Stütze der Viehhaltung erscheint, mit aufgenommen.

Der Mohar sendet seine Wurzeln tief in den Boden, weshalb er auch der Dürre vortrefflich widersteht; so führt Vilmorin ${ }^{2}$ ) an, dass bei der grossen Dürre von 1842, als der grösste Teil der Kulturpflanzen verdorrte, der Mohar keinen Augenblick zu vegetieren aufhörte und noch $8000 \mathrm{~kg}$ reifen Mohar p. ha lieferte.

In Gegenden mit kühlen, feuchten Sommern gedeiht dagegen der Mohar nicht.

Im grünen Zustande frisst das Vieh den Mohar nicht gern, nimmt ihn jedoch als Heu um so lieber an, je mehr sich die Pflanzen entwickelt haben, daher man zur Heuwerbung das Erscheinen der Rispen abwartet.

Wie sich die Nährstoffmengen in den versehiedenen Vegetationsstadien des Mohar stellen, ergiebt sich aus Analysen von Moser und Metzdorf ${ }^{3}$ ), welche dieselben in Ida-Marienhütte ansgefïhrt baben.

Wasser. Asche. Holzfaser. Nfr. Nh.

I. Schnitt 11. Juli, 8 bis $10.5 \mathrm{~cm}$ hoch . $80.95 \quad 12.5 \quad 2.4911 .44 \quad 4.5620 .94 \quad 7.1032 .58 \quad 4.9022 .54$

II. Schnitt 26. Juli, 21 bis $26 \mathrm{~cm}$ hoch.

III. Schnitt 10. August, 39-4l crn hoch?

IV. Schnitt 24. August, $47-63 \mathrm{~cm}$ hoch (in der Blüte). . .

V. Schnitt 7. Septbr. $47-63 \mathrm{~cm}$ hoch (nach der Blüte).

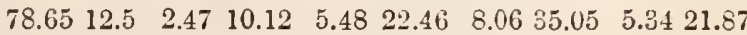

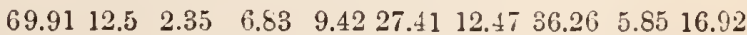

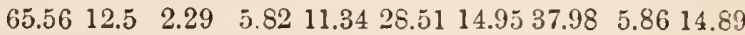

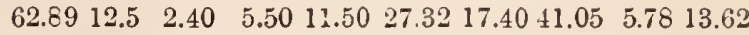

1) Vergl. Werner, Studienreise durch Ungarn, Landw. Jahrb. 1880.

2) Journ. d'Agric. prat. 1858 II pg. 373.

3) Wilda's Centralbl. 1861. I. 552. 
Die Erträge an Grünfutter und Heu stellen sich p. ha wie folgt: Es erzielten

Vianne, Boden leicht, fruchtbar . $45.000 \mathrm{~kg}$ Grünfutter - $\mathrm{kg}$ Heu $\mathrm{R}$ o b in e t, Kalkboden

In Frankreich bei grosser Dürre auf Kalkboden

In Grignon, Boden trocken, leicht, kreidig

Wilhelm, Ungarisch - Altenburg, 3 jähr. Durchschnitt

Mayer in Preuss bei Nimptsch auf mildem Lehmboden

Durchschnitt p. ha ca.: $29.100 \mathrm{~kg}$ Grïnfutter $6400 \mathrm{~kg} \mathrm{Heu}$.

Mayer in Preuss erntete $p$. ha an vollkommen reinen und reifen Samen $874 \mathrm{~kg}$, an Stroh $4641 \mathrm{~kg}$, an Spreu $234 \mathrm{~kg}$. Die Samen enthülsen sich schwer, bieten aber geschroten ein vorzügliches Kraftfutter für Rindvieh, ungeschroten für Geflügel.

Das Heu wird in Ungarn vorzugsweise an die Zugochsen verfüttert, doch fressen es auch Pferde und Schafe, nur verschmähen letztere die borstigen Rispen.

\section{Varietät: Panicum italicum mite $\mathrm{Al}$.}

\section{Kleine gelbe Kolbenhirse.}

Rispenähre: grün, aufrecht, nur die grösseren nickend, dünn, walzlich, mittellang; Borsten hellgrünlich-gelb, zahlreich, $5 \mathrm{~mm}$ lang. - Stroh: grünlich-gelb, mittellang, ziemlich blattreich. - Scheinfrucht: gesättigt gelb, klein ( $2 \mathrm{~mm}$ lang, $1.5 \mathrm{~mm}$ breit), gerundet.

Anzahl der Schösslinge 1.5; Halme kahl, fast ganz von der Blattscheide umschlossen, gelbgrün, Blätter rauh.

Die mittleren und grössten Halme zeigten folgenden Habitus:

$\begin{array}{lcc} & \text { Mittel } & \text { Maximum } \\ \text { Rispenlänge } & 11 \mathrm{~cm} & 14 \mathrm{~cm} \\ \text { Rispenbreite } & 1.5 \mathrm{~cm} & 2.5 \mathrm{~cm} \\ \text { Halmlänge } & 100 \mathrm{~cm} & 123 \mathrm{~cm} \\ \text { Halmdicke } & 0.4 \mathrm{~cm} & 0.5 \mathrm{~cm} \\ \text { Blattzahl } & 8 & 8 \\ \text { Blattlänge } & 23.25 \mathrm{~cm} & 29.66 \mathrm{~cm} \\ \text { Blattbreite } & 1.34 \mathrm{~cm} & 1.8 \mathrm{~cm} \\ \text { Blattfläche } & 498.56 \mathrm{qcm} & 961.02 \mathrm{qm} \\ \text { Halmfläche } & 120 & 193.29 " \\ \text { Gesammtläche } & 618.56 ", & 1154.31 "\end{array}$

Zeitig, in 80 Tagen schossend und blühend, nach 115 Tagen reifend.

Auf 1 ha wachsen 3.5 Millionen Pflanzen, mithin beträgt das Saatquantum, da 34.2 Millionen Samen auf $1 \mathrm{hl}$ entfallen, bei Drillsaat $0.13 \mathrm{hl}$, bei Breitsaat $0.18 \mathrm{hl} \mathrm{p}$. ha.

Nach Metzger, Pflanzenkunde, wild: in Indien, verwildert: im südlichen Frankreich; kultiviert: in Italien, Frankreich, der Schweiz, Baden, Oesterreich, Illyrien.

In Deutschland empfiehlt sie sich für wenig produktive, sandige Felder, auf denen die Rispenhirse nicht mehr gut gedeiht. Sie wird als Vogelfutter und zur Grützbereitung verwertet, steht aber als Futterpflanze dem Mohar nach. 


\section{Kleine, gelbe, dichte Kolbenhirse ohne Borsten.}

Rispenähre: grünlich-gelb, kurz, $8 \mathrm{~cm}$ (Max. $10 \mathrm{~cm}$ ) lang, sehr dicht, etwas lappig, aufrecht; Borsten griun, jedoch so klein und wenig zahlreich, dass sie für das unbewaffnete Auge verschwinden. Stroh: gelbgrün, markig, kurz. - Scheinfrucht: gelb, klein (2 mm lang, $1.5 \mathrm{~cm}$ breit), gerundet.

Anzahl der Schösslinge 1.2, Halme gelbgrün, $100 \mathrm{~cm}$ (Max. $118 \mathrm{~cm}$ ) lang, $0.38 \mathrm{~cm}$ dick, Blattzahl 6.6, Blätter $21.3 \mathrm{~cm}$ lang, $1.38 \mathrm{~cm}$ breit, Blattfläche 378.9 qcm, Halmfläche $114 \mathrm{qcm}$, Gesammtfläche $501.9 \mathrm{qcm}$.

Sehr zeitig, nach 73 Tagen blühend; nach 110 Tagen, am frühesten von allen reifend.

Auf 1 ha wachsen 5 Millionen Pflanzen, mithin beträgt das Saatquantum, da 36.7 Millionen Samen auf $1 \mathrm{hl}(=78 \mathrm{~kg})$ entfallen, bei Drillsaat $0.18 \mathrm{hl}$, bei Breitsaat $0.23 \mathrm{hl} \mathrm{p}$. ha.

Zur Kultur in Sïd-Deutschland geeignet.

\section{Varietät: Panicum italicum atrum Kcke.}

\section{Kileine schwarze Kolbenhirse.}

Rispenähre: dunkelbraun, sich nach der Spitze kolbig verdickend, aufrecht, einige hängend, klein, $8 \mathrm{~cm}$ (Max. $13 \mathrm{~cm}$ ) lang, $1.3 \mathrm{~cm}$ und an der dicksten Stelle $2 \mathrm{~cm}$ dick; Borsten zahlreich, braun, mittellang, beinahe $1 \mathrm{~cm}$ lang. - Stroh: schmutzig-gelbgrün bis violett, blattreich, feinhalmig, häufig markig. - Scheinfrucht: nicht ganz reif, so hellgelb, glatt; reif schwarzbraun, fleckig, fein querrunzelig, gerundet, verhältnismässig gross $\left(2^{\mathrm{y}} / 2 \mathrm{~mm}\right.$ lang, $2 \mathrm{~mm}$ breit).

Halme dunkelgrün; Zahl der Schösslinge 3.

Habitus eines mittleren und eines grössten Halmes:

$\begin{array}{lcc} & \text { Mittel } & \text { Maximum } \\ \text { Halmlänge } & 90 \mathrm{~cm} & 125 \mathrm{~cm} \\ \text { Halmdicke } & 0.3 \mathrm{~cm} & 0.33 \mathrm{~cm} \\ \text { Blattzahl } & 9 & 9 \\ \text { Blattlänge } & 22.6 \mathrm{~cm} & 28.7 \mathrm{~cm} \\ \text { Blattbreite } & 0.85 \mathrm{~cm} & 1.1 \mathrm{~cm} \\ \text { Blattfläche } & 345.78 \mathrm{qm} & 568.26 \mathrm{qcm} \\ \text { Halmfläche } & 81 \mathrm{M} & 129.64 ", \\ \text { Gesammtfäche } & 426.78 " & 707.90 ",\end{array}$

Zeitig, in 83 Tagen schossend und blühend, nach 113 Tagen reifend.

Auf 1 ha wachsen 3.5 Millionen Pflanzen, mithin beträgt das Saatquantum, da 27 Millionen Samen auf $1 \mathrm{hl}(=75 \mathrm{~kg})$ entfallen, bei Drillsaat 0.18 , bei Breitsaat $0.23 \mathrm{hl} \mathrm{p}$. ha.

Körnicke erhielt sie 1867 ans Ungar. Altenburg und gleicht sie in ihrem sonstigen Verhalten genau Panic. it. Metzgerii. 


\section{An hang.}

Panicum viride $L$.

\section{Grüner Fennich.}

Rispenähre: hellgrün, dünn, kurz, $10 \mathrm{~cm}$ lang, $1 \mathrm{~cm}$ dick, walzlich, ziemlich aufrecht; Aehrchen von den Hüllborsten weit überragt, letztere hellgrün, zahlreich, bis $1 \mathrm{~cm}$ lang. - Stroh: gelbgrün bis violett, feinhalmig. - Scheinfrucht: braunschwarzfleckig und ziemlich fest von den grau-grünen Elappen umschlossen, feinrunzelig, sehr klein, $1.5 \mathrm{~cm}$ lang, $1 \mathrm{~mm}$ breit.

Anzahl der Schösslinge 2, Halme gelbgrün, $95 \mathrm{~cm}$ lang, $0.33 \mathrm{~cm}$ dick, Blattzahl 6, Blätter $21.66 \mathrm{~cm}$ lang, $0.95 \mathrm{~cm}$ breit, Blattfläche $246.96 \mathrm{qcm}$, Halmfläche $98.53 \mathrm{qcm}$, Gesammtfläche $345.49 \mathrm{qcm}$, doch treten noch 4 Seitensprossen des Halmes mit 10 Blättern und einer Oberfläche von $275 \mathrm{qcm}$ hinzu, so dass die Gesammtoberfläche $620.49 \mathrm{qcm}$ ausmacht.

Zeitig, nach 75 Tagen schossend und blühend und 118 Tagen reifend.

Auf 1 ha wachsen 3 Hillionen Pflanzen, mithin beträgt das Saatquantum, da 48.2 Millionen auf $1 \mathrm{hl}(=75 \mathrm{~kg})$ entfallen, bei Drillsaat $0.08 \mathrm{hl}$, bei Breitsaat $0.11 \mathrm{hl} \mathrm{p}$. ha.

Für Sandboden in guter Düngung im Kontinentalklima zur Heu-, weniger zur Kornproduktion geeignet.

Weiden hammer ${ }^{1}$ ) drillte diese Hirse auf $7.8 \mathrm{~cm}$ und säete breitwürfig aus. Die Tiefe der Unterbringung betrug $1.3 \mathrm{~cm}$. Er erntete $3510 \mathrm{~kg} \mathrm{Heu} \mathrm{p.} \mathrm{ha} \mathrm{und} \mathrm{585-780} \mathrm{kg} \mathrm{Weidefutter} \mathrm{aus} \mathrm{dem} \mathrm{Stoppelauf-}$ schlag. Der Kornertrag stellte sich auf $526.5 \mathrm{~kg}$ und $3900 \mathrm{~kg}$ Stroh p. ha.

Das Heu wurde von Pferden und das Stroh auch von Kühen gern gefressen.

Der grüne Fennich ist die Stammform der Kolbenhirse und kommt wild in Mittel- und Süd-Europa etc. vor.

\section{Die biologischen Verhältnisse der Kolbenhirse.}

Die Samenkörner sollen vollkommen ausgereift sein, worauf namentlich in solchen Gegenden zu achten, in denen Kolbenhirsen nicht immer gut reifen, ferner ein möglichst hohes absolutes Gewicht und keinen multrigen Geruch besitzen, welchen sie bei nicht vorsichtiger Aufbewahrung leicht annehmen. Sie verlieren unter solchen

1) Mitteil. d. Ver. f. Land- u. Forstw. im Herzogt. Braunschweig. 
Umständen ihre Keimkraft, welche ibberhaupt schnell erlischt; so keimten nach Wilhelm ${ }^{1}$ ) von zweijährigen Samen 64 Proc., und von vierjährigen nur 3 Proc.

Gedörrte Samen dürfen ebenfalls nicht zur Saat verwandt werden, denn nach $\mathrm{Haberlandt}$ keimte bei fünfstündiger Einwirkung einer Wärme von $55^{\circ} \mathrm{C}$., sowohl ron trocknen als auch eingeweichten Samen kein einziger.

Die Samenkörner sind annähernd halb so gross als die der Rispenhirse, denn von der Kolbenhirse entfallen 33.5 Millionen auf $1 \mathrm{hl}(=75 \mathrm{~kg})$, und von der Rispenhirse durchschnittlich nur 15.5 Millionen auf $1 \mathrm{hl}(=77 \mathrm{~kg})$.

Die Menge des zum Keimen notwendigen Quellungswassers ist wahrscheinlich ebenso gering wie bei der Rispenhirse, wo es ungefähr 25 Proc. betrug. Die Kolbenhirse erfordert zum schnellen Aufkeimen sehr riel Wärme, denn nach Haberlandt erfolgte beim Mohar die Keimung mit dem Sichtbarwerden des Wirzelchens erst bei

\begin{tabular}{|c|c|c|c|}
\hline . & $10.25^{\circ} \mathrm{C}$. & $15.75^{\circ} \mathrm{C}$. & $19.00^{\circ} \mathrm{C}$. \\
\hline in Tagen . . . . . . . . . . . . . . & 7.5 & 2.75 & 2 \\
\hline $\begin{array}{l}\text { Durchschnittliches Längenwachstum in } \\
\text { mm pro Tag }\end{array}$ & 0.81 & 3.92 & 5.82 \\
\hline
\end{tabular}

Hieraus ersieht man, dass die Keimung erst bei höherer Temperatur wesentliche Fortschritte macht, und da ausserdem die Kolbenhirse gegen Frost in hohem Grade empfindlich ist, erscheint es zweckmässiger, mit der Aussaat zu warten, bis sich der Boden auf $12-15^{0} \mathrm{C}$. erwärmt hat.

Die Samenkörner dïrfen, weil sehr klein, auf Lehmboden nur $0.5 \mathrm{~cm}$, auf Mittelboden $1 \mathrm{~cm}$ und auf sehr leichtem Sande höchstens $1.5 \mathrm{~cm}$ tief untergebracht werden.

Der Wachsraum einer Pflanze unterliegt, je nach dem Habitus und den Anbaurerhältnissen, sehr grossen Abweichungen, und schwankte derselbe in Poppelsdorf zwischen 20 und $100 \mathrm{qcm}$ und das Mittel stellte sich auf $53 \mathrm{qcm}$.

Ueberhaupt ergaben sich für die in Poppelsdorf kultivierten Varietäten nebenstehende (Seite 902) Vegetationsrerhältnisse:

Die Vegetationszeit der Kolbenhirse ist länger als die der Rispenhirse und beträgt zwischen 110 und 165 Tagen, im Mittel 131 Tage, während das Mittel bei der Rispenhirse nur 106 Tage

1) Neue landw. Ztg. 1868. pg. 241. 


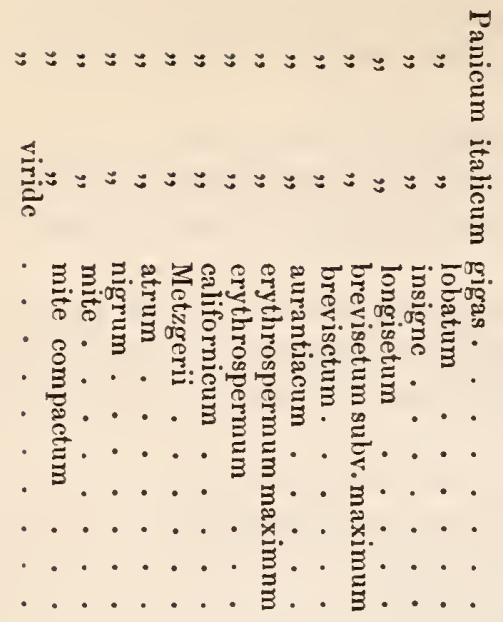

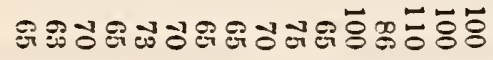

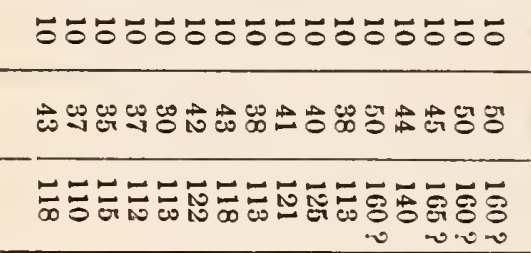

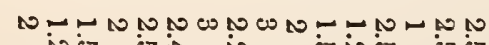

iver er is is bivio ic

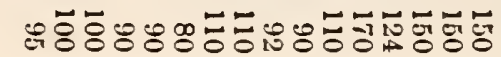

ด

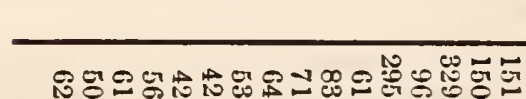

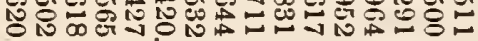
r ir

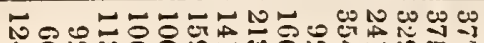

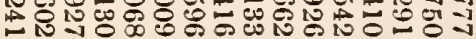

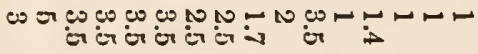

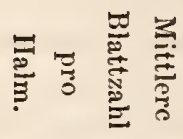

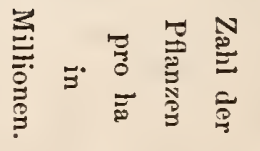

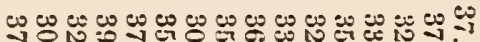
is - is $\rightarrow$ is 0 is is is it is is is 
ausmacht, demzufolge stellt sich auch die Wärmesumme bei der Kolbenhirse höher, nämlich auf $1800-3000^{\circ} \mathrm{C}$.

Obgleich nun auch die Kolbenhirse als Flachwurzler und eehte Krumepflanze anzusehen, so erträgt sie doch vortrefflich die Trockenheit und ist nach Risler die Verdunstung sehr gering, nämlich dieselbe beträgt beim Mohar auf 100 qem Oberfläche nur $1.84 \mathrm{gr}$ Wasser.

Betreffs der Bodenerschöpfung durch den Anbau der Kolbenhirse ist zu bemerken, dass darïber die Untersuchung von Moharbeu durch J. Moser einigen Anhalt bietet; derselbe fand 5.672 Proc. Asche und in derselben folgende Mineralstoffmengen:

\begin{tabular}{|c|c|c|c|c|}
\hline Kieselsäure & & & & 25.598 \\
\hline Schwefelsäure & & & & 3.584 \\
\hline Phosphorsäur & & & & 6.620 \\
\hline Eisenoxyd . & & & & 1.265 \\
\hline Kalkerde & & . & . & 9.515 \\
\hline Magnesia & & & & 11.719 \\
\hline Kali . & & & & 33.908 \\
\hline Natron . & & & & 3.910 \\
\hline Chlornatrium & & & & 3.881 \\
\hline
\end{tabular}

Die Feinde, welche hauptsächlich der Hirse gefährlich werden, sind schnellwachsende breitblättrige Unkräuter, weil diese die in ihrer ersten Jugendzeit sehr langsam vegetierenden Pflanzen leicht überwuchern, weshalb ihnen durch Jäten und Hacken entgegenzutreten ist.

Die Samenkörner leiden durch den Flugbrand (Ustilago Carbo Tul.), sowie von einem durch $\mathrm{K} \ddot{\mathrm{r} n \mathrm{nick} e}$ aufgefundenen Brandpilz (Ustilago Crameri Kcke.), letzterer verändert die Gesammtgestalt der Rispe nicht, und der brandige Fruchtknoten bleibt geschlossen.

Zur Reifezeit leidet sie stark durch Vogelfrass.

\section{Klima und Boden.}

Die Kolbenhirse verlangt ein warmes Kontinentalklima und leidet in feuchten, kühlen Sommern, daher ihr Anbau wohl kaum uber den $50^{\circ} \mathrm{n} . \mathrm{Br}$. in Europa und Asien, und nicht über den $45^{\circ}$ n. Br. in Nord-Amerika hinausgeht, und in Australien bis zum $40^{\circ}$ s. Br. reicht.

Ihr Anbau als Körnerfrucht und Futtergewächs ist in Ostindien, dem Sundaarchipel, China, Japan, Süd-Europa, Afrika, Nord-Amerika und Westindien verbreitet.

Gegen Dürre ist sie in hohem Grade widerstandsfähig.

In der kälteren gemässigten Zone gedeiht sie am besten auf den leichten Böden, z. B. auf dem humosen sandigen Lehm, oder lehmi- 
gen Sand, sowie auf Sandmergel- und Kalkböden, während schwere bindige Böden, welche jedoch in den wärmeren Klimaten den Vorzing verdienen, zu vermeiden sind.

Frisch umgebrochenes Grasland sagt der Kolbenhirse sehr zu.

\section{Düngung und Frnchtfolge.}

In Dungkraft stehende Böden werden sich im Allgemeinen besser als frisch gedüngte für die Kolbenhirse empfehlen, z. B. gut gedüngte und bearbeitete Hackfrüchte, wie Kartoffeln, Mais etc., welche nicht nur reichliche Mengen an Pflanzennährstoffen der Ackerkrume zuricklassen, sondern dieselbe auch der Nachfrucht möglichst frei von Unkraut übergeben.

Zuweilen. wenn die Kolbenhirse zur Grünfüterung benutzt wird, düngt man mit Stallmist, auch wïrden sich zur kräftigen Entwickelung der Pflanzen stickstoffhaltige Kunstdünger rortrefflich eignen.

Auf der Erzherzoglich Albrecht'schen Herrschaft UngarischAltenburg, in der auf Sandboden viel Mohar kultiviert wird, gestalten sich die Fruchtfolgen wie folgt:

I.

1) Mais, Rüben, Mohar ${ }^{1}$ )

2) Mohar, Mais

3) Roggen

4) Brache ${ }^{1}$ )

5) Weizen

6) Hafer

7) Griinmais ${ }^{1}$ )

8) Weizen.
II.

1) Brache ${ }^{1}$ )

2) Weizen

3) Mais

4) Mohar 1)

5) Weizen

6) Gerste

7) Wickfutter

8) Weizen

9) Hafer.

\section{Bodenbearbeitung, Aussaat, Pflege.}

Die Ackerkrume ist zur Kultur der Kolbenhirse vor Winter bis zur vollen Tiefe zu pflügen und im Frühjahr zu grubbern und mit der Egge resp. Walze zu präparieren, da die sehr kleinen Samenkörner im scbolligen Lande weniger gleichmässig aufgehen.

Die Zeit der Aussaat fällt meist mit der der Rispenhirse zu-

1) = gedüngt. 


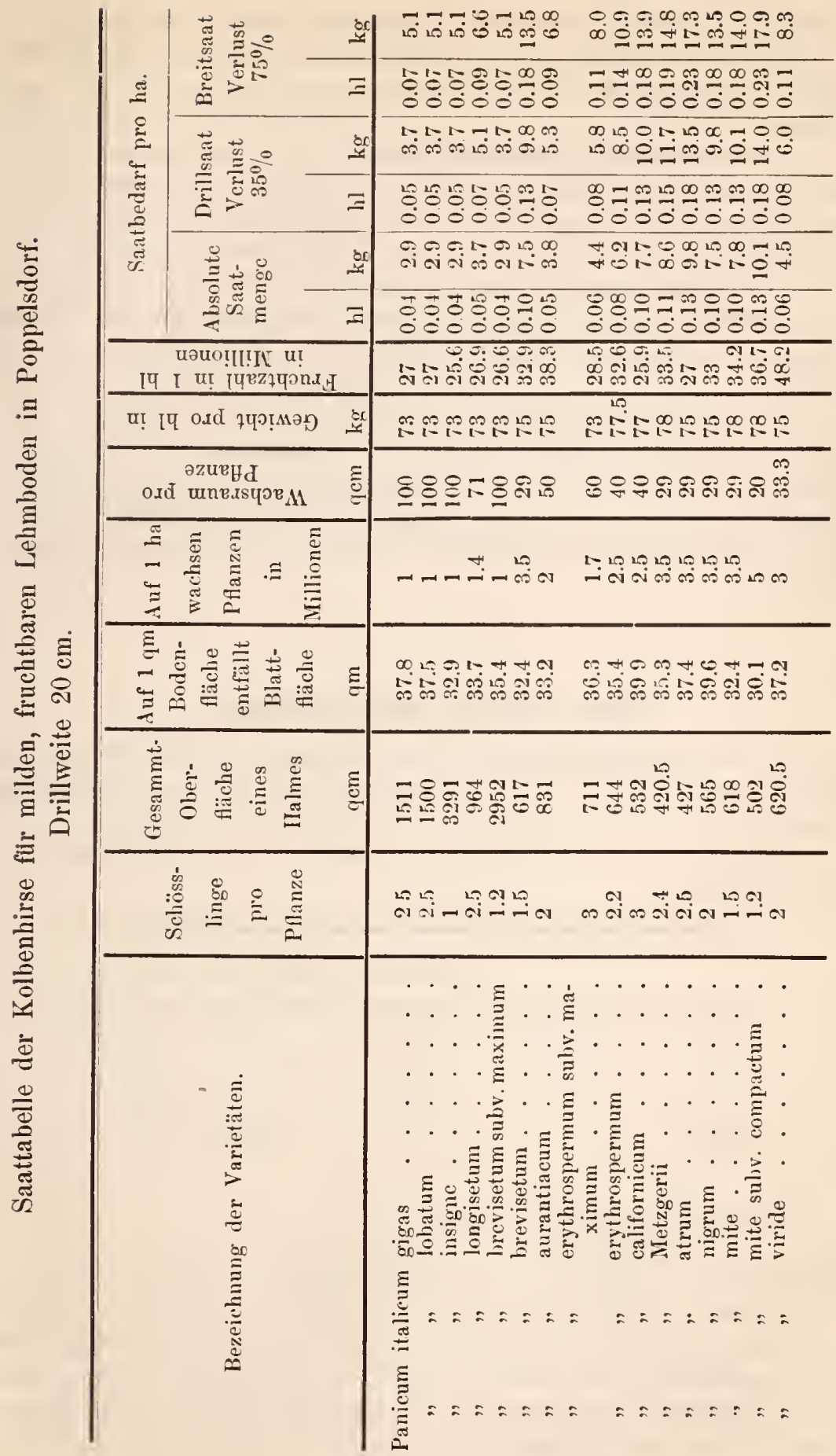


sammen, also in der wärmeren gemässigten Zone in den April (z. B. in Japan von April bis Juni), in der kälteren Anfang Mai bis Mitte Juni, doch lässt sie sich für Grünfutter bis zum August hin ausdehnen.

Die vorstehende Saattabelle (Seite 905) gibt den Saatbedarf pro ha fiur die in Poppelsdorf kultivierten Varietäten an; wobei zu bemerken ist, dass zur Grünfuttererzeugung die Saatquanta für die breitwürfige Aussaat um 33 Proc. zu erhöhen sind.

Die Aussaat hat auf gut abgetrocknetem Boden entweder mit einer Drillmaschine, oder mit der Hand über Kreuz und die Unterbringung mit leichten hölzernen Strauch-, oder Wieseneggen zu erfolgen.

Die Pflege der Kolbenhirse erstreckt sich nicht nur auf Verhütung der Verkrustung, wodurch die Keimpflänzchen am Hervorbrechen behindert werden, sondern auch auf Zerstörung des Unkrautes, weshalb man gern vor dem Auflaufen noch einmal eggt, nachher walzt und sobald als möglich durch Hacken und Jäten das Unkraut zerstört.

\section{Ernte, Ertrag und Benntzung.}

Ueber den zweckmässigsten Reifezustand, die Erntezeit und die Ausführung der Ernte verweise ich auf das bei der Rispenhirse Gesagte.

Die Erträge der Kolbenhirse stellen sich im Allgemeinen pro ha wie folgt:

\begin{tabular}{ll|r|r|r}
\hline \hline & & Mininum & Maximum & Mittel \\
\hline Körner 1 hl à $75 \mathrm{~kg}$ &. & $15 \mathrm{hl}$ & $35 \mathrm{hl}$ & $20 \mathrm{hl}$ \\
Stroh . . . . . . . . & $1200 \mathrm{~kg}$ & $2500 \mathrm{~kg}$ & $2500 \mathrm{~kg}$ \\
Spreu . . . . . . . . & $50 \mathrm{~kg}$ & $240 \mathrm{~kg}$ & $120 \mathrm{~kg}$
\end{tabular}

Die Körner (Mohar) entbalten an:

$\begin{array}{cccccc} & \text { Stickstoff- } & & \text { stickstoffreien } \\ \text { Trockensubstauz } & \text { Substanz } & \text { Fett } & \text { Extraktstoffen } & \text { Holzfasser } & \text { Asche } \\ \text { 87.5 Proc. } & 10 \text { Proc. } & \text { 4.1 Proc. } & 58.6 \text { Proc. } & \text { 11.6 Proc. 3.3 Proc. } \\ \text { Die Benutzung als Grinfutter und Heu } & \text { erreicht vorzugsweise }\end{array}$
im Steppenklima, wo es an Wiesen und Weiden fehlt, eine sehr grosse Bedeutung, und lasseu sich Erträge von $30000 \mathrm{~kg}$ Griinfutter und $6500 \mathrm{~kg}$ Heu pro ha recht wohl auf leichtem Boden erwarten. 
Im Mittel enthält das Grünfutter

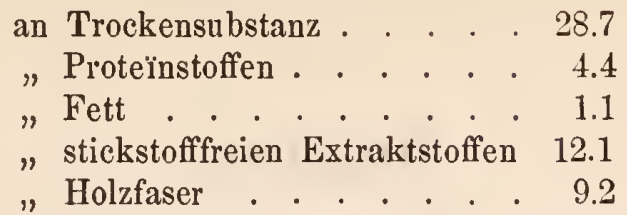

Nach E. Wolff beträgt der inittlere Procentgehalt an verdaulichen Nährstoffen:

$$
\begin{array}{cccc}
\text { Eiweiss } & \text { Kohlehydrate } & \text { Fett } & \begin{array}{c}
\text { Wahrscheinliches } \\
\text { Nährstoffverhältnis }
\end{array} \\
\text { 1.8 Proc. } & 11.8 \text { Proc. } & 0.3 \text { Proc. } & 1: 7
\end{array}
$$

und $100 \mathrm{~kg}$ Grünfutter besitzen einen Wert von $1.78 \mathrm{M}$.

Im grtinen Zustande frisst das Vieh die Kolbenhirse nicht sehr gern, doch wird sie als Heu von Pferden und Rindvieh gut aufgenommen.

Die Körner der Kolbenhirse sind weniger wertvoll als die der Rispenhirse und werden in gleicher Weise wie jene benutzt. 


\section{Bluthirse.}

\section{Panicum sanguinale L.}

Syn.: Deutsch: Blutfench, rotes Fingergras, Schwaden, Himmelstau. Engl.: Polish millet.

Rispe: violett, gefingert (9-13 Rispenäste), $20 \mathrm{~cm}$ lang. - Stroh: gelbgrün, fein. - Scheinfrucht: grünlich-violett, ron den Klappen fest umschlossen, spitzlich (4 mm lang, $11 / 2 \mathrm{~mm}$ breit).

Halme kahl, Blattscheiden rauhhaarig, Blattspreite wenig behaart. Halme $90 \mathrm{~cm}$ (IIax. $127 \mathrm{~cm}$ ) lang, $0.4 \mathrm{~cm}$ dick, Blattzahl 6, Blätter $14.7 \mathrm{~cm}$ lang, $1.1 \mathrm{~cm}$ breit, Blattfläche $193.4 \mathrm{qcm}$, Halmfläche $108 \mathrm{qcm}$, Gesammtfläche $301.4 \mathrm{qcm}$.

Nach Wilhelm wiegen 500-700 Körner, nach ₹. Rodiczky 965 Körner, und nach unseren Auszählungen 794 Körner $1 \mathrm{gr}$ und $100 \mathrm{cbcm}$ $58^{1 / 2} \mathrm{gr}$.

Diese Pflanze wächst wild auf den besseren, humosen Böden und wird rielfach auf sandig-moorigem Boden, so z. B. seit Jahrhunderten ${ }^{1}$ ) in der Görlitzer Haide (Nieder-Schlesien) und auch in Böhmen, Görz, Kärnten, Slavonien kultiviert.

Die Bluthirse reift ungleich und fällt leicht aus, weshalb sie im halbreifen Zustande zu ernten und sofort abzudreschen ist; das Stroh liefert ein wertrolles Futter.

Ton Rodiczky erzielte 1880 in Cngarisch-Altenburg $420 \mathrm{~kg}$ Körner, $1200 \mathrm{~kg}$ Strol und Wilhelm in Graz $520 \mathrm{~kg}$ Körner und $780 \mathrm{~kg}$ Stroh p. ha.

Die Körner werden wie die Schwaden (Glyceria fluitans) zur Breibereitung verwendet.

Diese Pflanze steht auf für Hirse geeignetem Boden dieser im Ertrage wesentlich nach.

Es kommt auf ihr ein Brandpilz vor (Ustilago Rabenhorstia Jul. Kühn), der die Aehren- und Hauptspindel zerstört. Als Gegenmittel hat sich das Einbeizen der Körner mit Kupfervitriol bewährt.

Die ägyptische Bluthirse ist mit dieser vollkommen identisch.

Nach Royle ${ }^{2}$ ) kommt sie in Indien wild und angebaut vor und ist wahrscheinlich von dort nach Europa gelangt.

1) Vergl. Mehler, Phys, ök. Bibliotkek. XIV. pg. 26; Beckmann, Grunds. der deutsch. Landw. 1806 pg. 161. Ma th io lus, Neues Kräuterbuch pg. 423. 1563. Casp. Bauhinus, Pinax theatri bot. 1623 pg. 8.

2) Illustr. of bot. of the Himalaya etc. 1839 pg. 418. 


\section{Mohrhirse.}

\section{Andropogon Sorghum Brot.}

\section{Gruppe I. Effusus Kcke. Lockere Mohrhirse.}

Varietät: Andropogon Sorghum technicus Kcke.

\section{Besenmohrhirse.}

Amerika: Broom-corn.

Ital.: Saggina da granate (Toscana), o da scope.

Fran z.: Sorgho à balais.

Sirak ${ }^{1}$ ) (in Istrien, dem kroatischen Littorale und in Dalmatien unter diesem Namen gebaut).

Rispe: sehr locker, die Spitzen der Rispenäste einseitig hängend; Zweige lang, sehr biegsam, an ihren unteren Teilen keine Früchte tragend, nicht verzweigt und besenförmig aus einem Punkte entspringend; $20-50 \mathrm{~cm}$ lang, dunkelgrün. - Halm: gelblich-grün, Stengel und Blattscheiden mit blutroten Streifen, markig, sehr dick ( $1.5-2 \mathrm{~cm}$ dick), 3-4 m hoch; blattreich, Blätter gross. - Scheinfrucht: je nach der Sorte hellrot bis braunrot, häufig hellrot mit blutroten Punkten, glänzend, Basis spitz, nach oben anschwellend $(6 \mathrm{~mm}$ lang, $4 \mathrm{~mm}$ breit, 76 Früchte $=1 \mathrm{gr}$ ).

Die Kultur in Poppelsdorf ergab folgende Resultate: Halm $2 \mathrm{~m}$ (Max. $3 \mathrm{~m}$ ) lang, $2 \mathrm{~cm}$ dick, Blattzahl 10, Blätter $57.6 \mathrm{~cm}$ lang, $5.4 \mathrm{~cm}$ breit, Blattläche $6220.8 \mathrm{qcm}$, Halmfläche $1200 \mathrm{qcm}$, Gesammttäche $7420.8 \mathrm{qcm}$. Rispenlänge $20-45 \mathrm{~cm}$. Die Samen reiften niemals aus, and in kühlen Sommern brachten es die Pflanzen nur bis zur Blüte.

Die in Amerika ${ }^{2}$ ) zur Besenfabrikation benutzten Sorten sind:

1) Tennessee-Evergreen. Erträge.

Liefert eine vorzügliche Qualität für Besen und Bürsten, sowie hohe

1) Lorenz, Wien. Land- und forstw. Zeit. $1862 \mathrm{pg} .179$.

2) Vergl. Traver's Broom-Curn Culturist and Broom Maker's Manuel, Chicago 1873. 
2) MIissouri-Evergreen.

Ist gröber und länger in den Rispen als obige Sorte.

3) Mohawk.

Rispe kurz und liefert nur 25 Proc. des Ertrages ron TennesseeEvergreen.

4) Early York und Shaker.

Im Allgemeinen dem Mohawk ähnlich.

5) Dwarf Broom-Corn.

Frühreif, Rispen sehr fein und namentlich zu Bürsten geeignet; sehr ertragreich, wird aber bei nassem Wetter leicht missfarbig; auch in Australien kultiviert.

6) Pine-tree.

Schlechteste Sorte.

7) New-Jersey oder Lairge Broom-Corn.

Eine der besten angebauten Sorten.

8) Shirley oder Black-brush.

Selten gebaut.

Was die Einführung dieser Pflanze in Nord-Amerika anbetrifft, so wird angenommen, dass zuerst Franklin ${ }^{1}$ ) an einer aus Ostasien stammenden Bürste noch einige Samen fand und diese aussäete, seit dieser Zeit hat nun der Anbau immer grössere Ausdehnung und Bedentung gewonnen, so dass jährlich mehrere Millionen Dollars daraus gewonnen werden. Connecticut River Valley in den Vereinigten Staaten war der erste Platz, wo die Rispen als Handelsartikel in grösserer Quantität gewonnen wurden und gegenwärtig ist Illinois das Centrum der Kultur der Besenhirse, und in Chicago, Cleveland und Philadelphia befinden sich grosse Fabriken.

In Europa wird wohl in Italien und zwar nach Arduino seit dem vorigen Jahrhundert in grösserer Ausdehnung die Kultur betrieben, und namentlich in Toscana werden auf gut gewässerten Böden bis 48000 Besen p. ha geerntet; aber auch in Portugal, Spanien, SüdFrankreich, Ungarn, Dalmatien, Istrien und Rumänien findet sich die Besenhirse vielfach angebaut, wenngleich hier meist nur für den eigenen $\mathrm{Be}$ darf. Die Terwendbarkeit dieser Pflanze ist eine überaus grosse, so dient das vermahlene Korn zur Brotbereitung und als Schweinefutter, mit den ganzen Körnern werden Truthühner aufgefüttert, die entkörnten Rispen werden zu Besen rerwandt, die Stengel dienen zur Bedachung und die grünen Pflanzen als Futter.

Ihre Kultur ist ferner eine sehr ausgebreitete, in China, Ost-Indien, Algier, Abessinien, wo sie selbst noch auf Höhen von $2500 \mathrm{~m}$ gedeiht, und überhaupt in Central-Afrika.

Leider eignet sie sich nicht zum Anbau in Deutschland, da ihre Tegetationsperiode zu lang ist, und sind damit angestellte Versuche als nicht gelungen anzusehen. So gelangte 1878 durch Vermittlung des preussischen landw. Ministeriums ron einem Deutsch-Amerikaner Julius Wach zu Stockbridge, Massach., Samen des Broom-Corn zu Anbaurersuchen an den ökonomisch-botanischen Garten, doch wurden nur negative Resultate erreicht.

1) Traver's Broom-corn Cult. etc. Chicago 1873. 
Varietät: Andropogon Sorghum saccharatus Pers.

\section{Zuckermohrhirse.}
Syn.: Amerika: Chinese or Sorghum sugar-cane, Chinese sugar millet.

Aegypten: Durrah beledi.

Franz.: Sorgho sucré, S. de la Chine; Houque saccharine.

Ital.: Sorgho zuccherino.

Japanisch: Morokoshi Kibi.

Malaiisch: Batari ${ }^{1}$ ).

Javan isch: Djogomutri.

Chines.: Kao-liang, (bei Royle ${ }^{2}$ ) Kow-leang ,tall-corn" d. h. hohes Getreide).

Rispe: anfangs straussartig ausgebreitet, dann mit der Spitze schweifartig überhängend, $30-36 \mathrm{~cm}$ lang, an der Spitze 16-21 cm breit; Aeste sehr lang, von unten bis oben hin platt und breit, ihre Zweige sehr lang, dicht am Aste anliegend. - Halm: gelbgrün mit blutroten Flecken, fest, markig, Mark zuckerhaltig, 3-4 m hoch. - Scheinfrucht: rot, wenn nicht ganz reif so hellrot, glänzend, wenig behaart, eirund, an der Basis spitz ( $6 \mathrm{~mm}$ lang, $4 \mathrm{~mm}$ breit, 45 Früchte $=1 \mathrm{gr}$ ).

In Poppelsdorf ergab die Kultur nachfolgende Resultate: Halm $200 \mathrm{~cm}$ lang, $1 \mathrm{~cm}$ dick, Blattzahl 10, Blätter $55 \mathrm{~cm}$ lang, $5 \mathrm{~cm}$ breit, Blattfläche $5500 \mathrm{qcm}$, Halmfläche $600 \mathrm{qcm}$, Gesammtfläche $6100 \mathrm{qcm}$.

Die Bestockungsfähigkeit ist sehr viel grösser als bei den ImphySorten, und entwickeln sich zwischen 5 und 12 Schösslinge pro Pflanze.

Der Zuckergehalt stellt sich nach Erni, Chemiker des „Departement of Agriculture" zu Washington, durchschnittlich auf:

3.99 Proc. unkrystallisierbaren Zucker

6.90 "Rohrzucker

Sa. 10.89 Proc. Zucker

1.075 specifisches Gewicht des Zuckersaftes.

Die Heimat dieser Varietät liegt wahrscheinlich in Indien und China, woselbst sie vielfach in der Regenzeit, also Mitte Juni bis Ende September gebaut und ihr Stroh als Viehfutter ${ }^{3}$ ) sehr geschätzt wird.

Die Zuckerhirse hatte zu Anfang dieses Jahrhunderts von China aus nach Frankreich unter dem Namen „Canne à sucre du Nord de la Chine" Eingang gefunden, doch war während der Kriegsjahre 1814 bis 15 dieselbe wieder verloren gegangen; später wurde diese Pflanze von Amerika aus, wo sie sich eingebürgert, wiederum empfohlen, doch die allgemeinere Aufmerksamkeit erst auf sie gelenkt, als der französische Konsul zu Schang-hai, de Montigny, 1850 der geographischen Gesellschaft in Paris Samen der Zuckerhirse einschickte, und Vilmorin und Beauregard es sich angelegen sein liessen, für eine möglichst weite Verbreitung dieser Pflanze zu sorgen. Diese Pflanze findet sich in Ostasien rom $30^{\circ} \mathrm{n}$. Br. bis in die Tropengegenden, so z. B. im Sunda-

1) F. A. W. Miquel, Fl. v. Nederlandsch Indie 1860. p. 504.

2) Illustr. of bot. of the Himalaya $1839 \mathrm{pg} .122$.

3) Royle, a. a. 0. 1839 pg. 419. 
Archipel verbreitet, und wird jetzt, ausser in Süd-Europa, sehr stark in Amerika und zwar ungefähr bis zum $40^{\circ} \mathrm{n}$. Br. hauptsächlich zur Sirupgewinnung und darüber hinaus zur Körner- und Grünfuttererzeugung angebaut.

Diese Zuckerhirse ${ }^{1}$ ) ist zarter, sowie leichter durch Windbruch leidend und liefert weniger, aber wohlschmeckenderen Sirup, mit geringerem Säuregehalt als die Imphy, so dass sie zur Sirupfabrikation der letzteren in Amerika vorgezogen wird.

Varietät: Andropogon Sorghum lencospermus Kcke.

\section{Lockere, weissfrüchtige Mohrhirse.}

Rispe: locker, ausgebreitet, bis $25 \mathrm{~cm}$ lang, Scheinfrüchte nicht leicht ausfallend. - Halm: gelblich-grün, markig, kräftig, mittellang. Scheinfrucht: weiss, sammetig, an der Basis spitz, nach oben eiförmig anschwellend, doch etwas eckig ( $6 \mathrm{~mm}$ lang, $4 \mathrm{~mm}$ breit, 58 Scheinfrüchte $=1 \mathrm{gr}$ ), Mehl vorzüglich.

In Poppelsdorf ergab die Kultur folgende Resultate: Halm $2 \mathrm{~m}$ lang, $1.8 \mathrm{~cm}$ dick, Blattzahl 8, Blätter $55.6 \mathrm{~cm}$ lang, $4.4 \mathrm{~cm}$ breit, Blattfläche $2446.4 \mathrm{qcm}$, Halmfläche $1080 \mathrm{qcm}$, Gesammtfläche $3526.4 \mathrm{qcm}$.

In warmen Sommern reiften einige Körner in der Rispe.

Sie wird vorzugsweise in China (Chifu) und in Ostindien zur menschlichen Nahrung benutzt.

\section{Gruppe II. Contractus Kcke. Dichte Mohrhirse.}

Varietät: Andropogon Sorghum Arduini Gmel.

\section{Dichte rotfrüchtige Mohrhirse.}

Aegypten: Durrah Nili oder Durrah Ouakeh ${ }^{2}$ ).

Kaffirland: Imphy.Zulus.

Amerika: Red Imphee.

Franz.: Sorgho imphy, Millet de la Cafrerie, Grand millet de Guinée, Dourra rouge.

Rispe: rot, sehr zusammengezogen, $Z$ weige strikt aufrecht und an die Spindel angedrückt, Klappen rot, meist kahl, länglich-eiförmig, bis $20 \mathrm{~cm}$ lang, Scheinfrüchte leicht ausfallend, reichfrüchtig, 500-5000

1) Smith, Imphee and Sorghum Culture. Transact. of the X.-Y. st. Vol.

2) Figari Bey, stud. scient. sull' Egitto 1864 pg. 101. 
Scheinfrüchte in der Rispe. - Halme dünn, lang $(2-5 \mathrm{~m}$ hoch, $2-5 \mathrm{~cm}$ dick), gelblich-griin, rotfleckig, sich wenig bestockend, durch Wind nicht leicht umbrechend. - Scheinfrucht: rot, glänzend, fast kahl, gross, voll, 60 Scheinfrüchte $=1 \mathrm{gr}$ und $1 \mathrm{hl}$ wiegt $581 / 2 \mathrm{~kg}$.

In Poppelsdorf kultiviert, ergaben sich folgende Resultate:

Halme $210 \mathrm{~cm}$ lang, $1.4 \mathrm{~cm}$ dick, Blattzahl 8, Blätter $43.5 \mathrm{~cm}$ lang, $3.7 \mathrm{~cm}$ breit, B Blattfläche beider Seiten $2575.2 \mathrm{qcm}$, Halmfläche $882 \mathrm{qcm}$, Gesammtfläche $3457.2 \mathrm{qcm}$. Die Pflanze entwickelte keine Seitentriebe und trat am 12/8. in Blüte, doch reifen nur in sehr warmen Jahren die Früchte einigermass en aus.

Das Vaterland ist Afrika, wo das Korn als Brotfrucht benutzt wird, während die Stengel einen zuckerreichen Saft liefern, der sich auf 50-80 Proc. belaufen, und 10-16 Proc. Zucker (Krystallzucker und Sirup) enthalten soll.

Im Jahre 1850 ging M. Leonard Wray, ein praktischer Zuckerpflanzer Ostindiens, nach Siidost-Afrika, und fand im Kaffirlande um die Hütten der Eingeborenen zuckerreiche Varietäten und Sorten des Sorghum angebaut und brachte Samen von diesen mit nach Europa und hauptsächlich nach Frankreich, Belgien und England. Da nun in Amerika schon die Zuckermohrhirse (Andropogon Sorghum saccharatus Pers.) gebaut wurde, so machte der amerikanische Gesandte in England, Mr. Buchanan, die Amerikaner auf diese neuen, sog. Imphy-Zuckerhirsen aufmerksam, und 1853 verbreitete sich deren Knltur hauptsächlich über die Südstaaten der Union.

In Spanien werden diese Zuckerhirsen ebenfalls angebaut und beschreibt Don Julian Pellon y Rodriguez ${ }^{1}$ ) in einem kleinen Schriftchen die angebauten Sorten und bespricht deren Kultur. Die ursprünglich kaffrischen Namen waren nun auch nach Spanien und Amerika mit übertragen worden, und hierbei wurde ihre Orthographie jeder der betreffenden Sprachen angepasst.

Die angebauten Sorten ${ }^{2}$ ) dieser Varietät sind nun folgende:

1) E-en-gha (amerikanisch), Enga (spanisch).

Rispe: gross, dicht, Rispenäste lang. - Halm: sehr fein, $3-4 \mathrm{~m}$ hoch, mit 14 Proc. Zucker, sehr süss. - Scheinfrucht: gelbrot, länglich; Vegetationsaeit $90-120$ Tage.

2) Boom-veva-na (amerikanisch), Boonvana (spanisch).

Rispe: gross, dicht. - Halm: kurz, dick, süss, rot gefleckt, steif, selten schwerer als $500 \mathrm{gr}$, saftreif, ergiebig, sehr geschätzt. - Scheinfrucht: anf gelbem Grund rote Punkte. Vegetationsdauer 100 Tage.

3) Shla-goo-va (amerikanisch), Sagova (spanisch).

Rispe: ein wenig ausgebreitet bis $30 \mathrm{~cm}$ lang; Klappen so lang als Scheinfrucht, rotgelb, meist wollig. - Halm: hoch, sehr süss, und der Zncker scheidet sich gut körnig aus. - Scheinfrucht: fleischfarben oder rot bis purpurrot, an der Basis meist heller werdend, eiförmig. - Vegetationsdauer 90-105 Tage.

4) Koombana (Name der Zulukaffern).

Koon-bu-na (amerik.), Combana (spanisch).

Rispe: klein, aufrecht. - Halm: kurz, sehr feinhalmig, doch nicht leicht umbrechend. - Scheinfrüchte: fleischfarben.

1) Wien, land- u. forstw. Zeit. 1859. 513.

2) Dep. of Agric. U. S. Rep. 1862. 1864; Transact. of the 11l. st. Agric. Soc. V. $1861 / 64$. 
5) Liberian (Name des Freistaates West-Afrika's, aus dem diese Hirse stammt).

Rispe: abgestutzt, sehr zusammengezogen, Rispenäste kurz und dicht an die Spindel gedrückt, $15 \mathrm{~cm}$ lang; Klappen kürzer als die Scheinfrucht, meist kahl. - Halm: mittelgross. - Scheinfrucht: an der Basis gelbrot, nach oben dunkler.

6) Vim-bis-chee-a-pa (amerik.), Vimbischuapa (spanisch).

Rispe: dicht, breit, $30-40 \mathrm{~cm}$ lang. - Halm : von allen am grössesten, $3.3-5 \mathrm{~m}$ hoch, $4-5 \mathrm{~cm}$ dick, sehr süss, der Saft enthält 14 Procent Zucker. - Scheinfrucht: gelbrot, plump. Erfordert ein sehr warmes Ḱlima und eine Vegetationsdauer von 4-5 Monaten.

7) Oom-se-a-na ${ }^{1}$ ) (amerik.). Onsiana (spanisch).

Syn.: Otaheit an, soll nach Mr. M. Day jr. 1859 durch das Patent-office in Illinois aus "Otaheiti" bezogen worden sein.

Als Spielart, welche Mr. Stew art in Minnesota U. S. durch Kreuzung von Chinese-sugar-cane mit Oom-se-a-na erzeugt haben soll, gilt:

Minnesota early amber; franz.: Sucré hâtif du Minnesote (Vilm.); ital.: Ambra del Minnesota per zucchero; deutsch: Ambrarohraus Minnesota.

Rispe: zusammengezogen. - Halm hoch, am zuckerreichsten von allen Sorten, sehr geschätzt. - Scheinfrucht: dunkel-purpur, mehr flach als rund.

Bestockt sich gut und reift in 4 Monaten.

8) E-a-na-moo-dee (amerik.), Anamody (spanisch).

Rispe: gross, steif, aufrecht. - Halm: etwas dünn, wenig saft- und zuckerreich, der Saft enthält nur zwischen 6 und 14 Proc. Zucker. Scheinfrucht: rötlich-gelb, plump. Vegetationsłauer $3 \frac{1}{2}-4$ M Monate.

9) Shla-goon-dee (amerik.), Sagondi (spaniseh).

Rispe: sehr steif, dicht, aufrecht. - Halm: zuckerreich. - Scheinfrucht: gelbrot. Tegetationsdauer $3 \frac{1}{2}$ Monat.

10) Zim-moo-ma-na (amerik.), Zimmomana (spanisch).

Rispe: kompakt, aufrecht, fein, reichsamig. - Halm: suiss. Scheinfrucht: rotgelb, plump.

Ausserdem werden noch angcbaut:

11) E-both-la (amerik.), Elota (spanisch).

12) Boo-ee-a-naa (amerik.), Boyana (spanisch).

13) See-en-gla (amerik.), Sienglana (spanisch).

14) Zim-ba-za-na (amerik.), Zimbazana (spanisch).

15) E-thlo-sa (amerik.), Eltosa (spanisch).

Zur Kultur in Mitteleuropa eignen sich am besten: Elota, Boyana, Sienglana, Zimbazana und insbesondere Eltosa, alle übrigen erfordern wärmere Klimate.

Das African oder Imphee-cane eignet sich namentlich für den Süden der Union besser als die Zuckermohrhirse (Chinese sugar-cane), denn da es dicker, kürzer und fester im Halm ist, brechen die Prairiewinde dasselbe weniger leicht nieder, und ausserdem ist es ertragreicher an Samen und krystallisiertem Zucker, so wurde 1868 auf einem MLeting der SugarGrower's Association in Michigan ${ }^{2}$ ) anerkannt, dass allerdings das „Chi-

1) Botanical Hist. of Sorgh. by Pech, Rep. of the commiss. of Agric. 1865. Washington.

2) Rep. of Agric. Departm. Washington 1868. 
nese sugar-cane" mehr und wohlschneckenderen Sirup, doch viel weniger krystallisierten Zucker liefere. Als die beste Sorte zur Gewinnung von Krystallzucker wurde Otaheitan angesehen.

Ausserdem dient der Same als vortreffliches Futter für Geflügel und die grüne Pflanze als Viehfutter.

\section{Tatarische Mohrhirse.}

Syn.: Early Sorgho ${ }^{1}$, Amerika.

Rispe: zusammengezogen, aufrecht, bis $20 \mathrm{~cm}$ lang; Deckspelzen schwarz, meist wollig und so lang als die Frucht. - Halm: gelblichgrün mit blutroten Flecken, dünn. - Scheinfrucht: hellrot, eckig, an der Spitze behaart, $6 \mathrm{~mm}$ lang, $4 \mathrm{~mm}$ breit, und 67 Scheinfriichte wiegen $1 \mathrm{gr}$.

Nur Scheinfrüchte lellrot, sonst Andropogon Sorghum Arduini Gmel. sehr ähnlich. Frühreif.

\section{Varität: Andropogon Sorghum Usorum N. ab E.}

\section{Dichte weissfrüchtige Mohrhirse.}

Amerika: White Imphee, White Liberian.

Franz.: Grand millet blanc.

It a 1.: Saggina bianca.

Rispe: sehr zusammengezogen, aufrecht, Zweige dicht an die Spindel gedrückt, grün, bis $30 \mathrm{~cm}$ lang; Aehrchen $2 \mathrm{~mm}$ breit, Klappen eiförmig, kahl, Innenseite weiss, - Halm: gelblich-grün, markig, kurz, fest, dick. - Scheinfrucht: weiss, sammetig, kantig, eiförmig $(6 \mathrm{~mm}$ lang, $4 \mathrm{~mm}$ breit), 75 Scheinfrüchte $=1 \mathrm{gr}$.

In Poppelsdorf kultiviert, ergaben sich folgende Resultate:

Halme $215 \mathrm{~cm}$ lang, $1.5 \mathrm{~cm}$ dick, Blattzahl 9, Blätter $57 \mathrm{~cm}$ lang, $5 \mathrm{~cm}$ breit, Blattfläche $5130 \mathrm{qcm}$, Halmfläche $967.5 \mathrm{qcm}$, Gesammtfläche $6097.5 \mathrm{qcm}$.

Die Scheinfrüchte reiften nur zum kleinsten Teil in einigen sehr warmen Jahren spät im Oktober.

Die in den vereinigten Staaten zur Zuckergewinnung angebaute und aus dem südöstlichen Afrika stammende Sorte ist „Nec-a-ga-na“ ${ }^{2}$ ), oder White Imphee.

Varietät: Andropogon Sorghum aethiops Kcke.

\section{Dichte schwarze Mlohrhirse.}

A merika: Black Imphee ${ }^{3}$ ).

Ital.: Saggina nera.

Franz.: Sorgho noir d'A frique, Grand millet noir.

1) Bot. Hist. of Sorgh. by Pech, Rep. of the Commiss. of Agric. 1865. Wash.

2) Pech, Botanic. Hist. of Sorgh. Rep. of the commiss. of Agric. 1865. Washington.

3) Pech, Botanic. Hist. of Sorgh. Rep. of the commiss. of Agric. 1865. Washington. 
Rispe: braunrot, sehr kompakt, anfrecht, $20 \mathrm{~cm}$ lang, Aehrchen eiförmig, $2 \mathrm{~mm}$ breit, etwas flach, Klappen kahl, braunrot, länger als die Scheinfrucht, Scheinfrïchte nicht leicht ausfallend. - Halm: gelblichgrün, mit blntroten Flecken, schilfig, dick. - Scheinfrucht: schwarz, glänzend, fast kahl, eckig $(6 \mathrm{~mm}$ lang, $4 \mathrm{~mm}$ breit, 52 Scheinfrüchte $=1 \mathrm{gr}$ ); Frucht rot.

In Poppelsdorf ergab ihr Anbau folgende Resultate: Halm $240 \mathrm{~cm}$ laug, $1.4 \mathrm{~cm}$ dick, Blattzahl 6, Blätter $47 \mathrm{~cm}$ lang, $5.2 \mathrm{~cm}$ breit, Blattfläche 2933 qcm, Halmfläche 1056 q cm, Gesammtfläche 3989 qcm.

In warmen Sommern reifen in Poppelsdorf die Früchte ziemlich gut aus. Wegen ihrer Frühreife lässt sie sich in Enropa noch im Weinklima kultivieren, sonst ist sie in den wärmeren Zonen von Europa, Afrika, Asien und Amerika verbreitet.

Zur Zeit des Plinius soll sie aus Indien nach Italien eingeführt worden sein, und sagt hierüber Plinius: ,Milium intra hos decem annos ex India in Italiam invectnm est, nigrum colore."

Die am meisten angebaute Sorte ist:

Nee-a-zee-na (amerik.), Ni-a-za-na (kaffrisch), Niazana $\left.(\mathrm{spanisch})^{1}\right)$.

Rispe: buschig. - Halm: sehr saftig und süss, liefert in Spanien 70-80 Proc. schleimigen, trüben Saft mit 15 Proc. Zucker, enthält wenig Holzfaser, and die entblätterten Stengel wiegen ca. $1 / 2$ kg. - Scheinfrüchte: rein schwarz, glänzend, gross, plump, rundlich.

Sehr früreif, reift in Amerika in 90-100 Tagen.

Bei den Zulnkaffern soll sie als die süsseste aller Imphy-Arten angesehen werden.

Sie wird vielfach zur Znckergewinnung, das Korn zar Mehl- und Brotbereitung, sowie zur Spiritusbrennerei, und die grüne Pflanze als Viehfutter benutzt.

\section{Varietät: Andropogon Sorghum bicolor L.}

\section{Zweifarbige Mohrhirse.}

Syn.: Ital.: Sorgho bicolore.

Franz.: Sorgho ou Houque bicolorée.

Engl.: Whitish Indian-Millet.

Hindustani: Kala-jooar nach Royle.

Arab.: Dnrrah Ahmar ${ }^{2}$ ).

Rispe: zusammengezogen, kompakt, aufrecht, eiförmig, bis $30 \mathrm{~cm}$ lang. - Halm: gelbgrïn, mit einigen blutroten Flecken, sehr fest, markig, bis $3 \mathrm{~m}$ lang. - Scheinfrucht: schwarz, Frucht weiss und aus den schwarzen Klappen hervorragend, wenig behaart (6 mm lang, $4 \mathrm{~mm}$ breit), an der Basis spitz, sonst rundlich.

In warmen Jahren erscheint die Rispe Anfangs August, nur ein Teil der Früchte erlangte eine ziemlich gute Ausreife.

Verbreitnng und Benutzung sind dem Andr. Sorgh. cernuus gleich,

1) Vergl. Smith, Imph. and Sorgh. cult. Transact. of the IIl. st. of Agric. Soc. V. 1861/64, und Wien. land- und forstw. Zeit. 1859, 514.

2) Figari Bey, Stud. scientif. sull' Egitto etc. 1864 pg. 104. 
nur soll aus dieser Hirse und Gerste auch eine Art Bier hergestellt werden, welches in Aegypten "buza", am oberen Nil "merisa", in Abessinien "tala" und "suoka", südlich davon "pombe" und am Zambese „boyaloa" genannt wird.

Varietät: Andropogon Sorghum cernuus Ard.

\section{Nickende Mohrhirse.}

Syn.: Franz.: Sorgho à epi blanc; Couscorn; Sorgho de Changallar, d'Afrique, penché; Barbonincliné.

Ital. : Saggina a collo torto.

Amerika: Rice-corn.

Turkestan: Dschugara, Dschungara (Vilmorin).

A egypten: Durrah seïfi oder sêfi ${ }^{1}$ ) $=$ Sommergetreide, weil Aussaat in Sommerperiode fällt.

Arabisch: Bischnat und Beschna in Algier.

Malta: Carambasse.

Sudan: Massakua.

Rispe: zusammengezogen, eiförmig, verästelt, bis $15 \mathrm{~cm}$ lang, hängend. Die Stengel biegen sich im oberen Teil gleich nach dem Hervorbrechen der Rispen aus den Scheiden sehr langsam um, dabei springen die äusseren Zellpartien auf der Aussenseite der Krümmung auf. Zur Blütezeit (Anfang September in Poppelsdorf, also sehr spät blühend) sind sie schon vollständig umgebogen, so dass die Spitze der Rispe nach der Erde gerichtet ist. - Halm: gelblich-grün, sehr fest, kräftig, markig, blattreich, 2-4 m hoch. - Scheinfrucht: weiss, sammetig, an der Basis schwach-rötlich und spitz, sonst kugelig ( $6 \mathrm{~mm}$ lang, $4 \mathrm{~mm}$ breit.)

Die Stengel wurden in Poppelsdorf $250 \mathrm{~cm}$ lang, $1.8 \mathrm{~cm}$ dick; Blattzahl 13, Blätter $51.8 \mathrm{~cm}$ lang, $7.2 \mathrm{~cm}$ breit, Blattfläche $9696.96 \mathrm{qcm}$, Halmfläche 1350 qcm, Gesammtfläche $11046.96 \mathrm{qcm}$. notreif.

In Poppelsdorf wurden nur in sehr warmen Sommern einige Körner

Viel in Indien, namentlich im Distrikt MIanipur, Aegypten und überhaupt in Afrika meist auf nicht bewässerbaren Böden als Sommerfrucht gebaut, und ist das Korn in diesen Ländern als menschliches Nahrungsmittel, so wie das Grünfutter ${ }^{2}$ ) und Stroh, welches den Ochsen 9 Monate hindurch zur Nahrung dient, sehr wichtig. Aber auch in Spanien, Portugal, Italien, in den Niederungen der dalmatinischen Flüsse und auch in neuerer Zeit in den Südstaaten der nordamerikanischen Union werden die Früchte, wie Reis oder Mais gekocht, zur Speise verwandt. Die Stengel dienen zur Dachbedeckung.

In Indien fällt die Saatzeit in den Oktober und die Ernte in den Januar; in Aegypten wird im Mai gesäet und Anfang August geerntet.

1) Figari Bey, Stud. scientif. sull' Egitto pg. 104, 1864.

2) Dies Grünfutter heisst nach Royle a. a. 0. p. 421 in Indien „Kurbee". 


\section{Die biologischen Verhältnisse der Mohrhirse.}

Die Samenkörner der Mohrhirse reifen in dem kälteren, gemässigten Klima je nach der Sorte entweder gar nicht, oder doch nur unsicher, und besitzen dann meist ein geringeres absolutes Gewicht, als die in wärmeren Klimaten gereiften.

Von den Mohrhirsen, welche in Poppelsdorf einigermassen ausreiften, wogen die Scheinfriichte

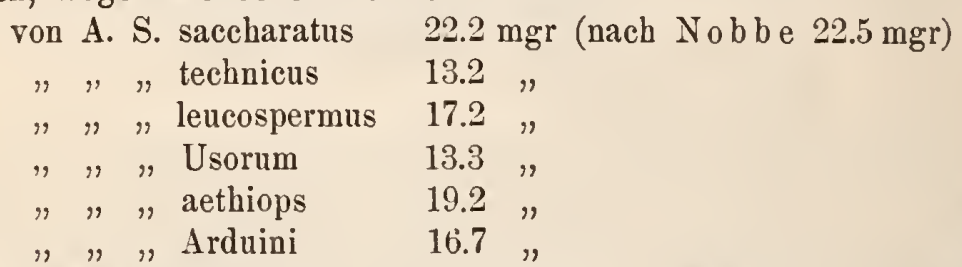

Die Originalfruchte von aus Spanien gesandten Sorten wiesen dagegen folgende Gewichte auf:

$$
\begin{aligned}
& \text { Sorgo azucarat . . } 19 \text { mgr } \\
& \text { Saina, Cadiz . . . } 23.7 " \\
& \text { Panizo, Cadiz . . . } 35.7 "
\end{aligned}
$$

Bei letzterer Sorte waren die Frïchte nicht fest von den Spelzen umschlossen, sondern nackt ausfallend.

Nach Horky und Klose betrug der Gewichtsanteil der Spelzen von afrikanischen Originalsorten nur 5 Procent rom Gewichte der ganzen Körner und hafteten die Spelzen nur an der Basis des Kornes, indem sie letzteres auch nicht einmal teilweise einzuschliessen vermochten; dagegen stellte sich der Procentanteil der Spelzen mitteleuropäischer Mohrhirsen im Durchschnitt einer grösseren Anzahl von Proben auf 13.45 Procent.

Die Keime betragen 5-6 Procent vom Gewicht des Kornes.

Bei fïnfstündiger Einwirkung einer Wärme von nur $55^{\circ} \mathrm{C}$. keimten nach $\mathrm{Haberlandt}$ von 100 trocknen Samenkörnern 6, ron eingeweichten keines.

Gemeinhin wird der Same vor dem Auslegen 24 Stunden eingeweicht.

Die normal ausgereiften Scheinfrïchte besitzen eine recht befriedigende Keimfähigkeit, denn es keimten von A. S. saccharatus (Nobbe) im Mittel 73 Proc., und die Beimengung fremder Bestandteile betrug 0.26 Proc. 
Die Tiefe der Unterbringung der Samen schwankt, je nach der Bodenbeschaffenheit zwischen $1.5-2.5 \mathrm{~cm}$. Die nnterste Keimungsgrenze zwischen $10-12^{\circ} \mathrm{C}$. und das Optinum zwischen 25 nnd $37.5^{\circ} \mathrm{C}$., mithin erst bei einer Bodenerwärmung von mindestens $15^{\circ}$ C. zur Einsaat geschritten werden sollte.

Nach Haberlandt erfolgte die Keimung bei A. S. saccharatus

\begin{tabular}{|c|c|c|c|}
\hline & bei $10.25^{\circ} \mathrm{C}$. & $15.75^{\circ} \mathrm{C}$ & $19^{\circ} \mathrm{C}$. \\
\hline $\begin{array}{l}\text { mit dem Sichtbarwerden des Würzelchens } \\
\text { in Tagen } \\
\text { Durchschnittliches Längenwachstum pro } \\
\text { Tag in } \mathrm{mm}\end{array}$ & $\begin{array}{l}25 \\
1.3\end{array}$ & $\begin{array}{l}7.25 \\
2.4\end{array}$ & $\begin{array}{l}6 \\
3.8\end{array}$ \\
\hline
\end{tabular}

mithin die späte Einsaat wohl gerechtfertigt erscheint.

Entsprechend der Tiefe der Unterbringung nnd der vorhandenen Wärme läuft das junge Pflänzchen in 7-14 Tagen nach der Saat auf nnd wächst in der ersten Zeit, namentlich bei kiihler Witterung sehr langsam fort, so dass es nicht selten Mitte Juli erst eine Höhe von $18-20 \mathrm{~cm}$ erreicht hat; von diesem Zeitpunkt tritt mit der zunehmenden Wärme auch ein sehr beschleunigtes Wachstum ein.

In der Regel entwickelt A. S. saccharatus 5-10 Schösslinge, während die Imphy-Arten meist nur einen Halm treiben.

In Poppelsdorf stellten sich die Vegetationsverhältnisse im Mittel wie folgt:

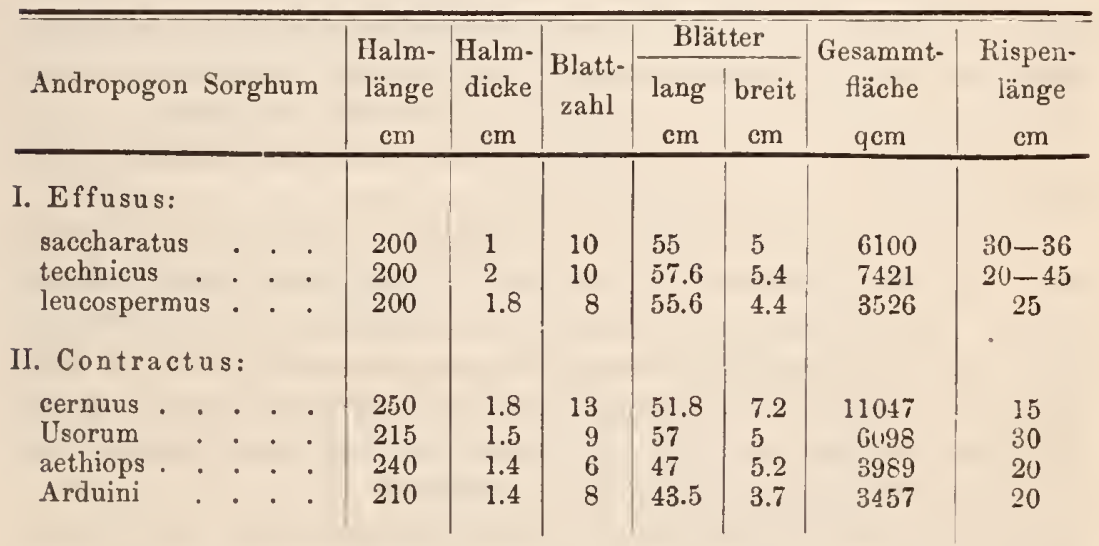

In den wärmeren Klimaten erreichen einzelne Varietäten der Mohrhirse eine Höhe von $4 \mathrm{~m}$ und darüber.

Ihr Wurzeltiefgang ist sehr beträchtlich, so dass die Pflanze 
nach Ueberwindung des Jugendstadiums kaum durch Trockenheit leidet, doch erweist sie sich in warmen, trocknen Klimaten für eine mässige Berieselung sehr daukbar.

Ferner ist die Mohrhirse rerpflanzbar, mithin sich lückige Bestände ausbessern lassen.

Da sich nun die verschiedenen Mohrhirsevarietäten bei zu naher Kultur kreuzen, und auch unter nicht ganz giinstigen Vegetationsbedingungen leicht degenerieren, z. B. wird bei den Zuckermohrhirsen das Mark saftlos und zuckerarm, so ist auf recht vollkommene Samen, welche die charakteristischen Eigenschaften der Sorte hesitzcn, und auf günstige Anbauverhältnisse zu achten.

Die Menge der Pflanzennährstoffe, welche sie dem Boden entnimint, ist nach E. Wolff sehr erheblich, denn es enthalten 1000 Teile :

\begin{tabular}{|c|c|c|c|c|c|c|c|c|c|}
\hline & 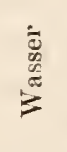 & 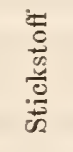 & 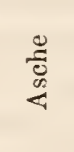 & 总 & $\stackrel{\check{\pi}}{\rightleftharpoons}$ & 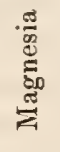 & 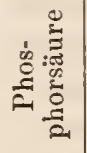 & 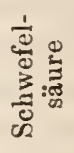 & 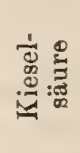 \\
\hline frischer Substanz & 800 & 3.7 & 13.0 & 1.8 & 1.2 & 0.5 & 0.8 & 0.4 & 3.7 \\
\hline Körner & 140 & 15.0 & 16.0 & 0.5 & 2.4 & 0.2 & 8.1 & - & 1.2 \\
\hline
\end{tabular}

Die Hauptfeinde der reifen Mohrhirse sind jedenfalls die Vögel, weshalb die Felder zur Reifezeit bewacht werden müssen.

Von anderen Feinden aus dem Tierreiche sind nur wenige bekannt geworden, was daran liegen mag, dass die Pflanze weder in Amerika, noch in Europa, sondern in Afrika die Hauptfrucht bildet, mithin sich ihre Feinde wohl noch der Kenntnis entziehen.

In Poppelsdorf frass die Raupe von Acronycta Rumicis L. die Blätter ab.

Die Larre der Getreidewanze (Chinch-bug), Micropus leucopterus Say, wird der Mohrhirse in Amerika in allen ihren Entwickelungsstadien sehr gefährlich, so saugen die jungen Larven ca. $2 \mathrm{~cm}$ tief unter der Erde den Saft aus den Wurzeln, später gehen sie am Halm empor, von dem Saft der jungen Pflanzenteile lebend, bis sie schliesslich Flügel erhalten und sich in Schaaren auf den Getreidefeldern niederlassen, wo sie das weiche Korn verzehren.

Zur Abhaltung der Insektenlarven vom Saatkorn gibt man in die Löcher bei horstweiser Saat etwas Gaskalk oder noch besser Naphtalin.

Im Allgemeinen bringt die Mohrhirse weit sicherere Ernten als der Mais, sobald man Sorge trägt, dass in der ersten Vegetationszeit 
das Unkraut zerstört wird. Andere Feinde scheinen ihr selten gefährlich zu werden, und hat sich in Amerika gezeigt, dass nicht einmal die Heuschrecken, so lange sie anderes Futter finden, die Mohrhirse annehmen.

In Afrika sollen die Termiten beträchtlichen Schaden verursachen können.

\section{Klima.}

Die Mohrhirse ist die Hauptbrotfrucht des tropischen und subtropischen Afrikas und greift dann, wenn auch weniger ausschliesslich als Brotfrucht dienend, nach Arabien und Klein-Asien über und wird vielfach in Indien, dem Sunda-Archipel, China und Japan gebaut.

In Siid-Europa wird sie ausser zur Kornproduktion, zur Erzeugung von Rispen zur Besen- und Bürstenfabrikation und zuweilen zur Sirup- und Grïnfuttergewinnung benutzt, und baut man sie zu diesen Zwecken auf der Balkanhalbinsel, in Rumı̈nien, Süd-Russland, wenn auch selten, doch häufiger in Siebenbürgen, Ungarn, Süd-Tirol, namentlich aber in Dalmatien, in Italien, auf der pyrenäischen Halbinsel und in Sid-Frankreich an.

Einen grossartigen Umfang hat aber der Anball und zwar vorzugsweise zur Sirup- und Rispengewinnung zur Herstellung ron Besen und Bürsten in Nord-Amerika gewonnen.

Die Nordgrenze der Kultur reicht im Steppenklima des südöstlichen Europas kaum ïber den $48^{\circ} \mathrm{n}$. Br., wenn es sich nicht um Grünfuttergewinnung handelt, hinaus, und sinkt nach Westen zu noch um einige Grade sïdlicher. Auch soll der Zuckergehalt abnehmen, je mehr sich der Anbau dieser Nordgrenze nähert, wenigstens führt Leplay an, dass sich unter dem $44^{\circ}$ n. Br. noch 15 Proc. Zucker fänden, und Dupeyrat, dass in Siid-Russland unter dem $45^{\circ} \mathrm{u}$. Br. nur noch 13-15 Proc. und in Siid-Frankreich unter $47,5^{\circ} \mathrm{n}$. Br. nur noch 10 Proc. zil finden seicn.

In den Nordstaaten der Union überschreitet hingegen die Kultur kaum den $40^{\circ} \mathrm{n}$. Br., weil in diesem Teile Amerikas, z. B. in Indiana ${ }^{1}$ ) das Frühjahr relativ spät eintritt, so dass erst Mitte Mai die Aussaat erfolgen kann, und zuweilen schon Ende September Nachtfröste vorkommen, wodurch das noch milchige Korn erfriert und der Saft bitter wird, weshalb hier auch die Kultur der Besenmohrhirse eher am Platze ist. In gewöhnlichen Sommern reift das Korn Mitte Oktober aus.

1) Transact. of the N-.Y. st. Agric. soc. 1857 pg. 129 flgde. 
Angenommen wird nun, dass die Mohrhirse durchschnittlich eine Vegetationszeit von 150 Tagen, sowie eine Wärmesumme bis zur Bliite von $3000^{\circ} \mathrm{C}$. und bis zur Reife von $4000^{\circ} \mathrm{C}$. beansprucht.

Gegen Dürre ist die Mohrhirse weit widerstandsfähiger als der Mais, doch darf sie nicht bei Beginn ihrer Vegetation von derselben betroffen werden, weil sie dann erheblich in ihrem Wachstum zurückgehalten wird, was auch bei nasskalter Witterung der Fall ist. Ferner verträgt sie von der Bliitezeit ab keine starken Stiirme, die leicht Windbruch veranlassen.

\section{Boden.}

Die Pflanze leidet gewöhnlich mehr durch fenchte Frübjahre als durch trockne Sommer, weshalb die losen, porösen Böden in Gegenden mit feuchter Friihjahrswitterung den Vorzug verdienen.

Die Mohrhirse und zwar sowohl Zucker- wie Besenmohrhirse, gedeiht am besten auf den lockeren, kalkhaltigen und fruchtbaren Mergellehmböden, und vorziiglich auf den sehr nahrnngsreichen, porösen, erst frisch umgebrochenen Steppenböden.

In den sehr warmen Klimaten ist das Gedeihen der Mohrhirse auch auf schwerem Thonboden gesichert, während in einem weniger warmen Klima auf warme, thätige Böden zu sehen ist.

Häufig werden zur Kornproduktion auch noch Böden herangezogen, die wegen ihrer schwachen Krume, ihrer geringen wasserfassenden und wasserhaltenden Kraft, sowie unbedeutenden Produktionskraft kaum anderes Getreide aufbringen. Es wird z. B. die Mohrhirse noch auf den trocknen, kalkig-grusigen, erdarmen Karstgebieten kultiviert, und dort als Hauptbrotfrucht dienend, so zwischen Pingnente, Montona und Buje, doch wird die Mohrhirse überall in Istrien, dem kroatischen Littorale und Dalmatien gebaut, und gibt es auch merkwürdigerweise dort Sumpfplantagen ${ }^{1}$ ). Bleibt nämlich in den Niederungen der Küstenflüsse, namentlich der Narenta, das Wasser so lange stehen, dass es zur Maiskultur zu spät wird, dann säet man Nohrhirse ein, die das 60-70fache Korn geben soll.

Zur Grïnfuttergewinnung bringt sie auf gut entwässerten Moorböden und Nenland, sowie auf reichem Allnvialboden sebr hohe Erträge.

1) Lorenz, Allg. land. und forstw. Ztg. Wien 1862 p. 179. 


\section{Düngnng.}

Zur Zuckergewinnung ist eine sehr stickstoffreiche Dïngung zu vermeiden, weil der Saft darnach leicht schleimig und salpeterhaltig, demzufolge zur Zuckerfabrikation ungeeignet wird.

Am meisten empfiehlt sich die Diingung zur Vorfrucht, oder die Anwendung eines gut zersetzten Kompostes, und auf Böden, welche Mangel an Phosphorsäure und Kali haben, das Ausstreuen daran reicher Kunstdïnger, weil diese beiden Pflanzennährstoffe zugleich auf die Vermehrung des Zuckergehaltes hinwirken, wie dies der frisch umgebrochene Prairieboden, der reich an denselhen ist, deutlich erkennen lässt.

Eine starke Stallmistduingung, z. B. von Rindviehmist, ist für die Produktion von Körnern und Rispen sehr vorteilhaft, während durch Gründiungung keine günstigen Resultate erzielt worden sind.

Gern wird auch mit Kalk und auf schwächlichen Saaten mit Jauche und Guano gediingt.

\section{Fruchtfolge.}

Erwartet man von der Mohrhirse einen bohen Körner-, Zuckeroder Grïnfutterertrag, so fordert sie eine an fertiger Pflanzennahrung reiche Ackerkrume, daher für wenig angreifende Vorfrïchte zu sorgen ist, anderenfalls, obgleich sie sonst in Bezug auf ihre Vorfriichte nicht wählerisch erscheint, bringt sie entsprechend geringere Erträge, wie dies beispielsweise eine Beobachtung Karmrodt's darthut, nach welcher sich das Getreide als bessere Vorfrucht wie die Hackfrüchte erwies, denu er erzielte an grüner Mohrhirse pro ha:

1858

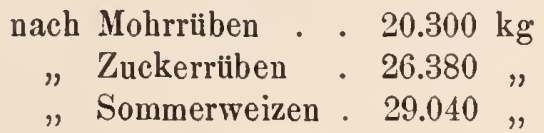

Auf den an fertiger Pflanzennahrung überreichen jungfräulichen Böden des Westens Nord-Amerikas ist die Mobrhirse mit sich selbst in hohem Grade verträglich, und nicht selten werden hier, z. B. von der Besenhirse, 8-10 Ernten ${ }^{1}$ ) hinter einander von demselben Felde genommen, ohne dass sich die letrte Ernte verschlechtert hätte.

Die Mohrhirse, namentlich, wenn sie zur Grünfuttererzeugung dient, beschattet den Boden verhältnismässig dicht und wenn gedrillt

1) The Third annual Rep. to the Legislature of Kansas 1874 pg. 232. 
und bearbeitet, so verbleibt der nachfolgenden Frucht ein wohl zubereiteter und durch die gegebene Düngung und die der Ackerkrume verbleibenden Stoppel- und Wurzelrückstände auch ein an Nährstoffen reicher Boden, in dem Getreidearten ein vorzügliches Gedeihen finden.

Es ist einleuchtend, dass die viel Dung beanspruchende Kultur von Grünfuttersorghum im kälteren gemässigten Klima nur in intensiv betriebenen Wirtschaften, in welchen der Schwerpunkt in der Futtererzeugung liegt, von Wert sein kann, vorausgesetzt, dass nicht andere Futtergewächse, z. B. Mais, unter gleichen Verhältnissen eine grössere Menge verdaulicher Nährstoffe von der Flächeneinheit liefern.

Weit grösser ist dagegen die Bcdeutung zur Futtererzeugung in den wärmeren, sehr trocknen Klimaten, wo andere Grünfuttergewächse sehr viel unsicherer sind und auch wohl kaum die gleiche Menge an Futter erzeugen können.

\section{Bodenbearbeitung.}

Die Bodenbearbeitung ist dieselbe wie zu Mais, d. h. es empfiehlt sich Tiefkultur, damit der Wurzelausbreitung nöglichst wenig mechanische Widerstände entgegenstehen. Selbstverständlich hat sie nach dem Stoppelumbruch der Vorfrucht noch vor Winter zu erfolgen, und zwar auf Böden mit gutem Untergrunde durch den Rajolpflug, sonst durch den Untergrundptlug. Nach dem Abeggen im Frühjahr pflügt man zur Saat, damit das Unkraut unterdrïckt wird und die Samenkörner in frischen Boden gelegt werden können. Eine Hauptbedingung des guten Auflaufens und Gedeihens der Saat liegt aber in der feinen Zubereitung des Ackers, weshalb die Saatfurche recht sorgsam zu ziehen, und der Acker mit Hülfe der Egge und Walze gut zu zerkleinern ist.

\section{Aussaat.}

Die Mohrhirse wird in Indien im Oktober, die Sommersaat (A. S. cernuus) in Aegypten Mitte Mai, die Herbstsaat im Delta Mitte August gesäet. In dem wärmeren gemässigten Klima Nord-Amerikas erfolgt die Aussaat rom 15. April bis 15. Mai, doch an den Grenzen ihrer Kultur in Illinois und Indiana vom 20. Mai ab, und nicht selten wird Besenhirse, welcher der Frosteintritt vor der Kornreife weniger schadet, als der Zuckerhirse, noch am 20. Juni bestellt.

In den wärmsten Gegenden Süd-Europas werden schon im 
März, weiter nach Norden im April, und unter dem $48^{\circ}$ n. Br. Mitte Mai, wenn Nachtfröste nicht mehr zu befürchten sind, die Samenkörner ausgelegt.

Was nun die Ermittelung der Grösse des Pflanzraumes anbetrifft, so ist derselbe von der Bodenbeschaffenheit, von dem Klima, dem Habitus der Sorte und dem Benutzungszweck abhängig; doch lässt sich nicht allein hiernach der Pflanzraum bestimmen, sondern auch nach der Bestockungsfähigkeit der Varietäten, z. B. erzeugt A. S. saccharatus 8-12 Schösslinge, während die iibrigen meist nur einen vollkommen entwickelten Halm hervorbringen.

In der nachfolgenden Saattabelle (Seite 926) baben wir eine Uebersicht der Pflanzräume und Saatquanta in den Hauptregionen der Mohrhirsekultur berechnet, bemerkt sei, dass das mittlere Gewicht von $1 \mathrm{hl}$ Samenkörner $70 \mathrm{~kg}$ beträgt, und $1 \mathrm{hl} \mathrm{A.} \mathrm{S.} \mathrm{saccha-}$ ratus 3.150 .000 Samenkörner, 1 hl der Imphy-Varietäten 3.850.000, und $1 \mathrm{hl}$ der Besenhirse 5.320.000 Samenkörner enthält.

Gewöhnlich wird der Same 24-48 Stunden, und in Amerika mit warmem Wasser, dem etwas Chlorkalk ${ }^{1}$ ) zugesetzt wird, eingeweicht.

Es scheint für die Zucker- und Körnerhirse im Allgemeinen die Dibbelkultur, und für die Besen- und Grünfutterhirse die Drillkultur bevorzugt zu werden. Doch findet auch für Korn- und Grünfutterhirse im extensiven Betriebe die Breitsaat Anwendung.

In Aegypten wird das Feld zur Herbstsaat, welche bewässert werden soll, in Quadrate von ca. 15 qm Grösse, die 60 Horste aufnehmen können, durch die Bewässerungsgräbchen eingeteilt, hierauf werden mit der Hacke flache Löcher gemacht und 3-5 Samenkörner hineingelegt und mit wenig Erde bedeckt.

Die Sommersaat wird nicht bewässert, weshalb jeder Horststelle nach dem Einlegen der Samenkörner 1/2 Ltr. Wasser gegeben wird. In Nord-Amerika wird mit Hülfe des ,Keystone-Planter" entweder gedibbelt oder gedrillt, selten breitwürfig gesäet oder gepflanzt, letzteres geschieht im Mai oder Juni, wenn die Pflanzen eine Höhe von $18-20 \mathrm{~cm}$ erreicht haben.

Das Auspflanzen ist auch fast allgemein in China verbreitet, und sind die Pflanzen häufig schon im April verpflanzbar.

In Europa wird entweder mit der Maschine gedrillt, oder nach einem Markeur mit der Hand gedibbelt.

Bei breitwuirfiger Aussaat bringt man die Samenkörner mit einer leichten Egge unter und walzt bei trocknem Wetter.

1) Smith, Imphee and Sorgh. cult. Transact. of the Ill. st. Agric. Soc. V. $1861-64$. 


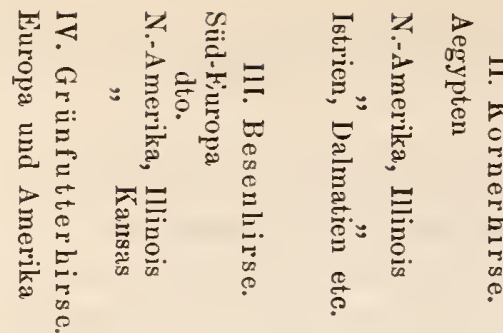

\begin{tabular}{|c|c|c|c|c|}
\hline 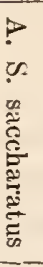 & 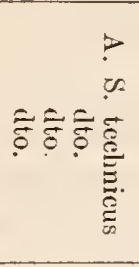 & 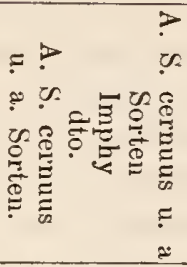 & 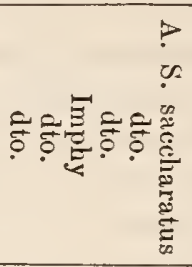 & 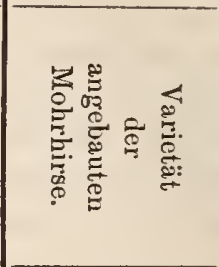 \\
\hline 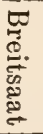 & 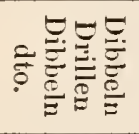 & 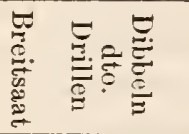 & 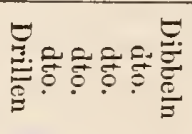 & 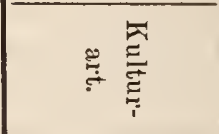 \\
\hline 1 & 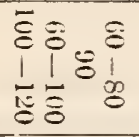 & $1 \underbrace{80}_{0}$ & 봉봉유용 & ङ \\
\hline 1 & 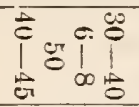 & $\left.1\right|_{\infty} ^{c} g e r$ & 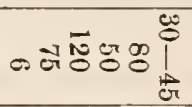 & $\begin{array}{l}\text { Entfernung } \\
\mathrm{S} \text { d. Horste in } \\
\text { der Reihe. }\end{array}$ \\
\hline$\stackrel{1}{8}$ & 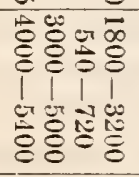 & 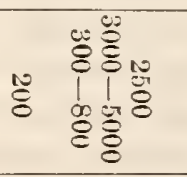 & 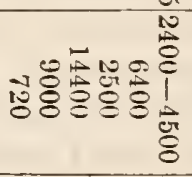 & 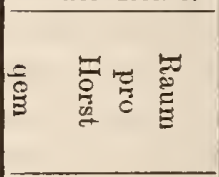 \\
\hline $\begin{array}{l}\text { er } \\
\text { हू } \\
\delta \\
\delta\end{array}$ & 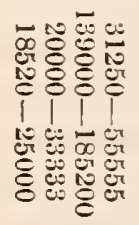 & 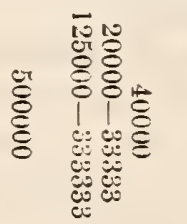 & 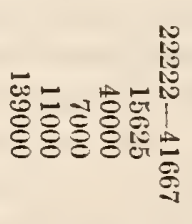 & 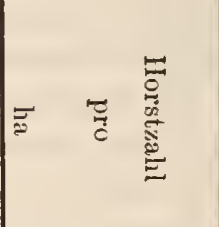 \\
\hline r & $i_{0} a r-i$ & $-\quad-\left.\infty\right|_{\text {er }} ^{e i}$ & $-\mid \begin{array}{llll}0.000 & 0 & 1 & 1 \\
0 & 1 & 1 & 1\end{array}$ & $\begin{array}{l}\text { Zahl d. Samen- } \\
\text { körner p. Horst. }\end{array}$ \\
\hline $\begin{array}{l}\text { er } \\
\text { ठ } \\
\S \\
\delta\end{array}$ & 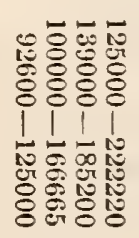 & 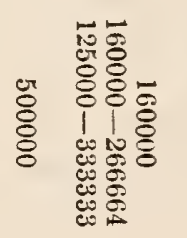 & 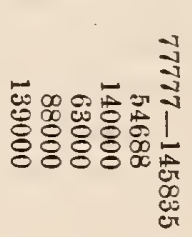 & 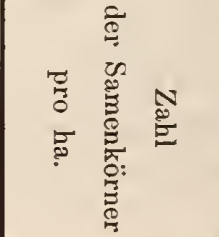 \\
\hline $\overrightarrow{0}$ & 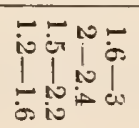 & $\left.e_{0}^{10} \quad\right|_{0} ^{\infty}$ & 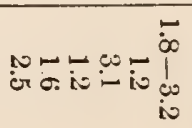 & 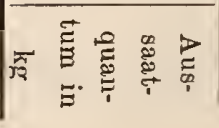 \\
\hline
\end{tabular}




\section{Pflege.}

Das Auflaufen der Samenkörner erfolgt je nach der Temperatur, der Bodenfeuchtigkeit, sowic ob das Samenkorn eingeweicht oder trocken ausgelegt wurde, in 3-4 oder in 14-20 Tagen.

Bei einer Höle der Pflänzchen von ea. $6 \mathrm{~cm}$ beginnt man gemeinhin mit dem Behacken, das sich nach Massgabe der Bodenerhärtung oder Verunkrautung niehrmals, sei es mit der Hand-, oder Pferdehacke, wiederholt.

Werden die jungen Pflänzchen durch Frost getroffen, so schneidet man die abgestorbenen Teile ab, und lässt sie von Neuen ansschlagen. Ist die Witterung günstig, dann lässt sich noch auf einen befriedigenden Ertrag hoffen.

Die Schösslinge der Zuckerhirse (A. S. saccharatus) erscheinen in der Regel bei einer Höhe des Haupthalmes ron $18-20 \mathrm{~cm}$, zu welchem Zeitpunkt auch das Verziehen und bei lückigem Stande das Nachpflanzen geschehen kann.

In der Regel lässt man bei der Dibbelkultur für Zuckerhirse bis 10 Halme im Horst stehen und bei Drillkultur gibt man den Halmen in der Reihe Zwischenräume von $15-20 \mathrm{~cm}$, für Körnerund Besenhirse nicht selten von $30-36 \mathrm{~cm}$, und gedibbelt lässt man in den Horsten $3-4$ der besten Halme stehen.

Verlangt man von der Besenhirse auch einen reichen Kornertrag, so bindet man vor der Ernte, wenn die Körner noch milchig sind, die Rispen an der Stelle wo sie abgeschnitten werden sollen, indem man sie umbicgt, mit den ebenso behandelten Halmen der nächstcn Reihe über Kreuz zusamnien; durch dieses Verfahren bleiben nicht nur die obcren Halmteile gerade und eignen sich besser zu Kehrbesen, sondern es gewinnen auch die Rispen an Qualität, die Körner reifen schneller und besser ans, und die Halme sind den Gefahren des Windbruchs weniger als die nicht umgebogenen und unter einander verbundenen ausgesetzt.

In den heissen und trocknen Ländern, in welchen eine Bewässerung der Molırhirse wïnschenswert erscheint, reicht man gewöhnlich mit 3 Bewässcrungen aus, von denen die erste am zweckmässigsten bei einer Höhe von $15-20 \mathrm{~cm}$, die folgende kurz vor dem Schosseu, und die letzte kurz nach der Blitte gegeben wird. 


\section{Ernte, Ansdrusch und Aufbewahrung.}

Die Körnerhirse ist reif, sobald die Samenkörner die charakteristische Farbe und Form der Sorte angenommen, sowie Halme und Blätter sich gelb gefärbt haben, und tritt dieser Zeitpunkt in Indien und im tropischen Afrika im Januar, in Aegypten bei der Sornmersaat im August, bei der Herbstsaat im Delta Ende Oktober, und in Süd-Europa im Laufe des Monat September ein.

Gemeinhin schneidet man die Rispen mit dem oberen Teil des Halmes ab, bringt sie auf die Dreschtenne, wo sie zum vollständigen Austrocknen der Sonne ausgesetzt werden und lässt sie dann durch Ochsen austreten, wie z. B. in Aegypten, oder drischt sie mit der Hand ab. In weniger heissen Klimaten empfiehlt es sich, die Rispen zum Austrocknen an einen luftigen Ort vor dem Ausdrusch aufzuhängen, und die gewonnenen Körner nur flach auf luftigen Böden aufzuschïtten, weil sie anderenfalls leicht verderben.

Der Zuckermohrhirse kommt der höchste Sirupgehalt (Glucose) im milchigen Zustande der Samenkörner zu, der geringste kurz ror der Blite und nach vollendeter Reife. In Nord-Amerika wird in neuester Zeit dahin gestrebt, statt des Sirups Krystallzucker (Saccharose) zu gewinnen, und gestiutzt auf seine 1879 ausgeführten Untersuchungen, zeigte Dr. Collier, dass sich die Saccharose mit der Ausreife der Samenkörner unausgesetzt vermehrt, so dass die Stengel mit der vollständigen Körnerreife auch das Maximum der Saccharose enthalten. Dieselbe nimmt jedoch nach einem harten Frost (mit Ausnahme bei Early Amber) ab.

Die folgende Tabelle enthält die Resultate der Untersuchungen an Zuckermohrhirse und Zuckerrohr.

\begin{tabular}{|c|c|c|c|c|}
\hline $\begin{array}{c}\text { Sorte. } \\
\text { Mohrhirse: }\end{array}$ & $\begin{array}{l}\text { Entwickelung } \\
\text { der } \\
\text { Pflanze. }\end{array}$ & $\begin{array}{l}\text { Datum } \\
\text { des } \\
\text { Schnittes }\end{array}$ & $\begin{array}{l}\text { Procent } \\
\text { Glucose }\end{array}$ & $\begin{array}{l}\text { im Saft } \\
\text { Saccharose }\end{array}$ \\
\hline $\begin{array}{l}\text { Early Amber } \\
\text { dto. } \\
\text { dto. } \\
\text { dto. }\end{array}$ & 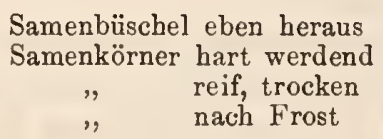 & $\begin{array}{l}\text { 18. Juli } \\
\text { 16. August } \\
\text { 16. Septbr. } \\
\text { 29. Oktbr. }\end{array}$ & $\begin{array}{l}3.7 \\
1.5 \\
0.6 \\
1.1\end{array}$ & $\begin{array}{r}3 \\
14 \\
15 \\
17\end{array}$ \\
\hline $\begin{array}{l}\text { Chinese } \\
\text { dto. } \\
\text { dto. } \\
\text { dto. }\end{array}$ & $\begin{array}{c}\text { Samenbüschel eben heraus } \\
\text { Samenkörner hart werdend } \\
, \quad \text { reif, trocken } \\
" \quad \text { nach Frost }\end{array}$ & $\begin{array}{l}\text { 6. August } \\
\text { 19. August } \\
\text { 13. Septbr. } \\
\text { 29. Oktbr. }\end{array}$ & $\begin{array}{l}5.5 \\
5.2 \\
1.4 \\
1.8\end{array}$ & $\begin{array}{r}1 \\
6 \\
13 \\
13\end{array}$ \\
\hline $\begin{array}{l}\text { White Liberian } \\
\text { dto. } \\
\text { dto. } \\
\text { dto. }\end{array}$ & $\begin{array}{c}\text { Samen in der Milch } \\
\quad, \quad \text { beinahe reif } \\
" \quad \text { reif und hart } \\
" \quad \text { nach Frost }\end{array}$ & $\begin{array}{l}\text { 26. Juli } \\
\text { 26. August } \\
\text { 27. Septbr } \\
\text { 29. Oktbr. }\end{array}$ & $\begin{array}{l}3.5 \\
1.4 \\
0.2 \\
2.1\end{array}$ & $\begin{array}{r}4 \\
13 \\
15 \\
13\end{array}$ \\
\hline
\end{tabular}




\begin{tabular}{|c|c|c|c|c|}
\hline Sorte: & $\begin{array}{c}\text { Entwickelung } \\
\text { der } \\
\text { Pflanze. }\end{array}$ & $\begin{array}{c}\text { Datum } \\
\text { des } \\
\text { Schnittes. }\end{array}$ & $\begin{array}{l}\text { Procent } \\
\text { Glucose }\end{array}$ & $\begin{array}{l}\text { im Saft } \\
\text { Saccharose }\end{array}$ \\
\hline Zuckerrohr: & & & & \\
\hline $\begin{array}{l}\text { Honduras } \\
\text { dto. } \\
\text { dto. } \\
\text { dto. }\end{array}$ & $\begin{array}{l}\text { Samenbüschel noch nicht } \\
\text { heraus } \\
\text { Samen in der Milch } \\
\text { " hart werdend } \\
\text { " nach hartem Frost }\end{array}$ & $\begin{array}{l}\text { 12. August } \\
\text { 13. Septbr. } \\
\text { 20. Oktbr. } \\
\text { 29. Oktbr. }\end{array}$ & $\begin{array}{l}5 \\
3.8 \\
1.3 \\
1.5\end{array}$ & $\begin{array}{r}1 \\
8 \\
15 \\
14\end{array}$ \\
\hline $\begin{array}{c}\text { La Ribbon-Cane } \\
\text { dto. }\end{array}$ & $\begin{array}{l}1879 \text { Pflanzung } \\
1878\end{array}$ & $\begin{array}{l}\text { 10. Novbr. } \\
\text { dto. }\end{array}$ & $\begin{array}{l}1.2 \\
0.5\end{array}$ & $\begin{array}{l}12 \\
16\end{array}$ \\
\hline La Red-Cane & 1878 & dto. & 1.2 & 14 \\
\hline
\end{tabular}

Hieraus ist ersichtlich, dass obige Sorten der Znckermohrhirse einen Saft liefern, welcher eben so reich an Krystallzucker ist, als der des Zuckerrohrs, und dass man zur Erzielung des höchsten Procentsatzes an Saccharose die volle Ausrcife der Samenkörner abwarten muss.

Die Ernte der Zuckermohrhirse erfolgt im wärmeren gemässigten Klima Europas und Nord-Amerikas Ende August und im September.

In einem grösseren Betriebe richtet man sich bei der Sirupund Alkoholgewinnung so eill, dass die Kampagne mit der Milchreife beginnt und mit der Samenreife beendet ist.

Unmittelbar vor dem Schneiden werden in Nord-Amerika mit den Händen, welche durch Lederhandschuhe geschitzt sind, die Blätter abgestreift, und darauf die Halme oberhalb des untersten Knotens abgeschnitten. Die Rispe kann nun vor oder nach dem Schnitt geköpft werden und zwar am zweiten Knoten von oben, denn bis dahin ist der Halm sehr zuckerarm und helfen die noch in ihm aufgespeicherten Reservestoffe eine gute Nachreife der Samenkörner herbeiführen, zu welchem Zweck die Rispen an einem luftigen Ort anfgehangen werden.

Die geköpften und entblätterten Halme werden in Bündeln $\mathrm{zu}$ 20 bis 30 Stiick frisch in die Fabrik gebracht und verarbeitet, weshalb man täglich nur das zu verarbeitende Quantum erntet. Ein Frost darf jedoch dic Stengel nicht treffen, weil hiernach der Saft bitter wird.

Die Halme lassen sich auch, getrocknet bis zum Februar, griin bis in den December hinein aufbewahren ${ }^{1}$ ).

$\mathrm{Zu}$ dem Ende trocknet man die Halme 1-2 Tage an der Sonne, in Folge dessen die Schnittwunden vertrocknen, und stellt sie dann in Bündeln in einer Scheune und zwar auf einem Gestell anf, damit

1) Mitteil. d. fr. ök. Gesellsch. z. St. Petersburg. 1858. pg. 30. 
nicht von dem feuchten Boden aus Fäulnis erzeugt wird. Ferner ist eine gute Lüftung, bisweilen Räucherung mit Schwefel und Bestrcuen der Diele mit Kohlenpulver nötig.

Die Ernte der Rispen und Besen der Besenhirse kann gleich nach der Blïte beginnen und erhält man dann das feinste, teuerste Material von Erbsenfarbe, oder man lässt die Pflanze ausreifen, wodurch gleichzeitig cin Kornertrag erzielt wird und entscheidet die Berechnung, welcher Zeitpunkt den Vorzug verdient.

In der wärmeren gemässigten Zone von Amerika und Europa erntet man die Rispenmohrhirse im September bis Mitte Oktober.

Die Rispen schneidet man in Amerika $60-75 \mathrm{~cm}$ vom Boden entfcrnt, wenn es sich um die Gewinnung von Besen handelt, oder $20 \mathrm{~cm}$ von der Rispe entfernt bei der Gewinnung des Materials zur Bürstenfabrikation. Die Rispen werden, zur Verhütung der Pilzbildung, zum Trocknen aufgehangen, und später auf einer den Flachsriffeln ähnlichen Vorrichtung cntkörnt.

Sehr erwünscht ist bei der Ernte schönes Wetter, weil die Rispen durch Regen missfarbig wcrden.

Die Griinfutterernte, wenn die Mohrhirse nicht abgeweidet wird, geschieht wie folgt:

In der Regel erscheint Anfang August die Rispe bei einer Höhe der Pflanze von 2.5-3 $\mathrm{m}$ und wird dann zur Heuwerbung oder zur Grünfuttergewinnung die Mohrhirsc gemähet. Die Stoppeln schlagen in warmen Sommern und auf kräftigem Boden wieder aus und treiben noch bis Ende Oktober 1-1.3 m hohe Triebe.

So erzielte Karmrodt im 1. Schnitt $46.800 \mathrm{~kg}$ Grünfutter p. ha, und Ende Oktober im 2. Schnitt noch $19.400 \mathrm{~kg}$.

Man will nun die Beobachtıng gemacht haben, dass der Nachwuchs geringer bei niedriger Stoppelhöhe ausfällt; es sollen nach 7 Tagen die Triebe mit einer Stoppelhöhe von $5 \mathrm{~cm}$ eine Länge von $16 \mathrm{~cm}$, die mit $13 \mathrm{~cm}$ Stoppclhöhe eine solche von $26 \mathrm{~cm}$ erreicht haben, weshalb es sich wohl empfehlen dürfte, nicht zu kurze Stoppeln stehen zu lassen, weil die in denselben noch verbleibenden Nährstoffe den Trieben zu Gute kornmen.

Mit dem Grünfutterschnitt lässt sich aber auch schon beginnen, wenn die Pflanzen $1 \mathrm{~m}$ hoch erwachsen sind und folgen dann diesem 1. Schnitt noch $1-2$ weitere Schnitte und erzielt man auf diese Weise in verschiedenen Perioden ein wertvolles Grinfutter.

Bis zur Blüte hin lässt sich die Pflanze als Grünfutter noch gut verwerten. 


\section{Erträge und Nahrungsbestandteile.}

Von der Körnerhirse werden in den tropischen Ländern bis zu 80 hl pro ha geerntet und zwar zeichnet sich dieselbe durch hohes Volumengewicht aus, das je mehr sich der Anbau seinen Grenzen nach Norden zu nähert, immer mehr abnimmt, daher schwankt dasselbe zwischen 65 und $80 \mathrm{~kg}$ und beträgt im Mittel $70 \mathrm{~kg}$ pro hl.

In Aegypten ${ }^{1}$ ) erntet man $26-54 \mathrm{hl}$ und im Mittel $33 \mathrm{hl} \mathrm{p.} \mathrm{ha.}$ Erträge, welche auch in Siid-Europa erzielt werden können.

Die geringsten Erträge bringt aber wohl das arme Karstgebiet von Istrien und Dalmatien, wo nach Lorenz ${ }^{2}$ ) 15.75 bis $21.40 \mathrm{hl}$, ja selbst nur $4.28 \mathrm{hl}$ pro ha geerntet werden.

Im Allgemeinen stellt sich der Ertrag wie folgt:

\begin{tabular}{l|r|r|r}
\hline \hline & Min. & Max. & Mittel \\
\hline beim Korn in hl & 4.3 & 80 & 40 \\
,$\quad$ Stroh in kg & $900^{\circ}$ & 12000 & 6000
\end{tabular}

Was die Zusammensetzung der Früchte angeht, so geben darüber folgende Analysen Auskunft. Es enthielten in 100 Teilen:

$$
\begin{array}{cc}
\text { Early amber. } & \text { Chinese sugar-corn }{ }^{3} \text { ) } \\
\text { (Imphy) } & \text { (A. S. saccharatus):. }
\end{array}
$$

\begin{tabular}{|c|c|c|c|}
\hline Wasser & ? & 10.57 & 9.93 \\
\hline Asche . & - & 1.81 & 1.47 \\
\hline Fett . & • & 4.60 & 3.95 \\
\hline Zucker & . & 1.91 & 2.70 \\
\hline Eiweiss & • & 4.55 & 5.34 \\
\hline Gummi & . & 1.10 & 0.72 \\
\hline Stärke & . & 68.55 & 70.17 \\
\hline Holzfaser & & 1.48 & 1.52 \\
\hline
\end{tabular}

Ferner liegen Analysen der Samen von Sorghum vulgare von Prof. T. Storer und Lewis ${ }^{4}$ ) vor, nach denen in 100 Teilen Trockensubstanz gefunden wurden:

1) Figari Bey, Studii scientif. sull' Egitto. II. 106.

2) Allg. land- und forstw. Ztg. Wien 1862. pg. 179.

3) Rep. of the Commiss. of Agric. 1879. pg. 101.

4) Bullet. of the Bussey-Instit. II. 1877. pg. 94-105. 


\begin{tabular}{|c|c|c|c|c|c|c|c|c|}
\hline & & & & & \multirow{2}{*}{$\begin{array}{l}\text { Same } \\
\text { reif }\end{array}$} & \multicolumn{3}{|c|}{ Same unreif } \\
\hline & & & & & & $\begin{array}{c}\text { in der } \\
\text { Blüte }\end{array}$ & $\begin{array}{l}\text { nach der } \\
\text { Blüte }\end{array}$ & $\begin{array}{c}\text { in der } \\
\text { Milchreife }\end{array}$ \\
\hline Rohproteïn & $\cdot$. & . & . & . & 8.63 & 7.38 & 9.65 & 9.72 \\
\hline Nfr. incl. Fett & . & . & . & . & 81.01 & 59.93 & 58.40 & 69.18 \\
\hline Cellulose & . . & . & .. & $\cdot$ & 7.46 & 28.26 & 25.42 & 16.32 \\
\hline Asche (frei vor & $\mathrm{n} \mathrm{K}_{0}$ & hlen & nsäu & re) & 2.90 & 4.43 & 6.53 & 4.78 \\
\hline
\end{tabular}

Die Zusammensetzung der Körner im natïrlichen Zustande unterliegt aber nicht unbeträchtlichen Schwankungen, wie die nachfolgende Tabelle zeigt:

\begin{tabular}{l|c|c|c|c|c|c}
\hline & $\begin{array}{r}\text { Trocken- } \\
\text { substanz. }\end{array}$ & $\begin{array}{c}\text { Substanz.halt. } \\
\text { Proc. }\end{array}$ & Fett. & $\begin{array}{c}\text { N-freie } \\
\text { Substanz. }\end{array}$ & $\begin{array}{c}\text { Holz- } \\
\text { faser. }\end{array}$ & Asche. \\
& Proc. & Proc. & Proc. & Proc. \\
\hline Minimum & 86.0 & 7.2 & 2.4 & 63.0 & 3.2 & - \\
Maximum & 88.1 & 11.0 & 3.8 & 73.0 & 3.5 & - \\
Mittel & 86.5 & 9.1 & 3.1 & 68.0 & 3.4 & 2.4
\end{tabular}

Die Halme sind rerhältnismässig zuckerreich und werden daher auf Sirup und Alkohol verarbeitet.

Nach einer Analyse ron Moser ${ }^{1}$ ) enthielten am 3. November geerntete Halme von A. S. saccharatus in 100 Teilen:

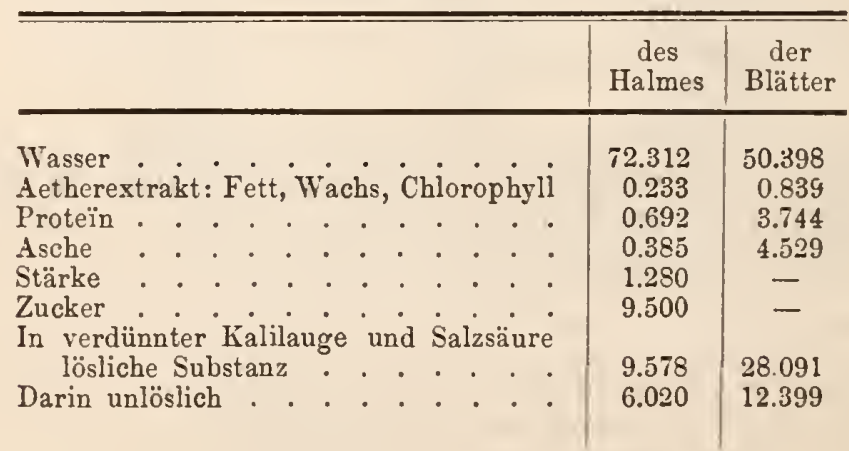

1) Land- u. forstw. Ztg. Wien 1862. pg. 357. 
Die Erträge an Sirup, Alkobol oder Branntwein pro ha ergeben sich aus nachstehender Uebersicht:

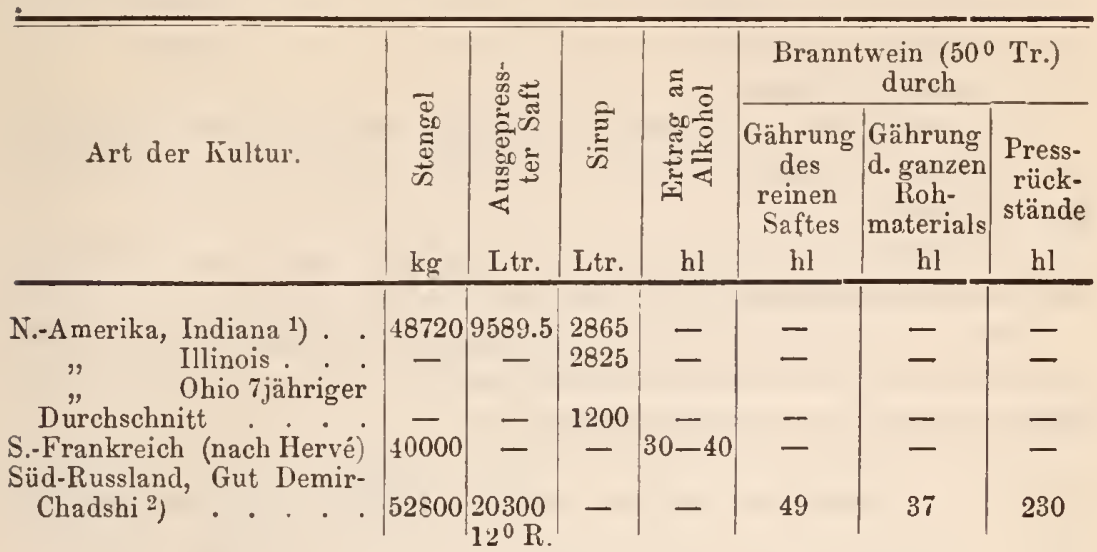

Der Durchschnittsertrag an Sirup stellt sich in N.-Amerika auf $12 \mathrm{hl}$, im Max. auf $30 \mathrm{hl}$ pro ha.

Von der Besenhirse werden an Rispen und Körnern pro ha geerntet:

\begin{tabular}{|c|c|c|}
\hline Ort der Kultur: & $\begin{array}{c}\text { Rispen } \\
\mathrm{kg}\end{array}$ & $\begin{array}{c}\text { Körner } \\
\text { hl }\end{array}$ \\
\hline 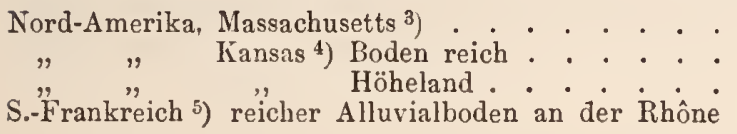 & $\begin{array}{l}1300 \\
1255 \\
560-900 \\
4250\end{array}$ & $\begin{array}{l}79 \\
67.5 \\
36 \\
51\end{array}$ \\
\hline
\end{tabular}

Hiernach stellt sich in Amerika die durchschnittliche Produktion an Rispen auf $1100 \mathrm{~kg}$ und an Korn auf $60 \mathrm{hl}$ pro ha.

Die Erträge in Siid-Frankreich sind ausserordentlich boch, und nur unter den gijnstigsten Bedingungen $z u$ erreichen.

An Grinfutter liefert die Mohrbirse pro ha:

In Frankreich im Durchschnitt . .

In Landes reichlich gedüngt, Maximum

Zn Mably, auf leichtem Boden . .

M. Favier

Graichen bei Leipzig

$$
\begin{array}{r}
100.000 \mathrm{~kg} \\
123.000 \\
44.000 \\
40-70.000 \\
60.000
\end{array}
$$

1) Transact. of the N.-I. st. Agric. Soc. 1857. pg. 129 flgde.

2) Mitteil. d. fr. ök. Gesellsch. zu St. Petersburg, 1858 pg. 30.

3) Traver's Broom-Corn Cult. 1873.

4) The Third annual Rep. to the Legisl. of Kansas 1874 pg. 233.

5) Gasparin, Cours d'Agric. III. 
Karmrodt, St. Nicolas

$66.000 \mathrm{~kg}$

Reylen bei Stuttgart

90.000 ,

Hölzlin bei Offenburg

98.000 ,

Hohbach in Böhmen . . . . . . . 26.600 "

Rohde in Eldena . . . . . . . . $17.400 "$

Durchschnittlich ist daher ein Ertrag von ca. $76.700 \mathrm{~kg}$ pro ha an Grïnfutter anzunehmen, und stellt sich der Heuertrag auf ungefähr 30 Procent.

Im Allgemeinen sind aber die Erträge und zwar selbst im Weinklima Deutschlands sehr unsichere.

Was den Futterwert des Grünsorghum anlangt, so untersuchte ihn Moser in dem Entwickelungsstadium, wo die Rispe aus der Blattumbiillung hervortritt und fand in

$$
\text { Wasser Asche Holzfaser Fett Nfr. Nh. }
$$

Probe Nr. I. 76.6 Proc. 0.8 Proc. 5.4 Proc. 1.5 Proc. 13.9 Proc. 1.8 Proc.

$\Rightarrow \quad$ II. $78.4 n \quad 1.3 n 6.2 n \quad-n 11.0,3.1$,
Durchschnitt: 77.5 Proc. 1.0 Proc. 5.8 Proc. 1.5 Proc. 11.7 Proc. 2.5 Proc.

Zum Verfüttern darf die Mohrhirse nicht zu alt werden, wenn sie dem Vieh behagen soll; sie wird von Kühen und Schweinen sehr gern anfgenommen und wirkt gtinstig auf die Quantität und Qualität des Milchertrages ein, wenn durch Hinzufügung von Kraftfutter ein günstiges Nährstoffverhältnis hergestellt worden ist.

Da sie mehrere Schnitte liefert, unterstiitzt sie die Sommerstallfütterung und bietet noch spät im Herbst ein vorzligliches Grünfutter.

\section{Benutzung.}

In der tropischen und subtropischen Zone werden vorzugsweise die Früchte der Mohrhirse zur Ernährung der Menschen benutzt, und leben die Neger Afrikas, sowie die Fellahs Aegyptens der Hauptsache nach von diesen Früchten.

$100 \mathrm{~kg}$ Scheinfrüchte liefern $58-60 \mathrm{~kg}$ enthülste Körner und $100 \mathrm{~kg}$ dieser geben $57 \mathrm{~kg}$ Mehl, $21 \mathrm{~kg}$ grobe und $20 \mathrm{~kg}$ feine Kleie.

Das Mehl ist weisser, dabei nahrhafter und haltbarer als das der anderen Hirsearten.

In den Ländern der wärmeren gemässigten Zone werden die Früchte hauptsächlich als Futter für Schweine und Geflïgel verwertet.

In China und Afrika bereitet man ans ihnen einen woblschmeckenden Branntwein, und werden die Friichte als "Darhikorn" zur Alkoholbereitung in die Brennereien Mittel-Europas verkauft.

Die Neger bereiten aus den Körnern einen roten Farbstoff zur 
Färbung ihrer Zeuge, auch stellte der Pharmaceut Hetet 1855 einen roten Farbstoff „Purpurholcine“ und einen gelben „Xantholcine" aus den Körnern von A. S. saccharatus her.

Die Benutzung auf Sirup ist nicht nur bei den Aegyptern, sondern auch weit über Nord-Amerika ${ }^{1}$ ) und hauptsächlich in den Staaten Illinois, Indiana und Ohio verbreitet.

In neuester Zeit soll es auch gelungen sein, durch die Ernte in der Vollreife und den Anbau frühreifer Sorten, Rohrzucker aus der Zuckermohrhirse zll gewinnen, doch scheint der von der Regierung zu Washington darauf ausgesetzte Preis von 100000 Dollars bis jetzt noch nicht vergeben zll sein.

Es scheint die Herstellung von krystallisiertem Rohrzucker nach den Erhebungen von $\mathrm{Mose}^{\circ}$ daran gescheitert zll sein, dass, wenigstens bei A. S. saccharatus, der Gehalt an Tranbenzucker und Stärkemehl des Stengels im Verhältniss zum vorhandenen Rohrzucker zu hoch ist. Nach Collier lässt sich jedoch durch die Ernte in der Vollreife der Körner dies Verhältnis guinstiger gestalten.

In Europa ergab die Sirupfabrikation weniger giunstige Resultate als in Nord-Amerika, denn obschon die ersten Versuche aus dem Jahre 1856 datieren, hat sie keineswegs an Ausdehnung gewonnen. Man sollte nun glauben, dass die Selıwarzerde Süd-Russlands ein sehr guinstiges Terrain für die Kultur der Zuckerhirse abgeben müsse, und ist in der That schon $1856 \mathrm{zu}$ Demir-Chadshi, im Akkerman'schen Kreise, unweit der deutschen Kolonie Sarata und dem Flecken Tatar-Bunarg eine Branntweinbrennerei erbaut worden, welche die Stengel der Zuckerhirse verarbeitete.

Auf diesem Gute wurden pro ha 34100 Horste mit 132000 Stengeln im Gewichte von $52800 \mathrm{~kg}$ erzielt, ein Ertrag, welcher den Durchschnittsertrag in Nord-Amerika iubertrifft, und trotzdem verlautet zur Zeit Nichts über eine weitere Ausdehnung dieser Brennereien.

Ferner ist mir auf privatem Wege bekannt geworden, dass die in S.-Russland auf Sirupfabrikation gegrïindeten Fabriken schon in kurzer Zeit haben eingehen müssen, so wurde z. B. im Lande der Donischen Kosaken, in dem Orte Bolschinsk, 1858 eine Fabrik dicht am Flusse Bolschaja gegründet, so dass es möglich war, die Zuckerhirseplantagen auf dem reichen, jungfräulichen Boden zu bewässcrn und hohe Roherträge zu erzielen, trotzdem liquidierte die Fabrik nach 4 Jahren ihres Bestehens mit 37000 Rubeln.

Del Grund des schlechten Ganges dieses Unternehmens wird nun in den zu kleinen Verhältnissen der Fabrik gesucht.

1) Ueber die Technik der Zuckergewinnung berichtet A. Gössmann, Beitr. z. Kenntnis d. sog. chines. Zuckerrohrs. Philadelphia. Abgedruckt in Henneberg's Journ. f. Landw, 6. Jahrg. 17. Heft p. 294. 
Am Don treten gewöhnlich schon Anfang September kleine Nachtfröste auf, demzufolge sich die Kampagne nur auf 4-5 Wochen beschränkt und die Fabrik nicht ausreichte, die Stengel ron 20 ha rechtzeitig zu verarbeiten, so dass ein Teil durch Frost zu Grunde gring; aus diesem Grunde muss eine Sirupfabrik, soll sie rentieren, mit einer Brennerei verbunden sein, um die rom Frost beschädigten Stengel auf Branntwein rerarbeiten zu können, doch ist in diesem Fall wiederum das Anlagekapital zu hoch.

Weit mehr scheint dagegen in Europa die Kultur der Besenhirse Erfolge anfzuweisen, denn nicht nur in Italien wird sie in allen Provinzen zur Gewinnung ron Besen, Bürsten, Grünfutter und Korn angebaut, sondern auch im siidlichen Frankreich finden sich ansgedehnte Kulturen und im sïdöstlichen Europa deckt man wenigstens den eignen Bedarf an Bürsten und Besen.

In Nord-Amerika, z. B. in Illinois, aber auch in Massachusetts, Kansas und Indiana wird ibre Kultur in sehr beträchtlichem Unfange betrieben und grosse Fabriken in Chicago, Cleveland, Philadelphia etc. verarbeiten das Rohmaterial, und bilden die Besen und Bürsten dieser Fabriken einen sehr bedeutenden Handelsartikel.

In den heissen, trocknen Ländern, denen es an Wiesen und Weiden fehlt, dient die Mohrhirse als willkommenes Grünfutter und das Stroh häufig als Brennmaterial.

Dagegen scheint die Mohrhirse als Grïnfutter für das kältere gemässigte Klima ungeeignet und nicht im Stande $\mathrm{zu}$ sein, andere Grünfuttergewächse und selbst nicht den Grünmais verdrängen zu können, wie dies aus einem Kulturversuch ron ron $\mathrm{Nathusius-}$ Königsborn ${ }^{1}$ ) und ron Rohde in Eldena bei Greifswald hervorgeht.

Letzterer legte am 1, und 2. Juni auf gut gedüngtem sandigen Lehmboden Zahnkornmais und Zuckerhirse auf $66 \mathrm{~cm}$ ron einander entfernte Kämme und zwar je 2 Samenkörner auf $10.5 \mathrm{~cm}$ Entfernung $4 \mathrm{~cm}$ tief aus. Schon nach 6 Tagen lief der Mais, nach 10 Tagen die Mohrhirse auf. Nach 10 Wochen wurden rom Mais $40000 \mathrm{~kg}$ und Mitte September in Bliite tretend, $56000 \mathrm{~kg}$ Grünfutter pro ha geerntet.

Die Zuckerhirse war dagegen in ihrer Entwickelung sehr weit zurïckgeblieben, denn es zeigten sich erst Anfang Oktober bei wenigen Pflanzen die Rispen. Am 8. Oktober wurde nun bei Eintritt des Frostes und zwar gleichzeitig mit dem zum Vergleich stehengebliebenen Mais die Zuckerhirse geerntet, und lieferte dieselbe $17520 \mathrm{~kg}$, der Mais aber $52800 \mathrm{~kg}$ Grtinfutter.

Hieraus folgt, dass die Kultur des Grünmaises in Nord-Deutsch-

1) Annal. d. Landw. 1557. pg. 265. 
land den Vorzug verdient, denn obgleich die Mohrhirse reicher an Proteïnstoffen als der Mais ist, also einen höheren Futterwert besitzt, so ist doch der Mehrertrag an Mais zu bedentend, als dass derselbe durch die bessere Qualität der Mohrhirse aufgewogen werden könnte.

Auch erbringen vergleichende Analysen ron Moser zwischen Mohrhirse und Mais den Nachweis, dass letzterer nicht allzu weit in Betreff seiner Nährstoffe gegen die Mohrhirse zurỉcksteht.

Moser fand in 100 Teilen:

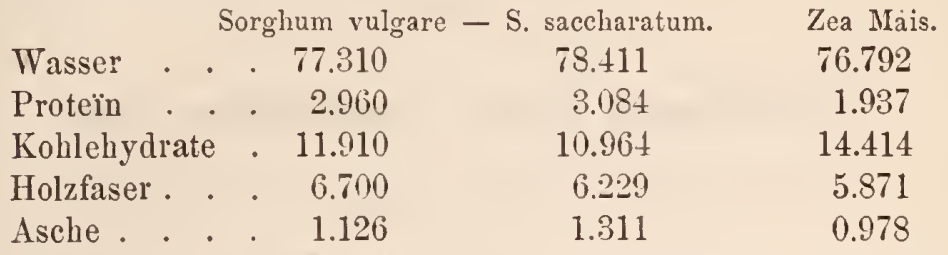

Hiernach ist der Mais ämer an Protcïnstoffen und reicher an Kohlehydraten, als Sorghum, doch liegen auch anderweite Analysen von Moser vor, bei denen das umgekehrte Verhältnis Platz greift.

Die Pflanzen wurden untersucht, als die Mohrhirse die Rispe entwickelt hatte, doch war dieselbe noch nicht aus der Blattumbiillung hervorgetreten, beim Mais zeigtcn sich die mämnlichen Blüten. 100 Teile enthielten:

Grünsorghum

$$
76.589
$$

0.775

1.765

5.403

1.545

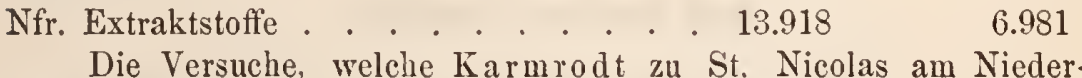

Grünmais. 85.444 rhein 1858 mit Sorghum und Mais anstcllte, fielen trotz des, Eldena gegeniiber, viel günstigeren Klimas, für Sorghum ebenfalls ungünstig aus.

Er erntete an Grünfutter pro ha

$$
\begin{aligned}
& \text { vom Sorghum . . } 25840 \mathrm{~kg} \text {, } \\
& \text { Zahnkornmais } 37400
\end{aligned}
$$

Hiernach scheint cs, als wenn die Kultur des Sorghum vorzugsweise in warmen und regenarmen Distrikten am Platze ist, um den Futtermais zu ersetzen, z. B. in Italien, Ungarn, Suid-Frankreich etc., weil er die Diirre besser als der Mais verträgt.

Nach E. Wolff entbält das Grünfutter an organischer Substanz 21.6 Proc., und darin an verdaulichem Proteïn 1.8 Proc., Kohlehydrat 11.9 Proc. und Fett 0.3 Proc., mithin ist das Nährstoffverbältnis wie 1 : 7.4, und stellt sich der Futterwert von $100 \mathrm{~kg}$ auf 1.72 Mark. 


\title{
Reis.
}

\author{
Oryza sativa L.
}

\section{Usitatissima Kcke. Gebräuchlicher Reis.}

Der Eiweiskörper im Bruche glasig, etwas glänzend.

(Koch- und backfähig.)

1. Communis Kcke. Grosser oder gemeiner Reis. Früchte gross $(5-7 \mathrm{~mm}$ lang).

A. Unbegrannt.

a. Frucht weiss.

Varietät: italica Al. Italienischer Reis.

Scheinfrucht gelbrötlich, Frucht weiss.

\section{Sorten:}

\section{Riso Bertone o mellone.}

Syn.: Franz.: Riz imberbe ou sans barbes, Riz d'Afrique.

Rispe: mittelgross, zusammengezogen. - Halm niedrig, Knoten schwarz, wenig blattreich. - Scheinfrucht: Anfangs grünlich, später rötlich und in der Reife gelbrötlich, feinhaarig, $81 / 2 \mathrm{~mm}$ lang, $3 \mathrm{~mm}$ breit, Frucht: graulich-weiss, abgeplattet, länglich.

Unsere Ausmessungen auf Reisfeldern bei Locate, Prov. Mailand ergaben 1881 folgende Resultate:

Rispe bis $20 \mathrm{~cm}$ lang mit 100 Scheinfrüchten, welche unenthülst $60 \mathrm{~kg} \mathrm{p.} \mathrm{hl} \mathrm{wogen,} \mathrm{dies} \mathrm{ist,} \mathrm{weil} \mathrm{Scheinfrüchte} \mathrm{grannenlos,} \mathrm{für} \mathrm{unge-}$ schälten Reis ein sehr hohes Gewicht, es liefern durchschnittlich $100 \mathrm{~kg}$ des ungeschälten Reises $50 \mathrm{~kg}$ geschälten Reis, dagegen gegrannte Sorten nur $40-45 \mathrm{~kg}$.

Halm $90 \mathrm{~cm}$ lang, $0.4 \mathrm{~cm}$ dick, Blattzahl 5, Blätter $30 \mathrm{~cm}$ lang, $0.9 \mathrm{~cm}$ breit, mithin beträgt die Gesammtoberfläche eines Halmes $378 \mathrm{qcm}$, und die einer Pflanze bei 4 Schösslingen $1512 \mathrm{qcm}$.

Diese Sorte ist sehr frühreif, da sie schon im August und wenn nach einer Vorfrucht erst im Mai gesäet, Ende September geerntet wird. Gemeinhin reift sie bei einer Aussaat $z$ wischen dem 1. und 15. März um 40-50 Tage früher als die späten in Ober-Italien angebauten Sorten. 
Nach Gasparin verlangt sie $2730^{\circ}$ Sonnenwärme und $1967^{\circ} \mathrm{im}$ Schatten gemessener Wärme.

Sie beansprucht aber zu reichlicher Produktion einen guten Boden, und wenn auch weniger, jedoch fliessendes Wasser, als die spätreifen Sorten. Letztere tragen aber reichlicher auf geringeren Böden, bewurzeln sich stärker und werden daher weniger leicht aus dem Boden gerissen, lassen das Unkrant, da sie den Boden besser beschatten, nicht leicht aufkommen und haben ein wertvolleres Korn.

Der Name „Bertone" soll von Breton (britannisch) und "Mellone" von der Melonenform der Scheinfrïchte abgeleitet sein.

In Italien wird sie hauptsächlich in den Provinzen Parma, Milano, Novara, Pavia und Brescia kultiviert, doch ist sie auch in Algier, Aegypten, auf Madagascar und unzweifelhaft auch in Ostasien verbreitet.

Ferner gehören dieser Varietät nachfolgende Sorten ${ }^{1}$ ) des ostindidischen Archipels an:

Paddy Gendjah-Marus; Mològ; Tjempi Utri (sehr frühreif); Lélé; Mirbun; Benggala; Bunturan; Gundil Slojur (frühreif).

Varietät: javanica Keke. Java-Reis.

Scheinfrucht dunkelrot, Frucht weiss.

Sorte n:

Pareh gundil, Java ${ }^{2}$.

Frucht weiss, mehlig, dick.

\section{Riso di Giava.} gebaut.

Heimat: Java; versuchsweise in der Provinz Bologna, Italien an-

In Mailand 1881 ausgestellt.

Varietät: paraguayensis Kcke. Paraguay-Reis.

Scheinfrucht schwärzlich, Frucht gross, weiss.

Sorte :

\section{Riso del Paraguay.}

Heimat: Paraguay: versuchsweise in Italien gebaut.

In Mailand 1881 ausgestellt.

\section{b. Frucht rotbraun.}

Varietät: sundensis Kcke. Sunda-Reis.

Scheinfrucht gelbrötlich, Frucht rotbraun.

\section{Sorten:}

$\mathrm{Zu}$ dieser Varietät gehören auf den Inseln des ostindischen Archipels: frühreif.

Paddy Mataram; Tjempi Blulook, sehr frühreif; Tjempi Kenanti,

1) Die aufgeführten Reissorten des ostindischen Archipels sind uns durch den Direktor des Haarlemer Kolonial-Nuseums, Herrn van Eeden, übersandt worden.

2) Miquel, Fl. v. Nederl. Indie (1860). 


\section{B. Begrannt.}

a. Frucht weiss.

Varietait: rulgaris Kcke. Gemeiner Reis.

Scheinfrucht und Grannen gelbrötlich.

\section{Sorten:}

\section{Carolina-rice.}

Syn.: Engl.: Common white rice.

Ital.: Risone biancone.

Spanisch und Portugiesisch: Arroz carolino.

Franz.: Riz de la Caroline, Riz américain, Caroline ordinaire.

De utsch: Carolina-Reis.

Rispe: ausgebreitet. - Halm: $1.20 \mathrm{~m}$ hoch. - Scheinfrucht: gelbrötlich, $7 \mathrm{~mm}$ lang, $3 \frac{1}{2} \mathrm{~mm}$ breit, $2 \mathrm{~mm}$ dick, Grannen kurz, gelblich; Frucht rein weiss, ein wenig glasig, länglich, feinmehlig, geruchlos.

Wohl eine der feinsten Reissorten.

Angebaut in South-Carolina, sowie in den übrigen Reis bauenden Staaten der nordamerikanischen Union, in Ostindien, Italien und auf Madagascar, aus welchem letzteren Lande er 1701 nach South-Carolina ${ }^{1}$ ) eingeführt wurde.

Bezugsquelle: Mailänder-Ausstellung 1881.

\section{Long grain Carolina-rice.}

Syn.: Franz.: Riz à grain long ou odorifère (Heuzé).

Deutsclı: Carolina-Reis mit langem Korn.

Rispe: ein wenig zusammengezogen. - Halm: 1.20-1.30 m hoch, selir steif, daher nicht leicht lagernd. - Scheinfrucht: gelbrötlich, in der Reife nicht leicht abfallend; Granne gelbrötlich, mittellang; Frucht weiss, lang, hochfein, wohl der feinste Reis der Erde.

Nach Indien 1868 eingefülırt, wird er in Bengalen als „Benafuli“" sehr geschätzt, auch sind mit ihm in Italien und Brasilien Anbauversuche gemacht worden.

\section{White bearded-rice.}

Syn.: Franz.: Riz à barbes blanches.

Deutscli: Weissbärtiger Reis.

Frucht weniger feiu als rom Carolina-Reis; Grannen heller und länger, auch nimmt er nit weniger reichem Wasser vorlieb.

Sehr nahe mit dem Carolina-Reis verwandt.

\section{Riso Ostiglione.}

Syn.: Ital.: Riso Novarese ed anche Americano.

Franz.: Riz novarais ou de Novare.

Deutsch: Novara-Reis.

Rispe: ausgebreitet, gross, bis $25 \mathrm{~cm}$ lang, mit 175 Scheinfrüchten. - Halm: sehr kräftig, wohl von den in Italien gebauten Sorten am

1) Klöden, Handb. d. Erdkunde, Vol. I. pg. 1050 (1873). 
längsten, blattreich, Knoten schwärzlich. - Scheinfrucht: gelbrötlich, $8.5 \mathrm{~mm}$ lang, $3.5 \mathrm{~mm}$ breit, $2 \mathrm{~mm}$ dick; Grannen gelbrötlich, lang; Frucht: weiss mit schwach gelblichem Anflug, mittelgross, länglich, wohlschmeckend.

Spätreif, denn ich fand ihn am 18. August 1881 bei Locate, Provinz Mailand, soeben abgebliuht, während der frühreife Riso Bertone nahezu reif war. Die Pflanze ist sehr robust, denn die Ausmessung latte folgendes Ergebnis: Halm $150 \mathrm{~cm}$ lang, $0.5 \mathrm{~cm}$ dick, Blattzahl 6.5, Blätter $47 \mathrm{~cm}$ lang, $1.2 \mathrm{~cm}$ breit, Gesammtoberfläche eines Halmes $948.2 \mathrm{qcm}$, einer Pflanze bei 1.5 Schösslingen $1422 \mathrm{qcm}$.

Diese Sorte ist in Italien aus dem Carolina-Reis herausgezüchtet worden, und wird vornehmlich ihres hohen Ertrages wegen, auf reichem Boden und mit gutem Wasser in den Provinzen Novara, Milano, Padova, Verona, Brescia und der Emilia gezogen.

\section{Riso Francone.}

Syn.: Franz.: Riz de Piémont.

Oryza sativa Caroliniana subv. dell' Ostiglione ${ }^{1}$ ).

Rispe: ein wenig zusammengezogen und kurz. - Halm: kräftig, $1.30 \mathrm{~m}$ hoch, blattreich. - Scheinfrucht: gelbrötlich, $7.5 \mathrm{~mm}$ lang, $3,5 \mathrm{~mm}$ breit, $2 \mathrm{~mm}$ dick; Grannen gelbrötlich, küirzer als bei Ostiglione, nur $4.5 \mathrm{~cm}$ lang; Frucht weiss und kleiner als bei Ostiglione, wohlschmeckend.

Unter gleichen Kulturverhältnissen wie Ostiglione gewachsene Pflanzen gaben nachfolgende Ausmessungsresultate:

Halme $130 \mathrm{~cm}$ lang, $0.5 \mathrm{~cm}$ dick, Blattzahl 6, Blätter $40 \mathrm{~cm}$ lang, $1.2 \mathrm{~cm}$ breit, Gesammtoberfläche pro Halm $837.7 \mathrm{qcm}$ und bei 1.5 Schösslingen $1256.55 \mathrm{qcm}$ pro Pflanze, und bleibt hiernach Francone nicht unbedeutend gegen Ostiglione in der Entwickelung zurück.

Stark in den italienischen Provinzen Novara, Milano, Distrikt Abiategrasso, Pavia und in neuerer Zeit auch in Spanien angebaut.

Der Name „Francone“ soll der des ersten Züichters sein.

\section{Riso nostrano o nostrale.}

Syn.: Spanisch: Arroz anegado.

Portug.: Arroz praganudo.

Engl.: Common rice.

Franz.: Riz commun.

Deutsch: Gemeiner Bartreis.

Cochinchina: Lua-chin-mua (Henzé).

Rispe: ein wenig zusammengezogen. - Halm: $1.30 \mathrm{~m}$ hoch. Scheinfrucht: gelbrötlich, länglich; Granne gelbrötlich, $8.5 \mathrm{~cm}$ lang; Frucht: $8 \mathrm{~mm}$ lang, $3 \mathrm{~mm}$ breit, $2 \mathrm{~nm}$ dick, ein wenig kurz, sehr weiss, Qualität gut, $1 \mathrm{hl}$ wiegt $50 \mathrm{~kg}$.

Eignet sich wegen seiner Frühreife für Ober-Italien (Ernte Anfang bis Mitte September) vortrefflich, zumal er auf weniger reichen Böden noch gut gedeiht. Vorzugsweise in den Provinzen Ravenna, Vicenza und Bologna gebaut.

Bezugsquelle: Mailänder-Ausstellung 1881.

1) Relazione intorno alle Condizioni dell' Agric. in Italia; 1876. 


\section{Riso d'Ostiglio.}

Diese Sorte ist dem Riso nostrano sehr nahe verwandt, nur Spelzen stärker behaart, Früchte kleiner und wohlschmeckender, Grannen und Halme länger (1.50 $\mathrm{m}$ hoch) und etwas spätreifer, denn er reift in den Provinzen Pavia, Novara und Nilano, in denen er hauptsächlich gebaut wird, in 160 Tagen.

Bezugsquelle: Mailänder-Ausstellung 1881.

\section{Gold seed rice.}

Syn.: Ital.: Risone d'oro.

Franz.: Riz à grain d'or.

Deutsch: Goldreis.

Rispe: ausgebreitet. - Halm: hoch. - Scheinfrucht: goldfarben, abgeplattet; Grannen gelbrötlich, kurz; Frucht weisslich, doch etwas glasig und ron schönem Perlmutterglanz.

In South-Carolina, wohin ihn 1785 Colonel Mayban (nach Heuzé) einführte, sehr geschälzt.

Versuchsweise in Italien (Abiategrasso) kultiviert.

Bezugsquelle: Mailänder-Ausstellung 1881.

\section{Riz des îles Philippines.}

Syn.: Riz Binambang.

Rispe: ein wenig hängend. - Halm: kräftig, bis $1.65 \mathrm{~m}$ hoch; Blätter stark behaart. - Scheinfrucht und Grannen gelbrötlich; Frucht weiss.

Spätreif. Häufig zu Batangas angebaut.

\section{Paddy ebbass, Sumatra.}

Franz.: Riz gros grain, bontot cabayo.

Rispe: ausgebreitet. - Halm: mittelhoch, $1.20 \mathrm{~m}$. - Scheinfrucht: gelbrötlich; Granne gelbrötlich. - Frucht weiss, wenig wohlschmeckend. Auf Sumatra als Bergreis angebaut.

Ferner gehören hierhin nachstehende Sorten des ostindischen Archipels:

Paddy ${ }^{1}$ ) Gendjah Koas; Gĕdap; Sambang; Gogo prampellan; Majangan Gogo; Srikuning, spätreif; Gajak, Granne kurz; Putih; Giliran Sungo; Lojor; Madura; Glembok; Wantego; Gendjah Malati; Sampanghurang; Mentjek, frühreif; Djowan; Katumba ; Madiun; Sampangan; Brondol; Kewal; Kletji Kenongo, frühreif; Kuntulan.

\section{Varietät: erythroceros Kcke.}

\section{Rotgranniger Reis.}

Scheinfrucht gelbrötlich, Grannen schmutzig-rot.

\section{Sorten :}

Im ostindischen Archipel werden gebaut: Burum.

Paddy Djeribongan; Longong; Indra, kurz begrannt; Kankungan;

1) Paddy $=$ Gebräuchlicher Reis. 
Varietät: xanthoceros Keke.

Violettgranniger Reis.

Scheinfrucht gelbrötlich, Grannen dunkelviolettbraun.

Sorten :

Im ostindischen Archipel werden gebaut:

Paddy Edju; Gunong-Kuning, Bergreis; Kapal; Paolan; Sogleng; Sekapril; Gogo Sembukan; Masmasen; Kalin; Marong-Medjoo; Kedangsari.

Varietät: melanoceros Al.

Schwarzgranniger Reis.

Scheinfrucht gelbrötlich, Grannen schwarz.

Sor te :

Black bearded-rice.

Syn.: Ital.: Riso americano con areste nere.

Deutsch: Carolina-Reis mit schwarzen Grannen.

Rispe: ein wenig zusammengezogen, klein, $12 \mathrm{~cm}$ lang. - Halm: kurz, $70 \mathrm{~cm}$ lang. - Scheinfrucht: gelbrötlich, $7 \mathrm{~mm}$ lang, $3^{1 / 2} \mathrm{~mm}$ breit, $2 \mathrm{~mm}$ dick; Granne schwarz, sehr lang $(8-9 \mathrm{~cm})$; Frucht weiss.

Zuweilen in Carolina mid Italien gebaut.

Varietät: rubra Kcke.

Roter Reis.

Scheiufrucht und Grannen rot.

Sorte n:

Im ostindischen Archipel werden gebaut:

Paddy Blambangan; Gondo puru.

Varietait: Hasskarlii Kcke.

Hasskarl's Reis.

Scheinfrucht rot, Grannen dunkelviolettbraun.

Sorten:

Im ostindischen Archipel werden gebaut:

Paddy Randa Kemassan; Tumbong Njiromoa; Utal.

Varietät: leucoceros Kcke.

Weissgranniger Reis.

Scheinfrucht schmutzigbraun, Grannen weisslich.

Sorte :

Arroz Moscado de Valencia.

Frucht sehr gelblich.

Erhalten durch Ant. Cipr. Costa 1881 aus Barcelona. 
Varietät: amaura $\mathrm{Al}$.

\section{Dunkler Reis.}

Scheinfrucht und Grannen braun.

\section{Sorte:}

Paddy Kidang auf Java.

Varietät: brunnea Kcke.

\section{Brauuer Reis.}

Scheinfrucht schmutzigr-braun, Grannen dunkelviolettbraun.

\section{Sorte :}

Paddy Srijaoon, Java.

b. Frucht weiss, rot gestreift.

Varietät: striata Heuzé.

Gestreifter Reis.

Scheinfrucht und Grannen gelbrötlich.

\section{Sorte :}

\section{Riso di Mantova.}

Syn.: Ital.: Risone Marozzi (Sumpfreis).

Franz.: Riz de Mantoue.

De utsch: Gestreifter Reis von Mantua.

Rispe: ausgebreitet, gross. - Halm mittelhoch, Knoten schwärzlich. - Scheinfrucht: gelblich; Grannen ziemlich kurz; Frucht in den Rillen ein wenig rot oder rosa (gestreift).

In Italien bevorzugt man diese Sorte für die auf Sumpfländereien namentlich um Mantua gelegenen permanenten Reisfelder.

Bezugsquelle : Mailänder-Ausstellung $1 \& 81$.

c. Frucht weiss, schwärzlich gestreift.

Varietät: catalonica Keke.

\section{Catalonischer Reis.}

Scheinfrucht braun, Grannen schwärzlich.

\section{Sorte:}

\section{Arroz de Cataluña.}

Syn.: Ital.: Riso Spagnola o Catalano.

Franz.: Riz catalan, d'Espagne, noirâtre de Chine, brun américain. 
Rispe : ausgebreitet, gross. - Halm: kräftig. - Scheinfrucht: braun; Granne schwärzlich bis schwarz, sehr lang; Frucht weiss, in den Rillen schwärzlich, ein wenig glasig, gross; Qualität untergeordnet.

Spätreif. In Ostasien, Spanien und zuweilen in Italien gebaut.

Bezugsquelle: Mailänder-Ausstellung 1881.

d. Frucht rötlich.

Varietät: Savannae Kcke.

Savannah-Reis.

Scheinfrucht gelbrot, Grannen rot.

Sorte:

Savannah-l’ice.

Rispe: ausgebreitet. - Halm: kräftig, $1.30 \mathrm{~cm}$ hoch, blattreich. Scheinfrucht: gelbrot, länglich, mittelgross; Grannen rot, lang; Frucht rötlich.

In South-Carolina, Georgia und Louisiana, wenn auch nur sporadisch, da die Scheinfrüchte in der Reife leicht abfallen, gebaut.

Heimat: wahrscheinlich Ostindien.

e. Frucht rotbraun.

Varietät: pyrocarpa Al.

Rotfrüchtiger Reis.

Scheinfrucht und Grannen gelbrötlich.

\section{S o r t e n :}

Im ostindischen Archipel werden gebaut:

Paddy Tjéré, Bergreis; Kopo, Loro Djawi; Mera; Atap; Tunggu.

\section{Yu-mi, China.}

Syn.: Deutsch: Kaiserreis.

Franz.: Riz impérial.

Rispe: ausgebreitet. - Scheinfrucht: gelbrötlich; Granne gelbrötlich; Frucht rot, länglich, wohlschmeckend.

Frïhreif und Bergreis ${ }^{1}$ ).

Die Einführung und Verbreitung dieses Reises in China wird dem Kaiser Kang-hi (1661-1722) zugescluieben.

\section{Varietät: Desvauxii Kckc.}

Desvaux's-Reis.

Scheinfrucht gelbrötlich, Grannen dunkelviolettbraun.

\section{Sorten:}

Im ostindischen Archipel werden gebaut:

Paddy Kletji Rujung; Bangdanunut; Randa-Gluje; Gambiran; Lagundi; Radjaussi; Gendjah Sumoivono.

1) Allen, Americ. Farm-book, 1850.

Kocrnicke u. Werner, Handb. d. Getreidebau's II. 


\section{Risone Barbarossa ${ }^{1}$ ), Chile.}

Scheinfrucht: gelbrötlich, klein; Grannen riolett, lang; Frucht rot. In Chile, Brasilien, sowie versuchsweise in Italien kultiviert. Bezugsquelle: Mailänder-Ausstellung 1881.

f. Frucht schwarzbraun.

Varietät: atrofusca Kcke.

\section{Schwarzbrauner Reis.}

Scheinfrucht gelbrötlich, Grannen rot.

Sorte :

Paddy Hapit, Java.

2. Minuta Presl. Kleiner Reis.

Scheinfrucht und Frucht klein. (Frucht weiss, $4 \mathrm{~mm}$ lang).

A. Frucht rundlich.

a. Unbegrannt.

Varietät: cyclina Al.

Rundkörniger Reis.

Scheinfrucht gelbrötlich.

Sorte 11:

Paddy undallong, Sumatra ${ }^{2}$ ).

Syn.: Franz.: Riz globuloide.

Rispe: zusammengezogen. - Halm nieđrig, Blätter mittelgross. Scheinfrucht: gelbrötlich; Frucht weiss, fast kreisrund, sehr klein.

\section{Paddy Sumbing, Jara.}

Rispe: Rispenäste stark hin- und hergebogen, ein wenig zusammengezogen. - Halm niedrig. - Scheinfrucht gelbrötlich; Frucht gelblichweiss, fast kreisrund.

Varietät: melanacra Kcke.

\section{Schwarzspitziger Reis.}

Scheinfrucht graurot, an den Endährchen der Rispenäste mit riolettbraunen Grannenspitzen.

\section{Sorte:}

\section{Paddy Sisirnaga, Java.}

Rispe: etwas zusammengezogen, reichsamig. - Halm: niedrig, nicht über $1 \mathrm{~m}$ hoch. - Scheinfrucht: graurot; Frucht gelblich-weiss, fast kreisrund, klein.

1) Unter diesem Namen 1881 auf der Ausstellung in Mailand ausgestellt.

2) Marsden, Hist. of Sumatra, London 1788 pg. 60. 
b. Begrannt.

Varietät: microcarpa Kcke.

KJeinfrüchtiger Reis.

Scheinfrucht gelbrötlich, Grannen rot.

Sorten:

Paddy Ketiran, Jara.

Rispe: zusammengezogen, reichsamig. - Halm: niedrig. - Scheinfrucht gelbrötlich; Granne rot, kurz; Frucht: gelblich-weiss, fast kreisrund, klein.

Bezugsquelle: Haarlemer-Kolonial-Museum.

\section{Riso giapponese.}

Deutsch: Japaner-Reis.

Rispe: zusammengezogen, reichsamig. - Halm: $1 \mathrm{~m}$ hoch. - Scheinfrucht: gelbrötlich; Grannen blassrot; Frucht sehr weiss, oval, klein.

Vegetationszeit $150-160$ Tage.

Dieser aus Japan stammende Reis wird versuchsweise in den Provinzen Ravenna, Bologna, Pavia und Novara angebaut.

Bezugsquelle: Mailänder-Ausstellung 1881.

B. Frucht länglich (unbegrannt).

Varietät: longior Al.

Länglicher Reis.

Seheinfrucht gelbrötlich.

Sor te:

Paddy Santong, nach MIarsden ${ }^{1}$ ) auf Sumatra gebaut.

\section{Glutinosa Lonr. Klebreis.}

Der Eiweisskörper im Bruche von stearinartigem Aussehen, matt. (Nur kochfähig).

1. Unbegrannt.

A. Frucht weiss.

Varietät: affinis Keke.

Verwandter Reis.

Scheinfrucht gelbrötlich.

\section{Sorten:}

Im ostindischen Archipel werden gebaut: Urel.

Kĕtan ${ }^{2}$ ) Senggolan; Tjempa; Nangka; Bunsing; Djambang; Lombok;

1) Hist. of Sumatra, London 1788 pg. 60 .

2) Kĕtan $=$ Klebreis im ostindischen Archipel. 


\section{Varietät: Miqueliana Kcke.}

\section{Miquel's Reis.}

Scheinfrucht graurotbraun.

\section{Sor t e :}

Këtan Laron, Java.

B. Frucht rotbraun.

Varietät: dubia Kcke.

\section{Zweifelhafter Reis.}

Scheinfrucht gelbrötlich.

Sor te :

Kĕtan Tjaruluk, Java.

\section{Begrannt.}

A. Frucht weiss.

Varietät: alba Al.

Weisser Reis.

Scheinfrucht und Grannen gelbrötlich.

Sor t e n :

Im ostindischen Archipel werden gebaut:

Kĕtan Papah-Sogling; Lojor; Kuning; Lilin; Gĕndu; Adjas Suko.

Varietät: zomica Kcke.

\section{Suppen-Reis.}

Scheinfrucht gelbrötlich, Granne rot.

\section{Sorten:}

Im ostindischen Archipel werden gebaut:

Kĕtan Bobol; Mandrajuda; Patrajuda; Mindjangan; Djambu.

Varietät: Heuzéana Kcke.

Henzé's Reis.

Scheinfrucht gelbrötlich, Grannen dunkelviolettbraun.

\section{Sorten:}

Im ostindischen Archipel werden gebaut:

Kĕtan Busseè; Djewineng; Krawang; Mulut; Mandalagiri; Surong. 
Varietät: isochroa Kcke.

\section{Gleichfarbiger Reis.}

Scheinfrucht und Grannen rot.

Sorten:

Im ostindischen Archipel werden gebaut:

Kětan Malele; Hurang.

B. Frucht rotbraun.

Varietät: Eedeniana Kcke.

Van Eeden's-Reis.

Scheinfrucht gelbrötlich; Grannen dunkelviolettbraun.

Sorte:

Kětan gurunini, Java.

C. Frucht schwarzbraun.

Varietät: melanocarpa $\mathrm{Al}$.

Schwarzfrüchtiger Reis.

Scheinfrucht und Grannen gelbrötlich.

Sor te :

Kĕtan Jtam, Java.

Rispe: ein wenig zusammengezogen, klein. - Scheinfrucht: gelbrötlich; Granne gelbrötlich, $4-5 \mathrm{~cm}$ lang; Frucht: schwarzbraun.

Frühreif.

Varietät: atra Kcke.

Schwarzer Reis.

Scheinfrucht gelbrötlich, Grannen dunkelviolettbraun.

Sorte :

Kĕtan Irang, Java. 


\section{Die biologischen Verhältnisse des Reises.}

Das Wasserquantım, welches dic Reispflanze zı ihrem Gedeihen beansprucht, iiberragt dasjenige anderer Getreidearten nicht unerheblich, obschon die Anspriiche der Reissorten unter sich, ganz abgesehen von dem Einfluss, welchen die klimatischen und Bodenverhältnisse ausiiben, sehr verschieden sind, und lassen sich zwei Hauptgruppen, der Bergreis und der Sumpfreis, unterscheiden.

Der Bergreis wurde wegen seiner Fähigkeit, ohne künstliche Bewässerung in den höheren Gebirgslagen des Monsungebietes zu gedeihen, von Loureiro, der ihn um die Mitte des vorigen Jahrhunderts in Cochinchina fand, als Oryza montana beschrieben; da jedoch botanische Unterschiede mit der Art: Oryza sativa L. nicht auffindbar sind, so ist der Bergreis mit derselben zu vereinigen.

Der Bergreis ist dort von allergrösster Bedeutung, wo es an fliessendem Wasser oder Sumpfland fehlt, denn es genügt ihm der Regenfall in der Regenperiode der tropischen und subtropischen Zone ind ausserdem verträgt er ein rauheres Klima, so dass er in Indien ${ }^{1}$ ) noch "erfolgreich in Höhen bis zu $1500 \mathrm{~m}$ gebaut wird.

Sobald die ersten Regenschaver im April oder Mai niedergehen, wird gesäet nnd nach 100-120 Tagen, also zeitig, geerntet.

Unter der Regierung des Kaisers Tschin-Tsung (998-1022) soll er zuerst in China angebaut worden sein. Jetzt erstreckt sich sein Verbreitungsgebiet uiber Japan, Cochinchina, Malák a, Sumatra, Java, die Philippinen, Réunion, Madagascar und einige Teile der Stidstaaten der nordamerikanischen Union.

Man hoffte nun, diesen harten und an Bewässerung im Monsungebiete nicht gebundenen Reis für die Landwirtschaft der wärmeren gemässigten Zone Europas gewinnen zu können und wurden die ersten hierauf abzielenden Anbauversuche in Frankreich ${ }^{2}$ ) schon 1753 durch Poivre in Isle de France gemacht; an diese schlossen sich solche von de Carro ${ }^{3}$ ), Nuvolone und Balbis 1834 bei Palermo, sowie von der Centralschule in Algier 1842 und von St. Denis du Sig in Algier 1855 an. Diese Versuche haben nun gezeigt, dass sich unter den gegebenen klimatischen Verhältnissen

1) Royle, Illustr. of bot. etc. $1839 \mathrm{pg} .19$ und Statement exhib. the Moral and Material progr. and cond. of India. 1872/73.

2) Barra l, Journ. d'Agric. prat. 1860 I. p. 57.

3) Vaterl. Blätter 1808 Nro. XI pg. 316, citiert durch Trautma n, Landwirtschaftslehre II. $1816 \mathrm{pg} .28$. 
ohne Bewässerung kein günstiges Resultat erzielen lässt, weil gerade in del Hauptvegetationsperiode die Regen ausbleiben.

Die hauptsächlichsten Benennungen, welehe er in seinem Anbaugebiet trägt, sind folgende: Mountain-rice, Hill-rice, Upland-rice, Dry-rice englisch; Riz de montagne ou sec, ou de Carro ${ }^{1)}$ französisch; Riso à secco italienisch; Arroz de secano spaniscli; Arroz de sequeiro portugiesisch; Sien-tao und Tsao-tao (frihreif), Kang-tao und Wan-tao (spätreif) chinesisch ${ }^{2}$ ); Okabo japanisch (nach Rein), Paddly rawa malaiisch, P. songo-negoro, P. tjereh javanisch ${ }^{3}$ ); Lua-ray in Cochinchina; Paddy-baggea auf den Molukken; Paddy Laddang auf Sumatra.

Der Sumpfreis, von dem frühe und späte Sorten gebaut werden, wächst nur auf künstlich inundiertem Terrain, oder auf solchem, das vermöge der tiefen Lage durch natürlichen Zufluss hinreichend mit Wasser versorgt wird. Im ersteren Falle lassen sich die Felder zeitweise trocken legen und periodisch mit anderen Friichten bestellen, es sind dies die sog. „alternicrenden Reisfelder", während die anderen, bei denen nur mit Unterbrechung durch Brachliegen, da sie sich nicht entwässern lassen, unausgesetzt Reis gebaut wird, „permanente Reisfelder" genannt werden. Die Vegetationszeit des Sumpfreises umfasst 150-200 Tage. Derselbe wird gemeinhin im März gesäet und im August, Oktober oder November geerntet.

Der wilde Reis (Newari bei den Telingas [von Nivara im Sanskrit] und Volunteer or Wild-rice in Nord-Amerika) findet sich nach Roxburgh ${ }^{4}$ ) in Indien allenthalben an den Ufern der Seeen in den Circars und wird wegen der Schmackhaftigkeit seiner Körner eingesammelt, doch ist er so wenig ertragreich, dass seine Kultur nicht lohnt; jedenfalls tritt er aber häufig als unangenehmes Unkraut auf, zumal der frïhreife (Drop-rice), der seine Körner bereits vor der Ernte ausfallen lässt, und dalier vorzugsweise die permanenten Reisfelder stark verunkrantet, und sich in Folge seiner Aehnlichkeit mit dem kultivierten Reis nicht ausjäten lässt.

Als Saatgut sind die absolut schwersten, vollkommen ausgebildeten, harten, sowie die charakteristischen Eigenschaften der Sorte stark ausprägenden Körner zı verwenden.

In Japan 5) legt man auf die Auswahl des Saatgutes grossen

1) Barra l, Journ. d'Agric. prat. 1860 I. pg. 57.

2) Heuzé, a. a. O. II. pg. 135 und 136.

3) Miquel, Fl. v. Nederl. Ind. pg. 370, (1860).

4) Fl. ind. II. pg. 201, (1832). Die Circars sind der Küstenstrich am Bengalischen Meerbusen von ungefähr $20-17^{\circ} \mathrm{n}$. Br.

5) 0. Kellner, Mitteil. aus d. agric.-chem. Lab. zu Tokio, die 1. Vers. Stat. XXX. Heft I, pg. 19. 
Wert und erfolgt dieselbe für das kommende Jahr vor der Ernte auf dem Felde. Man sammelt alsdann die bestentwickelten Rispen und streift die an dem oberen Teile derselben sitzenden Körner mit der Hand ab. Nur diese werden zur Aussaat benutzt und unmittelbar vor ihrer Verwendung nochmals durch Einwerfen in Wasser sortiert. Das Saatgut wird in Strohsäcken an luftigen trocknen Orten aufbewahrt.

Was die Beschaffenheit der Scheinfrüchte also des beschalten Kornes (Paddy) anbetrifft, so enthalten die in South-Carolina ${ }^{1}$ ) angebauten Sorten durchschnittlich 82.10 Teile Korn und 17.90 Teile Spelzen, während nach Horky und Klose begrannte Sorten aus Aegrpten und Spanien im Mittel 21.26 Proc. und unbegrannte 18.31 Proc. Spelzen aufwiesen. Die Frucht bestand aus 73.735 Proc. Albumen, 3.909 Proc. Keimling und 4.456 Proc. Samenschale.

Die Körner werden regelmässig vor der Saat eingeweicht, was sie im Verhältnis zu anderen Getreidearten merkwürdig gut rertragen, wie die Untersuchungen ron Schlag und Bressler beweisen, nach denen 80 Tage hindurch eingeweichte Reiskörner noch 44 Proc. keimfähige zeigten.

Das Reiskorn keimt leicht, sobald die Temperatur des Wassers $10-12^{\circ}$ C. erreicht hat; das Maximum der Keimungstemperatur beträgt $36-38^{\circ} \mathrm{C}$, das Optimum $30-32^{\circ} \mathrm{C}$.

Das Samenkoln des Sumpfreises wird kaum tiefer als $1 \mathrm{~cm}$ in den Schlamm gebettet, hingegen das des Bergreises bis $4 \mathrm{~cm}$ tief untcrgebracht.

Gemeinhin erscheint bei genügender Wärme das erste Blatt nach 10-12-14 Tagen und am 15. bis 20. Tage nach der Saat tritt die Pflanze an die Oberfläche des Wassers und nimmt eine schöne griine Farbe an, rorausgesetzt, dass das Wasser eine gleichmässige nicht zu niedrige Temperatur bewahrt und die jungen Pflänzchen gegen kalte Winde geschützt sind. In dieser Periode beginnen die Wurzeln sich zu befestigen, doch darf das Wasser nicht zu stark fliessen oder bewegt sein, weil durch den Wellenschlag die jungen Pflänzchen noch leicht ausgerissen werden, daher man häufig den Zufluss entweder sehr verringert, oder auch ganz abstellt, und erst wieder den vollen Wasserbedarf zulässt, sobald sich die Pflänzchen genügend angewurzelt haben. In der Regel hält man dann bis zur Blüte das Wasser gleichmässig hoch.

Das Schossen tritt bei mittelfrühen Sorten in der Regel 40 Tage nach dem Erscheinen der Pflanze an der Oberfläche des Wassers ein, 40-50 Tage später steht sie in Blüte und braucht zur Ausreife.

1) Shepard, Chemical examinat. of the Rice-pl. etc., in Transact. of the N.-Y. st. Agric. Soc. 1845 . IV. pg. 343. 
ebenfalls 40-50 Tage. Die Bluitezeit des Reises ist eine sehr kritische Periode, da Wind und Nässe in dieser Zeit den Körneransatz sehr ungiinstig becinflussen können.

Im Jahre 1881 besuchte ich die Reisfelder Ober-Italiens ${ }^{1}$ ) und stellte dort nachfolgende Wachstumsverhältnisse fest:

Dic Blattoberfläche ciner Pflanzc und zwar beide Blattseiten und die Halmoberfläche gemessen, betrug durchschnittlich $1500 \mathrm{qcm}$, und zwar besassen der frtibreife Bertone und der spätreife Novarese folgende Obcrflächen:

Riso

Halmoberfläche .

\begin{tabular}{|c|c|}
\hline Bertone & Novarese \\
\hline $108 \mathrm{qcm}$ & $225 \mathrm{qcm}$ \\
\hline 270 & 723.2 \\
\hline $378 \mathrm{qcm}$ & $948.2 \mathrm{qcm}$ \\
\hline & \\
\hline $1.512 "$ & .422 \\
\hline
\end{tabular}

Blattoberfläche .

Gesammtoberfliche eines Halmes Anzahl der Sprossen

Blattoberfläche einer Pflanze .

1.512, 1.422

Durchschnittlich nimmt eine Reispflanze einen Raun von $60 \mathrm{qcm}$ ein, mithin wachsen 1.6 Millionen Pflanzen auf 1 ha und dieselben besitzen eine Blattoberfläche von $250.000 \mathrm{qm}$, welche, da nach den Untersuchungen Schuibler's bewässcrte Pflanzen täglich ca. $200 \mathrm{gr}$ Wasser pro Quadratmeter Blattfäche verdunsten, täglich $50 \mathrm{cbm}$ Wasser verbrauchen.

Die Verdunstung des Wassers auf einer Fläche von der Grösse eines Hektars ist aber noch beträchtlicher, und beträgt diesclbe nach Perels ${ }^{2}$ ) in Italicn $120 \mathrm{cbm}$ oder $12-13 \mathrm{~mm}$ täglich.

Wollen wir aber das für ein Reisfeld notwendige Wasserquantum bestimmen, so darf auch dic Bodenfiltration nicht ausser Acht gelassen werden, die durchschnittlicb einen Wasserverlust von $50 \mathrm{cbm}$ beansprucht, mithin ergiebt sich ein täglich zu erneuernder Gesammtverlust von 20 cbm, welcher nahezu einem Verbrauche von 2.61 pro ha und Sekunde entspricht, und stimmt diese Zahl mit den von Cav. Patriar $\mathrm{ca}^{3}$ ) ermittelten Quantitäten ganz vorzüglich überein, denn nach demselben verbraucht

sehr schwerer Boden 2.0811 pro ha und Sekunde

schwerer Boden

mittlerer Boden

$2.3981, ", ", \quad$,

leichter Boden

$3.4861, ", \quad$,

$4.7731 ", "$,

Mittel 2.6371 pro ha und Sekunde.

Durchschnittlich beanspruchen dic Reisfelder Italiens innerhalb der Vegetationsperiode des Reises $12.000 \mathrm{cbm}$ Wasser pro ha.

Selbstverständlich werden sich in einem wärmeren Klima als

1) Werner, landw. Reiseskizzen aus O.-Italien. Landw. Jahrb. 1882 pg. 264.

2) Handb. d. landw. Wasserbaues 1877 p. 611.

3) Vergl. Markus, d. landw. Meliorationswesen 1881 S. 59. 
dasjenige Italiens ist, auch die zu verbrauchenden Wasserquanta entsprechend erböhen müssen.

So erhält z. B. der Reis nach Kresnik ${ }^{1}$ ) in Ostindien zehn Ueberstauungen à $22 \mathrm{~cm}$ Höhe, woron $7 \mathrm{~cm}$ zur Sättigung des Bodens und die iibrigen $15 \mathrm{~cm}$ als stagnierende Wasserschicht gerechnet werden, demnach im Ganzen $22000 \mathrm{cbm}$ Wasser pro ha erforderlich sind.

Der Reis lässt sich sehr gut verpflanzen und geschieht dies auch in rielen Lïndern.

Nit dem Herannahen der Reife senkt sich die Rispe, die Blätter erhalten eine gelbliche und die Spelzen die der Reissorte charakteristische Färbung.

Die Krankheiten des Reises sind sehr zahlreich und folgende zn erwähnen. Nehmen die jungen Pflanzen bald nach dem Auflaufen eine gelbe Färbung an, so ist dies ein Zeichen, dass das Wasser zu kalt ist. Wird diese Krankheit, in Italien "Grappo" genannt, nicht rechtzeitig durch Abstellen des Wassers, damit sich der Boden erst wieder erwärmt, behoben, so kiimmern die Pflanzen bis sich die Wasserwärme erhöht, wodurch der Erntecrtrag sehr empfindlich beeinträchtigt werden kann.

Nicht selten tritt aber auch die umgckehrte Ersclieinung ein, d. h. die Pflanze wächst auffallend kräftig und ihre Farbe ist nicht griingelb, sondern dunkelgriin; sie wächst demnach zu sehr ins Blatt, worunter immer der Samenertrag leidet. Diese zn iippige Vegetation muss daher zuriickgehalten werden, und geschieht dies entweder durch Beschleunigung des Zuflusses, damit das Wasser unter der notwendigen Mitteltemperatur bleibt, oder man rermindert den Zufluss, so dass sich das Wasser sehr stark erwärmt, denn in beiden Fällen rerzögcrt sich das Wachstum.

Eine sehr verderbliche auch in Carolina und auf Java gekannte und gefürchtete Reiskrankheit ist die in Italien mit dem Namen „Brusone" bezeichnete, welche unter Umständen die Ernte vollständig vernichten kann. Sie wird durch einen Kernpilz (Pleospora oryzae ${ }^{2}$ ) erzeugt, der mit seinem Mycel in allen Teilen der Pflanze wuchert, und je nach dem Grade seiner Ausbildung und dem Ort seiner Verbreitung, entweder die schwarze (Carolo nero o minore), oder die weisse Reiskrankheit (Carolo bianco o maggiore) hervorbringen kann. Bei ersterer nehmen die Blätter eine braunrote Farbe an, bei letzterer färben sich dic Rispen gelblich-weiss und rertrocknen. Die Krankheit erscheint während der Entwickelung der Rispen oder

1) Vorstudien über die Bodenbewässerung, Journ. f. Landw. XXXI. 1881. pg. 327 .

2) Haberlandt, Fühling's landw. Ztg. 1875. S. 552. 
in der Blüte und werden zunächst die kräftigsten Pflanzen an den Wasserrinnen von der Krankheit ergriffen, wie der Pilz iiberhaupt dort am stärksten auftritt, wo sich der Boden in einem vorzüglichen Düngungszustande befindet.

Die Verhiitung stauenden Wassers und die Auswahl solcher Reissorten, die sich gegen die Krankheit am widerstandsfähigsten gezeigt haben, sowie die Vermeidung zu stickstoffreichen Düngers werden als Mittel zur Bekämpfung dieser Krankheit anzusehen sein. In Carolina entfernt man beim Jäten des Unkrautes zugleich alle diejenigen Reispflanzen, welche durch ihre ungesunde weissliche Färbung verdächtig erscheinen.

Der Rost (ital.: Ruggine) stellt sich auf allen grïn gefärbten Pflanzenteilen sehr häufig ein, und sucht man in diesem Falle durch Abstellen des Wassers fuir einige Zeit seine Entwickelung zuriickzuhalten.

Als sehr gefährliche Feinde der Reiskultur sind ferner und zwar vorzugsweise für das wärmere gemässigte Klima Süd-Europas ${ }^{1}$ ) aufzuführen :

Lytrum Hyssopifolia L., Ysopblätteriger Weiderich. Ital. Corggiola dei fossi, o Erba Spagolina. Schadet durch Verstopfen der Gräben.

Lytrum Salicaria L., gemeiner Weiderich. Ital. Riparella, Salcerella. Stipa marina. Schadet wie oben.

Suffrenia filiformis Bellar. Ital. Suffrenia risajuola. Erstickt den jungen Reis und entzieht ilım die Nährstoffe.

Myriophyllum verticillatum L., quirlblitiges Tausendblatt. Ital. Millefoglio d'acqua. Bringt das Wasser zum Stauen und ist daher, weil sehr schädlich, auszurotten.

Myriophyllum spicatum L., ährenblütiges Tausendblatt. Ital. Millefoglio d'acqua, o dei Laghi, Roscola, Fertro. Schädigt wie oben.

Ceratophyllum demersum L., rauher Igellock. Ital. Code di Cavallo, Fertro. Schädigt wie oben.

Bidens cernuus L., nickender Wasserdost. Ital. Forbicina intera. Kann die Reispflanzen vollkommen unterdriicken.

Bidens tripartitus L., dreiteiliger Wasserdost. Ital. Canapa acquaticaforbicina. Wie oben.

Lycopus europaeus L., gemeiner Wolfstrapp. Ital. Erba sega o Marrobio acquatico. Wird bis $1 \mathrm{~m}$ hoch und unterdrickt den Reis. Utricularia vulgaris L, gemeiner Wasserhelm. Ital. Erba vescica, Raguaja, Ovo di bolla. Schädigt wie Myriophyllum.

1) Vergl. Werner, Landw. Reiseskizzen aus Ober-Italien. Landw. Jahrb. 1882. pg. 265. 
Gratiola officinalis L., gebräuchliches Gnadenkraut. Ital. Gratia Dei. Graziola, Fossicaria.

Polygonum Hydropiper L., Wasserpfeffer. Ital. Erba pepe, Pepe acquatico. Meist tritt derselbe in grosser Menge auf und ist dann sehr schädlich und nur durch Entwässerung zu entfernen.

Polygonum Persicaria L., gemeiner Knöterich. Ital. Cucitoli, Persicaria, Salcerella. Erreicht eine riesige Höhe, ich sah Pflanzen ron $2^{1} / 2 \mathrm{~m}$ Höhe. Die Vertilgung kann nur durch Jäten geschehen und ist die Pflanze durch Unterdrückung des Reises sebr gefährlich.

Sehr nachteilig durch Verstopfen der Gräben, in Folge dessen das Reisfeld versumpft, sind noch folgende Unkräuter:

Alisma Plantago L., gem. Froschlöffel; ital. Alismate Cavloccio, Mestola.

Sagittaria sagittifolia L., gem. Pfeilkraut; ital. Saetta. dei fossi.

Butomus umbellatus L., doldenblitige Schwanenblume; ital. Aglio

Potamogeton crispus L., krauses Samkraut; ital. Erba gala. d'acqua.

Potamogeton natans L., schwimmendes Samkraut; ital. Lingue

Caulinia Alaganensis Pollini, ital. Ranochina fasciolata.

Caulinia fragilis Willd., zerbrechliches Nixkraut; ital. Ranochina falcata.

Beide stauen gern auf neu angelegten Reisfeldern das Wasser, so dass die Anlagen rersumpfen.

Juncus conglomeratus L., geknäulte Binse; ital. Giunco.

Juncus articulatus L., gegliederte Binse; ital. Giunco nodoso. sorda.

Typha latifolia L., breitblättriges Kolbenrohr; ital. Sala, Mazza

Sparganium simplex Huds., einfache Igelskolbe; ital. Sparganio Mezzano.

Sparganium ramosum Huds., ästige Igelskolbe; ital. Biodo, Coltellanio.

Beide erscheinen rorzugsweise auf schlecht gehaltenen Feldern.

Iris Pseud-Acorus L., Wasserschwertlilie; ital. Acoro falso.

Cyperus Monti L., ital. Stiance da paduli.

Ist auf leichteren, sohlecht kultivierten Reisfeldern sehr gefäbrlich.

Cyperus conglomeratus, ital. Quadrettone.

$" \quad$ flarescens L., ital. Bottoncino.

$"$ difformis, ital. Giunco da Risaje.

Carex hirta L., ital. Carice.

Scirpus maritimus L., ital. Noceo.

" mucronatus L., ital. Giunco affilato.

Sehr schwer zu vertilgen, weil die Stolonen lang und weit verbreitet sind. 
Heleocharis acicularis R. Br., nadelförmiges Riet; ital. Capitelli, Spilloni. Es ist dies ein kleines nnscheinbares Pflänzchen, das aber den Boden dicht iiberzieht, den jungen Reis erstickt und das Wasser zum Stagnieren bringt. Die Vertilgung ist sebr schwer.

Heleocharis palustris R. B., Sumpf-Riet. Wie oben.

Leersia oryzoides Sw. Reisquecke; ital. Asperella.

Wächst häufig auf reichen Feldern und unterdriickt den Reis und entzieht durch ihre zahlreichen Stolonen dem Boden die Pflanzennährstoffe. Diese Quecke ist dem Reis sehr ähnlich, wodureh das Ausjäten wesentlich erschwert wird.

Nach Miquel ${ }^{1}$ ) kommen in Ostasien, Siidamerika und Abessinien noch vor: Leersia luzonensis Presl., und Leersia mexicana Kunth (Syn.: L. brasiliensis Spreng., L. contracta N. ab Es., L. abyssinica Hochst., Asprella brasiliensis und mexicana).

Panicum crus galli L., Hiihner-Hirse; ital. Panicastrella.

Dieses Gras wird dem Reis namentlich bei seiner ersten Entwickelung sehr gefährlich und lässt sich nur durch Jäten vor dem Schossen entfernen.

Glyceria fluitans R. Br., flutendes Schwadengras; ital. Gramigna olivella. Weil dem Reis vor dem Erscheinen der Blite sehr ähnlich, lässt es sich durch Jäten nur schwer vertilgen.

Arundo Phragmites L., gemeines Robr; ital. Canna da spassole. dolina.

Alopecurus geniculatus L., geknieter Fuchsschwanz; ital. Co-

Von den Kryptogamen sind gefährlich:

Pilularia globulifera L., kugelfrüchtiges Pillenkraut; ital. Pepe di palude.

Marsilia quadrifolia, vierblättrige Salvine; ital. Lente palustre. Salvinia natans All., schwimmende Salvine; ital. Erba pesce. Oedogonium capillaceum.

Encyonema.

Diese Pflänzchen überziehen das Wasser wie mit einem dichten Schleier, entnehmen die Pflanzennährstoffe und verhindern das Fliessen des Wassers.

Chara foetida in Italien und Ch. hispida in Spanien.

Verstopfen und erfuillen alle Gräben.

Auch tierische Feinde schädigen den Reis nicht selten in erheblichem Umfange, so z. B. der Blattfuss (Apus eancriformis Schäff.) und der Wasserskorpion (Nepa cinerea L.), welche durch ihre selı heftigen Bewegungen den jungen Reis entwnrzeln und hilft gegen dieselben kaum eine zeitweise Trockenlegung nach der Saat, weil

1) Fl. v. Nederl. Indie. 1860. 
sie des Nachts von einel Fläche zur anderen fliegen. Auch die Maulwurfsgrille (Gryllotalpa vulgaris Latreille) wühlt während der Trockenlegtung nach der Saat Gäng'e auf, wodurch viele keimende Pflinzchen zerstört werden. Dagegen hilft die Trockenlegung nach der Saat gegen die Zerstörungen der jungen Keime durch Wasserschnecken (Paludina und Limneus-Arten) und der jungen Blätter durch Helix-Arten.

Ferner stellen zwei Vogelarten aus der Familie der Finken, der Reisvogel (Fringilla oryzivora) und der Kreuzschnabel (Loxia maja) dem reifenden Reise in einer Weise nach, dass die Ernte Gefahr läuft, vernichtet $\mathrm{zu}$ werden, weshalb Vorrichtungen zur Abhaltung derselben anzubringen sind. Beide sind in Ostasien heimisch, doch kommt der Reisvogel auch in den Siudstaaten der Union vor.

Die Larve eines kleinen Käfers (Silvanus surinamensis Steph.) frisst in Amerika im Reiskorn.

Der Reiskäfer (Curculio oryzae L.) zerstört im Orient, SüdEuropa und in den Süd-Staaten der nordamerikanischen Union das Reiskorn.

\section{Klima.}

Die frühreifen Reissorten werden 100-120 Tage, die spätreifen 150-200 Tage nach der Aussaat geerntet und beanspruchen eine mittlere Frühjahrstemperatur von $13^{\circ} \mathrm{C}$, eine Sommertemperatur von $22-30^{\circ} \mathrm{C}$. und eine Durchschnittstemperatur von $20^{\circ} \mathrm{C}$. Die zur Ausreife notwendige Wärmesumme beträgt $3500-4500^{\circ} \mathrm{C}$.

Vorzugsweise ist die Reiskultur in der tropischen und subtropischen Zone verbreitet, und bildet hier, wie Grisebach hervorhebt, die Benutzung der Regenperiode, welche im Frühjahr dem Monsunwechsel folgt, fiur die ersten Vegetationspliasen des Reises die natürlichen Grundlagen seincr Kultur, daher denn auch hier der Bergreis $\mathrm{zu}$ gedeihen vermag.

Die Reiskultur reiclit auch stellenweise in die wärmere gemässigte Zone hinein und zwar am höchsten nach Norden $\left(45^{0} \mathrm{n}\right.$. Br. $)$ in Europa, während er in South-Carolina mit dem $38^{\circ} \mathrm{n}$. Br. abschneidet.

Auf der südlichen Hemisphäre, z. B. auf Madagascar und in Paraguay geht er kaum iiber den Wendekreis hinaus.

In Ober-Italien liegt die nördlichste Grenze der Reiskultur, daher hier auch nicht selten Ende April der Reif die junge Reispflanze schädigt, oder ein kaltes Frühjahr die Entwickelung stark zurückhält, weiterhin ist abcr zur vollkommenen Ausreife auch noch ein warmer, trockner September erforderlich. Im Allgemeinen reicht 
die Wärme kuapp hin, noch etrvas spätreife Sorten zur Reife zu bringen, in Folge desseu auch die italienischen Reisfelder keine zu dichte Umpflanzung mit stark schattenden Bäumen, wie Pappeln und Erlen vertragen.

Der Reis wird im ganzen Monsungebiete, so in Japan, Korea, China, auf den malaiischen Inseln, in Vorder- und Hinter-Indien, Afghanistan, Persien, Armenien, und Mesopotamien kultiviert. Wahrscheinlich gelangte er in Folge malaiischer Einwanderung nach Madagascar, durch die Araber aber kam er an die Ostkuiste Afrikas und in die Mittelmeerregion, z. B. in das Nildelta, und durch das tropische Afrika bis zur Westküste, wo er in Senegambien, Liberia, Guinea, am Kongo ete. gebaut wird.

In Süd-Europa findet sich seine Kultur auf der Balkanhalbinsel und zwar an der Maritza und in Griechenland, im Temesvarer Banat in Ungarn, im südlichen Kaukasien in Daghestan, in der friaulischen Tiefebene, in Italien namentlich um Mailand, Novara, Mantua, Verona, in der Romagna und auf Sicilien; in Spanien, soweit es die alten Wasserleitungen in den Huertas von Valencia gestatten; in Portugal bei Coïmbra, Estremadura und Algarve.

In Nord-Amerika wird der Reisbau in S.-Carolina, bis hinein nach N.-Carolina, Georgia, Alabama, Klorida, Louisiana und Mississippi betrieben, in letzteren Staaten gedeiht auch der Bergreis.

In Siid-Amerika baut man iln vorzugsweise in Columbien, Guyana, Brasilien, Paraguay etc.

\section{Boden.}

Mit Ausschluss des Torf-, Moor-, unfruchtbaren Sand- oder Geröllbodens nimmt der Reis mit allen Bodenarten vorlieb. Die schweren von Natur reichen Thon- und Lehmböden liefern die höchsten Erträge und fordern die kleinsten Wassermengen, weil die Verluste durch Versinken des Wassers gering sind. Nach Massgabe der zunehmenden Durchlässigkeit, also auf den leichteren kalkhaltigen Lehmböden mïssen Wasserzufluss und Dïngung vermehrt werden, wenn der Ertrag nicht bedeutend zuriickgehen soll. Auf den sehr durchlässigen Sandböden wird aber aus diesen Gründen, zumal wenn das Wasser bezahlt werden muss, die Reiskultur häufig nicht mehr berechtigt sein. Auf salzhaltigem Boden gedeiht der Reis nicht, wohl aber auf an und für sich tief gelegenen, feuchten Ländereien, auf denen eine andere Kultur mit gleich gutem Erfolge kaum noch betrieben werden kann, es sind dies die sog. bleibenden oder permanenten Reisfelder, welche Jahrzehnte hindurch bei Wässerung mit 
gutem Wasser und dann selbst ohne Düngung immerhin noch befriedigende Ernten abwerfen, wie dies auf den permanenten Reisfeldern der italienischen Provinzen Mantova und Verona der Fall ist; doch sind diese Felder weniger umfangreich und ergiebig als die sog. alternierenden oder temporären, welche, weil böher gelegen, sich entwässern lassen, so dass der Reisbau im Wechsel mit anderen Kulturen erfolgreich betrieben werden kann. Wo es angeht, legt man die temporären Felder gern an Hängen an, welche der Sonne gut ausgesetzt sind, doch darf es niemals, selbst im trockensten und heissesten Sommer, an dem nötigen Wasser fehlen, und ist ausserdem wohl zu beachten, dass stärkeres Gefälle auch grössere Wassermengen erfordert.

\section{Düngung.}

In Ober-Italien wird die Düngung, bestehend aus verrottetem oder kompostiertem Stallmist, in der Regel im Februar auf das Feld gebracht und unterpfliugt. Felder, welche in der Rotation das erste Ial Reis tragen, erhalten bis $30000 \mathrm{~kg}$, für die Folge nur 15000 bis $20000 \mathrm{~kg}$ pro ha.

Guano, Poudrette und andere sehr stickstoffreiche, die Pflanzen stark treibende Dünger dürfen nur mit Vorsicht und in Quantitäten von $200-250 \mathrm{~kg}$ pro ha aufgebracht werden, um ein allzustarkes Auftreten der Brusone-Krankheit zu vermeiden; vielfach wird auch mit gepulverten Leinkuchen, und zwar $300-400 \mathrm{~kg}$ pro ha gedlingt.

Sehr gern bringt man dell Reis in Gründiingung ron liaps, Roggen, Erbsen, Inkarnatklee, Saubohnen u. s. w. Als Kopfdüngung werden, wenn die Reispflanze $5 \mathrm{~cm}$ hoch, bis $4 \mathrm{hl}$ Lupinenkörner gegeben, welche unter Wasser in kurzer Zeit fanlen und auf die Dauer eines Jahres eine vortrefflich düngende Wirkung äussern.

Das Wasser führt den Reisfeldern ebenfalls düngende Substanzen zu, doch können dieselben füglich ausser Berechnung bleiben, da ja andererseits das Wasser auf den reich durchdüngten Feldern viele Pflanzennährstoffe löst und mit fortführt, weshalb solches Wasser noch mehrmals auf seine nährenden Bestandtheile benutzt werden kann.

In China zieht man nach Fortune ${ }^{1}$ ) ebenfalls Griunfuttergewächse zur Düngung heran und zwar zwei Leguminosen, nämlich ein Trifolium und eine Coronilla. Ein Verfahren, welches z. B. in den grossen Reisniederungen von Tschekiang ganz allgemein ist.

1) Grisebach, Ber. ï. d. Leist. d. geogr. und syst. Bot. wälrend d. J. 1848 (185̃) pg. 42 und 43 . 
Diese Grünfuttergewächse werden während des Winters zwischen zwei Reisernten eingeschaltet und ist dies Verfahren als Ersatz des animalischen Düngers von altersher üblich.

Auch in Japan werden nach Rein ${ }^{1}$ ) zum Zweck der Diingung Grünfuttergewächse und namentlich Leguminosen (z. B. Astragalus lotoides nach Kellner) angebant, wozll noch Gras und Kräuter treten, welche von Frauen und Kindern an Berghängen etc. gesammelt werden.

Zur Diingung benutzt man ferner Rapsstroh, Kalk, Asche, Grabenschlamm, menschliche Exkremente, zu denen in Japan noch eine Art Fischguano, sog. "Kass" tritt.

In Indien gibt es nach Roxburgh ${ }^{2}$ ) noch sehr viele Reisfelder, welche keine andere Düngung empfangen, als ihnen Regen und Luft bieten, doch werden die besten, und machen diese wohl den grösseren Teil aus, jührlich von den grossen Fliissen überflntet und hierdurch beduingt.

Immer wird dafür gesorgt, dass das Reisfeld nicht durch Bäume beschattet oder die freie Lufteirkulation behindert wird.

Das Ausstreuen des Diingers geschieht entweder vor dem Pfliigen und Umhacken, oder nach dem Ebnen des Feldes.

Mit Schlamm und Wasser bedeckt, zersetzen sich die Diing. stoffe bei Gegenwart von Kalk sehr schnell.

Der Reis entnimmt dem Boden in einer Mittelernte schr beträchtliche Quantitäten an Pflanzennährstoffen, welche durch Düngung $\mathrm{zu}$ ersetzen sind.

Nehmen wir die Mittelernte zll $42 \mathrm{hl}=2100 \mathrm{~kg}$ Korn und $2600 \mathrm{~kg}$. Stroh an, so werden dem Boden in $\mathrm{kg}$ pro ha entzogen:

Phosphor-Schwefel- Kiesel-

$\begin{array}{lrrrrrrr}\text { im Korn } & 26.7 & 6.5 & 7.4 & 12.4 & 68.5 & 0.8 & 0.8 \\ \text { im Sroh } & 26.5 & 9.9 & 1.8 & 11.7 & 29 & 9.4 & 192.7\end{array}$

Nach Johnston enthalten 1000 Teile

Wurzeln und Stoppeln . . 36.08 Teile Asche

Halme und Blätter . . 36.08 " ,

Spelzen . . . . . . $14.20 "$ "

Epidermis und Keimling . 11.64 " "

Geschälter Reis . . . $2.00 "$ "

1) Jahresber. d. Ver. f. Geogr. und Statist. in Frankfurt a. M. 1875/78.

2) Fl. ind. II, pg. 202 (1832). 
Die Asche enthielt in 1000 Teilen:

\begin{tabular}{|c|c|c|c|c|c|c|c|c|c|c|}
\hline & : & סี & $\underset{\Xi}{=}$ & 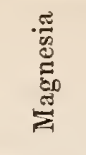 & 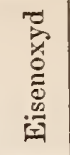 & 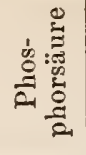 & 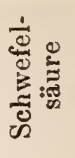 & $\frac{\check{0}}{\tilde{0}}$ & 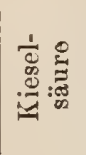 & $\frac{0}{3}$ \\
\hline im Korn & 18.48 & 10.67 & 1.27 & 11.69 & 0.45 & 53.36 & - & 0.27 & 3.35 & 0.46 \\
\hline in der Hülse & 1.60 & 1.58 & 1.01 & 1.96 & 0.54 & 1.86 & 0.92 & 0.34 & 89.71 & 0.48 \\
\hline im Stroh & 10.17 & 3.52 & 0.73 & 4.49 & 0.67 & 1.09 & 3.56 & 0.33 & 74.09 & 0.95 \\
\hline
\end{tabular}

\section{Fruchtfolge.}

In Ober-Italien wird der Reis gewöhnlich mit Ausnahme der permanenten Reisfelder, in die Fruchtfolge aufgenommen, während die permanenten durch unausgesetzten Reisbau ermädeten Felder einige Jahre brach liegen, und lässt sich auf grösseren Flächen ein vollständiger Turnus einführen, so dass $1 / 5-1 / 4$ der Felder immer in Brache liegen. Die temporären Reisfelder wechseln mindestens alle drei Jahre mit dem Trockenbau.

Der sehr anspruchsvollen Reispflanze ist nun eine solche Stellung in der Fruchtfolge zu geben, dass sie, zumal als einträglichste Frucht, vorzügliche Vegetationsbedingungen erhält.

Beispiele dieser Fruchtfolgen sind:

a) Fruchtfolge bei Vercelli.

1. Winterweizen*, $250 \mathrm{~kg}$ Guano,

2. Kleegras*,

3. Mais* mit Stallmist und Guano,

4. Reis (Ostiglione oder Francone),

5. Reis (Ostiglia),

6. Reis (Ostiglia)* mit 4 hl Lupinenkörnern.

1. Mais*,

b) Fruchtfolge bei Milano.

2. Weizen,

3. Klee*,

4. Reis (Bertone oder Francone) in Rotklee als Gründungung,

5. Ostiglia,

6. Ostiglia* mit 4 hl Lupinenkörnern. 
c) Fruchtfolge bei Pavia.
1. Weizen,
2. und 3. Wiesen*,
4. Mais*,
5. Reis,
6. Mais*.

1. Reis*,

2. Mais*,

3. Weizen,

4. Rothklee u. Ryegras*.

In der Regel folgt auf den Reis in Japan eine Winterfrucht, zu dem Ende wird z. B. der Raps im September auf Beete gesäet und nach der Reisernte ausgepflanzt. Weizen oder Gerste drillt man zwischen oder neben die Stoppeln der Reisreihen.

\section{Bodenbearbeitung.}

In Italien wird das Reisfeld im Winter mit dem DombaslePflug tief gepflugt und im Frühahr durch Egge oder Hacke möglichst geebnet, weil sonst an den höheren Stellen das Unkraut den Reis leicht kiberwuchert, während an den tieferen, wegen des zu hohen Wasserstandes, Bestockung und Wachstum zurïckgehalten werden. Nach dem Ebnen werden parallel den Pflugfurchen Längsdämme gezogen, welche auf denjenigen Feldern, die mehrmals hinter einander Reis tragen sollen, bei der Zubereitung des Feldes im nächsten Jahre bleiben, während die transversalen, deren Bestimmung es ist, je nach Beschaffenheit des Terrains, die einzelnen im Niveau liegenden Feldteile in mehr oder weniger grosse und mit Hitlfe der Wasserwagc genau zu planierende Bassins abzuteilen, nach der Erntc zerstört werden, weil sie die Bearbeitung hindern.

Die Dimensionen der Dämme hängen von der Beschaffenhcit des Terrains $a b$ und wechseln zwischen $16-40 \mathrm{~cm}$ Kronenbreitc und $40-65 \mathrm{~cm}$ Höhe.

Diese Dämme mulssen tadellos gearbeitet und nach dem Einlassen des Wassers gehörig gestampft werden. Unter Wasser werden dann auch noch die grösseren Schollen zerschlagen. Hat das Wasser sodann eine Standhöhe von $5 \mathrm{~cm}$ erreicht, so ist das Land zur Einsaat fertig.

In neuerer Zeit beginnt man die Bodenbearbeitung ${ }^{1}$ ) in der Weise vorzunehmen, dass Mitte April die Fläche unter Wasser gesetzt wird, worauf das Pflügen, Zerschlagen der Schollen, Einebnen u. s. w. beginnt. Auf diese Art sättigt sich der zu einem Brei gewordene Boden vollkommen mit Wasser und da derselbe durch

1) Siehe Markus, a. a. O. S. 83. 
die Zugtiere während des Pfligens ausserdem noch fest zusammengetreten wird, so erzielt man eine recht bedeutende Wasserersparnis für die ersten Wochen der eigentlichen Vegetation.

In Portugal ${ }^{1}$ ) wird im März oder April tief gepfliggt, und das Reisfeld in Abteilungen von $0.5-1$ ha Grösse eingeteilt, die rollständig geebnet und mit kleinen Dämmen von $1 \mathrm{~m}$ Breite in der Basis, $0.50 \mathrm{~m} \mathrm{Kronenbreite} \mathrm{und} 0.40 \mathrm{~m}$ Höhe umgeben werden. In diese Bassins leitet man das Wasser an eincr Ecke ein, während es an der diagonal gegenüberliegenden in ein anschliessendes, tiefer gelegenes Bassin abgeführt wird.

An den Flüssen der Reisregion in den Siidstaaten Nord-Amerikas ${ }^{2}$ ) findet sich ein leicht inundierbares, aus reichem AlluvialLehm bestehendes Terrain, auf dem, und namentlich bei der Stadt Saranuah, der feinste Export-Reis, der als Carolina-Reis in den Handel kommt, wächst.

Die Reisfelder besitzen dort eine Grösse zwischen 5 und 9 ha und werden mit Hiilfe von $1 \mathrm{~m}$ tiefen und $50 \mathrm{~cm}$ breiten Gräben bewässert und mit Erdwällen umgeben.

Die Zubereitung dieser Reisfelder ist jedoch eine ron einander sehr abweichende. Einige Pflanzer pflügen, wenn auch häufig nur flach, den Boden alljährlich Anfang Januar, andere, und zwar ist dies die am meisten verbreitete Methode, pfliigen gar nicht, sobald die Aecker unkrautfrei sind, sondern verbrennen im Friihjahr nur die Stoppeln und reissen zwischen den alten Stoppelreiben mit der Hacke oder einem kleinen Drillpflug Rillen auf, in welche die Samenkörner gesäet werden.

In Japan steigen die Reisfelder, den kleinen Wasserläufen folgend, terrassenförmig aus den Thälern empor und jedes Reisfeld, so klein es auch sei, denn ihr Flächeninhalt schwankt zwischen 1-2 und $300-400 \mathrm{qm}$, ist von einem $30-140 \mathrm{~cm}$ hohen Erdwall umgeben.

Die Beschaffung der notwendigen Wassermenge und die gute Anlage und Ausführung des Bewässerungssystems ist von der grössten Wichtigkeit.

Mit dem fehlenden Wasser schwindet die Hoffnung auf eine reiche Ernte, was von der Bevölkerung um so schwerer empfunden wird, als in den ausschliesslich Reis bauenden Ländern ein Ersatz durch anderes Getreide schwierig ist.

An Orten, in denen der Wasserzulauf im Sommer leicht versiegt, legt man deshalb künstliche Wasserbehälter an, und in ebenen Gegenden heben Schaufelräder das Wasser von den tieferen auf die höheren Stellen.

1) Perels, Handb. d. landw. Wasserbaues pg. 610 .

2) Russell, Cult. of Caroline-rice. Journ. of Agric. 1855-57.pg. 266. 
Die horizontalen Felder bilden nun nicht allein an den Berghängen, sondern auch in der Ebene Terrassen, und von den höher geleg'enen fliesst das Wasser in ruhiger Strömung zu den niederen ab, so dass es auf denselben uiberall gleich hoch steht.

Die trocken gelegten Felder werden nach der Düngung meist umgegraben, seltener seicht gepflügt.

Vor der Saat wird auf dic schweren Thonböden Wasser gelassen und das Feld durch Herumwaten vou Kinderu, Pferden ete., wclche es bis $60 \mathrm{~cm}$ tief durchkneten, in einen Sumpf verwandelt. Erdschollen, welche noch nicht gänzlich zerklcinert sind, zerschlägt man mit Hülfe eincs Holzspatens. Schliesslich wird ein hölzerner mit langen Zinken versehener Baum zur Ebenung durch den Schlamm geschleppt.

$\mathrm{Zu}$ Bergreis wird überall wie beim Getreide der Boden mit Hülfe des Spatens oder durch Pflug und Egge vorbereitet.

\section{Aussaat.}

Die Aussaatzeit des Sumpfreises richtet sich nach der physikalischen Beschaffenheit der Böden, nach der Temperatur des Wassers und der Luft und der Vegetationszeit der Reissorten.

Durchschnittlich wird gesäet und geerntet in:

\begin{tabular}{|c|c|c|}
\hline & Saatzeit. & Erutezeit. \\
\hline $\begin{array}{l}\text { Indien: } \\
\text { Frühreis } \\
\text { Spätreis } \\
\text { Sumpfreis (Boro) } \\
\text { Japan: }\end{array}$ & $\begin{array}{c}\text { Juni bis Anf. Juli } \\
\text { April } \\
\text { December }\end{array}$ & $\begin{array}{c}\text { Ende September } \\
\text { November, December } \\
\text { April, Mai }\end{array}$ \\
\hline $\begin{array}{l}\text { Südliche wärmere Orte und } \\
\text { spätreife bessere Sorten } \\
\text { Nördl., kühlere Orte u. früh- } \\
\text { reife weniger gute Sorten } \\
\text { China } \\
\text { Südstaaten von N.-Amerika } \\
\text { Guyana } \\
\text { Aegypten } \\
\text { Italien, spätreife Sorten } \\
\text { " frühreife Sorten } \\
\text { Spanien }\end{array}$ & $\begin{array}{c}\text { März, April } \\
\text { Anf. Mai bis Anf. Juni } \\
\text { Ende April bis Anf. Mai } \\
\text { März bis Mitte Mai } \\
\text { Mitte März b. Mitte April } \\
\text { Ende April bis Anf. Mai } \\
\text { März, April } \\
\text { Ende April bis Anf. Mai } \\
\text { MIärz }\end{array}$ & $\begin{array}{l}\text { September, Oktober } \\
\text { Oktober, Norember } \\
\text { Ende Oktober } \\
\text { Anf. September } \\
\text { September } \\
\text { Octbr. bis Mitte Novbr. } \\
\text { September } \\
\text { Anfang August } \\
\text { Ende Septbr., Anf. Okt. }\end{array}$ \\
\hline
\end{tabular}

Das Saatgut wird vor der Aussaat immer eingeweicht und geschieht dies in Italien in der Weise, dass man die Samenkörner in 
nicht gänzlich gefüllten Säcken, damit letztere nicht beim Aufquellen der Samenkörner zerreissen, 8-10, wohl auch 20-24 Stunden in die Zuleitungsgräben legt. Zuweilen wird aber auch in mit ausgegorener Mistjauche oder Wasser gefülten Bottichen geweicht.

In Japan legt man nach Kellner die mit Saatgut gefüllten Strohsäckchen 7-30, im Durchschnitt 10 Tage in fliessendes Wasser. Hierauf werden die aufgequollenen Körner auf Matten ausgebreitet, des Tags über an sonnige Plätze gelegt, öfters gemischt and des Nachts auf einem Häufchen rereinigt und bedeckt. Nach $4-5$ tägiger Behandlnng auf der Matte beginnt die Keinung.

Bei kiihler Witterung und in kalten Gegenden bringt man die gequollenen Samen in Strohsäekchen und erbält sie durch Aufgiessen von lauem Wasser warm oder man gräbt sie in einen Komposthaufen ein.

Der Sumpfreis wird in Italien, am Mississippi und zuweilen auch in Spanien breitwürfig gesäet, dagegen in South-Carolina und den übrigen Staaten der nordamerikanischen Reisregion vorzugstreise gedrillt und in China, Japan, Hindostan, auf den Philippinen, Java, Sumatra, in Indien, Aegypten, sowie auf den Reisfeldern von Murcia und Valencia in Spanien grösstenteils gepflanzt.

Die breitwïrfige Aussaat geschieht in Süd-Europa wie folgt:

Vor der Saat wird das Wasser bis zur Höhe ron $6-8 \mathrm{~cm}$ abgelassen, und hierauf der Same mit der Hand bei möglichst stillem Wetter eingesäet, damit durch den Wellenschlag die gleichmässige Verteilung des Samens nicht behindert wird. Der eingeweichte Same geht leicht unter, da sich sein spezifisches Gewicht durch das Quellen rermehrt hat, und drückt sich in den Schlamm ein. Durch Aufschlagen mit einem Brett, oder mittelst eines Rechens wird er dann etwas in den Boden gebracht. Nicht selten wird auch eine schwere Diele, auf welcher ein Arbeiter steht, von einem Pferde über das Feld geschleift und hinterher geht der Säemann, so dass der niedersinkende Schlamm den Samen bedeckt.

Das Aussaatquantum schwankt $z$ wischen 1.50 und $3 \mathrm{hl}$, und bringt man auf neue Reisfelder $2.10-2.30 \mathrm{hl}$, auf alte $2.75-3 \mathrm{hl}$ und auf sehr fruchtbare $1.50-1.75 \mathrm{hl}$ :

Gewöhnlich wird 2-3 Tage nach der Saat, damit der Reis gut keimt, das Feld soweit trocken gelegt, dass nur noch sehr wenig Wasser sichtbar bleibt.

In South-Carolina ${ }^{1}$ ) werden flache Rillen gezogen und in diese die Samenkörner ausgestreut, oder mit einer kleinen Drillmaschine auf $30 \mathrm{~cm}$ Keihenweite gedrillt. Das Saatquantum beträgt 1.80$2.70 \mathrm{hl}$ pro ha.

1) Russe1l, a. a. 0., pg. 266. 
Hierauf lässt man eine kleine Quantität Wasser 1-2 Tage lang darüber, wodurch die Samenkörner in den offenen Drillreihen eingeschlämmt werden oder man bedcckt sie mit Hülfe des Rechens.

Die Aussaat des Sumpfreises geschieht in Indien ${ }^{1}$ ) auf einem kleinen Pflanzbeet, welches bewïssert werden kann.

Ist die Witterung eine günstige gewesen, so baben die jungen Pflänzchen nach 40 Tagen eine Höhe von $25-40 \mathrm{~cm}$ erreicht und können nun ausgepflanzt werden.

Die Reisfelder sind indessen zur Aufnahme folgendermassen vorbereitet worden: Zunächst werden sie seicht gepflügt, sodann unter Wasser gesetzt und dadurch geebnet, dass ein Paar Ochsen oder Büffel einen langen Baumstamm über das Feld schleifen.

In dieses Schlanımfeld werden nun die jungen Pflanzen hineingeptlanzt.

Von nun an wird der Wasserzufluss den Ansprüchen der gebauten Sorte entsprechend, bis zum Eintritt der Erntezeit sorgsam reguliert.

Die Bestellungsarbciten beginnen in Japan im April mit Herrichtung eines Saatbeetes. Dasselbe wird mit einem $30-45 \mathrm{~cm}$ hohen Wall umgeben, sowie mit einem kleinen Wasserlauf in Verbindung gebracht. Nach dem Einlassen von $3-4 \mathrm{~cm}$ Wasser gräbt man das Saatbeet mebrere Male um und bearbeitet es dann mit einem Rechen so lange Zeit, bis sich ein feiner Schlamm gebildet hat.

Häufig wird nun mit Asche, grünen Pflanzen oder vergorener Jauche gediingt.

Hierauf säet man die Samenkörner, welche meist ein $6 \mathrm{~mm}$ langes Federchen getrieben haben, aus, und zwar 30-60 I pro Ar, welche den Pflanzenbedarf fiur 8-11 a (nach Kellner) decken.

Bei noch nicht ausgekeimten Samenkörnern zeigen sich die Federchen nach Verlauf von 4-5 Tagen.

Während der ersten 10 Tage wird das Saatbeet in der Regel nur des Nachts bewässert, damit es sich am Tage erwärmen und den Keimlingen genügend Sauerstoff zufliessen kann. Anfänglich wird $6 \mathrm{~cm}$, später, nachdem das erstc Blatt $2.5 \mathrm{~cm}$ lang geworden ist, nur noch $1.2 \mathrm{~cm}$ hoch bewässert.

Hierauf werden die Pflünzchen gewöbnlich $40-56$ Tage nach der Aussaat, sobald sie eine Höhe von $18-24 \mathrm{~cm}$ erreicht haben, auf ein wohlvorbereitetes Feld ausgepflanzt. $\mathrm{Zu}$ diescm Zweck zieht man die Pflänzchen sehr sorgfältig unter Wasser aus, um Verletzungen der Wurzeln möglichst zu vermeiden. Die ausgezogenen Pflänzchen bindet man in kleine mit der Hand umspannbare Bündel und

1) Roxb., Fl. ind. II. pg. 203 (1832). 
bringt sie auf das 8-10 cm tief unter Wasser stehende Reisfeld, auf dem meist Frauen das Auspflanzen besorgen und die Männer die Pflanzen zutragen.

Beim Pflanzen werden mit dem Daumen Löcher in den Boden gedriickt und in jedes 3-4, doch zuweilen bis 10 Pflänzchen gesetzt und zwar geschieht dies in Reihen und beträgt die Entfernung der Reihen, je nach Bodenbeschaffenheit, Sorte ttc. 20-33 cm und die Entferuung der Büschel in der Reihe $12-20 \mathrm{~cm}$, auch pflanzt man in der Quincux-Stellung auf $25 \mathrm{~cm}$ Entfernung.

Nach Kellner schwankt, auf die Fläche eines Ar berechnet, die Anzahl der Büschel von unter 1200 bis über 3000 .

In der Provinz Setsu, die ziemlich in der Mitte von Japan liegt und sich eines guten Bodens erfreut, sind die Anzahl der Büschel folgende:

$\begin{array}{lcc} & \text { Büschel pro Ar } & \text { Pflanzen pro Büschel } \\ \text { Frühreife Sorte } & 1410-1500 & 6-7 \\ \text { Mittelreife " } & 1320-1350 & 5-6 \\ \text { Späte } \quad, & 1200 & 4-5\end{array}$

Nach 14 Tagen werden die Pflanzen noch einmal fest angedrückt und etwaige Erdschollen mit den Händen zerkleinert.

Aehnlich wird in Spanien gepflanzt und zwar auf $30 \mathrm{~cm}$ Entfernung.

In China sind die Aussaatmethoden sehr verschieden, so säet man nach $\mathrm{Barlow}^{1}$ ) in der nordöstlichen Prorinz Pe-tschi-li mittelst des Pflanzstockes, womit Löcher gegraben oder Furchen gezogen werden, oder durch Breitsaat; in der Provinz Kiang-nan pflanzt man, und in der Provinz Kan-ton drillt man mit Hülfe eines Säepfluges.

Nach Fortune ${ }^{2}$ ) wird in Kiang-nan mit Beginn der Frühlingsregen im Mai gesäet, so dass der Reis Anfang Oktober reift. Es ist daher eine zweimalige Reisernte, wie im südlichen China, in Schang-hai nicht mehr möglich. Aber schon in Ning-po $\left(29^{\circ} \mathrm{n} . \mathrm{Br}\right.$.), wo der Sommer länger währt, erzielt man diese dadurch, dass man 2-3 Wochen nach der hier in die Mitte des Mai fallenden Saat eine zweite Saat in denselben Acker bringt. Diese, durch jene in der Entwickelung gehemmt, schiesst erst hoch auf, nachdem zu Anfang August die erstere geerntet ist und liefert demuächst eine zweite Erute im November.

Im südlichen China erhält man nicht bloss allgemein zwei Reisernten im Sommer, sôndern schaltet sogar noch eine Grünfrucht im Winter ein.

1) Voyage en Chine, 1805.

2) Grisebach, Ber. ü. d. Leist. d. geogr. und syst. Bot. während d. J. 1848 (1851) pg. 41. 
Auf Java und Sumatra wird der Rcis auf die nassen Felder (Sawah's) aus einer Pflanzschule verpflanzt. Die Aussaat geschieht zu Anfang oder um die Mitte der Regenzeit und reift der Reis je nach der Sorte und Höhenlage der Felder in 4-7 Monaten.

In günstigen Lag'en lassen sich recht gut zwei Reisernten alljährlich erziclen.

Zur Bestellung des Bergreises wartet man dagegen die Regenperiode ab, welche sieh in China gewöhnlich im Mai einstellt. Nachdem der Boden durch zweimaliges Pfliigen gelockert ist, wird der eine Nacht hindurch zur Beschleunigung seiner Keimung eingeweichte Same in kleinen Löchern ausgelegt, und zwar entfallen auf jedes Loch 2-4 Samenkörner und stellt sich das Saatquantum auf 2-3 hl pro ha. Einen Monat später wird mit dem Jäten und Hacken begonnen. In der Regel hackt man dreimal und zwar das erste Mal bei einer Höhe der Pflanzen von $20 \mathrm{~cm}$, vorausgesetzt, dass der Boden weder zu nass noch zu trocken ist. Nach drei Monaten tritt die Reife ein.

Nach Royle ${ }^{1}$ ) wird der Bergreis im Himalaya zur Regenzeit (Mitte Juni bis Septenıer) gesäet und hierbei folgendermassen verfahren.

Sobald rom Weizen als Vorfiucht die Aehren abgesichelt sind, wird das Stroh als Dïnger untergepflügt und beim Eintritt der ersten Regenschaner der Reis ausgesäet.

Auf Java ${ }^{2}$ ) wird ebenfalls dort, wo die Wasserverbältnisse odel andere Umstände, z. B. Unkrautwucherung, es nicht gestatten, nasse Reisfelder (Sawah's) anzulegen, auf trocknen Feldern, den sog. Tipar's und Gaga's (auf Ostjava Gogo, auf Sumatra von den Batta Laddang's genannt), Bergreis gebaut. Die Tipar's und Gaga's unterscheiden sich hauptsächlich dariu, dass zur Anlage erstercr eine mchr oder weniger grosse Strecke einer mit Wald oder Gesträueh besetzten Ebene hiervon so gesäubert wird, dass der Boden mit dem Pflug bcarbeitet werden kann, woranf der Reis breitwürfig wie anderes Getreide gesäet wird.

Die Gagafelder werden dagegen auf abgebrannten oder frisch geschlagenen, jedoeh nieht gerodeten Waldflaiehen angelegt, und wird hierzu der frisehe Waldboden nicht weiter bearbeitet, als dass man den Reis, dem cinige Baumwollensamen beigefügt wcrden, um nach der Reisernte 4-5 Monate später noeh eine Baumwollenernte elzielen zu können, in kleine Löcher auslegt.

Die Tipar's werden wohl 2-3 Jahre hinter einander bebaut,

1) Illustr. of bot. the Himal. and Cashmere 1839 .

2) Hasskarl in Flora 30 (1847) 496. 
dagegen die Gaga's gleich nach der Ernte verlassen, oder höchstens noch ein Jahr zum Mais- oder Tabackban benutzt und hiernach sind sie sehr bald wieder eine undurchdringliche Wildnis.

Aehnlich ist auch die Kultur des Upland-rice ${ }^{1}$ ) in dem östlichen Teil des Staates Mississippi, „Piney-Woods" genannt.

Hier wird nach dem Abräumen der geschlagenen, aber nicht gerodeten Stämme eines Fichtenwaldes, oder zwischen den Bäumen, wenn diese so wenig zahlreich sind, dass sich grosse Blössen finden der frische Waldboden mit einem einpferdigen Schälpflug ca. $5 \mathrm{~cm}$ tief umgebrochen und der Same eingedrillt. Die Zwischenräume werden behackt. Nach einigen Jahren ist jedoch der Boden für den Reisban vollständig erschöpft. Bedarf.

Dieser Reis dient nicht zur Ausfuhr, sondern nur zum eignen

\section{Pflege.}

Die Pflege hat sich der Hauptsache nach auf die Regulierung der Stauhöhe und Temperatur, sowie auf die Unkrautvertilgung zu ricliten.

In Italien sorgt man dafür, dass sich das Wasser in der ersten Zeit in solcher Höhe erhält, dass die Blattspitze über den Wasserspiegel hervorragt, auch ist die Temperatur durch schwächeren oder stärkeren $\mathrm{Zu}$ - oder Abfluss zu regeln, damit dieselbe immer gleichmässig bleibt, daher denn auch das Wasser niemals an ein und derselben Stelle dauernd einfliessen darf, sondern möglichst für einen örtlichen Wechsel zu sorgen ist. Häufig sind auch Sammelteiche vorhanden, in denen sich das Wasser, bevor es auf das Reisfeld abgelassen wird, erwärmen kann. Bis Johannis erreicht das Wasser in dem Reisfelde, je nach seiner Temperatur, eine Höhe ron $20-30 \mathrm{~cm}$, welche Stauhöhe bei der weiteren Entwickelung der Pflanze nicht überstiegen wird.

Auf sehr schwerem Boden ist auch eine periodische Bewässerung, die jeden 5., 6. oder 8. Tag erfolgt, zulässig.

In Italien wird, weil breitwiirfig gesäet, nicht gehackt, aber dafuir ein- oder zweimal das Unkraut gejätet, eine Arbeit, welche nngefähr drei Wochen erfordert (vom 24. Mai bis Ende Juni) und im Wasser durch Frauen und Kinder geschieht.

Während der Bestockung und des Schossens darf nicht gejätet

1) Allen, The americ. Farm-book (1850). 
werden, weil darunter die Bestockung leidet, oder die Schösslinge leicht knicken und sich nachher nicht wieder crbeben.

Die Arbeit des Jätens beginnt Morgens $3 \mathrm{Uhr}$ und endet am Nachmittag, doch wird bei der Schwierigkeit der Arbeit, denn die Arbeiter müssen in dem warmen Wasser vornübergebeugt bei glühender Sonnenhitze umberwaten, diese Arbeitszeit fuir einen vollen Arbeitstag gerechnet.

Im Juli lässt man zur möglichsten Vertilgung der Feinde des Reises das Wasser auf einige Tage ab, wodurch die Wassertiere, wie Fische, Insekten etc. zu Grunde gehen, sehr schnell faulen und den Boden für die Frucht des nächsten Jahres düngen.

Trifft Hagel den Reis beim Beginn des Schossens, so wird das Feld ebenfalls trocken gelegt, es vertrocknen dann die beschädigten primären Halme und die sekundären wachsen schnell nach und in den frei gewordenen Raum hinein.

In Carolina wird die Drillsaat gehackt, sobald die Pfänzchen $18 \mathrm{~cm}$ hoch sind, und zu dem Zweck das Reisfeld trocken gelegt. Nach dem Hacken lässt man wiederum reichlich Wasser zu. Nach Verlauf von 20-25 Tagen wicderholt sich das Hacken, und treibt zu dieser Zeit der Reis in den Halm. Vom 1. Juli ab bis zur Trockenlegung, 14 Tage vor der Saat, gibt man einen gleichmässigen Wasserzufluss und eine Wasserstandshöhe von $16-20 \mathrm{~cm}$.

Die Pflege der Reisfelder in Japan gestaltet sich nach Kellner wie folgt:

Nach dem Auspflanzen beginnt die Bewässerung und Unkrautvertilgung. Die Bewässcrung ist zum Zweck der Unkrautvertilgung etwas herabgesetzt, oder ganz unterbrochen, und dic Unkräuter, sowie die oben schwimmenden Reiswurzeln werden mit der Hand in den Schlamm unter die einzelnen Büschel gestossen.

Gewöhnlich riihrt man vor dieser Operation den Schlamm mittelst langer bölzerner Hacken auf und unterzieht sich dieser Arbeit bis zur Mitte des Juli 3-5 Mal in Zwischenräumen von 15-7 Tagen. Durch das Aufwühlen des Schlammes gelangen neue Bodenteilchen an die Pflanzen.

Von der Mitte Juli bis Mitte August (Zeit des Schossens) legt man das Feld in Intervallen von je 10 Tagen stets $2-3$ Tage trocken und hört dann mit der Bewässerung auf. Nur zur Bliitezeit, in welcher die physiologischen und chemischen Processe eine plötzliche Steigerung erfahren, setzt man die Felder 2-3 Tage unter Wasser. 


\section{Ernte, Ausdrusch und Aufbewahrung.}

Bei Beginn der Reife senkt sich die Rispe, und in der vollen Reife nehmen die Blätter und Halme eine blassgelbe Färbung, hingegen dic Rispen die charakteristische Farbe der Sorte an. Das Korn bricht zu dieser Zeit leicht iiber den Nagel.

Leider tritt die Reife sehr unglcichmässig ein, und da nun die Körner in der Vollreife leicht ausfallen, auch dic Rispe sich sehr bald so tief zu Boden senkt, dass sich der Reis olne grosse Verluste nicht ernten liisst, und die Rispe leicht abbricht, ferner durch Hagelschlag und Eintritt der Herbstregen der Ernte Verluste drohen, wartet man die Reife aller Frïchte einer Rispe nicht ab, sondern erntet, sobald die Mchrzahl reif ist, aber die iibrigen nicht mehr milchig sind.

Vor dem Schuitt stellt man das Reisfeld möglichst trocken.

Die Ernte geschicht in Italien mit der Sichel und zwar schneidet man den Halm in halber Höhe, legt den abgesichelten Reis in kleinen Büschelchen auf den Dämmen zum Trocknen nieder, und hierauf werden diese entweder nit dem eigenen Stroh oder Weidenruten gebınden und zum sofortigen Ansdrusch, der meist mit Hülfe einer Stiftendreschmaschine seltener durch Austreten erfolgt, auf die Tenne gebracht. Der abgedrosehene Reis wird dann auf einen mit Ziegeln oder Steinen gut abgepflasterten und der Sonnc ausgesetzten Platz, der "Aja", zum Trocknen dünn aufgeschïttet, mehrmals am Tage umgeriihrt und Abends in breiter aber niedriger prismatischer Form aufgehäuft, am nächstfolgenden Tage ist dic Behandlung die gleiche, nur dass am Abend kegelförmige Haufen von 30-50 hl Inhalt gebildet werden. Diese Behandlung wiederholt sich bis der Reis ganz trocken, sich leicht von der Spreu sondert und eine glänzende, harte Bruchfläehe zeigt. Hierauf wird er entweder auf der Getreidereinigungsmaschine oder durch Worfeln (Werfen mit Schaufeln) gereinigt. Auf den Speichern kann er dann bis zu einer Höhe ron $6-8 \mathrm{~m}$ aufgesehiehtet werden.

In Carolina ${ }^{1}$ ) wird der Reis mit Sicheln $30-45 \mathrm{~cm}$ rom Boden entfernt gesehnitten und auf die hoben Stoppeln gelegt. Bei gutem Wetter bindet man ihn nach 24 Stunden in Garben ron $12-15 \mathrm{~kg}$ Gewicht und stellt sie in Hocken auf. Nach einigen Tagen, wenn das Stroh ganz trocken geworden, werden die Garben auf flachen Booten in den Hauptkanälen nach den Dreschtennen gebracht oder

1) Favea u, Rep of the Cummiss. $186 \pi$. 
in Feimen von $10 \mathrm{~m}$ Länge, $2.75 \mathrm{~m}$ Breite und $3.3 \mathrm{~m}$ Höhe eingebanst, um gelegentlich durch Dreschmaschinen ansgedroschen zu werden.

Das Sehneiden des Reises geschieht in Japan und China mit kurzen, häufig gezähnten Sichcln dicht am Boden, hierauf wird er in kleine Garben gebunden, und damit er auf feuchtem Terrain oder bei feuchter Wittcrung weniger leieht answaelise, über Stangen aufgehangen, oder um die Erlenbäume längs der Gräben anfgeschichtct, und naeh dem Austrocknen dureh Tiere oder Menschen nach Hause getragen, um in Japan auf einem unseren Flachsriffeln ähnlichen Gerät entkörnt, oder wie auch in China mit Dreschflegeln aus Bambus gedrosehen zu werden.

In Indien ${ }^{1}$ ) lässt man einige Tage vor Eintritt der Ernte das Wasser aus den Reisfeldern ab.

Der Schnitt erfolgt mit Hülfe der Sichel und das Ernteprodukt wird auf trocknen, erhöhten Stellen zum Austrocknen ausgebreitet und hierauf entweder eingemietet oder durch Tiere ausgetreten. In letzterem Falle trocknet man das Korn naeh und bringt es in Haufen, welche mit Reisstroh eingedeckt werden.

\section{Erträge und Nahrungsbestandteile.}

Die Reiserträge stellen sieh pro ha wie folgt:

$\begin{array}{lrrr} & \text { Min. } & \text { Max. } & \text { Mittel } \\ \text { Korn in hl (Paddy) } & 12 & 100 & 46 \\ \text { Gewricht pro hl in kg } & 40 & 66 & 50 \\ \text { Stroh in kg } & 1000 & 6000 & 2600\end{array}$

Der Ernteertrag beträgt in Italien auf den permanenten Reisfeldern 28-32 hl, auf den temporären 45-60 hl, doch werden auf den besten Reisfeldern um Novara zuweilen 75 hl, ja selbst 100 hl geerntet und als Durchschnittsertrag werden für Italien $42.20 \mathrm{hl} \mathrm{p}$. ha angegeben. Es wiegt $1 \mathrm{hl}$ gegrannter unenthiilster Reis $40-45 \mathrm{~kg}$, ungegrannter $50 \mathrm{~kg}$, während geschälter Reis sein Gewicht auf 72 bis $80 \mathrm{~kg}$ erhöht. Im Durehschnitt gibt $1 \mathrm{hl}$ unenthülster Reis 30 bis 351 gesehälten Reis.

In der Regel liefert auf neuen Reisfeldern:

Bertone naeh Weizen mit Klee

Ostiglione im 2. Jahr . . .

$70 \mathrm{hl}$ pro ha,

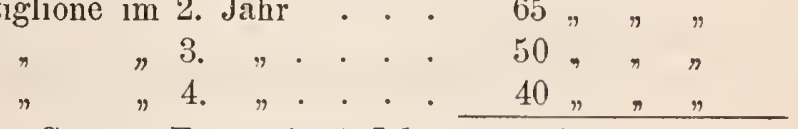

Summe Ertrag in 4 Jahren $225 \mathrm{hl}$

und durchsehnittlieh pro Jahr 56.25 hl pro ha.

1) Roxb. FY. ind. II. pg. 204 (1832). 
Auf den Savannah-swamps ${ }^{1}$ ) von South-Carolina erntet man von alten gut liultivierten Feldern an ungeschältem Reis (Paddy) $63-73 \mathrm{hl}$, auf den geringeren $36-45 \mathrm{hl}$ und auf Feldern mittlerer Qualität 40-50 hl pro ha.

Für Poltugal wird die Ernte auf 37.5 hl, tür Spanien auf $58 \mathrm{hl}$ pro ha angegeben.

Für Japan ${ }^{2}$ ) gehen die Angaben sehr weit auseinander. nach Le Gendre stellt sich der Eitrag auf $35 \mathrm{hl}$

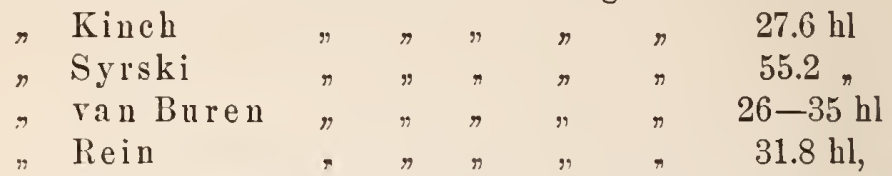

und das japanische Finanzministerium legt seinen Steuerberechnungen $23 \mathrm{hl} \mathrm{zu}$ Grunde.

Li ebscher gibt für Japan den Durchschnittsertrag an geschältem Reis auf $17.84 \mathrm{hl}$ pro ha an und wiirde dies einem Ertrag an ungeschältem Reis (Paddy) von ca. $35.68 \mathrm{hl}$ ausmachen, bei Annahme einer Volumenverringerung durch Enthïlsen von 50 Proc.

In nachstchenden Ländern stellen sich die Anbauflächen und Erträge wie folgt:

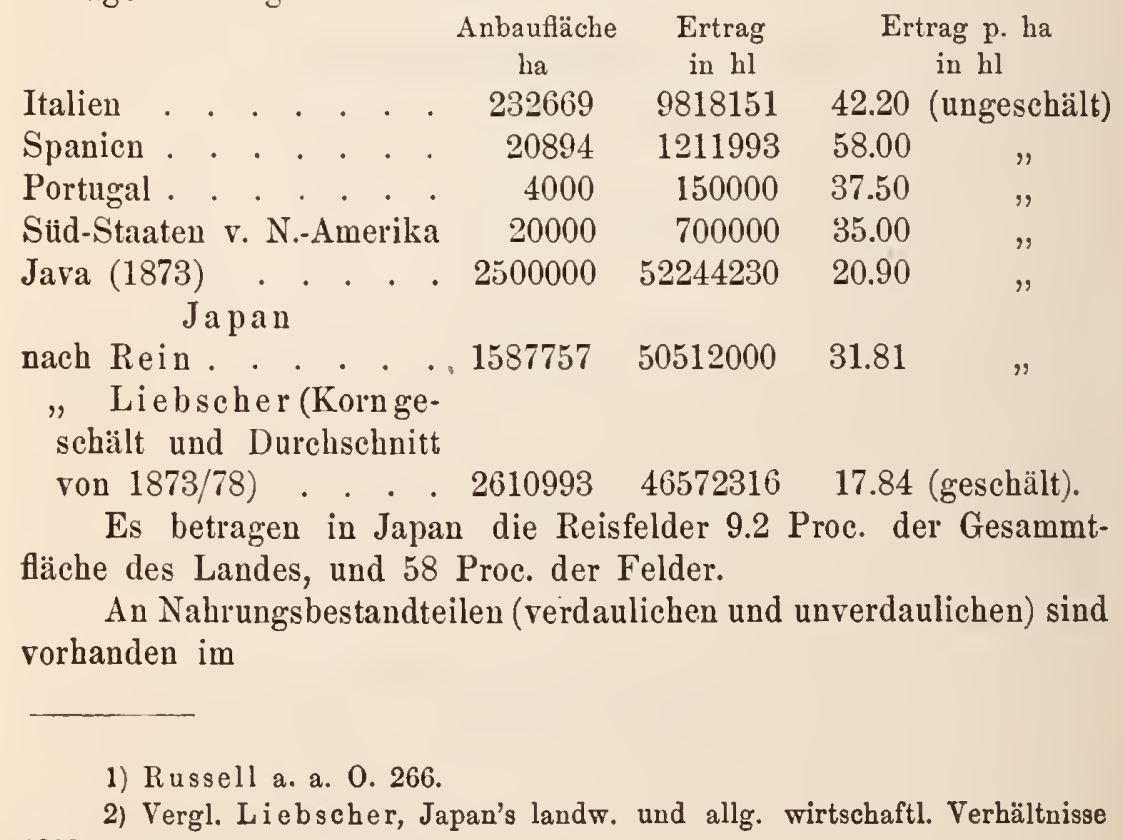
1882 . 


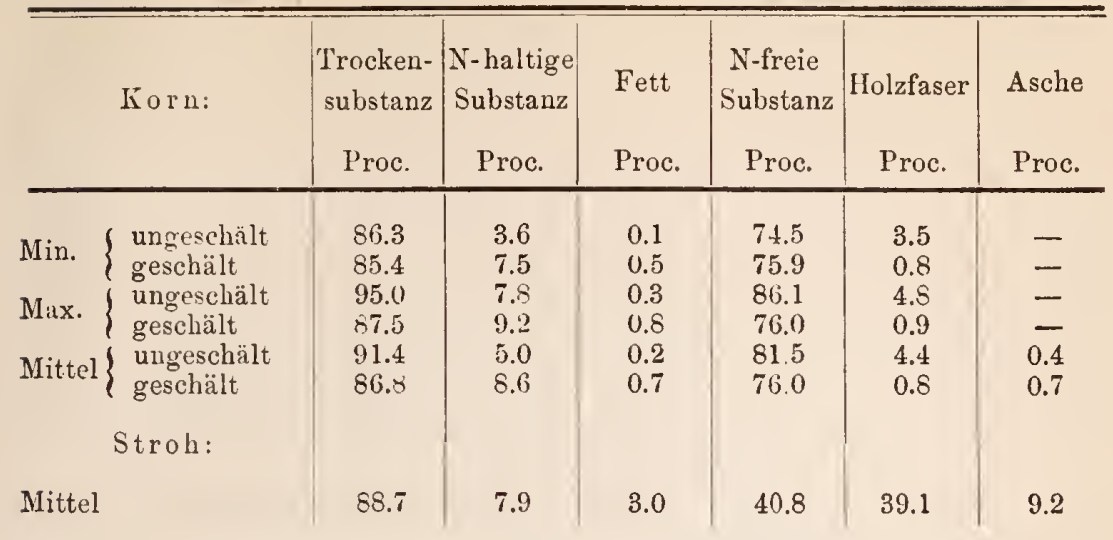

Der mittlere Procentgehalt an verdaulichen Nährstoffen beträgt nach E. Wolff :

\begin{tabular}{|c|c|c|c|c|c|c|}
\hline \multirow[b]{2}{*}{ im } & \multirow[b]{2}{*}{$\begin{array}{c}\text { Orga- } \\
\text { nische } \\
\text { Sub- } \\
\text { stanz }\end{array}$} & \multicolumn{3}{|c|}{ Verdauliche Nährstoffe } & \multirow[b]{2}{*}{$\begin{array}{l}\text { Wahr- } \\
\text { scheinl. } \\
\text { Nähr- } \\
\text { stoffver- } \\
\text { hältnis } \\
\text { wie 1: }\end{array}$} & \multirow[b]{2}{*}{ 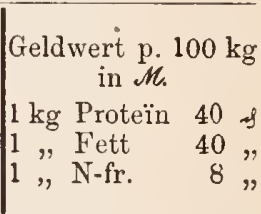 } \\
\hline & & Eiweiss & $\begin{array}{l}\text { Kohle- } \\
\text { hydrate }\end{array}$ & Fett & & \\
\hline Korn $\left\{\begin{array}{l}\text { ungeschält } \\
\text { geschält }\end{array}\right.$ & $\begin{array}{l}90.6 \\
56.1\end{array}$ & $\begin{array}{l}3.5 \\
6.8\end{array}$ & $\begin{array}{l}66.1 \\
68.6\end{array}$ & $\begin{array}{l}0.6 \\
0.6\end{array}$ & $\begin{array}{l}19.0 \\
10.3\end{array}$ & $\begin{array}{l}6.76 \\
8.46\end{array}$ \\
\hline Stroh & 79.5 & 2.4 & 43.9 & 0.9 & 19.2 & 4.84 \\
\hline
\end{tabular}

Ungeschältcr Reis (Paddy) gibt 47-50 Proc. geschälte Ware, 12-16 Proc. Bruchreis und 35-40 Proc. Spelzen und Kleie; durchschnittlich sind auf 100 Teile Korn 130 Teile Stroh zu rechnen.

Nach Braconnot enthält ungeschälter Reis von

Carolina Piemont.

\begin{tabular}{|c|c|c|}
\hline Stärke & 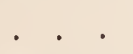 & 85.07 \\
\hline Holzfaser & & 4.80 \\
\hline Unkrystall. & Zucker & 0.29 \\
\hline Protcïn & . & 3.60 \\
\hline Gummi & & 0.71 \\
\hline Oel & & 0.13 \\
\hline Phosphors. & Kalk & 0.13 \\
\hline Wasser & . & 5.00 \\
\hline
\end{tabular}

und nach Rep. of the Commiss. of Agric. 1879 pg. 102 enthalten nachfolgende Sorten geschälten Reises: 


\begin{tabular}{|c|c|c|c|c|c|c|c|c|}
\hline 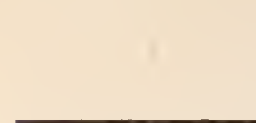 & $\begin{array}{l}\text { Fett } \\
\text { Proc. }\end{array}$ & $\begin{array}{l}\text { Gummi } \\
\text { Proc. }\end{array}$ & $\begin{array}{c}\text { Extrakt- } \\
\text { stoffe } \\
\text { Proc. }\end{array}$ & $\left\{\begin{array}{l}\text { Stärke } \\
\text { Proc. }\end{array}\right.$ & $\begin{array}{l}\text { Cellu- } \\
\text { lose } \\
\text { Proc. }\end{array}$ & $\begin{array}{l}\text { N-h. } \\
\text { Proc. }\end{array}$ & $\begin{array}{l}\text { Asche } \\
\text { Proc. }\end{array}$ & $\begin{array}{l}\text { Trasser } \\
\text { Proc. }\end{array}$ \\
\hline $\begin{array}{l}\text { Carolina gold-seed } \\
\text {," white," } \\
\text { Japan } \\
\text { Patna, Bengalen } \\
\text { White seed, Loui- } \\
\text { siana } \\
\text { Honduras, Louis. } \\
\text { Volunteer, dto. }\end{array}$ & $\begin{array}{l}0.27 \\
0.30 \\
0.42 \\
0.32 \\
\\
0.27 \\
0.30 \\
0.37\end{array}$ & $\begin{array}{l}1.57 \\
1.57 \\
1.74 \\
1.36 \\
1.44 \\
107 \\
1.35\end{array}$ & $\begin{array}{l}0.73 \\
0.57 \\
0.89 \\
0.57\end{array}$ & $\begin{array}{l}75.40 \\
75.47 \\
74.90 \\
76.71 \\
78.17 \\
78.27 \\
78.40\end{array}$ & $\begin{array}{l}0.17 \\
0.13 \\
0.17 \\
0.14 \\
0.19 \\
0.19 \\
0.40\end{array}$ & $\begin{array}{l}8.55 \\
8.31 \\
7.44 \\
7.70 \\
\\
6.65 \\
7.26 \\
6.83\end{array}$ & $\begin{array}{l}0.38 \\
0.34 \\
0.42 \\
0.35 \\
\\
0.33 \\
0.34 \\
0.40\end{array}$ & $\begin{array}{l}12.93 \\
13.31 \\
14.02 \\
12.85 \\
12.16 \\
11.80 \\
11.45\end{array}$ \\
\hline
\end{tabular}

Nach Atkinson ${ }^{1}$ ) ergeben sich von rohem japanischen Reis für die Trockensubstanz:

$\begin{array}{lccc} & \text { Gewöhnlicher } & \text { Glutinöser } & \text { Bergreis } \\ \text { Reis } & \text { Reis } & \\ \text { Ruhproteïn } & 7.00 & 5.87 & 8.75 \\ \text { Rohfett } & 2.29 & 3.44 & 2.58 \\ \text { Rohfaser } & 4.58 & 5.19 & 1.98 \\ \text { Stickstofffreie Stoffe } & 84.76 & 83.89 & 85.53 \\ \text { Asche } & 1.37 & 1.61 & 1.18\end{array}$

Zur genaueren Feststellung der Zusammensetzung des Klebreises iibergaben wir dem Vorsteher der Versuchsstation zu Poppelsdorf, U. Kreusler, einen enthiilsten Klebreis aus Siam, welchen wir durch van Eeden aus dem Kolonial-Museum zu Haarlem erhalten hatten. Es fanden darin U. Kreusle $\mathrm{r}^{\circ}$ und Dafert, berechnet auf Trockensubstanz ( $=86.72$ Proc. der lufttrocknen Körner):

Zucker

Rohproteïn Rohfett Rohfaser (Glycose) Dextrin Stärke Asche. 8.89 pCt. 0.68 pCt. 0.76 pCt. 8.65 pCt. 3.35 pCt. 76.98 pCt. 0.69 pCt.

Hiernach unterscheidet sich der Klebreis von dem gebräuchlichen durch merklich höheren Dextrin- und insbesondere Zuckergehalt.

U. Kreusler und Dafert priften nun auch das mikroskopische Verfahren und fanden, was auch schon vorher durch Körnicke festgestellt worden war, dass die Stärkekörnchen, welche sonst vollkommen normal erscheinen, nicht die charakteristische tiefblane bis blauschwarze Jodreaktion, sondern eine braunrötliche bis blauviolette Färbung zeigen, und zwar auch dann noch, nachdem sie sehr wiederholt mit Wasser gewaschen und vollständig von einander getrennt worden waren, also von einer Anlagerung von Dextrin, Zucker u. dgl. nicht mehr die Rede sein konnte.

1) On sake brewing. Memoirs of the University of Tokio, citiert durch Kellner, Landw. Versuchst. XXX. Heft 1, pg. 45. 
Nach alledem gewinnt es den Anschein, als ob hier eine neue, bei sonst unveränderten Eigenschaften specifisch mit Jod sich bräunende Stärkemodifikation vorläge.

\section{Benutzung.}

Der beschalte Reis (Paddy) ist noch keine Handelsware, sondern muss geschält werden.

Frïher wurde der Reis in Nord-Amerika in Holzmörsern enthiulst, jetzt werden hierzu iuberall vervollkommnete Maschinen angewandt, und auf einem Sortiercylinder die Kleie, das Mehl und der Bruch von den guten Körnern getrennt.

In Japan bearbeitet man den Paddy entweder in einem runden Stein- oder Holztrog mit hölzernen Stössern oder in Stampfmühlen, welche durch Wasserkraft bewegt werden.

In China ${ }^{1}$ ) finden sich ebenfalls verschiedene Vorrichtungen zum Enthïlsen; eine derselben besteht aus zwei kreisförmigen hölzernen Blöcken, welche derart iiber einander angebracht sind, dass der obere Block bei seiner durch eine Person bewirkten Bewegung mit der Oberfläche des unteren in Berührung kommt. Man wirft den Reis durch ein Loch des oberen Blockes hinein und derselbe fällt zwischen den Rändern der Blöcke zum Teil enthülst heraus. Zur Handelsware wird er aber erst in grossen steinernen Mörsern, in welchen man ihn mit schweren Keulen bearbeitct.

In Italien, wo früher nur Stampfmühlen den Reis enthülsten, hat sich jetzt die von Berti-Pichat empfohlene Graupenmühle ${ }^{2}$ ) verbreitet, bestehend aus einem Bodenstein aus Sandstcin und einem Läufer, welcher 250 Umgänge pro Minute macht und 400-1000 kg pro Stunde schält, - von dem unbegrannten mehr, von dem begrannten weniger.

Für den ersteren hat man besondere Grannenbrecher, die aus einem mit Eisenblech versehenen vertikalen Cylinder von $25 \mathrm{~cm}$ Durchmesser bestehen, dessen Aussenseite eine doppelte Reihe von $10-12 \mathrm{~cm}$ langen und $2 \mathrm{~cm}$ dicken, vierkanntigen, stählernen, spiralförmig angeordneten Spitzen trägt. Dieser massive Cylinder dreht sich in einem $2 \mathrm{~m}$ langen Hohlcylinder, dessen Innenseite ebenfalls mit denselben spiralförmig eingesetzten Spitzcn besetzt ist. Der

1) West, Agriculturwerkzeuge pg. 213.

2) Vergl. die Angaben von $D$ ünkelberg, Kulturtechnische Reiseskizzen aus Ober-Italien, Landw. Jahrb. 1881 pg. 924 flgde. 
erstere macht 300 Umgänge pro Minute und zwei Pferdekräfte entgrannen damit täglich $30.000 \mathrm{~kg}$ Reis.

Mit diesen Maschinen kann nun wohl der weisse verkäufliche Reis (Nr. 6) hergestellt werden, der aber damit noch nicht für den Grosshandel und den Verbrauch fertig ist.

Die weitere Verarbeitung erfolgt daher in besonderen Fabriken, von denen die der Gebrüder Malinverni in Vercelli näher besprochen werden soll, weil ja auch die deutsche Landwirtschaft von den Reisabfällen steigenden Gebrauch macht und diese je nach ihrem Ursprung einen sehr rerschiedenen Futterwert haben können.

Dic gedachte Fabrik arbeitet mit einem Wasserrad von effektiv 15 und einer Jonval-Turbine von 30 Pferdekräften, beide ron 12001 Wasser pro Sekunde bei einem Fall von nahehin $3 \mathrm{~m}$ gespeist.

In dieser Fabrik sind ausser den obigen Maschinen noch Reibmühlen aufgestellt, bestehend aus einer hölzernen oder eisernen Wand und einem Boden aus Sandstein, über welchem sich an einer senkrechten Welle zwei drehbar befestigtc aufrechte Mühlsteine von $1.25 \mathrm{~m}$ Durchmesser bewegen. Diese bestehen, um das Gerwicht zu verringern, nur je aus einem Steinring ron $10-20 \mathrm{~cm}$ Dicke und 30 bis $35 \mathrm{~cm}$ Breite, welcher durch ein Kreuz aus Holz oder Gusseisen, ähnlich wie in Oelmühlen, an die wagerechte Drehachse befestigt ist.

Die Umfänge dieser Miihlsteine schweben etwa $5 \mathrm{~cm}$ über dem Bodensteill, werden aber mittelst Gegengewichten in demselben Masse gehoben, als sich der Reis nnter und vor denselben anhäuft, wodurch derselbe einen gleichmässigen nicht allzu starken Druck erhält.

Dic Rcibmühle bedarf 2-3 Pferdekräfte und macht 30-40 Umgänge pro Minute.

Ausserdem passiert der geriebene Reis noch Bürstencylinder aus durchlöchertem Eisenblech oder feine Drahtgeflechte, die 200 Umläufe pro Minute machen.

Die Fabrik stellt vier Reisqualitäten oder Marken dar:

$$
\text { geglänzte }
$$

Nr. 1. Brillato Stella

Nr. 2. " A, ordinäre

Nr. 3. Camolino,

Nr. 4. Mereantile,

welche folgende Arbeiten erfordern:

I. Arbeit. Der ungeschälte Reis wird ron allem Staube und fremden Substanzen befreit und in den Grannenbrecher gebracht. Man erhält in Procenten Nr. 2. 96.65 Reis, Reisabfälle Nr. 3. 1.61, Unbrauchbares 1.74 .

II. Arbeit. Reis Nr. 2 geht durch den Staubcylinder, wird von Abfällen (Nr. 3 und 4) befreit und fällt auf die Graupenmiihle. Man gewinnt in Procenten: Reis Nr. 4. 78.92, Spreu Nr. 5. 20.61 und Abgang 0.47.

III. Arbeit. Bringt man Reis Nr. 5 unter das Stampfwerk, so 
erhält man nach 35-40 Minuten in Procenten: Mercantil-Reis Nr. 6. 87.63, Pistino Nr. 7. 2.65, Spreu Nr. 8. 8.48 und Abgang 1.24.

Bringt man dagegen Reis Nr. 5 unter Beifügung von Spreu in die Reibmühle, so ist die Arbeit vollkommen. Man erhält Procente: Mercantil-Reis Nr. 6. 88.50, Pistino Nr. 7. 1.78, Spreu Nr. 8. 8.48 und Abgang 1.24.

IV. Arbeit. Der Mercantil-Reis Nr. 6 wird mit Spreu vermischt, einerlei ob auf dem Stampfwerk oder der Reibmiihle 20 Minuten weiter verarbeitet und dann von der Spreu befreit, wiederholt gestampft und gerieben, mit der Vorsicht, dass dies nicht zu lange geschieht, weil er sonst anstatt weiss schwarz wird. Von 100 Teilen Mercantil-Reis erhält man dann einschliesslich $7 \mathrm{~kg}$ Spreu: CamolinoReis Nr. 9. 93.68, Mezzagrana Nr. 10. 0.43, Pistino Nr. 11. 1.15, Spreu Nr. 12. 10.70 und Abgang 1.04.

V. Arbeit. Um geglänzten Reis A Nr. 13 zu bereiten, muss man den Camolino Nr. 9 zweimal unter Beimischung von Spreu unter die Reibmizhle bringen und ihn zweimal reinigen. Man erhält dann von 108 Teilen Camolino und 13 Teilen Spreu: Geglänzter Reis A Nr. 13. 94.22, Mezzagrana Nr. 14. 0.81, Pistino Nr. 15. 1.52, Spreu $\mathrm{Nr}$. 16. 16.07 und $0.38 \mathrm{~kg}$ Abgang.

VI. Arbeit. Bringt man den geglänzten Reis A Nr. 13 unter Beimischung grober Weizenkleie 40 Minuten lang auf die Reibmiihle, so erhält man Brillato Stella und zwar aus 100 Teilen Brillato Stella und 14 Teilen grober Kleie, Nr. 17. Riso Stella Nr. 18. 93.33, Risetto Nr. 19. 2.00, Mezzagrana Nr. 20. 0.85, Pistino Nr. 21. 1.71, Kleie und Reismehl Nr. 22. 14.39 und Abgang 1.72.

Es folgt hieraus, dass man im besten Reisfuttermehl Abfälle von Weizenkleie mitkauft und dass es wesentlich diese ist, welche den Albumingehalt verstärkt. - Aus Muster Nr. 3 (s. I. Arbeit) erzeagt man Muster Nr. 23, das Erste ausschliesslich aus Sumpfhirse (Panicum Crus Galli L.) bestehend, hat einen Wert von 16-20 Lire pro $100 \mathrm{~kg}$, nnd wird gemahlen zu einem schlechten Schwarzbrod verarbeitet oder als Spreu verwendet.

Auch kam es schon vor, dass man diese Hirse im Verhältnis von 8-10 Proc. mit Kleesamen vermischte und dieses Falsifikat bis zu 36 Lire pro $100 \mathrm{~kg}$ verkaufte.

Nachdem Muster Nr. 5 (s. II. Arbeit) in gehöriger Menge zur Stampfung (III. Arbeit) gedient hat, wird es mit einem schweren, auf dem Bodenstein ruhenden senkrechten Läuferstein einer besonderen Reibmulhle gemahlen und zu Spreu Nr. 24 verarbeitet. Vermischt man dieses Produkt mit den Spreuarten Nr. 8 (III. Arbeit), Nr. 12 (IV. Arbeit) und Nr. 16 (V. Arbeit), so erhält man das bekannte Futtermittel aus Reis, das auch in Italien an Schweine, Rindvieh und Pferde gegeben wird. 
Setzt man $100 \mathrm{~kg}$ ungeschälten Reis zum Preise von 23 Lire an, so kann man erhalten:

$\left.\begin{array}{l}\text { I. Arbeit: } 96.65 \mathrm{~kg} \text { Nr. } 2 \\ \text { II. } \\ 76.27, \mathrm{Nr} .4\end{array}\right\}$ kommen nicht in den Handel.

III. $\quad " 66.83$ " Mercantile . . zu 0.35 Lire -23.39 Lire $+1.11=24.50$ L.

IV. $" 62.60 "$ Camolino .. $, 0.37,-23.47 "+1.09=24.56 ”$

V. " 58.98 " Brillato A. . " $0.40,-23.58,+1.48=2506 "$

VI. " $55.40, \quad$ Stella $, 0.43,-23.66,+1.32=25.09 ”$

Es sind nämlich hier auch noch die Preise der geringeren Erzeugnisse dem Marktpreis zuzusetzen, indem man etwa erhält bei der III. Arbeit: $2.65 \mathrm{~kg} \mathrm{Nr}$. 7 Pistino . . zu 0.23 Lire -0.61 Lire $\{1.12 \mathrm{~L}$.

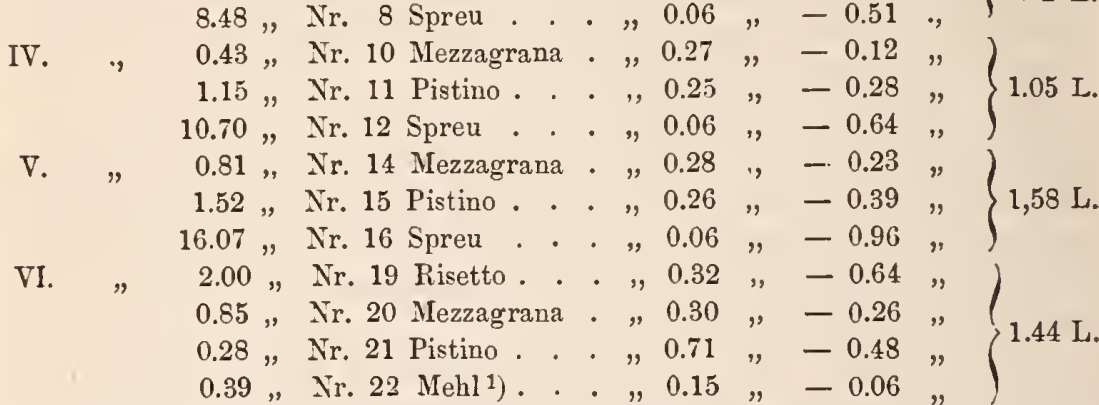

Es folgt aus Obigem, dass der durch die Verarbeitung erhöhte Wert des Reises die Unkosten der Behandlung reichlich deckt und einen Gewinn erzielen lässt, da ja auch die Produkte Nr. 24 und 25 hier nicht verrechnet sind, obwohl sie gewiss auch noch dem Reisfuttermehl zugesetzt werden.

Das Gewicht eines Hektoliters Reis in den verschiedenen Bearbeitungsstadien ist:

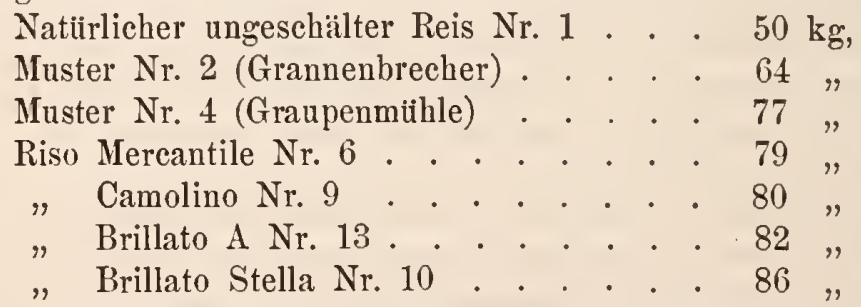

Ueber die Qualität der einzelnen Produkte sind die Meinungen verschieden. Manche halten den stark bearbeiteten und durchsichtig gemachten Reis Nr. 18 für besser, wie die Süditaliener, die denselben aus Bologna beziehen und die Franzosen. Andere halten den weniger bearbeiteten, wie Nr. 6 und 9 für besser und nahrbafter, weil er noch mit Mehl und Staub behaftet ist, wodurch die Brühe beim

1) Man rechnet hier nur $0.39 \mathrm{~kg}$ Mehl, weil die übrigen $14 \mathrm{~kg}$ aus Weizenkleien und nicht aus Reisabfall bestehen. 
Kochen dick und schleimig wird; so in Piemont und der Lombardei, wo man noch an die alte Bereitung des Reises gewöhnt ist.

Der bearbeitete Reis erfährt bei der Aufbewahrung keine chemische Veränderung, weil er die letzte Schicht der Fruchthülle, die Fruchtdecke, verliert. Diese aber bildet eine äusserst ölige, leicht sauer werdende und in Gärung ibergehende Substanz, welche Insekten anzieht und den Reis unbrauchbar macht.

Dies ist daher auch bei dem Ankauf von Reisfuttermehl zu beachten.

Sollte nach T'argioni das im Reisc enthaltene Albumin vorzugsweise im Keime abgelagert sein, so geht dasselbe schon bei der ersten, höchstens zweiten Bearbeitung mit der Spreu Nr. 5 weg, weil hierbei die Körner abgestumpft werden. Albumin, Fett, Gummi, Zucker und Holzfaser werden also durch die Bearbeitung so zu sagen gäızlich entfernt. Länger gelagerter Reis wird mit der Zeit an Wert verlieren, und um so eher, je weniger er bearbeitet ist, während der Brillato Stella, der fast nur aus Stärkemehl besteht, sich nicht durch Erhitzen, sondern nur durch Insekten verschlechtert. Derselbe kocht sich am besten und fast ganz zu Brei. Je weniger der Reis bcarbeitet ist, um so schwieriger kocht er sich, weshalb $\mathrm{Nr} .4$ (Sbramato) nie in der Küche verwendet wird.

Die Mchrzahl der Menschen auf der Erde lebt von Rcis, und haben diesclben, sobald sie nur auf Reisnahrung angewiesen sind, davon enorme Quantitäten zur Erzeugung der notwendigen plastischen Stoffe in ihrem Körper aufzunehmen, denn der Reis ist arm an Eiweiss hingegen reich an Kohlehydraten und zwar verhält sich das Eiweiss zu den Kohlehydraten wie 1:10.3; da nun ein erwachsener Europäer $125 \mathrm{gr}$ verdauliches Eiweiss notwendig hat, so miisste er zu seincr Ernährung täglich mindestens $1250 \mathrm{gr}$ nur enthülsten aber nicht weiter bearbeiteten Reis verzehren; annähernd stimmcn diese Quanta auch mit den von den Ostasiaten wirklich verzehrten Mengen überein, zumal dieselben durchschnittlich ein geringeres Gewicht als die Europäer aufweisen, z. B. braucht ein malaiischer Arbeiter HinterIndiens monatlich $28 \mathrm{~kg}$ Reis, ein Siamese sogar $32 \mathrm{~kg}$ und nicht viel weniger als $1 \mathrm{~kg}$ pro Tag nimint auch ein Japaner oder Chinese zu sieh.

Diese einscitige Ernährung führt bei den nur von Reis lebenden Menschen nicht selten eine Krankheit „Morbus oryceus“ herbei, welche Brennen an Händen, Fiussen, dem Rückgrat etc. erzeugt.

Bei den Ostasiaten liefert jedenfalls der in Wasserdampf gekochte Reis zu jeder der drei Hauptmahlzeiten das wichtigste Gericht. Nach diesen lieben ihn die Orientalen, welche ihn in Fleischbrtihe gekocht, mit Butter übcrgossen und mit Fleischstücken erfüllt, als „Pilau“ verzehren. 
Von den Europäern brauchen wohl die Engländer zur Darstellung ihrer Pudding's die grössten Reisquantitäten.

Die Friichte des klebrigen Reises (0. glutinosa) werden nicht wie die des stärkereichen gewöhnlichen Reises nach Europa ausgeführt, sondern dienen fast ausnahmslos den Eingeborenen Ostasiens zur Nahrung.

Dieser klebrige Reis zeichnet sich, wie wir gesehen haben, durch seinen Reichtum an Dextrin und Zucker aus, und liefert einen kleisterartigen, elastischen Teig, der Europäern nicht mundet, auch schwer rerdaulich sein soll.

Dieser hohe Dextrin- und Zuckergehalt ist jedoch der Benutzung zur Herstellung alkoholischer Getränke sehr guinstig, nnd stellen die Japaner daraus den Reiswein (Sake, Jahresproduktion $6 \frac{1}{2}$ Millionen hl nach Rein) und die Chinesen Reiswein und Arrak her, während der gewöhnliche Reis zur Stärkefabrikation Verwendung findet.

Die Abfälle der Reisverarbeitung, in Japan "Musa" genannt, werden dort den Pferden und Rindern als Kraftfutter gereicht. In Europa kommen diese Abfälle als Reiskleie, Futterreis oder Reisfuttermehl in den Handel, und können je nach ihrer Abstammung, einen sehr verschiedenen Futterwert besitzen, so enthält an verdaulichen Nährstoffen:

\begin{tabular}{|c|c|c|c|c|c|c|}
\hline & $\begin{array}{c}\text { Orga- } \\
\text { nische } \\
\text { Substanz } \\
\text { Proc. }\end{array}$ & $\begin{array}{c}\text { Eiweiss } \\
\text { Proc. }\end{array}$ & $\begin{array}{l}\text { Kohle- } \\
\text { hydrate } \\
\text { Proc. }\end{array}$ & $\begin{array}{l}\text { Fett } \\
\text { Proc. }\end{array}$ & $\begin{array}{l}\text { Nähr- } \\
\text { stoffver- } \\
\text { hältniss } \\
\text { wie l: }\end{array}$ & $\begin{array}{c}\text { Geldwert } \\
\text { pro } 100 \mathrm{~kg} \text {. } \\
\text { Mark }\end{array}$ \\
\hline Reisfuttermehl & 79.5 & 8.6 & 47.2 & 8.8 & 8.0 & 10.74 \\
\hline Reiskleie (Schalen) & 75.8 & 1.7 & 46.3 & 0.7 & 28.2 & 4.66 \\
\hline Futterreis & 85.4 & 6.7 & 65.8 & 1.4 & 10.4 & 8.50 \\
\hline
\end{tabular}

mithin ist das Reisfuttermehl am reichsten an Proteïnstoffen und Fett und empfiehlt sich demnach vorzüglich als Kraftfutter z. B. für Milchrieh.

Das Reisstroh dient zur Herstellung von Stricken, Sandalen, Besen, Papier, Hüten, zur Nahrung für Last- und Nutztiere und schliesslich zur Einstreu.

Die Kulturkosten pro Hektar Reisfeld stellen sich für OberItalien wie folgt: 
Pacht oder Interessen des Bodenpreises . . . 180 Lire,

Kulturkosten im Winter . . . . . . . . 50 ,

Bcackern . . . . . . . . . . . . 20 "

Ausgleichen und Hacken des Ackers . . . . . 4 "

Drei Hektoliter Samen . . . . . . . . 40 ",

Aussäen . . . . . . . . . . . . . . 20 "

Reinigen und Jäten. . . . . . . . . . . 40"

Beaufsichtigung des Feldes und Wässerung . . 5 ",

Schneiden der Ernte . . . . . . . . . . . 40 "

Ausdreschen . . . . . . . . . . . . . . 10 ,

Trocknen auf der Tenne und Aufsicht . . . . 16 "

Versicherung gegen Hagel . . . . . . . . . 30 "

Jährliche Amortisation und Zins der Anlagekosten 5 ",

Generalunkostenquote . . . . . . . . . 4 "

Reingewinn . . . . . . . . . . . 20 "

Die Gesammtkosten betragen sonach . . . 484 Lire, welche bei einem Durchschnittsertrage ron 42.20 hl Reis à 11.50 Lire gedeckt werden.

Hierbei ist die Düngung, als durch die Stroh- und Spreuernte aufgewogen, ausgenommen. 


\section{Sachregister.}

\section{A.}

Abweiden der Saaten . . . . . 79

Acker-Klassifikation . . . . . . 19

Aidurka-Hartweizen . . . . . . 421

Amidonnier blanc . . . . . 445

$"$ de Tartarie . . . . 445

" d'Heidelberg . . . 449

" noir compacte . . . 453

" roux . . . . . . 450

Ammoniak, schwefelsaures . . 27

Anbaustatistik d. Vereinigten Staat. 177

Andriolo rosso . . . . . . 399

And̆ropogon" Sorghum Brot. • . . 9409

dto. aethiops Kcke. . .915

dto. Arduini Gmel. . . 912

dto. bicolor L. . . . 916

dto. cernuus Ard. . . .917

dto. leucospermus Kcke .912

dto. saccharatus P. . . . 911

dto. technicus Kcke. . 909

dto. Usorum N. ab E. . 915

Arnautischer Hartweizen . . . . 422

Arroz de Alemania . . . . . .644

" carolino . . . . . . .940

" de Cataluña . . . . . .944

" Moscado de Valencia: . . 943

Aufbewahrung d. Getreides . . 113 $" \quad " \quad$ in Erdgruben . .". .... 114 Aufbewahrung des Getreides auf

Schüttböden . . . . . . 115

Aufbinden des Getreides . . . 9 90

Auffrieren des Bodens . . . . . 76

Augustweizen . . . . . . . 253

Ausdrusch des Getreides . . . 109

\begin{tabular}{|c|c|c|c|}
\hline & & & \\
\hline " & mit Naschinen & & \\
\hline & $\begin{array}{l}\text { durch Tiere } \\
\text {. }\end{array}$ & & \\
\hline Aussaat & - Gerste & & $66 ?$ \\
\hline$"$ & - Getreide & & \\
\hline & - Hafer & & 75 \\
\hline$"$ & - Kolbenhirse & & 9 \\
\hline & - Mais & & 84 \\
\hline
\end{tabular}

Aussaat - Mischel . . . . . . 592

" - Mohrhirse . . . . 924

$"$ " - Reis . . . . . 965

$" \quad$ - Rispenhirse . . . . 885

" - Roggen . . . . . 588

" - Weizen . . . . . 497

Avena brevis . . . . . . . 738

Colonia de Punta-Arenas . 698

comune di Viterbo . . . 713

del Llobregat . . . . 728

di Palermo . . . . 714

di Ruvo di Puglia . . 729

di Sibiria. . . . . 703

flandrese . . . . .718

grigia d'inverno . . . 720

marzuola . . . . . . 699

nera di Brie . . . 726

, d'Ungheria . . . 732

orientalis flava Kcke. . . 731

, gymnocarpa Kcke. 737 gymnocarpa Kcke. 737
MIetzgerii Kcke. . 730 obtusata Al. . . 730 pugnax Al. . . 732 tristis $\mathrm{Al} . .732$

ativa L. . . . . . . .681 aristata Krause • . 711 aurea Kícke. . . .715 brunnea Kcke. • . 721 . chinensis Fisch. . . 737 cinerea Kcke. • . 721 inermis Kicke. : .735 grisea Kcke. . . . 720

Krauseï Kicke. . . 719 montana Al. • . 728 mutica Al. . . 681 nigra Krause • . 724 nuda Al. . . $\left\{\begin{array}{l}737 \\ 735\end{array}\right.$ orientalis L. . . 730 patula Al. . . . 681 pennsylvanica • . 711 praegravis Langethal 705 rubida Kcke. . . 728 trisperma Schübler u. NIart. • . . 713 strigosa Schreb. . . .739 subspontanea Kicke. . . . 738 tartarica . . . . . 735 
Avoine à fourrage

739

à trois grains

713

blanche d'Adelaïde . . . T05

" de Hongrie . . . 730

" de Russie . $\left\{\begin{array}{l}707 \\ 730\end{array}\right.$

de Tartarie . . .730

de Turquie . . 730

brune hâtive . . . . 725

, tardive. . . . . 726

courte . . . . . . . 738

d'Amérique . . . . . . 707

de Chenailles . . . . . 725

de Chine . . . . . . 737

d'Écosse . . . . . .706

de Coulommiers . . . 726

de Meaux . . . . . 726

de Pithiviers . . . . . 723

de Podolie . . . . . 730

de Pologne . . . . . . 693

de Pstross . . . . . . 707

des Canaries . . . . . 707

de Soissons . . . . . 726

des Salines . . . . . 718

de Tartaric . . . . . 733

d'hiver de Provence. . T08

d'Orléans . . . . 725

du Banat . . . . . 707

du Canada . . . . . 707

du comte Baudissin . . . 707

du Kamtschatka . . $\left\{\begin{array}{l}707 \\ 704\end{array}\right.$

du Nord . . . . . . 718

fourchue . . . . . . 726

grisc . . . . . . 720

" de Houdan . . . . 723

hâtive d'Angerville : . $\quad 723$

" de Beauce . . . . 724

$"$ de Normandie . . 724

$"$ de Sibérie . . . T03

"d' Etampes . . . T24

7 d'Outarville . . . 724

jaune de Bourbourg . . T19

$"$ "Flandic . . . 718

Joanette . . . . . . 725

noire de Bcauce . . . . 723

" de Brie . . . . . 726

n de Champagne . . 726

$"$ de Hongrie . . . 732

de printemps des $\mathrm{C} \hat{\text { - }}$

tes du Tord . . . 725

de Russie . . . 732

de St. Lô . . . 726

des trois lunes . . 726

de Tartarie . . .735

de trois mois . . . 725

de Turquie . . . 732

d'hiver de Bretagne 726

d'Orient . . . . 732

nue grosse . . . . . .735

$n$ petite . . . . . 736
Avoine ordinaire blanche et barbue 711 patate. . . . . . 691 " jaune . . . . . 698 Picardie . . . . . . 723

pied de Mouche . . . 739

rougeâtre ou rouge . . . 722

Rousse couronnée . . . 722

strigieuse

739

\section{P.}

Backfähigkeit des Wrcizenmehles . 522

Backer-Guano . . . . . . . 30

Barley, Abyssinian black . . . 640

Alpine- . . . . . . 642

Annat- . . . . . .633

Black Winter-. . . . 617

Cape- . . . . . . . 639

Chesney - . . . . . 635

Chevalier- . . . . . 631

Common- . . . . . 630

Dunlop- . . . . . .630

Early english- . . . . 630

Fulham. . . . . . . 644

Golden- . . . . . . . 642

Golden-drop . . . . .634

$$
\text { Melon- . . . } 634
$$

Haliday- . . . . . .645

Hallet's Pedigree-Chevalier 631

Himalaya naked . . . . 619

Italian- . . . . . . 642

Kintbury- . . . . . .619

Long-eared . . . . . 636

Nepaul-naked . . . . 622

New-Beardless . . . . 632

Page's prolific . . . . .637

Peacock's- . . . . . 644

Porter- . . . . . . 636

Prima-Donna- . . . . 635

Probstier- . . . . . 623

Rough- . . . . . . .604

Scholey's warp Grown-Che-

valier . . . . . . 631

Scotch- . . . . . . . 633

Siberian- . . . . . . . 645

Webb's Kinver-Chevalier . 631

White Four-rowed Winter- 603

Bartweizen . . . . . . . . 327

Batari . . . . . . . . .911

Battledore . . . . . . . 644

Benutzung der Gerste . . . . 677

n des Hafers . . . . . 771

$"$ der Kolbenhirse . . .907

$"$ des Maises . . . . 862

" der Nohrhirse . . .934

$" \quad$ des Reises . . . . . 977

" der Rispenhirse . . . 889

" des Roggens . . . . 598

" des Spelzweizen . . . 527

$"$ des Weizens . . . 518 
Beetbau . . . . . . . . . 42

Bestockung des Roggens . . . . 570 der Ptanzen aus gebeizten Samenkörnern 465 Bewässerung des Getreides . . 75 Bewurzelung des Getreides . . . 14 Bianchetto . . . . . . . . 242 Biologische Verhältnisse d. Gerste 647

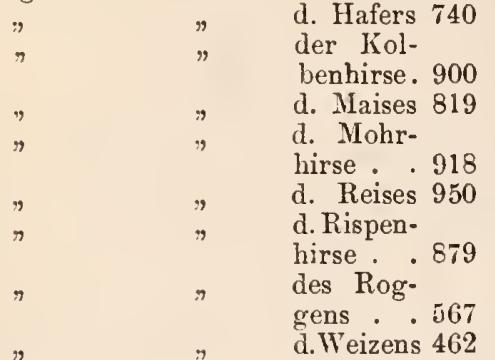

Bischnat 917

Bjugg

del país... . . 367

mitaden . . . . . . . 396

" Montjuich . . . . . . 349

" morisco . . . . . . . . 408

"Nonette de Lausanne . . . 402

, de Sesia . . . . . . . 396

" de Xérès . . . . . . . 411

Blé à balles panachées . . . . 299

„à épi carré . . . . . . . 255

\# à grain jaune de M. Bazin . 271

7 à quatre côtes . . . . . 388

, à six carrés . . . . . . . 404

"Album densum . . . . . 236

" amidonnier à courtes barbes . 448

\# $\pi$ blanc à épi velouté 451

$"$ de Tarascon . . 450

",$\quad$ élevé . . . .450

" $"$ noirâtre . . . 453

$" \quad$ " rose . . . . . 450

" $"$ roux compacte . 449

, anglais blanc . . . . . 236

" " de Bricquebec . . .315

$" \quad "$ des environs de Blois 236

$"$ " du Blaisois . . . . 236

" aubaine de Languedoc . . . 425

Aubanie blanche . . . . . 394

Aubron blanc . . . . . 394

barbu compacte . . . . 388

" Pictet . . . . . 327

Bladette de Lesparre . . . 305

blanc à duvet . . . . . 313

"à paille pleine . . . 233

"Charles . . . . . 222

$"$ de Décaze . . . . . 401

" de Flandre . . . . . 241

" de Hongrie . . . . . 236

" de Loudunais . . . . 241

" de Mareuil . . . . 236

" de la Mayenne . . . 220

" de la Sarthe . . . . 220
Blé blanc de la Vienne . . . 397

" " de Rome . . . . 242

$" \quad$ " des coteaux. . . . . 267

,,$\quad$ d'Essex . . . . . $\{212$

" , d'Oxford . . . . 213

$"$ " $"$ du Nord . . . . . . 241

" " Locar . . . . . 397

" " velouté . . . . . 313

" " Zè . . . . . . . 241

Blanchard . . . . . . 313

blanzé . . . . . . . 241

blazé de Lille . . . . . 241

bleu . . . . . . . .268

$"$ conique . . . . . .407

" d'Australie . . . . . 407

" d'Égypte . . . . . 407

" de Rivet . . . . . . 407

bleuâtre d'Égypte . . . . 406

" l'Areyron . . . 405

brun d'Heidelberg . . . . 405

buisson . . . . . . 397

carré de Chili . . . . . 265

" de Chine . . . . . 387

" de Sicile . . . . . . 382

Chevalier . . . . 236

Chicot blanc . . . . . 273

rouge de Caëu . . 307

Chiddam blanc de Mars . . 238 d'automne à épi blanc 216 à épi rouge 282

de märs à grain rouge 274

comprimé barbu . . . . 388

dacca Youssfi . . . . .411

d'Afrique noirâtre . . . . 435

d'Alger du général Galbois . 460

d'Alexandrie . . . . 417

d'Anatolie . . . . . . . 425

d'Andalousie . . . . . . 411

d'Anjou . . . . . . . 272

d'Australie blanc rond . . . 285

de Bergues . . . . . . 241

de Bohême . . . . . . 321

debout . . . . . . 268

de Bordeaux . . . . . . 305

de Caracas . . . . . . 337

de Carône . . . 273

de Caucase rouge sans barbes 306

de Cayran . . . . . $26^{7}$

de chapeau dc Toscane. . $35^{0}$

de Châtellerault . . . . . 397

de Constantine . . . . . 416

de Crepi . . . . . $26^{7}$

de Crête . . . . . . $38^{2}$

de Dantzic . . . . . $40^{2}$

de Fellenberg : . . . . . $26^{9}$

de Flandre à épi court : 388

de Géorgie . . . $41^{5}$

d'Égypte . . . . . 425

" à barbes noires . 417

de Haie . . . . . . . . 313

de Hunter . . . . . . . 214 
Blé de Jassy

. 369

de la Calédonie

417

de la Chine . . . . . . 247

de la Colombie. . . . . 337

de Lado . . . . . . . . 242

de l'Ardêche . . . . .415

de la Lozère . . . . . . 394

" " à barbes noires 398

de la Mecque . . . . . 402

de la Mongolie . . . . 397

de la Providence . . . . $\left\{\begin{array}{l}394 \\ 447\end{array}\right.$

de la Trinité . . . . . . 337

de l'île de Noé . . • . . 263

de l'Inde . . . . . . . . 247

de Manfredonia . . . . 416

de Mars à épi rouge . . 304

" " barbu de Toscane . 350

$" \quad "$ rouge de Brie . . . 273

" " "Noé . . 303

de Mogador . . . . . 416

de Nérac . . . . . . . . 267

de Noé . . . . . . . 268

de pays du Gâtinais . . . . 273

de Phalsbourg . . . . . . 382

de Polognc . . . . . . 234

" $"$ à épi velu . . . 489

$"$ " compacte . . 460

$"$ " mutique . . . 460

" , d'Astrakan . . . 458

de Poméranic . . . . $\left\{\begin{array}{l}406 \\ 267\end{array}\right.$

de Rampillon . . . . . 305

de Reiset . . . . . . 272

de Revel . . . . . . . 273

de Roussillon . . . . . 239

de saison . . . . . . . 267

de Salerne . . . . . . 115

de Saumur d'automne . . . 272

" de Mars . . . 273

de Scholey . . . . . 255

de Sibérie . . . . . . 394

de Sicile . . . . . . 425

de Silistrie . . . . . . 402

de soixante-dix jours . . .337

d'Espagne . . . . . . . 234

" noir . . . . . 435

des gouttières . . . . . 402

des Iles Barbades . . . . 337

de Taganrock . . . . . 397

" " compacte . . 388

"Talavera . . . . . 234

Tiflis . . . . $\{388$

"Toscane . . . . $\left\{\begin{array}{l}425 \\ 225\end{array}\right.$

"Touzelle anone . . . . 317

"Tunis . . . . . 417

"Varsovie . . . . . . . 234

"Victoria . . . . . . 337

"Vilmorin . . . . . . 270

"Whittingham . . . . 215
Blé de Zélande . . . . . . 241

d'hiver ordinaire . . . . . 267

d'Ismaël . . . . . . . 428

à harbes noires . . 417

d'Odessa barbu à épi court . 388

doré . . . . . . 257

d'Ostende . . . . . . 240

Drouillard . . . . . . 274

du cap . . . . . . . 327

"Caucase amélioré . . . 332

" . barbu . . . 332

"Dauphiné . . . . . 400

„Languedoc . . . . . $\left\{\begin{array}{l}306 \\ 394\end{array}\right.$

,Mesnil Saint-Firmin . . 271

dur d'Alger . . . . . . 415

de Barbarie . . . . . 409

" de Desfontaines . . . 415

" de Medeah . . . . . 417

" de Vendòme . . . . . 415

"dit Santa-Martha . . .420

" noir . . . . . . 427

durelle fastueuse . . . . . 429

égyptien . . . . . . . . 411

espagnol sans barbes . . . 242

Fern . . . . . . . 363

fin de Toulousc . . . . . 273

Gagarin . . . . . . 269

Galland . . . . . . 394

garagnon blanc . . . . 394

" de Grignon . . 398

" du Languedoc . . 398

Garreau . . . . . . 271

géant . . . . . . . 254

, d'Alger . . . . . . 394

" d'Eley . . . . . 216

" de St. Hélène . . . . 402

" de la Tréhonnais . . 272

généalogique : . . . . . 254

gouape de l'Anjou . . . . 404

gris de Russie . . . . . . 405

" "St. Land . . . . 272

". souris . . . . . . 407

grissard de Douai . . . 267

gros turquet . . . . . . 402

grossagne de Nérac . . . . 404

grossagne des Basses-Pyrénées 404

grossau blanc . . . . . 394

Haigh's prolific . . . . . 295

hérisson . . . . . . 388

$"$ rouge . . . . . 388

". sans barbe . 381

Hickling . . . . . . 256

". de Mars . . . . 270

hybride de Galland . . . 394

" "Russie . . . 427

Jacquin ". . . . . . 307

Jersey-Dantzick . . . . . 277

Joannet de Châtellérault . . 290

Kubanka . . . . . . 421

Lammas . . . . . $\left\{\begin{array}{l}290 \\ 253\end{array}\right.$ 
Blé Le Couteur-Dantzick . . . 277

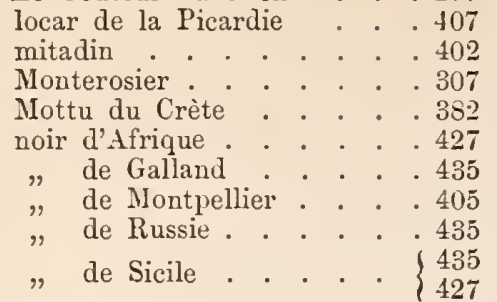
Napoléon . . . . . . . 274 Narbonne blanc . . . . . 239 Nonette de Lausanne . . . 402 ordinaire variété à épi compacte et barbu . . . . . 389 Paquêt . . . . . . 306 Perle . . . . . . 316 pétanielle blanche . . . . 400 de Nice . . . 397 d'Orient . . . . 397 noire . . . . 405 petit rouge Desvaux . . . 307 Pictet . . . . . . . 269 plat blanc . . . . . . 447 " brun ou noir . . . . 453 " d'Afrique . . . . . 453 " roux . . . . . 449 Pluie d'or . . . . . . . 294 Pomon . . . . . . .271 poulard blanc à barbes noires 398 " $"$ lisse ou carré . 397 , bleu . . . . . 407 " du Nord • • • . 394 Rab" velu d'Australie . . 406 Rafford . . . . . . . 306 Raton . . . . . . . 306 reçu de la Nouvelle-Zélande . 307 red chaff de Dantzik . . . 277 renflé à barbes blanches . . 400 Richelle blanche de Naples . 242 " $"$ de Provence 242 Roseau . . . . . . . 237 rouge anglais . . . . . . 290 d'Afrique . . . . 425 de Bretagne . . . . 306 d'Ecosse . . . . 296 de l'Aigle . . . . . 306 de Lectoure . . . . 305 de Marianopoli . . . 425 de Montpellier . . . 399 de Provence . . . . 303 de St. Laud . . . . 304 inversable . . . . 305 Prince Albert . . . . 297 " Touzard . . . . . 307 Rousselin . . . . . . 282 roux d'Armentières . . . . 267 " grand grillé . . . . 325 salonique . . . . . . 338
Blé saumon . . . . . $\left\{\begin{array}{l}271 \\ 235\end{array}\right.$

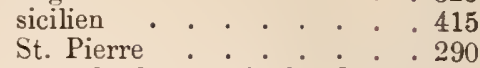

sans barbe sorti du Siaisse

d'Arles . . . . . . . . 239

Spalding . . . . . . . 291

Somon . . . . . . . . 271

souris . . . . . . . 402

Standard rouge . . . . . 298

suisse . . . . . . . . 241

Taganrock noir . . . . 427

rouge . . . . 425

Talavéra de Bellevue . . 234

tendre . . . . . . . 238

touzelle de Sardaigne . . . 398

" noir velouté . . . 405

trémois . . . . . . . 415

trimenia . . . . . . . 415

Tripet . . . . . . . . 428

Tunstall . . . . . . . 313

turc . . . . . . . . 268

velu de Talavéra . . . . 317

vert bâtard . . . . . . . 304

Victoria d'automne . . . . 272

" $"$ rose . . . . . 257

Blüte des Roggens . . . . . . . .570

Bluthirse . . . . . . . .908

Boden für Gerste . . . . . 662

$"$ "Hafer . . . . . .752

$"$ " Mais . . . . . . . $\$ 37$

" " Mohrhirse . . . . 922

" " Reis . . . . . . . 959

" " Rispenhirse . . . . . 883

" " Roggen . . . . . 580

". Weizen . . . . . 488

Bodenansprüche des Getreides . . 14 Bodenbearbeitung für Gerste . . 666

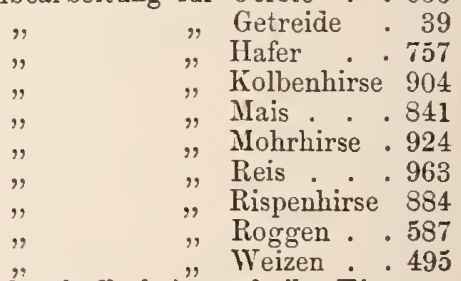

Bodenbeschaffenheit und ihr Einfluss auf die Keimung . . . . 54

Bodenbeschattung . . . . . 33

Bodenklima . . . . . . . 12

Bredkorn . . . . . . . 644

Broom-corn . . . . . . . .909

Byg, Almindeligt- . . . . . . 604

Common- . . . . . 604

Davids- . . . . . . . 619

Firtaxet- . . . . . .617

Hevede- . . . . . . . .619

Himmel- . . . . . . . .619

Sommer- . . . . . 604 


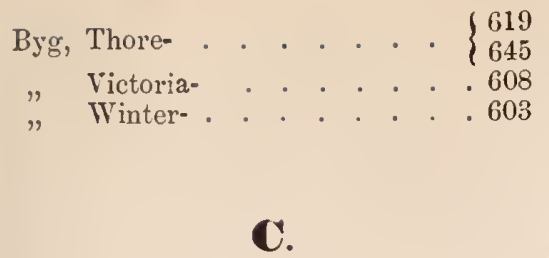

Carambasse

Cebada abanico

" comun . . . . . . 614

de 6-hileras . . . . 616

malting-barley . . . .631

Punta-Areuas . . . . 616

sin Cascara. . . . . .621

Tramasó . . . . . . 638

Centeio barazzo . . . . . . . 549

Centeno de Punta-Arenas . . . 562

Chica . . . . . . . 868

Chilisalpeter . . . . . . 27

Chinese sugar millet . . . . .911

Civada blanca . . . . . . .699

Corn, Adam's early- . . . . .781

Black Mexican-Sweet- . . 778

Blood-red . . . . . . 792

Blue Pop- . . . . . . .817

Briggs large early Sweet- .775

Brill's early Dwarf-Sugar- . 776

Brown- . . . . . . 814

Burr's Mammoth . . . . 777

Calico- . . . . . . 818

California- . . . . . . 772

Chicken- . . . . . . 791

Chinese Tree- . . . . . 802

Clinton- . . . . . . 783

Darling's early sugar . . . 776

Devcreaux . . . . . . 779

Douglass . . . . . 800

Early Canada white Flint- . 801

" eight rowed Canada- . 805

" King-Philip- . . .814

" Narraganset- . . . 778

"Tuscarora- . . . 802

Fancy Pop- . . . . 816

Forage- . . . . . . 772

Gourd-seed- • . . . . . 779

Improved King-Philip- . . 795

Kentucky white Dent- . . 779

Large eight-rowed Sweet- . 775

yellow

Flint- . 804

Ohio Dent- . . . . 784

Rhode-Island Sweet- . 775

Virginia white Flint- 799

white Pop- . . . 800

yellow eight-rowed Pop-804

" Flint-. . . 803

$"$ Gourd-seed with red cob. . 784

"Little yellow Pop- . . . . 791
Corn, Long Island- . . . . . 800

Middle sized eight-rowed yel-

low Flint-. . . . . 805

Mohaw's . . . . . . 808

New Joint Parching- . . 789

Nord-Carolina- . . . . . 779

Parching- . . . . . . . 789

Pearl- . . . . . . 819

Red Dent- . . . . . . . 786

Rhode Island-Asylum- . . 775

" " Cap- . . . 781

Rice Pop-". white Flint- . . . . . 787

Rocky Mountaius- . . . . 772

Sheep's Dent- . . . . . . 782

Snrall white Flint- . . . 799

" Pop- . . . 801

Smith early white . . . . 795

Speckled- . . . . . . . 818

Squaw- . . . . . .801

Stowel's Evergreeu Sugar- . 777

Texas- . . . . . . . 772

The golden Sioux- . . . 803

Twelve-rowed Flesh-color- . 816

Sweet- . . .777

Virginia y'ellow Dent- . . . 785

White Dent- . . . . . . 779

, King-Philip- . . . . 795

Wild- . . . . . . 772

\section{D.}

Dampfkultur . . . . . . . 43

Deina polonica . . . . . . 458

" $"$ clavata Al. . . 460

Deutscher Reis . . . . . . 643

Devaux's Speicher . . . . . . 116

Dichtigkeit des Pflanzenstandes . 56

Djogomutri . . . . . . . . 911

Drillmaschinen . . . . . . . 68

Drillsaat . . . . . . . . 67

Drillweiten . . . . . . . . . 67

Dörrapparat . . . . . . . . 94

Dörren des Getreides . . . . . 93

Dourra rouge . . . . . . .912

Dreifelderwirtschaft . . . . . 37

Dreimonatweizen . . . . . .415

Dreschkosten . . . . . . . . 111

Dreschmaschinen . . . . . 111

Dschugara . . . . . . . . .917

Düugung des Getreides . . . . 22

" für Gerste . . . . . 663

" " Hafer . . . . . 754

" " Kolbenhirse • . .904

" "Nais . . . . . 838

" " Mohrhirse . . . .923

$"$ " Reis . . . . . 960

" " Rispeulirse . . .884

" " Roggen . . . . . 582 
Düngung für Weizen

Durchschnittserträge . . . . . 123

Durrah Ahmar . . . . . . 916

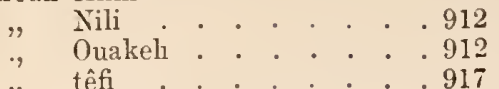

\section{E.}

Ebenbau

Einbansen des Getreides . - 104

Einbeizen des Weizens . . . . 465

Einkoln . . . . . . . . . . 455

Gemeines . . . . 456

Weichhariges rotes . . 455

Einquellen der Samenkörnel . . 54

Emmer . . . . . . . . 445

Aegyptischer . . . . 440

Breiter, roter sommer . 449

Dichter, rötlicher . . . 449

Grannen bajonnetförmig

gekrümınt . . . . . 451

Grosser, weisser, samme-

tiger . . . . . . . 451

Roter aus Serbien . . 450

" kahler, ästiger . . 453

" sammetiger . . . 4j2

", ästiger 454

, Sommer- . . . 450

Schwarzer sammetiger .453

$"$ " , ästiger 455

" Weisser"..". . . 445

aus Serbien •. 448

Engrain commun . . . . . 456

double . . . . . . 457

Entenschnabelweizen . . . . . 399

Entwässerung des Bodens . . . 76

Entwickelung der Grerste . . . 653 des Maises . . . 827

" des Weizens • • . 469

Epaule" blanche deautre barbu, blauc et velouté 442

Épeautre barbu, bleu et velouté 444

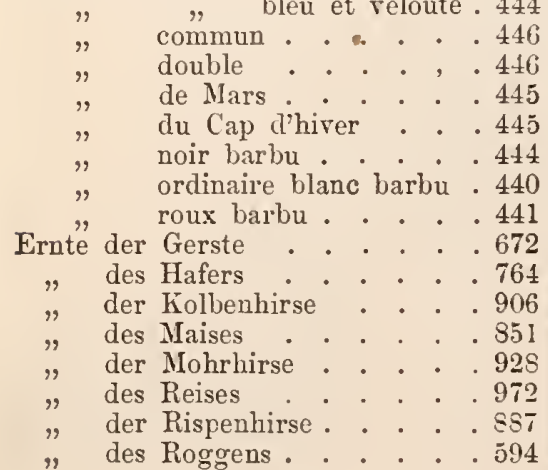

Ernte des Spelzweizens ... 511

" des Weizeus . . . . . 509

" auf Holzgeruisten . . . . 95

" mit Sense, Sichet und Sichel 88

" über die hohe Stoppel . . 95

Ernteentzug an Nährstoffen . . 24

Erntemethoden . . . . . . 88

". in Amerika . . 103

Erntezeiten . . . . . . . 87

Erträge an Körnern, Stroh u. Spreu 124

, der Gerste. . . . .674

, des Getreides . . . . 119

$"$ des Hafers . . . . . 766

" der Kiolbenhirse . . . . 906

. des Maises . . . . . 859

" der Mohrhirse . . . .931

. des Reises . . . . .973

" der Rispenhirse . . . 888

" des Roggens . . . . . 595

" des Weizens . . . . . 513

Escourgeon de Mar's . . . . 607

, noir . . . . . 617

Espelta de cebada . . . . . 644

Exportfähigkeit ron N.-Amerika u.

Russland . . . . . . . 194

\section{F.}

Fan . . . . . . . .644

Farro biauco a spigarada . . 440

Feunich, Grüuer . . . . . 900

Flachwurzler . . . . . . . . 16

Froment blanc de Brosson . . . 239

Chouroute . . . . 306 commuu, barbu, roux et glabre . . . . 368 commuu, barbu, roux et velouté . . . . 376 commun saus barbes . . 240 " " $"$ velouté blanc . 321

d'Afrique . . . . . 343

d'Alsace . . . . . . 382

de la Basse-Égypte . . 426

de Medeah •. •. . 413

de Taganrock d'Espagne 429

de Tiflis . . . . . 344

du duc de Portland : .293

dur violet . . . . . 427

grisâtre à épi velouté . 321

lisse d'Odessa . . . . 394

rouge de Burrel . . 293

, de M. Van Malders 305

tendre d'Afrique . . . 394

Fruchtfolge . . . . . . 32

$" \quad$ für Gerste . • . .

$"$ " Kolbenhirse . .904

" $"$ Mais . . . .839 
Fruehtfolge für Mohrhirse . . . 923

" $"$ Keis . . . .962

" . Rispenhirse . . . 884

" ,. Roggen . . . . 584

Weizen . . . 492

Fruehtwechselwirtschaft . . . . 38

Frühjahrsbestelluug . . . . . 44

Frumento Barberia. . . . . . 409

" bianeo . . . . . . 399

detto grosso . . . . 353

duro di Puglia . . . 411

farro . . . . . 435

fiorentino . . . . 368

grosso . . . . . 394

inazzocclio . . . . . 429

nostrano . . . . . 351

Rieti... . . . 353

'Taganrock . . . . 425

Veneto . . . . 408

\section{G.}

Gerst, Baard- . . . . . . . .644

" Speltige . . . . . . . 644

Gerste . . . . . . . 600

Adelaide- . . . . . . 639

Aegina- . . . . . . 615

Aegyptisehe aus Siout . .613

Aegyptisches Kiorn . • . 619

Altai- . . . . . .608

Apulisehe . . . . . 607

Aveiro- . . . . . .615

Bart- . . . . . . 643

Bären- . . . . . . 603

Benavente . . . . . 615

Bergstrasser . . . . . . 624

Bestehorn's verbesserte Che-

valier......631

Bigha- . . . . . . 615

Bläuliche aus Florenz . . 613

" $"$ Leonforte .613

" " Portici . . 613

"gemeine . . 614

614

CanadiseheMammuth Winter-611

Chesney- . . . . . . 635

Chevalier-. . . . . .631

Chilenische- . . . . . 612

Chinesisehe- . . . . . .612

Coïmbra- . . . . . . .615

Dalekarlien- . . . . . .610

Dinkel- . . . . . . . 643

Edel- . . . . . . .619

Englische Früh- . . . 630

Erfurter feinste . . . .625

Fächer- . . . . . 643

Florentinisehe . . . . 637

Gemeine vierzeilige Sommer- 604
Gerste, Glattgrannige zweizeilige a.

Persien . . . . . 640

Gold- . . . . . . 627

" Melone . . . . . 634

Goldtropfen . . . . . . 634

Grosse norwegisehe . . .611

" von Falster . . . 627

Hannakisehe . . . . . 628

Hellweg- . . . . . . .625

Himmels- . . . . $\left\{\begin{array}{l}619 \\ 645\end{array}\right.$

Japanische . . . . . 612

, 6-zeilige Winter 602

Jekaterinoslaw- . . . 630

Jerusalemer . . . . . $\quad \begin{aligned} & 643 \\ & 619\end{aligned}$

Imperial- . . . . . . . 643

Italienisehe . . . . . . 642

Kaiser- . . . . . . . 643

Kalina- . . . . . . 625

Karrierte . . . . . .606

Kleine Sand- . . . . . 604

Warthebruch- . . 606

Kurländisehe- . . . . . 608

Kurze sechszeilige Sommer- 601

Kurzgramnige sechszeilige a.

Japan . . . . . 600

Lange gemeine Winter- . 604

,$\quad$ seehszeilige Sommer- 602

" ", Winter- 601

L" zweizeilige . . 636

Nandschici- . . . 610

Naekte aus Charkow . .645

, Kaffee .... .645

$" \quad$ Nepaul . . . . 619

$"$ ostindisehe . . . 620

$"$ peruanische . . 619

" Reis- . . . .619

" selottische . . . 619

$"$ serbisehe . . . 645

" ungarische . . . 645

$"$ violette . . . 622

" vou Risso . . . 619

" zweizeilige . . 645

Nampto- . . . . . .619

Nepal- . . . . . . 622

Oregon- . . . . . .638

Ostindisehe . . . . . 617

Page's ergiebige . . . . 637

Perl- . . . . . .603

Persische . . . . . 638

Peters- . . . . . . 643

Pfauen- . . . . .643

Phoenix-..... . . 636

Poppelsdorfer . . . . 624

Porter- . . . . . . . 636

Prima-Donna . . . . . 635

Probsteier . . . . .623

Reading- . . . . . . \$336

Rettema- . . . . . .603 
Gerste, Riemen- . . . . . . 643

Ritter- . . . .631

Saas im Grund . . . 628

Samnio- . . . . 614

Sächsische Sand- . . . 626

Zucker- . . 626

Schlesische Zeil- . . . 605

Schottische Annat- . . .633

Schwarze abessinische . .640 " aus Ekholmen . 622

" "Persien . . 618

$" \quad$ gemeine Winter- 617 glattgrannige 4zeilige

Sommer . . 618

Winter- aus Tiflis 618

Schwärzliche .. . 640

Spiegel- . . . . . .643

Staminbaum- . . . .634

Svartlö- . . . . .611

Thor- . . . . . . 619

Tunis- . . . . .615

Turkestan- . . . . . .609

türkische . . . . . 643

Umeâ- . . . . . .610

Ungarische . . . 628

Upländische . . . . 630

Uruguay- . . . . . 639

Verästelte zweizeilige . . 646

Victoria- . . . . .608

Vierzeilige . . . . .603

" aus Irkutsk . 609

Voigtländer Oderbruch : $: 605$

Walachische . . . .619

Walper's . . . . 621

Weizen- . . . . . .609

Wucher- . . . .643

Wunder- . . . . . .621

Zea- . . . . . .607

Zeilen- . . . . . .643

Zermatt-. . . . . . 627

Zweizeilige . . . . .623

$" \quad$ australische .639

$" \quad$ jütländische .627

" glattgrannige schwarze aus Persien . . 641

Gerstenbau Italiens serbische. .529

$\begin{array}{ll}\text { Russlands } & \text { Spaniens }: \\ \text { d. Vereinigten Staaten } & 175\end{array}$

Getreidedepôt, Amerikanisches . . 116

Getreidehandel in Aegypten . . 197

\begin{tabular}{|c|c|}
\hline & Australien \\
\hline & "Belgien. \\
\hline & $"$ Bulgarien \\
\hline & "Dänemark \\
\hline & "Deutschland \\
\hline & Frankreich \\
\hline
\end{tabular}

Getreidehandel in Italien . . 201

"d. Niederlanden 201

Oesterreich . . 197

"Runänien : . 196

", Russland . . . 195

Serbien . . 196

"Skandinavien . 197

., Ungarn . . 196

und Getreideprobe 193

Getreideimport Englands . . . 197

Getreidenachlese . . . . . 103

Getreideproduktion u. Konsumtion 127

dto. in Aegypten . . . . 180

dto. "Algier . . . . 182

dto. "Australien . . . 183

dto. ", Belgien . . . 158

dto. "Britisch-Indien . . 179

dto. "Canada . . . . 178

dto. "Dänemark . . . 170

dto. "Deutschland . . 130

dto. "Frankreich : . . 138

dto. "Griechenland . . . 157

dto. "Grossbritannien . . 127

dto. "Italien . . . 148

dto. "den Niederlanden . 159 .

dto. "Oesterreich-Ungarn . 143

dto. "Portngal . . . 156

dto. "Rumänien . . . . 166

dto. "Russland . . . 161

dto. "Skandinarien . . . 167

dto. "Spanien . . . . 153

dto. " der Sclsweiz . . . 157

dto. " der Türkei . . . 167

dto. "d. Vereinigt. Staaten 171

dto. , d. Uebersichtstabellc 186

Getreidereinigungsinaschinen . . 113

Ghirka ostistaja . . . . 355

Grain elevator . . . 116

Grand millet blanc . . . . . 915

$" \quad "$ de Guinée . . . .912

" " noir . . . . .915

Grano bianco . . . . . . 242

carosella . . . . . . 242

comune . . . . . . . 351

di Losanno . . . . . 402

di Napoli . . . . . 297

di Zelanda . . . . . 241

duro di Realforte . . . 425

$"$ ex Apulia . . . 433

" Mazzocchio . . . 435

" nero . . . . . 427

"Saragolla: : : 412

Gallandt . . . . 394

gentilc bianco . . . 238

" " dei Toscani . 331

ibrido di Galland . . . 394

maiorica rossa . . . . 352

marzatico . . . . 4 415

marzuolo . . . . . 350

moro . . . . . . 396

Pilosella . . . . . . 402

Pisano . . . . . . 368 


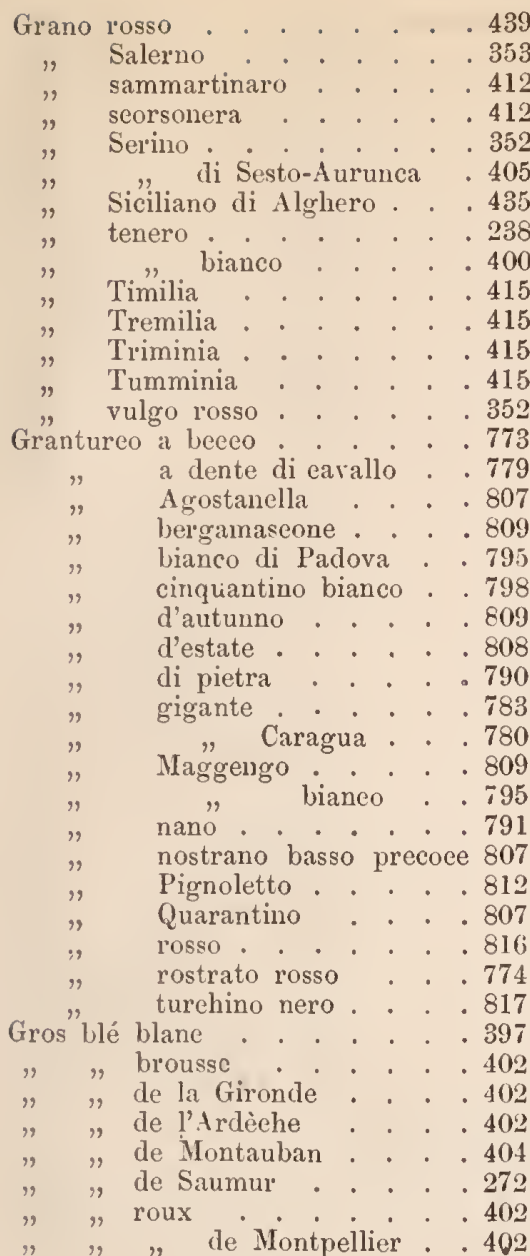

\section{H.}

Haeken der Drillsaaten . . . 78

Ilafer . . . . . . . . .681

Abrantes- . . . . . . . 23

Algier- . . . . . . 704

Amerikanischer Kartoffel- . 698

Apulischer . . . . . 729

Belgiseher Rispen- . . .687

Berg- . . . . . . . 728

Borkum- . . . . . . 685

Bourbourg-Gold- . . . . 719

Brauner norwegischer . . 724

$"$ tatariseher ge-

grannter Falinen- 735

Umeå . . . . 723
Hafer, Brauner ungegrannt.Rispen- 721

Charkow- . . . . . 701

Chinesischer Naekt- . . . 737

Doppel- . . . , . . . 713

Dreikörniger Lappländiseher 714

Ume̊ - . . 714

Druminond- . . . . 718

Iublauer Früh- . . . . 686

Eichel . . . . . . . 728

Engliseher Kartoffel- . . . 691

weisser . . 696

Fahnen- . . . . . 730

Finnländiseher . . . . . 702

Fliegenfuss- . . . . . . 739

Gabels- . . . . . . . 713

Gegrannter Dreikörniger . 713

Gold- . . .719

Gelber flandriseher . . .718

Georgiseher . . . . . 707

Gilmannsdorfer Früh- . . 686

Goldfalınen- . . . . . .731

Grauer ungegrannt. Winter- 720

" gegrannter Winter- 721

Grosser gelber . . . . 715

" nackter Thüringer .716

" Fahnen- .737

Halbwilder" . . . . . 738

Högen- . . . . . . . .699

Hoher Gold- . . . . . . 717

Hopetoun- . . . . . . . 689

Jekaterinoslaw - . . . . . 700

Irbit- . . . . . . . .701

Irkutsk- . . . . . . .702

Italienischer Fahnen- . . 734

Kamtsehatka- . . . . 704

Kartoffel-Gold- . . . . .716

Kaukasiseher . . . . 700

Kleiner naekter Falnen- . 738

Klump- . . . . . . .713

Kurz- . . . . . . . .738

Lappländischer . . . . . 700

Ligowo- . . . . . . .686

Luher- . . . . . . . 687

Mähriseher . . . . . .687

Milton- . . . . .694

Naekter . . . . . . 735

" kleiner . . . . 736

Nagpore . . . . . . 711

Nauener Frül- . . . . 684

Neuer australischer aus l'ortAdelaïde . . . . . 710

Neuer Gerst- . . . . . .705

Oderbruch- . . . . . . 681

Ossetiniseher . . . . . 717

Ostfriesischer Gold- . . 718

Peking- und Mongolei- . . 736

Petersburger . . . . . 717

l'odoliseher Gold- . . . . 717

Probsteier- . . . . 682

Raul- oder Sand- . . . 739

liheiniselier . . . . . .683 
Hafer, Roter Bruch-oder Moor- . 721

Rügen'scher' . . . . . 683

Sandy- . . . . . . 690

Sauerländer . . . . .715

Schatilowsky . . . . 701

Schlesischer Früh- . . .684

Schottischer Berlie- . . . 706

Berwick- . 691

Dun- . . .. . 722

früher Angus - 688

"Shirreff's 694

Kartoffel- . . 706

Long-Fellow- . 692

Providence- . 695

später Angus- . 688

Zwerg- . . 696

Schwarzer alter schottischer 727

Brie- . . . 726

Etampes- . . .724

gegrannter oder

Streit-Fahnen- . 731

Moldau- . . 727

schwedischer . . 727

tatarisch.Fahnen- 733

ungarischer " 732

Sehr fiüher Joanette- . . 725

Sibirischer Früh- . . . 703

Omsk- . . . 702

Sommer-Gabel- . . . . . 685

Später podolischer . . . 710

Tasmanischer . . . . 710

Tatarischer Grütz- . . .738

Tula- . . . . . . 701

Wald- . . . . . . . 728

Warthebruch- . . . . 681

Weisser australischer . .705

canadischer . . . 707

friesländischer . 682

gegrannter . . . 711

$" \quad$ gegrannter engl.

Fahnen- . . 730

neuseeländischer $\quad 711$

polnischer . . .693

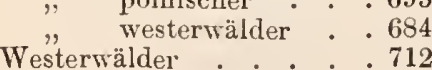

", Trauer- · 732

Umeå- . . . . . $\left\{\begin{array}{l}699 \\ 728\end{array}\right.$

Ungarischer Fahnen- .730

. " Gold- • . 716

Haferbau in Italien . . . . 152

"Oesterreich . . . 145

Russland . . . . . 164

" "Spanien . . . . . 155

" ,. d. Vercinigten Staaten 176

Hammelkorn . . . . . . 643

Handsaat . . . . . . . 65

Hartweizen . . . . . . . .409

Aidurka . . . . . 421

Altai . . . . . 423

Arnautka . . . . 422

Atalantis . . . . 423
Hartweizen Beloturka . . . . 421

Berberei . . . . 409

Bigha . . . . . . 432

blauer kahler . . . 427

Charkow . . . . . 428

Garnowka . . . . 422

Gersten- . . . . 418

Goldgelber . . . 426

Goldgelber aus Murcia 419

Grannen bajonnettförmig gekrümmt . . 430

krummzahniger . . 414

Kubanka . . . . 421

Kupjansk . . . . . 422

Murcia . . . . 424

Persien . . . $\left\{\begin{array}{l}413 \\ 424\end{array}\right.$

Rotähriger sammetiger aus Apulien . . 433

Rotähriger sammetiger aus Valencia . . 432

Roter aus dem Altai . 424 , sammetiger mit dunklen Grannen . 434

Rotblauer . . . . 425

Schmalähriger sammetiger . . . . 429

Schwarzmeer . . . 422

Sieruschka . . . . 431

Spelzartiger . . . . 411

Tschernuschka . . 431

Tunis . . . . . 417

Valencia . . $\left\{\begin{array}{l}411 \\ 419427\end{array}\right.$

von Volo. . . . 423

Weissähriger • . . 416

Xeres .1. . . . . 411

Herbstbestellung . . . . . . . 44

Himmelbyg . . . . $\quad . \quad . \quad 645$

Himmelkorn . . . . . . . . 619

Hirsebau in Oesterreich . . . 146

H" Russland . . . . 164

Hordeum distichum L. . . . . 623

dto. compositum Kcke. . 646

dto. erectum Schübl. $\quad 642$

dto. medicum Kcke. . 640

dto. nigrescens Kicke. . 640

dto. nigricans Sér. . 640

dto. nudum L. . . . 645

dto. nutans Schübl. . . 623

dto. persicum Kcke. . 641

dto. Zeocrithum L. . . 643

Hordeum hexastichum L. . . . 600

dto. brachyatherum Kcke. 600

dto. parallelum Kcke. . . 602

dto. pyramidatum Kicke. . 600

Hordeum tetrastichum Kicke. . . 603

dto. coeleste L. . . . 619

dto. coerulescens Sér. . 613

dto. limalayense Rittig. . 620

dto. leiorrhynchum Kcke. 619 
Hordeum tetrastichum nigrum Willd. 617 dto. pallidum Sér. . .603 dto. trifurcatum Schl. . 622 dto. violaceum Kcke. . . 622 dto. Walpersii Kcke. . .621 Hordeum vulgare L. . . . . 600

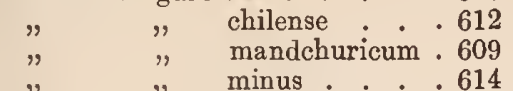
"Zeocrithum ramosum . 644 Hordi comú . . . . . . .614 " vano . . . . . . . .644 Hordiate polau y verd . . . . 622 Humusboden . . . . . . 18

Jéczmien ryzowy..... .644

Imphee, White- . . . . . .915

" Black- . . . . . .915

Imphy-Zulus . . . . . . . .912

Indian-Millet, Whitish- . . .916

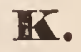

Kala jooar . 916

Kalidüngung . . . . . . . . 31

Kalkboden . . . . . . . . . 18

Kalkdïngung . . . . . . . . 31

Kao-liang . . . . . . . . 911

Keimfähigkeit der Gerste . . .649 des Saatgutes . . 46

Weizens . . 464

Keimfähigkeit, ihre Verminderung 48

Keimkraft, durch Beizen geschädigt 465

Keimatiefe beim Weizen . . . 466

Keimung der Gerste . . . .651

" des Hafers . . . . . 743

$"$ des Maises . . . . .822

, des Roggens . . . . 569

Keimungsprocess . . . . . 50

Keimzeit und Dauer derselben . 52

Kĕtan Irang . . . . . . . . 949

Itam . . . . . . . . 949

Klebergehalt des Weizens . . 486

Klima . . . . . . . . . 1

\begin{tabular}{|c|c|c|c|c|c|}
\hline & für & Gerste & & & \\
\hline 9 & $\eta$ & Hafer. & & & \\
\hline & $"$ & Kolbenhirse & & & \\
\hline & " & Mais & • & . & \\
\hline & $"$ & Mohrhirse & • & • & \\
\hline & $"$ & Reis & • & • & \\
\hline & $n$ & Rispenhirse & & . & \\
\hline & $"$ & Roggen . & . & - & \\
\hline & & Weizen & & & \\
\hline
\end{tabular}

Knochenmehl . . . . . . 30

Kochsalzdïngung . . . . . . 83

Kolbenhirse . . . . . . . 890

Braunborstige, rotkörnige . . . . 892

Californische . . . 891

Grosse gelappte italienische .. . . 890

Grosse kurzborstige . 894

Grössere kurzborstige 894

Grosse langborstige .890 ohne Borsten . 896

Grünborst. rotkörnige 892

Grosse schwarze . . 893

Kleine . . . . . 896

" dichte ohne

Borsten . . . 899

gelbe . . . 898

Kleinere kurzborstige 893

Kleine schwarze . . 899

Mohar . . . . . 896

Orangefarbene . . . 895

Konkurrenz im Getreidehandel . 201

Kontinental-Klima . . . . . . 1

Koppelwirtschaften . . . . . 37

Korn . . . . . . . . $\left\{\begin{array}{l}603 \\ 604\end{array}\right.$

„ Davids- . . . . . . .619

" Egyptik Rugeller- . . .619

Korngewicht des Weizens . . . 463

Krankheiten des Reises . . . .954

Krumepflanzen . . . . . . . 16

Kulturgrenzen des Getreides . . 4

Kupfervitriol als Beize . . . . 49

\section{$\mathbf{L}$.}

Lagergetreide . . . . . . 78

Lehmboden . . . . . . . 17

, Mergeliger . . . 17

Sandiger •. • • 17

Licht als Wachstumsbedingung $\quad 9$

\section{I.}

Mähemaschinen . . . . . 89

Mais . . . . . . . . .772

," à grain de corail . . . . 816

"Allerfrühester Szekler-Kuku-

rucz . . . . . . .813

arbre de la Chine . . . 802

" Banater.... . . . 808

" Benavente- . . . . . . .806

" blanc gros . . . . . . . 796

$"$ " de la Bresse . . . .796

" " dent de Cheval : . 779 
Mais blanc de Padoue " de Sarerdun 796 ". hâtif des Landes

796

Blauer Hühner- . . . . 793

Cannstatter- . . . . . 811

Caragua- . . . . . . 780

Chinesischer Baum- . . . 802

Cinquantino . . . . . 808

Citronengelber mit roten Spelzen

Curahua-

790

Cuzco bianco . . . . . 773

Czéndery- . . . . . . 808

d'automne à grain jaune $\quad 809$

d'Auxonne . . . . . . 809

de Cuzco blanc . . . . 773

dent de mouton . . . . . T\$2

de Pennsylvanie . . . . . 783

de pierre . . . . . . 790

de Yirginie . . . . . 799

d'Onona . . . . . . . 807

doré . . . . . . 809

Dunkelroter Hühner- . . . 792

Ellwanger . . . . . 811

épineux . . . . . . . 773

Früher canadischer weisser

Flintkorn- . . . . . . 801

Früher gelber Badener . . 810

Gallischer . . . . . . 786

géant Caragua . . . . . 780

de Chine . . . . $7=3$

" hybride de la Breille 797

Gelber geschnäbelter . . . 773

". grosser . . . . 809

" grobkörniger.Wurecker 814

". m. roten Grifielpunkten $\$ 15$

ungarischer... 810

Gestreifter aus Indiana . . 786

hâtif de Thourout . . . .807

Heinemann's September . . 812

Hühner- . . . . . . . 791

jaune à bec . . . . 773

" de Hongrie . . . . 810

" de l'Ohio . . . . $78 t$

"très-hâtif des Motteaux 813

Isabellfarbener . . . . . 814

King Philip blanc . . . 795

Kleiner spitzkörniger chinesischer

King-Philip . . . . . $81 t$

Kukurieza . . . . . . .810

Landes . . . . . . . 796

nain hâtif . . . . . . . 799

noir . . . . . . . 817

Ober-Innthaler . . . . 794

orange . . . . . . . 809

Orangegelbc1 Pferdezahn- 782

Paduaner . . . . . . 793

perle....... . 819

petit de la Chine . . . 774

Pfauen- . . . . . . 818

Pferdezahn mit roten Spelzen 782
Nais, Pinsingallo . . . . . 772

" pointu . . . . . . .773

" quarantain jaune . . . .807

Reichtragender Syrmier . . 812

Rosafarbener . . . . . 792

Roter . . . . . . .816

. Pferdezahn- . . . 786

, spitzkörniger . . . 774

" Zucker- . . . . . 778

rotschwarzer . . . . . . 817

Hühner- . . . 792

rouge à bec . . . . .774

, dent de Cheral . . . 786

Saffranfarbener Pferdezahn- 785

Schafzahnkorn- . . . . .782

Schmutzigblauer mit roten Spelzen . . . . . 818

Stein- . . . . . .790

sucré ridé . . . . . T76

Tuscarora- . . . . . . 802

Violetter mit weissen Spelzen 817

Weisser aus Abrantes . . . 798

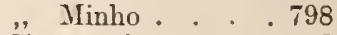

Cinquantino : : 798

Cuzco . . . 773

grobkörn. Murecker 794

Oberlānder a. Baden 793

Weissgelber . . . . . 818

Maiz amarillo de Ampurdan . .806

americano gigante . . . . 783

anaranjado . . . . . . 815

azucarado arrugado . . . 777

Blanca Redondo de Lecano . 797

Regalo de Llobregat 779

cuarenteno . . . . . . 807

curagua . . . . . . 790

alpiste . . . . 790

amarillo comun . . 790

Argentina . . . 792

blanco . . . . 788

$"$ de Aconcagua : . 791

chico lijero . . . . 782

de Argon . . . . . . . 806

diente de Caballo . . . 779

" , , amarillo . 782

Llampo.. . . . . . 783

moracho amarillo . . . . 806

$" \quad$ jaspeado . . . 818

", perla . . . . 788

morado comun . . . . . 786

multicolor . . . . . 819

picudo . . . . . . . 773

Ponte da Sòr . . . . . . 791

precoz . . . . . . T53

rosado . . . . . . . 793

tierno colorado . . . . . 787

tremés . . . . . . 807

uguye . . . . . . . . 778

Maize, Beaked . . . . . . 773

Old Forty-days . . . . 807

Poultry . . . . . . 791

Maisbau in Italien . . . . . . 151 
Maisbau in Oesterreich-Ungarn . 146 "Russland . . . . 164 , Spanien . . . . 154

Maisbier "d. Vereinigten Staaten 174

Maisfütterung . . . . . . 868

Maiskolben, Eingemachte . . 867

Maispräserven . . . . . . .867

Maissirup . . . . . . . . . 867

Maisstärke . . . . . . . . 866

Maiszucker . . . . . . . 867

Maizena . . . . . . . . . 866

Marselage grisâtre . . . . . . 306

Maschinensaat . . . . . . 65

Massakua . . . . . . . . 917

Meliga invernenga . . . . . . 809

Mergelboden . . . . . . . . 18

Mergeln . . . . . . . . . 31

Millio blanco de arneiros . . 799

" sequeiro . . . . . . 816

" temporao . . . . . . . 809

, Vianna . . . . . . . 796

Millet à graines blanches . . . 876

" Black-seeded . . . . . 875

" Common . . . . . . . 872

" de la Cafrerie . . . . . 912

" Grey-seeded . . . . . .871

" gris verdâtrc . . . . . 871

" noir. . . . . . . 875

$" \quad$ White seeded . . . . .876

Mohrhirse . . . . . . . . .909

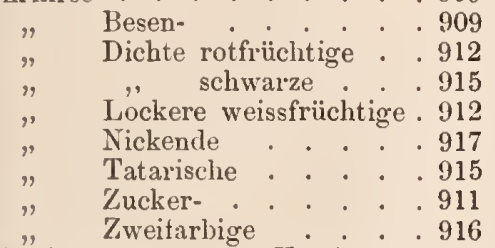

Moluhirsebau in den Vereinigten

Staaten

Moor-Damm-Kultur

Morokoshi-Kibi

.176

43 911

\section{N.}

Nachreifen des Getreides .

85

Niski Goli Jécam

645

\section{(.)}

Oat, Americain Potato-

Animal or Fly-

Australian-Cape- . . . . 690

" Barbachlow- . . . . . 695

"Berwick- . . . . . . . .691

"Black Tartarian . . . . . 733

"Blainslie-. . . . . . . 696
Oat, Bristle-pointed . . . . 739

737

712

722

late old Black-. $\quad .688$

or old Black- . $\quad 727$
white Tartarian- $\quad .730$

Cubian- . . . . . . 697

Cumberland early white .696

Drummond-. . . . . 718

Dutch. . . . . . . .682

Early Angus- . . . . . .688

Excelsior- . . . . . . .698

Flemish- . . . . . . . .718

Friesland- . . . . . . 682

Georgian- . . . . . 707

Grey Angus- . . . . . . 688

Halkerton- . . . . . . .693

Hallet's pedigree Black Tartarian- . . 733

white Canadian- . . 707

Helena-Montana . . . . . 709

Hopetoun- . . . . . . . 689

Kildrummie- . . . . . . 693

Large naked . . . . . 735

Late Angus- . . . . . 688

Long Fellow- . . . . . . 692

Meagre . . . . . . . 739

Milton- . . . . . . 694

Neffly- . . . . . . 732

New-Brunswick . . . . . 724

Norway . . . . . . . .697

Old Poland or Tom Finlay's . 693

Oregon- . . . . . . . .709

Orkney- . . . . . . . . 697

Poland- . . . . . . . .693

Potato- . . . . . . .691

Prolific Black Tartarian- . . 733

Providence- . . . . . . 695

Sandie- . . . . . . . . 690

Scotch Barley- . . . . 706

Berlie- . . . . . 706

Dwarf- . . . . . 696

Potato . . . . . 706

Shirreff's . . . . . . .694

Short . . . . . . . 738

Siberian early white. . . 703

Small naked . . . . . 736

Surprise . . . . . . 710

Three grained white . . . 713

Walla-Walla- . . . . . . 709

Waterloo- . . . . . . 697

Webb's challenge white Canadian- . . . . . . . 707

White Australian- . . . 705

" Canadian- . . . . 707

" or Common . . . .696

" Schönen or Beautiful- . 698

Oelen des Weizens . . . . . 528

Ordu golazu . . . . . . . 645

$"$ negru . . . . . . . 641 
Orge à café

à deux rangs d'Italie

à large épi . . . . . 643

bifurquée . . . . . . 622

bleue . . . . . .617

carrée de printemps . . .607

" d'hiver . . . . 603

, noire . . . . .617

céleste . . . . . .619

" de Constantine . . 645

Cheralier . . . . . 631

commune à épi noir . . . 617

bleuâtre . . . .614

crochue . . . . . . 622

d'Abyssinie . . . . . 640

d'Annat . . . . . .633

d'Amérique . . . . . 617

de David . . . . . . 619

d'Égypte . . . . . .619

d'été à quatre rangs . . . 60t

de Guimalaya . . . . 619

de Jerusalem . . . . $\left\{\begin{array}{l}619 \\ 645\end{array}\right.$

de la basse Égypte . . . .616

de la haute

de Lord Western . . . .633

de Nampto . . . . . .619

de Paon . . . . 643

643

de Russie .... . $\left\{\begin{array}{l}617 \\ 645\end{array}\right.$

- des Alpes

642

de Sibérie

$\left\{\begin{array}{l}619 \\ 645\end{array}\right.$

d'Espagne

645

de Valachie

619

du llolstein . . . . . 623

du Japon . . . . . . 643

du Nepaul . . . . . . 622

du Pérou . . . . $\left\{\begin{array}{l}619 \\ 6 \pm 5\end{array}\right.$

du Portugal . . . . .633

du Thibet . . . . . 645

éventail . . . . . . 643

faux-riz . . . . . . 643

fromentacée . . . . . 645

mondée . . . . . . 645

noire à deux rangs . . . .640

nue $\gg, \quad . \quad .640$

violette . . . . . . 622

petite nue . . . . . . 619

plate d'Italie . . . . . . 642

pyramidale . . . . . . 643

riz . . . . . . .643

sans barbes de l'Himalaya . 622

trifurquée . . . . . 622

Tictoria . . . . . . .608

Oryza sativa L. . . . . . . 938

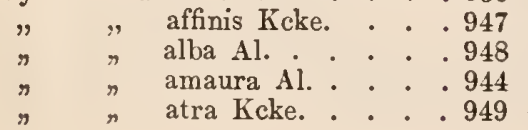

Oryza sativa atrofusca Kcke. . 946

brunnea Kcke. . .944

catalonica Kcke. . .944

cyclina Kcke. . . . 946

Desvauxii Kcke. . . 945

dubia Kcke. . . .948

Eediana Kcke. . . 949

erythroceros Kcke. . 942

glutinosa Lour . . 947

Hasskarlii Kcke, . 943

Heuzéana Kcke. . . 948

jaranica Kcke. . .939

isochroa Kicke. . . 949

italica Al. . . . 938

leucoceros Kcke. • . 943

longior Al. . . . 947

melanacra Kcke. • , 946

melanocarpa Al. . 949

melanoceros Al. . 943

microcar pa Kcke. $\quad 947$

minuta Presl. . . .946

Miqueliana Kcke. .948

paraguayensis Kcke. . 939

pyrocarpa Al. . . 945

rubra Kcke. . . .943

Savannae Kcke. . .945

striata Heuzé . . . 944

sundensis Kcke. . . 939

vulgaris Kcke. . . 940

xanthoceros Kcke. . 943

zomica Ḱcke. • . 948

Orzo a spiga lunga . . . . . 644

a ventaglio . . . . . .644

comune d'autunno . . . .603

$n$ di primavera . . 604

da caffée . . . . . . 645

dell' Himalaya . . . . .622

di America . . . . . .617

di Firenze . . . . . . .613

di Germania . . . . .641

di Leonforte . . . . . 613

di Nepaul . . . . . .622

marzuolo . . . . . . 604

maschio . . . . . . 644

mazzarella . . . . . 644

mondo . . . . . . . .619

monstarolo . . . . . . 619

nudo . . . . . . . 619

quadrato nero . . . . .618

trifurcato . . . . . .622

vernino . . . . . . 603

Orzola . . . . . . . . 614

\section{P.}

Paddy Ketiran . . . . . .947

\begin{tabular}{|c|c|c|c|c|c|c|}
\hline & Santong & & • & & & \\
\hline ", & Sisirnaga . & . & . & - & - & \\
\hline " & Sumbing . & • & . & - & . & \\
\hline & undallong & . & . & . & . & \\
\hline
\end{tabular}


Pamelle nue

Panicum italicum L dto. atrum Kcke. . . . . 899 dto. aurantiacum Kcke. .895 dto. brevisetum Kcke. . . 893 dto. $\rightarrow$ subv. insigne . . 894 dto., subv. maximum . . 894

dto. californicum Kcke. . 891

dto. erythrospermum Kcke. 892

dto. gigas Kcke. . . . . 896

dto. lobatum Kcke. . . 890

dto. longisetum Döll. . 890

dto. mite Al.. . . . . . 898

dto. Metzorii Koke. . 896

dto. nigrum Keke. . . .893

dto. rubrum . . . . 892

Panicum miliaceum L. . . . .871

dto. aereum Kcke. . . 875

dto. album Al. . . . 876

dto. atrum Keke . . .878

dto. aureum Kcke. . . 876

dto. badium Kcke. . . 874

dto. candidum Kcke. . .871

dto. cinereum Al. . . .871

dto. coccineum Kcke. . . 873

dto. dacicum lícke. . . .879

dto. flavum Keke. . . . 872

dto. griseum Kcke. . . .876

dto. laetum Kcke. • . .873

dto. luteum Kcke. . . .877

dto. nigrum Al . . . .875

dto. sanguineum Al. . .877

dto. subsanguineum Kcke. 878

Panicum sanguinale L. . . . 908

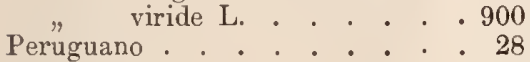

Pétanielle de Lavaur . . . . 404 noire de Nice. . . 396

rousse veloutée . . . 402

Pflege der Gerste . . . . . 671

des Getreides . . . . 75

des Hafers . . . . . . 763

der Kolbenhirse . . . .904

des Maises . . . . . 849

der Mohrhirse . . . . 927

des Reises . . . . . .970

der Rispenhirse . . . 887

des Roggens . . . . . 593

der Sommersaat . . . 77

des Weizens . . . . 506

der Wintersaat . . . . 77

Pilzkrankheiten der Gerste . . .658

des Hafers : . 749

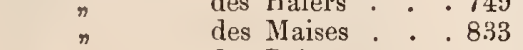

$n$ des Reises . . .954
des Roggens : .576

Plumagekorn des Weizens . . . 481

Poulage rouge du Mont d'Or . 402

Poulard Aubaine blanche
Poulard barbu de Russie . . . 397

blanc à barbes caduques 394 comprimé . . . 397 d'Australie . . 394 delaSeine-Inférieure 397 de Montauban . . 400 de Touraine . 397 du Blaisois . . 397 sans barbes . . 394 velu du Gâtinais . 401 velu de Tourainc . 401

brun de la Vienne ...405 carré velu ......402 d'Auvergne . . . . . . 399 à épi long . . 402 de Grenoble . . . . 399 des Hautes-Alpes . . . 394 doré de Bourgeois . . . 399 doré de Russie . . . . 394 géant à épi blanc . . . 394 , de Lille . . . . 394 du Milanais. . . 402 gros rouge . . . . . . 399 prolific cone . . . . 401 rouge bleu . . . . . . 399 , lisse de Beauce . . 399 de la Limagne . 399

St. Laud. . . . . . . . 394 touzelle des Alpes. . . 394 velu de la Beauce. . . 402 " Taganrock. . 401 Preisbestimmung des Getreides . . 187 Preise des Getreides in Preussen $u$.

England

Preise des Weizens . . . . . 191

Pulque....... . . 868

Putncy. . . . . . . . . 644

Pyros Trimenaios . . . . . . 415

\section{Q.}

Qualität des Getreides . . . . 124

Quellungswasser....... . 51

\section{IR.}

Red Jmphee . . . . . . . . . 913

Reifezeit des Getreides . . . . 83

Reinigung $u$. Sortieren d. Getreides 112

Reis Carolina . . . . . . 940 mit langem Korn . .940 m. schwarzen Grannen 943

Gemeiner . . . . . 9940

Gestreifter von Mantua . . 944

Gold- . . . . . . . 942

Kaiser . . . . . . . 945

Kleb- . . . . . . 947 
Reis Novara-

940 Yu-mi

Weissbärtiger . . . . . 940

Rice Black bearded . . . . .943

Common . . . . . .941

Common white . . . . 940

Gold-seed . . . . . . 942

Long grain Carolina . . . 940

Savannah- . . . . . . .945

White bearded . . . . . 940

Riso americano con areste nere $: 943$

Barbarossa . . . . . 946

Bertone o mellone . . . .938

biancone . . . . . 940

Catalano . . . . . . 944

del Paraguay . . . . . . 939

di Giava . . . . . . .939

di Mantova . . . . . 944

d'Oro . . . . . . .942

Francone . . . . . 941

giapponese . . . . . .947

Marozzi . . . . . . . 944

nostrano . . . . . . 941

Novarese . . . . . 940

Ostiglio . . . . . . . 942

, Ostiglione . . . . . . 940

Spagnola . . . . . . . 944

Rispenhirse . . . . . . .871

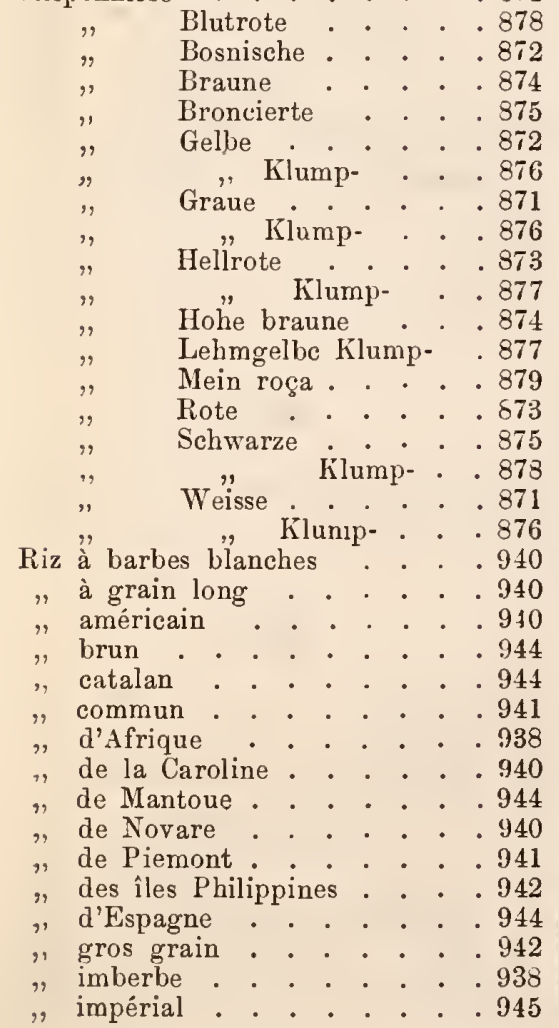

Riz noirâtre de Chine . . . . 944

,. odorifère . . . . . . . .940

" d'Allemagne . . . . . 643

Roggen . . . . . . . . 530

Abessinischer . . . . 562

Alands. . . . . . 555

Alpen- . . . . . . . 546

Altai- . . . . . . 562

ästiger aus der Türkei . 566

Astrachan'scher . . . . 554

Aulock'scher . . . . . 555

Bestehorn's Riesen- . . . 535

Böhmisch. Gebirgs-Stauden- 510

brauner aus Erzerum . . 565

Campiner- . . . . . 540

Canada- . . . . . .564

Champagner . . . . . 545

Correns-Stauden- . . . . 536

- Dunkelbrauner a. Erzerum 565

Eis- . . . . . . , 558

Eldenaer Bastard- . . . 536

Erzerum- . . . . .551

Erora- . . . . . 548

Finnländischer Nyland . 556

" Wasa . . 556

Fuchsiger aus Erzerum . 564

Garde du corps- . . . . 534

Gewöhnl.böhmisch. Winter- 541

Sommer- . . . . . 538

Giftkorn . . . . .538

Göttinger . . . . . 536

Graf Walderdorff's regene-

rierter. . . . . .531

Grosser russischer . . . 555

Hellweg . . . . . . 532

Hessischer . . . . .534

Jekaterinoslaw . . . 557

Jerusalemer . . . . 554

Johannis- . . . . . . 558

Irkutsk- $\therefore .561$

Italienischer . . . . . .550

Klafterbrunner . . . .531

Ḱlebkorn . . . . . . 558

Kolossal- . . . . . . 555

Lintelermarscher . . . 534

Livinenthaler . . . . . 544

Livländischer . . . . 561

Macugnaga . . . . . 543

Märkischer Stauden- . . 535

Mehrblütiger von Martiny 530

Minho . . . . . 548

Montagner regenerierter . 546

Norwegischer . . . . 553

Ostindischer . . . . . 564

Palermo. . . . . .550

Pennsylvanischer . . 563

Petersburger . . . . 555

Pirnaer . . . . . . 535

Podolischer Stauden- . . 554

Probsteier . . . . . . 532

Rheinischer . . . . 533

Römischer . . . . 549 
Roggen, Riesenstauden- . . $\{545$

Rumänischcr . . 542

Russischer . . . .558

russisches Schneekorn . 561

Saas. . . . . 544

Sächsisch.Sommer-Stauden-531

Saksonka . . . . . 557

Schilf- . . . . . 545

Schnee- . . . . . 552

Schwedischer- . . $\left\{\begin{array}{l}552 \\ 551\end{array}\right.$

" Sand- . . 552

Serbischer . . . .542

Spanischer Doppel- . . 547

Türkischer . . . . 550

Ukrainer . . . . .557

Umeã- . . . . . 551

Ungarischer . . . .541

Vielstengliger . . . 545

Waldkorn . . . . 558

Wallburger . . . .534

Westermarscher . . .534

Westerwälder . . . .531

Wollny- . . . . . 537

Zeeländer . . . . 539

Zermatt- . . . . . . 543

Roggenbau in Italien . . . . 152

in Oesterreich-Ungarn 145

in Russland . . 162

in Spanien . . . 155

in d. Vereinigt. Staaten $\mathbf{1 7 5}$

Russgerste . . . . . . . .617

Rye, Canada- . . . . . . . 564

"Giant- . . . . . . . . 544

"Nidsummer- . . . . . 558

"Northern- . . . . .563

"St. John's day- . . . . . 558

", Tyrolese- .. . . . . 544

"Western . . . . . . 563

\section{S.}

Saatgut, seine Beschaffenheit

der Gerste . . . . 647

des Hafer's . . . . 740

des Maises . . . .819

des Roggens . . . . . 567

des Weizens . . . .462

Saatmethoden . . . . . 65

Saatquantum, Bestimmung desselb. $56^{\circ}$

Saattabelle . . . . . . . 64

Saggina bianca . . . . 915

a collo torto . . .917

da granate o da scope . 909

nera. . . . . .915

Saisette de Tarascon . . . $\{239$

Salzlösungen, ihr Einfluss auf die

Keimung

53
Samenwechsel . . . . . 68

Sandboden . . . . . . 17

Lehmiger- . . . 18

Sandomirska Pszenica . . . . . 283

Saragolla di Calabria . . . 411

Sauerstoff, Einfluss a. d. Keimung 51

Scandella . . . . . 645

Schlegel-Dinkel . . . . . 437

Schröpfen der Saaten . . . . 80

Schwarzcrde . . . . . 21

Schwindung des Getreides bei der Aufbewahrung . . . . . 118

Sceklima . . . . . . . 1

Segól aus Vich . . . . . .548

Segola S. Giovanni . . . . 558

Seigle à gros grains . . . . . 549

buisson . . . . 558

Champagner-Hybride $\quad .545$

d'Archangel . . . . . . 558

de la Saint-Jean . . . 558

de Rome . . . . 549

d'Espagne double . . . 547

des Alpes ou de Montagne. 546

des forêts . . . . . 558

d'été de Saxe . . . . . 531

d'hiver de Saxe . . . 547

du Nord.... . . 558

géant ou tyrolien . . . 544

grand de Russie . . . 555

multicaule . . . . .558

roseau . . . . 545

Siaisse de Béziers

blanche . . . . 239

Sigam guanhe tengai . . . . 644

Silo . . . . . . . 114

Sinclair's Getreideturm . . . 116

Sirak . . . . . . 909

Skyffelkorn . . . . . . .644

Sorgho à balais . . . . . . $\$ 09$

à épi blanc : . . 917

bicoloré ... .916

d'Afrique . . . . . 917

de Changallar . . . .917

imphy . . . . . 912

noir d'Afrique . . . 915

penché . . . . . 917

sucré de la Chine . . .911

zuccherino . . . . .911

Sorghum sugar-cane . . . .911

Spalda . . . . . . 644

Specifisches Gewicht des Getreides 120

Spelz . . . . . . . . 436

Blauer sammetiger Grannen- 444

Winter-Kolben- . . 439

Dunkelroter Winter-Grannen- 442

Fuchs- . . . . . . 441

Grannen- . . . . 440

Roter Sommer-Kolben- . . 439

Winter-Kolben . . 439
" kahlerWinter-Grannen- 441

" sammetiger WinterGrannen- 
Spelz, rötlicher sammetiger Sommer -

Grannen- . . . . . . 443 rötlicher sammetiger Winter-

Grannen-

Russischer . . . . . . 448

Schwarzer Grannen- . . . 444

Winter-aus Afrika 453

Weisser sammetiger Winter-

Grannen- . . . 442

Sommer-Grannen . . 441

" $\quad$ Sommer-Grannen $\cdot .441$

Winter-Grannen- . . 440

Kolben- . 436

Spelzengewicht des Getreides . . 119

Spread ... . . . . . 644

Stallmistdüngung . . . . . 25

Staudenroggen . . . . . 572

Steppenklima . . . . . . . . 2

Stoppel- und Wurzelrückstände . 36

Superphosphat . . . . . 30

Süsskorngemüse . . . . . 866

\section{T.}

Taganrog-Bartweizen . . . 422

Tarwe, Arnhem . . . . 375

Dikkop . . . . . . 315

Haarlemermeer . . . 275

Roode Kaalarige Tiel. . . 307

Roozendaal... 275

" ruwarige Tiel. .339

Westland . . . 358

Witte Wilhelmina-Polder . 315

Zeeuwsch witte ....241

Thonboden ........ 17

Tieflage der Samenkörner . . . 55

Tiefkultur ....... . 41

Tierische Feinde der Gerste . . 658

" " des Hafers . . 750

" " des Maises . . . 833

" " des Reises . . . 957

$"$ des Roggens . . 578

Tortillas ......... des Weizens . . 866

Tosetto rosso . . . . . . 368

Touzelle blanche .... . . 317

" $"$ sans barbe . . 240

" rouge, barbue . . . . 368

" sans barbe . . 303

Transportkosten $u$. Transportfähig-

keit, des Getreides . . . . 189

Trigo Álaga . . . . . . . . 411

Alonso ...... 430

amarello de St. Martha . .420

Americano . . . . 240

arisnegro . . . $\left\{\begin{array}{l}399 \\ 416\end{array}\right.$

aza de corvo..... . 427
Trigo azulejo ...... 4416

azul o azuleuco . . . 4 416

berberisco ..... . 409

blanco . . . . . . 281

blanquillo ..... $\left\{\begin{array}{l}380 \\ 410\end{array}\right.$

canalvo o patta ....445

candeal amarillo largo . . 420

chamorrodeHungria 236

de barba negra. .435

de la Mancha . . 412

del Carmen . . . 435

desraspado deN urcia 235

negro . . . . 409

redondo . . . 420

tremesino marzal de

Raspa . . . . 348

velloso de Talavera 317

candealense . . . . . 331

candial . . . . . . 435

Carbillo . . . . . . 386

Cartagena rojo aristado . . 366

cerrado de Tunstall . . . . 313

Chamorro de Saumur . . . 272

chapado velloso . . . . 434

chinense . . . . . . . 387

claro de Raspa negra . . 433

cortesano . . . . . 431

de Australia . . . . . 233

de Bergues . . . . . . 241

de California . . . . 330

de Crepi ...... . 267

de Egipto . . . . . 393

de Jerez . . . . . . . 411

de la China . . . . 387

de la India . . . . . 387

de la Viuda . . . . . 386

de Nueva Holanda . . . 233

de Talavera ... . 234

de Tesoro . . . . . . 233

dorado de Murcia . . . 419

durazio rijo ......411

escaña menor .....4457

fanfarrón blanco . . . . 429

velloso raspinegro 432

n rubion . . 432

Fuerte de Sevilla... . 426

jejár de Valencia . . . 348

Ingles . . . . . . . 317

la Rioja . . . . . . 411

linaza . . . . . . 384

Macolo . . . . . . 426

Marianopoli . . . . 425

marzal da Covilhã . . . 350

mayor . . • . . . 411

Mesclilla de Serilla . . 410

mocho . . . . . . 380

Moruno ........ 409

mourisco . . . . . . 409

nero o rubion . . . 426

Noé pelado. . . . . 268 
Trigo Nomorado de Carvalho . . 420 obispado .......416 piche ....... 367 Pisana ....... 396 pulardo blanco Espanõl . . 400 recio de pastas . . . 4420 redondillo rubio recio . . 399 " " velloso blanco .400 ribeiro . . . . . . 349 ricello ...... . 242 rico de Napoles . . . 242 rojal ........ 411 rojo de Escocia . . . . 296 rubio ......4408 salmerone .....4430 salmonado ......235 Sennaar . . . . . 389 tierno . . . . . 238 Tremes .......415 Tremesino .... 415 trobat de Valencia . . 419 Victoria de Otoño . . . 272 white Lammas . . . . 317 Xexa . . . . . 368 Trimenon . . . . . .415

Triticum Cienfuegos Lag. . . . 449

Triticum compactum Host. . . . 379 dito albiceps Kcke. . . . 392 dito clavatum Al. . . 385 dito creticum Al. . . . 381 dito echinodes Kcke. . . 392 dito erinaceum Kcke . . 391 dito Fetisowii . . . . 391 dito Humboldtii Kcke. . . 379 dito hystrix Kcke. . . . 390 dito icterinum Al. . . . 387 dito linaza Kcke. . . . 384 dito sericeum Al. . . . 392 dito splendens Al. . . . 385 dito Wernerianum Kcke. . 381 dito Wittmackianum Kcke. 384 Triticum dicoccum Schr. . . . 445 dito atratum Al. . . 453 dito Bauhini Al. . . . 452 dito brunneum Al. . . 450 dito cladura Al. . . . 453 dito farrum Bayle . . .445 dito flexuosum Kcke. . . 451 dito Krausei Kcke. . . 454 dito majus Kcke. . . .451 dito melanura $\mathrm{Al}$. . . 455 dito pycnura $\mathrm{Al}$. . . 449 dito semicanum Krause .452 dito tricoccum Schübl. . . 448

Triticum durum Desf. . . . . 409 dito affine Kcke. . . 414 dito africanum Kcke. . . 432 dito alexandrinum Kcke. . 426 dito apulicum Kcke. . . 433 dito campylodon Kcke. . .414 dito circumflexum Kcke. . 430
Triticum durum erythromelan Kcke. 425 dito fastuosum Lag. . . 429 dito hordeiforme Host . . 418 dito italicum Al. . . . 432 dito leucomelan Al. . . 416 dito leucura $\Lambda \mathrm{l} . . .409$ dito meianocus h. Dresd. . 418 dito melanopus Al. . . 430 dito murciense Kcke. . . 424 dito niloticum Ḱcke. . . 434 dito obscurum Kicke. . .427 dito provinciale Al. . . 426 dito Reichenbachii Kcke. . 418 dito tagarocense Desv. . . 435 dito Valenciae Ḱcke. . 427 Triticum Koeleri . . . . . 313 Triticum monococcum L. . . 455 dito flavescens Keke. . . 457 dito Hornemanni Clem. . 455 dito vulgare lícke. . . .456 Triticum polonicum L. . . . 458 dito attenuatum Kiske. . 461 dito chrysospermum Kéke. 460 dito compactum Krause . 460 dito levissimum Haller . 458 dito rufescens Kicke. . . 458 dito villosum Desv. . . . 459

Triticum pruinosum . . . . 444

Trit” sordidulum . . . . . 425

Triticum Spelta L. . • • 436

dito albovelutinum licke. . 442
dito album Al.

dito Alefeldii Kcke. . . 439

dito Arduinii Al. . . 440

dito coeruleum Al. . . 444

dito rubrovelutinum lícke. 443

dito rufum Al. . . . 438

dito vulpinum Al. . . . 441

Triticum subfragile. . . . 302

Triticum tumonia $\quad \cdot$ turgidum $^{4} \cdot 415$

dito buccale Al. . . 401

dito dinura Al. . . . 402

dito Dreischianum Kítke. . 399

dito gentile Al. . . . . 396

dito jodura $\mathrm{Al}$. . . . 405

dito megalopolitanum licke. 400

dito melanatherum Kicke. . 396

dito mirabile Kicke. . . 409

dito nigrobarbatum Desv. 398

dito pseudo-cervinum lícke. 408

dito rubroatrum Kcke. . . 405

dito Salomonis Kicke. . . 401

dito speciosum Al. . . 399

Triticum vulgare L. . . . 209 dito albidum Al. . . . 209 dito alborubrum Kcke. . 277 dito barbarossa Al. . . 375 dito caesium Al. . . 372 dito coeruleo-velutinumkcke.378 dito cyanothrix Kckc. . . 326 dito Delfii Iŕcke. . . . . 322 
Triticum vulgare erythroleuconKcke. 357

dito erythrospermum Kcke. 337

dito ferrugineum Al. . . 358

dito fuliginosum Al. . . 378

dito graecum Kícke. . . 327

dito leucospermum Ḱcke . 313

dito lutescens Al. . . . 248

dito meridionale Kicke. . 373

dito miltura Al. . . . 286

dito pyrothrix Al. . . 324

dito subvelutinum Kcke. .375

dito turcicum Kcke. . . 374

dito velutinum $\mathrm{Al}$. . . 374

dito villosum Al. . . . . 319

Trockengewichts-Bestimmung des Maises

Trocknen des Getreides in mittelfeuchten Klimaten . . . . . 97

dito auf Harfen . . . . 95

dito in Hocken . . . . 98

dito in prismatischen Mandeln . . . . 97

dito in Puppen . . . . 99

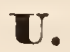

Unkraut in Gerste . . . . .657

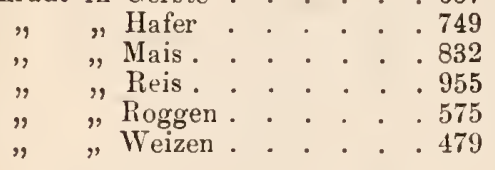

\section{v.}

Vallery's grenier molile . . . . 116

Veesen des Spelzweizen . . . . 464

Verdunstungsgrösse der Getreidepflanzen . . . . . . 10

Yoegeles - Dinkel . . . . . 438

Volumengewicht des Getreides . . 121

\section{W.}

Walzen der Saaten

Wärme, Wichtigkeit derselben bei der Keimung.

Wärmemengen der Pflanzen :

Wärmeverteilung •. · . ·

Wasser. Wert desselben für das Wachstum

Wasserverbrauch des Maises $\bigcirc 825$

$$
\text { " } \quad \text { " Koggens. . Weizens. . } 473
$$

Walzenarbeit . . . . . . 43

Weizen . . . . . . . 209

Aegyptischel" . . $\{246$

Ahr. . . . . . . 359

Alands-Insel- . . . . 371

Amerikanischer Prairie- . 266

", Sand- . 228

Andros- . . . . . . 369

Angermünder. . . . . 252

Atalanti. . . . . . . 334

Australischer gelber . . 406

Wechsel- . 285

Bart- aus England. . 362

Bentel-Jinthel . . . . 383

Berberei- . . . . . 245

Berdjansk- . . . . . 310

Bernsteinfarbener Winter. 261

Bigha- . . . . . . 346

Bismarck- . . . . . 313

Blauähriger Sommer-Bart- 372

Blauer englischer . . . 407

, sammetiger Bart- . 378

, , " englischer 405

" , Binkel- . 385

Blumen- . . . . . 292

Bogenser . . . . . 255

Böhm. sammet. Kolben. . 321

Brasilianischer . . . 277

Brauner Graunen- . . . 359

Braunroter franz. Land- . 303

Braunsamig. Sommer-Igel- 389

Braunschweiger . . . 289

Bundhorster Nisch- . . 251

Calcutta weisser Bart- . 336

Califoruischer . . . . . 380

Canadischer . . . . 279

Catanien . . . . . . 401

Chinesischer Igel- . . . 387

Clever Hochland . . . 358

Cretischer Binkel . . . 382

Delhi , . . . 336

Deutscher Grannen- . . 360

Dichter polnischer . . . 460

Dickähriger langgranniger polnischer . . . . 461

Dickkopf- . . . . . 315

Dreimonat- . . . . 348

Dünnähriger Bart- . . 414

Eifel- . . . . . . 252

Esula Binkel- . . . . 382

Fellenberg- . . . . . 269

Fern- oder April- . . . 363

Flandrischer . . . . 241

Frankensteiner . . . . 209

Früher gelber Noë'scher . 268

Fuchs- . . . . . . 359

Fülek- . . . . . 341

Galizischer Sommer- . . 275

Galland- . . . . . 394

Gelbähriger Binkel- . . 379

, aus Salerno. 353 
Weizen, Gelbảhriger von Kupjansk 355 Gelber kahler Winter-Igel- 389 Mecklenburger . . 319 Ghïka- Sommer-Igel- . 385 Gilmannsdorfer . . . 212

Glocken- . . . . . . 402

Goldblumen-Weizen . . 292

Goldene Aue . . . . . 319

Goldgelber Winter-Bart-. 338

Goldradt Sommer- . . 252

Graf Walderdorff's . . . 361

Graublauer Kolben- . . . 326 sammet. Bart- 378 aus Wjernoje 378

Griechischer a us Messenien 354 Petali . . . . . . 354

Haffkani- . . . . . 346

Haigh's ergiebiger . . 295

Halberstädter. . . . . 289

Hallet's genealogischer . 254 Nusery 291 Stammbaum . . 254

Hartsamiger sicilianischer Binkel-.... . 382

ITasselburger . . . . 250

Hecken- . . . . . 313

Helena- . . . . 402

Hickling's ergiebiger . . 256 Sommer- . . 270

Hunderttägiger . . . . 362

Jarica - . . . . . 345

Igel-. . . . . 385

Johannis- . . . . 361

Irkutsk- . . . . . . 371

Juldus- . . . . . 335

Juli-. . . . . . 250

Kaiser- . . . 248

Kíarystos . . . . 373333

Kastamuni-. . . . 345

Kaukasus- . . . . . 311

Kaukasischer Bart- . . 332

Keulen Binkel- ... . 385

Kis-T́r . . . . . 341

Kostroma . . . . 243

Krasnaja ostistaja. . . 370

Kuban- . .....4 421

Kíujavischer . . . . 210

Kulmer . . . . 211

Kupjansk-Igel- . . . . . 390

Kurzähriger deutscher. . 288 sanmet.Bart- 375

Lachsfarbener .... 235

Langähriger oder kahler 360 Langgranniger SommerIgel- . . . . . 390 Langsdorff . . . . . . . 338

Lappländischer . . . 312

Livorno . . . . . . 331

Manchester. . . . 319

Man-zi ..... . 247
Weizen, Marokkanischer. . . 402

März Chiddam . . . 238

Missolunghi . . . . 243

Mokry - . . . . . 340

Mount-Barker . . . 226

Nepal- . . . . . 356

Neuer Bastard . . . . 304 sehr eltragreicher

Igel- . . . . 387

Neu-Schottland . . . 266

Nichtlagernder roter

Wechsel- . . . . 305

Nordungarischer . . . 341

Normandie . . . . 398

Ostindischer Igel-. . . 390

Palermo Igel-. . . . . . 393

Pedigree-. . . . . 254

Pererodka . . . . 310

Perl- . . . 316

Persischer weisser Bart-. 3:35

Polnischer . . . . . 458

Preis von Oxford. . . 213

Prinz Albert. . . . . 297

Rheinischer Kling. . . 249

Richmond's Preis- . . . 328

, Riesen-. . 320

Ringelblumen- . . . 292

Roggen-... . . . 325

Rotähriger Probsteier . 287 weisser aus

Ostindien . 358

aus Persien . 358

„Turkestan 357

Kolben- aus

Ostindien . . 285

Roter August- . . . . . 290

Bart- aus Cartagena 366

" "Ostindien 37:2

" "Wjernoje 370

" "Umeå . . 371

" vom Altai. . 371

deutscher .. 287

aus Charkow. . 309

" Ostindien. . . 313

" dem Vispthal. 308

Goldtropfen . . 294

Igel- aus Wjernoje 391

kahler Wunder- . 408

Mai-. . . . 300

Missolunghi . . 308

sammetiger. . . 404

dito "Bart- aus Juldus. . . 377

dito " " Kastamuni. 377

dito englischer Bart- . . . 404

dito Kolben-. . . . . 324

dito Winter-Igel-. . . . 392

dito Wunder- . . . 409

Roter schlesischer Gebirgs- 288

" schottischer. . . 296

" schwachsammetiger

Bart- . . . . 375

" vom Altai . . . 311 
Weizen, Roter von Jekaterinoslaw 309 " " " Kupjansk . . 310 $" \quad$ " , Noё . . . 303 " " " St. Laud. . . 304 9?

"Wechsel- a. Böhmen 289 Winter-Taganrog. . 363 " " Talavera . . 296 Rotstroh- oder Dessauer- 286 Rumänischer. . . . $\left\{\begin{array}{l}276 \\ 311\end{array}\right.$ Russischer . . . . . 405 Sächsischer aus den deutschen Kolonien Russlands 355 Salmons- . . . . . 235

Sammetiger Essex- . . 315 roter polnischer 460 Talavera. . . 317 weiss. polnischer 459

Sand-" weiss. polnischer 459 " aus Münster . . . 362 Sandomir . . . . 283 Schilf- . . . . . . 237 Schlesischer Gebirgs- . . 211 Schmalähriger langgranniger roter polnischer. 458

Schönermark's . . . 212

Schottischer . . . 402 rauher . . 406

Schwarzblauer dickähriger sammetiger Bart- . . 406

Serbischer . . . . 312 " weiss begrannter 334

Smogger...... 245

Sommer-Blumen- . . 338

Sonora . . . . . 232

Svartlo̊ . . . . 322

Tasmanien . . . . 247

Theiss- . . . . . 341

Toskana-. . . . 350

Toskanisch. weisser Kolben 225

Tunesischer . . . 403

Turkestanischer aus Wjernoje ...... 334

Turkestanisch. rotähriger 374

Türkischer . . . . . 402

Ungarischer . . . 3 340

Urtoba- . . . . . 244

Valencia-. . . . 349

Victoria- . . . . $\left\{\begin{array}{l}272 \\ 337\end{array}\right.$

Walla-Walla . . . . 379

Wallachischer ... 343

Weisser Kolben-aus Murcia 235

Weissähriger Goldtropfen 257

Weissähriger Probsteier . 248 dito roter aus Ostindien . 357 dito " " Turkestan . 356 dito " Binkel- aus Sicilien . . . . 381 dito " Kolben- aus Ostindien . . . . 277
Weizen, Weissähriger roter Kolben. vom Altai 276

dito rotsamiger Taganrog . 397 dito sammetiger Binkel- 384 dito $"$ mit rotem Korn . . 392

dito " Igel mit weisslichem Korn . . 392 dito vom Altai. . . . . 355 Weisser aus Belgien . 241 " " Neuseeland . 318 Ostindien. . 246 Essex- . . . . 212 holländischer mit gelbem Korn . . 321 Mallorca . . . 380

" Nammuth - Som. mer-. . . . 280 polnischer . . 458 reichtragender Neapolitaner . . 242 " sammetiger Bart- 374 Weissspelziger Winter- . 250 Westerwälder . . . . 359 Wjernoje-Igel- . . . . . 391

Wispel- . . . . . 402

Zborower . . . . . 339

Zeeländer ..... 241

Zwätzener Sommer-. . . 251

Weizenbau in Italien . . . . 150 "Spanien. . . . 153

" "Russland ..... 163

" " den Ver. Staaten : 172

Weizenkorn, seine Qualität . . 521 Weizenmehl " $"$. . 519 Werbungsmethoden, künstliche . 106 Wheat, Allerton. . . . . . . . 261

Allias . . . . . . . 221

Amber-Straw . . . . 364 "Winter- . . . 261

Archer's prolific . . . 218

Arnautka- . . . . 422

Arnold's hybrid . . . 263

" Victor : . . 230

Awny . . . . . . 363

Baxter's . . . . . . 297

Bearded Flint- . . . . 386

Biddle's Imperial- . . . 248

Black-sea . . . . 422

Blood red . . . . 296

Blue Rivet . . . . .407

Blue Stem- . . . . 231

Bole's prolific . . . . 298

Bristol red . . . . 325

Broad-leaf Cape- . . . 224

Brodie's white . . . .213

Browick red . . . 293

Bull . . . . . . 325

Burwell's red . . . . 290

Callaby's purple-straw . . 226

Canada Club-Spring . . . 386

$"$ Flint- . . . 232 
Wheat, Cape-

Casey's white . . . 223

Caucasian . . . . 332

Champlain . . . . 346

Chancellor red . . . . 299

Cheltham. . . . . 216

Chidham . . . . 216

Chili- . . . . . 227

Chili square. . . . 265

Chub . . . . 381

Clawson- . . . . 280

Clover's red . . . . 293

Club . . . . $\left\{\begin{array}{l}281 \\ 386\end{array}\right.$

headed ... . 315

Cluster dwarf white. . .223

Common Rivet . . . . . 406

Compfsane Prize . . . . 279

Cone Rivet or Antifly . . 401

Courtney's six-rowed Chevalier.

Crate . . . . . 376

Crimson red . . . . 298

Dantzik red chaffed . . . 277

Defiance Spring- . . . 229

Deihl . . . . . 264

Demokrat . . . . . 264

Dorking Glory . . . 320

Dott . . . . . .365

Dowestons new . . . 258

Downy-Kent. . . . . 313

Drouved's new . . . . 300

Dudney . . . . . .224

Early East Barus- . . .221

"Eclipse dwarf . . 223

Lancaster . . . 366

Michigan . . . 325

Noé . . . . 268

Egyptian . . . . .347

Eley's Giant . . . 215

English Flint. . . . . 232

Farwer's. . . . . 259

Fenton white . . . 278

Fern or April . : . 363

Festal-Pedigree . . . 265

Flander's short-eared . . 388

Fraser's . . . . . 221

Fultz Winter-.... . 262

Geja . . . . . 248

General Harmon's improved

white Flint- . . . . 232

German Amber : : 261

Thickset . : 401

Giant St. Helena . . . 402

Gold Dust . . . . 301

Golden rough-chaff : . 325

"Swan . . . . 360

Grass- . . . 300

Haigh's prolific . . . 295

Haigh-Wath prolific . . .272
Wheat, Hallet's pedigree Goldendrop . . . . . 294 dito Hunter's white . . 214 dito red . . . . . 254 dito red Nursery : . 291 dito white Victoria . . 220

Hard-castle . . . . 221

Hartwood's . . . . 259

Harvey's prolific . . . . 299

Hatherthon's ?. . 222

Hedge. . . . . . 313

Henton . . . 224

Hicklings prolific . . . 256

Hoary-white . . . 313

" " Talavera . . 317

Hopetoun . . . . 217

Hunter's white . . . . 214

Huntlops prolific . . . 298

Hutchinson- . . . . 386

Jenning's white . . . 328

Incledons prolific . . . 256

Indiana . . . . 232

Irish . . . . . . .261

Italian Spring- . . 350

Kentuky . . . . 264

white chaff . . 386

Kessingland . . . . . 257

King William . . . .256

Lady Hall . . . . . 221

Lammas red . . . . 290

Langley's red . . . . 260

Large . . . . . . 232

Leghorn . . . . . 350

Longberried Winter- . . 365

Lord Ducie . . . . . . 222

"Wester . . . .221

Louisiana- . . . . . 281

Mainstay . . . . . 322

Manchester . . . . . 319

Michigan-Wick . . . 328

Mummy- . . . . . 259

Mungowell's- . . . .221

Murray's- . . . . .221

Muskingum-. . . . . 263

Nairn-prize . . . 222

New Sindh-Thoree . . 324

Norfolk . . . . . .256

North-Carolina . . . 231

Nova-Scotia . . . . 266

Odessa . . 263

Old Genesee red-chaff .280

" red Lammas. . . 290

, white Irish . . . 261

Oregon Club-.. . . 281

Original white Flint . . 232

Oxford prize . . . . 213 red . . . . 297

Paines defiance : . . 407

Pearl . . . . . 316

Pipcr's Thickset . . . . 382

Pole Rivet . . . . 399

Post . . . . . . 329 
Wheat, Prince Albert .

Pringle's white

Purple stalked Golden-drop 294

Red bearded Mediterranean 366

" beds. . . . . . 225

, Berwick. . . . . 299

"Britannia . . . . 306

" chaff . . . . . 302

" , Bald . . . . 280

", english . . . . . 290

"Golden-drop . . . . 294

" Kent..... . 290

" Langham . . . . . 298

" Marygold . . . . . 292

"Rostock . . . . . 297

"Russian. . . . . 370

" strawed. . . . . . 253

$"$ " white. . 279

" Talavera . . . . 296

" Wonder . . . . . 298

Richmond's Giant . . . 320

" Prize . . . 320

Rio-grande Spring . . . 330

Rochester . . . . . 232

Rough chaffed Essex . . 315

Sanford . . . . . . 330

Saumur Spring. . . . .273 yellow. . . . 272

Shiriff's Square headed- . 255

Shirreff's bearded white. .327

Shumaker . . . . . 301

Smooth Mediterranean . . 301

Soule's . . . . . 232

Spalding's prolific . . . 291

Square Sicilian Spring- . 382

Standard red . . . . 298

Striped chaff . . . . 299

Stuffed . . . . . 313

Taganrock smooth white .397

Talavera ..... 234

Tall cluster ..... . 224

Tappahannock- . . . 230

Taunton-Dean . . . . 315

Tham...... . 245

Thick-set . . . . . 256

" , club . . . . . 293

Tunstall Thick chaffed . . 313

Turkey . . . . . 347

Turkish flint. . . . . 347

Uxbridge ..... . 316

Velvet Beard . . . . 376

chaff ..... 376

Victoria red spring- . . 337

Vipound's white . . . 218

Virginian-May . . . . 300 white ... . 228

Volunteer ...... 222

TValker-...... 262

Walla-Walla Spring- . . 379

Washington-Glass . . . 230

Welub's Challenge white . . 220
Wheat, Webb's selected Golden-drop 257

White Calif' Hunter's white 214

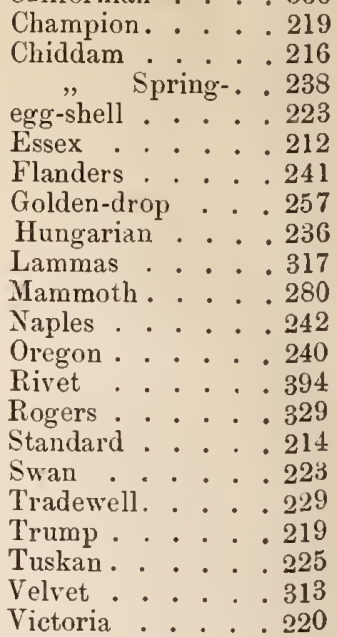

Whittington-. . . . 215

Woodley's superb . . . 261

Woolly eared ..... 313

Yellow Lammas.... . 253

Yorkshire-. . . . . . 232

Wunderweizen ...... 408

Wurzelathmung . . . . . . 40

Wurzeltiefgang . . . . . 15

\section{Z.}

Zea Mais. ........ 772

acuminata Kcke. . . . 773

alba Al. . . . . 793

alboflava Keke.. . . 818

alborubra Kcke. . . . 782

caesia Al. . . . . 817

chilena Kcke. . . . . 778

coeruleodulcis Kcke. . . 778

crococeras Kcke. . . 785

crocodon Kcke. ... 785

dierythra Kcke. . . . 818

dulcis Keke.... . . 776

flavodulcis Kcke... . .77t

flavorubra Kcke. . . . 783

gilva Kicke. . . . . 814

glaucomis Al. . . . 793

gracillima Kcke. . . . 789

haematornis Kcke. . . . 792

leucodon Al. . . . . 779

leucornis Al. . . . . 788

macrosperma Kl. . . . 773

melanornis Keke. . . . 792

multicolor Al. . . . 819

nigra Al. . . . . 817 
Zea Mais, orizoïdes Kcke. . . . 787 | Zea Mais, rugosa Bonaf. . . . . 775

" "Philippi Kcke. . . . 814 " " striata Al. . . . . . .818

" " pungens Kcke. . . . . 774

" $\quad$ pyrodon Al. . . . . . . 786

rubentidulcis hicke..778

" rubra Bonaf.. . . 816

" rubrocaesia Kcke. . . 818

" rubrodulcis Kcke. . . . 778

" rubropunctata Kcke. . .815

" rubrostriata Kcke. . . .786

"rubrovelata Kcke. . . .787

" " striatidens Kcke. . . . 786

" " tunicata Larranhaga . . 772

" " turgida Bonaf. . . . .812

" " uberior Kcke. . . . . . 777

", " violacea Kcke. . . . . .817

, ", virginica Bonaf. . . . . 799

" " vulgata Kcke. . . . . . 803

" " xanthodon Al. . . . . 782

" " xanthornis Kcke . . . . 790

Konen, Pflanzengeographische : $\quad 3$ 


\section{Druckfehler.}

Seite 186 In der Uebersichtstabelle der Getreideproduktion und Konsumtion sind in der Spalte "Mehreinfuhr in Mark" für die aussereuropäischen Länder die Zahlen fortzulassen.

, 317 Anstatt vellosa lies velloso.

" 336 " Delhie lies Delhi.

" 350 Z. 3 v. u. Anstatt Sigma lies Signo.

" 381 Z. 1 v. o. " Malorca lies Mallorca.

" 393 Z. 5 v. u. " " Ejipto lies Egipto.

$" 411$ Z. 18 v. o. " " Trigo á laga lies Tr. Álaga.

" 415 Z. 12 v. o. ", Puros lies Pyros.

" 426 Z. 10 v. u. ", nero lies negro.

"434 Z. 7 v. o. " vellosa lies velloso.

" 434 Z. 8 v. о. ", Patianchuclo lies Patianchuelo.

, 436 Z. 18 v. u. , blanches lies blanc.

, 436 Z. 17 v. u. , commune lies commun.

438 Z. 4 v. u. , rousse lies roux.

, 440 Z. 18 v. u. " blanche barbue lies blanc barbu.

" 447 Z. 11 v. u. ", commune lies commun. 



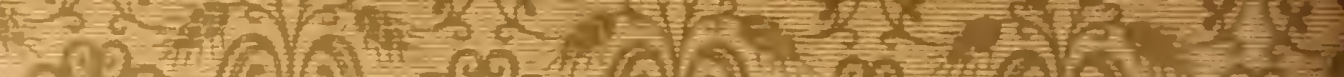

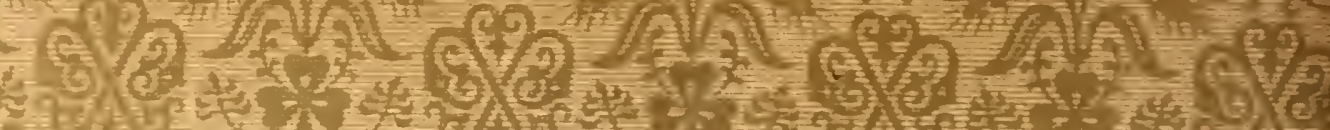
(

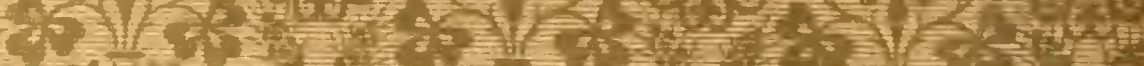

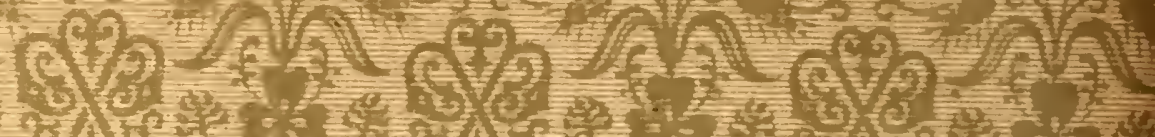
क the r.

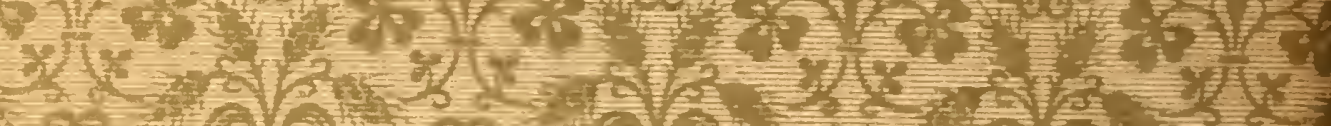

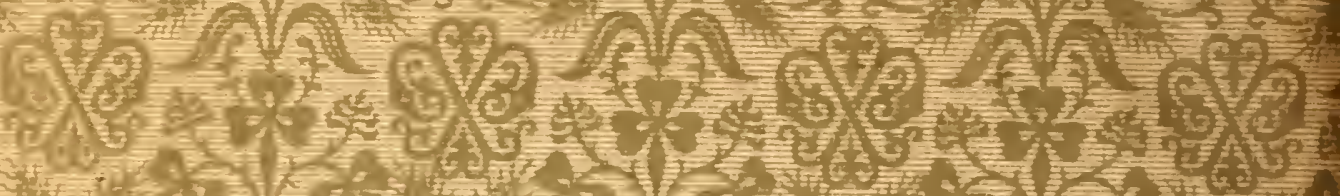
Ant

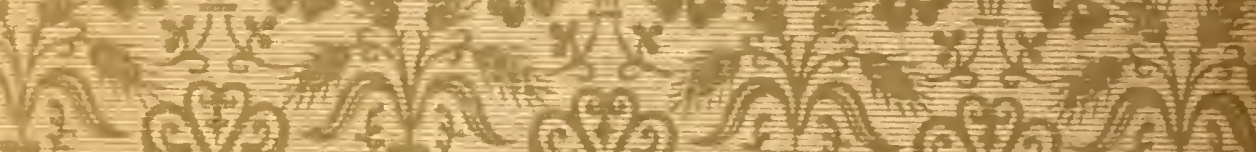

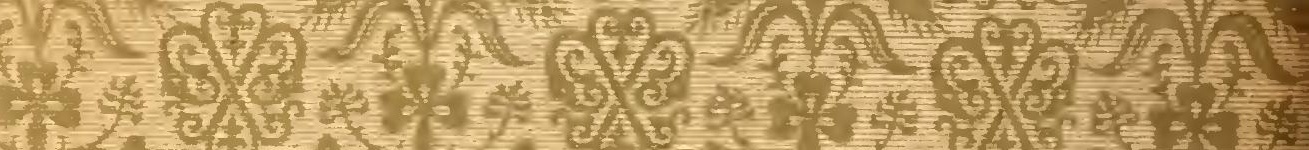

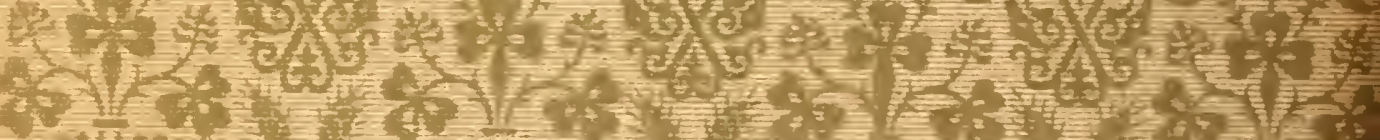

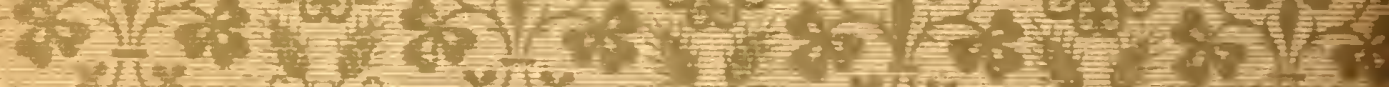

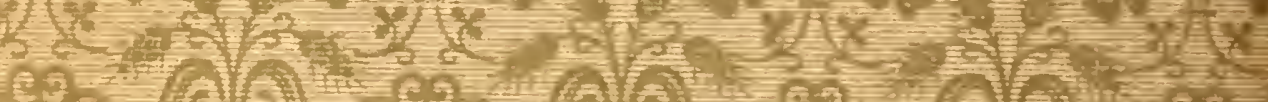

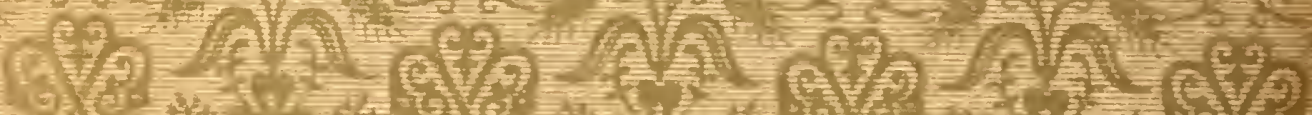
(2)

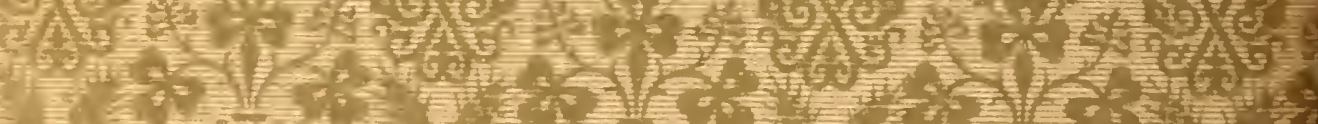

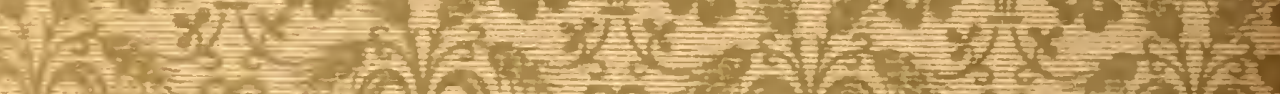
CD $A N$ OD W

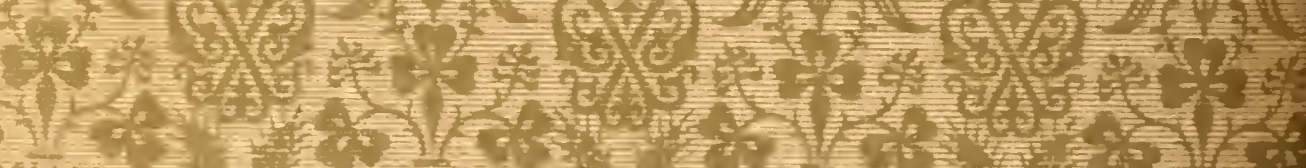

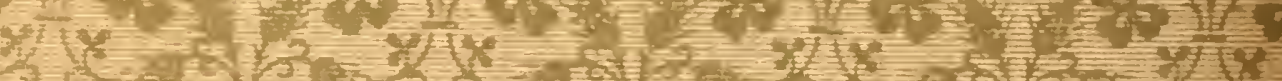
N N con an (2) 3 (8) 2 -

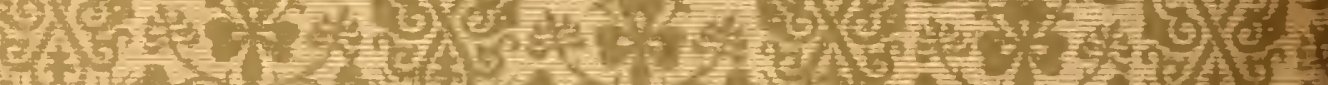

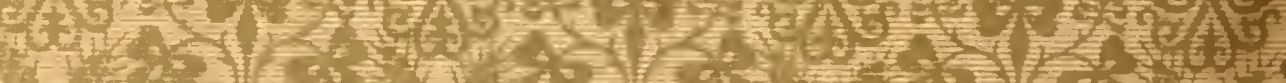

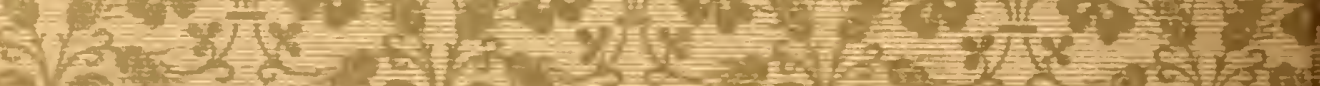
(

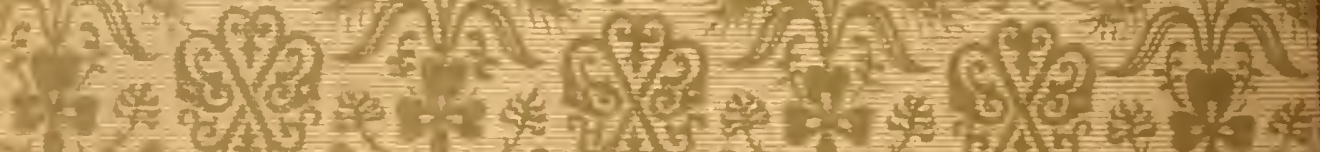




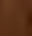

